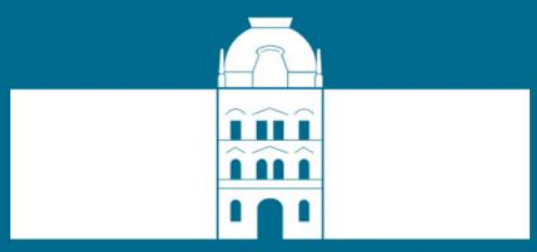

Univerza v Mariboru

36. mednarodna konferenca o razvoju organizacijskih znanosti: Odgovorna organizacija

(23. - 24. marec 2017, Portorož Slovenija)

\title{
(Konferenčni zbornik)
}

\author{
Uredniki: \\ dr. Olja Arsenijević \\ dr. Marko Ferjan \\ dr. Iztok Podbregar \\ dr. Polona Šprajc \\ dr. Dragan Trivan \\ dr. Yvonne Ziegler
}




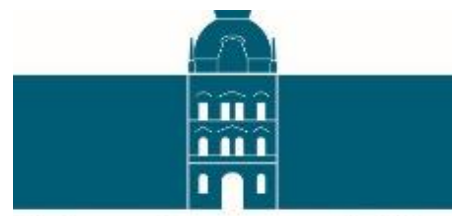

Univerzitetna založba

Univerze v Mariboru 


\section{(C) Univerzitetna založba Univerze v Mariboru}

Vse pravice pridržane. Brez pisnega dovoljenja založnika je prepovedano reproduciranje, distribuiranje, predelava ali druga uporaba tega dela ali njegovih delov v kakršnemkoli obsegu ali postopku, vključno $\mathrm{s}$ fotokopiranjem, tiskanjem ali shranjevanjem v elektronski obliki.

Naslov: 36. mednarodna konferenca o razvoju organizacijskih znanosti: Odgovorna organizacija, Slovenija, Portorož, 22. - 24. marec 2017, (konferenčni zbornik)

\section{Uredniški odbor:}

Olja Arsenijević (Univerzitet UNION - Nikola Tesla, Fakultet za poslovne studije i pravo Beograd, Srbija), Marko Ferjan (Univerza v Mariboru, Fakulteta za organizacijske vede, Slovenija), Iztok Podbregar (Univerza v Mariboru, Fakulteta za organizacijske vede, Slovenija), Polona Šprajc (Univerza v Mariboru, Fakulteta za organizacijske vede, Slovenija), Dragan Trivan (Univerzitet UNION - Nikola Tesla, Fakultet za poslovne studije i pravo Beograd, Srbija), Yvonne Ziegler (Frankfurt University of Applied Sciences, Germany)

\section{Programski odbor:}

Iztok Podbregar (Univerza v Mariboru, Fakulteta za organizacijske vede, Slovenija), Marko Ferjan (Univerza v Mariboru, Fakulteta za organizacijske vede, Slovenija), Olja Arsenijević (University UNION - Nikola Tesla, Faculty of Business Study and Law Belgrade, Serbia), Zvone Balantič (Univerza v Mariboru, Fakulteta za organizacijske vede, Slovenija), Sladjana Barjaktarović Rakočević (University of Belgrade, Faculty of Organizational Sciences, Serbia), Mojca Bernik (Univerza v Mariboru, Fakulteta za organizacijske vede, Slovenija), Roberto Biloslavo (Univerza na Primorskem, Fakulteta za management, Slovenija), Rado Bohinc (Univerzv v Ljubljani, Fakulteta za družbene vede, Slovenija), Alenka Brezavšček (Univerza v Mariboru, Fakulteta za organizacijske vede, Slovenija), Vlado Dimovski (Univerza v Ljubljani, Ekonomska fakulteta, Slovenija), Petr Doucek (University of Economics, Prague, Faculty of Informatics and Statistics, Czech Republic), Miro Gradišar (Univerza v Ljubljani, Ekonomska fakulteta, Slovenija), Tomaž Kern (Univerza v Mariboru, Fakulteta za organizacijske vede, Slovenija), Robert Leskovar (Univerza v Mariboru, Fakulteta za organizacijske vede, Slovenija), Branko Lobnikar (Univerza v Mariboru, Fakulteta za varnostne vede, Slovenija), Damjan Maletič (Univerza v Mariboru, Fakulteta za organizacijske vede, Slovenija), Sanja Marinković (University of Belgrade, Faculty of Organizational Sciences, Serbia), Žan Jan Oplotnik (Univerza v Mariboru, Ekonomsko - poslovna fakulteta, Slovenija), Bjoern Paape (RWTH Aachen University, Germany), Majda Pajnkihar (Univerza v Mariboru, Fakulteta za zdravstvene vede, Slovenija), Anita Pavković (University of Zagreb, Faculty of Economics and Business, Croatia), Uroš Rajkovič (Univerza v Mariboru, Fakulteta za organizacijske vede, Slovenija), Bojan Rosi (Univerza v Mariboru, Fakulteta za logistiko, Slovenija), Janez Stare (Univerza v Ljubljani, Fakulteta za upravo, Slovenija), Radovan Stojanović (University of Montenegro, Faculty of Electrical Engineering, Montenegro), Vjeran Strahonja (University of Zagreb, Faculty of Organization and Informatics, Croatia), Polona Šprajc (Univerza v Mariboru, Fakulteta za organizacijske vede, Slovenija), Daniel Tomić (Juraj Dobrila University of Pula, Faculty of Economics and Tourism "Dr. Mijo Mirković" Croatia), Dragan Trivan (University UNION - Nikola Tesla, Faculty of Business Study and Law Belgrade, Serbia), Borut Werber (Univerza v Mariboru, Fakulteta za organizacijske vede, Slovenija), Yvonne Ziegler (Frankfurt University of Applied Sciences, Germany), Hans Dieter Zimmermann (FHS St. Gallen, University of Applied Sciences, Switzerland) 


\section{Recenzentski odbor:}

Alenka Baggia, Mojca Bernik, Alenka Brezavšček, Eva Jereb, Tomaž Kern, Davorin Kofjač, Jure Kovač, Gregor Lenart, Robert Leskovar, Damjan Maletič, Matjaž Maletič, Miha Marič, Gozdana Miglič, Vesna Novak, Uroš Rajkovič, Vladislav Rajkovič, Matjaž Roblek, Marjan Senegačnik, Brane Šmitek, Polona Šprajc, Marko Urh, Goran Vukovič, Borut Werber, Anja Žnidaršič

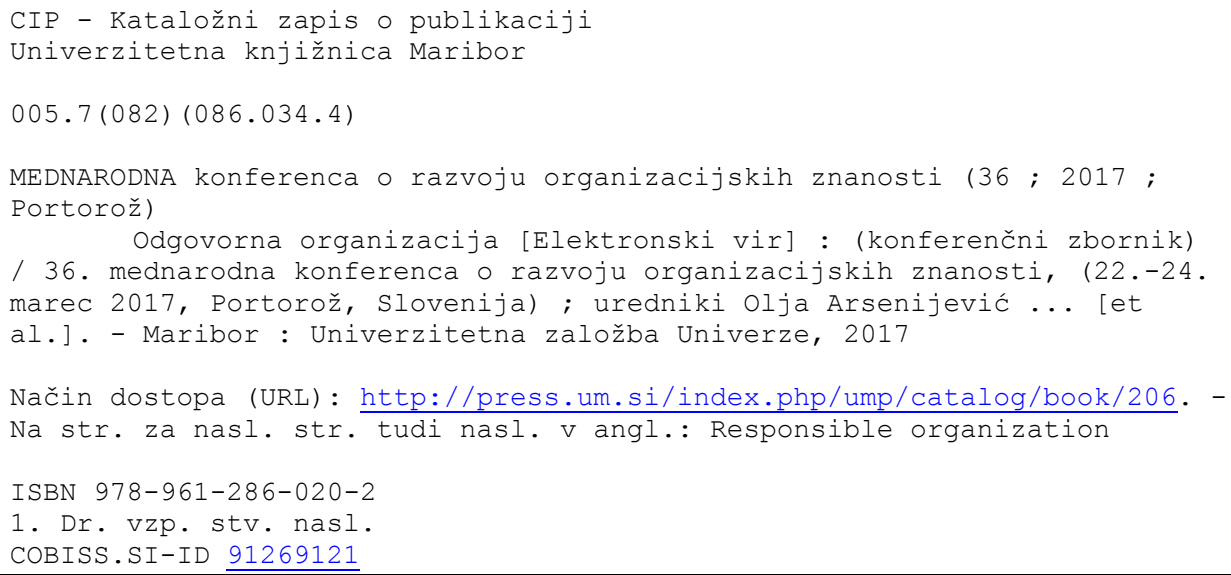

\section{Založnik:}

Univerzitetna založba Univerze v Mariboru

Slomškov trg 15, 2000 Maribor, Slovenija tel. +386225042 42, faks +38622523245

http://press.um.si, zalozba@um.si

\section{Izdajateljica:}

Univerza v Mariboru, Fakulteta za organizacijske vede

Kidričeva cesta 55a, $4000 \mathrm{Kranj}$, Slovenija tel. + 386 (0)4 2374 200, faks +386 (0)4 2374299

www.fov.um.si,info@fov.uni-mb.si

Cena: brezplačen izvod

Odgovorna oseba založnika:

prof. dr. Igor Tičar, rektor 
All rights reserved. No part of this book may be reprinted or reproduced or utilized in any form or by any electronic, mechanical, or other means, now known or hereafter invented, including photocopying and recording, or in any information storage or retriveal system, without permission in writing from the publisher.

Title: $\quad 36$ th International Conference on Organizational Science Development: Responsible Organization (March 22nd - 24th, 2017, Portorož, Slovenia) (Conference Proceedings)

\section{Editorial Committee:}

Olja Arsenijević (University UNION - Nikola Tesla, Faculty of Business Study and Law Belgrade, Serbia), Marko Ferjan (University of Maribor, Faculty of Organizational Sciences, Slovenia), Iztok Podbregar (University of Maribor, Faculty of Organizational Sciences, Slovenia), Polona Šprajc (University of Maribor, Faculty of Organizational Sciences, Slovenia), Dragan Trivan (University UNION - Nikola Tesla, Faculty of Business Study and Law Belgrade, Serbia), Yvonne Ziegler (Frankfurt University of Applied Sciences, Germany)

\section{Programme Committee:}

Iztok Podbregar (University of Maribor, Faculty of Organizational Sciences, Slovenia), Marko Ferjan (University of Maribor, Faculty of Organizational Sciences, Slovenia), Olja Arsenijević (University UNION - Nikola Tesla, Faculty of Business Study and Law Belgrade, Serbia), Zvone Balantič (University of Maribor, Faculty of Organizational Sciences, Slovenia), Sladjana Barjaktarović Rakočević (University of Belgrade, Faculty of Organizational Sciences, Serbia), Mojca Bernik (University of Maribor, Faculty of Organizational Sciences, Slovenia), Roberto Biloslavo (University of Primorska, Faculty of management, Koper, Slovenia), Rado Bohinc (University of Ljubljana, Faculty of Social Sciences, Ljubljana, Slovenia), Alenka Brezavšček (University of Maribor, Faculty of Organizational Sciences, Slovenia), Vlado Dimovski (University of Ljubljana, Faculty of Economics, Ljubljana, Slovenia), Petr Doucek (University of Economics, Prague, Faculty of Informatics and Statistics, Czech Republic), Miro Gradišar (University of Ljubljana, Faculty of Economics, Ljubljana, Slovenia), Tomaž Kern (University of Maribor, Faculty of Organizational Sciences, Slovenia), Robert Leskovar (University of Maribor, Faculty of Organizational Sciences, Slovenia), Branko Lobnikar (University of Maribor, Faculty of Criminal Justice and Security, Ljubljana, Slovenia), Damjan Maletič (University of Maribor, Faculty of Organizational Sciences, Slovenia), Sanja Marinković (University of Belgrade, Faculty of Organizational Sciences, Serbia), Žan Jan Oplotnik (University of Maribor, Faculty of Economics and Business, Maribor, Slovenia), Bjoern Paape (RWTH Aachen University, Aachen, Germany), Majda Pajnkihar (University of Maribor, Faculty of Health Sciences, Maribor, Slovenia), Anita Pavković (University of Zagreb, Faculty of Economics and Business, Croatia), Uroš Rajkovič (University of Maribor, Faculty of Organizational Sciences, Slovenia), Bojan Rosi (University of Maribor, Faculty of Logistics, Celje, Slovenia), Janez Stare (University of Ljubljana, Faculty of Administration, Ljubljana, Slovenia), Radovan Stojanović (University of Montenegro, Faculty of Electrical Engineering, Montenegro), Vjeran Strahonja (University of Zagreb, Faculty of Organization and Informatics, Croatia), Polona Šprajc (University of Maribor, Faculty of Organizational Sciences, Slovenia), Daniel Tomić (Juraj Dobrila University of Pula, Faculty of Economics and Tourism "Dr. Mijo Mirković", Croatia), Dragan Trivan (University UNION - Nikola Tesla, Faculty of Business Study and Law Belgrade, Serbia), Borut Werber (University of Maribor, Faculty of Organizational Sciences, Slovenia), Yvonne Ziegler (Frankfurt University of Applied Sciences, Germany), Hans Dieter Zimmermann (FHS St. Gallen, University of Applied Sciences, Switzerland) 


\section{Reviewers Committee:}

Alenka Baggia, Mojca Bernik, Alenka Brezavšček, Eva Jereb, Tomaž Kern, Davorin Kofjač, Jure Kovač, Gregor Lenart, Robert Leskovar, Damjan Maletič, Matjaž Maletič, Miha Marič, Gozdana Miglič, Vesna Novak, Uroš Rajkovič, Vladislav Rajkovič, Matjaž Roblek, Marjan Senegačnik, Brane Šmitek, Polona Šprajc, Marko Urh, Goran Vukovič, Borut Werber, Anja Žnidaršič

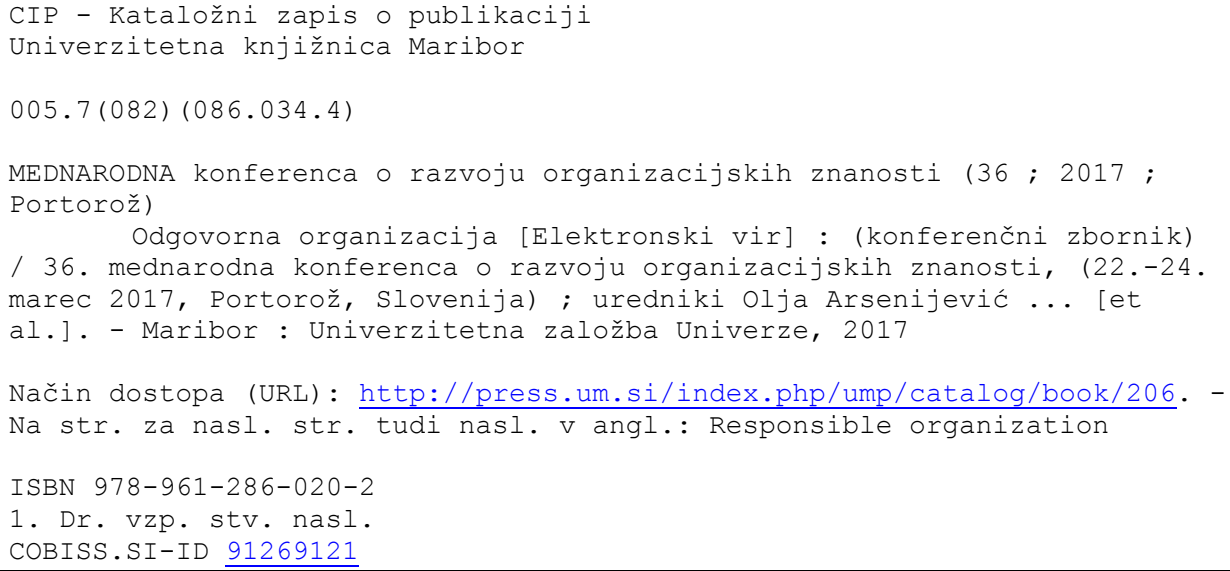

First published in 2017 by

University of Maribor Press

Slomškov trg 15, 2000 Maribor, Slovenia

tel. +386 225042 42, fax +38622523245

http://press.um.si, zalozba@um.si

\section{Co-published by}

University of Maribor, Faculty of Organizational Sciences

Kidričeva cesta 55a, $4000 \mathrm{Kranj}$, Slovenija

tel. + $386(0) 42374$ 200, faks +386 (0)4 2374299

www.fov.um.si, info@fov.uni-mb.si

Price: free copy

\section{For publisher:}

prof. dr. Igor Tičar, rector (University of Maribor) 


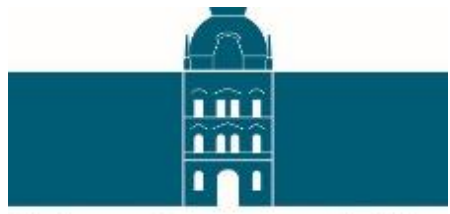

Univerzitetna založba Univerze v Mariboru

\title{
36. mednarodna konferenca o razvoju organizacijskih znanosti: Odgovorna organizacija
}

(22. do 24. marec 2017, Portorož, Slovenija)

(konferenčni zbornik)

\author{
Uredniki: \\ dr. Olja Arsenijević \\ dr. Marko Ferjan \\ dr. Iztok Podbregar \\ dr. Polona Šprajc \\ dr. Dragan Trivan \\ dr. Yvonne Ziegler
}




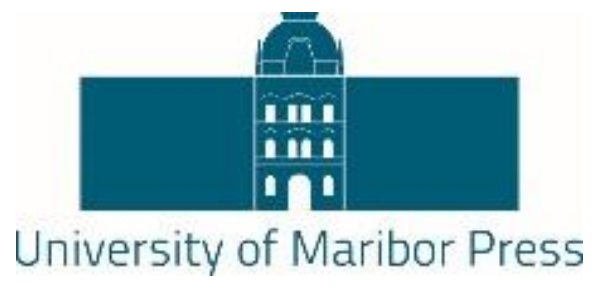

$3^{\text {th }}$ International Conference on Organizational Science Development: Responsible Organization (March 22 ${ }^{\text {nd }}-2^{\text {th }}, 2017$, Portorož, Slovenia)

(Conference Proceedings)

Editors:

dr. Olja Arsenijević

dr. Marko Ferjan

dr. Iztok Podbregar

dr. Polona Šprajc

dr. Dragan Trivan

dr. Yvonne Ziegler 


\section{Kazalo / Table of Contents}

KONFERENČNI PRISPEVKI / CONFERENCE PROCEEDINGS

Predgovor

Foreword

Iztok Podbregar

Strategija vključevanja načel ergonomije za doseganje optimalnega

delovnega učinka pri delu $z$ računalnikom

Strategy of Ergonomic Principles Integration for Optimal

Performance Achievement of Working with Computer

Zvone Balantič, Branka Balantič

Big Data and the R Programming Language

Igor Banjac, Dragan Vukmirovic, Marina Jovanovic Milenkovic

Skrb posameznika za kibernetsko varnost

Cybersecurity Caring Individuals

Igor Bernik

Uporaba multivariatnih statističnih metod pri analizi vloge profesorja pri motivaciji za učenje

The Use of Multivariate Statistical Methods in Analyzing the Role of Lecturer in Motivation for Learning

Sašo Bizant

Raziskovalno delo na Srednji strokovni šoli Vegova Ljubljana

Research Activities in the Upper Secondary School Vegova

Ljubljana

Uroš Breskvar

Corporate Social Responsibility: Towards a New Management

Paradigm

Slobodan Brezak 
Kvantitativna analiza učinkovitosti socialnega servisa za oskrbo starostnikov na domu Quantitative Analysis of Elderly Homecare Service Provider Efficiency

Alenka Brezavšček, Iztok Podbregar, Polona Šprajc

Javno zasebno partnerstvo kot orodje za koriščenje/uporabo sredstev iz Evropskih sruktrnih skladov (ESI)

Pulic-Private Partership as a Tool of Use the Funds from the European Structural Funds

Bety Breznik, Marko Koščak

Impediments to Acceptance and Implementation of Statistical

Be Overly Optimistic - the Effects of Accuracy in Financial Planning on Entrepreneurial Performance

Sven Carlin, Adriana Botman

Razvoj odločitvenih kriterijev za ocenjevanje prednosti pri dodeljevanju stanovanj

Evolution of Decision Criteria for Estimating Priorities in Housing Facilities Allocation

Bojan Cestnik, Alenka Kern

Vrzel v poznavanju managementa znanja v javni upravi Republike Slovenije

Knowledge Gaps in Knowledge Management in the Public

Administration of the Republic of Slovenia

Simon Colnar, Vlado Dimovski, Marko Colnar

Innovation of Shipping and Loading Information System and

Business Process Reengineering at Coal Company

Roman Danel, Jiří Skotnica

Izzivi tehnoloških sprememb in prihodnost dela

The Challenges of Technological Changes and the Future of Work Denis Dizdarević, Vesna Novak 
Management krhkosti na individualni ravni - potreba po obsežnem multidisciplinarnem pristopu

Management of Frailty at Individual Level - a Need for a

Comprehensive Multidisciplinary Approach

Branko Gabrovec, Marjetka Jelenc

Nasilje nad zaposlenimi v zdravstveni negi in preventivni organizacijski ukrepi

Violence Against Employees in Nursing Care and Preventive Organisational Measures

Branko Gabrovec, Marjetka Jelenc

Davek od dohodka ter odloženi davki in njihov vpliv na računovodske izkaze v Sloveniji, Hrvaški, BIH in Srbiji Income Tax, Deferred Tax and Their Impact on the Financial Statements in Slovenia, Croatia, BIH and Serbia

Renata Gabršek

Brezžični Holter monitor

Using Temporal Database for Representation and Reasoning in Maritime Applications

Anita Gudelj

Information Security Challenges - How to Prepare Professionals the Year Selection

Miha Indihar

Implementacija metodologije USALI v hotelirstvu s pomočjo 
Primerjava pravne ureditve pritožb v zdravstvu v Republiki

Sloveniji, Nemčiji in Veliki Britaniji

Caparison of Healthcare Complaints Regulation in the Republic of

Slovenia, Germany and the United Kingdom

Anka Kenda Mohorič, Robert Leskovar, Rajko Pirnat

Zdrava prehrana $\mathrm{v}$ socialno varstvenem zavodu

289

Healthy Nutrition in Residential Care Institutions

Sara Ketiš, Cirila Hlastan Ribič, Urška Rozman, Sonja Šostar Turk

Analiza organizacijske kulture v službi nujne medicinske pomoči za področje Gorenjske

Analysis of Organizational Culture in the Emergency Medical

Services of the Gorenjska Region

Tatjana Kitić Jaklič, Jure Kovač, Ksenija Tušek-Bunc

Vpliv virov informacij na nakupno odločanje mladih v Sloveniji in ZDA

The Impact of Sources of Information on the Purchasing Decisions of Young People in Slovenia and USA

Natalija Klemenčič, Beno Klemenčič

Daljinski nadzor ob uporabi Androidne aplikacije

Remote Monitoring Device Using Android Application

Jan Konečnik, Vojko Matko

The Impact of the Internet on the Tourists' travel Planning Process

Milica Kostic - Stankovic, Jelena Cvijovic, Velimir Stavljanin

Holistic Approach in Coastal Zone Management

Mirjana Kovačić, Astrid Zekić, Srećko Favro

Različne oblike organizacije pouka za boljše znanje tujega jezika

Different Organisational Teaching Formats for Ensuring Quality in Foreign Language Learning

Irena Krajnc

Opravljanje praktičnega usposabljanja v tujini, strah ali izziv?

Practical Training Abroad: Fears or Challenges?

Nataša Krajnc Zakrajšek

Z vključujočim vodenjem do odgovorne organizacije

From the Inclusive Management to the Responsible Organization Danijela Kralj 
Napredna nastavitev oskrbovalnih politik z odkrivanjem znanja iz podatkov $z$ orodjem Orange Advanced Setting of Supply Policies by Discovering Knowledge from Data Using Orange

Eva Krhač, Benjamin Urh, Matjaž Roblek

Zamenjave dovodov medicinskih plinov in njihovo preprečevanje Crossed Pipelines Connections of Medical Gases and Their Prevention Miljenko Križmarić

Biomasa, kot alternativni vir pridobivanja energije

Biomass as an Alterantive Source of Energy Recovery Tadeja Kuhar Osterman, Drago Vuk, Marjan Senegačnik

Zdrav življenjski slog v Študentskih domovih Univerze v Mariboru Healthy Lifestyle in Student Dormitories University of Maribor Darja Kukovičič

Zunanje izvajanje popisa vodomerov

Pregled poklicev v informacijski dejavnosti

Vpliv kakovosti socialnih interakcij na delovnem mestu na zaposlenčevo zavzetost za delo The Impact of the Quality of Social Interactions at the Workplace on Employee Work Engagement

Branko Lobnikar, Anja Cedilnik

On a Design of a Maintenance Performance Measurement System: a Sustainability Perspective

Damjan Maletič, Matjaž Maletič, Basim Al-Najjar, Boštjan Gomišček

Igrifikacija v študentskih organizacijah 
Pomen legalnosti in legitimnosti pri spoštovanju človekovih pravic ter pri zagotavljanju dobre uprave

The Importance of Legality ang Legitimacy to Respect Human

Rights and to Achieve Good Administration

Kornelija Marzel

Management upravljanja z ekološkim tveganji kot sestavni del strategije odgovornega podjetja

Management of Ecological Risks as an Integral Part of the Strategy of the Responsible Company

Dušan Mežnar

Efektivno črpanje evropskih sredstev

Effective Absorption of European Funds

Marija Michaud, Matjaž Maletič, Drago Vuk

Sistematični pristop $k$ evalvaciji izobraževalnih programov

Systematic Approach to the Training Programmes Evaluation

Gozdana Miglič

The Use of Process Approach in the Design of Social Services

Jan Ministr, Blanka Bazsová

Economic Valuation of Environmental Policy Effects - Why Should

Zorica Mitrović, Vladimir Obradović, Nataša Petrović

Vpliv izvajanja trajnostnih procesov na količino porabljene pitne vode $\mathrm{v}$ predelovalni industriji

The Impact of Sustainable Processes on the Consumption of

Drinking Water in the Manufacturing Industry

Melita Moretti, Mirko Markič

Organizational Restructuring and Cost Allocation Based on

Business Process Approach

Jovana Mrvić, Jelica Erceg, Maša Vukomanović, Ivan Todorović,

Stefan Komazec

Zdravtstveni absentizem v proizvodnem podjetju 
Introduction of a Lesson: A Guarantee of Motivation? The

Significance of the Lesson Introduction for Learners' Activation

Level in Business and Economics Teaching at German Vocational

Colleges

Andreas Gebhardt, Markus Mertens, Sandra Niedermaier, Julia Pelster,

Simon Wöllmecke, Bjoern Paape, Iwona Kiereta

Analiza modela notranjih institucionalnih evalvacij na Univerzi v Mariboru

Analysis of the Model of the Internal Institutional Evaluations at the University of Maribor

Miha Pauko, Franci Čuš

Evaluation Challenges of Research Projects Funded by Serbian

Ministry of Education and Science

Milica Pavićević, Marija Todorović, Zorica Mitrović

Investment in Venture Capital Funds in the Republic of Croatia:

Determinants and Challenges

Anita Pavković, Hrvoje Matešić

Business Innovation Discovery with a Social Impact by Croatian Business Students through Appreciative Inquiry Methodology Judita Peterlin, Vlado Dimovski, Daniela Garbin Praničević

Institutional Effects of Public-Private Partnership Act on the Status of Municipal Public Enterprises in Slovenia

Veronika Petkovšek, Primož Pevcin

Uporabnost energetske izkaznice pri določanju vrednosti nepremičnin

Applicability of Energy Performance Certificates when Valuating

Real Estates

Silvo Plesnik, Drago Vuk

Migracije in varnost $v$ družbi

Migracije and Safety Society

Iztok Podbregar, Dragar Trivan, Olja Arsenijević, Polona Šprajc

Pomen timskega dela med organizatorjem praktičnega pouka in

učnimi bazami

The Importance of Teamwork Between the Organizer of Practical Training and Teaching Bases

Polona Podlesnik 
Multifactor Analysis of Online Reputation of Slovak Teaching

Hospitals

Frantisek Pollak, Katarina Belovodska, Bozka Malinak

Zadovoljstvo, motiviranost in podjetnost zdravnikov javnega

zdravstvenega sistema $v$ luči zdravstvene reforme

Physicians Content, Motivation and Enterpreneurship in the

Aspect of the Slovenian Health Care Reform

Andrej Prlja, Vida Kampuš Trop

From Environmental Action to Climate Change Knowledge and

Back

Jelena Andreja Radaković, Nataša Petrović, Nemanja Milenković, Kristina Stanojević, Dejana Stevanović

New Approach in Designing (Self) Organizations as the Most Efficient Modality of Organizing

Milan Radosavljevic, Aleksandar Andjelkovic, Maja Andjelkovic,

Dragana Radosavljevic

Intellectual Capital Assessment Based on the Standardized

Visualization Methodology

Nikola Radovanovic, Veljko Dmitrovic, Snezana Knezevic

Spreadsheet Model for Managing Special Events

Teodora Rajkovic, Lena Djordjevic, Danica Lecic-Cvetkovic, Radul Milutinovic

eZdravje danes za jutri

eZdravje Today for Tomorrow

Živa Rant, Dalibor Stanimirović, Vedrana Matetić, Simon Indihar, Janja Zidarn, Mate Beštek, Andrej Žlander

Pogostost in višina prejete napitnine: faktorska analiza dejavnikov Influence Frequency and the Amount of Received Tips: Factor Analysis of Factors

Andrej Raspor

Dvojna kariera športnikov in družbena odgovornost v Sloveniji Dual Career of Athletes and Corporate Social Responsibility in Slovenia

Petra Robnik, Edvard Kolar 
Perception of Sales Organizations for Luxury Speed Boats' Sales in

Recession in Croatia

Siniša Rudelj, Milan Rudelj

The Role of Brand Ambassador in Online Campaigns

919

Sonja Savović, Slavica Cicvarić Kostić, Tamara Vlastelica

Črni ogljik in njegovi vplivi na kakovost zraka in nastanek srčno-

žilnih obolenj

Black Carbon and Its Impact on Air Quality and on Development of Cardio-vascular Diseases

Marjan Senegačnik, Drago Vuk, Nataša Petrović

Project Management in a VUCA World: Developing an Adaptive Leadership Style

Stefano Setti

Opredelitev kompetenčnega profila komercialista s pomočjo večkriterijske odločitvene metodologije

Definition of Sales Agent Competences Profile with Multi Attribute Decision Making Methodology

Stanka Solar, Uroš Rajkovič, Mojca Bernik

Measuring Deaccessioning in American Museums: A Structural

Equation Model / MIMIC Approach

Andrej Srakar, Marilena Vecco, Michele Piazzai, Miroslav Verbič

Multiple Chronic Conditions in Older People and Their Effects on

Health Care Utilization: A Network Analysis Approach Using

SHARE Data

Andrej Srakar, Valentina Prevolnik Rupel

The Impact of the Value Added Tax on the Business Performance of Companies

Bojana Starčević, Filip Žarkić

Dvig poklicnih kompetenc učiteljev z usposabljanjem v podjetju Improving the Vocational Competencies of Teachers with Training at the Enterprise

Gašper Strniša 
Pričakovanja zaposlenih $\mathrm{z}$ vidika opolnomočenja

Employee Expectations Towards Empowerment

Aleša Svetic

Vpliv izgube zaposlitve na ustanovitev lastnega podjetja

The Influence of Unemployment on Individual's Decision to Start up a Business

Aleša Svetic

Alkohol in psihoaktivne substance - vzrok za cestno prometne nesreče in cestno prometne prekrške

Alcohol and Psychoactive Substances: Causes of Traffic Accidents and Traffic Violations

Nevenka Šestan, Zvone Balantič, Metoda Dodič Fikfak

Vpliv oblike reaktorja na dezintegracijo odpadnega blata iz

čistilnih naprav

The Impact of Reactor Design on Disintegration of Waste Sludge

from Wastewater Treatment Plants

Marko Šetinc

Orodja kakovosti

1057

Quality Tools

Branko Škafar

Xerte 3.3 - pet let izkušenj z uporabo portala

Xerte 3.3 - Five Years of Experience in the Use of the Portal

Branislav Šmitek

Etika v kriznem menedžmentu

1075

Ethics in Crisis Management

Polona Šprajc, Domagoj Cingula, Iztok Podbregar

Kompetence ravnateljev, ki so pomembne za vodenje dijaških

1085

domov $v$ časih nenehnih sprememb

Competences of Headmasters Which are Important for

Management of Boarding Schools in Times of Constant Change

Saša Šterk

Podjetništvo v višjem šolstvu

1097

Entrepreneurship in Higher Vocational Education

Darko Števančec, Iris Fink Grubačević 
Vpliv standardov kakovosti na delo zaposlenih

The Influence of Quality Standards on Employees Work

Eva Šturm, Eva Krhač, Marcel Potrata

Implementation of Benchmarks in Investment Strategies of Pension Funds in SEE Region

Petar Taleski, Vasko Bogdanovski

Model za prediktivno vzdrževanje na proizvodnji liniji za

1141 avtomobilsko industrijo Predictive Maintenance Model for Automotive Production Line Jaka Toman, Vladislav Rajkovič, Mirjana Kljajić Borštnar

Slovensko španski Poslovni klub ECE Club de Negocios ECE

1151 España Canarias Eslovenia Slovenian Spanish Business Club ECE España Canarias Eslovenia Mladen Tomašič

Cyclical Characteristics of the Industrial Production in Croatia Daniel Tomić, Saša Stjepanović

Model zaposlovanja po opravljenem pripravništvu v zdravstveni negi Employment Model after Their Internship in Nursing Nina Trifoni, Vesna Novak

Diversification Effect of Investing in Gold

Dean Učkar, Ivan Budić

Kako postati ravnatelj osnovne šole

How to Become a Headmaster in Primary School Gregor Udovč

Ocena učinkovitosti prenove procesa na podlagi strukture procesa Assessment of Business Process Re-engineering Efficiency Based on Process Structure

Benjamin Urh, Eva Krhač, Matjaž Roblek, Tomaž Kern

Analiza spletnih strani za zaposlovanje s kadrovskega vidika Analysis of Web Sites for Employment from HR Perspective Marko Urh, Lea Zupan, Davorin Kofjač, Eva Jereb, 
Mexican SMEs in Organic Sector in the Asia Pacific Market:

Intarnationalization Strategies

José G. Vargas-Hernández, Ricardo Arechavala Vargas, Luz Alicia

Pulido García

Determining of Managerial Competencies: A Review of the Literature

Liridon Veliu, Mimoza Manxhari

Determinants of Domestic Value Added in EU Exports:

the Difference Between »new « and »core«

Member Countries

Nataša Vrh

Krožno gospodarstvo $\mathrm{v}$ slovenskih podjetjih

Circular Economy in Slovenian Companies

Petra Vujkovič, Polona Šprajc, Alenka Baggia

Why are Virtual Teams Perfect for Marketing?

Goran Vukovič, Miha Marič, Gašper Jordan

Strategija in kakovost visokega šolstva

Strategy and Quality of Higher Education

Borut Werber

The Role of Marketing Communications in Responsible

Organizations

Leposava Zecevic, Olgica Zecevic-Stanojevic, Ana Milenkovic

Urejanje managerskih plač v javnem sektorju

The Managers Salary in the Public Sector

Janez Zeni

Trajnostna družba prihodnosti, skozi kritični pregled trenutnega stanja

A Sustainable Society of the Future, through of a Critical Review of the Current Situation

Davorin Žnidarič

Percepcija zelenih informacijskih sistemov med slovenskimi managerji

Perception of Green Information System Concept among Slovenian Managers

Anja Žnidaršič, Alenka Brezavšček, Matjaž Maletič, Alenka Baggia, 
36. MEDNARODNA KONFERENCA O RAZVOJU ORGANIZACIJSKIH ZNANOSTI: OdgOVORNA ORGANIZACIJA (22. - 24. MAREC 2017, PorTOROŽ, SlOVENIJA)

O. Arsenijević, M. Ferjan, I. Podbregar, P. Šprajc, D. Trivan \& Y. Ziegler:

Kazalo

Ali imajo vodje in sledilci različen odnos do sprememb? Primer Gorenja, d.d.

Do Leaders and Followers Have Different Attitudes towards Change?

The Case of Gorenje, d.d.

Miha Žove 


36. MEDNARODNA KONFERENCA O RAZVOJU ORGANIZACIJSKIH ZNANOSTI:

OdgOVORNA ORGANIZACIJA (22. - 24. MAREC 2017, PORTOROŽ, SLOVENIJA)

O. Arsenijević, M. Ferjan, I. Podbregar, P. Šprajc, D. Trivan \& Y.

Ziegler

\section{Predgovor}

\section{IZTOK PODBREGAR}

Konferenca o razvoju organizacijskih znanosti je konferenca $\mathrm{z}$ najdaljšo tradicijo na Univerzi $\mathrm{v}$ Mariboru in vsako leto poveže študente, raziskovalce, gospodarstvenike in predstavnike javne uprave, ki delujejo na področju organizacije in managementa.

Tema letošnje, že 36. mednarodne konference o razvoju organizacijskih znanosti, je Odgovorna organizacija in se nanaša na širino organizacije v njenem notranjem in zunanjem okolju. Odgovornost do zaposlenih, poslanstva, strategije, procesov, tehnologije, razvoja so samo nekatera izmed področij, ki jim mora organizacija slediti. Identiteta organizacije se izkazuje $\mathrm{z}$ njenim vsestransko odgovornim ravnanjem in kaže vrednost navzven pri kupcih ali uporabnikih storitev. V času, ki ga živimo, smo vpeti $\mathrm{v}$ preplet tehnološkega in socialnega napredka, ki nenazadnje rezultira $\mathrm{v}$ posamezniku in družbi nasploh. Ravnanje organizacije se ravno tako ne veže samo na delovanje $\mathrm{v}$ lokalnem okolju temveč zaradi globalnih razsežnosti učinkuje tudi $\mathrm{v}$ mednarodnih dimenzijah. S temo konference želimo odpreti polje vprašanj in poiskati odgovore, ki bodo doprinesli $\mathrm{k}$ napredku organizacijskih ved. Materialni vplivi, komuniciranje, znanje in poštenje ter nenazadnje ideal odgovornega ravnanja lahko kot pomembni dejavniki obvladujejo pogosto nemirne situacije $\mathrm{v}$ in izven okolja naših organizacij. Ker smo časovno in prostorsko vpeti v vzorce, ki mnogokrat ne sledijo več našim preteklim izkušnjam, je naša želja, da s srečanjem na konferenci stopimo $\mathrm{v}$ korak $\mathrm{s}$ časom in prepoznamo dobre prakse, izoblikujemo nove metode in se seznanimo $\mathrm{z}$ aktualnimi trendi, ki jih organizacije vsakodnevno živijo.

\footnotetext{
NASLOV AVTORJA: dr. Iztok Podbregar, redni profesor, Univerza v Mariboru, Fakulteta za organizacijske vede, Kidričeva cesta 55a, 4000 Kranj, Slovenija, e-pošta: iztok.podbregar@fov.uni-mb.si
} 
$36^{\text {TH }}$ InTERnAtional CONFERENCE ON ORganizational SCIENCE DeVelopment: Responsible Organization (MARCH $22^{\mathrm{ND}}-24^{\mathrm{TH}}$, PORTOROŽ SLOVENIA)

O. Arsenijević, M. Ferjan, I. Podbregar, P. Šprajc, D. Trivan \& Y.

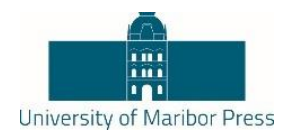

Ziegler

\section{Foreword}

\section{IZTOK PODBREGAR}

The conference on Organizational Sciences Development is a conference with the longest tradition at the University of Maribor. Each year, the conference brings together students, researchers, businessmen and public administration representatives, who are active in the area of organization and management.

The theme of this year's 36th international conference on Organizational Sciences Development is Responsible Organization referring to the wideness of an organization in its internal and external environment. The responsibility of the organization towards its employees, mission, strategy, processes, technology, and development are just a few areas in which the organization needs to follow the principles of responsibility. The identity of the organization is recognized through its versatile responsible activities, showing its value externally to the customers or recipients of the services offered by the organization. The concurrent mixture of technological and social progress influences individuals as well as the society. The impact of the organization is therefore not only local but global, making a mark on the international level. With this conference theme, we are opening new questions and seeking answers which could contribute to the progress of organizational sciences. Material influence, communications, knowledge, fairness, and nevertheless the ideal of responsible behaviour can be seen as influential factors which can contribute to occasional turbulent situations inside and outside our organizations. Since we are all caught up in moulded mind-sets, not following our experiences anymore, our wish was to keep up with the times and identify best practices, form new methods, and become familiar with the contemporary trends in organizations.

CORRESPONDENCE AdREss: Iztok Podbregar, Ph.D., Full Professor, University of Maribor, Faculty of Organizational Sciences, Kidričeva cesta 55a, 4000 Kranj, Slovenia, e-mail: iztok.podbregar@fov.uni-mb.si

DOI https://doi.org/10.18690/978-961-286-020-2.1

ISBN 978-961-286-020-2

(C) 2017 University of Maribor Press

Available at: http://press.um.si 


\title{
Strategija vključevanja načel ergonomije za doseganje optimalnega delovnega učinka pri delu $\mathrm{z}$ računalnikom
}

\author{
ZVONE BALANTIČ \& BRANKA BALANTIČ
}

Povzetek Pri delu z računalnikom pogosto pozabimo na vse negativne dejavnike, ki vplivajo na naše telo. Pri delu se pogosto dogaja, da smo preveč popustljivi do lastne nedoslednosti in prezremo nekatera načela ergonomije, ki bi jih morali upoštevati. Upoštevati moramo načelo pomembnosti, načelo frekvence, načelo funkcije in načelo sekvence.

Priporočljivo je oblikovati delovno mesto, ki je primerno za delo v sedečem in stoječem položaju. Pri pravilnem pozicioniranju telesa najprej človeku prilagodimo stol in šele nato sledi prilagajanje mize. Dinamične spremembe položaja telesa pri delu z računalnikom ugodno vplivajo na človeka in njegovo zdravje.

Različne antropološke dimenzije in spreminjanje položajev pri delu, zahtevajo uporabo sodobnih in cenenih tehničnih rešitev za prilagajanje soodvisnih sedežnih in delovnih površin.

Z uvajanje sedečega - stoječega dela močno zmanjšamo utrujenost telesa in izboljšamo kakovost pri opravljanju dela.

KLJUČNE BESEDE: ergonomija • sedeče-stoječe delovno mesto • absentizem • dinamično delo

\footnotetext{
NASLOV AVtORJev: dr. Zvone Balantič, redni profesor, Univerza v Mariboru, Fakulteta za organizacijske vede, Kidričeva 55a, 4000 Kranj, Slovenija, e-pošta: zvone.balantic@ fov.uni-mb.si; Branka Balantič, ŠC Kranj, Višja strokovna šola, Kidričeva 55, 4000 Kranj, Slovenija, e-pošta: branka.balantic@guest.arnes.si
} 
36 ${ }^{\text {TH }}$ International CONFEREnCE ON ORganizational Science DEVELOPMENT: ResPonsible ORGANIZATION (MARCH $22^{\mathrm{ND}}-24^{\mathrm{TH}}$, PORTOROŽ SLOVENIA)

O. Arsenijević, M. Ferjan, I. Podbregar, P. Šprajc, D. Trivan \& Y.

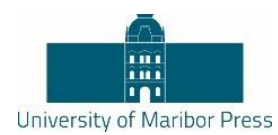

Ziegler

\title{
Strategy of Ergonomic Principles Integration for Optimal Performance Achievement of Working with Computer
}

\author{
ZVONE BALANTIČ \& BRANKA BALANTIČ
}

\begin{abstract}
When working with computer negative factors affecting our body are often ignored. At work, we are often not critical to our own inconsistency and we do not see some ergonomic principles that we should monitor. Principles of importance, frequency, function and sequence should be followed.
\end{abstract}

It is advised to design working place in such way that is suitable for sitting and standing working position. For appropriate sitting position, first chair is adapted to human followed by the adjustment of the desk. When working with a computer dynamic changes of body position have positive impact on human and health.

Different anthropological dimensions and changing positions at work demand utilization of modern and affordable technical solutions for adjustment of depended sitting and working surfaces.

With the introduction of sitting-standing working place human body exhaustion is reduced and quality of work is increased.

KEYWORDS: ergonomics • sit-stand workstation $\bullet$ absenteeism $\bullet$ dynamic work

CorResPondence AdDress: Zvone Balantič, Ph.D., Full Professor, University of Maribor, Faculty of Organizational Sciences, Kidričeva 55a, 4000 Kranj, Slovenia, e-mail: zvone.balantic@ fov.unimb.si; Branka Balantič, SC Kranj, Vocational College, Kidričeva 55, 4000 Kranj, Slovenia, e-mail: branka.balantic@guest.arnes.si 

ORGANIZACIJA (22. - 24. MAREC 2017, PORTOROŽ, SLOVENIJA)

Z. Balantič \& B. Balantič: Strategija vključevanja načel ergonomije za doseganje optimalnega delovnega učinka pri delu $\mathrm{z}$ računalnikom

\section{$1 \quad$ Uvod}

Vsakdo, ki želi svoje delo opravljati nemoteno in kakovostno, telesa ne sme preobremeniti. $\mathrm{V}$ takem primeru se telo ne more več pravočasno regenerirati in tako človek postane preveč izpostavljen obremenitvam. Lahko se pojavijo fiziološke in kognitivne motnje.

Človek pri svojem delu potrebuje prostor, v katerem se bo gibal in delo opravljal varno, brez posledic za svoje zdravje in zdravje drugih. Včasih je delo dokaj preprosto in od človeka ne zahteva dodatnih zaščitnih ukrepov, včasih pa so zaščitni ukrepi potrebni (rokavice, zaščitna obleka, pokrivala, maske ...). Zaradi izbrane delovne varovalne opreme (DVO) in osebne varovalne opreme (OVO) se lahko spremenijo razni pogoji za motorično aktivnost telesa (dosegi telesa, premiki telesnih segmentov, spremenjena kinetosfera, drugačni gibalni koti, zmanjšani moč in hitrost, povečan napor, nenatančnost ...) (Balantič, Z., Polajnar, A., Jevšnik, S., 2016). Delovni prostor, ki ga oblikujemo, mora ustrezati mnogim standardom in priporočilom. Brezkompromisno je treba upoštevati vsa priporočila glede varnosti in zdravja pri delu vseh delavcev, ki na teh mestih delajo, in vseh ljudi, ki bi se z neko drugo nalogo ali po naključju znašli na obravnavanem mestu. Zakonodaja zahteva, da so upoštevani vsi vplivi na varno in zdravo delo delavcev ter da so okolje, postopki, prostori, oprema in snovi primerni ter v skladu z namenom uporabe (Ur. 1. RS št.43/2011, 2011), (Health and Safety Commision, 2015).

Odrasli zaposleni opravljajo raznovrstne dejavnosti glede na njihove usposobljenosti in glede na njihove telesne sposobnosti. Človeško telo se ne stara premosorazmerno z leti, pač pa se vsaka življenjska funkcija spreminja različno glede na kumulativno časovno obdobje (Balantič, Z., Balantič, B., 2016). Ko omenjamo načela ergonomije, moramo imeti v mislih tudi zaposlene v različnih življenjskih obdobjih.

Dandanes živi skupaj več različnih generacij in vsaka od njih ima svoje značilnosti. Avtorji (Erjavšek, 2005) in (Goldman \& Schmalz, 2006), tipizirano delijo generacije na:

- veterane (rojeni med 1922 in 1945): spomini, vezani na krize pred, med in po drugi svetovni vojni; spoštujejo oblast, vodilne ljudi; dolžnosti postavijo na prvo mesto, šele nato užitek in zabavo; predani podjetju, kjer so zaposleni (živijo za delo); ne marajo sprememb; na tehnologijo gledajo kot na nekaj nujnega, ne toliko uporabnega;

- boomerje (t. i. otroci blaginje, rojeni med letoma 1946 in 1964): vzgojeni v obdobju optimizma, priložnosti in napredka (prvi televizorji, življenjski standard se je zvišal, krediti so bili vsakomur dosegljivi); gospodarska stabilnost, kulturni in socialni razmah; »vsi za enega, eden za vse«;

- X-erje (neXt - naslednji, rojeni med 1965 in 1980): padec iluzij; odraščali v senci povojne generacije; prva generacija, ki je odraščala ob obeh zaposlenih starših; otroci ločenih staršev; nasilje na TV-ju in ulici; droge; pozabljanje 
36 ${ }^{\mathrm{TH}}$ InTernational Conference ON ORganizational Science Development: RESPONSIBLE ORGANIZATION (MARCH $22^{\mathrm{ND}}-24^{\mathrm{TH}}$, PORTOROŽ SLOVENIA)

Z. Balantič \& B. Balantič: Strategy of Ergonomic Principles Integration for Optimal Performance Achievement of Working with Computer

tradicionalnih vrednot; najbolj raznolika generacija; zvesti so sebi, ne podjetju (ne živijo za delo, cenijo prosti čas); varnost si je treba ustvariti sam (z osebnim, strokovnim, finančnim razvojem); značilna visoka stopnja skeptičnosti;

- Y-arje (whY - zakaj, rojeni od 1981 do 2000): zelo številna generacija, saj so potomci boomerjev; otroci tehnološkega napredka, interneta; verjamejo, da je denar zato, da se potroši; samozavestni; iznajdljivi; podjetni; etnično in rasno zelo raznolika generacija; hočejo fleksibilne službe;

- Z-arje (rojeni po letu 2000): tehnologija jim je položena v zibelko; generacija, ki živi v nenehnem stresu; vsak ima svoj spletni profil (Facebook).

Različni ljudje, ki živijo in delajo $\mathrm{v}$ določenem prostoru, se srečujejo z določenimi antropometričnimi značilnostmi, kot so dosegi, razdalje in drža telesa. Racionalizacija pri postavitvi oziroma oblikovanju delovnega okolja je deloma domena antropometrije, deloma pa človeške presoje (Balantič, Z. in Balantič, B., 2014). Oblikovana so štiri načela, ki jih je prvič predstavil McCormick (McCormick, E. J., 1970). Ti principi so uporabni za velik del problematike oblikovanj delovnih okolij, kjer se sprašujemo "kaj dati kam?". Gre za razmišljanje o kontrolnih in kazalnih elementih, ki jih nameščamo za spremljanje in upravljanje procesov, kjer nastopi človek kot upravni sistem (kuhinje, stroji, trgovine, delavnice, baze podatkov, bolnice, banke ...) (Pheasant, S., Haslegrave, C. M., 2005). Ta načela so:

- načelo pomembnosti - najpomembnejši elementi morajo biti na najbolj dostopnih mestih;

- načelo frekvence - najbolj pogosto uporabljene stvari morajo biti na najbolj dostopnih mestih;

- načelo funkcije - stvari oziroma predmeti s podobnimi funkcijami morajo biti združeni v sklope;

- načelo sekvence - stvari, ki se običajno uporabljajo in pojavljajo v določenih zaporedjih, je treba umeščati v enakih zaporedjih.

Nekateri avtorji svoje zamisli opredelijo v okvire manjšega števila (4 ali 10) (Dan MacLeod LLC, 2016) (Middlesworth, M., 2016), drugi pa v okvir večjega števila ergonomskih načel (12) (Kermavnar, T., Dodič-Fikfak, M., 2013). V nadaljevanju bomo strategijo povezali $\mathrm{z}$ razmišljanji v okviru osmih ergonomskih načel (Balantič, Z., Polajnar, A., Jevšnik, S., 2016)

Pri analizi je treba predvideti nastanek poškodb in upoštevati morebitne negativne vplive na telo. Razmišljati je treba, kako izboljšati delo, da poškodbe ne nastanejo in da se jim tudi uspešno izognemo. 

ORGANIZACIJA (22. - 24. MAREC 2017, PORTOROŽ, SLOVENIJA)

Z. Balantič \& B. Balantič: Strategija vključevanja načel ergonomije za doseganje optimalnega delovnega učinka pri delu $\mathrm{z}$ računalnikom

Že dolgo je znano, da pri delu z računalnikom zelo pogosto pozabimo na vse negativne dejavnike, ki vplivajo na naše telo. Pri delu se zelo pogosto dogaja, da smo preveč popustljivi do lastne nedoslednosti. V času mobilnih tehnologij za resno delo najpogosteje izberemo prenosni računalnik, ki na račun kompaktnosti ne ustreza velikemu delu ergonomskih načel. Že v samem uvodu je potrebno poudariti, da je računalniško delovno mesto izjemno pogosto, vendar je tudi velikokrat neustrezno urejeno (Balantič, Z., 2000). Kljub temu, da nove tehnologije postajajo cenejše in so ustrezno vključene v konstrukcijske rešitve raznih naprav (stoli, mize, dodatna oprema, itd.), je uporaba teh dodatkov prevečkrat pogojena s stroški investicije. Neštetokrat so različni avtorji že dokazali, da je nakup ergonomske naprave pravzaprav investicija $\mathrm{v}$ zdravje človeka in ne strošek (Gauthy, R., 2009; Balantič Z. , 2012; Balantič, Z., Polajnar, A., Jevšnik, S., 2016).

\section{$2 \quad$ Metode in koncept}

$\mathrm{V}$ sedanjem času se je razširilo mnenje, da je sedenje "novo kajenje", s čemer izpostavljamo perečo problematiko sodobnega sveta. Strokovnjaki in znanstveniki opozarjajo, da nas pretirano sedenje ubija in povzroča nešteto zahrbtnih bolezni (rak, srčno-žilne bolezni in diabetes tip II)(Simons, C. C. J. M. et al., 2013; Patel, A. V. et al, 2010). Primerjava s kajenjem je primerna zato, ker $s$ tem poudarimo nepovračljivost procesa. Kronična obstruktivna pljučna bolezen (KOPB) je bolezen, kjer cigaretni dim poškoduje male dihalne poti in povzroči bronhiolitis in pljučni emfizem. Vse to vodi do trajnih sprememb na pljučih in do postopne zapore dihalnega sistema (Balantič, Z., Fležar, M., 2004). Dolgotrajno sedenje povzroči tudi nepopravljivo škodo našemu srčnožilnemu sistemu z okvarami venskih zaklopk, s preobremenitvami srca, s statičnimi obremenitvami mišičnega sistema itd. Na svetu je nepregledna množica uničevalcev zdravega načina življenja $\mathrm{v}$ obliki ergonomsko neprilagojenih elektronskih naprav. Avtomatizacija postaja sovražnik telesnega gibanja. Urbano človeštvo je praktično obsedelo, kar terja velik davek pri zdravju ljudi. Ljudje sedimo v službah - v pisarnah za računalnikom, $v$ avtomobilih in na kavču pred televizorjem. Tako, kot pri kajenju, lahko tudi v tem primeru vedenjske navade korenito spremenimo. Za te spremembe je potrebno spremeniti naše zavedanje o tveganjih, ki jih prinaša pretirano sedenje, potreben pa je tudi poseg v tehnični del vključevanja ergonomije za doseganje boljšega in predvsem manj tveganega delovnega učinka pri delu $\mathrm{z}$ računalnikom. Sedeče delo je pretežno statično, zato ga je potrebno čim bolj dinamizirati. Če hočemo doseči to spremembo, je potrebno zagotoviti še tehnično podporo za omogočanje stoječega dela. Tudi samo stoječe delo ima kar nekaj slabosti, saj statični tlak v telesu povzroči tudi nekatere nevšečnosti, ki s pretiravanjem prerastejo $v$ tveganja za zdravje (boleče noge, trde mišice, tremor, bolečine $\mathrm{v}$ križnem predelu hrbtenice itd.). Logični zaključki vodijo v smer zagotavljanja dinamičnih sprememb položajev pri delu.

Če želimo urediti sedeče delovno mesto, moramo poznati gabarite telesa in delovnega okolja v katerem opravljamo delo. V dane okvire moramo namestiti stol in mizo. Ključno je, da pri pravilnem umeščanju telesa najprej človeku prilagodimo stol in šele nato sledi prilagajanje mize. V praksi še vedno preredko srečamo konstrukcijske možnosti miz, ki 
36 $6^{\mathrm{TH}}$ InTernational Conference on ORganizational Science Development: Responsible Organization (MARCh $22^{\mathrm{ND}}-24^{\mathrm{TH}}$, Portorož Slovenia)

Z. Balantič \& B. Balantič: Strategy of Ergonomic Principles Integration for Optimal Performance Achievement of Working with Computer

bi omogočale različne nastavitve, zato nam miza narekuje pogoje za prilagoditve stola in telesa. Seveda je ta pristop popolnoma napačen.

Ugotavljamo, da gibajoče se telo prinaša fiziološke in finančne koristi:

- zmanjšajo se odsotnosti z dela zaradi posameznih incidentov, ki izvirajo iz neprilagojenih delovnih mest.

- zmanjša se občutek neugodja in neudobja, bolečine popustijo, poškodbe pa postanejo zelo redke,

- poveča se stopnja koncentracije pri delu, ob tem pa se dviga samozavest,

- opazno je znatno zmanjšanje bolniške odsotnosti (tudi do 40\%) (OSHA, 2016),

- zmanjšanje prezentizma in absentizma prinaša izjemne prihranke

- itd.

Analiza stroškov in koristi (ASK; angl. Cost Benefit Analiza - CBA), je jasna, saj je vložek v nakup električne dvižne mize (pogon z elektromotorji) od $520 €$ naprej, kar bi ob stroških absentizma (cca. $45 €$ na mesec) pomenilo dobrih 11 mesecev.

Zaradi zdravstvenega absentizma je bilo v Sloveniji v letu 1994 izgubljenih 12,7 milijona delovnih dni, v letu 2015 pa 9.836 .115 delovnih dni, kar je sicer dobrih 2 milijona dni manj, vendar številka še vedno predstavlja velik družbeni, organizacijski, socialni in ekonomski problem (slika 1) (NIJZ, 2017). 
36. MEDNARODNA KONFERENCA O RAZVOJU ORGANIZACIJSKIH ZNANOSTI: ODGOVORNA ORgANIZACIJA (22. - 24. MAREC 2017, PORTOROŽ, SlOVENIJA)

Z. Balantič \& B. Balantič: Strategija vključevanja načel ergonomije za doseganje optimalnega delovnega učinka pri delu $\mathrm{z}$ računalnikom

\begin{tabular}{|c|c|c|c|}
\hline \multirow{2}{*}{ OBMOČJE ZZZS } & \multicolumn{3}{|c|}{ ODSTOTEK BOLNIŠKEGA STALEŽA (\% BS) } \\
\hline & SKUPAJ & $\begin{array}{lr}\mathrm{V} & \text { BREME } \\
\text { DELODAJALCEV }\end{array}$ & V BREME ZZZS \\
\hline CELJE & 5,1 & 2,5 & 2,6 \\
\hline NOVA GORICA & 4,1 & 2,2 & 2,0 \\
\hline KOPER & 4,3 & 2,1 & 2,2 \\
\hline KRANJ & 3,7 & 1,9 & 1,8 \\
\hline LJUBLJANA & 3,4 & 1,6 & 1,8 \\
\hline MARIBOR & 4,7 & 2,3 & 2,4 \\
\hline MURSKA SOBOTA & 5,7 & 2,3 & 3,4 \\
\hline NOVO MESTO & 4,5 & 2,2 & 2,3 \\
\hline RAVNE NA KOROŠKEM & 5,6 & 2,1 & 3,5 \\
\hline KRŠKO & 6,0 & 2,9 & 3,1 \\
\hline S L O VENIJA & 4,2 & 2,0 & 2,2 \\
\hline
\end{tabular}

Slika 1: Odstotek bolniškega staleža v obdobju januar - december 2016 (NIJZ, 2017)

Pomenljiv je tudi pogled na količino sredstev, ki jih je Zavod za zdravstveno zavarovanje Slovenije (ZZZS) namenil za poplačilo bolniških odsotnosti v letih od 2008 do 2015 (slika 2).

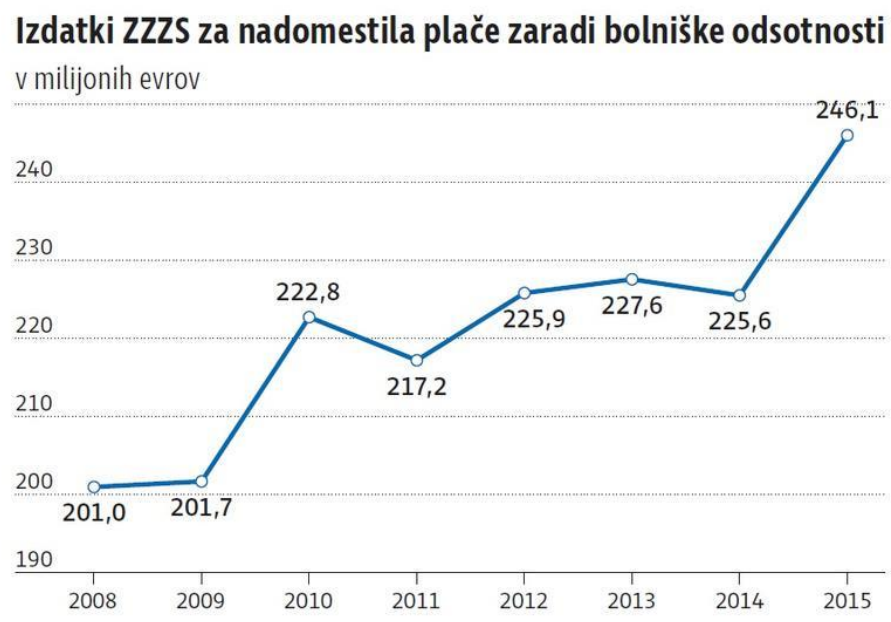

Slika 2: Izdatki ZZZS za nadomestila plač zaradi bolniške odsotnosti (DELO infografika, 2016)

Če želimo zmanjšati odsotnost delavcev zaradi absentizma je priporočljivo ukrepati na področju izboljšanja pogojev, ki povzročajo kostno-mišične težave in kronična obolenja. 
$36^{\mathrm{TH}}$ International Conference on ORganizational Science Development: RESPONSIBLE ORGANIZATION (MARCH $22^{\mathrm{ND}}-24^{\mathrm{TH}}$, PORTOROŽ SLOVENIA)

Z. Balantič \& B. Balantič: Strategy of Ergonomic Principles Integration for Optimal Performance Achievement of Working with Computer

Osredotočamo se na uporabo kombiniranih delovnih mest, vendar je prehod na to obliko delovnih mest lahko postopen (slika 3).

\begin{tabular}{|l|c|c|c|}
\hline Vrsta dela & $\begin{array}{c}\text { Sedeče delovno } \\
\text { mesto }\end{array}$ & $\begin{array}{c}\text { Stoječe delovno } \\
\text { mesto }\end{array}$ & $\begin{array}{c}\text { Kombinirano } \\
\text { delovno mesto }\end{array}$ \\
\hline Natančno delo (fina dela) & $\checkmark$ & $\boldsymbol{x}$ & $\checkmark$ \\
\hline Stresno delo & $\checkmark$ & $\checkmark$ & $\checkmark$ \\
\hline Koncentrirano delo & $\boldsymbol{x}$ & $\checkmark$ & $\checkmark$ \\
\hline Vsakdanje delo & $\checkmark$ & $\boldsymbol{x}$ & $\checkmark$ \\
\hline Če ste fizično aktivni več kot 5 ur tedensko & $\boldsymbol{x}$ & $\checkmark$ \\
\hline $\begin{array}{l}\text { Ce ste fizično aktivni manj kot 5 ur } \\
\text { tedensko }\end{array}$ & $\boldsymbol{x}$ & $\checkmark$ & $\checkmark$ \\
\hline $\begin{array}{l}\text { Ce ob mizi pri delu preživite več kot 5 ur } \\
\text { na dan }\end{array}$ & $\checkmark$ & $\boldsymbol{x}$ & $\checkmark$ \\
\hline $\begin{array}{l}\text { Če ob mizi pri delu preživite manj kot 5 ur } \\
\text { na dan }\end{array}$ & $\boldsymbol{x}$ & $\checkmark$ & $\checkmark$ \\
\hline Sodelovanje s sodelavci & $\boldsymbol{x}$ & $\checkmark$ & $\checkmark$ \\
\hline Dodatno zgorevanje energije (100 cal/dan) & & & \\
\hline
\end{tabular}

Slika 1: Priporočljiva izvedba delovnega mesta.

\section{$3 \quad$ Rezultati}

Sedeče-stoječe delovno mesto moramo prilagajati različnim antropometričnim dimenzijam ljudi, katerim je to delovno mesto namenjeno. Višine delovne površine lahko prilagodimo $\mathrm{z}$ brezstopenjskimi nastavitvami in to za vse vrste dela in za vsakega človeka posebej (običajno elektromotorni pogon). Če se skušamo orientirati glede nakupa dvižnih miz, kjer bomo omogočili sedeče delo, stoječe delo in kombinirano sedeče-stoječe delo, potem izberemo naslednja območja nastavljivih višin delovne površine (slika 4):

- Nastavljiva višina delovne površine pri sedečem delu:

- minimalno: $635 \mathrm{~mm}$ - $762 \mathrm{~mm}$ (razpon: $127 \mathrm{~mm}$ )

- optimalno: $558 \mathrm{~mm}-838 \mathrm{~mm}$ (razpon: $280 \mathrm{~mm}$ )

- Nastavljiva višina delovne površine pri stoječem delu:

- minimalno: $965 \mathrm{~mm}$ - $1066 \mathrm{~mm}$ (razpon: $101 \mathrm{~mm}$ )

- optimalno: $889 \mathrm{~mm}$ - $1194 \mathrm{~mm}$ (razpon: $305 \mathrm{~mm}$ )

- Nastavljiva višina delovne površine pri sedeče-stoječem delu:

- minimalno: $660 \mathrm{~mm}$ - $1016 \mathrm{~mm}$ (razpon: $101 \mathrm{~mm}$ )

- optimalno: $558 \mathrm{~mm}$ - $1194 \mathrm{~mm}$ (razpon: $305 \mathrm{~mm}$ ) 
Z. Balantič \& B. Balantič: Strategija vključevanja načel ergonomije za doseganje optimalnega delovnega učinka pri delu $\mathrm{z}$ računalnikom
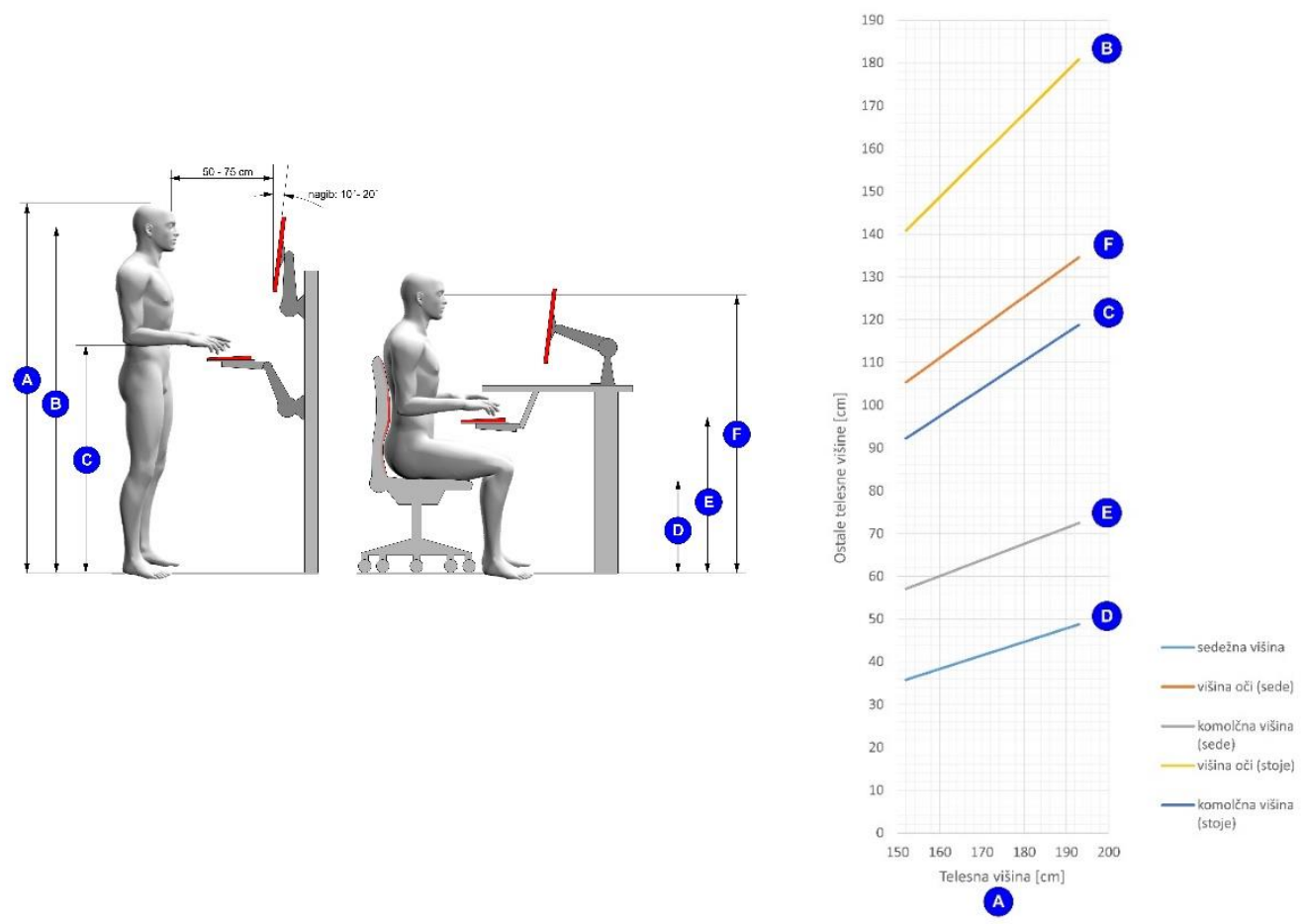

Slika 2: Priporočljive višine za sedeče in stoječe delo.

Ko načrtujemo delo v različnih položajih telesa (sedeče, stoječe, sedeče-stoječe), nam pravilni izbor ponuja tudi ustrezne dosege rok na takih površinah (Napaka! Vira sklicevanja ni bilo mogoče najti.) Načeloma želimo delo opraviti v zelenem področju (V - visoka prioriteta), nato $\mathrm{v}$ rumenem področju (srednja prioriteta) in v rdečem področju, kamor z dosegom rok najredkeje posežemo (nizka prioriteta). 
$36^{\mathrm{TH}}$ InTERnAtional CONFERENCE ON ORganizational SCIENCE DeVElopment: RESPONSIBLE ORGANIZATION (MARCH $22^{\mathrm{ND}}-24^{\mathrm{TH}}$, PORTOROŽ SLOVENIA)

Z. Balantič \& B. Balantič: Strategy of Ergonomic Principles Integration for Optimal

Performance Achievement of Working with Computer

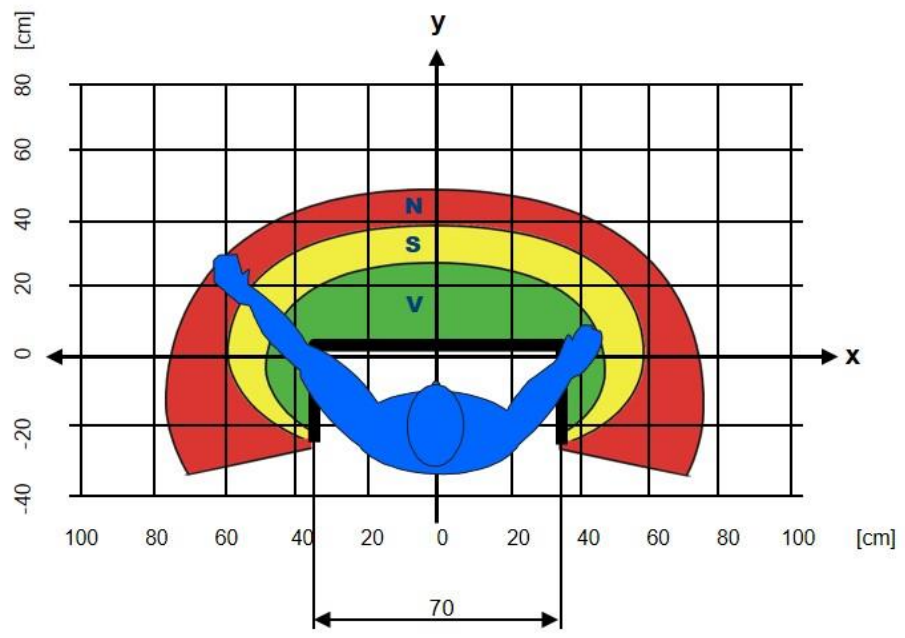

Slika 5: Področja dosegov na horizontalni površini (tloris).

\section{4}

\section{Razprava in zaključek}

Pri gibanju se kri skozi telo (predvsem noge) pretaka tudi ob aktivni pomoči mišic, ki ob krčenju stiskajo vensko ožilje. Vsak stisk mišice tako pomaga ustvarjati tlačno razliko, ki je potrebna za transport krvi proti srcu (Balantič, Z., Polajnar, A., Jevšnik, S., 2016) in prav zato je kombinirano delovno mesto (stoječ-sedeč položaj) eno od najboljših rešitev za izogibanje morebitnim težavam $\mathrm{v}$ gibalih in $\mathrm{v}$ hrbtenici. Najrazličnejše sodobne tehnične rešitve nam omogočajo uresničevanje zastavljenih načrtov, ko mizo lahko nastavljamo po višini za 300 do $400 \mathrm{~mm}$, ko temu sledimo z nagibnim in tudi po višini nastavljivim stolom, in ko si pomagamo s sledilnimi podporami za podlaket in ko tako lahko neovirano vodimo miško po delovni površini itd. Dvigovanja lahko omogočamo z uporabo električnih servomotorjev, plinsko vzmetnimi mehanizmi ali s pomočjo mehanskih vzvodov. V našem okolju najdemo vse več podjetij, ki sprejemajo stoječesedeče delo kot standard, kar je seveda razveseljivo. Žal pa preslabo poskrbimo za naša domača delovna okolja, kjer zelo redko najdemo kombinirana delovna mesta. Posebna kategorija pa so izobraževalne ustanove, kjer so od realizacije teh idej še dokaj oddaljeni.

Stoli, na katerih danes neprimerno več sedimo, kot smo včasih, so z leti postali zelo prilagodljivi fiziološkim lastnostim človeka. Trde podlage togih sedišč so zamenjale prilagodljive sedežne površine $\mathrm{z}$ raznovrstnimi nastavitvami in nastavljivimi upornostmi pri njihovem nagibanju, kar omogoča aktivno podporo telesa. Danes je na delovnem mestu pogosto $v$ uporabi t. i. ergonomska podlaga, ki razbremenjuje stopala človeka. Najnovejša tehnologija nam postreže $\mathrm{z}$ inovativnimi rešitvami, kot je npr. stol brez sedišča (angl. chairless chair) (Audi, 2016). Do vseh teh rešitev prihajajo inovatorji po svetu z upoštevanjem načel ergonomije (Balantič, Z., Polajnar, A., Jevšnik, S., 2016). 

ORGANIZACIJA (22. - 24. MAREC 2017, PORTOROŽ, SLOVENIJA)

Z. Balantič \& B. Balantič: Strategija vključevanja načel ergonomije za doseganje optimalnega delovnega učinka pri delu $\mathrm{z}$ računalnikom

Stanje na tem področju se bo drastično spremenilo, ko bodo managerji v slovenskih podjetjih razumeli kaj pomeni živeti ergonomijo.

\section{Literatura}

Audi. (2016). Chairless Chair for improved ergonomics in Audi's production plants. Pridobljeno iz https://www.audi-mediacenter.com/en/press-releases/chairless-chair-for-improvedergonomics-in-audis-production-plants-392

Balantič, Z. (2000). Človek - delo - učinek. Kranj: Moderna organizacija.

Balantič, Z. (2012). Sistemski pogled na ergonomijo. Delo in varnost; revija za varstvo pri delu in varstvo pred požarom, 48-54.

Balantič, Z. in Balantič, B. (2014). Ergonomska kultura za starajočo se delovno silo v informacijski družbi. Vzgoja in izobraževanje v informacijski družbi - VIVID 2014 (str. 32-40). Ljubljana: Fakulteta za organizacijske vede. Pridobljeno iz http://vivid.fov.uni-mb.si/sites/vivid.fov.unimb.si/files/IS2014web.pdf

Balantič, Z., Balantič, B. (2016). Integracija fiziologije starejših zaposlenih v strategijo Evrope 2020. 35th International Conference on Organizational Science Development (str. 41-55). Portorož: Moderna organizacija.

Balantič, Z., Fležar, M. (2004). Pregled delovanja dihalnega sistema. Kranj: Moderna organizacija.

Balantič, Z., Polajnar, A., Jevšnik, S. (2016). Ergonomija v teoriji in praksi. Ljubljana: Nacionalni inštitut za javno zdravje.

Balantič, Z., Polajnar, A., Jevšnik, S. (2016). Ergonomski izzivi (elektronska publikacija). Ljubljana: Nacionalni inštitut za javno zdravje.

Dan MacLeod LLC. (2016). 10 Principles of Ergonomics. Pridobljeno iz http://www.danmacleod.com/ErgoForYou/10_principles_of_ergonomics.htm

DELO infografika. (26. november 2016). Ikonomija. Pridobljeno iz Zaradi bolniških odsotnosti izgubljenih 9.836.115 dni: http://svetkapitala.delo.si/ikonomija/zaradi-bolniskih-odsotnostiizgubljenih-9-836-115-dni-435

Erjavšek, B. (2005). Generacije pri delu - Vodenje Veteranov, Bumerjev, Xerjev in Yerjev. Revija Kadri, 58-59.

Gauthy, R. (2009). Mišično-kostne bolezni, slabo razumljena »pandemija«. Evropski sindikalni inštitut ETUI-REHS, Oddelek za varnost in zdravje pri delu HESA.

Goldman, K., \& Schmalz, K. (2006). Buiders, Boomrs, Buster, Bridgers: Vive la (Generational) Difference! Health Promotion, 7, 159-161.

Health and Safety Commision. (2015). Managing health and safety, Construction (Design and Management) Regulations 2015. London: Crown.

Kermavnar, T., Dodič-Fikfak, M. (2013). Oblikovanje po meri človeka. Ljubljana: UKC Ljubljana, Klinični inštitut za medicino dela, prometa in športa in UL, Akademija za likovno umetnost in oblikovanje.

McCormick, E. J. (1970). Human Factors Engineering. New York: McGraw-Hill.

Middlesworth, M. (2016). Ergonomics plus. Pridobljeno iz 8 Fundamental Ergonomic Principles for Better Work Performance: http://ergo-plus.com/fundamental-ergonomic-principles/

NIJZ. (2017). NIJZ: Podatkovni portal. Pridobljeno iz Kazalniki po količini bolniškega staleža po območjih ZZZS: https://podatki.nijz.si/

OSHA. (jan 2016). Portal za varnost in zdravje pri delu. Pridobljeno iz Starejši in VZD: https://www.google.si/url?sa=t\&rct=j\&q=\&esrc=s\&source=web\&cd=1\&cad=rja\&uact=8\&ve $\mathrm{d}=0$ ahUKEwjSoaW_4srKAhWMEywKHbotC_EQFggaMAA\&url=http\%3A\%2F\%2Fwww.o 
$36^{\mathrm{TH}}$ International Conference on Organizational Science Development: Responsible Organization (MARCh $22^{\mathrm{ND}}-24^{\mathrm{TH}}$, Portorož Slovenia)

Z. Balantič \& B. Balantič: Strategy of Ergonomic Principles Integration for Optimal Performance Achievement of Working with Computer

sha.mddsz.gov.si\%2Fresources\%2Ffiles\%2FSlovenija_Kraja.pptx\&usg=AFQjCNHvNQr446 4xjR9q4f8vrwhqtqbVyA

Patel, A. V. et al. (2010). Leisure Time Spent Sitting in Relation to Total Mortality in a Prospective Cohort of US Adults. American Journal of Epidemiology, 172 (4): 419-429.

Pheasant, S., Haslegrave, C. M. (2005). Bodyspace: Anthropometry, Ergonomics and the Design of Work, Third Edition. London: Taylor \& Francis Ltd.

Polajnar, A., Verhovnik, V. (2007). Oblikovanje dela in delovnih mest. Maribor: Fakulteta za strojništvo.

Simons, C. C. J. M. et al. (2013). Physical Activity, Occupational Sitting Time, and Colorectal Cancer Risk in the Netherlands Cohort Study. American Journal of Epidemiology, 177 (6): 514-530.

Ur. 1. RS št.43/2011. (2011). Uradni list Republike Slovenije. Pridobljeno iz Zakon o varnosti in zdravju pri delu (ZVZD-1): http://www.uradni-list.si/1/objava.jsp?sop=2011-01-2039 
$36^{\text {Th }}$ International Conference on Organizational Science DEVElopMENT: Responsible ORganization (MARCH $22^{\mathrm{ND}}-24^{\mathrm{TH}}$, PORTOROŽ SLOVENIA)

O. Arsenijević, M. Ferjan, I. Podbregar, P. Šprajc, D. Trivan \& Y.

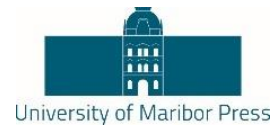

Ziegler

\title{
Big Data and the R Programming Language
}

\author{
IGOR BANJAC, DRAGAN VUKMIROVIĆ \& MARINA JOVANOVIĆ MILENKOVIĆ
}

\begin{abstract}
Big Data is a term that we have, in recent years, become accustomed to. New benefits of Big Data analytics are being discovered on a daily basis, and up to now, those benefits are far outweighing the drawbacks. As the amount of data being collected keeps rising at an unprecedented pace, so are the tools for analyzing, visualizing and predicting being perfected and invented. In recent years, the $\mathrm{R}$ programming language has emerged as a powerful tool for visualization (using packages such as ggplot2, written by Hadley Wickham), data wrangling (cleaning the data to extract useful information) and exploratory data analysis (getting insights from data). This paper will give an overview of Big Data, the R programming language and will give an example of the power of $\mathrm{R}$ using the hflights $\mathrm{R}$ package which contains the data about more than two hundred thousand flights out of Houston in 2011
\end{abstract}

KEYWORDS: big data $\bullet$ R programming language $\bullet$ ggplot2

CORRESPONDENCE AdDRESS: Igor Banjac, Belgrade Business School, Ulica Kraljice Marije 73, 11000 Belgrade, Serbia, e-mail: igor.banjac@yahoo.com; Dragan Vukmirović, University of Belgrade, Faculty of Organisational Sciences, 154 Jove Ilića Street, 11000 Belgrade, Serbia, email: vukmirovic.dragan@fon.bg.ac.rs; Marina Jovanović Milenković, University of Belgrade, Faculty of Organisational Sciences, 154 Jove Ilića Street, 11000 Belgrade, Serbia, e-mail: marinaj@fon.bg.ac.rs

DOI https://doi.org/10.18690/978-961-286-020-2.3

ISBN 978-961-286-020-2

(C) 2017 University of Maribor Press

Available at: http://press.um.si 
36 ${ }^{\mathrm{TH}}$ InTernational Conference ON ORganizational Science Development: RESPONSIBLE ORGANIZATION (MARCH $22^{\mathrm{ND}}-24^{\mathrm{TH}}$, PORTOROŽ SLOVENIA)

I. Banjac, D. Vukmirović \& M. Jovanović Milenković: Big Data and the R Programming Language

\section{Introduction}

The Big Data phenomenon has slowly, but surely, been gaining momentum in the last two decades. Huge amounts of data being collected at every corner have sparked an evolution of methods and ways of storing, processing, manipulating, and analyzing data. As soon as major IT companies had infered how collecting, cleaning, and analyzing large amounts of data yield valuable insights into how business ventures could be improved, so did all the other follow. Nowadays, almost every single industry is using Big Data technologies to improve their performance, from banks, retailers, to healthcare organisations.

As the quantity of data that were being collected was skyrocketing, so were the new software tools being invented and perfected. Among many of the free data analysis software packages that are available today, this paper will focus on the $\mathrm{R}$ programming language and environment for statistical computing and graphics, which has been on the rise in recent years.

\section{$2 \quad$ Big Data}

The term Big Data was first mentioned in a paper from 1997 by two NASA scientists while trying to describe difficulties of displaying datasets too large to be stored in a computer's main memory $[1,2]$. Today, it refers to datasets so large that they cannot be stored, managed or analyzed by traditional means $[3,4]$.

The three main characteristics of Big Data (also known as $3 \mathrm{Vs}$ ) are volume, velocity and variety [5].

Volume - the amount of data being created today is staggering. In 2010, Eric Schmidt, executive chairman of Google, stated that every day now we create as much data, as was created from the beginning of human civilization to the year 2003. This pretty much coincides with claims that in 2008 the world's servers processed 9.57 zettabytes of information [6].

Velocity - the speed at which new data is being created and stored rises exponentially. In 2011 every 60 seconds there were 510000 posted comments on Facebook, 293000 status updates, and 136000 uploaded photos [7]. In 2016300 hours of video were uploaded to YouTube every minute [8], and there were 58 million tweets on Twitter per day on average [9].

Variety - the sources of the data being collected, as well as the data themselves are more diverse than ever. Today they come in form of messages, updates, posts, videos, and images posted on social networks, logs, records of online shopping, GPS signals and locations from mobile phones, biometric data and vital parameters from smart watches and sensors just to mention some. 
In 2016, Josh James, the founder and CEO of Domo, gave his view on the amount of data being collected per minute (Image 1) which can be seen as a clear example of 3 Vs.

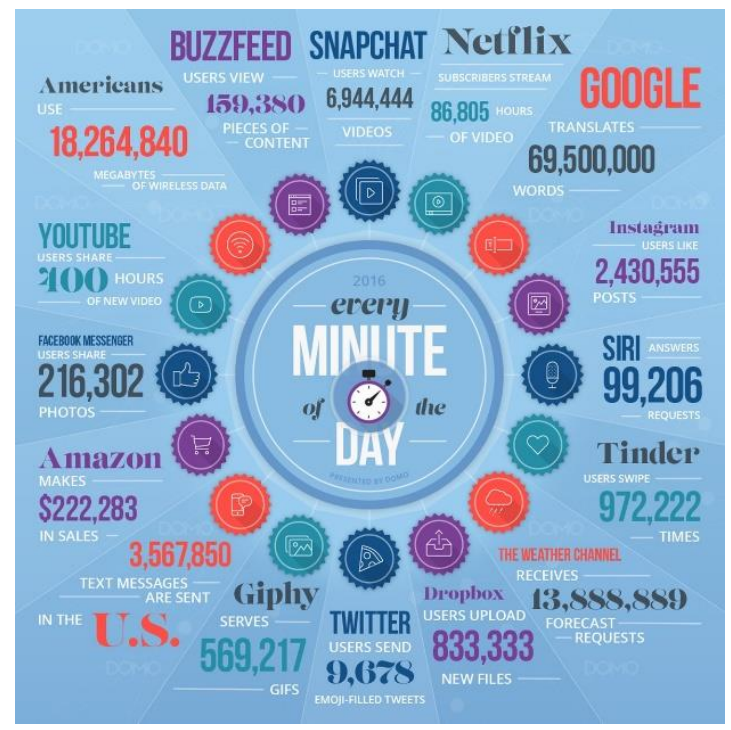

Image 1: On the internet in one minute

However, over $80 \%$ of data collected are unstructured data, which means that they cannot be analyzed in their current form. These are usually videos, photos, audio files, text documents and many other kinds of business documents. Even though these sort of files may have an internal structure, they are still considered unstructured because the data they contain don't fit neatly in a database. The data which don't reside in a relational database, but have organizational properties that are then easier to analyze are called semi structured data and they make up to about $10 \%$. Finally, structured data represent only $5 \%$ to $10 \%$ of all data. They can be stored in a SQL database with rows and columns and can be easily manipulated and analyzed [10].

\section{$3 \quad$ Data science and its tools}

With vast amounts of data now available, companies in almost every industry are focused on exploiting data for competitive advantage. At the same time, computers have become more powerful, and algorithms that can connect datasets to enable broader and deeper analyses than previously possible have been developed. The convergence of this phenomenon has given rise to the increasingly widespread business application of data science [11]. Generally, data science is the application of qualitative methods to solve relevant problems and predict outcomes [12]. 
$36^{\mathrm{TH}}$ InTERnATIONAL CONFERENCE ON ORganizational SCIENCE DeVElopment: RESPONSIBLE ORGANIZATION (MARCH $22^{\mathrm{ND}}-24^{\mathrm{TH}}$, PORTOROŽ SLOVENIA)

I. Banjac, D. Vukmirović \& M. Jovanović Milenković: Big Data and the R Programming Language

At the moment, data scientists are very much in demand. McKinsey Global Institute predicts a shortage of 140,000 to 190,000 data scientists in United States alone [13], while Harvard Business Review even went thus far to call it "the sexiest job of the 21 st century" [14].

There are many data science tools available today, but this paper will focus on $\mathrm{R}$, the leading tool for analytics, data mining, data science and machine learning projects according to 17 th annual KDnuggets software poll [15].

\section{$4 \quad$ The $R$ programming language and hflights dataset}

$\mathrm{R}$ is an open-source programming language and an environment for statistical computing and graphics [16], and is highly extensible. Its main strength lies in more than 9,000 highly specialized packages, of which some of the most notable are:

- dplyr - for data manipulation [17]

- tidyr - for data tidying [18]

- stringr - for working with strings [19]

- ggplot2 - for data visualization [20, 21]

Since at least $80 \%$ of data collected are unstructured, the first task, and also the least enjoyable one, is to clean and prepare the data for analysis. Data preparation is not just the first step, but must be repeated many times over the course of analysis as new problems come to light or new data are collected. It is often said that $80 \%$ of data analysis is spent on the process of cleaning and preparing the data [22]. The main goal is to obtain tidy datasets.

Tidy datasets are easy to manipulate, model and visualize, and have a specific structure: each variable is a column, each observation is a row, and each type of observational unit is a table. This framework makes it easy to tidy messy datasets because only a small set of tools is needed to deal with a range of un-tidy datasets [23].

$\mathrm{R}$ package hflights is a data only package containing records for commercial domestic flights that departed Houston in 2011 [24], a total of 227496 observations (rows) of 21 variables (columns). 
I. Banjac, D. Vukmirović \& M. Jovanović Milenković: Big Data and the R Programming Language

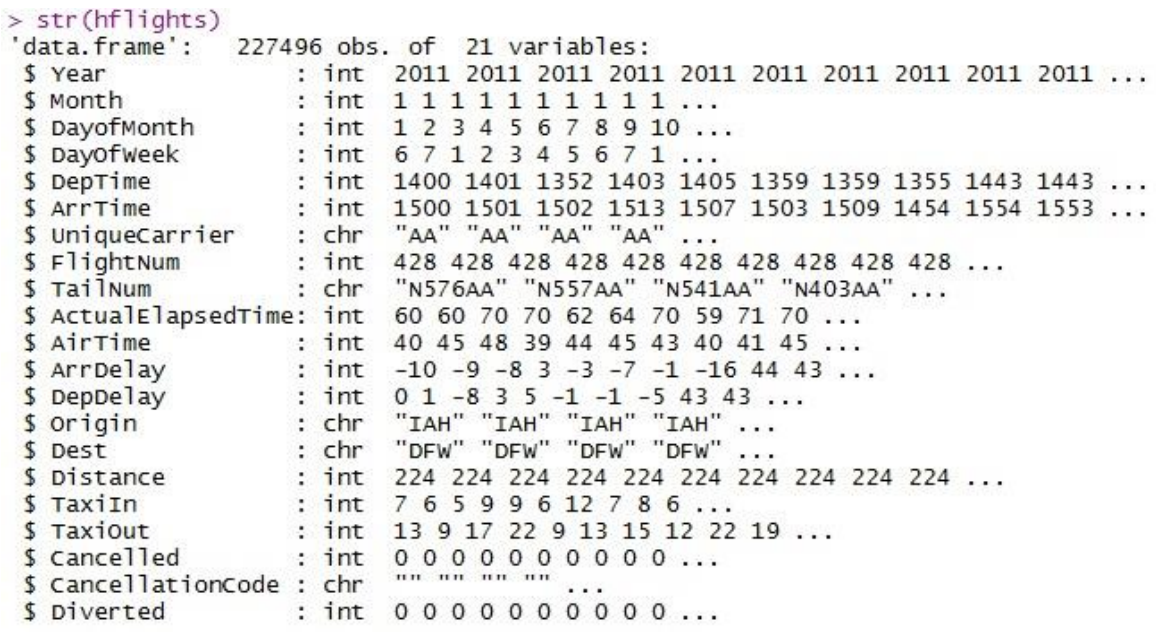

Image 2: Structure of hflights dataset 
$36^{\mathrm{TH}}$ InTERnAtional CONFERENCE ON ORganizational SCIENCE Development: RESPONSIBLE ORGANIZATION (MARCH $22^{\mathrm{ND}}-24^{\mathrm{TH}}$, PORTOROŽ SLOVENIA)

I. Banjac, D. Vukmirović \& M. Jovanović Milenković: Big Data and the R Programming Language

For easier manipulation, the following things will be done:

\# changing type of UniqueCarrier variable from integer to factor (categorical variable)

$>$ hflights\$UniqueCarrier <- as.factor(hflights\$UniqueCarrier)

\# changing type of DayOfWeek variable to factor (categorical variable)

$>$ hflights\$DayOfWeek <- as.factor(hflights\$DayOfWeek)

\# adding a new variable FlightDate composed of 3 existing variables

> FlightDate <- paste(hflights\$Year, hflights\$Month, hflights\$DayOfMonth, sep = “_“)

\# appending new FlightDate variable hflights and assigning it to dataset called "data" \# using the cbind function (bind by columns)

$>$ data <- cbind(hflights, FlightDate)

\# using dplyr's select function (selects desired columns), filter function (keeps rows matching

\# criteria) and the pipe operator to create a subset of "data" with all flights delayed on arrival \# and at the end assign it as well to "data"

$>$ data $\%>\%$

data $\%>\%$

select(DayOfWeek, UniqueCarrier, ArrDelay, DepDelay, Airtime, FlightDate) $\%>\%$

filter(ArrDelay > 0)

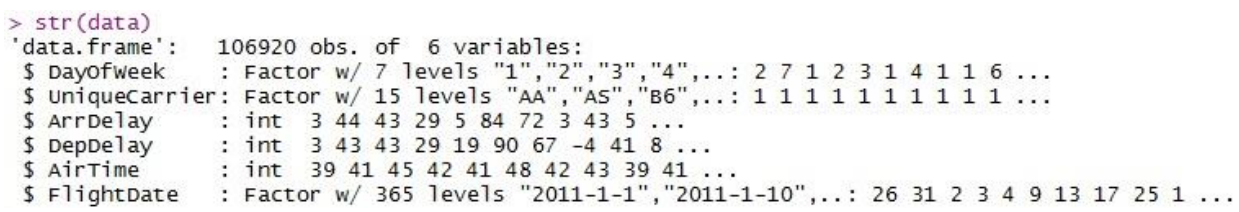

Image 3: A subset of hflights containing all flights delayed on arrival

$\begin{array}{lll}\text { summary(data) } & \\ \text { Dayofweek } & \text { Uniquecarrier } \\ 1: 16771 & \text { XE } & : 35429 \\ 2: 14243 & \text { CO } & : 34044 \\ 3: 13933 & \text { WN } & : 20685 \\ 4: 17256 & \text { OO } & : 8443 \\ 5: 16483 & \text { MQ } & : 1665 \\ 6: 13261 & \text { US } & : 1317 \\ 7: 14973 & \text { (other) }: 5337\end{array}$

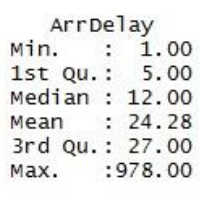

AirTime
Min. $: 22.0$
1st Qu. $: 60.0$
Median $: 109.0$
Mean $: 111.5$
3rd Qu. $: 145.0$
Max. $: 549.0$

FlightDate 2011-5-20: 565 2011-6-22: 564 2011-3-14: 558 2011-4-4 : 543 2011-6-21: 527 2011-4-25: 520 (other) :103643

Image 4: Summary statistics on data, subset of hflights 
I. Banjac, D. Vukmirović \& M. Jovanović Milenković: Big Data and the R Programming Language

Other single verb functions available in dplyr package for data manipulation are: arrange (reorders rows), mutate (adds new variables), and summarise (reduces variables to rows).

ggplot2 is the R package for producing statistical, or data, graphics. It is very powerful because users are not limited to a set of pre-specified graphics, but can create new graphics that are precisely tailored for their problems. It is designed to work iteratively. Users can start with a layer showing raw data, and then add layers of annotations and statistical summaries [21].

$>\operatorname{ggplot}($ data, $\operatorname{aes}(\mathrm{x}=$ ArrDelay, $\mathrm{y}=$ DepDelay $))$

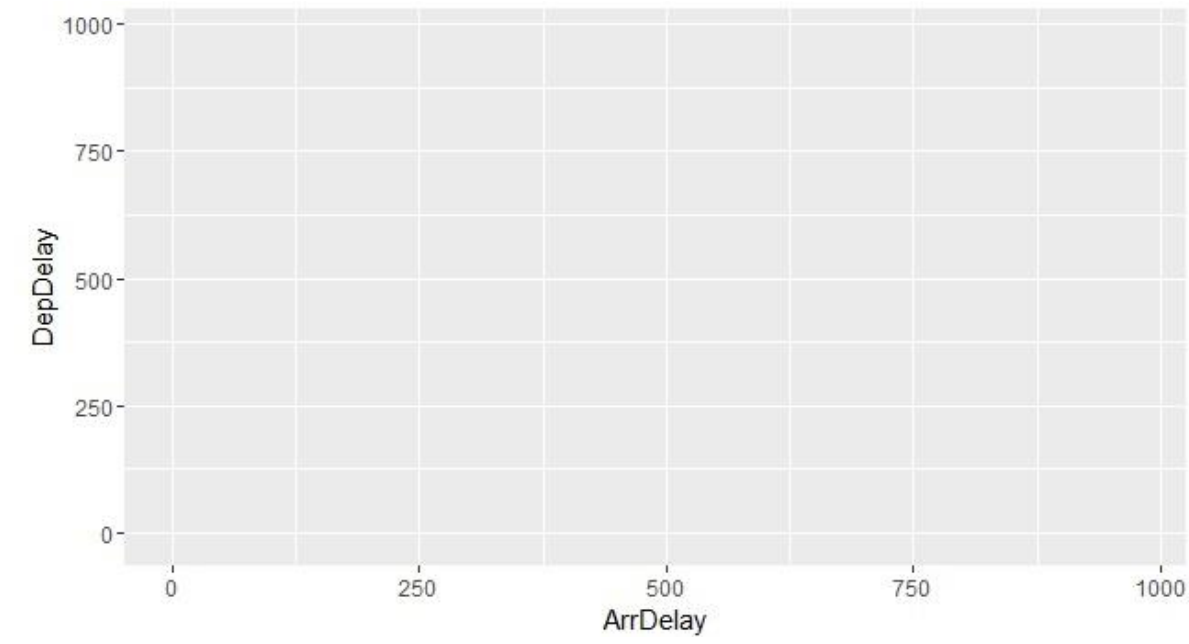

Image 5: Adding coordinate plane

$>\operatorname{ggplot}($ data, $\operatorname{aes}(\mathrm{x}=$ ArrDelay, $\mathrm{y}=$ DepDelay, colour $=$ UniqueCarrier $))+$ geom_point() 
$36^{\mathrm{TH}}$ International Conference on ORganizational Science Development: RESPONSIBLE ORGANIZATION (MARCH $22^{\mathrm{ND}}-24^{\mathrm{TH}}$, PORTOROŽ SLOVENIA)

I. Banjac, D. Vukmirović \& M. Jovanović Milenković: Big Data and the R Programming Language

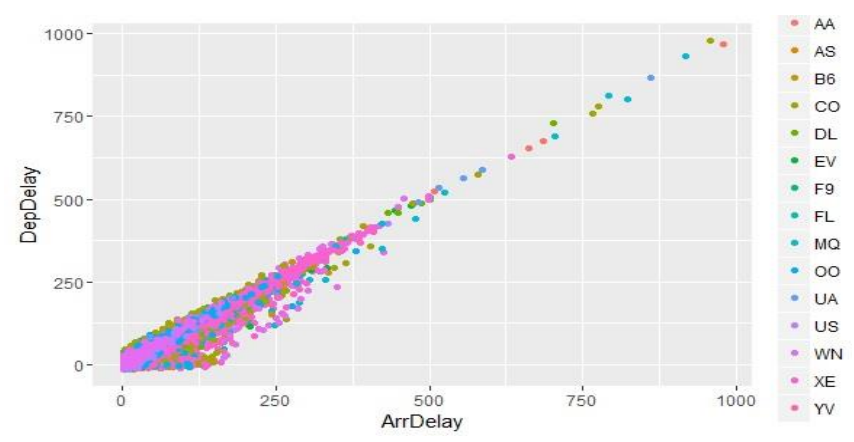

Image 6: Adding scatterplot

$>\operatorname{ggplot}($ data, aes $(\mathrm{x}=$ ArrDelay, $\mathrm{y}=$ DepDelay, colour $=$ UniqueCarrier $))+$ geom_point ()$+$

geom_smooth $($ method $=1 \mathrm{~m}$, colour $=$ "white")

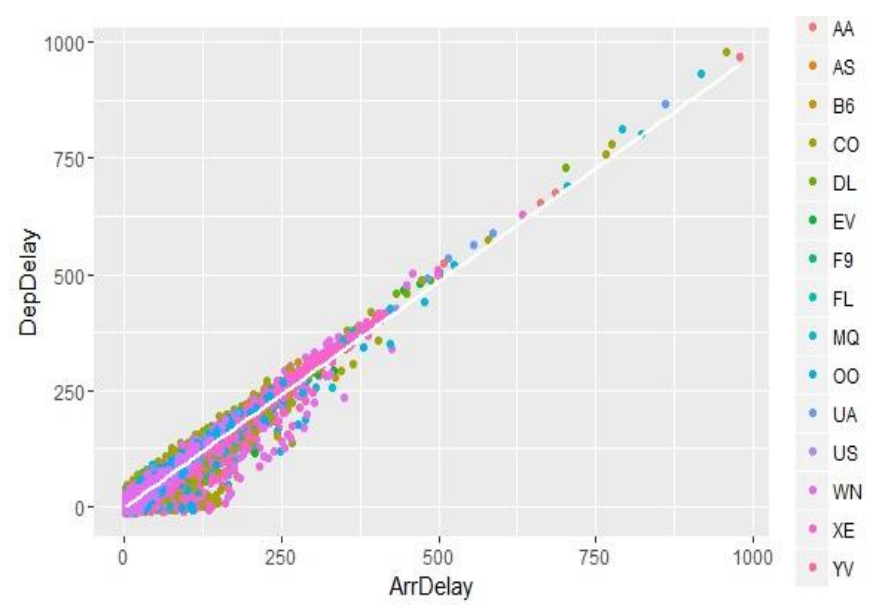

Image 7: Adding linear

$>\operatorname{ggplot}($ data, aes $(\mathrm{x}=$ ArrDelay, $\mathrm{y}=$ DepDelay, colour $=$ UniqueCarrier $))+$ geom_point ()$+$ geom_smooth $($ method $=1 \mathrm{~m}$, colour $=$ "white" $)+$ xlab("Arrival Delay") + ylab("Departure Delay") 

ORGANIZACIJA (22. - 24. MAREC 2017, PORTOROŽ, SLOVENIJA)

I. Banjac, D. Vukmirović \& M. Jovanović Milenković: Big Data and the R Programming Language

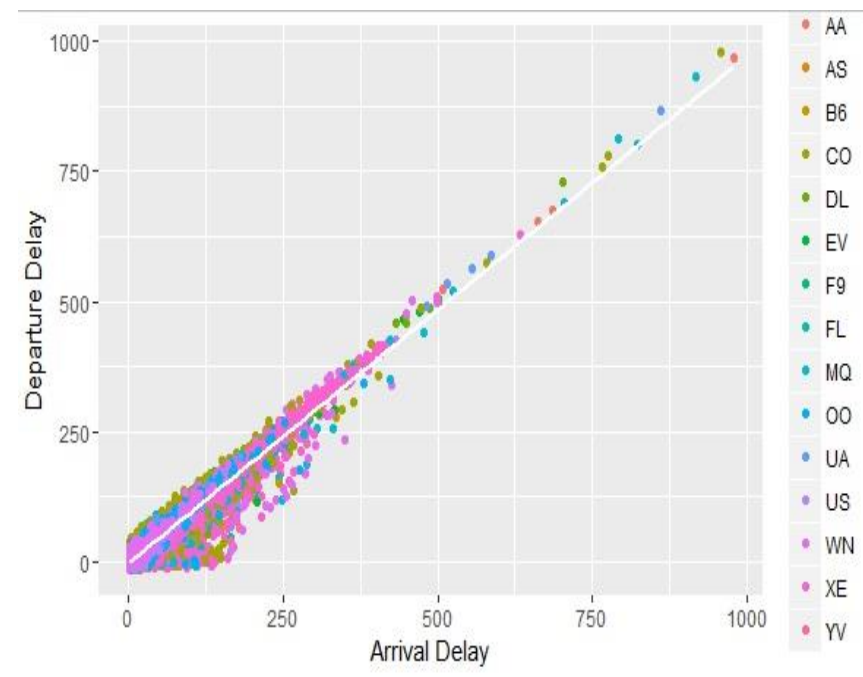

Image 8: Adding labels for $x$ and $y$ axis

> ggplot(data, aes $(\mathrm{x}=$ ArrDelay, $\mathrm{y}=$ DepDelay, colour $=$ UniqueCarrier $))+$ geom_point ()$+$ geom_smooth $($ method $=1 \mathrm{~m}$, colour $=$ "white" $)+$ xlab("Arrival Delay") + ylab("Departure Delay") + ggtitle("Linear model for arrival and departure delays")

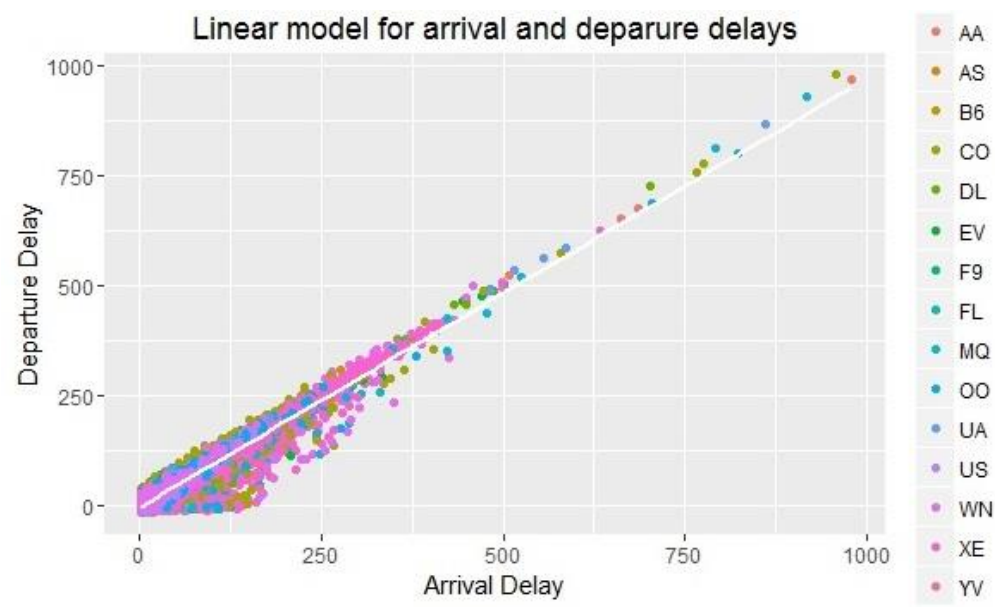

Image 9: Adding the title 
$36^{\text {Th }}$ International Conference on Organizational Science Development: RESPONSIBLE ORGANIZATION (MARCH $22^{\mathrm{ND}}-24^{\mathrm{TH}}$, PORTOROŽ SLOVENIA)

I. Banjac, D. Vukmirović \& M. Jovanović Milenković: Big Data and the R Programming Language

An important technique for displaying additional categorical variables on a plot is faceting. Faceting creates table of graphics by splitting the data into subsets and displaying the same graph for each subset [21].

$>\operatorname{ggplot}($ data, aes $(\mathrm{x}=$ DayOfWeek $))+$ geom bar(fill = "blue") + xlab("Day of week") + ylab("Number of delayed flights") + ggtitle("Flight delays by day of week")

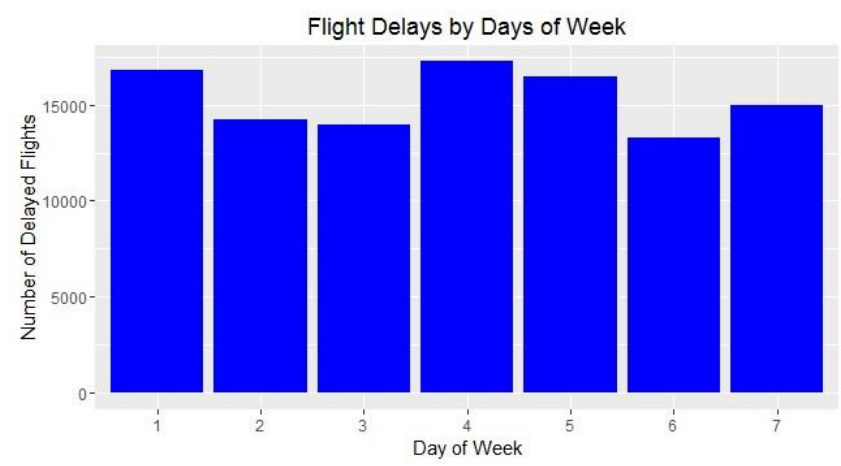

Image 10: Flight delays by day of week

$>\operatorname{ggplot}($ data, aes $(\mathrm{x}=$ DayOfWeek $))+$ geom_bar(fill = "blue") + xlab("Day of week") + ylab("Number of delayed flights") + ggtitle("Flight delays by day / airline") + facet_wrap( UniqueCarrier)

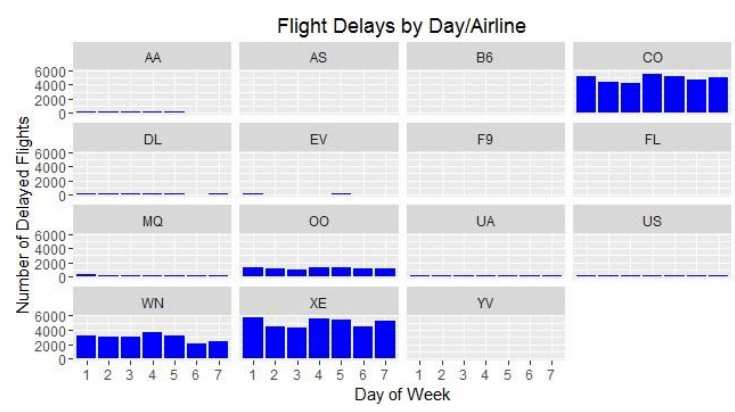

Image 11: Faceting by UniqueCarrier 
I. Banjac, D. Vukmirović \& M. Jovanović Milenković: Big Data and the R Programming Language

\# checking if there are any missing values (NA's) in the ArrDelay column of hflights $>$ sum(is.na(hflights $\$$ ArrDelay))

[1] 3622

\# checking the maximum arrival delay for each airline, excluding missing values

$>$ tapply(hflights $\$$ ArrDelay, hflights $\$$ UniqueCarrier, FUN = max, na.rm = TRUE)

Image 12: Maximum arrival delay by airline

In order to evaluate airline performances, a new dataset will be created with following variables: UniqueCarrier (airline company), delays (number of flights delayed on arrival for each airline), flights (total number of flights) and ratio (percentage of delayed flights). This will be done with the use of sqldf package which provides an easy way to perform SQL selects on R data frames [25].

\# calculating number of delayed flights by carrier

$>$ ndf <- sqldf("select UniqueCarrier, count(ArrDelay) as delayed from hflights where ArrDelay $>0$ group by UniqueCarrier")

\# calculating number of total flights by carrier while removing NA's from ArrDelay

$>$ tf <- sqldf("select UniqueCarrier, count(ArrDelay) as flights from hflights where ArrDelay is not null group by UniqueCarrier")

\# merging the results and creating the percentage of delayed flights column

$>$ stats $<$ - merge (ndf, tf, all = TRUE)

$>$ perc $<-$ with(stats, $100 *$ delayed/flights)

$>$ stats $<$ - cbind(stats, perc) 
$36^{\text {Th }}$ International Conference on Organizational Science Development: RESPONSIBLE ORGANIZATION (MARCH $22^{\mathrm{ND}}-24^{\mathrm{TH}}$, PORTOROŽ SLOVENIA)

I. Banjac, D. Vukmirović \& M. Jovanović Milenković: Big Data and the R Programming Language

$\begin{array}{lrrrr} & \text { Uniquecarrier } & \text { delayed } & \text { flights } & \text { perc } \\ 1 & \text { AA } & 963 & 3178 & 30.30208 \\ 2 & \text { AS } & 159 & 364 & 43.68132 \\ 3 & \text { B6 } & 266 & 673 & 39.52452 \\ 4 & \text { CO } & 34044 & 69373 & 49.07385 \\ 5 & \text { DL } & 1003 & 2591 & 38.71092 \\ 6 & \text { EV } & 780 & 2121 & 36.77511 \\ 7 & \text { F9 } & 463 & 832 & 55.64904 \\ 8 & \text { FL } & 657 & 2111 & 31.12269 \\ 9 & \text { MQ } & 1665 & 4504 & 36.96714 \\ 10 & \text { OO } & 8443 & 15781 & 53.50105 \\ 11 & \text { UA } & 1009 & 2033 & 49.63109 \\ 12 & \text { US } & 1317 & 4030 & 32.67990 \\ 13 & \text { WN } & 20685 & 44536 & 46.44557 \\ 14 & \text { XE } & 35429 & 71669 & 49.43420 \\ 15 & \text { YV } & 37 & 78 & 47.43590\end{array}$

Image 13: Percentage of delayed flights by airline

\# horizontal bar plot for the percentage of delayed flights by airline

\# airlines are sorted in ascending order from bottom

$>\operatorname{ggplot}($ stats, $\operatorname{aes}(\mathrm{x}=$ reorder(UniqueCarrier, flights $), \mathrm{y}=$ perc, fill $=$ perc $))+$ geom_bar(stat $=$ 'identity') +

scale_fill_gradient $($ low $=$ "green", high $=$ "red") +

coord_flip ()$+$

xlab("Airine (ascendingfrom bottom)") +

ylab("Delay rate")

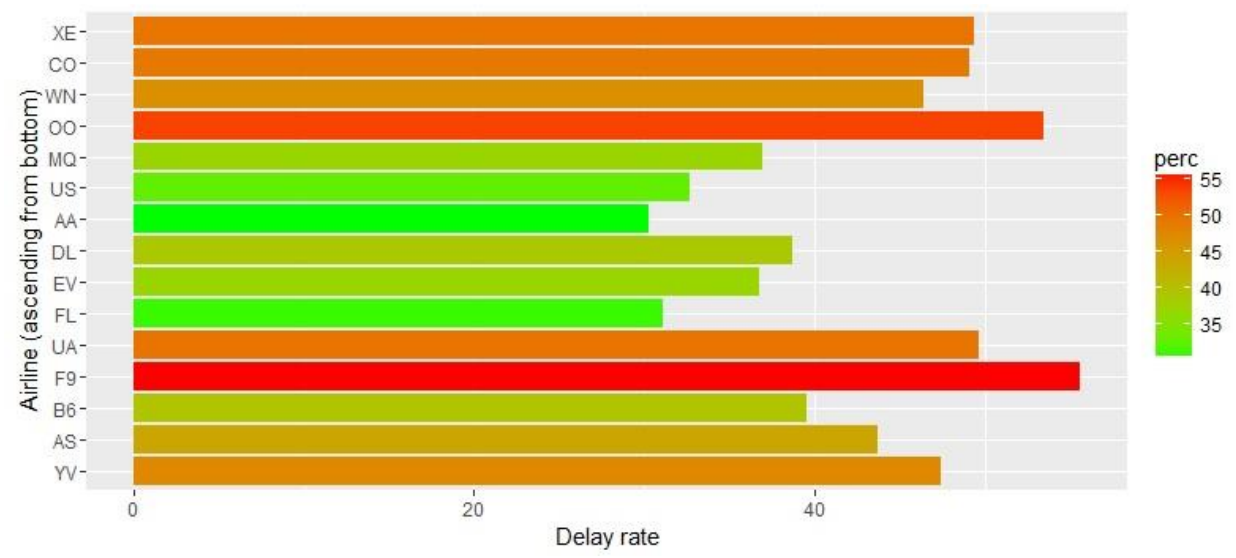

Image 14: Percentage of delayed flights by airline - horizontal bar graph 

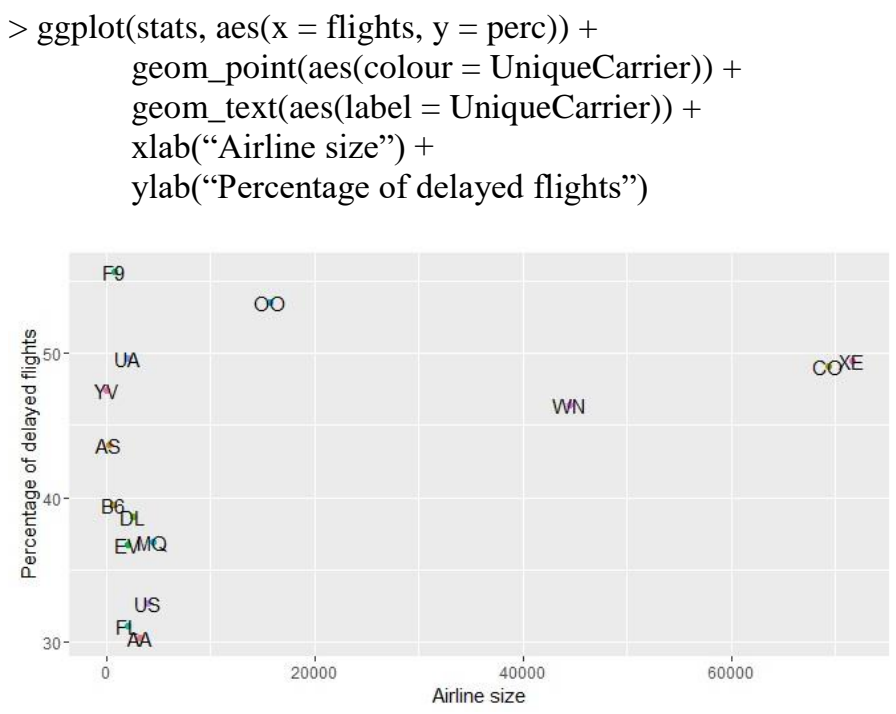

Image 15: Number of flights vs. percentage of delayed flights

The obvious conclusions that can be drawn from this simple analysis are:

- Airline company F9 has the highest rate of arrival delay, while AA has the lowest;

- there is a strong positive correlation between arrival delays and departure delays which may not be caused by flight time, but maybe rather by airport congestion;

- there is not an obvious positive correlation between airline size and percentage of flights delayed on arrival;

- the best airline choice would have been AA, FL or US as they tend to have a decent number of flights and a rather small percentage of flights delayed on arrival;

\section{Conclusion}

Big data is both the present and the future, and we are definitely not aware what surprises it has in store for us. What is obvious is that it offers a vast number of opportunities to harness the knowledge that the world is unknowingly offering. In this challenging quest, we have a trusted ally in $\mathrm{R}$, a versatile programming language and an environment for statistical computing and graphics whose popularity among world's data scientists is steadily rising. 
36 $6^{\mathrm{TH}}$ InTernational Conference on ORganizational Science Development: RESPONSIBLE ORGANIZATION (MARCH $22^{\mathrm{ND}}-24^{\mathrm{TH}}$, PORTOROŽ SLOVENIA)

I. Banjac, D. Vukmirović \& M. Jovanović Milenković: Big Data and the R Programming Language

\section{Literature}

[1] Cox, M. \& Ellsworth, D. Application-controlled demand paging for out-of-core visualization. Proceedings of the 8th conference on Visualization '97. 1997: p. 235-ff

[2] Oxford English dictionary. Retrieved from http://www.oed.com/view/Entry/18833\#eid301162177

[3] McAfee, A., Brynjolfsson, E., Davenport, T. H., Patil, D. J. \& Barton, D. Big data: the management revolution. Harvard Business Review, vol. 90, no. 10, pp. 60-68, 2012.

[4] Lynch, C. Big Data: how do your data grow? Nature, vol. 455, no. 7209, pp. 28-29, 2008.

[5] Laney, D. 3D data management: controlling data volume, velocity, and variety. Meta Group. Retrieved from http://blogs.gartner.com/doug-laney/files/2012/01/ad949-3D-DataManagement-Controlling-Data-Volume-Velocity-and-Variety.pdf

[6] Short, J. E., Bohn, R. E. \& Baru, C. How Much Information? 2010: Report on Enterprise Server Information. UCSD Global Information Industry Center, 2011.

[7] 100 social media statistics for 2012. The Social Skinny. Retrieved from http://thesocialskinny.com/100-social-media-statistics-for-2012

[8] YouTube Company Statistics. Statistics brain. Retrieved from http://www.statisticbrain.com/youtube-statistics

[9] Twitter Company Statistics. Statistic brain. Retrieved from http://www.statisticbrain.com/twitter-statistics/

[10] Ronk, J. Structured, semi structured and unstructured data. Retrieved from https://jeremyronk.wordpress.com/2014/09/01/structured-semi-structured-and-unstructureddata/

[11] Provost, F. \& Fawcett, T. Data science and its relationship to big data and data-driven decision making. Big Data, vol. 1, no. 1, pp. 51-59, 2013

[12] Waller, M. A. \& Fawcett, S. E. Data Science, Predictive Analytics, and Big Data: A Revolution That Will Transform Supply Chain Design and Management. Journal of Business Logistics. vol. 34, no. 2, pp. 77-84, 2013.

[13] Manyika, J., Chui, M., Brown, B., Bughin, J., Dobbs, R., Roxburgh, C. \& Byers, A. H. Big data: The next frontier for innovation, competition, and productivity. McKinsey Global Institute, 2011.

[14] Davenport, T. H. \& Patil, D. J. Data Scientist: The Sexiest Job of the 21st Century. Harvard Business Review, October 2012.

[15] Piatetsky, G. R, Python Duel As Top Analytics, Data Science software - Kdnuggets 2016 Software Poll Results. Retrieved from http://www.kdnuggets.com/2016/06/r-python-topanalytics-data-mining-data-science-software.html

[16] R: What is R? Retrieved from https://www.r-project.org/about.html

[17] dplyr $-\mathrm{R}$ project. Retrieved from https://cran.r-project.org/web/packages/dplyr/dplyr.pdf

[18] tidyr - R project. Retrieved from https://cran.r-project.org/web/packages/tidyr/tidyr.pdf

[19] Package 'stringr' - CRAN. Retrieved from https://cran.rproject.org/web/packages/tidyr/tidyr.pdf

[20] ggplot2 - $\mathrm{R}$ project. Retrieved from https://cran.rproject.org/web/packages/ggplot2/ggplot2.pdf

[21] Wickham, H. ggplot2 - Elegant Graphics for Data Analysis. Springer, 2016.

[22] Dasu, T. \& Johnson, T. Exploratory Data Mining and Data Cleaning. John Wiley \& Sons, 2013.

[23] Wickham, H. Tidy Data. Journal of Statistical Software, vol. 59, no. 10, 2014.

[24] Package 'hflights' $\quad \mathrm{R}$ Project. Retrieved from https://cran.rproject.org/web/packages/hflights/hflights.pdf 
ORGANIZACIJA (22. - 24. MAREC 2017, PORTOROŽ, SLOVENIJA)

I. Banjac, D. Vukmirović \& M. Jovanović Milenković: Big Data and the R

Programming Language

[25] Package 'sqldf' $\quad \mathrm{R}$ project. Retrieved from https://cran.rproject.org/web/packages/sqldf/sqldf.pdf 
30 36 $6^{\text {TH }}$ International Conference on Organizational Science Development:

Responsible Organization (MARCH $22^{\mathrm{ND}}-24^{\mathrm{TH}}$, PORTOROŽ SLOVENIA) 
36. MEDNARODNA KONFERENCA O RAZVOJU ORGANIZACIJSKIH ZNANOSTI: OdgOVORNA ORGANIZACIJA (22. - 24. MAREC 2017, PORTOROŽ, SLOVENIJA)

O. Arsenijević, M. Ferjan, I. Podbregar, P. Šprajc, D. Trivan \& Y. Ziegler

\title{
Skrb posameznika za kibernetsko varnost
}

\begin{abstract}
IGOR BERNIK
Povzetek Delovanje uporabnikov v kibernetskem prostoru je ogroženo z vidika varnosti in zasebnosti uporabnika. Cilj vsakega odgovornega posameznika bi moralo biti varno izmenjevanje informacij. Uporabniki varnost mnogokrat zanemarimo ali pa verjamemo, da bo zanjo poskrbel nekdo drug: ponudnik storitve, programska oprema ipd. Ker je za svojo varnost odgovoren vsak sam, moramo poskrbeti za ustrezne zaščitne ukrepe, ki zmanjšajo tveganja, minimalizirajo vpliv groženj in skrbijo za ustrezen nivo (kibernetske) varnosti. Prispevek prikazuje način delovanja uporabnikov in poda nekaj navodil k zagotavljanju kibernetske varnosti.
\end{abstract}

KLJUČNE BESEDE: kibernetska varnost • uporabniki • skrb • zaščita

NASLOV AVTORJA: dr. Igor Bernik, izredni profesor, Univerza v Mariboru, Fakulteta za varnostne vede, Kotnikova 8,1000 Ljubljana, Slovenija, e-pošta: igor.bernik@fvv.uni-mb.si

DOI https://doi.org/10.18690/978-961-286-020-2.4

ISBN 978-961-286-020-2

(C) 2017 Univerzitetna založba Univerze v Mariboru

Dostopno na: http://press.um.si 
$36^{\text {TH }}$ InTERnational CONFEREnCE ON ORganizational ScIENCE Development: Responsible Organization (MARCH $22^{\mathrm{ND}}-24^{\mathrm{TH}}$, PORTOROŽ SLOVENIA)

O. Arsenijević, M. Ferjan, I. Podbregar, P. Šprajc, D. Trivan \& Y.

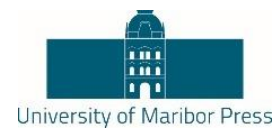

Ziegler

\title{
Cybersecurity Caring Individuals
}

\section{IGOR BERNIK}

\begin{abstract}
The users functioning in cyberspace is at risk in terms of security and privacy of them. In the cyberspace the goal of every responsible individual should be safe exchange of information. Users safety is often neglected or users believe that care will be taken by someone else, such us a service provider, software, etc. As the safety of every single user is responsible, they must provide for adequate protective measures to reduce the risks to minimize the impact of threats and provide for an appropriate level of (cyber) security. The article presents the users operating mode and provides basic guidelines to ensure cyber security.
\end{abstract}

KEYWORDS: cyber security $\bullet$ users $\bullet$ responsibility $\bullet$ protection

Correspondence AdDress: Igor Bernik, Ph.D., Associate Professor, University of Maribor, Faculty of Criminal Justice and Security, Kotnikova 8, 1000 Ljubljana, Slovenia, e-mail: igor.bernik@fvv.uni-mb.si 


\section{$1 \quad$ Uvod}

Razvoj informatike in informacijsko-komunikacijskih tehnologij je pripeljal do vsakodnevnega dela uporabnikov v kibernetskem prostoru in kritične odvisnosti sodobnega človeka od informacijsko komunikacijskih tehnologij. Vsebine $\mathrm{v}$ aktualnem kibernetskem prostoru imajo novo dimenzijo-dinamičnost. Le ta omogoča različne interakcije, dinamični preskok med storitvami in povezovanje posameznikovih želja, ki jih le-ta izraža skozi iskanja v iskalnikih, vsebinami, ki jih izmenjuje preko elektronske pošte, sporočilnih sistemih in spletnih socialnih omrežjih, če naštejemo le najpogosteje uporabljane in med večino uporabnikov tudi popularnejše storitve.

Ker se je veliko dejavnosti preneslo iz resničnega sveta $\mathrm{v}$ kibernetski prostor, se je temu prilagodila tudi kriminaliteta. Njeni prvi začetki so bili poizkusi posameznikov dokazati, da je vdor $\mathrm{v}$ informacijske sisteme mogoč; $\mathrm{z}$ razvojem sistemov in tehnologij ter omenjeno selitvijo dejavnosti, pa so kibernetski prostor odkrile tudi kriminalne skupine. Te so ponujene možnosti najprej uporabljale zgolj za medsebojno komunikacijo, kasneje pa so začele izvajati kazniva dejanja v kibernetskem prostoru. Obenem je kibernetski prostor globalen po definiciji, pravne norme in zakonodaja pa je praktično vedno vezana na (širše oziroma široko) lokalno okolje.

Kibernetska varnost in boj proti kibernetski kriminaliteti ni pomembna zgolj na organizacijski ravni in eventualno še na državni, saj nacionalna informacijska infrastruktura postaja čedalje večji dejavnik tveganja oz. je stalno ogrožena, pač pa izhaja iz potreb varnosti vsakega posameznika v mikro lokalnem okolju. Delovanje posameznika, njegove interakcije $\mathrm{v}$ okolju, vpliva na državo in doseganje ciljev nacionalne in mednarodne politike, ustvarjanje in razvijanje mednarodnih odnosov in mednarodno gospodarsko sodelovanje niso bili nikoli lažje dosegljivi kakor danes, ko smo v obdobju popolne kritične informacijskotehnološke odvisnosti. Nacionalna kritična infrastruktura s svojimi storitvami daje upravljavskemu aparatu države ali širše skupnosti občutek varnosti, avtonomnosti in suverenosti, to pa so glavni pojavi in dejavniki stabilnosti posamezne države oziroma skupnosti, kot je recimo Evropska unija. Z zlorabo ali uničenjem teh atributov je doseganje ciljev zunanje politike zelo enostavno. Ta ključna ranljivost sodobne družbe je pogosto tarča državnih in vojaških kibernetskih bojevnikov. Ne samo organizacije, tudi države morajo poskrbeti za razumevanje narave kibernetske kriminalitete in z njo povezanega kibernetskega bojevanja, če želijo zagotoviti ustrezno stopnjo varnosti prebivalstva.

Kibernetska kriminaliteta je ena glavnih stranskih učinkov informatizacije in sodobnega načina življenja. S svojim vplivom na osebno, socialno, ekonomsko, državno, informacijsko in kibernetsko varnost je postala pomembna varnostna problematika 21. stoletja (Comprehensive study on cybercrime, 2013) in ena izmed družbi najnevarnejših oblik kriminalitete. Če ne zaradi že dejansko povzročene škode pa vsaj zaradi široke obsega, stalne prisotnosti, razvoja groženj 
in visokih stroškov za obrambo. S tem, ko se povečuje globalno število uporabnikov kibernetskega prostora, razširjenost IKT, uporabe spleta in njegovih storitev, medsebojno povezovanje elektronskih elementov, ki jih povprečni uporabnik uporablja - informatizacija vozil, domov, medsebojno povezovanje domačih aparatov, nosljive naprave, IoT in podobno, se posledično veča tudi pogostost zlorab in njihov vpliv v prvi vrsti na posameznike, preko njih pa na organizacijske sisteme in družbo kot celoto. Poseben problem predstavlja omejena ozaveščenost in tehnično znanje uporabnikov: večina uporabnikov sledi tehnološkemu razvoju, razvoju kibernetskih groženj pa ne. Po zadnjih ocenah kibernetska kriminaliteta po številu primerov presega klasično nasilniško in finančno kriminaliteto, po finančnih posledicah pa organizirano trgovino z drogo in ljudmi (Peršak, 2009; Kshetri, 2013; Comprehensive study on cybercrime, 2013). Priča smo vse pogostejšim napadom, ki ciljajo nacionalne kritične infrastrukture ali pa se izvajajo za potrebe ekonomskega in državnega vohunjenja. Dovršena programska oprema in metode za vdore $\mathrm{v}$ informacijske sisteme lahko tako pride $\mathrm{v}$ roke tudi kriminalnim skupinam. Za prikaz delovanja uporabnikov smo izvedli pilotno raziskavo delovanja $\mathrm{v}$ kibernetskem prostoru, njihovega odzivanja na pojave kriminalitete in zaupanja $\mathrm{v}$ dostopne rešitve za zaščito informacijskega premoženja.

\section{$2 \quad$ Metoda}

Za potrebe ugotavljanja dejanskega stanja med uporabniki kibernetskega prostora v Sloveniji z vidika varnosti, je bila izvedena pilotna študija o delovanju uporabnikov. Ugotavljamo, kako uporabniki uporabljajo kibernetski prostor, na kakšen način zaščitijo vsebine pred nepooblaščeno uporabo in kakšno je stališče glede zasebnosti. Za ugotavljanje dejanskega stanja ozaveščenosti v Sloveniji je ključnega pomena dobro poznavanje védenja uporabnikov in nivoja ozaveščenosti o nevarnostih, ki jim pretijo.

Cilj študije je bil, da se med izpraševanci preveri, če pri rabi kibernetskega prostora uporabljajo zaščitne ukrepe in varnostne programe za varovanje svojih podatkov in če se jim zdi način uporabe varen. Anketa je bila objavljena na spletu www.1 ka.si. Povezavo do ankete so pomagali razširiti kolegi v kampanjah Safe.si, Spletno Oko in Varni na internetu. Anketiranci predstavljajo splošne uporabnike kibernetskega prostora in so obveščeni na podlagi prijav v omenjene storitve.

Anketa je vsebovala 27 vprašanj. Prvi sklop vprašanj se je nanašal na demografijo, nadalje so izpraševanci odgovarjali na vprašanja o tem, kako pogosto uporabljajo elektronske naprave in kibernetski prostor ter za kakšen namen. Anketo je v celoti izpolnilo 179 izpraševancev 78,4 \% moških in 21,6 \% žensk. Starostne skupine in stopnja izobrazbe so prikazane na sliki 1 in 2. 

ORGANIZACIJA (22. - 24. MAREC 2017, PORTOROŽ, SLOVENIJA)

I. Bernik: Skrb posameznika za kibernetsko varnost

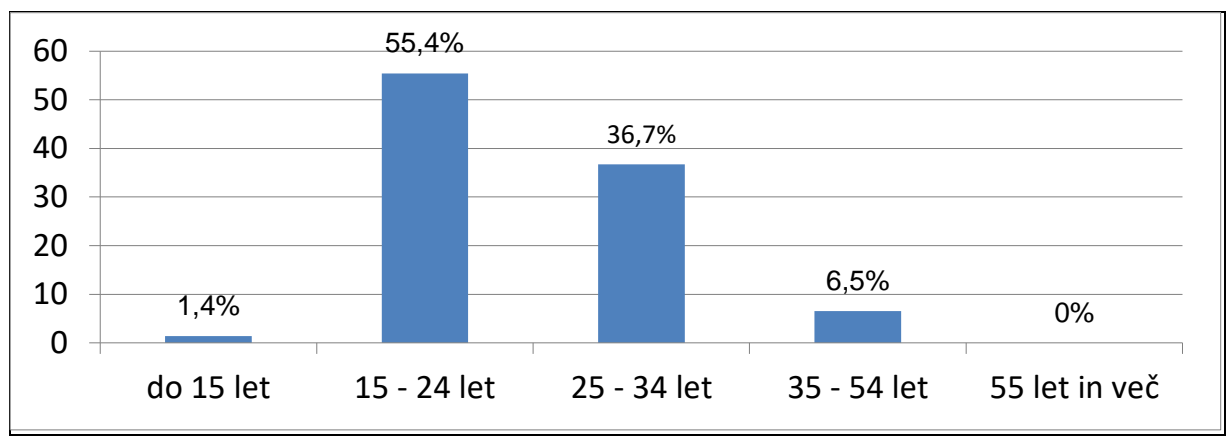

Slika 1: Starostne skupine

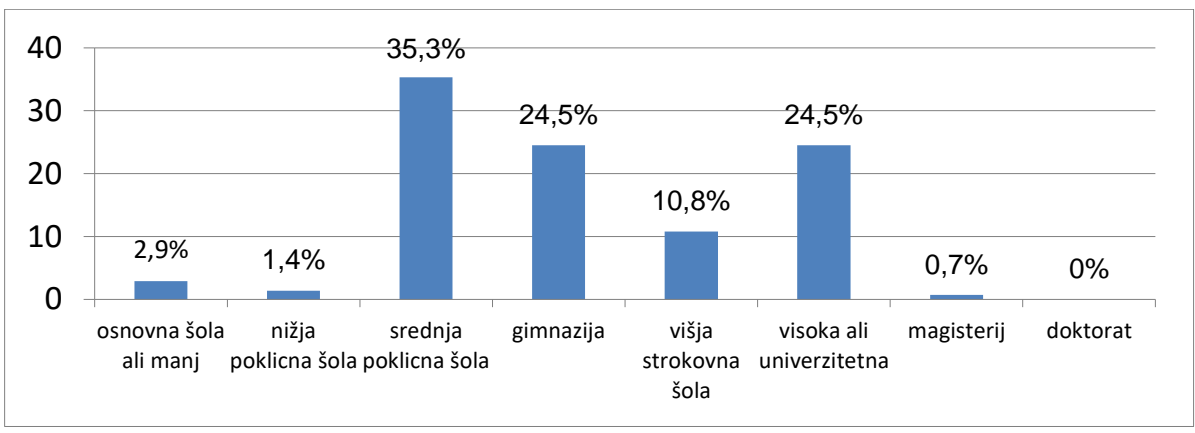

Slika 2: Stopnja izobrazbe

V nadaljevanju prikazujemo rezultate študije.

\section{$3 \quad$ Rezultati}

Na podlagi preživetega časa $\mathrm{v}$ kibernetskem prostoru med vprašanimi sklepamo na intenzivnost rabe tehnologij in storitev - slika 3.

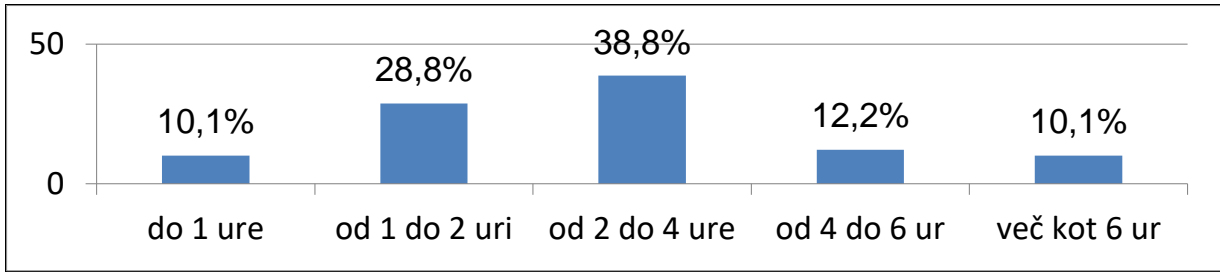

Slika 3: Povprečna dnevna uporaba kibernetskega prostora 
$36^{\mathrm{TH}}$ InTERnAtional CONFERENCE ON ORganizational SCIENCE DeVElopment: Responsible Organization (MARCh $22^{\mathrm{ND}}-24^{\mathrm{TH}}$, Portorož Slovenia)

I. Bernik: Cybersecurity Caring Individuals

Mesto in namen primarne uporabe kibernetskega prostora brez interakcije $\mathrm{v}$ spletnih socialnih omrežjih prikazuje slika 4.

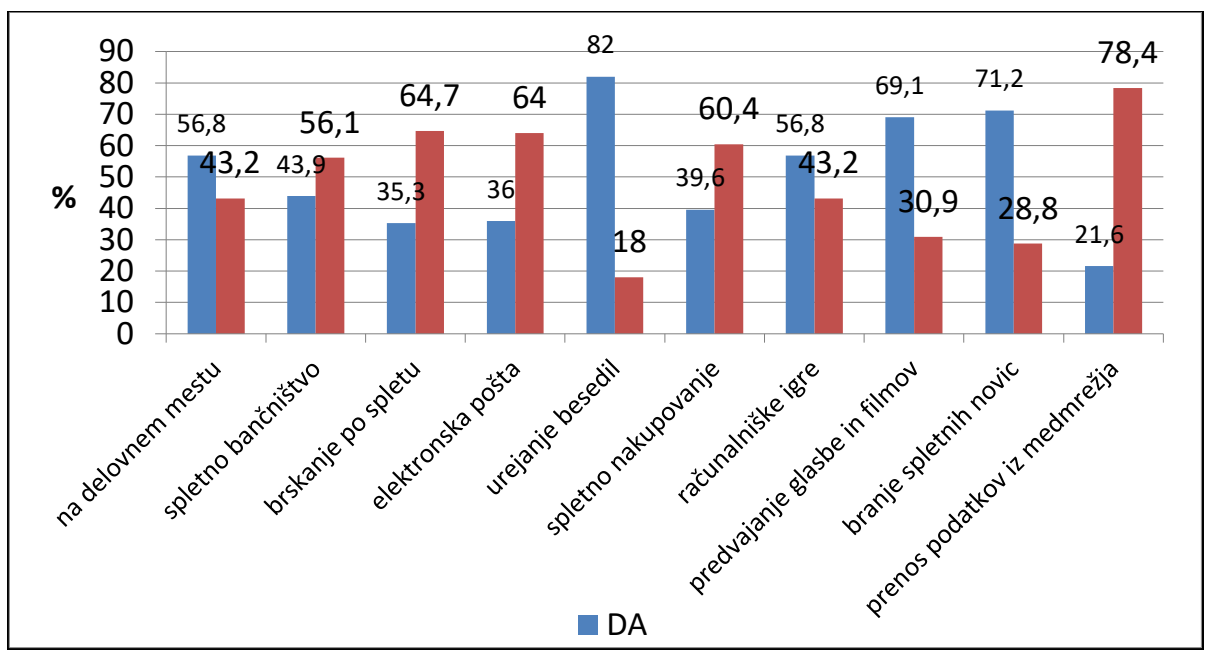

Slika 4: Je uporaba elektronskih naprav pri rabi kibernetskega prostora varna?

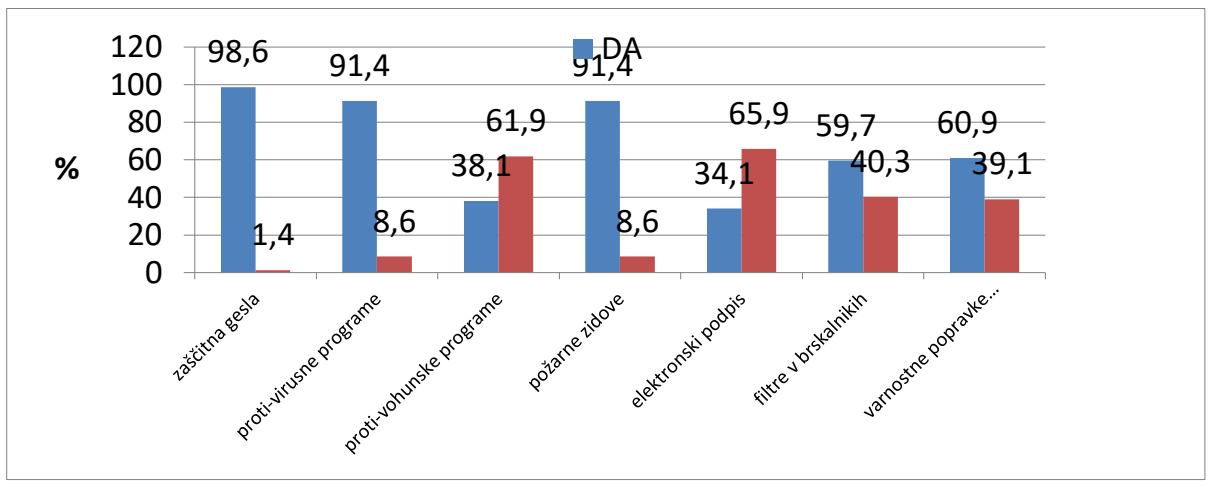

Slika 5: Raba osnovnih varnostnih elementov

Zanimivo je odstopanje, kjer $82 \%$ anketirancev meni, da so z uporabo urejevalnikov besedil (ki jih lahko razširimo na pisarniške programe), pri delu varni pred zlorabami. Nasprotno je pri prenosu podatkov iz medmrežja, kjer 78,4 \% anketirancev meni, da so njihovi podatki bolj izpostavljeni nevarnostim zlorabe. Tu pa bi uporaba kriptografije $\mathrm{v}$ večji meri odpravila nevarnosti. Uporabo varnostnih elementov za zaščito elektronskih naprav prikazuje slika 5 .

Slika ni prikazane rabe zaščite $\mathrm{s}$ prstnim odtisom, ki je fantastična možnost zaščite sodobnih naprav mobilnih naprav; uporablja jo le 0,3 odstotka vseh uporabnikov. 
Tehnologija je sicer večinoma na voljo na boljših in dražjih napravah. Verjamemo, da se bo v kratkem časi, ko se bo zaščita s prstnim odtisom prenesla tusi na cenejše naprave in bodo uporabniki zamenjevali stare, uporabljača kot osnovna zaščita uporabnikove varnosti in ohranjanja zasebnosti.

$\mathrm{Na}$ podlagi prikazanih in drugih rezultatov, pridobljenih iz anketnih odgovorov in primerjalne analize, širših izhodišč in primerljivih raziskav sklepamo na delovanje uporabnikov.

\section{$4 \quad$ Razprava in zaključki}

Uporaba elektronskih naprav, povezovanje $\mathrm{v}$ kibernetski prostor in stalno izmenjevanje podatkov so postali stalnice našega vsakdana. Dostop do informacij in povezovanje med uporabniki se je s pojavom kibernetskega prostora popolnoma spremenilo, to pa pomembno vpliva na naše delo, komunikacije in obnašanje v družbi. Rezultati kažejo (Slika 3), da je povprečen čas rabe kibernetskega prostora med večino uporabniki okoli 2 ure dnevno, kar je poleg uporabe IKT za delo/študij/šolo okvirno 1/4 posameznikovega prostega časa. Tudi zaradi tega dejstva je jasno, da je način delovanja in upoštevanje varnostnih načel izjemnega pomena. Drugo zanimivo dejstvo je dojemanje varnosti v kibernetskem prostoru (Slika 4), kjer se opaža relativno majhno razumevanje kibernetskih groženj s strani uporabnikov, zato pri interakciji s kibernetskim prostorom marsikdaj ne upoštevajo osnovnih varnostnih načel, saj za to ne čutijo potrebe. To se kaže pri rabi varnostnih rešitev (Slika 5), saj za zasebno delovanje uporabljajo osnovne zaščite, ki pa $\mathrm{v}$ današnji kompleksnosti kibernetskega prostora zagotavljajo le delno in najosnovnejšo zaščito, ne varujejo pa pred najpogosteje uresničenimi grožnjami. Leto 2016 na primer v kibernetski varnosti imenujemo tudi leto kripto virusov (Heater, 2016) oziroma Ransomware-a, saj so ena izmed izjemno perečih groženj, ki se ji lahko izognemo predvsem $\mathrm{z}$ razumevanjem in zavedanjem njihove prisotnosti (odpiranje priponk, povezovanje na spletne naslove).

Da bi zmanjšali možnost pojava kibernetske kriminalitete in drugih kibernetskih viktimizacij in s tem zmanjšali ogroženost predlagamo preproste in učinkovite smernice, ki v največji meri zmanjšajo ogroženost:

- previdnost pri odpiranju spletnih povezav, da se prepreči nameščanje škodljive kode;

- zavedanje, da z objavo zasebnih podatkov uporabniki omogočajo njihovo zlorabo;

- povratno odgovarjanje na sporočila, ki od uporabnika zahtevajo vnos uporabnikih imen in gesel za dostop do različnih storitev;

- previdnost pri nameščanju dodatkov in aplikacij na računalnik in mobilne naprave-manj nameščenih programov, manj možnosti zlorab;

- skrb za posodabljanje programske opreme z varnostnimi nadgradnjami; 
- gesla in PIN-kode se ne zaupajo nikomur. Enako tudi dostop do katerekoli elektronske naprave brez prisotnosti uporabnika;

- dvostopenjska avtentikacija pri vseh kritičnih in pogosto uporabljanih storitvah - tudi Google in Facebook;

- uporabo zdravega razuma pri dostopu do kibernetskega prostora in povezovanju v njem.

Izobraževanje in usposabljanje o nevarnosti kibernetske kriminalitete pri interakciji s kibernetskim prostorom mora na vseh ravneh družbenega življenja postati del vsakdana, za usposobitev ozaveščenega posameznika. Skladno s prenosom dela in podatkov v kibernetski prostor so se vanj prenesle tudi različne oblike kriminalitete. Hanson, Reyns in Fisher (2013) so raziskovali spletno šikaniranje in ugotovili, da je strah pred klasično kriminaliteto $\mathrm{v}$ kibernetskem prostoru večji od strahu pred isto kriminaliteto $\mathrm{v}$ fizičnem prostoru. Ta ugotovitev razkriva, da je strah $\mathrm{v}$ kibernetskem prostoru drugačen od strahu $\mathrm{v}$ fizičnem prostoru. Ljudje torej dojemajo kibernetski prostor kot drugačen, vzporedni svet, kjer tudi kriminaliteto dojemajo na drugačen način, saj drugače dojemajo tudi prostor. V raziskavi se v potrditev pojavljata še dve ugotovitvi: (1) ljudi je manj strah, če poznajo nekoga, ki je pred tem že bil viktimiziran in (2) nizka stopnja strahu kljub predhodni viktimizaciji. Druga raziskava v primeru klasične kriminalitete v kibernetskem prostoru pa se nanaša na zalezovanje in nadlegovanje prek spleta. Tako Sen (2013) kot tudi Hanson, Reyns in Fisher (2013) ugotavljajo, da je v kibernetskem prostoru stopnja strahu pred kriminaliteto večja kot $\mathrm{v}$ fizičnem okolju. Zato je potrebno, kot navajata Prislan in Bernik (2014) pri proučevanju kibernetske varnosti, poleg tehnološkega, procesnega in kriminološkega področja, proučiti tudi psihološke odzive posameznika. Šele po pravem informiranju in razumevanju nadaljujemo k primerni uporabi ukrepov kibernetske varnosti. Uporabniki se v svoji ne-rabi možnih ukrepov najbrž sploh ne zavedajo, kako zelo jih to ovira pri delu oziroma njihovem vsakdanjem življenju in s tem tudi razvoju.

Razvidno torej je, da uporabniki s preventivnim delovanjem, organizacije z ustrezno vzpostavljeno infrastrukturo in ukrepi za varno delo pomembno pripomorejo $\mathrm{k}$ ustrezni kibernetski varnosti posameznika, organizacij in družbe. Pa vendar bo zaradi naraščajočega problema kibernetske kriminalitete $\mathrm{v}$ nadaljnje potrebno zagotoviti še več rešitev, ki bodo povezale tehnične ukrepe, procesne izvedbe in delovanje uporabnikov v varnejši (kibernetsko)varnostni sistem organizacij.

\section{Uporabljeni viri}

Heater, B. (2106). The Growing Threat of Ransomware. Pridobljeno na http://www.pcmag.com/news/343547/the-growing-threat-of-ransomware

Henson, B., Reyns, B. W., Fisher, B. S. (2013). Fear of Crime Online? Examining the Effect of Risk, Previous Victimization, and Exposure on Fear of Online Interpersonal Victimization. Journal of Contemporary Criminal Justice, (29)4, 475-497.

Kshetri, N. (2013). Global cybersecurity: Issues and concerns. Journal of Global Information Technology Management, 14(4), 1. 
Peršak, N. (2009). Virtualnost, (ne)moralnost in škodljivost: Normativna vprašanja nekaterih oblik kibernetične kriminalitete. Revija za kriminalistiko in kriminologijo, 60(3), 191-198.

Prislan, K., Bernik, I. (2014). Dejavniki sprejemanja odločitev pri urejanju učinkovite informacijske varnosti v organizacijah. Varstvoslovje, (16)1, 50-67.

Sen, A. (2013). Linking Cyber Crime to the Social Media: A Case Study of Victims in Kolkata. V Jaishankar, J. (ur.), SASCV 2013 Proceedings. (str. 378-382). India: Second International Conference of the South Asian Society of Criminology and Victimology (SASCV).

United Nations Office on Drugs and Crime [UNODC]. (2013). Comprehensive study on cybercrime. New York, NY: United Nations Office on Drugs and Crime [UNODC]. Pridobljeno na http://www.unodc.org/documents/organizedcrime/UNODC_CCPCJ_EG.4_2013/CYBERCRIME_STUDY_210213.pdf 
40 36 $6^{\text {TH }}$ International Conference on Organizational Science Development:

Responsible Organization (MARCH $22^{\mathrm{ND}}-24^{\mathrm{TH}}$, PORTOROŽ SLOVENIA) 


\title{
Uporaba multivariatnih statističnih metod za analizo vloge profesorja pri motivaciji za učenje
}

\begin{abstract}
SAŠO BIZANT
Povzetek Dijaki, študentje in vsi zaposleni morajo biti pri svojem delu in učenju ustrezno motivirani, saj bodo tako bolj učinkovito in uspešno opravili zadane naloge. Ustrezna motivacija jim da voljo tudi za njihovo nadaljnje delo in učenje. Če se osredotočimo na dijake, jih za učenje lahko motivira predvsem profesor, seveda $\mathrm{z}$ ustreznim podajanjem snovi, osebnim odnosom.

Za potrebe raziskave je bila narejena anketa, ki je bila obdelana s pomočjo programa SPSS. V prispevku smo raziskali, kakšne lastnosti mora imeti dober profesor, da svoje dijake motivira k učenju. Na podlagi predhodnih analiz sem ugotovil, da mora biti profesor karizmatičen, pravičen in profesionalen pri svojem delu in odnosu do dijakov.
\end{abstract}

KLJUČNE BESEDE: motivacija • profesor • multivariatne statistične metode - učenje

NASLOV AVTORJA: mag. Sašo Bizant, učitelj strokovnih predmetov, ŠC Kranj, Strokovna gimnazija, Kidričeva cesta 55, 4000 Kranj, Slovenija, e-pošta: saso.bizant@guest.arnes.si

DOI https://doi.org/10.18690/978-961-286-020-2.5

ISBN 978-961-286-020-2

(C) 2017 Univerzitetna založba Univerze v Mariboru

Dostopno na: http://press.um.si 
36 ${ }^{\text {TH }}$ International CONFEREnCE ON ORganizational Science DeVelopment: Responsible Organization (MARCH $22^{\mathrm{ND}}-24^{\mathrm{TH}}$, PORTOROŽ SLOVENIA)

O. Arsenijević, M. Ferjan, I. Podbregar, P. Šprajc, D. Trivan \& Y.

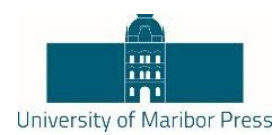

Ziegler

\title{
The Use of Multivariate Statistical Methods in Analyzing the Role of Lecturer in Motivation for Learning
}

\section{SAŠO BIZANT}

\begin{abstract}
In order to achieve set objectives more effectively and efficiently, pupils, students and employees need to be properly motivated for their work and study. With appropriate motivation they are given the will for their future work and learning. Focusing on pupils, the role of their lecturer is to motivate them with appropriate teaching methods as well as with personal approach.
\end{abstract}

The survey used in the study was processed with the SPPS software. In our study, we analyzed what characteristics a lecturer should possess in order to motivate his pupils for learning. On the basis of preliminary analysis we discovered that the lecturer needs to be charismatic, fair and professional in his work and in relationship towards his pupils.

KEYWORDS: motivation - lecturer - multi-variat statistical methods • learning

Correspondence AdDress: Sašo Bizant, M.S., teacher of professional subjects, SC Kranj, Professional Gymnasium, Kidričeva cesta 55, 4000 Kranj, Slovenia, e-mail: saso.bizant@guest.arnes.si 
S. Bizant: Uporaba multivariatnih statističnih metod za analizo vloge profesorja pri motivaciji za učenje

\section{Uvod}

»Kakšen mora biti profesor, da dijake pritegne k učenju«? To se sprašujejo vsi profesorji, dijaki in tudi njihovi starši, zato smo želeli s pomočjo ankete raziskati, kaj o tem menijo dijaki Srednje zdravstvene šole Ljubljana (SZŠ) in dijaki Šolskega centra Kranj (ŠC). Raziskava bi bila koristna in zanimiva za vse profesorje, ki jim je mar za delo dijakov, saj bi na podlagi rezultatov izvedeli, kaj dijaki od njih pričakujejo, kaj jih bolj spodbuja za učenje njihovega predmeta, kako pripraviti zanimivo učno uro in nenazadnje, kako se dijaku lažje približati ter mu pomagati. Torej, problem, ki ga bomo raziskovali v prispevku je, kakšne lastnosti mora imeti dober profesor, da dijake kar najbolj učinkovito in uspešno motivira za učenje. Preučevali smo naslednji dve raziskovalni trditvi:

- Profesor mora imeti veliko različnih sposobnosti in lastnosti, s katerimi pritegne učence k učenju.

- Obstajajo statistično značilne razlike med obravnavanima šolama v karizmatičnosti, objektivnosti in strokovnosti njihovih profesorjev.

\section{$2 \quad$ Metode raziskovanja}

Raziskava je potekala s pomočjo $\mathrm{v}$ ta namen posebej pripravljenega vprašalnika. Anketiranci so vrednotili trditve znotraj vprašalnika na podlagi Likertove lestvice, ki je zaradi enostavnosti razumljivosti pogosto uporabljena skala za merjenje stališč v družboslovnih raziskavah. Uporabili smo štiri stopenjsko lestvico (slika 1), kar pomeni, da smo srednjo, neopredeljeno vrednost izpustili. Na ta način smo anketirance prisilili, da so izrazili svoje jasno stališče in se opredelili za določeno stran.

\begin{tabular}{|c|c|c|c|}
\hline $\begin{array}{c}\text { Se ne } \\
\text { strinjam }\end{array}$ & $\begin{array}{c}\text { Deloma se } \\
\text { strinjam }\end{array}$ & $\begin{array}{c}\text { Večinoma se } \\
\text { strinjam }\end{array}$ & $\begin{array}{c}\text { Popolnoma se } \\
\text { strinjam }\end{array}$ \\
\hline 1 & 2 & 3 & 4 \\
\hline
\end{tabular}

Slika 3: Likertova lestvica uporabljena $v$ raziskavi

V vprašalniku smo lastnosti profesorja popisali s 14. različnimi spremenljivkami, ki so naslednje: 
$36^{\mathrm{TH}}$ International Conference on Organizational Science Development: Responsible Organization (MARCH $22^{\mathrm{ND}}-24^{\mathrm{TH}}$, PORTOROŽ SLOVENIA)

S. Bizant: The Use of Multivariate Statistical Methods in Analyzing the Role of Lecturer in Motivation for Learning

- Spr. 1 - ne sme ukazovati,

- Spr. 2 - imeti mora red,

- Spr. 3 - mora imeti smisel za humor,

- Spr. 4 - biti mora sproščen,

- Spr. 5 - uživati mora spoštovanje pri dijakih,

- Spr. 6 - biti mora prijazen,

- Spr. 7 - potrpežljiv mora biti s tistimi, ki težje razumejo snov,

- Spr. 8 - ne sme podcenjevati dijakov,

- Spr. 9 - govoriti mora razločno in razumljivo,

- Spr. 10 - dijake mora spodbujati k ustvarjalnosti,

- Spr. 11 - za uspehe mora dijake pohvaliti,

- Spr. 12 - kritiko naj izreka dijaku na štiri oči,

- Spr. 13 - na svojo pobudo sprejema kritiko dijakov,

- Spr. 14 - kazati mora navdušenje do svojega predmeta.

Anketirali smo dve referenčni skupini - dijake Srednje zdravstvene šole Ljubljane (SZŠ) in dijake Šolskega centra Kranj (ŠC). Na vsaki šoli je vzorec anketirancev obsegal 60 dijakov, skupno torej 120 dijakov 2.letnika. Dijaki so bili v vzorec izbrani naključno. Grafa na slikah 2 in 3 predstavljata strukturo anketirancev po spolu.

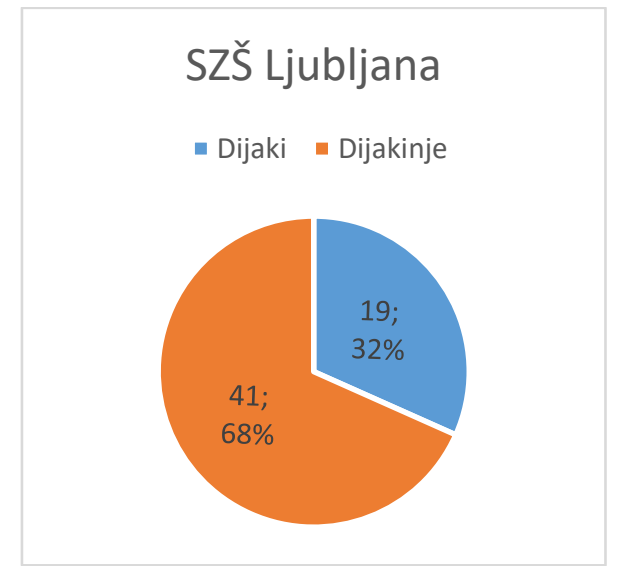

Slika 2: SZŠ - spol

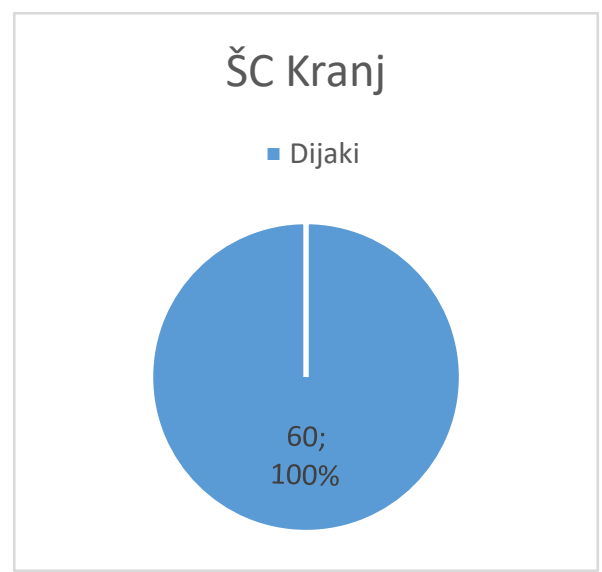

Slika 3: $\check{S} C-$ spol 
S. Bizant: Uporaba multivariatnih statističnih metod za analizo vloge profesorja pri motivaciji za učenje

Slika 2 prikazuje, da je vzorec SZŠ Ljubljana vključeval 32\% (19) dijakov in 68\% (41) dijakinj. Iz slike 3 pa je razvidno, da na ŠC Kranj ni bilo med anketiranci nobene dijakinje. To je bilo pravzaprav pričakovano, saj je večina dijakov na omenjeni srednji šoli moškega spola, zaradi tehničnih smeri šolanja.

Odgovore smo obdelali s pomočjo programa SPSS (Statistical Package for the Social Sciences). Izračunali smo opisne statistike in izvedli diskriminantno in faktorsko analizo. $\mathrm{V}$ nadaljevanju podajamo rezultate.

\section{$3 \quad$ Opisne statistike}

Opisne statistike so podane v tabeli 1

Tabela 1: Opisne statistike

\begin{tabular}{|l|c|c|c|c|c|}
\hline spremenljivka & $\mathrm{N}$ & $\begin{array}{c}\text { aritmetična } \\
\text { sredina }\end{array}$ & mediana & modus & $\begin{array}{c}\text { stand. } \\
\text { odklon }\end{array}$ \\
\hline ne sme ukazovati & 120 & 3.17 & 3.00 & 4.00 & 0.94 \\
\hline imeti mora red & 120 & 3.43 & 4.00 & 4.00 & 0.76 \\
\hline $\begin{array}{l}\text { mora imeti smisel za } \\
\text { humor }\end{array}$ & 120 & 3.55 & 4.00 & 4.00 & 0.68 \\
\hline biti mora sproščen & 120 & 3.68 & 4.00 & 4.00 & 0.63 \\
\hline $\begin{array}{l}\text { uživati mora } \\
\text { spoštovanje pri dijakih }\end{array}$ & 120 & 3.62 & 4.00 & 4.00 & 0.64 \\
\hline biti mora prijazen & 120 & 3.66 & 4.00 & 4.00 & 0.67 \\
\hline $\begin{array}{l}\text { potrpežljiv mora biti s } \\
\text { tistimi, ki težje } \\
\text { razumejo snov }\end{array}$ & 120 & 3.72 & 4.00 & 4.00 & 0.58 \\
\hline $\begin{array}{l}\text { ne sme podcenjevati } \\
\text { dijakov }\end{array}$ & 120 & 3.67 & 4.00 & 4.00 & 0.66 \\
\hline $\begin{array}{l}\text { govoriti mora razločno } \\
\text { in razumljivo }\end{array}$ & 120 & 3.69 & 4.00 & 4.00 & 0.60 \\
\hline $\begin{array}{l}\text { dijake mora spodbujati } \\
\text { k ustvarjalnosti }\end{array}$ & 120 & 3.37 & 4.00 & 4.00 & 0.75 \\
\hline $\begin{array}{l}\text { za uspehe mora dijake } \\
\text { pohvaliti }\end{array}$ & 120 & 3.42 & 4.00 & 4.00 & 0.75 \\
\hline $\begin{array}{l}\text { kritiko naj izreka } \\
\text { dijakov na štiri oči }\end{array}$ & 120 & 3.43 & 4.00 & 4.00 & 0.79 \\
\hline $\begin{array}{l}\text { na svojo pobudo } \\
\text { sprejema kritiko } \\
\text { dijakov }\end{array}$ & 120 & 3.43 & 4.00 & 4.00 & 0.75 \\
\hline $\begin{array}{l}\text { kazati mora navdušenje } \\
\text { do svojega predmeta }\end{array}$ & 120 & 3.57 & 4.00 & 4.00 & 0.71 \\
\hline
\end{tabular}

Aritmetična sredina pri vseh spremenljivkah je med 3 (večinoma se strinjam) in 4 (popolnoma se strinjam), kar pomeni, da so za dijake vse lastnosti profesorja, ki so jih 
36 ${ }^{\mathrm{TH}}$ InTernational Conference ON ORganizational Science Development: RESPONSIBLE ORGANIZATION (MARCH $22^{\mathrm{ND}}-24^{\mathrm{TH}}$, PORTOROŽ SLOVENIA)

S. Bizant: The Use of Multivariate Statistical Methods in Analyzing the Role of Lecturer in Motivation for Learning

opisovale naše spremenljivke, pomembne in se z njimi po večini strinjajo. Iz tega bi morda lahko sklepali, da odnos profesorja, njegov karakter in način podajanja snovi zelo pomemben pri motivaciji za učenje. Mediana (sredinska vrednost po položaju) in modus (najpogostejša vrednost) sta pri vseh spremenljivkah 4. Mediana je bila različna le pri spremenljivki »Ne sme ukazovati«, kjer je bila 3 .

\section{$4 \quad$ Multivariatne analize}

$\mathrm{Z}$ analizo zanesljivosti vprašalnika ugotavljamo, koliko je verjetno, da so odgovori istih anketirancev pri ponovljenem merjenju istih lastnosti enaki. Stopnjo zanesljivosti vprašalnika merimo $\mathrm{s}$ Cronbach's Alpha koeficientom. V primeru, da izmerjeni Cronbachov koeficient $\alpha$ zavzame vrednost večjo od 0,8 pomeni, da je merjeni del vprašalnika visoko zanesljiv (Šifrer in Bren, 2010). Ugotovili smo, da je vprašalnik dovolj zanesljiv in primeren za analizo oziroma obdelavo, saj je Cronbach's Alpha koeficient, ki smo ga izmerili na podlagi vseh štirinajstih spremenljivk, večji od 0.8 .

\section{1 $\quad$ Faktorska analiza}

Faktorska analiza poizkuša poenostaviti kompleksnost povezav med množico opazovanih spremenljivk z razkritjem skupnih razsežnosti ali faktorjev, ki omogočajo vpogled $\mathrm{v}$ osnovno strukturo podatkov. Metoda je uporabna $\mathrm{v}$ vseh tistih primerih, ko zaradi različnih vzrokov neposredno merjenje neke spremenljivke ni možno. $\mathrm{V}$ tem primeru merimo samo indikatorje pojma oz. konstrukta, ki ga neposredno ne moremo meriti. S faktorsko analizo nato ugotovimo ali je možno zveze med opazovanimi spremenljivkami (ali indikatorji) pojasniti z manjšim številom posredno opazovanih spremenljivk ali faktorjev (Fulgosi, 1988).

S pomočjo programa SPSS smo najprej proučevali povezanost spremenljivk tako, da smo izračunali vrednost Pearsonovega koeficienta korelacije. Rezultati si navedeni v tabeli 2. Krepko obarvane so tiste vrednosti, ki glede na svojo velikost najbolj izstopajo. Vidimo, da sta med seboj razmeroma dobro povezani spremenljivki »biti mora prijazen« in "potrpežljiv mora biti s tistimi, ki težje razumejo snov«. Prav tako sta po mnenju anketiranih dijakov povezani spremenljivki "potrpežljiv mora biti s tistimi, ki težje razumejo snov« in »ne sme podcenjevati dijakov«. Sledi povezava »biti mora sproščen« in »biti mora prijazen«. 
S. Bizant: Uporaba multivariatnih statističnih metod za analizo vloge profesorja pri motivaciji za učenje

Tabela 2: Povezanost med proučevanimi veličinami

Preden smo izvedli faktorsko analizo, smo preverjali, ali je ta glede na korelacije

Correlation Matrix

\begin{tabular}{|c|c|c|c|c|c|c|c|c|c|c|c|c|c|c|c|}
\hline & & $\begin{array}{c}\text { Spr. } \\
1\end{array}$ & $\begin{array}{c}\text { Spr. } \\
2\end{array}$ & $\begin{array}{c}\text { Spr. } \\
3\end{array}$ & $\begin{array}{c}\text { Spr. } \\
4\end{array}$ & $\begin{array}{c}\text { Spr. } \\
5\end{array}$ & $\begin{array}{c}\text { Spr. } \\
6\end{array}$ & $\begin{array}{c}\text { Spr. } \\
7\end{array}$ & $\begin{array}{c}\text { Spr. } \\
8\end{array}$ & $\begin{array}{c}\text { Spr. } \\
9\end{array}$ & $\begin{array}{c}\text { Spr. } \\
10\end{array}$ & $\begin{array}{c}\text { Spr. } \\
11\end{array}$ & $\begin{array}{c}\text { Spr. } \\
12\end{array}$ & $\begin{array}{c}\text { Spr. } \\
13\end{array}$ & $\begin{array}{c}\text { Spr. } \\
14\end{array}$ \\
\hline \multirow{26}{*}{ Correlation } & Spr.1 & 1.000 & .022 & .371 & .234 & .279 & 377 & 290 & .321 & 317 & .205 & 372 & 338 & 378 & 3 \\
\hline & Spr. & .022 & 1.000 & .344 & .233 & .216 & .161 & .537 & .546 & .291 & .217 & .239 & .112 & .299 & .288 \\
\hline & & & & & & & & & & & & & & & \\
\hline & Spr. & .371 & .344 & 1.000 & .482 & .381 & .433 & .364 & .546 & .413 & .338 & .319 & .326 & .512 & .514 \\
\hline & 3 & & & & & & & & & & & & & & \\
\hline & Spr. & .234 & .233 & .482 & 1.000 & .557 & .576 & .470 & .452 & .487 & .279 & .244 & .367 & .483 & .534 \\
\hline & 4 & & & & & & & & & & & & & & \\
\hline & Spr. & .279 & .216 & .381 & .557 & 1.000 & .448 & .448 & .346 & .374 & .376 & .347 & .284 & .500 & .477 \\
\hline & 5 & & & & & & & & & & & & & & \\
\hline & Spr. & .377 & .161 & .433 & .576 & .448 & 1.000 & .625 & .431 & .528 & .284 & .370 & .434 & .381 & .574 \\
\hline & 6 & & & & & & & & & & & & & & \\
\hline & Spr. & .290 & .537 & .364 & .470 & .448 & .625 & 1.000 & .662 & .499 & .348 & .323 & .416 & .430 & .568 \\
\hline & 7 & & & & & & & & & & & & & & \\
\hline & Spr. & .321 & .546 & .546 & .452 & .346 & .431 & .662 & 1.000 & .544 & .341 & .325 & .407 & .520 & .486 \\
\hline & 8 & & & & & & & & & & & & & & \\
\hline & Spr. & .317 & .291 & .413 & .487 & .374 & .528 & .499 & .544 & 1.000 & .452 & .396 & .359 & .406 & .451 \\
\hline & 9 & & & & & & & & & & & & & & \\
\hline & Spr. & .205 & .217 & .338 & .279 & .376 & .284 & .348 & .341 & .452 & 1.000 & .380 & .390 & .383 & .379 \\
\hline & 10 & & & & & & & & & & & & & & \\
\hline & Spr. & .372 & .239 & .319 & .244 & .347 & .370 & .323 & .325 & .396 & .380 & 1.000 & .482 & .465 & .264 \\
\hline & 11 & & & & & & & & & & & & & & \\
\hline & Spr. & .338 & .112 & .326 & .367 & .284 & .434 & .416 & .407 & .359 & .390 & .482 & 1.000 & .497 & .393 \\
\hline & 12 & & & & & & & & & & & & & & \\
\hline & Spr. & .378 & .299 & .512 & .483 & .500 & .381 & .430 & .520 & .406 & .383 & .465 & .497 & 1.000 & .514 \\
\hline & & & & & & & & & & & & & & & \\
\hline & $\begin{array}{l}\text { Spr. } \\
14\end{array}$ & .368 & .288 & .514 & .534 & .477 & .574 & .568 & .486 & .451 & .379 & .264 & .393 & .514 & 1.000 \\
\hline
\end{tabular}

spremenljivk sploh smiselna. To smo preverili s KMO (Kaiser, Mayer, Olhin) mero. Rezultati te analize so podani v tabeli 3 .

Tabela 3: KMO mera za velikost vzorca

KMO and Bartlett's Test

\begin{tabular}{|cc|c|}
\hline \multicolumn{2}{|c|}{ Kaiser-Meyer-Olkin Measure of Sampling Adequacy. } & .874 \\
Bartlett's Test of Sphericity & $\begin{array}{c}\text { Approx. Chi-Square } \\
\text { df }\end{array}$ & 91 \\
& Sig. & .000 \\
\hline
\end{tabular}



RESPONSIBLE ORGANIZATION (MARCH $22^{\mathrm{ND}}-24^{\mathrm{TH}}$, PORTOROŽ SLOVENIA)

S. Bizant: The Use of Multivariate Statistical Methods in Analyzing the Role of Lecturer in Motivation for Learning

KMO koeficient se nahaja na intervalu $[0,1]$ in je večji od 0.8 , kar pomeni, da je vzorec zelo primeren za faktorsko analizo. Delež varianc, ki je pojasnjena s skupnimi faktorji vidno v tabeli 4 , imenujemo tudi komunaliteta.

\section{Tabela 4: Tabela komunalitet}

Communalities

\begin{tabular}{|c|c|c|}
\hline & Initial & Extraction \\
\hline ne sme ukazovati & 1.000 & .469 \\
\hline imeti mora red & 1.000 & .842 \\
\hline mora imeti smisel za humor & 1.000 & .477 \\
\hline biti mora sprošèen & 1.000 & .699 \\
\hline uživati mora spoštovanje pri dijakih & 1.000 & .508 \\
\hline biti mora prijazen & 1.000 & .668 \\
\hline potrpežljiv mora biti s tistimi, ki težje razumejo snov & 1.000 & .691 \\
\hline ne sme podcenjevati dijakov & 1.000 & .720 \\
\hline govoriti mora razloèno in razumljivo & 1.000 & .504 \\
\hline dijake mora spodbujati k ustvarjalnosti & 1.000 & .444 \\
\hline za uspehe mora dijake pohvaliti & 1.000 & .687 \\
\hline kritiko naj izreka dijakou na štiri oèi & 1.000 & .579 \\
\hline na svojo pobudo sprejema kritiko dijakov & 1.000 & .571 \\
\hline kazati mora navdušenje do svojega predmeta & 1.000 & .638 \\
\hline
\end{tabular}

Extraction Method: Principal Component Analysis.

Iz tabele 4 lahko razberemo, da so komunalitete vseh spremenljivk dokaj visoke, kar pomeni, da so spremenljivke dovolj močno povezane med seboj. 
S. Bizant: Uporaba multivariatnih statističnih metod za analizo vloge profesorja pri motivaciji za učenje

Tabela 5: Lastne vrednosti in pojasnjene variance pridobljenih faktorjev

Total Variance Explained

\begin{tabular}{|c|c|c|c|c|c|c|c|c|c|}
\hline \multirow[b]{2}{*}{ Component } & \multicolumn{3}{|c|}{ Initial Eigenvalues } & \multicolumn{3}{|c|}{$\begin{array}{c}\text { Extraction Sums of Squared } \\
\text { Loadings }\end{array}$} & \multicolumn{3}{|c|}{$\begin{array}{c}\text { Rotation Sums of Squared } \\
\text { Loadings }\end{array}$} \\
\hline & Total & $\begin{array}{c}\% \text { of } \\
\text { Variance }\end{array}$ & $\begin{array}{c}\text { Cumulative } \\
\%\end{array}$ & Total & $\begin{array}{c}\% \text { of } \\
\text { Variance }\end{array}$ & $\begin{array}{c}\text { Cumulative } \\
\%\end{array}$ & Total & $\begin{array}{c}\% \text { of } \\
\text { Variance }\end{array}$ & $\begin{array}{c}\text { Cumulative } \\
\%\end{array}$ \\
\hline 1 & 6.209 & 44.351 & 44.351 & 6.209 & 44.351 & 44.351 & 3.573 & 25.523 & 25.523 \\
\hline 2 & 1.254 & 8.955 & 53.306 & 1.254 & 8.955 & 53.306 & 2.723 & 19.452 & 44.975 \\
\hline 3 & 1.033 & 7.377 & 60.683 & 1.033 & 7.377 & 60.683 & 2.199 & 15.708 & 60.683 \\
\hline & .842 & 6.016 & 66.699 & & & & & & \\
\hline 5 & .791 & 5.650 & 72.349 & & & & & & \\
\hline 6 & .683 & 4.875 & 77.225 & & & & & & \\
\hline 7 & .635 & 4.535 & 81.759 & & & & & & \\
\hline 8 & .580 & 4.140 & 85.899 & & & & & & \\
\hline 9 & .478 & 3.413 & 89.312 & & & & & & \\
\hline 10 & .400 & 2.859 & 92.171 & & & & & & \\
\hline 11 & .337 & 2.406 & 94.577 & & & & & & \\
\hline 12 & .306 & 2.183 & 96.760 & & & & & & \\
\hline 13 & .269 & 1.920 & 98.680 & & & & & & \\
\hline 14 & .185 & 1.320 & 100.000 & & & & & & \\
\hline
\end{tabular}

Extraction Method: Principal Component Analysis.

Iz tabele 5 razberemo, da nam program izračuna 3 faktorje za prvotnih 14 spremenljivk.

Spremenljivke smo razdelili na faktorje tako, da je vsaka spremenljivka pripadla tistemu faktorju, za katerega je imela največjo vrednost faktorske uteži. Na ta način smo dobili naslednje faktorje. 
36 ${ }^{\mathrm{TH}}$ InTernational Conference ON ORganizational Science Development: RESPONSIBLE ORGANIZATION (MARCH $22^{\mathrm{ND}}-24^{\mathrm{TH}}$, PORTOROŽ SLOVENIA)

S. Bizant: The Use of Multivariate Statistical Methods in Analyzing the Role of Lecturer in Motivation for Learning

1. faktor je sestavljen iz naslednjih spremenljivk:

- biti mora sproščen

- biti mora prijazen

- kazati mora navdušenje do svojega predmeta

- uživati mora spoštovanje pri dijakih

- mora imeti smisel za humor

- govoriti mora razločno in razumljivo

To lahko združimo v eno spremenljivko, ki smo jo glede na opisne lastnosti posameznih spremenljivk poimenovali »karizmatičen«.

2. faktor je sestavljen iz naslednjih spremenljivk:

- za uspehe mora dijake pohvaliti

- kritiko naj izreka dijakov na štiri oči

- dijake mora spodbujati k ustvarjalnosti

- ne sme ukazovati

- na svojo pobudo sprejema kritiko dijakov

To lahko združimo v eno spremenljivko, ki smo jo glede na opisne lastnosti posameznih spremenljivk poimenovali »objektiven«.

3. faktor je sestavljen iz naslednjih spremenljivk:

- imeti mora red

- ne sme podcenjevati dijakov

- potrpežljiv mora biti s tistimi, ki težje razumejo snov

To lahko združimo v eno spremenljivko, ki smo jo glede na opisne lastnosti posameznih spremenljivk poimenovali »strokoven«.

Ti trije faktorji zajemajo $60 \%$ variance. Naslednje vrednosti spremenljivk (od četrte naprej) so namreč manjše od 1, kar pomeni, da gre za lastne vrednosti faktorjev, ki jih bomo v nadaljevanju tudi podrobneje preučili. Gre za študijo povezav med spremenljivkami, tako da poizkušamo najti novo množico spremenljivk, ki predstavljajo to, kar je skupnega opazovanim spremenljivkam.

Število faktorjev pa lahko določimo tudi na drugi način, in sicer s pomočjo kolenskega diagrama. To je diagram, kjer na vodoravno os nanašamo faktorje, na navpično os pa ustrezne lastne vrednosti.

Kolenski diagram za naš primer je prikazan na sliki 4. Točko preloma smo dobili tako, da smo potegnili premico ki, se najbolj prilega večini točk $v$ grafu. Točke ki od te premice 
S. Bizant: Uporaba multivariatnih statističnih metod za analizo vloge profesorja pri motivaciji za učenje

najbolj odstopajo, predstavljajo možne faktorje. Iz slike 4 je torej razvidno, da lahko naše spremenljivke (vseh je 14) združimo v tri skupne faktorje.

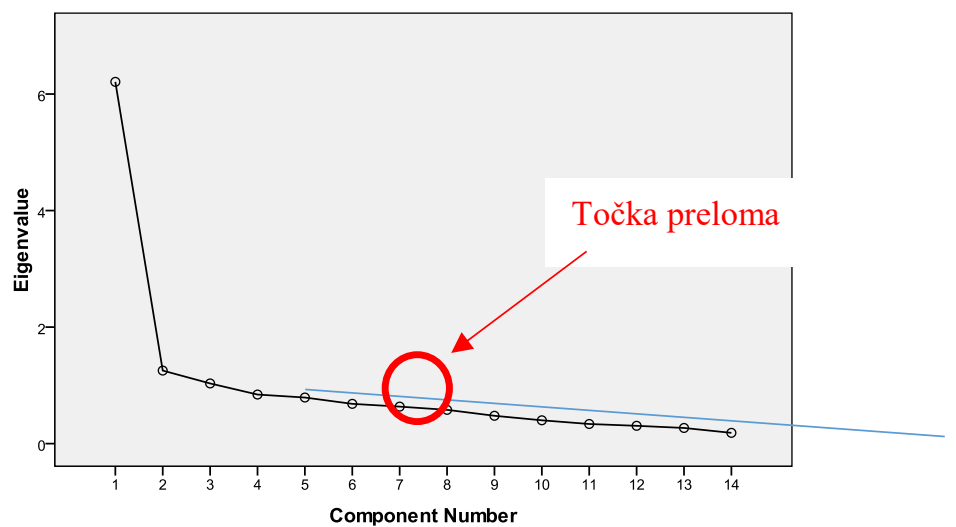

Slika 4: Kolenski diagram - diagram števila faktorjev v odvisnosti od lastnih vrednosti.

S pravokotno rotacijo (metodo »Varimax«) dobimo tabelo 6, v kateri so bolj natančno porazdeljene faktorske uteži, ki skupaj po določenih spremenljivkah predstavljajo nove faktorje. Tako bodo oblikovani trije novi faktorji, ki jih poimenujemo (okarakteriziramo) glede na to, katere spremenljivke vsebuje. 

RESPONSIBLE ORGANIZATION (MARCH $22^{\mathrm{ND}}-24^{\mathrm{TH}}$, PORTOROŽ SLOVENIA)

S. Bizant: The Use of Multivariate Statistical Methods in Analyzing the Role of Lecturer in Motivation for Learning

Tabela 6: Rotirana faktorska matrika

\begin{tabular}{|c|c|c|c|}
\hline \multicolumn{4}{|c|}{ Rotated Component Matrix ${ }^{a}$} \\
\hline & 1 & 2 & 3 \\
\hline biti mora sprošèen & .812 & .113 & .164 \\
\hline biti mora prijazen & .766 & .267 & .096 \\
\hline kazati mora navdušenje do svojega predmeta & .722 & .237 & .246 \\
\hline uživati mora spoštovanje pri dijakih & .653 & .259 & .117 \\
\hline mora imeti smisel za humor & .510 & .324 & .335 \\
\hline govoriti mora razloèno in razumljivo & .479 & .391 & .347 \\
\hline za uspehe mora dijake pohvaliti & .074 & .807 & .172 \\
\hline kritiko naj izreka dijakou na štiri oèi & .277 & .704 & .082 \\
\hline dijake mora spodbujati k ustvarjalnosti & .174 & .583 & .272 \\
\hline ne sme ukazovati & .364 & .565 & -.131 \\
\hline na svojo pobudo sprejema kritiko dijakov & .429 & .561 & .270 \\
\hline imeti mora red & .063 & .041 & .914 \\
\hline ne sme podcenjevati dijakov & .401 & .302 & .683 \\
\hline potrpežljiv mora biti s tistimi, ki težje razumejo snov & .542 & .212 & .593 \\
\hline
\end{tabular}

\section{$5 \quad$ Diskriminantna analiza}

Diskriminantna analiza je metoda za proučevanje odvisnosti, kadar je odvisna spremenljivka opisna, neodvisne spremenljivke pa so številske. Dobljene faktorje iz faktorske analize smo združil v nove spremenljivke: Karizmatičen, objektiven in strokoven. Spremenljivke so uporabljene v diskriminantni analizi, kjer opazujemo razliko med dvema šolama. V ta namen smo uporabili metodo Stepwise. To je hierarhična metoda, ki od vseh spremenljivk, ki jih vključimo v analizo izbere samo tiste, kjer so razlike med proučevanima skupinama statistično značilne. Rezultati analize Stepwise so podani v tabeli 7 . 
S. Bizant: Uporaba multivariatnih statističnih metod za analizo vloge profesorja pri motivaciji za učenje

Tabela 7: Rezultati analize Stepwise

\section{Discriminant - Stepwise Statistics}

\section{Eigenvalues}

\begin{tabular}{|l|r|r|r|r|}
\hline Function & Eigenvalue & $\%$ of Variance & Cumulative \% & $\begin{array}{c}\text { Canonical } \\
\text { Correlation }\end{array}$ \\
\hline 1 &, $104^{\mathrm{a}}$ & 100,0 & 100,0 &, 307 \\
\hline
\end{tabular}

a. First 1 canonical discriminant functions were used in the analysis.

Tabela 8: Wilks Lambda

Wilks' Lambda

\begin{tabular}{|l|r|r|r|r|}
\hline Test of Function(s) & Wilks' Lambda & Chi-square & df & \multicolumn{1}{c|}{ Sig. } \\
\hline 1 &, 906 & 11,587 & 2 &, 003 \\
\hline
\end{tabular}

Iz tabele 8 je vidno, da je diskriminantna funkcija statistično značilna, saj je p-vrednost $<0.05$

Tabela 9: Fisherjeva diskriminantna funkcija

Standardized Canonical Discriminant Function

Coefficients

\begin{tabular}{|c|c|}
\hline & Function \\
\cline { 2 - 2 } & 1 \\
\hline karizmatičen &, 686 \\
strokoven &, 762 \\
\hline
\end{tabular}

Iz tabele 9 je razvidno, da sta karizmatičnost in strokovnost lastnosti po katerih se po mnenju anketiranih dijakov obeh obravnavanih šol razlikujeta, objektivnost pa ne. Iz tabele 9 lahko razberemo tudi, da so pri ocenah strokovnosti večje razlike med šolama kot pri ocenah karizmatičnosti. Pozitiven predznak funkcije pa nakazuje, da so dijaki v prvi skupini svoje profesorje ocenili bolje kot dijaki v drugi skupini.

\section{Zaključek}

Dandanes se srečujemo z velikim problemom, kako dijake uspešno motivirati za učenje. Razvoj informacijske tehnologije in uporaba vedno boljših mobilnih telefonov jim vzame vedno več časa in pozornosti, zato se jim je še težje osredotočiti in pripraviti na delo in učenje. Kljub temu pa ima še vedno pomembno vlogo pri motivaciji za učenje ravno profesor, ki predstavlja nekakšno vez med dijakom in podano snovjo.

V prispevku smo proučevali, kakšne lastnosti mora imeti dober profesor, da svoje dijake motivira k učenju. Na podlagi predhodnih analiz smo ugotovili, da mora biti profesor karizmatičen, pravičen in profesionalen pri svojem delu in v odnosu do dijakov. Spoznali smo, da se anketirani dijaki popolnoma strinjajo s tem, da mora biti profesor predvsem prijazen, sproščen, da mora govoriti razločno, razumljivo in z navdušenjem razlagati vsebino predmeta. Na podlagi tega lahko potrdimo, da mora imeti profesor veliko 
36 $6^{\mathrm{TH}}$ InTernational Conference on ORganizational Science Development: RESPONSIBLE ORGANIZATION (MARCH $22^{\mathrm{ND}}-24^{\mathrm{TH}}$, PORTOROŽ SLOVENIA)

S. Bizant: The Use of Multivariate Statistical Methods in Analyzing the Role of Lecturer in Motivation for Learning

različnih sposobnosti in lastnosti, s katerimi pritegne učence k učenju. Menimo tudi, da mora profesor na svojo pobudo sprejemati tudi kritiko dijakov, saj s tem dobi povratne informacije o svojem delu in lahko na njihovi podlagi izboljša celoten proces podajanja snovi.

Rezultati naše raziskave potrjujejo tudi hipotezo 2. Dobljeni rezultati, ki izražajo mnenje anketiranih dijakov, so pokazali, da med profesorji izbranih šol obstajajo razlike, v karizmatičnosti, in strokovnosti profesorjev, v objektivnosti pa ne. Menimo, da je do teh razlik prišlo morda tudi zato, ker je profil dijakov na obeh šolah povsem različen. Dijaki na ŠC so bolj tehnično usmerjeni, medtem ko se dijaki na SZŠ učijo dela z ljudmi (bolniki) in morda zato pripisujejo medsebojnim odnosom večji pomen.

\section{Literatura}

Dahl, D. W. in Smimou, K. (2011). Does motivation matter? On the relationship between perceived quality of teaching and students' motivational orientations, Managerial Finance, 37 (7), strani 582-609.

Ferligoj, A, Kronegger, L. (2009). Metodološki zvezki, 6 (2), strani 135-153. Dostopano 12.11.2016 na: http://mrvar.fdv.uni-lj.si/pub/mz/mz6.1/ferligoj.pdf.

Fulgosi, A. (1988). Faktorska analiza, Školska knjiga 3.izd., Zagreb.

Geringer, J. (2003). Reflections on professional development: toward high-quality teaching and learning, Phi Delta Kappan, 84 (5), strani 373-374.

Jesenko, J. in Jesenko, M. (2007). Multivariatne statistične metode, Moderna organizacija, Kranj. Bren, M. (2013). Metodologija družboslovnega raziskovanja in multivariatne statistične metode, Študijsko gradivo, Univerza v Mariboru, Fakulteta za varnostne vede, Ljubljana.

Maureen, T. (2002). University impact on student growth: a quality measure?, Journal of Higher Education Policy and Management, 24 (2), strani 211-219

Šifrer, J., Bren, M (2010). SPSS-Multivariatne metode v varstvoslovju. Priročnik za študente magistrskega programa. Ljubljana: Fakulteta za varnostne vede.

http://vlado.fmf.uni-lj.si/vlado/podstat/Mva/FA.pdf (dostopano dne 8.11.2016) 


\section{Raziskovalno delo na Srednji strokovni šoli Vegova Ljubljana}

\section{UROŠ BRESKVAR}

Povzetek Prepoznavnost in uspešnost srednje šole je vedno bolj povezana $\mathrm{z}$ vključevanjem in vzpodbujanjem dijakov $\mathrm{v}$ raziskovalne dejavnosti. Vedno več je tudi projektov financiranih iz EU za podporo tovrstnih dejavnosti. Dijaki, ki se vključujejo v raziskovalne projekte dosegajo odlične rezultate pri različnih tekmovanjih in zaključne naloge krepko presegajo zahtevano stopnjo srednjih šol za odlično oceno. Pomembno bi bilo, da imajo tovrstni dijaki nadaljevati svoje raziskovalno delo na fakultetah, kjer naj bi dobili ustrezno podporo. Razvoj raziskovalnih dejavnosti je odvisen od usmeritve posamezne srednje šole. V članku je predstavljeno delo na področju raziskovalnega dela elektrotehniškoračunalniške strokovne šole in gimnazije Ljubljana.

KLJUČNE BESEDE: srednja šola • raziskovalno delo • projekti

NASLOV AVTORJA: dr. Uroš Breskvar, Elektrotehniško-računalniška strokovna šola in gimnazija Ljubljana, Vegova ulica 4, 1000 Ljubljana, Slovenija, e-pošta: uros.breskvar@vegova.com 
36 ${ }^{\text {TH }}$ International CONFEREnCE ON ORganizational Science Development: Responsible Organization (MARCH $22^{\mathrm{ND}}-24^{\mathrm{TH}}$, PORTOROŽ SLOVENIA)

O. Arsenijević, M. Ferjan, I. Podbregar, P. Šprajc, D. Trivan \& Y.

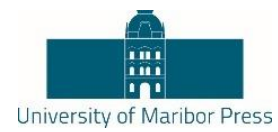

Ziegler

\title{
Research Activities in the Upper Secondary School Vegova Ljubljana
}

\section{UROŠ BRESKVAR}

\begin{abstract}
Recognition and success of a secondary high Schools are more and more connected with integration and encouragement of students into researching activities. More and more projects are financed from EU, from funds for such activities. Students who are involved in research projects, achieve excellent results. Their work exceeds the expected level of knowledge expected for excellent students. It would be very imported, that students continue their work on Faculties, where suitable help and support should be provided. Development of research activities depends from activities and goals on High Schools. The article presents the work of researching team The upper secondary school of electrical and computer engineering and technical gymnasium Ljubljana.
\end{abstract}

KEYWORDS: upper secondary school $\bullet$ research activities $\bullet$ projects

CorResPondence AdDRess: Uroš Breskvar, Ph.D., Electrotechnical and computer-Technical School and Grammar School Ljubljana, Vegova ulica 4, 1000 Ljubljana, Slovenia, e-mail: uros.breskvar@vegova.com 


\section{$1 \quad$ Uvod}

V skladu s smernicami razvoja šolstva v Sloveniji, ki su usklajene s smernicami šolstva EU, morajo učne ustanove prilagoditi in izvajati svoje programe tako, da bodo udeleženci pridobili aktualna znanja in bodo zaposljivi tudi izven meja Slovenije. Za uresničitev tega cilja je nujno povezovanje šol na mednarodni ravni in pripravljenost šole, da razvija znanstveno raziskovalno delo (Piesanen \& Vallijarvi, 2010).

Elektrotehniško-računalniška strokovna šola in gimnazija Ljubljana (v nadaljevanju Vegova Ljubljana) je vodilna strokovna šola v Sloveniji. Dosežki dijakov Vegove Ljubljana na maturi krepko presegajo ostale strokovne šole. Slika 1 prikazuje dosežke dijakov Vegove Ljubljana v primerjavi z državnim povprečjem.

K doseganju teh rezultatov zagotovo pripomore večletno prizadevanje šole, da stalno posodablja sam učni proces, da sodeluje pri mednarodnih projektih in vzpodbuja raziskovalno dejavnost med dijaki. Prav $\mathrm{z}$ namenom vzpodbujanja raziskovalne delavnosti, deluje na šoli Medpodjetniški izobraževalni center (MIC) in v letu 2016 je bil ustanovljen tudi prvi raziskovalni laboratorij. V nadaljevanju je predstavljeno delovanje $\mathrm{MICa}$ in raziskovalnega laboratorija in predstavljeni so tudi konkretni dosežki dijakov.

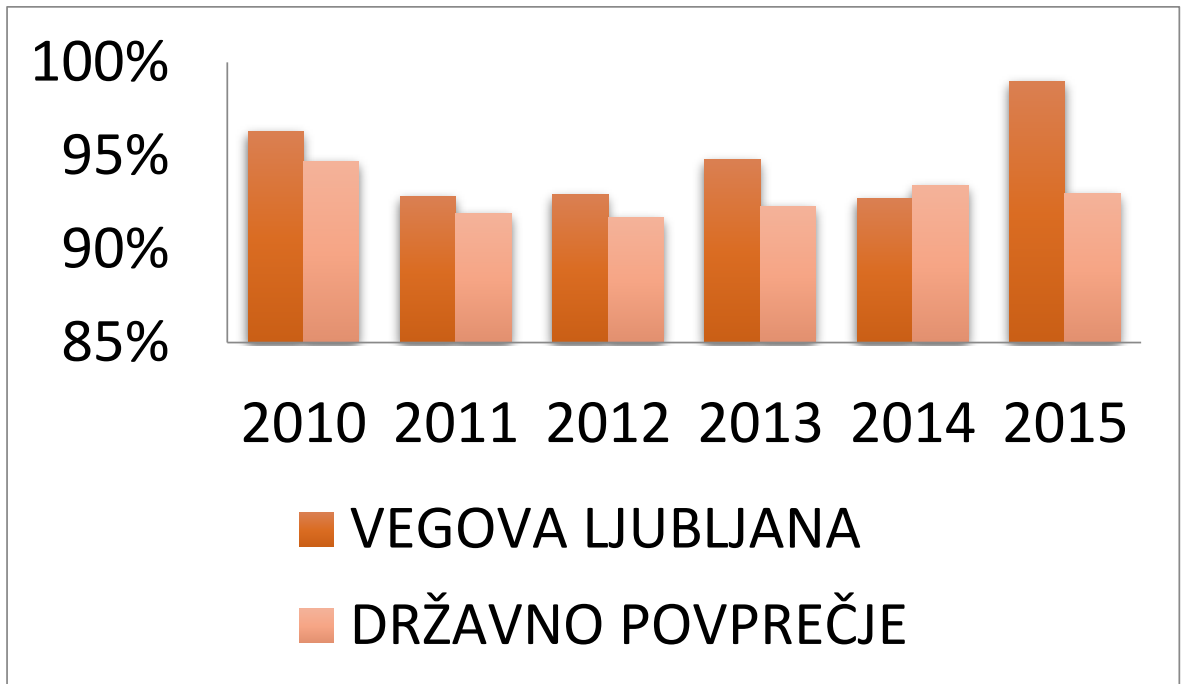

Slika 1: Dosežki dijakov Vegove Ljubljana v primerjavi z državnim povprečjem

\section{Medpodjetniški izobraževalni center - MIC}

Vegova Ljubljana je ustanovila Medpodjetniški izobraževalni center Ljubljana (MIC Ljubljana) z namenom, da okrepi povezave, ki jih šola že ima z gospodarstvom in drugimi razvojnimi akterji v državi (univerze in zavodi). Šola je organizacijsko enoto MIC dobila s sklepom vlade dne 6. 10. 2019. Šola je že pred ustanovitvijo MIC Ljubljana sodelovala 
36 ${ }^{\mathrm{TH}}$ International Conference ON ORganizational SCIENCE Development: ResPonsible ORganization (MARCH $22^{\mathrm{ND}}-24^{\mathrm{TH}}$, Portorož Slovenia)

U. Breskvar: Research Activities in the Upper Secondary School Vegova Ljubljana

pri oblikovanju povezav med sorodnimi šolami v državi. Z oblikovanjem Konzorcija strokovnih gimnazij, ki koordinira prenovo strokovnih gimnazij smo povezali strokovne gimnazije. MIC Ljubljana je sposoben pripraviti in se odzvati na predvidene projekte $\mathrm{v}$ okolju, ki so namenjeni razvoju kadrov in hkrati delovati kot povezovalni subjekt med podjetniško in izobraževalno sfero na konkretni ravni (Zeichner, 1992). Tako poleg izvajanja usposabljanj $\mathrm{v}$ šoli in podjetjih dodatno omogoča še prenos znanja in tehnologije. Zagotavlja pogoje za izvajanje obstoječih projektov in razvijanje novih $\mathrm{v}$ okviru vseživljenjskega učenja, in sicer na način, da ob istočasnem izvajanju različnih aktivnosti za spodbujanje mladih $\mathrm{k}$ šolanju za poklice in nadaljnji študij, ki jih država za svoj razvoj potrebuje, razvija kompetence zaposlenih ter prekvalifikacije in dokvalifikacije odraslih oseb. Tako MIC Ljubljana na eni strani pomembno prispeva $\mathrm{k}$ razvoju kompetenc dijakov in zaposlenih na šoli, kot tudi zunanjih partnerjev. Usmeritev Vegove Ljubljana je vodilo za razvoj in usmeritev MIC Ljubljana kot podporne enote razvoju šole in spodbujanju usmerjenosti v tehniške in naravoslovne poklice.

Prednostne naloge MIC Ljubljana so naslednje:

- izobraževanje in izvajanje praktičnega usposabljanja dijakov, odraslih doma in v tujini,

- usposabljanje za potrebe podjetij na področju elektrotehnike, strojništva, mehatronike in računalništva;

- usposabljanje in razvoj učiteljevih strokovnih kompetenc za potrebe profesionalnega in osebnega napredka;

- certificiranje in potrjevanje znanj zaposlenih in nezaposlenih;

- dolgoročno sodelovanje s podjetji, univerzami, institucijami in strokovnjaki iz gospodarstva;

- širjenje dejavnosti MIC Ljubljana na področje povezovanje sorodnih šol v državi kot podpora konzorcijem šol in podjetij;

- vzpostavitev izobraževalno/karierne vertikale od srednje šole preko univerze do zaposlitve;

- načrtovanje in izvajanje mednarodnih projektov in projektov iz kohezijskih in socialnih skladov.

Usmeritvene poti delovanja in razvoja MIC Ljubljana so tesno povezane s podporno vlogo pri razvoju strokovne šole in gimnazije:

- sodelovati pri spodbujanju inovativnost, podjetnost dijakov;

- podpora pri uvajanje izboljšav in kakovost pouka, raziskovalne dejavnosti za področje naravoslovja in tehnike;

- podpora pri izboljšavah na področju fleksibilnosti in kakovosti pouka, podpora pri usposabljanju glede na potrebe gospodarstva;

- podpora učiteljem pri prepoznavanju posebnih potreb srednješolcev in spodbujanje k samozaposlovanju;

- podpora pri zagotavljanju pogojev za rast in razvoj Vegove Ljubljana in konzorcijskih partnerjev (Konzorcij strokovnih gimnazij); 
- podpora pri zagotavljanju mednarodne mobilnosti dijakov in učiteljev (evropski projekti Lonardo da Vinci, Erasmus +), nameščanja dijakov in učiteljev na praktičnem usposabljanju in raziskovanju v podjetjih (Mobility of teachers and trainers, 2006);

- sodelovanje pri izboljševanju kakovosti okolja in ustrezne infrastrukture

- skozi svoje aktivnosti promovirati okoljsko ozaveščenost in odgovorno ravnanje do okolja (izraba obnovljivih virov);

- prispevati k skladnemu razvoju osrednjeslovenske regije, države.

Osnovni namen MIC Ljubljana je sodelovanje pri združiti srednješolskega (strokovne šole in strokovne gimnazije) okolja $\mathrm{v}$ enoten in učinkovit ter nacionalno konkurenčen inovacijski center, ki temelji na partnerstvu in zaupanju ter $\mathrm{z}$ dodatnim praktičnim usposabljanjem, sodelovanjem $\mathrm{z}$ univerzami prispevati $\mathrm{k}$ zagotavljanju kakovostnih poklicnih kadrov na mednarodno primerljivi ravni. V ta namen so splošni cilji MIC Ljubljana:

- ustvarjanje kreativnega in stimulativnega podpornega okolja za povezovanje izobraževalne in gospodarske sfere;

- izboljšanje pogojev za izvedbo izobraževanja dijakov, zaposlenih na Vegovi Ljubljana in partnerskih šolah;

- izboljšanje pogojev za izvedbo izobraževanja nezaposlenih, brezposelnih in širše zainteresirane javnosti,

- povečevanje števila usposabljanj brezposelnih in težje zaposljivih,

- zaposlovanje različnih strokovnjakov, ki bodo pripomogli k nadgradnji obstoječih programov in zagotovili višjo stopnjo strokovne usposobljenosti bodočih kadrov,

- aktivno povezovanje z malimi in srednjimi podjetji, s posebnim poudarkom na izvajanju usposabljanju za specifične proizvodne oziroma storitvene procese,

- aktivno povezovanje z malimi in srednjimi podjetji, s posebnim poudarkom na izvajanju usposabljanju za specifične raziskave v podjetjih,

- vlaganje $\mathrm{v}$ razvoj kompetentnih in konkurenčnih kadrov,

- povezovanje in izmenjava dobrih praks in znanj s partnerji v regiji, državi in v širšem mednarodnem okolju.

Vegova Ljubljana ima razvejano sodelovanje z 11 partnerji v državah Evropske unije. V janarju 2013 je podpisala Memorandum o sodelovanju z naslednjimi partnerji:

Partner 1: I. tehnička škola Tesla, Zagreb, Croatia

Partner 2: Oulu Vocational College; Oulu; Finland

Partner 3: La Croix Rouge, Brest, France

Partner 4: Berufskolleg Berliner Platz, Arnsberg, Germany

Partner 5: HLA - Die Flensburger Wirtschaftsschule, Flensburg, Germany

Partner 6: IES VALLE DE ELDA, SPAIN

Partner 7: EU - Geschaeftsstelle Bezirksregierung Arnsberg, Arnsberg, Germany

Partner 8: Vegova Ljubljana, Slovenia

Partner 9: Salpaus Further Education, Lahti, Finland

Partner 10: IES SAN VICENTE, Alicante, Spain

Partner 11: Staffatgymnasium, Soderhamn, Sweden 
Memorandum je podlaga za nameščanje dijakov v tujini in tujih dijakov v Sloveniji. Na tak način je določena partnerska vloga med podpisniki sporazuma in ustvarjeni so pogoji za nove projekte. MIC Ljubljanaje je intenzivno vključen $\mathrm{v}$ mednarodne projekte kot organizacijska enota Vegove Ljubljana. Dosedanjo pestrost in raznovrstnost mednarodnih povezav bomo še nadgradili, predvsem v prostoru Evropske unije (EU). Mednarodno sodelovanje je sestavni del načrtovanja z vsebinskega, organizacijskega, finančnega in kadrovskega vidika.

Zadnji mednarodni projekti Vseživljenjskega učenja (Leonardo da Vinci in Erasmus+):

1) 2009, Leonardo da Vinci mobility, 2008-5677-COM, EMPA (E-Learning materials for Placement Abroad);

2) 2011, Comenius partnership, COM-AV-95/11, BuGa - Preparing students for the World of Work through International Business games;

3) 2012, Leonardo da Vinci partnership, LDV-PAR-15/12, Learner mobility in everyday teaching;

4) 2013 Leonardo da Vinci mobility, LDV-MOB-16/13, On the Job Abroad Training and Experience;

5) 2014 Erasmus+, K1: KA1 - VET - 090/14, Better education, skills and trainings.

6) 2016 - 2018 ERASMUS + K1 - Innovative Learning Environments in Enterprises for The Development of Competencies, Skills and Knowledge (ILED), namestitev 100 dijakov in 10 učiteljev pri partnerjih.

MIC uspešno uresničuje zadane cilje, seveda si pa v skladu s smernicami EU želimo še več projektov in omogočiti še več dijakom in učiteljem nabiranja izkušenj pri partnerjih.

\section{$3 \quad$ Raziskovalni laboratorij}

Dijaki so če več let izražali željo po prostoru, ki bi omogočal njihovo raziskovalno dejavnost. Z letom 2016 je šola dobila dodatne prostore in en prostor je bil namensko urejen za izvajanje raziskovalne dejavnosti dijakov. Glavna prednost je, da imajo dijaki s pomočjo čitalca kartic, ki so ga sami razvili in izdelali, dostop do prostora brez mentorja in da lahko časovno praktično neomejeno v prostoru delajo. Dejansko v laboratoriju delajo na konkretnih izdelkih. Na slikah 2 in 3 lahko vidimo nekaj izdelanih izdelkov. 


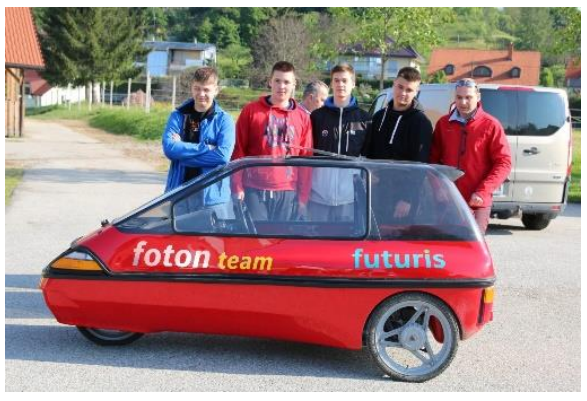

Slika 4: Električni avtomobil zmagovalec tekmovanja med električnimi vozili v Mariboru 2016

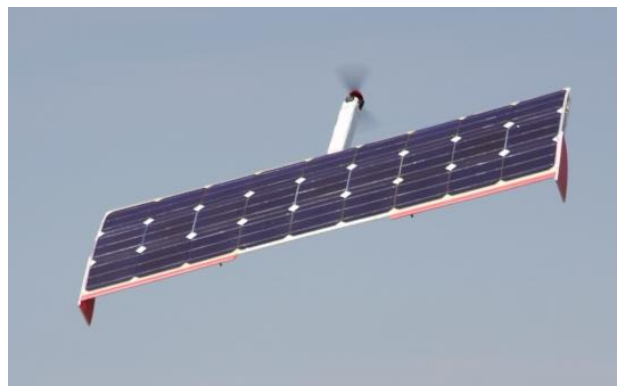

Slika 3: Solarno letalo Vega z aktualnim rekordom $v$ letenju $v$ Sloveniji

Vsekakor je na šoli želja, da bi imeli še več tovrstnih prostorov, saj ugotavljamo, da imajo dijaki zelo radi samostojno delo in da so različni krožki v zatonu.

\section{Delo v naprej}

Ker se je izkazalo, da dijaki za svoje raziskovalno delo potrebujejo prostor, ki je ustrezno opremljen in do katerega imajo neomejen dostop, bomo na šoli ustrezno opremili še nekaj prostorov namenjenih raziskovalni dejavnosti. Vsekakor upamo, da se bo čim več fakultet in/ali podjetij podprlo tovrstne laboratorije z opremo, ki jo same več ne potrebujejo ali jo lahko pogrešajo, se vključilo v delo s svojimi mentorji, ki bodo ustrezno usmerjali raziskovalce, bodo predstavljali svoje projektov in možnostjo vključitve dijakov itd.

\section{5}

\section{Zaključek}

Dijaki elektrotehnično-računalniške strokovne šole in gimnazije Ljubljana že vrsto let dosegajo odlične rezultate na različnih tekmovanjih, predstavljajo svoje dosežke na mednarodnih znanstvenih konferencah in dobivajo odlične ocene s strani delodajalcev, kjer opravljajo obvezno praktično usposabljanje $\mathrm{z}$ delom. Vsekakor je to rezultat usmeritve šole, kjer se načrtno vzpodbuja raziskovalna dejavnost dijakov. Pri tem je pomembna tudi oprema in prostor. S tem namenom je bil ustanovljen MIC in raziskovalni laboratorij, ki je nekako nadgradnja krožkom, ki so do sedaj predstavljali glavno izven šolsko dejavnost. Na šoli je vsako leto več dijakov vključenih v raziskovalne dejavnosti. Pomembna je povezanost šole s fakultetami, saj kar 95\% dijakov nadaljuje izobraževanje po končanju Vegove Ljubljana. Dijaki, ki so izkazali zanimanje za raziskovalno dejavnost in ga tudi potrdili, se običajno na fakultetah vključijo $\mathrm{v}$ raziskovalne laboratorije, kjer nadaljujejo svoje delo.

Za nadaljnji razvoj je šola zelo zainteresirana za povezovanje s fakultetami in delodajalci in za sodelovanje pri različnih projektih. 
$36^{\text {Th }}$ International Conference on Organizational Science Development:

RESPONSIBLE ORGANIZATION (MARCH $22^{\mathrm{ND}}-24^{\mathrm{TH}}$, PORTOROŽ SLOVENIA)

U. Breskvar: Research Activities in the Upper Secondary School

Vegova Ljubljana

\section{Literatura}

Mobility of teachers and trainers (2006). Dostopno na http://ec.europa.su/education/pdf/doc258_en.pdf

Piesanen, E. in Vallijarvi, S. (2010). Education and trening 2010: three studies to support school policy development Lot 2: teacher education curricula in the EU. Final report. Annexes. Finnish Institute for Education Research.

Zeichner, K. M. (1992). Rethinking the practicum in the professional development school partnership: Jurnal of Teacher Education, 43. št. 4. str. 296-307. 
$36^{\text {TH }}$ International Conference ON ORganizational Science DEVElopMENT: Responsible ORganization (MARCH $22^{\mathrm{ND}}-24^{\mathrm{TH}}$, PORTOROŽ SLOVENIA)

O. Arsenijević, M. Ferjan, I. Podbregar, P. Šprajc, D. Trivan \& Y.

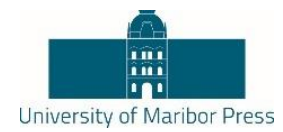

Ziegler

\title{
Corporate Social Responsibility: Towards a New Management Paradigm
}

\author{
SLOBODAN BREZAK
}

\begin{abstract}
The purpose of this paper is to highlight corporate social responsibility as a new management paradigm that has emerged as an alternative to the classical model of maximizing profits. Corporate social responsibility aims to create and maintain harmony between monetary and short-term goals of business systems, and social and environmental longterm goals of society as a whole. Comparison of the actual values achieved by business systems with built-in social responsibility allows us to confirm the hypothesis that socially responsible business systems can significantly contribute to social growth and development. Corporate social responsibility is becoming the norm through which to view the ethics of an organization, as well as readiness for dialogue with people and society as a whole, creating a real step towards a new control paradigm.
\end{abstract}

KLJUČNE BESEDE: ethics • business ethics • responsibility • management • corporate social responsibility (CSR)

CORRESPONDENCE ADDRESS: Slobodan Brezak, Chairman of the Board, Bauerfeind d.o.o. - Zagreb Uprava, Goleška 20, 10020 Zagreb, Croatia, e-mail: slobodan.brezak@bauerfeind.hr

DOI https://doi.org/10.18690/978-961-286-020-2.7

ISBN 978-961-286-020-2

(C) 2017 University of Maribor Press

Available at: http://press.um.si 


\section{Introduction}

The commencement of the third millennium is characterized by crisis, turbulent changes and general critical imbalances. Modern society has numerous centers of power outside the state authorities and separate from them. The new pluralism in society is focused on function and performance. Insensitivity of companies to the needs of citizens and society, a kind of isolation of the economy and the primacy economy seeks for itself in society, as well as the shaken human value system, are certainly among the major factors of the current world crisis. This current state of the global economy confirms the unsustainability of the current business principles, and it is crucial to change the mode and the use of scarce resources. Bridging the gap between business and the community seems of utmost importance. There is an urgent need for the study of corporate social responsibility (CSR).

It should be based on mutual trust and development and joint investment in the future. Therefore, it acquired its deserved place only in recent business history. In carrying out their activities, businesses directly affect the social environment. The increasing awareness of society about the impact that businesses have on the environment through their activities necessarily puts a lot of pressure on the organization from the community and civil society organizations. Boycotts and numerous social movements resulted in a complete shift in the way business is done, changing the focus from profits to community. This social climate has produced a phenomenon known as the new paradigm. Characteristics of the new paradigm are manifested through the following: (1) Competition in the form of joint struggles and aspirations in achieving positive developments, (2) Cooperation between parties reaching a point where all parties benefit and (3) Co-creation that encompasses the best of both competition and cooperation by establishing a balance between the objectives and the way in which they are achieved (Joba, Bryant Maynard \& Ray, 1993). The old paradigm promoted consumption and aggressive advertising and created new needs that had not existed before. Jobs were filled by looking for workers who corresponded to the needs of the workplace, while centralized decision-making and strict hierarchies resulted in large bureaucracies and one-sided communication, from the top down. Employees and managers were on opposite sides, and the emphasis was on specialization and fierce competition for the purpose of achieving stability and security. Economic motives, orientation on short-term solutions and unlimited exploitation of resources lead to measuring performance by using quantitative indicators, such as revenue and profit levels (Ferguson, 1993). The new paradigm is based on promoting appropriate levels of consumption, preserving quality and innovation. Jobs are formed around people, are flexible and allow autonomy and creativity. The emphasis is on decentralization and active participation of employees in decision-making and democratization. Organizations and managers have seen the instability of the economic system, leading them to accept risk, entrepreneurial behavior and cooperation, and place emphasis on human values and the way in which work is done. The importance of the work environment, employee health and consumer relations are integrated into long-term perspectives (Ferguson, 1993). 

Theoretical backround

The lessons learned with the advent of consumerism or the attack on the industry due to its destruction of the environment are an expensive way to understand that every business entity should think carefully about its impact and responsibilities and specify its objectives in relation to social responsibility. Social responsibility is not a passing trend; instead, it has a long term impact on the strategic orientation and practice of modern organizations. Strategies were always a process of making an appropriate choice among a range of options, and corporate social responsibility in this regard is no different (Porter \& Kramer, 2006). It is essentially a choice between different social problems that will be the focus of a certain system. Often short-term pressures to give results tend to neglect investment in creating value over the long term for the business system and society as a whole. However, there is evidence to suggest that business systems that invest in socially responsible activities do better (Bird, Hall, Momentè \& Reggiani, 2007). Ignoring the requirements of economic success and accepting social responsibility which cannot be supported economically leads to trouble. The social dimension is the dimension of survival (Drucker, 2005), because every business system exists both in society and in the economy.

The problem of socially responsible behavior of an organization can be dimensioned through business ethics, a socially responsibility business system and organizational culture (ideology, values, and attitudes). Each of the aforesaid dimensions is an integral part of an appropriate scientific discipline. Business ethics is mainly based on philosophy and religion, a socially responsible business system is mainly based on sociology and management, while organizational culture is based on psychology, sociology and anthropology. The noticeable inconsistency between the business world and the problems inherent to most of the population implies that the interests of society are not at the focus of business interests. This is compounded by the behavioral patterns of contemporary leaders, whose greed and non-legalistic behavior gave rise to doubts about the sincerity of business people, as well as the business world and capitalism and market-driven social order. This obvious paradox can be overcome with more effective usage of the available resources. Many people think that market freedom, democracy, transparency, global interaction, entrepreneurship as a way of thinking have no alternative if we want progress, growth and development (Schwab, 2003).

Social responsibility of a system may result from the impact of the system on society or arise as a problem of society itself. These two areas differ in everything except management of a system which is a part of the society and community. Modern organizations exist in order to provide certain services to the society. Therefore, they must exist within society. They have to exist within the community, they have to be someone's neighbors, and manage their operations in a social environment. At the same time, they employ people to do these jobs. Their social influence inevitably transcends the specific contributions for which they were created (Drucker, 2005).

Socially responsible business in the global business sector is also known as corporate social responsibility. In the widest sense of the term, the very concept and practice of 
corporate social responsibility relates to the entire range of company activities and all the relationships that the company establishes. The starting point of this statement lies in the fact that the company takes full responsibility for its activities that go beyond purely economic interests. So, what a company produces, how it affects the environment, how it employs, trains and influences the development of its own people, how it invests in the community and respects human and labor rights, how it buys and sells on the market all this combined determines the total impact of that company on society. The point of social responsibility is to maintain good relations, not only with consumers, but with all those interested in the company's business. Corporate social responsibility could be defined as "the attention with which in an ethical and socially responsible manner we relate to interest and influence groups found outside, but also within the organization".

The aim of social responsibility is to enable the creation of high standards of life for stakeholders, inside and outside the company, while at the same time preserving profitability (Hopkins, 2006). This definition has been accepted because it has the widest scope and emphasizes stakeholders, meaning "any group that can affect or is affected by the activities of the organization", located both outside and inside the organization (Polonsky \& Scott, 2005). Such an approach increases the area of responsibility of an organization, giving social responsibility activities a greater scope. One of the important elements of this definition is achieving benefits at the same time. Therefore, there is no conflict between the priorities and the joint realization of objectives based on cooperation. It is not realistic to expect or advocate an attitude that corporate social responsibility activities of an organization should not reap any benefits, as this is actually impossible, in that through every activity, whether it is socially responsible or not, the organization addresses its internal and external environment. Although business in general can be divided into sectors and industries, and an organization itself into certain departments and functions, all these divisions have one characteristic in common: namely, regardless which sector in the national economy or department in the company they belong to, they all interact with the environment with which they exchange tangible and intangible values. That is why the areas of application of corporate social responsibility are not observed through business classifications, but the relationships and exchanges that they achieve through their very existence. Therefore, the areas of application of social responsibility relate to interest and influence groups (Hubak, 2010).

Corporate social responsibility activities are most often seen as a marketing tool, which mainly encompasses just the consumers as one of the interest groups. Although consumers are important because businesses generate income, the relationship between the consumer and the organization excludes other influence and interest groups. The management of interest and influence groups represents the capability of an organization to manage conflicting objectives that individual stakeholders strive to achieve. It is a model which at its core is based on competition among organizations and among interests and influence groups. The organization is often placed in the center of mutually competing objectives, as investors seek to attain as high a return on their investment as possible, employees want better working conditions, the community wants to ensure that the organization undertakes philanthropic activities, the government wants to see jobs created and taxes paid... Although it seems very difficult to achieve, the aim of this 
approach is to encourage cooperation between these groups and establish a balance in such a way that none one of them is neglected in the long term. The essence of harmonious relations lies in balance and cooperation (Paul \& Nickerson, 2010). Management of these interest and influence groups can be defined as a moral act with which organizations include stakeholders, on the basis of their legitimate rights, in decision-making by integrating them in the organization and changing the business philosophy. But the concept of Stakeholder Management differs from the concept of Management of Stakeholders. The term Stakeholder Management refers to the described concepts which are based on cooperation, while Management of Stakeholders refers to a manipulative approach through which an organization tries to win over stakeholders, in order to achieve a unilateral advantage (Plaza-Úbeda, de Burgos-Jiménez \& CarmonaMoreno, 2010). Thus, in continuation we should consider solely management of interest and influence groups based on ethical cooperation and the desire to achieve a win-win result, because only this is sustainable over the long term and is a strategic guideline of an organization. Regardless of their positioning in relation to the organization, stakeholders are influenced by it, while at the same time exerting influence over it. Because of the mutual influence and need to coexist with each other, it is necessary that both sides acknowledge the other and that instead of through conflict, they cooperate in order to achieve a balance that will be of mutual benefit. In conclusion, social responsibility as a concept and philosophy at its core has cooperation and mutual value exchange. Three items need to be highlighted as a connection between CSR and marketing (Hubak, 2010):

1. Hopkins's definition of corporate social responsibility as the attention with which in an ethical and socially responsible manner we relate to interest groups of influence found outside, but also within the organization. The aim of social responsibility is to enable the creation of high standards of life for stakeholders, inside and outside the company, while at the same time preserving profitability (Hopkins, 2006).

2. The definition of marketing that defines it as an activity, set of institutions and processes with the aim of creating, communicating, delivering and exchanging goods that have value for customers, clients, partners and society as a whole (Gundlach \& Wilkie, 2009).

3. The concept of social marketing as the last stage of development of marketing in practice, which in addition to an exchange and benefits for the company and users includes the welfare of society as a whole (Previšić, Ozretić Došen, Kesić, Prebežac, Piri Rajh, Tomašević Lišanin, Tkalac Verčić, Renko, Pavičić, Sinčić, 2007).

Based on the above, it can be concluded that the definition of corporate social responsibility accepted for the purposes of this study and the definition of marketing showing itself in practice through the concept of social marketing actually complement each other and in no way are in conflict. All three definitions emphasize cooperation as the main prerequisite for the realization of benefits for all participants of the exchange and other individuals and groups that influence or may influence it. However, in order to establish cooperation and a relationship, it is necessary to communicate, thus bringing 
about exchange and creation of value. The connection between marketing and corporate social responsibility implies a logical question as to which specific marketing activities, within the concept of social marketing, can the company implement to be socially responsible and achieve cooperation and communicate successfully with stakeholders. Further, the term corporation entails large international enterprises which through a large number of foreign subsidiaries generate enormously high profits and have a large number of employees and shareholders. Regardless, the following division can be applied to the concept of an organization in terms of business entities i.e. a business entity participating in the local, national, regional or global markets. An organization integrates its socially responsible behavior into marketing activities and business (Kotler \& Lee, 2009):

1. Corporate promotion of social objectives - An organization provides funds, inkind contributions, or other corporate resources to increase awareness and concern about a social cause or to support fundraising, participation, or recruit volunteers for a cause.

2. Cause-related marketing - An organization commits to making a contribution or donating a percentage of revenue to a specific cause based on product sales.

3. Corporate social marketing - An organization supports the development and/or implementation of a behavior change campaign aimed at improving public health, safety, the environment, or the well-being of the community. The distinguishing feature is the focus on changing behavior, which differentiates it from cause promotions that focus on supporting awareness, fundraising, and volunteer recruitment for a cause.

4. Corporate philanthropy - An organization makes a direct contribution to a charity or cause, most often in the form of cash grants, donations, and/or in-kind services. This initiative is perhaps the most traditional of all corporate social initiatives and for many decades was approached in a responsive, even ad hoc manner.

5. Community volunteering - An organization supports and encourages employees, retail partners, and/or franchise members to volunteer their time to support local community organizations and causes.

6. Socially responsible business practices - An organization adopts and conducts discretionary business practices and investments that support social causes to improve community well-being and protect the environment.

The area of marketing in which responsible business practices are of great importance is internal marketing, which refers to "marketing efforts directed at company employees for the purpose of selecting, motivating and retaining the best people who will carry out their duties in the best possible way." Although at first glance this seems to be human resource management, which is defined as "a series of interconnected activities and management and organization tasks aimed at ensuring the appropriate number and structure of employees, their knowledge, skills and interests, motivations and behaviors necessary for achieving current, development and strategic goals of the organization", an important difference lies in communication. 
Human resource management is focused on processes and programs through which the objectives should be achieved, while internal marketing focuses on communication between the organization and top management and other employees. Internal marketing is used to convey messages and information to employees about the activities and programs that are designed as part of human resource management. It is therefore possible to conclude that they complement each other because this way, employees are given information about the processes, work method and possible changes, reducing uncertainty and resistance to change. Within internal marketing, we can talk about ethical behavior in communication which develops employee identification with the organization and its customers due to greater satisfaction, which is also manifested in a reduced number of departures from the organization, benefiting both the employees and organizations, making social responsibility a lever for efficient internal marketing. The financial contribution should not be the only criteria according to which employees are evaluated. A company applying CSR evaluates its employees according to the criterion of ethics and socially responsible behavior (Hubak, 2010).

\section{$3 \quad$ Socially Responsible Business}

Corporate social responsibility at its core has ethical conduct for the welfare and benefit of the organization and its stakeholders, so consequently, it is possible to see corporate social responsibility as ethical business behavior towards the environment and the stakeholders (Hopkins, 2006). Because of the positive advantage that the result of the cooperation is unrealistic, it is impossible to expect that the organization will not achieve a certain positive effect. Ethical behavior in the context of social responsibility refers to the moral responsibility of every individual or regarding the physical, mental, economical, spiritual or emotional effect of an organization's activities. In this case, moral responsibility exceeds self-interest and it is crucial that short-term benefits are replaced with ethical conduct. Since ethics and social responsibility are closely related through their concern for social well-being, it can be carried out with all stakeholders, members of that society and responsible business practices in marketing through an ethical approach to individual components of marketing. By accepting and independently using business practices and investments that support social goals in order to improve the welfare of the community and the environment, corporations in fact support socially responsible business practices. Socially responsible business practices are characterized by a focus on discretionary activities, and not those imposed by legislation or which are simply a result of our expectations. Therefore, it is crucial to point out the broad notion of community, which consists of the company employees, suppliers, distributors, partners from the non-profit and public sector and the public in general. The benefits may relate to health and safety, but also the psychological and emotional needs of the people (Kotler $\&$ Lee, 2005). The current period confirms the need to turn to adopting more responsible business practices as a result of legislation, consumer complaints and pressure from special interest groups - to the proactive search for corporate solutions to social problems and adopting new business practices that will help solve these problems. The above mentioned shift is a result of the following:

1. Socially responsible business practices can increase profit and income; 
36 ${ }^{\mathrm{TH}}$ International Conference on Organizational SCIEnce Development: RESPONSIBLE ORGANIZATION (MARCH $22^{\mathrm{ND}}-24^{\mathrm{TH}}$, PoRTOROŽ SLOVENIA)

S. Brezak: Corporate Social Responsibility: Towards a New Management Paradigm

2. Global consumers have more options and can choose on the basis of criteria that go beyond the product, price and distribution channels (consumer purchasing decisions are based on what kind of a reputation the company has in terms of fair and sustainable business practices and commitment to the welfare of the community);

3. The impact of increased public scrutiny and increasingly more sophisticated tactics to pressure driving force for investors and other shareholders is growing stronger;

4. Interest in higher productivity of the workforce and its retention has made the top individuals in corporations start thinking about the way that they could increase employee satisfaction, and improved their position;

5. Technology and increasingly frequent reports by third parties make the corporation's activities more visible, especially when things go wrong, as in the case of corporate scandals that contribute to public suspicion towards business. Businesses also strive more and more to present their activities in a positive light;

6. There is less and less information which is prohibited for public use. Potential clients are diverted from a caution-based position towards the expectation that they will be fully informed regarding the business practices, including the content of the product, raw materials and production process. It seems straightforward that changes of internal procedures and politics are an implication of numerous initiatives related to socially responsible practices. These are mainly related to changes in product offerings, facility design, production process, origin of raw materials and employee support.

Also, the initiative can impact external reporting of consumers and investors and consider the availability of consumers or their need for privacy, which is also taken into consideration upon decision making. Influencing external reporting to consumers and investors in the context of decision-making on hiring and the location of production facilities and other facilities implies the following initiative activities (Kotler \& Lee, 2005):

- Design of improved facilities;

- Additional process improvements;

- Recall of certain products;

- Selection of socially responsible suppliers;

- Selection of raw materials and packaging least harmful to the environment;

- Providing information on the materials used;

- Preparation of a staff support program;

- Measuring, monitoring and reporting on objectives and actions;

- Establishing guidelines for marketing aimed at children;

- Ensuring better access for citizens with special needs;

- Protecting the confidentiality of consumer data;

- Deciding on the location of plants, suppliers and retailers. 
S. Brezak: Corporate Social Responsibility: Towards a New Management Paradigm

It can be noticed that within the business world, there is growing acceptance of responsible business practices, whereby communication regarding responsible business practices is aimed at government (regulatory) bodies, investors, customers and special interest groups. Thus, a corporation may develop and implement its own business practices in cooperation with the public sector, non-profit organizations, suppliers and distributors.

It turns out the strategy of introducing corporate social responsibility is more resistant to the economic crisis, and companies that foster the principles of such operations have a better market position in relation to companies which do not implement them. Over the past two decades, the number of interest groups has risen to unprecedented proportions. Hundreds of stakeholders, such as consumer, private and governmental groups, operate on national, regional and local levels. Progressive companies encourage their managers to go a step further than required by the regulatory system and simply "do the right thing." Such socially responsible companies actively look for ways to protect the environment as well as the long-term interests of their consumers (Kotler, Bowen \& Makens, 2010).

Individual awareness of a responsible attitude of businesses towards society has existed for a long time. But this transformation into philosophy, a systematic approach, and therefore strategic guidelines for businesses, dates back only fifteen to twenty years ago, when it was realized that the division between economic operators and society is creating problems. The question whether "greedy capitalism" can be replaced by a system of "corporate social responsibility in market conditions" remains key. This has yet to become our reality and make our entire future better.

\section{$4 \quad$ Social Responsibility and marketing}

It is important to point out that an ethical approach to business and to long-term sustainable policies at the level of the organization must be carried out based on specific rules and procedures based on a codes of ethics which, if implemented consistently, becomes part of the organizational culture. Looking at social responsibility in the context of marketing means identifyng connections and concrete activities and concepts in which it can be integrated. Thus it is possible to prove that marketing as a discipline and function within the company can integrate ethical behavior. This means that corporate social responsibility (CSR) should be highlighted as part of the marketing strategy, namely because:

1. Corporate social responsibility can be a market opportunity. To look at social responsibility as a market opportunity, marketing needs to be considered as a process, because it is based on analyzing and identifying market opportunities that the company will try to exploit, in accordance with its capabilities, experience and financial means (Previšić, Ozretić Došen, Kesić, Prebežac, Piri Rajh, Tomašević Lišanin, Tkalac Verčić, Renko, Pavičić, Sinčić, 2007);

2. Corporate social responsibility as a basis for creating and building partnerships. Partnership between the organization and the stakeholders on the issue of social 
responsibility should be driven by joint efforts towards financial investment, time and human resources.

3. Corporate social responsibility as part of the company's cultural network. The paradigm as the essence, philosophy and foundation on which to build the business generates the organizational structure, power structure, control systems, routines and rituals, stories and symbols - elements which constitute the company's cultural network and are particularly significant from the CSR perspective (Johnson \& Scholes, 2002).

4. Corporate social responsibility as an integral part of the brand. It is obvious that because of its promise, personality and spirit, a brand has psychological significance and requires careful planning of all activities and processes over a longer period of time and systematic reporting of actual participation in social objectives for corporate social responsibility to be perceived as an integral element of brand identity. Corporate social responsibility can be made an integral part of the brand in three steps (Nieto, 2009): (a) An unforgettable experience that the brand provides through events on an annual basis and activities aimed at improving the living conditions and welfare of the community; (b) Connecting brand communication and social responsibility and sustainable initiatives, because this is the basis of the Word Of Mouth (WOM) marketing i.e. the story and the transmission of information on a particular brand; (c) By connecting sustainability and brand identity creation activities by communicating what the organization is doing in terms of social goals, creating a cycle of virtue, building the brand reputation, loyalty and differentiation.

5. Corporate social responsibility as an element of differentiation. Differentiation of the brand or the organization is based on the elements of the image and reputation, company resources or some other aspect that can be highlighted as unique in relation to the competition (Renko, 2005). To be precise, CSR is that element. It is important to point out that the element of differentiation does not automatically ensure a competitive advantage because it is preceded by a process of communication i.e. the transfer of the value of CSR in the market.

Corporate social responsibility is a concept of operations focusing on the value exchange between the organization and the stakeholders. This interdependence and awareness of inseparability has led to changes in rethinking business, shifting the focus from profits, hierarchical organization and closed systems towards sustainability, cooperation and joint action bringing benefits to all stakeholders.

Marketing and corporate social responsibility do not represent conflicting concepts and sides. Rather, they complement each other by establishing a balance between the goals set by the organization and those that held by the groups that greatly affect their operations. The historical moment which under the influence of market and social factors resulted in the current equal access at present contributes to that connection (Hubak, 2010). 
S. Brezak: Corporate Social Responsibility: Towards a New Management Paradigm

\section{Conclusion}

In order to bridge the gap between the business world and the community, it is necessary to study corporate social responsibility, based on mutual trust, development and joint investment in the future. For this reason, it is only in recent business history that CSR has been given its rightful place.

The connection between marketing and corporate social responsibility implies a logical question as to which specific marketing activities, within the concept of social marketing, can the company apply to be socially responsible and achieve cooperation and communicate successfully with stakeholders.

Corporate social responsibility is a concept of operations focusing on the value exchange between the organization and the stakeholders. This interdependence and awareness of the inseparability has led to changes in rethinking business, shifting the focus from profits, hierarchical organization and closed systems towards sustainability, cooperation and joint action bringing benefits to all stakeholders.

Finally, what remains to be done is to focus on developing such a program that will do the most good for the social cause, as well as the company, in the conviction that the public, non-profit, and private sectors can and should work together in order to achieve economic, social and environmental goals.

\section{Literature}

Bird, R., Hall, D. A., Momentè, F. \& Reggiani, F. (2007). What Corporate Social Responsibility Activities are Valued by the Market? Journal of Business Ethics, 76(2), 204.

Drucker, P. F. (2005). Najvažnije o menadžmentu. Zagreb: M.E.P. Consult.

Ferguson, M. (1993). The transformation of Values and Vocation. In : Ray, M. \& Rinzler, A. (Eds.), The new paradigm in business, emerging strategies for Leadership and organizational change (pp. 28-34). New York: Putman.

Gundlach, G. T. \& Wilkie, W. L. (2009). The American Marketing Association's New Definition of Marketing: Perspective \& Commentary on the 2007 Revision. Journal of Public Policy \& Marketing, 28(2), pp. 259-264.

Hopkins, M. (2006). What is Corporate Social Responsibility all about? Journal of Public Affairs, 6(3-4), pp. 298-306.

Hubak, M. D. (2010). Marketinška dimenzija društveno odgovornog poslovanja. EFZG - Serija članaka u nastajanju, 10(10), p. 27.

Joba, C., Bryant Maynard, H. Jr. \& Ray, M. (1993). Competition, Cooperation and co-Creation: insights from the World Business Academy. In : Ray, M. \& Rinzler, A. (Eds.), The new paradigm in business, emerging strategies for Leadership and organizational change (pp. 5057). New York: Putman.

Johnson, G. \& Scholes, K. (2002). Exploring Corporate Strategy, Text and Cases. Harlow: Prentice Hall, an imprint of Pearson Education Limited.

Kotler, P. \& Lee, N. (2005). Corporate Social Responsibility: Doing The Most Good For Your Company. New Jersey: John Wiley \& Sons, Inc. 
Kotler, P. \& Lee, N. (2009). DOP — društveno odgovorno poslovanje, suvremena teorija i najbolja praksa. Zagreb: MEP d.o.o.

Kotler, P., Bowen, J. T. \& Makens, J. C. (2010). Marketing u ugostiteljstvu, hotelijerstvu i turizmu. Zagreb: Mate d.o.o.

Nieto, D. (2009). Corporate Social Responsibility as part of your brand. Manager: British Journal of Administrative Management, Oct/Nov2009(68), pp. 28-29.

Paul, K. \& Nickerson, K. P. (2010). Harmonious relationship and stakeholder management compatible or contradictory paradigm? Proceedings of the Academy of Organizational Culture, Communications and Conflict, 15(1).

Plaza-Úbeda, J. A., de Burgos-Jiménez, J. \& Carmona-Moreno, E. (2010). Measuring Stakeholder Integration: Knowledge, Interaction and Adaptational Bahavior Dimensions. Juornal of Business Ethics, 93, pp. 419-420.

Polonsky, M. J. \& Scott, D. (2005). An empirical examination of the stakeholder strategy matrix. European Journal of Marketing, 39(9/10), pp. 1199-1215.

Porter, M. E. \& Kramer, M. R. (2006). Strategy and Society - The Link Between Competitive Advantage and Corporate Social Responsibility. Harvard Business Review, 84(12), 91.

Previšić, J., Ozretić Došen, Đ., Kesić, T., Prebežac, D., Piri Rajh, S., Tomašević Lišanin, M., Tkalac Verčić A., Renko, N., Pavičić, J., Sinčić, D. (2007). Osnove Marketinga. Zagreb: Adverta.

Renko, N. (2005). Strategija marketinga. Zagreb: Naklada Ljevak.

Schwab, K. (2003). 'Capitalism must develop more of a conscience'. Newsweek, 24 February, 412. 


\title{
Kvantitativna analiza učinkovitosti socialnega servisa za oskrbo starostnikov na domu
}

\begin{abstract}
ALENKA BREZAVŠČEK, IZTOK PODBREGAR \& POLONA ŠPRAJC
Povzetek V prispevku predstavljamo nekatere rezultate kvantitativne analize učinkovitosti socialnega servisa za oskrbo starostnikov na njihovem domu. Za potrebe te analize smo socialni servis modelirali s stohastičnim modelom množične strežbe tipa $\mathrm{M} / \mathrm{M} / \mathrm{r}$ - končno število strank. Izračunali smo vrednosti izbranih kvantitativnih karakteristik učinkovitosti. Pokazali smo, kako na vrednosti teh karakteristik vpliva sprememba števila strežnih mest in velikosti populacije strank, ki se uslug socialnega servisa poslužujejo. Uporabnost rezultatov smo ponazorili z numeričnim primerom. Ugotovili smo, da dobljeni rezultati predstavljajo koristno informacijo za odločanje predvsem v preliminarni fazi načrtovanja in vzpostavitve socialnega servisa.
\end{abstract}

KLJUČNE BESEDE: starostniki • oskrba na domu • socialni servis • sistem strežbe $\bullet$ učinkovitost $\bullet$ kvantitativna analiza

\footnotetext{
NASLOV AVtoRJEv: dr. Alenka Brezavšček, docentka, Univerza v Mariboru, Fakulteta za organizacijske vede, Kotnikova 8,1000 Ljubljana, Slovenija, e-pošta: alenka.brezavscek@ fov.unimb.si; dr. Iztok Podbregar, redni profesor, Univerza v Mariboru, Fakulteta za organizacijske vede, Kotnikova 8,1000 Ljubljana, Slovenija, e-pošta: iztok.podbregar@fov.uni-mb.si; dr. Polona Šprajc, docentka, Univerza v Mariboru, Fakulteta za organizacijske vede, Kidričeva cesta 55a, 4000 Kranj, Slovenija, e-pošta: polona.sprajc@fov.uni-mb.si
} 
$36^{\text {TH }}$ InTERnAtional CONFERENCE ON ORganizational SCIENCE Development: Responsible Organization (MARCH $22^{\mathrm{ND}}-24^{\mathrm{TH}}$, PORTOROŽ SLOVENIA)

O. Arsenijević, M. Ferjan, I. Podbregar, P. Šprajc, D. Trivan \& Y.

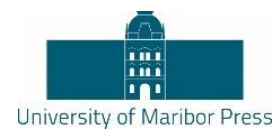

Ziegler

\title{
Quantitative Analysis of Elderly Homecare Service Provider Efficiency
}

\author{
ALENKA BREZAVŠČEK, IZTOK PODBREGAR, POLONA ŠPRAJC
}

\begin{abstract}
In the paper, we present some results of quantitative analyses of an elderly homecare service provider efficiency. For this purpose the service provider was modelled by the stochastic queueing model of type $\mathrm{M} / \mathrm{M} / \mathrm{r}$ - finite number of customers. According to the model, the values of selected quantitative performance measures were calculated. The dependence of these measures on changes of the number of servers as well as on the customers' population size was studied. The usefulness of the obtained results was illustrated by a numerical example. We found out that the model provides valuable information for decision making, which are worthwhile especially in the preliminary phase of the service provider foundation.
\end{abstract}

KEYWORDS: elderly $\bullet$ homecare $\bullet$ service provider $\bullet$ queueing system • efficiency $\bullet$ quantitative analysis

CoRRESPONDENCE AdDREss: Alenka Brezavšček, Ph.D., Assistant Professor, University of Maribor, Faculty of Organizational Sciences, Kidričeva 55a, 4000 Kranj, Slovenia, e-mail: alenka.brezavscek@fov.uni-mb.si; Iztok Podbregar, Ph.D., Full Professor, University of Maribor, Faculty of Organizational Sciences, Kidričeva 55a, 4000 Kranj, Slovenia, e-mail: iztok.podbregar@fov.uni-mb.si; Polona Šprajc, Ph.D., Assistant Professor, University of Maribor, Faculty of Organizational Sciences, Kidričeva 55a, 4000 Kranj, Slovenia, e-mail: polona.sprajc@fov.uni-mb.si

DOI https://doi.org/10.18690/978-961-286-020-2.8 

ORGANIZACIJA (22. - 24. MAREC 2017, PORTOROŽ, SLOVENIJA)

A. Brezavšček, I. Podbregar \& P. Šprajc: Kvantitativna analiza učinkovitosti socialnega servisa za oskrbo starostnikov na domu

\section{$1 \quad$ Uvod}

Staranje populacije ima pomembne učinke na celotno evropsko družbo. Z naraščanjem deleža ostarelih naraščajo stroški zdravstvene oskrbe kakor tudi potreba po storitvah dolgotrajne oskrbe (Rechel idr. 2009). Ker z razpoložljivimi kapacitetami formalne oskrbe ni mogoče zadostiti vsem zahtevam starostnikov, je zaznati povečano potrebo po storitvah oskrbe na njihovih domovih (Gannon in Davin, 2010).

Rezultati domačih raziskav nakazujejo, da se v Sloveniji soočamo s podobnimi težavami kot v ostalih državah EU (Prevolnik Rupel idr., 2010). Izvedene študije kažejo na neenakomerno geografsko razporeditev ponudbe formalne oskrbe za starostnike ter izkazujejo velike razlike med posameznimi občinami (Hlebec idr., 2014). Kljub razmeroma zadovoljivemu stanju na nekaterih bolj razvitih območjih smo predvsem na podeželskih predelih še vedno priča precejšnjemu deležu starostnikov, katerih potrebe po oskrbi niso zadovoljene (Hlebec idr., 2016). Slednje utemeljuje potrebo po vzpostavitvi dodatnih storitev formalne oskrbe za starostnike na njihovih domovih.

Kot možno rešitev za omilitev tega problema je bila v okviru razvojno raziskovalnega projekta $\mathrm{z}$ naslovom »Pomoč in oskrba starostnikov na domu v Sloveniji«, ki je bil izveden pod okriljem Društva akademija za krizno upravljanje (DAKU), predstavljena ideja o vzpostavitvi mreže t.i. "socialnih servisov«. Za slovenske razmere predstavlja socialni servis razmeroma novo organizacijsko obliko formalne oskrbe za starostnike na domu. Poleg enostavnih zdravstvenih storitev, bi lahko socialni servisi pokrivali širok spekter različnih storitev, prilagojenim izključno starostnikom, od pomoči v gospodinjstvu, socialnih, transportnih storitev, ipd. Za dolgoročno učinkovito delovanje socialnega servisa je ključnega pomena njegova ustrezna organizacija in zadovoljiva kadrovska struktura. Pred samo vzpostavitvijo je potrebno natančno proučiti ciljno populacijo starostnikov, analizirati njihove navade, želje in potrebe ter skladno s tem načrtovati kapacitete socialnega servisa tako, da bo zagotovljeno njegovo učinkovito delovanje, obenem pa bo zadoščeno želenemu nivoju kakovosti nudenih storitev.

Učinkovitost zdravstvenih sistemov, med katere lahko uvrstimo tudi mrežo socialnih servisov, običajno merimo na podlagi njihovih kapacitet in stroškov, povezanih $\mathrm{z}$ njihovim delovanjem. Na podlagi ustrezne odločitvene analize skušamo kapacitete sistema načrtovati tako, da bodo skupni stroški delovanja sistema minimalni. Izsledki v literaturi dokazujejo, da je za tovrstne analize zelo uporabna teorija sistemov množične strežbe (glej npr. Beichelt, 2006; Hudoklin Božič, 2003). Taka aplikacija omogoča izračun različnih kvantitativnih karakteristik učinkovitosti obravnavanega sistema, ki nudijo dobro in eksaktno osnovo pri odločanju.

V pričujočem prispevku bomo prikazali del rezultatov študije Šprajc, Podbregar in Brezavšček (2017), v kateri smo razvili stohastični model za popis delovanja socialnega servisa. Uporabnost modela bomo ilustrirali z numeričnim primerom. Analizirali bomo učinkovitost socialnega servisa $\mathrm{v}$ odvisnosti od števila strežnih mest in od velikosti 
$36^{\text {Th }}$ International Conference on Organizational Science Development: RESPONSIBLE ORGANIZATION (MARCH $22^{\mathrm{ND}}-24^{\mathrm{TH}}$, PORTOROŽ SLOVENIA)

A. Brezavšček, I. Podbregar \& P. Šprajc: Quantitative Analysis of Elderly Homecare Service Provider Efficiency

populacije strank, ki jih servis oskrbuje. Rezultate bomo komentirali in podali perspektive za nadaljnje delo na obravnavanem področju.

\section{Socialni servis kot sistem množične strežbe}

Kot je navedeno v Šprajc, Podbregar in Brezavšček (2017), lahko delovanje socialnega servisa popišemo s stohastičnim modelom množične strežbe tipa »M/M/r z omejeno (končno) populacijo strank« s parametri:

$\alpha$ - pogostost zahtev za storitev, s katerimi se stranke obračajo na socialni servis ( $1 / \alpha$ pomeni povprečni razmik med dvema zaporednima zahtevama strank)

$\sigma$ - pogostost zaključkov storitev s strani socialnega servisa ( $1 / \sigma$ pomeni povprečni čas,

ki ga socialni servis potrebuje za izvedbo želene storitve)

$r$ - število uslužbencev socialnega servisa, ki nudijo storitve strankam (t.i. strežba mesta)

$k$ - velikost populacije strank, ki se poslužujejo uslug socialnega servisa

Izbrani model omogoča izračun naslednjih kvantitativnih karakteristik učinkovitosti socialnega servisa:

Izbrani model omogoča izračun naslednjih kvantitativnih karakteristik učinkovitosti socialnega servisa:

- Intenzivnost prometa, ki nam pove delež časa, ko je posamezno strežno mesto zasedeno:

$$
\rho=\frac{\alpha}{r \sigma}
$$

- $\quad$ Verjetnost, da je v socialnem servisu v obravnavi natanko $i \operatorname{strank}^{1}, i=1 . . k:^{2}$

$$
\begin{aligned}
& p_{i}=\frac{1}{S} \frac{k !(r \rho)^{i}}{(k-1) ! i !}, \quad 0 \leq i \leq r \\
& p_{i}=\frac{1}{S} \frac{r^{r} k ! \rho^{i}}{r !(k-i) !}, \quad r \leq i \leq k
\end{aligned}
$$


- Delež strank, ki niso postrežene takoj, pač pa morajo na storitev socialnega servisa počakati:

$$
p_{\check{c}}=\sum_{i=r}^{k} p_{i}=1-\sum_{i=0}^{r-1} p_{i}
$$

- Povprečno število strank, ki so v socialnem servisu v obravnavi ${ }^{1}$ :

$$
E(N)=\sum_{i=0}^{k} i p_{i}
$$

- Povprečno število strank, ki na obravnavo v socialnem servisu čakajo:

$$
E\left(N_{q}\right)=\sum_{i=r}^{k}(i-r) p_{i}
$$

- Povprečno trajanje obravnave stranke v socialnem servisu:

$$
E(W)=E\left(W_{q}\right)+\frac{1}{\sigma}
$$

- Povprečni čas čakanja stranke na izvedbo želene storitve v socialnem servisu:

$$
E\left(W_{q}\right)=\frac{E\left(N_{q}\right)\left(\frac{1}{\alpha}+\frac{1}{\sigma}\right)}{k-E\left(N_{q}\right)}
$$

- Povprečni skupni stroški delovanja socialnega servisa $E(T C)$, ki jih dobimo kot vsoto povprečnih stroškov strežbe $E(S C)$ in povprečnih stroškov zaradi čakanja strank $E(W C)$ :

$$
E(T C)=E(S C)+E(W C)=r C_{s}+E\left(N_{q}\right) C_{w}
$$

V enačbi (10) smo s simbolom $C_{s}$ označili stroške (na enoto časa) posameznega strežnega mesta, s simbolom $C_{w}$ pa oportunitetne stroške (izgube; na enoto časa) zaradi čakanja posamezne stranke. 
$36^{\mathrm{TH}}$ International Conference on ORganizational Science Development: RESPONSIBLE ORGANIZATION (MARCH $22^{\mathrm{ND}}-24^{\mathrm{TH}}$, PORTOROŽ SLOVENIA)

A. Brezavšček, I. Podbregar \& P. Šprajc: Quantitative Analysis of Elderly Homecare Service Provider Efficiency

Veličine, ki jih izračunamo z uporabo enačb (1) - (10), predstavljajo dobro osnovo za različne odločitvene analize (glej Šprajc, Podbregar in Brezavšček, 2017), ki jih je smiselno izvajati predvsem v preliminarni fazi, ko se socialni servis šele vzpostavlja.

\section{$3 \quad$ Numerični primer}

Denimo, da v socialni servis, ki skrbi za 15 strank, v poprečju vsako uro pokliče ena stranka. Storitve, ki jih stranke žejo, so zelo raznolike, od enostavnih, ki ne vzamejo veliko časa (npr. svetovanje po telefonu), do časovno zahtevnih storitev (npr. zahtevna hišna opravila). Predpostavimo, da je povprečno trajanje storitve 30 minut. Predpostavimo tudi, da so stroški posameznega strežnega mesta $6,5 € / h$, izgube zaradi čakanja posamezne stranke pa ocenjujemo na 4,3 $€ / h$ (Smolej idr., 2008 citirano v Prevolnik Rupel idr., 2010).

V nadaljevanju bomo izračunali karakteristike učinkovitosti izbranega socialnega servisa. Pokazali bomo, kako na vrednosti teh karakteristik vpliva sprememba števila strežnih mest, ki jih servis nudi, in velikosti populacije strank, ki se poslužujejo uslug tega socialnega servisa.

\subsection{Odvisnost učinkovitosti socialnega servisa od števila strežnih mest}

Upoštevaje vrednosti parametrov $\alpha=1 / \mathrm{h}, \sigma=2 / \mathrm{h}, \mathrm{k}=15, \mathrm{C}_{\mathrm{s}}=6,5 € / \mathrm{h}$ in $\mathrm{C}_{\mathrm{w}}=4,3 € / \mathrm{h}$ smo za različne vrednosti $r$ s pomočjo enačb (1) - (10) izračunali karakteristike učinkovitosti socialnega servisa. Rezultati so navedeni $\mathrm{v}$ tabeli 1 . Zaradi boljše preglednosti so posamezne karakteristike prikazane tudi grafično v odvisnosti od števila strežnih mest (slike 1 - 4). 
36. MEDNARODNA KONFERENCA O RAZVOJU ORGANIZACIJSKIH ZNANOSTI: ODGOVORNA ORGANIZACIJA (22. - 24. MAREC 2017, PORTOROŽ, SLOVENIJA)

A. Brezavšček, I. Podbregar \& P. Šprajc: Kvantitativna analiza učinkovitosti socialnega servisa za oskrbo starostnikov na domu

Tabela 1: Karakteristike učinkovitosti socialnega servisa v odvisnosti od števila strežnih mest

\begin{tabular}{|l|c|c|c|c|c|}
\hline \multicolumn{1}{|c|}{$r$} & 2 & 3 & 4 & 5 & 6 \\
\hline$p$ & 0,25 & 0,167 & 0,125 & 0,1 & 0,083 \\
\hline$p_{0}$ & 0 & 0 & 0,001 & 0,002 & 0,002 \\
\hline $\mathrm{p}_{\check{c}}$ & 1 & 0,994 & 0,919 & 0,711 & 0,445 \\
\hline$E(N)$ & 11 & 9,02 & 7,24 & 6,02 & 5,39 \\
\hline $\mathrm{E}\left(N_{\mathrm{q}}\right)$ & 9 & 6,03 & 3,36 & 1,53 & 0,59 \\
\hline$E(W)[h]$ & 2,75 & 1,51 & 0,93 & 0,67 & 0,56 \\
\hline$E\left(W_{q}\right)[h]$ & 2,25 & 1,01 & 0,43 & 0,17 & 0,06 \\
\hline$E(S C)[€ / h]$ & 13 & 19,5 & 26 & 32,5 & 39 \\
\hline$E(W C)[€ / h]$ & 38,70 & 25,91 & 14,44 & 6,57 & 2,53 \\
\hline$E(T C)[€ / h]$ & 51,70 & 45,41 & 40,44 & 39,07 & 41,53 \\
\hline
\end{tabular}

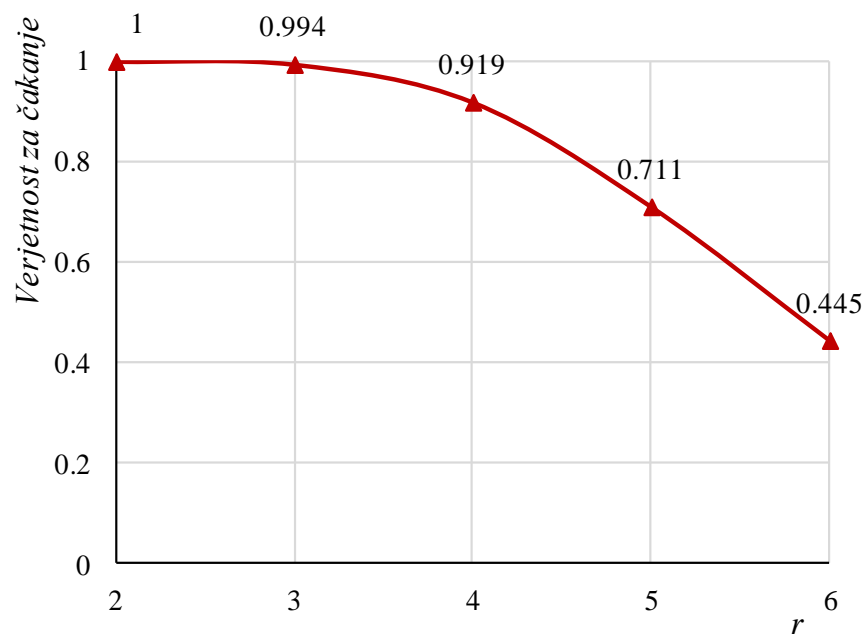

Slika 1: Verjetnost, da mora stranka, ki želi storitev socialnega servisa, ki skrbi za 15 strank, na strežbo počakati v odvisnosti od števila strežnih mest 
$36^{\text {TH }}$ International Conference on Organizational Science Development: RESPONSIBLE ORganization (MARCH $22^{\mathrm{ND}}-24^{\mathrm{TH}}$, Portorož SlOVENiA)

A. Brezavšček, I. Podbregar \& P. Šprajc: Quantitative Analysis of Elderly Homecare Service Provider Efficiency

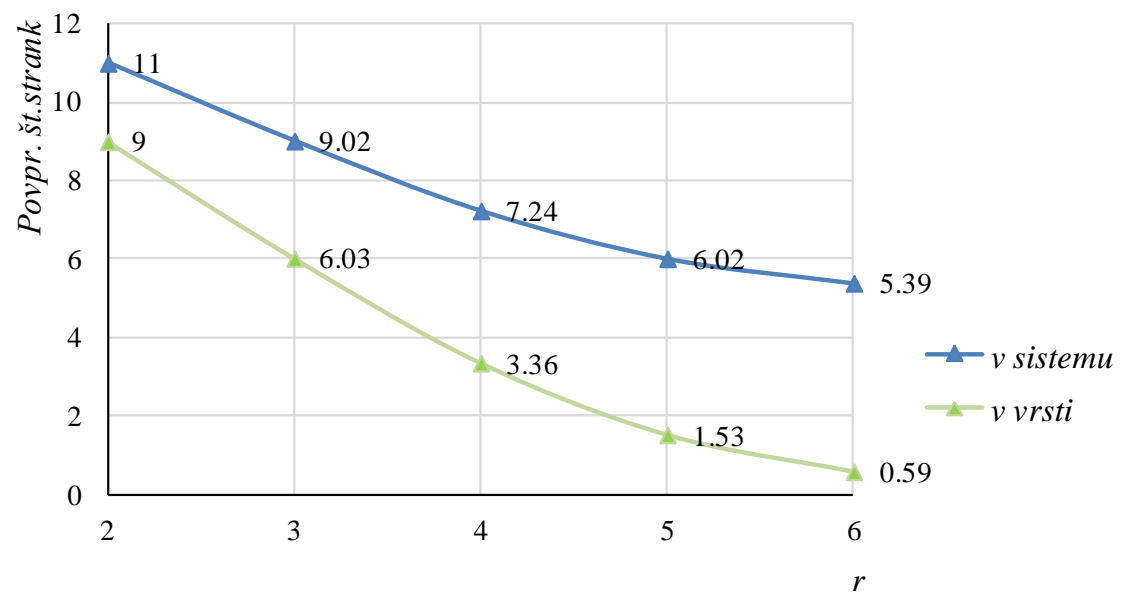

Slika 2: Povprečno število strank v socialnem servisu, ki skrbi za 15 strank, v odvisnosti od števila strežnih mest

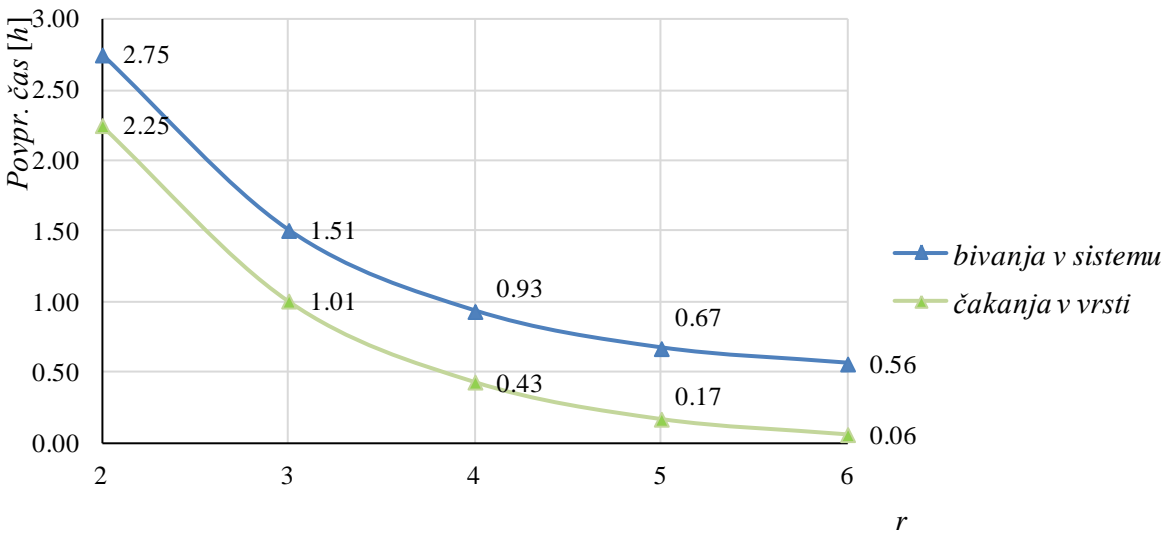

Slika 3: Povprečni čas bivanja stranke v socialnem servisu, ki skrbi za 15 strank, v odvisnosti od števila strežnih mest

Iz slik 1, 2 in 3 je razvidno, da se vse karakteristike učinkovitosti izbranega socialnega servisa $\mathrm{z}$ večanjem števila strežnih mest izboljšujejo. Verjetnost, da mora stranka na strežbo počakati pada (slika 1). Povprečno število strank v sistemu in v čakajočih strank se z povečevanjem števila strežnih mest zmanjšuje (slika 2). Prav tako se krajša povprečni čas obravnave stranke kakor tudi povprečni čas čakanja na strežbo (slika 3). Zavedati pa se moramo, da povečanje števila strežnih mest po eni strani res izboljšuje performanse sistema in znižuje stroške zaradi čakanja strank, po drugi strani pa povzroči porast stroškov strežbe. V praksi je vedno možno določiti optimalno število strežnih mest, ki 
A. Brezavšček, I. Podbregar \& P. Šprajc: Kvantitativna analiza učinkovitosti socialnega servisa za oskrbo starostnikov na domu

zagotavlja, da so skupni stroški delovanja sistema minimalni. It tabele 1 in slike 4 lahko razberemo, da je izbranem primeru to število enako 4. Povprečni skupni stroški delovanja socialnega servisa so tedaj enaki 39,07€/h.

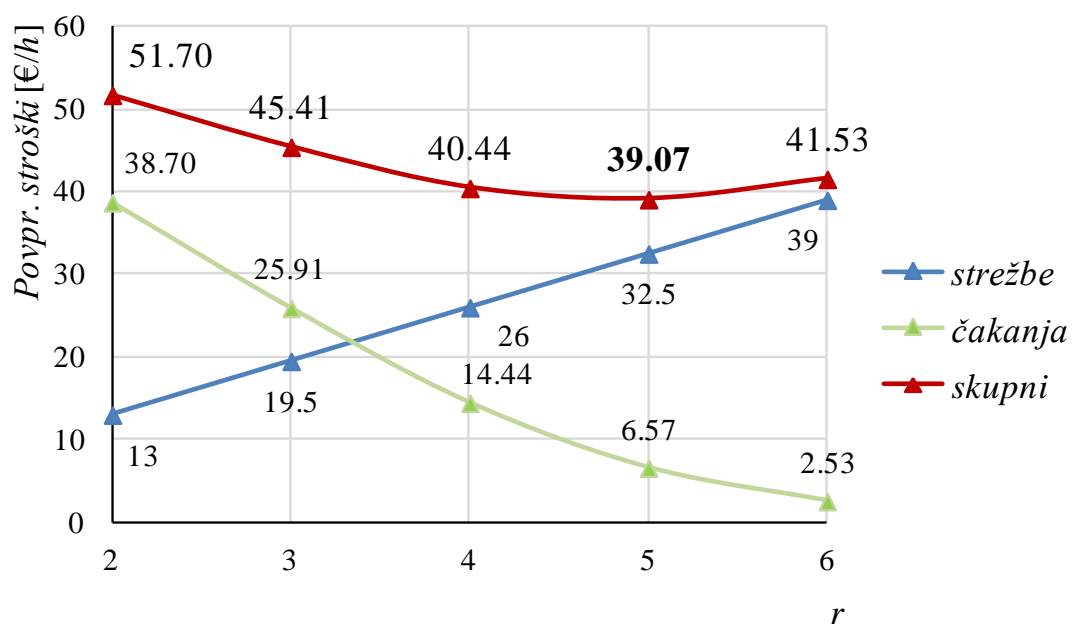

Slika 4: Povprečni stroški delovanja socialnega servisa, ki skrbi za 15 strank, v odvisnosti od števila strežnih mest

\subsection{Odvisnost učinkovitosti socialnega servisa od velikosti populacije strank}

Denimo, da izbrani socialni servis zaposluje 3 uslužbence. Zanima nas, kako se bodo vrednosti kvantitativnih parametrov učinkovitosti socialnega servisa spremenile, če se bo spremenila velikost populacije strank, ki jih ta servis oskrbuje.

Upoštevaje vrednosti parametrov $\alpha=1 / \mathrm{h}, \sigma=2 / \mathrm{h}, \mathrm{r}=3, \mathrm{C}_{\mathrm{s}}=6,5 € / \mathrm{h}$ in $\mathrm{C}_{\mathrm{w}}=4,3 € / \mathrm{h}$ smo za različne vrednosti $k$ s pomočjo enačb (1) - (10) zopet izračunali vse karakteristike učinkovitosti socialnega servisa. Rezultati so zbrani v tabeli 2 in prikazani grafično na slikah $5-8$. 
84 36 $6^{\text {TH }}$ International Conference on Organizational Science Development: RESPONSIBLE ORganization (MarCh $22^{\mathrm{ND}}-24^{\mathrm{TH}}$, Portorož SlOVENIA)

A. Brezavšček, I. Podbregar \& P. Šprajc: Quantitative Analysis of Elderly Homecare Service Provider Efficiency

Tabela 2: Karakteristike učinkovitosti socialnega servisa s tremi strežnimi mesti v odvisnosti

\begin{tabular}{|l|c|c|c|c|c|}
\hline \multicolumn{1}{|c|}{$k$} & 11 & 13 & 15 & 17 & 19 \\
\hline$p_{0}$ & 0,011 & 0.004 & 0.002 & 0.001 & 0 \\
\hline$p_{\check{c}}$ & 0,386 & 0,526 & 0,711 & 0,853 & 0,939 \\
\hline$E(N)$ & 3,85 & 4,82 & 6,02 & 7,49 & 9,13 \\
\hline $\mathrm{E}\left(N_{\mathrm{q}}\right)$ & 0,28 & 0,73 & 1,53 & 2,73 & 4,29 \\
\hline$E(W)[h]$ & 0,54 & 0,59 & 0,67 & 0,79 & 0,94 \\
\hline$E\left(W_{q}\right)[h]$ & 0,04 & 0,09 & 0,17 & 0,29 & 0,44 \\
\hline$E(S C)[€ / h]$ & 32,50 & 32,50 & 32,50 & 32,50 & 32,50 \\
\hline$E(W C)[€ / h]$ & 1,19 & 3,13 & 6,57 & 11,73 & 18,44 \\
\hline$E(T C)[€ / h]$ & 33,69 & 35,63 & 39,07 & 44,23 & 50,94 \\
\hline
\end{tabular}

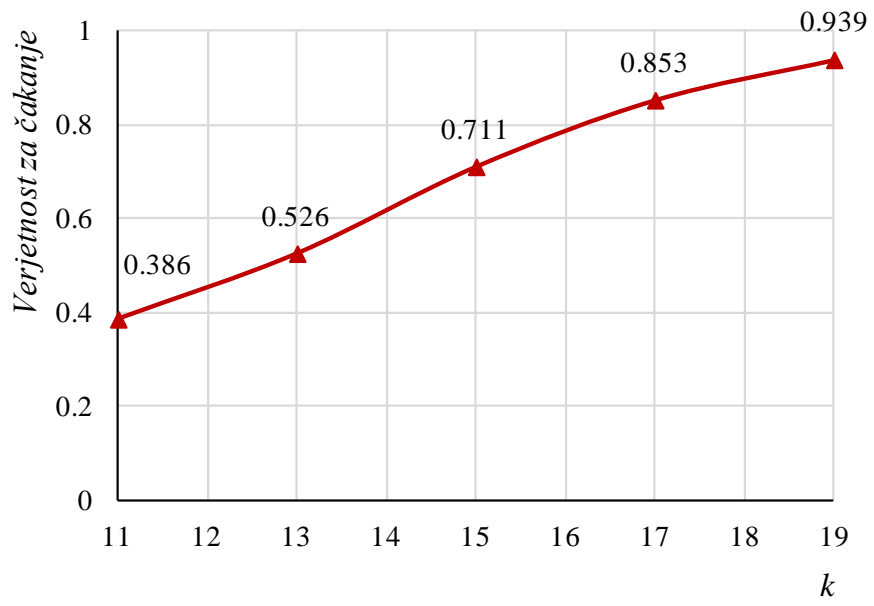

Slika 5: Verjetnost, da mora stranka, ki želi storitev socialnega servisa s tremi strežnimi mesti, na strežbo počakati v odvisnosti od velikosti populacije strank 

ORGANIZACIJA (22. - 24. MAREC 2017, PORTOROŽ, SLOVENIJA)

A. Brezavšček, I. Podbregar \& P. Šprajc: Kvantitativna analiza učinkovitosti socialnega servisa za oskrbo starostnikov na domu

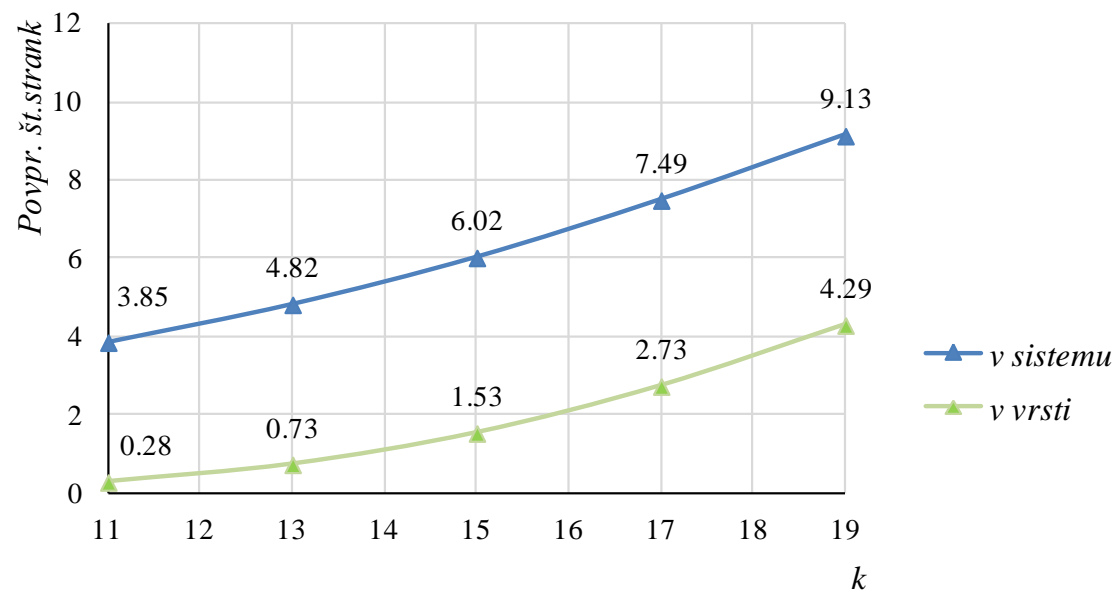

Slika 6: Povprečno število strank v socialnem servisu s tremi strežnimi mesti v odvisnosti od velikosti populacije strank

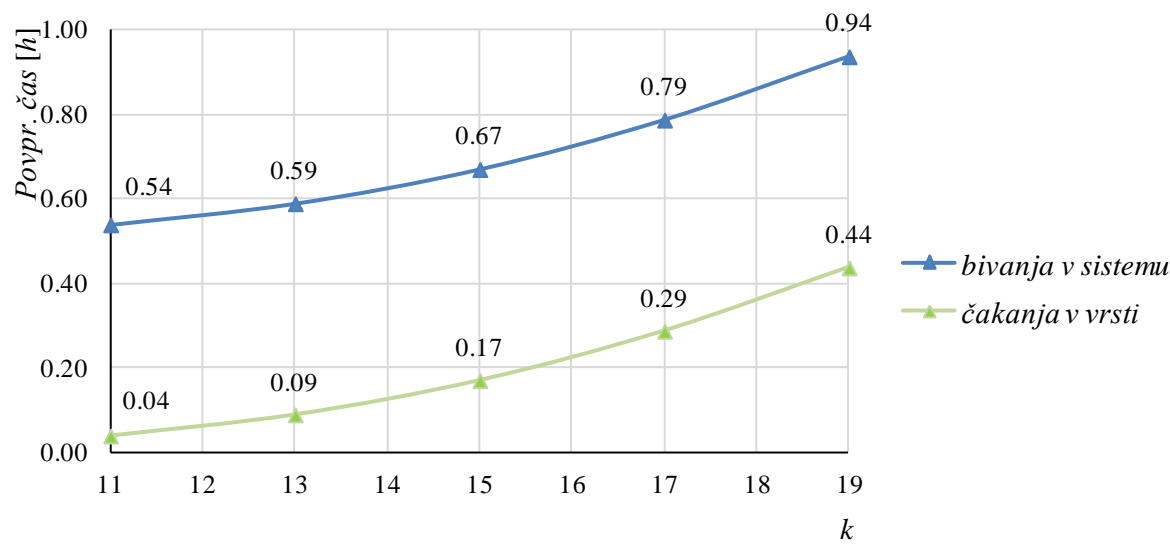

Slika 7: Povprečni čas bivanja stranke v socialnem servisu s tremi strežnimi mesti v odvisnosti od velikosti populacije strank 
$36^{\mathrm{TH}}$ InTERnAtional CONFERENCE ON ORganizational SCIENCE DeVElopment: ReSPONSIBLE ORGaNizATION (MARCH $22^{\mathrm{ND}}-24^{\mathrm{TH}}$, PorTOROŽ Slovenia)

A. Brezavšček, I. Podbregar \& P. Šprajc: Quantitative Analysis of Elderly Homecare Service Provider Efficiency

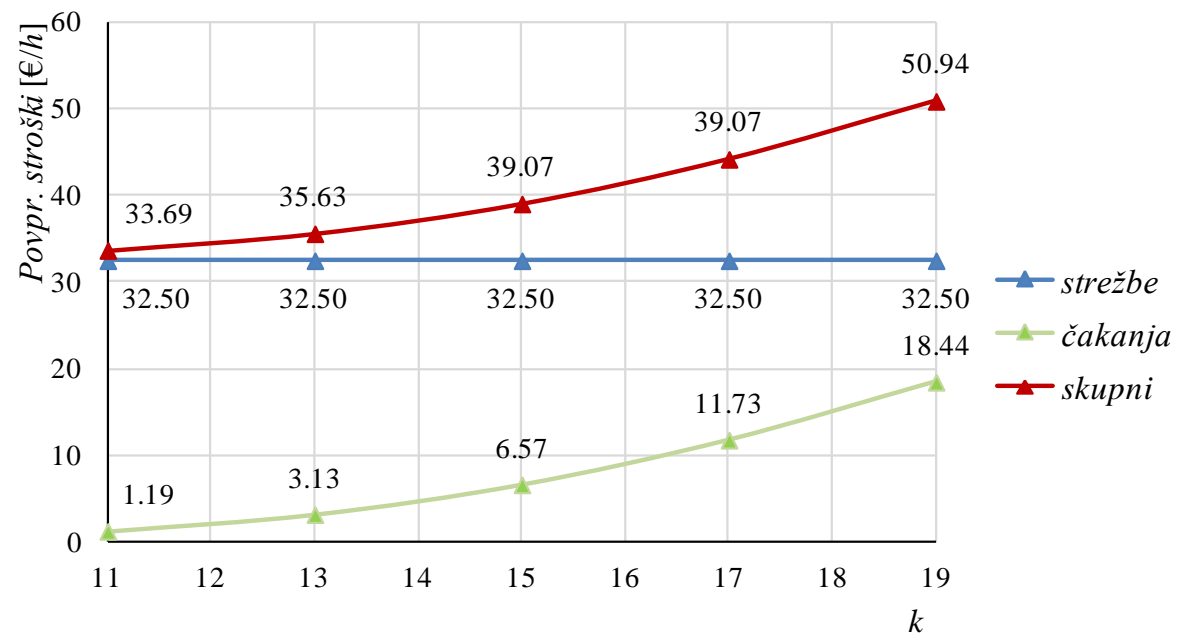

Slika 8: Povprečni stroški delovanja socialnega servisa s tremi strežnimi mesti v odvisnosti od velikosti populacije strank

Dobljeni rezultati dokazujejo, da se $\mathrm{z}$ večanjem velikosti populacije strank, ki se poslužujejo storitev socialnega servisa, vse karakteristike učinkovitosti slabšajo. Verjetnost da mora stranka na strežbo počakati narašča (slika 5). Prav tako narašča povprečno število strank v socialnem servisu in posledično povprečno število čakajočih strank (slika 6). Daljša se povprečni čas obravnave stranke in povprečni čas čakanja na strežbo (slika 7). Iz slike 8 pa je razvidno, da naraščajo tudi povprečni skupni stroški delovanja socialnega servisa. Upraviteljem socialnega servisa torej lahko svetujemo, da je v primeru, ko populacija strank, ki se poslužujejo storitev socialnega servisa, prične naraščati, smiselno razmišljati tudi o povečanju števila strežnih mest. Posledično moramo, če začne populacija strank upadati, razmišljati o zmanjšanju števila strežnih mest. Tako kot smo prikazali v prejšnjem poglavju, je z ustreznimi izračuni vedno možno določiti tako število strežnih mest, ki v danih razmerah zagotavlja minimalne povprečne skupne stroške delovanja socialnega servisa. To število strežnih mest predstavlja v danih razmerah optimalno rešitev.

\section{$4 \quad$ Zaključek}

$\mathrm{V}$ prispevku smo prikazali nekatere rezultate kvantitativne analize učinkovitosti socialnega servisa za oskrbo starostnikov na domu. Za potrebe te analize smo socialni servis modelirali s stohastičnim modelom množične strežbe tipa $\mathrm{M} / \mathrm{M} / \mathrm{r}$, končno število strank. Izvedli smo izračun izbranih kvantitativnih karakteristik učinkovitosti. Pokazali smo, kako na vrednosti teh karakteristik vpliva sprememba števila strežnih mest in velikosti populacije strank, ki se poslužujejo uslug socialnega servisa. 
A. Brezavšček, I. Podbregar \& P. Šprajc: Kvantitativna analiza učinkovitosti socialnega servisa za oskrbo starostnikov na domu

Za slovenske razmere predstavlja socialni servis razmeroma novo organizacijsko obliko formalne oskrbe starostnikov na njihovih domovih. Po našem mnenju bi imela vzpostavitev mreže socialnih servisov številne pozitivne učinke. Eden pomembnejših je dejstvo, da bi taka mreža nudila pozitivno dopolnitev javne zdravstvene infrastrukture, $s$ čemer bi se preobremenjeni zdravstveni sistemi lahko vsaj nekoliko razbremenili. Ugoden učinek bi dosegli predvsem na področjih, kjer je zaznati primanjkljaj obstoječe infrastrukture formalne oskrbe. Ideja o vzpostavitvi mreže socialnih servisov je tudi povsem v skladu s slovensko strategijo dolgotrajne oskrbe, ki je usmerjena k povečanju oskrbe starostnikov na domu (Prevolnik Rupel idr., 2010). Nedvomno bi taka storitev zelo pozitivno vplivala tudi na kakovost vsakdanjega življenja starostnikov, saj bi le-ti lahko bistveno dlje ostali na svojih domovih, kar bi pozitivno vplivalo na njihovo splošno mentalno zdravje (Bolin idr., 2008). Nenazadnje pa lahko trdimo, da vzpostavitev mreže socialnih servisov ponuja tudi atraktivno zaposlitveno priložnost za populacijo mladih brezposelnih, kar bi zopet pomenilo ugodne ekonomske učinke tudi na nivoju celotne države.

V nadaljnjih raziskavah bomo skušali pridobiti frekvenčne in geografske podatke o porazdelitvi števila slovenskih starostnikov, ki živijo doma in izkazujejo neizpolnjene potrebe po storitvah oskrbe. Ti podatki bodo služili kot osnova za oblikovanje modela omrežja socialnih servisov za celotno Slovenijo.

\section{Opombe}

${ }^{1}$ Vključene so tako tiste stranke, ki so že v obravnavi, kot tiste, ki na obravnavo šele čakajo.

${ }^{2}$ Vsoto S, ki je uporabljena v enačbah (2) in (3), izračunamo na naslednji način:

$$
S=\sum_{j=0}^{r-1} \frac{k !(r \rho)^{j}}{(k-j) ! j !}+\sum_{j=r}^{k} \frac{r^{r} k ! \rho^{j}}{r !(k-j) !}
$$

\section{Literatura}

Beichelt, F. (2006). Stochastic processess in science, engineering and finance. Boca Raton: Chapmna \& Hall/CRC.

Bolin, K., Lindgren, B., \& Lundborg, P. (2008). Informal and formal care among single-living elderly in Europe. Health Economics, 17(3), 393-409. doi: 10.1002/hec.1275.

Gannon, B., \& Davin, B. (2010). Use of formal and informal care services among older people in Ireland and France. The European Journal of Health Economics, 11(5), 499-511. doi: 10.1007/s10198-010-0247-1.

Hlebec, V. (2014). Individual and contextual determinants of social homecare usage in Slovenia. Zdravstveno varstvo, 53(4), 311-317. doi: 10.2478/sjph-2014-0034.

Hlebec, V., Srakar A., \& Majcen B. (2016). Determinants of unmet needs among Slovenian old population. Zdravstveno varstvo, 55(1), 78-85. doi: 10.1515/sjph-2016-0011.

Hudoklin Božič, A. (2003). Stohastični procesi 6th Ed. Kranj: Moderna organizacija.

Prevolnik Rupel, V., Ogorevc, M., \& Majcen, B. (2010). Long-term care system in Slovenia, ENEPRI research report No. 87. Pridobljeno 17.12.2016 iz http://www.ancienlongtermcare.eu/sites/default/files/Slovenia.pdf. 
$36^{\mathrm{TH}}$ InTERnATIONAL CONFERENCE ON ORganizational SCIENCE DeVElopment: RESPONSIBLE ORganization (MARCH $22^{\mathrm{ND}}-24^{\mathrm{TH}}$, Portorož SlOVENiA)

A. Brezavšček, I. Podbregar \& P. Šprajc: Quantitative Analysis of Elderly Homecare Service Provider Efficiency

Rechel, B., Doyle, Y., Grundy, E., \& McKee, M. (2009). How can health systems respond to population ageing? World Health Organization. Pridobljeno 17.12.2016 iz http://www.euro.who.int/_data/assets/pdf_file/0004/64966/E92560.pdf.

Šprajc, P., Podbregar, I. in Brezavšček, A. (2017). Homecare Service Provider as an Organizational Form of Support for the Elderly: Planning of Optimal Capacity, v recenzijskem postopku. 


\title{
Javno zasebno partnerstvo kot orodje za koriščenje/uporabo sredstev iz Evropskih strukturnih skladov (ESI)
}

\author{
BETY BREZNIK \& MARKO KOŠČAK
}

\begin{abstract}
Povzetek Prispevek predstavlja model javno-zasebnega partnerstva kot organizacije, ki lahko uspešno kandidira in koristi sredstva ESI skladov v obdobju 2014-2020. Predstavili bomo model delovanja lokalne akcijske skupine, ki deluje na obalnem območju in bo koristila/uporabila sredstva iz treh EU skladov in sicer Sklada za pomorstvo in ribištvo, Sklada za razvoj podeželja in Sklada za regionalni razvoj.
\end{abstract}

$\mathrm{V}$ ta namen je bila pripravljena skupna strategija lokalnega razvoja, ki je podlaga za pripravo javnega poziva in projektov, ki se bodo izvajali na območju. Kljub temu, da morajo rezultati projektov slediti ciljem četrte prednostne osi EU (povečanje zaposlovanja in ozemeljske kohezije), pa je velik poudarek tudi na projektih sodelovanja. Ključna vloga javno-zasebnega partnerstva je v povezovanju različnih sektorjev na območju, animaciji in predstavitvi aktivnosti, ki so lahko sofinancirane. Prav tako je lokalna skupina povezovalni člen med vsemi deležniki na lokalnem območju in organom upravljanja, ki je odgovoren za namensko porabo/uporabo finančnih sredstev. Takšen pristop/način lahko predstavlja uspešen model razvoja območja, saj upošteva posebnosti in vizijo lokalne skupnosti, prav tako pa je primer dobre prakse za koriščenje sredstev iz EU skladov. V prihodnosti pa bo verjetno navkljub vsej podpori javnih sredstev (tako domačih, kot EU), postalo čedalje večji izziv zagotoviti primeren dohodek in sposobnost preživetja tako kmečkim gospodarstvom in tudi ribičem.

KLJUČNE BESEDE: javno-zasebno partnerstvo • lokalna akcijska skupina • kmetijstvo • ribištvo • strategija lokalnega razvoja • razvoj lokalne skupnosti

NASLOv AVTORJEv: Bety Breznik, Ministrstvo za kmetijstvo, gozdarstvo in prehrano RS, Dunajska cesta 22, 1000 Ljubljana, Slovenija, e-pošta: bety.breznik@gov.si; dr. Marko Koščak, docent, Univerza v Mariboru, Fakulteta za turizem, Cesta prvih borcev 36, 8250 Brežice, Slovenija, epošta: marko.koscak@um.si

DOI https://doi.org/10.18690/978-961-286-020-2.9

ISBN 978-961-286-020-2

(C) 2017 Univerzitetna založba Univerze v Mariboru

Dostopno na: http://press.um.si 
36 ${ }^{\text {TH }}$ International Conference on Organizational Science Development: Responsible Organization (MARCH $22^{\mathrm{ND}}-24^{\mathrm{TH}}$, PORTOROŽ SLOVENIA)

O. Arsenijević, M. Ferjan, I. Podbregar, P. Šprajc, D. Trivan \& Y.

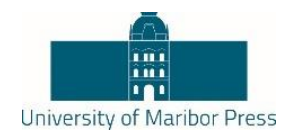

Ziegler

\title{
Public - Private Partnership as a Tool to Use the Funds from the European Structural Funds
}

\author{
BETY BREZNIK \& MARKO KOŠČAK
}

\begin{abstract}
The article describes a model of public-private partnership as an organization that can successfully stand and rewards absorption of the ESI Funds in the period 2014-2020. We present the model of operation of the local action group, which operates in the coastal area and the benefit / resources of the three EU funds, namely the Fund for Maritime and Fisheries, the Rural Development Fund and the Regional Development Fund. For this purpose, a common strategy for local development, has been prepared, which is the basis for the preparation of public calls and projects to be implemented in the area. Despite the fact that the results of the projects follow the objectives of the fourth priority axis EU (increasing employment and territorial cohesion), there is a strong emphasis on collaborative projects. The key role of public-private partnership is the integration of different sectors within the area, animation and presentation of the activities that can be financed. This is also a local group link between all stakeholders in the local area and the managing authority, which is responsible for the targeted use and application of funds. Such approach takes into consideration the specificities and vision of the local community, but it is also an example of a good practice for the use of EU funds. In the future, there will probably in spite of all the support of public funding (both domestic as EU) has become an increasing challenge to provide adequate income and viability of both sectors - agricultural and fisheries.
\end{abstract}

KEYWORDS: public-private partnerships $\bullet$ local action group $\bullet$ agriculture - fisheries - local development strategy • the development of local communities

CORRESPONDENCE ADDRESS: Bety Breznik, Ministry of Agriculture, Forestry and Food RS, Dunajska cesta 22, 1000 Ljubljana, Slovenia, e-mail: bety.breznik@gov.si; Marko Koščak, Ph.D., Assistant Professor, University of Maribor, Faculty of Tourism, Cesta prvih borcev 36, 8250 Brežice, Slovenia, e-mail: marko.koscak@um.si

DOI https://doi.org/10.18690/978-961-286-020-2.9

ISBN 978-961-286-020-2

(C) 2017 University of Maribor Press

Available at: http://press.um.si 


\section{$1 \quad$ Lokalni razvoj, ki ga vodi skupnost}

Slovenija je skladno z Uredbo 1303/2013/EU, pripravila partnerski sporazum, ki je strateški dokument in pomeni podlago za črpanje sredstev iz evropskih strukturnih in investicijskih skladov za obdobje 2014-2020. Vanj je vključenih vseh pet strukturnih in investicijskih skladov EU, katerih skupna določila oblikujejo skupni strateški okvir. S partnerskim sporazumom je bila tako tudi sprejeta odločitev, da se bo lokalni razvoj, ki ga vodi skupnost - pristop CLLD (Community-Led Local Development), izvajal enotno, ter da bodo pri tem sodelovali trije od petih evropskih strukturnih skladov (ESI) (Uredba EU, št. 1303/2013, 2013, Partnerski sporazum med Republiko Slovenijo in Evropsko komisijo za obdobje 2014-2020, 2014) .

Namen pristopa CLLD je spodbujanje celovitega in uravnoteženega razvoja lokalnih območij po pristopu »od spodaj navzgor«. Lokalnemu prebivalstvu omogoča, da z oblikovanjem lokalnih akcijskih skupin (LAS) aktivno odloča o prednostnih nalogah in razvojnih ciljih lokalnega območja, vključno $\mathrm{z}$ viri financiranja za doseganje ciljev, ki jih določijo v lokalni razvojni strategiji. Pristop CLLD v Sloveniji v programskem obdobju 2014-2020 vključuje tri sklade. To so Evropski kmetijski sklad za razvoj podeželja (EKSRP), Evropski sklad za regionalni razvoj (ESRR) in Evropski sklad za pomorstvo in ribištvo (ESPR).V programskem obdobju 2014-2020 je za izvajanje CLLD skupno namenjenih 96 mio EUR (evropska in nacionalna sredstva) iz treh skladov: EKSRP - 52 mio EUR, ESRR - 37 mio EUR in ESPR - 6,6 mio EUR. Tako imamo potrjenih 37 lokalnih akcijskih skupin in njihovih strategij, $100 \%$ (celotno) pokritost območja Slovenije, vse strategije lokalnega razvoja LAS vključujejo sklada EKSRP in ESRR; 4 strategije lokalnega razvoja LAS pa poleg obeh skladov EKSRP in ESRR, vključujejo tudi sklad ESPR (Uredba o izvajanju lokalnega razvoja, ki ga vodi skupnost v programskem obdobju 2014-2020, 2015; Uredba 508/2014 o evropskem skladu za ribištvo in pomorstvo, 2014).

Situacija je podobna tudi v drugih državah EU. Ker je izvajanje ukrepa CLLD, skladno z Uredbo 1303/2013 obvezno znotraj EKSRP, ga tako izvajajo Belgija, Luksemburg in Malta. Ostalih 25 držav članic se je odločilo za izvajanje ukrepa iz najmanj dveh skladov in sicer EKSRP in ESPR uporabljajo/koristijo Ciper, Danska, Estonija, Finska, Hrvaška, Irska, Latvija in Romunija; EKSRP in ESRR pa Avstrija, Slovaška in Nizozemska. Kombinacijo treh različnih skladov najdemo poleg Slovenije še pri Madžarski, Češki in Litvi. Vse ostale države pa načrtujejo uporabo iz vseh razpoložljivih skladov (Bolgarija, Nemčija, Španija, Francija, Italija, Poljska, Portugalska, Romunija, Švedska in Združeno kraljestvo) (Farnet Giude 10, Evropska Unija, 2016, Farnet Guide 11; Evropska Unija 2016). 
36 ${ }^{\mathrm{TH}}$ InTernational Conference on ORganizational Science Development: RESPONSIBLE ORGANIZATION (MARCH $22^{\mathrm{ND}}-24^{\mathrm{TH}}$, Portorož SLOVENIA)

B. Breznik \& M. Koščak: Pulic-Private Partership as a Tool of Use the Funds from the European Structural Funds

\subsection{Izvajanje CLLD v Sloveniji}

Kot že omenjeno, se pristop CLLD v Sloveniji v programskem obdobju 2014 2020 izvaja enotno iz treh skladov in tako imamo potrjene štiri LAS-e, ki vključujejo vse tri sklade. V LAS, ki se je oblikovala na obalnem območju, je glede na višino sredstev glavna vloga ribiškega sklada. Iz strategije lokalnega razvoja (SLR), je razvidno, da se bodo izvajali projekti, ki sledijo ciljem zagotavljanja dodane vrednosti, diverzifikacije, vseživljenjskega učenja, prenosa primerov dobrih praks, ohranjanje naravne in kulturne dediščine celotnega obmorskega področja in ohranjanje okolja. Zaznana je tudi želja po boljšem povezovanju tako na nivoju lokalnih skupnosti, med sektorji in panogami, kot tudi med različnimi skupinami iz drugih držav, prenosu idej, inovacij, izobraževanja in usposabljanja.

Z namenom uporabe še neizkoriščenega potenciala sladkovodne akvakulture na podeželju, ustvarjanja novih poslovnih priložnost in delovnih mest, spodbujanja tesnejših povezav in sodelovanja med deležniki, za krepitev vlog sektorjev in iskanja možnosti dodatnih virov zaslužka v okviru razvoja na lokalnem območju, se je izvajanje CLLD omogočilo tudi na določenih področjih, kjer je razvita sladkovodna akvakultura za prehrano ljudi. Glede na dejstvo, da je sektor sladkovodne akvakulture v Sloveniji dokaj razpršen, se je ta pristop ponudil kot možnost za povezovanje in prepoznavnost sektorja. Pri sladkovodni akvakulturi je dejavnost vezana večinoma na družinska podjetja, samostojne podjetnike, popoldansko dejavnost ali dopolnilno dejavnost na kmetiji, zato jim izvajanje pristopa CLLD, omogoča ohranjanje tradicije in naravne dediščine lokalnega območja, kjer je prisotna sladkovodna vzreja. To je edinstvena priložnost in možnost, da se v okviru skupnih strategij prepoznajo lokalni potenciali in potrebe, ki bodo omogočali dodano vrednost življenju na lokalnem območju z ohranjanjem obstoječih in ustvarjanjem novih delovnih mest. Hkrati je to priložnost za spodbujanje organiziranosti in povezanosti ribogojcev med seboj, možnosti skupnega nastopa na trgu, povečanja prepoznavnosti sektorja akvakulture na lokalnem območju, medregijskega in meddržavnega sodelovanja ter pridobivanja novih znanj, izmenjavo izkušenj in prenosov dobrih praks. Pri izvajanju CLLD pa je še dodatno prisoten element povezovanja s podeželjem, kar omogoča enoten pristop in boljše doseganje zastavljenih ciljev. Skladno z zahtevami doseganja ciljev pri izvajanju lokalne razvojne strategije, morajo izvedeni projekti zagotavljati ohranjanje delovnih mest, zagotavljanje dodane vrednosti, ustvarjanje novih delovnih mest, spodbuja se tudi podjetniška iniciativa in inovacije. Vsi ti dejavniki vodijo $\mathrm{k}$ doseganju specifičnega skupnega cilja, to je $\mathrm{k}$ povečanju zaposlovanja in ozemeljske povezanosti, kar je temeljni cilj četrte prednostne osi Unije. Tako so se na celinskem območju oblikovale tri LAS, ki vključujejo sektor sladkovodne akvakulture, kar je odlična popotnica za oblikovanje skupnih projektov iz vsej treh vključenih skladov. Iz SLR celinskih skupin je razvidno, da se želijo izvajati projekti, ki povezujejo različne sektorje (predvsem podeželje in turizem), ter ohranjanje bogate kulturne in naravne dediščine teh območij (Uredba 
o izvajanju lokalnega razvoja, ki ga vodi skupnost v programskem obdobju 20142020, 2015; Operativni program za pomorstvo in ribištvo 2014-2020; Ministrstvo za kmetijstvo, gozdarstvo in prehrano, 2014; Program razvoja podeželja; Ministrstvo za kmetijstvo, gozdarstvo in prehrano, 2014).

\section{Sodelovanje in povezovanje - ključ do vseh rešitev ?}

Eden od možnih organizacijskih oblik za uspešno sodelovanje pri pripravi in izvedbi razvojnih strategij je tudi javno-zasebno partnerstvo. Javno-zasebna partnerstva predstavljajo omrežja oziroma povezave, različne oblike sodelovanja med javnimi organi in poslovnim svetom, katerih cilj je zagotoviti zasebno iniciativo za financiranje, upravljanje, vzpostavljanje, prenovo, vodenje ali vzdrževanje infrastrukture oziroma izvajanje javnih storitev. Značilne za uspešna partnerstva so predvsem dolgoročne pogodbe in dogovori ter delitev tveganja in učinkov poslovanja. Javno-zasebna partnerstva so lahko tudi mehanizem, s katerim bi pripomogli $\mathrm{k}$ hitrejšem in večjem gospodarskem razvoju posameznih območij v državi (Martinšek, 2014).

V prihodnosti bo verjetno navkljub vsem državnim in evropskim posegom postalo čedalje težje zagotoviti kmečkim gospodarstvom in tudi ribičem primeren dohodek. Razlog leži v gospodarskem in strukturnem zaostanku kmetijstva, kakor tudi ribištva v Sloveniji (slednji sektor je še posebej ranljiv zaradi majhnosti obsega in akterjev, ki delujejo v njem). Zaradi vseh teh razlogov bi bilo primerno v kmetijski in ribiški politiki obravnavanega območja spodbujati in podpirati tudi lastne dohodkovno učinkovite iniciative kmetov in ribičev (pomoč za samopomoč). Uvajanje dopolnilnih dejavnosti bo še naprej ostala najpomembnejša prilagoditvena alternativa teh gospodarstev $\mathrm{v}$ obalnem, podeželskem in obmejnem območju ob slovensko-italijansko-hrvaški meji. Sodelovanje na ravni gospodarstev v obliki strojnih skupnosti, strojnih krožkov, proizvodnih kooperacij, med deležniki javnega in zasebnega sektorja, ne omogoča samo stroškovno bolj ugodno uporabo tehničnih agregatov za manjša gospodarstva, temveč prav tako olajša nadaljevanje gospodarjenja tistih kmetij, ki so se preusmerile $\mathrm{v}$ dopolnilno dejavnost. Podobno bi veljalo delovati tudi na področju boljše organiziranosti ribičev in celotnega sektorja na obali. Spodbujanje možnosti večkratne zaposlitve in sodelovanje v obeh sektorjih bi namreč lahko, vsaj za določen čas, pripomoglo $\mathrm{k}$ zmanjševanju stroškov in $\mathrm{s}$ tem $\mathrm{k}$ omejevanju slabosti kmečkih gospodarstev z majhno posestno strukturo ter ribičev zaradi zastarele opreme in drugih negativnih vzrokov. Tudi spodbujanje učinkovitih povezav za potrebe trženja, katerega osnovni cilj je doseči bistveno širše tržišče za kmečko-ribiška gospodarstva, je temeljna naloga prihodnje kmetijske politike, ki uvaja iniciativo CLLD, za spodbujanje partnerskega, javno-zasebnega povezovanja in delovanja na tem področju. Združevanje kmečkih in ribiških akterjev v proizvajalske skupnosti ali učinkovitejše zadruge oziroma javnozasebnega partnerstva $\mathrm{z}$ dosego boljšega tržnega položaja in s tem izboljšanja 
36 ${ }^{\mathrm{TH}}$ International Conference ON ORganizational SCIENCE Development: RESPONSIBLE ORGANIZATION (MARCH $22^{\mathrm{ND}}-24^{\mathrm{TH}}$, Portorož SLOVENIA)

B. Breznik \& M. Koščak: Pulic-Private Partership as a Tool of Use the Funds from the European Structural Funds

njihove dohodkovne strukture je prav tako ena od usmeritev kmetijske in ribiške politike za obravnavano območje (Koščak, 1999).

Usmeritve tovrstne politike naj torej spodbujajo investicije $\mathrm{v}$ področje poklicnega izobraževanja, svetovanja in raziskovanja, ki povečajo konkurenčno sposobnost in produktivnost kmetijstva in ribištva (upoštevaje nove ekološke potrebe $\mathrm{v}$ kmetijski in ribiški proizvodnji). To lahko postane bistvena gonilna sila sprememb velikosti posestne strukture kmečkih gospodarstev, ki so zaradi svoje perifernosti $\mathrm{v}$ večji meri ohranila ekološko ravnovesje in privlačno krajino.

Strateški nastavki za ureditev in razvoj podeželskih območij morajo upoštevati raznovrstne lastnosti tega podeželskega prostora. Ena od možnosti, kjer lahko v povezavi s kmetijstvom območje doseže svojo razvojno priložnost, je tudi turizem na podeželju. Vendar bo zelo težko govoriti o uspešnem modelu razvoja tega področja brez širše povezave med zaledjem in razvitim obalnim delom, če govorimo o primeru obalne lokalne akcijske skupine. To pa pomeni, da je edina kolikor toliko trajnostno smiselna rešitev oblikovanje regijskega turističnega proizvoda, ki bo temeljil na aktivnem vključevanju lokalnega prebivalstva, principih trajnostnega razvoja in na dobrem čezmejnem sodelovanju, nenazadnje tudi eventualnemu oblikovanju skupne turistične destinacije. Od teh treh načel je slednje še vedno najbolj oddaljeno, vendar $\mathrm{z}$ dobrimi obeti, da se mogoče stvari le premaknejo. $\mathrm{K}$ tem premikom prispevajo (in bodo $\mathrm{v}$ prihodnje še bolj) tudi evropski integracijski procesi, ki kot osnovno razvojno celico vsekakor predvidevajo regijsko povezovanje in oblikovanje medsebojnih povezav znotraj tega inštituta (Koščak, 1999; Koščak, 2012).

Politika regionalne samouresničitve lahko pomeni bistveno pomoč pri razvoju podeželja. Na razvoj regije, in to na katerem koli področju, naj bi odločilno vplivali prizadeti prebivalci, ki bi za to aktivirali vse svoje lastne moči. Strategija mora biti pri tem »pomoč za samopomoč«, kar sicer ne pomeni odrekanja javnim sredstvom; le da bi morala biti v veliko večji meri kot doslej vezana na same ideje, pobude in ukrepe. Težišče enotne regionalne strategije je, ob misli na konkurenčnost, tudi na razmišljanju o integraciji in koordinaciji različnih strokovnih programov in politike. To pa pomeni tudi možnost za čezmejno sodelovanje, seveda ko bodo tako strokovne (prej) kot politične (kasneje) razmere za to tudi v celoti dozorele.

$\mathrm{V}$ analizah primerov razvoja podeželja $\mathrm{v}$ obmejnih območjih so se pokazale nekatere ključne stične točke, ki jih strnjene navajamo kot povzetek oziroma kot tri ključne principe razvoja $\mathrm{v}$ prihodnje, ki velja tudi za naše obravnavano območje.

Harmonija med lokalnim prebivalstvom in okoljem: Ta princip temelji na potrebi za ustvarjanjem takih pogojev, ki bodo zagotavljali harmonijo med lokalnim prebivalstvom (ki občasno ali stalno prebiva $\mathrm{v}$ območju) in naravnimi kulturnimi in zgodovinskimi značilnostmi prostora. Potrebno je dolgoročno zagotoviti pomoč 
in podporo tistim usmeritvam $\mathrm{v}$ podeželskem in obmejnem prostoru, ki zagotavljajo izboljšanje kvalitete življenja na tak način, da bo primerljivo z urbanim ali pa se bo z njim dopolnjevalo. Ta pomoč naj bo zagotovljena dolgoročno, kar je edini temelj za uspešen razvoj v prihodnje.

Usklajeno delovanje: V preteklosti je bilo veliko škode povzročene zaradi ozkega sektorskega pristopa in togih usmeritev »od zgoraj navzdol«. Ti razvojni koncepti in usmeritve niso upoštevali vseh vidikov razvoja $\mathrm{v}$ posameznih podeželskih območjih, kakor tudi ne medsebojnih povezav med sosednjimi regijami. Zaradi tega naj bi bile vse usmeritve in razvojne strategije v prihodnje usklajene, in sicer ne glede na geografsko velikost območja. Zato je potrebno začeti s povezano in koordinirano aktivnostjo na nacionalni ravni, ki jo izvaja vlada $\mathrm{z}$ odgovornimi resorji na državnem (regionalnem in lokalnem) nivoju $\mathrm{v}$ tesni povezavi z lokalnim prebivalstvom. Ta zavest je $v$ razmišljanjih mnogih še vedno premalo prisotna.

Aktivno sodelovanje lokalnega prebivalstva: Samoumevno je, da ima lokalno prebivalstvo, ki prebiva $\mathrm{v}$ določenem podeželskem in obmejnem območju, veliko večji občutek in boljšo vizijo o tem, kakšne so potrebe za njihov prihodnji razvoj, kot ga ima lahko centralizirana državna administracija. Zaradi tega je bistvenega pomena, da se že od začetka priprav na razvojne programe upoštevajo vizije, želje, potrebe, potenciali ter podjetnost lokalnega prebivalstva iz območja razvoja. Tak pristop je zahteven in predstavlja izziv za vse sodelujoče na vseh ravneh. Vendar lahko le tako usklajena akcija prinese prave rezultate pri razvoju podeželskih in obmorskih območij (Koščak, 2012).

Za izvajanje CLLD-ja v programskem obdobju 2014 - 2020 je torej potrebno oblikovati Lokalno akcijsko skupino - LAS. Lokalno partnerstvo mora predstavljati javno zasebno partnerstvo, sestavljeno po načelu tripartitnosti, kar pomeni, da morajo sodelovati zasebni sektor, javni sektor in predstavniki civilne družbe. Skupina mora imeti določeno pravno formalno obliko, izbranega vodilnega partnerja in pregledne postopke delovanja.

Območje, za katero bo strategija določena, mora biti povezano in mora zagotavljati dovolj kritične mase na področju človeških, finančnih in ekonomskih virov, da se lahko podpira vzdržna razvojna strategija. Lokalne akcijske skupine z javnim pozivom izberejo projekte, ki se financirajo v okviru strategije in morajo slediti ciljem sklada, iz katerega se bo projekt financiral. Vse zahteve za oblikovanje lokalnega partnerstva in njegovih pravil delovanja, so opredeljene tako z evropsko in nacionalno zakonodajo (Breznik, 2011; Uredba o izvajanju lokalnega razvoja, ki ga vodi skupnost v programskem obdobju 2014-2020, 2015). 
36 ${ }^{\mathrm{TH}}$ InTernational Conference on ORganizational Science Development: RESPONSIBLE ORGANIZATION (MARCH $22^{\mathrm{ND}}-24^{\mathrm{TH}}$, PortoroŽ SLOVENIA)

B. Breznik \& M. Koščak: Pulic-Private Partership as a Tool of Use the Funds from the European Structural Funds

Enotno izvajanje pristopa CLLD z vključevanjem treh strukturnih skladov, 37 potrjenih LAS in njihovih strategij, ki delujejo na celotnem območju države so dokazi, da se vsi zavedamo pomembnosti lokalnega razvoja, tako na kmetijskem kot tudi na ribiškem in regionalnem področju. Zavedamo se pomena kmetijskega in ribiškega sektorja za lokalna območja in s tem iskanja dodatnih možnosti in virov za njihovo ohranitev. Zaradi vseh teh razlogov bi bilo primerno v kmetijski in ribiški politiki obravnavanega območja spodbujati in podpirati tudi lastne dohodkovno učinkovite iniciative kmetov in ribičev (pomoč za samopomoč).

\section{Literatura in viri}

Bety Breznik, 2011; Obalna akcijska skupina kot model medsektorskega sodelovanja v ribištvu: Management, izobraževanje in turizem : solidarnost za socialni kapital : 3 . znanstvena konferenca z mednarodno udeležbo, 20.-21. oktober 2011, Portorož : zbornik povzetkov referatov.

Koščak, M. (1999). Preobrazba slovenskega podeželja ob slovensko-hrvaški meji, Univerza v Ljubljani, Filozofska fakulteta, Oddelek za geografijo, Ljubljana.

Koščak, M. (2012). Po poteh dediščine - od teorije k praksi, Priročnik za načrtovanje trajnostnega razvoja $\mathrm{z}$ vključevanjem naravne in kulturne dediščine, STUDIO MKA d.o.o..

Martinšek, M. (2014). Javno zasebno partnerstvo, magistrska naloga, Fakulteta za družbene vede, Ljubljana.

Operativni program za pomorstvo in ribištvo 2014-2020, Ljubljana, Ministrstvo za kmetijstvo, gozdarstvo in prehrano, 2014. http://www.ribiski-sklad.si/OP_ESPR_20142020 (pridobljeno 28. 01.2017)

Uredba o izvajanju lokalnega razvoja, ki ga vodi skupnost, v programskem obdobju 20142020, Uradni list RS, št. 42/15, 28/16 in 73/16.

Uredba (EU) št. 1303/2013 evropskega parlamenta in sveta, z dne 17. decembra 2013 o skupnih določbah o Evropskem skladu za regionalni razvoj, Evropskem socialnem skladu, Kohezijskem skladu, Evropskem kmetijskem skladu za razvoj podeželja in Evropskem skladu za pomorstvo in ribištvo, o splošnih določbah o Evropskem skladu za regionalni razvoj, Evropskem socialnem skladu; kohezijskem skladu in Evropskem skladu za pomorstvo in ribištvo ter o razveljavitvi Uredbe Sveta (ES) št. 1083/2006, Uradni list Evropske Unije, L347/320 - 469.

Uredba (EU) št. 508/2014 Evropskega parlamenta in Sveta z dne 15. maja 2014 o Evropskem skladu za pomorstvo in ribištvo in razveljavitvi uredb Sveta (ES) št. 2328/2003, (ES) št. 861/2006, (ES) št. 1198/2006 in (ES) št. 791/2007 in Uredbe (EU) št. 1255/2011 Evropskega parlamenta in Sveta, Uradni list Evropske Unije, L149/1149.

Partnerski sporazum med Republiko Slovenijo in Evropsko Komisijo za obdobje 20142020, (pridobljeno 27. 01. 2017).

http://www.svrk.gov.si/fileadmin/svrk.gov.si/pageuploads/Dokumenti_za_objavo_na_vst opni_strani/PS_koncna_potrjena_141028.pdf. 
B. Breznik \& M. Koščak: Javno zasebno partnerstvo kot orodje za koriščenje/uporabo sredstev iz Evropskih strukturnih skladov (ESI)

Program razvoja podeželja; Ministrstvo za kmetijstvo, gozdarstvo in prehrano, Ljubljana 2014 http://www.program-podezelja.si/sl/prp-2014-2020/kaj-je-program-razvojapodezelja-2014-2020. (pridobljeno 28. 01. 2017).

Farnet Guide 10, European Commission, Directorate-General for Maritime Affairs and Fisheries, ISBN 978-92-79-60766-0, European Union, 2016.

Farnet Guide 11, European Commission, Directorate-General for Maritime Affairs and Fisheries, ISBN 978-92-79-60779-0, European Union, 2016. 

$36^{\mathrm{TH}}$ International Conference on ORganizational Science Development: RESPONSIBLE ORGANIZATION 


\title{
Impediments to Acceptance and Implementation of Statistical Process Control: The Case of Macedonia
}

\author{
VESNA BUCEVSKA
}

\begin{abstract}
There is no doubt that a company which wishes to be competitive in today's market should produce products and services of high quality. Statistical process control (SPC) is the application of statistical techniques to monitor, manage, analyze and improve the performance of a process by eliminating special causes of variation in processes. This paper examines the current status of implementation of SPC in the Macedonian companies based on a case study conducted on a sample of 60 Macedonian companies that have already registered to ISO 9001. The case study revealed that the SPC system is predominantly implemented in the large Macedonian companies. The key drivers for adopting and applying SPC system are: the need to increase profitability, ensure company growth and survival and retain the leading position in the industry. With regard to the importance of the ten key ingredients for successful introduction and implementation of SPC, it was found that top and senior management involvement and commitment, training and education in SPC, teamwork, process prioritization and definition are the crucial successful factors and the use of computer and SPC software packages are the least important ingredients for successful introduction and implementation of SPC in the Macedonian companies. The most applied SPC tools by the Macedonian companies are the more simple SPC techniques, while the key tools of SPC - control charts are used to lesser extent. The most important advantages that Macedonian companies achieved after adopting and implementing SPC system are: higher productivity, improved work efficiency, increased profitability and competitiveness. In order to ensure full and company-wide implementation of SPC, Macedonian companies plan to invest more in education and training at all company levels. Based on the findings of this case study, we have developed a systematic approach for successful introduction and implementation of $\mathrm{SPC}$ in the Macedonian companies.
\end{abstract}

KEYWORDS: Statistical process control (SPC) - quality - SPC implementation $\bullet$ case study

Correspondence Address: Vesna Bucevska, Faculty of Economics-Skopje, »Ss. Cyril and Methodius « University in Skopje, Гоце Делчев 9B, Skopje 1000, Republic of Macedonia, email: vesna.bucevska@eccf.ukim.edu.mk 
$36^{\mathrm{TH}}$ InTERnAtional CONFERENCE ON ORganizational SCIENCE DeVElopment: ReSPONSIBLE ORGANIZATION (MARCH $22^{\mathrm{ND}}-24^{\mathrm{TH}}$, PORTOROŽ Slovenia)

V. Bucevska: Impediments to Acceptance and Implementation of Statistical Process Control: The Case of Macedonia

Today almost every organization is aware of the importance of quality control and its continuous improvement for company's survival in the extremely turbulent environment. According to Montgomery (2009) quality control and improvement involve the set of activities used to ensure that the products and services meet requirements and are improved on a continuous basis. Statistical process control (SPC) has become an important approach to quality control and ensuring continuous quality improvement. Montgomery (2009)

There are many definitions of SPC. According to Hoerl (1996), SPC is a hands-on approach based on a coherent set of activities to analyse, improve and monitor processes based on statistical thinking. Smith (2003) defines SPC as the use of statistical applications to identify sources of variation, improve performance and to maintain control of production at higher quality levels.

Companies strongly need SPC due to the following reasons (Grewal and Gill, 2007):

- To discover when a process is out of control so that corrective action is taken well in time.

- To reduce the cost of internal failures, i.e. scrap and rework.

- To ensure that operators are paid only for good quality production.

- To eliminate frequent readjustments and interruptions in the process.

- Better utilization of labour, facilities and material.

To determine whether the given process has the potential or capability of meeting the specifications on various quality parameters and, if not, to undertake remedial actions to minimize the production of non-conforming products.

However, SPC should not be equated neither with statistics not with control. Statistical process control is about competitiveness (Oakland, 2007). Improvement of processes leads to better quality products and services and thus to higher customer satisfaction, higher sales and higher revenues. The net result is higher profitability and improved competitiveness.

While much has been written about SPC related topics, a more fundamental question, "How to improve the implementation of SPC on a company-wide basis?" has yet to merit a detailed empirical examination. The purpose of this paper is to contribute in making the introduction, adoption and implementation of statistical process control (SPC) system an effective part of any organizational setting. The effective application of SPC cannot be achieved unless the companies have a good understanding of the key factors that will make the implementation of SPC successful. In this paper, we report on the findings obtained from a case study conducted on a sample of 60 Macedonian companies that have gained ISO 9000 certification. The results presented here are focused on the profile of the 
Macedonian companies which implement SPC, key motives behind adopting the SPC system, the importance of the then key ingredients identified from the previous studies for successful implementation of SPC in the Macedonian companies, the current level of application of SPC techniques in the Macedonian companies, the advantages that Macedonian companies achieved after adopting and implementing SPC system and plans for future improvement of SPC on a company wide basis. Based on the findings of the case study, we propose a systematic approach for successful introduction and implementation of SPC in the Macedonian companies.

\section{The ten key ingredients for successful implementation of SPC}

Based on the literature review (Oakland, 2007; Antony, 2000 and Dale, 2007), we have identified the following ten key ingredients for successful introduction and implementation of SPC:

1. Top management commitment - To be successful, SPC must originate with the top management. Despite their differences, the quality leaders, Deming, Juran and Crosby agreed that commitment from the top management is an absolute necessity and that responsibility to quality belongs to management, not the workers. It has been found that one of the most common reasons for the failure of SPC implementation in many organizations is the lack of commitment and involvement of top and senior management (Mason and Antony, 2000). For the successful introduction and implementation of SPC system in the organization, members of top and senior management should believe in SPC as a powerful problem-solving tool and should give their full support.

2. Training and education for variability reduction process - Training should be focused on creation of control charts and their interpretation, application of quality tolls etc. In order to achieve the best results, SPC training should begin at the top level management, and then cascades down the hierarchy. The purpose of this training and education is to establish a corporate culture in which SPC is welcomed as a powerful technique for understanding, managing and reducing variation due to special causes. The training should not be just on a short-term basis, but it should be on a continuous basis. Some companies even appoint an SPC facilitator who establishes monitors and develops the SPC program. Such companies are less likely to experience difficulties in the introduction and implementation of SPC.

3. Corporate culture change - The success of SPC application is also largely dependent on the culture of the company. Without an appropriate culture, SPC cannot function effectively. The tools and some principles can be applied at the company, but the whole SPC system will not be able to prevail. The application of SPC requires a cultural change at the company. This is why the implementation of SPC takes long time at most of the companies. 
4. Process prioritization and definition - All products and services are produced through a number of processes which all contribute to the quality of the final product. Due to cost and time constraints, it is recommended to apply SPC only to a number of processes. These processes will be determined by prioritizing processes according to their technical and statistical criticality. Technical criticality refers to how important the process is relative to the quality of the final product and the production processes. Statistical criticality refers to both statistical stability and capability of the process. Once the processes have been prioritized, the next step is to define the processes in terms of its affiliation with other operations.

5. Selection of performance characteristics - It is very important to choose continuous performance characteristics or process parameters that are the most critical to the process performance and product quality and that can be measured accurately.

6. Teamwork - The today's dynamic business environment requires close cooperation and teamwork between various departments. Successful implementation of SPC demands teamwork between top management, the steering committee and the process action team which must identify the assignable causes of variation within the process and make the appropriate changes.

7. Adequate selection and interpretation of control charts - The primary tool used for SPC is the control chart which is supposed to detect the presence of special causes of variation and to bring a process into a state of statistical control by taking appropriate actions on the process, ranging from taking a re-check sample to the stopping of a production line in order to detect and eliminate these causes. Therefore, the emphasis must be placed on the selection of and interpretation of control charts and not on the construction of control charts. For variable data appropriate control charts are variable control charts (X-bar and R chart) and for attribute data, attribute charts must be used (for example, $\mathrm{p}$-chart).

8. Adequate measurement system - Measurement helps in understanding of a particular aspect of the product or process. Many organizations often ignore the variation associated with the measurement system that is certainly an important factor for the successful implementation of SPC in organizations. If the measurement system is not capable, the SPC study must be deferred. (Bird and Dale, 1994)

9. Use of pilot study - It is not recommended to apply SPC to all departments at the same time, but rather get know the advantages of SPC through a pilot study. Without performing a pilot study, there is a high possibility to overlook some of the essential ingredients for successful introduction and implementation of SPC. Once SPC is successfully applied to one process, it can be extended to other processes within the organization. 
10. Use of computer and SPC software packages - Over the past few years, the rise of a new generation of SPC computer packages has opened the door for full integration of real-time SPC in manufacturing with flexible, on-line analysis and data reporting throughout the company. When selecting SPC software, decisionmakers must understand their own production requirements and match them with the most appropriate level of investment for today. However, before using SPC software management must be sure that operators and other employees fully understand the principles of SPC.

The above identified ten key ingredients for successful implementation of SPC were examined on a sample of 60 Macedonian companies, using a case study.

\section{Research methodology and data collection}

Case study is a research method which excels at bringing us to an understanding of a complex organizational behaviour. Researcher Robert K. Yin (2014) defines the case study research method as an empirical inquiry that investigates a contemporary phenomenon within its real-life context; when the boundaries between phenomenon and context are not clearly evident; and in which multiple sources of evidence are used. Yin (2014)

The case study is especially appropriate when trying to extend experience or reconfirm previous research results. The case study typically involves a small number of cases. However they do not necessarily represent the larger population. Data collection for case studies may come from various sources (interviews, surveys, observation etc.). The case studies need not always include direct and detailed examinations as a source of evidence as required in qualitative research. Yin (2014)

In order to obtain a better picture of the current status of implementation of SPC, we conducted a case study consisting of questionnaire surveys and interviews with the representatives of companies' top management. A postal questionnaire was sent to the attention of general managers or quality mangers of 60 Macedonian companies that have already registered to ISO 9000 quality management system standard. The questionnaire consisted of the following parts: the profile of the company, including number of employees, annual turnover, average value of the total assets within the last two years and type of the industry, general information about the current level of application of SPC techniques in the companies and the importance of the ten key ingredients for successful implementation of SPC system.

We have focused only on ISO 9000 certified companies due to the fact that ISO 9000 standards challenge other well established quality management systems, such as SPC. (Skrabec, 1995) It is more likely that companies that obtained certification of ISO 9000 will have a good foundation to implement a quality management system such as SPC. 
$36^{\mathrm{TH}}$ International Conference ON ORganizational Science Development: RESPONSIBLE ORGANIZATION (MARCH $22^{\mathrm{ND}}-24^{\mathrm{TH}}$, PORTOROŽ SLOVENIA)

V. Bucevska: Impediments to Acceptance and Implementation of Statistical Process

Control: The Case of Macedonia

The 60 Macedonian companies were randomly selected from the list of companies obtained from the Macedonian Association for Quality Improvement at the Chamber of Commerce of the Republic of Macedonia. The type of industries that participated in the survey include: food, chemical, textile, metallurgy, construction, trade, transport, telecommunication and banking. However, only 43 Macedonian companies (33 manufacturing, 9 service companies and 1 commercial bank) responded to the questionnaire and indicated their willingness to provide further information.

In order to obtain further information concerning implementation of SPC in Macedonian companies, we have conducted interviews (based on a previously designed questionnaire) with the top managers of the companies that responded to the postal questionnaire. Those managers were asked to identify the key drivers behind adoption of SPC system, the advantages that they experienced after implementing SPC and future plans about SPC implementation in their companies.

\section{$4 \quad$ Profile of the respondents}

The Trade Company Law of the Republic of Macedonia enacted in April 2004 provides for four types of trading companies: large, medium-size, small and micro traders, based on the number of employees, annual turnover and average value of the total assets within the last two years. In addition to the first criterion, one more needs to be satisfied, in order for the company to be classified in a respective group.

The analysis of the profile of the surveyed companies showed that the highest number of respondents (about 63 per cent) come from companies with less than 250 employees. 37 per cent of the surveyed companies employed over 250 employees, 24 per cent of the respondents employed less than 50 employees and only 3 per cent of the surveyed companies were micro companies with less than 10 employees.

In terms of assets, $76 \%$ of the surveyed companies have over 11 million EUR total assets, 23 per cent of the companies have between 2 million and 11 million EUR assets and 1 per cent are small and micro enterprises having less than 2 million EUR assets in the last two years.

The majority of the respondents to the questionnaire were top managers (88\%), followed by quality managers $10 \%$ and marketing managers (2\%). It was also found that 93 per cent of the companies applying SPC have a quality department.

The survey covered both manufacturing and service companies mainly in the following industries: food, chemical, textile, metallurgy, construction, trade, transport, telecommunication and banking. The number of respondents by industries is shown in Table 1. 
V. Bucevska: Impediments to Acceptance and Implementation of Statistical Process

Control: The Case of Macedonia

\begin{tabular}{|l|l|}
\hline Industry & Number of companies \\
\hline Food processing industry & 12 \\
\hline Chemical industry & 8 \\
\hline Textile industry & 7 \\
\hline Metallurgy & 5 \\
\hline Construction industry & 3 \\
\hline Merchandise/wholesales & 2 \\
\hline Transport and telecommunication & 3 \\
\hline IT & 2 \\
\hline Banks & 1 \\
\hline Total & $\mathbf{4 3}$ \\
\hline
\end{tabular}

Table 1: Surveyed companies by industries

\section{$5 \quad$ Case study results}

\subsection{Key drivers behind SPC implementation in Macedonian companies}

First we have examined the motives behind introduction and application of SPC system in the Macedonian companies.

The following six key drivers were extracted from the literature review:

1. To increase profitability;

2. To ensure company growth and survival;

3. To remain the leading player in the industry;

4. To satisfy customers and increase client awareness of quality issues;

5. To increase competitiveness in an increasingly tough market;

6. To reduce operating expenses in view of a high level of competition within the industry.

The managers of Macedonian companies which were subject to this case study were asked to indicate on a five point Likert scale the extent to which one of above mentioned six motives influenced their decision to adopt and implement the SPC system.

The surveyed companies specified the need to increase profitability, ensure company growth and survival and retain the leading position in the industry as the key drivers for adopting and applying SPC system. Another important motive considered is to increase competitiveness in an increasingly tough market. Satisfying customers needs and increasing their awareness of quality issues as well as reducing operating expenses are rated as the least important motives of implementing SPC techniques. Table 2 contains the mean scores and standard deviations of all six key drivers behind implementing SPC system. 
$36^{\text {TH }}$ International Conference on Organizational Science Development: RESPONSIBLE ORGANIZATION (MARCH $22^{\mathrm{ND}}-24^{\mathrm{TH}}$, PORTOROŽ SLOVENIA)

V. Bucevska: Impediments to Acceptance and Implementation of Statistical Process Control: The Case of Macedonia

\begin{tabular}{|l|l|l|}
\hline Key drivers increase & Mean score & Standard deviation \\
\hline $\begin{array}{l}\text { Need to } \\
\text { profitability }\end{array}$ & 0,69 \\
\hline $\begin{array}{l}\text { Need to ensure company } \\
\text { survival and growth }\end{array}$ & 3,67 & 0,55 \\
\hline $\begin{array}{l}\text { Need to remain the } \\
\text { leading in the industry }\end{array}$ & 3,61 & 0,47 \\
\hline $\begin{array}{l}\text { Need to increase } \\
\text { competitiveness in an } \\
\text { increasingly tough } \\
\text { market }\end{array}$ & 3,54 & 0,65 \\
\hline $\begin{array}{l}\text { Need to satisfy customers } \\
\text { and increase client } \\
\text { awareness of quality } \\
\text { issues }\end{array}$ & 1,12 \\
\hline $\begin{array}{l}\text { Need to reduce operating } \\
\text { expenses in view of a } \\
\text { high level of competition } \\
\text { within the industry }\end{array}$ & 2,67 & 1,29 \\
\hline
\end{tabular}

Table 2: Key drivers behind implementation of SPC in Macedonian companies

\subsection{Importance of the ten key ingredients for successful introduction and implementation of SPC}

In order to determine how the companies which were subject to this case study rank the ten key ingredients according to their importance for the successful introduction and implementation of SPC, they were asked to rate them on a 1-to-5 response Likert scale:

- 5=Very Important

- 4=Important

- $3=$ Moderately Important

- $2=$ Of Little Importance

- $1=$ Unimportant

The scores were added together and divided by the number of observations per ingredient to determine the average score of each ingredient. The higher the score, the greater the importance of the ingredient. The average scores of each ingredient in ascending order are shown in Figure 1.

We decided to apply the Likert scale instead of yes/no questions because the Likert scale could provide a better picture of the current status of SPC implementation in the Macedonian companies. The relative weightings of key ingredients would assist 
companies to understand what ingredients are crucial for making SPC successful and what ingredients are not essential to successful introduction and implementation of SPC.

As we can see from the Figure 1, the most important key ingredients for successful introduction and implementation of SPC are the commitment and involvement of the top and senior management, training and education in SPC, teamwork and process prioritization and definition. All these four ingredients have an average score of more than 4. It was not surprising that commitment and involvement of top and senior management has been identified as the most important ingredient as all quality leaders and most of the authors of empirical studies (Dale, 2007; Oakland, 2007 and Xie and Goh, 1999) agree with that statement.

The findings of the survey have shown that "use of pilot study" and the "use of computer and SPC software packages" are considered as least important ingredients for successful application of SPC. 
$36^{\text {TH }}$ International Conference on Organizational Science Development: RESPONSIBLE ORGANIZATION (MARCH $22^{\mathrm{ND}}-24^{\mathrm{TH}}$, PORTOROŽ SLOVENIA)

V. Bucevska: Impediments to Acceptance and Implementation of Statistical Process Control: The Case of Macedonia

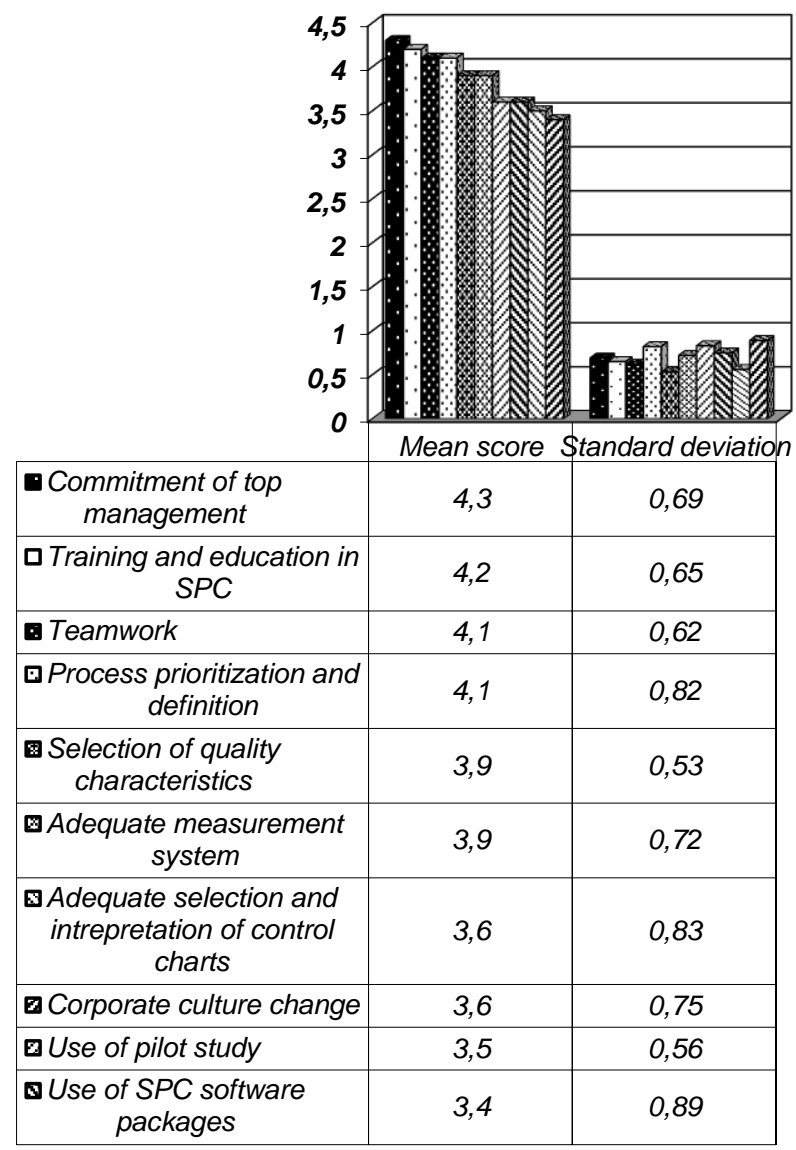

Figure 1: Importance of the ten key ingredients for successful introduction and implementation of SPC

\subsection{Current level of application of SPC techniques in the surveyed companies}

In order to assess the extent of the use of SPC tools, companies were asked to rate the extent of the use of the following SPC tools: histograms, check sheets, flow charts, Pareto analysis, cause and effect diagrams, scatter diagrams, Shewhart sample mean (X bar chart) and Shewhart sample range ( $R$-chart) charts as well as the special types of control charts (CUSUM, EWMA and multiple control charts).

The results of this case study have shown that the most applied SPC tools by the Macedonian companies are the more simple SPC techniques: check sheets (mean score $=4,12$ ), Pareto analysis (mean score $=3,81$ ), histograms (mean score $=3,69$ ) and flow charts (mean score $=3,62$ ). 
Macedonian companies use to lesser extent the histograms, scatter diagrams and the key tools of SPC i.e. the control charts. The most used control charts by the Macedonian companies are Shewhart sample mean (X bar-chart) and Shewhart sample range ( $R$-chart) charts. The results of this study have shown that Macedonian companies are not informed about the special types of control and their benefits. Therefore future actions should be taken in order to train employees to start applying them and take advantage of their benefits.

\begin{tabular}{|l|l|l|}
\hline SPC tools & Mean score & Standard deviation \\
\hline Check sheets & 4,12 & 0,69 \\
\hline Pareto analysis & 3,81 & 0,86 \\
\hline Histograms & 3,69 & 0,87 \\
\hline Flow charts & 3,62 & 0,89 \\
\hline $\begin{array}{l}\text { Shewhart sample mean }(\mathrm{X} \\
\text { bar-chart) }\end{array}$ & 2,78 & 0,91 \\
\hline $\begin{array}{l}\text { Shewhart sample range }(R- \\
\text { chart) }\end{array}$ & 2,57 & 0.90 \\
\hline Cause and effect diagrams & 2,35 & 0,84 \\
\hline Scatter diagrams & 2,20 & 0,98 \\
\hline Special control charts & 1,01 & 0,79 \\
\hline
\end{tabular}

Table 3: The extent of use of different SPC tools by Macedonian companies

\subsection{Advantages of implementing SPC and future}

In the interviews which we conducted with the top managers or quality managers of the Macedonian companies which responded to the postal questionnaires, we asked the managers to evaluate on a Likert scale of $1-5$ (where $1=$ no advantages and $5=$ great advantages) the overall advantages that they have experienced after from adopting and implementing the SPC system in their organizations.

On the basis of literature review we have made a list of the following advantages of applying SPC system:

1. Improved work efficiency;

2. Higher productivity;

3. Increased profitability;

4. Increased competitiveness;

5. Greater reliability (shifting control efforts from product to process);

6. Greater ease in pinpointing problem occurrences;

7. Provision of a usable measure of performance;

8. Clearer communication of objectives to employees;

9. Greater employee satisfaction;

10. Improved customer relations and 
$36^{\mathrm{TH}}$ International Conference on ORganizational Science Development: RESPONSIBLE ORGANIZATION (MARCH $22^{\mathrm{ND}}-24^{\mathrm{TH}}$, PORTOROŽ SLOVENIA)

V. Bucevska: Impediments to Acceptance and Implementation of Statistical Process

Control: The Case of Macedonia

\section{Greater customer satisfaction.}

The results of the conducted interviews have shown that the most important advantages achieved after adopting and implementing SPC system are:

1. Higher productivity;

2. Improved work efficiency;

3. Increased profitability and

4. Increased competitiveness.

The least significant benefits of implementing SPC according to the managers of the interviewed Macedonian companies are:

1. Clearer communication of objectives to employees;

2. Employee satisfaction;

3. Improved customer relations and

4. Greater customer satisfaction.

\begin{tabular}{|l|c|c|}
\hline \multicolumn{1}{|c|}{ Advantages of implementing SPC } & $\begin{array}{c}\text { Mean } \\
\text { score }\end{array}$ & $\begin{array}{c}\text { Standard } \\
\text { deviation }\end{array}$ \\
\hline Higher productivity & 3,95 & 0,65 \\
\hline Improved work efficiency & 3,75 & 0,62 \\
\hline Increased profitability & 3,73 & 0,66 \\
\hline Increased competitiveness & 3,57 & 0,79 \\
\hline Greater reliability & 3,42 & 0,85 \\
\hline Improved customer relations & 3,41 & 0,71 \\
\hline Greater customer satisfaction & 3,37 & 0,77 \\
\hline Greater ease in pinpointing problem occurrences & 3,34 & 0.85 \\
\hline Provision of a usable measure of performance & 3,29 & 0,55 \\
\hline Clearer communication of objectives to employees & 2,77 & 0,49 \\
\hline Employee satisfaction & 2,65 & 0.63 \\
\hline
\end{tabular}

Table 4: Advantages of implementing SPC

When asked about their future plans concerning SPC implementation, the interviewed managers stated that their priority for the next years is to invest in education and training at all levels in order to ensure full implementation of SPC (mean score of 3,85 on a fivepoint Likert scale). This is compliance with the previous findings about the importance of training as the key factor for successful implementation of SPC. The second ranked planning objective is the development of a comprehensive SPC software (mean score = 2,85 ) which can be achieved only in parallel with training at all organizational levels. 


\subsection{Conclusions and systematic approach for successful implementation of SCP in Macedonian companies}

Statistical process control (SPC) is a fundamental approach to quality control and improvement that is based on objective data and analysis. It is a bundle of statistical techniques for monitoring, managing, maintaining and improving the performances of a process. Although widely accepted and successfully implemented in a great number of Japanese, American and western companies, the number of Macedonian companies that know where to get stared and how to get started with SPC is still small.

This paper presents the results of a case study about current status of implementation of SPC conducted on a sample of 60 Macedonian companies having ISO 9000 certificate.

The data obtained from 43 Macedonian companies portray the profile of companies which have adopted and have been implementing the SPC system, the key drivers behind implementation of SPC, the importance of the 10 factors for successful introduction and implementation of SPC, the current level of application of SPC tools in the Macedonian companies, the advantages of implementing of SPC, as well as the future plans of the mangers of the interviewed companied regarding improvement of SPC implementation.

Based on the results of this case study, we have found out that SPC system is predominantly implemented in the large Macedonian companies. Small and medium sized companies, although aware of the benefits of SPC, cannot afford the implementation of this system due to the limited financial recourses. This case study identified the need to increase profitability, ensure company growth and survival and retain the leading position in the industry as the key drivers behind adopting and applying SPC system. A total of 10 key ingredients for successful introduction and implementation of SPC were assessed in this case study. From the analysis, it was found that top and senior management involvement and commitment, training and education in SPC, teamwork, process prioritization and definition are the crucial ingredients and the use of computer and SPC software packages are the least important ingredients for successful introduction and implementation of SPC in the Macedonian companies. The case study also revealed that the most important advantages that Macedonian companies achieved after adopting and implementing SPC system are: higher productivity, improved work efficiency, increased profitability and competitiveness. The priority of the Macedonian companies regarding improvement of SPC implementation in the next years is to invest in education and training at all company levels.

Based on the results of this case study, we have developed a systematic approach for successful application of SPC in the Macedonian companies (see Figure 2). 
V. Bucevska: Impediments to Acceptance and Implementation of Statistical Process Control: The Case of Macedonia

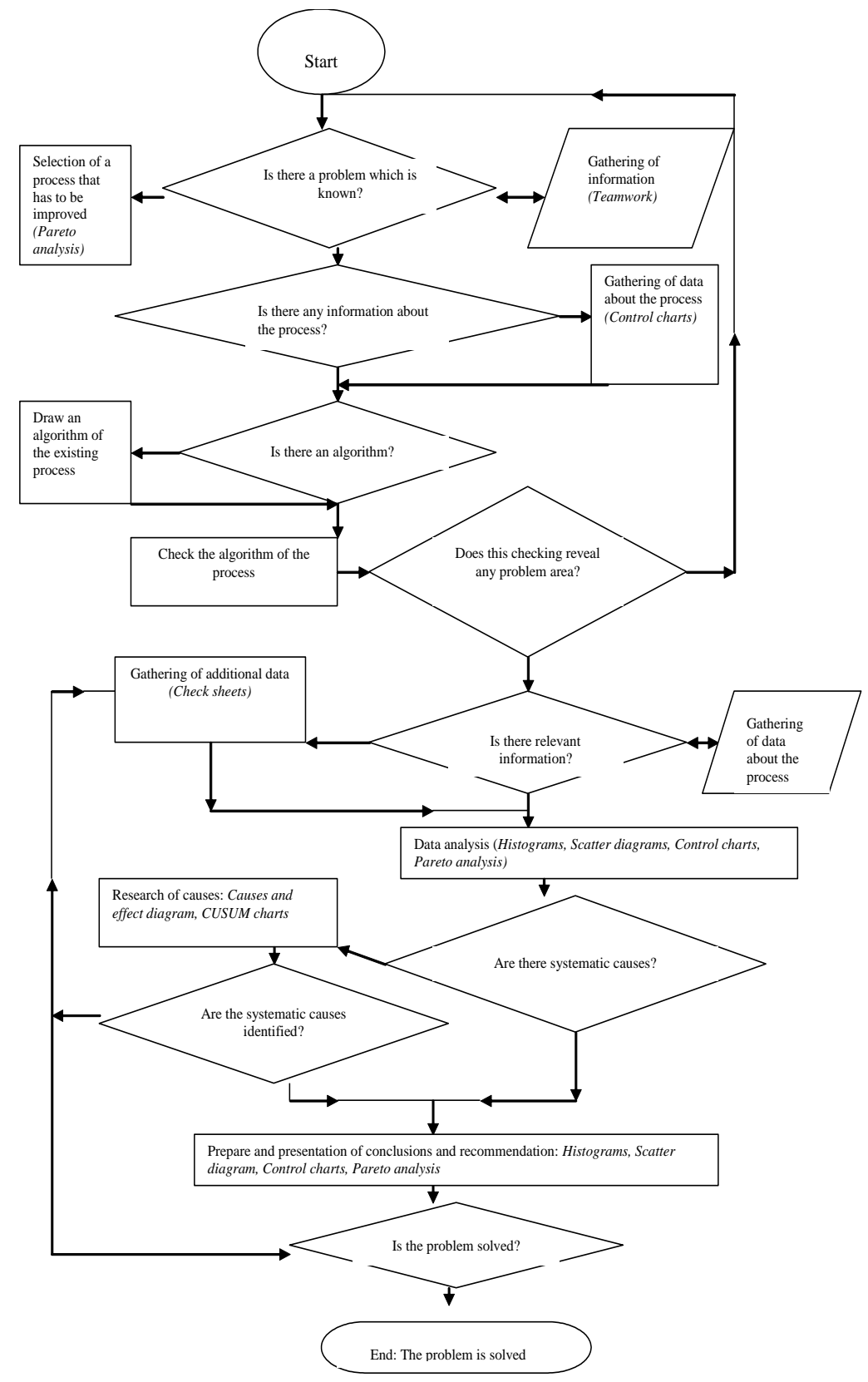

Figure 2: Systematic approach for successful implementation of SPC in Macedonian companies 
However, we should always bear in mind that SPC does not give answers to questions. On the contrary, it raises questions. Therefore, the above concept should be integrated in some of the concept for solving problems, such as Deming's cycle or Juran's programme for improving quality or some combination of the both concepts.

\section{Literature}

Antony, J. (2000). Ten key ingredients for making SPC successful in organisations. Measuring Business Excellence, Vol. 4, No. 4, pp. 7-10.

Bird, R. \& Dale, B. (1994). The misuse and abuse of SPC: a case study examination. International Journal of Vehicle Design, Vol. 15, No. 1/2, 99-107.

Chandra, J. M. (2001). Statistical Quality Control. CRC Press.

Dale, B. G. (2007). Managing Quality, $5^{\text {th }}$ ed., Prentice-Hall, Hemel Hempstead.

Grewal, C. and Gill, S. (2007). Measuring Statistical Process Control (SPC) Implementation in Indian Bicycle Industry: Some key findings. Udyog Pragati, Vol. 31, No. 3, July - September.

Hoerl, R. W. (1996). Enhancing the bottom-line impact of statistical methods. ASQC Statistics Division Newsletter, Vol. 15, No. 2, pp. 6-18.

Mason, B. and Antony, J. (2000). Statistical process control: an essential ingredient for improving service and manufacturing quality. Managing Service Quality, Vol. 10, No.4, pp. 233-238.

Montgomery, D.C. (2009). Statistical Quality Control: A Modern Introduction, $7^{\text {th }}$ ed., John Wiley $\&$ Sons.

Oakland, J. S. (2007). Statistical Process Control, 6th ed., Butterworth-Heinemann.

Skrabec, Q., "Maximizing the benefits of your ISO 9000 campaign", Industrial Engineering, Vol. 27 No. 4, pp. 34-8, April 1995.

Smith, G. M. (2003). Statistical Process Control and Quality Improvement, $5^{\text {th }}$ ed., Prentice Hall.

Stapenhurst, T. (2005). Mastering Statistical Process Control: A Handbook for Performance Improvement Using SPC Cases, Butterworth-Heinemann.

Stoop, I, Billiet, J., Koch, A, and Fitzgerald, R. (2010). Improving Survey Response: Lessons Learned from the European Social Survey (Wiley Series in Survey Methodology), Wiley Blackwell.

Xie, M. and Goh, T. N. (1999). "Statistical techniques for quality", The TQM Magazine, Vol. 11, No. 4, pp. 238-41.

Yin, R. K., Case study research: Design and method (Applied Social Research Methods) $5^{\text {th }}$ ed., SAGE Publications Inc., 2014. 
114 36 $6^{\text {Th }}$ International Conference on Organizational Science Development: Responsible Organization (MARCH $22^{\mathrm{ND}}-24^{\mathrm{TH}}$, PORTOROŽ SLOVENIA) 
$36^{\text {Th }}$ International Conference on Organizational Science DEVElopMENT: Responsible ORganization (MARCH $22^{\mathrm{ND}}-24^{\mathrm{TH}}$, PORTOROŽ SLOVENIA)

O. Arsenijević, M. Ferjan, I. Podbregar, P. Šprajc, D. Trivan \& Y.

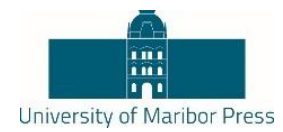

Ziegler

\title{
Be Overly Optimistic - the Effects of Accuracy in Financial Planning on Entrepreneurial Performance
}

\author{
SVEN CARLIN \& ADRIANA BOTMAN
}

\begin{abstract}
Literature suggests there is a positive relation between planning and results for small and medium enterprises. By using a polynomial regression model, we test the relation between specific aspects of financial planning and financial performance of small and medium enterprises in the Netherlands. The performance aspects analysed are gross margin, profit margin, debt ratio and inventory turnover. The financial planning aspects analysed are accuracy in budget, cash flow, sales and profit forecasts. No significant correlation between financial planning and performance has been found but among those who plan we found that accuracy in financial forecasting has a significant and positive effect on gross and profit margins. The findings also indicate that optimism (overly positive forecasting) improves gross margins but also increases risk by increasing debt.
\end{abstract}

KEYWORDS: Entrepreneurial finance $・$ financial planning $\bullet$ financial optimism

CoRrespondence AdDress: Sven Carlin, dhr. Dr., Amsterdam University of Applied Sciences, Amsterdam School of International Business, Fraijlemaborg 133, 1102 CV Amsterdam, Netherlands, e-mail: s.carlin@hva.nl; Adriana Botman, Amsterdam University of Applied Sciences, Amsterdam School of International Business, Fraijlemaborg 133, 1102 CV Amsterdam, Netherlands, e-mail: 
$36^{\mathrm{TH}}$ International Conference on ORganizational Science Development: Responsible Organization (MARCh $22^{\mathrm{ND}}-24^{\mathrm{TH}}$, Portorož Slovenia)

S. Carlin \& A. Botman: Be Overly Optimistic - the Effects of Accuracy in Financial Planning on Entrepreneurial Performance

\section{Introduction}

Financial planning is the focus of entrepreneurial finance courses where the emphasis is set on accuracy, accounting procedures and estimations. Previous studies on the effects of financial planning on businesses, especially new ventures are quite inconclusive. We attempt to shed some light on this gap by analysing to what extent does accuracy in financial planning affect new ventures' business performance.

\section{$1 \quad$ Theoretical framework}

Most of the literature is focused on strategic planning and is pre-web era when planning and especially financial models for growth were different. Mazzarol (2005) focuses on the entrepreneurial vision reflected in a business plan while Watts and Ormsby (1990) had set the stage for the positive correlation of strategic and operational planning with SME (small and medium enterprises) performance. Brinckmann, Grichnik and Kapsa (2010) research whether it is better for new ventures to "storm the castle" or engage in business planning and find a positive relation between performance and planning but do not research the extent of it. Rue and Ibrahim (1998) research the effect of accuracy in planning and business performance and find that businesses engaging in planning have significantly better sales growth. Gardene (1998) researches if forecasting has at all a positive effect on performance and does not find a correlation except for financial advice.

On the financial planning side, the research is scarce and mostly single factored. Headd (2000) finds that having more than $\$ 50,000$ in start-up capital increased the survivability of a SMEs. Mengel and Wouters (2015) find that education is antecedent of financial planning and control systems which in turn are antecedent of company performance. Cassar (2010) finds that entrepreneurs engaging in financial planning are overly optimistic in relation to forecasting sales and the number of employees.

Literature indicates that planning in general has a positive effect on results. In order to build on Mengel and Wouters, Cassar and Gardene this research is going to focus on the relation between financial planning accuracy and entrepreneurial performance.

\section{$2 \quad$ Data, methodology and results}

Due to research constrains the research has been executed only in the Netherlands. Research results would probably differ in other countries but the results should be significant for Europe. Randomly selected 2,500 SMEs from the Dutch Chamber of Commerce database of start-ups registered in the period of 2010 to 2016 of more than 100,000 have been approached expecting a response rate of $5 \%$ for statistical significance with a Z-score confidence level of $95 \%$. 148 responses have been received which is above the minimum 96 for the statistical significance of the sample. As a measure of financial accuracy, the difference between actual and forecasted expenses, cash flows, sales and profit has been researched. Business performance measures include gross margin, profit margin, debt to equity ratio and inventory turnover (Needles at all. 2011). 
S. Carlin \& A. Botman: Be Overly Optimistic - the Effects of Accuracy in Financial Planning on Entrepreneurial Performance

Each aspect of financial planning was compared to each aspect of business performance by analysing correlation and statistical significance.

The following hypotheses have been tested:

1) H1: There is a statistically significant difference in the mean of the gross margin, profit margin, debt ratio and inventory turnover of new ventures who participated in financial planning compared to new ventures who didn't participate in financial planning.

H0: There is no statistically significant difference in the mean of the gross margin, profit margin, debt ratio and inventory turnover of new ventures who participated in financial planning compared to new ventures who didn't participate in financial planning.

The mean gross margin, profit margin, debt ratio and inventory of businesses that do partake in financial planning is higher than those that don't but using a t-test no significance has been found as the p-value was 0,6941 for gross margins, 0,7931 for profit margins, 0,3333 for debt ratios and 0,8946 for inventory turnover. As all are higher than 0,5 the null hypothesis fails to be rejected.

2) H1: There is a significant correlation between accuracy in financial planning and an increase in business performance.

H0: There is no a significant correlation between accuracy in financial planning and an increase in business performance.

The closest is the accuracy to $0 \%$ of error the better should financial metrics be. A polynomial regression is used in order to establish whether accuracy influences business performance. The correlation coefficient and P-value at a 95\% significance level will determine if $\mathrm{HO}$ can be rejected. 
118 36 $6^{\mathrm{TH}}$ INTERNATIONAL CONFERENCE ON ORganizATIONAL SCIENCE DeVElopment: RESPONSIBLE ORGANIZATION (MARCH $22^{\mathrm{ND}}-24^{\mathrm{TH}}$, PORTOROŽ SLOVENIA)

S. Carlin \& A. Botman: Be Overly Optimistic - the Effects of Accuracy in Financial Planning on Entrepreneurial Performance

\begin{tabular}{|l|l|r|r|r|l|}
\hline Accuracy & financial performance & Multiple R & R-square & P-Value & Nul hypothesis \\
\hline Budget forecast & Gross margin & 0.4544 & 0.2065 & 0.0019 & REJECTED \\
\hline Cash flow forecast & Gross margin & 0.5423 & 0.2941 & 0.0003 & REJECTED \\
\hline Sales forecast & Gross margin & 0.3739 & 0.1398 & 0.0215 & REJECTED \\
\hline Profit forecast & Gross margin & 0.5082 & 0.2582 & 0.0003 & REJECTED \\
\hline \multicolumn{7}{|l|}{} \\
\hline Budget forecast & Profit margin & 0.1344 & 0.0181 & 0.6224 & ACCEPTED \\
\hline Cash flow forecast & Profit margin & 0.2072 & 0.0429 & 0.3808 & ACCEPTED \\
\hline Sales forecast & Profit margin & 0.4857 & 0.2359 & 0.0012 & REJECTED \\
\hline Profit forecast & Profit margin & 0.4952 & 0.2452 & 0.0007 & REJECTED \\
\hline \multicolumn{7}{|l|}{} \\
\hline Budget forecast & Debt ratio & 0.0759 & 0.0058 & 0.8604 & ACCEPTED \\
\hline Cash flow forecast & Debt ratio & 0.166 & 0.0275 & 0.541 & ACCEPTED \\
\hline Sales forecast & Debt ratio & 0.2666 & 0.0711 & 0.1584 & ACCEPTED \\
\hline Profit forecast & Debt ratio & 0.2594 & 0.0673 & 0.1693 & ACCEPTED \\
\hline \multicolumn{7}{|l|}{} \\
\hline Budget forecast & Inventory turnover & 0.1992 & 0.0397 & 0.8167 & ACCEPTED \\
\hline Cash flow forecast & Inventory turnover & 0.3936 & 0.1549 & 0.6036 & ACCEPTED \\
\hline Sales forecast & Inventory turnover & 0.3403 & 0.1158 & 0.5082 & ACCEPTED \\
\hline Profit forecast & Inventory turnover & 0.1313 & 0.0172 & 0.9167 & ACCEPTED \\
\hline
\end{tabular}

Table 1: Research results

From the findings in table 1 it can be concluded that there is no statistically significant correlation between the accuracy of any form of financial planning and the debt ratio or inventory turnover. Either the correlation coefficient $r$ isn't high enough or the $p$-value isn't low enough or both in all of the results concerning those two measures of business success.

However, there is a significant correlation between the following factors:

- Accuracy in budgeting and the gross margin

- Accuracy in cash flow forecasting and the gross margin

- Accuracy in sales forecasting and the gross margin

- Accuracy in sales forecasting and the profit margin

- Accuracy in profit forecasting and the gross margin

- Accuracy in profit forecasting and the profit margin

Interestingly, there is always a correlation between the accuracy of financial planning and the gross margin which could be due to the fact that gross margins are the simplest to forecast for start-ups whereas operational and financial costs are more volatile. For accuracy in budgets and cash flow forecasting to the gross margin there is a positive 
36. MEDNARODNA KONFERENCA O RAZVOJU ORGANIZACIJSKIH ZNANOSTI: ODGOVORNA ORGANIZACIJA (22. - 24. MAREC 2017, PORTOROŽ, SLOVENIJA)

S. Carlin \& A. Botman: Be Overly Optimistic - the Effects of Accuracy in Financial Planning on Entrepreneurial Performance

correlation with a polynomic trend-line to the second degree meaning that the more accurate budgets or cash flow forecasting is, the higher the gross margin tends to be.

The correlation between optimism in sales forecasting and profit forecasting to the gross margin and profit margin is quite interesting. In the introduction of this paper it was noted that businesses tend to overestimate their future sales and profits by being too optimistic (Cassar, 2010). The question asked is whether this would affect the business performance.

It seems as though new ventures that overestimate their sales and profits tend to do better than those that underestimate their sales and profits. The polynomial trend-line is positively correlated and skewed to a higher positive inaccuracy (overestimation) while correlation intercepts are not significant but positive. Correlation intercepts between forecasting accuracy and performance are shown in table 2.

\begin{tabular}{|l|r|}
\hline & Intercept \\
\hline Budget forecasting accuracy and gross margin & 0.4934 \\
\hline Budget forecasting accuracy and profit margin & 0.1356 \\
\hline Budget forecasting accuracy and debt ratio & 0.0433 \\
\hline \multicolumn{2}{|}{$\mid$} \\
\hline Sales forecasting accuracy and gross margin & 0.6581 \\
\hline Sales forecasting accuracy and profit margin & 0.1747 \\
\hline Sales forecasting accuracy and debt ratio & -0.1303 \\
\hline \multicolumn{2}{|c|}{} \\
\hline Cash flow forecasting accuracy and gross margin & 0.6488 \\
\hline Cash flow forecasting accuracy and profit margin & 0.1632 \\
\hline Cash flow forecasting accuracy and debt ratio & -0.2385 \\
\hline \multicolumn{2}{|}{$\mid$} \\
\hline Profit forecasting accuracy and gross margin & 1.01 \\
\hline Profit forecasting accuracy and profit margin & 0.6155 \\
\hline Profit forecasting accuracy and debt ratio & -0.082 \\
\hline
\end{tabular}

Table 2: Correlation between financial optimism and performance

Unfortunately, the testing of statistical significance was outside of the scope of this study. However, the found results have to be noted and further research is necessary on optimism in entrepreneurial finance field. What can be understood is that being overly optimistic in forecasts increases gross margins but also it increases debt ratios which could be a two-edged sword. As said, further research is necessary in order to appraise the correct influence of forecasting optimism on entrepreneurial success. 
$36^{\mathrm{TH}}$ International Conference on ORganizational Science Development: RESPONSIBLE ORGANIZATION (MARCH $22^{\mathrm{ND}}-24^{\mathrm{TH}}$, PORTOROŽ SLOVENIA)

S. Carlin \& A. Botman: Be Overly Optimistic - the Effects of Accuracy in Financial Planning on Entrepreneurial Performance

\section{Conclusion}

It is very unfortunate but our research does not provide evidence to sustain the findings of Watts and Ormsby (1990), Brinckmann, Grichnik and Kapsa (2010), Rue and Ibrahim (1998) but only confirms what Gardene (1998) has found, i.e. that there isn't a statistical correlation between financial planning and entrepreneurial success. This should a positive for all of those who want to be entrepreneurs but think their lack of financial planning knowledge would be a disadvantage. The statistical insignificance of financial planning on performance leads to the conclusion that financial knowledge is just a small influence on entrepreneurial success and that entrepreneurs can succeed by working with their strengths, as entrepreneurs, like people, are all different.

Nevertheless, there is no negative correlation between the presence of financial planning and business performance for new ventures nor a negative correlation for new ventures who prove to be accurate in its forecasting.

There are many other benefits of financial planning that ought to be considered other than its effect on profitability. As mentioned in the theoretical framework, financial planning gives a business the tools to implement certain strategies, to predict the needs of funds, and to maintain cash flow stability within the business.

Nevertheless, there is no negative correlation between the presence of financial planning and business performance for new ventures, nor a negative correlation for new ventures who prove to be accurate in their forecasts. There are many other benefits of financial planning that ought to be considered other than its effect on profitability. Financial planning gives a business the tools to implement certain strategies, to predict the needs of funds, and to maintain cash flow stability within the business.

Despite the statistical insignificance, we hope to have given some value to the entrepreneurial body of knowledge that will bring to more coherence in the scientific perspective on entrepreneurial success and perhaps even help entrepreneurs in their endeavors.

However, there is statistical significance between the accuracy in financial planning with those entrepreneurs who engage in financial planning and entrepreneurial success, building on the findings of Mengel and Wouters (2015) and especially Cassar (2010). We build on Cassar's findings that entrepreneurs engaging in financial planning are overly optimistic in relation to forecasting sales and the number of employees by finding that being overly optimistic does indeed lead to missed targets but it also leads to higher levels of success, measured by improvements in gross margin and profit margins.

There is a deep necessity for further research in the field of entrepreneurial finance as most research papers, including this one, merely scratch the surface of the potential body of knowledge. Perhaps researches are discouraged from doing research because of the many cases with no statistical significance that make it difficult to find funding. 
S. Carlin \& A. Botman: Be Overly Optimistic - the Effects of Accuracy in Financial Planning on Entrepreneurial Performance

Nevertheless, entrepreneurship and entrepreneurial finance should be studied in depth in order to find what really matters and add value to the current inconclusive body of knowledge. Our recommendation for further research is to make a comprehensive analysis that includes all possible topics and effect on entrepreneurial finance. This is a huge task but essentially important in order to remove the stigma of incoherence from current research on entrepreneurial finance.

Start-ups are in an environment where rules, common practices and patterns change constantly, but this is not a reason to avoid doing research in the field. Even if results will be of weak statistical significance any kind new knowledge in the field is a building block for the research community and advice for the many starting entrepreneurs essential for the constant renovation of our economies.

Our research based advice to entrepreneurs would be to engage in financial planning, invest time to make it as accurate as possible in order to prevent risky situations like higher debt levels that overly optimistic entrepreneurs tend to have.

We hope to have set a small stepping stone in the research area of measuring financial planning and performance and indicated new future potential research areas like financial planning optimism.

\section{Literature}

Brinckmann, J., Grichnik, D. \& Kapsa, D. (2010). Should entrepreneur plan or just storm the castle? A meta-analysis on contextual factors impacting the business planning performance in small firms. Journal of Business Venturing, No. 25, pp. $24-40$.

Cassar, G. (2010). Are individuals entering self-employment overly optimistic? An empirical test of plans and projections on nascent entrepreneur expectations. Strategic Management Journal, No. 31, pp. $822-840$.

Gadenne, D. (1998). Critical Success Factors for Small Business: An Inter-industry comparison. International Small Business Journal, No. 17, pp. 36-56.

Headd, B. (2000). Business success: Factors leading to surviving and closing successfully. Center for Economic Studies, US Department of Commerce, Bureau of the Census. http://www2.census.gov/ces/wp/2001/CES-WP-01-01.pdf, accessed 04 September 2016.

Mazzarol, T. (2000). Planning and Growth Characteristics of Small Business Owner-Managers. 35th Entrepreneurship, Innovation and Small Business conference, Barcelona. http://www.cemi.com.au/sites/all/publications/EISB2005MAZZAROL.pdf,accessed September 2016.

Mengel, S. \& Wouters, M. (2015). Financial planning and control in very small start-up companies: antecedents and effects on company performance. International Journal of

Entrepreneurship and Small Business, Vol 26, No. 2, pp. $191-216$.

Needles, B., Powers, M. \& Crosson, S. (2011). Accounting Principles (11th ed.). South-Western, Cengage Learning EMEA, Andover, UK.

Rue, L., \& Ibrahim, N. (1998). The relationship between planning sophistication and performance in small business. Journal of Small Business Management, Vol. 36, No. 4, pp. 24 - 32. 
122 36 $36^{\text {Th }}$ International CONFERENCE ON ORganizational SCIENCE Development: RESPONSIBLE ORGANIZATION (MARCH $22^{\mathrm{ND}}-24^{\mathrm{TH}}$, PORTOROŽ SlOVENIA)

S. Carlin \& A. Botman: Be Overly Optimistic - the Effects of Accuracy in Financial Planning on Entrepreneurial Performance

Watts, L.R. \& Ormsby, J.G. (1990). The Contribution of Operational and Strategic Planning to Small Firm Performance. Journal of Small Business Strategy, 1990, Vol 1, No. 2 


\title{
Razvoj odločitvenih kriterijev za ocenjevanje prednosti pri dodeljevanju stanovanj
}

\author{
BOJAN CESTNIK \& ALENKA KERN
}

\begin{abstract}
Povzetek V prispevku predstavimo pomen učinkovitega, nedvoumnega in jasnega oblikovanja prednostnih kategorij in časovni razvoj kriterijev pri odločanju o dodelitvi stanovanj, ki jih oddaja in prodaja Stanovanjski sklad RS. Za uspešno izvedbo vseh potrebnih faz $\mathrm{v}$ postopku dodeljevanja stanovanj je potrebno predhodno jasno definirati in transparentno predstaviti pogoje in prednostne kategorije postopka izbora najemnika ali kupca stanovanja. Celoten proces dodeljevanja stanovanj tako ne sme dopuščati dvoma glede verodostojnosti vseh odločitev, potrebnih za izpeljavo posameznih razpisov. Poudarek je na prikazu možnosti, ki jih za dosego cilja izboljšanja razumevanja in dostopnosti do razpisnih pogojev ponujata razvoj spletnih tehnologij in vedno bolj razvita informacijskokomunikacijska tehnologija. Opazen je tudi trend izboljšanja in povečanja uporabe spletnih storitev s strani državljanov, ki si rešujejo svoje stanovanjsko vprašanje. Predstavljen je tudi potek razvoja oblikovanja prednostnih kategorij, v katere so uvrščeni prosilci za stanovanja, ki se je glede na prednostno obravnavane skupine s časom spreminjal. Procesa izbora najemnikov in kupcev stanovanj temeljita na večletnih pozitivnih izkušnjah, pridobljenih na javnih razpisih Sklada, in s pomočjo informacijske podpore predstavljata stabilno, transparentno ter zanesljivo metodologijo izbora kupcev in najemnikov $\mathrm{v}$ skladu $\mathrm{z}$ določili posameznega razpisa. Sistem dodeljevanja stanovanj, ki se je razvijal in dopolnjeval glede na usmeritve državne stanovanjske politike, je postal vsestransko sprejet in uveljavljen način dodeljevanja stanovanj zainteresiranim prosilcem ter posledično izpostavljen primer dobre prakse, ki jo $\mathrm{v}$ določenih segmentih že povzemajo tudi druge institucije.
\end{abstract}

KLJUČNE BESEDE: stanovanja - Stanovanjski sklad RS • dodeljevanje stanovanj • prednostne kategorije $\bullet$ spletne storitve $\bullet$ transparentno poslovanje

NASLOv AVTORJEV: dr. Bojan Cestnik, direktor, Temida d.o.o., Dunajska cesta 51, 1000 Ljubljana, Slovenija, e-pošta: bojan.cestnik@temida.si; Alenka Kern, Stanovanjski sklad RS, Poljanska cesta 31, P. P. 2044, Slovenija, e-pošta: alenka.kern@ssrs.si 


\title{
Evolution of Decision Criteria for Estimating Priorities in Housing Facilities Allocation
}

\author{
BOJAN CESTNIK \& ALENKA KERN
}

\begin{abstract}
In this paper we present the importance of effective, explicit and clear formation of priority categories and the evolution of developing criteria used estimating priorities in the process of housing allocation by the Housing Fund of the Republic of Slovenia. In order to successfully carry out all the necessary stages in the process of allocating housing, conditions and priority categories of the selection process (of tenants or buyers) must be clearly and transparently defined in advance. The whole process of housing allocation cannot allow any doubts regarding credibility of the procedures necessary to execute the respective tenders. Furthermore, the possibility of achieving better understanding and accessibility of the tender conditions relies heavily on increased usage of web services by the citizens, who are solving their housing problem; the process takes into account the advantages offered by the web technologies along with the information and communication technology development. Moreover, the evolution of developing the priority categories, in which applicants for housing are classified, is presented with the focus on the changes in reference to preferentially treated groups. The process of selecting tenants and buyers of housing is based on several years of experience, gained through The Fund's public tenders and information technology support. It represents a balanced, transparent and reliable selection methodology of buyers and tenants in accordance with the tender provisions. The housing allocation system, which was developed and amended according to the guidelines of state housing policy, has been exposed as an example of good practice for allocating housing to interested applicants; in some cases it was also adopted by other public institutions.
\end{abstract}

KEYWORDS: Housing • The Housing Fund of the Republic of Slovenia • housing allocation - priority categories - Web services • transparent business

Correspondence AdDress: Bojan Cestnik, Ph.D., managing director, Temida d.o.o., Dunajska cesta 51, 1000 Ljubljana, Slovenia, e-mail: bojan.cestnik@temida.si; Alenka Kern, Hausing Fund RS, Poljanska cesta 31, P. P. 2044, Slovenia, e-mail: alenka.kern@ssrs.si 
B. Cestnik \& A. Kern: Razvoj odločitvenih kriterijev za ocenjevanje prednosti pri dodeljevanju stanovanj

\section{$1 \quad$ Uvod}

Za uspešno in odgovorno poslovanje mora organizacija nenehno stremeti k strokovnosti, zakonitosti, ciljni naravnanosti, usmerjenosti $\mathrm{k}$ javnim in zasebnim uporabnikom, gospodarnosti, kakovosti, učinkovitosti, integriteti, transparentnosti, nepristranskosti, racionalnosti, znanju, odgovornosti ter vzajemnemu spoštovanju. Upoštevanje navedenega je zlasti pomembno na področju pravic, ki so vezane na osnovne potrebe človeka. Eden izmed največjih življenjskih izzivov posameznika je rešitev stanovanjskega vprašanja, saj slednje vpliva na kvaliteto življenja posameznika in družine. Razmere na stanovanjskem področju v Sloveniji ne omogočajo doseganja reševanja stanovanjskega vprašanja $\mathrm{v}$ celoti, pri čemer so $\mathrm{v}$ najslabšem položaju predvsem mladi, kar dodatno povečuje potrebo po odgovornem ravnanju nosilcev izvajanja stanovanjske politike. Stanovanjski sklad RS je v letih svojega delovanja postal nacionalno in mednarodno prepoznaven izvajalec stanovanjske politike države, ki s stalnimi javnimi razpisi, javnimi pozivi in programi nudi pestrost produktov za gradnjo, dokončanje, rekonstrukcijo ter nakup in najem stanovanj.

\subsection{Delovanje in vloga Stanovanjskega sklada RS}

Stanovanjski sklad RS je bil ustanovljen leta 1991 s Stanovanjskim zakonom za financiranje Nacionalnega stanovanjskega programa in za spodbujanje gradnje stanovanjskih objektov, obnovo in vzdrževanje stanovanj ter stanovanjskih hiš. V prvih letih svojega delovanja je s ponujanjem posojil pod ugodnimi pogoji neposredno podpiral državljansko iniciativo pri zasebni gradnji stanovanjskih objektov in neprofitne stanovanjske organizacije. Po prvem desetletju je sodeloval tudi pri spodbujanju državljanov $\mathrm{k}$ stanovanjskemu varčevanju $\mathrm{z}$ dvema novima projektoma, in sicer nacionalno varčevalno shemo in subvencijami za mlade družine, katerih glavni cilj je bil izboljšati stanovanjski status mladih družin (Cestnik in sod., 2001; 2008). Izvedba je bila velika obveznost in hkrati tudi velik izziv. Sklad projektno in strokovno sodeluje z javnim in zasebnim sektorjem ter $\mathrm{s}$ svojim delovanjem na različnih področjih prispeva $\mathrm{k}$ doseganju ciljev, zastavljenih $\mathrm{v}$ razvojnih, prostorskih in socialnih razvojnih programih države ter $\mathrm{k}$ ureditvi razmer na stanovanjskem področju in izboljšanju zakonodaje na področju njegovega delovanja. Izrednega pomena je tudi povezovanje organizacije s sorodnimi institucijami, predvsem s ciljem pridobivanja podatkov, izmenjave izkušenj in dobrih praks ter usklajevanja stališč glede razvoja stanovanjske politike. Zaradi majhnega števila zaposlenih, številčnosti in zahtevnosti nalog ter kompleksnosti sistemskih rešitev za opravljanje posameznih procesov Sklad pogodbeno sodeluje z zunanjimi strokovnjaki, ki izvajajo izvoz in uvoz podatkov za tehnično izvedbo javnih pozivov in razpisov, ki se med drugim nanaša tudi na vzpostavitev povezave s Centralnim registrom prebivalstva in na tehnološke rešitve načina izvedb javnih razpisov za dodelitev stanovanj.

\section{Reševanje stanovanjskega vprašanja preko razpisov}

Način reševanja stanovanjskega vprašanja državljanov preko javnega razpisa je edinstven in specifičen tako na slovenskem kot evropskem področju. Stanovanja, ki jih Sklad 
$36^{\mathrm{TH}}$ InTERnATIONAL CONFERENCE ON ORganizational SCIENCE DeVElopment: Responsible Organization (MARCh $22^{\mathrm{ND}}-24^{\mathrm{TH}}$, Portorož Slovenia)

B. Cestnik \& A. Kern: Evolution of Decision Criteria for Estimating Priorities in Housing Facilities Allocation

nameni za oddajo v najem ali prodajo preko javnih razpisov, pridobi z nakupom ali lastno investicijo. Sklad celotno razpisno dokumentacijo, kot so splošni pogoji prodaje oz. najema, prioritetni razredi, komercialne skice, sklepi o določitvi najemnine oz. cene, določila zakonodaje, protokol izbora, temeljito pripravi. Prednostni razredi za primer večjega interesa za posamezno stanovanje so opredeljeni z natančno definiranimi kriteriji razvrščanja. Razpisna dokumentacija je objavljena $\mathrm{v}$ medijih in na spletni strani, pri čemer je poudarek na čim boljšem razumevanju zainteresirane javnosti. Sklad je v času razpisa deležen veliko pozornosti s strani zainteresiranih kupcev kot tudi medijev, saj je povpraševanje po stanovanjih običajno večje od ponudbe. Najpogostejša vprašanja so, na kakšen način lahko posameznik kupi oziroma najame stanovanje in kakšne so možnosti, da je za nakup oziroma najem izbran. Navedeni način oddaje in prodaje stanovanj predstavlja tudi določene omejitve, kot so primerjava in fleksibilnost z ostalimi akterji na trgu, saj zaradi razpisnih pogojev obstajajo določene omejitve, ki jih glede na izide in uspešnost oddaje in prodaje Sklad naknadno ne more prilagajati in spreminjati. Besedilo najemne in prodajne pogodbe je za vse enako in se ga ne da spreminjati oziroma dopolnjevati na željo najemnikov ali kupcev, prav tako so $\mathrm{z}$ razpisom javno določene najemnine in cene stanovanj ter postopek prijave in izbora.

Poslovna procesa oddaje in prodaje stanovanj preko razpisov sta sestavljena iz več faz. Prva faza je priprava javnega razpisa z vso potrebno dokumentacijo (splošni pogoji najema oziroma prodaje, najemna oziroma prodajna pogodba, sklepi o določitvi najemnine oz. cene, določila zakonodaje...), ki določa pogoje ustreznosti in zahteve prijave za najem ali nakup stanovanj. Pred objavo posameznega razpisa je potrebno opraviti tudi vsa potrebna testiranja za nemoteno oddajo vlog s strani zainteresiranih prosilcev. Sledi faza, v kateri zainteresirani vlagatelji izpolnijo in oddajo predpisano papirno ali elektronsko vlogo. Način oddaje vloge je odvisen od njihovih preferenc. Z oddajo vloge na razpis se prijavitelj strinja s pogoji razpisa, ki so javno objavljeni in veljajo za vse prijavitelje, kar vsak prijavitelj potrdi s podpisom izjave na vlogi. Prejete vloge pregledajo strokovne službe, za nepopolne vloge prosilce pozovejo na dopolnitev, popolne prijave pa razvrstijo glede na prednostne kategorije, ki so določene vnaprej ter jih vključijo v proces dodeljevanja stanovanj. Naključni računalniški izbor se izvede, kadar je več prosilcev za posamezno stanovanje razvrščenih $v$ isto prednostno kategorijo. Razvrstitveni kriteriji in pravila za določitev kategorije so določena vnaprej in vključujejo lastnosti kot so družinski status, zdravstveno stanje, število otrok in podobno. Če se dva ali več kandidatov uvrsti $v$ isto kategorijo, je uporabljen naključni izbor, da se izbere posamezni vlagatelj za najem ali nakup vsakega stanovanja. Izbor najemnikov oziroma kupcev rednega dela razpisnega roka poteka $\mathrm{v}$ prisotnosti notarja pred petčlansko komisijo, naključno izbrano med zainteresiranimi prosilci za sodelovanje $\mathrm{v}$ tej komisiji. Rezultati izbora so dokumentirani in dokončni, njihovo naknadno spreminjanje ni mogoče. Rezultati izbora so ustrezno hranjeni in na voljo za vpogled oziroma pojasnjevanje posameznih odločitev. Po zaključenem postopku izbora najemnikov in kupcev oziroma dodeljevanja stanovanj, se vse prosilce obvesti o izidu izbora. Sledi sklepanje pogodb z izbranimi najemniki in kupci, ogledi, predogledi in primopredaje stanovanj, spremljanje plačil in skrb za odpravo reklamacij. Poslovna procesa oddaje in prodaje stanovanj sta razvidna iz Slike 1. 
B. Cestnik \& A. Kern: Razvoj odločitvenih kriterijev za ocenjevanje prednosti pri dodeljevanju stanovanj

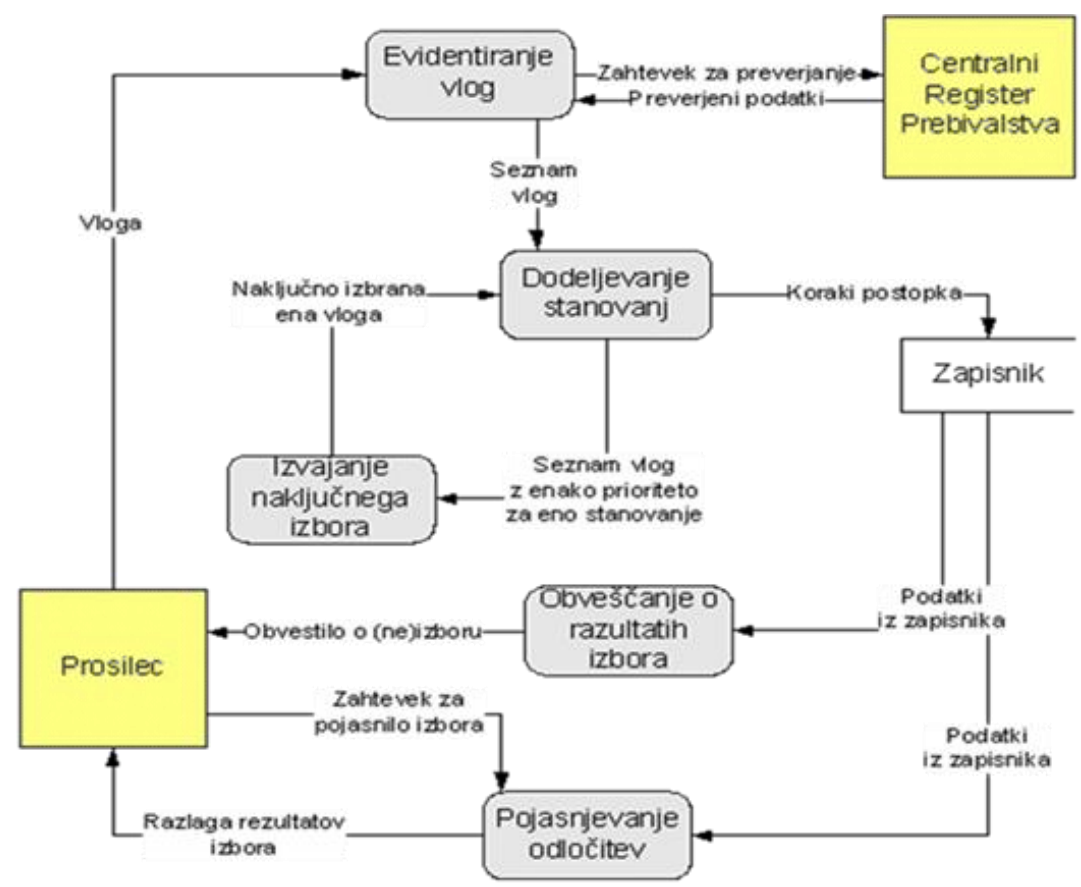

Slika 1: Prikaz postopka dodeljevanja stanovanj preko javnega razpisa na Stanovanjskem skladu RS

Informacijski sistem za dodeljevanje stanovanj mora biti pregleden in imeti razumljiv vpogled v vse faze procesa, zaželena pa je tudi fleksibilnost sistema za spremembe. Poleg tega mora vsebovati več nadzornih mehanizmov, ki zagotavljajo celovitost in zaupnost podatkov, ki se obdelujejo. $\mathrm{S}$ temi mehanizmi lahko ohranimo visoko raven verodostojnosti. Za poenostavljene postopke nazora mora sistem vključevati tudi module za povezljivost $\mathrm{z}$ drugimi razpoložljivimi storitvami e-uprave kot je npr. Centralni register prebivalstva. Sklad je preko e-povezave s Centralnim registrom prebivalstva dodatno izboljšal kvaliteto vnosa in obdelave prejetih vlog in skrajšal čas vnosa. Tovrstna e-povezava omogoča hitrejši in enostavnejši vnos podatkov, manjša je možnost napake pri vnosu vlog, omogočena je sprotna kontrola osebnih podatkov, pravočasno delovanje po upravnem postopku z upoštevanjem vseh rokov, več časa pa je lahko namenjenega preverjanju podatkov in vlog.

\section{Pomen oblikovanja in razumevanja javnih razpisov}

$V$ razpisni dokumentaciji se natančno opredeli pogoje, način oddaje oziroma prodaje ter definira prednostne kategorije, ki se upoštevajo v primeru, da je za isto stanovanje zainteresiranih več prosilcev. Največji izziv in hkrati ozko grlo razumevanja je odločitev 
$36^{\text {Th }}$ International Conference on Organizational Science Development: Responsible Organization (March $22^{\mathrm{ND}}-24^{\mathrm{TH}}$, Portorož SLOVENIA)

B. Cestnik \& A. Kern: Evolution of Decision Criteria for Estimating Priorities in Housing Facilities Allocation

o tem, kako izraziti ključne dejavnike, ki vplivajo na razporeditev v posamezni prednostni razred, zaradi česar je potrebno veliko pozornosti nameniti natančnemu in nedvoumnemu definiranju pogojev in posameznih prednostnih kategorij. Te morajo biti opisane jasno, nedvoumno in razumljivo, $s$ čemer preprečimo možnost za pristranske in enostranske razlage. Dejavniki odločitve na osnovi posameznega javnega razpisa se morajo prenašati na učinkovit način, to je na kratko in jedrnato. Ustrezni načini odločanja morajo biti izčrpni, preprosti in intuitivno razumljivi. To je zlasti pomembno, ko se razpravlja o spremembah oz. uvedbah novih prednostnih kategorij, ki so v primeru večjega interesa obravnavane prednostno. Za doseganje navedenega je $\mathrm{v}$ pomoč razpoložljiva informacijsko komunikacijska tehnologija, ki omogoča bistveno boljše korake do razumevanja posameznih kriterijev določitve. Primer definicije mlade družine po Zakonu o nacionalni stanovanjski varčevalni shemi in subvencijah mladim družinam za prvo reševanje stanovanjskega vprašanja: »Mlada družina je življenjska skupnost obeh ali enega izmed staršev z enim ali več otroki oziroma posvojenci, pri čemer vsaj en otrok še ni šoloobvezen v koledarskem letu javnega poziva." Primer jasnega in nedvoumnega definiranja mlade družine kot prednostne kategorije po javnem razpisu 2016: »Za mlado družino po tem razpisu se šteje družina, v kateri vsaj en otrok v času prijave še ni šoloobvezen. Enako velja za enostarševske družine, ki morajo izrecno navesti, da se statusno opredeljujejo kot take. Za otroka, ki še ni šoloobvezen, se šteje otrok, rojen po vključno 01.01.2011. Še ne rojenega otroka po slovenski zakonodaji in tem razpisu ni mogoče uveljavljati oziroma navajati kot člana mlade družine, saj to pravico otrok prejme šele $\mathrm{z}$ rojstvom.«

\section{$4 \quad$ Razvoj kriterijev odločanja za dodelitev stanovanj}

V zadnjem desetletju je prišlo do sprememb glede razpisov za dodeljevanje stanovanj $\mathrm{v}$ najem ali nakup, kar bomo opisali s ponazoritvijo razvoja prednostnih kategorij. Analiza razvoja kriterijev odločanja za dodelitev stanovanj preko oblikovanja prednostnih kriterijev je uporabna za analitično ovrednotenje preteklosti in inovativno načrtovanje prihodnosti. Prikazali bomo, kako se spremembe prednostnih kategorij odražajo $\mathrm{v}$ osnovnih konceptualnih modelih odločanja in podpore. Uravnoteženje ponudbe in povpraševanja na trgu nepremičnin, tako s stanovanji za najem kot nakup, je ena od glavnih nalog Sklada. Ker je ponudba stanovanj običajno manjša od povpraševanja, se za določitev prednostnega vrstnega reda uporablja prednostna razvrstitev prosilcev. Ko je več prosilcev za isto stanovanje $\mathrm{v}$ enakem prednostnem razredu, se kupec oziroma najemnik izbere s pomočjo naključnega računalniškega izbora. Dodeljevanje stanovanj prosilcem je že sama po sebi strateška in občutljiva naloga. Od leta 2002 je bil sistem izbora kupcev oz. najemnikov stanovanj s pomočjo prednostnih kategorij uspešno uporabljen za podporo trinajstih razpisov za oddajo in prodajo stanovanj, kljub začetnim številčnejšim pojasnjevanjem in dokazovanjem pravilnosti. Opisan sistem dodeljevanja stanovanj zagotavlja pregleden in razumljiv vpogled $\mathrm{v}$ vseh fazah postopka in vključuje več kontrolnih mehanizmov, ki zagotavljajo celovitost in zaupnost obdelanih podatkov. Stanovanjsko politiko je potrebno zasnovati tako, da je stabilna in trajna, kar pomeni, da se ne spreminja pogosto in hkrati omogoča pregledno uvajanje in refleksijo subtilnih 
B. Cestnik \& A. Kern: Razvoj odločitvenih kriterijev za ocenjevanje prednosti pri dodeljevanju stanovanj

sprememb na osnovi novih dejstev ter predvsem zakonodaje, ki je na stanovanjskem področju bistvenega pomena.

\subsection{Prednostne kategorije}

V vsakokratnem javnem razpisu za oddajo ali prodajo stanovanj so določene in opredeljene prednostne kategorije prosilcev, ki se uporabijo $\mathrm{v}$ primeru, da je za isto stanovanje zainteresiranih več prosilcev. Za boljšo preglednost in predvsem boljše razumevanje so prioritetni razredi navedeni tudi v tabeli, ki so poleg protokola izbora in naključnega izbora sestavni del razpisne dokumentacije vsakokratnega javnega razpisa. Prednostne kategorije po zadnjih razpisih so mlade družine, v kateri vsaj en otrok še ni šoloobvezen, družine $\mathrm{z}$ osnovnošolskim otrokom, družine, gibalno ovirane osebe in mladi. Dodatno prednost lahko uveljavljajo prosilci, ki so ali še vedno redno varčujejo v nacionalni stanovanjski varčevalni shemi. Znotraj prednostne kategorije mlade družine imajo dodatno prednost tiste mlade družine, ki ustrezno izkažejo, da prvič rešujejo svoje stanovanjske vprašanje oziroma tega vprašanja nimajo zadovoljivo rešenega. Kriterij za uvrstitev v prioritetni razred je tudi število otrok $(3$ ali več, $2,1,0)$ in izbira stanovanja (glavna, dodatna). Primer prednostnih kategorij za stanovanja, ki niso namenjena gibalno oviranim osebam (GOO), je razviden iz Tabele 1. 
$36^{\mathrm{TH}}$ InTERnATIONAL CONFERENCE ON ORganizational SCIENCE DeVElopment: RESPONSIBLE ORGANIZATION (MARCH $22^{\mathrm{ND}}-24^{\mathrm{TH}}$, PORTOROŽ SLOVENIA)

B. Cestnik \& A. Kern: Evolution of Decision Criteria for Estimating Priorities in Housing Facilities Allocation

Tabela 1: Primer prednostnih kategorij pri dodeljevanju stanovanj

\begin{tabular}{|c|c|c|c|c|c|c|}
\hline GOO & Vrsta & Št. otrok & Reševanje & Shema & Želja & Prioriteta \\
\hline$*$ & $\begin{array}{c}\text { mlada } \\
\text { družina }\end{array}$ & 3 in več & prvič & da & prva & P001 \\
\hline$*$ & $\begin{array}{l}\text { mlada } \\
\text { družina }\end{array}$ & 3 in več & prvič & da & dodatna & P002 \\
\hline$*$ & $\begin{array}{c}\text { mlada } \\
\text { družina }\end{array}$ & 3 in več & prvič & ne & prva & P003 \\
\hline$*$ & $\begin{array}{c}\text { mlada } \\
\text { družina }\end{array}$ & 3 in več & prvič & ne & dodatna & P004 \\
\hline$*$ & $\begin{array}{c}\text { mlada } \\
\text { družina }\end{array}$ & 3 in več & ponovno & da & prva & P005 \\
\hline$*$ & $\begin{array}{c}\text { mlada } \\
\text { družina }\end{array}$ & 3 in več & ponovno & da & dodatna & P006 \\
\hline$*$ & $\begin{array}{c}\text { mlada } \\
\text { družina }\end{array}$ & 3 in več & ponovno & ne & prva & P007 \\
\hline$*$ & $\begin{array}{c}\text { mlada } \\
\text { družina }\end{array}$ & 3 in več & ponovno & ne & dodatna & P008 \\
\hline$*$ & $\begin{array}{c}\text { mlada } \\
\text { družina }\end{array}$ & 2 & prvič & da & prva & P009 \\
\hline * & $\begin{array}{c}\text { mlada } \\
\text { družina }\end{array}$ & 2 & prvič & da & dodatna & P010 \\
\hline$*$ & $\begin{array}{c}\text { mlada } \\
\text { družina }\end{array}$ & 2 & prvič & ne & prva & P011 \\
\hline$*$ & $\begin{array}{c}\text { mlada } \\
\text { družina }\end{array}$ & 2 & prvič & ne & dodatna & P012 \\
\hline$*$ & $\begin{array}{c}\text { mlada } \\
\text { družina }\end{array}$ & 2 & ponovno & da & prva & P013 \\
\hline$*$ & $\begin{array}{c}\text { mlada } \\
\text { družina }\end{array}$ & 2 & ponovno & da & dodatna & P014 \\
\hline$*$ & $\begin{array}{c}\text { mlada } \\
\text { družina }\end{array}$ & 2 & ponovno & ne & prva & P015 \\
\hline$*$ & $\begin{array}{c}\text { mlada } \\
\text { družina }\end{array}$ & 2 & ponovno & ne & dodatna & P016 \\
\hline * & $\begin{array}{c}\text { mlada } \\
\text { družina }\end{array}$ & 1 & prvič & da & prva & P017 \\
\hline$*$ & $\begin{array}{c}\text { mlada } \\
\text { družina }\end{array}$ & 1 & prvič & $\mathrm{da}$ & dodatna & P018 \\
\hline$*$ & $\begin{array}{c}\text { mlada } \\
\text { družina }\end{array}$ & 1 & prvič & ne & prva & P019 \\
\hline
\end{tabular}

Prednostna kategorija za stanovanja, ki zagotavljajo tudi gibalno oviranim osebam (GOO) neoviran dostop, vstop in uporabo stanovanja ter skupnih prostorov, namenjenih temu stanovanju, so ne glede na vrsto družine oziroma starost gibalno ovirane osebe (prosilec ali njegov ožji družinski član) in število otrok, gibalno ovirane osebe. 


\subsection{Potek razvoja prednostnih kategorij}

Z objavo javnega razpisa za najem ali prodajo nepremičnin so določene zahteve za prijavo prosilcev za kandidiranje na vsakokratnem razpisu. Opredeljen je podroben opis postopka z modelom podpore za celovito odločitev oziroma pravila za razvrstitev prijav glede na njihovo prioriteto. Glavni namen odločitvenega modela je pojasniti morebitne nejasnosti, ki bi lahko izhajale iz tekstovnih dokumentov razpisa. Oblikovanja prednostnih kategorij prosilcev so temeljila na smernicah, pridobljenih iz državne politike in vsakokratne zakonodaje, stanju na trgu in delovanju Sklada. Potrebna je skrbno načrtovana in pregledno predstavljena politika, ki se odraža tudi $\mathrm{v}$ javnih razpisih. Od leta 2002 je prišlo do sprememb razvrščanja v prednostne kategorije oziroma do spremembe prioritetnih razredov glede na usmeritve stanovanjske politike, pri čemer se zahteve za vsakokratni razpis niso drastično spremenile. Spremembe prioritetnih razredov se morajo odražati tudi $\mathrm{v}$ tekstovnih dokumentih razpisa ter $\mathrm{v}$ odločitvenem modelu. Razvoj oziroma spremembe prednostnih kategorij pri dodeljevanju stanovanj lahko umestimo v štiri vrste in sicer dodajanje novih prednosti, sprememba vrstnega reda pomembnosti prednostih kriterijev, sprememba glavne prednostne ciljne skupine ter sprememba kriterija za izpolnjevanje pogojev znotraj posamezne prednostne kategorije. V nadaljevanju bomo opisali prednostne kategorije po letih javnih razpisov. V letu 2002 je Sklad pričel s prodajo 135 stanovanj, za katere so bili objavljeni trije razpisi; če niso bila prodana $\mathrm{v}$ sklopu razpisa SA, so bila prenesena v razpisa SB in SC. Na začetku so bili prosilci razvrščeni le $\mathrm{v}$ štiri kategorije. Prednost pri nakupu teh stanovanj so imeli prosilci, ki so imeli odobreno posojilo s strani Sklada in varčevalci v nacionalni stanovanjski varčevalni shemi, znotraj njih pa mlade družine, za katere je bil kriterij starost staršev. V naslednjih razpisih se je število prednostnih kategorij povečalo. Z uvedbo novih prednostnih kategorij je prišlo do zmanjšanja števila naključnih izborov med enakovrednimi prosilci, vendar so imele tovrstne odločitve tudi drugačne posledice. $\mathrm{V}$ naslednjem razpisu je bila glavna prednost varčevanje $\mathrm{v}$ nacionalni stanovanjski varčevalni shemi, pri čemer so imeli dodatno prednost tisti varčevalci, ki so zaključevali $\mathrm{z}$ varčevanjem. Znotraj varčevalcev so imele znova prednost mlade družine. V letu 2003 se je uvedla dodatna prednost za stanovanja, ki so prednostno namenjena gibalno oviranim osebam. Absolutno prednost za nakup teh stanovanj se daje gibalno oviranim osebam. V istem letu je bila sprejeta odločitev, da je potrebno v smeri zasledovanja ciljev uvesti socialne kategorije, kot so starost, število otrok in podobno. Leta 2004 je Sklad preko razpisa ponudil največje število stanovanj, skupno 852, vendar je bil pričakovan interes večji od ponudbe, zato je prišlo do spremembe odločitvenih kriterijev. Glavna ciljna skupina so bili varčevalci nacionalne stanovanjske varčevalne sheme, ki so zaključili z varčevanjem, znotraj njih pa so imele dodatno prednost mlade družine, mladi do 30 let in družine. Med mladimi družinami in družinami so imele dodatno prednost družine $\mathrm{z}$ večjim številom otrok. Pri tem ne smemo zanemariti dejstva, da dejansko število oddanih prijav na razpis ni odvisno od števila prednostnih kategorij, temveč je najbolj odvisno od same ponudbe stanovanj v posameznem razpisu. $Z$ letom 2006 status mlade družine ni bil več vezan na starost staršev, temveč na starost otrok. Glede na spremembo zakonodaje in siceršnje spremembe, tudi na trgu nepremičnin, so za pripravo odločitvenih kriterijev strokovne službe opravile številne študije in analize. Oblikovali so 
$36^{\mathrm{TH}}$ International Conference ON ORganizational Science Development: RESPONSIBLE ORGANIZATION (MARCH $22^{\mathrm{ND}}-24^{\mathrm{TH}}$, PORTOROŽ SLOVENIA)

B. Cestnik \& A. Kern: Evolution of Decision Criteria for Estimating Priorities in Housing Facilities Allocation

se prednostni kriteriji kot sledijo: Mlada družina, družina, gibalno ovirane osebe in mlad par. Znotraj prednostnih kategorij so imeli dodatno prednost varčevalci $v$ nacionalni stanovanjski varčevalni shemi, znotraj mladih družin in mladih parov pa so imeli dodatno prednost tisti, ki so prvič reševali svoje stanovanjsko vprašanje. Ti kriteriji odločanja so veljali vse do leta 2014. Pomen natančnega definiranja odločitvenih kriterijev in prednostnih kategorij se je kot utemeljen izkazal že v fazi prejemanja prijav za nakup stanovanj v Ljubljani leta 2006, saj smo prejeli preko 3.000 prijav prosilcev za nakup 62 stanovanj. Največ prednostnih kategorij je bilo leta 2010 v razpisu SJ za prodajo stanovanj v Kopru in sicer kar 1.134. Trend naraščanja števila kategorij za razvrstitev je mogoče opaziti v prvih desetih razpisih (od 2002 razpis SA do 2010 razpis SJ). Zaradi velikega števila prednostnih kategorij je tudi veliko težje razumevanje in interpretiranje. Kakovost storitev Sklada kot javnega sklada je v veliki meri odvisna od sposobnosti zaposlenih glede razumevanja modela in nadzora poslovnih procesov. Od leta 2012 je sledila je "normalizacija" števila kategorij. Glavna prednostna kategorija kupcev stanovanj tako ostajajo mlade družine $\mathrm{z}$ vsaj enim predšolskim otrokom (s prednostjo prvega reševanja stanovanjskega problema), sledijo družine z osnovnošolskim otrokom, družine z vzdrževanim otrokom, gibalno ovirane osebe in mlade osebe. Dodatna prednost je varčevanje $\mathrm{v}$ nacionalni stanovanjski varčevalni shemi. V zadnjih treh razpisih (SL, SM in SO) je bila predlagana poenostavitev tabele odločanja s prednostnimi razredi ( 80 , 108 in 60 kategorij). V tabeli št. 2 je prikazanih 12 razpisov za prodajo in razpis SL, ki se uporablja za podporo procesa oddaje stanovanj v najem. Razpisi so opisani z oznako razpisa, letom objave razpisa, številom razpoložljivih stanovanj, številom oddanih vlog za izbor in številom kategorij za razvrstitev prijav. 

ORGANIZACIJA (22. - 24. MAREC 2017, PORTOROŽ, SLOVENIJA)

B. Cestnik \& A. Kern: Razvoj odločitvenih kriterijev za ocenjevanje prednosti pri dodeljevanju stanovanj

Tabela 2: Število prednostnih kategorij po razpisih Sklada

\begin{tabular}{|c|c|c|c|c|}
\hline Razpis & Leto & Stanovanja & Prijave & Prednostne kategorije \\
\hline SA & 2002 & 78 & 36 & 4 \\
\hline SB & 2002 & 73 & 135 & 4 \\
\hline SC & 2002 & 32 & 311 & 10 \\
\hline SD & 2003 & 429 & 1831 & 38 \\
\hline SE & 2004 & 852 & 2057 & 220 \\
\hline SF & 2006 & 258 & 424 & 180 \\
\hline SG & 2006 & 116 & 3427 & 308 \\
\hline SH & 2007 & 387 & 285 & 352 \\
\hline SI & 2008 & 140 & 24 & 352 \\
\hline SJ & 2010 & 24 & 76 & 1134 \\
\hline SL & 2012 & 504 & 700 & 80 \\
\hline SM & 2014 & 342 & 630 & 108 \\
\hline SO & 2016 & 85 & 280 & 60 \\
\hline
\end{tabular}

\section{Povečanje uporabe spletnih storitev}

Udeležba državljanov in izboljšanje njihovega sodelovanja $\mathrm{v}$ spletnih storitvah je zelo zapleteno in zahtevno delo (Capgemini in sod., 2014). Na uporabnost spletnih storitev vplivajo tehnološka opremljenost ponudnikov in uporabnikov e-storitev, razvitost komunikacij in okolja ter razvoj in uporaba interneta. Poročilo EU za e-upravo iz leta 2015 kaže, da so spletne javne storitve v Evropi pametne, vendar bi lahko bile pametnejše in da morajo v več kot polovici primerov uporabniki še vedno izpolniti obrazce s podatki, ki so že na voljo v upravi. Poročilo EU za e-upravo leta 2016 pa kaže, da so se javne storitve, dostopne na spletu, izboljšale neenakomerno. Uporaba mobilnih naprav za dostop do interneta je v velikem porastu, vendar je še vedno samo ena od treh spletnih strani javnih uprav mobilno prijazna. Sklad zainteresiranim državljanom, ki si želijo rešiti stanovanjsko vprašanje, omogoča prijavo na razpis preko tiskane vloge ali spletne vloge. Pri uporabi spletne vloge, kot načina zbiranja podatkov, je potrebno upoštevati specifične lastnosti te metode. Med drugim je potreben poseben postopek sestavljanja in oblikovanja spletne vloge, in sicer na način, da pridobimo čim bolj kakovostne in popolne podatke, 
$36^{\text {Th }}$ International Conference on Organizational Science Development: Responsible Organization (March $22^{\mathrm{ND}}-24^{\mathrm{TH}}$, Portorož SLOVENIA)

B. Cestnik \& A. Kern: Evolution of Decision Criteria for Estimating Priorities in Housing Facilities Allocation

na katerih uslužbenci izvajajo čim manj kontrol oziroma dodatnih obdelav. Preko oddaje spletne vloge je možno bistveno zmanjšati količino manjkajočih podatkov in $\mathrm{s}$ tem povečati število popolnih vlog, za kar je potrebno sprotno izvajati nove raziskave in ustvarjati mehanizem komunikativne interakcije med javnim skladom in državljani. Možnost oddaje vloge preko spleta zmanjšuje obremenitev tako za uporabnika kot tudi za organizacijo. Že od samega začetka vpeljave možnosti oddaje vloge preko spleta, smo naredili posamezne izboljšave v smeri enostavne uporabe oziroma izpolnjevanja. Dejstvo namreč je, da spletna vloga omogoča boljše »komuniciranje« z uporabnikom. Podlago pri kreiranju spletne vloge je predstavljala papirna vloga. Potrebno je bilo temeljito strukturirati posamezne strani, jih razumljivo oblikovati ter pri tem upoštevati določila iz zakonodaje. Dodatna izboljšanja sodelovanja in udeležbe državljanov smo dosegli tudi preko študij, ki temeljijo na motivacijskih faktorjih in individualnih sposobnosti $\mathrm{v}$ spletnih interakcijah. S pomočjo Chadwickovega (2011) predloga za opazovanje notranjih institucionalnih spremenljivk in institucionalne dinamike za spodbujanje spletnega sodelovanja in udeležbe smo si zadali izboljšati sodelovanje državljanov ter njihovo udeležbo pri konkretnih primerih javnih stanovanjskih spletnih storitev. Naš prvi cilj je bil ugotoviti vzroke za manjše število elektronsko oddanih vlog v primerjavi s številom oddanih tiskanih vlog. Začeli smo z iskanjem lastnosti, ki povečujejo tveganje za neuspeh. Drugi korak je bil načrtovanje smernic, ki zmanjšujejo identificirano tveganje. Sprememba ciljev ljudi, njihovih namenov in odnosa so ključni faktorji, ki vodijo do spremembe vedenja glede elektronskih vlog. Z željo po dodatni izboljšavi spletne udeležbe in sodelovanja državljanov ter hkrati po manjšem številu nepopolnih vlog smo izvedli tri glavna dejanja: pregledali smo in revidirali spletni uporabniški vmesnik, pregledali vsa komunikacijska sporočila ter začeli pogosteje vključevati socialna omrežja kot kanal za komunikacijo. Pregledati in revidirati spletni uporabniški vmesnik je popolnoma v skladu s Chadwickovimi predlogi. Elektronska spletna vloga je bila prvotno zasnovana kot preprosta in enostavna za dostop, uporabo in navigacijo, izpolnitev in oddaja je bila enako oziroma mogoče celo manj kompleksna kot izpolnitev in oddaja tiskane vloge po pošti. Drugo dejanje je bil pregled vseh komunikacijskih sporočil za boljšo jasnost (Kern in sod., 2011). Ugotovili smo, da s predstavitvijo bolj osebnih informacij dosežemo izboljšanje občutka državljanov glede učinkovitosti spletne vloge. Tretja faza je bila bolj pogosto vključevanje socialnih omrežij v vlogi komunikacijskega kanala. Ta faza je vključevala redne objave na različnih socialnih omrežjih z namenom obveščanja zainteresirane javnosti. Med drugim je bil cilj tega tudi nevtralizirati morebitne negativno obarvane novice, ki se lahko pojavijo v medijih. Uvedba in upoštevanje predlaganih smernic izboljšanja vmesnika, bolj osebnih in jasnih sporočil v smeri komunikacije z uporabniki ter splošne širše komunikacije preko različnih poti je pripomogla $\mathrm{k}$ izboljšanju stopnje popolnosti elektronsko oddanih prijav, in sicer $\mathrm{z}$ $38,3 \%$ na $92,2 \%$. Navedena stopnja kaže na to, da imajo zainteresirani državljani sposobnost razumeti in sodelovati pri elektronski oddaji prijav, vendar je potrebno izvajati različne postopke, kot so opisani zgoraj. Z ustrezno uveljavitvijo predlaganih smernic in opazovanjem treh preprostih spremenljivk je Skladu uspelo ohraniti razmerje med vloženimi elektronskimi in papirnimi vlogami (približno na polovici) in zelo izboljšati popolnost elektronskih prijav. To je rezultat predvsem prilagoditve 
uporabniškega vmesnika, jasnost komunikacijskih sporočil in vključevanje socialnih omrežij kot kanalov komuniciranja.

V prispevku smo predstavili način reševanja stanovanjskega vprašanja državljanov preko javnih razpisov. Zaradi sprememb na področju zakonodaje in usmeritev države so se skozi razvoj spreminjale tudi prednostne kategorije, ki so imele prednost $\mathrm{v}$ primeru večjega interesa po posameznem stanovanju. Prikazali smo, da je vsakokratni javni razpis izredno zahteven in za uspešno izvedbo zahteva natančno opredeljene kriterije in spremljanje vseh faz procesa. Izrednega pomena je jasno in nedvoumnemu definiranje pogojev in posameznih prednostnih kategorij, s čemer preprečimo možnost za pristranske in enostranske razlage. Preko možnosti, ki jih nudi sodobna tehnologija in zavedanje organizacije po odgovornem poslovanju, smo opisali korake, ki vodijo do izboljšanja uporabe spletnih storitev. Za uspešno delovanje mora biti organizacija $\mathrm{v}$ stalni komunikaciji s svojimi uporabniki, saj na ta način pridobiva različne predloge s strani tistih, ki so jim storitve namenjene. Veliko stvari je možno predvideti ter jih spraviti v svojo funkcijo, da le-te pripomorejo $\mathrm{k}$ izboljšanju uporabnosti in so $\mathrm{v}$ obojestransko korist.

\section{Literatura}

Capgemini, IDC, Sogeti, IS-practice and Indigov, RAND Europe, DTI (2014). Delivering on the European Advantage? How European governments can and should benefit from innovative public services. eGovernment Benchmark, Final insight report, Luxembourg, Publication office of the European Union, May 2014.

Chadwick, A. (2011). Explaining the Failure of an Online Citizen Engagement Initiative: The Role of Internal Institutional Variables. Journal of Information Technology and Politics.

Cestnik, B., Bohanec, M. (2001). Decision support in housing loan allocation: a case study. In: C. Giraud-Carrier, N. Lavrač, S. Moyle, B. Kavšek (Eds.). ECML/PKDD01 Workshop, Freiburg, September 3rd, 2001. Integrating aspects of data mining, decision support and meta-learning (IDDM-2001): position, developments and future directions.

Cestnik, B., Kern, A., Modrijan, H. (2008). Semi-automatic Ontology Construction for Improving Comprehension of Legal Documents. In: M.A. Wimmer, H.J. Scholl, and E. Ferro (Eds.) EGOV 2008, 7th International Conference, Turin, Italy, August 31 - September 5, 2008. Proceedings, Lecture Notes in Computer Science, Springer, pp. 328-339, 2008.

EU eGovernment Report (2015 in 2016). Dostopno na http://ec.europa.eu/.

Kern, A., Modrijan, H., Cestnik, B. (2011). Improving Efficiency of Public Funding Process by Enhancing Clarity of Decisions. In: IFIP EGOV 2011, 10th International Conference, Defft, Netherlands. 
136 36 $6^{\text {Th }}$ International Conference on Organizational Science Development:

Responsible Organization (MARCH $22^{\mathrm{ND}}-24^{\mathrm{TH}}$, PORTOROŽ SLOVENIA) 
36. MEDNARODNA KONFERENCA O RAZVOJU ORGANIZACIJSKIH ZNANOSTI: OdgOVORNA ORGANIZACIJA (22. - 24. MAREC 2017, PORTOROŽ, SLOVENIJA)

O. Arsenijević, M. Ferjan, I. Podbregar, P. Šprajc, D. Trivan \& Y. Ziegler

\title{
Vrzel $v$ poznavanju managementa znanja $v$ javni upravi Republike Slovenije
}

\author{
SIMON COLNAR, VLADO DIMOVSKI \& MARKO COLNAR
}

Povzetek Management znanja predstavlja mlado in neraziskano disciplino. Prvi znanstveni članek s področja sega v leto 1974, na veljavi pa je management znanja pridobil sredi devetdesetih let prejšnjega tisočletja (Hribar, 2016). Znanstvenih objav, ki so povezane s tematiko, je malo, še posebej malo pa je znanstvenih objav, ki se nanašajo na management znanja v javni upravi Republike Slovenije. $\mathrm{V}$ prispevku predstavimo pregled znanstvenih objav s področja managementa znanja $\mathrm{v}$ javni upravi Republike Slovenije s pomočjo ene izmed najbolj obsežnih in vsestranskih raziskovalnih baz podatkov, Web of Science. Avtorji Agranoff (2007) in Argote \& Ingram (2000) trdijo, da je kljub naraščanju zavedanja o pomenu prenosa znanja $\mathrm{v}$ javnem sektorju, raziskav na to temo še vedno premalo. $\mathrm{Na}$ podlagi raziskave avtorji postavimo trditev, da je glede na število znanstvenih objav $\mathrm{s}$ področja managementa znanja $\mathrm{v}$ javni upravi Republike Slovenije v obdobju 2007-2016 prisotna vrzel. S prispevkom želimo spodbuditi nadaljnje raziskave in nove znanstvene objave s tega področja ter na kratko predstaviti pozitivne učinke vpeljave managementa znanja v javno upravo Republike Slovenije.

KLJUČNE BESEDE: management znanja $\bullet$ javna uprava $\bullet$ znanstvene objave -Web of Science

NASLOV AVTORJEV: Simon Colnar, mag., Univerza v Ljubljani, Ekonomska fakulteta, Kardeljeva
ploščad 17, 1000 Ljubljana, Slovenija, e-pošta: simon.colnar@ef.uni-lj.si, dr. Vlado Dimovski,
redni profesor, Univerza v Ljubljani, Ekonomska fakulteta, Kardeljeva ploščad 17, 1000 Ljubljana,
Slovenija, e-pošta: vlado.dimovski@ @ef.uni-lj.si; dr. Marko Colnar, Ministrstvo za izobraževanje,
znanost in šport, Masarykova cesta 16, 1000 Ljubljana, Slovenija, e-pošta: marko.colnar@gov.si 
36 ${ }^{\text {TH }}$ International Conference on Organizational Science DeVElopment: Responsible ORGanization (MARCH $22^{\mathrm{ND}}-24^{\mathrm{TH}}$, PORTOROŽ SLOVENIA)

O. Arsenijević, M. Ferjan, I. Podbregar, P. Šprajc, D. Trivan \& Y.

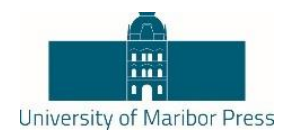

Ziegler

\title{
Knowledge Gaps in Knowledge Management in the Public Administration of the Republic of Slovenia
}

\author{
SIMON COLNAR, VLADO DIMOVSKI, MARKO COLNAR
}

\begin{abstract}
Knowledge management represents a young and unexplored discipline. The first scientific paper in the field dates back to 1974, while the discipline received more recognition in the nineties (Hribar, 2016). The number of scientific publications related to the topic of knowledge management in the public sector is relatively small, which especially applies to scientific publications about knowledge management in the public administration of the Republic of Slovenia. In this paper, we present an overview of scientific publications in the field of knowledge management in the public administration of the Republic of Slovenia, with the help of one of the most extensive and comprehensive research databases, Web of Science. Authors Agranoff (2007) and Argote \& Ingram (2000) argue that although the awareness of the importance of knowledge transfer in the public sector is increasing, there is still lack of research related to the topic. Based on research, we propose that based on the number of scientific publications in the field of knowledge management in the public administration of the Republic of Slovenia in the period 20072016, there is a gap. With this paper, we want to encourage additional research and new scientific publications in the field and briefly present the potential positive effect of the introduction of knowledge management into the public administration of the Republic of Slovenia.
\end{abstract}

KEYWORDS: Knowledge Management • Public Administration • Scientific Publications $\bullet$ Web of Science

CorResPondence AddRess: Simon Colnar, M.D., Faculty of Economics, University of Ljubljana, Kardeljeva ploščad 17, 1000 Ljubljana, Slovenia, e-mail: simon.colnar@ef.uni-lj.si, Vlado Dimovski, Ph.D., Full professor, Faculty of Economics, University of Ljubljana, Kardeljeva ploščad 17, 1000 Ljubljana, Slovenia, e-mail: vlado.dimovski@ef.uni-lj.si; Marko Colnar, Ph.D., Ministry of Education, Science and Sport, Masarykova cesta 16, 1000 Ljubljana, Slovenia, e-mail: marko.colnar@gov.si 
36. MEDNARODNA KONFERENCA O RAZVOJU ORGANIZACIJSKIH ZNANOSTI: ODGOVORNA ORGANIZACIJA (22. - 24. MAREC 2017, PORTOROŽ, SLOVENIJA)

S. Colnar, V. Dimovski \& M. Colnar: Vrzel v poznavanju managementa znanja v javni upravi Republike Slovenije

\section{Uvod}

$\mathrm{V}$ literaturi in $\mathrm{v}$ praksi velikokrat zasledimo pojme, kot so javni sektor, javna uprava in državna uprava, zato je najprej potrebno razjasniti njihove opredelitve. Širša definicija pojma javni sektor je namenjena nacionalnim statističnim potrebam in zajema državne organe in samoupravne lokalne skupnosti, javne agencije, javne sklade, fundacije, gospodarske družbe, javna podjetja, zasebne zavode, javne gospodarske zavode, zbornice in druge pravne osebe (Oblak, 2014, str. 4). Javno upravo lahko definiramo kot del procesa javnega upravljanja, ki poteka na izvršilni ravni. Je strokovni aparat, ki zagotavlja strokovne podlage za politično odločanje ter izvršuje sprejete politične opredelitve parlamenta, vlade, občinskega sveta in župana. Javno upravo sestavljajo državna uprava z vlado na čelu, občinske uprave z župani in nosilci javnih pooblastil (Virant, 2009, str. 19). Državna uprava je največji del javne uprave. Temeljna organizacijska oblika državne uprave so ministrstva, ki so organizirana po delovnih področjih. Državna uprava ima dve glavni funkciji. Prva je izvrševanje zakonov, državnega proračuna ter drugih političnih odločitev nosilcev zakonodajne in izvršilne oblasti, druga funkcija pa je priprava strokovnih podlag za politično odločanje nosilcev zakonodajne in izvršilne oblasti (Oblak, 2014, str. 6).

Kljub določenim ugodnim kazalnikom, ki nakazujejo na okrevanje gospodarstva $\mathrm{v}$ Republiki Sloveniji, kot je npr. 2,3\% rast BDP v letu 2016 (UMAR, 2017) in ugodna napoved glede rasti BDP $\mathrm{v}$ prihodnjih letih, poročila uglednih tujih organizacij, kratko predstavljena v nadaljevanju, opozarjajo, da je javna uprava v Republiki Sloveniji neučinkovita in kot taka ni prispevala veliko $\mathrm{k}$ rahlemu izboljšanju stanja v Republiki Slovenije od krize 2008 naprej, čeprav bi lahko veliko več. Vse od osamosvojitve Republike Slovenije naprej se javna uprava že srečuje z zahtevami po temeljiti preobrazbi, s katero bi bila javna uprava Republike Slovenije bolj učinkovita in uporabnikom prijaznejša. Številni projekti na tem področju v zadnjih 25 letih dajejo vtis, da smo še vedno precej na začetku poti do potrebne prenove javne uprave Republike Slovenije (Colnar, Dimovski \& Colnar, 2016). OECD (2015) je opozoril na problem neučinkovitosti javne uprave $\mathrm{v}$ Republiki Sloveniji in sicer konkretno na pomanjkanje strategije pri znižanju števila zaposlenih in sredstev namenjenih za plače javnih uslužbencev ter na nemotiviranost zaposlenih v javnem sektorju. Lipnik (2016) je povzel podatke Svetovne banke in izpostavil, da imamo enega najslabše delujočih javnih sektorjev v evrskem območju. World Economic Forum nas po kriteriju učinkovitosti javnega sektorja uvršča med najslabše države na svetu. Analiza pokaže, da imajo države kot so Sierra Leone, Gvatemala in Kirgizistan bolj učinkovito javno upravo kot Republika Slovenija (Domovina, 2016). Hkrati smo priča razvoju sodobnih informacijskokomunikacijskih tehnologij, s čimer ima tudi javna uprava Republike Slovenije vedno več možnosti za zajem, shranjevanje in distribucijo znanja. Ravno informacijskokomunikacijska tehnologija omogoča, da je znanje na voljo številnim uporabnikom in v različnih multimedijskih oblikah. Izpostavljeno je že bilo, da lahko znanje v javni upravi Republike Slovenije predstavlja konkurenčno prednost, vendar vsaj do danes ni oprijemljivih rezultatov, da je temu res tako (Colnar, Dimovski \& Colnar, 2016). Management znanja je sicer področje, ki je pridobilo na veljavi sredi devetdesetih letih 
$36^{\mathrm{TH}}$ International Conference on ORganizational Science Development: Responsible Organization (MARCH $22^{\mathrm{ND}}-24^{\mathrm{TH}}$, PortoroŽ SLOVENIA)

S. Colnar, V. Dimovski \& M. Colnar: Knowledge Gaps in Knowledge Management in the Public Administration of the Republic of Slovenia

prejšnjega tisočletja in predstavlja mlado disciplino, ki je slabše raziskana (Hribar, 2016). Posledično je tudi literatura na tematiko managementa znanja in še posebej managementa znanja $\mathrm{v}$ javnem sektorju relativno skopa.

Poročila tujih organizacij nam pokažejo, da je javna uprava Republike Slovenije neučinkovita in je po mnenju nekaterih podjetnikov, kot je npr. Boscarol (2015), javna uprava Republike Slovenije zgolj birokratski aparat. Velja pa tudi, da je javna uprava Republike Slovenije izrazito hierarhično organizirana (Colnar \& Colnar, 2015). Smiselno se je tako vprašati tudi, kaj je na področju javne uprave Republike Slovenije in managementa znanja $\mathrm{v}$ zadnjih letih prispevala akademska stroka. Namen prispevka je preučiti najpomembnejša znanstvena dela na področju managementa znanja $\mathrm{v}$ javni upravi Republike Slovenije, cilj pa je s pomočjo sekundarnih podatkov iz baze Web of Science prikazati pojavljanje člankov $\mathrm{s}$ področja managementa znanja $\mathrm{v}$ javni upravi Republike Slovenije. Avtorji v povezavi z neraziskanostjo področja postavimo trditev, da je glede na število znanstvenih objav s področja managementa znanja $v$ javni upravi Republike Slovenije v obdobju 2007-2016 prisotna vrzel. Raziskava je omejena na podatkovno bazo Web of Science in na znanstvena dela v angleškem jeziku. Pri iskanju smo uporabili za slovensko okolje prirejeno metodologijo, ki jo v svojem prispevku o pojavljanju managementa znanja po posameznih ključnih pojmih v češkem okolju uporabil Špaček (2016). S prispevkom predvsem prispevamo k boljšemu pregledu znanstvenih del s področja managementa znanja v javni upravi Republike Slovenije. Z dobljenimi rezultati pa želimo spodbuditi prihodnje raziskave in nova znanstvena dela na tem področju.

\section{$1 \quad$ Management znanja}

Management znanja ima ogromno definicij. Drucker (1999) ga definira kot koordinacijo in izkoriščanje resursov, da se ustvari korist in konkurenčna prednost. Asian Productivity Organization (2013) management znanja opredeli kot niz novih organizacijskih praks s širokim pomenom $\mathrm{v}$ na znanju temelječem gospodarstvu. Čeprav se včasih zdi samoumevno pa je potrebno vseeno nedvoumno razumeti, kaj pomeni znanje. Podobno kot obstaja mnogo definicij za management znanja, jih je veliko tudi za razjasnitev samega pojma znanje. Najbližje se nam zdi definicija, ki jo podajo avtorji O'Dell, Grayson, Essaides, et al. (1998), ki znanje opredelijo kot udejanjeno informacijo.

Znanje sicer $\mathrm{v}$ grobem razdelimo $\mathrm{v}$ dve kategoriji, eksplicitno in tacitno znanje. Eksplicitno znanje je lahko izraženo $\mathrm{v}$ besedah in številkah in je lahko prenosljivo drugim. Shranjeno je v različnih oblikah, kot so dokumenti, knjige, priročniki, navodila, pravilniki, slike, patenti, baze podatkov, itd. Tacitno znanje pa najdemo v zaposlenih (gre za njihove veščine, izkušnje, posebne spretnosti, misli, itd.). Tacitno znanje težko dokumentiramo in je težje prenosljivo drugim. Da bi ga lahko delili, ga je potrebno pretvoriti v eksplicitno obliko znanja, ki je preko komunikacije lažje prenosljiva drugim, največkrat se to zgodi s kodifikacijo ali socialno interakcijo (Asian Productivity Organization, 2009). Tacitno znanje, ki ga težko kodificiramo pa lahko predstavlja vir 
S. Colnar, V. Dimovski \& M. Colnar: Vrzel v poznavanju managementa znanja v javni upravi Republike Slovenije

trajne konkurenčne prednosti, saj ga konkurenti težko kopirajo (Ranucci \& Souder, 2015).

\subsection{Zakaj management znanja $\mathrm{v}$ javnem sektorju?}

Tuji avtorji Agranoff (2007) in Argote \& Ingram (2000) pojasnijo, da obstaja zavedanje o pomenu delitve znanja tudi v javnem sektorju, a je še vedno večina literature usmerjana v obravnavanje znanja v gospodarstvu. Špaček (2016) dodaja, da je kljub temu, da je splošno znano, da se javni sektor razlikuje od gospodarstva in ima nekatere unikatne lastnosti, implementacija managementa znanja tudi $\mathrm{v}$ javnem sektorju lahko koristna. Samo znanje je že prepoznano kot strateški resurs, ki prinaša rezultate v različnih oblikah organizacij, a je še vedno največ iniciativ povezanih z managementom znanja, ki se udejanjijo v privatnem sektorju. Obstajajo pa tudi primeri uspešne vpeljave managementa znanja v javnem sektorju (Batista \& Quandt, 2015). Kljub potencialu, ki ga management znanja ima, številni avtorji, kot so Arora (2011), Okunoye, Innola \& Karsten (2002) ter Zaharova \& Zelmene (2004), ugotavljajo, da praktične aplikacije zagotavljanja javnih storitev z uporabo orodij managementa znanja še niso razširjene. Tuji avtorji kot enega izmed glavnih razlogov za pomanjkanje praktičnih aplikacij, ki temeljijo na managementu znanja, izpostavljajo predvsem kulturo in način delovanja javnega sektorja, ki prej ovira kot podpira različne poskuse k povezovalni kulturi, ki stremi k izboljšavam ali ki prinaša spremembe (Bureš, 2003; Lekhi, 2007; McDermott \& O'Dell, 2001). Številne organizacije, ki delujejo $\mathrm{v}$ javnem sektorju $\mathrm{v}$ praksi, se po celem svetu soočajo z izzivi, kot so hiter razvoj informacijsko-komunikacijskega okolja, zahteve po zmanjšanju birokracije in znižanje stroškov. Hkrati imajo na voljo vedno manj zaposlenih, podjetja in državljani pa imajo dostop do vedno več informacijskokomunikacijskih rešitev za uporabo storitev, ki jih ponuja javni sektor. Zaradi omenjenih izzivov in dejavnikov so bila tudi orodja managementa znanja prepoznana kot strateški resurs tudi $\mathrm{v}$ javnem sektorju in $\mathrm{v}$ večini javnih organizacij po celem svetu (Asian Productivity Organization, 2013).

\subsection{Kaj management znanja prinaša $v$ javni sektor?}

Današnje hitro spreminjajoče se okolje tudi od javnega sektorja zahteva povezovanje organizacij pri njihovem delovanju, da lahko le-te učinkovito služijo državljanom in podjetjem. Management znanja je eden izmed ključnih elementov pri uspešnem povezovanju organizacij, saj le-to zahteva učinkovite načine deljenja informacij in znanja s strani različnih virov (Asian Productivity Organization, 2013). Znanje vse bolj predstavlja kritično osnovno sredstvo za vzdrževanje ali ustvarjanje konkurenčne prednosti in hkrati pripomore $\mathrm{k}$ stalnemu izboljševanju in inovacijam (Al-Khouri, 2014). Management znanja je tako danes postal ključna dejavnost pri ohranjanju uspešne organizacije s ciljem prepoznavanja ključnega znanja, oblikovanjem novega potrebnega znanja in prenašanjem znanja med zaposlenimi (Jashapara, 2011). Praktični primeri uporabe managementa znanja postajajo vse bolj pomembni tudi pri izboljšanju sposobnosti odločanja, pri ustvarjanju učečih se organizacij in pri stimuliranju spremembe kulture ter pri samem vplivu na inovacije. Management znanja pa lahko 
$36^{\mathrm{TH}}$ International Conference on Organizational Science Development: Responsible Organization (March $22^{\mathrm{ND}}-24^{\mathrm{TH}}$, Portorož Slovenia)

S. Colnar, V. Dimovski \& M. Colnar: Knowledge Gaps in Knowledge Management in the Public Administration of the Republic of Slovenia

prispeva tudi k natančnemu definiranju kaj javna uprava zna, kje je to znanje shranjeno, kako naj bi bilo znanje shranjeno in kako prenesti znanja zaposlenim, ki ga potrebujejo, hkrati pa je tudi lahko orodje, ki izpostavi področja, kjer so potrebna nova znanja oziroma identificira tista področja, kjer se je potrebno učiti na preteklih napakah (Frost, 2010). Pomemben je lahko tudi prispevek managementa znanja k višji stopnji odgovornosti in transparentnosti ter večji stopnji odzivnosti posameznih organov na zahteve s strani podjetij in državljanov (Špaček, 2016).

\section{Rezultati raziskave}

Uporabili smo bazo podatkov Web of Science, ki predstavlja eno izmed najobsežnejših in vsestranskih raziskovalnih podlag oziroma baz podatkov, ki je na voljo raziskovalcem. Zagotavlja dostop do zanesljivih znanstvenih objav za posamezna področja znotraj akademske ali znanstvene discipline. Za potrebe iskanja znanstvenih objav na temo managementa znanja v javni upravi Republike Slovenije smo uporabili niz ključnih besed, ki se navezujejo na tematiko in je viden v tabeli 1. Uporabljena metoda dela je bila naslednja: iskalni niz (ključna beseda v angleščini, pr. Knowledge Management) -> Public Administration (področje preučevanja) -> English (jezik znanstvene objave) -> Slovenia (država znanstvene objave). Pri tem smo se osredotočili na temo, v kateri je bila objava, ter na sam naslov objave. V obeh primerih smo izvedli dva posamezna iskanja objav in sicer s pomočjo dobesednega iskalnega niza (uporaba " ") in nekoliko bolj svobodnega iskanja brez uporabe “". Številke, ki so zapisane v oklepajih, pomenijo, da se je sicer pojavila znanstvena objava pri posameznem iskalnem nizu, a da se je omenjeni članek pojavil tudi pri predhodnem iskalnem nizu in gre za podvajanje rezultatov. Rezultati raziskave so predstavljeni v tabeli 1 in prikazujejo posamezna znanstvena dela, ki smo jih našli v bazi podatkov Web of Science.

\begin{tabular}{|c|c|c|c|c|c|}
\hline ID & $\begin{array}{c}\text { Iskalni niz: Ključna } \\
\text { beseda }\end{array}$ & »Tema $«$ & Tema & »Naslov Naslov & \\
\hline $\mathbf{1}$ & $\begin{array}{c}\text { Knowledge } \\
\text { management }\end{array}$ & 0 & 2 & 0 & 0 \\
\hline $\mathbf{2}$ & Knowledge systems & 0 & $3(1)$ & 0 & 0 \\
\hline $\mathbf{3}$ & $\begin{array}{c}\text { Knowledge } \\
\text { processes }\end{array}$ & 0 & $3(1)$ & 0 & 0 \\
\hline $\mathbf{4}$ & Knowledge-based & 1 & $1(1)$ & 0 & 0 \\
\hline $\mathbf{5}$ & $\begin{array}{c}\text { Knowledge } \\
\text { technology }\end{array}$ & 0 & $2(1)$ & 0 & $1(1)$ \\
\hline $\mathbf{6}$ & $\begin{array}{c}\text { Knowledge } \\
\text { technologies }\end{array}$ & 0 & $2(2)$ & 0 & $1(1)$ \\
\hline $\mathbf{7}$ & Evidence-based & 0 & 0 & 0 & 0 \\
\hline $\mathbf{8}$ & Knowledge city & 0 & 0 & 0 & 0 \\
\hline $\mathbf{9}$ & $\begin{array}{c}\text { Information } \\
\text { management }\end{array}$ & 0 & $6(1)$ & 0 & 0 \\
\hline
\end{tabular}


36. MEDNARODNA KONFERENCA O RAZVOJU ORGANIZACIJSKIH ZNANOSTI: ODGOVORNA ORGANIZACIJA (22. - 24. MAREC 2017, PORTOROŽ, SLOVENIJA)

S. Colnar, V. Dimovski \& M. Colnar: Vrzel v poznavanju managementa znanja v javni upravi Republike Slovenije

\begin{tabular}{|c|c|c|c|c|c|}
\hline 10 & $\begin{array}{c}\text { Knowledge } \\
\text { management process }\end{array}$ & 0 & $1(1)$ & 0 & 0 \\
\hline 11 & $\begin{array}{c}\text { Knowledge } \\
\text { management system }\end{array}$ & 0 & $1(1)$ & 0 & 0 \\
\hline 12 & Knowledge sharing & $1(1)$ & $1(1)$ & $1(1)$ & $1(1)$ \\
\hline 13 & Stakeholder analysis & 0 & $1(1)$ & 0 & 0 \\
\hline 14 & $\begin{array}{c}\text { Innovation } \\
\text { management }\end{array}$ & 0 & 0 & 0 & 0 \\
\hline 15 & $\begin{array}{c}\text { Organizational } \\
\text { knowledge }\end{array}$ & $1(1)$ & $1(1)$ & 0 & 0 \\
\hline 16 & $\begin{array}{l}\text { Organizational } \\
\text { learning }\end{array}$ & 0 & 0 & 0 & 0 \\
\hline 17 & $\begin{array}{c}\text { Learning } \\
\text { organization }\end{array}$ & 0 & 0 & 0 & 0 \\
\hline 18 & $\begin{array}{l}\text { Knowledge } \\
\text { organization }\end{array}$ & 0 & $1(1)$ & 0 & $1(1)$ \\
\hline 19 & $\begin{array}{c}\text { Collaborative } \\
\text { organization }\end{array}$ & 0 & 0 & 0 & 0 \\
\hline 20 & Knowledge worker & 0 & 0 & 0 & 0 \\
\hline 21 & Benchmarking & 2 & $4(2)$ & $1(1)$ & $1(1)$ \\
\hline 22 & Benchlearning & 0 & 0 & 0 & 0 \\
\hline 23 & Collective thinking & 0 & 0 & 0 & 0 \\
\hline 24 & E-government & $4(2)$ & $4(4)$ & $3(3)$ & $3(3)$ \\
\hline
\end{tabular}

Tabela 1: Znanstvene objave s področja managementa znanja v javni upravi Republike Slovenije v obdobju 2007-2016

Vir: Web of Science (2016), (prirejena metodologija po Špaček (2016))

Na podlagi rezultatov pridobljenih iz baze podatkov Web of Science smo preverili našo trditev, da je glede na število znanstvenih objav s področja managementa znanja $\mathrm{v}$ javni upravi Republike Slovenije v obdobju 2007-2016 prisotna vrzel. Glede na tabelo 1 lahko ugotovimo, da smo za obdobje 2007-2016 v bazi podatkov Web of Knowledge našli 19 znanstvenih objav, ki so na tak ali drugačen način povezane $\mathrm{z}$ managementom znanja. Podatek o relativno majhnem številu znanstvenih objav s področja managementa znanja v javni upravi Republike Slovenije sam po sebi še ni dovolj dober dokaz, da vrzel dejansko obstaja. Za potrebe primerjalne analize, smo avtorji ponovili raziskavo za sosednjo Italijo, ki se je podobno kot Republika Slovenija, že soočala s potrebami po reformi javne uprave $\mathrm{v}$ preteklem tisočletju (Mele \& Ongaro, 2014). Po enaki metodologiji kot za Republiko Slovenijo smo ugotovili, da je v bazi podatkov Web of Knowledge 90 različnih znanstvenih objav, ki obravnavajo management znanja v javni upravi Italije v obdobju 2007-2016. Neposredna primerjava absolutnega števila znanstvenih objav v Italiji in v Republiki Slovenija tudi ni dovolj dober dokaz o vrzeli v Republiki Sloveniji, saj ima Italija približno 60 milijonov prebivalcev (Worldometers, 
$36^{\text {Th }}$ International Conference on Organizational Science Development: RESPONSIBLE ORGANIZATION (MARCH $22^{\mathrm{ND}}-24^{\mathrm{TH}}$, PORTOROŽ SlOVENIA)

S. Colnar, V. Dimovski \& M. Colnar: Knowledge Gaps in Knowledge Management in the Public Administration of the Republic of Slovenia

2017). Tudi podatka o skupnem številu znanstvenih objav s področja managementa znanja v javni upravi vseh držav v obdobju 2007-2016 (3.153 - brez podvajanja rezultatov) ne moremo uporabiti kot dokaz o vrzeli na področju managementa znanja $\mathrm{v}$ javni upravi Republike Slovenije v obdobju 2007-2016.

Podrobnejša analiza izbranih znanstvenih objav po posameznih ključnih besedah v javni upravi Republike Slovenije v obdobju 2007-2016 pa nam pokaže, da obstaja primanjkljaj predvsem pri pomembnih temah, kot so knowledge management, innovation management, organizational knowledge, learning organization in knowledge organization, ki so v javni upravi Republike Slovenije praktično neraziskane. Splošna analiza znanstvenih objav nam pokaže tudi, da večina izmed 19 znanstvenih objav ni povezana s pojmi, kot so učinkovitost, produktivnost ali inovativnost javnega sektorja, kar naj bi bila glavna dodana vrednost implementacije managementa znanja $v$ okolje javne uprave Republike Slovenije. Večina izmed znanstvenih objav je vezana predvsem na področje informacijsko-komunikacijske tehnologije, pri čemer pa velja izpostaviti, da se je z leti okrepilo zavedanje, da je management znanja precej manj povezan s samo tehnologijo, kot je povezan z ljudmi in socialnimi strukturami (Mischen, 2015).

Splošne trditve, da obstaja vrzel na področju znanstvenih objav s področja managementa znanja v javni upravi Republike Slovenije avtorji tako ne moremo potrditi, lahko pa potrdimo, da obstaja vrzel pri znanstvenih objavah na pomembnih področjih managementa znanja, ki se osredotočajo predvsem na ljudi, organizacijsko kulturo in socialne strukture ter ki hkrati spodbujajo napredek na področjih produktivnosti, učinkovitosti ter inovativnosti javnega sektorja in predstavljajo področja, ki bi morala biti predmet prihodnjih raziskav. Poglobitev obstoječe raziskave glede vrzeli znanstvenih objav s področja managementa znanja v javni upravi Republike Slovenije v obdobju 2007-2016 bi bila razdelitev 19 znanstvenih objav, ki smo jih našli, v okvir posameznih pomembnih področij managementa znanja, kot jih opredelijo Botha, Kourie \& Snyman (2008) in so vidna v tabeli 2.

\begin{tabular}{|c|c|c|}
\hline $\begin{array}{c}\text { Tisto, česar še ne } \\
\text { vemo }\end{array}$ & 1. Odkrivanje znanja & 2. Kreiranje znanja \\
\hline Tisto, kar že vemo & 3. Shranjevanje znanja & 4. Delitev znanja \\
\hline & Znanje, ki ga že imamo & Znanje, ki ga še nimamo \\
\hline
\end{tabular}

\section{Tabela 2: Štiri glavna področja managementa znanja}

Vir: Botha, Kourie \& Snyman (2008)

Na podlagi umestitve vsake izmed 19 preučevanih obstoječih znanstvenih objav v enega izmed predlaganih štirih področij bi lahko dobili poglobljen vpogled $\mathrm{v}$ glavna področja managementa znanja, kjer morebiti obstaja vrzel v javni upravi Republike Slovenije v obdobju 2007-2016. 


\section{Omejitve managementa znanja}

Kljub potencialnim pozitivnim učinkom managementa znanja, ki smo jih predstavili, pa sta Bolisani \& Handzic (2015) izpostavila, da kljub 20 letom zgodovine in vedno večjem vplivu tudi v akademskem svetu, management znanja še vedno, podobno kot druga »nova« področja, trpi zaradi pomanjkanja priznavanja. Ne glede na vrsto organizacije, je za uspešno implementacijo managementa znanja potrebno doseči spremembo vedenja in miselnosti zaposlenih, kar je kompleksen in dolgotrajen proces. Velikokrat se iniciative managementa znanja izjalovijo ravno zaradi premajhne pozornosti, ki je posvečena spremembi vedenja in miselnosti pri zaposlenih (Asian Productivity Organization, 2013). Pozornost za uspešno implementacijo managementa znanja je potrebno nameniti iskanju ravnovesja med delom, ki se posveča ljudem in delom, ki išče ter vzpostavlja potrebno tehnologijo. Ravnovesje Maier (2002) izpostavi kot enega izmed kritičnih dejavnikov uspešne implementacije managementa znanja v organizacijo. Strokovnjaki opozarjajo tudi pred pastmi pri merjenju rezultatov managementa znanja in sicer, da pri interpretaciji rezultatov ne moremo govoriti o številu timov, sestankov, klikov na internetnih straneh ali številu baz podatkov, ki jih je sicer lahko kvantificirati, a ne prinašajo posebne dodane vrednosti (Al-Khouri, 2014). Skrb vzbujajoče so bile tudi prve raziskave o uspešnosti implementacije managementa znanja, Lucier \& Torsiliera (1997) sta namreč ugotovila, da kar $84 \%$ programov oziroma iniciativ povezanih z managementom znanja ne doseže želenih učinkov. Vseeno potencial pri implementaciji managementa znanja v okolje javne uprave Republike Slovenije obstaja.

\section{Sklep}

Javna uprava Republike Slovenije je že 25 let predmet debat o njeni prenovi, a vseeno avtorji ugotavljamo, da še vedno ni jasno izoblikovanega koncepta o prenovi javne uprave z vidika potreb njenih uporabnikov. Kljub postopnemu okrevanju Republike Slovenije, je miselnost $\mathrm{v}$ javni upravi Republike Slovenije danes še vedno precej naklonjena varčevanju. Kakšnih drugih metod optimizacije niti ni zaslediti. Tako velja razmisliti o ukrepih, kot so vpeljava mehkih metod (management znanja), ki ne pomenijo nujno velikih investicij, hkrati pa imajo relativno visok potencial ob pravilni uvedbi.

$\mathrm{S}$ pomočjo analize znanstvenih objav $\mathrm{v}$ bazi podatkov Web of Science smo uspeli prikazati, da na posameznih področjih managementa znanja $\mathrm{v}$ javni upravi Republike Slovenije obstaja vrzel, ki ponuja akademski stroki priložnost nadaljnjega raziskovanja področja. Različna poročila in raziskave tujih organizacij služijo kot opozorilo, da je stanje v praksi na področju javne uprave Republike Slovenije še precej bolj resno in da je potrebno čimprejšnje ukrepanje. Na takšen ali drugačen način ima namreč javna uprava Republike Slovenije velik vpliv na gospodarstvo in državljane Republike Slovenije, kar še povečuje pomen premišljenega strateškega ukrepanja v prihodnosti, saj so spremembe $\mathrm{v}$ današnjem hitro se spreminjajočem okolju edina konstanta. Management znanja v pravilni obliki tako lahko prispeva $\mathrm{k}$ doseganju dolgoročnih ciljev javne uprave Republike Slovenije, kot so višje zadovoljstvo strank, krajši roki izvajanja storitev, večja učinkovitost delovanja ter bolj inovativno okolje. Sama implementacija nikakor ni 
$36^{\text {Th }}$ International Conference on Organizational Science Development: Responsible Organization (MARCH $22^{\mathrm{ND}}-24^{\mathrm{TH}}$, PortoroŽ SLOVENIA)

S. Colnar, V. Dimovski \& M. Colnar: Knowledge Gaps in Knowledge Management in the Public Administration of the Republic of Slovenia

enostavna, pozornost je potrebno nameniti predvsem zaposlenim, organizacijski kulturi, ki je v javni upravi Republike Slovenije precej specifična oziroma jo primanjkuje in pa managementu. S pravilnim pristopom bi lahko znanje v javni upravi Republike Slovenije dejansko pomenilo konkurenčno prednost.

\section{Literatura}

Agranoff, R. (2007). Managing within networks. Washington DC: Georgetown University Press.

Al-Khouri, A.M. (2014). Fusing Knowledge Management into the Public Sector: a Review of the Field and the Case of the Emirates Authority. Journal of Knowledge Management, Economics and Information Technology, 4 (3).

Argote, L. \& Ingram P. (2000). Knowledge transfer: A basis for competitive advantage in firms. Organizational Behaviour and Human Decision Processes, 82 (1), 150-169.

Arora, E. (2011). Knowledge Management in Public Sector. Journal of Arts Science \& Commerce, II (1), pp. 165-171.

Asian Productivity Organization (2013). Knowledge Management for the Public Sector. Report on the APO Research on Knowledge Management for Public-Sector Productivity (11-RP-09-GERES-B).

Asian Productivity Organization (2009). Knowledge Management: Facilitators' Guide. Tokyo.

Batista, F. \& Quandt, C. (2015). Knowledge Management Practices and Organizational Improvements in Brazilian State-Controlled Companies. Proceedings of the 16th European Conference on Knowledge Managemet (ECKM), 2015.

Bolisani, E. \& Handzic, M. (2015). Advances in Knowledge Management - Celebrating Twenty Years of Research and Practice. Heidelberg: Springer, 2015

Boscarol, I. (2015). Radijska oddaja Spetek. Najdeno dne 15.10.2016 na spletnem naslovu http://val202.rtvslo.si/2015/10/spet-cez-pet-tvitni-me-nezno-ivo-boscarol/.

Botha, A., Kourie, D. \& Snyman, R. (2008). Coping with Continious Change in the Business Environment, Knowledge Management and Knowledge Management Technology, Chandice Publishing Ltd..

Bureš, V. (2003). Cultural Barriers in Knowledge Sharing. G, E+M Ekonomics and Management, Liberec, 6, pp. 57-62.

Colnar, S. \& Colnar, M. (2015). Management in informatizacija kot orodji za prenovo slovenske državne uprave. Slovenski javni sektor na razpotju sprememb: Zbornik prispevkov.

Colnar, S., Dimovski, V. \& Colnar, M. (2016). Management znanja v javni upravi Republike Slovenije. Informatika v javni upravi 2016: zbornik, 5.-6. December, Kongresni center Brdo pri Kranju. 1. Izd. Ljubljana: Slovensko društvo Informatika, 2016, 8. str.

Domovina.je (2016). Področja, kjer je Slovenija med najslabšimi na svetu: učinkovitost javnega sektorja. Najdeno dne 3.11.2016 na spletnem naslovu https://www.domovina.je/podrocja-kjerje-slovenija-med-najslabsimi-na-svetu-ucinkovitost-javnega-sektorja/.

Drucker, P.F. (1999). Management Challenges for the 21th Century. New York Harper Collins.

Frost, A. (2010). Knowledge Management Tools - An Educational KM Site. Najdeno dne 26.10.2016 na spletnem naslovu http://www.knowledge-management-tools.net/.

Hribar, T. (2016). Pojavljanje managementa znanja v znanstveno-raziskovalnih člankih. Najdeno dne, $15.10 .2016 \quad$ na $\quad$ spletnem naslovu http://eucilnica.mfdps.si/public/mod/data/view.php?d=1\&rid=494.

Jashapara, A. (2011). Knowledge management: an integrated approach. Harlow (Essex): Pearson Education, London. 
S. Colnar, V. Dimovski \& M. Colnar: Vrzel v poznavanju managementa znanja v javni upravi Republike Slovenije

Lekhi, R. (2007). Public Service Innovation: A Research Report for the Work Foundation's Knowledge Economy Programme. The Work Foundation, London.

Lipnik, K. (2016). Slovenija šampion - imamo eno najslabših javnih uprav. Najdeno dne 1.11.2016 na spletnem naslovu http://www.finance.si/8848037/Slovenija-sampion-imamo-enonajslabsih-javnih-uprav?metered=yes\&sid=477657140.

Lucier, C. \& Torsiliera, J. (1997). Why Knowledge Programs Fail? Strategy and Business, 4th quarter, pp. 14-28.

Maier, R. (2002). Knowledge Management Systems. Berlin, Heidelberg: Springer-Verlag.

McDermott, R. \& O'Dell, C. (2001). Overcoming Cultural Barriers to Sharing Knowledge. Journal of Knowledge Management, 5(1), pp. 76-85.

Mele, V. \& Ongaro, E. (2014). Public Sector Reform in a Context of Political Instability: Italy 1992-2007. International Public Management Journal, 17 (1), 111-142.

Mischen, P.A. (2015). Collaborative Network Capacity. Public Management Review, 17(3), 380403.

Oblak, A. (2014). Ocenjevanje delovne uspešnosti javnih uslužbencev. Najdeno dne 11.1.2017 na spletnem naslovu http://www2.fu.uni-lj.si/diplome/pdfs/magistrska/oblakirma.pdf.

O'Dell, C., Grayson, C.J., Essaides, N.O., et al. (1998). If only we knew what we know. New York: Free Press.

OECD (2015). OECD Economic Surveys Slovenia 2015. Najdeno dne 30.10.2016 na spletnem naslovu http://www.oecd.org/eco/surveys/Slovenia-2015-overview.pdf.

Okunoye, A., Innola E. \& Karsten, H. (2002). Benchmarking Knowledge Management in Developing Countries: Case of Research Organizations in Nigeria, the Gambia, and India. Proceedings of the 3rd European Conference on Knowledge Management, September 24-25, Dublin, Ireland.

Ranucci, R.A. \& Souder, D. (2015). Facilitating tacit knowledge transfer: routine capability trustworthiness, and integration in M\&As. Journal of Knowledge Management, 19 (2), 257276.

Špaček, D. (2016). Knowledge management in public administration - what can be found in research outputs in the Czech Republic - preliminary findings. Proceedings of the 20th international conference on current trends in public sector research. Volume 20, 2016, pages 94-101.

UMAR (2017). Ekonomsko ogledalo. Najdeno dne 11.1.2017 na spletnem naslovu http://www.umar.gov.si/fileadmin/user_upload/publikacije/eo/2017/EO0117-s1.pdf.

Virant, G. (2009). Javna uprava. Fakulteta za upravo, Ljubljana.

Worldometers (2017). Italy Population. Najdeno dne 23.1.2017 na spletnem naslovu http://www.worldometers.info/world-population/italy-population/.

Zaharova, S. \& Zelmene, K. (2004). Knowledge Management in Delivering Customer Oriented Services in Public Sector. Proceeding of IFIP International Federation for Information Processing, pp. 37-46.

Znanstveno-raziskovalna baza podatkov Web of Science (2016). Iskalni nizi: ključne besede. $\begin{array}{llll}\text { Najdeno dne na } & 15.10 .2016 \text { naslovu: }\end{array}$ https://apps.webofknowledge.com/WOS_GeneralSearch_input.do?product=WOS\&SID=Y1j3 x1D1F9A9M1D8Ift\&search_mode=GeneralSearch. 
148 36 $6^{\mathrm{TH}}$ International Conference on ORganizational Science Development:

Responsible Organization (MARCH $22^{\mathrm{ND}}-24^{\mathrm{TH}}$, PORTOROŽ SLOVENIA) 
$36^{\text {TH }}$ International Conference on Organizational Science DEVElopMENT: Responsible ORganization (MARCH $22^{\mathrm{ND}}-24^{\mathrm{TH}}$, PORTOROŽ SLOVENIA)

O. Arsenijević, M. Ferjan, I. Podbregar, P. Šprajc, D. Trivan \& Y.

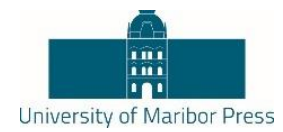

Ziegler

\title{
Innovation of Shipping and Loading Information System and Business Process Reengineering at Coal Company
}

\author{
ROMAN DANEL \& JIŘí SKOTNICA
}

\begin{abstract}
The article describes information support of expedition and sales of the hard coal at company OKD (the only producer of hard coal in the Czech Republic). In 2002-2006 there was designed and implemented, in cooperation with the ATP Soukup Ltd., a comprehensive information management system for coal sales. Later was deployed Business Process Reengineering based on analysis of business processes related to shipping and sales at individual mines to reduce costs and to achieve the consolidation of operations at all OKD mines. The proposed system was implemented in OKD with a central dispatching of sales in headquarters. The system brought during its activity to OKD significantly increasing efficiency of coal sales.
\end{abstract}

KEYWORDS: Business Process Reengineering • OKD • coal sales • coal expedition • information systems $\bullet$ daily loading plan $\bullet$ SAP R/3

CORRESPONDENCE ADDRESS: Roman Danel, Ph.D., VŠB-Technical University of Ostrava, Faculty of Mining and Geology, Institute of Economics and Control Systems, 17. listopadu 15/2172, 708 33 Ostrava - Poruba, Czech Republic, e-mail: roman.danel@vsb.cz; Jiří Skotnica, ATP Soukup Ltd., Pikartská 1337/7, 71607 Ostrava, Czech Republic, e-mail: skotnica@atpsoukup.cz

DOI https://doi.org/10.18690/978-961-286-020-2.14

ISBN 978-961-286-020-2

(C) 2017 University of Maribor Press

Available at: http://press.um.si 
$36^{\mathrm{TH}}$ International Conference on ORganizational Science Development: Responsible Organization (MARCH $22^{\mathrm{ND}}-24^{\mathrm{TH}}$, Portorož Slovenia)

R. Danel \& J. Skotnica: Innovation of Shipping and Loading Information System and Business Process Reengineering at Coal Company

\section{Introduction}

The only producer of hard coal in the Czech Republic is OKD, a. s. (joint stock company). Mining of hard (black) coal in the Czech Republic reached its peak in the second half of the twentieth century. Coal was mined from more than twenty mines, 120000 employees and the annual production amounted to 30 million tons (1975).

OKD was transformed from a state enterprise by privatization (in 1998 and subsequently in 2003) into a private joint stock company (owned by New World Resources Plc, http://www.newworldresources.eu/en).

Since then, there has been a gradual reduction of mining, and coal is now mined in the Czech Republic only in the Ostrava-Karvina region (North Moravia). The number of active coal mines decreased from the maximum of 21 down to five today (Darkov, ČSM, Lazy, Paskov and Karviná). OKD, with 12 thousand employees and an annual output of 8 million tons of coal (2014; 43 thousand tons of raw coal per day in October 2015), is currently one of the largest employers and companies in the Czech Republic (OKD Annual Report, 2015).

At the time of change in ownership, change in the company structure and subsequent reduction of operations to cut costs, customer demand for maintaining the quality (quality parameters) of coal and coke began to increase. Due to increasing competition from foreign suppliers (Poland, China...) the pressure on coal and coke prices also increased. In this situation it was not possible to provide the required quality and price without the support of production in the form of information systems and automation (Ministr \& Pritner, 2014). IT/ICT technologies interlink the entire orders - planning - production shipment - sale chain (Fig. 1), and provide the information necessary for effective management (Hančlová \& Ministr, 2013 ). Therefore, during the 1990s OKD introduced, at some mines, local management systems for controlling sales; most coal preparation plants were equipped with an information system supplied by ATP Soukup Ltd. The economic activities of OKD were then supported by implementing the SAP R/3 ERP system. Later, between 2002 and 2006, a complex sales control system was implemented at OKD which integrated and substantially simplified controlling activities for the planning of loading and shipping (Danel et al, 2015). The information system was also purchased by the sister company OKD Doprava (now it is a part of company AWT), providing for transport of coal by rail. 
R. Danel \& J. Skotnica: Innovation of Shipping and Loading Information System and Business Process Reengineering at Coal Company

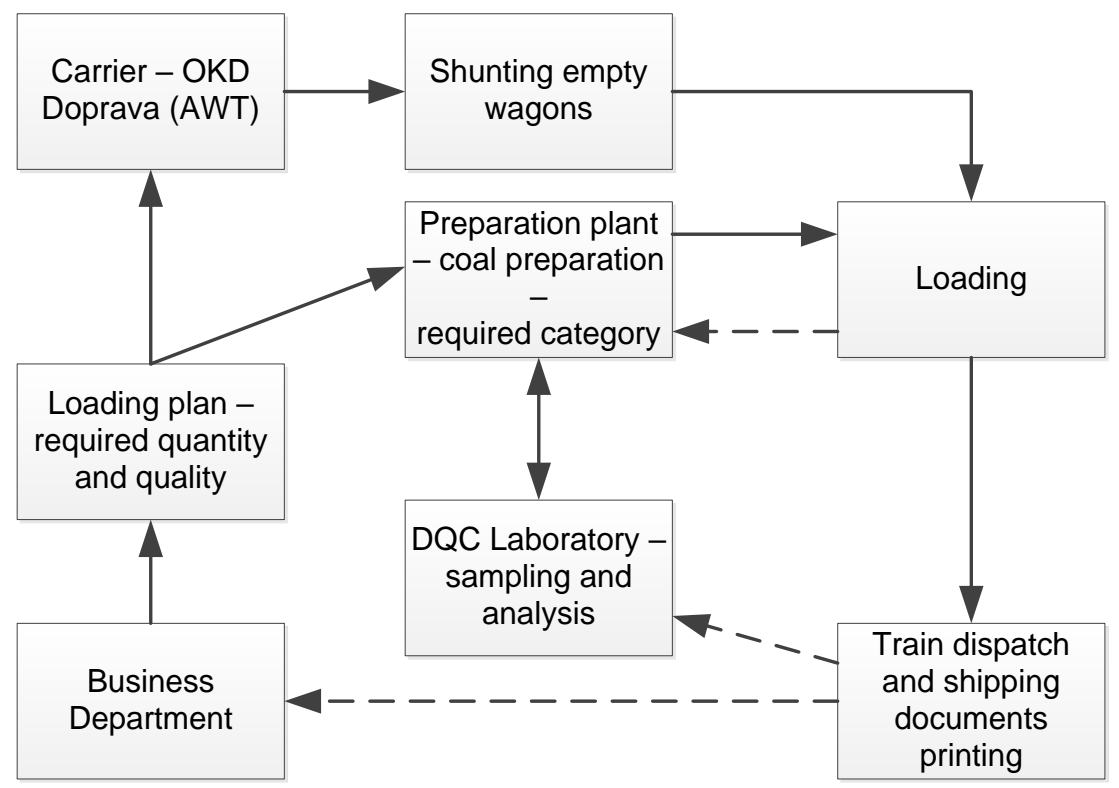

Figure 1: Scheme of coal dispatch subsystems. Solid lines - information flow from business department to customer, dashed lines - information for balance overview (Danel, 2014)

\section{$2 \quad$ Definition of the problem}

Notwithstanding the enormous scope of informatization of production processes at OKD, the efficiency of the operated information systems was not enough. The problem was in the operation of isolated information systems from various suppliers and the need for their interconnection. Another problem was the fact that in the case of implementation of the complex sales management information system, it was necessary to implement the same at all the branches of the company BOS ("Báňská obchodní společnost", affiliated company of OKD providing trading services) at the respective mines. However, each branch had a different work style and various outputs were generated. Some of the agenda (e.g. printing of bills of lading necessary for the handover of wagons to the public transport company - České dráhy, a.s.) at certain mines was provided by BOS and some by the transport company (OKD Doprava).

\section{Proposed Innovation of Shipping and Loading Information System at OKD}

Due to the demand of the company owners for higher efficiency of sales processes, the OKD company sales and shipping processes were subject to analysis as a whole, as well as at the respective mines. 
$36^{\text {Th }}$ International Conference on Organizational Science Development: RESPONSIBLE ORGANIZATION (MARCH $22^{\mathrm{ND}}-24^{\mathrm{TH}}$, PORTOROŽ SLOVENIA)

R. Danel \& J. Skotnica: Innovation of Shipping and Loading Information System and Business Process Reengineering at Coal Company

The analysis showed that the weak point of OKD was its shipping points of BOS, where:

Each shipping point performs different activities

- Shipping points produce various balance outputs and overviews, even though they perform the same activities

- Non-conformation in the division of activities between OKD shipping points and the OKD Doprava transport company office

Non-conformation in the handover of information between the shipping point, coal preparation plant management and company laboratory (quality control and management department).

Based on the analysis, OKD prepared a project whose goal was to unify the information procedures at all shipping points, the transport company's offices and coal preparation plants' offices, so as to simplify and unify handover and presentation of information. The project, which was prepared by the internal IT/ICT department of OKD, presumed the implementation of the entire system in the SAP R/3 environment. The solution should have included direct access to the SAP system from technological worksites at the respective mines, including railway and road weighing systems. This solution proved to be unrealistic. The reason being not only the technical complexity and high costs (particularly due to the increasing number of user licences for access to SAP), but mainly due to the fact that the coal preparation plant is responsible for the production of products. The preparation plant verifies loading data and is responsible for their correctness. The preparation plant management must have available information about production of a balance nature. It submits to its superior bodies data about the preparation plant's yield and production balance per month. Therefore, the preparation plant, as an integral part of the management chain, cannot be left out of the control system. However, compared to the preparation plant's operation, which is non-stop, the SAP corporate information system does not work in 24/7 mode; at the time of the project proposal the system was shut down at night from 10 PM to 4 AM, due to system backup and maintenance.

Therefore, we designed a variant solution - project or upgrade and innovation of the sales information system, which would solve the situation at the respective mines and, at the same time, would enable complex management of sales and shipping for the entire company from a central control office. The design accepted the fact that orders and contracts are made by the sales department in SAP R/3 and, therefore, this database must be the initial starting point for the sales management system.

The main goal during the design of the subsystem for the BOS information system, at the branch offices level, was:

Unification of the system for the collection of data about loading for BOS needs at all OKD coal preparation plants in terms of technical equipment and application software. Implementation of automated systems at all BOS offices in OKD and thereby unification of work and management and handover of information at these offices. 
Connection of the branch office shipping subsystem with the master information system in SAP R/3. The local system at the branch office should receive, from SAP, information about the production and loading plan, and the required quality parameters from contracts and orders. It should transmit information about the course of production and performance of the shipping plan back to SAP.

Connection of the transport company's (OKD Doprava) information system to the designed system (information services for logistics are described in Bindzár et al, 2011).

At the time of design of the project, loading at OKD totalled about 25,000 railway wagons monthly.

Another problem is also the unification of management and handover of information, which differ substantially at the respective plants, particularly in cooperation between the coal preparation plant, BOS forwarding office and OKD Doprava transit railway sidings.

\section{$4 \quad$ BPR of Shipping and Sales at OKD}

The analysis of corporate processes at the shipping points of OKD found differences caused by:

- Different technologies used for coal preparation and shipping at individual mines

- Differences in the production range at respective preparation plants (certain preparation plants are specialized in the production of specific ranges such as UVPK, heating coal, etc.)

- Topological differences (certain preparation plants have their shipping point or OKD railway sidings physically outside the company premises. For example: Dukla or 9. květen coal preparation plants, whose railway sidings, as well as shipping office, are in Horní Suchá at the František Coal Mine, several kilometers away)

- Various customer requirements - certain preparation plants perform shipping for wholesalers, others ship small orders (e.g. Důl Lazy Mine)

- "Historical" reasons - during "paper" and telephonic management there was not sufficient pressure for unification, which led to certain specifics in the way preparation plants work and communicate with respective entities, which participate in management.

After the analysis of corporate shipping and sales processes at OKD, and based on studies of operation of the current corporate information systems, Business Process Reengineering (BPR) was proposed, which consists of expansion of the function of the sales and shipping central dispatching control office (located in Ostrava) so that the following are connected online: preparation plants' information systems, sales and shipping information systems, and laboratory information systems at the respective mines. In the BPR proposal the activities of shipping points at the mines were reduced so that all management activities and production of balance outputs and overviews will be performed at the central control office operated in $24 / 7$ mode. The central control office 
$36^{\mathrm{TH}}$ International Conference on ORganizational Science Development: RESPONSIBLE ORGANIZATION (MARCH $22^{\mathrm{ND}}-24^{\mathrm{TH}}$, PORTOROŽ SLOVENIA)

R. Danel \& J. Skotnica: Innovation of Shipping and Loading Information System and Business Process Reengineering at Coal Company

will provide for drafting of loading plans for the respective mines based on information provided by the SAP system from registered contracts and orders. Based on information from various information systems and databases of cutting tests (which provide information about the presumed quality of coal from specific mined coalfaces) reviewed loading plans will be handed over to coal preparation plants for execution. From the coal preparation plants' IS the central control office can monitor, in real time, the actual status of performance of the loading plan and check whether OKD will provide the quantity and quality required by the customer (Fig. 2).

Furthermore, the local shipping points at the mines will only provide for printing of transport documents and collection of data. This will enable substantial reduction in the number of employees at the shipping points, which will, considering the number of mines, exceed the required increase in the number of employees at the central control office to ensure non-stop operation.

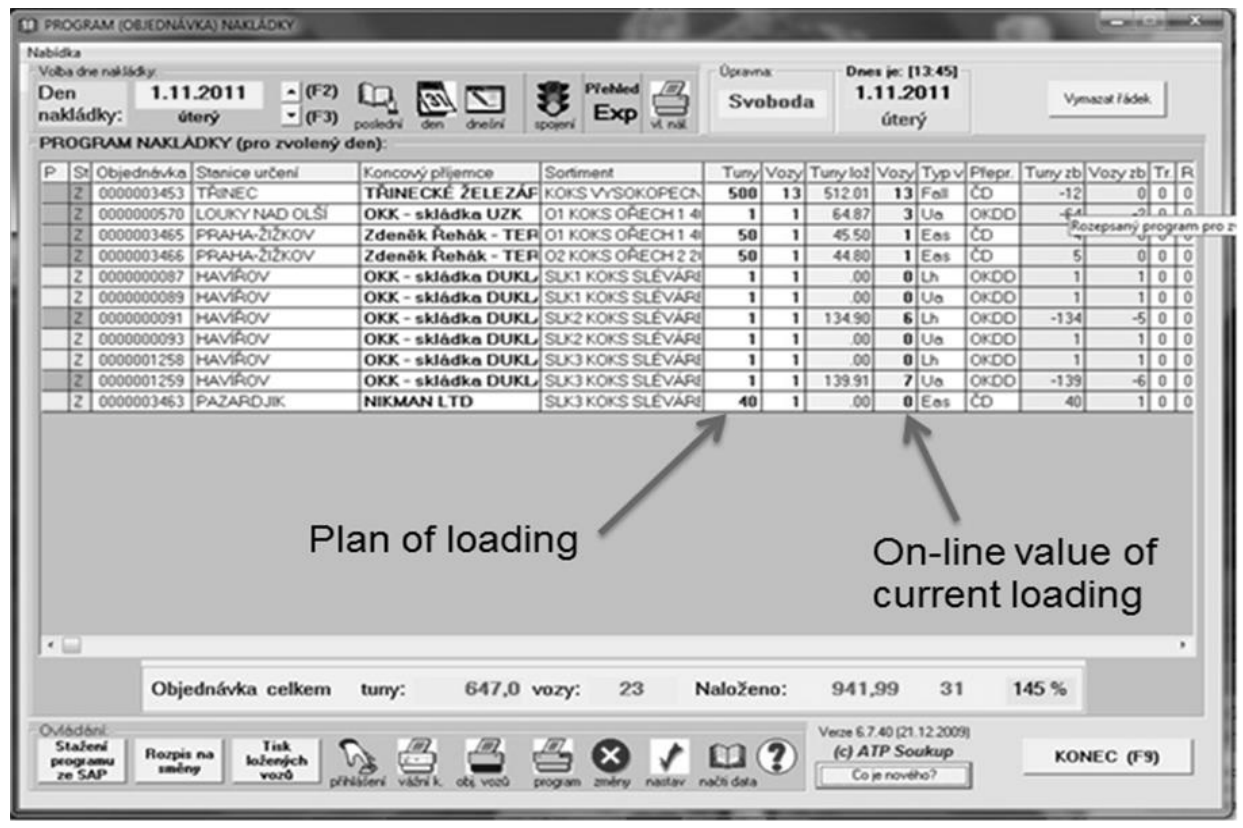

Figure 2: Daily loading programme taken from SAP and monitoring its loading in real time

5 Implementation and Discussion of Results

The proposed project was accepted by OKD and gradually implemented in cooperation with ATP Soukup Ltd. (IT/ICT supplier to coal preparation plants), OKD IT (internal 
IT/ICT management department), and with AWT (the supplier company, formerly OKD Doprava).

The pilot project for shipping point software was implemented at Lazy Mine (this mine was chosen due to the technological complexity of its operations and wide product range) and after a half-year trial period it was implemented at the other mines (to this day it is operated at the Lazy, Darkov, Karviná and ČSM mines; the František, Dukla, and 9. květen mines were gradually shut down and the Paskov Mine will be closed in spring 2017). Later on these systems also connected to the shipping points of two Ostrava coke plants, which were operated until the sale of the coking operations to Metalimex (Prague). The total costs of system implementation were about three million Czech crowns (the price excludes modifications and supplies of HW and network infrastructure; $1 €=27$ CZK). Nevertheless, this investment was returned in quite a short time; from direct savings in the form of staff cuts to improvement in information for production and more flexible reaction to customer requirements. Also, the costs of system maintenance were reduced due to the unification of the operational technical and software equipment. Currently, the management staff has the available information and tools that allow both coal quality control and sales management. This approach has resulted in significant economic effects on the production of coal:

- There has been a reduction in the number of operating staff.

- Timely information regarding significant deviations from the required quality parameters has allowed for corrective action in the course of coal preparation.

- The quality of production has stabilized significantly.

- The work efficiency has increased (as a result of the on-line control of staff performance with the possibility to review the course of production).

- The support for process control complies with ISO 9000 (Pawliczek \& Piszczur, 2013).

\section{Conclusion}

Executed BPR brought cost savings and greater efficiency in the management of coal sales. A necessary condition for success in this area is to support the company's management for implementation.

To reach an ideal state the system of a shipping and sales information system control needs to be supplemented with a prediction function. This requires connection to the System for Monitoring of Mining at OKD from ProSystem Ltd., connection to mining transport and logistics control model and information about filling of containers. This would enable acquiring information about the presumed quality of mined raw coal sufficiently in advance to enable optimization of which mine should perform a specific order (and thereby reduce the costs of coal preparation if the quality of the raw coal is substantially different to the quality required by customers). 
$36^{\mathrm{TH}}$ InTERnAtional CONFERENCE ON ORganizational SCIENCE Development: Responsible Organization (MARCh $22^{\mathrm{ND}}-24^{\mathrm{TH}}$, Portorož Slovenia)

R. Danel \& J. Skotnica: Innovation of Shipping and Loading Information System and Business Process Reengineering at Coal Company

During the monitoring of certain activities of the coal processing and shipping process, it would be suitable to use further information technologies, e.g. RFID for monitoring the flow of raw material. However, due to the present situation of OKD, which slipped into a difficult financial situation in 2016 (due to incorrect investments in the past and extremely low coal prices on the global market), we cannot currently foresee any further development and innovation of the implemented systems.

\section{Literature}

Bindzár, P., Balog, M., \& Straka, M. (2011). Information services for participants in the logistics chain haulage. In Transport and Logistics: Carpathian Logistics Congress, $9^{\text {th }}$ special issue 27. 30. September 2011, nr. 9, Košice, Slovak Republic, pp. 417-426.

Danel, R. (2014). Management and modelling of sales of coal. In International Symposium on Earth Science and Technology. Fukuoka, Japan, pp. 27-31.

Danel, R., Kozel, R., Chlopecký, J., Vilamová, Š., \& Piecha, M. (2015). Information support for sales management in the company OKD a.s. In $11^{\text {th }}$ International Conference on Strategic Management and its Support by Information Systems - SMSIS 2015. Uherské Hradiště, Czech Republic, pp. 46-54.

Hančlová, J. \& Ministr, J. et al. (2015). The Determinants of IT Adoption in SMEs in the CzechPolish Border Areas. In: Information Technology for Development. Routledge. 2015. Vol. 21, issue 3, pp. 426-444.

Hančlová, J. \& Ministr, J. (2013). The Use of ICT Tools as Innovations in SMEs in the CzechPolish Border Areas. In IDIMT-2013 Information technology Human values, Information and Economy. Praha, Czech Republic, pp. 129-136.

Ministr, J. \& Pitner, T. (2014). Towards an Ecosystem for Academic-industrial Cooperation. In IDIMT-2014 Networking Societies - Cooperation and Conflict. Poděbrady, Czech Republic, pp. 71-78.

OKD Annual Reports. (2015). Retrieved from http://www.okd.cz/en/about-us/annual-reports.

Pawliczek, A., \& Piszczur, R. (2013) Utilization of modern management methods with special emphasis on ISO 9000 and 14000 in contemporary Czech and Slovak companies. In $11^{\text {th }}$ International Conference on Liberec Economic Forum. Sychrov, Czech Republic, pp. 436-445. 


\title{
Izzivi tehnoloških sprememb in prihodnost dela
}

\section{DENIS DiZDAREVIĆ \& VESNA NOVAK}

\begin{abstract}
Povzetek Tehnološka nezaposlenost, pojav ki je aktualen že desetletja, v današnjem času dosega nove razsežnosti. Vse več razprav je o tem, ali je tehnologija glavni krivec za naraščujoč trend stopnje nezaposlenosti po vsem svetu, zato v prispevku obravnavamo vpliv tehnoloških sprememb na trg dela. $\mathrm{V}$ slovenskih podjetjih $\mathrm{z}$ več kot sto zaposlenimi smo izvedli raziskavo, da bi ugotovili njihov pogled na nadomeščanje delavcev $\mathrm{s}$ tehnologijo, ter na razloge in posledice, ki jih prinaša nova tehnologija. Razpravljali smo o stališčih, ugotovitvah in predlogih različnih avtorjev ter podali naša stališča in argumente. Ugotovili smo, da tehnološka nezaposlenost ni enostaven problem, da se ta pojav prepleta $\mathrm{z}$ različnimi problematikami, ter da tehnologija predstavlja različne nevarnosti, ki so morda na prvi pogled manj vidne.
\end{abstract}

KLJUČNE BESEDE: trg dela • vpliv tehnologije na trg dela • tehnološka nezaposlenost

\footnotetext{
NASLOV AVTORJEv: Denis Dizdarević, denisd@gmx.com; dr. Vesna Novak, docentka, Univerza v Mariboru, Fakulteta za organizacijske vede, Kidričeva cesta 55a, 4000 Kranj, Slovenija, vesna.novak@fov.uni-mb.si
} 
36 ${ }^{\text {TH }}$ International CONFEREnCE ON ORganizational Science Development: Responsible Organization (MARCH $22^{\mathrm{ND}}-24^{\mathrm{TH}}$, PORTOROŽ SLOVENIA)

O. Arsenijević, M. Ferjan, I. Podbregar, P. Šprajc, D. Trivan \& Y.

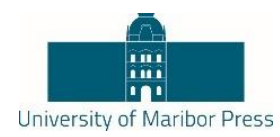

Ziegler

\title{
The Challenges of Technological Changes and the Future of Work
}

\author{
DENIS DIZDAREVIĆ, VESNA NOVAK
}

\begin{abstract}
Technological unemployment, a phenomenon which is topical for decades, nowadays reaches new dimensions. There are more and more discussions about whether the technology is the main culprit for the rising trend of the unemployment rate around the world, therefore, in this paper we discuss the impact of technological change on the labor market. We conducted a research in Slovenian companies that employed more than one hundred people, to find out their views on replacing workers with technology and its reasons and consequences. We discussed the observations, conclusions and proposals of different authors and presented our views and arguments. We found that technological unemployment is not a simple problem, that this phenomenon is intertwined with a variety of issues, and that the technology presents a series of hazards which may be less visible at first sight.
\end{abstract}

Keywords: labour market $\bullet$ the impact of technology on the labour market

- technological unemployment

CORRESPONDENCE AdDRESS: Denis Dizdarević, denisd@gmx.com; Vesna Novak, Ph.D., Assistant Professor, University of Maribor, Faculty of Organizational Sciences, Kidričeva cesta 55a, 4000 Kranj, Slovenia, e-mail: vesna.novak@fov.uni-mb.si

DOI https://doi.org/10.18690/978-961-286-020-2.15 


\section{Uvod}

Tehnologija izpodriva človeka $\mathrm{z}$ delovnega mesta, posledično določena delovna mesta izginjajo oziroma jih nadomestijo stroji. Ti predstavljajo cenejšo delovno silo kot človek, poleg tega jih ni potrebno uvajati, ne potrebujejo počitka, malice in podobno. Zaradi tehnološkega razvoja se povečuje produktivnost, kar privede do hiperprodukcije, situacije, ko proizvedemo več, kot lahko prodamo, ali kot je potreba trga. Rifkin (2007) opisuje, da delavci izgubljajo delo tudi $\mathrm{v}$ revnejših državah, kamor podjetja selijo industrijo, saj se tudi tam vedno več delovnih procesov avtomatizira, s čimer se poveča produktivnost, potrebne pa je manj delovne sile. Avtor meni, da situacijo še dodatno otežuje rast prebivalstva, saj bo potrebno ustvariti nad milijardo novih delovnih mest po svetu, vendar se število delovnih mest po celi zemlji krči.

Problem, ki smo ga zasledili je, da se delavci težko izobražujejo za nove tehnologije v takem tempu, kot se te razvijajo, zato je prekvalifikacija zaposlenih vedno težja. Prav tako izobraževanje specifičnega kadra traja leta, izdelava stroja za opravljanje enakega dela pa je veliko ceneješa in hitrejša, če ta tehnologija že obstaja. Med novimi tehnologijami velja omeniti 3D printerje, ki predstavljajo nov način dela $\mathrm{v}$ mnogih panogah in tako posegajo po delu v zdravstvu, gradbeništvu in drugih dejavnostih. Tudi digitalizacija, ki je močno olajšala delo, saj omogoča delo na daljavo, prinaša spremembe v oblike dela, saj povečuje število prekarno zaposlenih delavcev in zaposlitev izven delovnega razmerja, ki imajo manj socialnih pravic. Zaradi tehnoloških sprememb in eksponentnega naraščanja kapacitet procesorjev so vse bolj ogrožena tudi umska dela. Napredek tehnologije $\mathrm{v}$ logistiki in komunikaciji omogoča selitev vedno več proizvodnih dejavnosti seli v revnejše države. Vse večja uporaba tehnologije tako v industriji, kot v vsakdanjem življenju, ima velik vpliv tudi na okolje in samo zemljo. Tako se soočamo se s pomanjkanjem naravnih virov in samo nevarnostjo onesnaženja do te mere, da bi to lahko povzročilo množično izumrtje.

Nekateri menijo, da bo tehnološka singularnost povzročila, da bodo roboti opravljali dela namesto ljudi, ljudje pa bodo počivali ob obilju bogastva. Drugi vidijo predvsem nevarnost, da bi umetna inteligenca lahko izbrisala vsa bitja, ki bi jih videla kot tekmece za kontrolo nad zemljo, med ta bitja pa spada tudi človek (Luckerson, 2014).

Opisana problemska stanja so nas vodila v raziskavo vpliva tehnoloških sprememb na trg dela. V teoretičnih izhodiščih smo opisali nove tehnologije in njihov vpliv na prihodnost dela. V nadaljevanju pa smo raziskali pogled podjetij na nadomeščanje delavcev s tehnologijo, ter na razloge in posledice ki jih prinaša nova tehnologija. Razpravljali smo o stališčih, ugotovitvah in predlogih različnih avtorjev ter podali naša stališča in argumente.

\section{Teoretično izhodišče vpliva novih tehnologij na prihodnost dela}

Pojem tehnologije, ki izvira iz grške besede téchnē (umetnost, obrt) opozarja na racionalno sposobnost ustvarjanja in proizvajanja. Sodobna tehnologija je nastala iz starodavne téchnē $\mathrm{z}$ razvojem sklepanja in znanja $\mathrm{v}$ znanosti, $\mathrm{v}$ tem smislu je tehnologija 
$36^{\mathrm{TH}}$ International Conference on ORganizational Science Development: RESPONSIBLE ORGANIZATION (MARCH $22^{\mathrm{ND}}-24^{\mathrm{TH}}$, PORTOROŽ SLOVENIA)

D. Dizdarević \& V. Novak: The Challenges of Technological Changes and the Future of Work

neodtujljiva od človekovih dejavnosti in ne prebiva samo v visokotehnoloških izdelkih, temveč tudi na področju znanstvenega znanja, človeškega razumevanja, in organizacije družbenih institucij. Tehnologija omogoča, da je delo lahko bolj produktivno, medtem po drugi strani lahko pripomore k namenu varčevanja energije, prav tako lahko omogoči zmanjšanje onesnaženja okolja pri proizvodnji (Eriksson, 2013, str. 61-62). Tehnologija pa nima samo pozitivnih učinkov in vidikov, kar je opisal že Marx (1867). Z vidika delavca je stroj lahko samo materialna manifestacija kapitalistične dominacije. Poleg nižjih plač in negotovega preživetja, stroj pretvori podjetje v svet trpljenja. Telesni napor dela se lahko zmanjša, vendar se pogoji na delovnem mestu slabšajo (Marx, 1867, str. 552). V današnjem času so delavci zaradi novih tehnologij in s tem konkurenčnosti vse bolj izpostavljeni »prisili« po čim večji produktivnosti. V povezavi s povedanim, pa je zaskrbljujoč podatek, da v Evropski uniji že vsak četrti delavec trpi zaradi stresa na delovnem mestu (Razboršek, 2008).

Med novejšimi tehnologijami lahko omenimo:

- 3D tiskanje, ki lahko zagotovi velike prihranke pri stroških montaže, saj lahko natisne že sestavljene produkte. S tehnologijo 3D tiskanja lahko sedaj podjetja eksperimentirajo z novimi idejami brez obsežne izgube časa in obsežnih stroškov, prav tako pa 3D tiskanje lahko celo izpodbija metodo množične proizvodnje $\mathrm{v}$ prihodnosti. Danes se skoraj vse od letalskih in vesoljskih komponent do igrač za otroke izdeluje s pomočjo 3D tiskalnikov. Ena najpomembnejših vlog 3D tiskanja je $v$ zdravstveni industriji. S tehnologijo 3D tiskanja lahko kirurgi proizvajajo nekatere nadomestne dele telesa (spletna stran 3ders).

- Nanotehnologijo, ki je trenutno še $\mathrm{v}$ začetni fazi in potrebna bodo še desetletja, preden jo bomo zares začeli uporabljati. Področje nanotehnologije ima zelo velik potencial in bo lahko imelo izjemno velik učinek na področju proizvodnje, medicine, izgradnje novih računalnikov in oskrbe $\mathrm{z}$ energijo. Ker gre pri nanotehnologiji za upravljanje na molekularni ravni, bo to področje avtomatizirano, saj človek ni dovolj natančen za opravljanje tega dela. Potrebno bo le nekaj vrhnuskih strokovnjakov. Če bo v prihodnosti nanoproizvodnja nadomestila klasično proizvodnjo, bo to imelo velik vpliv na zaposlenost (Ford, 2009).

- Umetno inteligenco, ki je običajno opredeljena kot znanost, ki omogoča računalnikom, da delajo stvari, za katere je potrebna inteligenca, kot ko to opravlja človek. Večina mnenj $\mathrm{v}$ psihologiji glede človeške inteligence ni kot ena sposobnost ali kognitivni proces, temveč kot niz ločenih komponent. Raziskave na področju umetne inteligence so predvsem osredotočene na naslednje komponente inteligence: učenje, sklepanje, reševanje problemov, zaznavanje in jezikovno razumevanje (Copeland, 2000).

Posledica tehnološkega napredka je tudi globalizacija in z njo povezana prihodnost dela. Vsakdanje izkušnje kažejo, da se globalizacija odraža v povečevanju dostopa do cenovno ugodnih produktov iz držav z nizkim plačilom. Ko tuja nizko kvalificirana delovna sila opravi svoje delo, se delni ali končni proizvodi uvozijo nazaj. Ta celoten proces pritiska 
na nizko kvalificirane delavce na domačem trgu, da znižajo ceno svojega dela. Neposredni dokazi kažejo, da outsourcing igra veliko vlogo $\mathrm{v}$ moderni proizvodnji. Podjetje Nike zaposluje relativno majhno število delavcev $v$ ZDA na področju marketinga in drugih storitev, na drugi strani pa je veliko ljudi zaposlenih v državah z nizkim plačilom, kjer proizvajajo obutev, ki jih nato Nike odkupi (Anderton, Brenton in Whalley, 2006). Ekonomisti so prepričani, da liberalizacija trgovanja in investicij prinaša vsesplošno korist ekonomiji, vendar teorija kaže, da obstajajo posledice, kot je začasna ali stalna izguba službe in prihodkov nekvalificiranih delavcev v industrijskih državah. Globalizacija je samo eden od faktorjev, ki lahko negativno vpliva na situacijo manj kvalificiranih delavcev v industrijskih državah (Anderton, Brenton in Whalley, 2006, str. 143).

\section{$3 \quad$ Raziskava}

\subsection{Namen in potek raziskave}

Namen raziskave je bil ugotoviti mnenja podjetij o možnostih, da bodo v prihodnosti nove tehnologije in stroji zamenjali človeka na delovnem mestu ter ugotoviti mnenja podjetij, kakšne so lahko koristi in kakšni so lahko negativni vplivi pri uvedbi novih tehnologij in strojev v podjetjih.

Raziskavo smo izvedli v mesecu juniju 2015 s pomočjo anketnega vprašalnika, ki je bil poslan v 526 podjetij v Republiki Sloveniji. Zajeta so bila vsa podjetja, ki so leta 2014 imela 100 ali več zaposlenih, seznam podjetij smo pridobili na AJPES-U. Anketa je bila anonimna, poslana v kadrovsko službo, vodji tehnološkega oddelka ali naslovljena na podobno delovno mesto. Prejeli smo 124 izpolnjenih vprašalnikov. V nadaljevanju predstavljamo rezultate, ki se nanašajo na obravnavano tematiko tega prispevka, $\mathrm{v}$ celoti je raziskava podana v magistrskem delu (Dizdarević, 2015). .

\subsection{Rezultati}

V tabeli 1 so predstavljeni odgovori na vprašanje: »Ocenite, $v$ kakšnem obsegu pričakujete, da bodo na naštetih področjih tehnološke spremembe nadomestile vaše zaposlene«. Podjetja so ocenila na lestvici od 1 (v zelo majhnem obsegu) do 5 (v zelo velikem obsegu), da pričakujejo najmanj zamenjav zaposlenih s strani tehnologije na področjih vodstvenih funkcij $(1,42)$, pravne službe $(1,51)$ in kadrovske dejavnosti $(1,67)$, največ zamenjav pa pričakujejo na področju proizvodnje $(2,83)$ ter logistike in skladiščenja $(2,68)$. Poudariti je potrebno, da so vsa področja dobila povprečje manj kot 3 , kar je označevalo srednji obseg vpliva. 
$36^{\text {Th }}$ International Conference on Organizational Science Development: RESPONSIBLE ORGANIZATION (MARCH $22^{\mathrm{ND}}-24^{\mathrm{TH}}$, PORTOROŽ SLOVENIA)

D. Dizdarević \& V. Novak: The Challenges of Technological Changes and the Future of Work

\begin{tabular}{|c|c|c|c|c|c|}
\hline & $\mathrm{N}$ & Minimum & Maximum & Mean & Std. Deviation \\
\hline $\begin{array}{l}\text { IT - informacijska } \\
\text { tehnologija }\end{array}$ & 121 & 1 & 5 & 2,26 & 1,160 \\
\hline Kadrovska dejavnost & 122 & 1 & 5 & 1,67 & 0,776 \\
\hline $\begin{array}{l}\text { Računovodstvo in } \\
\text { finance }\end{array}$ & 123 & 1 & 5 & 2,13 & 0,991 \\
\hline Pravna služba & 120 & 1 & 5 & 1,51 & 0,778 \\
\hline Vodstvene funkcije & 122 & 1 & 5 & 1,42 & 0,666 \\
\hline Logistika in skladiščenje & 120 & 1 & 5 & 2,68 & 1,078 \\
\hline Marketing & 122 & 1 & 5 & 1,89 & 0,911 \\
\hline Prodaja & 120 & 1 & 5 & 1,86 & 0,929 \\
\hline Proizvodnja & 121 & 1 & 5 & 2,83 & 1,130 \\
\hline Razvoj in raziskave & 121 & 1 & 5 & 1,78 & 0,953 \\
\hline
\end{tabular}

Tabela 1: Opisne statistike za nadomeščanje zaposlenih s tehnologijo po področjih

V tabeli 2 so predstavljeni odgovori na vprašanje: »Ocenite, kako močno našteti dejavniki zavirajo uvedbo novih tehnologij in strojev pri zamenjavi človeka na delovnem mestu«. Podjetja so ocenjevala na lestvici od 1 (sploh ne zavira) do 5 (zelo zavira), kako močno našteti dejavniki zavirajo uvedbo tehnologij ali strojev na delovna mesta in pri tem zamenjavo delavcev. Kot največje zaviranje so ocenili strošek nabave tehnologije $(3,58)$, strošek uvedbe tehnologije $(3,54)$ in pa nepoznavanje tehnologije $(3,48)$; najmanj jih zavira zakonodaja $(2,70)$ in pa moralni zadržki $(2,74)$. Nobeden od dejavnikov po mnenju anketiranih podjetij ne izstopa kot zelo zavirajoč.

\begin{tabular}{|c|c|c|c|c|c|}
\hline & $\mathrm{N}$ & $\begin{array}{l}\text { Minimu } \\
\mathrm{m}\end{array}$ & Maximum & Mean & Std. Deviation \\
\hline Zakonodaja & 122 & 1 & 5 & 2,70 & 0,985 \\
\hline Strošek nabave tehnologije & 124 & 1 & 5 & 3,58 & 0,903 \\
\hline Strošek uvedbe tehnologije & 122 & 1 & 5 & 3,54 & 0,919 \\
\hline Strošek vzdrževanja in uporabe & 123 & 1 & 5 & 3,29 & 0,885 \\
\hline Pridobitev ustreznega kadra & 123 & 1 & 5 & 3,13 & 0,905 \\
\hline Nepoznavanje tehnologije & 120 & 1 & 5 & 3,47 & 0,907 \\
\hline Nedostopnost tehnologije na trgu & 120 & 1 & 5 & 3,03 & 0,995 \\
\hline $\begin{array}{c}\text { Moralni zadržki (zamenjava človeka s } \\
\text { strojem; okoljevarstvo, ...) }\end{array}$ & 122 & 1 & 5 & 2,74 & 1,011 \\
\hline Premajhen izkoristek & 121 & 1 & 5 & 2,85 & 1,005 \\
\hline
\end{tabular}

Tabela 2: Opisne statistike za dejavnike, ki zavirajo uvedbo novih tehnologij 

ORGANIZACIJA (22. - 24. MAREC 2017, PORTOROŽ, SLOVENIJA)

D. Dizdarević \& V. Novak: Izzivi tehnoloških sprememb in prihodnost dela

V tabeli 3 so predstavljeni odgovori na vprašanje: »Ocenite, kako veliko korist vidite v naštetih posledicah uvedbe novih tehnologij in strojev«. Podjetja so ocenila na lestvici od 1 (zelo majhna korist) do 5 (zelo velika korist), da največjo korist, kot posledico tehnologije in strojev, vidijo v večji natančnosti $(4,08)$, večji produktivnosti $(3,90)$ in nespremenjeni kakovosti dela $(3,74)$, najmanjšo korist pa $\mathrm{v}$ tem, da ni potrebe po kadrovskem oddelku $(2,45)$ in $\mathrm{v}$ tem, da ni delavskih pravic $(2,60)$. Večino koristi so anketirana podjetja v povprečju ocenila kot velike.

\begin{tabular}{|c|r|r|r|r|r|}
\hline & $\mathrm{N}$ & Minimum & Maximum & Mean & Std. Deviation \\
\hline Večja produktivnost & 123 & 2 & 5 & 3,90 & 0,706 \\
Nižji strošek dela & 123 & 1 & 5 & 3,63 & 0,900 \\
Manjša odsotnost & 122 & 1 & 5 & 3,72 & 0,816 \\
Večja natančnost & 121 & 2 & 5 & 4,08 & 0,759 \\
Nespremenjena kakovost dela & 122 & 1 & 5 & 3,74 & 0,861 \\
Ni delavskih pravic & 123 & 1 & 5 & 2,60 & 0,956 \\
Stroj ne potrebuje izobraževanja & 124 & 1 & 5 & 2,84 & 1,092 \\
Ni potrebe po kadrovskem & 124 & 1 & 5 & 2,45 & 1,054 \\
\hline
\end{tabular}

Tabela 3: Opisne statistike za koristi posledic uvedbe novih tehnologij

$\mathrm{V}$ tabeli 4 so predstavljeni odgovori na vprašanje: »Ocenite, kako bi našteti ukrepi vplivali na trg dela v primeru, če bodo nove tehnologije in stroji zamenjali večino zaposlenih «. Podjetja so ocenila na lestvici od 1 (zelo negativno) do 5 (zelo pozitivno) vpliv naštetih ukrepov na trg dela $\mathrm{v}$ primeru, če bi nova tehnologija in stroji zamenjali večino zaposlenih. Kot najbolj pozitivna ukrepa so ocenili podjetju ugodnejša zakonodaja za zaposlovanje $(3,64)$ in znižanje davka na dobiček $(3,36)$, najmanjšo oceno pa sta dobila znižanje minimalne plače $(2,43)$ in zmanjšanje delavskih pravic $(2,47)$.

\begin{tabular}{|c|c|c|c|c|c|}
\hline & $\mathrm{N}$ & Minimum & Maximum & Mean & Std. Deviation \\
\hline Povišanje davka na dobiček & 121 & 1 & 5 & 2,64 & 0,885 \\
\hline Znižanje davka na dobiček & 118 & 1 & 5 & 3,36 & 0,874 \\
\hline $\begin{array}{l}\text { Povečanje delavskih pravic (večja plača, krajši } \\
\text { delovnik, večja moč sindikata, itd.) }\end{array}$ & 122 & 1 & 5 & 3,22 & 0,858 \\
\hline $\begin{array}{l}\text { Zmanjšanje delavskih pravic (manjša plača, daljši } \\
\text { delovnik, manjša moč sindikata, itd.) }\end{array}$ & 121 & 1 & 4 & 2,47 & 0,837 \\
\hline Podjetju ugodnejša zakonodaja za zaposlovanje & 120 & 1 & 5 & 3,64 & 0,765 \\
\hline Uvedba univerzalnega temeljnega dohodka & 119 & 1 & 5 & 3,06 & 0,806 \\
\hline Znižanje minimalne plače & 120 & 1 & 5 & 2,42 & 0,958 \\
\hline
\end{tabular}

Tabela 4: Opisne statistike za vpliv naštetih ukrepov na trg dela 
$36^{\text {Th }}$ International Conference on Organizational Science Development: ReSPONSIBLE ORGANIZATION (MARCH $22^{\mathrm{ND}}-24^{\mathrm{TH}}$, PORTOROŽ Slovenia)

D. Dizdarević \& V. Novak: The Challenges of Technological Changes and the Future of Work

\section{Razprava}

izobraževanje, medicina, znanost, itd. Tako se npr. roboti že uspešno vključujejo na področje kirurgije, v književnosti pa npr. sprogramirani računalnik lahko ustvari skoraj tri četrtine besedila romana. Enako se dogaja tudi na področju glasbe in filma, kjer lahko $\mathrm{z}$ novo tehnologijo posnamejo vsak posamezen gib in izraz igralca in ga nato predelajo ter uporabijo tudi po igralčevi smrti (Rifkin, 2007). Prednosti takih tehnologij so velike, npr. robot, ki izvaja kirurška dela, je bolj natančen od človeka, nima težav s koncentracijo, ni potrebe po dolgem izobraževanju in praksi, z množično uporabo takega robota, pa se tudi cena posega na enoto znatno zmanjša. Delovna mesta, za katera Cordray (2014) meni, da jih bodo roboti prevzeli v prihodnosti, so: telemarketing, avtomatizirane storitve dostave, upravljanje kanalizacij, davčni pripravljalci, obdelava fotografij, vnos podatkov in knjižničarji.

Raziskava je pokazala, da anketirana podjetja najmanj zamenjav zaposlenih s strani tehnologije pričakujejo na področjih vodstvenih funkcij ( $\bar{x}=1,42)$, pravne službe ( $\bar{x}$ $=1,51$ ) in kadrovske dejavnosti ( $\bar{x}=1,67)$; največ zamenjav pa na področjih proizvodnje ( $\bar{x}=2,83)$ ter logistike in skladiščenja $(\bar{x}=2,68)$. Anketo za podjetja so večinoma reševali v kadrovski službi, zato menimo, da zelo nizko ocenjena možnost, da bo tehnologija ogrozila njihova delovna mesta izvira iz dejstva, da precenjujejo svojo nenadomestljivost. Anketiranci so ocenili, da v zelo majhnem obsegu pričakujejo nadomestitev zaposlenih s tehnologijo in stroji na področju pravne službe in kadrovske dejavnosti. Menimo, da anketiranci niso razmišljali transparentno, saj bi lahko upoštevali, da če zaposlene nadomestimo s tehnologijo in stroji na drugih področjih, se zmanjša potreba po kadrovski in pravni dejavnosti $\mathrm{v}$ organizaciji. Menimo, da bo v prihodnosti vsekakor potrebno razmišljati o poklicih, ki jih bo lahko v celoti zamenjala nova tehnologija. Frey in Osborne (2013) vidita v naslednjih dveh desetletjih najbolj ogrožena delovna mesta: telemarketing, računovodje, maloprodajalci, neprimičninski agenti, komercialni piloti, ekonomisti. Najmanj ogroženi pa so zobozdravniki, terapevti in gasilci.

Rifkin (2007) dodaja, da vsa avtomatizacija in stroji zaradi vse hitrejšega tempa dela s seboj prinašajo tudi stres, z namenom, da bi povečali produktivnost. Vsi stroji povzročajo nek napor, to je lahko zvok stroja, slika monitorja, itd. Mednarodna organizacija dela (v Rifkin, 2007) pravi, da je v 20. stoletju stres postal eden od največjih zdravstvenih problemov. Tudi Marx (1867, str. 552) je že napovedal, da stroj diktira tempo proizvodnje in prisili delavca do roba bioloških zmogljivosti. Stroj odvzame delavcu vsakakršno veselje do proizvajanja, hkrati pa pripelje do monotonosti dela. V EU že vsak četrti delavec trpi zaradi stresa na delovnem mestu (Razboršek, 2008). Potrebno pa je omeniti, da stres ni samo posledica tehnologije, ampak je posledica nezadovoljstva $\mathrm{z}$ delovnimi razmerami, tudi zaradi "prisile" k čim večji produktivnosti. 
Ugotovili smo, da so povečana produktivnost, večja natančnost, nespremenjena kakovost dela, nižji strošek dela in večji dobiček pomembni razlogi za zamenjavo delavcev s tehnologijo in stroji. Anketirana podjetja so odgovorila, da vidijo največjo koristnost kot posledico uvedbe novih tehnologij za podjetja $\mathrm{v}$ večji natančnosti $(\overline{\boldsymbol{x}}=4,08)$. Kelly (2012) navaja, da so že ustvarili robota, ki lahko opravlja več različnih opravil, vendar so transportni stroški postali višji kot proizvodni. Nadaljuje, da nekaterih opravil brez robotov sploh ne bi mogli opravljati, npr. iskanje rakavih celic, hitro računanje, raziskovanje vesolja. Kot drugo največjo koristnost so podjetja ocenila večjo produktivnost ( $\bar{x}=3,90)$. Rifkin (2007, str. 197-206) omenja, da tehnologija in posledično večja produktivnost vplivata tudi na kmetijstvo. Zaradi povečane produktivnosti se je zmanjšalo število zaposlenih v kmetijski industriji s $60 \%$ delovnega prebivalstva v kmetijstvu leta 1850 na manj kot 2,7\% danes. Traktor je tako s kmetij izrinil delovnega konja. Rastlinski biologi so uvajali nove vrste paradižnikov, koruze in ostale zelenjave. Povečala se je uporaba insekticidov, herbicidov in kemičnih pesticidov. $\mathrm{V}$ preteklosti je en kmet pridelal količino hrane, da je lahko nahranil štiri ljudi, danes pridela toliko, da lahko nahrani več kot 78 ljudi. Doctorow (v Wohlsen, 2014) meni, da če se korist od povečane produktivnosti ne porazdeli med vse, bomo prišli do točke, kjer ne bo dovolj ljudi, da bodo kupili vse, kar roboti proizvedejo ter da, če bi se odprava privatne lastnine odvila mirno, bi nas roboti lahko praktično osvobodili dela.

Anketirana podjetja vidijo najmanjšo korist za podjetje kot posledico uvedbe novih tehnologij v tem, da ni potrebe po kadrovskem oddelku $(\bar{x}=2,45)$ in v tem, da ni delavskih pravic ( $\bar{x}=2,60$ ). Menimo, da ko tehnologija zamenja človeka oziroma večje število zaposlenih, tam res ni več potreben samostojni kadrovski oddelek, prav tako delavci izgubljajo svojo pogajalsko moč in posledično pravice. Poudariti je še potrebno outsourcing v tuje države zaradi cenejše delovni sile, kar posledično omogoča tehnološki razvoj.

V raziskavi nas je tudi zanimalo, kako podjetja ocenjujejo vpliv posameznih ukrepov, če bi nove tehnologije in stroji zamenjali večino zaposlenih. Raziskava je pokazala, da anketirana podjetja uvedbo univerzalnega temeljnega dohodka (UTD) ocenjujejo kot niti pozitiven niti negativen ukrep $(\bar{x}=3,06)$. Menimo, da bi bilo potrebno o pravici do zajamčenega ustreznega dohodka za vsakega državljana $\mathrm{v}$ nadaljevanju temeljito razpravljati, še posebej, če se lastništvo produkcijskih sredstev ne spremeni. To je namreč ena od redkih možnosti, ki bi državljanom zagotavljala že samo preživetje, po drugem pa tudi kupno moč za nakup izdelkov, vendar tudi to ni dovolj zaradi krize presežne vrednosti, do katere prihaja vse hitreje zaradi povečane produktivnosti. Rifkin (2007, str. 398-406) pravi, da je potrebno koristi od povečane produktivnosti razdeliti med vse člane družbe, ker bo potrebno vedno manj delavcev, zato meni, da je smiselno oblikovati univerzalni temeljni dohodek $\mathrm{v}$ zameno za opravljanje neke skupnostne storitve, ki bi koristila družbi. Menimo, da uvedba UTD-ja ne bi smela temeljiti na opravljanju prostovoljnega dela, saj bi šlo v tem primeru le za opravljanje dela v zameno za nepošteno plačilo ter za nelojalno konkurenco zaposlenim. Smisel UTD-ja je socialna varnost in 
$36^{\mathrm{TH}}$ InTERnATIONAL CONFERENCE ON ORganizational SCIENCE DeVElopment: RESPONSIBLE ORGANIZATION (MARCH $22^{\mathrm{ND}}-24^{\mathrm{TH}}$, PORTOROŽ SLOVENIA)

D. Dizdarević \& V. Novak: The Challenges of Technological Changes and the Future of Work

možnost za preživetje, zato vidimo UTD kot nadomestilo vseh socialnih prispevkov, ta pa mora biti dovolj visok, da ljudem omogoča preživetje.

Kot najbolj negativna ukrepa pa anketiranci ocenjujejo znižanje minimalne plače ( $\bar{x}$ $=2,43)$ in zmanjšanje delavskih pravic $(\bar{x}=2,47)$. Opažamo nelogičnost ocene ukrepa znižanja minimalnih plač, saj že vrsto let lobirajo prav za njeno znižanje.

Anketirana podjetja so kot največji dejavnik, ki zavira uvedbo novih tehnologij in strojev, ocenila strošek nabave tehnologije ( $\bar{x}=3,58)$, strošek uvedbe tehnologije $(\bar{x}=3,54)$ in pa nepoznavanje tehnologije $(\bar{x}=3,48)$; najmanj jih zavira zakonodaja $(\bar{x}=2,70)$ in moralni zadržki ( $\bar{x}=2,74)$. Nobeden od dejavnikov po mnenju anketiranih podjetij ne izstopa kot zelo zavirajoč. Strošek nabave in implementacije novih tehnologij je za podjetja trenutno še previsok, kar potrjuje še ocena dejavnika premajhen izkoristek ( $\bar{x}$ $=2,85$ ). Nedostopnost tehnologije na trgu so podjetja ocenila z $\bar{x}=3,03$, kar lahko pripišemo tudi globalizaciji, saj danes lahko pridobimo izdelke, končne produkte, kot proizvodne stroje s celotnega sveta.

Kot najbolj pozitiven ukrep na trgu dela v primeru, če bi tehnologija zamenjala večino zaposlenih, so podjetja ocenila podjetju ugodnejšo zakonodajo za zaposlitev ( $\bar{x}=3,64)$. Tudi avtorja Brynjolfsson in McAfee (2011, str. 77-81) kot možne predloge navajata sprostitev zakonodaje za zaposlovanje in odpuščanje, zmanjšanje davka na delo in davčne olajšave za zaposlovanje ljudi ter zmanjšanje socialnih prispevkov. Vse našteto bi lahko kvalificirali kot ugodnejšo zakonodajo za zaposlitev. Pri tem moramo upoštevati tudi negativne posledice teh ukrepov na delavce, državo in družbo.

Naslednji pozitiven ukrep v primeru, če bi tehnologija zamenjala večino zaposlenih, podjetja vidijo v znižanju davka na dobiček $(\bar{x}=3,36)$. Ti rezultati so pričakovani, saj se podjetja sama od sebe ne bodo odrekla dobičku. Kot je trdil Henry George, bi moralo lastništvo vseh neprimičnin v državi pripadati prav državi, saj si tako korporacije ne bi mogle nabirati moči $\mathrm{z}$ nakupom zemljišč in objektov. Lastništvo neprimičnin res zmanjšuje fleksibilnost delovne sile, vendar namen ljudi ni biti potrošna delovna sila za potrebe podjetij. Omenimo lahko, da so bili delavci v ZDA v času Eisenhowerja po 2. svetovni vojni veliko bolj zaščiteni kot danes, pa so vseeno podjetja zaposlovala več ljudi kot sedaj. Prav tako pa je v času Eisenhowerja davek na dobiček znašal 91 \%. Menimo, da bi bilo potrebno ob znižanju obdavčitev na zaposlovanje in delo povečati davek na dobiček in uvesti progresivno obdavčenje, kar bi onemogočalo tako hitro rast prepada med revnimi in bogatimi. 
V prispevku smo obravnavali tehnološke spremembe in delo $\mathrm{v}$ prihodnosti. Ugotovili smo, da nova tehnologija prinaša podjetjem veliko koristi, po drugi strani pa je povezana z mnogimi problemi na trgu dela, npr. z naraščujočo tehnološko nezaposlenostjo, $\mathrm{s}$ prekomerno proizvodnjo produktov ter $\mathrm{z}$ globalizacijo.

Tehnološki razvoj je skoraj nemogoče ustaviti, zato menimo, da se bomo tudi $\mathrm{v}$ prihodnosti soočali s podobnimi problemi. Čeprav nedvomno tehnologija prinaša tudi pozitivne učinke, pa obstaja nevarnost, da bo ta razvoj prišel do točke tehnološke singularnosti in nastopa umetne inteligence. Ta pa ne ogroža samo delovna mesta, ki jih človek pozna, ampak tudi sam obstoj človeštva. Smatramo, da pri terminologiji in pojmovanju na področju umetne inteligence širša javnost ni dovolj seznanjena o tej tematiki, niti o tem kakšne posledice bi lahko ta razvoj imel. Zato menimo, da bomo v prihodnosti temu problemu namenjali več pozornosti.

Razpravljali smo tudi o tehnološki nezaposlenosti in nadomeščanju delavcev s tehnologijo, kar ni nov pojav, saj se s tem ljudje srečujejo že od pojava prvega stroja. Skozi zgodovino pa se ta trend konstantno povečuje, zato lahko zaključimo, da tehnologija uniči več delovnih mest, kot jih proizvede. Podjetja nimajo zadržkov glede nadomeščanja delavcev s stroji in praktično jih nič ne omejuje, da to storijo, če je to le ekonomsko upravičeno. Omenili smo, da je to tudi eden od razlogov za vedno večjo družbeno neenakost, še večji problem pa vidimo v nerazporejeni koristi od povečane produktivnosti oz. v lastništvu produkcijskih sredstev. Posledica tehnološkega razvoja je tudi globalizacija. Po eni strani je ta pojav povečal trg, pridobimo lahko surovine z drugega konca sveta, ki jih v naših krajih primanjkuje, po drugi strani pa se pojavlja težava selitve proizvodnje $\mathrm{v}$ države, kjer je delovna sila cenejša in tako povečuje brezposelnost domače države.

Menimo, da so za rešitev težav, ki jih prinašajo nove tehnologije potrebne velike sistemske spremembe, prav tako, da je o omenjenih problemih potrebno čim več razpravljati in jih v najkrajšem možnem času odpraviti.

\section{Literatura}

Anderton, R., Brenton, P., Whalley, J. (2006). Globalisation and the Labour Market: Trade, technology and less-skilled workers in Europe and the United States. Velika Britanija: Routledge.

Brynjolfsson, E. in McAfee, A. (2011). Race Against The Machine: How The Digital Revolution Is Accelerating Innovation, Driving Productivity, And Irreversibly Transforming Employment And The Economy. Massachusetts, Lexington: Digital Frontier Press.

Copeland, B. J. (2000). A Brief History of Computing. Pridobljeno 20.1.2017 na $h t t p: / / w w w . a l a n t u r i n g . n e t / t u r i n g \_a r c h i v e / p a g e s /$ reference\%20articles/briefhistofcomp.htm $l$.

Cordray, R. (2014). What Jobs Will Robots Take From Humans in The Future?, Wired. Pridobljeno 13.7.2015 na http://www.wired.com/2014/07/jobs-will-robots-take-humans-future/ 
168 36 $6^{\text {TH }}$ International Conference on Organizational Science Development: RESPONSIBLE ORGANIZATION (MARCH $22^{\mathrm{ND}}-24^{\mathrm{TH}}$, PORTOROŽ SLOVENIA)

D. Dizdarević \& V. Novak: The Challenges of Technological Changes and the Future of Work

Eriksson, C. (2013). Economic Growth and the Environment. Oxford: University Press, Velika Britanija.

Ford, M. (2009). The Lights In The Tunnel: Automation, Accelerating Technology And The Economy Of The Future. ZDA: Acculant Publishing.

Frey, C. in Osborne, M. (2013). The Future of Employment: How Susceptible are Jobs to Computerisation? Technological Forecasting and Social Change, Vol. 114, str. 254-280.

Kelly, K. (24.12.2012). Better Than Human: Why Robots Will - And Must — Take Our Jobs. Wired. Pridobljeno 13.7.2015 na http://www.wired.com/2012/12/ff-robots-will-take-our-jobs/

Luckerson, V. (2.12.2014). 5 Very Smart People Who Think Artificial Intelligence Could Bring the Apocalypse. Time. Pridobljeno 28.7.2015 na http://time.com/3614349/artificialintelligence-singularity-stephen-hawking-elon-musk/

Marx, K. (1867). Capital Volume I: Critique of Political Economy. Hamburg.

Razboršek, N. (2008). Stres povzročajo tudi tehnološke novosti. Delo, str. 19.

Rifkin, J. (2007). Konec dela: Zaton svetovne delavske sile in nastop posttržne dobe. Ljubljana: Krtina.

Wohlsen, M. (8.8.2014). When Robots Take All the Work, What'll Be Left for Us to Do? Wired. Pridobljeno 13.7.2015 na http://www.wired.com/2014/08/when-robots-take-all-the-workwhatll-be-left-for-us-to-dol 


\title{
Management krhkosti na individualni ravni - potreba po obsežnem multidisciplinarnem pristopu
}

\author{
BRANKO GABROVEC \& MARJETKA JELENC
}

Povzetek Danes lahko večina ljudi pričakuje, da bo živela dlje, kot naši predhodniki. Demografsko staranje predstavlja enega najresnejših izzivov, s katerim se sooča večina evropskih držav, pa tudi držav po vsem svetu. $\mathrm{Ob}$ tem pa je potrebno posebej poudariti, da doživljanje visoke starosti še ne pomeni odsotnost bolezni pri visoki starosti. Podaljšanje življenjske dobe tako spremlja tudi podaljšana doba življenja v bolezni. Starostnike spremlja t.i upad psihofizičnih sposobnosti. V EU sta starostna krhkost in oslabljenost pogost in obenem naraščajoč multidimenzionalni zdravstveni in socialni izziv, povezan s fizičnim, kognitivnim in funkcionalnim upadanjem starajoče se populacije. Prevalenca starostne oslabelosti in krhkosti z leti progresivno narašča in je hkrati glavni faktor vpliva na povečanje stroškov zdravljenja pri starejših. Ker se lahko proces, ki vodi do starostne krhkosti in oslabljenosti upočasni ali celo popolnoma zavre, je primeren za zgodnje intervencije. Zgodnje intervencije lahko najdemo na večih področjih, zato mora biti management obvladovanja krhkosti usmerjen $\mathrm{v}$ obširno in celostno obravnavo: preventiva, klinični management, fizična aktivnost, prehrana, zdravila in informacijske tehnologije.

KLJUČNE BESEDE: krhkost - upravljanje krhosti - staranje • multimorbidnos

NASLOV AVTORJEV: Branko Gabrovec, Nacionalni inštitut za javno zdravje, Trubarjeva 2, 1000 Ljubljana, Slovenija, e-pošta: branko.gabrovec@nijz.si; Marjetka Jelenc, Nacionalni inštitut za javno zdravje, Trubarjeva 2, 1000 Ljubljana, Slovenija, e-pošta: marjetka.jelenc@nijz.si

DOI https://doi.org/10.18690/978-961-286-020-2.16

ISBN 978-961-286-020-2

(C) 2017 Univerzitetna založba Univerze v Mariboru

Dostopno na: http://press.um.si 
$36^{\text {TH }}$ InTERnAtional CONFERENCE ON ORganizational SCIENCE DEVELOPMENT: ResPonsible ORGANIZATION (MARCH $22^{\mathrm{ND}}-24^{\mathrm{TH}}$, PORTOROŽ SLOVENIA)

O. Arsenijević, M. Ferjan, I. Podbregar, P. Šprajc, D. Trivan \& Y.

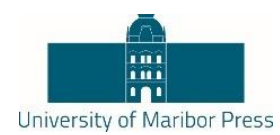

Ziegler

\title{
Management of Frailty at Individual Level - a Need for a Comprehensive Multidisciplinary Approach
}

\author{
BRANKO GABROVEC \& MARJETKA JELENC
}

\begin{abstract}
Today most of people can expect to live longer than their predecessors. Most of the European as well as world countries are faced with serious challenge of demographic aging of their citizens. However there is a need to emphasize that longevity means absence of disease at old age. Extension of life expectancy is accompanied with extension of life in disease. Elderly are faced with a decline of psychophysical abilities. Frailty and disability are common and increasing multidimensional health and social challenge in EU, which is connected with physical, cognitive and functional decline at ageing population. Prevalence of frailty and disability is increasing progressively with age, and it is also a main factor of increasing health expense in elderly population.
\end{abstract}

As the process which leads to frailty and disability can be slowed down or even completely reversed, it can be appropriate for early interventions. Early interventions can be found in multiple fields, so the management of frailty should be directed in comprehensive and holistic treatment: prevention, clinical management, physical exercise, nutrition, drugs and informational technologies.

KEYWORDS: frailty $\bullet$ frailty management $\bullet$ ageing $\bullet$ multimorbidity

CORRESPONDENCE ADDRESS: Branko Gabrovec, National Institute of Public Health, Trubarjeva 2, 1000 Ljubljana, Slovenia, e-mail: branko.gabrovec@ nijz.si; Marjetka Jelenc, National Institute of Public Health, Trubarjeva 2, 1000 Ljubljana, Slovenia, e-mail:marjetka.jelenc@nijz.si 
B. Gabrovec \& M. Jelenc: Management krhkosti na individualni ravni - potreba po obsežnem multidisciplinarnem pristopu

\section{$1 \quad$ Staranje}

Svetovna zdravstvena organizacija (WHO) je izdala prvo svetovno poročilo o staranju in zdravju (World report on aging and health 2015). Danes lahko večina ljudi na svetu pričakuje, da bo živela v svoja 60-ta leta ali dlje (World economic and social survey, 2007). V kombinaciji z zmanjševanjem števila rojstev, vodi podaljšanje življenjske dobe $\mathrm{k}$ hitremu staranju populacij po vsem svetu. Te spremembe so dramatične in posledice so velike. Otrok rojen v Braziliji ali Myanmarju v letu 2015 lahko pričakuje, da bo živel 20 let dlje, kot tisti, ki se je rodil pred 50 leti. V Islamski Republiki Iranu je v letu 2015, samo eden od desetih prebivalcev starejši od 60 let. $V$ samo 35 letih pa je pričakovati, da bo to razmerje 1 proti 3 . Hitrost staranja prebivalstva se je zelo povečala in je danes veliko večja, kot je bila v preteklosti (World report on ageing and health, 2015). Pričakovati je, da bodo mlajši, ob zavedanju, da lahko pričakujejo bistveno daljšo življenjsko dobo svoje življenje drugače načrtovali, na primer, da bodo pričeli z razvojem svoje poklicne kariere kasneje, prej pa se bodo v večji meri posvetili družini, ipd (World report on ageing and health, 2015).

Ob tem pa je potrebno posebej poudariti, da bodo priložnosti, ki izhajajo iz podaljšane življenske dobe odvisne predvsem od enega ključnega faktorja; to je zdravje. Če bi dodatna leta življenja zaznamoval upad fizičnih in duševnih spodobnosti, bi to pomenilo veliko breme, tako za starejše kot tudi za družbeno skupnost. Žal je potreba povedati, da kljub pogosti domnevi, da podaljšanje življenjske dobe spremlja tudi podaljšana doba dobrega zdravja, temu ni tako. Dokazov, da starejši danes živijo ob boljšem zdravju in sposobnostih, kot so njihovi starši v istih letih, ni. Med starejši so opazne velike razlike v zdravju, ki niso naključne. Nekaj raznolikosti lahko pripišemo genetiki (Steves, Spector \& Jackson, 2012), večina drugih razlik pa je posledica fizičnega in socialnega okolja $v$ katerem živimo. Tu vključujemo dom, soseščino in širšo skupnost, ki lahko direktno vplivajo na naše zdravje ali na ovire ter spodbude, ki se odražajo na priložnostih, odločitvah in vedenju vsakega posameznika. Odnos, ki ga imamo z okoljem se razlikuje glede na družino v katero smo rojeni, spol in narodnost. Vpliv okolja pogosto vodi v razlike v zdravju in neenak dostop do zdravja (Commission on Social Determinants of Health, 2008). Kumulativen učinek vseh teh različnosti prispeva k neenaki dostopnosti do zdravja skozi ves življenjski ciklus (Dannefer, 2003). Ti trendi so vidni (Slika 1) skozi fizične sposobnosti v življenskem cilkusu na primeru študije zdravja žensk v Avstraliji (Beard et al., 2015). 
$36^{\mathrm{TH}}$ International Conference on ORganizational Science Development: RESPONSIBLE ORganization (MARCH $22^{\mathrm{ND}}-24^{\mathrm{TH}}$, Portorož SLOVENIA)

B. Gabrovec \& M. Jelenc: Management of Frailty at Individual Level - a Need for a Comprehensive Multidisciplinary Approach

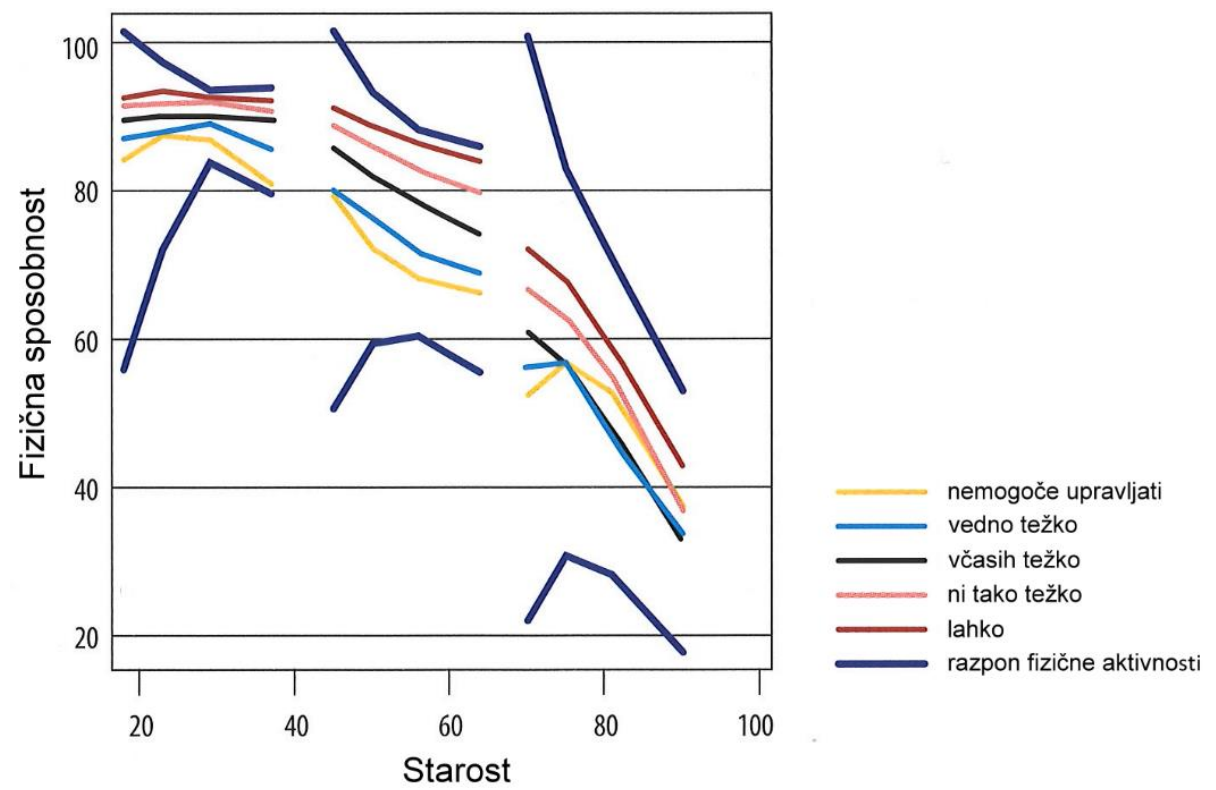

Slika 1: Razpon fizične sposobnosti v okviru življenjskega ciklusa žensk v Avstraliji, razdeljeno po dohodkih. Vir: Beard et al., 2015.

Slika 1 prikazuje prikazuje fizične sposobnosti v življenjskem ciklusu žensk, razdeljenih v kvartile primerljivih dohodkov. Večji razpon fizične sposobnosti imajo osebe z večjimi dohodki. Ta povezanost dohodkovne spodobnosti in zdravja mora imeti veliko vlogo pri oblikovanju politik, saj imajo ljudje $\mathrm{z}$ največjimi zdravstvenimi potrebami praviloma najmanj sredstev (World report on ageing and health, 2015).

Kljub temu ni potrebno, da bi pozni starosti prevladovalo slabo zdravje. Večina zdravstvenih težav s katerimi se soočajo starejši je povezanih z kroničnimi boleznimi. Mnoge od teh se lahko preprečijo, omilijo ali pa odložijo z bolj zdravim načinom življenja. Druge zdravstvene težave lahko učinkovito obravnavamo, če jih pravočasno odkrijemo. In tudi pri ljudeh, ki jim pešajo sposobnosti, lahko podporno okolje zagotovi, da živijo dostojno življenje $\mathrm{v}$ osebnostni rasti (World report on ageing and health, 2015).

Ne glede na to, da 70-ta še ne delujejo kot nova 60-ta leta, ni razloga, da ne bi bilo tako $\mathrm{v}$ prihodnosti. Potreben bo skladen in usmerjen odgovor med različnimi sektorji in deležniki (Beard et al., 2012). Starajoča se populacija potrebuje obsežen in ustrezen odziv s strani javnega zdravja, da bi sprejeli vse možne ukrepe, ki lahko vlivajo na boljše zdravje v starejšem življenjskem obdobju (Lloyd-Sherlock et al., 2012; Smith, 2010). 
B. Gabrovec \& M. Jelenc: Management krhkosti na individualni ravni - potreba po obsežnem multidisciplinarnem pristopu

\section{$2 \quad$ Krhkost}

Demografsko staranje predstavlja enega najresnejših izzivov, s katerim se sooča večina evropskih držav. Podpora aktivnemu in zdravemu staranju je zato pomembna tako za izboljšanje kvalitete življenja prebivalstva, kot tudi za zmanjšanje pritiska na zdravstvene sisteme (The Action Group on Frailty Story, 2015). Kontinuirano podaljševanje pričakovane življenjske dobe je vsekakor pomemben dosežek. Prebivalci Evropske unije (EU) sicer živijo dlje, vendar mnogi z eno ali več dolgotrajnih bolezenskih stanj, marsikje $\mathrm{v}$ slabem zdravstvenem stanju in $\mathrm{z}$ zmanjšano kvaliteto življenja. Za mnoge starost prinaša odvisnost od drugih, starostno krhkost, oslabljenost (angl. frailty) in/ali kronične bolezni. Izziv družbi torej ni zgolj podaljševanje pričakovane življenjske dobe, ampak zdrava in samostojna starost. Zato je potrebna čimprejšnja implementacija trajnostnih in učinkovitih zdravstvenih ter socialnih rešitev, ki se bodo učinkovito kosale $\mathrm{s}$ povečevanjem starostne krhkosti, oslabljenosti, pridruženimi kroničnimi boleznimi, kognitivnim upadom in njihovimi posledicami (The Action Group on Frailty Story, 2015; European Innovation Partnership on Active and Healthy Ageing, 2016).

$\mathrm{V}$ EU sta starostna krhkost in oslabljenost pogost in obenem naraščajoč multidimenzionalni zdravstveni in socialni izziv, povezan s fizičnim, kognitivnim in funkcionalnim upadanjem starajoče se populacije. V eni izmed študij so ugotovili, da znaša prevalenca starostne krhkosti in oslabljenosti približno $10 \%$ pri starosti nad 60 let in kar $25 \%$ pri starosti 80 let in več (Garcia-Garcia et al., 2011). Starostna krhkost in oslabljenost sta tudi glavna faktorja vpliva povečanja stroškov zdravljenja pri starejših (Gill et al., 2010; Bock et al., 2015).

\subsection{Upravljanje krhkosti}

Ker se lahko proces, ki vodi do starostne krhkosti in oslabljenosti upočasni ali celo popolnoma zavre, je primeren za zgodnje intervencije. Starostna krhkost in oslabljenost sta namreč močan rizični faktor za izgubo mobilnosti, padce, odvisnost od drugih, institucializem in smrt in zato so zgodnje intervencije in morebitno zdravljenje ključnega pomena (Clegg et al., 2013). Poleg tega je stanje priznan napovedovalec izidov medicinskih in kirurških intervencij, ki jih je potrebno upoštevati in ne zgolj pripisati dejstvu, da gre za starejše paciente. Glede na pospešeno staranje populacije v večini evropskih držav in $\mathrm{s}$ tem povezanim povečanim številom posameznikov $\mathrm{z}$ okvarami ter odvisnostjo od drugih bi intervencije pripomogle k odlogu odvisnosti od drugih, kar pa je glavni vzrok poseganja po zdravstvenih in socialnih storitvah (Rodríguez-Artalejo \& Rodríguez-Mañas, 2014).

Management obvladovanja krhkosti in zgodnjih intervencij zahteva širok multidisciplinaren pristop: preventiva, klinični management, telesna aktivnost, prehrana, zdravila, IKT. V različnih zdravstvenih sistemih po svetu že obstajajo določeni programi, nacionalni plani in navodila obvladovanja posameznih področij, zato je potreben pregled obstoječe literature ter dobrih praks, programov in nacionalnih planov na vseh omenjenih področjih. 
$36^{\text {Th }}$ International Conference on Organizational Science Development: RESPONSIBLE ORGANIZATION (MARCH $22^{\mathrm{ND}}-24^{\mathrm{TH}}$, PORTOROŽ SLOVENIA)

B. Gabrovec \& M. Jelenc: Management of Frailty at Individual Level - a Need for a Comprehensive Multidisciplinary Approach

Primer $\mathrm{z}$ vadbo induciranih sprememb v muskulaturi mlajših odraslih in starostnikov prikazujemo v Tabeli 1.

\begin{tabular}{|l|c|c|c|}
\hline \multicolumn{1}{|c|}{ Populacija } & $\begin{array}{c}\text { Dolžina vadbe } \\
\text { (v tednih) }\end{array}$ & $\Delta$ MCV (\%) & $\Delta$ MCV (\%) \\
\hline Starejši $(65-81$ let) & 16 & 19.0 & 0.17 \\
\hline Starejši $(65-81$ let) & 12 & 16.7 & 0.20 \\
\hline Starejši $(65-81$ let) & 10 & 17.0 & 0.25 \\
\hline Starejši (65-81 let) & 12 & 37 & 0.44 \\
\hline Mlajši odrasli & 24 & 26.8 & 0.16 \\
\hline Mlajši odrasli & 12 & 15.0 & 0.18 \\
\hline
\end{tabular}

Tabela 1: Odstotek povečanja mišične mase z vadbo moči pri mlajših odraslih osebah in starejših (Povzeto po: Narici et al., 2004).

Starejši posamezniki se soočajo z hipertrofijo mišičnih vlaken. Raziskave kažejo (Tabela 1), da dnevna vadba pri starejših na podoben način vpliva na rast in vdržljivost mišičevja, kot pri mlajših odraslih posameznikih (Povzeto po: Narici et al., 2004).

\section{$3 \quad$ Projekt skupnega ukrepanja proti krhkosti}

Evropsko inovativno partnerstvo za aktivno in zdravo staranje (European Innovation Partnership on Active and Healthy Ageing - EIP AHA) je rezultat zavzetosti EU v naslavljanju izziva starostne krhkost in oslabljenosti. Junija 2012 so se partnerji EIP AHA (inštituti, druge znanstvene ustanove in inštitucije) organizirali v šest akcijskih skupin, med katerimi je tudi Akcijska skupina za preventivo starostne krhkosti in oslabljenosti (Action Group on Frailty Prevention). Delo skupine je bilo usmerjeno v izboljševanje stanja na področju preventive starostne krhkosti in oslabljenosti ter organizacije podpore, ki bi oslabelim, krhkim starejšim in tistim, ki zanje skrbijo olajšala življenje (The Action Group on Frailty Story, 2015).

Z namenom spodbujanja pristopa $\mathrm{k}$ prevenciji starostne krhkosti je $\mathrm{v}$ javnozdravstvenem programu za leto 2015 Evropska komisija razpisala skupen program na področju starostne krhkosti in oslabljenosti, tako imenovan »Joint Action-JA on Frailty Prevention« oz. Skupno evropsko ukrepanje za preprečevanje starostne krhkosti in oslabljenosti. »Joint Action« oz. skupno ukrepanje je poseben mehanizem za financiranje evropskih projektov. Članice EU se zavedajo, da se lahko starostno krhkost in oslabljenost kot javnozdravstveni in socialni izziv zmanjšuje, skupen projekt »JA on Frailty Prevention« pa predstavlja priložnost za sodelovanje in napredek k skupnim odločitvam na tem področju.

Projekt »Joint Action on Frailty Prevention - JA ADVANTAGE« poteka od decembra 2016 do decembra 2019. Namenjen je obširnemu in celostnemu pristopu $\mathrm{k}$ promociji 
B. Gabrovec \& M. Jelenc: Management krhkosti na individualni ravni - potreba po obsežnem multidisciplinarnem pristopu

zdravega in neodvisnega življenja $v$ zreli starosti $v$ EU. Nacionalni inštitut za javno zdravje vodi delovni sklop managementa krhkosti pri posamezniku in bo vključeval naslednja področja: preventiva, klinični management, fizična aktivnost, prehrana, zdravila in informacijske tehnologije. K celotnemu JA ADVANTAGE bo sklop prispeval poročilo na omenjenih področjih (metodologija, pregled literature, pregled dobrih praks, programi in nacionalni plani držav članic EU), ter European guide in priporočila za management krhkosti.

\section{$4 \quad$ Zaključek}

Danes lahko ljudje pričakujejo, da bodo živeli dlje, kot njihovi predhodniki. Demografsko staranje predstavlja pomemben izziv. Glede na to, da dodana leta življenja ne predstavljajo zgolj zdrava leta, pa demografsko staranje predstavlja predvsem velik javnozdravstveni izziv. Med izzive spada tudi starostna oslabelost in krhkost, stanje, ki lahko vodi v bolezen ali možnost poškodbe. Krhkost z leti progresivno narašča in je hkrati pomemben faktor vpliva na povečanje stroškov zdravljenja pri starejših. Kljub vsemu pa je krhkost stanje, katero se lahko v veliki meri zavre in zaustavi. Na to imajo vpliv: preventiva, klinična obravnava, prehrana, fizična aktivnost, zdravila in informacijsko komunikacijske tehnologije. Obravnava in upravljanje krhkosti potrebuje obsežen multidisciplinaren pristop. Evropska komisija sofinancira projekt »JA ADVANTAGE«, ki bo naslovil obravnavo krhkosti skozi področja, ki lahko vplivajo na upravljanje krhkosti.

\section{Literatura}

Beard, J. R., Biggs, S., Bloom, D. E, Fried, L. P, Hogan, P., Kalache, A., et al. (2012). Global population aging: peril or promise? Introduction. V: Beard JR, Biggs S, Bloom DE, Fried LP, Hogan P, Kalache A, et al., (Ur.). Geneva: World Economic Forum; 2012. pp. 4 - 13.

Beard, J. R., Officer, A., De Carvalho, I. A., Sadana, R., Pot, A. M., Michel, J.P., Lloyd-Sherlock, P., et al. (2015). The World report on ageing and health: a policy framework for healthy ageing. Lancet. Dostopno na: http://www.thelancet.com/journals/lancet/article/PIIS01406736\%2815\%2900516-4/fulltext?rss\%3Dyes

Bock, J. O., Heider, D., Brenner, H., et al. (2015). The impact of frailty on health care costs. 11th World Congress in Health Economics. Milan.

Clegg, A., Young, J., Iliffe, S., et al. (2013). Frailty in elderly people. Lancet; 381:752-762.

Commission on Social Determinants of Health (2008). Closing the gap in a generation: health equity throught action on social determinants of health. Final report of the Commission on Social Determinants of Health. Geneva: World Health Organisation.

Dannefer, D. (2003). Cumulative advantage/disadvantage and the life course: cross-fertilising age and social science theory. J Gorontol B Psychol Sci Soc Sci. Vol. 58, No. 6, str. S327 - 337.

European Innovation Partnership on Active and Healthy Ageing. (2014). Prevention and early diagnosis of frailty and functional decline, both physically and cognitive, in older people. European Commission.

Garcia-Garcia, F. J., Gutierrez Avila, G., Alfaro-Acha, A., et al. (2011). Toledo Study Group. The prevalence of frailty syndrome in an older population from Spain. The Toledo Study for Healthy Aging. J Nutr Health Aging. Vol. 15, str. 852 - 856. 
$36^{\text {Th }}$ International Conference on Organizational Science Development: Responsible Organization (MARCh $22^{\mathrm{ND}}-24^{\mathrm{TH}}$, Portorož Slovenia)

B. Gabrovec \& M. Jelenc: Management of Frailty at Individual Level - a Need for a Comprehensive Multidisciplinary Approach

Gill, T. M., Gahbauer, E. A., Han, L., et al. (2010). Trajectories of disability in the last year of life. N Engl J Med. Vol. 362, str. 1173 - 1180.

Lloyd-Sherlock, P., McKnee, M., Ebrahim, S., Gorman, M., Greengross, S., Prince, M., et al. (2012). Population ageing and health. Lancet. Vol. 379, No. 9823, str. 1295 - 1296.

Narici, M. V., Reeves, N. D., Morse, C. I., Maganaris, C. N. (2004). Muscular adaptations to resistance exercise in the elderly. J Musculoskel Interact. Vol. 4, No. 2, str. $161-164$.

Rodríguez-Artalejo, F., Rodríguez-Mañas, L. (2014). The frailty syndrome in the public health agenda. J Epidemiol Community Health. Vol. 68, str. 703 - 704.

Smith, A. (2010). Grand challenges of our aging society: workshop summary. National Academies Press. Washington (DC).

Steves, C. J., Spector, T. D., Jackson, S.H. (2012). Ageing, genes, environment and epigenetics: what twin studies tell us now, and in the future. Age Aging. Vol. 41, No. 5, str. $581-586$.

The Action Group on Frailty Story, 2012-2014. (2015). European Commission.

World economic and social survey 2007. (2007). Development in an aging world. New York: United Nations.

Dostopno

na:

http://www.un.org/en/development/desa/policy/wess/wess_archive/2007wess.pdf .

World report on ageing and health. (2015). World health Organisation. Geneva, Switzerland. 


\title{
Nasilje nad zaposlenimi $\mathbf{v}$ zdravstveni negi in preventivni organizacijski ukrepi
}

\author{
BRANKO GABROVEC \& MARJETKA JELENC
}

\begin{abstract}
Povzetek Predstavljamo rezultate 5 raziskav o nasilju nad zaposlenimi v zdravstveni negi. $\mathrm{V}$ raziskavo smo vključili zaposlene na področju psihiatrije, domov starejših občanov, reševalnih služb, patronaže in Centrov za zdravljenje odvisnosti. Raziskave smo izvedli z neeksperimentalno vzorčno metodo raziskovanja. Inštrument raziskave je bil strukturiran anketni vprašalnik. Raziskave smo izvedli v letih 2013 do 2016. Ugotovili smo visoko izpostavljenost zaposlenih nasilju na delovnem mestu s strani pacientov. V največji meri so izpostavljeni verbalnemu nasilju, pogosto tudi fizičnemu in spolnemu nasilju. Največji odstotek zasledimo pri zaposlenih v psihiatrični zdravstveni negi. Med raziskanimi področji je na delovnem mestu pogosto tudi lateralno nasilje. Raziskava identificira problematiko zagotavljanja varnosti in kakovosti obravnave na področju izbruha agresije. Usmerjena je na področje, ki ga sedanja regulativa in delovna praksa ne pokrivata. Raziskave na področju zdravstvene nege in ostalih deležnikov, ki prihajajo v stik s agresivnim pacientom, do sedaj niso zajemale širšega kroga deležnikov, niti obravnavale potrebo po nastanku dodatnega funkcionalnega izobraževanja. Primer organizacijskega modela zagotavljanja varnosti in kakovosti obravnave ob agresiji pacienta nam s preliminarnimi rezulati prikazuje svojo uspešnost.
\end{abstract}

KLJUČNE BESEDE: zdravstvena nega - agresija • nasilje • varnost • kakovost obravnave

NASLOV AVTORJEV: Branko Gabrovec, Nacionalni inštitut za javno zdravje, Trubarjeva 2, 1000 Ljubljana, Slovenija, e-pošta: branko.gabrovec@nijz.si; Marjetka Jelenc, Nacionalni inštitut za javno zdravje, Trubarjeva 2, 1000 Ljubljana, Slovenija, e-pošta: marjetka.jelenc@nijz.si 
36 ${ }^{\text {TH }}$ International Conference on Organizational Science DeVelopment: Responsible ORganization (MARCH $22^{\mathrm{ND}}-24^{\mathrm{TH}}$, PORTOROŽ SLOVENIA)

O. Arsenijević, M. Ferjan, I. Podbregar, P. Šprajc, D. Trivan \& Y.

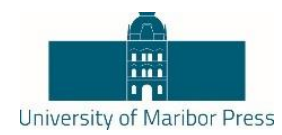

Ziegler

\title{
Violence Against Employees in Nursing Care and Preventive Organisational Measures
}

\author{
BRANKO GABROVEC \& MARJETKA JELENC
}

\begin{abstract}
Results of 5 researches on violence on employees in nursing care are presented. In this research we have included nursing employees in psychiatric nursing care, homes for the elderly, paramedic services, community nursing and drug addiction rehabilitation Centres. Researches were carried out by means of quantitative, non-experimental research, with a questionnaire being used as the method for gathering data. Researches were carried out from 2013 to 2016 . We have found a high exposure to violence of employees in nursing care from patients. In the greater extend they are exposed to verbal violence, often also to physical violence and sexual harassment. The highest prevalence can be observed at psychiatric nursing care. In the researched fields we have also found a lateral violence in community nursing. Research identifies issues of assuring safety and quality of treatment in the field of aggression. It is directed to the field that is not covered yet by present regulative or work practice. Researches in the field of nursing care, which deal with aggressive patient, have not yet included wider circle of stakeholders or discuss the need of additional functional training for employees. An example of organisational model on safety and quality assurance of patient's aggressive behaviour shows us preliminary results that confirm successful rate of the model.
\end{abstract}

Keywords: nursing care $\bullet$ aggression $\bullet$ violence $\bullet$ quality of treatment

CoRRESPONDENCE AdDRESS: Branko Gabrovec, National Institute of Public Health, Trubarjeva 2, 1000 Ljubljana, Slovenia, e-mail: branko.gabrovec@ nijz.si; Marjetka Jelenc, National Institute of Public Health, Trubarjeva 2, 1000 Ljubljana, Slovenia, e-mail:marjetka.jelenc@nijz.si 
36. MEDNARODNA KONFERENCA O RAZVOJU ORGANIZACIJSKIH ZNANOSTI: ODGOVORNA 179 ORGANIZACIJA (22. - 24. MAREC 2017, PORTOROŽ, SLOVENIJA)

B. Gabrovec \& M. Jelenc: Nasilje nad zaposlenimi v zdravstveni negi in preventivni organizacijski ukrepi

\section{$1 \quad$ Nasilje nad zaposlenimi $\mathrm{v}$ zdravstvenem varstvu}

Zdravstveni delavci se soočajo s številnimi zdravstvenimi tveganji med opravljanjem zdravstvene dejavnosti posameznikom ali skupnosti (Ozturk \& Babacan, 2014). Raziskave kažejo, da se medicinske sestre pogosteje soočajo z nasiljem na delovnem mestu, kot drugi profili v zdravstvenem varstvu. Najbolj izspostavljeni so zdravstveni delavci $\mathrm{v}$ urgentnih službah, še posebej $\mathrm{v}$ zaprtih in intenzivnih psihiatričnih enotah (Clerk, 1989 in Kiran, 2003). Tudi (Van Leeuwen \& Harte, 2011) menita, da je število resnih incidentov povezanih $\mathrm{z}$ agresijo visoko.

Clements in sodelavci (2005) ugotavljajo, da se zdravstveni delavci (še posebej zaposleni v zdravstveni negi) pogosto soočajo z nasiljem pacientov. Kar $35-80 \%$ zdravstvenih delavcev se je vsaj enkrat soočilo $\mathrm{z}$ fizičnem nasiljem na delovnem mestu, od tega je bila skupina zaposlenih v zdravstveni negi najbolj izpostavljena (Clements, et al., 2005). V Švedski raziskavi (Soares, 2000) avtor ugotavlja, da je bila večina sodelujočih v raziskavi $(85 \%)$ v svoji karieri izpostavljena nasilju, od tega $57 \%$ v zadnjem letu. Izsledki Švicarske raziskave (Hahn, et al., 2010) kažejo, da je $72 \%$ medicinskih sester doživelo verbalno nasilje s strani pacientov in obiskovalcev, $42 \%$ jih je doživelo fizično nasilje v zadnjem letu. Zeller in sodelavci (2009) ugotavljajo tudi pogostost nasilja nad zaposlenimi v zdravstveni negi v domovih starejših občanov. Enako tudi Franz in sodelavci (2010), ugotavljajo, da je bilo kar 83,9 \% zaposlenih v zdravstveni negi izpostavljenih fizičnemu nasilju. Najvišjo stopnjo nasilja nad zaposlenimi v Združenih državah Amerike ugotavljajo pri zdravstvenih asistentih, ki so zaposleni na področju dolgotrajne oskrbe (Gates, et al., 2005).

Pomembni so podatki o nasilnem vedenju pacientov v psihiatričnih bolnišnicah, zlasti na zaprtih oddelkih, ki se gibljejo od 3,9 \% pa vse do 37 \% v različnih delih sveta (v Sloveniji med 6 in $7 \%$ ). Ob nasilnem vedenju na psihiatričnih oddelkih je največ poškodovanih med osebjem, kar opozarja na potrebo po ustreznem znanju vsega psihiatričnega osebja o pravočasnem prepoznavanju in preprečevanju nasilnega vedenja pri psihiatričnih pacientih (Groleger v Pregelj \& Kobentar, 2009). Da je malo narejeno za varnost zdravstvenih delavcev pred vse pogostejšim nasiljem bolnikov nad osebjem, meni tudi Čebašek Travnikova (2009).

Navkljub visokemu odstotku je število verjetno še višje zaradi pogostega neporočanja incidentov (Gates, et al., 2011). Podobno meni tudi Stokowski (2010), ki pravi, da do 70 $\%$ incidentov in zlorab nad medicinskimi sestrami ostane neporočanih.

\section{Metoda}

Raziskave smo izvedli z neeksperimentalno vzorčno metodo raziskovanja. Inštrument raziskave je bil strukturiran anketni vprašalnik. Raziskave smo izvedli v letih 2013 do 2016 (Gabrovec \& Lobnikar, 2014; Gabrovec, Eržen \& Lobnikar, 2014; Gabrovec, 2015; Gabrovec \& Lobnikar, 2015; Gabrovec \& Eržen, 2016). Podatki so bili analizirani z opisno statistiko, korelacijo, Kolmogorov-Smirnovim testom, Pearsonovim $\chi^{2}$ testom, 
$36^{\text {Th }}$ International Conference on Organizational Science Development: ResPonsible ORGaNizATION (MARCH $22^{\mathrm{ND}}-24^{\mathrm{TH}}$, PortoroŽ Slovenia)

B. Gabrovec \& M. Jelenc: Violence Against Employees in Nursing Care and Preventive Organisational Measures

Mann-Whitney U testom in linearno regresijo s $\mathrm{p}<0,05$ stopnjo značilnosti. Za statistično analizo smo uporabili programa SPSS v. 21 in Amos. V posameznih raziskavah smo zabeležili naslednji vzorec zaposlenih v zdravstveni negi: psihiatrija $(\mathrm{N}=303)$, domovi starejših občanov $(\mathrm{N}=527)$, reševalne službe $(\mathrm{N}=246)$, patronaža $(\mathrm{N}=337)$ in Centri za zdravljenje odvisnosti $(\mathrm{N}=42)$.

Rezulati

Vrste in pogostost nasilja nad zaposlenimi na različnih področjih zdravstvene nege prikazujemo v Sliki 1. Na področju zdravstvene nege intenzivnih psihiatričnih oddelkov smo ugotovili (Gabrovec, Eržen \& Lobnikar, 2014; Gabrovec \& Lobnikar 2015), da je $92,6 \%$ anketiranih zaposlenih $\mathrm{v}$ zadnjem letu doživelo verbalno agresijo s strani bolnika. Fizično nasilje je s strani bolnikov v zadnjem letu doživelo 84,2\% anketiranih. Kar 63,5\% zaposlenih je bilo v preteklosti celo poškodovanih s strani bolnika. Zelo pogosto je tudi verbalno nasilje svojcev, kar 40,9\%. Omembe vredno je tudi verbalno nasilje sodelavcev $(13,3 \%)$ in nadrejenih $(13,8 \%)$. Zaposleni se soočajo tudi s spolnim nasiljem s strani bolnikov $(24,6 \%)$. Ugotovili smo pomembne pozitivne korelacije med verbalnim nasiljem, fizičnem nasiljem in spolnim nadlegovanjem. Zaposleni se pri svojem delu počutijo ogrožene $(2,52 \pm 0,62)$, v veliki meri sta prisotna strah $(2,49 \pm 0,60)$ in negotovost $(2,36 \pm 0,69)$. Razumevanje sodelavcev je veliko $(1,34 \pm 0,57)$, nekoliko manjše je razumevanje nadrejenih $(1,74 \pm 0,73)$. Raziskava kaže tudi na to, da ni povezave med starostjo, spolom, delovno dobo in izobrazbo.

\begin{tabular}{|c|c|c|c|c|c|}
\hline & Psihiatrija & DSO & $\begin{array}{l}\text { Reševalne } \\
\text { službe }\end{array}$ & Patronaža & MTD \\
\hline $\mathrm{N}$ & 303 & 527 & 246 & 337 & 42 \\
\hline Verbalno nasilje & $92,6 \%$ & $71,7 \%$ & $78 \%$ & $56,1 \%$ & $85,7 \%$ \\
\hline Fizično nasilje & $84,2 \%$ & $63,8 \%$ & $49,6 \%$ & $3,5 \%$ & $28,6 \%$ \\
\hline Poskkodoba & $63,5 \%$ & $36,8 \%$ & $26,8 \%$ & $3,5 \%$ & $9,5 \%$ \\
\hline $\begin{array}{l}\text { Spolno } \\
\text { nadlegovanje }\end{array}$ & $24,6 \%$ & $35,5 \%$ & $24,4 \%$ & $30 \%$ & $7,1 \%$ \\
\hline NIJZ & & & & & \\
\hline
\end{tabular}

Slika 1: Vrste in odstotek nasilja nad zaposlenimi v zdravstveni negi. Povzeto po: (Gabrovec \& Lobnikar, 2014; Gabrovec, Eržen \& Lobnikar, 2014; Gabrovec, 2015; Gabrovec \& Lobnikar, 2015; Gabrovec \& Eržen, 2016). 
$\mathrm{V}$ zdravstveni negi reševalnih služb je verbalno nasilje s strani pacienta $\mathrm{v}$ zadnjem letu doživelo 78,0 \% vseh anketiranih. 49,6 \% jih je v zadnjem letu doživelo fizično nasilje. Poškodovanih s strani pacienta v svoji karieri je bilo $26,8 \%$. Spolno nadlegovanje je s strani pacienta $\mathrm{v}$ zadnjem letu doživelo $24,4 \%$ anketiranih. Ugotovili smo povezanost med soočanjem in doživljanjem strahu $(p=0,017)$, med fizičnim nasiljem in doživljanjem ogroženosti $(p=0,005)$, ter med doživljanjem fizičnega nasilja s strani pacienta in pomanjkanjem znanja za obvladovanje agresivnega pacienta $(p=0,012)$ (Gabrovec, 2015).

Na področju zdravstvene nege $\mathrm{v}$ domovih starejših občanov je raziskava pokazala, da so zaposleni $v$ zdravstveni negi $\mathrm{v}$ domovih za starešje $\mathrm{v}$ nevarnosti glede možnosti pojava nasilja. V zadnjem letu so se zaposleni največkrat soočili z verbalnim nasiljem $(71,7 \%)$, fizičnim nasiljem $(63,8 \%)$, in spolnim nasiljem $(35,5 \%)$. Kar $35,5 \%$ je bilo poškodovanih. Med izbruhom agresije se zaposleni soočajo z ranljivostjo, strahom in negotovostjo (Gabrovec \& Eržen, 2016).

V patronažni zdravstveni negi je 56,1 \% zaposlenih v zadnjem letu doživelo verbalno agresijo s strani pacientov. Veliko je tudi vertikalnega in horizontalnega nasilja na delovnem mestu (42,1 \%). 29,8 \% jih je odgovorilo, da so v zadnjem letu doživeli spolno nadlegovanje s strani pacienta. $7 \%$ jih je doživelo spolno nadlegovanje s strani sodelavcev ali nadrejenih. Kljub temu se zaposleni počutijo dokaj varne na delovnem mestu (3,8, std. dev.:0,64; na lestvici od 1 do 5$)$. Ko se zaposleni soočajo z agresijo pri pacientu imajo največkrat občutke negotovosti $(3,80)$, strahu $(3,78)$, nemoči $(3,48)$, pa tudi občutke neempatije s strani nadrejenih (2.49) in neempatije s strani sodelavcev (2.25).

Zaposleni v zdravstveni negi Centrov za zdravljenje odvisnosti so se v zadnjem letu največkrat srečali z verbalno agresijo (85,7 \%), fizičnim nasiljem $(28,6 \%), 7,1 \%$ jih je doživelo spolno nadlegovanje.

\section{Organizacijski model zagotavljanja varnosti in kakovosti $v$ primerih agresivnega izbruha pacienta}

Organizacijski model obravnave agresije celostno zajema obvladovanje agresije pri psihiatričnem bolniku. Postavlja teoretične okvirje obvladovanja in praktične tehnike pri uporabi posebnih varovalnih ukrepov (PVU) in fizičnega oviranja. Organizacijski model je podlaga funkcionalnega izobraževanja, ki temelji predvsem na praktičnem izobraževanju.

Le manjši del zdravstvenega osebja (medicinske sestre, zdravstveni tehniki, zdravniki, klinični psihologi) zaznava svoje delo kot nevarno. Žrtve nasilnega vedenja psihiatričnih bolnikov so najpogosteje medicinske sestre in zdravstveni tehniki, predvsem ob sprejemu v bolnišnico proti volji, ob prisilnem zadrževanju oziroma oviranju in ob aplikaciji zdravil. Sodelujoči menijo, da bi potrebovali več usposabljanja s področja samoobrambe, dodatne kompetentne sodelavce, predvsem moškega spola, treninge komunikacije in 
$36^{\mathrm{TH}}$ International Conference ON ORganizational Science Development: RESPONSIBLE ORGANIZATION (MARCH $22^{\mathrm{ND}}-24^{\mathrm{TH}}$, PORTOROŽ SLOVENIA)

B. Gabrovec \& M. Jelenc: Violence Against Employees in Nursing Care and Preventive Organisational Measures

boljše sodelovanje znotraj kolektiva. Poleg tega so mnenja, da bi zdravstveni delavci, ki so žrtve nasilnega vedenja bolnika, bili deležni sistematične pomoči. Občasno pri nasilnih dogodkih intervenira tudi varnostna služba, ki pa za tovrstne intervencije ni usposobljena, zato bi bilo potrebno organizirati posebna usposabljanja zanje (Mrevlje \&Umek, 2011). Potrebo po sistematičnem izobraževanju navajata že Poster in Ryan (1993). Ugotavljata, da bi moralo biti vse zdravstveno osebje primerno usposobljeno in trenirano za prevencijo in obvladovanje nasilnega vedenja, komunikacijo in včasih uporabo fizične sile (Poster \& Ryan, 1993).

Zdravstveni delavci potrebujejo sistematično in kontinuirano izobraževanje obvladovanja agresivnih situacij (praktični del) in izdelavo splošnih ali internih smernic obvladovanja. Izdelava smernic mora vključevati sodelovanje psihiatrične stroke in splošnih borilnih prijemov ter načel, kar je pomembno za ohranjanje terapevtskega odnosa s pacientom. Smernice naj kot splošni ali interni dokument zajemajo vse vidike fizičnega oviranja, spremstva, aplikacije terapije, samoobrambnih prijemov in fiksacije. Navodila fizičnega oviranja služijo kot enotno izhodišče ukrepanj za vse osebje in postopke ter osnovno izhodiščno točko fizičnega oviranja. Izdelava smernic in kontinuirano strokovno izobraževanje prinaša zdravstvenim delavcem samozavest in znanje obvladovanja agresivnih situacij ter posledično bolj uspešno in varno obvladovanje nastalih situacij (Gabrovec, 2009).

Podlage za organizacijski model zagotavljanja varnosti pred agresivnimi psihiatričnimi bolniki so Zakon o duševnem zdravju (Uradni list Republike Slovenije št. 77/2008), Priporočila in smernice za uporabo posebnih ukrepov v psihiatriji (Dernovšek \& Novak, 2001) ter Protokol fizičnega oviranja s pasovi pacientov v bolnišnicah.

Organizacijski model zagotavljanja varnosti smo razdelili na naslednje sklope:

- Ocena stanja in prepoznavanje dejavnikov, ki povečujejo tveganje za agresivno vedenje;

- Uporaba vedenjsko kognitivnih in deeskalacijskih tehnik;

- Uporaba posebnega varovalnega ukrepa;

- Uporaba prilagojenih tehnik fizičnega oviranja za obvladovanje agresivnosti;

- Ukrepi po izbruhu agresivnosti;

- Izobraževanje z modelom funkcionalnega usposabljanja.

\subsection{Ocena uspešnosti modela}

V letih 2010 - 2013 smo izvajali pilotski projekt funkcionalnega izobraževanja v različnih psihiatričnih bolnišnicah, oddelkih, psihiatričnih domovih in CUDV. Izobraževanje je bilo v obliki delavnic usmerjeno predvsem praktično delo prilagojenih tehnik fizičnega oviranja za obvladovanje agresivnega vedenja. Uspešnost modela smo merili tako, da so anketirani $\mathrm{v}$ raziskavi navedli s katerimi čustvi in stanji se soočajo pri agresivnem psihiatričnem bolniku in kako so se ta čustva in stanja spremenila po izobraževanju. 
B. Gabrovec \& M. Jelenc: Nasilje nad zaposlenimi v zdravstveni negi in preventivni organizacijski ukrepi

V preglednici 1 navajamo nekatere kompetence in stanja, ki jih zaposleni doživljajo pri obravnavi agresivnega psihiatričnega bolnika (na lestvici od 1 do 3 ).

Preglednica 1: Pri obravnavi psihiatričnega bolnika se zdravstveni delavci soočamo $s / z$ :

\begin{tabular}{|l|c|c|c|c|c|}
\cline { 2 - 6 } \multicolumn{1}{c|}{} & $\mathrm{N}$ & Min & Max & $\begin{array}{c}\text { Srednja } \\
\text { vrednost }\end{array}$ & Std. odklon \\
\hline Strahom & 303 & 1,00 & 3,00 & 2,3927 &, 67172 \\
Negotovostjo & 303 & 1,00 & 3,00 & 2,3267 &, 70159 \\
Nemočjo & 303 & 1,00 & 3,00 & 2,0198 &, 70917 \\
Neznanjem & 303 & 1,00 & 3,00 & 1,6898 &, 73430 \\
Jezo & 303 & 1,00 & 3,00 & 1,6601 &, 70473 \\
Obupanostjo & 303 & 1,00 & 3,00 & 1,7360 &, 82766 \\
Ogroženostjo & 303 & 1,00 & 3,00 & 2,4290 &, 66667 \\
Nerazumevanjem & 303 & 1,00 & 3,00 & 1,4257 &, 60920 \\
sodelavcev & & & & &, 74692 \\
Nerazumevanjem & 303 & 1,00 & 3,00 & 1,7888 & \\
nadrejenih & & & & \\
Veljavni N & 303 & & & & \\
\hline
\end{tabular}

Anketirani so $\mathrm{v}$ največji meri soočajo s/z: ogroženostjo $(2,42)$, strahom $(2,39)$, negotovostjo $(2,32)$, nemočjo $(2,01)$, nerazumevanjem nadrejenih $(1,78)$, obupanostjo $(1,73)$, neznanjem $(1,68)$, jezo $(1,66)$, najmanj pa $z$ nerazumevanjem sodelavcev $(1,42)$. Od 303 anketiranih zaposlenih se je funkcionalnega izobraževanja udeležilo 182 oseb. Koliko so se njihove kompetence in stanja spremenila po izvedenem usposabljanju prikazujemo v preglednici 2. 
$36^{\mathrm{TH}}$ InTERnATIONAL CONFERENCE ON ORganizational SCIENCE DeVElopment: ReSPONSIBLE ORGaNiZATION (MARCH $22^{\mathrm{ND}}-24^{\mathrm{TH}}$, PortoroŽ Slovenia)

B. Gabrovec \& M. Jelenc: Violence Against Employees in Nursing Care and Preventive Organisational Measures

Preglednica 2: Identifikacija kompetenc in stanj pridobljenih z izobraževanjem

\begin{tabular}{|l|c|c|c|c|c|}
\cline { 2 - 6 } \multicolumn{1}{c|}{} & $\mathrm{N}$ & Min & Max & $\begin{array}{c}\text { Srednja } \\
\text { vrednost }\end{array}$ & Std. odklon \\
\hline Organiziranost & 182 & 1,00 & 3,00 & 2,6868 &, 54188 \\
Strokovnost & 182 & 1,00 & 3,00 & 2,7857 &, 43749 \\
Odločnost & 182 & 1,00 & 3,00 & 2,7473 &, 48385 \\
Proaktivnost & 182 & 1,00 & 3,00 & 2,6374 &, 49341 \\
Samozaupanje & 182 & 1,00 & 3,00 & 2,6758 &, 51429 \\
Strah & 182 & 1,00 & 3,00 & 2,1154 &, 73799 \\
Nemoč & 182 & 1,00 & 3,00 & 2,2802 &, 70792 \\
Negotovost & 182 & 1,00 & 3,00 & 2,4890 &, 66265 \\
Neznanje & 183 & 1,00 & 3,00 & 2,5792 &, 66548 \\
Veljavni N & 182 & & & & \\
\hline
\end{tabular}

Anketirani navajajo, da so se vse predlagane trditve po izobraževanju pri njih izboljšale. Ocenili so, da so se pri njih na bolje najbolj spremenile naslednje trditve: »Strokovnost« $(2,78)$, , Odločnost« $(2,74)$ in »Organiziranost« $(2,68)$. Najslabše so ocenili naslednji trditvi: »Strah« $(2,11)$ in »Nemoč« $(2,28)$. Ostale trditve so ocenili: »Samozaupanje« $(2,67)$, »Proaktivnost« $(2,63)$, »Neznanje« $(2,57)$ in »Negotovost« $(2,48)$. Najbolje ocenjena trditev »Strokovnost « kaže na visoko dodano vrednost izobraževanja, najslabše ocenjena, »Strah« pa na to, da bi bilo dobro v predlagan organizacijski model izobraževanja vključiti še temo obvladovanja strahu. Spremenljivko »strah«smo prevelili tudi z uporabo Wilcoxon Signed-rank testa, ki je potrdil, da pri večini anketiranih ni prišlo do statistično značilnih razlik v obdobju pred in v obdobju po izobraževanju.

\section{$5 \quad$ Razprava}

Rezultati vseh raziskav kažejo na visoko izpostavljenost nasilju zaposlenih v zdravstveni negi. Zaposleni s strani pacientov najpogosteje doživljajo verbalno nasilje, pogosto tudi fizično nasilje in spolno nadlegovanje. Odstotki nasilja so še posebej visoki v psihiatrični zdravstveni negi, $v$ domovih starejših občanov in patronaži. Zaskrbljujoč je tudi odstotek horizontalnega in lateralnega nasilja (tudi do $42 \%$ - v patronaži). Ugotovili smo, da nasilje pacientov ne zavisi od spola, starosti ali stopnji izobrazbe v zdravstveni negi, ravno tako, da so vrste nasilja povezane. Verbalno nasilje vodi v fizično, spolno nasilje, ipd. 
36. MEDNARODNA KONFERENCA O RAZVOJU ORGANIZACIJSKIH ZNANOSTI: ODGOVORNA 185 ORGANIZACIJA (22. - 24. MAREC 2017, PORTOROŽ, SLOVENIJA)

B. Gabrovec \& M. Jelenc: Nasilje nad zaposlenimi v zdravstveni negi in preventivni organizacijski ukrepi

Raziskave kažejo na to, da obstaja potreba po širšem pristopu obvladovanja nasilja na delovnem mestu. Nekatere psihiatrične ustanove so že uspešno izvedle nekatere ukrepe na tem področju, kar dokazuje zmanjšanje števila agresivnih izbruhov. Primer organizacijskega modela zagotavljanja varnosti in kakovosti obravnave ob agresiji pacienta nam s preliminarnimi rezulati prikazuje svojo uspešnost.

\section{Literatura}

Clements, P.T., DeRanieri, J.T., Clark, K., Manno, M.S. \& Kuhn, D.W. (2005). Workplace violence and corporate policy for health care settings. Nursing Economics. Vol. 23, No. 3, str. $119-124$.

Clerk, J.M. (1989). Introduction to working conditions and environment. 2nd ed. Geneva. International Labour Office.

Čebašek - Travnik, Z. (2009). Zdravniki kot žrtve nasilja. Družinska medicina, 7(6). Dostopno na: http://www.drmed.org/javne_datoteke/novice/datoteke/774-II.cZdrav \%8Devic2009.pdf

Dernovšek, M. \& Novak, G.V. (2001). Priporočila in smernice za uporabo posebnih ukrepov v psihiatriji. Ljubljana: Viceversa - priročnik.

Franz, S., Zeh, A., Schablon, A., Kuhnert, S. \& Nienhaus, A. (2010). Agression and violence against health care workers in Germany - a cross sectional retrospective survey. BMC Health Services Research. Vol. 10, str. 51.

Gabrovec, B. (2009). Nasilno vedenje v duhu novih praks: smernice fizičnega oviranja Ljubljana: Zbornica zdravstvene in babiške nege - Zveza strokovnih društev medicinskih sester, babic in zdravstvenih tehnikov Slovenije, Sekcija medicinskih sester in zdravstvenih tehnikov v psihiatriji.

Gabrovec, B., \& Lobnikar B. (2014). Organizational model of ensuring safety and quality of treatment of aggressive psychiatric patients in mental health nursing in Slovenia = Organizacijski model zagotavljanja varnosti in kakovosti obravnave agresije pri pacientu z duševno motnjo v zdravstveni negi na področju psihiatrije v Sloveniji. Obzornik zdravstvene nege. Vol. 44, No. 4, str. 286 - 293.

Gabrovec, B., Eržen I. \& Lobnikar B. (2014). The prevalence and the nature of violence directed at the medical staff in psychiatric health care in Slovenia. HealthMed. Vol. 8, No. 2, str. 228 234.

Gabrovec, B. (2015). The prevalence of violence directed at paramedic services personnel = Prevalenca nasilja nad zaposlenimi v reševalnih službah. Obzornik zdravstvene nege. Vol. 49, No. 4, str. 284 - 294.

Gabrovec, B., \& Lobnikar B. (2015). The analysis of the role of an institution in providing safety and quality in psychiatric health care. Anadolu psikiyatri dergisi. Vol. 16, No. 6, str. 420 - 425.

Gabrovec, B., \& Eržen I. (2016). Prevalence of violence towards nursing staff in Slovenian nursing homes $=$ Prevalenca nasilja nad zaposlenimi $\mathrm{v}$ zdravstveni negi $\mathrm{v}$ domovih starejših občanov. Zdravstveno varstvo. Vol. 55, No. 3, str. 212 - 217.

Gates, D.M, Gillespie, G.L. \& Succop, P. (2011). Violence against nurses and its impact on stress and productivity. Nursing Economics. Vol. 29, No. 2, str. 59 - 67.

Gates, D., Fitzwater, E. \& Succop, P. (2005). Reducing assaults against nursing home caregivers. Nursing Research. Vol. 54, No. 2, str. 119 - 127.

Groleger, U. (2009). Agresivnost. V P. Pregelj, \& R. Kobentar (Ur.), Zdravstvena nega in zdravljenje motenj $v$ duševnem zdravju. Ljubljana: Rokus Klett.

Hahn, S., Müller, M., Needham, I., Dassen, T., Kok, G. \& Halfens, R.J. (2010). Factors associated with patient and visitors violence experienced by nurses in general hospitals in Switzerland: a cross-sectional survey. Journal of Clinical Nursing. Vol. 19, No. 23-24, str. 3535 - 3546. 
$36^{\text {Th }}$ International Conference on Organizational Science Development: Responsible Organization (MARCH $22^{\mathrm{ND}}-24^{\mathrm{TH}}$, PortoroŽ SLOVENIA)

B. Gabrovec \& M. Jelenc: Violence Against Employees in Nursing Care and Preventive Organisational Measures

Kiran, S. (2003). The evaluation of occupational factors levels and relation with expose disease in health workers. Izmir: Dokuz Eylul Univ.

Mrevlje, P. T. \& Umek, P. (2011). Safety Issues in Psychiatric Settings. Varstvoslovje, Journal of Criminar Justice and Security. Vol. 13, No. 4, str. 431 - 443.

Poster, E., \& Ryan, J. (1993). At risk of assault. Nursing Times. Vol. 23, str. 30 - 33.

Van Leeuwen, M. E, Harte, J. M. (2011). Violence against care workers in psychiatry: Is prosecution justified? International journal of law and psychiatry. Vol. 35, No. 5, str. 317 323.

Ozturk, H.\& Babacan, E. (2014). The occupational safety of health professionals working at community and family health centers. Iranian Red Crescent Medical Journal. Vol. 16, No. 10, e16319.

Soares, J. J. F., Lawoko, S. \& Nolan, P. (2000). The nature, extent and determinants of violence against psychiatric personnel. Work and Stress. Vol. 14, No. 2, str. 105 - 120.

Stokowski, L. A. (2010). Violence: not in my job description. Workplace Violence in Healthcare Settings. Dostopno na: http://www.medscape.com/viewarticle/727144 .

Zakon o duševnem zdravju. (2008). Uradni list Republike Slovenije št. 77/2008.

Zeller, A., Hahn, S., Needham, I., Kok, G., Dassen, T. \& Halfens, R.J.G. (2009). Aggressive behavior of nursing home residents toward caregivers: a systematic literature review. Geriatric Nursing. Vol. 30, No. 3, str. 174 - 187. 
36. MEDNARODNA KONFERENCA O RAZVOJU ORGANIZACIJSKIH ZNANOSTI: ODGOVORNA ORGANIZACIJA (22. - 24. MAREC 2017, PORTOROŽ, SLOVENIJA)

O. Arsenijević, M. Ferjan, I. Podbregar, P. Šprajc, D. Trivan \& Y. Ziegler

\title{
Davek od dohodka ter odloženi davki in njihov vpliv na računovodske izkaze v Sloveniji, Hrvaški, BIH in Srbiji
}

\author{
RENATA GABRŠEK
}

Povzetek Davčne bilance se v večini primerov razlikujejo od poslovnih bilanc. Namen raziskave je bil predstaviti razlike $\mathrm{v}$ davčni obveznosti, odloženih davkih in rezultatu poslovanja podjetij v različnih državah. Narejena je bila simulacija izračunov poslovnih in davčnih bilanc za štiri države. Izhodišče so bili enaki prihodki, stroški in odhodki. Nato se je dodal vpliv lokalnih zakonov in računovodskih standardov, ki so vplivali na različne višine davka od dohodka, odloženih davkov ter dobička ali izgube.

V raziskavo smo vključili države, ki se med seboj razlikujejo po svojih zakonih o davku od dobička, vse pa imajo v svoje lokalne računovodske standarde vključene mednarodne standarde računovodskega poročanja. $\mathrm{V}$ raziskavo smo vključili Slovenijo, Hrvaško, Federacija Bosne in Hercegovine ter Srbija.

Raziskava je pokazala, da najmanj davka plačujejo podjetja v BIH, največ pa v Hrvaški. Najdaljši rok za plačilo davka imajo v Srbiji, v Sloveniji pa so najboljši pogoji za koriščenje davčne izgube iz preteklih let.

KLJUČNE BESEDE: davek od dohodka • računovodski izkazi • odloženi davek $\bullet$ zakoni $\bullet$ računovodski standardi

NASLOV AVtORJEv: Renata Gabršek, Kapitalska družba, d. d., Dunajska cesta 119, 1000 Ljubljana, Slovenija, e-pošta: renata.gabrsek@ telemach.net

DOI https://doi.org/10.18690/978-961-286-020-2.18

ISBN 978-961-286-020-2

(C) 2017 Univerzitetna založba Univerze v Mariboru

Dostopno na: http://press.um.si 
$36^{\mathrm{TH}}$ International Conference on Organizational Science Development: Responsible Organization (MARCH $22^{\mathrm{ND}}-24^{\mathrm{TH}}$, PORTOROŽ SLOVENIA)

O. Arsenijević, M. Ferjan, I. Podbregar, P. Šprajc, D. Trivan \& Y. Ziegler

\title{
Income Tax, Deferred Tax and Their Impact on the Financial Statements in Slovenia, Croatia, BIH and Serbia
}

\author{
RENATA GABRŠEK
}

\begin{abstract}
Tax statements in most cases differ from the financial statements. The purpose of the research was to present the differences in tax liabilities, deferred taxes and results of operations of companies in different countries. The simulation calculations of business balance sheets and tax balance sheets was made for the four countries. The starting point were identical the amounts of revenues, costs and expenses. Then added the impact of local laws and accounting standards, which have an impact on different heights of the income tax, deferred taxes, profit or loss.
\end{abstract}

In study included countries, which differ in their laws on corporation tax, all of them have in their local accounting standards International Financial Reporting Standards and International Accounting Standards. In comparing, were included Slovenia, Croatia, BIH and Serbia.

The research showed that the least tax paying companies in BIH and the more tax paying companies in Croatia. The maximum period for the tax payment are in Serbia, while Slovenia are the best conditions for the benefit tax losses from previous years.

KEYWORDS: income tax $\bullet$ financial statements $\bullet$ deferred tax $\bullet$ laws $\bullet$ accounting standards

CORRESPONDENCE ADDRESS: Renata Gabršek, Kapitalska družba, d. d., Dunajska cesta 119, 1000 Ljubljana, Slovenia, e-mail: renata.gabrsek@telemach.net 


\section{Predstavitev}

Davek od dohodka spada med najpomembnejše davke, ki privabijo ali odvrnejo tuji kapital. Višina davčne stopnje in koriščenje davčnih olajšav v skladu z zakoni, ki urejajo to področje vplivajo na odločitev investitorjev o tem, kam bodo investirali.

V raziskavi smo upoštevali zakonodajo na področju davka od dohodka posamezne države in njihove računovodske standarde, nismo pa raziskovali drugih področij obdavčitve (npr. davek na dodano vrednost, dohodnina itd). Prav tako nas ni zanimala morebitna dvojna obdavčitev med državami iz našega vzorca in sporazumi podpisani za namene odprave dvojne obdavčitve. Zanimalo nas je, kakšen bi bil poslovni rezultat, davek od dohodka in odloženi davki podjetja v vsaki od izbranih držav ob predpostavki enakih prihodkov, odhodkov in stroškov ter upoštevanju zakonodaje in računovodskih standardov posamezne države.

Države, ki smo jih vključili v raziskavo so Slovenija, Hrvaška, Federacija Bosne in Hercegovine ter Srbija. Čeprav Bosno in Hercegovino sestavljata dve avtonomni entiteti in sicer Federacija Bosne in Hercegovine ter Republika Srbska (poleg samoupravnega okrožja Brčko) v nadaljevanju predstavljamo podatke le za Federacijo Bosne in Hercegovine (BIH).

Na primeru vsake od držav so predstavljene razlike med poslovno in davčno bilanco, vpliv različnih stopenj davka na davčno obveznost in čisti poslovni izid ter odloženi davki. V raziskavi smo primerjali stroške amortizacije, stroške rezervacij za dana jamstva ob prodaji proizvodov, stroške reprezentance in davčne izgube.

\section{$2 \quad$ Metoda dela}

Pregledali smo dosedanje raziskave $\mathrm{s}$ področja obdavčevanja $\mathrm{v}$ Sloveniji in tujini. Določili smo, katere države bomo vključili v raziskavo. Nato smo preučili Zakon o davku od dohodka in računovodske standarde za vsako od izbranih držav. Definirali smo višino prihodkov, odhodkov in stroškov, ki so bili v primerjalni metodi enaki. Izračunali smo poslovne in davčne bilance za vsako od držav ob upoštevanju vpliva lokalne zakonodaje in računovodskih standardov na davčno obveznost, odložene davke in poslovni rezultat. $\mathrm{V}$ raziskavi smo predstavili različno obravnavo stroškov amortizacije, stroškov rezervacij, stroškov reprezentance $\mathrm{v}$ vsaki od držav. Na primeru davčne izgube so predstavljene posledice $\mathrm{v}$ odloženih davkih in možnosti koriščenja davčne izgube $\mathrm{v}$ prihodnjem obdobju.

\subsection{Pregled preteklih raziskav}

Na področju davkov, davčnih stopenj, obdavčevanja in poročanja je bilo opravljenih že veliko raziskav. Izvedena je bila primerjava davčnih stopenj med Slovenijo in drugimi državami EU ter primerjalno na države OECD (Pavšič, 2009), raziskava davka od dobička kapitala fizičnih oseb v Sloveniji in Nemčiji (Slatič, 2010), primerjava 
$36^{\mathrm{TH}}$ International Conference on ORganizational Science Development: RESPONSIBLE ORGANIZATION (MARCH $22^{\mathrm{ND}}-24^{\mathrm{TH}}$, PORTOROŽ SLOVENIA)

R. Gabršek: Income Tax, Deferred Tax and Their Impact on the Financial Statements in Slovenia, Croatia, BIH and Serbia

obdavčitve plač v Sloveniji in na Hrvaškem (Talevski, 2010), analiza obdavčitev dobička pravnih oseb v Sloveniji, Švedski, Nemčiji, Angliji, Franciji in Nizozemski (Brajovič, 2009), primerjava obdavčitev dohodka pravnih oseb kneževine Liechenstein v primerjavi z obdavčitvijo v Sloveniji (Valek, 2013) in primerjava davka od dohodka pravnih oseb v Srbiji, BIH in Sloveniji (Zemljak, 2011).

Narejena je bila raziskava, kako davčne spremembe vplivajo na obnašanje davkoplačevalcev (Acuna, 2009), iz poslovnih bilanc leta 2008 je bil ugotovljen vpliv davčne stopnje na obremenitev podjetij (Vargas, 2015), študija opravljena na vzorcu avstralskih in britanskih podjetij je pokazala, da je imela finančna kriza vpliv tudi na terjatve za odložene davke, ki pa so najpogosteje za neizrabljene davčne izgube (Badenhorst in Ferreira, 2016). Ugotavljal se je ekonomski vpliv dobrega imena v računovodskih in davčnih izkazih (Ivancevich et al., 2013) in analiziral odnos med davčnim in računovodskim poročanjem $\mathrm{v}$ Italiji po obvezni uvedbi mednarodnih standardov računovodskega poročanja v letu 2005 (Gavana et al., 2013).

\subsection{Uporaba Mednarodnih standardov računovodskega poročanja in zakonodaja o računovodstvu}

Mednarodni računovodski standard št. 12 (Koželj, 2006) predpisuje računovodsko obravnavanje davka iz dobička. Predpisuje, da se mora davek če še ni plačan pripoznati kot obveznost, če pa plačani znesek preseže odmerjeni davek se pripozna kot terjatev. Standard predpisuje, kako obračunati sedanje in prihodnje posledica davka ter pripoznavanje odloženih terjatev in odloženih obveznosti za davek.

\section{Slovenija}

Po vstopu Slovenije v Evropsko unijo se je število podjetij, ki pripravljajo računovodske izkaze v skladu z Mednarodnimi standardi računovodskega poročanja zelo povečalo. V slovenski pravni red se prenaša Uredba številka 1606 Evropskega parlamenta in Sveta o uporabi mednarodnih računovodskih standardov (Uredba EU, 2002) v skladu z Uredbo Komisije Evropskega parlamenta številka 1126 (Uredba komisije ES, 2008). Uredba določa, da morajo družbe pripraviti konsolidirane računovodske izkaze skladno z Mednarodnimi standardi računovodskega poročanja in Mednarodnimi računovodskimi standardi, če so njihovi vrednostni papirji na datum bilance stanja sprejeti v trgovanje na reguliranem trgu katerekoli države članice Evropske unije.

Zakon o gospodarskih družbah - ZGD-1I, (Uradni list Republike Slovenije, 2015) v 54. členu določa, da morajo tudi banke in zavarovalnice ter druge družbe če tako odloči skupščina (in za dobo najmanj pet let) sestavljati posamične računovodske izkaze v skladu z Mednarodnimi standardi računovodskega poročanja.

Slovenija je zaradi uskladitve lokalnih standardov $\mathrm{z}$ Mednarodnimi standardi računovodskega poročanja $\mathrm{v}$ letu 2006 prenovila Slovenske računovodske standarde SRS 2006 (Uradni list Republike Slovenije, 2005), ki niso smeli biti v nasprotju z 
R. Gabršek: Davek od dohodka ter odloženi davki in njihov vpliv na računovodske izkaze v Sloveniji, Hrvaški, BIH in Srbiji

Mednarodnimi standardi računovodskega poročanja in so veljali do 31. decembra 2015. Od 1. januarja 2016 veljajo novi Slovenski računovodski standardi - SRS 2016 (Uradni list Republike Slovenije, 2015), ki so samostojni standardi in so v celoti usklajeni z Mednarodnimi standardi računovodskega poročanja.

\section{Hrvaška}

Kot ostale države članice Evropske unije je morala tudi Hrvaška najkasneje do 20. julija 2015 v nacionalne računovodske sisteme vključiti odredbo Direktive 2013/34/EU Evropskega parlamenta in sveta z dne 26. julij 2013 (Direktiva EU, 2013). Cilj Direktive je bil vzpostavitev ravnovesja med različnimi interesi uporabnikov računovodskih izkazov. Letni računovodski izkazi morajo resnično in pošteno prikazovati sredstva in obveznosti ter poslovni izid. Hrvaška je v letu 2015 objavila nov Zakon o računovodstvu (Narodne novine, 2015), ter objavila Mednarodne standarde računovodskega poročanja v hrvaškem jeziku.

\section{Bosna in Hercegovina}

V BIH je bila uporaba Mednarodnih računovodskih standardov od leta 2009 predpisana v Zakonu o računovodstvu in reviziji (Zakon o računovodstvu i reviziji, Službene novine Federacije BiH, 2009).

\section{Srbija}

V Srbiji je bil v letu 2013 sprejet Zakon o računovodstvu (Službeni glasnik Republike Srbije, 2013) v katerem je predpisana obvezna uporaba Mednarodnih računovodskih standardov za velika podjetja od 1. januarja 2014 dalje. Za mala in srednja podjetja pa je predpisana uporaba Mednarodnega standarda računovodskega poročanja za mala in srednja podjetja. Srednja podjetja se sama odločijo ali bodo uporabljala celotne Mednarodne standarde računovodskega poročanja ali Mednarodni standard računovodskega poročanja za mala in srednja podjetja.

\subsection{Davek od dohodka}

Države z lokalnimi Zakoni določajo višino davka, ki ga morajo podjetja obračunati in plačati, predpišejo kaj je osnova za davek, kaj zmanjšuje ali povečuje davčno osnovo, določajo priznane in nepriznane stroške in prihodke, določajo olajšave, višino amortizacijskih stopenj za opredmetena in neopredmetena osnovna sredstva, katere rezervacije so ob oblikovanju priznane in v kakšnem procentu, določajo obdobje za koriščenje davčne izgube in vrsto drugih določb.

V Sloveniji je davčna stopnja 17\% (do 31.12.2016) določena v 60. členu Zakona o davku od dohodkov pravnih oseb - ZDDPO-2 (Uradni list Republike Slovenije, 2015). Obdavčeni so dohodki rezidentov, ki imajo vir v Sloveniji in izven Slovenije ter dohodki nerezidentov, ki imajo vir v Sloveniji. Zakon o davčnem postopku - ZDavP-2 (Uradni list 
$36^{\mathrm{TH}}$ International Conference on Organizational Science Development: RESPONSIBLE ORGANIZATION (MARCH $22^{\mathrm{ND}}-24^{\mathrm{TH}}$, PORTOROŽ SLOVENIA)

R. Gabršek: Income Tax, Deferred Tax and Their Impact on the Financial Statements in Slovenia, Croatia, BIH and Serbia

Republike Slovenije, 2015) v 358. členu določa rok za oddajo davčnega obračuna in v 370. členu rok za plačilo. Davčni obračun je potrebno pripraviti v 3 mesecih po zaključku davčnega obdobja in davek plačati v 30 dneh od oddaje davčnega obračuna.

Hrvaška je v 28. členu Zakona o davku od dohodka (Zakon o porezu na dohodak, Narodne novine, 2014) predpisala $20 \%$ obdavčitev podjetij. Obdavčeni so dohodki rezidentov Republike Hrvaške, ki opravljajo dejavnosti in ki ustvarjajo dohodke. V 35. členu Zakona je določen rok za oddajo davčnega obračuna in plačilo davka. Davek od dobička je potrebno plačati v 4 mesecih po zaključenem obdobju.

BIH je 26. februarja 2016 sprejela novi Zakon o davku od dobička (Zakon o porezu na dobit, Službene novine Federacije BiH, 2016), ki v 31. členu predpisuje 10\% obdavčitev. V 49. členu določa rok za oddajo davčne napovedi in v 53. členu rok plačila. Davčni obračun je potrebno oddati $v 30$ dneh po zaključenem obdobju in plačati $v 20$ dneh po oddanem obračunu.

V Srbiji je v Zakonu o davku od dobička (Zakon o porezu na dobit pravnih lica, Službeni glasnik Republike Srbije, 2015) v 39. členu določena 15\% obdavčitev. V 63. členu je določen rok za oddajo davčnega obračuna in plačilo davka. Davčni obračun je potrebno oddati v 180 dneh od izteka obdobja za katerega se poroča in istočasno tudi plačati.

\subsection{Odloženi davki}

Posledice davčnih predpisov so vidne kot razlike med davčnimi in poslovnimi izkazi ter so lahko stalne (trajne) ali začasne. Stalne razlike so tiste, ki so dokončne (davčno nepriznani odhodki ali neobdavčeni prihodki) in ne bodo imele vpliva na prihodnja obdobja ter posledično tudi ne povzročajo odloženih davkov. Začasne razlike pa bodo imele vpliv na prihodnja davčna obdobja in so pomembne za izračunavanje odloženih davkov.

Glede na vpliv na davčni izkaz govorimo o dveh vrstah odloženih davkov. Če odloženi davek predstavlja plačilo davka v prihodnjih obdobjih govorimo o terjatvah za odložene davke, če pa bomo v prihodnih obdobjih morali plačati davek govorimo o obveznostih za odložene davke. V poslovnih izkazih se odloženi davki vedno pripoznajo kot dolgoročni.

\section{$3 \quad$ Raziskava}

\subsection{Amortizacija}

$\mathrm{Z}$ amortizacijo se $\mathrm{v}$ stroške poslovanja razporeja del vrednosti opredmetenih in neopredmetenih osnovnih sredstev. Višina davčno dovoljene stopnje amortizacije je v Sloveniji, Hrvaški in BIH določena v Zakonu o davku od dohodka. V Srbiji pa to področje ureja Pravilnik o načinu razvrščanja stalnih sredstev po skupinah in načinu določanja amortizacije za davčne namene (Pravilnik o načinu razvrstavnja stalnih sredstava po grupama i načinu utvrđivanja amortizacije za poreske svrhe, Službeni glasnik Republike 
Srbije, 2010). V Sloveniji, Hrvaški in BIH je zakonsko predpisana metoda amortiziranja - enakomerno časovno (oziroma proporcionalno). Srbija ima v Pravilniku stalna sredstva razdeljena v pet skupin, za prvo skupino je predpisano proporcionalno amortiziranje, za ostale skupine pa degresivno amortiziranje $\mathrm{z}$ metodo padajoče osnove.

Do odloženih davkov pride le $\mathrm{v}$ primeru, če je amortizacija za poslovne namene obračunana $\mathrm{v}$ višjem znesku kot je davčno priznana ali v primeru, ko podjetje uporabi drugačno metodo amortiziranja kot je davčno dovoljena.

V našem primeru smo določili letni strošek amortizacije računalniške opreme, ki ga podjetja za poslovne namene amortizirajo $\mathrm{v}$ enem letu, kar za davčne namene ni dovoljeno. Za vsako državo smo predstavili vpliv na davek od dobička, odloženi davek in čisti poslovni izid.

\begin{tabular}{|l|r|r|r|r|r|r|r|r|}
\cline { 2 - 9 } \multicolumn{1}{c|}{} & \multicolumn{2}{c|}{ Slovenija } & \multicolumn{2}{c|}{ Hrvaška } & \multicolumn{2}{c|}{ BIH } & \multicolumn{2}{c|}{ Srbija } \\
\cline { 2 - 9 } & \multicolumn{2}{|c|}{31.12 .2015} & \multicolumn{2}{c|}{31.12 .2015} & \multicolumn{2}{c|}{31.12 .2015} & \multicolumn{2}{c|}{31.12 .2015} \\
\cline { 2 - 9 } & Poslovna & Davčna & Poslovna & Davčna & Poslovna & Davčna & Poslovna & Davčna \\
\cline { 2 - 9 } & bilanca & bilanca & bilanca & bilanca & bilanca & bilanca & bilanca & bilanca \\
\hline $\begin{array}{l}\% \text { davka v } \\
\text { državi }\end{array}$ & & $17 \%$ & & $20 \%$ & & $10 \%$ & & $15 \%$ \\
\hline Prihodki & 300.000 & 300.000 & 300.000 & 300.000 & 300.000 & 300.000 & 300.000 & 300.000 \\
\hline Stroški & -50.000 & $\mathbf{- 4 5 . 0 0 0}$ & -50.000 & $\mathbf{- 4 5 . 0 0 0}$ & -50.000 & $\mathbf{- 4 3 . 3 3 0}$ & -50.000 & $\mathbf{- 4 3 . 0 0 0}$ \\
\hline Odhodki & -8.000 & -8.000 & -8.000 & -8.000 & -8.000 & -8.000 & -8.000 & -8.000 \\
\hline $\begin{array}{l}\text { Dobiček/Izguba } \\
\text { pred } \\
\text { obdavčitvijo }\end{array}$ & 242.000 & 247.000 & 242.000 & 247.000 & 242.000 & 248.670 & 242.000 & 249.000 \\
\hline $\begin{array}{l}\text { Davek od } \\
\text { dohodka } \\
\text { pravnih oseb }\end{array}$ & $\mathbf{- 4 1 . 9 9 0}$ & & $\mathbf{- 4 9 . 4 0 0}$ & & $\mathbf{- 2 4 . 8 6 7}$ & & $\mathbf{- 3 7 . 3 5 0}$ & \\
\hline $\begin{array}{l}\text { ODLOŽENI } \\
\text { DAVEK }\end{array}$ & $\mathbf{8 5 0}$ & 5.000 & $\mathbf{1 . 0 0 0}$ & 5.000 & $\mathbf{6 6 7}$ & 6.670 & $\mathbf{1 . 0 5 0}$ & 7.000 \\
\hline $\begin{array}{l}\text { Čisti } \\
\text { dobiček/Izguba }\end{array}$ & $\mathbf{2 0 0 . 8 6 0}$ & & $\mathbf{1 9 3 . 6 0 0}$ & & $\mathbf{2 1 7 . 8 0 0}$ & & $\mathbf{2 0 5 . 7 0 0}$ & \\
\hline
\end{tabular}

Tabela 6: Vpliv amortizacije na odložene davke in poslovni izid.

V vseh štirih državah znašajo prihodki v poslovni bilanci 300.000 eur, stroški 50.000 eur in odhodki 8.000 eur. Računalniško opremo vsa podjetja v prvem letu amortizirajo v celoti. Celoten strošek amortizacije računalniške opreme znaša 10.000 eur, kar za davčne namene ni dovoljeno. V Sloveniji in Hrvaški je davčna stopnja amortizacije računalniške opreme $50 \%$, obračunana $\mathrm{z}$ enakomerno časovno metodo. Zato 5.000 eur ni davčno priznanih in predstavlja osnovo za odložene davke. V BIH je davčno priznana stopnja amortizacije računalniške opreme $33,33 \%$, zato 6.670 eur ni davčno priznanih in predstavlja osnovo za odloženi davke. V Srbiji je davčno priznana stopnja amortizacije računalniške opreme $30 \%$ in se izračuna $\mathrm{z}$ degresivno metodo amortiziranja $\mathrm{z}$ metodo padajoče osnove. $V$ prvem letu se kot osnova za amortizacijo upošteva nabavna vrednost 
$36^{\text {Th }}$ International Conference on Organizational Science Development: RESPONSIBLE ORGANIZATION (MARCH $22^{\mathrm{ND}}-24^{\mathrm{TH}}$, PORTOROŽ SLOVENIA)

R. Gabršek: Income Tax, Deferred Tax and Their Impact on the Financial Statements in Slovenia, Croatia, BIH and Serbia

računalniške opreme v naslednjih letih pa knjigovodska vrednost. Davčno nepriznanih stroškov je v prvem letu 7.000 eur in predstavljajo osnovo za odložene davke.

\subsection{Rezervacije}

Rezervacije se v skladu s Slovenskim računovodskim standardom 10 oblikujejo za obveznosti, ki izhajajo iz obvezujočih preteklih dogodkov in se bodo po predvidevanjih poravnale $\mathrm{v}$ prihodnjih obdobjih, ter katerih velikost je mogoče zanesljivo oceniti. Natančno je določeno kdaj se rezervacija pripozna (bolj možno kot ne oziroma obveznost je večja kot $50 \%$ ),

Zakon o davku od dohodka pravnih oseb v Sloveniji v 20. členu določa, da se prizna kot odhodek zavezanca znesek rezervacij, ki ustreza 50\% oblikovanih rezervacij, razen če v zakonu (ostalih členih ZDDPO-2) ni določeno drugače.

V Hrvaški Zakon o davku od dobička v 11. členu določa, da so rezervacije za dana jamstva $100 \%$ priznana, tudi v Srbiji Zakon o davku od dobička v 22. b členu dovoljuje $100 \%$ priznane stroške oblikovanih rezervacij za dana jamstva ob prodaji proizvodov. V BIH Zakon o davku od dobička v 13. členu določa, da je davčno priznana višina stroška rezervacij $4 \%$ letnih prihodkov, ki jih podjetje ustvari od prodaje proizvodov za katere daje garancije.

V našem primeru smo določili strošek oblikovanih rezervacij in njihov vpliv na odložene davke, višino davka od dobička in poslovni izid.

\begin{tabular}{|c|c|c|c|c|c|c|c|c|}
\hline & \multicolumn{2}{|c|}{ Slovenija } & \multicolumn{2}{|c|}{ Hrvaška } & \multicolumn{2}{|c|}{$\mathrm{BIH}$} & \multicolumn{2}{|c|}{ Srbija } \\
\hline & \multicolumn{2}{|c|}{31.12 .2015} & \multicolumn{2}{|c|}{ 31.12.2015 } & \multicolumn{2}{|c|}{31.12 .2015} & \multicolumn{2}{|c|}{31.12 .2015} \\
\hline & Poslovna & Davčna & Poslovna & Davčna & Poslovna & Davčna & Poslovna & Davčna \\
\hline & bilanca & bilanca & bilanca & bilanca & bilanca & bilanca & bilanca & bilanca \\
\hline \% davka v državi & & $17 \%$ & & $20 \%$ & & $10 \%$ & & $15 \%$ \\
\hline Prihodki & 300.000 & 300.000 & 300.000 & 300.000 & 300.000 & 300.000 & 300.000 & 300.000 \\
\hline Stroški & -50.000 & -47.500 & -50.000 & -50.000 & -50.000 & -49.000 & -50.000 & -50.000 \\
\hline Odhodki & -8.000 & -8.000 & -8.000 & -8.000 & -8.000 & -8.000 & -8.000 & -8.000 \\
\hline $\begin{array}{l}\begin{array}{l}\text { Dobiček/Izguba pred } \\
\text { obdavčitvijo }\end{array} \\
\end{array}$ & 242.000 & 244.500 & 242.000 & 242.000 & 242.000 & 243.000 & 242.000 & 242.000 \\
\hline $\begin{array}{l}\text { Davek od dohodka } \\
\text { pravnih oseb }\end{array}$ & -41.565 & & -48.400 & & -24.300 & & -36.300 & \\
\hline ODLOŽENI DAVEK & 425 & 2.500 & $\mathbf{0}$ & 0 & 100 & 1.000 & $\mathbf{0}$ & 0 \\
\hline Čisti dobiček/Izguba & 200.860 & & 193.600 & & 217.800 & & 205.700 & \\
\hline
\end{tabular}

Tabela 7: Vpliv oblikovanja rezervacij na odloženi davek in poslovni izid.

Pri podjetjih v vseh štirih državah znašajo prihodki v poslovni bilanci 300.000 eur, stroški 50.000 eur in odhodki 8.000 eur. Letni strošek rezervacij za dana jamstva ob prodaji proizvodov znaša 5.000 eur. V Sloveniji je davčno priznanih $50 \%$ oblikovanih rezervacij 
R. Gabršek: Davek od dohodka ter odloženi davki in njihov vpliv na računovodske izkaze v Sloveniji, Hrvaški, BIH in Srbiji

za dana jamstva ob prodaji proizvodov zato bo 2.500 eur stroškov priznanih ob porabi ali odpravi rezervacije. Za znesek odloženega davka v višini 425 eur oblikujemo terjatev za odložene davke. Hrvaška in Srbija imata rezervacije za dana jamstva priznana v celoti in zaradi tega ne prikazujeta odloženih davkov. Hrvaška ima zaradi višje davčne stopnje znesek davka višji kot Slovenija, Srbija pa manjšega zaradi nižje davčne stopnje in v celoti priznanega stroška rezervacije. V BIH je višina davčno priznanih stroškov rezervacij odvisna od celotnih prihodkov iz prodaje proizvodov za katere se oblikujejo rezervacije. Davčno priznanih stroškov rezervacij je v višini 4\% letnih prihodkov od prodaja za katere se daje garancija. V našem primeru smo določili, da znašajo letni prihodki iz prodaj proizvodov za katere se oblikujejo rezervacije 100.000 eur. Ker je znesek davčno priznanega stroška rezervacij 4.000 eur moram od 1.000 eur oblikovati za 100 eur odloženih davkov.

\subsection{Reprezentanca}

V Sloveniji je v 31. členu Zakona o davku od dobička priznanih 50\% stroškov reprezentance, v Hrvaški je v 7. členu Zakona o davku od dobička davčno priznanih $30 \%$ stroškov reprezentance in $\mathrm{v}$ BIH je $\mathrm{v} 12$. členu Zakona o davku od dobička davčno priznanih 30\% stroškov reprezentance. V Srbiji je v 15. členu Zakona o davku od dobička davčno priznanih stroškov reprezentance v višini $0,5 \%$ celotnih prihodkov.

V nadaljevanju so prikazane razlike med državami za stroške reprezentance, vpliv davčnih stopenj na višino davka od dobička ter vpliv na poslovno bilanco podjetja. Ker gre za stalne razlike ti stroški nimajo vpliva na odložene davke. Stroški reprezentance so namenjeni pogostitvi, zabavi in darilom, ki jih podjetje nameni poslovnim partnerjem.

\begin{tabular}{|c|c|c|c|c|c|c|c|c|}
\hline & \multicolumn{2}{|c|}{ Slovenija } & \multicolumn{2}{|c|}{ Hrvaška } & \multicolumn{2}{|c|}{$\mathrm{BIH}$} & \multicolumn{2}{|c|}{ Srbija } \\
\hline & \multicolumn{2}{|c|}{31.12 .2015} & \multicolumn{2}{|c|}{31.12 .2015} & \multicolumn{2}{|c|}{31.12 .2015} & \multicolumn{2}{|c|}{31.12 .2015} \\
\hline & Poslovna & Davčna & Poslovna & Davčna & Poslovna & Davčna & Poslovna & Davčna \\
\hline & bilanca & bilanca & bilanca & bilanca & bilanca & bilanca & bilanca & bilanca \\
\hline $\begin{array}{lll}\% & \text { davka } & \mathrm{v} \\
\text { državi } & \\
\end{array}$ & & $17 \%$ & & $20 \%$ & & $10 \%$ & & $15 \%$ \\
\hline Prihodki & 300.000 & 300.000 & 300.000 & 300.000 & 300.000 & 300.000 & 300.000 & 300.000 \\
\hline Stroški & -50.000 & -47.000 & -50.000 & -45.800 & -50.000 & -45.800 & -50.000 & -45.500 \\
\hline Odhodki & -8.000 & -8.000 & -8.000 & -8.000 & -8.000 & -8.000 & -8.000 & -8.000 \\
\hline $\begin{array}{l}\text { Dobiček/Izguba } \\
\text { pred } \\
\text { obdavčitvijo }\end{array}$ & 242.000 & 245.000 & 242.000 & 246.200 & 242.000 & 246.200 & 242.000 & 246.500 \\
\hline $\begin{array}{ll}\text { Davek od } \\
\text { dohodka } \\
\text { pravnih oseb }\end{array}$ & -41.650 & & -49.240 & & -24.620 & & -36.975 & \\
\hline $\begin{array}{l}\text { ODLOŽENI } \\
\text { DAVEK }\end{array}$ & 0 & & 0 & & 0 & & 0 & \\
\hline $\begin{array}{l}\text { Čisti } \\
\text { dobiček/Izguba }\end{array}$ & 200.350 & & 192.760 & & 217.380 & & 205.025 & \\
\hline
\end{tabular}

Tabela 8: Razlike v poslovni in davčni bilanci, ki nimajo vpliva na odložene davke. 
$36^{\mathrm{TH}}$ International Conference on Organizational Science Development: RESPONSIBLE ORGANIZATION (MARCH $22^{\mathrm{ND}}-24^{\mathrm{TH}}$, PORTOROŽ SLOVENIA)

R. Gabršek: Income Tax, Deferred Tax and Their Impact on the Financial Statements in Slovenia, Croatia, BIH and Serbia

Pri podjetjih v vseh štirih državah znašajo prihodki v poslovni bilanci 300.000 eur, stroški 50.000 eur in odhodki 8.000 eur. Strošek reprezentance znaša 6.000 eur. V Sloveniji je davčno priznanih 50\% stroškov reprezentance, v Hrvaški in BIH je davčno priznanih 30\% stroškov za reprezentanco. V Srbiji je davčno priznan strošek reprezentance v višini $0,5 \%$ celotnih prihodkov davčnega obdobja. Davčno nepriznanih stroškov reprezentance v Sloveniji je 3.000 eur, v Hrvaški in BIH 4.200 eur in v Srbiji 4.500. Iz primera vidimo vpliv višine davka in višine stalnih razlik na čisti dobiček.

\subsection{Davěna izguba}

Davčna izguba je presežek odhodkov nad prihodki. Davčno izgubo v davčnem obdobju lahko zavezanec pokriva z zmanjšanjem davčne osnove v naslednjih davčnih obdobjih. Ker bo davčna izguba $v$ prihodnjih letih zmanjševala pozitivno davčno osnovo in ti odhodki v prihodnjih poslovnih izkazih ne bodo vidni, je potrebno oblikovati terjatve za odložene davke. To pa le pod pogojem, da obstaja verjetnost pokrivanja davčne izgube oziroma, da podjetje pričakuje obdavčljivo osnovo v prihodnjih obdobjih.

36. člen Zakona o davku od dohodka pravnih oseb v Sloveniji omogoča koriščenje davčne izgube neomejeno število let, vendar le do višine $50 \%$ pozitivne davčne osnove $\mathrm{v}$ posameznem letu. V Hrvaški je možno koristiti davčno izgubo v obdobju petih let, vsako leto v višini pozitivne davčne osnove (17. člen Zakona o davku od dobička). 25. člen Zakona o davku od dobička v BIH dovoljuje koriščenje davčne izgube v petih letih, vsako leto v višini pozitivne davčne osnove. Tudi v Srbiji je dovoljena poraba davčne izgube v petih letih, vsako leto v višini pozitivne davčne osnove (32. člen Zakona o davku od dobička).

Primer vpliva davčne izgube na odložene davke in kasnejše koriščenje prikazujemo v tabeli 4 in 5. 
36. MEDNARODNA KONFERENCA O RAZVOJU ORGANIZACIJSKIH ZNANOSTI: ODGOVORNA ORGANIZACIJA (22. - 24. MAREC 2017, PORTOROŽ, SLOVENIJA)

R. Gabršek: Davek od dohodka ter odloženi davki in njihov vpliv na računovodske izkaze v Sloveniji, Hrvaški, BIH in Srbiji

\begin{tabular}{|c|c|c|c|c|c|c|c|c|}
\hline & \multicolumn{2}{|c|}{ Slovenija } & \multicolumn{2}{|c|}{ Hrvaška } & \multicolumn{2}{|c|}{$\mathrm{BIH}$} & \multicolumn{2}{|c|}{ Srbija } \\
\hline & \multicolumn{2}{|c|}{31.12 .2014} & \multicolumn{2}{|c|}{31.12 .2014} & \multicolumn{2}{|c|}{31.12 .2014} & \multicolumn{2}{|c|}{ 31.12.2014 } \\
\hline & Poslovna & Davčna & Poslovna & Davčna & Poslovna & Davčna & Poslovna & Davčna \\
\hline & bilanca & bilanca & bilanca & bilanca & bilanca & bilanca & bilanca & bilanca \\
\hline \% davka v državi & & $17 \%$ & & $20 \%$ & & $10 \%$ & & $15 \%$ \\
\hline Prihodki & 100.000 & 100.000 & 100.000 & 100.000 & 100.000 & 100.000 & 100.000 & 100.000 \\
\hline Stroški & -90.000 & -90.000 & -90.000 & -90.000 & -90.000 & -90.000 & -90.000 & -90.000 \\
\hline Odhodki & -70.000 & -70.000 & -70.000 & -70.000 & -70.000 & -70.000 & -70.000 & -70.000 \\
\hline $\begin{array}{l}\text { Dobiček/Izguba } \\
\text { pred obdavčitvijo }\end{array}$ & -60.000 & -60.000 & -60.000 & -60.000 & -60.000 & -60.000 & -60.000 & -60.000 \\
\hline $\begin{array}{l}\text { Davek od } \\
\text { dohodka pravnih } \\
\text { oseb }\end{array}$ & 0 & 0 & 0 & 0 & 0 & 0 & 0 & 0 \\
\hline $\begin{array}{l}\text { ODLOŽENI } \\
\text { DAVEK }\end{array}$ & 10.200 & 60.000 & 12.000 & 60.000 & 6.000 & 60.000 & 9.000 & 60.000 \\
\hline $\begin{array}{l}\text { Čisti } \\
\text { dobiček/Izguba }\end{array}$ & -49.800 & & -48.000 & & -54.000 & & -51.000 & \\
\hline
\end{tabular}

Tabela 9:Vpliv davčne izgube na odložene davke in poslovni izid

Prihodki so v podjetjih v vseh štirih državah 100.000 eur, stroški 90.000 eur in odhodki 70.000. Ker je davčna izguba 60.000 eur in pričakujemo v naslednjih letih pozitivno davčno osnovo pripoznamo v poslovni bilanci terjatev za odložene davke. Iz primera je razvidna višina terjatev za odloženi davek glede na stopnjo davka v vsaki od držav in vpliv na čisto izgubo.

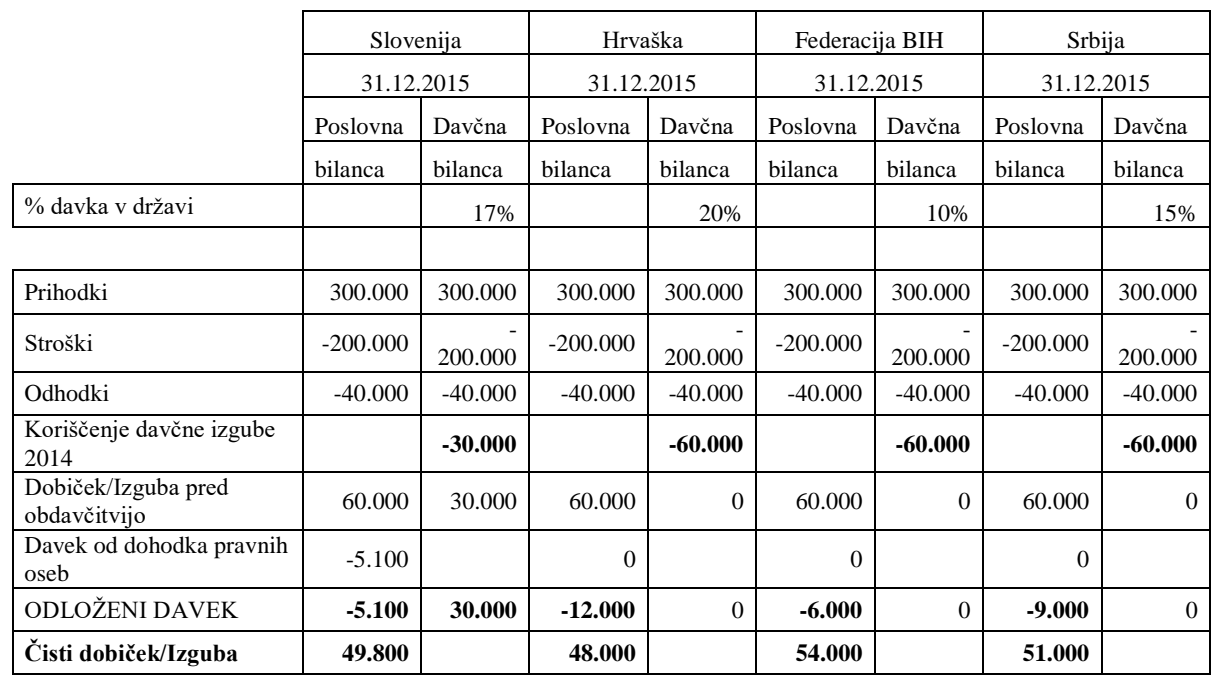

Tabela 10: Vpliv porabe davčne izgube na odložene davke in poslovni izid 
$36^{\mathrm{TH}}$ International Conference on Organizational Science Development: RESPONSIBLE ORGANIZATION (MARCH $22^{\mathrm{ND}}-24^{\mathrm{TH}}$, PORTOROŽ SLOVENIA)

R. Gabršek: Income Tax, Deferred Tax and Their Impact on the Financial Statements in Slovenia, Croatia, BIH and Serbia

Prihodki so v podjetjih v vseh štirih državah 300.000 eur, stroški 200.000 eur in odhodki 40.000 eur. Ker so imela podjetja v letu 2014 davčno izgubo in pripoznala terjatev za odloženi davek, so v letu 2015 izkoristila davčno izgubo in zmanjšala osnovo za davek od dohodka. Ker je v Sloveniji dovoljeno koristiti davčno izgubo le v višini $50 \%$ pozitivne davčne osnove je zmanjšala terjatev za odložene davke le za polovico, vse ostale države pa v celoti. Prikazan je vpliv na odložene davke in čisti dobiček po posamezni državi.

\section{$4 \quad$ Zaključek}

V raziskavo vključene države Slovenija, Hrvaška, Bosna in Hercegovina ter Srbija so vsaka v svoj pravni red vključile obvezno uporabo Mednarodnih standardov računovodskega poročanja in Mednarodne računovodske standarde. Vsaka država z lokalnimi Zakoni določa višino davka od dohodka, ki ga morajo podjetja obračunati in plačati, predpiše kaj je osnova za davek, kaj zmanjšuje in kaj povečuje davčno osnovo, določajo priznane in nepriznane stroške, odhodke in prihodke, določajo olajšave, višino amortizacijskih stopenj za opredmetena in neopredmetena osnovna sredstva, katere rezervacije so ob oblikovanju priznane in $\mathrm{v}$ kakšnem procentu, določajo obdobje za koriščenje davčne izgube in vrsto drugih določb. Posledice davčnih predpisov so vidne kot razlike med davčnimi in poslovnimi izkazi ter so lahko stalne ali začasne. Stalne razlike so tiste, ki so dokončne in ne bodo imele vpliva na prihodnja obdobja ter posledično tudi ne povzročajo odloženih davkov. Začasne razlike pa bodo imele vpliv na prihodnja davčna obdobja in so pomembne za izračunavanje odloženih davkov.

Na primeru vsake od držav smo ugotovili razlike med poslovnimi in davčnimi bilancami, razlike med stalnimi in začasnimi razlikami, vpliv različnih stopenj obdavčitve po državah na davčno obveznost in čisti poslovni izid. Primerjali smo stroške amortizacije, stroške rezervacij za dana jamstva ob prodaji proizvodov, stroške reprezentance in davčne izgube.

Davčna obveznost je najnižja v Bosni in Hercegovini (10\%) sledijo Srbija (15\%), Slovenija (17\%) in Hrvaška (20\%). Odložene davke smo pripoznali pri vsaki od držav vendar v različnih primerih in različnih višinah. Davčno izgubo je možno koristiti neomejeno število let le v Sloveniji, vendar le v višini $50 \%$ pozitivne davčne osnove za posamezno leto. Zato se terjatev za odložene davke iz davčnih izgub v Sloveniji odpravlja počasneje kot pri ostalih državah. Odložene davke smo pripoznali zaradi rezervacij za dana jamstva in amortizacije nad dovoljeno davčno stopnjo. Letno dovoljeni procent amortizacije računalniške opreme je najvišji v Sloveniji in Hrvaški.

Pri stalnih razlikah med poslovno bilanco in davčno bilanco na primeru reprezentance smo ugotovili, da je v Sloveniji priznan strošek v najvišjem procentu, v podjetjih kjer imajo velike prihodke iz poslovanja pa bi bil znesek davčno priznanih stroškov reprezentance najvišji v Srbiji. 
Rok za oddajo davčnega izračuna je najkrajši v Bosni in Hercegovini. Davčni obračun je potrebno oddati v 30 dneh po zaključku davčnega obdobja in davek plačati v 20 dneh od oddaje obračuna. Najdaljši čas za oddajo davčnega obračuna imajo v Srbiji, kjer ga je potrebno oddati $\vee 180$ dneh po zaključku davčnega obdobja in istočasno tudi plačati davek. V Sloveniji je rok za oddajo davčnega izračuna $v$ treh mesecih po zaključku davčnega obdobja in plačilo davka $v 30$ dneh po oddaji davčnega obračuna. V Hrvaški je rok za oddajo davčnega obračuna in plačilo davka v 4 mesecih po zaključku davčnega obdobja.

\section{Literatura}

Acuna, H. M. (2009). On the effect of personal taxes on personal income, Dissertation, The florida state university college of social sciences and public policy, Florida.

Badenhorst, W. M., \& Ferreira, P. H. (2016). The Financial Crisis and the Value-relevance of Recognised Deferred Tax Assets, Australian Accountig Review, 26 (3), 291-300.

Brajovič, G. (2009). Primerjalnopravna analiza obdavčitve dobička pravnih oseb v izbranih evropskih državah, Pravna fakulteta, Maribor.

Direktiva 2013/34/EU Evropskega parlamenta in Sveta z dne 26. junija 2013 o letnih računovodskih izkazih, konsolidiranih računovodskih izkazih in povezanih poročilih nekaterih vrst podjetij. Dostopno na

http://eur-lex.europa.eu/legal-content/SL/TXT/?uri=CELEX:32013L0034

Gavana, G., Guggiola, G., \& Marenzi, A. (2013). Evolving Connections between Tax and Financial Reporting in Italy, Accounting in Europe, 3, 43-70.

Ivancevich, S. H., Henning, S. L., Hermanson, D. R., \& Ivancevich, D. M. (2013). The Economic Impact of Iternational Differences in the Accounting and Tax Treatments of Goodwill: How Are Prospective Acquirers of U. S. Hospitality Interests Affected? The Journal of Hospitality Financial Management, 4, 21-31.

Koželj, S. (2006). Mednarodni standardi računovodskega poročanja. Ljubljana: Zveza računovodij, finančnikov in revizorjev Slovenije.

Pavšič, M. (2009). Davek od dohodka pravnih oseb ter primerjana davčnih stopenj znotraj EU, Ekonomsko-poslovna fakulteta, Maribor.

Pravilnik o načinu razvrstavnja stalnih sredstava po grupama i načinu utvrđivanja amortizacije za poreske svrhe (2010). Službeni glasnik Republike Srbije, št. 116/04 i 99/10.

Slatič, T. (2010). Davek od dobička iz kapitala fizičnih oseb v Sloveniji in Nemčiji, Ekonomskoposlovna fakulteta, Maribor.

Slovenski računovodski standardi (2006). Uradni list Republike Slovenije št. 118/2005.

Slovenski računovodski standardi (2016). Uradni list Republike Slovenije št. 95/2015.

Talevski, T. (2010). Primerjalna analiza obdavčitev plač v Sloveniji in na Hrvaškem glede na Zakon o dohodnini, Ekonomsko-poslovna fakulteta, Maribor.

Uredba 2002/1606/EU Evropskega parlamenta in Sveta z dne 19. julija 2002 o uporabi mednarodnih računovodskih standardov. Dostopno na

http://www.racunovodja.com/mdokumenti/mrs.pdf

Uredba Komisije (ES) št. 1126/2008 z dne 3. novembra 2008: Uradni list Evropske unije L 320/2008, L 338/2008, L 339/2008, L 17/2009, L 21/2009, L 80/2009, L 139/2009, L 149/2009, L 191/2009, L 239/2009, L 244/2009, L 311/2009, L 312/2009, L 314/2009, L 347/2009, L 77/2010, L 157/3/2010, L 166/6/2010, L 186/10/10, L 46/1/11, L 146/1/12, L 360/1/12, L 360/78/12, L 360/145/12, L 61/6/13, L 90/78/13, L 95/9/13, L 5/11/2014, L 330/20/2015, L $336 / 49 / 2015$. 
$36^{\text {TH }}$ International Conference on Organizational Science Development: RESPONSIBLE ORGANIZATION (MARCH $22^{\mathrm{ND}}-24^{\mathrm{TH}}$, PORTOROŽ SLOVENIA)

R. Gabršek: Income Tax, Deferred Tax and Their Impact on the Financial Statements in Slovenia, Croatia, BIH and Serbia

Valek, T. (2013). Analiza obdavčitve od dohodka pravnih oseb Kneževine Liechtenstein v primerjavi z obdavčitvijo v Sloveniji, Pravna fakulteta, Maribor.

Vargas, M. V. (2015). From accrued to paid income tax: A review of effective tax rate calculation, Revista de Contabilidad, 18 (1), 68-77.

Zakon o gospodarskih družbah - ZGD - 1I (2015). Uradni list Republike Slovenije št. 42/2006, 60/2006, 33/2011, 91/2011, 32/2012, 57/2012, 44/2013, 55/ 2015.

Zakon o davčnem postopku - ZDavP-2 (2015). Uradni list Republike Slovenije, št. 117/2006, 90/2007, 76/2008, 56/2008, 92/2008, 5/2009, 96/2009, 110/2009 - ZDavP-2B, 43/2010, 59/2011, 30/2012, 24/2012, 94/2012, 81/2013, 50/2014, 23/2015, 82/2015.

Zakon o davku od dohodkov pravnih oseb - ZDDPO-2 (2016). Uradni list Republike Slovenije št. 117/2006, 90/2007, 76/2008, 56/2008, 92/2008, 5/2009, 96/2009, 110/2009

2B, 43/2010,59/2011, 30/2012, 24/2012, 94/2012, 81/2013， 50/2014, 23/2015， 82/2015, $68 / 2016$.

Zakon o porezu na dohodak (2014). Narodne novine št. 177/04, 90/05, 57/06, 146/08, 80/10, 22/12, $148 / 13,143 / 14$.

Zakon o porezu na dobit (2016). Službene novine Federacije BiH, broj 15/2016.

Zakon o porezu na dobit pravnih lica (2015). Službeni glasnik Republike Srbije, br. 25/01, 80/02 dr. zakon, 80/02, 43/03, 84/04, 18/10, 101/11, 119/12, 47/13, 108/13, 68/14 - dr. zakon, 142/14, $91 / 15$ - autentično tumačenje, 112/15.

Zakon o računovodstvu (2015). Narodne novine št. 109/07, 54/13, 121/14, 134/15.

Zakon o računovodstvu i reviziji v Federaciji Bosne in Hercegovine (2009). Službene novine Federacije Bosne in Hercegovine št. 83/2009.

Zakon o računovodstvu (2013). Službeni glasnik Republike Srbije št. 46/2006, 111/2009, 99/2011, $62 / 2013$.

Zemljak, M. (2011). Davek od dohodka pravnih oseb v Srbiji, Bosni in Hercegovini in Sloveniji, Ekonomsko-poslovna fakulteta, Maribor. 
36. MEDNARODNA KONFERENCA O RAZVOJU ORGANIZACIJSKIH ZNANOSTI: OdgOVORNA ORGANIZACIJA (22. - 24. MAREC 2017, PORTOROŽ, SLOVENIJA)

O. Arsenijević, M. Ferjan, I. Podbregar, P. Šprajc, D. Trivan \& Y. Ziegler

\title{
Brezžični Holter monitor
}

\author{
KLEMEN GLUŠIČ \& VOJKO MATKO
}

Povzetek Snemanje in analiza elektrokardiogramov je rutinska metoda za preučevanje električne aktivnosti srca in tako predstavlja nepogrešljiv vir zdravstvenega stanja kardiovaskularnega sistema pri klinični obravnavi pacientov. Za natančno diagnosticiranje zgolj kratkotrajne meritve pogosto ne zadoščajo. Kadar obstaja sum občasnih srčnih motenj, katerih na običajni meritvi elektrokardiograma ni mogoče zaslediti, lahko specialist kardiolog pacientu predpiše Holter monitor, s katerim spremljamo električne meritve srca v dolgotrajnih, celodnevnih meritvah. Izdelali smo brezžičen Holter monitor $\mathrm{z}$ aktivno BLE povezljivostjo $\mathrm{z}$ mobilnimi napravami, ki jih poganja Android. To prinaša številne praktične kakor tudi zdravstvene prednosti, ki smo jih podrobneje predstavili v posameznih sklopih članka. Predstavili smo koncept, ki uporabo brezžičnih Holter naprav širi tudi v neprofesionalno, domače okolje.

KLJUČNE BESEDE: Holter • EKG • elektrokardiografija • elektrokardiogram • elektrokardiograf • Bluetooth • BLE

NASLOV AVTORJEv: Klemen Glušič, Univerza v Mariboru, Fakulteta za elektrotehniko, računalništvo in informatiko, Smetanova ulica 17, 2000 Maribor, Slovenija, e-pošta: klemeng@gmail.com; dr. Vojko Matko, izredni profesor, Univerza v Mariboru, Fakulteta za elektrotehniko, računalništvo in informatiko, Smetanova ulica 17, 2000 Maribor, Slovenija, epošta:, vojko.matko@um.si

DOI https://doi.org/10.18690/978-961-286-020-2.19

ISBN 978-961-286-020-2

(C) 2017 Univerzitetna založba Univerze v Mariboru

Dostopno na: http://press.um.si 
36 ${ }^{\text {TH }}$ International CONFEREnCE ON ORganizational Science Development: Responsible Organization (MARCH $22^{\mathrm{ND}}-24^{\mathrm{TH}}$, PORTOROŽ SLOVENIA)

O. Arsenijević, M. Ferjan, I. Podbregar, P. Šprajc, D. Trivan \& Y.

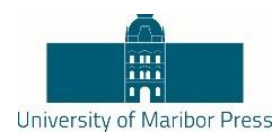

Ziegler

\title{
Wireless Holter Monitor
}

\author{
KLEMEN GLUŠIČ \& VOJKO MATKO
}

\begin{abstract}
Recording and analysis of electrocardiograms is a routine method for researching electrical activity of the heart and thus represents an indispensable source of health condition of cardiovascular system at clinical treatment of patients. Short measurements are often insufficient for precise diagnosis. Whenever a suspicion for occasional heart anomaly arises, which are usually undetectable with common electrocardiogram measurement, a cardiologist specialist may diagnose patient with a Holter device, which monitors electrical activity of the heart in long-term, daylong measurements. We have designed a wireless Holter monitor with active BLE connectivity with Android based mobile devices. This brings plethora of practical as well as medical advantages, which we have presented in individual segments in the article. We have demonstrated a concept of wireless Holter devices in unprofessional, home environment.
\end{abstract}

KEYWORDS: Holter $\cdot$ ECG electrocardiography $\bullet$ electrocardiogram • electrocardiograph $\bullet$ Bluetooth $\bullet$ BLE

CORRESPONDENCE ADDRESS: Klemen Glušič, University of Maribor, Faculty of Electrical Engineering and Computer Science, Smetanova ulica 17, 2000 Maribor, Slovenia, e-mail: klemeng@ gmail.com; Vojko Matko, Ph.D., Associate Professor, University of Maribor, Faculty of Electrical Engineering and Computer Science, Smetanova ulica 17, 2000 Maribor, Slovenia, email: vojko.matko@um.si 


\section{$1 \quad$ Uvod}

Svetovna zdravstvena organizacija (WHO) v svojih raziskavah ugotavlja, da so kardiovaskularne bolezni poglaviten vzrok smrti po vsem svetu (World Health Organization, 2014). Za namene ugotavljanja in prepoznavanja bolezenskih stanj je na voljo več metod, ena najosnovnejših in uporabljenih pa je preučevanje električne aktivnosti srca z elektrodami na površini kože merjenca, ki jo aparat zazna in prikaže $\mathrm{v}$ obliki neprekinjene EKG krivulje (Kosmač, 2015). Tako zajet signal se imenuje elektrokardiogram in omogoča relativno hiter ter natančen vpogled v električno aktivnost srca. Meritve električnih aktivnosti srčne mišice tako predstavljajo nepogrešljiv vir zdravstvenega stanja kardiovaskularnega sistema pri klinični obravnavi pacientov (Hampton, 2013).

EKG naprave primarno uporabljajo $\mathrm{v}$ medicinskih ustanovah, rutinsko pri kontrolnih zdravstvenih pregledih, spremljanju pacientov na intenzivni negi, med operacijskimi posegi in pri diagnosticiranju težav s srcem, kot so miokardni infarkt, motnje srčnega ritma, povečanje srca, sistemske bolezni, okvare zaklopk in druge srčno-žilne bolezni. (Sonjak, 2013)

Vendar dostopnost in cenovna ugodnost tehnologije omogoča čedalje večji prodor naprav v neprofesionalno, domače okolje. Tako dandanes obstaja vrsto različnih EKG naprav, a prav vse delujejo po enakem principu. Tehnično se razlikujejo predvsem po natančnosti meritev, številu elektrod in namenu uporabe.

\section{$2 \quad$ Holter sistemi}

Za natančno diagnosticiranje zgolj kratkotrajni laboratorijski EKG posnetki pogosto ne zadoščajo, sej se namreč nekateri bolezenski dogodki in pomembne spremembe $\mathrm{v}$ delovanju srca ne pojavijo vedno med kratkotrajno EKG meritvijo. Nekatere srčne motnje so pogojene $\mathrm{z}$ dnevnim ritmom, pacientovo fizično aktivnostjo in faktorji iz okolice.

Kadar obstaja sum občasnih srčnih motenj, katerih na običajni EKG meritvi ni mogoče zaznati, lahko specialist kardiolog pacientu predpiše Holter monitor - prenosni elektrokardiograf, s katerim spremljamo električne aktivnosti srca $\mathrm{v}$ dolgotrajnih, celodnevnih meritvah, običajno vsaj 24 ur do enega tedna ali več. Pacient tako v običajnem življenjskem slogu opravlja vsakdanja opravila, pri čemer ga ves čas spremlja Holter monitor in beleži elektrokardiogram v digitalni obliki (Majerle, 2015).

Ob pregledu Holter monitorjev naletimo na pestro izbiro. Delijo se glede na velikost, funkcionalnost in število kanalov, ki jih lahko izmerijo, od česar je odvisen obseg merjenih podatkov oziroma število odvodov. Vsem je skupno, da so sestavljeni iz enote, ki jo pacient nosi okrog pasu in elektrod, ki jih pripnemo na prsni koš. Pri tem je zelo pomembno, da si pacient na poseben list beleži čim več opažanj med meritvami z določitvijo časa dogodkov, izjemne aktivnosti tekom dneva, čas odhoda v posteljo, čas 
$36^{\text {Th }}$ International Conference on Organizational Science Development: ResPonsible Organization (MARCh $22^{\mathrm{ND}}-24^{\mathrm{TH}}$, PORTOROŽ SLOVENia)

K. Glušič \& V. Matko: Wireless Holter Monitor

zbujanja, jemanje zdravil in morebitne težave. (Specialistična kardiološka ambulanta Vasacor, 2017)

V praksi se izkaže, da so zapisniki lahko nenatančni, kar predstavlja pomemben faktor pri uspešni diagnozi. Prav tako se lahko zgodi, da bolnik ne zabeleži aktivnosti v času, ko Holter posname motnje ritma.

Omejena je tudi praktičnost običajnih Holter naprav, saj mora pacient napravo po meritvah dostaviti nazaj do specialista kardiologa oziroma usposobljene osebe, ki nato analizira signal, kar je neekonomično in časovno neefektivno, posledično pa je na nitki tudi pacientovo zdravje.

Brezžični BLE Holter sistemi

Čeprav na trgu obstaja pester izbor sestavnih modulov za izgradnjo Holter monitorja, smo se zavoljo miniaturizacije odločili za izdelavo lastne 3-kanalne Holter naprave, ki je prikazana na

Slika 5. Štiri-plastna tiskanina tako meri pičlih $73 \mathrm{~mm}$ x $31 \mathrm{~mm}$, pri čemer dobršen del zasedejo komponente za razhroščevanje. V nadaljnjih revizijah bi lahko tako napravo še zmanjšali, s čimer bi dosegli še višjo praktičnost uporabe.

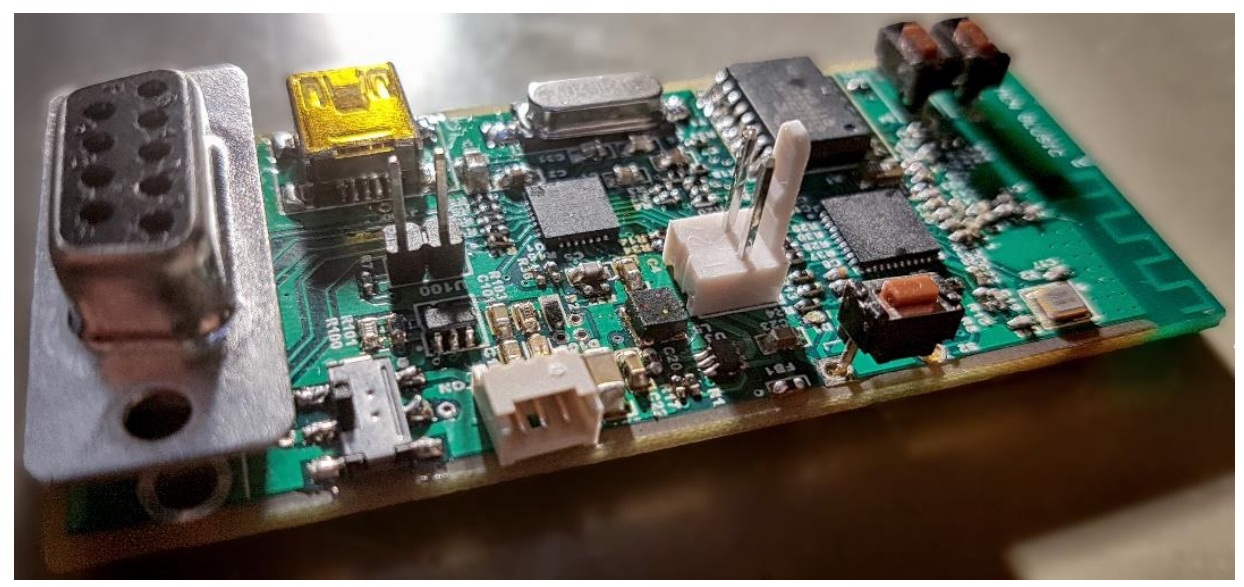

Slika 5: Tiskanina naprave v velikosti $73 \mathrm{~mm} \times 31 \mathrm{~mm}$.

Z obzirom na dejstvo, da je amplituda elektrokardiograma razmeroma majhna in se giblje od $0,01 \mathrm{mV}$ do $3 \mathrm{mV}$, je za zajem signala potreben kvaliteten, analogno-digitalni pretvornik z resolucijo najmanj $1 \mathrm{pV}$. Podjetje Texas Instruments je eno vodilnih na področju rešitev za medicinske namene. Med drugim v svojem repertoarju izdelkov nudijo tudi namenske analogno-digitalne pretvornike za merjenje EKG signalov 
Eden takšnih je $A D S 1293$, ki v našem Holter monitorju skrbi za 24-bitno resolucijo pretvorbe, kar zagotavlja diferenčno 3-kanalno biopotencialno merjenje z zelo varčno porabo energije (Majerle, 2015).. Vsak kanal zmore 25,6 ksps, prav tako pa jim lahko posamično nastavljamo frekvenco vzorčenja in pasovno širino, $s$ čimer jih lahko v celoti prilagodimo vrsti aplikacije. Vgrajen ima programabilni ojačevalnik, interni oscilator, aktivne digitalne filtre in integrirana vezja, specifična za zajemanje EKG signalov. Prav tako omogoča vrsto alarmov, kot so detekcija napačno priključenih elektrod, zaznavanje srčnega spodbujevalnika, izpraznjena baterija in drugi (Texas Instruments, 2014.

Osrčje naprave je sistem na čipu (ang. System on Chip - SoC) Texas Instruments CC2541, ki v enem samem integriranem vezju združuje mikrokrmilnik z BLE (ang. Bluetooth Low Energy) oddajnikom in sprejemnikom. Preko SPI vodila skrbi za konfiguracijo ADS1293, nadzor $\mathrm{AD}$ pretvorbe in aktivno komunikacijo z mobilnim telefonom (Texas Instruments, 2013).

$\mathrm{V}$ ta namen smo izdelali namensko aplikacijo za operacijski sistem Android, ki omogoča konstantno brezžično komunikacijo s Holter monitorjem preko BLE. Čeprav je naprava opremljena s 512 megabitnim EEPROM pomnilnikom S25FL512SAGMFI013 proizvajalca Cypress Semiconductor Corp, na katerega lahko preko SPI protokola shranjujemo EKG meritve, lahko le-te $\mathrm{v}$ realnem času spremljamo tudi v Androidni aplikaciji, prav tako pa jih lahko zajemamo in shranjujemo $v$ besedilno datoteko formata CSV, ki se shrani v interni pomnilnik ali microSD kartico na telefonu. Aplikacija lahko meritve posreduje na poljuben e-poštni naslov z natančnimi časovni žigi in aktivnim izbranim profilom uporabnika, zato lahko napravo brez težav uporablja več ljudi.

$\mathrm{Z}$ obzirom na to, da je Holter monitor prenosna naprava, ki je namenjena uporabi vsaj 24 ur brez prekinitev, smo za napajanje poskrbeli s prenosno Li-Ion baterijo, ki jo lahko napolnimo tudi $\mathrm{z}$ integriranim mini-USB polnilcem, brez, da bi baterijo pri tem odklapljali iz naprave in s tem prekinili aktivne meritve.

Na sliki 2 je prikazana blokovna shema naše Holter naprave. Osrednja enota je sistem na čipu, ki je sestavljen iz mikrokrmilniškega dela in Bluetooth Low Energy oddajnika/sprejemnika, s katerim komuniciramo z mobilnim telefonom. Mikrokrmilnik je $\mathrm{z}$ SPI vodilom povezan $\mathrm{z}$ analogno-digitalnim pretvornikom, s katerim zajemamo EKG signal z merilnih elektrod. Prav tako je mikrokrmilnik preko SPI povezan z zunanjim EEPROM pomnilnikom, kamor shranjuje in po potrebi bere EKG meritve. Napravo lahko upravljamo bodisi preko namenskih digitalnih vhodov in izhodov (ang. General-purpose input/output - GPIO) bodisi z večfunkcijskimi tipkami, medtem ko stanje naprave prikazujejo LED diode. Napajanje zagotavljamo s prenosno Li-Ion baterijo. 
$36^{\text {Th }}$ International Conference on Organizational Science Development: ResPonsible Organization (MARCh $22^{\mathrm{ND}}-24^{\mathrm{TH}}$, PORTOROŽ SLOVENia)

K. Glušič \& V. Matko: Wireless Holter Monitor

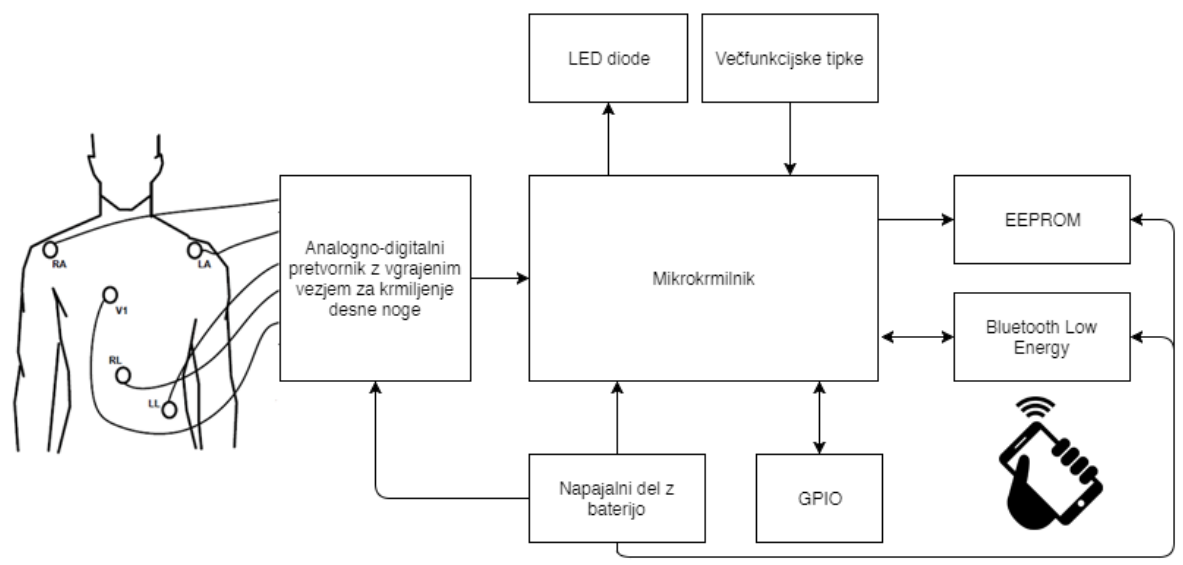

Slika 2: Blokovni diagram brezžičnega Holter monitorja.

\section{4}

Rezultat

EKG meritve smo izvajali na človeškem telesu pri dnevnih aktivnostih. Grafa na sliki 3 in sliki 4 predstavljata trenutek, ko je testni pacient hodil, pri čemer je zaradi gibanja prišlo do manjših anomalij $\mathrm{v}$ signalu. Še kvalitetnejši signal bi dobili z uporabo ustreznejših elektrod in gela za ultrazvok, prav tako pa bi bilo v Androidno aplikacijo smiselno implementirati še filtre za glajenje signala in samodejno zaznavo značilnih segmentov $P, Q, R, S, T$, ki se periodično pojavljajo v signalu.

Na sliki 3 je prikazana naša Androidna aplikacija, ki izrisuje trenuten zajem EKG signala med testiranjem.

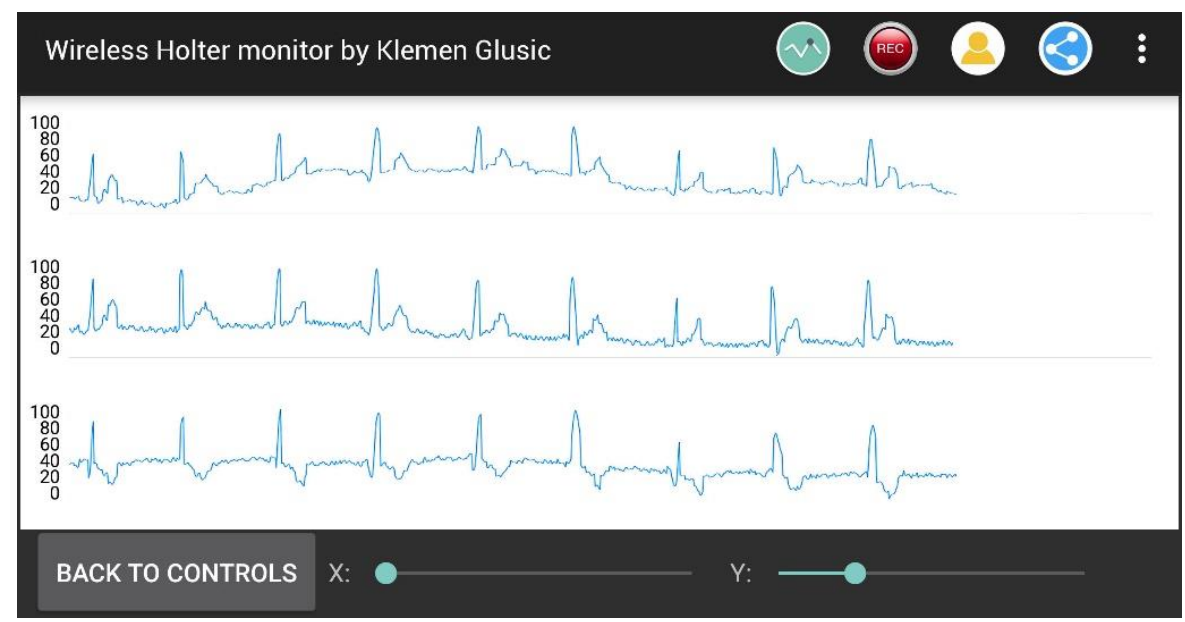

Slika 3: Zajem signala v realnem času z namensko Androidno aplikacijo (slika, ki jo vidimo na mobilnem telefonu). 
Istočasno je aplikacija EKG signal snemala $\mathrm{v}$ podatkovno datoteko, ki smo jo nato posredovali na računalnik in izrisali v programu Matlab, kot prikazuje slika 4.

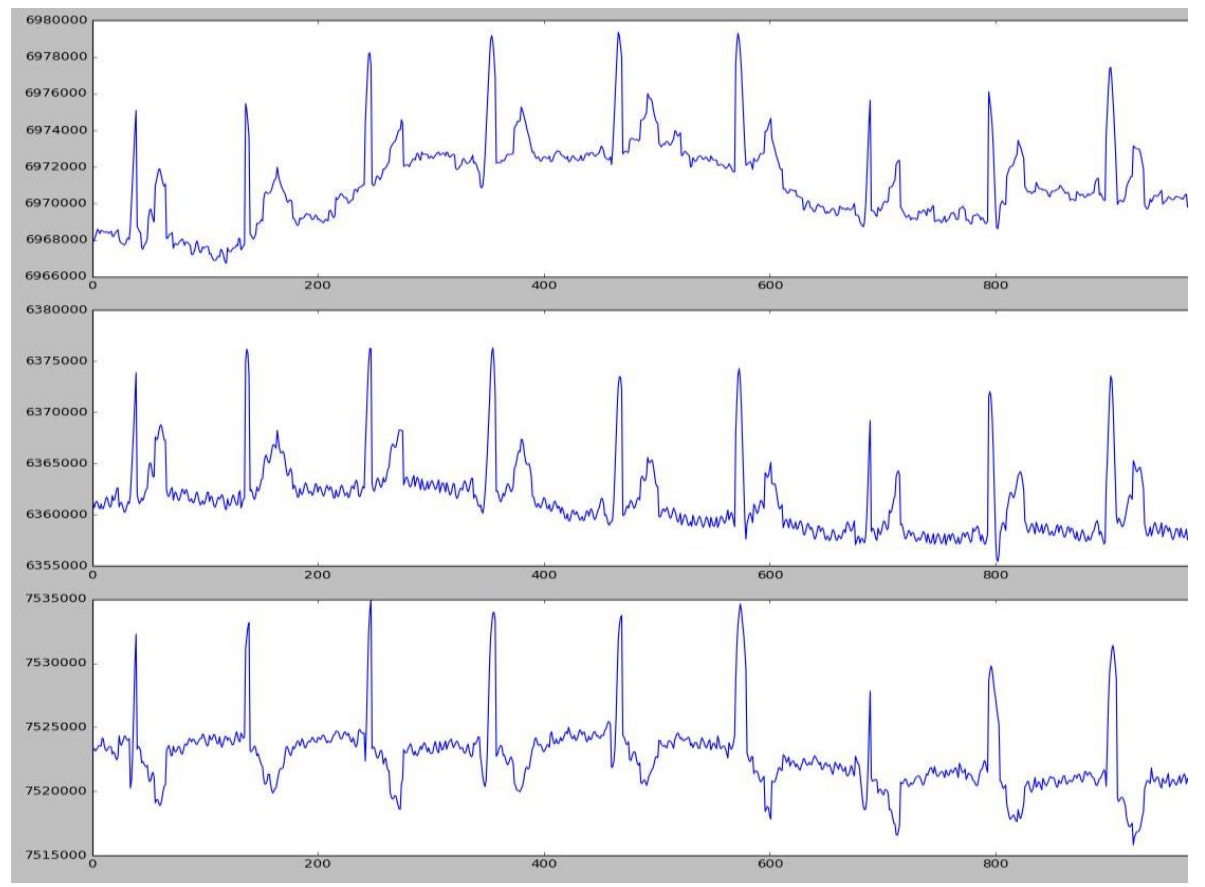

Slika 4: Izris meritev, ki smo jih z aplikacijo preko e-poštnega naslova poslali na računalnik.

\section{5}

\section{Zaključek}

Po podatkih ameriškega združenja za srce (American Heart Association, 2017) pojavnost kardiovaskularnih bolezni narašča globalno, pri čemer je ishemična bolezen srca $\mathrm{v}$ razvitih državah poglaviten vzrok umrljivosti, ta trend pa bo le še naraščal. Da bi se z njim spopadli, bo potrebno $\mathrm{v}$ okviru nujne medicinske pomoči uvesti tehnološke izboljšave in postopke, ki bodo zmanjšali umrljivost zaradi srčno-žilnih bolezni.

Po raziskavah je najbolj pereče časovno okno od trenutka nastopa simptomov do bolnišnične oskrbe, saj vsakih dodatnih 30 minut poveča umrljivost za 7,5 \% v prvem letu po nastanku akutnega koronarnega sindroma (Rawles idr., 1990). Pri tem je potrebno omeniti še dejstvo, da lahko traja tudi več kot 24 ur, preden pacient sprejme odločitev, da bo poiskal strokovno pomoč (Winkler, 2013).

Ta nepremagljiv problem bi lahko odpravili s povezljivostjo s pametnim mobilnim telefonom, ki si ga dandanes lasti tako rekoč vsakdo. Mobilna aplikacija je namreč v realnem času venomer povezana $\mathrm{z}$ napravo, zato lahko v primeru zaznane srčne ishemije 
$36^{\mathrm{TH}}$ International Conference on ORganizational Science Development: RESPONSIBLE ORGANIZATION (MARCH $22^{\mathrm{ND}}-24^{\mathrm{TH}}$, PORTOROŽ SLOVENIA)

K. Glušič \& V. Matko: Wireless Holter Monitor

ali druge srčne anomalije nemudoma obvesti uporabnika, obenem pa lahko s takojšnjim in neposrednim prenosom EKG podatkov $\mathrm{v}$ ustrezni koronarni center povsem spremeni koncept zdravstvene oskrbe pacientov.

To bi botrovalo k zmanjšanju zamude pri obravnavi akutnih bolnikov, obenem pa bi prehospitalnim enotam močno olajšalo izvajanje triaže, saj bi razpolagale $\mathrm{s}$ podrobnejšimi podatki o pacientu in bi se lahko tako pravočasno pripravile na sprejem in njegovo zdravljenje. Pri tem je najpomembnejše dejstvo, da bi se skrajšal čas v primeru nastanka akutnega koronarnega sindroma do izvedbe diagnostičnega terapevtskega posega, s čimer bi se povečala uspešnost zdravljenja in zmanjšala smrtnost bolnikov (Gibson idr., 2007).

Prav tako so pametni telefoni opremljeni s številnimi senzorji, ki razpolagajo $\mathrm{s}$ vsestransko natančnimi podatki o dejavnosti pacienta, kar bi odpravilo problematiko z nepopolnimi dnevniki, katere morajo izpolnjevati med Holter meritvami.

Velika prednost uporabe brezžičnega Holter sistema pa je v tem, da uporaba še zdaleč ni omejena le na bolnišnično oskrbo. Čedalje večji delež populacije namreč vlaga $v$ preventivno zdravje, pri čemer bi lahko bila tovrstna naprava nepogrešljiv pripomoček, zlasti glede na dejstvo, da je za razliko od komercialnih Holter monitorjev, ki jih dandanes uporabljajo $\mathrm{v}$ zdravstvenih ustanovah, cenovno neprimerno ugodnejši in povsem dostopen za vsakogar, ki bi želel kadarkoli enostavno preveriti svoje fiziološko stanje in telesno pripravljenost. Le-ta je še posebej aktualna tako pri vrhunskih kakor tudi pri rekreativnih športnikih, ki dajejo posebno noto na svoje zdravstveno stanje.

\section{Literatura}

American Heart Association. Heart Disease and Stroke Statistics - 2017 Update. (2017). Pridobljeno 2. 2. 2017 , http://circ.ahajournals.org/content/early/2017/01/25/CIR.0000000000000485

Sonjak D. (2013). Izvedba preprostega brezžičnega elektrokardiografa. Diplomsko delo. Univerza v Mariboru, Fakulteta za elektrotehniko, računalništvo in informatiko. Mesto: Maribor.

Gibson, C. M., Ciaglo. L. N., Southard. M. C., Takao. S., Harrigan. C., Lewis, J., Filopei, J. idr (2007). Diagnostic and prognostic value of ambulatory ECG (Holter) monitoring in patients with coronary heart disease: a review. Pridobljeno 14. 1. 2017, s https://www.ncbi.nlm.nih.gov/pubmed/17221332

Hampton J. R. (2013). The ECG Made Easy, 8e, Paperback. Mesto: Churchill Livingstone.

Kosmač M. (2015). Načrtovanje in izdelava enokanalnega ekg sistema za uporabo z računalniškomerilno kartico Red Pitaya. Diplomsko delo. Univerza v Ljubljani, Fakulteta za elektrotehniko. Mesto: Ljubljana.

Majerle T. (2015). Razvoj prenosnega merilnika EKG. Diplomsko delo. Univerza v Ljubljani, Fakulteta za elektrotehniko. Mesto: Ljubljana.

Rawles J. M., Metcalfe M. J., Shirreffs C., Jenntngs K., Kenmure A. C. F. (1990). Association of patient delay with symptoms, cardiac enzymes, and outcome in acute myocardial infarction. European Heart Journal. 1990;11:643- 648. 
Specialistična kardiološka ambulanta Vasacor. (2017). Opis preiskav. Pridobljeno 22. 1. 2017, s http://www.vasacor.si/index.php?option=com_content\&view=article \&id=11\&Itemid=13

Texas Instruments. (2014). ADS1293 Low-Power, 3-Channel, 24-Bit Analog Front-End for $\begin{array}{lllllll}\text { Biopotential Measurements. } & \text { Pridobljeno } & 8 . & 2 . & 2017, & \mathrm{~s}\end{array}$ http://www.ti.com/lit/ds/symlink/ads1293.pdf

Texas Instruments. (2013). 2.4-GHz Bluetooth ${ }^{\mathrm{TM}}$ low energy and Proprietary System-on-Chip. Pridobljeno 12. 2. 2017, s http://www.ti.com/lit/ds/symlink/cc2541.pdf

Winkler C., Funk M., Schindler D. M., Hemsey J. Z., Lampert R., Drew B. J.. (2013). Arrhythmias in Patients with Acute Coronary Syndrome in the First 24 Hours of Hospitalization. Pridobljeno 13. 2. 2017, s https://www.ncbi.nlm.nih.gov/pmc/articles/PMC3848954/

World Health Organization. (2014). Global status report on noncommunicable diseases 2014. Pridobljeno 26. 2. 2017 , http://apps.who.int/iris/bitstream/10665/148114/1/9789241564854_eng.pdf 
$210 \quad 36^{\text {Th }}$ International Conference on Organizational Science Development: Responsible Organization (MARCH $22^{\mathrm{ND}}-24^{\mathrm{TH}}$, PORTOROŽ SLOVENIA) 
$36^{\text {TH }}$ International Conference on Organizational Science DEVElopMENT: Responsible ORganization (MARCH $22^{\mathrm{ND}}-24^{\mathrm{TH}}$, PORTOROŽ SLOVENIA)

O. Arsenijević, M. Ferjan, I. Podbregar, P. Šprajc, D. Trivan \& Y.

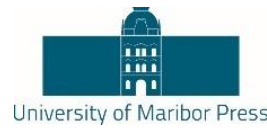

Ziegler

\title{
Using Temporal Database for Representation and Reasoning in Maritime Applications
}

\begin{abstract}
ANITA GUDELJ
Abstract Continued data processing, data extraction and data analysis assist the European Commission's monitoring of the implementation of EU legislation. This includes the development of methodologies to create aggregated information from existing data sources. Aggregated search activities can include up to date and historical information data relating to vessel characteristics, ship movements, vessels involved in incidents or transportation of cargoes. It is application domain where it is needed to reconstruct earlier database states or even store future database states. The different database states are have to be stored as temporal data. Conventional databases and their implementations as database management systems (DBMS) are not the best solution. The reason is that these databases represent the state of particular system at a single moment of time. They support modification operations which facilitate the transition from one consistent database state to another. It is also possible in practice to store timestamps in classical DBMS and model the temporal aspects mentioned above in this way. This paper proposes different approach to managing temporal data. This approach timestamps data by extending the data structures with special timestamp attributes. The result is temporal relation data model for the provision and access of maritime information.
\end{abstract}

KEYWORDS: historical information $\bullet$ maritime data $\bullet$ temporal database • ATSQL

CORRESPONDENCE AdDRESS: Anita Gudelj, University of Split, Faculty of Maritime Studies, Ulica Ruđera Boškovića 37, 21000 Split, Croatia, e-mail: anita@pfst.hr

DOI https://doi.org/10.18690/978-961-286-020-2.20

ISBN 978-961-286-020-2

(C) 2017 University of Maribor Press

Available at: http://press.um.si 
$36^{\text {Th }}$ International Conference on Organizational Science Development: RESPONSIBLE ORGANIZATION (MARCH $22^{\mathrm{ND}}-24^{\mathrm{TH}}$, PORTOROŽ SLOVENIA)

A. Gudelj: Using Temporal Database for Representation and Reasoning in Maritime Applications

\section{Introduction}

One of activities of the European Maritime Safety Agency (EMSA) is monitoring several databases populated with maritime information and data for non-commercial use. These data have to support the Agency's operational tasks in various areas of interest such as accident investigation, ship reporting, exchanging traffic data at regional level based on AIS data or Port State Control (EMSA, 2016).

Continued data processing, data extraction and analysis assist the European Commission's monitoring of the implementation of EU legislation. It is necessary to create aggregated information from existing data sources. This can include up to date and historical information and data relating to vessel characteristics, ship movements in European waters, vessels involved in incidents... It is needed to reconstruct earlier database states or even store future database states. This database application is temporal in nature, and the different database states have to be stored as temporal data.

Database Management Systems (DBMS) are supposed to model and record part of the real-world in a well-defined format. Conventional DBMS is used to store and to process the data which refer to the information that is valid at the current time. A temporal database records time-varying information (Kostenko, 2007). They assume that data values are associated with timestamps which represent the time during which this data value was valid in the real world and/or the time during which this data value was recorded in the database. Time-varying data are of great importance in many database applications, such as data mining. In this paper the author used one approach timestamps data by extending the data structures with special timestamp attributes. This modelling technique provides expressive and efficient ways to model, store and query different time-state of the stored data.

\section{$2 \quad$ Application domain}

\subsection{Data specification}

The data specifications are composed of 3 lots describing the minimum types of data that EMSA would like to receive.

\section{Vessels}

Information and data shall cover vessels registered with a valid IMO number. Updated detailed characteristics of the world's fleet should include the following attributes:

- IMO number - vessel's IMO number

- Name

- MMSI - Maritime Mobile Service Identity number is a unique identifier assigned to a vessel. 
A. Gudelj: Using Temporal Database for Representation and Reasoning in Maritime Applications

- Ship type

- Flag

- Hull type

- Gross tonnage

- Deadweight

- Year of built

- Classification Society

- Status.

\section{Historical data}

The provision of annual historical data on ship movements (port calls, anchorage, passing, movements and AIS notifications) should be monthly updated including the following details:

- Port of origin

- Port of destination

- Next port of call

- Time stamps

- AIS_Position

- IMO number.

Historical data is a valuable data source used for vessel traffic analyses, port calling information, risk assessment and accident investigation. The data is also used for analysing the vessels movements on a global scale, potential trends in the shipping market or vessel behaviour patterns for prosecution of illegal activities.

\section{Vessel Movements Report}

The vessel movements report provides data on the position of thousands of ships around the world, based on historical AIS data collected by terrestrial AIS stations since 2009 . The AIS position reports are performed for:

- one or more vessels for a given period of time

- all vessels movements in particular port or area (defined by geographical coordinates).

In most cases, typical time resolution of a vessel movements report is 5 minutes or 1 hour (time resolution is the time between two sequential position records of each vessel) depending on the customer requirements.

Data included in a standard vessel movement report:

- DATE / TIME - timestamp of the position report (in UTC) 
$36^{\mathrm{TH}}$ International Conference on ORganizational Science Development: Responsible Organization (MARCh $22^{\mathrm{ND}}-24^{\mathrm{TH}}$, Portorož Slovenia)

A. Gudelj: Using Temporal Database for Representation and Reasoning in Maritime Applications

- IMO

- Name

- Latitude - geographical latitude (in degrees)

- Longitude - geographical longitude (in degrees)

- Course - course over ground (in degrees)

- Speed - speed over ground (in knots)

- Heading - heading of the vessel's hull (in degrees)

- Navstat - navigational status (according to AIS specification)

- Dimensions - length and beam of the vessel

- Draught - draught of the vessel at time of the position record

- Destination - next destination of the vessel according to AIS

- Eta - estimated time of arrival

- AIS type - vessel's type according to AIS specification.

\section{A list of casualties}

A list of casualties (at least serious and very serious) shall be submitted indicating:

- MMSI

- Seriousness of casualty

- Casualty date

Casualty type.

\section{Event Tracking}

Events Report is a service through which you can get informed when vessels changed their:

- Movement status - vessels were under way (speed higher than 0.5 knots) or not moving (speed equal to or lower than 0.5 knots)

- IN RANGE / OUT OF RANGE STATUS

- Destination

- IMO number

- Draught

- Name.

This service is perfect to:

- analyse when specific vessel or a list of vessels were moving

- explore when vessels got loaded or discharged considering the draught changes

- find out when vessels changed their destination or IMO number 
A. Gudelj: Using Temporal Database for Representation and Reasoning in Maritime

Applications

- see when vessel gone out of range (turned its AIS off, experienced problem with the AIS or just left our coverage zone).

\section{$2.2 \quad$ Non-temporal data model}

In practice, it is possible to store timestamps in classical DBMS and model the temporal aspects in this way. A non-temporal relation database model was designed based on a case study, described in previous section, via Entity Relationship (ER) Diagram and normalization of tables (Silbershatz, et al. 2005). The ER diagram is outlined on Image 1.

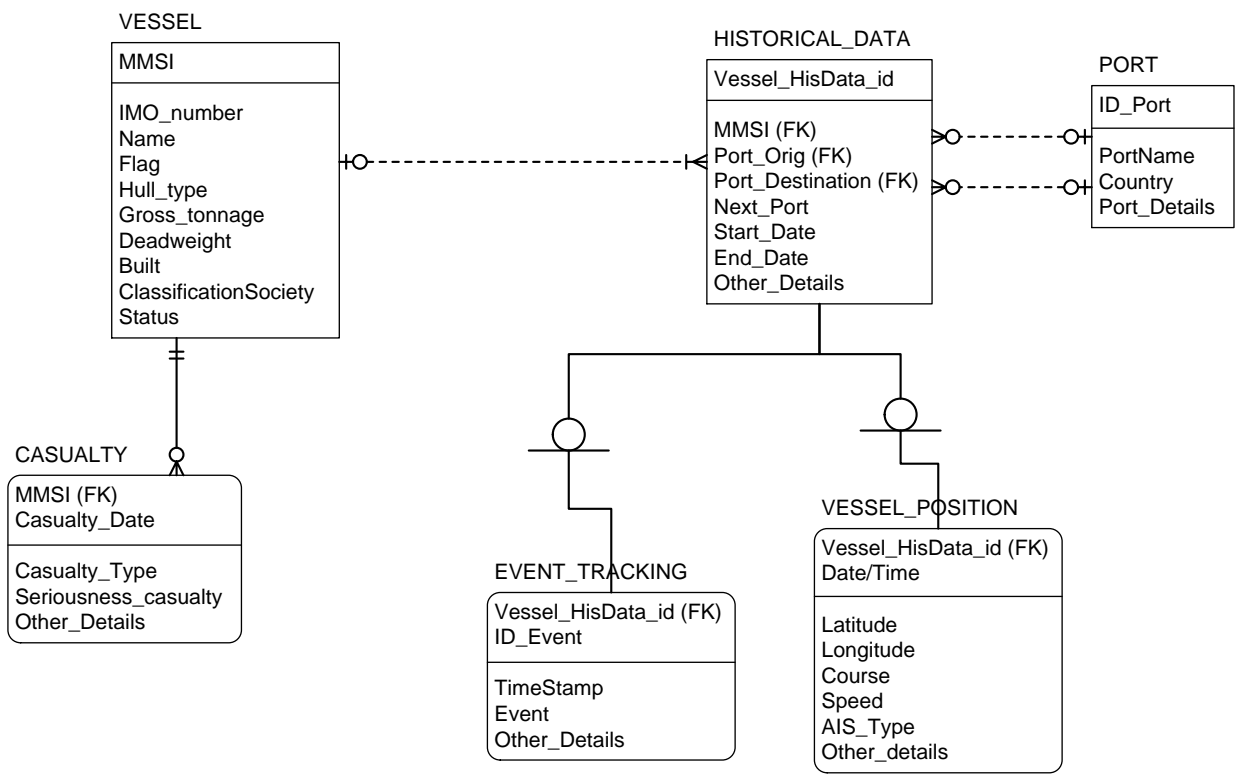

Image 1: Non-temporal ER diagram for the provision and access of maritime data and information. Source: By author

On the ER diagram, we can view the entities: Vessel, Port, Causality, Historical_Data, Vessel_Position and Event_Tracking. Among these entities, relationships exist which connect all the entities in the diagram. The entity "vessel" involves information about vessel which can have one or more stored historical data. Also, Vessel and Causality are connected which means that a vessel had one or more incident or it had no incidents. In a similar way, other entities are connected via relationships in a meaningful way. 
$36^{\mathrm{TH}}$ International Conference on ORganizational Science Development: RESPONSIBLE ORGANIZATION (MARCH $22^{\mathrm{ND}}-24^{\mathrm{TH}}$, PORTOROŽ SLOVENIA)

A. Gudelj: Using Temporal Database for Representation and Reasoning in Maritime Applications

Temporal information processing

Non-temporal data model and DBMS only handle an instant-time state of an object during its whole life time, and not consider the object's history and future. So researchers bring forward the technology of temporal database, in order to solve the problem about how to handle temporal information in the real world. Now, application systems, which can provide the function of temporal information processing, are in a more and more mature development.

A relation DBMS stores data in relations, sometimes also called tables. Temporal Data Model is extension of relational model by adding temporal attributes to each relation. In that way, it becomes possible to store different database states. Changes are viewed as additions to the information stored in the database.

\subsection{Time model}

The time models in temporal database systems can be categorized into the following:

Valid-state time: The associated time is used to indicate when certain event occurs or when certain fact is considered to be true in the real world. Database that supports validtime state is termed as historical database (Snodgrass, 2000; Snodgrass et al. 1996a).

Valid-state time can be incorporated in relational database system. It implies that relation database becomes temporal database by adding date/time column(s) into the relation with some granularity to indicate the validity of the desired fact. It can be:

- point time event or fact

- duration point or fact that is associated with specific time period in some granularity.

Transaction-state time: The associated time refers to the time when the information was actually stored in the database. Transaction-state time is used in temporal database systems to model and record the history of changing state of the transaction-state database tables (Snodgrass et al. 1996b).

Bitemporal-state time: Associated time refers to both valid-state time and transactionstate time yield in bitemporal data model.

\subsection{Data models for temporal database}

A more systematic way to define temporal data models is based on generalizing a nontemporal relation data model into a temporal one. Using generalization means that all constructs of the underlying non-temporal data model (its data structures, operations and integrity constraints) are enhanced to support the management of time-varying data 
A. Gudelj: Using Temporal Database for Representation and Reasoning in Maritime Applications

(Steiner, 1998). A data unit can be anything from an attribute value to a tuple or object to a collection of tuples or objects to a database.

The temporal features that characterize temporal data models are (Steiner, 1998):

- the semantics of time representation (valid time/transaction time)

- whether timestamp is applied to a tuple or to individual attributes

- whether attribute values are defined for the same or different time period in the same tuple (homogeneous tuple/heterogeneous tuple)

- whether time is represented as points or intervals.

In this paper, the approach timestamps data by extending the data structures with special timestamp attributes is used.

\section{TimeDB and ATSQL2}

TimeDB is the only available commercial product, which supports the management of temporal data with temporal query language, a temporal data definition language, a temporal manipulation language and temporal constraints.

TimeDB is prototype temporal relation DBMS which was implemented at the Swiss Federal Institute of Technology, Zürich (Steiner, 1998). TimeDB is based on the extension approach with respect to the data structure. It means that the temporal relations are achieved by adding additional timestamp attributes to non-temporal relations. TimeDB provides bitemporal statements, and handles valid time and/or transaction time.

TimeDB supports the temporal query language ATSQL2 (Applied TSQL2). ATSQL2 was proposed in 1995 (Gou et al. 2010) and accepted by ANSI in 1996 (Snodgrass et al. 1996a, 1996b). ATSQL2 extends standard SQL and it can support traditional applications.

Also, ATSQL2 supports many temporal features such as:

- valid time/transaction time statements

- temporal queries

- temporal insert, update and delete statements

- temporal tables and view

- temporal constraints and assertions.

However, TimeDB is not temporal DBMS, it was made as front-end to a commercial relation DBMS, such as Oracle, which translate temporal statements into standard SQL statements. 
$36^{\text {Th }}$ International Conference on Organizational Science Development: Responsible Organization (MARCh $22^{\mathrm{ND}}-24^{\mathrm{TH}}$, Portorož Slovenia)

A. Gudelj: Using Temporal Database for Representation and Reasoning in Maritime Applications

\subsection{Temporal aspects of TimeDB}

\section{Timeflag semantics}

ATSQL2 distinguishes three different models to evaluate SQL statement: snapshot semantics, sequenced / non-sequenced semantics.

Snapshot semantics means that only database state valid at the current time instance is evaluated. This correspondent to evaluating a non-temporal statements over a nontemporal databases. In ATSQL2 statements without time flags have this semantics.

In ATSQL2, temporal statements are classified into two classes: sequenced and nonsequenced statements (Steiner, 1998). Sequenced statements are evaluated over all states of data, which are stored in a temporal database. A query with sequenced semantics returns a temporal data. Statements with non-sequenced semantics treat the time flags as any other user defined attribute. The algebra operations have non-temporal semantics. This allows the comparison of different database states with each other.

Sequenced statements have snapshot reducible semantics. So, the result of a sequenced query is equivalent to the sequence of the results of a corresponding non-temporal query evaluated on each database state. This means that a particular state of the result is derived solely from the database state at the same time instant.

In ATSQL2, a sequenced or non-sequenced valid-time statement starts with key word validtime or non-sequenced validtime, respectively. It will be presented in next section. Since ATSQL2 supports both valid time and transaction time, the step from a nontemporal to a temporal statement may be done either with respect to valid time or transaction time or both.

\section{Time operators}

TimeDB supports spans which is duration of time (e. g. two years and one month), events (e. g. June 12, 1964) and time intervals (e. g. from 1980 to 1990). In ATSQL2, spans, events and time intervals are treated just as any other values such as strings, integers etc. Thus these values may appear anywhere in select and where clauses where expressions are allowed (Steiner, 1998).

In this paper time intervals are used as timestamps. In ATSQL2 time intervals are closed on the lower and open on the upper bound (e.g. [1980-1990)). Time intervals may be compared either with other time intervals using the comparison operations precedes, overlaps, meets, contains and =, or they may be compared with events. The syntax of these operators is given in Table 1 where $\mathrm{X}$ and $\mathrm{Y}$ are time intervals. 
A. Gudelj: Using Temporal Database for Representation and Reasoning in Maritime

Applications

Table 1: The comparison operators for time intervals (Steiner, 1998)

\begin{tabular}{|c|c|}
\hline OPERATOR & MEANING \\
\hline X PRECEDES Y & $\operatorname{END}(\mathrm{X})<\operatorname{BEGIN}(\mathrm{Y})$ \\
\hline X MEETS Y & END(X) + "1 MOMENT" = BEGIN(Y) \\
\hline X OVERLAPS Y & $\exists t: t \in X$ and $t \in Y$ \\
\hline X CONTAINS Y & $\operatorname{BEGIN}(Y) \geq \operatorname{BEGIN}(X)$ and $\operatorname{END}(Y) \leq \operatorname{END}(X)$ \\
\hline $\mathrm{X}=\mathrm{Y}$ & $\operatorname{BEGIN}(\mathrm{X})=\operatorname{BEGIN}(\mathrm{Y})$ and $\operatorname{END}(\mathrm{X})=\operatorname{END}(\mathrm{Y})$ \\
\hline
\end{tabular}

\section{$5 \quad$ Problem solution}

\subsection{Temporal data definition with TimeDB}

In this section we will apply proposed framework for temporal database to the nontemporal database model shown on Image 1. The intention is to support the provision and access of historical maritime information.

As mentioned before, with TimeDB, it is convenient for users to create temporal or nontemporal table. The user however should still be allowed using the legacy queries and should get the same results as if he was working with the non-temporal relational DBMS. This can be achieved by evaluating legal SQL queries on snapshots of the temporal tables at time instant now. This is called temporal upward compatibility.

From conceptual model on Image 1 non-temporal tables VESSEL, HISTORICAL_DATA, VESSEL_POSITION and EVEN_TRACKING should be altered, in this case, to valid-time tables. This means that after migration, the data is kept track of with respect to valid time. The following statements are part of ATSQL2 code for table definitions. 
$36^{\text {Th }}$ International Conference on Organizational Science Development: Responsible Organization (MARCh $22^{\mathrm{ND}}-24^{\mathrm{TH}}$, Portorož Slovenia)

A. Gudelj: Using Temporal Database for Representation and Reasoning in Maritime Applications

/* ------ Data definitions ------*/

SET CALENDRIC SYSTEM decimal;

* -.--- non-temporal table -.-.-.*/

CREATE TABLE PORT (ID_Port INTEGER PRIMARY KEY, PortName CHAR(15), Country CHAR(15), Port_Details TEXT);

/* ------ temporal tables ----.*/

CREATE TABLE VESSEL (MMSI INTEGER PRIMARY KEY, IMO_number INTEGER, Name CHAR(30), Flag CHAR(15), Hull_type CHAR(10), Gross_tonnage INTEGER, Deadweight INTEGER, Year_built DATE, ClassificationSociety CHAR(10), Status CHAR(10)) AS VALIDTIME;

CREATE TABLE HISTORICAL_DATA (Vessel_HisData_id CHAR(10) PRIMARY KEY, MMSI INTEGER REFERENCES VESSEL(MMSI), Port_Orig CHAR(5) REFERENCES PORT(ID_Port), Port_Destination CHAR(5) REFERENCES PORT(ID_Port), Start_Date DATETIME, End_Date DATETIME, Other_Details VARCHAR(30)) AS VALIDTIME;

CREATE TABLE EVENT_TRACKING (ID_Event CHAR(10), Vessel_HisData_id CHAR(10) REFERENCES HISTORICAL_DATA(Vessel_HisData_id), TimeStamp DATETIME, Event CHAR(10), Other_Details VARCHAR(30),

PRIMARY KEY (ID_Event, Vessel_HisData_id))

AS VALIDTIME;

CREATE TABLE VESSEL_POSITION (Vessel_HisData_id CHAR(10) REFERENCES HISTORICAL_DATA(Vessel_HisData_id), Date_Time DATETIME, Latitude REAL, Longitude REAL, Course REAL, Speed REAL, AIS_Type INTEGER, Other_Details VARCHAR(30), PRIMARY KEY (Vessel_HisData_id, Date_Time) AS VALIDTIME;

/* -.---- non-temporal table --.-.-*/

CREATE TABLE CASUALITY (Casuality_Date DATE PRIMARY KEY, MMSI INTEGER REFERENCES VESSEL (MMSI), Casuality_Type VARCHAR(20), Seriousness_casualt CHAR(15), Country CHAR(15), Other_Details TEXT);

Just like general SQL statements, ATSQL2 statements use the keywords "create table" to create a database table. The temporal tables are defined by "AS VALIDTIME" reserved word, to indicate valid-time support. These tables are defined in the form of adding new column, which is used to store valid time in the backend database. The creating non-temporal tables follow the method of traditional DBMS. The referential integrity is preserved by using "REFERENCES" keyword.

\subsection{Temporal data manipulation}

Under the temporal semantics, inserting, deleting and updating operations are given richer connotation than the same operations under traditional non-temporal semantics. Depending on the valid time during which the operations are referenced, either tuple's splitting operation or tuple's merging operation will appear. In this paragraph we will present only two operations. 
A. Gudelj: Using Temporal Database for Representation and Reasoning in Maritime

Applications

Inserting data with merging operation

Example 1: The relation VESSEL becomes temporal as shown in Table 2. The information of table VESSEL after adding new vessels' information into it are shown in Table 3.

Table 2 Temporal data before record insertion

\begin{tabular}{|c|c|c|c|c|c|c|c|c|c|c|}
\hline VALID & MMSI & IMO & Name & Flag & Hull_type & Gross & $\begin{array}{c}\text { Dead } \\
\text { weight }\end{array}$ & Built & $\begin{array}{c}\text { Class } \\
\text { Society }\end{array}$ & $\begin{array}{l}\text { Statu } \\
\text { s }\end{array}$ \\
\hline $\begin{array}{c}{[2011 / 12-} \\
\text { forever })\end{array}$ & $\begin{array}{c}35497900 \\
0\end{array}$ & $\begin{array}{c}942661 \\
1\end{array}$ & $\begin{array}{c}\text { Global } \\
\text { Uranus }\end{array}$ & Panama & 1335 & 7745 & 12999 & 2010 & & Active \\
\hline $\begin{array}{c}{\left[\begin{array}{c}2006 / 09 / 08- \\
\text { forever })\end{array}\right.} \\
0\end{array}$ & $\begin{array}{c}22041700 \\
9\end{array}$ & $\begin{array}{c}932148 \\
\text { Maersk }\end{array}$ & Denmark & & $\begin{array}{c}17079 \\
4\end{array}$ & 156907 & 2006 & $\begin{array}{c}\text { American } \\
\text { Bureau of } \\
\text { Shipping }\end{array}$ & Active \\
\hline $\begin{array}{c}{[2006 / 01 / 01-} \\
\text { forever })\end{array}$ & $\begin{array}{c}56448100 \\
0\end{array}$ & $\begin{array}{c}929245 \\
0\end{array}$ & $\begin{array}{c}\text { Sima } \\
\text { Perfect }\end{array}$ & $\begin{array}{c}\text { Singapor } \\
\text { e }\end{array}$ & & 14036 & 17281 & 2005 & $\begin{array}{c}\text { Bureau } \\
\text { Veritas }\end{array}$ & Active \\
\hline $\begin{array}{c}{\left[\begin{array}{c}\text { 2008/09/08- } \\
\text { forever })\end{array}\right.} \\
\begin{array}{c}72501820 \\
0\end{array}\end{array}$ & $\begin{array}{c}742775 \\
2\end{array}$ & $\begin{array}{c}\text { Amadeo } \\
\text { I }\end{array}$ & Chile & & 9737 & 5675 & 1976 & $\begin{array}{c}\text { Det } \\
\text { Norske } \\
\text { Veritas }\end{array}$ & Active \\
\hline
\end{tabular}

Value-based insertion is defined as:

> VALID PERIOD '1981/01/01 -2008/09/08'

INSERT INTO VESSEL VALUES

(725018200, 7427752, Amadeo I, Chile, 9737, 5675, 1976, Det Norske Veritas, Active);

Table 3 Temporal data after record insertion

\begin{tabular}{|c|c|c|c|c|c|c|c|c|c|c|}
\hline VALID & MMSI & IMO & Name & Flag & $\begin{array}{l}\text { Hull } \\
\text { type }\end{array}$ & Gross & $\begin{array}{c}\text { Dead } \\
\text { weight }\end{array}$ & Built & $\begin{array}{l}\text { Class } \\
\text { Society }\end{array}$ & Status \\
\hline \begin{tabular}{|c|}
$2011 / 12-$ \\
forever)
\end{tabular} & $3549^{\prime}$ & 94266 & & Pana & 1335 & 7745 & 12999 & 2010 & & Activ \\
\hline $\begin{array}{c}2006 / 09 / 0 \\
8 \text {-forever) }\end{array}$ & 2204 & 9321 & $\begin{array}{l}\text { Emma } \\
\text { Maersk }\end{array}$ & Denı & & & 156907 & 2006 & $\begin{array}{l}\text { Amer } \\
\text { Burea } \\
\text { Shipp }\end{array}$ & Acti \\
\hline $\begin{array}{c}{[2006 / 01 / 0} \\
1 \text {-forever) }\end{array}$ & 564481000 & 9292450 & $\begin{array}{l}\text { Sima } \\
\text { Perfect }\end{array}$ & $\begin{array}{c}\text { Singapor } \\
\mathrm{e}\end{array}$ & & 14036 & 17281 & 2005 & $\begin{array}{l}\text { Bureau } \\
\text { Veritas }\end{array}$ & Act \\
\hline $\begin{array}{c}{[1981 / 01 / 0} \\
1 \text {-forever) }\end{array} \mid$ & 725018200 & 7427752 & Amadeo I & Chile & & 9737 & 5675 & 1976 & $\begin{array}{c}\text { Det } \\
\text { Norske } \\
\text { Veritas }\end{array}$ & Act \\
\hline
\end{tabular}

The period stated after the word VALIDTIME denotes the time when each tuple is valid. This allows the restriction of selection results and definition of views on the stated period and the restriction of time for definition of assertions and constraints. 
$36^{\mathrm{TH}}$ International Conference on ORganizational Science Development: RESPONSIBLE ORGANIZATION (MARCH $22^{\mathrm{ND}}-24^{\mathrm{TH}}$, PORTOROŽ SLOVENIA)

A. Gudelj: Using Temporal Database for Representation and Reasoning in Maritime Applications

\section{Updating data}

Example 2: The former name of the GLOBAL URANUS ship was Golden Kimi until December 2011. This is a temporal upward compatible modification and it is also expressible in TimeDB.

> VALID PERIOD 'beginning- 2011/12' UPDATE VESSEL

SET Name= 'Golden Kimi'

WHERE IMO=9426611;

This results in the following VESSEL table.

Table 4 Temporal data after updating

\begin{tabular}{|c|c|c|c|c|c|c|c|c|c|c|}
\hline VALID & MMSI & IMO & Name & Flag & Hull_type & Gross & $\begin{array}{c}\text { Dead } \\
\text { weight }\end{array}$ & Built & $\begin{array}{c}\text { Class } \\
\text { Society }\end{array}$ & Status \\
\hline $\begin{array}{c}{\left[\begin{array}{c}2010 / 03 / 29 \\
-2011 / 12\end{array}\right.} \\
{\left[\begin{array}{l}2011 / 12- \\
\text { forever) }\end{array}\right.}\end{array}$ & 354979000 & 9426611 & Golden Kimi & Panama & 1335 & 7745 & 12999 & 2010 & Active \\
\hline $\begin{array}{c}{[2006 / 09 / 08} \\
\text {-forever })\end{array}$ & 220417000 & 9321483 & Emma Maersk & Denmark & & 170794 & 156907 & 2006 & $\begin{array}{c}\text { American } \\
\text { Bureau of } \\
\text { Shipping }\end{array}$ & Active \\
\hline $\begin{array}{c}{[2006 / 01 / 01} \\
\text {-forever })\end{array}$ & 564481000 & 9292450 & Sima Perfect & Singapore & & 14036 & 17281 & 2005 & $\begin{array}{c}\text { Bureau } \\
\text { Veritas }\end{array}$ & Active \\
\hline $\begin{array}{c}{[1981 / 01 / 01} \\
\text {-forever })\end{array}$ & 725018200 & 7427752 & Amadeo I & Chile & & 9737 & 5675 & 1976 & $\begin{array}{c}\text { Norske } \\
\text { Veritas }\end{array}$ & Active \\
\hline
\end{tabular}

\subsection{Examples of temporal queries}

TimeDB supports snapshot query, sequenced query and non-sequenced query. We will only give a few special query example

\section{Sequenced queries}

Sequenced semantics of queries means that queries are evaluated using temporal relation operations, which interpret the timeflags of tuple and use them for calculation of tuple timeflag of the resulting relation. Sequential query which adds the prefix keywords "validtime", "transaction", "validtime and transaction" or "transaction and validtime" to indicate the time dimension to which the query operator refers (Guo et al., 2010).

Example 3: We would like to know maximum valid time for a ship with IMO number 9426611 which has different names stored in the database.

> VALID (SELECT MMSI, IMO

FROM VESSEL

WHERE IMO=9426611) (PERIOD); 
A. Gudelj: Using Temporal Database for Representation and Reasoning in Maritime Applications

This results in the following tuple.

\begin{tabular}{ccc} 
VALID & MMSI & IMO \\
\hdashline$[2010 / 03 / 29-f o r e w e r)$ & 35497900094 & 26611
\end{tabular}

In ATSQL2, the keyword (PERIOD) is used to denote that a set of tuples shall be coalesced. This keyword can appear after any reference to a table in the FROM-clause or at the end of a temporal ATSQL2 query.

Also, it is possible to create a temporal view. A temporal view is a virtual temporal table. For example, a valid-time view contains data with valid timeflags.

Example 4 (Analyse the shipping traffic in specific area or port): For the past year it is need to determine the vessels for which the destination port was SUEZ.

> CREATE VIEW U1(Name, IMO) AS

VALIDTIME PERIOD '[2015/01/01-2016/01/01)'

SELECT a2.Name AS Name, a2.IMO AS No

FROM VESSEL a2, HISTORICAL_DATA b2

WHERE b2.Port_Destination='Suez' AND a2.MMSI=b2.MMSI;

Example 5: (Temporal query) Which ships didn't have an event for at least 1 hours continuously?

> VALIDTIME SELECT a1.Name, a1.MMSI

FROM VESSEL AS a1,

(VALID SELECT a2.MMSI, a2.Vessel_HisData_id, a3.Vessel_HisData_id FROM HISTORICAL_DATA AS a2, EVENT_TRACKING AS a3

WHERE a2.Vessel_HisData_id=a3.Vessel_HisData_id AND

$(\operatorname{valid}(\mathrm{a} 3))>=$ interval '1'hours)

AS

b1

WHERE a1.MMSI=b1.MMSI;

\section{Non-sequenced semantics}

Non-sequenced semantics of queries express that the queries are evaluated using algebra operations, which treat the time information like any other attribute. These operations have the same semantics as the corresponding non-temporal operations and do not interpret the timeflag of tuples, but allow these timeflags to be referred to as if they were user-defined attributes.

Example 6: To determine which ship's name was changed, we must simultaneously consider two consecutive states of the vessel table, before and after the changing. This requires a nonsequenced query. 
$36^{\text {Th }}$ International Conference on Organizational Science Development: Responsible Organization (MARCh $22^{\mathrm{ND}}-24^{\mathrm{TH}}$, Portorož SLOVENia)

A. Gudelj: Using Temporal Database for Representation and Reasoning in Maritime Applications

\section{> NONSEQUENCED VALIDTIME}

SELECT IMO, I1.Name AS Old_name, I2.Name AS New_Name

FROM VESSEL AS I1, VESSEL AS I2

WHERE I1.IMO = I2.IMO AND I1.Name<>I2.Name AND

VALIDTIME (I1) MEETS VALIDTIME (I2);

The result is following non-temporal tuples, because NONSEQUENCED is not followed by a period expression.

\begin{tabular}{ccc} 
IMO & Old_name & New_Name \\
\hline 9426611 & Golden Kimi & Global Uranus
\end{tabular}

TimeDB supports valid-time assertions and valid-time table- and column-constraints. Valid-time assertions are defined by using the CREATE ASSERTION statement. Also, ATSQL2 allows the use of the keyword VALID to denote that the assertion should be checked using temporal semantics. Similarly, valid-time column-constraints such as referential integrity and CHECK constraints may be declared as temporal in ATSQL2 by writing VALID in front of the column-constraint.

Example 7: It is necessary to ensure that the event 'change name' ensures the existence of a tuple with a new name in the table VESSEL. This fast has to be valid from timestamp when the event occurred.

$>$ CREATE ASSERTION change_name

VALID CHECK (NOT EXISTS

(SELECT * FROM VESSEL AS u1, VESSEL AS u1,

(SELECT a1.Vessel_HisData_id, a1.MMSI, a2.Vessel_HisData_id, a2.TimeStamp

FROM HISTORICAL_DATA AS a1, EVENT_TRACKING AS a2

WHERE a1.Vessel_HisData_id=a2.Vessel_HisData_id AND a2.event='change name') AS b

WHERE u1.MMSI=b.MMSI AND u1.MMSI = u2.MMSI AND

u1.Name $<>$ u2.Name AND VALIDTIME(u1) MEETS

VALIDTIME(u2) AND

BEGIN(VALIDTIME(u2))= b.TimeStamp ));

\section{Conclusion}

This paper has proposed a data model for the temporal database for the provision and access maritime data and information. The model is based on the data models which are discussed in (Steiner, 1998). Proposed data model is designed from underlying nontemporal by adding attributes with timeflags. 
A. Gudelj: Using Temporal Database for Representation and Reasoning in Maritime

Applications

About 30 years ago, the importance of temporal support for database applications was recognized and considerable research effort was put into the development of temporal database systems. From presented examples, we can see that ATSQL2 covers all aspects of the language for DBMS. The methods for updating, retrieving and evaluating temporal rules have also been presented. The author has tried to discuss several directions of research and merge different perspectives. It is the authors' belief that the modelling and language concepts presented in this paper will stimulate discussion and multidisciplinary approaches in realization of future data base for temporal representation maritime data and information and reasoning in maritime domain.

\section{Literature}

Guo, H., Tang, Y., Yang, X., Ye, X. (2010). Improvement and extension to ATSQL2. In Temporal Information Processing Technology and Its Application, Y. Tang et al, Eds. Tsinghua University Press, Beijing and Springer-Verlag Berlin Heidelberg, pp. 245-259.

Kostenko, B. (2007). Temporal preprocessor: Towards temporal applications development. Proceedings of SYRCODIS'07, the 4th Spring Young Researchers Colloquium on Databases and Information Systems (pp. 1-3). CEUR-WS.org, Moscow, Russia, June 21-22 2007.

Silbershatz, A., Korth, H., Sudarshan, S. (2005). Database System Concepts. McGraw Hill, 5th Edition.

Snodgrass, R. (2000). Developing Time-Oriented Database Applications in SQL. 1st edn., Morgan Kaufmann Publishers, Inc., San Francisco, pp: 504.

Snodgrass, R., Böhlen, M., Jensen, C., Steiner, A. (1996). Adding Valid Time to SQL / Temporal. ANSI X3H2-96-501r2, ISO/IECC JTC1/SC 21/WG 3 DBL-MAD-146r2. November 1996, 77 pages. ftp://ftp.cs.Arizona/edu/tsql/tsq12/sq13/mad146.ps

Snodgrass, R., Böhlen, M., Jensen, C., Steiner, A. (1996). Adding Transaction Time to SQL/ Temporal. ANSI X3H2-96-502r2, ISO/IECC JTC1/SC 21/WG 3 DBL-MAD-147r2.

Steiner, A. (1998). A Generalisation Approach to Temporal Data Models and their Implementations, $\mathrm{PhD}$ thesis, ETH Zürich.

Tansel, A., Clifford, J., Jajodia, S., Segev, A., Snodgrass, R. (1993). Temporal Databases: Theory, Design and Implementation. The Benjamin/Cummings Publishing Company, Redwood City.

EMSA- European Maritime Safety Agency (2016). Annex I - Tender Specification. www.emsa.europa.eu.

Historical AIS Data Services (2016). Vessel Movements Report. Retrieved from https://www.vesselfinder.com/historical-ais-data\#vessel-movements-report

TimeConsult (2005). Retrieved from http://www.timeconsult.com 
226 36 $6^{\text {Th }}$ International Conference on Organizational Science Development:

Responsible Organization (MARCH $22^{\mathrm{ND}}-24^{\mathrm{TH}}$, PORTOROŽ SLOVENIA) 
$36^{\text {TH }}$ International Conference on Organizational Science DEVElopMENT: Responsible ORganization (MARCH $22^{\mathrm{ND}}-24^{\mathrm{TH}}$, PORTOROŽ SLOVENIA)

O. Arsenijević, M. Ferjan, I. Podbregar, P. Šprajc, D. Trivan \& Y.

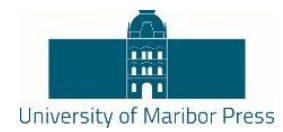

Ziegler

\title{
Information Security Challenges - How to Prepare Professionals
}

\author{
JIŘí HOLOŠKA, PETR DOUCEK \& LEA NEDOMOVÁ
}

\begin{abstract}
As information and communication technologies (ICT) keep developing and are being increasingly used in e-commerce, e-government, social networks and other areas, they more and more influence the regular life of citizens as well as the running of organizations regardless of their legal form. An information society brings rapid information changes. This speed is a big challenge for those who - for some reasons - needs to keep reliable and provable information. These can be business persons, officials, attorneys, judges or investigators etc.

This article presents information about teaching process on University of Economics, Prague in the area of ICT security and ICT security management. It presents the minor specialization and possible knowledge and skills that could obtain successful graduates of this course package. Especially attention is paid to new course Digital Forensic Analysis and experience, which have been collected last semester and are under evaluation at this time.
\end{abstract}

KEYWORDS: ICT security • security management • penetration testing • risk management $\bullet$ information society

CORRESPONDENCE AdDRESS: Jiří Hološka, University of Economics, Prague, nám. Winstona Churchilla 1938/4, 13067 Praha 3, Czech Republic, e-mail: kiri.holoska@vse.cz; Petr Doucek, CSc., University of Economics, Prague, nám. Winstona Churchilla 1938/4, 13067 Praha 3, Czech Republic, e-mail: doucek@vse.cz; Lea Nedomová, M.D., University of Economics, Prague, nám. Winstona Churchilla 1938/4, 13067 Praha 3, Czech Republic, e-mail: lea.nedomova@vse.cz 
$36^{\text {Th }}$ International Conference on Organizational Science Development: RESPONSIBLE ORGANIZATION (MARCH $22^{\mathrm{ND}}-24^{\mathrm{TH}}$, PORTOROŽ SLOVENIA)

J. Hološka, P. Doucek \& L. Nedomová: Information Security Challenges - How to Prepare Professionals

Information Systems and Information and Communication Technologies (IS/ICT) represent on one hand very effective tool for making all processes faster and reliable (Webster, 1994), but on the other hand these process are not fully under the control of responsible persons (process owners). For our business is more and more typically that all knowledge about the process management are hidden somewhere in information systems and in case of its disruption processes remain without control and they are often running by unknown and undefined way.

ICT security is more and more accepted as system property, it is standardized and implemented in accordance with systems of common valid rules and it is measured and audited (Svatá, 2012). It became an integral and inseparable part of information and communication technology. Threats and attacks are already changing and there are also changing goals of these activities. There are penetrating social networks and/or games into corporate information systems on one hand, on the great boom of Internet of Things (IoT) and use of mobile devices on the other hand. Security especially of mobile devices is very disputable and we have not data queues for evaluating longer operation of this kind of device.

Professionals facing and having solve these classes of problems are obligatory to dispose on one hand a large set of theoretical knowledge and on the other hand the set of practical skills as well. The minor specialization "Business Information System Security" offers to students of "Information Management" basic knowledge in areas that are appropriate to this hard job.

Contribution presents general content of this minor specialization with accent on topics that are taught in the frame of this specialization. Also content of selected courses are introduce in this article. The summary of practical experiences with teaching theses course on Faculty of Informatics and Statistics, University of Economics, Prague are discussed in this contribution.

\section{Concept of Information Security Teaching}

Security classes on University of Economics, Prague are focused on education students for position CSO (Chief Security Officer). This position is managerial in its majority, but it also requires a lot of practical ICT and/or business oriented skills. Splitting problems into two categories of courses allow to present essential, generally valid information in obligatory courses and extended ones into the sum of elective courses. The education has a managerial accent and does not offer discussions and examples of very deep technical problems. 


\section{What Offers the Specialization}

Minor specialization "ICT Security" offers theoretical knowledge and practical skills for it graduates. Obligatory courses show longer valid theoretical principles, accent of elective courses is on practical skills from managerial point of view.

\subsection{Obligatory courses}

Obligatory course are focused on theoretical back ground and essential principles of ICT security in a corporation. The course of ISMS (Information Security Management Systems) offers definition of essential terms in this area, it also presents basic relations to other corporate management's disciplines as quality management, risk management and auditing of information systems. All changes in corporate IS/ICT are realized by project approach, so it is taught project management level on basic level. Other advanced level of project management is offered as elective course and its topics is project portfolio management. The topic of the obligatory courses is the course Audit. Skills and knowledge that get students in this course can be applied by auditing process in the whole area of corporate informatics and in ISMS auditing as well.

\section{Information Security Management Systems}

This course represents theoretical background for further education in ICT security topics. It also defines general frame of information security investigation - the family of international standards 27000 (ISO 27005, 2011). The goal of it is to present to students Information Security Management System concept based on Deming's managerial PDCA (Deming, 1982 ) approach and on international standards of family 27000 (Susanto, Almunawar and Tuan, 2011). Further sources is also the NIST standards family 800 (NIST 800-37, 2011). The graduate of the course will be able to realize the security risk analysis, to design ISMS in organization, evaluate aspects of risk management in cyberspace (ISO 27032, 2012), to measure (Doucek, 2008) and to manage it.

\section{Project Management}

The aim of the course is to offer to student basic and essential knowledge about the general theory of project management and its application on ICT area with special impact on ERP (Enterprise Resource Planning) systems - its development and implementation. Upon successful completion of this course students will be able to develop project plan by the help of MS Project software tool, to apply tools supporting business process reengineering (DFD - Data Flow Diagrams), BPMN - Business Process Model and Notation, EPC diagrams), to design the contracts on ERP systems implementation, to provide project cost and benefit management, design the ERP configuration. Each week the students will have to solve case study in relation to the topics of lectures. The unique case study is solved during the whole semester. 
$36^{\mathrm{TH}}$ International Conference on Organizational Science Development: RESPONSIBLE ORGANIZATION (MARCH $22^{\mathrm{ND}}-24^{\mathrm{TH}}$, PORTOROŽ SLOVENIA)

J. Hološka, P. Doucek \& L. Nedomová: Information Security Challenges - How to Prepare Professionals

\section{Information Systems Audit}

The aim of this course is to acquaint students with the development, content, tools and problems of implementation of the audit of information systems and its linkages to financial audits. It is therefore an attempt to contribute to reducing the gap between what users expect from an audit and what results they can actually receive (so called audit expectation gap). Upon the successful completion, the students will be able on the base of risk analysis or other scoping procedures to refine the audit objectives, define the realistic objectives of the audit in a particular environment, select the appropriate evaluating criterion, design audit plan, realize the different types of audit and/or assurance (in cooperation with other professionals according to the focus of the audit) and create the final audit report. Content of the course is based on principles of IT Governance, standards decomposition: ISACA and ISA professional standards, IS/ICT standards. Also following frameworks as CoBit 5, Intosai, IT Assurance Guide, Val IT, Risk IT and COSO are presented in the frame of this course. On tutorials are presented examples of different types of information system audit - e.g. audit of information system department, audit of information system outsourcing (cloud computing, data base audit, chosen information technology process audit, audit of project), information system security etc. Other aspects of enterprise architecture design, implementation and improvement are in realization to IT governance are presented to students.

\subsection{Elective courses}

Elective courses make deeper various aspects of ICT security. Its main role is to offer portfolio of in time information and presenting new methods and methodologies. This part of contribution offers two main views on the minor specialization. One from it is the overview of taught courses with information about areas of ICT security where students get additional information. The second one is the evaluation of the course Digital Forensic Analysis, which has been taught in winter semester 2016/2017 for the first time and its general evaluation of first results and reactions of students.

\section{Modern Risk Management}

This subject is focused on the modern risk management area, process managed organizational concept, basic legislation foundation principles, the competencies of process owners and control owners, internal control concept including testing and audit of internal controls (NIST 800-37, 2011). Upon successful completion of this course, students will be able to design, implement and testing and/or audit of internal controls plus evaluation of their effectiveness. The course contents operational excellence principles and their practical use, Sarbanes - Oxley Law (SOX) in brief, details of SOX302, SOX404 and SOX906, COSO principles (Svatá, 2012; Svatá and Fleischman, 2011). It also defines risk classification and basic processes and terms of risk management and also offers guide lines for it interpretation into business (NIST 800-30, 2010). 


\section{Digital Forensic Analysis}

The importance for cybercrime investigation is instantly growing over the last few years. This creates a large demand for cyber security analysts, incident handlers and forensic analysts (Veber, Nedomova and Doucek, 2016).

Training of a forensic analyst is a long and expensive process which takes approximately three to five years of intensive education. The course of Digital Forensics at the University of Economics, Prague does not aim for training independent analysts, but rather introduce different fields of digital forensics to students so they can continue and start pursuing their career path if interested. It has been based on ISO norms ISO 27015 (ISO 27015, 2012), ISO 27042 (ISO 27042, 2015) and ISO 27043 (ISO 27043, 2015). The purpose of digital forensic class at University of Economics, Prague is to provide the state of art of methodologies in data acquisition and OS level artefacts analysis which would allow students to interpret process and user action on examined evidence. With limited time given to the lectures, students will be exposed with complex techniques for data acquisition and basic analysis of the NTFS file system architecture, data recovery, data carving, binary file identification, Windows registry parsing, Windows log parsing, data de-duplication and document indexing. Course is focused on digital evidence acquisition and basic methods of digital data processing. Upon successful completion of this course, students will be able to provide proper digital evidence acquisition, documentation of data acquisition procedures and data processing procedures including simplified final report.

The course is designed to properly introduce state of art methods for digital evidence acquisition as well as best practices for handling and processing acquired evidence. The main expectation is that students who successfully pass this course will have strong understanding of the nature of digital evidence and its proper handling.

Tools used in practical assignments are mostly freeware or compiled Python application developed by forensic community as a proof of concept software. This allowed to distribute the tools to the students for after class projects or for later self-study activities. Basic hardware tools students had a chance to work with were the Wiebetech writeblockers. Wiebetech ComboDock v5 and Wiebetech USB 3.0 were chosen for their robust design and extended support for GNU/Linux OS based imagers which were a part of the course.

Evidence acquisition was performed on a custom build live Linux distribution and FTK imager on MS Windows (Fig. 1). Students experienced the difference between MS Windows and GNU Linux hard drive identification and several different approaches for evidence collection under specific situations and conditions including data extraction from exotic hard drives with vendor-specific connectors. Live evidence acquisition of encrypted disk volumes, and logical acquisition of cloud drives. 
$36^{\text {Th }}$ International Conference on Organizational Science Development: RESPONSIBLE ORGANIZATION (MARCH $22^{\mathrm{ND}}-24^{\mathrm{TH}}$, PORTOROŽ SLOVENIA)

J. Hološka, P. Doucek \& L. Nedomová: Information Security Challenges - How to Prepare Professionals

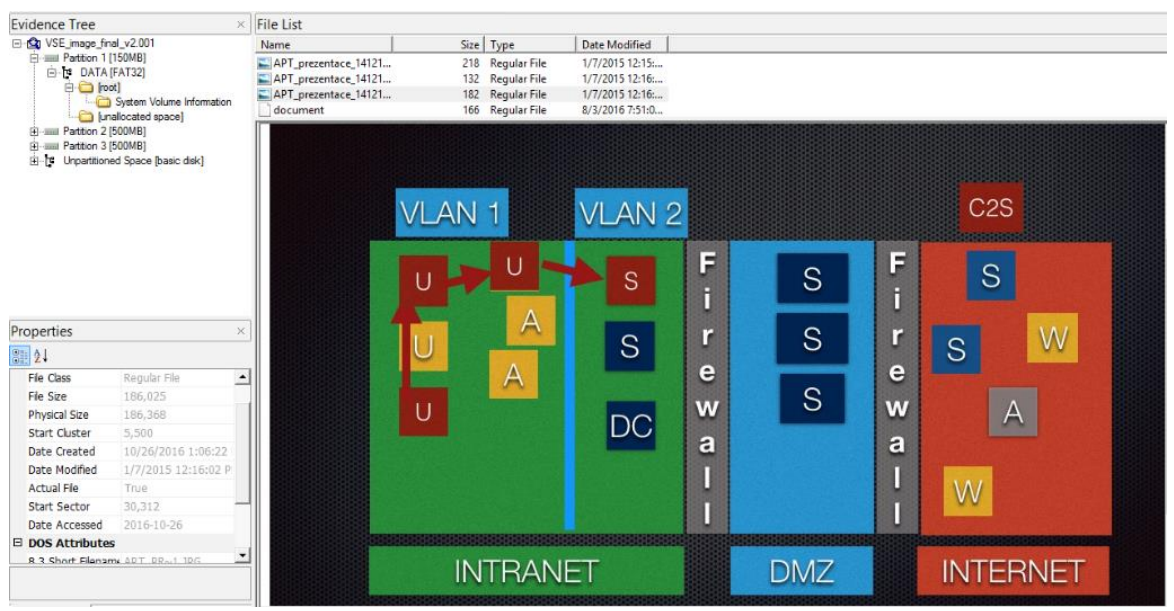

Figure 1: Content of Acquired Image Open in FTK Imager Source. authors

As for evidence integrity and handling, a formal track of records for each piece of evidence is essential. Students are challenged to cooperate and put together all required information as a part of head to head competition in between four teams.

An important part of the course is the understanding of basic artefacts of a like the NTFS file system. During the assignments, students are guided through the process of analysis of Alternative Data Streams as well as native time stamp records in a MFT table. This helps to understand basic anti-forensic techniques of data hiding and time stamping (Fig. 2).

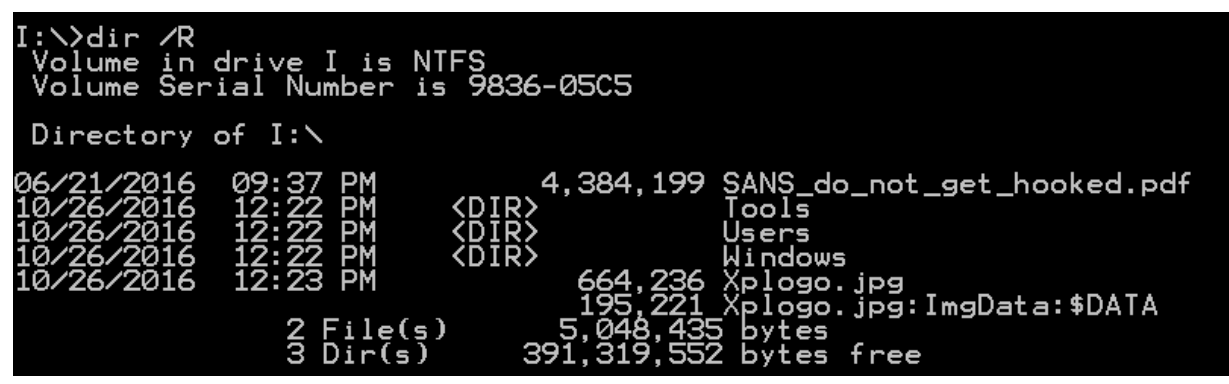

Figure 2: Alternative Data Stream Discovery on live System

Source: authors

The difference between online and offline analysis of ADS is that during offline MFT parsing, it is possible to get time stamps of ASD content as shown by Table 1. Time records are a crucial piece of information during any incident response analysis (Mitropoulos, Patsos and Douligeris, 2006). 
36. MEDNARODNA KONFERENCA O RAZVOJU ORGANIZACIJSKIH ZNANOSTI: ODGOVORNA ORGANIZACIJA (22. - 24. MAREC 2017, PORTOROŽ, SLOVENIJA)

J. Hološka, P. Doucek \& L. Nedomová: Information Security Challenges - How to

Prepare Professionals

Table 5: Alternative Data Stream Analysis from Off-line NTFS Master File Table export

\begin{tabular}{|c|c|c|c|c|c|c|}
\hline $\begin{array}{c}\operatorname{RecN} \\
\mathbf{0}\end{array}$ & $\begin{array}{c}\text { Delete } \\
\text { d }\end{array}$ & $\begin{array}{c}\mathbf{A D} \\
\mathbf{S}\end{array}$ & Filename & $\begin{array}{l}\text { siCreateTi } \\
\text { me (UTC) }\end{array}$ & $\begin{array}{c}\text { siModTi } \\
\text { me } \\
\text { (UTC) }\end{array}$ & $\begin{array}{l}\text { siMFTModTi } \\
\text { me (UTC) }\end{array}$ \\
\hline 105 & 0 & 0 & Xplogo.jpg & $\begin{array}{l}2016-10-26 \\
11: 23: 00\end{array}$ & $\begin{array}{l}2016-10- \\
26 \\
11: 23: 03\end{array}$ & $\begin{array}{l}2016-10-26 \\
11: 23: 03\end{array}$ \\
\hline 105 & 0 & 1 & $\begin{array}{l}\text { Xplogo.jpg:ImgD } \\
\text { ata }\end{array}$ & $\begin{array}{l}2016-10-26 \\
11: 23: 00\end{array}$ & $\begin{array}{l}2016-10- \\
26 \\
11: 23: 03\end{array}$ & $\begin{array}{l}2016-10-26 \\
11: 23: 03\end{array}$ \\
\hline
\end{tabular}

During the course the students are introduced to case studies examples and they are challenged to propose a proper approach for artefact analysis and explain why.

While the interpretation of operating system artefacts is important, the understanding of data processing of stored data is of the same importance. Due to the fact, different techniques for data filtering and string matching were explained to the students. Provided class assignment case data can be filtered based on known hash rules, regular expressions or fuzzy hashing rules. The primary fuzzy hash algorithm used in an assignment is a hamming distance measure based SDHash.

The course was very well accepted by the students. During the preparation phase of the course the main expectation was that the students will be more interested in the theoretical part of the course. The course evaluation was completely different from what was expected at the beginning of the course development. Students showed large desire in deep technical assignments more than just theoretical background of the subject.

Based on the feedback we plan to extend class assignments for e-discovery assignments consisting of email, instant messaging and document processing. Processed data will be filtered based on keywords, hash matching rules and regular expressions.

\section{Information System Security Law}

The aim of the course is to present the data security relevant legal framework, targeting primarily on the ICT environment. Upon successful completion of this course, students will be able to identify main data security relevant laws applicable to the environment of their employer. Students will be also able to apply requirements under the particular acts. The main contribution of this course is that it is taught by lawyer and shows different presentation of ICT aspects. The course also concludes Czech and the EU regulations as well (hierarchy of acts and regulations in the Czech Republic and their relevance; the legislative process in the Czech Republic; EU regulations and their relevance; relevant foreign and international standards - FISMA, Sarbanes-Oxley Act; appeal process; basic terms explanation. Privacy and personal data protection (protection of personal rights - 
$36^{\text {Th }}$ International Conference on Organizational Science Development: ReSPONSIBLE ORGANIZATION (MARCH $22^{\mathrm{ND}}-24^{\mathrm{TH}}$, PORTOROŽ Slovenia)

J. Hološka, P. Doucek \& L. Nedomová: Information Security Challenges - How to Prepare Professionals

based on the Constitution; privacy protection - based on the Constitution, Civil Code; personal data protection - Personal data protection act, 95/46/EC).

\section{Information Security Penetration Testing}

The main goal of this course is to familiarize students with penetration tests of information systems security, also called ethical hacking. Students will learn how to practically employ current techniques and methodologies of information system security assessment. Presented methodologies of penetration tests are OWASP (Open Web Application Security Project), ISSAF (Information Systems Security Assessment Framework), OSSTMMM (Open Source Security Testing Methodology Manual) and PTES (Penetration Testing Execution Standard) with relation to special techniques as are sniffing, spoofing, password cracking, brute forcing etc. The course focuses both on technical and managerial skills. Upon successful completion of this course, students will be able to conduct penetration test including the creation of the final report. They will also be able to manage tests in terms of planning, operational management and implementation of countermeasures. The courses completes knowledge in the field of penetration testing.

\section{$4 \quad$ Conclusions}

Today's crucial dependency of our society on IS/ICT generates new requirements on information security. Based on international standards, several courses focused on information security have been developed on Faculty of Informatics and Statistics, University of Economics, Prague. Its relative wide portfolio contents legal aspects of information security, Information Security Management Systems theory and practice, risk analysis. The new topic added to this family it the course of Digital Forensic Analysis that has been started in winter semester 2016/2017. The course covers main skills and knowledge in digital evidence acquisition, evidence handling, MS Windows OS artifact analysis, data correlation and reporting. Main focus is aimed on proper evidence acquisition under different conditions and Windows artefact correlation. The combination of above presented courses offers to students to get basic overview about information security both from theoretical point of view as to get practical skills.

Acknowledgements

Paper was processed with contribution of long term institutional support of research activities by Faculty of Informatics and Statistics, University of Economics, Prague (IP 400040) and project GAČR 17-02509S.

\section{Literature}

Deming, W., E. (1982). Out of the Crisis, MIT, The MIT Press, Cambridge, MA, DEMOP 0-26254115-7 
Doucek, P. (2008). Applied information management - Management reference model - Security metrics. In: IDIMT - 2008 Managing the Unmanageable. Linz: Trauner Verlag, pp. 81-106. ISBN 978-3-85499-448-0.

ISO/IEC 27005:2011 Information technology - Security Techniques - Information security risk management. International Organization for Standardization, Geneva, Switzerland.

ISO/IEC TR 27015:2012 Information technology - Security techniques - Information security management guidelines for financial services. International Organization for Standardization, Geneva, Switzerland

ISO/IEC 27032:2012 Information technology - Security techniques - Guidelines for cybersecurity. International Organization for Standardization, Geneva, Switzerland

ISO/IEC 27042:2015 Information technology - Security techniques - Guidelines for the analysis and interpretation of digital evidence. International Organization for Standardization, Geneva, Switzerland

ISO/IEC 27043:2015 Information technology - Security techniques - Incident investigation principles and processes. International Organization for Standardization, Geneva, Switzerland

Mitropoulos, S., Patsos, D., \& Douligeris, C. (2006). On Incident Handling and Response: A stateof-the-art approach. In: Computers and Security, Vol. 25, No. 5, pp. 351-370.

NIST 800-37:2010 Rev1: Guide for Applying the Risk Management Framework to Federal Information Systems: A Security Life Cycle Approach. National Institute of Standards and Technology, U.S. Department of Commerce

NIST 800-30:2012 Rev1: Guide for Conducting Risk Assessments. National Institute of Standards and Technology, U.S. Department of Commerce

Susanto, H., Almunawar, M. N., \& Tuan, Y. C. (2011). Information security management system standards: A comparative study of the big five. In: International Journal of Electrical \& Computer Sciences. Vol. 11, No. 05, pp. 23-29.

Svatá, V. (2012). Audit informačního systému. Praha: Professional Publishing.

Svatá, V., \& Fleischmann, M. (2011). IS/IT Risk management in Banking Industry. Acta Oeconomia Pragensia, Vol 19, No.3, pp. 43-60. ISSN 0572-3043

Veber, J., Nedomova, L., \& Doucek, P. (2016). Corporate Digital Incident Investigation. Quality Innovation Prosperity [online]. Vol. 20, No. 1, pp. 57-70. ISSN 1335-1745. DOI: 10.12776/QIP.V20I1.656.

Webster, F., 1994. What Is Information Society? In.: The Information Society, Vol. 10, No. 1, pp.123. 
236 36 $6^{\text {Th }}$ International Conference on Organizational Science Development:

Responsible Organization (MARCH $22^{\mathrm{ND}}-24^{\mathrm{TH}}$, PORTOROŽ SLOVENIA) 


\title{
Nagrajevanje aktivnih dijakov $v$ dijaškem domu in izbor za športnika leta
}

\begin{abstract}
MIHA INDIHAR
Povzetek Ukvarjanje s športom ima številne razsežnosti, ki se jih ljudje lotevamo na najrazličnejše načine: pri nekaterih gre za profesionalen pristop, saj je šport njihova zaposlitev oziroma vrsta finančnega dohodka; pri drugih gre za aktivno preživljanje prostega časa, druženje ali veselje do gibanja; pri nekaterih za preventivo proti različnim oblikam bolezni ali slabega počutja; v šolah pa gre med drugimi tudi za obvezno obliko izobraževanja. Dijaški domovi imajo pri spodbujanju $\mathrm{k}$ športnim aktivnostim specifično vlogo, saj (lahko) pri spremljanju dijaka združujejo vse zgoraj naštete pristope. V dijaškem domu Ivana Cankarja vzgojitelji poskušamo dijake spodbuditi, da čas preživijo čim bolj produktivno, v okviru z njihovimi zmožnostmi, pričakovanji in interesi. Športne aktivnosti so med dijaki med najbolj priljubljenimi, zato se trudimo, da jih pri tem nagradimo $\mathrm{z}$ različnimi oblikami. Izbor za športnika leta $\mathrm{v}$ dijaškem domu je nagrada za dijakinjo in dijaka, ki sta $v$ šolskem letu najbolj izstopala $s$ športnimi rezultati. Pri tovrstnem izboru pa ne gre zgolj za iskanje najboljših, temveč predvsem za nagrajevanje aktivnih dijakov, saj vsak posameznik, ki sodeluje na športnih področjih dobi različne oblike potrdila.
\end{abstract}

KLJUČNE BESEDE: nagrajevanje $・$ dijaški dom • mladi $•$ prosti čas

Naslov AVtorJev: Miha Indihar, Dijaški dom Ivana Cankarja, Poljanska cesta 26, 1000 Ljubljana, Slovenija, e-pošta: miha.indihar@dic.si

DOI https://doi.org/10.18690/978-961-286-020-2.22

ISBN 978-961-286-020-2

(C) 2017 Univerzitetna založba Univerze v Mariboru

Dostopno na: http://press.um.si 
$36^{\text {TH }}$ InTERnAtional CONFERENCE ON ORganizational SCIENCE Development: Responsible Organization (MARCH $22^{\mathrm{ND}}-24^{\mathrm{TH}}$, PORTOROŽ SLOVENIA)

O. Arsenijević, M. Ferjan, I. Podbregar, P. Šprajc, D. Trivan \& Y.

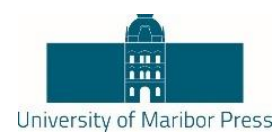

Ziegler

\title{
Awarding Active Students in a Boarding School and the Athlete of the Year Selection
}

\author{
MIHA INDIHAR
}

\begin{abstract}
Doing sports has a number of different dimensions which can be done in a variety of ways: some take it professional, because sport is their job or type of financial income; others take it as a leisure activity, socialisation or the joy of movement; it can be also a preventive care against different forms of disease or indisposition; in schools is sport compulsory form of education. Boarding school play a big role in encouraging students to engage in sports due to ability of combining all different approaches. In Ivan Cankar boarding school are trying to encourage students to spend their leisure time in boarding school productivly within their capabilities, expectations and interests. Sports activities are among the most popular activities, so we try to reward them in various ways. Competition for the sportsman of the year in boarding school is the reward for a girl and a boy that were the best in sports. The purpose of the competiton is not looking for the most succesful students, but rewarding active students, because every individual that participate in the event gets a certificate.
\end{abstract}

KEYWORDS: reward $\bullet$ boarding school $\bullet$ young $\bullet$ leisure

CorRespondence Address: Miha Indihar, Student Dormitory Ivan Cankar, Poljanska cesta 26, 1000 Ljubljana, Slovenia, e-mail: miha.indihar@dic.si 
M. Indihar: Nagrajevanje aktivnih dijakov v dijaškem domu in izbor za športnika leta

\section{Uvod}

Različne oblike nagrajevanja predstavljajo močno sporočilo o vrednotenju posameznikovega udejstvovanja. Pri odraslih je najbolj pogosta oblika nagrajevanja v obliki financ, pri mlajših pa so te nagrade nekoliko drugačne. Pri tem je potrebno poudariti, da nagrade niso pomembne le za tiste posameznike, ki izstopajo in pri različnih dejavnostih kažejo boljše rezultate kot drugi; pri nagrajevanju je pomembno predvsem to, da vsi tisti, ki vložijo določeno energijo v neko delo (ali dejavnost) dobijo potrdilo za svojo prizadevnost.

V dijaških domovih poznamo različne oblike nagrajevanja; v Dijaškem domu Ivana Cankarja (v nadaljevanju DIC) je najvišja nagrada za posameznega dijaka nagrada ob koncu srednješolskega izobraževanja, kjer vzgojiteljski zbor izbere tiste dijake, ki se v času bivanja v dijaškem domu s svojim delom in vedenjem odlikujejo ter izkazujejo druge vrline oziroma sposobnosti (30. člen Pravilnika o bivanju). Pri vrednotenju dijakovega dela poznamo tudi druge različne oblike nagrajevanja, med drugimi tudi vsakoletni izbor za športnico in športnika leta. Tovrstno nagrajevanje je za dijake zelo pomembno, saj so športno-rekreativne dejavnosti med dijaki praviloma najbolj priljubljene in hkrati tudi številčno najbolj zastopane.

$\mathrm{Ob}$ tem se pojavlja vprašanje, koliko dijakov sodeluje pri športno-rekreativnih dejavnostih, kot del različnih tekmovanj, koliko je teh tekmovanj in kako ovrednotenje njihovih dosežkov vpliva na motivacijo za nadaljnje sodelovanje. Menimo namreč, da se dijake $\mathrm{v}$ (prostem) času sprostitve radi preizkušajo med seboj, ali v obliki medsebojnega tekmovanja ali pa v preizkušanju svojih spretnosti in zmožnosti.

\section{$1 \quad$ Prosti čas}

Pomen prostega časa se je v preteklosti spreminjal, na različne poglede tega pojma pa so med drugimi vplivale tudi družbene spremembe. Prosti čas je sodobnejši pojem, ki ga Černigoj - Sadar (1991) dojema kot dopolnilo $\mathrm{k}$ delu, nastal pa naj bi $\mathrm{v}$ procesu industrializacije, ko so nastajale meje med posameznimi področji življenja (plačano delo, družina, prosti čas). Kuhar (2007) meni, da definiranje prostega časa ni enostavno, saj gre za dojemanje pojma skozi percepcijo posameznika, kjer se oblikuje njegovo dojemanje prostočasnih dejavnosti. Omenjeno teorijo lahko potrdimo pri obravnavanju posamezne dejavnosti, ki jo v enakih okoliščinah nekdo dojema kot sprostitev, drugemu je lahko to dopolnilna dejavnost, spet nekaterim pa služba in profesionalno delo.

Teorije in definicije prostega časa so poskušali definirati tudi številni drugi avtorji (Bajzek, 2008; Ule in Miheljak, 1995; Fenwick in Smithe, 1997; Kuhar, 2007; Kristančič, 2007; Ule, 2002), ki so se osredotočali na različne okoliščine ki pomembno vplivajo na vprašanje dojemanja prostega časa. Razlike, ki nastajajo pri različnih teorijah niso posledica medsebojnega nestrinjanja, temveč gre za vprašanje iz kakšnega vidika posamezni avtorji pristopajo k pojmu »prosti čas«. Ena najbolj pogostih definicij se nanaša na tisti čas, ki ga posameznik uporablja za oddih, izpopolnjevanje in izobraževanje; ni pa to edini aspekt dojemanja prostega časa. 
$36^{\text {TH }}$ International Conference on Organizational Science Development: Responsible Organization (MARCh $22^{\mathrm{ND}}-24^{\mathrm{TH}}$, Portorož Slovenia)

M. Indihar: Awarding Active Students in a Boarding School and the Athlete of the Year Selection

Ule (2016) opozarja na dileme prostega časa v sedanjem času. Pravi, da zaradi okoliščin (produkcija modnih stilov, trendov, elektronske in zabavne industrije) potrošniška družba hote ali nehote zmanjšuje prostor avtonomije in vzdržuje nadzor nad prosim časom mladih. Temu se pridružujejo še vsi tisti, ki bedijo nad vzgojo in odraščanjem mladih in skušajo poleg delovnega časa mladih, s svojimi pedagoškimi intervencijami načrtovati in nadzirati tudi njihov prosti čas. $\mathrm{V}$ zadnjih desetletjih se tako zmanjšuje pomembna značilnost in razlika med prostim časom mladih in odraslih. Prosti čas ni več prost, saj je ravno tako nadzorovan kot prosti čas odraslih. Poleg klasičnih nadzornih dejavnikov v obliki pedagoških intervencij staršev in učiteljev ga v veliki meri nadzoruje potrošnja industrija, predvsem nove tehnologije in mediji.

\section{$2 \quad$ Motivacija}

$\mathrm{Na}$ vsakega človeka $\mathrm{v}$ nekem trenutku vplivajo številni divergentni faktorji oziroma elementi, ki botrujejo na njegovo odločitev, hkrati pa pri vsakem posamezniku obstajajo tudi številni različni razlogi za posamezna dejanja, pojasnjujeta Musek in Pečjak (1997) in dodajata, da na podlagi tega lahko trdimo, da se nobena aktivnost ne začne sama po sebi in brez razloga. Človekove aktivnosti in njegovo vedenje so motiviranji, pojavljajo pa se kot konsekvenca različnih potreb in gibal, ki nanj vplivajo. Potrebe, cilji in posledično motivirano vedenje avtorja opredeljujeta kot prvine motivacijske situacije in pojasnjujeta, da se posameznikovi motivi uresničujejo z motiviranim obnašanjem.

Ko poskušamo poiskati različne oblike $\mathrm{s}$ katerimi bi spodbudili mlade $\mathrm{k}$ različnim udejstvovanjem, je polega nagrajevanja ena od najbolj pogostih oblik motiviranje. Gre za nekoliko bolj psihološki pojem $\mathrm{s}$ katerimi poskušamo spodbujati in usmerjati posameznike $\mathrm{k}$ tistim ciljem, ki jih sami dojemajo kot prioritetno dejavnost $\mathrm{v}$ prostem času. Na podoben način motivacijo definira tudi Pintrich (1996), ki pravi, da gre za proces, ki poskuša spodbujati in k določenemu cilju usmerjati posamezno delovanje. Nekoliko bolj podrobno je pojem motivacije opredelil Uhan (2000), ki pojasnjuje, da gre za stalen spodbujevalen proces osmišljanja osebnega delovnega življenja in doživljanja zadovoljstva, ki hkrati omogoča kreativno aktivnost, usmerjenost k efektivnosti, osebni rasti in ekspertnosti ter participacijo posameznikov k dovršenosti.

Kadar prihaja do motiviranja drugega je zelo pomembno poznavanje njegovih ambicij, sposobnosti in preteklih aktivnosti. Še posebej to velja pri najstnikih, ki zelo pogosto potrebujejo primerno spodbudo, vendar je ob tem potrebno paziti, da spodbudo najstnik ne interpretira kot siljenje $\mathrm{k}$ nečemu. Pri motiviranju dijakov v dijaškem domu sledimo nekaterim načelom, ki jih omenja Denny (1997), predvsem dejstvu, da posameznika motivira že to, da napreduje. Motivacija navadno ne traja dolgo in zahteva priznanje kot nekakšno preverjanje ali smo pravilno usmerjeni in ali imajo naša delovanja smisel. Za motivacijo je tako potreben nek cilj, čeprav pogosto motivira že samoudeležba, kateri dajemo pri nagrajevanju dijakov tudi posebno vrednost. Avtor (prav tam) omenja tudi izziv, ki pa motivira le v primeru, kadar je možna zmaga. 
Ko v DIC-u poskušamo ovrednotiti dijakove aktivnosti in udejstvovanja, poskušamo najti primeren način, ki bo poleg nagrade hkrati tudi motiv za nadaljnje sodelovanje. Zato se pri tem držimo nekaterih prej omenjenih načel, predvsem vrednotenje nekoliko bolj pomembnih dosežkov kot tudi ovrednotenje samoudeležbe dijakov pri različnih aktivnostih.

\subsection{Nagrajevanje}

V strokovni literaturi je zelo malo teorije o nagrajevanju mladostnikov, saj se strokovnjaki na tem področju prednostno osredotočajo na teorije nagrajevanja otrok in nagrajevanja zaposlenih. Nagrajevanje otrok je pomembno zaradi pozitivnih vzgojnih učinkov, nagrajevanje zaposlenih pa ima že močnejšo eksistencialno vrednost, saj tovrstno nagrajevanje odrasli najbolj pogosto povezujemo s financami.

Ker mladostniki niso več otroci, so pa na poti v odrasli svet, ima nagrajevanje bolj psihološke učinke; ne gre več za vzgojne prijeme, temveč potrditev njihovega udejstvovanja in vložene energije, ki pomembno vplivajo na razvoj njihove identitete. Musek in Pečjak (1995) pravita, da je pri razvoju lastne identitete predvsem pomembno to, da o sebi in svojih vlogah ne odločamo na podlagi želja drugih, temveč izberemo lastno identiteto. Nagrajevanje ima pri tem izreden pomen, saj na ta način mladostnik dobiva različne potrditve na svoji poti in dodaten zagon za nadaljevanje dela. Mladostniki se namreč pri svojem odraščanju večkrat znajdejo na razpotju in v dilemi glede svoje prihodnosti in smisla svojega delovanja. Gre za normalen proces odraščanja, ki ga preko teorije o iskanju svojega položaja v svetu pojasnjujeta tudi Juul in Jensen (2002). Avtorja menita, da je potreba po tem, da poiščemo samega sebe ter svoje mesto v odnosu do drugih naravna in tudi zdrava potreba človeka, hkrati pa tudi ena temeljnih eksistencialnih potreb, ki predstavlja konflikt med potrebo, da se razvijemo kot del skupnosti, ki ji pripadamo in potrebo, da skrbimo za svojo integriteto. Potrditev (nagrada), ki jo dobi mladostnik na nekem področju, je lahko ključni element, ki osmisli njegovo odraščanje, hkrati pa pripomore k motivaciji za prihodnost.

Cencič (1986) pravi, da je nagrada značilna metoda pozitivne podkrepitve, ki konsolidira tendenco ponavljanja določenega dejanja, ob enem pa je tudi najmočnejše sredstvo spodbujanja, katera kot zunanja iniciativa socialnega učenja razvija voljo za delovanje in premagovanje naporov. Omeniti velja še mnenje Opare (2005), ki meni, da bi moral vsak šlski organ sprejeti politiko nagrajevanja za vse posameznike.

\subsubsection{Negativni učinki nagrajevanja}

Nagrajevanje pa nima le pozitivnih učinkov, ki so pogosto povezani z nadaljnjo motivacijo, temveč se lahko pojavijo tudi negativni učinki, ki destruktivno vplivajo na razvoj najstnika. Cowley (2007) se sicer osredotoča na nagrajevanje otrok, vendar nekatere vzporednice lahko poiščemo tudi $\mathrm{v}$ drugih obdobjih odraščanja. Avtorica namreč pravi, da nagrade izgubijo svoj učinek v kolikor so prepogoste in se posamezniku zanje ni več potrebno truditi. 
$36^{\mathrm{TH}}$ International Conference on ORganizational Science Development: RESPONSIBLE ORGANIZATION (MARCH $22^{\mathrm{ND}}-24^{\mathrm{TH}}$, PoRTOROŽ SLOVENIA)

M. Indihar: Awarding Active Students in a Boarding School and the Athlete of the Year Selection

Tudi Vovk (2011) se posveča nekoliko bolj negativnim vplivom nagrajevanja otrok, vendar menimo, da so njene trditve primerne tudi za druga obdobja, ne glede na starost posameznika, kljub temu, da se ob tem zavedamo, da posameznik v različnih obdobjih različno interpretira pomen nagrajevanja. Avtorica namreč pravi, da posamezniki pogosto iščejo potrditev zato, da naredijo vtis, $s$ tem pa izgubijo samomotivacijo in so odvisni od mnenja drugih. $\mathrm{V}$ tem primeru vzrok njihovega udejstvovanja ni v samem udejstvovanju pri aktivnostih iz veselja, temveč delajo stvari zaradi priznanja. V razredu sistem nagrajevanja lahko ustvarjajo tekmovalnost, ljubosumje, zavist in nezaupanje, hkrati pa lahko ogrožajo sodelovanje. Do podobnih negativnih učinkov nagrajevanja lahko pride tudi v dijaškem domu ali vzgojni skupini, zato je potrebno poiskati sistem, ki ga bodo sodelujoči znali spoštovati ter ga upoštevati pri nagrajevanju, da ne pride do negativnih učinkov.

\subsection{Vrednotenje rezultatov na športnem področju}

Enakopravno in pravično vrednotenje različnih dejavnosti je pogosto izredno težavno delo predvsem zato, ker je praktično nemogoče popolnoma objektivno ovrednotiti različne dosežke. Pri tem se pojavijo številne raznolikosti, ki pomembno vplivajo na kriterij, med njimi gotovo vrednotenje posameznika pri moštvenih športih v primerjavi z nekom, ki nastopa zgolj $\mathrm{v}$ individualnih športnih panogah. V spodnji tabeli si lahko ogledate sistem točkovanja, ki ga uporabljamo pri vrednotenju posameznikovih rezultatov ob koncu šolskega leta.

Tabela 1: Točkovanje za športnika leta

\begin{tabular}{|c|c|c|c|c|c|c|c|c|}
\hline $\begin{array}{l}\downarrow \text { St. } \\
\text { točk }\end{array}$ & $\mathbf{D}, \mathbf{P}$ & D, E & DIC - P & DIC - E & $\mathbf{M}-\mathbf{P}$ & $\mathbf{M}-\mathbf{E}$ & $Z$ - P & $Z-\mathbf{E}$ \\
\hline 10 & 1. mesto & & & & & & & \\
\hline 9 & & 1. mesto & & & & & 1. mesto & \\
\hline 8 & 2. mesto & 2. mesto & & & 1. mesto & & & 1. mesto \\
\hline 7 & 3. mesto & 3. mesto & & & & 1. mesto & 2. mesto & \\
\hline 6 & & & & & 2. mesto & 2. mesto & & 2. mesto \\
\hline 5 & & & 1. mesto & & 3. mesto & 3. mesto & 3. mesto & \\
\hline 4 & & & 2. mesto & 1. mesto & & & & 3. mesto \\
\hline 3 & $\begin{array}{c}\text { udeležb } \\
\mathrm{a}\end{array}$ & & 3. mesto & 2. mesto & & & & \\
\hline 2 & & $\begin{array}{c}\text { udeležb } \\
\text { a }\end{array}$ & & 3. mesto & udeležba & udeležba & udeležba & udeležba \\
\hline 1 & & & $\begin{array}{c}\text { udeležb } \\
\text { a }\end{array}$ & udeležba & & & & \\
\hline
\end{tabular}

Legenda: D - Domijada (srečanje dijaških domov iz vse Slovenije, ki od leta 2003 poteka na Rogli); DIC - tekme, ki potekajo v organizaciji dijaškega doma (notranja tekmovanja); 
M - meddomska tekmovanja (tekmovanja, ki potekajo med ljubljanskimi dijaškimi domovi oziroma tekmovanja, ki potekajo med dijaškimi domovi zahodne regije); Z zunanja tekmovanja, ki niso $\mathrm{v}$ organizaciji dijaških domov, vendar dijaki zastopajo Dijaški dom Ivana Cankarja (primer: Ljubljanski maraton); P - posamična tekmovanja; E - ekipna tekmovanja.

Sistem točkovanja je prirejen športno-rekreativnemu udejstvovanju dijakov v dijaških domovih in ga je zaradi svoje narave težko uporabiti kot takega $\mathrm{v}$ drugih ustanovah, društvih in drugih organizacijah. Pri ovrednotenju posameznih tekmovanj smo nekoliko večji poudarek dali individualnim tekmovanjem. Podlaga nekoliko višjega ovrednotenja individualnih tekmovanj ni v tem, da bi bili ekipni rezultati cenjeni nižje, temveč zaradi dejstva, da v ekipnih športih pogosto sodelujejo tudi tisti posamezniki, ki h končnemu rezultatu ne prispevajo toliko znanja in/ali spretnosti ter vloženega časa ali energije (pri moštvenih športih odigranih minut). Če pojasnimo bolj preprosto - za ekipne rezultate dobijo vsi člani ekipe isto število točk, ne glede na odigrane minute in prispevek k končnemu rezultatu, kar potencialno pomeni, da je posameznik lahko sicer v ekipi, vendar na tekmi odigra zgolj nekaj sekund. Posameznik, ki nastopa v individualnih športih pa je odvisen zgolj od tega, koliko znanja in spretnosti v primerjavi z drugimi bo pokazal sam.

Pri sistemu točkovanja smo se izogibali popularnosti posamezne športne panoge med dijaki, številčno udeležbo in druge karakteristike, ki bi lahko spremenila vrednostno lestvico. Odličen primer je šah za dekleta, ki je med najslabše obiskanimi športnimi dejavnostmi na sploh v dijaških domovih po Sloveniji, kar pomeni, da dekleta, ki zgolj sodelujejo pri šahu zagotovo dobijo veliko točk pri meddomskih tekovanjih. Če šah za dekleta primerjamo $\mathrm{z}$ nogometom za fante, kjer je konkurence izredno veliko, lahko vidimo, da pri ovrednotenju njihovih uvrstitev ne delamo nikakršnih razlik. Vsakdo ima namreč priložnost, da se udeleži katerihkoli dejavnosti, zato se v največji možni meri izogibamo medsebojnih razlik, ki bi lahko pomenile tudi diskriminacijo do posameznikov, zmotno pa bi bilo lahko tudi vzgojno sporočilo sodelujočim.

Po tem sistemu lahko vidimo, da je najvišje ovrednoteno tekmovanje za posameznike na Domijadi, ki je najvišje in najpomembnejše možno tekmovanje za dijaške domove $\mathrm{v}$ Sloveniji; gre za nekakšno državno prvenstvo dijaških domov, ki potekajo enkrat letno, že nekaj let zapored konec aprila na Rogli. Na to tekmovanje se med ekipnimi športi lahko uvrstijo le štiri najboljše po predhodnih tekmovanjih, po dva iz vzhodne in dva zahodne strani Slovenije. Do sedaj je bil med posameznimi športi uvrščen le tek, od lanskega leta dalje pa je na seznamu individualnih športov tudi strelstvo, na sestankih organizacijskega odbora pa vedno znova iščemo možnost za dodatne športne panoge.

Visoko so ovrednotene tudi visoke uvrstitve med prve tri pri zunanjih tekmovanjih, saj nastopajoči pri teh tekmah zastopajo DIC tudi izven njihovega prostega časa, ki ga imajo $\mathrm{v}$ dijaškem domu. Na ta način ovrednotimo njihovo pripadnost domu ter jih spodbujamo da s svojimi aktivnostmi nadaljujejo $\mathrm{v}$ domu ter poskušajo na podlagi svojih izkušenj navdušiti tudi druge sovrstnike. 
$36^{\mathrm{TH}}$ International Conference on ORganizational Science Development: Responsible Organization (MARCh $22^{\mathrm{ND}}-24^{\mathrm{TH}}$, Portorož Slovenia)

M. Indihar: Awarding Active Students in a Boarding School and the Athlete of the Year Selection

Pomembno mesto pri ovrednotenju smo namenili tudi sami udeležbi, ki je lahko zelo močan pozitivni motivacijski dejavnik ne le pri nadaljnjem udejstvovanju, temveč predvsem pri razvoju posameznikove identitete, ki smo jo omenili v eni prejšnjih vrstic. Najbolj ovrednotena udeležba je sodelovanje na Domijadi, vendar ne le zaradi narave tekmovanja (najpomembnejše tekmovanje za dijaške domove v Sloveniji) temveč tudi zaradi dejstva, da podlaga za odhod na Domijado ni le sodelovanje v ekipi v predhodnih tekmovanjih, temveč je sodelovanje na Domijadi hkrati tudi nagrada za tiste dijake, ki s svojim zgledom, delovanjem in vedenjem pozitivno vplivajo na prijetnejše bivanje $\mathrm{v}$ dijaškem domu.

\section{3 Šnortnica in športnik leta}

V dijaškem domu Ivana Cankarja že tretje leto zapored statistično spremljamo vse posameznike, ki se udeležujejo tekmovanj na različnih področjih, vendar v okviru izbora za športnico/športnika leta le tiste, ki pri tem zastopajo dijaški dom. V preteklem šolskem letu je pri tem sodelovalo $73(13 \%)$ dijakov, med njimi $30(7 \%)$ deklet in $43(31 \%)$ fantov. Odstotki v oklepaju so navedeni le približno, saj se število dijakov med šolskim letom zaradi vpisov in izpisov spreminja.

Med dekleti je 14 (46,7 \%) dijakinj sodelovalo zgolj pri eni športni dejavnosti, ostala dekleta pa so sodelovala večkrat. Dekleta so imela v celotnem šolskem letu 21 vseh tekmovanj, od tega je bilo 8 ekipnih in 15 posamičnih tekmovanj, med njimi pa sta bili dve tekmovanji šteli tako za ekipno, kot tudi za posamično tekmo (tek in strelstvo). 8 tekmovanj za dekleta je potekalo znotraj doma, 7 je bilo takih, ki so potekala med preostalimi dijaškimi domovi, nekaj deklet pa se je udeležilo tudi ljubljanskega maratona (zunanja tekmovanja).

Med fanti je bilo $12(27,9 \%)$ tistih, ki so sodelovali le enkrat, na več različnih tekmovanjih pa je sodelovalo 31 (72,1 \%) dijakov. Fantje so imeli v celotnem šolskem letu 26 vseh tekmovanj, od tega je bilo 12 ekipnih in 17 posamičnih tekmovanj, med njimi pa so tri tekmovanja štela tako za ekipno kot posamično tekmo (dvakrat tek in enkrat strelstvo). Domskih tekmovanj za fante je bilo 10, meddomskih je bilo 14, fantje pa so se dvakrat udeležili tudi zunanjih tekmovanj (ljubljanski maraton in skopski maraton.

Med prvimi tremi dekleti je bila razlika le 5 točk, športnica leta pa je bila dijakinja, ki se je prvenstveno (zelo uspešno) udeleževala tekaških tekmovanj. Tek med preostalimi športi morda res za odtenek bolj izstopa glede na možnost pridobivanja točk, vendar to zaradi dejstva, da gre za najbolj enostavno športno-rekreativno dejavnost, saj tek spada med osnovno gibanje človeka posledično pa je dostopnejše večjemu številu dijakov. Dijakinja, ki je bila na lanskoletnem izboru uvrščena na drugem mestu se je nekoliko bolj intenzivno posvečala šahu, tretje uvrščena pa strelstvu. Omenjeni panogi nista med tistimi, ki bi se jih dijaki udeleževali množičneje, kar je še en dokaz kako močan vpliv imajo lahko manj popularni športi pri tovrstnem nagrajevanju. 
Povsem druga oblika dinamike izbora za športnika leta se je dogajala med fanti. Športnik leta je bil skorajda odločen že ob polovici šolskega leta, saj je omenjeni dijak sodeloval $\mathrm{v}$ popolnoma vseh športnih panogah in v prav vseh je pomembneje izstopal po spretnostih in znanju od vrstnikov. Ker je bil v lanskem šolskem letu zaključni letnik, se bo v letošnjem šolskem letu dinamika spet dodatno spremenila, saj so bili rezultati zadnjih dveh let izredno podobni. Dijak, ki je bil uvrščen na drugo mesto je imel pred tretje uvrščenim točkovno gledano relativno varno prednost, pomembne točke pa si je pridobil predvsem pri tekaškem udejstvovanju. Tretje uvrščeni dijak si je pomembne točke pridobil pri udejstvovanju v različnih športnih panogah in je najboljši primer dijaka, ki v nobeni dejavnosti ni pomembneje izstopal, vendar se je njegovo aktivnost ovrednotilo do te mere, da je pridobil prednost pred dijaki, ki so sodelovali le $\mathrm{v}$ nekaterih dejavnostih. $\mathrm{S}$ tem je dokazal, da je mogoče priti visoko tudi z vztrajanjem in pridnostjo, kar ima spet močno vzgojno sporočilo in spodbudo tudi na drugih področjih (šola, delo, ...).

Omeniti velja, da so zgoraj zabeleženi rezultati le posledica tistih dijakov, ki so sodelovali na tekmovanjih; poudariti moramo, da poleg teh dijakov obstajajo tudi tisti, ki na športnih tekmovanjih zaradi različnih vzrokov (pomanjkanje časa, pomanjkanje motivacije, neuvrstitev v ekipo - v ekipi je po pravilniku meddomskih tekmovanj le 8 dijakov) ne sodelujejo, vendar se udeležujejo športno rekreativnih dejavnostih znotraj doma. V ta sklop zabeleženih dijakov, ki jih spremljamo ne uvrščamo tistih dijakov, ki trenirajo različne športne dejavnosti in se znotraj doma ne udeležujejo nobenih aktivnosti.

Ob koncu šolskega leta organiziramo podelitev za športnika leta, na katerem poskrbimo tako za nagrade za športnika in športnico leta, kot tudi tiste, ki so se uvrstili na drugo in tretje mesto; preostali dijaki pa za sodelovanje na različnih domskih in meddomskih tekmovanjih dobijo potrdila. Omenjena potrdila arhiviramo v njihovo osebno mapo »DIC je svet«, ki jo dobijo ob koncu srednješolskega izobraževanja v obliki različnih referenc za njihove spretnosti, znanja, sodelovanja in dosežke

\section{Sklep}

Izbora za športnika leta smo se lotili zaradi lažje statističnega spremljanja nekaterih podatkov (število udeleženih dijakov, število športnih dogodkov, tekmovanj, notranjih športnih organizacij, meddomskih tekmovanj - meddomska povezanost, ...); hkrati pa tudi zaradi ovrednotenja prostočasnega udejstvovanja dijakov.

Ugotovili smo, da skoraj $15 \%$ dijakov udeležuje različnih tekmovanj pri katerih zastopa dijaški dom, dijaki lahko pa izbirajo med širokim izborom športnih dejavnosti. Kljub temu, da so nekatere dejavnosti $\mathrm{v}$ okviru meddomskih tekmovanj $\mathrm{v}$ naprej določene (nogomet, košarka, odbojka, namizni tenis, tek, šah, strelstvo) pa se dijaki lahko udeležijo tudi številnih drugih tekmovanj izven doma, pri nagrajevanju (točkovanju) za športnika leta pa se upoštevajo vsa tekmovanja, pri katerih zastopa tudi DIC. Dijaški dom na ta način skrbi za aktivno preživljanje prostega časa, razvoj identitete in integriteto posameznika. Menim, da bi se tem športnim aktivnostim lahko pridružilo še več dijakov, predvsem zaradi želje povezovanja dijakov iz različnih dijaških domov. Glede na izkušnje lahko rečem, da se veliko več dijakov ukvarja z različnimi športnimi 
$36^{\mathrm{TH}}$ International Conference on ORganizational Science Development: Responsible Organization (MARCH $22^{\mathrm{ND}}-24^{\mathrm{TH}}$, Portorož Slovenia)

M. Indihar: Awarding Active Students in a Boarding School and the Athlete of the Year Selection

aktivnostmi, le zaradi okoliščin se velikokrat »ustrašijo« besede tekmovanje, saj jim pogosto to prestavlja določeno stopnjo stresa ter frustracij preteklih let, dilem glede samopodobe $\mathrm{v}$ primerjavi $\mathrm{z}$ drugimi dijaki in manjvrednostnega občutka ob slabših rezultatih in/ali nižjih uvrstitvah. Delo vzgojitelja (mentorja) je pri tem ključnega pomena, saj lahko s primernim pristopom pripomore, da posameznik spozna prednosti teh udejstvovanj, le-te pa lahko ob primernem spremljanju tudi vzljubijo.

V uvodu smo si med drugimi postavili tudi raziskovalno vprašanje glede števila tekmovanj. Število tekmovanj je relativno veliko (v preteklem šolskem letu jih je bilo 21 za dijakinje in 26 za dijake). Pri tem ne gre za preveliko število, ki bi lahko preobremenjevale dijake, temveč gre za raznovrstne dejavnosti, torej za vsakega nekaj. Dejavnosti in tekmovanja, ki jih imamo v domu so prilagojena na letne čase; ob toplejših dnevih je več dejavnosti zunaj (tek, nogomet, atletika, ...), ob hladnejših dnevih pa več dejavnosti organiziramo znotraj doma (šah, namizni tenis, strelstvo, ...).

Ovrednotenje dijakovih dosežkov lahko različno vpliva na njihovo nadaljnje sodelovanje, zato je pristop do vsakega posameznika izredno pomemben. $\mathrm{V}$ prihodnosti bi bilo smiselno narediti raziskavo glede njihovega vrednotenja teh rezultatov, spremljanja njihove osebnostne rasti na tem področju in kako vse skupaj vpliva na njihovo bivanje $v$ dijaškem domu. Menimo namreč, da se dijaki v prostem času radi preizkušajo v različnih dejavnostih, vendar so te preizkušnje $\mathrm{v}$ različnih oblikah. Nekaterim so medsebojna tekmovanja izziv, drugi pa poiščejo bolj individualne oblike preizkušanja svojih spretnosti in znanj in napredka, predvsem skozi tekaške aktivnosti. Ko omenjamo tek je potrebno poudariti, da se s tekom v DIC-u ukvarja več dijakov kot jih uspemo zabeležiti ali spremljati, saj je veliko takih za katere sploh ne vemo (ali ugotovimo pozneje), da se $\mathrm{s}$ tem športom sploh ukvarjajo, vendar ne v okviru organiziranih tekmovanj.

\section{Literatura}

Bajzek, J. (2008). Odiseja mladih. Radovljica: Didaktika.

Cencič, M. (1986). Dinamika vzgojnega dela v šoli. Ljubljana: Državna založba Slovenije.

Cowley, S. (2007). Kako krotiti malčke. Ljubljana: Modrijan založba d.o.o.

Černigoj-Sadar, N. (1991). Moški in ženske v prostem času: socialne in psihološke dimenzije načinov preživljanja prostega časa. Ljubljana: Znanstveno in publicistično središče.

Denny, R. (1997). O motivaciji za uspeh. Ljubljana: Gospodarski vestnik.

Fenwick, E., \& Smith, T. (1997). Adolescenca - Priročnik preživetja za staršse in mladostnike. Ljubljana: Kres.

Jensen, H., \& Jesper J. (2009). Od poslušnosti do odgovornosti. Radovljica: Didaktika d.o.o. .

Kristančič, A. (2007). Svoboda izbire - moj prosti čas. Ljubljana: AA Inserco, svetovalna družba.

Kuhar, M. (2007). Prosti čas mladih v 21. stoletju. Socialna pedagogika vol. 11, No. 4, str. 453473.

Musek, J., \& Pečjak, V. (1995). Psihologija. Ljubljana: EDUCY.

Musek, J., \& Pečjak, V. (1995). Psihologija. Ljubljana: Educy.

Opara, B. (2005). Otroci s posebnimi potrebami v vrtcih in šolah. Ljubljana: Centerkontura.

Pintrich, R. P., \& Schunk, H. D. (1996). Motivation in education: theory, research and applications. New Jersey: Prentice-Hall, Inc., Englewood Cliffs. 
Uhan, S. (2000). Vrednotenje dela II. - Motivacija - Uspešnost-Plača (osebni dohodek). Kranj: Založba Moderna organizacija.

Ule, M. (2002). Mladina: fenomen dvajsetega stoletja, V: Miheljak, V. (ur.): Mladina 2000 slovenska mladina na prehodu v tretje tisočletje. Maribor: Aristej.

Ule, M. (2016). Spremembe prostega časa mladih v času novih tehnologij in medijev. Iskanja Vol. 34, No. 53-54, str. 10-18.

Ule, M., \& Miheljak, V. (1995). Prihodnost mladine. Ljubljana: DZS, d.d. Ljubljana in Ministrstvo za šolstvo in šport, Urad Republike Slovenije za mladino.

Vovk, M. (2011). Nagrajevanje se ne obnese. Spletna stran: https://www.iskreni.net/druzina/starsevstvo/81-temeljne-drze/914-nagrajevanje-se-neobnese.html Pridobljeno, 19.1.2017.

Zakon o gimnazijah, (Uradni list RS, št. 12/96 in 59/01) in 58. člen Zakona o poklicnem in strokovnem izobraževanju (Uradni list RS, št. 12/96 in 44/00) - Pravilnik o bivanju v dijaškem domu. 
248 36 $6^{\text {TH }}$ International Conference on ORganizational Science Development:

Responsible Organization (MARCH $22^{\mathrm{ND}}-24^{\mathrm{TH}}$, PORTOROŽ SLOVENIA) 
36. MEDNARODNA KONFERENCA O RAZVOJU ORGANIZACIJSKIH ZNANOSTI: OdgOVORNA ORGANIZACIJA (22. - 24. MAREC 2017, PORTOROŽ, SLOVENIJA)

O. Arsenijević, M. Ferjan, I. Podbregar, P. Šprajc, D. Trivan \& Y. Ziegler

\title{
Implementacija metodologije USALI v hotelirstvu s pomočjo informacijskega sistema PANTHEON
}

\author{
GORDANA IVANKOVIČ \& DEJAN BAŠ
}

Povzetek Turizem v Sloveniji postaja, glede na sedanjo stopnjo razvitosti in obstoječe razvojne možnosti, ena od vodilnih dejavnosti slovenskega gospodarstva. Zaradi globalizacije trgov in potrebe investitorjev po primerljivosti računovodskih izkazov mora tudi turizem slediti harmonizaciji računovodskih rešitev ter uporabi enotnih računovodskih standardov (Ivankovič, Klobučar, in Vidic, 2002). Posledično so vse države zahodne Evrope in številne druge države po svetu sprejele enoten sistem spremljanja in prikazovanja rezultatov poslovanja hotelov, imenovan USALI (»Uniform System Of Accounts For The Lodging Industry«, 2014). V slovenskem hotelskem sektorju metodologija še ni implementirana, ker statistično spremljanje gospodarskih kategorij in računovodsko poročanje ni poenoteno z mednarodnimi standardi, potekajo pa določene faze razvoja, ki bodo omogočile implementacijo. Pri implementaciji metodologije bodo odločilno vplivali tako slovenski računovodski standardi, kot tudi informacijska tehnologija, ki mora omogočati popoln zajem podatkov na izvoru in s tem uporabo in izdelavo poročil na podlagi USALI (Ivankovič in Planinc, 2011). Za namene raziskave smo se odločili, da bomo osnovne usmeritve metodologije USALI implementiral v poslovodno računovodski sistem (PRS) Datalab Pantheon in prikazali slabosti in prednosti informacijskega sistema Pantheon ter priporočila za izboljšave in lažjo implementacijo.

KLJUČNE BESEDE: hotel • USALI • informacijski sistem Datalab Pantheon

\footnotetext{
NASLOV AVTORJev: Gordana Ivankovič, Univerza na Primorskem, Fakulteta za turistične študije Turistica, Obala 11a, 6320 Portorož, Slovenija, e-pošta: gordana.ivankovic@fts.upr.si; Dejan Baš, BARS d.o.o., Sitarjevška cesta 29, 1270 Litija, Slovenija, e-pošta: bas.dejan@gmail.com
}

DOI https://doi.org/10.18690/978-961-286-020-2.23

ISBN 978-961-286-020-2

(C) 2017 Univerzitetna založba Univerze v Mariboru

Dostopno na: http://press.um.si 
$36^{\text {TH }}$ InTERnAtional CONFERENCE ON ORganizational SCIENCE Development: Responsible Organization (MARCH $22^{\mathrm{ND}}-24^{\mathrm{TH}}$, PORTOROŽ SLOVENIA)

O. Arsenijević, M. Ferjan, I. Podbregar, P. Šprajc, D. Trivan \& Y.

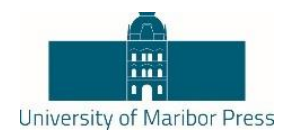

Ziegler

\title{
USALI Implementation with PANTHEON Business Accouting
}

\author{
GORDANA IVANKOVIČ \& DEJAN BAS̆
}

\begin{abstract}
With respect to its current situation and development opportunities, tourism is becoming one of Slovenia's leading industries. In line with market globalisation and investors' need to use comparable accounting statements, tourism needs to follow the path of harmonisation of accounting solutions and use of uniform accounting standards. To this end, all Western European countries and many other countries globally have adopted a uniform system for monitoring and documenting business results in the lodging industry - USALI (Uniform System Of Accounts For The Lodging Industry, 2014). The Slovenian hotel industry has yet to implement this methodology, since its statistical monitoring of economic categories and its statements of accounts are not yet harmonised with international standards; however, certain developmental processes that will enable implementation have been commenced. The course of implementation of methodology will strongly depend on Slovenian accounting standards and information technology, which must enable capturing of complete source data, and based on this, USALI-based reporting. For the purpose of this research, the essential guidelines of the USALI methodology were implemented in the Datalab Pantheon accounting software with the aim of identifying the weaknesses and advantages of the Pantheon information system, as well as draft proposals for the system's improvement and easier implementation.
\end{abstract}

KEYWORDS: hotel • USALI • information system Datalab Pantheon

CoRRESPONDENCE AdDRESS: Gordana Ivankovič, University of Primorska, Faculty of Tourism Studies - Turistica, Obala 11a, 6320 Portorož, Slovenia, e-mail: gordana.ivankovic@ fts.upr.si; Dejan Baš, BARS d.o.o., Sitarjevška cesta 29, 1270 Litija, Slovenia, e-mail: bas.dejan@ gmail.com 


\section{Uvod}

Prispevek turizma je v Sloveniji leta 2004 znašal 10,9\%, medtem ko je v letu 2015 dosegel 13\% delež BDP, kar je povečanje za dobri 2 odstotni točki (WTTC, 2016). Tudi število prenočitev se je pomembno povečalo; iz 9,314 mio v letu 2008 na rekordnih 10.342 v letu 2015 (SURS,2016), kar predstavlja 11 odstotno povečanje. Žal pa fizičnim podatkom ne sledi tudi poslovna uspešnost hotelskih podjetij v Sloveniji, saj na agregatni ravni SKD 55.100 (hoteli in podobni nastanitveni obrati) še vedno beležijo negativni poslovni izid. V proučevanem obdobju 2008-2015 je bilo leto 2012 po poslovni uspešnosti najbolj neuspešno, saj se je negativni čisti poslovni izid iz 21 mio povečal na 88 mio, medtem ko znaša $v$ letu 2015 negativni čisti poslovni izid še vedno 6 mio (GVIN, 2016). V mednarodnem hotelirstvu je hotelska soba tista osnova za kazalnike, ki omogoča tudi mednarodne primerjave. Prihodek na razpoložljivo sobo (Revenue per available room - RevPAR) je v letu 2008 znašal $20.776 €$, v letu 2015 pa le $19.741 €$ (Surs, 2016; Gvin 2016; lastni izračuni); kar pomeni, da je vrednost kazalnika v primerjavi z izhodiščnim letom nižja za $5 \%$, kljub temu, da so nočitve porasle v istem obdobju za dobrih $8 \%$. Ocenjujemo, da je razlog slabim poslovnim rezultatom, poleg »tranzicijskih zgodb « z drugim krogom privatizacije in lastništev hotelskih podjetij, ki pogosto niso povezane $\mathrm{z}$ osnovno dejavnostjo, tudi $\mathrm{v}$ mednarodni poslovni neprimerljivosti hotelskih podjetij v Sloveniji.

Raziskava predstavlja izhodišča in možnosti uvedbe mednarodnega računovodskega standarda USALI za prikaz uspešnosti poslovanja hotelov, s pomočjo informacijskega sistema Datalab Pantheon. V začetnem delu smo raziskali in okvirno predstavili metodologijo USALI $\mathrm{z}$ najpomembnejšimi značilnostmi ter predstavili osnovne značilnosti informacijskega sistema Pantheon. V nadaljevanju smo preučili in prikazali funkcionalne možnosti implementacije metodologije s pomočjo IS Pantheon.

\section{Metodologija USALI v prihodnosti nujni sestavni del vsakega hotelskega poslovodno informacijskega sistema.}

Enotni računovodski sistem spremljanja in prikazovanja rezultatov poslovanja USALI (Uniform System Of Accounts for the Lodging Industry) je metodologija, ki omogoča primerljivost rezultatov poslovanja hotela ne glede na velikost in kakovost hotela, ter okolje, iz katerega hotel izvira. To je sistem, ki zadovoljuje potrebe notranjih in zunanjih uporabnikov po informacijah o prihodkih, stroških in poslovnem izidu na stroškovnih mestih, mestih odgovornosti, oddelkih in v obratih ter drugih organizacijskih enotah $\mathrm{v}$ hotelskem podjetju (Ivankovič, Klobučar, in Vidic, 2002). Zasnovan je tako, da zagotovi informacije za poslovodenje decentraliziranih delov, znotraj velikih hotelskih poslovnih sistemov, in je v celoti usklajen s posebnostmi hotelirstva kot dejavnosti.

Večina slovenskih hotelov metodologije za sedaj še ne uporablja, vendar lahko kot posledico globalizacije pričakujemo, da bo v prihajajočih letih uporabnikov metodologije vedno več (Planinc, Ivankovič, Jerman, in Maravič, 2014). Strategija razvoja slovenskega turizma 2012-2016 v okviru 1.8. odstavka - »Spremljanje uspešnosti poslovanja 
$36^{\mathrm{TH}}$ InTERnATIONAL CONFERENCE ON ORganizational SCIENCE DeVElopment: Responsible ORGanization (MARCh $22^{\mathrm{ND}}-24^{\mathrm{TH}}$, PORTOROŽ SLOVENiA)

G. Ivankovič \& D. Baš: USALI Implementation with PANTHEON Business Accouting

turističnega gospodarstva na državni in podjetniški ravni« predlaga, da se kazalniki uspešnosti poslovanja turističnih podjetij razdelijo na družbeno-kulturno področje, okoljsko področje in ekonomsko področje. Med značilnosti ekonomskega področja pa navaja lastnosti, ki jih predpisuje metodologija USALI, kar pomeni, da Strategija razvoja slovenskega turizma tudi v praksi priporoča uporabo metodologije (Strategija razvoja slovenskega turizma 2012-2016, 2012).

Porast uporabe omenjene metodologije spremljanja in merjenja poslovnih kazalnikov pa posledično pomeni tudi pojav potrebe po poslovodno računovodskih sistemih (PRS), ki implementacijo USALI podpirajo. V ta namen bodo proizvajalci PRS v Sloveniji morali preučiti zahteve svojih naročnikov in svoje proizvode prilagoditi potrebam na prihajajočih trgih.

\section{$2 \quad$ Splošno o metodologiji USALI}

Vsako podjetje potrebuje za izvedbo spremljanja poslovanja različna sredstva. Dve bistveni sestavini, ki omogočata kvalitetno spremljanje poslovanja sta primeren računovodsko informacijski sistem (IS) ter računovodski standardi oziroma usmeritve, ki narekujejo pravila za spremljanje in poročanje. S tem namenom je že leta 1926 Hotelirska zveza mesta New York sprejela prvo izdajo metodologije USALI.

Trenutno veljavna izdaja USALI je že 11. zapored in je v osnovi podrejena ameriškim splošno sprejetim standardom (US GAAP-US Generaly accepted accouting principles), ki se bistveno razlikujejo od trenutno veljavnih računovodskih standardov v Sloveniji, vendar pa so določene lastnosti, zaradi približanja globalnim trgom, že pripravljene $\mathrm{v}$ skladu z Mednarodnimi standardi računovodskega poročanja (International Financial Reporting Standards (IFRS)) (»USALI 11 Guide«, 2015).

V okviru teh standardov predstavlja metodologija USALI dopolnilni sistem prikaza ekonomske uspešnosti poslovanja $v$ hotelski dejavnosti, ki je namenjena izdelavi poročil za eksterne uporabnike ter izdelavi poročil za interno spremljanje poslovanja, ki so pomemben vir informacij pri sprejemanju poslovnih odločitev.

Metodologija USALI deli hotel, kot osnovno obračunsko enoto, na več mest odgovornosti oziroma oddelkov. Oddelki so namreč izhodišče za grajenje kontnega načrta in celotnega šifranta hotela, s pomočjo katerih pa v nadaljevanju pripravljamo vsa poročila, ki jih metodologija narekuje. Metodologija je razdeljena na pet poglavji. Prva tri poglavja metodologije natančno predpisujejo obliko poročil za notranje in zunanje poročanje, četrto poglavje narekuje smernice za poročanje po oddelkih, izdelavo kontnih planov in šifrantov, peto poglavje pa podaja smernice za izdelavo pojasnil za bruto poročanje v primerjavi z neto poročanjem. V prvem poglavju so predpisana poročila po posameznih oddelkih za operativno vodstvo oddelkov ter zbirni izkazi, za vodstvo in lastnike, ki zbirno prikazujejo delovanje oddelkov. Drugo poglavje metodologije določa sistem izdelave finančnih poročil, ki so namenjena tako vodstvu kot zunanjim uporabnikom. Tretji del metodologije pa prikazuje sistem matrik, ki vsebujejo poslovne kazalnike po sekcijah hotela, ter splošne poslovno finančne kazalnike. Izdelava poročil v 
G. Ivankovič \& D. Baš: Implementacija metodologije USALI v hotelirstvu s pomočjo informacijskega sistema PANTHEON

skladu s temi pravili torej predstavlja kvalitetno orodje za nadzor nad samim hotelskim poslovanjem ter ugotavljanje položaja hotela $\mathrm{v}$ primerjavi $\mathrm{s}$ povprečjem $\mathrm{v}$ panogi na mednarodni ravni.

\subsection{Kontni okvir po USALI}

Temelj vsakega računovodskega standarda je kvalitetno in pravilno zasnovan kontni načrt. Kljub temu 11. izdaja USALI, za razliko od predhodnih izdaj, ne narekuje natančne izdelave kontnega načrta, ker se je v praksi izkazalo, da uporabniki preferirajo izdelavo in uporabo lastnih kontnih načrtov (»USALI 11 FAQ«, 2016). Večja svoboda pri oblikovanju kontnega načrta omogoča tudi lažjo prilagoditev veljavnim računovodskim standardom in zakonodaji države, kjer se hotel nahaja. V 11. metodologiji ni več določene natančne strukture kontov, pač pa so snovatelji oblikovali natančen vodnik prihodkov in stroškov (Revenue and Expense guide), na podlagi katerega lahko uporabnik metodologije pripravi ne samo kontne načrte, pač pa tudi šifrante prodajnih in stroškovnih artiklov. Poleg tega pa je konte možno oblikovati tudi na podlagi predlog za izdelavo poročil. Za vsak prikazan prodajni artikel metodologija natančno določa, v kateri oddelek artikel spada, ter ime konta, na katerega se prihodek knjiži (»Data Plus, Inc.«, 2015). Kljub temu pa je za implementacijo še vedno splošno sprejeta praksa, ki je v skladu z metodologijo 10. izdaje USALI. Podporo informatizaciji integralnega informacijskega sistema, od mesta nastanka stroška in mest odgovornosti, do korporacijske ravni, omogoča kontni načrt, ki je pripravljen po naslednjih načelih (Peršić, 2015):

Za vsako raven so določene po tri številke, kar v osnovi zahteva uporabo 12 mestnega kontnega načrta, ki ga večina informacijskih rešitev podpira. Vsaka skupina podpira hierarhijo medsebojno povezanih številk in $\mathrm{s}$ tem uporabniku podaja specifično informacijo. Kljub temu sodobna informacijska tehnologija omogoča dodatne indikatorje, ki poleg sintetičnih in analitičnih števil, ki so obvezna in morajo biti pripravljena v skladu z USALI, omogočajo identifikacijo oddelka in lastniške strukture brez uporabe prvih šestih številk. Slednje je še posebej dobrodošlo v Sloveniji, kjer morajo podjetja kontne načrte podrediti Slovenskim računovodskim standardom.

Mesta odgovornosti po USALI

\subsection{Mesta odgovornosti po USALI}

Kot smo že navedli, je v velikih hotelskih poslovnih sistemih potrebno zagotoviti informacije za poslovodenje decentraliziranih delov, za kar je še posebej primerna uporaba standardov USALI, ki so $\mathrm{v}$ celoti usklajeni s posebnostmi hotelirstva kot dejavnosti. Metodologija USALI definira načela oblikovanja mest odgovornosti ter predstavitev načina poročanja, tako na ravni mest odgovornosti, kot za višje ravni poslovodstva in tudi za lastnike ter ostale zunanje uporabnike. Koncept mest odgovornosti je zastavljen tako, da so dobičkovna in prihodkovna mesta odgovornosti ločena od stroškovnih mest odgovornosti. USALI pa za vsako mesto odgovornosti narekuje tudi svoje poročilo. Seznam mest odgovornosti je prikazan v tabeli 1. 
$36^{\mathrm{TH}}$ International Conference on ORganizational Science Development: Responsible Organization (MARCH $22^{\mathrm{ND}}-24^{\mathrm{TH}}$, PORTOROŽ SLOVENIA)

G. Ivankovič \& D. Baš: USALI Implementation with PANTHEON Business Accouting

\begin{tabular}{|c|c|c|}
\hline \multicolumn{3}{|l|}{ DOBIČKOVNI CENTRI } \\
\hline 1. Nastanitev & 2. Hrana in pijača & 3.x Ostali poslovni oddelki \\
\hline \multicolumn{3}{|l|}{$\begin{array}{l}\text { PRIHODKOVNI } \\
\text { CENTER }\end{array}$} \\
\hline 4. Ostali razni prihodki & \multicolumn{2}{|c|}{\begin{tabular}{|lll}
$\begin{array}{l}\text { Provizije, najem prostorov in opreme, garancije, } \\
\text { odpovedi,... }\end{array}$ & \\
\end{tabular}} \\
\hline \multicolumn{3}{|l|}{ STROŠKOVNI CENTRI } \\
\hline $\begin{array}{l}\text { 5. Administracija in } \\
\text { splošni str. }\end{array}$ & $\begin{array}{|ll|}\text { 6. } & \begin{array}{l}\text { Informacijsko } \\
\text { telekomunikacijski } \\
\text { sistemi }\end{array} \\
\end{array}$ & 7. Prodaja in marketing \\
\hline $\begin{array}{l}\text { 8. Investicijsko in tekoče } \\
\text { vzdrževanje }\end{array}$ & 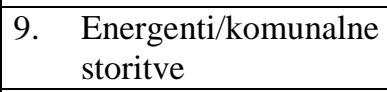 & 10. Upravljalske provizije \\
\hline $\begin{array}{l}\text { 11. Prihodki in odhodki od } \\
\text { drugih aktivnosti }\end{array}$ & 12. Pralnica perila & 13. Prehrana zaposlenih \\
\hline
\end{tabular}

Tabela 1: Seznam mest odgovornosti po USALI

Oblikovanje mest odgovornosti in spremljanje poslovanja po teh mestih omogočata prenos odgovornosti, dolžnosti in pooblastil $z$ višjega poslovodstva na nižje poslovodstvo, saj se v velikih podjetjih višje poslovodstvo namreč ne more ukvarjati z vsakdanjimi dogodki in sprejemati vsakdanjih odločitev. Oddelki tako predstavljajo samostojne organizacijske enote, ki same spremljajo, načrtujejo, nadzorujejo stroške in prihodke za posamezna obračunska obdobja, ter za svoje delo in uspeh tudi sprejemajo odgovornost. Vsak poslovni dogodek se s tem evidentira tam, kjer je nastal, s tem pa lahko natančno določimo mesto nastanka oziroma odgovornost $\mathrm{z}$ nastale prihodke in stroške, kar pa je pomembna informacija za sprejemanje pravilnih poslovnih odločitev.

\subsection{Poročila po USALI na ravni dobičkovnih mest}

Metodologija USALI natančno narekuje: način zbiranja, evidentiranja in poročanja o prihodkih, stroških in delnem izidu poslovanja za osnovne dejavnosti, s katerimi se ukvarjajo hotelski poslovni sistemi. Ta pravila so prikazana v petih poglavjih enajste izdaje USALI:

- Poglavje 1. Poslovna poročila - prikazujejo izdelavo zbirnega izkaza poslovnega izida za upravo in lastnike ter poslovna poročila za posamezne oddelke prikazane v tabeli 1 .

- Poglavje 2. Finančna poročila - prikazujejo izdelavo bilance stanja, izkaz poslovnega izida, izkaz vseobsegajočega donosa, izkaz gibanja kapitala, izkaz denarnega in finančnega toka ter pojasnila k finančnim izkazom.

- Poglavje 3. Finančni in poslovni kazalniki - Prikazujejo izdelavo finančnih kazalnikov in poslovnih analiz.

- Poglavje 4. Vodič po prihodkih in stroških - podaja usmeritve za izdelavo šifrantov, kontnih planov in oddelkov. 
36. MEDNARODNA KONFERENCA O RAZVOJU ORGANIZACIJSKIH ZNANOSTI: ODGOVORNA 255 ORGANIZACIJA (22. - 24. MAREC 2017, PORTOROŽ, SLOVENIJA)

G. Ivankovič \& D. Baš: Implementacija metodologije USALI v hotelirstvu s pomočjo informacijskega sistema PANTHEON

- Poglavje 5. Bruto poročanje nasproti neto poročanju.

\section{Informacijski sistem kot podpora poslovodno računovodsekmu sistemu}

Informacijski sistem pretvarja podatke, ki sami po sebi nimajo vsebine, v uporabniku razumljive in za odločanje primerne informacije. Obenem informacijski sistem skrbi tudi za shranjevanje teh podatkov. Sestavljen je iz računovodstva, statistike, načrtovanja, analiziranja in različnih operativnih evidenc. Najpomembnejši kvantitativni del informacijskega sistema predstavlja računovodstvo, ki s pomočjo zbiranja, evidentiranja, klasificiranja in urejanja podatkov preko informacijskega sistema pripravlja informacije, ki služijo pri poslovnih odločitvah. Posebnost računovodstva je $\mathrm{v}$ tem, da poslovne procese in stanja izraža vrednostno. Računovodstvo mora informacije zagotavljati pravočasno, kvalitetno ter transparentno. Zagotoviti pa mora poročila primerna za notranje in zunanje uporabnike. Zunanji uporabniki so lastniki kapitala, potencialni vlagatelji, posojilodajalci, partnerji podjetja, država in širša javnost. Notranji uporabniki so zaposleni v podjetju, ki na podlagi zadolžitev in odgovornosti sprejemajo poslovne odločitve in so del poslovnega sistema. To najbolje zagotavlja integriran informacijski sistem, ki omogoča večkratno uporabo podatkov po tem, ko so bili le ti vneseni v sistem. To mora zagotavljati tako, da vrednostno izražene kvalitativne in naturalne podatke hrani $\mathrm{v}$ okviru baze podatkov, ki je osnova za zbiranje, usmerjanje, integriranje in kakovostno pripravljanje informacij $\mathrm{v}$ podporo poslovodnemu odločanju. Kvalitetno integriran informacijski sistem je rezultat poglobljenega sodelovanja med poslovodstvom, operativnimi delavci ter strokovnjaki na področju informacijskih tehnologij, od faze projektiranja, do faze, kako poslovodstvo podatke koristi iz enotnih baz. Pri tem je potrebno upoštevati vse posebnosti hotelske industrije ter materialne, denarne in informacijske tokove. Da bi lahko računovodstvo postreglo s kvalitetnimi informacijami za odločanje, mora biti informacijska tehnologija zgrajena na podlagi medsebojno dobro povezanih modulov, ki jih je možno sistematično nadgrajevati in razvijati, a nadgradnja ne sme vplivati na module, ki sprememb ne potrebujejo (Peršić, 2015).

\subsection{Informacijski sistem Pantheon}

Gre za sodoben računalniško podprt poslovni informacijski sistem za vodenje, upravljanje in razvoj podjetja ali ERP - Enterprise Resource Planning, po slovensko celovita informacijska rešitev, ki ga razvija slovensko podjetje Datalab Tehnologije d.d. Podjetje je sistem začelo razvijati že leta 1997, v tem času pa je postalo eno vodilnih razvijalcev integriranih poslovnih informacijskih sistemov za mala, srednja in velika podjetja v Sloveniji. Sistem je poleg slovenske lokalizacije na voljo še za v 22 državah znotraj in izven EU. Poslanstvo podjetja je razvijati uporabnikom prijazen poslovni informacijski sistem, ki omogoča enostavno zbiranje, analiziranje, planiranje in kontroliranje podatkov, transakcij in procesov, s tem pa omogočiti podjetjem večjo konkurenčnost (»Datalab Enterprise«, 2016). Pantheon je primeren IS za vse vrste dejavnosti. Funkcionalno pokriva področje veleprodaje, maloprodaje, storitev, proizvodnje, kmetijske dejavnosti ter vodenja računovodstva $\mathrm{v}$ javnih podjetjih in zavodih. Sistem se neprestano razvija in dopolnjuje z novimi funkcionalnostmi, dokaz 
$36^{\mathrm{TH}}$ InTERnAtional CONFERENCE ON ORganizational SCIENCE DeVElopment: Responsible Organization (MARCH $22^{\mathrm{ND}}-24^{\mathrm{TH}}$, PORTOROŽ SLOVENiA)

G. Ivankovič \& D. Baš: USALI Implementation with PANTHEON Business Accouting

kakovosti pa je več kot 49500 prodanih licenc. Razvoj sistema še posebej veliko pozornost posveča poslovni analitiki, ki poleg, načrtovanja, analitike, v naprej pripravljenih nadzornih plošč omogoča tudi oblikovanje lastnih poročil.

\section{Prikaz možnosti implementacije USALI v informacijski sistem pantheon}

Implementacija metodologije USALI je zapleten in dolgotrajen proces, ki za podjetje predstavlja velik vložek. Izhodišča, ki jih ponuja IS Pantheon, so le osnova, na kateri bi bilo možno delujoč sistem zgraditi s pomočjo sodelovanja strokovnjakov na področju poznavanja metodologije USALI in strokovnjakov na področju informacijskih tehnologij.

\subsection{Predpogoj za implementacijo is pantheon $v$ hotelsko podjetje}

IS Pantheon, kot klasičen ERP sistem, je $\mathrm{v}$ osnovi namenjen zbiranju, spremljanju in obdelovanju standardnih, komercialnih, knjigovodskih in računovodskih poslovnih procesov, kot so nabava, prodaja, servis, naročila, proizvodnja, obračun plač, vodenje zalog, spremljanje registra osnovnih sredstev in pripravi računovodskih poročil in obračunov itd... Hotelsko poslovanje pa poleg navedenih funkcionalnosti obsega še veliko povsem specifičnih funkcij, kot so:

- Recepcijsko poslovanje (rezervacije, prijave in odjave gostov, planiranje zasedenosti kapacitet.

- Specializiran sistem za gostinstvo (spremljanje prodaje po lokalih, mizah, natakarjih itd...).

- Menjalniško poslovanje.

- Povezave z blagajnami in drugimi napravami (telefon, Pay-TV, kodne kartice za vstop v sobe...).

- Povezave z internetnimi stranmi za rezervacije.

- Upravljanje kapacitet za počitniško dejavnost (kolonije, sindikalne počitniške kapacitete....).

- Upravljanje dodatnih kapacitet ( kongresni center, športni center...).

- Zdraviliško poslovanje $\mathrm{z}$ beleženjem zdravstvenih storitev za zdravilišča (povezava z ZZZS).

- Samopostrežni terminali za check-in in check-out.

- (»MAOP hotelski informacijski sitem«, 2016)

Zaradi tega bi bilo v primeru implementacije predhodno potrebno zagotoviti zunanji hotelski informacijski sistem, ki bi omogočal vodenje vseh potrebnih evidenc za spremljanje hotelskega poslovanja ter urediti brezhibno podatkovno komunikacijo med hotelskim sistemom in IS Pantheon.

$\mathrm{Na}$ tržišču je precejšnje število ponudnikov, ki ponujajo tovrstne rešitve. Za primer naj jih navedem le nekaj: Hotelski sistem Gastrodat in Gastroweb (že povezana s Pantheonom), sistem Protel PMS (že povezan s Pantheonom), sistem MAOP, hotelski 
sistem MAIS Fidelity itd... Ponudniki tovrstnih rešitev se v osnovi specializirajo za razvoj sistemov za podporo hotelirjem, ne osredotočajo pa se na druge dele poslovanja, kot je računovodstvo, trgovina... Kljub temu pa se zavedajo, da je za dober celovit informacijski sistem hotela potrebna kvalitetna integracija in povezava hotelskega sistema $\mathrm{z}$ računovodskim sistemom. Zaradi tega ima večina ponudnikov svoje sisteme že prilagojene za povezovanje $\mathrm{z}$ računovodskimi informacijskimi sistemi.

\subsection{Kontni plan, knjiženje po hotelskih enotah in mestih odgovornosti}

V poglavju 2.1 smo že opisali specifične zahteve metodologije, za oblikovanje kontnega načrta. Metodologija USALI predvideva 12 mestni kontni načrt, kar sistem Pantheon v celoti podpira, saj omogoča uporabo 13 mestnega kontnega načrta. Omejitev pa predstavlja zakonska podlaga, saj slovenska zakonodaja in standardi določajo natančno predpisano obliko kontnega načrta, ki je ne smemo spreminjati, razen na analitičnem nivoju (Kavčič in Ivankovič, 2003). To pomeni, da prvih šest številk (prve tri številke predstavljajo hotel, druge tri številke pa oddelek v hotelu) kontnega plana v okviru USALI ne smemo uporabljati. Pri Datalab Tehnologije d.d. so za potrebe rešitve tega problema predlagali, da se hotele in oddelke $\mathrm{v}$ hotelih loči z uporabo šifranta oddelkov. Šifre oddelkov lahko kreiramo premišljeno (prve tri številke predstavljajo hotel, druge tri številke pa oddelek $v$ hotelu). Idealno bi bilo, če bi imeli hierarhično strukturo oddelkov oziroma razširjene/dodatne dimenzije oddelkov. V Pantheonu smo trenutno omejeni le z eno dimenzijo oddelkov in eno dimenzijo stroškovnih nosilcev. Datalab Tehnologije d.d. trenutno že pripravlja sistem hierarhične strukture tako oddelkov kot stroškovnih nosilcev. To pomeni, da bomo v bližnji prihodnosti lahko uporabljali prvi nivo oddelkov za določitev hotela in drugi nivo oddelkov za določitev oddelka znotraj hotela.

\subsection{Pregled možnosti implementacije USALI po poglavjih}

Pri raziskavi smo preučili samo metodologijo USALI in njene zahteve ter predstavili osnovne zmožnosti IS Pantheon. Poleg tega smo v sodelovanju s proizvajalcem IS Pantheon, podjetjem Datalab tehnologije d.d., preučili možnosti za implementacijo ter pripravili priporočila za spremembe in dopolnitve IS, ki bi bile potrebne za implementacijo USALI.

Povzamemo lahko, da je implementacija šifrantov, kontnega načrta in stroškovnih nosilcev, kot predpogoj za uvedbo v sistem, v celoti mogoča, vendar bi moral uporabnik predhodno skrbno pripraviti načrt vsakega posameznega dela. Implementacija poslovnih poročil, opisanih v prvem poglavju, ki predstavljajo jedro metodologije USALI, je mogoča z minimalnim vložkom, saj je znotraj sistema možno zagotoviti vse potrebne podatke in izdelati izpise poročil. V sklopu uvedbe finančnih poročil po USALI je implementacija bilance stanja, izkaza poslovnega izida in izkaza stanja kapitala v celoti izvedljiva. Ostala finančna poročila so izvedljiva pogojno ali pa $\mathrm{z}$ bistvenim posegom $\mathrm{v}$ program. Matrike $\mathrm{v}$ tretjem poglavju USALI so izvedljiv $\mathrm{z}$ delno ali bistveno prilagoditvijo sistema, finančne kazalniki pa je možno pripraviti brez posegov v program 
$36^{\text {Th }}$ International Conference on Organizational Science Development: Responsible Organization (MARCH $22^{\mathrm{ND}}-24^{\mathrm{TH}}$, Portorož SLOVENia)

G. Ivankovič \& D. Baš: USALI Implementation with PANTHEON Business Accouting

v sklopu poslovne inteligence ZEUS. Prikaz možnosti za implementacijo je prikazan v tabeli 2.

\begin{tabular}{|c|c|c|c|c|c|}
\hline \multirow{2}{*}{\multicolumn{2}{|c|}{ VRSTA POROČILA - USALI 11}} & \multicolumn{4}{|c|}{ MOŽNOST IMPLEMENTACIJE V PANTHEON } \\
\hline & & \multirow{2}{*}{\begin{tabular}{c|c|} 
BREZ & \\
DOPOLNITEV \\
\end{tabular}} & \multirow{2}{*}{$\begin{array}{c}\text { Z MANJŠIMI } \\
\text { DOPOLNITVAMI } \\
\end{array}$} & \multirow{2}{*}{\begin{tabular}{|c|} 
Z BISTVENIMI \\
DOPOLNITVAMI
\end{tabular}} & \multirow{2}{*}{\begin{tabular}{|l|} 
NE OMOGOČA \\
\end{tabular}} \\
\hline Poglavje 1 & Poslovna poročila za upravo in lastnike & & & & \\
\hline & Poslovna poročila po mestih odgovornosti & & $\checkmark$ & & \\
\hline \multirow[t]{8}{*}{ Poglavje 2} & Bilanca stanja & $\checkmark$ & & & \\
\hline & Izkaz stanja kapitala & $\checkmark$ & & & \\
\hline & Izkaz poslovnega izida & & $\checkmark$ & & \\
\hline & Izkaz vseobsegajočega donosa & $\checkmark$ & & & \\
\hline & Izkaz gibanja kapitala - d.d. & & & & $\checkmark$ \\
\hline & $\begin{array}{l}\text { Izkaz gibanja kapitala - d.o.o., s.p. ostale } \\
\text { kapitalske oblike }\end{array}$ & & & & $\checkmark$ \\
\hline & Izkaz denarnega toka - neposredna metoda & & $\checkmark$ & & \\
\hline & Izkaz denamega toka - posredna metoda & & & $\checkmark$ & \\
\hline \multirow[t]{8}{*}{ Poglavje 3} & Matrika kazalnikov - sobe & & & $\checkmark$ & \\
\hline & Matrika kazalnikov - hrana in pijača & & & $\checkmark$ & \\
\hline & Matrika kazalnikov - golf & & & $\checkmark$ & \\
\hline & Matrika kazalnikov - SPA & & & $\checkmark$ & \\
\hline & Matrika kazalnikov - parking & & & $\checkmark$ & \\
\hline & Matrika kazalnikov - energija & & & $\checkmark$ & \\
\hline & Matrika kazalnikov - plače & & & $\checkmark$ & \\
\hline & Finančni kazalniki & $\checkmark$ & & & \\
\hline Poglavje 4 & Vodič po prihodkih in stroških & \multicolumn{4}{|c|}{$\begin{array}{l}\text { Podaja usmeritve za izdelavo šifrantov, kontnega } \\
\text { plana in oddelkov }\end{array}$} \\
\hline Poglavje 5 & Bruto poročanje nasproti neto poročanju & \multicolumn{4}{|c|}{ Podaja usmeritve za poročanje } \\
\hline \multicolumn{2}{|c|}{$\begin{array}{l}\text { DELEŽ MOŽNOSTI ZA IMPLEMENTACIJO GLEDE NA } \\
\text { STOPNJO ZAHTEVNOSTI IMPLEMENTACIJE }\end{array}$} & $22,22 \%$ & $22,22 \%$ & $44,44 \%$ & $11,11 \%$ \\
\hline
\end{tabular}

\section{Tabela 2: Prikaz možnosti implementacije poročil USALI 11 v Pantheon}

\section{$5 \quad$ Zaključek in usmeritve za prihodnost}

Datalab Tehnologije d.d. razvijajo informacijski sitem, ki je primeren za širok spekter dejavnosti, od samostojnih podjetnikov, ki predstavljajo mikro gospodarske enote, do velikih podjetji s korporativno strukturo upravljanja. Sistem ponuja celo paleto rešitev: izdelavo računov, ponudbe, vodenje zalog, osnovna sredstva, plače s kadrovsko evidenco, carinsko poslovanje, servisne storitve itd. Poleg standardnih sistemov za spremljanje poslovanja veliko pozornost posvečajo tudi sistemu za izdelavo poslovne analitike, ki predstavlja veliko dodano vrednost za vodstvo podjetji, obenem pa je primerno tudi za implementacijo dela metodologije USALI. Kljub temu da je IS Pantheon izjemno kvalitetno orodje za spremljanje poslovanja, pa zaradi specifičnosti poslovanja hotelske industrije ne omogoča celovitega spremljanja poslovanja hotela. Predpogoj za implementacijo je dopolnitev sistema z zunanjim sistemom za spremljanje poslovanja hotela, ki ne pokriva finančnega in računovodskega spektra informacijske tehnologije. Na slovenskem tržišču je zadosti ponudnikov tovrstnih programov, ki že imajo izdelano integracijo z IS Pantheon. Poleg tega pa je pomembna dodana vrednost IS Pantheon tudi v tem, da njegova odprta programska koda omogoča lastne dopolnitve in izboljšave ter s tem tudi dopušča možnost za implementacijo metodologije USALI.

Implementacija metodologije USALI je pogojena tudi s tem, da je IS Pantheon v celoti podrejen pravilom slovenske zakonodaje in Slovenskim računovodskim standardom. Kot 
G. Ivankovič \& D. Baš: Implementacija metodologije USALI v hotelirstvu s pomočjo informacijskega sistema PANTHEON

tak posledično ni prilagojen izdelavi poročil po USALI. Kljub temu pa lahko rečemo, da bi bila implementacija z večjimi ali manjšimi prilagoditvami mogoča.

Pri implementaciji tako močnega informacijskega in poročevalskega analitičnega orodja je potrebno omeniti tudi finančni/stroškovni vidik. Zaradi obsežnosti metodologije, specifike šifrantov in specifike določenih poročil, za katere bi bile potrebne bistvene prilagoditve programa, se je potrebno vedno vprašati tudi o razmerju med stroškom implementacije in koristjo. Stroški nakupa in uvedba sistema ter strokovno usposabljanje kadrov bi vsekakor predstavljali precejšnji zalogaj, ki si ga manjša hotelska podjetja sigurno ne bi mogla privoščiti.

Sklenemo lahko, da IS Pantheon pogojno ponuja možnost za implementacijo metodologije USALI, ki bo s prihajajočimi trendi na področju hotelske dejavnosti prej ali slej postala obvezno orodje, kakor tudi konkurenčna prednost vsakega hotela. Morda bi lahko prav Datalab tehnologije d.d. bilo tisto podjetje, ki bi prvo med slovenskimi ponudniki IT rešitev na trg lansiralo tovrstno rešitev in v ožjem ekonomskem bazenu postalo vodilno na področju turistične IT infrastrukture. Vsekakor bi bila to zanimiva naložba za prihodnost, saj se moramo zavedati, da je turizem ena izmed večjih in hitreje rastočih vej svetovne industrije.

\section{Literatura}

American Hotel \& Lodging Association Washington. (2014). USALI 11 - Uniform Sistem of Accounts for the Lodging Industry 11th edition. Lansing: American Hotel \& Lodging Educational Institute

Data plus, Inc. (2015). Pridobljeno 15.5.2016 iz http://www.dphs.com/wpcontent/uploads/documents/General\%20Ledger/File\%20Maint/Hospitality\%20Industry\%20C hart\%20of\%20Accounts.pdf

Datalab Enterprise. (2016). Pridobljeno 20.5.2016 iz http://www.datalab.si/pantheon/enterprise/

Datalab tehnologije d.d. (2016). Pantheon ME [Računovodski informacijski sistem]. Na uporabo pridobljeno od BARS d.o.o.

Gvin, 2016. Spletni servis, ki omogoča celovit vpogled v položaj podjetij na slovenskem trgu, Ljubljana.

Ivankovič, G. in Planinc, T. (2011). Računovodske informacije za poslovno odločanje v turizmu. Koper: Univerza na Primorskem

Ivankovič, G., Klobučar, N. in Vidic, D. (2002). Možnosti spremljanja uspešnosti poslovanja v slovenskih hotelih po standardu USALI. Annales, Series historia et sociologia, 1, 177-188.

Kavčič, S. in Ivankovič, G. (2003). Vzpostavljanje razmer za pridobivanje računovodskih in drugih podatkov potrebnih za metodologijo USALI v Sloveniji. Ljubljana: Ekonomska fakulteta.

MAOP hotelski informacijski sistem. (2016), Pridobljeno 31.5.2016 iz http://www.maop.si/resitve/hotelski_informacijski_sistem/

Planinc, T., Ivankovič, G., Jerman, M. in Uran Maravić, M. (2014). Corporate social responsibility as a part of benchmarking analysis: case studiy of the Slovenian and Croatian hotel industry. The sustainable city IX, 1. 477-478. Pridobljeno 14.5.2016 iz $\underline{\text { https://books.google.si/books?id=CY21BAAAQBAJ } \& \text { printsec }=\text { frontcover } \& d q=\text { sustainable }+\mathrm{c}}$ 
36 ${ }^{\mathrm{TH}}$ International Conference on ORganizational Science Development: Responsible Organization (MARCH $22^{\mathrm{ND}}-24^{\mathrm{TH}}$, Portorož SLOVENia)

G. Ivankovič \& D. Baš: USALI Implementation with PANTHEON Business Accouting

ity $+\mathrm{IX} \& \mathrm{hl}=\mathrm{s} 1 \& \mathrm{sa}=\mathrm{X} \& \mathrm{ved}=0 \mathrm{ahUKEwi99qPp1YzOAhXFPRQKHQIxCIoQ6AEIHjAA \# v=on}$ epage \&q=sustainable\%20city\%20IX\&f=false

Peršić, M. (2015). Računovodstvo odgovornosti v hotelirstvu = Računovodstvo odgovornosti u hoteljerstvu. V: S. Jankovič (Ur.), M. Peršić (Ur.). Priročnik za Benchmarking v hrvaškem in slovenskem hotelirstvu $=$ Priručnik za Benchmarking $u$ hrvatskom $i$ slovenskom hotelijerstvu (str. 2-5). Opatija: Sveučilište u Rijeci, Fakultet za manadžment u turizmu i ugostiteljstvu.

Peršić, M. (2015). Poročanje po mestih odgovornosti = Izvještavanje po centrima odgovornosti. V:

S. Jankovič (Ur.), M. Peršić (Ur.). Priročnik za Benchmarking v hrvaškem in slovenskem hotelirstvu $=$ Priručnik za Benchmarking $u$ hrvatskom $i$ slovenskom hotelijerstvu (str. 5-42).

Opatija: Sveučilište u Rijeci, Fakultet za manadžment u turizmu i ugostiteljstvu.

Slovenski računovodski standardi 2016. (2016). Slovenski inštitut za revizijo.

Strategija razvoja slovenskega turizma 2012-2016. (2012). Vlada Republike Slovenije.

SURS, 2016, Statistični urad Republike Slovenije. Podatkovni portal SI-STAT. Pridobljeno 30.12.2016 iz: http://www.stat.si.

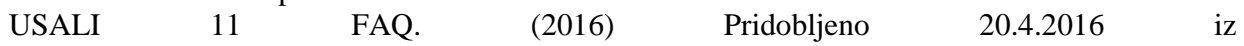
https://www.ahlei.org/Resources/USALI/Uniform-System-of-Accounts-for-the-LodgingIndustry-FAQ/

\begin{tabular}{llllll}
\hline USALI & 11 & Guide. & (2015). & Pridobljeno & 10.5 .2016
\end{tabular} http://www.hftp.org/hospitality resources/usali guide/

WTTC, 2016. World Travel ، Tourism Council. Travel „Tourism. Economic Impact 2016 Slovenia, London:WTTC. 


\title{
Mediacija v poslovnem okolju kot podpora poslovodstvu
}

\author{
MATEJA KALAN \& MARTINA RAZDEVŠEK
}

\begin{abstract}
Povzetek Temeljno raziskovalno vprašanje je ugotoviti prednosti mediacije oziroma mediativnega načina komuniciranja v poslovnem okolju. Namen raziskave je ugotavljanje razlik, ki se pojavljajo med zaposlenimi glede na to, ali poslovodstvo mediativen način komuniciranja uporablja v praksi ali ne.
\end{abstract}

Ob začetku raziskave smo proučili teoretična izhodišča $v$ domači in tuji literaturi. Zaposleni so preko intraneta izpolnili spletni anketni vprašalnik, sledila je kvantitativna raziskava. Rezultati so lahko v podporo poslovodstvu, saj je analiza pokazala zelo različen pogled na reševanje konfliktov med zaposlenimi, ki so se z mediativnim načinom reševanja konfliktov že srečali, in med tistimi, ki takega načina še ne poznajo. Ta razlika je očitna tudi pri zaupanju zaposlenih notranjemu mediatorju, torej mediatorju, ki je njihov sodelavec in usposobljen za mediatorja $\mathrm{v}$ poslovnem okolju. Pri analizi rezultatov nadalje ugotavljamo, da s pomočjo mediativnega načina komuniciranja $\mathrm{v}$ poslovnem okolju možnost za nastanek konfliktov zmanjšamo, oziroma jih lahko hitreje rešimo. Uspešno poslovodstvo se zaveda, da vodenje temelji na podeljevanju odgovornosti, kar velja tudi za konflikte. Rešitev vedno izhaja iz nas samih in mediacija je možnost, da jo poiščemo v sebi, jo svobodno izrazimo in zanjo prevzamemo odgovornost. Tak način dela pozitivno vpliva na posameznika, organizacijo in na družbo kot celoto.

Raziskava kaže bistvene elemente, ki so koristni za posameznika, kar je v pomoč tudi poslovodstvu. Takšne raziskave še nismo zasledili, omejitev pa vidimo predvsem $\mathrm{v}$ tem, da je bila narejena le $\mathrm{v}$ dveh slovenskih podjetjih, ki delujeta na področju storitev. Odpira se možnost za nove raziskave, narejene v še več podjetjih, različnih po številu zaposlenih in po opravljanju dejavnosti.

KLJUČNE BESEDE: konflikt • poslovna mediacija • poslovodstvo

NASLOV AVTORICV: Mateja Kalan, e-pošta: mateja.kalan70@gmail.com; Martina Razdevšek, epošta: martina.razdevsek@gmail.com.

DOI https://doi.org/10.18690/978-961-286-020-2.24

ISBN 978-961-286-020-2

(C) 2017 Univerzitetna založba Univerze v Mariboru

Dostopno na: http://press.um.si 


\title{
Mediation in the Business Environment to Support Management
}

\author{
MATEJA KALAN \& MARTINA RAZDEVŠEK
}

\begin{abstract}
The fundamental research question is to determine the advantages of mediation, i.e. of the mediatory communication approach in business environment. The purpose of the research is to assess the differences in employees' opinions regarding the application of the mediatory communication approach by their management in practice.
\end{abstract}

At the beginning of the research, we considered the theoretical background in foreign and national references. Employees completed the survey web questionnaire over the intranet, followed by quantitative analysis. The management can rely on these results, since the analysis indicated a very different view on conflict management by the employees who were already informed about the mediatory conflict management, compared to the ones who were not knowledgeable about that approach. Such a difference is also obvious with regard to employees' confidence in an internal mediator, i.e. the mediator who is their coworker and is qualified to be a mediator in business environment. Further, in results analysis, we established that the possibility for conflicts to appear can be decreased or they can be solved faster by the use of the mediatory communication approach in business environment. Successful management is aware that leadership is based on giving responsibility, which also applies to conflicts. The solution can always be found in ourselves, and mediation offers us the possibility to look for it in ourselves, to express it freely, and to take the responsibility for it. Such an approach in working environments has a positive effect on individuals, organisations, and society as a whole.

Research has indicated substantial elements useful for the individual, and they can be helpful for the management as well. We have not found any research like this; however, the limitation of our research is the fact that it was conducted within only two large enterprises in services industry. It opens up the possibility for new surveys conducted in even more enterprises, varied in the number of employees and their business activities.

KEYWORDS: conflict • business mediation $\bullet$ management

CORRESPONDENCE ADDRESS: Mateja Kalan, e-mail: mateja.kalan70@gmail.com; Martina Razdevšek, e-mail: martina.razdevsek@gmail.com

DOI https://doi.org/10.18690/978-961-286-020-2.24 
M. Kalan \& M. Razdevšek: Mediacija v poslovnem okolju kot podpora poslovodstvu

\section{$1 \quad$ Uvod}

Veliki potrošniki naše energije so pogosto konfliktne situacije. Ta potrošnik je nepotreben, zato je še kako pomembno, da se zavedamo obstoja drugih poti in izrabe drugih možnosti. Ena med njimi je zagotovo mediacija in mediativen način reševanja takih situacij. Zavedanje poslovodstva o obstoju te možnosti je ključnega pomena za njeno uvedbo v poslovni model (Insam et al. 2016, 233).

Ustvarjanje $\mathrm{v}$ posameznem podjetju in celotni družbi bogatijo različna mnenja posameznikov. Prav ta pa nemalokrat povzročajo konflikte, ki bi jih morali znati reševati po poti, ki bi dala nov zagon vsakemu posamezniku - tako, kot je v svoji pesmi We just disagree zapisal Dave Mason (1977):

There ain't no good guys,

There ain't no bad guys,

There's only you and me, And we just disagree.

\section{Dave Mason}

Ko se poslovodstvo zave, da so različna mnenja posameznikov edina prava pot, ki vodi k uspešnemu cilju, je uspeh zagotovljen (Winters 2016, str. 179). Znati se moramo le še slišati in cilje med seboj uskladiti. Ljudje smo bolj ali manj sočutni do drugih ljudi (Trompenaars, Hampden - Turner 2011, str. 25). Določenim posameznikom je ta sposobnost prirojena, drugi se morajo takega načina delovanja učiti. Naučiti se morajo znati poslušati in ob tem sogovornike tudi slišati. To je začetek transformacije človeka (Mack 1999, str. 15). Šele ob lastnem »preporodu « lahko prepoznamo potrebe drugih, jih slišimo, vidimo, občutimo, vonjamo in okusimo. To je tudi temelj, na katerem gradi mediacija - v prvi vrsti na zaznavanju sogovornika z vsemi čutili, v nadaljevanju pa tudi celotnega okolja (Conti et al. 2013, str. 362-368), ki nas obdaja. Mediacija je priznavanje drugega, sprejemanje njegovega mnenja, delovanja (Cella in Fallowfield 2008, str. 167180). V veliko pomoč nam je pri tem spoznanje, da so ljudje v svoji naravi dobri, le naš vidik jih morda občasno dela drugačne. Zavedati se moramo, da posameznika lahko sprejmemo le takšnega, kakršen je, saj ga ne moremo spremeniti. Spremenimo lahko sebe, in sicer z zavedanjem, da smo sposobni sprejemanja drugih. Vse navedeno velja tudi za poslovno okolje (Bühring - Uhle, Kirchhoff in Scherer, 2006, str. 10). V mediacijo moramo preprosto verjeti - tudi v poslovnem okolju - še posebej pomembno pa je, da v to verjame poslovodstvo (Lande 2000, str. 137).

Cilj raziskave je bil ugotoviti, v kolikšni meri zaposleni že poznajo mediacijo, oziroma jim je blizu. Zanimal nas je njihov odnos do mediativnega načina reševanja konfliktnih situacij. Raziskovali smo morebitno željo zaposlenih, da bi mediacijo $v$ obliki mediacijske pisarne $\mathrm{v}$ prihodnje imeli $\mathrm{v}$ podjetju. $\mathrm{Z}$ ustanovitvijo takšne pisarne bi se povečala možnost, da nestrinjanje začnemo reševati hitro. To pogosto pomeni, da ga lahko v najhitrejšem možnem času rešimo v začetni fazi in tako ne dovolimo, da se razraste. Mediacijo bi imeli zares blizu, izvajala bi se lahko v samem podjetju, in sicer takoj, ko bi se izkazala potreba za to. 
$36^{\mathrm{TH}}$ InTERnATIONAL CONFERENCE ON ORganizational SCIENCE DeVElopment: Responsible Organization (MarCh $22^{\mathrm{ND}}-24^{\mathrm{TH}}$, Portorož Slovenia)

M. Kalan \& M. Razdevšek: Mediation in the Business Environment to Support Management

\section{$2 \quad$ Teoretična izhodišča}

Konflikti so del vsakdanjika, tudi v poslovnem okolju. To so zgodbe o zatrtih, neopaženih in odrinjenih vprašanjih, ki opredelijo notranje jedro, oblikujejo vrednote in prepričanja (Cloke in Goldsmith 2011, str. 155). Uspešen menedžer se tega zaveda in to odgovornost sprejema. Prav on je namreč tisti, ki je lahko mediator v vsakem trenutku, na vsakem mestu. Mediator se poslužuje spodbujanja in »coachinga«, da bi posameznike popeljal od opisanega načina pogovora $\mathrm{k}$ temu, da bi v pogovoru več premišljevali, da bi stopili korak nazaj in premislili o tem, česa si morda želi sogovornik in kako bi se lahko oba premaknila naprej (Crawley in Graham 2011, str. 98). Prav bi bilo, da vodja pozna vseh pet zaznavnih tipov ljudi in tako prepozna značilnosti posameznega tipa - značaj, ki iz njega izhaja, ter posledično način reagiranja $v$ določeni situaciji (Prabowo 2015, str. 37 47):

- $\mathrm{V}=$ vizualni,

- $\mathrm{A}=$ avditivni,

- $\mathrm{K}=$ kinestetični,

- $\mathrm{O}=$ olfaktorični (vonjalni) in

- $\mathrm{G}=$ gustatorični (okušalni čut).

Včasih je že pogled z druge perspektive rešitev problema, kot je napisal Novak (1997, str. 30-35). Priznavanje drugačnosti in njeno sprejemanje je zagotovo pristop, ki obrodi sadove in vodi $k$ uspešnosti posameznika in posledično organizacije. Povedano na kratko: morda bomo tako našli način, kako »živeti z ne«, četudi ne moremo »priti do da« (Baruch Bush in Folger 2004, str. 223).

Pogosto se sprašujemo, kakšen je pravi vodja, in kakšno je vodenje, ki prinaša rezultate. Morda je pravi izraz "prvinsko « vodenje (Goleman, Boyatzis in McKee 2011, str. 42 53), s katerim naj bi vodja znal v ljudeh, ki jih vodi, zbujati dobre občutke. To se zgodi, ko vodja ustvari resonanco - val pozitivne energije, ki v ljudeh spodbudi najboljše, kar premorejo. Temeljna naloga vodenja je torej v svojem jedru čustvena, do česar so v svojih raziskavah prišli številni avtorji (Caruso, Mayer in Salovey 2002, str. 55-74; Ayoko in Callan 2010, str. 220-235; Jin 2010, str. 159-181; Beatty 2005, str. 122-144; Kim in Jung 2010, str. 336-347). Svoje bogato znanje s tega področja sta O'Connor in Seymour (2011, str. 16) zapisala v nekaj stavkih:

- imeti moraš sposobnost biti usmerjen v cilj - vedeti moraš, kaj hočeš, v vsaki situaciji moraš imeti jasno predstavo o cilju,

- ob tem moraš biti sposoben zaznavati čustveno ostrino - biti moraš pozoren in imeti odprte vse svoje čute, da boš lahko opazil, kaj dobivaš, ter

- znati moraš biti prožen - da boš lahko spreminjal, kar počneš, dokler ne boš dobil, kar hočeš. 
Zgoraj navedeno velja za vsakega posameznika v prav vsakem trenutku. Ta spoznanja morajo še posebej veljati za vodje, saj le takšni lahko dobro vodijo svoje zaposlene (Kanisauskas 2016, str. 40; Alina, 2016, str. 103-107). S takšnim sprejemanjem svojih zaposlenih lahko povišujejo njihovo zavzetost do dela, ta pa vodi le v eno smer - v uspešnost organizacije, kar jo dela odlično (Guschina, Titova, \& Frolova 2016, str. 166). To so značilnosti vodje, ki pri svojem delu uporabljajo tudi elemente mediativnega pristopa (Hayes 2013, str. 55; MacKinnon, Coxe in Baraldi 2012, str. 1-14; Chen in Chang 2013, str. 489-500; Moore 2014, str. 33).

Zaradi navedenih spoznanj moramo posvetiti še več pozornosti raziskavam na področju poslovne mediacije in jo skušamo v največji možni meri vključiti v poslovne sisteme. To je bil tudi povod za našo raziskavo, s katero smo želeli ugotoviti poznavanje mediacije in mediativnih pristopov zaposlenih. Predvsem pa je bil temeljni cilj naše raziskave zaznati razliko med poslovnim sistemom, katerega vodje tak način že podpirajo, in drugim poslovnim sistemom, katerega vodje takega načina dela še ne prepoznajo kot prednostnega načina vodenja, ki vodi organizacijo k odličnosti.

\section{Metodologija}

Vzorec $\mathrm{v}$ naši raziskavi so bili zaposleni v dveh velikih slovenskih podjetjih (bolnišnica, letališče). Narejena je bila spletna anketa, katere povezava je bila poslana 1150 zaposlenim. Vrnjenih je bilo 143 vprašalnikov, kar predstavlja 12-odstotno odzivnost. Raziskava je potekala med avgustom in oktobrom 2016.

V raziskavi smo pozvali zaposlene, naj nam sporočijo svoje izkušnje s postopki mediacije, in sicer: kakšne so prednosti in slabosti mediacije, kakšne vrste mediacije poznajo, kje se najpogosteje pojavljajo vzroki za nastanek konflikta, kaj je po njihovem mnenju bistvo mediacije in kakšni so pričakovani rezultati. Istočasno smo anketirance prosili za posredovanje njihovih demografskih podatkov. Zanesljivost merjenja je bila testirana s pomočjo Cronbachovega koeficienta alfa in je na ravni 0,841 .

\section{$4 \quad$ Rezultati}

V raziskavo so bili vključeni zaposleni dveh slovenskih podjetij, ki delujeta na področju storitvene dejavnosti. $\mathrm{V}$ enem podjetju (bolnišnica) poslovodstvo načrtno usposablja zaposlene tudi na področju mediatorstva, da bi kot poslovni mediatorji posredovali $\mathrm{v}$ notranjih sporih (med zaposlenimi, med vodstvom in zaposlenimi ...). Drugo podjetje (letališče) te možnosti nima vključene $\mathrm{v}$ svoj poslovni model. Rezultati raziskave so pokazali različno odzivnost zaposlenih $\mathrm{v}$ posameznem podjetju na postopke mediacije. Iz slik 1 in 2 je razvidno, da se, $\mathrm{v}$ primerjavi $\mathrm{z}$ letališčem, $\mathrm{v}$ bolnišnici veliko več zaposlenih strinja, da je rešitev spora možna s pomočjo mediacijskega postopka, in sicer na vseh ravneh med zaposlenimi. Anketiranci v obeh podjetjih prednost mediacijskemu postopku dajejo pri reševanju sporov med zaposlenimi na isti ravni. 
266 36 $6^{\text {TH }}$ International Conference on Organizational Science Development: Responsible ORganization (MARCH $22^{\mathrm{ND}}-24^{\mathrm{TH}}$, PoRTOROŽ SLOVENIA)

M. Kalan \& M. Razdevšek: Mediation in the Business Environment to Support Management

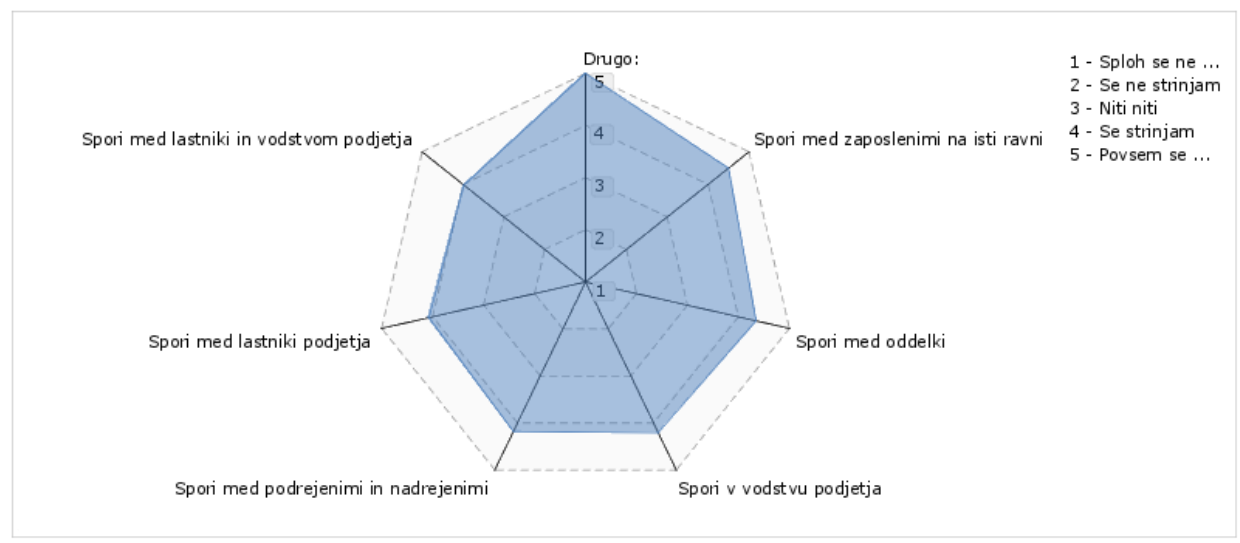

Slika 1: Ocena primernosti spora za mediacijski postopek (bolnišnica)

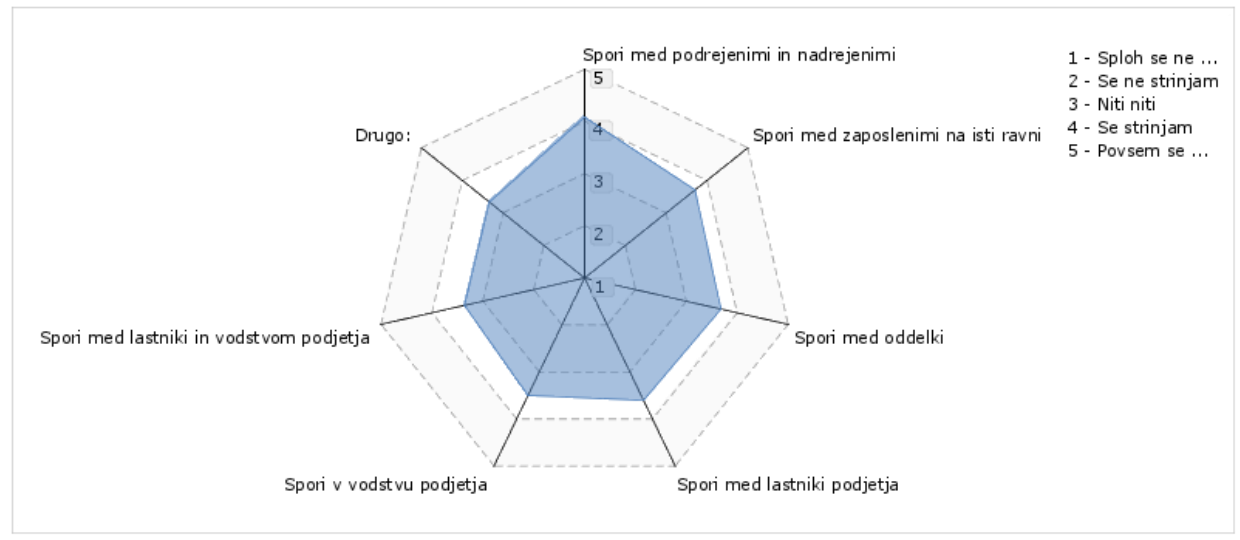

Slika 2: Ocena primernosti spora za mediacijski postopek (letališče)

Iz slik 3 in 4 je razvidna razlika pri zaposlenih $\mathrm{v}$ poznavanju bistvenih elementov mediacijskega postopka. Visok odstotek zaposlenih $\mathrm{v}$ bolnišnici vidi možnost $\mathrm{v}$ mediativnem načinu reševanja sporov, predvsem bi se za sodelovanje pri mediaciji odločili zato, ker bi lahko sodelovali pri iskanju rešitve (70 \%). 

ORGANIZACIJA (22. - 24. MAREC 2017, PORTOROŽ, SLOVENIJA)

M. Kalan \& M. Razdevšek: Mediacija v poslovnem okolju kot podpora poslovodstvu

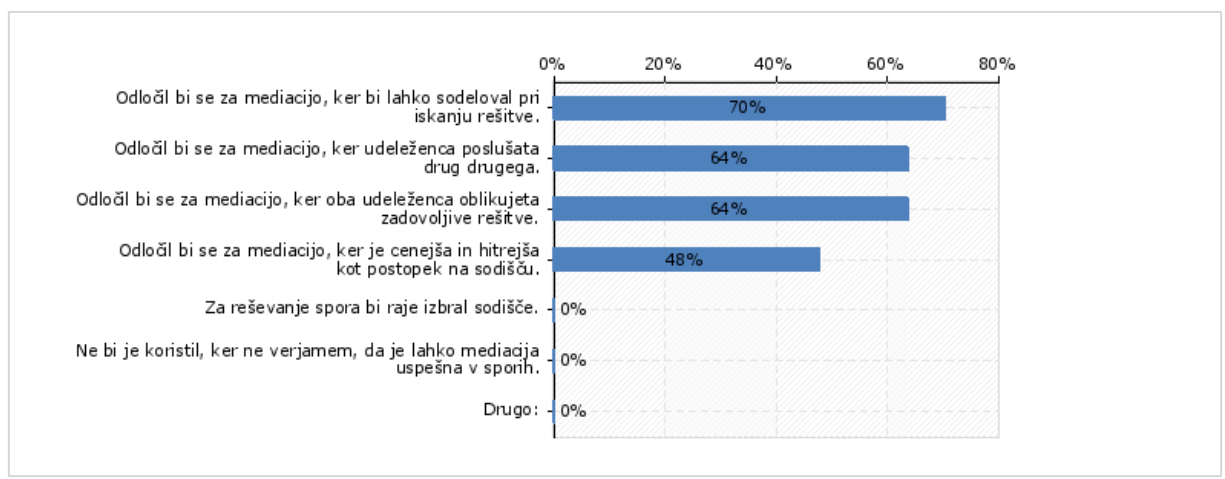

Slika 3: Odstotek odločitev za sodelovanje v mediacijskem postopku (bolnišnica)

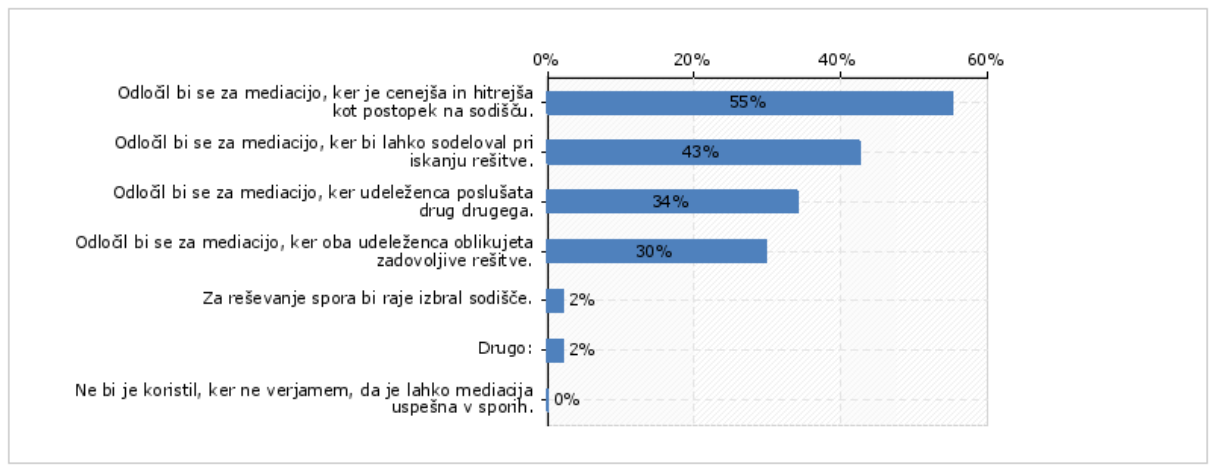

Slika 4: Odstotek odločitev za sodelovanje v mediacijskem postopku (letališče)

Na slikah 5 in 6 je očitno vidna razlika pri zaupanju notranjemu mediatorju. V bolnišnici bi se 16 odstotkov zaposlenih odločilo za reševanje spora s pomočjo notranjega mediatorja, na letališču pa so le 4 odstotki takih zaposlenih. Na splošno velja, da bi se največ zaposlenih odločilo za mediatorja, ki je usposobljen za reševanje mediacijskih postopkov, ne glede na poklic, ki ga opravlja. 
268 36 $6^{\text {TH }}$ International Conference on ORganizational Science Development: ResPonsible ORGanization (MARCH $22^{\mathrm{ND}}-24^{\mathrm{TH}}$, PORTOROŽ Slovenia)

M. Kalan \& M. Razdevšek: Mediation in the Business Environment to Support Management

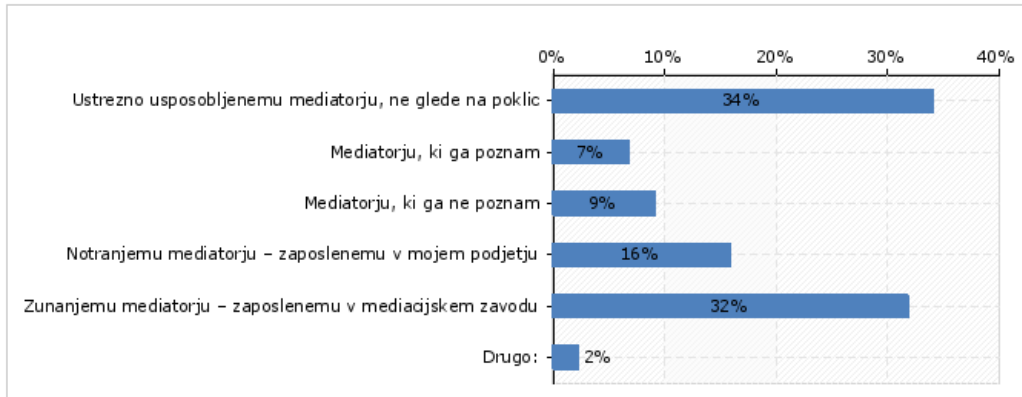

Slika 5: Odstotek zaupanja v mediatorja (bolnišnica)

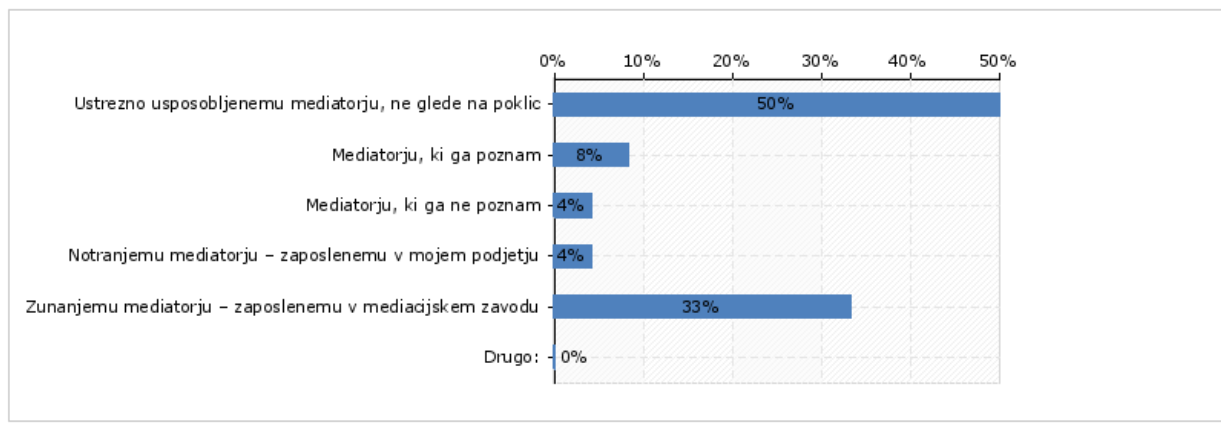

\section{Slika 6: Odstotek zaupanja v mediatorja (letališče)}

Sliki 7 in 8 kažeta bistveno višjo stopnjo zaupanja zaposlenih v bolnišnici v postopke mediacije, ki potekajo v okviru organizacije, torej mediacije znotraj poslovnega okolja. Razlika je 8 odstotnih točk pri proaktivni mediaciji in 16 pri neformalni mediaciji.

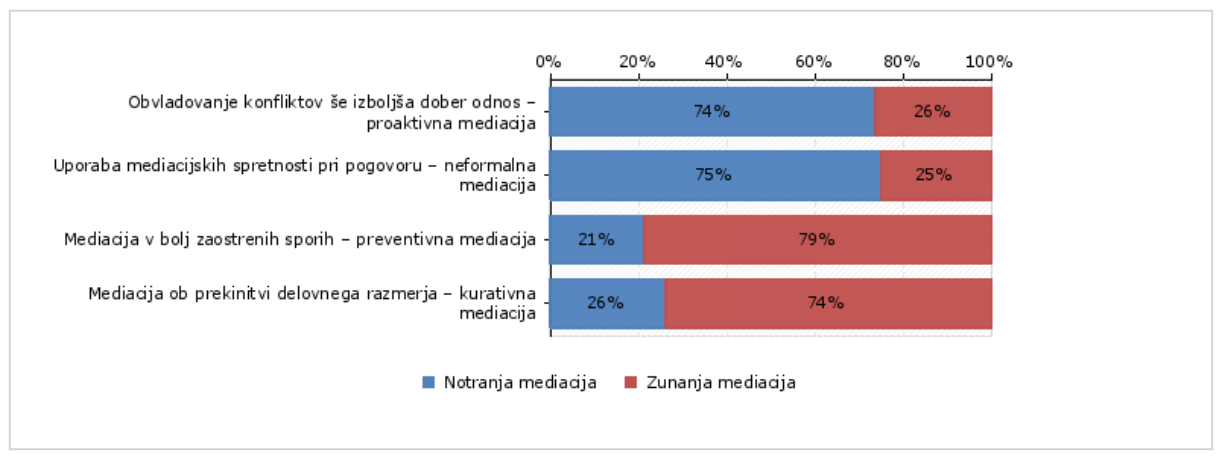

Slika 7: Odstotek primernosti oblike mediacije (bolnišnica) 
36. MEDNARODNA KONFERENCA O RAZVOJU ORGANIZACIJSKIH ZNANOSTI: ODGOVORNA ORGANIZACIJA (22. - 24. MAREC 2017, PORTOROŽ, SLOVENIJA)

M. Kalan \& M. Razdevšek: Mediacija v poslovnem okolju kot podpora poslovodstvu

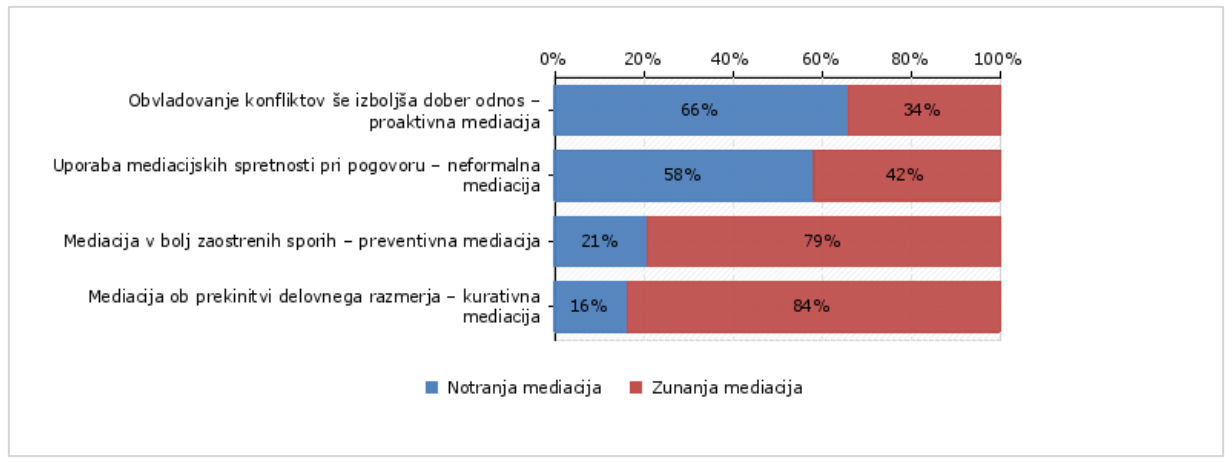

Slika 8: Odstotek primernosti oblike mediacije (letališče)

Demografski podatki na slikah 9 in 10 so pokazali različno stopnjo izobrazbe anketirancev v obeh podjetjih. Predvsem je vidna razlika na stopnji visoko izobraženega kadra, ki je v bolnišnici za 17 odstotnih točk višja od zaposlenih na letališču.

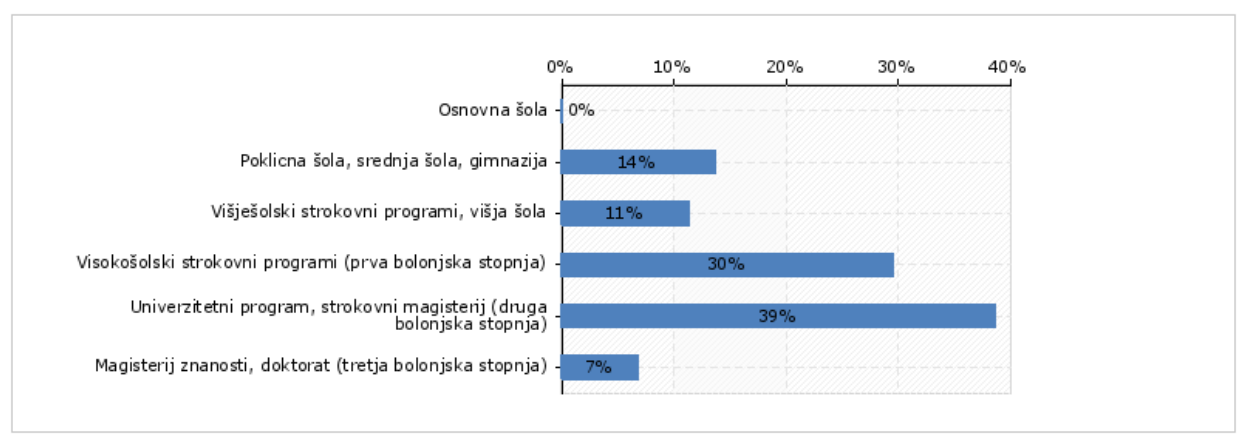

Slika 9: Odstotek zaposlenih z doseženo formalno izobrazbo (bolnišnica)

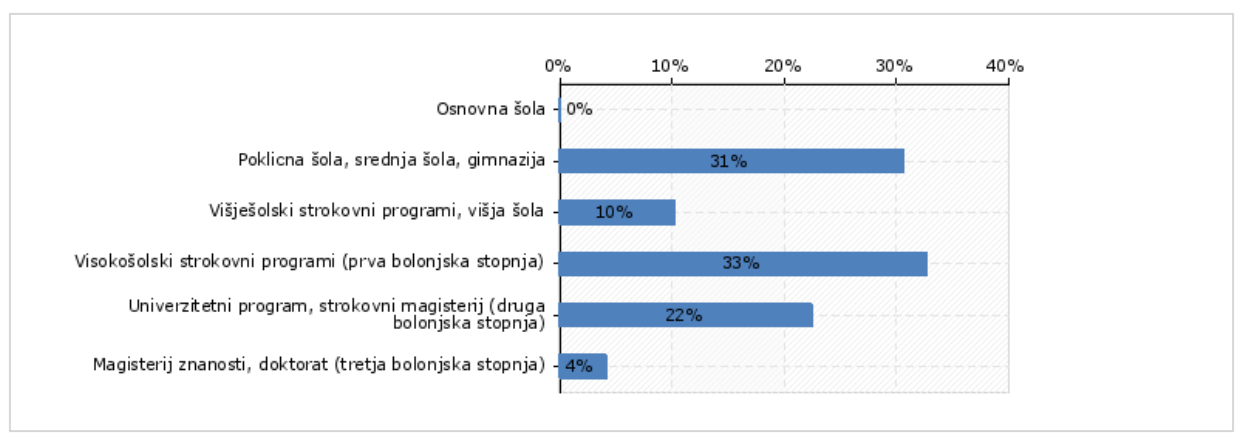

Slika 10: Odstotek zaposlenih z doseženo formalno izobrazbo (letališče) 
$36^{\mathrm{TH}}$ International Conference on ORganizational Science Development: Responsible Organization (MARCh $22^{\mathrm{ND}}-24^{\mathrm{TH}}$, Portorož SLOVENia)

M. Kalan \& M. Razdevšek: Mediation in the Business Environment to Support Management

$\mathrm{V}$ raziskavi smo predstavili najpomembnejše razlike, ki so se pokazale med podjetjem, kjer zaposleni mediacijo in mediativen postopek reševanja sporov na delovnem mestu že poznajo, in podjetjem, kjer se zaposleni s tem načinom dela še ne srečujejo.

5

\section{Razprava}

Analiza raziskave je pokazala, da zaposleni na mediacijo in mediativen način reševanja sporov gledajo drugače, če se z njo srečujejo dnevno, oziroma če poslovodstvo tak način komuniciranja podpira in ga tudi izvaja.

Zaposleni v bolnišnici so z višjo oceno kot zaposleni na letališču ocenili možnosti, ki jih ima mediativen način reševanja sporov na vseh zaposlitvenih ravneh (med zaposlenimi na isti ravni, med nadrejenimi in podrejenimi ter tudi med oddelki). V podjetju, kjer poznajo mediacijo in mediacijski postopek, se zaposleni zavedajo, da je bistvo mediacije prav sodelovanje pri iskanju rešitve, kar pomeni, da je udeleženec - mediant - kasneje tudi veliko bolj zavezan k spoštovanju rešitve, ki jo je sam predlagal in jo sprejel. Eno temeljnih načel mediacije je tudi poslušanje sogovornika. V visokem odstotku, ki so ga zaposleni v bolnišnici namenili tej prednosti, se kaže način njihovega razmišljanja. Ta namreč dolgoročno vodi do situacije, ko do konfliktov ne prihaja več, saj se zaposleni poslušajo in znajo spoštovati mnenje sodelavcev. Očitna razlika je opazna na grafu, kjer so zaposleni ocenili zaupanje notranjemu mediatorju. V bolnišnici bi se 16 odstotkov zaposlenih odločilo za reševanje spora s pomočjo notranjega mediatorja, na letališču pa so le 4 odstotki takih zaposlenih. V obeh podjetjih bi se največ zaposlenih odločilo za mediatorja, ki bi bil usposobljen za reševanje mediacijskih postopkov, ne glede na poklic. Raziskava je pokazala, da zaposleni v podjetju, kjer poslovodstvo podpira mediacijo, tej bistveno bolj tudi zaupajo. Zaposleni v bolnišnici so ocenili, da je praktično na vseh področjih notranja mediacija bistveno bolj uspešna od zunanje mediacije. Prednost imata proaktivna mediacija, kjer obvladovanje konfliktov še izboljša odnos, in neformalna mediacija, ki zajema uporabo mediacijskih spretnosti pri pogovoru. Veliko razliko med anketiranci opažamo tudi v stopnji izobrazbe, in sicer med visoko izobraženim kadrom. Zaposleni v bolnišnici namreč dosegajo bistveno višjo formalno izobrazbo, kar je morda tudi smer, v katero bi poslovodstvo moralo usmeriti svojo pozornost - dati možnost zaposlenim, ki se želijo izobraževati in usposabljati, dosegati višjo stopnjo formalne izobrazbe in se razvijati tudi na področju neformalnega usposabljanja.

Zadovoljni zaposleni so srečni in zato zavzeti za delo. Posledično so učinkoviti, kar bi moralo biti največje zadovoljstvo njihovih nadrejenih, s tem pa tudi celotnega poslovodstva.

Rezultati raziskave kažejo, da se zaposleni zavedajo prednosti mediacije in mediativnega načina komuniciranja. Tak način delovanja prinaša prednost $\mathrm{v}$ vsakdanjik zaposlenih slehernega poslovnega sistema, saj obvladuje konflikte že na samem začetku, s čimer bi ti sčasoma izginili. Tak način dela vodi v izboljšan odnos na vseh zaposlitvenih ravneh 
M. Kalan \& M. Razdevšek: Mediacija v poslovnem okolju kot podpora poslovodstvu

poslovnega sistema. Rezultati raziskave so pokazali, da se $\mathrm{v}$ obeh podjetjih zaposleni $\mathrm{v}$ več kot 70 odstotkih tedensko srečujejo s konflikti, a v bolnišnici zaposleni bolj verjamejo $\mathrm{v}$ mediativen način komuniciranja. Uvedba usposabljanja mediatorjev je $\mathrm{v}$ tem podjetju $\mathrm{v}$ začetni fazi, poslovodstvo in zaposleni pa verjamejo $\mathrm{v}$ uspeh, ki $\mathrm{v}$ takih primerih lahko pride le dolgoročno. Zaposleni poznajo temeljne prednosti mediacije, kot so poslušanje sodelavca, sodelovanje pri iskanju rešitve obeh zaposlenih, ki sodelujeta v mediacijskem postopku. Prav slednja prednost prinaša zadovoljstvo zaposlenih in zadovoljen zaposleni daje podjetju bistveno več. Ozaveščeni zaposleni vedo, da jim pri tem lahko pomagajo sodelavci, ki so usposobljeni kot notranji mediatorji, ne glede na to, kakšen poklic opravljajo. Zavedajo se tudi, da je mediacija hitra in najcenejša rešitev, ob tem pa ni nikakršnih negativnih tveganj, saj sta medianta pri mediaciji vedno navzoča prostovoljno in se o predlagani rešitvi sporazumeta. Sporazumno sprejete odločitve ljudje odobravamo in jim zato lažje in bolj zavzeto sledimo. Rezultati raziskave bi morali vplivati na odločitev menedžerjev o uvedbi mediacijskih pisarn v podjetjih, saj je iz njih razvidno, da kar desetina zaposlenih odide iz podjetja zaradi nerešenih konfliktov. V vzorcu, ki je bil zajet $\mathrm{v}$ raziskavi, je $\mathrm{v}$ veliki meri prisoten profil zaposlenih, ki se svojih sposobnosti in pravic zaveda. To je izobražen kader, ki ga podjetje lahko nadomesti le $\mathrm{z}$ visokimi stroški izobraževanja novozaposlenih na njihovih delovnih mestih. V organizacijah, kjer to zavedanje ni prisotno, se pojavlja velika fluktuacija, še prej pa visok odstotek odsotnosti zaradi bolezni, kar se vse odraža $\mathrm{v}$ visokih stroških podjetja in posledično slabšem poslovnem rezultatu. Posledično je to slabo za družbo, saj bolezen vsakega posameznika negativno vpliva na učinkovitost družbe in na okolje.

Znanstveni prispevek tega članka je priprava zadnjega aktualnega pregleda spoznanj o poslovni mediaciji, predstavitev lastne kvantitativne raziskave o vplivnih dejavnikih na možnost uvedbe mediacijske pisarne $\mathrm{v}$ podjetjih $\mathrm{v}$ Sloveniji in predstavitev mediacije na primerno celovit način ter v luči, ki je do sedaj ni obravnaval še nihče in je v svetovni znanstveni literaturi še neraziskano področje.

V raziskavi smo naleteli na omejitve predvsem zaradi odpora nekaterih posameznikov do takih raziskav, saj menijo, da je uvedba mediacijske pisarne nepotreben strošek, ki bi ga imelo podjetje. Prav zato je treba vztrajati pri raziskavah na tem področju in osveščati zaposlene, predvsem pa poslovodstvo. Uvedba mediacijske pisarne v podjetju je velika prednost prav zanj, saj se na ta način izogne bistveno višjim stroškom, kadar je spor treba reševati na sodišču. Omejitev raziskave je predstavljalo tudi dejstvo, da se na sodelavce nismo mogli obrniti osebno, pač pa le preko intraneta, s čimer nismo dosegli vseh zaposlenih. Bistveno omejitev gotovo predstavlja tudi to, da je bila raziskava izvedena le $\mathrm{v}$ dveh podjetjih. Ni bilo naključje, da smo za raziskavo izbrali eno podjetje, kjer mediacijski način komuniciranja že poteka $\mathrm{v}$ praksi, in drugo, kjer mediacije še ne prepoznajo kot potencialne konkurenčne prednosti. Iz raziskave je moč razbrati razlike v odnosu zaposlenih do mediacije in mediativnega načina komuniciranja.

V prihodnje predlagamo še več takšnih raziskav, ki bi poslovodstvo prepričale, da je najučinkovitejše reševanje konfliktov prav s pomočjo poslovne mediacije, torej reševanje spora v samem izvoru. Tak način je namreč najhitrejši, najcenejši in najuspešnejši, saj medianta, s pomočjo mediatorja, rešitev najdeta sama, s čimer se najbolj zavežeta $\mathrm{k}$ 
$36^{\mathrm{TH}}$ International Conference on Organizational Science Development: RESPONSIBLE ORGANIZATION (MARCH $22^{\mathrm{ND}}-24^{\mathrm{TH}}$, PORTOROŽ SLOVENIA)

M. Kalan \& M. Razdevšek: Mediation in the Business Environment to Support Management

njenemu spoštovanju. Po mnenju zaposlenih bi bila ob nastanku konflikta mediacijska pisarna lahko v pomoč, vsekakor pa se zavedajo, da največ uspeha prinaša mediativen način komuniciranja, s katerim obvladujemo konflikte že v začetni fazi. Tudi naše mnenje se pridružuje mnenju zaposlenih, saj se kot mediatorji zavedamo, da dobri medosebni odnosi na delovnem mestu prinašajo največje zadovoljstvo zaposlenih, kar povečuje njihovo učinkovitost, ta pa podjetje vodi v odličnost.

\section{Zahvala}

Kot udeleženka usposabljanj (mediacija, družinska mediacija in poslovna mediacija) bi se želela zahvaliti gospe Ivanki Marič, ki s svojimi viri znanja v Zavodu Arsis gradi novo kulturo odnosov - vedno znova namreč navdihuje in navdušuje.

\section{Literatura}

Alina, N. (2016). Trends And Dimensions Of Digital Economy. Annals-Economy Series, 4, 103107.

Ayoko, O. B., \& Callan, V. J. (2010). Teams' reactions to conflict and teams' task and social outcomes: The moderating role of transformational and emotional leadership. European Management Journal, 28 (3), 220-235.

Beatty, B. (2005). Emotional leadership. The essentials of school leadership, 122-144.

Bühring - Uhle, C., Kirchhoff, L., \& Scherer, G. (2006). Arbitration and mediation in international business. Kluwer Law International.

Bush, R. A. B., \& Folger, J. P. (2004). The promise of mediation: The transformative approach to conflict. John Wiley \& Sons.

Caruso, D. R., Mayer, J. D., \& Salovey, P. (2002). Emotional intelligence and emotional leadership. In Kravis-de Roulet Leadership Conference, 9th, Apr, 1999, Claremont McKenna Coll, Claremont, CA, US. Lawrence Erlbaum Associates Publishers.

Cella, D., \& Fallowfield, L. J. (2008). Recognition and management of treatment-related side effects for breast cancer patients receiving adjuvant endocrine therapy. Breast cancer research and treatment, 107 (2), 167-180.

Chen, Y. S., \& Chang, C. H. (2013). Greenwash and green trust: The mediation effects of green consumer confusion and green perceived risk. Journal of Business Ethics, 114 (3), 489-500.

Cloke, K., \& Goldsmith, J. (2011). Resolving conflicts at work: eight strategies for everyone on the job. John Wiley \& Sons.

Conti, A. S., Dlugosch, C., Schwarz, F., \& Bengler, K. (2013, June). Driving and speaking: revelations by the head-mounted detection response task. In Proc. 7th International Driving Symposium on Human Factors in Driver Assessment, Training, and Vehicle Design (pp. 362368).

Crawley, J., \& Graham, K. (2011). Mediation for managers: Resolving conflict and rebuilding relationships at work. Nicholas Brealey Publishing.

Goleman, D., Boyatzis, R., \& McKee, A. (2001). Primal leadership: The hidden driver of great performance. Harvard business review, 79 (11), 42-53.

Guschina, E. G., Titova, T. A., \& Frolova, E. V. (2016). The Host Population and the Migrants in Modern Tatarstan: Social Roles and Intergroup Distance. Journal of Organizational Culture, Communication and Conflict, 20, 166.

Hayes, A. F. (2013). Introduction to mediation, moderation, and conditional process analysis: A regression-based approach. Guilford Press. 
Insam, A., Huebner, D., Briem, J., Hanft, N., \& Stipanowich, T. (2016). Promoting ConflictCompetent Leadership and Holistic Conflict Management. Pepp. Disp. Resol. LJ, 16, 233.

Jin, Y. (2010). Emotional leadership as a key dimension of public relations leadership: A national survey of public relations leaders. Journal of Public Relations Research, 22 (2), 159-181.

Kanisauskas, S. (2016). Creative technologies entrapped by instrumental mind. Filosifija sociologija., 27(1), 40.

Kim, M. H., \& Jung, M. S. (2010). The effect of head nurse's emotional leadership on nurse's job satisfaction \& organizational commitment. Journal of Korean Academy of Nursing Administration, 16 (3), 336-347.

Lande, J. (2000). Getting the faith: why business lawyers and executives believe in mediation. Negot. L. Rev, 137.

Mack, J. E. (1999). Passport to the cosmos: Human transformation and alien encounters. Crown Publishers.

MacKinnon, D. P., Coxe, S., \& Baraldi, A. N. (2012). Guidelines for the investigation of mediating variables in business research. Journal of Business and Psychology, 27 (1), 1-14.

Moore, C. W. (2014). The mediation process: Practical strategies for resolving conflict. John Wiley \& Sons.

Novak, B. (1997). Raziskovanje uspešnosti. Andragoška spoznanja, 3 (1), 30-35.

O'Connor, J., \& Seymour, J. (2011). Introducing NLP: Psychological skills for understanding and influencing people. Conari Press.

Prabowo, J. (2015). Optimizing VAKOG as human senses in teaching English for young learners. Language Circle: Journal of Language and Literature, 10 (1).

Trompenaars, F., \& Hampden - Turner, C. (2011). Riding the waves of culture: Understanding diversity in global business. Nicholas Brealey Publishing.

Winters, A. (2016). Regardless of Potential Scrutiny, the Arbitration Clause of the Fair Pay and Safe Workplaces Executive Order (2014) Should Not Have a Resounding Impact. Ohio St. J. on Disp. Resol., 31, 179. 
274 36 ${ }^{\text {Th }}$ International Conference on Organizational Science Development:

Responsible Organization (MARCH $22^{\mathrm{ND}}-24^{\mathrm{TH}}$, PORTOROŽ SLOVENIA) 
36. MEDNARODNA KONFERENCA O RAZVOJU ORGANIZACIJSKIH ZNANOSTI: OdgOVORNA ORGANIZACIJA (22. - 24. MAREC 2017, PORTOROŽ, SLOVENIJA)

O. Arsenijević, M. Ferjan, I. Podbregar, P. Šprajc, D. Trivan \& Y. Ziegler

\title{
Primerjava pravne ureditve pritožb v zdravstvu v Republiki Sloveniji, Nemčiji in Veliki Britaniji
}

\author{
ANKA MOHORIČ KENDA, ROBERT LESKOVAR \& RAJKO PIRNAT
}

Povzetek Pravice pacientov se $\mathrm{v}$ državah članicah Evropske unije razlikujejo glede na ureditev zdravstvenega sistema in jurisdikcije, ki so pogosto odvisne od prevladujočih kulturnih in družbenih norm. Raznolikost urejenosti pacientovih pravic v Republiki Sloveniji, Nemčiji in Veliki Britaniji je posledica suverene pravice držav članic, da urejajo zdravstveni sistem s svojo nacionalno zakonodajo. Na ureditev nacionalne zakonodaje pomembno vplivajo različnost ureditve pravnega sistema, kultur in prednostni cilji razvojne politike. Posamezne države Evropske unije imajo unificirane pravice pacientov $\mathrm{v}$ enem zakonu, medtem, ko imajo druge države problematiko razdrobljeno $\mathrm{v}$ več zakonih in podzakonskih aktih. Pristop se razlikuje z intenziteto pozornosti, ki jo države članice namenjajo pravicam pacientov. Iz ugotovitev zbranih podatkov izhaja, da reševanje pritožb $\mathrm{v}$ sistemih zdravstvenega in socialnega varstva $v$ Nemčiji in Veliki Britaniji odraža stanje jasnega razumevanja kakovosti zdravstvenih storitev, ki jih pacienti pričakujejo. Nadzor nad izvajanjem sistema pritožb predstavlja pomembno vodilo $\mathrm{k}$ izboljševanju kakovosti izvajanja zdravstvenih storitev, spodbuja pristojne $\mathrm{k}$ pospešeni odzivnosti in spodbuja izboljševanje sistema. Izsledki ugotovitev nakazujejo na pomen vzpostavitve celovitosti procesnih rešitev, informatizacijo pritožbenega postopka in integracijo z delovnimi okolji ob upoštevanju ustreznih zakonskih in regulativnih zahtev.

KLJUČNE BESEDE: pritožbe $\mathrm{v}$ zdravstvu • zakon o pacientovih pravicah • izboljševanje sistema $\bullet$ primerjalna ureditev

NASLOV AVTORJEV: Anka Mohorič Kenda, Farmed d.o.o., Sadjarska ulica 40, 2327 Rače, Slovenija, e-pošta: anka@proquality.si; dr. Robert Leskovar, redni profesor, Univerza v Mariboru, Fakulteta za organizacijske vede, Kidričeva cesta 55a, 4000 Kranj, Slovenija, e-pošta: robert.leskovar@fov.uni-mb.si; dr. Rajko Pirnat, redni profesor, Univerza v Ljubljani, Pravna fakulteta, Poljanski nasip 2, 1000 Ljubljana, Slovenija, e-pošta: rajko.pirnat@pf.uni-lj.si

DOI https://doi.org/10.18690/978-961-286-020-2.25

ISBN 978-961-286-020-2

(C) 2017 Univerzitetna založba Univerze v Mariboru

Dostopno na: http://press.um.si 
36 ${ }^{\text {TH }}$ International Conference on Organizational Science DeVElopment: Responsible ORganizATION (MARCH $22^{\mathrm{ND}}-24^{\mathrm{TH}}$, PORTOROŽ SLOVENIA)

O. Arsenijević, M. Ferjan, I. Podbregar, P. Šprajc, D. Trivan \& Y.

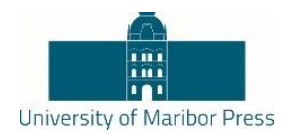

Ziegler

\title{
Comparison of Healthcare Complaints Regulation in the Republic of Slovenia, Germany and the United Kingdom
}

\author{
ANKA MOHORIČ KENDA, ROBERT LESKOVAR \& RAJKO PIRNAT
}

\begin{abstract}
The patients' rights differ in Member States of European Union depending on their regulation of Healthcare system and jurisdictions that are often dependent upon prevailing cultural and social norms. Diversity arrangement of patients' rights in the Republic of Slovenia, Germany and the UK is due to the sovereign power of Member States to regulate Healthcare system with their national laws. The national regulations significantly affect the organizational diversity of the legal system, culture and development policy priorities. Some European Union countries have unified patients' rights in one law, while other countries have these contents fragmented into several acts and regulatory provisions. The approach varies due to the intensity of attention by Member States given to patients' rights. Findings from collected data show that the complaints resolution in the health and social care in Germany and UK represents a clear understanding of patients' expectation about quality in health services. The control mechanism during the implementation indicates an important guide to improve health services quality encourages the competent authorities to speed up the responsiveness and promotes system improvement. The results of the research indicate significant importance of establishing integrity of process, computerization of appeal procedure and integration into working environment, taking into account the relevant legal and regulatory requirements.
\end{abstract}

KEYWORDS: appeals in Health Care • Patients' rights Act • system improvement $\bullet$ a comparative view

CORRESPONDENCE AdDRESS: Anka Mohorič Kenda, Farmed d.o.o., Sadjarska ulica 40, 2327 Rače, Slovenia, e-mail: anka@proquality.si; Robert Leskovar, Ph.D., Full Professor, University of Maribor, Faculty of Organizational Sciences, Kidričeva cesta 55a, 4000 Kranj, Slovenia, e-mail: robert.leskovar@fov.uni-mb.si; Rajko Pirnat, Ph.D., Full Professor University of Ljubljana, Faculty of Law, Poljanski nasip 2, 1000 Ljubljana, Slovenia, e-mail: rajko.pirnat@pf.uni-lj.si 
A. Mohorič Kenda, R. Leskovar \& R. Pirnat: Primerjava pravne ureditve pritožb v zdravstvu v Republiki Sloveniji, Nemčiji in Veliki Britaniji

\section{$1 \quad$ Uvod}

Pravice pacientov se $\mathrm{v}$ državah članicah Evropske unije razlikujejo glede na ureditev zdravstvenega sistema in $\mathrm{v}$ jurisdikcijah, ki so pogosto odvisne od prevladujočih kulturnih in družbenih norm. Na uveljavljanje pravic pacientov opozarja Direktiva 2011/24/EU o čezmejnem zdravstvenem varstvu ${ }^{1}$, ki je stopila v veljavo 25. oktobra 2013. Člen 4, odstavek 2, Direktive 2011/24/EU v poglavju II, Pristojnosti držav članic $\mathrm{v}$ zvezi s čezmejnim zdravstvenim varstvom $\mathrm{v}$ okviru pristojnosti določa, da mora država članica, ki izvaja zdravljenje zagotoviti, da so vzpostavljeni pregledni pritožbeni postopki in mehanizmi za paciente, da uveljavljajo pravna sredstva $\mathrm{v}$ skladu z zakonodajo države članice zdravljenja, kadar ti utrpijo škodo nastalo $\mathrm{v}$ sistemu zdravstvenega varstva. Reševanje pritožb v sistemih zdravstvenega in socialnega varstva v Nemčiji in Veliki Britaniji odražajo stanje, ki temelji na jasnem razumevanju kakovosti zdravstvenih storitev, ki jih pacienti pričakujejo. Lister, Flemming idr. (2008) opozarjajo, da nadzor nad sistemom pritožb predstavlja pomembno vodilo $\mathrm{k}$ izboljševanju kakovosti izvajanju zdravstvenih storitev, spodbuja pristojne $\mathrm{k}$ pospešeni odzivnosti in vzpodbuja izboljševanje sistema. Predstavljamo urejenost in način delovanja pritožbenega sistema pacientov $\mathrm{v}$ 1) Republiki Sloveniji; s prepletajočo značilnostjo modela sistema zdravstvenega varstva Nemčije in Velike Britanije, na prevladujoči uveljavitvi Bismarckovega modela sistema zdravstvenega varstva; 2) Nemčiji; kot predstavnici germanskega pravnega reda $\mathrm{z}$ ureditvijo Bismarckovega modela sistema zdravstvenega varstva, ki temelji na obveznem $\mathrm{z}$ zakonom predpisanim javnim zdravstvenim zavarovanjem in 3) Veliki Britaniji; kot predstavnici anglosaksonskega pravnega reda z ureditvijo Beveridgovega modela sistema zdravstvenega varstva, ki ga upravlja in financira država.

\subsection{Republika Slovenija}

V Republiki Sloveniji način postopkovnega varstva pacientovih pravic ureja Zakon o pacientovih pravicah $(\mathrm{ZPacP})^{2}$. Pacientove pravice ureja 5. člen $\mathrm{ZPacP}$ in zbrane $\mathrm{v}$ seznamu štirinajstih (14) pravic. Posamezne pacientove pravice so delno urejene $\mathrm{v}$ zakonskih in podzakonskih aktih. Brulc (2006) poudarja, da: »V Republiki Sloveniji reševanje pritožb $\mathrm{v}$ sistemu zdravstvenega in socialnega varstva ureja Zakon o pacientovih pravicah (ZPacP), ki $\mathrm{v}$ enem aktu celovito in sistematično ureja petnajst občih pacientovih pravic in postopke za njihovo uveljavljanje, kadar so te kršene (str. 96). Sistem uresničevanja pacientovih pravic po ZPacP je izpeljan iz dveh (2) pravic, in sicer: 1) pravice do brezplačne pomoči pri uresničevanju pacientovih pravic (49, do 53., 55. in 89. člen) in 2) pravice do obravnave kršitev pacientovih pravic (47., 48. In 56. do 79. člen). Pravica do obravnave kršitev pacientovih pravic daje pacientu, ki meni, da so mu bile kršene pravice možnost, da spor razreši na dveh ravneh: 1) v okviru prve obravnave domnevne kršitve, ki se izvaja pred pristojno osebo izvajalca zdravstvenih storitev, kjer je kršitev nastala - t.i. postopek z zahtevo za prvo obravnavo, in 2) v okviru druge obravnave domnevne kršitve, ki se izvaja v postopku pred Komisijo Republike Slovenije za varstvo pacientovih pravic $(\mathrm{KVPP})^{3}$ t.i. postopek $\mathrm{z}$ zahtevo za drugo obravnavo. 
$36^{\mathrm{TH}}$ International Conference on ORganizational Science Development: RESPONSIBLE ORGanization (MARCH $22^{\mathrm{ND}}-24^{\mathrm{TH}}$, PORTOROŽ SLOVENIA)

A. Mohorič Kenda, R. Leskovar \& R. Pirnat: Caparison of Healthcare Complaints Regulation in the Republic of Slovenia, Germany and the United Kingdom

Zakonodajalec je med način reševanja sporov $\mathrm{v}$ okviru druge obravnave domnevne kršitve uvrstil poleg poravnave tudi mediacijo, kot eno najbolj značilnih oblik alternativnega reševanja sporov, ki jo v primerjavi s pravdnim (sodnim) postopkom odlikuje vrsta prednosti, kot so: neformalnost, zaupnost, hitrost, nadzor nad potekom in izidom postopka, fleksibilnost pri oblikovanju kreativnih rešitev, itd.

Pomembne postopkovne določbe zadevajo roke za uveljavljanje pravice do obravnave kršitev pacientovih pravic. Prvo zahtevo zaradi domnevno: 1) neustreznega odnosa zdravstvenih delavcev ali sodelavcev lahko pacient vloži najpozneje v 15. dneh od domnevne kršitve; 2) neustreznega ravnanja pri zdravstveni oskrbi (npr. zaradi varnostnega zapleta ali zdravstvene napake) lahko pacient vloži najkasneje v 30. dneh po končani zdravstveni oskrbi.; 3) v treh mesecih po preteku rokov iz prejšnjih odstavkov, če je za kršitev izvedel kasneje oziroma so se posledice kršitev pokazale kasneje.

ZPacP se je po letih uporabe izkazal za primeren pristop reševanja pravic pacientov, vendar njegova uporaba $v$ praksi razkriva tudi vrsto pomanjkljivosti. $Z$ implementacijo zakona $\mathrm{v}$ prakso se pomanjkljivosti odražajo pri uresničevanju nekaterih pravic iz kataloga pacientovih pravic, ki naj bi vsebino vsake pravice podrobno in primerno opredeljeval. Pravica do spoštovanja pacientovega časa in pravica do drugega mnenja sta se ob implementaciji izkazali za premalo vsebinsko normirani in posledično $\mathrm{v}$ praksi neuresničljivi. Opredeljeni nadzor se izkazuje za podnormiranega, kar je tudi razlog za uvedbo inšpekcijskega nadzora Zdravstvenega inšpektorata RS nad določenimi zakonskimi določili v pripravljeni spremembi Zakona. Veljavni zakonski akti, ki urejajo uresničevanje pravic pacientov $\mathrm{v}$ sistemu zdravstvenega in socialnega varstva $\mathrm{v}$ postopku z zahtevo za obravnavo kršitev pacientovih pravic izključujejo pogoj za uresničevanje pravice do morebitnega sodnega varstva, kot to opredeljuje določilo 23. člena Ustave Republike Slovenije (v nadaljevanju: URS), saj so odločitve senata KVPP po svoji pravni naravi upravni akti (ZPacP, Uradni list Republike Slovenije 15/08, str. 85). Pravica do pritožbe ali drugega pravnega sredstva v Republiki Sloveniji (25. člen URS), poudarja Pirnat (2011) »se še posebej nanaša na upravne organe, organe lokalnih skupnosti in nosilce javnih pooblastil; zoper posamične akte mora biti zagotovljeno učinkovito redno pravno sredstvo, torej tako, ki je devolutivno in ima praviloma suspenziven učinek; omejitev te pravice je treba presojati po strogem testu sorazmernosti« (str. 59). URS v 23. členu določa pravico do sodnega varstva, $v$ skladu s katero ima vsakdo pravico, da o njegovih pravicah in dolžnostih ter o obtožbah proti njemu brez nepotrebnega odlašanja odloča neodvisno, nepristransko in z zakonom ustanovljeno sodišče.

»Priseben človek pravno odgovarja za svoje ravnanje - civilno, premoženjsko, kazensko, lahko disciplinsko in ne nazadnje moralno, saj je taka odgovornost nujna zaradi urejanja odnosov in sožitja med ljudmi. Ubi societas ibi ius. Zato določa Ustava v 23. členu, da o človekovih pravicah in dolžnostih odloča poseben oblastni organ - sodišče. Odškodninska odgovornost je eden izmed temeljev civilnega - obligacijskega prava; poleg svobode o človekovem ravnanju, kot je to sistematiziral francoski pravnik in filozof Duguit«. (Planinšec, 2004, str. 266) 
A. Mohorič Kenda, R. Leskovar \& R. Pirnat: Primerjava pravne ureditve pritožb v zdravstvu v Republiki Sloveniji, Nemčiji in Veliki Britaniji

Brulc in Pirc Musar (2006) navajata, da je pravica do drugega mnenja med ostalimi pacientovimi pravicami prav posebej urejena. Drugo mnenje je v zadnjem času precej razširjena dejavnost, vendar je v pretežnem delu predmet zasebne zdravstvene dejavnosti. $\mathrm{V}$ kolikor ta pravica ni dovolj jasno opredeljena, se lahko izrodi. Za vsako stanje ali zdravstveni problem je namreč možno imeti ali pridobiti drugo oz. drugačno mnenje. Pravica mora biti jasno definirana in zagotovljena, kadar je to smiselno in koristno za pacienta in njegovo zdravljenje, še posebej iz razloga, ker javni sistem ne krije stroškov za vsako drugo mnenje, ki bi ga pacient želel pridobiti. V Zakonu je pravica do drugega mnenja trenutno urejena precej drugače kot $\mathrm{v}$ drugih primerljivih državah, pri čemer so nekatere opredelitve o tej pravici nejasne in povzročajo težave pri njenem uresničevanju. Ministrstvo za zdravje (2016) navaja, da je v letu 2015 prejelo več kot 600 pisnih pritožb in vprašanj pacientov, ki se nanašajo tako na pacientove pravice, kot tudi na področje pravic iz obveznega in dopolnilnega zdravstvenega zavarovanja, ki še vedno predstavljajo večinski del prejetih pritožb in vprašanj. ${ }^{4}$ (V praksi se odraža, da je bolj kot pomanjkljiva vsebina posameznih pravic, problematičen način njihovega uresničevanja, saj so postopki precej zapleteni in nejasni. Pomanjkanje natančnejše definicije in vsebine posameznih pravic ter enotno urejenega postopka uresničevanja pacientovih pravic postaja $\mathrm{z}$ ozaveščenostjo pacientov vedno večji problem, saj niso v naprej ob vsakokratni zdravstveni obravnavi seznanjeni $\mathrm{z}$ načinom in možnostjo uveljavljanja pravic. Pritožbene poti so v praksi prepuščene posameznim zdravstvenim zavodom in njihovim vodstvenim ekipam, na kar so opozarjali že predlagatelji v predlogu Zakona o pacientovih pravicah pred sprejetjem ZPacP. ${ }^{5}$

\section{$1.2 \quad$ Nemčija}

Nemško ministrstvo za zdravje je krepitev pacientovih pravic vnesla kot osrednjo skrb v svojo zdravstveno politiko. Reforma zdravstvenega varstva v letu 2007 je prvič upoštevala tudi pravice in interese pacientov. $\mathrm{Z}$ zakonom o pacientovih pravicah 'Patientenrechtegesetz', ki je bil objavljen prvič v okviru Civilnega zakona 'Das Bürgerlichen Gesetzbuch' leta 2002, je bil v novi različici objavljen februarja leta 2013, $\mathrm{v}$ katerem je nemška zvezna vlada okrepila položaj pacientov s ponudniki in zdravstvenimi zavarovalnicam ter $\mathrm{s}$ splošnimi pravicami in dolžnostmi, $\mathrm{v}$ katerem so prvič pravice in dolžnosti pacientov v razmerju do zdravljenja urejeni kolektivno. S tem so se okrepile pravice pacientov, ki v preteklosti niso bile urejene v enotnem aktu. Pravice pacientov izhajajo iz splošnih določil Ustave in spremljajočih aktov, v katerih so varovane pravice pacientov in načini reševanja pritožb v okviru: 1) Listine o pacientovih pravicah (1999); kot dopolnitev k Listini o pacientovih pravicah (1999) je Zvezno ministrstvo za zdravstvo je v septembru leta 2007 izdalo dokument Pravice pacientov v Nemčiji ('Patientenrechte in Deutschland'), ki vključuje pravice zdravstvenega zavarovanja in izvajanja zdravstvenih storitev; 2) Listine o pacientovih pravicah, ki jim je bila kršena medicinska oskrba (2005); sprejete na podlagi Direktive Evropskega parlamenta in sveta 2005/29/ES; ${ }^{6}$ 3) Zvezni zakon o varstvu podatkov (1990), t.i. 'Bundesdatenschutzgesetz'. 
36 $6^{\text {Th }}$ International Conference on Organizational Science Development: Responsible Organization (March $22^{\mathrm{ND}}-24^{\mathrm{TH}}$, Portorož SLOVENIA)

A. Mohorič Kenda, R. Leskovar \& R. Pirnat: Caparison of Healthcare Complaints Regulation in the Republic of Slovenia, Germany and the United Kingdom

Z novim zakonom so se okrepile pravice pacientov na področju civilnega zakonika (deut. Bürgerlichen Gesetzbuch - BGB). Slednji z novo ureditvijo združuje predhodno partikularno urejene pravice, kot denimo: 1) pravica do samostojne privolitve: nemška ustava, člen 2 navaja, da ima vsakdo pravico do življenja in telesne celovitosti, po katerem je svoboda posameznika nedotakljiva. Poudarjena je pravica do privolitve $\mathrm{v}$ zdravstveno oskrbo, pred kakršno koli njeno izvedbo. 2) pravica do obveščenosti o lastnem zdravju: je neposredno povezana s pravico do samostojne privolitve. Pacient ima pravico do obveščenosti o svojem zdravstvenem stanju in verjetnem razvoju ter njihovimi posledicami pred izvedbo zdravljenja. 3) pravica seznanitve $\mathrm{z}$ zdravstveno dokumentacijo: pacient ima pravico do dostopa njegovega medicinskega zapisa. 4) pravica do varstva zasebnosti in varstva osebnih podatkov: gre za spoštovanje pacientove zasebnosti v odnosu med pacientom in zdravnikom. Nemški kazenski zakonik, člen 203 navaja, da je zločin, v primeru, če zdravstveni delavec razkriva informacije brez dovoljenja pacienta. 5) pravica do pritožbe in odškodnine: pritožba se lahko vloži neposredno pri izvajalcu zdravstvenih storitev ali na urad za obravnavo pritožb, ki jo vodi posebna komisija v na strani bolnišnice.

$\mathrm{Z}$ vidika organiziranosti uresničevanje pacientovih pravic po nemškem Zakonu o pacientovih pravicah 'Das Patientenrechtegesetz' (BGBl. I, 277, str. 26) iz leta 2013, sistem reševanja pacientovih pritožb v zdravstvu vključuje: 1) zastopnika pacientovih pravic nemške vlade kot podporo neodvisne stranke in varuha pacientov ter njihovega svetovalca; 2) bolnišnični svet, ki je dobil pravico (op. ne pa tudi dolžnost) izvajanja obravnav pritožbenega postopka. Podobna ureditev velja tudi za izvajanje dolgotrajne zdravstvene nege. Pri tem morajo povračilo zavarovanja samostojno zagotavljati lokalni izvajalci zdravstvenih storitev in svetovalne pisarne, pogosto $\mathrm{V}$ sodelovanju $\mathrm{Z}$ bolnišničnimi sveti; 3) upravo bolnišnice, za katero po letu 2006 velja ureditev v okviru regije; 4) deželne Zdravniške zbornice, ki podpirajo obravnavo pritožb v zvezi z vlogo pri opredeljevanju in uveljavljanju kodeksa strokovnega ravnanja; 5) neodvisno arbitražno komisijo: skupino zbornic, ki izvrši poziv in izvede arbitražni postopek. Zakonodaja iz leta 2004 ureja priporočila zastopanja pacienta, kar se običajno izvede brez glasovalne pravice. V skrajnih primerih je pritožba lahko rezultat in proces v postopkih obravnave civilnega, kazenskega, socialnega in delovno sodnega sistema. Slednji so posebna sodišča v primeru večjih kršitev iz naslova ne vestnega opravljanja delovnih obveznosti. V takšnih primerih se posamezniku izreče 'graja' oziroma opomin in izvrši globa; 6) pritožbene urade, ki se financirajo z zvezno vlado s strani regij in zasebnih virov; v nekaterih primerih imajo zdravstvene oddelke, ki zagotavljajo pravno svetovanje in obravnavajo pritožbe ter odškodnine; 7) neodvisne zastopnike pacientov in vodje skupin za samopomoč, ki delujejo na nacionalni in lokalni ravni in jih financirajo bolnišnični sveti. Organizirani so v 22 manjših regionalnih skupin.

Organizacijska odgovornost pritožb pacientov na področju zdravstvenega varstva je določena z nemško zvezno vlado in 16 deželnimi vladami ('Landesregierung') . Veljavni zakoni in predpisi priznavajo samostojno ureditev nemškega zdravstvenega varstva z 292 bolniškimi fondi (vključujoč negovalno in dolgotrajno zdravstveno oskrbo), podrejenimi članicam izvoljenih oblasti, ki zastopajo delodajalce in zaposlene. V obstoječem sistemu 
A. Mohorič Kenda, R. Leskovar \& R. Pirnat: Primerjava pravne ureditve pritožb v zdravstvu v Republiki Sloveniji, Nemčiji in Veliki Britaniji

je urejenih 49 zasebnih zavarovalnic. Bolnišnične uprave in zavarovalnice izdajo interne predpise in smernice, ki določajo skupni pravni okvir za reševanje pritožb pacientov. Zdravstveni strokovnjaki so odgovorni za profesionalno ravnanje $\mathrm{v}$ postopku oskrbe pacienta $\mathrm{v}$ skladu z medicinskim kodeksom in $\mathrm{v}$ okviru deželnih strokovnih združenj (t.i. 'Zbornice'). Deželna strokovna združenja zagotavljajo neodvisne arbitražne komisije. Pristojni organi, ki izvajajo funkcijo reševanja pritožb, uporabljajo isti pristop. Bolnišnice in IZD na primarnem nivoju imajo veliko stopnjo avtonomije pri ravnanju s pacienti, 'pritožbe in njihov način reševanja je prepuščen njihovi lastni izvedbi, vendar morajo pri tem upoštevati pojasnila in smernice, ki jih izdajajo pristojne Zdravniške zbornice'.

V Nemčiji obstaja od leta 1975 tako imenovana 'Strokovna in arbitražna komisija Zdravniške zbornice Nemčije', ki deluje neodvisno za potrebe reševanja pritožb pacientov. Nastopa kot drugo stopenjski organ o zahtevi za obravnavo kršitev pacientovih pravic in rešuje večje kršitve, ki se odražajo v nevestnem opravljanju delovnih obveznosti medicinskih strokovnjakov. Strokovna komisija izvedencev, ki odloča o posameznem primeru deluje neodvisno in je sestavljena iz treh (3) članov: predsednika, ki je usposobljen za opravljanje sodno / pravne funkcije, ter dveh članov iz zdravstvene stroke, pri čemer mora biti en član natančno iz strokovnega področja na katerega se nanaša obravnavani primer. Reševanje izvensodnih poravnav poteka $v$ sodelovanju z neodvisno arbitražno komisijo, ki jo sestavlja en član s področja prava, ter ostali člani iz medicinsko strokovnega področja. Število članov je odvisno od zahtevnosti obravnavanega primera. Arbitražni postopek se nanaša na družbeno pravne vidike primera in določa okoliščine poravnave. V primeru, ko je predmet obravnave strokovno delo zdravnika, o tem odloča Strokovna komisija, ki se le izjemoma vključi v odločanje o arbitražnem predlogu in le v primeru, ko ni neuspešna arbitražna komisija. Postopka se izvajata ločeno in zanju velja, da sta za pacienta brezplačna. Javnost je o delovanju tako imenovane 'Strokovne in arbitražne komisije Zdravniške zbornice Nemčije' seznanjena z javnimi objavami preko letnih statističnih poročil ter novinarskih in javnih konferenc.

\subsection{Velika Britanija}

Velika Britanija z vidika pravnega reda nima sprejete zakonodaje o splošnih pacientovih pravicah v enotnem aktu. Področje varstva pacientovih pravic je v Veliki Britaniji urejeno v številnih ustavno zakonskih in podzakonskih aktih. Reševanje pritožb v zdravstvu poteka pod okriljem Nacionalne zdravstvene službe (National Health Service - NHS). Predpis, ki ureja delovanje NHS v okviru pritožb, določa 'The Handbook to the NHS Constitution (t.i. Statut NHS'), ki ga je izdalo Ministrstvo za zdravje Velike Britanije. Statut omogoča razlago posameznih pravic in obveznosti iz pravic delovanja NHS ter pravne vire za uresničevanje pravic pacientov. V svoji vsebini opredeljuje pravila posameznih vlog, varovanje in zagotavljanje nacionalne zdravstvene službe. Pravice, ki jih pacienti v Veliki Britaniji uveljavljajo so zbrane v seznamu petnajstih (15) pravic. Ministrstvo za zdravje Velike Britanije ne preiskuje pritožb pacientov, saj je slednje potrebno preiskati brez političnega vmešavanja, da se zagotovi vprašanje nepristranskosti. Pritožbe pacientov so vitalno pomemben element učinkovitega pritožbenega postopka, ki omogoča izboljševanje izvajanja storitev zdravstvenega in 
$36^{\mathrm{TH}}$ International Conference on ORganizational Science Development: Responsible Organization (MarCh $22^{\mathrm{ND}}-24^{\mathrm{TH}}$, Portorož Slovenia)

A. Mohorič Kenda, R. Leskovar \& R. Pirnat: Caparison of Healthcare Complaints Regulation in the Republic of Slovenia, Germany and the United Kingdom

socialnega varstva. So dragocen vir povratnih informacij o izvajanju zdravstvenih storitev, še posebej, kadar so te storitve povezane $\mathrm{z}$ vodenjem in se nanašajo na procese upravljanja s tveganji. ${ }^{7}$

Vsaka organizacija, ki deluje pod okriljem NHS ima organiziran pritožbeni postopek. Vsak pacient, ki je koristnik zdravstvenega sistema v Veliki Britaniji ima možnost do pritožbe kadar ni zadovoljen s prejeto zdravstveno oskrbo oz. zdravljenjem ali v primeru njene zavrnitve. Ob zavrnitvi ima pacient pravico do pritožbe, ki se smatra kot preiskava in na katero mora prejeti popoln in hiter odgovor. (The Medical Protection Society limited, 2011) V kolikor pacient ni zadovoljen s prejeto storitvijo nacionalne zdravstvene službe ima na prvi stopnji pravico vložiti zahtevek za pritožbo neposredno pri izvajalcu zdravstvene storitve ali sproži t.i. (Choices complaint process) neposredni NHS pritožbeni postopek. (The Medical Protection Society limited, 2012) Pacient, ki ni zadovoljen z načinom izvajanja postopka obravnave kršitve pri NHS ali njenim izidom, ima pravico do pritožbe na drugo stopnjo, na neodvisni pristojni organ, t.i. parlamentarnega varuha človekovih pravic (angl.'Parliamentary and Health Service Ombudsman' - PHSO) ali v primeru, ko se pritožba nanaša na javno zdravstveno storitev na t.i. krajevni organ varuha človekovih pravic (angl. Local Goverment Ombudsman). Slednji izvaja neodvisne preiskave, ki izhajajo iz nelojalnega ali nepravilnega delovanja ali slabega izvajanja službe NHS v Veliki Britaniji (Department of Health, 2013. The Handbook to the NHS Constitution).

Protokol pritožbenega postopka ni predpisan z zakonom, vendar priporočila in smernice zagotavljajo pravni okvir znotraj katerega se uporabljajo načela skrbnega ravnanja $\mathrm{v}$ postopku obravnave pritožb. V okviru pritožbenega postopka, ki ga obravnava NHS ima pacient pravico seznanjenosti: 1) s postopkom obravnave, 2) z ustreznostjo obravnave, 3) rezultatom preiskave in imeti možnost: 1) posredovanja svoje pritožbe neodvisnemu pristojnemu organu, parlamentarnemu varuhu človekovih pravic - PHSO, 2) vložiti zahtevek za sodno varstvo, v kolikor meni, da bi lahko sklep odločitve NHS izhajal iz malomarnega ali nezakonitega ravnanja; 3) prejeti nadomestilo, v kolikor je bila dokazana škoda, ki jo je pacient utrpel.

NHS pritožbeni postopek določa vodilo 'Professional support and expert advice' (2011), ki vsebuje priporočila za učinkovito izvajanje pritožbenega postopka. Pritožnik je lahko pacient ali zdravstveni delavec, ki je bil deležen kršitev oziroma poseg v osebnostno integriteto. V primeru uveljavljanje zahteve za kršitev pacientovih pravic, ki niso del pravic iz obsega zdravstvenega in socialnega zdravstvenega varstva, je PHSO dolžan sodelovati s krajevnimi varuhi človekovih pravic. $\mathrm{V}$ tem primeru procesno izvajanje zahtev za kršitev pacientovih pravic določa: 1) postopek, ki se izvaja v okviru javnega zdravstva in socialnega varstva odraslih, 2) dvostopenjski proces lokalnega postopka $\mathrm{z}$ odškodnino v okviru delovanja PHSO in uveljavljanja človekovih pravic in temeljnih svoboščin.

V primeru, ko se pacient odloči uveljavljati zahtevek za odškodnino se v postopek, ki ga izvaja NHS vključi tudi t.i. Medicinsko zavarovalno združenje (angl. 'Medical protection 
A. Mohorič Kenda, R. Leskovar \& R. Pirnat: Primerjava pravne ureditve pritožb v zdravstvu v Republiki Sloveniji, Nemčiji in Veliki Britaniji

society' - MPS), ki stremi k reševanju pritožbenega zahtevka na način, ki ne vključuje pravdnega postopka. Zahtevo za uveljavitev pravice do obravnave kršitve pacientovih pravic lahko pritožnik vloži v roku 12 mesecev od nastanka kršitve oz. od trenutka zavedanja kršitve. V postopku obravnave kršitve pacientovih pravic, ima pritožbeni vodja pravico do diskrecijske pravice, $v$ kolikor zato obstaja utemeljeni razlog (t.j. zavarovanje pravice in pravne koristi stranke) in je namreč še mogoče izvesti preiskavo (Health Act 2009 (c. 21), Part 1, Chapter 1- NHS Constitution; p. 3.) Pritožba zoper zdravstvenega delavca, lahko poteka neposredno ali jo poda zastopnik. V postopku obravnave kršitve pacientovih pravic, ni njuno potrebna prisotnost pacienta.

Določena je izjema, v primeru, ko gre za pritožbo zoper skrbno ravnanje zdravstvenega delavca. V vsebinskem smislu se zahteva preiskavo, ob dokazanem pomanjkljivem delovanju s pravili ravnanja stroke je zdravstveni delavec dolžan podati svoj zagovor. Evidenca pritožb mora vsebovati kopije vseh dopisov med pritožnikom in timom ljudi, dodeljenim za reševanje pritožbe (tudi pacientovim zastopnikom in/ali Varuhom človekovih pravic). Po zaključku pritožbenega postopka in izteku zakonskega roka za tožbo, je potrebno v zvezi s pritožbenim primerom celotni osnutek dokumentacije uničiti. Korespondenco med Zdravniško zbornico in pristojnim osebjem za reševanje pritožbenega zahtevka je na splošno potrebno upoštevati pri izbrisu spisa in je obravnavana privilegirano.

Državna administracija ('Secretary of State') vsako leto objavi poročilo sestave NHS po vsaki reviziji in je dolžna $\mathrm{v}$ izkazih zagotavljati poročanje za obdobje desetih let. Na vsake tri leta objavi poročilo o vplivu predpisov, ki veljajo v sklopu ureditve izvajanja NHS tako za paciente, zdravstveno osebje kakor tudi njene člane. (Department of Health, 2009).

\section{Izbrani pokazatelji diferenčnosti}

$\mathrm{Na}$ osnovi študije literature je ureditev pritožb na procesno organizacijski ravni $\mathrm{v}$ Republiki Sloveniji, Nemčiji in Veliki Britaniji mogoče predstaviti z izbranimi pokazatelji diferenčnosti:

\subsection{Republika Slovenija}

- Odzivni čas na pritožbo: rok za potrditev prejema pritožbenega zahtevka ni z zakonom predpisan

- Korespondenca: uveljavitev zahtevka za pritožbo v slovenskem jeziku

- Kakovost opravljenih storitev: preverjanje s spremljanjem ponovljivostjo odklonov izvajanja zdravstvenih storitev in presojami sistema ISO

- Servis in podpora: z zakonom opredeljeno postopkovno načelo

- Neodvisna obravnava: ni opredeljena

- Strokovno svetovanje pacientu: brezplačno svetovanje in pomoč ZPP Kontaktna točka: ena ali več kontaktnih točk v postopku z zahtevo za prvo obravnavo 
$36^{\text {Th }}$ International Conference on Organizational Science Development: Responsible Organization (MarCh $22^{\mathrm{ND}}-24^{\mathrm{TH}}$, Portorož Slovenia)

A. Mohorič Kenda, R. Leskovar \& R. Pirnat: Caparison of Healthcare Complaints Regulation in the Republic of Slovenia, Germany and the United Kingdom

kršitev pacientovih pravic (pri IZD), ena kontaktna točka z zahtevo za drugo obravnavo kršitev pacientovih pravic (pristojna KVPP pri MZ).

- Klicni center: /

- Komunikacija: pisno in/ali telefonsko, elektronska pošta, neposredno z osebnim stikom s pritožnikom in/ali njegovim pooblaščencem

- Internet: zahtevek za pritožbo je možno oddati preko telefonskega razgovora, elektronske pošte, pisno s klasično pošto, ustno na zapisnik.

\section{$2.2 \quad$ Nemčija}

- Odzivni čas na pritožbo: rok za potrditev prejema pritožbenega zahtevka je 3 dni Korespondenca: uveljavitev zahtevka za pritožbo v nemškem in angleškem jeziku

- Kakovost opravljenih storitev: z merjenjem ponovljivostjo odklonov izvajanja zdravstvenih storitev, akreditacijski programi, uveljavljanjem odškodninskih zahtevkov, periodičnem strokovnem preverjanju znanja strokovnjakov zaposlenih v zdravstvu na nacionalnem nivoju.

- Servis in podpora: organizacijske smernice in priporočila v lokalnem okolju, hitro in fleksibilno odzivanje na pritožbo

- Neodvisna obravnava: Strokovna in arbitražna komisija Zdravniške zbornice Nemčije

- Strokovno svetovanje pacientu: brezplačno svetovanje in pomoč sta razdrobljeni

- Kontaktna točka: več kontaktnih točk v postopku z zahtevo za obravnavo kršitev pacientovih pravic za prvo in drugo obravnavo kršitev pacientovih pravic (ne glede na raven izvajanja zdravstvene dejavnosti).

- Klicni center: vzpostavljen na nacionalnem nivoju

- Komunikacija: pisno in/ali neposredno z osebnim stikom po predhodni najavi ali na povabilo

- Internet: zahtevek za pritožbo je možno oddati le pisno s klasično pošto ne glede na vrsto zahteve za obravnavo kršitve.

\subsection{Velika Britanija}

- Odzivni čas na pritožbo: 3 dni za potrditev prejema pritožbenega zahtevka Korespondenca: uveljavitev zahtevka za pritožbo v več jezikovni izbiri

- Kakovost opravljenih storitev: z merjenjem ponovljivostjo odklonov izvajanja zdravstvenih storitev, akreditacijski programi, uveljavljanje odškodninskih zahtevkov, periodičnem strokovnem preverjanju znanja strokovnjakov zaposlenih v zdravstvu na nacionalnem nivoju.

- Servis in podpora: nacionalne smernice in priporočila za udeležence sistema zdravstvenega varstva, hitro in fleksibilno odzivanje na pritožbo

- Neodvisna obravnava: neodvisni pristojni organ PHSO

- Strokovno svetovanje pacientu: brezplačno svetovanje in pomoč zagotavlja NHS služba in služba zdravstvenega varstva 

ORGANIZACIJA (22. - 24. MAREC 2017, PORTOROŽ, SLOVENIJA)

A. Mohorič Kenda, R. Leskovar \& R. Pirnat: Primerjava pravne ureditve pritožb v zdravstvu v Republiki Sloveniji, Nemčiji in Veliki Britaniji

- Kontaktna točka: več kontaktnih točk v postopku z zahtevo za obravnavo kršitev pacientovih pravic za prvo in drugo obravnavo kršitev pacientovih pravic (odvisno od tega ali je IZD del javne ali zasebne zdravstvene mreže)

- Klicni center: vzpostavljen na nacionalnem nivoju

- Komunikacija: pisno in/ali telefonsko (avdio \& video konference), elektronska pošta, neposredna z osebnim stikom s pritožnikom in/ali njegovim pooblaščencem

- Internet: zahtevek za pritožbo je možno oddati preko telefonskega razgovora, online informacijskega sistema, elektronske pošte, pisno s klasično pošto.

\begin{tabular}{|l|c|c|c|c|l|}
\hline Pokazatelj & $\begin{array}{c}\text { Republika } \\
\text { Slovenija }\end{array}$ & Nemčija & $\begin{array}{c}\text { Velika } \\
\text { Britanija }\end{array}$ & $\begin{array}{c}\text { Povprečna } \\
\text { ocena }\end{array}$ & $\begin{array}{l}\text { Pomembnost } \\
\text { obravnave }\end{array}$ \\
intemet / on-line & 0 & 0 & 5 & 1.7 & ZELO \\
\hline svetovanje pacientu & 2 & 2 & 3 & 2.3 & POMEMBNO \\
\hline kakovost storitev & 0 & 4 & 4 & 2.7 & POMEMBNO \\
\hline klicni center & 3 & 4 & 4 & 2.7 & \\
\hline odzivni čas & 0 & 5 & 5 & 3.3 & \\
\hline neodvisna obravnava & 0 & 5 & 5 & 3.3 & ZMERNO \\
\hline kontaktna točka & 3 & 4 & 4 & 3.7 & \\
\hline korespondenca & 3 & 5 & 5 & 4.3 & \\
\hline servis in podpora & 5 & 5 & 5 & 5.0 & PREPROSTO \\
\hline svetovanje pacientu & 5 & 5 & 5 & 5.0 & \\
\hline
\end{tabular}

Slika 11: Izbrani pokazatelji raznolikosti procesnih zahtev pritožbenega postopka $v$ Sloveniji, Nemčiji in Veliki Britaniji (Vir: lasten vir)

Prikazani podatki v tabeli 1 ponazarjajo diferenco ureditve $\mathrm{v}$ izvajanju pritožbenega postopka in ugotavljanju preferenc opazovanih atributov. Izhajamo iz treh (3) opazovanih ureditev in desetih (10) kategorij oz. pokazateljev ter njihove minimalne in maksimalne vrednosti. Vsota seštevka ponazarja ovrednoteno pomembnost. Za vsak izbrani pokazatelj s številom nič (0) definira min. vrednost ob pogoju, da zanj ne obstaja definirani kriterij; število ena (1) - ne zagotavlja pokazatelja; število dve (2) - nizko zagotavljanje pokazatelja; število tri (3) - zadovoljivo zagotavljanje pokazatelja; število štiri (4) - primerno zagotavljanje pokazatelja; vse do max. vrednosti pet (5) točkovne lestvice - visoka raven zagotavljanja pokazatelja. Splošno velja, da vsak opazovani atribut statistično zadošča pogoju pomembnosti in bližje kot je izračunani atribut vrednosti nič (0), večji je razkorak pomembnosti izbrane kategorije (glej prikaz v tabeli 2). 
$36^{\mathrm{TH}}$ InTERnAtional CONFERENCE ON ORganizational SCIENCE DeVElopment: RESPONSIBLE ORGANIZATION (MARCH $22^{\mathrm{ND}}-24^{\mathrm{TH}}$, PORTOROŽ SLOVENIA)

A. Mohorič Kenda, R. Leskovar \& R. Pirnat: Caparison of Healthcare Complaints Regulation in the Republic of Slovenia, Germany and the United Kingdom

Iz opazovanega je razvidno, da sta v ospredju zelo pomembna dejavnika 1) svetovanje pacientu in internet / on-line možnost oz. elektronska dostopnost povezave s pacientom; med pomembne pokazatelje se v s primerjavo umešča 1) kakovost storitev in 2) klicni center; med zmerno pomembne pokazatelje glede na razpoložljivost podatkov združujemo 1) odzivni čas, 2) neodvisna obravnava, 3) kontaktna točka, 4) korespondenca med zdravstvenim osebjem in pacientom oz. vlagateljem zahtevka; na ravni preprosto prepoznane oz. osnovne pomembnosti vpliva na izvajanje pritožbenega postopka združujemo 1) servis in podporo ter 2) svetovanje pacientu.

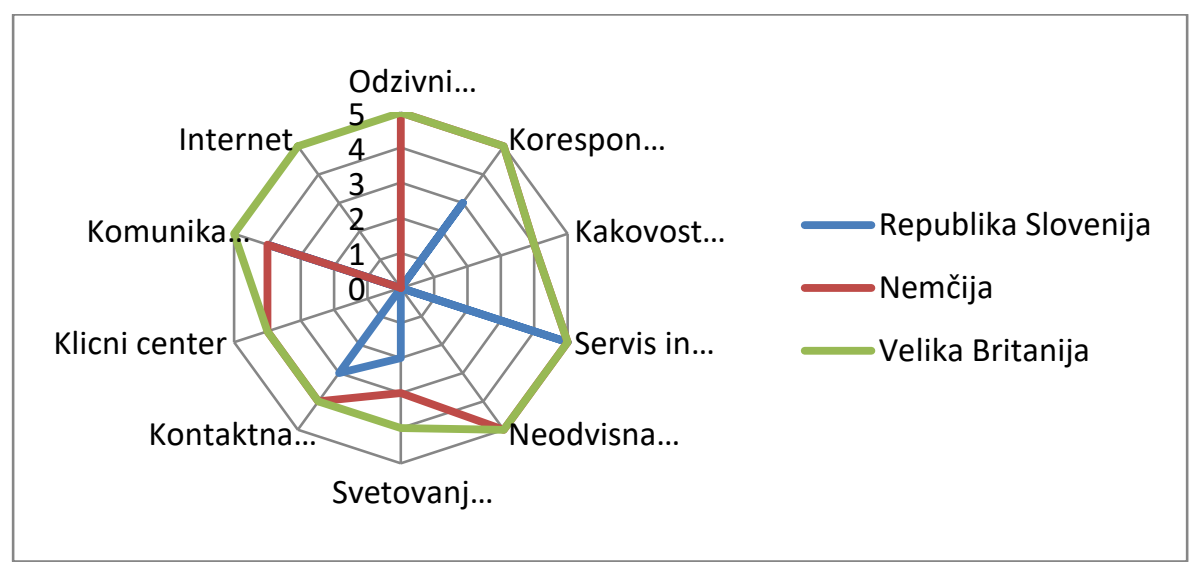

Slika 12: Grafični prikaz izbranih pokazateljev raznolikosti procesnih zahtev pritožbenega postopka $v$ Sloveniji, Nemčiji in Veliki Britaniji (Vir: lasten vir)

Na podlagi empiričnega pregleda in iz razvidnega prikaza virtualizacije podatkov ima Velika Britanija po naši oceni glede na izbrano pomembnost diferenčnosti pokazateljev primernejšo organizacijsko ureditev pritožbenega sistema kot jo imata Republika Slovenija in Nemčija. V Republiki Sloveniji nacionalna kontaktna točka ni vzpostavljena, kakor tudi ne enoten klicni center za pomoč pritožnikom. Republika Slovenija nima vzpostavljenega nacionalnega portala za vlaganje pritožbenih zahtevkov, kot to omogoča NHS v Veliki Britaniji, ki bi transparentno omogočal pregled in spremljanje nenehnega izboljševanja izvajanja zdravstvenih storitev zlasti na podlagi zahteve, ki izhaja iz potrebe reševanja pritožb pacientov.

\section{$3 \quad$ Zaključek}

Reševanja pritožb v sistemih zdravstvenega in socialnega varstva v številnih Evropskih državah odraža stanje, ki temelji na jasnem razumevanju kakovosti zdravstvenih storitev, ki jih pacienti pričakujejo. Nadzor nad sistemom pritožb po navedbah Lister, Flemming idr. (2008) predstavlja pomembno vodilo $\mathrm{k}$ izboljševanju kakovosti, spodbuja pristojne $\mathrm{k}$ pospešeni odzivnosti in vzpodbuja izboljševanje sistema. Republika Slovenija je s sprejetjem direktive 2011/24/EU Evropskega parlamenta in Sveta o uveljavljanju pravic 
A. Mohorič Kenda, R. Leskovar \& R. Pirnat: Primerjava pravne ureditve pritožb v zdravstvu v Republiki Sloveniji, Nemčiji in Veliki Britaniji

pacientov pri čezmejnem zdravstvenem varstvu zavezana $\mathrm{k}$ prizadevanju doseganja trajnostne gospodarske in družbene koristi evropskih sistemov in storitev ter interoperabilnih aplikacij eZdravje.

Nemčija in Velika Britanija sta razvili pritožbeni sistem, ki v sistemu zdravstvenega varstva zaposlene usmerja k nenehnemu izboljševanju. Rezultati izbranih kriterijev se v primerjavi z Republiko Slovenijo razlikujejo glede na prepoznane prednostne cilje posamezne države in razvojne usmeritve. Velika Britanija in Nemčija imata vzpostavljene zahteve, ki imajo vpliv na izboljševanje pritožbenega postopka in na stopnjo skrbnosti izvajanja zdravstvenih storitev, opredeljene $\mathrm{v}$ zakonskih oz. podzakonskih aktih. Predstavljeni načini in urejenost izvajanja pritožbenega postopka primerjalno med državami nakazuje na pomen vzpostavitve celovitosti procesnih rešitev, informatizacijo pritožbenega postopka in integracijo z delovnimi okolji ob upoštevanju ustreznih zakonskih in regulativnih zahtev.

\section{Opombe}

${ }^{1}$ Direktiva 2011/24/EU Evropskega parlamenta in Sveta z dne 9. marca 2011 o uveljavljanju pravic pacientov pri čezmejnem zdravstvenem varstvu, UL L 88, 4.4.2011, str. 45.

${ }^{2}$ Zakon o pacientovih pravicah (Uradni list RS, št. 15/08); v nadaljevanju: ZPacP.

${ }^{3}$ Komisija Republike Slovenije za varstvo pacientovih pravic (KVPP); Zaradi uresničevanja ZPacP, Uradni list RS, št. 15/08. Zakon opredeljuje potrebno po sestaviti KVPP.

${ }^{4}$ Državno poročilo o stanju na področju varstva pacientovih pravic za leto 2016, str 12.

${ }^{5}$ Ministrstvo za zdravje RS, 2006, EVA 2005-2711-0080, str. 14.

${ }^{6}$ Direktiva Evropskega parlamenta in sveta 2005/29/ES o nepoštenih poslovnih praksah podjetij v razmerju do potrošnikov na notranjem trgu ter o spremembi Direktive Sveta 84/450/EGS, direktiv Evropskega parlamenta in Sveta 97/7/ES, 98/27/ES in 2002/65/ES ter Uredbe (ES) št. 2006/2004 Evropskega parlamenta in Sveta.

${ }^{7}$ DE00000764934, Goverment UK, Ministerial Correspondence and Public Enquiries, Department of Health, 2013.

\section{Literatura}

Bundesministerium der Justiz und fur Verbraucherschutz. Bürgerlichen Gesetzbuch - BGB. RGB1. P.195, BGB1. I S. 42, 2909; BGB1. 2003 I S. 738; BGBl. 2016 I S. 1190, 1216. Dostopno na: http://www.gesetze-im-internet.de/bundesrecht/bgb/gesamt.pdf

Bundesministerium für Gesundheit (2007). Patientenrechte in Deutschland. Leitfaden für

Patientinnen/Patienten und Ärztinnen/Ärzte, Berlin, BMG-G-G407, s.1-22.

Bundesministerium für Gesundheit (2005). Charta der Rechte, Berlin, s.1-22.

Brulc, U. (2006). Pacientove pravice de lege ferenda in njihov vpliv na izvajalce zdravstvenih storitev ter zdravstveno osebje. Bilten Ekonomika, Ljubljana, 22 (4); str. 96-97; str.96.

Brulc, U., Pirc Musar, N. (2008). Zakon o pacientovih pravicah (ZPacP), Uvodna pojasnila, GV Založba, Ljubljana, str. 1-189; str. 5, str. 163-164.

Department of Health UK (2015). The Handbook. The NHS Constitution, pp. 1-160, p. 81-85.

Direktive Evropskega parlamenta in sveta 2005/29/ES, z dne 11. maja 2005 o nepoštenih poslovnih praksah podjetij v razmerju do potrošnikov na notranjem trgu ter o spremembi Direktive Sveta 84/450/EGS, direktiv Evropskega parlamenta in Sveta 97/7/ES, 98/27/ES in 2002/65/ES 
36 ${ }^{\mathrm{TH}}$ International Conference on ORganizational Science Development: Responsible Organization (MarCh $22^{\mathrm{ND}}-24^{\mathrm{TH}}$, Portorož Slovenia)

A. Mohorič Kenda, R. Leskovar \& R. Pirnat: Caparison of Healthcare Complaints Regulation in the Republic of Slovenia, Germany and the United Kingdom

ter Uredbe (ES) št. 2006/2004 Evropskega parlamenta in Sveta (Direktiva o nepoštenih poslovnih praksah), Uradni list Evropske unije, list Evropske unije L 149/22, Listina.

Direktiva 2011/24/EU, Uradni list Evropske unije, list Evropske unije L 88/63, člen 14, točka 2, a) odstavek, Listina.

Lister, G., Flemming, R., Boudioni, M., Dekkers, F., Jakubowski, E., Favelle, H. (2008). Handling Complaints in Health and Social Care: International Lessons for England. National Audit Office, UK. pp. 1-37; p. 25.

Medical Protection Society limited (2010). NHS Complains in UK, Regulation and Principals, pp. $1-20 ;$ p. 15.

Medical Protection Society limited (2013). Casebook. Complaints culture. Vol. 21 (1); pp. 1- 28; p. 8.

Ministrstvo za zdravje RS (2006). Zakon o pacientovih pravicah - predlog za obravnavo (ZPacP), Ljubljana: Ministrstvo za zdravje, EVA 2005-2711-0080; str. 1-57; str. 4-5; str. 14.

Ministrstvo za zdravje RS (2016). Državno poročilo o stanju na področju varstva pacientovih pravic 2016, Ljubljana: Ministrstvo za zdravje, št.: 07000-4/2016/3, 13. oktober 2016, str. 113 ; str. 12.

Patientenrechtegesetz - PRG, Bundesanzeiger, Anzahl .9/2013. Dostopno na: http://www.bgbl.de/xaver/bgbl/start.xav?startbk=Bundesanzeiger

Pirnat, R., Apohal Vučković, L., Brezovnik, B., Grafenauer, B., Kodele Purg, Š., Kovač, P., Pirc Musar, N., Šoltes, I., Trpin, G., Virant, G. (2011). Razvoj slovenske javne uprave 1991-2011. Uradni list Republike Slovenije, Ljubljana, II. poglavje, Pregled na razvoj slovenske državne uprave, 1-271; str. 51-78; str.59.

Planinšec, V. (2004). Zdravnikova strokovna napaka, zmota, zaplet-pravni vidik. Medicina in Pravo: izbrana poglavja. 2001, 2002, 2003, Maribor, str. 129-133. 
36. MEDNARODNA KONFERENCA O RAZVOJU ORGANIZACIJSKIH ZNANOSTI: OdgOVORNA ORGANIZACIJA (22. - 24. MAREC 2017, PORTOROŽ, SLOVENIJA)

O. Arsenijević, M. Ferjan, I. Podbregar, P. Šprajc, D. Trivan \& Y. Ziegler

\title{
Zdrava prehrana v socialno varstvenem zavodu
}

\author{
SARA KETIŠ, CIRILA HLASTAN RIBIČ, URŠKA ROZMAN \& SONJA ŠOSTAR TURK
}

Povzetek Zdrava in uravnotežena prehrana odločilno vplivata na zdravstveno stanje. Za dosego optimalnih rezultatov je potrebno $v$ našo prehrano vključiti mnogo različnih živil v okviru posameznih skupin živil. $\mathrm{V}$ raziskavi smo obravnavali prehrano oseb $\mathrm{z}$ motnjami $\mathrm{v}$ duševnem razvoju $\mathrm{v}$ socialno varstvenem zavodu. $\mathrm{V}$ izbranem zavodu načrtujejo jedilnike na podlagi smernic zdravega prehranjevanja za vzgojno izobraževalne ustanove. Omejili smo se na mleko in mlečne izdelke. Želeli smo ugotoviti trenutno stanje vnosa hranil, zaužitih z mlečnimi izdelki. Vnos mlečnih izdelkov smo izračunali na podlagi analize (v kateri je sodelovalo 60 oseb z motnjami v duševnem razvoju) celodnevnih obrokov pet dni zapored. Celodnevni energijski vnos mlečnih izdelkov je bil tri dni $\mathrm{v}$ času naših merjenj nad $400 \mathrm{kcal}$, kar je glede na priporočila o vnosu mleka previsoko. Vnos beljakovin z mlečnimi izdelki je tretji in četrti dan merjenj presegal priporočeno vrednost $95,42 \mathrm{~g}$. Vsebnosti ogljikovih hidratov so bile vse dni nad 28,95 g, kar ni skladno s priporočili. Previsoke vrednosti vnosa hranil so se kazale predvsem ob neupoštevanju normativov porcioniranja hrane ter $\mathrm{v}$ dnevih, ko so bili mlečni izdelki vključeni $\mathrm{v}$ tri obroke dnevno. Zaradi naraščanja števila starejših oseb pri katerih se potrebe po hranilih razlikujejo glede na mlajšo populacijo predlagamo, da se zraven izbranih smernic upoštevajo še referenčne vrednosti za vnos hranil.

KLJUČNE BESEDE: hranilne vrednosti živil $\bullet$ mleko $\bullet$ smernice zdravega prehranjevanja

NASlov AVtoric: Sara Ketiš, Megal d.o.o., Sovretova pot 50, 2250 Ptuj, Slovenija, e-pošta: sara.ketis@gmail.com; dr. Cirila Hlastan Ribič, izredna profesorica, Nacionalni inštitut za javno zdravje, Trubarjeva cesta 2, 1000 Ljubljana Slovenija, e-pošta: cirila.hlastan@um.si; dr. Urška Rozman, asistentka, Univerza v Mariboru, Fakulteta za zdravstvene vede, Žitna ulica 15, 2000 Maribor, Slovenija, e-pošta: urska.rozman@um.si; dr. Sonja Šostar Turk, redna profesorica Univerza v Mariboru, Fakulteta za zdravstvene vede, Žitna ulica 15, 2000 Maribor, Slovenija, epošta: sonja.sostar@um.si

DOI https://doi.org/10.18690/978-961-286-020-2.26

ISBN 978-961-286-020-2

(C) 2017 Univerzitetna založba Univerze v Mariboru

Dostopno na: http://press.um.si 
$36^{\text {TH }}$ International Conference on Organizational Science DeVElopment: Responsible ORganizATION (MARCH $22^{\mathrm{ND}}-24^{\mathrm{TH}}$, PORTOROŽ SLOVENIA)

O. Arsenijević, M. Ferjan, I. Podbregar, P. Šprajc, D. Trivan \& Y.

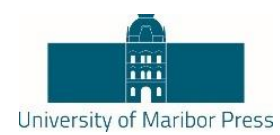

Ziegler

\title{
Healthy Nutrition in Residential Care Institution
}

\author{
SARA KETIŠ, CiRILA HLASTAN RIBIČ, URŠKa ROZMAN \& SONJA ŠOSTAR TURK
}

\begin{abstract}
A healthy and balanced diet has a significant effect on health. To achieve optimal results, we need to include different food groups into our diet. Our research deals with a healthy diet of people with mental health disorders that are living in a care home, where menu is prepared in accordance with nutritional guidelines for educational institutions. We focused on milk and dairy products. The goal was to determine the current nutritional values of consumed dairy products. The intake of dairy products was calculated by analysing every meal consumed in a day for five consecutive days (60 people with mental health disorders participated in the analysis). On three days, the daily caloric intake of dairy products was above $400 \mathrm{kcal}$ which is too high in accordance with milk consumption guidelines. On the third and fourth day, the intake of dairy protein exceeded the recommended value of $95,42 \mathrm{~g}$. The intake of carbohydrates exceeded $25,95 \mathrm{~g}$ the whole time during the analyses, which does not comply with the recommendations. The excessive nutritional values were primarily the result of non-compliance with food-portioning standards and of including dairy products in three meals per day on certain days. Due to the increasing number of older persons whose nutrient requirements differ from the younger generation, we would like to recommend that, in addition to the chosen guidelines, reference values for nutrient intake should also be taken into consideration.
\end{abstract}

KEYWORDS: nutritional values $\bullet$ milk $\bullet$ nutritional guidelines

CorResPondence AdDress: Sara Ketiš, Megal d.o.o., Sovretova pot 50, 2250 Ptuj, Slovenia, email: sara.ketis@gmail.com; Cirila Hlastan Ribič, Ph.D., Associate Professor, National Institute of Public Health, Trubarjeva cesta 2, 1000 Ljubljana Slovenia, e-mail: cirila.hlastan@um.si; Urška Rozman, Ph.D., Assistant, University of Maribor, Faculty of Health Sciences, Žitna ulica 15, 2000 Maribor, Slovenia, e-mail: urska.rozman@um.si; Sonja Šostar Turk, Ph.D., Full Professor, University of Maribor, Faculty of Health Sciences, Žitna ulica 15, 2000 Maribor, Slovenia, e-mail: sonja.sostar@um.si

DOI https://doi.org/10.18690/978-961-286-020-2.26

ISBN 978-961-286-020-2

(C) 2017 University of Maribor Press

Available at: http://press.um.si 
S. Ketiš, C. Hlastan Ribič, U. Rozman \& S. Šostar Turk : Zdrava prehrana v socialno varstvenem zavodu

\section{$1 \quad$ Uvod}

Hrana je nujno pomembna za naš obstoj, je vse tisto, kar jemo in pijemo, ter nam nudi za življenje potrebno energijo. Zdrava in uravnotežena prehrana v mladosti je dobra naložba za zdravo starost. Uravnoteženo prehrano zagotavljajo določena razmerja esencialnih hranilnih snovi v količinah, ki omogočajo nemoteno delovanje vseh funkcij $v$ našem organizmu (Pokorn 2001). Prehrana sodobnega človeka je revna $\mathrm{z}$ vitamini in minerali, premalo je prehranskih vlaknin, sadja in zelenjave, preveč pa bele moke, belega sladkorja in maščob (Artnik in sod. 2012). Za dosego uravnotežene prehrane se poslužujemo normativov in referenčnih vrednosti vnosa hranilnih snovi, ki so specifične glede na spol, starost, telesno dejavnost in druga stanja ter jih pojmujemo glede na priporočene, ocenjene ali orientacijske vrednosti (Hlastan-Ribič 2009).

\subsection{Sestavine hrane}

Za vzdrževanje telesnih funkcij potrebujemo energijo. Dovod energije v telo poteka skozi porabo prehranskih ogljikovih hidratov, maščob in alkoholov. Posameznikova bilanca energije temelji na energijskem vnosu in porabi energije. Porabo energijo lahko razdelimo na tri sestavne dele in sicer: porabo energije med počitkom, telesno aktivnost in toplotni učinek hrane. Fizična aktivnost je komponenta, ki je najmanj konstantna. Prehranske študije so pokazale, da se vnos energije s starostjo zmanjšuje. Potreba po energiji je odvisna od starosti, spola, višine, telesne teže in telesne aktivnosti (Bernstein in Luggen 2010). V Preglednici 1 so prikazane priporočene količine vnosa hranil za mladostnike in otroke v Preglednici 2 priporočene količine vnosa hranil za moške in ženske (Referenčne vrednosti za vnos hranil, DACH, 2004).

Preglednica 1: Priporočene količine vnosa hranil za otroke in mladostnike (Gabrijelčič Blenkuš in sod. 2005, str. 20)

\begin{tabular}{ccccc}
\hline $\begin{array}{c}\text { Otroci/starost } \\
\text { (leta) }\end{array}$ & $\begin{array}{c}\text { Dnevni } \\
\text { energijski } \\
\text { vnos (kcal) }\end{array}$ & $\begin{array}{c}\text { Ogljikovi } \\
\text { hidrati }(\mathbf{g})\end{array}$ & $\begin{array}{c}\text { Beljakovine } \\
\mathbf{>} \mathbf{5 0} \%\end{array}$ & $\begin{array}{c}\text { Maščobe } \\
\mathbf{( g )}\end{array}$ \\
\hline $\mathbf{1 0}-\mathbf{1 5} \%$ & $<\mathbf{3 0} \%$ \\
\hline $\mathbf{7}-\mathbf{9}$ & 2000 & $>232$ & $46-70$ & $<64$ \\
$\mathbf{1 0}-\mathbf{1 2}$ & 2400 & $>282$ & $56-84$ & $<78$ \\
$\mathbf{1 3}-\mathbf{1 4}$ & 2800 & $>320$ & $64-96$ & $<88$ \\
$\mathbf{1 5}-\mathbf{1 8}$ & 3100 & $>346$ & $69-104$ & $<95$ \\
\hline
\end{tabular}


$36^{\text {TH }}$ International Conference on Organizational Science Development: RESPONSIBLE ORGANIZATION (MARCH $22^{\mathrm{ND}}-24^{\mathrm{TH}}$, PORTOROŽ SLOVENIA)

S. Ketiš, C. Hlastan Ribič, U. Rozman \& S. Šostar Turk : Healthy Nutrition in Residential Care Institution

Preglednica 2: Priporočene količine vnosa hranil za ženske in moške (Referenčne vrednosti za vnos hranil, DACH, 2004)

\begin{tabular}{ccccc}
\hline $\begin{array}{c}\text { Ženske/moški } \\
\text { (leta) }\end{array}$ & $\begin{array}{c}\text { Dnevni } \\
\text { energijski vnos } \\
\text { (kcal) }\end{array}$ & $\begin{array}{c}\text { Ogljikovi } \\
\text { hidrati }(\mathbf{g})\end{array}$ & $\begin{array}{c}\text { beljakovin } \\
\mathbf{e} \\
(\mathbf{g})\end{array}$ & $\begin{array}{c}\text { maščobe } \\
(\mathbf{g})\end{array}$ \\
\hline $\mathbf{2 5}-\mathbf{5 0}$ & $2300 / 2900$ & $320 / 400$ & $85 / 110$ & $65 / 80$ \\
$\mathbf{5 0}-\mathbf{6 5}$ & $2000 / 2500$ & $275 / 345$ & $75 / 95$ & $55 / 70$ \\
Več kot 65 & $1800 / 2300$ & $250 / 320$ & $70 / 85$ & $50 / 65$ \\
\hline
\end{tabular}

$\mathrm{Na}$ podlagi različne sestave, izvora in pomena $\mathrm{v}$ prehrani ločimo ogljikohidratna, beljakovinska, maščobna in mlečna živila, sadje, zelenjavo, sladkorna živila in vodo (Herlič in sod. 2009). Ogljikovi hidrati, maščobe in beljakovine so makrohranila in služijo kot vir energije. Telo potrebuje makrohranila $\mathrm{v}$ razmeroma velikih količinah (Požar 2003). Potrebe po ogljikovih hidratih se na podlagi spola, starosti in telesne teže razlikujejo. Priporočila energijskih potreb navajajo $10-15 \%$ beljakovin, $15-30 \%$ maščob in $50-75 \%$ ogljikovih hidratov, glede na celodnevni energijski vnos (WHO 2003).

Preglednica 3: Porazdelitev priporočenih energijskih vnosov po posameznih obrokih (Gabrijelčič Blenkuš in sod. 2005, str. 28)

\begin{tabular}{ll}
\hline Zajtrk & $\begin{array}{l}18-22 \% \text { celodnevnega energijskega } \\
\text { vnosa }\end{array}$ \\
Dopoldanska malica & $10-15 \%$ celodnevnega energijskega \\
& vnosa \\
Kosilo & $35-40 \%$ celodnevnega energijskega \\
& vnosa \\
Popoldanska malica & $10-15 \%$ celodnevnega energijskega \\
& vnosa \\
Večerja & $15-20 \%$ celodnevnega energijskega \\
& vnosa \\
\hline
\end{tabular}

Sestavljeni ogljikovodiki vsebujejo veliko hranilnih snovi. V telesu razpadajo počasneje in nam dalj časa dajejo občutek sitosti (Gavin in sod. 2007). Smernice prehranjevanja priporočajo, da naj ljudje za dobro življenje modro izbirajo ogljikove hidrate, vnos hrane naj bo bogat s prehranskimi vlakninami, sadjem, zelenjavo s celimi zrni, vsebnost mlečnih maščob naj bo nizka, belega sladkorja se izogibajmo (Bernstein in Luggen 2010).

Beljakovine gradijo telo. Prisotne so $\mathrm{v}$ živih celicah, hormonih in encimih. Telo oskrbujejo $\mathrm{z}$ aminokislinami, obenem pa skupaj $\mathrm{z}$ aminokislinami sodelujejo pri mnogih presnovnih procesih (Peakenpaugh 2007). Pomanjkanje beljakovin oslabi organizem, tako da ta postane dovzetnejši za bolezni. Premalo beljakovin v naši prehrani povzroči slabokrvnost, zaostanek v rasti, prebavne motnje, srčno-žilne anomalije in zmanjšano 

ORGANIZACIJA (22. - 24. MAREC 2017, PORTOROŽ, SLOVENIJA)

S. Ketiš, C. Hlastan Ribič, U. Rozman \& S. Šostar Turk : Zdrava prehrana v socialno varstvenem zavodu

absorpcijo hranil. Pomembno je uživanje beljakovin z veliko biološko vrednostjo, to so beljakovine živalskega izvora, ki skupaj z železom zagotavljajo visoko kvalitetne beljakovine in esencialne aminokisline, vitamin $\mathrm{B}_{12}$ in druga pomembna hranila (Bernstein in Luggen 2010).

Maščobe so lipidi, ki so večini sestavljene iz trigliceridov, fosfolipidov in sterolov. Neporabljene maščobe delujejo kot izolator, ohranjajo toploto telesa ter ščitijo notranje organe pred poškodbami. (Bernstein in Luggen 2010).

Preglednica 4: Hranilne snovi v temeljnih skupinah živil (Mrzlikar 1997, str. 17)

\begin{tabular}{cc}
\hline ŽIVILA & HRANILA \\
\hline Žita in žitni izdelki & Ogljikovi hidrati, beljakovine, vitamini \\
Sadje in zelenjava & Ogljikovi hidrati, vitamini, \\
mikroelementi
\end{tabular}

\subsection{Varnost živila}

Osnova zdrave prehrane je varna prehrana. Ko govorimo o varnosti živila, s tem ciljamo na živilo, ki v primeru priprave oz. uživanja na predviden način ni škodljivo zdravju potrošnika, hkrati pa njegova varnost temelji na živilu, ki ni mikrobiološko, kemično, fizično ali fizikalno kontaminirano oz. sega obseg njegove kontaminacije le do mere, ki ne ogroža zdravja. (Zavod za zdravstveno varstvo Celje 2011). Zagotavljanje varnega živila je glavna naloga živilsko predelovalne industrije. Tukaj velja omeniti da ne gre le za zdravstveno ustreznost, marveč tudi za mikrobiološko kakovost (Kuln in Šedlbauer 2003), pri čemer je pojav globalizacije v svetu dodatno povečal tveganje za kontaminacijo živil. Kontaminacija se lahko pojavi od primarne proizvodnje pa vse do končne uporabe. Zaradi možnosti okužb je potrebno na podlagi analize tveganja vedno znova posodabljati mikrobiološke kriterije (Guisse 2002).

Mikrobiološki kriteriji pomagajo ugotavljati primernost proizvoda na osnovi določenih parametrov kontaminacije proizvoda $\mathrm{z}$ določenim številom mikroorganizmov, vključno s paraziti. Gre za ugotavljanje števila bakterij, plesni, alg, virusov, kvasovk in parazitov. Pri analizi je zmeraj potrebno upoštevati dejstvo, da so mikroorganizmi neenakomerno porazdeljeni v živilu. Namen uporabe mikrobioloških kriterijev je zaščita zdravja potrošnika, ocena varnosti živila glede na namen uporabe, preverjanje primernosti postopkov proizvodnje in ne nazadnje preverjanje HACCP (angl. Hazard Analysis Critical Control Point) sistema. Kriteriji so podani v obliki standardov, priporočenih 
$36^{\text {Th }}$ International Conference on Organizational Science Development: RESPONSIBLE ORganization (MARCH $22^{\mathrm{ND}}-24^{\mathrm{TH}}$, Portorož SLOVENIA)

S. Ketiš, C. Hlastan Ribič, U. Rozman \& S. Šostar Turk : Healthy Nutrition in Residential Care Institution

vrednosti in specifikacij (Klun in Šedlbauer 2003). HACCP je sistematični in preventivni pristop k proizvodnji, pripravi in distribuciji varne hrane. Sistem se uporablja z namenom izboljšave kakovosti živil in v prvi meri za preventivo. Pri načrtovanju proizvodnega obrata moramo poznati morebitna tveganja $\mathrm{v}$ proizvodnji na podlagi katerih ocenimo kritične kontrolne točke in kontrolne točke v procesu. (Raspor 2004). Naslednji postopek je postavitev ukrepov v primeru odstopanj ter zagotavljanje, da tvegani izdelki ne pridejo do potrošnika. Vso dokumentacijo, ki se nanaša na HACCP sistem je potrebno evidentirati ter sproti preverjati oziroma opravljati revizijo HACCP-a takrat, ko se pojavijo spremembe $\mathrm{v}$ procesu, opremi, ko uporabljamo druge sestavine itd., saj $\mathrm{v}$ teh primerih obstaja možnost novih tveganj (MacDonald 2001).

\section{$2 \quad$ Načrtovanje jedilnika}

Najpomembnejše in osnovno opravilo pri ponudbi prehrane je pravilno načrtovanje jedilnika. Zajeti moramo hranilno sestavo, ekonomičnost in atraktivnost hrane. Da dosežemo vse prej omenjene komponente je nujno poznavanje prehrambnih navad in potreb po hranilih za ljudi oziroma bolnike. Hranilno in energijsko uravnotežen obrok hrane je bistveni del načrtovanja jedilnikov. Najpomembneje je da določen obrok vsebuje živila iz 4 ali 7 skupin (izdelki iz žit, mleko in mlečni izdelki, meso, ribe, sadje in zelenjava ter živila, ki vsebujejo veliko maščob in sladkorjev), saj je le na tak način mogoče zagotavljati dnevne potrebe po energijskih in esencialnih hranilnih snoveh (Pokorn 2004). Pri načrtovanju jedilnikov so nam v pomoč smernice zdravega prehranjevanja $\mathrm{v}$ vzgojno izobraževalnih ustanovah, smernice zdravega prehranjevanja za dojenčke, smernice delavcev v delovnih organizacijah, praktikum jedilnikov v vzgojno izobraževalnih ustanovah, praktikum jedilnikov zdravega prehranjevanja bolnikov v bolnišnica in starostnikov v domovih za starejše občane. S pomočjo referenčnih vrednosti za vnos hranil lahko natančno določimo potrebe po hranilih za različne kategorije, kot so spol, starost, fizična aktivno itd. Smernice zdravega prehranjevanja predstavljajo strokovno podlago za zagotavljanje zdravstveno ustrezne prehrane $\mathrm{v}$ vrtcih, šolah, zavodih za izobraževanje otrok in mladostnikov s posebnimi potrebami in dijaških domovih, bolnišnicah, domovih za starejše. Cilja smernic sta priprava in uresničevanje novih prehranskih smernic $\mathrm{v}$ različnih ustanovah ter prilagoditev jedilnikov hranilnim in energijskim potrebam v skladu z aktualnimi smernicami (Ministrstvo za zdravje 2005). $\mathrm{V}$ prehranskih smernicah se upoštevajo prehranska priporočila $\mathrm{z}$ referenčnimi vrednostmi za vnos hranil iz prejšnjih let, sodobna načela, spoznanja stroke o zdravi prehrani ter posebnosti določene organizacije oziroma ustanove. Referenčne vrednosti vsebujejo priporočila, ocenjene in orientacijske vrednosti za energijski vnos in vnos hranil za vse starosti in oba spola, ki veljajo v področju Srednje Evrope (Avstrija, Nemčija, Švica). Te izbrane referenčne vrednosti zagotavljajo vse življenjsko pomembne presnovne, fizične in psihične funkcije in ustrezajo zmerno težki telesni dejavnosti (Gabrijelčič Blenkuš in sod. 2005).

Smernice zdravega prehranjevanja navajajo uživanje obrokov večkrat dnevno (4 do 5 krat) v manjših količinah, kajti takšni obroki pripomorejo k znižanju vsebnosti maščob v 
S. Ketiš, C. Hlastan Ribič, U. Rozman \& S. Šostar Turk : Zdrava prehrana v socialno varstvenem zavodu

krvi in imajo pozitiven učinek na raven glukoze. Najpomembnejši in nujen obrok je zajtrk, saj je od njega odvisna dnevna storilnost (Gabrijelčič Blenkuš in sod. 2005).

\subsection{Raziskave na področju prehranjevalnih navad v Sloveniji}

Po podatkih nacionalne raziskave $» Z$ zdravjem povezan življenjski slog « se v Sloveniji zdravo in pretežno zdravo prehranjuje le $23 \%$ odraslega prebivalstva. Pri tem so posebej ogrožene naslednje skupine prebivalstva: moški, ljudje iz nižjih družbenih slojev, osebe z nižjo stopnjo izobrazbe, aktivno zaposleni, prebivalci vaškega bivalnega okolja in vzhodnega slovenskega zdravstvenega področja ter populacija $v$ starosti med 25 in 49 let (Zaletel-Kragelj 2004, str. 18). Oceno o tem, kakšne so prehranjevalne navade v Sloveniji, nam poleg zgoraj omenjene raziskave posredujejo tudi javnomnenjska raziskava »Slovensko javno mnenje« (SJM 1994, 1996, 1999) in še nekatere epidemiološke raziskave. Enaka raziskava $» Z$ zdravjem povezan življenjski slog«, ki je potekala od leta 2001 med odraslimi prebivalci Slovenije, starimi 25 - 64 let, je proučevala vedenjske dejavnike tveganja in nekatere kronične nenalezljive bolezni. Številne študije so pokazale povezavo med samoocenjenim zdravjem in izidom bolezni pri različnih kroničnih boleznih. V letu 2008 je največ vprašanih menilo, da k slabemu zdravju in visoki umrljivosti odraslih prebivalcev Slovenije najbolj prispevata stres (27 $\%)$ in nepravilna prehrana (16,3\%). Prebivalci Slovenije imamo v povprečju nezdrave prehranjevalne navade. Neredno uživamo zajtrk, delež tistih, ki zajtrka ne uživajo, pa še narašča. Uživamo prevelike količine zdravju škodljivih maščob, soli in sladkorja. Čezmerna hranjenost in debelost sta $\mathrm{v}$ svetu in Sloveniji velika javnozdravstvena problema, ki se povečujeta (Artnik in sod. 2012). Raziskava, v kateri je sodelovalo 100 slovenskih dijakov in študentov, je pokazala, da se večina anketirancev prehranjuje nezdravo, $58 \%$ dijakov in $68 \%$ študentov se tega dejstva zaveda (Kvas 2013).

Raziskavo smo izvedli v socialno varstvenem zavodu v katerem bivajo osebe z motnjami $\mathrm{v}$ duševnem razvoju. Osebe, ki imajo prirojeno nižjo stopnjo inteligentnosti, nižje sposobnosti na spoznavnem, govornem, motoričnem in socialnem področju, so osebe z motnjami v duševnem razvoju (Praček 2006). V izbranem zavodu poteka načrtovanje jedilnikov $\mathrm{s}$ pomočjo smernic zdravega prehranjevanja za vzgojno izobraževalne ustanove. Raziskava je temeljila na posnetku oz. študiji trenutnega stanja vnosa hranilnih snovi mlečnih izdelkov glede na priporočila smernic zdravega prehranjevanja v vzgojnoizobraževalnih ustanovah in referenčnih vrednosti vnosa mlečnih izdelkov. $Z$ dobljenimi rezultati smo želeli oceniti prehranjevalne navade in prehranski vnos mleka ter mlečnih izdelkov pri uporabnikih zavoda, oceniti kakovost priprave hrane ter preveriti skladnost jedilnikov sprejetimi smernicami zdrave prehrane za vzgojno izobraževalne ustanove.

\section{Metode}

Raziskava glede vnosa mlečnih izdelkov v kateri je sodelovalo 60 oseb je vključevala analizo celodnevnih obrokov, pet dni zapored, $\mathrm{z}$ namenom ocenitve dejanskega prehranskega vnosa mleka in mlečnih izdelkov med uporabniki zavoda. Upoštevali smo 
$36^{\text {Th }}$ International Conference on Organizational Science Development: Responsible ORGANIZATION (MARCH $22^{\mathrm{ND}}-24^{\mathrm{TH}}$, PORTOROŽ SLOVENIA)

S. Ketiš, C. Hlastan Ribič, U. Rozman \& S. Šostar Turk : Healthy Nutrition in Residential Care Institution

le obroke, ki so vključevali mlečne izdelke. V vzorčenje nismo vključili prigrizkov in zaužite tekočine. V prehranski dnevnik smo vpisovali vrste in količino zaužitih mlečnih izdelkov za vsako osebo posebej. Na podlagi receptur, ki smo jih pridobili pri vodji prehrane, smo tehtali ponujene obroke. Po končanem hranjenju smo stehtali še morebitne ostanke in tako dobili vnos živil $\mathrm{v}$ gramih. Iz pridobljenih podatkov smo s pomočjo računalniške aplikacije Odprta platforma za klinično prehrano (OPKP 2010) ocenili energijski in hranilni vnos. Odprta platforma za klinično prehrano je spletno orodje, ki omogoča spremljanje prehranskih navad in preverjanje prehranskih vrednosti. Aplikacija je prvovrstno namenjena bolnikom, kliničnim dietetikom in zdravnikom kot pomoč za načrtovanje jedilnikov in oblikovanju prehranskih načrtov v procesu zdravljenja (OPKP 2010). V leksikon jedi smo vnesli količine vsakega mlečnega živila posebej, iz katerega je sestavljena jed, npr. mlečni zdrob (pšenični zdrob, mleko, kakav) in dobili vrednosti hranil za vsako živilo posebej. Nato smo izračunali skupen vnos mlečnih izdelkov v posameznem obroku. Uporabili smo metodo tehtanja. Rezultate raziskave smo podali na podlagi povprečnih vrednosti količine energije $\mathrm{v}$ kcal in povprečne količine posameznih makrohranil. Rezultate smo primerjali z referenčnimi vrednostmi za vnos hranil (Referenčne vrednosti za vnos hranil, DACH, 2004) ter s priporočenimi dnevnimi vnosi mleka in mlečnih izdelkov (Kersting in sod. 2003).

\section{$4 \quad$ Rezultati in diskusija}

Glede na povprečno težo, starost in velikost smo s pomočjo izračuna bazalnega metabolizma ugotovili, da bi uporabniki zavoda na dnevi ravni v povprečju potrebovali $2.000 \mathrm{kcal}$, ob predpostavki, da gre za fizično precej neaktivne osebe. Glede na priporočila referenčnih vrednosti vnosa hranil smo si zastavili cilj, da bi naj uporabniki zaužili vsaj $50 \%$ ogljikovih hidratov, maksimalno $30 \%$ maščob in maksimalno $20 \%$ beljakovin, da bi zadostili celotnim potrebam po energiji (Gabrijelčič Blenkuš in sod. 2005). Na podlagi prej omenjenih referenčnih vrednosti smo izračunali, da bi dnevno potrebovali 262,46 g ogljikovih hidratov, 64,52 g maščob in 95,24 g beljakovin. Zaradi lažjega prikaza smo za vse tri obroke izračunali še potrebe po hranilih in energiji za vsak obrok. Zajtrk mora zadovoljiti $20 \%$ dnevnih energijskih potreb, kosilo 37,5 \% in večerja $17,5 \%$ (Gabrijelčič Blenkuš in sod. 2005). Energijska vrednost enega litra pasteriziranega mleka s 3,5 \% mlečne maščobe znaša: 660,36 kcal (OPKP 2010). Na podlagi aktualnih priporočil o vnosu mleka in mlečnih izdelkov za odrasle osebe, ki predlagajo med 0,4 1 in 0,6 1 mleka na dan (Kersting in sod. 2003), smo izračunali, da bi uporabniki zavoda z mlečnimi izdelki morali telesu dnevno zagotoviti med 264,02 in $395,70 \mathrm{kcal}$. V preglednicah 5 in 6 so prikazani jedilniki v času raziskave. 
S. Ketiš, C. Hlastan Ribič, U. Rozman \& S. Šostar Turk : Zdrava prehrana v socialno varstvenem zavodu

Preglednica 5: Glavni obroki v času naših merjenj

\begin{tabular}{|c|c|c|c|c|c|}
\hline Obroki/dnevi & Dan 1 & Dan 2 & Dan 3 & Dan 4 & Dan 5 \\
\hline Zajtrk & $\begin{array}{l}\text { Beli kruh, } \\
\text { perutninska } \\
\text { klobasa, } \\
\text { kivi }\end{array}$ & $\begin{array}{l}\text { Črni } \\
\text { kruh, } \\
\text { namaz }\end{array}$ & $\begin{array}{l}\text { Črni kruh, } \\
\text { skuta, kisla } \\
\text { smetana }\end{array}$ & $\begin{array}{c}\text { Kruh s } \\
\text { semeni, } \\
\text { sir } \\
\text { edamec, } \\
\text { paradižnik }\end{array}$ & $\begin{array}{l}\text { Jogurt, } \\
\text { sirova } \\
\text { štručka, } \\
\text { jabolko }\end{array}$ \\
\hline Kosilo & $\begin{array}{l}\text { Goveja juha } \\
\text { z rezanci, } \\
\text { ocvrt file } \\
\text { osliča, } \\
\text { krompirjeva } \\
\text { solata }\end{array}$ & $\begin{array}{c}\text { Mešana } \\
\text { juha z } \\
\text { zelenjavo, } \\
\text { pica, } \\
\text { sadni } \\
\text { jogurt }\end{array}$ & $\begin{array}{l}\text { Cufti, pire } \\
\text { krompir, } \\
\text { kefir }\end{array}$ & $\begin{array}{l}\text { Poletna } \\
\text { juha, } \\
\text { testenine } \\
\text { carbonara, } \\
\text { zelena } \\
\text { solata- } \\
\text { kristal }\end{array}$ & $\begin{array}{c}\text { Panirana } \\
\text { poli } \\
\text { klobasa, } \\
\text { krompirjeva } \\
\text { solata, } \\
\text { kuhana } \\
\text { zelenjava }\end{array}$ \\
\hline Večerja & $\begin{array}{c}\text { Mlečni gris, } \\
\text { kakav }\end{array}$ & $\begin{array}{c}\text { Carski } \\
\text { praženec, } \\
\text { kompot }\end{array}$ & $\begin{array}{l}\text { Cvetačna } \\
\text { juha s } \\
\text { krompirjem } \\
\text { in mesom }\end{array}$ & $\begin{array}{l}\text { Frutolino, } \\
\text { jabolko }\end{array}$ & $\begin{array}{c}\text { Mlečni riž, } \\
\text { kakav }\end{array}$ \\
\hline
\end{tabular}

Preglednica 6: Dopoldanska in popoldanska malica v času naših merjenj

\begin{tabular}{lccccc}
\hline Obroki/dnevi & Dan 1 & Dan 2 & Dan 3 & Dan 4 & Dan 5 \\
\hline $\begin{array}{l}\text { Dopoldanska } \\
\text { malica }\end{array}$ & $\begin{array}{l}\text { Jogurt z } \\
\text { okusom } \\
\text { breskve }\end{array}$ & Hruške & $\begin{array}{l}\text { Banana, } \\
\text { jabolka }\end{array}$ & Kompot & Jabolko \\
$\begin{array}{l}\text { Popoldanska } \\
\text { malica }\end{array}$ & Lubenica & $\begin{array}{l}\text { Vaniljev } \\
\text { puding }\end{array}$ & $\begin{array}{c}\text { Čokoladni } \\
\text { puding }\end{array}$ & $\begin{array}{c}\text { Jogurt z } \\
\text { okusom } \\
\text { jagode }\end{array}$ & Desert \\
\hline
\end{tabular}

V raziskavi o vnosu hranil pri osebah z motnjami v duševnem razvoju smo ugotovili, da povprečna vrednost energijskega vnosa pridobljenega iz mleka in mlečnih izdelkov $(447,228 \mathrm{kcal})$ ne ustreza prehranskim priporočilom o vnosu mleka in mlečnih izdelkov, saj so vnosi drugi, tretji in četrti dan naših merjenj presegali $400 \mathrm{kcal}$ (Slika 1). Te dni so bili mlečni izdelki na jedilniku pri treh obrokih. 
$36^{\mathrm{TH}}$ International Conference on ORganizational Science Development: Responsible ORGANIZATION (MARCH $22^{\mathrm{ND}}-24^{\mathrm{TH}}$, PORTOROŽ SLOVENIA)

S. Ketiš, C. Hlastan Ribič, U. Rozman \& S. Šostar Turk : Healthy Nutrition in Residential Care Institution

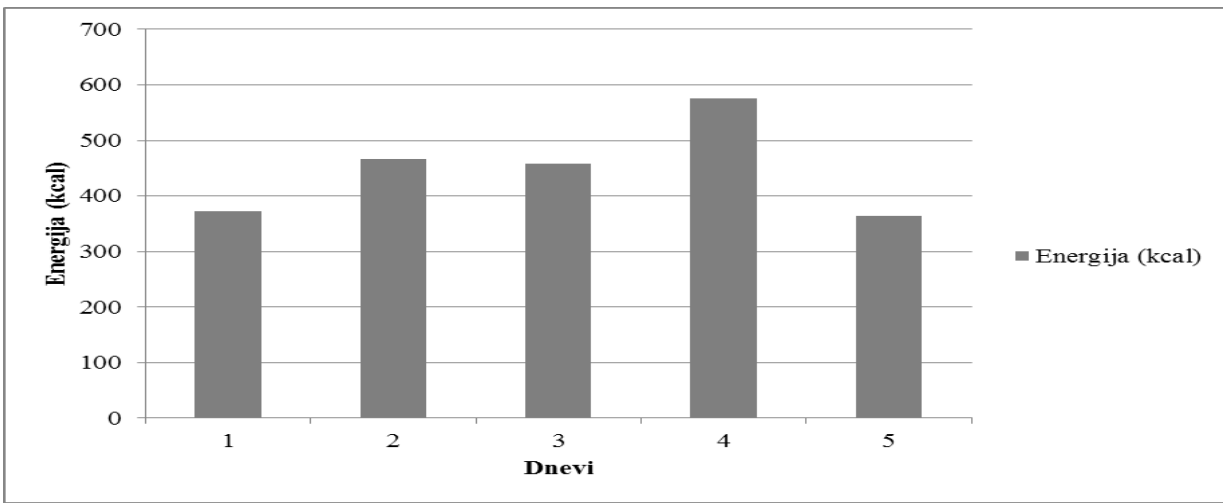

Slika 1: Celodnevni vnos energije, pridobljene iz mlečnih izdelkov

Delež energije iz ogljikovih hidratov v prehrani narašča, vendar je še zmeraj prenizek glede na priporočila, ki navajajo vsaj 50 \% energijskega vnosa, kot spodnji še sprejemljiv delež (Gabrijelčič Blenkuš in sod. 2009). Osebe vključene v raziskavo bi glede na zdravstveno stanje in delovne omejitve morale dnevno vnesti 262,46 g ogljikovih hidratov. V primeru, da vnesejo minimalni sprejemljiv vnos mleka $(0,41)$ in mlečnih izdelkov, to znaša 19,32 g ogljikovih hidratov. Z 0,6 1 mleka pa vnesejo 28,95 g ogljikovih hidratov (OPKP 2010). Ob predpostavki, da vnesejo priporočene količine mleka ter mlečnih izdelkov, bi vnesli med 7,36 \% in 11,03\% celodnevnega vnosa ogljikovih hidratov. Iz Slike 2 razberemo, da je povprečen vnos ogljikovih hidratov $(53,35 \mathrm{~g})$ nad ustreznimi prehranskimi vrednostmi o vnosu mleka in mlečnih izdelkov. Najvišji vnos se pojavi četrti dan raziskave, ko preseže $68 \mathrm{~g}$.

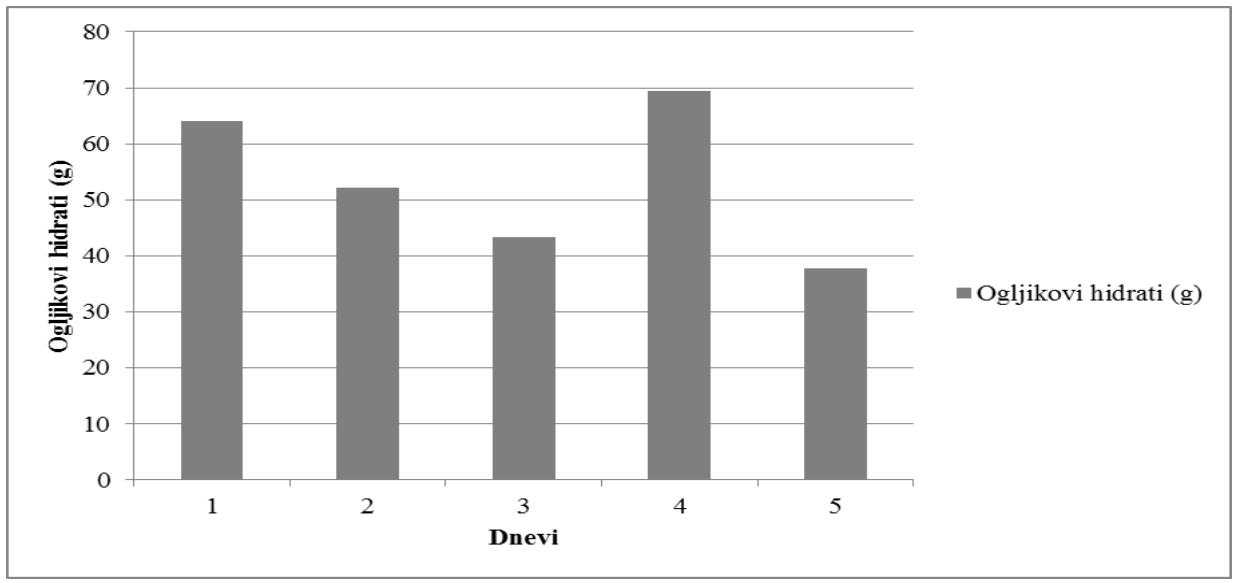

Slika 2: Celodnevni vnos ogljikovih hidratov, pridobljenih iz mlečnih izdelkov 

ORGANIZACIJA (22. - 24. MAREC 2017, PORTOROŽ, SLOVENIJA)

S. Ketiš, C. Hlastan Ribič, U. Rozman \& S. Šostar Turk : Zdrava prehrana v socialno varstvenem zavodu

Po priporočilih vnos maščob naj ne bi presegal $30 \%$ (v našem primeru 64,52 g maščob dnevno) povprečnega dnevnega energijskega vnosa (Hlastan Ribič in sod. 2008). V 0,4 1 pasteriziranega polnomastnega mleka je 14,67 gramov skupnih maščob; v 0,6 litra pa 21,99 gramov (OPKP 2010). V primeru zaužitja priporočenega dnevnega odmerka mleka in mlečnih izdelkov bi pripomogli $\mathrm{k}$ vnosu med $22,73 \%$ in 34,08 \% celodnevnega vnosa maščob. $\mathrm{V}$ dnevih, ko smo izvajali meritve, je bil povprečen vnos maščob, pridobljenih iz mleka ter mlečnih izdelkov v mejah normale tretji, četrti in peti dan meritev $(21,87 \mathrm{~g})$ (Slika 3). Drugi dan je bil vnos maščob glede na zaužite mlečne izdelke previsok, ta dan so osebe, ki so sodelovale v raziskavi jedle sadni jogurt in mlečni namaz. Prvi dan je vnos skupnih maščob, zaužitih z mlekom in mlečnimi izdelki meril pod $10 \mathrm{~g}$, kar je spodnja meja.

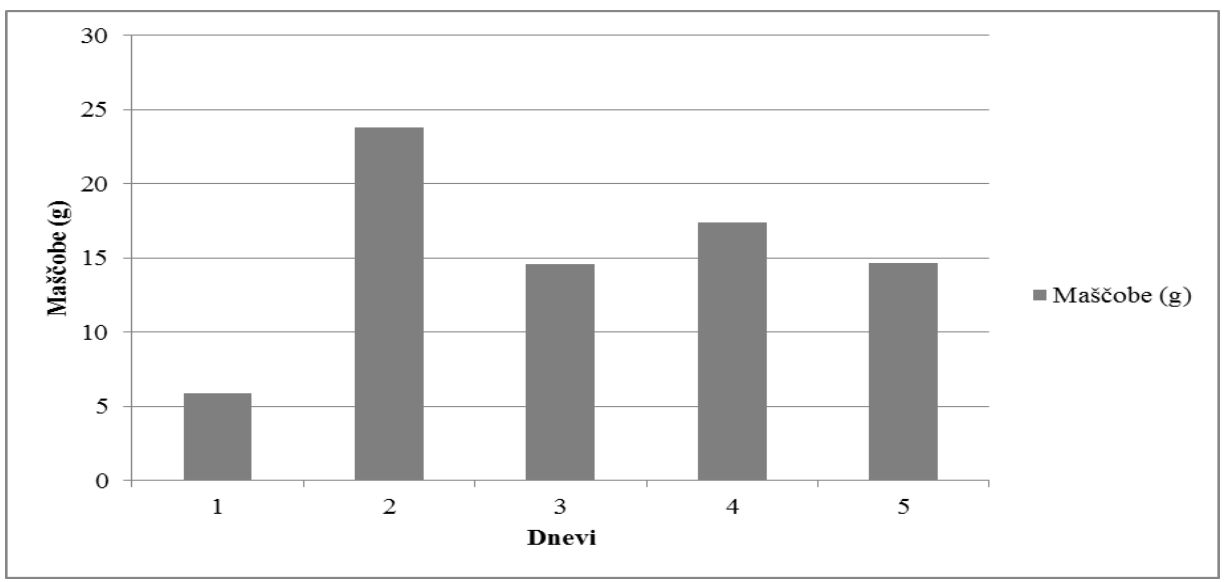

Slika 3: Celodnevni vnos maščob, pridobljenih iz mlečnih izdelkov

Sprejemljivi delež beljakovin v prehrani je $20 \%$ (Gabrijelčič Blenkuš in sod. 2005). Glede na priporočene vrednosti bi uporabniki morali dnevno zaužiti $95,24 \mathrm{~g}$ beljakovin. $\mathrm{V}$ primeru, da udeleženci raziskave vnesejo med 0,41 in 0,61 mleka na dan, znaša količina zaužitih beljakovin med 13,73 in 20,57 gramov (OPKP 2010), to znaša 21,59 \% maksimalne celodnevne količine beljakovin. Iz Slike 4 nazorno razberemo, da vnos beljakovin iz mleka in mlečnih izdelkov pri osebah $\mathrm{z}$ motnjami $\mathrm{v}$ duševnem razvoju vključenih $\mathrm{v}$ raziskavo ne ustreza prehranskim priporočilom o vnosu mleka in mlečnih izdelkov tretji in četrti dan (ta dneva so bili mlečni izdelki prisotni pri treh dnevnih obrokih). Skladnost s prehranskimi priporočili o vnosu beljakovin pridobljenih mleka in mlečnih izdelkov ponazarja prvi, drugi in tretji dan meritev. Povprečna količina vnosa beljakovin, pridobljenih iz mleka in mlečnih izdelkov znaša 24,23 g. 
$36^{\text {Th }}$ International Conference on Organizational Science Development: RESPONSIBLE ORGANIZATION (MARCH $22^{\mathrm{ND}}-24^{\mathrm{TH}}$, PORTOROŽ SlOVENIA)

S. Ketiš, C. Hlastan Ribič, U. Rozman \& S. Šostar Turk : Healthy Nutrition in Residential Care Institution

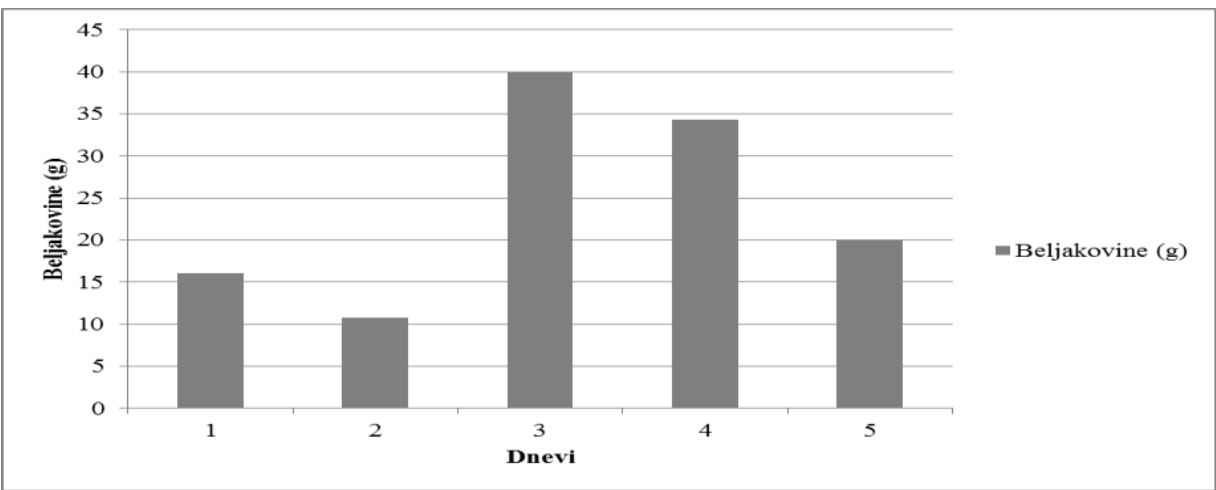

Slika 4: Celodnevni vnos beljakovin, pridobljenih iz mlečnih izdelkov

\section{$5 \quad$ Zaključki}

$\mathrm{V}$ raziskavi smo ocenili posnetek trenutnega stanja prehranjevalnih navad in prehranskega vnosa mleka in mlečnih izdelkov, ki ga dnevno zaužijejo uporabniki v socialno varstvenem zavodu, kjer bivajo osebe $\mathrm{z}$ motnjami v duševnem razvoju.

Rezultati glede povprečne vrednosti vnosa hranil z mlekom in mlečnimi izdelki so pokazali, da so mlečni izdelki na jedilniku prisotni vsakodnevno pri več obrokih, kar ustreza priporočilom smernic o zdravi prehrani. Ugotovili smo, da so uporabniki glede na smernice zdravega prehranjevanja v vzgojno-izobraževalnih ustanovah v povprečju $\mathrm{z}$ mlečnimi izdelki zaužili energijsko nekoliko prebogato hrano. Vnos ogljikovih hidratov z mlečnimi izdelki je bil previsok. Beljakovinski vnos z mlekom in mlečnimi izdelki ni ustrezal priporočenim normativom. Previsoke energijske vrednosti so se kazale predvsem $\mathrm{v}$ dnevih, ko so bili mlečni izdelki vključeni v tri obroke ter ob neupoštevanju normativov porcioniranja. Razlogi za različne vsebnosti hranil so bile tudi želje uporabnikov po količini hrane, na katero pa lahko zaposleni v določeni meri lahko vplivajo.

Primeren način zagotavljanja ustrezne količine hranil je upoštevanje smernic zdravega prehranjevanja ter upoštevanje porcioniranja hrane, ki pride iz centralne kuhinje zavoda. Pripravljeni jedilniki so glede na naše raziskave o vnosu hranil z mlekom in mlečnimi izdelki skladni z aktualnimi priporočili o vnosu mleka in mlečnih izdelkov. Ob neupoštevanju smernic pride do neuravnoteženih obrokov, kar lahko v primeru prevelike količine porcij vodi $\mathrm{v}$ debelost, $\mathrm{v}$ primeru premajhne količine pa $\mathrm{v}$ podhranjenost ter pomanjkanje mikro in makrohranil za delovanje osnovnih življenjskih funkcij (Mikuš in Poljšak, 2011). Zaradi različnosti oseb, ki bivajo v socialno-varstvenih zavodih, dobljenih rezultatov glede vnosa hranil s pomočjo mleka in mlečnih izdelkov ni mogoče posploševati. Ugotovitve se nanašajo le na manjšo populacijo oseb $\mathrm{z}$ motnjami $\mathrm{v}$ duševnem razvoju, ki so sodelovale v raziskavi. Omeniti je treba, da raziskava ne daje celotne slike o vnosu mleka in mlečnih izdelkov, saj smo meritve izvajali le pet dni. Za ugotovitev dejanskega stanja vnosa mleka in mlečnih izdelkov bi bile potrebne dalj časa 

ORGANIZACIJA (22. - 24. MAREC 2017, PORTOROŽ, SLOVENIJA)

S. Ketiš, C. Hlastan Ribič, U. Rozman \& S. Šostar Turk : Zdrava prehrana v socialno varstvenem zavodu

trajajoče meritve, saj bi le tako lahko podali splošno oceno o celodnevnem vnosu mleka in mlečnih izdelkov.

Energijske potrebe starejših oseb so nižje kakor energijske potrebe mlajših. Poudariti velja, da kljub nižjim energijskim potrebam starejših oseb ostajajo potrebe po hranilih, vitaminih in mineralih enake kot pri mlajših osebah (Bernstein in Luggen 2010). Ker število starejših oseb v zavodu narašča, menimo, da bi bilo treba jedilnike nekoliko prirediti. Predlagamo, da se jedilniki v zavodu načrtujejo na podlagi referenčnih vrednosti za vnos hranil (Referenčne vrednosti za vnos hranil, DACH, 2004). Referenčne vrednosti glede vnosa hranil predstavljajo povprečne vrednosti o energijskem in hranilnem vnosu v vseh starostnih obdobjih, zato menimo, da so boljša podlaga za načrtovanje jedilnikov kakor smernice zdravega prehranjevanja za vzgojno-izobraževalne ustanove, saj slednje ustrezajo le ožjemu starostnemu obdobju.

\section{Literatura}

Artnik, B. in drugi. (2012). Zdravje in vedenjski slog prebivalcev Slovenije. Trendi v raziskavah CINDI 2001-2004-2008. Ljubljana: IVZ Republike Slovenije.

Bernstein, M., \& Schmidt Luggen, A. (2010). Nutrition for the older adult. Sudbury Massachusetts: Jones and Bartlett publishers.

Gabrijelčič Blenkuš, M., Gregorič, M., Tivadar, B., Koch, V., Kostanjevec, S., Fajdiga Turk, V., Žalar, A., Lavtar, D., Kuhar, D., \& Rozman, U. (2009). Prehrambene navade odraslih prebivalcev Slovenije z vidika varovanja zdravja. Ljubljana: Pedagoška fakulteta, Univerza v Ljubljani.

Gabrijelčič Blenkuš, M., Pograjac, L., Gregorič, M., Adamič, M., \& Čompa, A. (2005). Smernice zdravega prehranjevanja v vzgojno-izobraževalnih ustanovah (od prvega leta starosti naprej). Ljubljana: RS Ministrstvo za zdravje.

Gavin, ML., Dowahen, SA., \& Izenberg, N. (2007). Otrok v formi: praktični vodnik za vzgojo zdravih otrok-od rojstva do najstniških let. Ljubljana: Mladinska knjiga.

Herlič, M., Jevremov, K. Komerički, J. (2009). Prehrana in dietetika. Maribor: IC Piramida, Višja strokovna šola.

Guisse, C. (2002). Microbiology in food and animal feeding stuffs. ISO Bulletien March 2002, str. $17-19$

Hlastan Ribič, C. in drugi. (2008a). Smernice zdravega prehranjevanja za študente z jedilniki. Ljubljana: CINDI Slovenija.

Hlastan Ribič, C. in drugi. (2008b). Praktikum jedilnikov zdravega prehranjevanja v vzgojnoizobraževalnih ustanovah. Ljubljana: Ministrstvo za zdravje in Zavod RS za šolstvo.

Hlastan Ribič, C. (2009). Uvod v prehrano (učbenik za študente medicine in stomatologije). IVZ RS. Univerza v Ljubljani, MF, Katedra za javno zdravje. Dostopno na http://www.mf.uni1j.si/dokumenti/0c25dbf8ab6ae9111bd98430c04328f2.pdf

Hlastan Ribič, C. (2010). Zdrava prehrana in javno zdravje. Ljubljana: MF

Kersting, M., Alexy, U., \& Rothmund, M. (2003). Fakten zur Kinderernahrung 1. Izdaja. Muenchen: Marseille H.

King, DE., Mainous, AG., Lambourne, CA. (2012). Trends in dietary fiber intake in the United States, 1999-2008. J. Acad. Nutr. Diet. Vol. 112, No. 5, str. 642-648.

Klun, N. \& Šedlbauer, M. (2003). Mikrobiološka kakovost živil in standardi. Ljubljana: Biotehniška fakulteta. 
$36^{\text {Th }}$ International Conference on Organizational Science Development: RESPONSIBLE ORGANIZATION (MARCH $22^{\mathrm{ND}}-24^{\mathrm{TH}}$, PORTOROŽ SLOVENIA)

S. Ketiš, C. Hlastan Ribič, U. Rozman \& S. Šostar Turk : Healthy Nutrition in Residential Care Institution

Koch, V. (1997). Prehrambene navade odraslih prebivalcev Slovenije z vidika varovanja zdravja. Doktorska disertacija. Ljubljana: Biotehniška fakulteta Univerze v Ljubljani.

Kvas, M. (2013). Prehranjevalne navade mladih. Diplomsko delo. FZV, UM. Dostopno na http://dkum.uni-mb.si/IzpisGradiva.php?id=40232

MacDonald, D. J. (2001). HACCP: Reviewing. International food Hygiene, Vol. 12, str. 6-9.

Mikuš, R.P., Poljšak, B. (2011). Zdrava prehrana kot temelj zdravja starejših. Posvetovanje: Aktivno in zdravo staranje.

Ministrstvo za zdravje. (2005). Smernice zdravega prehranjevanja v vzgojno-izobraževalnih ustanovah (od prvega leta starosti naprej). Dostopno na http://www.mz.gov.si/fileadmin/mz.gov.si/pageuploads/javno_zdravje_09/Smernice_zdraveg a_prehranjevanja.pdf

Mrzlikar, H. (1997). Prehrana zdravega in bolnega otroka. Ljubljana: Kmečki glas.

OPKP 2010 (Odprta platforma za klinično prehrano) Dostopno na

http://www.opkp.si/sl_SI/cms/pomoc/pomoc-pri-delu-z-opkp/makrohranila,

Peckenpaugh, NJ. (2007). Nutrition essentials and diet therapy. State University of New York College at Colorado: Edinburgh : Elsevier Saunders.

Pokorn, D. (2004). Dietna prehrana bolnika. Ljubljana: Založba Marbona.

Pokorn, D. (2001). Oris zdrave prehrane: Priporočena prehrana. Ljubljana: IVZ Republike Slovenije.

Požar, J. (2003). Hranoslovje zdrava prehrana-učbenik za predmet Zdrava prehrana in dietetika v 2. letniku srednjih šol za program tehnik zdravstvene nege. Maribor: Obzorja.

Praček, M. (2006). Prosti čas odraslih oseb z zmernimi in težjimi motnjami v duševnem razvoju v domu Škofljica. Diplomsko delo. PEF, UL. Dostopno na https://books.google.si/books/about/Prosti_\%C4\%8Das_odraslih_oseb_z_zmernimi_in.html?i d=7nF6NAAACAAJ\&redir_esc $=y$

Raspor, P. (2004). Mikrobiologija in biotehnologija v proizodnji varnih živil. Ljubljana: Biotehniška fakulteta.

Referenčne vrednosti za vnos hranil (2004). 1. izdaja, Nemško prehransko društvo, Avstrijsko prehransko društvo, Švicarsko društvo za raziskovanje prehrane, Švicarsko združenje za prehrano. Prevedlo in izdalo Ministrstvo za zdravje RS,.

Whitney, E., \& Rolfes Rady, S. (2008). Understanding nutrition, 11th ed. Belmont, CA: Wadsworth Publishing.

World health organization WHO. (2003). Diet, nutrition and the prevention of chronic diseases. Joint WHO/FAO expert consultation. WHO Tehnical Report Sereries no. 916 Geneva.

Zaletel Kragelj, L., Fras, Z., \& Maučec Zakotnik, J., (2004). Tvegana vedenja, povezana z zdravjem in nekatera zdravstvena stanja pri odraslih prebivalcih Slovenije. Ljubljana: CINDI Slovenija.

Zavod za zdravstveno varstvo Celje. O varnosti živil. Dostopno na http://www.zzv-ce.si/o-varnosti$\underline{\text { zivil }}$ 


\title{
Analiza organizacijske kulture v službi nujne medicinske pomoči za področje Gorenjske
}

\author{
TATJANA KITIĆ JAKLIČ, JURE KOVAČ \& KSENIJA TUŠEK BUNC
}

Povzetek Za uspešno doseganje ciljev tako profitnih kot neprofitnih organizacij je učinkovit organizacijski model ključnega pomena. Organizacijski model ima tri pojavne razsežnosti: strukturno, procesno in kulturno, vsaka od teh razsežnosti pa doda pomemben delež za razvoj organizacije. Ker je trenutno v ospredju predvsem potreba po reformi na področju zdravstvenega sektorja, ob tem pa za področje službe nujne medicinske pomoči ( $v$ nadaljevanju NMP) še posebej velja, da $\mathrm{v}$ tem trenutku obstaja izredno aktualna težnja $\mathrm{k}$ poenotenju ter vzpostavitvi sodobne in učinkovite organizacije urgentnih centrov, smo v prispevku prikazali analizo organizacijske kulture v službi NMP. Identifikacija vseh vplivnih dejavnikov na organizacijski model NMP je namreč predpogoj za oblikovanje uspešne in učinkovite mreže NMP.

Opravili smo presečno raziskavo med zaposlenimi v službi NMP v organizacijskih enotah Osnovnega zdravstva Gorenjske (v nadaljevanju $\mathrm{OZG}$ ) in razkrili rezultate, ki so primerljivi z rezultati raziskav s področja preučevanja organizacijske kulture $\mathrm{v}$ zdravstvu, opravljenimi drugod po svetu.

KLJUČNE BESEDE: organizacijska kultura - nujna medicinska pomoč • organizacijski model

\footnotetext{
Naslov AVtorJev: Tatjana Kitić Jaklič, Osnovno zdravstvo Gorenjske, Zdravstveni dom Kranj, Gosposvetska ulica 10, 4000 Kranj, Slovenija, e-pošta: tkitic@gmail.com; dr. Jure Kovač, redni profesor, Univerza v Mariboru, Fakulteta za organizacijske vede, Kidričeva cesta 55a, 4000 Kranj, Slovenija, e-pošta: jure.kovac@fov.uni-mb.si; dr. Ksenija Tušek Bunc, docentka, Univerza v Mariboru, Medicinska fakulteta, Taborska ulica 8, 2000 Maribor, e-pošta: ksenija.tusekbunc@guest.arnes.si
} 
$36^{\text {TH }}$ InTERnAtional CONFERENCE ON ORganizational SCIENCE Development: Responsible Organization (MARCH $22^{\mathrm{ND}}-24^{\mathrm{TH}}$, PORTOROŽ SLOVENIA)

O. Arsenijević, M. Ferjan, I. Podbregar, P. Šprajc, D. Trivan \& Y.

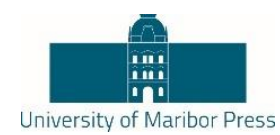

Ziegler

\title{
Analysis of Organizational Culture in the Emergency Medical Services of the Gorenjska Region
}

\author{
TATJANA KitiĆ JAKLiČ, JuRE KovaČ \& KSENiJA TuŠEK BunC
}

\begin{abstract}
An organizational model is a key factor in the successful achievement of the objectives of both profit and non-profit organizations. An organizational model has three manifest dimensions: structural, procedural and cultural - each of which plays an important role in the development of the organization as a whole. Given that the need for health sector reform is now in the forefront and that a very strong current trend towards the unification and establishment of a modern, efficient and stable organization of emergency centres is particularly relevant to the field of Emergency Medical Services (hereinafter, EMS), we depict an analysis of the organizational culture of EMS. Identifying all contributing factors to the EMS organizational model is a prerequisite to formulating a successful and efficient EMS network.
\end{abstract}

In carrying out this study, we conducted a cross-sectional research survey among EMS staff employed at the organizational units of the Primary Health Care Services of Gorenjska, (hereinafter, OZG), revealing results that are comparable to the results of studies on the organizational culture of the health care sector conducted elsewhere in the world.

KEYWORDS: organizational culture - emergency medical service • organizational model

CORRESPONDENCE AdDRESS: Tatjana Kitić Jaklič, Basic health Gorenjska, Kranj Health Centre, Gosposvetska ulica 10, 4000 Kranj, Slovenia, e-mail: tkitic@gmail.com; Jure Kovač, Ph.D., Full Professor, University of Maribor, Faculty of Organizational Sciences, Kidričeva cesta 55a, 4000 Kranj, Slovenia, e-mail: jure.kovac@fov.uni-mb.si; Ksenija Tušek Bunc, Ph.D., Assistant Professor, University of Maribor, Faculty of Medicine, Taborska ulica 8, 2000 Maribor, Slovenia, e-mail: ksenija.tusek-bunc@guest.arnes.si 
T. Kitić Jaklič, J. Kovač \& K. Tušek Bunc: Analiza organizacijske kulture v službi nujne medicinske pomoči za področje Gorenjske

\section{$1 \quad$ Uvod}

Demografske spremembe, neverjetno hiter tehnološki razvoj, vse večje zahteve uporabnikov zdravstvenih storitev in naraščajoči stroški zdravstva ob prisotni globalni gospodarski krizi so tisti neugodni trendi zunanjega okolja, zaradi katerih so zdravstveni sistemi po vsem svetu pred velikimi izzivi (Walshe in Smith, 2011, str. 3). Glavno vodilo pri opravljanju zdravstvene dejavnosti še vedno ostaja zagotavljanje kakovostnih zdravstvenih storitev uporabnikom, zagotavljanje varnosti uporabnikov in zaposlenih, ter racionalna uporaba obstoječih resursov. Pri tem pa velja, da je eden od pristopov za spremljanje in nadzor delovanja zdravstvenih zavodov in organizacij, merjenje njihove učinkovitosti in uspešnosti (Veillard et al., 2005; Kuhar et al., 2008).

Zelo pomemben del zdravstvenega varstva predstavlja služba nujne medicinske pomoči (v nadaljevanju NMP). To je javna služba, ki opravlja medicinsko oskrbo nenadno obolelih ali poškodovanih oseb, ter je sestavni del mreže javne zdravstvene službe na primarni (predbolnišnični) in sekundarni ravni zdravstvene dejavnosti. Razlogov za aktualno težnjo po reorganizaciji sistema NMP v Sloveniji je več, a jo je med drugim potrebno razumeti tudi s stališča trenda večanja števila obravnav v tej službi (Cabrera et al., 2000; Fischer et al., 2000; Kitić Jaklič in Kovač, 2015). Sodobno in premišljeno zgrajen sistem NMP, še posebej tisti na primarni ravni, pa je brez dvoma pogoj za boljše izhode zdravljenja in nižje stroške zdravstvene obravnave v nadaljevanju oskrbe na vseh drugih ravneh zdravstvenega varstva.

Za uspešno doseganje ciljev tako profitnih kot neprofitnih organizacij je učinkovit organizacijski model ključnega pomena. Organizacijski model ima tri pojavne razsežnosti: strukturno, procesno in kulturno (Rozman in Kovač, 2012, str. 211). Vsaka od teh razsežnosti doda pomemben delež za razvoj organizacije. V nadaljevanju se bomo osredotočili izključno na dimenzijo razsežnosti organizacijske kulture.

\subsection{Organizacijska kultura}

Organizacijska kultura označuje celovit sistem norm, vrednot, predstav, prepričanj in simbolov, ki določajo način obnašanja in odzivanja zaposlenih na probleme, s katerimi se srečujejo pri svojem vsakodnevnem delu, ter usposablja in motivira ljudi, da so kljub svojim različnostim usmerjeni k doseganju skupnih organizacijskih ciljev (Ivanko, 2002, str. 236; Williams, 2009, str. 102; Rozman in Kovač, 2012, str. 289). Vlogo in pomen organizacijske kulture za organizacijo je kljub vsemu izredno težko razumeti, ker gre za zapleten in večdimenzionalen pojav.

Ob različnih pogojih, v katerih deluje neko podjetje oziroma organizacija, se oblikujejo različne organizacijske kulture. Proces oblikovanja organizacijske kulture je zapleten, njegova naravnanost in obseg spreminjanja pa odvisna od ugotovitev, do katerih pridemo po predhodno opravljenih fazah analize in vrednotenja procesa (Rozman in Kovač, 2012, str. 298-305). Ob ugotovljeni usklajenosti med strategijo organizacije in organizacijsko kulturo so naše aktivnosti usmerjene na zagotavljanje ohranjanja in nadaljnji graditvi 
$36^{\mathrm{TH}}$ International Conference on ORganizational Science Development: RESPONSIBLE ORGANIZATION (MARCH $22^{\mathrm{ND}}-24^{\mathrm{TH}}$, PORTOROŽ SLOVENIA)

T. Kitić Jaklič, J. Kovač \& K. Tušek Bunc: Analysis of Organizational Culture in the Emergency Medical Services of the Gorenjska Region

obstoječe kulture, ob ugotovljeni medsebojni neskladnosti strategije in organizacijske kulture pa moramo naše aktivnosti usmeriti v preoblikovanje slednje.

V prispevku bomo prikazali analizo organizacijske kulture v službi NMP za področje gorenjske regije. Na tej osnovi bo opravljena študija predstavljala izhodišče za svetovanje v procesu spreminjanja organizacijskega modela za to službo.

\section{$2 \quad$ Metodologija raziskave}

\subsection{Instrument}

Raziskavo smo opravili s pomočjo anonimnega vprašalnika zaprtega tipa, ki je obsegal več delov in skupno 82 vprašanj. Za ocenjevanje organizacijske kulture je bil uporabljen vprašalnik po predlogi standardiziranega vprašalnika OCAI (ang. Organizational Cultural Assessment Instrument) - merilnega instrumenta za ocenjevanje organizacijske kulture avtorjev Camerona in Quinna, ki smo ga le nekoliko vsebinsko prilagodili za uporabo v okolju službe NMP (Cameron in Quinn, 2006, str. 20-25). Po pregledu različnih merilnih instrumentov se je OCAI vprašalnik namreč izkazal za uporabnejšega, gledano iz perspektive naše raziskave, pri čemer velja pripomniti, da idealnega merilnega inštrumenta pravzaprav nimamo na voljo (Bellot, 2011). Uporabili smo sistem točkovanja, z vrednostno lestvico od 1 do 10.

OCAI temelji na teoretičnem modelu konkurenčnih vrednot - CVF (ang. Competing Values Framework). Razvrstitev v ustrezen tip organizacijske kulture je odvisna od stopnje izraženosti za posamezen skupek vrednot po dveh dimenzijah, in sicer dimenziji prilagodljivosti in diskretnosti / stabilnosti in kontrole (grafično prikazana na osi $\mathrm{x}$ ), ter dimenziji intovertiranosti in integracije /ekstrovertiranosti in diferenciacije (grafično prikazano na osi y). Tip kulture se nato določi z raziskovanjem prisotnosti šestih dimenzij (prevladujoče značilnosti organizacije, vodenje v organizaciji, upravljanje s človeškimi viri, povezanost udeležencev $\mathrm{v}$ celoto, strateške opredelitve organizacije in kriterij uspeha), ki se jih dodatno še natančneje opredeli na podlagi vsake od štirih trditev za določen tip kulture (Cameron in Quinn, 2006, str. 151; Zachariadou et al., 2013). Organizacijsko kulturo s tem uporabljenim merilnim instrumentom tako lahko razvrstimo $\mathrm{v}$ enega od štirih tipov organizacijskih kultur: kultura klana, adhokratična kultura, kultura hierarhije in kulture trga (slika 1). 
T. Kitić Jaklič, J. Kovač \& K. Tušek Bunc: Analiza organizacijske kulture v službi nujne medicinske pomoči za področje Gorenjske

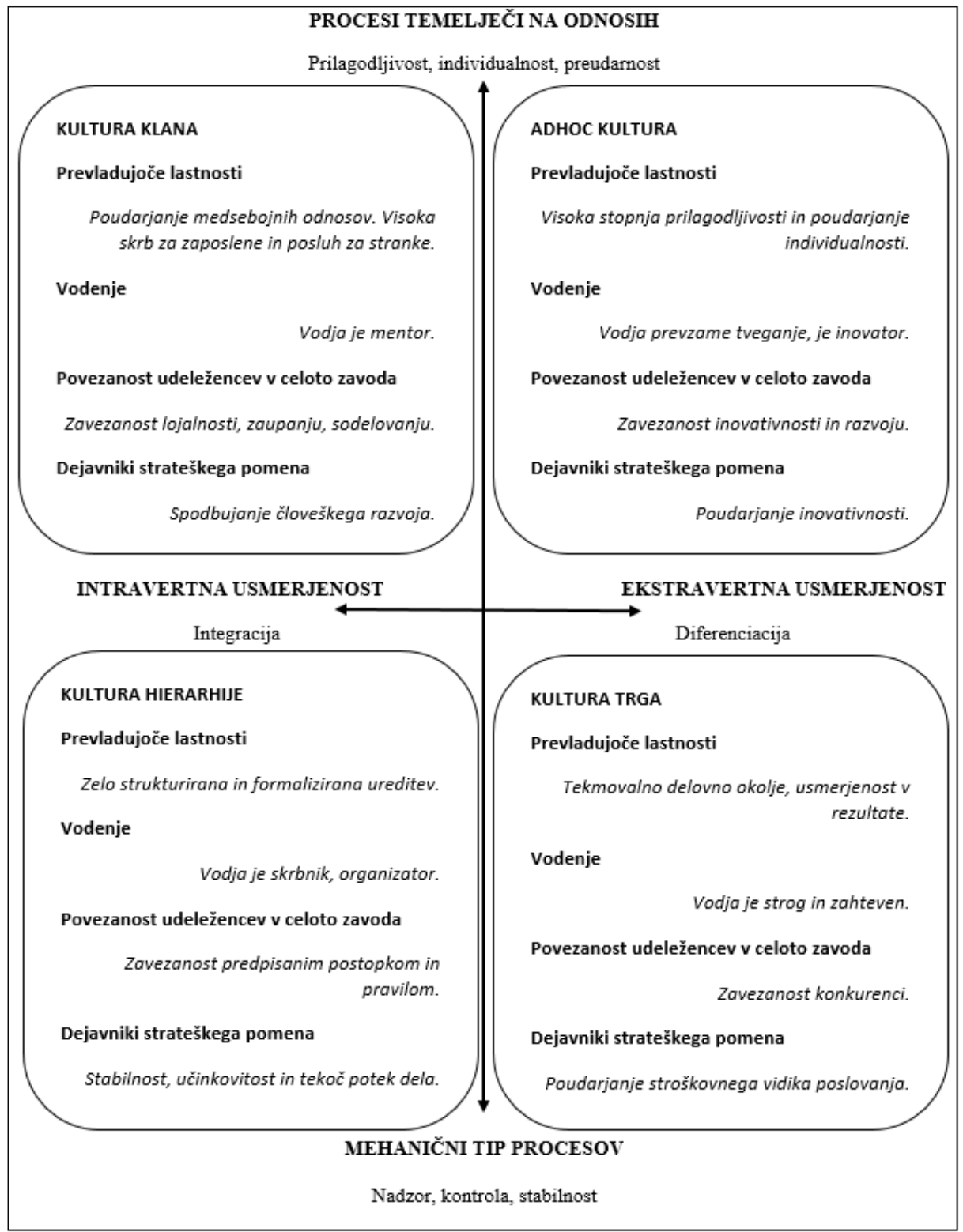

Slika 1. Model konkurenčnih vrednot/CVF model (povzeto po Cameron in Quinn, 2006 in Jacobs et al., 2013) 
$36^{\text {TH }}$ International Conference on Organizational Science Development: RESPONSIBLE ORGANIZATION (MARCH $22^{\mathrm{ND}}-24^{\mathrm{TH}}$, PORTOROŽ SLOVENIA)

T. Kitić Jaklič, J. Kovač \& K. Tušek Bunc: Analysis of Organizational Culture in the Emergency Medical Services of the Gorenjska Region

\subsection{Udeleženci}

Vprašalniki so bili posredovani službi NMP vseh organizacijskih enot Osnovnega zdravstva Gorenjske (v nadaljevanju OZG) in tam razdeljeni med zaposlene v tej službi. Število posredovanih vprašalnikov za zaposlene je bilo odvisno od njihovega števila $\mathrm{v}$ posamezni enoti, pri tem smo upoštevali število zaposlenih za leto 2014 (podatek na zadnji dan leta, to je 31.12.2014; posredovala ga je kadrovska služba OZG). Skupno število zaposlenih v službi NMP je bilo 114. Za ZD Radovljica in ZD Bohinj velja, da nimajo zaposlenih izključno $\mathrm{v}$ tej službi, zato so $\mathrm{v}$ opravljanje službe NMP razporejeni zaposleni iz drugih delovišč (se torej izvaja ob njihovem rednem delu oziroma v obliki dežurstva).

Anketiranci so izpolnjene vprašalnike vračali $\mathrm{v}$ za ta namen postavljene kartonaste skrinjice, da smo lahko zagotovili anonimnost. Na skrinjicah je bila napisana tudi povezava do spletne ankete, a so se nanjo odzvali le redki posamezniki in je bilo njihovo število zanemarljivo. Presečna raziskava je tekla v času od 1.1.2016 do 31.3.2016.

\subsection{Statistična analiza}

Podatke smo urejali v programu Microsoft Excel. Uporabljena je bila osnovna deskriptivna statistična analiza. S pomočjo statističnega računalniškega programa SPSS smo za ugotavljanje razlik med preučevanimi spremenljivkami uporabili multivariatno analizo, in sicer statistični metodi $t$ test in analizo variance ANOVA ter post hoc multiple primerjave.

\section{$3 \quad$ Rezultati}

\subsection{Opis vzorca}

Med zaposlenimi, ki so sodelovali v raziskavi, je bilo $63 \%$ žensk in $37 \%$ moških. $45,8 \%$ zaposlenih je bilo starih od 31 do 40 let, $29 \%$ od 21 do 30 let, $20,8 \%$ je bilo starih od 41 do 50 let in $4,2 \%$ je tistih, ki so bili stari od 51 do 60 let. 37,5\% zaposlenih je imelo dokončano visoko šolo, $29 \%$ srednjo šolo ter $33,3 \%$ zaposlenih univerzitetno izobrazbo. Med anketiranimi je bilo največ medicinskih sester (37,5\%), sledijo jim dežurni zdravniki (33,3 \%) in reševalci ( $25 \%$ ), le $4,2 \%$ zaposlenih je bilo urgentnih zdravnikov. $37,5 \%$ zaposlenih je imelo 10 do 20 let delovne dobe, 33,3\% je imelo 5 do 10 let delovne dobe, $12,5 \%$ zaposlenih je imelo manj kot 5 let delovne dobe, le po 8,3\% zaposlenih pa 21 do 30 let oziroma 31 do 40 let delovne dobe. Večina udeležencev je bilo zaposlenih v ZD Kranj (71 \%), po 8 \% udeležencev v ZD Škofja Loka in ZD Bohinj, 13 \% udeležencev pa v ZD Radovljica.

\subsection{Analiza organizacijske kulture v službi nujne medicinske pomoči}

Organizacijsko kulturo smo s tem uporabljenim merilnim instrumentom tako razvrstili v enega od naslednjih štirih tipov organizacijskih kultur: kultura klana, adhokratična 
T. Kitić Jaklič, J. Kovač \& K. Tušek Bunc: Analiza organizacijske kulture v službi nujne medicinske pomoči za področje Gorenjske

kultura, kultura hierarhije in kulture trga. Posamezne značilnosti naštetih tipov so prikazane $\mathrm{v}$ sliki 1 .

Seštevek povprečnih vrednosti za trenutno in želeno stanje posamezne kulture so prikazane $\mathrm{v}$ tabeli 1 in grafično na sliki 2. Zaposleni v službi NMP so trenutno kulturo zaznali predvsem kot kulturo klana in kulturo hierarhije. Kultura hierarhije sicer ima rahlo višjo povprečno vrednost kot kultura klana, vendar rezultati $t$ testa za odvisne vzorce kažejo na to, da med njimi ni statistično značilnih razlik [t(23) = -,712; $\mathrm{p}=, 484]$. Kot najbolj zaželena izstopa kultura klana, katere povprečna vrednost je precej višja od ostalih.

\begin{tabular}{lll}
\hline & $\sum \mathrm{M}$ & \\
\cline { 2 - 3 } & Trenutno & Želeno \\
\hline Kultura klana & 17,3 & 27,3 \\
Adhoc kultura & 10,9 & 10,8 \\
Kultura trga & 12,9 & 8,2 \\
Kultura hierarhije & 18,8 & 13,7 \\
\hline
\end{tabular}

Tabela 1. Organizacijska kultura zaposlenih v službi NMP - seštevek povprečnih vrednosti 
310 36 $6^{\text {TH }}$ International Conference on Organizational Science Development: Responsible Organization (March $22^{\mathrm{ND}}-24^{\mathrm{TH}}$, Portorož Slovenia)

T. Kitić Jaklič, J. Kovač \& K. Tušek Bunc: Analysis of Organizational Culture in the Emergency Medical Services of the Gorenjska Region

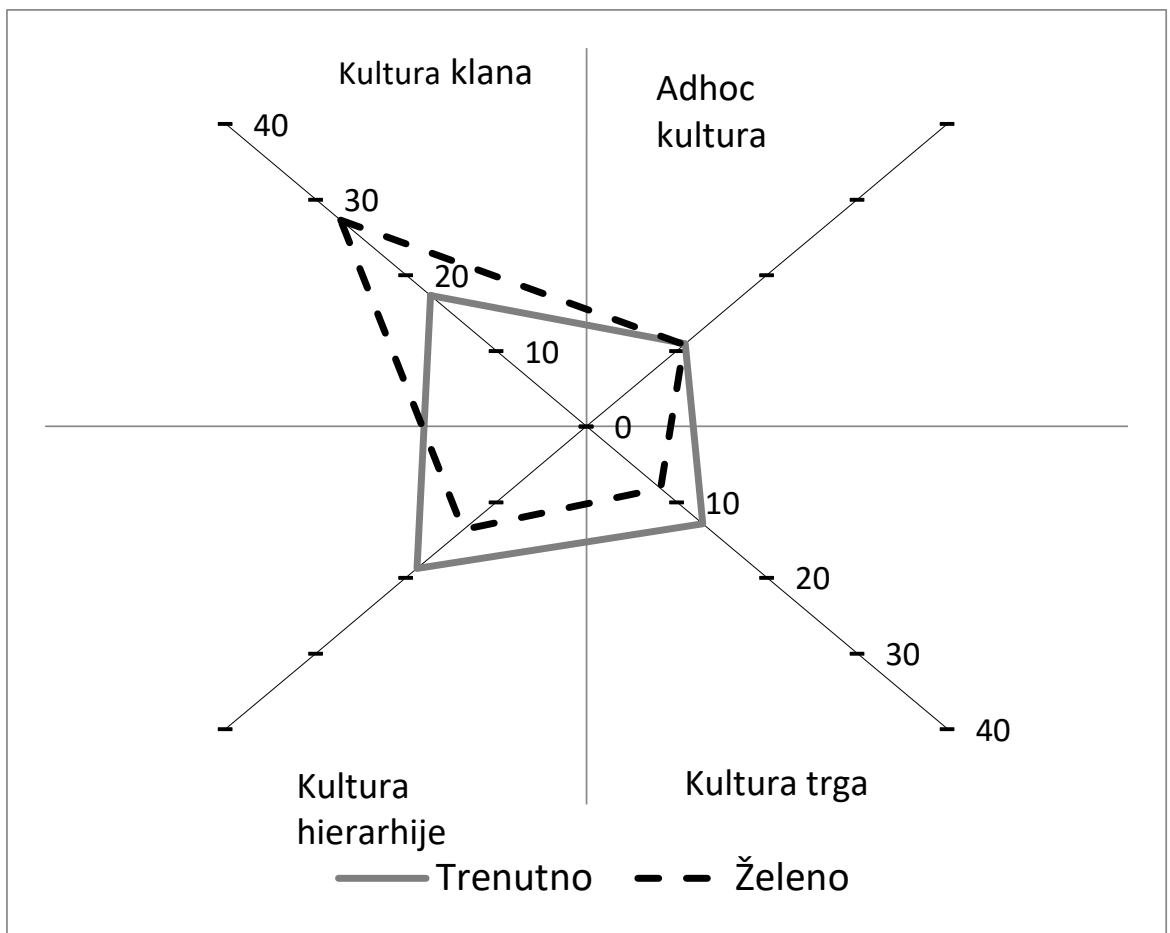

Slika 2. Organizacijska kultura zaposlenih v službi NMP - grafični prikaz

Natančnejši prikaz rezultatov analize organizacijske kulture po posameznih dimenzijah je $v$ tabeli $2 \mathrm{a}$ in $2 \mathrm{~b}$. 
T. Kitić Jaklič, J. Kovač \& K. Tušek Bunc: Analiza organizacijske kulture v službi nujne medicinske pomoči za področje Gorenjske

\begin{tabular}{|c|c|c|}
\hline \multirow{2}{*}{$\begin{array}{l}\text { PREVLADUJOČE } \\
\text { LASTNOSTI }\end{array}$} & \multicolumn{2}{|l|}{$\mathrm{M}$} \\
\hline & Trenutno & Želeno \\
\hline Kultura klana & 3,2 & 4,3 \\
\hline Adhoc kultura & 1,9 & 1,7 \\
\hline Kultura trga & 1,9 & 1,9 \\
\hline Kultura hierarhije & 3,1 & 2,0 \\
\hline \multirow[t]{2}{*}{ VODENJE } & \multicolumn{2}{|l|}{$\mathrm{M}$} \\
\hline & Trenutno & Želeno \\
\hline Kultura klana & 3,0 & 4,2 \\
\hline Adhoc kultura & 1,8 & 1,4 \\
\hline Kultura trga & 2,5 & 1,1 \\
\hline Kultura hierarhije & 2,4 & 3,2 \\
\hline \multirow[t]{2}{*}{ STIL VODENJA } & \multicolumn{2}{|l|}{$\mathrm{M}$} \\
\hline & Trenutno & Želeno \\
\hline Kultura klana & 3,0 & 5,0 \\
\hline Adhoc kultura & 2,0 & 1,6 \\
\hline Kultura trga & 2,2 & 1,3 \\
\hline Kultura hierarhije & 2,8 & 2,0 \\
\hline
\end{tabular}

Tabela 2a. Organizacijska kultura zaposlenih v službi NMP - po posameznih lastnostih (prevladujoče lastnosti, vodenje in stil vodenja) 
$36^{\mathrm{TH}}$ International Conference on Organizational Science Development: Responsible Organization (MARCh $22^{\mathrm{ND}}-24^{\mathrm{TH}}$, Portorož Slovenia)

T. Kitić Jaklič, J. Kovač \& K. Tušek Bunc: Analysis of Organizational Culture in the Emergency Medical Services of the Gorenjska Region

\begin{tabular}{|c|c|c|}
\hline \multirow{2}{*}{$\begin{array}{l}\text { POVEZANOST V } \\
\text { CELOTO }\end{array}$} & \multicolumn{2}{|l|}{$\mathrm{M}$} \\
\hline & Trenutno & Želeno \\
\hline Kultura klana & 2,7 & 4,7 \\
\hline Adhoc kultura & 1,7 & 1,7 \\
\hline Kultura trga & 2,4 & 1,2 \\
\hline Kultura hierarhije & 3,3 & 2,4 \\
\hline \multirow{2}{*}{$\begin{array}{l}\text { STRATEŠKE } \\
\text { USMERITVE }\end{array}$} & \multicolumn{2}{|l|}{$\mathrm{M}$} \\
\hline & Trenutno & Želeno \\
\hline Kultura klana & 2,5 & 4,6 \\
\hline Adhoc kultura & 1,8 & 2,3 \\
\hline Kultura trga & 1,7 & 1,2 \\
\hline Kultura hierarhije & 4,1 & 2,0 \\
\hline \multirow[t]{2}{*}{ KRITERIJ USPEHA } & \multicolumn{2}{|l|}{$\mathrm{M}$} \\
\hline & Trenutno & Želeno \\
\hline Kultura klana & 2,8 & 4,5 \\
\hline Adhoc kultura & 1,8 & 2,2 \\
\hline Kultura trga & 2,3 & 1,5 \\
\hline Kultura hierarhije & 3,1 & 2,0 \\
\hline
\end{tabular}

Tabela 2b. Organizacijska kultura zaposlenih v službi NMP - po posameznih lastnostih (povezanost v celoto, strateške usmeritve, kriterij uspeha) 
T. Kitić Jaklič, J. Kovač \& K. Tušek Bunc: Analiza organizacijske kulture v službi nujne medicinske pomoči za področje Gorenjske

S pomočjo analize variance (ANOVA) smo preverjali, kako so starost, poklicni profil in delovna doba udeležencev vplivali na zaznavo trenutnega in želenega stanja organizacijske kulture. Iz tabele 3 je razvidno, da je starost statistično pomembno vplivala le na zaznavo trenutnega stanja pri kulturi hierarhije. Glede na to da je bila testna vrednost statistično pomembna, smo izvedli tudi post-hoc teste za primerjavo med starostnima skupinama (tabela 4), ki so razkrili, da je najmlajša skupina udeležencev (21 do 30 let) trenutno stanje kulture hierarhije zaznavala $\mathrm{v}$ manjši meri kot skupina udeležencev starosti od 31 do 40 let. Ostale razlike med skupinami niso bile statistično pomembne.

\begin{tabular}{lccccc}
\hline & SS & df & MS & $F$ & $P$ \\
\hline klan_trenutno & 144,443 & 2 & 72,222 & 2,350 & 0,121 \\
klan_želeno & 24,003 & 2 & 12,001 & 0,600 & 0,558 \\
adhoc_trenutno & 4,406 & 2 & 2,203 & 0,421 & 0,662 \\
adhoc_želeno & 1,154 & 2 & 0,577 & 0,091 & 0,913 \\
trga_trenutno & 3,042 & 2 & 1,521 & 0,060 & 0,942 \\
trga_želeno & 1,674 & 2 & 0,837 & 0,093 & 0,912 \\
hierarhija_trenutno & 180,433 & 2 & 90,216 & 4,436 & $0,025^{*}$ \\
hierarhija_želeno & 71,193 & 2 & 35,597 & 1,557 & 0,235 \\
\hline
\end{tabular}

*p vrednost je statistično pomembna na ravni $p<, 05$.

Tabela 3. Rezultati analize variance - vpliv starosti na zaznavanje organizacijske kulture (legenda:

\begin{tabular}{cccccc}
\hline & (I) Starost & (II) Starost & M razlike & SE & P \\
\hline hierarhija_trenutno 21 do 30 let & 31 do 40 let & $-6,311$ & 2,18051 & $0,03^{*}$ \\
& & 41 do 50 let & $-5,457$ & 2,64073 & 0,144 \\
\cline { 2 - 5 } 31 do 40 let & 41 do 50 let & 0,854 & 2,43246 & 0,94 \\
\hline
\end{tabular}

*p vrednost je statistično pomembna na ravni $\mathrm{p}<, 05$.

Tabela 4. Rezultati post hoc testov - vpliv starosti na zaznavanje organizacijske kulture

Naslednja analiza se nanaša na preverjanje vpliva delovnega mesta na zaznavo organizacijske kulture (tabela 5). Rezultati analize variance so pokazali, da je med delovnimi mesti prihajalo do statistično pomembnih razlik $\mathrm{v}$ zaznavi organizacijske kulture na področjih adhokratične kulture (želeno stanje) in kulture hierarhije (želeno stanje). Za dodatne primerjave smo izvedli tudi post-hoc teste (tabela 6), ki so pokazali, da so si reševalci v višji meri želeli adhokratično kulturo $\mathrm{v}$ primerjavi z dežurnimi zdravniki in da so si dežurni zdravniki v višji meri želeli hierarhično kulturo v primerjavi $\mathrm{v}$ medicinskimi sestrami. 
$36^{\text {Th }}$ International Conference on Organizational Science Development: Responsible Organization (March $22^{\mathrm{ND}}-24^{\mathrm{TH}}$, Portorož Slovenia)

T. Kitić Jaklič, J. Kovač \& K. Tušek Bunc: Analysis of Organizational Culture in the Emergency Medical Services of the Gorenjska Region

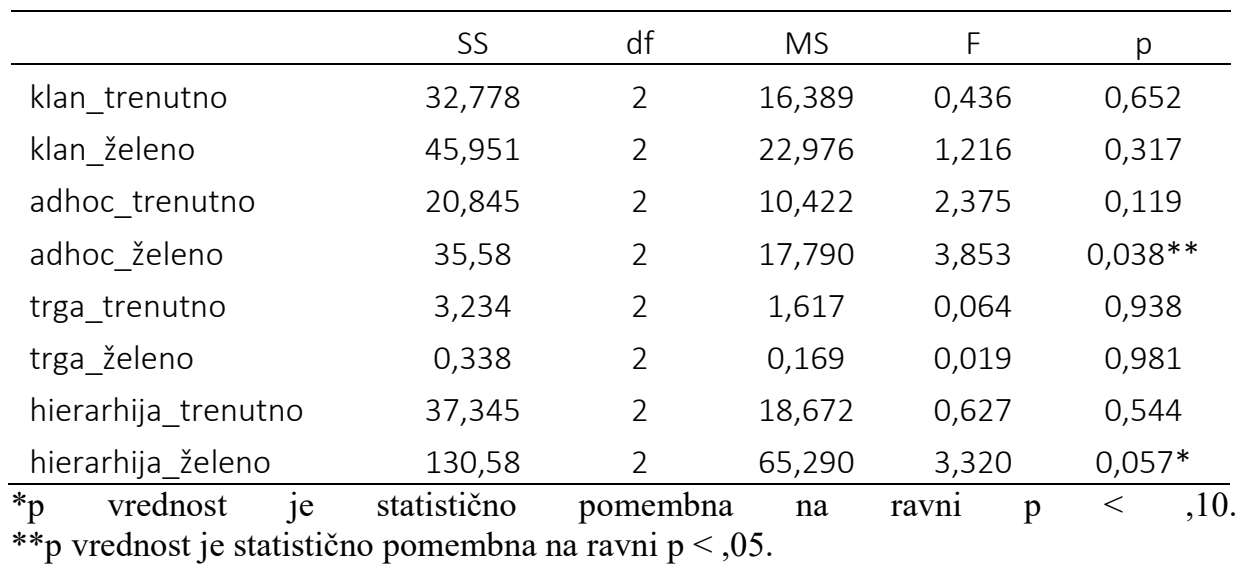

Tabela 5. Rezultati analize variance - vpliv delovnega mesta na zaznavanje organizacijske kulture

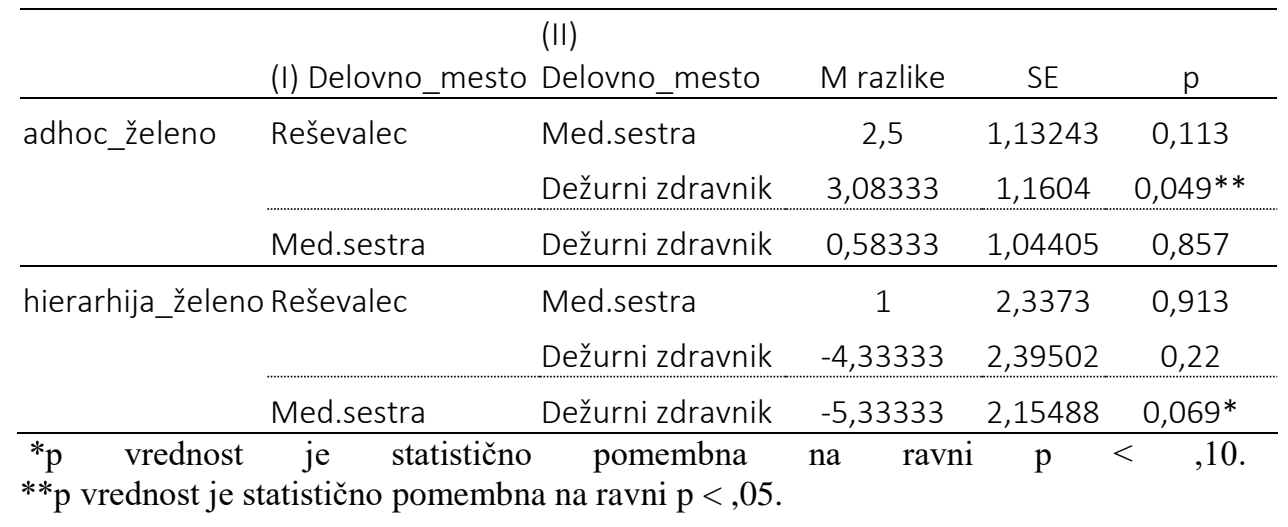

Tabela 6. Rezultati post hoc testov - vpliv delovnega mesta na zaznavanje organizacijske kulture

Pri tem dolžina delovne dobe zaposlenih v službi NMP ni vplivala statistično pomembno na zaznavanje organizacijske kulture (tabela 7). 
T. Kitić Jaklič, J. Kovač \& K. Tušek Bunc: Analiza organizacijske kulture v službi nujne medicinske pomoči za področje Gorenjske

\begin{tabular}{lccccc}
\hline & SS & $\mathrm{df}$ & $\mathrm{MS}$ & $\mathrm{F}$ & $\mathrm{P}$ \\
\hline klan_trenutno & 154,417 & 4 & 38,604 & 1,084 & 0,392 \\
klan_želeno & 65,778 & 4 & 16,444 & 0,838 & 0,518 \\
adhoc_trenutno & 4,278 & 4 & 1,069 & 0,193 & 0,939 \\
adhoc_želeno & 23,583 & 4 & 5,896 & 1,073 & 0,397 \\
trga_trenutno & 34,861 & 4 & 8,715 & 0,350 & 0,841 \\
trga_želeno & 10,569 & 4 & 2,642 & 0,293 & 0,879 \\
hierarhija_trenutno & 43,292 & 4 & 10,823 & 0,315 & 0,864 \\
hierarhija_želeno & 68,611 & 4 & 17,153 & 0,704 & 0,599 \\
\hline
\end{tabular}

Tabela 7. Rezultati analize variance - vpliv delovne dobe na zaznavanje organizacijske kulture

\section{$4 \quad$ Diskusija}

Analiza je v naši raziskavi razkrila, da zaposleni trenutno kulturo zaznavajo predvsem kot kulturo hierarhije $\left(\sum \mathrm{M}=18,8\right)$, ki je imela le rahlo višjo povprečno vrednost kot kultura klana $\left(\sum \mathrm{M}=17,3\right)$. $\mathrm{S}$ tem so rezultati naše raziskave povsem primerljivi $\mathrm{z}$ ugotovitvami raziskav opravljenih v tujini in v našem prostoru. Skela Savičeva (2006) je denimo za štirinajst slovenskih bolnišnic prikazala rezultate, ki so primerljivi z rezultati naše raziskave, ter prav tako kot vodilno razkrila organizacijsko kulturo hierarhije. V raziskavi, opravljeni na vzorcu 20 splošnih bolnišnic s področja Aten, je bila kot dominantna kultura razkrita kultura hierarhije (47\% anketiranih), sledile pa so ji kultura klana $(23,8 \%)$, kultura trga $(17,3 \%)$ in adhokratična kultura (11,8\%) (Goula et al., 2014). Zanimive podatke je razkrila tudi raziskava organizacijske kulture za področje akutnih bolnišnic v Veliki Britaniji, saj je prikazala spreminjanje organizacijske kulture preko časovnega obdobja 2001/2002 do 2007/2008. In sicer so zaposleni še vedno v večjem deležu zaznavali kulturo kot kulturo klana (53\% v letu 2001/2002 oziroma 39\% v letu 2007/2008), opazen pa je bil največji vzpon kulture hierarhije (4\% oziroma 13\%), kar pripisujejo vzpostavljanju nadzora in uvajanju birokratskih pravil, uveljavljanjem kliničnih smernic, implementacijo protokolov in standardov (Jacobs et al., 2013).

Kot najbolj zaželena je $\mathrm{v}$ naši raziskavi izstopala kultura klana $\left(\sum \mathrm{M}=27,3\right)$, katere povprečna vrednost je bila precej višja od ostalih. Nadalje smo z našo raziskavo ugotovili, da starost statistično pomembno $(\mathrm{p}<0,05)$ vpliva na zaznavo trenutnega stanja pri kulturi hierarhije $(\mathrm{F},=4,436 ; \mathrm{p}=0,025)$, pri čemer najmlajša skupina udeležencev (21 do 30 let) trenutno stanje kulture hierarhije zaznava v manjši meri kot skupina udeležencev starosti od 31 do 40 let. Izkazalo se je tudi, da med delovnimi mesti prihaja do statistično pomembnih razlik $(p<0,10$ oziroma $p<0,05) \quad v$ zaznavi organizacijske kulture na 
$36^{\text {Th }}$ International Conference on Organizational Science Development: Responsible Organization (March $22^{\mathrm{ND}}-24^{\mathrm{TH}}$, Portorož Slovenia)

T. Kitić Jaklič, J. Kovač \& K. Tušek Bunc: Analysis of Organizational Culture in the Emergency Medical Services of the Gorenjska Region

področjih adhokratične kulture želeno stanje $(\mathrm{F}=3,853 ; \mathrm{p}=0,028)$ in kulture hierarhije želeno stanje $(F=3,320 ; p=0,057)$, pri čemer si reševalci v višji meri želijo adhokratično kulturo $\mathrm{v}$ primerjavi z dežurnimi zdravniki in da si dežurni zdravniki v višji meri želijo hierarhično kulturo v primerjavi v medicinskimi sestrami. Pri tem dolžina delovne dobe zaposlenih v službi NMP ni vplivala statistično pomembno na zaznavanje organizacijske kulture. Tudi Skela Savič (2006) je v svoji raziskavi ugotavljala različno zaznavanje organizacijske kulture glede na poklicni profil, saj so zaposleni $\mathrm{v}$ zdravstvu organizacijsko kulturo prepoznavali kot usmerjeno $\mathrm{v}$ kontrolo in stabilnost, medtem ko je bila pri tistih $v$ upravi ta izrazito hierarhična in tržno usmerjena.

\section{$5 \quad$ Zaključek}

V prispevku je prikazana analiza organizacijske kulture za področje službe NMP za eno od slovenskih regij. Zaposleni $\mathrm{v}$ tej službi trenutno kulturo zaznavajo kot kulturo hierarhije, torej zelo strukturirano in formalizirani ureditvi podrejeno organizacijo, $s$ poudarjanjem stabilnosti, stalnosti, učinkovitosti in kontrole. Pri tem velja, da management zdravstvenih organizacij $\mathrm{v}$ slovenskem prostoru pomen pravilnega usmerjanja organizacijske kulture še ne prepoznava kot pomembnega.

Identifikacija vseh vplivnih dejavnikov na organizacijski model NMP je zanesljivo predpogoj za oblikovanje uspešne in učinkovite mreže NMP $\mathrm{v}$ naši državi. Preoblikovanje organizacijskega modela NMP, ki smo mu priča dandanes, pa mora temeljiti na vzdrževanju enake dostopnosti zdravstvenih storitev, ob hkratni implementaciji sistema spremljanja kazalcev kakovosti.

\section{Literatura}

Bellot J. Defining and assessing organizatonal culture. Nursing Forum 2011, 46 (1): 29-37.

Cabrera E, Taboada M, Iglesias ML, Epelde F, Luque E. Optimization of healthcare emergency departments by agent-based simulation. Procedia Comput Sci 2000, 4: 1880-89.

Cameron KS, Quinn RE. Diagnosing and changing organizational culture: Based on the competing values framework. San Francisco: Jossey-Bass, cop.Anon, 2006.

Fischer AJ, O'Halloran P, Littlejohns P, Kennedy A, Butson G. Ambulance economics. J Public Health Med 2000, 22 (3): 413-21.

Gorišek K. Zadovoljstvo zaposlenih - ali vsebina pojma prerašča ime fenomena? [Online] Dostopno na: http://www.delavska-participacija.com [11.8.2016].

Goula A, Kefis B, Stamouli A, Pierrakos G, Sarris M. Investigation of the organizational culture of general public hospitals. Archives of Hellenic Medicine 2014, 31 (4), 452-60.

Ivanko Š. Strukture in procesi v organizaciji. Ljubljana: Visoka upravna šola, Univerza v Ljubljani, 2002.

Jacobs R, Mannion R, Davies HTO, Harrison S, Konteh F, Walshe K. The relationship between organizational culture and performance in acute hospitals. Social Science \& Medicine 2013, 76: $115-125$.

Kitić Jaklič T, Kovač J. The impact of demografic changes on the organization of emergency medical services - The case of Slovenia. Organizacija 2015, 48 (4): 247-59. 
T. Kitić Jaklič, J. Kovač \& K. Tušek Bunc: Analiza organizacijske kulture v službi nujne medicinske pomoči za področje Gorenjske

Körner M, Wirtz MA, Bengel J, Göritz AS. Relationship of organizational culture, teamwork and job satisfaction in interprofessional teams. BMC Health Services Research 2015, 15:243.

Kuhar M, Marušič D, Robida A. Metodologija za merjenje uspešnosti in učinkovitosti delovanja javnih bolnišnic v Sloveniji. Bilt - Ekon Organ Inform Zdrav 2008, 24 (2): 45-53.

Rozman R, Kovač J. Management. Ljubljana: GV Založba, 2012.

Skela Savič B. Organizacijska kultura in uvajanje sprememb v slovenskih bolnišnicah: subkulture in mesto zdravtsvene nege? Obzor Zdr N 2006, 40: 187-196.

Veillard J, Champagne F, Klazinga N, Kazandjian V, Arah OA, Guisset AL. A performance assessment framework for hospitals: the WHO regional office for Europe PATH project. Int J Qual Health Care 2005; 17 (6): 487-96.

Walshe K., Smith J. Healthcare management. Berkshire: Open University Press, 2011.

Williams C. Principles of Management. Mason: South-Western Cengage Learning, 2009.

Zachariadou T, Zannetos A, Pavlakis A. Organizational culture in the primary healthcare setting of Cyprus. BMC Health Services Research 2013, 13:112. 
318 36 $6^{\text {TH }}$ International Conference on Organizational Science Development:

Responsible Organization (MARCH $22^{\mathrm{ND}}-24^{\mathrm{TH}}$, PORTOROŽ SLOVENIA) 


\title{
Vpliv virov informacij na nakupno odločanje mladih $\mathbf{v}$ Sloveniji in ZDA
}

\author{
NATALIJA KLEMENČIČ \& BENO KLEMENČIČ
}

\begin{abstract}
Povzetek V prispevku smo obravnavali vpliv posameznih virov informacij na mlade porabnike pri odločanju o nakupu posameznih skupin izdelkov in storitev. Omejili smo se na populacijo mladih v starosti od 15 do 24 let v Sloveniji in ZDA. Tržni segment mladih je pomemben in zanimiv za industrijo in oglaševalce $\mathrm{v}$ proučevanih državah in nasploh. V empiričnem delu prispevka smo ugotavljali vpliv posameznih virov informacij na nakupno odločanje mladih porabnikov pri izbiri oblačil, vpliv sodobnih spletnih medijev (Facebook, Twitter, Google, Youtube) na nakup posameznih skupin izdelkov in storitev ter primerjali skupini mladih iz Slovenije in ZDA v zaznavanju vpliva posameznega vira informacij na nakup oblačil. Poznavanje nakupnega in informacijskega vedenja je pomembno za podjetja pri oblikovanju marketinških strategij. $\mathrm{Z}$ raziskavo ugotavljamo pomemben vpliv sodobnih spletnih medijev na nakupne odločitve pri izbiri oblačil v obeh državah. Sodobni spletni mediji imajo največji vpliv na nakup TV, avdio in računalniške opreme, oblačil ter izdelkov za osebno nego in zdravje. $\mathrm{Z}$ diskriminantno analizo smo tudi ugotovili, da sta oglasna pošta in izložbe v prodajalnah tista vira, ki najbolj prispevata $\mathrm{k}$ razliki $\mathrm{v}$ zaznavanju vpliva informacijskih virov na nakup oblačil med mladimi v Sloveniji in ZDA.
\end{abstract}

KLJUČNE BESEDE: viri informacij • nakupno odločanje • mladi porabniki • sodobni spletni mediji

\footnotetext{
NAslov AVtoRJEv: Natalija Klemenčič, Ekonomska šola Murska Sobota Višja strokovna šola, Noršinska ulica 13, 9000 Murska Sobota, Slovenija, e-pošta: natklemencic@gmail.com; dr. Beno Klemenčič, ravnatelj, Ekonomska šola Murska Sobota Višja strokovna šola, Noršinska ulica 13, 9000 Murska Sobota, Slovenija, e-pošta: beno.klemencic@gmail.com
} 
36 ${ }^{\text {TH }}$ International Conference on Organizational Science DeVelopment: Responsible Organization (MARCH $22^{\mathrm{ND}}-24^{\mathrm{TH}}$, PORTOROŽ SLOVENIA)

O. Arsenijević, M. Ferjan, I. Podbregar, P. Šprajc, D. Trivan \& Y.

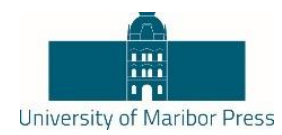

Ziegler

\title{
The Impact of Sources of Information on the Purchasing Decisions of Young People in Slovenia and USA
}

\author{
NATALIJA KLEMENČIČ \& BENO KLEMENČIČ
}

\begin{abstract}
In the article we dealt with the impact of individual sources of information on young consumers when making decisions about purchasing individual groups of products and services. The population was limited to youth aged from 15 to 24 in Slovenia and the USA. The market segment of youth is important and interesting for the industry and advertisers in the studied countries but also in general. In the empiric part of the article we determined the impact of individual sources of information on the decision making of young consumers when purchasing clothes as well as the impact of modern online media (Facebook, Twitter, Google, Youtube) on the purchase of individual groups of products and services and compared the groups of young people from Slovenia and the USA regarding the perception of impact of individual sources of information on the purchase of clothes. Knowing shopping and information behaviour is important for companies for designing the marketing strategy. This research determined an important impact of modern online media on purchasing decisions when choosing clothes in both countries. Modern online media have the biggest impact on purchasing TV, audio and computer equipment as well as clothes and products for personal care and health. The discriminant analysis determined that direct mail and shopping windows are the sources that mostly contribute to the difference in perception of the impact of information sources on the purchase of clothes among young people in Slovenia and the USA.
\end{abstract}

KEYWORDS: information sources $\bullet$ purchasing decision $\bullet$ young consumers

- modern online media

CoRRESPONDENCE AdDRESS: Natalija Klemenčič, School of Economics Murska Sobota Vocational College, Noršinska ulica 13, 9000 Murska Sobota, Slovenia, e-mail: natklemencic@gmail.com; Beno Klemenčič, Ph.D., Headmaster, School of Economics Murska Sobota Vocational College, Noršinska ulica 13, 9000 Murska Sobota, Slovenia, e-mail: beno.klemencic@gmail.com

DOI https://doi.org/10.18690/978-961-286-020-2.28

ISBN 978-961-286-020-2

(C) 2017 University of Maribor Press

Available at: http://press.um.si 


\section{$1 \quad$ Uvod}

Pritiski v sodobnem tržnem okolju so vse večji in zahtevajo od podjetij in tržnikov, ki želijo ohraniti konkurenčno prednost ter dosegati optimalne prodajne rezultate, da poznajo in povsem razumejo porabnike in njihovo nakupno vedenje. $\mathrm{V}$ procesu nakupnega odločanja imajo pomembno vlogo informacije in informacijsko vedenje porabnikov. Iz množice informacij, s katerimi se porabniki vsakodnevno soočamo, bi naj izbrali zase pomembne informacije oziroma spodbude, ki bi nam omogočili izpeljati nakupno odločitev. Informacije so tiste, ki so pomembne za smotrno odločanje in ravnanje. Informacijsko vedenje porabnikov se običajno prične z željo porabnikov po informacijah in obsega celoto aktivnosti, ki služijo pridobivanju, obdelavi, shranjevanju in nadaljnjemu posredovanju želenih informacij. Poznavanje nakupnega in informacijskega vedenja je pomembno za podjetja in tržnike $\mathrm{v}$ prodajni mreži pri oblikovanju trženjskih spletov, za segmentacijo trga, pozicioniranje in oblikovanje marketinških strategij. Rezultati proučevanja informacijskega vedenja porabnikov so uporabni predvsem v marketinški znanosti.

V empiričnem delu prispevka želimo ugotoviti, v kolikšni meri vplivajo posamezni viri informacij na mlade porabnike v starosti od 15 do 24 let v Sloveniji in ZDA pri odločanju o nakupu oblačil ter pri odločanju o nakupu posameznih skupin drugih izdelkov in storitev. Ugotavljamo tudi razlike med mladimi porabniki v obeh proučevanih državah.

Podrobneje smo proučevali mlade v starosti od 15 do 24 let. Po podatkih Združenih narodov je v ZDA mladih v starosti od 15 do 24 let več kot 43 milijonov in predstavljajo pomemben tržni segment (Hoyer in MacInnis 1997, 353; Solomon in Rabolt 2009, 185186; Peter in Olson 2005, 326). Raziskave v svetu kažejo, da so mladi finančno dobro podprti, nerazumno trošijo, kupujejo svojo identiteto in prijateljstvo, so dovzetni za novosti in si veliko upajo (Solomon 2011, 543-544). Poznavanje tržnih potreb potrošnikov in razumevanje svojih kupcev je zelo pomembno za vse, ki so vpleteni v proces proizvodnje in trženjske aktivnosti (Solomon in Rabolt, 2004, 25; Shulz, 2008, 394-399). Informacije, pridobljene $\mathrm{z}$ raziskovanjem porabnikov lahko uporabimo na štirih področjih: marketinški splet, segmentacija, pozicioniranje in diferenciacija ter analiza okolja in raziskovanje marketinga.

\section{$2 \quad$ Nakupno odločanje in viri informacij}

Posamezniki sprejemamo v življenju različne odločitve. Nekatere so bolj pomembne, druge manj. Pri odločanju izbiramo med dvema ali več alternativami. Za porabnika je pomembno, da ima na voljo alternativne možnosti izbire. Če porabnik nima možnosti izbirati med alternativami, je prisiljen kupiti določen izdelek. Proces odločanja ima v raziskovanju vedenja porabnikov pomembno mesto. Obravnavamo ga s posebno pozornostjo, saj je rezultat procesa odločanja prav nakup ali opustitev nakupa izdelka (Klemenčič 1999, 39). Nekateri avtorji delijo proces porabnikovega odločanja v pet faz (Kotler in Armstrong 2012, 177; Solomon in dr. 2013, 314; Solomon 2011, 333; Ferell in Hartline 2011, 155; Schneider 2013, 107). Proces odločanja se začne, ko porabnik 
$36^{\mathrm{TH}}$ International Conference on ORganizational Science Development: RESPONSIBLE ORGANIZATION (MARCH $22^{\mathrm{ND}}-24^{\mathrm{TH}}$, Portorož SLOVENIA)

N. Klemenčič \& B. Klemenčič: The Impact of Sources of Information on the Purchasing Decisions of Young People in Slovenia and USA

zazna razliko med dejanskim in želenim ali idealnim stanjem. Vrzel med dejanskim in želenim stanjem je problem, ki ga porabnik prepozna kot potrebo. Stopnji prepoznavanja potreb sledi zbiranje informacij, ki jih porabnik potrebuje za ugotavljanje in ovrednotenje alternativ. V tej fazi so ključnega pomena zunanji viri informacij. Stopnji zbiranja informacij in ovrednotenja alternativ ter odločitve in nakupa je pogosto težko ločiti. Nakupu sledi ponakupna predelava informacij. Porabniki pri nakupnem odločanju ne gredo nujno skozi vseh teh pet stopenj, ampak lahko katero izmed njih preskočijo ali se premikajo na prejšnjo stopnjo (Kotler 2004, 204).

Za lažje nakupno odločanje uporabljajo porabniki različne razpoložljive vire informacij. Kot vire informacij lahko označimo vse osebe ali objekte, ki nastopajo kot oddajniki, pošiljatelji informacije; na primer prodajalci, družinski člani, prijatelji, oglasi v časopisih, oglasi na televiziji, izložbe v prodajalnah, idr. Porabniki lahko pridobijo informacije iz več virov. Ti zajemajo osebne vire (družina, prijatelji, sosedje, znanci), komercialne vire (oglaševanje, prodajno osebje, prodajo po spletu, embalažo, izložbe), javne vire (masovni mediji, internetne strani, potrošniške informacije, sodobni spletni mediji) in izkušnje porabnikov (Kotler in Armstrong 2012, 178). Za iskanje informacij si več časa vzamejo mlajši, bolj izobraženi posamezniki, ki radi kupujejo in ženske (Solomon in dr. 1999, 217). Mladi aktivno iščejo namige za nakup od njihovih vrstnikov in oglasov. Oglaševanje, orientirano na mlade, je tipično akcijsko usmerjeno in običajno upodablja skupino mladih, ki ta produkt uporabljajo.

Mladi se zavedajo, da modna industrija postavlja meje ponudbe. Manj pa se mladi zavedajo moči in vpliva različnih informacijskih virov, predvsem medijev in interneta, ki vplivajo na njihove odločitve. Porabniki pogosto uporabljajo pri iskanju informacij neformalne oz. socialne vire. Porabniki prejemajo in iščejo informacije o izdelku iz različnih virov: od prodajalcev $\mathrm{v}$ trgovinah, s komunikacijo od ust do ust in iz masovnih medijev (časopisov in revij, televizije, katalogov, idr.) ter v zadnjem času vse bolj z interneta (Blackwell at al., 2001; Peter \& Olson, 2005, 200; Blyte, 2008, 263). Tržniki bodo morali posvečati vse več pozornosti sodobnim spletnim medijem (Facebook, Twitter, Google, Youtube). Zadnje raziskave kažejo, da se vse večji delež porabnikov prvič seznani s kupljenim izdelkom ali storitvijo preko spletnega oglaševanja (Verderber 2016, 32).

\section{$3 \quad$ Raziskava in ugotovitve}

V prispevku želimo odgovoriti na temeljno raziskovalno vprašanje: v kolikšni meri vplivajo posamezni viri informacij (in posebej sodobni spletni mediji) na mlade porabnike v starosti od 15 do 24 let v Sloveniji in ZDA pri odločanju o nakupu oblačil ter posameznih skupin izdelkov in storitev.

V empiričnem delu prispevka želimo doseči naslednje cilje: (1) ugotoviti vpliv posameznih virov informacij na nakupno vedenje mladih porabnikov pri izbiri oblačil; (2) ugotoviti, v kolikšni meri vplivajo spletni mediji (Facebook, Twitter, Google, ...) na nakup posameznih skupin izdelkov in storitev in (3) primerjati skupini mladih iz 
Slovenije in ZDA v zaznavanju vpliva posameznega vira informacij na nakup oblačil. Ugotavljanje pomembnosti vpliva posameznih virov informacij v Sloveniji in ZDA smo ugotavljali s sledečima hipotezama:

Hipoteza 1: Skupini mladih iz Slovenije in ZDA se statistično pomembno ne razlikujeta v percepciji vpliva spletnih medijev (Facebook, Twitter, Google, Youtube) na nakup posameznih skupin izdelkov ali storitev.

Hipoteza 2: Noben posamezni vir informacij ne vpliva diskriminirajoče na oceno skupnega vpliva informacij na nakup oblačil pri mladih v Sloveniji in ZDA.

\subsection{Vzorec in metodologija}

Vzorec kvantitativne raziskave, $\mathrm{N}=303$, predstavljajo dijaki in študentje $\mathrm{v}$ starosti od 15 do 24 let iz Slovenije in ZDA. V kvotni vzorec raziskave je bilo vključenih 161 dijakov in študentov iz Slovenije in 142 dijakov in študentov iz ZDA.

Za anketiranje smo uporabili spletno orodje Fakultete za družbene vede Ljubljana - 1KA. Anketiranje je potekalo v obdobju od 13. 10. 2015 do 16. 12. 2015. V Sloveniji smo za posredovanje anket dijakom in študentom zaprosili predavatelje in vodstva šol ter fakultet. V ZDA so anketo izpolnili mladi iz šol in fakultet $\mathrm{v}$ mestih: Boston (Massachusetts), Austin (Texas), Fort Wayne (Indiana) in Berkeley (California).

Vprašalnik vsebuje 30 vprašanj. Anketirancem je bil posredovan v slovenskem in angleškem jeziku. Osrednji del vprašalnika zajema dve področji: (1) Percepcija vpliva posameznega vira informacij na nakup oblačil in (2) Percepcija vpliva spletnih medijev (Facebook, Twitter, Google, ...) na nakup posameznih skupin izdelkov in storitev.

V osrednjih področjih vsebuje vprašalnik večstopenjsko Likertovo lestvico od 1 do 5 , po kateri anketiranci ovrednotijo percepcijo vpliva vira informacij na nakupno odločitev (kjer pomeni ocena 1 - čisto nič, ocena 5 - povsem) in vpliv spletnih medijev (Facebook, Twitter, Google, ...) na nakup posameznih skupin izdelkov in storitev (kjer pomeni ocena 1 - čisto nič, ocena 5 - povsem). Večstopenjska lestvica je bila uporabljena tudi $\mathrm{v}$ predhodnih raziskavah vedenja porabnikov. Iz analize smo izločili vse anketirance, ki niso odgovorili na 5 ali več vprašanj (upoštevana so tudi vsa podvprašanja).

\section{$4 \quad$ Rezultati raziskave}

Vnos in analitično obdelavo podatkov smo izvedli s pomočjo programske opreme IBM SPSS Statistics 22. Za obdelavo podatkov smo uporabili deskriptivno statistiko, t-test in diskriminantno analizo. V nadaljevanju razlagamo najpomembnejše ugotovitve izvedene raziskave.

V raziskavo smo zajeli 303 mladih iz Slovenije in ZDA v starosti od 15 do 24 let. Prerez anketirancev po državi in spolu prikazuje spodnja tabela. 
$36^{\text {TH }}$ International Conference on Organizational Science Development: RESPONSIBLE ORGANIZATION (MARCH $22^{\mathrm{ND}}-24^{\mathrm{TH}}$, Portorož SLOVENIA)

N. Klemenčič \& B. Klemenčič: The Impact of Sources of Information on the Purchasing

Decisions of Young People in Slovenia and USA

\begin{tabular}{|ll|r|r|r|}
\hline & & \multicolumn{2}{|c|}{ Spol } & \multirow{2}{*}{ Total } \\
\cline { 3 - 4 } & \multicolumn{1}{|c|}{ moški } & \multicolumn{1}{c|}{ ženski } & \multicolumn{1}{c}{161} \\
\hline Država & Slovenija & 54 & 107 & 142 \\
& ZDA & 46 & 96 & 303 \\
\hline
\end{tabular}

\section{Tabela 1: Prerez anketirancev po državi in spolu}

Z raziskavo smo želeli ugotoviti percepcijo vpliva posameznega vira informacij na nakup oblačil. Anketiranci so v anketi ocenjevali vpliv posameznih informacijskih virov na nakup oblačil. Rezultati so prikazani v tabeli 2 .

\begin{tabular}{|c|c|c|c|c|c|c|c|c|}
\hline \multicolumn{2}{|l|}{ Država } & $\begin{array}{l}\text { TV in } \\
\text { radio } \\
\text { oglasi }\end{array}$ & $\begin{array}{c}\text { Revije o } \\
\text { modi in } \\
\text { kataloška } \\
\text { prodaja }\end{array}$ & $\begin{array}{c}\text { Izložbe v } \\
\text { prodajalnah }\end{array}$ & $\begin{array}{c}\text { Oglasna } \\
\text { pošta }\end{array}$ & $\begin{array}{c}\text { Prijatelji } \\
\text { in } \\
\text { znanci }\end{array}$ & $\begin{array}{c}\text { Oglasni } \\
\text { panoji }\end{array}$ & $\begin{array}{c}\text { Facebook, } \\
\text { Twitter, } \\
\text { Google }\end{array}$ \\
\hline \multirow[t]{3}{*}{ Slovenija } & Mean & 2,12 & 2,70 & 3,51 & 2,91 & 3,48 & 2,20 & 3,01 \\
\hline & $\mathrm{N}$ & 161 & 161 & 161 & 161 & 161 & 161 & 161 \\
\hline & $\begin{array}{l}\text { Std. } \\
\text { Deviation }\end{array}$ & 1,029 & 1,239 & 1,152 & 1,282 & 1,119 & 1,113 & 1,292 \\
\hline \multirow[t]{3}{*}{ ZDA } & Mean & 2,12 & 2,65 & 2,53 & 1,88 & 3,68 & 1,81 & 2,52 \\
\hline & $\mathrm{N}$ & 142 & 142 & 142 & 142 & 142 & 142 & 142 \\
\hline & $\begin{array}{l}\text { Std. } \\
\text { Deviation }\end{array}$ & 1,188 & 1,277 & 1,319 & 1,108 & 1,048 & 1,065 & 1,335 \\
\hline \multirow[t]{3}{*}{ Total } & Mean & 2,12 & 2,68 & 3,05 & 2,43 & 3,58 & 2,02 & 2,78 \\
\hline & $\mathrm{N}$ & 303 & 303 & 303 & 303 & 303 & 303 & 303 \\
\hline & $\begin{array}{l}\text { Std. } \\
\text { Deviation }\end{array}$ & 1,105 & 1,255 & 1,325 & 1,307 & 1,089 & 1,107 & 1,332 \\
\hline
\end{tabular}

Tabela 2: Opisna statistika ocen virov informacij po državah

Iz tabele 2 je razvidno, da imajo največji vpliv na nakupno odločitev slovenske mladine v starosti od 15 do 24 let pri izbiri oblačil naslednji informacijski viri: izložbe v prodajalnah $(3,51)$, prijatelji in znanci $(3,48)$ in Facebook, Twitter, Google $(3,01)$. Najmanjši vpliv imajo TV in radio oglasi $(2,12)$ in oglasni panoji $(2,20)$. V ZDA imajo največji vpliv na mlade porabnike prijatelji in znanci $(3,68)$, revije o modi in kataloška prodaja $(2,65)$, izložbe v prodajalnah $(2,539$ in sodobni spletni mediji $(2,52)$. Najmanjši vpliv imajo oglasni panoji $(1,81)$ in oglasna pošta $(1,88)$.

Proučevali smo tudi vpliv posameznih spletnih medijev (Facebook, Twitter, Google, ...) na nakup posameznih izdelkov in storitev. Rezultate prikazuje tabela 3. 

ORGANIZACIJA (22. - 24. MAREC 2017, PORTOROŽ, SLOVENIJA)

N. Klemenčič \& B. Klemenčič: Vpliv virov informacij na nakupno odločanje mladih v

Sloveniji in ZDA

\begin{tabular}{|c|c|c|c|c|c|c|c|c|c|}
\hline Država & & $\begin{array}{l}\text { Prehrambeni } \\
\text { izdelki }\end{array}$ & Oblačila & $\begin{array}{l}\text { TV, } \\
\text { audio, } \\
\text { rač. }\end{array}$ & $\begin{array}{c}\text { Gospodinjski } \\
\text { izdelki }\end{array}$ & $\begin{array}{l}\text { Izdelki za } \\
\text { šport in } \\
\text { rekreacijo }\end{array}$ & $\begin{array}{c}\text { Izdelki } \\
\text { za } \\
\text { osebno } \\
\text { nego in } \\
\text { zdravje }\end{array}$ & $\begin{array}{l}\text { Avto } \\
\text { moto } \\
\text { izdelki }\end{array}$ & $\begin{array}{l}\text { Turistične } \\
\text { storitve }\end{array}$ \\
\hline \multirow[t]{3}{*}{ Slovenija } & Mean & 2,10 & 2,98 & 3,00 & 2,30 & 2,72 & 2,76 & 2,53 & 3,01 \\
\hline & $\mathrm{N}$ & 161 & 161 & 161 & 161 & 161 & 161 & 161 & 161 \\
\hline & $\begin{array}{l}\text { Std. } \\
\text { Deviation }\end{array}$ & 1,179 & 1,289 & 1,173 & 1,249 & 1,226 & 1,202 & 1,295 & 1,358 \\
\hline \multirow[t]{3}{*}{$\overline{Z D A}$} & Mean & 2,52 & 2,68 & 2,75 & 2,01 & 2,24 & 2,65 & 1,77 & 1,99 \\
\hline & $\mathrm{N}$ & 142 & 142 & 142 & 142 & 142 & 142 & 142 & 142 \\
\hline & $\begin{array}{l}\text { Std. } \\
\text { Deviation }\end{array}$ & 1,270 & 1,427 & 1,291 & 1,263 & 1,310 & 1,395 & 1,134 & 1,209 \\
\hline \multirow[t]{3}{*}{ Total } & Mean & 2,30 & 2,83 & 2,88 & 2,16 & 2,50 & 2,71 & 2,17 & 2,53 \\
\hline & $\mathrm{N}$ & 303 & 303 & 303 & 303 & 303 & 303 & 303 & 303 \\
\hline & $\begin{array}{l}\text { Std. } \\
\text { Deviation }\end{array}$ & 1,239 & 1,361 & 1,234 & 1,262 & 1,286 & 1,295 & 1,278 & 1,385 \\
\hline
\end{tabular}

Tabela 3: Opisna statistika ocen vpliva spletnih medijev na nakup posameznih izdelkov in storitev po državah

Iz tabele 3 je razvidno, da na mlade porabnike $\mathrm{v}$ Sloveniji vplivajo spletni mediji najbolj na nakup turističnih storitev $(3,01), \mathrm{TV}$, audio in računalnikov $(3,00)$ ter oblačil $(2,98)$. Najmanjši vpliv imajo spletni mediji na nakup prehrambenih izdelkov $(2,10)$. Mladi porabniki v ZDA zaznavajo največji vpliv spletnih medijev na nakup TV, audio in računalnikov $(2,75)$, oblačil $(2,68)$ in izdelkov za osebno nego in zdravje $(2,65)$. Spletni mediji imajo najmanjši vpliv na nakup avto moto izdelkov $(1,77)$.

Postavljeno ničelno hipotezo $\mathrm{H} 1$ preizkušamo $\mathrm{s}$ t-testom (procedura Independent Samples T Test). Rezultate t-testa prikazujemo v tabeli 4. Hipoteza se sprejme, če je stopnja značilnosti $\mathrm{P} \geq(\alpha=0,05)$, kar pomeni, da razlika ni značilna. $\mathrm{V}$ primeru, da je zadoščeno navedenim pogojem le pri posameznih dejavnikih, se ničelna hipoteza sprejme delno, $\mathrm{z}$ navedbo dejavnika. Rezultati t-testa pokažejo, da ničelno hipotezo H1 sprejmemo delno. Razlike med mladimi v Sloveniji in ZDA niso značilne za naslednje dejavnike: oblačila, TV, audio, računalniki ter izdelki za osebno nego in zdravje. Za navedene dejavnike na podlagi vzorčnih podatkov ničelno hipotezo sprejmemo.

\begin{tabular}{|l|c|c|c|}
\hline & t & df & Sig. (2-tailed) \\
\hline Prehrambeni izdelki & $-2,983$ & 301 &, 003 \\
\hline Oblačila & 1,905 & 301 &, 058 \\
\hline TV, avdio, računalniki & 1,781 & 301 &, 076 \\
\hline Gospodinjski izdelki & 2,012 & 301 &, 045 \\
\hline Izdelki za šport in rekreacijo & 3,287 & 301 &, 001 \\
\hline Izdelki za osebno nego in zdravje & 0,771 & 301 &, 441 \\
\hline Avto moto izdelki & 5,450 & 301 &, 000 \\
\hline Turistične storitve & 6,920 & 301 &, 000 \\
\hline
\end{tabular}

Tabela 4: t-test razlik med aritmetičnima sredinama ocen dveh skupin 
$36^{\text {TH }}$ International Conference on Organizational Science Development: RESPONSIBLE ORGANIZATION (MARCH $22^{\mathrm{ND}}-24^{\mathrm{TH}}$, PORTOROŽ SLOVENIA)

N. Klemenčič \& B. Klemenčič: The Impact of Sources of Information on the Purchasing Decisions of Young People in Slovenia and USA

Za dejavnike: prehrambeni izdelki, gospodinjski izdelki, izdelki za šport in rekreacijo, avto moto izdelki in turistične storitve rezultati t-testa pokažejo značilne razlike. Na podlagi vzorčnih rezultatov za te vire zavrnemo ničelno hipotezo in potrdimo alternativno hipotezo, da se mladi razlikujejo $\mathrm{v}$ percepciji vpliva spletnih medijev na nakup posameznih skupin izdelkov ali storitev med državama.

Postavljeno alternativno hipotezo 2 , da noben posamezni vir informacij ne vpliva diskriminirajoče na oceno skupnega vpliva informacij pri mladih v Sloveniji in ZDA smo preizkusili z diskriminantno analizo z dvema skupinama. Namen diskriminantne analize je proučevanje razlik med enotami dveh ali več vnaprej poznanih skupin, pri čemer je pripadnost enot $\mathrm{v}$ eni od skupin določena $\mathrm{z}$ vrednostmi spremenljivk, ki jih želimo ugotoviti. $\mathrm{V}$ našem primeru želimo ugotoviti kakšna je razlika $\mathrm{v}$ zaznavanju vpliva informacijskih virov med skupinama mladih v Sloveniji in ZDA.

\begin{tabular}{|l|r|r|r|r|}
\hline Function & Eigenvalue & \% of Variance & Cumulative \% & Canonical Correlation \\
\hline 1 &, $435^{\mathrm{a}}$ & 100,0 & 100,0 &, 551 \\
\hline
\end{tabular}

a. First 1 canonical discriminant functions were used in the analysis.

Wilks' Lambda

\begin{tabular}{|l|r|r|r|r|}
\hline Test of Function(s) & Wilks' Lambda & Chi-square & df & Sig. \\
\hline 1 &, 697 & 107,850 & &, 000 \\
\hline
\end{tabular}

Tabela 5: Diskriminantna analiza za niz neodvisnih spremenljivk (viri informacij)

Lastna vrednost (eigenvalue) je 0,435, kar kaže na slabšo diskriminantno funkcijo. Koeficient kanonične korelacije je 0,551 in kaže, da povezava med diskriminantno funkcijo in skupinami obstaja. Wilksova lamba je 0,697 , kar pomeni, da aritmetične sredine diskriminantnih vrednosti med skupinami niso značilno različne. Ker je v našem primeru stopnja značilnosti manjša od 0,05 , smemo alternativno domnevo o razlikah aritmetičnih sredin diskriminantnih vrednosti skupin sprejeti s tveganjem, manjšim od 0,05 . Standardizirani koeficienti v tabeli 6 kažejo, da izložbe $v$ prodajalnah in oglasna pošta prispevata največ k razlikovanju med skupinama mladih v Sloveniji in ZDA.

\begin{tabular}{|l|r|}
\hline & \multicolumn{2}{|c|}{ Function } \\
\cline { 2 - 2 } & \multicolumn{1}{|c|}{1} \\
\hline Revije o modi in kataloška prodaja &,- 374 \\
Izložbe v prodajalnah &, 587 \\
Oglasna pošta &, 727 \\
Prijatelji in znanci &,- 634 \\
Facebook, Twitter, Google &, 336 \\
\hline
\end{tabular}

Tabela 6: Standardizirani kanonični koeficienti diskriminantne funkcije 
Iz tabele 7 je razvidno, da se skupini mladih v Sloveniji in ZDA razlikujeta po vplivu virov informacij na nakup oblačil. Oglasna pošta in izložbe $\mathrm{v}$ prodajalnah diskriminirajoče vplivajo na oceno skupnega vpliva informacij med mladimi v Sloveniji in ZDA.

\begin{tabular}{|l|r|}
\hline & \multicolumn{1}{|c|}{ Function } \\
\cline { 2 - 2 } & \multicolumn{1}{|c|}{1} \\
\hline Oglasna pošta &, 651 \\
Izložbe v prodajalnah &, 604 \\
Facebook, Twitter, Google &, 281 \\
TV in radio oglasia &, 172 \\
Prijatelji in znanci & -139 \\
Oglasni panoji &, 136 \\
Revije o modi in kataloška prodaja &, 028 \\
\hline
\end{tabular}

Pooled within-groups correlations between discriminating variables and standardized canonical discriminant functions

Variables ordered by absolute size of correlation within function.

a. This variable not used in the analysis.

Tabela 8: Strukturna matrika z diskriminatornimi utežmi za faktorje glede na oceno virov informacij

Klasifikacijska matrika $\mathrm{v}$ tabeli 9 prikazuje število $\mathrm{z}$ diskriminantno funkcijo pravilno razvrščenih enot v skupini. Program je pravilno uvrstil 75,9 \% obravnavanih enot.

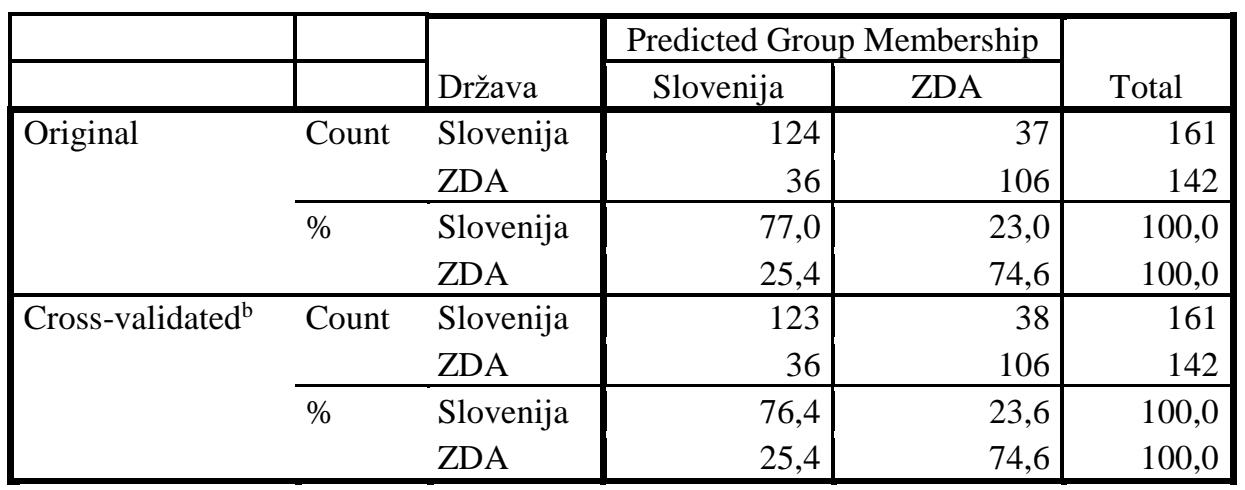

a. $75,9 \%$ of original grouped cases correctly classified.

b. Cross validation is done only for those cases in the analysis. In cross validation, each case is classified by the functions derived from all cases other than that case.

c. $75,6 \%$ of cross-validated grouped cases correctly classified. 
$36^{\mathrm{TH}}$ International Conference on ORganizational Science Development: RESPONSIBLE ORGANIZATION (MARCH $22^{\mathrm{ND}}-24^{\mathrm{TH}}$, Portorož SLOVENIA)

N. Klemenčič \& B. Klemenčič: The Impact of Sources of Information on the Purchasing Decisions of Young People in Slovenia and USA

$\mathrm{Na}$ podlagi ugotovitev diskriminantne analize postavljeno alternativno hipotezo 2 zavrnemo. Z diskriminantno analizo smo namreč ugotovili, da sta oglasna pošta in izložbe v prodajalnah tista vira informacij, ki prispevata $\mathrm{k}$ razliki v ocenjevanju virov kot celote.

\section{$5 \quad$ Zaključek}

V podjetjih oblačilne industrije se morajo zavedati pomena informacij, ki jih potrebujejo $\mathrm{v}$ procesu marketinškega odločanja in oblikovanja marketinških strategij. Podjetja potrebujejo informacije o tržnem okolju, o ciljnih trgih, predvsem pa morajo poznati svoje porabnike, proces njihovega nakupnega odločanja in njihovo informacijsko vedenje. Od svežih in aktualnih informacij je odvisen uspeh podjetja. Ustrezne trženjske informacije podjetju služijo za oblikovanje trženjskih strategij, ki zagotavljajo konkurenčnost podjetja, omogočajo zadovoljitev potreb porabnikov, poznavanje trženjskega okolja in doseganje primerjalnih prednosti v tekmovanju s konkurenti.

V prispevku smo proučevali vpliv informacijskih virov pri odločanju o nakupu oblačil ter drugih skupin izdelkov in storitev. Ugotovili smo, da imajo na mlade porabnike $\mathrm{v}$ Sloveniji največji vpliv pri nakupu oblačil izložbe v prodajalnah, prijatelji in znanci ter Facebook, Twitter, Google. V ZDA imajo največji vpliv prijatelji in znanci. Ugotavljamo tudi povečan vpliv spletnih medijev na nakup posameznih skupin izdelkov in storitev. Med mladimi porabniki v Sloveniji in ZDA prihaja do razlik v vplivu spletnih medijev na nakup posameznih skupin izdelkov in storitev. Na mlade porabnike v Sloveniji spletni mediji najbolj vplivajo na nakup turističnih storitev, v ZDA pa na nakup TV, avdio in računalnikov. Z diskriminantno analizo smo ugotovili, da se skupini mladih $\mathrm{v}$ proučevanih državah najbolj razlikujeta $\mathrm{v}$ oceni vpliva oglasne pošte in izložb $\mathrm{v}$ prodajalnah na nakup posameznih skupin izdelkov in storitev. Oglasna pošta in izložbe v prodajalnah imajo namreč v Sloveniji bistveno večji vpliv na nakupno odločanje kot $\mathrm{v}$ ZDA. Z raziskavo smo ugotavljali tudi razlike $\mathrm{v}$ informacijskem vedenju med mladimi $\mathrm{v}$ Sloveniji in ZDA. Ugotovili smo, da obstajajo med mladimi v proučevanih državah značilne razlike v vplivu posameznih virov na nakupno odločanje. Tudi z diskriminantno analizo smo ugotovili, da oglasna pošta in izložbe $\mathrm{v}$ prodajalnah diskriminirajoče vplivajo na skupno oceno virov informacij. Oglasni panoji na ulici imajo v ZDA manjši pomen kot v Sloveniji. Glede na njihov vpliv predlagamo podjetjem in trgovcem v Sloveniji večji poudarek na oglasni pošti in izložbah v prodajalnah. V ZDA imajo pomemben vpliv na nakup oblačil sodobni spletni mediji. Oblačilni industriji in globalnim trgovcem predlagamo v ZDA večji poudarek na oglaševanju po spletu in uporabo sodobnih spletnih medijev (Facebook, Google, Twitter, Youtube).

\section{Literatura}

Blackwell, R. D., Miniard, P. W., \& Engel, J. F. (2001). Consumer behavior. Ft. Worth: Harcourt College Publishers.

Blythe, J. (2008). Consumer Behavior. London: Thomson Learning. 
N. Klemenčič \& B. Klemenčič: Vpliv virov informacij na nakupno odločanje mladih v

Sloveniji in ZDA

Ferell, O. C., \& Hartline, M. D. (2011). Marketing Strategy. Mason: Fifth Edition, South - Western Cengage Learning.

Hoyer, W. D. \& Macinnis, D. J. (1997). Consumer behavior. New York: Houghton Mifflin Company.

Klemenčič, B. (1999). Informacijsko vedenje mladih pri nakupu oblačil. Maribor: Ekonomsko poslovna fakulteta.

Klemenčič, B., \& Klemenčič, N. (2013). Internet in spletna družbena omrežja kot sodobna vira informacij in načina prodaje. V Balantič Z., et al. (Ur.), Pametna organizacija: talenti, vitka organiziranost, internet stvari. (378-384). Kranj: Moderna organizacija.

Klemenčič, B., \& Števančec, D. (2013). Comparison between Germany and the USA in the youth clothing industry. African Journal of Business Management, Vol. 7, str. 1335-1343.

Kotler, P., \& Armstrong, G. (2012). Principles of Marketing. New Jersey: Pearson/Prentice Hall.

Peter, P. J., \& Olson, J. C. (2005). Consumer Behavior and Marketing Strategy. Boston: Irwin McGraw-Hill.

Schneider. G. P. (2013). E-business. Andover: Cengage Learning.

Solomon, M. R. (2011). Consumer Behavior, Buying, having and being. New Jersey: Pearson Education.

Solomon, M. R., \& Rabolt, N. J. (2009). Consumer Behavior, In fashion. New Jersey: Prentice Hall.

Solomon, M. R., Bamossy, G., \& Askegaard, S. (2013). Consumer Behavior: A European Perspective. Harlow: Pearson Education Limited.

Verderber, G. (2016). Kateri oglaševalski kanali najbolj vplivajo na nakupno odločanje? Marketing Magazin, No. 418. str. 32. 
$330 \quad 36^{\text {Th }}$ International Conference on Organizational Science Development:

Responsible Organization (MARCH $22^{\mathrm{ND}}-24^{\mathrm{TH}}$, PORTOROŽ SLOVENIA) 
$36^{\text {Th }}$ International Conference on Organizational Science DEVElopMENT: Responsible ORganization (MARCH $22^{\mathrm{ND}}-24^{\mathrm{TH}}$, PORTOROŽ SLOVENIA)

O. Arsenijević, M. Ferjan, I. Podbregar, P. Šprajc, D. Trivan \& Y.

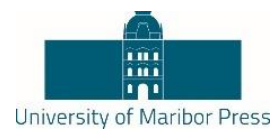

Ziegler

\title{
Remote Monitoring Device Using Android Application
}

\author{
JAN KONEČNIK \& VOJKO MATKO
}

\begin{abstract}
The paper displays the approach, how to realize a less comprising measurement system connected to an Android platform which enables the measuring of voltage, current, resistance, temperature and heartbeat among which the user can choose in an graphical user interface. The measuring application is intended for various means of measuring in industrially dangerous and medically isolated areas (where there are different hazards, such as infection and poisoning, or in places that must be kept sterile), dangerous areas (electrical hazard due to high voltage, the danger of falling of a high building, vacuum environment, pressure environment, underwater environment, chemically toxic environment, space environment, etc.) and various test environments (where the measuring device can also be destroyed for the experiment due to its affordability). The advantage of this application is low manufacturing costs, so it is easily replaceable in case of damage.
\end{abstract}

KEYWORDS: Terms-Android $・$ Bluetooth $・$ C++ $\bullet$ Java $・$ Wireless measuring module

CORRESPONDENCE ADDRESS: Jan Konečnik, University of Maribor, Faculty of Electrical Engineering and Computer Science, Smetanova ulica 17, 2000 Maribor, Slovenia, e-mail: jan.konecnik@gmail.com, Vojko Matko, Ph.D., Associate Professor, University of Maribor, Faculty of Electrical Engineering and Computer Science, Smetanova ulica 17, 2000 Maribor, Slovenia, e-mail: vojko.matko@um.si

DOI https://doi.org/10.18690/978-961-286-020-2.29

ISBN 978-961-286-020-2

(C) 2017 University of Maribor Press

Available at: http://press.um.si 
$36^{\text {Th }}$ International Conference on Organizational Science Development: RESPONSIBLE ORGANIZATION (MARCH $22^{\mathrm{ND}}-24^{\mathrm{TH}}$, PortoroŽ SLOVENIA)

J. Konečnik \& V. Matko: Remote Monitoring Device Using Android Application Introduction

The development of wireless communications has seen big advances recently. In the recent years, Bluetooth (BT ${ }^{1}$ (WB, 2017; BS, 2017; Berišaj, 2017) has become one of the most widespread and popular technologies. BT is a wireless technological standard for exchanging data over short distances (up to $100 \mathrm{~m}$ ). It uses a communication frequency in the range of 2400 to $2480 \mathrm{MHz}$ and creates its own connection area. The technology is very cheap and the usage also is not charged. The connection between devices is relatively simple, as the devices start communicating when they are within reach of the signal, but the users still have the option to accept or decline the connection. Seeing as BT is standardized (IEEE 802.15 2), it is expected to receive adequate software support for various types of devices, timely corrections, higher speed, etc. One of the disadvantages of BT technology is a large battery consumption in case of constant network usage. Speed could also be seen as a disadvantage, although it has become faster due to new elements and protocol versions. Until now, BT has mostly been used for exchanging data, sound, and films between two or more telephones; however, that is far from what it is capable of.

There are different versions of BT technologies (WB, 2017). The initial versions BT v1.0 and v1.1 contained a lot of problems (problems with connection, data transfer ...) and their speed was below $500 \mathrm{kbit} / \mathrm{s}$. The upgraded version 1.2 improved the connection speed, increased the data transfer rate to $1 \mathrm{Mbit} / \mathrm{s}$, and introduced the possibility of an UART $^{2}$ connection (WUART, 2017; Durda, 2014). In the version v2.0 + EDR ${ }^{3}$, the speed was increased to $2.1 \mathrm{Mbit} / \mathrm{s}$, the energy consumption was lowered in comparison to the previous version, and some improvements were added (lower energy consumption, device compatibility, and higher security). The newer versions, such as the v3.0 + $\mathrm{HS}^{4}$, reach speeds up to $24 \mathrm{Mbit} / \mathrm{s}$, but individual modules have a much higher price than the previous. The latest version $\mathrm{v} 4.0 \mathrm{LE}^{5}$ is an improved version of the 3.0, which is not as widespread and it is used by a limited number of mobile phone manufacturers.

Other alternatives compared to BT technology:

- ZigBee (ZigBee, 2017): range up to $100 \mathrm{~m}$, lower complexity, low power consumption, reduced abundance.

- WiMAX (WiMAX, 2017): range up to $50 \mathrm{~km}$, higher speed, higher price, reduced abundance.

- Wi-fi (WIFI, 2017; IEEE, 2003): range up to $100 \mathrm{~m}$, higher complexity, higher power consumption, higher price.

The Android operating system used in this research was the version 4.0. Ice Cream Sandwich $\left(\mathrm{API}^{6} 15\right)$. Its advantages are an open source operating system, high speed system performance, the use of various open source libraries that enable the creation of their own applications without licensing costs, good user flexibility, PC connectivity, and more. To reach a good performance, the mobile device Samsung i9100Galaxy S2, which has a large screen, a fast dual-core processor and good connectivity, was used. The 
constructed measuring application can be used everywhere, without internet connection, because BT creates its own network, which is a major advantage. For different measuring purposes, different sensors are connected to the measuring module, which reads the signals and transmits it via the BT network. On the other side the user can connect to it with a mobile device using an Android operating system, with which the implemented measurements can be controlled. The user has the option to monitor the measurement results, the selection of which is offered by a software application. By selecting the desired measured quantity we send a command via the BT network to the measuring module. The command receives and implements the request to read the desired signal from the sensors and transfers the measurement to the Android device. BT was selected because it is affordable, widespread and ready to use on any mobile device using the Android operating system (WA, 2017; GOA, 2017; GDEV, 2017; Wei-Meng, 2012). BT can be found in various devices, it is used by over 2000 manufacturers, which is also an important reason for the selection of this network.

The measuring application fills a gap in the market, since it is made for Android operating systems (the advantage of which is open source programming). It is intended for various means of measuring in medically isolated areas (where there are different hazards, such as infection and poisoning, or in places that must be kept sterile), dangerous areas (electrical hazard due to high voltage, the danger of falling of a high building, vacuum environment, pressure environment, underwater environment, chemically toxic environment, space environment, etc.) and various test environments (where the measuring device can also be destroyed for the experiment due to its affordability), because we are not limited by cables, it is enough for the mobile device to be in the signal range of the measuring module (Miloševič et al., 2011; Yang \& Gerla, 2011; Patrick et al., 2008; Lai et al., 2013; Patel \& Wang, 2010; Hii \& Chung, 2011; Zhang \& Xiao, 2009; Burgos et al., 2010; Pereira et al., 2011; Gandhewar \& Dheikh, 2010).

\section{The Android operating system}

\subsection{General information on Android}

The Android operating system is based on the Linux operating system. Google wanted Android to be open sourced and free of charge, which is why the majority of development codes are freely available online. Another advantage is that individual hardware developers can add upgrades and accessories, in order to differentiate themselves from their competitors. This simple development model made Android operating system very desirable and piqued interest in many manufacturers. This is especially true for companies affected by the emergence of Apple's iPhone, which has emerged as a revolution in the world of smart phones. Companies like Motorola and Sony Ericsson, which have developed their own operating systems for many years, therefore desperately needed a new way of reviving their products, which they found in the Android operating system. The main advantage of Android is that it offers a unified approach to the use of application development. The developers only have to develop Android and their applications can run various different devices. In the world of smart phones, applications are the most important part of the chain, which is why the manufacturers see Android as 
$36^{\text {Th }}$ International Conference on Organizational Science Development:

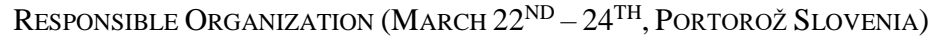

J. Konečnik \& V. Matko: Remote Monitoring Device Using Android Application

their best hope in the fight against the iPhone, which manages a large base of applications (Miloševič et al., 2011; Yang \& Gerla, 2011; Patrick et al., 2008; Lai et al., 2013; Patel \& Wang, 2010; Hii \& Chung, 2011; Zhang \& Xiao, 2009; Burgos et al., 2010; Pereira et al., 2011; Gandhewar \& Dheikh, 2010).

\subsection{Features of Android}

Since Android is an open source system that enables open sources and free accessibility to adjustments, there are no specific software and hardware configurations. However, Android automatically supports the following features (Wei-Meng, 2012):

- Data Storage - it uses the $\mathrm{SQL}^{7}$ database to store data.

- Connectivity - it supports $\mathrm{GSM}^{8} \mathrm{EDGE}^{9}, \mathrm{IDEN}^{10}, \mathrm{CDMA}^{11}, \mathrm{EV}^{-D^{12}}{ }^{12}$, $\mathrm{UMTS}^{13}, \mathrm{BT}^{14}, \mathrm{Wi}-\mathrm{Fi}^{15}, \mathrm{LTE}^{16}$ and WiMAX ${ }^{17}$

- Communication - it supports $\mathrm{SMS}^{18}$ and $\mathrm{MMS}^{19}$

- Web browser - it is based on the open sourced WebKit, together with Chrome's V8 JavaScript drive.

- Media support - it supports the following media: H.263, H.264 (MP4 ${ }^{20}$ or $3 \mathrm{GP}^{21}$ ), MPEG-4 SP ${ }^{22}$, AMR ${ }^{23}, \mathrm{AMR}^{-W B^{24}}$ (3GP), AAC ${ }^{25}, \mathrm{HE}^{-A A C}{ }^{26}$ (MP4 or 3GP), MP3 ${ }^{27}, \mathrm{MIDI}^{28}$, Ogg Vorbis, $\mathrm{WAV}^{29}, \mathrm{JPEG}^{30}, \mathrm{PNG}^{31}, \mathrm{GIF}^{32}$ and $\mathrm{BMP}^{33}$.

- Hardware support - accelerometer, camera, digital compass, proximity sensor and $\mathrm{GPS}^{34}$.

- Multi-touch screens

- Multi-tasking applications

- Flash support

- Tethering - support for sharing an Internet connection

\subsection{Structure of Android}

The Android operating system can be divided into five sections in four major layers, which can be seen on (Wei-Meng, 2012):

- Linux kernel - this is the core, on which Android is based on. This layer contains all lower-level drivers for different hardware components.

- Libraries - it contains all the codes, which provide the main features of the Android operating system. For example, SQL provides support for databases, which can be used by an application.

- Android runtime - it is on the same level as the libraries and provides a set of core libraries for developers using the Java programming language. It also contains the Dalvik Virtual Machine, which allows the application to run in its own process and which is designed especially for Android and optimized for battery-powered mobile devices with limited memory.

- Application framework - it offers various Android capabilities to software developers, which they can use in their own applications. 
Applications - on the highest level we can find the built-in applications (such as Contacts, Browser, Telephone, and others), as well as all the application that can be downloaded from the Android Market. Every designed application is located on this level.

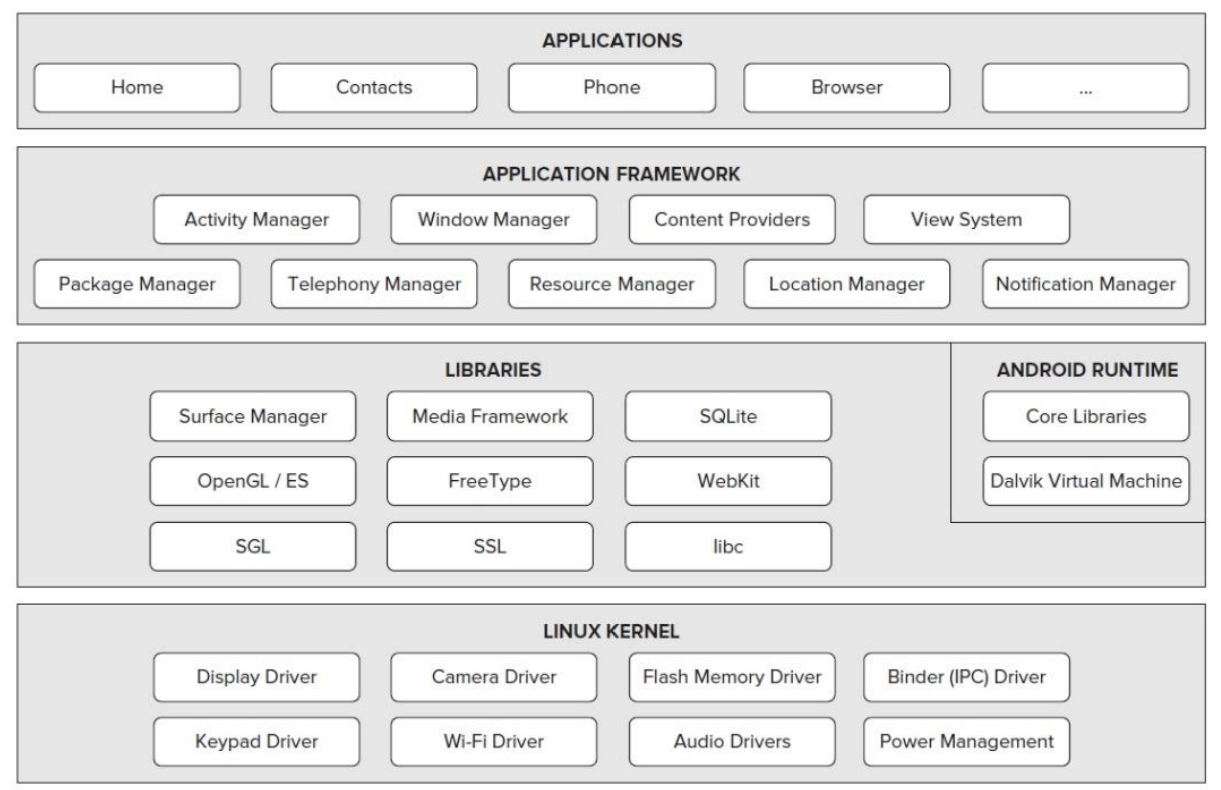

Figure 1: Layers that form the Android operating system (Wei-Meng, 2012).

\subsection{Application Developer Community}

Due to the widespread use of the Android operating system, there is a large community of developers around the world. This makes it much easier to solve problems and to find like-minded developers to exchange ideas and experience with. The most common sites for developers are:

- Stack Overflow (SE, 2014) - If you have questions on a certain topic, you can find a suitable answer on this site. The site is set up like a forum and gives the other developers the option to vote for the most suitable answer to a question, which speeds up the problem-solving process.

- Google Android Training (DET, 2013) - This site was set up by Google to train new software developers and it contains many useful topics, which include code sections that are very useful for developers, who are starting with the basics.

- Android Discuss (GAD, 2017) - A discussion group, set up by Google. Here you can find discussions on various aspects of Android programming that are monitored by a Google application development team, which makes this a good place to clear any doubts and learn new tips and tricks. 
$36^{\mathrm{TH}}$ International Conference on ORganizational Science Development: RESPONSIBLE ORGANIZATION (MARCH $22^{\mathrm{ND}}-24^{\mathrm{TH}}$, PORTOROŽ SLOVENIA)

J. Konečnik \& V. Matko: Remote Monitoring Device Using Android Application

3

Hardware

\subsection{Measuring module}

A remote measuring module is an important part in the implementation of measurements and recording of various quantities with the help of sensors and sending the data to a mobile device (Napaka! Vira sklicevanja ni bilo mogoče najti.).

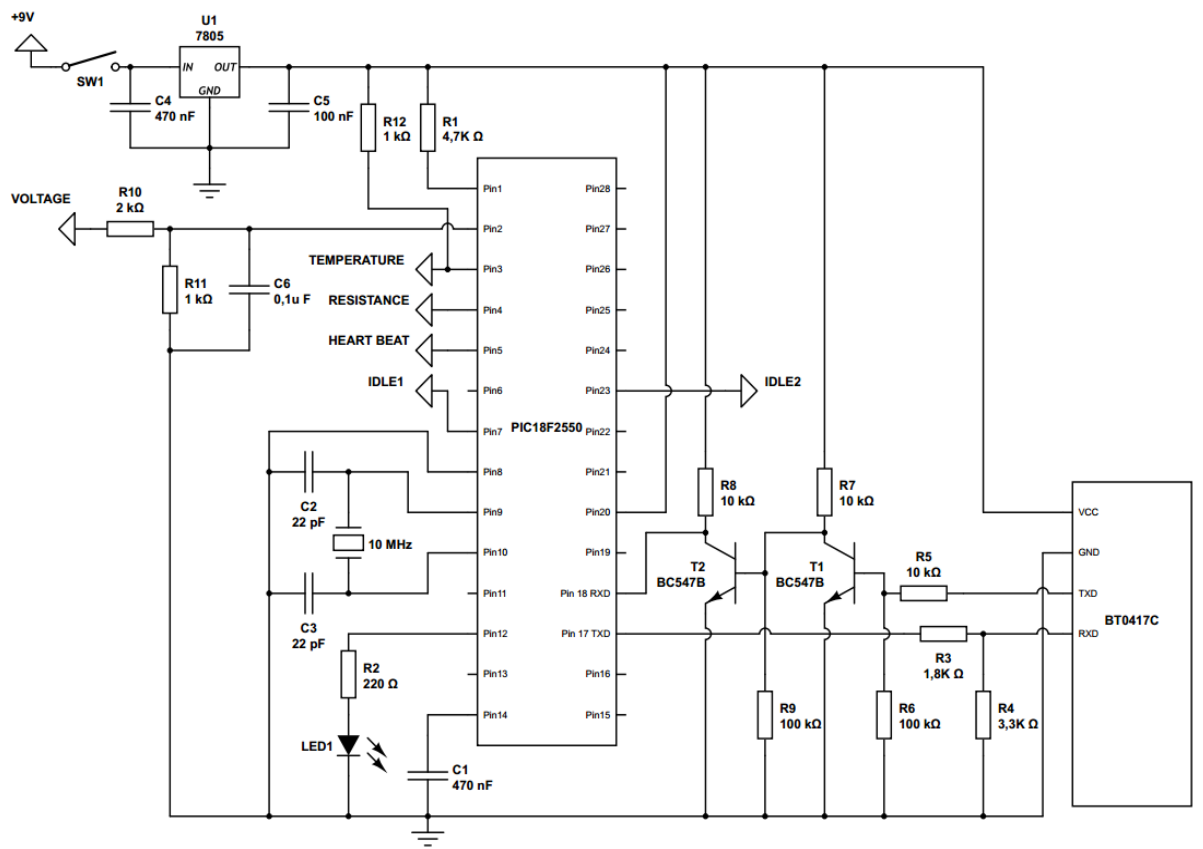

Figure 2: Diagram of a measuring module microcontroller circuit (Microchip, 2004).

The central part of the selected measuring module is a microcontroller PIC18F2550 (Microchip, 2004) that captures the signals with an 8-bit conversion (5 V = 255 bits), which is sufficient for an accurate representation on a screen of a mobile device. Microcontroller PIC18F2550 was selected because of a sufficient number of analogue inputs (up to 13 analogue inputs), high-speed A/ $\mathrm{D}^{35}$ conversion (about $20 \mu \mathrm{s}$ ), the ability to communicate with the BT module via the UART (WUART, 2017; Durda, 2014) connection and affordability (about 7 EUR). UART is a part of the hardware, which converts the data between the parallel and serial form. Communication between the microcontroller and the BT module runs on two channels, TXD ${ }^{36}$ and $\mathrm{RXD}^{37}$ (Napaka! Vira sklicevanja ni bilo mogoče najti.). The measuring application (together with hardware and software) enables a dynamic time for one measurement, $28 \mathrm{~ms}$ from the beginning, when the command for measuring has been given on the $\mathrm{n}$-th channel, to the time it is displayed on the mobile device screen. $20 \mathrm{~ms}$ of that time is used for reading and sending an individual analogue channel. Napaka! Vira sklicevanja ni bilo mogoče 
najti. shows the measuring module circuit with the microcontroller PIC18F2550 and the connection with a BT module via the two communication pins TXD and RXD. The microcontroller operates at a frequency of $48 \mathrm{MHz}$. In addition to the analogue inputs, it also enables the use of sensors with an $\mathrm{I}^{2} \mathrm{C}$ and an SPI bus. The BT module with the label RF-BT0417C was used (MDFLY, 2017). It operates at a frequency from $2.4 \mathrm{GHz}$ to 2.48 $\mathrm{GHz}$, it covers up to $10 \mathrm{~m}$, which places it in the 2 . class of radio transmit power, it is relatively easy to use and falls in the lower price range. The current consumption during the time the modules are connecting reaches 20 to $30 \mathrm{~mA}$. When the devices are connected it consumes $8 \mathrm{~mA}$ to maintain the connection. It operates at a $3.3 \mathrm{~V}$ voltage range, so it is necessary to equalize the voltage levels between the module and the microcontroller. The appropriate equalization of voltage levels (WordPress, 2017) is obtained by a resistive divider and by two NPN transistors, connected to a non-inverting binding. The communication is good within a $10 \mathrm{~m}$ range from the module, the signal may be lost at a greater distance. The module (BT-0417C) uses the BT circuit 2.0 + EDR, which means that it can transfer data at speeds up to $2.1 \mathrm{Mbit} / \mathrm{s}$. The majority of low-cost BT modules work at this transmission speed, which is why this module was chosen. More expensive modules with the $3.0+\mathrm{HS}$ and 4.0 versions reach speeds up to $24 \mathrm{Mbit} / \mathrm{s}$. In general, it can be emphasised that BT is reliable, because it uses an algorithm of pseudorandom frequency hopping with a maximum of 1600 frequency jumps per second. Such speed of frequency hopping makes tapping the connections very difficult. For example, in certain cases a frequency hopping with over 79 channels per second is used to secure a connection (Berišaj, 2017).

\subsection{Sensors and measuring quantities}

Four analogue inputs for measuring voltage, resistance, temperature, and heart rate were used on the microcontroller PIC18F2550. Other possible inputs include current measurement, impedance measurement, pressure measurement ... Four channels (AN0 AN3) were included in the experimental measuring application, although the software interface is designed for six measuring channels (AN0 - AN4 and AN8), with a possible extension of up to 13 channels (AN0 - AN12). It is important that they match the voltage range of 0 to $5 \mathrm{~V} \mathrm{~A} / \mathrm{D}$ of the converter in the microcontroller. There are various possibilities, five of them were used for demonstration in the experimental measuring application:

- voltage measurement by a resistive divider,

- current measurement indirectly via voltage (optional),

- resistance measurement by the method of one known resistance,

- temperature measurement by LM35,

- heart rate measurement by the method of light reflection on the tip of a finger.

\subsubsection{Voltage measurement}

Voltage measurement is carried out in a measuring range of 0 to $15 \mathrm{~V}$, using a voltage divider with resistances of R10 and R11. (Napaka! Vira sklicevanja ni bilo mogoče 
$36^{\mathrm{TH}}$ International Conference on ORganizational Science Development: ResPonsible Organization (MARCH $22^{\mathrm{ND}}-24^{\mathrm{TH}}$, PORTOROŽ SLOVENiA)

J. Konečnik \& V. Matko: Remote Monitoring Device Using Android Application

najti.). Voltage-divider ratio is taken into account later in the program, but the accuracy of the measurement result suffers at the expense of a larger measuring range, which is why in our case it is limited to two decimals. Measurement resolution for the $15 \mathrm{~V}$ range is therefore 0,0586 .

\subsubsection{Current measurement}

Optionally, a current (Figure. 3) up to $100 \mathrm{~mA}$ can also be measured indirectly through the measurement of voltage and a known resistance with an accuracy of $1 \%$. Through the known resistance of $50 \Omega$ flows a current on which the voltage is measured. A highquality reference resistor of $50 \Omega$ with a low tolerance of $0.1 \%$ or better and a quality voltage source are needed. Unknown current is calculated through Ohm's law.

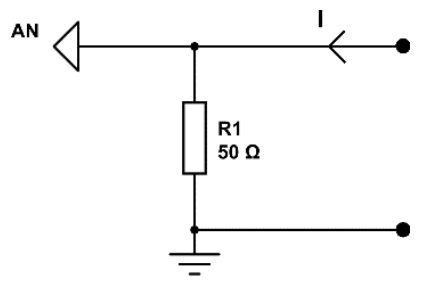

Figure. 3: Diagram of current measurement, AN is connected to the analogue input (Fig. 1).

\subsubsection{Resistance measurement}

Measuring unknown real resistance is based on the measurement of voltage on a resistive divider that has a known resistance of $1 \mathrm{k} \Omega$ and the other is determined based on the size of the voltage (Figure 4). The method for measuring resistance, which is used in the measurement application, has a measuring range from $20 \Omega$ to $10 \mathrm{k} \Omega$, with the more accurate measurements ranging up to $5 \mathrm{k} \Omega$, where the error is up to $5 \%$. The measurement error arises mainly due to the resolution of the A/D conversion, because of the $0.1 \%$ tolerance resistance and the voltage source. To calculate the unknown resistance, we used (1):

$R_{X}=\frac{U_{a d c} \times 1 k \Omega}{5 V-U_{a d c}}$

Where:

$R_{x}=$ unknown resistance $(\Omega)$,

$U_{a d c}=$ measured voltage on the analogue input. 
J. Konečnik \& V. Matko: Remote Monitoring Device Using Android Application

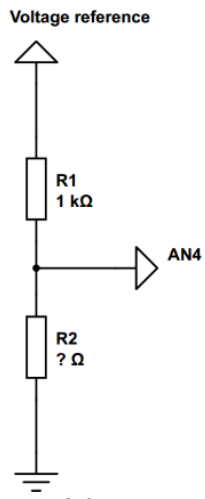

Figure 4: Method used for resistance measurement.

\subsubsection{Temperature measurement}

For measuring temperature, a low-cost, accurate temperature sensor LM35 (TI, 2017) with the accuracy of $10 \mathrm{mV} /{ }^{\circ} \mathrm{C}$ was used (

Figure 5). By default, it can measure temperatures up to $150^{\circ} \mathrm{C}$. But since there is often no need for such a wide measuring range, it can be limited. We limited it to $100^{\circ} \mathrm{C}$, whereby we gained in accuracy. The restriction was carried out with the operational amplifier MCP602 (MMCP602, 2017), with gain of 5 (the default measuring range is from $0^{\circ} \mathrm{C}$ to $150^{\circ} \mathrm{C}$, and at $150^{\circ} \mathrm{C}$ we get $1.5 \mathrm{~V}$ at the output of the meter, after gain of 5 at $100^{\circ} \mathrm{C}$ we get $5 \mathrm{~V}$ at the outlet of the meter.) A broader measuring range provides better accuracy (

Figure 5). We get a measuring range from 0 to $100^{\circ} \mathrm{C}$. It is possible to connect other temperature sensors for higher temperature ranges, as long as they correspond with the measuring range of the analogue input.

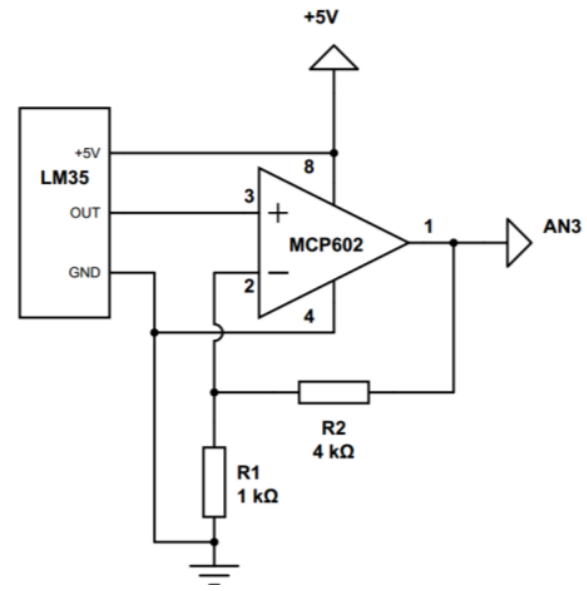

Figure 5: Temperature sensor LM35 and determining the temperature range with the operational amplifier MCP602 (MMCP602, 2017). 


\subsubsection{Heart rate measurement}

The measuring method of measuring reflection of infrared (hereinafter $\mathrm{IR}^{38}$ ) light on the tip of a finger is used for heart rate measurement (Bhatt, 2017). We put the tip of a finger on the transmitting and receiving IR diode with the peak wavelength of $940 \mathrm{~nm}$ (Figure 6). The transmitting IR diode shines a constant light, the power of which can be set with an R1 trimmer on Figure 6, in order to best adjust the transparency of our finger. The

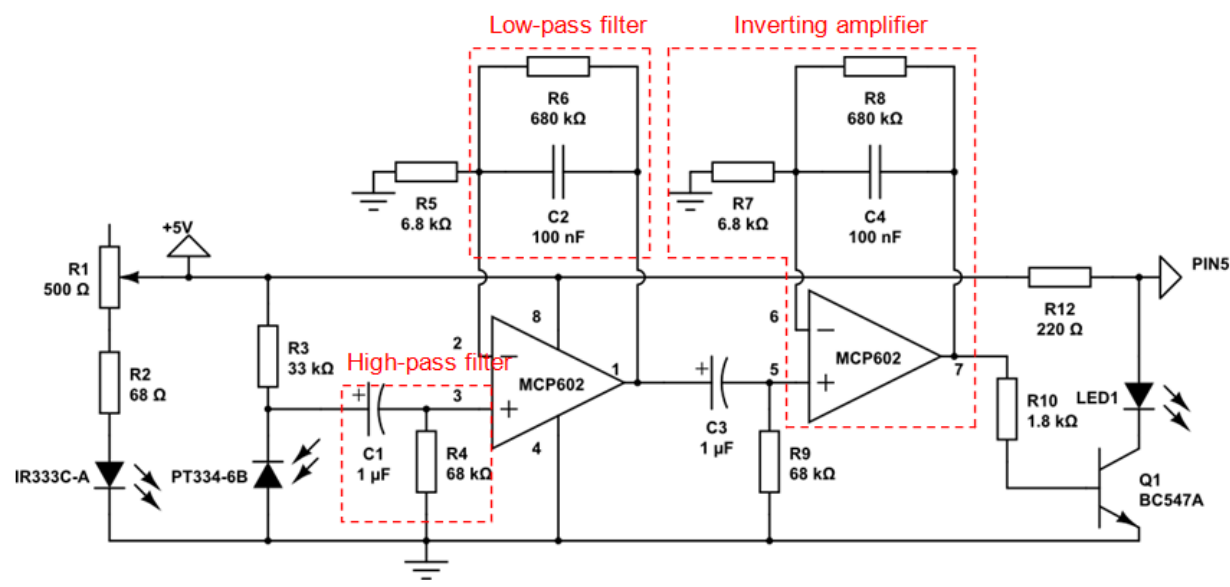

Figure 6: Heart rate sensor circuit (Bhatt, 2017).

receiving diode measures the light from the reflection of the finger bone. When the heart runs the blood through a blood vessel, the illumination of the bone is changed, which is detected by the IR diode. The MCP602 operational amplifier amplifies an x10201 amplification with two operational amplifiers (Bhatt, 2017) (Figure 6), low- and highpass RC filters were also added to eliminate interference. The low-pass filter is set at a critical frequency of $2.34 \mathrm{~Hz}$, which provides a measurement with a maximum of 150 beats per minute. The high-pass filter was added to remove the DC component.

The microcontroller transmits signals via the BT module (Napaka! Vira sklicevanja ni bilo mogoče najti.) to the Android mobile device, where the programme implements the pulse counter on the positive signal edge (WSG, 2017) and displays heart beats per minute. Figure 6 shows the circuit of the heart rate meter with two operational amplifiers in a non-inverting configuration and a low- and high-pass filter.

\subsection{Android mobile device}

For the measuring application we used the Android mobile phone Samsung I9100 Galaxy S2 (Samsung, 2017) with the Android operating system 4.0.3 Ice Cream Sandwich (API 15). The connection for data transfer was set between the BT module BT0417C v2.0 + 
EDR and the Android BT v3.0 + HS. The modules have to be paired before the first use. The default manufacturer code 1234 was used for the pairing. Later, the UUID ${ }^{39}$ (WUUID, 2017) and MAC Address ${ }^{40}$ (WMAC, 2017) are needed, through which the modules can be connected. In this case the UUID was: 00001101-0000-1000-800000805F9B34FB and the MAC Address was: 00:12:09:25:92:57. The connection status is signalled by a blue LED $^{41}$ light on the measuring module that blinks when idle and lights up when connected.

\section{Software}

The measuring application uses two main programming languages. For the measuring module the programming language is $\mathrm{C}++11$ (WC, 2017) with the software tool CCS ${ }^{42}$ (CCS, 2017), version PCWHD 4.083, and for the Android mobile device Java SE 7 (WJAVA, 2017) with the software tool Eclipse 4.3 was used (EF, 2017).

\subsection{C++ and CCS}

Programming language $\mathrm{C}++$ is one of the most widespread programming languages. It can be written in a variety of compilers, for this project CCS was chosen. The program loaded on the microcontroller executes the function of reading the analogue inputs, and obtains the request, which analogue input module to forward to the BT module, according to the wishes of the user of the mobile device with Android OS.

\subsection{Java and Eclipse}

The programming language Java, which was developed as a replacement for $\mathrm{C}++$, has expanded substantially in the recent years with the emergence of the Android operating system. There are three versions of Java: $\mathrm{J}_{2} \mathrm{SE}^{43}$ - the standard version for personal computers, J2 $\mathrm{EE}^{44}$ - the business version, and $\mathrm{J}_{2} \mathrm{ME}^{45}$ - the version for mini devices (phones, tablets ...), which is relevant for our project. Programming in this programming language is also interesting because of the open source language. Application developers can use different programming tools, such as Eclipse, with the SDK ${ }^{46}$ library (WSDK, 2017; Developers, 2017), which allows the development of various applications. Eclipse uses a graphic interface that allows the user to easily control the measurement results, which are received on the Android mobile device via wireless BT connection. It also allows the use of graphic elements, such as graphs, sliders, buttons, and animations, which are especially important for graphical design. The AChartEngine library (VC, 2017), which is very popular among developers and perfected for a wide variety of users and developers of Android applications, since it provides ready-made parts of the program, was used for making graphs in the project.

\section{$5 \quad$ Application structure}

Figure 7 is a flow chart that shows the operation of the entire application with the activities from start-up, connection, and selection of measured quantities to the exit from the application. 
$36^{\mathrm{TH}}$ International Conference on Organizational Science Development: ResPonsible Organization (MARCH $22^{\mathrm{ND}}-24^{\mathrm{TH}}$, PORTOROŽ SLOVENiA)

J. Konečnik \& V. Matko: Remote Monitoring Device Using Android Application

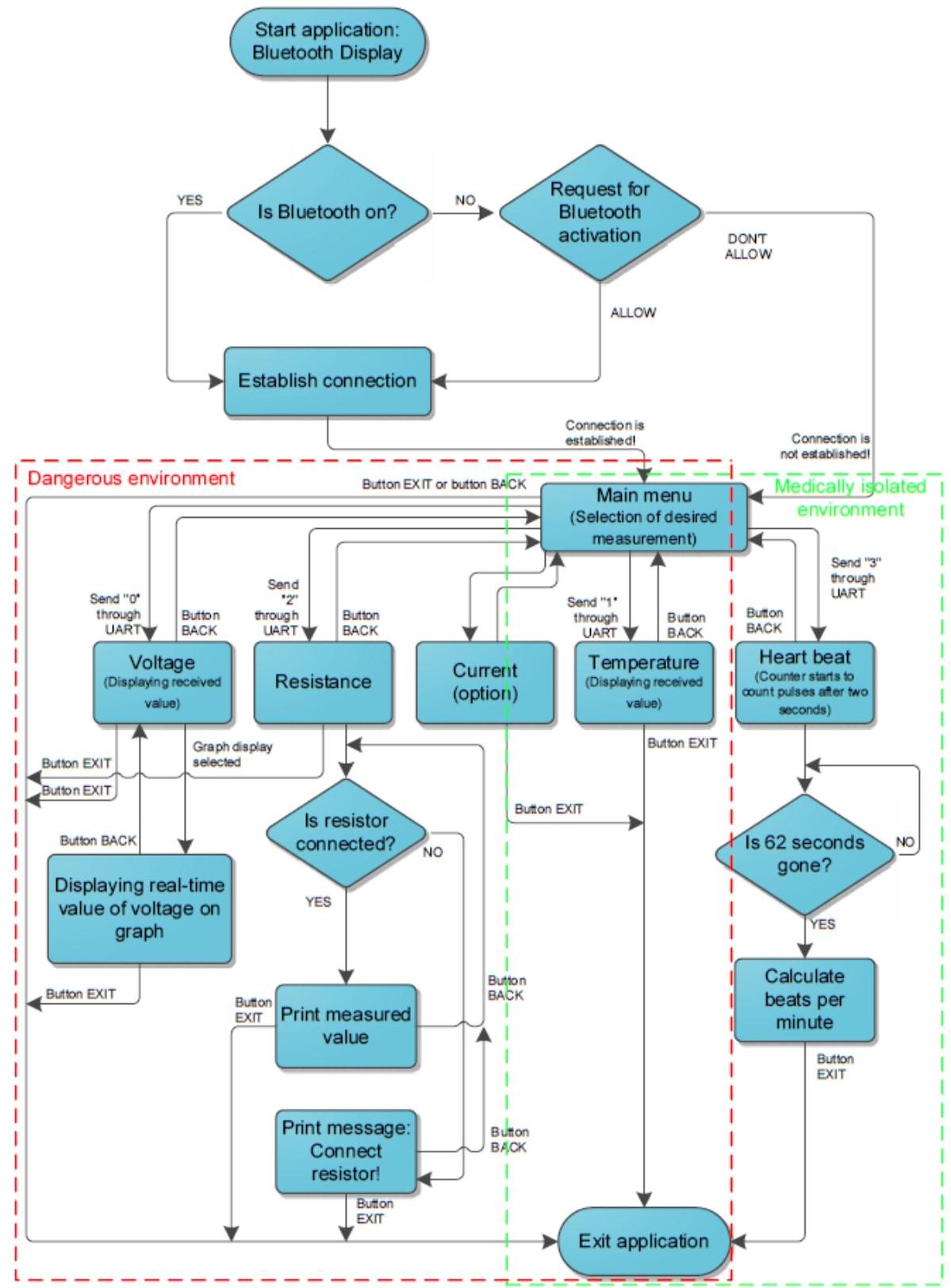

Figure 7: Measuring application flow chart.

At the start-up of the application and the connection with the measuring module, we can choose from a variety of measuring sensors. Each sensor selection is described below. 
Upon starting the application we get a request to turn on the BT interface, unless it is already turned on. If we allow the application to turn BT on or if it is already turned on, the device starts to connect with the measuring module. After a successful connection, the status of the connection is indicated (D2 - LED) (Figure 8). Now we can access the signals, which we want to measure or observe.

The first choice is voltage. By pressing the button "Voltage" we choose measuring voltage (Figure 8).

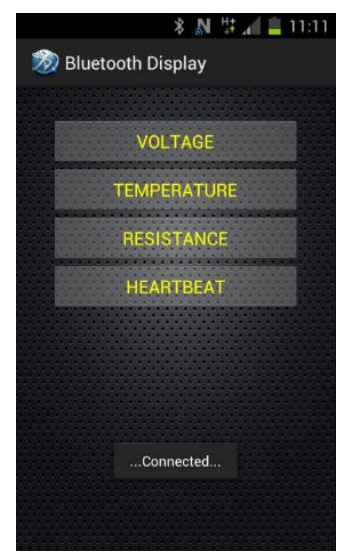

Figure 8: The measurement menu (The measuring module and the mobile device are connected)

The display shows the measured voltage and the selected measuring range of $15 \mathrm{~V}$ ((a) (b)

Figure 9).

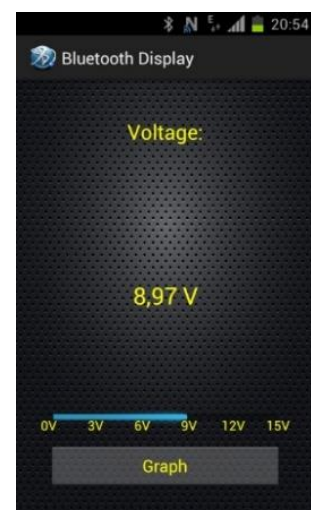

(a)

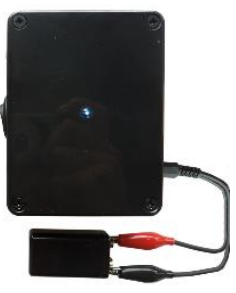

(b) 
$36^{\text {Th }}$ International Conference on Organizational Science Development: ResPonsible Organization (MARCH $22^{\mathrm{ND}}-24^{\mathrm{TH}}$, PORTOROŽ SLOVENiA)

J. Konečnik \& V. Matko: Remote Monitoring Device Using Android Application

Figure 9: Voltage measurement. (a) The first submenu: Voltage. (b) Measuring module connected with $9 \mathrm{~V}$ battery

After selecting the option "Graph", the display switches to the graphical display mode for voltage measurement, where we can observe the dynamical changes of the voltage measurement (Figure 10).

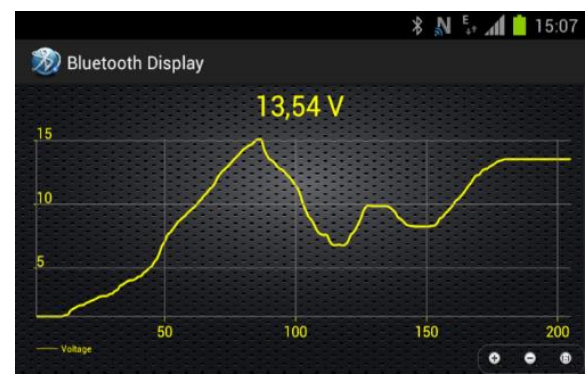

Figure 10: Submenu Graph (Dynamical power supply voltage measuring)

We can leave the submenu by pressing the "back" button on an Android mobile device or we can leave the application directly by pressing the "desktop" button.

The following submenu shows temperature measurement with the range of temperature measurement on the left (Figure 11).

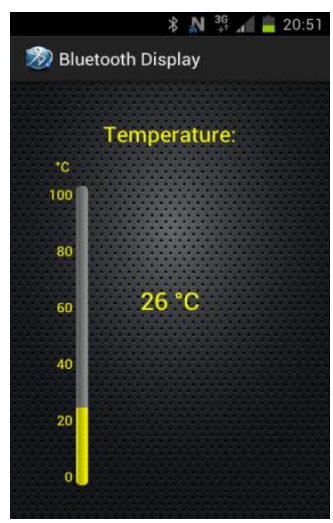

(a)

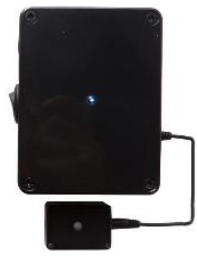

(b)

Figure 11: Temperature measurement. (a) Temperature display with a scale of 0 to $100^{\circ} \mathrm{C}$. (b) Measuring module connected with temperature sensor.

The submenu for measuring resistance tells us to connect a resistor, in case there is no resistor connected to the meter. After we connect the resistor, the measured resistance value and the measuring range are displayed on the left (Figure 11). In case the resistance value is bigger than $999 \Omega$, the unit for resistance measurement changes to $\mathrm{k} \Omega$, whereby 
$10 \mathrm{k} \Omega$ is the maximum value that can be measured by the previously described method (Figure 4).

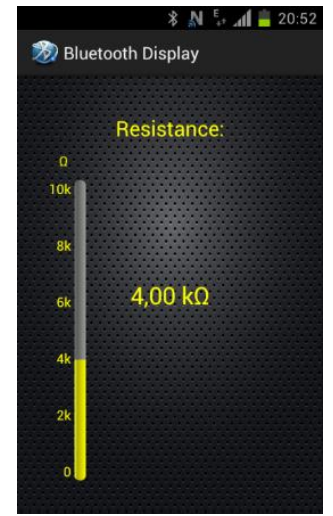

(a)

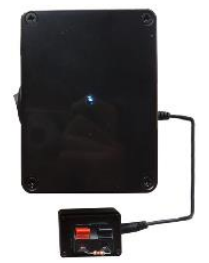

(b)

Figure 11: Resistance measurement. (a) Displayed value of the measured resistance 4 $k \Omega$. (b) Measuring module connected with resistor socket.

If we select the virtual button "Heartbeat" in the main menu and keep a finger on the heartbeat sensor (Figure 6) for at least one minute, the number of heart beats per minute is displayed (Figure 13). We start counting the heartbeat from the second second onward (time delay) up to sixty two seconds, when the number of heart beats per minute is displayed $-\mathrm{bpm}^{47}$.

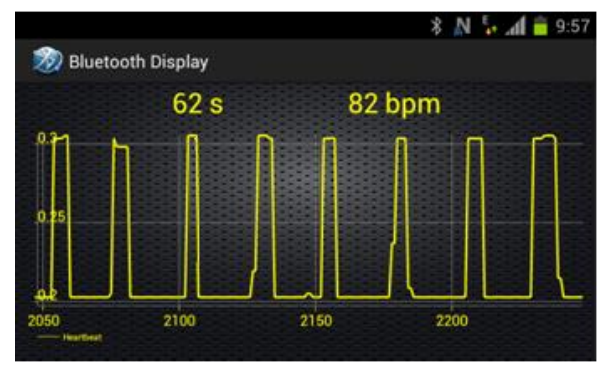

(a)

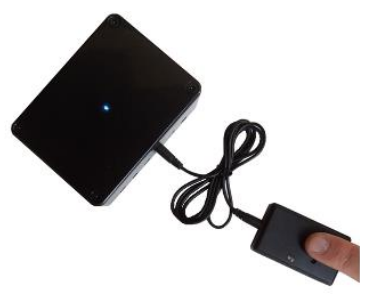

(b)

Figure 13: Heartbeat measurement. (a) Measurement and heartbeat counting per minute. (b) Measuring module connected with heartbeat sensor.

\section{Architecture of the local network}

The local network consists of: an Android mobile device, a measuring module and sensors (

Figure 14). The measuring module can be accessed by all devices with the Android operating system and the correct code to connect with the BT module. 


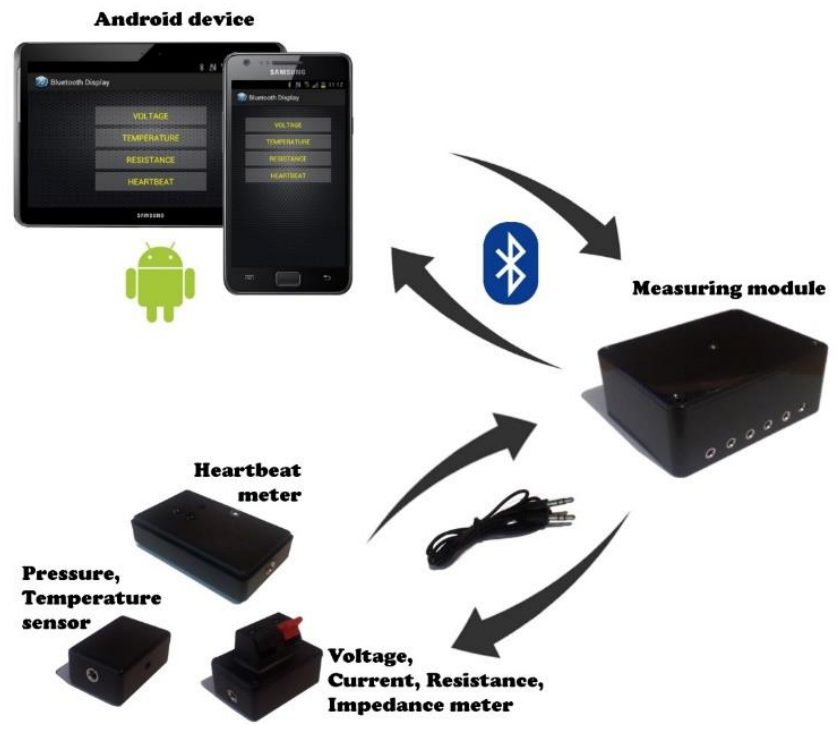

Figure 14: The measuring system for capturing, connectivity and displaying the measurement results.

The main menu displays the selection of available measuring sensors. By choosing one of the sensors, the connection is established, which means that the mobile device verifies, whether the measuring module is available and the connection is possible. With appropriate choice of measurement variables, the measurement start. Whenever we leave the measuring of the variable, return to the menu and choose a new sensor, the connection is always re-established. Because, in case the devices are no longer in the range of the signal, the measuring data transmission is pointless.

\section{$7 \quad$ Conclusion}

This research is about a measurement application that displays the results on a mobile device using the Android operating system, which can be used in dangerous, medically isolated, and test environments.

A major advantage of this application is that it is designed for multiple useful areas of measurement, in contrast to other applications that are usually designed for a specific measurement. The user has the option to select, which quantity to measure. Another big advantage are high-quality and large screens on Android mobile devices, which have recently achieved excellent resolutions, contrasts and fast refreshing rates. On account of this, it is possible to create graphical interfaces with a variety of graphic accessories. We should also mention the compatibility of various applications with all Android devices, high speeds of the devices, affordable prices and up to date development. Another 
advantage is the BT network and its widespread use on all devices. Since devices with a BT interface can create a connection with each other, they do not need other networks and can be used free of charge. The measurements can also be performed in areas without a publicly accessible network.

When comparing the data transmission speed with other applications, we can rank this application in the middle, since it reaches the transmission speed of up to $3 \mathrm{Mbit} / \mathrm{s}$. There are networks with higher data transmission speeds (e.g. Wi-Fi with a speed of up to 600 $\mathrm{Mbit} / \mathrm{s}$ ), as well as much slower networks (e.g. 3G UMTS with a speed of up to 384 $\mathrm{kbit} / \mathrm{s})$. The delay and the time of one measurement depends on the choice of sensor, controller, and the BT module. The faster the module, the higher the price. This experimental application is suitable for measurement of various quantities, where the required dynamics of $20 \mathrm{~ms}$ is sufficient for a single measurement.

Compared to other networks, the disadvantage of this approach is a limited distance between the measuring module and the Android mobile device. The BT module in this price range can only connect within a range of $10 \mathrm{~m}$ to the other device. One of the disadvantages is power consumption. More energy is consumed (up to $30 \mathrm{~mA}$ ) when connecting to another device than when maintaining the connection $(8 \mathrm{~mA})$. Also, the more sensors are connected, the faster the battery loses power. The fact that only one device can be connected to the measuring application can also be seen as a disadvantage. Disturbances in the form of lost packets from the BT module occur during data reception, which can be limited, if we know the measurement ranges and the approximate size of the data received. A display of higher quality without lost packets would require the verification of received information, which would further delay the measurement application.

The experimental application showed that the system is good enough to be widely applied for measurements in ordinary and special areas, such as medically isolated areas, special test areas and areas that are dangerous due to proximity to electricity, chemicals and industry.

The measurement application (measuring module, sensors, meters and competent software for the microcontroller and the Android platform) was created with small funds, which amounted to around $50 \mathrm{EUR}$, excluding the purchase of a mobile device. The low cost of the construction is a major advantage, since, in case the module is ruined (dangerous or test environment), buying a new module is not very problematic.

\section{Notes}

\footnotetext{
${ }^{1}$ Bluetooth

${ }^{2}$ Universal Asynchronous Receiver/Transmitter

${ }^{3}$ Enhanced Data Rate

${ }^{4}$ High Speed

${ }^{5}$ Low Energy

${ }^{6}$ Application Programming Interface

${ }^{7}$ Structured Query Language
} 
$36^{\text {Th }}$ International Conference on Organizational Science Development: ResPonsible Organization (MARCH $22^{\mathrm{ND}}-24^{\mathrm{TH}}$, PORTOROŽ SLOVENiA)

J. Konečnik \& V. Matko: Remote Monitoring Device Using Android Application

${ }^{8}$ Global System for Mobile communications

${ }^{9}$ Enhanced Data rates for Global Evolution

${ }^{10}$ Integrated Digital Enhanced Network

${ }^{11}$ Code Diversion Multiple Access

${ }^{12}$ EVolution Data Optimized

${ }^{13}$ Universal Mobile Telecommunications System

${ }^{14}$ Bluetooth

${ }^{15}$ Synonym for WLAN - Wireless Local Area Network

${ }^{16}$ Long Term Evolution

${ }^{17}$ Worldwide Interoperability for Microwave Access

${ }^{18}$ Short Message Service

${ }^{19}$ Multimedia Messaging System

${ }^{20}$ Or MPEG-4 Part 14 - Moving Picture Experts Group.

${ }^{21}$ Or 3GPP — Third Generation Partnership Project.

${ }^{22}$ Moving Picture Experts Group — Simple Profile

${ }^{23}$ Adaptive Multi Rate audio codec

${ }^{24}$ Adaptive Multi Rate WideBand

${ }^{25}$ Advanced Audio Coding

${ }^{26}$ High Efficiency Advanced Audio Coding

${ }^{27}$ Or MPEG-1 or MPEG 2 Audio Layer 3 - Moving Picture Experts Group

${ }^{28}$ Musical Instrument Digital Interface

${ }^{29}$ Waveform Audio File Format

${ }^{30}$ Joint Photographic Experts Group

${ }^{31}$ Portable Network Graphic

${ }^{32}$ Graphical Interchange Format

${ }^{33} \mathrm{BitMaP}$

${ }^{34}$ Global Positioning System

${ }^{35}$ Analogue/Digital conversion

${ }^{36}$ Transmit

${ }^{37}$ Receive

${ }^{38}$ Infrared

${ }^{39}$ Universally Unique Identifier

${ }^{40}$ Media Access Control Address

${ }^{41}$ Light Emitting Diode

${ }^{42}$ Custom Computer Services

${ }^{43}$ Java 2 Platform Standard Edition

${ }^{44}$ Java 2 Platform Enterprise Edition

${ }^{45}$ Java 2 Platform Micro Edition

${ }^{46}$ Software Development Kit

${ }^{47}$ Beats Per Minute

\section{References}

WB (2017). Bluetooth. Accessible at: http://en.wikipedia.org/wiki/Bluetooth BS - Bluetooth SIG (2017). Accessible at: http://www.bluetooth.com/Pages/Bluetooth-Home.aspx Berišaj, S. (2017). Bluetooth. Accessible at: https://slo-tech.com/clanki/modrizob/modrizob.shtml WUART (2017). Accessible at: https://en.wikipedia.org/wiki/Universal_asynchronous_receiver/transmitter

Durda, F. (2014). Serial and UART Tutorial. Accessible at: https://www.freebsd.org/doc/en/articles/serial-uart/

ZigBee, 2017. Accessible at: http://en.wikipedia.org/wiki/ZigBee 
WiMAX (2017). WiMAX. Accessible at: http://en.wikipedia.org/wiki/WiMAX

WIFI (2017). Wi-Fi. Accessible at: http://en.wikipedia.org/wiki/Wi-Fi

IEEE (2003). Wireless Medium Access Control (Mac) and Physical Layer (Phy) Specifications for Low-Rate Wireless Personal Area Networks (Lr-Wpans); IEEE Standard for Information Technology 802.15.4.

WA (2017). Android. Accessible at: http://en.wikipedia.org/wiki/Android_(operating_system)

GOA (2017). Android offical. Accessible at: http://www.android.com/

GDEV (2017). Developers. Accessible at: http://developer.android.com/index.html

Wei-Meng, L. (2012). Beginning Android 4 Application Development. Indianapolis: Wiley, John \& Sons, Inc., 2-5.

Milosevic, M.; Shrove, M.T.; Jovanov, E. (2011). Applications of smartphones for ubiquitous health monitoring and wellbeing manage.. J. Inf. Technol. Appl., 1, 7-14.

Yang, S.; Gerla, M. (2011). Personal Gateway in Mobile Health Monitoring. In Proceedings of 2011 IEEE International Conference on Pervasive Computing and Communications Workshops (PERCOM Workshops), Seattle, WA, USA, 21-25, 636-641.

Patrick, K.; Griswold, W.G.; Raab, F.; Intille, S.S. (2008). Health and the mobile phone. Am. J. Prev. Med., 35, 177-181.

Lai, X.; Liu, Q.; Wei, X.; Wang, W.; Zhou, G.; Han, G. (2013). A survey of body sensor networks. Sensors, 13, 5406-5447.

Patel, M.; Wang, J. (2010). Applications, challenges, and prospective in emerging body area networking technologies. IEEE Wirel. Commun., 17, 80-88.

Hii, P.C.; Chung, W.Y. (2011). A comprehensive ubiquitous healthcare solution on an Android mobile device. Sensors, 11, 6799-6815.

Zhang, Y.; Xiao, H. (2009). Bluetooth-based sensor networks for remotely monitoring the physiological signals of a patient. IEEE Trans. Inf. Technol. Biomed., 13, 1040-1048.

Burgos, A.; Goñi, A.; Illarramendi, A.; Bermudez, J. (2010). Real-time detection of apneas on a PDA. IEEE Trans. Inf. Technol. Biomed., 14, 995-1002.

Pereira, O.; Caldeira, J.M.; Rodrigues, J.J. (2011). Body sensor network mobile solutions for biofeedback monitoring. Mobile Netw. Appl., 16, 713-732.

Gandhewar, N.; Sheikh, R. (2010). Google Android: An emerging software platform for mobile devices. Int. J. Comput. Sci. Eng., 1, 12-17.

Stack Exchange (2014). Stack Overflow. Accessible at: http://nickcraver.com/blog/2016/02/17/stack-overflow-the-architecture-2016-edition/

DET (2013). Developers Training. Accessible at: http://developer.android.com/training/index.html

GAD (2017). Android Discuss. Accessible at: http://groups.google.com/group/android-discuss

Microchip (2004). PIC18F2550 datasheet. Accessible at: http://ww1.microchip.com/downloads/en/devicedoc/39632b.pdf

MDFLY (2017). Bluetooth. Wireless TTL Transceiver Module RF-BT0417C. Accessible at: http://www.mdfly.com/products/wireless-bluetooth-ttl-transceiver-module.html

WordPress (2017). Bluetooth Module Interfacing with Microcontroler. Accessible at: http://vshamu.files.wordpress.com/2011/03/bluetooth.jpg

Texas Instruments (2017). LM35 Precision Centigrade Temperature Sensors datasheet. Accessible at: http://www.ti.com/lit/ds/symlink/lm35.pdf

MMCP602 (2017). Microchip. MCP602 datasheet. Accessible at: http://ww1.microchip.com/downloads/en/devicedoc/21314g.pdf

Bhatt, R. (2017). Heart Rate Measurement from Fingertip. Accessible at: http://embeddedlab.com/blog/?p=1671

WSG (2017). Signal Edge. Accessible at: http://en.wikipedia.org/wiki/Signal_edge

Samsung (2017). Samsung Galaxy S2 offical. Accessible at: http://www.samsung.com/global/microsite/galaxys $2 / \mathrm{html} /$ feature.html 
$36^{\mathrm{TH}}$ International Conference on Organizational Science Development: RESPONSIBLE ORGANIZATION (MARCH $22^{\mathrm{ND}}-24^{\mathrm{TH}}$, PORTOROŽ SlOVENIA)

J. Konečnik \& V. Matko: Remote Monitoring Device Using Android Application

WUUID (2017). UUID. Accessible at: http://en.wikipedia.org/wiki/Universally_unique_identifier WMAC (2017). MAC Address. Accessible at:http://en.wikipedia.org/wiki/MAC address

WC (2017). C++. Accessible at: https://en.wikipedia.org/wiki/C\%2B\%2B

CCS - Custom Computer Services Inc. (2017). CCS. Accessible at: http://www.ccsinfo.com/

WJAVA

(2017). JAVA.

Accessible

at:

https://en.wikipedia.org/wiki/Java_(programming_language)

Eclipse Foundation (2017). ECLIPSE. Accessible at: http://www.eclipse.org/

WSDK - Wikipedia (2017). SDK. Accessible at:

http://en.wikipedia.org/wiki/Software_development_kit

Developers (2017). SDK. Accessible at: http://developer.android.com/sdk/index.html

ViewSoft Company (2017). A Chart Engine. Accessible at:

http://www.achartengine.org/index.html 
$36^{\text {Th }}$ International Conference on Organizational Science DEVElopMENT: Responsible ORganization (MARCH $22^{\mathrm{ND}}-24^{\mathrm{TH}}$, PORTOROŽ SLOVENIA)

O. Arsenijević, M. Ferjan, I. Podbregar, P. Šprajc, D. Trivan \& Y.

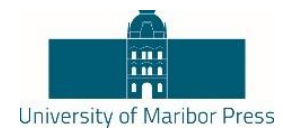

Ziegler

\title{
The Impact of the Internet on the Tourists' Travel Planning Process
}

\author{
Milica Kostic - Stankovic, Jelena CVijovic \& Velimir Stavluanin
}

\begin{abstract}
Information and communication technologies have introduced key changes in the field of tourism. Great importance is given to social networks, whose rapid development and widespread application lead to a change in the behavior of users of tourist products and services, which have become increasingly interconnected and ready to share information with others. Web sites and social networks are becoming indispensable source of critical information before, during and after tourists' trips, which significantly influence their decision-making process and behavior. In the phase before traveling, websites of tourist organizations and online reviews of other tourists are beneficial for deciding where to travel and what products/services to use. During trips, tourists use mobile technology to search for desired information, but also to post photographs and comments on their actual experience. In the post-traveling phase, tourists express their (dis)satisfaction online and spread e-word of mouth.
\end{abstract}

KEYWORDS: traveling experience $\bullet$ decision-making $\bullet$ reviews $\bullet$ e-word of mouth

CORRESPONDENCE AdDRESS: Milica Kostic - Stankovic, Ph.D. University of Belgrade, Faculty of Organizational Sciences, 154 Jove Ilića Street, 11000 Belgrade, Serbia, e-mail: milicak@fon.bg.ac.rs; Jelena Cvijovic, Ph.D., Economics Institute, 16 Kralja Milana Street, 11000 Belgrade, Serbia, e-mail: jelena.cvijovic@ecinst.org.rs; Velimir Stavljanin, Ph.D., University of Belgrade, Faculty of Organizational Sciences, 154 Jove Ilića Street, 11000 Belgrade, Serbia, email: velimirs@fon.bg.ac.rs 
36 ${ }^{\mathrm{TH}}$ InTernational CONFERENCE ON ORganizational Science Development: ResPonsible Organization (MARCH $22^{\mathrm{ND}}-24^{\mathrm{TH}}$, Portorož SLOVENia)

M. Kostic - Stankovic, J. Cvijovic \& Velimir Stavljanin: The Impact of the Internet on the Tourists' Travel Planning Process

Internet and communication technologies affect tourists in all stages of the tourist product and services purchasing process before, during, and after use, but with different degrees and different objectives (Minazzi, 2015). Several studies have pointed out the impact of Internet and social media on the decisions of tourists, particularly for the purpose of information retrieval, planning of vacations and purchasing decision (Vermeulen \& Seegers, 2009). Even though tendency of tourists to use Internet and social media in various stages of travel planning is changed in accordance with the cultural and age differences (Wilson et al., 2012), it is becoming increasingly important factor for both, tourists and tourists organizations. Although interest for this topic evidently exists, the impact of social media on both sides needs to be more thoroughly examined, in order tourist organizations to develop proper strategies of online marketing communication in relation to specific target groups.

\subsection{The influence of Internet in the tourists' decision-making process}

Internet and social media in the stage before travelling help tourists to make decisions and set some expectations for the next tourist experience (Xiang et al., 2014). Internet makes it easy to explore and increases the power of users who receive a more active role in the decision making process (Parra-Lopez et al., 2012). Study by Google Think Insights (2013), which included a sample of tourists who travel for pleasure and those who travel for business reasons, showed a very high concentration of their online activities at this stage. The seven most common online activities of respondents were: research of possible travelling options, reading of comments of other passengers, research of the destination, transport, hotels and viewing online travel ads, starting thinking about certain journey, watching video materials about others' experiences or about a destination, finding additional information about the upcoming trip and looking for reviews and critics from familiar people. Thus, Internet and social media can stimulate new ideas or affect the transformation process of needs to a specific travelling desire. Another study of authors van der Lans et al. (2010) confirmed that social media at this stage are mainly beneficial for deciding where to travel and gathering of new ideas. Academic studies confirmed the importance of online tourists' reviews during this step of travel planning, because they can be particularly useful source of information for tourists (Anderson, 2012). In this context, online comments, photos and videos of other tourists can help in decision-making of tourists. It has been shown that sharing videos and photographs on social networks has a positive impact on reducing the perceived risks and have a positive influence on the decision making process (Mauri, 2012).

Overall, in the phase before traveling, when tourists are yet to make certain decision, tourists' recommendations on accommodation and transport, sightseeing routes and attractions and the like, represent a rich sources of information that help others to identify a group of alternatives and therefore narrow the selection (O'Connor, 2010). Once they identify a set of alternatives, travelers compare them, trying to make the best choice. Moreover, sometimes tourists may be experiencing cognitive dissonance if the 
information obtained is not in accordance with their beliefs or simply in the case of uncertainty about the choices made. In these cases, social media can play a crucial role in order to confirm the validity of the decisions brought by tourists (Minazzi, 2015). They usually compare the ratings, rankings, reviews and visual content for each alternative, before they reach final decisions. At the same time, corporate websites and social network profiles of hotels and other tourist organizations can help tourists not only to interact with the company, but also to enter into concrete action (eg. to book an accommodation, flight etc). However, it is not uncommon that after the initial choice (that often is only reservation and does not represent a binding decision), tourists make changes as a result of unexpected situations or cognitive dissonance. The study of authors Libai et al. (2010) found that a significant majority of respondents actually make some kind of change of the original itinerary after searching certain information online, which represents a growing threat for tourism organization. Ability of tourism organizations to convince tourists that their initial choice really is the right one, lies in implementation of different promotional activities through the Internet and social media and partnerships with tour operators (Jun et al., 2007). For example, when a person reserves a flight on the airplane website, before concluding the purchase process, he may be asked to make reservations of other services such as accommodation, car rentals and so on.

\subsection{The impact of Internet on tourists' activities during trips}

Recent studies highlight the increasing importance of Internet and social media during tourists' trips mainly because of the development of mobile technology. Passengers continue to search for information and make decisions during their trips. With the development of mobile technology, tourists can be connected to each other via the Internet during travel. Tourists generally use multiple devices at various stages of travel planning, but the phase of travelling is dominated by mobile devices. Through mobile phones, they are constantly looking for important information about: weather, restaurants, sites, leisure activities, etc. Searching for information during trips may also help tourists to reduce perceived risk of making wrong choices and increase the perception of security of their choices (Schroeder \& Penninghton-Gray, 2014). In particular, tourists use mobile applications and websites in real time to make decisions about transportation, hotels, restaurants, etc. But the diffusion of mobile technology is particularly influenced by the possibilities of creating and sharing information related to their experience in real time (Buhalis \& Foerste, 2013).

Another important activity of tourists during their trips is posting online assessments and reviews containing a detailed description of experiences of trips on websites allowing this opportunity. These activities can be a great opportunity for hotels and hospitality organizations since they can immediately intervene, while the user who complained is still in the hotel. However, this would mean a meaningful social media management in real time and having employees in charge of this task, which is rarely the case in practice (Munar \& Jacobsen, 2014). 
$36^{\mathrm{TH}}$ International Conference on ORganizational Science Development: Responsible Organization (MarCh $22^{\mathrm{ND}}-24^{\mathrm{TH}}$, Portorož Slovenia)

M. Kostic - Stankovic, J. Cvijovic \& Velimir Stavljanin: The Impact of the Internet on the Tourists' Travel Planning Process

\subsection{Post-traveling tourists' online activities}

According to Cheung and Thadani (2012), 45\% of tourists upon return from the trip immediately put certain traveling-related content on social media and leave different comments. After returning home, tourists assess the quality of the entire traveling experience and express their satisfaction or dissatisfaction with services that are used during the travel on specific sites. In some cases, tourists are further encouraged to set positive comments by receiving thanksgiving email sent by hotels or travel agencies soon after returning. Munar and Jacobsen (2014) have studied the behavior of tourists - Internet users and pointed out that even $78 \%$ of them shared content on social media in the stage after using the service. In the same way, Wilson et al. (2012) found that most young tourists often share experiences about traveling on social networks this stage. In other cases, tourists are using social networks to interact with tourist organization or travel agency to make a compliment or complaint with the service provided. In the second case, a timely response to user complaints is essential for successful customer care (Kaplan \& Haenlein, 2010). Interaction with customers at this stage, through Internet and social media, can be a unique opportunity to develop customer loyalty and long-term mutually beneficial relationship.

\section{Sharing travel experiences via social media}

During their trips, tourists create different stories based on their own experiences, which then share with others. Stories can be produced at different levels: inhabitants (tradition, heritage, etc.), tourist destination (history, culture, etc.), recreation (employees, tourist guides, etc.), and stories of other tourists at certain destination (Moscardo, 2010). With the development of ICT in the tourism sector, the spread of these narrative discourse; which constitute a combination of the meanings of texts, images and videos, is evident. Tourists can, at first, listen to the stories of other tourists and then publish and create their own. These first-hand stories can be shared with during and after treaveling, which affects the behavior of other toursts and image of tourist organizations and destinations. However, it is essential that tourists register certain tourist experience in their memory in order to share it later. Tung and Ritchie (2011) identified four dimensions that allow the tourist experience became memorable:

- Valence of experience: positive emotions and feelings are more memorable than negative. When feeling positive emotions, it is more likely that tourists provide more details on their experience;

- Expectations: unplanned, unexpected events can boost the memory of a certain experience;

- Possible results of the trip: the social relations created by the experience (eg, friendship, love), intellectual development achieved thanks to a trip (eg, learning about the history and culture of a destination), self-discovery (eg, changes in the state of mind of tourists that occurred during the trip) and overcoming physical challenges (eg, development of sport skills and expertise) and the like;

- Memory: it can be supported by photos, videos, stories, souvenirs, etc. 
Moreover, the use of social media during the trip, thanks to mobile technologies, encourages instant sharing the tourists' stories that can produce reactions of other passengers in real time (Kozinets et al., 2010). This concept is called a mobile storytelling and can be defined as a structured and common presentation of visual material produced by the mobile device and the amended text and/or music and sounds (Klastrup, 2007). Mobile storytelling implies that the story is produced by multiple social interaction and co-creation of people from generally different groups.

\section{$3 \quad$ E-word of mouth in tourism sphere}

E-word of mouth can be defined as any positive or negative statements of potential, current or former users of certain tourist product or organization, which are available to wider public via Internet. Unlike the traditional concept of word of mouth, e-word of mouth consists of, generally speaking, text messages sometimes accompanied with visual elements, which are not necessarily addressed to a specific person but to anyone who reads it (Rosen, 2009). The message has, in this case, a longer life and it is asynchronous because it is not essential that the interaction between persons who is sending and receiving the information is held at the same time (Cheung \& Thadani, 2012). In fact, other users can read e-recommendations and critics and after a long time. While in the case of traditional word of mouth, tourists interact with small group of people they know, in the electronic environment, millions of people, unfamiliar to each other, can access attitudes of others (Libai et al., 2010). In this context, it may be difficult to determine the authenticity of the message, because the information are coming from individuals who are geographically and culturally different and belong to different social groups (Gruen et al., 2006; Litvin et al., 2008). Therefore, internet users generate "weak links" with others in order to obtain information on the specific characteristics of tourist products or services (Gruen et al., 2006). E-word of mouth can be divided into organic, or internal, which is spontaneously created by tourists, or enhanced or external, which occurs when tourist organization encourages customers to promotion them by sharing word of mouth (Libai et al., 2010). These actions are the basis of a viral marketing campaign in which the company develops online marketing communications and encourages customers to pass on positive messages to other members of their social network. 
$36^{\mathrm{TH}}$ International Conference on ORganizational Science Development: ResPonsible Organization (MARCH $22^{\mathrm{ND}}-24^{\mathrm{TH}}$, Portorož SLOVENia)

M. Kostic - Stankovic, J. Cvijovic \& Velimir Stavljanin: The Impact of the Internet on the Tourists' Travel Planning Process

Table 1. Corporate activities that support the generation of e-word of mouth (Minazzi, 2015)

\begin{tabular}{|l|l|}
\hline 1 & $\begin{array}{l}\text { Strive to achieve the highest possible customer satisfaction, in order to } \\
\text { encourage the spontaneous spread of positive comments at all tourists } \\
\text { traveling phases }\end{array}$ \\
\hline 2 & $\begin{array}{l}\text { Plan communication through social media: opt for a particular mix of social } \\
\text { media and approach to communication }\end{array}$ \\
\hline 3 & Identify opinion leaders for each social media \\
\hline 4 & Create interesting content that engages users and enables the easy access \\
\hline 5 & Promote interaction and information sharing \\
\hline 6 & $\begin{array}{l}\text { Immediately answer all customer questions and provide efficient customer } \\
\text { service }\end{array}$ \\
\hline 7 & Invite users of social media to action \\
\hline 8 & Engage in conversation on websites of other organizations \\
\hline
\end{tabular}

The problem of legitimacy and authenticity of tourists' word of mouth is one of the key current challenges. The problem that may appear here reflects in that the act of rewarding customers for spreading of ratings can generate the decline in credibility or bias, especially in an online environment where the source of the message is unknown (Minazzi, 2015). First of all, e-word of mouth mainly explain who to buy or use particular tourist product or service, and thus have a favorable attitude toward the product or service (Hu et al., 2012). Second, people who post a comment on the internet are generally very satisfied or very dissatisfied because consumers with moderate satisfaction are not equally stimulated to express their perceptions online. Third, consumers rely on rating (average grade given by a large number of individuals) because it is intuitive and easy to understand, especially in cases where there are numerous information that can be taken into account (Hu et al., 2012). Because of the subjective nature of online recommendation, since rating does not always express the full quality of product or service, that could be sometimes misleading. However, some studies suggest that Internet users are generally aware of these sources of bias, which is compensated by using additional information about the product or service in order to form a high quality of perception and make proper decision (Banerjee \& Fudenberg 2004). The fourth source of bias are the users themselves who used to deliberately manipulate others, by leaving the misleading comments, owing to possible decontextualization and anonymity (Doh \& Hwang, 2009). This can generate false positive or negative comments that can be placed by organizations (companies and competitors) or by the customers. In the first case, tourists can be motivate to leave positive reviews in order to obtain discounts or affordable services from tourist organizations, while, in the second case, organizations can leave comments tehmselves in order to improve their own reputation or harm the reputation of rivals. This can be particularly damaging in case the initiator of false comments take control of the "mood" of greater social group in relation to particular tourist product or service (Munar \& Jacobsen, 2014). There are two categories of social media that allow the spread of e-word of mouth: peer networks and anonymous peer 
review sites. Peer networks appeared to help achieving greater confidence than anonymous peer review sites that offer more information and different perspectives (Heinonen, 2011). Another common difference in the tourism sector appears between a famous anonymous review sites and booking sites. Anyone can comment on anonymous peer-review sites, while booking sites allow customers to post comments only after making actual reservation, which allows a smaller percentage of false comments (Tiwari \& Richards, 2013). On the other hand, the credibility of peer-review sites has been criticized because it is easy to publish false comments since all users, including those who have never used particular tourist serviced, can post a comment (Munar \& Jacobsen, 2014). Hotels sometimes offer incentives to consumers to encourage them to publish positive comments rewarding them with discounts or additional services. Moreover, some companies are specialized in enforcement techniques that are aimed at creating a certain corporate image create fake profiles on social networks and traveling websites or pay freelance writers to prepare professional texts and post them online. However, despite criticism, peer-review sites have been increasingly used by users who are able to correctly interpret the message with regard to the presence of biased information.

\section{Conclusion}

Custom and direct communication, availability, ability to share different types of content (text, photos and video clips) enabled tourists as well as tourist organizations to development close contact online and effective interaction in all stages of purchasing and using of tourist products and services. Web sites and social networks have become indispensable source of critical information before, during and after tourist trips, which significantly influence the decision-making process on visiting certain destinations, using the services of particular hotels or restaurants etc. Today, tourists search the internet and conduct the selection of certain tourist organizations and sites, read reviews and comments of others, but also convey their own traveling experiences. This situation imposes the necessity that tourist organizations constantly monitor, analyze and timely response at tourists' comments and critics in order to generate positive image and consumer satisfaction. By creating adequate internet and social media marketing communication strategies related to deferent target groups, tourist organizations can make themselves more attractive to tourists and generate positive word of mouth which can positively reflect on their online image and reputation.

\section{Literature}

Anderson, C.K. (2012). The impact of social media on lodging performance. Cornell Hospitality Review, Vol. 12, No. 5, pp. 4-12.

Banerjee, A, \& Fudenberg, D. (2004). Word-of-mouth learning. Game Economics Behavior, Vol. 46, No. 1, pp. 1-22.

Buhalis, D., \& Foerste, M.K. (2013). SoCoMo marketing for travel and tourism. In: Information and communication technologies in tourism 2014. Springer International Publishing, pp 175185. 
$36^{\text {Th }}$ International Conference on Organizational Science Development: RESPONSIBLE ORGANIZATION (MARCH $22^{\mathrm{ND}}-24^{\mathrm{TH}}$, PORTOROŽ SLOVENIA)

M. Kostic - Stankovic, J. Cvijovic \& Velimir Stavljanin: The Impact of the Internet on the Tourists' Travel Planning Process

Cheung, C.M., \& Thadani, D.R. (2012). The impact of electronic word-of-mouth communication: A literature analysis and integrative model. Decision Support Systems, Vol. 54, pp. 461-47.

Doh, S.J, \& Hwang, J.S. (2009). How consumers evaluate eWOM (electronic word-of-mouth) messages. Cyberpsycholocical Behaviour, Vol. 12, No. 2, pp. 193-197.

Google Think Insights (2013) The 2013 traveler. Retrieved from http://www.google.ca/think/ research-studies/2013-traveler.html.

Gruen, T.W., Osmonbekov, T., \& Czaplewski, A.J. (2006). eWOM: The impact of customer-tocustomer online know-how exchange on customer value and loyalty. Journal of Business Research, Vol. 59, No.4, pp. 449-456.

Heinonen, K. (2011). Consumer activity in social media: managerial approaches to consumers' social media behavior. Journal of Consumer Behaviour, Vol. 10, No. 6, pp. 356-364.

Hu, N., Bose, I., Koh, N.S., \& Liu, L. (2012). Manipulation of online reviews: an analysis of ratings, readability, and sentiments. Decision Support Systems, Vol. 52, pp. 674-684.

Jun, S.H., Vogt, C.A., \& MacKay, K.J. (2007) Relationships between travel information search and travel product purchase in preterit contexts. Journal of Travel Research, Vol. 45, No. 3, pp. 266-274.

Kaplan, A.M., \& Haenlein, M. (2010). Users of the world, unite! The challenges and opportunities of social media. Business Horizonts, Vol. 53, No. 1, pp. 59-68.

Klastrup, L. (2007). Telling \& sharing? Understanding mobile stories \& future of narratives, $7^{\text {th }}$ International digital arts and culture conference the future of digital media culture.

Kozinets, R.V., De Valck, K., Wojnicki, A.C., \& Wilner S.J. (2010). Networked narratives: understanding word-of-mouth marketing in online communities. Journal of Marketing, Vol. 74, No. 2, pp. 71-89.

Libai, B., Bolton, R., Bügel, M.S., de Ruyter, K., Götz, O., Risselada, H., \& Stephen, A.T. (2010). Customer-to customer interactions: broadening the scope of word of mouth research. Journal of Service Research, Vol. 13, No. 3, pp. 267-282.

Litvin S.W., Goldsmith, R.E., \& Pan, B. (2008). Electronic word-of-mouth in hospitality and tourism management. Tourism Management, Vol. 2, No. 3, pp. 458-468.

Mauri, A.G. (2012). Hotel revenue management: Principles and practices. New York: Pearson Education.

Minazzi, R. (2015). Social Media Marketing in Tourism and Hospitality, Dordrecht: Springer.

Moscardo, G.M. (2010). The shaping of tourist experience: The importance of stories and themes. In: M. Morgan, P. Lugosi, J.R.B. Ritchie (Eds), The tourism and leisure experience: Consumer and managerial perspectives. Bristol: Channel View Publications.

Munar, A.M., \& Jacobsen, J.K.S. (2014). Motivations for sharing tourism experiences through social media. Tourism Management, Vol. 43, pp. 46-54.

O'Connor, P. (2010). Managing a hotel's image on TripAdvisor. International Journal of Hospitality Marketing Management, Vol. 19, No. 7, pp. 754-772.

Parra-Lòpez, E., Gutiérrez-Tano, D., Diaz-Armas, R.J., \& Bulchand-Gidumal, J. (2012). Travellers 2.0: motivation, opportunity and ability to use social media. In M. Sigala, E. Christou, U. Gretzel (Eds), Social media in travel, tourism and hospitality. Theory, practice and cases. Surrey: Ashgate Qualman.

Rosen, E, (2009), The anatomy of buzz revisited: Real-life lessons in word-of-mouth marketing. New York: Random House LLC.

Schroeder, A., \& Pennington-Gray, L. (2014). The role of social media in international tourist's decision making. Journal of Travel Research, Vol. 56, No. 1, pp. 32-42.

Tiwari, A, \& Richards, T.J. (2013). Anonymous social networks versus peer networks in restaurant choice. Annual Meeting Agricultural and Applied Economics Association, Washington, DC.

Tung, V.W.S., \& Ritchie, J.R. (2011). Exploring the essence of memorable tourism experiences. Annual Tourism Research, Vol. 38, No. 4, pp. 1367-1386. 
M. Kostic - Stankovic, J. Cvijovic \& Velimir Stavljanin: The Impact of the Internet on the Tourists' Travel Planning Process

van der Lans, R., van Bruggen, G., Eliashberg, J., \& Wierenga, B, (2010), A viral branching model for predicting the spread of electronic word of mouth. Marketing Science, Vol. 29, No. 2, pp. 348-365.

Vermeulen, I.E., \& Seegers, D. (2009). Tried and tested: the impact of online hotel reviews on consumer consideration. Tourism Management, Vol. 30, No.1, pp.123-127.

Wilson, A., Murphy, H., \& Fierro, J.C. (2012). Hospitality and travel the nature and implications of usergenerated content. Cornell Hospitality Quarterly, Vol.53, No.3, pp. 220-228.

Xiang, Z., \& Gretzel, U. (2010). Role of social media in online travel information search. Tourism Management, Vol. 31, pp.179-188. 
360 36 $6^{\text {TH }}$ International Conference on Organizational Science Development: Responsible Organization (MARCH $22^{\mathrm{ND}}-24^{\mathrm{TH}}$, PORTOROŽ SLOVENIA) 
$36^{\text {Th }}$ International Conference on Organizational Science DEVElopMENT: Responsible ORganization (MARCH $22^{\mathrm{ND}}-24^{\mathrm{TH}}$, PORTOROŽ SLOVENIA)

O. Arsenijević, M. Ferjan, I. Podbregar, P. Šprajc, D. Trivan \& Y.

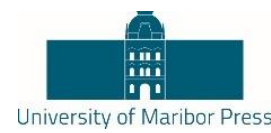

Ziegler

\title{
Holistic Approach in Coastal Zone Management
}

\author{
MiRJANA KovaČIĆ, ASTRID ZeKIĆ \& SREĆKO FAVRO
}

\begin{abstract}
Coastal Zone Management is the responsibility of the public administration, namely the state, regional and local government units. The big number of laws and by-laws and their volatility, the decision-making system that does not recognize the value of resources or the weaknesses regarding human capital, all this contributes to increased and uncontrolled exploitation.
\end{abstract}

The Croatian coastal area is still afflicted by capital interests, which makes the requirements for an appropriate approach to its management ever more complex. The lack of understanding and the declarative behavior of political elites generate the unprofessional selection of personnel, and the public administration is not focused on meeting the public interests. It is absolutely imperative therefore to make a change that will encapsulate a holistic approach to managing coastal resources through the adoption of positive experience of other countries.

The authors analyze the Croatian public administration and the education level of its personnel. The purpose of the study is to identify the current organization of the public sector and its shortcomings. The aim is to point to the need for greater expertise of human resources, especially the management that directly or indirectly controls the coastal zone. The specific objective of the paper is to emphasize the need for continuous training of management and employees in order to understand and improve the activities, processes and procedures aimed at effective management of coastal areas.

KEYWORDS: coastal area - human resources - public administration • management, holistic approach $\bullet$ Croatia

CORRESPONDENCE ADDRESS: Mirjana Kovačić, Ph.D., University of Rijeka, Faculty of Maritime Studies, Studentska ul. 2, 51000, Rijeka, Croatia, e-mail: mirjana051@gmail.com; Astrid Zekić, M.D., University or Rijeka, Faculty of Maritime Studies, Studentska ul. 2, 51000, Rijeka, Croatia, e-mail: astrid.zekic@ gmail.com; Srećko Favro, Ph.D., Adriatic Expert d.o.o., Put Supavla 1, 21000 Split, Croatia, e-mail: srecko.favro@efst.hr

DOI https://doi.org/10.18690/978-961-286-020-2.31

ISBN 978-961-286-020-2

(C) 2017 University of Maribor Press

Available at: http://press.um.si 
$36^{\mathrm{TH}}$ International Conference ON ORganizational Science Development: Responsible Organization (MarCh $22^{\mathrm{ND}}-24^{\mathrm{TH}}$, Portorož Slovenia)

M. Kovačić, A. Zekić \& S. Favro: Holistic Approach in Coastal Zone Management

Coastal areas are defined on multiple levels and are often in conflict with each other. Each level has its specific interests and goals. Coastal zone management in Croatia is under the authority of the public administration, namely regional and local government units. The level of education and the effectiveness of the management and administratively professional personnel are the subject of this paper's analysis. Due to specific characteristics of this resource, the role of the public administration, which has to be in the function of development and above all the public interest, is emphasized in this paper.

\section{Coastal Area - defining the content and concept}

Coastal area is an extremely important Croatian resource through which multiple geographic, economic, demographic, cultural, linguistic and other effect are achieved. It is the area of the largest economic potential, but also one of the most vulnerable ones. Authors Koboević, Milošević-Pujo and Kurtela (2012) say that the importance of coastal area will increase in the future due to the growing number of people who would like to live and work there.

The coast in wider sense represents the area where various natural and geographical elements operate while in the narrow sense it represents land and maritime area consisting of the lowest levels of low waters up to the zone of waves influences. That area makes a combination of two different natural environment, land and sea that abut.

Since the coastal area is the subject of the research carried out by experts of various scientific profiles, i.e. fields of research, there are various definitions in the literature. Authors Filipić and Šimunović (1993) define coastal area as the zone that unites land and sea into a unique life unit, with the area on which it is possible to identify social and economic conditions that are closely associated with that space.

The coastal area is a resource, i.e. part of the total economic development value. According to the authors Cicin-Sain and Knechtu (1998), coasts are an asset of priceless value, attractive places for a vacation and to live but also a very important part of national heritage. Kovačić and Komadina (2011) state that the coastal area in the mainland can cover the whole basin area, large ecosystems, national parks and also entire regions, while its maritime part can cover sea area where the economic zone can be declared.

The most valuable resources are located in the coastal zone. Croatian economic activity is significantly oriented towards that area as one of the comparative advantages. Therefore, special attention should be given to coastal zone management and personnel.

The public administration domain is of strategic importance for state functioning. A successful state functioning depends on the quality of public administration. The ultimate 
goal of administration operations is to provide public service to citizens. Croatian Strategy for the Development of Public Administration for the period from 2015 to 2020 defines the development of public administration in the three basic directions:

- simplification and modernization of administrative proceedings, as well as providing a reliable and prompt support of the public administration to citizens and businesses by the implementation of e-government

- improvement of the development system and human resources management in order to create a modern civil service

- public administration reform in accordance with the best practice and experiences of good management according to European standards.

\subsection{Development of Public Administration in Croatia}

In the 1970s, management reforms of public administration were observed as mechanism to overcome disadvantages of a traditional bureaucratic model of administration and to develop alternative models that would suit the new global economic environment (Mikulić, 2009). The development process of public administration management started at the same time as the changes that took place in business and economic processes. Requests to revise service quality that the public administration provides arose at the same time, as well as the need to manage and supervise public administration expenses. Requests to modernize public administration system have been made to bearers of political decisions, as well as to provide adequate public services to stimulate enterpreneurial climate and to ensure a better living standard.

Reaching these demands involves changes in the organizational structure and processes, financial resources but also the development of new knowledge and skills as well as changes in the system of values and organizational culture. Public management should strive for an effective implementation of laws and creation of a transparent, user-oriented, rational, professional, effective and efficient public administration.

By the end of the 80s of the last century, Western countries were implementing public administration reforms based on economic and social changes in order to strengthen democracy and orientation towards citizens. In transition countries, including Croatia, such development of the public administration didn't take place. The lack of a comprehensive public administration reform consequently affects social and economic development.

The implementation of reforms also includes improving the quality of human resources. The importance of education, ethics and appropriate organizational culture stand out in processes of modernization of public administration and public sector and within the need of strengthening institutional capacities of administrative organizations which is the basis for the inclusion in the European integration believe Musa at al. (2007). Therefore, the system of administrative education and officials' development should guarantee the creation of a high quality personnel who will contribute to the increase of the public administration quality. 
The weakness of the administrative education in Croatia is reflected in the fragmentation and incompleteness with the common rule that on managerial positions in public administration are employed primarily lawyers by education which isn't good for the practice because public administration is a multidisciplinary field. Public administration can be studied only on several polytechnics, while specialist postgraduate study of public administration can be studied only at the University in Zagreb from 2005. Authors Koprić and Marčetić (2002) think that without the personnel educated for the service in public administration Croatia won't be able to create a smaller, more economical, more efficient and effective, responsible, fair, sustainable and quality administration.

Systems of administrative education of other western European countries have the aim to acquire higher education degrees within the administrative profession. Although educational systems of modern European countries are associated with jurisprudence, the economic and political approach are more and more emphasized. The possibility to specialize within the administrative profession contributes to the final "product" of education who would be able to deal with demands of the future workplace in any segment of the public administration. A more efficient administration means a greater chance of success in economy and for citizens.

The system of administrative education, as well as the public administration itself, is under a constant reform. The adjustment in challenges of public needs and specific requirements is achieved by improving administrative capacities .

\subsection{The Analysis of the Level of Education of Public Administration in Croatia}

Educated and competent personnel is the basis for the development of public administration. The level of education of the public administration in Croatia is analyzed below (Figure 1).

On the $1^{\text {st }}$ January 2015 , there were 56.200 employees in the state services plus 151.158 employees in public services. In the broader sense, employees are officials, staff members, support staff, laborers, external assistants and consultants and political appointees. In the narrower sense, it refers exclusively to public officials. 
M. Kovačić, A. Zekić \& S. Favro: Holistic Approach in Coastal Zone Management

\section{Civil servants}

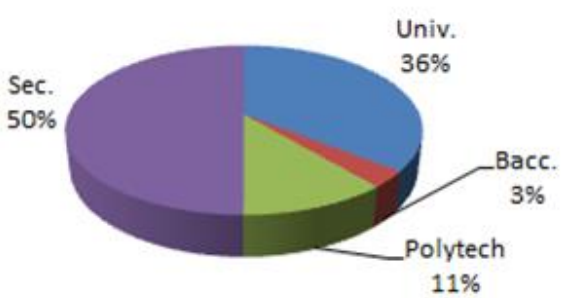

Public officers

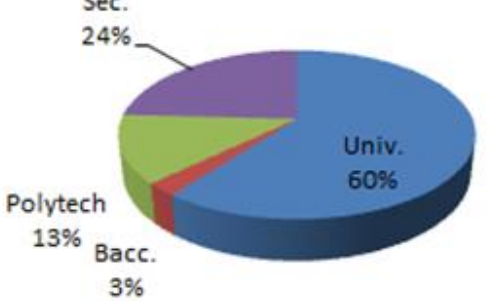

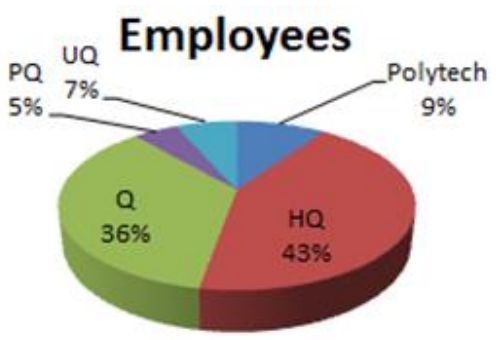

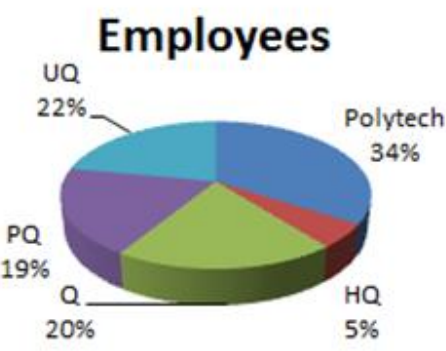

Figure 3: The number of employees in the public administration

Source: Authors according to Croatian Strategy for the Development of Public Administration for the period from 2015 to 2020

It is evident that in the civil service persons with secondary education and those who graduated from the university and vocational studies are mostly represented. Persons who completed undergraduate studies are least represented. Therefore, on the $1^{\text {st }}$ January 2015 there were 56.220 employees in the state services, out of which $28.43 \%$ of officials completed graduated studies or vocational studies (before classified as high expertise), $2.51 \%$ undergraduate studies (before classified as higher expertise), and $41.85 \%$ completed secondary school (classified as medium expertise). The remaining percentage (27.21\%) represents persons with lower expertise (highly qualified (HQ), qualified (Q), partly qualified (PQ) and unqualified (UQ) persons).

On the $1^{\text {st }}$ January 2015 there were 151.158 employees in state services, out of which $51.51 \%$ employees completed graduate studies or vocational studies (before classified as high expertise), $2.13 \%$ undergraduate studies (before classified as higher expertise) and $25.63 \%$ of employees completed secondary school. The remaining percentage $(20.73 \%)$ represents persons with lower expertise (highly qualified (HQ), qualified (Q), partly qualified (PQ) and unqualified (UQ) persons).

\subsection{The Role of Management or How to Motivate Public Officials}

Human resource management in the context of coastal zone management requires for each workplace to provide professional and responsible staff. At the same time it should 
$36^{\mathrm{TH}}$ International Conference on ORganizational Science Development: Responsible Organization (MARCh $22^{\mathrm{ND}}-24^{\mathrm{TH}}$, Portorož Slovenia)

M. Kovačić, A. Zekić \& S. Favro: Holistic Approach in Coastal Zone Management

be enabled for every individual and organization to achieve set goals (Suša, 2009). Today, the importance of human resources is in the increase, so management has become something more important than just delegating tasks. The content of management refers to personnel's needs that include personnel planning, their selection, education, training, professional orientation, relations at work, motivation and salary.

Public administration as a service for citizens primarily has to connect with citizens' needs at all levels and it has to rely on assumptions that ensure focus on results. Modern society wants public administration that will be guided by the criterion of efficiency and therefore motivate employees and have an influence on the quality of the service (Kanoti, 2009).

In recent years, there has been an increase of activities focused on professional training and specialization of officials. These activities include seminars, round tables, conferences, lectures, workshops, training, and thematically they can cover a variety of areas such as law, finances, strategic planning and management, the use of pre-accession EU funds, and many others.

Jambrek and Penić (2008) believe that human resource management is of strategic, developmental and long-term nature, which means that tasks and activities aren't static and separated from each other, but require a constant rethinking in therms of organizational goals and connecting in relevant activities. Because of that, continuous investments into human resources are needed and the motivational factor, that affects job satisfaction and encourages efficiency, is very important. Motivated employees perform tasks more efficiently, and the efficiency of management is reflected in the ability to recognize the needs at all levels, on the individual level and at the level of organization. Brčić and Vuković (2008) state that managers (leaders) in public administration should be devoted to work in order to be able to organize tasks effectively. They have to be of high moral and in particular they have to recognize opportunities and introduce organizational changes on time. Their role requires a high level of skills in the selection of motivational techniques that can be drivers of efficient work. Special emphasis should be placed on motivating employees through participation in the decision-making process. Public administration in Croatia doesn't deal enough with motivational techniques, and doesn't analyze enough the organization of work and in this respect there are no elaborated criteria.

Directing the organization of public administration according to organizational goals, continuous learning and improvement establishes foundations to establish clear rules of work and to encourage development of employees.

\section{$4 \quad$ Management of Coastal Resource}

Coastal area is a resource subject to intense economic activities and, consequently, conflict and incompatibility of structures in often inevitable. 
Coastal area management deals with contradictory problems of different sectors such as spatial and regional development, environment protection, zoning, economic development and aspects of social and cultural development. At the same time coastal areas always represent a part of the local territory and are within a specific region. That is why it is necessary to bring the local processes closer to citizens through decentralization within the local units and creation of conditions for rationalization of their territorial structure. To achieve this it is necessary to consider development as a qualitative measure which requires a holistic approach, especially on the part of management structures. This implies the functioning of the total coastal area development sustainability.

Managing must be based on trusted and accurate information. Otherwise, it is difficult to make the right decisions. Thus, it can be concluded that the information system is an important factor of the decision-making process, but also of the entire coastal area management system. The public administration has a number of different data, from those related to the natural system, to those concerning human activities and laws. This data must be used transparently and responsibly, because the decisions that are not made on time or are wrong affect the development, and the society as a whole.

\section{$5 \quad$ Conclusion}

Problems of coastal zone management are mainly manifested in the overlap of responsibilities of some institutions and the lack of expertise and responsibility of management and employees. Therefore, a management system should be established that will enable one management and integration of all decisions made for a certain area. Cooperation between different levels of public administration and depoliticization of public administration is necessary.

The need for management that will develop an effective and efficient public administration by promoting responsibility, expertise and development of all employees is essential both for Croatia and other coastal countries today. Understanding the coastal area as a precious and irreplaceable maritime resource should cease to be declarative. Only then, coastal zone management can and will come to life on the fact of sustainable development.

\section{Literature}

Brčić, R., Vuković, K. (2008). Uloga organizacijskih vrijednosti u javnoj upravi. Ekonomski pregled, Vol. 59, No. 1-2, pp. 51-69.

Cicin-Sain, B. \& Knecht, R. W. (1998). Integrated Coastal and Ocean Management, Concepts and Practices. Washington D.C.: Island Press.

Filipić, P.,Šimunović, I. (1993). O ekonomiji obalnih područja: planiranje i upravljanje. Split: The University of Split, the Faculty of Economy in Split.

Jambrek, I., Penić, I. I. (2008). Upravljanje ljudskim potencijalima u poduzećima - ljudski faktor, motivacija zaposlenika kao najvažniji čimbenici uspješnosti poslovanja poduzeća. The almanac of the Faculty of Law in Rijeka, Vol. 29, No. 2, pp. 1181-1206. 
$36^{\text {Th }}$ International Conference on Organizational Science Development: Responsible Organization (March $22^{\mathrm{ND}}-24^{\mathrm{TH}}$, Portorož Slovenia)

M. Kovačić, A. Zekić \& S. Favro: Holistic Approach in Coastal Zone Management

Kanoti, D. (2009). Motivacija javnih službenika kao čimbenik djelotvornosti. Hrvatska $i$ komparativna javna uprava: časopis za teoriju i praksu javne uprave, Vol. 9, No. 2, pp. 317322.

Koboević, Ž., Milošević-Pujo, B., Kutrela, Ž. (2012). Održivi razvoj i integrirano upravljanje obalnim područjem-procesi uspješne zaštite obalnog mora. Naše more, Vol. 59, No. 3-4, pp. 176-188.

Koprić, I., Marčetić, G. (2002). Obrazovanje upravnog osoblja: iskustva i izazovi. Croatian Public Administration, Vol. 4, No. 3-4, pp. 515-566.

Kovačić, M., Komadina, P. (2011). Upravljanje obalnim područjem i održivi razvoj. Rijeka: The University of Rijeka, Faculty of Maritime Studies Rijeka.

Mikulić, S. (2009). Uloga upravljanja ljudskim potencijalima u procesu decentralizacije. Hrvatska i komparativna javna uprava: časopis za teoriju i praksu javne uprave, Vol. 9, No. 4, pp. 10911126.

Musa, A., Đulabić, V., Vukojičić, T., Škarica, M. (2007). Obrazovanje za javnu upravu. Croatian Public Administration, Vol. 7, No. 2, pp. 289-317.

Suša, B. (2009). Menadžment ljudskih resursa. Novi Sad: CEKOM - books d.o.o.

Strategy for the Development of Public Administration for the period from 2015 to 2020. (Official Gazette 70/15). 


\title{
Različne oblike organizacije pouka za boljše znanje tujega jezika
}

\begin{abstract}
IRENA KRAJNC
Povzetek Pri pouku tujega jezika je zelo pomembno, da so učenci dobro motivirani in zainteresirani za pouk, kar predstavlja za nas učitelje vedno znova nov izziv. Prispevek na kratko predstavi različne oblike organizacije pouka tujega jezika za boljše in trajnejše znanje ter rabe tujega jezika $\mathrm{V}$ konkretni situaciji. Pouk lahko poteka na različne načine in $\mathrm{v}$ različnih oblikah odvisno od razpoložljivih prostorov, sredstev in iznajdljivosti učitelja. Organizacijsko lahko poteka klasično v učilnici ali v računalnici, na prostem pred šolo, v domačem kraju, v širši okolici ali celo v tujini. Dandanes je v svetu vedno bolj pomembno znanje več jezikov in zato uvajamo večjezičnost tudi $\mathrm{v}$ šole. To pa pomeni za učitelje nove organizacijske izzive, saj poteka pouk v številnih kombiniranih skupinah. Učitelj mora biti iznajdljiv in fleksibilen pri planiranju učnih korakov in vsebin, pri čemer mora vedeti, na kateri stopnji nadaljevati oz. katero stopnjo izbrati in kako jo izvesti v razredu. To je eden od ključnih izzivov pri poučevanju in učenju tujega jezika danes.
\end{abstract}

KLJUČNE BESEDE: tuji jeziki • organizacija pouka • različne oblike dela • kombinirani pouk $\bullet$ izzivi

NASlov AVTORICE: Irena Krajnc, učiteljica, Osnovna šola Antona Ingoliča, Spodnja Polskava, Spodnja Polskava 240, 2331 Pragersko, Slovenija, e-pošta: irena.krajnc@ingoliceva.si

DOI https://doi.org/10.18690/978-961-286-020-2.32

ISBN 978-961-286-020-2

(C) 2017 Univerzitetna založba Univerze v Mariboru

Dostopno na: http://press.um.si 


\title{
Different Organisational Teaching Formats for Ensuring Quality in Foreign Language Learning
}

\author{
IRENA KRAJNC
}

\begin{abstract}
Motivation and interest is the most important issue in foreign languages classes. To achieve this is always a new challenge for the teachers. The contribution presents different forms of organizing foreign language classes to achieve better and more sustainable knowledge and the use of foreign language in real situations. The lessons depend on the available space, resources and ingenuity of the teacher. The lessons can take place in a classroom or in a computer room, outdoors, in hometown or its surroundings or even abroad. Nowadays the knowledge of more languages is getting more and more important. This is the reason why multilingualism is introduced in schools. This is a new organisational challenge as the lessons are performed in combined classes, groups of different level students. The teacher must be resourceful and flexible in planning of learning steps and contents. The main problem is which level to continue with or which level to choose and how to perform it in the class. This is one of the key challenges in teaching and learning foreign languages in today's world.
\end{abstract}

KEYWORDS: foreign languages - the organization of classes $\bullet$ various forms of work $\bullet$ combined lessons $\bullet$ challenges

CoRRESPONDENCE AdDRESS: Irena Krajnc, Teacher, Anton Ingoliča Primary School Spodnja Polskava, Spodnja Polskava 240, 2331 Pragersko, Slovenia, e-mail: irena.krajnc@ingoliceva.si 


\section{Različne oblike organiziranja pouka tujega jezika}

Pri pouku tujega jezika je pomembno, da so učenci dobro motivirani in zainteresirani za pouk, kar predstavlja za nas učitelje vedno znova nov izziv. V razredu mora prevladovati pozitivna klima in pozitiven odnos do vseh jezikov, saj stremimo za razvojem večjezičnosti, medkulturnim ozaveščanjem in vsebinskim ter metodičnim povezovanjem jezikov med seboj. Pouk mora biti razgiban in dobro organiziran. Poiskati moramo različne medpredmetne povezave, kakor tudi mednarodne povezave $\mathrm{z}$ raznimi mednarodnimi projekti, kjer se znanje poglablja in smiselno uporabi.

Pouk lahko poteka na različne načine in $\mathrm{v}$ različnih oblikah odvisno od razpoložljivih prostorov, sredstev in iznajdljivosti učitelja. Organizacijsko lahko poteka klasično v učilnici ali v računalnici, na prostem pred šolo, v domačem kraju, v širši okolici ali celo $\mathrm{v}$ tujini.

Mlajši učenci imajo raje in so uspešnejši pri učenju tujega jezika, če je le-ta čim bolj razgiban, pester in zanimiv. Starejši učenci so večinoma bolj statični, a imajo radi izzive, različne metode dela in učne strategije. Velikokrat je potrebno učilnico preurediti glede na to, kaj učitelj planira in kaj želi z učenci doseči. Prestaviti je treba klopi in stole, razdeliti učence $\mathrm{v}$ pare ali skupine, pripraviti dodaten material za pouk in predvideti čas za določeno dejavnost. Pogosto je zato potrebno več časa in so zato priporočljive strnjene učne ure. To mora učitelj planirati že pred začetkom novega šolskega leta in sporočiti vodstvu šole, da lahko odgovorna oseba za urnike pripravi primeren urnik.

$\mathrm{Na}$ kratko bom predstavila nekaj oblik in načinov dela pri pouku tujega jezika, ki jih v moji praksi pogosteje uporabljam.

Individualna oblika dela je individualno učenje, kjer posameznik individualno predela ali pripravi neko učno snov.

Govorni nastop pripravijo in izvedejo učenci praviloma individualno.

Semafor je primeren za izražanje mnenja. Učenci dvigujejo barvne kartončke (rdeč, rumen, zelen) glede na njihovo znanje ali napredek v znanju.

Delo v dvojicah ali $v$ skupinah poteka v parih ali skupinah, ki se, odvisno od zastavljenega cilja, določi po učenčevi izbiri, učiteljevi izbiri ali žrebanju.

Viharjenje možganov (Brainstorming) je zelo dobrodošlo za motivacijo na začetku pouka. Učence izzoveš, da povedo čim več asociacij na določeno besedo ali temo. Primerna je za odkrivanje lastnih idej, spoznavanje raznolikosti idej in možnosti alternativnih rešitev.

Za utrjevanje določene snovi je primerno delo na delovnih točkah ali postajah. Delovne postaje so razporejene po učilnici, učenci se, najbolje $\mathrm{v}$ paru, pomikajo od ene postaje do druge in rešujejo določene naloge. Na razpolago so tudi dane rešitve, ki jih uporabijo za samovrednotenje svojega dela. 
$36^{\text {Th }}$ International Conference on Organizational Science Development: RESPONSIBLE ORGANIZATION (MARCH $22^{\mathrm{ND}}-24^{\mathrm{TH}}$, PORTOROŽ SLOVENIA)

I. Krajnc : Different Organisational Teaching Formats for Ensuring Quality in Foreign Language Learning

Metoda snežne kepe je uporabna za sodelovalno učenje. Na primer, učenci so razdeljeni v skupine po štiri. Vsaka skupina ima določeno nalogo. Ko jo opravijo, se zamenjajo člani skupine tako, da se po dva učenca pomikata naprej v smeri urinega kazalca.

Tržnica znanja se lahko izvaja individualno, v parih ali v skupinah. Svoje pridobljeno znanje prodajajo za gumbe, palčke, lističe ali igralni denar.

Didaktične igre in kvizi so zelo dobrodošli za vse starostne skupine za utrjevanje in poglabljanje znanja.

Analiza polja sil ZA-PROTI je za učence zelo motivacijska oblika dela. Učenci, razdeljeni v skupine, iščejo argumente za in proti na neko določeno trditev ali temo. Učenci ob širjenju besedišča razvijajo tudi iskanje dobrih argumentov.

Debata je nadgradnja analize polja sil za-proti. Izobraževalna debata je uravnoteženo strukturiran komunikacijski dogodek o pomembni temi, v kateri se soočita dve (lahko tudi več) nasprotujočih si strani in poskušata prepričati publiko/sodnike. Razumeti jo moramo kot proces, ne kot enkraten, zaključen dogodek. Debata se kot izmenjava mnenj, razpravljanje in argumentiranje, uporablja pri pouku kot aktivna metoda učenja za spodbujanje kritičnega mišljenja. Učenci $\mathrm{v}$ debati razvijajo govor, razmišljanje in argumentiranje, razvijajo veščine javnega nastopanja, dvigujejo svojo samozavest, razvijajo veščine timskega dela, znajo poslušati in dati povratno informacijo (vrstniško vrednotenje) ter oceniti svoj napredek (samovrednotenje).

Medpredmetno povezovanje in sodelovanje uresničujemo na različne načine. Učitelji tujih jezikov se večinoma povezujemo $\mathrm{z}$ učitelji geografije, glasbene in likovne umetnosti, slovenščine, tehnike, računalništva in športa, pa tudi z ostalimi. Pred začetkom šolskega leta se sestanemo, poiščemo skupne interese, zastavimo skupne cilje in okvirno določimo termin izvajanja. Naše večletne povezave in projekti so: Avstralija, svetovni dan miru, Promet, Prebivališča, Dediščina gre v šole.

Mednarodno povezovanje in sodelovanje dosegamo z raznimi mednarodnimi projekti, kot so Comenius, Erasmus, iEARN, eTwinning. Organiziramo razne strokovne ekskurzije v tujino in povezujemo učence s sovrstniki preko interneta po svetu.

Spletne učilnice, ki jih učitelji pripravimo posebej za določene razrede in predmete, so primerne za individualno ali sodelovalno delo in učenje tujega jezika $\mathrm{v}$ šoli ali doma. $\mathrm{V}$ spletne učilnice naložimo učitelji določeno snov, naloge in internetne povezave, ki so učencem v pomoč pri učenju, utrjevanju znanja, samostojnem raziskovalnem delu in delu na daljavo.

Večjezičnost razvijamo z motiviranjem učencev za učenje več jezikov, sodelujemo v raznih projektih, pri samem pouku pa redno primerjamo vsebine in metode učenja med seboj in poskušamo večjezičnost ozavestiti. 


\section{$2 \quad$ Kombinirani pouk}

Kombinirani pouk je organizacija poučevanja več razredov istočasno. Je poučevanje v starostno in programsko heterogenih oz. kombiniranih oddelkih (Nolimal, 2007). Kombiniran oddelek nastane tako, da združimo učence dveh ali več razredov v eni učilnici. Tovrstni pouk dobimo, če združimo učence različne starosti $\mathrm{v}$ eni učilnici in pouk poteka pod vodstvom enega učitelja (Poljak, 1984). Značilnost kombiniranega pouka je sočasna organizacija in izvedba dveh ali več učnih načrtov v eni učilnici, kar zahteva od učitelja veliko mero fleksibilnosti pri načrtovanju, organizaciji in izvedbi pouka ter pedagoških izkušenj (Nolimal, 2001).

Kombinirani pouk ne predstavlja nekaj novega $\mathrm{v}$ šolstvu, saj je bil $\mathrm{v}$ preteklosti pogosto organiziran na manjših šolah zaradi manjšega števila otrok v posameznih razredih. Kombinirani pouk tujih jezikov pa predstavlja nov izziv za učitelje tujih jezikov. Pouk se namreč $\mathrm{z}$ uvedbo t. i. neobveznih izbirnih predmetov od četrtega do devetega razreda osnovne šole organizira v kombiniranih skupinah (Zakon o osnovni šoli, 2013).

Pouk drugega tujega jezika je v zadnjih desetletjih doživel že kar nekaj sprememb v sami organizaciji. Najprej se je izvajal kot interesna dejavnost ali krožek, nato kot zgodnje učenje tujega jezika, kot izbirni predmet od 7. do 9. razreda, nadalje kot obvezni predmet od 7. do 9. razreda in od leta 2014/2015 kot neobvezni izbirni predmet od 4. do 9. razreda. Sprva smo bili učitelji tujih jezikov navdušeni nad neobveznim tujim jezikom, ki je večinoma nemščina, a ko smo bili postavljeni v konkretno situacijo, smo spoznali pomanjkljivosti pri organiziranju in izvajanju takega pouka.

Kombinirani pouk tujega jezika mora učitelj še posebej pozorno načrtovati, organizacijsko in snovno, saj so lahko v eni skupini učenci dveh, treh ali več različnih razredov, oziroma učenci z različnimi predznanji in različne starosti. Pri načrtovanju, organiziranju in izvajanju kombiniranega pouka moramo upoštevati naslednja načela (Nolimal, 2009):

1. Načelo oblikovanja starostno in programsko zaporednih učnih skupin (manjša odstopanja $\mathrm{v}$ starosti učencev, vsebinska in didaktično-metodična usklajenost).

2. Načelo programske usklajenosti (Poiščemo vsebinske in ciljne povezave, iste ali sorodne vsebine.).

3. Načelo smotrne organiziranosti in racionalne izrabe časa (tematsko usklajen pouk, skupna motivacija in zaključek, več direktnega in skupinskega pouka).

4. Načelo fleksibilnosti (časovna razporeditev učnih vsebin, organizacijska izvedba homogenih ali heterogenih skupin).

5. Načelo enake pozornosti posameznim jezikovnim ravnem.

6. Načelo ustreznosti razvojni stopnji (upoštevanje predznanja, sposobnosti, morebitne individualne posebnosti).

Izpostavila bi štiri največje težave oziroma izzive pri organizaciji pouka drugega tujega jezika, ki jih opažam kot učiteljica kombiniranega pouka. 
$36^{\text {Th }}$ International Conference on Organizational Science Development: RESPONSIBLE ORGANIZATION (MARCH $22^{\mathrm{ND}}-24^{\mathrm{TH}}$, PORTOROŽ SLOVENIA)

I. Krajnc : Different Organisational Teaching Formats for Ensuring Quality in Foreign Language Learning

\subsection{Normativ}

Za oblikovanje učne skupine za pouk neobveznega izbirnega predmeta je 28 učencev, lahko tudi do 30 učencev. Tako nastala skupina je sestavljena iz učencev dveh ali več razredov ne glede na njihovo predznanje. Učenci si lahko vsako leto premislijo, izstopijo, naslednje leto pa se lahko ponovno vpišejo k pouku drugega tujega jezika. Kombinirani pouk jezika $\mathrm{v}$ tako velikih skupinah otežuje delo vsem udeležencem, učencem in učiteljem. Učitelji nehote pouk prenatrpamo z ukazi in navodili. Paziti je treba, kaj smo rekli eni skupini, kaj drugi, kaj tretji, da smo dovolj jasni, nazorni in zanimivi, da nas po petih ali šestih urah pouka še sploh poslušajo in se ob tem tudi kaj naučijo.

\subsection{Komunikacija in različni načini dela}

Razvijanje komunikacije in besedišča pri 28 ali celo 30 učencih in to še kombiniranega pouka, je pogosto slabše izvedljiva. Učenje jezika, ki temelji na komunikaciji in didaktičnih igrah, je v tako veliki kombinirani skupini veliko težje in manj uspešno kot $\mathrm{v}$ manjši, homogeni skupini. Prav tako jih ne morem peljati v računalniško učilnico, da bi lahko uporabljali IKT, kakor tudi ne v telovadnico, kjer bi se lahko gibali in igrali in se podzavestno učili in sprejemali nemščino. Učenci so zelo radovedni, sodelovalni in vedoželjni, zato potrebujejo razgiban pouk z različnimi metodami in oblikami dela.

\subsection{Prostor}

Več je učencev v razredu, manj je možnosti za izvajanje gibalno-didaktičnih iger in preurejanje učilnice glede na potrebe mešane skupine otrok upoštevajoč starost in predznanje tujega jezika. Fizično ločim učence glede na način dela, ki sem ga predhodno pripravila, da ne motijo preveč drug drugega, oz. pripravim učilnico tako, da lahko sodelujejo v skupinah glede na sposobnosti, ali jih pomešam, da se lahko učijo drug od drugega.

\section{4 Čas}

Pouk imajo učenci večinoma sedmo ali osmo uro, ko so že utrujeni in jih učitelj težje motivira za delo. Zato menim, da bi ure pouka tujega jezika morale biti na začetku pouka in ne na koncu.

Kot učiteljica te izzive rešujem na različne načine. Za načrtovanje in pripravo na pouk kombiniranega pouka izbirnega tujega jezika potrebujem veliko več časa kot za ostale ure pouka. Poučevanje otrok sprejemam z vso odgovornostjo in se zavedam, kako pomembna je dobra organizacija za uspešno izveden pouk. V lanskem šolskem letu sem imela pri pouku nemščine kot drugega tujega jezika kombinirano skupino 26 učencev četrtega in petega razreda. V letošnjem šolskem letu z učenjem nemščine nadaljujejo vsi lanski četrtošolci, medtem ko so se od lanskih petošolcev za nadaljevanje učenja odločili le trije. Tako je letošnja kombinirana skupina sestavljena iz skupno 22 učencev, od katerih jih je osem četrtošolcev, enajst petošolcev in trije šestošolci. 
Pouk načrtujem po tematskih sklopih in iščem povezave ter rdečo nit, ki ji učenci sledijo. Kljub trem različnim skupinam in pozni uri pouka $v$ urniku, poskušam delo organizirati čim bolj zanimivo, poučno in zabavno. Večinoma so učenci razdeljeni v skupine, da laže spremljam njihov napredek in jih usmerjam pri delu. Nenehno krožim od ene skupine do druge. V kombinirani učni skupini treh oddelkov se posamezni skupini lahko posvetim le 15 minut (npr. 15 min. 4. razredu, 15 min. 5. razredu, 15 min. 6. razredu). To predstavlja tako fizični (priprava učilnice), organizacijski (skupinsko delo, delo v parih) kot vsebinski izziv, saj si želim, da bi vsi učenci napredovali v znanju in spretnostih v skladu s svojo doseženo ravnjo znanja in sposobnostmi. Občasno učence fizično ločim tako, da ima določena skupina pouk pred uro $\mathrm{v}$ urniku in se lahko takrat posvetim samo njim.

Pouk začnemo in končamo vedno s pesmico ali kakšno motivacijsko igro. Potem učencem razdelim delo. Učenci pišejo v zvezke, rešujejo učne liste, gledajo oz. poslušajo video ali zvočni posnetek, se igrajo razne didaktične igre, tvorijo dialoge itn. Skupine organiziram glede na težavnost učne snovi in po lastni presoji. Včasih je bolje, da delajo skupaj učenci iste učne skupine, da ne motijo druge skupine pri učenju ali reševanju nalog, drugič je boljše, da jih pomešam in tako starejši pomagajo mlajšim.

Zapis na tablo oz. primerno pripravljena projekcija za kombiniran pouk treh razredov pomeni še dodatni izziv za učitelja. Zapise po navadi pripravim v različnih barvah, ampak le za dve skupini hkrati, ker se učenci sicer ne znajdejo in narobe prepisujejo, če je tabelni zapis preveč raznolik.

Glede na svojo prakso ugotavljam, da uzakonjena organizacijska sprememba v obliki kombiniranih skupin pri pouku tujega jezika ne omogoča optimalnega učenja in znanja tujega jezika, kjer je poudarek na komunikacijskem pristopu ter neprekinjenem in kontinuiranem jezikovnem vnosu (Učni načrt, 2013). Menim, da imajo učenci pravico do pouka tujega jezika $\mathrm{v}$ homogenih skupinah, kjer so iste starosti in kjer so razlike $\mathrm{v}$ ravni znanja manjše. Za učenje tujega jezika bi zaradi aktivne vloge učencev pri razvijanju sporazumevalne zmožnosti morali biti normativi za oblikovanje učne skupine nižji. Ti ne bi smeli presegati 20 učencev v skupini. Zaradi narave učenja jezika bi morala biti zagotovljena najmanj triletna vertikala pouka tujega jezika. To pomeni, da bi učenci imeli možnost nadaljevati z učenjem tujega jezika v homogeni skupini od 4. do 6. razreda in od 7. do 9. razreda osnovne šole. Iz predlaganega sledi, da bi bilo optimalno poučevanje in učenje tujega jezika zagotovljeno tako, da bi bil pouk umeščen $\mathrm{v}$ urnik obveznega dela programa, ko so učenci najbolj dojemljivi za učenje.

O tej problematiki oz. o položaju drugega tujega jezika v OŠ je potekala tudi javna razprava (MIZŠ, 2016), katere povzetek je dostopen na http://www.mizs.gov.si/si/medijsko_sredisce/novica/article/55/9920/ (MIZŠ, 2017).

Učitelji ocenjujemo, da je s trenutno ureditvijo neobveznih izbirnih predmetov oteženo delo in načrtovanje pouka drugega tujega jezika. Zaradi organizacije pouka, ki poteka v heterogenih starostnih skupinah, pa pada kakovost pouka. 
$36^{\mathrm{TH}}$ International Conference on Organizational Science Development: ResPonsible Organization (MARCH $22^{\mathrm{ND}}-24^{\mathrm{TH}}$, Portorož Slovenia)

I. Krajnc : Different Organisational Teaching Formats for Ensuring Quality in Foreign Language Learning

V kombinirani skupini:

- ni dovolj časa za ustno izražanje in kakovostno poslušanje ter za utrjevanje naučenega,

- v 2 VIO učenci 4. razreda ne morejo biti samostojni pri reševanju nalog, saj znajo premalo,

- da bi delali brez učiteljeve pomoči,

- učenci nadaljevalci (5. in 6. razred) so zaradi tega večino časa brez učitelja in je

- njim samim prepuščeno, koliko delajo brez učiteljevega nadzora in pomoči,

- je zaradi velikosti skoraj nemogoč osebni pristop, ki je pri pouku tujega jezika nujen,

- priprava materiala (možnih 6 nivojev) vzame učitelju preveč časa,

- se zaradi starostno heterogenih skupin pojavi problem ocenjevanja,

- se težje izvajajo nekatere oblike dela, npr. igranje vlog, saj ena skupina preglasi druge,

- je problem tudi z učilnico, saj večinoma učitelji nimajo stalne učilnice za pouk $2 \mathrm{TJ}$ in zato

- nimajo dovolj časa za preurejanje učilnice, npr. za izvajanje gibalno-didaktičnih iger in za

- delo po skupinah.

\section{$3 \quad$ Zaključek}

Rada sem učiteljica in z vso odgovornostjo sprejemam vse novosti in spremembe pri organizaciji pouka in poučevanju tujega jezika. Vendar menim, da uvedba drugega tujega jezika kot neobveznega izbirnega predmeta zaradi kombiniranih skupin, previsokih normativov in vsakoletnega ponovnega oblikovanja skupin, ni najbolj ustrezna rešitev. Kljub učiteljevim organizacijskim in vsebinskim prilagoditvam sta se znižali kvaliteta in količina znanja učencev ter njihov odnos do učenja tujega jezika. S tem se pridružujem mnenjem mnogih učiteljev tujega jezika, ki so se odzvali na izhodišča za ureditev položaja drugega tujega jezika (MIZŠ, 2016), in upam, da bo glas stroke upoštevan z namenom, da učence $\mathrm{z}$ znanjem več jezikov pripravimo na izzive sodobne, globalne in večjezične družbe (Evropska komisija, 2015).

\section{Literatura}

Evropska komisija (2015). Language competencies at school and at work. New evidence on national language tests and on the value of language skills on the labour market. Bruselj: Evropska komisija.

Ministrstvo za izobraževanje, znanost in šport. (2016). Ureditev položaja drugega tujega jezika $v$ osnovni šoli. Izhodišča za javno razpravo. Dostopno na: http://www.mizs.gov.si/fileadmin/mizs.gov.si/pageuploads/Aktualno/Poucevanje tujega jezi ka_Izhodisca_javna_razprava_pop.doc 
I. Krajnc : Različne oblike organizacije pouka za boljše znanje tujega jezika

Ministrstvo za izobraževanje, znanost in šport. (2017). Povzetek javne razprave o položaju drugega tujega jezika vosnovni šoli. Dostopno na:

http://www.mizs.gov.si/si/medijsko_sredisce/novica/article/55/9920/

Nolimal, F. (2009). Kombinirani pouk, Strokovne priprave učiteljev za poučevanje v oddelkih dopolnilnega pouka slovenščine $\mathrm{v}$ tujini. Zavod RS za šolstvo. Dostopno na: http://www.zrss.si/slovenscina/gradiva/GRA_Kombinirani_pouk_FaniNolimal_3jul09.pdf.

Nolimal, F. (2007). Kombinirani oddelki in kombiniran pouk v osnovnih šolah v Sloveniji in tujini. $\mathrm{V}$ : Vzgoja in izobraževanje: revija za teoretična in praktična vprašanja vzgojno izobraževalnega dela, Vol. 38, No. 6 (2007), str. 10-18.

Nolimal, F. (2001). Kombinirani pouk včeraj, danes, jutri. Didaktični priročnik. Ljubljana. Zavod RS za šolstvo.

Poljak, V. (1984). Didaktika. Zagreb. Školska knjiga.

Požarnik Marentič, B. (2000): Psihologija učenja in pouka, Ljubljana: DZS.

Učni načrt (2013). Program osnovna šola, Drugi tuji jezik v 4. do 9. razredu, Neobvezni izbirni predmet, Ljubljana: Ministrstvo za izobraževanje, znanost in šport, Zavod Republike Slovenije za šolstvo.

Dostopno

na:

http://www.mizs.gov.si/fileadmin/mizs.gov.si/pageuploads/podrocje/os/devetletka/program_r azsirjeni/Drugi_TJ_izbirni_neobvezni.pdf.

Zakon o osnovni šoli (2013), Uradni list Republike Slovenije, št. 63/2013. 
378 36 $6^{\text {TH }}$ International Conference on Organizational Science Development:

Responsible Organization (MARCH $22^{\mathrm{ND}}-24^{\mathrm{TH}}$, PORTOROŽ SLOVENIA) 
36. MEDNARODNA KONFERENCA O RAZVOJU ORGANIZACIJSKIH ZNANOSTI: OdgOVORNA ORGANIZACIJA (22. - 24. MAREC 2017, PORTOROŽ, SLOVENIJA)

O. Arsenijević, M. Ferjan, I. Podbregar, P. Šprajc, D. Trivan \& Y. Ziegler

\title{
Opravljanje praktičnega usposabljanja v tujini, strah ali izziv?
}

\author{
NATAŠA KRAJNC ZAKRAJŠEK
}

Povzetek Praktičnega usposabljanja $\mathrm{z}$ delom kot sestavni in obvezni del v prenovljenih programih srednjega strokovnega, srednjega poklicnega in srednjega poklicno-tehničnega izobraževanja izvajamo tudi na Srednji zdravstveni šoli Celje. Razširili smo ga tudi v tujino in s tem dijakom omogočili, da si odprejo možnosti zaposlitve po končanem šolanju. Vzpostavili smo stik z gospodom Michaelom Mocnikom v Bad Aiblingu, ki je direktor tamkajšnjega doma starostnikov. Mesečno lahko dva do štirje dijaki opravljajo praktično usposabljanje, izbere jih direktor sam po predhodno oddanih vlogah in opravljenem razgovoru z njimi na naši šoli. Omogoči jim tudi finančno podporo v smislu prevoza, nastanitve, prehrane in na koncu tudi nagrade. Pogoj je polnoletnost. Nekaterim dijakom to predstavlja izziv, drugim velik strah. Dijaki sami potujejo v Bad Aaibling. Gre za nadgradnjo samostojnosti, razširitve obzorja, izpopolnjevanja $\mathrm{v}$ znanju nemškega jezika. $Z$ dijaki po vrnitvi opravimo analizo, pregledamo ocenjevalni list mentorja ter se pogovorimo o morebitnih težavah. Rezultati so pokazali, da je zanimanje za naše dijake zelo veliko po končanem šolanju in zato jim tudi ponudijo pomoč pri iskanju zaposlitve $\mathrm{v}$ tujini. Nekje sedemdeset odstotkov dijakov vidi v usposabljanju priložnost kot izziv, ostalim pa to predstavlja strah, ki so ga do zdaj zelo dobro premagali in naredili velik korak v življenju.

KLJUČNE BESEDE: praktično usposabljanje z delom $\bullet$ tujina $\bullet$ izziv $\bullet$ strah

NASLOV AVTORICE: Nataša Krajnc Zakrajšek, Srednja zdravstvena šola Celje, Ipavčeva 10, 3000 Celje, Slovenija, e-pošta: krajnc.zakrajsek@gmail.com

DOI https://doi.org/10.18690/978-961-286-020-2.33

ISBN 978-961-286-020-2

(C) 2017 Univerzitetna založba Univerze v Mariboru

Dostopno na: http://press.um.si 
$36^{\text {TH }}$ InTERnAtional CONFERENCE ON ORganizational SCIENCE Development: Responsible Organization (MARCH $22^{\mathrm{ND}}-24^{\mathrm{TH}}$, PORTOROŽ SLOVENIA)

O. Arsenijević, M. Ferjan, I. Podbregar, P. Šprajc, D. Trivan \& Y.

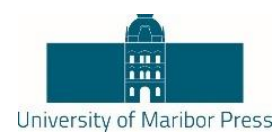

Ziegler

\title{
Practical training abroad: fears and challenges?
}

\author{
NATAŠA KRAJNC ZAKRAJŠEK
}

\begin{abstract}
Practical training is a compulsory part of programmes taught at Secondary School for Nurses Celje. We successfully started sending students abroad to have their practical work carried out abroad. Mr. Michael Mocnik from Bad Aibling, Germany, is the managing director of a nursing home. Every month 2 to 4 students from our school travel to Germany. They are chosen by Mr. Mocmik and his decision is based on their applications, interviews and CVs. The exchange also covers the travelling costs, accommodation, food and a small amount of financial support. However, the students must be 18 or more. This is an upgrade of our students' independence, expanding their horizons, gaining advanced knowledge of nursing care and German language. When the students return home, we analyse their work and evaluate the benefits or problems of the exchange. The results show that in most cases our students become very interesting for future employers at home and abroad. Approximately $70 \%$ of our students see the exchange programmes as a challenge and the rest of the are afraid of working abroad.
\end{abstract}

KEYWORDS: practical training abroad $\bullet$ working abroad $\bullet$ challenge $\bullet$ fear

CoRRESPONDENCE AdDRESS: Nataša Krajnc Zakrajšek, Middle School of Nursing in Celje, Ipavčeva 10, 3000 Celje, Slovenia, e-mail: krajnc.zakrajsek@gmail.com 
N. Krajnc Zakrajšek: Opravljanje praktičnega usposabljanja v tujini, strah ali izziv?

\section{$1 \quad$ Uvod}

Gospodarsko in šolsko bolj razvite države so spoznale, da kakovostnega poklicnega izobraževanja ni mogoče organizirati brez soudeležbe in soodgovornosti delodajalcev ter njihovih združenj. Za poklicno in strokovno izobraževanje je bistveno razvito socialno partnerstvo. Socialno partnerstvo je temeljni pogoj za načrtovanje izobraževanja, pripravo izobraževalnih programov in izvajanje praktičnega izobraževanja $v$ podjetjih. Ker je večina strokovnih izobraževalnih programov namenjena več delovnim situacijam hkrati, in ne le enemu delu v konkretnem delovnem procesu, je strokovno usposabljanje nujno nadaljevanje procesa poklicnega izobraževanja (Jereb, 1998). Vpeljava praktičnega usposabljanja je prinesla velik korak pri spoznavanju in nadgradnji izobraževanja $\mathrm{v}$ srednjih šolah. Praktično usposabljanje je tudi zelo primerna oblika aktivnega učenja za nadgrajevanje med osebnostnih kompetenc, kot so kritičnost, samokritičnost, delo v skupini, etičnost itd. (Kristl in drugi, 2007). Malo katera šola ima možnost to usposabljanje razširiti preko meja, kot je to uspelo nam na Srednji zdravstveni šoli Celje. Pri nas je to že utečena praksa, da vsakoletno pošljemo dijake četrtih letnikov na usposabljanje v Bad Aibling. Zainteresiranost dijakov je precej velika in je potrebno opraviti izbor med njimi. Prav tako se kaže interes tudi s strani direktorja tega doma s katerim imamo sklenjeno pogodbo, da spozna dijake. Morda nekoč postanejo njegovi zaposleni. Dijaki zdravstvene stroke so precej iskan kader v Nemčiji saj je njihovo znanje po zaključenem šolanju zelo cenjeno in pripravljeni so na takojšnjo vključitev v delovni proces. Omeniti pa je potrebno, da so dijaki postavljeni pred veliko preizkušnjo ko se odločijo za usposabljanje v tujini.

\section{$2 \quad$ Praktično usposabljanje $\mathrm{z}$ delom}

Za uspešno izvedbo izobraževalnega programa sta zadolžena in odgovorna oba socialna partnerja, šola in delodajalci. Pri delodajalcih se izvaja praktično usposabljanje z delom (PUD). Možina et al. menijo (1998, str. 178), da s pojmom usposabljanje oziroma strokovno usposabljanje označujemo proces razvijanja tistih človekovih sposobnosti, ki jih posameznik potrebuje pri opravljanju nekega konkretnega dela $\mathrm{v}$ okviru določene dejavnosti. Poleg praktičnih znanj in spretnosti dijak pridobi tiste spretnosti, ki jih v šolskih delavnicah ni moč pridobiti, predvsem:

- pridobivanje praktičnih izkušenj ter povezovanje izobraževanja in dela,

- nadgrajevanje $\mathrm{v}$ šoli pridobljenih znanj ter prenos teoretičnega znanja $\mathrm{v}$ neposredno prakso v delovnem okolju,

- usposabljanje in razvoj specifičnih spretnosti ter kompetenc poklica,

- spoznavanje novih učnih situacij in tehnoloških procesov,

- spoznavanje novih delovnih sredstev, naprav, pripomočkov, materialov idr.,

- učenje sodelovanja in timskega dela ter komunikacije in nastopa pred strankami,

- razvijanje odgovornosti: za lastno delo, za kakovost, potrebno pri poklicnem delu, za upoštevanje predpisov iz varnosti in zdravja pri delu ter varovanja okolja 
Praktično usposabljanje $\mathrm{z}$ delom je potrebno razvijati zaradi dokončne poklicne socializacije dijakov, ki pa pri delodajalcu ne more potekati na enak način, kot poteka $\mathrm{V}$ šoli. Delodajalce je potrebno spodbujati k usposabljanju mentorjev za delo z dijaki (Bela knjiga, 2011). Nujno je, da pri izvedbi programa šola in delodajalci tesno sodelujejo. Za povezovanje med njima je zadolžen organizator praktičnega izobraževanja na šoli. Organizator praktičnega izobraževanja skrbi za organizacijo in za vse aktivnosti ter podporo pri izvajanju praktičnega pouka in praktičnega usposabljanja (Justinek A., 2011). V pomoč so vodniki za praktično usposabljanje z delom, ki jih je izdal Center za poklicno izobraževanje Republike Slovenije.

\section{$3 \quad$ Prijava in izbor}

Vsi zainteresirani dijaki četrtih letnikov imajo možnost, da se prijavijo s pisno prijavo za izvajanje Praktičnega usposabljanja z delom v domu v Bad Aiblingu. Edini pogoj je polnoletnost. Dijaki se s prijavo predstavijo direktorju gospodu Michaelu Mocniku, ki osebno opravi razgovore $\mathrm{z}$ vsakim posebej na naši šoli. Pogovor je uraden, kot da se prijavljajo na prosto delovno mesto.

Dijake poučimo naj bo prijava uradna saj je dokument s katerim izrazijo zanimanje za prosto delovno mesto. Prijava je sestavljena iz uvoda, jedra in zaključka. Uvod prijave vsebuje uvodni pozdrav in informacijo o njihovem namenu. $\mathrm{V}$ jedru poudarijo svojo ustreznost za razpisano delovno mesto in na kratko izpostavijo tiste sposobnosti, delovne izkušnje, znanje itd., ki jih najbolj opozarjajo na njihovo ustreznost za objavljeno delovno mesto. Želeno je da predstavijo tudi nivo znanja nemškega jezika, ki so ga že osvojili saj je to tudi obvezen predmet v šoli. V zaključku poskušajo na nevsiljiv način izraziti svojo pripravljenost za izvajanje praktičnega usposabljanja. Priložiti je potrebno tudi fotografijo.

Po pregledu vseh vlog, gospod Michael Mocnik opravi osebni razgovor na Srednji zdravstveni šoli Celje z vsemi prijavljenimi dijaki. Ponavadi se zaključi v nemškem jeziku, saj dijaki precej dobro govorijo nemško. O mnenju in posebnostih dijakov se informira tudi pri šolskih organizatoricah praktičnega usposabljanja, da ne bi spregledali kakšnega pomembnega podatka, ki bi lahko bil ključen in moteč pri opravljanju praktičnega usposabljanja. Dijake o izboru gospod direktor seznani osebno. Vedno skuša omogočiti, da čim več dijakov dobi možnost in pridobi bogate izkušnje z opravljanjem praktičnega usposabljanja v tujini.

\section{Potovanje, nastanitev}

Pred dijaki odidejo na pot poskrbimo, da opravijo varstvo pri delu in sklenemo individualno kolektivno učno pogodbo za vsakega dijaka posebej. Strošek, ki ga imajo dijaki je sklenitev zdravstvenega zavarovanja za tujino. Dijaki potujejo z vlakom, stroške vozovnic krije delodajalec.

Pot poteka iz Celja v Zidani most, nato pot vodi do Rosenheima. Tam presedejo na vlak za Bad Aibling Kurpark. Potujejo približno osem ur. Samo potovanje se ne šteje v 
N. Krajnc Zakrajšek: Opravljanje praktičnega usposabljanja v tujini, strah ali izziv?

obvezne ure, ki jih morajo opraviti. Vsekakor pa se že na poti srečajo z uporabo nemškega jezika in svojo iznajdljivostjo.

Ko prispejo v Bad Aibling jih tam pričaka gospod Michael Mocnik in vodilna medicinska sestra, ki je tudi naša nekdanja dijakinja. Nastanijo se v samem domu Haus Wittelsbach, Senioren- und Pflegeheim. Prav tako imajo dijaki nastanitev, prehrano in službena oblačila zagotovljena brezplačno. Stanje oskrbovancev je trenutno 126 .

\section{$5 \quad$ Potek praktičnega usposabljanja $\mathrm{z}$ delom}

Praktično usposabljanje $\mathrm{z}$ delom je sestavni in obvezni del $\mathrm{v}$ prenovljenih programih srednjega strokovnega, srednjega poklicnega in srednjega poklicno-tehničnega izobraževanja (srednja medicinska sestra/zdravstvenik, kozmetični tehnik in bolničarnegovalec) (Justinek A., 2011). V četrtem letniku morajo dijaki opraviti 152 ur, v štirih tednih. $\mathrm{Z}$ delom pričenjajo zjutraj ob sedmi uri in se vključujejo $\mathrm{v}$ sam potek dela $\mathrm{v}$ domu. Sodelujejo $\mathrm{z}$ mentorjem in vsemi zaposlenimi. Prav tako morajo napisati dnevnik praktičnega pouka $\mathrm{v}$ slovenskem jeziku. Najdejo ga na spletni strani šole (http://www.szsce.si/izobrazevanje-mladine/prakticno-izobrazevanje/). Podatke pa pridobijo iz dokumentacije oskrbovancev, ki je izključno v nemškem jeziku. Po končanem usposabljanju pa mentor dijake oceni po ocenjevalnem listu, ki smo ga posredovali skupaj z individualno kolektivno učno pogodbo.

\section{$6 \quad$ Strah ali izziv?}

Musek J. (2005) meni, da ima malo čustev ima takšen vpliv na naše obnašanje in počutje kot strah. Je osnovni mehanizem za preživetje, ki se sproži kot odgovor na določene dražljaje, kot so bolečina ali nevarnost. Je sposobnost prepoznavanja nevarnosti in vodi $\mathrm{k}$ potrebi po soočenju z nevarnostjo ali begu pred njo (temu rečemo odziv boj ali beg). Ko se odločimo za boj je to naš izziv. Razumemo da dijaki čutijo strah, ščemenje v trebuhu, ki spominja na tremo in nervozno navdušenje. Ne vedo kaj jih čaka na poti, niti kakšni bodo sodelavci, kako bodo obvladali jezik, se bodo znašli v dani situaciji, katere bodo njihove dnevne naloge in čakali bodo ali jih bodo vrgli v vodo, oni pa bodo morali splavati. Vprašali se bodo : »Ali smo storili prav, nam je tega treba? « Seveda, so! Naj to sprejmejo to kot izziv in uspelo jim bo.

Naša naloga je da jim nudimo oporo $\mathrm{v}$ smislu dosegljivosti na telefon ali preko elektronske pošte, če se znajdejo v težavah.

\section{$7 \quad$ Analiza in ugotovitve}

\subsection{Instrument raziskovanja}

Po končanem praktičnem usposabljanju organizatorice prejmemo ocenjevalne liste, ki jih temeljito pregledamo. Za vse dijake pripravimo anketo o zadovoljstvu in samem poteku praktičnega usposabljanja. V šolskem letu jo je izpolnilo 16 dijakov, torej vsi ki so bili v Bad Aiblingu. 
$36^{\mathrm{TH}}$ InTERnAtional CONFERENCE ON ORganizational SCIENCE DeVElopment: Responsible Organization (MARCh $22^{\mathrm{ND}}-24^{\mathrm{TH}}$, Portorož Slovenia)

N. Krajnc Zakrajšek: Practical training abroad: fears and challenges?

Kot instrument raziskovanja je bila uporabljena anketa. Anketa je bila anonimna.

Sestavljena je bila v obliki vprašalnika (uporabili smo Likertovo pet stopenjsko lestvico in tri vprašanja odprtega tipa). Pri vsakem vprašanju pa smo podali možnost da so pripisali mnenje oz. obrazložitev, ki se je nanašala na vprašanje. Povprašali smo tudi po spolu anketiranih.

Anketiranim smo podali tudi obrazložitev vseh pet stopenj, ki so pomenile:

1 -se absolutno ne strinjam, 2 - se ne strinjam, 3 - niti se ne strinjam, niti se strinjam, 4 - se strinjam, 5 -se absolutno strinjam.

Za obdelavo podatkov, pridobljenih z metodo anketnega vprašalnika, smo za statistično obdelavo uporabili SPSS - Program za statistično obdelavo podatkov.

\subsection{Raziskovalna vprašanja}

Predvsem nas je zanimalo kako so bili dijaki zadovoljni z izborom in razgovorom $\mathrm{z}$ gospodom Michaelom Mocnikom, z organizacijo potovanja, nastanitvijo, odnos zaposlenih in stanovalcev do dijakov.

Pod odprti tip vprašanj pa nas je zanimalo;

- Kaj bi spremenili?

- Kakšen pogled imajo na usposabljanje v tujini?

- Ali jim je to predstavljajo strah ali izziv?

\subsection{Analiza rezultatov}

Analiza ankete je pokazala, da so dijaki zelo zadovoljni z izborom in razgovorom $\mathrm{z}$ gospodom Michaelom Mocnikom. Povprečna ocena znaša 4,2, kar nam pove da so res zadovoljni. Nekateri so se počutili kot da opravljajo razgovor za službo in so se tudi temeljito pripravili.

Prav tako jim je bilo v večini všeč način potovanja, z vlakom. Fantje so bili navdušeni, da so potovali z vlakom, pri dekletih smo zasledili da so bili starši malo v dvomih glede na to da je potovanje v tujo državo in glede presedanja na vlaku. Izkušnje so pokazale, da do zapletov ni prišlo in so bili dijaki zelo iznajdljivi med potovanjem. Rezultati so nam pokazali, da to res drži, saj znaša povprečna ocena 4,25 in standardni odklon 0,861 .

Tudi z nastanitvijo so bili zadovoljni v 92\%. Nastanjeni so bili v samem domu, prav tako so imeli možnost vseh brezplačnih obrokov. Edina težava, ki se je pojavila je bila slaba povezava z Wi-fi omrežjem. Nezadovoljstvo predstavlja samo $8 \%$.

Pri samem zadovoljstvu zaposlenih in stanovalcev do dijakov pa smo bili presenečeni nad rezultatom saj so dijaki v 100\% zadovoljni z odnosom, tako povprečna ocena znaša 5. Izrazili so, da so vsi zelo spoštljivi, prijazni. Sprejeli so jih v team. Trudili so se s 
N. Krajnc Zakrajšek: Opravljanje praktičnega usposabljanja v tujini, strah ali izziv?

počasnim in razločnim govorom nemškega jezika. Uporabljali zelo malo slovenskega jezika. Upoštevali so mnenja in poglede dijakov na izvajanje negovalnih intervencij. Čutiti je bilo toplino in sproščen odnos so zapisali. Znanje in razumevanje nemškega jezika pa so precej poglobili.

Pri odprtem tipu vprašanja: Kaj bi spremenili?

V večini so zapisali, da nič oziroma bi usposabljanje podaljšali.

Kakšen imajo pogled na usposabljanje $\mathrm{v}$ tujini?

Usposabljanje v tujini vidijo kot možnost nadaljnjih zaposlitev. Menijo, da bi moralo imeti še več dijakov to možnost, da bi se lahko usposabljanja udeležilo. Izpostavili so, da bi bilo potrebno $\mathrm{v}$ okviru naše šole na izobraževanju za mentorje dijakom na usposabljanju prestaviti kako iskan ter zaželen zdravstveni kader so v Nemčiji ter da so $\mathrm{z}$ njimi ravnali enakovredno kot $\mathrm{z}$ ostalimi člani tima. Tega dijaki pri nas niso začutili $\mathrm{v}$ taki meri kot pri njih. Prav tako so bili presenečeni, ko so prejeli kontakt samega gospoda direktorja, da se obrnejo nanj v primeru, da bodo iskali zaposlitev preko meja.

Ali jim je to predstavljajo strah ali izziv?

Nekje sedemdeset odstotkov dijakov vidi v usposabljanju priložnost kot izziv, ostalim pa to predstavlja strah, ki so ga do zdaj zelo dobro premagali in naredili velik korak v življenju. Pri strahu so navedli, da so imeli pomisleke pri potovanju, komunikaciji v nemškem jeziku in predvsem štiri tedenski odsotnosti od doma brez staršev in samostojnost pri izbiranju odločitve $\mathrm{v}$ danih situacijah. Izziv je del celote predvsem pri mladostnikih v času njihovega odraščanja. Ravno fantje, ki se pri praktičnem pouku bolj znajdejo kot pri teoriji je vsem to usposabljanje pomenilo izziv. Dekleta pa so bila v dvajsetih odstotkih malo skeptična in so kljub temu strah odlično premagala in usposabljanje opravila z odliko.

\section{Diskusija}

Organizatorice praktičnega usposabljanja, ki dijake ves čas spremljamo smo zelo zadovoljne in ponosne nanje, da nas zastopajo in predstavljajo $\mathrm{v}$ tako pozitivni luči tudi preko meja. Prav tako smo kot Srednja zdravstvena šola Celje verjetno ena redkih, če ne edini v Sloveniji, ki dijakom omogočamo to možnost usposabljanja v tujini. To pa nam ne bi uspelo brez gostoljubnosti gospoda direktorja Michaela Mocnika, ki ima zelo široko vizijo v bodoče za zdravstveni poklic in smo v dogovarjanju sodelovanja še na področju kozmetike, da bi prav tako dekleta smeri kozmetični tehnik imele možnost usposabljanja $v$ enem izmed salonov v Nemčiji.

Dijaki so imeli možnost izraziti lastno mnenje glede dobrih in slabih lastnostih Praktičnega usposabljanja $\mathrm{z}$ delom. Veseli smo, da je dobrih lastnosti več, naša naloga pa je zmanjšati število slabih lastnosti oziroma jih odpraviti. Trenutno nezadovoljstvo predstavlja Wi-fi omrežje, ki je tudi najcenejša povezava med dijaki in domačimi. Pojavilo se je tudi nekaj domotožja, ki so ga lahko s kontaktom s starši dijaki lažje 
premagali. V prihodnosti so nam zagotovili, da bodo poskrbeli za dobro omrežje, saj so $\mathrm{v}$ načrtu adaptacijska dela $\mathrm{v}$ domu.

Naša želja je tudi, da bi lahko vsako skupino dijakov same organizatorice osebno obiskale. Se z njimi pogovorile in pomagale pri premagovanju straha, ki se bi morebiti pojavil. Tistim, ki to usposabljanje predstavlja pa izziv pa bi jih skupaj z gospodom direktorjem pomagale pri odpiranju nadaljnjih možnosti zaposlitve in nadaljevanja študija $\mathrm{v}$ tujini.

S tako uspešnim sodelovanjem smo lahko več kot zadovoljni, nam kot izobraževalni ustanovi in prav tako staršem takšno usposabljanje ne predstavlja velikih stroškov. Predvidevamo lahko, da bi se usposabljanja udeležilo zelo malo dijakov v kolikor bi bilo plačljivo, ker bi to predstavljajo prevelike stroške staršem. Trenutno pa jim stroške predstavlja samo zavarovanje za primer nezgode. Na koncu lahko povzamemo, da naj usposabljanje še naprej ostane izziv, straha pa naj bo čim manj ali pa nič. Vračajo naj se zadovoljni dijaki, pohvala mentorjev in gospoda direktorja pa bo nagrada za nas, ki smo jih na to pripravili in poučevali vsa štiri leta.

\section{Literatura}

Dnevniki Praktičnega usposabljanja z delom. Dostopno na http://www.szsce.si/izobrazevanjemladine/prakticno-izobrazevanje/

Jereb, J. (1998). Teoretične osnove izobraževanja. Kranj: Moderna organizacija.

Justinek, A. (2011). MUNUS 2 - Praktično usposabljanje z delom, Vodnik za organizatorje. Ptuj: Šolski center.

Krek J. et al. (2011). Bela knjiga. Dostopno na http://pefprints.pef.uni-1j.si/1196/1/pp_11-62.pdf.

Kristl, J. et al. (2007). Smernice za praktično usposabljanje na Univerzi v Ljubljani. Ljubljana: Univerza.

Možina, S. et al.(1998). Management kadrovskih virov. Ljubljana: Fakulteta za družbene vede.

Musek, J. (2005). Strah in anksioznost. V: J. Musek (Ur.), Predmet, metode in področja psihologije (str. 144-145). Ljubljana: Filozofska fakulteta, oddelek za psihologijo. 
36. MEDNARODNA KONFERENCA O RAZVOJU ORGANIZACIJSKIH ZNANOSTI: OdgOVORNA ORGANIZACIJA (22. - 24. MAREC 2017, PORTOROŽ, SLOVENIJA)

O. Arsenijević, M. Ferjan, I. Podbregar, P. Šprajc, D. Trivan \& Y. Ziegler

\section{Z vključujočim vodenjem do odgovorne organizacije}

\section{DANIJELA KRALJ}

Povzetek Hitre spremembe v sodobni družbi terjajo od organizacij učinkovito, fleksibilno in transparentno vodenje ter usmerjenost $\mathrm{v}$ implementacijo novih procesov in krepitev razvojno znanstvenega dela. Če upoštevamo zakonitosti svetovnega trga in medkulturne izmenjave, se temu primerno pojavljajo nove zahteve glede pravil, etičnih standardov in kulturnih kompetenc $\mathrm{v}$ odnosu do zaposlenih in zunanjih deležnikov. Povsem nove razsežnosti odpira 4. svetovna industrijska revolucija in Agenda za trajnostni razvoj do leta 2030, ki s svojimi cilji predstavlja krovni program razvoja sveta in vključujoče družbe prihodnosti. S potrebo po prilagajanju je seveda logično vprašanje, kateri poslovni model uporabiti, da bomo pri vseh teh izzivih učinkoviti in uspešni. To so $\mathrm{v}$ kratkem ključni dejavniki, ki v zadnjih letih narekujejo skokovit razvoj in uvajanje poslovnega modela $\mathrm{z}$ vključujočim vodenjem. Vključevanje, bolj kot »integracija« ali »mainstream« tokovi, je medtem postalo eno od glavnih načel vključujočega razvoja, pri udejanjanju strategij, vizij in poslanstva organizacije, upravljanju organizacijskega funkcionalnega znanja in spodbujanju etike poslovanja, krepitve kulturne in poslovne kompetentnosti. Njegova vloga je izjemnega pomena za organizacijsko kulturo, ki ob vrednotah, virih in ciljih v notranjem okolju odgovorno deluje $\mathrm{v}$ odnosu do zunanjih deležnikov in širšega družbenega okolja. V prispevku sem predstavila sestavine in funkcije vključujočega poslovanja v Univerzitetnem kliničnem centru Ljubljana. Vodstvo z zgledom in vključujočim vodenjem krepi kompetentnost in odgovornost celotnega kolektiva do zunanjega okolja, predvsem v smislu doseganja ravnotežja med zdravstvenimi potrebami okolja, razpoložljivimi viri, potrebami po storitvah zdravstvenega sektorja, zlasti pa glede na cilje nacionalnega zdravja ter človekovo dostojanstvo in zdravstvene potrebe bolnikov.

KLJUČNE BESEDE: vključujoče vodenje • družbena odgovornost • trajnostni razvoj $\bullet$ kulturne kompetence

NASLOV AVTORICE: mag. Danijela Kralj, Univerzitetni klinični center Ljubljana, Zaloška cesta 7, 1000 Ljubljana, Slovenija, e-pošta: danijela.kralj@kclj.si 
36 ${ }^{\text {TH }}$ International Conference on Organizational Science Development: Responsible ORganizATION (MARCH $22^{\mathrm{ND}}-24^{\mathrm{TH}}$, PORTOROŽ SLOVENIA)

O. Arsenijević, M. Ferjan, I. Podbregar, P. Šprajc, D. Trivan \& Y.

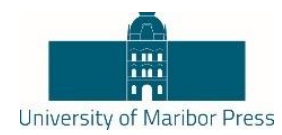

Ziegler

\title{
From the Inclusive Management to the Responsible Organization
}

\section{DANIJELA KRALJ}

\begin{abstract}
Rapid changes in modern society require that organizations have effective, flexible and transparent management and that they focus on the implementation of new processes and strengthen the development of scientific work. If we consider the legality of the global market and cultural exchange, new requirements regarding the rules of ethical standards and cultural competences in relation to employees and external stakeholders occur. The world's fourth industrial revolution and the agenda for sustainable development by 2030 opens up a completely new dimensions and with its objectives represents an umbrella program of world development and an inclusive society of the future. Following the need to adapt we logically need to ask ourselves a question which business model should we use, so that we will deal with all these challenges efficiently and effectively. These are short key factors which in recent years dictated abrupt development and implementation of the business model of inclusive management. In the meantime, inclusion has become the main principles of inclusive development, more than "integration" or "mainstream", in implementation of strategies, visions and mission of the organization, the management of organizational functional knowledge and the promotion of business ethics, strengthening the cultural and business competence. Its role is of the utmost importance for an organizational culture that next to the values, resources and targets in the indoor environment, act responsibly in relation to external stakeholders and the wider social environment. In this article I present components and functions of inclusive business at the University Medical Centre Ljubljana. With setting an example and with inclusive leadership, leaders strengthen the competence and responsibility of the entire collective to the external environment, particularly in terms of achieving a balance between the health needs of the environment, the available resources and service needs of the health sector, especially in relation to the objectives of national health and human dignity and patient's health needs.
\end{abstract}

KEYWORDS: inclusive leadership - corporate social responsibility • sustainable development $\bullet$ cultural competence

Correspondence AdDress: Danijela Kralj, M.S., University Medical Centre Ljubljana, Zaloška cesta 7, 1000 Ljubljana, Slovenia, e-mail: danijela.kralj@kclj.si

DOI https://doi.org/10.18690/978-961-286-020-2.34

ISBN 978-961-286-020-2

(C) 2017 University of Maribor Press

Available at: http://press.um.si 
Kritične in odgovorne javnosti danes zahtevajo, da organizacije, s katerimi sobivajo, upoštevajo interese svojih notranjih in zunanjih deležnikov (Simončič, 2015: 110). Razumevanje odgovornosti se razmeram primerno spreminja, poglablja in postaja resnejše. Predvsem pa vedno več ljudi razume, da je odgovornost organizacij v resnici odgovornost posameznikov, ki sprejemajo odločitve. Tako so npr. udeleženci letošnjega Svetovnega gospodarskega foruma $\mathrm{v}$ Davosu med nosilne teme uvrstili poziv $\mathrm{k}$ odzivnemu, odgovornemu in bolj vključujočemu vodenju (Schwab, 2017).

Končno odgovornost za vse odločitve v organizaciji nosijo vrhnji managerji, ki morajo biti zgled drugim managerjem in zaposlenim (Rejc Buhovac, 2014: 1). Tega dejstva se zavedajo tudi organizacije, ki v strategijo svojega poslovanja vključujejo izvajanje družbeno odgovornih načel (Simončič, 2015). Organizacija mora razširiti svojo predstavo o raznolikosti tako, da se vključuje v sisteme, ki predstavljajo njeno okolje. Gledano s splošne družbene, ekološke in sistemske perspektive, je pojem vključevanja že uveljavljen kot osrednja točka upravljanja raznolikosti in varstva človekovih pravic zaposlenih v javnem in zasebnem sektorju (Mor Barak, 2016).

Vsak posameznik je edinstven, hkrati pa ima veliko skupnega $\mathrm{z}$ drugimi. Pojem raznolikosti se nanaša na strpnost, spoštovanje in upoštevanje, ki ga podjetje kaže v odnosu do vsakega posameznika. Skladna politika raznolikosti ustvarja vključujoče okolje in vsem zaposlenim daje enake možnosti, da se počutijo spoštovani in cenjeni, saj jim z vključevanjem omogoča, da lahko neposredno vplivajo na svoj položaj in politiko poslovanja. To pomeni, da se vključujoča politika ravnanja z ljudmi osredotoča na prepoznavanje in spoštovanje posameznikove osebnosti, kompetentnosti in ne morda le pomanjkljivosti. Zaposleni, ki se počutijo vključene, cenjene in nagrajene so bolj zavzeti in motivirani. Svetovna raziskava (Pollitt, 2005) med 3 milijoni zaposlenih je pokazala, da je vključujoče in harmonično okolje ključni dejavnik pri zavzetosti in predanosti zaposlenih (Šentprima, 2015).

Navedeno potrjuje, da zanimanje za koncept vključevanja, zlasti po septembru 2015, ko je bila na svetovnem vrhu Združenih narodov in držav sveta sprejeta Agenda za trajnostni razvoj in vključujočo svetovno družbo do leta 2030 (v nadaljevanju: Agenda 2030) skokovito narašča. Na socialnem, izobraževalnem in delovnem področju že vrsto let potekajo poglobljene, kvantitativne raziskave, ki potrjujejo, da ima vključevanje in vključujoče vodenje $\mathrm{v}$ primerjavi z drugimi, bolj rigidnimi modeli bistvene prednosti. Avtorica Mor Barak ugotavlja, da so očitne tako pri etičnem voditeljstvu in upravljanju raznolikosti kot pri varstvu človekovega dostojanstva v delovnem okolju (Mor Barak, 2016).

Avtorica tega prispevka, Z vključujočim vodenjem do odgovorne organizacije, se je namesto kvantitativnega raziskovanja odločila za kvalitativen, praktično naravnan pristop ob prilagojeni uporabi metod akcijskega raziskovanja. V primerjavi s kvantitativnimi metodami, ki so praviloma bolj usmerjene $\mathrm{v}$ znanstveno-teoretično argumentacijo, se akcijsko raziskovanje osredotoča na konkretna vprašanja. V primeru tega prispevka, torej 
$36^{\mathrm{TH}}$ International Conference on ORganizational Science Development:

Responsible Organization (MARCH $22^{\mathrm{ND}}-24^{\mathrm{TH}}$, Portorož Slovenia)

D. Kralj : From the Inclusive Management to the Responsible Organization

na praktične razsežnosti vključujočega vodenja v UKC Ljubljana, tako kot je prikazano v nadaljevanju (3. Poglavje). Glede tega se avtorica sklicuje na ugotovitve različnih avtorjev, strokovnjakov in praktikov, da se s tem namenom akcijsko raziskovanje vse bolj uveljavlja tudi v našem znanstveno-raziskovalnem prostoru (Podmenik, Bembič, 2015:105-113; prim. Aleksić, IRVD, 2016).

\section{Vključujoče delovno okolje in družbeno odgovorno ravnanje}

S svetovnimi standardi in programskimi dokumenti o razvoju svetovne družbe prihodnosti, politikami in strategijami Evropske unije, smernicami OECD in prakso mednarodnih ustanov je beseda vključevanje dobila ključno vlogo v političnem, ekonomskem, družbenem pomenu. Tudi v Sloveniji je vse več prispevkov in zgledov, ki govorijo o pomenu vključevanja. Na področju vzgoje in izobraževanja denimo, prav tako politike ravnanja $\mathrm{v}$ odnosu do socialno bolj šibkejših. Na drugih področjih so medtem besedne zveze vključujoča politična participacija, vključujoča gospodarska rast, vključujoče poslovanje prerasle $\mathrm{v}$ nosilne misli napredka, trajnostnega razvoja in vključujoče družbe prihodnosti. (Kečanović, 2014-I:1238-1251).

Vključujoče delovno okolje je sestavni del vključujoče družbe in prav tako svetovno uveljavljen model vključujočega vodenja (Inclusive Leaderschip). Je okolje vzajemnega spoštovanja med delodajalci in zaposlenimi, tako da zmorejo ta skupni potencial izkoristiti tudi v smislu večje poslovne uspešnosti, varnosti in zdravja, krepitve socialnih vezi in solidarnosti, pretoka idej in znanja, napredka, trajnostnega razvoja. Zaposleni, ki jim delodajalec z vključevanjem omogoča, da lahko dejavno vplivajo na poslovne rezultate in obenem na izboljšanje svojega delovnega in socialnega položaja, imajo večji občutek pripadnosti in odgovornosti za skupne vrednote kolektiva. Večja odgovornost za skupne vrednote kolektiva zmanjšuje stroške in hkrati povečuje učinkovitost tudi tako, da pozitivno učinkuje na sistem notranjih kontrol, kar zmanjšuje verjetnost škodnih dogodkov in odklonskih dejanj že na ravni tveganj. Z vključujočim delovnim okoljem se povečuje odgovornost do zunanjega okolja $\mathrm{v}$ smislu skupnih projektov z lokalnimi oblastmi, državo in civilno družbo pri zmanjševanju revščine, neenakosti, brezposelnosti in izključevanja, pri zaščiti naravnega okolja in trajnostnem razvoju (IRVD, 2016a).

Pri vzpostavitvi vključujočega delovnega okolja so na prvem mestu vrednote, ki nastajajo kot motivacijski dejavnik in usmerjajo vedenje zaposlenih, ko ni posebej zapisanih navodil ali pravil obnašanja oziroma ravnanja (Rejc Buhovac, 2014:1).

Vključujoče delovno okolje na prvo mesto vrednostne lestvice postavlja varstvo človekovega dostojanstva, kar z drugimi besedami pomeni, da je vsako delo z dostojnimi delovnimi pogoji in dostojnim plačilom samo po sebi vrednota. Ob zajamčenih pogojih varstva človekovega dostojanstva vključujoče delovno okolje zajema upravljanje raznolikosti, podporo znanju in informiranost. Prav tako primeren odnos do zunanjega, lokalnega, nacionalnega, globalnega okolja. Varstvo človekovega dostojanstva V delovnem okolju zahtevajo že temeljna načela in konkretne določbe ustave ter mednarodnih dokumentov o varstvu človekovih pravic. Medicinska stroka opozarja na neposredno zvezo med izključevanjem in drugimi odklonskimi dejanji na eni ter stanjem 
bolezni in izostankov na delovnem mestu zaradi bolniškega staleža (absentizem), prisotnosti na delu kljub bolezni (prezentizem) in poklicnih bolezni na drugi strani (Kečanović, 2014-II: 2-3).

\subsection{Vključujoče vodenje kot načelo organizacijske etike in poslovne morale}

Svetovni škandali, ki so $\mathrm{v}$ tem stoletju pahnili svetovno družbo in nacionalna gospodarstva v globoko krizo, za katero še ni videti konca, so med drugim pokazali, kako so vse velike besede o poslovni morali in integriteti padle na izpitu etike poslovanja. Zaradi tega so danes besede, kot je denimo korporativna integriteta, bolj slabšalna kot etična kategorija. Tudi to je odločilno prispevalo, da ima vključevanje $\mathrm{v}$ primerjavi $\mathrm{z}$ nedoločnostjo in neoprijemljivostjo besedne zveze korporativna integriteta dejansko moralne učinke. $Z$ vsem tem je vključevanje vedno bolj pomembno načelo organizacijske etike, poslovne morale in družbene odgovornosti (Kečanović, 2015). Vzemimo, npr., Strategijo razvoja slovenske javne uprave do leta 2020 (SJU 2020) in Politiko Vlade Republike Slovenije za napredno in kakovostno javno upravo, Novartisov kodeks etičnega ravnanja zaposlenih v družbi Lek, d.d. ali Etični kodeks Ekonomske fakultete Univerze v Ljubljani. Vsi navedeni dokumenti med temeljna načela uvrščajo prav vključevanje. Če upoštevamo, da gre za strateške dokumente in etična vodila, pomeni, da ne gre več samo za splošni okvir in deklarativne izjave, ampak za izvedbene dokumente, pri čemer je vključevanje eno od poglavitnih načel vključujočega vodenja in uporabne etike poslovanja, in sicer tako $\mathrm{v}$ javnem kot $\mathrm{v}$ zasebnem sektorju (IRVD, 2016b).

Hollander (2012: 3) vključujoče vodenje opredeljuje kot vodenje razmerij, s katerimi lahko dosegamo stvari v obojestransko korist. Pomeni, tako notranjih kot zunanjih deležnikov poslovanja. Doseganje vodenja na tej ravni pomeni delati stvari z ljudmi, kar je bistvo vključenosti. $Z$ gledišča družbene odgovornosti: delati dobro, za posameznika in skupno dobro. $Z$ besedami Agende trajnostnega razvoja in vključujoče svetovne družbe do leta 2030: za ljudi in planet (Slovenski prevod, MZZ:2016).

Izboljšanje odločanja in doseganje želenega cilja z vključujočim vodenjem ni oprto samo na delovanje ene osebe, temveč zagotavlja pogoje in enake možnosti, ki spodbujajo poštene rezultate za vse deležnike. Vključujoče vodenje spoštuje konkurenco in sodelovanje kot del participativnega procesa, tako da z uporabno etiko vključevanja krepi moralno odgovornost $\mathrm{v}$ odnosu do deležnikov notranjega in zunanjega, družbenega okolja. Kečanović pravi, da ima etika vključevanja kot uporabna različica socialne oziroma javne etike dolgo zgodovino. $\mathrm{V}$ taki ali drugačni obliki jo zasledimo pri starodavnih mislecih, ko bodisi $\mathrm{v}$ socialni poeziji, verskih naukih ali razpravah o dobrih navadah in vrlinah tedanjega človeka pozivajo $\mathrm{k}$ sožitju, medsebojnem spoštovanju in ravnanju iz plemenitih nagibov (IRVD, 2016c). Prvine etike vključevanja najdemo v Ustavi Republike Slovenije: svoboda izražanja in pravica dobiti informacijo javnega značaja (39. člen URS), ki je kot ustavna vrednota strateški cilj in motivacijski dejavnik pri oblikovanju etične infrastrukture vključujočega javnega prostora; pravica sodelovati pri upravljanju javnih zadev (44. Člen URS), ki je ključnega pomena za uporabno etiko vključevanja in oblikovanje njenih etičnih infrastruktur po posameznih področjih, 
$36^{\mathrm{TH}}$ International Conference on ORganizational Science Development:

Responsible ORGanization (MARCH $22^{\mathrm{ND}}-24^{\mathrm{TH}}$, PortoroŽ SLOVENiA)

D. Kralj : From the Inclusive Management to the Responsible Organization

zakonih in sektorskih politikah javne uprave, politike, strategije in kodeksov njenega etičnega ravnanja (IRVD, 2016d).

Vlada Republike Slovenije je v zgoraj navedeni politiki napredka in kakovosti sodobne javne uprave opredelila temeljne vrednote, med njimi: sodelovanje, pravičnost in vključenost. »Sodelujemo z vsemi deležniki na pravičen in organiziran način, jih seznanjamo in vključujemo v procese tako, da zagotavljamo vključenost vseh ključnih deležnikov, še posebej najranljivejših skupin. Delujemo etično, profesionalno, strokovno, racionalno, odgovorno in samostojno $\mathrm{v}$ zakonitih in razumnih rokih (Vlada RS, 2015).

Razvoj vključujoče družbe prihodnosti je eden izmed ciljev, ki jih določa Agenda za trajnostni razvoj do leta 2030. Razvoj digitalne družbe, ki jo prinaša 4. industrijska revolucija, je povezan z razvojem pametnih mest, pametnih zdravstvenih organizacij, digitalnih državljanov. Transformacija zdravstvenih organizacij v digitalni družbi pomeni spremembo v načinu komunikacije in odnosa do pacienta, aktivno vključenost pacienta pred, med in po zdravstveni obravnavi in sodoben način dostopa do pacienta (Oroszy, Pustatičnik, 2016).

\subsubsection{Organizacijska kultura in etika komuniciranja}

Komuniciranje in kultura sta najtesneje povezana - komuniciranje je način, kako se kultura prenaša in ohranja. Zato se razlike $v$ kulturi in kulturna (ne)kompetentnost najbolj odraža prav na področju komuniciranja med zdravstvenimi delavci in uporabniki zdravstvenih storitev.

Kulturne kompetence in veščine kliničnega komuniciranja omogočajo, da je komunikacijski proces uspešen ne glede na morebitne kulturne, jezikovne in družbene razlike in vodi h kakovostnemu informiranju, opolnomočenju in sodelovanju (Čebron idr., 2016:197-199).

Izvajalci zdravstvenih storitev so pri vsakodnevni zdravstveni oskrbi dolžni spoštovati osebnost in dostojanstvo pacienta, zlasti njegovo dostojanstvo in človekove pravice. V povezavi s tem seveda tudi moralna, kulturna, verska, filozofska in druga osebna prepričanja. Paziti je treba na spoštovanje zasebnosti in samostojnosti pacienta pri odločanju o zdravljenju. Zgled vključujočega vodenja se tukaj pokaže pri reševanju konkretnih problemov in etičnih dilem, kako misliti in uresničevati etično, vključujoče komuniciranje in ravnanje $\mathrm{v}$ odnosu do pacienta, notranjega in zunanjega okolja zdravstvene organizacije. Kako ponovno krepiti zaupanje v zdravstveni sistem in soljudi, ko pa so se uničujoče politične prakse izključevanja in spodkopavanja ugleda zdravstvenim ustanovam že prelile $\mathrm{v}$ profesionalne in medsebojne odnose?. Vse to potrjuje ugotovitve strokovnjakov, da ne samo organizacije, ampak celotna družba potrebuje več prostora in posluha za sočloveka, v besedah in dejanjih (Pondelek, 2016).

Zgled vključujočega vodenja in etičnega komuniciranja predpostavlja tudi strožje varstvo zasebnosti na zdravstvenem področju, ki izhaja iz same situacije, v kateri se znajde bolna oseba in občutljivosti osebnih podatkov, ki jih to področje obdeluje. Ti podatki po naravi 
stvari globoko posegajo v samopodobo in osebno dostojanstvo posameznika. Marsikdaj lahko razkritje osebnih podatkov o bolezni vpliva na tako ali drugače negativno obravnavo človeka v socialnem ali celo družinskem okolju. Zato lahko razkritje podatkov o bolezni posameznika, ki je že zaradi bolezni same bolj občutljiv v dojemanju lastne osebnosti, bistveno globlje prizadene njegovo dostojanstvo, mu povzroči posledice, na primer v zvezi z opravljanjem dela, ali kako drugače izzove duševne bolečine in škodo na različnih področjih osebnostnega razvoja. Zaradi tega je varstvo osebnih podatkov na zdravstvenem področju pomembno, tako v smislu ustavnega varstva zasebnosti in drugih človekovih pravic kot temeljnega dostojanstva bolnikov (Kralj, 2007:11).

\subsection{Kulturne kompetence}

V danih razmerah, ko lahko rečemo, da se tudi zdravstvene storitve globalizirajo, z migracijskimi tokovi pa $\mathrm{v}$ domače okolje prihajajo ljudje iz različnih kulturnih okolij, so kulturne kompetence prav tako sestavina vključujočega vodenja. Prizadevanja zdravstvene stroke so na tem področju primeri dobre prakse, ki raznolikost ljudi jemlje kot skupni potencial za večjo učinkovitost in uspešnost poslovanja (Čebron idr., 2016:14).

Kulturne kompetence predstavljajo skupek znanj in veščin $\mathrm{v}$ odnosih in ravnanju $\mathrm{z}$ ljudmi. So v pomoč posamezniku, da izboljša svoje razumevanje, občutjivost, sprejemanje, spoštovanje in odzivanje na kulturne razlike in odnose, ki iz njih izhajajo. Na zdravstvenem področju prispevajo $k$ boljšemu razumevanju, osveščanju, strpnosti in sodelovanju ljudi iz različnih kultur. Vse to pripomore $\mathrm{k}$ bolj kakovostnim storitvam in večji konkurenčnosti v globalnem prostoru in trženju zdravstvenih storitev.

Kulturne kompetence zajemajo:

- zavedanje vpetosti v lastno kulturo, refleksijo lastnih predsodkov, stereotipov in pogledov na svet;

- dojemanje razlik med kulturami;

- poznavanje različnih kulturnih praks in svetovnih nazorov;

- medkulturne veščine: sposobnost, da se zavemo razlik in jih upoštevamo pri odnosu do uporabnika zdravstvenih storitev;

- medkulturne izkušnje: osebne izkušnje z ljudmi iz različnih okolij;

- motivacijo za razvijanje kulturno kompetentne zdravstvene oskrbe, ki predstavlja postopen proces, $\mathrm{v}$ katerem se posameznik stalno izpopolnjuje (Čebron idr., 2016:15).

Kulturno kompetentna ali transkulturna zdravstvena oskrba se je $\mathrm{v}$ izrazito večkulturnih državah (na primer ZDA, Kanada, Avstralija, Velika Britanija) razvila že konec petdesetih let 20. stoletja kot specialistično in kot splošno področje zdravstvene nege. Raziskave kažejo, da ima kulturno kompetentna zdravstvena oskrba veliko prednosti in pomemben vpliv na zdravstvene izide ter dobro počutje vseh udeleženih. Pri uporabnikih je opaziti povečanje zaupanja in lažje vzpostavljanje stikov z zdravstvenimi delavci, 
$36^{\mathrm{TH}}$ International Conference on ORganizational Science Development:

Responsible ORGanization (MARCH $22^{\mathrm{ND}}-24^{\mathrm{TH}}$, PortoroŽ SLOVENiA)

D. Kralj : From the Inclusive Management to the Responsible Organization

večje upoštevanje njihovih zdravstvenih nasvetov, manj pogoste posledice napačne uporabe zdravil ter boljšo zdravstveno pismenost prebivalcev. Na drugi strani pa zdravstveni delavci naredijo manj napak pri določanju diagnoz, nudijo bolj kakovostno zdravstveno oskrbo in zdravstveno vzgojno delo. $V$ zdravstvu pogosto pride do situacije, ko pripadnost določeni skupini velja za nadrejeno, to pa na dinamiko dela deluje negativno, konfliktno in zmanjšuje medsebojno sodelovanje, vpliva pa tudi na slabše izide zdravstvene obravnave. Zato je potrebno tudi v svojem delovnem okolju dejavno skrbeti za spoštovanje različnosti, razvijati komunikacijske veščine in ustvarjati zaupanje med zdravstvenimi delavci (Čebron idr., 2016:18).

\subsection{Družbena odgovornost}

Obstajajo številne definicije družbene odgovornosti podjetij, med bolj uveljavljenimi je definicija Evropske komisije, ki je družbeno odgovornost podjetij (Corporate social responsibility - CSR) opredelila »kot koncept, po katerem podjetja $\mathrm{v}$ svoje poslovne dejavnosti in odnose z interesnimi skupinami prostovoljno vključujejo družbena in okoljska vprašanja« (Evropska komisija, 2011).

V Slovarju slovenskega knjižnega jezika je družbena odgovornost opredeljena kot »družbena korist; družbena morala, norma; družbena ureditev, zavest « (ZRC-SAZU, 2016). Izraz »družbena odgovornost«, se je pričel širše uporabljati v zgodnjih sedemdesetih letih prejšnjega stoletja, čeprav so organizacije in vlade različne vidike družbene odgovornosti udejanjale že proti koncu 19. stoletja, v nekaterih primerih pa še bolj zgodaj (Simončič, 2015). Inštitut za razvoj družbene odgovornosti je družbeno odgovornost opredelil kot »odgovornost organizacije za vplive njenih odločitev in dejavnosti na družbeno okolje, ki skozi pregledno in etično ravnanje prispeva k trajnostnemu razvoju, vključujoč zdravje in blaginjo družbe, upošteva pričakovanja deležnikov, je v skladu z veljavno zakonodajo in mednarodnimi normami ravnanja ter je integrirana v celotno organizacijo in se razvija v vseh njenih odnosih « (IRDO, 2016).

Strategija držav Evropske unije, ki je opisana v dokumentu Evropa 2020 (Evropska komisija, 2010, str. 5), ima v ospredju tri prednostne prvine: pametno rast (razvoj gospodarstva, ki temelji na znanju in inovacijah), trajnostno rast (spodbujanje bolj konkurenčnega in zelenega gospodarstva, ki gospodarneje izkorišča vire) in vključujočo rast (utrjevanje gospodarstva $\mathrm{z}$ visoko stopnjo zaposlenosti, ki krepi socialno in teritorialno kohezijo). Uresničljiva je le v družbeno odgovorni družbi, ki želi krepiti blaginjo prebivalstva in nesebično skrbeti za višjo kakovost bivanja sedanje in bodočih generacij (Simončič, 2015).

Organizacije družbeno odgovornost vpeljujejo v svoje delovanje na različne načine, bodisi s sprejemanjem etičnih kodeksov, poklicnih kodeksov, načrtov integritete itd. Temelj za družbeno odgovorno ravnanje pa predstavlja mednarodni standard ISO 26000:2010, Navodila za družbeno odgovornost. Standard ne postavlja zahtev kot jih poznamo pri standardu ISO 9001:2008. V standardu ISO 26000 je definiranih sedem ključnih vprašanj v zvezi z družbeno odgovornostjo, ki jih je potrebno uresničevati s celostnim pristopom: 
- organizacijsko vodenje - zagotavljati odgovornost in preglednost na vseh nivojih ter uporabljati vodenje, ki ustvarja takšno organizacijsko kulturo, da se lahko temeljne vrednosti družbene odgovornosti upoštevajo pri poslovnih odločitvah;

- človekove pravice - spoštljivo ravnati z vsakim posameznikom in se posebej potruditi za ljudi iz ranljivih skupin;

- delovne prakse - zagotoviti pravične, varne in zdrave delovne razmere za delavce in jih pritegniti v dvosmerne diskusije, da bi prepoznali delavske skrbi;

- okolje - prepoznati in izboljšati okoljske vplive delovanja, vključno z izkoriščanjem virov in ravnanjem z odpadki;

- poštene prakse delovanja - spoštovati pravo in prakticirati poštenost in odgovornost v poslovanju z drugimi;

- vprašanja potrošnikov - zagotavljati zdrave in varne proizvode, ustrezne informacije in promovirati tranjostno porabo;

- udeležba v skupnosti in razvoj - biti dober sosed in biti vključen v izboljševanje razmer v lokalni in širši skupnosti (Zadravec Pešec, 2012).

Čeprav družbena odgovornost po ISO 26000 ni pravno predpisana, je v sodobnih razmerah vse bolj tržna nuja. Odjemalci vse bolj pazijo, ali kupujejo izdelke in storitve družbeno odgovornih ali drugih podjetij. Družbena odgovornost se splača dolgoročno, pogosto pa tudi kratkoročno. Taka spoznanja podpira tudi citat iz ISO 26000: »Družbena odgovornost podpira: konkurenčno prednost, ugled, sposobnost pritegniti in zadržati sodelavce ali člane, odjemalce, stranke ali uporabnike, vzdrževanje morale, zagnanosti in produktivnosti zaposlenih, stališča investitorjev, lastnikov, dajalcev, darovalcev in finančnikov ter odnose s podjetji, oblastnimi organi, mediji, dobavitelji, kolegi, odjemalci in družbeno skupnostjo v kateri organizacija deluje« (Mulej, Hrast, 2012: 312-313).

Kljub vsemu, kar je dejansko pozitivnega pri konceptu družbene odgovornosti, se zdi, da nad njo visi tudi senca dvoma, kar je $\mathrm{v}$ tem delu prispevka nujno vsaj $\mathrm{v}$ kratkem in vendarle čim bolj objektivno, $\mathrm{z}$ argumenti kritično ovrednoti. Pri nekaterih avtorjih, ki jih povzemajo tudi v našem prostoru, je namreč v središču družbene odgovornosti poudarek na ekonomski koristi in dobičkonosnosti. Ta naj bi bil osnova vsem ostalim oblikam oziroma področjem družbene odgovornosti (Geva, 2008:5). Če to postavimo v širši okvir navedene Agende 2030 za trajnostni razvoj in vključujočo svetovno družbo prihodnosti, ugotovimo, da je ravno pretirano poudarjanje ekonomske koristi in dobičkonosnem vidiku družbene odgovornosti pripeljalo svet $\mathrm{v}$ razmere, kakršne so danes. To seveda ne pomeni, da je treba koncept družbene odgovornosti zavreči, temveč je tudi z gledišča tega prispevka pomembno opozoriti na potrebo po zamenjavi paradigme (Kečanović, 2017).

Če je doslej kot nosilna misel koncepta družbene odgovornosti veljalo merilo organizacijske učinkovitosti in odgovornosti za profit, se z Agendo 2030 nosilna misel tudi pri družbeni odgovornosti spremeni v skrb za ljudi in planet. V obrnjenem vrstnem redu se torej po letih malikovanja profita $\mathrm{v}$ središče pozornosti ponovno vrača človek $\mathrm{z}$ moralno in siceršnjo odgovornostjo za naravno in družbeno okolje. $V$ tem je bistvo razlike 
$36^{\mathrm{TH}}$ International Conference on ORganizational Science Development:

Responsible Organization (MARCH $22^{\mathrm{ND}}-24^{\mathrm{TH}}$, Portorož Slovenia)

D. Kralj : From the Inclusive Management to the Responsible Organization

med profitno naravnanim, rigidnim in vključujočim vodenjem, kar je osrednji del predmeta tega prispevka: Z vključujočim vodenjem do odgovorne organizacije.

\section{Vključujoče vodenje in družbeno odgovorno delovanje UKCL v odnosu na standard ISO 26000:2010}

Univerzitetni klinični center Ljubljana (v nadaljevanju UKCL) je javni zdravstveni zavod, ki opravlja zdravstveno dejavnost na sekundarni in terciarni ravni ter izobraževalno in raziskovalno dejavnost. Izjemoma izvaja tudi primarno zdravstveno dejavnost. UKCL je največja zdravstvena ustanova v Sloveniji. Konec leta 2016 je bilo v UKCL več kot 7800 zaposlenih in skoraj 2200 bolniških postelj. Te številke UKCL uvrščajo med največje bolnišnice v Srednji Evropi. Zavod poleg zdravljenja najtežjih pacientov v Sloveniji skrbi za razvoj medicine, zdravstvene in babiške nege, medicinske rehabilitacije, visoko specializirane laboratorijske dejavnosti, farmacije in ostalih ved $\mathrm{v}$ slovenskem prostoru. V sodelovanju z izobraževalnimi institucijami izobražuje kadre vseh zdravstvenih poklicev. Pestra dejavnost UKCL in vpetost v širše družbeno okolje nakazuje na njegovo naravnanost $\mathrm{k}$ družbeno odgovornemu delovanju. Univerzitetni klinični center je v Poslovniku sistema vodenja UKCL opredelil ključne strateške cilje, ki kažejo na orientiranost UKCL k družbeno odgovorni organizaciji. Strateški cilji UKCL:

- Referenčna evropska bolnišnica

- Pacient v središču pozornosti

- Učinkovita organizacija in upravljanje

- Motivirani in usposobljeni zaposleni

- Odgovornost do okolja (UKCL, 2014a).

UKCL si prizadeva za vzpostavitev sodobne, učinkovite in fleksibilne organiziranosti in izboljševanje učinkovitosti upravljanja. Dejavnosti UKCL so organizirane kot: temeljna zdravstvena dejavnost, dejavnosti skupnega pomena, strateško upravljanje in poslovno administrativne storitve. Temeljna zdravstvena dejavnost je organizirana na klinikah, kliničnih inštitutih, kliničnih oddelkih, centrih in službah ter centrih odličnosti. Centri in službe se oblikujejo za posamezna strokovna področja znotraj klinik, kliničnih inštitutov in oddelkov. Centri odličnosti se ustanovijo za vrhunska, mednarodno uveljavljena področja dela.

UKCL je ustanova, sestavljena iz 134 organizacijskih enot: klinik, kliničnih inštitutov in kliničnih oddelkov, centrov, služb in sektorjev. Na vseh teh ravneh potekajo tudi vse ključne odločitve, povezane tako $\mathrm{z}$ oskrbo bolnikov, kot tudi $\mathrm{z}$ razvojnim in raziskovalnim delom. Te odločitve so usklajene s cilji in usmeritvami na ravni UKCL. Vsaka enota ima svojega vodjo, ki jo zastopa in je odgovoren za organizacijo dela, izpolnjevanje načrtovanega dela, strokovni razvoj, uravnoteženost delovanja enote s finančnimi viri, vzdušje in odnose med zaposlenimi v enoti. Klinike, ki imajo v sestavi več notranjih organizacijskih enot (kliničnih oddelkov), vodijo strokovni direktor, glavna medicinska sestra in poslovni direktor; klinične oddelke pa vodijo predstojniki in glavne medicinske sestre. Samostojne klinike in klinični inštituti imajo skupno poslovno 
upravljanje, posamezne enote pa vodijo predstojniki in glavne medicinske sestre. Samostojne diagnostične enote imajo skupno poslovno upravljanje, posamezne enote pa vodijo predstojniki.

Za posamezna strokovna področja so znotraj klinik, kliničnih inštitutov in kliničnih oddelkov oblikovani centri in službe, ki jih vodijo vodje. Dejavnosti skupnega pomena so potrebne za izvajanje temeljne zdravstvene dejavnosti. V okviru dejavnosti so za posamezna področja oblikovane službe, oddelki in enote. Strateške službe nudijo strokovno podporo vodstvu UKCL pri izvajanju nalog strateškega vodenja UKCL. Vse službe v okviru strateškega upravljanja se organizacijsko vežejo v upravo UKCL in ji tudi neposredno odgovarjajo. Za opravljanje dejavnosti strateškega upravljanja in poslovno administrativnih storitev so organizirani sektorji, službe, oddelki in enote $\mathrm{v}$ treh sklopih:

- področje za splošno pravno in kadrovsko izobraževalno dejavnost, področje za ekonomsko in finančno dejavnost, področje za komercialno dejavnost, informacijsko področje;

- strateške službe;

- službe skupnega pomena (UKCL, 2016).

\subsection{Organizacijsko vodenje in vključevanje}

Vodje na vseh nivojih s svojim delovanjem dajejo zgled za uresničevanje usmeritev in ciljev pri vsakdanjem delu. Cilji in kazalniki za spremljanje uresničevanja ciljev so razgrajeni po klinikah in kliničnih oddelkih ter prilagojeni specifikam organizacijskih enot. UKCL ima z uravnoteženim sistemom kazalnikov (BSC) jasen, konsistenten in pregleden sistem vodenja in upravljanja na različnih ravneh. Uravnotežen sistem kazalnikov z ozirom na 10 strateških ciljev ustanove služi kot orodje, ki omogoča klinikam, kliničnim oddelkom, službam in organizacijskim enotam uresničevanje strateških ciljev ustanove, sprejemanje operativnih in strateških odločitev, preverjanje učinkovitosti ukrepov in nenehno izboljševanje. Standardizirane analize in poročila za potrebe različnih ravni vodenja (vodstvo UKCL, klinike, klinični oddelki, OE in službe) omogočajo hitrejši pregled lastne organizacijske enote, enotne definicije kazalnikov omogočajo lažje analize in opredelitev ključnih učinkovitih ukrepov (UKCL, 2014b). 


\section{KAKSKADNOST UPRAVLJANJA UKCL}

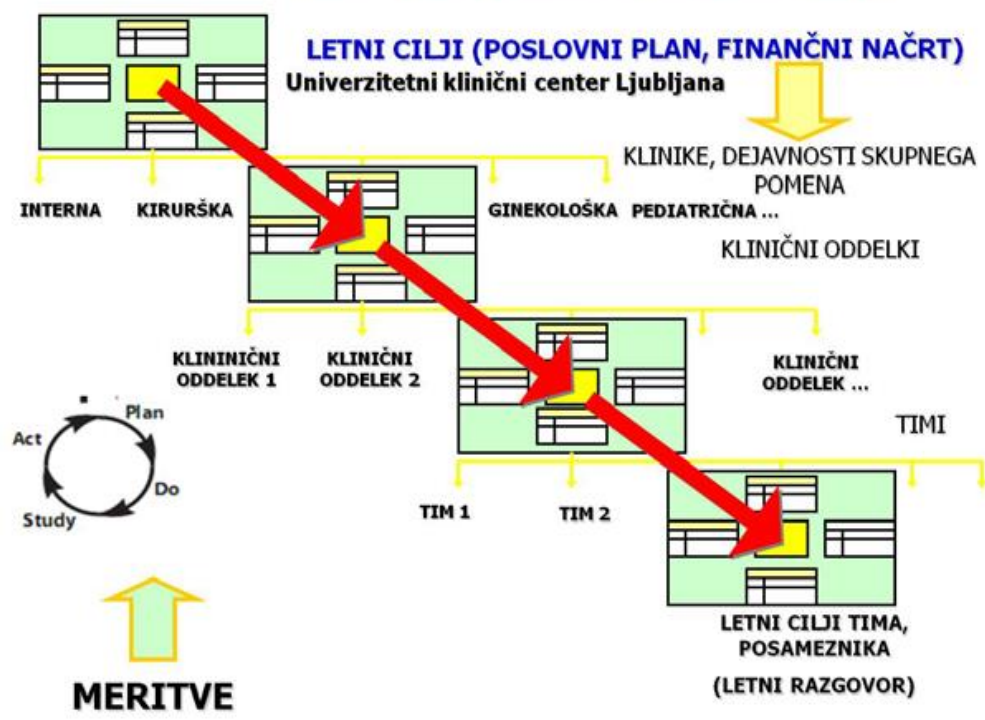

Slika 1: Shema kaskadnosti upravljanja v UKC Ljubljana

\section{2 Človekove pravice}

UKCL si aktivno prizadeva za zaščito človekovih pravic zaposlenih, zato je s pomočjo pravne službe in pooblaščenk za varnost pacientov in zaposlenih v letu 2011 sprejel pravilnik »Ukrepi za zaščito zaposlenih pred trpinčenjem, spolnim in drugim nadlegovanjem in diskriminacijo na delovnem mestu v Univerzitetnem kliničnem centru Ljubljana«. Istočasno so bili imenovani pooblaščenci za nenasilje. Pripravljeni in uveljavljeni so protokoli, ki se uporabljajo zaradi potreb reševanja nasilja na samem delovnem mestu, kjer ga zdravstveni delavci prepoznajo v nasilnem obnašanju in nasilnih dejanjih posameznih pacientov. V letu 2011 je bila v UKCL ustanovljena skupina, ki je pripravila projekt mediacija v UKCL. Projektna skupina je pripravila Pravilnik o delu centra za mediacijo UKCL in o postopku mediacije V UKCL. Imenovan je bil tudi koordinator za mediacijo.

Zaščita zaposlenih pred trpinčenjem in mirno reševanje sporov je opredeljena tudi v 12. Poglavju Priročnika za upravljanje s človeškimi viri v UKCL. Oba procesa sta prikazana tudi z diagramom poteka kar pripomore $\mathrm{k}$ boljšemu poznavanju procesa. Glede na pestro medijsko izpostavljenost UKCL kot ustanove ter medijsko izpostavljenost zaposlenih so bila v letu 2015 sprejeta Etična pravila za zaposlene v UKCL. Gre predvsem za pravila v povezavi s poslovanjem in zaposlenimi. Etična pravila, ki nastanejo na relaciji zdravstveni delavec - pacient, obravnavajo stanovski etični kodeksi zdravstvenih 
delavcev. UKCL želi s pripravljeni ukrepi ustrezno reševati spore, ki nastajajo kot posledica medsebojnih nesoglasij, raznih sporov in nasilja med zaposlenimi in pacienti.

\subsection{Delovne prakse}

UKCL je v letu 2009 pričel s pripravami na vpeljavo mednarodnega standarda kakovosti DVN (Det Norsk Veritas). V priprave na vpeljavo standarda so bili vključeni zaposleni iz posameznih enot UKCL, ki delujejo kot koordinatroji sistema vodenja kakovosti. Ti so na svojih enotah širili znanje s področja kakovosti in skrbeli za izvedbo vseh aktivnosti za uspešno opravljeno mednarodno akreditacijo DNV, s katero UKCL dokazuje ustrezno vodenje kakovosti, kar UKCL uvršča med odlične bolnišnice. Posamezne enote UKCL so pridobile certifikat ISO 9001:2008, celoten UKCL pa je ta certifikat pridobil za področje »menedžmenta bolnišnice«. V zadnjih letih je UKCL kandidiral za nagrado poslovne odličnosti Republike Slovenije, nazadnje ponovno leta 2015 ter prejel priznanje Evropske fundacije za managment kakovosti EFQM - Recognised for Excelence 4star.

\subsection{Okolje}

Ohranjanje naravovarstvene odgovornosti do okolja, požarne varnosti in varstva pred sevanji, skrbno ravnanje z nevarnimi snovmi, odpadki je eden izmed ciljev UKCL.

Načrt gospodarjenja z odpadki UKCL predstavlja za zavod pomemben dokument na vseh ravneh, saj vpeljuje učinkovito okoljevarstveno politiko, organizacijo, logistiko, aktivnosti in navodila za ustrezno ravnaje $\mathrm{z}$ različnimi vrstami nastalih odpadkov. Hkrati pa določa tudi naloge in odgovornosti za posameznika, da se na celostni ravni vzpostavi učinkovit sistem ravnanja z odpadki, ki bo zadostil potrebam zavoda, zakonodaje, okoljevarstvenim smernicam in programskim ciljem na področju ravnanja z odpadki $\mathrm{v}$ RS.

Skladno z Zakonom o varnosti in zdravju pri delu - ZVZD-1 (Ur. List. RS, št. 43/2011) UKCL kot delodajalec organizira teoretično in praktično usposabljanje zaposlenih za varno opravljanje dela. Usposabljanje za varno in zdravo delo se izvaja na delovnem mestu in je sestavni del uvajanja v delo. Praktično usposabljanje zaposlenih in preverjanje njihove praktične usposobljenosti izvedejo vodje delavcev, če gre za posebna dela pa s pomočjo specialistov za posamezna področja dela in mentorjev.

\subsection{Poštene prakse delovanja}

Z željo povečati odprtost UKCL in povečati sodelovanje $\mathrm{z}$ društvi pacientov in društvi, ki delajo v dobro pacientov, je bil julija 2009 ustanovljen Svet pacientov UKCL. Svet pacientov je posvetovalno telo vodstva UKCL in sicer o temah, za katere UKCL želi pridobiti povratne informacije, in za teme, ki jih predlaga Svet pacientov sam. Svet sestavljajo člani društev, združenj, zvez, ustanov in zainteresirani posamezniki. Poslovnik določa, da ima Svet pacientov najmanj 7 članov. Člane sveta imenuje generalni direktor UKCL. Članice in člani imajo mandat 3 leta. Svet pacientov UKCL je organiziral že več okroglih miz, med drugim v letu 2010: »Okroglo mizo o sodelovanju med 
organizacijami pacientov in UKCL « in v letu 2012: 》Okroglo mizo o aktivni vlogi pacienta v UKCL«(UKCL, 2017a).

UKCL omogoča prostovoljcem, da se vključujejo v delo osebja UKCL. Koordinatorica prostovoljskega dela pripravi uvodno izobraževanje za prostovoljke in prostovoljce $\mathrm{v}$ UKCL na temo: »Predstavitev UKCL in posebnosti prostovoljskega dela $\mathrm{v}$ bolnišnici«. Prostovoljci organizirano in na dogovorjeni način prispevajo k izboljšanju kakovosti življenja in bivanja bolnikov v UKCL tako, da jim krajšajo čas, se z njimi družijo, jih spremljajo, se z njimi pogovarjajo, jim berejo, igrajo igre in jim nudijo druge manjše zaposlitvene dejavnosti. Rehabilitirani bolniki lahko na željo bolnika, nudijo pomoč v smislu moralne podpore in posredovanj izkušenj (UKCL, 2017b).

$\mathrm{Z}$ dobavitelji medicinskega in nemedicinskega materiala, zdravil in medicinsko tehničnih pripomočkov si UKCL prizadeva za doseganje trajne koristi. Člani strokovnih komisij za vodenje postopkov oddaje javnega naročila oblikujejo razpisne pogoje $\mathrm{v}$ smislu strokovno tehničnih parametrov. Nabavna služba UKCL izvaja primerjalne analize na širšem evropskem trgu (sicer pa se vsa obsežnejša javna naročila objavljajo tudi v Uradnem listu EU), tako na področju cen kot tudi strokovnih kriterijev.

\subsection{Vprašanja potrošnikov (pacientov)}

UKCL si prizadeva za strokovno, kakovostno in učinkovito individualno zdravstveno obravnavo. Vsakdo si zasluži, da je obravnavan spoštljivo, skrbno in varno ne glede na spol, raso, versko pripadnost, ekonomski ali družbeni položaj, izobrazbo, narodnost, spolno usmeritev. Za celovito seznanjenost pacientov s pacientovimi pravicami in njihovimi dolžnostmi je UKCL poleg obvestil pred ambulantami in na oddelkih, na spletni strani objavil napotke pacientom kako ravnati v primeru kršitev le teh.

V letu 2015 je v Urad za pritožbe in pohvale v UKC Ljubljana prispelo skupno 628 zadev, te zajemajo: zahteve za prvo obravnavo, pritožbe, pohvale iz zadev označenih pod razno. Zadeve so bile posredovane s strani pacientov, njihovih svojcev, bližnjih ali pooblaščencev.

UKC Ljubljana spremlja zadovoljstvo uporabnikov storitev z nacionalnimi anketami in lastnimi anketami. Na vseh hospitalnih oddelkih UKC Ljubljana je bila v letu 2010 uvedena uporaba enotnega vprašalnika o zadovoljstvu pacientov $\mathrm{z}$ bolnišnično zdravstveno obravnavo, z letom 2011 pa tudi za specialistično in urgentno ambulantno obravnavo.

Eden od pomembnih ciljev UKCL je tudi zagotavljanje ugleda UKCL v širši javnosti. Vodstvo UKCL redno spremlja objave $\mathrm{v}$ medijih (tako o UKCL kot o dogodkih $\mathrm{v}$ zdravstvu), posreduje medijem informacije o poslovanju UKCL in izvaja načrtno strategijo odnosov s predstavniki medijev in drugimi javnostmi. Komunikacijska infrastruktura za obveščanje splošne in posebnih javnosti je pestra, tako vodstvo UKCL preko tiskovnih konferenc obvešča javnost, zdravniki in vodstveni delavci UKCL so pogosto gosti $\mathrm{v}$ radijskih ali televizijskih oddajah, kjer odgovarjajo na vprašanja 
pacientov oz. njihovih svojcev. UKCL obvešča javnost o poslovanju in delu UKCL, o novih pridobitvah in potrebah za nadaljnji razvoj. Ob vseh pomembnih dogodkih povabi medije (npr. donatorske akcije za zbiranje sredstev za nakup aparatov, otvoritev novih ambulant ...)

\subsection{Udeležba v skupnosti in razvoj}

UKCL sodeluje z izobraževalnimi institucijami in si prizadeva za izvajanje čim bolj kakovostnih strokovnih programov in praktičnih usposabljanj za študente. UKCL izvaja izobraževalno dejavnost za potrebe Medicinske fakultete v Ljubljani in Mariboru, Fakultete za farmacijo, Fakultete za zdravstvo v Ljubljani, Fakulteta za zdravstvo Angele Boškin, Srednje zdravstvene šole $\mathrm{v}$ Ljubljani ter drugih šol na dodiplomski in podiplomski ravni. Sodeluje pri oblikovanju vsebine izobraževalnih programov $\mathrm{s}$ področja zdravstva in daje pobude za dograjevanje teh programov. Izvaja podiplomsko izobraževanje zdravstvenih strokovnjakov in zdravstvenih sodelavcev, oblikuje in izvaja delovanje komisij za strokovne izpite za zdravstvene strokovnjake in zdravstvene sodelavce. UKCL izvaja tudi lastno izobraževanje za potrebe pedagoškega, strokovnega in znanstveno-raziskovalnega dela. Le ustrezno usposobljeni zdravstveni delavci lahko zagotavljajo kakovostne in varne zdravstvene storitve. UKCL redno meri in upošteva zadovoljstvo odjemalcev izobraževalnih storitev. Izobraževalne storitve prilagaja sodobnim razvojnim trendom. Zaposleni UKCL v obliki dopolnilnega delovnega razmerja na Medicinski fakulteti Ljubljana sodelujejo v pedagoškem procesu, $v$ nekaterih primerih pa kot predstojniki katedre.

V UKCL poteka intenzivno timsko raziskovalno delo, v katerega so vključeni različni profili zaposlenih. Financiranje raziskav skozi evropske projekte, projekte in programe Javne agencije za raziskovalno dejavnost Republike Slovenije, sodelovanje z industrijo in drugimi partnerji omogoča, da zdravstvo pridobi dodatna sredstva, zunaj omejenega zdravstvenega proračuna. S terciarnimi razvojno-raziskovalnimi projekti UKCL tudi neposredno investira $v$ raziskave. S celotno raziskovalno dejavnostjo zaposleni v UKCL nenehno izboljšujejo kakovost obravnave bolnikov. UKCL spodbuja raziskovalno delo na vseh nivojih, od študentov Medicinske in Zdravstvene fakultete, mladih zdravnikov, medicinskih sester in drugih sodelavcev, do rednih profesorjev in akademikov. Doprinos vseh je dragocen in nenadomestljiv.

UKCL sodeluje s številnimi $\mathrm{z}$ zdravstveni in socialni zavodi $\mathrm{v}$ regiji in državi in si prizadeva za izvajanje celostne in kontinuirane zdravstvene oskrbe, kar zahteva tesno partnersko sodelovanje. Povezuje se tudi z akademskimi in drugimi bolnišnicami v tujini. Partnersko sodeluje pri skupnih razvojno - raziskovalnih projektih, izmenjavi primerov dobrih praks, znanj ter študijski izmenjavi (UKCL, 2017c).

\section{$4 \quad$ Sklepne misli}

V prispevku sem si prizadevala zajeti čim več dejavnikov, ki ne samo da potrjujejo vse večji pomen vključujočega vodenja za družbeno odgovorno delovanje organizacij, ampak ob upoštevanju organizacijskih posebnosti in (globalnega) konteksta poslovanja 
pokažejo, kako se z vključevanjem uspešno spopasti z novimi izzivi in pri tem slediti univerzalnim standardom, kot jih navaja denimo omenjena Agenda za trajnostni razvoj sveta do leta 2030. Za bralca, ki ga bo prispevek morda spodbudil, da z raziskovanjem naslovne misli tega prispevka nadaljuje in jo obogati s svojimi spoznanji, je lahko dodaten izziv, ki se mu sama na tem mestu žal nisem uspela bolj posvetiti, izziv družbene odgovornosti v smislu zamenjave paradigme na področju družbene odgovornosti. V mislih imam razliko, kar sem pri družbeni odgovornosti v kratkem povzela, med rigidnim in vključujočim modelom vodenja. $Z$ drugimi besedami med sedanjimi profitno naravnanimi in vključujočimi organizacijami svetovne družbe prihodnosti. $Z$ besedami Agende 2030 - z vključujočim vodenjem za ljudi in planet.

V primerjavi z nekaterimi drugimi pristopi, ki od organizacij terjajo, da se pri prilagajanju novim razmeram odrečejo utečenim načinom dela in si zaradi tega večinoma po nepotrebnem povečujejo še stroške, vključujoče vodenje vztraja, da se dobre navade, moralna prepričanja in etična kultura organizacij ohranijo in krepijo z večjo zmogljivostjo prilagajanja, upoštevanja skupnega potenciala raznolikosti in uspešnega delovanja, tako $\mathrm{v}$ notranjem kot $\mathrm{v}$ zunanjem okolju. Na primeru dobre prakse $\mathrm{v}$ UKCL sem pokazala, kako $\mathrm{z}$ vključujočim vodenjem tudi družbena odgovornost in ravnanje $\mathrm{z}$ ljudmi, zaposlenimi in zunanjimi deležniki pridobita na kakovosti, kulturnih in poslovnih kompetencah. Pri vsem tem pa ni treba odvečnih sprememb, obremenitev in stroškov.

Kljub temu, da UKCL na področju družbene odgovornosti še ni pridobil certifikata ISO 26000 , lahko $\mathrm{z}$ vključujočim vodenjem njegovo delovanje smiselno umestimo $\mathrm{v}$ sedem ključnih točk, ki jih predvideva standard ISO 26000 za družbeno odgovornost. Iz zgoraj prikazanega je razvidno, da je delovanje UKCL zelo široko razvejano. Aktivnosti, ki jih izvaja, zajemajo vse od etičnega poslovanja, enakopravnega in korektnega obravnavanje zaposlenih in pacientov, spoštovanja temeljnih pravic zaposlenih in pacientov, razvoja in izobraževanja do odgovornega ravnanja z okoljem in lokalno skupnostjo. Vidimo, da se v posameznih segmentih tesno prepletajo prvine vključujočega vodenja in družbene odgovornosti. Vključujoče vodenje pomembno vpliva na etiko komuniciranja, medsebojne odnose in dobro počutje, zdravje in zadovoljstvo zaposlenih na delovnem mestu. Z vsem tem pa tudi na boljše delovne rezultate. Če sklenem s prirejenim ljudskim rekom, za vključujoče vodenje in poslovanje je morda še najbolj značilno, da »dobra volja je najbolja«.

\section{Priloga}

Nekaj uporabnih nasvetov kako biti vključujoč:

1. SPOŠTUJ DRUGE: Ceni vsakega posameznika. Bodi odprt za vsa stališča, različne poglede.

2. NE SODI, NE DA SE PREPRIČAŠ: Ne delaj predpostavk o sodelavcih. Najprej se prepričaj in poskusi razumeti, preden si ustvariš svojo sliko/preden narediš zaključke.

3. POZNAJ SEBE: Pomembno je, da poznaš in razumeš lastne vrednote in preference /prioritete ter kako lahko vplivajo na tvoje vedenje do drugih. 
4. PAZI NA SVOJE BESEDE: Bodi pozoren na to, kaj rečeš. Nekoga lahko nehote/brez da bi se tega zavedal, prizadeneš.

5. POSLUŠAJ IN PROSI ZA RAZLAGO: Pazljivo poslušaj. Vsak dvom takoj razjasni (Šentprima, 2015: 46).

\section{Literatura in viri}

Aleksič, D. (2016): Vključujoče izobraževanje kot akcijsko raziskovanje - primer iz prakse. IRVD - Inštitut za razvoj vključujoče družbe. Dosegljivo na: http://www.irvd.si/wpcontent/uploads/2014/07/Dr-Darija-Aleksi\%C4\%87-Vklju\%C4\%8Dujo\%C4\%8Deizobra\%C5\%BEevanje.pdf (20.12.2016).

Čebron, L. U. (ur.) (2016): Kulturne kompetence in zdravstvena oskrba: priročnik za razvijanje kulturnih kompetenc zdravstvenih delavcev. Nacionalni inštitut za javno zdravje. Dosegljivo na: $\quad$ http://www.nijz.si/sites/www.nijz.si/files/publikacije-datoteke/prirocnik kulturne_kompetence_2016.pdf (16.01.2017).

Evropska komisija. (2010). Evropa 2020. Strategija za pametno, trajnostno in vključujočo rast. Bruselj: Evropska komisija. Dosegljivo na: http://ec.europa.eu/eu2020/pdf/1_SL_ ACT_part1_v1.pdf (2.1.2017).

Evropska komisija. (2011): Sporočilo komisije evropskemu parlamentu, svetu, evropskemu ekonomsko-socialnemu odboru in odboru regij. Obnovljena strategija EU za družbeno odgovornost podjetij za obdobje 2011-14. Dosegljivo na: http://www.europarl.europa.eu/ meetdocs/2009_2014/documents/com/com_com\%282011\%290681_/com_com\%282011\%29 0681_sl.pdf (2.1.2017).

Geva, A. (2008, marec): Three Models of Corporate Social Resposibility: Interrelationship between Theory, Research, and Practice. Business and Society Reviw, 113(1), str.5. Dosegljivo na: http://onlinelibrary.wiley.com/doi/10.1111/j.1467-8594.2008.00311.x/epdf (15.2.2017).

Hollander, E.P. (2009): Inclusive Leadership: The Essential Leader Follower Relationship. str. 3. Dosegljivo na: https://books.google.si/books?id=YpGTyZH_v10C\&pg=PA23\&hl $=$ sl\&source $=$ gbs_selected_pages\&cad $=2 \# \mathrm{v}=$ onepage $\& q \& \mathrm{f}=$ false $(2.1 .2017)$.

Kečanović, B. (2014-I): Pomen vključujoče družbe pri urejanju in nadzoru lobiranja, v: Kocbek, M. idr. (ur): Podjetje in delo 6-7/2014. Dnevi slovenskih pravnikov. Portorož. str. 1238-1251).

Kečanović, B. (2014-II): Vključujoče delovno okolje: Etična infrastruktura v podporo implementaciji Slovenskih smernic korporativne integritete. str. 2 - 3. Dosegljivo na: http://www.irvd.si/wp-content/uploads/2014/11/Kecanovic-vkljucevanje-etika-in-SSKI.pdf (10.12.2016)

Kečanović, B., Politika etičnega poslovanja in etična infrastruktura $\mathrm{v}$ podporo uresničevanju strateških ciljev javne uprave, v: Aristovnik, A. (2015): Zbornik prispevkov XXII. Dnevi slovenske uprave, Ljubljana; dosegljivo na spletni strani IRVD: http://www.irvd.si/wpcontent/uploads/2015/05/Kecanovic.pdf (10.12.2016).

Kečanović, B. (2017): Družbena odgovornost podjetja na prelomu 21. Stoletja - AGENDA 2030. Dosegljivo na : http://www.irvd.si/druzbena-odgovornost-podjetja-na-prelomu-21-stoletjaagenda-2030 (21.2.2017).

Kralj, D. (2007): Varstvo osebnih podatkov na področju zdravstva. Magistrsko delo. Fakulteta za podiplomske državne in evropske študije. Kranj. (str. 11).

IRDO -Inštitut za razvoj družbene odgovornosti. Dosegljivo na: http://www.irdo.si/druzbena odgovornost.html (26.12.2016).

IRVD - Inštitut za razvoj vključujoče družbe. (2016a): Vključujoče delovno okolje. Dosegljivo na: http://www.irvd.si/druzba/delovno-okolje/ (26.12.2016). 
$36^{\mathrm{TH}}$ International Conference on ORganizational Science Development: ReSPONSIBLE ORGaNiZATION (MARCH $22^{\mathrm{ND}}-24^{\mathrm{TH}}$, PORTOROŽ Slovenia)

D. Kralj : From the Inclusive Management to the Responsible Organization

IRVD - Inštitut za razvoj vključujoče družbe. (2016b): Dobra praksa urejanja etike vključevanja in vključujočega delovnega okolja $\mathrm{v}$ etičnih kodeksih. Dosegljivo na: http://www.irvd.si/vkljucujoca-druzba/dobra-praksa-etike-vkljucevanja-urejanjavkljucujocega-delovnega-okolja-v-eticnih-kodeksih/ (26.12.2016).

IRVD - Inštitut za razvoj vključujoče družbe. (2016c): Ne pusti se - vključi se v prizadevanja za etiko vključevanja, Dosegljivo na: http://www.irvd.si/ne-pusti-se-vkljuci-se-v-prizadevanjaza-etiko-vkljucevanja/ (26.12.2016).

IRVD - Inštitut za razvoj vključujoče družbe. (2016d): Prvine etike vključevanja v Ustavi RS, mednarodnih aktih, praksi Ustavnega sodišča in standardih pravnega urejanja družbenih odnosov. Dosegljivo na: http://www.irvd.si/vkljucujoca-druzba/prvine-etike-vkljucevanja-vustavi-rs-mednarodnih-standardih-praksi-ustavnega-sodisca/ (26.12.2016).

Mor Barak, M.E. (2016): Managing diversity: Toward a globally inclusive workplace, University of Southern Californija - Fourth edition, Sage Publications Inc. London, str. 8-9.

Mulej, M., Hrast, A. (2012): Družbena odgovornost politikov namesto podpore za neoliberalizem. v : Kečanović, B. (ur) Javna etika in integriteta: Odgovornost za skupne vrednote. Zbornik KPK. Ljubljana. str. 312-313.

MZZ - Ministrstvo za zunanje zadeve. Dosegljivo na: http://www.mzz.gov.si/si/zunanja

politika_in_mednarodno_pravo/mednarodnorazvojno_sodelovanje_in_humanitarna_pomoc/politi ke_mrs/cilji_trajnostnega_razvoja/ (26.12.2016).

Oroszy, D., Pustatičnik, P. (2016): Transformacija zdravstvenih organizacij v digitalni družbi. 25. letna konferenca Slovenskega združenja za kakovost in odličnost. November. Portorož.

ZRC - SAZU. Znanstveno raziskovalni center. Slovenska akademija znanosti in umetnosti. Dosegljivo na: http://bos.zrc-sazu.si/cgi/a03.exe?name=sskj_testa\&expression=dru\%C5\% BEbena+odgovornost\&hs=1 (2.1.2017).

Pondelek, D. (2016): Strategija vključujočega in etičnega komuniciranja in delovanja, v: 4. industrijska revolucija na psiholoških temeljih vključujoče družbe prihodnosti; gradivo posveta IRVD in EF UL. Ljubljana. 29. November 2016. Dosegljivo na: http://www.irvd.si/ (23.01.2017).

Rejc Buhovac, A. (2014): Poslovni model z vključujočim delovnim okoljem. Dosegljivo na: http://www.irvd.si/wp-content/uploads/2014/11/Dr-Rejc-Buhovac-Poslovni-modelvklju\%C4\%8Dujo\%C4\%8Dega-delovnega-okolja.pdf (10.12.2016).

Šentprima. (2015): Priročnik vodenje raznolikosti v podjetju. str. 33, 46. Dosegljivo na: http://www.sentprima.com/wp-content/uploads/2015/01/prironik-vodenje-raznolikosti-vpodjetju_entprima-2015.pdf (13.1.2017).

Schwab, K. (2017): A call for responsive and responsible leadership, povzeto po WTF 2017. Dosegljivo na: https://www.weforum.org/agenda/2017/01/a-call-for-responsive-and-responsible-leadership/ (23.01.2017).

UKCL - Univerzitetni klinični center Ljubljana. (2014a): Poslovnik sistema vodenja UKCL. Interno gradivo.

UKCL - Univerzitetni klinični center Ljubljana. (2014b): Poslovnik sistema vodenja UKCL. Interno gradivo.

UKCL - Univerzitetni klinični center Ljubljana. (2016): Letno poročilo 2015. Dosegljivo na: http://www.kclj.si/dokumenti/POSLOVNO_POROCILO_2015_web.pdf (12.12.2016).

UKCL - Univerzitetni klinični center Ljubljana. (2017a): Svet pacientov. Dosegljivo na: http://www.kclj.si/index.php?dir=/pacienti_in_obiskovalci/podatki_za_paciente/svet_paciento $\underline{\mathrm{v}}(10.1 .2017)$.

UKC̄L - Univerzitetni klinični center Ljubljana. (2017b): Prostovoljstvo v UKC Ljubljana. Dosegljivo na: http://www.kclj.si/index.php?dir=/pacienti_in_obiskovalci/podatki_za_ prostovoljce (10.1.2017). 
UKCL - Univerzitetni klinični center Ljubljana. (2017c): Izobraževanje in raziskovanje. Dosegljivo na: http://www.kclj.si/index.php?dir=/strokovna javnost/izobrazevanje in raziskovanje (16.1.2017).

Vlada Republike Slovenije. (2015): Politika napredka in kakovosti javne uprave. Dosegljivo na: http://www.mju.gov.si/si/delovna_podrocja/razvoj_projektov_kakovost_javne_uprave in_kohezijska_politika/strategija_razvoja_javne_uprave/ (10.12.2016).

Zadravec Pešec, R. (2012): Konferenca "Družbena odgovornost in izzivi časa". Institut informacijskih znanosti. Maribor. Dosegljivo na: http://home.izum.si/cobiss/oz/2012_2/html/ clanek_06.html\#d0e166 (2.1.2017). 
406 36 $6^{\text {TH }}$ International Conference on Organizational Science Development: RESPONSIBLE ORGANIZATION 


\title{
Napredna nastavitev oskrbovalnih politik z odkrivanjem znanja iz podatkov $z$ orodjem Orange
}

\author{
EVA KRHAČ, BENJAMIN URH \& MATJAŽ ROBLEK
}

Povzetek V prispevku smo analizirali potrebe podjetij po zalogah ter prikazali optimalen način obvladovanja zalog na primeru podjetja Gumitehna d.o.o. Pri izbiri in analizi kriterijev, ki vplivajo na določitev optimalne politike oskrbe in vodenja zalog smo uporabili orodje Orange. Ugotovili smo, da je model uporaben v praksi.

KLJUČNE BESEDE: vodenje zalog - oskrbovalne politike - odkrivanje znanja iz podatkov

\footnotetext{
NASLOV AVTORJEv: Eva Krhač, mag., asistentka, Univerza v Mariboru, Fakulteta za organizacijske vede, Kidričeva cesta 55a,4000 Kranj, Slovenija, e-pošta: eva.krhac@ fov.uni-mb.si; dr. Benjamin Urh, višji predavatelj, Univerza v Mariboru, Fakulteta za organizacijske vede, Kidričeva cesta 55a,4000 Kranj, Slovenija, e-pošta: benjamin.urh@fov.uni-mb.si; dr. Matjaž Roblek, docent, Univerza v Mariboru, Fakulteta za organizacijske vede, Kidričeva cesta 55a,4000 Kranj, Slovenija, e-pošta: matjaz.roblek@um.si
} 
$36^{\text {TH }}$ InTERnAtional CONFERENCE ON ORganizational SCIENCE DeVelopment: Responsible Organization (MARCH $22^{\mathrm{ND}}-24^{\mathrm{TH}}$, PORTOROŽ SLOVENIA)

O. Arsenijević, M. Ferjan, I. Podbregar, P. Šprajc, D. Trivan \& Y.

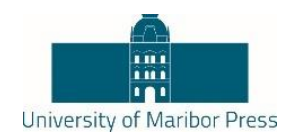

Ziegler

\title{
Advanced Setting of Supply Policies by Discovering Knowledge from Data Using Orange
}

\author{
EVA KRHAČ, BENJAMIN URH \& MATJAŽ ROBLEK
}

\begin{abstract}
In this paper we analyzed the needs for inventory in enterprises and presented the optimal method for managing inventory in the case of Gumitehna Ltd. In the selection and analysis of criteria that affect the determination of the optimal policy of supply and inventory management we used the tool Orange. We have found that the model is useful in practice.

KEYWORDS: Inventory Management - Supply Policies • Knowledge Discovery from Data
\end{abstract}

Correspondence Address: Eva Krhač, M.D., Assistant, University of Maribor, Faculty of Organizational Sciences, Kidričeva cesta 55a,4000 Kranj, Slovenija, e-mail: eva.krhac@ fov.unimb.si; Benjamin Urh, Ph.D., Senior Lecturer, University of Maribor, Faculty of Organizational Sciences, Kidričeva cesta 55a,4000 Kranj, Slovenija, e-mail: benjamin.urh@fov.uni-mb.si; dr. Matjaž Roblek, Assistant Professor, University of Maribor, Faculty of Organizational Sciences, Kidričeva cesta 55a,4000 Kranj, Slovenija, e-mail: matjaz.roblek@um.si

DOI https://doi.org/10.18690/978-961-286-020-2.35ＩSBN 978-961-286-020-2

(C) 2017 University of Maribor Press

Available at: http://press.um.si 


\section{$1 \quad$ Uvod}

Obvladovanje zalog $\mathrm{v}$ trgovinskih podjetjih se ciljno posveča izogibanju previsoki in prenizki zalogi. Ǐčce se tiste ravni zalog, s katerimi je omogočeno doseganje visoke stopnje servisiranja kupcev, istočasno pa se obseg denarnih sredstev vezanih v zaloge bistveno ne poveča (Grčar, 2010, str. 9). Z vidika skladiščnega poslovanja zalogo razumemo kot neko količino določenega blaga, odloženo ali uskladiščeno na določenem mestu - skladišču v podjetju (Ljubič, 2000, str. 347). Pri tem naj bi bila optimalna zaloga tista, pri kateri bodo ob maksimalni zanesljivosti poslovanja stroški zalog minimalni (Završnik, 2008, str. 61). Višina optimalne zaloge se konstantno spreminja in je odvisna od spreminjanja različnih dejavnikov, ki vplivajo na zalogo (Grčar, 2010, str. 9). Torej en, statično in enkratno določen model vodenja zalog ni optimalen, ko gre izdelek skozi različne faze svojega življenjskega cikla.

$\mathrm{Z}$ vidika stopnje servisiranja stranke so pomembni individualni parametri posameznega izdelka s katerimi zagotavljamo želeno stopnjo. $Z$ vidika celovitega upravljanja zalog podjetja pa je pomembno, da se zaloge izdelkov s podobnimi lastnostmi, določajo z enako nabavno politiko, da bi poenotili postopke naročanja in samo avtomatizacijo naročanja (povečali učinkovitost upravljanja zalog). Cilj je, da porabljamo čim manj virov za določanje čim bolj optimalnih zalog. V tem primeru potrebujemo kriterije po katerih bomo izdelke opredelili in razvrstili $\mathrm{v}$ skupine ter jim določili najprimernejše politike obvladovanja zalog. Pomembno je tudi, da bomo lahko pravočasno zaznali spremembe tržnih ali oskrbovalnih parametrov ter spremenili politike oskrbe posameznim izdelkom tako, da jih bomo razvrstili v bolj optimalne skupine.

Na področju literature obstajajo modeli, ki po različnih kriteriji razvrščajo izdelke in jim dodeljujejo oskrbovalne politike ter posledično določajo višino zalog in zagotavljajo optimalne ravni v skladu $\mathrm{z}$ najboljšo prakso (Stevenson, 2015, str. 546 - 582). Cilj raziskave je bil najti naprednejši način za obdelavo podatkov o izdelkih in določevanje politik obvladovanja zalog. V ta namen smo testirali primernost orodja Orange, ki je odprtokodno orodje za vizualizacijo in analizo podatkov, razvito na Univerzi v Ljubljani, Fakulteti za računalništvo in informatiko, Laboratoriju za bioinformatiko. Orodje Orange podpira KDD (angl. Knowledge Discovery from Data, slo. odkrivanje znanja iz podatkov). KDD je netrivialen proces odkrivanja implicitnega, doslej neznanega in potencialno uporabnega znanja iz podatkov (Kljajić, 2015). Osnovna ideja je razvoj sistema ali orodja, ki bo pregledal ogromno število podatkov, odkril vzorce in zakonitosti $\mathrm{v}$ teh podatkih ter se na podlagi tega naučil napovedati prihodnje vrednosti.

Kot realni primer smo uporabili podjetje Gumitehna d.o.o., katerega primarna dejavnost je prodaja gumeno-tehničnih izdelkov (maloprodaja, veleprodaja) na območju Slovenije, Evropske unije ter na območju nekdanje Jugoslavije (Kovač, 2015, str. 5). Glavni problem, s katerim se podjetje sooča, je obvladovanje zalog in sicer s prekomerno zalogo določenih izdelkov in prav tako tudi s pomanjkanjem zalog drugih izdelkov. Prekomerne zaloge jim povzročajo nepotrebne stroške zalog in skladiščenja, pomanjkanje zalog pa stroške nezaloženosti (oziroma pomanjkanja) in posledično tudi izgubo strank. Trenutna 
$36^{\mathrm{TH}}$ International Conference on ORganizational Science Development: RESPONSIBLE ORGANIZATION (MARCH $22^{\mathrm{ND}}-24^{\mathrm{TH}}$, PORTOROŽ SLOVENIA)

E. Krhač, B. Urh \& M. Roblek: Advanced Setting of Supply Policies by Discovering Knowledge from Data Using Orange

praksa v podjetju je naročanje zalog na podlagi kvalitativne metode, ki temelji predvsem na subjektivni presoji direktorja podjetja, komercialistov ter poslovodje. Ko se zaloga artikla zelo zmanjša, se naroči nova zaloga - pri tem se upoštevata dobavni čas ter cena artikla. S pomočjo orodja Orange smo želeli pridobiti nabor politik obvladovanja zalog, primernih za podjetje Gumitehna d.o.o.

\section{Metoda dela}

$\mathrm{V}$ prvem delu je bila opravljena teoretična raziskava strokovne literature ter gradiva $\mathrm{s}$ področja vodenja zalog, $v$ kateri smo raziskali njihov pomen, vrste ter možne stroške, ki nastajajo kot njihova posledica. Prav tako smo raziskali politike ravnanja z zalogami in kazalce upravljanja z zalogami. V drugem, empiričnem delu, smo predlagali primerne politike ravnanja z zalogami za posamezne skupine artiklov. Najprej smo naredili analizo trenutnega stanja vodenja zalog v podjetju Gumitehna d.o.o.: prikazali poslovni model, razložili obstoječe politike ravnanja $\mathrm{z}$ zalogami in prikazali trenutno stanje zalog. Potrebne podatke smo pridobili od podjetja, in sicer del podatkov iz razgovorov $\mathrm{z}$ zaposlenimi v podjetju, drugi del podatkov o artiklih pa so zaposleni izvozili iz programa VASCO v Microsoft Excel. Artikle smo razdelili v skupine s pomočjo osmih kriterijev. V nadaljevanju smo uporabili orodje Orange, ki nam je pomagalo pri osnovni statistiki ter ugotovitvi vrstnega reda pomembnosti kriterijev. Politike obvladovanja zalog smo predlagali na podlagi teoretične raziskave, primerjave $\mathrm{z}$ že obstoječimi primeri, raziskanimi kvantitativnimi metodami napovedovanja ter na podlagi izkušenj in predlogov zaposlenih $\mathrm{v}$ podjetju.

\section{Raziskava}

Na podlagi predhodnih raziskav smo se $\mathrm{v}$ izhodišču odločili razdeliti artikle po kriterijih: A-B-C analize, $x-y-z$ analize, sezonskega gibanja, velikosti artikla, življenjskega cikla artikla, porekla dobavitelja, dobavnega časa artikla in dostave artikla. Za izdelavo A-B$\mathrm{C}$ analize smo uporabili podatke o porabljeni količini v letu 2015 in letni vrednosti. Za izdelavo x-y-z analize pa podatke o porabi po terminskih enotah (mesecih) v letu 2015. Enake podatke, vendar za zadnja tri leta, smo uporabili tudi za razvrščanje artiklov po kriteriju sezonsko gibanje, s pomočjo katerega smo želeli preveriti sezonska nihanja.

Pri sezonskem kriteriju smo uporabili naslednja pravila (Ljubič, 2008, str. 26): ciklus nihanja od enega maksimuma/minimuma do drugega maksimuma/minimuma je eno leto, maksimum in minimum sta vedno $\mathrm{v}$ istem obdobju ciklusa, odstopanje maksimuma/minimuma od povprečja je večje od polovice standardnega odklona. $\mathrm{V}$ primeru, da se neki pojav želi označiti kot sezonski, se mora sezonski vzorec ponoviti vsaj dvakrat (Ljubič, 2008, str. 26).

Pri kriteriju velikost artikla smo artikle razdelili po principu LMN analize, ki se uporablja predvsem takrat, ko se morajo določiti dimenzije skladišča ali transportnih sredstev (Brajnović, 2014, str. 26). Analizo LMN smo prilagodili potrebam podjetja ter artikle razdelili iz treh razvrstili v pet skupin: 
E. Krhač, B. Urh \& M. Roblek: Napredna nastavitev oskrbovalnih politik z odkrivanjem znanja iz podatkov $\mathrm{z}$ orodjem Orange

- skupina 1 - artikli, ki spadajo v skupino $0 \mathrm{~cm} * 0 \mathrm{~cm}$ do $25 \mathrm{~cm} * 25 \mathrm{~cm}$,

- skupina 2 - artikli, ki spadajo v skupino $26 \mathrm{~cm} * 26 \mathrm{~cm}$ do $50 \mathrm{~cm} * 50 \mathrm{~cm}$,

- skupina 3 - artikli, ki spadajo v skupino $51 \mathrm{~cm} * 51 \mathrm{~cm}$ do $75 \mathrm{~cm} * 75 \mathrm{~cm}$,

- skupina 4 - artikli, ki spadajo v skupino $76 \mathrm{~cm} * 76 \mathrm{~cm}$ do $100 \mathrm{~cm} * 100 \mathrm{~cm}$,

- skupina 5 - artikli, ki spadajo v skupino nad $101 \mathrm{~cm} * 101 \mathrm{~cm}$.

Kriterij življenjski cikel artikla je sestavljen iz petih faz (Product life cycle, 2009). Vsaka faza za prodajalca pomeni drugačen izziv, predstavlja različen nivo donosov in vsaka zahteva drugačno strategijo trženja, financiranja, proizvodnje, nakupa in kadrovanja. Kriterij življenjski cikel artikla smo delno prilagodili in artikle razdelili na tri skupine, in sicer: U (uvajanje/rast), Z (zrelost) in P (upadanje). V katero skupino spada posamezni artikel, smo se odločali na podlagi razlik v prodaji. Pri tem smo preučevali prodane količine (seštevek prodane količine) in porabo po mesecih v zadnjih treh letih. Primerjali smo tudi, koliko mesecev v letih se je artikel prodajal ter znane želje kupcev, dobaviteljev in samega podjetja.

Pri kriteriju poreklo dobavitelja smo tako dobili 11 skupin, in sicer Češka republika, Indija, Indonezija, Italija, Kitajska, Madžarska, Nemčija, Poljska, Slovenija, Srbija in Turčija.

Kriterij dobavni čas artikla, opredeljuje, koliko tednov od trenutka naročila je potrebno, da je artikel dostavljen v podjetje. Kriterij je vezan na prejšnji kriterij, saj je dobavni čas artikla odvisen od tega, iz katere države artikel prihaja. Pri tem kriteriju smo tako dobili osem skupin, in sicer:

- en teden - artikli iz Slovenije, Italije in Nemčije,

- dva tedna - artikli iz Turčije, Srbije, Italije, Madžarske in Češke republike,

- tri tedne - artikli iz Italije in Nemčije,

- štiri tedne - artikli iz Italije, Nemčije in Češke republike,

- šest tednov - artikli iz Poljske,

- 12 tednov - artikli iz Turčije, Kitajske in Indije,

- 18 tednov - artikli iz Indonezije,

- 26 tednov - artikli iz Nemčije.

Zadnji kriterij, dostava artiklov, smo določili ali se artikel prodaja v Sloveniji, tujini ali v Sloveniji in tudi v tujini.

Zanimalo nas je, kateri kriteriji so bolj pomembni za delitev artiklov? Predpostavka je bila, da bi lahko naredili dve skupini glede pomembnosti kriterijev, in sicer:

- zelo pomembni kriteriji: A-B-C analiza, x-y-z analiza, življenjski cikel artikla, dobavni čas artikla,

- manj pomembni kriteriji: poreklo dobavitelja, dostava artikla, sezonsko gibanje, velikost artikla. 
$36^{\text {Th }}$ International Conference on Organizational Science Development: RESPONSIBLE ORGANIZATION (MARCH $22^{\mathrm{ND}}-24^{\mathrm{TH}}$, PORTOROŽ SLOVENIA)

E. Krhač, B. Urh \& M. Roblek: Advanced Setting of Supply Policies by Discovering Knowledge from Data Using Orange

\section{$4 \quad$ Rezultati}

Najprej smo izdelali podatkovni model v orodju Orange, sestavljen iz diskretnih podatkov - atributov, ki jih je predstavljalo naših osem kriterijev, in iz treh odločitvenih razredov:

- izdelki se naročajo na podlagi statističnih izračunov,

- izdelki se naročajo na podlagi preteklih izkušenj komercialistov,

- izdelki se ne naročajo na zalogo.

Tabela 1 prikazuje pravila, na podlagi katerih smo se odločali pri določanju odločitvenih razredov.

\begin{tabular}{|c|c|c|c|c|}
\hline Odločitveni razred & A-B-C & $\mathbf{x - y - z}$ & $\begin{array}{c}\text { Življenjski } \\
\text { cikel }\end{array}$ & Dobavni čas \\
\hline $\begin{array}{c}\text { Izdelki se naročajo na } \\
\text { podlagi statističnih } \\
\text { izračunov }\end{array}$ & $\begin{array}{c}\text { za A artikle; } \\
\text { za B artikle; } \\
\text { za C artikle }\end{array}$ & $\begin{array}{c}\mathrm{x}, \mathrm{y} \text { in } \mathrm{z} ; \\
\mathrm{x}, \mathrm{y} \text { in } \mathrm{z} ; \\
\mathrm{x} \text { in } \mathrm{y}\end{array}$ & Vse 3 faze & $\begin{array}{c}\text { vsi dobavni } \\
\text { časi }\end{array}$ \\
\hline $\begin{array}{c}\text { Izdelki se naročajo na } \\
\text { podlagi preteklih } \\
\text { izkušenj komercialistov }\end{array}$ & $\mathrm{C}$ & $\mathrm{z}$ & $\mathrm{Z}, \mathrm{P}$ & $\begin{array}{c}\text { vsi dobavni } \\
\text { časi }\end{array}$ \\
\hline $\begin{array}{c}\text { Izdelki se ne naročajo na } \\
\text { zalogo }\end{array}$ & $\mathrm{C}$ & $\mathrm{z}$ & $\mathrm{P}$ & do 4 tedne \\
\hline
\end{tabular}

\section{Tabela 13: Lastnosti posameznih kriterijev za odločitvene razrede}

Odločitvene razrede smo določali na podlagi štirih kriterijev (atributov), za katere smo predvidevali, da so bolj pomembni. »Pravila« pri izbranih štirih kriterijih (atributih) so bila določena na podlagi raziskane literature. Izbrani podatki so konsistentni, podatkovni model pa ni vseboval manjkajočih ali neznanih vrednosti, saj smo vse take vrednosti nadomestili $\mathrm{z}$ najverjetnejšimi, kot to nalagajo pravila priprave podatkov za uvoz $\mathrm{v}$ Orange. Izdelan podatkovni model smo uvozili v izbrano orodje Orange ter najprej naredili opisno statistiko posameznih kriterijev in odločitvenih razredov.

Analiza je pokazala (slika 1), da 404 artikli (10,9\%) pripadajo skupini A in so glede na A-B-C analizo zelo pomembni za poslovanje podjetja. Skupini B, pri omenjeni analizi, pripada 1.171 artikel $(31,7 \%)$, skupini C pa 2.119 artiklov $(57,4 \%)$. Kot vidimo, je največ $\mathrm{C}$ artiklov, ki pa so najmanj pomembni za poslovanje. 
E. Krhač, B. Urh \& M. Roblek: Napredna nastavitev oskrbovalnih politik z odkrivanjem znanja iz podatkov z orodjem Orange

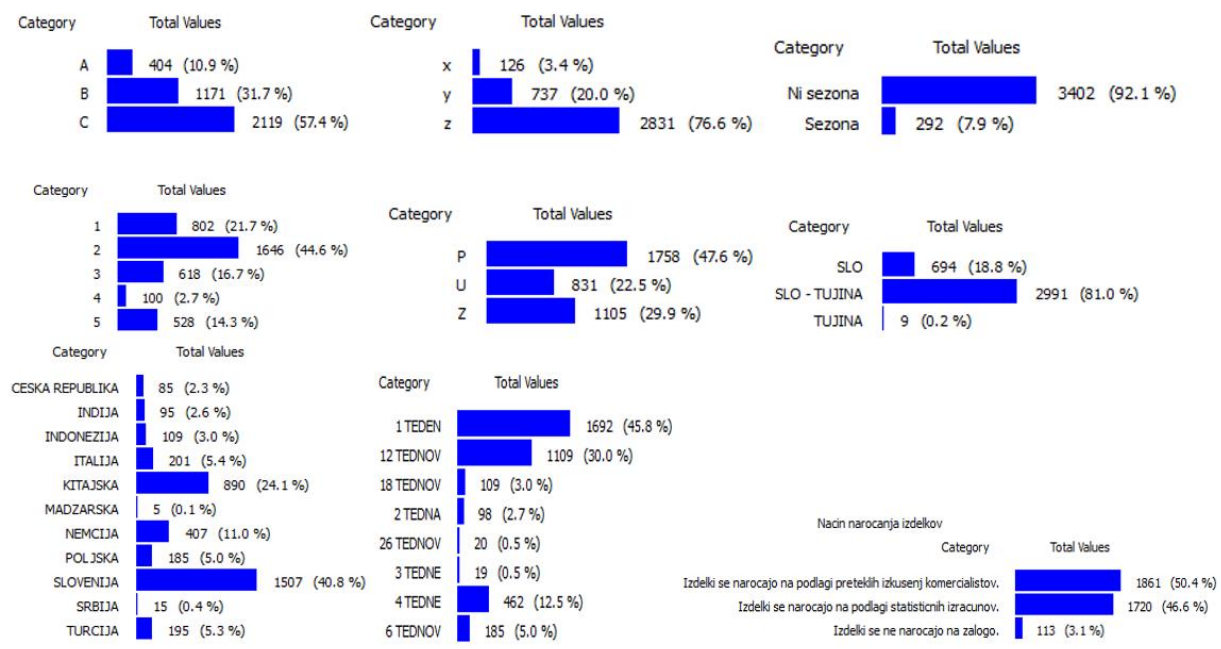

Slika 6: Primer prikaza opisne statistike v orodju Orange

V nadaljevanju smo pregledali opisno statistiko $x-y-z$ analize in ugotovili, da je najmanj $\mathrm{x}$ artiklov, in sicer samo $126(3,4 \%)$. V to skupino spadajo artikli, za katere lahko zanesljivo napovemo porabo. Naslednji so y artikli, ki jih je 737 (20,0\%), največji skupini pa pripadajo z artikli. Artiklov, ki pripadajo z skupini, je 2.831 (76,6\%). Problem skupine z je, da je njihova napoved porabe nezanesljiva.

Naslednja je bila narejena opisna statistika za kriterij sezonsko gibanje, ki je pokazala, da je sezonskih artiklov samo 292 (7,9\%). Ostalo so nesezonski artikli, in sicer 3.402 artikla $(92,1 \%)$. Naslednji kriterij je bil velikost artikla. Iz opisne statistike smo ugotovili, da 1.646 artiklov (44,6 \%), pripada skupini 2, ki je največja skupina pri tem kriteriju.

Opisna statistika je pokazala, da je najmanjša skupina artiklov tista, ki predstavlja artikle v uvajanju v prodajni program podjetja. Skupino sestavlja 831 artiklov, kar predstavlja $22,5 \%$ prodajnega programa. Naslednja skupina so artikli v zrelosti, in sicer je takih 1.105 (29,9\%). Največjo skupino sestavljajo artikli, ki so v padanju - takih je 1.758 (47,6 $\%)$.

Ugotovili smo, da najmanj artiklov prihaja iz Madžarske, in sicer samo $5(0,1 \%)$, največje število artiklov pa prihaja iz Kitajske (24,1 \%) in Slovenije (40,8 \% prodajnega programa podjetja). Naslednji je bil kriterij dobavni čas, ki je v veliki meri odvisen od kriterija poreklo dobavitelja. Ugotovili smo, da ima 1.692 artiklov (45,8 \%) dobavni čas 1 teden.

Zadnji kriterij, ki smo ga obravnavali, je dostava artiklov, ki nam pove, ali se artikli prodajajo samo v Sloveniji, samo v tujino ali pa povsod. Samo v tujino se prodaja samo 
$36^{\text {Th }}$ International Conference on Organizational Science Development: RESPONSIBLE ORGANIZATION (MARCH $22^{\mathrm{ND}}-24^{\mathrm{TH}}$, PORTOROŽ SlOVENIA)

E. Krhač, B. Urh \& M. Roblek: Advanced Setting of Supply Policies by Discovering Knowledge from Data Using Orange

9 artiklov (0,2 \%), samo v Sloveniji pa 694 artiklov (18,8 \%). Največji delež prodajnega programa podjetja zavzemajo artikli, ki se prodajajo tako v Sloveniji kot tudi v tujini, takih je 2.991 artiklov $(81,0 \%)$.

Na koncu smo pogledali tudi, koliko artiklov pripada posameznemu odločitvenemu razredu na podlagi »pravil«, ki smo jih sami določili na začetku oblikovanja podatkovnega modela (tabela 1). Izkazalo se je, da je največ takih artiklov, ki bi se lahko naročali na podlagi preteklih izkušenj komercialistov, in sicer jih je 1.861, kar predstavlja $50,4 \%$ prodajnega programa podjetja. Naslednji so artikli, ki bi se v prihodnosti naročali izključno na podlagi statističnih izračunov. Takih artiklov je 1.720, kar predstavlja 46,6 $\%$ prodajnega programa podjetja. Zadnjo skupino pa sestavljajo artikli, za katere že zdaj lahko rečemo, da jih v prihodnosti ni treba naročati na zalogo. Takih artiklov je 113, kar predstavlja $3,1 \%$ prodajnega programa podjetja.

V nadaljevanju smo uporabili vizualizacijo linearno projekcijo (angl. Linear Projection), ki vizualno prikazuje, kateri kriteriji (atributi) vplivajo na posamezni odločitveni razred (slika 2). Na naročanje na podlagi preteklih izkušenj komercialistov vplivajo predvsem A-B-C analiza in $x-y-z$ analiza ter $v$ manjši meri tudi sezonsko gibanje in dostava artiklov. $\mathrm{Na}$ to, da se artikli ne naročajo na zalogo, vplivata predvsem analizi A-B-C in x-y-z, na naročanje na podlagi statističnih izračunov pa vplivajo vsi izbrani kriteriji (atributi).

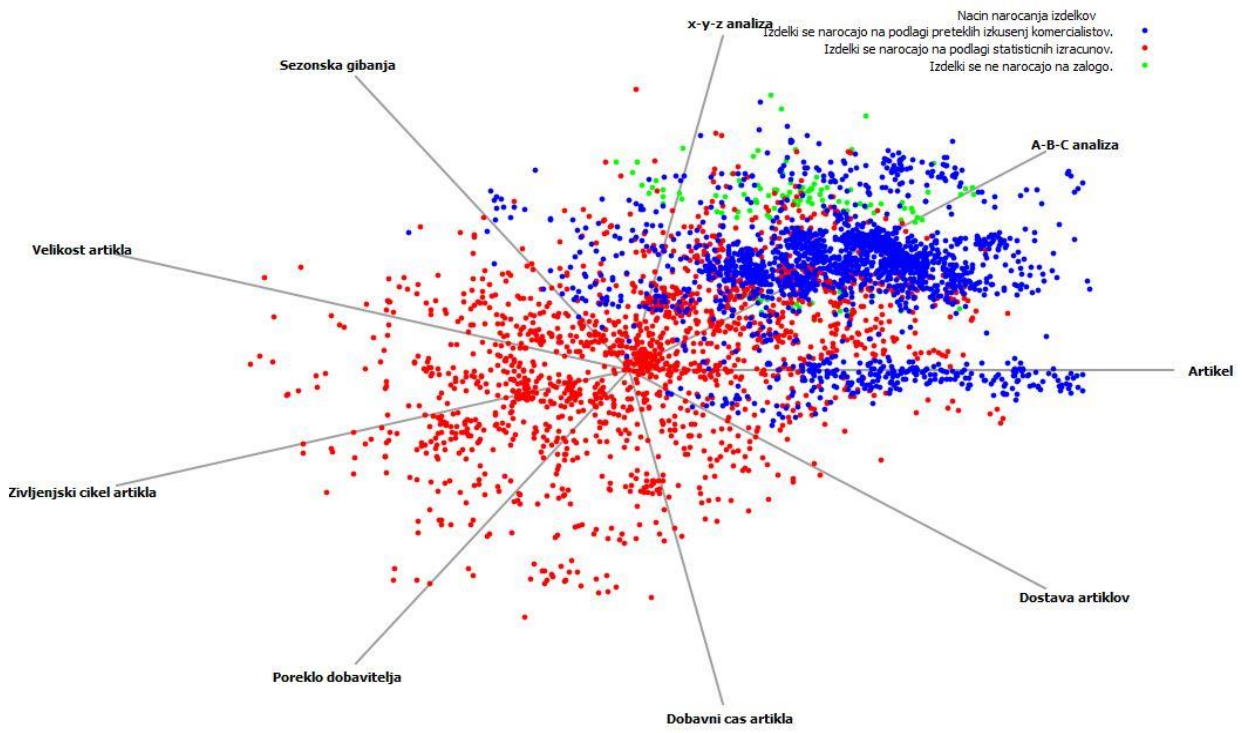

Slika 2: Linearna projekcija

V nadaljevanju smo uporabili Nomogram, s pomočjo katerega smo poiskali odgovore na vprašanja o pomembnosti posameznih kriterijev. Pri artiklih, ki se lahko v prihodnosti 
naročajo na podlagi preteklih izkušenj komercialistov (slika 3), so bolj pomembni kriteriji: A-B-C analiza, x-y-z analiza, dobavni čas artikla in življenjski cikel artikla, Pri artiklih, ki se lahko v prihodnosti naročajo na podlagi statističnih izračunov, so bolj pomembni kriteriji: A-B-C analiza, $x-y-z$ analiza, življenjski cikel artikla in dobavni čas artikla, Pri artiklih, ki jih v prihodnje ni treba naročati na zalogo, so bolj pomembni kriteriji: sezonsko gibanje, življenjski cikel artikla, velikost artikla in dobavni čas artikla, Opazili smo, da sta za naročanje na zalogo kriterija dostava artikla in sezonsko gibanje najmanj pomembna:

- pri naročanju na podlagi preteklih izkušenj komercialistov - sedmo in šesto mesto od sedmih kriterijev,

- pri naročanju na podlagi statističnih izračunov - šesto in sedmo mesto od sedmih kriterijev.

Ugotovili smo, da so za naročanje na zalogo bolj pomembni A-B-C in x-y-z analizi, dobavni čas ter življenjski cikel artikla.
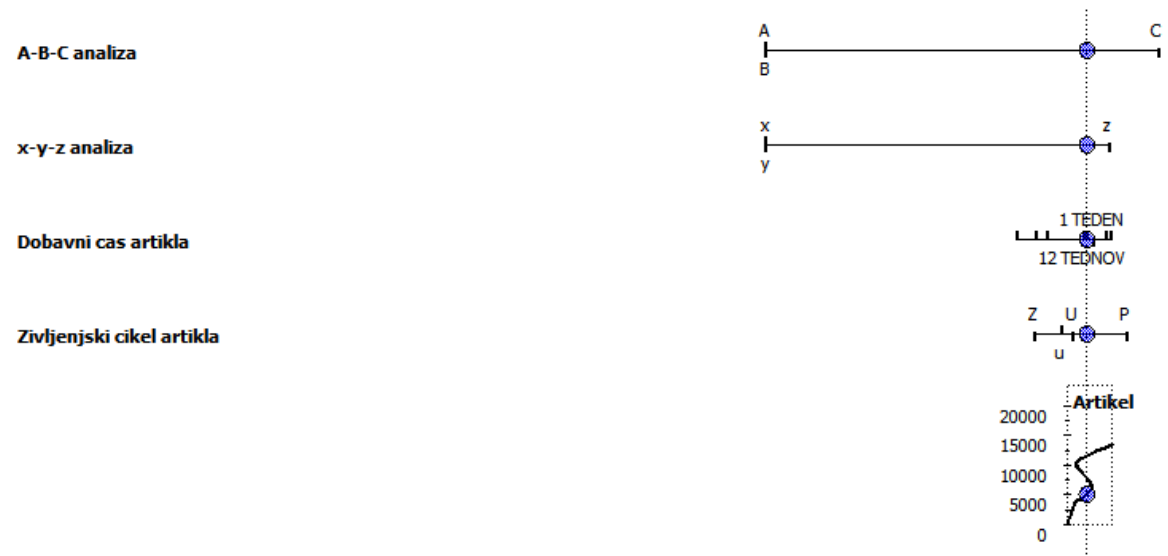

Slika 3: Primer Nomogram 1 (a)

V nadaljevanju smo uporabili algoritem $\mathrm{CN} 2$, ki na podlagi preučenih primerov prikazuje pravila, ki se lahko $\mathrm{v}$ nadaljevanju upoštevajo za naročanje na zalogo in sprotno naročanje. S podatkovnim modelom smo ugotovili, da je $100 \%$ naročil narejenih na podlagi preteklih izkušenj komercialistov, kadar je artikel C, z in ni sezonski (slika 4). 


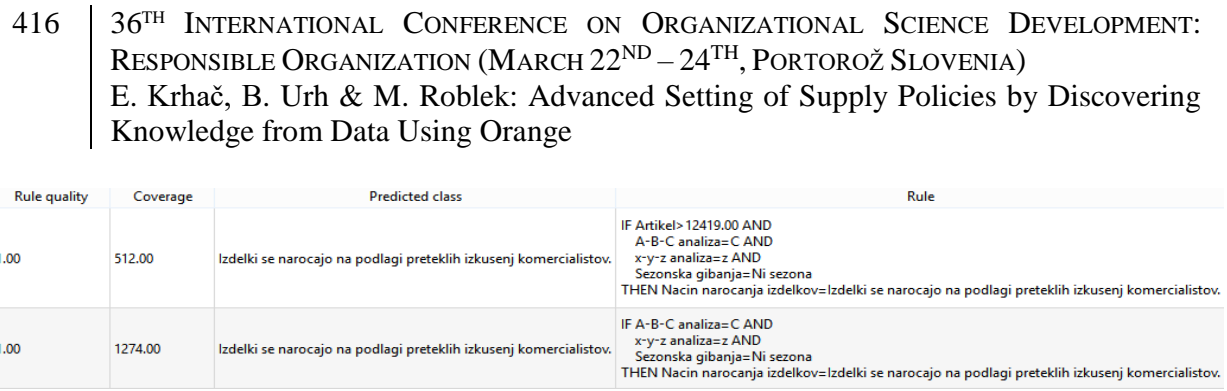

Slika 7: Algoritem CN2 (a)

S podatkovnim modelom smo ugotovili, da je $100 \%$ naročil narejenih na podlagi statističnih izračunov, kadar je artikel B ali A (slika 5).

\begin{tabular}{|l|l|l|l|}
\hline 1.00 & 1171.00 & Izdelki se narocajo na podlagi statisticnih izracunov. & $\begin{array}{l}\text { IF A-B-C analiza=B } \\
\text { THEN Nacin narocanja izdelkov=Izdelki se narocajo na podlaqi statisticnih izracunov. }\end{array}$ \\
\hline 1.00 & 404.00 & Izdelki se narocajo na podlagi statisticnih izracunov. & IF A-B-C analiza=A \\
THEN Nacin narocania izdelkov=Izdelki se narocaio na bodlaai statisticnih izracunov.
\end{tabular}

Slika 5: Algoritem CN2 (b)

S podatkovnim modelom smo ugotovili, da se $99 \%$ naročil ne naroča na zalogo, kadar je artikel C, sezonski, v padanju in je njegov dobavni čas 1 teden (slika 6).

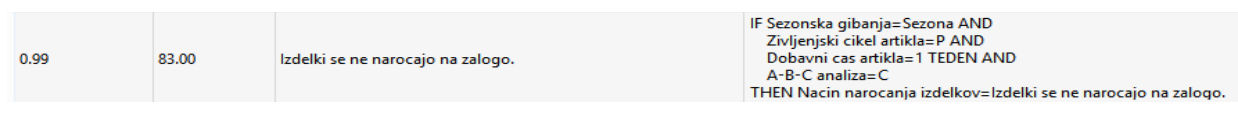

\section{Slika 6: Algoritem CN3 (c)}

Izmerili smo tudi natančnost klasifikatorjev, ki se uporabljajo za klasifikacijo novih primerov, in sicer na podlagi množice že klasificiranih primerov. Uporabili smo štiri klasifikatorje (Naive Bayes, CN2 rules, kNN in Classification Tree) ter tri mere za ocenjevanje učenja (CA, AUC, Brier). CA (klasifikacijska točnost) prikaže razmerje med številom pravilno napovedanih in številom vseh napovedanih primerov. V številkah to pomeni, da je cilj pri klasifikacijski točnosti dobiti večjo oceno, ker večja kot je ocena, boljša je kvaliteta napovedanih primerov. AUC (ploščina pod ROC krivuljo) pa prikaže verjetnost, da bo klasifikator pravilno razločil med pozitivnimi in negativnimi primeri, torej je cilj ponovno dobiti višjo oceno oziroma oceno bližje številki 1,0000. Brierjeva ocena preko vseh testnih primerov oceni različnost med ciljno in dejansko napovedano distribucijo. Idealno je, kadar klasifikator vedno natančno napove pravilni razred, kar nam prikaže številka 0,0000 - torej je cilj, da je Brierjeva ocena bližja številki 0,0000 . Pri klasifikatorjih CN2 rules in kNN je prišlo do overfittinga (̌̌e sta CA in AUC enaka 1,0000 ter Brier enak 0,0000), kar pomeni, da sta se klasifikatorja predobro prilagodila podatkom iz učne množice ter sta podala slabe rezultate za nove podatke (Kljajić, 2015/2016). Kot vidimo na sliki 7, ima najboljšo oceno klasifikator Naive Bayes, ki izračuna pogojne verjetnosti za vsak razred pri danih vrednostih (vseh) atributov za dani novi primer. 
E. Krhač, B. Urh \& M. Roblek: Napredna nastavitev oskrbovalnih politik z odkrivanjem znanja iz podatkov $\mathrm{z}$ orodjem Orange

\begin{tabular}{|l|c|c|c|c|}
\multicolumn{1}{|c|}{ Method } & CA & AUC & Brier \\
\hline 1 & Naive Bayes & 0.9981 & 1.0000 & 0.0104 \\
\hline 2 CN2 rules & 1.0000 & 1.0000 & 0.0000 \\
\hline 3 & kNN & 1.0000 & 1.0000 & 0.0000 \\
\hline 4 & Classification Tree & 0.9803 & 0.9988 & 0.0241 \\
\hline
\end{tabular}

Slika 78: Natančnost klasifikatorjev

V nadaljevanju smo uporabili matriko napake (angl. Confusion Matrix), ki vsebuje informacije o dejanskih in klasificiranih napovedih sistema. Matrika je ocena kakovosti klasifikacijskega modela, ki ga je v našem primeru predstavljal Naive Bayes. Matrika napake je za naročanje artiklov na podlagi preteklih izkušenj komercialistov dosegla 100 $\%$ pravilnih odgovorov, za naročanje na podlagi statističnih izračunov $99,6 \%$ pravilnih odgovorov ter za nenaročanje na zalogo prav tako $100 \%$ pravilnih odgovorov.

\begin{tabular}{|c|c|c|c|c|}
\hline & $\begin{array}{c}\text { Izdelki se } \\
\text { naročajo na } \\
\text { podlagi } \\
\text { preteklih } \\
\text { izkušenj } \\
\text { komercialistov. }\end{array}$ & $\begin{array}{c}\text { Izdelki se } \\
\text { naročajo na } \\
\text { podlagi } \\
\text { statističnih } \\
\text { izračunov. }\end{array}$ & $\begin{array}{c}\text { Izdelki se } \\
\text { ne } \\
\text { naročajo } \\
\text { na zalogo. }\end{array}$ & \\
\hline $\begin{array}{c}\text { Izdelki se naročajo na } \\
\text { podlagi preteklih } \\
\text { izkušenj } \\
\text { komercialistov. }\end{array}$ & $100,0 \%$ & $0,4 \%$ & $0,0 \%$ & $\mathbf{1 . 3 0 2}$ \\
\hline $\begin{array}{c}\text { Izdelki se naročajo na } \\
\text { podlagi statističnih } \\
\text { izračunov. }\end{array}$ & $0,0 \%$ & $99,6 \%$ & $0,0 \%$ & $\mathbf{1 . 2 0 4}$ \\
\hline $\begin{array}{c}\text { Izdelki se ne naročajo } \\
\text { na zalogo. }\end{array}$ & $0,0 \%$ & $0,0 \%$ & $100,0 \%$ & $\mathbf{8 0}$ \\
\hline & $\mathbf{1 . 2 9 7}$ & $\mathbf{1 . 2 0 9}$ & $\mathbf{8 0}$ & $\mathbf{2 . 5 8 6}$ \\
\hline
\end{tabular}

Tabela 14: Matrika napake

Na koncu smo naredili še predikcije, s pomočjo katerih smo ugotavljali, kako dobro model napoveduje oziroma koliko je model zanesljiv. Pri tem je bilo uporabljenih 12 naključnih primerov artiklov - po štiri za vsak način naročanja. Na podlagi predikcije je bilo ugotovljeno, da so vsi trije klasifikatorji (kNN, Naive Bayes in Classification Tree) točno napovedali vseh 12 naključno izbranih primerov. 
$36^{\text {Th }}$ International Conference on Organizational Science Development: RESPONSIBLE ORGANIZATION (MARCH $22^{\mathrm{ND}}-24^{\mathrm{TH}}$, PORTOROŽ SLOVENIA)

E. Krhač, B. Urh \& M. Roblek: Advanced Setting of Supply Policies by Discovering Knowledge from Data Using Orange

\section{$5 \quad$ Diskusija}

Razvrstitev materialnih postavk $\mathrm{v}$ skupine $\mathrm{X}, \mathrm{Y}$ in $\mathrm{Z} \mathrm{v}$ kombinaciji $\mathrm{z}$ razvrstitvijo $\mathrm{v}$ razrede $\mathrm{A}, \mathrm{B}$ in $\mathrm{C}$ je pomembna pri (Roblek, 2013) planiranju materialnih potreb, določanju količin za nabavo, naročanju in obnavljanju zalog, izdajanju materiala $\mathrm{V}$ izdelavo ter knjiženju in obračunu porabe.

Pri učinkovitem upravljanju z zalogami nas zanimata dva podatka, in sicer kdaj naročiti in koliko naročiti. Pri določanju količine za nabavo (Ljubič, 2000, str. 361):

- $\quad$ pri A artiklih in za x, y in z artikle se priporoča uporabo Wagner-Whitinovega algoritma,

- $\quad$ pri B artiklih in za $\mathrm{x}, \mathrm{y}$ in $\mathrm{z}$ artikle se priporoča uporaba pravila najmanjših skupnih stroškov gospodarjenja z materialom,

- $\quad$ pri $\mathrm{C}$ artiklih in za $\mathrm{x}, \mathrm{y}$ in $\mathrm{z}$ artikle se priporoča uporaba pravila fiksnih ekonomičnih količin z velikimi varnostnimi zalogami.

Pri naročanju in obnavljanju zalog oziroma pri odločanju, kdaj naročiti (Ljubič, 2000, str. 361):

- $\quad$ pri A artiklih in za $\mathrm{x}, \mathrm{y}$ in $\mathrm{z}$ artikle se priporoča naročanje posamičnih potreb po planu materialnih potreb,

- $\quad$ pri B artiklih in za $\mathrm{x}, \mathrm{y}$ in $\mathrm{z}$ artikle se priporoča naročanje združenih potreb za več terminskih enot,

- pri C artiklih in za:

- $\mathrm{x}$ in $\mathrm{y}$ artikle se priporoča naročanje po letnih pogodbah v optimalnih naročilnih količinah,

- $\mathrm{z}$ artikle se priporoča naročanje po dejanskih potrebah.

$\mathrm{Na}$ podlagi teoretične raziskave smo spoznali značilnosti posameznih politik obvladovanja zalog, kar nam je potem pomagalo pri ugotovitvi, katera politika je primerna za obvladovanje posameznih zalog. V nadaljevanju je prikazan predlog sprememb pri obvladovanju zalog v podjetju Gumitehna d.o.o., ki vključuje uporabo tako kvalitativnih kot tudi kvantitativnih metod za predvidevanje povpraševanja. Za posamezne artikle predlagamo uporabo kvantitativnih metod, ki bi morale podati dovolj natančno napoved povpraševanja, predlog pa je prikazan v tabeli 3. Primer interpretacije tabele 3: za A, x artikle, zrele ali v padanju, vseh dobavnih časov priporočamo model ekonomsko optimalne količine naročila $\mathrm{z}$ upoštevanjem količinskih popustov. 
E. Krhač, B. Urh \& M. Roblek: Napredna nastavitev oskrbovalnih politik z odkrivanjem znanja iz podatkov z orodjem Orange

\begin{tabular}{|c|c|c|c|}
\hline & \multicolumn{3}{|c|}{ Deterministično planiranje } \\
\hline & $\mathbf{X}$ & $\mathbf{Y}$ & $\mathbf{Z}$ \\
\hline \multirow{2}{*}{$\mathbf{A}$} & $\begin{array}{c}\text { Model ekonomsko } \\
\text { optimalne količine } \\
\text { naročila z upoštevanjem } \\
\text { količinskih popustov }\end{array}$ & $\begin{array}{l}\text { Model ekonomsko } \\
\text { optimalne količine } \\
\text { naročila na podlagi } \\
\text { povprečja }\end{array}$ & \\
\hline & $\begin{array}{c}\text { Zrelost, padanje; vsi } \\
\text { dobavni časi }\end{array}$ & $\begin{array}{c}\text { Zrelost, padanje; vsi } \\
\text { dobavni časi } \\
(78,67 \% \text { Ay } \\
\text { artiklov) } \\
\end{array}$ & \\
\hline \multirow{4}{*}{ B } & \multicolumn{3}{|c|}{ Nabavljanje majhnih količin, ki krijejo potrebe vsake terminske enote } \\
\hline & \multicolumn{3}{|c|}{ Zrelost, padanje; dobavni čas do 1 tedna $(27,50 \%$ Bxvz artiklov) } \\
\hline & \multicolumn{3}{|c|}{ Nabavljanje velikih količin, ki krijejo potrebe več terminskih enot } \\
\hline & \multicolumn{3}{|c|}{ Zrelost, padanje; dobavni čas vsaj 2 tedna (28,93 \% Bxyz artiklov) } \\
\hline \multirow{5}{*}{$\mathbf{C}$} & Stohastično planiranje & & Deterministično planiranje \\
\hline & $\begin{array}{l}\text { Q model - kontinuirano } \\
\text { spremljanje zalog }\end{array}$ & $\begin{array}{c}\text { Q model - } \\
\text { kontinuirano } \\
\text { spremljanje zalog }\end{array}$ & Po dejanskih potrebah \\
\hline & $\begin{array}{c}\text { Zrelost, padanje; krajši } \\
\text { dobavni časi } \\
(22,22 \% \text { Cx artiklov })\end{array}$ & $\begin{array}{l}\text { Zrelost, padanje; } \\
\text { krajši dobavni časi } \\
(44,12 \% \mathrm{Cy} \\
\text { artiklov) }\end{array}$ & $\begin{array}{c}\text { Zrelost, padanje; krajši } \\
\text { dobavni časi } \\
(61,25 \% \mathrm{Cz} \text { artiklov })\end{array}$ \\
\hline & $\begin{array}{l}\text { P model - periodično } \\
\text { spremljanje zalog }\end{array}$ & & \\
\hline & $\begin{array}{c}\text { Zrelost, padanje; daljši } \\
\text { dobavni časi } \\
(55,56 \% \mathrm{Cx} \text { artiklov })\end{array}$ & & \\
\hline
\end{tabular}

Tabela 3: Primerne politike obvladovanja zalog za posamezne lastnosti kriterijev

Za vse ostale kombinacije predlagamo uporabo tako kvalitativnih kot tudi kvantitativnih metod predvidevanja povpraševanja. Za podjetje je uporabna predvsem napoved prodajnega osebja, ki pri predvidevanju uporablja znanje in izkušnje osebja. Pri tem se je seveda treba zaščititi pred pristranskostjo osebja, zato predlagamo uporabo posameznih orodjih in pripomočkov za pridobivanje podatkov in informacij o posameznih pojavih. Za podjetje se nam zdijo najbolj uporabne in enostavne tržne raziskave o artiklih, analiza življenjskega ciklusa artiklov ter analogija s preteklostjo istih ali podobnih artiklov. Predlagamo, da pri predvidevanju povpraševanja $v$ podjetju uporabijo obe vrsti metod in rezultate nato primerjajo. $\mathrm{V}$ primeru, da bi se $\mathrm{v}$ rezultatih pojavila prevelika razlika, so lahko prepričani, da je bilo predvidevanje napačno (oziroma da je izbrana metoda 
$36^{\mathrm{TH}}$ International Conference on ORganizational Science Development: RESPONSIBLE ORGANIZATION (MARCH $22^{\mathrm{ND}}-24^{\mathrm{TH}}$, PORTOROŽ SLOVENIA)

E. Krhač, B. Urh \& M. Roblek: Advanced Setting of Supply Policies by Discovering Knowledge from Data Using Orange

nenatančna). Potem lahko izberejo še kakšen drug način predvidevanja povpraševanja oziroma uporabijo še kakšno dodatno metodo.

Na koncu smo pregledali, v kolikšnem odstotku bi lahko izboljšali obvladovanje zalog, ter ugotovili, da predlagane spremembe natančno obvladujejo zaloge pri vsaj $44 \%$ artiklov iz posamezne skupine. Ocenjene so samo spremembe glede uporabe kvantitativnih metod. Uporaba obeh vrst metod pa pomaga pri obvladovanju ostalih zalog.

\section{$6 \quad$ Zaključek}

Ugotovili smo, da $\mathrm{z}$ modelom in algoritmi v orodju Orange, lahko pravilno napovemo v več kot 99,6 \% primerov. Cilji, ki smo si jih zadali na začetku dela z orodjem, so bili doseženi, kar pomeni, da je model uporaben v praksi.

Ne smemo pa pozabiti še na možnosti izboljšanja podatkovnega modela $v$ prihodnosti, ki pa jih vidimo v bolj relevantnem vzorcu - vsi odločitveni razredi bi morali imeti enako število primerov, trenutno pa sta prva dva odločitvena razreda imela veliko večje število primerov kot pa tretji odločitveni razred.

Za uvedbo predlaganih sprememb je treba izpolniti tudi nekaj pogojev. Za dobro obvladovanje zalog je treba najprej dobro poznati lastnosti artiklov, zato je potreben dostop do veliko kakovostnih informacij o artiklih. Za lažje razumevanje vseh informacij je uporabna grafična oblika, ki omogoča tudi krajši čas preučevanja podatkov. Prav tako je pomembno tudi konstantno vodenje statistike napovedi v preteklosti, ki omogoča pregled nad točnostjo napovedi in omogoča hitro prilagajanje na spremembe.

Da bi se pri obvladovanju zalog upoštevale vse spremembe $\mathrm{v}$ zalogah, je treba postopek iz empiričnega dela večkrat ponavljati - predlagamo, da se postopek ponavlja enkrat letno. Pri ponavljanju postopka se lahko uvede tudi nekaj sprememb. Prva sprememba, ki bi bila smiselna, je sprememba v določanju kriterijev - kriteriji, ki so se do zdaj pokazali kot manj pomembni, se lahko izločijo iz raziskave, doda pa se lahko tudi kakšen nov kriterij.

Prav tako bi bilo treba vnaprej pripraviti predloge posameznih analiz in izračunov (npr. v Microsoft Excelu), v katere bi se vnašale samo spremembe, kar bi omogočilo hitrejše analize in odločanje. Za potrebe raziskave smo večino analiz opravili v Microsoft Excelu, za kar smo potrebovali veliko časa, saj smo vse tabele nastavljali na novo. Omeniti moramo tudi dejstvo, da smo imeli največ težav pri pripravljanju podatkov za empirični del s trenutnim informacijskim sistemom VASCO, saj ne omogoča dostopa do potrebnih podatkov ali pa so zaposleni za iskanje podatkov porabili več časa, kot je bilo predvideno. Zato kot zadnjo spremembo, ki bi v prihodnje doprinesla $\mathrm{k}$ hitrejši in kakovostnejši analizi, predlagamo investicijo v nadgradnjo informacijskega sistema. Nadgradnja bi morala omogočati enostaven in hiter dostop do vseh podatkov o preteklosti artiklov. 
E. Krhač, B. Urh \& M. Roblek: Napredna nastavitev oskrbovalnih politik z odkrivanjem znanja iz podatkov $\mathrm{z}$ orodjem Orange

\section{Literatura}

Brajnović, A. (2014). Upravljanje zalihama u dobavnom lancu (Diplomski rad). Rijeka: Pomorski fakultet u Rijeci.

Grčar, G. (2010). Obvladovanje zalog v podjetju Toko d.o.o (Diplomsko delo). Ljubljana: Ekonomska fakulteta.

Kovač, E. (2012). Analiza računovodskih izkazov s kazalniki (Diplomsko delo). Bled: Višja strokovna šola za gostinstvo in turizem Bled.

Krhač, E. (2016). Politike obvladovanja zalog v podjetju Gumitehna d.o.o., magistrsko delo, Univerza v Mariboru, Fakulteta za organizacijske vede

Ljubič, T. (2000). Planiranje in vodenje proizvodnje: modeli, metode, podatki. Kranj: Moderna organizacija.

Ljubič, T. (2008). Predvidevanje in napovedovanje v oskrbovalni verigi. Kranj: Moderna organizacija.

Product life cycle. (2009). The Economist. Pridobljeno: 24. 7. 2016 na http://www.economist.com/node/14301365

Stevenson, J. S. (2015). Operations Management: Inventory Management, McGrawHill, str. 546 582

Kljajić Borštnar, M. (2015). Gradivo za predavanja: Odkrivanje znanja v podatkih, študijsko leto 2015/2016.

Roblek, M. (2012). Gradivo za predavanja: Predvidevanje, planiranje in operativno vodenje poslovanja

Urh, B. (2012). Gradivo za predavanja: Razvoj proizvodov in proizvodnih procesov.

Završnik, B. (2008). Management nabave in oskrbnih verig. Maribor: Ekonomsko-poslovna fakulteta. 
422 36 $6^{\text {TH }}$ International Conference on Organizational Science Development:

Responsible Organization (MARCH $22^{\mathrm{ND}}-24^{\mathrm{TH}}$, PORTOROŽ SLOVENIA) 


\title{
Zamenjave dovodov medicinskih plinov in njihovo preprečevanje
}

\author{
MILJENKO KRIŽMARIĆ
}

Povzetek Pred kratkim so javni mediji poročali o primeru zamenjave dovoda kisika $(\mathrm{O} 2)$ in dušikovega oksidula $(\mathrm{N} 2 \mathrm{O})$ v Urgentnem centru Splošne bolnišnice »Dr. Franca Derganca" Nova Gorica. Izvedli smo eksperimentalno raziskavo v simuliranem kliničnem okolju, kjer smo med scenarijem, zamenjali dovod O2 in N2O. Simulator bolnika METI HPS je skozi obrazno masko dobival $100 \%$ dušikov oksidul namesto kisika. Ugotavljamo padec delnega tlaka kisika $\mathrm{v}$ arterijski krvi $(\mathrm{PaO} 2)$ iz začetnih $113 \pm 1 \mathrm{mmHg}$ na $45 \pm 1 \mathrm{mmHg}$. Prav tako pride do desaturacije hemoglobina, visoke frekvence dihanja in zmanjšanja delnega tlaka ogljikovega dioksida $\mathrm{v}$ arterijski krvi. Za preprečitev takih primerov je bistveno, da ni možnost zamenjave dovodov medicinskih plinov. Medicinske spojke so zato izvedene s posebnimi varnostnimi mehanizmi (NIST: non-interchangeable screw-threaded, DISS: Diameter Index Safety System in specifične končne spojke za vsak poseben plin). Pred priklopom medicinske opreme je potrebno vsak del plinske napeljave testirati $\mathrm{s}$ tlakom višjim od nazivnega tlaka. Vsi izvori plinov se zaprejo, razen plina katerega preverjamo, le-ta pa mora biti prisoten samo na spojkah namenjenih temu plinu, na ostalih spojkah pa ne. Morebitne napake na novih instalacijah medicinskih plinov se morajo hitro odkriti, saj lahko privedejo do smrti bolnikov.

KLJUČNE BESEDE: zamenjava medicinskih plinov - dušikov oksidul • varnost bolnika

NASLOV AVTORJA: dr. Miljenko Križmarić, izredni profesor, Univerza v Mariboru, Fakulteta za zdravstvene vede, Žitna ulica 15,2000 Maribor, Slovenija, e-pošta: miljenko.krizmaric@um.si 
36 ${ }^{\text {TH }}$ International CONFEREnCE ON ORganizational Science Development: Responsible Organization (MARCH $22^{\mathrm{ND}}-24^{\mathrm{TH}}$, PORTOROŽ SLOVENIA)

O. Arsenijević, M. Ferjan, I. Podbregar, P. Šprajc, D. Trivan \& Y.

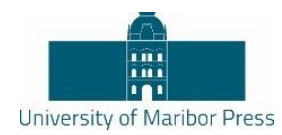

Ziegler

\title{
Crossed Pipelines Connections of Medical Gases and Their Prevention
}

\author{
MILJENKO KRIŽMARIĆ
}

\begin{abstract}
A case of cross-connection between oxygen (O2) and nitrous oxide (N2O) gas pipelines had been recently reported in a newly constructed emergency centre in General hospital "Dr. Franca Derganca" Nova Gorica. We conducted experimental simulation-based research where $\mathrm{O} 2$ and $\mathrm{N} 2 \mathrm{O}$ pipelines were cross-connected during scenario in simulated clinical environment. The simulated human patient simulator (METI HPS) had received 100\% nitrous oxide instead of oxygen through the nonrebreathing oxygen mask. We observed a drop in arterial oxygen partial pressure $(\mathrm{PaO} 2)$ from $113 \pm 1 \mathrm{mmHg}$ to $45 \pm 1 \mathrm{mmHg}$. We also find oxygen desaturation, higher respiratory rate and lower $\mathrm{CO} 2$ partial pressure in arterial blood. It is essential to ensure that there is no possibility of a cross-connection between medical gas pipeline systems. Connections can be made by gas-specific connectors (NIST: non-interchangeable screwthreaded, DISS: Diameter Index Safety System and gas specific terminal units). Before attachment of medical equipment, each section of the piping system must be subjected to a test pressure higher than the working pressure. All sources of test gas shall be disconnected from all of the medical gas systems with the exception of the one system to be checked. Errors in installation of a new gas delivery system was prevented by prompt discovery of improper oxygen supply.
\end{abstract}

KEYWORDS: cross-connection of medical gases $\cdot$ nitrous oxide $\bullet$ patient safety

CORRESPONDENCE AdDREss: Miljenko Križmarić, Ph.D., Associate Professor, University of Maribor, Faculty of Health Sciences, Žitna ulica 15,2000 Maribor , Slovenia, e-mail: miljenko.krizmaric@um.si

DOI https://doi.org/10.18690/978-961-286-020-2.36

ISBN 978-961-286-020-2

(C) 2017 University of Maribor Press

Available at: http://press.um.si 


\section{$1 \quad$ Uvod}

V šempetrski bolnišnici so po poročanju javnih medijev marca 2016 nudili nujno medicinsko pomoč delavcu, poškodovanemu na delovnem mestu. Ob neuspešnem oživljanju so posumili, da je nastala tehnična napaka. Sprožili so preiskavo in ugotovili, da je iz cevi, iz katere bi moral dotekati kisik, prihajal dušikov oksidul oziroma smejalni plin (didušikov oksid, $\mathrm{N}_{2} \mathrm{O}$ ). Na reanimacijskem stativu, iz katerega je namesto kisika pritekal dušikov oksidul, so namreč obravnavali sedem bolnikov, več od njih pa jih je pozneje umrlo.

Zamenjan dovod medicinskih plinov je redek dogodek, a ima lahko hude posledice (Petty, 1995). Največkrat sta zamenjana dovoda kisika in dušikovega oksidula, poročajo pa tudi o drugih kombinacijah zamenjanih medicinskih plinov. Alarmi v povezavi $\mathrm{s}$ plinskimi instalacijami se sprožajo samo pri padcu tlaka $\mathrm{v}$ napeljavi, ne pa $\mathrm{v}$ primeru prisotnega napačnega plina (Das, 2013). Posledica zamenjave je huda hipoksija, zato v kolikor je le mogoče, spremljamo mešanico plinov z ustreznim monitoringom.

Zamenjavo medicinskih plinov preprečimo z uporabo posebnih spojk na ceveh (angl. NIST: non-interchangeable screw-threaded, DISS: Diameter Index). Te spojke povežejo cev, ki jo vodimo na medicinski aparat, kot na primer na mehanični ventilator ali na anestezijsko delovno postajo (Rampesad, 2012)

Ko se pojavijo opisani neželeni dogodki, ni vzrok samo v posameznem dejavniku, ampak je prisotnih več faktorjev, ki privedejo do nesreče. James Reason je zasnoval model za zmanjšanje takih napak (Reason, 1997). Model ima več nivojev, ki ščitijo bolnika pred neželenimi dogodki. Podoben »SHELL « model so zasnovali zaradi lažjega razumevanja interakcij med človekom, okoljem, medicinsko opremo in postopki (Hawkins, 1993).

Namen prispevka je bil ugotoviti, kakšen je časovni potek vitalnih funkcij na simulatorju, ki spontano diha $100 \%$ dušikov oksidul skozi masko z zbiralnikom. Ker maska ne more popolnoma tesniti se z dušikovim oksidulom meša nekoliko atmosferskega zraka. Zrak prihaja tudi skozi varnostno odprtino, ki je na bočni strani maske.

\section{2}

\section{Metode}

Raziskavo smo izvedli v Simulacijskem centru Medicinske fakultete Maribor. Slika 1 prikazuje simulator METI HPS (CAE Healthcare, Kanada), ki je spontano dihal skozi masko z nepovratnim dihanjem in zbiralnikom (angl. NRB - Nonrebreathing mask). Maska ima varnostno odprtino $\mathrm{z}$ indikatorjem dihanja (majhna kroglica $\mathrm{v}$ cevki), ki pogosto zamenja eno od treh zaklopk. Na sliki 1 vidimo varnostno odprtino na desni strani obrazne maske. $\mathrm{V}$ masko se $\mathrm{v}$ kliničnem okolju dovaja kisik, a smo $\mathrm{v}$ našem primeru dovajali $100 \%$ dušikov oksidul, saj sta bila zamenjana dovoda kisika in dušikovega oksidula. V 26 minuti eksperimenta smo stransko varnostno odprtino na NRB maski zamašili in tedaj sta delovali samo dve zaklopki (spodnja zaklopka med zbiralnikom in masko in ena stranska zaklopka na levi strani maske). 


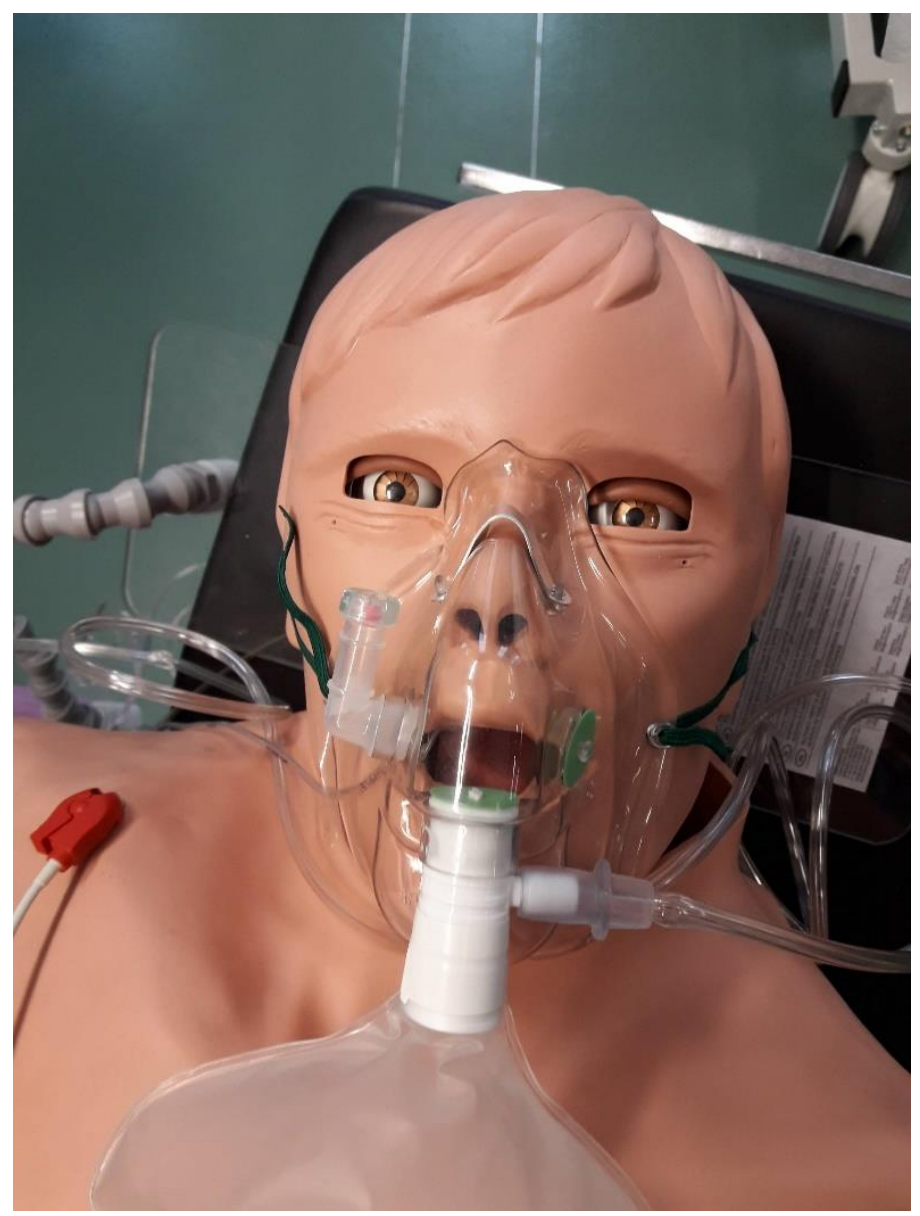

Slika 1: Aplikacija $100 \% \mathrm{~N}_{2} \mathrm{O}$ skozi NRB masko

V prvem delu raziskave smo predstavili časovni potek respiratornih in hemodinamičnih spremenljivk, ki smo jih beležili na vsako minuto. Celoten eksperiment je trajal 37 minut. Razlike v poteku fizioloških funkcij smo izračunali s parnim parametričnim statističnim testom (SPSS ver. 23, IBM Armonk). V drugem delu raziskave smo prikazali načine zaščite pred zamenjavo plinov s posebnimi spojkami in kako sistemsko pristopiti $\mathrm{k}$ preprečevanju takih napak.

\section{Rezultati}

Na sliki 2 vidimo časovni potek spreminjanja delnega tlaka kisika $v$ arterijski krvi $\left(\mathrm{P}_{\mathrm{a}} \mathrm{O}_{2}\right)$ simuliranega bolnika. Takoj v začetni fazi opazimo strmo padanje $\mathrm{P}_{\mathrm{a}} \mathrm{O}_{2}$. Pred aplikacijo maske je simulator dihal atmosferski tlak in zabeležili smo delni tlak kisika $113 \pm 1 \mathrm{mmHg}$. Med aplikacijo NRB maske in dihanju dušikovega oksidula je delni tlak kisika padel na 
M. Križmarić: Zamenjave dovodov medicinskih plinov in njihovo preprečevanje

$45 \pm 1 \mathrm{mmHg}$. V 26. minuti je opaziti ponovni padec delnega tlaka na vrednost $30 \pm 4$ $m m H g$. Padec se je zgodil zaradi zamašene stranske odprtine na NRB maski

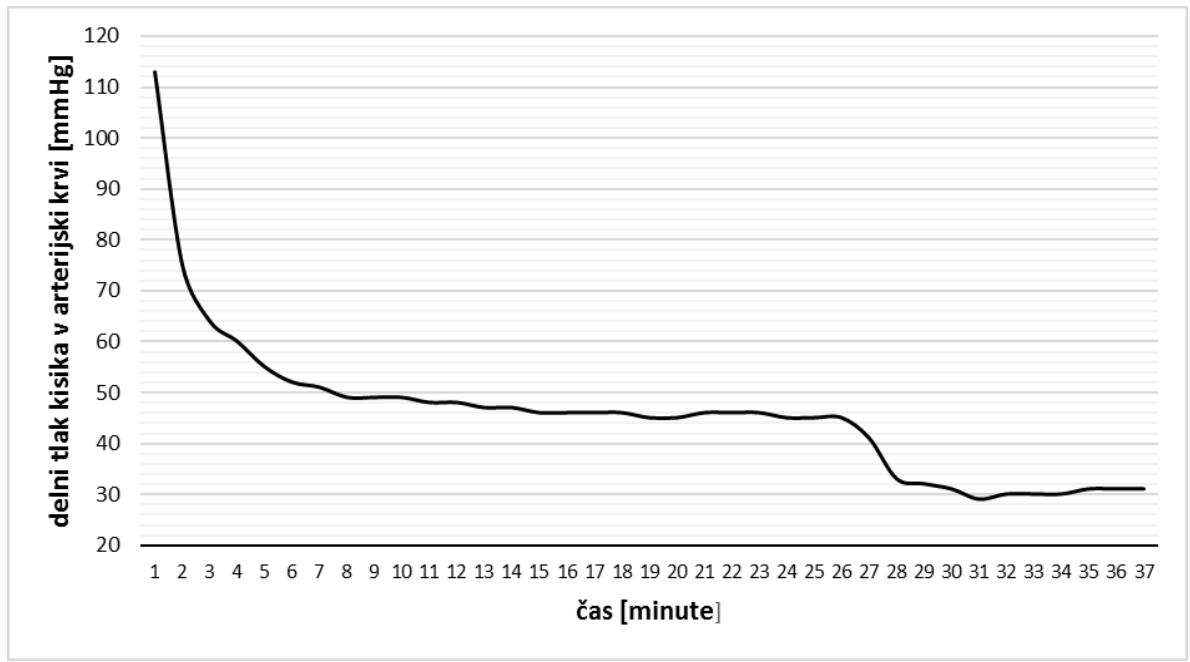

Slika 2: Časovni potek delnega tlaka kisika v arterijski krvi $\left(\mathrm{P}_{a} \mathrm{O}_{2}\right)$

Posledice manjšega delnega tlaka kisika $v$ arterijski krvi so vidne na sliki 3. Oksigenacija hemoglobina s kisikom $\mathrm{v}$ arterijski krvi $\left(\mathrm{S}_{\mathrm{p}} \mathrm{O}_{2}\right)$ je odvisna namreč od $\mathrm{P}_{\mathrm{a}} \mathrm{O}_{2}$. Nasičenost hemoglobina s kisikom je iz $98,8 \pm 0,35 \%$ padla na $85,5 \pm 0,5 \%(p<0,001)$ in po zmašitvi zaklopke na še nižjo vrednost $65,0 \pm 5,7$. Na sliki vidimo strmi padec po 26 . minuti, ki sovpada s padcem $\mathrm{P}_{\mathrm{a}} \mathrm{O}_{2}$, kar je posledica disociacijske oblike krivulje za kisik. Ta krivulja je v obliki črke » $\mathrm{S}$ « in je v tem območju tlaka strma - majhen padec delnega tlaka kisika $\mathrm{v}$ arterijski krvi povzroči velik padec nasičenosti hemoglobina s kisikom. 
$36^{\text {TH }}$ International Conference on Organizational Science Development: RESPONSIBLE ORGANIZATION (MARCH $22^{\mathrm{ND}}-24^{\mathrm{TH}}$, PORTOROŽ SLOVENIA)

M. Križmarić: Crossed Pipelines Connections of Medical Gases and Their Prevention

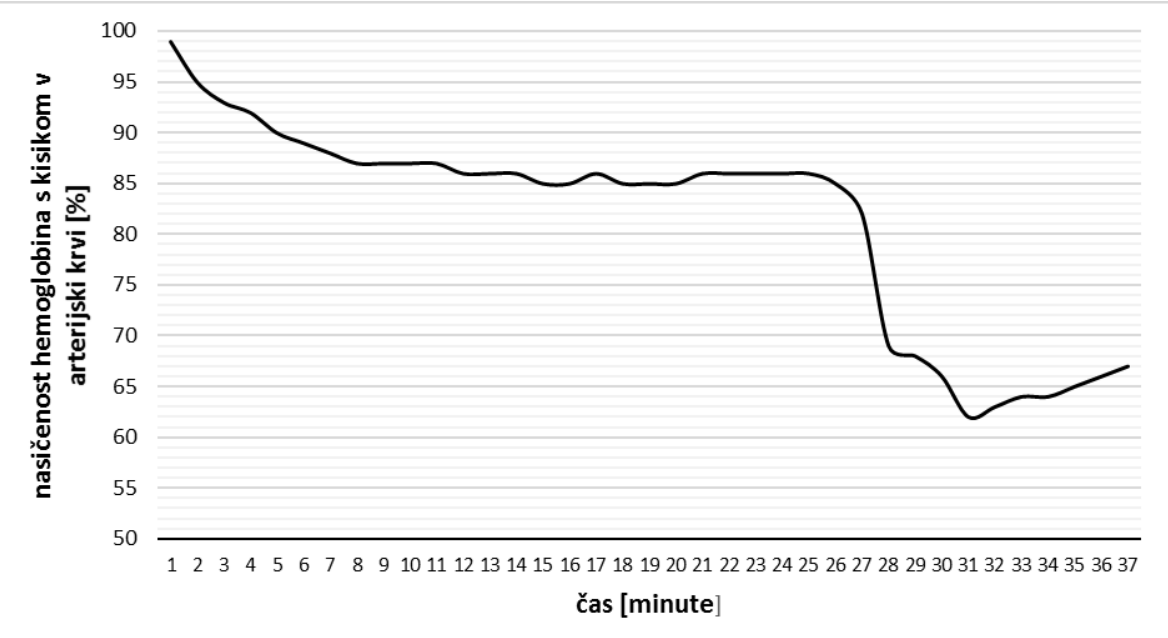

Slika 3: Časovni potek nasičenosti hemoglobina v arterijski krvi $\left(\mathrm{S}_{p} \mathrm{O}_{2}\right)$

Slika 4 prikazuje kontinuirano padanje delnega tlaka ogljikovega dioksida $\left(\mathrm{P}_{\mathrm{a}} \mathrm{CO}_{2}\right)$ iz normalnih vrednosti $40,8 \pm 0,4 \mathrm{mmHg}$ na $33,3 \pm 0,6 \mathrm{mmHg}$ ter na nekoliko višjo vrednost $33,5 \pm 0,7 \mathrm{mmHg}$ pri zaprti stranski odprtini maske v 26. minuti eksperimenta. Simulator zaradi nizkih vrednosti kisika v krvi poskuša nadomestiti kisik s povečano frekvenco in volumnom dihanja, kar privede do višjega izplavljanja ogljikovega dioksida iz telesa.

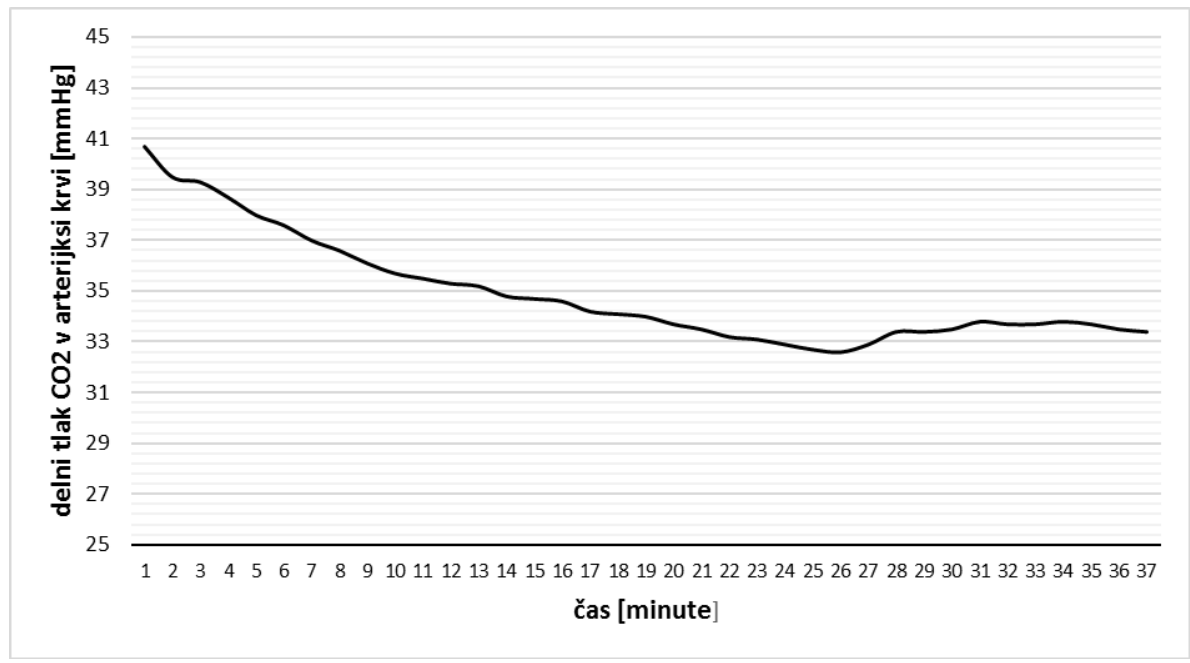

Slika 4: Časovni potek delnega tlaka ogljikovega dioksida $\left(\mathrm{P}_{a} \mathrm{CO}_{2}\right)$ v arterijski krvi 
M. Križmarić: Zamenjave dovodov medicinskih plinov in njihovo preprečevanje

Spreminjanje frekvence srca je prikazano na sliki 5. Začetna fekvenca srca je bila $72 \pm 1$ utripov na minuto, nakar se je zaradi kompenzacije povišala na $90 \pm 3$ utripov na minuto $(\mathrm{p}<0,001)$, med zaprto odprtino pa na še višjo vrednost $98 \pm 2$ utripa na minuto. Kot vidimo simulator kompenzira hipoksijo, ki nastane zaradi dovajanja hipoksične dihalne zmesi dušikovega oksidula. Višja frekvenca srca povzroči višji minutni volumen srca in tako se poskuša kompenzirati dostava kisika do tkiv.

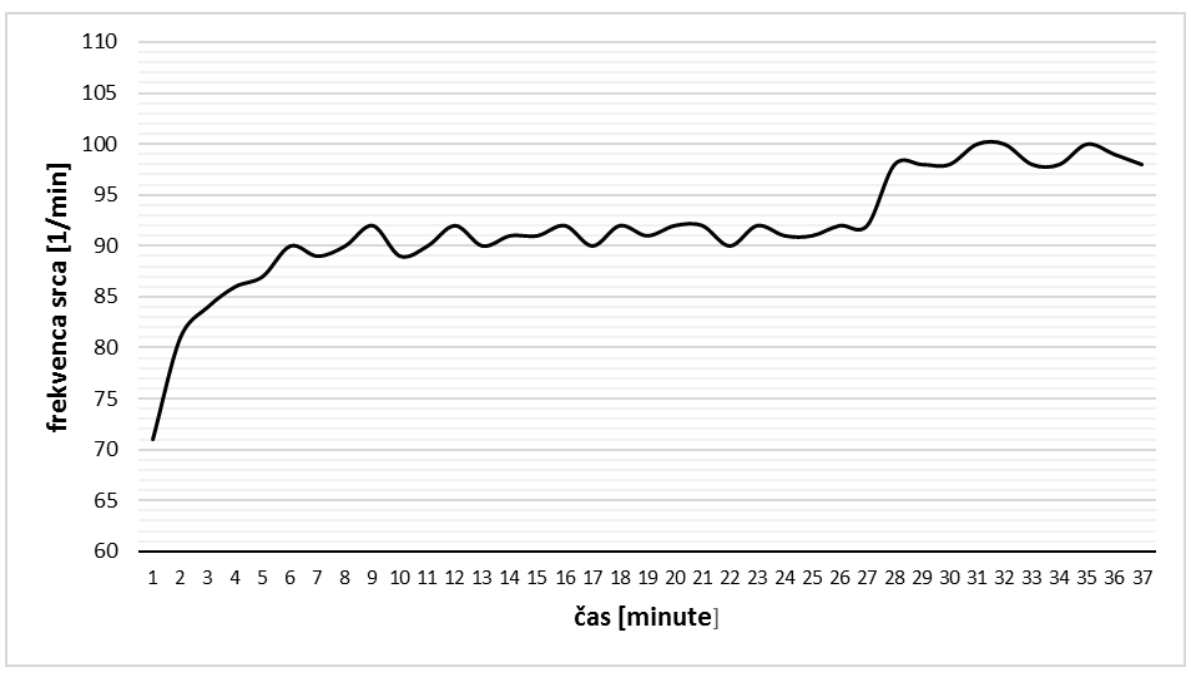

Slika 5: Časovni potek frekvence srca

Respiratorna funkcija simuliranega bolnika je prikazana na slikah 6 in 7. Zaradi dovajanja hipoksične mešanice se sprožijo kompenzacijski mehanizmi in frekvenca dihanja prične naraščati (slika 6). Frekvenca naraste iz $13,5 \pm 0,7$ vdiha na minuto, na $26,9 \pm 2,4$ vdiha na minuto. Ko zapremo stransko odprtino maske, naraste frekvenca dihanja na $30,7 \pm 1,0$ $(\mathrm{p}<0,001)$. 
$36^{\text {Th }}$ International Conference on Organizational Science Development: ResPonsible Organization (MARCh $22^{\mathrm{ND}}-24^{\mathrm{TH}}$, Portorož SLOVENia)

M. Križmarić: Crossed Pipelines Connections of Medical Gases and Their Prevention

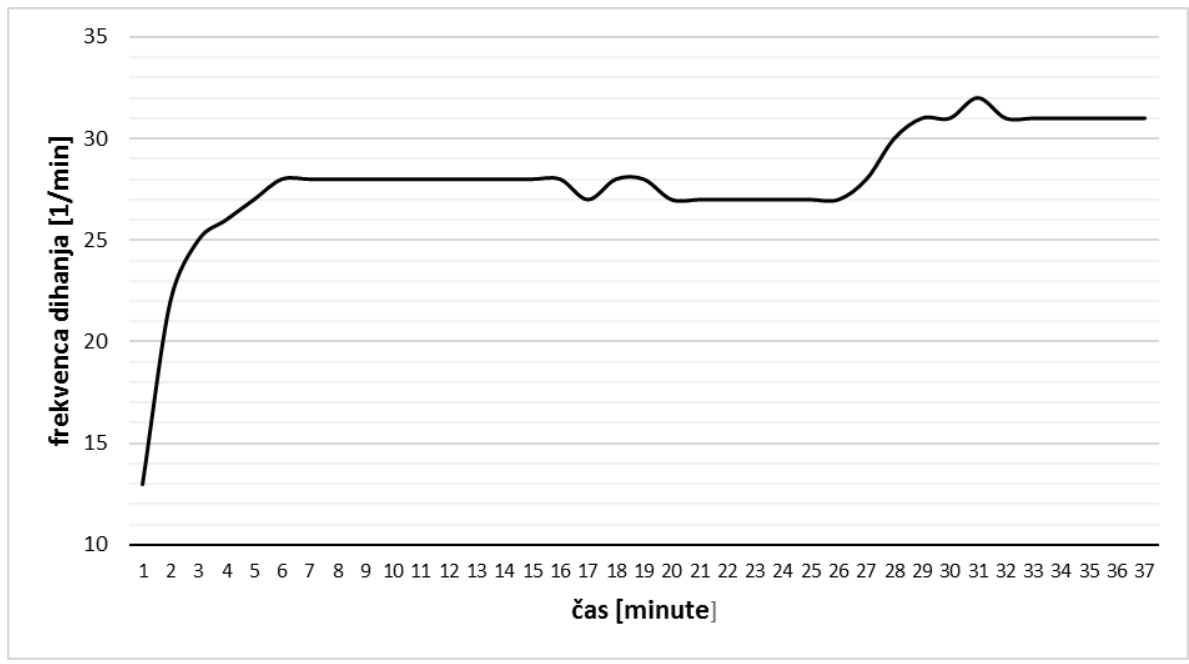

Slika 6: ‘̆asovni potek frekvence dihanja

Vzporedno $\mathrm{z}$ višanjem frekvence se povečuje minutni dihalni volumen $\left(\mathrm{V}_{\mathrm{T}}\right)$, kar je prikazano na sliki 7. Iz začetnih $780 \pm 45 \mathrm{ml}$ se je $\mathrm{V}_{\mathrm{T}}$ povečal na $1573 \pm 70 \mathrm{ml}$ in ob zaprti stranski odprtini na $1784 \pm 56 \mathrm{ml}(\mathrm{p}<0,001)$. Iz začetnih, nekaj čez 9 litrov minutne ventilacije se minutni volumen (MV) poveča na 45 litrov/minuto in ob zaprti stranski odprtini NRB maske na 55 litra/minuto. Tudi v tem primeru gre za mehanizem s katerim organizem skuša kompenzirati motnjo zaradi nizkega deleža kisika v vdihanem zraku.

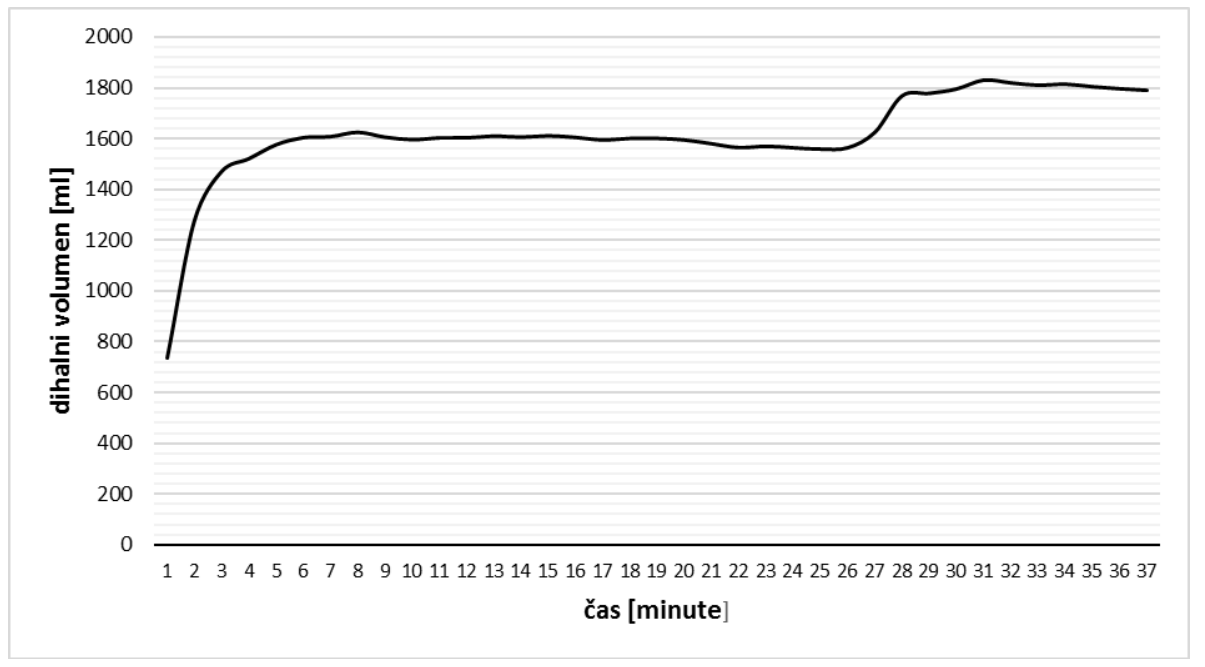

Slika 7: Časovni potek dihalnega volumna 
Medicinski pripomočki so načrtovani na tak način, da je čim manjše tveganje za napake. Na sliki 8 vidimo NIST (angl. NIST - non-interchangeable screw-threaded) obliko vtikača plinskih spojk, ki prepreči, da bi se napačne cevi medicinskih plinov med seboj zamenjale. Uporabnik $\mathrm{v}$ tem primeru ne more $\mathrm{v}$ spojko aparata namenjeno dušikovem oksidulu priključiti cev za kisik.

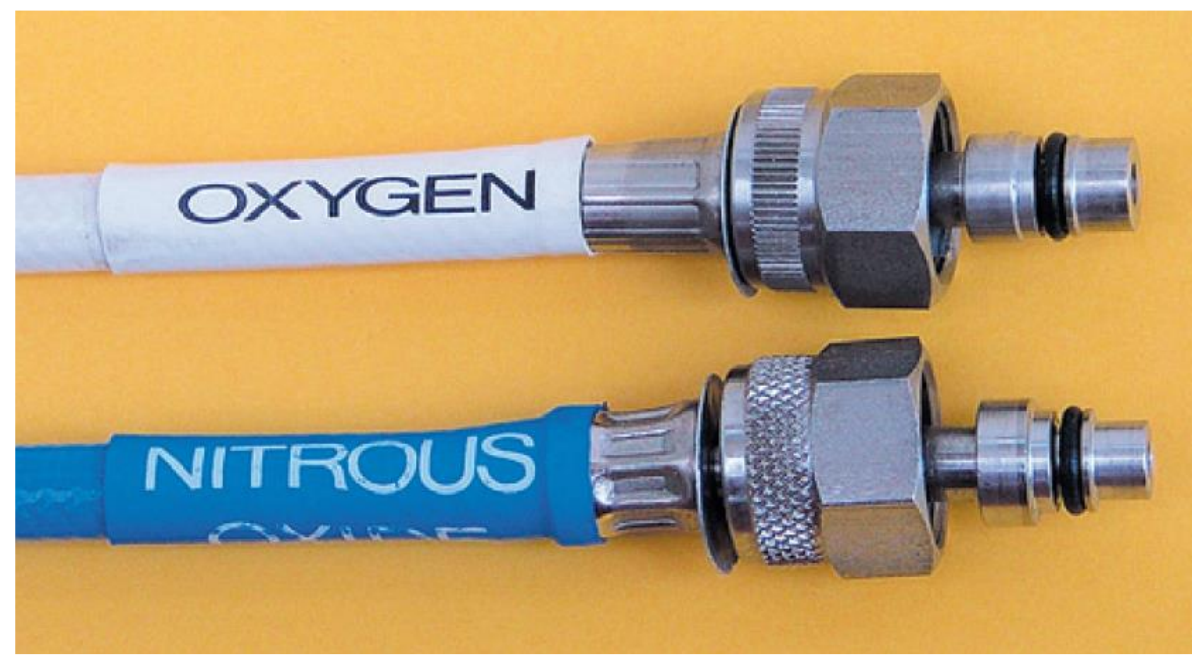

Slika 8: NIST spojke različnih premerov

Na sliki 9 je na levi strani Reasonov model zaščite pred neželenimi dogodki oziroma učinki. Model je podoben »švicarskemu siru«, kjer luknje predstavljajo skrite sistemske napake ali latentne pogoje, ki privedejo do neželenega učinka. Luknje se lahko pojavijo ali izginejo, so aktivne ali neaktivne. Rezine v modelu pa predstavljajo obrambo, ki ščitijo bolnika pred napakami. Desni del slike predstavlja »SHELL« model, kjer »S« pomeni softver (Software), »H« hardver (Hardware), »E« okolje (Environement) in $» \mathrm{~L} «$ ljudi (Liveware) (Rampesad, 2012). Teh pet blokov modela ima iregularne stranice, ki jih moramo med seboj prilagajati. S prilagajanjem ustvarjamo interakcijo med posameznimi bloki in ko je zagotovljeno popolno prileganje, se zmanjša tveganje za napake. 
$36^{\text {Th }}$ International Conference on Organizational Science Development: Responsible Organization (MARCh $22^{\mathrm{ND}}-24^{\mathrm{TH}}$, Portorož Slovenia)

M. Križmarić: Crossed Pipelines Connections of Medical Gases and Their Prevention

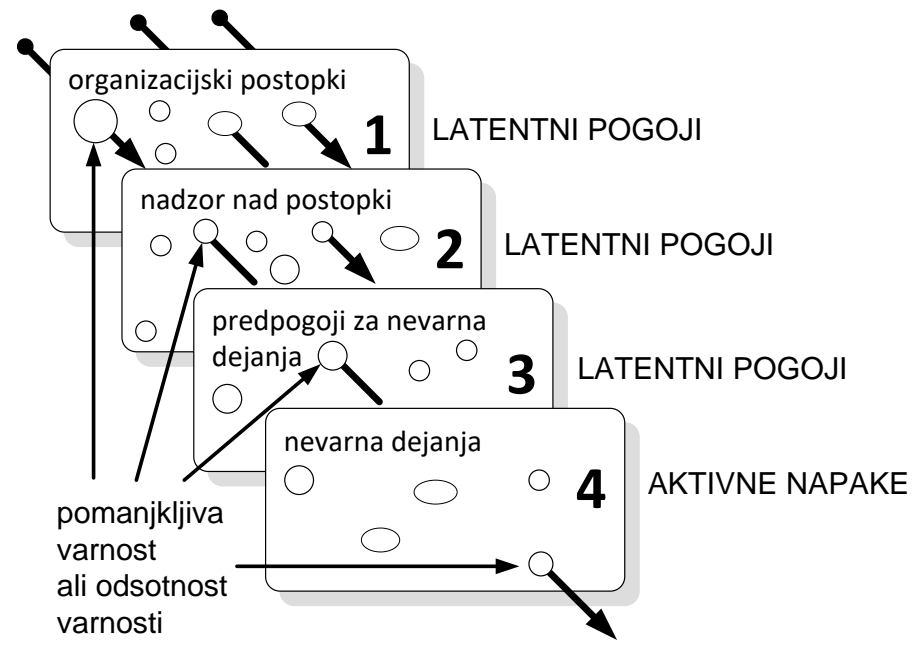

\section{NEŽELEN UČINEK}

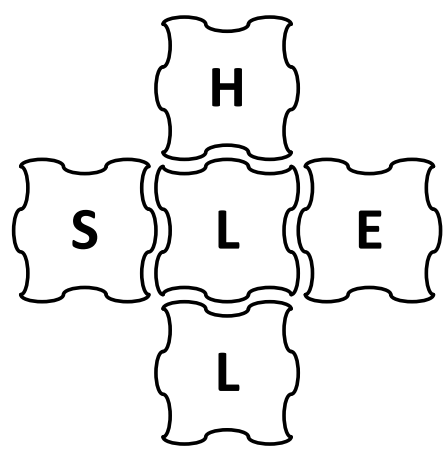

Slika 9: Reason model (levo) in SHELL model (desno)

\section{4}

\section{Razprava}

Za izvedbo simulacijskega scenarija smo morali fizično predelati plinske instalacije, da smo dobili hipoksično mešanico dihalnih plinov. Zamenjati je bilo potrebno dovod kisika in dušikovega oksidula. Na NRB masko (angl. NRB - Non rebreather mask) smo dovajali $100 \%$ kisik, v resnici pa je tekel 100\% dušikov oksidul. Originalna različica NRB maske ima 3 zaklopke, od tega dve stranski, ki se odpreta pri izdihu in eno zaklopko med zbiralnikom kisika in masko, ki se odpre ob vdihu. Stranski zaklopki onemogočita, da med vdihom bolnik vdihne zrak iz atmosfere, spodnja zaklopka pa onemogoči da bi izdihan zrak bolnik izdihal $\mathrm{v}$ zbiralnik. Tako bolnik vdihuje čisti kisik, ki se nabira $\mathrm{v}$ zbiralniku. Navadno na tako masko z zbiralnikom dovajamo med 60 in $80 \%$ deleža kisika $\mathrm{v}$ vdihanem zraku, saj zaradi tesnjenja prihaja do uhajanja kisika in vdihovanja zraka iz 
okolice (Branson, 1993). Naša različica NRB maske je imela samo dve zaklopki in varnostno odprtino, ki je namenjena situacijam, v katerih bi nepokreten bolnik ostal brez dovoda kisika. Pri maski s tremi zaklopkami bolnik ne bi mogel vdihniti kisika zaradi praznega zbiralnika, prav tako ne bi mogel vdihniti zraka iz okolice, saj bi mu to preprečili dve stranski zaklopki. Če je pa na maski vgrajena varnostna zaklopka, bolnik skozi njo lahko dobi nekaj atmosferskega zraka, če pride do prekinitve dovoda kisika. Naš simulator je $\mathrm{v}$ prvem delu eksperimenta dobival zrak skozi to odprtino, ko pa smo jo zamašili po 26 minuti je bilo vidno koliko nam je prispevala. Delni tlak kisika v arterijski krvi je zaradi zamašene varnostne odprtine padel za $15 \mathrm{mmHg}$, kar je relativno visoka vrednost. Varnostna odprtina skozi katero prihaja atmosferski zrak tako prispeva 15 $m m H g$ delnega tlaka.

Delni tlak kisika $\mathrm{v}$ alveolah $\left(\mathrm{P}_{\mathrm{A}} \mathrm{O}_{2}\right)$, ki je primerljiv $\mathrm{z}$ delnim tlakom kisika $\mathrm{v}$ arterijski krvi $\left(\mathrm{P}_{\mathrm{a}} \mathrm{O}_{2}\right)$, je pri dihanju na atmosferskem tlaku enak: $\mathrm{P}_{\mathrm{A}} \mathrm{O}_{2}=\mathrm{F}_{\mathrm{I}} \mathrm{O}_{2} \cdot\left(\mathrm{P}_{\mathrm{B}}-\mathrm{P}_{\mathrm{H} 2 \mathrm{O}}\right)-$ $\left(\mathrm{P}_{\mathrm{a}} \mathrm{CO}_{2} / \mathrm{RQ}\right)=0,21 \cdot(760-47)-(40 / 0,8)=100 \mathrm{mmHg}$. Pri tem je $\mathrm{F}_{\mathrm{I}} \mathrm{O}_{2}$ delež kisika $\mathrm{v}$ vdihanem zraku 21\%, $\mathrm{P}_{\mathrm{B}}$ je atmosferski tlak $760 \mathrm{~mm} \mathrm{Hg}, \mathrm{P}_{\mathrm{H} 2 \mathrm{O}}$ je parni tlak vode $47 \mathrm{mmHg}$, saj se zrak v dihalih navlaži, $\mathrm{P}_{\mathrm{a}} \mathrm{CO}_{2}$ je delni tlak ogljikovega dioksida v arterijski krvi 40 $m m H g$ in RQ je respiratorni kvocient 0,8. (Kacmarek, 2013). Kot vidimo so vrednosti na našem simulatorju primerljive $\mathrm{s}$ fiziološkimi vrednostmi. Pri delnem tlaku kisika 40 $\mathrm{mmHg}$ je nasičenost hemoglobina $70 \%$, pri $50 \mathrm{mmHg}$ je nasičenost $80 \%$ in pri $60 \mathrm{mmHg}$ je nasičenost $90 \%$ (Cohen, 2013). Tudi v tem primeru nam simulator daje primerljive vrednosti glede na krivuljo vezave kisika na hemoglobin.

Pri delnem tlaku $\mathrm{PaO}_{2}$ pod $40 \mathrm{mmHg}$ se zahteva hitro ukrepanje, saj je prisotna huda hipoksemija (nasičenost hemoglobina, $\mathrm{S}_{\mathrm{p}} \mathrm{O}_{2}, 70 \%$ ), ki ogroža življenje. V tem primeru se zahteva takojšnja aplikacija kisika in uporaba ventilatorja. Na simulatorju smo kritično hipoksemijo $(40 \mathrm{mmHg}$ ) dosegli ko smo zaprli stransko odprtino na NRB maski. Bolnik izgubi zavesti pri delnem tlaku kisika v arterijski krvi pri $30 \mathrm{mmHg}$ (Lindholm, 2006). To vrednost smo dosegli po preteku 5 minut pri zaprti varnostni odprtini.

Kakšni so torej varnostni mehanizmi za preprečevanje aplikacije hipoksične mešanice? Na nivoju uporabnika, če gledamo model »SHELL« je to interakcija med L-H (LivewareHardware). V tem primeru je hardver plinska spojka, ki je tako izdelana, da jo ne moremo priključiti na napačno vtičnico. To so sistemi NIST (Non-interchangeable screw threaded), DISS (Diameter Indexed Safety System, ZDA) in PISS (Pin Index Safety System). PISS je sistem zatičev ki omogoči, da določena tlačna posoda ustreza samo regulatorju tlaka za to posodo. NIST sistem ima različne premere vtikačev, ki ustrezajo samo določeni vtičnici (Bland, 2012).

Reasonov model »švicarskega sira« lahko uporabimo, ko želimo imeti širši pogled na varnost. Prva rezina modela na levem delu slike 9, vsebuje varnostne pristope $\mathrm{z}$ organizacijskimi navodili in postopki. $\mathrm{V}$ tej rezini so prisotna navodila oziroma pravilniki, kako kontrolirati instalacije medicinskih plinov glede na mednarodne standarde. V šempetrskem primeru ni bil izveden test končne kontrole identitete plina, tako kot bi moral biti, in pojavila se je luknja v rezini. Naslednja rezina, ki bi naj ščitila 
$36^{\text {Th }}$ International Conference on Organizational Science Development: Responsible Organization (MARCh $22^{\mathrm{ND}}-24^{\mathrm{TH}}$, Portorož Slovenia)

M. Križmarić: Crossed Pipelines Connections of Medical Gases and Their Prevention

bolnika v Reasonovem modelu je nadzor nad postopki kontrole instalacij. Tudi v tej rezini je varnost zatajila, saj niso bile kontrole ustrezno izvedene.

Po končani novogradnji ali kakršnikoli spremembi na obstoječem sistemu plinskih instalacij je potrebna končna kontrola identitete plina, dobavljenega na vsaki priključni enoti. Sistem, ki ga testiramo, moramo priključiti na normalni delovni tlak (5 bar). Drugi sistemi morajo biti v tem času izolirani od vtičnic medicinskih plinov. Prekontrolira se vsaka soba, da se prepriča, da preizkusni zrak prihaja iz vsake priključne enote, na kateri je napis testiranega plina, ne pa iz nobene druge enote. Pri gradnji nove bolnišnice v Avstraliji so odkrili 14 napačno spojenih vtičnic (priključnih enot) od katerih so bili na šestih mestih zamenjani plini, ki bi lahko vodili v smrt bolnikov (Tingay, 1978). Cevovodi se morajo testirati na tesnost, kjer se 24 ur testira na dvojnem delovnem tlaku (10,5 bar). V tem času ne sme priti do puščanja plinov. Na dokončanih instalacijah se pri delovnem tlaku prav tako ne sme zaslediti puščanje pri 24 ur trajajočem testu. Če je priključenih več kot 50 priključnih enot pa se lahko sprejme padec tlaka 0,15 bara.

Večina nesrečnih dogodkov se ne bi pripetila, če bi sistemi bili ustrezno testirani (Dinnick, 1979). Simulator, ki smo ga validirali, se je pokazal kot dobro orodje za učenje študentov ali zaposlenih zdravstvenih delavcev. Fiziološke funkcije simulatorja so se spreminjale glede na podatke iz literature.

\section{Literatura}

Bland, H., Borton, C. \& Jafri S. (2012). The supply of anaesthetic and other medical gasses. V Davey, A. J., \& Diba, A. (Ur). Ward's Anaesthetic Equipment: London: Elsevier Health Sciences.

Branson, R. D. (1993). The nuts and bolts of increasing arterial oxygenation: devices and techniques. Respir Care. No. 38, str. 672-86

Cohen, Z. (2016). Gas Exchange and Transport. V Kacmarek, R. M., Stoller, J. K., \& Heuer, A. (Ur). Egan's fundamentals of respiratory care. London: Elsevier Health Sciences.

Das, S., Chattopadhyay, S., \& Bose, P. (2013). The anaesthesia gas supply system. Indian journal of anaesthesia. Vol. 57, No. 5, str. 489.

Dinnick, O. P. (1979). Medical gases--piping problems. Eng Med. Vol. 8, No. 4, str. 243-247.

Hawkins, F. H., \& Orlady, H. W. (1993). Human factors in flight (2nd ed.). England: Avebury Technical.

Kacmarek, R. M., Stoller, J. K., \& Heuer, A. (2016). Egan's fundamentals of respiratory care. St. Louis Missouri: Elsevier Health Sciences.

Lindholm, P., \& Lundgren, C. E. (2006). Alveolar gas composition before and after maximal breath-holds in competitive divers. Undersea Hyperb Med. Vol. 33, No. 6, str. 463-7.

Petty, W. C. (1995). Medical gases, hospital pipelines, and medical gas cylinders: how safe are they? AANA J. Vol. 63, str. 307-324.

Rampesad, S. E. \& Rampersad C. (2012) Error, Man and Machine. V Davey, A. J., \& Diba, A. (Ur). Ward's Anaesthetic Equipment: London: Elsevier Health Sciences.

Reason, J. T. (1997). Managing the risks of organizational accidents. Aldershot: Ashgate.

Tingay, M. G., Telsey, A. H., Willis, R. J., Thompson, Md J., Chalmers, A. H. \& Cousins, M. J. (1978) Gas identity hazards and major contamination of the medical gas system in a new hospital. Anaesthesia and Intensive Care. No. 6, str. 202 
36. MEDNARODNA KONFERENCA O RAZVOJU ORGANIZACIJSKIH ZNANOSTI: OdGOVORNA ORGANIZACIJA (22. - 24. MAREC 2017, PORTOROŽ, SLOVENIJA)

O. Arsenijević, M. Ferjan, I. Podbregar, P. Šprajc, D. Trivan \& Y. Ziegler

\title{
Biomasa, kot alternativni vir pridobivanja energije
}

\author{
TAdeja Kuhar Osterman, Drago VuK \& MaRJan SENEGAČniK
}

Povzetek Glavni cilji evropske energetske in podnebne politike so varnost oskrbe, konkurenčnost in trajnost. Države članice EU so se zavezale znižati emisije toplogrednih plinov do leta 2030 za $40 \%$ glede na delež iz leta 1990 in delež vse porabe energije iz obnovljivih virov energije zvišati na vsaj $27 \%$. Slovenija je ena najbolj gozdnatih držav v Evropi, zato les predstavlja pomemben obnovljiv vir energije. Slovenska zakonodaja $\mathrm{z}$ novim Energetskim zakonom ugodno vpliva tudi na razvoj in umeščnje tehnologij pridobivanja električne energije in toplote iz obnovljivih virov energije.

Predstavljen je primer pridobivanja električne energije $s$ tehnologijo soproizvodnje električne energije in toplote $\mathrm{z}$ uplinjanjem lesne biomase $\mathrm{v}$ slovenskem podjetju BIOFIT d.o.o. V podjetju svojo osnovno proizvodno dejavnost pridobivanja lesne biomase usmerijo $\mathrm{v}$ pridobivanje lesne biomase neposredno iz gozdov, ki je osnovna surovina za uplinjanje. Nevodljivo energijo spremenijo v vodljivo električno energijo in toploto.

KLJUČNE BESEDE: soproizvodnja toplote in električne energije • lesna biomasa • obnovljivi viri energije

NASLOV AVTORJEV: Tadeja Kuhar Osterman, direktorica, BIOFIT d.o.o., Visoko 39, 4212 Visoko, Slovenija, e-pošta: tadeja.kuhar@bio-fit.net; dr. Drago Vuk, redni profesor, Univerza v Mariboru, Fakulteta za organizacijske vede, Kidričeva cesta 55a, 4000 Kranj, Slovenija, e-pošta: drago.vuk@fov.uni-mb.si; dr. Marjan Senegačnik, docent, Univerza v Mariboru, Fakulteta za organizacijske vede, Kidričeva cesta 55a, 4000 Kranj, Slovenija, e-pošta: marjan.senegacnik@fov.uni-mb.si 
36 ${ }^{\text {TH }}$ International CONFEREnCE ON ORganizational Science Development: Responsible Organization (MARCH $22^{\mathrm{ND}}-24^{\mathrm{TH}}$, PORTOROŽ SLOVENIA)

O. Arsenijević, M. Ferjan, I. Podbregar, P. Šprajc, D. Trivan \& Y.

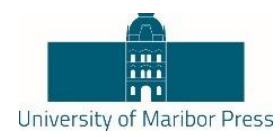

Ziegler

\title{
Biomass as an Alterantive Source of Energy Recovery
}

\author{
TAdeja Kuhar Osterman, DRago VuK \& MARJAn SENEGaČNIK
}

\begin{abstract}
The main objectives of European energy and climate policy are security of supply, competitiveness and sustainability. EU Member States have committed themselves to $40 \%$ reduction of greenhouse gas emissions as a share of 1990 by 2030 and to increase a share of all energy consumption from renewable energy sources to at least $27 \%$. Slovenia is one of the most forested countries in Europe, therefore wood is an important renewable energy source. Slovenian legislation with the new Energy Act has a positive influence over development and implementation of renewable energy electricity and heat generating technologies.

It is introduced an example of the technology of co-generating electricity and heat through biomass gasification in the Slovenian company BIOFIT 1.l.c. At its core production activities, wood biomass production target acquisition biomass directly from the forest, which is the basic raw material for gasification. The unmanageable energy is transforming into conducted energy which is electricity and heat.
\end{abstract}

KEYWORDS: generating plant CHP • renewable energy sources • wood biomass

CorresPondence AdDress: Tadeja Kuhar Osterman, CEO, BIOFIT d.o.o., Visoko 39, 4212 Visoko, Slovenia, e-mail: tadeja.kuhar@bio-fit.net; Drago Vuk, Ph.D., Full Professor, University of Maribor, Faculty of Organizational Sciences, Kidričeva cesta 55a, 4000 Kranj, Slovenia, e-mail: drago.vuk@fov.uni-mb.si; Marjan Senegačnik, Ph.D., Assistant Professor, University of Maribor, Faculty of Organizational Sciences, Kidričeva cesta 55a, 4000 Kranj, Slovenia, e-mail:: marjan.senegacnik@fov.uni-mb.si 


\section{$1 \quad$ Uvod}

Evropska komisija je predstavila nov energetski in podnebni okvir ukrepov do leta 2030. Emisije toplogrednih plinov naj bi znižali za 40 \% glede na delež iz leta 1990, energija iz obnovljivih virov pa naj bi predstavljala najmanj $27 \%$ vse porabe energije, kar je zavezujoči cilj za vse države članice EU (Politika EU, 2016).

Zmanjšanje porabe energije in koriščenje obnovljivih virov energije so za bodoč razvoj našega okolja izrednega pomena. Pomembno je zvišati raven samooskrbe kot tudi prihranke emisij $\mathrm{CO}_{2}$, skrajševati transportne poti in $\mathrm{s}$ tem povezne nevarnosti nesreč, omejiti uporabo fosilnih goriv in krepitev regionalnega gospodarskega razvoja. Zadnjih deset let zaznamo pomembno povečanje pridobivanja energije iz biomase, sonca, vode in vetra. V Nemčiji so od leta 2003 do leta 2008 delež obnovljivih virov energije na primarni porabi podvojili. Energetska izraba biomase v Nemčiji zavzema s trenutnimi, skoraj $70 \%$, največji delež pridobljene končne energije iz obnovljivih virov. Na področju pridobivanja toplote njen delež presega $90 \%$, s tem da je pretežni delež toplotnega pridobivanja iz lesa (C.A.R.M.E.N., 2016).

Soočamo se $\mathrm{z}$ izjemno rastjo prebivalstva in tudi $\mathrm{z}$ vedno večjo porabo energije, ki povzroča nestabilne cene in tudi moteno oskrbo. Evropsko gospodarstvo je močno odvisno od uvoza nafte, zato mora EU ukrepati, da bi to odvisnost vsaj delno odpravili ali ublažili. Prometni sektor ima močne ambicije, da bi se nafto nadomestilo $\mathrm{z}$ alternativnimi gorivi in izgradilo potrebno infrastrukturo. S tem bi v letu 2020 ustvarili prihranke pri uvozu nafte $\mathrm{v}$ višini 4,2 milijarde EUR letno, ki bi v letu 2030 narasli na 9,3 milijarde EUR letno. Dosegli bi dodatne prihranke v višini milijarde EUR zaradi ublaženih skokov cen. Raziskava Evropske podnebne fundacije kaže, da bi »zeleni« avtomobili do leta 2025 lahko ustvarili približno 700.000 dodatnih delovnih mest (Zelena energija za promet, 2016).

Podobno situacijo opažamo tudi v energetskem sektorju, kjer še vedno močno prednjači odvisnost od fosilnih goriv. Skupno daje premog skoraj $50 \%$ porabljene energije, nafta in naftni proizvodi več kot $30 \%$ ter plin $10 \%$. Vse bolj se uveljavljata proizvodnja energije iz odpadkov in proizvodnja biogoriv. Potrebne so naložbe v energijo iz obnovljivih virov, ki bi se po morale opirati na okrepljene mreže in medsebojne povezave ter na jasen in trden zakonodajni okvir. Razvoj projektov na energetskem področju bo dodatno okrepil regionalno stabilnost in ustvarjal nova delovna mesta (Coulon, 2015).

Evropska komisija je predstavila glavne tri cilje energetske politike EU: varnost oskrbe, konkurenčnost in trajnost. Določila in predstavila energetske in podnebne cilje za leto 2020, 2030 in 2050, ki predstavljajo zavezujoče obveze za vse države članice EU. Ti cilji so predstavljeni v tabeli št. 1 (Politika EU, 2016). 
$36^{\text {Th }}$ International Conference on ORganizational Science Development: RESPONSIBLE ORGANIZATION (MARCH $22^{\mathrm{ND}}-24^{\mathrm{TH}}$, PORTOROŽ SLOVENIA)

T. Kuhar Osterman, D. Vuk \& M. Senegačnik : Biomass as an Alterantive Source of Energy Recovery

\begin{tabular}{|l|l|l|l|}
\hline \multirow{2}{*}{ Ukrep } & \multicolumn{3}{|c|}{ energetski in podnebni cilji Evropske unije } \\
\cline { 2 - 4 } & 2020 & 2030 & 2050 \\
\hline zmanjšanje TGP za & $\mathbf{2 0} \%$ & $\mathbf{4 0} \%$ & $\mathbf{8 0 - 9 5} \%$ \\
\hline delež energije iz OVE & $\mathbf{2 0} \%$ & $\mathbf{2 7} \%$ & \\
\hline $\begin{array}{l}\text { povečati energijsko } \\
\text { učinkovitost za }\end{array}$ & $\mathbf{2 0} \%$ & $\mathbf{2 7 - 3 0} \%$ & \\
\cline { 1 - 3 } & & & \\
\end{tabular}

Tabela 15: Energetski in podnebni cilji EU (Politika EU, 2016).

Dosedanji uspehi izvajanja ukrepov članic držav EU so (Komisija evropskih skupnosti, 2016):

- zmanjšanje toplogrednih plinov za $18 \%$ med letoma 1990-2012,

- delež energije iz obnovljivih virov energije se je z 8,5 \% leta 2005 povečal na $14,1 \%$ leta 2012 ,

- do leta 2020 se bo energijska učinkovitost predvidoma povečala za 18-19 \%, kar je le nekoliko manj od načrtovanih $20 \%$, ki jih lahko dosežemo le z uveljavitvijo vseh potrebnih zakonov EU držav članic.

Tri četrtine držav EU, med katerimi je tudi Slovenija, mora rabo energije do leta 2020 znižati. Slovenija je zadnji dve leti znižala rabo energije predvsem zaradi šibke gospodarske aktivnosti in šibkih zim, ki so zmanjšale rabo energije za ogrevanje. Nasprotni učinek pa ustvarja visoka raven porabe energije v prometnem sektorju.

\section{$2 \quad$ Pregled literature}

Pri ogrevanju je v Sloveniji najpomembnejši obnovljiv vir les, pri elektriki pa hidroenergija. Ostalih obnovljivih virov energije je bilo leta 2014 v Sloveniji le $12 \%$, v EU pa zaradi izkoriščanja vetrne energije trikrat več. Podpore obnovljivim virom energije zadnja leta močno naraščajo. Znesek podpor je iz leta 2005 do leta 2015 narastel iz izplačanih 16 milijonov EUR na 110 milijonov EUR. Zadnja leta je prevladala podpora sončnim elektrarnam, leta 2014 pa je dobrih 15 milijonov EUR podpor izplačanih tudi elektrarnam na lesno biomaso (UMAR, 2016). 

ORGANIZACIJA (22. - 24. MAREC 2017, PORTOROŽ, SLOVENIJA)

T. Kuhar Osterman, D. Vuk \& M. Senegačnik : Biomasa, kot alternativni vir pridobivanja energije

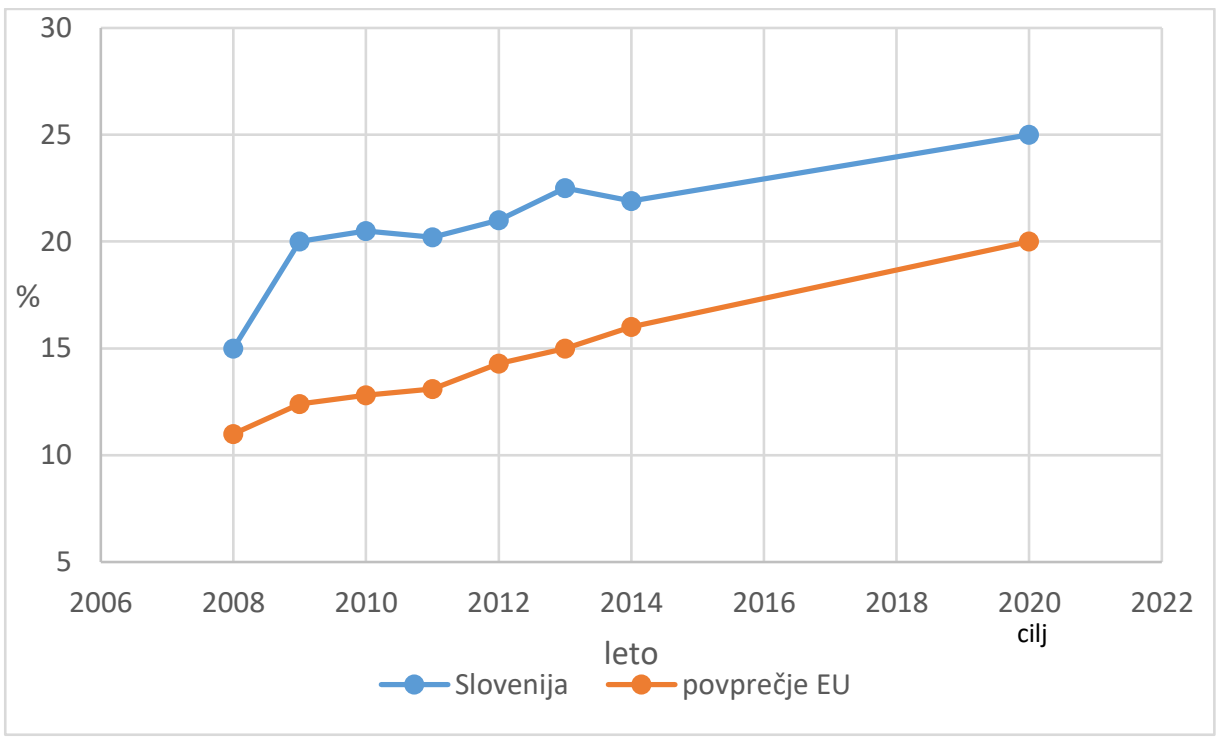

Slika 9: Delež rabe obnovljivih virov energije v bruto končni rabi energije, v \% (UMAR, 2016).

\subsection{Energetska zakonodaja in cilji slovenske politike}

Vlada Republike Slovenije je na podlagi evropskih direktiv pripravila Akcijski načrt za obnovljive vire energije (AN OVE, 2016), Akcijski načrt za učinkovito rabo energije (AN URE, 2016) in Akcijski načrt za skoraj ničenergijske stavbe (AN Snes, 2016).

Leta 2014 je Državni zbor Republike Slovenije sprejel Energetski zakon (EZ-1, 2014). Energetski zakon je $\mathrm{v}$ slovensko zakonodajo prinesel več evropskih direktiv in uredb $\mathrm{s}$ področja trga $\mathrm{z}$ zemeljskim plinom in električno energijo ter energetske učinkovitosti in obnovljivih virov energije.

»Zakon določa načela energetske politike, pravila delovanja trga $\mathrm{z}$ energijo, načine in oblike izvajanja gospodarskih javnih služb na področju energetike, načela in ukrepe za doseganje zanesljive oskrbe $\mathrm{z}$ energijo za povečanje energetske učinkovitosti in varčevanja $z$ energijo ter za večjo rabo energije iz obnovljivih virov, določa pogoje za obratovanje energetskih naprav, ureja pristojnosti, organizacijo in delovanje Agencije za energijo ter pristojnosti drugih organov, ki opravljajo naloge po tem zakonu« (EZ1,2014). 
$36^{\text {TH }}$ International Conference on Organizational Science Development: RESPONSIBLE ORGANIZATION (MARCH $22^{\mathrm{ND}}-24^{\mathrm{TH}}$, PORTOROŽ SLOVENIA)

T. Kuhar Osterman, D. Vuk \& M. Senegačnik : Biomass as an Alterantive Source of Energy Recovery

Cilji slovenske energetske politike za obnovljive vire energije so (AN OVE, 2010):

- zagotoviti $25 \%$ delež obnovljivih virov energije v končni rabi energije in $10 \%$ obnovljivih virov energije v prometu do leta 2020,

- ustaviti rast porabe končne energije,

- uveljaviti učinkovito rabo energije in obnovljive vire energije kot prioritete gospodarskega razvoja,

- dolgoročno povečati delež obnovljivih virov energije v končni rabi energije do leta 2030 in dalje.

Sektorski cilj Akcijskega načrta za obnovljive vire energije (AN OVE, 2010) je doseganje $39,3 \%$ obnovljivih virov energije za električno energijo v bruto končni rabi energije. V referenčnem letu 2005 je bilo $28,48 \%$ električne energije proizvedene iz obnovljivih virov energije, leta 2008 pa $29,50 \%$. Cilj bo zahteval povečanje proizvodnje električne energije iz obnovljivih virov energije kot tudi obvladovanje rasti porabe električne energije.

Na nacionalni ravni sprejeti in izvajani ukrepi za spodbujanje večje uporabe energije iz obnovljivih virov so naslednji (AN OVE, 2010):

1. podpora proizvodnji električne energije iz obnovljivih virov energije,

2. podpore za energetsko sanacijo stavb,

3. shema za prenovo javnih stavb v okviru projektov energetskega pogodbeništva,

4. podpore za vgradnjo sistemov ogrevanja na obnovljive vire energije,

5. dolgoročna strategija za spodbujanje naložb energetske prenove stavb,

6. podpore za izgradnjo daljinskih sistemov na lesno biomaso,

7. podpore za demonstracijske projekte celovite energetske sanacije stavb,

8. akcijski načrt za skoraj ničenergijske stavbe,

9. podpore za naložbe v kmetijska gospodarstva,

10. podpore za naložbe $\mathrm{v}$ predelavo/trženje in/ali razvoj kmetijskih proizvodov,

11. podpore za naložbe v vzpostavitev in razvoj nekmetijskih dejavnosti,

12. podpore za naložbe $\mathrm{v}$ gozdarske tehnologije ter predelavo, mobilizacijo in trženje gozdnih proizvodov,

13. strategija razvoja prometa v RS,

14. obvezna uporaba obnovljivih virov energije, soproizvodnje in odvečne toplote $v$ sistemih daljinskega ogrevanja.

\subsection{Obnovljivi viri energije in energetski potenciali lesne biomase}

Med obnovljive vire energije uvrščamo vse vire energije, ki jih zajemamo iz stalnih naravnih procesov. Mednje sodijo sončno sevanje, veter, vodni tok (hidroenergija), rastlinska biomasa in zemeljski toplotni tokovi (geotermalna energija). Zajemanje obnovljivih virov energije vira ne izčrpa kot je to pri rabi fosilnih goriv. 
V Sloveniji največ biomase za energetske namene uporabljamo iz gozdnega in industrijskega lesa, slame, gnojevke, blata iz čistilnih naprav, pa tudi iz energijskih rastlin, kot je na primer koruza.

Najpomembnejši vir biomase v Sloveniji predstavlja gozd, čigar potencial ni odvisen le od dejanske količine lesa $\mathrm{v}$ gozdu, vendar tudi od načela gospodarjenja z gozdovi, od proizvodnega procesa $\mathrm{v}$ gozdu, ki vključuje izbiro tehnologije in način dela, kot tudi od trga gozdno lesnih proizvodov in socioekonomskih razmer lastnikov gozdov. Teoretični potencial lesne biomase iz gozdov predstavlja vsa lesna biomasa, ki jo teoretično lahko pridobimo iz gozda. Tako je teoretični potencial lesne biomase iz gozdov lahko najvišji dovoljen posek lesa. Dejanski potencial je običajno manjši od teoretičnega (Krajnc, Piškur, 2009).

Leta 2014 je po podatkih Zavoda za gozdove Slovenije (ZGS, 2016 a) površina gozda znašala 1.181 .943 ha, kar pomeni, da je bila Slovenija leta $201458,3 \%$ porasla z gozdovi. Iz slike št. 2 lahko razberemo delež gozda po posameznih gospodarskih enotah Slovenije.

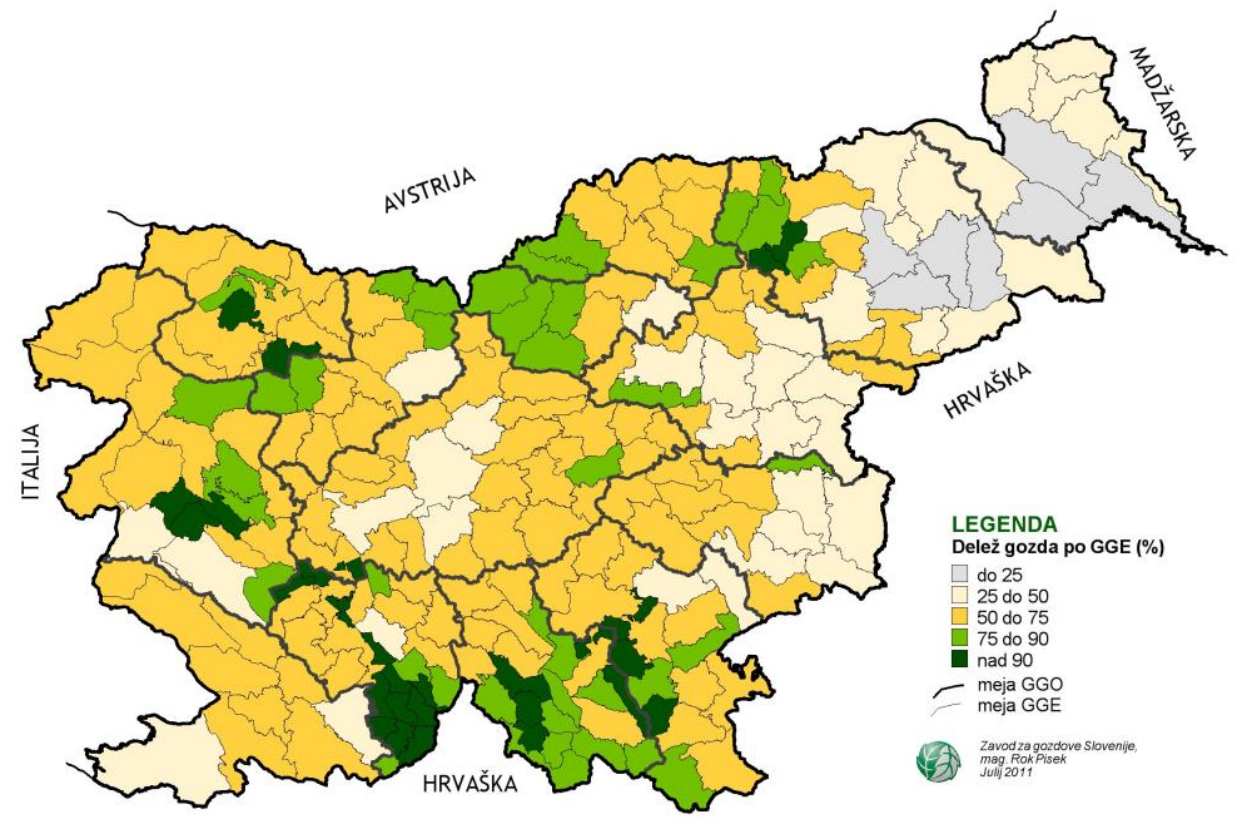

Slika 10: Gozdnatost Slovenije po posameznih gospodarskih enotah (ZGS, 2016 b).

Upoštevajoč soglasja in dovoljenja za posege v gozdni prostor, ki jih izdaja Zavod za gozdove Slovenije, kot tudi nezakonite posege vanj, je bilo v letu 2014 opravljenih 2.265 posegov v skupni površini 401 ha. Lesna zaloga slovenskih gozdov je znašala $346.074 .000 \mathrm{~m}^{3}$ oziroma $293 \mathrm{~m}^{3} / \mathrm{ha}$. Absolutni letni prirastek se je povečal za $1,1 \%$ in 
$36^{\mathrm{TH}}$ International Conference ON ORganizational Science Development: Responsible ORGANIZATION (MARCH $22^{\mathrm{ND}}-24^{\mathrm{TH}}$, PORTOROŽ SLOVENIA)

T. Kuhar Osterman, D. Vuk \& M. Senegačnik : Biomass as an Alterantive Source of Energy Recovery

znaša $8.582 .000 \mathrm{~m}^{3}$ oziroma $7,27 \mathrm{~m}^{3} / \mathrm{ha}$. Če podatke o lesni zalogi časovno ekstrapoliramo na leto 2014, znaša aktualna povprečna lesna zaloga vseh gozdov približno $300 \mathrm{~m}^{3} / \mathrm{h}$. Večina okroglega lesa iz gozdov je namenjena nadaljnji predelavi v lesnopredelovalni industriji. Dobra četrtina okroglega lesa iz gozdov se uporablja za energetske namene (Krajnc, Čebulj, 2012).

Krajnc et al. (2012) navajajo, da je bilo v Sloveniji leta 2010 proizvedenih okrog 850.000 $\mathrm{nm}^{3}$ lesnih sekancev in 55.000 do 60.000 ton peletov in briketov. $18 \%$ vseh slovenskih proizvajalcev lesih sekancev lesne sekance izvaža. Leta 2010 so izvozili $27 \%$ celotne slovenske proizvodnje lesnih sekancev.

Na sliki št. 3 je prikazan diagram, ki prikazuje vhodne surovine za proizvodnjo lesnih sekancev (Piškur et al. 2016). Skoraj polovico surovine predstavljajo veje, vrhači ter zeleni odrez, ki predstavljajo tudi najprimernejšo vhodno surovino za kurjavo.

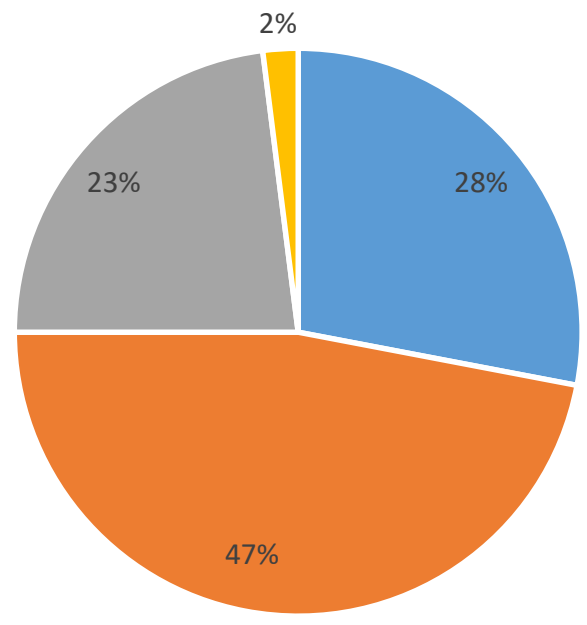

- Okrogli les

- Veje, vrhači, zeleni odrez

- Ostanki predelave lesa

- Ostalo

Slika 11: Surovina za proizvodnjo sekancev v letu 2014 (Piškur et al. 2016)

\section{$2.3 \quad$ Opis primera}

$\mathrm{V}$ raziskavo smo zajeli slovensko podjetje, ki se zadnje desetletje intenzivno ukvarja s pridobivanjem in prodajo lesne biomase. Dejavnost zajema strojno zbiranje in izvoz sečnih ostankov po sečnji, mletje sečnih ostankov, od hlodovine do vejevja ter odvozom pridobljenih lesnih sekancev do vmesnih skladišč ali končnega kupca oz. kotlovnice. 
$\mathrm{V}$ podjetju letno proizvedejo $75.000 \mathrm{~nm}^{3}$ lesnih sekancev. Od tega pridobijo $90 \%$ svežih ali zelenih sekancev in $10 \%$ lesnih sekancev iz hlodovine oz. energijskega lesa. Večji del lesa pridobivajo neposredno iz gozdov, zato je proizvodnja podjetja s svojim celotnim strojnim parkom prilagojena pridobivanju lesne biomase neposredno iz gozdov. Proizvodnji proces pridobivanja lesne biomase v podjetju zajema ključna podprocesa in sicer: proces pridobivanja lesne biomase neposredno iz gozdov za pridobivanje svežih (zelenih) sekancev za potrebe velikih porabnikov ter proces pridobivanja lesne biomase iz hlodovine. S trenutno tehnologijo in organizacijo zadovoljijo predvsem velike tuje kupce, kot so velike elektrarne in ogrevalni sistemi, ki jim dobavljajo sveže, zelene sekance.

\section{Opredelitev problema}

Visoko kakovostne lesne sekance pridobivajo izključno iz hlodovine. Nabavna cena hlodovine predstavlja od 65 do $70 \%$ končne cene lesne biomase (BIOFIT, 2016 a). Hlodovino za namen sušenja skladiščijo vsaj osem mesecev in ustvarjajo velike zaloge. S sušenjem lesa na zraku dosežejo srednje nizko vsebnost vode, ki je od 30 od $35 \%$. Za stabilnejše skladiščenje oz. preprečevanje pregrevanja skladiščnih lesnih sekancev, boljše izkoristke in manj pepela pri izgorevanju, mora biti vsebnost vode nižja in sicer med 25 in $30 \%$.

Predmet raziskave je analiza obstoječega proizvodnega procesa pridobivanja lesne biomase, uvedba proizvodne naprave soproizvodnje električne energije in toplote, ki omogoča pretvorbo kemične energije lesne biomase v vodljivo električno energijo. Cilj raziskave je implementacija novih tehnologij in prenova proizvodnega procesa pridobivanja lesne biomase $\mathrm{z}$ namenom doseganja visokokakovostnih lesnih sekancev neposredno iz gozda.

\section{$3 \quad$ Metode}

$\mathrm{Na}$ podlagi analize obstoječega proizvodnega procesa pridobivanja lesne biomase $\mathrm{v}$ obravnavanem podjetju, analize in izvlečkov strokovne literature iz področja obnovljivih virov energije, rezultatov opravljenih ustnih intervjujev $\mathrm{z}$ lastniki in zastopniki podjetja ter analize tehnologij pridobivanja toplote iz lesne biomase smo izdelali model rešitve, ki zajema uvedbo tehnologije soproizvodnje električne energije in toplote $\mathrm{z}$ uplinjanjem lesne biomase ter reorganizacijo proizvodnega procesa.

\section{$4 \quad$ Rezultati in ugotovitve}

Podana je rešitev za doseganje visokokakovostne lesne biomase, ki je pridobljena neposredno iz gozdov, ki zajema naslednje ključne spremembe:

- opustitev približno 8 mesečnega skladiščenja energijskega lesa v hlodovini,

- opustitev mletja energijskega lesa v hlodovini,

- uvedba sortiranja sečnih ostankov pri pripravi materiala za mletje v gozdu, 
$36^{\text {Th }}$ International Conference on Organizational Science Development: Responsible Organization (MARCh $22^{\mathrm{ND}}-24^{\mathrm{TH}}$, Portorož Slovenia)

T. Kuhar Osterman, D. Vuk \& M. Senegačnik : Biomass as an Alterantive Source of Energy Recovery

- uvedba ločenega mletja sečnih ostankov glede na kakovost vhodne surovine,

- uvedba ločenega razkladanja glede na kakovost pridobljene lesne biomase,

- uvedba sejanja pridobljene lesne biomase,

- uvedba dosuševanja lesne biomase na prodajno vsebnost vode.

V obstoječ proizvodnji proces uvedemo tehnologijo podjetja Terra-Tec GmbH TT-WGS 49 (Terra-Tec Wood Gas System 49 kW) iz Nemčije soproizvodnje električne energije in toplote z uplinjanjem lesne biomase $49 \mathrm{~kW}$ nazivne električne in $80 \mathrm{~kW}$ toplotne moči. Tehnologija omogoča pretvorbo kemične energije lesne biomase v vodljivo, električno energijo. Uvedli smo proizvodno napravo, ki omogoča prilagoditev vgradnje naprave na individualne prostorske danosti in potrebe investitorja, ki $\mathrm{v}$ obravnavanem primeru razpolaga s prostimi prostorskimi zmogljivostmi. Dobavitelj projektira ter dobavi celotno dozirno tehniko za potrebe preskrbe proizvodne naprave in sušenje lesnih sekancev za nadaljnjo prodajo.

Tehnologija pridobivanja električne energije in toplote $\mathrm{z}$ uplinjanjem lesne biomase obsega:

1. skladišče s sušilnico lesnih sekancev,

2. dnevni zalogovnik sejanih sekancev,

3. reaktor in dodelava plina,

4. motor $\mathrm{z}$ generatorjem.

\subsection{Tehnologija proizvodne naprave SPTE $z$ uplinjanjem lesne biomase}

Vhodna surovina lesnega uplinjevalca je lesna biomasa, iz katere pridobljeni lesni plin služi kot pogonsko gorivo za motor z notranjim izgorevanjem, ki je priključen na generator. Električna energija se preko merilnih naprav oddaja v električno omrežje. Toplota, nastala pri izgorevanju lesnega plina predstavlja vir toplote za sušenje lesnih sekancev.

S soproizvodnjo toplotne in električne energije dosegamo pri navedeni tehnologiji visoke izkoristke z 78,2 \% (Terra-Tec, 2015).

\section{Priprava lesnih sekancev za uplinjanje}

Vhodna kakovost lesnih sekancev glede na vsebnost vode, granulacijo in vrsto lesa, ni pomembna, ker material vstopa v sistem na sušilnici, katere vir toplote je toplota iz hladilnega sistema motorja uplinjevalca. S sušenjem lahko dosežemo poljubne stopnje vsebnosti vode lesnih sekancev. Suhi lesni sekanci preko transportnih polžev prehajajo na linearno vibracijsko sejalnico, ki ločuje drobne $(<7 \mathrm{~mm})$ in grobe delce $(>80 \mathrm{~mm})$ od uporabnih in primernih za uplinjanje $(8-80 \mathrm{~mm})$. (Terra-Tec, 2015). 
Sejani sekanci se $\mathrm{v}$ dnevnem zalogovniku še dodatno sušijo $\mathrm{s}$ toploto, ki nastaja pri procesu hlajenja plina. Preko transportnega polža se suhi sekanci z manj kot $5 \%$ vsebnosti vode popolnoma avtomatsko dozirajo $\mathrm{v}$ prekat $\mathrm{z}$ dvema loputama, ki ju upravljajo pnevmatski cilindri. Prekat, ki je skoraj zračno nepropusten preprečuje dotok zraka $\mathrm{v}$ reaktor, kar zagotavlja konstanten podtlak $\mathrm{v}$ reaktorju. $\mathrm{V}$ rektorju je nameščen senzor, ki preko računalniškega krmiljenja zagotavlja pravilno polnjenje reaktorja.

Uplinjanje v trdni plasti

Srce bioplinske naprave predstavlja uplinjevalec ali »reaktor«. Podjetje Terra-Tec GmbH uporablja za uplinjanje lesa tehniko uplinjanja $\mathrm{v}$ trdni plasti (Festbettvergasertechnik) $\mathrm{v}$ obliki enosmernega uplinjanja. Ta tehnika ima primerjalno $z$ drugimi tehnikami nižji izkoristek uplinjanja. Prednost izvedbe je predvsem v tem, da vsebuje surov plin manj nečistoč, kot so katrani in s tem z manj zahtevno pripravo plina proizvedemo lesni plin, ki je primeren za pogon motorja (Terra-Tec, 2015).

Pri zagonu reaktorja je potreben inicialen vžig za aktivacijo uplinjevalnega procesa. Eksotermična reakcija povzroči oksidacijo biomase. Nastala toplota povzroči nadaljnje reakcije, ki trdno snov spremenijo v gorljiv plin. Mineralni deli biomase po zaključenem uplinjanju na spodnjem delu reaktorja izhajajo v prašni obliki (pepelu) po plinovodu skupaj z lesnim plinom. Glede na gorivo uplinjevalno sredstvo deluje enosmerno. Enosmerni uplinjevalec lahko deluje v nadtlaku (ventilator vpihava uplinjevalno sredstvo $\mathrm{z}$ ventilatorjem) kot tudi v podtlaku (s potisnim ventilatorjem na koncu plinovoda). Ker pri obratovanju v nadtlaku lahko hitro pride do varnostnih težav zaradi uhajanja plina, praviloma enosmerni uplinjevalci delujejo z nizkim podtlakom. Pri uplinjaju v trdni plasti biomasa med uplinjanjem miruje, zato so temperature razmeroma konstantne. Delne procese uplinjanja lahko razdelimo $\mathrm{v}$ štiri cone (Terra-Tec, 2015):

- Kemični proces zajema pretvorbo kemično vezane energije iz biomase $\mathrm{v}$ gorljiv plin, ki je zmes ogljikovega monoksida, vodika in metana. Istočasno želimo preprečiti tvorbo težkih ogljikovodikov, kot so katrani. Na to vplivajo predvsem temperatura, toplotna izolacija reaktorja, vsebnost vode in granulacija biomase in dotok zraka.

- Pirolitično razpadanje. Pod pirolizo razumemo razpad kemičnih vezi z delovanjem toplote na visoki temperaturi brez kisika. Makro molekularni deli biomase razpadejo pri temperaturi okrog $600^{\circ} \mathrm{C}$. Poleg različnih plinov $(\mathrm{CO}$, $\mathrm{CO}_{2}, \mathrm{CH}_{4}, \mathrm{H}_{2} \mathrm{O}$ ) nastanejo tudi trde snovi, kot je lesno oglje in koks ter tudi težke ogljikovodikove spojine, kot so katrani. Tvorba katranov se praviloma pri še višjih temperaturah v oksidacijski coni kompenzira s termičnim razkrojem, ki se imenuje kreking.

- Oksidacija, katero povzroči dodajanje zraka oz. kisika uplinjevalnemu sredstvu. Težke ogljikovodikove spojine reagirajo s kisikom zelo eksotermno, kar povzroči visoke temperature tudi do $2.000^{\circ} \mathrm{C}$. Zaradi nevarnosti topljenja kovinskih delov v praksi je težko preseči $1.400^{\circ} \mathrm{C}$. Nastala toplota v oksidacijski coni pokriva potrebo po energiji celotnega uplinjanja. 
$36^{\text {TH }}$ International Conference on Organizational Science Development: RESPONSIBLE ORGANIZATION (MARCH $22^{\mathrm{ND}}-24^{\mathrm{TH}}$, PORTOROŽ SLOVENIA)

T. Kuhar Osterman, D. Vuk \& M. Senegačnik : Biomass as an Alterantive Source of Energy Recovery

- Redukcijska cona, v kateri oksidacijska produkta ogljikov dioksid in vodna para reagirata na račun dodatne toplote s trdimi delci (ogljem).

Na koncu plinovoda je nameščen potisni ventilator, ki vzdržuje celoten proces uplinjanja $\mathrm{v}$ podtlaku. Tako pridobljen lesni plin s pepelom, ogljikovim prahom in ostalimi nečistočami ima pri izhodu iz reaktorja od $500-600^{\circ} \mathrm{C}$ (Interni vir 2).

\section{Priprava plina}

V celotnem procesu priprave lesnega plina se plin ohladi in očisti. Ob hlajenju nastali kondenzat se zbira v posameznih komponentah priprave plina in se s strani upravljalca naprave odstranjuje s črpalko. Priprava lesnega plina poteka po naslednjih komponentah naprave (Interni vir 2):

1. Filter vročega plina sestoji iz dveh enakih komponent, v katerih so vgrajene sintrane kovinske sveče, ki zadržijo vse trde delce na površini filtrov. Preko sistemsko vodenega periodičnega komprimiranega čiščenja od zgoraj se pepel zbira v zbiralnih posodah.

2. Hladilnik vročega plina je prenosnik toplote po drobnih ceveh nizkega preseka, ki za hlajenje sesa prostorski zrak. Ker ne želimo kondenziranja vode in katranov, se plin na tem mestu hladi do največ $110^{\circ} \mathrm{C}$.

3. Čiščenje kondenzata in hlajenje plina sta dve ločeni enoti, ki sta hlajeni z vodo. Čistilec kondenzata ima vgrajene štiri cevi z dvojno steno za hlajenje. Na notranji strani hladilnih cevi nabran kondenzat $\mathrm{v}$ intervalih postrgajo pnevmatski cilindri in zbirajo kondenzat $\mathrm{v}$ spodnjem delu komponente. Hladilnik plina je zgrajen enako kot hladilnik vročega plina, le da na tem mestu plin hladimo $\mathrm{z}$ vodo. Temperatura lesnega plina na izhodu iz hladilnika pade na $70^{\circ} \mathrm{C}$.

4. Lovilec kondenzata. $\mathrm{Na}$ tem delu priprave plina nenadno razširjenje premera voda povzroči padec statičnega pritiska, kar privede $\mathrm{k}$ nadaljnji ohladitvi plina in zaradi rosenja h kondenziranju vodne pare.

Za tem pripravljen lesni plin prečka še varovalni filter, ki deluje kot zaščita motorju pri nepredvidenih motnjah in prav tako povzroča izločanje kondenzata, stransko puhalo in mešalno cono, kjer se lesni plin meša $\mathrm{z}$ zrakom in končno doseže zgorevalno komoro motorja.

\section{Motor z generatorjem}

V kogeneraciji se očiščen in ohlajen lesni plin pretvori v toplotno in električno energijo. Motor je predelan dizelski motor podjetja MWS Löschenkohl iz Nemčije. Kot generator je montiran asinhronski generator podjetja SEVA (Interni vir 2).

S šestimi cilindri, vsak z 1,64 1 volumna zmogljivostjo motorja, proizvaja kogeneracija okrog $49 \mathrm{~kW}$ električne energije. Zaradi različnih vzdrževalnih del lahko pri polni 
obremenitvi pričakujemo okrog 6500 ur letno (Interni vir 2). Mešanje zraka z lesnim plinom je regulirano z lambda sondo.

\section{Bakla}

Bakla služi kot varovalni del naprave in jo potrebujemo pri zagonu. Lesni plin vsebuje zelo strupen ogljikov monoksid. Le ta zgori na bakli s pomožnim zgorevanjem priklopljen na propan. Na ta način neizkoriščeni lesni plin vedno brez ostankov izgori. $\mathrm{Na}$ ta način preprečujemo uhajanje v okolje ali zaostajanje plina v sistemu. Presežek lesnega plina nastane (Interni vir 2):

- pri zagonu naprave, ker je reaktor še prehladen, da bi sintetiziral lesni plin primeren za zagon motorja,

- pri okvari motorja ter

- pri izklopu celotnega sistema.

\section{Kondenzat}

Pri hkratnemu črpanju kondenzata bi lahko prišlo do kratkega stika plina. Zato črpanje izvajamo po komponentah v periodičnih razmakih. Kondenzat se filtrira preko aktivnega oglja in na ta način omogoča odvajanje v kanalizacijo.

\section{Računalniško upravljanje}

Celoten sistem je upravljan in nadzorovan preko računalniškega sistema. Nadzor je mogoč s temperaturnimi senzorji, merilci pritiska in oddajniki, ki omogočajo takojšen izklop sistema v primeru motenj.

\section{Uporaba nastale toplote}

Lesni uplinjevalec na treh mestih oddaja termično energijo v obliki toplote:

- hladilnik vročega plina (medij: zrak)

- vodno hlajenje plina (medij: voda-glikol)

- SPTE - vodno hlajenje motorja (medij: voda-glikol)

Segret zrak hlajenja hladilnika vročega plina se uporabi neposredno za sušenje lesnih sekancev v zalogovniku sekancev.

Vodno hlajenje plina in motorja je vezano na hladilnik in izmenjevalec, ki preko zmogljivega ventilatorja vpihava zrak na temperaturi med 60 in $70^{\circ} \mathrm{C}$ na sušilnico lesnih sekancev, ki se delno uporabijo za lastno porabo elektrarne in presežki za nadaljnjo prodajo. 
$36^{\mathrm{TH}}$ International Conference on ORganizational Science Development: Responsible Organization (MARCh $22^{\mathrm{ND}}-24^{\mathrm{TH}}$, Portorož Slovenia)

T. Kuhar Osterman, D. Vuk \& M. Senegačnik : Biomass as an Alterantive Source of Energy Recovery

\section{Uporaba električne energije}

Generator oddaja električno energijo neposredno v omrežje. Zmogljivost generatorja je odvisna od kakovosti lesnega plina, le ta pa od kakovosti lesnih sekancev in drugih pogojev okolja. Iz navedenih razlogov proizvedena električna moč SPTE niha med 35 in $55 \mathrm{~kW}$ el.

Slika 4 predstavlja enostavno tehnološko shemo sistema.

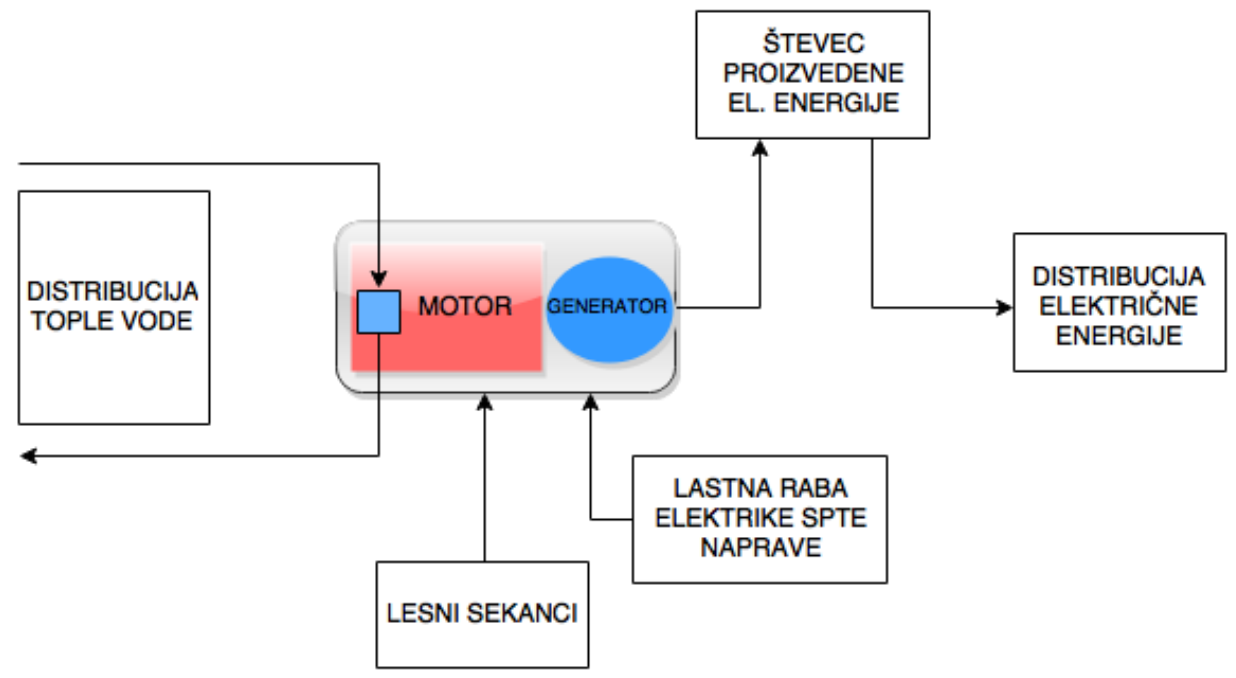

Slika 12: Tehnološka shema delovanja proizvodne naprave SPTE z uplinjanjem lesne biomase (BIOFIT d.o.o., 2016 b).

\subsubsection{Nazivne moči proizvodne naprave SPTE $\mathrm{z}$ uplinjanjem lesne biomase}

V spodnji tabeli št. 2 so navedene nazivne moči proizvodne naprave SPTE $z$ uplinjanjem lesne biomase.

\begin{tabular}{|l|c|c|}
\hline Nazivana električna moč & $49 \mathrm{~kW}$ & $29,7 \%$ \\
\hline Moč koristne toplote & $80 \mathrm{~kW}$ & $48,5 \%$ \\
\hline Skupna moč & $129 \mathrm{~kW}$ & \\
\hline Skupni izkoristek & & $\mathbf{7 8 , 2} \%$ \\
\hline
\end{tabular}

Tabela 16: Nazivna moč proizvodne naprave SPTE z uplinjanjem lesne biomase (TerraTec, 2015). 
Podjetje je izvedlo naložbo v času veljave starega Energetskega zakona (EZ-UPB2, 2007). Po izvedbi celotne investicije in opravljenem zagonu proizvodne naprave SPTE so v podjetju BIOFIT d.o.o. pripravili vso potrebno dokumentacijo in speljali postopke pridobivanja deklaracije proizvodne naprave SPTE in podpore kot finančne pomoči za tekoče poslovanje na Agenciji za energijo ter Centru za podpore. Proizvodnja toplote in električne energije poteka sočasno ob visokih izkoristkih, kar uvršča proizvodno napravo med proizvodne naprave $\mathrm{s}$ soproizvodnjo toplote in električne energije $\mathrm{z}$ visokim izkoristkom.

\section{Reorganizacija proizvodnega procesa pridobivanja lesne biomase v podjetju}

Z uvedbo proizvodne naprave SPTE uvedemo spremembe proizvodnega procesa pridobivanja lesne biomase neposredno iz gozdov. Sortiranje predstavlja nov ukrep v celotnem proizvodnem procesu od gozda do končnega kupca. Uvedemo sejanje in sušenje lesne biomase $\mathrm{v}$ sušilnici, katere vir toplote je proizvedena toplota proizvodne naprave SPTE z uplinjanjem lesne biomase.

$\mathrm{V}$ prenovljenem proizvodnem procesu opustimo nabavo in mletje hlodovine. Visokokakovostno lesno biomaso pridobimo neposredno iz gozda $\mathrm{z}$ dodatnimi ukrepi sortiranja, sejanja in sušenja lesne biomase.

\section{5}

\section{Zaključek}

Na podlagi analize stanja na energetskem trgu kot tudi strategij slovenske in evropske politike smo ugotovili visoko pomembnost uporabe lesne biomase kot obnovljivega vira energije za energetske namene. Izvedli smo analizo obstoječega pridobivanja lesne biomase $\mathrm{v}$ podjetju BIOFIT d.o.o. V podjetju pridobivajo sveže, zelene sekance neposredno iz gozda ter lesne sekance iz hlodovine. $Z$ obstoječim proizvodnim procesom ne zagotavljajo dovolj visoke kakovosti lesnih sekancev, niti ne zmogljivosti, predvsem zaradi previsoke nabavne cene hlodovine. Les sušijo na zraku vsaj osem mesecev, s čimer ustvarjajo visoke zaloge.

Prispevek je nastal na osnovi magistrske naloge $\mathrm{z}$ naslovom Uvajanje tehnologij pridobivanja električne energije in toplote $\mathrm{z}$ uplinjanjem lesnih sekancev avtorice Tadeje Kuhar Osterman, zato v raziskavi podamo model rešitve $\mathrm{z}$ uvedbo nove tehnologije proizvodne naprave soproizvodnje električne energije in toplote, ki vključuje sušilnico za lesno biomaso. Kemično energijo lesne biomase pretvorimo $\mathrm{v}$ vodljivo, električno energijo. Pridobljeno toploto proizvodne naprave uporabimo za sušenje lesne biomase. $Z$ ukrepi sortiranja, sejanja in sušenja prenovimo proizvodni proces pridobivanja lesne biomase in pridobimo visokokakovostne lesne sekance za nadaljnjo prodajo. 
$36^{\mathrm{TH}}$ InTERnAtional CONFERENCE ON ORganizational SCIENCE DeVElopment: ReSPONSIBLE ORGaNizATION (MARCH $22^{\mathrm{ND}}-24^{\mathrm{TH}}$, PORTOROŽ Slovenia)

T. Kuhar Osterman, D. Vuk \& M. Senegačnik : Biomass as an Alterantive Source of Energy Recovery

\section{Literatura}

AN URE (2016, April 2). Akcijski načrt za energetsko učinkovitost za obdobje 2014-2020. Dosegljivo na http://www.energetikaportal.si/fileadmin/dokumenti/publikacije/an_ove/an_ove_2010-2020_final.pdf

AN OVE (2016, April 20). Akcijski načrt za obnovljive vire energije 2010-2020 Slovenija. Dosegljivo na http://www.energetikaportal.si/fileadmin/dokumenti/publikacije/an_ove/an_ove_2010-2020_final.pdf

AN sNES (2016, Mai 22). Akcijski načrt za skoraj ničenergijske stavbe za obdobje do leta 2020. Dosegljivo na http://www.energetikaportal.si/fileadmin/dokumenti/publikacije/an_ure/an_ure_2020_sprejet_maj_2015.pdf

BIOFIT d.o.o. (2016 a). Intervju z lastnikom podjetja BIOFIT d.o.o., g. Marijanom Kuharjem (interno gradivo). Visoko: BIOFIT d.o.o.

BIOFIT d.o.o. (2016 b). Tehnološka shema delovanja proizvodne naprave SPTE z uplinjanjem lesne biomase (interno gradivo). Visoko: BIOFIT d.o.o.

C.A.R.M.E.N. (2016, Mai 15). Holzvergasung-Wärme und Strom aus fester Biomasse. Dosegljivo na http://holzgas-info.de

Coulon, P.J. (2015). Mnenje Evropskega ekonomsko-socialnega odbora o energiji - dejavniku razvoja in poglobljenega pristopnega procesa Zahodnega Balkana. Dosegljivo na www.eesc.europa.eu/resources/.../eesc-2015-02407-00-01-ac-tra-sl.docx

Energetski zakon (EZ-1). Uradni list RS št. 17/2014.

Energetski zakon (EZ-UPB2). Uradni list RS št. 27/2007.

Komisija evropskih skupnosti (2016, Jun 12). Sporočilo Komisije Evropskemu parlamentu, Svetu, Evropskemu ekonomsko-socialnemu odboru in odboru regij: Zelena energija za promet evropska strategija za alternativna goriva. Dosegljivo na http://eur-lex.europa.eu/legalcontent/SL/ALL/?uri=CELEX\%3A52013PC0017

Krajnc, N., Piškur, M. (2009). Proizvodnja in raba lesa uporabnega v energetske namene v Sloveniji. EGES, 13(1), 73-75.

Krajnc, N., Čebulj, T. (2012). Katalog proizvajalcev polen in sekancev. Založba Silva Slovenica, Ljubljana.

Krajnc, N., Jemec, T., Piškur, M., Petek, J.. (2012). Slovenia. Ljubljana: Unspecified.

Piškur, M., Simončič, P., Dolenšek, M., Krajnc, N. (2016). Potenciali lesne biomase. Posvet: Visoka šola za upravljanje podeželja Grm: Energetika kot razvojna priložnost slovenskega podeželja.

Politika EU (2016, Mai 23). Energija. Dosegljivo na https://europa.eu/europeanunion/topics/energy_sl

Terra-Tec (2015). Nazivna moč proizvodne naprave SPTE z uplinjanjem lesne biomase. Nemčija: Terra-Tec GmbH.

UMAR (2016, April 12). Poročilo o razvoju 2016. Dosegljivo na http://www.umar.gov.si/fileadmin/user_upload/publikacije/pr/2016/PoR_2016_s.pdf

Zelena energija za promet (2016, Mai 4). Evropska strategija za alternativna goriva, SPOROČILO KOMISIJE EVROPSKEMU PARLAMENTU, SVETU, EVROPSKEMU EKONOMSKOSOCIALNEMU ODBORU IN ODBORU REGIJ. Dosegljivo na http://eur-lex.europa.eu/legalcontent/SL/TXT/?uri=CELEX\%3A52013PC0017

ZGS (2016, Mai 5 a). Poročilo Zavoda za gozdove Slovenije o gozdovih za leto 2014. Dosegljivo na http://www.zgs.si/ slo/zavod/publikacije/letna_porocila/index.html

ZGS (2016, Mai 2 b). Gozdnatost Slovenije: Zavod za gozdove Slovenije. Dosegljivo na http://www.zgs.si/slo/gozdovi_slovenije/o_gozdovih_slovenije/gozdnatost_in_pestrost/index. html 


\section{Zdrav življenjski slog v Študentskih domovih Univerze v Mariboru}

\section{DARJA KUKOVIČIČ}

Povzetek V študentskih domovih, ki so druga članica Univerze v Mariboru, ima 2.900 stanovalcev možnost aktivnega preživljanja prostega časa $\mathrm{z}$ udejstvovanjem $\mathrm{v}$ številnih obštudijskih dejavnostih. Velik poudarek se namenja razvoju športne kulture, zato so $v$ študentskem kampusu na voljo zunanja športna igrišča, telovadnica, fitnes na prostem, notranji fitnesi $\mathrm{v}$ študentskih domovih, prostori za igranje namiznega tenisa in prostori $\mathrm{z}$ boks vrečami.

V sklopu projekta " Zdrav življenjski slog v Študentskih domovih Maribor " je načrtovana organizirana vadba različnih športnih aktivnosti ter izvedba predavanj s področja zdrave prehrane, gibanja, duševnega zdravja in zasvojenosti. Načrtovane dejavnosti so izrednega pomena za pridobivanje znanja mladostnikov, za oblikovanje njihovih stališč in vedenj za zdrav življenjski slog.

KLJUČNE BESEDE: študentski domovi $\bullet$ stanovalci $\bullet$ športna rekreacija • zdravje

\footnotetext{
NASLOV AVTORICE: mag. Darja Kukovičič, pomočnica direktorice, Univerza v Mariboru, Študentski domovi, Gosposvetska cesta 83, 2000 Maribor, Slovenija, e-pošta: darja.kukovicic@um.si 
36 ${ }^{\text {TH }}$ International CONFEREnCE ON ORganizational Science Development: Responsible Organization (MARCH $22^{\mathrm{ND}}-24^{\mathrm{TH}}$, PORTOROŽ SLOVENIA)

O. Arsenijević, M. Ferjan, I. Podbregar, P. Šprajc, D. Trivan \& Y.

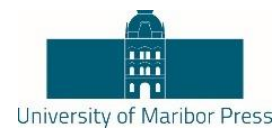

Ziegler

\title{
Healthy Lifestyle in Student Dormitories University of Maribor
}

\section{DARJA KUKOVIČIČ}

\begin{abstract}
Student dormitories, which are the second member of the University of Maribor, they have 2.900 residents all the possibilities for a quality spend free time through involvement in many extracurricular activities. Special emphasis is given to the development of sports culture that is why the student campuses offer an outdoor sports courts, gym, outdoor fitness, indoor fitness, rooms for table tennis and rooms with boxing bags.

Within the project "Healthy Lifestyle in Student Dormitories Maribor" is planned to be organized practice of various sports activities and the implementation of lectures in the field of healthy nutrition, exercise, mental health and addiction. Planned activities are of utmost importance for young people to gain knowledge and to form their attitudes and behaviours for a healthy lifestyle.
\end{abstract}

KEYWORDS: student dormitories $\bullet$ residents $\bullet$ sports recreation $\bullet$ health

CORRESPONDENCE ADDRESS: Darja Kukovičič, M.S., Assistant Director, University of Maribor, Student Dormitories Maribor, Gosposvetska cesta 83, 2000 Maribor, Slovenia, e-mail: darja.kukovicic@um.si 
D. Kukovičič: Zdrav življenjski slog v Študentskih domovih Univerze v Mariboru

Dejavnost študentskih domov je javna služba. Opravljajo jo lahko univerze, drugi zavodi, gospodarske družbe, samostojni podjetnik posameznik in druge pravne osebe. Pri opravljanju dejavnosti morajo zagotoviti zastopanje študentskih interesov pri upravljanju.

Študentski dom se lahko ustanovi v okviru univerze kot njena članica. Študenti, člani študentskega sveta stanovalcev, zastopajo študentske interese pri upravljanju v skladu z zakonom, aktom o ustanovitvi in statutom (UL RS, št. 75 /2016).

\subsection{Predstavitev Študentskih domov Univerze v Mariboru}

Študentski domovi Univerze v Mariboru delujejo od leta 1964 z namenom zagotavljanja kakovostnih razmer za bivanje, študij in preživljanje prostega časa čim večjemu številu študentov Univerze v Mariboru.

Vodstvo si prizadeva, da so Študentski domovi sinonim za kakovost, prijetno in varno bivanje, zanesljivost, prilagodljivost in možnost dodatnih obštudijskih dejavnosti ter kakovostnega preživljanja prostega časa.

$\mathrm{Z}$ zagotavljanjem konkurenčnih cen omogočamo bivanjem vsem zainteresiranim, ki izpolnjujejo pogoje statusa študenta, oz. stanovalca študentskih domov.

V študijskem letu 2016 / 2017 je omogočeno bivanje 2867 študentom Univerze v Mariboru v 16 nastanitvenih objektih na petih lokacijah v neposredni bližini centra mesta.

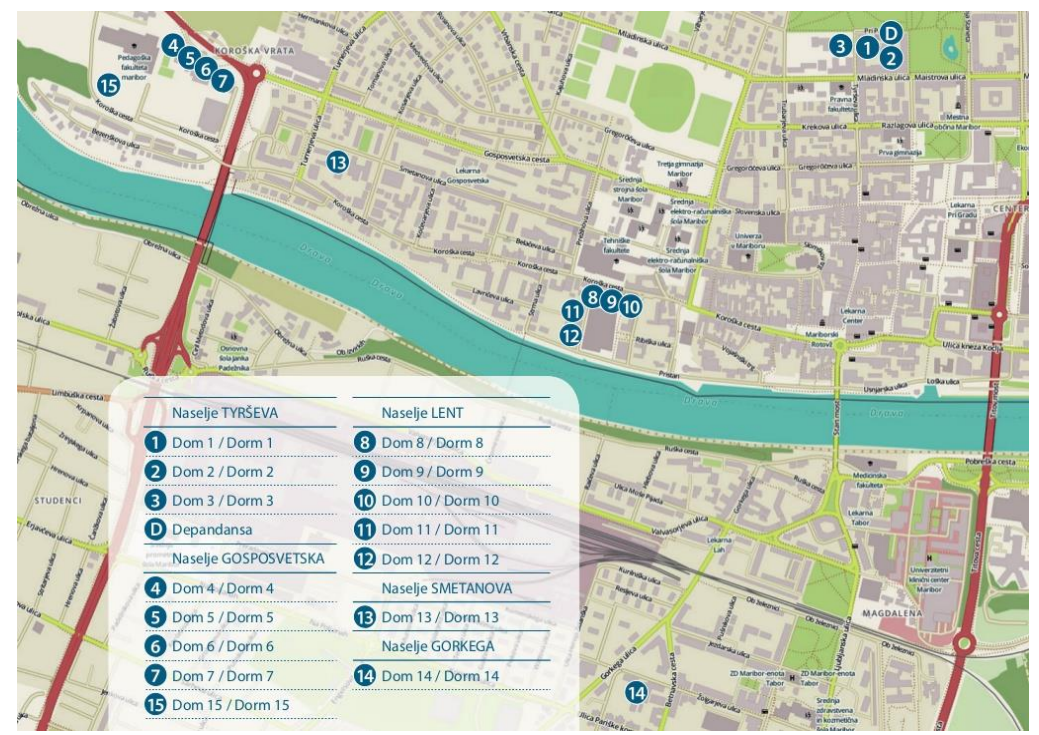

Slika 1: Lokacije študentskih domov Univerze v Mariboru 
$36^{\text {Th }}$ International Conference on Organizational Science Development: ResPonsible Organization (MARCH $22^{\mathrm{ND}}-24^{\mathrm{TH}}$, Portorož SLOVENia)

D. Kukovičič: Healthy Lifestyle in Student Dormitories University of Maribor

Pogoji, ki jih morajo izpolnjevati študenti za subvencionirano bivanje vključujejo tudi zahtevo, da imajo stalno prebivališče oddaljeno najmanj $25 \mathrm{~km}$ od kraja študija.

V naslednji tabeli so v odstotkih prikazani deleži vseljenih študentov po posameznih regijah.

\begin{tabular}{|c|c|c|c|c|}
\hline $\begin{array}{ll}\text { Regija } & \begin{array}{l}\text { Delež v \% } \\
\text { po letih }\end{array} \\
\end{array}$ & 2015 & 2014 & 2013 & 2012 \\
\hline JV Slovenija & 2 & 2 & 3 & 3 \\
\hline Goriška & 1 & 1 & 1 & 2 \\
\hline Gorenjska & 2 & 2 & 1 & 1 \\
\hline Notranjsko-kraška & 1 & 1 & 1 & 1 \\
\hline Obalno-kraška & 1 & 1 & 1 & 1 \\
\hline Osrednje-slovenska & 2 & 2 & 2 & 1 \\
\hline Podravska & 11 & 11 & 11 & 12 \\
\hline Pomurska & 22 & 22 & 21 & 23 \\
\hline Spodnje-posavska & 5 & 5 & 5 & 6 \\
\hline Savinjska & 31 & 32 & 29 & 30 \\
\hline Koroška & 12 & 13 & 16 & 17 \\
\hline Zasavska & 2 & 2 & 2 & 3 \\
\hline Tujci (druge države) & 8 & 7 & 7 & 7 \\
\hline
\end{tabular}

Tabela 17: Vseljeni študenti po regijah.

\section{Obštudijske dejavnosti Študentskih domov Univerze v Mariboru}

\subsection{Pomen prostega časa}

Prosti čas ima predvsem za mlade pomembno dimenzijo. Prosti čas ne pomeni samo večje svobode izbire dejavnosti in odnosov, ampak pomeni tudi čas zmanjšanega nadzora nad posameznikom. 
D. Kukovičič: Zdrav življenjski slog v Študentskih domovih Univerze v Mariboru

Že sodobna industrija prostega časa za mlade s produkcijo modnih stilov, trendov, elektronske in zabavne industrije hote ali nehote zmanjšuje prostor avtonomije in vzdržuje nadzor nad prostim časom mladih.

Nekreativni prosti čas, ki ga mladi preživijo na pasivni način, je zato čas, ki vzbuja le malo zadovoljstva in je zelo tvegan. Prosti čas je nekaj najbolj zaželenega, vendar ga ljudje preživljajo $\mathrm{z}$ dejavnostmi, ki nudijo najmanj zadovoljstva in najmanj prispevajo $\mathrm{k}$ samopodobi posameznikov in imajo majhen socialen pomen (gledanje televizije, branje lahkega čtiva, obsedenost z igrami, opijanje, drogiranje).

Med tem, ko je aktivna in kreativna izraba prostega časa $s$ športom naporna, terja določeno disciplino, vadbo, znanje in sposobnosti. Sodobna potrošniško naravnana kultura skozi medije in javno mnenje ne privzgaja teh zmožnosti in dejavnosti, prej nasprotno. Če je posameznik preutrujen, anksiozen, mu manjka discipline za preseganje začetnega odpora do potrebnih naporov in vadbe, se bo odločil za takšno preživljanje prostega časa, ki je manj naporno, čeprav nudi le malo zadovoljstva, samospoštovanja, užitka in ima majhen socialni pomen.

Problem pasivnega prostega časa nastane tedaj, ko takšno početje postane načelna ali edina strategija za preživljanje prostega časa. Ko se vzorci pasivnega prostega časa spremenijo v navado, temeljito vplivajo na kvaliteto življenja v celoti (Ule, Rener, Čeplak, Tivadar, 2000, str. 62 - 68).

\subsection{Prispevek k trajnostnemu razvoju zavoda}

Študentski domovi delujejo skladno s cilji Nacionalnega programa visokega šolstva za dvig kakovosti visokega šolstva in znanstvenega raziskovanja na področju izboljšav prostorskih razmer in opremljenosti visokošolskih institucij (Kolar, 2011, str. 27).

Študentski domovi kot javni zavod sledijo tudi smernicam trajnostnega razvoja Univerze v Mariboru. Vsi zaposleni se zavedamo odgovornosti in pomena zagotavljanja optimalnih pogojev za osebnostno in intelektualno rast stanovalcev študentskih domov.

V zadnjih letih smo vse domove opremili s koši za ločevanje odpadkov, stanovalce osveščamo in spodbujamo $\mathrm{k}$ doslednemu ločevanju odpadkov. Na podlagi natečaja za oblikovanje obvestil smo natisnili nalepke za opozarjanje $\mathrm{k}$ varčevanju pri porabi električne in toplotne energije ter pri porabi vode.

Vsak študentski dom je opremljen s pokrito kolesarnico, skladno z načeli trajnostne mobilnosti za pogostejšo rabo koles med stanovalci študentskih domov.

\subsection{Ponudba obštudijskih dejavnosti}

Študentom $\mathrm{z}$ nastanitvijo $\mathrm{v}$ domovih ne zagotavljamo zgolj ležišča in internetne povezave, temveč si prizadevamo nuditi pestre prostočasne aktivnosti s kvalitetnimi vsebinami. 
$36^{\mathrm{TH}}$ InTERnAtional CONFERENCE ON ORganizational SCIENCE DeVElopment: ResPonsible Organization (MARCH $22^{\mathrm{ND}}-24^{\mathrm{TH}}$, Portorož SLOVENia)

D. Kukovičič: Healthy Lifestyle in Student Dormitories University of Maribor

V sklopu Letnega programa dela zavoda delno zagotavljamo izvedbo obštudijskih dejavnosti ( $\mathrm{s}$ študijem povezane interesne dejavnosti študentov ) s sredstvi, ki jih določimo $v$ finančnem načrtu zavoda $v$ skladu $\mathrm{z} 2$. alinejo 1 . odstavka 72 a čl.- ZVis.

V Letni program dela Študentskih domov vključimo nabor interesnih dejavnosti Študentskega sveta stanovalcev študentskih domov, ki jih delno finančno podpremo v želji za njihovo uspešno realizacijo.

V današnjem času gospodarske krize so mnogi mladi ljudje prisiljeni poleg izobraževanja tudi delati, tako da imajo dejansko manj prostega časa, zato je še toliko bolj pomembno, da ga kvalitetno preživljajo. Stanovalcem so na voljo študijske sobe, likovne in glasbene sobe, ter prostori za zabavo in druženje.

Primer študijske sobe s sodobno multimedijsko opremo.

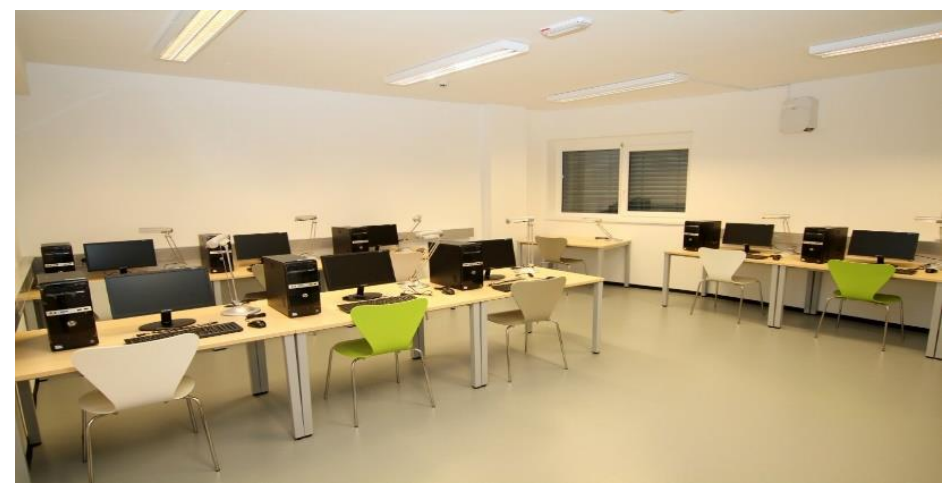

Slika 2: Śtudijska soba

Glasbene sobe se koristijo za vadbo različnih instrumentov in glasbenih zvrsti.

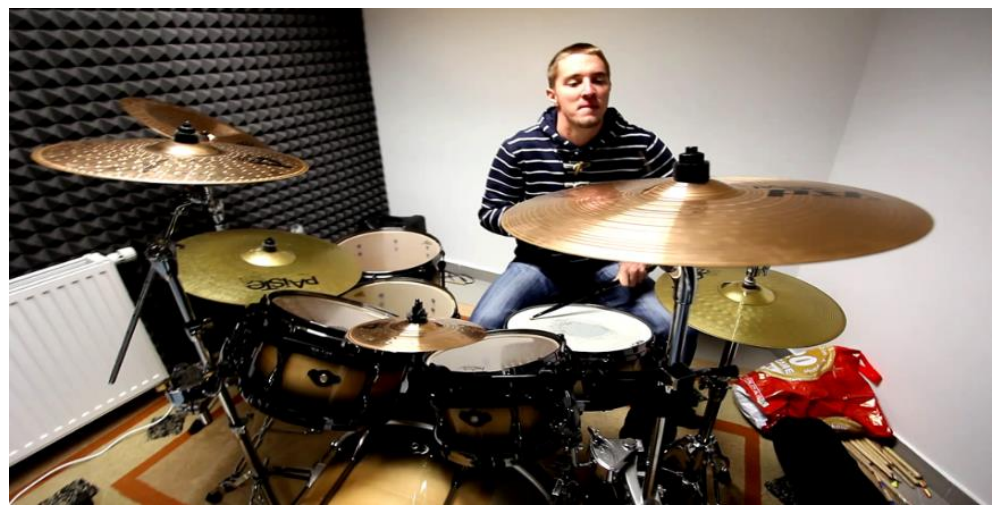

Slika 3: Glasbena soba 

ORGANIZACIJA (22. - 24. MAREC 2017, PORTOROŽ, SLOVENIJA)

D. Kukovičič: Zdrav življenjski slog v Študentskih domovih Univerze v Mariboru

Likovne sobe so namenjene mladim ustvarjalcem in študentom likovne pedagogike.

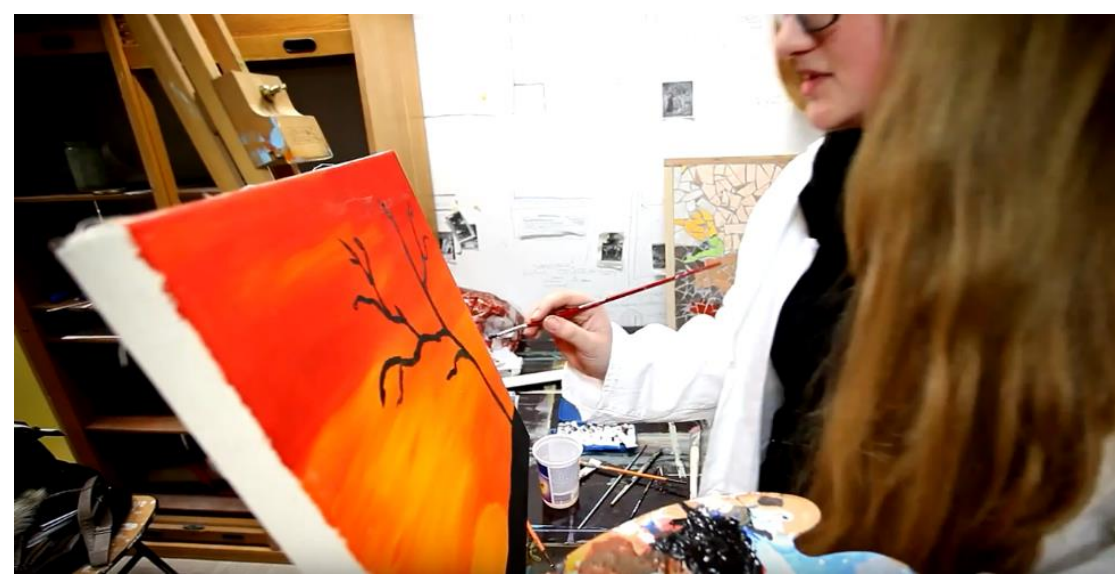

Slika 4: Likovna soba

V vsakem naselju so prostori, ki si jih stanovalci lahko rezervirajo za zabavo, druženje in različne dejavnosti.

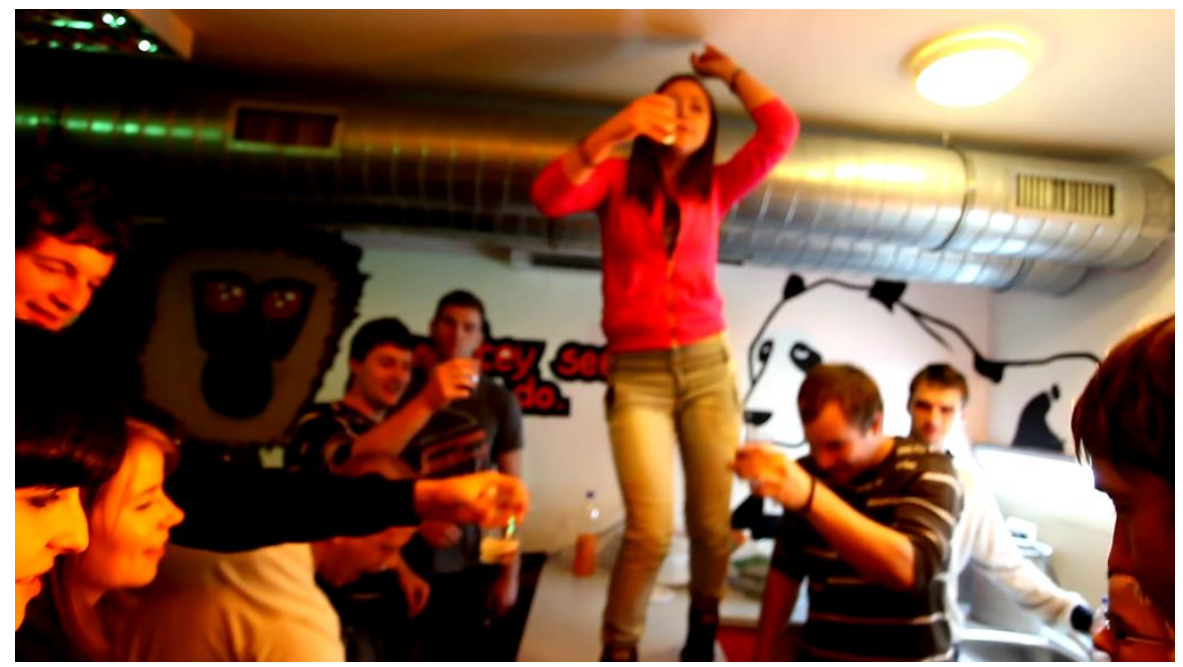

Slika 5: Prostori za zabavo in druženje

Športni način življenja je danes $\mathrm{v}$ » udobju » sodobne civilizacije eden od smiselnih načinov bivanja, ki se pri posamezniku odraža v: 
$36^{\mathrm{TH}}$ International Conference on ORganizational Science Development: ResPonsible Organization (MARCH $22^{\mathrm{ND}}-24^{\mathrm{TH}}$, Portorož SLOVENia)

D. Kukovičič: Healthy Lifestyle in Student Dormitories University of Maribor

- redni vsakodnevni športni aktivnosti,

- skrbi za zdravje in njegovo utrjevanje,

- skrbi za lepo, čisto, sposobno telo in zdrav duh,

- zmernosti v hrani in pijači,

- negativnem odnosu do kajenja in drog ter drugih škodljivih odvisnosti,

- zavedanju, da je potrebna ustrezna športna vadba ali fizično delo ter intelektualni napor vse življenje, saj le to omogoča posamezniku razvoj do pozne starosti,

- stalnem stiku z naravo, da jo bomo čimbolj neokrnjeno zapustili bodočim rodovom,

- skrbi za pozitivne duhovne in moralne vrednote bivanja.

Športni način življenja je sistem vrednot, ki jih postopno že od rane mladosti vključujemo v svoj osebni življenjski slog in sčasoma postanejo del našega notranjega sveta. Takšen življenjski vzorec postane individualna potreba vsakega posameznika, ki izhaja iz njega samega, vzpostavi se notranja disciplina vsakega posameznika. Športni način življenja nam daje univerzalno energijo in s tem odpira nove razsežnosti bivanja (Bizjan, 2004).

Vodstvo Študentskih domov posebno pozornost namenja športni infrastrukturi v študentskem kampusu, saj velja prepričanje o pozitivnem vplivu redne vadbe na zdravje in dobro počutje, ter s tem povezane boljše učne sposobnosti.

Z organizirano vadbo športnih aktivnosti želimo študentom ob strokovni pomoči športnih pedagogov približati poznavanje in osnovno obvladovanje tehnike nekaterih športnih disciplin, jim dati možnost izpopolnjevanja znanj $\mathrm{v}$ športu in prilagoditi nivo vadbe njihovim motoričnim in funkcionalnim sposobnostim.

S pestro ponudbo možnih aktivnosti si prizadevamo, da bi mladino odvračali od razvad uživanja alkohola in drugih substanc, kajenja cigaret in zasvojenosti z video igricami, zato dajemo prednost aktivnostim, ki so izrednega pomena za pridobivanje znanja mladostnikov, za oblikovanje njihovih stališč in vedenj za zdrav življenjski slog.

Na podlagi razpoložljivih rezultatov izvedene ankete Evroštudent izhaja, da se opaža porast števila študentov, ki se soočajo s kroničnimi boleznimi, težavami z duševnim zdravjem, omejenimi senzornimi sposobnostmi in specifičnimi učnimi težavami.

Z ozirom na številne pozitivne učinke športa in zanimanje mladih za šport in rekreacijo, se tudi v prihodnje namenja veliko pozornosti za aktiviranje mladih in nudenje pogojev za športno udejstvovanje $\mathrm{v}$ študentskem kampusu.

V letu 2017 pričenjamo z uvedbo projekta » Zdrav življenjski slog v Študentskih domovih Univerze v Mariboru », $\mathrm{s}$ katerim bomo omogočili dodatne ure vodene športne vadbe in organizirali tematska predavanja o pomenu telesne vadbe in zdravega načina prehranjevanja. 
D. Kukovičič: Zdrav življenjski slog v Študentskih domovih Univerze v Mariboru

Sredstva za financiranje projekta bomo delno zagotovili iz naslova tržne dejavnosti zavoda, aktivno pa bomo iskali možnosti prijave na ustrezne razpise.

V sodelovanju s habilitiranimi učitelji športne vzgoje Univerze v Mariboru bomo organizirali vodeno vadbo na obstoječi športni infrastrukturi Študentskih domov.

\subsection{Fitnes na prostem}

S pomočjo sofinanciranja Fundacije za šport smo v letu 2016 uspeli razširiti fitnes na prostem in postaviti naprave, ki so prilagojene uporabi gibalno oviranih oseb. Fitnes na prostem se razteza na 400 kvadratnih metrov površine v naselju Gosposvetska ter je opremljen z dvajsetimi napravami.

$Z$ vodeno vadbo se študentom omogoča pravilna izvedba vaj za obremenitev določenih delov telesa ter razvoj motoričnih sposobnosti.

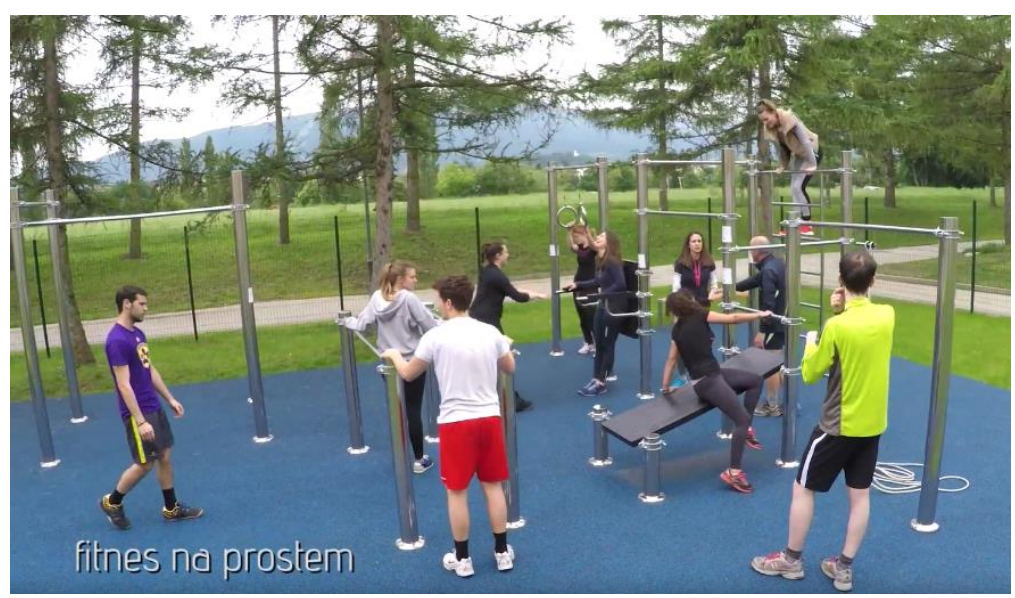

Slika 6: Vodena vadba v fitnesu na prostem

Fitnes na prostem koristijo tudi člani Društva študentov invalidov Slovenije, saj je vadba prilagojena tudi gibalno oviranim osebam. 
$36^{\text {TH }}$ International Conference on Organizational Science Development: RESPONSIBLE ORGANIZATION (MARCH $22^{\mathrm{ND}}-24^{\mathrm{TH}}$, PORTOROŽ SLOVENIA)

D. Kukovičič: Healthy Lifestyle in Student Dormitories University of Maribor

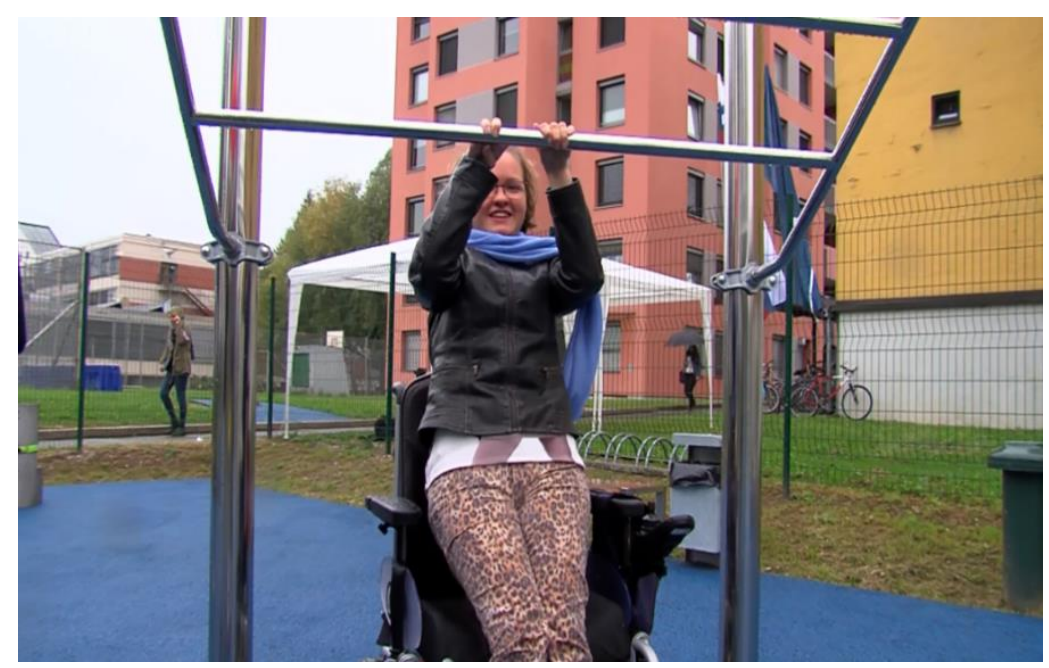

Slika 7: Prilagojene naprave za gibalno ovirane osebe

\subsection{Fitnes centri v naseljih}

V vsakem študentskem naselju so opremljeni fitnes centri v kletnih etažah študentskih domov.

Beležimo izjemen obisk v vseh obdobjih koledarskega leta.

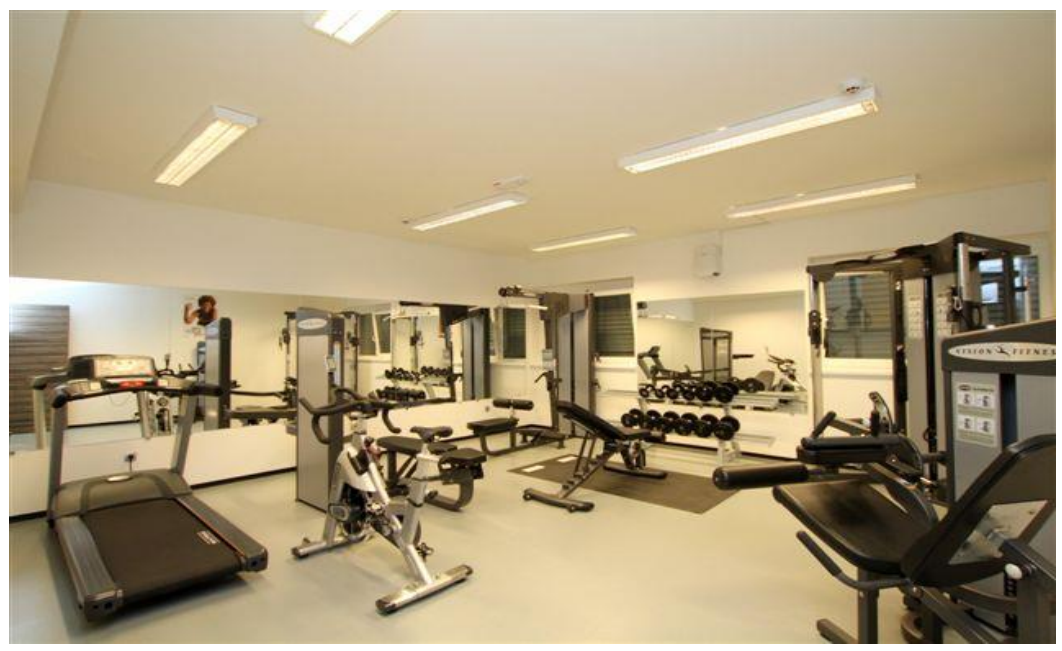

Slika 8: Primer notranjega fitnesa v študentskem domu 
D. Kukovičič: Zdrav življenjski slog v Študentskih domovih Univerze v Mariboru

\section{3 Športne aktivnosti $v$ telovadnici}

V prostorih telovadnice Študentskih domov poteka vadba aerobike, pilatesa in zumbe.

Namen vadbe je $\mathrm{v}$ težnji, da študenti prepoznajo gibanje kot protiutež vsakdanjemu študijskemu naporu.

Vadba aerobike in zumbe je priljubljena predvsem med žensko populacijo, njeni cilji pa so v koordinirani izvedbi plesnih struktur v različnih ritmih in tempu glasbe. Pilates izboljšuje fleksibilnost in moč telesa, ter spodbuja k pravilni drži telesa, ter krepi notranje in majhne mišične skupine. $Z$ vadbo joge se študenti seznanijo $\mathrm{z}$ različnimi tehnikami telesnega in duševnega sproščanja.

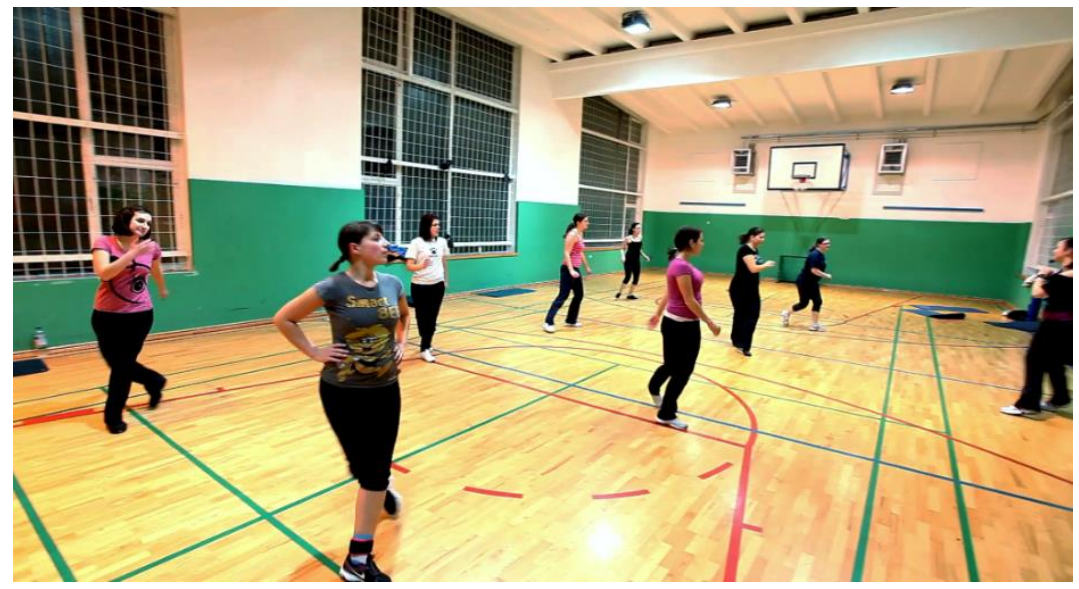

Slika 9: Vodena vadba v telovadnici $\check{S} D$

\subsection{Kolesarjenje}

Organizirani kolesarski izleti stanovalcev študentskih domov pomenijo predvsem zabaven družabni dogodek in način spoznavanja bližnje okolice univerzitetnega mesta Maribor.

Izvedba izletov z vodnikom pripomore $\mathrm{k}$ seznanjanju študentov s pravili vožnje v skupini in z varno vožnjo po cesti. V sodelovanju s kolesarko mrežo Maribor pa imajo lastniki koles v študentskem naselju tudi možnost učenja osnovnih veščin za servisiranje in popravilo koles. 


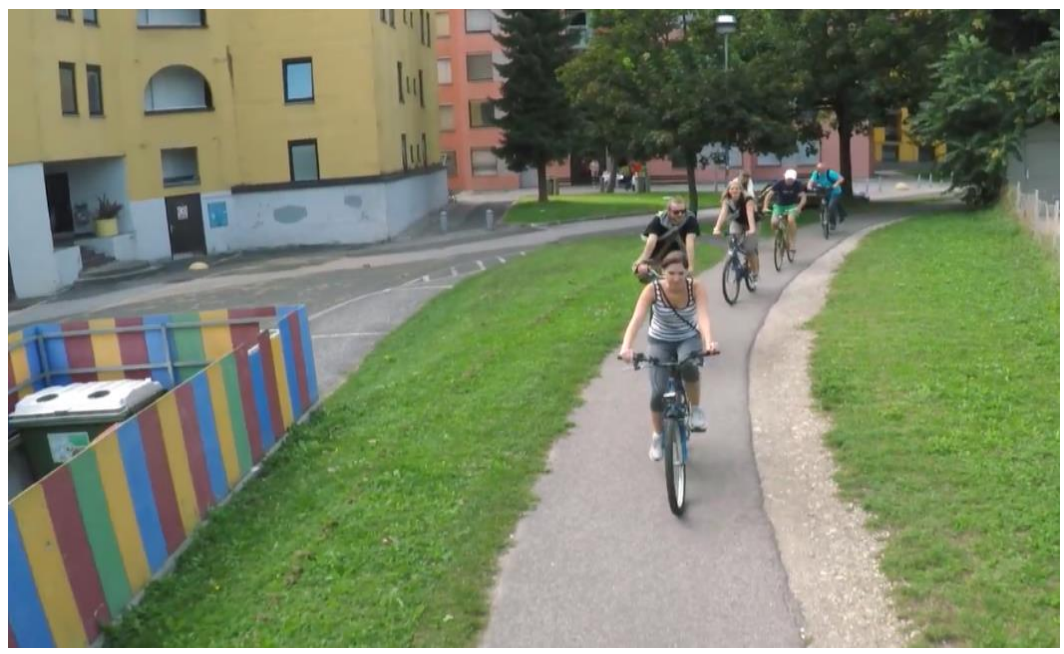

Slika 10: Kolesarski izlet stanovalcev $\check{S} D U M$

\subsection{Nordijska hoja in pohodništvo}

Nordijska hoja je ena najbolj dostopnih in varnih oblik rekreacije. Krepi srčno - žilni sistem, izboljšuje vzorec vsakdanje hoje ter je lahko sestavni del kondicijskega treninga. Lokacija študentskega kampusa ima dobro izhodišče za hojo na bližnje griče in mariborsko Pohorje.

4

Zaključek

Šport je lahko izredno močno vzgojno sredstvo. Nauči nas, da moramo za dosego dobrega rezultata vztrajno, dosledno in redno delati, nauči nas premagovati napor, težave, krize, uspehe in neuspehe ter stanja, ki so sestavni del življenja.

Ob športu si privzgajamo delovne navede, samospoštovanje, samozaupanje, red, disciplino, odgovornost, spoštovanje do sebe in drugih ter premagovanje individualnih slabosti.

Športna dejavnost v mladosti je dobra šola za kasnejše » zrelo » življenje (Bizjan, 2004).

Z organizacijo vodene vadbe želimo motivirati in pritegniti še večje število stanovalcev Študentskih domov in študentov s posebnimi potrebami za aktivno preživljanje prostega časa na prostem in $\mathrm{v}$ športnih objektih.

S pestro ponudbo športnih aktivnosti bomo poskrbeli za promocijo športa med študentsko populacijo, za zanimivo obliko druženja na prostem, za večjo telesno aktivnost in zmanjševanje zdravstvenih težav kot posledico prekomernega sedenja, ter s tem boljšo učno uspešnost. 
D. Kukovičič: Zdrav življenjski slog v Študentskih domovih Univerze v Mariboru

\section{Literatura}

Bizjan, 2004, str.8, Šport mladim : Priročnik za športno vzgojo, Ljubljana: Chatechismus, Bizjan, 2004, str.13, Šport mladim : Priročnik za športno vzgojo, Ljubljana: Chatechismus, Ule, Rener, Čeplak, Tivadar, 2000, str. 62 - 68, Socialna ranljivost mladih, MŠS̆, Urad RS za mladino,

Miheljak, 2002, Mladina 2000, Slovenska mladina na prehodu v tretje tisočletje, MŠŠ, Urad RS za mladino

Kolar, 2011, str. 27, Drzna Slovenija - Predloga Nacionalnega programa visokega šolstva 2011 2020 in Raziskovalne in inovacijske strategije Slovenije $2011-2020$,

\section{Drugo}

- Poročilo skupine habilitiranih učiteljev športne vzgoje UM, (2016)

- Zakon o visokem šolstvu (ZVis ), Ul RS, št. 75/2016, čl. 31, str. 8 
464 36 ${ }^{\text {Th }}$ International Conference on Organizational Science Development:

Responsible Organization (MARCH $22^{\mathrm{ND}}-24^{\mathrm{TH}}$, PORTOROŽ SLOVENIA) 
36. MEDNARODNA KONFERENCA O RAZVOJU ORGANIZACIJSKIH ZNANOSTI: OdgOVORNA ORGANIZACIJA (22. - 24. MAREC 2017, PORTOROŽ, SLOVENIJA)

O. Arsenijević, M. Ferjan, I. Podbregar, P. Šprajc, D. Trivan \& Y. Ziegler

\title{
Zunanje izvajanje popisa vodomerov
}

\author{
BRIGITA LEBAN \& TOMAŽ KERN
}

Povzetek Prispevek obravnava procesno in stroškovno analizo izvajanja popisa vodomerov na območju lokalnega trga občin Jesenice in Žirovnica. Namen raziskave je bil ugotoviti, ali je stroškovno učinkovitejše zunanje izvajanje popisa vodomerov (izdvajanje procesa) ali izvajanje $\mathrm{v}$ okviru dejavnosti oskrbe s pitno vodo. Ti popisi se izvajajo ročno, zato je bil namen ugotoviti tudi, ali je daljinsko odčitavanje stroškovno učinkovitejše od ročnega popisa. Cilj raziskave je bil priti do odgovora, ali je za izvajalca javne službe oskrbe s pitno vodo smotrno oddajanje ponavljajočega se procesa zunanjemu izvajalcu. Raziskavo smo izvajali na osnovi procesnih in stroškovnih podatkov, pridobljenih pri izvajalcu gospodarske javne službe oskrbe s pitno vodo. Na tej osnovi smo izvedli kalkulacije stroškov in izračunali kritično točko menjave vodomerov. Ugotovili smo, da je na lokalnem trgu smotrneje in družbeno odgovorneje izvajati proces v okviru podjetja, ki izvaja dejavnost oskrbe s pitno vodo.

KLJUČNE BESEDE: vodomer $・$ izdvajanje izvajanja procesa $\bullet$ porabljena voda $\bullet$ izvajalec $\bullet$ lokalni trg

NAslov AVtORJEV: Brigita Leban, JEKO-IN d. o. o., Cesta maršala Tita 51, 4270 Jesenice, Slovenija, e-pošta: brigita.leban@jeko-in.si, brigita.leban11@gmail.com, dr. Tomaž Kern, redni profesor, Univerza v Mariboru, Fakulteta za organizacijske vede, Kidričeva cesta 55a, 4000 Kranj, Slovenija, e-pošta: tomaz.kern@um.si

DOI https://doi.org/10.18690/978-961-286-020-2.39

ISBN 978-961-286-020-2

(C) 2017 Univerzitetna založba Univerze v Mariboru

Dostopno na: http://press.um.si 
36 ${ }^{\text {TH }}$ International CONFEREnCE ON ORganizational Science DeVelopment: Responsible ORganization (MARCH $22^{\mathrm{ND}}-24^{\mathrm{TH}}$, PORTOROŽ SLOVENIA)

O. Arsenijević, M. Ferjan, I. Podbregar, P. Šprajc, D. Trivan \& Y.

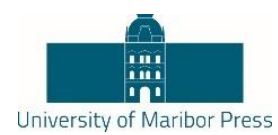

Ziegler

\title{
Outsourcing of Census Water Meters
}

\author{
BRIGITA LEBAN \& TOMAŽ KERN
}

\begin{abstract}
In our article, we conduct process and cost analysis of water meters census on the local market, for communities Jesenice and Žirovnica. The purpose of this research was to determine whether it is more costefficient to outsource the process of collecting data from water meters, or linked it with the supply of drinking water. Those readings are carried out manually. Our intent was also to determine whether the remote reading is more cost-efficient than manual reading.

Focus in the research was to get an answer, whether it is reasonable to leave this repetitive process of data collection to outsourcing. The research has been done on costs data and process itself, where data was obtained from the contractor for drinking water supply. We calculate costs and the critical point for changing water meters. We show, that, at the local market, is rational and socially responsible to implement the process within the company, which carries out the activity of drinking water supply and not outsourcing the process.
\end{abstract}

KEYWORDS: water meter $\bullet$ process outsourcing $\bullet$ used water $\bullet$ provider $\bullet$ local market

Correspondence AdDRESS: Brigita Leban, JEKO-IN d. o. o., Cesta maršala Tita 51, 4270 Jesenice, Slovenia, e-mail: brigita.leban@jeko-in.si, brigita.leban11@gmail.com, Tomaž Kern, Ph.D., Full Professor, University of Maribor, Faculty of Organizational Sciences, Kidričeva cesta 55a, 4000 Kranj, Slovenia, e-mail: tomaz.kern@um.si

DOI https://doi.org/10.18690/978-961-286-020-2.39 ISBN 978-961-286-020-2

(C) 2017 University of Maribor Press

Available at: http://press.um.si 


\section{$1 \quad$ Uvod}

Voda je naravno bogastvo in po podatkih Evropske agencije za okolje je Slovenija bogata $\mathrm{z}$ vodami, čeprav te niso enakomerno prostorsko razporejene, in kot navaja Rismal (2012, 181), je država v imenu državljanov pooblaščeni skrbnik vodnega bogastva.

V zadnjih tridesetih letih se je vodna zakonodaja v EU osredotočila na zaščito vodnih virov in uspešno prispevala $k$ varstvu voda. Obsežna zakonska regulativa, ki se nanaša na kakovost pitne vode, oskrbo s pitno vodo in načine ter oblike delovanja gospodarskih javnih služb oskrbe s pitno vodo, je predpisana tudi v Sloveniji.

Dobava pitne vode uporabnikom je organizirana v lokalnem okviru. Na slovenskem trgu so občine v letu 2013 izbrale 98 izvajalcev obvezne gospodarske javne službe (GJS) oskrbe s pitno vodo (Ministrstvo za okolje in prostor 2016). Na lokalni ravni je izbran en izvajalec, saj konkurenca v tej dejavnosti ni možna.

Na ravni lokalne skupnosti je oskrba s pitno vodo določena na osnovi občinskih odlokov in pravilnikov. $Z$ odlokom občine natančneje opredelijo delovanje oskrbe na svojem območju, zato se tudi odloki v različnih lokalnih skupnostih med seboj razlikujejo.

Oskrba s pitno vodo se lahko izvaja preko oseb javnega in zasebnega prava. Zakon o gospodarskih javnih službah (ZGJS) (Ur. 1. RS, št. 32/1993) v 6. členu predvideva pet načinov, preko katerih lahko republika ali lokalna skupnost zagotavljata GJS:

- režijski obrat,

- javni gospodarski zavod,

- javno podjetje,

- koncesija oseb zasebnega prava in

- vlaganje kapitala v dejavnost oseb zasebnega prava.

Organizacijska oblika, znotraj katere se izvaja komunalna dejavnost, mora na eni strani težiti k varovanju in izpolnjevanju splošnega družbenega interesa, na drugi strani pa mora biti dovolj učinkovita, da lahko izkazuje ustrezen poslovni uspeh (Klemenčič 1997, 127). Komunalna dejavnost se financira $\mathrm{z}$ zaračunavanjem storitev. Oskrba s pitno vodo je individualna poraba, zato se zaračuna posameznemu uporabniku, medtem ko se skupna komunalna poraba, kjer posamezniku ni mogoče določiti porabe, financira iz proračunskih sredstev, kot je npr. urejanje javnih površin.

Cene oskrbe s pitno vodo so bile v preteklosti regulirane na državni ravni, sedaj je ta pristojnost na lokalni ravni. Uredba za oblikovanje cen storitev obveznih občinskih gospodarskih javnih služb varstva okolja (Ur. 1. RS, št. 87/2012, 109/2012) določa metodologijo za oblikovanje cen, potrjevanje cen pa je v pristojnosti organa občine.

Državna zakonodaja predvideva družbe, preko katerih se izvaja GJS oskrbe s pitno vodo, in lokalna zakonodaja procese, ki jih mora $\mathrm{v}$ okviru storitev javne službe zagotavljati 
upravljavec javnega vodovoda. Pri tem način izvajanja posameznih procesov ni določen. Za upravljavca javnega vodovoda je med drugim pomembno, da izvaja dejavnost tako, da so učinkovito zadovoljene potrebe prebivalcev, brez ustvarjenega dobička. Pri tem ima upravljavec javnega vodovoda možnost izdvajanja izvajanja posameznega procesa in izvajanja preko zunanjega partnerja.

V nadaljevanju je izvedena raziskava, katere namen je bil ugotoviti, ali je stroškovno učinkovitejše zunanje izvajanje popisa vodomerov (izdvajanje procesa) ali izvajanje v okviru dejavnosti oskrbe s pitno vodo. Ti popisi se izvajajo ročno, zato je bil namen ugotoviti tudi, ali je daljinsko odčitavanje stroškovno učinkovitejše od ročnega popisa.

\section{Zunanje izvajanje (izdvajanje) procesa}

Do what you do best, and outsource the rest. (Peter Drucker)

Zunanje izvajanje oz. izdvajanje procesa (angl. outsourcing) označuje prenos nekaterih ponavljajočih se dejavnosti in odločitev podjetja $\mathrm{k}$ zunanjim izvajalcem, na osnovi pogodbenega odnosa. Pri tem ni nujno, da gre samo za prenos dejavnosti, lahko gre tudi za prenos pravic odločanja in poslovnih prvin. Poslovne prvine so surovine, zaposleni, objekti, oprema, tehnologija in druga sredstva, ki omogočajo izvajanje dejavnosti. Na osnovi pravic odločanja se lahko sprejemajo odločitve glede določenih elementov prenesenih dejavnosti (Greaver 1999, 3).

V literaturi zasledimo več avtorjev, ki razlagajo termin outsourcing. V zadnjih dvajsetih letih se uporablja več povezanih izrazov, ki se nanašajo na različne vidike razmerij med organizacijami. Tako glede na lokacijo izvajanja ločimo izvajanje na istem mestu ali v državi (angl. onshore), izvajanje v drugi državi, na isti celini (angl. nearshore) in izvajanje na zunanji lokaciji, običajno v Aziji, na Bližnjem vzhodu, v Afriki in Latinski Ameriki (angl. offshore) (Butterwoth, Kuchler, \& Westdijk 2013, 13). Leta 2005 se je pojavil angl. izraz craudsourcing, ki dobesedno pomeni oddajanje dejavnosti množici ljudi, ki sodelujejo $\mathrm{v}$ pobudah in besednih virih, ki se nanašajo na število praks javnega naročanja, katerih namen je iskanje, ocenjevanje in vključevanje dobaviteljev blaga in storitev (Estellés-arolas \& González-ladrón-de-guevara 2012,1). Istega leta se je pojavil tudi angl. izraz multisourcing, kjer se izvaja sodelovanje $\mathrm{z}$ več ponudniki $\mathrm{z}$ različnimi zmožnostmi izvajanja storitev in dostavnimi kompetencami (Varanasi 2006, 3), pri čemer glavni izvajalec prevzame odgovornost in vodenje ostalih izvajalcev. Na trgu se je kasneje pojavil še angl. izraz vested outsorcing, kjer stranki skleneta vzajemno koristen dogovor s poudarki na vrednotah in vzajemnem uspehu. Zlato pravilo je, da eno podjetje ne sme pridobiti premoženja zaradi večjih odhodkov drugega podjetja in obratno. (Vitasek 2010, 14-15).

V slovenskem jeziku uporabljamo več terminov, ki označujejo prevod angleškega izraza outsourcing. Uporabljajo se izrazi, kot so: izdvajanje procesa, zunanje izvajanje, izločanje dejavnosti, zunanja oskrba, najem storitev, uporaba zunanjih virov, zunanje oskrbovanje, zunanje izkoriščenje zmogljivosti, oddajanje del in še drugi. Samo 
poimenovanje nakazuje lahko tudi različne oblike sodelovanja. V prispevku bomo uporabljali izraz zunanje izvajanje.

Zunanje izvajanje dejavnosti je posebna sodelovalna strategija organizacije (Kavčič 2007, 303). Ne gre za nov koncept, niti v Sloveniji. Velik del slovenskega izvoza je temeljil na oblikah, podobnih zunanjemu izvajanju dejavnosti - proizvodnji sestavnih delov, materialov ipd. za tuje proizvajalce, na t. i. dodelavnih poslih (nem. Lohnarbeit) (Kavčič \& Bončina 2015, 101-102).

Zunanje izvajanje proizvodnje ali proizvodnih procesov je običajen način za proizvodnjo blaga in storitev (Palugod \& Palugod 2011, 13). Je oblika pogodbenega dela, pri kateri se kupec odloča, kakšne rezultate bi rad imel; proces, po katerem bo delo izpeljano, pa je povsem ponudnikova odločitev (Prijatelj Petelinkar 2008, 5).

Cilji teh usmeritev na strani organizacij so zniževanje stroškov izvajanja poslovnih procesov in dolgoročna finančna stabilnost, $\mathrm{s}$ tem povečevanje konkurenčne prednosti in trajnostna rast ter nenazadnje zadovoljstvo vseh vključenih deležnikov (Kavčič \& Bončina 2015, 102).

Podjetje Ernst \& Young je za določene proizvajalce in storitve izvedlo raziskavo in $\mathrm{v}$ poročilu Zunanje izvajanje dejavnosti v Evropi $(2013,11-18)$ podalo svoje ugotovitve. Glavni razlogi za zunanje izvajanje v letu 2013 so bili zmanjšanje stroškov, izboljšanje učinkovitosti in zmanjšanje števila zaposlenih in nato dobro uveljavljena usmeritev. Poleg tega ugotavljajo, da imajo $\mathrm{v}$ državah $\mathrm{z}$ daljšo tradicijo zunanjega izvajanja več pozitivnih izkušenj, kar poglablja zaupanje $\mathrm{v}$ zunanje izvajanje. Za prve generacije naročnikov zunanjih storitev je bil glavni razlog znižanje stroškov. Ta razlog je sedaj že dejstvo, zato se iščejo dodatni vzvodi za nadaljnji razvoj odnosov z zunanjim izvajalcem. Tako druge generacije zunanjih izvajalcev omogočajo več udobja in prevzemajo večje odgovornosti.

Novejša raziskava Deloitte Consulting LLP (2016, 3-10) izpostavlja tri ključne trende. Podjetja razširjajo svoj pristop do zunanjega izvajanja, ko so spoznala, da to pomeni več kot le preprosto rezanje stroškov. Pri tem anketiranci menijo, da so inovacije ključni del vrednosti, ki izhajajo iz pogodbenega razmerja zunanjega izvajanja. Drugi prepoznani trend je, da so organizacije spremenile pogoje, $s$ katerimi so začele pogodbeno zunanje izvajanje. Mnogi menijo, da dejavno spremljajo vključevanje inovacij v pogodbeno določilo zunanjega izvajanja. Večina anketiranih si še vedno prizadeva za opredelitev, sledenje in za motiviranje inovacij, pri tem pa so negotovi, kako to pravilno opredeliti v pogodbi. Zakonodajna in internetna varnostna tveganja so prioriteta anketirancev. Tretji prepoznani trend so organizacije, ki spreminjajo način upravljanja pogodbenih odnosov $\mathrm{z}$ zunanjimi izvajalci $\mathrm{z}$ namenom povečati koristi vseh pogodbenih strank. Ti trendi $\mathrm{v}$ smeri hitrih sprememb na trgu zunanjega izvajanja se bodo verjetno nadaljevali tudi po letu 2018 in jih bomo sprejemali kot običajne. 
Tradicionalno se na splošno vlada in gospodarske javne službe ne poslužujejo zunanjega izvajanja, vendar je raziskava pokazala, da se tudi v tej dejavnosti že izvajajo zunanje storitve (Ernst \& Young 2013, 12).

V okviru storitev javne službe mora upravljavec javnega vodovoda po določilih odloka na lokalnem trgu Jesenic in Žirovnice, kjer je zgrajen javni vodovod, zagotoviti določene naloge in opravila, med njimi tudi pridobivanje podatkov o odvzemu pitne vode iz javnega vodovoda zaradi obračuna storitev javne službe.

Pravilnik o merilnih instrumentih (Ur. 1. RS, št. 19/2016) opredeljuje vodomer kot merilo, ki je zasnovano za merjenje, pomnjenje in prikaz prostornine vode, ki pri danih pogojih merjenja teče skozi merilni pretvornik. Redni odčitek vodomera se na lokalnem trgu izvaja mesečno za pravne osebe, trimesečno za večstanovanjske objekte in pri fizičnih uporabnikih enkrat letno. Ker se komunalne storitve obračunavajo mesečno, se storitve, vezane na porabo vode, $\mathrm{v}$ obdobju med rednimi odčitki vodomerov obračunavajo na bazi akontacije, ki se določi glede na povprečno porabo vode $\mathrm{v}$ preteklem obdobju, ali sporočenega mesečnega odčitka.

Dejanska poraba se ugotavlja z odčitkom stanja na števcu. Takrat se opravi tudi poračun glede na razliko med obračunano količino in dejansko porabljeno vodo v obračunskem obdobju med odčitkoma. Na računu zato lahko takrat prihaja do odstopanj: pri uporabnikih, ki so porabili več vode, kot jo je bilo obračunane na bazi mesečne akontacije, je znesek na računu temu primerno višji; pri uporabnikih, ki so porabili manj vode, kot jo je bilo obračunane, pa je znesek na računu toliko nižji.

Vsi vodomeri morajo biti overjeni skladno z Zakonom o meroslovju (ZMer-1-UPB1, Ur. 1. RS, št. 26/05 - uradno prečiščeno besedilo). Overitev je postopek, ki je določen $s$ Pravilnikom o postopku overitve meril (Ur. 1. RS, št. 97/14), katerega namen je ugotoviti, ali merilo izpolnjuje predpisane meroslovne zahteve. Veljavnost overitve je pet let. Za odčitavanje porabljene pitne vode se lahko uporabljajo le overjeni vodomeri.

V nadaljevanju je izvedena stroškovna analiza popisa vodomerov, na osnovi katere bo možna poslovna odločitev, ali izvajati proces popisa vodomerov v podjetju ali ta proces opravljati z zunanjim izvajalcem. Pri tem je pomembno, da se pri odločitvi glede zunanjega izvajanja storitev analizirajo in proučijo vsa možna tveganja in koristi, ki jih ta oblika sodelovanja lahko prinese. Upoštevati je treba predvsem dolgoročne koristi sodelovanja.

\section{Kalkulacija stroškov popisovanja vodomerov v podjetju}

Kalkulacija je drug izraz za izračun cene iz znanih podatkov o stroških, ki nastanejo pri procesu. Stroški predstavljajo pomembne dejavnike, ki vplivajo na uspešnost poslovanja podjetja, zato so posledično prisotni v vseh strukturah odločanja. 
Kalkulacija se lahko opravi na osnovi planskih ali dejanskih podatkov o stroških določenega procesa. Računamo jih za izračun cen blaga ali storitve. Poleg tega kalkulacije sestavljamo tudi za izračun učinkovitosti poslovanja, kot sta rentabilnost in ekonomičnost. Kalkulacije je možno opredeljevati in ločevati na več vidikov, kar za našo raziskavo ni pomembno.

Za izračun stroškov pri popisu vodomerov smo izvedli delitveno kalkulacijo, ker gre za masovno storitev popisovanja vodomerov. Povprečne stroške (PS) izračunamo tako, da celotne stroške (CS) delimo s številom odčitanih vodomerov $(\mathrm{N})$.

$$
P S=\frac{C S}{N}
$$

Za izračun celotnih stroškov smo upoštevali stroške dela, opreme in osnovnih sredstev ter izpad dohodka (oportunitetne stroške).

\subsection{Stroški dela}

Slovenski računovodski standard 13 (2016) določa, da so stroški dela:

a) plače, ki pripadajo zaposlenim, $\mathrm{v}$ bruto znesku;

b) nadomestila plač, ki skladno $\mathrm{z}$ zakonom, s kolektivno pogodbo ali pogodbo o zaposlitvi pripadajo zaposlenim za obdobje, ko ne delajo, v bruto znesku, ki bremeni organizacijo;

c) dajatve v naravi, darila in nagrade zaposlenim ter zanje plačani ali njim povrnjeni zneski, ki niso v neposredni zvezi s poslovanjem;

d) odpravnine, ki pripadajo zaposlenim, ko nehajo delati $\mathrm{v}$ organizaciji, in drugi dohodki, ki pripadajo zaposlenim skladno z zakonom, s kolektivno pogodbo ali pogodbo o zaposlitvi v bruto znesku;

e) dajatve, ki se dodatno obračunavajo od postavk od a) do d) in bremenijo izplačevalca.

Za opazovano podjetje predstavlja strošek plače vzdrževalca vodovodnega sistema za leto 2015 v višini 15.950 evrov (JEKO-IN, 2016). V ta strošek so vključeni redno delo, letni dopust, prazniki, regres, minulo delo, stalnost, prostovoljno dodatno pokojninsko zavarovanje, nadurno delo, boleznine, prevoz na delo, prehrana med delom, ostala povračila in prispevki.

Tabela 18 prikazuje izračun obremenitve dela popisovalca. Razvidno je, da zaposleni opravi 1568 ur efektivnega dela, kar predstavlja 75 odstotkov ur dela pri polni zaposlenosti 2088 ur letno. 
$36^{\text {TH }}$ International Conference on ORganizational Science Development: Responsible ORganization (MARCH $22^{\mathrm{ND}}-24^{\mathrm{TH}}$, Portorož SLOVENIA)

B. Leban \& T. Kern: Outsourcing of Census Water Meters

Tabela 18: Izračun obremenitve dela po popisovalcu

\begin{tabular}{ccccccc}
\hline Opis & $\begin{array}{c}\text { Število } \\
\text { ur }\end{array}$ & $\begin{array}{c}\text { Mesečno } \\
\text { stevilo dni }\end{array}$ & $\begin{array}{c}\text { Mesečno } \\
\text { število ur }\end{array}$ & $\begin{array}{c}\text { Število } \\
\text { mesecev }\end{array}$ & $\begin{array}{c}\text { Letno } \\
\text { stevilo ur }\end{array}$ & $\begin{array}{c}\text { Letno } \\
\text { število dni }\end{array}$ \\
\hline Obveznost & 8 & 21,75 & 174 & & 2088 & 261 \\
ur & 8 & 2,25 & 18 & & 216 & 27 \\
Dopust & 8 & 1,25 & 10 & 12 & 120 & 15 \\
Bolniška & 8 & 0,83 & 7 & 12 & 80 & 10 \\
Prazniki & 8 & 1,09 & 9 & 11 & 105 & 13 \\
Malica & 0,5 & 1653 & 131 & & 1568 & 196 \\
\hline Prisotnost & & 16,33 & & & &
\end{tabular}

Časovno se odčitki vodomerov razlikujejo, zato je v Tabela 19 izveden preračun odčitkov obdobju enega leta. Prikazan je tudi izračun časa, ki je potreben za popis vseh vodomerov.

Tabela 19: Izračun časa za popis vodomerov letno

\begin{tabular}{|c|c|c|c|c|c|c|c|c|}
\hline Opis & $\begin{array}{l}\text { Št. } \\
\text { vodo- } \\
\text { merov }\end{array}$ & $\begin{array}{c}\text { Št. } \\
\text { popisov } \\
\text { na leto }\end{array}$ & $\begin{array}{l}\text { Redni } \\
\text { popis }\end{array}$ & $\begin{array}{l}\text { Ponoven } \\
\text { popis v \% }\end{array}$ & $\begin{array}{l}\text { Št. ponovno } \\
\text { popisanih }\end{array}$ & $\begin{array}{c}\text { Št. } \\
\text { popisov } \\
\text { letno }\end{array}$ & $\begin{array}{l}\text { Čas (min) } \\
\text { za } 1 \text { popis }\end{array}$ & $\begin{array}{c}\text { Skupen čas } \\
\text { v urah }\end{array}$ \\
\hline Dejavnost & 521 & 12 & 6252 & $5 \%$ & 313 & 6565 & 11,49 & 1257,12 \\
\hline Hišni sveti & 376 & 4 & 1504 & $5 \%$ & 75 & 1579 & 8,57 & 225,56 \\
\hline Gospodin. & 3750 & 1 & 3750 & $8 \%$ & 300 & 4050 & 8,57 & 578,48 \\
\hline Skupaj & 4647 & & 11506 & & 688 & 12194 & & 2061,16 \\
\hline
\end{tabular}

Čas (število minut) za en popis je izračunan na vzorcu (dejanskega) popisa 400 števcev vodomerov $\mathrm{v}$ sedmih dneh. $\mathrm{V}$ gospodinjstvih znaša čas popisa 8,57 minute. Popis industrijskih števcev je po naših izračunih daljši za 34,23 odstotka.

Izračun časa za popise ne vključuje časa, potrebnega za prevoz do posameznega vodomera, ter časa, potrebnega za vnos podatkov iz terminala $\mathrm{v}$ bazo podatkov, bolniških izostankov ali letnega dopusta, ponovnega popisovanja zaradi nepravilnosti ali reklamacij, izgube časa in ponovnih obiskov pri odjemalcih zaradi odsotnosti odjemalca.

Potrebno število zaposlenih za popis vodomerov je izračunano na osnovi števila letnega popisa (

Tabela 20). 
Tabela 20: Rekapitulacija stroškov dela

\begin{tabular}{lr}
\hline Opis & \\
\hline Ure, potrebne za popis & 2061 \\
Razpoložljive ure delavca & 1568 \\
Potrebno število zaposlenih & 1,31 \\
\hline Dnevne ure popisovalca & 7,5 \\
Povprečno število popisov na uro & 6 \\
Povprečno število popisov na dan & 44 \\
\hline Strošek dela v EUR & 20973 \\
Strošek dela v EUR na en popisan vodomer & 1,72 \\
\hline
\end{tabular}

\subsection{Oprema in osnovna sredstva}

Osnovna sredstva in oprema (drobni inventar) so sredstva, ki jih ima organizacija v lasti ali finančnem najemu ali jih na drug način obvladuje ter jih uporablja pri ustvarjanju proizvodov ali opravljanju storitev oziroma dajanju v najem ali za pisarniške namene in jih bo po pričakovanjih uporabljala $\mathrm{v}$ te namene $\mathrm{v}$ več kot enem obračunskem obdobju (SRS 2016).

Za popis vodomerov je izveden izračun opreme in osnovnih sredstev, ki se nanašajo na službeno vozilo, delovna oblačila, varovalna sredstva, zaščitna sredstva, stroške poslovnih prostorov in opreme, potrebne za popis. V Tabela 21 so prikazani stroški, ki se nanašajo na službeno vozilo.

Tabela 21: Izračun letnega stroška vozila

\begin{tabular}{lr}
\hline Vrsta stroška & V EUR \\
\hline Amortizacija* & 0 \\
Gorivo & 1500 \\
Zimske gume (240 EUR/kos, uporabnost 3 leta) & 320 \\
Vzdrževanje vozila & 2594 \\
Tehnični pregled in povračilo za uporabo cest & 145 \\
Zavarovanje vozila & 251 \\
\hline Letni tekoči stroški vozila & 4810 \\
\hline
\end{tabular}


$36^{\text {Th }}$ International Conference on Organizational Science Development: Responsible Organization (MARCh $22^{\mathrm{ND}}-24^{\mathrm{TH}}$, Portorož Slovenia)

B. Leban \& T. Kern: Outsourcing of Census Water Meters

V strošek vozila ni vključena amortizacija, ker je vozilo amortizirano. Če bi prišlo do nakupa novega vozila, bi bilo treba upoštevati amortizacijo v višini 14,3 odstotka od nabavne vrednosti. Nabavna vrednost vozila, primernega za to dejavnost, je približno 10.000 evrov. V tem primeru bi bilo treba upoštevati amortizacijo v višini 1430 evrov, vendar bi bili posledično nižji stroški za vzdrževanje vozila. Strošek bi tako pri nabavi novega vozila ostal enak.

Strošek zaščitne in delovne obleka znaša na letni ravni 192 evrov. Pri tem so upoštevane delne (letne) vrednosti, če je določen kos zaščitnega oblačila ali opreme v uporabi več kot eno leto (bunda, dežna obleka ...).

Strošek poslovnih prostorov in opreme, ki nastane na letni ravni, je 440 evrov in vključuje strošek garderobne omarice in telefona ter tabličnega računalnika za popis. Stroški, kot so ogrevanje, električna energija, varovanje, zavarovanje, čiščenje, pisalna miza in omare, računalnik ipd., ne nastajajo, ker popisovalec vodomerov nima svojih poslovnih prostorov. Stroški programske opreme ne nastajajo, ker se za obdelavo podatkov uporabljajo povezave, ki so že vključene v ostale programe, ki so neodvisne od popisov. $\mathrm{V}$ Tabeli 5 je prikazana rekapitulacija stroškov opreme in osnovnih sredstev, ki so potrebni za popis vodomerov. Delo popisa se kljub obsegu, ki za določen čas zahteva dva zaposlena, izvaja z enim vozilom. Delo se organizira tako, da ga na območjih, kjer je koncentracija vodomerov večja, izvajata dva popisovalca in zato ni potrebno dodatno vozilo. Ostali stroški se nanašajo na dva izvajalca.

Tabela 22: Rekapitulacija stroškov opreme in osnovnih sredstev

\begin{tabular}{lr}
\hline Opis & V EUR \\
\hline Strošek vozila & 4810 \\
Strošek delovnih oblačil in sredstev & 383 \\
Strošek poslovnih prostorov in opreme & 440 \\
\hline Skupaj letni stroški & 5633 \\
Strošek na popisni vodomer & 0,46 \\
\hline
\end{tabular}

\subsection{Izpad dohodka}

Po definiciji so oportunitetni stroški opuščene priložnosti, torej ovrednotenje druge najboljše alternative, ki je nismo izbrali. So donos, ki ga ne bomo ustvarili, ker nismo izbrali variante, ki ga prinaša. So vrednost dobrine ali storitve, ki smo se ji odrekli (Bradač, 2011). Opredelitev stroškov, ki jo uporabljajo ekonomisti, je širša od računovodske. Ekonomski stroški vključujejo poleg eksplicitnih denarnih izdatkov tudi tiste oportunitetne stroške, ki so nastali, ker lahko vire uporabljamo na alternativne načine (Samuelson \& Nordhaus 2002, 129-130).

Izpad dohodka (oportunitetne stroške) $\mathrm{v}$ tem primeru predstavljajo stroški ponovnega odčitavanja zaradi nepravilnosti ali reklamacij in stroški ponovnega prihoda na mesto odčitavanja, ker stranke ni bilo doma. To vrsto stroškov smo upoštevali z razlogom: če 
ne bi bilo ponovnih popisov, bi lahko popis vodomerov izvajali z manj urami dodatnega zaposlenega. Dodatne ure popisa, ki presegajo efektivne ure popisovalca, izvaja zaposleni, ki skrbi za vzdrževanje vodovodnega sistema in vodovodnih priključkov. Ta $\mathrm{v}$ tem času ne more izvajati svojega dela, zato so upoštevani tudi oportunitetni stroški.

Oportunitetni stroški so subjektivni in jih ne more meriti nihče drug kot tisti, ki izbira. Zato se jih ne da zlahka prevesti v dimenzijo vira, denarja ali dobrine. Oportunitetni stroški obstajajo samo v trenutku odločanja, takoj zatem izginejo, kar seveda pomeni, da se ti stroški nikoli ne ustvarijo, tega, kar smo zavrgli, ne moremo uživati (Bradač, 2011). Tabela 23 prikazuje oceno izpada dohodka (oportunitetnih stroškov), ki je preračunan na uro dela drugega zaposlenega, ki izvaja dodatna dela popisa.

\section{Tabela 23: Izpad dohodka}

\begin{tabular}{lr}
\hline Ocenjena količina & V \\
& EUR \\
\hline Stroški ponovnega odčitavanja nepravilnosti, približno 180 števcev letno & 369 \\
Stroški ponovnega odčitavanja reklamacij, približno 140 števcev letno & 287 \\
Stroški ponovnega prihoda, ker stranke ni bilo doma, približno 370 števcev letno & 407 \\
\hline Skupaj letni stroški & 1063 \\
\hline
\end{tabular}

\subsection{Povzetek stroškov}

V Tabela 24 so zbrani analizirani stroški, ki nastanejo v obdobju enega leta pri popisu vodomerov in se nanašajo na stroške dela, opremo in osnovna sredstva in na izpad dohodka, ki nastane zaradi ponovnega odčitavanja vodomerov.

Tabela 24: Povzetek stroškov

\begin{tabular}{lr}
\hline Opis & V EUR \\
\hline Strošek dela & 20973 \\
Oprema in osnovna sredstva & 5633 \\
Izpad dohodka & 1063 \\
Skupaj letni stroški & 27669 \\
Število popisov letno & 12194 \\
\hline Izračun stroška odčitavanja na merilno mesto & 2,27 \\
\hline Ponudba za popis vodomera & 2,30 \\
Razlika med stroški in ponudbo & 0,03 \\
Razlika med stroški na leto & 377 \\
\hline
\end{tabular}

Zunanje izvajanje popisa vodomerov $\mathrm{v}$ podjetjih, ki izvajajo oskrbo s pitno vodo $\mathrm{v}$ Sloveniji, ni splošno, zato je bila lahko pridobljena le ena ponudba izvajalca te storitve, ki že izvaja storitev pri enem oskrbovalcu s pitno vodo. Iz kalkulacije stroškov popisa vodomera je razvidno, da je strošek izvedbe popisa v okviru organizacije podjetja, ki izvaja oskrbo s pitno vodo, nižji za 0,03 evra od ponudbe zunanjega izvajalca. Pri tem ni 
potrebno nadaljnje presojanje, ali so koristi zaposlenega v podjetju večje od zunanjega izvajalca.

\section{$5 \quad$ Opredelitev kritične točke gospodarnosti popisa}

Oskrba s pitno vodo je dejavnost, ki se izvaja le na določenem območju in se praviloma ne more izvajati po tržnem načelu. Je dejavnost, ki mora zadovoljevati potrebe prebivalcev in pri tem ne sme ustvarjati dobička. Vseeno je vprašanje, zelo pomembno za podjetje, kakšen je potreben količinski obseg izvedenih storitev.

Z izračunom kritične točke želimo prikazati, na kateri ravni opravljenih popisov vodomerov se v podjetju pokrijejo vsi stroški odčitavanja vodomerov. Pri tem je treba upoštevati predpostavke, da je cena storitve enaka in se ne spreminja, da se storitve izvajajo konstantno preko celega leta in da so variabilni stroški konstantni in fiksni stroški absolutno fiksni. Upoštevani so podatki o stroških za leto 2015, saj so podatki za pretekla obdobja manj uporabni, se spreminjajo. Za odločitve so pomembni in uporabni podatki, ki se nanašajo na tekoče poslovanje.

Nastale stroške za leto 2015 smo razdelili na fiksne in variabilne. Fiksni stroški, ki jih imenujemo lahko tudi »stalni«, »splošni« ali »nepovratni« stroški, so neodvisni od količine izvedenega produkta ali storitve in se ne spreminjajo. Variabilni stroški, lahko tudi »spremenljivi« stroški, predstavljajo izdatke, ki se spreminjajo s količino izvedenih produktov oziroma storitev in vključujejo vse stroške, ki niso fiksni (Samuelson \& Nordhaus 2002, 116).

Po definiciji vedno drži, da so celotni stroški seštevek fiksnih in variabilnih stroškov. Deyhle kritično točko imenuje prag dobička $(1997,40)$, točka ravnovesja ali točka polnega pokritja stroškov in ničelna točka, kjer sta $v$ tej točki dobiček in izguba enaka ničli.

Izračun kritične točke je naslednji, ob tem, da so v tem primeru prihodki enaki celotnim stroškom:

$$
P C \times Q=\frac{V C}{q} \times Q+F C
$$

Obseg dejavnosti se izračuna na osnovi naslednje formule:

$$
Q=\frac{F C}{P C-\frac{V C}{q}}
$$

Pri čemer pomeni:

$\mathrm{Q}=$ količina (obseg) storitev

$\mathrm{FC}=$ fiksni stroški 
$\mathrm{PC}=$ prodajna cena

$\mathrm{VC} / \mathrm{q}=$ variabilni stroški na enoto obsega opravljenih storitev

Za izračun kritične točke smo v prvi fazi razdelili stroške na variabilne in fiksne, kar prikazuje

Tabela 25 .

Tabela 25: Razdelitev stroškov na fiksne in variabilne

\begin{tabular}{lccc}
\hline Stroški v EUR & Skupaj & Fiksni & Variabilni \\
\hline Strošek dela & 20973 & 20973 & 0 \\
Gorivo & 1500 & 0 & 1500 \\
Zimske gume (240 EUR/kos, uporabnost 3 & 320 & 320 & 0 \\
leta) & 2594 & 420 & 2174 \\
Vzdrževanje vozila & 145 & 145 & 0 \\
Tehnični pregled in povračilo za uporabo & 251 & 251 & 0 \\
cest & 383 & 383 & 0 \\
Zavarovanje vozila & 440 & 440 & 0 \\
Strošek delovnih oblačil in sredstev & 1063 & 0 & 1063 \\
Strošek poslovnih prostorov in opreme & 27669 & 22933 & 4737 \\
Izpad dohodka & & & \\
\hline Skupaj & & & \\
\hline
\end{tabular}

Kritična točka, kjer so pokriti vsi stroški s prihodki, je dosežena pri višini 27669 evrov. Pri tem moramo upoštevati že omenjene predpostavke, da je cena storitve enaka in se ne spreminja, da se storitve izvajajo konstantno preko celega leta in da so variabilni stroški konstantni in fiksni stroški absolutno fiksni. Trenutne stroške procesa popisa vodomerov v okviru oskrbe s pitno vodo na lokalnem trgu pokriva cena storitve.

Pri tem se postavi vprašanje, ali je klasično odčitavanje vodomerov učinkovitejše od daljinskega odčitavanja vodomerov.

\section{Daljinski popis vodomerov}

Daljinski popis vodomerov je tehnologija, ki omogoča avtomatsko zbiranje podatkov o porabljeni pitni vodi in s tem lažje izvajanje procesa popisa. Avtomatsko zbrani podatki pri uporabnikih se prenašajo v centralno bazo podatkov. Daljinski popis vodomerov omogoča zbiranje aktualnih dejanskih podatkov, za katere se izstavi račun in ni potreben akontativni pavšalni obračun.

Daljinski popis vodomerov se uporablja že več kot trideset let. V koraku z razvojem so v uporabi tudi različne tehnike prenosa podatkov. Uporabljajo se lahko prenosi podatkov preko radijske frekvence ali telefonske platforme. Ravno tako je več možnosti zbiranja podatkov. Najbolj pogosta načina sta, kjer lahko popisovalec zbira podatke z ročnim 
terminalom, ko se vozi ali hodi mimo vodomerov, in se nato prenesejo podatki iz ročnih terminalov v centralno bazo, angl. drive by, walk by. Lahko se zbirajo podatki tudi preko GSM-vmesnika, ki sporoča podatke o porabljeni vodi uporabnika neposredno v podatkovno bazo izvajalca oskrbe s pitno vodo. Pri tem je frekvenca odčitkov možna dnevno, vendar se je uporabniki običajno ne poslužujejo, ker se v tem primeru iztrošijo baterije v oddajniku pred petletnim zakonskim rokom menjave. Obstajajo še druge tehnike odčitavanja, kot so odčitavanje na dotik, preko satelita idr.

Nadalje so na trgu različne alternativne opreme za odčitavanje podatkov in različne vrste in dimenzije vodomerov. Vsi prenosi podatkov morajo temeljiti na predpisanih standardih. Poenostavljeno, to so vodomeri, nadgrajeni s povezovalnimi moduli. Po Pravilniku o merilnih instrumentih (Ur. 1. RS, št. 19/2016) je obvezna overitev vodomerov za obdobje petih let. Menjava vodomerov je pri izvajanju oskrbe s pitno vodo obvezna. Dodaten strošek pri daljinskem odčitavanju vodomerov predstavljajo povezovalni modul na vodomeru in koncentrator $\mathrm{v}$ naseljih, kjer je visoka koncentracija števcev, ter na drugi strani oprema, potrebna za odčitavanje, kot so ročni čitalci, programska oprema in njeno vzdrževanje.

Daljinsko odčitavanje števcev velja za dražjo obliko odčitavanja porabe vode kot fizični popis vodomerov. Za vgradnjo se podjetja odločajo zaradi različnih vzrokov. Razlogi so lahko nedostopnost vodomernega jaška ali, kot Hawley $(2000,68)$ povzema po Stevensu (1984), da so nekateri tipi sistema avtomatskega odčitavanja vodomernih števcev kot merilo pripravljenosti zasebnih sektorjev, da uporabljajo manj človeških virov za proizvodnjo storitev.

Pri analizi procesa $\mathrm{v}$ opazovanem podjetju smo upoštevali dejstvo, da izvaja popis vodomerov na lokalnem trgu Jesenic in Žirovnice 1,31 popisovalca. Preverili smo stroškovni vidik v primeru, da bi popise, ki presegajo enega zaposlenega, izvajali z daljinskim odčitkom. Pri tem bi se izvajal daljinski odčitek vodomerov tam, kjer se voda uporablja za dejavnost in je potreben mesečni popis vodomerov. V Tabela 26 je prikazana primerjava izvedenega popisa na letni ravni $\mathrm{z}$ ročnim odčitkom vodomerov in kombinacija ročnega in daljinskega odčitka vodomerov.

Tabela 26: Primerjava stroškovnega vidika dveh vidikov popisa

\begin{tabular}{lcc}
\hline Stroški v EUR & Ročni popis & Kombinacija* \\
\hline Strošek dela & 20973 & 16000 \\
Gorivo & 1500 & 1500 \\
Zimske gume (240 EUR/kos, uporabnost 3 leta) & 320 & 320 \\
Vzdrževanje vozila & 2594 & 2594 \\
Tehnični pregled in povračilo za uporabo cest & 145 & 145 \\
Zavarovanje vozila & 251 & 251 \\
Strošek delovnih oblačil in sredstev & 383 & 192 \\
Strošek poslovnih prostorov in opreme & 440 & 440 \\
Izpad dohodka & 1063 & 0 \\
Daljinski odčitek vodomerov & 0 & 6510 \\
\hline
\end{tabular}


* Kombinacija predvidenih odčitkov za polni delovni čas enega zaposlenega in delni preostali daljinski popis

V stroških daljinskega odčitka vodomerov so upoštevani enoletni amortizacijski stroški (20-odstotna amortizacijska stopnja) radijsko povezovalnih modulov, ročnega terminala, programske opreme in njeno vzdrževanje. Stroški daljinskega odčitka so izračunani na osnovi trenutne ponudbe na trgu, ki ustreza trenutnemu stanju vodomerov.

Iz izvedene analize je razvidno, da sta ročni popis vodomerov in kombinacija ročnega in daljinskega odčitka vodomera stroškovno skoraj enaka.

\section{7}

\section{Sklep}

$\mathrm{V}$ prispevku smo proučevali stroškovno analizo procesa popisa vodomerov v okviru izvajanja dejavnosti gospodarske javne službe oskrbe s pitno vodo. Zanimalo nas je vprašanje, ali je zunanje izvajanje procesa stroškovno ugodnejše od lastnega izvajanja popisa vodomerov.

Rezultati analize popisa vodomerov so pokazali skoraj enake stroške odčitka enega vodomera v podjetju kot pri zunanjem izvajalcu. Strošek popisa enega vodomera v podjetju znaša 2,27 evra in pri zunanjem izvajalcu 2,30 evra. Pri letnem obsegu 12.194 odčitkov ugotovljena razlika predstavlja 366 evrov nižje stroške, če popis izvaja podjetje samo. Na osnovi stroškovnega vidika je smotrno izvajati proces v lastni režiji.

Ostale prednosti izvajanja popisa $\mathrm{v}$ okviru izvajalca oskrbe s pitno vodo so poznavanje strank in terena, kje so ti vodomeri. Ob zaznanih nepravilnostih ali nepooblaščenem poseganju na vodomeru zaposleni poroča podjetju in to se lahko na te nepravilnosti odzove. Na drugi strani pa obstaja tveganje zaradi poznavanja strank, da bi popisovalec beležil odčitke, ne da bi jih odčital z vodomerov. Tveganje predstavljajo tudi možne daljše bolniške odsotnosti popisovalca. Kar so na eni strani prednosti izvajanja popisa $\mathrm{v}$ okviru izvajalca oskrbe s pitno vodo, so na drugi strani slabosti izvajanja popisa pri zunanjem izvajalcu, in obratno.

Izveden je bil tudi preračun, da bi se dejavnost izvajala kombinirano z ročnim in daljinskim odčitkom vodomerov. Na osnovi stroškovne analize so rezultati pokazali, da je smotrno izvajati kombiniran popis, saj je strošek kombiniranega popisa višji le za 283 evrov, če se ure ostalih delavcev, ki so sodelovali pri popisu, prodajo na trgu. V nasprotnem primeru daljinski odčitek ni ekonomsko upravičen strošek. Drugi vidik, ki lahko prevladuje, pa je dostopnost vodomerov. Kadar gre za težko dostopne vodomere, lahko ta dejavnik pretehta stroškovnega.

\section{Literatura}

Bradač, A. (2011). Ekonomija. Ljubljana: Zavod IRC. 
Butterwoth, G., Kuchler, M., \& Westdijk, S. (2013). Outsourcing in Europe : An indepth review of drivers, risks and trends in the European outsourcing Market. Ernst and Young.

Deloitte Consulting LLP. (2016). 2016 Global Outsourcing Survey: Outsourcing accelerates forward. Deloitte Consulting LLP (June). Dostopno na https://www2.deloitte.com/content/dam/Deloitte/us/Documents/process-and-operations/uscons-sdt-gos-exec-summary-2016.pdf (2. 1. 2017).

Deyhle, A. (1997). Kontroling in kontroler v praksi. Ljubljana: Gospodarski vestnik.

Estellés-Arolas, E., \& González-Ladrón-de-Guevara, F. (2012). Towards an integrated crowdsourcing definition. Journal of Information Science, (X), 1-14.

Greaver, M. F. (1999). Strategic outsourcing: A atructured approach to Outsourcing Decisions and Initiatives. American Management Association Publication. New York: American Management Association Publication.

JEKO-IN. (2016). Interni podatki. Jeko-in, d. o. o., Jesenice.

Kavčič, K. (2007). Zunanje izvajanje dejavnosti: analiza slovenskih podjetij. Management, 2(4), 303-318.

Kavčič, K., \& Bončina, K. (2015). Iz raziskav v podjetniško prakso: Razvojno snovanje strategij zunanjega izvajanja dejavnosti. Koper: Fakulteta za Management.

Klemenčič, T. (1997). Komunalno gospodarstvo. Ljubljana: Svetovalni center.

Ministrstvo za okolje in prostor. (2016). Oskrba $s$ pitno vodo. Dostopno na http://www.mop.gov.si/si/delovna_podrocja/voda/oskrba_s_pitno_vodo/ (9. 12. 2016).

Palugod, N., \& Palugod, P. A. (2011). Global trends in offshoring and outsourcing. International Journal of Business and Social Science, 2(16), 13-19.

Pravilnik o merilnih instrumentih. Uradni list RS, št. 19/2016.

Pravilnik o postopku overitve meril. Uradni list RS, št. 97/2014.

Prijatelj Petelinkar, N. (2008). Prednosti in slabosti zunanjega izvajanja računovodstva. Magistrska naloga, Univerza v Ljubljani, Ekonomska fakulteta.

Rismal, M. (2012). Problemi upravljanja voda v Sloveniji in gospodarjenja z njimi. Gradbeni vestnik, 61 (8), 177-182.

Samuelson, P. A., \& Nordhaus, W. D. (2002). Ekonomija. Ljubljana: GV Založba.

Slovenski računovodski standardi (SRS). Uradni list $R S$, št. 95/2015.

Uredba za oblikovanje cen storitev obveznih občinskih gospodarskih javnih služb varstva okolja. Uradni list RS, št. 87/2012, 109/2012.

Varanasi, B. (2006). Multisourcing - A Comparative to Outsourcing. EA Consulting, Inc., 1(2), 111.

Vitasek, K. (2010). Vested Outsourcing: Five Rules That Will Transform Outsourcing. New York: Palgrave MacMillan.

Zakon o gospodarskih javnih službah (ZGJS). Uradni list RS, št. 32/1993.

Zakon o meroslovju (ZMer-1-UPB1). Uradni list RS, št. 26/05 - uradno prečiščeno besedilo. 
36. MEDNARODNA KONFERENCA O RAZVOJU ORGANIZACIJSKIH ZNANOSTI: OdgOVORNA ORGANIZACIJA (22. - 24. MAREC 2017, PORTOROŽ, SLOVENIJA)

O. Arsenijević, M. Ferjan, I. Podbregar, P. Šprajc, D. Trivan \& Y. Ziegler

\title{
Pregled poklicev v informacijski dejavnosti
}

\author{
RoBert LeSKovar, ALENKA BAgGia \& GORAN VuKOVIČ
}

Povzetek V prispevku je predstavljeno trenutno stanje na področju poklicev, ki si povezani z informacijsko dejavnostjo, nato pa so podane najverjetnejše usmeritve in perspektive. Pri analizi trga dela so porabljeni javno dostopni viri zaposlitvenega portala Eures (European Commision, 2017). Opisan je pristop Evropske komisije k opredelitvi veščin, kompetenc in poklicev ESCO (Evropska komisija, 2017), s posebnim poudarkom na poklicih $\mathrm{v}$ informacijski dejavnosti. To področje izstopa po predvidenem številu novih delovnih mest. Informacijska dejavnost je $\mathrm{v}$ prispevku opredeljena kot področje dela $\mathrm{v}$ organizaciji, kjer so nujna znanja s področja informacijskih in komunikacijskih tehnologij. Zato je ta dejavnost vključena $\mathrm{v}$ praktično vse gospodarske panoge kot tudi državno in javno upravo. Predstavljeni so tipični poklici v obravnavani dejavnosti in kratki opisi izbranih poklicev, ki jih opredeljuje Ministrstvo za delo v ZDA (United States Department of Labor, 2017). Zahtevni poklici v informacijski dejavnosti oz. strokovnjaki na tem področju so $\mathrm{v}$ globalnem in tudi lokalnem okolju zelo iskani in dobro plačani. Prikazani bodo primeri kariernih poti diplomantov programov Organizacija in management Fakultete za organizacijske vede UM. Podane so nekatere ključne dileme poklicnih svetovalcev v zvezi s temi poklici.

KLJUČNE BESEDE: poklici v informacijski dejavnosti - klasifikacija • veščina $\bullet$ kompetenca $\bullet$ poklicno svetovanje

\footnotetext{
NASLOV AVTORJEv: dr. Robert Leskovar, redni profesor, Univerza v Mariboru, Fakulteta za organizacijske vede, Kidričeva cesta 55a,4000 Kranj, Slovenija, e-pošta: robert.leskovar@fov.unimb.si; dr. Alenka Baggia, docentka, Univerza v Mariboru, Fakulteta za organizacijske vede, Kidričeva cesta 55a,4000 Kranj, Slovenija, e-pošta: alenka.baggia@fov.uni-mb.si; dr. Goran Vukovič, redni profesor, Univerza v Mariboru, Fakulteta za organizacijske vede, Kidričeva cesta 55a,4000 Kranj, Slovenija, e-pošta: goran.vukovic@fov.uni-mb.si
}

DOI https://doi.org/10.18690/978-961-286-020-2.40

ISBN 978-961-286-020-2

(C) 2017 Univerzitetna založba Univerze v Mariboru

Dostopno na: http://press.um.si 
$36^{\text {TH }}$ InTERnAtional CONFERENCE ON ORganizational SCIENCE DeVElopment: Responsible ORganizATION (MARCH $22^{\mathrm{ND}}-24^{\mathrm{TH}}$, PORTOROŽ SLOVENIA)

O. Arsenijević, M. Ferjan, I. Podbregar, P. Šprajc, D. Trivan \& Y.

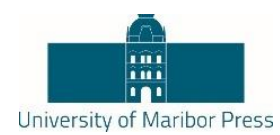

Ziegler

\title{
Professional Outlook in Computer and Information Technology
}

\author{
ROBERT LESKOVAR, ALENKA BAGGIA, GORAN VUKOVIČ
}

\begin{abstract}
This paper presents the current state of the professions associated with computer and information technology. Further, the likely directions and perspectives of the professions are given. The analysis of the labour market is based on publicly available sources of employment portal Eures. The European Commission's approach to the definition of skills, competences and occupations (ESCO) is presented with the focus on careers in computer and information technology. This area is characterised by the estimated large number of new jobs. Information activity is defined as the area of work in an organization where certain know-how in the field of information and communication technologies is required. Therefore, information activity is incorporated in virtually all industries as well as government and public administration. Typical occupations in this activity are outlined with brief descriptions of selected professions as defined by the US Ministry of Labor. Demanding professions or experts in the information activity are highly sought in the global and local environment and also well paid. Several examples of the career paths of graduates of program Organization and management of information systems at the Faculty of Organizational Sciences UM are shown. The key dilemmas of professional advisers in relation to these professions are outlined.
\end{abstract}

KEYWORDS: professions in information activity $\bullet$ classification $\bullet$ skill $\bullet$ competence $\bullet$ professional advising

CorResPondence AdDREss: Robert Leskovar, Ph.D., Full Professor, University of Maribor, Faculty of Organizational Sciences, Kidričeva cesta 55a, 4000 Kranj, Slovenia, e-mail: robert.leskovar@fov.uni-mb.si; Alenka Baggia, Ph.D., Assistant Professor, University of Maribor, Faculty of Organizational Sciences, Kidričeva cesta 55a, 4000 Kranj, Slovenia, e-mail: alenka.baggia@fov.uni-mb.si; Goran Vukovič, Ph.D:, Full Professor, University of Maribor, Faculty of Organizational Sciences, Kidričeva cesta 55a, 4000 Kranj, Slovenia, e-mail: goran.vukovic@fov.uni-mb.si

DOI https://doi.org/10.18690/978-961-286-020-2.40

ISBN 978-961-286-020-2

(C) 2017 University of Maribor Press

Available at: http://press.um.si 


\section{$1 \quad$ Uvod}

V poročilu Evropske komisije (European Commision, 2013) najdemo opredelitev razlike med poklici in delovnimi mesti. Poklici so skupina delovnih mest, ki vključujejo podobne naloge in zahtevajo podobne sposobnosti. Poklicev se ne sme zamenjati z delovnimi mesti in nazivi delovnih mest. Medtem ko je delovno mesto vezano na določen delovni kontekst in ga izvaja ena oseba, poklici združujejo delovna mesta po skupnih podobnostih. Kot primer lahko navedemo razlike med delovnim mestom in poklicem: "vodja projekta za razvoj prezračevalnega sistema letala Superfly 900 " je delovno mesto, "vodja projekta", "letalski inženir" ali "inženir za prezračevanje" pa so poklici, znotraj katerih lahko opredelimo več delovnih mest.

Poklic se lahko uporablja tudi kot naziv delovnega mesta. Delodajalci za novačenje lahko v razpisu za prosto delovno mesto uporabljajo tudi naziv poklica, npr. "vodja projekta". Ta definicija je zelo povezana s teorijo Ability-Motivation-Opportunity (AMO), katere zasnovo predstavijo (Appelbaum, Bailey, Berg, \& Kalleberg, A, 2000), kasneje pa jo (Hughes, 2007) aplicira tudi na področje informacijske dejavnosti. Na sliki 1 je prikazan večkriterijski model izbire delavca v skladu s teorijo AMO.

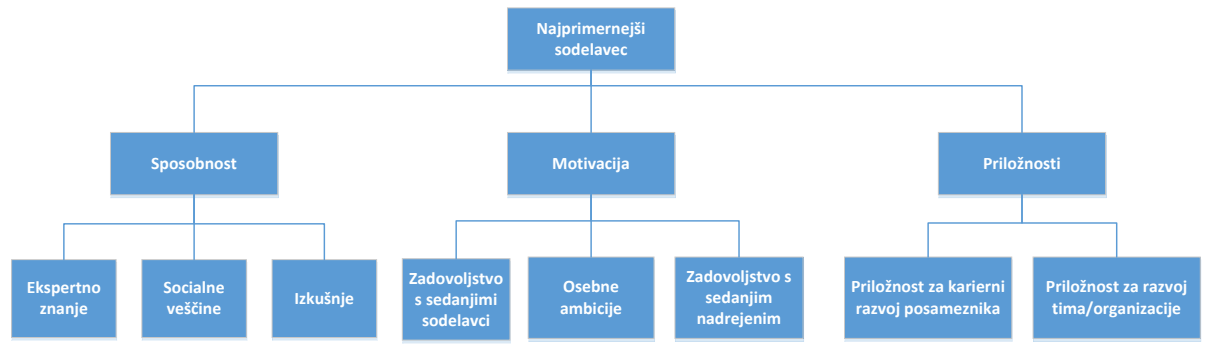

Slika 1: Večkriterijski model izbire sodelavca - model AMO.

Model AMO se uporablja v naprednih kadrovskih službah za izbiro, individualno vrednotenje in nagrajevanje, za sodelovanje pri odločanju, evalvacijah, timskem delu in podobno (Bos-Nehles, Van Riemsdijk, \& Kees Looise, 2013; Jiang, Lepak, Hu, \& Baer, 2012). Praksa je pokazala, da je tak pristop $\mathrm{v}$ interesu tako zaposlenega kot tudi delodajalca.

Delovno mesto posamezniku omogoča strokovni razvoj. Diplomanti, ki ne delajo na svojem študijskem področju, si v hitro razvijajočih se panogah $\mathrm{v}$ nekaj letih bistveno zmanjšajo zaposlitvene možnosti v primarnem poklicu (Leskovar, Bernik, Balantič, \& Kovač, 2015).

Parry (1996) definira kompetence kot nabor povezanega znanja, obnašanja in veščin, ki vplivajo na večji del opravljanja delovnih obveznosti posameznika. Kompetenca je del posameznikove osebnosti, na osnovi katere merimo tudi učinkovitost posameznika. Posameznikove kompetence so odvisne tudi od vrste in načina dela, ki ga opravlja posameznik (Sandberg, 2000). 
$36^{\text {TH }}$ International Conference on Organizational Science Development: RESPONSIBLE ORGanization (MARCh $22^{\mathrm{ND}}-24^{\mathrm{TH}}$, PORTOROŽ SLOVENIA)

R. Leskovar, A. Baggia \& G. Vukovič: Professional Outlook in Computer and Information Technology

Obstajajo različni načini delitve kompetenc, eno od delitev predstavlja (Majcen, 2009), ki kompetence deli na generične, ključne in skupne. Miglič (2006) poudarja, da je v praksi pogosto razlikovanje med kompetencami, ki se nanašajo na vedenjske značilnosti posameznika in so vzročno povezane z njegovim uspešnim delom in kompetencami, ki so pomenijo sposobnost izvajati poklicne dejavnosti. Prvo razumevanje kompetenc se usmerja na vložek, ki pomaga dosegati delovno uspešnost, medtem ko se drugo usmerja na dokazane rezultate kompetenc.

Pred zaposlitvijo se večina izobražuje, pri čemer se predpostavlja, da študent/dijak želi pridobiti ekspertno znanje, socialne veščine in izkušnje. Trend izobraževanja je t.i. osredotočenje na znanje, veščine in kompetence. Na kakovosten izid študija vplivajo še: kompetentni in družbeno odgovorni učitelji (Kunter et al., 2013), primerni materialni pogoji (Schmid \& Abell, 2003), spodbujevalno socialno okolje poklicnih svetovalcev (Sargeant, 2016), sošolcev, prijateljev (Gainen, 1995) in družine (Jeynes, 2014). Prehod iz srednješolskega izobraževanja na univerzo je za marsikaterega dijaka boleč (Borgen \& Borgen, 2016; Petty, 2014). Podobno kot Sargeant (2016), menimo, da svetovalne službe lahko pozitivno vplivajo na izbor področja študija. Informacijska dejavnost je zelo perspektivno področje, zato ga bomo obravnavali v tem članku.

\section{Pregled trga dela - EURES in Zavod RS za zaposlovanje}

Evropski parlament (Evropski parlament, 2013) je leta 2013 objavil, da na področju IKT dela okoli 7 milijonov ljudi, od katerih je 30 odstotkov žensk. Sektor vsako leto ustvari 120.000 novih delovnih mest. Takratna projekcija je bila, da bodo leta $2015 \mathrm{v}$ EU podjetja potrebovala 700.000 informatikov več, kot jih bo predvidoma na voljo. Poizvedbi v zaposlitvenem portal EURES (4.11.2016) le z dvema ključnima besednima zvezama je pokazala preko 94 tisoč zadetkov:

- "Systems analysts"; 16,398 zadetkov pregledano prvih 110 zadetkov

- "IT specialist"; 78,261 zadetkov; pregledano prvih 100 zadetkov (tabela 1).

Tabela 1. Poizvedbi v EURES, 4.11.2016 s ključnima besednima zvezama "Systems analysts" in "IT specialist".

\begin{tabular}{|l|l|}
\hline "Systems analysts" & "IT specialist" \\
\hline Category: Systems analysts & Category: Systems analysts \\
- Systems analysts & - IT Specialist \\
- Junior System Analyst & - IT Specialist SAP ERP HCM \\
- System Analyst / System Engineer & - IT Specialist System Design / Project \\
- System Design / Analyst for big & Management \\
customers & - IT Infrastructure Specialist \\
- Informatie Analist / Business Analist & - IT Product Specialist \\
(NL) & - Product Specialists, Video Analytics \\
- GIS Analyst Intern & \\
\hline
\end{tabular}


R. Leskovar, A. Baggia \& G. Vukovič: Pregled poklicev v informacijski dejavnosti

- Functional analysts

- System Test Engineer

- Senior System Engineer for Back-end Systems

Category: Software developers

- System Analyst

- MIS Systems Analyst

- Business Systems Analyst

- Infor Baan - Business Systems

Analyst

- Clinical System Support Analyst

- System Test Analyst

- Finance Systems Support Analyst

- Business Analyst - Finance systems

- Technical Business Analyst

- Data Analyst- Housing System

- IT Business Analyst / Business

Systems Analyst

- Senior Java Developer / Systems

Analyst : Financial

- Data Analyst - eContent and System

Reporting

Category: Information and communications technology service managers

- System Analyst

- System Analyst Contract

Management System

- System Analyst: Sales \& Front End

Systems

- System Analyst/Developer

- Ergo - Functional Analyst Sales \&

Front End Systems

- Process and System Business Analyst (SAP)

- Ergo - Funtional Analyst - Contract

Management System

- Functional Analyst

Category: Computer network professionals

- System Analyst
Category: Software developers

- IT Applications Specialist

- ICT Service Delivery Specialist

- IT Infrastructure Specialist

- IT Support Specialist - IT Support

Technician

- IT Network Lead / IT Network

Specialist

Category: Commercial sales representatives

- IT Specialist

Category: Sales and marketing managers

- Telecommunication Sales Specialist IT Sales Graduates

- Telecommunication Sales Specialist -

IT Sales Consultant

Category: Information and communications technology sales professionals

- IT Specialist / IT Consultant - ERP

Category: Information and communications technology professionals

- IT Business Technical Specialist

- IT-Spezialist

Category: Contact centre salespersons

- IT Sales Specialist

Category: Systems administrators

- Senior IT Specialist

- Senior IT Specialist /

Systemadministrator

- BI Specialists to GFRT, Group IT

- IT Spezialist

- IT Operations Specialist - Database

- Senior Security Specialist in Group IT 
$36^{\mathrm{TH}}$ InTERnATIONAL CONFERENCE ON ORganizational SCIENCE DeVElopment: RESPONSIBLE ORGANIZATION (MARCH $22^{\mathrm{ND}}-24^{\mathrm{TH}}$, PORTOROŽ SLOVENIA)

R. Leskovar, A. Baggia \& G. Vukovič: Professional Outlook in Computer and Information Technology

Category: Information and communications technology user support technicians

- System Analyst

- IT System Support Officer

Category: Finance managers

- Supervisor Accounting \& System

Analyst (SAP)

Category: Shop sales assistants

- IT Business Systems Analyst

- Pensions Systems Analyst

Category: Commercial sales

representatives

- Sage X3 Systems Analyst

Category: Training and staff development professionals

- HR Systems Support Analyst

- Senior Business Analyst - Retail

Systems

- Business Systems Analyst (ERP/BI)

Category: General office clerks

- Systems Data Analyst

Category: Human resource

managers

- Analyst (Travelport HR Information

Systems)

Category: Software and applications

developers and analysts not

elsewhere classified

- Senior Digital Analyst

- Pensions Consulting Analyst / IT

Systems - Data Analyst

- System Engineer/System

Administrator

- Analyste fonctionnel

- Analyste décisionnel - Business

Intelligence

\section{Category: Information and} communications technology service managers

- IT Specialist

- IT Specialist mit Interesse an Retail Solutions

- IT Specialist programmeur

- IT Specialist for Procurement Support

- project- en onderzoeksmedewerker IT specialist (informaticus) voornamelijk in webtechnologie (B)

- IT Manager

Category: Accounting associate professionals

- Specilaist Controlling

\section{Category: Computer network} professionals

- IT Specialist 2nd level

- IT Specialist 3rd level

- ICT-specialist

Category: Computer network and systems technicians

- IT Support Specialist

Category: Training and staff development professionals

- IT Service Support Specialist

- IT Infrastructure specialist

- BI Specialist

- Data Entry Specialist

- Business Improvement Specialist

- Active Directory Specialist

Category: Information and

communications technology user

support technicians

- IT Specialist Customer Service

- IT-Spezialist Problemmanagement

- IT Consultant

- IT Support 
R. Leskovar, A. Baggia \& G. Vukovič: Pregled poklicev v informacijski dejavnosti

\begin{tabular}{|l|l|}
\hline - Business Analyst for Tax reporting & $\begin{array}{l}\text { Category: Information and } \\
\text { solutions }\end{array}$ \\
- Analyste fonctionnel / fonctionnelle & $\begin{array}{l}\text { operations technicians } \\
\text { informatique }\end{array}$ \\
- Business Analyst & - Dev Infrastructure Specialist \\
- Analyste/Programmeur JAVA & Category: Advertising and \\
- Infrastructure Analyst & marketing professionals \\
- Functioneel Analyst (B) & - Marketing specialist IT \\
- Test Engineer / Analys Engineer till & \\
Experis IT (S) & Category: Commercial sales \\
- Implementation Analyst & representatives \\
- Data Analyst & - IT Security Specialist \\
- Business Intelligence Analyst & - Presale - IT Sales Specialist \\
- systeem - en netwerkbeheerder (B) - & \\
skrbnik omrežja & Category: Software and applications \\
- Systeem Architect (B) & developers and analysts not \\
- Analyste-programmeur / Analyste- & elsewhere classified \\
programmeuse informatique & - IT Consultant Specialist \\
- Analyste d'application & - Support Specialist IT \\
- IT Systeem- en netwerkbeheerder (B) & - ICT Specialist \\
- Analyste-programmeur / Analyste- & \\
programmeuse informatique & Category: Database and network \\
- EPOS Test Analyst & professionals not elsewhere classified \\
- Test Analyst - Claims & - IT Security Specialist \\
& - IT Specialist \\
& Category: Electronics engineers \\
& - Senior IT Support Specialist \\
& Category: Engineering professionals \\
& not elsewhere classified \\
& - Analog IC Design Engineer \\
\hline
\end{tabular}

Iskanje zgolj po dveh delovnih mestih "Systems analysts" in "IT specialist" je pokazalo, da smo našli kar eno osmino napovedanih delovnih mest iz leta 2014. Vsako od iskanih delovnih mest spada v kar 12 oz. 20 različnih kategorij delovnih mest. Kakšno pa je stanje pri poklicih, ki so primerni za zasedbo delovnega mesta? $\mathrm{Na}$ to vprašanje bomo odgovorili v naslednjem poglavju. Stanje v Sloveniji smo raziskali leta 2014 in ugotovili (Leskovar et al., 2015), da so "analitiki in snovalci informacijskih sistemov med najbolj iskanimi, deficitarni so $\mathrm{v}$ vseh slovenskih regijah (večletni podatki Zavoda RS za zaposlovanje)" (Zavod Republike Slovenije za zaposlovanje, 2015). 
$36^{\mathrm{TH}}$ International Conference on ORganizational Science Development: RESPONSIBLE ORGANIZATION (MARCH $22^{\mathrm{ND}}-24^{\mathrm{TH}}$, PORTOROŽ SLOVENIA)

R. Leskovar, A. Baggia \& G. Vukovič: Professional Outlook in Computer and Information Technology

\section{ESCO - pristop Evropske komisije k opredelitvi veščin, kompetenc in poklicev}

Portal ESCO vsebuje seznam poklicev, poklicnih skupin, veščin in kompetenc ter omogoča preslikavo poklicev v klasifikacijo, ki jo opredeljuje mednarodna organizacija za delo ILO: ISCO 2008 in ISCO 1998 (International Labour Organization, 2016). Na sliki 2 je delno prikazana hierarhija poklicev ESCO (Evropska komisija, 2017).

\begin{tabular}{|c|c|c|}
\hline & A & B \\
\hline 1 & source & target \\
\hline 3 & POKLICl & Menedžerji \\
\hline 4 & $\mathrm{POKLICl}$ & Poklici za neindustrijski način dela \\
\hline 6 & $\mathrm{POKLICl}$ & Poklici za storitve, prodajalci/prodajalke \\
\hline 7 & POKLICl & Strokovnjaki/strokovnjakinje \\
\hline 8 & $\mathrm{POKLICl}$ & Tehniki/tehnice in strokovni sodelavci/strokovne sodelavke \\
\hline 12 & Strokovnjaki/strokovnjakinje & Strokovnjaki/strokovnjakinje za vzgojo in izobraževanje \\
\hline 13 & Strokovnjaki/strokovnjakinje & Strokovnjaki/strokovnjakinje znanstvenih in tehnično-tehnoloških ved \\
\hline 14 & Strokovnjaki/strokovnjakinje & Zdravstveni strokovnjaki/zdravstvene strokovnjakinje \\
\hline 15 & Strokovnjaki/strokovnjakinje & Pravni strokovnjaki/pravne strokovnjakinje, strokovnjaki/strokovnjakinje družbenih ve \\
\hline 16 & Strokovnjaki/strokovnjakinje & Strokovnjaki/strokovnjakinje za poslovanje in upravljanje \\
\hline 17 & Strokovnjaki/strokovnjakinje & Strokovnjaki/strokovnjakinje za informacijske in komunikacijske tehnologije \\
\hline 23 & Strokovnjaki/strokovnjakinje za podatkovne zbirke in računalniška omrežja & Strokovnjaki/strokovnjakinje za računalniška omrežja \\
\hline 24 & Strokovnjaki/strokovnjakinje za podatkovne zbirke in računalniška omrežja & AnalitikJanalitičarka za obdelavo podatkov \\
\hline 25 & Strokovnjaki/strokovnjakinje za podatkovne baze in računalniška omrežja, $d . n$. & Skrbnik/skrbnica za varnost (obdelava podatkov/T) \\
\hline 26 & Strokovnjaki/strokovnjakinje za podatkovne baze in računalniška omrežja, $\mathrm{d}$. n. & Direktor/direktorica računalniške varnosti \\
\hline 27 & Strokovnjaki/strokovnjakinje za podatkovne baze in računalniška omrežja, $d . n$. & Varnostni direktor/varnostna direktorica (obdelava podatkov/IT) \\
\hline 28 & Strokovnjaki/strokovnjakinje za podatkovne baze in računalniška omrežja, $d . n$. & Varnostni upravitelj/varnostna upravitelijca za IT \\
\hline 29 & Strokovnjaki/strokovnjakinje za podatkovne baze in računalniška omrežja, $d . n$. & Upravitelj/upraviteljica računalniške varnosti \\
\hline 30 & Strokovnjaki/strokovnjakinje za podatkovne baze in računalniška omrežja, $d . n$. & IT preiskovalec/preiskovalka \\
\hline 31 & Strokovnjaki/strokovnjakinje za podatkovne baze in računalniška omrežja, $\mathrm{d}$. n. & Strateg/strateginja za IT \\
\hline 32 & Sistemski upravljavci/sistemske upravljavke & Upraviteli/upravitelijica sistemov \\
\hline 33 & Sistemski upravljavci/sistemske upravljavke & Skrbnik/skrbnica omrežij \\
\hline 34 & Sistemski upravljavci/sistemske upravljavke & Nadzornik/nadzornica dostopa (obdelava $p$ \\
\hline 35 & Sistemski upravljavci/sistemske upravljavke & Skrbnik/skrbnica sistema \\
\hline
\end{tabular}

\section{Slika 2: Delni prikaz hierarhije poklicev po ESCO.}

Na sliki 3 je prikazan graf povezav od pojma "Poklic" do nivoja veščin/kompetenc pri štirih tipičnih poklicih $\mathrm{v}$ informacijski dejavnosti. Prikazani so vsi poklici, ki so opredeljeni kot skupina "Strokovnjaki/strokovnjakinje za informacijske in komunikacijske tehnologije" (skupno 66 pojavov poklicev). $\mathrm{Za}$ poklice Analitik/analitičarka sistemov, Sistemski inženir/sistemska inženirka, Razvijalec aplikacij/razvijalka aplikacij in Administrator/administratorka zbirke podatkov pa so izrisane tudi veščine/kompetence. $V$ trenutni verziji ESCO ne ločuje med veščino in kompetenco. 


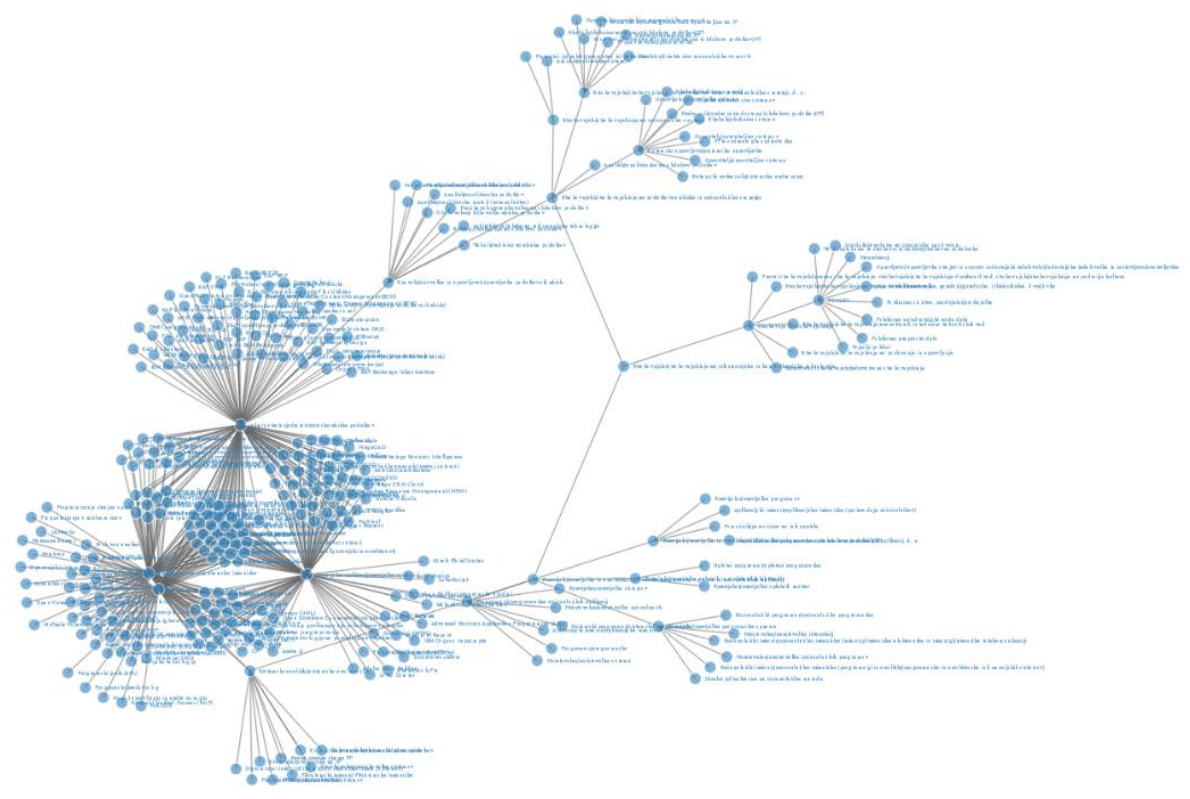

Slika 3. Graf povezav od pojma "Poklic" do nivoja veščin/kompetenc pri štirih tipičnih poklicih $v$ informacijski dejavnosti.

\section{Pristop Ministrstva za delo ZDA - Department of Labor USA}

Portal Ministrstva za delo ZDA (United States Department of Labor, 2017)je zelo pragmatičen. Osredotoča se na vsebino dela, najverjetnejšo smer in stopnjo izobrazbe ter povprečno plačo poklica $\mathrm{v}$ preteklem letu.

Pričakovano povečanje števila delovnih mest v ZDA za obdobje 2014 do 2024 je 12 odstotkov, kar je več kot poprečja za vse poklice. Absolutne številke za ZDA: število zaposlenih v letu 2014 je bilo 3.9 milijona, do leta 2024 je pričakovati dodatnih 488 tisoč novih delovnih mest. Deloma je to povečanje povezano z uvajanjem storitev v oblaku, masovnih podatkov, interneta stvari in rešitev za mobilne odjemalce. V maju 2015 je bila mediana letne plače v IKT dejavnosti 81 tisoč USD, mediana za vse dejavnosti pa je bila 36 tisoč USD. Na portalu so izpostavljeni naslednji poklici (slika 4):

Raziskovalec na področju računalništva in informatike:

- Arhitekt računalniškega omrežja

- Računalniški programer

- Specialist za računalniško podporo

- Računalniški sistemski analitik

- Administrator baze podatkov 
R. Leskovar, A. Baggia \& G. Vukovič: Professional Outlook in Computer and Information Technology

- Analitik za informacijsko varnost

- Administrator omrežja in računalniškega Sistema

- Razvijalec programske opreme

- Razvijalec spletnih vsebin

\begin{tabular}{|c|c|c|c|c|}
\hline & OCCUPATION & JOB SUMMARY & ENTRY-LEVEL EDUCATION $\theta \hat{\nabla}$ & 2015 MEDIAN PAY 9 \\
\hline \multirow[t]{2}{*}{ 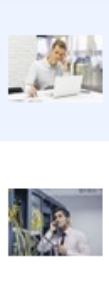 } & $\begin{array}{l}\frac{\text { Computer and }}{\text { Information }} \\
\text { Research Scientists }\end{array}$ & $\begin{array}{l}\text { Computer and information research scientists invent and design } \\
\text { new approaches to computing technology and find innovative } \\
\text { uses for existing technology. They study and solve complex } \\
\text { problems in computing for business, medicine, science, and } \\
\text { other fields. }\end{array}$ & Doctoral or professional degree & $\$ 110,620$ \\
\hline & $\begin{array}{l}\text { Computer Network } \\
\text { Architects }\end{array}$ & $\begin{array}{l}\text { Computer network architects design and build data } \\
\text { communication networks, including local area networks (LANs), } \\
\text { wide area networks (WANs), and intranets. These networks } \\
\text { range from small connections between two offices to } \\
\text { next-generation networking capabilities such as a cloud } \\
\text { infrastructure that serves multiple customers. }\end{array}$ & Bachelor's degree & $\$ 100,240$ \\
\hline \multirow[t]{2}{*}{$\sum_{2} 8$} & $\begin{array}{l}\frac{\text { Computer }}{\text { Programmers }} \\
\underline{ }\end{array}$ & $\begin{array}{l}\text { Computer programmers write and test code that allows computer } \\
\text { applications and software programs to function properly. They } \\
\text { tum the program designs created by software developers and } \\
\text { engineers into instructions that a computer can follow. }\end{array}$ & Bachelor's degree & $\$ 79,530$ \\
\hline & $\begin{array}{l}\text { Computer Support } \\
\underline{\text { Specialists }}\end{array}$ & $\begin{array}{l}\text { Computer support specialists provide help and advice to people } \\
\text { and organizations using computer software or equipment. Some, } \\
\text { called computer network support specialists, support information } \\
\text { technology (IT) employees within their organization. Others, } \\
\text { called computer user support specialists, assist non-IT users } \\
\text { who are having computer problems. }\end{array}$ & See How to Become One & $\$ 51,470$ \\
\hline & $\begin{array}{l}\text { Computer Systems } \\
\text { Analysts }\end{array}$ & $\begin{array}{l}\text { Computer systems analysts study an organization's current } \\
\text { computer systems and procedures and design information } \\
\text { systems solutions to help the organization operate more } \\
\text { efficiently and effectively. They bring business and information } \\
\text { technology (IT) together by understanding the needs and } \\
\text { limitations of both. }\end{array}$ & Bachelor's degree & $\$ 85,800$ \\
\hline & $\begin{array}{l}\frac{\text { Database }}{\text { Administrators }} \\
\end{array}$ & $\begin{array}{l}\text { Database administrators (DBAs) use specialized software to } \\
\text { store and organize data, such as financial information and } \\
\text { customer shipping records. They make sure that data are } \\
\text { available to users and are secure from unauthorized access. }\end{array}$ & Bachelor's degree & $\$ 81,710$ \\
\hline al & 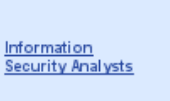 & $\begin{array}{l}\text { Information security analysts plan and carry out security } \\
\text { measures to protect an organization's computer networks and } \\
\text { systems. Their responsibilities are continually expanding as the } \\
\text { number of cyberattacks increases. }\end{array}$ & Bachelor's degree & $\$ 90,120$ \\
\hline Es & $\begin{array}{l}\text { Network and } \\
\frac{\text { Computer Systems }}{\text { Administrators }}\end{array}$ & $\begin{array}{l}\text { Computer networks are critical parts of almost every } \\
\text { organization. Network and computer systems administrators are } \\
\text { responsible for the day-to-day operation of these networks. }\end{array}$ & Bachelor's degree & $\$ 77,810$ \\
\hline & $\begin{array}{l}\text { Software } \\
\text { Developers }\end{array}$ & $\begin{array}{l}\text { Software developers are the creative minds behind computer } \\
\text { programs. Some develop the applications that allow people to do } \\
\text { specific tasks on a computer or another device. Others develop } \\
\text { the underlying systems that run the devices or that control } \\
\text { networks. }\end{array}$ & Bachelor's degree & $\$ 100,690$ \\
\hline & Web Developers & $\begin{array}{l}\text { Web developers design and create websites. They are } \\
\text { responsible for the look of the site. They are also responsible } \\
\text { for the site's technical aspects, such as its performance and } \\
\text { capacity, which are measures of a website's speed and how } \\
\text { much traffic the site can handle. In addition, web developers } \\
\text { may create content for the site. }\end{array}$ & Associate's degree & $\$ 84,970$ \\
\hline
\end{tabular}

Slika 4. Poklici, ki jih izpostavlja USA Department of Labor (jan. 2017, objava dec. 2015). 

ORGANIZACIJA (22. - 24. MAREC 2017, PORTOROŽ, SLOVENIJA)

R. Leskovar, A. Baggia \& G. Vukovič: Pregled poklicev v informacijski dejavnosti

\section{$5 \quad$ Primeri karier sto skoraj naključnih diplomantov programa "Organizacija in management informacijskih sistemov" FOV - portal LinkedIn}

Diplomanti programov Organizacija in management informacijskih sistemov (OMIS) so se uveljavili na širokem področju zaposlitev. Ta spekter obsega strokovnjake, ki:

- pretežno delajo z ljudmi (specialisti za uvajanje rešitev, klicni centri, IT podpora, vodenje projektov),

- delajo tako z ljudmi kot tudi s tehnologijo in predstavljajo povezavo med uporabniki in tehnološko usmerjenimi razvijalci rešitev (sistemski, podatkovni in poslovni analitiki, oblikovanje in izvajanje kibernetske varnosti, vodenje informacijske dejavnosti)

- pretežno delajo s tehnologijo (programiranje, oblikovanje rešitev, administriranje baz podatkov in omrežja, tehnološka varovanje informacijskih dobrin)

Na sliki 5 je prikazano drevo proučevanih diplomantov (pobrisani priimki), ki smo jih skoraj naključno pridobili na platformi LinkedIn. Kaže se, da je večina zaposlitev diplomantov povezana s tehnologijo, kombinacijo tehnologije in dela $\mathrm{z}$ ljudmi, najmanj zaposlitev pa je izključno delo z ljudmi.

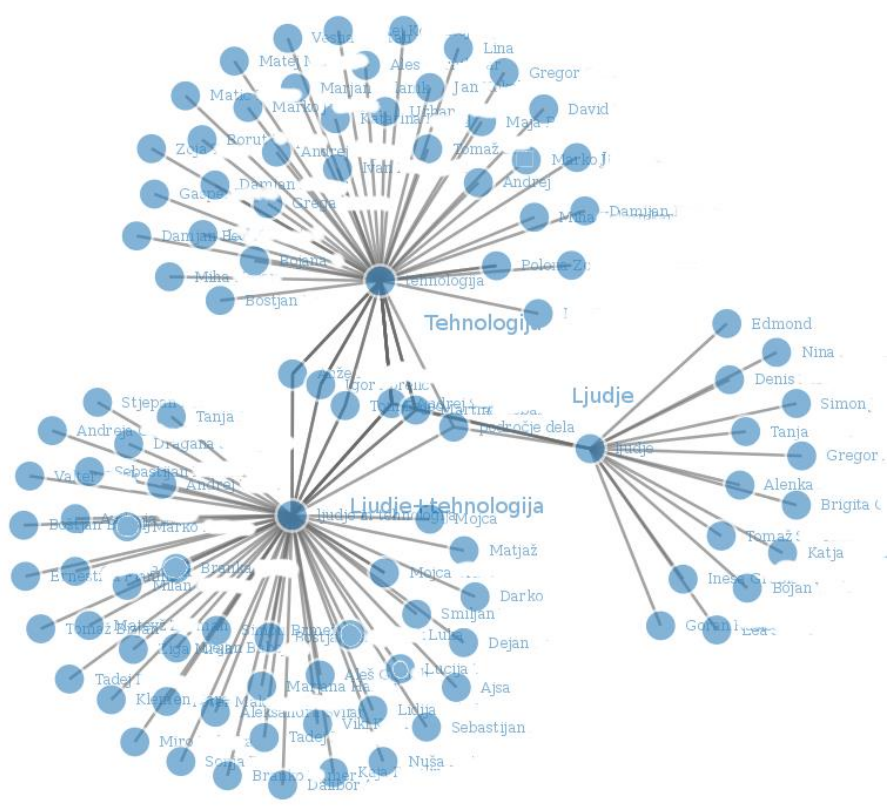

Slika 5. Področja zaposlitev diplomantov FOV-OMIS. 
$36^{\mathrm{TH}}$ InTERnATIONAL CONFERENCE ON ORganizational SCIENCE DeVElopment: RESPONSIBLE ORGANIZATION (MARCH $22^{\mathrm{ND}}-24^{\mathrm{TH}}$, PORTOROŽ SLOVENIA)

R. Leskovar, A. Baggia \& G. Vukovič: Professional Outlook in Computer and Information Technology

Kot enega zanimivejših primerov več kot 20 letne karierne poti izpostavljamo diplomanta A, ki jo predstavljamo v Tabeli 2.

Tabela 2: Karierna pot diplomanta A.

\begin{tabular}{lll}
\hline Čas & Delovno mesto & Podjetje \\
\hline Trenutno stanje & Poslovni analitik & Podjetje 6 \\
& Samostojni podjetnik & Podjetje 5 \\
& Vodja projekta & Podjetje 4 \\
& Vodilni konzultant & Podjetje 3 \\
& Vodja svetovalcev & Podjetje 2 \\
& Izkušeni svetovalec & Podjetje 2 \\
& Produktni vodja & Podjetje 2 \\
& Vodja storitev za stranke & Podjetje 2 \\
& Analitik storitev & Podjetje 2 \\
\hline Začetno stanje & Konzultant & Podjetje 1
\end{tabular}

\section{Dileme poklicnega svetovanja za poklice $v$ informacijski dejavnosti}

Natančno določanje sposobnosti, motivacije in priložnosti je praktično neizvedljivo za poklicne svetovalce. Večina svetovalcev se zanaša predvsem na svoje izkušnje, "občutek". Čeprav so zaposlitvene možnosti na področju informacijske dejavnosti dobre, se dijaki pogosteje odločajo za študij na fakultetah z manjšim zaposlitvenim potencialom. Razlog za to iracionalno odločanje so predvsem "stara družba« iz srednje šole, idealizirane predstave o določenih vrstah študija in pogosto kljubovanje racionalnim argumentov okolice. Podatki kažejo, da so študenti ob prvem neuspešnem poskusu v večjem deležu uspešno diplomirali, če vztrajajo na prvotno izbranem visokošolskem programu in te-tega ne menjajo.

\section{$7 \quad$ Zaključek}

Pristop Evropske komisije k opredelitvi veščin, kompetenc in poklicev ESCO je sistematičen, a nedokončan. Obsega enciklopedijo vseh poklicnih skupin in poklicev, pri katerih pa $v$ trenutni verziji še ne ločuje med veščinami in kompetencami. Ameriški pristop je pragmatičen in enostaven, osredotočen na rezultat - delovna mesta. Pri teh uporablja letno plačo kot orientacijo za bodoče študente. 
Področja informacijske dejavnosti, v katerih je pričakovati nastanek največ novih delovnih mest in tudi poklicev so računalniški oblak, storitve v oblaku (computer cloud, cloud services), internet stvari (Internet of things), kibernetska varnost (cybersecurity), strojno učenje/kognitivno računalništvo (machine learning/cognitive computing), digitalne valute (digital currencies) in virtualna realnost (virtual reality).

Karierne poti nekaterih diplomantov FOV na programu OMIS kažejo, da je večina zaposlitev diplomantov povezana s tehnologijo, kombinacijo tehnologije in dela z ljudmi, najmanj pa izključno delo z ljudmi.

Poklicni svetovalci $\mathrm{v}$ srednjih šolah imajo lahko pomembno vlogo pri podajanju racionalnih argumentov (zaposlitvene možnosti, pričakovana višina plače) za izbiro nadaljevanja študija in poklica dijakov.

\section{Literatura}

Appelbaum, E., Bailey, T., Berg, P., \& Kalleberg, A, L. (2000). Manufacturing Advantage: Why High-Performance Work Systems Pay off. Cornell University Press.

Borgen, S. T., \& Borgen, N. T. (2016). Student retention in higher education: Folk high schools and educational decisions. Higher Education, 71(4), 505-523. http://doi.org/10.1007/s10734015-9921-7

Bos-Nehles, A. C., Van Riemsdijk, M. J., \& Kees Looise, J. (2013). Employee Perceptions of Line Management Performance: Applying the AMO Theory to Explain the Effectiveness of Line Managers' HRM Implementation. Human Resource Management, 52(6), 861-877. http://doi.org/10.1002/hrm.21578

European Commision. (2013). European Classification of Skills/Competences, Qualifications and Occupations. Retrieved from https://ec.europa.eu/esco/portal/document/sl/8e9cf30d-97994f95-ae29-e05c725b24c7

European Commision. (2017). EURES The European Job Mobility Portal. Retrieved January 15, 2017, from https://ec.europa.eu/eures/public/homepage

Evropska komisija. (2017). ESCO Evropska klasifikacija Spretnosti, Kompetenc, Kvalifikacij in Poklicev. Retrieved January 15, 2017, from https://ec.europa.eu/esco/

Evropski parlament. (2013, April 30). V informatiki in komunikacijah premalo žensk, predsodki ostajajo. Evropski Parlament Novice.

Gainen, J. (1995). Barriers to success in quantitative gatekeeper courses. New Directions for Teaching and Learning, 1995(61), 5-14.

Hughes, J. H. J. (2007). The Ability-Motivation-Opportunity Framework for Behavior Research in IS. 2007 40th Annual Hawaii International Conference on System Sciences (HICSS'07), 1-10. http://doi.org/10.1109/HICSS.2007.518

International Labour Organization. (2016). ISCO International Standard Classification of $\begin{array}{lllll}\text { Occupations. } & \text { Retrieved } & \text { January } & 15, & \text { 2017, }\end{array}$ http://www.ilo.org/public/english/bureau/stat/isco/isco08/

Jeynes, W. (2014). Family factors and the educational success of children. Routledge.

Jiang, K., Lepak, D. P., Hu, J., \& Baer, J. C. (2012). How Does Human Resource Management Influence Organizational Outcomes? A Meta-analytic Investigation of Mediating Mechanisms. Academy of Management Journal, 55(6), 1264-1294. http://doi.org/10.5465/amj.2011.0088 
$36^{\text {Th }}$ International Conference on Organizational Science Development: RESPONSIBLE ORGANIZATION (MARCH $22^{\mathrm{ND}}-24^{\mathrm{TH}}$, PORTOROŽ SLOVENIA)

R. Leskovar, A. Baggia \& G. Vukovič: Professional Outlook in Computer and Information Technology

Kunter, M., Klusmann, U., Baumert, J., Richter, D., Voss, T., \& Hachfeld, A. (2013). Professional competence of teachers: Effects on instructional quality and student development. Journal of Educational Psychology, 105(3), 805-820. http://doi.org/10.1037/a0032583

Leskovar, R., Bernik, M., Balantič, Z., \& Kovač, J. (2015). Anketa o zaposljivosti diplomantov Fakultete za organizacijske vede v obdobju 2004-2014. In P. Doucek, A. Novak, \& B. Paape (Eds.), Internacionalizacija in sodelovanje: zbornik 34. mednarodne konference o razvoju organizacijskih znanosti (pp. 591-598). Portorož.

Majcen, M. (2009). Management kompetenc: Izdelava modela kompetenc ter njegova uporaba za razvoj kadrov in za vodenje zaposlenih k doseganju ciljev. Ljubljana: GV Založba.

Miglič, G. (2006). Izkušnje slovenske uprave s kompetencami in usposabljanjem vodilnih uslužbencev za delo EU. In Slovenija v evropski družbi znanja in razvoja: Slovenski politološki dnevi (pp. 52-54). Portorož: Slovensko politološko društvo.

Parry, S. B. (1996). Just What Is a Competency?(And Why Should You Care?). Training, 35(6), 58.

Petty, T. (2014). Motivating first-generation students to academic success and college completion. College Student Journal, 48(2), 257-264.

Sandberg, J. (2000). Understanding Human Competence at Work: An Interpretative Approach. The Academy of Management Journal, 43(1), 9-25. Retrieved from http://www.jstor.org/stable/1556383

Sargeant, A. (2016). Partnerships for Success : Working Together in Higher Education for Student Success, $1-5$.

Schmid, C., \& Abell, P. (2003). Demographic Risk Factors, Study Patterns, and Campus Involvement as Related to Student Success Among Guilford Technical Community College Students. Community College Review, 31(1), 1.

United States Department of Labor. (2017). Computer and Information Technology Occupations. Retrieved January 15, 2017, from https://www.bls.gov/ooh/computer-and-informationtechnology/home.htm

Zavod Republike Slovenije za zaposlovanje. (2015). Retrieved January 31, 2017, from http://www.ess.gov.si/ 
36. MEDNARODNA KONFERENCA O RAZVOJU ORGANIZACIJSKIH ZNANOSTI: OdgOVORNA ORGANIZACIJA (22. - 24. MAREC 2017, PORTOROŽ, SLOVENIJA)

O. Arsenijević, M. Ferjan, I. Podbregar, P. Šprajc, D. Trivan \& Y. Ziegler

\title{
Vpliv kakovosti socialnih interakcij na delovnem mestu na zaposlenčevo zavzetost za delo
}

\author{
BRANKO LOBNIKAR \& ANJA CEDILNIK
}

\begin{abstract}
Povzetek V prispevku analiziramo kakovost socialnih interakcij na delovnem mestu in njihov vpliv na zaposlenčevo zavzetost za delo. Zavzetost zaposlenih razumemo kot stopnjo, do katere so zaposleni pripravljeni uporabiti svoja kognitivna, čustvena in fizična sredstva pri izvajanju dejavnosti, povezanih z delom. Zavzetost za delo se opisuje tudi kot merilo čustvene in razumske navezanosti in pripadnosti posameznika organizaciji in njenemu uspehu. Ker na zavzetost zaposlenih vplivajo socialne interakcije, ki jih doživljamo na delovnem mestu, smo predpostavili, da narava in kakovost teh interakcij pomembno vpliva na zavzetost za delo. Pri tem nas je zanimalo, kako na zavzetost vplivajo interakcije, ki jih zaposleni razumejo kot zaželene (socialna opora) in kako tiste, ki jih razumejo kot nezaželene (socialno spodkopavanje). Pri tem smo izhajali iz dveh predpostavk: več kot je pozitivnih socialnih interakcij, višja je zavzetost za delo ter da skrb organizacije za kakovostne socialne interakcije (kakovostno komuniciranje) prispeva k večji zavzetosti za delo. Za potrebe raziskave smo izvedli anketiranje na priložnostnem in nenaključnem vzorcu 151 zaposlenih v Sloveniji. Vprašalnik je zajemal 67 spremenljivk (Cronbach alfa 0.81). Ugotovili smo, da na zaposlenčevo pripravljenost dobro delati, ne glede na starost, vrsto dela in čas zaposlitve, močno vplivajo emocije in vsebina komunikacij, s katerimi se zaposleni soočajo na delovnem mestu. Skozi njih se namreč izraža kakovost interakcij zaposlenih. Bolj kot posameznik zaznava neko komunikacijo kot prijetno in oporno, bolj je zavzet za delo.
\end{abstract}

KLJUČNE BESEDE: zavzetost za delo • odnosi na delovnem mestu • socialna opora • socialno spodkopavanje

\footnotetext{
NASLOV AVTORJEV: dr. Branko Lobnikar, izredni profesor, Univerza v Mariboru, Fakulteta za varnostne vede, Kotnikova 8,1000 Ljubljana, Slovenija, e-pošta: branko.lobnikar@fvv.uni-mb.si; mag. Anja Cedilnik, Univerza v Mariboru, Fakulteta za varnostne vede, Kotnikova 8,1000 Ljubljana, Slovenija, e-pošta: anja.cedilnik@gmail.com
} 
$36^{\mathrm{TH}}$ International Conference on Organizational Science Development: Responsible Organization (MARCH $22^{\mathrm{ND}}-24^{\mathrm{TH}}$, PORTOROŽ SLOVENIA)

O. Arsenijević, M. Ferjan, I. Podbregar, P. Šprajc, D. Trivan \& Y.

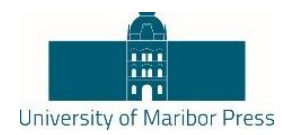

Ziegler

\title{
The Impact of the Quality of Social Interactions at the Workplace on Employee Work Engagement
}

\author{
BRANKO LOBNIKAR \& ANJA CEDILNIK
}

\begin{abstract}
In the paper, the authors will examine the quality of social interactions in the workplace and their impact on work engagement. Engagement of employees can be described as the level at which employees use their cognitive, emotional and physical resources in the implementation of activities related to the work. Furthermore, engagement can be described as a measure of emotional and intellectual attachment and affiliation of the individual to the organization and its success. Engagement is more than just the satisfaction and loyalty of the individual to the organization, the latter is in fact a set of personal satisfaction, motivation, belonging, pride and willingness to do some more work in the organization. However, as the personal satisfaction is affected by social interactions, largely by those we are experiencing in the workplace, we believe that these impact on work engagement. In the study we examined the importance of both positive and negative social interactions and determine in what way and to what extent they are related to work engagement. For the purposes of study authors carried out a survey on non-random sample of 151 employees. The questionnaire consisted of 67 variables (Cronbach alpha 0.81). The results showed that employees' engagement, regardless of age, type of work and time of employment, is affected by emotions and the nature of communication at the workplace. Employees face those feelings in the workplace in conjunction with superiors and colleagues. The quality of the interactions among employees is expressed through them. The more an individual is happy, the higher the level of job satisfaction is and commitment to the work.
\end{abstract}

KEYWORDS: work engagement $\bullet$ workplace relations $\bullet$ social undermining - social support

CoRRESPONDENCE AdDRESS: Branko Lobnikar, Ph.D., Associate Professor, University of Maribor, Faculty of Criminal Justice and Security, Kotnikova 8,1000 Ljubljana, Slovenija, e-mail: branko.lobnikar@fvv.uni-mb.si; Anja Cedilnik, M.S., University of Maribor, Faculty of Criminal Justice and Security, Kotnikova 8,1000 Ljubljana, Slovenija, e-mail: anja.cedilnik@gmail.com 


\section{Pomen socialnih interakcij na zavzetost zaposlenih za kakovostno delo}

\subsection{Socialne interakcije na delovnem mestu}

Socialne interakcije razumemo kot relativno trajne medosebne odnose zaposlenih $\mathrm{v}$ delovnem okolju. Za nastanek socialnih interakcij na delovnem mestu je tako potrebno trajnejše in ponavljajoče se sodelovanje med dvema ali več osebami. Oporne socialne interakcije spodbujajo sodelovanje zaposlenih, podrejenih in nadrejenih, boljše načrtovanje in boljše razumevanje vrednot organizacije. Zaposleni namreč potrebujejo socialne interakcije, da lahko uspešno rešujejo probleme. Učinkoviti in zadovoljujoči medosebni odnosi pa so prvi pogoj za osebno in poklicno srečo (Smeh, Visočnik, 2013). Socialne interakcije na delovnem mestu so oblikovane kot svojstveni odnosi med sodelavci in vsebujejo tako osebno kot tudi formalno noto (Smeh, Visočnik, 2013) in lahko nastanejo na dva načina. Možina, Bernik in Svetic (2004) navajajo institucionalni in spontani način. Arzenšek in Kožuh (2011) pa medosebne odnose na delovnem mestu razdelita v štiri skupine; (a) skupino, ki vsebuje prijateljsko sodelovanje in je usmerjena k skupnemu cilju, (b) skupino, ki vsebuje nasprotovalno tekmovanje in ni usmerjena $\mathrm{k}$ skupnemu cilju, (c) skupino, ki vsebuje prijateljsko tekmovanje in je usmerjena $\mathrm{k}$ različnim ciljem $\mathrm{z}$ medsebojno pomočjo ter (d) skupino, ki vsebuje nasprotovalno sodelovanje in je usmerjena $\mathrm{k}$ skupnemu cilju $\mathrm{z}$ nasprotovanjem enega proti drugemu. Celostno razumevanje socialnih interakcij je možno le s poznavanjem kognitivnih sposobnosti, strukture in procesov, ki tvorijo podlago za razvoj socialnega bitja (Repovš, 2002).

$\mathrm{V}$ organizacijah se posamezniki srečujejo $\mathrm{z}$ vrsto različnih vedenj, negativnimi in pozitivnimi. Lahko so tudi skrajnostna in se pojavljajo tako rekoč v vsaki organizaciji. Pogosto predstavljajo izziv menedžerjem, saj takšno vedenje vpliva na vse procese, ki se odvijajo v organizaciji. Primer pozitivne socialne interakcije je na primer prijateljstvo na delovnem mestu, primer skrajne negativne socialne interakcije pa sovraštvo ali maščevanje na delovnem mestu.

Heaphy in Dutton (2008) ugotavljata, da imajo pozitivne socialne interakcije na delovnem mestu ugodne psihološke učinke. Prijateljstvo Berman, West in Richter (2002) na delovnem mestu definirajo kot neavtoritarno razmerje na delovnem mestu, ki vsebuje obojestransko zaupanje, predanost, naklonjenost in skupne vrednote. Številni avtorji so prepričani, da prijateljski odnosi delo olajšajo in pripomorejo $\mathrm{k}$ doseganju boljših rezultatov, kar je cilj vsake organizacije (Pagon, Lobnikar in Butinar, 2014). Turk (2010) opisuje, da je pri skupnem delovanju med sodelujočimi mogoče zaznati najmanj tovariške in včasih celo prijateljske pojave. Prijateljske pojave zaznamujejo različne prvine zbliževanja in sicer medsebojna privlačnost, sorodnost čustvovanja, sorodnost razmišljanja, medsebojna zaupljivost, medsebojna iskrenost, medsebojno vplivanje in medsebojna pomoč. Sorodnost čustvovanja kot sestavina prijateljstva je pomembna, saj ljudje na različne načine občutijo pojave v okolju, ti jih na različne načine prizadenejo. Vključuje obzirnost do drugega in lahko vodi do okrepitve ali ohladitve prijateljstva. Sorodnost razmišljanja je pomembna sestavina pri delu, kjer sodeluje več ljudi in je 
$36^{\text {Th }}$ International Conference on Organizational Science Development: Responsible Organization (MARCh $22^{\mathrm{ND}}-24^{\mathrm{TH}}$, Portorož Slovenia)

B. Lobnikar \& A. Cedilnik: The Impact of the Quality of Social Interactions at the Workplace on Employee Work Engagement

njihovo delovanje usmerjeno $\mathrm{v}$ doseganje istega cilja. Zaupljivost je lastnost človeka, $\mathrm{s}$ katero se izraža bližina, značilna za prijateljstvo. Za zaupljivost je pomembna podobnost razmišljanja in čustvovanja in zaupljivost je posledica medsebojne privlačnosti. Pri zaupanju je potrebno omeniti še pomembna dejavnika kot sta zanesljivost in pravičnost. Iskrenost je lastnost posameznika, ki ima pošten, odkrit, naklonjen odnos do drugih in nastane iz zaupljivosti. Iskrenost se nanaša na razmišljanja in čustvovanja posameznika. Za iskrenost je pomembna resnicoljubnost in poštenost. Vplivanje je delovanje na nekoga drugega, kar se izraža v njegovem delu, ravnanju in mišljenju. Za dober potek poslov in obstoj dobrih vezi v javnem življenju, posebej pri izvajanju skupnih projektov, je treba zagotoviti uspešno medsebojno vplivanje udeležencev. Za dobro opravljanje dela in projektov je medsebojna pomoč koristna in je lahko neposredna ali posredna. Medsebojna pomoč je usmerjenja $\mathrm{k}$ prijateljevi uspešnosti in pomeni, da se z njim veselimo njegovih/njenih uspehov. Pomembni dejavniki medsebojne pomoči so zato prizadevnost, izvirnost in samozavednost (Turk, 2010).

Tako kot pri zaželenih (pozitivnih) socialnih interakcijah na delovnem mestu poznamo tudi pri negativnih interakcijah celo plejado vedenj. Hse in Standards (2004) stres na delovnem mestu opisujeta kot simptom slabih odnosov med zaposlenimi in kot tak lahko resno vpliva na produktivnost. Organizacije in podjetja, ki se s svojimi zaposlenimi redno pogovarjajo in imajo vpeljane postopke za upravljanje $\mathrm{z}$ neželenim vedenjem na delovnem mestu, imajo več možnosti, da se izognejo slabim posledicam stresa. Nasilje na delovnem mestu je stresor, ki domnevno vodi v izgorelost. Izgorelost je sindrom, ki se pojavi kot odgovor na izpostavljenost stresorjem na delovnem mestu in vsebuje tri komponente: izčrpanost, cinizem in znižano učinkovitost (Couto in Lawoko 2011). Pri pregledu literature lahko ugotovimo, da avtorji različno obravnavajo problem nasilnega vedenja na delovnem mestu. Ameriški avtorji največkrat govorijo o »nasilju na delovnem mestu« (workplace violence) in/ali o »agresivnosti na delovnem mestu (workplace aggression), medtem pa evropski raziskovalci proučujejo »ustrahovanje na delovnem mestu« (workplace bullying) oz. »šikaniranje na delovnem mestu« (workplace mobbing). Včasih lahko zasledimo tudi analize, ki obravnavajo »osorno vedenje na delovnem mestu « (incivility in the workplace). Za vse te pristope sicer ne moremo trditi, da je mogoče med njimi postaviti enačaj, vsekakor pa med njimi prihaja do večjega ali manjšega vsebinskega prekrivanja. Skupno vsem pristopom je, da obravnavajo vedenja, ki imajo negativen vpliv na organizacijsko uspešnost in učinkovitost, saj pojav katerega koli prej omenjenega deviantnega vedenja ustvarja sovražno delovno okolje in negativno vpliva tako na dobro počutje zaposlenih kot tudi na organizacijske rezultate (Pagon, Lobnikar, Butinar, 2014).

\subsection{Zavzetost za delo}

Zavzetost za delo je postal popularen koncept, tako v poslovnem svetu kot tudi akademskem. V vsakodnevnem življenju zavzetost razumemo kot vključenost, predanost, strast, navdušenost, absorpcijo, osredotočenost in energijo. Pojem zavzetosti se je prvič pojavil $v$ devetdesetih letih prejšnjega stoletja, uporabila pa ga je organizacija Gallup, ki je med drugim ugotovila, da so zavzeti zaposleni eden izmed petih 
najpomembnejših izzivov za organizacijo. $V$ ta namen so večja mednarodna svetovalna podjetja razvila lastne koncepte in orodja za spremljanje zavzetosti. Kljub temu, da se pojem zavzetosti v različnih svetovalnih podjetjih na prvi pogled razlikuje, pa termin kot tak izhaja iz predanosti podjetju, čustveni pripadnosti podjetju in želje po tem, da posameznik v podjetju tudi ostane. Po Kahnu (1990), etnografu, ki je v devetdesetih letih tudi prvi konceptualiziral pojem zavzetost na delu, naj bi zavzetost prinašala pozitivne rezultate, tako na ravni posameznika (osebna rast in razvoj) kot tudi na ravni organizacije (kakovostno delovanje). Delovno zavzetost lahko razumemo tudi kot protiutež izgorelosti, zavzeti zaposleni namreč na delo gledajo kot izziv in ne kot nekaj, kar je stresno in obremenjujoče.

Zavzetost vsebuje tri postavke - energija, vključenost in učinkovitost, kar je pravo nasprotje delovne izgorelosti, ki vsebuje izčrpanost, cinizem in zmanjšano učinkovitost. Iz tega sklepamo, da sta zavzetost in izgorelost tesno povezani postavki. Zavzetost za delo se razlikuje od psihološkega stanja kot je zadovoljstvo z delom ali deloholizem. Na prvi pogled bi lahko celo enačili zavzetega zaposlenega $\mathrm{z}$ deloholikom, vendar je njuna motivacija za delo povsem različna. Zavzeti delavci namreč delo opravljajo radi, ker v tem vidijo izziv in zabavo, deloholike pa vodi kompulzivna, notranja sila, ki se ji ne morejo upreti. Ker so zavzeti zaposleni bolj predani svojemu delu, so tudi redkeje odsotni $\mathrm{z}$ dela. Njihov cilj je uspešno delovati $\mathrm{v}$ organizaciji dolga leta. Zato je cilj vsakega podjetja skrbeti za njihovo zavzetost, saj so takšni zaposleni so namreč vedno pripravljeni narediti še več kot je sicer potrebno. Pri zavzetih zaposlenih je storilnost večja, manj je napak in so redko vpleteni v delovne nesreče in poškodbe (Schaufeli, 2012). Karanges in sodelavci (2014) ugotavljajo, da je zavzetost za delo izraz zaposlenih, predstavlja njihov trud in opredeljuje njihovo vlogo na delovnem mestu. Koristi zavzetosti za delo prispevajo k pozitivnim izidom organizacije skozi povečano produktivnostjo in višjim zadovoljstvom z delom. Avtorji poudarjajo pomen internega komuniciranja, ki ga opisujejo kot proces, ki omogoča pretok informacij, s tem pa zagotavlja občutek pripadnosti in zaupanje med zaposlenimi. Zaposleni se na delovnem mestu srečujejo z različnimi interakcijami, kot dve pomembnejši, ki se dotikata poslovnega življenja zaposlenega, pa avtorji navajajo povezavo $\mathrm{z}$ organizacijo in povezavo $\mathrm{z}$ neposredno nadrejenim. Povezave $\mathrm{z}$ organizacijo oziroma podjetjem in njihovimi okvirji delovanja so za zaposlene eden izmed pomembnejših dejavnikov. Razmerja, v katerih se v podjetju znajdejo, so pomemben del pri oblikovanju delovnega okolja. Le-to ima lahko pozitiven ali negativen učinek na vrednote, podporo in identifikacijo posameznika s podjetjem.

Za razliko od zadovoljstva zaposlenih je zavzetost koncept, ki se neposredno povezuje tudi z uspešnostjo podjetja in njegovimi poslovnimi rezultati. Torej gre za nadgradnjo koncepta zadovoljstva, saj zavzetost vključuje tudi delovno uspešnost zaposlenih. Zavzetost je dejavnik, ki je namreč povezan $\mathrm{z}$ visokim zadovoljstvom zaposlenih in obenem njihovo visoko delovno uspešnostjo. Glavni cilj menedžerjev je namreč doseči pričakovane rezultate, kar pa je možno le $\mathrm{v}$ okolju, kjer so se ljudje pripravljeni maksimalno angažirati za dosego le teh. Iz prakse je razvidno, da so dobri poslovni rezultati možni tudi takrat, ko je zadovoljstvo ljudi nizko. Običajno je to v poslovnih okoljih, kjer prevladuje strah, kontrola in prisila. Kako dolgo pa bo ta uspeh trajal in kako 
$36^{\mathrm{TH}}$ International Conference on ORganizational Science Development: ReSPONSIBLE ORGANIZATION (MARCH $22^{\mathrm{ND}}-24^{\mathrm{TH}}$, PorTOROŽ Slovenia)

B. Lobnikar \& A. Cedilnik: The Impact of the Quality of Social Interactions at the Workplace on Employee Work Engagement

dolgo bo v takem okolju možno zadržati ali privabiti zdrave in talentirane ljudi, pa je seveda drugo vprašanje.

(Ne)zazvzetost vpliva na poslovne rezultate in podatki, ki jih navaja Gallup v svoji raziskavi, so zgovorni (Bakovnik, 2013):

- Med primerljivimi poslovnimi okolji dosegajo podjetja, kjer je zavzetost visoka, 18 x višjo vrednost dobička na delnico kot podjetja, kjer je zavzetost zaposlenih nizka, obenem pa tudi rastejo hitreje kot njihovi konkurenti.

- Okolja z visoko zavzetimi zaposleni se odlikujejo z 18 \% višjo produktivnostjo, $12 \%$ višjo profitabilnostjo in povečano inovativnostjo zaposlenih, kar posledično spet vpliva na boljši poslovni uspeh podjetja.

- Poslovna okolja z velikim številom aktivno nezavzetih beležijo 31 do $51 \%$ višjo fluktuacijo kot okolja, kjer je veliko zavzetih zaposlenih.

- Visoka zavzetost rezultira $\mathrm{v}$ številnih navidezno nepomembnih aktivnostih, ki jih zaposleni vsak dan izvajajo, in ki posledično kreirajo višjo zavzetost kupcev.

- Visoka zavzetost je povezana z nizko stopnjo absentizma in nižjim številom delovnih nesreč.

Študije so dokazale, da so številni delovni in intrapersonalni dejavniki tesno povezani z zavzetostjo za delo. Dejavniki se razlikujejo od podjetja do podjetja, vsekakor pa so za zavzetost zaposlencev pomembni tisti, ki omogočajo priložnosti za razvoj, omogočajo avtonomijo in nudijo povratne informacije, podporo sodelavcev in nadrejenih. Dokazano je namreč, da samo-učinkovitost, upanje, optimizem in samospoštovanje ter sposobnost uravnavati in zaznavati čustva posameznika, predhodniki zavzetosti za delo (Schaufeli, 2012). Gallup je s svojimi raziskavami med drugim odkril, da je ključ do zavzete delovne sile vodja in da so bolj zavzeti tisti delavci, ki imajo na delovnem mestu razvita prijateljstva (Markos, 2010). Zaposleni, ki so izrazito motivirani in resnično zavzeti za svoje delo, so najmočnejše orožje zoper konkurenco. Da takšni tudi ostanejo, imajo pomembno vlogo tisti, ki odločajo, tako na ravni posameznika, kar vključuje predvsem psihološke dejavnike kot tudi na ravni poslovnega sistema. Pri obeh pa igrajo pomembno vlogo informacije, s katerimi se da natančno predvideti rezultat odločanja, kar je seveda precej redko, saj običajno poznamo le del informacij, in tako običajno odločanja in soodločanja potekajo v negotovosti (Dovžan, 2014). Karanges in sodelavci (2014) zavzetost za delo povezujejo z višjo produktivnostjo in izboljšanimi organizacijskimi rezultati. Medtem ko se za glavno vodilo zavzetosti za delo identificirana podpora, se interna komunikacija šteje kot ključna pri vzdrževanju procesov dela in rezultatov zaposlenih. Avtorji ugotavljajo, da tako dojemanje podpore kot tudi identifikacija igrata pomembno vlogo $\mathrm{v}$ povezavi $\mathrm{z}$ interno komunikacijo med zaposlenimi in njihovo zavzetostjo. 
B. Lobnikar \& A. Cedilnik: Vpliv kakovosti socialnih interakcij na delovnem mestu na zaposlenčevo zavzetost za delo

\section{Opis uporabljene metode, instumentarija in vzorca}

Podatke smo zbirali s pomočjo spletne ankete. Zbiranje podatkov je potekalo od 27. 10 . 2015 do 16. 2. 2016. Končno število anket, uporabljenih v analizi, je bilo 151.59 anket je bilo neustrezno izpolnjenih, zato odgovori niso bili vključeni v nadaljnjo analizo. V raziskavi smo uporabili priložnosten in nenaključen vzorec, saj so bile enote (anketiranci) izbrane nenaključno, s pomočjo snežene kepe. Vzorec je zato nereprezentativen in je potrebno rezultate interpretirati z zadržki. Populacija, znotraj katere smo izbrali vzorec, so bili polnoletni in zaposleni državljani in državljanke Republike Slovenije.

Vprašalnik, s katerim smo merili kakovost socialnih interakcij na delovnem mestu in njihov vpliv na zavzetost za delo je sestavljen iz osmih sklopov in vsebuje 67 trditev. Prvi sklop vprašanj se nanaša na osnovne podatke o naravi zaposlitvenega odnosa in na velikost podjetja $\mathrm{v}$ katerem so anketiranci zaposleni. Drugi sklop vprašanj vsebuje vprašanja, ki se nanašajo na stališča do dela zaposlenih (ali zaposleni vedo kaj se pričakuje od njih, imajo pri svojem delu na voljo vse kar potrebujejo, jih vodja upošteva kot osebo, itd). V tretjem sklopu vprašanj so vprašanja, ki se nanašajo na osebna stališča zaposlenih do njihovega dela (ali zaposleni doživljajo uspehe, ali so pri delu sproščeni, ali se izogibajo stresnim nalogam, ali je komunikacija med nadrejenimi in zaposlenimi težavna, itd.). Četrti sklop vprašanj se nanaša na stališča, kako zaposleni ocenjujejo komuniciranje med sodelavci. Peti sklop vprašanj se nanaša na stališča do sodelavcev. Šesti in sedmi sklop vprašanj se nanašata na stališča do nadrejenih, kako zaposleni ocenjujejo svoje nadrejene. Zadnji, to je osmi sklop, vsebuje demografska vprašanja. Vprašanja od drugega do sedmega sklopa so bila merjena na petstopenjski lestvici, pri čemer je 1 pomenilo sploh se ne strinjam in 5 močno se strinjam.

V končno analizo je bilo vključenih 151 zaposlenih, od tega $56 \%$ moških. Največ anketirancev je bilo iz starostne skupine skupino od 31 do 40 let (38\%), sledi starostna skupina od 21 do 30 let (33\%) ter starostna skupina nad 41 let (29\%). Največ anketirancev ima dokončano štiriletno srednjo šolo $(28,9 \%)$, sledijo anketiranci $z$ dokončano višjo šolo $(15,6 \%)$ in anketiranci z dokončano visoko šolo $(15,6 \%)$.

Za ugotavljanje zanesljivosti merskega instrumenta smo uporabili Cronbachov koeficienta alfa, ki meri zanesljivost vprašalnika na osnovi korelacij med spremenljivkami. Vrednosti, ki jih Cronbach alfa lahko zavzame, so med 0 in 1 «(Šifrer in Bren, 2011: 34). Vrednost od 0 do 0,5 pomeni, da vprašalnik ni zanesljiv, od 0,5 do 0,8 pomeni, da je vprašalnik srednje zanesljiv, če je vrednost večja od 0,8 pomeni, da je vprašalnik zelo zanesljiv. Cronbach alfa v našem primeru znaša 0,815 , kar pomeni, da gre za visoko zanesljiv vprašalnik. V analizo zanesljivosti je bilo zajetih 60 spremenljivk, in sicer vprašanja iz drugega, tretjega, četrtega, petega, šestega in sedmega sklopa vprašanj. 
$36^{\text {Th }}$ International Conference on Organizational Science Development: RESPONSIBLE ORGANIZATION (MARCH $22^{\mathrm{ND}}-24^{\mathrm{TH}}$, PORTOROŽ SLOVENIA)

B. Lobnikar \& A. Cedilnik: The Impact of the Quality of Social Interactions at the Workplace on Employee Work Engagement

\section{Predstavitev in interpretacija rezultatov}

V nadaljevanju predstavljamo rezultate analize po posameznih vsebinskih sklopih in sicer opisno statistiko ter porazdelitev trditev v posamezne sklope; za vsak vsebinski sklop smo namreč opravili faktorsko analizo (metoda analiza glavnih komponent), te faktorje pa smo $\mathrm{v}$ nadaljevanju uporabili pri diskriminantni in regresijski analizi. $\mathrm{V}$ tabelah $\mathrm{v}$ nadaljevanju so označene vrednosti, v kolikšni meri posamezen faktor pojasni celotno varianco ter faktorske uteži pri posamezni trditvi.

Tabela 1: Opisna statistika in faktorska porazdelitev trditev o stališču zaposlenih do dela

\begin{tabular}{|l|c|c|c|c|}
\hline & Povpr. & S.O. & \multicolumn{2}{|c|}{ Faktor } \\
\cline { 3 - 5 } & & & $\begin{array}{c}\text { Individualna } \\
\text { spodbuda in } \\
\text { motivacija } \\
(46,4 \%)\end{array}$ & $\begin{array}{c}\text { Jasna } \\
\text { navodila } \\
\text { in } \\
\text { primerna } \\
\text { sredstva } \\
(23,4 \%)\end{array}$ \\
\hline Vem, kaj se pričakuje od mene. & 4.50 & .708 & &, 847 \\
\hline $\begin{array}{l}\text { Imam na voljo vse, kar } \\
\text { potrebujem, da dobro opravim } \\
\text { svoje delo. }\end{array}$ & 3.99 & .920 & &, 767 \\
\hline $\begin{array}{l}\text { Pri delu imam možnost praktično } \\
\text { vsak dan delati tisto, v čemer sem } \\
\text { dober. }\end{array}$ & 3.42 & 1.167 &, 625 & \\
\hline $\begin{array}{l}\text { V zadnjem tednu so pohvalili } \\
\text { moje delo ali prepoznali moje } \\
\text { dosežke. }\end{array}$ & 2.75 & 1.444 &, 847 & \\
\hline $\begin{array}{l}\text { Moj vodja me upošteva kot } \\
\text { osebo. }\end{array}$ & 3.64 & 1.199 &, 815 & \\
\hline $\begin{array}{l}\text { Nekdo v organizaciji načrtno } \\
\text { skrbi in spodbuja moj razvoj. }\end{array}$ & 2.60 & 1.364 &, 818 & \\
\hline Moje mnenje šteje in se upošteva. & 3.06 & 1.293 &, 854 & \\
\hline
\end{tabular}

V tabeli 1 lahko vidimo, da zaposleni zelo dobro vedo, kaj se pričakuje od njih na delovnem mestu, prav tako pa ocenjujejo, da imajo zadosti delovnih sredstev, da bi delo lahko dobro opravili. Še najslabše ocenjujejo skrb za njihov profesionalni razvoj v podjetju, lahko pa bi rekli tudi, da pogrešajo povratne informacije o tem, kako pomembni/dobri so za podjetje, $\mathrm{v}$ katerem delajo. Trditve so se porazdelile $\mathrm{v}$ dva vsebinska sklopa in sicer $\mathrm{v}$ individualno spodbudo in motiviranost za delo ter vsebinski sklop, ki opisuje jasna navodila in oceno primernosti delovnih sredstev. S slednjim vsebinskim sklopom so zaposleni bolj zadovoljni kot s prvim. 
V tabeli 2 so prikazani rezultati analize, ki se vežejo na oceno določenih interakcijskih situacij na delovnem mestu. Zaposleni sebe dojemajo kot dobro usposobljene za delo, in tudi z rezultati svoje dela so zadovoljni, saj zelo nizko ocenjujejo trditev, da je to, kar naredijo, neustrezno. Tako se tudi ne izogibajo nalog, ki se jim zdijo stresne. Tako kot pri prejšnjem vsebinskem sklopu pa lahko ugotovimo, da zaposleni pogrešajo pogovor $\mathrm{s}$ svojimi nadrejenimi o njihovem razvoju in profesionalnem napredku.

Tabela 2: Opisna statistika in faktorska porazdelitev trditev o naravi delovnih interakcij

\begin{tabular}{|c|c|c|c|c|c|}
\hline & Povpr. & S.O. & $\begin{array}{c}\text { Priložnost } \\
\text { za osebni } \\
\text { in } \\
\text { poslovni } \\
\text { razvoj } \\
(30,5 \%)\end{array}$ & $\begin{array}{l}\text { Usposobljenost } \\
\text { za delo in } \\
\text { sproščenost ob } \\
\text { delu }(18,6 \%)\end{array}$ & $\begin{array}{c}\text { Iskanje } \\
\text { napak pri } \\
\text { delu in } \\
\text { izogibanje } \\
\text { stresnim } \\
\text { situacijam } \\
(11,8 \%)\end{array}$ \\
\hline $\begin{array}{l}\text { Pomembnost mojega dela se } \\
\text { zrcali tudi v poslanstvu našega } \\
\text { podjetja. }\end{array}$ & 2.70 & 1.384 & ,739 & & \\
\hline $\begin{array}{l}\text { Moji sodelavci so iskreno } \\
\text { zavzeti za dobro in kakovostno } \\
\text { delo. }\end{array}$ & 3.12 & .978 & ,724 & & \\
\hline $\begin{array}{l}\text { V službi imam veliko dobrih } \\
\text { sodelavcev. }\end{array}$ & 3.71 & .992 & ,516 & & \\
\hline $\begin{array}{l}\mathrm{V} \text { zadnjih } 6 \text { mesecih so se } \mathrm{z} \\
\text { menoj pogovarjali o mojem } \\
\text { razvoju in napredku. }\end{array}$ & 2.51 & 1.414 & ,869 & & \\
\hline $\begin{array}{l}\text { Tekom zadnjega leta sem imel } \\
\text { priložnost za učenje in razvoj. }\end{array}$ & 2.78 & 1.469 & ,874 & & \\
\hline $\begin{array}{l}\text { Pri svojem delu doživljam } \\
\text { uspehe. }\end{array}$ & 3.43 & 1.137 & ,569 & & \\
\hline $\begin{array}{l}\text { Kar naredim, je pogosto } \\
\text { neustrezno. }\end{array}$ & 1.79 & 1.001 & & ,540 & \\
\hline $\begin{array}{l}\text { Rezultati mojega dela kažejo, } \\
\text { da sem usposobljen za svoje } \\
\text { delo. }\end{array}$ & 4.02 & .942 & & ,801 & \\
\hline Pri delu sem sproščen. & 3.67 & 1.183 & & ,779 & \\
\hline $\begin{array}{l}\text { Izogibam se nalogam, ki se mi } \\
\text { zdijo stresne. }\end{array}$ & 2.43 & 1.255 & & & ,720 \\
\hline $\begin{array}{l}\text { Pozoren sem na to, kaj drugi } \\
\text { naredijo narobe. }\end{array}$ & 2.96 & 1.233 & & & ,763 \\
\hline
\end{tabular}

V tabeli št. 3 so opisane ocene anketiranih o naravi komuniciranja na delovnem mestu. Še najbolj pogosto pogrešajo informacije $\mathrm{s}$ strani svojih nadrejenih, pri čemer $\mathrm{s}$ povprečno oceno okoli 3 ocenjujejo, da je komuniciranje med zaposlenimi in njihovimi šefi pogosto težavno. Rezultat je še posebej zaskrbljujoč, saj so menedžerji pomemben vir informacij za zaposlene in prav preko komuniciranja $\mathrm{z}$ nadrejenimi zaposleni pridobivajo podatke, ki jim omogočajo kakovostno opravljanje dela. Spremenljivke v tem vsebinskem sklopu so se porazdelile v en faktor, ki smo ga poimenovali »Pomanjkljivosti pri komuniciranju«. 
$36^{\mathrm{TH}}$ International Conference on ORganizational Science Development: RESPONSIBLE ORGANIZATION (MARCH $22^{\mathrm{ND}}-24^{\mathrm{TH}}$, PORTOROŽ SLOVENIA)

B. Lobnikar \& A. Cedilnik: The Impact of the Quality of Social Interactions at the Workplace on Employee Work Engagement

Tabela 3: Opisna statistika za spremenljivke o naravi komuniciranja na delovnem mestu

\begin{tabular}{|l|r|r|}
\hline & Povprečje & $\begin{array}{c}\text { Std. } \\
\text { odklon }\end{array}$ \\
\hline Pri delu pogrešam več komunikacije s sodelavci. & 2.93 & 1.294 \\
\hline $\begin{array}{l}\text { Pri delu pogrešam več natančnih informacij s strani } \\
\text { nadrejenih. }\end{array}$ & 3.07 & 1.317 \\
\hline $\begin{array}{l}\text { Komunikacija med nadrejenimi in zaposlenimi je } \\
\text { pogosto težavna. }\end{array}$ & 2.89 & 1.314 \\
\hline
\end{tabular}

Narava interakcij med zaposlenimi in njihovimi šefi je opisana tudi $\mathrm{v}$ tabeli $4 \mathrm{v}$ nadaljevanju, kjer lahko vidimo, da zaposleni ocenjujejo, da si nadrejeni vzamejo premalo časa za kakovostno komuniciranje z zaposlenimi, kljub vsemu pa anketirani ne poročajo, da bi bili njihovi šefi neupravičeno kritizerki do njih ali pa namerno zamerljivi. $Z$ rezultatov lahko ugotovimo, da zaposleni niso pogosto izpostavljeni nezaželenim interakcijam, pogrešajo pa bolj kakovostno pozitivno interakcijo s svojimi nadrejenimi. Tudi pri tem vsebinskem sklopu so se spremenljivke porazdelile v en vsebinski sklop.

Tabela 4: Opisna statistika o naravi interakcij z nadrejenimi

\begin{tabular}{|l|c|c|}
\hline & Povprečje & Std. odklon \\
\hline Nadrejeni so me že obravnavali zviška. & 2.02 & 1.210 \\
\hline Nadrejeni mojega dela nikoli ne pohvalijo. & 2.09 & 1.325 \\
\hline $\begin{array}{l}\text { Nadrejeni si ne vzamejo dovolj časa za komunikacijo } \\
\text { z mano. }\end{array}$ & 2.35 & 1.332 \\
\hline Nadrejeni me pogosto ne poslušajo. & 2.51 & 1.310 \\
\hline Nadrejeni mi namerno ustvarjajo težave. & 1.39 & .766 \\
\hline Nadrejeni me kritizirajo v prisotnosti ostalih. & 1.47 & .822 \\
\hline
\end{tabular}

V tabeli št. 5 lahko vidimo, da anketirani ocenjujejo, da imajo njihovi nadrejeni pogosto prevelika pričakovanja, in da v povprečju ocenjujejo, da jim njihovi nadrejeni nalagajo preveč dela. Prav tako pa lahko ocenimo, da se zaposleni zelo redko s svojimi nadrejenimi družijo tudi $\mathrm{v}$ prostem času in da le redki svoj odnos $\mathrm{z}$ nadrejenim ocenjuje kot prijateljski. 


\section{Tabela 5: Opisna statistika za trditve o odnosu zaposlenega z nadrejenimi}

\begin{tabular}{|c|c|c|c|c|}
\hline & Povpr. & S.O. & $\begin{array}{l}\text { Povezanost } \mathrm{z} \\
\text { nadrejenimi v } \\
\text { zasebnem } \\
\text { življenju in } \\
\text { njihova } \\
\text { podpora } \\
(35,6 \%)\end{array}$ & $\begin{array}{c}\text { Prevelike } \\
\text { zahteve do } \\
\text { zaposlenih in } \\
\text { poseg v } \\
\text { zasebno } \\
\text { življenje } \\
(22,1 \%)\end{array}$ \\
\hline $\begin{array}{lrll}\mathrm{Z} & \text { nadrejenimi } & \text { smo } & \text { tudi } \\
\text { osebno prijatelji. } & & \\
\end{array}$ & 2.22 & 1.17 & 875, & \\
\hline $\begin{array}{l}\text { Nadrejeni komentirajo moje } \\
\text { delo in mi opažanja tudi } \\
\text { povedo. }\end{array}$ & 3.30 & 1.05 & 668 & \\
\hline $\begin{array}{l}\text { Nadrejeni mi stojijo ob strani, } \\
\text { ko sem v stresni situaciji. }\end{array}$ & 2.98 & 1.30 & ,706 & \\
\hline $\begin{array}{l}\text { Z nadrejenimi se družimo tudi } \\
\mathrm{v} \text { prostem času. }\end{array}$ & 1.93 & 1.19 & ,809 & \\
\hline $\begin{array}{l}\text { Nadrejeni mi nalagajo preveč } \\
\text { dela. }\end{array}$ & 2.76 & 1.43 & & ,752 \\
\hline $\begin{array}{l}\text { Nadrejeni so se že vtikali v } \\
\text { moje zadeve izven službe. }\end{array}$ & 1.92 & 1.08 & & ,594 \\
\hline $\begin{array}{l}\text { Nadrejeni imajo pogosto } \\
\text { prevelika pričakovanja. }\end{array}$ & 3.53 & 1.09 & & ,700 \\
\hline
\end{tabular}

Ker je kakovost komuniciranja pogoj za uspešne in učinkovite odnose na delovne mestu, smo v nadaljevanju izvedli večkratno regresijo, kjer smo kot odvisno spremenljivko upoštevali vsebinski sklop, prikazan v tabeli 3 (»Pomanjkljivosti pri komuniciranju«). V tabeli 6 vidimo, katere spremenljivke bomo uporabili v večkratni regresiji. Z uporabo različnih vsebinskih sklopov smo lahko pojasnili 48 variance odvisne spremenljivke, rezultati analize, prikazane v tabeli 7 pa nam kažejo, da je bil uporabljen model statistično značilen.

Tabela 6: Povzetek regresijske analize za odvisno spremenljivko »Pomanjkljivosti pri komuniciranju«

\begin{tabular}{|c|c|c|c|c|}
\hline Model & $\overline{\mathrm{R}}$ & R kvadrat & Prilagojen R kvadrat & Std. napaka ocene \\
\hline 1 & $716^{a}$ &, 513 & 480 & ,73106301 \\
\hline \multicolumn{5}{|c|}{$\begin{array}{l}\text { a. Napovedne: (Konstanta), Iskanje napak pri delu in izogibanje stresnim situacijam, Usposobljenost za } \\
\text { delo in sproščenost ob delu, Priložnost za osebni in poslovni razvoj, Prevelike zahteve nadrejenih in } \\
\text { njihov poseg v zasebno življenje, Jasna navodila in primerna sredstva, Nerazumevanje in nespoštovanje } \\
\text { s strani sodelavcev, Povezanost z nadrejenimi v zasebnem življenju in njihova podpora, Individualna } \\
\text { spodbuda in motivacija }\end{array}$} \\
\hline
\end{tabular}

Tabela 7: Statistična značilnost ocenjenega regresijskega modela

\begin{tabular}{||l|l|r|r|r|r|r||}
\hline \multicolumn{2}{||c|}{ Model } & $\begin{array}{c}\text { Vsota } \\
\text { kvadratov }\end{array}$ & df & Povprečje & F & p-vrednost \\
\hline \multirow{2}{*}{1} & Regresija & 67,021 & 8 & 8,378 & 15,675 &, $000^{\mathrm{b}}$ \\
\cline { 2 - 7 } & Preostala & 63,600 & 119 &, 534 & & \\
\hline \hline
\end{tabular}


$36^{\text {TH }}$ International Conference on Organizational Science Development: ReSPONSIBLE ORGANIZATION (MARCH $22^{\mathrm{ND}}-24^{\mathrm{TH}}$, PORTOROŽ Slovenia)

B. Lobnikar \& A. Cedilnik: The Impact of the Quality of Social Interactions at the Workplace on Employee Work Engagement

\begin{tabular}{||c|c|c|c||}
\hline \multicolumn{1}{|c|}{ Skupaj } & 130,621 & 127 & \\
\hline a. Odvisna spremenljivka: Pomanjkljivosti pri komuniciranju & \\
\hline b. Napovedne: (Konstanta), Iskanje napak pri delu in izogibanje stresnim situacijam, Usposobljenost za \\
delo in sproščenost ob delu, Priložnost za osebni in poslovni razvoj, Prevelike zahteve nadrejenih in \\
njihov poseg v zasebno življenje, Jasna navodila in primerna sredstva, Nerazumevanje in nespoštovanje \\
S strani sodelavcev, Povezanost z nadrejenimi v zasebnem življenju in njihova podpora, Individualna \\
spodbuda in motivacija. \\
\hline
\end{tabular}

Iz analize izhaja, da smo, da smo $\mathrm{z}$ večkratno regresijo dobili naslednje spremenljivke, ki statistično značilne vplivajo na odvisno spremenljivko »Pomanjkljivosti pri komuniciranju« (spremenljivke smo razvrstili glede na vrednost beta):

- Nerazumevanje in nespoštovanje $\mathrm{s}$ strani sodelavcev $(\mathrm{B}=0,378)$,

- Individualna spodbuda in motivacija $(B=-0,263)$,

- Jasna navodila in primerna sredstva $(B=-0,240)$,

- Iskanje napak pri delu in izogibanje stresnim situacijam $(B=0,217)$.

Vse napovedne spremenljivke imajo p-vrednost manjšo od 0,05 . Od štirih napovednih spremenljivk imata dve spremenljivki negativno beto. Prva napovedna spremenljivka, ki ima negativno beto $(-0,263)$, je Individualna spodbuda in motivacija. Druga spremenljivka, ki ima negativno beto $(-0,240)$ je faktor Jasna navodila in primerna sredstva. Spremenljivki Nerazumevanje in nespoštovanje s strani sodelavcev in Iskanje napak pri delu in izogibanje stresnim situacijam imata pozitivno beto. Manjša kot je individualna spodbuda in motivacija, manj je kakovostne komunikacije. In manj kot je jasnih navodil in primernih sredstev, manj je učinkovite komunikacije med zaposlenimi. Medtem, ko velja, da manj kot je nerazumevanja in več spoštovanja s strani sodelavcev, več je zaželene kakovostne komunikacije. In manj kot je iskanja napak in izogibanja stresnih situacij, več je kakovostne komunikacije med zaposlenimi.

\section{$4 \quad$ Razprava}

Iz analize lahko ugotovimo, da bolj kot zaposleni na delovnem mestu doživljajo pozitivne socialne interakcije, bolj so zavzeti za delo. Ugotovili smo namreč, da je najvišja povprečna vrednost pri faktorju Nerazumevanje in nespoštovanje s strani sodelavcev pri spremenljivki Nadrejeni me pogosto ne poslušajo, pri faktorju Pomanjkanje komunikacije na delovnem mestu ima največjo aritmetično sredino spremenljivka Pri delu pogrešam več natančnih informacij s strani nadrejenih, pri faktorju Usposobljenost za delo in sproščenost ob delu, pa smo najvišjo aritmetično sredino ugotovili pri spremenljivki Rezultati mojega dela kažejo, da sem usposobljen za svoje delo. Rezultati naše raziskave potrjujejo ugotovitve dosedanjih raziskav, da skrb organizacije za kakovostne socialne interakcije prispeva $\mathrm{k}$ večji zavzetosti zaposlenih za delo. $\mathrm{V}$ vsaki organizaciji so namreč najpomembnejši ljudje, ki so v njej zaposleni. $Z$ vidika vodenja je zato zelo pomembno, da zaposleni natančno vedo, kaj se od njih pričakuje, da so vnaprej postavljeni jasni kriteriji, s katerimi merimo njihovo uspešnost, ter da sproti dobivajo povratne informacije, kako dobri so pri svojem delu. Poleg tega morajo biti vodje 
dostopni, saj so glavni vir informacij, znati morajo dobro poslušati in biti v medsebojni komunikaciji spoštljivi. Nikoli ne moremo poudariti dovolj, da so največje premoženje vsake organizacije njihovi zaposleni. Njihova zavzetost je tako odvisna od tega, kako vodje z njimi ravnajo, do tega, kako zaposleni vidijo svoje cilje in cilje organizacije, kakšne so nagrade za njihov prispevek in v kolikšni meri se lahko razvijajo in so obenem vključeni $\mathrm{v}$ odločitve, ki jih zadevajo. Zavzeti zaposleni so namreč pripravljeni nadpovprečno vlagati energijo $\mathrm{v}$ svoje delo in dosegati izjemne rezultate, $\mathrm{s}$ tem pa vplivajo na poslovne rezultate podjetja oziroma organizacije. Podjetja, ki razumejo in poznajo upravljanje človeških virov, vedo, da je dodana vrednost organizacije $v$ inovacijskih sposobnostih zaposlenih in učinkovitem ravnanju z njimi in ne v večanju števila zaposlenih ali dodajanju kapitala.

\section{Literatura}

Arzenšek, A., Kožuh, P. (2011). Medosebni odnosi in vsebina dela kot dejavnika stresa pri srednjem managementu. Management, 6(2), 177-189.

Bakovnik, N. (2013). Gallupovo poročilo o zavzetosti zaposlenih na delovnem mestu 2013. Pridobljeno na: www.delavska-participacija.com/priloge/2018-1.docx

Berman, E. M., West, J. P. in Richter, M. N. Jr. (2002). Workplace relations: Friendship patterns and consequences (according to managers). Public Administration Review, 62(2), 217 - 231.

Couto, M. T. in Lawoko, S. (2011). Burnout, workplace violence and social support among drivers and conductors in the road passenger transport sector in Maputo City, Mozambique. Journal Of Occupational Health, 53(3), 214-221.

Dovžan, H. (2014). Z znanjem do delovne uspešnosti. Ljubljana: IUS Software, GV Založba. Heaphy, E. D. in Dutton, J. E. (2008). Positive social interactions and the human body at work: Linking organizations and physiology. Academy of Management Review, 33(1), 137-162.

Hse, T. in Standards, M. (2004). Working together to reduce stress at work. Management, 11, 14.

Markos, S. in Sridevi, S. (2010). Employee Engagement: The Key to Improving Performance. International Journal of Business and Management, 5, 89-96.

Možina, S., Bernik, J. in Svetic, A. (2004). Osnove managementa. Piran: Visoka šola za podjetništvo.

Kahn, W. A. (1990). Psychological conditions of personal engagement and disengagement atwork. Academy of Management Journal, 33, 692-724.

Karanges, E., Beatson, A., Johnston, K. in Lings, I. (2014). Optimizing employee engagement with internal communication: A social exchange perspective. Journal of Business Market Management, 7, 329-353.

Pagon, M., Lobnikar, B. in Butinar, J. (2014). Dve skrajnosti organizacijskega življenja: prijateljstvo in nasilno vedenje na delovnem mestu. V Jože Florjančič, Björn Paape (ur.) Kadri in management: izbrana poglavja. Kranj: Moderna organizacija.

Repovš, G. (2000). Opredelitev pojma socialna resničnost z vidika interakcije posameznika z okoljem. Psihološka obzorja, 9(4), 89-104.

Schaufeli, W. B. (2012). Work Engagement. What Do We Know and Where Do We Go? Romanian Journal of Applied Psychology, 14, 3-10.

Smeh, T, Visočnik N. (2013). Izbrani vprašalniki za uporabo na področju psihologije dela in organizacije. Medosebni odnosi na delovnem mestu. Univerza v Ljubljani: Filozofska fakulteta. 
508 36 $6^{\text {TH }}$ International Conference on Organizational Science Development: RESPONSIBLE ORGaNizATION (MARCH $22^{\mathrm{ND}}-24^{\mathrm{TH}}$, Portorož SlOVENIA)

B. Lobnikar \& A. Cedilnik: The Impact of the Quality of Social Interactions at the Workplace on Employee Work Engagement

Šifrer, J. in Bren, M. (2011). SPSS - Multivariatne metode v vartvoslovju. Ljubljana, Fakulteta za varnostme vede.

Turk, I. (2010). O osebni in poslovni odličnosti. Ljubljana: Zveza ekonomistov Slovenije. 
$36^{\mathrm{TH}}$ InTERnAtional CONFERENCE ON ORganizational SCIENCE Development: Responsible Organization (MARCh $22^{\mathrm{ND}}-24^{\mathrm{TH}}$, PORTOROŽ SLOVENIA)

O. Arsenijević, M. Ferjan, I. Podbregar, P. Šprajc, D. Trivan \& Y. Ziegler

\title{
On a Design of a Maintenance Performance Measurement System: a Sustainability Perspective
}

\author{
DAMJAn MALETIČ, MATJAŽ MALETIČ, BASIM AL-NAJJAR \& BOŠTJAN GOMIŠČEK
}

\begin{abstract}
Measuring maintenance performance is important for companies to monitor whether their planned objectives are achieved or not. It is essential to have a good overview about the performance of maintenance processes in order to align maintenance objectives with the manufacturing and company's objectives. This can be attained through a proper maintenance performance measurement system which is consisted of indicators for measuring and monitoring the important elements of the maintenance function. A framework for maintenance performance measurement based on sustainability aspects is proposed. Additionally, an overview of maintenance indicators is presented. The relevant elements that are needed to develop a maintenance performance measurement system are discussed in this study as well. Findings derived from this study have relevant practical implications as measuring and monitoring of maintenance performance measures is vital in detecting the deviations, as well as to take timely actions, and nevertheless to achieve the desired objectives. In this regard, presented maintenance performance indicators can be useful for asset managers to develop an effective maintenance performance measurement system.
\end{abstract}

KEYWORDS: maintenance $\cdot$ performance measurement $\bullet$ performance indicators $\bullet$ maintenance performance measurement system

CorRespondence AdDress: Damjan Maletič, Ph.D., Assistant Professor, University of Maribor, Faculty of Organizational Sciences, Kidričeva cesta 55a, 4000 Kranj, Slovenia, e-mail: damjan.maletic@ fov.uni-mb.si; Matjaž Maletič, Ph.D., Assistant Professor, University of Maribor, Faculty of Organizational Sciences, Kidričeva cesta 55a, 4000 Kranj, Slovenia, e-mail: matjaz.maletic@fov.uni-mb.si; Basim Al-Najjar, Ph.D., Professor, Linnaeus University, School of Engineering, P G Vejdes väg, 35195 Växjö, Sweden, e-mail: basim.al-najjar@lnu.se; Boštjan Gomišček, Ph.D., Full Professor, University of Wollongong in Dubai, Faculty of Business, Blocks 5, 14 \& 15, Al Sufouh Street Dubai Knowledge Village - Dubai, United Arab Emirates, e-mail: BostjanGomiscek@uowdubai.ac.ae 
$36^{\mathrm{TH}}$ International Conference on Organizational Science Development: Responsible Organization (MARCh $22^{\mathrm{ND}}-24^{\mathrm{TH}}$, Portorož Slovenia)

D. Maletič, M. Maletič, B. Al-Najjar \& B. Gomišček: On a Design of a Maintenance

Performance Measurement System: a Sustainability Perspective

In the face of current global competition and increasing demands from stakeholders, there is a distinct need to improve manufacturing performance (Van Horenbeek \& Pintelon 2014). In addition, with increased global competition for manufacturing, many companies are seeking ways to gain competitive advantages with respect to cost, service, quality, and on-time deliveries (Luxhoj et al., 1997). Furthermore, as a consequence of the increased demands manufacturing companies face a great pressure to reduce their production costs (Wang et al., 2007). In order to ensure a good performance of production processes, asset managers need a good overview of maintenance processes and performance. In this regard, maintenance performance measurement (MPM) is considered as an essential element of any manufacturing organization. Without having a formal measurement system for performance, it is difficult to plan, control and improve the maintenance process (Áhrén \& Parida, 2009). Further, performance monitoring establishes a bridge between, on the one hand, the operational level in terms of productivity, performance efficiency, quality rate, availability or production cost and, on the other hand, the strategic level in terms of company`s profit and competitiveness (Kans \& Ingwald, 2008).

Nowadays maintenance function plays a critical role in a company's ability to compete on the basis of cost, quality, and delivery performance (Swanson, 1997), in particular with the aim of enhancing the production and maintenance performance continuously and cost-effectively (Al-Najjar, 2007). Therefore, the scope of maintenance has shifted from a narrowly defined operational perspective, to an organizational strategic perspective (Simoes, Gomes, \& Yasin, 2011). With this change in the mindset of asset managers, it has become essential to measure the performance of manufacturing processes to understand the tangible and, if possible, intangible contribution of the maintenance towards business goals (Kumar \& Parida, 2008).

Drawing on the performance measurement literature (e.g. Áhrén \& Parida, 2009; Parida $\&$ Chattopadhyay, 2007) this study present the key elements that are needed to develop a maintenance performance measurement system. More importantly, this study aims to present an approach for supporting organization's asset management strategy implementation, especially since performance measurement is vital for asset management (Maletič et al. 2017; Maletič, 2015) in terms of balancing the costs, opportunities and risk against the desired performance of assets, to achieve the organizational objectives (ISO $55000,2014)$.

\section{$2 \quad$ Performance measurement system}

From the operations perspective, a business performance measurement system (PMS) is mainly perceived as a 'set of metrics used to quantify both the efficiency and effectiveness of actions' (Neely, 1994). In this regard, Neely (1994) proposed the following distinct definitions: 
D. Maletič, M. Maletič, B. Al-Najjar \& B. Gomišček: On a Design of a Maintenance Performance Measurement System: a Sustainability Perspective

- a performance measurement can be defined as the process of quantifying the efficiency and effectiveness of an action,

- a performance measure can be defined as a metric used to quantify the efficiency and/or effectiveness of an action,

- a performance measurement system can be defined as the set of metrics used to quantify both the efficiency and effectiveness of an action.

As a response to relatively narrow point of view of performance measuring, a more advanced approaches of PMSs to include financial and non-financial performance measures, as well as explaining cause-and-effect relationships between the various measures, and providing better insight in terms of links between PMS and organisation's strategy have been proposed (e.g. Kaplan and Norton, 1996). Furthermore, Gomes Gomes, Yasin, and Lisboa (2011) suggest that organisations should (among other performance measures) also pay attention to softer performance measures, such as social responsibility.

Like other manufacturing functions, the performance measurement is important in managing the maintenance function (Muchiri et al., 2011). Thus, it is important that organizations us indicators, which are utilized to evaluate the effectiveness of maintenance carried out (Wireman 1998). As stated by Galar, Parida, Kumar, Stenström, and Berges (2011), organizations that use maintenance indicators in exchange achieve benefits such as increased life and availability of equipment, improved product quality, reduced costs of breakdowns and spare parts inventory, and therefore a reduction of overall maintenance cost.

\section{$3 \quad$ Sustainability MPM framework}

The aim of the proposed approach is to introduce sustainability concepts into a hierarchical MPM framework. Corporate sustainability is now widely conceptualised in terms of the "triple bottom line' (TBL) (Elkington, 1999) which implies that organisations will create more value over the long run if they take into consideration environmental (planet), social (people), and financial (profit) issues (Dyllick \& Hockerts, 2002; Holliday, 2001). Where sound economic performance (profit) in the past was expected to guarantee corporate success, business is today increasingly led by the so-called triple bottom line in which economic results are balanced by the minimisation of ecological footprints and attention to social aspects (Lee, 2009). As aforementioned, the major focus of sustainable performance is integrating the performance in economic, social and environmental terms simultaneously (Liyanage et al., 2009). Additionally, it is also important to link and integrate the overall objectives and strategy of a company when designing the MPM framework (Parida \& Chattopadhyay, 2007).

Prior research (Liyanage et al., 2009) indicated that it is important to incorporate business sustainability in operational terms, following three distinct levels within an organization. Therefore, our proposed MPM framework (Figure 1) takes into consideration the different levels in an organization. In the proposed framework several indicators are 
$36^{\text {Th }}$ International Conference on Organizational Science Development: Responsible Organization (March $22^{\mathrm{ND}}-24^{\mathrm{TH}}$, Portorož SLOVEnia)

D. Maletič, M. Maletič, B. Al-Najjar \& B. Gomišček: On a Design of a Maintenance Performance Measurement System: a Sustainability Perspective

included to measure the maintenance performance from the sustainability point of view. Additionally, the framework also consists of technical KPIs which are also divided into different three levels.

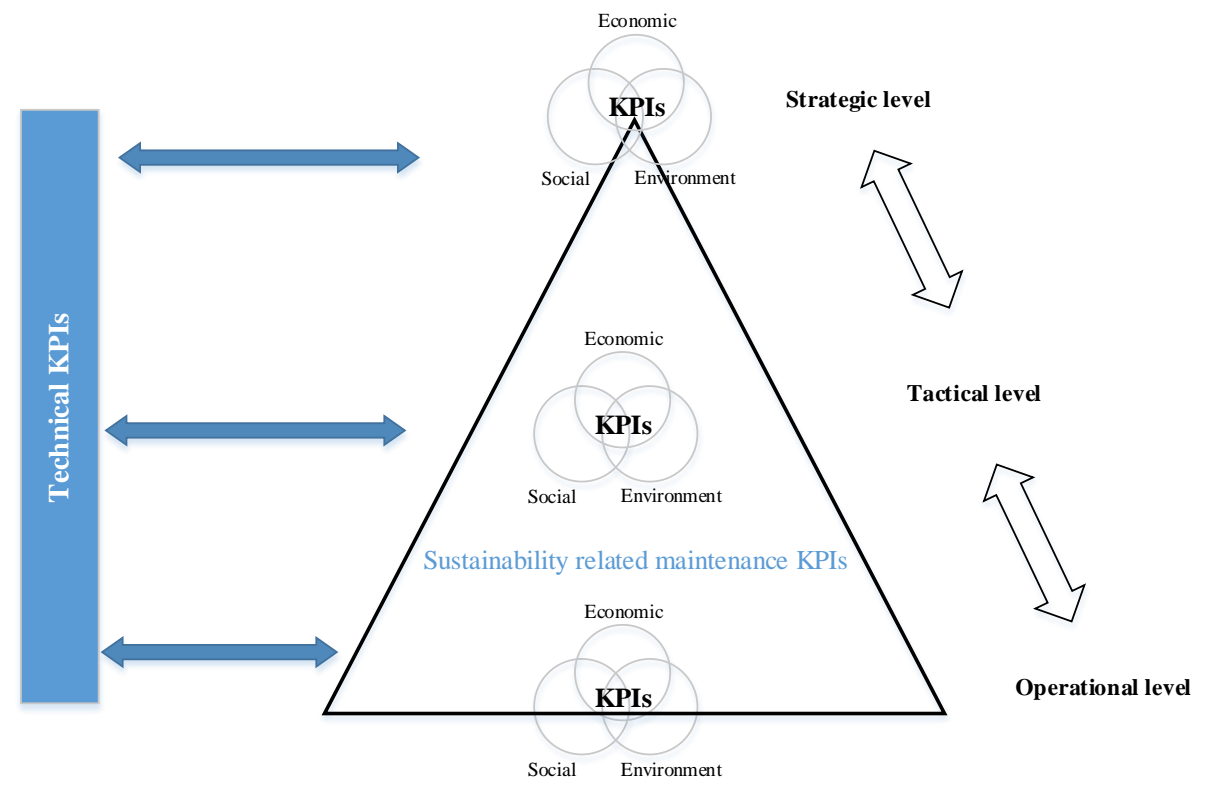

Figure 1: The proposed sustainability MPM framework

As mentioned above the KPIs are divided in three different levels which are: Operational, tactical and strategic. A summary of some selected indicators is shown in Table 1. 
D. Maletič, M. Maletič, B. Al-Najjar \& B. Gomišček: On a Design of a Maintenance

Performance Measurement System: a Sustainability Perspective

Table 1: KPIs related to triple bottom line

\begin{tabular}{|c|c|c|c|}
\hline $\begin{array}{l}\text { Triple bottom } \\
\text { line }\end{array}$ & $\begin{array}{c}\text { Strategic level } \\
\text { (KPIs) }\end{array}$ & $\begin{array}{c}\text { Tactical Level } \\
\text { (KPIs) }\end{array}$ & $\begin{array}{l}\text { Operational } \\
\text { level (KPIs) }\end{array}$ \\
\hline Social & $\begin{array}{l}\text { Customer } \\
\text { satisfaction } \\
\text { Employee } \\
\text { satisfaction } \\
\text { Employee } \\
\text { complaints } \\
\text { Number } \\
\text { accidents } \\
\text { Number of legal } \\
\text { cases } \\
\text { Health, safety, } \\
\text { security (HSS) } \\
\text { losses } \\
\text { HSS complaints } \\
\end{array}$ & $\begin{array}{l}\text { Employee turnover } \\
\text { rate } \\
\text { Employee complaints } \\
\text { Number of } \\
\text { accidents/incidents } \\
\text { Compensation paid } \\
\text { HSS complaints }\end{array}$ & $\begin{array}{l}\text { Employee } \\
\text { absentees } \\
\text { Employee } \\
\text { complaints }\end{array}$ \\
\hline Environment & $\begin{array}{l}\text { Environmental } \\
\text { complaints } \\
\text { Green innovation } \\
\text { initiatives } \\
\text { (number) }\end{array}$ & $\begin{array}{l}\text { Environmental } \\
\text { complaints } \\
\text { Level of usage of } \\
\text { chemicals related to } \\
\text { maintenance work } \\
\% \text { change of energy } \\
\text { use } \\
\text { Consumption } \\
\text { energy by type } \\
\% \text { change in volume } \\
\text { of hazardous waste } \\
\% \text { change of raw } \\
\text { materials used }\end{array}$ & $\begin{array}{ll}\text { Volume } & \text { of } \\
\text { rejections } & \\
\text { Scrap } & \\
\text { Re-work } & \text { of } \\
\text { product } & \end{array}$ \\
\hline Economic & $\begin{array}{l}\text { Maintenance } \\
\text { budged } \\
\text { Return } \\
\text { maintenance } \\
\text { investment } \\
\text { (ROMI) } \\
\text { Cost of } \\
\text { maintenance task } \\
\text { Investments in } \\
\text { cleaner technology }\end{array}$ & $\begin{array}{l}\text { Maintenance } \\
\text { cost/unit } \\
\text { Maintenance cost } \\
\text { Production cost }\end{array}$ & $\begin{array}{l}\text { Maintenance } \\
\text { cost per unit of } \\
\text { products }\end{array}$ \\
\hline
\end{tabular}

For production equipment, ensuring the system function is the prime maintenance objective. Maintenance has to provide the required reliability, availability, efficiency and 
$36^{\text {Th }}$ International Conference on Organizational Science Development: RESPONSIBLE ORGANIZATION (MARCH $22^{\mathrm{ND}}-24^{\mathrm{TH}}$, PORTOROŽ SLOVENIA)

D. Maletič, M. Maletič, B. Al-Najjar \& B. Gomišček: On a Design of a Maintenance Performance Measurement System: a Sustainability Perspective

capability of production system in accordance to the need of these characteristics (Muchiri et al., 2010). As such, the results of the maintenance process can be summarized as reliability, availability and operability of technical systems (Muchiri et al., 2011). These are the essential elements that asset managers seek to address and thus in this regard, several indicators can be used as proposed in Table 2.

Table 2: Technical KPIs

\begin{tabular}{|c|c|c|c|}
\hline Technical KPIs & $\begin{array}{c}\text { Strategic level } \\
\text { (KPIs) }\end{array}$ & $\begin{array}{c}\text { Tactical Level } \\
\text { (KPIs) }\end{array}$ & $\begin{array}{c}\text { Operational level } \\
\text { (KPIs) }\end{array}$ \\
\hline & $\begin{array}{c}\text { Capacity } \\
\text { utilization } \\
\text { Overall equipment } \\
\text { effectiveness } \\
\text { (OEE) }\end{array}$ & $\begin{array}{c}\text { Availability } \\
\text { Quality rate } \\
\text { Productivity rate } \\
\text { Number of } \\
\text { stoppages } \\
\text { Mean time to } \\
\text { repair (MTTR) } \\
\text { Mean time } \\
\text { between failure } \\
\text { (MTBF) } \\
\text { Overall equipment } \\
\text { effectiveness } \\
\text { (OEE) }\end{array}$ & $\begin{array}{c}\text { Production rate } \\
\text { Number of defects } \\
\text { Number of } \\
\text { stoppages/downtime }\end{array}$ \\
\hline
\end{tabular}

\subsection{Relevant elements in developing the MPM system}

In order to remain competitive and improve organization`s performance one should measure the maintenance performance as well (Maletič et al; 2012; Maletič, 2015; AlNajjar, Hansson, \& Sunnegårdh, 2004). However, for successful development and deployment of MPM it essential to consider different related issues and challenges:

- Understanding the maintenance process in detail before implementation of MPM (Parida and Kumar, 2006);

- Interaction of the maintenance function with other organizational functions consideration of corporate and maintenance strategy when developing MPM (Muchiri et al., 2011);

- Selecting the right MPIs for measuring MPM (Parida \& Kumar, 2006);

- Use of decision support methods of selection of the maintenance performance indicators (Van Horenbeek, 2014).

- IT support - the common database for data acquisition and analysis (Al-Najjar, 1996; Kans \& Ingwald, 2008);

- Assessment of maintenance impact from sustainability perspective (Liyanage et al., 2009). 
D. Maletič, M. Maletič, B. Al-Najjar \& B. Gomišček: On a Design of a Maintenance Performance Measurement System: a Sustainability Perspective

Measuring performance of maintenance is complex as it involves various indicators with multiple criteria at various hierarchical levels (Parida \& Kumar, 2006). Thus, the challenges associated with the development and implementation of the MPM system need to be considered in order to successfully develop and implement the MPM system. Discussion and conclusion

This paper contributes to efforts to address measuring and managing of the drivers for maintenance performance by presenting a conceptual framework for structuring key maintenance performance indicators. This framework is intended to support, rather than to replace, an existing performance measurement framework, by adding sustainability aspect in all hierarchical levels of an organization.

The interesting question is what issues are important to be considered in order to meet the necessary technical conditions that influence the sustainability performance of a given industrial facility (Liyanage et al., 2009). The proposed framework (Figure 1), for instance, illustrates which are the possible indicators related to sustainability aspect that organizations should measure at all three levels (operational, tactical and strategic). The measurement performance indicators (MPIs) should be considered from the perspective of the multi-hierarchical levels of an organization. The first hierarchical level could correspond to the corporate or strategic level, the second to the tactical or managerial level, and the third to the functional/operational level (Parida \& Chattopadhyay, 2007). Developing an organization that regards sustainability as a cornerstone for doing business requires a strategic approach that integrates economic, environmental and social considerations in all aspects of business on an on-going basis (Bonn \& Fisher, 2011). Our study tried to attempt this issue by suggesting the conceptual framework that provides guidelines for incorporating indicators from operational up to strategic level by the inclusion of the Triple bottom line in each of the levels. In this way we try to incorporate the notion of sustainability separately for each of the levels.

Moreover, it is important that an organization uses indicators, which are utilized to evaluate the effectiveness of the maintenance processes carried out (Wireman, 1998). It is also essential that indicators form the lower levels are aligned with the indicators at the higher level. For example, MPIs like availability, production rate and quality rate at the operational and tactical level should correspond to OEE aggregated at the strategic level. Nevertheless, the aforementioned indicators also affect the capacity utilization at the strategic level.

The purpose of this paper was to present and discuss the development of a conceptual sustainability MPM framework that can contribute to organizations seeking improvement in the way they manage measurements of the efficiency and effectiveness of the maintenance processes. Further, it can be applied as a decision support tool to select the most appropriate maintenance strategy that will led to the desired maintenance performance. The latter is of great importance, since maintenance is vital for sustainable performance of any industrial operation (Parida \& Chattopadhyay, 2007). 
$36^{\text {Th }}$ International Conference on Organizational Science Development: Responsible Organization (March $22^{\mathrm{ND}}-24^{\mathrm{TH}}$, Portorož Slovenia)

D. Maletič, M. Maletič, B. Al-Najjar \& B. Gomišček: On a Design of a Maintenance

Performance Measurement System: a Sustainability Perspective

\section{Literature}

Áhrén, T., \& Parida, A. (2009). Maintenance performance indicators (MPIs) for benchmarking the railway infrastructure: A case study. Benchmarking: An International Journal, 16(2), pp. 247258.

Al-Najjar, B., 1996. Total quality maintenance. An approach for continuous reduction in costs of quality products. Journal of Quality in Maintenance Engineering, 2(3), 4-20.

Al-Najjar, B. (2007). The lack of maintenance and not maintenance which costs: A model to describe and quantify the impact of vibration-based maintenance on company's business. International Journal of Production Economics, 107(1), pp. 260-273.

Al-Najjar, B, Hansson, M. A., \& Sunnegårdh, P. (2004). Benchmarking of maintenance performance: a case study in two manufacturers of furniture. IMA Journal of Management Mathematics, 15(3), 253-270. doi:10.1093/imaman/15.3.253

Dyllick, T., \& Hockerts, K. (2002). Beyond the business case for corporate sustainability. Business Strategy and the Environment, 11(2), 30-141.

Bonn, I. \& Fisher, J. (2011). Sustainability: the missing ingredient in strategy. Journal of business Strategy, 32(1), pp.5-14.

Elkington, J. (1999). Cannibals with Forks: The Triple Bottom Line of 21st Century Business, Capstone Publishing Ltd, Oxford.

Galar, D., Parida, A., Kumar, U., Stenström, C., \& Berges, L. (2011). Maintenance metrics: A hierarchical model of balanced scorecard. Proceedings of the IEEE International Conference on Quality and Reliability, 14-17 Sept. 2011, Bangkok, pp.67 - 74.

Gomes, C.F., Yasin, M.M., \& Lisboa, J.V. (2011). Performance measurement practices in manufacturing firms revisited. International Journal of Operations \& Production Management, 31(1), 5-30.

Holliday, C. (2001). Sustainable growth, the DuPont way. Harvard Business Review, 79, 129-34.

ISO 55000 (2014). Asset management - Overview, principles and terminology

Lee, K.H. (2009). Why and how to adopt green management into business organizations? The case study of Korean SMEs in manufacturing industry. Management Decision, 47(7), pp. 11011121 .

Liyanage J. P., Badurdeen, F. \& Ratnayake, R.M. C. (2009) Industrial Asset Maintenance and Sustainability Performance: Economical, Environmental, and Societal Implications. Handbook of Maintenance Management and Engineering, Chapter 24, 665-693.

Luxhoj, J., Riis, J. and Thorsteinsson, U. (1997). Trends and perspectives in industrial maintenance management. Journal of Manufacturing Systems, 16(6), pp.437-53.

Kans, M., \& Ingwald, A. (2008). Common database for cost-effective improvement of maintenance performance. Int. J. Production Economics, 113 (2008) 734-747.

Kaplan, R.S., Norton, D.P. (1996). The Balanced Scorecard: Translating Strategy into Action. Harvard Business School, Boston.

Kumar, U., \& Parida, A. (2008). Maintenance Performance Measurement (MPM) System.in

Kobbacy, K.A.H., \& Murthy, D.N.P. (Eds.), Complex System Maintenance Handbook, Springer, London, pp. 459-478.

Maletič, D. (2015). Interaction between Quality Management, Production and Maintenance Performance, $\mathrm{PhD}$ thesis, Faculty of Organizational Sciences, University of Maribor, Kranj.

Maletič, D., Maletič, M., \& Gomišček, B. (2012). The relationship between continuous improvement and maintenance performance. Journal of Quality in Maintenance Engineering, 18(1), pp. 30 - 41. http://dx.doi.org/10.1108/13552511211226175

Maletič, D., Maletič, M., Al-Najjar, B., Gotzamani, K., Gianni, M., Kalinowski, T. B., \& Gomišček, B. (2017, in press). Contingency factors influencing implementation of physical asset management practices. Organizacija. 
D. Maletič, M. Maletič, B. Al-Najjar \& B. Gomišček: On a Design of a Maintenance Performance Measurement System: a Sustainability Perspective

Muchiri, P. N., Pintelon, L., Martin, H., \& De Meyer, A.-M. (2010). Empirical analysis of maintenance performance measurement in Belgian industries. International Journal of Production Research, 48(20), 5905-5924. doi:10.1080/00207540903160766

Muchiri, P., Pintelon, L., Gelders, L., \& Martin, H. (2011). Development of maintenance function performance measurement framework and indicators. International Journal of Production Economics, 131(1), pp. 295 - 302.

Neely, A.D. (1994). Performance measurement system design - third phase. Performance Measurement System Design Workbook.

Parida, A., \& Chattopadhyay, G. (2007). Development of a multi-criteria hierarchical framework for maintenance performance measurement (MPM). Journal of Quality in Maintenance Engineering, 13(3), pp. 241-258.

Parida, A., \& Kumar, U. (2006). Maintenance performance measurement (MPM): issues and challenges. Journal of Quality in Maintenance Engineering, 12(3), pp. 239-251.

Simoes, J.M., Gomes, C.F., \& Yasin, M.M. (2011). A literature review of maintenance performance measurement: a conceptual framework and directions for future research. Journal of Quality in Maintenance Engineering, 17(2), pp. 116-37.

Van Horenbeek, A., \& Pintelon, L. (2014). Development of a maintenance performance measurement framework-using the analytic network process (ANP) for maintenance performance indicator selection. Omega, Vol. 42, No. 1, pp. 33-46.

Wang, L., Chu, J., \& Wu, J. (2007). Selection of optimum maintenance strategies based on a fuzzy analytical hierarchy process. International Journal of Production Economics, Vol. 107, pp. 151-63.

Wireman, T., 1998. Developing Performance Indicators for Managing Maintenance. New York: Industrial Press. 
518 36 $6^{\text {Th }}$ International Conference on Organizational Science Development:

Responsible Organization (MARCH $22^{\mathrm{ND}}-24^{\mathrm{TH}}$, PORTOROŽ SLOVENIA) 
36. MEDNARODNA KONFERENCA O RAZVOJU ORGANIZACIJSKIH ZNANOSTI: OdgOVORNA ORGANIZACIJA (22. - 24. MAREC 2017, PORTOROŽ, SLOVENIJA)

O. Arsenijević, M. Ferjan, I. Podbregar, P. Šprajc, D. Trivan \& Y. Ziegler

\title{
Igrifikacija v študentskih organizacijah
}

\author{
TILEN MARKUn, MARKo URH, EVA JEREB \& DAVORIN KOFJAČ
}

Povzetek Prispevek obravnava pogostost uporabe igrifikacije v študentskih organizacijah Fakultete za organizacijske vede Univerze v Mariboru. Najprej je opredeljena igrifikacija, kjer gre za uporabo elementov iger $\mathrm{v}$ neigralnih kontekstih. Nato sta predstavljena dva pomembnejša elementa igrifikacije, to sta mehanika in dinamika iger. Zatem so predstavljene študentske organizacije fakultete in rezultati raziskave o pogostosti uporabe elementov mehanike iger v posameznih organizacijah ter vplivu le teh na motivacijo in povezavo med pogostostjo ukvarjanja $\mathrm{z}$ igrami ter igrificiranimi sistemi in percepcijo pomembnosti elementov mehanike iger. Rezultati kažejo na nizko stopnjo uporabe elementov mehanike iger $\mathrm{v}$ študentskih organizacijah. Največjo motivacijo predstavljajo nagrade $\mathrm{v}$ obliki pohval in pridobitvijo določene ravni, statusa ali naziva.

KLJUČNE BESEDE: igrifikacija $\bullet$ mehanika iger $\bullet$ študentske organizacije $•$ motivacija

\footnotetext{
NASLOV AVTORJEV: Tilen Markun, študent, Univerza v Mariboru, Fakulteta za organizacijske vede, Kidričeva cesta 55a, 4000 Kranj, Slovenija, e-pošta: tilen.markun@ gmail.com; dr. Marko Urh, višji predavatelj, Univerza v Mariboru, Fakulteta za organizacijske vede, Kidričeva cesta 55a, 4000 Kranj, Slovenija, e-pošta: marko.urh@fov.uni-mb.si; dr. Eva Jereb, redna profesorica, Univerza v Mariboru, Fakulteta za organizacijske vede, Kidričeva cesta 55a, 4000 Kranj, Slovenija, e-pošta: eva.jereb@fov.uni-mb.si; dr. Davorin Kofjač, docent, Univerza v Mariboru, Fakulteta za organizacijske vede, Kidričeva cesta 55a, 4000 Kranj, Slovenija, e-pošta: davorin.kofjac@fov.unimb.si
} 
$36^{\mathrm{TH}}$ International Conference on Organizational Science DeVelopment: Responsible ORganizATION (MARCh $22^{\mathrm{ND}}-24^{\mathrm{TH}}$, PORTOROŽ SLOVENIA)

O. Arsenijević, M. Ferjan, I. Podbregar, P. Šprajc, D. Trivan \& Y.

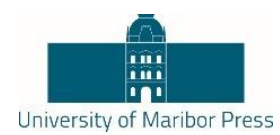

Ziegler

\title{
Gamification in Student Organisations
}

\author{
TILEN MARKun, Marko URH, Eva JEREB \& DAVORIN KofJAČ
}

\begin{abstract}
In the article the frequency of the use of gamification in student organizations at Faculty of Organizational Sciences University of Maribor is described. First, the gamification is defined, which involves the use of games elements in nongaming contexts. Two important elements of gamification, game mechanics and game dynamics, are described. Then the student organizations and the research results of the frequency of the use of the gamification elements in student organizations are presented. The impact of these elements on the motivation and the link between the frequency of engaging in games and the perception of the importance of the use of the gamification elements are researched. The results indicate a low level of the use of the gamification elements in student organizations. The greatest motivation elements are different praises and acquiring of certain level, status or title.
\end{abstract}

KEYWORDS: gamification • game mechanics • student organizations • motivation

CORRESPONDENCE ADDRESS: Tilen Markun, Student, University of Maribor, Faculty of Organizational Sciences, Kidričeva cesta 55a, 4000 Kranj, Slovenia, e-mail: tilen.markun@gmail.com; Marko Urh, Ph.D., Senior Lecturer, University of Maribor, Faculty of Organizational Sciences, Kidričeva cesta 55a, 4000 Kranj, Slovenia, e-mail: marko.urh@ fov.unimb.si; Eva Jereb, Ph.D., Full Professor, University of Maribor, Faculty of Organizational Sciences, Kidričeva cesta 55a, 4000 Kranj, Slovenia, e-mail: eva.jereb@fov.uni-mb.si; Davorin Kofjač, Ph.D., Assistant Professor, University of Maribor, Faculty of Organizational Sciences, Kidričeva cesta 55a, 4000 Kranj, Slovenia, e-mail: davorin.kofjac@fov.uni-mb.si

DOI https://doi.org/10.18690/978-961-286-020-2.43

ISBN 978-961-286-020-2

(C) 2017 University of Maribor Press

Available at: http://press.um.si 
T. Markun, M. Urh, E. Jereb \& D. Kofjač: Igrifikacija v študentskih organizacijah

\section{$1 \quad$ Uvod}

Vsaka organizacija stremi $\mathrm{k}$ čim boljšemu poslovanju. Za dosego le tega pa potrebuje strokovno usposobljen in motiviran kader. Tako sistemi za upravljanje v organizaciji poskušajo spodbuditi delavce $\mathrm{k}$ doseganju ciljev in rezultatov v skladu s cilji organizacije (Aguinis, 2009; Gruman \& Saks, 2011). Ena izmed oblik, ki se v zadnjem času pojavlja na področju spodbujanja in motiviranja zaposlenih $\mathrm{k}$ čim večji delovni uspešnosti pa je igrifikacija (ang. gamification). Podobno kot želijo podjetja in druge organizacije k uspešnemu delu spodbuditi svoje zaposlene, poskušajo tudi študentske organizacije spodbuditi svoje študentske predstavnike za aktivno sodelovanje in čim bolj učinkovito delo. Pri študentskih organizacijah Fakultete za organizacijske vede je moč zaslediti pomanjkanje motivacije za delo $\mathrm{v}$ teh organizacijah ali celo izrazito pasivnost nekaterih članov. Študenti so mogoče preobremenjeni s študijem in drugim delom ali pa ne prepoznajo dodane vrednosti in priložnosti, ki se jim ponuja $\mathrm{z}$ vključevanjem in delom v posameznih študentskih organizacijah. Tako smo si zastavili vprašanje ali bi lahko z uporabo igrifikacije $v$ študentskih organizacijah spodbudili delo študentskih predstavnikov. Zanimalo nas je, kako pogosto se študenti sploh srečajo z elementi igrifikacije, ali jih omenjeni elementi motivirajo za delo $\mathrm{v}$ posameznih študentskih organizacijah in na koncu, če obstaja povezava med pogostostjo ukvarjanja z igrami in igrificiranimi sistemi ter percepcijo pomembnosti elementov mehanike iger $\mathrm{v}$ obštudijskem okolju.

\section{$2 \quad$ Igrifikacija}

Pri igrifikaciji gre za uporabo elementov iger v neigralnih kontekstih. Srečamo jo na področju izobraževanja, športa, dela in drugje. Ne glede na področje uporabe je njen namen narediti določen proces za uporabnika bolj zanimiv, bolj privlačen. Začetki igrifikacije segajo v leto 2008, pojem pa izvira iz industrije digitalnih medijev. Večje zanimanje je termin dosegel šele $\mathrm{v}$ drugi polovici leta 2010. Vzporedno so se razvijali tudi drugi izrazi, kot na primer: »produktivne igre«, »nadzorovana zabava«, »igrificiran dizajn«, »plasti igre« in »aplicirano igranje«. Vseeno je igrifikacija ostala najpopularnejši izraz v neigralniškem svetu (Deterding, 2011).

Na področju dela, bodisi v podjetjih ali drugih organizacijah se pogosto uporablja tako imenovana delovna igrifikacija (ang. work gamification). S to vrsto se srečujemo tudi v študentskih organizacijah. Delovno igrifikacijo lahko smatramo kot element upravljanja delovne uspešnosti, ki uporablja tehnologijo za takojšno povratno informacijo o uspešnosti in s tem naredi delovne naloge bolj prijetne (Cardador et al., 2016). Delovna igrifikacija ne pomeni spreminjanja dela $\mathrm{v}$ igro, ampak uporabo igralnih funkcij ali elementov mehanike iger za usmerjanje želenega vedenja delavca.

Med najbolj tipične elemente mehanike iger uvrščamo točke (ang. points), ravni (ang. levels), značke (ang. badges), dosežke (ang. achievements), izzive (ang. challanges), virtualne dobrine (ang. virtual goods) in lestvice (ang. leaderboards) (Bunchball, 2010). Točke predstavljajo obliko merjenja uspeha $\mathrm{z}$ uporabo števil; za določeno akcijo ali kombinacijo akcij igralce nagradimo $\mathrm{z}$ določenim številom točk. Če so uporabljene v 
pravi obliki, so lahko odlična motivacija. Z njimi lahko uporabnike nagradimo čez celoten spekter igralnega sistema. Različne kategorije točk lahko uporabimo za spodbujanje različnih odzivov pri igralcih, bodisi jih koristijo kot indikator statusa, za omogočanje razširitev ali za kupovanje virtualnih dobrin in daril. Pri uporabi tovrstne igralne mehanike je izjemno pomembna uravnoteženost. Premalo dobljenih točk za igralca pomeni občutek prikrajšanosti, preveč pa občutek nepomembnosti točkovanja. Oboje lahko privede do zmanjšane motivacije za sodelovanje. Ravni ali nivoji so igralna mehanika, kjer igralci s pridobitvijo zadostnega števila točk, izkušenj ali s časom napredujejo, s tem pa dosežejo nov mejnik. Predstavljajo kombinacijo več želenih odzivov v daljšem časovnem obdobju. Cilj je motivacija uporabnikov za kontinuirano participacijo. Običajna praksa je, da z višjimi nivoji postane tekmovanje težje in časovno bolj potratno. Nagrada za dosežen nivo so lahko točke, dosežki, darila in omogočen dostop do novih delov igre. Značke, dosežki in izzivi dajejo igralcu možnost, da jih opravi in za to prejme določeno nagrado, ki je lahko v fizični ali virtualni obliki. S tem pri ljudeh povečujemo občutek, da delujejo ciljno usmerjeno. Za uspešno implementacijo potrebujemo sistem, kjer bodo te igralne mehanike vidne (npr. profil igralca, ki je viden ostalim) (Markun, 2016). Virtualne dobrine predstavljajo nefizične in neopredmetene elemente, ki jih lahko kupimo v okviru platforme, v kateri sistem deluje (Bunchball, 2010). Kot plačilno sredstvo lahko uporabimo točke, ravni pa nam določajo velikost nabora elementov, med katerimi izbiramo. Sešek (2015) opisuje lestvice kot prikaz uspešnosti na podlagi rangiranih dosežkov sodelujočih, ki omogočajo primerjanje in spodbujajo tekmovalnost. Lestvice so lahko vidne vsem uporabnikom ali vsakemu posamezniku (npr. ocena).

Različni elementi mehanike iger pa pridejo do izraza šele z ustrezno dinamiko iger. Dinamika predstavlja nastajajoča obnašanja, ki izhajajo iz igranja (Urh e tal., 2015). Canfield (2016) navaja naslednje elemente dinamike iger:

- osvajanje ozemlja ali pridobitev sredstev pred drugimi akterji (npr. Risk, StarCraft);

- napoved, ki mogoča ali spodbuja igralce uganiti, kaj se bo zgodilo in vključuje elemente sreče (npr. Ruleta);

- prostorsko sklepanje, kjer gre za sposobnost manipuliranja predmetov (npr. Tetris);

- preživetje, ki predstavlja zelo močno orodje dinamike, kjer se v igre vključujejo stalne nevarnosti za življenje (npr. Minecraft);

- uničenje;

- gradnja, ki vključuje izgradnjo mest, utrdb, likov (različne osebnosti), ali karkoli drugega (npr. SimCity);

- ujemanje;

- izogibanje;

- trgovanje;

- sodelovanje (npr. The Settlers of Catan);

- dirka do konca, kjer se pomembno, kdo prvi prečka ciljno črto (npr. Mario Cart). 
Ruhi (2015) opisuje, kako podjetja naredijo smiselno ogrodje za uporabo igrifikacije v podjetju. Po njegovem mnenju so najbolj pomembne dinamike: kontekst, tekmovanje, omejitve, izbira/odločitev, naključje, posledice, zaključek in nadaljevanje, sodelovanje. Kontekst sistema vzpostavi začetno točko za igralce, da spoznajo, katere tipe aktivnosti lahko uporabijo. Enostaven primer, na katerem lahko razložimo dinamiko iger, je igra s kartami tarok, kjer skozi vrsto aktivnosti igralci prevzamejo določeno nalogo (npr. igralec napove vse vzetke) in hkrati med seboj tekmujejo (tekmovanje). Celotna igra bazira na točkah. Sistem ima tudi svoje omejitve (v tem primeru pravila igre). Naključje je dinamika, kar prav tako lahko vključimo $\mathrm{v}$ naš sistem. Ta spodbudi dodatno zanimanje med igralci. V našem primeru je deljenje kart naključje, saj se pred vsako igro premešajo. Povratna zveza daje informacije uporabnikom in jim sporoči prednosti in slabosti njihovih odločitev ter možne posledice (npr. smiselnost odločitve za izbiro določene karte se vidi v vsakem vzetku). Dinamika zaključka in nadaljevanja sta dva pomembna elementa. S tem lahko igralcem med igro pokažemo njihov napredek ali jih vidno umestimo na dokončan del obveznosti s prihajajočimi obveznostmi (vsaka končana igra se točkuje, beležimo pa lahko tudi skupni rezultat in lestvico najboljših igralcev). Te dinamike omogočajo, da so igralci $\mathrm{v}$ okolju ciljno usmerjeni in imajo občutek, da napredujejo.

V našem primeru, kjer gre za sistem več študentskih organizacij na fakulteti, poleg individualnih dinamik pridejo v poštev tudi skupinske dinamike, ki poleg omenjenega tekmovanja vključujejo še sodelovanje (v predstavljenem primeru taroka je to igra, ko se 2 igralca združita in igrata proti ostalima dvema), dinamiko, ki vključuje skupno delo s ciljem vzajemne koristi. Skupinske (oz. družbene dinamike) tipično zahtevajo večjo zavezo končnih uporabnikov, kar pomeni delovanje skozi daljše časovno obdobje $\mathrm{v}$ primerjavi z individualnimi dinamikami iger (Ruhi, 2015).

\section{Študentske organizacije}

Na Fakulteti za organizacijske vede (FOV) v procesu zagotavljanja kvalitetnih obštudijskih dejavnosti obstaja kar nekaj organizacij. Vsaka organizacija ima svoje specifike in je prilagojeno za določene vrste projektov. Študentski svet Fakultete za organizacijske vede (ŠS FOV) je v prvi vrsti avtonomen organ FOV, ki skrbi za nemoten potek študijskega procesa in sooblikuje celotno fakulteto in njene študijske programe, hkrati pa je temeljna organizacija za koncipiranje in izvedbo projektov. V njem deluje najmanj trinajst članov $\mathrm{z}$ enoletnim mandatom, nujno pa sta vsaj po dva predstavnika vsakega letnika dodiplomskega in podiplomskega magistrskega študija. Pod okriljem ŠS FOV deluje Društvo študentov Fakultete za organizacijske vede (FOVŠ), ki skrbi za nemoteno izvajanje projektov. Vsi člani ŠS FOV so tudi člani društva FOVŠ. Namen ustanovitve društva leta 2010 je bil izboljšanje kvalitete življenje študentov na FOV (O društvu, 2016). Društvo je odgovorno za izvedbo večine projektov študentov. Med najbolj pomembnimi so: Udeležba študentov na mednarodni konferenci o razvoju organizacijskih znanosti v Portorožu, kjer lahko študenti vsako leto sodelujejo na sekcijah konference $\mathrm{s}$ svojimi prispevki, študentskimi posterji ali pa se udeležijo mednarodnega tekmovanja v študiji primera, projekt "Šport«, kjer imajo študenti možnost brezplačne rekreacije v na voljo pa so tudi aktivnosti, kot so smučanje, odbojka 
na mivki, ang. paintball, rafting ipd., ki se organizirajo glede na povpraševanje študentov, projekt mednarodne izmenjave študentov. Naslednja organizacija se imenuje ESTIEM (European Students of Industrial Engineering and Management), kjre gre za evropsko združenje študentov industrijskega inženiringa in managementa, ki je bilo ustanovljeno leta $1990 \mathrm{z}$ namenom povezovanja študentov iz cele Evrope in ustvarjanja platforme za izvajanje različnih projektov s skupnim ciljem ustvarjanja boljših poslovnih priložnosti za mlade. (About ESTIEM, 2016). Edina lokalna skupina v Sloveniji, Študentsko društvo ESTIEM LG Kranj, obstaja od leta 2013 v Kranju na Fakulteti za organizacijske vede, polnopravno članstvo pa je pridobila leta 2014. Od začetka delovanja so člani lokalne skupine Kranj organizirali vrsto mednarodnih in lokalnih projektov. Med najodmevnejšimi mednarodnimi dogodki velja omeniti projekta BrainTrainer, ki se ukvarja predvsem $\mathrm{z}$ razvojem mehkih veščin posameznika $\mathrm{v}$ poslovnem svetu, in Europe3D Slovenija, kjer so udeleženci iz cele Evrope Slovenijo v enem tednu spoznavali v treh pogledih: političnem, ekonomskem in kulturnem. Študentska organizacija Fakultete za organizacijske vede (ŠO FOV) je ena izmed štirih organizacijskih enot Študentske organizacije Univerze v Mariboru (ŠOUM). ŠOUM je stanovska skupnost študentov mariborske univerze, ki je bila ustanovljena na podlagi Zakona o skupnosti študentov iz leta 1994. Namen organizacije je izvajanje študentskih interesnih in obštudijskih dejavnosti ter vodenje študentske politike na področju izobraževanja, socialnega in ekonomskega položaja študentov ter mednarodnega sodelovanja (ŠOUM, splošni opis, 2016). Razlog za ustanovitev ŠO FOV je izhajal iz konkretnih potreb, saj je Fakulteta za organizacijske vede dislocirana od sedeža univerze. Za študente organizirajo velik spekter projektov, s katerim želijo zagotoviti kontinuiran in kakovosten razvoj na področju kulture, izobraževanja, športa, mednarodnega sodelovanja in drugih interesnih področij delovanja študentov. Študentsko izobraževalno društvo AIESEC (International Association of Students in Economic and Commercial Sciences) je največje društvo na svetu, vodeno s strani študentov. Deluje v 126 državah sveta z več kot 5.000 partnerskimi organizacijami, število članov pa je že preseglo 70.000. Glavni namen organizacije je vodenje mednarodne platforme za izmenjavo študentov, s katero želijo odkrivati vodstvene potenciale mladih, ki bodo imeli pozitiven vpliv na družbo, v kateri živijo. Študenti se lahko odločijo za bodisi plačano ali prostovoljno izmenjavo v kopici mednarodnih podjetij (ŠMIC - AIESEC, 2016). Sedež ene izmed lokalnih enot AIESEC v Sloveniji je v Kranju na Fakulteti za organizacijske vede. Ostali dve sta locirani v Ljubljani in Mariboru. Naslednjo organizacijo predstavljajo Tutorji FOV. Na Fakulteti za organizacijske vede tutorstvo obstaja že vrsto let. V študijskem letu 2012/13 so se sistemu prvič pridružili tudi tutorji iz vrst visokošolskih učiteljev in profesorjev. Namen tutorjev je $\mathrm{v}$ prvi vrsti pomoč študentom na prehodu iz srednješolskega okolja $\mathrm{v}$ univerzitetno okolje. Študentom pomagajo pri težavah, na katere naletijo ob študiju: bodisi z zapiski, s pomočjo pri iskanju inštrukcij, reševanju problematike s profesorji in ostalimi vprašanji, povezani s študijem. Tutorji imajo svoje redne sestanke, prav tako pa se na rednih sestankih dobivajo s člani iz vrst visokošolskih učiteljev in profesorjev. 
T. Markun, M. Urh, E. Jereb \& D. Kofjač: Igrifikacija v študentskih organizacijah

\section{Metoda dela}

\section{Vzorec}

V raziskavi je sodelovalo 43 predstavnikov študentskih organizacij. Od tega je 22 (51\%) moških in 21 (49\%) žensk. Povprečna starost sodelujočih je bila 23 let in 4 mesece. 35 (81\%) predstavnikov je študentov 1 . stopnje in $8(19 \%)$ študentov 2. stopnje. $16(37 \%)$ je študentov programa Organizacija in management informacijskih sistemov, $15(35 \%)$ Organizacija in management kadrovskih in izobraževalnih sistemov in $12(28 \%)$ programa Inženiring poslovnih sistemov. Podatki so prikazani v Tabeli 1.

\section{Tabela 1: Splošni podatki}

\begin{tabular}{|c|c|c|}
\hline \multirow{2}{*}{ Spol } & moški & $51 \%$ \\
\cline { 2 - 3 } Starost & ženske & $49 \%$ \\
\hline \multirow{2}{*}{\begin{tabular}{|c|} 
Stopnja \\
študija
\end{tabular}} & $1 . \quad$ stopnja 4 mesece \\
\cline { 2 - 3 } & $2 . \quad$ stopnja & $81 \%$ \\
\hline \multirow{2}{*}{$\begin{array}{c}\text { Študijski } \\
\text { program }\end{array}$} & $\begin{array}{c}\text { OM kadrovskih in izobraževalnih } \\
\text { sistemov }\end{array}$ & $19 \%$ \\
\cline { 2 - 3 } & Inženiring poslovnih sistemov & $37 \%$ \\
\hline
\end{tabular}

\section{Instrument}

Za zbiranje podatkov smo uporabili tehniko ankete, ki je bila dostopna preko spletne strani 1 ka.si. Vprašanja smo razdelili na dva glavna dela. V prvem delu smo zbirali tako imenovane splošne podatke, kot so: spol, starost, študijski program, stopnja študija, trenutni letnik vpisa, skupna povprečna ocena in študentska organizacija, v okviru katere je študent aktiven. V drugem delu smo $\mathrm{v}$ okviru sedmih sklopov vprašanj (skupaj 54) zbirali podatke o tem, kako pogosto se študenti srečajo $\mathrm{s}$ posameznimi elementi igrifikacije $\mathrm{v}$ študentskih organizacijah in kako jih le ti motivirajo za delo ter pogostost ukvarjanja $\mathrm{z}$ igrami in igrificiranimi sistemi na splošno. Študenti so na ta vprašanja odgovarjali z označevanjem vrednosti od 1 , ki predstavlja najmanjšo vrednost, do 5 , ki predstavlja najvišjo vrednost.

\section{$5 \quad$ Rezultati}

Kot prvo nas je zanimalo, kako pogosto se $\mathrm{v}$ posameznih organizacijah na fakulteti študenti srečujejo $\mathrm{z}$ elementi igrifikacije. Za potrebo odgovora na prvo vprašanje smo odgovore anketirancev razdelili na 5 delov glede na študentsko organizacijo, iz katere študent prihaja. Združili smo podatke Študentskega sveta FOV in FOVŠ, saj se vsi 
$36^{\mathrm{TH}}$ International Conference on ORganizational Science Development: Responsible Organization (MARCH $22^{\mathrm{ND}}-24^{\mathrm{TH}}$, Portorož Slovenia)

T. Markun, M. Urh, E. Jereb \& D. Kofjač: Gamification in Student Organisations

projekti in sestanki obeh združenj vodijo kot eno, ostale organizacije pa so še ESTIEM, AIESEC, ŠO FOV in Tutorji FOV.

Srečevanje z igrifikacijo smo nato preverili z vprašanji »Kako pogosto ste (bili) pri delovanju v vaši študentski organizaciji ...?«, kjer smo med različne elemente vključili tudi elemente igrifikacije:,
a) Dobili dodatne točke za delo (v obliki nagrade)
b) Razvrščeni v lestvice (npr. po uspehu, prisotnosti na sestankih, količini dela,
c) ki ste ga opravili)
d) Nagrajeni z individualnimi pohvalami
e) Lahko dosegali različne ravni, statuse, nazive
f) Nagrajeni z materialnimi nagradami
g) Nagrajeni zgolj po naključju, sreči (npr. žrebanje)
h) Sodelovali s sovrstniki pri projektih na FOV
i) Imeli za pripravo projekta, pisanje poročil in drugih obveznosti (nalog)
j) premalo časa
k) Imeli za pripravo in izvedbo projekta premalo časa
l) Kaznovani za slabo/neuspešno opravljeno nalogo/obveznost

Ugotovili smo, da se predstavniki ŠS FOV in FOVŠ $(M=2,2368$ in $S D=0,7009)$ kot tudi predstavniki ESTIEMa $(M=2,30$ in $S D=0,55)$ in Tutorji FOV $(M=2,25$ in $S D=0,58)$ le redko srečujejo z elementi mehanike iger. Predstavniki ŠO FOV $(M=2,93$ in $S D=0,20)$ in AISECa $(M=2,76$ in $S D=0,11)$ pa se z elementi mehanike iger srečujejo nekoliko večkrat. Študentski predstavniki AISECa se napram vsem ostalim organizacijam najpogosteje srečujejo z elementi kot so: individualne pohvale $(M=4,33$ in $S D=0,58)$, lestvice $(M=4,00$ in $S D=0,00)$ in ravni, statusi, nazivi $(M=4,00$ in $S D=1,00)$. Z individualnimi pohvalami se pogosto srečujejo tudi predstavniki ŠO FOV $(M=3,33$ in $S D=1,16$ ). Predstavniki ESTIEMa se najpogosteje srečujejo $\mathrm{z}$ elementi doseganja različnih ravni, statusov in nazivov $(M=3,27$ in $S D=1,42)$, tutorji pa z elementi individualne pohvale $(M=3,17$ in $S D=0,75)$. Rezultati so prikazani v Tabeli 2. 
36. MEDNARODNA KONFERENCA O RAZVOJU ORGANIZACIJSKIH ZNANOSTI: ODGOVORNA ORGANIZACIJA (22. - 24. MAREC 2017, PORTOROŽ, SLOVENIJA)

T. Markun, M. Urh, E. Jereb \& D. Kofjač: Igrifikacija v študentskih organizacijah

Tabela 2: Povprečne vrednosti in standardni odkloni za posamezne študentske organizacije

\begin{tabular}{|c|c|c|c|c|c|c|c|c|c|c|c|c|}
\hline & & $\mathrm{a}$ & $\mathrm{b}$ & c & d & $\mathrm{e}$ & $\mathrm{f}$ & $\mathrm{g}$ & $\mathrm{h}$ & $\mathrm{i}$ & $\mathrm{j}$ & $\mathrm{N}$ \\
\hline \multirow{2}{*}{ ESTIEM } & $\mathrm{M}$ & 2,05 & 1,68 & 2,91 & 3,27 & 2,05 & 2,00 & 3,82 & 2,00 & 1,77 & 1,23 & \multirow{2}{*}{22} \\
\hline & SD & 1,09 & 0,89 & 1,07 & 1,42 & 1,00 & 0,82 & 1,18 & 0,76 & 0,61 & 0,43 & \\
\hline \multirow{2}{*}{ TUTORJI } & M & 2,33 & 2,33 & 3,17 & 1,67 & 1,83 & 1,00 & 4,33 & 2,00 & 2,33 & 1,50 & \multirow{2}{*}{3} \\
\hline & SD & 1,37 & 1,51 & 0,75 & 0,82 & 1,60 & 0,00 & 0,52 & 0,89 & 0,82 & 0,55 & \\
\hline \multirow{2}{*}{$\begin{array}{l}\text { ŠS FOV in } \\
\text { FOVŠ }\end{array}$} & $\mathrm{M}$ & 2,21 & 2,11 & 2,63 & 2,63 & 2,00 & 1,37 & 3,74 & 2,16 & 2,21 & 1,32 & \multirow{2}{*}{19} \\
\hline & SD & 1,36 & 1,05 & 1,26 & 1,42 & 1,15 & 0,83 & 1,33 & 1,21 & 1,18 & 0,58 & \\
\hline \multirow{2}{*}{ ŠO FOV } & $\mathrm{M}$ & 3,00 & 2,67 & 3,33 & 2,67 & 3,33 & 1,00 & 5,00 & 3,00 & 3,33 & 2,00 & \multirow{2}{*}{3} \\
\hline & SD & 0,00 & 0,58 & 1,16 & 0,58 & 2,08 & 0,00 & 0,00 & 0,00 & 0,58 & 1,00 & \\
\hline \multirow{2}{*}{ AISEC } & M & 3,00 & 4,00 & 4,33 & 4,00 & 2,00 & 1,67 & 3,00 & 2,00 & 2,33 & 1,33 & \multirow{2}{*}{3} \\
\hline & SD & 1,00 & 0,00 & 0,58 & 1,00 & 0,00 & 0,58 & 0,00 & 1,00 & 0,58 & 0,58 & \\
\hline
\end{tabular}

$\mathrm{M}$ - povprečna vrednost, $\mathrm{SD}$ - standardni odklon, $\mathrm{N}$ - število

Nadalje nas je zanimalo, kaj študente najbolj motivira za delo. Tudi tukaj smo med različne motive vključili elemente mehanike iger in postavili vprašanje $» K o l i k o$ vas motivirajo našteti

elementi?«:

a) Nagrade za delo v obliki dodatnih točk

b) Razvrščanje v lestvice, ki so vidne vsem udeležencem (npr. prisotnost)

c) Razvrščanje v lestvice, ki so vidne le vam (npr. ocena za delo)

d) Nagrade za dosežke v obliki individualnih pohval

e) Nagrade, pridobljene z dosego določene ravni, statusa, naziva

f) Nagrade za dosežke v obliki materialnih nagrad

g) Nagrade, prejete iz naključja, sreče (npr. na podlagi žreba)

h) Sodelovanje s sovrstniki in skupinsko delo

i) Omejen čas za pripravo projektnega načrta, projektnega poročila ali drugih

j) obveznosti in nalog

k) Omejen čas za izvedbo projekta

1) Kazni za zamujanje časovnih rokov pri pripravi projektnega načrta ali

m) poročila

n) Kazni za neuspešno opravljanje obveznosti ali neuspešno izvedbo projekta

o) Pridobivanje dodatnih točk za aktivno delo pri projektih študentskih

p) organizacij na FOV

Ugotovili smo, da predstavnike študentskih organizacij najbolj motivirajo elementi mehanike iger, kot so: individualne pohvale $(M=3,40$ in $S D=0,98)$ in dosega določene ravni, statusa, naziva $(M=3,40$ in $S D=1,06)$. Najmanj pa jih motivirajo elementi, kot so: naključno nagrajevanje $(M=2,23$ in $S D=1,21)$, lestvice $(M=2,28$ in $S D=1,13)$ in kazni $(M=2,35$ in $S D=1,29)$.

$\mathrm{Na}$ koncu nas je zanimalo, ali obstaja povezava med pogostostjo ukvarjanja z igrami in igrificiranimi sistemi ter percepcijo pomembnosti uporabe elementov mehanike iger $\mathrm{v}$ okviru delovanja študentskih organizacij. Ugotovili smo šibko povezanost le med enim 
$36^{\mathrm{TH}}$ International Conference on ORganizational Science Development: ResPonsible ORGaNizATION (MARCH $22^{\mathrm{ND}}-24^{\mathrm{TH}}$, PORTOROŽ SLOVENIA)

T. Markun, M. Urh, E. Jereb \& D. Kofjač: Gamification in Student Organisations

elementom mehanike iger in sicer doseganju določene ravni, statusa, naziva $(r=0,297$; Sig. (2-tailed) pri 0,05) in pogostostjo ukvarjanja z igrami in igrificiranimi sistemi. Med ostalimi elementi mehanike iger in pogostostjo ukvarjanja $\mathrm{z}$ igrami ni bilo zaslediti povezave. Tako lahko zaključimo, da pogostost ukvarjanja z igrami in igrificiranimi sistemi pri študentskih predstavnikih ni povezana s percepcijo pomembnosti elementov mehanike iger.

\section{$6 \quad$ Zaključek}

$\mathrm{Z}$ raziskavo, opravljeno med predstavniki študentskih organizacij, smo ugotovili nizko stopnjo srečevanja študentov z elementi igrifikacije v posameznih organizacijah. Manjšo izjemo predstavljata ŠO FOV in AIESEC, kjer je bila pogostost srečevanja malo nad povprečjem. Rezultati kažejo na to, da študentske predstavnike najbolj motivirajo nagrade v obliki pohval in tiste, ki so pridobljene $\mathrm{z}$ dosego določene ravni, statusa, naziva. Sicer pa smo odkrili, da jih za delo močno motivira medsebojno sodelovanje in skupinsko delo. Najmanj jih motivirajo elementi mehanike iger, kot so: lestvice, naključno nagrajevanje in elementi tekmovanja in kazni. Študenti so na splošno za delo pri projektih motivirani zaradi pridobitve kompetenc, znanja, izkušenj in poznanstev. Povezave med pogostostjo ukvarjanja $\mathrm{z}$ igrami in igrificiranimi sistemi ter percepcijo pomembnosti posameznih elementov mehanike iger ni. Obstaja le šibka linearna povezava med pogostostjo ukvarjanja $\mathrm{z}$ igrami in nagradami, pridobljenimi z dosego določene ravni, statusa, naziva. Na podlagi ugotovljenega menimo, da bi $\mathrm{v}$ sisteme posameznih študentskih organizacij sistemsko lahko vpeljali določene elemente igrifikacije, seveda s poudarkom na tistih, ki študente najbolj motivirajo. Pri vpeljavi teh elementov pa moramo biti pazljivi in gledati na sistem kot celoto ter spremljati rezultate.

\section{Literatura}

About ESTIEM. (2016). ESTIEM. Dostopno na https://www.estiem.org/default.aspx?PageId=523 Aguinis, H. (2009). Performance management. Upper Saddle River, NJ: Pearson Prentice Hall.

Bunchball, Inc. (2010). Gamification 101: An introduction to the use of game dynamics to influence behavior. Dostopno na http://www.bunchball.com/sites/default/files/downloads/gamification101.pdf

Canfield, C. D. (2016). Everyone: Review examples of core game dynamics. Dostopno na https://trello.com/c/SQ0h4Dtk/9-everyone-review-examples-of-core-game-dynamics-clickfor-a-list

Cardador, M.T., et al. (2016). A theory of work gamification: Something old, something new, something borrowed, something cool?, Human Resource Management Review, http://dx.doi.org/10.1016/j.hrmr.2016.09.014

Deterding, S., Dixon, D., Khaled, R., Nacke, L. (2011). From Game Design Elements to Gamefulness: Defining Gamifiacation. MindTrek, Vol. 11, str. 9 - 15.

doi: $10.1145 / 2181037.2181040$

Gruman, J. A., \& Saks, A. M. (2011). Performance management and employee engagement. Human Resource Management Review, Vol. 21, No. 2, str. 123 - 136.

Markun, T. (2016). Uporaba igralnih mehanik v Študentskih organizacijah fakultete. Diplomsko delo. 
T. Markun, M. Urh, E. Jereb \& D. Kofjač: Igrifikacija v študentskih organizacijah

O društvu. (2016) Društvo študentov Fakultete za organizacijske vede - FOVŠ. Dostopno na http://www.fovs.si/o-drustvu

Ruhi, U. (2015). Level Up Your Strategy: Towards a Descriptive Framework for Meaningful Enterprise Gamification. Technology Innovation Management Review, Vol. 5, No. 8, str. 5 16. Dostopno na http://timreview.ca/article/918

Sešek, U. (2015). Igrifikacija izobraževanja - norost ali rešitev (str. 881 - 893). V: EDUvision 2015: Sodobni pristopi poučevanja prihodnjih generacij. EDUvision. Ljubljana: December 3 - 4 , 2015.

ŠMIC - AIESEC. (2016). ŠMIC. Dostopno na http://www.smic.si/sl-SI/Content/Details/164

ŠOUM - OE ŠO FOV. (2016). ŠOUM. Dostopno na http://soum.si/sl-SI/Content/Details/139

Urh, M., Vukovič, G., Jereb, E., Pintar, R. (2015). The Model for Introduction of Gamification into E-learning in Higher Education. Procedia-Social and Behavioral Sciences, 197, str. 388-397, doi: 10.1016/j.sbspro.2015.07.154 
$530 \quad 36^{\text {Th }}$ International Conference on Organizational Science Development:

Responsible Organization (MARCH $22^{\mathrm{ND}}-24^{\mathrm{TH}}$, PORTOROŽ SLOVENIA) 
36. MEDNARODNA KONFERENCA O RAZVOJU ORGANIZACIJSKIH ZNANOSTI: ODGOVORNA ORGANIZACIJA (22. - 24. MAREC 2017, PORTOROŽ, SLOVENIJA)

O. Arsenijević, M. Ferjan, I. Podbregar, P. Šprajc, D. Trivan \& Y. Ziegler

\title{
Pomen legalnosti in legitimnosti pri spoštovanju človekovih pravic ter zagotavljanju dobre uprave
}

\author{
KORNELIJA MARZEL
}

Povzetek Strategija razvoja javne uprave 2015 -2020, ki jo je Vlada Republike Slovenije sprejela v letu 2015, ima namen modernizirati javno upravo. Strategija izhaja iz skupnega cilja povečati konkurenčnost gospodarstva tudi skozi fleksibilno ter hitro odzivno javno upravo, ki bo delovala pregledno, strokovno, družbeno odgovorno ter skladno z načeli dobrega upravljanja. Dobro upravljanje in dobra uprava predstavljata generičen pojem za legalno, legitimno in dostojno ravnanje, ki ga od oblasti terjamo tako posamezniki kot tudi poslovni subjekti.

Ne glede na mnoga pravila, načela in postopkovne zahteve pa se, kot ugotavlja Varuh človekovih pravic Republike Slovenije v svojih letnih poročilih, v postopkih odločanja o pravicah, obveznostih in pravnih koristih ter pri zagotavljanju določenega blaga in storitev, dogajajo kršitve človekovih pravic. Te kršitve niso vedno le posledica nelegalnega ravnanja organov javne uprave, temveč velikokrat izvirajo iz njihovega nelegitimnega postopanja, ki ni skladno z načelom dobrega upravljanja. V prispevku avtorica obrazloži, vsebinsko napolni in analizira pojme legalnost, legitimnost ter dobra uprava; odgovori na vprašanje, kdo nadzira pojave ne/legalnega ravnanja in kdo pojave ne/legitimnega ravnanja oblasti; torej ravnanja organov oblasti $\mathrm{v}$ najširšem pomenu besede, ki lahko vodijo do dobre ali slabe uprave ter posredno tudi do dviga ali padca konkurenčne sposobnosti države.

KLJUČNE BESEDE: varuh človekovih pravic • varovanje človekovih pravic - javna uprava $\bullet$ legalnost $\bullet$ legitimnost $\bullet$ dobro upravljanje $\bullet$ dobra uprava

\footnotetext{
NASLOV AVTORICE: dr. Kornelija Marzel, nadomestnica varuhinje, Varuh človekovih pravic Repuplike Slovenije, Dunajska cesta 56, 1109 Ljubljana, Slovenija, e-pošta: kornelija.marzel@varuh-rs.si
} 
36 ${ }^{\text {TH }}$ International Conference on Organizational Science DeVelopment: Responsible Organization (MARCH $22^{\mathrm{ND}}-24^{\mathrm{TH}}$, PORTOROŽ SLOVENIA)

O. Arsenijević, M. Ferjan, I. Podbregar, P. Šprajc, D. Trivan \& Y.

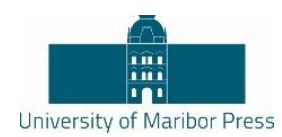

Ziegler

\title{
The Importance of Legality and Legitimacy in Respecting Human Rights and Ensuring Good Administration
}

\author{
KORNELIJA MARZEL
}

\begin{abstract}
The purpose of the Public Administration Development Strategy 2015-2020, adopted in 2015 by the Government of the Republic of Slovenia, is to modernise public administration. The strategy is based on the common goal of increasing the competitiveness of the economy through flexible and responsive public administration, which will work in a professional, transparent and socially responsible manner in compliance with the principles of good management. Good management and good administration are generic terms for the legal, legitimate and decent conduct that is required of the authorities by both individuals and business entities.
\end{abstract}

In its annual reports, the Human Rights Ombudsman of the Republic of Slovenia notes that, despite numerous regulations, principles and procedural requirements, human rights are violated in procedures for deciding on rights, obligations and legal entitlements, and in the provision of certain goods and services. These violations are not solely a consequence of the illegal conduct of public administration bodies, but often arise from their illegitimate actions that are not in compliance with the principle of good management. In the article, the author explains and interprets the terms legality, legitimacy and good administration. She answers the question of who is responsible for dealing with illegal/legal conduct and who for the illegitimate/legitimate conduct of authorities, i.e. the conduct of the authorities in the broadest sense of the word, which may lead to good or bad administration and, in turn, raise or undermine the competitiveness of the country.

KEYWORDS: Human Rights Ombudsman • protection of human rights • public administration $\bullet$ legality $\bullet$ legitimacy $\bullet$ good management $\bullet$ good administration

CORRESPONDENCE AdDREss: Kornelija Marzel, Ph.D., Deputy Ombudsmen, The Human Rights Ombudsman of the Republic of Slovenia, Dunajska cesta 56, 1109 Ljubljana, Slovenia, e-mail: kornelija.marzel@varuh-rs.si 
K. Marzel: Pomen legalnosti in legitimnosti pri spoštovanju človekovih pravic ter zagotavljanju dobre uprave

\section{$1 \quad$ Uvod}

Uspešna in učinkovita javna uprava je izrednega pomena za gospodarski napredek, za razvoj države in za splošno družbeno blaginjo. Pri tem ni možno zaobiti dejstva, da je uprava zgolj eden izmed podsistemov družbe, ki morajo vsi skupaj delovati v smeri dviga konkurenčnosti države. Zaradi omenjenega je vlada prepoznala nujnost modernizacije javne uprave, ki se je dejansko začela že leta $1997 .{ }^{1}$ Takrat je bila spodbujena s spremembami, ki jih je narekovala priključitev Evropski uniji. Modernizacija javne uprave oziroma njeno reformiranje dejansko pomeni prilagoditev uprave in njenega dela nastajajočim družbenim spremembam. S temi nameni so bili sprejeti mnogi novi zakoni: Zakon o državni upravi ${ }^{2}$, Zakon o javnih uslužbencih ${ }^{3}$, Zakon o sistemu plač v javnem sektorju ${ }^{4}$, Zakon o javnih financah ${ }^{5}$ Zakon o javnih naročilih ${ }^{6}$ in drugi. Začele so se sistematično odpravljati administrativne ovire, uvajati e-uprava ter sistemi kakovosti v javni upravi, vse s ciljem, da se povečata strokovnost in učinkovitost javnega sektorja. Zelo pomembno vlogo pri tem je imelo izvajanje načel novega upravljanja javnega sektorja - NUJS (angl. New Public Management), ki temelji predvsem na prenašanju podjetniških konceptov $\mathrm{v}$ javno upravo. Ti koncepti so: usmerjenost $\mathrm{k}$ uporabnikom storitev, uvajanje poslovnih metod dela, uporaba standardov uspešnosti ter drugi koncepti.

Modernizacija javne uprave je tako tesno povezana z načelom dobrega upravljanja, po katerem deluje tudi Varuh človekovih pravic Republike Slovenije (v nadaljevanju: Varuh). V svojih letnih poročilih Varuh poudarja, da so na posameznih področjih potrebne spremembe na zakonodajni ravni (eden izmed takih primerov so inšpekcijske službe), terja pa tudi spremembe v upravni kulturi zlasti v smeri partnerskega odnosa med upravo in strankami, večje odprtosti, prijaznosti, dostopnosti oziroma uprave v službi državljanov in upoštevanja etičnih standardov poslovanja, kar bo vse vodilo $\mathrm{k}$ strokovnim odločitvam in ravnanjem, ki ne bodo samo zakonita, temveč bodo zagotavljala tudi pravičnost in dobro upravo ob spoštovanju človekovih pravic in svoboščin.

Od zadnjega strateškega dokumenta, ki je pomenil reformo javne uprave, je preteklo že več kot deset let (2005) in uprava je bila pravzaprav v tem obdobju podvržena inertnemu delovanju. Ni bilo jasne usmeritve, kako naprej, ni bilo izvedene analize sprejetih ukrepov, bili pa so sprejeti mnogi predpisi, ki so ločeno, nepovezano in neodvisno urejali posamezna izdvojena področja, vse to pa je bilo pogojeno z vsakokratno oblastjo.

Med ostalimi so vzroki, ki so vlado v letu 2015 ponovno spodbudili k sprejemu strateškega dokumenta o javni uprav naslednji: padec Slovenije na lestvici globalne konkurenčnosti, ${ }^{7}$ neugodne ugotovitve Organizacije za razvoj in sodelovanje - OECD (angl. Organisation for Economic Cooperation and Development), da Slovenija v okviru ukrepov za izhod iz krize ni predvidela ukrepov za povečanje učinkovitosti javnega sektorja ter nujno potrebna izpolnitev predhodnih pogojev $\mathrm{v}$ okviru pridobivanja finančnih sredstev Evropske unije, kot vse sledi iz Strategije razvoja javne uprave 20152020 (v nadaljevanju: strategija) 
$36^{\text {Th }}$ International Conference on Organizational Science Development: Responsible Organization (March $22^{\mathrm{ND}}-24^{\mathrm{TH}}$, Portorož SLOVEnia)

K. Marzel: The Importance of Legality and Legitimacy in Respecting Human Rights and Ensuring Good Administration

Nadaljnji razvoj in reformiranje javne uprave bosta tako izhajala iz omenjene strategije, jasne vizije in sprejetih akcijskih načrtov za napredek. Temeljni cilj modernizacije je prilagodljiva in hitro odzivna uprava, ki bo delovala pregledno, strokovno in odgovorno ter tudi skladno $\mathrm{z}$ načeli dobrega upravljanja. Takšna uprava naj bi delovala družbeno odgovorno in ustvarjala učinkovito zakonodajno okolje ter spodbudno poslovno vzdušje.

Strategija zajema večinoma javno upravo, vsebuje pa tudi smernice za ves javni sektor (npr. glede plač, števila zaposlenih, upravnega postopka), prav tako so v strategiji podane usmeritve za posamezne resorje (zdravstvo, socialno varstvo, šolstvo, okolje, kultura idr.), ki bodo sprejeli programe in izvedbene akte. ${ }^{8}$

V strategiji je podana vizija vlade organizirati upravo na način, da bo sledila:

- zakonitosti in vladavini prava,

- strokovnosti in profesionalnosti,

- participaciji,

- preglednosti, integriteti in preprečevanju korupcije,

- odzivnosti in usmerjenosti k uporabniku,

- usmerjenosti h konsenzu in vključenosti,

- pravičnosti,

- inovativnosti, uspešnosti in učinkoviti rabi virov,

- odgovornosti.

Vlada je $\mathrm{z}$ upoštevanjem omenjenih postulatov $\mathrm{v}$ posebnem poglavju strategije podala tudi ključna področja za modernizacijo javne uprave, in sicer po naslednjem vrstnem redu:

- odprto in transparentno delovanje z ničelno toleranco do korupcije,

- učinkovito upravljanje s človeškimi viri,

- krepitev usposobljenosti javnih uslužbencev,

- sistem vodenja kakovosti v javnem sektorju,

- izboljšanje zakonodajnega okolja,

- modernizacija inšpekcijskega nadzora,

- učinkovita informatika, dvig uporabe e-storitev, digitalizacija in interoperabilnost,

- učinkovita raba virov. ${ }^{9}$

Konkretni cilji s predvidenimi ukrepi, potrebnimi finančnimi viri ter odgovornimi za izvedbo dajejo upanje dejanske prenove javne uprave. Pomanjkanje politične volje, prevelik vpliv politike na upravljanje s kadri, nestabilno politično, gospodarsko, ekonomsko in finančno okolje ter drugi dejavniki so tisti, ki lahko v prihodnosti zavrejo napredek in Slovenijo na lestvici konkurenčnosti pahnejo na »nižje« mesto. Pri tem so ogroženi gospodarska rast in socialna povezanost na eni strani ter razvoj vseh demokratičnih procesov v državi vključno s človekovimi pravicami in svoboščinami na 
K. Marzel: Pomen legalnosti in legitimnosti pri spoštovanju človekovih pravic ter zagotavljanju dobre uprave

drugi strani. Pomembno vlogo pri tem imajo nadzorni mehanizmi; tako sodni postopki oziroma drugi formalni postopki, kjer se prvenstveno obravnavajo vprašanja zakonitosti ravnanj organov oblasti kot tudi neformalni načini, ki pa so primarno namenjeni legitimnosti, dobremu upravljanju in varstvu človekovih pravic. Najbolj razširjen in najpomembnejši mehanizem tega varstva je institucija ombudsmana, s čimer se strinjajo Kaučič (2008), Radinović (2001), Remac (2014) in Rovšek (2002). ${ }^{10}$ Radinović kot eno izmed ključnih področij delovanja ombudsmana prepozna dobro upravo (angl. good administration) oziroma slabo upravo (angl. maladministration).

\section{$2 \quad$ Pristojnosti Varuha}

Primarna naloga Varuha je varovanje človekovih pravic in svoboščin. Pri tem se Varuh po ZVarCP lahko sklicuje na zakonitost, načela pravičnosti in dobrega upravljanja.

$\mathrm{URS}^{11} \mathrm{v}$ povezavi z obsegom nadzora določa pristojnosti Varuha v razmerju do državnih organov, organov lokalne samouprave in nosilcev javnih pooblastil. Varuh ima torej pristojnost do vseh oblastnih pristojnosti $\mathrm{v}$ javni sferi; ne more pa kontrolirati tistih razmerij in odnosov, ki nastanejo med posamezniki in organizacijami v zasebni sferi (Trpin, 1993). ${ }^{12}$

Posebnosti veljajo za sodišča. Glede na njihovo samostojnost in neodvisnost so Varuhova pooblastila pri nadzoru nad delom sodišč omejena tako, da takšnega položaja v strukturi državne ureditve ne ogrožajo.

Zaradi Varuhovih utesnjenih pooblastil do sodstva, omejenosti tega prispevka, pa tudi zato, ker so ravno upravna razmerja tista, s katerimi se vsak posameznik v življenju najpogosteje srečuje na tak ali drugačen način, je v nadaljevanju posebna pozornost posvečena upravnim razmerjem, njihovi legalnosti in legitimnosti ter dobremu upravljanju, kar vse vodi do dobre ali slabe uprave. Dejansko gre za razmerja med organi javne uprave, kot jih opredeljuje Strategija razvoja javne uprave 2015 - 2020 na eni strani, ter strankami - posamezniki in poslovnimi subjekti na drugi strani, torej za "upravne postopke, ki so zakonsko predpisani in jih lahko vodijo samo organi javne uprave in nihče drug v državi« (Marzel, 1999). Za upravne postopke je bistveno oblastno odločanje. To poglavitno lastnost je treba naglasiti, saj subjekta upravnih razmerij - za razliko od sodnih postopkov - nista $v$ enakovrednem položaju. Eno stran upravnega razmerja namreč predstavlja država oziroma oblast $v$ širšem pomenu besede. Ker gre za razmerja med šibkejšim posameznikom ter močnejšo oblastjo in ker je $v$ njem poleg zasebnega interesa vedno prisoten tudi javni interes, je treba šibkejšo stran zaščititi pred morebitnimi zlorabami.

Pri tem pa ne moremo mimo dejstva, da posamezniki ne prihajamo $\mathrm{v}$ stik $\mathrm{z}$ javno upravo samo takrat, kadar država proti nam vodi določene upravne postopke. Pomemben delež upravnih razmerij se namreč odvija med posamezniki in izvajalci javnih služb, ki zagotavljajo javne dobrine. 
$36^{\mathrm{TH}}$ International Conference on ORganizational Science Development: RESPONSIBLE ORGANIZATION (MARCH $22^{\mathrm{ND}}-24^{\mathrm{TH}}$, PORTOROŽ SLOVENIA)

K. Marzel: The Importance of Legality and Legitimacy in Respecting Human Rights and Ensuring Good Administration

Poleg že omenjenega velja izpostaviti še pogostost upravnih razmerij. Vsakodnevno vstopamo v upravna razmerja, pri tem pa smo podvrženi situacijam, kjer lahko pride do zlorab, nezakonitih postopkov, slabega upravljanja in kršitev človekovih pravic. Varuh v teh razmerjih nadzoruje spoštovanje človekovih pravic, zakonitost in načela dobrega upravljanja, ki služijo kot neke vrste »odprt vhod« za vsa prihodna ravnanja, ki bodo skladna z razumevanjem pojma dobro upravljanje. Gre za bistveno drugačna pooblastila, ki so posameznim organom (upravnim in sodnim) dana $\mathrm{v}$ formalnih postopkih. Neformalne oblike nadzora nad delovanjem oblasti (kamor poleg nadzora civilne družbe in medijev spadata tudi parlamentarni nadzor in Varuh) so cenejše, predvsem pa niso osredotočene samo na zakonitost ravnanj organov oblasti, niso tako strogo uokvirjene $\mathrm{v}$ določena pravna razmerja in zato tudi lahko bolj upoštevajo raznovrstnost življenjskih situacij in razmerij, ki nastanejo med oblastjo in posameznikom, kot ugotavlja Kaučič (2008) in kar je še posebej evidentno pri upravnih razmerjih.

\section{Legalnost, legitimnost in dobro upravljanje kot ocenitveni standardi Varuha}

Legalnost in legitimnost je možno opredeliti v povezavi s konceptom dobre uprave. Dobro upravljanje in dobra uprava namreč predstavljata generičen pojem za zakonito, strokovno, primerno in dostojno ravnanje oblasti do posameznika.

Če imamo pri legalnosti v mislih zakonitost ali pravnost delovanja oblasti, pa z legitimnostjo označujemo upravičenost, sprejemljivost ali pravičnost oblasti, njenih organov in uslužbencev. Na splošno se legitimnost lahko opiše kot »kakovost, ki golo moč transformira v upravičeno avtoriteto « (Teršek, 2014). Človekove pravice ustvarjajo vsebino legitimnosti in »predstavljajo minimalni standard upravičenosti, sprejemljivosti in legitimnosti oblasti, institucij, pravil in zavezujočih odločitev« (Teršek, 2014).

Nujno je upoštevati, da vzpostavitev oblasti (države) predstavlja zgolj temelj za njeno legalnost, kar pa za legitimnost ne zadostuje. Predpisi so namreč legitimni takrat, kadar izvirajo iz morale, običajev, etike in kulture in so ravno zaradi opredeljenega upravičljivi in družbeno sprejemljivi. Zagotavljanje človekovih pravic omogoča prenos težišča od legalnosti k legitimnosti oblasti.

Glede na zgodovinske vzroke za nastanek ombudsmana, torej omejiti oblast $\mathrm{v}$ njeni samovolji, je povsem jasno, da je imel tudi slovenski Varuh v začetni fazi obstoja največ dela s pojavi nelegalnega delovanja oblasti; za kar je sicer pristojnost primarno podeljena sodstvu, ki je formalizirano, specializirano in ustanovljeno ravno zaradi kontrole zakonitosti. Varuh pa se mora čedalje bolj posvečati nelegitimnim ravnanjem ter ravnanjem, ki so nasprotna dobremu upravljanju, vse s ciljem spremeniti prakso ravnanja oblasti v smeri dobre uprave. Ob tem ni možno zanikati pomembnosti Varuha pri varovanju človekovih pravic, kot ugotavljajo Kaučič (2008), Reif (2004), Remac (2013), Rovšek (2002) in drugi. Navedeno je sicer zgodovinsko najbolj značilno za mlade države na začetku demokratičnega razvoja, ki so morale ravno zaradi zagotavljanja in ohranjanja demokratičnih standardov posebno skrb nameniti temeljnim človekovim pravicam in 
svoboščinam, kar pa še posebej velja za Slovenijo, ki je je v razvoju demokracije šele nekje v »najstniški« dobi.

Moderniziranje javnega uprave in ravnanje skladno s koncepti dobre uprave pomeni odločanje na osnovi takšne avtoritete, ki ne temelji na "podeljeni moči«, ampak na zakonitosti, korektnosti, dostojnosti in učinkovitosti. V možnosti sklicevanja Varuha na načela pravičnosti in dobrega upravljanja je videti podlago za predlaganje izjemnih rešitev v posamičnih utemeljenih primerih, ki jih predpisi ne predvidevajo (Rovšek, 2002). Dobro upravljanje je tisto, kar prerašča legalnost in legitimnost ter kot tako pomeni več od tega. $Z$ njim lahko razrešujemo specifične probleme, okoliščine in situacije, na primer molk organa lahko nadomesti učinkovita in uspešna mediacija, upravna dejavnost se tako razvija v zakonito, primerno ter učinkovito oblast (Kovač, 2012).

Zadrego in svojstven izziv pri dobrem upravljanju (ki teži k dobri upravi) ter ravnanju, skladnem z načeli pravičnosti, predstavlja opredelitev standardov tovrstnega ravnanja javne oblasti oziroma uprave. Omenjeni izraz dobro upravljanje je imensko naveden v ZVarCP in v Strategiji razvoja javne uprave 2015 - 2020 kot besedna zveza, pri čemer pa se v zakonodajah drugih držav govori o angl. the right to good administration, good governance, good administrative behaviour, maladministration in o drugih ujemajočih se pojmih, ki generalizirajo bodisi dobro ali slabo upravo, katere ravnanje pa ni nujno nezakonito. V tem okviru gre za, v kakršnem koli pogledu sporno, nespodobno ravnanje uprave, in sicer za oblast ter upravo s katero koli administrativno napako, takšno upravo, ki ni odzivna, ki zamuja in ki na sploh ravna neprimerno. Na dobro upravo se je možno sklicevati vedno, ko »organi nekorektno in neupravičeno otežujejo uveljavljanje pravic posameznikov, ne da bi bilo to ravnanje bilo nujno v nasprotju s predpisi« (Grad, Kaučič, Ribičič in Kristan, 1996). Poudariti velja, da dobro upravljanje in pravičnost izvirata tudi iz mednarodnih pogodb in mednarodnih načel: nanašata se na odprtost, preglednost, dostopnost, odzivnost, etičnost, poštenost, ekonomičnost in na uspešnost ter učinkovitost.

Dobra uprava se opira na etična pravila, za katera pa ni nujno, da so normativno urejena (z nacionalnimi predpisi ali mednarodnimi akti); gre za višji standard ravnanja uprave, kot pa ga določajo pravne norme. Ravnanje uprave oziroma oblasti mora biti ne le legalno, pač pa javnost pričakuje ravnanje, ki bo skladno z moralo, etiko in tudi običaji. Kot že poudarjeno ti standardi sicer navadno niso nikjer »opredmeteni«, načela o tem niso zapisana, ampak so navedena zgolj primeroma. Dopusten je sklep, da se standardi dobre uprave nadgrajujejo in izvirajo iz razvoja demokratične družbe ter pričakovanja javnosti $v$ zvezi z upravnim delovanjem.

Eden izmed pionirjev negativne definicije uprave, $\mathrm{tj}$. slabe uprave, $\mathrm{v}$ povezavi $\mathrm{z}$ delom ombudsmanov, je bil Richard Crossman. Ta je slabi upravi pripisal naslednje značilnosti: "pristranost, zanemarjanje posla, nepazljivost, nemarnost, zamude, nekompetentnost, podlost in druge « (Harlow in Rawling, 2009). Evropski varuh človekovih pravic (v nadaljevanju: Evropski varuh) pa je leta 1998 kot protiutež slabi upravi formuliral termin dobre uprave, ki ga sestavlja več vidikov. (The European ombudsman, 1999). Prvi vidik je materialni in se nanaša na zakonitost, enakost, sorazmernost, izogibanje kakršnim koli 
$36^{\mathrm{TH}}$ InTERnAtional CONFERENCE ON ORganizational SCIENCE DeVElopment: RESPONSIBLE ORGANIZATION (MARCH $22^{\mathrm{ND}}-24^{\mathrm{TH}}$, PORTOROŽ SLOVENIA)

K. Marzel: The Importance of Legality and Legitimacy in Respecting Human Rights and Ensuring Good Administration

zlorabam oblasti, objektivnost, nepristranost, ravnanje, skladno zakonskim pričakovanjem, poštenost $\mathrm{v}$ obnašanju ter doslednost. Naslednji je procesni vidik, ta vsebuje odgovarjanje in vso komunikacijo v primernem jeziku, odločitev odgovornega $\mathrm{v}$ čim krajšem času (kjer ne gre nujno zgolj za spoštovanje zakonskega roka, pač pa se lahko odloči v bistveno krajšem času), prevod dokumentacije s strani kompetentne osebe, upoštevanje pravice do obrambe, dajanje odgovorov in odločanje v razumnih rokih. Poleg teh vidikov pa so pomembne še obveze, ki se nanašajo na neposredne dolžnosti oblasti v odnosu do strank, in sicer gre za obveznost zagotavljanja jasnih in razumljivih informacij ter korektnih nasvetov, dajanje primernih odgovorov na telefonske klice, prijazno obnašanje, opravičilo za napake, javni dostop do Evropskega kodeksa ravnanja javnih uslužbencev ter drugo.

Bistvo dobrega upravljanja sloni na NUJS, ki ga je razvila OECD; pri tem pa izhajala iz stališča o povezanosti trga in države (OECD, 2004, 2015). Dobro upravljanje vključuje učinkovitost javnega sektorja in tudi način izvajanja oblasti s strani javnih uslužbencev in organov, način oblikovanja javnih politik ter zagotavljanja javnih dobrin. Gre torej za »skupne naloge politično-upravnega sistema ali učinkovitost in uspešnost javnih oblasti in politik v najširšem smislu« (Kovač in Leben, 2015). Posebej je pri tem poudarjena vloga oblasti oziroma vlade, ki mora pri strateškem načrtovanju sodelovati z vsemi, ki prispevajo k družbenemu napredku. Vlada je namreč zavezana k »aktivni koordinaciji vseh družbenih akterjev« (Kovač, 2006).

V sklopu dobrega upravljanja je možno opredeliti koncept dobre uprave, ki poudarja usmerjenost uprave k uporabnikom ter obsega več pravic uporabnikov oziroma strank v upravnem razmerju, za katerega je sicer značilna izrazita birokratska miselnost »nadvlade« in premoči organa uprave, ki v postopku odloča. Principi dobre uprave omogočajo razvojno "prevešanje iz avtoritarnega in centraliziranega $\mathrm{v}$ servisno, decentralizirano in participativno delovanje države« (Kovač in Leben, 2015). Koncept dobre uprave po mnenju navedenih avtorjev pomeni učinkovito izvajanje oblasti, javnega interesa in javnih storitev ob spoštovanju pravic ter interesov strank. Pomeni enega izmed vidikov dobrega upravljanja; nanaša se na pravne elemente, pa tudi na vodenje in upravljanje organizacije ter na njeno kakovost. Uprava mora $\mathrm{z}$ uporabo načel dobre uprave mit in splošno prepričanje javnosti, da je birokracija namenjena sama in si ponovno pridobiti zaupanje javnosti $\mathrm{v}$ njeno delo. Takšen način dela »pomeni splet upravičenj demokratičnega odnosa do strank in učinkovitega upravljanja za pravno predvidljiv in odgovoren način izvajanja oblasti in javnih storitev« (Tomaževič in Aristovnik, 2015).

Dobro upravljanje in dobro upravo se uvrščata v sklop teorij o trajnostnem družbenem razvoju, ki ga označujejo: zakonitost, odprtost, preglednost in odgovornost, poštenost in enakost, vključujoč mehanizme svetovanja in participacije, uspešnost in učinkovitost, jasna, pregledna in uporabna zakonodaja, konsistentnost in jasnost pri oblikovanju politik ter visoki standardi etičnega ravnanja, meni Beneška komisija (European Commission for Democracy through Law, 2011). 
K. Marzel: Pomen legalnosti in legitimnosti pri spoštovanju človekovih pravic ter zagotavljanju dobre uprave

Dobra uprava pomeni zakonito in obče pravilno ravnanje uprave $\mathrm{v}$ smeri pravičnega, dostojnega in dobrega ravnanja in je nasprotje slabi upravi (angl. maladministration). $\mathrm{V}$ sodobni demokratični družbi sama legalnost delovanja uprave ni dovolj; uprava mora biti poleg tega, da ravna po pravnem redu, tudi legitimna in tako sprejemljiva $\mathrm{z}$ vidika družbene opravičenosti. V povezavi z dobro upravo je moč govoriti o upravi kot o oblasti, ki zaradi mnogih uvedenih principov, načel in pravil nima več »gospodujočega položaja«, ampak se usmerja k strankam, ki so tako s svojimi pravicami »vrhovni vladarji« upravnega razmerja (Milenković, 2012), med katerima se vzpostavlja partnerski odnos.

Idealna doktrina dobre uprave je usmerjena $\mathrm{v}$ optimalno zadovoljitev tistih družbenih potreb, ki so predpostavka uravnoteženega družbenega razvoja. Dobra uprava temelji na načelih odprtosti, participacije, odgovornosti, učinkovitosti in povezanosti. Poglavitna prvina dobre uprave je hiter odziv na potrebe družbe, enako tudi enakovrednost obeh, tako uprave kot stranke; kar je vse skupaj bistvo sodobnih demokratičnih uprav, ko je že ugotovljeno. Uprava mora delovati po načelu usmerjenosti k stranki, vendar le tako dolgo, da njeni interesi ne posegajo $\mathrm{v}$ pravice drugih ali $\mathrm{v}$ javno korist.

Dobra uprava sledi naravi upravnega postopka, ki s svojimi pravili in standardi (predvsem temeljnimi načeli) omejuje avtoriteto in oblast upravnega organa. V dvomu naj se posamezne določbe skladno $\mathrm{z}$ namenom upravnega postopka razlagajo $\mathrm{v}$ korist stranke. Modernizaciji uprave sledi zakonodajalec $\mathrm{z}$ ukinitvijo splošne krajevne pristojnosti, $\mathrm{z}$ uvajanjem elektronskega poslovanja, $\mathrm{z}$ obveznostjo pridobivanja podatkov iz uradnih evidenc po uradni dolžnosti upravnih organov in z drugimi načeli, s katerimi se upravno delovanje čedalje bolj preveša iz sfere oblastnega postopanja $v$ sfero servisnega ravnanja, vse pa na način, da se zagotavljajo človekove pravice in svoboščine, kar omogoča transformacijo legalne oblasti v legitimno oblast.

\section{$4 \quad$ Zaključek}

Dobro upravljanje je $\mathrm{v}$ slovenski zakonodaji omenjeno le $\mathrm{v}$ enem zakonu, in sicer $\mathrm{v} 3$. členu ZVarCP, ki pravi, da »Varuh pri svojem delu ravna po določilih ustave in mednarodnih pravnih aktov o človekovih pravicah in temeljnih svoboščinah in da se pri svojih intervencijah lahko sklicuje tudi na načela pravičnosti in dobrega upravljanja.«

Dobro upravljanje in dobra uprava sta nadalje pojmovno omenjeni še v Strategiji razvoja javne uprave 2015 - 2020, kjer piše, »da državljani kot tudi poslovni subjekti potrebujemo fleksibilno in hitro odzivno upravo, ki bo delovala transparentno, strokovno, odgovorno ter skladno z načeli dobrega upravljanja.«

Strategija predvideva modernizacijo javne uprave v smeri, da bo ta delovala po načelih dobrega upravljanja. Našteva posamezna načela in vrednote dobre uprave, kot so preglednost, odgovornost, participacijo in druge. Nekatere izmed teh prvin so vsebovane v URS, v temeljnih načelih predpisa, ki ureja splošni upravni postopek, v zakonu, ki ureja področje javnih uslužbencev ter še drugje. 
$36^{\mathrm{TH}}$ International Conference on Organizational Science Development: RESPONSIBLE ORGANIZATION (MARCH $22^{\mathrm{ND}}-24^{\mathrm{TH}}$, PORTOROŽ SLOVENIA)

K. Marzel: The Importance of Legality and Legitimacy in Respecting Human Rights and Ensuring Good Administration

Glede na zapisano se soočamo z vprašanjem, kako vsebinsko napolniti dobro upravljanje in dobro upravo.

Po mnenju Pečariča (2008) »načelo dobrega upravljanja razlagamo tudi kot krovno načelo celotne javne uprave ravnati po načelih zakonitosti, pravne varnosti in predvidljivosti, politične nevtralnosti, usmerjenosti $\mathrm{k}$ uporabniku, odprtosti in preglednosti, kakovosti, uspešnosti in učinkovitosti in ne bi smelo v svojem bistvu zajemati samo varovanja človekovih pravic in temeljnih svoboščin, ampak tudi smotrnost, uspešnost, učinkovitost, sorazmernost, racionalnost in odzivnost delovanja javne uprave «.

Dobra uprava prispeva k splošni blaginji in k povečanju zaupanja javnosti v njeno delo. Pri tem ima pomembno vlogo Varuh. Ta ima namreč pri presoji delovanja oblasti bistvene pristojnosti, še zlasti, ker ne ugotavlja samo, ali uprava kot oblast deluje legalno, pač pa se pri kršitvah človekovih pravic osredotoča na legitimnost in načela dobrega upravljanja. Tako usmerja delovanje uprave proti novim horizontom legalnosti in legitimnosti, posredno pa vpliva tudi na konkurenčno sposobnost države.

\section{Opombe}

${ }^{1}$ Reforma javnega sektorja v Sloveniji je bila spodbujena od zunaj. Začela se je brez jasne strategije, saj je dejansko izvirala iz odločitve za priključitev Slovenije Evropski uniji, ta je temeljila na posebnem dokumentu - akcijskemu načrtu, sestavni del tega pa je bil tudi Temeljni načrt za izvedbo reforme javne uprave v obdobju 1997-1999. Prva prava Strategija nadaljnjega razvoja javnega sektorja 2003-2005 je bila s strani vlade sprejeta šele julija 2003.

${ }^{2}$ Ur. 1. RS, št. 52/2002, 110/2002 - ZDT-B, 56/2003, 61/2004, 123/2004, 93/2005, 89/2007 - odl. US, 126/2007 - ZUP-E, 48/2009, 8/2010 - ZUP-G, 8/2012 - ZVRS-F, 21/2012, 47/2013, 12/2014, 65/2014 - ZVRS-H, 90/2014, 51/2016, v nadaljevanju: ZDU-1.

${ }^{3}$ Ur. 1. RS, št. 56/2002, 110/2002 - ZDT-B, 2/2004 - ZDSS-1, 23/2005, 62/2005 - odl. US, 75/2005 - odl. US, 113/2005, 21/2006 - odl. US, 23/2006 - skl. US, 62/2006 - skl. US, 68/2006 - ZSPJS-F, 131/2006 - odl. US, 11/2007 - skl. US, 33/2007, 69/2008 - ZTFI-A, 69/2008 - ZZavar-E, 65/2008, 40/2012 - ZUJF, v nadaljevanju: ZJU.

${ }^{4}$ Ur. 1. RS, št. 56/2002, 110/2002 - ZDT-B, 72/2003, 126/2003, 70/2004, 53/2005, 14/2006, 27/2006 - skl. US, 68/2006, 121/2006, 1/2007 - odl. US, 57/2007, 10/2008, 17/2008, 58/2008, 69/2008 - ZTFI-A, 69/2008 - ZZavar-E, 80/2008, 120/2008 - odl. US, 48/2009, 91/2009, 107/2009 - odl. US, 98/2009 - ZIUZGK, 13/2010, 59/2010, 85/2010, 94/2010 - ZIU, 107/2010, 35/2011 ORZSPJS49a, 110/2011 - ZDIU12, 27/2012 - odl. US, 40/2012 - ZUJF, 104/2012 - ZIPRS1314, 46/2013, 46/2013 - ZIPRS1314-A, 101/2013 - ZIPRS1415, 50/2014, 25/2014 - ZFU, 95/2014 ZUPPJS15, 82/2015, 90/2015 - ZUPPJS16, 88/2016 - ZUPPJS17, v nadaljevanju: ZSPJS.

${ }^{5}$ Ur. 1. RS, št. 79/1999, 124/2000, 79/2001, 30/2002, 110/2002 - ZDT-B, 56/2002 - ZJU, 127/2006 - ZJZP, 14/2007 - ZSPDPO, 109/2008, 49/2009, 38/2010 - ZUKN, 107/2010, 110/2011 - ZDIU12, 46/2013 - ZIPRS1314-A, 101/2013, 101/2013 - ZIPRS1415, 38/2014 - ZIPRS1415-A, 14/2015 ZIPRS1415-D, 55/2015 - ZFisP, 96/2015, 80/2016, v nadaljevanju: ZJF

${ }^{6}$ Ur. 1. RS, št. 91/2015, Uradni list Evropske unije, št. 307/2015, 307/2015, v nadaljevanju: ZJN-3. 
${ }^{7}$ Po lestvici svetovne konkurenčnosti švicarskega inštituta za razvoj menedžmenta za leto 2014 je Slovenija med 60. državami z 52. padla na 55. mesto. V letu 2015 je bila Slovenija med 61. državami na 49. mestu (Slovenija na lestvici svetovne konkurenčnosti 6 mest višje, 2015).

${ }^{8}$ Po Strategiji razvoja javne uprave za 2015-2020 v sklop javne uprave sodijo državna uprava, občinske uprave in nosilci javnih pooblastil. V sklop javnega sektorja pa po omenjeni strategiji sodijo: državni organi, uprave samoupravnih lokalnih skupnosti, javne agencije, javni skladi, javni zavodi in javni gospodarski zavodi, druge osebe javnega prava, če so posredni uporabniki državnega proračuna ali proračuna lokalne skupnosti.

${ }^{9}$ Povzeto po Strategiji razvoja javne uprave $2015-2020$

${ }^{10}$ Izraz ombudsman izvira iz Švedske in je sinonim za zastopnika, poverjenika, predstavnika, pooblaščenca, mediatorja. Ombudsman je nastal leta 1809 na Švedskem in je bil najprej namenjen nadzoru izvršilne oblasti in kaznovanju državnih uslužbencev. Nadaljnje pristojnosti ombudsman so bile podajanje mnenj, priporočil in predlogov parlamentu ter tako izboljšati delovanje oblasti. Sprva je bila naloga te institucije nadzor nad zakonitostjo delovanja oblasti, nato se je nadzor razširil še na dobro oziroma slabo upravljanje, po padcu totalitarizma in z razvojem demokracije ter človekovih pravic pa je postala primarna naloga institucije varstvo človekovih pravic v razmerju do oblasti. Ombudsman je po skandinavskem vzoru splošen izraz za institucijo neformalnega varstva in promocije človekovih pravic. V Sloveniji je Varuh človekovih pravic predviden v 159. členu Ustave Republike Slovenije in je namenjen varovanju človekovih pravic v razmerju do državnih organov, organov lokalne samouprave in nosilcev javnih pooblastil. Ustanovljen je bil z Zakonom o varuhu človekovih pravic (Ur. 1. RS, št. 71/93, 15/1994 - popr., 56/2002 - ZJU, 109/2012, v nadaljevanju: ZVarCP) ter je z delom začel 1. 1. 1995.

11 Arhar, F., Blaha, M., Bučar, F., Čebulj, J., Deisinger, M., Dular, J., . . Kresal, B. (2010). Komentar Ustave Republike Slovenije. (L. Šturm, Ured.) Kranj: Fakulteta za državne in evropske študije (v nadaljevanju: URS)

${ }^{12}$ Več o pristojnostih Varuha v Marzel (2016).

\section{Literatura}

Arhar, F., Blaha, M., Bučar, F., Čebulj, J., Deisinger, M., Dular, J., . . Kresal, B. (2010). Komentar Ustave Republike Slovenije. (L. Šturm, Ured.) Kranj: Fakulteta za državne in evropske študije.

Beneška komisija (European Commission for Democracy through Law). (9. 3. 2011). Stocktaking on the Notions of "Good Governance" and "Good Administration", Study no. 470/2008, CDL (2011)006.

http://www.venice.coe.int/webforms/documents/default.aspx?pdffile=CDL(2011)006-e.

Grad, F., Kaučič, I., Ribičič, C., \& Kristan, I. (1996). Državna ureditev Slovenije. Ljubljana: Uradni list Republike Slovenije.

Harlow, C., \& Rawling, R. (2009). Law and Administration, Third Edition. Campbridge: Campbridge, University Press Grad, F., Kaučič, I., Ribičič, C., \& Kristan, I. (1996). Državna ureditev Slovenije. Ljubljana: Uradni list Republike Slovenije.

Kaučič, I. (2008). Človekove pravice in svoboščine. V A. Kozarov (Ured.), Ustavna ureditev Slovenije (str. 97-173). Ljubljana: GV Založba.

Kovač, P. (2006). Pravni in sociološki vidiki javnih pooblastil. Ljubljana: Univerza v Ljubljani, Fakulteta za upravo.

Kovač, P. (2012). Ethics of Officials in the Context of (Slovene) Good Administration. The NISPAcee Journal of Public Administration and Policy 5(1), str. 23-53.

Kovač, P., \& Leben, A. (2015). Dobra uprava v praksi izbranih enot slovenske javne uprave. Slovenski javni sektor na razpotju strateških sprememb:zbornik prispevkov, XXII Dnevi slovenske uprave. (A. Aristovnik, Ured.) Ljubljana: Fakulteta za upravo. 
$36^{\text {Th }}$ International Conference on Organizational Science Development: Responsible Organization (MARCh $22^{\mathrm{ND}}-24^{\mathrm{TH}}$, Portorož SLOVENia)

K. Marzel: The Importance of Legality and Legitimacy in Respecting Human Rights and Ensuring Good Administration

Marzel, K. (1999). Pomen motivacije in razvoja za pripadnost in delovno uspešnost, primer Upravnih enot $v$ Republiki Sloveniji, magistrsko delo. Ljubljana: Univerza v Ljubljani, Fakulteta za družbene vede.

Marzel, K. (2016). Analiza institucij varuha človekovih pravic s poudarkom na legalnosti in legitimnosti, doktorska disertacija,Ljubljana: Univerza v Ljubljani, Fakulteta za upravo.

Milenković, D. (2012). Princip dobre uprave (good administration). Pridobljeno 15. 11. $2015 \mathrm{iz}$ http://ombudsman.yucom.org.rs/princip-dobre-uprave-good-administration/

OECD. (2004). Principles of Corporate Governance. Pridobljeno 30. 11. 2015 iz http://www.oecd.org/corporate/ca/corporategovernanceprinciples/31557724.pdf

OECD. (2015). Principle of Corporate Governance. Pridobljeno 1. 12.2015 iz http://www.keepeek.com/Digital-Asset-Management/oecd/governance/g20-oecd-principlesof-corporate-governance-2015_9789264236882-en\#page1

Pečarič, M. (2008). Uradništvo med formalnim in neformalnim vplivom na politiko in državljane. Ljubljana: Uradni list Republike Slovenije

Radinović, D. (2001). Ombudsman i izvršna vlast-Institucija ombudsmana na početki XXI vijeka. Beograd: Službeni glasnik, Savet za državnu upravu Vlade Republike Srbije.

Reif, L. (2004). The Ombudsman, Good Governance and the International Human Rights System. Leiden, The Netherlands: Kominklijke Brill NV.

Remac, M. (2013). Standards of Ombudsman Assessment: A New Normative Concept. Pridobljeno

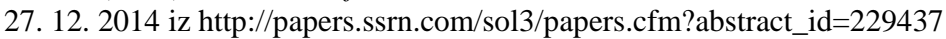

Remac, M. (2014). Coordinating ombudsmen and the judiciary. A comparativce view on the relations between ombudsmen and the judiciary in the Netherlands, England and the European Union. Pridobljeno 20. 5. 2015.

Rovšek, J. (2002). Neformalni mehanizmi varstva človekovih pravic-ombudsmani in varuh človekovih pravic. V M. Cerar, J. Jamnikar, \& M. Smrkolj (Ured.), Dokumenti človekovih pravic z uvodnimi pojasnili (str. 127-145). Ljubljana: Društvo Amnesty International Slovenije, Mirovni inštitut.

Slovenija na lestvici svetovne konkurenčnosti 6 mest višje. (29. 11. 2015). Pridobljeno iz http://www.spiritslovenia.si/novice/2015-05-27-Slovenija-na-lestvici-svetovnekonkurencnosti-6-mest-visj

Teršek, A. (2014). Teorija legitimnosti in sodobno ustavništvo. Koper: Univerzitetna založba Annales.

Tomaževič, N. \& Aristovnik, A. (2015). Povezanost zadovoljstva zaposlenih z elementi dobre uprave: Primer slovenske javne. Slovenski javni sektor na razpotju strateških sprememb. zbornik prispevkov, XII Dnevi slovenske uprave. (A. Aristovnik, Ured.) Ljubljana: Fakulteta za upravo.

The European ombudsman. (1999). The European Ombudsman annual report for 1998. Strasbourg: The Euoropean Ombudsman.

Vlada Republike Slovenije. (2015). Strategija razvoja javne uprave 2015-2020. Pridobljeno 8. 7. 2016 http://www.mju.gov.si/fileadmin/mju.gov.si/pageuploads/JAVNA_UPRAVA/Kakovost/Strat egija_razvoja_JU_2015-2020/Strategija_razvoja_SLO_final_web.pd

Zakon o varuhu človekovih pravic (ZVarCP). Ur. list RS, št. 71/1993, 15/1994 - popr., 56/2002 ZJU, 109/2012.

Zakon o javnih financah (ZJF). Ur. 1. RS, št. 79/1999, 124/2000, 79/2001, 30/2002, 110/2002 ZDT-B, 56/2002 - ZJU, 127/2006 - ZJZP, 14/2007 - ZSPDPO, 109/2008, 49/2009, 38/2010 ZUKN, 107/2010, 110/2011 - ZDIU12, 46/2013 - ZIPRS1314-A, 101/2013, 101/2013 ZIPRS1415, 38/2014 - ZIPRS1415-A, 14/2015 - ZIPRS1415-D, 55/2015 - ZFisP, 96/2015, 80/2016. 
K. Marzel: Pomen legalnosti in legitimnosti pri spoštovanju človekovih pravic ter zagotavljanju dobre uprave

Zakon o državni upravi (ZDU-1). Ur. 1. RS, št. 52/2002, 110/2002 - ZDT-B, 56/2003, 61/2004, 123/2004, 93/2005, 89/2007 - odl. US, 126/2007 - ZUP-E, 48/2009, 8/2010 - ZUP-G, 8/2012 ZVRS-F, 21/2012, 47/2013, 12/2014, 65/2014 - ZVRS-H, 90/2014, 51/2016.

Zakon o javnih uslužbencih (ZJU). Ur. 1. RS, št. 56/2002, 110/2002 - ZDT-B, 2/2004 - ZDSS-1, 23/2005, 62/2005 - odl. US, 75/2005 - odl. US, 113/2005, 21/2006 - odl. US, 23/2006 - skl. US, 62/2006 - skl. US, 68/2006 - ZSPJS-F, 131/2006 - odl. US, 11/2007 - skl. US, 33/2007, 69/2008 - ZTFI-A, 69/2008 - ZZavar-E, 65/2008, 40/2012 - ZUJF.

Zakon o sistemu plač v javnem sektorju (ZSPJS). Ur. 1. RS, št. 56/2002, 110/2002 - ZDT-B, 72/2003, 126/2003, 70/2004, 53/2005, 14/2006, 27/2006 - skl. US, 68/2006, 121/2006, 1/2007 - odl. US, 57/2007, 10/2008, 17/2008, 58/2008, 69/2008 - ZTFI-A, 69/2008 - ZZavar-E, 80/2008, 120/2008 - odl. US, 48/2009, 91/2009, 107/2009 - odl. US, 98/2009 - ZIUZGK, 13/2010, 59/2010, 85/2010, 94/2010 - ZIU, 107/2010, 35/2011 - ORZSPJS49a, 110/2011 ZDIU12, 27/2012 - odl. US, 40/2012 - ZUJF, 104/2012 - ZIPRS1314, 46/2013, 46/2013 ZIPRS1314-A, 101/2013 - ZIPRS1415, 50/2014, 25/2014 - ZFU, 95/2014 - ZUPPJS15, 82/2015, 90/2015 - ZUPPJS16, 88/2016 - ZUPPJS17.

Zakon o javnih naročilih (ZJN-3). Ur. 1. RS, št. 91/2015, Uradni list Evropske unije, št. 307/2015, 307/2015. 
544 36 $6^{\text {Th }}$ International Conference on Organizational Science Development:

Responsible Organization (MARCH $22^{\mathrm{ND}}-24^{\mathrm{TH}}$, PORTOROŽ SLOVENIA) 


\section{Management upravljanja $z$ ekološkimi tveganji kot sestavni del strategije odgovornega podjetja}

\section{DUŠAN MEŽNAR}

Povzetek Uspešna podjetja se vedno bolj zavedajo pomena družbene odgovornosti. Kratkoročno in dolgoročno strategijo in delovanje podrejajo pričakovanjem okolja, ter si povečujejo konkurenčno prednost in zagotavljajo pregledno in trajnostno delovanje. Osnovni namen tega referata je prikazati model, kako je v strategijo poslovanja implementirana odgovornost podjetja $\mathrm{z}$ vidika managementa obvladovanja ekoloških tveganj. V referatu so opredeljeni cilji, strategija, proces in pa konkretna implementacija managementa okoljskih tveganj pri proizvodnji ivernih plošč $\mathrm{z}$ merjenjem učinkov, modeliranju ter simulacijami predvidevanj učinkov.

KLJUČNE BESEDE: management $\cdot$ ekološka tveganja - strategija • odgovorno podjetje

NASlOv AVTORJA: dr. Dušan Mežnar, Slovenija, e-pošta: dusan.meznar@gmail.com 
$36^{\text {TH }}$ InTERnational CONFERENCE ON ORganizational SCIENCE Development: Responsible Organization (MARCH $22^{\mathrm{ND}}-24^{\mathrm{TH}}$, PORTOROŽ SLOVENIA)

O. Arsenijević, M. Ferjan, I. Podbregar, P. Šprajc, D. Trivan \& Y.

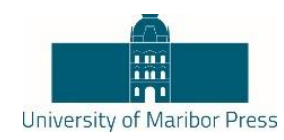

Ziegler

\title{
Management of Ecological Risks as an Integral Part of the Strategy of the Responsible Company
}

\author{
DUŠAN MEŽNAR
}

\begin{abstract}
Successful companies are becoming increasingly aware of the importance of social responsibility. Short-term and long-term strategy and operation is subordinated to the expectation of the environment with goal to increase the competitive advantage and provide a transparent and sustainable operation. The primary purpose of this paper is to present a model how the business strategy is implemented in the company in terms of management control ecological risks. The paper defines the objectives, strategy, process and the implementation of the management of environmental risks in the production of particle boards by measuring the effects of modeling and simulation predictions effects.
\end{abstract}

KEYWORDS: management $・$ ecological risks $・$ strategy $\bullet$ suistainable company

CoRRESPONDENCE AdDRESS: Dušan Mežnar, Ph.D., Slovenija, e-mail: dusan.meznar@gmail.com

DOI https://doi.org/10.18690/978-961-286-020-2.45

(C) 2017 University of Maribor Press

Available at: http://press.um.si

ISBN 978-961-286-020-2 
D. Mežnar: Management upravljanja z ekološkimi tveganji kot sestavni del strategije odgovornega podjetja

\section{$1 \quad$ Uvod}

Glavni namen odgovornega obnašanja podjetij je poleg skrbi za konkurenčnost, ekonomičnost, dobiček tudi upoštevati druge in prispevati $\mathrm{k}$ reševanju okoljskih in družbenih problemov ter ustvarjati trajnostno družbo. Dejstvo je, da se ob upoštevanju standardov odgovornega obnašanja krepi blagovna znamka, ugled in tudi tržna pozicija podjetja. Višji ugled utrjuje poslovne povezave, zagotavlja zvestobo kupcev, omogoča kakovostno dobavno verigo in prinaša nove poslovne priložnosti.

\section{$2 \quad$ Upravljanje stveganji}

\subsection{Definicija upravljanja s tveganji}

Upravljanje s tveganji je proces upravljanja, sprejemanja odločitev in aktivne kontrole izvorov nevarnosti, upoštevaje politične, socialne, ekonomske in tehnične faktorje, ter ocenjevanje tveganj povezanih $\mathrm{z}$ določenimi izvori nevarnosti.

Upravljanje s tveganji opredeljujejo naslednje definicije :

Ko rezultati nekega dogodka niso znani vnaprej in jih ne moremo predvideti, govorimo o tveganju (Doherty, 1985, str. 1).

Tveganje je variacija izidov, ki se lahko pojavijo $v$ določenem obdobju $v$ dani situaciji (Williams, 1981, str. 4).

Tveganje je prisotno povsod tam, kjer ljudje niso zmožni kontrolirati ali popolnoma predvideti prihodnosti (Diacon, 1992, str. 73)

Tveganje je negotova situacija, v kateri se lahko pojavi večje število izidov, od katerih je lahko eden ali več nezaželjenih (Merkhofer, 1987, str. 2).

\subsection{Cilji upravljanja s tveganji}

Cilji upravljanja s tveganji so predvsem usmerjeni v ukrepe za preživetje podjetja ob izrednih dogodkih kot so katastrofalne izgube, prekinitvi proizvodnje, nestabilnosti denarnega toka, ekoloških ali naravnih katastof. (Williams in Heins ,1989, str. 21):

- preživetje podjetja - predvsem v smislu stroškovnega managementa;

- zagotavljanjanje stabilnosti dohodkov - upravljanje s tveganji mora preprečiti prevelika odstopanja od poslovnih načrtov družbe;

- neprekinjeno delovanje podjetja - s pomocjo ucinkovitega upravljanja s tveganji se odpravijo zastoji, ki so posledica morebitnih nesreč, oz. se minimizira njihov čas v poslovanju; 
$36^{\text {Th }}$ International Conference on Organizational Science Development: Responsible Organization (March $22^{\mathrm{ND}}-24^{\mathrm{TH}}$, Portorož Slovenia)

D. Mežnar: Management of Ecological Risks as an Integral Part of the Strategy of the Responsible Company

- nemotena rast in razvoj podjetja - ukrepi za preprečevanje dogodkov, ki bi lahko zavirali želeni razvoj podjetja;

- socialna odgovornost - ukrepi za zaščito kupcev, dobaviteljev, zaposlenih pred morebitnimi nevarnostmi

- ekonomičnost - tudi stroški upravljanja s tveganji morajo biti kar se da nizki;

Kot vplivi na okolje so definirani vsi tisti vplivi, ki imajo lahko negativne posledice na okolje in človeka in sicer zajemajo : klimatske spremembe, tanjšanje ozonske plasti, zakisanje, izkoriščanje neobnovljivih virov surovin, razraščanje biomase, fotokemična tvorba oksidantov, človeško zastrupljanje.

Vpliv na okolje bi lahko definirali kot vsoto vsek posameznih vplivov in sicer :

$$
\text { Vpliv na okolje }=\boldsymbol{C}_{c}+\boldsymbol{I}_{o d}+\boldsymbol{I}_{\boldsymbol{a}}+\boldsymbol{I}_{a d}+\boldsymbol{I}_{\boldsymbol{e}}+\boldsymbol{I}_{p o c}+\boldsymbol{I}_{h t}
$$

\subsection{Klimatske spremembe (climate changes)}

Oceno vplivov klimatskih sprememb se izračuna glede na potenciale globalnega segrevanja (Heijungs, 1992, str.21), kjer je $C_{c}$ kazalec klimatske spremembe, izražen kot masa ekvivalentov $\mathrm{CO}_{2}, f_{k s}$ karakterizacijski faktor klimatske spremembe za substanco i $\left(\mathrm{CO}_{2}, \mathrm{~N}_{2} \mathrm{O}, \mathrm{CH}_{4}, \mathrm{VOC}_{S}\right.$ itd. $)$, ki je odvisen od trajanja vplivanja in $m_{i}$ masa te substance.

$$
C_{c}=\sum_{i}^{n} f_{k s, i m_{i}}
$$

\subsection{Tanjšanje ozonske plasti (ozone depletion)}

Antropogene emisije povzročajo stratosferno tanjšanje ozona. Posledica tega je povečenje deleža ultravijoličnega sevanja na Zemljino površino in seveda s tem tudi škodljive vplive na zdravje ljudi in živali ter vplive na kopenske in vodne ekosisteme. Koncept izračuna karakterizacijskih faktorjev tanjšanja ozona (Wuebbles, 1988, str.187), je identičen izračunu za karakterizacijske faktorje klimatskih sprememb, le da so faktorji tanjšanja ozona določeni za trenutno stanje. Kazalec tanjšanja ozonske plasti $I_{\text {od }}$ prikazuje potencial emisij CFC (kloro-fluoro ogljikovodikov) in drugih halogenskih ogljikovodikov, ki prispevajo k tanjšanju ozonske plasti. Izražen je kot:

$$
I_{o d}=\sum_{i}^{n} f_{o d, i} m_{i}
$$

Pri čemer je $f_{o d}$ karakterizacijski faktor tanjšanja ozona za substanco i in $m_{i}$ masa te substance. 


\subsection{Zakisanje (acidification)}

Kazalec zakisanj $I_{a}$ nam pove kakšen vpliv na materiale, zemljo, podtalnico, površinske vode, biološke organizme in ekosisteme imajo snovi $\mathrm{SO}_{2}, \mathrm{NOx}, \mathrm{HCl}$ in $\mathrm{HF}$. Karakterizacijski faktor zakisanja predstavlja maksimalni potencial povzročitve kislih padavin na nek medij (Heijungs, 1992, str.143), izražen z maso ekvivalentov $\mathrm{SO}_{2}$ :

$$
I_{a}=\sum_{i}^{n} f_{a, i m_{i}}
$$

$f_{a}$ karakterizacijski faktor kislih padavin za substanco $i, m_{i} p a$ masa te substance.

\subsection{Izkoriščanje neobnovljivih virov surovin (abiotic depletion)}

Izkoriščanje fosilnih goriv, kovin in mineralov je skupek izkoriščanja neobnovljivih virov. Vpliv je izračunan po enačbi(Heijungs, 1992, str.56),:

$$
I_{a d}=\sum_{i}^{n} \frac{m_{i}}{m_{i, r}}
$$

kjer je $m_{i}$, masa izkoriščenih virov na funkcijsko enoto in $m_{i}, \mathrm{r}$ masa ocenjene svetovne zaloge tega vira.

\subsection{Razraščanje biomase (eutrophication)}

Kazalec razraščanja je definiran kot razraščanje pod vplivom dušika, fosforja in ogljika, ki se rezultira $v$ rasti biomase. Vpliv razraščanja biomase lahko ocenimo po naslednji enačbi:

$$
I_{e}=\sum_{i}^{n} f_{e, i m_{i}}
$$

$I_{e}$ je kazalec razraščanja izražen z maso ekvivalentov $\mathrm{PO}_{3}-$ ali $\mathrm{NO}_{3}$, $\boldsymbol{f}_{\boldsymbol{e}, \boldsymbol{i}}$ karakterizacijski faktor razraščanja za substanco i in $\boldsymbol{m}_{\boldsymbol{i}}$ masa te substance, izpuščene v zrak, vodo ali zemljo.

\subsection{Fotokemična tvorba oksidantov (photochemical oxidants creation)}

Kazalec fotokemične tvorbe oksidantov je povezan s potencialom hlapnih organskih substanc in dušikovih oksidov $\mathrm{k}$ ustvarjanju fotokemičnega ali poletnega smoga (Wuebbles, 1988, str.29): 
$36^{\mathrm{TH}}$ International Conference on ORganizational Science Development: RESPONSIBLE ORGANIZATION (MARCH $22^{\mathrm{ND}}-24^{\mathrm{TH}}$, PORTOROŽ SLOVENIA)

D. Mežnar: Management of Ecological Risks as an Integral Part of the Strategy of the Responsible Company

ker je $I_{p o c}$ kazalec fotokemične tvorbe oksidantov,

$$
I_{p o c}=\sum_{i}^{n} f_{p o c, i} m_{i}
$$

$f_{p o c}$ karakterizacijski faktor fotokemične tvorbe oksidantov za substanco i in

$m_{i}$ masa te substance, ki sodeluje pri ustvarjanju fotokemičnega smoga.

\section{7 Človeško zastrupljanje (human toxicity)}

Kazalec človeškega zastrupljanja predstavlja skupek izpustov v zrak, vodo in prst, ki vplivajo na zdravje človeka, pri čemer pa so karakterizacijski faktorji gleda na sprejemljive vrednosti mase zaužitih toksičnih snovi (Heijungs, 1992, str.24),:

$$
I_{h t}=\sum_{i}^{n} f_{h t, i m_{i}}
$$

kjer je $\boldsymbol{I}_{\boldsymbol{h} \boldsymbol{t}}$ kazalec človeškega zastrupljanja,

$\mathbf{f}_{\mathbf{h t}}$ karakterizacijski faktor človeškega zastrupljanja za substanco $i$ in

$\boldsymbol{m}_{\boldsymbol{i}}$ masa te substance

Dejstvo pa je da narava proizvodnje ivernih plošč vpliva na omenjene elemente, sicer minorno, a vendarle. Glede na to, da je narava proizvodnje takšna, da je največji del povezan z hlapljivimi snovmi fenoli, nitriti, prahu, ki se emitira v zrak, je bila posvečena tudi največja pozornost onesnaženju zraka.

Del potencialnega onesnaževanja, ki se nanaša na izlitje v vodo ali zemljo je zaradi zaprtega sistem proizvodnje zelo malo verjeten in je možen samo ob izrednih dogodkih kot so potresi ali poplave.

\section{$4 \quad$ Model managementa upravljanja z ekološkimi tveganji}

Bistveno za vsako podjetje je jasna opredelitev ciljev . Ko ugotovi, katera ekološka tveganja ogrožajo njegovo poslovanje, jih mora oceniti in nato izbrati ukrepe za izboljšanje varnosti,jih aplicirati v prakso in nadzirati njihovo izvajanje.

Model managementa upravljanja z ekološkimi tveganji sloni na pricipu stalne interakcije med planiranjem, analizo in predvidevanjem in predstavlja kot tak osnovo za celovito upravljanje s tveganji (COT) kar je tudi razvidno iz slike 1 . 


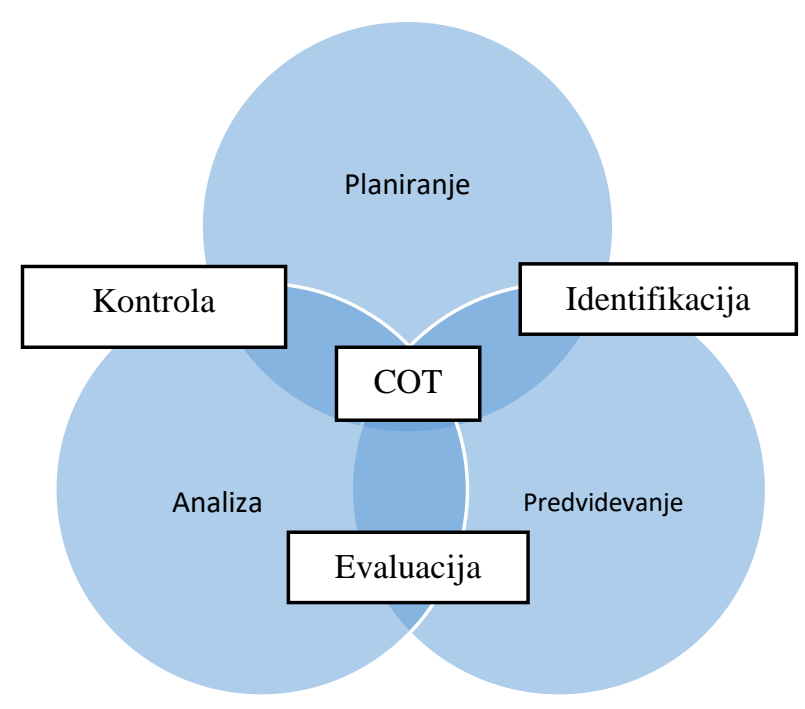

Slika 1 : Princip COT

Model na sliki 2 je sestavljen iz 6 korakov in sicer :

I. Določitev ciljev : ki so lahko tudi kotradiktorni in se je potrebno o njih odločati in jih kasneje na podlagi prakse in morebitnih spremenjenih okoliščin potrebno tudi ustrezno prilagajati in spreminjati.

II. Opredelitev tveganj ko se pojavijo pogoji za novo tveganje ali se spremeni njegova precepcija in ko se spremeni stopnja določenega tveganja

III. Ocena tveganj:opredelitev verjetnosti, da škoda nastopi; opredelitev finančnega učinka škode in možnost vnaprejšnjega napovedovanja.

IV. Vrednotenje tveganj $V$ tej fazi ovrednotimo vpliv potencialnih izgub na podjetje predvsem $\mathrm{z}$ vidika pogostosti in resnosti škod.

V. Izbira najbolj ustrezne metode ali kombinacije metod poznamo v osnovi naslednje metode: (izogibanje tveganjem, zadržanje tveganj, prenos tveganj (zavarovalni), nadzor nad škodami).

VI. Preverjanje pravilnosti odločitev in nenehne izboljšave v prejšnjih korakih, predvsem $v$ petem pri izbiri metode za posamezne vrste tveganj. Potrebno je oceniti rezultate upravljanja s tveganji in uvesti potrebne spremembe za zmanjšanje potencialnih ekoloških problemov. 
$36^{\text {Th }}$ International Conference on Organizational Science Development: Responsible Organization (March $22^{\mathrm{ND}}-24^{\mathrm{TH}}$, Portorož SLOVENia)

D. Mežnar: Management of Ecological Risks as an Integral Part of the Strategy of the Responsible Company

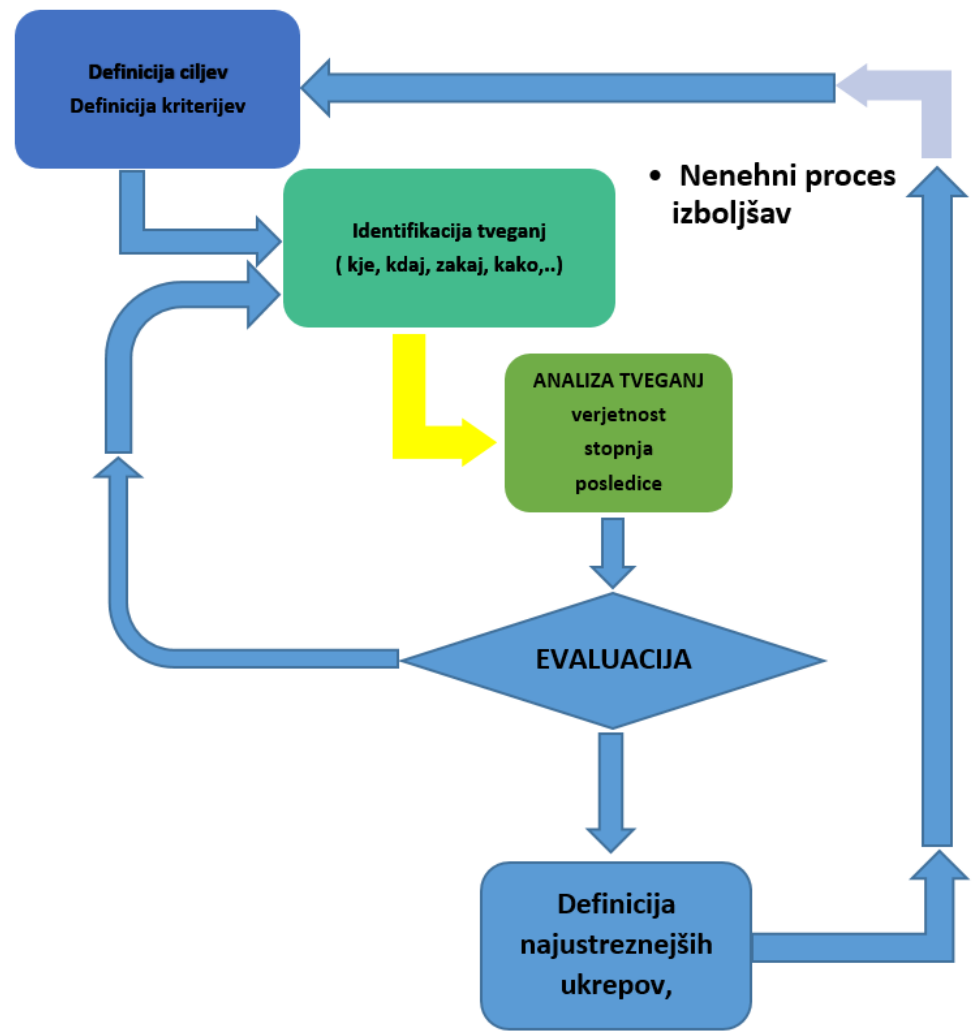

Slika 2 : Model managementa upravljanja z ekološkimi tveganji

\section{$5 \quad$ Aplikacija modela managementa obvadovanja ekoloških tveganj pri proizvodnji ivernih plošč na primeru Lesne TIP d.o.o.}

Ocenjevanje in simulacija dodatne in celotne obremenitve zunanjega zraka jesestavni del obratovalnega monitoringa naprave in tudi $\mathrm{k}$ boljšemu pregledu stanja kakovosti zunanjega zraka v okolici naprave.

Doseganje ustrezne kakovosti zunanjega zraka je pomembno v vsakdanjem življenju, saj vpliva na kvaliteto našegaživIjenja. Onesnaženje zunanjega zrakaje možno omejiti do določene meje. Zato mora vsako podjetje za svoje obratovanje imeti dovoljenje, v katerem so predpisani pogoji obratovanja podjetja. Le to določa pogoje obratovanja naprave in zagotavlja varovanje zdravja okoliskega prebivalstva in predstavlja nekakšen kompromis med sprejemljivo omejitvijo obratovanja podjetja in sprejemljivim onesnaženjem zunanjega zraka, ki ga podjetje povzroča. 
V primeru proizvodnje ivernih plošč v Lesni TIP so najpomenbmejši polutanati prašni delci $\left(P M_{10}\right)$, dušikov dioksid $\left(\mathrm{NO}_{2}\right)$, žveplov dioksid $\left(\mathrm{SO}_{2}\right)$, benzene ter dušikovi okisidi $\left(\mathrm{NO}_{x}\right)$. Torej polutanti (Tabela 1), ki vplivajo tako na tanjšanje ozonske plasti, zakisanje, razraščanje biomase, fotokemična tvorbo oksidantov in človeško zastrupljanje.

Tabela 1: Dovoljene mejne vrednosti polutantov (vir : EIMV, str.4)

\begin{tabular}{|c|c|c|c|c|c|c|c|c|}
\hline & \multicolumn{2}{|c|}{$\overline{P M_{10}}$} & \multicolumn{2}{|c|}{$\mathrm{NO}_{2}$} & \multicolumn{2}{|c|}{$\mathrm{SO}_{2}$} & \multirow{2}{*}{$\begin{array}{c}\text { benzen } \\
\text { letno } \\
\text { pouprečje }\end{array}$} & \multirow{2}{*}{ 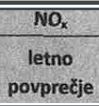 } \\
\hline & $\begin{array}{c}\text { letno } \\
\text { povprežje }\end{array}$ & $\begin{array}{l}\text { dnevna } \\
\text { vrednost }\end{array}$ & $\begin{array}{c}\text { letno } \\
\text { pouprečje }\end{array}$ & $\begin{array}{c}\text { urna } \\
\text { vrednost }\end{array}$ & $\begin{array}{c}\text { letno } \\
\text { pouprečje }\end{array}$ & $\begin{array}{l}\text { dnevna } \\
\text { vrednost }\end{array}$ & & \\
\hline SOP $\left[\mathrm{kg} / \mathrm{m}^{\prime}\right]$ & $? 0$ & & 26 & & 8 & 50 & & 19,5 \\
\hline $\mathrm{ZOP}\left[\mu \mathrm{g} / \mathrm{m}^{3}\right]$ & 18 & 35 & 32 & & 12 & 75 & 35 & 24 \\
\hline
\end{tabular}

Pri predstavitvi uporabe modela sem se zaradi kompleksnosti celovitega modela omejil samo na predstavitev modeliranaja in simulacije onesnaženja zraka.

\subsection{Meritve atmosferskih vplivov}

Oceno celotne obremenitve se je izvedlo z meritvami kakovosti zraka na izbranih merilnih mestih ( Slika 6). Ocena dodatne obremenitve zunanjega zraka pa se je izvedla z modelskim izračuni širjenja okolice, zato so pri izdelavi pomembne tudi meritve meteoroloških spremenIjivk: meritev hitrosti vetra ( slika 3), meritve rože vetrov (slika 4), meritve temperature zraka ( slika 4) in meritve relativne vlage $\mathrm{v}$ zraku ( slika 5).

Dejstvo pa je, da vsaka ocena kakovosti zunanjega zraka vsebuje možnost odstopanja rezultatov od realnega stanja. Modelski izračuni oziroma simulacije dopolnijo oceno kakovosti zunanjega zraka s prostorsko razporeditvijo širjenja onesnaženja. Tako dobimo boljši pregled, kaj se v okolju dogaja, kako obsežno je onesnaženje določene naprave in kateri deli okolice naprave so najbolj obremenjeni.

\section{a) Meritev hitrosti vetra}

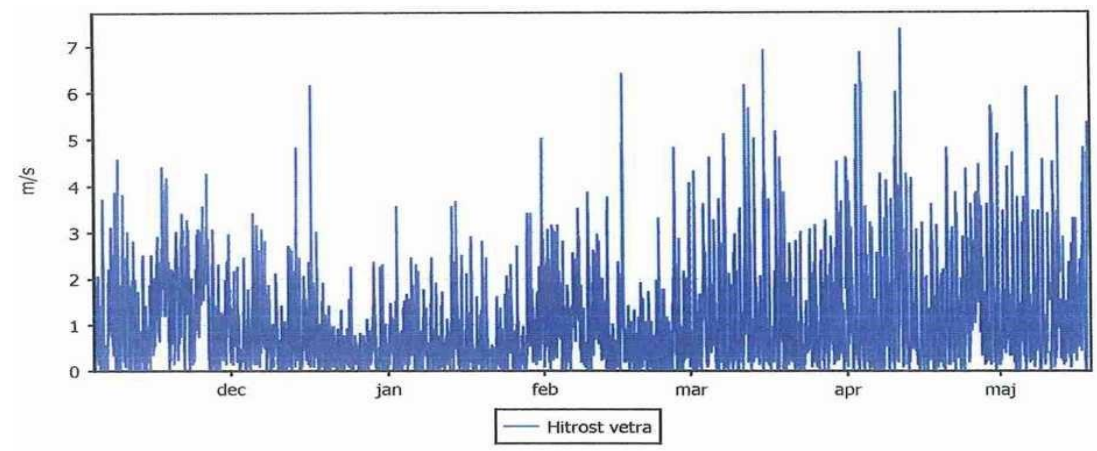

Slika 3 : Meritev hitrosti vetra (vir : EIMV, str.6) 
554 36 $6^{\text {TH }}$ International Conference on Organizational Science Development: RESPONSIBLE ORGANIZATION (MARCH $22^{\mathrm{ND}}-24^{\mathrm{TH}}$, PORTOROŽ SLOVENIA)

D. Mežnar: Management of Ecological Risks as an Integral Part of the Strategy of the Responsible Company

b) Roža vetrov

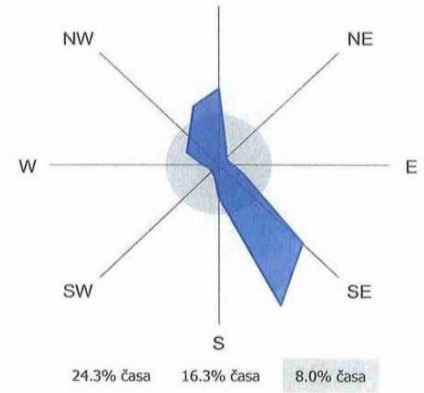

Slika 4 : Roža vetrov(vir : EIMV, str.6)

\section{c) Temperatura zraka}

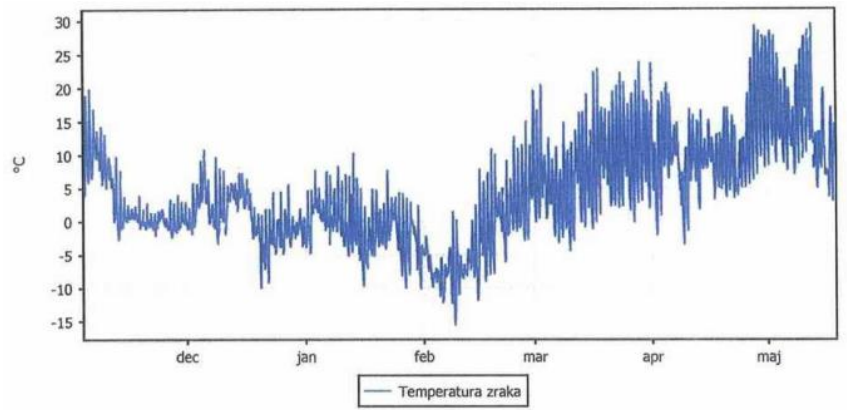

Slika 4 : Meritev temperatur zraka (EIMV, str.8)

\section{d) Relativna vlaga $v$ zraku}

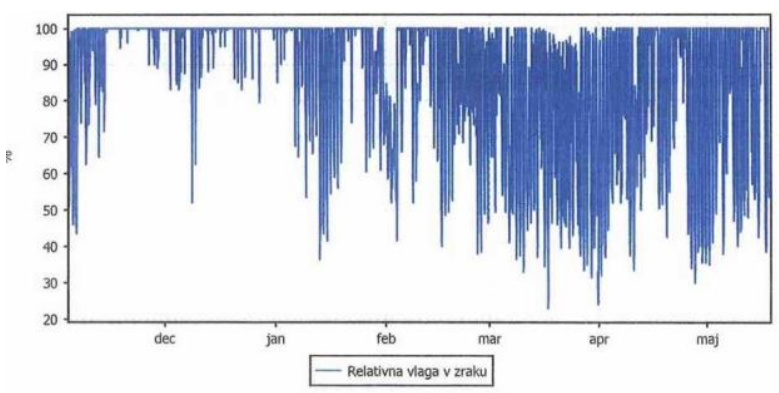

Slika 5 : Meritev realtivne vlage v zraku(vir: EIMV, str.8) 
Kljub temu, da so tako meritve kot modelski izračuni obremenjeni z neko negotovostjo, potrebujemo oba procesa za dobro oceno kakovosti zunanjega zraka. Ravno kombinacija meritev in modelskih izračunov ponuja najboljši pregled stanja v okolju.

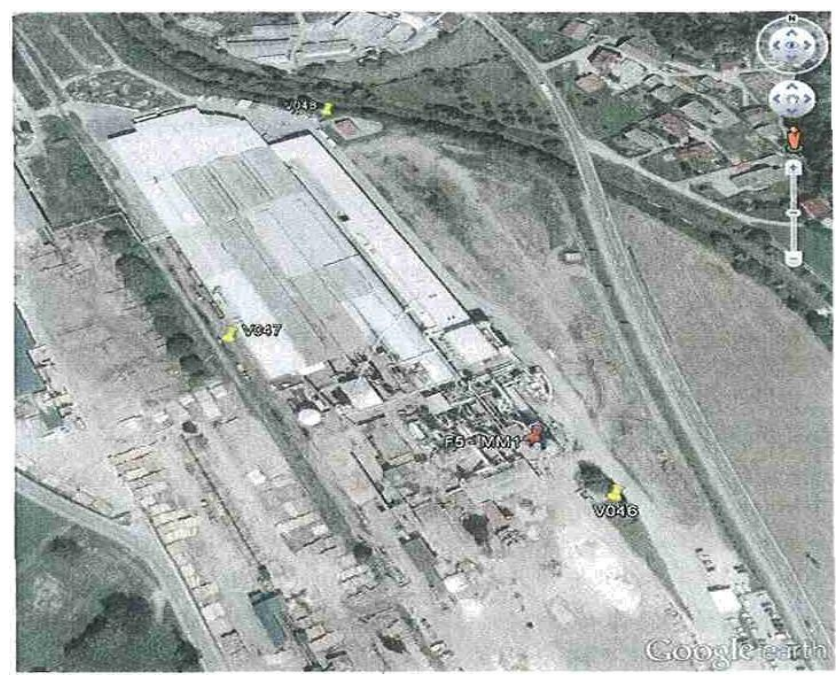

Slika 6: Področje tovarne ivernih plošč Lesna TIP d.o.o. ter merilna mesta(vir : EIMV, str.9)

\subsection{Modeliranje širjenja onesnaženja $v$ zunanjem zraku in ocena dodatne obremenitve zunanjega zraka}

Ocena širjenja onesnaženja $\mathrm{v}$ zunanjem zraku, ki so posledica obratovanja posameznega vira emisij snovi $\mathrm{v}$ zrak, se pripravlja $\mathrm{z}$ modelskimi izračuni. $\mathrm{Z}$ njimi je możno iskati reprezentativna mesta za izvajanje monitoringa kakovosti zunanjega zraka. Razen tega se $\mathrm{z}$ njimi izvaja ocenjevanje dodatne obremenitve zunanjega zraka, s katero se določi, kolikšen je prispevek določene naprave $\mathrm{k}$ skupnemu onesnażenju zraka v okolici naprave. Prednost modeliranja pred meritvami kakovosti zunanjega zraka je tudi $\mathrm{v}$ pripravi prostorske razporeditve onesnażenja. Meritve namreč podajajo samo vrednosti na lokaciji merilnih mest, na podlagi teh podatkov pa sije težko predstavljati, kakšno je onesnażenje v bližnji okolici.

Pri modeliranju širjenja onesnaženja $\mathrm{v}$ zunanjem zraku $\mathrm{v}$ kombinaciji $\mathrm{z}$ meteorološkimi napovedmi iz operativnih mezoskalnih napovedi je možno pripraviti tudi nekajdnevno napoved širjenja onesnaženja, $s$ katero je mogoče predvideti, kdaj se bodo pojavile neugodne meteorološke razmere. Dejstvo je, da se neugodne meteorološke situacije ne pojavljajo enakomerno preko celega leta. Slika 7 prikazuje model,ki je nastal na osnovi topografske structure terena okoli tovarne ivernih plošč in meritev atmosferskih vplivov 
556 36 $36^{\text {TH }}$ International Conference on Organizational Science Development: ReSPONSIBLE ORGaNizATION (MARCH $22^{\mathrm{ND}}-24^{\mathrm{TH}}$, Portorož Slovenia)

D. Mežnar: Management of Ecological Risks as an Integral Part of the Strategy of the Responsible Company

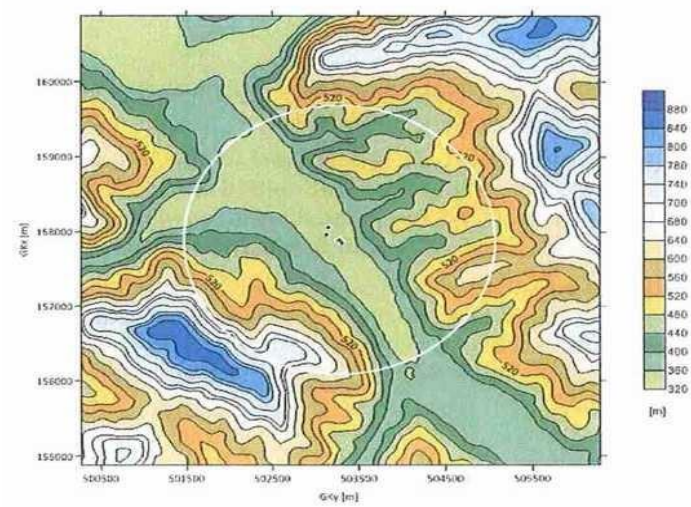

Slika 7: Topografska struktura terena okoli tovarne ivernih plošč (vir : EIMV, str.11)

\subsection{Simulacije širjenja onesnaženja $v$ zunanjem zraku}

$\mathrm{Na}$ osnove modela širjenja onesnaženja, meritev in ob upoštevanju različnih atmosferskih pogojev so se izvedle simulacije onesnaženja okolja in dale naslednje rezultate pri čemer pa so se zaradi objektivnosti rezultatov uporabili različni algoritmi. Rezultati simulacij pa so prikazani na sliki 8 in sliki 9.

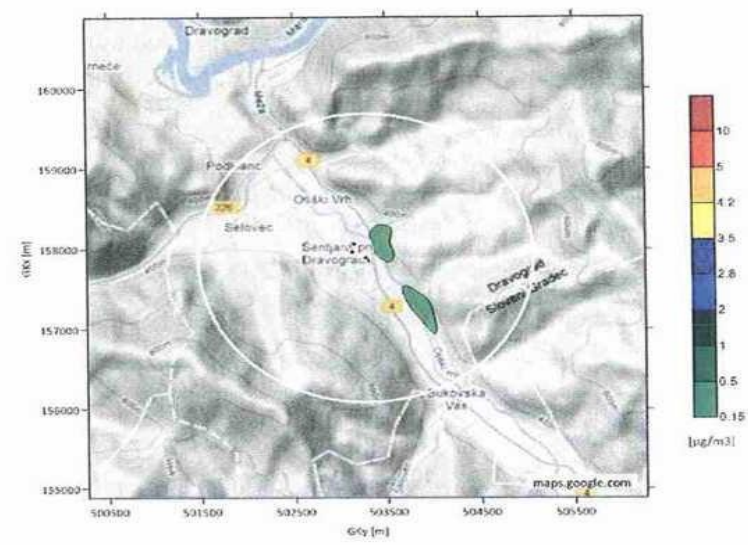

Slika 8 : Simulacija povprěnnih koncentracij benzena (mezoskalarni model Alladin) (vir : EIMV, str.18) 


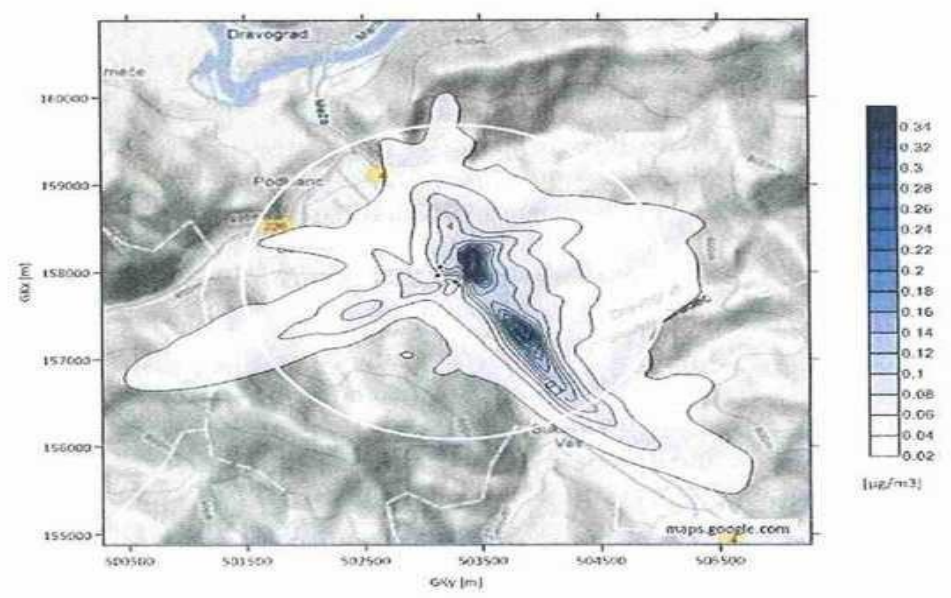

Slika 9 : Simulacija na osnovi avtomatske skale koncentracij (vir : EIMV, str.18)

Meritve, modeliranje ter simulacije so pravzaprav dobra osnova za management upravljanja z ekološkimi tveganji. Upoštevanje ekoloških normativov posredno vpliva na ekonomičnost proizvodnje, povečuje konkurenčnost podjetja. $\mathrm{Ob}$ upoštevanju standardov odgovornega obnašanja se krepi blagovna znamka, ugled in tudi tržna pozicija podjetja. Višji ugled utrjuje poslovne povezave, zagotavlja zvestobo kupcev, omogoča kakovostno dobavno verigo in prinaša nove poslovne priložnosti

\section{Zaključek}

Predstavljen model v Tovarni ivernih plošč Lesna TIP d.o.o. prikazuje, kako je v strategijo poslovanja implementirana odgovornost podjetja $\mathrm{z}$ vidika managementa obvladovanja ekoloških tveganj. Dejstvo je, da stalno merjenje, simulacije in ukrepanje daje poslovanju novo dodano vrednost, predvsem pa bistveno zmanjšuje ekološka tveganja, ki jim je tovarna in okolica tovarne zaradi narave proizvodnje izpostavljena. $\mathrm{Z}$ jasno opredelitvijo ciljev, izvajanjem strategije, meritvami , modeliranjem ter simulacijami pogojev, ki jim je podjetje glede ekoloških tveganj izpostavljeno se je sicer strošek poslovanja zaradi ukrepov managementa z ekološkim tveganji malce povečal, dolgoročno pa pomeni zelo velik prihranek, stabilnejše poslovanje ter korak naprej $\mathrm{k}$ viziji postati odgovorno podjetje

\section{Literatura}

Diacon S. R., Carter R. L.(1992).Success in Insurance. Nottingham: Clays Ltd.

Doherty Neil A.(1985). Corporate Risk Management. New York: McGraw-Hill Book Company. Merkhofer Miley W.(1987). Decision Science and Social Risk Management. Dordrecht: D. Reidel Publishing Company. 
$36^{\text {Th }}$ International Conference on Organizational Science Development: RESPONSIBLE ORGANIZATION (MARCH $22^{\mathrm{ND}}-24^{\mathrm{TH}}$, PORTOROŽ SLOVENIA)

D. Mežnar: Management of Ecological Risks as an Integral Part of the Strategy of the Responsible Company

Williams C. Arthur JR, Heins Richard M.(1981).Risk Management and Insurance. Fourth Edition. New York: McGraw-Hill Book Company.

Williams C. A., Heins R. M.(1989). Risk Management and Insurance. New York: McGraw-Hill Book Company, 1989.

Heijungs R., Guinée J., Huppes G., Lankreijer R. M., Udo de Haes H. A., Wegener Sleeswijk A., AnsemsM. M., Eggels P. G., van Duin R., de Goede H. P.(1992). Environmental Life Cycle Assessment of products. Guide and Backgrounds. CML, Leiden University, Leiden.

Wuebbles D.J., (1988). An executive summary of relative effects on stratospheric ozone of halogenated methanes and ethanes of social and industrial interest. United Nations Environment Programme, LawrenceLivermore NationalLaboratory report UCRL-99842.

EIMV- Elektroištitut Milan Vidmar. (2012). Ocena celotne in dodatne obremenitve podjetja Lesna TIP Otiški Vrh 
$36^{\text {Th }}$ International Conference on Organizational Science DEVElopMENT: Responsible ORganization (MARCH $22^{\mathrm{ND}}-24^{\mathrm{TH}}$, PORTOROŽ SLOVENIA)

O. Arsenijević, M. Ferjan, I. Podbregar, P. Šprajc, D. Trivan \& Y.

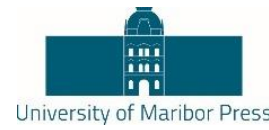

Ziegler

\title{
Effective Absorption of European Funds
}

\author{
MariJa Michaud, MATJaž MaLetič \& DRago VuK
}

\begin{abstract}
There are many opportunities, as well as challenges, for absorption of EU funds. Successful project applications require a lot of effort, knowledge and ingenuity. For effective absorption of European funds, the following factors are essential: excellent practical knowledge of project management and administrative financial rules, as well as EU guidelines and policies. It could be argued that the role of the project leader is vital for organization to highlight its state-of-the-art technology and services. Project leader has essential role in putting organization's efforts to join the successful consortium as well. This article summarizes the theory in the field of EU funds and presents the results of the nation-wide research on the effectiveness of EU funding. The factors that are affecting successful absorption of funds are identified. The guidelines for successful application based on model of long-term absorption, are exposed.
\end{abstract}

KEYWORDS: European Union • European funds • Cohesion policy • EU Financial framework $\bullet$ Project management

CorRespondence AdDress: Marija Michaud, Society for Development and Social Innovation AINE, Podreča 133, 4211 Mavčiče, Slovenia, e-mail: marija.michaud@gmail.com; Matjaž Maletič, Ph.D., Assistant Professor, University of Maribor, Faculty of Organizational Sciences, Kidričeva cesta 55a, 4000 Kranj, Slovenia, e-mail: matjaz.maletic@fov.uni.mb.si, Drago Vuk, Ph.D., Full Professor, University of Maribor, Faculty of Organizational Sciences, Kidričeva cesta 55a, 4000 Kranj, Slovenia, e-mail:drago.vuk@fov.uni.mb.si

DOI https://doi.org/10.18690/978-961-286-020-2.46

ISBN 978-961-286-020-2

(C) 2017 University of Maribor Press

Available at: http://press.um.si 
$36^{\mathrm{TH}}$ InTERnATIONAL CONFERENCE ON ORganizational SCIENCE DeVElopment: Responsible Organization (MarCh $22^{\mathrm{ND}}-24^{\mathrm{TH}}$, Portorož Slovenia)

M. Michaud, M. Maletič \& D. Vuk: Effective Absorption of European Funds

Of the 77 billion EUR earmarked for research and development in the period 2014-2015, research organizations and universities received $66 \%$ of the money, private organizations $27 \%$ and public organizations $7 \%$, at European level. The proportion was different at Slovenian level, with private sector receiving $48 \%$, research organizations $28 \%$ and universities $18 \%$.

Slovenian organizations are involved in 277 contracts signed for co-financing, with the proportion of EU co-financing being EUR 95.74 million. That puts Slovenia on the 19th place among EU Member States in cooperation on projects of the Horizon Programme. Slovenian low success rate amounts to $9.9 \%$ (EU average is $13.1 \%$ ).

The Commission recommended three main improvements in research and development for Slovenia:

- improvement of quality and internationalization of the public research sector to boost competitiveness;

- development of venture capital for SMEs;

- ensuring innovation pleasant circumstances to increase the economic potential and competitiveness.

The success of applications to calls increases with the evaluation of the application prior to submission from one of the relevant evaluators in the European database for research and innovation (RI). The chances of successful application will greatly increase by connecting to the appropriate partner group. Useful innovative ideas of sustainability and compliance with program guidelines and an upgrade to similar projects that were already proposed should be applied. Successful application to at least five projects per year may bring the company more money than a salesperson of products or services, so it is quite worth the effort (Stern, 2016). The following paper outlines some of the issues related to successful absorption of EU funds.

\section{Theoretical foundations of European funds}

\subsection{Institutions and bodies of the European Union}

Europe has a unique institutional arrangement, where general policy guidelines and interests of the EU as a whole are commonly set. The European Commission proposes majority of the legislation. The European Parliament, in agreement with the EU Council, decides on the adoption of the proposed legislation. The EU also has two advisory bodies: the European Committee of the Regions (COR) and the European Economic and Social Committee (EESC) (COR, 2015).

The European Commission implements EU law (jointly with the Court of Justice of the EU). It proposes new laws and regulations to the European Parliament and the Council, 
manages the EU budget and allocates funds and represents the European Union at international level to conclude agreements between the EU and other countries. It consists of a chairman of the commission and commissioners, one from each member country.

Inter institutional bodies (EU, 2016) act as supporting bodies to institutions and bodies. Executive Agencies (EU, 2016) carry out the tasks related to the management of one or more EU programs. Their operation is limited in time depending on the specific period, with the seat needed to be at the European Commission. These agencies are:

- Executive Agency European Research Council (ERC)

- Executive Agency for Education, Audiovisual and Culture (EACEA)

- Executive Agency for Competitiveness and Innovation (EACI)

- Research Executive Agency (REA)

- Executive Agency for the Trans-European Transport Network (TEN-T EA)

- Executive Agency for Health and Consumers (EAHC).

European Institute of Innovation and Technology is an independent decentralized body of the EU, combining the best scientific, economic and educational institutions, and promoting the innovation capacity of the European Union.

\subsection{Sectoral Policies of the European Union - centralized management}

The law that governs individual activities is the basis for the implementation of European policies in various areas and sectors. Parts of its legislative competence have the Member States transferred to the EU, in particular in the field of agriculture and fisheries, while in other parts, such as culture, research, etc. the legislative competences are shared with the European Community (EU, 2016).

The basis for co-financed growth and sustainable development is the monitoring of European sectoral documents and policies. Tracking European trends, long-term policies and strategies is crucial for the development of quality products and services. Innovation, based on smart and sustainable growth, is rewarded with the means for development and economic growth of the country. Calls need to be identified within policies and programs.

\subsection{Overview of European programs 2014-2020 in relation to the European budget (adapted from SBRA, 2016)}

All programs have within the program guidelines set priorities. Each call has an annual key priority areas and guidelines within which tangible results in tackling the challenges are sought. Each project application must meet those.

1.a. Competitiveness for growth and employment (Horizon 2020, COSME program for the competitiveness of enterprises, Erasmus +, the EU Programme for Social Change and Innovation, CEF, Fiskus) 
$36^{\mathrm{TH}}$ International Conference on ORganizational Science Development: Responsible Organization (March $22^{\mathrm{ND}}-24^{\mathrm{TH}}$, Portorož Slovenia)

M. Michaud, M. Maletič \& D. Vuk: Effective Absorption of European Funds

1.b. Economic, social and territorial cohesion (Cohesion policy, European Territorial Cooperation)

2. Sustainable growth: natural resources (Common Agricultural Policy, the European Agricultural Fund for Rural Development, the European Fund for Maritime Affairs and Fisheries, Life 2014-2020)

3. Security and Citizenship (Creative Europe, Health for Growth, Consumer protection, Europe for Citizens program for the Rights and Citizenship Programme Justice Facility on Migration and Asylum)

4. Europe in the world (Instrument for Pre-Accession Assistance, the European Neighborhood Instrument, the Partnership, the Development Cooperation Instrument, the European Development Fund (EDF))

\subsection{Slovenian sectoral policies - decentralized management}

Based on normative basis of the EU, Slovenia needs for the implementation of the cohesion policy for the period-specified financial perspective to prepare programming documents at two hierarchical levels: the national strategic reference framework on the first level, outlining a strategy for achieving a faster convergence with an emphasis on the mobilization of cohesion policy at national level; and operational programs on the other, specific level. For the period 2014-2020, the following documents have been accepted:

- A partnership agreement between Slovenia and the European Commission 20142020

- The Slovenian strategy of smart specialization - S4

- Operational Programme for cohesion policy in the 2014-2020 programming period.

The National Strategic Reference Framework contains situation analysis, strategy and defines the basic mechanisms for achieving the objectives of the strategy, including establishing the number of operational programs and basic financial allocations. The European Commission endorses the National Strategic Reference Framework with an order and confirms it, if it is coordinated with EU strategic guidelines for cohesion and the development strategy of the EU. Currently the base is Europe 2020 strategy (EU Funds, 2016).

Slovenia, in the 2014-2020 period, has an indicative 3.255 billion EUR from the European Structural Funds and the Cohesion Fund, of which 159.8 million EUR are earmarked for CEF (for transport) and 64 million EUR for the ETC programs. Other means are used to achieve the EU 2020 strategy priority areas of the strategy for smart growth and creating jobs: research and innovation, information and communication technologies, enhancing the competitiveness of small and medium-sized enterprises, support for the transition to a low carbon economy. 
Investments will be an appropriate mix of measurements geared towards supporting the soft contents with clear market potential, increasing added value and will contribute to improve access to financial resources. It will combine investment in human resources, activity, mobility, research, development and innovation and increasing energy and material efficiency. With incentives, Slovenia will create the conditions for long-term stable environment, taking into account social challenges (demographic trends, pressures on the environment, access to food, etc.), the development of new, quality jobs and preserving existing ones with the changed structure of the economy.

In the period 2014-2020, we are not talking about regional or sectoral projects, but about comprehensive and good projects that will contribute to the achievement of the objectives/results. Regional projects will be possible to finance within the defined substantive priority axes based on the division into East and West cohesion region.

\subsection{International financial mechanisms}

The EEA Financial Mechanism and the Norwegian Financial Mechanism are support from Iceland, Liechtenstein and Norway to economically backward states of the European Union.

Swiss contribution to the Slovenian-Swiss Cooperation Programme reduces economic and social disparities in the enlarged European Union.

\section{Approving of EU multi annual financial framework}

MFF is an agreement on the priorities and the main framework of the European budget expenditure. It is the basis for the annual budgets and implementation and funding of European policies. Negotiations for the adoption of the new financial framework starts two years before the expiry of the previous frame; for the period 2014-2020 it started in July 2011 and ended in the second half of 2013. In year 2018 negotiations for the next financial framework will open.

As stated in Article 312 of the Lisbon Treaty, the European Commission will make a proposal to negotiate the adoption of the financial framework based on the circumstances. The Council of Europe start lengthy negotiations and the results of those negotiations must ultimately be approved by the European Parliament. After the approval, the Council shall adopt a regulation on the MFF.

\subsection{Positive changes of the European financial framework for 2014-2020}

The European Commission proposed the rationalization of the programs for the current financial framework. Since 2014, there are 22 fewer programs, replaced by joint programs, allowing simplification, greater synergy and joint implementation of rules and procedures. Clearer and more consistent rules on the eligibility of costs, simplified procurement procedures, the transition to electronic management applications to receive funds and cost-effective monitoring of audit procedures are all positive changes. 
$36^{\mathrm{TH}}$ International Conference on ORganizational Science Development: Responsible Organization (March $22^{\mathrm{ND}}-24^{\mathrm{TH}}$, Portorož Slovenia)

M. Michaud, M. Maletič \& D. Vuk: Effective Absorption of European Funds

Amendment of Financial Regulation brings shorter payment periods, greater predictability of spending of funds in multi annual programs, the elimination of income from interest on pre-financing and electronic communication between beneficiaries and authorities.

Coherence between sectoral rules and financial regulation was established. Introduced were sectoral frameworks Horizon 2020, Erasmus +, Creative Europe, Instruments for external action, the Horizontal regulation on monitoring and financing of the CAP, whose aim is primarily »greening «. Priority areas such as resource efficiency, climate change, environment and energy security and efficiency started to be included. Different programs are designed to promote synergies in the use of EU funds and the priority achievement of the objectives of Strategy 2020. This approach seeks to ensure greater consistency, simplification and cost-efficiency for the benefit of the final beneficiaries, small and medium-sized enterprises.

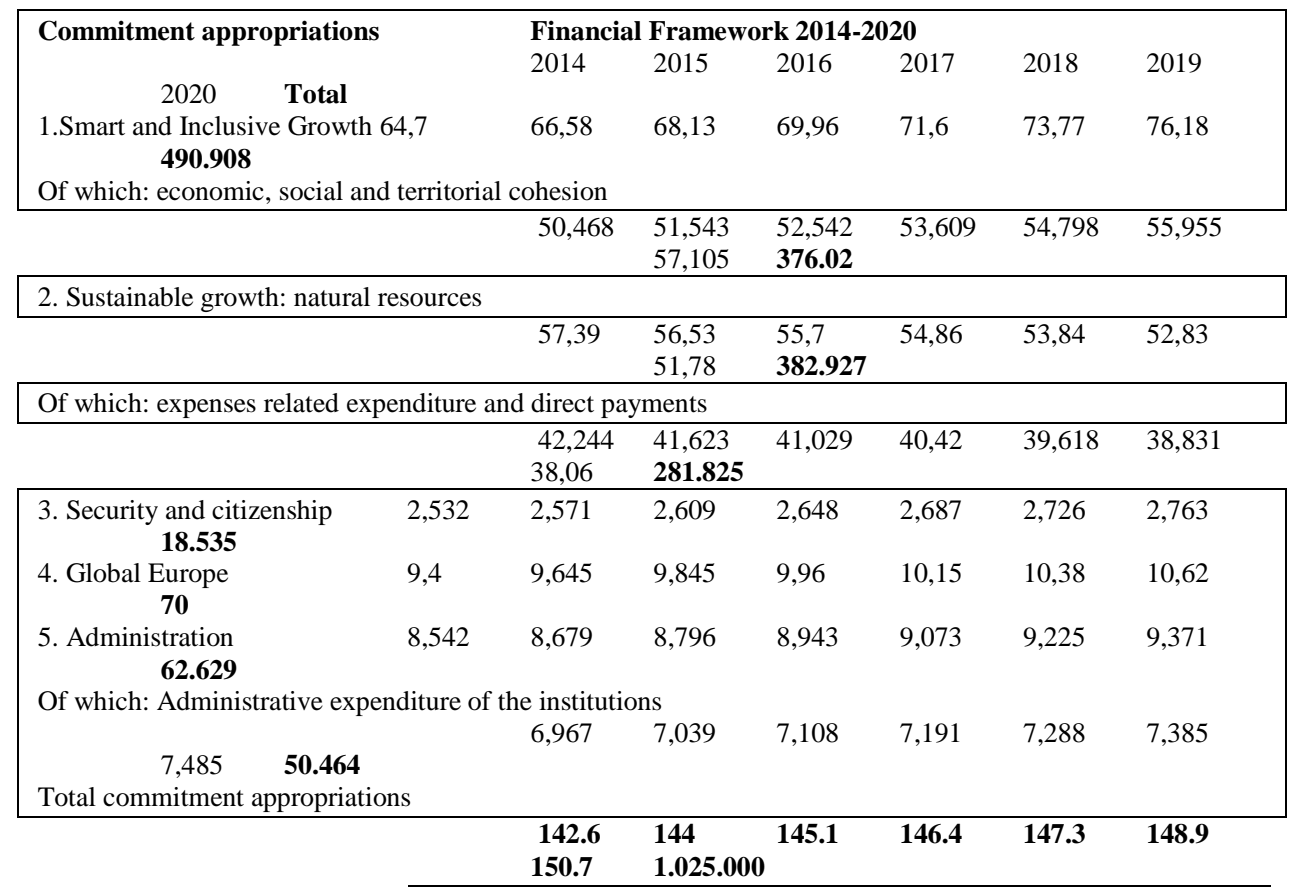

Table 1: Financial Framework: 2014-2020 


\section{$4 \quad$ Display of the current status}

\subsection{Role of the State}

Depending on the market situation, the EU indirectly adjusts to these annual budgets, so there may be deviations from the planned funds, which are proposed and adopted in the multi annual financial framework. Therefore, it is suggested that the organization keeps to date with annual budgets, ongoing measurements and EU guidelines, because in this way, they are aware of the possible changes to the written or called conditions and restrictions.

As Pia Ahrenkilde Hansen, representative of the European Commission (EurActiv, 2010), stated, the individual countries are the ones that are responsible for the dramatically low absorption of structural funds during the financial crisis. Many Member States are establishing short-term incentive programs that allow public organizations to rely primarily on national assets and not assets of the EU.

\subsection{Co-financing}

The problem arises in providing co-financing. In accordance with the rules of EU, public authorities can access money from the Structural Funds only if they can ensure matching funds from national, regional or local budgets themselves. In times of economic crisis, many Member States reduce public budgets and focus only on the most important public services. Therefore, it is increasingly difficult to find money to co-finance structural projects supported by the EU. This leads to the ironic situation: the beneficial projects, that could create higher economic growth, development, innovation, social inclusion and the much-needed jobs in regions confronting high unemployment, are disabled. This is also in violation with the main guidelines of the Strategy 2020, Strategy for sustainable, smart and inclusive growth. It also answers the question why there is a difference between the actual and planned absorption of structural funds. The state must postpone or reduce the anticipated use of resources, due to the lack of money or using it for other purposes, instead of providing the matching funds itself.

The achievement of ambitious objectives of Slovenia's Development Strategy can only be done with significantly improved absorption capacity of the country to receive funding from Brussels (Wostner, 2005). Because of this, it is necessary to restructure the budget of the Republic of Slovenia, improve the capacity for preparation of projects/programs and skills for effective administrative management of European funds.

\subsection{Calls}

Information on calls for the allocation of EU funds should be searched in different places. In addition to monitoring the European and Slovenian official document, it is required to monitor the publication of ministries, agencies, directorates and other institutions. Companies are to a greater extent submitting their proposals, financed with European 
$36^{\mathrm{TH}}$ International Conference on ORganizational Science Development: Responsible Organization (March $22^{\mathrm{ND}}-24^{\mathrm{TH}}$, Portorož Slovenia)

M. Michaud, M. Maletič \& D. Vuk: Effective Absorption of European Funds

funds, in Slovenia than in Brussels. Even the performance of the assets acquired and successfully completed projects in Slovenia is higher than in Brussels.

Information about European funds for companies lack transparency and straightforwardness. Many organizations are dismayed by an extensive and complex documentation. There's an opinion that most of the "project time" is devoted to the administrative work. Most organizations are not applying to EU tenders because of too heavy administrative rules (Michaud and Pavčič, 2013).

Due to tight time frames and limited capacities, fewer organizations respond to the participation in informative events of individual calls. In certain European events, also the participation via webinars is enabled.

Companies are not turning enough to the advisory organizations for the preparation and management of the application and project documentation. The problem is the risk, cost, expertise and quality of organizations.

The possibility that the company successfully obtains European funds ranges between 10 and 30 percent. When necessary documentation is properly prepared, such options could rise to 50 percent (Stern, 2016). The big problem is the risk of selection.

The reason why organizations do not apply to calls and appeals on the EU is the lack of financial resources. In Slovenia, in case of smaller projects we have to fund the project entirely with our own debt instruments, while at the longer projects, we can ask for reimbursement based on the interim reports. Each call documentation has a defined payment dynamics. A certain degree of co-financing is also set: it ranges between 50\% for demonstration projects, $75 \%$ for research and development projects, $100 \%$ for support projects and public awareness. An organization should provide other means in a different manner in the form of financing the costs of labor, material costs, travel expenses, subcontractors, rent, operating costs and other costs associated with the project.

Purpose and long-term vision of the organization and generating ideas in this direction are of paramount importance. Tender deadlines are often too short, so it is important that we have ideas ready on stock. This enables us to concretize the idea and bring it into compliance with the tender conditions at the time of the outcome of the call. For proper guidance of the long-term vision of organization and projects, it is required to monitor European policies and documents, which coincide with the field development. Necessary challenges, which the EU wants to meet, must also be identified and thus complementary adapt own challenges, wishes and needs (Stern, 2016). It is necessary to know the existing cutting-edge services, concepts, products, processes or approaches to tackle the challenges of individual priorities. They need to be synchronized with the "beyond state of the art" quality and innovative upgrade.

\subsection{Registration}

Registration for the call must consist of precise documentation and all necessary explanations and indicators of how the project will contribute to the implementation of 
development strategies and policies. Each project must contribute to improving operations, increasing employment and technological progress and increasing the competitiveness of the EU. It should include indicators and facilitate the monitoring of the effects (Stern, 2016).

The most common clerical errors in the award of the tender documentation arise from unfamiliarity with European sectoral policies, unfamiliarity with the current state of development and consequently lack of innovative ideas. There's also the problem of lack of precise definition of project tasks for individual work packages with concrete measurable results. Namely, Europe is interested in what specific project contributes to society, especially how it implements the European high score goals and priorities. Longterm project results, usefulness and availability to the general public and sustainable impact of the project are also important. In addition to the clerical errors, most common are also administrative errors among which an untimely submitted call application is regarded. The problem often occurs in the electronic version of the document, because the servers are fully occupied on the last day of submission. Sometimes the problem is the incomplete address on the envelope, insufficient number of copies or missing annexes, such as various certificates of the company.

The most common financial mistakes in the planning of the project are: money disproportionately distributed between the project partners or within the work packages, inaccurate evaluation of the project by cost categories and inflating the project budget. Work tasks should be financially realistically balanced between work packages and material, labor resources, which are actually being used in the project.

\section{Management}

We assume that the leader of the European project has characteristics that are common to all leaders. Productivity through democratic way of managing is in the long-term the largest. In high-risk situations, the project should direct via tasks management. Successful leaders transform structure, strategy, culture and processes of the organization to adapt to the demands of the environment and thereby successfully achieve goals. Impact on the employees to pursue higher goals encourage initiative, using rhetoric that is consistent with the motivational process (Michaud, 2009).

Irrespective of the type of organization that excellent managers run, the leaders have common elements in behavior: vision, passion and self-drive, dedication and a strong belief in the moral correctness of the vision and willingness in personal risk, confidence, determination and perseverance and creating an image and role. They know that they must convince members with competency, credibility, confidence and personal example. The combination of high expectations and confidence in staff increases their selfconfidence and motivation. There is evidence that individuals respond with their best performance if leaders expect that of them, and conversely sink to despair and laziness, if they learn that their leaders look at them as incompetent. Leaders selectively promote those motives which are particularly important to achieve the vision and mission. McClelland and associates have defined three main motives that have long-term and 
$36^{\mathrm{TH}}$ InTERnATIONAL CONFERENCE ON ORganizational SCIENCE DeVElopment: Responsible Organization (March $22^{\mathrm{ND}}-24^{\mathrm{TH}}$, Portorož Slovenia)

M. Michaud, M. Maletič \& D. Vuk: Effective Absorption of European Funds

short-term impact on the functioning of the followers: integration or companionship, strength and achievements (Michaud, 2009).

Professional staff, which deals with European projects must, besides having an excellent expert knowledge, be also highly motivated, extremely flexible and innovative. Staff must be capable of dealing in stressful situation. The strain on people in organizations is great. In the past, more than two people were doing the work that one person is dong today (Vila, 2000). The majority of people working on the projects must furthermore perform regular work in organizations.

\section{The problem of absorption of European funds}

We proceed from the premise that improving the absorption of EU funds is necessary (Rudolf and Struna, 2008). This is needed for effective work in organizations that do not have sufficient resources to carry out socially beneficial development and project work and for the realization of social, regional and economic progress in the EU and Slovenia (Mulec, 2008). Furthermore, it is also essential to eliminate the differences between planned and actual dynamics of disbursement of EU funds and the development of competitiveness and innovation in Slovenia is also.

The problem many companies have is that they do not know how to successfully get EU funds. Companies lack qualified personnel, right management, organizational structure and ambitions to form a goal of regular participation in European projects.

Because of clumsiness and unfamiliarity with the rules of the game, in addition to the lack of time and effort that are required for proper preparation of applications to EU projects, the companies choose not to apply or don't properly fulfill the application (Mazgan, 2015).

\section{Slovenian research on the effectiveness of absorption of European funds}

The purpose of the research is to make a snapshot of the situation and to set guidelines, resources and model of effective acquisition of EU funds. The technique of collecting data is performed using the on-line questionnaire of closed type. Eight issues are broken down into sub-entries. Objectivity and impartiality of the representativeness of the sample was achieved with the help of the Institute of Information Science, which allowed access to the database SICRIS, Information System on research organizations in Slovenia. In addition to the base, covering about 2,000 recipients of the survey, the invitation to the fulfillment of a survey was published also at Enterprise portal, Slovenian Regional Development Fund, the portal Young entrepreneur and the Society for Rural Development sites. In the message aimed at the respondents, we asked to forward the survey also to business partners. The survey was transmitted to the participants in various projects across Slovenia. We received 205 responses, of which 196 were valid. The online survey was clicked at least nine hundred times, which means that the majority has decided not to participate due to the unfamiliarity with the topic, the survey's length and similar. 
The collected data was analyzed using descriptive research methods and descriptive statistics. The results were calculated by the program for the processing of statistical data SPSS. Complete survey and data can be viewed in the source Michaud (2016).

\section{$8 \quad$ Results}

\subsection{Demographics}

Summary of demographic profile of respondents shows that female gender dominates, but only for $10.2 \%$, at survey fulfillment. The most common age is between 30 and 49 years $(67.2 \%)$. The educational structure is high with university degree dominating $(40,31 \%)$, followed by a doctorate $(25.51 \%)$. The most frequent working period is between 20 and 29 years $(35.60 \%)$. More than half of the respondents work as a management staff $(51 \%)$, followed by professional staff $(29.6 \%)$. The predominant activity of the respondents is research, development, science and technology (30.6\%). The most common forms of organization in which respondents are employed are institute $(40.8 \%)$ and limited liability company (31.6\%). Financing profit-making, by selling own products and services on the market, is the main source of revenue (40,31\%). Michaud (2016)

\subsection{Hypothesis}

On the basis of the problem, a hypothesis was proposed: $\mathrm{H} / 1$ preparation, management, organization, purpose, professional competence, finances, long-term vision of the organization are in association with the successful acquisition of EU funds. We accept the hypothesis due to the level of statistical significance of $p \leq 0.05$. Furthermore, Pearson product-moment correlation coefficient, respectively the correlation between the preparation, management, organization, purpose, professional competence, finances, long-term vision of the organization and the successful acquisition of EU funds is $r=$ 0.23 .

Certain issues of empirical research are divided into lots. The following table shows the values of the results. The first letter of the set indicates the affiliation of question to the variable. The hypothesis is based on an average calculation of variables. Michaud (2016)

\begin{tabular}{|l|l|l|l|l|}
\hline $\begin{array}{l}\text { Correlation: preparation - P, } \\
\text { management - V, organization - O, } \\
\text { purpose - N, professionalism - S, } \\
\text { finance - F, long-term vision of the } \\
\text { organization - D }\end{array}$ & $\begin{array}{l}\text { Pearson } \\
\text { Correlation }\end{array}$ & Sig. (1-tailed) & $\mathrm{N}$ \\
\hline $\begin{array}{l}7.2 \text { a. establishment of project } \\
\text { management office }\end{array}$ & $\mathrm{O}$ & 0.323 & 0.000 & 187 \\
\hline $\begin{array}{l}7.5 \text { c. monitoring of the long-term EU } \\
\text { strategy }\end{array}$ & S,N & 0.314 & 0.000 & 183 \\
\hline
\end{tabular}


$36^{\mathrm{TH}}$ International Conference on ORganizational Science Development: Responsible Organization (MarCh $22^{\mathrm{ND}}-24^{\mathrm{TH}}$, Portorož Slovenia) M. Michaud, M. Maletič \& D. Vuk: Effective Absorption of European Funds

\begin{tabular}{|c|c|c|c|c|}
\hline $\begin{array}{l}7.2 \text { c. managing multiple projects } \\
\text { simultaneously in a transparent and } \\
\text { coordinated way }\end{array}$ & V & 0.294 & 0.000 & 186 \\
\hline $\begin{array}{l}7.1 \text { c. each project preparation is based } \\
\text { on the draft, in line with EU policies } \\
\text { and guidelines }\end{array}$ & $\mathrm{P}$ & 0.278 & 0.000 & 184 \\
\hline $\begin{array}{l}\text { 7.1 d. financial framework is accurate } \\
\text { and balanced with time lines and work } \\
\text { nackages }\end{array}$ & $\mathrm{F}$ & 0.223 & 0.001 & 182 \\
\hline $\begin{array}{l}7.1 \text { a. project application is prepared } \\
\text { hv multinle teams }\end{array}$ & $\mathrm{V}, \mathrm{P}, \mathrm{O}$ & 0.186 & 0.005 & 186 \\
\hline $\begin{array}{l}7.5 \text { b. knowledge, flexibility and } \\
\text { regional integration are constant }\end{array}$ & $\mathrm{S}, \mathrm{O}$, & 0.182 & 0.006 & 185 \\
\hline $\begin{array}{l}7.5 \text { a. EU is seen as an opportunity to } \\
\text { develop new products and services, }\end{array}$ & $\mathrm{P}, \mathrm{V}, \mathrm{O}, \mathrm{D}, \mathrm{S}$ & 0.174 & 0.009 & 184 \\
\hline $\begin{array}{l}7.3 \text { c. project results are useful, } \\
\text { accessible to the general public and }\end{array}$ & $\mathrm{N}, \mathrm{D}$ & 0.164 & 0.013 & 184 \\
\hline 8b. Expertise & S & 0.162 & 0.014 & 185 \\
\hline Average & & 0.23 & 0.005 & 185 \\
\hline
\end{tabular}

Table 2: Correlation of hypothesis variables

\subsection{Guidelines}

Organizations that successfully obtain EU funds have good leadership, organization, preparation, professionalism and purpose. They have a project office established, project application is prepared by multiple teams and they monitor long-term strategies and policies of EU. They also prepare projects, based on the outline draft harmonized with EU policies and guidelines and their accurate financial framework is balanced with time lines and work packages. Multiple projects are managed in a transparent and coordinated way.

Organizations should not be afraid of complicated administrative rules and risk selection. After the breakthrough over the heaviest initial phase of participation in projects, each next project is easier and more distinguished due to wider experiences. Indirectly, there's a technological and development growth and influence on social development.

\subsection{Identification of factors}

According to the organizations, the factors that most influence the success of the project application are:

expertise (4.46), reliable and strong partners (4.46), detailed administrative instructions (4.38), innovation (4.35) will and motivation (4.34), project team's initiative (4.26), available time (4.26), available staff (4.24), financial resources (4.23), organization's creativity (4.19), good IT support (3.95) and risk (3.45). 


\subsection{Model}

According to the presented problems and results based on the carried out research, we have prepared a model of effective absorption of EU funds. The model is based on the technical, organizational, personnel and financial work.

For a model to work in practice, each organization requires an exceptional leader - the driving force that has the ability to influence, recognize, network, encourage and guide the individual's potential for successful implementation of the set tasks, goals, visions and missions (Michaud, 2009).

The elements of the model include: identification of the challenges of society and policies, technology and market trends; identification of calls and appeals and applying to several calls; creating ideas; a good leader and an expert team; strong partners; implementation of activities to create innovative solutions and long-term results.

\section{$9 \quad$ Conclusions and Proposals}

Preparations, management, organization, purpose, professional competence, finances, long-term vision of the organization are important in connection with the successful acquisition of EU funds.

The more organization has governed its technical, organizational, personnel and financial part, the better they are in getting European funds. The basis for this is a great leader who, with the help of a good team, carries out the tasks of the project office. In addition to the technical and professional excellence, the contribution to the challenges and objectives of the EU should be at the forefront. Expert partners, convincing approach and innovation are the key to success.

Organizations that successfully receive EU funding, apply also to other various tenders, which they successfully complete, thus fully absorb the provided means. The scope and principles of acquisition and implementation of projects are well known to them. In European projects they are mainly involved as a partner in the consortium.

Information about European funds is sufficiently accessible; they are looking primarily at the websites or in Newsletters of the European agencies and directorates and they contact also Representative of the EU institutions in Slovenia. They are aware of the risk of project selection, but that does not stop them at applying to multiple calls. EU is seen as an opportunity to develop new products and services, acquiring new knowledge, ideas, partners and markets. Knowledge, flexibility and regional integration are constant guidelines in the development of the organization.

We suggest professional help from the state to the organizations in preparing applications for tenders and project management. The state could organize a European accelerator. Regular transfer of knowledge from organizations that successfully raise funds to the organizations that are beginning to get familiar with that area is crucial. There is an urgent 
$36^{\mathrm{TH}}$ International Conference on ORganizational Science Development: Responsible Organization (March $22^{\mathrm{ND}}-24^{\mathrm{TH}}$, Portorož Slovenia)

M. Michaud, M. Maletič \& D. Vuk: Effective Absorption of European Funds

need for the provision of the funds for pre-financing and co-financing of projects as this helps economic growth. Companies and indirectly the state could in the long run get a large part of revenue in the way of obtaining EU funds, which can be bigger and easier obtained than from the sales of the products on the market.

Our suggestion is that a public database of project results is available to all and organized on the level of Slovenia and the EU. In that way, a big leap towards social contribution is made in the long run. Many of the results, that have been successfully developed, could be applied in various organizations. With that, we avoid duplication of financing for development, which was with the European taxpayers' money already purchased by the final consumers.

We also suggest further research on the acquisition of project funds on the overall European level and the study on what happens with the project results and how many are already available for use to the general public. Hereby we mean additional assets acquired in the form of knowledge. Also the study on the impact of the project results on social development would be quite interesting.

\section{Literature}

Bebler, A. (2007). Uvod v evropske integracije [Introduction into the European integration]. Uradni list RS.

Mazgan, N. (2015). Kako napisati uspešno prijavo na razpis za evropski denar [How to write successful application on an invitation for tenders for European Funds].Finance.si. Retrieved from https://startaj.finance.si/

MGRT, (2013). Poročilo o črpanju sredstev EKP za leto 2013 [The report on the absorption of funds EKP 2013]. Ljubljana: Ministrstvo za gospodarski razvoj in tehnologijo (MGRT).

Michaud, M. (2009). Vpliv vodenja na uspešnost posameznika. [The impact of Management on the performance of an individual]. Kranj: Moderna organizacija

Michaud, M. (2011). Več milijard evropskega denarja leži pod birokracijo [Several billion of European money lies beneath the bureaucracy]. Finance.

Michaud, M. (2016). Model pridobivanja evropskih sredstev (Magistrsko delo) [Model of absorption of EU funds (Master's thesis)]. Kranj: Univerza v Mariboru, Fakulteta za organizacijske vede.

Michaud, M., \& Pavčič, T. (2013). Vseslovenska raziskava o učinkovitosti črpanja evropskih nepovratnih sredstev [Slovene research on the effectiveness of the utilization of EU grants]. Ljubljana: CNVOS.

Moussis, N. (1999). Evropska unija (pravo, ekonomija, politika) [The European Union (law, economics, politics)]. Littera picta.

Mrest. (2012). Kako se uspešno prijaviti na razpis [How to successfully apply for grant]. Sklad dela Zasavje.

Mulec, B. (2008). Kohezijska politika Evropske unije [Cohesion policy of the European Union]. Ljubljana: Založba Koščak.

Računsko sodišče RS. (2013). Poenostavitve sistema izvajanja evropske kohezijske politike: Revizijsko poročilo [Simplification of the implementation system of European cohesion policy: Audit report]. Ljubljana: Računsko sodišče Republike Slovenije. 
M. Michaud, M. Maletič \& D. Vuk: Effective Absorption of European Funds

Rudolf, M., \& Struna, D. (2008). Nujno moramo izboljšati uspešnost črpanja sredste in kohezijske politike [We urgently need to improve successfulness of absorption of funds and cohesion policy] Glas Gospodarstva, 18-19.

Stern, B. (2011). Evropska nepovratna sredstva. Službeno gradivo [European grants. Official material]. Pro-Eco d.o.o.

Vila, A. (2000). Organizacija v postmoderni družbi [The organization in postmodern society]. Kranj: Moderna organizacija.

Vuk, D.(1998). Metodologija raziskovalnega dela [The methodology of research work]. Kranj: Moderna organizacija.

Vuk, D.(2008). Zapiski predavanj [Lecture notes]. Kranj: Fakulteta za organizacijske vede.

Websites

Crawford D. (2013). What makes a good project manager. PM solutions. Retrieved April 20, 2016, from http://www.pmsolutions.com/resources/view/what-makes-a-good-project-managerl/

COR. (2015). Institutional bodies. Retrieved April 20 from http://cor.europa.eu/en/Pages/home.aspx

Electronic procurement. Supplement to the Official Journal of the European Union. (14.3.2013). Portal EU. Retrieved October 20, 2015, from http://ted.europa.eu/TED/main/HomePage.do

European cohesion funds for the development of Slovenia. (14.3.2013) Government portal with information about life in EU. Retrieved April 14, 2013, from http://www.evropa.gov.si/si/vsebina/novice/aktualne-teme/2009/evropska-kohezijskasredstva-za-razvoj-slovenije/

EU. (2016). EU institutions and bodies. (14.4.2016). EU. Retrieved April 14, 2016, from http://europa.eu/about-eu/institutions-bodies/index_sl.htm

EU Skladi. (2016). Cohesion 2020. (1.1.2014). The Republic of Slovenia Government Office for Development and European cohesion policy. Retrieved April 14, 2016, from http://www.euskladi.si/sl/ekp

Negotiations on the priorities and the budgetary framework for EU revenue and expenditure for the period 2014-2020. (29.6.2011). Government Office for Development and European Affairs. Retrieved December 15, 2013, from http://www.svrez.gov.si/si/teme_in_projekti/naslednji_vecletni_financni_okvir_evropske_uni jel

Stern B. (2016). European grants and their potential for development, research, investment and education. (21.4.2016). Publisher Forum Media. Retrieved April 21, 2016, from https://www.okolje.eu/wp-content/uploads/2015/05/Beno-Stern.pdf

Council of Europe. (14.4.2016). Council of Europe. Retrieved April 14, 2015, from http://www.coe.int/

Ministry of Education, Science and Sport. (29.11.2016). Retrieved January 25, 2017, from http://www.mizs.gov.si/si/delovna_podrocja/direktorat_za_znanost/sektor_za_znanost/dogod ki_in_obvestila/mednarodna_konferenca_obzorje_2020_kje_smo_kako_naprej/ 
574 36 $6^{\text {Th }}$ International Conference on Organizational Science Development:

Responsible Organization (MARCH $22^{\mathrm{ND}}-24^{\mathrm{TH}}$, PORTOROŽ SLOVENIA) 
36. MEDNARODNA KONFERENCA O RAZVOJU ORGANIZACIJSKIH ZNANOSTI: ODGOVORNA ORGANIZACIJA (22. - 24. MAREC 2017, PORTOROŽ, SLOVENIJA)

O. Arsenijević, M. Ferjan, I. Podbregar, P. Šprajc, D. Trivan \& Y. Ziegler

\title{
Sistematični pristop k evalvaciji izobraževalnih programov
}

\author{
GOZDANA MigLiČ
}

Povzetek Namen prispevka je pojasniti temeljne značilnosti in prednosti sprotne ter stalne evalvacije oblikovanja in izvajanja programov izobraževanj ter spremljanja posledic izobraževanja, zlasti z vidika posameznika in njegovega neposrednega delovnega okolja. Dodatni namen prispevka pa je tudi spodbuditi zaposlene, še posebej vodilne delavce in kadrovske specialiste, $\mathrm{k}$ evalvaciji izobraževanja kot enemu izmed virov informacij za načrtovanje izobraževanja zaposlenih.

KLJUČNE BESEDE: evalvacija $•$ proces izobraževanja - izobraževalni programi $\bullet$ reakcija $\bullet$ učenje $\cdot$ vedênje $\cdot$ rezultati

NASlOV AVtORICE: dr. Gozdana Miglič, docentka, Univerza v Mariboru, Fakulteta za organizacijske vede, Kidričeva cesta 55a, 4000 Kranj, Slovenija, e-mail: gozdana.miglic@ fov.unimb.si 
$36^{\text {TH }}$ InTERnational CONFERENCE ON ORganizational SCIENCE Development: Responsible Organization (MARCH $22^{\mathrm{ND}}-24^{\mathrm{TH}}$, PORTOROŽ SLOVENIA)

O. Arsenijević, M. Ferjan, I. Podbregar, P. Šprajc, D. Trivan \& Y.

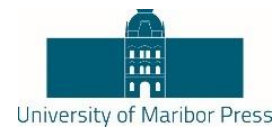
Ziegler

\title{
Systematic Approach to the Training Programmes Evaluation
}

\section{GOZDANA MigLIČ}

\begin{abstract}
The aim of this paper is to explain the basic characteristics and advantages of regular and permanent evaluation of how training programmes are devised and performed and what their results are, especially from the point of view of the individual and his/her direct working environment. A further aim of the paper is to encourage employees, especially managers and human resources specialists, to evaluate training as it is one of the sources of information for the planning of employees training.
\end{abstract}

KEYWORDS: evaluation $\bullet$ training process $\bullet$ training programs $\bullet$ reaction $\bullet$ learning $\bullet$ behavior $\bullet$ results

Correspondence Address: Gozdana Miglič, Ph.D., Assistant Professor, University of Maribor, Faculty of Organizational Sciences, Kidričeva cesta 55a, 4000 Kranj, Slovenia, e-mail: gozdana.miglic@fov.uni-mb.si 


\section{Pomen izobraževanja za organizacije in posameznike}

Družba in svet, v katerem živimo, se naglo spreminjata. Posledic teh intenzivnih sprememb ne moremo $\mathrm{v}$ celoti napovedati, vendar moramo biti nanje čim bolj pripravljeni. Eden možnih in najbolj ustreznih odgovorov na izzive spreminjajočega se okolja je prav gotovo nenehno posodabljanje obstoječega znanja in pridobivanje novega.

Vzporedno z zasičenostjo trga delovne sile se veča tudi potreba po dodatnih znanjih in veščinah, po nenehnem dopolnjevanju, posodabljanju in prilagajanju obstoječih kompetenc. Meje med poklicnim in splošnim znanjem izginjajo in vse bolj govorimo o zaposljivosti oseb in manj o poklicih. Vedno bolj postaja očitna potreba po interdisciplinarnosti, ki zahteva, da posameznik hkrati obvladuje več znanj in delovnih spretnosti.

Da sta opravičljiva, morata izobraževanje in razvoj prispevati $\mathrm{k}$ doseganju organizacijskih ciljev. Čeprav izobraževanje ni vedno pravo »zdravilo« za vse organizacijske bolezni, pa lahko kakovostni programi izobraževanja dosežejo pozitivne rezultate. Na tržišču obstoja široka ponudba vsakovrstnih programov izobraževanja, za katere pa bi bilo nestvarno misliti, da temeljijo na ustreznih ocenah potreb ali pa da je preizkušena njihova sposobnost doseganja učnih ciljev. Njihovi uporabniki ne pridobivajo informacij, s katerimi bi ugotavljali in določali koristnost takšnih programov. Pogosto so edine ocene programov, ki so na voljo organizaciji, ocene, ki jih o programih izdelajo njihovi izvajalci, te pa ne vključujejo prenosa znanja. Evalvacija uspešnosti izobraževanja tako ne seže prek merjenja reakcije in le redke so primerjave vedenja in delovnih rezultatov udeležencev izobraževanja pred in po izobraževanju (Dahiya in Ajeya, 2011). To potrjuje tudi v ZDA narejen pregled uporabljanih evalvacijskih metod, ki dokazuje, da večina evalvacij ( 86 \%) zajema le reakcije udeležencev neposredno po končanem izobraževanju (Eseryel, 2002). Pozitivne reakcije so sicer pomembne, vendar pozitivni občutki ne pomenijo nujno tudi ustrezne stopnje pridobljenega znanja. Sorazmerno malo je bilo poizkusov zbrati podatke, nanašajoč se na spremembe delovne uspešnosti udeležencev izobraževanj, s pomočjo zasledovanja dolgoročnih učinkov izobraževanja na delovnem mestu (angl. follow-up). Le evalvacija, pri kateri tako udeleženec kot tudi njegova organizacija skupaj ugotavljata, ali je določen program izpolnil želena pričakovanja, lahko zagotovi smernice za morebitne spremembe organizacijske strategije izobraževanja in razvoja.

Ob navedenem pa ne smemo zanemariti tudi pomena sredstev, vloženih v izobraževanje. Sredstva, namenjena izobraževanju, bodo koristno porabljena le, če bo posledica izobraževanja izboljšana učinkovitost zaposlenih in če bo imela organizacija neposredno korist. Če je izobraževanju dodana merljiva vrednost, ga vodilni kadri sprejemajo kot pomembnega za organizacijskih uspeh, $\mathrm{v}$ nasprotnem primeru pa ga ocenjujejo kot odvečni način porabe sredstev ter ga ne podpirajo in ne spodbujajo. 
$36^{\text {Th }}$ International Conference on Organizational Science Development: Responsible Organization (MARCh $22^{\mathrm{ND}}-24^{\mathrm{TH}}$, Portorož Slovenia) G. Miglič : Systematic Approach to the Training Programmes Evaluation

\section{Opredelitev evalvacije v izobraževanju}

Pojem evalvacija razlagamo na različne načine. Splošna definicija evalvacija izobraževanja pravi, da je to proces zbiranja informacij, katerega cilj je izboljšati odločanje, povezano z izobraževanjem; vključuje tako subjektivna stališča udeležencev izobraževanja, kot tudi objektivna dejstva (ITOL, 2017; Learning, Training, and Human Performance Glossary, 2017).

Druga definicija je nekoliko širša in opredeljuje evalvacijo izobraževanja kot »...vsak poskus zagotoviti povratne informacije o učinkih izobraževalnega programa in ocena vrednosti izobraževanja, glede na dobljene informacije« (Hamblin, 1974, v Fayolle, 2007). Opredelitev poudarja nujnost preučevanja situacije pred izobraževanjem in po njem, pri čemer je treba upoštevati posameznike, njihovo znanje, veščine in odnos ter njihove sposobnosti uporabe le-tega pri doseganju organizacijskih ciljev. V okviru izobraževanja in razvoja morajo zato biti ocenjene vse okoliščine, ki vplivajo na posameznikovo sposobnost združevanja njegovega znanja in veščin.

Omeniti velja tudi tretjo opredelitev, ki poudarja pospeševalno dimenzijo evalvacije. Evalvacijo pojmuje kot orodje vodilnih delavcev za pospeševanje učenja in olajševanje aktivnosti, povezanih z učenjem. Definicija pravi, da je evalvacija učenje in hkrati proces kar se le da sistematičnega in objektivnega odločanja o smotrnosti, ustreznosti, učinkovitosti in vplivu učenja na delo posameznika s ciljem izboljšati trenutne in naslednje učne aktivnosti, npr. načrtovanje, oblikovanje izobraževalnih programov, načrtovanje in izvedba neposrednega izobraževanja (Developing, 2011).

Najbolj poenostavljeno, hkrati pa tudi omejeno pojmovanje evalvacije je, da kot zadnja faza zaključuje proces sistematičnega izobraževanja. Evalviranje uspešnosti izobraževanja je nepogrešljiv element vsakega sistematičnega pristopa $\mathrm{k}$ izobraževanju. Vrednotenje izobraževanja je kontinuiran proces, ki mora biti prisoten $\mathrm{v}$ vseh stopnjah cikla izobraževanja in zajema primerjanje želenih rezultatov izobraževanja $\mathrm{z}$ dejanskim dosežki. Faza evalvacije poteka skozi celoten proces izobraževanja. To v praksi pomeni, da poteka vzporedno s fazami analize, oblikovanja, razvijanja in implementacije izobraževanja. Evalvacija je $\mathrm{v}$ tem primeru proces določanja vrednosti in učinkovitosti programov izobraževanja. Njen namen je zbrati in dokumentirati delovno učinkovitost udeležencev izobraževanja med izobraževanjem in kasneje na delovnem mestu, ugotoviti morebitne probleme in jih odpraviti (Goldstein, 1993).

Ne glede na razlike med posameznimi opredelitvami, je evalvacija proces zbiranja informacij, katerega cilj je kakovostno odločanje in vključuje tako subjektivni/kvalitativni vidik (mnenje), kakor tudi objektivni/kvantitativni (dejstva) vidik.

\section{$3 \quad$ Tipi evalvacije izobraževanja}

Evalvacijski nameni so na splošno razvrščeni v tri širše kategorije, iz katerih izvirajo trije glavni tipi evalvacij, in sicer analiziranje potreb po izobraževanju in načrtovanje 
izobraževanja ter formativna in sumativna evalvacija. Večina evalvacij je oblikovana tako, da ustreza vsem trem namenom, čeprav se poudarek na vsakem izmed njih spreminja med posameznimi stopnjami evalvacijskega procesa. Zaradi svojevrstnega zlivanja namenov je razlikovanje med različnimi tipi evalvacije včasih zamegljeno, vendar pa razlikovanje njihovih namenov pomaga pri razumevanja evalvacijskih postopkov (Guskey, 2003).

\subsection{Analiziranje potreb po izobraževanju in načrtovanje izobraževanja}

Načrtovanje izobraževanja je prvi korak v nizu programskih dejavnosti in je izhodišče za vse nadaljnje dejavnosti, tudi evalvacijske. Vključuje oceno, običajno temelječo na vnaprej določenih standardih programa ali poglavitnih lastnostih izbranih dejavnosti, na podlagi katere so podrobno opredeljeni cilji izobraževanja, predlog ali načrt njihovega doseganja, koncept, ki podpira izbrani načrt, celovit evalvacijski načrt in oceno izvedljivosti skupaj s trajanjem ter dosegljivimi viri.

Ta tip evalvacije je pravzaprav ocena potreb po izobraževanju, ki pri modelu sistematičnega izobraževanja pomeni njegovo prvo fazo, $v$ praksi pa je tako tesno povezana $\mathrm{z}$ evalvacijo uspešnosti in učinkovitosti izobraževanja, da lahko velja za prvi korak evalvacije. Zaradi tega je včasih označena tudi kot predformativna evalvacija (angl. preformative evaluation) (Scriven, 1991, v Guskey, 2003) ali kot preventivna evalvacija. Pomaga namreč pri ugotavljanju, ali so načrtovane dejavnosti ustrezne za doseganje pričakovanih ciljev, poleg tega pa omogoča tudi izslediti in pravočasno odpraviti težave, ki bi se lahko pojavile v nadaljnjih fazah evalvacije, s čimer omogoča doseganje še drugih evalvacijskih namenov. Poleg ugotavljanja in ocenjevanja potreb po izobraževanju vključuje še oceno značilnosti udeležencev oz. ciljne skupine, ki ji je izobraževanje namenjeno, analizo vsebin izobraževanja standarde in merila uspešnosti doseganja izobraževalnih ciljev in delovne uspešnosti, analizo značilnosti delovnega okolja in možnosti uporabe novega znanja ter spretnosti, vključno z morebitnimi ovirami ipd.

\subsection{Formativna - notranja evalvacija izobraževanja}

Analiziranju potreb po izobraževanju in načrtovanju sledi formativna evalvacija, ki ugotavlja prednosti in slabosti programa izobraževanja v njegovih razvojnih fazah. Zbira informacije o programu med njegovo izvedbo in tik po njem, pri čemer pretežno uporablja kvalitativne analitične metode (Patton, 2002).

Njen namen je zagotoviti sprotne informacije o poteku načrtovanih dejavnosti in o pričakovanem napredku, dobljene informacije pa so podlaga za morebitne izboljšave (Scriven 1967, v Guskey, 2003). Njen namen ni dokazovati ali ugotavljati veljavnost in uspešnost izobraževanja, temveč najti in odpraviti konkretne težave $\mathrm{v}$ razvijanju programa. Ugotavlja, kako najbolj poudariti in izkoristiti učni proces oz. izboljšati konkreten program, politiko, skupino ljudi (evalvacija zaposlenih), proizvod ali storitev. 
Ker je njen namen izboljšati učinkovitost posegov znotraj preučevanega okolja, je omejena le na konkretne okoliščine, pri čemer ni posploševanja ugotovitev prek meja okolja, v katerem se izvaja. Zato pri formativni evalvaciji prevladuje poudarek na procesih (procesna evalvacija), ki delujejo znotraj programov, in ne toliko na njegovih rezultatih, ob upoštevanju, da cilji izobraževanja niso statična komponenta. Je kot notranji sistem vodenja, ki zagotavlja informacije za sprotne ali kasnejše prilagoditve programa (angl. »form and inform«) (Burnham, 1995).

Večinoma je formativna evalvacija ponavljajoči se proces $\mathrm{v}$ življenju posameznega izobraževalnega programa. Je sestavni del programa in je vključena že $\mathrm{v}$ njegovo zasnovo, je t. i. evalvacija »od spodaj in od znotraj« (zato pogosto imenovana tudi notranja evalvacija), pri čemer je tudi evalvator dejavni udeleženec programa (Macur, 1995). Da bi ostala formativna evalvacija učinkovita in da bi se izognili nerealističnim pričakovanjem, jo Scriven (1991, v Guskey, 2003) priporoča kot »zgodnje svarilo«, kar pomeni, da naj bi bila formativna evalvacija zgodnja verzija zaključne, celovite evalvacije.

Formativna evalvacija se usmerja na uspešnost vseh ključnih funkcij izobraževanja ter zajema njegove najbolj pomembne in opazne vidike, npr. izvajalca izobraževanja, reakcije udeležencev, porabo virov (npr. finančni, materialni, kadrovski) ipd. Na ta način ugotavlja področja, na katerih se kažejo morebitna nestrinjanja ali negotovosti sodelujočih Clardy, 2012)..

\subsection{Sumativna - zunanja evalvacija izobraževanja}

Sumativna evalvacija, ki se izvaja s primerjavo med načrtovanimi cilji, stroški in stranskimi učinki po koncu programa ali tik pred njim, ugotavlja, ali so izobraževanju sledile merljive spremembe delovne uspešnosti, $v$ nadaljevanju pa skuša presojati tudi vrednost teh sprememb (Bramley, 2003).

Njen namen je s presojo uspešnosti in učinkovitosti programa pri doseganju ciljev ter $\mathrm{z}$ ugotavljanjem dosežene vrednosti programa zagotoviti celovito oceno programa. Opisuje, kaj je bilo doseženo, kakšne so posledice (pozitivne, negativne), kakšni so končni rezultati (pričakovani in nepričakovani) in včasih tudi, ali koristi opravičujejo stroške. To je t. i. evalvacija »od zgoraj in od zunaj« (Burnham, 1995; Macur, 1995), ki povzema programske rezultate in ocenjuje skupno vrednost predmeta evalvacije, pri čemer so njeni temeljni nameni povezani z odgovornostjo.

Medtem ko formativna evalvacija poudarja presojo oblike in poteka procesa z uporabo meril procesa ter daje povratne informacije o pripravi in izvedbi izobraževanja, sumativna evalvacija uporablja za oceno programa izobraževanja merila rezultatov ter zagotavlja povratno informacijo o uspešnosti procesa. Formativna evalvacija je torej namenjena izboljšanju, sumativna pa zagotavlja informacije za odločitve, povezane s programi (nadaljevanje ali ukinitev programa, prilagoditve, razširitev itd.) (Reid, Barrington, Brown, 2004). 
Bramley (2003) sumativno evalvacijo deli v dva koraka: izolacija rezultatov ali učinkov programa ter določitev »valute« oz. veljave teh učinkov. Pri tem so najpogostejša vprašanja: ali je program povzročil spremembe $\mathrm{v}$ učenju, se je delovna uspešnost udeležencev po izobraževanju povečala, so se kazalci organizacijske uspešnosti izboljšali ali so ostali enaki, kakšna je vrednost sprememb ipd.

Za izobraževanje so pomembni vsi trije tipi evalvacije - analiza potreb po izobraževanju ter formativna in sumativna evalvacija. Nobena izmed evalvacij naj ne bi bila zanemarjena, saj bi tako manjkale pomembne informacije o načrtovanju, razvijanju in izvedbi izobraževanja. Uporaba posameznega tipa se spreminja glede na potek programa izobraževanja, vsi trije pa so enako pomembni za celovito evalvacijo.

\section{$4 \quad$ Razlogi za evalvacijo izobraževanja}

Evalvacija kot proces določanja vrednosti in učinkovitosti izobraževanja praviloma nudi odgovore na vprašanja o vplivu izobraževanja na posameznike in organizacijo, o povračilu v izobraževanje vloženih sredstvih, o uporabi novih znanj in veščin $\mathrm{v}$ delovnem okolju, o vplivu programov na spreminjanje nagnjen, vedenja ali veščin ter prek tega na delovne rezultate udeležencev (Fayolle, 2007).

Učinkovita evalvacija je torej ključna tako za izobraževanje neposredno, kakor tudi za funkcijo izobraževanja v širšem smislu. Pogosto je evalvacija razumljena kot nekaj, kar se izvaja, če je čas. V marsikateri organizaciji nadomeščajo evalvacijo $\mathrm{z}$ občutkom: »kaže, da je v redu, kar nadaljujmo s tem«. Tudi tam, kjer se evalvacija izvaja, ima večinoma le vlogo orodja, ki je uporabljeno po končanem izobraževanju, nikakor pa ne tudi vloge pomoči pri načrtovanju in spremljanju organizacijskega izobraževanja skozi različne stopnje razvoja in implementacije (Boehle, 2006; Clark, 2017; Reay, 1994).

Razlogi za evalvacijo se razlikujejo glede na vloge in odgovornosti, ki jih imajo v procesu izobraževanja posamezniki ali skupine. Ne glede na to pa za evalvacijo obstaja vsaj pet temeljnih razlogov (Fayolle, 2007; Bramley, Newbay, 1990, v Goldstein, 1993):

- povratna informacija - povezovanje učnih rezultatov z učnimi cilji in zagotavljanje kakovosti;

- nadzor - povezovanje med izobraževanjem in organizacijskimi aktivnostmi, upoštevajoč stroškovno učinkovitost;

- raziskava - določanje razmerja med učenjem, izobraževanjem in prenosom znanja na delovno mesto;

- intervencija - vpliv rezultatov evalvacije na okoliščine, v katerih je vrednotenje izvedeno;

- vplivnost - uporaba evalvacijskih podatkov $\mathrm{v}$ okviru organizacijske politike odločanja. 
$36^{\text {Th }}$ International Conference on Organizational Science Development: Responsible Organization (MARCh $22^{\mathrm{ND}}-24^{\mathrm{TH}}$, Portorož Slovenia) G. Miglič : Systematic Approach to the Training Programmes Evaluation

\subsection{Zagotavljanje povratnih informacij o oblikovanju in izvajanju programov izobraževanja}

Evalvacija je še posebej pomembna $\mathrm{v}$ smislu zagotavljanja negativnih povratnih informacij na objektiven način. Veliko organizatorjev in izvajalcev izobraževanja vidi v evalvaciji sredstvo potrjevanja uspešnosti svojega dela. To je sicer prav in je tudi eden izmed ključnih namenov evalvacije. Kljub temu pa so negativne povratne informacije pomembnejše, saj pomagajo ugotoviti spremembe, ki so nujne, da postane program/aktivnost še bolj učinkovit, in vrste modifikacij, ki morajo biti vpeljane v vsebino, strategijo, metode/tehnike, učne pripomočke itd. (Dahiya in Ajeya, 2011).

Evalvacija v tem smislu je dragoceno orodje za spreminjanje in izboljševanje aktivnosti izobraževanja. To je še posebej pomembno, kadar se določene aktivnosti ponavljajo skozi daljše obdobje in izkušnje prvih skupin bogatijo koristi nadaljnjih.

Z vidika oblikovanja, načrtovanja in izvajanja izobraževanja ter učenja se glavni razlog za evalvacijo nanašajo na (Reid et al., 2004; Tziner, Fisher, Senior in Weisberg, 2007):

- zagotavljanje povratnih informacij izvajalski instituciji o uspešnosti in kakovosti ugotavljanja potreb po izobraževanju posameznih ciljnih skupin, o oblikovanju programov, o organizaciji njihove izvedbe itd.;

- ugotavljanje primernosti programa izobraževanja za posamezne ciljne skupine udeležencev;

- zagotavljanje povratnih informacij izvajalcu izobraževanja o uspešnosti podajanja in uporabljenih metodah (je del njegove učne izkušnje);

- možnosti sprotnih izboljšav že med potekom izvajanja programa izobraževanja ali ob naslednji ponovitvi;

- spremljanje in evalviranje učnega napredka udeleženca (je del njegove notranje motivacije in del njegovega učnega procesa);

- ugotavljanje, do katere mere so bili doseženi posameznikovi učni cilji oziroma ali bo potrebno še nadaljnje izobraževanje.

\subsection{Zagotavljanje povratnih informacij o porabi virov}

Pomemben razlog za evalvacijo je vpliv njenih rezultatov na odločitve o razporejanju virov, namenjenih izobraževanju (npr. načrtovanje finančnih sredstev). Koristnost izobraževanja ni samo po sebi umevna in avtomatična, ampak morajo organizatorji in oblikovalci izobraževanj pogosto opravičevati porabo sredstev, namenjenih izobraževanju in dokazovati, da izobraževanje prispeva $\mathrm{k}$ celoviti uspešnosti organizacije. Organizatorji in izvajalci izobraževanj morajo biti pripravljeni dokazovati, da so čas, napori in denar, porabljeni za načrtovanje in izvajanje izobraževanja, prinesli rezultate, ki opravičujejo investicijo (Dahiya in Ajeya, 2011). 
Z vidika organizacije, ki napotuje svoje zaposlene na izobraževanje, je tako najpomembnejši razlog za evalvacijo zagotavljanje informacij, potrebnih za (Reay, 1994):

- presojo učinkovitosti uporabe virov, namenjenih izobraževanju in razvoju;

- izboljšanje prihodnjega dela in povečanja učinkovitosti programov izobraževanja;

- ugotavljanje obsega, do katerega je izobraževanje prispevalo k reševanju organizacijskih problemov;

- pridobivanje stalnih povratnih informacij o veljavnem sistemu izobraževanja, aktualnosti programskih vsebin, kakovosti izvedbe itd.;

- zagotavljanje sredstev za ocenjevanje organizacije, ki izvaja izobraževanje, in ugotavljanje, katera izvajalska organizacija zmore in zna bolje zadovoljiti potrebe naročniške organizacije;

- utemeljevanje upravičenosti funkcije izobraževanja v organizaciji.

\section{$5 \quad$ Ravni in vidiki evalvacije izobraževanja}

Kategorizacija evalvacijskih aktivnosti $\mathrm{v}$ določeno hierarhijo je predmet številnih teoretičnih razprav. Tradicionalni koncept oziroma model evalvacije izobraževanja datira v pozna šestdeseta leta prejšnjega stoletja in je povezan z delom Donalda Kirkpatricka (1967). Ta koncept, ki velja za temeljnega, so v nadaljevanju dograjevali številni teoretiki in praktiki, kot so npr. Bramley, Newby (1984), Goldstein (1993), Jons (1970), Marsden (1991), Sunita in Ajeya (2011), Warr, Bird in Rackham (1970).

Kirkpatrickov tradicionalni štiri stopenjski model, ki je tudi najpogosteje uporabljen v praksi, predstavlja strukturiran pristop $\mathrm{k}$ evalvaciji programov izobraževanja. Temelji na izobraževalnih ciljih in zagotavlja osnovo za strogo povezavo z analizo potreb po izobraževanju. Model priporoča več vzporednih merjenj in vključuje merjenje neposredne reakcije udeležencev po končanem izobraževanju, merjenje učenja v okviru programov izobraževanja, vedenjskih sprememb na delovnem mestu in ugotavljanje končne koristnosti celotnega izobraževanja (Kirkpatrick, 1998).

Evalvacija izobraževanja se torej izvaja na štirih ravneh, od katerih vsaka zahteva drugačne evalvacijske tehnike (Kirkpatrick, 1998; Rajeev, Madan in Jayarajan, 2009):

- izhodiščna raven - reakcija: meri, kaj udeleženci izobraževanja mislijo in čutijo o izobraževanju;

- takojšnja raven - učenje: meri, kaj se udeleženci naučijo med izobraževanjem;

- vmesna raven - vedenje: meri učinke izobraževanja na posameznikovo delovno uspešnost;

- končna raven - rezultati: meri učinke izobraževanja na organizacijsko učinkovitost (Preglednica 1). 
Za izvajane evalvacije je treba določiti cilje za vsako izmed ravni. Evalvacija je najlažja na prvi in drugi ravni, medtem ko se na višjih zahtevnost procesa strmo povečuje. Kot že rečeno, je bilo sorazmerno malo poizkusov zbrati podatke, nanašajoč se na spremembe delovne uspešnosti udeležencev izobraževanj, s pomočjo zasledovanja dolgoročnih učinkov izobraževanja na delovnem mestu. Le evalvacija, pri kateri tako udeleženec kot tudi njegova organizacija skupaj ugotavljata, ali je določen program izpolnil želena pričakovanja, lahko zagotovi smernice za morebitne spremembe strategije izobraževanja in razvoja (Bramley, 2003). Eden izmed razlogov so težave merjenja in problem ločevanja vzrokov in posledic na višjih ravneh. Ker so organizacijske spremembe povezane s številnimi vzroki, je pogosto težko natančno določiti, koliko je npr. zmanjšanje pritožb strank samo rezultat določenega izobraževanja. K težavnosti evalvacij na višjih ravneh prispeva tudi časovni zamik med zaključkom izobraževanja in njegovimi učinki na organizacijo. Ne glede na to pa je dejstvo, da bolj ko je evalvacija dosledna, kakovostna in uspešna na začetnih ravneh, večja je verjetnost, da izobraževanje vpliva na učinkovitost posameznega oddelka in organizacije kot celote (Reid et al., 2004). 

ORGANIZACIJA (22. - 24. MAREC 2017, PORTOROŽ, SLOVENIJA) G. Miglič : Sistematični pristop k evalvaciji izobraževalnih programov

Preglednica 1: Povzetek poteka evalvacije izobraževanja na vseh štirih ravneh

\begin{tabular}{|c|c|c|c|}
\hline RAVEN & DEJAVNOSTI & $\begin{array}{c}\text { KOMPONENTE DODANIH } \\
\text { VREDNOSTI }\end{array}$ & NAČIN OCENJEVANJA \\
\hline 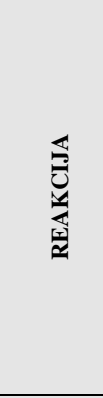 & $\begin{array}{l}\text { Na podlagi } \\
\text { ugotovljenih potreb } \\
\text { je program } \\
\text { oblikovan ali izbran } \\
\text { in izveden. }\end{array}$ & $\begin{array}{l}\text { Izvedena analiza potreb } \\
\text { po izobraževanju, izdelan } \\
\text { načrt izobraževanja, } \\
\text { določene ciljne skupine, } \\
\text { izbrane metode učenja, } \\
\text { izdelana učna gradiva, } \\
\text { izdelan urnik, določen } \\
\text { kraj izvedbe. }\end{array}$ & $\begin{array}{l}\text { Evalvacijski vprašalniki merijo } \\
\text { reakcijo udeležencev glede na: } \\
\text { vsebino, ustreznost in obseg } \\
\text { izobraževanja; homogenost, } \\
\text { sodelovanje v skupini; učne } \\
\text { metode interaktivnost, zabavnost) } \\
\text { in pripomočke, } \\
\text { uporabnost in grafični videz učnih } \\
\text { gradiv, čas izvedbe, trajanje, } \\
\text { primernost lokacije, namestitev, } \\
\text { postrežbo ipd. }\end{array}$ \\
\hline 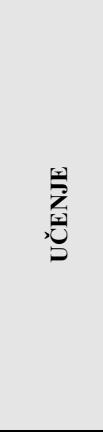 & $\begin{array}{l}\text { Udeležencem so } \\
\text { posredovane } \\
\text { vsebine programa } \\
\text { izobraževanja } \\
\text { (znanje, spretnosti, } \\
\text { odnosi). }\end{array}$ & $\begin{array}{l}\text { Posredovano znanje } \\
\text { (dejstva, pravila, } \\
\text { postopki, politike, } \\
\text { koncepti, teorije); } \\
\text { izoblikovani odnosi } \\
\text { (vrednote, dojemanja, } \\
\text { prepričanja, slogi, } \\
\text { občutki); } \\
\text { utrjevanje različnih tipov } \\
\text { spretnosti (percepcijske, } \\
\text { verbalne, kognitivne, } \\
\text { ročne, psihomotorične). }\end{array}$ & $\begin{array}{l}\text { Evalvacija učenja udeležencev z } \\
\text { različnimi testi, simulacijami itd. } \\
\text { po končanem izobraževanju. }\end{array}$ \\
\hline 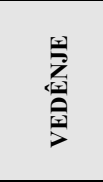 & $\begin{array}{l}\text { Učenci prenašajo } \\
\text { vedênje iz učilnice } \\
\text { na delovna mesta. }\end{array}$ & $\begin{array}{l}\text { Izboljšanje } \\
\text { posameznikovih kazalcev } \\
\text { delovne uspešnosti: } \\
\text { obseg dela, kakovost dela, } \\
\text { poraba časa. }\end{array}$ & $\begin{array}{l}\text { Delovne rezultate oz. } \\
\text { spremenjeno delovno uspešnost } \\
\text { udeleženca meri udeleženec sam } \\
\text { in/ali drugi. }\end{array}$ \\
\hline 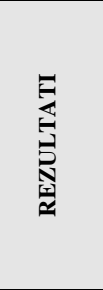 & $\begin{array}{l}\text { Posledica izboljšane } \\
\text { delovne uspešnosti } \\
\text { je spremenjena } \\
\text { uspešnost } \\
\text { organizacije. }\end{array}$ & $\begin{array}{l}\text { Izboljšanje kazalcev } \\
\text { organizacijske uspešnosti: } \\
\text { produktivnost,dobiček, } \\
\text { timsko delo, število } \\
\text { nezgod, } \\
\text { manj odsotnosti z dela, } \\
\text { manj zapuščanja } \\
\text { organizacije. }\end{array}$ & $\begin{array}{l}\text { Analiza stroškov in koristi ter } \\
\text { primerjava različnih podatkov } \\
\text { pred izobraževanjem } \\
\text { in po njem. }\end{array}$ \\
\hline
\end{tabular}

\section{Diskusija}

Pomen evalvacije izobraževanja se je spreminjal skozi obdobja, in sicer vzporedno s spreminjanjem vloge in pomena izobraževanja. V zgodnjih 80 . letih 20. stoletja je bila evalvacija povezana z ugotavljanjem pomena funkcije izobraževanja, katerega cilj je bilo opravičevati njegov obstoj pred najvišjim vodstvom, predvsem tistim, ki zagotavlja 
$36^{\mathrm{TH}}$ International Conference on ORganizational Science Development: Responsible ORGanization (MARCH $22^{\mathrm{ND}}-24^{\mathrm{TH}}$, Portorož SLOVENia) G. Miglič : Systematic Approach to the Training Programmes Evaluation

finančna sredstva in odloča o izobraževanju. V sredini 80. let se je zanimanje prevesilo $\mathrm{k}$ razvijanju in standardiziranju evalvacijskih postopkov, v zgodnjih 90. pa je bil glavni poudarek evalvacije na dokazovanju kakovosti izvajalcev in organizatorjev izobraževanja. Ti poudarki prevladujejo tudi zdaj (Developing, 2011).

Iz evalvacijske literature (npr. Fayolle, 2007; Kirkpatrick, 1998; Sunita in Ajeya, 2011) je razvidno, da večina praktikov in teoretikov označuje evalvacijo kot najtežjo izmed vseh dejavnosti, povezanih z izobraževanjem. To nikakor ne preseneča, saj je evalvacija slabo opredeljena, pri čemer ima različne pomene glede na udeležence in okoliščine evalvacije. Pregled literature namreč odkriva številne opredelitve evalvacije in opazno nedoslednost pri uporabi z njo povezanih pojmov, kar povzroča še dodatne težave pri uvajanju evalvacije v prakso.

Tako kot so številne opredelitve evalvacije, so deljena tudi mnenja o njenih namenih. Nameni evalvacije izobraževanja segajo od zelo nedoločenih, npr. "preizkušanje učinkovitosti učnih gradiv in programov » (Marsden, 1991), do zelo podrobnih in strnjenih modelov, ki skušajo vzporedno zadostiti več namenom. Med prevladujoča mnenja o namenih sodi prepričanje, da je evalvacija namenjena dokazovanju utemeljenosti obstoja oddelkov za izobraževanje, kar si je morda mogoče razložiti s pogostimi poskusi omejevanja sredstev, namenjenih izobraževanju, in s tem tudi delovanja teh oddelkov. Občasno pa se pojavlja tudi prepričanje, da sploh ni treba opredeljevati evalvacijskih namenov (kar ne pomeni hkrati, da evalviranje ni potrebno), saj so ti odvisni od različnih dejavnikov. Evalvacija naj bi tako bila odgovor na vprašanje, kaj želimo vedeti o izobraževanju, in naj bi bila oblikovana glede na želje tistih, ki jim bodo posredovane evalvacijske ugotovitve.

Čeprav le malo avtorjev meni, da je glavni namen evalvacije ugotavljanje reakcije udeležencev na izobraževanje, in jih večina soglaša, da je njen temeljni namen presojanje kakovosti in vrednosti programov s ciljem izboljšav ali/in ugotavljanja koristi izobraževanja, pa se večina evalvacij v praksi omejuje le na ugotavljanje reakcij na programe izobraževanja (Goldstein, 1993) in opisovanje različnih testiranj znanja in načinov dokazovanja obvladovanja spretnosti (Bramley, 2003). Sorazmerno malo pa je poizkusov zbrati informacije, nanašajoče se na morebitno povečanje delovne uspešnosti, s katerim bi posameznik in organizacija ugotovila, ali je program dejansko dosegel pričakovane rezultate (Sunita in Ajeya, 2011). To najverjetneje lahko razložimo z dejstvom, da večina izvajalcev izobraževanja razume oblikovanje in izvajanje izobraževanja kot svojo prvenstveno skrb. Poleg tega domnevamo, da je prevladujoče zanašanje in odvisnost od reakcije po končanem izobraževanju posledica neobvladovanja kvantitativnih tehnik merjenja in pomanjkanja finančnih sredstev, časa in izkušenosti z vsestransko evalvacijo. K temu pa brez dvoma lahko dodamo že omenjene nejasnosti, povezane z opredeljevanjem evalvacije, njenih značilnosti in namenov.

Vendar pa Bramley (2003) ugotavlja, da se zanimanje za evalvacijske metodologije, vključno $\mathrm{z}$ oblikovanjem meril, oblikovanjem evalvacijskih študij, preučevanjem etičnih vrednot in, ugotavljanjem težav $\mathrm{z}$ ocenjevanjem delovne uspešnosti $\mathrm{v}$ organizacijah, opazno povečuje. Organizacije prepoznavajo potrebo po uvajanju sistematičnega 
izobraževanja, posledica česar je povečano zanimanje za evalvacijo programov izobraževanja kot sredstvo ugotavljanja uspešnosti doseganja ciljev. S poudarjanjem kakovosti so programi izobraževanja pod vedno strožjim nadzorom, ki ga spodbuja tudi spremljanje učinkovitosti porabe sredstev, vloženih v izobraževanje.

Kljub temu pa lahko zatrdimo, da je za večino praktikov evalvacija še vedno sorazmerno omejena dejavnost, ki se izvaja (če se) pretežno po končanem programu. Takšno razmišljanje potrjuje tudi pregledana evalvacijska literatura, ki sicer poudarja vsestranskost, vendar večinoma pri teoretičnih izhodiščih in manj v praksi. Zasledili namreč nismo nikakršnih poročil o programih izobraževanja, pri katerih bi bili zbrani različni evalvacijski podatki od začetnega do končnega ocenjevanja, z njihovo primerjavo in analizo ter s pripravo zaključnega poročila in priporočil.

Cilji, ki jih želijo organizacije doseči z izobraževanjem, so številni in raznoliki. Čeprav izobraževanje ni vedno pravo sredstvo za premagovanje vseh organizacijskih težav, pa kakovostno oblikovan in izveden program izobraževanja prinaša koristne rezultate.

Beseda evalvacija celo sproža vrsto čustvenih obrambnih reakcij. Pogosto se zdi, da so težave povezane z napačnim razumevanjem vloge evalvacije, ki ne vključuje zavedanja, da so programi izobraževanja del dinamičnega procesa, zaradi česar jih je smiselno spremljati, dopolnjevati in obnavljati toliko časa, dokler niso doseženi pričakovani rezultati.

Evalvacija izobraževanja je proces zbiranja informacij, potrebnih za zadovoljitev specifičnih namenov, hkrati pa tudi proces določanja vrednosti in učinkovitosti programov izobraževanja. Evalvacija izobraževanja zbira informacije, potrebne za odločitve, povezane z izobraževanjem, ki se nanašajo na izbor, razvijanje ali prilagajanje učnih dejavnosti, nadzor kakovosti, ocenjevanja vračanja investicije v izobraževanje, ugotavljanje prihodnjih potreb po izobraževanju ali za povezovanje strategije izobraževanja $\mathrm{z}$ organizacijskimi cilji. S primerjavo med želenimi in dejanskimi rezultati zagotavlja nadzor nad programom med njegovim izvajanjem in nad veljavnostjo njegovih rezultatov.

Opredelitev evalvacije je povezana $\mathrm{z}$ določanjem njenih namenov. Sprva je bila večina evalvacijskih namenov omejena na dokazovanje opravičenosti obstoja oddelka za izobraževanje, na zagotavljanje koristi izobraževanja za organizacijo glede na vložena sredstva (analiza stroškov in koristi) in na ugotavljanje zadovoljstva udeležencev z izobraževanjem. Sčasoma so se izoblikovali še drugi nameni, npr. izboljšati program, sprejemati odločitve o programu in zagotavljati podatke potrebne za dokazovanje učinkovanja programa izobraževanja na vedênje ciljne skupine. V 90. letih 20. stoletja so se tako izoblikovali štirje evalvacijski nameni: a) ugotoviti, ali je izobraževanje doseglo cilje, b) odkriti tipe sprememb, ki jih morajo izvajalci izobraževanja vnesti, da bi izboljšali obliko, vsebino in izvedbo programa, c) informirati izvajalce izobraževanja, ali so udeleženci dosegli potrebno znanje in spretnosti, č) uravnotežiti stroške in rezultate izobraževanja (Burnham, 1995. 
$36^{\mathrm{TH}}$ InTERnAtional CONFERENCE ON ORganizational SCIENCE DeVElopment: RESPONSIBLE ORGANIZATION (MARCH $22^{\mathrm{ND}}-24^{\mathrm{TH}}$, PORTOROŽ SLOVENIA) G. Miglič : Systematic Approach to the Training Programmes Evaluation

Če povežemo problematiko opredelitve evalvacije $\mathrm{z}$ določanjem njenih namenov in ciljev, menimo, da naj bi vsaka opredelitev evalvacije izobraževanja vključevala več elementov, in sicer kaj evalvacija je, kaj vključuje in kakšen je njen namen. Glede na to opredeljujemo evalvacijo kot analitični proces, ki vključuje zbiranje in združevanje subjektivnih in objektivnih podatkov iz različnih virov, pridobljenih z različnimi tehnikami, o vseh (ali izbranih) fazah procesa izobraževanja. Evalvacija vodi k sintezi podatkov v poročilo, ki vključuje povzetek rezultatov in priporočila, nanašajoča se na evalvirani program.

Temeljni namen evalvacije je vplivati na odločitve o smiselnosti nadaljnjega izvajanja programa in morebitnih prilagoditvah ter zagotavljati podatke o razmerju med stroški programa in koristmi. Glede na to naj bi evalvacija zadovoljevala vsaj osem namenov:

- ugotavljanje veljavnosti orodij in metod analiziranja potreb po izobraževanju,

- preverjanje veljavnosti ugotovljenih potreb po izobraževanju in ciljev izobraževanja,

- preverjanje ali preoblikovanje izbranih rešitev,

- preverjanje ali preoblikovanje strategije izobraževanja,

- ugotavljanje reakcije udeležencev in izvajalcev izobraževanja,

- ocenjevanje obsega pridobljenega znanja in spretnosti pri udeležencih,

- ocenjevanje delovne uspešnosti udeležencev,

- ugotavljanje, ali so bili doseženi organizacijski cilji.

$\mathrm{Na}$ sploh za spodbujanje celovitosti evalvacije velja, da je celo manj uspešno kot spodbujanje celovitosti procesa izobraževanja ali sistema izobraževanja, ki smo ju obravnavali v prejšnjih poglavjih. Le malo je avtorjev (in še ti se pojavljajo šele od konca 80. in začetka 90. let 20. stoletja, npr. Kirkpatrick (1989), ki poudarjajo vsestransko evalvacijo, vključno z zbiranjem podatkov pred oblikovanjem programa oz. na njegovem začetku, med njegovim potekom, in poprogramske evalvacijske tehnike, združujoče različne metode zbiranja podatkov.

Pri evalvaciji se torej celovitost ne nanaša le na upoštevanje več organizacijskih ravni (in ne le individualne), ampak tudi na povezovanje različnih tipov evalvacije, $\mathrm{tj}$. od analize potreb po izobraževanju na posameznih ravneh organizacije do merjenja vplivov, ki jih je imelo izobraževanje na teh ravneh, hkrati pa zadovoljevanje pričakovanja različnih posrednih in neposrednih uporabnikov njenih rezultatov.

Kljub temu pa v praksi daleč prevladuje neposredno poprogramsko ugotavljanje reakcije udeležencev, vendar so tudi ti podatki redko uporabljeni (Marsden, 1991). Omejenost takšne evalvacije izhaja iz subjektivnosti dobljenih podatkov, ki ne dajejo nikakršnih informacij o tem, ali je izobraževanje prispevalo $\mathrm{k}$ doseganju organizacijskih ciljev, ciljev posameznika, neposrednih programskih ciljev ipd.

Glede na opisane pomanjkljivosti prevladujočega pogleda na evalvacijo menimo, da je potreben nov pogled, in sicer v obliki modela, ki bi povezoval več stopenj: 
- potrditev, ali je ugotovljena težava $\mathrm{v}$ resnici posledica pomanjkanja usposobljenosti in znanja, ter določitev dejanskih ciljev;

- določitev najustreznejše strategije izobraževanja;

- ugotovitev, ali je bila izbrana strategija uspešno udejanjena;

- ugotovitev, ali je prišlo do učenja in kakšen je njegov obseg;

- ugotovitev rezultatov uporabe novega znanja in spretnosti (na ravni posameznika);

- ugotovitev vplivov in vrednosti izobraževanja (na organizacijski ravni).

Preden zaključimo, želimo omeniti še pomen izbora metod ter tehnik za ugotavljanje sprememb, do katerih pride med prenašanjem znanja. Namen evalvacije opredeljuje vrsto potrebnih informacij, to pa vpliva na odločitev o izbiri najustreznejšega evalvacijskega orodja. Literatura je polna nasvetov o evalvacijskih tehnikah, ki marsikdaj obsegajo od enostavnih vprašalnikov do sestavljenih statističnih postopkov, pri čemer je ista tehnika pogosto opisana pod različnimi imeni. Poleg tega tudi ugotavljamo, da večini tehnik primanjkuje objektivnosti, zaradi česar je mogoče podatke razlagati tako, kot je v danem trenutku najustrezneje. Čeprav ne zanikamo pomena metodološkega vidika evalvacije, pa menimo, da je razumevanje evalvacije kot niza tehnik nepopolno, saj je evalvacijo treba razumeti v širšem pomenu in povezano z okoliščinami, v katerih se odvija.

Če povzamemo: prednosti evalviranja izobraževanja so različne in večplastne. Evalvacijo izobraževanja lahko razumemo kot diagnostično tehniko, ki omogoča presojo programa glede na doseganje različnih ciljev. Informacije se lahko uporabijo za izbiro ali preoblikovanje programa, za ugotavljanje, ali je udeležencem program všeč, ali so se česa naučili in ali je izobraževanje vplivalo na njihovo delovno uspešnost.

Spremljanje in evalviranje izobraževanja in njegovih rezultatov nista bistvena le za uspeh vsakega programa izobraževanja, ampak tudi za organizacije, ki vlagajo v razvoj svojih kadrovskih virov. Brez evalvacije ni gotovosti, da je program izobraževanja dosegel opredeljene cilje, da so ti cilji pravi za organizacijo ali da sta bili kakovost in ustreznost izobraževanja doseženi na stroškovno najprimernejši način. To pa so informacije, ki zagotavljajo učinkovitost načrtovanja prihodnjih učnih dogodkov.

Ne glede na prednosti evalvacija ne bo rešila vseh problemov, ki se pojavljajo pri izobraževanju, vendar je pomemben korak naprej. Mnogokrat lahko že uporaba povsem preprostega postopka, npr. testiranje udeležencev pred izobraževanjem in po njem, opazno izboljša veljavnost dobljenih informacij, vendar pa to še ni razlog za podcenjevanje njene kompleksnosti in zapostavljanje njene vloge kot dela oblikovanja programa izobraževanja in sploh kot del razvoja kadrovskih virov.

V sodobnem poslovnem okolju se vsi, ki so kakor koli povezani z izobraževanjem, nenehno srečujejo $\mathrm{z}$ gospodarnim odločanjem, $\mathrm{z}$ vprašanji razvojnih sposobnosti in 
$36^{\mathrm{TH}}$ InTERnATIONAL CONFERENCE ON ORganizational SCIENCE DeVElopment: Responsible Organization (MARCh $22^{\mathrm{ND}}-24^{\mathrm{TH}}$, Portorož Slovenia) G. Miglič : Systematic Approach to the Training Programmes Evaluation

vrednosti programov izobraževanja, ki jih ponujajo ali kupujejo. Vedno bolj se pojavljajo zahteve po dokazovanju kakovosti programov izobraževanja kot izhodišču odločanja o pomenu izobraževanja za organizacije. Pri ugotavljanju koristnosti izobraževanja in njegovega vpliva na delovno uspešnost posameznika in organizacije se porajajo številna vprašanja, npr. ali konkretni program izobraževanja vodi k izboljšani delovni uspešnosti, ali program dosega cilje, za katere je bil oblikovan, ali so izbrani načini izobraževanja in učenja učinkovitejši kot drugi ipd.

Odgovore na takšna in podobna vprašanja, temelječe na objektivnih dokazih, je mogoče dobiti le z evalvacijo, zaradi česar naj bi bila ta sestavni del procesa oblikovanja izobraževanja, še celo več - bila naj bi nedeljivi del funkcije izobraževanja. Žal pa večina organizacij ne ugotavlja koristnosti izobraževanja svojih zaposlenih ali pa je evalvacija omejena na iskanje najenostavnejših informacij.

\section{Literatura}

Boehle, S. (2006). Are You Too Nice to Train? Training Magazine. Dostopno na: http://www.trainingmag.com/msg/content display/training/e3iwtqVX4kKzJL\%2BEcpyFJFrFA\% 3D\%3D?imw=Y [11. 1. 2017].

Bramley, P. (2003). Evaluating Training Effectiveness. CIPD Publishing.

Burnham, R. B. (1995), Evaluating Human Resources, Programs, and Organisations, Malabar, Florida: Kreiger Publishing Company.

Clark, D. (2017). Instructional System Development- Evaluation phase. http://www.nwlink.com/ donclark/hrd/sat6.html [9. 1. 2017].

Clardy, A. (2012). The Management Training Tool Kit. AMACOM Div American Mgmt Assn. HRD Press.

Developing an Effective Evaluation Plan. Setting the course for effective program evaluation. (2011). Atlanta, Georgia.

Eseryel, D. (2002). Approaches to Evaluation of Training: Theory \& Practice. Educational Technology \& Society 5 (2) 2002.

Fayolle, A. (Ed.) (2007). Handbook of Research in Entrepreneurship Education: Contextual perspectives, Vol. 2. Edward Elgar Publishing.

Goldstein, I. L. (1993). Training in organizations: Needs assessment, development and evaluation. Pacific Grove, CA: Brooks/Cole.

Guskey, T. R. (2003). What make professional development effective, Phi Delta Kappan 84 (10), (June 2003), 748-750.

Hamblin, A. C. (1974). Evaluation and control of training. London; New York: McGraw-Hill. ITOL's UK (2017). Glossary of Training Terms. The Institute of Training and Occupational Learning. Dostopno na: http://www.itol.org/itols-uk-glossary-of-training-terms/. http://www.itol.org/ [11. 1. 2017].

Kirkpatrick, L. D. (1998). Evaluating Training Programs. The Four Levels. San Francisco: BerrettKoehler Publishers.

Learning, Training, and Human Performance Glossary. (2017). Dostopno na: http://www.nwlink.com/ donclark/hrd/glossary/e.html [11. 1. 2017].

Macur, M. (1995): Evalvacijske študije. V: Ograjenšek, I., Tršinar, I. (ur.): Statistika dela, delovnih in življenjskih pogojev: zbornik referatov 5. mednarodnega statističnega posvetovanja, Radenci '95. Ljubljana: Statistični urad Republike Slovenije: Statistično društvo Slovenije, str. 296-306. 
Marsden, J. (1991) Evaluation: Towards a definition and statement of purpose, Australian Journal of Educational Technology, 7(1), 31-38, pp. 31-38. Dostopno na http://www.ascilite.org.au/ajet/ajet7/marsden.html [22. 1. 2017].

Patton, M. (2002). Qualitative evaluation and research methods. Thousand Oaks, Calif.: Sage Publications.

Rajeev P., Madan, M. S. \& Jayarajan, K. (2009). Revisiting Kirkpatrick's Model - an Evaluation of an Academic Training Course. Current Science, 96 (2), 272 -276.

Reay, G. D. (1994). Evaluating Training. London: Kogan Page.

Reid, M. A.; Barrington, H.; Brown, M. (2004). Human Resource Development: Beyond Training Interventions. 7th ed. McGraw-Hill Education.

Sunita, D. \& Ajeya, J. (2011). Review of training evaluation. International Journal of Computer Science and Communication. Vol. 2, No. 1, January-June 2011, 11- 16.

Tziner, A., Fisher, M., Senior, T. \& Weisberg, J. (2007). Effects of Trainee Characteristics on Training Effectiveness. International Journal of Selection and Assessment, 15 (2), 167-174. 
592 36 $6^{\text {TH }}$ International Conference on ORganizational Science Development:

Responsible Organization (MARCH $22^{\mathrm{ND}}-24^{\mathrm{TH}}$, PORTOROŽ SLOVENIA) 
$36^{\mathrm{TH}}$ InTERnational CONFERENCE ON ORganizational SCIENCE Development: Responsible Organization (MARCh $22^{\mathrm{ND}}-24^{\mathrm{TH}}$, PORTOROŽ SLOVENIA)

O. Arsenijević, M. Ferjan, I. Podbregar, P. Šprajc, D. Trivan \& Y.

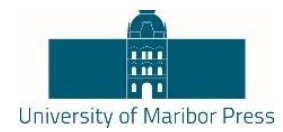

Ziegler

\title{
The Use of Process Approach in the Design of Social Services
}

\author{
JAN MINISTR \& BLANKA BAZSOVA
}

\begin{abstract}
The organizations that provide social services have limited resources, and they need effective management to meet of their targets. Process approach, combined with tools of methodological framework ITIL enables to create suitable design of the structure of an organization or its department which provides social services effectively. The procedure that is described in the paper, uses for process analysis of social services the tools "Process cards" and "Activity diagram". The process analysis, which is performed in this manner, clearly identifies and describes the individually working role in frame of provided social service. Competencies of individual of working roles within the concrete social services are described by the "Matrix RACI" (Responsible, Accountable, Control and Informed). The demands of time or cost on human resources of the key social services can modeled using the method of determining the FTE (Full Time Equivalent). The procedure will be illustrate in the article on example of a proposal "Provision of social housing services".
\end{abstract}

KEYWORDS: process analysis • process $\bullet$ Activity diagram $\bullet$ working role

CORRESPONDENCE AdDRESS: Jan Ministr, Ph.D. VŠB - Technical University of Ostrava, Faculty of Economics, Skolská tř. 33, 70200 Moravská Ostrava a Př́voz, Czech Republic, e-mail: jan.ministr@vsb.cz; Blanka Bazsova, Ph.D. VŠB - Technical University of Ostrava, Faculty of Economics, Skolská tř. 33, 70200 Moravská Ostrava a Přívoz, Czech Republic, e-mail: blanka.bazsova@vsb.cz 
$36^{\text {Th }}$ International Conference on Organizational Science Development: Responsible Organization (MARCH $22^{\mathrm{ND}}-24^{\mathrm{TH}}$, Portorož Slovenia)

J. Ministr \& B. Bazsova: The Use of Process Approach in the Design of Social Services

\section{Introduction}

Organizational structure formalizes relationships between workers in order to achieve the common goals of the organization. Any organizational structure sets the rules of communication and thus unites various corporate activities, processes and human resources. According to some authors, the organizational structure is the optimal level of specialization, cooperation, combination and concentration of production capacity and scientific-technological complex. Optimal organizational structure does not exist is always adapted to the conditions that are unique to each organization (Danel, 2016). It depends on many factors, which are e.g. the size, strategy, focus, life cycle, and the like (Danel \& Ǩepka, 2015). The general principles of organization theory reveal the regularities in the organization that are characteristic of all organizational systems. These include the degree of centralization, specialization and complexity. (Bazsová et al., 2015). Centralization or decentralization of organizational structures is determined by the measure of application of the decision making powers superiors and the degree of delegation the competence and responsibility (Cimbálníková, 2009). However, each individual system has specific methods for organizing, peculiarities of functioning and structure. Among the challenges current theories of the organization include the question of the degree of centralization of management system, which is directly connected with the detection level at which accepts a solution (Danel et al., 2012). However, each individual system has specific methods for organizing, peculiarities of functioning and structure. Among the challenges current theories of the organization include the question of the degree of centralization of management system, which is directly connected with the detection level at which accepts a solution. In a well-managed enterprise, emphasis is placed on the customer and the quality of the product or service (Tvrdikova, 2007). Therefore, many businesses encounter have divisional organizational structure. Individual divisions in this structure are created by focusing on a particular type of customer or territory or process segment. We distinguish between the divisional structure of the customer, geographic or process. In addition to these type structures we encounter the term bureaucracy bureaucratic structure. The bureaucratic organizational structure is characterized clearly and exactly defined division of activities departments and responsibilities of personnel (Becker at al., 2012).

Organizations that provide social housing, can generally characterized by the following properties:

- they specialize in a particular type of customer;

- they doing business in a particular geographical area, which is due to low social status of the population;

- they have limited financial resources;

- they characterized by more staff turnover.

These features are crucial for defining the organizational structure of the department and its effective management (Ministr \& Pitner, 2014). The main requirements should include: 
- applying a process approach when the process is described on the basis of clearly defined activities, corresponnding job roles and indicators of their performance;

- clear definition of the competencies of individual job roles within the process;

- creating a simple and clear organizational documentation to facilitate the rapid incorporation of new employees to easily understand what to do and what are responsible.

Authors of the contribution based on the above characteristics and requirements of the organization that provides social housing, have created a methodical procedure that meets the given requirements and business conditions. The basis of methodical procedure is to creating a process model of providing social housing, which is based on the life cycle of the service, using principles and tools of methodological framework ITIL.

\section{Description of the methodical procedure}

The first step of the procedure is to creating a process model in the form of process cards that textually describe the properties and running of each subprocesses (Doucek, 2010). The running of the activities of subprocess for better understanding by emploee is visualized as activity diagram using the swiming lane for each specific job role.

Competences of individual job roles are clearly showed by way of RACI matrix whose columns are formed by individual work roles and lines of individual activities of the subprocess (Bucksteeg et al., 2012). The intersection of columns and rows clearly determines the competence of job roles in an activity of subprocess (Responsible, Accountable, Control and Informed).

Process performance is modeled and subsequently monitored by using the indicator FTE (Full Time Equivalent) for each job role.

Creating of process model

Process model of providing services can be described using of Process cards of subprocesses that realize the service. This procedure can be divided into four basic steps (See image 1) which are:

- Creating a basic description of the process.

- Processing of Process cards.

- Validation by management.

- Verification of relations. 


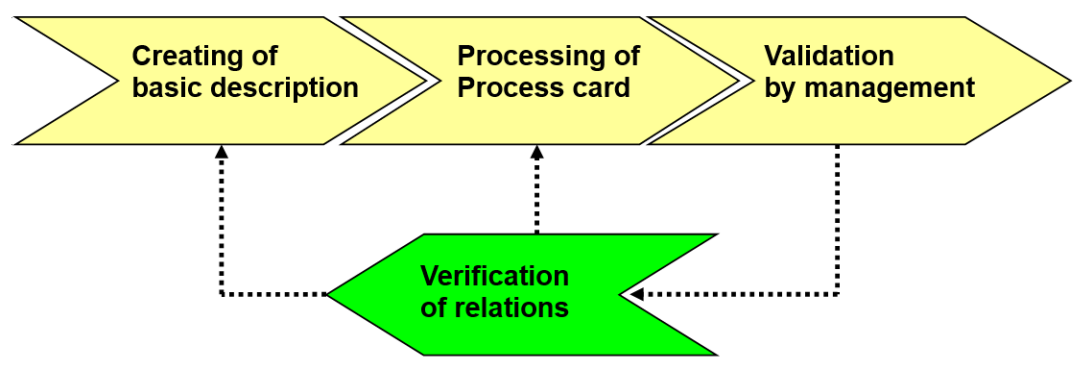

Image 1: [Procedure of processing the Process card. Source:own ]

The basic description of the process must be done in cooperation with top management to achieve decomposition of strategic objectives of the organization into individual subprocesses. The basic description of the process consists of ( ̌Repa, 2012):

- Objective of process that represents why is given process used and what the management wants to achieve.

- Added value, which is a form of fulfilling the objectives of the process.

- Customer of process that represents the subscriber of the process, it may be eg. a different organizational unit, individual customer other company.

- Process owner, who is the employee who is responsible for the entire running of the process for its correctness and accuracy.

- Key inputs that represent all the inputs needed to start the process, these inputs can be physical nature (eg. raw materials, semi-finished products, etc.) or immaterial (data, decisions, etc.).

- Key outputs that represent what is the product of the process that created by its performing (product, service, written submissions etc.).

Processing of process card extends the basic description of the process of the following characteristics:

Key legislation related to the process.

- Main products that are used within the process

- The sequence of activities (basic process steps which are a base for Activity diagram creating).

- Basic characteristics of individual process operations (responsibility of employees, the importance of the activity for an organizational unit: key or supportive, the time duration of activity, Activity mode: continuous, seasonal, gusty).

- Basic indicators (metrics) process (incidence, FTE, performance indicators and quality)

- Cooperation organizational departments in the running of the process activities. 
Verification of relations between subprocesses are used to confirm the validity of the description of subprocesses. Is carried out so long until all the discrepancies between the individual processes are removed.

Validation by the management of the organization approve the structure and content of a model with respect to a defined mission and goals of the company. This step of the ensures consistency of Key Performance Indicators (KPI) across all described subprocesses.

\subsection{Creating of the Activity diagram}

Activity diagram is usefull diagram that describes dynamic aspects of the subprocess. In our case it used to visualize the running of individual activities within the subprocesses. The usage of swimming pools for individual job roles increases the ability to understand the logic of the process for employees.

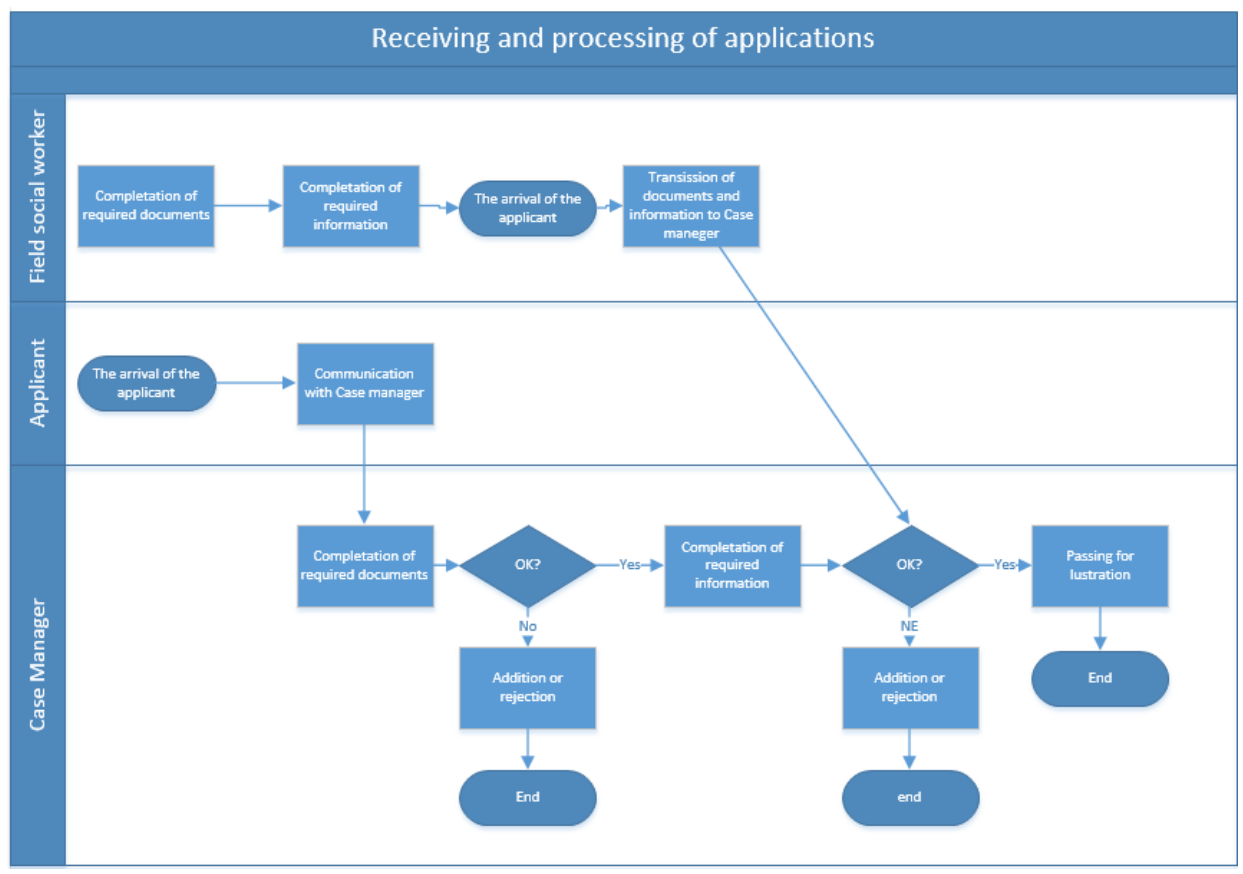

Image 2: [Activity digram - Receiving and processing of applications. Source:own]

\subsection{Creating of the RACI matrix}

The use of RACI matrix is a simple form of creating the competency model (Motschnig $\&$ Pitner, 2014). Responsibility matrix RACI is the method used to assign and display 
$36^{\text {Th }}$ International Conference on Organizational Science Development: Responsible Organization (MARCh $22^{\mathrm{ND}}-24^{\mathrm{TH}}$, Portorož Slovenia)

J. Ministr \& B. Bazsova: The Use of Process Approach in the Design of Social Services

responsibility of individual job roles in an activities of process of the organization. RACI is an acronym of the first letters of words:

- $R$ - Responsible (who is responsible for the execution of activity or subprocess)

- A-Accountable (who is responsible for the activity or subprocess, he is responsible for what is done).

- $\quad$ - Consulted (who can provide cost advice and consultation to the activity or subprocess).

- I - Informed (Who should be informed about the progress of a activity or subprocess and assignment decisions).

Table 1: [RACI matrix - Receiving and processing of applications. Source:own]

\begin{tabular}{|l|c|c|c|}
\hline Activity / job role & $\begin{array}{c}\text { Case } \\
\text { manager }\end{array}$ & $\begin{array}{c}\text { Field } \\
\text { social } \\
\text { worker }\end{array}$ & Applicant \\
\hline Completion of required documents & $\mathbf{A}$ & $\mathbf{R}$ & \\
\hline Completion of required information & $\mathbf{A}$ & $\mathbf{R}$ & \\
\hline $\begin{array}{l}\text { Transition of documents and } \\
\text { information to case manager }\end{array}$ & $\mathbf{A}$ & $\mathbf{R}$ & \\
\hline Consultation with the case manager & $\mathbf{A}, \mathbf{R}$ & & $\mathbf{R}$ \\
\hline Addition or rejection & $\mathbf{A}, \mathbf{R}$ & & $\mathbf{I}$ \\
\hline Passing for lustration & $\mathbf{A}, \mathbf{R}$ & & $\mathbf{I}$ \\
\hline
\end{tabular}

Monitoring of process performance

The main problem of administrative processes measuring is a correctly set of indicators for each process which would be derived from goal of process and its added value. Using of Full Time Equivalent in processes brings for managers many advantages when they can to compare use of working time particular clerks which working in another processes in the same manner (Ministr \& Pitner, 2014). FTE represents the available working fund given to type of working role that is subsequently assigned to particular working activities of processes. Exploitation of working type role (source) can be to determine as:

$$
v_{i}=\sum_{j=1}^{n} \frac{c_{i j}}{F T E_{i}}
$$

Where is:

$i \quad$ type of source 


$\begin{array}{ll}\boldsymbol{v}_{\boldsymbol{i}} & \text { exploitation i-th type of source } \\ \boldsymbol{j} & \text { number of process activity } \\ \boldsymbol{n} & \text { number of process activities } \\ \boldsymbol{c}_{\boldsymbol{i j}} & \text { time allocated on j-th process activity executed by i-th of source } \\ \boldsymbol{F T E} & \text { Full Time Equivalent of i-th type source }\end{array}$

Using FTE as indicator of process performance is supported by the excel tables and graphs.

\section{$3 \quad$ Case study}

The methodical procedure of process description and its visualization by Activity diagram and RACI matrix has been implemented and verified in Ostrava city in organization which provides social housing services. Given service began to be provided from September 2016. Social hosing use approximately 400 users. The operation of this service is in charge of a working team that has eight members and their workload is typically in the 75 to 90 percent of disposable FTE. The target value of use this social housing service is 600 users. Management of the organization by using a process model in association with the monitoring of employees found out that the increase in the number of users of the service will also require staffing increases. Specifically, about two Case managers and two Field social workers.

\section{Conclusion}

Descripted methodical procedure leads employees of organization to process management of work and thus higher work efficiency and quality of social housing. Other advantages of this methodology is clear and understandable definition of the competencies of individual job roles within the individual subprocess using RACI matrix. The process card together with activity diagram accurately describe the sequence of work activities assigned to individual job roles within the subprocesses and forms the basis for high-quality processing of job descriptions when an employee can easily understand what has in fact do. The monitoring of employees using the FTE facilitates their transparent and fair remuneration.

\section{Acknowledgements}

This work was supported by Grant "The Research Team for the Modelling of Economics and Financial Processes at VSB - Technical Universitz of Ostrava" with reference number CZ.1.07/2.3.00./20.0296 and project SP 2017/141.

\section{Literature}

Bazsova, B., Křížová, A., \& Řeháček, P. (2015) Teorie organizace. Př́stupy, metody, nástroje, softwarová podpora. Ostrava: VŠB-TU Ostrava. ISBN 978-80-248-3790-1. 
Becker, J. et al. (2012) Modernizing Processes in Public Administrations: Process Management in the Age of e-Government and New Public Management (BPM Competence). New York: Springer.

Bucksteeg, M. et al. (2012). ITIL® 2011: Stručný a srozumitelný výklad. Brno: Computer Press. ISBN 978-80-251-3732-1.

Cimbálníková, L. (2009). Základy managementu. 3. přeprac. vyd., Olomouc: Univerzita Palackého. ISBN 978-80-244-2352-4.

Danel, R. et al. (2012) Best practices in design of database of brownfield revitalization project. In $12^{\text {th }}$ International Multidisciplinary Scientific Geoconference, SGEM 2012, Vol. III. Sofia: STEF92 TECHNOLOGY, 2012, pp. 49-56. ISSN 1314-2704.

Danel, R. \& Řepka, M. (2015). Analysis of Weak Points of Collaboration of VŠB-Technical University of Ostrava with Industry in the Fields of Automation and Information Science. In 23nd Interdisciplinary Information Management Talks IDIMT-2015. Poděbrady, Czech Republic, pp. 147-154. ISBN 978-3-99033-395-2.

Danel, R. (2016). Adapting IT/ICT Education To Current Reuirements from Practice. In IDIMT 2016 Information Technology and Society Interaction and Interdepence - 24nd Interdisciplinary Information Management Talks. Poděbrady, Czech Republic, pp. 63-68. ISBN 978-3-99033-869-8.

Doucek, P. (2010). Human Resources in ITC - ITC Effect on GDP. In Doucek P. et al eds., In IDIMT-2010 - Information Technology - Human Values, Innovation and Economy 18th Interdisciplinary Information Management Talks. Linz: TRAUNER, 2010. pp. 97-105. ISBN 978-3-85499-760-3.

Ministr, J. \& Pitner, T. (2014). Modelling and Simulation of Public Administration Processes. In FOCUS 2020 - Proceedings of $33^{\text {rd }}$ International Conference on Organizational Science Development. Portorož (Slovenia): University of Maribor, pp. 460-466. ISBN 978-961-232274-8.

Ministr, J. \& Pitner, T. (2014). Towards an Ecosystem for Academic-industrial Cooperation. In IDIMT-2014 Networking Societies - Cooperation and Conflict. Linz: Trauner, 2014, pp. 71-78. ISBN 978-3-99033-340-2.

Motschnig, R., Pitner, T. et al. (2014). Constructive Communication in International Teams: An Experience-Based Guide. Münster: WAXMANN Verlag GmbH. ISBN 978-3-8309-3025-9.

Řepa, V. (2012). Procesně ř́zená organizace. Prague: Grada. ISBN978-80247-4128-4.

Tvrdikova, M. (2007). Support of decision making by business intelligence tools. In Proceedings of 6th International Conference on Computer Information Systems and Industrial Management Applications. Elk (Poland): IEEE Computer Soc. 2007. pp. 364-368. ISBN 978-0-7695-2894-6. 
$36^{\text {TH }}$ INTERNATIONAL CONFERENCE ON ORganizational SCIENCE DeVElopment: Responsible ORGANIZATION (MARCH $22^{\mathrm{ND}}-24^{\mathrm{TH}}$, PORTOROŽ SLOVENIA)

O. Arsenijević, M. Ferjan, I. Podbregar, P. Šprajc, D. Trivan \& Y. Ziegler

\title{
Economic Valuation of Environmental Policy Effects - Why Should We Bother about the Value of the Initiatives?
}

\author{
ZORICA MitRović, Vladimir OBRAdOVIĆ \& NATAŠA PETROVIĆ
}

\begin{abstract}
In recent years, there is a rising interest in improving methods of economic valuation to better inform decision-makers in the process of developing new initiatives concerning the environment. This growing significance of performing an economic valuation of environmental policy initiatives launched a number of studies.
\end{abstract}

The purpose of this paper is to provide comparative analysis and evaluation of different approaches employed in practice and to develop recommendations for both economic valuation methods and economic metrics.

The method of systematic literature review will be used to acquire advanced knowledge on different applications of economic valuation methods, critical evaluation, and integration of the findings.

The most important results of the comparative analysis will reveal how and to what extent use of the economic valuation methods enables decision makers to include economic benefits of environmental initiatives in policy development process. The importance of findings of this paper may be significant if we consider the limited resources that are at disposal to policy makers for implementation of different initiatives.

The paper will lead to conclusions how economic value can supply the information necessary to justify environmental policy initiative. Finally, the paper will show if there is a need for standardization of economic valuation process and economic metrics to enable quality decision-making based on exact data and spending funds in a rational manner.

KEYWORDS: environmental policy • economic valuation • evaluation • environmental economics

CorRespondence AdDREss: Zorica Mitrović, Ph.D., University of Belgrade, Faculty of organizational sciences, Jove Ilića 154, Belgrade 166136, Serbia, e-mail: zorica.mitrovic@fon.bg.ac.rs; Vladimir Obradović, Ph.D., University of Belgrade, Faculty of organizational sciences, Jove Ilića 154, Belgrade 166136, Serbia, e-mail: obradovicv@fon.rs; Nataša Petrović, Ph.D., University of Belgrade, Faculty of organizational sciences, Jove Ilića 154, Belgrade 166136, Serbia, e-mail: petrovicn@ fon.bg.ac.rs

DOI https://doi.org/10.18690/978-961-286-020-2.49

ISBN 978-961-286-020-2

(C) 2017 University of Maribor Press

Available at: http://press.um.si 
$36^{\text {Th }}$ International Conference on Organizational Science Development: RESPONSIBLE ORGANIZATION (MARCH $22^{\mathrm{ND}}-24^{\mathrm{TH}}$, PORTOROŽ SLOVENIA)

Z. Mitrović, V. Obradović \& N. Petrović: Economic Valuation of Environmental Policy Effects - Why Should We Bother about the Value of the Initiatives?

What is the value of environmental policies? It is the straightforward question, but decision makers too often lack precise answers. Although there are some deliberations about effects of new policies, mostly information about a value of the initiative in most cases is inadmissible missing.

The fact is that evaluation of the environmental policies is vital for many reasons. Some of them include that improvement of environmental quality, protection of the natural resource, and ideally improve environmental conditions. Accordingly, the only way to know if given policy will make a difference is to evaluate a policy's economic and social impacts. Environmental policy evaluation provides the means by which decision makers can determine the value or impacts of different initiatives in the field of environmental policy. Economic valuation enables the assignment of money values to changes in environmental services and functions and stocks of environmental assets (Pearce \& Seccombe-Hett, 2000).

Although literature review recognizes the importance of economic evaluation of environmental policies and initiatives in this field, such evaluations have been rare relative to the volume of environmental policy initiatives, as well as relative to the amount of evaluation of theirs non-economic impacts. It is evident that economic evaluation of environmental policy would help move environmental decision making closer to better decision making through consideration of both economic and social impacts. In this paper, we are advocating that economic valuation of environmental policies and initiatives that are results of such policies have a defining role in policy deliberation and decision making. We argue that decision makers in policy development process should rely on different types of analysis and evaluations that enable information on the economic value of policies and initiatives in this field.

Theoretical and empirical research in different fields including econometrics, social and behavioral sciences provides useful frameworks for systematizing information on the economic value of alternative environmental initiatives. To contribute the formulation and evaluation of environmental policy, there is a need to advance the scientific basis of economic valuation.

\section{Enviromental policy and economic valuation}

The environmental policy process usually begins with the recognition of a potential environmental problem brought up by stakeholders and a response by the policy maker. The expected response is in the form of the legislature. For the candidate country like Serbia, the process is sometimes initiated as a request in the process of accession to the European Union (Jednak and Kragulj, 2015). Accordingly, Serbia has to align with EU environmental standards in their process to join the EU. The policy response is then usually implemented by the regulatory agency. For example, Environmental Protection 
Agency develops specific programs or projects, policy instruments, to achieve legislative goals that include specific requirements that industry must follow.

During this process of environmental policy making and implementation, one approach is to base policy decisions on moral principles, and the other is to base policy choice on the intrinsic values and rights, that will inevitably involve trade-offs (Heal, 2005). Still, the majority opinion is that environmental assets are mostly priceless. This mean that there cannot be acceptance of tradeoffs for these assets, or it is even immoral to place a value on goods, such as clean air or water, which are seen as a right for all (Pearce \& Seccombe-Hett, 2000). Hence the third approach, «strict utilitarianism», it is to make a decision based solely on economic efficiency (Goulder \& Kennedy, 1997)(Heal, 2005).

We argue here that economic valuation should be included prospectively to inform the deliberative process leading up to policy decisions. The choice of specific valuation method may vary because of the purpose or the role that it will play in the policy process. The key is to select the valuation method that could provide the necessary information to policymakers.

Looking back, the first attempts at using economic science to investigate environmental problems and help policymakers to rich their decisions regarding environmental policy started in the second half of the 20th century. The very important role played the Society of Environmental and Resource Economics by developing instruments to value and intcorporate economic impacts on the environment into decision making through costbenefit analysis (Gómez-Baggethun, De Groot, Lomas, \& Montes, 2010). One of the most important contributions of Environmental Economics was to contribute to the systematic evaluation of the ecological dimension in decision making regarding services provided by natural capital. They argued that ecological dimension should be adequately quantified in terms comparable with economic services and manufactured capital (Costanza, et al., 1997). Hence the range of methods for economic valuation is developed to enable better economic decision-making. The goal was to provide decision makers with better information about the values of ecosystems in balancing the advantages and disadvantages of human actions that may impact ecosystems (Bingham, et al., 1995).

Even though it does not include all possible sources of value, economic valuation allows environmental impacts to be compared on the same basis as financial costs and benefits of any project or policy (Pearce \& Seccombe-Hett, 2000). Still it is much broader than the narrow concept of financial value and includes both tangible and intangible values, which could contribute to human well-being. Also, this broad interpretation is the rationale for the "total economic value" framework that underlies economic valuation (Heal, 2005).

Policymakers use Total Economic Valuation (TEV) framework to include the multiple ways that individuals could value an ecosystem. It classifies these various values or benefits and ensures that all elements of value are recognized in empirical analyses. The Total economic value framework includes "use values" and "nonuse values" (Krutilla, 
$36^{\text {Th }}$ International Conference on Organizational Science Development: RESPONSIBLE ORGANIZATION (MARCH $22^{\mathrm{ND}}-24^{\mathrm{TH}}$, PORTOROŽ SLOVENIA)

Z. Mitrović, V. Obradović \& N. Petrović: Economic Valuation of Environmental Policy Effects - Why Should We Bother about the Value of the Initiatives?

1967). The use values relate to either current or future use of environmental resources by an individual or group. On the other hand, nonuse values result from the simple existence of the resource. Also, use values can be divided into consumptive uses and nonconsumptive uses.

Further, TEV is based on defining value based on individual preferences. The approach is based on environmental gains and losses regarding increase or decrease in human wellbeing measured by individuals' willingness to pay (WTP) (Pearce \& Seccombe-Hett, 2000). The challenge is that environmental services are often not explicitly priced and their value cannot be easily observed. In contexts where there are either no apparent markets or the imperfect markets, determining of people's preferences can be valued in a few different ways. Respectively, the second element of TEV framework includes Willingness to Pay and Willingness to Accept. The former economic measure is used to measure the value of the willingness to pay for a change, and the second willingness to accept compensation for the change, or the minimum amount of money accepted as compensation.

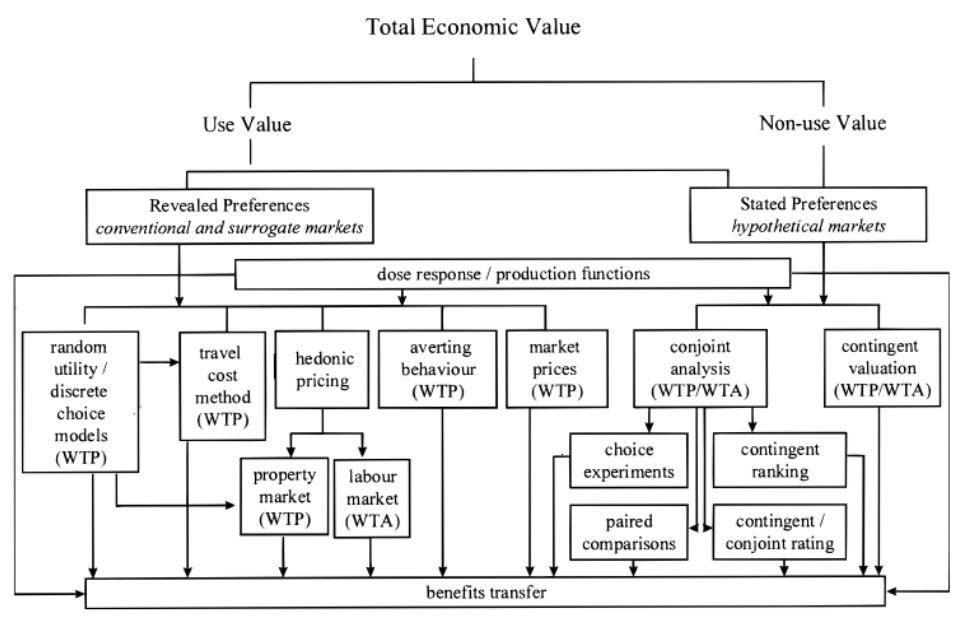

Figure 1 - Total Economic Value Framework (Pearce \& Seccombe-Hett, 2000)

There are various techniques for monetary valuation. But in the context of economic valuation how they are related or can be used is even more important. Figure 1 shows Total Economic Value framework, as well as techniques for economic valuation and relations with different elements of the framework. As already discussed the two elements of the framework are «use and nonuse vaule» and «Willingness to Pay and Willingness to Accept». Further, the two basic approaches to valuation involve "stated" preferences and "revealed" preferences. The former are preferences conveyed by a respondent to questions, and the other one is identified from the behavior of an individual, but it is not explicitly connected to the environmental resource (Pearce \& Seccombe-Hett, 2000). 
Revealed preferences are related to conventional and surrogate markets, while the stated preferences are related to hypothetical markets. Further, for estimating nonuse values, the only two techniques that could be used are contingent valuation and conjoint analysis.

It is important to notice that expressing the monetary value is one way to place the society value on uses of environmental resources. In this case, economic valuation is an instrument of Measuring public preferences for environmental resources. For example, the revealed preference methods such as travel cost or hedonic pricing are preferred by economists because it enables that an actual choice demonstrates the good or service to be valued has been selected by those whose monetary values are being measured (Bingham, et al, 1995). On the other hand, these revealed preference methods can be problematic because of the assumption of so-called motivational pluralism that underlies human choices that may not be informed by self-interested utility considerations alone but may also include the fulfillment of other-considering motivations (Wegner \& Pascual, 2011).

Improving information about the value of environmental resources will require improving valuation methods. There are issues related to the complexity of environmental decisions as well as to specific valuation techniques.

\section{Economic valuation application}

The literature review showed several uses of economic valuation in decision-making in the field of environmental policy: Cost - benefit analysis of projects or policies, Costeffectiveness analysis, Pricing Policy, Design of Environmental Taxes, National Accounting etc.

The role of economic valuation is to help policymakers to balance the costs and social benefits generated by environmental policies (Feuillettea, et al., 2016). Since mid-1980s, the use of Cost - benefit analysis in European environmental policy has been continuously rising (Börger, 2014). Similarly, in the United States since 1981 legislation has demanded that all new major regulations be subjected to CBA (Pearce \& SeccombeHett, 2000). Some authors argue that the rising use of cost-benefit is the result of the need to make a choice among policies that involve trade-offs between demands of economies and ecosystems, which could not be simultaneously satisfied (Wegner \& Pascual, 2011). Hence, cost-benefit analysis is increasingly being used to evaluate projects and policies in this field, and to provide the needed information in decision making about projects or policies that will deliver maximum net benefits to society (Daily, et al., 2009). Basically, cost-benefit analysis evaluates alternative policy options by measuring their impacts on the environmental resources through a monetary indicators, identifying positive changes on environmental resources as benefits and negative changes as costs. The total net benefit of each policy option is then calculated in terms of net present value (NPV). Those with the highest NPV are assumed to bring about the largest increase in social welfare (Pearce, Atkinson, \& Mourato, 2006). 


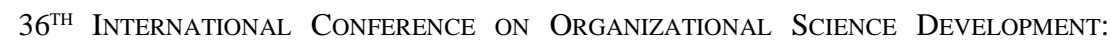
Responsible Organization (MARCh $22^{\mathrm{ND}}-24^{\mathrm{TH}}$, Portorož SLOVENia)

Z. Mitrović, V. Obradović \& N. Petrović: Economic Valuation of Environmental Policy Effects - Why Should We Bother about the Value of the Initiatives?

Further, the application of CBA usually uses two types of economic values: use values divided into direct use and indirect use, and non-use values divided into bequest for future generations, altruistic and existence values of the biodiversity components (Heal, 2000). The challenge in CBA application is to capture the non-market benefits which are not so easy to assess, unlike use values which could be easily assessed using market prices. Revealed preference and stated preference methods that could be used to estimate nonmarket benefits are already presented within TEV framework. Revealed preference methods include hedonic pricing and travel cost method, while stated preference methods refer to hypothetical markets and using willingness to pay (WTP) based on contingent valuation or choice experiments. The third type of valuation methods that can be used is the cost-based method. Some of the examples are the cost of avoided damages, replacement costs, substitute costs, restoration costs or impact on productivity (Barbier, 2009). Also, some authors noticed that the benefits transfer method is increasingly used to perform a large number of CBA at low costs (Johnston \& Rosenberger, 2010). Benefit transfer is defined as the use of results from pre-existing primary studies at one or more sites or policy contexts to predict welfare estimates and related information for other sites or policy contexts (Johnston, Rolfe, Rosenberger, \& Brouwer, 2015). Once the values for all benefits is estimated they are aggregated to give the "total economic value" of the targeted environmental factors.

Although the literature often mentions an increasing use of CBA to support environmental decision-making, some authors argue that their actual utilization remains limited in practice because of the lack of progress in our understanding of human behavior and ecological change (Wegner \& Pascual, 2011). The question is, are we ready to evaluate environmental resources based on individual economic preferences? Using this method we have to assume first that individuals could perceive intangible benefits from nature and have sufficient understanding of environmental resources. Second, that individuals are deciding independently from others, independent of the institutional context, on what value to attribute to environmental resources and how to use a monetary unit of measure. Still, there are concerns about the ecological threshold or unequal distribution of wealth in a society which can substantially limit the use of cost-benefit analysis in environmental policy decision-making (Wegner \& Pascual, 2011). To avoid limitations of the cost-benefit analysis, policies should be evaluated using different types of decision-making instruments and economic valuation methods composed in an appropriate framework for specific environmental choice.

In some cases, policymakers use cost-benefit analysis complementary with costeffectiveness analysis to assess cost-effective way to implement selected environmental policy initiative or in the case when many effects cannot be expressed in monetary form. In recent years, there is a rising trend in the application of cost-effectiveness analysis in studies where the costs and effectiveness of all possible initiatives are compared to select the option that maximizes environmental gains for a given set of resource constraints. CEA could be performed either as an ex-ante analysis to find the most cost-effective option for achieving environmental policy objectives or as ex-post analysis to evaluate the cost-effectiveness of implemented initiatives (Görlach, Eduard, \& Newcombe, 2006). 
Pricing policy as a method of economic valuation is used for the design of enviromental policies. The idea is to elicit precise, individual-level willingness to pay (WTP) and anticipate the effect of pricing on behavior (Pearce \& Seccombe-Hett, 2000). For example, governments could develop water pricing policies to allow full cost recovery of water services, including direct, environmental and resource costs (Kanakoudis et al. 2016) (Kejser, 2016). Further, analysis on carbon pricing and climate policies in OECD countries resulted in recommends that governments could ensure coherent policies surrounding the gradual phase-out of fossil fuel emissions and consistent signals to stakeholders by putting an explicit price on every tonne of CO2 emitted (OECD, 2013). Also, transportation policy with high impact on the environment is usually based on the notion that the increase of fuel prices have negative effects on fuel consumption and carbon dioxide (CO2) emissions (Pereira \& Coelho, 2015). Further, there is a bulk of economic literature on climate policy and instrument choice regarding carbon pricing policies such as carbon taxes, cap-and-trade programs, or hybrid approaches. In these discussions, carbon pricing policies are often described as the most economically efficient response to climate-related externalities or the most cost-effective way to accomplish a given emissions mitigation objective (Jenkins, 2014).

Further, OECD countries are rapidly increasing use of environmental taxation to address a wide range of environmental issues (OECD, 2011). The goal is to directly address the failure of markets to take environmental impacts into account by incorporating these impacts into prices (OECD, 2011) These taxes could be calculated on the basis of political and other impacts related or unrelated to their original form from an economic perspective. But also could be designed to reflect the monetary value of the extra damage done by one extra unit of pollution (Pearce \& Seccombe-Hett, 2000). Theory of environmental taxation consider environmental taxes as corrective taxes that provides incentives to lower pollution emissions, but also as taxes within the larger tax system using environmental tax revenue to lower other taxes and interact with the rest of the tax system (Williams, 2016).

Also, there is a growing interest in modifying the system of national accounts to include the economic role played by the environment. The idea is to include both data on environmental protection and environmental degradation. It is argued that by deducting the monetary value of the damage to environmental assets from the net national product through depreciation would give a better measure of the level of economic activity (Pearce \& Seccombe-Hett, 2000). Since environmental accounts provide analytical information, this can provide an objective foundation for evaluating policy proposals and understanding the impact on the economy. The detailed data which underlie the accounts can help identify policy choices which further both environmental protection and economic growth (Hecht, Ghani Mian, \& Rahman, 1999).

Economic valuation is sometimes used as a tool in asset management. The monetary value indicates the WTP for different features of a given asset, so hat the asset can be managed in accordance with features that impacts the highest WTP (Pearce \& SeccombeHett, 2000). Similarly, there are participatory exercises in valuation that involve a direct 
$36^{\text {Th }}$ International Conference on Organizational Science Development: RESPONSIBLE ORGANIZATION (MARCH $22^{\mathrm{ND}}-24^{\mathrm{TH}}$, PORTOROŽ SLOVENIA)

Z. Mitrović, V. Obradović \& N. Petrović: Economic Valuation of Environmental Policy Effects - Why Should We Bother about the Value of the Initiatives?

questionnaire approach to allow people to express preferences for or against environmental changes based on monetary values for the proposed changes. The purpose of such techniques is to ensure that the final change is acceptable to those who are likely to be most affected by it through identification of gains and losses to different stakeholders.

Economic valuation in policymaking in the European Commission is applied through indicators such as resource productivity. The indicator is calculated by dividing gross domestic product (GDP) by domestic material consumption (DMC) (Science Communication Unit, 2013). The basic purpose of this indicator is to signal if the economy is growing faster than resource use. Further, to make the concept of green growth working policymakers need indicators that would capture the pattern of the quality of economic growth over time and steer the policy making process. Even though there are various indicators such as the Environmental Sustainability Index and the Environmental Performance Index, and nither one has appropriately built in element of economic value that clearly shown the relation between environment and the economy. In this regard, Economic and Social Commission for Asia and the Pacific - ESCAP has expanded the scope of eco-efficiency indicator, primarily developed for the business sector to the economy-wide level to provide policymakers with the tool for implicating environment, economy and efficiency in policy optioning. ESCAP has done this by developing eco-efficiency indicators (EEI) to measure the status and progress of ecoefficiency in the economy (ESCAP, 2009). The specific task of EEI is to address the different sustainability demands by balancing economic and ecological goals. In this context particular challenges include (ESCAP, 2009):

1. Impacts of economic activity on the environment (e.g. resource consumption, pollution emissions, waste);

2. Effects of resource productivity on the economy (e.g. economic efficiency);

3. Impacts of environmental degradation on economic productivity (e.g.reduction in absorptive capacity, loss of forest cover);

4. Effects of environmental improvement on society (e.g.congestion costs, improvement in well- being, social costs).

The concept of eco-efficiency indicators includes measuring both the intensity of resource-use and intensity of environmental impacts through environmental cost and economic output. For example, environmental costs can be pollution emissions, energy or water used or cost associated with an environmental burden such as traffic congestion costs (ESCAP, 2009). On the other side, the economic output can be value added to benefit (GDP per capita), unit of product or service (per km, per m2) or cost associated with an environmental burden such as traffic congestion costs (ESCAP, 2009).

\section{Conclusions and recommendations}

Economic valuation in evaluation of environmental policies provides the means by which policymakers can improve the decision making process. Although literature review 
Z. Mitrović, V. Obradović \& N. Petrović: Economic Valuation of Environmental Policy Effects - Why Should We Bother about the Value of the Initiatives?

recognizes the importance of economic evaluation of environmental policies and initiatives, such evaluations have been rare relative to the volume of environmental policy initiatives and the amount of evaluation of non-economic impacts. Accordingly, the aim of this paper was to raise the awareness about the need for application of methods of economic valuation to better inform decision-makers in the process of developing new initiatives concerning the environment.

We argued that decision makers should use different types of analysis and evaluations to include information on the economic value in process of deciding on policies and initiatives in this field. Some of them we explored: Cost - benefit analysis of projects or policies, Cost-effectiveness analysis, Pricing Policy, Design of Environmental Taxes, National Accounting etc. But, also we identified eco-efficiency indicator that could be proved as very important in decision making on macro level.

One of the most important findings of anayzing this instruments was that there is growing significance and vast of studies launched to exercise economic valuation and include information in environmental policy decision-making processes, still there is not enough evidence to form firm critical opinion. On the other hand we can draw up some conclusions. First, there is a need to develope alternative approaches to include economic value in environmental decision-making and assess their effectiveness. Second, there is need to improve methodology of economic valuation. Finally, the fact is that policymakers have limited resources at disposal and they need to include the information on economic value to make better decisions. Environmental economics are work in progress and mostly economic valuation is not mandatory as analysis during the process of policy making. Mostly it depends on the country or the preassuere in the case of EU candidate countries. The policy makers are then left to themselves to learn through trail and error. Finally, to avoide that countries measure just the worth of demage to the ecosystem or to undervalue some initiatives there is a need to sstandardization of economic valuation process and economic metrics. This will enable quality decisionmaking based on exact data and spending funds in a rational manner.

\section{Literature}

Barbier, E., Baumgartner, S., Chopra, K., Costello, C., Duraiappah, A., Hassan, R., et al. (2009). In S. Naeem, D. Bunker, A. Hector, M. Loreau, \& C. Perrings, Biodiversity, Ecosystem Functioning \& Human Wellbeing (pp. 248-262). Oxford: Oxford University Press.

Bingham, G., Bishop, R., Brody, M., Bromley, D., Clark, E., Cooper, W., et al. (1995). Issues in ecosystem valuation: improving information for decision making. Ecological Economics (14), 73-90.

Börger, T. B. (2014). Incorporating ecosystem services in marine planning: the role of valuation. Marine Policy (46), 161-170.

Costanza, R., d'Arge, R., de Groot, R., Farberparallel, S., Grasso, M., Hannon, B., et al. (1997). The value of the world's ecosystem services and natural capital. Nature (387), 253-260.

ESCAP. (2009). Eco-efficiency Indicators: Measuring Resource-use Efficiency and the Impact of Economic Activities on the Environment. United Nations publication. 
$36^{\text {Th }}$ International Conference on Organizational Science Development: Responsible Organization (MARCH $22^{\mathrm{ND}}-24^{\mathrm{TH}}$, PortoroŽ SLOVENIA)

Z. Mitrović, V. Obradović \& N. Petrović: Economic Valuation of Environmental Policy Effects - Why Should We Bother about the Value of the Initiatives?

Daily, G., Polasky, S., Goldstein, J., Kareiva, P., Mooney, H., Pejchar, L., et al. (2009). Ecosystem services in decision making: time to deliver. Frontiers in Ecology and the Environment, 7 (1), 21-28.

Feuillettea, S., Levrel, H., Boeuf, B., Blanquartd, S., Gorine, O., Monacof, G., et al. (2016). The use of cost-benefit analysis in environmental policies: Some issues raised by the Water Framework Directive implementation in France. Environmental Science \& Policy, 57, 79-85.

Goulder, L., \& Kennedy, D. (1997). Valuing ecosystem services: philosophical bases and empirical methods. In G. Daily, Nature's Services: Societal Dependence on Natural Ecosystems (pp. 2347). Washington, D.C.: Island Press.

Gómez-Baggethun, E., De Groot, R., Lomas, P., \& Montes, C. (2010). The history of ecosystem services in economic theory and practice: From early notions to markets and payment schemes. Ecological Economics, 1209-1218.

Görlach, B., Eduard, I., \& Newcombe, J. (2006). How are we performing? The Role of ex-post Cost-Effectiveness-Analyses in European Environmental Policies. Paper presented at the 2006 Berlin Conference on the Human Dimensions of Global Environmental Change.

Heal, G. B.-F. (2005). Valuing Ecosystems Services: Toward Better Environmental Decisionmaking. Washington, D.C.: National Research Council.

Heal, G. (2000). Nature and the Marketplace. Capturing the Value of Ecosystem Services. Washington (D.C.): Island Press.

Hecht, J., Ghani Mian, H., \& Rahman, A. (1999). The Economic Value of the Environment: Cases from South Asia. IUCN.

Jantzen, J. (2006). The economic value of natural and environmental resources. /: Institute for Applied Environmental Economics.

Jednak, S., Kragulj, D. (2015). Economic instruments and funds for implemenation of Sustainable development goals in serbia. Serbian Project Management Journal 5(2), 11-20.

Jenkins, J. (2014). Political economy constraints on carbon pricing policies: What are the implications for economic efficiency, environmental efficacy, and climate policy design? Energy Policy (69), 467-477.

Johnston, R. J., \& Rosenberger, R. S. (2010). Methods, trends, and controversies in contemporary benefit transfer. Journal of Economic Surveys (24), 479-510.

Johnston, R., Rolfe, J., Rosenberger, R., \& Brouwer, R. (2015). Introduction to Benefit Transfer Methods. In R. Johnston, J. Rolfe, R. Rosenberger, \& R. Brouwer, Benefit Transfer of Environmental and Resource Values - A Guide for Researchers and Practitioners (pp. 19-59). London: Springer Science+Business Media Dordrecht.

Kanakoudis, V., Tsitsifli, S., Gonelas, K., Papadopoulou, A., Kouziakisb, C., \& Lappos, S. (2016). Determining a socially fair drinking water pricing policy: the case of Kozani, Greece. Procedia Engineering (162), 486 - 493.

Kejser, A. (2016). European attitudes to water pricing: Internalizing environmental and resource costs. Journal of Environmental Management (183), 453-459.

Krutilla, J. (1967). Conservation reconsidered. American Economic Review (57), 777-786.

OECD. (2013). Climate and Carbon: Aligning Prices and Policies. Paris: OECD Publishing.

OECD. (2011). Environmental Taxation- A Guide for Policy Makers. Paris: OECD Publishing.

Pearce, D., \& Seccombe-Hett, T. (2000). Economic Valuation and Environmental DecisionMaking in Europe. Environmental Science and Technology (34), 1419-1425.

Pearce, D., Atkinson, G., \& Mourato, S. (2006). Cost-benefit Analysis and the Environment: Recent Developments. Paris: OECD.

Pereira, T. F., \& Coelho, J. B. (2015). Assessment of the effectiveness of fuel and toll pricing policies in motorway emissions: An ex-post analysis. Research in Transportation Economics (51), 83-93. 

ORGANIZACIJA (22. - 24. MAREC 2017, PORTOROŽ, SLOVENIJA)

Z. Mitrović, V. Obradović \& N. Petrović: Economic Valuation of Environmental Policy Effects - Why Should We Bother about the Value of the Initiatives?

Science Communication Unit, U. o. (2013). Science for Environment Policy Resource Efficiency Indicators. Bristol: Report produced for the European Commission DG Environment.

Wegner, G., \& Pascual, U. (2011). Cost-benefit analysis in the context of ecosystem services for human well-being: A multidisciplinary critique. Global Environmental Change, 492-504.

Williams, R. (2016). Environmental Taxation. Resource for the Future - Discussion Paper, 16-24. 
612 36 $6^{\text {Th }}$ International Conference on Organizational Science Development: Responsible Organization (MARCH $22^{\mathrm{ND}}-24^{\mathrm{TH}}$, PORTOROŽ SLOVENIA) 
36. MEDNARODNA KONFERENCA O RAZVOJU ORGANIZACIJSKIH ZNANOSTI: ODGOVORNA ORGANIZACIJA (22. - 24. MAREC 2017, PORTOROŽ, SLOVENIJA)

O. Arsenijević, M. Ferjan, I. Podbregar, P. Šprajc, D. Trivan \& Y. Ziegler

\title{
Vpliv izvajanja trajnostnih procesov na količino porabljene pitne vode $\mathrm{v}$ predelovalni industriji
}

\author{
MELITA MORETTI \& MIRKO MARKIČ
}

Povzetek V prispevku predstavimo ugotovitve raziskave, ki smo jo izvedli med 285 organizacijami v predelovalni dejavnosti v Sloveniji, s katero smo želeli ugotoviti morebitni vpliv posameznih standardov izvajanja trajnostno naravnanih procesov v organizaciji (ISO 14001:2009, ISO 9001:2008 in ISO 50001:2011), vpliv povečanja količine ponovno porabljene vode $\mathrm{v}$ proizvodnih procesih, vpliv uporabe posameznih alternativnih virov vode (meteorne/padavinske vode, voda iz vodnjaka, lastni vodovodni sistem) ter lastnosti organizacije (velikost, dejavnost, statistična regija) na količino porabljene pitne vode $\mathrm{v}$ predelovalni dejavnosti v Sloveniji. Z analizo smo ugotovili, da na porabo pitne vode $\mathrm{v}$ predelovalni dejavnosti $\mathrm{v}$ Sloveniji vpliva pridobljeni certifikat po standardu ISO 14001:2009, povečanje količine ponovno porabljene vode (kot tehnološke in/ali hladilne vode) v proizvodnih procesih in uporaba lastnega vodovoda v procesu proizvajanja.

KLJUČNE BESEDE: management • pitna voda • predelovalna dejavnost • raziskava $\bullet$ trajnostni razvoj

\footnotetext{
Naslov AVtorjev: dr. Melita Moretti, Univerza na Primorskem, Fakulteta za managment, Canakrjeva 5, p.p. 761, 6101 Koper, Slovenija, e-pošta: melita.moretti@amis.net, dr. Mirko Markič, redni profesor, Univerza na Primorskem, Fakulteta za managment, Canakrjeva 5, p.p. 761, 6101 Koper, Slovenija mirko.markic@ fm-kp.si
} 
$36^{\text {TH }}$ InTERnAtional CONFERENCE ON ORganizational SCIENCE Development: Responsible Organization (MARCH $22^{\mathrm{ND}}-24^{\mathrm{TH}}$, PORTOROŽ SLOVENIA)

O. Arsenijević, M. Ferjan, I. Podbregar, P. Šprajc, D. Trivan \& Y.

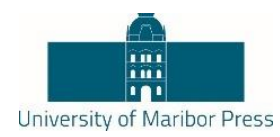

Ziegler

\title{
The Impact of Sustainable Processes on the Consumption of Drinking Water in the Manufacturing Industry
}

\author{
MElita MORETTI \& MiRKO MARKIČ
}

\begin{abstract}
The article presents the results of a partial survey that was conducted in 285 manufacturing companies in the Republic of Slovenia. Our aim was to determine the possible impact of environmental standards (ISO 14001:2009, ISO 9001:2008 and ISO 50001:2011), water re-use, the use of alternative sources of water (rainwater, wells, private water supply system), and enterprise characteristics such as size, economic activity, and statistical region on the consumption of drinking water in the manufacturing industry in Slovenia. The analysis showed that the implementation of the ISO 14001: 2009 standard, increasing water re-use, and the use of private water supply systems had an impact on the consumption of drinking water in the manufacturing sector in Slovenia.
\end{abstract}

KEYWORDS: management $\bullet$ drinking water $\bullet$ manufacturing $\bullet$ survey $\bullet$ sustainable development

CORRESPONDENCE AdDRESS: Melita Moretti, Ph.D., University of Primorska, Faculty of Management, Canakrjeva 5, p.p. 761, 6101 Koper, Slovenia, e-mail: melita.moretti@amis.net, Mirko Markič, Ph.D., Full Professor, University of Primorska, Faculty of Management, Canakrjeva 5, p.p. 761, 6101 Koper, Slovenia, e-mail: mirko.markic@ fm-kp.si 


\section{$1 \quad$ Introduction}

Water is a key natural resource for most manufacturing enterprises, so it is vital that they plan, organize, lead, control, as well as reduce, their consumption of it (Moretti and Markič 2016). According to SURS's data (2015), manufacturing enterprises are also the biggest consumers of drinking water in Slovenia. By reducing their consumption of drinking water through re-use and/or by using alternative sources of water such as water wells, their own water distribution systems, and rainwater, enterprises can use water in a more sustainable manner, thereby protecting the environment (Elliott 2013; Moretti and Markič 2016). Executive management plays a decisive role in the implementation of sustainable development policies in companies (Možina and Kovač 2006; Kralj 2005). Without the active support and direct participation of management, policies for sustainable management will not translate into work results (Možina and Kovač 2006; Kralj 2005).

The greater focus on the protection of the environment and on sustainable development has led enterprises to adopt the ISO 14001:2009 environmental management system, the ISO 9001:2008 quality management system, and the ISO 50001:2011 energy management system (Sebhatu and Enquist 2007). While the adoption of these standards enables enterprises to gain competitive advantage, it has also been met with criticism. Chen $(2004,53)$ writes that the ISO 14001 standard does not measure the actual environmental performance of an enterprise. It does not provide clear guidelines for reducing pollution and improving environmental performance, so it is entirely possible for enterprises to have adopted the standard and still produce pollution (Curkovic and Sroufe 2011, 74). Enterprises that have adopted the standard can claim to have improved environmental practices without truly improving their environmental performance or implementing technologies to reduce pollution (Sebhatu and Enquist 2007, 469). In a 2002 survey of 212 enterprises, Piskar and Dolinšek (2006) showed that the adoption of ISO 9001 had a positive effect on technical quality but only an indirect one on operational performance. Flores Argüelles $(2013,44)$ used SWOT analysis to identify certain weaknesses of ISO 50001: the implementation process requires more effort if enterprises have not previously adopted an ISO standard, enterprises do not have to disclose information to the public, and enterprises that are already energy-efficient have less of a reason to adopt the standard. It thus has to be emphasized that the formal adoption of an environmental standard does not guarantee higher competitiveness, operational performance or meeting goals for reducing the consumption of drinking water.

The article presents the results of a survey that was conducted in 285 manufacturing enterprises in the Republic of Slovenia. The article focuses on the importance and possible impact of various standards of implementation of sustainable processes in companies, the impact of re-using drinking water, and the possible impact on drinking water consumption of the use of alternative sources of water such as wells, private water supply systems, and rainwater. 
$36^{\mathrm{TH}}$ InTERnATIONAL CONFERENCE ON ORganizational SCIENCE DeVElopment: Responsible Organization (March $22^{\mathrm{ND}}-24^{\mathrm{TH}}$, Portorož Slovenia)

M. Moretti \& M. Markič: The Impact of Sustainable Processes on the Consumption of Drinking Water in the Manufacturing Industry

The article consists of four parts. The introductory part is followed by a presentation of sustainable water-related processes in the manufacturing industry. The third part of the article describes the methodology, the sample, and the findings of the survey. The final part consists of a discussion of the most important findings of the survey and recommendations for further research.

\section{Sustainable water-related processes in the manufacturing industry}

We will discuss drinking water and its use, alternative water sources, and water re-use, as well as the ISO 14001:2009, ISO 9001:2008, ISO 50001:2011 environmental standards.

\subsection{Drinking water, alternative sources of water, and water re-use}

Drinking water is water intended for drinking, domestic purposes, food production, and trade that complies with health suitability standards irrespective of origin or type of delivery (NIJZ 2010). The supply of drinking water in the EU is organized by supply zones that are geographically defined and where water quality is considered approximately uniform (EU 2014, 3). EU policies on drinking water has, over the past few decades, contributed to the development the high quality of drinking water across the EU. Slovene legislation is tied to EU legislation. According to the Waters Act (Zakon o vodah (ZV-1), Uradni list RS, No. 67/2002), water rights acquired on the basis of a water permit (for uses specified in Article 125 of the Waters Act) or concessions (for uses specified in Article 136 of the Waters Act) have to be obtained for every use of public water or marine assets that exceeds general use (NIJZ 2010). For example, a water permit/concession/right has to be obtained for the private supply of drinking water or the supply of drinking water provided as a commercial public service, for technological purposes, the extraction of heat, the irrigation of agricultural land or other areas, propelling water mills, saws or similar installations, for the use of water specified in Article 118 of the Waters Act, even in the case of uses for which a concession has to be obtained such as the production of beverages, the needs of bathing areas and such like, if the use involves mineral, thermal or thermo-mineral water etc (ibid.). In manufacturing, water is used for cooling, preparation of raw materials, mixtures or materials for manufacture, cleaning, degreasing, rinsing, product performance tests, and testing of fittings and machinery.

According to the Waters Act, a water permit has to be obtained for taking water from the following areas or catchments:

- springs;

- watercourses (rivers);

- lakes;

- wells;

- drainages, etc. 
Water that can be re-used includes technological wastewater, which is used for supplying steam boilers, cooling condensers, reactors, machines with internal combustion, and so on (Lobnik 2008, 1). Its composition and quantity depends on industry type, technology and process type, raw materials, and finished products (Žgajnar Gotvajn, Kalčikova and Zagorc-Končan 2013, 3). Cooling water, which is used in the majority of cooling processes, also falls under the umbrella of technological wastewater (ibid.). To reduce water consumption, water discharge, and costs, it is possible to use a closed cooling system where water circulates, returning to the cooling system after cooling (ibid.). With re-use equipment, water can also be re-used for irrigation and technological and sanitary purposes (CWG 2015, 19).

\subsection{Sustainable water-related standards in the manufacturing industry}

The ISO 14001:2009 EMS belongs to the ISO 14000 family of environmental management systems (Tuominen, Tuominen in Malmberg 2011). The ISO 14001:2009 standard can be applied to all types of organizations and can be of assistance to the management in meeting their environmental goals (Sebhatu and Enquist 2007, 471; Kralj 2013, 91) The ISO 14001:2009 model is based on the Plan-Do-Check-Act (PDCA) methodology (Kralj 2013, 79). ISO 14001:2009 can help formulate environmental policies, identify environmental considerations, create performance indicators in absolute, relative or indexed values, set environmental goals and draw up programs to meet them, record-keeping, carrying out internal audits, planning, implementing improvements in sustainable water-related processes, etc (Vujoševič 2006, 79-80; Kralj 2013, 109-129).

The ISO 9001:2008 Quality Management System is part of the ISO 9000 family. The purpose of ISO 9001:2008 is to ensure that products meet regulations and customers' requirements and thus improve customer satisfaction (Unterlechner, Meško Štok and Markič 2009, 78). ISO 9001:2008 helps resolve problems in resource management, which becomes more efficient (costs come down) (Tricker 2013).

The ISO 50001:2011 energy management system is one of the newer ISO standards and is based on the management system model, which is also the basis of the ISO 9001 and ISO 14001 standards (Bunse et al. 2011; Brown and Desai 2014). The standard can be adopted irrespective of the type of energy: drinking water, technological water, electricity, natural gas, coke of coal, heating oil, $\mathrm{CO}_{2}$ emissions, etc. It is useful for organizations of all sizes, no matter the geographical, cultural, and social conditions (McKane 2010). The aim of ISO 50001:2011 is to enable organizations to set up systems and procedures which are needed to improve energy efficiency (Park et al. 2009). The standard specifies in detail the requirements for establishing and implementing energy policies, setting objectives and targets, and drawing up action plans (Park et al. 2009; Chiu, Lo and Tsai 2012; Brown and Desai 2014). 
$36^{\text {Th }}$ International Conference on Organizational Science Development: Responsible Organization (March $22^{\mathrm{ND}}-24^{\mathrm{TH}}$, Portorož SLOVENIA)

M. Moretti \& M. Markič: The Impact of Sustainable Processes on the Consumption of Drinking Water in the Manufacturing Industry

\section{Research}

The aim of our research was to determine the possible impact of environmental standards, water re-use, the use of alternative sources of water, and enterprise characteristics such as size, economic activity, and statistical region on the consumption of drinking water.

\subsection{Methodology}

The quantitative research instrument used was a closed-type questionnaire. Both the questions and the answers were adapted from studies by Bunse et al. (2011), Tricker (2013), Eliott (2013), Blewitt (2014), Brown and Desai (2014), and CWG (2015). The questionnaire was first tested for clarity and comprehensibility on a small group of 10 executive managers that was selected from the sample of companies that participated in the survey. No comprehension problems were reported, so the questionnaire was left unchanged. The questionnaire was sent by e-mail. The data was collected in November and December of 2014 through the Centre of Social Informatics at the Faculty of Social Sciences of the University of Ljubljana. Cronbach's Alpha was used to determine the reliability of the variables. According to Bartholomew, Knott, and Moustaki $(2011,45)$, an alpha score higher than 0.7 indicates a high degree of reliability. In our case, Cronbach's alpha was 0.914 , indicating a high degree of internal consistency. The collected data was analysed using SPSS 23 . We conducted a basic statistical analysis (frequencies, frequency percentage, arithmetic mean, standard deviation) as well as a regression analysis that was used to analyse the factors that impact the consumption of drinking water in manufacturing enterprises.

\subsection{Sample}

The total population of all small, medium-sized, and large enterprises in the manufacturing sector that was listed in the Gvin.com business directory on 19 November 2014 was included in the survey. On that day, 1913 enterprises were listed in the directory: 104 large enterprises (250+ employees), 463 medium-sized enterprises (50249 employees), and 1346 small enterprises (10-49 employees).

The sample consisted of executive managers and persons directly involved in strategic development - environmental protection officers, technology managers, and ecologists in small, medium-sized, and large enterprises in the manufacturing industry. As it was our belief that these persons had the most information and power to influence policies for the sustainable management of drinking water, it was decided to only send the questionnaire to them. A total of 285 questionnaires were returned, indicating a response rate of $14.9 \%$. The response rate was deemed sufficient for further statistical analysis.

Data on participating enterprises:

- based on size: $44.9 \%$ (128) large enterprises, $35.4 \%$ (101) medium-sized enterprises, and $19.6 \%$ (56) small enterprises; 
- based on economic activity: $22.5 \%$ (64) manufacture of metal products, except machinery and equipment, $13.7 \%$ (39) manufacture of electrical equipment, 8.4 $\%$ (23) manufacture of rubber and plastic products, $8.1 \%$ (23) manufacture of food products, $6.7 \%$ (19) manufacture of basic metals, $0.7 \%$ (2) manufacture of motor vehicles, trailers, and semi-trailers, manufacture of other transport equipment, and manufacture of furniture and wearing apparel;

- based on statistical region: most enterprises were based in the Savinja Statistical Region (58 enterprises; $0.7 \%$ ); the fewest in the Coastal-Karst Statistical Region ( 2 enterprises, $0.7 \%$ ).

\subsection{Basic statistical analysis}

The enterprises that participated in the survey supplied their water from the following sources: public water supply networks, private water supply networks, private wells (groundwater), rainwater, and/or other sources (rivers, mineral springs, and spring water). Table 1 shows the average amount of water used (in $1000 \mathrm{~m}^{3}$ ) in the enterprises.

Table 1: Amount of water used (in $1000 \mathrm{~m}^{3}$ )

\begin{tabular}{|c|l|c|}
\hline Label & \multicolumn{1}{|c|}{ Variable } & Mean \\
\hline Q9aa_1 & Public water supply 2012 & $9,090.08$ \\
\hline Q9aa_2 & Public water supply 2013 & $8,350.59$ \\
\hline Q9ab_1 & Self-supply - ground waters (wells) 2012 & $7,346.29$ \\
\hline Q9ab_2 & Self-supply - ground waters (wells) 2013 & $7,093.46$ \\
\hline Q9ac_1 & $\begin{array}{l}\text { Self-supply - running water (rivers, streams, private water } \\
\text { supply systems) 2012 }\end{array}$ & $55,026.93$ \\
\hline Q9ac_2 & $\begin{array}{l}\text { Self-supply - running water (rivers, streams, private water } \\
\text { supply systems) 2013 }\end{array}$ & $48,162.02$ \\
\hline Q9ad_1 & Self-supply - other (rainwater) 2012 & 52.01 \\
\hline Q9ad_2 & Self-supply - other (rainwater) 2013 & 69.61 \\
\hline
\end{tabular}

Most of the participating enterprises (257 enterprises) used the public water supply in the production process. 79 enterprises use it for cooling, 57 enterprises for the preparation of raw materials/mixtures/materials for productions, 63 enterprises use them for both purposes, and 57 enterprises use it for purposes of cleaning, degreasing, rinsing, product performance tests, and testing of fittings and machinery (Table 2). Table 2 also shows that 66 enterprises used their own water supply systems and wells, especially for cooling. 15 enterprises also used rainwater, mainly for cooling. 
$36^{\mathrm{TH}}$ InTERnATIONAL CONFERENCE ON ORganizational SCIENCE DeVElopment: RESPONSIBLE ORGANIZATION (MARCH $22^{\mathrm{ND}}-24^{\mathrm{TH}}$, PORTOROŽ SLOVENIA)

M. Moretti \& M. Markič: The Impact of Sustainable Processes on the Consumption of Drinking Water in the Manufacturing Industry

Table 2: Water sources and production processes in which they are used

\begin{tabular}{|c|c|c|c|c|c|}
\hline \multirow[t]{2}{*}{ Water source } & \multirow{2}{*}{$\begin{array}{l}\text { Numbe } \\
\text { r of } \\
\text { enterpr } \\
\text { ises }\end{array}$} & \multicolumn{4}{|c|}{ Production process } \\
\hline & & Cooling & $\begin{array}{c}\text { Preparation of } \\
\text { raw } \\
\text { materials/mixtur } \\
\text { es/materials for } \\
\text { production }\end{array}$ & Both & Other \\
\hline Public water supply & 257 & 79 & 57 & 63 & $57 *$ \\
\hline $\begin{array}{l}\text { Private water supply } \\
\text { system }\end{array}$ & 39 & 20 & 3 & 14 & $2 *$ \\
\hline Private well & 27 & 10 & 5 & 8 & $4 *$ \\
\hline Rainwater & 15 & 11 & 4 & 1 & $1 *$ \\
\hline $\begin{array}{l}\text { Other (rivers, springs, } \\
\text { mineral springs) }\end{array}$ & 25 & 22 & 4 & 0 & 0 \\
\hline
\end{tabular}

* cleaning, degreasing, rinsing, product performance tests, testing of fittings and machinery

173 enterprises implemented the ISO 14001:2009 standard, 219 enterprises implemented the ISO 9001:2011 standard, while 27 enterprises implemented the ISO 50001:2011 standard (see Table 3).

Table 3: Implemented environmental standards

\begin{tabular}{|l|r|}
\hline \multicolumn{1}{|c|}{ Environmental standard } & \multicolumn{1}{c|}{ f } \\
\hline $\begin{array}{l}\text { ISO 14001:2009 (environmental } \\
\text { management system) }\end{array}$ & 173 \\
\hline $\begin{array}{l}\text { ISO 9001:2011 (quality } \\
\text { management system) }\end{array}$ & 219 \\
\hline $\begin{array}{l}\text { ISO 50001:2011 (energy } \\
\text { management system) }\end{array}$ & 27 \\
\hline
\end{tabular}

The respondents had to give their opinion as to the success of their enterprises in reducing the consumption of drinking water in the past three years (in comparison with previous years). The respondents could choose one of seven answers: (1) very unsuccessful; (2) unsuccessful; (3) somewhat unsuccessful; (4) neither unsuccessful nor successful; (5) somewhat successful", (6) successful; (7) very successful. Table 4 shows that the statement "Increasing the amount of re-used water (as technological and/or cooling water) in the manufacturing process" received the highest score $(\mathrm{M}=4.78)$, while "The use of rainwater in the manufacturing process" received the lowest score $(M=3.30)$. The standard deviation ranged from 1.76 to 1.99 . 
36. MEDNARODNA KONFERENCA O RAZVOJU ORGANIZACIJSKIH ZNANOSTI: ODGOVORNA ORGANIZACIJA (22. - 24. MAREC 2017, PORTOROŽ, SLOVENIJA)

M. Moretti \& M. Markič: Vpliv izvajanja trajnostnih procesov na količino porabljene pitne vode $\mathrm{v}$ predelovalni industriji

Table 4: Performance indicators on the reduction of the consumption of drinking water

\begin{tabular}{|l|l|c|c|}
\hline Label & \multicolumn{1}{|c|}{ Variable } & M & SD \\
\hline Q8a & Meeting water reduction goals. & 4.48 & 1.65 \\
\hline Q8b & $\begin{array}{l}\text { The use of private wells in the manufacturing } \\
\text { process. }\end{array}$ & 3.95 & 1.91 \\
\hline Q8c & $\begin{array}{l}\text { The use of a private water supply system in the } \\
\text { manufacturing process. }\end{array}$ & 3.90 & 1.99 \\
\hline Q8d & $\begin{array}{l}\text { Increasing the amount of re-used water (as } \\
\text { technological and/or cooling water) in the } \\
\text { manufacturing process. }\end{array}$ & 4.78 & 1.76 \\
\hline Q8e & $\begin{array}{l}\text { The use of rainwater in the manufacturing } \\
\text { process. }\end{array}$ & 3.30 & 1.77 \\
\hline
\end{tabular}

\subsection{Regression analysis of drinking water consumption}

The performance indicator Q8a "Meeting water reduction goals" was used as the dependent variable. The following were used as independent variables: the performance indicators Q8b "The use of private wells in the manufacturing process", Q8c "The use of a private water supply system in the manufacturing process", Q8d "Increasing the amount of re-used water (as technological and/or cooling water) in the manufacturing process", and Q8e "The use of rainwater in the manufacturing process", size, economic activity, and statistical region, as well as the environmental standards ISO 14001:2009, ISO 9001:2011, and ISO 50001:2011.

The regression model was confirmed to be valid (the residuals were distributed normally). The multicollinearity test showed that the VIF values (1.00) of individual statements were not sufficiently high $(<2)$ as to have had an impact on the results.

The Stepwise method was used during regression analysis. The analysis showed that the regression model explained $15.85 \%$ of the variance of the dependent variable (Table 5). The F-test $(\mathrm{F}=27.613)$ and the significance level $(\mathrm{sig}=0.000)$ also indicate the existence of a relationship between the variables ( $\mathrm{sig}<0.05)$.

Table 5: Multiple correlation coefficient and the determination coefficient

\begin{tabular}{|c|l|l|l|l|}
\hline Model & $\begin{array}{c}(\mathrm{r}) \\
\text { Correlation } \\
\text { coefficient }\end{array}$ & $\begin{array}{c}\text { (R2) } \\
\text { Determination } \\
\text { coefficient }\end{array}$ & $\begin{array}{c}\text { Adjusted (R2) } \\
\text { determination } \\
\text { coefficient }\end{array}$ & $\begin{array}{c}\text { Standard } \\
\text { error }\end{array}$ \\
\hline 1 & 0.405 & 0.164 & 0.158 & 1.611 \\
\hline
\end{tabular}

We found that, despite expectations to the contrary, that only three variables - ISO 14001:2009 (unstandardized Beta = 0.603), Q8d "Increasing the amount of re-used water (as technological and/or cooling water) in the manufacturing process" (unstandardized Beta $=0.403$ ), and Q8c"The use of a private water supply system in the manufacturing 
$36^{\mathrm{TH}}$ International Conference on ORganizational Science Development: RESPONSIBLE ORGANIZATION (MARCH $22^{\mathrm{ND}}-24^{\mathrm{TH}}$, PORTOROŽ SLOVENIA)

M. Moretti \& M. Markič: The Impact of Sustainable Processes on the Consumption of Drinking Water in the Manufacturing Industry

process" (unstandardized Beta $=0.313$ ) - had a positive effect on reducing the consumption of drinking water (see Table 6).

Table 6: Regression coefficient estimates

\begin{tabular}{|c|c|c|c|c|c|}
\hline \multirow[t]{2}{*}{ Model 1} & \multicolumn{2}{|c|}{ Unstandardized coefficients } & \multirow{2}{*}{$\begin{array}{c}\text { Standardized Beta } \\
\text { coefficient }\end{array}$} & \multirow[t]{2}{*}{$\mathrm{t}$} & \multirow[t]{2}{*}{ sig } \\
\hline & Beta & Standard error & & & \\
\hline Constant & 2.875 & 0.321 & & 13.600 & 0.000 \\
\hline Q8c & 0.313 & 0.048 & 0.356 & 6.525 & 0.000 \\
\hline Q8d & 0.403 & 0.049 & 0.451 & 7.988 & 0.019 \\
\hline $\begin{array}{l}\text { ISO } \\
14001: 2009\end{array}$ & 0.603 & 0.196 & 0.168 & 3.077 & 0.023 \\
\hline
\end{tabular}

Notes: Q8c - the use of a private water supply system in the manufacturing process; Q8d - increasing the amount of re-used water (as technological and/or cooling water) in the manufacturing process

Variables such as the use of rainwater in the manufacturing process (Q8e), the use of private wells in the manufacturing process (Q8b), size, economic activity, statistical region, ISO 50001:2011, and ISO 9001: 2008 do not have a statistically significant effect on meeting water reduction goals (see Table 7).

Table 7: Variables excluded from the regression model

\begin{tabular}{|l|l|c|c|}
\hline \multicolumn{1}{|c|}{ Model 1 } & Beta In & $\mathrm{t}$ & sig \\
\hline Q8b & $0.069^{\mathrm{c}}$ & 0.907 & 0.365 \\
\hline Q8e & $0.028^{\mathrm{c}}$ & 0.461 & 0.645 \\
\hline Size & $0.049^{\mathrm{c}}$ & 0.900 & 0.369 \\
\hline Economic activity & $0.086^{\mathrm{c}}$ & 1.372 & 0.171 \\
\hline Statistical region & $0.023^{\mathrm{c}}$ & 0.423 & 0.673 \\
\hline ISO 50001:2011 & $0.002^{\mathrm{c}}$ & 0.044 & 0.965 \\
\hline ISO 9001: 2008 & $0.073^{\mathrm{c}}$ & 1.311 & 0.191 \\
\hline
\end{tabular}

Legend: Q8b - the use of private wells in the manufacturing process; Q8e - the use of rainwater in the manufacturing process

\section{Conclusion}

The aim of our research was to determine the possible impact of environmental standards (the ISO 14001:2009 EMS, the ISO 9001:2008 QMS, and the ISO 50001:2011 EMS), water re-use (for technological and cooling purposes), the use of alternative sources of water (rainwater, wells, private water supply systems), and enterprise characteristics such as size, economic activity, and statistical region on the consumption of drinking water. 
The analysis showed that the implementation of the ISO 14001: 2009 standard, increasing water re-use for technological and cooling purposes, and the use of private water supply systems had an statistically significant effect on reducing the consumption of drinking water in the manufacturing sector in Slovenia, while the rest of the factors did not have a statistically significant effect. Our findings were similar to those of other studies, as they showed that the adoption of ISO 9001 (Pivka 2000; Rebernik 2000) and ISO 50001 (Flores Argüelles 2013) had a statistically insignificant impact compared to the cost of implementing them.

As some of the biggest consumers of drinking water, enterprises in the manufacturing industry can reduce their consumption of water by improving their work processes and by making use of alternative sources of drinking water, thereby reducing water stress and protecting the environment.

Our findings offer new theoretical and practical insights which will be of use for the successful adoption of sustainable policies in theory, research, and practice in enterprises and other organizations. We also provide recommendations for further research:

- We found that in consumption of drinking water in Slovenia is being successfully reduced through the sustainable management of drinking water and certain factors of innovation and the organizational system. It would be of interest to research the influence of other factors such as economic-financial factors, technical-technological factors, etc., in Slovenia and other EU countries.

- We found that innovation factors and the organization of production processes have an effect on the development of sustainable management of drinking water in enterprises in the manufacturing industry in Slovenia. Research should be extended to organizations in sectors such as water supply, sewerage, accommodation and food service activities, and human health and social work activities.

- We found that organizations that use drinking water more sustainably use larger amounts of water in production, both from the public water supply and from private catchments (private water supply systems, rivers, streams), as well as wells and rainwater. It would be of interest to research the prospect aspects of water consumption per unit of output.

- The survey should be expanded by looking at newer and not yet implemented quality and excellency standards such as social responsibility, the EFQM Excellence Model, risk management, project management, health and safety management, etc.

\section{Literature}

Bartholomew, D., Knott, M. \& Moustaki, I. (2011). Latent variable models and factor analysis. Chichester, Hoboken: Wiley.

Blewitt, J. (2014). Understanding sustainable development. London: Routledge. 
$36^{\text {Th }}$ International Conference on Organizational Science Development: Responsible Organization (March $22^{\mathrm{ND}}-24^{\mathrm{TH}}$, Portorož Slovenia)

M. Moretti \& M. Markič: The Impact of Sustainable Processes on the Consumption of Drinking Water in the Manufacturing Industry

Brown, M. \& Desai, D. (2014). The ISO 50001 Energy Management Standard: What is it and how is it changing? Strategic Planning for Energy and the Environment, Vol. 34, No. 2, pp. 16 - 25.

Bunse, K, Vodicka, M., Schönsleben, P., Brülhart, M. \& Ernst, F. O. (2011). Integrating energy efficiency performance in production management - gap analysis between industrial needs and scientific literature. Journal of Cleaner Production, Vol. 19, No. 6/7, pp. 667 - 679.

Chen, B. (2004). ISO 14001, EMAS, or BS 8555: an assessment of the environmental management systems for UK businesses. Retrieved from http://citeseerx.ist.psu.edu/viewdoc/download?doi=10.1.1.533.7741\&rep=rep1\&type=pdf

Chiu, T. Y., Lo, S. L. \& Tsai, Y. Y. (2012). Establishing an integration-energy-practice model for improving energy performance indicators in ISO 50001 energy management systems. Energies, Vol. 5, No. 1, pp. 5324 - 5339.

Curkovic, S. \& Sroufe, R. (2011). Using ISO 14001 to promote a sustainable supply chain strategy. Business Strategy and the Environment, Vol. 20, No. 2, pp. 71 - 93.

CWG - Clean Water Group. (2015). Sistemi za obdelavo in tretiranje vode [Water treatment systems].

Retrieved

from

http://cwg.hr/images/downloads/6180/cwg_general_catalogue_slo.pdf

Elliott, J. (2013). An introduction to sustainable development. London: Routledge.

EU - European Commission. (2014). Zbirno poročilo o kakovosti pitne vode v EU, ki obravnava poročila držav članic za obdobje 2008-2010 v skladu z Direktivo 98/83/ES [Synthesis Report on the Quality of Drinking Water in the EU examining the Member States' reports for the period 2008-2010 under Directive 98/83/EC]. Retrieved from http://eur-lex.europa.eu/legalcontent/SL/TXT/?uri=CELEX:52014DC0363

Flores Argüelles, M. (2013). Towards sustainable energy consumption in German industrial sector: Is ISO 50001:2011 leading the way? Retrieved from http://rcube.ritsumei.ac.jp/bitstream/10367/5883/1/51211623.pdf

Kralj, D. (2013). Odličnost ravnanja z okoljem [Excellence in environmental management]. Maribor: Pivec.

Kralj, J. (2005). Management: temelji managementa, odločanje in ostale naloge managementa [Management: Basics of management, decision-making and other tasks of management]. Koper: Fakulteta za management.

Lobnik, A. (2008). Navodila za vaje pri predmetu Ekologija in okoljevarstvo [Notes on Ecology and environmentalism]. Maribor: Univerza v Mariboru, Fakulteta za strojništvo.

McKane, A. (2010). Thinking globally: How ISO 50001 energy management can make industrial energy efficiency standard practice. Retrieved from https://escholarship.org/uc/item/92d8q553

Moretti, M. \& Markič, M. (2016). Trajnostno upravljanje s pitno vodo v predelovalni dejavnosti [Sustainable management of drinking water in manufacturing]. Koper: Založba Univerze na Primorskem.

Možina, S. \& Kovač, J. (2006). Menedžment znanja: znanje kot temelj razvoja na poti $k$ učečemu se podjetju [Knowledge management: knowledge as the foundation of a learning organization]. Maribor: Pivec.

NIJZ - Nacionalni inštitut za javno zdravje. 2010. Pogosta vprašanja o pitni void [Frequently asked questions about drinking water]. Retrieved from http://www.nijz.si/sl/pogostavprasanja-o-pitni-vodi

Park, C. W., Kwon, K. S., Kim, W. B., Min, B. K., Park, S. J., Sung, I. H., Lee, K. S., Lee, J. H. \& Seok, J. (2009). Energy consumption reduction technology in manufacturing: A selective review of policies, standards, and research. International Journal of Precision Engineering and Manufacturing, Vol. 10, No. 5, pp. 151 - 173.

Piskar, F. \& Dolinšek, S. (2006). Učinki standarda kakovosti ISO [The impact of the ISO quality standard]. Koper: Fakulteta za management. 
M. Moretti \& M. Markič: Vpliv izvajanja trajnostnih procesov na količino porabljene pitne vode $\mathrm{v}$ predelovalni industriji

Pivka, M. (2000). Management kakovosti [Quality management]. Maribor: Ekonomsko-poslovna fakulteta.

Rebernik, M. (2000). Certifikati kakovosti in dobičkonosnost podjetja: kakovost in ISO 9000 [Quality certifications and company profitability: quality and ISO 9000]. Kapital, Vol. 10, No. 231, p. 35 .

Sebhatu, S. P. \& Enquist, B. (2007). ISO 14001 as a driving force for sustainable development and value creation. The TQM Magazine, Vol. 19, No. 5, pp. 468 - 482.

SURS - Statistični urad Republike Slovenije. (2015). Izkoriščanje voda v industriji [Water use in industry]. Retrieved from http://www.stat.si/StatWeb/prikazinovico?id=6069\&idp $=13 \&$ headerbar $=11$

Tricker, R. (2013). IS0 9001: 2008 for small businesses. London: Routledge.

Tuominen, K., Tuominen, R. \& Malmberg, L. (2011). Johtamisstandardit-pikaoppaat: Kestävää ympäristönhallintaa pähkinässä - ISO 14001 \& EMAS [Management standards - quick guides: sustainable management standards - ISO 14001 \& EMAS]. Turku: Oy Benchmarking.

Unterlechner, M., Meško Štok, Z. \& Markič, M. (2009). Inoviranje, kakovost in Lean Six Sigma v proizvodnem procesu [Innovation, quality and Lean Six Sigma in the production process]. Koper: Fakulteta za management.

Vujoševič, N. (2006). Vodilo za okoljske standard [Environmental standard guidelines]. Ljubljana: GV založba.

ZV-1 - Zakon o vodah [Waters Act (ZV-1)]. Uradni list RS, št. 67/2002.

Žgajnar Gotvajn, A., Kalčikova, G. \& Zagorc - Končan, J. (2013). Industrijski procesi in trajnostni razvoj [Industrial processes and sustainable development]. Ljubljana: Fakulteta za kemijo in kemijsko tehnologijo. 
626 36 $6^{\text {Th }}$ International Conference on Organizational Science Development: Responsible Organization (MARCH $22^{\mathrm{ND}}-24^{\mathrm{TH}}$, PORTOROŽ SLOVENIA) 
$36^{\mathrm{TH}}$ International Conference on Organizational Science Development: Responsible Organization (MARCh $22^{\mathrm{ND}}-24^{\mathrm{TH}}$, PORTOROŽ SLOVENIA)

O. Arsenijević, M. Ferjan, I. Podbregar, P. Šprajc, D. Trivan \& Y. Ziegler

\title{
Organizational Restructuring and Cost Allocation Based on Business Process Approach
}

\author{
Jovana MrVić, JelicA ERCEG, MaŠA VuKOMANOVIĆ, IVAN TODOROVIĆ \& \\ STEFAN KOMAZEC
}

\begin{abstract}
Modern authors agree that organizational structure and business processes are some of the main elements of an organization. This paper aims to show the importance of proper process analysis and immense advantages it can bring in terms of organizational restructuring. Presented methodology shows the importance of adequate cost allocation as a result of detailed process analysis on a specific restructuring project. Successful process mapping and process analysis help not only in visualizing the process with all of participants included, but also in allocating the costs that each of them requires and making the precise assessment of different units' financial performance. After process analysis is conducted and exact financial results are gathered, proper ground base for defining a new organizational structure can be set. Data used in this paper were gathered during a restructuring project of one public enterprise from Serbia, performed by the consultant team from the Faculty of Organizational Science at the University of Belgrade in 2016.
\end{abstract}

KEYWORDS: business - process $\bullet$ mapping $\bullet$ analysis $\bullet$ optimization • organizational structure $\cdot$ restructuring $\bullet$ cost allocation $\bullet$ performance

CORRESPONDENCE ADDRESS: Jovana Mrvić, Ph.D., University of Belgrade, Faculty of organizational sciences, Jove Ilića 154, Belgrade 166136, Serbia, e-mail: mrvic.jovana@fon.bg.ac.rs, Jelica Erceg, Ph.D., University of Belgrade, Faculty of organizational sciences, Jove Ilića 154, Belgrade 166136, Serbia, e-mail: erceg.jelica@fon.bg.ac.rs, Maša Vukomanović, ddr., University of Belgrade, Faculty of organizational sciences, Jove Ilića 154, Belgrade 166136, Serbia, e-mail: vukomanovic.masa@fon.bg.ac.rs, Ivan Todorović, Ph.D., University of Belgrade, Faculty of organizational sciences, Jove Ilića, 154, Belgrade 166136, Serbia, e-mail: todorovic.ivan@fon.bg.ac.rs, Stefan Komazec, Ph.D., University of Belgrade, Faculty of organizational sciences, Jove Ilića 154, Belgrade 166136, Serbia, e-mail: komazec.stefan@fon.bg.ac.rs 
$36^{\text {Th }}$ International Conference on Organizational Science Development: Responsible Organization (MARCH $22^{\mathrm{ND}}-24^{\mathrm{TH}}$, Portorož SLOVENIA)

J. Mrvić, J. Erceg, M. Vukomanović, I. Todorović \& S. Komazec: Organizational Restructuring and Cost Allocation Based on Business Process Approach

Structural approach and emphasizing organizational structure in terms of hierarchy levels, vertical relations, control range and graphical visualizations was leading direction for many years, when it comes to organizational design changes (Mintzberg, 1980). However, there are additional components of organizational structure that should be considered in organizational design (Daft, 2004). As structural approach, in most cases, did not lead to the desired results, processes were the ones that came in the forefront in terms of organizational structure design and organizational change (Todorović, Komazec, Marič, \& Krivokapić, 2013). Hammer and Champy (1993) were one of the first authors that introduced the term of process reengineering and the significance of processes and process improvements within the organization.

\subsection{Process approach and organizational structure design}

Authors from the field of organizational design define organizational structure differently, but most of them agree that organizational structure is one of the main elements of every organization. Organizational structure defines the way organizations assign their work and tasks and achieve coordination of realization (Mintzberg, 1979). Certain authors describe organizational structure as a group of patterns, developed and integrated as a mutual activation entity by individuals from the organizations (Dulanović \& Jaško, 2009). Processes on the other hand, are other very important organization elements (Kates \& Galbraith, 2008). They are being performed through the entire organization and create the pathways for satisfying the customer needs. Business processes are core of the transformation mechanism, which is generating new value and enables the organization to differ from competitors (Osterwalder \& Pigneur, 2010).

Processes can also be defined as a set of interrelated activities that transform inputs into outputs (Scheer, 2009). They enable inputs to be transformed into outputs (Laguna \& Marklund, 2013). Taking all of these definitions into account, the purpose of every organization can be defined as the usage of certain inputs and their transformation to desired outputs, by using set of interrelated activities, which results in products or services provided (Komazec, Todorović, \& Jevtić, 2012). There are authors that explain business processes as the activities performed in organizations, that are coordinated via communication between the people involved. As sentences used to communicate are naturally structured by subject, verb, and object, subject in this term describes the actor, the verb the action and the object explaines what is affected by the action. Subjects represent agents of an action in a process, which can be either technical or human. A process structures the actions of each subject and coordinates the required communication among the subjects (Fleischmann, Schmidt, Stary, Obermeier, \& Brger, 2014). This perspective provides a coherent procedural framework to model and analyze business processes, its focus is the cooperation of all stakeholders involved in the strategic, tactical, and operational issues, sharing their knowledge in a networked structure. There are also authors who emphasize the importance of process perspective in managing strategic dualities - pairs of imperatives that are equally important but to some degree in conflict 
with one another, like global integration and local responsiveness, low cost and differentiation and flexibility and efficiency (Birkinshaw, Crilly, Bouquet, \& Lee, 2016). As structural approach is about defining functions within an organization, control range and levels of hierarchy, it makes employees focused on their tasks within the function units, not having the bigger picture of other activities and other units, that are often part of the same process as activities they perform (Jeston \& Nelis, 2008). On the other hand, process perspective defines an organization as a business process network (Jaško, Čudanov, Jevtić, \& Krivokapić, 2013). There are many authors that emphasize the importance of core processes of an organization and the need of creating the horizontal structure within the organization. The aim of horizontal structure is coordinating employees, not in strictly defined functional units, but around the core processes. Some authors also emphasize the significance of process modeling. Processes should be modeled in the way that enable employees to be aware of the influence they make not only on process performance but also on organizational structure as well (Becker, Kugeler, \& Rosemann, 2003). Therefore, communication and cooperation between employees are being improved, teams responsible for the specific processes are being more efficient in performing their tasks, generating better financial results, affecting better product quality as well, which all lead to bigger satisfaction for both employees with results and consumers with the products and services provided.

Process reengineering can be defined as fundamental analysis and evaluation of process performed within the organization that will ensure significant results in terms of efficiency, expenses, product and services quality (Hammer, 2007). It is important to understand that the maximum gain accrues from intelligent process design followed by strategic, intelligent technology deployment to support those processes (Conger, 2014). Some authors emphasize organizational restructuring and business process reengineering as two biggest changes that can be made within the organization. Organizational restructuring refers to complex organizational changes including new strategy definition, structure, control range and hierarchy levels, technology, organizational culture, employee coordination and processes as well (Erić \& Stošić, 2013). The aim of reengineering is creating proper organizational structure based on core processes that will improve efficiency within the organization and make customers more satisfied with the product and services delivered as outcomes of the processes performed (Janićijević, 2004).

\subsection{Cost centers in organization}

Control centers are the parts of an organization controlled by the manager responsible for the specific organizational unit and its outcomes (Jaško, Čudanov, Jevtić, \& Krivokapić, 2013). The aim of control centers, referred as responsibilities centers as well, is to evaluate and measure the results of different functional units in order to take proper steps for improving their efficiency. Managers of different units are responsible for creating and delivering reports and presenting their unit results to the top management. By collecting different reports, top management is gathering decision making data, which is 
$36^{\mathrm{TH}}$ InTERnATIONAL CONFERENCE ON ORganizational SCIENCE DeVElopment: Responsible Organization (MARCh $22^{\mathrm{ND}}-24^{\mathrm{TH}}$, Portorož Slovenia)

J. Mrvić, J. Erceg, M. Vukomanović, I. Todorović \& S. Komazec: Organizational Restructuring and Cost Allocation Based on Business Process Approach

significant for potential improvements within the whole organization (Healy \& Palepu, 2012).

Each control center uses its own resources, has its own goals and functional barriers. Depending on the activities they perform as well as the way input and outputs are measured, there are cost centers, revenue centers, profit centers and investment centers as centers of control (Jaško, Čudanov, Jevtić, \& Krivokapić, 2013). Cost centers require that costs must be assigned to organizational units according to their source. A cost center is a unit of activity within the company to which costs can be practically and equitably assigned. A cost center can be a department, a group of workers, it could represent one job, one process or one machine (Vanderbeck, 2012). Keeping the track of cost centers is important in the light of making sensible decisions when it comes to cost of the product company markets. Product design and new product-introduction decisions will be influenced by the anticipated cost and profitability of the product (Bruns \& Kaplan, 1987).

Proper cost allocation identifies both profitable parts of the organization and the ones that need significant improvements in different areas including process performance and employee coordination (Kaplan \& Cooper, 1998). Having all mentioned in mind, we can say that business processes approach and proper cost allocation are ground base for designing organizational structure. In this paper specific cost allocation methodology will be presented as the starting point of the new structure design of one Serbian public enterprise.

\section{$2 \quad$ Methodology}

In order to acquire all the necessary information and cover wide variety of activities of the analyzed company, methodology that was used by the consultant team required several steps. Firts step was to analyze formal documentation of the company, especially financial documentation as well as the human resources documentation. This analysis provided an insight into the current situation of the company. Furthermore, consultant team held numerous meetings with top management of the company. The goal was to learn about business processes within the company based on which new organization solution was developed. Having in mind a wide range of different businesses and activities in specific company it was also necessary to conduct interviews with managers at the lower levels of hierarchy who provided consultant team detailed information about processes in all organizational units. After gathering all the necessary information about processes, the next step was process visualization using process mapping system. The aim of this step is to precisely map current process flow in order to detect potential drawbacks and bottlenecks. Maps should be designed in such way they are easily understood to all stakeholders involved (Nash \& Poling, 2008). In that light, consultants used swim lane diagrams for visualization and thorough analysis of the processes. Detailed financial analysis was a ground base for improvement of cost allocation method that was in use so far. Consultants used spreadsheet tool for financial modeling, which can be easily adapted by changing the input variables, so that projection model becomes 
useful for showing the impact of different assumptions and/or strategies for the future (Tjia, 2009). The results were used for process optimization and improvement of organizational structure. Only the combination of all afore mentioned steps could provide the consultants with significant amount of information and create the starting point for further analysis and solution development.

\section{Company analysis and problem Identification}

The primary area of analyzed company is providing all utility services for the municipality. Beside core businesses, it also has other services in its portfolio. Company was divided on ten sectors including core and non-core businesses. Our focus will be on non-core operations. The main non-core part is the Bottling water plant and brewery. Along with the plant for exploitation of mineral water, new line for the production of beer was opened. This means that the plant was divided on two departments as shown on Figure 1.

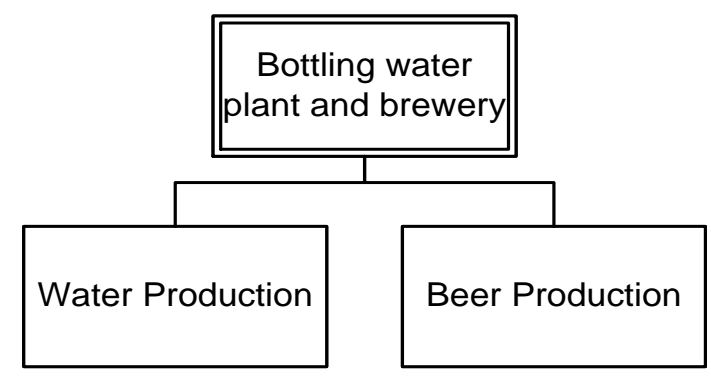

Figure 1: [Organizational structure of the Bottling water plant and brewery]

Distribution of products should currently be performed with a smaller number of employees, since its market position at this moment does not justify the existence of a complex and evolving organizational units dealing with the matter. What is essential is the fact that the price of production is currently too high, mainly due to high depreciation. A major problem is the lack of sales, or the lack of adequate market share. The plant has the capacity and the necessary technology, but production itself has no economic justification. Low demand on the market leads to big problems in business which is the reason why this part of the company operates with a negative financial result. Currently, there are 17 different jobs with 31 employees regarding the plant itself. Bearing in mind the results of further analysis, it was found that there are more employees who perform activities that are, wholly or substantially, related to the factory. There were 20 employees identified in Sales Department, who exclusively or mainly perform sales operations, warehouse operations, transportation and the repair of water coolers. Thus, the number of employees that are directly related to the production and distribution of water and beer now increases and it is 51 in total. The current process flow and its participants are presented on Figure 2. 
$36^{\mathrm{TH}}$ International Conference on ORganizational Science Development: Responsible Organization (MARCh $22^{\mathrm{ND}}-24^{\mathrm{TH}}$, Portorož Slovenia)

J. Mrvić, J. Erceg, M. Vukomanović, I. Todorović \& S. Komazec: Organizational Restructuring and Cost Allocation Based on Business Process Approach

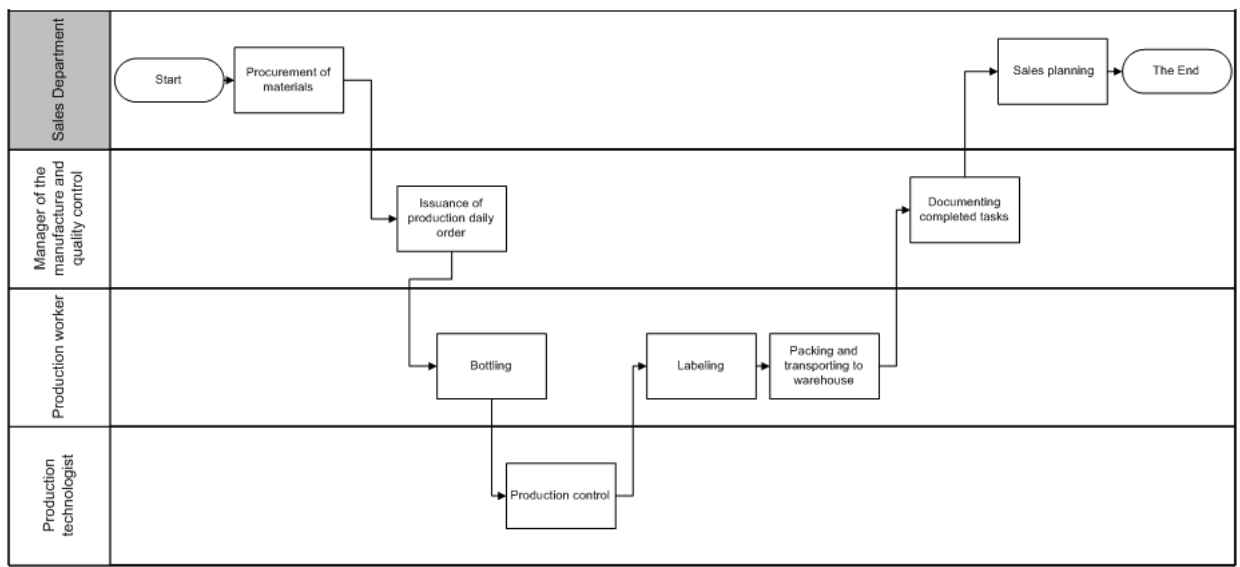

Figure 2: [Process flow of water bottling]

Due to existing organizational structure, large number of employees that are engaged on activities related to the Bottling water plant and brewery is located in other organizational units. It is important to understand the essence of the process being implemented and its interdependence so that all the employees who are responsible for the same processes should be located within the same unit. Current situation is causing issues and, most importantly, incorrect assessment of organizational units' financial performance.

According to analyzed financial documentation it was found that this company uses cost accounting in order to trace costs. Most of the costs are directly assigned to specific targets as well as most revenues. However, indirect cost cannot be traced directly to a cost object because they are usually common (Hammer \& Champy, 1993)n to several cost objects so they need to be assigned to cost objects using cost allocations (Drury, 2008). The main problem is that they have been using the same allocation keys for the last 25 years. During that period of time, the company has changed its activities numerous times, abandoning what was no longer desirable and starting many new businesses. As it happened, the old allocation keys were no longer appropriate. The company had one Joint Operations Department that consisted of Finance, Human Resources, Legal Department and Sales Department etc. This department had common revenues and expenses that refer to the whole company. Joint income is mainly formed of financial income from interest and income obtained from the issuance of objects that do not belong to any particular organizational unit, but the company as a whole. Common expenses resulted from the operations carried out within this department for all other organizational units of the company. They needed to be redistributed to proper organizational units. Using the existing allocation keys these revenues and expenses were allocated only on the organizational units that had positive financial result and ignoring other parts of the company. The Bottling water plant and brewery had negative financial result so it was excluded from this allocation. 
In addition, having analyzed the processes in every organizational unit, the consultant team detected one more problem regarding salary costs. There were many employees that were officially employed and working for one organizational unit according to their contracts, but in reality they were operating for completely different organizational part. That was not recorded in any type of internal documentation so these costs were neglected in the analysis of financial result of many organizational parts including Bottling water plant and brewery as well. Nonetheless, some other cost types were not allocated to the appropriate target, such as cost of vehicle maintenance. Therefore, many of the existing organizational units had positive financial result according to financial statement, but in reality they were operating with loss. The Bottling water plant and brewery already had negative financial result, but having afore mentioned problems in mind, consultant team had to determine the real financial image of the plant which was far worse than the one presented.

\section{$4 \quad$ Results and discussion}

In order to determine true performance of the Bottling water plant and brewery several steps were taken. First of all, new allocation keys for the whole company were defined in order to allocate joint revenues and expenses. Then, salary costs of the employees that work only for the plant but are presently located in some other organizational units were ascribed to the plant (Sales Department and Security). The last step was definition of special allocation keys for cost and revenues that belong only to specific units (Vehicle maintenance).

New allocation key represents composite weight in which number of employees of organizational unit compared to total number of employees participates with 0.8 , and share of organizational unit in the total revenue with 0.2. Regarding nature of the Joint Operations Department affairs, consultant team estimated that number of employees is more important factor for cost allocation and that is the reason for such distribution between weights. According the new allocation keys Bottling water plant and brewery gained the part of joint revenues and expenses which is shown on Figure 3.

The main problem was with the Sales Department which was explained previously trough the swim lane diagram. There were 20 employees that have been working only for the factory. From the total amount of their salaries about $40 \%$ referred to the Bottling water plant and brewery. Also, Security employees only guarded several locations including the plant so their salaries needed to be redistributed as well. There were six locations which were guarded by the exact number of security employees, so each organizational part got equal percentage of salary costs as shown on Figure 4.

Furthermore, only several organizational units have their own vehicles, so the cost of vehicle maintenance must be allocated only to those units and at the same time excluded from overall cost allocation based on afore mentioned allocation keys. It was necessary to determine special allocation key for this type of costs, based on the number of vehicles 
$36^{\mathrm{TH}}$ International Conference on ORganizational Science Development: RESPONSIBLE ORGANIZATION (MARCH $22^{\mathrm{ND}}-24^{\mathrm{TH}}$, PORTOROŽ SLOVENIA)

J. Mrvić, J. Erceg, M. Vukomanović, I. Todorović \& S. Komazec: Organizational

Restructuring and Cost Allocation Based on Business Process Approach

each organizational unit owns. According to these criteria the plant gained specific sum of vehicle maintenance costs that represent $12 \%$ of the total amount of this cost type.

\begin{tabular}{|c|c|c|c|c|c|c|c|}
\hline $\begin{array}{c}\text { Organizational } \\
\text { part }\end{array}$ & $\begin{array}{c}\begin{array}{c}\text { Number } \\
\text { of } \\
\text { Employe } \\
\text { es }\end{array} \\
\end{array}$ & Revenue & $\begin{array}{c}\% \text { of total } \\
\text { employee } \\
\text { number }\end{array}$ & $\begin{array}{c}\% \text { of } \\
\text { total } \\
\text { revenue }\end{array}$ & Weight & $\begin{array}{c}\text { Allocated } \\
\text { revenue }\end{array}$ & $\begin{array}{l}\text { Allocated } \\
\text { expenses }\end{array}$ \\
\hline $\begin{array}{l}\text { Organizational unit } \\
1\end{array}$ & 9 & $11,163,571$ & $1,70 \%$ & $0,49 \%$ & $1,46 \%$ & 517,197 & $3,341,707$ \\
\hline $\begin{array}{l}\text { Organizational unit } \\
2\end{array}$ & 68 & $1,068,376,092$ & $12,83 \%$ & $46,66 \%$ & $19,60 \%$ & $6,960,722$ & $44,974,532$ \\
\hline $\begin{array}{l}\text { Organizational unit } \\
3\end{array}$ & 15 & $27,386,733$ & $2,83 \%$ & $1,20 \%$ & $2,50 \%$ & 889,238 & $5,745,533$ \\
\hline $\begin{array}{l}\text { Organizational unit } \\
4\end{array}$ & 195 & $463,277,649$ & $36,79 \%$ & $20,23 \%$ & $33,48 \%$ & $11,892,843$ & $76,841,892$ \\
\hline $\begin{array}{l}\text { The Bottling water } \\
\text { plant and brewery }\end{array}$ & 31 & $72,205,658$ & $5,85 \%$ & $3,15 \%$ & $5,31 \%$ & $1,886,178$ & $12,186,952$ \\
\hline $\begin{array}{l}\text { Organizational unit } \\
5\end{array}$ & 18 & $20,047,084$ & $3,40 \%$ & $0,88 \%$ & $2,89 \%$ & $1,027,320$ & $6,637,707$ \\
\hline $\begin{array}{l}\text { Organizational unit } \\
6\end{array}$ & 37 & $57,400,483$ & $6,98 \%$ & $2,51 \%$ & $6,09 \%$ & $2,161,952$ & $13,968,777$ \\
\hline $\begin{array}{l}\text { Organizational unit } \\
7\end{array}$ & 46 & $36,138,695$ & $8,68 \%$ & $1,58 \%$ & $7,26 \%$ & $2,578,547$ & $16,660,477$ \\
\hline $\begin{array}{l}\text { Organizational unit } \\
8\end{array}$ & 44 & $129,285,532$ & $8,30 \%$ & $5,65 \%$ & $7,77 \%$ & $2,760,305$ & $17,834,850$ \\
\hline $\begin{array}{l}\text { Organizational unit } \\
9\end{array}$ & 67 & $404,559,977$ & $12,64 \%$ & $17,67 \%$ & $13,65 \%$ & $4,847,573$ & $31,321,082$ \\
\hline TOTAL & 530 & $2,289,841,474$ & & & & & \\
\hline & & & Employees & Revenue & & & \\
\hline & & Weight & 0,8 & 0,2 & & & \\
\hline
\end{tabular}

Figure 3: [Allocation of joint revenues and expenses]

\begin{tabular}{|l|r|l|r|r|}
\hline \multicolumn{2}{|c|}{ Sales Department } & \multicolumn{3}{c|}{ Security } \\
\hline Organizational part & Salary costs & Organizational part & Weight & Salary costs \\
\hline Sales Department & $16,348,993$ & Headquarter & $17 \%$ & $3,751,285$ \\
\hline The Bottling water plant and brewery & $15,096,048$ & Bottling water plant and brewery & $17 \%$ & $3,751,285$ \\
\hline Organizational unit 1 & $1,950,068$ & Organizational unit 1 & $17 \%$ & $3,751,285$ \\
\hline Organizational unit 2 & $1,415,598$ & Organizational unit 2 & $17 \%$ & $3,751,285$ \\
\hline Organizational unit 3 & 520,293 & Organizational unit 3 & $17 \%$ & $3,751,285$ \\
\hline Organizational unit 4 & $1,029,244$ & Organizational unit 4 & $17 \%$ & $3,751,285$ \\
\hline Organizational unit 5 & $1,927,385$ & & & \\
\hline TOTAL & $\mathbf{3 8 , 2 8 7 , 6 3 0}$ & & $\mathbf{2 2 , 5 0 7 , 7 1 2}$ \\
\hline
\end{tabular}

Figure 4: [Ascribed salary costs of Sales Department and Security] 
When all the changes were made and all the costs were allocated, it was possible to determine the real financial result of the Bottling water plant and brewery. As previously mentioned this plant already had negative financial result of about 12 million RSD. After rightfully allocated expenses the real loss was 42 million RSD. It was the sign for the consultant team that serious changes needed to be done in order to provide further existence of the plant.

\begin{tabular}{|l|r|r|r|}
\hline & Total revenues & Total expenses & Financial result \\
\hline Before allocation & $72,205,658$ & $83,906,647$ & $\mathbf{- 1 1 , 7 0 0 , 9 8 9}$ \\
\hline After allocation & $74,091,836$ & $115,967,124$ & $\mathbf{- 4 1 , 8 7 5 , 2 8 8}$ \\
\hline
\end{tabular}

Figure 5: [Financial result of the Bottling water plant and brewery]

First step was to relocate certain employees whose main activities already referred to the distribution activities for the plant exclusively. Next phase was to create a new Sales Department as one of the key parts of the plant, as presented on Figure 6. This will create the conditions for increasing the efficiency of the organization through better management and more precise execution and allocation of responsibility for the results to be achieved. What is more important is that this will improve the allocation of costs on the level of the whole company. 
$36^{\mathrm{TH}}$ International Conference on ORganizational Science Development: Responsible Organization (March $22^{\mathrm{ND}}-24^{\mathrm{TH}}$, Portorož SLOVEnia)

J. Mrvić, J. Erceg, M. Vukomanović, I. Todorović \& S. Komazec: Organizational

Restructuring and Cost Allocation Based on Business Process Approach

Current structure

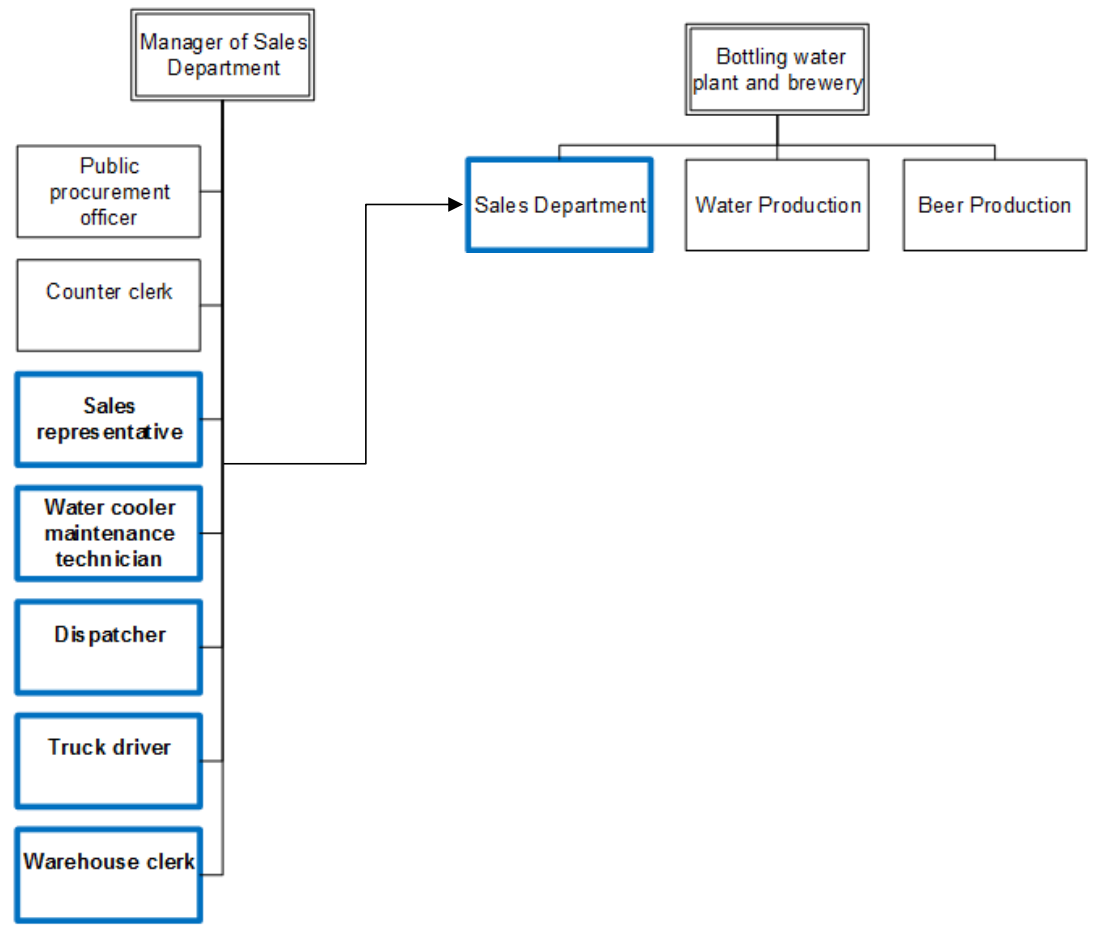

Figure 6: [Proposed reorganization of Bottling water plant and brewery]

Previous steps chronologically lead to the change in the number of employees in all departments based on the processes. Key processes analyzed related to the production, bottling, and distribution of products which are now relocated in the plant, provided the necessary number of employees. When it comes to the production, taking into account the technology which carries out production and bottling of water and beer, in certain extent it already defines the necessary capacity. Bearing in mind the current volume of production and organization of work with existing technology, estimated number of employees on the jobs that are directly related to production is decreased on 36 .

Further emphasis should be on developing sales and marketing activities to influence the improvement of market position and, consequently, the development of the entire organizational unit. Increased volume of production and different organization of the distribution network would lead to the need for new jobs. With that in mind, the number of employees should increase and relative to that new shifts could be introduced. However, the strategic decisions of the future way of doing business will continue to define the development plans for the plant. It is already clear that they will be in any case 
J. Mrvić, J. Erceg, M. Vukomanović, I. Todorović \& S. Komazec: Organizational Restructuring and Cost Allocation Based on Business Process Approach

largely based on improving distribution and sales network. Otherwise, the performance of such activities within the company would be irrational and unjustified.

It should be mentioned that the suggested number of employees actually represents a transitional solution which is based on the potential that the plant now has, and it is consequently subject to change.

\section{Conclusion}

processes. Key users of process output are those who see outcomes of the process of the organization and employees are the ones who see the structure. A well-designed structure which is based on the main processes will enable the coordination of employees in the direction of defining business strategy and meet the needs of users. This paper presents modern methodology of process analysis, whose adequate implementation should lead to significant results in improving organizational structure. By the example of the public enterprise presented, it is proved that process analysis can significantly help in proper perceiving of performance different organizational units have. It helps in realizing the participants in each process, all the costs they require, and the profit they generate. Only in this manner, by adequate process analysis and right cost allocation, the proper ground base for defining new organizational structure can be set. Achieving optimal compliance of these two elements will have a direct impact on other elements of the organization, enable coordination of employees, contribute to the realization of the strategy and business objectives, faster response to requests from the environment, increase the efficiency of resources and should be the goal that each organization will strive to fulfill. Limitation of this analysis was the lack of market study and sales estimation data, which could have affected the results, but only in term of number of employees. Proposed solution regarding process optimization and organizational structure would remain the same despite sales potential. Further research in this area might be oriented towards measuring the performance of employees and business results after aligning process map and organizational structure.

\section{Literature}

Becker, J., Kugeler, M., \& Rosemann, M. (2003). Process Management: A Guide for the Design of Business Processes. Berlin: Springer.

Birkinshaw, J., Crilly, D., Bouquet, C., \& Lee, Y. S. (2016). How do firms manage strategic dualities? A process perspective. Academy of Management Discoveries, Vol. 2, No. 1, 51-78.

Bruns, W., \& Kaplan, R. (1987). Accounting \& Management: Field Study Perspectives. Boston: Harvard Business Press.

Carmeli, A., \& Tishler, A. (2004). The Relationships between Intangible Organizational Elements and Organizational Performance. Strategic Management Journal, 1257-1278.

Conger, S. (2014). Handbook on Business Process Management. Heidelberg: Springer.

Daft, R. L. (2004). Organization theory and Design, 8th edition. Mason, Ohio: Thomson - Southern Western. 
$36^{\text {Th }}$ International Conference on Organizational Science Development: Responsible Organization (MARCh $22^{\mathrm{ND}}-24^{\mathrm{TH}}$, Portorož Slovenia)

J. Mrvić, J. Erceg, M. Vukomanović, I. Todorović \& S. Komazec: Organizational Restructuring and Cost Allocation Based on Business Process Approach

Drury, C. (2008). Management and Cost Accounting. London: Pat Bond.

Dulanović, Ž., \& Jaško, O. (2009). Organizaciona struktura i promene. Belgrade: University of Belgrade, Faculty of Organizational Sciences.

Erić, D. D., \& Stošić, I. S. (2013). Korporativno restrukturiranje. Beograd : Institut ekonomskih nauka.

Fleischmann, A., Schmidt, W., Stary, C., Obermeier, S., \& Brger, E. (2014). Subject-Oriented Business Process Management. Heidelberg: Springer Publishing Company.

Hammer, M. (2007). The Process Audit. Harvard Business Review, 85(4), 1-14.

Hammer, M., \& Champy, J. (1993). Reengenering the Corporation. New York: Harper Collins.

Healy, P. M., \& Palepu, K. G. (2012). Business analysis valuation: Using financial statements. Boston: Cengage Learning.

Janićijević, N. (2004). Upravljanje organizacionim promenama. Beograd: Centar za izdavačku delatnost Ekonomskog fakulteta u Beogradu.

Jaško, O., Čudanov, M., Jevtić, M., \& Krivokapić, J. (2013). Projektovanje organizacije. Beograd : Fakultet organizacionih nauka.

Jeston, J., \& Nelis, J. (2008). Management by Process - A roadmap to sustainable Business Process Management. Oxford: Elsevier Ltd.

Kaplan, R. S., \& Cooper, R. (1998). Cost \& effect: using integrated cost systems to drive profitability and performance. Brighton, Massachusetts: Harvard Business Press.

Kates, A., \& Galbraith, J. (2008). Designing Your Organization. San Francisco: Jossey-Bass.

Komazec, S., Todorović, I., \& Jevtić, M. (2012). Application of Process Organization Model as a Basis for Organizational Structure Improvement. Strategic Management 17(4), pp. 41-49.

Laguna, M., \& Marklund, J. (2013). Business Process Modeling, Simulation and Design. New York: CRC Press.

Mintzberg, H. (1979). The Structuring of Organization. New Jersey: Prentice Hall, Englewood Cliffs.

Mintzberg, H. (1980). Structure in 5's: A Synthesis of the Research on Organization Design. Management science, 26(3), 322-341.

Nash, M., \& Poling, S. R. (2008). Mapping The Total Value Stream - A Comprehensive Guide for Production and Transactional Processes. New York: Taylor \& Francis Group LLC.

Osterwalder, A., \& Pigneur, Y. (2010). Business model generation. New Jersey: John Wiley \& Sons.

Scheer, A. W. (2009). Business process engineering: reference models for industrial enterprises. Berlin, Germany: Springer-Verlag.

Todorović, I., Komazec, S., Marič, M., \& Krivokapić, J. (2013). Cost-Effective Restructuring Based on Process Approach. Organizacija, 46(4), 157-163.

Vanderbeck, E. (2012). Principles of Cost Accounting. Cengage Learning. 
36. MEDNARODNA KONFERENCA O RAZVOJU ORGANIZACIJSKIH ZNANOSTI: OdgOVORNA ORGANIZACIJA (22. - 24. MAREC 2017, PORTOROŽ, SLOVENIJA)

O. Arsenijević, M. Ferjan, I. Podbregar, P. Šprajc, D. Trivan \& Y. Ziegler

\title{
Zdravstveni absentizem v proizvodnem podjetju
}

\author{
SAŠO NUNAR \& MOJCA BERNIK
}

Povzetek V raziskavi, na katero se članek navezuje, smo se posvetili analizi in interpretaciji podatkov, ki smo jih pridobili iz proizvodnega podjetja. Skušali smo prikazati, katere vrste absentizma je bilo v podjetju največ ter kakšna je bila stopnja absentizma od maja 2015 do maja 2016. Prav tako nas je zanimalo, v katerem proizvodnem obratu v podjetju je bilo največ absentizma in zakaj ter katere vrste absentizma so v posameznih obratih dominirale.

Ugotovili smo, da je bilo v ostalih službah, ki sicer niso del proizvodnje, temveč predstavljajo režijo, največ primerov bolniške odsotnosti, takoj zatem pa glede na primere sledi proizvodni obrat D. Rezultati so se med seboj nekoliko razlikovali, saj smo podatke o primerih bolniške odsotnosti analizirali za celotno leto 2015 in tekoče leto 2016, o stopnji absentizma pa smo upoštevali podatke, ki so nam bili na voljo, in sicer od maja 2015 do maja 2016. Najbolj pogost vzrok za odsotnost z dela je bila v vseh obratih kot tudi v ostalih službah (režija), boleznina.

$\mathrm{Na}$ koncu oziroma v zaključku smo podali predloge ukrepov, s katerimi bi podjetje zdravstveni absentizem lahko zmanjšalo in ga obvladovalo.

KLJUČNE BESEDE: zdravstveni absentizem • delovni pogoji • zdravje • ukrepi • proizvodno podjetje

\footnotetext{
NASLOV AVTORJEv: Sašo Nunar, Univerza v Mariboru, Fakulteta za organizacijske vede, Kidričeva cesta 55a, 4000 Kranj, Slovenija, e-pošta: nunar123@gmail.com; dr. Mojca Bernik, docentka, Univerza v Mariboru, Fakulteta za organizacijske vede, Kidričeva cesta 55a, 4000 Kranj, Slovenija, e-pošta: mojca.bernik@fov.uni-mb.si
} 
36 ${ }^{\text {TH }}$ International CONFEREnCE ON ORganizational Science DeVElopment: Responsible ORGanizATION (MARCH $22^{\mathrm{ND}}-24^{\mathrm{TH}}$, PORTOROŽ SLOVENIA)

O. Arsenijević, M. Ferjan, I. Podbregar, P. Šprajc, D. Trivan \& Y.

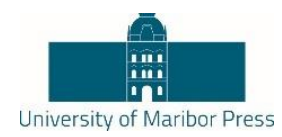

Ziegler

\title{
Sickness Absenteeism in the Manufacturing Company
}

\section{SAŠO NUNAR \& MOJCA BERNIK}

\begin{abstract}
In the article we focused on the analysis and interpretation of results obtained from the manufacturing company. We discussed what type of absenteeism was most common and what level of absenteeism was recorded in the period between May 2015 and May 2016. Furthermore, we recorded the types of absenteeism in different production units that were most common.
\end{abstract}

We determined that the majority of sick leaves were taken by the workers that represent administration and not those that were part of the production units. Administration was followed by production unit D.

The results varied amongst each other as the data for sick leave was analysed for the period from 2015 to 2016 while the data for the level of absenteeism was only available for the period from May 2015 till May 2016. The most common cause of absence from work in all production units and other positions (administration) was sickness.

In the conclusion we provided suggestions on how the company could minimize absenteeism and remain low levels of sick leave.

KEYWORDS: sickness absenteeism - working conditions • health • measures $\bullet$ manufacturing company

CORRESPONDENCE AdDRESS: Sašo Nunar, University of Maribor, Faculty of Organizational Sciences, Kidričeva cesta 55a, 4000 Kranj, Slovenia, e-mail: nunar123@gmail.com; Mojca Bernik, Ph.D., Assistant Professor, University of Maribor, Faculty of Organizational Sciences, Kidričeva cesta 55a, 4000 Kranj, Slovenia, e-mail:mojca.bernik@fov.uni-mb.si 


\section{$1 \quad$ Uvod}

Zdravstveni absentizem predstavlja čas, $\mathrm{v}$ katerem zaposleni zaradi bolezni, nege družinskega člana ali poškodbe ne dela in je z delovnega mesta tudi odsoten (Vučković, 2010). Zdravstveni absentizem spremlja v Sloveniji Nacionalni inštitut za javno zdravje, ki analizira podatke koriščenja bolniškega staleža. Pri pregledu podatkov lahko vidimo, da je zdravstveni absentizem v Sloveniji precej stabilen, saj je v letu 2015 znašal 4,1\%, enak odstotek pa je bil tudi v prvi polovici leta 2016 (NIJZ, 2017). Glede na to, da se zdravstveni absentizem v Evropi giblje med 3-6\% (EFILWC, 2017), lahko rečemo, da Slovenija ne spada $\mathrm{v}$ vrh evropskih držav, ki se spopadajo z največjim odstotkom zdravstvenega absentizma. Kljub temu skušajo podjetja v Sloveniji zmanjšati oziroma omejiti zdravstveni absentizem, ki se odraža tako v organizacijskih kot finančnih problemih. Delavec namreč zaradi odsotnosti ne opravlja del in nalog, ki so določene z opisom delovnega mesta oziroma za katere je zadolžen, hkrati pa potrebuje pri prihodu nazaj na delovno mesto veliko časa, da nadoknadi zamujeno delo (Martimo, 2006). To podjetju predstavlja upočasnjevanje delovnega procesa ter izgubo delovnega časa, ki bi ga delavec opravil, če bi bil na delovnem mestu prisoten in se kaže tako v posrednih in neposrednih stroških (Cucchiella et al, 2014). Podjetje mora za učinkovito delovanje namesto delavca, ki je z dela odsoten zaradi takih ali drugačnih razlogov, zaposliti ali dodatno obremeniti drugega delavca, ki bo dela in naloge namesto odsotnega delavca tudi učinkovito opravil. Tu je potrebno omeniti, da če je zaposleni specialist na svojem področju in delovno mesto oziroma delovne naloge zahtevajo določeno vrsto poklicne specializacije, se lahko stroški zaradi zaposlitve zunanjega delavca oziroma zaradi dodatnega usposabljanja že zaposlenega delavca, še povečajo.

Podjetja, ki se soočajo $\mathrm{z}$ visokim deležem zdravstvenega absentizma, izvajajo različne ukrepe in metode, s pomočjo katerih želijo zmanjšati zdravstveni absentizem in ga ob tem tudi uravnati (Rae, 2005; Roelen in Groothoff, 2010; Ammendolia et al. 2016) Izkušnje, ki so predstavljene v zborniku primerov in praks 14-ih slovenskih podjetij (ZZZS, 2010) dokazujejo, da lahko podjetja zdravstveni absentizem obvladujejo že z nekaterimi aktivnostmi in ciljanimi programi, za kar ni potrebno spreminjati zakonodaje. Največkrat se poslužujejo ergonomskih prilagoditev na delovnih mestih, sodelovanja $z$ osebnimi zdravniki in ZZZS, izobraževanja in usposabljanje zaposlenih, spodbujanja zaposlenih o zdravem načinu življenja, motiviranja zaposlenih, promocije zdravja na delovnem mestu itd. S temi ukrepi želi podjetje zdravstveni absentizem znižati do mere, da bodo posledice ukrepov vidne tudi na področju stroškov dela in pozitivnem vplivu na opravljanje dela zaposlenih, kar pa se posledično kaže v večji učinkovitosti in uspešnosti ne le zaposlenih, temveč celotnega podjetja.

Za podjetja je pomembno, da konstantno spremljajo gibanje zdravstvenega absentizma ter ga ob morebitnih odklonih $\mathrm{v}$ negativno smer $\mathrm{z}$ različnimi ukrepi skušajo zmanjšati in obdržati na nizki ravni. Na ta način se ne izognejo samo organizacijskim in finančnim težavam, ampak ohranjajo produktivnost na najvišji možni ravni. 


\section{$2 \quad$ Metodologija raziskovanja}

V članku se osredotočamo na problem, ki se na nanaša na odsotnost $\mathrm{z}$ dela zaradi zdravstvenih težav. $\mathrm{V}$ našem primeru gre za proizvodno podjetje, ki se zaradi proizvodnega procesa in $\mathrm{s}$ tem težjimi delovnimi razmerami sooča $\mathrm{z}$ visokim deležem zdravstvenega absentizma. Na to nakazujejo podatki o deležu zdravstvenega absentizma, ki je bil v podjetju najvišji maja 2015 in je znašal 6,78\%, v Sloveniji pa je v tem času v povprečju znašal 3,97\% (NIJZ, lastna obdelava podatkov, 2017)

Na osnovi podatkov, ki smo jih pridobili s strani podjetja, smo analizirali zdravstveni absentizem od maja 2015 do maja 2016. Za obdobje enega leta smo se odločili zaradi ogromne količine podatkov in različnih vrst dela v podjetju. Ravno tako smo analizirali vrste absentizma za eno leto, pri čemer smo se zaradi dostopnosti podatkov omejili na leto 2015. Proces pridobivanja podatkov je potekal tako, da smo podatke najprej zbrali po posameznih obratih in ostalih službah v podjetju, temu pa je sledila podrobna analiza podatkov, ki je temeljila na uporabi računalniškega orodja Excel.

$\mathrm{Z}$ analizo podatkov smo skušali odgovoriti na naslednja raziskovalna vprašanja:

1. Kako se je stopnja zdravstvenega absentizma gibala po mesecih od maja 2015 do maja 2016?

2. Kakšna je bila stopnja zdravstvenega absentizma od maja 2015 do maja 2016 ?

3. V katerih obratih $v$ podjetju je bilo največ zdravstvenega absentizma?

4. V katerem mesecu je bilo največ poškodb pri delu?

5. Katere vrste absentizma je bilo $v$ podjetju leta 2015 in $v$ tekočem letu največ?

6. Kateri so glavni vzroki, da do zdravstvenega absentizma v podjetju sploh prihaja?

7. S katerimi ukrepi bi v podjetju lahko kar najbolje zmanjšali zdravstveni absentizem?

\section{$3 \quad$ Analiza zdravstvenega absentizma v proizvodnem podjetju}

V tem poglavju se bomo osredotočili na analizo podatkov, ki smo jih pridobili na podlagi zbiranja podatkov po posameznih obratih in ostalih službah, ki predstavljajo režijo. Za začetek si oglejmo, kako se je bolniška odsotnost na ravni celotnega podjetja gibala $\mathrm{v}$ obdobju od maja 2015 do maja 2016 (slika 1). 


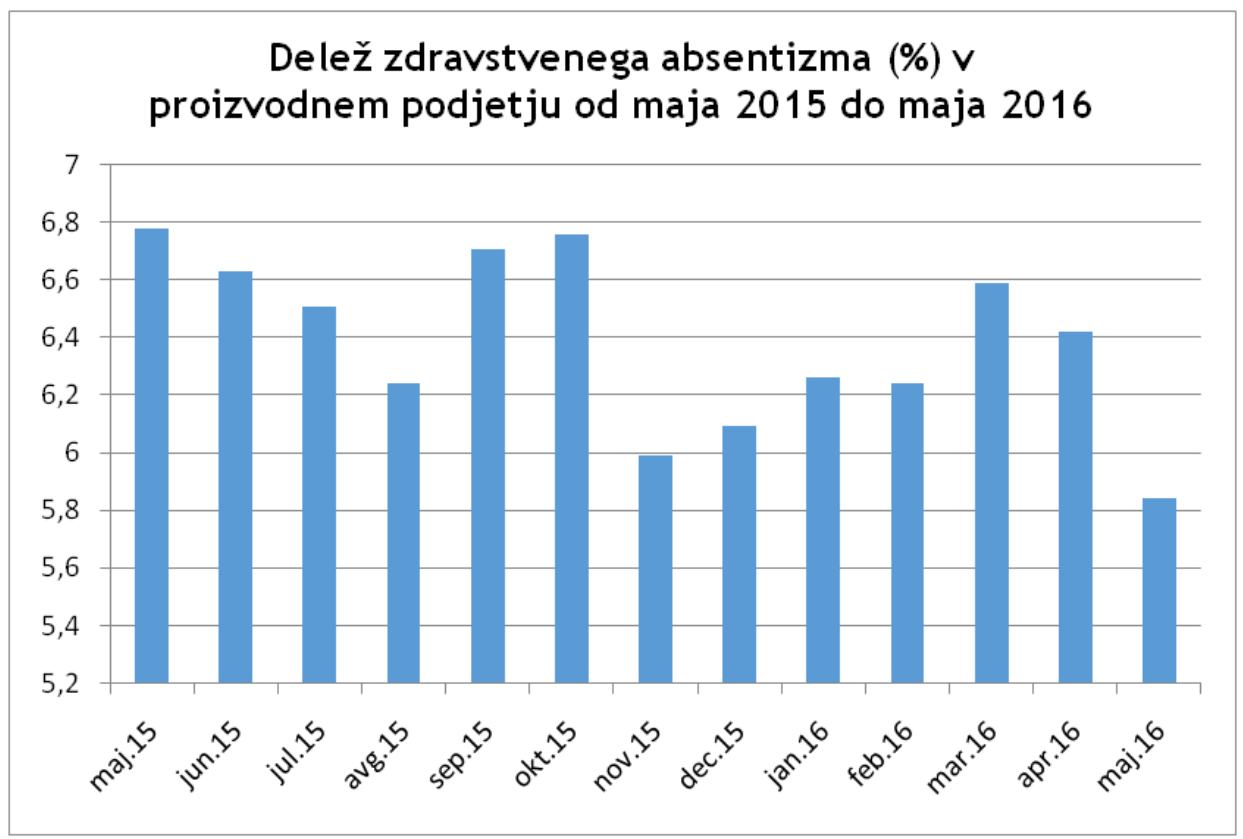

Slika 1: Deležzdravstvenega absentizma v proizvodnem podjetju od maja 2015 do maja 2016

Iz slike 1 lahko razberemo, da se je delež bolniške odsotnosti zmanjševal od maja 2015 do avgusta 2015 in se nato septembra istega leta spet nekoliko povečal. Novembra 2015 je viden padec deleža bolniške odsotnosti, vendar se decembra začne povečevati in doseže vrh marca 2016. Od marca 2016 je zabeleženo zmanjševanje deleža zdravstvenega absentizma do maja 2016. Najvišji delež je bil maja 2015 in sicer 6,78\%. Leto kasneje, maj 2016, je za isti mesec delež skoraj 1\% manjši.

Na osnovi pridobljenih podatkov smo $\mathrm{v}$ nadaljevanju izračunali delež zdravstvenega absentizma za celotno podjetje od maja 2015 do maja 2016. V tem obdobju je znašal $6,46 \%$, kar je skrb vzbujajoče.

\subsection{Deleži zdravstvenega absentizma po obratih}

V proizvodnem podjetju deluje 5 obratov, ki so del proizvodnje in smo jih označili s črkami od A do E ter ostale službe skupaj, ki ne spadajo v proizvodnjo, temveč predstavljajo režijo.

Tabela 1 prikazuje delež zdravstvenega absentizma za vsak obrat v podjetju ter režijo, ki jih zajemamo in analiziramo kot eno celoto. 
36 ${ }^{\text {TH }}$ International Conference on Organizational Science Development: RESPONSIBLE ORGANIZATION (MARCH $22^{\mathrm{ND}}-24^{\mathrm{TH}}$, PORTOROŽ SLOVENIA)

S. Nunar \& M. Bernik: Sickness Absenteeism in the Manufacturing Company

Tabela 1: Deleži zdravstvenega absentizma po obratih (\%)

\begin{tabular}{|l|l|l|l|l|l|l|}
\hline & & & & & \\
& Obrat A & Obrat B & Obrat C & Obrat D & Obrat E & Ostale službe \\
\hline maj.15 & 8,28 & 7,21 & 6,88 & 8,22 & 5,53 & 5,64 \\
\hline jun.15 & 7,63 & 9,81 & 9,6 & 6,82 & 6,91 & 3,56 \\
\hline jul.15 & 9,38 & 8,78 & 6,86 & 8,39 & 6,83 & 2,73 \\
\hline avg.15 & 8,47 & 9,83 & 7,16 & 7,41 & 7,02 & 2,87 \\
\hline sep.15 & 9,15 & 13,36 & 6,63 & 8,49 & 6,1 & 2,99 \\
\hline okt.15 & 9,2 & 9,47 & 7,99 & 7,38 & 6,62 & 3,79 \\
\hline nov.15 & 6,94 & 5,45 & 8,53 & 6,68 & 5,05 & 4,31 \\
\hline dec.15 & 7,91 & 6,39 & 5 & 7,69 & 7,05 & 3,72 \\
\hline jan.16 & 7,55 & 9,87 & 7,9 & 6,89 & 3,89 & 4,2 \\
\hline feb.16 & 7,57 & 7,49 & 8,32 & 6,75 & 5,2 & 4,7 \\
\hline mar.16 & 6,78 & 8,69 & 8,73 & 6,64 & 7,4 & 4,28 \\
\hline apr.16 & 8,2 & 7,5 & 7,95 & 5,22 & 7,41 & 4,42 \\
\hline maj.16 & 6,73 & 5,26 & 8,61 & 4,96 & 7,47 & 3,62 \\
\hline POVPREC JE & 7,98 & 8,39 & 7,7 & 7,04 & 6,34 & 3,91 \\
\hline
\end{tabular}

V obdobju od maja 2015 do maja 2016 je bil v povprečju najmanjši delež zdravstvenega absentizma $v$ režiji (ostale službe) in sicer 3,91\%. Najvišji delež zdravstvenega absentizma v režiji je bil maja 2015, ko se je povzpel na 5,64\%.

Najvišji delež zdravstvenega absentizma lahko opazimo v obratu B, ki je septembra 2015 znašal kar 13,36\% in je bil tudi v povprečju glede na ostale obrate najvišji $(8,39 \%)$. Zatem mu s 7,98\% sledi obrat A, na tretjem mestu glede na povprečje pa je obrat C s 7,7\% deležem zdravstvenega absentizma. Povprečni delež bolniške odsotnosti je v obratu D znašal 7,04\%, v obratu E pa 6,34\%. 


\subsection{Zdravstveni absentizem po urah}

Poleg deleža zdravstvenega absentizma, nas je zanimalo tudi število ur, ko so bili delavci odsotni. Tabela 2 prikazuje število odsotnosti delavcev v urah po posameznih mesecih.

Tabela 2: Odsotnost delavcev v urah

\begin{tabular}{|l|l|}
\hline & Odsotnost $\mathbf{v}$ urah \\
\hline maj.15 & 12727,4 \\
\hline jun.15 & 13027,2 \\
\hline jul.15 & 13360,7 \\
\hline avg.15 & 11609 \\
\hline sep.15 & 13042,6 \\
\hline okt.15 & 13206,5 \\
\hline nov.15 & 11153 \\
\hline dec.15 & 12326 \\
\hline jan.16 & 11672 \\
\hline feb.16 & 11598 \\
\hline mar.16 & 13476 \\
\hline apr.16 & 12004 \\
\hline maj.16 & 11554 \\
\hline
\end{tabular}

Kot lahko vidimo, je bilo v juliju 2015 kar 13.360,7 ur odsotnosti, medtem ko je bilo naslednji mesec skoraj 2000 ur bolniške odsotnosti manj, natančneje 1751,7 ur. Razlog za to je v tem, da je bilo v avgustu manj bolniško odsotnih delavcev kot v drugih mesecih. Prav tako bi lahko razlog za to pripisali manjšemu številu delavcev na delovnih mestih, saj so nekateri delavci poleti na dopustih. S tem se zmanjša število delavcev, ki delajo v podjetju, posledično pa gre tako manj ljudi na bolniško, saj so ostali na dopustu.

Največje število ur odsotnosti je bilo marca 2016 in sicer 13.476 ur. Mesec prej, torej februarja pa je bilo omenjenih ur 1878 manj. Za tako stanje bi lahko bil vzrok povečano število bolezenskih stanj, ki so v prehodnih obdobjih bolj pogoste, kar pa brez resne analize ne moremo z gotovostjo trditi. Gibanje odsotnosti v urah prikazuje slika 2. 


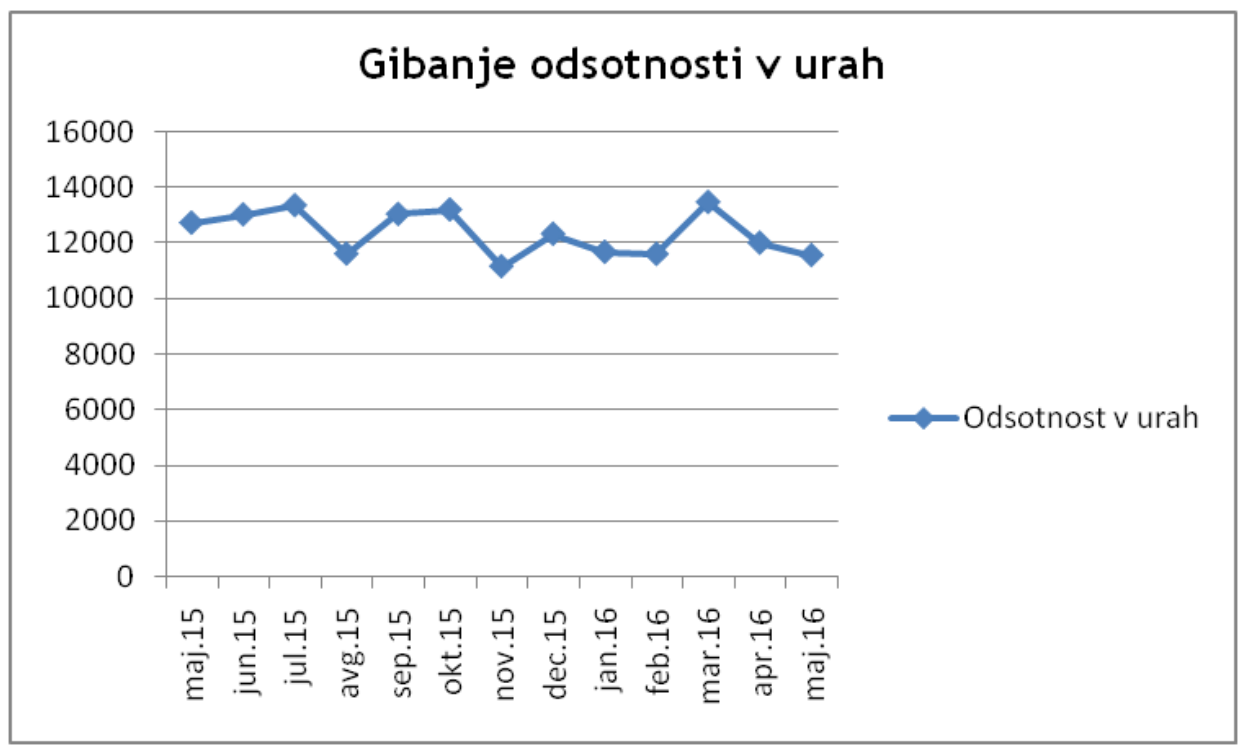

Slika 2: Odsotnosti v urah po mesecih

Kot lahko vidimo, je odsotnost od maja 2015 do maja 2016 razgibana. Od maja 2015 pa do julija istega leta je vidno rahlo povečevanje števila ur, medtem ko je avgusta opazno znižanje. Septembra se zopet začne povečevati in se novembra ponovno zmanjša. Nihanje oziroma povečevanje in zmanjševanje števila ur odsotnosti se tako nadaljuje vse do maja 2016. V nadaljevanju si s tabelo 3 oglejmo odsotnost $\mathrm{z}$ dela $\mathrm{v}$ urah tudi po obratih in režiji, ki delujejo v podjetju. 

ORGANIZACIJA (22. - 24. MAREC 2017, PORTOROŽ, SLOVENIJA)

S. Nunar \& M. Bernik: Zdravstveni absentizem v proizvodnem podjetju

Tabela 3: Odsotnost z dela v urah po obratih

\begin{tabular}{|l|l|l|l|l|l|l|}
\hline & Obrat A & Obrat B & Obrat C & Obrat D & Obrat E & Ostale službe \\
\hline maj.15 & 2744 & 960 & 1760 & 2843 & 1739 & 2537 \\
\hline jun.15 & 2655 & 1372 & 2584 & 2499 & 2257 & 1660 \\
\hline jul.15 & 3397 & 1284 & 1932 & 3212 & 2324 & 1040 \\
\hline avg.15 & 2708 & 1304 & 1840 & 2596 & 2170 & 991 \\
\hline sep.15 & 3012 & 1717 & 1742 & 2972 & 1939 & 1660 \\
\hline okt.15 & 3060 & 1215 & 2123 & 2572 & 2116 & 2121 \\
\hline nov.15 & 2248 & 686 & 2217 & 2266 & 1575 & 2161 \\
\hline dec.15 & 2819 & 872 & 1428 & 2830 & 2385 & 1992 \\
\hline jan.16 & 2548 & 1252 & 2071 & 2324 & 1277 & 2200 \\
\hline feb.16 & 2444 & 900 & 2120 & 2189 & 1578 & 2367 \\
\hline mar.16 & 2409 & 1208 & 2483 & 2543 & 2496 & 2337 \\
\hline apr.16 & 2667 & 964 & 2064 & 1828 & 2276 & 2205 \\
\hline maj.16 & 2328 & 708 & 2326 & 1872 & 2416 & 1904 \\
\hline POVPREČJE & 2695,31 & 1110,92 & 2035,1 & 2503,5 & 2042,2 & 1936,5 \\
\hline SKUPAJ & 35039 & 14442 & 26690 & 32546 & 26548 & 25175 \\
\hline
\end{tabular}

Najvišje povprečje je imel obrat A, ki je znašal 2.695,31 ur odsotnosti z dela. V enem letu je bilo skupno število ur v obratu A 35.039 ur. Sledi mu obrat D z 32.546 urami odsotnosti, nato obrat C z 26.690 urami, na četrtem mestu je obrat E z 26.548 urami odsotnosti, na predzadnjem mestu pa so ostale službe z 25.175 urami odsotnosti. Najmanj ur odsotnosti z dela je bilo v obratu B, v katerem je bilo skupno število ur odsotnosti 14.442. Presenetljivo je dejstvo, da ima režija razmeroma visoko število ur odsotnosti z dela $\mathrm{v}$ primerjavi $\mathrm{z}$ ostalimi obrati, ki spadajo $\mathrm{v}$ proizvodni del podjetja in $\mathrm{v}$ katerem delavci opravljajo težja oziroma bolj zahtevna fizična dela. Skupno je bilo v podjetju zaradi bolniške odsotnosti izgubljenih kar 160.440 ur. 
Za boljšo predstavo si oglejmo še tortni diagram, s katerim ponazorimo deleže posameznih obratov odsotnosti z dela.

\section{Deleži odsotnosti z dela $v$ urah po obratih}

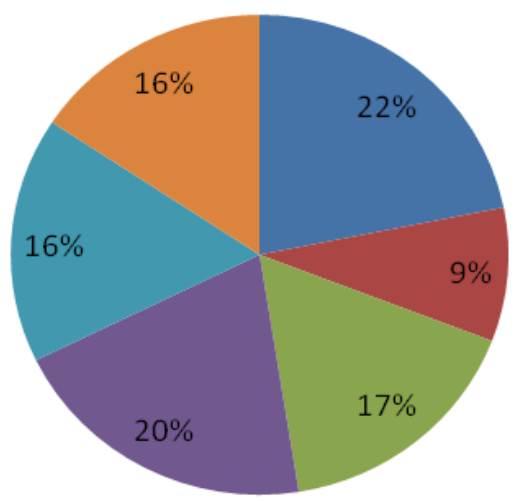

- Obrat A

- Obrat B

- Obrat C

- Obrat D

Obrat E

Ostale službe

Slika 3: Deleži odsotnosti z dela v urah po obratih in režiji

Iz slike 3 lahko razberemo, da je bil največji delež odsotnosti z dela v urah po posameznih proizvodnih obratih v obratu A z 22\%, sledi pa mu obrat D z $20 \%$.

\subsection{Vrste zdravstvenega absentizma v proizvodnem podjetju leta 2015}

V tem poglavju bomo prikazali tiste vrste bolniških odsotnosti, ki so bile v podjetju najbolj pogoste. Analizirali smo podatke za celotno leto 2015, od januarja do decembra. Tabela 4 prikazuje, koliko primerov določene vrste bolniške odsotnosti je bilo v obratih in ostalih službah proizvodnega podjetja. 

ORGANIZACIJA (22. - 24. MAREC 2017, PORTOROŽ, SLOVENIJA)

S. Nunar \& M. Bernik: Zdravstveni absentizem v proizvodnem podjetju

Tabela 4: Število primerov vrst absentizma po obratih (2015)

\begin{tabular}{|c|c|c|c|c|c|c|}
\hline $\begin{array}{l}\text { PRIMERI } \\
(2015)\end{array}$ & \begin{tabular}{|l|} 
OBRAT \\
A \\
\end{tabular} & $\begin{array}{l}\text { OBRAT } \\
\text { B } \\
\end{array}$ & \begin{tabular}{|l|} 
OBRAT \\
C \\
\end{tabular} & \begin{tabular}{|l} 
OBRAT \\
D \\
\end{tabular} & \begin{tabular}{|l} 
OBRAT \\
E \\
\end{tabular} & \begin{tabular}{|l} 
OSTALE \\
SLUŽBE \\
\end{tabular} \\
\hline $\begin{array}{l}\text { Boleznina do } \\
30 \text { dni }\end{array}$ & 172 & 73 & 123 & 201 & 126 & 256 \\
\hline $\begin{array}{l}\text { Boleznina od } \\
4 \text { - } 30 \text { dni }\end{array}$ & 100 & 37 & 50 & 84 & 74 & 113 \\
\hline $\begin{array}{l}\text { Boleznine } \\
\text { doplačila } \\
\text { odplačila }\end{array}$ & 2 & 4 & 4 & 7 & 2 & 1 \\
\hline $\begin{array}{l}\text { Boleznine } \\
\text { nad 30 dni - } \\
80 \% \text { ZUJP } \\
\end{array}$ & 49 & 30 & 27 & 31 & 30 & 37 \\
\hline $\begin{array}{l}\text { Boleznine } \\
\text { nad } 30 \text { dni - } \\
90 \% \text { ZUJP }\end{array}$ & 37 & 25 & 41 & 41 & 40 & 35 \\
\hline $\begin{array}{l}\text { Darovanje } \\
\text { krvi }\end{array}$ & 12 & 14 & 25 & 31 & 32 & 47 \\
\hline Nega & 2 & 3 & 4 & 17 & 5 & 16 \\
\hline $\begin{array}{l}\text { Nesreča } \\
\text { izven dela }\end{array}$ & 38 & 19 & 32 & 62 & 27 & 40 \\
\hline $\begin{array}{l}\text { Nesreča na } \\
\text { delu }\end{array}$ & 21 & 0 & 21 & 30 & 22 & 15 \\
\hline $\begin{array}{l}\text { Poškodba na } \\
\text { delu }\end{array}$ & 31 & 0 & 13 & 37 & 18 & 2 \\
\hline Spremstvo & 2 & 9 & 1 & 11 & 6 & 17 \\
\hline $\begin{array}{l}\text { Poškodba } \\
\text { izven dela - } \\
70 \% \text { ZUJP }\end{array}$ & 27 & 10 & 18 & 40 & 9 & 8 \\
\hline
\end{tabular}

Največ boleznin do 30 dni za leto 2015 (od januarja do decembra - v prejšnjih poglavjih smo analizirali podatke od maja 2015 do maja 2016) je bilo v ostalih službah in sicer kar 256 primerov tovrstne bolniške odsotnosti, najmanj pa v obratu B (73). V ostalih službah je največje število zaposlenih, zato je tudi primerov bolniške odsotnosti več, medtem ko je v obratu B najmanj zaposlenih.

Prav tako je bilo boleznin od 4 - 30 dni največ v ostalih službah 113 ter najmanj v obratu B. Največ odsotnosti zaradi darovanja krvi je bilo prav tako v ostalih službah 47 , medtem ko je bilo najmanj tovrstne odsotnosti v obratu A 12 in B 14. Iz tabele lahko vidimo, da 
je bilo največ nesreč izven dela v obratu $\mathrm{D}$ (62). Potrebno je poudariti, da na nesreče, izven dela vplivajo vse ostale aktivnosti, ki jih imajo delavci oziroma zaposleni v času, ko niso na delovnem mestu in ne opravljalo del in nalog, ki so dodeljene s strani delodajalca.

$\mathrm{V}$ času prisotnosti delavca na delovnem mestu oziroma v podjetju je bilo največ nesreč 30 in poškodb 37 na delu v obratu D in najmanj v obratu B (0).

Skupno je bilo tako v obratu A (493) primerov bolniške odsotnosti, v obratu B (224), v obratu C (359), v obratu D (592), v obratu E (391) ter v ostalih službah 587. Največ primerov je bilo tako v obratu $\mathrm{D}$, takoj za njim so ostale službe, najmanj pa v obratu $\mathrm{B}$. Da bi bolje ponazorili število primerov bolniške odsotnosti, si oglejmo diagram, ki ponazarja deleže zaposlenih $\mathrm{v}$ vseh obratih. $\mathrm{S}$ tem bomo lažje med seboj primerjali primere odsotnosti v posameznih obratih.

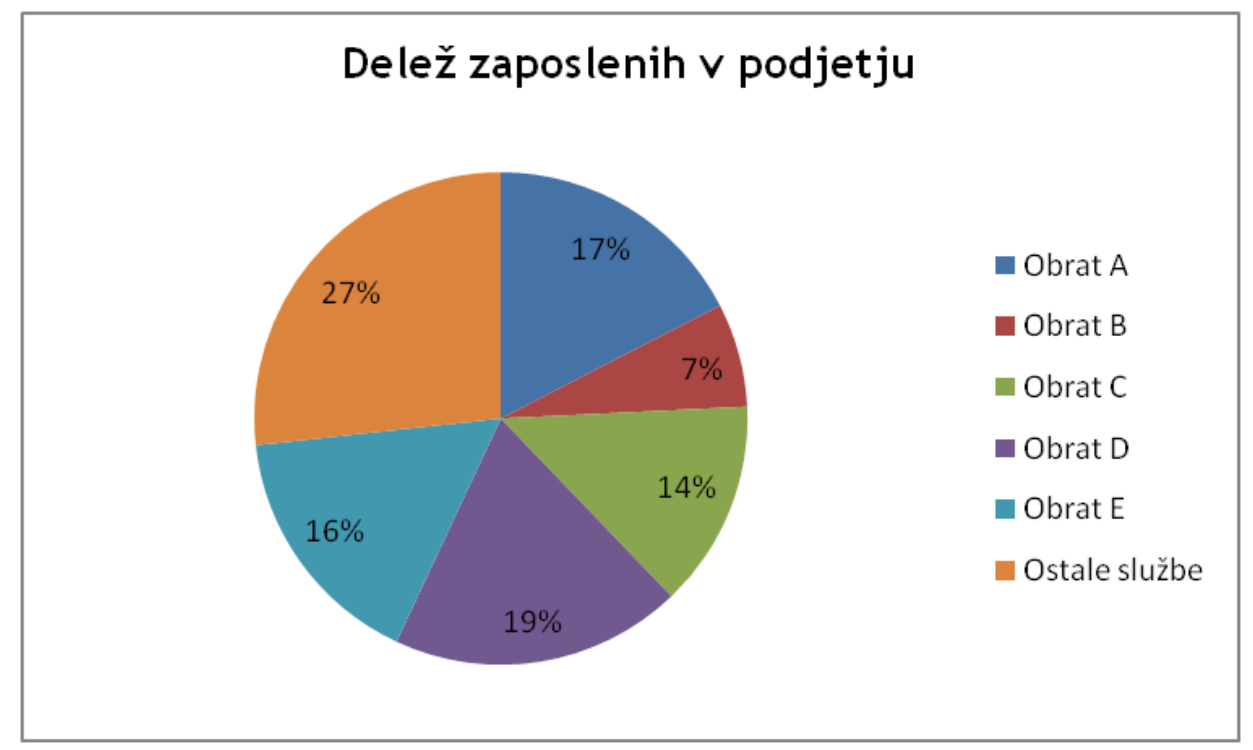

Slika 4 : Delež zaposlenih v podjetju na dan 31.5.2016

Z sliko 4 si lahko pomagamo pri delni obrazložitvi števila primerov odsotnosti zaradi zdravstvenih razlogov v posameznih obratih. Obrat D in ostale službe so po številu primerov zelo blizu, čeprav se delež zaposlenih razlikuje za $8 \%$. V obratu $\mathrm{D}$, ki spada v proizvodnjo, delavci opravljajo težja fizična dela kot $\mathrm{v}$ ostalih službah, zato je tudi število primerov bolniške odsotnosti večje. $V$ ostalih službah pa je število primerov večje zato, ker je zaposlenih $8 \%$ več ljudi kot v obratu D. V obratu A je $17 \%$ vseh zaposlenih in je število primerov odsotnosti za 94 manjše kot $\mathrm{v}$ ostalih službah. V obratu $\mathrm{E}$ je $16 \%$ vseh zaposlenih, v obratu C 14\% in v obratu B 7\%, kar je najmanj. Na osnovi analize lahko trdimo, da so bile glavni razlog za bolniško odsotnost v letu 2015 boleznine. 

ORGANIZACIJA (22. - 24. MAREC 2017, PORTOROŽ, SLOVENIJA)

S. Nunar \& M. Bernik: Zdravstveni absentizem v proizvodnem podjetju

S pomočjo tabele 5 si oglejmo še število izgubljenih delovnih dni zaradi posameznih vrst bolniških odsotnosti v posameznih obratih podjetja.

Tabela 5: Število izgubljenih delovnih dni glede na vrsto bolniške odsotnosti (2015)

\begin{tabular}{|c|c|c|c|c|c|c|}
\hline $\begin{array}{l}\text { IZGUBLJENI } \\
\text { DNEVI (2015) }\end{array}$ & OBRAT A & OBRAT B & OBRAT C & OBRAT D & OBRAT E & $\begin{array}{l}\text { OSTALE } \\
\text { SLUŽBE }\end{array}$ \\
\hline $\begin{array}{l}\text { Boleznina do } \\
30 \text { dni }\end{array}$ & 833 & 372 & 470 & 809 & 579 & 911 \\
\hline $\begin{array}{l}\text { Boleznina od } \\
4 \text { - } 30 \mathrm{dni} \\
\end{array}$ & 708 & 262 & 367 & 403 & 502 & 695 \\
\hline $\begin{array}{l}\text { Boleznine } \\
\text { doplačila } \\
\text { odplačila }\end{array}$ & 15 & 83 & 87 & 154 & 1 & 21 \\
\hline $\begin{array}{l}\text { Boleznine } \\
\text { nad } 30 \text { dni - } \\
80 \% \text { ZUJP }\end{array}$ & 669 & 426 & 348 & 424 & 393 & 426 \\
\hline $\begin{array}{l}\text { Boleznine } \\
\text { nad } 30 \text { dni - } \\
90 \% \text { ZUJP }\end{array}$ & 603 & 446 & 831 & 843 & 726 & 626 \\
\hline $\begin{array}{l}\text { Darovanje } \\
\text { krvi }\end{array}$ & 12 & 14 & 25 & 31 & 32 & 47 \\
\hline Nega & 9 & 4 & 7 & 38 & 11 & 52 \\
\hline $\begin{array}{l}\text { Nesreča } \\
\text { izven dela }\end{array}$ & 393 & 161 & 313 & 570 & 251 & 364 \\
\hline $\begin{array}{l}\text { Nesreča na } \\
\text { delu }\end{array}$ & 251 & 0 & 216 & 329 & 256 & 145 \\
\hline $\begin{array}{l}\text { Poškodba na } \\
\text { delu }\end{array}$ & 576 & 0 & 228 & 688 & 342 & 31 \\
\hline Spremstvo & 2 & 1 & 1 & 11 & 6 & 17 \\
\hline $\begin{array}{l}\text { Poškodba } \\
\text { izven dela - } \\
70 \% \text { ZUJP }\end{array}$ & 407 & 230 & 227 & 542 & 88 & 114 \\
\hline SKUPAJ & 4478 & 1999 & 3120 & 4842 & 3187 & 3449 \\
\hline
\end{tabular}

Pri boleznini do 30 dni lahko opazimo, da je bilo največ izgubljenih delovnih dni v ostalih službah, in sicer 911, najmanj pa v obratu B. Pri bolezninah doplačila - izplačila izstopata obrat D s 154 izgubljenimi dnevi in obrat E, v katerem je bil izgubljen le 1 dan zaradi tovrstne bolniške odsotnosti. Največ boleznin nad 30 dni (90\% ZUJP) je bilo v obratu D, kjer je bilo število izgubljenih delovnih dni 843. Zatem mu s 831 izgubljenimi dnevi sledi obrat C in nato obrat E 726 dni. Ker je bilo število primerov nesreč in poškodb na delu največ v obratu $\mathrm{D}$, potem je logično, da je tudi število izgubljenih dni zaradi bolniške odsotnosti najvišje v obratu D. Bolniške odsotnosti je bilo zaradi nesreč na delu 329 dni, medtem ko jih je bilo zaradi poškodb na delu 688 dni. Leta 2015 je bilo tako v obratu D 4842 dni bolniške odsotnosti, kar je bilo največ v primerjavi z ostalimi obrati, v obratu A 
4478 dni, v ostalih službah 3449 dni, 3187 dni v obratu E, 3120 dni v obratu C ter 1999 dni v obratu B.

\section{$4 \quad$ Zaključek}

S podatki, ki smo jih analizirali in interpretirali, smo prišli do zaključka, da je bil delež zdravstvenega absentizma v obdobju od maja 2015 do maja 2016 nad slovenskim povprečjem, saj je znašal 6,46\%. Najvišji je bil meseca maja 2015 in sicer $6,78 \%$. Najvišji delež zdravstvenega absentizma je bil v obratu B in je v povprečju $8,39 \%$, pri čemer je meseca septembra 2015 dosegel kar 13,36 \%. V nadaljevanju smo pri pregledu vrst zdravstvenega absentizma ugotovili, da so bile glavni vzrok zdravstvenega absentizma, boleznine. Največ primerov odsotnosti je bilo zaradi boleznin do 30 dni, saj je bilo tako v letu 2015 kot tudi v letu 2016 največ izgubljenih dni prav zaradi prej omenjene vrste bolniške odsotnosti. Največ primerov zdravstvenega absentizma je bilo zaradi boleznin do 30 dni v ostalih službah, kar je sicer kljub večjemu številu zaposlenih še vedno presenetljivo, saj ne spadajo $\mathrm{v}$ proizvodnjo. To pomeni, da naj se zaposleni $\mathrm{v}$ ostalih službah ne bi soočali s težjimi delovnimi pogoji in opravljali težja fizična dela, zaradi katerih bi bili delavci bolj nagnjeni k bolezninami.

Največ poškodb na delu je bilo leta $2015 \mathrm{v}$ obratu D in sicer 37 , prav tako pa je bilo v tem obratu istega leta tudi največ nesreč na delu 30. Čeprav je bilo leta 2016 do maja manj poškodb na delu v obratu D kot pa v obratu A, kjer jih je bilo največ, je bilo število izgubljenih dni zaradi poškodb na delu še vedno večje v obratu D, kar lahko sklepamo, da se delavci $\mathrm{v}$ omenjenem obratu soočajo s težjimi delovnimi pogoji in opravljajo zahtevnejša dela kot $\mathrm{v}$ drugih obratih.

Glede na pridobljene podatke, njihovo analizo in naravo dela $\mathrm{v}$ proizvodnem podjetju, predlagamo, da podjetje opravi razgovor z zaposlenimi, ki se vrnejo iz bolniškega staleža. $\mathrm{Na}$ ta način bo podjetje pridobilo točne informacije o vzroku za bolniško odsotnost, saj bodo zaposleni na ta način lahko nadrejenemu povedali za morebitne težave, ki jih pestijo na delovnem mestu ter morda celo predlagali nekatere izboljšave ali spremembe, $\mathrm{s}$ pomočjo katerih bi zdravstveni absentizem lahko zmanjšali.

Glede na to, da gre za proizvodno podjetje, predlagamo ustanovitev delovne skupine, ki bi poškodbe in nesreče obravnavala takoj, ko bi se pripetile. S tem bi dobili vpogled na to, zakaj prihaja do nesreč in poškodb na delu, po obravnavi in analizi vzrokov za njihove nastanke pa bi izdelali načrt oziroma uvedli ukrepe, s katerimi bi preprečili, da se določene poškodbe in nesreče, ki so jih obravnavali, ne bi več ponovile. Tu gre lahko za izboljšanje delovnih pogojev, dodatno usposabljanje in izobraževanje o uporabi strojev in naprav ter o varnem delu, dodatno pregledovanje in vzdrževanje strojev in naprav ipd.

Podjetje bi lahko za zmanjšanje zdravstvenega absentizma uvedlo tudi promocijo zdravja na delovnem mestu, s katero bi izvajali ukrepe kot so izobraževanje o zdravem načinu življenja, preventivni zdravstveni pregledi, boljši delovni pogoji, vključevanje v nekatere športne aktivnosti v okviru podjetja, usposabljanje za varno delo, izdelali bi lahko brošure 
o pravilnih držah in gibih pri opravljanju posameznih del tako v proizvodnji kot v ostalih službah itd.

Glede na rezultate analize, ki smo jih ugotovili, lahko rečemo, da se proizvodno podjetje sooča s precejšnim deležem zdravstvenega absentizma, na kar kažejo tudi podatki o primerih in dnevih odsotnosti. V podjetju bi bilo zato $\mathrm{v}$ bodočnosti potrebno razširiti raziskavo, kjer bi v obratih, kjer je največ absentizma oziroma, kjer je največ poškodb in nesreč na delu ter boleznin, anketirali zaposlene ter s tem pridobili podatke, ki bi nam pokazali, zakaj prihaja do tako velikih odsotnosti z delovnega mesta. Potrebno bi bilo tudi ugotoviti, kakšni so delovni pogoji zaposlenih v obratih, kjer je največ poškodb in nesreč, kakšna dela tam opravljajo delavci ter kako to posledično vpliva na dovzetnost delavcev za poškodbe. Poleg tega bi bilo potrebno pridobiti podatke še o tem, do kakšnih vrst nesreč in poškodb na delu sploh prihaja.

$\mathrm{Na}$ ta način bi lahko proizvodno podjetje sistemsko spremljalo gibanje zdravstvenega absentizma in sproti izvajalo ukrepe v primeru njegovega povečanja. Dolgoročno gledano bi na ta način podjetje zagotavljalo ne samo zadovoljne zaposlene na delovnem mestu, temveč tudi njihovo večjo produktivnost.

\section{Literatura}

Ammendolia, C. Cote, P., Cancelliere, C. Cassidy, J.D., Hartvigsen, J., Boyle, E., Soklaridis, S., Stern, P., Amickll, B. (2016). Healthy and productive workers using intervetion mapping to design a workplace health promotion and wellness program to improve presenteeism, BMC Public Health, doi: 10.1186/s12889-016-3843-x,

Cucchiella, F., Gastaldi, M., Ranieri, L. (2014). Managing absenteeism in the workplace: the case o fan Italian multiutility company, 10th International Strategic Management Conference, Procedia - Social and Behavioral Sciences 150, 1157 - 1166, doi: 10.1016/j.sbspro.2014.09.131

EFILWC-European Fundation fort he Improvement of Living and Working Conditions. (2010). Absence form work. -dostopno na: http://www.eurofound.europa.eu/sites/default/files/ef_files/docs/ewco/tn0911039s/tn0911039 s.pdf

Martimo K.P. (2006). REducing sickness absenteeism at the workplace-what to do and how? Scand J Work Environ Health, 32(4), 253-255, doi:10.5271/sjweh.1008.

NIJZ-Nacionalni inštitut za javno zdravje (2017). Bolniški stalež. Dostopno na http://www.nijz.si/sl/podatki/bolniski-stalez

Rae, D. (2005). How to Reduce Sickness Absences in Sweden: Lessons from International Experience, OECD, Economics Department Working Papers, No. 442, OECD, http://dx.doi.org/10.1787/157504218841

Roelen, C.A.M., Groothoff, J.W. (2010). Rigorous management of sickness absence provokes sickness presenteeism, Occupational Medicine, 60(4), 244-246, doi:10.1093/occmed/kqq010

Vučković, R. (2010). Obvladovanje zdravstvenega absentizma-izziv za družbo. V Kos D. (ur) Zdravstveni absentizem v Sloveniji - Zbornik primerov iz prakse 14 slovenskih podjetij. Dostopno na: https://www.gzs.si/pripone/Zdravstveni\%20absentizem\%20v\%20Sloveniji.pdf

ZZZS-Zavod za zdravstveno zavarovanje Slovenije. (2010). Zdravstveni absentizem v Sloveniji Zbornik primerov iz prakse 14 slovenskih podjetij, ur. Damjan Kos.: 
654 36 $6^{\mathrm{TH}}$ International Conference on Organizational Science Development: RESPONSIBLE ORGANIZATION (MARCH $22^{\mathrm{ND}}-24^{\mathrm{TH}}$, PORTOROŽ SLOVENIA) 
$36^{\text {TH }}$ International Conference ON ORganizational SCIENCE Development: Responsible ORganization (MARCH $22^{\mathrm{ND}}-24^{\mathrm{TH}}$, PORTOROŽ SLOVENIA)

O. Arsenijević, M. Ferjan, I. Podbregar, P. Šprajc, D. Trivan \& Y. Ziegler

\title{
Introduction of a Lesson: A Guarantee of Motivation? The Significance of the Lesson Introduction for Learners' Activation Level in Business and Economics Teaching at German Vocational Colleges
}

\author{
Andreas Gebhardt, Markus Mertens, SANDra NiEdermaier, JUlia Pelster, \\ SIMON WÖLLMECKE, BJÖRN PAAPE \& IWONA KIERETA
}

\begin{abstract}
As the significance of the action-oriented approach increases, so does the relevance of motivation diagnostics for critically reflecting on different teaching and learning methods. The introduction of a lesson is a definitive phase for motivating students in a teaching-learning sequence. The project presented here and conducted during the practical teacher training phase in a vocational college, correlates the two factors 'lesson introduction' and 'motivation of students'. It examines which impacts the application of different methods has on the motivation of students. To this end, vocational college students engaged in business and economics learning are asked about their current motivation. This quantitative survey is based on a combination of the PANAVA and the experience sampling methods.
\end{abstract}

Derived findings show that an inductive lesson introduction motivates students more strongly than a deductive or an informative one. Furthermore, an inductively introduced lesson results in students' learning motivation being more prolonged compared to the deductive method.

KEYWORDS: lesson introduction $\bullet$ deductive $\bullet$ inductive $\bullet$ motivation $\bullet$ business and economics teaching $\bullet$ activation of students $\cdot$ German vocational college • PANAVA $・$ ESM

CORRESPONDENCE ADDRESS: Andreas Gebhardt, RWTH Aachen University, Faculty of Economics, Templergraben 64, 52056 Aachen, Germany, Markus Mertens, RWTH Aachen University, Faculty of Economics, Templergraben 64, 52056 Aachen, Germany, Sandra Niedermaier, RWTH Aachen University, Faculty of Economics, Templergraben 64, 52056 Aachen, Germany, Julia Pelster, RWTH Aachen University, Faculty of Economics, Templergraben 64, 52056 Aachen, Germany, Simon Wöllmecke, RWTH Aachen University, Faculty of Economics, Templergraben 64, 52056 Aachen, Germany, Björn Paape, Dr. paed. Dr. phil. Dipl.Kfm. Dr. h.c., Professor, RWTH Aachen University, Faculty of Economics, Templergraben 64, 52056 Aachen, Germany, e-mail: paape@wiwi.rwth-aachen.de; Iwona Kiereta, Dr. phil., RWTH Aachen University, Economic Dedactics, Templergraben 64, 52056 Aachen, Germany, e-mail: kiererta@wiwi.rwth-aachen.de

DOI https://doi.org/10.18690/978-961-286-020-2.53

ISBN 978-961-286-020-2

(C) 2017 University of Maribor Press

Available at: http://press.um.si 
$36^{\mathrm{TH}}$ International Conference on ORganizational Science Development: Responsible Organization (March $22^{\mathrm{ND}}-24^{\mathrm{TH}}$, Portorož Slovenia)

A. Gebhardt, M. Mertens, S. Niedermaier, J. Pelster, S. Wöllmecke, B. Paape \& I. Kiereta: Introduction of a Lesson: A Guarantee of Motivation? The Significance of the Lesson Introduction for Learners' Activation Level in Business and Economics Teaching at German Vocational Colleges

\section{Is the introduction of a lesson a guarantee of motivation?}

At the interface between classic scholastic teaching and vocational teaching, the target group analysed in this paper occupies a special position in research on teaching and learning. On the one hand, students at German secondary school level II are working towards the target of achieving various vocational qualifications but on the other hand it is increasingly difficult to awaken students' interest for topics of scholastic learning (cf. Dubs 2009: 425). However, German vocational colleges in particular are committed to an action-oriented approach (cf. APO-BK.NRW 2011: §1) in terms of vocational qualification. Vocational college students should be activated towards independently exploring subject content. Within the framework of the current project, we thus adhere to Rheinberg's definition where motivation is understood to be the activating orientation of one's own actions. It is usual procedure in school teaching that in particular the first phase of a lesson is intended to motivate students to more closely interact with the learning content. While Klafki's (1996) functional relevance of the lesson introduction remains practically intact, its significance has been emphasized in more recent literature, such as Meyer (2011). The lesson introduction - as the first characteristic phase of any teachinglearning process - can take various methodological forms. What has remained relatively unresearched in this context is the degree of influence of the methodological form of lesson introduction on the motivation of students during a teaching unit. The study project at hand will evaluate the concrete relevance of this introduction as part of the teachinglearning process of secondary school level II students attending German vocational college. To this effect, the research question will be addressed of the extent to which the choice of method of lesson introduction by the teacher has an impact on the activation of the students. This leads on to the question of whether specific methods of introduction are more suitable than others for sustaining students' learning motivation longer. Finally, our study findings will be evaluated in order to formulate a recommendation on the use of the method choice as an influencing factor for learning motivation.

\section{$2 \quad$ Research and theoretical backgrounds}

Although motivation diagnostics are a much discussed topic, the relevance of motivation for learning in a classroom context is widely accepted (cf. Deutscher Bildungsrat 1970: 134). Research findings up to now on the development of learning motivation have shown that it is dependent on three process features: the duration and the quality of the learning phase as well as an individual's functional state. All three factors are, however, influenced by a person's current level of motivation (cf. Engeser 2005b: 160). The classical basic model of motivation psychology postulates that the current motivation (state) of an individual is composed of an interaction of individual characteristics (motive, interests) and the specific situation at hand. Accordingly, actions result from the personal motives of a person and the incentives of a situation (cf. Rheinberg 2004: 22). In a school context, a number of such sources of motivational incentives can be identified which may lead to actions by students. For example, if a student is focusing on an imminent examination, 
36. MEDNARODNA KONFERENCA O RAZVOJU ORGANIZACIJSKIH ZNANOSTI: ODGOVORNA ORGANIZACIJA (22. - 24. MAREC 2017, PORTOROŽ, SLOVENIJA)

A. Gebhardt, M. Mertens, S. Niedermaier, J. Pelster, S. Wöllmecke, B. Paape \& I.

Kiereta: Introduction of a Lesson: A Guarantee of Motivation? The Significance of the Lesson Introduction for Learners' Activation Level in Business and Economics Teaching at German Vocational Colleges

an incentive for her would be the achieving of good grades and consequent professional success (cf. Rheinberg 2008: 129). The evaluation system represents a purposed-centred motivation incentive in which students in a specific situation with different options for action are trying to calculate in a purpose-rational manner the outcome and the related consequences of a choice of action (cf. Heckhausen 2010: 373). However, explorative analyses have revealed that a purely purpose-rational justification of learning motivation fell too short of the mark, since an activity also manifests intrinsic incentives for action (cf. Rheinberg 1989: 63). Actions from which no - or even a negative - outcome may be expected (cf.. Heckhausen 2010: 375) can be explained by the activity incentive of a specific situation. The occurrence of a purpose-centred motivation incentive is contextdependent. On the other hand, the activity incentive is completely independent of context (cf. Engeser 2005a: 60). Even when quite severely negative consequences of an action exist, a situation can offer an incentive to implement an action (cf. Rheinberg 2004: 23). The experiencing of an activity incentive is a very affectively coloured state for a person and - as such - closely connected to the third process feature of learning: the functional state. Whereas in the past the other two features (quality and duration) have been thoroughly researched, precisely this third variable in the learning motivation process is in need of such (cf. Engeser 2005b: 160).

In teaching-learning arrangements, a teacher deliberately construes different situations which are to contribute to learning success. This includes the lesson introduction, which is didactically and methodologically processed by the teacher in order to make it accessible to students in the lesson. However, the function of the introduction does not only entail making the learning topic cognitively accessible; it also has an affective dimension. In the sense of action-oriented teaching and learning, the lesson introduction may also encompass a psychomotor dimension (cf. Meyer 2011: 134). Klafki described the process of introducing a lesson as a two-sided approach: on the one hand, the teacher endeavours to allow the students to work through the topic in an independent manner; on the other hand, the teacher tries to awaken students' enthusiasm for the topic (cf. Klafki 1996: 44).

In this paper, 'inductive lesson introduction' has been chosen as a reference point. This choice was made solely in order to be able to compare the data material. That an inductive reference point was favoured has principally to do with a business and economics didactical perspective, which is based on topical occurrences in society and industry as directional and motivational factors. In relation to the literature analysis, particularly the following hypotheses are to be tested:

Hypothesis 1: An inductive lesson introduction activates students' motivation to a greater extent than do the other types of introduction.

Hypothesis 2: An inductive lesson introduction activates students longer throughout the teaching-learning sequence than do deductive introduction methods. 
$36^{\text {Th }}$ International Conference on Organizational Science Development: RESPONSIBLE ORGANIZATION (MARCH $22^{\mathrm{ND}}-24^{\mathrm{TH}}$, Portorož SlOVENIA)

A. Gebhardt, M. Mertens, S. Niedermaier, J. Pelster, S. Wöllmecke, B. Paape \& I. Kiereta: Introduction of a Lesson: A Guarantee of Motivation? The Significance of the Lesson Introduction for Learners' Activation Level in Business and Economics Teaching at German Vocational Colleges

3 Analysis

\subsection{Methodological approach}

For measuring and analysing situational motivation we used Schallberger's PANAVA system, which is based on Wundt's two dimensions of motivational state from 1896: pleasure-displeasure and activation (cf Heckhausen 2010: 376, Rheinberg 2004: 37). The dimensions of the first classification were subjected to an axial rotation of 45 degrees by Watson et al. (cf. Watson 1988: 1064), resulting in the formation of two dimensions: on the one hand, positive activation (PA) and on the other negative activation (NA) (cf. Heckhausen 2010: 376). In an extended German-language version, Schallberger incorporates the non-rotated dimension of valence (VA) (cf. Rheinberg 2004: 37). In this final version, the PANAVA system incorporates a total of ten items with a bipolar Likert measuring scale (cf. Schallberger 2005: 12f.). ${ }^{1}$ Particularly the PA dimension is of interest for motivation diagnostics, since it depicts the motivational core. However, it is possible to be both negatively and positively activated in one situation. Hereby, particularly valence correlates with the absence of negative activation ( $\mathrm{r}=-.70)$ (cf. ibid. 17).

The development of current motivation (state measurement) is dependent on the specific (learning) situation. For this reason, the measuring of motivation during a teaching sequence has to take place repeatedly, since different situations occur (cf. Vollmeyer 2002: 283). The activity incentive of a concrete situation can only then be analysed in detail if the motivation-relevant feeling is assessed directly when an action is being carried out (cf. Rheinberg 2004: 35). Such a procedure, however, imposes special conditions on the survey instrument, which should involve as few items as possible in order to avoid the action process being interrupted too often. The chosen items must, furthermore, be very clearly formulated and should avoid redundancies (cf. Schallberger 2005: 12). Schallberger's PANAVA system fulfils these criteria and is appropriate for measuring in a classroom environment (cf. ibid.: 72).

As it is to be expected that it will not be possible to permanently assess over the whole procedure of action implementation, we draw on Csikszentmihalyi's experience sampling method (ESM). The test persons are subject to an acoustic signal at regular intervals which indicates that they have to fill out the survey instrument (cf. Csikszentmihalyi 1977: 285). Moreover, the gathered data can be compared with an extensive collection of benchmark values (25,000 measuring points of $\mathrm{N}=529$ adults) (cf. Rheinberg 2004: 40). Schallberger's PANAVA system is appropriate for ascertaining an individual functional state during a specific situation. 

ORGANIZACIJA (22. - 24. MAREC 2017, PORTOROŽ, SLOVENIJA)

A. Gebhardt, M. Mertens, S. Niedermaier, J. Pelster, S. Wöllmecke, B. Paape \& I. Kiereta: Introduction of a Lesson: A Guarantee of Motivation? The Significance of the Lesson Introduction for Learners' Activation Level in Business and Economics Teaching at German Vocational Colleges

\subsection{Research design}

The survey population is composed of all students of the four German vocational colleges that we got to know as part of the practical teaching training phase $(\mathrm{N}=9879)$. In order to establish the target population, a simple random sample was drawn from the survey population, which satisfies the fundamental requirements of representativeness (cf. Bortz 2003: 402). Since the colleges have different subject-related focal points, first of all a specific sample selection is undertaken so that the data sets are comparable. Consequently, only students from the business and economics segment are surveyed. Having recourse to interferential statistical techniques enables the errors to be cleared which arise when the whole population is reduced to the sample that is to be analysed. The survey within the business and economics area is carried out via a random sample. The consequent distribution of the population is as natural as possible, thus enabling inferences to be drawn for the entire population. In total, the sample covers a raw data portfolio of 317 surveyed students. Any incomplete and invalid responses were removed from the data set, leaving a sampling frame of $n=252$ students to be analysed. 'Invalid' responses were any variability in the response structure as well as multiple responses per item. Data sets were gathered from a total of five different full-time and part-time educational programmes. The largest group to be examined $-35.3 \%(\mathrm{~N}=89)-$ was that of the educational programme Höhere Handelschule

In order to achieve an environment which is as natural as possible, we refrained from having the survey investigator defining the lesson introduction or even herself preparing the teaching-learning sequence. On account of the choice of field experiment, it can rather be expected that the external validity will be higher (cf. Schnell/Hill/Esser 2008: 226). Additionally, details are recorded about the selected media or the method of instruction at the respective measuring points. The investigator is provided with an observation form on which she records amongst other things the chosen lesson introduction of the teacher and assigns it to a main category. In order to render the evaluation of motivation-relevant feelings easier, four main categories of lesson introduction were defined for the study at hand. The category informative lesson introduction, for instance, manifests in the disclosure of the learning goals for the lesson. Working on case studies, on the other hand, is an example of how the onset of a lesson can take place via a further category: students are confronted with a concrete problem (inductive lesson introduction). The third main category of lesson introduction here is formed by the developing of subject material through students encountering an object. The teacher showing a comic or a film is an example of this deductive category (cf. Meyer 2011: 133-135). Further lesson introductions are grouped under others.

The selected students received a cover sheet at the beginning of a teaching-learning arrangement on which statistical details were asked for in order to evaluate these groupspecifically. This cover sheet contains several copies of the previously described survey instrument (cf. Section 3.1). So that the development of the current motivation can be 
$36^{\text {Th }}$ International Conference on Organizational Science Development: Responsible Organization (MARCh $22^{\mathrm{ND}}-24^{\mathrm{TH}}$, Portorož Slovenia)

A. Gebhardt, M. Mertens, S. Niedermaier, J. Pelster, S. Wöllmecke, B. Paape \& I. Kiereta: Introduction of a Lesson: A Guarantee of Motivation? The Significance of the Lesson Introduction for Learners' Activation Level in Business and Economics Teaching at German Vocational Colleges

measured during an entire teaching situation, a measuring series is also undertaken at the beginning of the teaching-learning unit. This ascertains the origin of the state variables prior to their being influenced by the lesson introduction initiated by the teacher. In the sense of the ESM, students were required to fill in such a sheet following an acoustic signal. In the context of this analysis, this signal was given at 15-minute intervals. On the one hand, this procedure means that data can be gathered sufficiently frequently without causing too much disruption to a class and on the other hand, the 45- or 90-minute rhythm of a teaching-learning sequence is adhered to.

This analytical method is applied per class of students as an exercise unit as well as a course of data collection, allowing students to practice with the data collection sheets and ensuring that interference variables are kept to a minimum.

\section{$4 \quad$ Evaluation and discussion of findings}

\subsection{Evaluation procedure}

In order to evaluate the gathered raw data, the bipolar PANAVA scale is transformed into a seven-point scale. Finally, the values for each individual item are summed up so that a total value per item is obtained. The scale values of the items 'stressed', 'annoyed', 'nervous', 'worried', 'relaxed' 'in a good mood', 'calm' and 'carefree', which are assigned to the negative activation (NA) scale, are summed up into an NA value. This procedure is carried out likewise for the positive activation (PA) and valence (VA) values $^{2}$. In order to test our hypotheses we have, then, a data set from the sample frame of $n=252$ containing 1250 measuring points. A reliability analysis of the PA, NA and VA values revealed a very highly accurate measurement of the respective items with a Cronbach's alpha of at least $\alpha=.875 .^{3}$

The resulting scale comprises apart from activity-specific experiencing also personal differences which reveal whether the surveyed person is in a more positively or more negatively activated state. Individual differences impact the activation scale both positively and negatively as well as the valence by $20-24 \%$ (cf.. Schallberger 2005: 32). Differences in state of mind were indicated in the survey framework as a deviation from the mean. This was done via standardization with the help of $\mathrm{z}$-transformation of each of the individual PANAVA values. On the basis of the thus-gathered data, we will now discuss our previous hypotheses and test them (cf. Section 1).

\subsection{Evaluation process for Hypothesis 1}

Hypothesis 1: An inductive lesson introduction activates students' motivation to a greater extent than do the other types of introduction. 

ORGANIZACIJA (22. - 24. MAREC 2017, PORTOROŽ, SLOVENIJA)

A. Gebhardt, M. Mertens, S. Niedermaier, J. Pelster, S. Wöllmecke, B. Paape \& I. Kiereta: Introduction of a Lesson: A Guarantee of Motivation? The Significance of the Lesson Introduction for Learners' Activation Level in Business and Economics Teaching at German Vocational Colleges

With the help of the selected survey instrument, we aim to prove which form of lesson introduction incurs a higher degree of activation in students. In order to obtain comparable values, the difference between the first and the second measuring points of the PA and NA values has to be ascertained. It is seen that the highest measurement differences occur with the inductive lesson introduction. Positive activation drops in relation to the standardized mean value by $\delta z M_{\text {ind }}=0.10$, whereby negative activation rises by $\delta z M_{\text {ind. }}=0.12$. With regard to the individual components of the PA and NA dimensions, this implies the following: On the one hand, the enthusiasm and the level of energy as elements of the PA dimension increase with an inductive lesson introduction. On the other hand, the feelings of worry and nervousness as features of the NA dimension are reduced. A detailed analysis of the individual items of the PA dimension shows that no item in particular is responsible for lowering the PA dimension. A specific component of the PA dimension as a source of the change is not evident, since the dispersion of the change is relatively homogenous. The reduction of the PA value cannot be specifically explained using the current data base. It is left to future empirical research, then, to try to elucidate this phenomenon and its causal connections or to implement the existing study design with a larger sample population. The analysis of the NA values produces an exactly opposite picture: here we can see that, as already described above, students subjected to an inductive lesson introduction experience higher negative activation. However, those components of the NA dimension responsible for this increase cannot be identified here.

Summarizing, we can say that the activation level of the PA dimension is declining. As will be discussed in Section 4.3 in more detail, the declining activation level balances out again along the whole measuring period (measuring points 1-4). The confrontation with concrete learning material - which is consciously chosen in the inductive lesson introduction and which requires them to find a generally valid solution - particularly activates students in the NA dimension. A confrontation of this kind leads, for example, to the stress level rising or nervousness increasing. It should be observed at this point, though, that an increase in stress or nervousness is not necessarily regarded by students as being detrimental, unlike the negative connotation of the item would lead us to expect. An example is that of a pilot who will experience particularly high stress levels in different moments of a flight. However, she will, in retrospect, claim that she, on account of a passion for flying, found the situation to be a positive one.

At this point it should be noted that the inductive lesson introduction incurs the greatest activation of students. The phenomenon (the drop in the PA value and the increase in the NA value) is recognizable in deductive and other types of introduction of new learning content, but in a weaker form. The PA value for the deductive introduction dropped by $\delta z M_{\text {ded. }}=-0.04$ and for the other types of introduction by $\delta z M_{\text {sons. }}=-0.07$. The NA values increased by 0.04 and. 0.03 . Therefore, the first hypothesis can be confirmed. Evaluation Process for Hypothesis 2 
$36^{\mathrm{TH}}$ International Conference ON ORganizational Science Development: Responsible Organization (March $22^{\mathrm{ND}}-24^{\mathrm{TH}}$, Portorož Slovenia)

A. Gebhardt, M. Mertens, S. Niedermaier, J. Pelster, S. Wöllmecke, B. Paape \& I. Kiereta: Introduction of a Lesson: A Guarantee of Motivation? The Significance of the Lesson Introduction for Learners' Activation Level in Business and Economics Teaching at German Vocational Colleges

Hypothesis 2: An inductive lesson introduction activates students longer throughout the teaching-learning sequence than do deductive introduction methods.

As described under 'research design', four classifications of lesson introduction were implemented (cf. Section 3.2). For the informative introduction, the size of the sample is relatively small with only one class set, so that the data obtained do not enable any meaningful conclusions to be drawn on the course of motivation. Also a further analysis with the values from a large comparative study containing $\mathrm{N}=529$ adults and 25,000 measuring points did not result in further findings (cf. Rheinberg 2004: 14). For this reason, we refrain from a further analysis of the course of motivation.

The inductive lesson introduction is a further observation category. Here, we had recourse to three class sets with $n=67$ and 328 measuring points when analysing the course of motivation.

For motivation diagnostics, in particular the PA components are of relevance because these reflect the current motivation of the students. Valence as a third-order factor with the components 'happy' and 'satisfied' is a variable which is independent from an activity and cannot be influenced by the choice of lesson introduction. Our research question addresses the motivation during the current activity. A particular relationship between the PA values and the valence can thus not be assumed. A complete analysis of the affective space with the help of the valence is, then, dispensed with. Decisive to the discussion of our hypotheses are the values of the PA and NA dimensions, which correspond to a second order (cf. Schallberger 2005: 16).

At the beginning of the teaching-learning sequence, at measuring point 1 , we have the summed up, standardized PA values of $\mathrm{SM}=0.23$. After the lesson introduction, this drops initially to the value $S M=0.13$. The drop in the positive activation values following the inductive introduction signifies that students are less energized, more tired, duller and more bored. During the course of the lesson, this negative trend reverses so that by the end of the lesson positive activation reaches the original value of $\mathrm{SM}=0.22$, signifying that the students are again full of energy, more awake, more motivated and more enthusiastic. Since the differences between the SM values at the beginning and at the end of the teaching-learning sequence are similar, we can at this point refrain from a significance test (two-sided t-test) in order to compare the differences.

The subsequent measuring points 5-7 refer to a class set of $n=20$. Here, the basis is an observed double-period lesson. On account of a lack of comparative values, these data cannot be correlated to the previous measuring points. For this reason, in the remaining analysis, these data will not be taken into consideration, and a more in-depth analysis of the course of motivation subject to the inductive approach will be conducted in particular within the measurement points 1 to 4 . The value of negative activation (NA values) deviates at the beginning of the lesson (measuring point 1 ) minimally negatively from the 

ORGANIZACIJA (22. - 24. MAREC 2017, PORTOROŽ, SLOVENIJA)

A. Gebhardt, M. Mertens, S. Niedermaier, J. Pelster, S. Wöllmecke, B. Paape \& I. Kiereta: Introduction of a Lesson: A Guarantee of Motivation? The Significance of the Lesson Introduction for Learners' Activation Level in Business and Economics Teaching at German Vocational Colleges

mean value $(\mathrm{SM}=-0.04)$. Further on, the NA value increases at measuring point 2 to $\mathrm{SM}=0.07$ and drops at measuring point 3 to a still-positive value of $\mathrm{SM}=0.05$. At measuring point 4 - the end of the lesson - a momentarily highest value is reached $(\mathrm{SM}=0.17)$ (cf. Fig. 1 in Appendix). A two-sided t-test of these paired samples at the beginning of the lesson (measuring point 1 ) and the end of the lesson (measuring point 4) shows that the change is significant $(t(65)=-2142, p<0.05)$.

Table 1: t-Test Paired Samples

\begin{tabular}{|c|c|c|c|c|c|c|c|c|}
\hline \multicolumn{9}{|c|}{ Test - Paired Samples } \\
\hline & \multicolumn{5}{|c|}{ Paired Differences } & $\mathbf{T}$ & df & Sig. \\
\hline & \multirow[t]{2}{*}{ Mean } & \multirow[t]{2}{*}{$\begin{array}{l}\text { Standard } \\
\text { error }\end{array}$} & \multirow[t]{2}{*}{ SD } & \multicolumn{2}{|c|}{$\begin{array}{l}\text { 95\% Confidence } \\
\text { Interval of the } \\
\text { Difference }\end{array}$} & & & \\
\hline & & & & Lower & Upper & & & \\
\hline $\begin{array}{l}\text { NA_1 } \\
- \\
\text { NA_4 }\end{array}$ & $\begin{array}{c}- \\
.20788\end{array}$ & .78834 & $\begin{array}{c}.097 \\
04\end{array}$ & -.40168 & -.01408 & -2.142 & 65 & .036 \\
\hline
\end{tabular}

These changes in the values show that the surveyed students become more stressed, annoyed, nervous and worried during the course of the lesson. However, this does not allow the conclusion that the students feel that this is a negative state to be in or judge it as such. The values of the negative activation, i.e. NA components such as increasing nervousness or the level of stress, can, at this point, be explained by students' direct involvement with the learning material- which is an integral part of the inductive approach.

In contrast with the increase of the NA values over the whole course of the lesson, the PA values remain on average at a constant level. In order to confirm Hypothesis 2, the PA values of the deductive lesson introduction are compared with each other. The analysis is composed of two class sets of $n=44$ and the resulting 245 measuring points. Here we can see that the PA value corresponding to measuring point 1 ( $\mathrm{SM}=0.2)$ drops during the course of the teaching-learning sequence. At measuring point 4 , this value is $\mathrm{SM}=0.14$. A similar picture arises if we observe the NA values. Starting with the measuring point 1 with the value of $\mathrm{SM}=-0.04$, the $\mathrm{SM}$ value drops during the course of the lesson to the value $\mathrm{SM}=-0.33$ at measuring point 4 (cf. Figs. 2 und 3 in Appendix). The level of significance is, in this case, a satisfactory $\mathrm{p}<0.05 .{ }^{4}$ 
$36^{\text {Th }}$ International Conference on Organizational Science Development: Responsible Organization (MARCh $22^{\mathrm{ND}}-24^{\mathrm{TH}}$, PortoroŽ SLOVENia)

A. Gebhardt, M. Mertens, S. Niedermaier, J. Pelster, S. Wöllmecke, B. Paape \& I. Kiereta: Introduction of a Lesson: A Guarantee of Motivation? The Significance of the Lesson Introduction for Learners' Activation Level in Business and Economics Teaching at German Vocational Colleges

Table 2: Friedman Test

\begin{tabular}{|l|r|}
\hline \multicolumn{2}{|c|}{ Statistics for test $^{\mathbf{a}}$} \\
Chi-squared & 40 \\
df & 10.749 \\
Asymptotic significance & 3 \\
\hline
\end{tabular}

a. Friedman Test

If we compare the progression of the PA as well as the NA values of the inductive approach with those of the deductive one, we see that the level of positive activation remains constant with the inductive lesson introduction. In contrast, positive activation drops with the deductive introduction over the course of the lesson by $35 \%$. Negative activation rises with the inductive introduction from the first to the fourth measurement by $440 \%$. During the same time period, negative activation drops with the deductive introduction to a lesson by $175 \%$. This means that with a deductive introduction, NA components such as nervousness or the stress level are reduced. Thus, students subjected to this type of introduction are activated for a shorter time period than with the inductive approach. Although students are more relaxed, contented and quiet when a deductive approach is implemented, this can be explained by their being less involved with the learning material. This tendency of a dropping activation level is - as described above also observable in the PA dimension.

In summary, we can state that with a deductive lesson introduction, there is a more shortterm activation of students in contrast with the inductive approach. Thus, Hypothesis 2: 'An inductive introduction to new learning content activates students over a longer time period in the teaching-learning sequence than do deductive introduction methods' can, on the basis of our data material, be confirmed.

\section{$5 \quad$ Conclusions and outlook}

Within the framework of this empirical study of the significance of the introduction of a lesson for the activation level of learners in business and economics lessons, we can state that there is a correlation between the choice of lesson introduction and student activation. Testing of the two hypotheses has confirmed that the teacher can influence the motivation activation of learners via the choice of lesson introduction. Analysis of Hypothesis 1 has demonstrated that the lesson introduction is a guarantee of motivation, since the students were activated by every form of introduction. However, the inductive introduction to a lesson resulted, relatively, in the strongest activation cf.. Section 4.2). Analysis of the data material also clearly showed that an inductive approach not only activates students the most strongly, but also, compared with a deduction approach, has the strongest longterm activation over an entire teaching-learning sequence (cf. Hypothesis 2, Section 4.3). 
A. Gebhardt, M. Mertens, S. Niedermaier, J. Pelster, S. Wöllmecke, B. Paape \& I. Kiereta: Introduction of a Lesson: A Guarantee of Motivation? The Significance of the Lesson Introduction for Learners' Activation Level in Business and Economics Teaching at German Vocational Colleges

The investigations of the study at hand focus in particular on the methodological design of the lesson introduction. The data which were gathered for the study at hand during a practical teacher training phase are not sufficient to make sound statements about further factors such as media selected, social form of the class, and age structure, with regard to their impact on the motivational activation of learners. In the sense of a holistic observation, deeper analyses are required with respect to the selected media and the social form. As stated in Section 4.2, it should be investigated via a more precise component analysis what exactly caused the drop in the PA value and the increase of the NA value.

On the basis of this empirical analysis, we can recommend that inductive lesson introductions should be used for the business and economics subjects at secondary school level II in order to activate students more strongly and more sustainably while they engage with learning contents.

\section{Appendix}

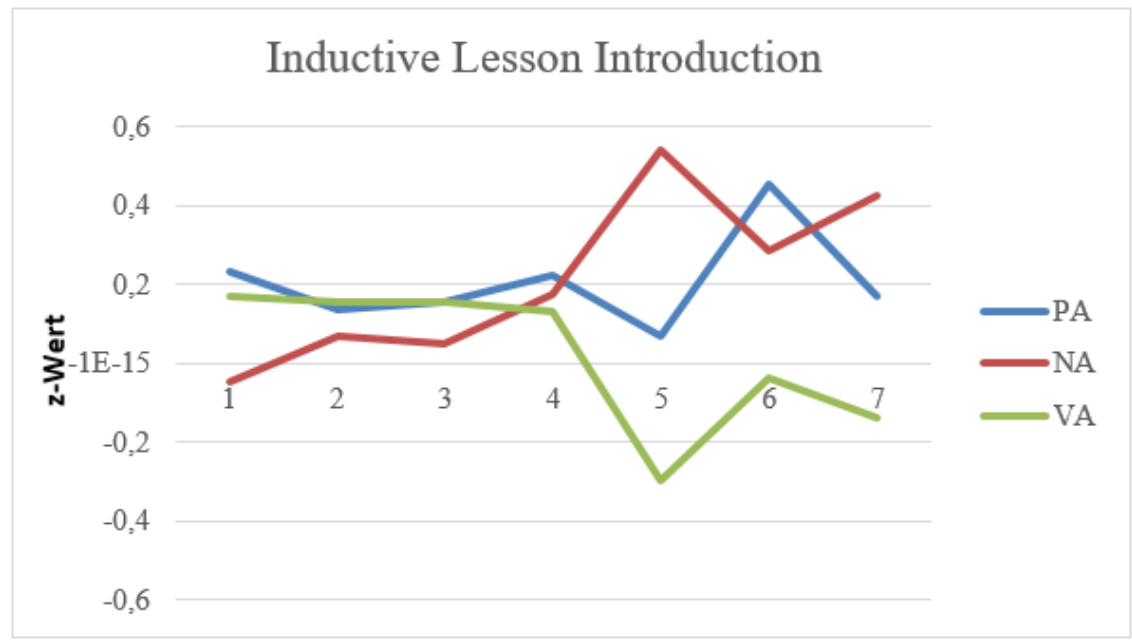

Figure 1:Distribution of the z-values-inductive lesson introduction 
36 ${ }^{\mathrm{TH}}$ InTernational Conference on ORganizational Science Development: RESPONSIBLE ORGANIZATION (MARCH $22^{\mathrm{ND}}-24^{\mathrm{TH}}$, PORTOROŽ SLOVENIA)

A. Gebhardt, M. Mertens, S. Niedermaier, J. Pelster, S. Wöllmecke, B. Paape \& I. Kiereta: Introduction of a Lesson: A Guarantee of Motivation? The Significance of the Lesson Introduction for Learners' Activation Level in Business and Economics Teaching at German Vocational Colleges

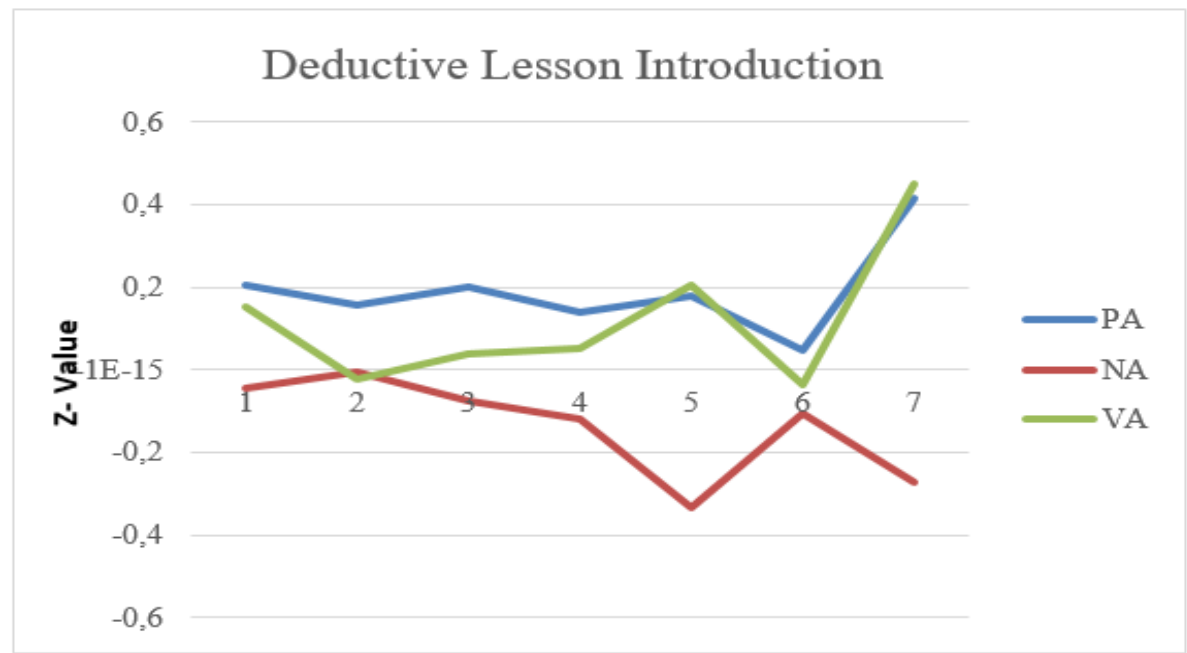

Figure 2: Distribution of the $z$-values-deductive lesson introduction

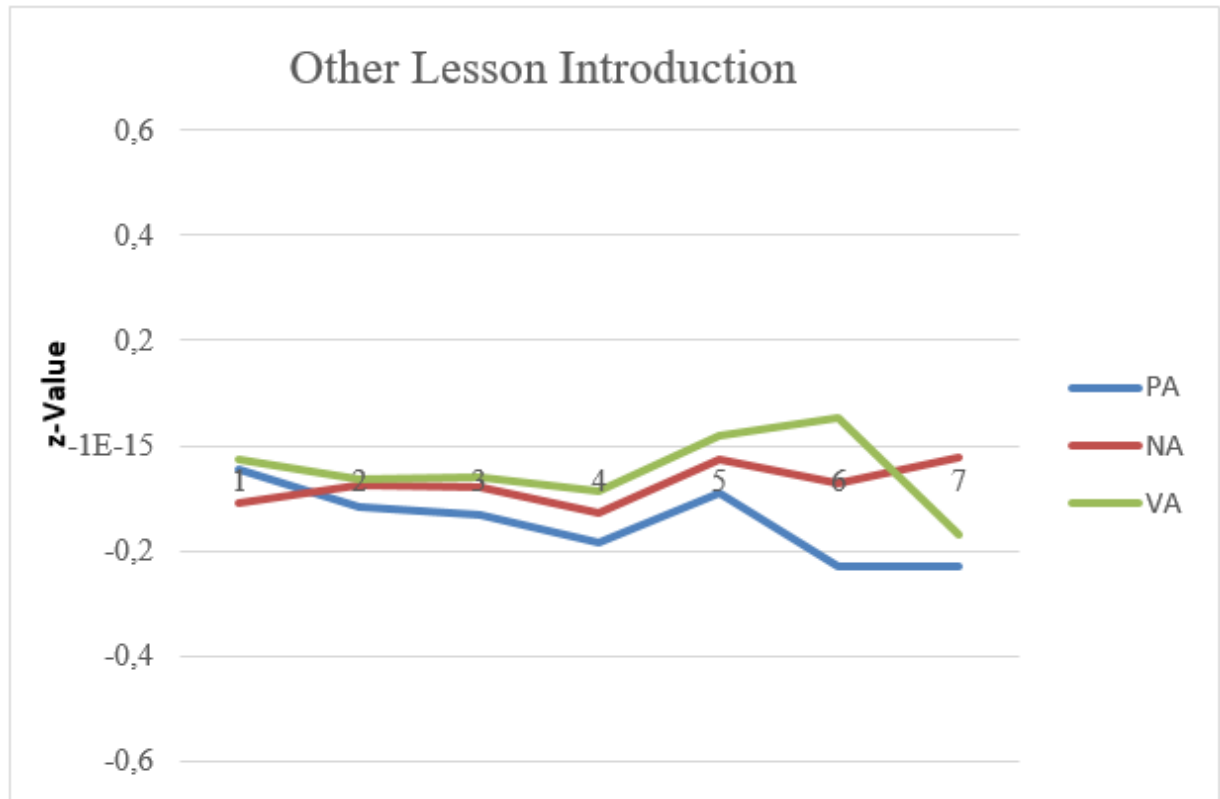

Figure 3: Distribution of the z-values - other forms of lesson introduction 
A. Gebhardt, M. Mertens, S. Niedermaier, J. Pelster, S. Wöllmecke, B. Paape \& I. Kiereta: Introduction of a Lesson: A Guarantee of Motivation? The Significance of the Lesson Introduction for Learners' Activation Level in Business and Economics Teaching at German Vocational Colleges

Table 3: Reliability statistics PA value

\begin{tabular}{|r|r|}
\multicolumn{2}{|c|}{ Reliability statistics PA value } \\
\begin{tabular}{|} 
Cronbachs \\
Alpha
\end{tabular} & No. of items \\
\hline .912 & \\
\hline
\end{tabular}

Table 4: Reliability statistics NA value

\section{Reliability statistics NA value}

\begin{tabular}{|r|r|}
\hline $\begin{array}{l}\text { Cronbach's } \\
\text { Alpha }\end{array}$ & No. of items \\
\hline .939 & \\
\hline
\end{tabular}

Table 5: Reliability statistics VA value

\section{Reliability statistics VA value}

\begin{tabular}{|r|r|}
\hline $\begin{array}{l}\text { Cronbach's } \\
\text { Alpha }\end{array}$ & No. of items \\
\hline .875 & 7 \\
\hline
\end{tabular}

\section{Notes}

${ }^{1}$ The items of the three dimensions (PANAVA) are available from the questionnaire (cf. Fig. 5 Appendix).

${ }^{2}$ PA items: 'energetic' vs. 'lacking energy', 'wide awake' vs. 'tired', 'highly motivated' vs. 'dull', 'enthusiastic' vs. 'bored'; VA items: 'happy' vs. 'unhappy', 'satisfied' vs. 'dissatisfied'.

${ }^{3}$ The exact values can be seen in Tables 3-5 of the Appendix.

${ }^{4}$ The Friedman test was used here, since several paired samples (measuring points 1-4) were selected during the analysis.

\section{Literature}

APO-BK.NRW (Ausbildungs- und Prüfungsordnung Berufskolleg des Landes NordrheinWestfalen) (2011): Verordnung über die Ausbildung und Prüfung in den Bildungsgängen des 
$36^{\mathrm{TH}}$ International Conference on Organizational Science Development: Responsible Organization (MARCh $22^{\mathrm{ND}}-24^{\mathrm{TH}}$, PortoroŽ SLOVENia)

A. Gebhardt, M. Mertens, S. Niedermaier, J. Pelster, S. Wöllmecke, B. Paape \& I. Kiereta: Introduction of a Lesson: A Guarantee of Motivation? The Significance of the Lesson Introduction for Learners' Activation Level in Business and Economics Teaching at German Vocational Colleges

Berufskollegs. Vom 26. Mai 1999 zuletzt geändert durch Verordnung vom 10. Juli 2011. SGV.NRW.223.

Bortz, J. / Döring, N. (2003): Forschungsmethoden und Evaluation für Human- und Sozialwissenschaftler, 3., überarbeitete Auflage, Berlin/ Heidelberg/ New York: Springer.

Csikszentmihalyi, M./ Larson, R./ Prescott, S. (1977): The Ecology of Adolescent Activity and Experience, in: Journal of Youth and Adolescence,6, (3), S. 281-294.

Deutscher Bildungsrat (1970): Empfehlungen der Bildungskommission. Strukturplan für das Bildungswesen, Stuttgart: Ernst Klett Verlag.

Dubs, R. (2009): Lehrerverhalten. Ein Beitrag zur Interaktion von Lehrenden und Lernenden im Unterricht; : 2., überarbeitete Auflage, Stuttgart: Franz Steiner Verlag.

Engeser, S./ Vollmeyer, R. (2005a): Tätigkeitsanreize und Flow-Erleben, in: Vollmeyer, Regina/ Brunstein, Joachim (Eds.): Motivationspsychologie und ihre Anwendung, Stuttgart: Kohlhammer.

Engeser, S. et. al. (2005b): Motivation, Flow-Erleben und Lernleistung in universitären Lernsetting, in: Zeitschrift für Pädagogische Psychologie 19, (3), pp. 159-172.

Heckhausen, J./ Heckhausen, H. (2010): Motivation und Handeln, 4., überarbeitete und erweiterte Auflage, Berlin/ Heidelberg: Springer.

Klafki, W. (1996): Studien zur Bildungstheorie und Didaktik. Zeitgemäße Allgemeinbildung und kritisch-konstruktive Didaktik, 5. Auflage, Weinheim: Beltz.

Rheinberg, F.(1989): Zweck und Tätigkeit, Göttingen: Hogrefe.

Rheinberg, F./ Vollmeyer, R./ Burns, B. D. (2001): FAM: Ein Fragebogen zur Erfassung aktueller Motivation in Lern- und Leistungssituationen, in: Diagnostica, 47, pp. 57-66.

Rheinberg, F. (2004): Motivationsdiagnostik, Göttingen: Hogrefe.

Rheinberg, F. (2008): Motivation, 7., aktualisierte Auflage, Stuttgart: Kohlhammer.

Rheinberg, F./ Vollmeyer, R. (2012): Motivation. Stuttgart: Kohlhammer.

Meyer, H. (2011): Unterrichtsmethoden, Band 2, 14. Auflage, Berlin: Cornelsen.

Schallberger, U. (2005): Forschungsberichte aus dem Projekt: "Qualität des Erlebens in Arbeit und Freizeit" Untersuchungen mit der Experience Sampling Method, Nr. 6, Kurzskalen zur Erfassung der Positiven Aktivierung, Negativen Aktivierung und Valenz in Experience Sampling Studien (PANAVA-KS) Theoretische und methodische Grundlagen, Konstruktvalidität und psychometrische Eigenschaften bei der Beschreibung intra- und interindividueller Unterschiede, Zürich.

Schnell, Rainer/ Hill, Paul B./ Esser, Elke (2008): Methoden der empirischen Sozialforschung, 8., unveränderte Auflag, München: Oldenbourg Wissenschaftsverlag.

Vollmeyer, Regina/ Rheinberg, Falko (1999): Motivation and metacognition when learning a complex system, in: European Journal of Psychology of Education, 14, pp. 541-554.

Vollmeyer, Regina/ Rheinberg, Falko (2002): Die Erfassung der aktuellen Motivation, in: Stiensmeier-Pelster, Joachim/ Rheinberg, Falko (Eds.): Diagnostik von Selbstkonzept und Lernmotivation, Göttingen: Hogrefe.

Watson, David/ Clark, Lee Anna/ Tellegen, Auke (1988): Development and Validation of Brief Measures of Positive and Negative Affect: The PANAS Scales, in: Journal of Personality and Social Psychology, 54, (6), pp. 1063-1070. 


\title{
Analiza modela notranjih institucionalnih evalvacij na Univerzi v Mariboru
}

\author{
MIHA PAUKO \& FRANCI ČUŠ
}

\begin{abstract}
Povzetek V prispevku smo prikazali in analizirali model notranjih institucionalnih evalvacij na Univerzi $\mathrm{v}$ Mariboru. Model je potrjen $\mathrm{z}$ raziskavo, ki temelji na ustrezni teoriji, dolgoletnih izkušnjah ter primerih dobre prakse. Predstavljena so ključna spoznanja in rezultati iz uresničenega projekta notranjih institucionalnih evalvacij. Podana je utemeljitev vpeljave notranjih institucionalnih evalvacij, in pozitivni odzivi ob neodvisnih zunanjih evalvacijah posameznih visokošolskih zavodov in njihovih študijskih programov. Rezultati projekta so osnova za izboljšanje nadaljnjega načrtovanja in izvajanja dejavnosti v okviru "follow up« notranjih institucionalnih evalvacij na Univerzi v Mariboru kakor tudi bližajočemu se prenašanju postopkov ponovnih akreditacij študijskih programov z državne agencije na univerzo.
\end{abstract}

KLJUČNE BESEDE: visoko šolstvo $\bullet$ univerza $\bullet$ članica universe $\bullet$ kakovost v visokem šolstvu $\bullet$ vodenje kakovosti $\cdot$ zunanja evalvacija $\bullet$ notranja evalvacija

\footnotetext{
NAslov AVtorJev: mag. Miha Pauko, vodja, Univerza v Mariboru, Univerzitetni športni center Leona Štuklja, Leona Štuklja, Koroška cesta 130, 2000 Maribor, Slovenija, e-pošta: miha.pauko@um.si; dr. Franci Čuš, redni profesor, Univerza v Mariboru, Fakulteta za strojništvo, Smetanova ulica 17, 2000 Maribor, Slovenija, e-pošta: franc.cus@um.si
} 
36 ${ }^{\text {TH }}$ International CONFEREnCE ON ORganizational Science DEVELOPMENT: ResPonsible ORGANIZATION (MARCH $22^{\mathrm{ND}}-24^{\mathrm{TH}}$, PORTOROŽ SLOVENIA)

O. Arsenijević, M. Ferjan, I. Podbregar, P. Šprajc, D. Trivan \& Y.

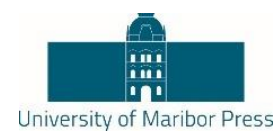

Ziegler

\title{
Analysis of the Model of the Internal Institutional Evaluations at the University of Maribor
}

\author{
MIHA PAUKO \& FRANCI ČUŠ
}

\begin{abstract}
In the article we break down and analyse the model of internal institutional evaluations at the University of Maribor. The model is supported by research based on adequate theory, long years of experience and best practice examples. We present key findings and results of the completed project of internal institutional evaluations, and provide arguments supporting the introduction of internal institutional evaluations. The analysis is rounded up by positive feedback from independent external evaluations of selected higher education institutions and their study programmes. Results of the project will be applied to further improve the planning and implementation of activities under the follow-up process of internal institutional evaluations at the University of Maribor, as well as to the upcoming transfer of the study programme accreditation process from the national agency to the university.
\end{abstract}

KEYWORDS: higher education $\bullet$ university $\bullet$ university member $\bullet$ quality assurance in higher education $\bullet$ quality management $\bullet$ external evaluation • internal evaluation

Correspondence AdDress: Miha Pauko, M.S., Head of the Sports Centre, University of Maribor, University Sports Centre Leon Štukelj, Koroška cesta 130, 2000 Maribor, Slovenia, e-mail: miha.pauko@um.si; Franci Čuš, Ph.D., Full Professor, University of Maribor, Faculty of Mechanical Engineering, Smetanova ulica 17, 2000 Maribor, Slovenia, e-mail: franc.cus@um.si

DOI https://doi.org/10.18690/978-961-286-020-2.54ＩSBN 978-961-286-020-2

(C) 2017 University of Maribor Press

Available at: http://press.um.si 
M. Pauko \& F. Čuš: Analiza modela notranjih institucionalnih evalvacij na Univerzi v Mariboru

\section{$1 \quad$ Zagotavljanje kakovosti na Univerzi v Mariboru}

Univerza v Mariboru (UM) je po velikosti druga izmed štirih slovenskih javnih univerz. Ustanovljena je bila leta 1975 in šteje v letu 2017 okoli 15 tisoč študentov, ki so vpisani $\mathrm{v}$ študijske programe njenih 17 fakultet.

Članice univerze od leta 2000 periodično izvajajo samoevalvacije v skladu s Pravilnikom o ocenjevanju kakovosti na Univerzi v Mariboru ${ }^{1}$. Za kakovost članic UM so odgovorni njihovi dekani, odgovornost za kakovost celotne univerze pa prevzema njen rektor. V okviru univerzitetne uprave je bila leta 2006 ustanovljena Služba za kakovost, danes nadgrajena kot Oddelek za kakovost in trajnostni razvoj. Na UM je bilo doslej izvedenih več institucionalnih zunanjih evalvacij: CRE - Association of European Universities (1998), »follow-up« EUA - European University Association (2004 in 2013) ter NAKVIS Nacionalna agencija Republike Slovenije za kakovost v visokem šolstvu (2013).

\section{Komisija za ocenjevanje kakovosti univerze}

Komisija za ocenjevanje kakovosti univerze (v nadaljevanju komisija) deluje od leta 1997 in ima status stalne komisije Senata UM. Trenutno šteje 27 članov. Komisija spremlja in izvaja institucionalno ocenjevanje kakovosti pedagoškega, znanstvenoraziskovalnega in umetniškega dela članic univerze ter univerze kot celote, deluje pa v skladu z Zakonom o visokem šolstvu, Merili za akreditacijo in zunanjo evalvacijo visokošolskih zavodov in študijskih programov ${ }^{2}$ NAKVIS, Statutom UM, Poslovnikom kakovosti $\mathrm{UM}^{3}$ ter omenjenim pravilnikom.

Komisija samostojno in neodvisno sprejema odločitve, pri čemer poleg zakonodaje dosledno uporablja merila in standarde; zagotavlja objektivno presojo vseh članic UM; predpisuje sestavo poročil skupin strokovnjakov, iz katerih so razvidne prednosti in morebitne neskladnosti pri delovanju zavodov, predvsem pa priporočila za odpravo morebitnih pomanjkljivosti; upošteva samoevalvacijska poročila kot podlago za zunanjo evalvacijo.

Komisija o svojih ugotovitvah, sprejetih sklepih in stališčih, predlogih in mnenjih sproti obvešča Senat UM, ki mu je odgovorna, in mu predlaga ustrezne odločitve. Obravnava in odloča o zadevah s področja vodenja kakovosti na UM in na njenih članicah ter spremlja postopke samoevalvacije in evalvacije univerze in njenih članic.

Delovanje komisije je v skladu z evropskimi standardi in smernicami za zagotavljanje kakovosti v evropskem visokošolskem prostoru $(\mathrm{ESG})^{4}$. Namen teh standardov je:

- določiti skupni okvir (podlago) za sisteme kakovosti pri poučevanju in učenju na institucionalni, nacionalni in evropski ravni,

- omogočiti zagotavljanje (presojo) in izboljševanje kakovosti visokošolskega izobraževanja v evropskem visokošolskem prostoru (EHEA), 
$36^{\text {Th }}$ International Conference on Organizational Science Development: Responsible Organization (MARCH $22^{\mathrm{ND}}-24^{\mathrm{TH}}$, Portorož Slovenia)

M. Pauko \& F. Čuš: Analysis of the Model of the Internal Institutional Evaluations at the University of Maribor

- vzpostaviti medsebojno zaupanje, kar bo olajšalo mobilnost in priznavanje v državah in zunaj njihovih meja,

- zagotoviti informacije o kakovosti visokošolskega izobraževanja v EHEA.

- Trije deli standardov in smernic ESG obsegajo:

- ESG za notranje zagotavljanje kakovosti (notranji sistem kakovosti),

- ESG za zunanje zagotavljanje kakovosti (zunanji sistem kakovosti),

- ESG za agencije.

\section{$3 \quad$ Notranje institucionalne evalvacije članic univerze}

Komisija je v letu 2008 pristopila k izvedbi projekta notranjih institucionalnih evalvacij znotraj UM. Te evalvacije so predstavljale pripravo na zunanje evalvacije, ki jih izvajajo skupine strokovnjakov, imenovane s strani nacionalnega evalvacijskega organa. Notranje institucionalne evalvacije na UM so potekale na enak način in po istih merilih kot zunanje institucionalne evalvacije v Sloveniji.

Komisija je na podlagi pridobljenih znanj in izkušenj razvila na osnovi opravljenih raziskav izvirni model evalvacij ${ }^{5}$. Cilj je bil izboljšanje in razvoj vodenja kakovosti na UM ter zato podana utemeljitev vpeljave notranjih institucionalnih evalvacij na UM. Komisija je izvedla notranje institucionalne evalvacije na naslednjih članicah UM:

- Pravna fakulteta (november 2008),

- Fakulteta za gradbeništvo (maj 2009),

- Fakulteta za kmetijstvo in biosistemske vede (november 2009),

- Fakulteta za varnostne vede (maj 2010),

- Fakulteta za kemijo in kemijsko tehnologijo (november 2010),

- Fakulteta za organizacijske vede (maj 2011),

- Ekonomsko-poslovna fakulteta (november 2011),

- Pedagoška fakulteta (maj 2012),

- Medicinska fakulteta (november 2012),

- Fakulteta za logistiko (maj 2013),

- Fakulteta za naravoslovje in matematiko (november 2013),

- Fakulteta za energetiko (maj 2014) in

- Fakulteta za turizem (november 2015).

Komisija ni izvedla notranjih institucionalnih evalvacij na štirih izmed članic UM, saj so le-te že predhodno prestale preverjanje kakovosti s strani nacionalnega evalvacijskega organa.

Pravilnik o ocenjevanju kakovosti Univerze v Mariboru vključuje in opredeljuje vse postopke notranje institucionalne evalvacije članic UM, kot začetek postopka, izbor evalvatorjev, vloga, notranja evalvacijska komisija, dokumentacija, obisk notranje evalvacijske komisije in poročilo notranje evalvacijske komisije. 


\subsection{Postopek notranjih institucionalnih evalvacij}

Komisija je objavila razpis za evalvatorje na podlagi Meril za izbiro evalvatorjev za potrebe notranjih institucionalnih evalvacij na $\mathrm{UM}^{6}$. Rektor $\mathrm{UM}$ je na predlog komisije $\mathrm{s}$ sklepom imenoval neodvisne petčlanske evalvacijske komisije z UM, sestavljene iz treh visokošolskih učiteljev, strokovnega sodelavca komisije ter predstavnika študentov. S sestavami evalvacijskih komisij so morala vodstva članic UM, predvidenih za notranjo institucionalno evalvacijo, predhodno soglašati.

Osnova za izvajanje projekta notranjih institucionalnih evalvacij so bila Merila za akreditacijo in zunanjo evalvacijo visokošolskih zavodov in študijskih programov NAKVIS. Evalvacijske komisije so tako ocenjevale fakultete po naslednjih področjih: 1) vpetost v okolje; 2) delovanje visokošolskega zavoda; 3) kadri; 4) študenti; 5) materialne razmere ter 6) zagotavljanje kakovosti, inovativnosti in razvojne naravnanosti.

Evalvirane fakultete so $\mathrm{v}$ skladu $\mathrm{z}$ navedenimi merili posredovale strokovni službi komisije/evalvacijskim komisijam zahtevano in razpoložljivo dokumentacijo za pričetek notranjega evalvacijskega postopka (vlogo, strateški načrt razvoja, letni delovni načrt, program dela in finančni načrt, zadnje samoevalvacijsko poročilo, izpolnjen pregledni vprašalnik za pripravo na notranjo evalvacijo idr.). Člani evalvacijskih komisij so proučili predloženo dokumentacijo ter si priskrbeli še dodatne informacije preko spletnih strani evalviranih fakultet.

Dvodnevni evalvacijski obiski na evalviranih fakultetah so potekali po vnaprej natančno dogovorjenih urnikih in $\mathrm{v}$ obliki intervjujev $\mathrm{s}$ posameznimi predstavniki vodstev (dekanom, prodekani, tajnikom), študenti nefunkcionarji, študenti funkcionarji, visokošolskimi učitelji, asistenti, mladimi raziskovalci in podiplomskimi študenti, nepedagoškimi delavci, člani komisij za ocenjevanje kakovosti ter predstavniki delodajalcev.

Evalvacijske komisije so najkasneje v 30 dneh po opravljenih evalvacijskih obiskih izdelale zaključna poročila o notranjih institucionalnih evalvacijah in jih posredovale strokovni službi komisije, le-ta pa takoj še vodstvom evalviranih fakultet, ki so imela nato 15 dni časa, da nanje podajo morebitne pripombe. V zaključnih poročilih so evalvatorji zapisali ugotovljene prednosti in slabosti, prav tako pa tudi priporočila za izboljšanje stanja. Na podlagi slednjih so evalvirane fakultete pristopile k izdelavi akcijskih načrtov korektivnih ukrepov za odpravo ugotovljenih pomanjkljivosti oziroma za krepitev ugotovljenih prednosti.

Poročila o notranjih institucionalnih evalvacijah, pripadajoče pripombe vodstev evalviranih fakultet ter akcijske načrte korektivnih ukrepov evalviranih fakultet je najprej obravnavala komisija, nato pa še Senat UM. Navedeni dokumenti so javno objavljeni na spletnih straneh komisije ${ }^{7}$. 
$36^{\text {Th }}$ International Conference on Organizational Science Development: ResPonsible Organization (MARCH $22^{\mathrm{ND}}-24^{\mathrm{TH}}$, PORTOROŽ Slovenia)

M. Pauko \& F. Čuš: Analysis of the Model of the Internal Institutional Evaluations at the University of Maribor

\subsection{Analiza notranjih institucionalnih z zunanjimi evalvacijami}

Notranje institucionalne evalvacije so bile po svoji vsebini in izvedbi zelo podobne zunanjim institucionalnim evalvacijam, ki potekajo $\mathrm{v}$ slovenskem visokošolskem prostoru od leta 2006:

- evalvatorji so uporabili ista merila (nacionalna evalvacijska merila),

- evalvirani visokošolski zavodi so pripravili za potrebe evalvacijskih komisij isto dokumentacijo,

- izvajalci so bili usposobljeni kandidati za člane evalvacijskih komisij,

- eden izmed članov evalvacijskih komisij je bil obvezno iz vrst študentov,

- obiski na evalviranih visokošolskih zavodih so potekali na isti način,

- poročila evalvacijskih komisij so bila izdelana po zelo podobnem principu,

- vodstva evalviranih visokošolskih zavodov so imela možnost do pripomb na končno evalvacijsko poročilo,

- evalvacijska poročila so javno objavljena.

Notranje institucionalne evalvacije pa so se od zunanjih institucionalnih evalvacij vendarle tudi deloma razlikovale, in sicer:

- komisija je predlaga članico UM, na kateri je ekspertna komisija neodvisnih evalvatorjev izvedla notranjo institucionalno evalvacijo (pri zunanjih institucionalnih evalvacijah visokošolski zavod pozove NAKVIS),

- člani evalvacijskih komisij so bili izključno iz vrst zaposlenih in študentov UM (pri zunanjih institucionalnih evalvacijah člani evalvacijskih komisij ne prihajajo $\mathrm{z}$ iste univerze),

- na predlog komisije je člane evalvacijskih komisij imenoval rektor UM (pri zunanjih institucionalnih evalvacijah člane evalvacijskih komisij imenuje Svet NAKVIS),

- eden izmed članov evalvacijske komisije pri zunanjih institucionalnih evalvacijah prihaja iz tujine.

\subsection{Evalvatorji v postopkih notranjih institucionalnih evalvacij}

Pri izvedenih notranjih institucionalnih evalvacijah je sodelovalo po 5 evalvatorjev pri vsakem projektu (bodisi kot predsedniki ali člani komisij ali predstavniki študentov), skupaj torej 65 . Še posebej smo k prijavam na razpise za izbor evalvatorjev spodbujali člane ter nadomestne člane komisije. Upoštevati je treba še dejstvo, da je strokovni sodelavec komisije sodeloval v vseh 13 projektih in je bil hkrati kontaktna oseba notranje evalvacijske komisije v predhodnih usklajevanjih s presojano fakulteto. Splošni razpisni pogoji za evalvatorja zahtevajo:

- dobro poznavanje visokega šolstva,

- seznanjenost s sistemi za zagotavljanje kakovosti v visokem šolstvu, 
M. Pauko \& F. Čuš: Analiza modela notranjih institucionalnih evalvacij na Univerzi v Mariboru

- delovanje v komisijah za ocenjevanje kakovosti,

- aktivno sodelovanje pri izdelavi samoevalvacijskih poročil v okviru samoevalvacijskih komisij.

Posebni pogoji pri notranjih institucionalnih evalvacijah pa so naslednji:

- poznavanje metod poučevanja in učenja,

- vodstvene izkušnje pri pedagoškem in raziskovalnem delu,

- izkušnje pri finančnem poslovanju,

- strokovni prispevek pri razvijanju, oblikovanju oziroma pripravi ter evalvaciji študijskih programov oziroma evalvaciji visokošolskih zavodov,

- ustrezne mednarodne izkušnje s tega področja.

V kolikor je potrebno, komisija oceni kandidata tudi po naslednjih kompetencah:

- komunikacijske sposobnosti,

- sposobnost dela $\mathrm{v}$ evalvacijski skupini in dela $\mathrm{z}$ drugimi (predvsem predstavniki presojanega zavoda), nekonfliktnost,

- sposobnost vodenja intervjujev, postavljanja vprašanj, pomembnih za objektivno presojo, poslušanja, povzemanja dejstev, pomembnih za evalvacijsko poročilo,

- nepristranskost oziroma neodvisnost.

\section{$4 \quad$ Ocena notranjih institucionalnih evalvacij}

Na UM smo bili že od samega pričetka projekta notranjih institucionalnih evalvacij mnenja, da bo izvedba le-teh na posameznih fakultetah UM izredno dobrodošla v smislu njihovega nadaljnjega razvoja. $Z$ zanesljivostjo lahko trdimo, da so članice UM, ki so prestale notranjo institucionalno evalvacijo, bistveno bolje pripravljene na tovrstne zunanje institucionalne evalvacije, ki periodično sledijo $\mathrm{v}$ okviru akreditacijskih postopkov visokošolskega zavoda ali njegovih študijskih programov. Ta izboljšana pripravljenost se zrcali predvsem z zavedanjem o skrbi za kakovost, potrebi po vodenju kakovosti, bistveno izboljšanih samoevalvacijskih poročilih ter kontinuiranem spremljanju kakovosti v posameznih procesih. Opravljene notranje institucionalne evalvacije so bile po splošni oceni vseh vpletenih zelo uspešne ter izvedene v smislu obojestranskega zadovoljstva.

Strokovna služba komisije je takoj po zaključenem evalvacijskem obisku posredovala evalvirani članici UM dva anketna vprašalnika: prvi je bil namenjen vodstvu fakultete, drugi pa študentom, ki so sodelovali $\mathrm{v}$ intervjujih. Na podlagi obeh izpolnjenih vprašalnikov je komisija prejela dragocene povratne informacije in jih analizirala ter se poskušala izogniti morebitnim ponavljajočim se napakam pri izvedbi nadaljnjih notranjih evalvacij. Po dveh opravljenih notranjih institucionalnih evalvacijah sta bila tudi omenjena anketna vprašalnika analizirana in dopolnjena. 
$36^{\text {Th }}$ International Conference on Organizational Science Development: RESPONSIBLE ORGANIZATION (MARCH $22^{\mathrm{ND}}-24^{\mathrm{TH}}$, PorTOROŽ SLOVENIA)

M. Pauko \& F. Čuš: Analysis of the Model of the Internal Institutional Evaluations at the University of Maribor

Anketni vprašalnik je sestavljen iz treh delov: prvega sklopa s ponujenimi odgovori, drugega sklopa z možnostjo navedbe morebitnih predlogov, ter še dveh vprašanj, pri katerih je odgovor opisen.

Uvodoma smo analizirali vprašalnike na podlagi prvih dveh sklopov, ki se nanašata na zadovoljstvo vodstva presojane fakultete ter predstavnikov njenih študentov $\mathrm{z}$ delom evalvatorjev. Notranjo evalvacijsko komisijo so ocenili po naslednjih segmentih:

- načrtovanje evalvacijskega obiska in usklajevanje evalvatorjev z vodstvom evalvirane fakultete,

- seznanitev evalvirane fakultete z namenom institucionalne evalvacije na uvodnem sestanku,

- ustreznost urnika obiska oziroma trajanja posameznih intervjujev,

- način in izvedba opravljenih intervjujev,

- izbira izpraševancev,

- izbira in vrstni red postavljenih vprašanj,

- prilagojenost postavljenih vprašanj izpraševancem,

- razumljivost postavljenih vprašanj,

- možnost za objektivno izražanje mnenj izpraševancev,

- učinkovitost izpraševalcev,

- seznanjenost evalvatorjev z organiziranostjo in pravnim položajem evalvirane fakultete,

- seznanjenost evalvatorjev z dejavnostjo evalvirane fakultete,

- seznanjenost evalvatorjev s posebnostmi evalvirane fakultete,

- način predstavitve končnega poročila na zaključnem sestanku,

- končne ugotovitve evalvatorjev glede evalvirane fakultete,

- trajanje evalvacijskega obiska,

- splošna ocena izvedbe evalvacije.

Nekoliko prilagojen, a zelo podoben vprašalnik so izpolnili tudi študenti, ki so sodelovali $\mathrm{v}$ razgovorih $\mathrm{z}$ notranjo evalvacijsko komisijo. Posamezne segmente so ocenili s pomočjo lestvice ocenjevanja od 1 do 5 , pri čemer 1 pomeni skrajno nezadovoljen, 5 pa zelo zadovoljen. Točke smo sešteli in enostavno pretvorili $\mathrm{v}$ odstotne točke ter jih $\mathrm{v}$ preglednici 1 prikazali po posameznih članicah UM, ki so sodelovale v tem projektu. 

ORgANIZACIJA (22. - 24. MAREC 2017, PORTOROŽ, SLOVENIJA)

M. Pauko \& F. Čuš: Analiza modela notranjih institucionalnih evalvacij na Univerzi v Mariboru

\section{Preglednica 1: Ocena notranjih evalvacijskih komisij v postopkih notranjih institucionalnih evalvacij članicah UM (v\%)}

\begin{tabular}{|c|c|c|}
\hline & $\begin{array}{c}\text { ocena } \\
\text { vodstva fakultete }\end{array}$ & $\begin{array}{c}\text { ocena } \\
\text { predstavnikov } \\
\text { študentov }\end{array}$ \\
\hline EPF & 90,6 & 76,3 \\
\hline FE & 100,0 & 91,8 \\
\hline FG & 98,6 & 54,3 \\
\hline FKBV & 94,1 & 94,1 \\
\hline FKKT & 100,0 & 94,1 \\
\hline FL & 92,5 & 82,4 \\
\hline FNM & 88,2 & 91,8 \\
\hline FOV & 95,0 & 84,7 \\
\hline FT & 91,3 & 77,6 \\
\hline FVV & 87,1 & 68,2 \\
\hline MF & 87,1 & 87,1 \\
\hline PEF & 87,1 & 71,3 \\
\hline PF & 98,6 & 82,9 \\
\hline$\varnothing$ & 93,2 & $\mathbf{8 1 , 6}$ \\
\hline
\end{tabular}

Vir: arhivsko gradivo strokovne službe komisije

Iz ocen v preglednici 1 je že na prvi pogled razvidno, da so ocene notranjih evalvacijskih komisij, ki so jih prejele od vodstev presojanih fakultet oziroma njihovih predstavnikov študentov, izjemno dobre. Vodstvi Fakultete za kemijo in kemijsko tehnologijo ter Fakultete za energetiko so evalvatorjem dodelile kar maksimalno število točk! Pri ocenah predstavnikov študentov nekoliko izstopata nizki oceni s strani Fakultete za gradbeništvo ter Fakultete za varnostne vede, začudilo pa nas je, da jih predstavniki navedenih fakultet v nadaljevanju vprašalnika niso argumentirali, npr. s konkretnimi predlogi za izboljšanje.

V vprašalnikih je bilo nadalje zastavljeno vprašanje "Katere so po vašem mnenju prednosti in pomanjkljivosti notranje institucionalne evalvacije fakultete? «. Sledi zapis nekaterih odgovorov (v primerih, ko so se odgovori na isto vprašanje ponavljali, smo jih zapisali samo enkrat):

Prednosti (povzetek):

- Možnost preverbe ustrezno zastavljenega dela, spodbuda ob dobri oceni za nadaljnje delo.

- Ponovno smo premislili o opredelitvi naših dosežkov in srednjeročnih ciljih ter uvideli zunanje in notranje omejitve, ki pomembno vplivajo na naš razvoj.

- Ugotovitev dobrih in slabih strani dela na fakulteti.

- Koristno za primerjavo v evropskem prostoru.

- Pripomore k izboljšanju vrednotenja kakovosti. 
$36^{\text {Th }}$ International Conference on Organizational Science Development: Responsible Organization (March $22^{\mathrm{ND}}-24^{\mathrm{TH}}$, Portorož SLOVEnia)

M. Pauko \& F. Čuš: Analysis of the Model of the Internal Institutional Evaluations at the University of Maribor

- Objektivni posnetek stanja.

- Koristni predlogi za izboljšanje.

- Dvig samozavesti zaradi dobrih ocen.

- Ocena dejanskega stanja institucije, ki pripomore k izboljšanju (popravku).

- Neodvisno mnenje o fakulteti.

- Nekdo od zunaj te spomni na pomanjkljivosti oziroma nekdo neodvisen te izmeri z merili, ki so primerljiva s sorodnimi ocenjenimi ustanovami.

- Kritičen pogled od zunaj.

- Evalvacija je pripomogla k razmisleku, kje smo in kaj lahko storimo za višjo kakovost našega dela.

- Celostna analiza organiziranosti in dejavnosti fakultete ter »pogled od zunaj«, ki pokaže na možnosti izboljšav in dopolnitev organiziranosti ter izvajanja dejavnosti.

- Evalvirani so bili vsi segmenti fakultete, tako da so zaposleni dobili celostno podobo o njej ter o ugotovljenih pomanjkljivostih in možnostih za izboljšanje.

- Aktualnost evalviranja zastavljenih ciljev, motivacija za nadaljnje delo.

- Zavedanje, da se je s konkurenco potrebno primerjati.

- Možnost, da tudi asistenti javno izrazijo svoje mnenje.

- Pogled z drugimi očmi na institucijo, spoznavanje njenih prednosti in slabosti; skušamo se spremeniti in skozi spremembe doseči zastavljene cilje.

- Objektiven pogled na situacijo, dejavnost in razvoj nekoga, ki ni obremenjen z vsakodnevnim vodenjem.

- Zunanji ocenjevalci opazijo nepravilnosti prej in jih neobremenjeno ovrednotijo.

- Priprava na zunanjo evalvacijo.

- Prikaz dejanskega stanja na fakulteti in možnosti za izboljšanje le-tega.

- Opozarjanje na obstoječe probleme.

- Podani predlogi za reševanje problemov ter možnost, da tudi študenti izrazijo svoja mnenja.

Pomanjkljivosti (povzetek):

- Prezgodnja evalvacija glede na dejstvo, da je bila fakulteta ustanovljena šele pred nekaj leti.

- Bistvenega problema (finance) ne more rešiti.

- Samo formalno seznanjanje.

- Ni vsebinske ocene dela.

- Poudarek na formaliziranih (vizija, ankete ...), manj na vsebinskih vprašanjih.

- Veliko vloženega dela, še posebej kontaktne osebe evalvirane fakultete.

- Težnja po uniformiranosti, neupoštevanje argumentov fakultete v končnem poročilu.

- Večina predlogov se nanaša na področja, za katera fakulteta sama ne more oblikovati efektnih akcijskih načrtov (finance, prostori, stimulacija ...) - slabost 
M. Pauko \& F. Čuš: Analiza modela notranjih institucionalnih evalvacij na Univerzi v Mariboru

takšnega ocenjevanja v preslabi povezavi z nadrejenimi nivoji (UM, pristojno ministrstvo).

- Veliko navedenih pomanjkljivosti v končnem poročilu se je nanašalo na slabosti: zakonske ureditve visokega šolstva $v$ Sloveniji, na katere fakulteta nima vpliva in jih ne more odpraviti, saj jo k uporabljanim rešitvam zavezuje zakonodaja; ta vidik bi mogel biti drugače zaobjet $v$ poročilu, kot je bil.

- Časovno neustrezna evalvacija zaradi nedokončanega študijskega bolonjskega procesa.

- Premajhna seznanjenost evalvatorjev z dejanskim stanjem na fakulteti.

- Premalo kritičnosti s strani evalvatorjev.

- Notranja evalvacija je preveč površinska, formalna in birokratična.

Analizo vprašalnika končujemo še $\mathrm{z}$ drugim zastavljenim vprašanjem »Ali je institucionalna evalvacija pripomogla $\mathrm{k}$ izboljšanju vrednotenja kakovosti, in če, na kakšen način?«. Spodaj navajamo nekatere odgovore, največkrat so se glasili »da«:

- Izdelava akcijskega načrta za načrtno spremljanje kakovosti dela.

- Opozorjeni smo bili na določene pomanjkljivosti, na podlagi katerih je vodstvo fakultete pripravilo akcijski načrt za odpravo pomanjkljivosti.

- Vsaka evalvacija pripomore k izboljšanju vrednotenja kakovosti.

- Natančno smo preučili ugotovljene pomanjkljivosti in takoj izdelali akcijski načrt za njihovo odpravo.

- Predlogi so bili vključeni v akcijski načrt in program dela fakultete, ugotovljene pomanjkljivosti pa odpravljamo.

- Prevetritev stanja, identifikacija nekaterih formalnih pomanjkljivosti (manjkajoča anketa zadovoljstva delavcev).

- Umestitev oziroma zunanja ocena stanja, manjši prispevek k dejanskim vsebinskim izboljšavam.

- Uredili so se nekateri postopki in načini dela, v vodenje kakovosti so vključili nekatere dodatne načine in področja.

- Bistvene izboljšave lahko spodbudi nov visokošolski zakon, večja avtonomija UM in posameznih njenih članic ter stabilen model financiranja pedagoškega in raziskovalnega dela.

- Komisija za ocenjevanje kakovosti je dobila nove smernice, kje so naše šibke točke, kaj bi lahko oziroma kaj moramo storiti za izboljšanje položaja fakultete.

- Pomemben prispevek evalvacije $\mathrm{k}$ izboljšanju kakovosti je predvsem $\mathrm{v}$ tem, da je bilo vodstvo fakultete spodbujeno $\mathrm{k}$ aktivnemu razmišljanju o kakovosti ter da so se v pripravi na evalvacijo in pri pripravi ukrepov za odpravo pomanjkljivosti predstavniki vodstva in zaposleni v strokovnih službah zavedli različnih aspektov kakovosti, ki bi sicer ostali zanemarjeni (informacijski sistem, sistematsko obravnavanje možnosti za izboljšave, mnenje študentov).

- Evalvacija je pomagala identificirati pomanjkljivosti, ki smo jih takoj začeli odpravljati in s tem pripomogli k izboljšanju kakovosti. 
$36^{\text {TH }}$ International Conference on Organizational Science Development: RESPONSIBLE ORGANIZATION (MARCH $22^{\mathrm{ND}}-24^{\mathrm{TH}}$, PorTOROŽ SLOVENIA)

M. Pauko \& F. Čuš: Analysis of the Model of the Internal Institutional Evaluations at the University of Maribor

- Aktualizacija ciljev akcijskega načrta za stalno in načrtno spremljanje kakovosti dela.

- Poskrbela je za dodatno legitimacijo sledenja kakovosti na fakulteti.

- Le delno: na področjih, ki niso bistvena za poučevanje in raziskovanje.

- Na podlagi akcijskega načrta bodo pristopili k realizaciji potencialnih izboljšav, ki lahko pripomorejo k izboljšanju kakovosti.

- Pričakujejo večje razumevanje pomena vodenja kakovosti in interes za dejavnosti, povezane z vodenjem kakovosti vseh zaposlenih na fakulteti.

- Evalvacija pripomore $\mathrm{k}$ pospešenem izvajanju predlaganih rešitev, $\mathrm{k}$ čemur pa morajo več prispevati tudi študenti.

Ob koncu analize anketnih vprašalnikov lahko ugotovimo, da smo s pretežno pozitivnimi odgovori izpraševancev dobili spodbudne ocene in povratne informacije glede izvedbe notranjih institucionalnih evalvacij članic UM, saj so jih le-te dobro sprejele in bodo na podlagi njih poskušale dvigniti raven kakovosti na vseh področjih. Po drugi strani pa so zapisane pripombe in negativna mnenja, ki so bila sicer $v$ manjšini, dragocena informacija za načrtovalce (strokovna služba komisije) in izvajalce bodočih evalvacij (evalvatorje), ki bodo skušali takšne pomanjkljivosti v prihodnje odpraviti.

$\mathrm{Z}$ rezultati te ankete je bila seznanjena tudi komisija, ki je inicirala notranje institucionalne evalvacije na UM, in iz vrst katere prihaja pretežno število evalvatorjev, ki sodelujejo v projektu notranjih institucionalnih evalvacij na UM. Z optimizmom lahko domnevamo, da pohvalna mnenja o posameznih segmentih, ki jih obravnava pričujoča anketa, še krepijo ugotovljene prednosti in pozitivni pristop $\mathrm{v}$ projektu notranjih institucionalnih evalvacij. Seveda pa se zavedamo, da le-te še zdaleč niso optimalne in ne potekajo brez pomanjkljivosti, zato bodo negativno izražena mnenja in zapisane pripombe dobronamerno prispevala $\mathrm{k}$ dvigu kakovosti nadaljnjih notranjih institucionalnih evalvacij na UM.

\subsection{Ključne ugotovitve}

Ob zaključku projekta notranjih institucionalnih evalvacij fakultet UM, ki ga je v obdobju 2008-2015 izvedla komisija, ugotavljamo naslednje (še posebej so izpostavljeni spoznanja in izkušnje avtorja, ki je sodeloval v projektu od faze njegovega načrtovanja preko izvedbe do oblikovanja zaključkov):

- na UM smo razvili potek notranje institucionalne evalvacije visokošolskega zavoda,

- izdelali smo model notranje institucionalne evalvacije visokošolskega zavoda,

- definirali smo postopke priprave na notranjo institucionalno evalvacijo, evalvacijski obisk notranje evalvacijske komisije ter ostale aktivnosti z vidika presojanega visokošolskega zavoda kot tudi z vidika notranjih presojevalcev, 
- model notranje institucionalne evalvacije visokošolskega zavoda smo potrdili z raziskavo, ki temelji na praktičnih primerih, podkrepljenih z ustrezno teorijo in izkušnjami iz primerov dobre prakse,

- analizirali smo model notranje institucionalne evalvacije visokošolskega zavoda.

Glede na zastavljene delovne predpostavke ob namenu izdelave modela notranjih institucionalnih evalvacij na UM so bile le-te $\mathrm{v}$ celoti uresničene in potrjene:

- s pomočjo modela notranjih institucionalnih evalvacij članic UM so izboljšani njihovi procesi vodenja kakovosti,

- članice UM lahko model notranje institucionalne evalvacije uporabijo pri pripravi dejavnosti, povezanih tako z notranjo kot tudi zunanjo institucionalno evalvacijo,

- model je prispeval $\mathrm{k}$ bistveno boljši pripravljenosti članic UM pred obveznim cikličnim zunanjim preverjanjem kakovosti s strani nacionalnega evalvacijskega organa - zunanjimi evalvacijami NAKVIS.

Iz analize in razprav ugotavljamo, da je model notranje institucionalne evalvacije visokošolskega zavoda zanesljivo pripomogel tudi k dvigu kakovosti in konkurenčnosti procesov (izobraževanje, raziskovanje, vodenje kakovosti, kultura kakovosti, zadovoljstvo zaposlenih, zadovoljstvo študentov, višja raven izobrazbe ...) na celotni UM.

\section{$5 \quad$ Nadgradnja projekta notranjih institucionalnih evalvacij}

Za uspeh evalvacijskega procesa je nujno potrebno, da se le-ta ne konča z zaključnim evalvacijskim poročilom (Slika 1). Pri spremljanju so ključnega pomena vse aktivnosti, ki potekajo na določeni instituciji po zaključeni evalvaciji. V skladu z institucionalno avtonomijo evalviranih fakultet, se lahko le-te same odločijo, ali bodo upoštevale priporočila evalvatorjev za odpravo ugotovljenih pomanjkljivosti oziroma krepitev prednosti. Vendar pa kljub temu pričakujemo, da bo vsaka evalvirana fakulteta analizirala lastne izkušnje in rezultate evalvacije (tako v smislu samoevalvacije kot tudi dela evalvacijske komisije) ter obravnavala priporočila navedena $\mathrm{v}$ zaključnem poročilu.

Po zaključeni prvotni notranji evalvaciji ekspertne skupine komisije že evalvirano fakultete po nekaj letih še naknadno evalvirajo (»follow up«). Na zahtevo komisije le-ta sestavi skupino treh ocenjevalcev, ki ovrednotijo vpliv prvotne evalvacije na razvoj institucije ter izkušnje pridobljene po uvedbi ukrepov. $Z$ zanesljivostjo lahko trdimo, da se v času evalvacijskega obiska na sedežu presojane fakultete omenjena vpliv in izkušnje v pozitivnem smislu prepoznajo na več nivojih, tako celotnega zavoda kot vodstva in posameznikov.

Projekt »follow up« notranjih institucionalnih evalvacij zaključi postopek spremljanja kakovosti in prispeva $\mathrm{k}$ bistveno boljši pripravljenosti članic UM pred obveznim cikličnim zunanjimi evalvacijami $\mathrm{v}$ okviru postopkov ponovne akreditacije visokošolskega zavoda in njegovih študijskih programov. 
$36^{\text {Th }}$ International Conference on Organizational Science Development: Responsible Organization (March $22^{\mathrm{ND}}-24^{\mathrm{TH}}$, Portorož SLOVENIA)

M. Pauko \& F. Čuš: Analysis of the Model of the Internal Institutional Evaluations at the University of Maribor

6

Sprememba zakona o visokem šolstvu

Državni zbor Republike Slovenije je 17. novembra 2016 sprejel Zakon o spremembah in dopolnitvah zakona o visokem šolstvu (ZViS-K), tako da bo v bližnji prihodnosti prišlo do ključnih sprememb na področju zagotavljanja kakovosti v slovenskem visokem šolstvu. NAKVIS bo na univerze, v skladu z njihovo avtonomijo, prenesla del svojih dosedanjih aktivnosti: akreditacijske postopke študijskih programov (akreditacijo novih, podaljšanje in morebitno ukinitev obstoječih), tako da bodo univerze o tovrstnih akademskih vsebinah poslej odločale same. Tudi UM bo morala vzpostaviti svoj neodvisni akreditacijski organ. Na UM smo na navedene in pričakovane spremembe dobro pripravljeni, tudi zaradi izvajanja projekta notranjih institucionalnih evalvacij njenih članic (Slika 1).

Pri ponovnih programskih akreditacijah bo seveda potrebno poglobljeno pregledati obstoječe študijske programe, še zlasti z vidika njihovih vsebin ter učnih izidov. Zavedati se je potrebno, da bo določene študijske programe potrebno ponovno prenoviti, združevati ali ukiniti. Pri novih postopkih se UM ne sme povsem zapreti, temveč obdržati sedanjo prakso NAKVIS, ko pri teh sodelujejo tudi strokovnjaki iz tujine.

Pričakovati je tudi spremembo Meril za akreditacijo in zunanjo evalvacijo visokošolskih zavodov in študijskih programov NAKVIS, tako zaradi spremenjene zakonodaje kot tudi zaradi spremenjenih standardov ESG za notranje zagotavljanje kakovosti v visokošolskih zavodih (sistem kakovosti zavoda):

1.1 standard: politika za zagotavljanje kakovosti,

1.2 standard: oblikovanje in odobritev (sprejem) študijskih programov,

1.3 standard: $\mathrm{k}$ študentom usmerjeno učenje, poučevanje in ocenjevanje,

1.4 standard: vpis študentov, njihovo napredovanje, priznavanje in potrjevanje njihovega znanja,

1.5 standard: učitelji,

1.6 standard: razmere za študij in pomoč študentom,

1.7 standard: upravljanje z informacijami,

1.8 standard: obveščanje javnosti,

1.9 standard: stalno spremljanje in redno presojanje študijskih programov,

1.10 standard: ciklično zunanje presojanje zavoda v skladu s standardi ESG. 

ORGANIZACIJA (22. - 24. MAREC 2017, PORTOROŽ, SLOVENIJA)

M. Pauko \& F. Čuš: Analiza modela notranjih institucionalnih evalvacij na Univerzi v Mariboru

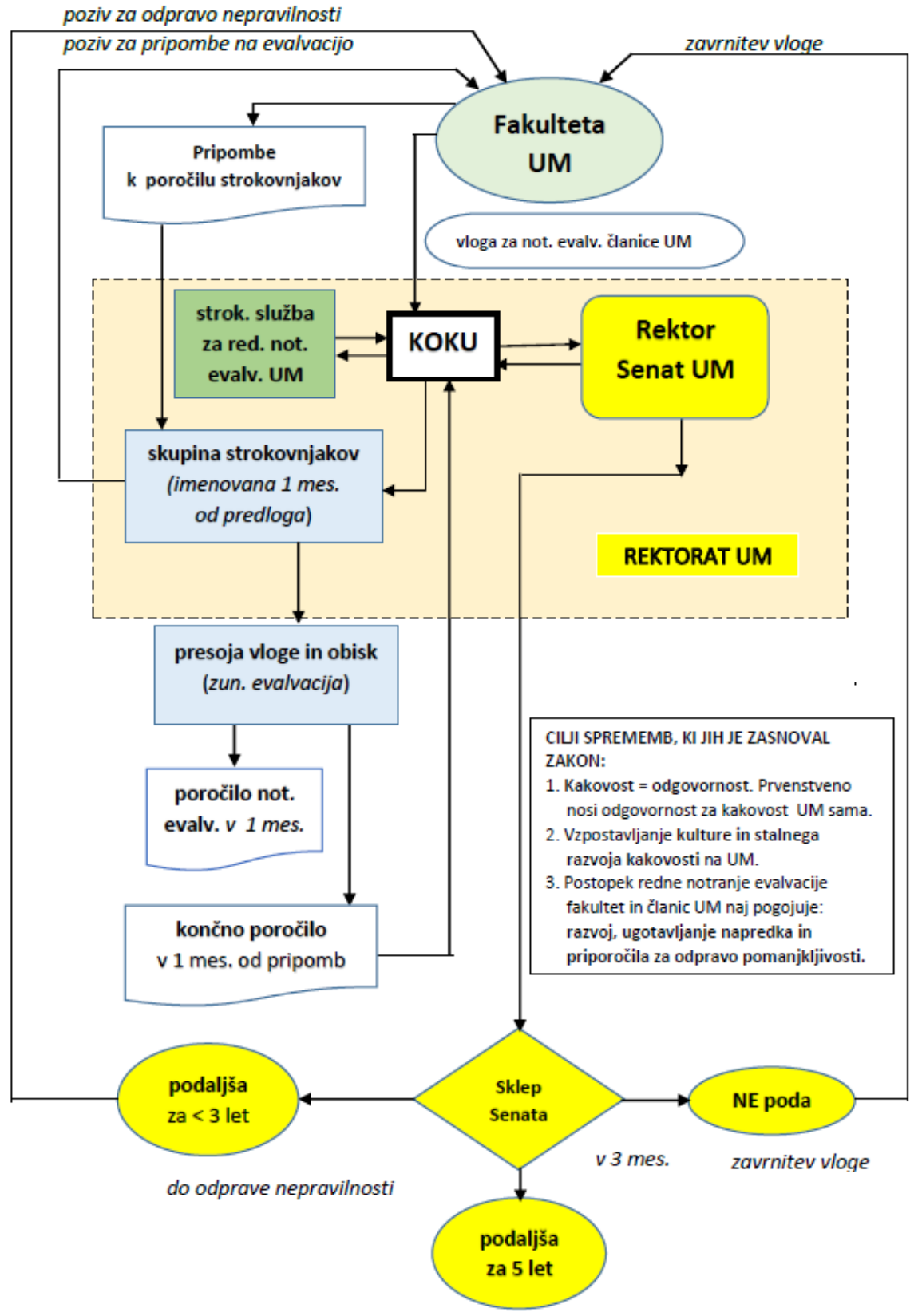

Slika 1: Postopek notranje evalvacije na UM 
$36^{\text {Th }}$ International Conference on Organizational Science Development: Responsible Organization (March $22^{\mathrm{ND}}-24^{\mathrm{TH}}$, Portorož SLOVENIA)

M. Pauko \& F. Čuš: Analysis of the Model of the Internal Institutional Evaluations at the University of Maribor

\section{$7 \quad$ Sklepi}

Komisija je doslej izvedla »follow up « notranje institucionalne evalvacije na osmih članicah UM. Na podlagi izdelanega modela notranjih institucionalnih evalvacij na UM potekajo tudi vsi posamezni procesi »follow up« notranjih institucionalnih evalvacij. Poročila o »follow up« notranjih institucionalnih evalvacijah, pripadajoče morebitne pripombe vodstev evalviranih fakultet ter akcijske načrte korektivnih ukrepov evalviranih fakultet najprej obravnava komisija, nato pa še Senat UM. Vsi dokumenti so javno objavljeni na spletnih straneh komisije ${ }^{8}$.

Sprememba Zakona o visokem šolstvu za področje ponovne akreditacije študijskih programov zahtevajo od UM in njenih članic:

- profesionalizacijo presoje kakovosti študijskih programov,

- transparentnost (merila, javnost dela),

- zaupanja v sistem za presojo kakovosti na UM,

- skladnosti z nacionalnimi in evropskimi standardi ESG.

V skladu s spremembami zakona o visokem šolstvu so bodoče naloge UM, komisije ter Oddelka za kakovost in trajnostni razvoj UM:

- določiti postopke evalvacije študijskih programov,

- izvajati evalvacije študijskih programov,

- izvajati notranje institucionalne evalvacije,

- vzpostaviti in posodabljati register strokovnjakov,

- imenovati skupine strokovnjakov za evalvacije in sodelovati pri njihovem izobraževanju,

- javno objavljati odločitve Senata UM in evalvacijska poročila,

- voditi evidenco študijskih programov,

- sodelovati s fakultetami, jim svetovati in spodbujati izvajanje samoevalvacij,

- sodelovati z mednarodnimi institucijami za zagotavljanje kakovosti v visokem šolstvu,

- skrbeti za skladnost delovanja UM s smernicami in načeli na področju zagotavljanja kakovosti,

- zbirati in analizirati poročila o samoevalvacijah in zunanjih evalvacijah fakultet.

\section{Literatura in viri}

${ }^{1}$ Pravilnik o ocenjevanju kakovosti na Univerzi v Mariboru. (2016). Obvestila Univerze v Mariboru, XXXIV-8-2016, 30. novembra 2016.

${ }^{2}$ Merila za akreditacijo in zunanjo evalvacijo visokošolskih zavodov in študijskih programov NAKVIS. (2014). Uradni list Republike Slovenije št. 40, 3. junija 2014.

${ }^{3}$ Poslovnik kakovosti Univerze v Mariboru. (2016). Obvestila Univerze v Mariboru, XXXIV-52016, 30. septembra 2016. 
M. Pauko \& F. Čuš: Analiza modela notranjih institucionalnih evalvacij na Univerzi v

Mariboru

${ }^{4}$ Standards and Guidelines for Quality Assurance in the European Higher Education Area. (2015). European Association for Quality Assurance in Higher Education. Dostopno na http://www.eua.be/Libraries/quality-assurancelesg 2015.pdf?sfvrsn=0

${ }^{5}$ Pauko, M. (2011). Izdelava modela notranjih institucionalnih evalvacij na Univerzi v Mariboru. Magistrsko delo. Dostopno na https://dk.um.si/Dokument.php?id=22884

${ }^{6}$ Merila za izbiro in potrditev evalvatorjev za potrebe notranjih evalvacij na UM. Dostopno na http://www.um.si/kakovost/evalvacije/Documents/Merila-evalvatorji-KOKU23nov09.pdf

7 Dokumenti o notranjih evalvacijah članic UM. Dostopno na https://www.um.si/kakovost/evalvacije/Strani/Notranje-evalvacije---poročila.aspx

8 Dokumenti o »follow up« notranjih evalvacijah članic UM. Dostopno na https://www.um.si/kakovost/evalvacije/Strani/Follow-up-notranje-evalvacije---poročila.aspx 
686 36 $6^{\mathrm{TH}}$ International Conference on ORganizational Science Development:

Responsible Organization (MARCH $22^{\mathrm{ND}}-24^{\mathrm{TH}}$, PORTOROŽ SLOVENIA) 
$36^{\text {Th }}$ International Conference on Organizational Science DeVElopment: Responsible ORGANIZATION (MARCH $22^{\mathrm{ND}}-24^{\mathrm{TH}}$, PORTOROŽ SLOVENIA)

O. Arsenijević, M. Ferjan, I. Podbregar, P. Šprajc, D. Trivan \& Y.

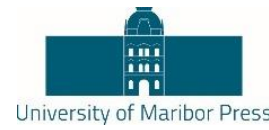

Ziegler

\title{
Evaluation Challenges of Research Projects Funded by Serbian Ministry of Education and Science
}

\author{
MilicA PAVIĆEVIĆ, MARIJA TODOROVIĆ \& ZORICA MITROVIĆ
}

\begin{abstract}
Research projects are instruments that Serbian government applies to secure their research policy goals and to manage the development of research area.

The purpose of this paper is to examine different evaluation methods and metrics for the assessment of research projects within the context of public investment. The main goal is to synthesize the knowledge from previous studies and identify key challenges in the evaluation process in order to develop recommendations for effective evaluation system of research projects funded by Serbian Ministry of education and science.
\end{abstract}

Desk research, secondary data analysis, and systematic literature review will be used to analyze and identify key findings from different countries' perspective and to compare different national experiences.

The result of the paper will be a comparative analysis of different evaluation practices used for the measurement of public initiatives effectiveness. Further, the paper will provide recommendations for evaluation methodology of research projects funded by Serbian ministry of sciences. The findings will be used for creating the basic set of key performance indicators in order to overcome (potential) evaluation challenges of the research projects. The paper is intended for both academics and public officials engaged in research policy development.

\section{KEYWORDS:}

Correspondence AdDress: Milica Pavićević, University of Belgrade, Faculty of organizational sciences, Jove Ilića 154, Belgrade 166136, Serbia, e-mail: milica.pavicevic@ fon.bg.ac.rs; Marija Todorović, Ph.D., University of Belgrade, Faculty of organizational sciences, Jove Ilića 154, Belgrade 166136, Serbia, e-mail: todorovicm@ fon.bg.ac.rs; Zorica Mitrović, Ph.D., University of Belgrade, Faculty of organizational sciences, Jove Ilića 154, Belgrade 166136, Serbia, e-mail: zorica.mitrovic@fon.bg.ac.rs; 
$36^{\text {Th }}$ International Conference on Organizational Science Development: RESPONSIBLE ORGANIZATION (MARCH $22^{\mathrm{ND}}-24^{\mathrm{TH}}$, PORTOROŽ SLOVENIA)

M. Pavićević, M. Todorović \& Z. Mitrović: Evaluation Challenges of Research

Projects Funded by Serbian Ministry of Education and Science

\section{$1 \quad$ Background}

In its aspiration to become a knowledge-based society, the Republic of Serbia recognizes the crucial role of science and innovation in the development of its competitiveness and sustainability. The necessity of investing in the development of science and innovation is imperative for the development of the modern economy of the Republic of Serbia. This primarily includes the acceleration of reforms initiated in these areas, which contributes to directing focus on the areas with added value (Kutlača \& Mitrović \& Mosurović, 2011).

Adopted "Strategy on Scientific and Technological Development of the Republic of Serbia 2016-2020" strategically defined the steps to support the promotion of excellence in science and innovation, as well as the establishment of adequate research system within these activities. In the previous period, the implementation and realization of the steps defined within the previous framework of the "Strategy for Scientific and Technological Development of the Republic of Serbia 2010-2015" took place in difficult conditions of the economic crisis that hit the Republic of Serbia, which resulted in numerous difficulties that reflected in the lack of implementation of certain steps and inadequate support through the system of financing dedicated to the development of this segment.

Based on the results of research conducted through the analyses of annual reports, the conclusion can be drawn that current allocation of the Republic of Serbia from the budget and other sources for the development of scientific research is insufficient and significantly below the EU average (The Ministry of Education, Science and Technological Development 2016).

Namely, even though according to the Strategy, budgetary funds should have reached $0.9 \%$ of the gross domestic product by the end of 2014, they remained below $0.5 \%$ of the gross domestic product, thus positioning the Republic of Serbia well below the EU average which is $2.06 \%$. In addition, according to 2013 data, the largest amount of funds $(59.5 \%)$ came from the budget, while own funds acquired on the market account for $25.1 \%$ of total assets only, compared to the corresponding European average of $63 \%$ (The Ministry of Education, Science and Technological Development, 2016).

The proportion of funds intended for material costs of research has so far been at an extremely low level i.e. $3.2 \%$ of total assets, and it is affecting the quality, scope, and relevance of scientific research and the results of innovation activities. Such trend in the development and improvement of research excellence has the greatest impact on experimental research and the possibility of their market commercialization, due to insufficient funds for testing and prototype development. Through the analysis of the results achieved in the previous project cycle that may be of relevance for the economy and market commercialization of projects, it arises that patents and technical solutions account for only $3.3 \%$ of total results (The Ministry of Education, Science and Technological Development, 2016). 
Despite significantly reduced funds allocated for the field of scientific research activities, based on the results of research conducted for the previous strategic period, it is stressed that the Republic of Serbia has improved its scientific research potential, maintained critical mass and recorded success in certain areas at the international level.

However, international visibility of scientific papers is recognized as a problem, given that most of the papers, as much as $60 \%$ of them, are published in national journals, and it also affects the citation of Serbian scientists, which is still lagging behind the European average (The Ministry of Education, Science and Technological Development, 2016).

Some of the abovementioned results of the previous project cycle researches indicate that the researchers are not using the full potential of the development in the sector of science and research for new products and services that can be commercialized and verified on the market, but rather for overproduction of scientific papers with no significant international visibility.

As a result of the current level of development and challenges in the context of scientific research, as well as reduced funding and investment in their growth in the Republic of Serbia, there is a need to establish, develop and apply appropriate evaluation system. Defining the system of evaluation, along with systematic monitoring and applying different qualitative and quantitative criteria will transfer limited financial support to those sectors and areas with higher added value and profitability of investments, as well as a series of direct and indirect socio-economic benefits (Pejić \& Radivojević, 2016).

\section{Evaluation of research projects}

The systematic and objective process that evaluates the impact of public policies and the implementation of their programs through the assessment of their relevance, efficiency, feasibility and effectiveness in achieving the originally set objectives is called STI evaluation system (Fahrenkrog, 2002).

The introduction of an adequate evaluation system of publicly funded project provides exclusive information essential for impact assessment of the policies to be defined, and as a support for the creation of new public policies, measurement of the achieved level of performance of the Ministry and other related scientific and research institutions and the work of their management, as well as the support of their administration which represents results based management using this information. Also, the evaluation process is applied to measure the justification of budget funds invested in specific programs and projects, and to provide support in the evaluation of the most cost-effective publicly funded projects and programs, i.e. applying performance-based budgeting (Mackay, 2007).

Generally speaking, the functions of an evaluation process can be divided into several categories, such as: legitimizing function and information provision, functioning as justification of earmarked budget funds and raising public awareness about policies, learning and mediating function for the purpose of linking key stakeholders and obtaining 
$36^{\mathrm{TH}}$ International Conference on ORganizational Science Development: RESPONSIBLE ORGANIZATION (MARCH $22^{\mathrm{ND}}-24^{\mathrm{TH}}$, PORTOROŽ SLOVENIA)

M. Pavićević, M. Todorović \& Z. Mitrović: Evaluation Challenges of Research Projects Funded by Serbian Ministry of Education and Science

feedback for further steps, as well as controlling and steering function, in order to monitor compliance with the adopted set of rules and make decisions on the future set of public policies in this area (EVAL- INNO, 2012).

STI evaluation process can be implemented at several levels, depending on the objective evaluation itself. Policy evaluation and system evaluation are at the highest level where, in addition to public policies at different levels and decisions made as their consequences, the system of financing that includes these policies is also evaluated. Furthermore, there are also sector and organizational evaluations, which involve evaluation of research and scientific work of individual organizations, industries, and areas. On the lower level, there are portfolio and program evaluation, and this paper will further provide the analysis of project evaluation, as one of their segments. Project evaluation is based on specific projects that are publicly funded, with defined duration, allocated resources, and costs. Since the evaluation of projects involves assessment of planned and incurred costs and potential direct or indirect benefits achieved by that project, the purpose of their evaluation is to achieve effectiveness and efficiency of public budgetary investments, as well as their justification (EVAL- INNO, 2012).

When selecting a set of key performance indicators and their application in the process of assessment and evaluation of publicly funded projects, it is also very important to take into consideration the time when the evaluation process is to be carried out. In this respect, Piric and Reeve (1997) define three types of evaluation processes, taking into account the time of actual evaluation, namely, ex-ante evaluation, ex-post evaluation, and monitoring interim evaluation.

According to Bulathsinhala (2015), ex-ante evaluation is applied when defining goals of R\&D publicly funded projects, while ex-post evaluation is based on the achieved level of performance and results upon project completion. As stated by Capron and de la Potterie (1997), ex-ante evaluation practice is implemented at the selection stage of those projects that should be publically funded. On the other hand, when it comes to ex-post evaluation, Pirić and Reeve (1997) point out that even though the data used under this method are more reliable, they are less significant when it comes to the assessment of future steps and projects.

Monitoring and evaluation of the performance of an implementation of publicly funded projects and justification of investment funds in the same involve the use of both quantitative and qualitative indicators, i.e., performance indicators. As pointed out by Pejic and Radivojevic (2016), there is no universal measure of success of these publicly funded projects, nor should be used only one indicator of performance, bearing in mind that none of them provides a complete picture of the evaluation of the project, nor can examine every aspect of the project. In some cases, though quantitative methods appear to be better for the application, it is more appropriate to use qualitative methods, taking into account the type of project in which the intangible results are the primary ones (Piric \& Reeve, 1997). 

ORGANIZACIJA (22. - 24. MAREC 2017, PORTOROŽ, SLOVENIJA)

M. Pavićević, M. Todorović \& Z. Mitrović: Evaluation Challenges of Research Projects Funded by Serbian Ministry of Education and Science

According to the field of application, Capron \& de la Potteri (1997) present a brief review of quantitative and qualitative methods that can be used in the process of evaluation of publicly funded projects. Their research provided a brief review of the relevance and potential drawbacks that may arise during its implementation for each method. Among most applicable methods for the project, the selection is multicriteria analysis, relevance trees, cost-benefit analysis, scenario method; and for the assessment of the impact that research projects can have the most applicable methods are peer review, dynamic modeling, econometrics, etc.

\section{$3 \quad$ What can we learn from others?}

The processes of ex-ante and ex-post evaluation are specifically regulated and present the standard practice for the research projects financed by public funds in developed and developing countries. Although in some countries we can find a comprehensive evaluation systems that ensure accountability, transparency and learning, provide good basis for the policy makers and ensure trust in review processes, while in other countries this process is mainly focused on a specific group of performances (e.g. publications and citations) excluding impact on different aspect on society. For this reason, the paper is further focused on the experiences of other countries, as well as examples of good practice.

The reason why the experience of other countries is significant, as examples of good practice and for the assessment of the challenges in the evaluation system, is the fact that many countries based their evaluation system on the experience of other countries or in cooperation with others. For example, Austria-based its evaluation system on German Ministry of Research and Education expertise and experience, and Germany has developed its evaluation system in cooperation with Australian National University. Australia is one of the first countries that have introduced performance-based funding criteria for university research institutes since the early 1990 s.

Analyzing evaluation systems of Germany, Austria, Poland, Ireland, Slovenia, etc. we can conclude that the ex-ante evaluation criteria are mainly based on the scientific quality of the project, scientific quality of the scientists involved and financial aspects. The aim of ex-ante evaluation is the right decision in selection of research projects. When it comes to ex-post evaluation Dinges (2005) emphasizes the value of ex-post project evaluations and the fact that the ex-post evaluations constitute a solid source of information for decision makers in the policy process.

The ex-post evaluation provided by the Austrian Science Fund refers to the next aspects of research projects (Dinges, 2005):

- Scientific success of the project

Impact on scientific discipline, contribution to further development of science, quality of dissemination of the scientific results (publications, activities at conferences and so on); This is a core criterion for the ex-post review. It gives 
$36^{\text {Th }}$ International Conference on Organizational Science Development: RESPONSIBLE ORGANIZATION (MARCH $22^{\mathrm{ND}}-24^{\mathrm{TH}}$, PORTOROŽ SLOVENIA)

M. Pavićević, M. Todorović \& Z. Mitrović: Evaluation Challenges of Research

Projects Funded by Serbian Ministry of Education and Science

useful information concerning the effectiveness of funding and reliability of the project selection process.

- Development of human resources

Project leader development, his impact in the scientific community (national and international), further, enrolment of young researchers.

- Effects beyond scientific field

These effects are not considered sufficiently not taken into account, it is difficult to merit them, and they may be visible only after a few years after the study.

- Project performance

Performances are mainly related to expenses and effectiveness of the resource usage without compromising the quality of the project. The aim is to justify the appropriate use of funds.

- Future perspectives of the research work

The future category perspectives of the research work relate to the extent to which the project broke new ground scientifically, and hence provides the project coordinator with useful information about the scientific relevance of performed research.

A similar system can be found in Poland. Poland has introduced performance-based funding system, according to what the evaluation process is based on set of indicators addressing: scientific excellence -publications, international projects; scientific potential -human capital, infrastructure; material results of research and scientific activities - i.e. patents, commercialization of knowledge, transfer of technologies; other activities - i.e. social activity, popularization of science.

Austrian Council for Research and Technology Development has a high and independent impact on technology and innovation policy and Austrian Government. Funding programme includes ex-ante, inter and ex-post evaluation and key recommendations of the Council are addressing the evaluation culture: synchronized ex-ante and ex-post evaluation; provided support to evaluation process; monitoring of the process validity; institutionalization of the evaluation; self-evaluation of performing institution plus external evaluation; transparency of the evaluation process and reports; feedback from the evaluation process; implementation of the evaluation results. Further, there are applicable standards for the evaluation process (Platform Research and Technology Policy Evaluation, 2016)

When analyzing ex-post evolution, there is an agreement the most indicators are focused on publications and citations and that the link of scientific research and technology and direct economic effect are not common in many evaluation systems. In the early 2000s, the lack of indicators that reflect the impact of scientific research on society is noted. Godin \& Doré (2003) interviewed 17 research centers and as a result developed indicators that reflect the impact of scientific researchers to different aspects of society (culture, politics, institutions, administration, health, environment, education, etc.). 
Countries like Estonia, Lithuania, Latvia, Portugal, Ireland are specially focused on the evaluation of the investments in research, science on the economy, education, employment, etc. (European Commision, 2012). For example, Ireland has introduced the framework for the economic impact of R\&D projects This framework consists of (PA Consulting, 2011):

- inputs (different sources of funds),

- outputs (programmes, projects, efficiency and effectiveness of programme delivery, etc.),

- outcomes (publications, citations, research reputation, sustainability of wider research activities, patents and licenses secured, education courses, spin-out companies, etc.),

- additional effects (deadweight - would it happened anyway? impact on other programmes, substitution, multiplier effects, etc.);

- impact (turnover increases as result of the commercialization of research, increased investment by industry in research, institutional income from enhanced research capability Influence on policy, quality of life impacts, etc.)

Slovenia, as one of the countries in the region, also presents an example of good practice in the field of the evaluation of research project. Slovenia has the Research and Innovation Strategy for the period of 2011 - 2020, adopted by the Slovenian Parliament. The strategy includes a comprehensive system for the evaluation of research activities in institutes and universities, as well as system of independent monitoring and reporting. Further, strategy implies the setting of different set of indicator for: measuring the scientific excellence, institution and international visibility; cooperation with the users; measure social relevance of the research work; revenues from licensing, number of patents; number of spin-off projects; applicative success of the public research organizations (European Commision, 2015).

\section{$4 \quad$ Evaluation challenges of research projects}

Peer review report provided by European Commission provides case studies from other countries as examples of good practice as well as recommendations for the improvement of research and innovation systems for different countries. From the set of those reports, we chose to analyze reports on research system of Hungary and Bulgaria since their systems are more familiar with research system of the Republic of Serbia. The Hungarian R\&I system suffers from "a poor evaluation culture and from a persistent lack of independent, external, programme-level and instrument-level evaluations" despite a legal obligation to conduct R\&D programme evaluation (European Commision, 2016). According to this report, Hungary had little experience in design, implementation, and evaluation of R\&I strategies. 
$36^{\text {Th }}$ International Conference on Organizational Science Development: RESPONSIBLE ORGANIZATION (MARCH $22^{\mathrm{ND}}-24^{\mathrm{TH}}$, PORTOROŽ SLOVENIA) M. Pavićević, M. Todorović \& Z. Mitrović: Evaluation Challenges of Research Projects Funded by Serbian Ministry of Education and Science

The aim of the evaluation process is to ensure accountability, transparency, and learning in R\&I policy. The application of objective methods should be the basis of policy makers for the adoption of certain amendments.

Recommendations for the evaluation system improvement refer to the application of international peer review standards; and public fund allocation according to performance. According to that recommendation, this further means that "Hungary must increase the share of public research and innovation funding awarded by competitive, performancebased programmes at both the individual and institutional level" (European Commision, 2016).

Bulgarian research system is also focused on a performance-based system. Peer review report provided by European Commission for Bulgaria address, among others, the issue of restoring trust in grant review processes. Regard to this it is recommended to improve monitoring and evolution system. In order to avoid conflict of interest, monitoring and evaluation should be provided by independent stakeholders. Those processes should be planned, organized and transparent where the coordination between independent evaluators and ministries is one of the key issues.

In order to develop performance-based system Bulgarian government has developed regulations for monitoring and evaluating the research performance, and according to this report, the main challenge is developing the funding model and effectively implementing it. Besides setting indicators, evaluation process, management system, there is an arising issue of trust in performance-based funding. As for the other countries, evaluation system should be based on stakeholder participation in the development of evaluation criteria, but since the performance-based funding in Bulgaria is in developing phase the implications of alternative models need to be properly analyzed. It is also recommended that researchers need to be involved in the system. (European Commision, 2015)

\section{$5 \quad$ Conclusion}

According to "Strategy on Scientific and Technological Development of the Republic of Serbia 2016-2020" there are defined steps to support the promotion of excellence in science and innovation, as well as the establishment of adequate research system within these activities. Since an adequate evaluation system of the publicly funded project provides exclusive information for policy decision-makers, measurement of the achieved level of performance of the Ministry and other related scientific and research institutions, as well as the support to their administration procedure of project selection, the improvement of the evaluation system can significantly contribute this. The evaluation process is applied to measure the justification of budget funds invested in specific programs and projects. Considering the fact that current allocation of the Republic of Serbia from the budget and other sources for the scientific research is significantly below the EU average, the evaluation process is of crucial importance. 
M. Pavićević, M. Todorović \& Z. Mitrović: Evaluation Challenges of Research Projects Funded by Serbian Ministry of Education and Science

Based on expertise and experience of other countries and the stated fact about research system in Serbia we can see that the future of research system is in performance-based funding. In that context we can highlight next challenges: increasing focus on impact of research project on society, creation of different set of indicators that include effects beyond scientific field, stakeholder active participation, creation of ex-post evaluation process and provision of support to evaluation process, synchronization of ex-ante and ex-post evaluation; monitoring of the evolution process validity; transparency of the evaluation process and reports, developing standards standards for the evaluation process.

Beside this, one of the key issues is the implementation of the evaluation results since it can be an effective way to direct public fund allocation according to performance and to influence decision-makers. The process of evaluation system development is very sensitive, and as we could see on the example of Bulgaria, this phase requires the in-depth analysis of alternative evaluation models and methods, advantage and disadvantages to select the optimal solution for the evaluation system of the research project funded by Serbian Ministry of Education, Science and Technological Development.

\section{Literature}

Bulathsinhala, N. A. (2015). Ex-ante evaluation of publicly funded R\&D projects: Searching for exploration. Science \& Public Policy (SPP), 42(2).

Capron, H., \& de la Potterie, B. V. P. (1997). Public support to R\&D programmes: an integrated assessment scheme. OCDE: Policy Evaluation in Innovation and Technology. Towards Best Practices. OCDE. París, 35-47.

Dinges, M. (2005). The Austrian Science Fund: Ex post evaluation and performance of FWF funded research projects. Vienna: Institute of technology and regional policy.InTeReg Research Report No. 42-2005.

European Commision. (2015). Peer Review of the Bulgarian Research and Innovation System Horizon 2020 Policy Support Facility. Brussel.

European Commision. (2016). Peer Review of the Hungarian Research and Innovation System Horizon 2020 Policy Support Facility. Brussel.

European Commision, R. P. (2012). Evaluation of results and impact of EU-funded investments in the field of education and science during the programming period 2004-2006. Latvia.

EVAL-INNO. (2012). Research, Technological Development, and Innovation Evaluation Standards. Retrieved from https://www.zsi.at/object/publication/3182/attach/Evaluation_Standards_SCREEN_ENGLIS H__OK.pdf

Fahrenkrog, G. (Ed.). (2002). RTD Evaluation Toolbox: Assessing the Socio-economic Impact of RTD-policies: Strata Project HPV 1 CT 1999-00005. European Commission, Joint Research Centre.

Garcia, C., \& Sanz Menendez, L. (2004). Competition for funding as an indicator of research competitiveness: The Spanish R\&D Government Funding. Unidad de Politicas Comparadas CSIC - Working Paper 04-15.

Godin, B., \& Doré, C. (2003). Measuring the Impacts of Science: Beyond the Economic Dimension. Canadian Science and Innovation Indicators Consortium (CSIIIC).

Keith, M. (2007). How to build M\&E Systems to Support Better Government, The International Bank for Reconstruction and development/ The World Bank, Washington, D.C. 
Kutlača, Đ., \& Mitrović, Z., \& Mosurović, M. (2011). The system for monitoring and evaluation of innovation projects. XV International Symposium on Project Management. Project Management in Serbia - successes, and opportunities. Serbian Project Management Association. (pp. 58-62).

Pejić, S., \& Radivojević, R. (2016). Objectivity and Reliability of Data Obtained by Quantitative Methods for Measuring Scientific Success. XXII Skip Trendovi razvoja- Nove tehnologije u nastavi, Zlatibor.

Pirić, A., \& Reeve, N. (1997, June). Evaluation of public investment in R\&D-towards a contingency analysis. In OECD Conference on Policy Evaluation in Innovation and Technology: Towards Best Practices. pp. 26-27.

Platform Research and Technology Policy Evaluation \& Austrian Council for Research and Technology Development (Eds.). (2007). Evaluation of Austrian Research and Technology Policies - A Summary of Austrian Evaluation Studies from 2003 to 2007. Retrieved from http://www.fteval.at/upload/Evaluation_Austrian_technology_policies.pdf

Platform Research and Technology Policy Evaluation. (2016). Evaluation Standards in Research and Technology Policy. Vienna: fteval. Retrieved from http://www.fteval.at/upload/fteval_Standards_english.pdf

PA Consulting (2011). Ten Years On: Confirming Impacts from Research Investment. A case study focusing on the direct commercial and economic impacts from exchequer investment into centers and initiatives supported by the Programme for Research in Third-Level Institutions (PRTLI) 2000-2006.

The Ministry of Education, Science and Technological Development, \& The World Bank, \& European Commission. (2016). Strategy on Scientific and Technological Development of the Republic of Serbia for the period 2016-2020, Research for Innovation. 
$36^{\text {TH }}$ International Conference on Organizational Science DEVElopMENT: Responsible ORganization (MARCH $22^{\mathrm{ND}}-24^{\mathrm{TH}}$, PORTOROŽ SLOVENIA)

O. Arsenijević, M. Ferjan, I. Podbregar, P. Šprajc, D. Trivan \& Y.

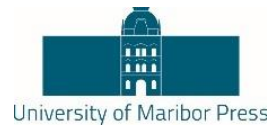

Ziegler

\title{
Investment in Venture Capital Funds in the Republic of Croatia: Determinants and Challenges
}

\author{
ANITA PAVKOVIĆ \& HRVOJE MATEŠIĆ
}

\begin{abstract}
Venture capital and private equity funds are important parts of a financial system as they secure capital to companies without funds which would enable them to form optimal financial arrangements with other financial intermediaries.

This paper studies those factors influencing development and further investment into venture capital funds in the Republic of Croatia. The paper will also explain the importance of supporting investment in venture capital and the way such investments influence gross domestic product development, examine the relationship between the taxation and legal system with investment trends into venture capital funds.

The results will test the hypothesis that the extent of venture capital fund investments, within an unfavorable tax-legal environment, is highly determined by the rules to which pension funds need to adhere regarding the investment of their own capital into these projects.
\end{abstract}

KEYWORDS: private equity $\bullet \mathrm{SME} \cdot$ pension funds

Correspondence AdDress: Anita Pavković, Ph.D., Associate Professor, University of Zagreb, Faculty of Economics and Business, Trg J.F. Kennedyja 6, 10000 Zagreb, Croatia, e-mail: apavkovic@efzg.hr; Hrvoje Matešić, Privredna Banka Zagreb P.L.C., Radnička cesta 50, 10000 Zagreb, Croatia, e-mail: hrvoje.matesic@pbz.hr 
$36^{\text {Th }}$ International Conference on Organizational Science Development: RESPONSIBLE ORGANIZATION (MARCH $22^{\mathrm{ND}}-24^{\mathrm{TH}}$, PORTOROŽ SLOVENIA)

A. Pavković, H. Matešić: Investment in Venture Capital Funds in the Republic of Croatia: Determinants and Challenges

The term venture capital usually refers to those funds acquiring ownership in small and middle sized companies during their initial development or expansion phase, in order to sell for a greater value following growth and consolidation. This business practice represents investment companies who invest capital collected from institutional investors or affluent individuals into high risk projects with potentially high returns on the investment. The primary goal of investment companies is gaining control of the management package of the company they are investing in.

This paper will present a systematic overview of significant factors influencing the development of venture capital generally, with emphasis on the Republic of Croatia. Data on investment into private equity funds will be collected for companies from Mideast Europe and compared with Croatian data, where an attempt will be made to determine the level of activity in Croatia regarding this type of investment industry. The importance of investing in the development of this type of industry will be analyzed, focusing on investment in small and middle sized companies. Investments by existing funds in Croatia will be presented and a conclusion will be offered on the reason for Croatia lagging behind developed European Union (EU) and Central Eastern Europe countries (CEE) regional nations with regard to private equity funds.

Secondary data sources were used in the work, which were analyzed by induction and deduction as well as compilation and comparison methods. The data were collected from research by the European Private Equity Association (EVCA) and various dependent publications from EVCA. A part of the data was also collected from the public service FINA (company financial reports).

The article provides a significant contribution to understanding further steps which need to be undertaken in order to increase the level of investment in this type of industry in the Republic of Croatia. Analysis has revealed an increase of activity in the Republic of Croatia aimed at attracting this type of investment, but it is still far below the European investment average as measured by the ratio of investments in the total Gross domestic product (GDP). The work will show vital macroeconomic factors which need to be improved in order to increase private equity (PE) and venture capital (VC) investment.

\section{Defining and determining venture capital in Croatia}

Venture capital funds have been regulated in the Republic of Croatia with the Law on investment funds passed in 2006 (Narodne novine, Law on investment funds, 2005). The Croatian legislature recognized private equity and venture capital funds as open investment funds of venture capital with private equity.

A new Law on alternative investment funds was passed in 2014, which regulated the work of those funds allowing them to invest in risky ventures on the market. The new law regulated specific types of equity capital funds: private equity and venture capital 
funds. The aim of this legislature was to mirror the American definition of these terms, where venture capital represents investment in new companies (so-called start up), while private equity has a broader definition referring to financial acquisitions (buying shares in a company by a new management team and buying shares in a company from the existing management team) and investments in a company which has already developed its own product and distribution network, needing new capital for further ventures (Narodne novine, Law on alternative investment funds, 2014).

\section{The significance of venture capital}

Venture capital funds, from 2007 to 2012, invested 265 billion Euros in European companies, where over $80 \%$ of the investment was in companies with fewer than 250 employees (Invest Europe/PEREP_Analytics, 2015).

The funds invest in small and middle-sized companies as these are more flexible, oriented toward innovation and are capable of faster growth than large companies. (National Venture Capital Association, 2012)

In the 2012 to 2015 period, Croatia saw 103 million Euros invested through venture capital funds, which is, on average, 25 million Euros annually (HANFA, 2015). For example, the total EU investment was 4,741 million Euros, which shows that $0.02 \%$ of the total funds were invested in Croatia, which is equal to the percentage of these types of investments in GDP $(0.02 \%)$. The EU average is $0.30 \%$, while the average in other countries of the region is $0.13 \%$ (Invest Europe/PEREP_Analytics, 2015).

A total of 7 venture capital funds were registered in Croatia on 2015/12/31. Alternative venture capital funds represent $0.06 \%$ of the total value of all funds in Croatia (HANFA, 2015).

Croatian funds rarely publish more data than required by regulatory agencies, which hinders the potential investor (qualified investor) in reaching a positive decision to enter into a fund. Information for investors is regulated by a set of rules which do not regulate the presentation of alpha-yields (amount of yield above the market share, i.e. the fund yield adjusted for the portfolio risk). A quality comparison of yield and risk is hindered due the lack of an adapted standard-index which the funds should issue (Vukas, Gvozdanović \& Jalšenjak, 2012). At this time, none of the funds follow the Global Investment Performance Standards (GIPS) guidelines ${ }^{1}$.

Retirement funds in the European Union participated with $21 \%$ of total accumulated funds from 2007 to 2012, which were invested as venture capital, while $30 \%$ of the funds were collected from institutional investors such as retirement funds, insurance societies and academic institutions (European Venture Capital Association /Perep Analytics, (2013)). 
$36^{\text {Th }}$ International Conference on Organizational Science Development: Responsible Organization (MARCh $22^{\mathrm{ND}}-24^{\mathrm{TH}}$, Portorož Slovenia)

A. Pavković, H. Matešić: Investment in Venture Capital Funds in the Republic of Croatia: Determinants and Challenges

Retirement funds are able to invest up to $1 \%$ of the fund capital in the Republic of Croatia, while voluntary retirement funds can invest up to $2 \%$ of their total assets ${ }^{2}$. Retirement funds can invest exclusively into shares of alternative domestic private equity investment funds, meaning that they cannot make these types of investments outside the domestic market (Narodne Novine (2007)).

According to data on 2015/12/31, retirement funds invested $0.25 \%$ of their total assets into alternative private equity investment funds (HANFA, 2015.), which is almost four times below the maximum provision. Viewed in relation to the EU, Croatia sees far less investment, several times below the maximum provision (up to $2 \%$ ). There is the question of whether the maximum threshold needs to be withdrawn, since the retirement funds do not use the present maximum. The answer to this question can be sought in the ownership structure of retirement funds in Croatia, which are almost $90 \%$ owned by banking groups, while $85 \%$ of financial ownership in Croatia is comprised of banks (HNB 2015). Thus, the market is expressly bank centric and shallow, which is reflected in the inadequate investment in private equity, venture capital funds in Croatia. Furthermore, retirement funds can invest only in venture capital funds which are invested in companies earning solely on the domestic market. This drastically restricts the range of funds, making them incapable of investing in fast-growing IT companies making their earnings on the foreign market. For this reason, a change in policy is essential, allowing investment into those companies with earnings outside the domestic market.

Knowledge, innovation, greater efficiency and improvement in competitiveness are vital factors influencing economic growth. According to Popov and Roosenboom (2009) 12\% of the total European industrial innovations stem from companies funded by venture capital. The same authors (2009) concluded that investment in research and development ( R \& D) in companies funded by venture capital is more effective than investing in $\mathrm{R} \&$ $\mathrm{D}$ in other companies. The research was conducted on a sample of $21 \mathrm{EU}$ countries from 1977 to 2004.

Companies funded by venture capital produce significant innovations (Lerner et al, 2011). Thus, investment in development and innovation, measured by the percentage of GDP is a vital factor influencing growth before the aforementioned factors.

An average investment over a period of 10 years (2004-2014) in the EU28 has grown from 1.7 to $2.1 \%$. Almost all member states recorded a rise in investment in R \& D, while Croatia saw a decline from 1.1 to $0.79 \%$ (Eurostat, 2015.)

According to Bečić and Dabić (2008), the key reasons for the decline in the business sector are insufficient investments in research and development, lack of connection between the academic and business communities, the existing structure of research and development funding and the low level of investment in tertiary education.

It can be concluded that investment in research and development can increase production, innovative processes and knowledge distribution to all economic subjects, facilitating economic growth and employment. 
A. Pavković, H. Matešić: Investment in Venture Capital Funds in the Republic of Croatia: Determinants and Challenges

The taxation and legal spheres are assessed by a method developed by the European Venture Capital Association (EVCA). The legal and taxation environments were first assessed in 2003, which has since been revised and expanded for new European Union members. The last available analysis dates back to 2008 and covers 27 member states.

The Republic of Croatia achieved a composite result of 2.22. Considering the European Union average of 1.85 , Croatia greatly lags behind the most advanced members of the European Union in terms of adapting the system to venture capital. The result is influenced by a very high rate of income tax, frequent changes in taxation laws, insufficient transparency of the public sector and a slow legal system (Švaljek, 2008).

Šimić (2015) notes that changes in tax rates in the Republic of Croatia occur frequently, requiring a great deal of time to calculate and pay taxes, resulting in a negative view of business in Croatia.

\section{Prospects for further venture capital development in Republic of Croatia}

Alternative venture capital funds are the least developed part of the financial sector in the Republic of Croatia. We have already mentioned that venture capital investments in the Republic of Croatia are $0.02 \%$ of the GDP, which is 15 times less than average. According to Marović (2011), $0.1 \%$ of GDP invested in venture capital yields a growth in GDP of $0.4 \%$. These data indicate that the Croatian industry of venture capital is still underdeveloped and that foreign investors have not found economic viability in steering their investments toward Croatia.

About $80 \%$ of all investments in the European Union are done through small and middlesized companies, where 50\% of these companies have less than 20 employees (Špoljarić, 2010).

The characteristics of small and middle-sized company leaders are that they face greater growth restrictions than large corporations. They react sooner and are more vulnerable to poor regulation practices and other difficulties stemming from the environment (corruption, for example) (Šonje, 2010.)

Croatian venture capital funds have already invested in 21 companies. What follows is a review and analysis of investment through four indicators:

- Number of employees - grows or falls (from the time the fund entered into company ownership until 2015)

- Total income - trends in income realization; is income above or below the sector average

- EBIT - is the profit margin above or below the average 
$36^{\mathrm{TH}}$ International Conference on Organizational Science Development: RESPONSIBLE ORGANIZATION (MARCH $22^{\mathrm{ND}}-24^{\mathrm{TH}}$, PORTOROŽ SLOVENIA)

A. Pavković, H. Matešić: Investment in Venture Capital Funds in the Republic of Croatia: Determinants and Challenges

- Export - has income from export increased - this indicator can provide an answer to the question of fund investment in companies earning their income on the domestic or foreign market.

The analysis was conducted on the basis of completed financial reports of companies in which venture capital funds were invested in the Republic of Croatia. Furthermore, the analysis included 17 companies (of a total of 21 which have received investments). Companies from which the funds were withdrawn were not included (4), leaving those where the funds were still present.

The following results were obtained (Table 1):

\begin{tabular}{|l|c|}
\hline & Before investment / 2015 \\
\hline Total number of employees & $+11.12 \%$ \\
\hline Total income & $-0.10 \%$ \\
\hline EBIT & $-81.74 \%$ \\
\hline Export & $46.95 \%$ \\
\hline
\end{tabular}

Table 1. Authors own production: Results of reached investments

Source: Calculated by the authors on the basis of completed financial reports for 2004, 2005, 2006, 2007, 2008, 2009, 2010, 2011, 2012, 2013, 2014 and 2015.

Through the observation of results, it is evident that companies financed by venture capital have followed European trends where the total numbers of employees and export have shown above average increases. However, total income has not risen, while the EBIT is significantly decreased. The reason for the drastic decline of gross income can be found in the fact that of 17 investments, almost 50\% were in companies undergoing restructuring. Croatia has seen a predominant investment in retail with 33\%, contrary to American and European investments, which are predominantly in the IT sector (over $60 \%$ ). Food production is next on the list with $21 \%$, while communication and IT services show $13 \%$ each. In the U.S.A., $65 \%$ of investments are in IT, biotechnology and telecommunications (National Venture Capital Association, 2012), while European funds invest $60 \%$ in biotechnology, computing and IT (European Venture Capital Association, 2012).

It is important to note that the analysis did not include the Tele 2 ltd Company, which was founded by a venture capital fund (Questus). Tele 2 ltd is a telecommunications company which has entered the Croatian market, founded in 2005 and exited with a $100 \%$ sale of shares in 2009. The company, at the point of sale, realized an income of 157 million Euros with an EBIT of 7 million Euros.

In view of the fact that European venture capital fund investments participate in IT companies with over $60 \%$, we will analyze available data for companies registered in the 
36. MEDNARODNA KONFERENCA O RAZVOJU ORGANIZACIJSKIH ZNANOSTI: ODGOVORNA ORGANIZACIJA (22. - 24. MAREC 2017, PORTOROŽ, SLOVENIJA) 703

A. Pavković, H. Matešić: Investment in Venture Capital Funds in the Republic of Croatia: Determinants and Challenges

Republic of Croatia for software production. The data, which included 2,172 companies reveal the following:

\begin{tabular}{|l|r|r|}
\hline \multicolumn{2}{|c|}{$\mathbf{2 0 1 0}$} & \multicolumn{1}{|c|}{$\mathbf{2 0 1 1}$} \\
\hline Number of employees & 8,402 & 8,887 \\
\hline $\begin{array}{l}\text { Business earnings per employee (in } \\
\text { thousands of Kuna) }\end{array}$ & 522,774 & 537,768 \\
\hline Total income & $4,390,352,159$ & $4,796,869,35$ \\
& & 1 \\
\hline Income from exports & $744,180,807$ & $989.966,645$ \\
\hline Ratio of domestic income & $17 \%$ & $21 \%$ \\
\hline Net export (import export) & $314,381,033$ & $521,247,059$ \\
\hline Gross profit & $430,448,083$ & $478,772,496$ \\
\hline Coefficient of current liquidity & 1.623 & 1.543 \\
\hline Coefficient of advanced liquidity & 1.44 & 1.381 \\
\hline Coefficient of indebtedness & 0.551 & 0.58 \\
\hline
\end{tabular}

Table 2. Authors own production: Indicators of results from the IT sector in the Republic of Croatia

Source: Suggestions for Business Impulse - 2013, Society of Croatian Independent Software Exporters - CISEx -/ www.cisex.org, pp. 2.

Table 2 shows that software production has seen a growth in income of $9.2 \%$, number of employees of $5.7 \%$ and net export of $63 \%$. In 2011, companies in this branch have shown results above the average for the Croatian economy. Software companies show a satisfactory level of liquidity and a low level of debt. Low levels of debt can be viewed in two ways: companies in this sector do not own significant material property and, in accordance with this, are not suitable for bank financing as banks do not have anything to secure (in the form of mortgage security); the second is related to venture capital investments as they are high risk businesses characterized by high growth rates and, as seen in Table 2, show income and export growth during crises. The assumption is that the funds, with business angels, should analyze these 2,127 companies in order to develop further. If the overall economic situation in Croatia is observed, it is obvious that the development of innovative and fast growing software companies could assist in economic restructuring and lead to greater growth. Business owners in this branch opt for higher risk undertakings which are more profitable. These business owners should be in the focus of venture capital. Venture capital, as its name suggests, seeks out projects of higher risk, which these are. 
$36^{\mathrm{TH}}$ International Conference on Organizational Science Development: RESPONSIBLE ORGANIZATION (MARCH $22^{\mathrm{ND}}-24^{\mathrm{TH}}$, PORTOROŽ SLOVENIA)

A. Pavković, H. Matešić: Investment in Venture Capital Funds in the Republic of Croatia: Determinants and Challenges

\section{Conclusion}

The conducted study has shown that venture capital funds in the Republic of Croatia are the least developed facet of the financial system. Despite the fact that only seven funds are registered in Croatia, it is obvious that supply has exceeded demand for this type of financing. The development of these funds requires the allocation of funds for technological and product development, and Croatia is lagging behind the EU26 in this respect, while the past decade has shown a decrease in $\mathrm{R} \& \mathrm{D}$ investment to $0.79 \%$. It has been shown that countries investing in R \& D attract more venture capital investment.

Furthermore, the tax and legal environment in Croatia is unfavorable. There are no direct incentives in the Republic of Croatia for venture capital investment, while the taxation rate is among the highest in Europe. It is necessary to reduce income tax and introduce investment incentives for research and development, following effective European solutions.

In order for retirement funds to increase investment in these types of funds, it is necessary to introduce measures of fund efficiency based on alpha income or GIPS guidelines, whereby retirement funds may more easily analyze and reach decisions as to which funds are profitable and which are not. If those problems were resolved, the retirement fund investment would increase.

Croatian venture capital funds have so far mainly invested in retail and production companies (51\% of total investments), which is not in accordance with European trends (where over $60 \%$ of investment is in the IT sector). This has resulted in income stagnation in $2015(-0.1$ to $0.0 \%)$ since retail companies (especially those oriented exclusively toward the domestic market) are very limited in terms of income growth due to the small market size. Thus, it is essential that venture capital funds begin investing in IT companies, which have the highest growth potential and, as our analysis has shown, grow faster than the Croatian average, with a very good profitability margin, employees and overall capitalization. Even though capitalization increases, it is exactly this factor which is key (and limiting) to potential growth. In order for companies to grow, they need capital, which needs to be covered by their own property and venture capital.

Notes

${ }^{1}$ Global Investment Performance Standards - a set of voluntary standards based on the primary principles of public announcement and fair data presentation on the funds efficacy. The standard was developed by AIMR - Association for Investment Management and Research

${ }^{2}$ Rules on additional investment criteria and investment limitations of retirement funds, Art. 10. 
A. Pavković, H. Matešić: Investment in Venture Capital Funds in the Republic of Croatia: Determinants and Challenges

\section{Literature}

Bečić, E. i Dabić, M. (2008) Analiza ulaganja poslovnog sektora Republike Hrvatske u istraživanje i razvoj. Revija za sociologiju [online], 39(1-2), pp 69-84. Retrieved from http://hrcak.srce.hr/file/41964

European Venture Capital Association /Perep Analytics, (2008). Retrieved from http://www.evca.eu/uploadedfiles/home/press_room/Yearbook 2012 Presentation all.pdf

European Venture Capital Association /Perep Analytics, (2013).

Eurostat (2015) Comparative price levels for investment

HANFA (2015) Društva za upravljanje investicijskim fondovima

HNB (2015) Bilten o bankama. Retrieved from https://www.hnb.hr/analize-ipublikacije/redovne-publikacije/bilten-o-bankama

Invest Europe/PEREP_Analytics, 2015., $\quad$ Retrieved from http://www.investeurope.eu/media/476271/2015-european-private-equityactivity.pdf

Lerner, J., Sørensen, M. \& Strömberg, P., (2011) Private Equity and Long-Run Investment: The Case of Innovation. The Journal of Finance, 66(2), pp. 445-477.

Marović, M. (2011) Halo fond - spremni smo na investiciju. U: Marović, M., ur., Kako financirati poslovanje fondova rizičnog kapitala [online]. Zagreb: Hrvatska Private Equity i Venture Capital Asocijacija, pp 31-36. Retrieved from http://www.alternative-

pe.hr/documents/kako_financirati_poslovanje_fondovima_rizicnog_kapitala_hvca.p df

National Venture Capital Association (2012) Yearbook 2012. [online], Retrieved from http://www.nvca.org/index.php?option=com content\&view=article\&id=257\&Itemi $\mathrm{d}=103$

Narodne Novine, (2005) Zakon o investicijskim fondovima, Zagreb, Narodne novine d.d.

Narodne Novine (2007) Pravilnik o dodatnim kriterijima ulaganja i investicijskim ograničenjima mirovinskih fondova, članak 10., NN/07

Narodne Novine (2014.) Zakon o alternativnim investicijskim fondovima, Zagreb, Narodne Novine d.d.

Popov, A \& Roosenboom, P., (2009). Does private equity investments spur innovation? Evidence from Europe. s.I: European Central Bank

Popov, A \& Roosenboom, P., (2009). On the real effects of private equity investment: Evidence from new business creation. s.I.: European Central Bank

Šimić, M., (2015), Atraktivnost Hrvatske u privlačenju ulagača rizičnog kapitala. Retrieved from http://hrcak.srce.hr/140303

Špoljarić D., (2010), Investicijski fondovi rizičnog kapitala i porezni aspekti njihovog djelovanja. Doktorska disertacija. Zagreb: Pravni fakultet

Šonje, V. (2010) Financiranje malih i srednjih poduzeća u krizi: između želja i mogućnosti. HUB Analize [online], 22, pp. 2. Retrieved from http://www.hub.hr/Default.aspx?art=1952\&sec=508 
$36^{\text {Th }}$ International Conference on Organizational Science Development: RESPONSIBLE ORGANIZATION (MARCH $22^{\mathrm{ND}}-24^{\mathrm{TH}}$, PORTOROŽ SLOVENIA)

A. Pavković, H. Matešić: Investment in Venture Capital Funds in the Republic of Croatia: Determinants and Challenges

Švaljek, S. (2008) Ulaganje u privatni vlasnički i rizični kapital u Hrvatskoj: porezno i pravno okruženje. Privredna kretanja i ekonomska politika [online], 17(113), pp. 5384. Retrieved from http://hrcak.srce.hr/20366

Vukas, J., Gvozdanović, I. i Jalšenjak, B. (2012) Elementi poslovne etike u financijskom sektoru s naglaskom na investicijske fondove. Obnovljeni život [online], 67(1), pp. 45-57. Retrieved from http://hrcak.srce.hr/index.php?show=clanak\&id_clanak_jezik=113191 
$36^{\text {Th }}$ International Conference on Organizational Science DeVelopment: Responsible ORganization (MARCH $22^{\mathrm{ND}}-24^{\mathrm{TH}}$, PORTOROŽ SLOVENIA)

O. Arsenijević, M. Ferjan, I. Podbregar, P. Šprajc, D. Trivan \& Y.

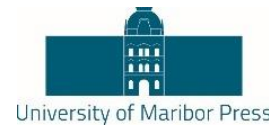

Ziegler

\title{
Business Innovation Discovery with a Social Impact by Croatian Business Students through Appreciative Inquiry Methodology
}

\author{
Judita PETERlin, Vlado Dimovski \& DANIELA GARBIN PRANIČEVIĆ
}

\begin{abstract}
Our paper demonstrates Croatian business students' engagement in an international contest AIM2flourish where we research business innovations with a social impact. Three business innovations are highlighted in order to provide insight into main characteristics of a business innovation together with environmental and social value. Appreciative inquiry was used as a research methodology. Students were empowered together with local business in Croatia. AIM2flourish project was presented at several courses at the Faculty of Economics University of Split and students were invited to apply. We conducted first appreciative inquiry with the interested students in order to give them the overview of how appreciative inquiry is conducted. Business students performed appreciative inquiry within the local business community and in-depth researched 3 companies. AIM2flourish exercise enabled insight into productive business community of Split region, Croatia. Students gained pride of their local community and got to know personally some of the successful managers in the local community. Establishing a dialogue with the business owners and managers proved to be the critical component for a successfully conducted AIM2flourish of our students. We establish that it is necessary to prepare the students well so that they are self-confident and curious in researching a personal story of businessmen, business model, business innovation and managerial context.
\end{abstract}

KEYWORDS: appreciative inquiry $\bullet$ change management $\bullet$ sustainable leadership $\bullet$ management education keyword

Correspondence Address: Judita Peterlin, Ph.D., Assistant Professor, University of Ljubljana, Faculty of Economics, Kardeljeva ploščad 17, 1000 Ljubljana, Slovenia, e-mail: judita.peterlin@ef.uni-lj.si; Vlado Dimovski, Ph.D., Full Professor, University of Ljubljana, Faculty of Economics, Kardeljeva ploščad 17, 1000 Ljubljana, Slovenia, e-mail: vlado.dimovski@ef.uni-lj.si; Daniela Garbin Praničević, Ph.D., Associate Professor, University of Split, Faculty of Economics, Cvite Fiskovića 5, 21000 Split, Croatia, e-mail: daniela@efst.hr

DOI https://doi.org/10.18690/978-961-286-020-2.57

ISBN 978-961-286-020-2

(C) 2017 University of Maribor Press

Available at: http://press.um.si 
$36^{\text {Th }}$ International Conference on Organizational Science Development:

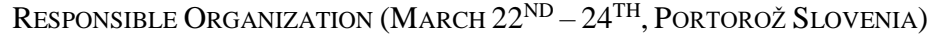

J. Peterlin, V. Dimovski \& D. Garbin Praničević: Business Innovation Discovery with a Social Impact by Croatian Business Students through Appreciative Inquiry Methodology

Our paper provides an overview, process and methodology insight of the AM2flourish project implementation for management (Daft, 2012) educational purposes. AIM2flourish (2016) is supported by UN Global Goals (2016) and seeks business innovations in the local community that are reported by business students. AIM2flouirsh is based on an online platform that is open to international business education community. Students under the mentorship of their professors publish business innovations around the globe build on the appreciative inquiry methodology. We offer preliminary results, implementation lessons learned and recommendations for professors who wish to incorporate this kind of developmental activity into their courses.

International collaboration offers a high level of specialization, gaining knowledge from different participants and faster business process (Pavlić \& Gudelj, 2015, p. 135). Lyles and Salk (in Pavlić \& Gudelj, 2015, p. 138) state several conditions for a successful knowledge transfer in an international collaboration: (1) flexibility of the organization; (2) organized trainings; (3) technological expertise; (4) setting formal goals; (5) specialization of the members; (6) support of the top management. In contemporary educational and business environment e-learning and e-collaboration platforms are becoming a vital part of international collaborations. Main goal of an e-learning platform is knowledge management in a digital society and a better quality, flexibility and adjustment to the global students' learning needs. Inkpen (in Pavlić \& Gudelj, 2015, p. 147) states that strategic partnerships have an important role in the process of knowledge management and developing new knowledge and skills. Through new technological solutions new web platforms have developed for learning and collaboration (Pavlić \& Gudelj, 2015, p. 147). Based on the higher informational literacy e-learning is becoming a standard that strengthens efficiency of the learning process. E-learning is becoming a sustainable solution that satisfies the need for a lifelong learning in a flexible and cheaper way (Garbin Praničević \& Zovko, 2015, p. 154). Garbin Praničević and Zovko (2015, p. 168) specifically stress the need for tourism workers to recognize the usefulness of new technologies, e-learning and its educational impact. Moreover, technology has to be incorporated in the tourism and hospitality education program via one of the available elearning platforms as early is possible in education process. In Garbin Praničević \& Šerić (2014) study provided in tourism studies education process is verified the positive relationship between the use of Moodle as available e-learning platform and the final study outcome. The aim of the research is to present the methodology of appreciative inquiry within social innovation education. The research question is: What are the benefits of appreciative inquiry integration for the business community and students' education? The method we used is appreciative inquiry that was developed by professor Cooperrider. The instrument is well structured and can be downloaded from the AIm2flourish platform. The sample comprised of Croatian students at the Faculty of economics University of Split. Three teams of students volunteered and participated at the AIM2flourish contest. 
J. Peterlin, V. Dimovski \& D. Garbin Praničević: Business Innovation Discovery with a Social Impact by Croatian Business Students through Appreciative Inquiry Methodology

\section{$2 \quad$ Method}

Case studies (Frankfort-Nachmias \& Nachmias, 2008) of AIM2flourish cases are implemented following AIM2flourish methodology implementation. Preparation was carried out in Spring 2016 by studying the materials, given on the AIM2flourish platform for the professors and the students. The materials are continuously improved upon professors' and students' feedback. Regularly, one of the authors participated in the videoconferences with AIM2flourish professors and organizing team where we reported on progress and identified challenges. Opportunity was given to express questions and receive guidelines for an efficient support of students' business innovation stories within their local community. Based on the first group of students who participated in the AIM2flourish project at the Faculty of Economics University of Split in the period from April-July 2016 we provide the findings of the implementation process. AIM2flourish project was presented at several courses at the Faculty of Economics University of Split and students were invited to apply. We conducted first appreciative inquiry (Cooperrider, Whitney \& Stavros, 2008) with the interested students in order to give them the overview of how appreciative inquiry is conducted in business community through story telling (Colville, Brown \& Pye, 2011). In the final selection, appreciative inquiry with Student A was conducted on $19^{\text {th }}$ April 2016, appreciative inquiry with Student B was conducted on $19^{\text {th }}$ April 2016, appreciative inquiry with Student $C$ was conducted on $22^{\text {nd }}$ April 2016, appreciative inquiry with Student D was conducted on $26^{\text {th }}$ April 2016.

Appreciative inquiry is a methodology that seeks a positive core within an individual an/or organization. It is well-structured instrument that wishes to build upon positive past as this gives energy and will to perform also in the future. It deals with the focus what do you want more of: bad or good. Appreciative inquiry can be adjusted to the situation of analysis.

\section{$3 \quad$ Findings}

Our findings present the benefits of appreciative inquiry for the students and for the local community. During the appreciative inquiry students got to know local business people and also designed a model of social innovation that is based on the appreciative inquiry consideration. Proof quotes of appreciative inquiry demonstrate the personality traits of the business students who participated in our AIM2flourish project (Table 1). 

RESPONSIBLE ORGANIZATION (MARCH $22^{\mathrm{ND}}-24^{\mathrm{TH}}$, Portorož SLOVENIA)

J. Peterlin, V. Dimovski \& D. Garbin Praničević: Business Innovation Discovery with a Social Impact by Croatian Business Students through Appreciative Inquiry Methodology

\begin{tabular}{|c|c|c|c|c|}
\hline & Student A & Student B & Student C & Student D \\
\hline $\begin{array}{l}\text { Enthusiastic } \\
\text { situation in the } \\
\text { past }\end{array}$ & $\begin{array}{l}\text { Demonstrating } \\
\text { creativity in } \\
\text { designing jewelry } \\
\text { and selling it }\end{array}$ & $\begin{array}{l}\text { "I am an IT } \\
\text { demonstrator on the } \\
\text { faculty and in one } \\
\text { moment all the } \\
\text { technical support } \\
\text { fell down, } \\
\text { microphones didn't } \\
\text { work, it was very } \\
\text { nice for me because } \\
\text { I could show to } \\
\text { people what } \\
\text { actually I do on this } \\
\text { faculty. So, } \\
\text { everything stopped } \\
\text { and I was there and } \\
\text { checked everything } \\
\text { and repaired it". }\end{array}$ & $\begin{array}{l}\text { Second semester at } \\
\text { the faculty and } \\
\text { Erasmus exchange }\end{array}$ & $\begin{array}{l}\text { "Studying } \\
\text { beginnings, } \\
\text { the first time } \\
\text { working in a big } \\
\text { environment, in } \\
\text { different teams who } \\
\text { have different } \\
\text { opinions, and during } \\
\text { three year } \\
\text { experience I } \\
\text { changed but nobody } \\
\text { said to me you need } \\
\text { to change. I changed } \\
\text { by myself because } \\
\text { my work gave me } \\
\text { input and } \\
\text { information how to } \\
\text { be better" }\end{array}$ \\
\hline Vision of 2026 & $\begin{array}{l}\text { "I hope I will do } \\
\text { something that will } \\
\text { help the world, } \\
\text { something that will } \\
\text { be better for our } \\
\text { environment and... } \\
\text { Really, I don't think } \\
\text { too much about that } \\
\text { but I want to do } \\
\text { something that will } \\
\text { be good for all } \\
\text { people around me. } \\
\text { And not to make } \\
\text { things just to earn } \\
\text { money and make } \\
\text { profit because I think } \\
\text { it is better when our } \\
\text { community is happy } \\
\text { than making rich. I } \\
\text { don't know but for } \\
\text { now I want people } \\
\text { around me to have a } \\
\text { better life. That's all". }\end{array}$ & $\begin{array}{l}\text { "I would really like } \\
\text { for people to start } \\
\text { buying electric cars } \\
\text { and I think this is } \\
\text { the main goal for } \\
\text { population, actually } \\
\text { for global } \\
\text { population. Stop } \\
\text { using fossil fuels } \\
\text { and start with } \\
\text { electricity". }\end{array}$ & $\begin{array}{l}\text { "I see the poverty } \\
\text { lowered down. I see } \\
\text { more focus on } \\
\text { environment and } \\
\text { sustainability, let say } \\
\text { more electric cars. } \\
\text { Especially, in } \\
\text { Croatia, which we } \\
\text { don't have, waste } \\
\text { management } \\
\text { because in Croatia } \\
\text { no waste } \\
\text { management exists. I } \\
\text { think technology } \\
\text { will go up. And } \\
\text { maybe, it's hard to } \\
\text { say but maybe we'll } \\
\text { have small robots or } \\
\text { something similar. } \\
\text { But I think a lot of } \\
\text { things will be based } \\
\text { on solar energy". }\end{array}$ & $\begin{array}{l}\text { "I think that they } \\
\text { will over use } \\
\text { technology. I think } \\
\text { we need to control } \\
\text { technology because } \\
\text { I don't want to face } \\
\text { that technology } \\
\text { controls us". }\end{array}$ \\
\hline $\begin{array}{l}\text { Personal } \\
\text { characteristics }\end{array}$ & $\begin{array}{l}\text { independent, curious, } \\
\text { seeks experiences in } \\
\text { different fields }\end{array}$ & $\begin{array}{l}\text { ambitious, } \\
\text { determined }\end{array}$ & $\begin{array}{l}\text { hard working, } \\
\text { searching for } \\
\text { balance }\end{array}$ & $\begin{array}{l}\text { persistent, curious, } \\
\text { well-organized, } \\
\text { demanding towards } \\
\text { herself and others }\end{array}$ \\
\hline $\begin{array}{l}\text { Interest in } \\
\text { business } \\
\text { innovation (UN } \\
\text { Global Goals) } \\
\end{array}$ & creative industry & $\begin{array}{l}\text { car industry, } \\
\text { electrical cars }\end{array}$ & $\begin{array}{l}\text { sustainable tourism, } \\
\text { sustainable cities } \\
\text { and communities } \\
\text { (Global Goal 11) }\end{array}$ & $\begin{array}{l}\text { sustainable cities } \\
\text { and communities } \\
\text { (Global Goal 11) }\end{array}$ \\
\hline
\end{tabular}

\section{Table 1: [Our students/participants identification at AIM2flourish 2016]}

Selected business innovation themes were selected by the students and approved by professors according to the criteria provided at the AIM2flourish platform and UN Global Goals platform (http://www.globalgoals.org/). Our experiences with the support of the organizing theme are good. 
J. Peterlin, V. Dimovski \& D. Garbin Praničević: Business Innovation Discovery with a Social Impact by Croatian Business Students through Appreciative Inquiry Methodology

One of the authors participated at several AIM2Flourish Professors "Faculty Fair"'s hosted by Isabel Rimanoczy. On $12^{\text {th }}$ May Claire Summers joined together with the coauhour video conference from UN Global Compact PRME offices in New York City. At these video international conferences we met our AIM2Flourish colleagues, shared our ideas, stories, challenges and experiences and learned what's new and improved with AIM2FlourishAIM2Flourish in the classrooms, it was also a good opportunity to ask questions and give updates. Business students performed under the supervision of one of the coauthors appreciative inquiry within the local business community and in-depth researched 3 companies (Table 2).

\begin{tabular}{|l|l|l|l|l|}
\hline & $\begin{array}{l}\text { Information about the } \\
\text { company }\end{array}$ & $\begin{array}{l}\text { Year of } \\
\text { foundati } \\
\text { on }\end{array}$ & $\begin{array}{l}\text { Number of } \\
\text { employees }\end{array}$ & $\begin{array}{l}\text { Business } \\
\text { Location }\end{array}$ \\
\hline $\begin{array}{l}\text { Hotel } \\
\text { Split }\end{array}$ & $\begin{array}{l}\text { Four-Star Hotel Split, one of } \\
\text { the first A-category hotels of } \\
\text { this type in Croatia, family-run } \\
\text { Boutique-hotel }\end{array}$ & 2012 & $\begin{array}{l}11-50 \\
\text { (seasonal) }\end{array}$ & $\begin{array}{l}\text { Podstrana, } \\
\text { Croatia } \\
\text { http://hotelsplit. } \\
\text { com/ }\end{array}$ \\
\hline $\begin{array}{l}\text { Eco- } \\
\text { Village }\end{array}$ & $\begin{array}{l}\text { well-known tourist destination, } \\
\text { preserved the memory of the } \\
\text { life of our ancestors, conjure } \\
\text { up a picture of life in peace and } \\
\text { unspoiled nature, show the } \\
\text { beauty of tradition and cultural } \\
\text { heritage, Dalmatian hinterland }\end{array}$ & $/$ & $\begin{array}{l}\text { Family } \\
\text { members } \\
\text { Croatia }\end{array}$ & \\
\hline $\begin{array}{l}\text { Steora } \\
\text { Smart } \\
\text { bench }\end{array}$ & $\begin{array}{l}\text { First Croatian and European } \\
\text { company which is in trend with } \\
\text { the latest technology of smart } \\
\text { benches. }\end{array}$ & 2014 & $\begin{array}{l}11-50 \\
\text { (students) }\end{array}$ & Klis, Croatia \\
\hline
\end{tabular}

Table 2: [Identification of participating businesses in Croatia]

Source: Milat, A. (2016), Đurđević; H. \& Zovko, L. (2016), Statovci, A. (2016). AIM2flourish international contest submission.

\subsection{First green hotel in Croatia}

Dalmatia has a tourist industry highly flourishing, therefore one of the business students, Ana Milat (2016) identified a business innovation in sustainable tourism sector.

\subsubsection{Business Benefit}

The hotel is recognized as the first a green hotel in Croatia. As such it ought to remain trendy and keep innovating. Business benefit from the innovation is definitely strengthening the brand position and image through the identity of green hotel, reducing 
36 $6^{\mathrm{TH}}$ International Conference on ORganizational Science Development: ReSPONSIBLE ORGaNizATION (MARCH $22^{\mathrm{ND}}-24^{\mathrm{TH}}$, PortoroŽ Slovenia)

J. Peterlin, V. Dimovski \& D. Garbin Praničević: Business Innovation Discovery with a Social Impact by Croatian Business Students through Appreciative Inquiry Methodology

the cost (using renewable materials such as aluminum and glass the innovation was also taking care of sustainability), attracting and motivating the local employees (stimulation, good reference) and potential investors (working long term and also profitable). One of the business benefits is sales increase and market share increase. For example, 3,61\% (451 overnights) of total (12 494) overnights from the United States tourists has been made in Hotel Split which is a huge number as it has only 40 rooms. As Americans are the leaders in green tourism it is an important fact as well as the fact that the majority of the guests of Hotel Split come from Western Europe (Great Britain, Germany, Belgium, Switzerland and France) which are also known as eco-tourists.

\subsubsection{Societal and Environmental Benefit}

They employ 18 people during whole year and 40 during summer season which is really great amount as they have only 40 rooms. They also cooperate with local businesses and providers, hospitals, local artists, schools and faculties, domestic associations, organizations and European projects such as Near Zero Energy Hotels. Croatian Ministry of tourism has supported their project as they clean the beach and the underwater in front of the hotel what resulted in gaining of White flag. The impact on the environment is definitely positive as it is designed by the principles of green and environmentally friendly construction.

\subsubsection{Overall Impact}

It was primary the location, architecture, luxury, design and the green facet of the innovation and overall good management that has the positive impact in raising the attractiveness, competitiveness, number of tourists and consequently rising of the revenues and profits. The overall impact on profits is the best attested by the fact that the profit growth rate in 2015 is $90,94 \%$, according to the Poslovna Hrvatska's database. As the first project of that type in Croatia they had a great impact on local community and environment. Since then we have only one Near Zero Energy Hotel (Adriatica in Supetar) and 41 hotels certificated by Sustainable Hotel Certificate by UPUHH (Croatian Hotel Business Association), such as Palace and Esplanade in Zagreb, Astoria, Hotel Iadera Zadar, Punta Skala Resort or Hotel Sveti Križ in Trogir.

\subsubsection{Innovation}

The business innovation of Hotel Split is the construction and managing a family-owned hotel with an extraordinary location as a Near Zero Energy Hotel (neZEH). It was a new business model based on cost reduction and sustainability through environmentally friendly materials during the construction, raising the awareness of employees, local community and tourists as well as the improved process of energy management.

Main information about this business innovation with a social impact is stated in Table 3 . 
J. Peterlin, V. Dimovski \& D. Garbin Praničević: Business Innovation Discovery with a Social Impact by Croatian Business Students through Appreciative Inquiry Methodology

\begin{tabular}{|l|}
\hline Key Ideas \\
\hline Sustainable and environmentally friendly guesthouse: the key idea of the innovation \\
is reasonable exploitation of the environment on the existing unused lot. The main \\
focus is on: \\
(1) sustainability; (2) competitiveness; (3) cost reduction; (4) practicality; (5) \\
ecologically friendly; (6) social responsibility; (7) social and ecological \\
awareness. \\
\hline Goal 8; Goal 11; Goal 13 Global Goals Solution \\
\hline
\end{tabular}

\section{Table 3: [Green hotel Split]}

Source: Milat, A., AIM2flourish international contest submission, based on appreciative inquiry with Mladen Tomić, director of Hotel Split, May 17 ${ }^{\text {th }}, 2016$.

\subsection{Eco-village as a sustainable way of living}

Helena Đurđević and Luka Zovko (2016) identified a business innovation in sustainable community and different lifestyle.

\subsubsection{Key Ideas}

Eco-ethno Village Škopljanci is family estate which has preserved the past for the future. In the center of the village are 20 years old, stone houses of which 12 of them are fully restored to the smallest details in order to preserve the original format, respecting tradition and architecture of the area. Members of the family Škopljanac represent the pioneers of rural tourism, and thanks to the rural Olympics, Bullfights, Mid- summer nights; beauty contest Dalmatian hinterland is the most famous tourist complex of its kind in Croatia.

\subsubsection{Innovation}

It covers an area of up to 300000 square meters' village with 20 houses, entailing more than 1700 exhibits from the Dalmatian region. There is an increased growth in profit and number of tourists which shows great influence on the tourism market in the region. On a daily level there is always about 300 people arriving, some of them in groups and some of them individually. They organize many manifestations which connect people with their roots of the past. An example of that are bullfights, a traditional manifestation, where people are coming, not only to see bulls, but also to hang out together in the nature, eat traditional food and enjoy in the fresh air. In 2015 there were 15000 visitors, mostly families with their kids.

The main competitive advantage of their business model is that they grow their own food. A farm with domestic animals and BIO garden makes possible to serve organic food in their tavern, so you can be sure you eat a healthy food. Food in Škopljanci is prepared 
$36^{\text {Th }}$ International Conference on Organizational Science Development: RESPONSIBLE ORGANIZATION (MARCH $22^{\mathrm{ND}}-24^{\mathrm{TH}}$, Portorož SLOVENIA)

J. Peterlin, V. Dimovski \& D. Garbin Praničević: Business Innovation Discovery with a Social Impact by Croatian Business Students through Appreciative Inquiry Methodology

according to the original recipes of our ancestors who passed their knowledge and experience from generation to generation.

A village, which the Ministry of Culture has protected as a protected monument, currently has two apartments and three taverns where they can accommodate about 130 people, with a large hall for 250 people, and a myriad of small taverns. Except bullfights, this place is well-known by "Ojkanje" singing, a tradition of polyphonic folk singing, which was in 2010 signed in UNESCOs List of Intangible Cultural Heritage in Need of Urgent Safeguarding as representative of Croatia. In this way they preserved culture of this area and introduce it to the people around the world.

Village Radošić, where ethno-eco village Škopljanci is places, is covered with centuriesold pubescent oak forest (Pubescent oaks), a protected natural monument of Croatia. Cultural Club "Ognjiste" started a project "preserve oak to our honor "which tries to educate younger generations with the importance of preserving natural resources. Through educational workshops and school in nature they are trying to introduce to children the beauty of the flora and fauna of the Dalmatian hinterland.

\subsubsection{Business Benefit}

Everyday concerns about a healthy living without stress brings visitors to eco-ethno village. This kind of business innovation opens the door to new concepts in sustainable tourism and the way in doing business. Most towns are highly polluted and quiet noisy. People are concerned only about their jobs and don't have time to relax. That kind of living is not giving opportunities for healthy diet and taking some time for their own families.

The power of this concept could be seen through constant growth, not only in aspect of guests, but also in profit. This concept has been approved by numerous business people and it can be said that this concept is of great importance. Numerous celebrations like weddings, birthdays and anniversaries are celebrated in this area. Also, you cannot bypass the business aspect that these areas offer: Business meetings, team building and conferences are indispensable events.

\subsubsection{Societal and Environmental Benefit}

This village is doing its business in a small local community. Today we still have many areas that suffer from the consequences of war that happened during the end 20 of century in this region. As a result of that, in the area of Lećevica there is less than 200 people, so anything what can start progress of the community is welcome.

In such an economic situation, the eco-ethno village has enabled economic development of the region. Before they started their own business, there was emphasized emigration and the withering away of the area. From the moment when this project started, it allowed 
J. Peterlin, V. Dimovski \& D. Garbin Praničević: Business Innovation Discovery with a Social Impact by Croatian Business Students through Appreciative Inquiry Methodology

the people who live there to be also involved in the project. Eco-ethno village makes this possible in a way that they enable everything they need for the business, if they do not have in sufficient quantities, purchased from the local community.

Other thing that shows social benefit from their innovation is hiring local people. As the village is far from the big cities, need for extra workers is satisfied by people in the community. Most of the work is done by family Škopljanci, but because of increasingly growth there is need for extra workers. On daily levels there are 10 to 20 workers. On the other hand, for some manifestations like bullfights there are around 200 people who work on that kind of events.

It is interesting that the visitors, in the rural complex in Škopljanci, are not served by waiters. The family Škopljanac developed a specific relationship with guests who are not more guests when they come there. Everything is open, everything is available, to serve themselves, eat and drink what they want, when they want and where they want. Former stables, barns and rural farm buildings were converted into favorable facilities for staying overnight and for holidays.

Main information about this business innovation with a social impact is are stated in Table 4.

\section{Overall Impact}

Focusing on tradition, environment and local community gives them opportunity to improve community in many ways. This way of doing business is environmental friendly and does not harm the nature, even promotes the awareness about the importance and dependence upon nature and its fruits. By buying different natural products from neighbors around them and hiring them, they also effect the development of the local community. Eco-ethno village has enormous impact on society and environment around it.

\section{UN Global Goals Solution}

Goal 8; Goal 11; Goal 13

Table 4: [Eco village]

Source: Đurđević \& Zovko, AIM2flourish international contest submission, based on appreciative inquiry, May, 2016.

\subsection{Smartbench}

Arta Statovci (2016) identified a business innovation in sustainable technological sector. 
$36^{\mathrm{TH}}$ International Conference on ORganizational Science Development: RESPONSIBLE ORGANIZATION (MARCH $22^{\mathrm{ND}}-24^{\mathrm{TH}}$, Portorož SLOVENIA)

J. Peterlin, V. Dimovski \& D. Garbin Praničević: Business Innovation Discovery with a Social Impact by Croatian Business Students through Appreciative Inquiry

Methodology

\subsubsection{Key Ideas}

First Croatian and European company which is in trend with the latest technology of smart benches. Steora ${ }^{\mathrm{TM}}$ : (1) the most awarded Croatian Start-up with the best innovation in 2015; (2) solar powered smart bench; (3) basic and exclusive features.

\subsubsection{Business Benefit}

By implementing smart bench Steora, each business will have opportunity to be part of the global trend, smart cities. Furthermore by installing advertising options in Steora's display and internet connection can be used to deliver advertising in order to generate revenue. Another benefit for business comes with built-in sensors of movement which enable counting passing pedestrians. This data can be very useful both for statistical and commercial purposes.

High Definition Display: Steora has the option of a 19" weather and vandalism resistant screen that can be used to display any desired information, picture or video. The Screen is built in to fit design perfectly and positioned sideways for optimal visibility.

Advertising: Advertising with Steora is backed by newest software that combines best characteristics of internet advertising and street advertising. By installing one of Steora's three advertising options, Steora's display and internet connection can be used to deliver advertising in order to generate revenue.

Reach Analytics: Steora comes with built-in sensors of movemenArt which enable counting passing pedestrians. This data can be very useful both for statistical and commercial purposes.

\subsubsection{Societal and Environmental Benefit}

The innovation faces environmental problems that bustling and very populated cities have today. Steora is the latest in smart bench technology, creatively harnessing green solar energy to provide practical solutions to increasingly pressing problems. From providing smart USB charging, mobile Internet, local information, to data gathering and revenue generation from advertisements. Steora is more than a bench. Steora is the future. Steora is suited to any environment, whether bustling town or national park.

\subsubsection{Innovation}

Smartbench has the following innovative characteristics: 1) Solar power; 2) Mobile device charging; 3) Mobile internet; 4) resistant to vandalism; 5) high quality build materials. 
J. Peterlin, V. Dimovski \& D. Garbin Praničević: Business Innovation Discovery with a Social Impact by Croatian Business Students through Appreciative Inquiry

Methodology

Solar Power: The solar panels generate around 110W of electricity per hour. Steora's solar panels are situated under the seat, cover the whole upper surface and enable maximum solar power absorption.

Mobile Device Charging: Steora is equipped with an independently developed wireless device charger, allowing newer generations of smart phones and watches to charge without a cable. It also provides two smart USB connectors with an output power of 10 $\mathrm{W}$, providing fast charging for mobile devices whilst ensuring battery protection.

Mobile Internet: Internet access is constantly available within a four-meter diameter of the bench, delivered by a superfast $4 \mathrm{G}$ mobile router. It is also possible to limit each users access to enable equal access to everyone. It is able to provide Internet packages in association with the best network agencies available in each country.

Resistant to Vandalism: Steora is bolted down and locked to prevent any unauthorized opening. There is also a sophisticated tracking system, enabling us to pinpoint its exact location at all times. If Steora is ever shut down, an alert is sent through to our internal tracking system to ensure immediate notification of the clients.

High Quality Build Materials: Steora is made from high quality materials to ensure protection against weather and rusting. $3 \mathrm{~mm}$ thick steel plate with a bearing capacity of $1000 \mathrm{~kg}$ which is sand blasted and laminated to achieve a high gloss finish. Panels and screen are covered with homogenous polycarbonate, which is often used in things like police shields.

Main information about this business innovation with a social impact are stated in Table 5.

\begin{tabular}{|l|}
\hline \multicolumn{1}{|c|}{ Overall Impact } \\
\hline $\begin{array}{l}\text { employing young local students, developing entrepreneurship in the local community, } \\
\text { "role model" }\end{array}$ \\
\hline Goal 11; Goal 12; Goal 13 \\
\hline
\end{tabular}

\section{Table 5: [Smartbench]}

Source: Arta Statovci, 2016. AIM2flourish international contest submission, based on the appreciative inquiry with Ivan Mrvoš, director of Hotel Split, May 16th, 2016.

\section{Conclusion}

AIM2flourish exercise enabled insight into productive business community of Split region, Croatia. Students gained pride of their local community and got to know personally some of the successful managers that could potentially also offer them an 
$36^{\text {Th }}$ International Conference on Organizational Science Development: RESPONSIBLE ORGANIZATION (MARCH $22^{\mathrm{ND}}-24^{\mathrm{TH}}$, PORTOROŽ SLOVENIA)

J. Peterlin, V. Dimovski \& D. Garbin Praničević: Business Innovation Discovery with a Social Impact by Croatian Business Students through Appreciative Inquiry Methodology

employment. Establishing a dialogue with the business owners and managers proved to be the critical component for a successfully conducted AIM2flourish of our students. We establish that it is necessary to prepare the students well so that they are self-confident and curious in researching a personal story of businessmen, business model, business innovation and managerial context.

International collaboration of developing Croatian students' business knowledge and skills through an online platform of AIM2flourish demonstrated to be a valuable experience for all the participants. The process itself provided a lot of learning material and collaboration was flexibile, trainings were provided for students, technological support developed, formals goals were set by the AIM2flourish and collaboration partners, each of the participants had its own speciality and the support of the faculty's management was given. We therefore conclude that AIM2flourish meets the main goal of an e-learning platform, that is knowledge management in a digital society and a better quality, flexibility and adjustment to the global students' learning needs. Based on the higher informational literacy e-learning of business students through AIM2flourish platform about business innovations strengthens efficiency of the learning process.

\section{Literature}

AIM2flourish platform (2016). Business innovations of students: AIM2Flourish connects students with business leaders to discover and learn about innovations that do good and do well. Retrieved from http://aim2flourish.com/

Colville, I., Brown, A. D., \& Pye, A. (2011). Simplexity: Sensemaking, organizing and storytelling for our time. Human Relations, Vol. 65, No. 1, pp. 5-15.

Cooperrider, D. L., Whitney, D., \& Stavros, J.M. (2008). Appreciative Inquiry Handbook for Leaders of Change. Brunswick, OH: Crown Custom Publishing.

Daft, R. L. (2012). New Era of Management (10th Ed.). Australia: South-Western, Cengage Learning.

Đurđević, H., \& Zovko, L. (2016). Eco village - AIM2flourish international contest submission. Split: University of Split, Faculty of Economics.

Garbin Praničević, D. \& Šerić, M. (2014): The Role of ICT in Education: a Longitudinal Study Based on Tourism Students Perceptions. Zagreb International Review of Economics \& Business, Vol. 17, Special Conference Issue, pp. 49-64.

Garbin Praničević, D., \& Zovko, A. (2015). Suvremena tehnologija kao podrška edukaciji u turizmu. In M. Jadrić, \& Ćukušić, M. (Eds.), Informacijsko-komunikacijske tehnologije u cjeloživotnom učenju (pp. 151-172). Split: Sveučilište u Splitu, Ekonomski fakultet.

Frankfort-Nachmias, C., \& Nachmias, D. (2008). Research Methods in the Social Sciences (7th ed.). New York: Worth Publishers.

Milat, A. (2016). Green hotel Split - AIM2flourish international contest submission. Split: University of Split, Faculty of Economics.

Pavlić, D., \& Dudelj, M. (2015). Suradnja i e-učenje u međunarodnum poslovnom okruženju. In M. Jadrić, \& Čukušić, M. (Eds.), Informacijsko-komunikacijske tehnologije u cjeloživotnom uс̌enju (pp. 135-150). Split: Sveučilište u Splitu, Ekonomski fakultet.

Statovci, A. (2016). Steora smartbench - AIM2flourish international contest submission. Split: University of Split, Faculty of Economics. 

ORGANIZACIJA (22. - 24. MAREC 2017, PORTOROŽ, SLOVENIJA)

J. Peterlin, V. Dimovski \& D. Garbin Praničević: Business Innovation Discovery with a Social Impact by Croatian Business Students through Appreciative Inquiry Methodology

UN Global Goals platform (2016). Global goals identification solutions. Retrieved from http://www.globalgoals.org/ 
720 36 $6^{\text {TH }}$ International Conference on Organizational Science Development: Responsible Organization (MARCH $22^{\mathrm{ND}}-24^{\mathrm{TH}}$, PORTOROŽ SLOVENIA) 
$36^{\text {TH }}$ International Conference on Organizational Science DeVElopment: Responsible ORGANIZATION (MARCH $22^{\mathrm{ND}}-24^{\mathrm{TH}}$, PORTOROŽ SLOVENIA)

O. Arsenijević, M. Ferjan, I. Podbregar, P. Šprajc, D. Trivan \& Y. Ziegler

\title{
Institutional Effects of Public-Private Partnership Act on the Status of Municipal Public Enterprises in Slovenia
}

\author{
VERONIKA PETKOVŠEK \& PRIMOŽ PEVCIN
}

\begin{abstract}
The paper presents the legal status of existing public enterprises in Slovenia before and after the adoption of Public-Private Partnership Act, that demanded the reorganization of existing public enterprises in the period 2007-2009. The aim of the paper is to evaluate the influence of institutional framework changes on public enterprises, caused by new legislation. Descriptive methods, like literature review and comparative analysis are used to obtain results on institutional changes of public enterprises. The results give some useful directions for further analysis or research of reorganization and its influence on existing public enterprises.
\end{abstract}

KEYWORDS: public enterprise $\bullet$ reorganization $\bullet$ public-private partnership

CORRESPONDENCE AdDRESS: Veronika Petkovšek, M.S., Senior Lecturer, University of Ljubljana, Faculty of Administration, Gosarjeva ulica 5, 1000 Ljubljana, Slovenia, e-mail: veronika.petkovsek@fu.uni-lj,si; Primož Pevcin, Ph.D., Associate Professor, University of Ljubljana, Faculty of Administration, Gosarjeva ulica 5, 1000 Ljubljana, Slovenia, e-mail: primoz.pevcin@fu.uni-lj.si 
$36^{\text {Th }}$ International Conference on Organizational Science Development: ResPonsible Organization (MARCh $22^{\mathrm{ND}}-24^{\mathrm{TH}}$, Portorož Slovenia) V. Petkovšek \& P. Pevcin: Institutional Effects of Public-Private Partnership Act on the Status of Municipal Public Enterprises in Slovenia

Public utilities that meet the needs of the public, are a fundamental and irreplaceable condition for life and work, and the normal development of every society. Economic indicators and a significant part of the indicators of social development are directly related to the level of development of public utilities (Rakar et al., 2010, p. 242). Also according to the principles of EU legislation, utility services are regarded as essential and should be subject to certain public service obligations. These services would not be produced if there was no intervention by the competent public authorities (Cruz, 2013, p. $4)$.

European Community harmonized the implementation of the public service activities and established common requirements to be followed by the EU Member States. When national authorities decide about the activities to provide public goods and about the extent of their provision, they should also decide on the method of allocation and distribution of public goods and services (Brezovnik, 2009, 179).

Slovenia provides public services by specific legal persons, e.g. public institutions, public commercial institutions, public enterprises etc., established by the state or municipality. Municipalities provide public commercial services primarily in two ways: through public enterprises and by awarding concessions. Public enterprises became a principal form of local public services provision. To enable and encourage mutual help and cooperation between entities from the public and the private sectors, which would lead to economical and efficient provision of public services and other goods or services in the public interest, Slovenia adopted the Public-Private Partnership Act in 2006, that came into force in 2007 (Bauby \& Similie, pp. 116-117). Besides establishing forms, rules and procedures for implementation of public-private partnership, the Act also determined the transformation of existing public enterprises, which in the specified period should made the appropriate changes in their organization status or should their founders consider about the need to change and adapt their current status to new legislative conditions.

The aim of the paper is to present the legal status of existing public enterprises in Slovenia before and after the adoption of Public-Private Partnership Act, that demanded the reorganization of existing public enterprises in the period 2007-2009 and evaluate the influence of institutional framework changes on public enterprises. Descriptive methods, like literature review and comparative analysis are used to obtain results on legal status changes of public enterprises, caused by Public-Private Partnership Act. The paper first presents public enterprise as one of the forms (also the most widespread form) of local commercial public services provision in Slovenia. Further on, the paper presents the legal status of public enterprise in Slovenia and some open questions before the adoption of the Public-Private Partnership Act and after that the legal status changes that the mentioned Act has caused to existing public enterprises. The conclusion gives some useful directions for further analysis or research of reorganization and its influence on existing public enterprises. 
V. Petkovšek \& P. Pevcin: Institutional Effects of Public-Private Partnership Act on the Status of Municipal Public Enterprises in Slovenia

\section{Public enterprise as a form of local public service provision}

Form of local public service provision is prescribed by the municipality by decree to ensure its implementation within the functionally and spatially complete supply systems. The municipal decree regulates conditions for the provision and use of public goods; sources of funding and the manner of their formation; rights and obligations of users; position of the infrastructure for the public service (Grafenauer, 2009, p. 213).

In Slovenia, a municipality may provide commercial public services via the municipal administration body, by establishing public institutes and public enterprises, by awarding concessions and in any other way determined by law. Overhead plant is a relatively rare form of local commercial public services provision. It may be used when it would be uneconomical or irrational to establish a public enterprise or to give a concession due to the small size or the characteristics of the service. Public commercial institute is also a very rare form of local commercial public services provision. It is used when a public service, due to its nature, cannot be provided as a profit activity or if profit is not a goal of such a service. Public commercial institute may be either a legal entity of public law or an entity without legal personality. (Pevcin \& Rakar, 2015, pp. 705-706). Concession is the only possible form providing commercial public services, performed by a legal person of private law. By its nature, it is a form of public-private partnership (Institut for Public-Private Partnership, 2017).

Public enterprise is the most widespread form of local commercial public services provision. The concept of public enterprise was brought in Slovenian legal order in the nineties of the previous century, introduced by the Companies Act in 1988. The Act reintroduced market activities, allowed the creation of companies in the private, mixed and social property, and allowed the creation of all forms of commercial companies. The Act introduced a public enterprise as a separate legal structure with its own legal personality, which is set to be established as an enterprise in social ownership or as an enterprise in mixed ownership (Brezovnik, 2009, 186). Public enterprise is used for the provision of one or more services of increased volume or when economic public service is a monopoly. In both cases, services are required to be performed profitably (Pevcin \& Rakar, 2015, pp. 705-706). Public enterprise can be established as a Limited Liability Company or as a Public Limited Company. Public limited company is the appropriate form of a public enterprise when the enterprise has a larger number of founders and shareholders of private capital, because in such case more transparency and formalities in business is necessary. If the public enterprise has no private shareholders, then there is no special need to be organized as a public limited company. Even if there are more founders, then the most appropriate form of organization is limited liability company, which gives the shareholders a much greater autonomy in managing their interrelationships (Bratina, 2004, p. 7). 
$36^{\text {Th }}$ International Conference on Organizational Science Development: ResPonsible Organization (MARCh $22^{\mathrm{ND}}-24^{\mathrm{TH}}$, Portorož Slovenia) V. Petkovšek \& P. Pevcin: Institutional Effects of Public-Private Partnership Act on the Status of Municipal Public Enterprises in Slovenia

Reorganization of existing public enterprises in Slovenia

Slovenia experienced reorganization of the existing public enterprises, which had happened in the period 2007-2009 due to the adoption of the Public-Private Partnership Act (Official Gazette of RS, no. 127/06). The Law demanded reorganization of the existing public enterprises (to transform into a company or remain public enterprise) and awarding concessions to public enterprises which had transformed into companies.

\subsection{The legal status of public enterprises in Slovenia before reorganization}

Before the adoption of the Public-Private Partnership Act, the inclusion of the private sector in traditional public sphere of public services was allowed by the Public Utilities Act (ZGJS, Official Gazette of RS, no. 32/1993) for the provision of commercial public services used in the form of concessionary relationship and in the form of capital investment in the activities of private law; and by the Institutions Act, which has allowed awarding concessions for non-commercial public services provision (Institut for PublicPrivate Partnership, 2017).

Since the nineties until today there have been three concepts of public enterprises in the Slovenian legal system, based in particular on the system of property ownership. According to Public Utilities Act a public enterprise was a form of the commercial public services provision. Public enterprise did not have its own status, because this regime was directly relied on the regulation of commercial companies. A public enterprise could have, as a commercial company, also shared capital. The status of a public enterprise therefore did not differentiate from commercial companies, the significant difference was only in the management rights, where the state or local government as a founder of such enterprise had special founder's rights, independent of its capital structure. Under the Public Utilities Act a public enterprise can be established only for the provision of commercial public services or for the performance of activities that are carried out in a manner of public utilities (Brezovnik, 2009, p. 181; Trpin, 2007, p. 6).

Further on, in 2007 the The Transparency of Financial Relations and Maintenance of Separate Accounts for Different Activities Act (ZPFOLERD, Official Gazette of RS, no. $53 / 2007,65 / 2008$ ) changed the definition of a public enterprise into a broader definition. According to this Act a public enterprise is any enterprise over which the public authorities may perform a dominant influence. Therefore, a public enterprise is any organization with legal form of public institutions, public commercial institutions, public enterprises established under the Public Utilities Act and enterprises, in which public authorities have a dominant position (Brezovnik, 2009, p. 182: Trpin, 2007, pp. 6-7).

The position of private capital in the public enterprise in terms of its legal certainty was unsustainable, as stated by Brezovnik (2009, p. 187). The public enterprise was a commercial company on one side, whose shareholder may have been a person of private law, and on the other hand, it carried out activities in the public interest, which prices were regulated by the state or local governments. Brezovnik (2009, p. 189) also points 

the Status of Municipal Public Enterprises in Slovenia

out to the question of establishment of public enterprises. The formation of public enterprise is controversial in both cases, when a public enterprise is set up by the state or by the local community and also when it is set up by several founders (public-public partnership). The regulation is not clear which legal instrument forms a public enterprise. There are also shortcomings in the relationship between the founder of public enterprise and the public enterprise. In relation to public enterprise, the State or local community act as a regulator of public services implemented by the public sector on one hand, and on the other hand, as the enterprise's (co-)founder or the owner of the majority of capital share. Proceeding from that the state or the local community have a dual role (Brezovnik, 2009, p. 190).

\subsection{Reorganization of existing public enterprises in Slovenia in accordance with the Public-Private Partnership Act}

In 2006, Slovenia adopted the Public-Private Partnership Act that entered into force in March 2007. The Act had a strong influence on the legal status of public enterprises (especially Articles 141, 142 and 143), especially for further organisation and operation of the public enterprises providing public services. It has determined the rules of transformation of existing public enterprises, which shall mutatis mutandis apply also to public institutions and public commercial institutions (Brezovnik, 2010, p. 24). In the sence of public institutions' regulation, Tičar \& Zajc (2010, p. 211) highlight the importance of a repeal of Article 80 in the 1999 Public Finance Act by the Public-Private Partnership Act. The Article 80 of Public Finance Act specifically regulated the privatization of public institutions (also public commercial institutions and public enterprises), more specifically it had frozen all privatization initiatives since it did not allow the transfer of capital investments or establishment rights of the state or municipality in public institutions. Privatization was possible only if so provided by a specific law on the performance of a public service, but since 2002, no such laws had been adopted. This restriction was then removed with the implementation of the PublicPrivate Partnership Act in 2007.

The Act provides the definition of the legal status of public enterprises. The aim of the new regulation is to differentiate between genuine public enterprises that shall remain exclusively publicly owned to perform public service activities, and other public enterprises that shall be transformed into commercial companies. There are two options for the public enterprises in which there are private equity stakes. One option is that a public enterprise can be transformed into a commercial company in accordance with the Companies Act, and the other option is that the public enterprise status can be retained, provided that the private equity stakes are in a way nullified in the public enterprise, and that only the equity stakes owned by-the Republic of Slovenia or local communities remain (Kocbek, 2011, p. 86). Public enterprises where private investors holded shares had to be transformed into commercial companies and public enterprises that wanted to remain public enterprises had to transfer the private ownership to the State or local community. The decision had to be taken by the founder of the enterprise within three years from the adoption of the Act, which is by March 2010. Under the new regulation a 
$36^{\mathrm{TH}}$ International Conference on ORganizational Science Development: RESPONSIBLE ORGANIZATION (MARCH $22^{\mathrm{ND}}-24^{\mathrm{TH}}$, PORTOROŽ SLOVENIA) V. Petkovšek \& P. Pevcin: Institutional Effects of Public-Private Partnership Act on the Status of Municipal Public Enterprises in Slovenia

public enterprise may be an enterprise which is wholly owned by the state or local government (Hrovatin, 2010, p. 102; Brezovnik, 2010, p. 24; Trpin, 2007, p. 6).

The Act also regulates awarding concessions to public enterprises, which are transformed into a commercial company. First, the founder shall award concessions without public tender to the commercial companies that were created out of the public enterprises where provided persons of private law have no investments in such enterprises. This had to be done within one year, by March 2008. And the second, public enterprises transformed into commercial companies must obtain a concession in compliance with the legislation. The concession should be awarded within one year by the founder of the enterprise as a result of the bidding process on the public tender. In determining the duration of the concession the founder of a public enterprise have to take into account the nature of the public service and the extent of its implementation, current investment in the public service and the degree of their depreciation and any necessary new investments and other circumstances. When deciding on the duration of the concession the founder have to determine the minimum necessary duration of the concession in accordance with the Act. The founder had to do the bidding process on the public tender by March 2008 also in the case of those commercial companies providing commercial public services that had been already transformed on the basis of previous regulations (Hrovatin, 2010, p. 102; Brezovnik, 2010, p. 24; Trpin, 2007, p. 13).

Mužina (2007, p. 37-38) highlights the fact that the reorganization of existing public enterprises itself does not mean exemption from the Public Procurement Act (Official Gazette of RS, no. 128/2006), therefore even after an eventual reorganization the commercial company will have to fully operate in accordance with these rules. Procurement rules would no longer be mandatory only at the moment when local communities lose a managerial or financial control in commercial company, and if they would leave the entire business to market regulations. Further on, the reorganization also does not mean reducing supervision, because even after the reorganization all the conditions that the legal entity may be a subject of audit by the Slovenian Court of Audit, continue to be met. Similarly, also the decision-making power in the administrative procedure, has remained unchanged, as far as it is undertaken on the basis of public authorization.

\subsection{Evaluation of institutional changes of public enterprises under new legislation}

Public-Private Partnership Act (PPPA) has brought changes to institutional framework of public enterprises in Slovenia. Key changes are presented bellow in Table 1. Before reorganization, public enterprise had no own legal status, it was a part of legal regime of commercial public services and it could be founded in one of the forms of commercial companies. After the adoption of the PPPA, public enterprise has a clear definition of the legal status; it can either be transformed into a commercial company or retain public enterprise. Despite that, Brezovnik (2008) argues that the legal status of public enterprises is still disputed due to missing evidence on the final outcome or reorganization. The 
V. Petkovšek \& P. Pevcin: Institutional Effects of Public-Private Partnership Act on the Status of Municipal Public Enterprises in Slovenia

majority of public enterprises operate like commercial companies and on one hand behave like private law companies, while on the other hand have public law status.

\begin{tabular}{|l|l|l|}
\hline Public enterprise & Before PPPA & After PPPA \\
\hline Legal status & $\begin{array}{l}\text { No own status (Public } \\
\text { Utilities Act); part of } \\
\text { legal regime of } \\
\text { commercial } \\
\text { services }\end{array}$ & $\begin{array}{l}\text { Commercial company } \\
\text { (Companies Act) } \\
\text { Public enterprise }\end{array}$ \\
\hline Capital & $\begin{array}{l}\text { Possible shared capital } \\
\text { (public and private) }\end{array}$ & $\begin{array}{l}\text { Only public capital (State } \\
\text { or local government) }\end{array}$ \\
\hline Ownership & Majority public & 100\% public \\
\hline Founder & $\begin{array}{l}\text { The State, local } \\
\text { government, public- } \\
\text { private partnership }\end{array}$ & $\begin{array}{l}\text { The } \\
\text { government }\end{array}$ \\
\hline
\end{tabular}

Table 1: Institutional changes of public enterprises after the PPPA

Source: own source

After the adoption of PPPA, significant changes were done in the ownership structure of the public enterprise. Before, public enterprise should have a majority of public ownership, therefore also shared capital investments were possible. Under the new regime a only public ownership is required, meaning only public capital investments are possible, either from the State or local government. Referring to this, the founder of public enterprise under the new regime is only the State or local government.

Empirical evidence from communal utilities show that the majority retained their status as public enterprise, with $100 \%$ local community ownership. Their decision, not to change the public enterprise status, was mostly taken due to the reason of avoidance of public tendering for the award of the concession. At that time some enterprises with mixed ownership have not yet been transformed into public enterprises with only public ownership, despite the wish to do so. The reasons were, on one side, that some private investors did not want to give up their ownership rights and on the other hand, some public utilities did not have enough resources to overtake their shares. Empirical evidence also points out to the advantages of retaining status of a public enterprise, which are: quicker work (no need for public tender), better utilization of labour and capital, better organization of work, better cooperation between the local community and the enterprise (Hrovatin, 2010, p. 105).

Solely publicly owned enterprises avoid the competition from domestic and foreign private companies. Public ownership is not economically rational, as private investors in public enterprises intend to bring greater efficiency due to market competition. Private investors are also intended to require rational behavior in order to reduce costs. Mandatory tendering does not always guarantee greater economic efficiency. Preparation 
$36^{\text {Th }}$ International Conference on Organizational Science Development: RESPONSIBLE ORGANIZATION (MARCH $22^{\mathrm{ND}}-24^{\mathrm{TH}}$, PORTOROŽ SLOVENIA)

V. Petkovšek \& P. Pevcin: Institutional Effects of Public-Private Partnership Act on the Status of Municipal Public Enterprises in Slovenia

of tenders, closuring contracts, monitoring their execution require high transaction costs and further on also possible higher prices and lower quality, which at the end may not offset the potential benefits of lover costs in private provision of local services (Hrovatin, 2010, pp. 105-106).

\section{Conclusion}

In Slovenia, local commercial public services are most often provided by public enterprises, followed by concessions and (rarely) overhead plants. Slovenia faced the reorganization of existing public enterprises in the period 2007-2009 with the adoption of a Public-Private Partnership Act, which has influenced the legal status of public enterprises and brought significant changes in their ownership. The sole ownership of the public enterprises by the state or local government has increased public ownership and control in Slovenia. The Act has left the decision on the organizational structure of public enterprises to their founders.

Empirical evidence point to the fact that the majority of existing public enterprises retained their status as public enterprise, with $100 \%$ local community ownership (in the case of public utilities), mostly due to the reason of avoidance of public tendering for the award of the concession. However, public ownership is not always economically rational, especially because of the exemption of market competition.

As there are still some open questions present e.g. on the legal status of public enterprises, a research about the current state of public enterprises in Slovenia would be needed, which would more specifically give an insight to the organizational structure of public enterprises and after all an insight into the reorganization process. The results of such research could give evidence also about the final outcome of the reorganization, whether it was implemented in accordance with the law.

\section{Literature}

Bauby, P. \& Similie, M.M. (2010). The Governance of Basic Public Services Europe Chapter. GOLD III Report. United Cities and Local Governments. Paris: Reconstruire l'Action Publique. Bratina, B. (2004). Poslovni izidi gospodarskih javnih služb in tržnih dejavnosti v javnih podjetjih. Pravna praksa 2, 6-9.

Brezovnik, B. (2008). Izvajanje javnih služb in javno-zasebno partnerstvo. Maribor: Lex Localis. Brezovnik, B. (2009). Aktualna vprašanja pravne ureditve javnega podjetja v Sloveniji. Lex Localis - Revija za lokalno samoupravo, 7(2), pp. 177-195.

Brezovnik, B. (2010). Zakon o javno-zasebnem partnerstvu. Pristojnosti in naloge občine z uvodnimi pojasnili in komentarjem. Maribor: Lex Localis.

Da Cruz, N.F., Berg, S.V. \& Marques, R.C. (2013). Managing Public Utilities: Lessons from Florida. LEX Localis - Journal of Local Self Government, 11(2), pp. 101-118.

Dijkgraaf, E. \& Gradus, R. H. J. M. (2013). Cost advantage cooperations larger than private waste collectors. Applied Economics Letters, 20, 702-705. 
V. Petkovšek \& P. Pevcin: Institutional Effects of Public-Private Partnership Act on the Status of Municipal Public Enterprises in Slovenia

Grafenauer, B. (2009). Analiza organizacije izvajanja lokalnih gospodarskih javnih služb na primeru dveh slovenskih občin. Lex Localis - Revija za lokalno samoupravo, 7(2), pp. 209 219.

Hrovatin, N. (2010). Public-Private Partnerships in Slovenia: Reverse Financial Innovations Enhancing the Public Role. In Bailey et al. (eds.). Innovations in Financing Public Services. Hampshire: Palgrave Macmillan.

Institut for Public-Private Partnership. (2017). Available at www.pppforum.si

Kocbek, M. (2011). Retaining Public Enterprise Status Through Own Shares. Lex Localis - Revija za lokalno samoupravo, 9(1), pp. 85-101.

Mužina, A. (2007). Preoblikovanje javnih zavodov po zakonu o javno zasebnem partnerstvu možnosti in posledice. In Hočevar, F. (ed.). Javno-zasebno partnerstvo. 14. strokovno srečanje ekonomistov in poslovodnih delavcev v zdravstvu. Radenci, 17. in 18. maj 2007.

Pevcin, P. \& Rakar, I. (2015). Local Public Services in Slovenia - Lega, Organisation, Economic, and Financial Aspects, Croatian and Comparative Public Administration, 15(3), 697-714.

Rakar, A. et al. (2010). Zaščita in ohranjanje vrednosti gospodarske javne infrastrukture. Geodetski vestnik, 54(2), pp. 242-252.

Tičar, B. \& Zajc, K. (2010). Public-Private Partnerships in Slovenia: Recent Developments and Perspectives. Review of Central and East European Law, 35, pp. 191-215.

Trpin, G. (2007) Tržna dejavnost in preoblikovanje javnih zavodov, Lex Localis - revija za lokalno samoupravo, 5(3), pp. 1-13. 
$730 \quad 36^{\text {Th }}$ International Conference on ORganizational Science Development: Responsible Organization (MARCH $22^{\mathrm{ND}}-24^{\mathrm{TH}}$, PORTOROŽ SLOVENIA) 


\title{
Uporabnost energetske izkaznice pri določanju vrednosti nepremičnin
}

\author{
SILVO PLESNIK \& DRAGO VUK
}

\begin{abstract}
Povzetek Slovenija je z Energetskim zakonom (EZ-1) vpeljala obveznost izdelave in izdaje energetskih izkaznic (EI) za stavbe. Za stavbe v lasti javnega sektorja je bil rok obvezne pridobitve EI določen neodvisno od morebitnega kupoprodajnega posla. Za stavbe v lasti zasebnega sektorja pa je bila obveznost pridobitve EI določena sukcesivno, vezana na kupoprodajne posle. Kljub nekaterim problemom ob uvedbi EI je bilo doslej izdanih že skoraj 50.000 energetskih izkaznic obeh tipov - računskih in merjenih. Pri tem je bilo mogoče ugotoviti, da je kvaliteta EI močno vezana na kvaliteto pridobljenih vhodnih podatkov, ki so potrebni pri izdelavi EI. Po EZ-1 je za pravilnost podatkov odgovoren naročnik EI, izdelovalec pa jih je dolžan preveriti skladno z možnostmi. Prav preveritev ustreznosti predloženih podatkov je največja težava s katero se srečujejo izdelovalci EI. Zaradi tega se v javnosti že poraja dvom v kvaliteto izdanih EI in s tem zaupanje v EI kot javne listine.
\end{abstract}

Prispevek prikazuje težave pri izdelavi EI, ki jih zakonodajalec ni ali ni mogel predvideti, hkrati pa je iz prispevka mogoče ugotoviti, kako uporabna je EI pri postopkih določanja vrednosti nepremičnin.

KLJUČNE BESEDE: energetska izkaznica • vhodni podatki • ukrepi • ocenjevanje vrednosti

\footnotetext{
Naslov Avtorjev: Silvo Plesnik, direktor, Svetovanje Silvo Plesnik s.p., Kajuhova ulica 11, 3000 Celje, Slovenija, e-pošta: silvo.plesnik@ario.net; dr. Drago Vuk, redni profesor, Univerza v Mariboru, Fakulteta za organizacijske vede, Kidričeva cesta 55a, 4000 Kranj, Slovenija, e-pošta: drago.vuk@fov.uni-mb.si
} 
$36^{\text {TH }}$ InTERnAtional CONFERENCE ON ORganizational SCIENCE DeVelopment: Responsible Organization (MARCH $22^{\mathrm{ND}}-24^{\mathrm{TH}}$, PORTOROŽ SLOVENIA)

O. Arsenijević, M. Ferjan, I. Podbregar, P. Šprajc, D. Trivan \& Y.

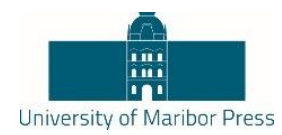

Ziegler

\title{
Applicability of Energy Performance Certificates when Valuating Real Estates
}

\author{
SILVO PLESNIK \& DRAGO VUK
}

\begin{abstract}
Slovenia has introduced the obligatory issue of Energy Performance Certificates (EPC) for buildings by implementing the Energy Act 1. The deadline for the mandatory obtaining of EPCs for buildings owned by public sector is independent of the potential sales transactions. However, the deadline for the mandatory obtaining of EPCs for buildings owned by the private sector was defined successively, dependent of the sales transactions. Despite some problems when introducing the EPC, almost 50,000 EPCs of both types have already been issued. As a matter of fact, we found out that the EPC quality is dependent on the input data quality necessary for the EPC elaboration. According to Energy Act 1 the person ordering the EPC is responsible for the data correctness; however, the elaborator is obliged to check the data as possible. Checking the data is actually the biggest trouble that EPC elaborators face with. Therefore, doubts concerning the EPC quality and consequently the trust in the EPC as a valid public document are arising publicly.
\end{abstract}

Our article is aimed at presenting problems when elaborating EPCs which were not and could not be foreseen by the legislator, as well as at stating how the EPCs are applicable in the procedures of real estate valuations.

KeYwORDS: Energy Performance Certificate (EPC) - input data • measures $\bullet$ valuation

CorresPondence AdDress: Silvo Plesnik, CEO, Consulting Silvo Plesnik s.p., Kajuhova ulica 11, 3000 Celje, Slovenia, e-mail: silvo.plesnik@ ario.net; Drago Vuk, Ph.D., Full Professor, University of Maribor, Faculty of Organizational Sciences, Kidričeva cesta 55a, 4000 Kranj, Slovenia, e-mail: drago.vuk@fov.uni-mb.si 
S. Plesnik \& D. Vuk: Uporabnost energetske izkaznice pri določanju vrednosti nepremičnin

\section{$1 \quad$ Uvod}

Ocenjevanje vrednosti nepremičnin je zahtevna in odgovorna naloga. Zaradi širšega družbenega pomena nepremičnin in zaradi njihovega vpliva na splošna in posebna družbeno socialna razmerja $\mathrm{v}$ družbi, je proces postopka ocenjevanja vrednosti premoženja reguliran z zakoni in drugimi pravnimi akti. Izvajanje tega procesa je skozi posamezne zakone zaupano specializiranim strokovnjakom z ustreznimi državnimi imenovanji oz. dovoljenji.

Vpliv objektov na okolje z vidika porabe energije na svoj način kaže Energetska izkaznica (EI). V Sloveniji je EI mogoče izdelovati po dveh postopkih. Rezultat obeh se kaže $\mathrm{v}$ predstavljenih energijskih kazalnikih in predlaganih generičnih ukrepih. Ti so povezani z izboljšanjem energetskih karakteristik objektov. Logičen je torej sklep, da je mogoče ugotoviti vzročno-posledično povezavo med energetsko učinkovitostjo objektov in njihovo tržno vrednostjo oziroma njihovo medsebojno odvisnost.

Ocenjevalci vrednosti nepremičnin se pri svojem delu srečujejo z uvedenimi in javno dostopnimi energetskimi izkaznicami. Problem pri EI je $\mathrm{v}$ tem, ali $\mathrm{v}$ celoti zaupati in izkoristiti informacije o energijskih lastnostih tistih stavb, ki jih obravnavajo zaradi primerljivosti z ocenjevanimi nepremičninami.

Nekaj že izdanih računskih energetskih izkaznic smo analizirali tako, da smo k vsaki izbrani računski energetski izkaznici izvedli še preračun na njeno drugo varianto merjeno energetsko izkaznico. Seveda je to bilo izvedeno ob predpostavki, da se uporabniki stavbe obnašajo povsem običajno oz. kot se uporabniki v Sloveniji obnašajo v povprečju. Pri pregledu stavb, za katere so bile izdelane EI obeh tipov, je bilo namreč ugotovljeno, da ni razloga, da zgornje predpostavke ne bi bilo mogoče uporabiti - stavbe so bile povprečno vzdrževane, izvedene iz povprečnih gradbenih materialov. V stavbah je bilo vzpostavljeno običajno bivalno ugodje. Prav tako je bila uporabljena predpostavka, da so bili za izdelane računske energetske izkaznice pridobljeni podatki o vgrajenih gradbenih materialih ter njihovi debelini korektni in so odražali dejansko stanje.

S primerjavo obeh smo skušali ugotovili, ali je mogoče tako dobljenim energijskim rezultatom potencialnih primerljivih stavb zaupati do takšne mere, da bi se bilo $\mathrm{v}$ postopkih ocenjevanja vrednosti nepremičnin mogoče $\mathrm{v}$ celoti opreti na njih oz. na njihove energijske kazalnike. Prav tako smo skušali ugotoviti, ali je mogoče $\mathrm{z}$ ustrezno mero previdnosti uporabiti informacije, ki jih podajajo generični podatki zabeleženi v EI.

Vpliv podatkov in informacij, ki jih vsebujejo izdelane energetske izkaznice, je mogoče prikazati $v$ cenitvenih postopkih ugotavljanja vrednosti nepremičnin. Ocenjevalci morajo skladno z metodologijo ocenjevanja opraviti tržne analize primerljivih nepremičnin. Pri ugotavljanju vrednosti po načinu tržnih primerjav mora tudi na primerljivih nepremičninah znati kritično pretehtati energijske lastnosti. Te so sicer razvidne iz vsebine energetske izkaznice. Takšne podatke je mogoče s pomočjo natančnejše analize 
$36^{\text {Th }}$ International Conference on Organizational Science Development: ResPonsible Organization (MARCH $22^{\mathrm{ND}}-24^{\mathrm{TH}}$, Portorož Slovenia)

S. Plesnik \& D. Vuk: Applicability of Energy Performance Certificates when Valuating Real Estates

obravnavati bistveno lažje in vsekakor bolj verodostojno. Natančnih informacij o primerljivih nepremičninah namreč nikakor ni mogoče pridobiti zgolj s podatki, ki so dosegljivi v okviru zbranih uradnih podatkov o kupoprodajnih vrednostih nepremičnin (npr. Portal Trgoskop - GURS - Internetni vir 1).

\section{$2 \quad$ Metode dela}

Pozornost je bila $\mathrm{v}$ začetku osredotočena na prikaz in določitev načina raziskovanja za empirično dokazovanje hipoteze, ki je bila postavljena tako: $\mathrm{z}$ uvedbo energetskih izkaznic je mogoče dosegati natančnejše vrednotenje nepremičnin z upoštevanjem energijskih kazalnikov in predlaganih generičnih ukrepov, ki so sestavni del energetske izkaznice.

Najprej je bilo predstavljeno obravnavano raziskovalno področje, ki je osnova razvoju metodologije raziskovanja. V nadaljevanju je bil predstavljen prikaz obeh metod izdelovanja energetskih izkaznic (EI): računske energetske izkaznice (rEI) in merjene energetske izkaznice (mEI), prikazane so bile metodologije cenitve objektov/nepremičnin, čemur je sledila sestava testa medsebojnega odnosa. Na koncu so bili predstavljeni postopki izvedbe testiranja in podan pristop analize podatkov.

Pričujoča metodologija raziskovalnega dela predstavljene naloge je bila utemeljena na dokazovanju hipoteze.

Raziskovanje je bilo osredotočeno na analizo rezultatov testa medsebojnega odnosa vpliva in neodvisnih spremenljivk, ki so se nanašale na iskanje obstoječega nivoja povezanosti, oziroma soodvisnosti obeh sicer neodvisnih spremenljivk: EI in tržne vrednosti nepremičnine. Ugotavljanje te povezave je predstavljalo temelj pri potrjevanju glavne hipoteze.

Kombinacija kvalitativnih podatkov, ki pripomorejo $\mathrm{k}$ temeljitemu elaboratu in kvantitativnih podatkov, ki omogočajo preliminarne teste odnosov, lahko spodbujajo tako vpogled v obstoječe stanje, kot vpogled v pričakovano stanje oziroma relacije (Yauch \& Steudel, 2003, str. 473).

Delo je bilo utemeljeno predvsem na metodah kot so: induktivna in deduktivna metoda za razlago teoretičnih izhodišč; metoda kompilacije za pomoč pri povzemanju tujih raziskovalnih in drugih rezultatov; metoda izdelanega testa medsebojnih vplivov, za obdelavo lastno pridobljenih podatkov; metoda njihove analize; metoda sinteze za združitev pridobljenih informacij v želeno celoto. Slednja je zajemala stanje na področju cenitve nepremičnin tako $\mathrm{z}$ vidika nepremičninskega kot tudi energetskega vidika, pregled uvajanja in vzpostavitev sistema izdelovanja in izdajanja energetskih izkaznic ter prikaz načinov vrednotenja nepremičnin v praksi.

V nalogi je bila uporabljena metoda IMRAD, ki je najprimernejše orodje za določitev strukture znanstvenoraziskovalnih del. Ime tega orodja je skovanka angleških besed: 
S. Plesnik \& D. Vuk: Uporabnost energetske izkaznice pri določanju vrednosti nepremičnin

- I Introduction;

- M Methods;

- R Resaults;

- A And

- D Discussion

I - uvod nas vpelje v tematiko, obravnavano v nalogi. $\mathrm{M}$ - metode, so metode, ki zajemajo teoretična izhodišča, predstavljajo obstoječe stanje in metodo raziskave. $\mathrm{R}$ - so rezultati izvedene analize in D - diskusija oz. zaključek.

\section{Določanje vrednosti nepremičnin}

\subsection{Splošno}

Ocenjevanje vrednosti nepremičnin oziroma vrednosti pravic na nepremičninah je v RS zaupano pretežno pooblaščenim ocenjevalcem in sodnim cenilcem (v nadaljevanju ocenjevalcem). Ocenjevalci morajo pri svojem delu dosledno upoštevati Slovenski poslovnofinančni standard 2 (SPS-2), ki določa vse tiste postopke in načela, ki jih je treba upoštevati pri ocenjevanju vrednosti. Prav tako je SPS-2 potrebno upoštevati pri delu na drugih področjih, povezanih z ocenjevanjem vrednosti, pri izdelavi analiz in oblikovanju mnenj ter pri načinu predstavitve analiz in mnenj naročniku in uporabnikom. Vsebina tega standarda je za razumevanje predloženega dela zelo pomembna, saj gre za uradni akt napisan koncizno in celovito. Slovenski poslovno finančni standard je $\mathrm{v}$ celoti usklajen z Mednarodnimi standardi ocenjevanja vrednosti (MSOV, 2013). SPS-2 je mogoče pogledati na svetovnih spletnih straneh. Zaradi tega ga na tem mestu ne povzemamo.

Iz citiranih standardov (MSOV, 2013) lahko vsaj posredno razberemo koristnost orodja kot je EI ocenjevalcu pri njegovemu delu. Kljub temu, da je EI predpisana z zakonom, lahko kot takšna predstavlja strokovno oporo ocenjevalcu. Metodologijo ocenjevanja vrednosti predpisujejo Mednarodni standardi ocenjevanja vrednosti (MSOV, 2013).

Ti standardi vodijo in usmerjajo ocenjevalca pri njegovem delu, s čimer se omejuje njegov subjektivni vpliv na končni rezultat. $\mathrm{S}$ tem je zagotovljena njegova največja mogoča objektivnost. Okvir standardov najlaže opišemo z nazivi glavnih poglavij standardov, ki jasno odražajo njihovo vsebino. V nadaljevanju so našteta vsebinska poglavja, ki predstavljajo vsebinski okvir MSOV:

- ocenjevanje vrednosti in presoja

- nepristranskost

- strokovna usposobljenost

- cena, strošek in vrednost

- $\operatorname{trg}$

- tržna dejavnost

- tržni udeleženci 
$36^{\mathrm{TH}}$ InTERnATIONAL CONFERENCE ON ORganizational SCIENCE DeVElopment: RESPONSIBLE ORGANIZATION (MARCH $22^{\mathrm{ND}}-24^{\mathrm{TH}}$, PORTOROŽ SLOVENIA)

S. Plesnik \& D. Vuk: Applicability of Energy Performance Certificates when

Valuating Real Estates

- specifični dejavniki podjetja

- združevanje

- podlaga vrednosti

- tržna vrednost

- stroški posla

- vrednost za naložbenika

- poštena vrednost

- posebna vrednost

- sinergijska vrednost

- predpostavke

- prisilna prodaja

- načini ocenjevanja vrednosti

- način tržnih primerjav

- na donosu zasnovan način

- nabavnovrednostni način

- metode uporabe

- vhodni podatki za ocenjevanje vrednosti

Okvir MSOV torej vključuje splošno sprejete zasnove, načela in opredelitve pojmov ocenjevanja vrednosti, na katerih temeljijo mednarodni standardi ocenjevanja vrednosti. Ta okvir naj bi upoštevali pri uporabi posameznih standardov in načinih uporabe ocenjevanja vrednosti.

\subsection{Načini ocenjevanja vrednosti}

Za določitev vrednosti, opredeljene z ustrezno podlago vrednosti (glej 25. do 28. odstavek okvira MSOV), je mogoče uporabiti enega ali več načinov ocenjevanja vrednosti. Trije načini, ki so opisani in opredeljeni v tem okviru, so glavni načini, ki se uporabljajo za ocenjevanje vrednosti. Vsi temeljijo na ekonomskih načelih ravnovesja cen, pričakovanih koristih ali substitucij. Uporaba več kot enega načina ali metode ocenjevanja vrednosti je zlasti priporočljiva, kadar ni na voljo dovolj stvarnih ali opazovanih vhodnih podatkov, ki bi omogočali, da bi že z eno samo metodo lahko prišli do zanesljive sklepne ugotovitve (MSOV, 2013).

\subsubsection{Način tržnih primerjav}

Način tržnih primerjav nakazuje vrednost s primerjavo ocenjevanega sredstva $\mathrm{z}$ enakimi ali podobnimi sredstvi, za katera so na voljo informacije o cenah (MSOV, 2013).

Pri tem načinu je $\mathrm{v}$ prvem koraku treba proučiti cene za posle enakih ali podobnih sredstev, ki so se v zadnjem času pojavili na trgu. Če je bilo v zadnjem času le malo takih poslov, bo morda treba ustrezno proučiti tudi cene enakih ali podobnih sredstev, ki so na borzi ali ponujeni $\mathrm{v}$ prodajo, vendar je treba jasno ugotoviti in kritično analizirati ustreznost teh informacij. Informacije o cenah iz drugih poslov bo morda treba prilagoditi 
S. Plesnik \& D. Vuk: Uporabnost energetske izkaznice pri določanju vrednosti nepremičnin

glede na vse razlike med pogoji dejanskega posla in podlago vrednosti ter vse predpostavke, ki jih je treba sprejeti pri ocenjevanju vrednosti. Obstajajo lahko tudi razlike $\mathrm{v}$ pravnih, ekonomskih ali fizičnih značilnostih sredstev iz drugih poslov in sredstva, katerega vrednost se ocenjuje (MSOV, 2013).

\subsubsection{Na donosu zasnovan način}

$\mathrm{Na}$ donosu zasnovan način nakazuje vrednost s pretvorbo prihodnjih denarnih tokov $\mathrm{v}$ sedanjo vrednost kapitala (MSOV, 2013).

Ta način upošteva donos, ki ga bo sredstvo ustvarilo v okviru svoje dobe koristnosti, in nakazuje njegovo vrednost $\mathrm{v}$ procesu kapitalizacije. Kapitalizacija pomeni pretvorbo donosa $\mathrm{v}$ sedanjo vrednost $\mathrm{z}$ uporabo ustrezne diskontne mere. Tok donosa lahko izhaja iz pogodbe ali pogodb, lahko pa tudi nima pogodbene podlage, npr. pričakovani dobiček, ustvarjen $\mathrm{z}$ uporabo ali posedovanjem sredstva.

Metode, ki spadajo v na donosu zasnovan način, so:

- metoda kapitalizacije donosa, pri čemer se za normalizirani donos tipičnega obdobja uporablja ena mera za vsa tveganja ali splošna mera kapitalizacije;

- metoda diskontiranega denarnega toka, pri čemer se diskontna mera uporablja za vrsto denarnih tokov za prihodnja obdobja, ki se diskontirajo na sedanjo vrednost;

- različni modeli ocenjevanja vrednosti opcij.

$\mathrm{Na}$ donosu zasnovan način se lahko uporablja za ocenjevanje obveznosti z upoštevanjem denarnih tokov, potrebnih za poravnavanje obveznosti do njihove dokončne poravnave (MSOV, 2013).

\subsubsection{Nabavnovrednostni način}

Nabavnovrednostni način nakazuje vrednost $\mathrm{z}$ uporabo ekonomskega načela, da kupec za sredstvo ne bo plačal več, kot je cena za pridobitev sredstva enake koristnosti z nakupom ali z gradnjo oziroma izdelavo (MSOV, 2013).

Ta način temelji na načelu substitucije, da cena, ki bi jo kupec na trgu plačal za sredstvo, katerega vrednost se ocenjuje, ne bi bila višja od stroškov za nakup ali gradnjo oziroma izdelavo enakovrednega sredstva, razen če gre za neprimeren čas, težave ali nevšečnosti, tveganje ali druge dejavnike. Pogosto je sredstvo, katerega vrednost se ocenjuje, zaradi starosti ali zastarelosti manj privlačno od drugega, ki bi ga bilo mogoče kupiti ali izdelati. $\mathrm{V}$ takem primeru utegnejo biti potrebne tudi prilagoditve na ceno drugega možnega sredstva glede na zahtevano podlago vrednosti (MSOV, 2013). 
$36^{\mathrm{TH}}$ International Conference on ORganizational Science Development: RESPONSIBLE ORGANIZATION (MARCH $22^{\mathrm{ND}}-24^{\mathrm{TH}}$, PORTOROŽ SLOVENIA)

S. Plesnik \& D. Vuk: Applicability of Energy Performance Certificates when

Valuating Real Estates

\subsection{Izvedba cenitve}

Izvedba cenitve neke konkretne nepremičnine, denimo stavbe z zemljiščem, je torej izredno kompleksno delo, ki mora po svoji strukturi natančno slediti predstavljeni metodologiji. Po svoji vsebini je prilagojena vsakokratnim razmeram konkretne nepremičnine v konkretnem fizičnem, poslovnem in tržnem okolju. Ni namen natančno opisovanje postopka cenitve, čeprav je za razumevanje naloge dobro poznavanje le-tega nujno. Natančna obravnava bi namreč preveč obremenila obseg naloge.

Vsekakor pa je za korektno ocenjevanje vrednosti nepremičnin potrebno pridobiti relevantne, kakovostne vhodne podatke, ki so $\mathrm{v}$ nadaljevanju lahko podlaga za samo izvedbo cenitve.

\subsubsection{Vhodni podatki za ocenjevanje vrednosti}

Vhodni podatki za ocenjevanje vrednosti se nanašajo na podatke in druge informacije, ki se uporabljajo pri posameznem načinu ocenjevanja vrednosti, opisanem v tem standardu. Ti vhodni podatki so lahko dejanski ali predpostavljeni (MSOV, 2013)

Primeri dejanskih vhodnih podatkov so:

- cene, ki jih dosegajo enaka ali podobna sredstva,

- dejanski denarni tokovi, ki jih ustvari sredstvo,

- dejanska cena enakih ali podobnih sredstev.

Primeri predpostavljenih vhodnih podatkov so:

- ocenjeni ali predvideni denarni tokovi,

- ocenjena cena hipotetičnega sredstva,

- zaznan odnos tržnih udeležencev do tveganja.

Običajno se bolj zanašamo na dejanske vhodne podatke; kadar pa so ti manj pomembni, npr. kadar so dokazi o dejanskih poslih starejšega datuma, kadar pretekli denarni tokovi niso značilni za prihodnje denarne tokove ali kadar je dejanska informacija o ceni že stara, bodo predpostavljeni vhodni podatki pomembnejši (MSOV, 2013).

Ocenjevanje vrednosti bo po pravilu izvedeno $\mathrm{z}$ večjo gotovostjo in natančnostjo, če je na razpolago več vhodnih podatkov. Pri raziskovanju, preverjanju in potrjevanju podatkov pa moramo biti še posebej pozorni, kadar so na razpolago le omejeni vhodni podatki (MSOV, 2013).

Kadar vhodni podatki vključujejo dokaze o izvedenem poslu, je treba pazljivo preveriti, ali so bili pogoji takega posla skladni z zahtevano podlago vrednosti (MSOV, 2013). 
S. Plesnik \& D. Vuk: Uporabnost energetske izkaznice pri določanju vrednosti nepremičnin

Iz vrste in vira vhodnih podatkov za ocenjevanje vrednosti bi se morala kazati podlaga vrednosti, ki pa je spet odvisna od namena ocenjevanja vrednosti. Za prikaz tržne vrednosti je na primer mogoče uporabiti različne načine in metode, pod pogojem, da se pri vseh uporabljajo podatki, ki izhajajo $\mathrm{s}$ trga. Za način tržnih primerjav bodo že po opredelitvi uporabljeni vhodni podatki, ki izhajajo s trga. Za prikaz tržne vrednosti naj bi se uporabljal na donosu zasnovan način z uporabo vhodnih podatkov in predpostavk, ki jih imajo tržni udeleženci. Za prikaz tržne vrednosti z uporabo nabavno vrednostnega načina bi bilo treba ceno sredstva enake koristnosti in ustrezno amortizacijo določiti z analizo stroškov in amortizacije na tržni podlagi. Katera metoda ali metode ocenjevanja vrednosti so najustreznejše in najprimernejše, bo odvisno od razpoložljivih podatkov in okoliščin trga za sredstvo, katerega vrednost se ocenjuje. Če ocena temelji na ustrezno analiziranih podatkih $\mathrm{s}$ trga, bi moral vsak uporabljeni način ali metoda zagotoviti oceno tržne vrednosti (MSOV, 2013).

Načini in metode ocenjevanja vrednosti so na splošno skupni mnogim vrstam ocenjevanja vrednosti. Vendarle pa ocenjevanje vrednosti različnih vrst sredstev vključuje tudi različne vire podatkov, ki morajo odražati razmere na trgu, na katerem se sredstva vrednotijo. Izhodiščna naložba v nepremičnino v lasti družbe bo na primer vrednotena glede na ustrezen trg nepremičnin, na katerem se s to nepremičnino trguje, medtem ko bo vrednost delnic te iste družbe ocenjena glede na trg, na katerem se s temi delnicami trguje (MSOV, 2013).

\section{Splošno o energetski izkaznici}

Metodologija za izračun energijskih lastnosti stavbe, kot strokovno verificirana metodologija, podaja način izračuna tistih nujnih parametrov, ki določajo lastnosti stavbe, ki so bistvene tudi za izračun njene vrednosti:

- letne potrebe toplote $(\mathrm{kWh} / \mathrm{m} 2 / \mathrm{a})$ za ogrevanje stavbe in letnega potrebnega hladu za hlajenje stavbe ter

- dovedene energije za delovanje stavbe $(\mathrm{kWh} / \mathrm{m} 2 / \mathrm{a})$ potrebne za sisteme, ki so $\mathrm{v}$ njej: za ogrevanje na tekoča in plinasta goriva ter biomaso; toplotne črpalke; toplotno podpostajo daljinskega ogrevanja; za pripravo tople vode; za hlajenje; za prezračevanje in za razsvetljavo.

Izračun vrednosti energijskih lastnosti stavb poteka nato po predpisanemu standardiziranemu računalniškemu programu - diagramu poteka (Slika 1).

Metodologija je utemeljena je na določbah veljavnih slovenskih standardov, ki so nastali s privzemom mednarodnih evropskih oziroma tujih nacionalnih standardov, predvsem standarda SIST EN ISO 13790.

V svojem dodatku tehnična smernica o učinkoviti rabi energije, TSG-1-004, določa navodilo za izračun:

- letne porabe energije za posamezne vrste energentov in 
$740 \quad 36^{\mathrm{TH}}$ InTERnational CONFERENCE ON ORganizational SCIENCE Development: RESPONSIBLE ORGANIZATION (MARCH $22^{\mathrm{ND}}-24^{\mathrm{TH}}$, PORTOROŽ SLOVENIA)

S. Plesnik \& D. Vuk: Applicability of Energy Performance Certificates when

Valuating Real Estates

- specifičnih emisij $\mathrm{CO} 2$ za posamezne vrste energentov.

V energetski izkaznici stavbe so obvezni sestavni del izračunane vrednosti vseh štirih energijskih lastnosti naštetih prej in seveda posebej grafično prikazane.

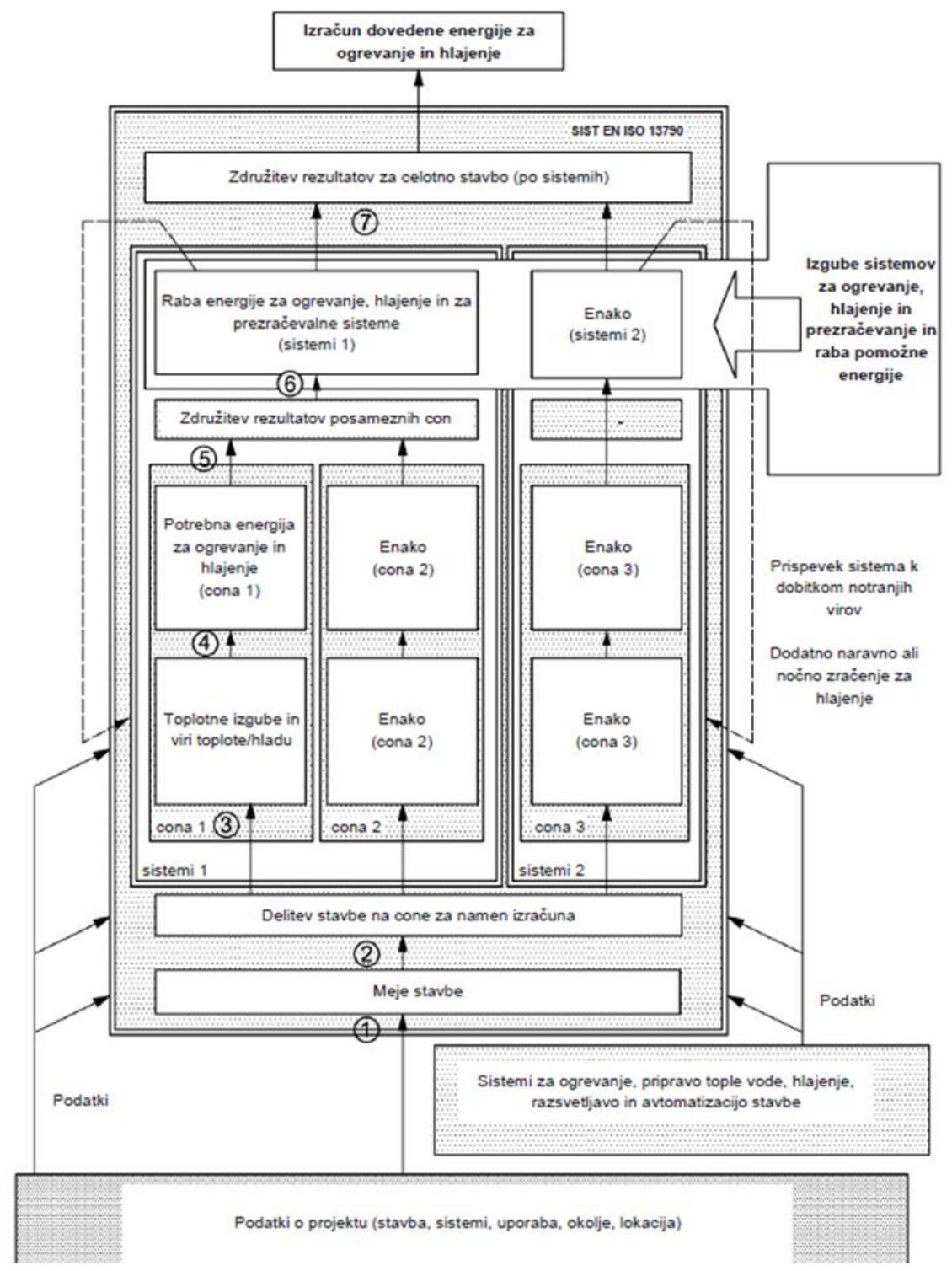

Slika 1: TSG -1-004 
S. Plesnik \& D. Vuk: Uporabnost energetske izkaznice pri določanju vrednosti nepremičnin

Energetska izkaznica (EI) je prvenstveno namenjena kupcu oz. najemniku stavbe (nepremičnine). Nujni in pomembni sestavni del EI je poleg kazalnikov tudi nabor ukrepov za izboljšanje energetske učinkovitosti stavbe.

V izkaznici predlagani ukrepi so generični, oblikovani na podlagi ogleda in študije stanja, rabe energije in izkušenj iz podobnih stavb. Seveda pa so v povezavi z vrednostjo nepremičnine navedeni ukrepi tisti, ki odpravljajo zastaranosti (fizične, funkcionalne in ekonomske). Na ta način vplivajo na zmanjšanje tekočih stroškov uporabe stavbe ter $\mathrm{s}$ tem povečujejo njeno tržno atraktivnost oziroma tržno vrednost.

Ob izvedbi ukrepov za izboljšanje ovoja stavbe, kot bistvenega elementa za zmanjšanje porabe energije $\mathrm{v}$ stavbi, ne gre samo za zmanjšanje porabe energije in zmanjšanje fizičnega zastaranja. Gre tudi za delno odpravo funkcionalnega zastaranja (večja debelina toplotne izolacije na fasadi, zamenjava oken, zamenjava ogrevalnih naprav...). Sinergija ukrepov za izboljšanje energijske učinkovitosti lahko omogoča doseganje višjih vrednosti nepremičnin kot znaša finančni vložek za izvedbo ukrepov URE, ob hkratnem boljšem bivalnem ugodju.

Iz ugotovljenega je mogoče zaključiti, da uvedba EI močno vpliva na vrednost nepremičnin tudi z vidika osnovnega poslanstva EI (s prikazom energijskih kazalnikov, izpustov TGP C02 ter opisom generičnih ukrepov za energijsko izboljšanje stavbe). Z upoštevanjem izdane EI ima potencialni kupec/najemnik možnost kvalitetnejše presoje glede izpeljave nepremičninskega posla na osnovi relevantnih informacij, podanih $\mathrm{s}$ strani neodvisnega strokovnjaka za izdelavo EI.

Energetske izkaznice stavb se izdelujejo že od leta 2013. Vse so zbrane v registru izdanih energetskih izkaznic. Doslej je bilo v RS izdanih med 45.000 in 50.000 EI.

EI izdelujejo neodvisni strokovnjaki z licenco na zahtevo stranke, ki nosi tudi stroške za njeno izdelavo in izdajo. EI se izdeluje po natančno predvidenem postopku. Poznamo dva postopka, oz. dve metodi izdelave: računsko metodo in metodo meritev. Tako tudi imenujemo pridobljena rezultata: RAČUNSKA ENERGETSKA IZKAZNICA (rEI) ali MERJENA ENERGETSKA IZKAZNICA (mEI) (Zakonski vir 1-4).

Osnova računske metode so evropski standardi:

- SIST EN ISO 13790 (izračun energije za ogrevanje in hlajenje)

- SIST EN ISO 6946 (izračun toplotne prehodnosti)

- SIST EN ISO 13370 (izgube skozi tla)

- SIST EN ISO 10211 in SIST EN ISO 14683 (toplotni mostovi)

- SIST EN ISO 13789 (transmisijske in ventilacijske izgube)

- Set SIST EN 15316

- in drugi. 
$36^{\text {Th }}$ International Conference on Organizational Science Development: RESPONSIBLE ORGANIZATION (MARCH $22^{\mathrm{ND}}-24^{\mathrm{TH}}$, PORTOROŽ SLOVENIA)

S. Plesnik \& D. Vuk: Applicability of Energy Performance Certificates when Valuating Real Estates

Po računski metodi izračunamo energijsko bilanco stavbe upoštevaje energijske tokove skozi ovoj stavbe, energijske tokove zaradi prezračevanja, energijo za ogrevanje tople vode, energijo za delovanje sistemov, energijo za razsvetljavo, kot tudi energijo, ki jo moramo stavbi zagotavljati in energijo pridobljeno iz notranjih virov, sončnega sevanja ter energijo vračljivih izgub. Energijsko bilanco ugotavljamo za določena časovna obdobja: urna, mesečna, ali letna. Vse na podlagi predpostavke, da mora notranja temperatura stavb znašati 20 stopinj $C$, zunanjo temperaturo pa določa mesečno povprečje temperature izbrane cone. Računske energetske izkaznice se izdajajo za obstoječe stanovanjske in novozgrajene stavbe.

Diagram (Slika 2) nazorno prikazuje energijske tokove za stanovanjske stavbe (Plesnik, Vuk, 2015).

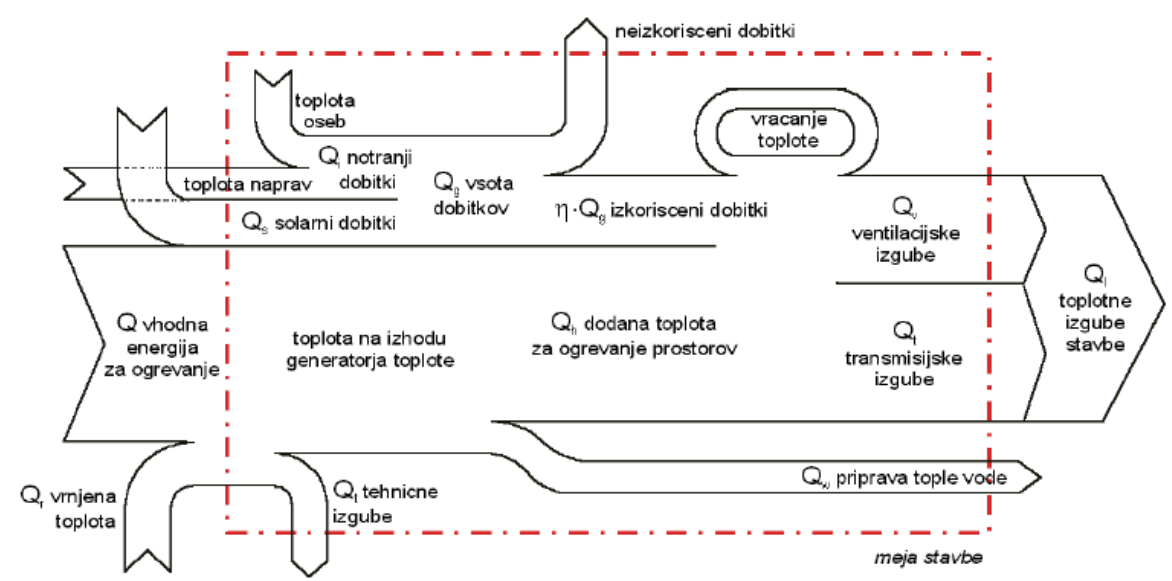

Vir: SIST EN 832:1999/AC:2002 (razveljavljen v letu 2008)

Slika 2: Toplotne karakteristike stavb-izračun potrebne energije za ogrevanjeStanovanjske stavbe

Podlaga za izdelavo merjene EI so izmerjene vrednosti porabljene energije v stavbi, ali njenem posameznem delu. Podatke o dobavljeni energiji posreduje naročnik v obliki računov ali drugih verodostojnih listin. Merjene energetske izkaznice se izdajajo za obstoječe nestanovanjske stavbe, ki pa so v uporabi vsaj eno leto. Če pa neodvisni strokovnjak presodi, da podatki o dejanski rabi energije niso zanesljivi, se tudi v tem primeru namesto mEI izdela rEI (Zakonski vir 1).

\section{$5 \quad$ Oblikovanje testa medsebojnih vplivov}

Namen raziskave je ugotoviti vpliv energetske izkaznice na določanje vrednosti nepremičnin. To smo ugotavljali na osnovi testa medsebojnega vpliva, pri katerem smo primerjali ugotovljene vrednost EI pridobljene tako po računski metodi (rEI) kot tudi po 
S. Plesnik \& D. Vuk: Uporabnost energetske izkaznice pri določanju vrednosti nepremičnin

merjeni metodi (mEI), seveda za iste stavbe. Pri tem so nam njegovi rezultati omogočili izdelavo zaključka, ki je delno potrdil postavljeno hipotezo. V nalogi se torej nismo ukvarjali s tezo, da spoznanja, ki sledijo iz izdelane EI, vplivajo bodisi na višjo ali nižjo vrednost lastninske/nepremičninske pravice na neki nepremičnini. Ukvarjali smo se predvsem s tem, koliko so ta spoznanja lahko $\mathrm{v}$ pomoč ocenjevalcu pri presoji verodostojnosti dobljenega rezultata cenitve. Skušali smo torej ugotoviti, kolikšen je vpliv spoznanj iz energetske izkaznice na natančnost postopka ocenjevanja vrednosti nepremičnine.

Sinergija ukrepov za izboljšanje energijske učinkovitosti lahko omogoča doseganje višjih vrednosti nepremičnin, kot znaša finančni vložek za izvedbo ukrepov učinkovite rabe energije, ob hkratnem boljšem bivalnem ugodju. Tej trditvi lahko tudi zaupamo, mogoče pa jo je seveda dokazati na konkretnih primerih.

Energetska izkaznica je dokument, ki ima status javne listine (Zakonski vir 8). Vsaka izdana energetska izkaznica je javnosti dostopna preko spletne strani Geodetske uprave Republike Slovenije (Internetni vir 7). Pooblaščeni ocenjevalec vrednosti vešč svojega dela (imenovan tudi veščak) mora $\mathrm{v}$ cenitvi obravnavano stavbo oceniti tudi $\mathrm{z}$ vidika njene energijske učinkovitosti. Le-to pa lahko razbere prav iz podatkov in informacij, zapisanih $\mathrm{v}$ EI. Ko stavbo oceni tudi z vidika njene energijske učinkovitosti, je to podatek, ki pomembno vpliva na oceno vrednosti stavbe. Seveda pa se v praksi praviloma izdelujejo EI le po eni od obeh možnih metodologij: izdelujejo se bodisi merjene energetske izkaznice mEI, bodisi računske energetske izkaznice rEI. Za proces cenitve vrednosti lastninske pravice na nepremičnini je potrebno izdelati EI po obeh znanih metodah. Takšna celovitost spoznanj, ki sledijo iz podatkov in informacij izdelanih EI po obeh metodologijah izdelovanja EI, ocenjevalcu ponudi odgovarjajoči vpogled v energijsko učinkovitost oz. neučinkovitost obravnavane stavbe.

Ta lastnost se odrazi v samem postopku ocenjevanja stavbe/izboljšave kot fizično, funkcionalno in/ali ekonomsko zastaranje.

Načini ocenjevanja vrednosti lastninske/nepremičninskih pravic na nepremičnini so opisani predhodno. Predstavljeni so trije načini izdelave ocene vrednosti: na donosu zasnovan način, nabavnovrednostni način in način tržnih primerjav. Pri slednjem primerjamo objekt cenitve z obstoječimi primerljivimi objekti, za katere poznamo njim lastne tržne parametre.

Pri tem je ocenjevalcu v veliko pomoč morebiti že izdelana in javno objavljena energetska izkaznica za konkretni primerljivi objekt. Pravilno razumevanje neposrednega ali pa posrednega vpliva EI na vrednotenje je v fazi izvajanja cenitev zelo pomembno.

Poleg mnogih drugih skupnih lastnosti morata imeti obravnavana in primerljiva nepremičnina kar najbolj podobne energetske lastnosti. To je mogoče povzeti na osnovi javno objavljenih energetskih izkaznic oziroma v njih predstavljenih rezultatih. 
$36^{\mathrm{TH}}$ International Conference on ORganizational Science Development: RESPONSIBLE ORGANIZATION (MARCH $22^{\mathrm{ND}}-24^{\mathrm{TH}}$, PORTOROŽ SLOVENIA)

S. Plesnik \& D. Vuk: Applicability of Energy Performance Certificates when Valuating Real Estates

Zaradi različnih metod izdelave EI njihovi rezultati predstavljajo določeno nevarnost za ocenjevalca. Prav zaradi prevelikega tveganja uporabe objavljenih rezultatov predlagamo, da se za primerljivi objekt izdela EI tudi po metodologiji, po kateri še ni bila izdelana. $\mathrm{S}$ tem je mogoče zmanjšati morebitne napake $\mathrm{v}$ dobljenih rezultatih, ki so predstavljeni $v$ EI. Na ta način se zmanjša tudi tveganje za izvedbo korektnega ocenjevanja vrednosti. Seveda je pri tem potrebno predpostaviti, da se uporabniki stavbe obnašajo povsem običajno, povprečno.

Za namen raziskave je bilo potrebno za stavbe, katerih energetske izkaznice so že bile izdelane na osnovi predpisane metode in objavljene, dodatno izdelati energetske izkaznice še po metodi, ki prvotno ni bila uporabljena. Katero metodo izdelave EI za konkretni objekt izbrati v praksi sicer ni prosta odločitev pooblaščenega izdelovalca, temveč je predmet predpisa. Oba tipa EI služita istemu namenu in bi kot takšni morali zagotavljati enaki, ali enostavno primerljivi informaciji.

Predstavitev izdelanih EI bi po obeh metodologijah v celotnem obsegu preveč obremenila predloženi tekst, zato je podan zgolj tabelarični prikaz dobljenih vrednosti, povzetih iz obeh tipov energetskih izkaznic po posameznih objektih.

Primerjava rezultatov energetske učinkovitosti primerjanih stavb med računskimi in merjenimi energetskimi izkaznicami 
36. MEDNARODNA KONFERENCA O RAZVOJU ORGANIZACIJSKIH ZNANOSTI: ODGOVORNA ORGANIZACIJA (22. - 24. MAREC 2017, PORTOROŽ, SLOVENIJA)

S. Plesnik \& D. Vuk: Uporabnost energetske izkaznice pri določanju vrednosti nepremičnin

\begin{tabular}{|c|c|c|c|c|c|c|c|c|}
\hline & Računska ener & getska izkaznica & & & Merjena energ & getska izkaznica & & \\
\hline \multirow[t]{2}{*}{\begin{tabular}{|l|} 
Lokacija stavbe \\
in \\
kondicionirana \\
povr šina
\end{tabular}} & \begin{tabular}{|l} 
Potrebna \\
toplota za \\
ogrevanje \\
kWh/m2/a
\end{tabular} & \begin{tabular}{|l|} 
Dovedena \\
energija za \\
delovanje \\
stavbe \\
$\mathrm{kWh} / \mathrm{m} 2 / \mathrm{a}$
\end{tabular} & $\begin{array}{l}\text { Primarna } \\
\text { energija } \\
\mathrm{kWh} / \mathrm{m} 2 / \mathrm{a}\end{array}$ & $\begin{array}{l}\text { Emisije } \mathrm{CO} 2 \\
\mathrm{~kg} / \mathrm{m} 2 / \mathrm{a}\end{array}$ & $\begin{array}{l}\text { Dovedena } \\
\text { energija } \\
\mathrm{kWh} / \mathrm{m} 2 / \mathrm{a}\end{array}$ & $\begin{array}{l}\text { Dovedena } \\
\text { električna } \\
\text { energija } \\
\text { kWh/m2/a }\end{array}$ & $\begin{array}{l}\text { Primarna } \\
\text { energija } \\
\mathrm{kWh} / \mathrm{m} 2 / \mathrm{a}\end{array}$ & $\begin{array}{l}\text { Emisije } \mathrm{CO} 2 \\
\mathrm{~kg} / \mathrm{m} 2 / \mathrm{a}\end{array}$ \\
\hline & 1 & 2 & 3 & 4 & 5 & 6 & 7 & 8 \\
\hline 1. $x=124330$ & 42,0 & 80,0 & 60,0 & 10,0 & 40,0 & 56,0 & 145,0 & 46,0 \\
\hline \multicolumn{9}{|l|}{$Y=518504$} \\
\hline \multicolumn{9}{|l|}{$987 \mathrm{~m} 2$} \\
\hline 2. $x=91291$ & 52,0 & 117,0 & 136,0 & 34,0 & 52,0 & 26,0 & 12,0 & 15,0 \\
\hline \multicolumn{9}{|l|}{$Y=474160$} \\
\hline \multicolumn{9}{|l|}{$221 \mathrm{~m} 2$} \\
\hline 3. $x=123618$ & 102,0 & 201,0 & 262,0 & 64,0 & 77,0 & 12,0 & 113,0 & 27,0 \\
\hline \multicolumn{9}{|l|}{$Y=530236$} \\
\hline \multicolumn{9}{|l|}{$208 \mathrm{~m} 2$} \\
\hline 4. $x=117649$ & 145,0 & 252,0 & 68,0 & 10,0 & 80,0 & 12,0 & 38,0 & 38,0 \\
\hline \multicolumn{9}{|l|}{$Y=549247$} \\
\hline \multicolumn{9}{|l|}{$120 \mathrm{~m} 2$} \\
\hline 5. $X=122685$ & 149,0 & 266,0 & 316,0 & 79,0 & 86,0 & 9,0 & 118,0 & 28,0 \\
\hline \multicolumn{9}{|l|}{$Y=519866$} \\
\hline $174 \mathrm{~m} 2$ & & & & & & & & \\
\hline
\end{tabular}

Tabela 1a (vir: Silvo Plesnik, 2016) 
$36^{\mathrm{TH}}$ International Conference on ORganizational Science Development: RESPONSIBLE ORGANIZATION (MARCH $22^{\mathrm{ND}}-24^{\mathrm{TH}}$, PORTOROŽ SLOVENIA)

S. Plesnik \& D. Vuk: Applicability of Energy Performance Certificates when Valuating Real Estates

\begin{tabular}{|c|c|c|c|c|c|c|c|c|}
\hline & Računska ener & getska izkaznic & & & Merjena ener $g$ & getska izkaznica & & \\
\hline \multirow[t]{2}{*}{$\begin{array}{l}\text { Lokacija stavbe } \\
\text { in } \\
\text { kondicionirana } \\
\text { površina }\end{array}$} & $\begin{array}{l}\text { Potrebna } \\
\text { toplota za } \\
\text { ogrevanje } \\
\text { kWh/m2/a }\end{array}$ & \begin{tabular}{|l|} 
Dovedena \\
energija za \\
delovanje \\
stavbe \\
kWh/m $2 / a$
\end{tabular} & $\begin{array}{l}\text { Primarna } \\
\text { energija } \\
\text { kwh/m2/a }\end{array}$ & $\begin{array}{l}\text { Emisije } \mathrm{CO} 2 \\
\mathrm{~kg} / \mathrm{m} 2 / \mathrm{a}\end{array}$ & $\begin{array}{l}\text { Dovedena } \\
\text { energija } \\
\text { kWh/m2/a }\end{array}$ & $\begin{array}{l}\text { Dovedena } \\
\text { električna } \\
\text { energija } \\
\text { kWh/m2/a }\end{array}$ & $\begin{array}{l}\text { Primarna } \\
\text { energija } \\
\text { kwh/m2/a }\end{array}$ & $\begin{array}{l}\text { Emisije } \mathrm{CO} 2 \\
\mathrm{~kg} / \mathrm{m} 2 / \mathrm{a}\end{array}$ \\
\hline & 1 & 2 & 3 & 4 & 5 & 6 & 7 & 8 \\
\hline 6. $x=122835$ & 27,0 & 60,0 & 99,0 & 24,0 & 390,0 & 88,0 & 609,0 & 175,0 \\
\hline \multicolumn{9}{|l|}{$Y=450059$} \\
\hline \multicolumn{9}{|l|}{$48 \mathrm{~m} 2$} \\
\hline 7. $x=122660$ & 43,0 & 83,0 & 106,0 & 28,0 & 205,0 & 61,0 & 358,0 & 100,0 \\
\hline \multicolumn{9}{|l|}{$Y=520392$} \\
\hline \multicolumn{9}{|l|}{$4.164 \mathrm{~m} 2$} \\
\hline 8. $x=130541$ & 32,0 & 70,0 & 74,0 & 17,0 & 125,0 & 42,0 & 117,0 & 27,0 \\
\hline \multicolumn{9}{|l|}{$Y=536620$} \\
\hline \multicolumn{9}{|l|}{$156 \mathrm{~m} 2$} \\
\hline 9. $x=111674$ & 59,0 & 117,0 & 138,0 & 34,0 & 86,0 & 34,0 & 96,0 & 20,0 \\
\hline \multicolumn{9}{|l|}{$Y=518925$} \\
\hline \multicolumn{9}{|l|}{$232 \mathrm{~m} 2$} \\
\hline 10. $x=123658$ & 135,0 & 276,0 & 257,0 & 65,0 & 132,0 & 33,0 & 98,0 & 21,0 \\
\hline \multicolumn{9}{|l|}{$Y=520405$} \\
\hline $301 \mathrm{~m} 2$ & & & & & & & & \\
\hline
\end{tabular}

Tabela 1 b (vir: Silvo Plesnik, 2016)

$\mathrm{V}$ tabelah 1a in $1 \mathrm{~b}$ so prikazane izračunane vrednosti štirih tipičnih energijskih vrednosti dobljenih iz rEI in mEI za deset obravnavanih stavb. Že bežen pogled na vrednosti, predstavljene $\mathrm{v}$ tabelah $1 \mathrm{a}$ in $1 \mathrm{~b}$, pokaže na velika razhajanja $\mathrm{v}$ vsaj delno primerljivih vrednostih energijskih lastnosti stavbe. Seveda je, poznavajoč razlike v pristopih izdelave EI, moč razumeti od kod tako veliko razlikovanje dobljenih vrednosti. Ni pa mogoč enostaven odgovor na vprašanje, katera od obeh EI je s svojimi rezultati vplivnejša na rezultat ugotavljanja oziroma izvajanja ocenjevanja vrednosti lastninske pravice na stavbi/nepremičnini.

Dobljeni rezultati oziroma vrednosti so prikazane v stolpcih 2 ter 5 in 6 iz tabel $1 \mathrm{a}$ in $1 \mathrm{~b}$. 
36. MEDNARODNA KONFERENCA O RAZVOJU ORGANIZACIJSKIH ZNANOSTI: ODGOVORNA ORGANIZACIJA (22. - 24. MAREC 2017, PORTOROŽ, SLOVENIJA)

S. Plesnik \& D. Vuk: Uporabnost energetske izkaznice pri določanju vrednosti nepremičnin

\begin{tabular}{|l|l|c|l|c|c|}
\hline & Stolpec 2 & Stolpca 5 in 6 & Razlika & \multicolumn{2}{|c|}{ Razlika (absolutno) } \\
\hline & \multicolumn{1}{|c|}{1} & 2 & $2-1$ & abs (2-1) & \\
\hline S1: & 80 & $40+56=96$ & $96-80=16$ & 16 & $\mathrm{kWh} / \mathrm{m} 2 / \mathrm{a}$ \\
\hline S2: & 117 & $52+26=78$ & $78-117=-39$ & 39 & $\mathrm{kWh} / \mathrm{m} 2 / \mathrm{a}$ \\
\hline S3: & 201 & $77+12=89$ & $89-201=-112$ & 112 & $\mathrm{kWh} / \mathrm{m} 2 / \mathrm{a}$ \\
\hline S4: & 252 & $80+12=92$ & $92-252=-160$ & 160 & $\mathrm{kWh} / \mathrm{m} 2 / \mathrm{a}$ \\
\hline S5: & 266 & $86+9=95$ & $95-266=-171$ & 171 & $\mathrm{kWh} / \mathrm{m} 2 / \mathrm{a}$ \\
\hline S6: & 60 & $390+88=478$ & $478-60=418$ & 418 & $\mathrm{kWh} / \mathrm{m} 2 / \mathrm{a}$ \\
\hline S7: & 83 & $205+61=266$ & $266-83=186$ & 186 & $\mathrm{kWh} / \mathrm{m} 2 / \mathrm{a}$ \\
\hline S8: & 70 & $125+42=167$ & $167-70=97$ & 97 & $\mathrm{kWh} / \mathrm{m} 2 / \mathrm{a}$ \\
\hline S9: & 117 & $86+34=120$ & $120-117=3$ & 3 & $\mathrm{kWh} / \mathrm{m} 2 / \mathrm{a}$ \\
\hline S10: & 276 & $132+33=165$ & $165-276=-111$ & 111 & $\mathrm{kWh} / \mathrm{m} 2 / \mathrm{a}$ \\
\hline
\end{tabular}

Tabela 2 (vir: Silvo Plesnik, 2016)

Podobno neprimerljive so vrednosti primarne energije in emisij CO2. Tudi pri teh vrednostih ni moč ugotoviti kakršnekoli medsebojne soodvisnosti. To je pa vsaj za nestrokovnjake povsem nerazumljivo.

Dejstvo, da ni neke vidne soodvisnosti med mEI in rEI, ki bi se kazala kot neko stalno razmerje, je moteče tako za izdelovalce izkaznic, kot za nekatere njihove naročnike. Ti želijo zaupanja vredno informacijo, podobno kot je prikazan energijski razred z nalepko na gospodinjskih aparatih oz. v zadnjem času tudi pri prodaji avtomobilov. EI so za naprave, ki za svoje delovanje porabljajo energijo, že precej uveljavljene. V nadaljevanju bodo podani nekateri odgovori na vprašanje o vzrokih za ugotovljeno neodvisnost med $\mathrm{rEI}$ in $\mathrm{mEI}$ na $\mathrm{v}$ tabeli 2 predstavljenih primerih.

Najenostavneje je, da neskladje pripišemo površni ali netočni rabi metodologije.

Če izključimo metodološke nepravilnosti, ki so mogoč razlog za tolikšne razlike in ki izvirajo iz uporabljenih matematičnih in fizikalnih zakonitosti, uporabljenih za izvedene računske operacije, ki so podlaga za izdelavo merjenih ali računskih energetskih izkaznic in, če izključimo tudi sicer mogoče povsem trivialne računske napake med samo izdelavo EI, lahko pomislimo tudi na druge napake, ki se lahko pojavijo v procesu izdelave EI. Če prve omenjene mogoče napake, s katerimi je lahko obremenjen izračun EI, imenujemo napake objektivne narave (sistematične napake), lahko napake drugega tipa imenujemo napake subjektivne narave (naključne napake). Te napake so vezane na pomanjkljive, neverodostojne vhodne podatke, ki jih sicer po zakonodaji posreduje naročnik EI. Izdelovalec jih mora privzeti zgolj $\mathrm{s}$ trezno presojo in vsaj minimalnim preverjanjem pravilnosti. Lahko gre tudi za napake, za katere bi lahko trdili, da izvirajo iz pomanjkljivega znanja ali nedoslednosti izdelovalca EI. Izdelovalci EI so sicer 
$36^{\text {Th }}$ International Conference on Organizational Science Development: RESPONSIBLE ORGANIZATION (MARCH $22^{\mathrm{ND}}-24^{\mathrm{TH}}$, PORTOROŽ SLOVENIA)

S. Plesnik \& D. Vuk: Applicability of Energy Performance Certificates when Valuating Real Estates

strokovnjaki bodisi gradbene, bodisi strojne ali elektrotehniške stroke, posebej došolani za izdelavo EI.

Kljub temu, da so pridobili licenco za izdelavo EI, niso enako usposobljeni za vsa tehniška področja, ki skupaj predstavljajo interdisciplinarno in multidisciplinarno tematiko, ki jo tvori objekt kot energetski porabnik. Njihovo razumevanje posameznih specifičnih energijskih posebnosti stavbe je različno, zato je utemeljeno sklepati, da včasih tudi zmotno uporabljajo metodološke principe povezane z izdelavo EI.

Mogoče so tudi napake, ki izvirajo iz nekritične uporabe komercialnih računalniških programov, ki jih uporabljajo izdelovalci energetskih izkaznic.

Za razumevanje $\mathrm{v}$ Tabeli 2 dobljenih rezultatov smo se osredotočili na obravnavo mogočih konkretnih napak pri izdelavi EI, imenovanih napake subjektivne narave. Za obravnavo napak objektivne narave niti ne razpolagamo $\mathrm{z}$ dovolj ustreznim multidisciplinarnim teoretičnim znanjem, pa tudi sicer bi taka obravnava močno presegla cilje tega dela.

Nepravilna ali nenatančna uporaba računalniških programov, ki jih za izdelavo EI uporabljajo izdelovalci, je lahko eden od vzrokov za napake dobljenih in objavljenih rezultatov. Izdelovalci za izdelavo računske EI uporabljajo prilagojene komercialne računalniške programe različnih podjetij: Ursa, KI/TrimoExpert in ArchMAID. Le-ti so kot opcija ponujeni izdelovalcem pri vnosu podatkov v fazi izdelovanja rEI preko državne mreže pri Ministrstvu za infrastrukturo, področje energetike. Njihova uporaba zahteva obilo praktičnih izkušenj in veliko predhodno pridobljenega znanja. Vsi našteti programi zahtevajo natančne vhodne podatke, ki jih je potrebno pravilno vnesti.

Izdelovalci EI absolvirajo ustrezna usposabljanja in opravijo ustrezni preizkus znanja. Pri tem izobraževanje za uporabo računalniškega programa ni zahtevano, tudi se ne izvaja. Računalniški programi so uporabniku prijazno naravnani, vendar pri vnosu podatkov ponujajo velik izbor različnih možnosti. Pri uporabi pa je potrebno iskati kompromisne možnosti med podatki iz nabora in med resničnimi podatki, ki so lastni obravnavani stavbi.

Razpoložljivost in pravilnost vhodnih podatkov sta nalogi naročnika. Toda kako od praviloma neveščega naročnika pričakovati natančne podatke, denimo že o debelini posameznih plasti ovoja v vsakem prerezu, kot o dejansko uporabljenih materialih. Vešč izdelovalec je lahko torej tudi napačno informiran, manj vešč izdelovalec pa lahko celo nekritično sprejema in povzema posredovane informacije. Posebej problematični so naročniki, ki niso bili investitorji zgradbe; so lahko drugi, ali tretji, ali..., lastniki. Zajem podatkov o zgradbi takšnega lastnika je zelo težko opravilo tudi za veščega izdelovalca EI. Prav tako so pogosto vprašljivi podatki o porabljenih energentih za delovanje stavbe, kot tudi za njeno ogrevanje oz. hlajenje. Nemalokrat so ti podatki s strani naročnika zgolj ocenjen približek, saj so večinoma zelo nedosledni pri vodenju energetske bilance lastne stavbe ali najetega stanovanja. 
S. Plesnik \& D. Vuk: Uporabnost energetske izkaznice pri določanju vrednosti nepremičnin

Napake, s katerimi so obremenjene EI, so bolj naključne kot pa sistemske narave. Obilje mnogih mogočih napak v procesu izdelave EI nas navaja tudi k dvomom o popolni verodostojnosti teh javnih dokumentov.

Ta ugotovitev pa nas napoti k izdelavi ustreznih kontrolnih mehanizmov, ki bi zagotovili popolnega zaupanja vredno javno listino, imenovano EI. Ti pa za enkrat še ne obstajajo oz. niso vpeljani.

Energetske izkaznice lahko s svojimi informacijami bistveno prispevajo h kvaliteti ocenjevalčevega dela oziroma prispevajo $\mathrm{k}$ večji kakovosti in objektivnosti opravljene cenitve. V EI so zbrani podatki in informacije, ki so ocenjevalcu sicer večkrat nedostopni, nedosegljivi ali celo predmet najrazličnejših manipulacij.

S pomočjo podatkov o energetskih lastnostih primerljivih stavb, tako kvalitativnih (generični ukrepi) kot kvantitativnih (energijski kazalniki), je mogoče izvesti prilagajanja na ocenjevano nepremičnino. Tega tipa prilagoditev doslej ni bilo mogoče zaznati $\mathrm{v}$ izdelanih cenitvenih poročilih ocenjevalcev vrednosti nepremičnin. Vzrok za to je mogoče iskati tudi v ugotovljeni (ne)uporabnosti podatkov, ki jih nudi EI.

Prilagoditve v povezavi z energijskimi lastnostmi obravnavane in primerljivih stavb je mogoče izvesti na dva načina. Pri tem ne sme biti zanemarjeno dejstvo, da ima velik vpliv na končno vrednost nepremičnine tudi bivalno ugodje. Slednje je skozi postopek izvedbe prilagoditev mogoče opazovati kot kvalitativne prilagoditve (slabše, podobno, boljše) in sicer v mejah vpliva, ki ga mora določiti ocenjevalec (po lastnih izkušnjah do +/- 20\%).

Kvantitativne prilagoditve je $\mathrm{v}$ povezavi $\mathrm{z}$ energetsko učinkovitostjo mogoče izvesti s pomočjo kvantitativnih podatkov o primerljivih nepremičninah - energetski kazalniki. Pri tem načinu izvajanja prilagoditve je, kot že ugotovljeno, potrebno biti zelo previden. Gre namreč za manj zanesljive podatke, ki jih je potrebno uporabljati zelo kritično. Iz previdnosti zaradi prevelikega tveganja na določitev vrednosti nepremičnine je ta del prilagoditev smiselno omejiti na vsega $5-10 \%$ (lastne izkušnje). Kvalitativno prilagoditev je mogoče izvesti na način sorazmernosti s pomočjo razlike $\mathrm{v}$ vrednosti energetskih kazalnikov med obravnavano in primerljivimi nepremičninami.

\section{Zaključek in predlog}

\subsection{Doseganje cilja in potrditev hipoteze}

$Z$ uvedbo energetskih izkaznic je mogoče dosegati natančnejše vrednotenje nepremičnin $\mathrm{z}$ upoštevanjem energijskih kazalnikov in predlaganih generičnih ukrepov, ki so sestavni del energetske izkaznice.

To je bila osnovna hipoteza magistrskega dela. 
$36^{\mathrm{TH}}$ International Conference on ORganizational Science Development: ResPonsible Organization (MARCH $22^{\mathrm{ND}}-24^{\mathrm{TH}}$, PortoroŽ Slovenia)

S. Plesnik \& D. Vuk: Applicability of Energy Performance Certificates when Valuating Real Estates

Iz raziskave pa je mogoče ugotoviti, da postavljena hipoteza ni v celoti potrjena. V delu, ki se nanaša na generične ukrepe, je energetska izkaznica $\mathrm{v}$ procesu vrednotenja nepremičnin lahko dober pripomoček. Nikakor pa tega ne moremo ugotoviti za energijske kazalnike.

Da bi hipotezo dokazali, smo s pomočjo predložene raziskave detajlno opisali vlogo, namen in pomen energetskih izkaznic, opisali postopek njihove izdelave, prikazali izdelani energetski izkaznici: računsko energetsko izkaznico rEI in merjeno energetsko izkaznico mEI. Iz obeh so razvidne energijske lastnosti stavbe, kot tudi spisek generičnih lastnosti. V nasprotju s pričakovanji smo ugotovili, da ni nikakršne neposredne primerljivosti oziroma soodvisnosti med obema vrstama izkaznic. Seveda smo uporabili predpostavko, da se uporabniki v stavbi obnašajo običajno/povprečno.

Prav tako smo $\mathrm{v}$ teh poglavjih detajlno prikazali postopek cenitve vrednosti nepremičninskih pravic na stavbah oz. nepremičninah, pokazali zahtevnost tega dela in potrebo po verodostojnih vhodnih podatkih. Prav te pa smo, v določenem delu, našli v že izdelanih in izdanih energetskih izkaznicah. Kvaliteta verodostojnih podatkov, ki jih vsebuje EI, predvsem pa njihova razpoložljivost, skozi status javne listine, sta izjemen prispevek k objektivnemu ocenjevanju vrednosti stavbe.

Prav tako lahko zatrdimo, da je s predloženo raziskavo dokazano, da smo predpostavljeni cilj raziskave dosegli, saj smo spoznali vpliv energetskih izkaznic na vrednotenje nepremičnin v Sloveniji.

S pomočjo raziskave smo ugotovili, da je z uvedbo energetskih izkaznic mogoče dosegati natančnejše vrednotenje nepremičnin z upoštevanjem predlaganih generičnih ukrepov, ki so sestavni del energetske izkaznice, ne pa tudi z upoštevanjem energijskih kazalnikov.

\section{Predlog}

Za doseganje verodostojnejših podatkov o energijskih kazalnikih bi za izdelavo energetskih izkaznic bilo potrebno izdelati in vpeljati enoten računalniški program ter izvesti dodatna usposabljanja izdelovalcev EI. S tem bi lahko odpravili tiste napake, ki nastajajo kot napake slučajne narave, odvisne od posameznih izdelovalcev in se odrazijo v nepravilno izračunanih energetskih kazalnikih.

Prav tako predlagamo, da se za potrebe ocenjevanja vrednosti za primerljivi objekt izdela EI tudi po metodologiji, po kateri še ni bila izdelana. S tem je mogoče zmanjšati morebitne napake $\mathrm{v}$ dobljenih rezultatih, ki so predstavljeni v EI.

Na ta način je mogoče zmanjšati tveganje za izvedbo korektnega ocenjevanja vrednosti. 
S. Plesnik \& D. Vuk: Uporabnost energetske izkaznice pri določanju vrednosti nepremičnin

\subsection{Zaključna razprava}

Ugotovljeno je bilo, da so energetske izkaznice lahko pripomoček pri ocenjevanju vrednosti lastninske pravice na stavbi le $\mathrm{v}$ delu, ki se nanaša na predstavitev generičnih ukrepov. Prav tako je bilo ugotovljeno, da energetske izkaznice zaradi neverodostojnih energetskih kazalnikov niso vsega zaupanja vredne javne listine. Glede na poznavanje materije je mogoče ugotoviti, da s seboj nosijo tako subjektivne kot morda celo tudi objektivne napake. Pri tem je mogoče ugotoviti, da gre med obema tipoma EI za večje razlike, ki so odvisne od več dejavnikov. Med njimi je zelo pomemben način uporabe stavbe s strani uporabnikov. Da ne bi prihajalo do večjih odstopanj med obema načinoma izdelave EI, bo potrebno razmisliti o spremembi zakonodaje v smislu hkratne izdelave EI in uteževanja - ponderiranja obeh postopkov izdelovanja EI. Na ta način bo mogoče zagotoviti večje zaupanje v EI.

Kot pripomoček pri cenitvi je energetsko izkaznico, kljub temu, da z njo lahko razpolagamo, potrebno obravnavati previdno in z uporabo kontrolnih mehanizmov, če so le-ti na voljo. Brezpogojno zaupanje podatkom in informacijam, ki jih nudi elaborat energetske izkaznice, je torej napačno. Še posebej je to lahko tvegano, ko primerjamo sestavine primerljivih stavb in obravnavano stavbo celo napačno ocenimo.

Iz raziskave je mogoče podati ugotovitev, da je pri uporabi dobljenih rezultatov izračunov energijskih kazalnikov za potrebe ocenjevanja vrednosti potrebno biti zelo pazljiv in kritičen, saj gre za rezultate, ki so posledica vhodnih podatkov in mnogih predpostavk. Prav zaradi tega je potrebno ugotoviti, da v začetku naloge postavljena hipoteza ne more biti potrjena $\mathrm{v}$ delu, ki se nanaša na natančnejše vrednotenje nepremičnin $\mathrm{z}$ upoštevanjem energijskih kazalnikov.

Glede uporabe podatkov - predlogov generičnih ukrepov, zapisanih v energetskih izkaznicah, pa je mogoče zaključiti, da so za natančnejše vrednotenje nepremičnin zelo pomembni, saj je z njihovo pomočjo mogoče izvajati natančnejše prilagoditve sestavin primerljivih nepremičnin. Hipoteza je v tem delu torej potrjena.

\section{Literatura in viri}

\section{Strokovna literatura:}

IVSC - International Valuation Standards Council (2013). Mednarodni standardi ocenjevanja vrednosti (MSOV, 2013), Slovenski inštitut za revizijo, Ljubljana.

Yauch, C.A., \& Steudel, H.J. (2003). Complementary use of qualitative and quantitative cultural assessment methods, Sage publications, New York.

Plesnik, S., Vuk, D., (2015). Povezava med učinkovito rabo energije in vrednostjo nepremičnin, 34. Mednarodna konferenca o razvoju organizacijskih znanosti - Internacionalizacija in sodelovanje, Portorož.

Plesnik, S., (2016). Vpliv energetske izkaznice na vrednotenje nepremičnin, Magistrsko delo. Kranj. 
S. Plesnik \& D. Vuk: Applicability of Energy Performance Certificates when

Valuating Real Estates

\section{Tehnične smernice in standardi:}

Toplotne karakteristike stavb - Izračun potrebne energije za ogrevanje - Stanovanjske stavbe, Slovenski inštitut za standardizacijo SIST EN 832:1999/AC: 2002 (standard SIST EN 832 razveljavljen v letu 2008)

Tehnična smernica TSG-1-004: 2010

\section{Viri iz Uradnega lista Republike Slovenije:}

Zakonski vir 1: Pravilnik o metodologiji izdelave in izdaji energetskih izkaznic stavb, Uradni list RS št. 92/2014 (19.12.2014).

Zakonski vir 2: Pravilnik o spremembah in dopolnitvah Pravilnika o metodologiji izdelave in izdaji energetskih izkaznic stavb, Uradni list RS, št. 93/2012 (07.12.2012).

Zakonski vir 3: Pravilnik o usposabljanju, licencah in registru licenc neodvisnih strokovnjakov za izdelavo energetskih izkaznic, Uradni list RS št. 6/2010 (29. 1. 2010).

Zakonski vir 4: Pravilnik o spremembi Pravilnika o usposabljanju, licencah in registru licenc neodvisnih strokovnjakov za izdelavo energetskih izkaznic, Uradni list RS, št. 23/2013 (18.03.2013).

\section{Internetni viri:}

Internetni vir 1: Trg nepremičnin, http://www.trgnepremicnin.si/sl/trgoskop/(24.05.2016)

\section{Drugi viri:}

Plesnik, S., (2016). Interno gradivo, neobjavljeno zaradi varovanja poslovnih podatkov in informacij. 
36. MEDNARODNA KONFERENCA O RAZVOJU ORGANIZACIJSKIH ZNANOSTI: OdgOVORNA ORGANIZACIJA (22. - 24. MAREC 2017, PORTOROŽ, SLOVENIJA)

O. Arsenijević, M. Ferjan, I. Podbregar, P. Šprajc, D. Trivan \& Y. Ziegler

\title{
Migracije in varnost $v$ družbi
}

\author{
IzTOK Podbregar, Dragan Trivan, Olja ARSEniJeVić \& POlONA ŠPRAJC
}

Povzetek V svetu, ki ga živimo dandanes je eno večjih vprašanj s katerim se srečuje sleherni posameznik in organizacije vprašanje varnosti. Pogled na zagotavljanje mirnega in urejenega okolja v katerem lahko dosegamo svoje cilje ter uresničujemo svoje želje, je pogled organizacij, ki želijo izpolnjevati svoje poslanstvo. Priložnosti in nevarnosti, ki jih predpostavljajo politična, zakonodajna, okoljevarstvena in druga vprašanja, so pogosto zunanji okvir vplivov, ki jih organizacije morajo obvladovati in predvidevati morebitna tveganja. Spremembe, ki jih narekujejo tudi nemiri v svetu, migracije ljudi in terorizem, povzročajo posledice na ravni kvalitete življenja posameznika pa tudi na ravni trga dela ter $\mathrm{v}$ organizacijah. $\mathrm{S}$ prispevkom želimo osvetliti temeljna vprašanja varnosti, ki naj bi jih zagotavljalo urejeno socialno, kulturno in politično okolje držav ter po drugi strani delovalo kot pozitivna spodbuda za skupno strpno življenje ljudi ter učinkovito in uspešno delovanje organizacij.

KLJUČNE BESEDE: varnost • migracije • odgovornost • družba

\footnotetext{
NASLOV AVTORJEv: dr. Iztok Podbregar, redni profesor, Univerza v Mariboru, Fakulteta za organizacijske vede, Kidričeva cesta 55a, $4000 \mathrm{Kranj}$, Slovenija, e-pošta: iztok.podbregar@fov.uni-mb.si; dr. Dragan Trivan, profesor, Univerza »Union-Nikola Tesla«, Fakulteta za poslovne vede in pravo, Staro sajmište 29, 11070 Novi Beograd, Srbija, e-pošta: dtrivan@gmail.com; dr. Olja Arsenijević, profesorica, Univerza »Union-Nikola Tesla«, Fakulteta za poslovne vede in pravo, Staro sajmište 29, 11070 Novi Beograd, Srbija, e-pošta: olja.arsenijevic@fpsp.edu.rs; dr. Polona Šprajc, docentka, Univerza v Mariboru, Fakulteta za organizacijske vede, Kidričeva cesta 55a, 4000 Kranj, Slovenija, e-pošta: polona.sprajc@fov.unimb.si
} 
$36^{\text {Th }}$ International Conference on Organizational Science DeVElopment: Responsible ORGANIZATION (MARCH $22^{\mathrm{ND}}-24^{\mathrm{TH}}$, PORTOROŽ SLOVENIA)

O. Arsenijević, M. Ferjan, I. Podbregar, P. Šprajc, D. Trivan \& Y.

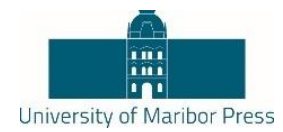

Ziegler

\title{
Migrations and Safety in Society
}

\author{
IzTOK Podbregar, Dragan Trivan, OlJa ARSENIJEVIĆ \& POlONA ŠPRAJC
}

\begin{abstract}
Nowadays we live in a world where each individual and organisation is confronted with the question of security. The standpoint of organisations, which are eager to pursue its mission, is to ensure a peaceful environment, where we can attain our objectives and satisfy our desires. Risks, which are posed with political, juristic, environmental and other questions, are often an external framework of influences, that organisation has to cope with and presuppose their possible risks. Wars, migrations and terrorism are leading to changes on a level of living of each individual, but they influence also on the labour market and organisations. With the contribution, we want to pinpoint the basic questions of security that should be enabled in the first place by social, cultural and political environment of each country. Apart from that security is a positive incentive for the mutual human tolerance and the responsible, efficient and successful operation of organisations.
\end{abstract}

KEYWORDS: safety $\bullet$ migration $\bullet$ responsibility $\bullet$ society

CorRespondence AdDress: Iztok Podbregar, Ph.D., Full Professor, University of Maribor, Faculty of Organizational Sciences, Kidričeva cesta 55a, 4000 Kranj, Slovenia, e-mail: iztok.podbregar@fov.uni-mb.si; Dragan Trivan, Ph.D., Professor, University »Union-Nikola Tesla«, Faculty of business studies and law, Staro sajmište 29, 11070 Novi Beograd, Serbia, email: dtrivan@gmail.com; Olja Arsenijević, Ph.D., Professor, University »Union-Nikola Tesla«, Faculty of business studies and law, Staro sajmište 29, 11070 Novi Beograd, Serbia, e-mail: olja.arsenijevic@fpsp.edu.rs; Polona Šprajc, Ph.D., Assistant Professor, University of Maribor, Faculty of Organizational Sciences, Kidričeva cesta 55a, 4000 Kranj, Slovenia, e-mail: polona.sprajc@fov.uni-mb.si 


\section{$1 \quad$ Uvod}

Varnostna vprašanja so rezultat globalizacijskih procesov in so del neizbežne dejanskosti. Zaradi posledic vojn in neugodnih razmer $\mathrm{v}$ družbi pogosto zaznavamo negativno zaznamovanost okolja $\mathrm{v}$ katerem živimo in delamo. Vpliv kratenja temeljnih človekovih pravic, pravic do človeškega dostojanstva so resne težave današnjega časa, ki lahko vodijo tudi do resnih posledic v okolju organizacij. Problematika migracij se umešča v cel sklop civilizacijskih vprašanj, ki so povezana s politiko izobraževanja, zdravstva, sociale, kulture in nasploh varnostno problematiko. Če želimo razumeti stanje današnje družbe, moramo razumeti tudi tovrstne vplive ter obvladovati tveganja, ki lahko povzročijo tudi v organizacijah resne težave.

Varnost $\mathrm{v}$ organizacijah je mehanizem, ki zagotavlja stanje obvladovanja kriznih situacij, ki nastopijo v primeru notranjih in zunanjih vzvodov. Če se v prispevku dotikamo vprašanj varnostne narave, bi v prvi vrsti izpostavili zunanje dejavnike, ki lahko nastopijo s silami konkurenčnosti, zmanjšanja kupne moči ali celo situacij, ki jih pogojuje neurejenost prostora. To pomeni, da je soočanje s spremembami družbenega, socialnega in kulturnega značaja lahko $\mathrm{v}$ veliki meri tudi posledica neuravnoteženega delovanja organizacij in širšega okolja.

\section{Varnost}

Perspektiva posledic kriznih obdobij, ki so povezana s silami migracij, so prisotna tako v osebnih življenjih posameznikov kot tudi v pogledu organizacij. Predvideva se, da je za reševanje situacij, ki so povezana $\mathrm{z}$ negotovostjo posameznika pogosto potreben veliko bolj sistematičen pristop reševanja parcialnih interesov in interesov družbe kot celote. Človeška humanost $\mathrm{v}$ pogojih kriznih situacij je najpogosteje tisto orodje, ki še vedno v največji meri lahko reši stisko posameznika.

Človekova varnost usmerja koncept varnosti k preživetju, dobrobiti in svobodi ljudi (Bajpai, 2000). Človekova varnost je cilj, končni smisel vseh varnostnih prizadevanj. Druge oblike varnosti, npr. vojaška, niso končni cilji, temveč so lahko le sredstva za končni cilj, ki ga predstavlja človekova varnost (Harvard Program of Humanitarian Policy and Conflict Research, 2001).

Jorge Nef je združil razsežnosti človekove varnosti in predlagal klasifikacijo na osnovi analize elementov svetovnega sistema, ki so: ekologija/okolje, ekonomija, družba, vlada in kultura (King in Murray, 2001/02). Prva razsežnost je okoljska, osebna in fizična varnost, ki je pravica posameznikov in skupnosti do ohranjanja njihovega življenja, zdravja in bivanja $v$ trajnostno varnem okolju. Druga razsežnost je ekonomska varnost, ki pomeni dostop do zaposlitve in virov za vzdrževanje lastnega obstoja, zmanjšanje pomanjkanja, izboljšanje materialne kakovosti življenja v skupnosti. Socialna varnost pomeni odmik od diskriminacije zaradi starosti, spola, narodnosti ali socialnega statusa. Politična varnost predstavlja pravico do predstavništva, neodvisnosti, različnosti mnenj itd. Med socialne/družbene grožnje pa spadajo rast prebivalstva, migracije, tokovi beguncev itd. (Nef, 1999). 
Če želimo govoriti o silah migracij, ki vplivajo na spremembe v moči družbe, organizacije in posameznika, je reakcija na krizne situacije pogosto pogojena $\mathrm{z}$ nacionalnimi in mednarodnimi okviri. Migracije so del današnje realnosti in premiki prebivalstva vplivajo tudi na situacije, ki rezultirajo v trgu dela, reakcijah lokalnega prebivalstva in drugem. Razumevanje celovitega problema, ki spremlja potek migracij vpliva tudi na vprašanje povezano $\mathrm{z}$ varnostjo in pogoji nacionalne varnosti posamezne države. Orodja, ki zagotavljajo obstanek varnosti v okolju so najpogosteje vezana na državne aparate in pogosto tudi aparat medijev. Slednji so z močjo tradicije in socialnih oziroma družbenih omrežij tisti, ki lahko v veliki meri povzročijo stopnjo nemira, spodbujajo določena usmerjena vprašanja in prispevajo $\mathrm{k}$ navideznemu neobvladovanju kriznih razmer.

S prispevkom izpostaviti nekaj varnostnih vprašanj, ki so relevantne za vsako družbo. Zaznavanje neugodnih situacij pogosto nima enostavnega odgovora ali rešitev. Ko se v družbi pojavijo vprašanja neugodnih razmer, krize, ki je povezana z migracijami ali vzorci nehumanosti, so to ena izmed pogostih različnih tipov generiranja krize. V duhu sprememb, narave kriznih situacij, se prebivalstvo oziroma družba srečuje z vprašanji, ki potrebujejo aktivnosti najprej na mednarodni, nacionalni ravni pa tudi na ravni posameznega lokalnega okolja. Preventiva je lahko ena izmed rešitev, ki v smeri obvladovanja kriznih razmer predstavlja možnost za ugodno varnostno politiko države. $\mathrm{Na}$ drugi strani pa je pogosto reševanje situacij, na katere kot posamezniki nimamo posebnega vpliva, potrebno hitrega in uspešnega reševanja.

\subsection{Pojem nacionalne varnosti}

$\mathrm{V}$ mednarodnem in nacionalno varnostnem okolju 21. stoletja se soočamo $\mathrm{z}$ raznovrstnimi sodobnimi viri ogrožanja in tveganja varnosti. Njihovi nosilci so praviloma nedržavni subjekti, po naravi pa so kompleksni, pogosto težko predvidljivi in imajo lahko multiplikatorski značaj in učinek. Republika Slovenija je na različne vire ogrožanja in tveganja dodatno občutljiva zaradi svoje geografske raznolikosti, omejenosti naravnih virov in prostora ter ozemeljske prehodnosti (Resolucija o strategiji nacionalne varnosti Republike Slovenije, 2010).

Viri ogrožanja in tveganja nacionalne varnosti Republike Slovenije se z vidika porekla pojavljajo na globalni, nadnacionalni in nacionalni ravni.

Za globalne vire ogrožanja in tveganja je poleg globalnega porekla in univerzalnolokalnih posledic njihovega delovanja značilno, da zaradi svojega multiplikatorskega značaja vplivajo na nastanek drugih varnostnih groženj in tveganj ter hkrati povečujejo njihove učinke in posledice. Med te vire sodijo zlasti podnebne spremembe, finančna, gospodarska in socialna tveganja ter krizna žarišča (Resolucija o strategiji nacionalne varnosti Republike Slovenije, 2010).

Nadnacionalni viri ogrožanja in tveganja nacionalne varnosti imajo transnacionalno poreklo in čezmejne razsežnosti. Med te vire ogrožanja in tveganja sodijo predvsem terorizem, nedovoljene dejavnosti na področju konvencionalnega orožja, orožij za 
I. Podbregar, D. Trivan, O. Arsenijević \& P. Šprajc: Migracije in varnost v družbi

množično uničevanje in jedrske tehnologije, organiziran kriminal, nezakonite migracije, kibernetske grožnje in zloraba informacijskih tehnologij in sistemov, dejavnost tujih obveščevalnih služb in vojaške grožnje (Resolucija o strategiji nacionalne varnosti Republike Slovenije, 2010).

Nacionalni viri ogrožanja in tveganja nacionalne varnosti so po izvoru povezani z dogajanjem in pojavi v nacionalnem okolju, mednje pa sodijo predvsem ogrožanje javne varnosti, naravne in druge nesreče, omejenost naravnih virov ter degradacija življenjskega okolja, zdravstveno-epidemiološke grožnje ter določeni dejavniki negotovosti (Resolucija o strategiji nacionalne varnosti Republike Slovenije, 2010).

Zagotavljanje nacionalne varnosti Republike Slovenije temelji na delovanju obrambnega sistema, sistema notranje varnosti ter sistema varstva pred naravnimi in drugimi nesrečami kot podsistemov sistema nacionalne varnosti, vključuje pa tudi zunanjepolitične, gospodarske, informacijske in druge dejavnosti, ki neposredno vplivajo na nacionalno varnost. Navedene (pod)sisteme se bo tudi $\mathrm{v}$ prihodnje nadgrajevalo, predvsem pa povezovalo $\mathrm{v}$ skladno celoto $\mathrm{z}$ namenom povečevanja učinkovitosti celotnega nacionalno varnostnega sistema (Resolucija o strategiji nacionalne varnosti Republike Slovenije, 2010).

V sklopu prispevka v kratkem predstavljamo obrambni sistem in sistem notranje varnosti v Republiki Sloveniji.

Obrambni sistem Republike Slovenije predstavlja celoto političnih, normativnih, organizacijskih, vojaških, kadrovskih, materialno-finančnih, obveščevalno-varnostnih, informacijsko-komunikacijskih, razvojno-raziskovalnih, izobraževalnih in drugih dejavnosti, ki jih organizira država za učinkovito zagotavljanje obrambe. Tvorijo ga Slovenska vojska kot nosilka vojaške obrambe in razvoja vojaških zmogljivosti ter nevojaški deli obrambnega sistema, ki oblikujejo in izvajajo obrambno politiko, zagotavljajo pogoje za delovanje celotnega obrambnega sistema, zagotavljajo nevojaške zmogljivosti za podporo Slovenski vojski in zavezniškim silam ter izvajajo priprave in ukrepe za potrebe obrambe države in delovanje obrambnega sistema v kriznih razmerah (Resolucija o strategiji nacionalne varnosti Republike Slovenije, 2010).

Sistem notranje varnosti predstavljajo institucionalni nosilci varnostnih nalog. V ta sistem so vključeni tudi pravosodni in drugi državni organi ter institucije, ki z uresničevanjem nalog prispevajo k notranji stabilnosti in varnosti. Republika Slovenija za zagotavljanje notranje varnosti razvija učinkovit, fleksibilen in odziven varnostni sistem ter omogoča sodelovanje in vključevanje drugih subjektov pri opravljanju zadev in nalog javne varnosti. Notranjo varnost zagotavlja $\mathrm{z}$ delovanjem institucij javne varnosti, policije, državnega tožilstva, inšpekcijskih in nadzornih organov, obveščevalno-varnostnih služb, drugih državnih organov, organizacij z javnimi pooblastili, različnih varnostnih služb in organizacij zasebnega prava ter organov lokalne samouprave na temelju njihovega medsebojnega sodelovanja, tako v Republiki Sloveniji, kot na mednarodni ravni (Resolucija o strategiji nacionalne varnosti Republike Slovenije, 2010). 
Migracije in ogrožanje nacionalne varnosti je problemsko stanje tudi za Slovenijo. Posledice migracij se kažejo v spremljajočih kriznih razmerah, pomanjkanju rešitev $\mathrm{s}$ strani nacionalnih politik in pogosto vključujejo različne ukrepe, ki na dolgi rok morajo rešiti in stabilizirati stanje v družbi. Razprave o uravnavanju situacij morajo reagirati na ekonomsko, zdravstveno, socialno in psihosocialno ozadje družbe. Z namenom zagotavljanja miru, dostojanstva in dolgoročne stabilnosti družbe, se lahko nadejamo pravega napredka družbe.

Migracijska kriza od perspektive posameznih držav do lokalnih okolij spodbuja inovativne rešitve politike, načelne usmeritve in strategije, ki lahko na dolgi rok izkoristijo pozitivno plat premikov prebivalstva. Nekaj glavnih povezav vidimo $\mathrm{v}$ povezanosti migracij s takojšnjo in etično reakcijo, ki na dolgi rok rezultira v mostu med domačim prebivalstvom in migranti.

Diskusija o migracijah nas spodbuja o naslednjih vprašanjih: kako premiki prebivalstva rezultirajo v okoljih; na kakšen način se družba sooča s premostitvijo kulturnih razsežnosti; kako je z vprašanjem humanosti; ali je zaradi migracij ogrožena varnost prebivalstva; kakšne so specifične vloge nacionalne politike in mednarodne skupnosti; kako se management organizacij odziva na krizo povezano z migracijami ter nenazadnje, kako se rešujejo konflikti, povezani z migracijskimi tokovi.

Cohen (2006) razlikuje osem tipov migracij: legalne ekonomske migracije, nelegalne ekonomske migracije, migracije beguncev, neodvisne migracije žensk, usposobljeni začasni migranti, usposobljeni dolgotrajni migranti, množične notranje selitve in turizem. Vzroki za migracije so navadno ekonomski, kulturni, demografski, politični oziroma psihološki. Vsem pa je skupno dejstvo, da si ljudje želijo izboljšati svoje življenje.

$\mathrm{V}$ pogledu mednarodnih migracij, kontekstu negotovih napovedi, pomanjkljivih informacij in težko predvidljivih dogodkov pestrost migracijskega fenomena ne predstavlja le izziv humanitarnim, ekonomskim, socialnim in kulturnim vidikom, temveč tudi varnostni, obrambni in zunanji politiki države (Kopač v Prezelj, 2007). Migracije prebivalstva vplivajo na nacionalni ravni države kot grožnja javnemu redu, gospodarski blaginji, politični stabilnosti, kulturnim vrednotam ipd. (Kopač v Prezelj, 2007).

Migracije iz kakršnihkoli razlogov, spreminjajo odnose med državljani. Odnosi lahko rezultirajo tudi $\mathrm{v}$ trenjih in so posledica različnih navad, vrednot, potreb in želja. Na področju varnosti je potrebno vedeti, da je omejitev trenj lahko možna s strani nacionalnega aparata varnosti $\mathrm{v}$ delnem okviru. Veliko večjo moč pri tem ima lahko medijski aparat in obveščanje s strani države, ki pri državljanih spodbujajo pozitivne vidike multikulturnosti in sprejetosti drugačnosti.

Braniti koncept (eno)nacionalne države preko osredotočenja na varnostne vidike sodobnih migracij ni problematično le zato, ker so na tak način ogrožene temeljne vrednote humanizma (človek je človeku največja vrednost!), ko torej država tujca, ki 
I. Podbregar, D. Trivan, O. Arsenijević \& P. Šprajc: Migracije in varnost v družbi

vstopi na njeno ozemlje že v začetku ne obravnava kot človeka vrednega pomoči (kot bi $\mathrm{v}$ primeru, če bi bil prisiljen bežati pred različnimi oblikami preganjanja, pričakoval vsak od nas!), temveč tudi zato, ker tako (pre)ozko interpretiranje pojma »varnost« ne zagotavlja racionalnega in učinkovitega odgovora suverene oblasti na procese ekonomske globalizacije in družbene integracije (Jazbec, 2003).

\subsection{Migracijski management}

Migracije povzročajo številne spremembe v ekonomskih in socialnih odnosih modernih družb. Razumevanje razlogov in narave migracij je ključno za oblikovanje migracijskega managementa in migracijske politike. Izziv za zakonodajalce Evropske unije je tako management mednarodnih migracij oziroma upravljanje $\mathrm{z}$ migracijami. Eden izmed pomembnejših ciljev je integracija priseljencev, saj lahko le ta na način enakopravno sodelujejo pri razvoju družbe, v katero so prišli. Mnoge države še vedno sledijo enostranskemu pristopu k migracijam, kar pomeni, da si prizadevajo upravljati migracije v skladu s svojimi lastnimi interesi. Posledica tega je nepregleden in neusklajen sistem reguliranja mednarodnih migracij ter uvedba različnih avtonomnih migracijskih politik (Zakšek, 2006).

Če izhajamo iz našega vprašanja o percepciji varnosti v družbi in navezavi na aktualne problematike današnjega časa, je eno izmed vprašanj nedvomno upravljanje domačih in mednarodnih migracij. Pomanjkanje mehanizmov in vzvodov za reševanje problematike, mnogo držav vidi ravno v strategijah za migracijski management, ki bi maksimiziral pozitivne in minimiziral negativne posledice mednarodnih migracij (The Berne Initiative, 2004).

\section{$4 \quad$ Zaključek}

Nacionalno varnostna politika Republike Slovenije je uravnotežena celota vizije, strategij, programov, načrtov in dejavnosti države, potrebnih za odzivanje na vire ogrožanja in tveganja njene nacionalne varnosti ter $\mathrm{s}$ tem za uresničevanje njenih nacionalno varnostnih ciljev, usmerjenih $\mathrm{k}$ zaščiti slovenskih nacionalnih interesov (Resolucija o strategiji nacionalne varnosti RS, 2010).

Nacionalno varnostno politiko Republike Slovenije sestavljajo zlasti zunanja politika, obrambna politika, politika zagotavljanja notranje varnosti ter politika varstva pred naravnimi in drugimi nesrečami. $\mathrm{V}$ skladu $\mathrm{s}$ sodobnim večdimenzionalnim razumevanjem pojma nacionalne varnosti pa se upošteva tudi varnostni vidik politike države na gospodarskem, socialnem, okoljskem, zdravstvenem, demografskem, izobraževalnem, znanstveno-tehnološkem, informacijskem in drugih področjih (Resolucija o strategiji nacionalne varnosti RS, 2010).

Temeljni namen uresničevanja nacionalno varnostne politike Republike Slovenije bo tudi v prihodnje zagotoviti čim višjo stopnjo človekove varnosti, ustrezen družbeni razvoj in blaginjo slovenske družbe ter ohraniti nacionalno identiteto slovenskega naroda, poleg tega pa skupaj z uresničevanjem sprejetih mednarodnih obveznosti naše države prispevati 
36 ${ }^{\mathrm{TH}}$ International Conference on Organizational Science Development: RESPONSIBLE ORGANIZATION (MARCH $22^{\mathrm{ND}}-24^{\mathrm{TH}}$, PORTOROŽ SLOVENIA)

I. Podbregar, D. Trivan, O. Arsenijević \& P. Šprajc: Migrations and Safety in Society

k ohranjanju miru ter $\mathrm{h}$ krepitvi varnosti in stabilnosti v širši in ožji mednarodni skupnosti (Resolucija o strategiji nacionalne varnosti RS, 2010).

Republika Slovenija bo razvijala mehanizme za krepitev splošne varnostne kulture, ki je utemeljena na ozaveščanju, preventivi, strpnosti, solidarnosti, sodelovanju in pomoči med ljudmi ter na kulturi miru in nenasilja pri zagotavljanju varnosti (Resolucija o strategiji nacionalne varnosti RS, 2010).

S prispevkom smo želeli opozoriti na prilagoditve strategij mednarodne in nacionalne politike za obvladovanje ogroženega in zapletenega mednarodnega okolja. Dejstvo je, da so vplivi migracij in varnostna vprašanja neizogibno povezana $\mathrm{z}$ najrazličnejšim spektrom organizacij ter učinkujejo na vsakega državljana. Pri tem je najpomembneje izpostaviti človeško dostojanstvo ter utemeljenost njegovih osnovnih človekovih pravic in svoboščin. Sprememba na ravni premikov prebivalstva ni nekaj, kar bi bilo dejstvo samo današnjega časa. Je pa res, da v Sloveniji nismo bili vajeni večjih multikulturnih premikov kot smo jim priča v zadnjem obdobju. Smotrnost preučitve varnostnih vprašanj $\mathrm{v}$ primeru migracij zatorej vidimo predvsem $\mathrm{v}$ tem, da se vzpostavlja politika, ki bo zagotavljala ustrezne razmere za življenje državljanov, na drugi strani pa spodbujala čim večje možnosti integracije posameznikov, ki iščejo svoj prostor v mirnem okolju, okolju, ki bo zagotavljalo možnost napredka in razvoja.

\section{Literatura}

Bajpai, K. (2000). Human Security: Concept and Measurement. Kroc Institute Occasional Paper No. 19; OP:1, 1-64. University of Notre Dame. Notre Dame, Indiana. Dostopno na: http://www.nd.edu/ krocinst/ocpapers/op_19_1.PDF (12. december 2006).

Cohen, R. (2006). Migration and its enemies: global capital, migrant labour, and the nation-state. Aldershot, Burlington (VT): Ashgate, cop.

Harvard Program of Humanitarian Policy and Conflict Research. (2001). Comparison of Human Security Definitions/Definitions of Human Security. Human Security Workshop, Harvard School of Public Health, Harvard University, USA. Dostopno na http://www.gdrc.org/sustdev/husec/Comparisons.pdf http://www.gdrc.org/sustdev/husec/Definitions.pdf (12. december 2006).

Jazbec, F. (2003). Upravljanje migracije. Ampak. Dostopno na http://odnos.si/clanki/druzboslovne_vsebine/migracije/upravljanje_migracije/(18.februar 2017).

King, G. in Murray, C. J. L. (2001/02). Rethinking Human Security. Political Science Quarterly, Vol. 116(4), 584-610.

Prezelj, I. (2007). Nujnost medresorskega sodelovanja in koordiniranja v boju proti terorizmu: Nekateri primeri iz Republike Slovenije. Bilten Slovenske vojske, Generalštab Slovenske vojske, September $2007-9 /$ Št. 2.

Nef, J. (1999). Human Security and Mutual Vulnerability - the Global Political Economy of Development and Underdevelopment. Electronic version, 2nd edition, International Development Research Centre, Ottawa, Canada. Dostopno na http://www.idrc.ca/en/ev-9383201-1-DO_TOPIC.html (12. december, 2006).

Resolucija o strategiji nacionalne varnosti Republike Slovenije, 2010 (Uradni list RS, št. 92/07).

Resolucija o migracijski politiki Republike Slovenije (Uradni list RS, št. 106/2002). 

ORGANIZACIJA (22. - 24. MAREC 2017, PORTOROŽ, SLOVENIJA)

I. Podbregar, D. Trivan, O. Arsenijević \& P. Šprajc: Migracije in varnost v družbi

The Berne Initiative: A Global Consultative Process for Inter-State Cooperation on Migration Management. Dostopno na https://www.iom.int/key-migration-terms (18. februar 2017).

Zakšek, T. (2006). Menedžment mednarodnih migracij v Evropski uniji. Diplomsko delo. Ljubljana: Ekonomska fakulteta. 
762 36 ${ }^{\mathrm{TH}}$ International Conference on Organizational Science Development: RESPONSIBLE ORGANIZATION (MARCH $22^{\mathrm{ND}}-24^{\mathrm{TH}}$, Portorož SLOVENiA) 


\title{
Pomen timskega dela med organizatorjem praktičnega pouka in učnimi bazami
}

\author{
POLONA PODLESNIK
}

\begin{abstract}
Povzetek Timsko delo je pri organizaciji praktičnega pouka bistvenega pomena za kakovostno in uspešno delo, zato se mora organizator praktičnega pouka timskega dela lotiti strokovno in sistematično. Njegovo delo zajema vsakodnevno načrtovanje in interdisciplinarno sodelovanje z vodstvenimi delavci učnih baz, vodstvom šole in učiteljicami praktičnega pouka. Tudi na Srednji zdravstveni šoli Celje je praktični pouk sestavni in obvezni del v programih bolničar negovalec, zdravstvena nega, poklicno tehničnem programu in izobraževanju odraslih. Izvaja se v kabinetih za praktični pouk na šoli, večinoma pa poteka v učnih bazah. Tedensko imamo na praktičnem pouku okrog 500 dijakov, kar predstavlja velik organizacijski zalogaj tako za šolo kot za delodajalce. Glede na veliko število dijakov, med njimi je vedno več dijakov s posebnimi potrebi se skoraj tedensko pojavljajo težave. Delodajalci, mentorji ter dijaki teh problemov ponavadi ne morejo reševati sami. Zato jih je potrebno reševati sprotno, premišljeno, predvsem pa korektno, da ne pride do napak. Kot vodja tima tukaj nastopi organizator praktičnega pouka, sodelujejo pa vsi trije subjekti. Analiza timskega dela med šolo in delodajalci je pokazala, da je sodelovanje zelo dobro in da do hujših kršitev še ni prišlo.
\end{abstract}

KLJUČNE BESEDE: timsko delo • praktični pouk • dijaki •učne baze

Naslov Avtorice: Polona Podlesnik, Srednja zdravstvena šola Celje, Ipavčeva 10, 3000 Celje, Slovenija, e-pošta: polona.podlesnik@gmail.com 
$36^{\text {Th }}$ International Conference on Organizational Science Development: Responsible ORganization (MARCh $22^{\mathrm{ND}}-24^{\mathrm{TH}}$, PORTOROŽ SLOVENIA)

O. Arsenijević, M. Ferjan, I. Podbregar, P. Šprajc, D. Trivan \& Y.

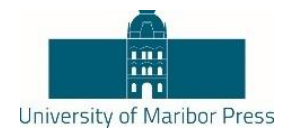

Ziegler

\title{
The Importance of Teamwork Between the Organizer of Practical Training and Teaching Bases
}

\author{
POLONA PODLESNIK
}

\begin{abstract}
When organizing practical training, teamwork is essential for successful work, therefore, the organizer of practical training should pay attention to teamwork and it has to be addressed professionally and systematically.
\end{abstract}

His work includes daily planning and interdisciplinary cooperation with executives from teaching bases, school management and teachers of practical training.

On Secondary School for Nurses Celje practical training is very important. It is a compulsory part of the following educational programmes: nursing, nursing assistant and education for adults.

It is performed in school classrooms for practical work and in learning bases. Every week there are approximately 500 students involved in practical trainig, which represents a huge organizational task for both schools and employers. Due to a large number of students, there is an increasing number of students with special needs. It can cause problems to employers, mentors and students. Such problems need to be addressed very carefully in order to avoid further complications.

Analysis of teamwork between schools and employers has shown that in most cases cooperation is very good and there are no major problems.

KEYWORDS: teamwork $\bullet$ practical training $\bullet$ students $\bullet$ teaching bases

Correspondence Address: Polona Podlesnik, Middle School of Nursing in Celje, Ipavčeva 10, 3000 Celje, Slovenia, e-pošta: polona.podlesnik@gmail.com 
P. Podlesnik: Pomen timskega dela med organizatorjem praktičnega pouka in učnimi bazami

\section{$1 \quad$ Uvod}

Timi niso nujno formalne narave. Oblikujejo se lahko spontano, neformalno, kot odgovor na potrebo po čim bolj uspešni, hitri in učinkoviti realizaciji določene naloge. Vsako delovno mesto ima prednosti in slabosti. Tudi delo organizatorja praktičnega pouka ni $\mathrm{v}$ vseh pogledih vedno preprosto. Velikokrat se znajde v težkih situacijah, v katerih ne sme biti nepristranski za vse subjekte, ki so povezani med sabo. V našem primeru so ti trije subjekti šola, učne baze in organizator praktičnega pouka. V primeru težav moramo ravnati, kot pravita pregovora "V slogi je moč" in "Več glav več ve", ter se s primerno komunikacijo lotiti problema. Zavedati se je potrebno, da si članov tima nikoli ne izbiramo sami, zato je prilaganje in sodelovanje bistvenega pomena. Za vsem tem pa imamo še predpise, ki nam narekujejo kako moramo opravljati določeno delo. V šoli imamo šolsko zakonodajo, delodajalci, ki izhajajo iz zdravstvenega okolja imajo svoje predpise, potem pa so še tukaj različni dijaki med katerimi jih je tudi vedno več $s$ posebnimi potrebami. Vse to na delo ne sme vplivati, predvsem pa tega ne smejo občutiti pacienti, saj je rezultat našega sodelovanja zadovoljen pacient. Zato na podlagi prepletanja različnih strokovnih skupin govorimo o interdisciplinarnem pristopu. Težave torej rešujemo z odprtim pristopom in občutkom medsebojnega spoštovanja in zaupanja.

\section{Timsko delo}

Definicij tima in timskega dela je veliko, bistvo pa je, da gre za sodelovanje posameznikov, postavljenih pred skupno nalogo. Timsko delo pomeni, da si vsi vključeni $\mathrm{v}$ sistem prizadevajo delovati $\mathrm{v}$ dobro skupnemu cilju, imajo skupno namero in delujejo skupaj v doseganju tega cilja. Zato pa morajo med člani učinkovitega tima vladati spoštovanje, zaupanje in sodelovanje (Silvester, P., 2011, str. 74). Torej je timsko delo predpogoj za dober uspeh. Vsekakor pa ni samoumevno, da se bo sodelovanje ljudi pri realizaciji določenega cilja oz. naloge razvilo do meje, ko bomo lahko rekli, da ti posamezniki sestavljajo uigran in učinkovit tim, če ne bomo za to pripravljeni.

V strokovni literaturi lahko najdemo vrsto definicij, konceptualnih modelov, taksonomij in empiričnih študij, ki dokazujejo pomen timskega dela in raziskujejo dejavnike, ki zagotavljajo optimalno uspešnost in učinkovitost timskega dela. Salas in drugi (2005) so na podlagi kompleksne študije strokovne literature in raziskav zadnjih 20 let izluščili pet temeljnih dejavnikov, ki pogojujejo učinkovito timsko delo, ne glede na vrsto tima ali področje delovanja: 1.) vodenje, 2.) medsebojno spremljanje uspešnosti, 3.) medsebojna podpora, 4.) prilagodljivost in 5.) timska naravnanost.

Za implementacijo omenjenih dejavnikov znotraj tima je najprej potrebno zagotoviti:,

- kognitivni model timskega dela (ang. »shared mental model of team work «),

- ustrezen način medsebojne komunikacije (ang. »closed-loop communication) in

- visoko stopnjo medsebojnega zaupanja. (Salas et al., 2005) 
$36^{\mathrm{TH}}$ INTERNATIONAL CONFERENCE ON ORganizational SCIENCE DeVElopment: RESPONSIBLE ORGANIZATION (MARCH $22^{\mathrm{ND}}-24^{\mathrm{TH}}$, PORTOROŽ SLOVENIA)

P. Podlesnik: The Importance of Teamwork Between the Organizer of Practical Training and Teaching Bases

Kognitivni model timskega dela pomeni, da posamezniki jasno razumejo, zakaj in kako so povezani z drugimi pri opravljanju dela, kaj vse obsega timsko delo, katere timske kompetence so potrebne za uspešno delo in kako lahko pripomorejo k oblikovanju dobrih medosebnih odnosov znotraj tima. Prav tako morajo člani specifičnega tima dobro poznati namen in cilje tima, svojo vlogo in naloge, notranje procese in zaželen način vedenja. Le tako lahko svoje delovanje usmerijo v dosego skupnega cilja.

Med najbolj pomembnimi elementi, ki vplivajo na učinkovitost in uspešnost tima so:

Vodenje: vodenje tima pomeni sposobnost vplivati in spodbujati sodelavce, da bodo sledili želenim ciljem. Zato je vloga vodje usmerjanje tima $v$ proces iskanja najustreznejše rešitve ne pa samo definiranje problemov. Ker ima navadno vodja največji dostop do informacij je njegova naloga da poskrbi, da člani tima razumejo cilje tima, morebitne ovire, razpoložljive vire in vlogo posameznika v timu. Vodja spremlja notranje in zunanje okolje tima, koordinira delo in vloge posameznih članov, spremlja in odpravlja morebitne pomanjkljivosti članov tima. V kolikor pride do neustreznih notranjih procesov (neproduktivnega reševanja konfliktov) ukrepa in uvede morebitne spremembe. S svojimi dejanji, predvsem pa vedenjem ustvarja klimo, ki vzpodbuja ali zavira zaželeno vedenje in uspešnost tima.

Medsebojno spremljanje uspešnosti: nenehno spremljanje uspešnosti dela članov tima omogoča pravočasno prepoznavo, preprečitev in popravilo morebitnih napak. To je še posebno pomembno $\mathrm{v}$ stresnih situacijah, ko se zgodi največ napak, saj se takrat posamezniki pogosto ne zavedajo pomanjkljivosti svojega dela. Spremljanje uspešnosti ter konstruktivno dajanje in sprejemanje informacij veča učinkovitost tima. Če članom tima niso jasne posameznikove naloga in vloga, je vprašljiva tudi relevantnost in konsistentnost povratne informacije. Pogoj za učinkovito spremljanje delovne uspešnosti je visoka stopnja zaupanja in odprta, kohezivna klima, saj v nasprotnem primeru to lahko postane priložnost za negativno izpostavljanje posameznikovih slabosti in napak.

Medsebojna podpora: medsebojna podpora pomeni dajanje povratnih informacij, pomoč pri opravljanju nalog ali prevzemanje delovnih zadolžitev. V kolikor tim ugotovi, da je posameznik pri svojem delu preobremenjen in delo presega njegove zmožnosti, njegovo delo ustrezno prerazporedi med ostale člane in ga na ta način razbremeni. V nasprotnem primeru lahko v timu pride do upada uspešnosti. Za učinkovito podporo sta potrebna naslednja pogoja: jasno razumevanje nalog in vlog posameznikov ter medsebojno spremljanje uspešnosti.

Prilagodljivost: prilagajanje predvideva kontinuirano spremljanje ali obstoječi procesi zagotavljajo učinkovitost tima ter odkrivanje in odpravljanje morebitnih napak, spreminjanje načrta dela in drugo.

Timska naravnanost sodelujočih: timska naravnanost pomeni med drugim tudi željo večati osebno uspešnost skozi sodelovanje v timu. Timsko delo je bogat vir različnih izkušenj in občutij, ki posamezniku dajejo priložnost za zadovoljevanje njegovih potreb, 
P. Podlesnik: Pomen timskega dela med organizatorjem praktičnega pouka in učnimi bazami

doseganje pričakovanih rezultatov, potrditev in spoštovanje. Razumevanje zapletenega timskega dogajanja je za posameznika tudi neke vrste intelektualni izziv, ki lahko pozitivno vpliva na delovanje celotnega tima.

Komunikacija: nedvomno je za uspešno timsko delo potrebno zagotoviti tudi učinkovito in nemoteno komunikacijo ter razvoj in ohranjanje zaupanja med člani tima, saj pomanjkanje medsebojnega zaupanja pomeni izgubljanje časa $\mathrm{v}$ medsebojnem preverjanju in ščitenju lastnih interesov.

Prepričani smo, da je uspešnost nalog, ki jih timi izvajajo izredno odvisna tudi od učinkovitosti komunikacijskega procesa. Komunikacija je za timsko delo ključnega pomena, saj omogoča pretok informacij in virov, kar je zelo pomembno, če želimo doseči, da si posamezniki isto sporočilo enako interpretirajo.

Dobra in kvalitetna komunikacija znotraj tima je eden izmed pogojev za izmenjavo znanj, izkušenj in informacij ter posledično tudi eden izmed pogojev za učinkovito učenje in upoštevanje preteklih izkušenj v nadaljnjem delu.

Za uspešnost tima je pomembno, da so njegovi člani visoko motivirani za delo, da so pripravljeni vložiti veliko napora $\mathrm{v}$ uresničevanje ciljev, da bi zadovoljili tako svoje interese kot tudi interese organizacije.

Pomembno je, da besede tim ne razumemo kot skupino, ki je podrejena enemu posamezniku, ki ni več prvi med enakimi, ampak eden nad vsemi. Tim ne sme biti poligon za individualiste, ampak okolje, ki spodbuja sodelovanje. Pri tem mora imeti pred seboj jasno vizijo in cilj delovanja. Posamezni člani, pa tudi tim kot celota, morajo biti odprti za kontinuirano izpopolnjevanje svojih znanj. Potrebno je tudi jasno razdeliti naloge in zadolžitve, definirati odgovornosti, način poročanja in informiranja, poskrbeti za kvalitetno komunikacijo ter sprotno vrednotenje in prilagajanje spremembam.

Glavni elementi uspešnega timskega dela so:

- odprta in iskrena komunikacija,

- neobsojajoče in nekaznovano vzdušje, člani tima se medsebojno dopolnjujejo v znanju in sposobnostih

- jasna navodila,

- jasne in znane vloge in naloge članov tima,

- spoštljivo vzdušje, spodbuja sproščeno izražanje idej, mnenj, vprašanj, dilem,

- delitev odgovornosti za timski uspeh,

- prepoznavanje in predelava konfliktov,

- spodbuja občutek zaupanja med člani,

- redna in rutinska srečanja, komunikacija in prenos informacij

- spodbujanje prenosa znanja in izkušenj. (Silvester, P., 2011, str. 74-75). 
$36^{\text {TH }}$ International Conference on Organizational Science Development: Responsible ORGANiZATION (MARCH $22^{\mathrm{ND}}-24^{\mathrm{TH}}$, PoRTOROŽ SLOVENIA)

P. Podlesnik: The Importance of Teamwork Between the Organizer of Practical Training and Teaching Bases

\section{Organizator praktičnega pouka}

Organizator praktičnega pouka je lahko, kdor izpolnjuje pogoje za učitelja praktičnega pouka v kateremkoli izobraževalnem programu, za katerega opravlja vzgojnoizobraževalno delo organizatorja praktičnega pouka (Uradni list RS, št. $\underline{48 / 11}$ in 92/12).

$\mathrm{Na}$ srednjih poklicnih in strokovnih šolah je sistematiziran kot strokovni delavec $\mathrm{z}$ naslednjimi nalogami:

- skrbi za povezovanje šole in dela oz. uspešen potek izvajanja praktičnega pouka in praktičnega usposabljanja $\mathrm{z}$ delom pri delodajalcih,

- skrbi za organizacijo, za vse aktivnosti in podporo pri izvajanju praktičnega pouka in praktičnega usposabljanja z delom pri delodajalcih,

- stalno in neposredno komunicira $\mathrm{z}$ ravnateljem, pripravlja predloge in organizira dogodke za tesnejše povezovanje šole in delodajalcev

- ima odgovorno vlogo sodelavca za zagotavljanje izvedbe dela izobraževalnega programa, ki se izvaja pri delodajalcih

- $\mathrm{k}$ aktivnostim povezovanja med šolo in delom pritegne še druge učitelje in strokovne sodelavce šole

- poznati mora kadrovske in materialne pogoje za izvajanje praktičnega izobraževanja $v$ šoli in pri delodajalcu

- imeti mora uglajen, spoštljiv in strokoven nastop, ker tesno sodeluje z vodstvi posameznih organizacij (za dobavo materialov in opreme), z vodstvom šole, $\mathrm{z}$ učitelji, z dijaki in njihovimi starši. (Justinek, 2011)

Organizator praktičnega izobraževanja lahko s svojim odnosom in delom odpira šoli možnosti za dobro sodelovanje in povezovanje z delovnim okoljem kot tudi s socialnimi partnerji, lahko pa ga $\mathrm{z}$ neprimernim in neustreznim odnosom tudi zapira.

\section{Učne baze}

Praktično izobraževanje $\mathrm{v}$ poklicnem in strokovnem izobraževanju je določeno $\mathrm{z}$ izobraževalnim programom in se izvaja kot praktični pouk in kot praktično usposabljanje $\mathrm{z}$ delom.

$\mathrm{Na}$ Srednji zdravstveni šoli Celje poteka praktični pouk v kabinetih za praktični pouk na šoli, večinoma pa poteka v različnih zdravstvenih, socialnovarstvenih in drugih zavodih, ki imajo status učne baze, pridobljen pri Ministrstvu za zdravje Republike Slovenije. Učne baze so za naše izobraževanje zelo pomembne saj je praktični pouk temeljna vsebina učnega procesa, kjer dijak teoretična znanja iz zdravstvene nege in pridobljena znanja v kabinetih iz šole prenese v klinično okolje in $\mathrm{s}$ tem $\mathrm{v}$ živo spoznava svoj bodoči poklic.

Naša največja učna baza za izvajanje praktičnega pouka v programu zdravstvena nega je Splošna bolnišnica Celje, ki se nahaja v neposredni bližini šole. V njej je praktični pouk 
P. Podlesnik: Pomen timskega dela med organizatorjem praktičnega pouka in učnimi bazami

organiziran za dijake srednjega strokovnega in srednjega poklicno-tehniškega izobraževanja, smer srednja medicinska sestra/srednji zdravstvenik. Praktični pouk vodijo učitelji praktičnega pouka na osmih kliničnih oddelkih.

Dijaki srednjega poklicnega izobraževanja, smer bolničar negovalec pa praktični pouk opravljajo v Domu ob Savinji Celje, Domu Sv. Jožef Celje in Domu Lipa Štore.

Tedensko imamo na praktičnem pouku v Splošni bolnišnici Celje 410 dijakov, v domovih pa 110 dijakov.

Pred pričetkom šolskega leta z navedenimi ustanovi sklenemo kolektivno učno pogodbo.

\section{$5 \quad$ Raziskava}

Raziskava je bila izvedena med vodilnimi delavci kliničnih oddelkov na katerih poteka praktični pouk. Sodelovale so vse učne baze in se na anketni vprašalnik z veseljem odzvale ter ga izpolnile $\mathrm{v}$ dogovorjenem roku. Anketa je bila anonimna, vprašanja so bila zaprtega tipa $\mathrm{z}$ možnostjo dopolnjevanja mnenja, na koncu pa smo dodali še dve vprašanji odprtega tipa.

Rezultate smo obdelali s pomočjo programa za statistično obdelavo podatkov.

\subsection{Analiza ankete in ugotovitve}

$\mathrm{Na}$ samem začetku nas je zanimalo dijaki katerega izobraževalnega programa pri njih opravljajo praktični pouk. Pri $70 \%$ delodajalcev opravljajo praktični pouk dijaki programa zdravstvena nega in pri 30\% dijaki smeri bolničar negovalec.

Na vprašanje ali se jih zdi pomembno, da dijaki v dveh letnikih opravljajo praktični pouk v samem kliničnem okolju in ne samo v strokovnih učilnicah so vsi pritrdilno odgovorili in pripisali da bi moralo biti samega praktičnega pouka še več v kliničnem okolju saj se dijaki neposredno vključijo $\mathrm{v}$ sam proces dela in so seznanjeni z novostmi.

Zanima nas je tudi kakšno sodelovanje poteka med učitelji praktičnega pouka in vodstvenimi delavci ter delavci v kliničnem okolju. Anketirani menijo da je sodelovanje v $72 \%$ zelo dobro, $28 \%$ pa jih meni da dobro. Pri tem vprašanju smo bili veseli vseh predlogov, ki so jih navedli saj lahko samo na takšen način izvemo kaj in kako lahko popravimo sodelovanje. Izpostavili so občasne težave o sami izvedbi dela pri mentorjih praktičnega pouka z dijaki in zaposlenimi. Včasih prihaja do razhajanja pri načinu izvajanju določenih postopkov in posegov. Kljub temu, da je delo opravljeno, ga dijaki izvajajo po standardih, zaposleni pa na podlagi izkušenj in z improvizacijo. Po normativih so dijaki na praktičnem pouku razporejeni v skupine po $10-12$ dijakov. Sama skupina pa združi že majhne šume $\mathrm{v}$ moteče dejavnike na oddelku, kar je včasih moteče za paciente in zaposlene. $V$ preteklem šolskem letu pa so vodilni delavci opazili, da je prišlo na oddelkih v sklopu praktičnega pouka, Pud-a in opravljanja poklicne mature do vmešavanja dijakovih staršev, ki so zaposleni v ustanovi. 
$36^{\text {TH }}$ International Conference on Organizational Science Development: RESPONSIBLE ORGANIZATION (MARCH $22^{\mathrm{ND}}-24^{\mathrm{TH}}$, PORTOROŽ SLOVENIA)

P. Podlesnik: The Importance of Teamwork Between the Organizer of Practical Training and Teaching Bases

Zelo pomembna je tudi komunikacija med organizatorjem, kot vodjo tima in učnimi bazami. Postavili smo vprašanje ali organizator pogosto prihaja na ogled dela $v$ klinično okolje in ali so vodilni delavci seznanjeni kdaj se in na kakšen način se lahko obrnejo nanj v primeru pojava težav. Vsi se vsakoletno, pred pričetkom novega šolskega leta osebno srečajo z organizatorjem praktičnega pouka, ki jih seznani s kontaktnimi podatki in razporedom dela za celotno šolsko leto. Praksa je pokazala, da do sedaj ni prihajalo do večjih težav, ki bi za reševanje potrebovale prisotnost organizatorja praktičnega pouka ampak so jih reševali sprotno že z učitelji praktičnega pouka na samih oddelkih.

Vsakoletno se število dijakov s posebnimi potrebami veča. To predstavlja za učitelje praktičnega pouka posebne prilagoditve in o tem so dolžni delodajalce obvestiti. V anketi naj je zanimalo ali dijaki s posebnimi potrebami izstopajo iz skupine, če so moteči in ali zaposleni opazijo da jim morajo učitelji praktičnega pouka posvetit več pozornosti. Anketirani so v $65 \%$ navedli, da je opaziti dijake s posebnimi potrebami, ampak šele tedaj ko so nanje opozorili učitelji praktičnega pouka in so bili zato nanje pozorni. V $35 \%$ pa menijo, da dijaki sploh ne izstopajo. Menijo pa, da v kolikor so pri morebitnem incidentu dijakov vključeni tudi sami pacienti zahtevajo, da se o kršitvi obvesti tudi šolo oz. organizatorja praktičnega pouka kljub temu da je bil problem takoj rešen.

Pri vprašanjih odprtega tipa pa nas je zanimalo:

- Kako bi ocenili organizatorja praktičnega pouka?

- Navedite s katerimi težavami ste se največkrat srečali in ali so bile uspešno rešene?

O oceni organizatorja praktičnega pouka ni bilo navedene nobene kritike, izpostavili so hiter in takojšen odziv v primeru težav. Pohvalili so tudi njegov način dela, komunikacijo in pozitiven ter korekten odnos prav do vseh, ki so bili vključeni, tako dijaki, učitelji praktičnega pouka in zaposleni v kliničnem okolju.

Med težave s katerimi so se največkrat srečevali so navedli neprimerna komunikacija do zaposlenih in med dijaki samimi, neupoštevanje pravil varstva pri delu, ne prevzemanje odgovornosti v njihovi pristojnosti, osebna neurejenost in laganje pa tudi kraje.

Na podlagi pridobljenih rezultatov ankete smo zelo zadovoljni, da smo pridobili povratne informacije delodajalcev in lahko povzamemo, da je sodelovanje dobro, vsekakor pa bomo upoštevali tudi podane predloge in jih skušali realizirati $\mathrm{v}$ smislu še boljšega sodelovanja.

\section{Literatura}

Pravilnik o izobrazbi učiteljev in drugih strokovnih delavcev $\mathrm{v}$ poklicnem in strokovnem izobraževanju Uradni list RS (št. $\underline{48 / 11}$ in $\underline{92 / 12}$ ) 
P. Podlesnik: Pomen timskega dela med organizatorjem praktičnega pouka in učnimi bazami

Justinek, A. (2011) MUNUS 2 - praktično usposabljanje z delom, Vodnik za organizatorje. Ptuj: Šolski center

Zakon o poklicnem in strokovnem izobraževanju, 2006. Uradni list RS (št.79/2006)

Silvester, P. M., Komunikacija in sodelovanje v timu (str.74), PSIHOTERAPEVTSKI ukrepi za vsakdanjo rabo 3: (zbornik), Begunje, 18. In 19. November 2011. Begunje: Psihiatrična bolnišnica, 2011

Salas, E., Sims, E. D., Burke, C. S. (2005). Is there a "Big Five" in Teamwork? Small Group Research. Sage Publications. Dostopno na: http://sgr.sagepub.com/cgi/content/abstract/36/5/555.

Babnik. B., Temelji uspešnega timskega dela. Dostopno na http://www.solinstitut.com/content.php?section=strokovni_prispevki\&page=95 
772 36 $36^{\mathrm{TH}}$ InTERnational CONFERENCE ON ORganizational SCIENCE DeVelopment: RESPONSIBLE ORGANIZATION (MARCH $22^{\mathrm{ND}}-24^{\mathrm{TH}}$, Portorož SLOVENiA) 
$36^{\text {Th }}$ International Conference on Organizational Science DEVElopMENT: Responsible ORganization (MARCH $22^{\mathrm{ND}}-24^{\mathrm{TH}}$, PORTOROŽ SLOVENIA)

O. Arsenijević, M. Ferjan, I. Podbregar, P. Šprajc, D. Trivan \& Y. Ziegler

\title{
Multifactor Analysis of Online Reputation of Slovak Teaching Hospitals
}

\author{
FRANTISEK POLLAK, KATARINA BELOVODSKA \& BOZKA MALINAK
}

\begin{abstract}
The paper discusses the issue of online reputation, more specifically the ways and methods of its measurements in selected entities operating in the healthcare sector. A thorough multifactor analysis of reputation in the virtual world of the Internet was conducted on a specific sample of entities/ subjects - Slovak Teaching Hospitals. Using a careful statistical testing relationships between factors were examined in order to identify and describe basic facts affecting online reputation of those entities in the hyper competitive market environment of the Internet. The findings identified by the analysis conducted on the selected part of the global market, can be effectively used in any market for the purpose of increasing competitiveness of selected entities from (not only) healthcare sector.
\end{abstract}

KEYWORDS: reputation $\bullet$ reputator $\bullet$ internet $\bullet$ healthcare

CorResPOndence AdDREsS: Frantisek Pollak, Ph.D., University of Presov, Faculty of Management, Street 17 November 1, 08078 Prešo ,Slovakia, e-mail: frantisek.pollak@unipo.sk; Katarina Belovodska, MUDr., J. A. Reiman Faculty Hospital in Presov, Jána Hollého, 08001 Prešov, Slovakia, e:mail: katarina.belovodska@gmail.com; Bozka Malinak, M.S., Acuity Engineering \& Consulting Services Ltd, 10327122 St NW Edmonton, AB, T5N1M1 Canada, email: bozka.malinak@gmail.com 
$36^{\mathrm{TH}}$ INTERNATIONAL CONFERENCE ON ORganizational SCIENCE DeVElopment: RESPONSIBLE ORGANIZATION (MARCH $22^{\mathrm{ND}}-24^{\mathrm{TH}}$, PoRTOROŽ SLOVENIA)

F. Pollak, K. Belovodska \& B. Malinak: Multifactor Analysis of Online Reputation of Slovak Teaching Hospitals

\section{$1 \quad$ Introduction}

Reputation is an extremely important factor for gaining and strengthening consumer trust and confidence in the virtual as well as real world (Helm, et al., 2011, Gottschalk, 2011, Pollák, et al. 2016). Trust building is a long and arduous process and includes feelings, impressions and experiences of people who came into contact with the given company / business entity. Business entities pay this matter due attention. (Kanel, 2013) Its importance is undeniably gaining momentum, especially in the current period when a good reputation, long-lasting dominant position on the market and a huge success are not possible only thanks to innovative know-how and unique products, determination, undying entrepreneurial spirit, flexibility and capability in the particular field of business. The vision of a successful business needs a bit more than just that (Balmer and Greyser, 2003). A positive reputation is increasingly becoming one of the most effective tools around one's tough competition. According to surveys carried out by foreign research agencies, when faced with a choice between two products with comparable properties, $89 \%$ of consumers ultimately decided on the basis of the popularity of the brand and its reputation. Moreover, $72 \%$ of them added that the company's reputation influences their purchasing decisions and investments to the great extent (Pollák, 2015).

\subsection{Reputation, the basic characteristics}

When it comes to the actual process of building a corporate reputation, it is necessary to focus on the selected baseline characteristics linked with the process of positive reputation building. According to Svoboda (2009), reputation has three dimensions:

- primary reputation,

- secondary reputation,

- cyclical reputation.

This is a rather interesting view. What exactly is meant by these different dimensions? Primary reputation takes into account first-hand experience a customer has with the business entity - the face to face experience. This experience is immediate and personal. Psychologists call the phenomenon a first impression. Following the first contact, consumers strongly perceive significant attributes of the business entity and form their opinion on the entity. Employees who are in a direct contact with customers shape their perception. Secondary reputation is rather indirect and largely relies on the communication with the media, relatives, friends, as well self-presentation. The contact thus established is impersonal and mediated and easily influenced by various prejudices and stereotypes that usually refer to the behavior of different groups or individuals. Such stereotypes and prejudices negatively influence individuals leading to wrong conclusions. Cyclical reputation is influenced by social attitudes. If the social attitudes are in their favor, they do not feel the need to change their behavior. If, however, attitudes are negative, they try to change their behavior, products, or services through appropriate tools. 


\subsection{Reputation in the online environment, online reputation management}

Many Slovak and foreign authors (Kanika, 2016, Sasko, 2014, Pollák and Belovodská, 2015) argue that the concept of online reputation may cover many aspects ranging from organic presence in the search results, through traditional channels of marketing communication to its presence in its own virtual channels via social media. Reputation is thus the result of the activities carried out by a business entity on the Internet. Reputation also includes interaction with customers and their reactions (Fill, 2009). Today, there is no need to question why the online reputation is important, but rather how to analyze the current state of online reputation and how to get started with its active management (Marsden, 2013). In the following three points we will point out a few facts that are crucial for active online branding:

- the number of potential online customers is increasing,

- availability of information on the Internet,

- need to keep the brand under control.

It is an objective fact that the number of potential online customers is increasing. More and more companies are becoming aware of the fact that online presence is a necessity. Consumers enjoy fast access to and favorable prices of services and goods on the Internet. It is likely that people soon will buy online goods and services mainly because of their convenience and not only for favorable prices. Therefore, online presence and reputation are crucial for attracting new customers. Online references and reviews have a similar effect as recommendations from customers. Overlooking online reputation may mean the difference between success and failure or bankruptcy (Leboff, 2011). Another very important factor speaking in favor of online presence is the ever-increasing availability of information. Nowadays many people are familiar with social networks which also feature online reviews. It is quite possible that a lot of things we do offline will become online matters. Therefore, it is important to remember that online and offline world are closely linked and our business activities in the offline world will be eventually reflected in our online reputation (Marsden, 2013). Online reputation management is one of the best possible ways to find out the current status of business entity's corporate brand. It is more than possible that our customers will at some point of time leave a review on the Internet. In addition to web platforms and websites it is necessary to control all the "other" media associated with our brand like interaction with customers, fans or even competitors (Pollák, 2015). The article provides an insight into the active reputation management in the online environment using a thorough analysis of one of the available methodologies. Moreover, the article also evaluates data, identifies common background and provides recommendations regarding the subject matter, namely top-selling brand of cars operating on the Slovak market.

\section{Aims and methods}

The main objective of the paper is to present chosen option for measuring online reputation of selected entities operating in the healthcare sector with an aim to increase 
$36^{\mathrm{TH}}$ International Conference on Organizational Science Development: RESPONSIBLE ORGANIZATION (MARCH $22^{\mathrm{ND}}-24^{\mathrm{TH}}$, PoRTOROŽ SLOVENIA)

F. Pollak, K. Belovodska \& B. Malinak: Multifactor Analysis of Online Reputation of Slovak Teaching Hospitals

their competitiveness through a better understanding of the basic determinants of effective management of online reputation. Based on the current state of the issue theoretical knowledge and bases were accumulated, that provide knowledge base for the subsequent empirical research. A thorough multifactor analysis of reputation in the virtual world of the Internet was conducted on a specific sample of entities, all 11 Slovak Teaching Hospitals, compared to non-profit organization INEKO (2016) ranking (in table indicate in \% as INEKO rating). For the purpose of this research we used modified multifactor sentiment analysis on which we would like to demonstrate model option for measuring total online reputation (TOR) of selected entities. Methodology of the modified multi-factor analysis of the total online reputation TOR described by Pollák et al. (2016), brings more variability in its application on a broader spectrum of subjects than standard multi-factor analysis introduced by Sasko (2014). Moreover, it also brings a comprehensive look at the reputation of the given entity relative to the total possible reputation expressed as a percentage. Methodology used in the TOR index uses n-factors.

For each of analyzed subject, the first step analyses the sentiment of the first 10 results on Google. As for the number of groups, the standard is at least two groups: 1st group: name of the entity, 2nd group: instead of adding another keyword to the search engine, we repeated the measurement with one parameter, this time in the Google tab "News". It should be pointed out that in terms of the dynamics of published reports this was the least stable parameter. In any case, the number of groups is not particularly limited. Quantification is then ensured by unifying the scores into the percentage form. This is based on the assumption that within a single group the entity may receive a maximum score of 155 points - the ratio 1 point $=0.645 \%$. For purpose of our analysis with 2 groups, the entity may receive a maximum score of 310 points - the ratio 1 point $=0.32 \%$.

Second step identifies the determinants of online reputation, the so-called reputators. Reputator can be any determinant that can objectively affect the perceived online reputation of the entity, while its value can be quantified as a percentage. Normally these are important web pages, catalogues or social networks that can significantly affect the reputation of the entity. Given the various business fields entities operate in, reputation determinants cannot be clearly defined in advance. In terms of advantage quantification, it is possible to approach individual reputation determinants by unification of partial rankings - for example Google and Facebook ranks the subjects on a scale of 1-5. For the purpose of further analysis, we needed to unify reputation determinants by recalculating the percentages.

In the third step we can calculate the total advantage of the entity's online reputation with regard to its pre-defined competitors, as follows: Standard equation Pollák, et al. (2016) features specific determinants of online reputation and their weight. The basic reputation determinant is the ASA percentage score. The equation allows us to take into account any number of other reputation determinants. For the calculation itself it is necessary to determine the weights of individual reputation determinants which are normally determined depending on the subject and target market. If the weight of individual 
reputation determinants is not known in advance, the simplified formula for calculating the overall online reputation is as follows:

$$
T O R=\frac{R_{A S A}+\sum_{i=1}^{n} R_{i}}{n+1}
$$

Where:

TOR - Total online reputation $\mathrm{v} \%$

$\mathrm{R}_{\mathrm{i}}$ - Reputation determinant (\% score according to the particular $\mathrm{i}$ - reputation determinant)

$\mathrm{R}_{\mathrm{ASA}}$ - ASA reputation determinant (\%score according to the advanced sentiment analysis)

$\mathrm{N}$ - Number of determinants

In this case, the value of the overall online reputation is an arithmetic average of individual indicators (partial score according to individual determinants). Relations among factors (online reputation score based on the advanced sentiment analysis compared to the indices of reputation offered by the main Internet players, such as Facebook, Google and major local catalog portal Azet.sk provide as a part of their ratings) were then examined in thorough statistical testing using non-parametrical methods, such as Kendall rank coefficient, in order to identify and describe basic facts affecting online reputation of selected entities in the hypercompetitive market environment of the Internet.

\section{$3 \quad$ Results and discussion}

Each of the set of selected entities, in this case all 11 Slovak Teaching Hospitals, try to shape their reputation both within real and virtual world through their management. For the purposes of our research, we focused on the virtual world of the Internet.

\subsection{Overview table of partial score}

Using the advanced sentiment analysis (ASA), we calculated partial score presenting the power of online reputation of entities based on the nature of the first 10 Google search results. Google and its search results are, however, only one of many ways in which potential customers can access relevant information. Considering the previous research in the field of healthcare, we identified the following other determinants of online reputation (reputators) of healthcare entities, in particular:

- Google (reviews on the scale 1-5),

- Facebook (reviews on the scale 1-5),

- Azet.sk (reviews on the scale 1-5). 
$36^{\mathrm{TH}}$ INTERNATIONAL CONFERENCE ON ORganizational SCIENCE DeVElopment: RESPONSIBLE ORGANIZATION (MARCH $22^{\mathrm{ND}}-24^{\mathrm{TH}}$, PoRTOROŽ SLOVENIA)

F. Pollak, K. Belovodska \& B. Malinak: Multifactor Analysis of Online Reputation of Slovak Teaching Hospitals

Each of these reputators has five-point scale system which determines the overall score. For the purposes of further analysis scores of partial reputators were unified and converted into a percentage. Before we analyze the results by statistical testing, it is necessary to expound the specific values and partial score for the analyzed subjects through the overview table. The following table presents partial results - measured values of individual determinants / score of partial reputators of online reputation/ as well as score of total (overall) online reputation:

\begin{tabular}{|c|c|c|c|c|c|c|c|c|}
\hline $\begin{array}{c}\text { Rank } \\
\text { (INEKO) }\end{array}$ & $\begin{array}{c}\text { Town/ Result } \\
\text { sentiment }\end{array}$ & $\begin{array}{c}\text { ASA } \\
\text { score } \\
(\%)\end{array}$ & $\begin{array}{c}\text { FB rating } \\
(\%)\end{array}$ & $\begin{array}{c}\text { Google } \\
\text { rating } \\
(\%)\end{array}$ & $\begin{array}{c}\text { azet } \\
\text { rating } \\
(\%)\end{array}$ & $\begin{array}{c}\text { Number of } \\
\text { pages indexed } \\
\text { by Google }\end{array}$ & $\begin{array}{c}\text { INEKO } \\
\text { rating } \\
(\%)\end{array}$ & $\begin{array}{c}\text { TOR } \\
\text { score } \\
(\%)\end{array}$ \\
\hline 1. & $\begin{array}{l}\text { Faculty Hospital } \\
\text { Nitra }\end{array}$ & 11.84 & 72.00 & 80.00 & 40.00 & 77200 & 60.10 & 50.96 \\
\hline 2. & $\begin{array}{l}\text { Faculty Hospital F. } \\
\text { D. Roosevelt } \\
\text { Banská Bystrica }\end{array}$ & 57.92 & 90.00 & 80.00 & 60.00 & 27400 & 56.00 & 71.98 \\
\hline 3. & $\begin{array}{l}\text { Central Military } \\
\text { Hospital SNP } \\
\text { Ruzomberok } \\
\end{array}$ & 50.56 & 100.00 & 70.00 & 100.00 & 25200 & 55.10 & 80.14 \\
\hline 4. & $\begin{array}{l}\text { University Hospital } \\
\text { Martin }\end{array}$ & 70.40 & 80.00 & 0.00 & 100.00 & 67000 & 52.40 & 83.47 \\
\hline 5. & $\begin{array}{l}\text { Faculty Hospital } \\
\text { Nove Zamky }\end{array}$ & 31.36 & 76.00 & 74.00 & 100.00 & 30300 & 47.50 & 70.34 \\
\hline 6. & $\begin{array}{l}\text { Faculty Hospital } \\
\text { J.A.Reimana } \\
\text { Presov }\end{array}$ & 36.80 & 74.00 & 74.00 & 0.00 & 22700 & 42.70 & 61.60 \\
\hline 7. & $\begin{array}{l}\text { Faculty Hospital } \\
\text { Trencin }\end{array}$ & 47.36 & 66.00 & 66.00 & 100.00 & 62700 & 42.20 & 69.84 \\
\hline 8. & $\begin{array}{l}\text { Faculty Hospital } \\
\text { Trnava }\end{array}$ & 26.88 & 66.00 & 60.00 & 100.00 & 58700 & 35.40 & 63.22 \\
\hline 9. & $\begin{array}{l}\text { University Hospital } \\
\text { Bratislava }\end{array}$ & 37.76 & 84.00 & 80.00 & 0.00 & 157000 & 35.30 & 67,25 \\
\hline 10. & $\begin{array}{l}\text { University Hospital } \\
\text { of L. Pasteur } \\
\text { Kosice }\end{array}$ & 51.52 & 78.00 & 80.00 & 0.00 & 160000 & 30.30 & 69.84 \\
\hline 11. & $\begin{array}{l}\text { Faculty Hospital } \\
\text { Zilina }\end{array}$ & 32.64 & 60.00 & 70.00 & 40.00 & 61000 & 23.20 & 50.66 \\
\hline
\end{tabular}

\section{Table 1: [Overall (Total) online reputation]}

In the first step, we focused on analyzing reputation of the selected subject using broad sentiment analysis. For each analyzed subject we took into account the first ten results after typing in the selected keywords - name of the university hospital - in the search engine Google. The first results featured, as expected, hospitals' own websites. This came out as not surprising fact since the situation is almost the same for all sectors of business. It was expected that the following nine search results will be of a neutral character, however, this was confirmed only in two cases - university hospitals in Prešov and 
Košice. Neutral search results are mostly various sub-pages of the homepage or various formal references found on pages related to the government (state, county or city). Although they do not damage the reputation of the subject, they definitely do not add to its value with respect to the virtual "attractiveness". Positive search results related to the searched subject are from the point of view of Internet users more interesting, especially if users have no direct experience with any of those. The perception of the subject is thus established on very subjective - virtual experience. In this case, the positive sentiment regarding the studied subject was generally associated with the presence of the subject on Wikipedia or its profile on Facebook or other social media showing up in the first ten search results. Reviews of the studied subject appearing in the first ten search results after typing in the name of the studied subject were also considered as positive sentiment. An interesting finding highlighting the pitfalls of neutral reputation is a situation where the previously mentioned university hospitals in Prešov and Košice (both reaching in the first measurement of one parameter almost $30 \%$ of the total possible reputation) achieved a score only slightly higher than the University Hospital of Nitra (the winner of the evaluation carried out by the Institute INEKO), which recorded a significant negative sentiment in three out of ten Google search results. However, it compensated this loss by achieving three positive sentiments on positions 2,4 and 8 . Neutral sentiments can be easily removed and replaced with negative sentiments. The absence of positive sentiment can get any subject to red numbers.

Then we repeated the measurements using only one parameter, the full name of the subject. This time we focused on the results found in the tab "News". Based on the results we can state that the subjects are relatively good in mastering media communication. Except for three cases, namely University Hospital Nitra, Trnava and Bratislava, the subjects have not recorded more than one negative sentiment - negative reporting in the first 10 search results. However, there was no clear winner. The first place is held by the University Hospital in Košice and the University Hospital in Martin, who achieved almost the maximum level of positive reputation. It should be pointed out that we made a methodological adjustment in the case of the Faculty Hospital in Martin, since "Martin" is also a very popular male name. Therefore, we had to search the results for this hospital using quotes, which indeed might (but did not have to) affected the accuracy of the search results.

In the second step we analyzed reputation of the analyzed subject calculating their reputation using the following: reviews on Facebook, Google and Azet.sk. Interestingly enough, the studied subjects got better reviews on the first two mentioned websites than they achieved in the study carried out by the institute INEKO. We also appreciate the fact that all of the analyzed subjects got such positive reviews. This shows they have penetrated into the market. Since these are university hospitals, this is not surprising at all. With regard to the website Azet.sk, nearly half of the reviews had a five stars rating, which in some cases meant $100 \%$ rating. The winner of the evaluation carried out by the institute INEKO University Hospital Nitra together with the University Hospital Žilina achieved the rating of only $40 \%$. University hospitals in Bratislava, Košice and Prešov did not have any review on the website Azet.sk. However, it should be noted that although 
36 ${ }^{\mathrm{TH}}$ International Conference on Organizational Science Development: RESPONSIBLE ORGANIZATION (MARCH $22^{\mathrm{ND}}-24^{\mathrm{TH}}$, Portorož SLOVENIA)

F. Pollak, K. Belovodska \& B. Malinak: Multifactor Analysis of Online Reputation of Slovak Teaching Hospitals

these hospitals as a whole did not have any reviews, their clinics and departments often had. Nevertheless, our analysis was aimed only at the university hospitals as a whole.

In the third step of the analysis we calculated the overall reputation. The clear winner is the University Hospital in Martin, which rating exceeded $80 \%$ of the total value of positive online reputation. The University Hospital in Martin was followed by the Central Military Hospital Ružomberok. Then we have the University Hospital in Žilina and Nitra with $50 \%$ rating. Interestingly enough, University Hospital Nitra was according to the INEKO Institute rated as the best university hospital in Slovakia.

The following figures point out some interesting outcomes of the analysis:

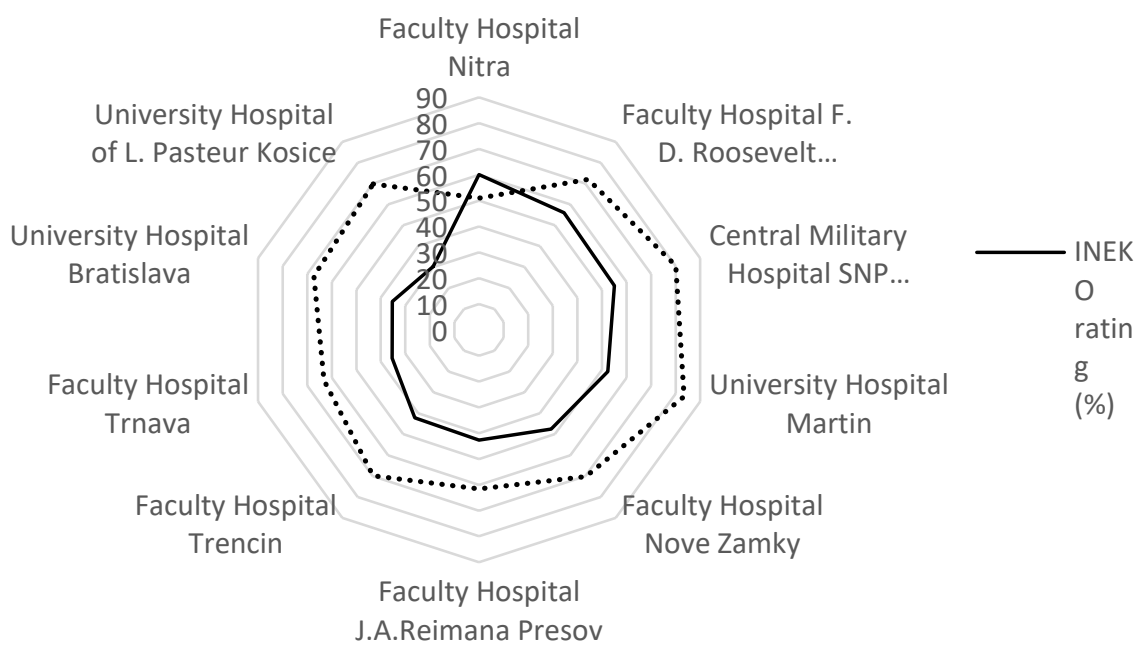

Figure 1: [INEKO rating vs. Overall On-line Reputation]

In comparison with the results of the institute INEKO, the score of the analyzed subjects with regard to their online reputation was around $25 \%$. The University Hospital in Nitra has recorded a decline in their online reputation when compared to results of INEKO by a little more than $9 \%$. On the basis of the analysis we were able to proceed with the statistical analysis of the selected context. Regarding the correlation between INEKO rating and the level of overall virtual reputation, at the chosen significance level of $5 \% \mathrm{p}-$ value is sharply higher than 0.05 . We have therefore confirmed no statistically significant 
correlation between INEKO rating and TOR rating since each ranking method uses different factors.

\begin{tabular}{|c|c|c|c|c|}
\hline \multirow[b]{2}{*}{ Variables } & \multicolumn{4}{|c|}{$\begin{array}{l}\text { Kendall Tau Correlations } \\
\text { Level of signific ance: } p<0.05\end{array}$} \\
\hline & \begin{tabular}{|c|} 
Valid \\
$\mathrm{N}$
\end{tabular} & $\begin{array}{l}\text { Kendall } \\
\text { Tau }\end{array}$ & Z & p-level \\
\hline INEKO \& TOR & 10 & 0,134840 & 0,542 & 0,587322 \\
\hline
\end{tabular}

Table 2: [INEKO rating vs. Overall On-line Reputation]

With regard to organic search results (first 10) on Google in the tab "All" and "News" and INEKO rating we can conclude the following:

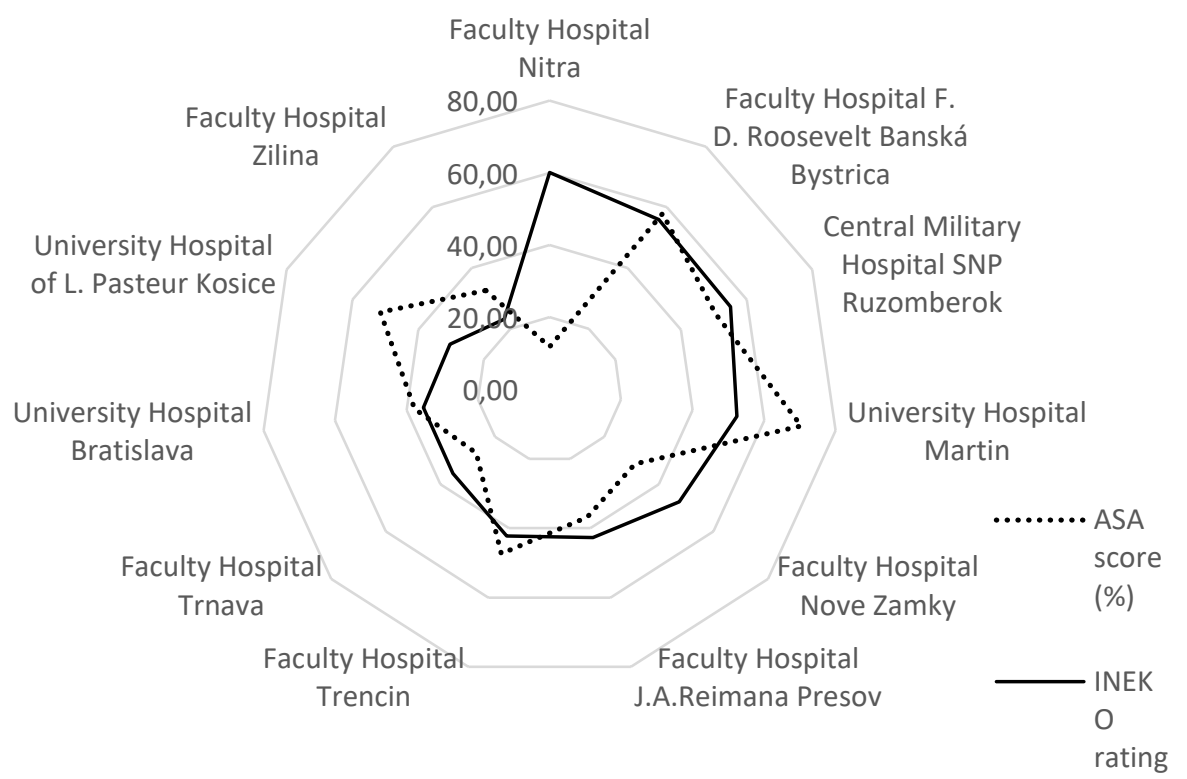

(\%)

Figure 2: [INEKO rating vs. Reputation by ASA]

Except for one case, the virtual reviews found in the search engine Google are more or less same as INEKO's reviews. Based on the results of the analysis, we tested and analyzed the selected context. Regarding the correlation between INEKO's rating and the level of virtual reputation according to ASA, at the chosen significance level of 5\% the p-value is sharply higher than 0.05 . Even in this case we were not able to confirm a statistically significant correlation between ASA score and INEKO's rating. 
36 ${ }^{\mathrm{TH}}$ International Conference on Organizational Science Development: RESPONSIBLE ORGANIZATION (MARCH $22^{\mathrm{ND}}-24^{\mathrm{TH}}$, PoRTOROŽ SLOVENIA)

F. Pollak, K. Belovodska \& B. Malinak: Multifactor Analysis of Online Reputation of Slovak Teaching Hospitals

\begin{tabular}{|c|c|c|c|c|}
\hline \multirow[b]{2}{*}{ Variables } & \multicolumn{4}{|c|}{$\begin{array}{l}\text { Kendall Tau Correlations } \\
\text { Level of significance: } p<0.05\end{array}$} \\
\hline & $\begin{array}{c}\text { Valid } \\
\mathrm{N}\end{array}$ & $\begin{array}{l}\text { Kendall } \\
\text { Tau }\end{array}$ & $\bar{Z}$ & p-level \\
\hline \& INEKO & 10 & $-0,022222$ & $-0,089443$ & 0,928730 \\
\hline
\end{tabular}

Table 3: [INEKO rating vs. Reputation by ASA]

Our next goal was to analyze the presence of the selected subject on virtual social networks, both in terms of user reviews and ratings. The following figure will show us these parameters:

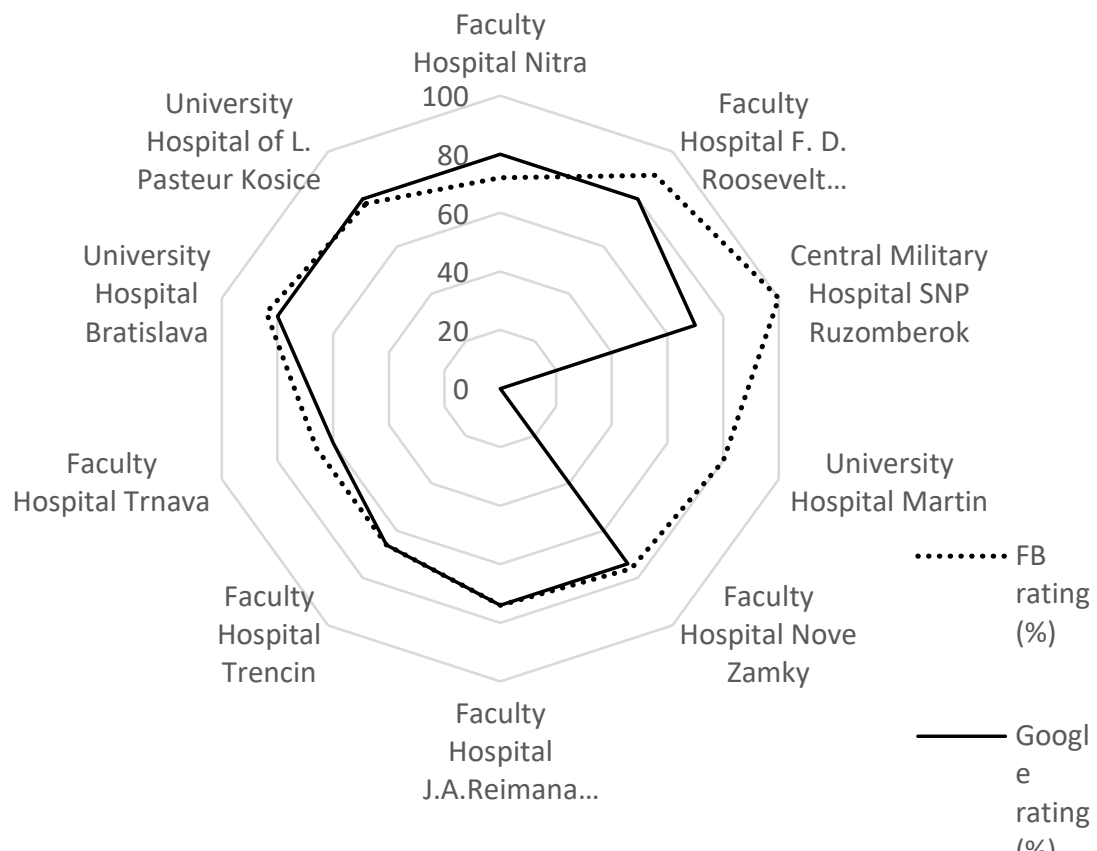

Figure 3: [Activity on VSN]

It is clear that values measured on Facebook and Google are almost the same, expect for the University Hospital in Martin which at the time of the analysis did not have any review on Google. 
As a final step we analyzed the connection between the scores of broad sentiment analysis and the total number of Google index pages of the subject.

\begin{tabular}{|c|c|c|c|c|}
\hline \multirow[b]{2}{*}{ Variables } & \multicolumn{4}{|c|}{$\begin{array}{l}\text { Kendall Tau Correlations } \\
\text { Level of significance: } p<0.05\end{array}$} \\
\hline & \begin{tabular}{|c|} 
Valid \\
$\mathrm{N}$
\end{tabular} & $\begin{array}{l}\text { Kendall } \\
\text { Tau }\end{array}$ & $Z$ & p-level \\
\hline \& Google & 10 & 0,02222 & 0,089443 & 0,928730 \\
\hline
\end{tabular}

Table 4: [Number of Google indexed pages vs. Reputation by ASA]

We can conclude that at the chosen significance level of $5 \%$ the p-value was $>0.05$. We did not confirm a statistically significant correlation between variables. This only confirms the already known facts about the importance of quality over quantity.

\section{$4 \quad$ Conclusions}

We agree with the author Juraj Sasko (2014), who states, the active online reputation management utilizing platforms like Google, Facebook and YouTube can greatly facilitate active communication with the public, help in acquiring and evaluating feedback or speed up implementation of measures related to a crisis marketing communication. However, a wide variety of platforms requires a comprehensive approach. Reputation is perception and reality reflecting the total sets of components of the most complex asset of an organization. Knowledge and understanding are considered one of the major contributions for sequences of connected factors, determinants, standardization, and formation of a systematically exhaustive exploration of the mathematical model, model checking as powerful tool of the presented paper.

From the point of view of analyzed subjects, hospitals in the leading positions have a distinctive advantage in terms of their online reputation among Internet users. In case the user seeking information about a particular subject does not encounter positive reputation indicators, this can ultimately affect his/ her overall perception of the entity. This is especially true if we are speaking about users who have not personally visited the subject yet and they make their opinions solely on the basis of information present in the online environment. Hospitals should attempt to curb negative publicity, and vice versa, to enhance and work on the positive publicity. This can be achieved particularly through the active online communication policy like dissemination of positive information through renowned major online newspapers or social networks. The best way to remove negative or neutral publicity in the first ten search results is a literal displacement of negative publicity by a thoughtful marketing communication policy conducted in the online environment. In general, it would seem that the most effective model of the comprehensive online reputational management is to focus on dominant reputation determinants, namely Google search results and active management of the profile on one 
$36^{\mathrm{TH}}$ INTERNATIONAL CONFERENCE ON ORganizational SCIENCE DeVElopment: RESPONSIBLE ORGANIZATION (MARCH $22^{\mathrm{ND}}-24^{\mathrm{TH}}$, PORTOROŽ SLOVENIA)

F. Pollak, K. Belovodska \& B. Malinak: Multifactor Analysis of Online Reputation of Slovak Teaching Hospitals

of the social networks. Doing so may be have positive effect only in the short term, users will demand content from platforms unused by/ or presenting the entity (Facebook and Google+, as resulting from the analysis), regardless of who is the content manager of the profile on these platforms. In this way, selected entities presenting themselves as official profiles can attract (or not) a large number of customer base. As indicated above, active instruments of the online reputational management can greatly facilitate active communication with public, help in acquiring and evaluating feedback or speed up implementation of measures related to a crisis marketing communication. Without a strong base of users none of this is possible, not with a significant result.

The findings identified by the analysis conducted on the local market (in this case, used as a model example), can be effectively used in any market for the purpose of increasing competitiveness of (not only) selected entities.

\section{Acknowledgement}

This article is one of the partial outputs of the currently solved research grant VEGA no. 1/0806/16 entitled „Research on issues of consumer behavior of a new generation of customers with emphasis on identifying preferences and usability of mobile platforms in the process of e-commerce of the subjects localized predominantly on the Central European Market".

\section{Literature}

Helm, S., et al. (2011). Reputation Management. Berlin: Springer-Verlag.

Gottschalk, P. (2011). Corporate Social Responsibility, Fovernance and Corporate Reputation. USA: World Scientific Publishing Co. Pte. Ltd.

Pollák, F., et al. (2016). Sustainable E-marketing of Selected Tourism Subjects from the Mediterranean Through Active Online Reputation Management. In Volume 166 of the series Lecture Notes of the Institute for Computer Sciences, Social Informatics and Telecommunications Engineering, Toronto: Springer, pp. 692-703.

Kaenel, A., Ch., von. (2013). Vertrauen bei Online-Transaktionen - Vertrauenstypen im OnlineEntscheidungsfindungsprozess. Dissertation Nr. 4190. Der Universität St.Gallen, Hochschule für Wirtschafts, Rechts und Sozialwissenschaften sowie Internationale Beziehungen (HSG). Retrieved from http://verdi.unisg.ch/www/edis.nsf/SysLkpByIdentifier/4190/\$FILE/dis4190.pdf

Balmer, J., \& Greyser, S. (2003), Revealing the Corporation: Perspectives on Identity, Image, Reputation, Corporate Branding and Corporate-level Marketing. Oxford: Routledge.

Pollák, F. (2015). On-line reputačný manažment v podmienkach stredoeurópskeho virtuálneho trhu. Prešov: Bookman. (Slovak)

Svoboda, V. (2009). Public relations - moderně a účinně. Praha: Grada Publishing a.s. ISBN 97880-24728-66-7 (Czech)

Kanika, D. (2016). Prečo je online reputácia dôležitá? Retrieved from $\mathrm{http} / / / \mathrm{www}$.pranswer.com/sk/manazment-povesti-referencie-a-recenzie/preco-je-onlinereputacia-dolezita/ (Slovak)

Sasko, J. (2014) Dbáte na hodnotu svojej značky? Retrieved from http://www.podnikajte.sk/manazmentmarketing/c/1392/ category/ marketing/article /onlinereputacny-manazment.xhtml (Slovak) 
F. Pollak, K. Belovodska \& B. Malinak: Multifactor Analysis of Online Reputation of

Pollák, F., \& Belovodská, K. (2015). Multifactor analysis of online reputation as a tool for enhancing competitiveness of selected health care providers, In Annual international conference on enterprise marketing and globalization, Global science and technology forum, Singapore, pp. 6-12.

Fill, C. (2009). Marketing Communications: Interactivity, Communities and Content. 5th Edition. UK: Pearson Education Ltd.

Marsden, H. (2013). Guard Your Reputation On-line. Birmingham: Smartebookshop.

Leboff, G. (2011). Sticky marketing - Jak zaujmout, ziskat a udržtet si zákazníky. Prague: Management Press. (Czech)

Ineko. (2016). Hospital of the year 2016. Retrieved from http://nemocnice.ineko.sk/ nemocnica_roka/2016/ 
786 36 $36^{\mathrm{TH}}$ International CONFERENCE ON ORganizational Science Development: Responsible Organization (MARCh $22^{\mathrm{ND}}-24^{\mathrm{TH}}$, PORTOROŽ SlOVENIA) 


\title{
Zadovoljstvo, motiviranost in podjetnost zdravnikov javnega zdravstvenega sistema $v$ luči zdravstvene reforme
}

\author{
ANDREJ PRLJA \& VIDA KAMPUŠ TROP
}

\begin{abstract}
Povzetek V Sloveniji že dve desetletji govorimo o nujnosti zdravstvene reforme. Pozornost javnosti je usmerjana predvsem na plače. Zdravniške organizacije pa vendarle dajejo prednost ureditvi standardov in normativov dela.

Najprej smo raziskali zadovoljstvo zdravnikov javnih bolnišnic z materialnim stanjem in perspektivo sistema, njihovih ustanov ter osebno. Zdravniki so nezadovoljni z vsem naštetim le s svojim trenutnim materialnim stanjem so še na meji zadovoljstva.
\end{abstract}

Nadaljnja raziskava je pokazala, da jim je varnost zaposlitve največja prednost javnega in hkrati slabost zasebnega zdravstva. Obratno veja za možnost zaslužka. Kot delovna motivacija so jim od zaslužka pomembnejši osebni razvoj, delovni pogoji in zanimivost dela. Večina zdravnikov tudi ni poslovno podjetnih.

V javnih občilih smo opazili velik razkorak med zahtevami nosilcev stavke, interesi Vlade in javnosti. Zato smo primerjali poročila medijev v času zdravniške stavke, novembra 2016 in v enakem obdobju 2015. Pričakovano je število prispevkov leta 2015 manjše, vsebinsko pa v obeh obdobjih prevladujejo komentarji o materialnih zahtevah zaposlenih in potencialnih posledicah za javni plačni sistem, ne pa o vsebinskih vprašanjih reforme.

Na koncu predstavljamo naše videnje razhajanj stališč in interesov udeleženih ter njihov vpliv na izid stavke in reforme.

KLJUČNE BESEDE: zdravniki $\bullet$ zadovoljstvo $\bullet$ motivacija $\bullet$ podjetnost $\bullet$ zdravstvena reforma

NASLOV AVtorJev: Andrej Prlja, dr. med., Zavod Medici E in A, Zgornja Senica 2e, 1215 Metvode, Slovenija, e-pošta: andrej.prlja@ siol.net; dr. Vida Kampuš Trop, docentka, Univerza v Mariboru, Fakulteta za organizacijske vede, Kidričeva cesta 55a, 4000 Kranj, Slovenija, e-pošta: vida.kampus-trop@fov.uni-mb.si 


\title{
Physicians Content, Motivation and Enterpreneurship in the Aspect of the Slovenian Health Care Reform
}

\author{
ANDREJ PRLJA \& VIDA KAMPUŠ TROP
}

\begin{abstract}
The debate over the need of the health care reform lasts for over two decades. The public attention is orientated on the income claims. The physicians try to point out the need of the structural changes, particularly the standards and norms.

We made an inquiry about the content of the Slovenian public hospital physicians, with the material status and perspective of the system as whole, its institutions and themselves. They are dissatisfied with all above, only the personal material status is still on the edge of the content,

Further research revealed the security of the employment as the greatest advantage of the public and disadvantage of the private health sector. Opposite is true for the profit opportunities. Personal development, working condition and attraction of the work are greater work motivators than the income. The majority of the physicians are not active as entrepreneurs.
\end{abstract}

In the media we detected substantial disparity between the strike claims, Government point of view and the public interest. We compared the media news in November 2016 (physicians strike time) and November 2015. As expected, the frequency of relevant news was much less in 2015. Still the accent was on income claims and their potential effect on public budged, not on the substantial reform issues.

In conclusion we present our view of these disagreements and their influence on the strike and reform perspectives.

KEYWORDS: physicians $\bullet$ content $\bullet$ motivation $\bullet$ entrepreneurship $\bullet$ health reform

CorRespondence AdDress: Andrej Prlja, dr. med., Institute Medici E in A, Zgornja Senica 2e, 1215 Metvode, Slovenia, e-mail: andrej.prlja@siol.net; Vida Kampuš Trop, Ph.D., Assistant Professor, University of Maribor, Faculty of Organizational Sciences, Kidričeva cesta 55a, 4000 Kranj, Slovenia, e-mail: vida.kampus-trop@fov.uni-mb.si

DOI https://doi.org/10.18690/978-961-286-020-2.63 
A. Prlja \& V. Kampuš Trop: Zadovoljstvo, motiviranost in podjetnost zdravnikov javnega zdravstvenega sistema v luči zdravstvene reforme

\section{$1 \quad$ Uvod}

Več kot dve desetletji trajajo razprave o nujnosti nove zdravstvene reforme v Sloveniji. Kljub burnim razpravam in napovedim reform do sedaj konkretnega rezultata še ni. Eden od razlogov je tudi medsebojno nerazumevanje udeleženih, zlasti med politiko, industrijo, zdravniki in bolniki.

Glede na poročila v medijih imamo vtis, da je komunikacija med razpravljavci slaba, da bolj sporočajo svoja stališča in se niti ne trudijo slišati in razumeti stališča in motive drugih. Tako se, na primer, večina zdravniških pobud glede zdravstvene reforme praviloma sprevrže v neproduktivno razpravo o plačah. Predpogoj za kvalitetno razpravo o vsebini reform pa je po našem prepričanju poznati stališča in motive vseh vpletenih.

$\mathrm{Z}$ vprašanji motivacije zdravnikov za delo in poslovne aktivnosti se $\mathrm{v}$ okviru podiplomskega študija na FOV v Kranju ukvarjamo že od leta 2008. V večih raziskavah smo ugotovili, da za zdravnike $\mathrm{v}$ javnem sektorju sam zaslužek nikoli ni bil med tremi najpomembnejšimi motivacijskimi dejavniki (Kampuš Trop, Prlja, 2010; Prlja, Kampuš Trop, 2015; Prlja, 2016).

\subsection{Namen in cilji prispevka}

Namen našega prispevka je prikazati zadovoljstvo zdravnikov glede materialnega stanja v zdravstvu, njihovo videnje razlik med javnim in zasebnim sektorjem ter njihovo motivacijo za delo. Pomemben namen članka je tudi prikazati, kako je bila javnost $\mathrm{v}$ pisnih medijih obveščana o zdravstvu in zdravstveni reformi $v$ času zdravniške stavke 2016.

Cilji prvega dela članka je zato podati povzetke nekaterih rezultatov naše doslej najobsežnejše raziskave (Prlja, 2016) v zvezi z zadovoljstvom zdravnikov, njihovem videnju razlik med javni in zasebnim zdravstvom in motivacijskimi dejavniki za delo. Cilji drugega dela članka pa je prikazati povzetke analize poročanja pisnih medijev o zdravstvu in zdravstveni reformi ter s tem potrditi našo domnevo, da se mediji pretežno osredotočajo na popularne teme o zdravstvu namesto na zdravstveno reformo.

\subsection{Uporabljena metodologija in hipoteze}

Najobsežnejša raziskava o zadovoljstvu $\mathrm{z}$ materialnim stanjem in perspektivami celotnega zdravstvenega sistema, ustanov, kjer so anketirani zdravniki zaposleni in osebno, pomenu določenih motivacijskih dejavnikov za njihovo delo ter o dojemanju razlik med zasebnim in javnim zdravstvom je bila opravljena med zdravniki vseh štirih bolnišnic gorenjske regije $\mathrm{v}$ okviru magistrske naloge (Prlja, 2016). Do rezultatov raziskave smo prišli preko preverjanja treh hipotez s pomočjo opisne statistike, testov deleža, $\mathrm{t}$ in Z-testov, neparametričnega Wilcoxonovega testa predznačenih rangov (angl. Wilcoxon Signed Rank Test) ter parnih t-testov. Te tri hipoteze so: 
- Hipoteza H1: Večina bolnišničnih zdravnikov je nezadovoljnih z materialnim stanjem in prihodnostjo javnega zdravstvenega sistema, javne zdravstvene ustanove, kjer je zaposlena in osebno.

- Hipoteza H2: Bolnišnični zdravniki vidijo pomembne razlike med javnim in zasebnim sektorjem v zdravstvu glede varnosti, zaslužka, možnosti odločanja, nivoja strokovnosti, neodvisnosti stroke, sodelovanjem z drugimi strokami in pogajanja z zavarovalnicami.

- Hipoteza H3: Bolnišničnim zdravnikom zaslužek ni najpomembnejši motivacijski dejavnik.

V naši zadnji raziskavi smo pregledali število in vsebino člankov o zdravstvu v častnikih Delo, Dnevnik in Finance med 1. in 30. novembrom 2016 (čas zdravniške stavke) in istim obdobjem 2015. Statistično smo domneve o nesorazmerjih poročanja med populističnimi temami in reformskimi vprašanji preverjali s testom deleža in tako testirali našo četrto hipotezo:

- Hipoteza H4: V člankih izbranih časopisov (Delo, Dnevnik, Finance) se je očitno pogosteje pisalo o drugih kategorijah povezanih z zdravstvom kakor o reformi.

\section{Povzetek rezultatov raziskave o zadovoljstvu zdravnikov glede materialnih dejavnikov, dojemanja razlik med javnim in zasebnim zdravstvom ter o motivaciji za delo in podjetniško-poslovne aktivnosti}

\subsection{Osnovna analiza o sodelujočih zdravnikih v raziskavi}

Razdeljenih je bilo 159 anket. Izpolnjeno anketo je vrnilo 99 zdravnikov (62,2 \%), med njimi $53 \%$ zdravnikov in $47 \%$ zdravnic. Vsi anketirani zdravniki so bili redno zaposleni v javnem zdravstvenem zavodu (bolnišnici), stari od 30 let do 73 let, povprečno 47,3 let ,standardni odklon 9,9 let. Delovne dobe so imeli anketiranci v povprečju 17,1 leto s standardnim odklonom 10,1 leto. Najstarejši zdravnik je imel 42 let delovne dobe, najmlajši še ni dopolnil enega leta delovne dobe. Delovne dobe kot specialist ima najstarejši 39, najmlajši nič. Povprečna specialistična doba je 10,1 let s standardnim odklonom 9,8 let. Struktura po spolu, starosti in delovni dobi v naši raziskavi je primerljiva $\mathrm{s}$ povprečji slovenskih bolnišnic glede na letna poročila Zavoda za zdravstveno zavarovanje (ZZS). 

ORGANIZACIJA (22. - 24. MAREC 2017, PORTOROŽ, SLOVENiJA)

A. Prlja \& V. Kampuš Trop: Zadovoljstvo, motiviranost in podjetnost zdravnikov javnega zdravstvenega sistema v luči zdravstvene reforme

\subsection{Povzetek rezultatov preverjenih hipotez}

\subsubsection{Preverjanje hipoteze o zadovoljstvu zdravnikov $\mathrm{z}$ materialnem stanjem in perspektivo}

Zdravniki so ocenjevali stanje na treh nivojih: nivo javnega zdravstva, ustanove, v kateri je anketirani zdravnik zaposlen, ter osebno materialno stanje in perspektiva. Uporabljena je bila 5 stopenjska lestvica (od 1- zelo zadovoljen do 5 - zelo nezadovoljen).

Zdravniki so bili $\mathrm{z}$ materialnim stanjem in perspektivo $\mathrm{v}$ javnem zdravstvu večinoma nezadovoljni. Najbolj nezadovoljni so bili glede materialne perspektive javnega zdravstvenega sistema $(4,22)$, malo manj z njegovim trenutnim $(4,00)$. Še najbolj so bili zadovoljni s lastnim materialnim stanjem $(2,86)$, malo manj pa glede perspektiv izboljšanja lastnega materialnega stanja $\mathrm{v}$ prihodnosti $(3,71)$.

Za lažje preverjanje hipoteze s testom deleža smo ocenjevalno lestvico skrčili (rekodirali) iz 5-stopenjske v 3-stopenjsko po spodaj prikazanem načinu:

- zadovoljen = zelo zadovoljen in pretežno zadovoljen

- niti/niti = niti/niti

- nezadovoljen = zelo nezadovoljen in pretežno nezadovoljen

Tako združene rezultate ocen prikazuje Slika 1. Skoraj zadovoljna je bila večina zdravnikov le $\mathrm{z}$ osebnim materialnim statusom (59 \%). Pri vseh ostalih kategorijah, vključno z osebno materialno perspektivo, je prevladovalo nezadovoljstvo z deleži od 59 $\%$ do $87 \%$. Večino smo opredelili kot $50 \%$ ali več.

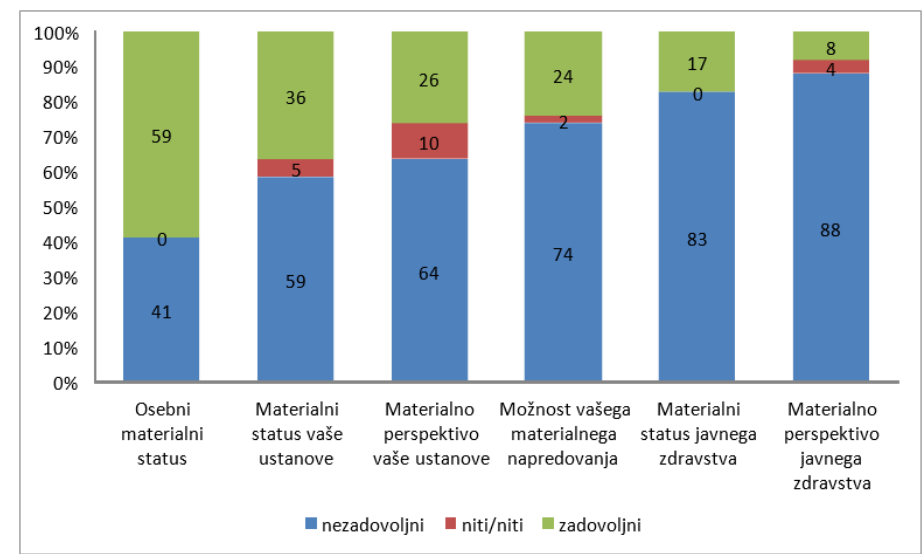

Slika 1: Zadovoljstvo z materialnim stanjem in perspektivo javnega zdravstvenega sistema, javnih zdravstvenih ustanov in osebno 
36 ${ }^{\mathrm{TH}}$ International Conference on Organizational Science Development: RESPONSIBLE ORGANIZATION (MARCH $22^{\mathrm{ND}}-24^{\mathrm{TH}}$, PORTOROŽ SLOVENIA)

A. Prlja \& V. Kampuš Trop: Physicians Content, Motivation and Enterpreneurship in the Aspect of the Slovenian Health Care Reform

Hipotezo smo testirati $\mathrm{z}$ enostranskim testom deleža $\mathrm{s}$ pod hipotezo, da je večina zdravnikov nezadovoljna $z M_{i}\left(H_{0}: \pi_{M_{i}}=0,5\right.$ in $\left.H_{1}: \pi_{M_{i}}>0,5\right)$. $M_{i}$ se nanaša na posamezne trditve povezane $\mathrm{z}$ oceno materialnega stanja in materialne perspektive javnega sistema, ustanove in osebno. Ker gre za velik vzorec smo uporabili $\mathrm{Z}$ test. $\mathrm{Ob}$ normalni razporeditvi in $5 \%$ tveganju, je kritična vrednost $Z_{\alpha}=1,65$.

Za vse spremenljivke, razen za osebno materialno stanje, so bile izračunane statistike testa večje od kritične vrednosti: nezadovoljstvo večine zdravnikov z materialnim stanja javnega zdravstva $(Z=6,53)$, materialnim statusom ustanove $(Z=1,71)$, perspektivo javnega zdravstvenega sistema $(Z=7,54)$, ustanove, kjer so zaposleni $(Z=2,71)$ in možnostmi osebnega materialnega napredovanja $(Z=4,72)$. Le z osebnim materialnim stanjem je bila večine še zadovoljna $(Z=-1,65)$.

S temi rezultati je bila potrjena hipoteza $\mathrm{H1}$, da je večina bolnišničnih zdravnikov nezadovoljna $\mathrm{z}$ materialnim stanjem in prihodnostjo javnega zdravstvenega sistema, javne zdravstvene ustanove, kjer je zaposlena, in možnostjo osebnega materialnega napredovanja.

\subsubsection{Preverjanje hipoteze o videnju nekaterih pomembnih razlik med javnim in zasebnim zdravstvenim sektorjem z očmi bolnišničnih zdravnikov}

Anketirane zdravnike smo spraševali ali ponujene dejavnike vidijo kot prednost ali slabost javnega oziroma zasebnega zdravstva. Iz Slike 2 je razvidno, da nekateri zdravniki niso izpolnili vseh rubrik ali pa več hkrati. 
A. Prlja \& V. Kampuš Trop: Zadovoljstvo, motiviranost in podjetnost zdravnikov javnega zdravstvenega sistema v luči zdravstvene reforme
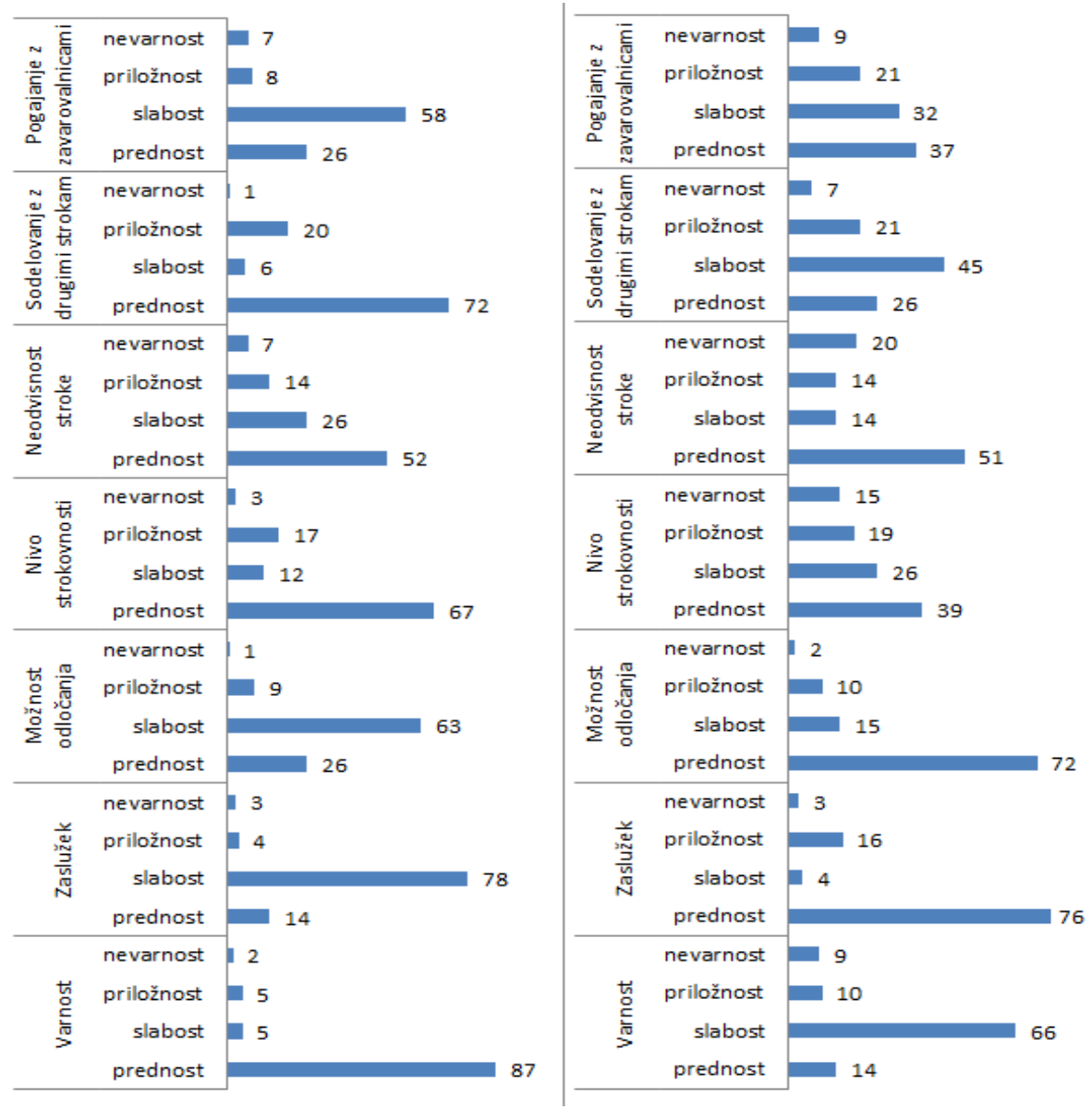

Slika 2: Število zdravnikov glede na oceno prikazanih dejavnikov kot prednosti oziroma slabosti javnega in zasebnega zdravstvenega sektorja

Dejavnike so ocenjevali na 4 stopenjski lestvici, kjer sta bili diametralno nasprotni vrednosti prednost (1) in nevarnost (4) ter na vmesnem delu priložnost (2) in slabost (3).Lestvica (nastala na osnovi našega večletnega opazovanja v zdravstvu) je sicer specifična, ocenjujemo pa, da jo lahko uporabimo kot urejenostno in je zato primeren neparametrični test.

Kot največjo prednost javnega zdravstva so anketirani zdravniki videli varnost zaposlitve (87:14). Za največja prednost zasebnega zdravstva so ocenili možnost zaslužka (76:14). Prednosti javnega zdravstva sta bili še nivo strokovnosti (67:39) in sodelovanje z drugimi strokami (72:26). Zasebniki pa naj bi imeli večjo možnost odločanja (72:26) in pogajanja z zavarovalnicami (37:26) kot zaposleni v javnih zdravstvenih ustanovah. Kot največja 
$36^{\mathrm{TH}}$ International Conference on Organizational Science Development: Responsible Organization (MARCH $22^{\mathrm{ND}}-24^{\mathrm{TH}}$, Portorož SlOVENIA)

A. Prlja \& V. Kampuš Trop: Physicians Content, Motivation and Enterpreneurship in the Aspect of the Slovenian Health Care Reform

slabost javnega zdravstva je bila izpostavljena možnost zaslužka (78:4), največja slabost zasebnikov pa varnost zaposlitve (66:5).

Uvodoma omenjeno Hipotezo H2 smo testirali z Wilcoxon-ovim testom predznačenih rangov. Z negativnim rangom so bili označeni odgovori, ki so dajali prednost zasebnemu, pozitivno javnemu in $\mathrm{z}$ enačajem, če so ju enačili. Razlike povprečnih rangov so bile velike, največja pri sodelovanju $\mathrm{z}$ drugimi strokami $(15,00: 33,27)$, najmanjša pri možnosti odločanja $(31,95: 32,38)$. Kot prednost javnega zdravstva (pozitivni rang) so zdravniki videli varnost ( 69 zdravnikov), sodelovanje z drugimi strokami (56 zdravnikov) in nivo strokovnosti (39 zdravnikov). Kot prednosti zasebne zdravstvene dejavnosti (negativni rang) pa je 67 zdravnikov videlo možnost zaslužka, 55 možnost odločanja in 33 možnost pogajanja z zavarovalnicami. Pri neodvisnosti stroke ni prevladujoče ocene glede prednosti v javnem ali zasebnem zdravstvu.

Statistično značilne razlike pri $5 \%$ tveganju smo našli pri šestih dejavnikih. Prednosti javnega sektorja pred zasebnim so bile varnost $(\mathrm{p}=0,000<0,05)$, sodelovanje $\mathrm{z}$ drugimi strokami $(\mathrm{p}=0,000<0,05)$, nivo strokovnosti $(\mathrm{p}=0,000<0,05)$. Prednost zasebnega pred javnim sektorjem so bile zaslužek $(p=0,000<0,05)$, možnost odločanja $(p=0,000<0,05)$, pogajanje $\mathrm{z}$ zavarovalnicami $(\mathrm{p}=0,000<0,05)$.Pri oceni "neodvisnosti stroke" pa zdravniki niso videli pomembnih razlik. ( $\mathrm{p}=0,654>0,05)$.

Tako je bila potrjena hipoteza H2: Bolnišnični zdravniki vidijo pomembne razlike med javnim in zasebnim sektorjem v zdravstvu glede varnosti, zaslužka, možnosti odločanja, neodvisnosti stroke, sodelovanja $\mathrm{z}$ drugimi strokami in pogajanja z zavarovalnicami.

\subsubsection{Preverjanje hipoteze o pomembnosti nekaterih motivacijskih dejavnikov za delo bolnišničnih zdravnikov}

Za preverjanje uvodoma omenjene hipoteze $\mathrm{H} 3$ smo najprej uporabili 5 stopenjsko lestvico od 1 (nepomembno) do 5 (nepogrešljivo). Kot nepogrešljiv je bil največkrat ocenjen dejavnik "zanimivost dela" (67), sledita osebni razvoj (55) in delovni pogoji (46). Noben motivacijski dejavnik ni bil izpostavljen kot izrazito nepomemben. Kot pomemben (ocena 4) je bil zaslužek ocenjen 45-krat, kot nepogrešljiv 29-krat. Razmerja pomembnosti motivacijskih dejavnikov za anketirane zdravnike prikazuje Slika 3.

Pomembnost zaslužka v primerjavi z ostalimi motivacijskimi dejavniki smo preverili z enostranskimi parnimi t-testi. Za vsak par smo zastavili statistični hipotezi: Povprečna pomembnost zaslužka je enaka $\left(\mathrm{H}_{0}: \mathrm{M}_{\mathrm{i}}\left(\mu_{\mathrm{z}}=\mu_{\mathrm{i}}\right)\right.$ oziroma manjša $\left(\mathrm{H}_{\mathrm{i}}: \mathrm{M}_{\mathrm{i}}\left(\mu_{\mathrm{z}}<\mu_{\mathrm{i}}\right)\right.$ kot povprečna pomembnosti motivacijskega dejavnika $M_{i} . M_{i}$ se nanaša na enega od naštetih dejavnikov (razen zaslužka). Oznaka $\mu_{\mathrm{i}}$ je povprečna pomembnost faktorja Mi, oznaka $\mu_{\mathrm{z}}$ pa povprečna pomembnost zaslužka. 
A. Prlja \& V. Kampuš Trop: Zadovoljstvo, motiviranost in podjetnost zdravnikov javnega zdravstvenega sistema v luči zdravstvene reforme

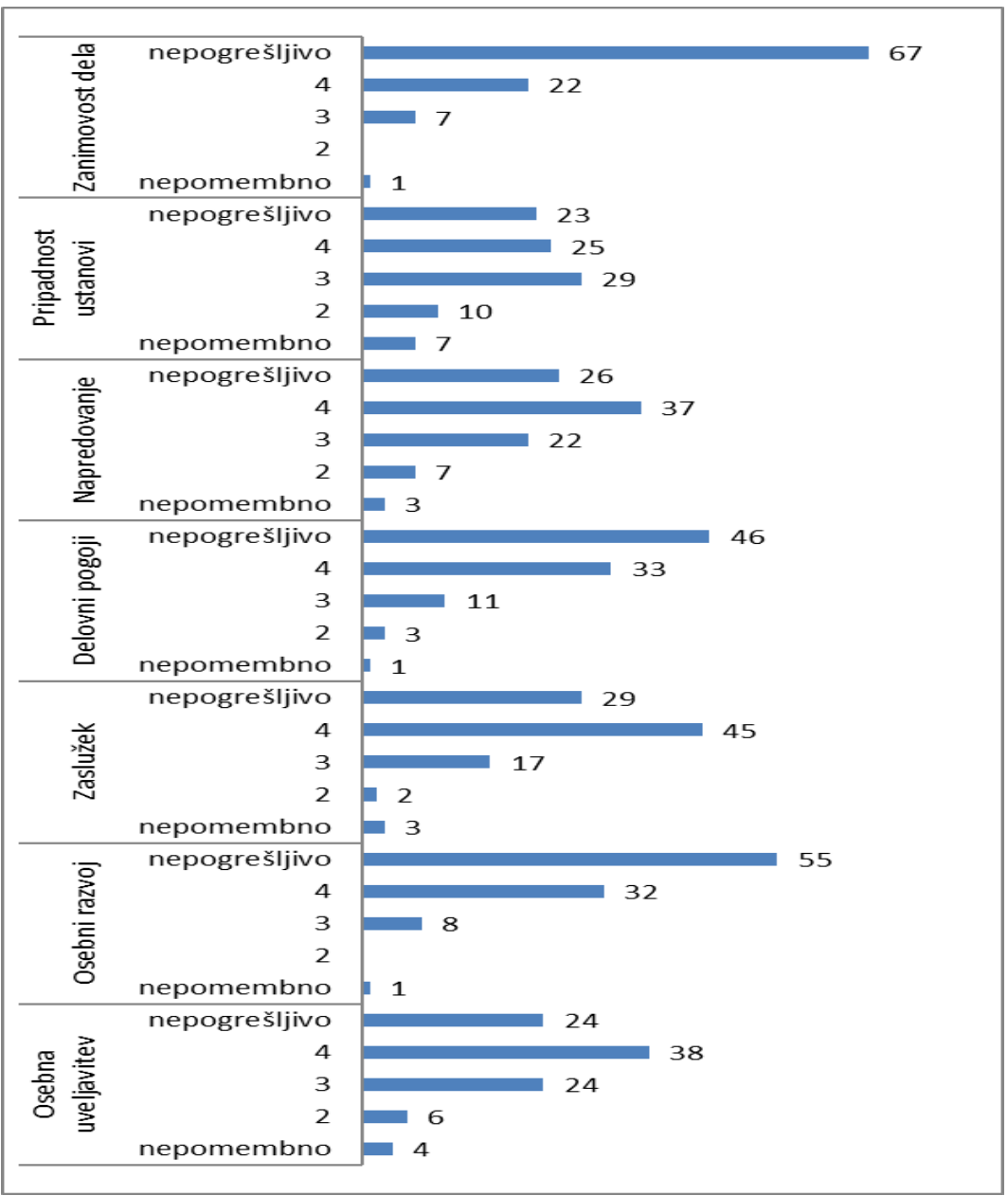

Slika 3: Pomen motivacijskih dejavnikov (varnost, osebni razvoj, zaslužek, delovni pogoji, napredovanje, pripadnost ustanovi in zanimivost dela) za anketirane zdravnike

Skladno s pričakovanji je bil zaslužek nižje ocenjen pri treh parih: v primerjavi z osebnim razvojem $(3,99: 4,47)$, delovnimi pogoji $(3,97: 4,27)$ in zanimivostjo dela $(3,99: 4,59)$. Enako so bile tudi njihove enostranske $p$ vrednosti (preračunane kot $p / 2<0.05$ ) manjše od 0.05: osebni razvoj $(\mathrm{p}=0,000<0,05)$, delovni pogoji $(\mathrm{p}=0,001<0,05)$ in zanimivost dela $(\mathrm{p}=0,000<0,05)$.

V nasprotju s pričakovanji pa je imel zaslužek višjo povprečno oceno pri 3 parih: v primerjavi $\mathrm{z}$ osebno uveljavitvijo $(4,02: 3,77), \mathrm{z}$ napredovanjem $(4.01: 3,81)$ ter $\mathrm{s}$ pripadnostjo ustanovi $(4,01: 3,51)$. Skladno $s$ tem so njihove enostranske p-vrednosti 
$36^{\mathrm{TH}}$ International Conference on Organizational Science Development: Responsible ORGanization (MARCH $22^{\mathrm{ND}}-24^{\mathrm{TH}}$, Portorož SlOVENIA)

A. Prlja \& V. Kampuš Trop: Physicians Content, Motivation and Enterpreneurship in the Aspect of the Slovenian Health Care Reform

(preračunane kot 1-p/2>0.05): osebna uveljavitev $(1-\mathrm{p} / 2=0,977>0,05)$, pripadnost ustanovi $(1-\mathrm{p} / 2=1,000>0,05)$ in napredovanje $(1-\mathrm{p} / 2=0,962>0,05)$. Zato ne moremo trditi, da je zdravnikom zaslužek manj pomemben od njih.

Ker pa so (vsaj) trije dejavniki (osebni razvoj, delovni pogoji, zanimivost dela) pomembnejši motivacijski dejavniki kot zaslužek smo dokazali hipotezo H4: Bolnišničnim zdravnikom zaslužek ni najpomembnejši motivacijski dejavnik.

\section{Povzetek raziskave o medijskem poročanju o zdravstvu v času zdravniške stavke 2016 in leto pred njo}

Zdravniška stavka novembra 2016 naj bi bila usmerjena predvsem v spodbuditev reforme za boljši, bolnikom in izvajalcem prijaznejši zdravstveni sistem. Na osnovi pregleda člankov v pisnih medijih pa smo imeli vtis, da so prevladovala poročila o finančnih posledicah in političnih nesoglasjih zaradi stavke. Zato smo natančneje pregledali in analizirali članke o zdravstvu v časnikih Delo, Dnevnik, in Finance, objavljenih novembra 2016 (čas zdravniške stavke) in novembra 2015 (leto dni pred stavko) in tako preverili uvodoma omenjeno četrto hipotezo.

Po prevladujoči vsebini smo jih razvrstili v naslednje kategorije: O stavki (nevtralna poročanja o poteku stavke), Politikantstvo (nesoglasja v koaliciji, med strankami, poročila o učinkih stavke "utemeljenih" s pogojniki: "bi bilo, če", ocene brez analiz), O organizaciji (o organizacijskih težavah in rešitvah v zdravstvu), O reformi (karkoli o vsebini reforme), Dodatni stroški (prispevki, ki poudarjajo samo povečanje stroškov, npr. povišanja plač, potencialno povečevanje prispevne stopnje, obdavčitev, itd.), O zdravnikih (prispevki o delu zdravnikov ali ustanov), Drugo o zdravstvu (prispevki s področja zdravstva, ki niso uvrščeni v druge kategorije in ne zadevajo stavko ali reformo), O zdravljenju (predstavitve zdravljenj). Javni sektor (prispevki o javnem sektorju), O javnih naročilih, O korupciji v zdravstvu, Reklame (komercialne reklame za snovi ali postopke, ki naj bi pomagali pri različnih zdravstvenih težavah), Pisma bralcev (prispevki in reakcije bralcev).

\subsection{Osnovna analiza o poročanju o zdravstvu v pisnih medijih}

Rezultate osnovne analize o poročanju o zdravstvu na osnovi pregleda 279 prispevkov v časnikih Delo, Dnevnik in Finance podaja Tabela 1.

Pričakovano je bilo prispevkov o zdravstvu več v času stavke (110:169). O možni stavki je novembra 2015 pisal Dnevnik (1 krat), ostali nič. V novembru 2016 so o stavki pisali vsi.

Zanimivo je, da je bilo prispevkov o organizacijskih problemih več leta 2015 (28:13). Vendar je bilo v od tega 6 člankov o pomanjkanju anesteziologov v KC Maribor in 13 o farsi izbora direktorja KC Ljubljana. O slednjem je bil novembra 2016 objavljen še 1 članek (Dnevnik) in tako "realno" razmerje $(9: 12)$. Večina teh prispevkov je poudarjala 
A. Prlja \& V. Kampuš Trop: Zadovoljstvo, motiviranost in podjetnost zdravnikov javnega zdravstvenega sistema v luči zdravstvene reforme

probleme brez stvarnih rešitev. Žerdin (2016) je analitično poudaril bistveno vsebinsko razliko med zdravstvenim zavodom (izvaja poslanstvo) in gospodarsko družbo "Zdravstveni dom d.o.o." (ustvarja dobiček). Dva prispevka sta predstavila načelne poglede na javne zdravstvene zavode (nujnost preoblikovanja zdravstvenih zavodov v neprofitne gospodarske družbe).

Pred stavko so se s potencialnimi dodatnimi stroški sprotnih zdravniških zahtev ukvarjali v 8-ih člankih, ob stavki v 16-tih.

O delu zdravnikov ali ustanov so vsi članki v obeh obdobjih predstavljali le slabo delo zdravnikov ali ustanov (8:17). Novembra 2015 ni bilo nobenega pisma bralcev na temo zdravstva. Zato pa so $\mathrm{v}$ času stavke močno prevladovala negativna mnenja o delu zdravnikov ali stavki (14). Trije zdravniki in 1 bralka so temu ugovarjali.

Zelo zanimivo se nam je zdelo praktično nično poročanje ali razpravljanje o vsebini zdravstvene reforme: Delo (0:0), Dnevnik (0:2) in Finance (2:2). Podobno je z javnimi naročili (2:3) in korupciji $\mathrm{v}$ zdravstvu (1:4). So se pa bolje odrezale reklame o "zdravilnih" učinkovinah ali postopkih (0:6).

Prispevkov o načinih zdravljenja ali bolezni je bilo več novembra 2015 (34:25), verjetno zaradi nasičenja na temo zdravstva v 2016.

O javnem sektorju na splošno je bilo več poročanja 2016 (9:14),pretežno o nesoglasjih med Fidesom in ostalimi sindikati oziroma z vlado zaradi parafiranega.

\begin{tabular}{|c|c|c|c|c|c|c|}
\hline & $\begin{array}{l}\text { Delo } \\
2015 \\
\end{array}$ & $\begin{array}{l}\text { Delo } \\
2016\end{array}$ & $\begin{array}{l}\text { Dnevnik } \\
2015\end{array}$ & $\begin{array}{l}\text { Dnevnik } \\
2016\end{array}$ & $\begin{array}{l}\text { Finance } \\
2015\end{array}$ & $\begin{array}{l}\text { Finance } \\
2016\end{array}$ \\
\hline O stavki nevtralno & $\overline{0}$ & 13 & 1 & 8 & 0 & 0 \\
\hline Politikantstvo & 1 & 8 & 0 & 15 & 0 & 1 \\
\hline $\begin{array}{r}\text { Organizacija } \\
\text { zdravstva }\end{array}$ & 18 & 8 & 10 & 2 & 0 & 3 \\
\hline$O$ reformi & $\mathbf{0}$ & $\mathbf{0}$ & 0 & 2 & 2 & 2 \\
\hline Dodatni stroški & 2 & 7 & 6 & 5 & 0 & 4 \\
\hline O zdravnikih & 5 & 7 & 3 & 10 & 0 & 0 \\
\hline $\begin{array}{l}\text { Diugo o } \\
\text { zdravstvu }\end{array}$ & 5 & 7 & 10 & 0 & 1 & 1 \\
\hline O zdravljenju & 12 & 10 & 17 & 14 & 5 & 1 \\
\hline O javnem sektorju & 5 & 6 & 4 & 5 & 0 & 2 \\
\hline $\begin{array}{l}\text { O javnih naročilih } \\
\text { O korupciji v }\end{array}$ & 1 & 1 & 0 & 2 & 1 & 0 \\
\hline $\begin{array}{l}\text { zdravstvu } \\
\text { Reklame za }\end{array}$ & 0 & 3 & 0 & 0 & 1 & 1 \\
\hline $\begin{array}{l}\text { "zdravila" } \\
\text { Pisma.menja }\end{array}$ & 0 & 1 & 0 & 5 & 0 & 0 \\
\hline bralcev & 0 & 6 & 0 & 10 & 0 & 1 \\
\hline Skupaj & 49 & 75 & 51 & 78 & 10 & 16 \\
\hline
\end{tabular}

Tabela 1 : Preglednica števila člankov v časopisih Delo, Dnevnik in 
36 ${ }^{\mathrm{TH}}$ International Conference on Organizational Science Development: RESPONSIBLE ORGANIZATION (MARCH $22^{\mathrm{ND}}-24^{\mathrm{TH}}$, PORTOROŽ SLOVENIA)

A. Prlja \& V. Kampuš Trop: Physicians Content, Motivation and Enterpreneurship in the Aspect of the Slovenian Health Care Reform

Finance glede na prevladujočo vsebino, november 2015 in november 2016

\subsection{Rezultati preverjanja hipoteze o vsebini poročanja pisnih medijev o zdravstvu}

S testi deleža smo preverjali število in strukturo pregledanih člankov. Nična hipoteza $\left(\mathrm{H}_{0}\right)$ je bila, da je delež primerjanih kategorij enak, nasprotna $\left(\mathrm{H}_{1}\right)$, da je bilo člankov ene kategorije očitno manj. Tako smo prišli do naslednjih rezultatov:

$\mathrm{V}$ času stavke je ukvarjanje $\mathrm{s}$ "politikantskimi" učinki stavke in opisi očitnih organizacijsko-kadrovskih pomanjkljivosti močno prevladovalo nad vprašanji reforme $\left(\chi^{2}=5,41>\chi_{0,05,1=}^{2} 3,841\right)$. Podobno je bilo $\mathrm{z}$ vprašanji korupcije in javnih naročil. Prevlado prispevkov, ki pretežno problematizirajo prihodkovna vprašanja zdravnikov nad prispevki o reformi smo zaradi majhnosti vzorca dokazovali z binomskim testom $(\mathrm{P}=0,0059) . \mathrm{Ob}$ izločitvi prispevkov o primeru Radan in o predstojniku Inštituta za anatomijo $\mathrm{v}$ Ljubljani se je značilno povečalo število negativnih prispevkov o delu zdravnikov ali zdravstvenih ustanov v letu 2016 v primerjavi z $2015\left(\chi^{2}=11,98\right)$.

Menimo, da je s temi rezultati dokazana uvodoma omenjena hipoteza H4: V člankih izbranih časopisov (Delo, Dnevnik, Finance) se je pogosteje pisalo o drugih kategorijah kakor o zdravstveni reformi.

Zaključna razprava

V Sloveniji že vrsto let potekajo, večinoma brezplodne, razprave o zdravstvenem sistemu in reformi. Ponovno so se razplamtele v času zdravniške stavke 2016.

Dejstvo je, da Slovenija nima dovolj sredstev za nivo zdravstvene zaščite kot jo imajo nekatere druge države, na primer Nemčija, Švedska ali sosednja Avstrije. Obstaja zelo velik prepad med realnim stanjem in populističnimi stališči. Praktično vse politične stranke govorijo o ohranitvi javnega zdravstva, le ena pa se je vprašala, kaj je od tega sploh ekonomsko vzdržno (Zupančič, 2014).Dobre želje so premalo. Potrebno je zagotoviti določene pogoje za uspešno delo, vzpostaviti pa tudi kontrolo za preprečevanje odklonov.

Izkušnje iz tujine in tudi slovenska raziskava (Kušar,Smrke in Fakin, 2012), kažejo, da kombinacija javnih in zasebnih storitev omogoča boljši izkoristek sredstev in kadra, boljšo oskrbljenost prebivalstva in zadovoljstvo bolnikov. Leto kasneje so tudi pokazali (Kušar,Smrke in Fakin, 2013), da je slovensko zdravstvo glede na vložena sredstva zelo uspešno, da pa bo v prihodnosti nujna reforma.

V razpravah o delovanju in reformi zdravstvenega sistema so udeleženi vsaj štirje močni dejavniki: politika, industrija, zdravniki in bolniki. $\mathrm{V}$ dosedanjih polemikah smo opazili predvsem nerazumevanje udeleženih med sabo in majhno pripravljenost upoštevanja stališč nasprotnih si strani. 
A. Prlja \& V. Kampuš Trop: Zadovoljstvo, motiviranost in podjetnost zdravnikov javnega zdravstvenega sistema v luči zdravstvene reforme

Glede zdravniških prizadevanj je najbolj očitno nerazumevanje pogledov zdravnikov na zdravstveni sistem in njihovih motivov za delo. $\mathrm{V}$ javnosti se stalno potencirajo prizadevanja za izboljšanje prihodkov, reformska prizadevanja pa ostajajo v ozadju. Zato poudarjamo izsledke lastnih raziskav, kjer je očitno zdravniško nezadovoljstvo z materialnim stanjem javnega zdravstvenega sistema, zdravstvenih ustanov in osebno. Čeprav večina zdravnikov jasno vidi možnosti večjega zaslužka v zasebnem sektorju, večini bistveno več pomenijo zanimivost dela, osebni razvoj in pogoji dela. Dohodek je seveda pomemben za osebni standard, ni pa to prevladujoč dejavnik zdravniških poklicnih in tudi poslovno organizacijskih aktivnosti ( glej več v Prlja, 2016; Prlja, Kampuš Trop, 2015; Kampuš Trop, Prlja, 2010).

Iz tega sledi, da želijo zdravniki, kot osnovni nosilci zdravstvene dejavnosti, prvenstveno zdraviti in ne služiti, ter ljudi obravnavati kot bolnike in ne kot stranke. Zdravniki tekom šolanja tudi ne dobijo nobenih poslovnih znanj. Pričakujejo, da bo medicina izvzeta tržnim pravilom, ter verjamejo, da se izgubi nekaj temeljnega, če bi na medicino začeli gledali kot na posel (Harbin, 2010). Vseeno pa današnji čas zaradi nesorazmerja med razpoložljivimi in potrebnimi sredstvi od zdravnika vedno bolj zahteva, da ni le zdravnik, ampak tudi podjetnik (Larkin, 2009). Boljše obvladovanje poslovnih principov in njihova uporaba v medicini, namreč pomeni tudi boljšo oskrbo bolnikov (Harbin, 2010).

Poleg organizacijsko podjetniških znanj in usposobljenosti pa bodo zdravniki in njihove organizacije morali spremeniti pristop do medijev in javnosti. Dobre želje in nameni ne pomenijo veliko, če se reformska prizadevanja predstavljajo v javnosti v slabi luči. Potencialne, predvsem finančne, posledice, večne razprave o plačah, elegije o organizacijsko-kadrovskih težavah brez realističnih predlogov rešitev, ne vodijo $\mathrm{v}$ reforme. To smo tudi poudarili v drugem delu prispevka.

Reforma seveda ni naloga samo zdravnikov, ampak tudi vseh nas. Sredstva so omejena, zahteve velike in treba se bo odločiti, kaj sploh hočemo od zdravstva : da vrši poslanstvo (neprofitno vendar racionalno) ali pa se podredi tržnim zakonitostim (ustvarja profit). Nato pa se potrebno posvetiti vprašanjem vsebine, obsega in oblike sistema zdravstvenega varstva pri nas, ne pa se izgubljati $v$ obrobnostih, ne glede na njihov navidezni pomen.

\section{7}

\section{Sklep}

$\mathrm{V}$ nasprotju z javnim mnenjem in poročili zdravnikom zaslužek ni primarni motiv delovanja. $V$ razpravah o javnem sistemu zdravstvenega varstva so udeleženi vsaj štirje dejavniki: politika, izvajalci, bolniki in industrija, vsak s svojimi pogledi, interesi in možnostmi vpliva. Bolj ali manj uspešno se objektivno predstavljajo javnosti. Ocenjujemo, da je trenutna pripravljenost poslušati, slišati in uskladiti različne interese med omenjenimi skupinami slaba, zato so take tudi medsebojna komunikacija in predstavitve $\mathrm{v}$ javnosti. Realne možnosti kakovostnih, večini sprejemljivih rešitev $\mathrm{v}$ bližnji prihodnosti ocenjujemo kot slabe, saj se pozornost stalno (pre)usmerja na potencialne finančne in politične posledice,ne pa na vsebino in delovanje zdravstvenega sistema. 
36 ${ }^{\mathrm{TH}}$ International Conference on Organizational Science Development: RESPONSIBLE ORGANIZATION (MARCH $22^{\mathrm{ND}}-24^{\mathrm{TH}}$, PORTOROŽ SLOVENIA)

A. Prlja \& V. Kampuš Trop: Physicians Content, Motivation and Enterpreneurship in the Aspect of the Slovenian Health Care Reform

\section{Literatura}

Kampuš Trop, V. in Prlja, A. (2010). Podjetniško znanje in potencial zdravnikov. In T. Kern, V. Rajkovič, B. Paape in M. Ferjan (Eds.), 29. mednarodna konferenca o razvoju organizacijskih znanosti Človek in organizacija (str. 143-144). Kranj: Moderna organizacija.

Kušar, B., Fakin, S. in Smrke, D. (2012). Javno - zasebno partnerstvo v slovenskem zdravstvu. Zbornik 31. Mednarodne Konference O Razvoju Organizacijskih Znanosti 21. - 23.3. 2012, Portorož, Slovenija. Kakovost, Inovativnost, Prihodnost, 553 -561.

Kušar, B., Fakin, S. in Smrke, D. (2013). Primerjava slovenskega zdravstvenega sistema z nekaterimi kazalci učinkovitosti evropskih držav: primerjava med vloženimi sredstvi in rezultati zdravstvenih sistemov. Zbornik 32. Mednarodne Konference O Razvoju Organizacijskih Znanosti, 20. - 22. 3. 2013, Portorož, Slovenija. Pametna Organizacija: Talenti, Vitka Organiziranost, Internet Stvari, 511- 518.

Larkin, H. (2009). Surgeon or entrepreneur? It's possible-maybe even necessary to be both. ESCRS Eurotimes, 36.

Harbin, T. (2010). What every Doctor Should Know...But Was Never Taught in Medical School. Coralville: F.E.P. International Inc.

Prlja, A. in Kampuš Trop, V. (2015). Ali obstaja motiviranost bolnišničnih zdravnikov za poslovno aktivnost in podjetnost? In P. Doucek, A. Novak in B. Paape (Eds.), zbornik 34. mednarodne konference o razvoju organizacijskih znanosti, Internacionalizacije in sodelovanja, Slovenija, Portorož, 25.-27.3.2015 (str. 957-967). Kranj: Moderna organizacija.

Prlja, A. (2016). Poslovna podjetnost bolnišničnih zdravnikov gorenjske regije. Magistrska naloga. Univerza v Mariboru: Fakulteta za organizacijske vede Kranj.

Okrožnica članom Fides glede izida pogajanj - začasna prekinitev stavkovnih aktivnosti v okviru splošne stavke zdravnikov in zobozdravnikov do 23.01.2017 (22.11.2016)

Zupančič, M. (18.8.2014). Nova politika obljublja čim bolj polno košarico pravic. Delo, str.3.

Žerdin, A. (17.11.2016). Zdravstveni dom, d.o.o. Delo, str. 5

Delo, 2 - 30 november 2015, št. 254-278

Delo, 2 - 30 november 2016, št. 254-278

Dnevnik, 2-30. november 2015, št. 254-278

Dnevnik, 2-30. november 2016, št. 254-278

Finance, 2-30 november 2015, št. 211-231

Finance, 2-30 november 2016, št. 211-231 
$36^{\text {Th }}$ International Conference on Organizational Science DEVElopMENT: Responsible ORganization (MARCH $22^{\mathrm{ND}}-24^{\mathrm{TH}}$, PORTOROŽ SLOVENIA)

O. Arsenijević, M. Ferjan, I. Podbregar, P. Šprajc, D. Trivan \& Y.

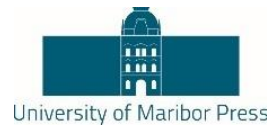

Ziegler

\title{
From Environmental Action to Climate Change Knowledge and Back
}

\author{
Jelena Andreja Radaković, NataŠa Petrović, Nemanja Milenković, \\ KRISTINA STANOJEVIĆ \& DEJANA STEVANOVIĆ
}

\begin{abstract}
Considering the importance of climate change issues as the integral part of present day's students' body of environmental knowledge, as well as a needful part of their social and personal life, this paper will be focused on the scientific research of the organized academic environmental activities (promotion action on climate change) in achieving learning objectives of climate change knowledge. Our research relied on growing body of research and case studies that have predefined environmental education and its objectives in education for sustainable development, with deep understanding of environmental issues and skills for active participation in sustainability problem solving. For the purpose of our research, we surveyed students of the University of Belgrade - Faculty of Organizational Science, Serbia, not only on their attitude toward the environmental action referred to gaining climate change knowledge, but also on their achievement levels in faculty environmental studies program. An analysis of the results was carried out using the SPSS 24 software package.
\end{abstract}

KEYWORDS: environmental action $\cdot$ climate change $\cdot$ climate change knowledge $\bullet$ project-based learning

CORRESPONDENCE ADDRESS: Jelena Andreja Radaković, University of Belgrade, Faculty of organizational sciences, Jove Ilića 154, Belgrade 166136, Serbia, e-mail: jelena.radakovic@fon.bg.ac.rs; Nataša Petrović, Ph.D., University of Belgrade, Faculty of organizational sciences, Jove Ilića 154, Belgrade 166136, Serbia, e-mail: petrovicn@ fon.bg.ac.rs; Nemanja Milenković, University of Belgrade, Faculty of organizational sciences, Jove Ilića 154, Belgrade 166136, Serbia, e-mail: milenkovic.nemanja@fon.bg.ac.rs; Kristina Stanojević, University of Belgrade, Faculty of organizational sciences, Jove Ilića 154, Belgrade 166136, Serbia, e-mail: kristina.stanojevic@fon.bg.ac.rs; Dejana Stevanović, University of Belgrade Faculty of Transport and Traffic Engineering, Vojvode Stepe 305, Beograd 161904 ,Serbia, e-mail: stevanovic.dejana@gmail.com 
$36^{\mathrm{TH}}$ INTERNATIONAL CONFERENCE ON ORganizational SCIENCE DeVElopment: RESPONSIBLE ORGANIZATION (MARCH $22^{\mathrm{ND}}-24^{\mathrm{TH}}$, PortoroŽ SLOVENIA)

J. A. Radaković, N. Petrović, N. Milenković, K. Stanojević \& D. Stevanović: From

Environmental Action to Climate Change Knowledge and Back

\section{$1 \quad$ Introduction}

Environmental problems (Bonnett, 2007; Mert, 2006; Robert, Flood \& Carson, 1993) reached their critical point in the $21^{\text {st }}$ century and continue to rapidly grow: global warming, the deterioration of living conditions, disruption of the ozone layer, the impacts of conservation, increase in the amount of solid waste, radioactive contamination, destruction of forests, the extinction of plant and animal species... (Petrović, 2016). Further on, the increase of the global population has produced growth of natural resources consumption (Symth, 2004).

The environmental crisis is getting worse and leading to the necessity of adopting of the concept of sustainable development in which environmental education and education for sustainable development play a key role as the most important part for a sustainable future (UNESCO, 2012). In the late eighties of the last century, the concept of Education for Sustainable Development is developed, whose goals were defined in the nineties in Agenda 21 (1992). It must be noted that knowledge itself is not enough for a responsible attitude towards the environment (Hines, Hungerford, \& Tomera, 1986/87; Hungerford $\&$ Volk, 1990), and that adequate education for environment must have the following outcomes: a deep understanding of the environment, skills and opportunities to actively participate in solving environmental problems.

Furthermore, global warming and consequently climate change are the biggest environmental problems which representing the most serious challenge for the present and future generations of humans because they are bringing a new understanding of progress and development of science and technology. The United Nations recognized "the link between climate change and human rights as an important step towards protecting the fundamental rights of communities across the planet" (UNEP, 2015). These are the reasons why it is considered that education must be "an essential element of the global response to climate change" (UNESCO, 2017). Such education should be "encouraging innovative teaching approaches to integrate climate change education (...) as well as enhancing non-formal education programmes" (UNESCO, 2017).

Bearing the above in mind, in our paper we chose to research students' views and opinions related to their participation in the project of promoting practical knowledge on climate change at the Belgrade Science Festival and consequently improvement of their knowledge. Our research included all 45 students (100 percent) enrolled at the elective course Design for Environment at the University of Belgrade - Faculty of Organizational Sciences, the Republic of Serbia, who participated in the project "Beware: save the polar bear." An analysis of the results was carried out using the SPSS 24 software package. 


\section{$2 \quad$ Background}

\subsection{Environmental education and climate change knowledge}

The Belgrade charter talks about a new approach to social development that emphasizes the protection and improvement of the environment, which is only possible with the reform of the education system, because "environmental education is the most important element of common response to the environmental crisis" (UNESCO-UNEP,1975).

Tbilisi declaration adopted in 1977, provides a detailed description of the objectives of environmental education. It talks about the need to foster awareness and concern about the economic, social, political and environmental interdependence in urban and rural areas, providing a chance for everyone to acquire knowledge, skills and abilities necessary to work on the preservation and improvement of the environment. "Environmental education is a process that allows individuals to explore environmental issues, engage in problem solving, and take action to improve the environment. As a result, individuals develop a deeper understanding of environmental issues and have the skills to make informed and responsible decisions" (EPA, 2016).

The universal goals of environmental education included (UNESCO-UNEP, 1977):

1. Awareness - help community groups and individuals in gaining awareness and sensitivity towards the environment and the problems associated with it.

2. Knowledge - help community groups and individuals to acquire varied experience and a basic understanding of the environment and problems related to it.

3. Attitudes - help community groups and individuals in the adoption of a set of values and a sense of interest in the environment and problems related to it.

4. Skills - help social groups and individuals acquire the skills for identifying and solving environmental problems.

5. Participation - to provide opportunities for community groups and individuals to actively participate in solving environmental problems at all levels of work.

When it comes to typical environmental education relating to climate change, it must be emphasized that knowledge about climate change "helps young people understand and address the impact of global warming, encourages changes in their attitudes and behavior and helps them adapt to climate change-related trends" (UNESCO, 2017).

\subsection{Environmental education and climate change knowledge}

Created in 2007, the Science Festival was organized in order to call public attention to science as an inseparable part of life and to provide an inspiring, new and fresh look at different scientific fields. From the very beginning, the essential part of its mission was to bring science closer to non-scientific audience and to provoke interest in scientific work, and furthermore in understanding its impacts in everyday life. 
$36^{\mathrm{TH}}$ INTERNATIONAL CONFERENCE ON ORganizational SCIENCE DeVElopment: RESPONSIBLE ORGANIZATION (MARCH $22^{\mathrm{ND}}-24^{\mathrm{TH}}$, PortoroŽ SLOVENIA)

J. A. Radaković, N. Petrović, N. Milenković, K. Stanojević \& D. Stevanović: From

Environmental Action to Climate Change Knowledge and Back

Ten years since its launch, the Science Festival is far beyond its humble beginnings: at this moment, it is one of the top five science festivals in Europe, while at local level SSF represents the most popular and most important annual scientific event. The last five Science Festivals recorded 30,000 visitors in four days and hosted 45 scientific and educational institutions with over 550 scientific demonstrators.

Since 2007 the Science Festival is a member of European Science Events Association (EUSEA) and in 2015, the EUSEA Annual Conference took place in Belgrade, Serbia, hosted by the Serbian Science Festival.

"The Festival is guided by the idea to popularize science in order to reach a broad audience, and to provide its own contribution to the promotion of science and technology pointing to their crucial importance in a modern society. Countless scientific exhibitions, lectures, interactive presentations, well-known contributing lecturers, enthusiastic audience and more than 200,000 visitors from 2007 to the present, are the best proofs that it succeeded." (Science Festival, 2017)

The climate change project "Beware: save the polar bear" presented at the Science Festival had a goal to educate visitors of Festival about climate change and climate change consequences, the not-so-slow extinction of polar bears, and polar caps melting. Polar bears are very important for addressing climate change because they depend on sea ice for survival and are directly affected by climate change - moreover, they serve as an essential indicator of species, due to the fact that ice is actually melting, and that the atmosphere is warming. The preservation of the polar bear, means that we need to restore the lower levels of carbon dioxide in the atmosphere, prevent the melting of the Arctic ice, create reforestation of Amazon, and reduce greenhouse gas emissions.

Visitors of the Festival, stood on a moving platform and entered an original created virtual reality simulation that featured a live feed of them standing on a tiny iceberg that was melting, thus showing them how it actually felt for the polar bears, losing their habitat right under their feet. Beside the exhibition of project itself and the simulation game, students educated visitors on the greenhouse effect, facts on climate change and global warming and polar bears, and gave them tips on how to reduce their carbon footprint.

\section{Methodology}

For our research we chose the ungraduated students of the University of Belgrade Faculty of Organizational Sciences, enrolled at the elective course Design for Environment in the winter semester of 2016/2017 academic school year, which participated in the project "Beware: save the polar bear" in the organization of the Centre for environmental management and sustainable development and EkoFON (students' environmental organization) of the Faculty of Organizational Sciences - University of Belgrade, the Republic of Serbia. 
At this course, a framework and a curriculum for good environmental higher education are developed on a wide scale of scientific and practical knowledge of the environment and environmental science as a good benchmark for the adequate improvement of students' knowledge, as well as a promotion of higher order thinking skills in a cooperative context for learning and evaluation (NAAEE, 1996; Petrovic, Jeremic, Petrovic, \& Cirovic, 2014). It must be noted that this course is also based on projectbased learning, as relevant learning model for the $21^{\text {st }}$ century (Baker, Trygg, Otto, Tudor, \& Ferguson, 2011). This teaching method enables students to gain knowledge and skills by working on an original project that addresses a global issue - climate change. In this way, in addition to environmental knowledge, students get familiar with: how to promote environmental protection, environmental science in its broadest sense, as well as management, project management, logistics, human resource management, event management, financial management, marketing, public relations.

After the Science Festival in Belgrade that took place in December of 2016, the authors of the paper conducted the research. For the purpose of our study, we uses special designed questionnaire. The questionnaire consisted of 21 questions in total. The first four questions were general. From question 5 to question 11, participants were asked to give their response on their views and impressions on Belgrade Science Festival. From question 12 to question 21, the participants were asked to express their opinions about: preparations for climate change project, participation in the project at the Science Festival, motivation for acquiring more specific environmental knowledge, possible changing of environmental behavior as well as further engaging in inenvironmental actions. The Likert scale from 1 to 5 has been used ( 1 - Absolutely no, 2 - I don't agree, 3 - I don't know, 4 - I agree, 5 - Absolutely yes). These questions fall into the category of the most significant ones because they directly refer to the main goals of our research and research questions:

An analysis of the results was carried out using the SPSS 24 software package. Descriptive statistics have been used in order to analyze the characteristics of the sample. The Mann Whitney U Test was conducted in order to compare two independent groups in regard to a observed scale variable. The $p$ value is used to indicate if the differences between two particular groups that were in this research are statistically significant (where $\mathrm{p}<0.05$ is considered statistically significant at the $95 \%$ confidence level).

\section{$4 \quad$ Results and discussion}

When it comes to the students who took the survey:

- 24 of them (53.3 percent) were female while 21 of them (46.7 percent) were male.

- Of the surveyed respondents 25 of them (55.56 percent) completed a 4 year high school, and 20 of them (44.44 percent) a secondary occupational school.

- 16 respondents (35.6 percent) is from Belgrade, while the other 29 of them $(64.4$ percent) are from different cities of the Republic of Serbia. 
36 ${ }^{\mathrm{TH}}$ International Conference on Organizational Science Development: Responsible ORGANiZATION (MARCH $22^{\mathrm{ND}}-24^{\mathrm{TH}}$, Portorož Slovenia)

J. A. Radaković, N. Petrović, N. Milenković, K. Stanojević \& D. Stevanović: From

Environmental Action to Climate Change Knowledge and Back

After descriptive statistics, Mann-Whitney rank test has been used in order to examine differences in answers between two categories:

- Female/male ratio,

- 4 year high school completed/ocupational school completed ratio.

When it comes to testing the difference in the responses of female and male students, there are observed differences in responses to the allegations:

- "This type of work motivated me in environmental change for the better".

- "This type of work has motivated me to continue to participate in environmental actions".

The results by gender show that:

- Female students showed a greater degree of willingness for environmental change for the better (mean rank for women - 26.44 and for men - 19.07, significant $\mathrm{p}=0.037)$.

- Females showed a greater willingness to participate in future environmental actions (mean rank for women - 26.42 for men - 19.10, $\mathrm{p}=0.040$ significant).

The average score for the statement: "This type of work motivated me in environmental change for the better" for female students is 4.54 and for male students is 4.14 , which shows greater difference between female and male students. Also, there is a greater difference in the statement: "This type of work has motivated me to continue to participate in environmental actions" where the average score for female students is 4.58 , while for male students is 4.09 . The arithmetic mean by gender for these two statements and absolute arithmetic mean difference are given in the Table 1 and Figure 1.

Table 1. The arithmetic mean of statements by gender and absolute arithmetic mean difference

\begin{tabular}{|l|c|c|c|}
\hline Statement & \multicolumn{2}{|c|}{$\begin{array}{c}\text { Arithmetic } \\
\text { mean (tn) }\end{array}$} & $\begin{array}{c}\text { Absolute } \\
\text { arithmetic } \\
\text { mean } \\
\text { difference }\end{array}$ \\
\cline { 2 - 3 } & Female & Male & 0.40 \\
\hline $\begin{array}{l}\text { This type of work motivated me in } \\
\text { environmental change for the better }\end{array}$ & 4.54 & 4.14 & \\
\hline $\begin{array}{l}\text { This type of work has motivated me to continue } \\
\text { to participate in environmental actions }\end{array}$ & 4.58 & 4.09 & 0.49 \\
\hline
\end{tabular}


J. A. Radaković, N. Petrović, N. Milenković, K. Stanojević \& D. Stevanović: From Environmental Action to Climate Change Knowledge and Back

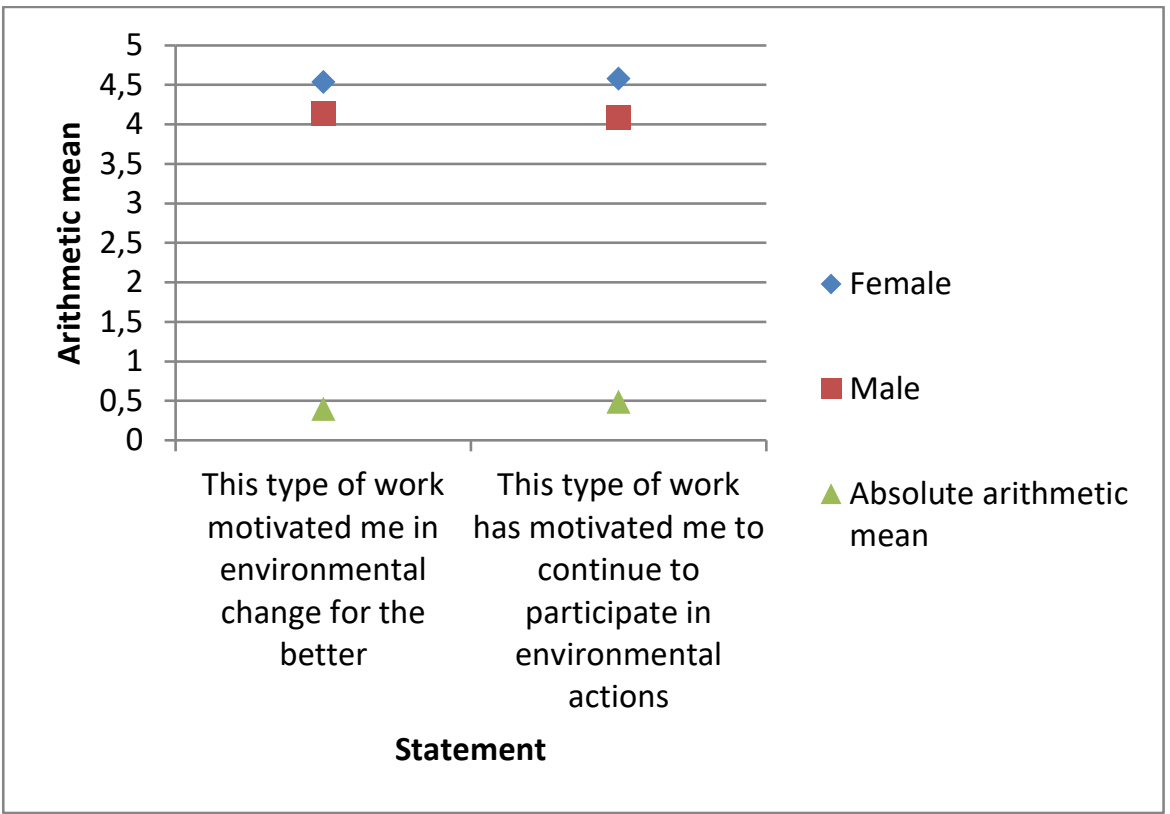

Figure 1. The arithmetic mean of statements by gender and absolute arithmetic mean difference

These results could be explained by previous research that show that (Eisler, Eisler, \& Yoshida, 2003):

- Females have more positive attitudes toward nature and the environment than males.

- $\quad$ "Females are more likely than males to show a motivation to behave responsibly to protect nature and the environment".

- Females showed more hope than males of making the world a better place by changing their environmental behaviors.

Obtained results are of great interest having in mind the importance of the linkages between environmental protection and security and gender roles as well as necessary involvement of female in environmental education (OSCE, 2009). Also, engaging female in environmental protection helps societies to develop "the sense of responsibility needed to maintain a good balance between humans and the earth's resources" (UN, 2002).

In addition, in our research we examined the differences in the responses of students who have completed 4 year high school and university students who have completed secondary occupational school. A statistically significant difference was found in the assessment of only one claim: "This type of work has motivated me to continue to participate in environmental actions." Results show that students who have completed a 
4 year high school are more willing to participate in environmental actions than the students who have completed an occupational school (average ranking for 4 year high school students - 26.4, the average ranking for occupational school students 18.75 , significance $\mathrm{p}=0.033$ ).

These results can be explained on the basis of the curriculum in biology and sociology as subjects in 4 year high schools where they taught the basics of ecology and environmental problems (Univerzitet u Nišu, Prirodno matematički fakultet, 2017) as opposed to occupational schools that do not have these subjects. On the one hand, this is associated with the results of previous studies that have shown that when it comes to environmental education in the Republic of Serbia, the data about educational curriculum and programs has shown an evident lack of formal and permanent environmental education at all levels of formal education (Klemenovic, 2004; Pavlovic, 2011; Petrovic, 2010; Petrovic, Jeremic, Petrovic, \& Cirovic, 2014; Trumic, Petrovic, \& Radojicic, 2009). On the other hand the results of our research show the necessity of not only to implement formal environmental education, but of the development of such education, which includes the necessary environmental activities with the aim of promoting and protecting the environment in the long run. Or environmental education must include "participation in activities that lead to the resolution of environmental challenges" (EPA, 2016).

What should be pointed out as the biggest success of the project "Beware: save the polar bear" is the fact that 40 of the surveyed students ( 88.9 percent) answered affirmatively to the question whether they would take part in the Science Festival again, and that the opinions of students on project-based learning organized in this way are:

- A good way to gain knowledge in the field of ecology and environmental protection.

- An interesting and pleasant experience.

- Gained new knowledge and experiences.

- Fun, interesting and educational.

- The Science Festival and this project encouraged me to think more about subject of climate change and change my behavior for the better.

Further on, in order to evaluate the student's satisfaction with their preparation and participation in the project "Beware: save the polar bear" as well as their assessment to the statements relating to their motivation to learn more about environmental issues treated by the project - climate change, and then consequently change their environmental behavior and continue with environmental activities, the students gave marks on a rating scale from 1 to 5 based on the truthfulness of the statement ( 1 - Absolutely no, 2 - I don't agree, 3 - I don't know, 4 - I agree, 5 - Absolutely yes), and we calculated the arithmetic mean. The ranked results based on the assessment given by students to our 10 statements are shown in the Table 2 . 
J. A. Radaković, N. Petrović, N. Milenković, K. Stanojević \& D. Stevanović: From Environmental Action to Climate Change Knowledge and Back

Table 2. The ranked assessment of statements by students

\begin{tabular}{|l|c|c|}
\hline Statement & $\begin{array}{c}\text { Arithmetic mean } \\
\left(\mathbf{t}_{\mathbf{n}}\right)\end{array}$ & Rank \\
\hline $\begin{array}{l}\text { I would participate again in this or similar } \\
\text { activities }\end{array}$ & 4.87 & 2 \\
\hline $\begin{array}{l}\text { Preparations for the Festival have helped } \\
\text { me to better assimilate knowledge on } \\
\text { climate change and polar bears }\end{array}$ & 4.67 & 3 \\
\hline $\begin{array}{l}\text { This type of work has motivated me to } \\
\text { learn more about ecology and } \\
\text { environmental protection }\end{array}$ & 4.64 & 4 \\
\hline $\begin{array}{l}\text { Participation in the Festival was } \\
\text { interesting and fun }\end{array}$ & 4.62 & 5 \\
\hline $\begin{array}{l}\text { Participation in the festival has helped me } \\
\text { to better assimilate knowledge on climate } \\
\text { change and polar bears }\end{array}$ & 4.60 & 6 \\
\hline $\begin{array}{l}\text { This type of work has motivated me to } \\
\text { learn more about climate change and polar } \\
\text { bears }\end{array}$ & 4.51 & 7 \\
\hline $\begin{array}{l}\text { Other subjects should incorporate } \\
\text { participating in similar projects }\end{array}$ & 4.42 & 8 \\
\hline $\begin{array}{l}\text { This type of work has motivated me to } \\
\text { change my environmental behavior for the } \\
\text { better }\end{array}$ & 4.36 & 8 \\
\hline $\begin{array}{l}\text { This type of work has motivated me to } \\
\text { continue to participate in environmental } \\
\text { actions }\end{array}$ & 4.36 & 8.16 \\
\hline $\begin{array}{l}\text { Preparations for the Festival were } \\
\text { interesting and fun }\end{array}$ & & 8 \\
\hline
\end{tabular}

From the calculated results the following can be concluded:

- The highest average rating of 4.87 received the statement: "I would participate again in this or similar activities" (rank 1), which says that the students liked this active method.

- Next, the average score of 4.67 for the statement: "Preparations for the Science Festival have helped me to better assimilate knowledge on climate change" (rank 2) which shows that project-based learning gives better results in gaining knowledge and teaching the curriculum.

- Statement: "This type of work has motivated me to learn more in ecology and environmental protection" also received a high rating - 4.64 .

\section{$4 \quad$ Conclusion}

The gained results from our research showed following: 
- Students who have completed 4 year high school are more likely to participate in the environmental actions.

- Project-based learning as a this teaching method resulted with students' showed greater motivation to learn something more, better acceptance of knowledge and willingness to participate again in similar activities.

- Female students showed a greater degree of willingness for environmental improvement and participation in environmental actions.

- Gender roles are significant predictors of perception of nature, environmental problems and environmental behavior.

Definitely, the survey results showed a positive result on our research questions, and encouraged us to continue with this kind of specific project-based learning in higher environmental education. This specific research shows us that this teaching method is without a doubt, a tool of students' interest.

Beside this, a growing number of educators are facing the challenges of modern higher education, such as keeping students motivated and increasing the knowledge and awareness on specific problems. Our climate change orientated case study was an excellent way to make students interested in the core of this important global environmental issues. Our results also pointed out the effectiveness of the proposed project application in improving the students' scientific environmental knowledge.

\section{Literature}

Agenda 21 (1992). United Nations Earth Samit in Rio, 1992. Retrieved from http://www.un.org.

Baker, E., Trygg, B., Otto, P., Tudor, M., \& Ferguson, L. (2011). Project-based Learning Model, Relevant Learning for the $21^{\text {st }}$ Century. Pacific Education Institute.

Bonnett, M. (2007). Environmental Education and the Issue of Nature. Journal of Curriculum Studies, 39(6), pp. 707-721.

Eisler, A.D., Wester, M., Yoshida M., \& Bianchi G. (1999). Attitudes, beliefs, and opinions about suicide: A cross-cultural comparison of Sweden, Japan, and Slovakia. Latest contribution to cross-cultural psychology, pp. 176-191, Amsterdam: Swets \& Zeitlinger.

Faculty of Organizational Sciences - FOS (2017). Knjiga predmeta. Retrieved from http://www.fon.bg.ac.rs/downloads/2014/02/P-8-2-Knjiga-predmeta.pdf. (In Serbian)

Hines, J.M., Hungerford, H.R., \& Tomera, A.N. (1986/87). Analysis and synthesis of research on responsible environmental behavior: A meta-analysis. Journal of Environmental Education, 18, pp. 1-8.

Hungerford, H.R., \& Volk, T.L. (1990). Changing learner behavior through environmental education. The journal of environmental education, 21(3), pp. 8-21.

Klemenovic, J. (2004). Činioci ekološkog vaspitanja i obrazovanja. Pedagoška stvarnost, 50(5-6), pp. 366-381. (In Serbian)

Mert, M. (2006). Determination of consciousness level of high school students on the environmental training and solid wastes topics: master of education. Hacettepe University.

North American Association for Environmental Education - NAAEE (1996). Environmental Education Materials: Guidelines for Excellence. NAAEE, Rock Spring, GA. 
J. A. Radaković, N. Petrović, N. Milenković, K. Stanojević \& D. Stevanović: From Environmental Action to Climate Change Knowledge and Back

Organization for Security and Co-operation in Europe - OSCE (2009). Gender and Environment: A guide to the integration of gender aspects in the OSCE's environmental projects.

Pavlovic, V. (Ed.) (2011). Univerzitet i održivi razvoj. Beograd: Fakultet političkih nauka. (In Serbian)

Petrovic, N. (2010). Development of higher environmental education program. Management Časopis za teoriju i praksu menadžmenta, 15(56), pp. 35-41.

Petrovic, N., Jeremic, V., Petrovic, D., \& Cirovic, M. (2014). Modeling the Use of Facebook in Environmental Higher Education. In G. Mallia (Ed.), The Social Classroom: Integrating Social Network Use in Education, pp. 100-119.

Petrovic, N., Jeremic, V., Petrovic, D., \& Cirovic, M. (2014). Modeling the Use of Facebook in Environmental Higher Education. G. Mallia (Ed.), The Social Classroom: Integrating Social Network Use in Education (p. 100-119). Hershey, PA: Information Science Reference.

Petrović, N. (2016). Ekološki menadžment, treće izmenjeno i dopunjeno izdanje. Beograd: Fakultet organizacionih nauka. (In Serbian)

Robert, L., Flood, E. \& Carson, R. (1993). Dealing with complexity. Plenum.

Science Festival (2017). About Science Festival. Retrieved from http://festivalnauke.org/InEnglish2.

Symth, J. (2004). Environment and education: A view of a changing scene. Environmental Education Research, 12(4), pp. 247-264.

Trumic, M., Petrovic, N., Radojicic, Z. (2009). Ekološka svest u formalnom osnovnom obrazovanju Republike Srbije. XXXVII Symposium on Operation Research, SYM-OP-IS 2009, Ivanjica, p. 3-6. (In Serbian)

United Nations - UN (2002). Importance of women's participation in protecting environment stressed, as women's commission holds second expert panel discussion. Retrieved from http://www.un.org/press/en/2002/WOM1325.doc.htm.

United Nations Educational, Scientific and Cultural Organization - UNESCO (2012). ESD Sourcebook. Learning \& Training Tools, No. 4. Paris: UNESCO. Retrieved from http://unesdoc. unesco.org/images/0021/002163/216383e.pdf.

United Nations Educational, Scientific and Cultural Organization - UNESCO (2017). Climate Change Education. Retrieved from http://en.unesco.org/themes/education-sustainabledevelopment/cce.

United Nations Educational, Scientific and Cultural Organization - United Nations Environment Programme - UNESCO-UNEP (1975). The Belgrade Charter. Retrieved from http://unesdoc.unesco.org/images/0001/000177/017772eb.pdf.

United Nations Educational, Scientific and Cultural Organization - United Nations Environment Programme - UNESCO-UNEP (1977). The Tbilisi Declaration. Retrieved from http://www.gdrc.org/uem/ee/tbilisi.html.

United Nations Environment Programme - UNEP (2015). New UN Report Details Link between Climate Change and Human Rights. Retrieved from http://www.unep.org/NewsCentre/default.aspx?DocumentID=26856\&ArticleID=35630.

United States Environmental Protection Agency - EPA (2016). What is Environmental Education? Retrieved from https://www.epa.gov/education/what-environmental-education.

Univerzitet u Nišu, Prirodno matematički fakultet (2017). Programi gimnazija. Retrieved from http://tesla.pmf.ni.ac.rs/people/nesiclj/predavanja/metodika/programi\%20skola/plan\%20i $\% 20$ program\%20za\%20gimnaziju.pdf. (In Serbian) 
812 36 $6^{\text {Th }}$ InTERnational CONFERENCE ON ORganizational SCIENCE Development: Responsible Organization (MARCh $22^{\mathrm{ND}}-24^{\mathrm{TH}}$, PORTOROŽ SlOVENIA) 
$36^{\text {Th }}$ International Conference on Organizational Science Development: Responsible ORganization (MARCH $22^{\mathrm{ND}}-24^{\mathrm{TH}}$, PORTOROŽ SLOVENIA)

O. Arsenijević, M. Ferjan, I. Podbregar, P. Šprajc, D. Trivan \& Y.

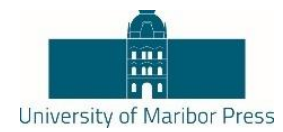

Ziegler

\title{
New approach in designing (Self) Organizations as the most efficient modality of organizing
}

\author{
Milan Radosavljevic, Aleksandar Andjelkovic, Maja AndJElKovic \& \\ DRAGANA RADOSAVLJEVIC
}

\begin{abstract}
The fact is that in modern conditions mechanistic deterministic concept is dominated in the organization and management of organizational systems. The essence of these concepts is the understanding of the organization as a machine, i.e. clock mechanism, where there is a high degree of determinism and schematism and where man is viewed as a pendant to the machine. This concept is increasingly becoming an obstruction for the further improvement of economic and social development, since it is facing a different environment, and above all, great turbulence and uncertainties.
\end{abstract}

The paper discusses a new approach in designing the organizational structure, in such a way that the same design principles on the selforganization, as the most complex, but also the most efficient modalities organization. This approach is more natural, more responsive to changing circumstances, based on a stochastic basis, and in order to apply it is necessary to know the laws of nature and natural organization as a true source of all forms and modalities of organization and management. Knowledge of the natural organization, analogously can be transferred to the artificial organization, disorganizing and reorganizing.

Keywords: environmental action - climate change - climate change knowledge $\bullet$ environmental literacyself organization $\bullet$ natural organization - artificial organization

CORRESPONDENCE ADDRESS: Milan Radosavljevic, Ph.D., University „Union-Nikola Tesla”, Faculty of Business Studies and Law, Belgrade, Staro sajmište 29, 11070 Novi Beograd, Serbia, email: milan.radosavljevic@fpsp.edu.rs; Aleksandar Andjelkovic, Ph.D., Professor, University „Union-Nikola Tesla”, Faculty for Strategic and Operational Management, Staro sajmište 29, 11070 Novi Beograd, Serbia, e-mail: aleksandar.andjelkovic@fsom.edu.rs; Maja Andjelkovic, Ph.D., Professor, University „Union-Nikola Tesla”, Faculty for Strategic and Operational Management, Staro sajmište 29, 11070 Novi Beograd, Serbia, e-mail: maja.andjelkovic@fsom.edu.rs; Dragana Radosavljevic, Ph.D., Senior Lecturer, University „Union-Nikola Tesla”, Faculty of Business Studies and Law, Belgrade, Staro sajmište 29, 11070 Novi Beograd, Serbia, e-mail: Dragana.radosavljevic@ fpsp.edu.rs 
$36^{\mathrm{TH}}$ International Conference on Organizational Science Development: ResPonsible ORGaNizATION (MARCH $22^{\mathrm{ND}}-24^{\mathrm{TH}}$, PORTOROŽ SLOVENIA)

M. Radosavljevic, A. Andjelkovic, M. Andjelkovic \& D. Radosavljevic: New approach in designing (SELF) ORGANIZATIONS as the most efficient modality of organizing

\section{Introduction}

Modern scientific analysis and research show that in the organization, as an element of management, still predominantly apply classical concepts set by the classical theorists of organization and management from the last century. There is no doubt that they represented a great innovation in the past, that they have made significant progress to the organization and that they have contributed to the overall progress and development of civilization, especially in terms of incremental changes, small uncertainty and weaker interdependencies between individual elements of the organization.

In modern terms, the classic concepts that are based on mechanistic deterministic bases cannot "reject" the effect that they had in the past, because there have been a radical and fundamental changes in all aspects of life and work. Technological and organizational, but also cultural and social environment and infrastructure have been dramatically changed, a social reality made them more complex, because it is necessary to "carry" with a much larger number of variables than it was in the past. Therefore, the classical models of organization in modern conditions are unacceptable, because they do not produce satisfactory results.

Exit from the situation is in the application of the concepts of self-organization, selfregulation and self-preservation, as higher quality models of organizing of the collective work, or the organizations. When in the preliminary concept of the design, construction, maintenance or management of organizations occur a problem, solutions should be sought in the natural order, ie. how nature resolves and how it solves certain problems. Through the concept of "creative imitation" of what is happening in the cosmos, it is possible to construct an organization with a significant level of performance in relation to the organizations that are making by classic concepts of organization theory of a hundred or more years. It is shown that creative imitation has always been a source for creating ideas and design thinking in order to build organizational structures. In order to create the conditions for that, pre-knowledge of the original is necessary, ie. the essence and content of the natural order. A practice show that it is precisely the creative imitation in modern conditions is an instrument for creating a successful organization.

\section{The sources of organization, disorganizing and reorganizing}

There is a famous saying, that all that exists in the natural and social order is created in the process of organizing and that everything disappears and dies in the process of disorganizing. Therefore, we can hypothesize that the organizing and disorganizing are two parallel processes, ie. "That in the natural order, the process to organize simultaneously causes disorganizing process, which is the condition and basis for the new organization. These principles are particularly well observed in the biological world, his creation, maintenance, development and improvement (Vucenovic, \& Lekovic, 1998, 160). The above indicates that there is no organization without disorganizing and that the disorganizing is the requirement for the organizing. 
Although at first glance it seems irrational to deal with issues of natural and artificial organization, or the organizing and disorganizing, it can be concluded that the understanding of these phenomena, condition for controlling and improving the organization as a science, as well as skills. It is especially important understanding of the two forms of organization such as: natural and artificial. Thanks to these forms of organization, the universe is created and everything that exists on earth.

For all forms of organizing and disorganizing the crucial knowledge is that these processes are not created out of nothing, but to have their causes, which confirms the statement pronounced long ago that in the natural and social (organizational) order each result has its roots from which it arises. The source of organizing and disorganizing, or the reorganization are the movements, and that is actually a change in general. The movement may be different, with different forms, such as: mechanical, thermal, chemical, electric, magnetic, etc. For (self) organization of special significance are two forms of movement, as follows: rapprochement, or attraction and distancing or repulsions. These two forms create, or decompose (self) organization.

The attraction is a form of movement in which the particles of matter getting closer together in order to come closer to each other and to establish channels of communication, and in the end to connect systems and thereby create systems of higher level of complexity. In this form of movement, new groups are formed and they are called organizations (herbal, animal, businesses, etc.) which establish qualitatively new relations in the two entireties, but also in the environment in which they operate. By connecting the individual elements lose their individual properties, but at the same time they get a new quality. As a new entirety, they continue further movement, trying to connect with the elements of the environment in which they exist, which establish new relations in the natural order. This knowledge becomes the fundamental basis for the design and construction of various organizations.

The opposite form of natural movement is repulsion in which the particles of matter, or the elements of the whole, either separate or move away from each other, or other particles in order to operate under the principles of "free shooter". Attraction and repulsions act simultaneously, which is natural, because any distancing of a particle or element from another, also represents rapprochement to another parcel or item. For the self-organization it is significant that this type of movement leads to disorganization of the organization with the aim to break the established relationships and channels of communication and destroy what attraction has created. By breaking the existing links, the particles of matter and other elements are trying to connect with other particles and elements and in this way to establish some new entireties. This process is continuous and for understanding of self-organization is vital, because through the process of rapprochement and distancing, natural or artificial group and entirety are created or disappeared. In other words, the process of organizing, disorganizing and reorganizing are permanent, as in the natural, as well as in artificial organization. 
$36^{\mathrm{TH}}$ INTERNATIONAL CONFERENCE ON ORganizational SCIENCE DeVElopment: ResPonsible ORGaNizATION (MARCH $22^{\mathrm{ND}}-24^{\mathrm{TH}}$, PORTOROŽ SLOVENIA)

M. Radosavljevic, A. Andjelkovic, M. Andjelkovic \& D. Radosavljevic: New approach in designing (SELF) ORGANIZATIONS as the most efficient modality of organizing

These two basic forms of movement (attraction and repulsions), cause changes, and changes to the problem and the need that they prevent, and then solve. This objectively and fully establish the cause-effect relationships and connections between the movementthe change - the problem - regulation i.e. that the movements are basic cause of changes or problems and regulations. According to this, if there is no movement, there would be no changes, or that if there is no change there would be no problems, and thus there is no need to solve problems, which is the activity of organization and management. Labeling of movement as the cause of change, which create problems and needs to get through the management and organization they prevent, and when they occur it is important to quickly solve them, because this is a natural, logical and scientific way of explaining the causal connections and relationships in the natural and social order (Adizes, et al., 2002).

For the organization and to organize it is important to know that the world has survived thanks to the movement, or the attraction and repulsions. If there were only attraction, it would bring to the organization, i.e. the creation of new living creatures, or organizations in the social system. This would increase the entropy of function of the natural, or the artificial system because there would be only procreation. Nature has solved this problem so that it is parallel with the attraction built opposite direction, and it is repulsions that leads to death of living creatures, or the organization in social systems. Nature has solved this problem so that it is parallel with the attraction built opposite direction, and it is repulsions that lead to death of living creatures, or the organization in social systems. So, there is no death without birth, nor does it have birth without dying. Translated into the language of the organization, there is no organization without disorganizing, i.e. to create something, it must be another entirety previously must be degraded, or the system.

If between the attractions and repulsions a state hibernation existed, this would result in their balance in which there would be no movement, and therefore no change, or the life. Consequently, there would be no organizing or disorganizing as two mutually conditioned process. This further means that there would be no evolution, but also there would be no entropy as its opposite, and thus no natural, or the social order (Radosavljevic, 2005).

\section{$3 \quad$ Natural and artificial organization as modalities}

It has already been noted that there are two types of movement. They exist in the natural order, thus creating the (self) organization, as until now the most perfect modalities of organizing. Apart from the natural, there is an artificial organization, which results from of the human mind and intelligence. By understanding the natural organization, it is possible to design and build artificial organizational structure and thus to raise their level of organization and the functioning, which requires something beyond explanation.

Natural organizing. Natural organization, or self-organization function on the principles of nature, and that means the objective of the law. In other words, they act independently from our will, whether a man knows them or not, whether they are respected, or denied. 
M. Radosavljevic, A. Andjelkovic, M. Andjelkovic, D. Radosavljevic: New approach in designing (SELF) ORGANIZATIONS as the most efficient modality of organizing

Natural laws are stable and do not change often, and when they change it leads to imbalance, and the radical changes to the cataclysms, such as droughts, floods, earthquakes, etc. The epilogue of this situation is that in the natural order, there are few natural law, which are respected and in the case of non-compliance, nature punishes often harsher than any other force. ${ }^{1}$

It is a different thing among artificial organizations. They are the result of man's knowledge, skills and experience. Artificial organizations are built on the basis of social, organizational, economic, sociological and other principles which are largely subjective and are heavily influenced by ignorance and uncertainty as well as a number of internal and external variables. In other words, economists and organizers must bear in mind that the "social reality is more complex than natural phenomena, not only because it is necessary to cope with a much larger number of variables, but also because of greater variability, less uniformity and greater difficulty of isolating of each factor separately. " This is completely different from the natural and technical sciences in which is the lower level of uncertainty, a smaller number of variables which are taken into the account, the greater uniformity and standardization in building models, than in organizational sciences (Pizano, \& et al., 2015).

Artificial organizing is done by natural and artificial elements, using the knowledge of the natural order of organization and above all the knowledge in the biological world. The natural element in the artificial organization is a man, and the artificial are material resources (raw materials, materials, semi-finished products). However the man in the organization, is not absolutely natural, but he must be also artificial, ie. to leave their basic natural properties (egoism, lack of organization, free operation and conduction, etc.), to accept the rules set by the man, or to fit in the limitations defined by the organization. By limiting individual freedoms through organizational arrangements, the man provides a greater degree of freedom at the level of the entirety as higher level of quality, which corresponded to the famous Aristotle's maxim that "a part is important, but the whole is much more important," and that for the interest of the entirety, interests or pats of the objectives can be sacrificed. However in organized structures that are created by a man it must be kept in mind that the sacrifice of the objectives or interests of the entirety makes sense only if such sacrifice can achieve greater effects at the level of the entirety. If this is not achieved Aristotle's thought has no purpose.

It turns out that the man is the most natural when he is born, and during the time through different forms and forms of organization becomes more artificial, so that he is the least naturalness upon death. Organization "carves" man and conditionally said "killing" his naturalness, through various concepts, technical and technological regimes, settings and restrictions. This brings us to the conclusion that the organization of artificial creations are constituted by the man and made up of natural elements that are unnaturally adapted to the needs and goals of the organization.

The man did not even meet the minimum functioning of the legality of self-organization, and above all, the universe, man and other creatures as a result of self-organization. The 
$36^{\mathrm{TH}}$ International Conference on Organizational Science Development: ResPonsible ORGaNizATION (MARCH $22^{\mathrm{ND}}-24^{\mathrm{TH}}$, PORTOROŽ SLOVENIA)

M. Radosavljevic, A. Andjelkovic, M. Andjelkovic \& D. Radosavljevic: New approach in designing (SELF) ORGANIZATIONS as the most efficient modality of organizing

question is whether he will ever succeed in that. Because of these objective constraints major unknowns remain in the natural order, especially when it comes to anatomical, physiological and functional dimensions. By this it is absent and even today there are lacks of the ability to set rules and principles of legality or the functioning of the natural order, or the self-organization on a large scale transfer to the design, construction and maintenance of artificial organization, i.e. enterprises, institutions, agencies, entrepreneurial, and other organizational groups.

However, it can be concluded that the medicine, biology, cosmology and other sciences have given certain information which analogously can be applied to organizational systems as artificial creations, as the organization itself can contribute to the development of these sciences. So the analogy between natural and technical sciences can be transferred to the social or organizational science. With the development of natural sciences, analogies and metaphors will receive an even greater intensity in applications in social, or the organizational sciences. This will lead to increased quality of social organization, and thus to increased efficiency and effectiveness of organizational systems.

\section{Specifics of self-organized structures}

Natural and artificial organization as modalities of organized structures have some common, but also a number of specific particularities that distinguish them. Common to both structures is that they have the same source, and that is the movement and to the form of movement called attraction. In one and to the other permanent structure changes occur and it is a condition of life, because where there is no change there is no life. It turns out that where there is no change, there is no movement, but there is also no problem, and thus there is no need for regulation and management. However, where there are no problems, there is no life, because it is shown that there are no problems only in the dead organizations or between dead people, which is the greatest problem (Radosavljevic, 2015).

Self organizations have a number of characteristics that distinguish them from others, and above all from artificial organizations. Differences exist even in some elements cause and effect vertical. Thus, the changes which take place in the natural order occur in the same or similar pattern, while changes in artificial organizations occur nonlinear, often turbulent and radically. Therefore, the management of organizational systems is harder because the changes, and thus the problems that arise from these changes are more complex and accompanied with great uncertainties.

The primary characteristic of any type of self-organization is its integrity. Natural organizations are formed as a entirety, from parts of which are connected to each other and between which is realized iterative relationship. Parts are relatively independent, but any change in one part causes changes in other parts, or on the level of the whole organization. As the complexity of the (self) of the organization increases, its autonomy 
M. Radosavljevic, A. Andjelkovic, M. Andjelkovic, D. Radosavljevic: New approach in designing (SELF) ORGANIZATIONS as the most efficient modality of organizing

in relation to the surroundings also increases. That legality exists in artificial organizations. Small enterprises are more depending on the environment. Today, transnational and multinational companies have a high level of independence, which is why traditional power has changed in favor of corporations, to the detriment of the country.

Another characteristic is that each self-organized entity establishes a relationship with the environment in which it is located, which means that it receives from the environment certain inputs, performs transformation processes and ultimately achieves output, that gives the environment a product or service. This means that no self-organized structure can not stand on the principle of a closed system, because in the natural order anything is not self sufficient, nor can it survive as an autonomous and independent part. Of course, it is a entity of some parts and at the same time some parts of the entity. The situation is similar with artificial systems, and organizations.

The third characteristic of self-organized structure is their dynamism. Every organization, including self-organization, must be changed, at least by the dynamic, which changes the environment. So it's not enough to just change the organization. It should be changed at the same pace as the environment, thus ensuring the survival, but not the progress. If the organization is changing slowly in relation to the environment, it is doomed to extinction. The organization must change faster than the environment, but it also has to create changes in the environment, in order to be able to use the benefits of its own progress. If this does not happen, faster organizational change in relation to the environment, may even be counterproductive. Example of dinosaurs confirms this in the best way. They disappeared, because they have not managed to adapt to the changes that have occurred in the environment. The same situation will occur also in business organizations.

Each (self) organization is unique and distinctive entity. This is the fourth specificity of self-organization. This can be seen the best in the case of every living being, including plants, animals, and also humans. All the studies show that there are no two same humans on the earth, even when it comes to twins. Mathematicians and medical experts have tried to define what number of people on Earth should be in order to find two same men. According to Brown, this number would $2 \times 10$ on $6 \times 2 \times 10$ on 7 . It is actually a number that can not be expressed mathematically, which means that every man is unique entity with its own desires, interests, motives, and psychological characteristics.

This fact is important for business organizations, as it is in the previous contexts deduced that in the world there are no two the same organization, because it is known that the organization is made up of people. Although men are the same in its anatomical and physiological characteristics, they, as well as organizations vary in their awareness, knowledge and skills, thinking, organizational behavior and practices, culture, relationships, etc. This characteristic causes a number of implications in artificial organization, because it shows that every person in the organization will be motivated and inspired in a different way than the other, and that according to to the above, every 
$36^{\mathrm{TH}}$ InTERnAtional CONFERENCE ON ORganizational SCIENCE DeVelopment: ResPonsible ORGaNizATION (MARCH $22^{\mathrm{ND}}-24^{\mathrm{TH}}$, PORTOROŽ SLOVENIA)

M. Radosavljevic, A. Andjelkovic, M. Andjelkovic \& D. Radosavljevic: New approach in designing (SELF) ORGANIZATIONS as the most efficient modality of organizing

man must be adapted to a particular mode of communication, the one that corresponds to its characteristics.

That means that there is no place for universal and uniform management with different people, as today's management problems arise because old concepts of organization and management in modern conditions are applied. Whenever a man was trying to solve contemporary problems by using outdated concepts of organization and management, he was creating even greater problems, because the problems are caused due to inadequate application of the concept or technical solutions. This imposes the need of the individual, rather than a uniform approach towards the people in the organization. This is much more difficult to establish, but it is possible, which brings into question the presence and still great application of classical concepts and organizational models.

Although each man is autonomous and individual, he can only survive in cooperation with other people, but also with elements of the environment to which he belongs, which gives him the social character and purpose, but also power, because a man does not have a great strength or unlimited intellectual power in order to be able to cope with the threats that come from nature, or because of the inability to solve complex problems individually. Therefore, man teams up with other people and becomes part of the environment or its subsystem. He must adjust their conduct to the environment, and work on its sustainable development and improvement, because in this way he increases the chances for his own survival, but also to spread his dominance and power.

The fifth characteristic of self-organization refers to life expectancy. Each self-organized structure has its life, which can not be indefinitely extended. Over time, each selforganization leads to the depletion of its own energy potential to eventual result, death. Therefore, any self-organization has the ability to reproduce, as the process where new self-organizations are created. But the limits of reproduction or regeneration in all the self-organizations (animals, plants and humans) are limited, since every living thing (plant, animal and human) in the stage of maturity, or old age is not able to reproduce their own kind, and also not to provide their own survival. Man has possibly succeeded by the acquisition of new knowledge to extend impregnating time of regeneration and reproduction, and reproduction of their kind. The example of expanding the boundaries for artificial insemination in the Republic of Serbia from 40 to 42 years is illustrative enough to confirm the above conclusion, there similar cases in the biological, the animal world. $^{2}$

What is characteristic for each self-organization is the fact that own disappearance, or death can not be avoided. Thus, each organization has its origin (birth), its growth and development, the zenith, the line of degressivity and finally the disappearance, or death. From the above it is concluded that everything that was created, must disappear, the only difference is in the length of the life. The average human life expectancy in modern conditions is about 75 years, the butterfly lives a day, stars a few million years, and so 
M. Radosavljevic, A. Andjelkovic, M. Andjelkovic, D. Radosavljevic: New approach in designing (SELF) ORGANIZATIONS as the most efficient modality of organizing

on. For all of this, the common thing is that they have the same path of movement, the same result, and this is the final disappearance.

The above rule can be applied to business organizations too. So those have their own life cycles, and they are the result of the life cycle of a product or service. If the product or service is lasting and stable on the market, it is logical that the organization is likely to be long-lasting, and longevity itself is a great value. What distinguishes life century of self-organization and artificial organization, is that the life of self-organization can not be indefinitely extended in order to avoid death. The lifespan of the company or organization can be theoretically and indefinitely extended, provided they live with permanent changes and to coordinate their changes with the changes in the environment. An example of a major automaker Ford confirms it.

This auto giant has managed to hold more than a century, thanks to adaptations, or changes that are permanently introduced, especially the changes accepted by the customers. Therefore, Ford today is not Ford from fifty or one hundred years ago. It has managed to hold because it has changed its models according to the customers' requirements and it will continue to exist if it considers the changes. It will happen with any other organization too.

The sixth characteristic of self-organization is their stability and self-renewal ability of its structure. Self-organization permanently exchanges matter, energy and information with the environment and seek to increase the ability of self-preservation in spite of the permanent changes that occur in their structure. An example of this is confirmed by the pancreas. It turns out that the pancreas most of its cells replaces every twenty-four hours, the white blood cells are renewed every ten days, a $98 \%$ protein in the human brain change every month. These changes occur permanently, but within the same pattern of events and behavior, changes happen, but the basic shape and form of the organism remains preserved. Self-organized structures beside those that are permanent, or temporary changes, continue to operate in the same way in the environment that changes. This characteristic of self-organization demonstrates their ability to self-preservation (Vucenovic, Radosavljevic, \& Markovic, 2011).

Let us imagine what would be the results achieved in modern business, when business organizations and their management were trained to self-preservation and selforganization, i.e. to create and design the organizational structure and carry out their restructuring, and that this happens in the context of a pattern of functioning. In other words, to do permanently redesigning and adapting of the organization, but what is important is not to "demolish walls and foundations' of the existing organization, or to do the redesign of the so-called "light partitions".

Self-organized structures are striving to expand its field of operation and master the elements of the environment they belong to. This is present in the plant world, even in parasitic plants (weeds) that replicate and spread its influence and domination, even though certain agro technical and agrochemical measures taken for its destruction. In the 
$36^{\mathrm{TH}}$ International Conference on Organizational Science Development: ResPonsible ORGaNizATION (MARCH $22^{\mathrm{ND}}-24^{\mathrm{TH}}$, PORTOROŽ SLOVENIA)

M. Radosavljevic, A. Andjelkovic, M. Andjelkovic \& D. Radosavljevic: New approach in designing (SELF) ORGANIZATIONS as the most efficient modality of organizing

animal world, as a kind of self-organization there is also a tendency to dominate and greater impact on the environment in which it operates. Animals have their own territory and borders that are kept away from other animals and try to expand it over time, and ensure their safety. Man, as the most perfect specimen of self-organization also wants to expand its influence and domination in the environment where he lives, and beyond. He wants to take control of other people, and because of that he takes a variety of actions and activities. The nature of man is that he wants to rule other people.

There is the expansion of field of influence in business too. All large companies were once small, but over time expanded its business and the impact from the local switched to wider markets. Today, transnational and multinational companies, which control a substantial part of the global market, are not satisfied with the conquered large markets, but are still trying to expand. Here, as in other spheres proved to be a rule that in the essence of a man that he is not satisfied with the achievements and fulfillment of each objectives, then the second and generally higher-ranking objectives are formed.

From these natural characteristics of man as a self-organization that seeks to continuously expand its influence, the competition in various fields are created, as the basis of any prosperity and the progress of civilization. Being a leader means to have power and influence. Therefore, every kind of sport, business and scientific competition endeavors to achieve better or the best results, because there is a special place and status in the organization, or society for the best people.

The seventh characteristic of self-organization is the flexibility and adaptability. Flexibility means that self-organization, and living organisms, and beings are able to adapt themselves to changing conditions and situations in the environment where they live and operate. It was found that in each self-organization, and in every living being or their parts, there is a matter, energy and information. For the matter and energy even the ancient Greeks knew, and the information as a mandatory element of every living was discovered by $\mathrm{N}$. Wiener. Adaptation, the flexibility is precisely based on the information, or the channel feedback. It shows the status and influence of the environment on the functioning of self-organization and in the perspective it will increasingly gain in importance. In regard to the foregoing, it says: "The task of education in the future will be to increase the man's adaptability, the ability they need to cope with continuous changes. The faster pace of development is, the more attention must be paid to the prediction of future events (Toffler, 1997, 319).

The eighth characteristic of self-organization is their hierarchy, and this characteristic is valid for artificial organizations too. Thus, the hierarchy is natural order, which was formulated by Darwin through the phrase "bigger species eat smaller species". This phrase in modern conditions was transformed into a rule that "faster species eat slower species." Regardless of the correctness of the two, the fact is that natural and therefore social order can not exist and survive without a hierarchy of relations between lower and 
higher system in hierarchical relationships. In other words, the hierarchy is the eternal law that will exist until there is a world and life.

What will change over time is the base of the hierarchy. With the advances in technology and the humanization of society, hierarchy based on power will disappear, or the law of one to issue orders and other commitments to carry out those tasks, in case they do not do that, sanctions follow. A new form of hierarchy is formed and established, and that is the hierarchy of knowledge (ignorance). Knowledge, skills and abilities will have the highest hierarchical level, so that the experts, scientists and so-called. white coats and "Golden Collars" will be at the top, and those who have less, or lack of knowledge, they will be at the lower, or at the bottom of the hierarchy and forced to listen to and act on the ideas and the ideas of experts. Thus, knowledge, and not the government, today and in perspective will have the most power, while ignorance will be subordinated and without any power and authority. That is what largely happened in modern organizations. Thanks to the above, many poor countries in natural resources have achieved great success, because on the highest hierarchical top they set the human competence (Radosavljevic, 2012, 53-55).

Those specificities speak enough about the functioning of self-organization. They are more or less related to the artificial organization and detection of legality of functioning of self-organization and development of the natural sciences, and many rules and principles can be applied to artificial organization.

If the artificial organizations could be built on the principles of self-organization, they would be very efficient, that they would automatically respond to changes in the environment. But it is practically impossible in modern conditions, because the man could not detect many secrets of functioning of nature. He probably will not for long be able to uncover all dimensions of self-organization, which due to their complexity, partly because of insufficient knowledge of natural laws based on the creation, growth and development, and maintenance of self-organized system. However, the acquisition of new knowledge in biology, medicine, particularly in anatomy, physiology and other natural sciences and with the help of information technology, many secrets are revealed and there will be fewer secrets. This creates conditions for the legality of functioning of self organizations is transferred to the artificial, or organizations that man designs, builds and maintains.

\section{What analog things may be transferred from self-organization to an artificial organization?}

The fact that the technological changes experienced such a success that the existing modalities of organizing and designing of organizational structures became a limiting factor in the operation and management of organizational systems. In other words, radical change in the last few decades on many issues occurred, but they did not take place in the sphere of organization and management. The tendency "accelerated technological steps" a lag of organizational improvement is frightening, and calls into question the survival of 
$36^{\mathrm{TH}}$ INTERNATIONAL CONFERENCE ON ORganizational SCIENCE DeVElopment: RESPONSIBLE ORGANIZATION (MARCH $22^{\mathrm{ND}}-24^{\mathrm{TH}}$, PortoroŽ SlOVENIA)

M. Radosavljevic, A. Andjelkovic, M. Andjelkovic \& D. Radosavljevic: New approach in designing (SELF) ORGANIZATIONS as the most efficient modality of organizing

the teachings of the organization, which is responsible for everything that exists on earth (Andjelkovic, 2016, 13).

One of the ways to overcome the current crisis of an organization is the application of knowledge of self-organization, and above all knowledge of anatomy and physiology of man as the most perfect product of self-organization. At that should be borne in mind that man is not the ideal product of the natural order, as in the natural order and social there is nothing ideal and perfect. It should be borne in mind that man is not the ideal product of the natural order, as there is nothing ideal and perfect in natural and social order. He is an integral whole and social being with the interest and the unique desires, needs and abilities, which makes him a unique and remarkable being. It has already been stated that in the world there are no two same people, even if it was about the twins, and in order to make that happen, a population number that can not be expressed mathematically would be necessary. This leads to the conclusion that every man is anatomically and physiologically similar to each other, but they differ primarily in knowledge and skills, psychological and other characteristics.

As the man as a modality of self-organization is not ideal, it is logical that there is no organization as an organized group in which the man is its mandatory element, are not ideal. This is because every man is unique and has specific requirements, interests and motives in relation to the other man. In this sense, there is a large space for man's improvement, upgradation and enhances its ability to work, behavior and life in general. When a man, or any other organization reached the level of perfection, it would have failed, because in the natural and social order there is no perfection, but permanent growth and development. All the better results in sports competitions, where better results are permanently achieved in all disciplines, but also in other areas, show and prove that human possibilities are endless, provided that the man does not limit and hamper himself.

Discovering the secrets of the functioning of man as a kind of self-organization is possible to formulate certain rules that can be transferred to the artificial systems and organizations. Everything that exists in the organization (company, hospital, church, sports team, school, theater, etc.), there is in man too. Also by getting to know the man and the manner of his operation, it is possible to design, construct and maintain artificial organizations. In man there are inputs, transformation processes and outputs. Thanks to food, water and air which people use and transformation process in which inputs are transformed into outputs, the man survives, grows and develops. If there is a discrepancy between the inputs, i.e. that the inputs are higher, through the transformation processes outputs are corrected, thus causing obesity, and storage of excess input in the human body. In case of lack of inputs (food, water, and in the company of raw materials, materials, spare parts, assemblies and subassemblies) body uses reserves, and in the company warehouse, to establish the continuity of life, or business process. 
M. Radosavljevic, A. Andjelkovic, M. Andjelkovic, D. Radosavljevic: New approach in designing (SELF) ORGANIZATIONS as the most efficient modality of organizing

There is a brain, heart, executive parts (hands and feet), blood, eyes, ears, skin, etc, in a man. All of this exists in the organization as a result of human labor, as a result of using the model of self-organization in the creation of business and other organizations.

In organizations, the General manager can be compared with the brain in the human body. It is the most important, but also the authority which is the most complex and whose secret operation is not discovered yet. It performs the most complex functions of the human organism. According to the above, in every organization there is a control body in the names of directors, General, Executive or President of the corporation. The heads of the depth and breadth of the organization are the executive parts, like muscles in the human body. In humans, it is known that the arms and legs, or the executive body parts do everything devised by brain, and this situation should be in every organization.

Cash and financial system in the organization, as well as its circulation can be likened to the bloodstream, or what is the blood in the human body, it is money in the organization. Where blood does not reach it leads to atrophy of certain parts of the body, and where money does not reach, as the basic element of motivation leads to the extinction of certain parts of the organization, and ultimately of the organization itself. Therefore, it is primary to provide correct rules, and supply and distribution of money in the organization, similar to the distribution of blood in the human body.

The human eyes are compared with the sector for planning and forecasting, and the development sector. These sectors need to see the future and to permanently scan the environment, in order to transmit information to the brain, or the top management for a decision that will align its operation with the needs and the changes that occur in the environment. In this way uncertainty is reduced, which in modern conditions tends to increase.

Marketing Department is compared with the ears and eyes. Therefore, their task is to listen to the needs, interests and desires of customers and through the transformational processes in the feedback regulation attempts to convert the output, which is the product or service. From the extent of the importance of the ears and eyes of a man can be seen by the fact that nature gave man two ears, two eyes because of the importance of listening and viewing in relation to other functions, primarily the rhetoric and speech. Functional differences in the organs of hearing and speech in humans is that the man learns to speak up to three years and not learn how to be quiet for the whole life. Therefore, the organization should give emphasis on listening, primarily desires, interests and needs, as well as customer complaints.

The skin is considered as a protective jacket, but also as a mirror of every man. It automatically protects humans from external influences. And there are organized protective bodies that protect people, property, information and other tangible and intangible elements of the organization. 
$36^{\mathrm{TH}}$ INTERNATIONAL CONFERENCE ON ORganizational SCIENCE DeVElopment: RESPONSIBLE ORGANIZATION (MARCH $22^{\mathrm{ND}}-24^{\mathrm{TH}}$, PortoroŽ SlOVENIA)

M. Radosavljevic, A. Andjelkovic, M. Andjelkovic \& D. Radosavljevic: New approach in designing (SELF) ORGANIZATIONS as the most efficient modality of organizing

Cited shows and proves that between a man as a product of the organization and artificial organization there is a high degree of similarity, and that principles of self-organized organization can be successfully transferred to the artificial organization, in order make them successful.

In this sense, it is necessary that the organizers, and managers know the basic characteristics of self-organization, in order transfer and apply certain rules of functioning of this to the artificial organizations such as enterprises, institutions, banks, hospitals, agencies, church, military and other organizations. In this context, managers must be multidisciplinary professionals who will know the theory and science of management and organization, as well as psychology, sociology, working with people, communication, money management, but above all the management itself (Radosavljevic, 2016).

\section{6}

\section{Summary}

The above indicates and proves to be a significant source of self-organization in the acquisition of knowledge that can be used in the design, construction, maintenance and management of artificial, consciously organized organizations and systems. In this way, "creative imitation" is actually performed of what is happening in the natural organization.

Considering the fact that the practice of organizing artificial systems still uses the postulates of classical organization that in modern conditions can not give proper effect, in perspective there will be a need to introduce a new concept of organization based on the principles of self-organization, as the most perfect way of organizing. The paper points out the importance of flexibility and adaptability, hierarchy, stability and importance of life with changes.

By studying self-organization and natural sciences, and above all medicine, biology, chemistry, psychology and other sciences and applying their knowledge in the creation of organizations and their management, raises the professionalism of the organization and management as part of the social humanities. This is significant, because the decision on organization, disorganization and reorganization, as well as the modalities and concepts of governance must be made by the scientific or the factual basis, as is the case in medicine, biology, mathematics, statistics, operational research including technical sciences. Otherwise, the organization as a science will eventually lose its professionalism and objectivity, because there is no traceability and it is not documented why a decision was made and why it is one and the same decision in some organizations has brought a variety of outcomes, and the effects. Explanations that there is a large number of variables that the organizations meet, are not satisfactory, especially in the contemporary intellectual organizations that are supported by new technologies.

The knowledge of self-organization can be used to increase the performance of corporate organization, with different ownership or organizational types, different sizes, and so on. 
For the successful use of most knowledge, funding is not required, which is often a limiting factor in certain acts or inaction. In this sense, we should have in mind the saying of J. Goethe: "We are too old to criticize something, or young enough to do something and change it."

\section{Notes}

${ }^{1}$ Floods, imbalance in the plant and animal world are the result of inadequate respect of the nature by man, who is himself a part of that nature.

2 In the Republic of Serbia in 2017, the standard is adopted that the time for artificial insemination moves from forty to forty-two years, counting to the fact that period for the reproductive capacity of women is extended for two years. This is a major breakthrough because it is expected that the success of artificial insemination in a prolonged reproductive ages will be the same as in the previous (abridged) reproductive ages.

\section{Literature}

Adizes. (2002). Change Management, Adizes Institute, Novi Sad.

Andjelkovic, M. (2016). Application of New Technologies in the Management and Economy, ANTIM, Belgrade.

Pizano, D., \& et al. (2015). Interviews with the great economists, Mate, Zagreb.

Radosavljevic, M. (2015) Change management and changes in management (script), Faculty of Business Studies and Law, Belgrade.

Radosavljevic, M. (2016). Management-Theory and Practice, FPSP, Belgrade.

Radosavljevic, Z. (2005). Medicine management, EDCOM, Belgrade.

Radosavljevic, Z. (2012). Knowledge management, FORKUP, Novi Sad.

Toffler, A. (1997). Future Shock, PS Grmec, Belgrade.

Vucenovic, V., \& Lekovic, B. (1998). Management-Philosophy and Technology, Zelnid, Belgrade. Vucenovic, V., Radosavljevic, Z., \& Markovic, A. (2011). (Self) Organisation, FORKUP, Novi Sad. 
828 36 $6^{\text {Th }}$ InTERnational CONFERENCE ON ORganizational SCIENCE Development: Responsible Organization (MARCh $22^{\mathrm{ND}}-24^{\mathrm{TH}}$, PORTOROŽ SlOVENIA) 
$36^{\text {Th }}$ International Conference on Organizational Science DEVElopMENT: Responsible ORganization (MARCH $22^{\mathrm{ND}}-24^{\mathrm{TH}}$, PORTOROŽ SLOVENIA)

O. Arsenijević, M. Ferjan, I. Podbregar, P. Šprajc, D. Trivan \& Y.

Ziegler

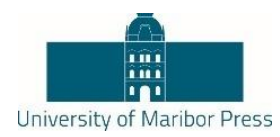

\title{
Intellectual Capital Assessment Based on the Standardized Visualization Methodology
}

\author{
Nikola Radovanovic, VelJKo DMitRovic \& SNEZANA KNEZEVIC
}

\begin{abstract}
For the organization to realize its own market value and competitive strength, it needs to identify and assess its intellectual capital. Intellectual capital comprises all non-material assets that affect the market value of organizations, which is why the identification and analysis of the intellectual capital drivers is not an easy task. A project named "EVLIA", co-funded by the European Union under the South East Europe 2007-2013 ERDF programme, was launched at the end of 2012 with the aim to provide a framework for identification and assessment of intellectual assets with the emphasis on intellectual property rights for the purpose of raising finance and determining strength of organizational intellectual capital. Within the project, a standardized methodology for the evaluation of intangible assets from the financial and economical perspectives has been developed. The overall assessment of the methodology provided by the project emphasized its usefulness for the identification and analysis of intangible assets and its applicability by organizations coming from various sectors and in different sizes.
\end{abstract}

KEYWORDS: intellectual capital • valuation • intellectual property • intangible assets

CorResPOndence AdDREsS: Nikola Radovanovic, Intellectual Property Office, Kneginje Ljubice 5, 11000 Beograd, Serbia, e-mail: nradovanovic@zis.gov.rs; Veljko Dmitrovic, Ph.D., University of Belgrade, Faculty of Organizational Sciences, 154 Jove Ilića Street, 11000 Beograd, Serbia, email: dmitrovicv@fon.bg.ac.rs; Snezana Knezevic, Ph.D., University of Belgrade, Faculty of Organizational Sciences, 154 Jove Ilića Street, 11000 Beograd, Serbia, e-mail: knezevic.snezana@fon.bg.ac.rs 
$36^{\mathrm{TH}}$ International Conference on Organizational Science Development: RESPONSIBLE ORGANIZATION (MARCH $22^{\mathrm{ND}}-24^{\mathrm{TH}}$, PORTOROŽ SLOVENIA)

N. Radovanovic, V. Dmitrovic \& S. Knezevic: Intellectual Capital Assessment Based on the Standardized Visualization Methodology

\section{Introduction}

The growing importance of intellectual capital in the last few decades has been discussed by many. Being a crucial factor to sustainable development and a market value driver of companies, intellectual capital has been rightfully under a magnifier. Theoreticians have tried to divide intellectual capital in many ways. Brooking (1996) divides intellectual capital into four categories: market assets, intellectual property, infrastructure and human-centered capital. Sveiby (1997) stated that intellectual capital comprises three dimensions: collaborators' competence, internal components and external components. On the other hand, Edvinsson and Malone (1997) define intellectual capital as the knowledge, applied experience, organizational technology, customer relationships and professional abilities that give a competitive advantage. Generally accepted notion is that intangible assets, as the core of company's intellectual capital, determine the company's market strength and potential in sustainable manner. According to Lev and Schwartz (1971), Lev (1999, 2001), all of the intangible assets of an organization make up its intellectual capital. In many studies, the focus was often put on the knowledge as the generator and a driver of various intellectual capital sources. Kessels (2001) ephasized the increased attention to the capability and efficiency for the creation, expansion and application of knowledge in the knowledge-based economy era.

Due to its character of being non-material, intangible assets are difficult to capture and measure. There are many different methodologies and models which can be applied for that purpose. There is a continuing need of investors and creditors to precisely evaluate the potential of new investment or lending opportunities in regard to companies' intangibles. Such reliable intangible assets evaluation model would be beneficial to financial institutions prior to making decisions on what to fund. Issues with financial reports provided by companies often include non-adequate inclusion of information on intellectual property rights in the reports (Radovanovic et al, 2016).Tsai et al. (2016) stated that, in order to provide other useful information different from financial statements for investors or creditors to measure the firm's value in investment opportunities or loans, and also to assist them make more accurate decisions more effectively, it is important to build a more effective and reliable intangible assets value evaluation or prediction model. Axtle Ortiz (2006) suggested the application of an analogy from an accounting expression: intellectual capital equals the difference between intellectual assets and intellectual liabilities, suggesting that the concept of intellectual capital should be equated with intangible assets. Development of a new tool for the assessment of intellectual capital of companies was the goal of a project launched under the South East Europe Programme and named EVLIA - making full value of good ideas by leveraging intellectual assets for financing SMEs in South East Europe.

EVLIA methodology was developed based on the concept of competitive relevance. It aimed at supporting the efforts of visualization and analysis of intangible assets of a company, as its intellectual capital elements, for the purpose of developing competitive position of that company. The report based on the analysis is created for both internal and external purposes. It may serve as a basis for financing decisions by banks or other 
financial intermediaries. However, in order to use the method efficiently, the management of the company needs to be aware of its strategy and of the importance of company's tangible and intangible resources for its business. In that way, the appropriate assessment may take place based on the grouping of intangible assets according to the methodology.

The grouping of intangible assets into four groups within the EVLIA method was developed based on various methods of analysis and value assessment suggested by authors and experts in the area of intellectual capital and intangible assets, such as "Intangibles Scorecard" (Gu and Lev, 2002, 2011.), "Skandia Navigator" (Edvinsson and Malone, 1997), "Intangible Asset Monitor" (Sveiby, 1997, 1998-2013.), "Holistic Value Approach" (Roos et al., 1997; Pike and Roos, 2000; Pike et al., 2002), "Technology Factor" (1998; Khoury et al., 2001) and "Intellectual Capital Audit" (Brooking, 1996).

Separately from the grouping of intangible assets, a list of key performance indicators was developed in order for the evaluators of the methodology to be able to assess the overall efficiency of the EVLIA approach.

EVLIA methodology has been developed with the support of Ms. Sara Giordani, founder of TTP Lab (Technology Transfer Program \& Laboratory), whose research concepts were used as the basis of the methodology. The lead partner of the project was the Chamber of Commerce Industry Craft and Agriculture of Venice. It should be noted that the Economic and Financial Evaluation Methodology elaborated by the Italian Patent and Trademark Office (DGLC-UIBM) has been used as the background of the EVLIA project.

\section{Intangible assets assessment model}

For the purpose of the project, a model which would look at the potential of all identified intangible assets in an organization from four perspectives (creation, functioning, planning and transferability) needed to be developed. The first step is to analyze how the asset was created or obtained, or to visualize the asset, which is then followed by the assessment of the methods of asset utilization and its measurement. The second part of this analysis is to identify the needs regarding the required intangible assets and complementary resources in terms of costs and investments, and to assess their influence on organizational activities, while the analysis is completed with the assessment of the assets relevance to other entities.

The analysis, therefore, required construction of a set of questions determining the strength of each identified intangible asset through these four perspectives. Identified intangible assets were grouped into four groups based on the EVLIA model of intangible asset types: human resources, intellectual property, organizational capital and relational capital. 
$36^{\mathrm{TH}}$ INTERNATIONAL CONFERENCE ON ORganizational SCIENCE DeVElopment: RESPONSIBLE ORGANIZATION (MARCH $22^{\mathrm{ND}}-24^{\mathrm{TH}}$, PORTOROŽ SLOVENIA)

N. Radovanovic, V. Dmitrovic \& S. Knezevic: Intellectual Capital Assessment Based on the Standardized Visualization Methodology

\section{1) Human resources}

This group included four subgroups: entrepreneurial experience, staff education and competences, tacit knowledge and staff motivation and loyalty. Entrepreneurial experience is determined by years of experience, quality of experience, management style and business continuity availability. Staff education and competences is assessed based on costs of trainings, coverage of needed competences, trainings performed, and other. Tacit knowledge is assessed by the share of tacit knowledge in an enterprise, identified key personnel with the tacit knowledge, significance of tacit knowledge to company's business, and similar. Finally, staff motivation and loyalty is analyzed based on the existence of mechanisms for the employees to participate in business development (e.g. idea banks), efficiency of such mechanisms, assessment of employees' satisfaction and motivation, credibility of management, and other.

\section{2) Intellectual property}

There were six subgroups for the intellectual property: know-how (codified knowledge), business secrets, patented and non-patented inventions, trademarks and brands, designs and copyrights. All six are evaluated based on the existence of the relevant intellectual property, expenditures for creating/developing particular intellectual property, exploitation potential, their impact on business, management capabilities and transferability aspects.

\section{3) Organizational capital}

The group of organizational capital includes: procedures for production/supply of services, certificates, project/operations management and administrative systems. All of them are evaluated based on the existence of the relevant elements (procedures, certificates, project or operations management systems, IT-based administrative systems), expenditures for investing into them, IT integration level, exploitation potential, their impact on business and transferability aspects.

\section{4) Relational capital}

This group includes four subgroups: customer attraction, customer portfolio management, management of suppliers, and cooperation and networks. All four are evaluated based on the existence of systems and initiatives, the level of IT integration, exploitation potential, ability to create value, impact on business, efficacy in regard to competitors, expenditures for investing into them, and the importance of the element to other enterprises.

The structure of the model is given in Table 1 below: 
N. Radovanovic, V. Dmitrovic \& S. Knezevic: Intellectual Capital Assessment Based on the Standardized Visualization Methodology

\begin{tabular}{|c|c|c|c|}
\hline $\begin{array}{c}\text { Human } \\
\text { Resources }\end{array}$ & $\begin{array}{c}\text { Intellectual } \\
\text { property }\end{array}$ & $\begin{array}{c}\text { Organizational } \\
\text { Capital }\end{array}$ & $\begin{array}{c}\text { Relational } \\
\text { Capital }\end{array}$ \\
\hline $\begin{array}{c}\text { Entrepreneurial } \\
\text { experience }\end{array}$ & $\begin{array}{c}\text { Codified } \\
\text { knowledge. } \\
\text { Databases, } \\
\text { procedures and } \\
\text { manuals }\end{array}$ & $\begin{array}{l}\text { Methods/procedures } \\
\text { for production/ supply } \\
\text { of services }\end{array}$ & $\begin{array}{l}\text { Customer } \\
\text { attraction }\end{array}$ \\
\hline $\begin{array}{l}\text { Staff education and } \\
\text { competences }\end{array}$ & $\begin{array}{c}\text { Business } \\
\text { information. } \\
\text { Trade and } \\
\text { business secrets }\end{array}$ & Certifications & $\begin{array}{c}\text { Customer } \\
\text { portfolio } \\
\text { management }\end{array}$ \\
\hline $\begin{array}{l}\text { Know-how and } \\
\text { tacit knowledge }\end{array}$ & $\begin{array}{l}\text { Patents and } \\
\text { inventions }\end{array}$ & $\begin{array}{l}\text { Project management } \\
\text { tools and systems }\end{array}$ & $\begin{array}{c}\text { Suppliers } \\
\text { management }\end{array}$ \\
\hline \multirow[t]{2}{*}{$\begin{array}{c}\text { Staff motivation } \\
\text { and loyalty }\end{array}$} & $\begin{array}{c}\text { Trademarks and } \\
\text { brands }\end{array}$ & Administrative system & $\begin{array}{c}\text { Cooperation and } \\
\text { networks }\end{array}$ \\
\hline & $\begin{array}{c}\text { Designs and } \\
\text { models }\end{array}$ & & \\
\hline
\end{tabular}

Table 1: Types of intangible assets (source: EVLIA intangibles visualization guidelines)

Each intangible asset has been evaluated with the overall score, based on the input of companies' managers who would provide the answers for the assessment. This approach provides companies with the insight into the competitive value of their intellectual capital drivers and with the necessary information on what is company's competitive weapon or where an improvement should be made. The users of the model would be able to do additional analysis, such as SWOT or portfolio analysis, based on the initial result.

\section{$3 \quad$ Analysis}

To assess the efficiency and applicability of the EVLIA approach, evaluators were asked to analyze the approach based on determined key performance indicators (KPI). The scores for each KPI were given in the range from 0 to 100 , where 0 marked that the EVLIA tool is not aligned with the given KPI, 50 signaled that the improvement was necessary, and 100 acknowledged that the given KPI is aligned with the tool. The set of approved key performance indicators for the quantitative evaluation of the EVLIA approach is given in the Table 2. The EVLIA tool in this paper comprises the EVLIA model and the described methodology attached to it. 
$36^{\text {TH }}$ International Conference on Organizational Science Development: RESPONSIBLE ORGANIZATION (MARCH $22^{\mathrm{ND}}-24^{\mathrm{TH}}$, PORTOROŽ SLOVENIA)

N. Radovanovic, V. Dmitrovic \& S. Knezevic: Intellectual Capital Assessment Based on the Standardized Visualization Methodology

\begin{tabular}{|l|l|l|}
\hline No. & Name of KPI & Description \\
\hline 1 & Strategy fit & $\begin{array}{l}\text { Does the tool set help to evaluate assets } \\
\text { which are of strategic importance of a } \\
\text { company? }\end{array}$ \\
\hline 3 & Coherence & $\begin{array}{l}\text { Is the valuation tool set coherent with the } \\
\text { needs of the users? }\end{array}$ \\
\hline 4 & Corporate development stages & $\begin{array}{l}\text { Does the valuation tool set reflect the } \\
\text { business model/value creation process of } \\
\text { a company? }\end{array}$ \\
\hline 5 & Loan collateral & $\begin{array}{l}\text { Which are the stages of corporate } \\
\text { development the valuation approach is } \\
\text { useful for? }\end{array}$ \\
\hline 6 & Mergers and acquisitions & $\begin{array}{l}\text { Does the qualitative/quantitative } \\
\text { valuation approach help to use } \\
\text { IP/intangible assets as loan collateral? }\end{array}$ \\
\hline 7 & Financing conditions & $\begin{array}{l}\text { Does the qualitative/quantitative } \\
\text { valuation approach support valuations for } \\
\text { mergers and acquisitions? }\end{array}$ \\
\hline
\end{tabular}

Table 2: List of KPIs

Source: final report of the EVLIA project

The evaluators were selected among the project partners from eight countries - Austria, Bulgaria, Croatia, Greece, Hungary, Romania, Serbia and Slovenia. The average scores given by the evaluators are presented in the Table 3 .

\begin{tabular}{|l|l|}
\hline KPI & Score \\
\hline Strategy fit & 96.25 \\
\hline Coherence & 74.38 \\
\hline Value creation model & 79.38 \\
\hline Corporate development stages & 88.13 \\
\hline Loan collateral & 72.86 \\
\hline Mergers and acquisition & 74.29 \\
\hline Financing conditions & 85.71 \\
\hline
\end{tabular}

Table 3: Quantitative assessment of KPIs

Source: final report of the EVLIA project 
As seen in the table 3, the highest score for the alignment of EVLIA tool with the crucial business factors is given for the KPI - strategy fit. Two KPIs which follow are corporate development stages and financing conditions. Other KPI also got high scores, but all of them are below 80.00 . Following the overall scores, the evaluators provided remarks for each KPI and its alignment with the EVLIA tool.

- KPI 1 - Strategy fit:

It has been assessed that the qualitative evaluation enabled by the EVLIA tool includes all important intangible assets issues of a company which are or should relate to strategy fit. Also, the opinion of the evaluators was that the scoring system in the EVLIA tool provides better understanding to company management on main advantages/disadvantages of their own intangible assets.

\section{- KPI 2 - Coherence:}

Regarding the possible improvement of coherence of the EVLIA tool, the evaluators proposed that organizations primarily need to adopt certain IPR management strategies, in order to make the valuation tool set more coherent with the need of the users. Another issue with this indicator could be that the person involved in the evaluation is sometimes able to estimate certain intangible assets subjectively.

\section{- KPI 3 - Value creation model:}

It has been generally accepted that the value creation process is reflected in the valuation tool developed by EVLIA methodology. Additionally, the EVLIA tool could bring up specific aspects which were not in company's focus in the value creation model, enabling the company to reassess the model.

\section{- KPI 4 - Corporate development stages:}

The evaluators' remark stated that the EVLIA tool has good coverage of corporate development stages in a company. Also, the experience of the IPR holders showed that valuation approach is useful in all development stages of the company because they the value of their IP rights may vary in different development stages.

\section{- KPI 5 - Loan collateral:}

It has been proposed that, in order to make the valuation approach useful to use intangible assets as loan collateral, it would be helpful to construct quantitative valuation tools for other IP types, especially if they are related to the intellectual property rights which are being evaluated. Regarding the banks' perspective, the opinion of the evaluators was that, given the banks are generally sensitive to well-prepared business plans and well presented, there is a need for the application of standardized valuation methodologies, 
$36^{\text {TH }}$ International Conference on Organizational Science Development: RESPONSIBLE ORGANIZATION (MARCH $22^{\mathrm{ND}}-24^{\mathrm{TH}}$, PORTOROŽ SLOVENIA)

N. Radovanovic, V. Dmitrovic \& S. Knezevic: Intellectual Capital Assessment Based on the Standardized Visualization Methodology

such as EVLIA tool. However, it was also emphasized that the banks reluctantly use the data of the evaluation in which they did not participate.

- KPI 6-Mergers and acquisitions:

The evaluators suggested that the valuation approach proposed by EVLIA allows the third party, that wants to acquire the company, to have a general picture of that company. Companies that implement certain IPR strategies in the evaluation of mergers and acquisitions should give more importance to valuation by the EVLIA tool.

\section{- KPI 7 - Financing conditions:}

The opinion is that the use of the EVLIA tool could help in increasing company's reputation among financial institutions as well as its possibility to obtain favorable loans. However, much work needs to be done in raising banks' awareness on the potential market strength of intangible assets. Another big issue is the lack of market liquidity in most countries.

The overall remark from the evaluators was that the companies where this methodology was applied under the project understood the methodology and applied it in the appropriate way.

\section{Conclusion}

Based on the evaluation of the alignment of EVLIA methodology with the key performance indicators identified, it can be concluded that the EVLIA tool is suitable for assessing potential of intangible assets of companies, or their intellectual capital, while at the same time contributing to business needs of companies. The highest alignment is recorded between the tool and strategy fit, which suggests that the tool is appropriate as a supporting instrument in designed strategies of companies. Very high marks were given for the coverage of corporate development stages and financing conditions with the EVLIA tool. This suggests that EVLIA tool is adequately designed to cover various phases of a specific intangible asset which a company may have and that it can serve as a supporting lever for reaching decision on financing of specific project or product/service of a company. There is an issue with the market liquidity in most of the countries involved in the project, especially when it comes to patents. It may be concluded that the methodology described in this paper could help in increasing certainty on the value of patents, therefore improving conditions for the increase in market liquidity for patents.

The methodology is suitable to companies operating in diverse sectors and regardless of their size. However, suitability of the methodology is questionable when it comes to startup companies, as some crucial information regarding important intangible assets in all four groups may lack. In certain industries, there is also a need to include other 

ORGANIZACIJA (22. - 24. MAREC 2017, PORTOROŽ, SLOVENIJA)

N. Radovanovic, V. Dmitrovic \& S. Knezevic: Intellectual Capital Assessment Based on the Standardized Visualization Methodology

intellectual property types, such as geographical indications and appellations of origin, in the methodology.

Regarding access to financing, it should be emphasized that banks always need more reassurances on the market strength of company's intangible assets. This could be overcome with the inclusion of banks and their representatives in the evaluation process based on the EVLIA methodology. Another reason to support this is the lack of market liquidity for intellectual property rights, which may cause the banks to hesitate in using intellectual property rights as a collateral as they would not be able to do much with it on the market.

The EVLIA methodology and tool are the product of the "EVLIA" project supported by the South East Europe programme (2012-2014).

\section{Literature}

Axtle Ortiz, M. A. (2009). Analysis and valuation of intellectual capital according to its context. Journal of Intellectual Capital, Vol. 10, No. 4.

Brooking, A. (1996). Intellectual capital: core asset for the third millennium. London: International Thomson Business Press.

Edvinsson, L., \& Malone, M. S. (1997). Intellectual capital: realizing your company's true value by finding its hidden brainpower. New York: Harper Business.

Gu, F., \& Lev, B. (2011). Intangible Assets: Measurement, Drivers, Usefulness. In: Schiuma, G., (Ed.), Managing Knowledge Assets and Business Value Creation in Organizations: Measures and Dynamics, IGI Global, (pp. 110-124).

Gu, F., \& Lev, B. (2003). Intangible Assets: Measurement, Drivers, Usefulness, Working paper \#2003-05 Boston University School of Management Accounting.

Kessels, J. (2001). Verleiden tot kennisproductiviteit Enschede. Universiteit Twente.

Khoury, S., Daniele, J., \& Germeraad, P. (2001). Selection and Application of Intellectual Property Valuation Methods in Portfolio Management and Value Extraction. Les Nouvelles, September edition.

Khoury, S. (1998). Valuing Intellectual properties. The Dow Chemical Company.

Lev, B. (2001). Intangibles: Management, measurement and reporting. Washington, DC: Brookings Institute.

Lev, B. (1999). Seeing is believing. A better approach to estimating knowledge capital. $C F O$ Magazine, CFO Publishing Corporation, February 1999. Boston, MA.

Lev, B., \& Schwartz, A. (1971). On the use of the economic concept of human capital in financial statements. The Accounting Review Vol. 52, pp. 3-5.

Pike, S., \& Roos, G. (2000), Intellectual capital measurement and holistic value approach (HVA). Works Institute Journal (Japan), Vol. 42.

Roos, G., Roos, J., Dragonetti, N., \& Edvinsson, L. (1997). Intellectual capital: navigating in the new business landscape. New York: New York University Press.

Pike, S., Rylander, A., \& Roos, G. (2002), Intellectual capital management and disclosure. In: Bontis, N. \& Choo, C. W. (Eds), The strategic management of intellectual capital and organizational knowledge. New York: Oxford University Press, (pp. 657-671).

Radovanovic, N., Dmitrovic, V., \& Knezevic, S. (2016). Protection of intellectual property rights - What do financial reports say?, Proceedings of the 15th International Symposium SymOrg 
36 ${ }^{\mathrm{TH}}$ International Conference on Organizational Science Development: Responsible ORGANIZATION (MARCH $22^{\mathrm{ND}}-24^{\mathrm{TH}}$, PORTOROŽ SLOVENIA)

N. Radovanovic, V. Dmitrovic \& S. Knezevic: Intellectual Capital Assessment Based on the Standardized Visualization Methodology

2016, Reshaping the Future Through Sustainable Business Development and Entrepreneurship, 10-13 June 2016, Zlatibor, Republic of Serbia, Ca: Faculty of organizational sciences, pp: 673-677.

Sveiby, K.E. (1998-2013). Measuring Intangibles and Intellectual Capital - An Emerging First Standard. Retrieved from http://www.sveiby.com/articles/emergingstandard.html.

Sveiby, K.E. (1997) The new organizational wealth: managing \& measuring knowledge-based assets. San Francisco: Berrett-Koehler Publishers.

Tsai, C.F, Lu, Y.H., Hung, Y.C., \& Yen, D.C. (2016). Intangible assets valuation: The machine learning perspective. Neurocomputing, Vol. 175, pp. 110-120. 
$36^{\text {Th }}$ International Conference on Organizational Science DEVElopMENT: Responsible ORganization (MARCH $22^{\mathrm{ND}}-24^{\mathrm{TH}}$, PORTOROŽ SLOVENIA)

O. Arsenijević, M. Ferjan, I. Podbregar, P. Šprajc, D. Trivan \& Y.

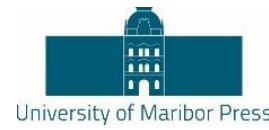

Ziegler

\title{
Spreadsheet Model for Managing Special Events
}

\author{
TEODORA RAJKOVIC, LENA DJORDJEVIC, DANICA LECIC-CVETKOVIC \& RADUL \\ MILUTINOVIC
}

\begin{abstract}
Special events are very important part of cultural and social experience today. Achieving success and excellence of these events requires suitable decision making model. Therefore, this paper presents spreadsheet model for managing special events. Spreadsheets are widely used by end-users as modelling and analytical tools and spreadsheet packages are inexpensive and run on machines of modest specification. Easy learning, flexibility in usage and a great possibility for complex analysing made spreadsheets accepted by many users at all levels, from beginners to experts. The model is based on the feedback control systems methodology. All elements of a feedback loop (reference, system, sensor, comparator and controller) are defined during creation of the model. Input elements are manipulated through controller, in accordance with desired effects on output of the system. Output variables of a system have to follow a certain reference over time. Main references of feedback control model are planned income per day and total planned income. Basic parameters are defined by quantifying of qualitative characteristics. Proposed model results in corrective actions that can significantly increase the revenue and number of special event visitors.
\end{abstract}

KEYWORDS: Special Events $・$ Spreadsheet model $\bullet$ Management $\bullet$ Control systems

CORRESPONDENCE ADDRESS: Teodora Rajkovic, University of Belgrade, Faculty of Organizational Sciences, 154 Jove Ilića Street, 11000 Beograd, Serbia, e-mail: teodora.rajkovic@gmail.com; Lena Djordjevic, University of Belgrade, Faculty of Organizational Sciences, 154 Jove Ilića Street, 11 000 Beograd, Serbia, e-mail: lena.djordjevic@fon.bg.ac.rs, Danica Lecic-Cvetkovic, Ph.D., Associate professor, University of Belgrade, Faculty of Organizational Sciences, 154 Jove Ilića Street, 11000 Beograd, Serbia, e-mail: danica@fon.bg.ac.rs; Radul Milutinovic, University of Belgrade, Faculty of Organizational Sciences, 154 Jove Ilića Street, 11000 Beograd, Serbia, email: radul.milutinovic@ fon.bg.ac.rs 


\section{Introduction}

Special events represent (DeLisle, 2009): "A set of actions and activities designed to collect specified profile and number of participants regarding to common reason, in order to achieve given objectives in projected time and place". Special events are happening with intention, precisely defined goals, purpose and way of organizing. They are unrepeatable and unique and set to encourage participants to meet their own needs (Getz, 1997).

There are numerous input parameters that can influence success of the event realization. As it is mention, a basic characteristic of a special event is a unique and unrepeatable content designed for a specific group of people. Therefore, it cannot be known in advance how successful the event would be. In line with previous, we propose control model with purpose to improve managing of special event. The model is based on planned values and includes quantification of qualitative characteristics. One of the main contributions is proposed control actions that have potential to increase number of visitors and, consequently, profit.

The model is created in accordance with the feedback loop principle and developed in spreadsheet. Spreadsheet is very useful tool for fast, simple and easy data processing and analysis. Modern control theory and feedback control systems methodology implementation makes spreadsheet even more powerful analytical tool.

Results obtained through the model are compared with the reference (external input of a system) in order to define proper control actions. When one or more output variables need to follow a certain reference over time, inputs are manipulated in order to obtain planned effect on the output of the system. In this way the results quality can be increased (Bubnicki, 2002).

\section{Special events in culture}

Special events are designed for wide variety of population and can be arranged in any sphere of life. They may have cultural, exploratory, scientific, entertainment and socialhumanitarian character. Special event program offers original content. In that way they attract a lot of public attention, media and sponsors (Goldblatt, 2005).

There are different types of special events, but some of the most popular are (DeLisle, 2009):

- Grand openings;

- Cocktail events;

- Festivals;

- Concerts;

- Sales events; 
T. Rajkovic, L. Djordjevic, D. Lecic-Cvetkovic \& R. Milutinovic: Spreadsheet Model for Managing Special Events

- Sporting events and tournaments; etc.

Organization of special events implies defining of stakeholders, event goals and goals of its participants. Therefore, the key stakeholders of special event are (Bodwin et al. 2006):

- Organizer;

- Sponsors;

- Participants and visitors;

- Associates involved in setting up and execution of the event;

- Media;

- Environment.

In managing special events there are three basic types of groups (O`Toole, 2007):

- Informal groups - independent groups that are formed through the interaction of event organization members;

- Command groups - groups typical for most of events, consisted of event organizers, agents and organization employees;

- Boards, committees and executive groups - the board is comprised of permanent members; the committee members are elected or delegated from different organizational units; the executive group is temporary formal group chosen in order to solve problems.

The goal of special event is not always mainly linked to participant`s satisfaction. Goals are primarily marketing-economic oriented, for example: increasing of profit, number of participants, building-up company's reputation, etc. Precisely defined objective of special events reduces indetermination and improves their organization. They can be classified as follows (Goldblatt, 2005):

1. Economic - market share, profit, costs, etc;

2. Political and social - political position, living standards, employment, etc;

3. Ethic - cultural awareness, giving help those in need, environmental goals, etc;

4. Personal satisfaction of the purchaser - celebrations, meetings, jubilees, which often leads to mixing tasks and objectives (these types of objectives are transformed into the task with the economic objectives).

When organizing special event, each objective supports the next higher level objective (Image 1) and each higher level objective guides objectives on a lower levels. Activities are required for the fulfilment of the objectives. They create the chain value-objective (Jasko et al. 2013). 
$36^{\text {TH }}$ International Conference on Organizational Science Development: RESPONSIBLE ORGANIZATION (MARCH $22^{\mathrm{ND}}-24^{\mathrm{TH}}$, PORTOROŽ SLOVENIA)

T. Rajkovic, L. Djordjevic, D. Lecic-Cvetkovic \& R. Milutinovic: Spreadsheet Model for Managing Special Events

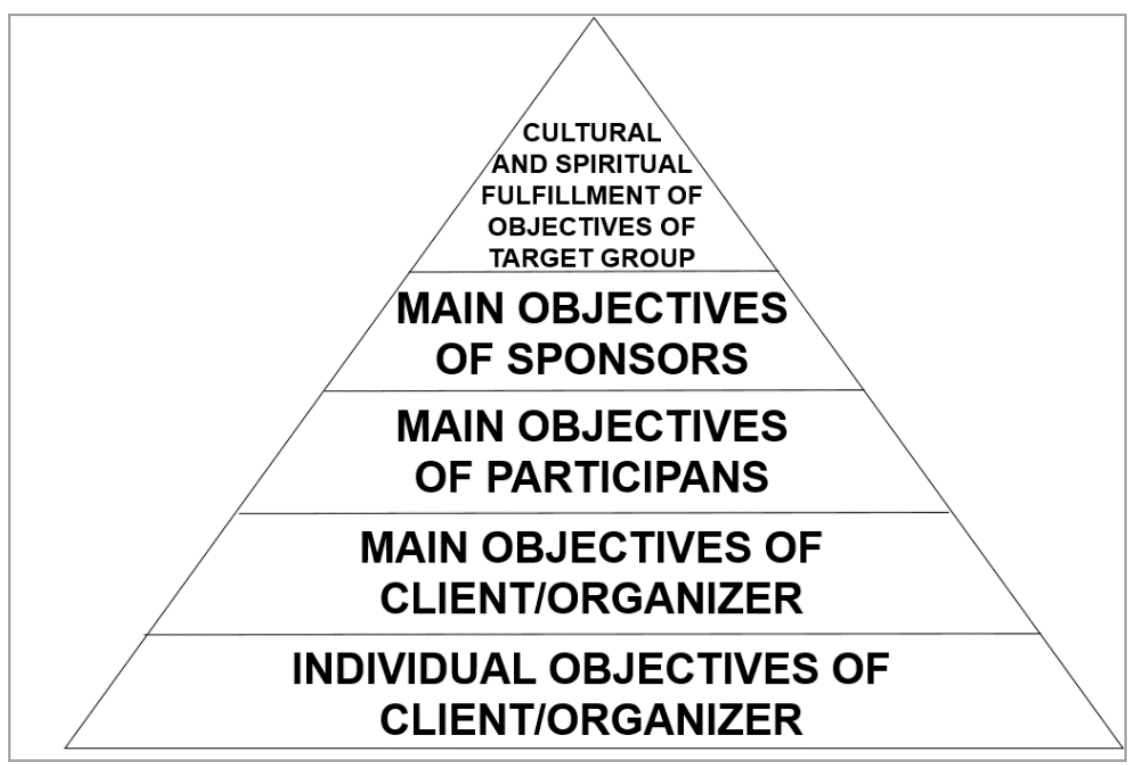

Image 1: [ The hierarchy of objectives for special events organization - adapted from (Jasko et al., 2013) ]

\section{$3 \quad$ Modern control theory}

The control theory deals with the foundations, methods and decision making algorithms needed for developing computer programs. It considers control algorithms design, which may be executed by technical devices, used for information processing and decision making. Control algorithms are understood as programs, procedures and formulas for the determination of control decisions. At the beginning, the control theory was oriented to the automatic control of technical devices and processes. Today, the full automatization of the control considers automatization of operations, executing mechanisms control, intelligent tools and robots which can be used as objects of the external control that contains inner controlling systems and devices. Development of various technical processes, complex plants and control of computers, initiated development of modern control theory. According to aforementioned, the control theory or the control science presents a basic discipline for the automatic robotics, control and information technology and management (Bubnicki, 2002).

A control system design includes following steps (Antic et al. 2012):

- Defining the system which should be controlled, make a decision about types of sensors and actuators which should be used and where should they be placed;

- Making a model of the resulting system which should be controlled;

- If necessary, simplifying the model to make it traceable; 
- Analyzing and determining properties of the resulting model;

- Making a decision about performance specifications;

- Making a decision about the type of controller which should be used;

- If possible, designing a controller to meet the specifications. If not, modify them or generalize the type of controller for the model;

- Making a simulation of the resulting controlled system;

- If necessary, repeat everything from the start;

- Choose appropriate hardware and software, implement the controller;

- If necessary, make the controller tuned on-line.

Feedback control system has six basic elements, shown on Image 2 (Doyle et al. 1990):

- System;

- Input;

- Sensor;

- Comparator;

- Controller;

- Output.

Reference presents an external input of a system. A controller has a role to manipulate inputs of a system in order to obtain planned effects on output. The main goal of the control theory is to calculate at least one solution in form of corrective action which implementation results in system stability. Value from sensor is subtracted from planned value to create an error signal, amplified by controller. Sensor can be presented as a device which converts input (or a physical stimulus) into a readable output. The element that performs a comparison of the actual and planned value and calculates the error is called comparator. The controller responds to the error signal and produces a signal which impacts system. The controller must calculate control signal and change the state of the system which is being controlled (Doyle et al. 1990).

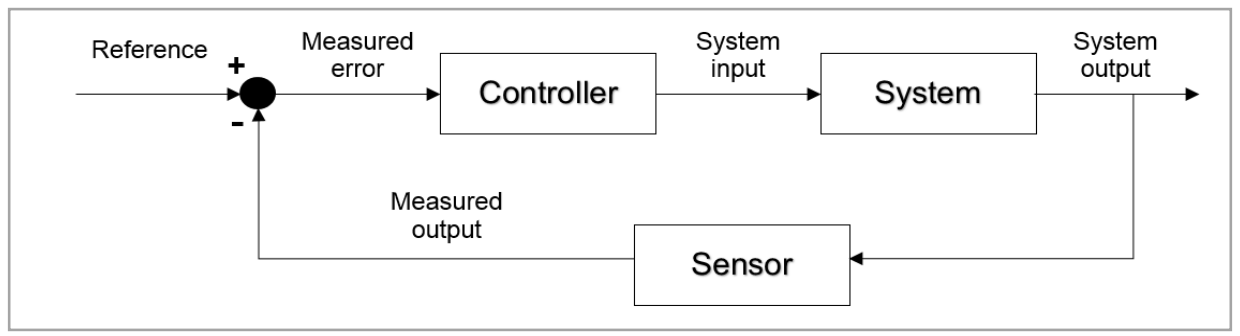

Image 2: [ Feedback control system ]

Feedback loop presents an active and used concept in almost all area of activity. In accordance with the feedback control process, the state or output of the system defines the way in which the control has to be computed (Neculai, 2005). The term control has many meanings and often varies between communities. We define control as the use of algorithms and feedback in engineered systems. For example, thermostat is a simple 
$36^{\mathrm{TH}}$ International Conference on Organizational Science Development: RESPONSIBLE ORGANIZATION (MARCH $22^{\mathrm{ND}}-24^{\mathrm{TH}}$, PORTOROŽ SLOVENIA)

T. Rajkovic, L. Djordjevic, D. Lecic-Cvetkovic \& R. Milutinovic: Spreadsheet Model for Managing Special Events

example of feedback control that everyone is familiar with. The device measures temperature and then compares it to a desired set point. It uses the feedback error between those two to operate the heating, e.g., to turn heat on when the temperature is lower and to turn it off when the temperature is higher than desired (Åström \& Murray, 2009).

\section{$4 \quad$ Spreadsheet model for managing special events}

Spreadsheets can be defined as a tool designed for tabular calculations (Djordjevic, 2016). Thanks to flexibility and simplicity, spreadsheets are suitable for usage by professional engineers, end-users and executors with a lower level of knowledge. Spreadsheet applications are used in a wide range of organizational functions. They can be used for various business tasks, modelling, simulation, data analysis and decision making. Spreadsheet simulation implies the usage of spreadsheet for the model presenting, execution of the calculation and generating output reports (Kostic, 2008). They can be very useful tool for "What if ...?" analysis. It allows the designer to determine model sensitivity to variations of parameters. Users, from beginners to experts, make important decisions based on a spreadsheet, while organizations rely on them in terms of data storage, forecasting, analysis and decision-making (Djordjevic \& Antic, 2016).

In this paper, we propose model for managing special events based on the feedback control systems methodology, implemented in spreadsheet. All elements of a feedback loop (reference, system, sensor, comparator and controller) are defined during creation of the model. Procedures in this spreadsheet model are automated through Visual Basic for Application (VBA).

Considering numerous factors and variable performances of the special events organization, feedback control methodology can be considered as appropriate for modelling of this process. In the case of special events, planned outputs are: high attendance of the event, satisfaction of visitors, stakeholders and organizers, achieved business results, event recognition and strengthening brand identity. Elements which can affect result include data and information about competitive events, expectations of visitors and participants, resources used, market trends, social and cultural factors, restrictions and regulations. Control problem, modelled in this paper, refers to event attendance and profitability.

Inputs of the model are planned number of visitors per day $t,(t=1, \ldots, T)$, total planned income, current day of the event $t$ and ticket price. Additional input elements used in this spreadsheet model (Image 3) involve name and code of the event, place where event is organized, beginning and end of event (dates). 

ORGANIZACIJA (22. - 24. MAREC 2017, PORTOROŽ, SLOVENIJA)

T. Rajkovic, L. Djordjevic, D. Lecic-Cvetkovic \& R. Milutinovic: Spreadsheet Model for Managing Special Events

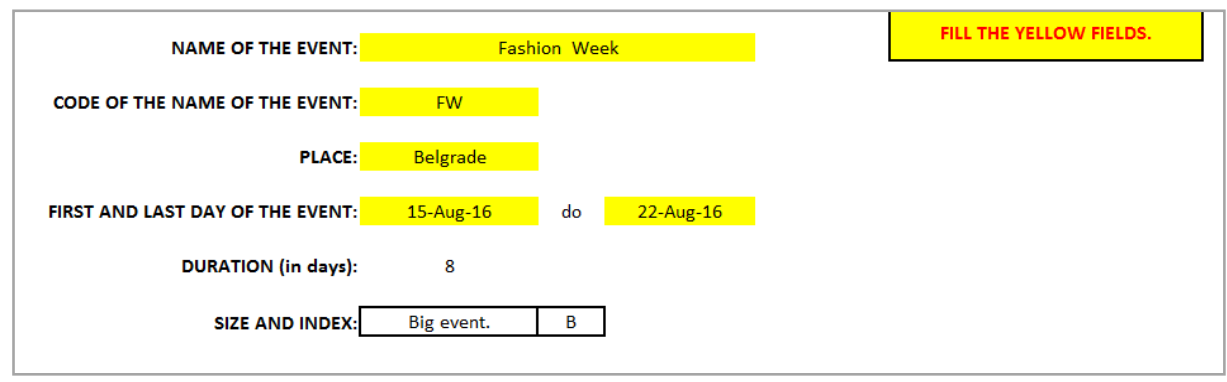

Image 3: [ Form for filling basic data ]

According to entered dates, model calculates total duration of the event in days and defines size and index of the event size. Total duration of the event limits value in cell where current day $t$ is entered. Image 4 exemplifis input elements of the model with concrete values.

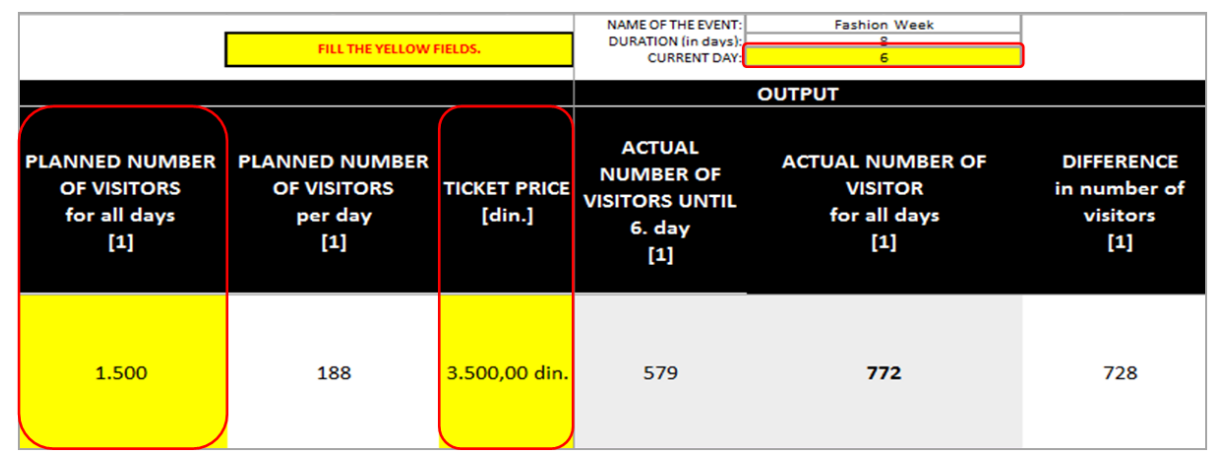

Image 4: [ Input elements of feedback control model ]

The income depends on number of sold tickets and price per ticket. It is monitored for all days of the time horizon $(t=1, \ldots T)$. Number of tickets that should be sold in $t$ is calculated as planned number of tickets for $t$ plus those which are not sold in $t$ - 1 (difference between planned and actual number of sold tickets for day $t-1$ ). For example, if planned income for the first day is not realized, then sale for the second day should be planned number of tickets for that day increased by number of tickets representing difference between planned and actual number of tickets sold in previous day.

Elements of a feedback loop for proposed special event control model are (Image 5):

1. System - managing of the special event income;

2. Input - planned number of visitors per day $t$, total planned income (TPI), current day of the event $t(t=1, \ldots T)$ and ticket price $(P T)$;

3. Sensor-actual income of the event until day $t$; 
36 ${ }^{\mathrm{TH}}$ International Conference on Organizational Science Development: RESPONSIBLE ORGANIZATION (MARCH $22^{\mathrm{ND}}-24^{\mathrm{TH}}$, PORTOROŽ SLOVENIA)

T. Rajkovic, L. Djordjevic, D. Lecic-Cvetkovic \& R. Milutinovic: Spreadsheet Model for Managing Special Events

4. Comparator - negative difference in comparing actual income until day $t$ and planned income until day $t$;

5. Controller - additional number of tickets which should be sold in order to achieve planned income of the event (NTS);

6. Output - actual income for day $\boldsymbol{t}$ (TAIt) and total actual income at the end of event.

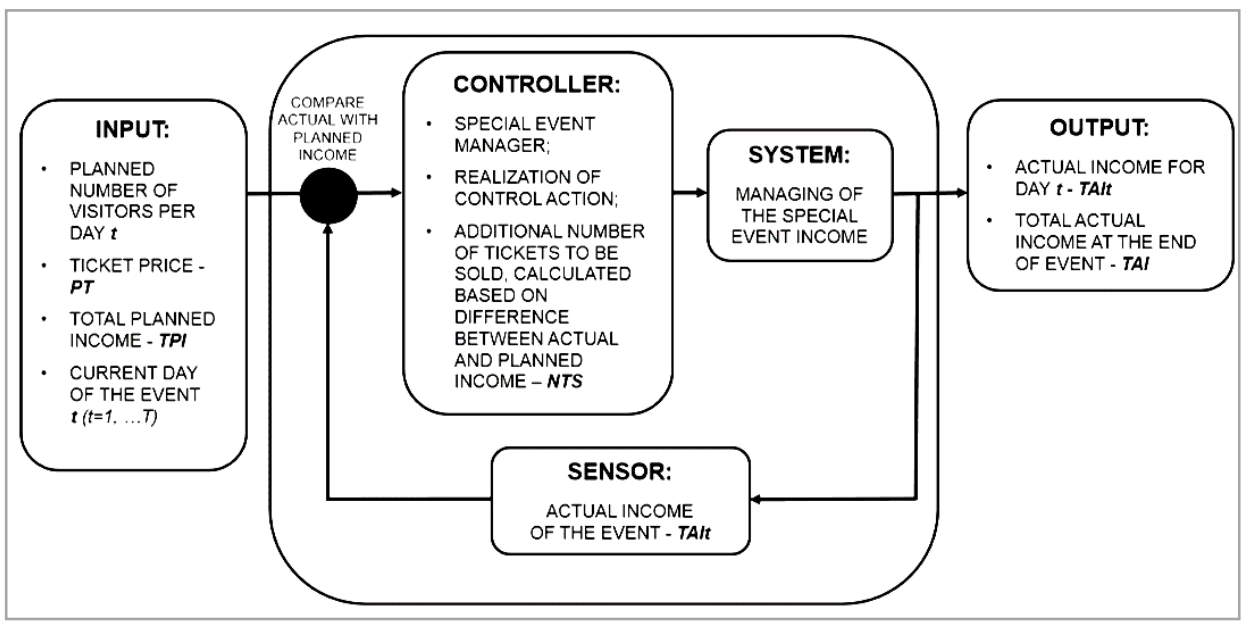

Image 5: [ Elements of a feedback loop for special event control model ]

In order to explain this model, we use the following notations:

- $\boldsymbol{t}$ - current day of the event;

- $\boldsymbol{T}$ - number of time periods-days $(t=1, \ldots, T)$;

- $\boldsymbol{T A I I}$ - total actual income per day $t$;

- $\quad \boldsymbol{T P I t}$ - total planned income per day $t$;

- $\quad \boldsymbol{N T t}$ - number of tickets sold in day $t$;

- NTS - number of tickets which should be sold to achieve planned income;

- $\boldsymbol{T I}$ - total income of the event;

- $\boldsymbol{P T}$ - price per ticket.

Total actual income for day $t$ represents sum of total actual income for day $t-1$ and number of tickets sold in day $t$ multiplied with price per ticket. Moreover, this can be seen from the following formula (1)

$T A I_{t}=T A I_{t-1}+P T^{*} N T t,(t=1, \ldots, T)$

Total planned income for day $t$ can be calculated as total planned income divided with number of days. Also, total planned income until day $t$ (including day $t$ ) is calculated as sum of total planned incomes until day $t$, including planned income for day $t$. 

ORGANIZACIJA (22. - 24. MAREC 2017, PORTOROŽ, SLOVENIJA)

T. Rajkovic, L. Djordjevic, D. Lecic-Cvetkovic \& R. Milutinovic: Spreadsheet Model for Managing Special Events

Difference between total actual income until day $t$ and planned income until day $t$ is divided with ticket price, which results in additional number of tickets that should be sold in order to achieve planned income. In this case, control actions (Image 6) should be defined:

1. If actual income in day $t$ is greater than planned one, difference is not calculated and actions aren't recommended (Image 6, a).

2. Otherwise, difference is calculated and consequential actions are proposed (Image 6, b).

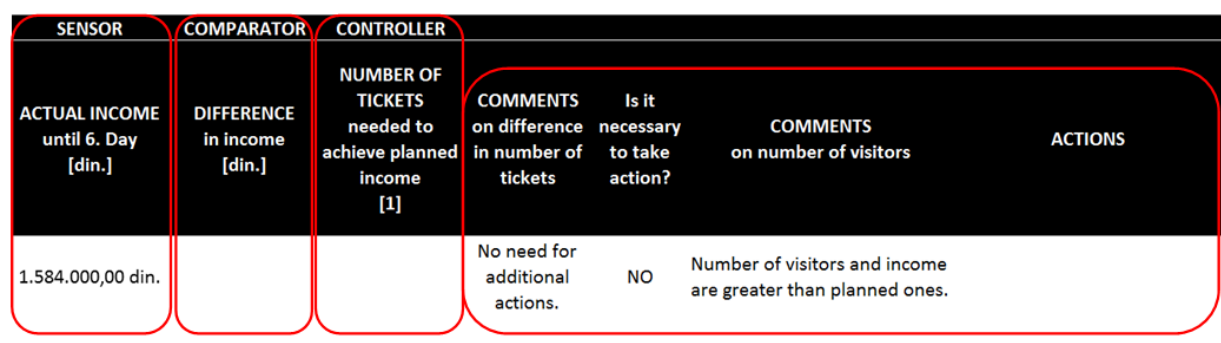

(a) No negative difference between actual and planned income until day $t$

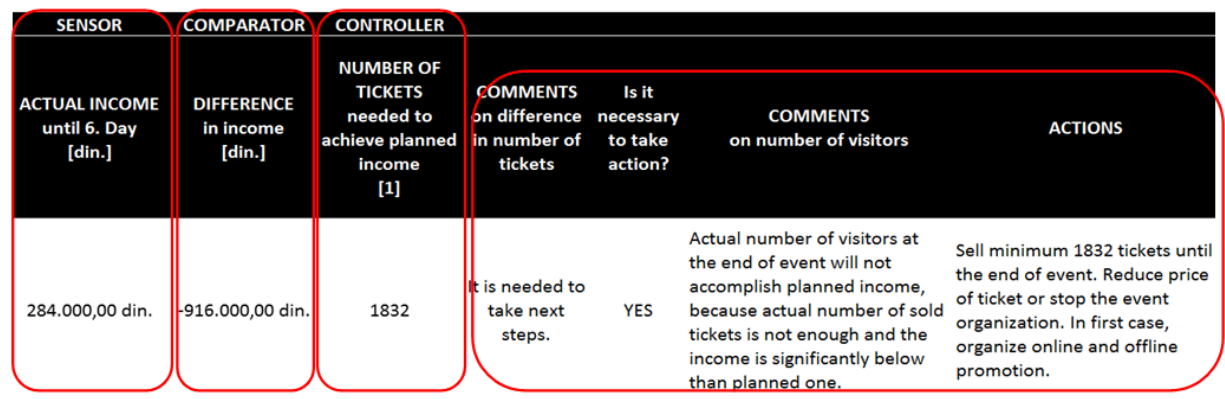

(b) Difference exist between actual and planned income until day $t$

\section{Image 6: [ Elements of feedback control model in spreadsheet ]}

Sensor transmits value of total actual income until current day $t$. Output from the sensor is input to the comparator. Comparator compares actual income value with planned one. Output of the comparator is difference between those two incomes. This presents input for controller which divides that difference with price per ticket. In that way controller refers to number of tickets that should be sold in order to achieve planned income until day $t$ (Formula 2). Comparison algorithm, previously described, can be also presented trough pseudocode (Image 7). Controller function can be realized in position of event manager. 

RESPONSIBLE ORGANIZATION (MARCH $22^{\mathrm{ND}}-24^{\mathrm{TH}}$, PortoroŽ SLOVENIA)

T. Rajkovic, L. Djordjevic, D. Lecic-Cvetkovic \& R. Milutinovic: Spreadsheet Model for Managing Special Events

(TPIt - TAIt) / PT

If calculated number of tickets is sold next day or by the end of the event, total actual income will achieve planned one. If total actual income is higher than planned, than total actual is total income at the end of the event.

\begin{tabular}{|l|}
\hline If $t<T$ then \\
If $T A I t<T P I t$ then \\
$N T S=(T P I t-T A I t) / P T$ \\
End if \\
Else \\
$T I=T A I t$ \\
End if
\end{tabular}

Image 7: [ Pseudocode of the comparison algorithm]

As it is already described, control actions are defined in accordance with additional number of tickets that should be sold it the case when actual income for day $t$ is less than planned. Unsatisfactory number of visits in day $t$ implies that total number of visitors at the end of the event will not be accomplished and income will be lower than planned. Control actions indicate minimum number of tickets that should be sold until the end of the event and suggestions about ticket price reduction, organization of online and offline promotion or even termination of the event.

\section{$5 \quad$ Conclusion}

Nowadays special events represent very important part of cultural and social experience. They have clear purpose and they are very popular in every field of business, fun, etc. Special events are unique and unrepeatable with original content. It is designed for a specific group of people in order to encourage them to meet their own needs. Success of the event realization depends of a large number of input parameters and it cannot be certainly known in advance.

In this paper we presented application of spreadsheet model with feedback loop in managing of special events. Focal point of this paper is feedback control system for managing special events, which should contribute to achieve at least planned income. One of the most important results of special event control model is proposed control actions. Corrective measures are based on the deviation of actual target from planned. Their realisation should insure additional sale of tickets.

In further research, this model can be improved by including new variables and constraints, related to event zones, zone diversity and attendance of event in relation to the variety of a service per zone. Each zone should provide certain benefits through services, such as closeness to the stage, possibility of sitting or standing, food, drinks, etc. Thus, zone prices should differ due to offered features. In that case total income 
would be sum of total incomes for all zones. Constraint can be defined as maximum capacity of zone (maximum number of visitors), while additional output presents zone share and zone rank, in total income.

\section{Literature}

Antic, S., Kostic, K., \& Djordjevic, L. (2012). Spreadsheet model of inventory control based on modern control theory (pp. 1365-1373). XIII International Symposium SymOrg 2012: Innovative management \& business performance. Zlatibor: Faculty of Organizational Sciences.

Åström, K., \& Murray, R. M. (2009). Feedback systems: an introduction for scientists and engineers. New Jersey: Princeton University Press.

Bodwin, G., Allen, J., O’Toole, W., Harris, R., \& McDonell, I. (2006). Events management. Oxford: Butterworth-Heinemann.

Bubnicki, Z. (2002). Modern Control Theory. New York: Springer Berlin Heidelberg.

Doyle, J., Francis, B., \& Tannenbaum, A. (1990). Feedback control theory. United Kingdom: Macmillan.

DeLisle, L. J. (2009). Creating special events. Illinois: Sagamore Publishing.

Djordjevic, L. (2016). Error detection and analysis in implementation of dynamic discrete inventory control models, doctoral dissertation (in Serbian). Belgrade: Faculty of Organizational Sciences.

Djordjevic, L., \& Antic, S. (2016). Application of modern control theory to inventory control in pharmaceutical distribution company (pp. 962-969). XV International Symposium SymOrg 2016: Reshaping the future through sustainable business development and entrepreneurship. Zlatibor: Faculty of Organizational Sciences.

Getz, D. (1997). Event management and event tourism. New York: Cognizant Communications Corporation.

Goldblatt, J. (2005). Special events: event leadership for a new world. New Jersey: J. Wiley \& Sons, Hoboken.

Jasko, O., Cudanov, M., Jevtic, M., \& Krivokapic, J. (2013). Organizational theory (in Serbian). Belgrade: Faculty of Organizational Sciences.

Kostic, K. (2008). Creation and use of business models (in Serbian). Belgrade: Faculty of Organizational Sciences.

Neculai, A. (2005). Modern control theory-a historical perspective. Romania: Research Institute for Informatics, Centre for Advanced Modelling and Optimization.

O'Toole, W. (2007). Corporate event project management. New York: John Wiley \& Sons, Hoboken. 
$850 \quad 36^{\text {Th }}$ International CONFEREnCE ON ORganizational Science Development: RESPONSIBLE ORGANIZATION (MARCH $22^{\mathrm{ND}}-24^{\mathrm{TH}}$, PORTOROŽ SLOVENIA) 
36. MEDNARODNA KONFERENCA O RAZVOJU ORGANIZACIJSKIH ZNANOSTI: OdgOVORNA ORGANIZACIJA (22. - 24. MAREC 2017, PORTOROŽ, SLOVENIJA)

O. Arsenijević, M. Ferjan, I. Podbregar, P. Šprajc, D. Trivan \& Y. Ziegler

\section{eZdravje danes za jutri}

\section{ŽIVA RANT, DALIBOR STANIMIROVIĆ, VEDRANA MATETIĆ, SIMON INDIHAR, JANJA ZIDARN, MATE BEŠTEK \& ANDREJ ŽLENDER}

Povzetek Nacionalni inštitut za javno zdravje (NIJZ) je s 1.12.2015 prevzel upravljanje rešitev projekta eZdravje. Projekt eZdravje je vodilo Ministrstvo za zdravje, sofinancirala ga je Evropska unija iz Evropskega socialnega sklada in je predstavljal enega večjih projektov informatizacije javnih storitev. Projekt se je zaključil novembra 2015. NIJZ je v upravljanje prevzel 20 rešitev $\mathrm{v}$ različnih fazah uvedbe, med njimi eRecept, eNaročanje, Centralni register podatkov o pacientih, portal zVEM. Rešitve se postopoma uvajajo po vsej Sloveniji. Pri uvajanju se srečujemo z različnimi izzivi. V prispevku bodo predstavljene najbolj odmevne rešitve in trenutno stanje s kazalniki.

KLJUČNE BESEDE: eZdravje • eRecept • eNaročanje • Centralni register podatkov o pacientih $\bullet \mathrm{zVEM}$

NASLOV AVTORJEV: Živa Rant, Nacionalni inštitut za javno zdravje, Trubarjeva 2, 1000 Ljubljana, Slovenija, e-pošta: ziva.rant@ nijz.si; dr. Dalibor Stanimirović, Nacionalni inštitut za javno zdravje, Trubarjeva 2, 1000 Ljubljana, Slovenija, e-pošta: dalibor.stanimirovic@nijz.si; Vedrana Matetić, Nacionalni inštitut za javno zdravje, Trubarjeva 2, 1000 Ljubljana, Slovenija, e-pošta: vedrana.matetic@nijz.si; Simon Indihar, Nacionalni inštitut za javno zdravje, Trubarjeva 2, 1000 Ljubljana, Slovenija, e-pošta: simon.indihar@nijz.si; Janja Zidarn, Nacionalni inštitut za javno zdravje, Trubarjeva 2, 1000 Ljubljana, Slovenija, e-pošta: janja.zidarn@nijz.si; Mate Beštek, Nacionalni inštitut za javno zdravje, Trubarjeva 2, 1000 Ljubljana, Slovenija, e-pošta: mate.bestek@nijz.si; mag. Andrej Žlender, Nacionalni inštitut za javno zdravje, Trubarjeva 2, 1000 Ljubljana, Slovenija, e-pošta: andrej.zlender@nijz.si

DOI https://doi.org/10.18690/978-961-286-020-2.68

ISBN 978-961-286-020-2

(C) 2017 Univerzitetna založba Univerze v Mariboru

Dostopno na: http://press.um.si 
$36^{\text {TH }}$ International Conference on Organizational Science DeVElopMent: Responsible ORGANIZATION (MARCH $22^{\mathrm{ND}}-24^{\mathrm{TH}}$, PORTOROŽ SLOVENIA)

O. Arsenijević, M. Ferjan, I. Podbregar, P. Šprajc, D. Trivan \& Y.

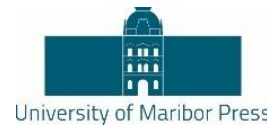

Ziegler

\title{
eZdravje Today for Tomorrow
}

\section{ŽIVA RANT, DALIBOR STANIMIROVIĆ, VEDRANA MATETIĆ, SIMON INDIHAR, JANJA ZIDARN, MATE BEŠTEK \& ANDREJ ŽLENDER}

\begin{abstract}
National Institute of Public Health (NIJZ) has taken over the governance of the eHealth project solutions on 1 December 2015. eHealth project was run by the Ministry of health and it was co-financed by the EU under the European Social Fund The Project was finished in November 2015. As part of eHealth, NIJZ has taken over the governance of 20 solutions, some of them are gradually being implemented across Slovenia, among them are ePrescription, eAppointment, Central Register of patient data and Portal zVEM. NIJZ is facing different challenges, while trying to introduce the solutions into the health care environment. This paper presents the most popular solutions and state of their deployment including core indicators.
\end{abstract}

KEYWORDS: eHealth • ePrescription • eAppointment $\bullet$ Central Register of patient data $\bullet$ Portal zVEM

CORRESPONDENCE ADDRESS: Živa Rant, National Institute of Public Health, Trubarjeva 2, 1000 Ljubljana, Slovenia, e-mail: ziva.rant@nijz.si; Dalibor Stanimirović, National Institute of Public Health, Trubarjeva 2, 1000 Ljubljana, Slovenia, e-mail: dalibor.stanimirovic@nijz.si; Vedrana Matetić, National Institute of Public Health, Trubarjeva 2, 1000 Ljubljana, Slovenia, e-mail: vedrana.matetic@nijz.si; Simon Indihar, National Institute of Public Health, Trubarjeva 2, 1000 Ljubljana, Slovenia, e-mail: simon.indihar@nijz.si; Janja Zidarn National Institute of Public Health, Trubarjeva 2, 1000 Ljubljana, Slovenia, e-mail: janja.zidarn@nijz.si; Mate Beštek, National Institute of Public Health, Trubarjeva 2, 1000 Ljubljana, Slovenia, e-mail: mate.bestek@nijz.si; Andrej Žlender, M.S. National Institute of Public Health, Trubarjeva 2, 1000 Ljubljana, Slovenia, e-mail: andrej.zlender@nijz.si

DOI https://doi.org/10.18690/978-961-286-020-2.68

ISBN 978-961-286-020-2

(C) 2017 University of Maribor Press

Available at: http://press.um.si 


\section{$1 \quad$ Uvod}

Nacionalni inštitut za javno zdravje (NIJZ) je s 1. decembrom 2015 prevzel upravljanje rešitev projekta eZdravje. Projekt eZdravje, ki se je pričel izvajati leta 2008, je do navedenega datuma vodilo Ministrstvo za zdravje. Projekt je sofinancirala Evropska unija iz Evropskega socialnega sklada, s 15-odstotnim financiranjem pa je sodelovala tudi Republika Slovenija. Projekt eZdravje je predstavljal enega večjih projektov informatizacije javnih storitev v Sloveniji. Po zaključenem sofinanciranju projekta $\mathrm{s}$ strani Evropskega socialnega sklada, se sredstva za nadaljnji razvoj in vzdrževanje rešitev eZdravja zagotavljajo iz proračuna Republike Slovenije. NIJZ je v upravljanje prevzel dvajset rešitev, ki so nastale v okviru projekta eZdravje. Rešitve se postopoma širijo v uporabo po vsej Sloveniji.

Zakon o zbirkah podatkov s področja zdravstvenega varstva (ZZPPZ) v svojem 14. členu opredeljuje eZdravje kot na nacionalni ravni usklajen zdravstveni informacijski sistem, ki z delovanjem na enotni informacijsko-komunikacijski infrastrukturi omogoča:

- obdelavo zdravstvenih in drugih podatkov, podrobneje določenih v $14 . b$ členu tega zakona in v Prilogi 2;

izvajanje storitev eZdravja, ki z elektronskimi sredstvi omogočajo obdelavo podatkov iz prejšnje alinee za namene, določene pri posamezni zbirki eZdravja.

ZZPPZ je tudi osnovna pravna podlaga za rešitve eZdravja. Zakon določa obdelavo podatkov in zbirke podatkov s področja zdravstvenega varstva in eZdravja, njihove upravljavce ter upravičence do podatkov. Poleg tega zakona je za delovanje eZdravja pomemben tudi Zakon o varstvu osebnih podatkov (ZVOP-1-UPB1).

Prispevek opisuje nekatere najbolj odmevne rešitve eZdravja in njihovo trenutno stanje.

\section{Primeri uporabe rešitev eZdravja}

V nadaljevanju podajamo opis najbolj uporabljanih rešitev eZdravja.

\section{$2.1 \quad$ eRecept}

Najbolj poznana in najbolj uporabljana je rešitev eRecept, nacionalna rešitev za elektronsko predpisovanje in izdajanje zdravil. Zanjo lahko rečemo, da je primer dobre prakse. Pri razvoju je v konzorciju sodelovalo sedem programerskih hiš. Rešitev je že uvedena na nacionalni ravni in se dnevno uporablja pri vseh izvajalcih zdravstvenih dejavnosti.

\subsubsection{Cilji eRecepta}

- povečati varnost pacientov z zmanjšanjem števila napak pri uporabi zdravil 
- vključevanje podpore za predpisovanje zdravil z generičnim imenom in izdajo zdravila z liste medsebojno zamenljivih zdravil

- zagotoviti pregled interakcij med zdravili pri predpisovanju in izdaji zdravil

- zagotoviti učinkovitejše predpisovanje in uporabo zdravil z upoštevanjem podatkov o predhodno predpisanih in izdanih zdravilih

- zmanjšati administrativne stroške

- zagotoviti potrebne podatke za različne raziskave in analize

\subsubsection{Glavne funkcionalnosti}

- elektronsko predpisovanje zelenih in belih receptov

- strukturiran predpis

- predpis zdravila iz Centralne baze zdravil (CBZ)

- preverjanje interakcij

- preverjanje kontraindikacij

- elektronsko podpisovanje paketa

- vpogled v eRecepte pacienta

\subsubsection{Proces predpisovanja in izdaje zdravila}

Zdravnik pregleda seznam zdravil, ki jih pacient že jemlje. Izbere zdravilo. Lahko ga izbere izmed tistih pri stalni terapiji ali iz Centralne baze zdravil. Zdravnik ima možnost preveriti interakcije in kontraindikacije. Rešitev omogoča tudi preverjanje ustreznosti zdravila za športnike zaradi uvrstitve na listo prepovedanih snovi, vendar podatki trenutno niso ažurni. Zdravnik tako pripravi podatke predpisa in preveri ustreznost. Paket podpiše $\mathrm{z}$ digitalnim potrdilom in ga pošlje $\mathrm{v}$ centralno bazo e-receptov.

V lekarni s pomočjo KZZ farmacevt pridobi podatke pacienta, izbere recept in zdravilo za izdajo. Pripravi zdravilo in ga izda.

\subsubsection{Prednosti eRecepta}

Povečala se je varnost pacientov in odpravile so se napake, ki so bile posledice napačnega zapisa ali slabo berljive pisave. Za obnovljive recepte pacientu ni potrebno obiskati vedno iste lekarne, ponovitve izdaje zdravil lahko dvigne v katerikoli lekarni v Sloveniji. Ponovno predpisovanje zdravila je poenostavljeno, zato zdravnik porabi manj časa, ki ga lahko posveti pacientu. Zdravnik lahko pri predpisovanju zdravil preveri interakcije, kontraindikacije in prisotnost na listi prepovedanih snovi za športnike. Poenostavljen je tudi postopek v primerih, ko pacientu ni potrebno obiskati zdravnika zgolj zato, da prevzame recept. Spremljanje porabe zdravil je poenostavljeno, zanesljivost podatkov se je povečala. eRecept prinaša tudi manj administrativnih stroškov, npr. zaradi nakupa obrazcev, tiskanja in arhivov. 


\section{$2.2 \quad$ eNaročanje}

eNaročanje je informacijski sistem za namene elektronske napotitve in elektronskega naročanja na zdravstvene storitve iz primarne na sekundarno in terciarno raven in znotraj sekundarne in terciarne ravni.

Rešitev nudi pacientom hitro, varno in učinkovito naročanje na zdravstvene storitve. Poenostavlja izbiro izvajalca zdravstvene storitve glede na čakalno dobo in kraj izvedbe ter omogoča učinkovito obveščanje naročenega pacienta o morebitnih spremembah terminov in potrebnih predpripravah na izvedbo zdravstvene storitve. Izvajalci zdravstvene dejavnosti zagotavljajo:

- posredovanje napotnic $\mathrm{v}$ elektronski obliki

- omogočanje e-naročanja

- poročanje o prvih prostih terminih

- poročanje o čakalnih dobah v nacionalni čakalni seznam

\subsubsection{Cilji eNaročanja}

- povečati kvaliteto oskrbe pacientov s povečanjem kakovosti informacij za triažo in prenosom informacij o že prej izvedenih preiskavah

- pripomoči k opolnomočenju pacienta $\mathrm{z}$ vzpostavitvijo celovitega pregleda nad možnimi izvajalci in informacijami, potrebnih za odločitev o izbiri izvajalca

- povečati razpoložljivost dostopa do storitev s hitrim in učinkovitim naročanjem

- zagotoviti potrebne podatke za različne raziskave in analize

\subsubsection{Komponente eNaročanja}

eNaročanje sestavljajo napotovanje, naročanje in čakalne vrste.

Pri napotovanju zdravnik napotovalec izdela elektronski dokument e-napotnica $\mathrm{v}$ informacijskem sistemu napotovalca, ki ga zdravnik napotovalec elektronsko podpiše. V centralnem sistemu eNaročanje se hrani elektronsko podpisan dokument.

Na osnovi e-napotnice se izvede naročanje na izbrano storitev preko spletne strani. Pri tem se upošteva informacije o prvem prostem terminu. Naročanje lahko izvaja administrator na infotočki, zdravnik, medicinska sestra ali pacient.

Na osnovi podatkov v centralnem sistemu se v čakalnih vrstah vzpostavi centralni čakalni seznam na osnovi nočnih priklicov dejanskih podatkov o čakajočih. Obstaja tudi spletna stran za pregled podatkov. 
36 ${ }^{\mathrm{TH}}$ International Conference on Organizational Science Development: RESPONSIBLE ORGANIZATION (MARCH $22^{\mathrm{ND}}-24^{\mathrm{TH}}$, PORTOROŽ SLOVENIA)

Ž. Rant, D. Stanimirović, V. Matetić, S. Indihar, J. Zidarn, M. Beštek \& A. Žlender: eZdravje Today for Tomorrow

\subsubsection{Proces eNaročanja}

Napotovanje: Zdravnik v lokalnem informacijskem sistemu izvajalca izdela elektronsko napotnico. Pri tem veljajo enaka pravila in strokovnimi kriteriji, kot so veljali za izdane papirnate zelene napotnice. Elektronsko ga podpiše in prenese $\mathrm{v}$ centralni sistem eNaročanja.

Naročanje: Na napoteno zdravstveno storitev lahko pacienta naroči administrator na infotočki, zdravnik, medicinska sestra ali pa se pacient naroči sam preko spletnega portala zVem. To je nov način poleg obstoječih načinov za naročanje (telefon, osebni obisk).

Na osnovi podatkov o napotnici dobimo seznam izvajalcev in prvi prosti termin glede na izbor parametrov. Izberemo termin in dobimo potrditev. $\mathrm{S}$ tem smo zapisani v čakalno vrsto pri izvajalcu. Pred obravnavo pacient dobi obvestilo o bližajočem se datumu obravnave. $\mathrm{S}$ tem se bo zmanjšalo število predvidenih obravnav, na katere pacient ne pride. Po opravljeni obravnavi se izvede poročilo o opravljeni storitvi.

\subsubsection{Prednosti eNaročanja}

Zmanjšala se bo obremenitev vpisnih mest za naročanje $\mathrm{v}$ bolnišnici, manj bo telefonskega naročanja. Skrajša se čas vpisa pacienta - eNapotnica je že v sistemu, jo samo preberemo. Ni več potrebno fizično zbiranje napotnic. Poročila o čakalnih dobah se pripravljajo avtomatsko, zaradi česa se zmanjša obremenitev zdravstvenega osebja. Za paciente se poveča dostopnost naročanja: pacient se lahko sam naroči na portalu, pred tem pa pregledal možne termine, izvajalce, čakalne dobe. Naročanje lahko opravi kadarkoli, ni vezan na čase za naročanje posameznih ambulant in čakanje na pogosto prezasedenih telefonskih linijah. Lahko pa ga že ob izdelavi napotnice naroči osebni zdravnik ali medicinska sestra. Fizične napotnice mu ne bo potrebno več dostavljati v bolnišnico.

\subsection{Centralni register podatkov o pacientih (CRPP)}

CRPP je zbirka podatkov eZdravja o pacientih s stalnim ali začasnim prebivališčem $\mathrm{v}$ Republiki Sloveniji (ZZPPZ), ki vsebuje sledeče podatke o pacientih:

- povzetek podatkov o pacientu,

- pacientovo zdravstveno dokumentacijo.

\subsubsection{Namen CRPP}

Podatki v CRPP se obdelujejo z namenom, da se izvajalcem zdravstvene dejavnosti, tako v Sloveniji kot tudi v tujini, omogoči dostop do podatkov in izmenjava podatkov za izvajanje zdravstvene oskrbe in mrliško pregledne službe ter $\mathrm{z}$ namenom ažuriranja podatkov zdravstvene dokumentacije (ZZPPZ). 


\subsubsection{Komponente CRPP}

V CRPP se zbirajo podatki $\mathrm{v}$ obliki dokumentov. Ti so lahko bodisi popolnoma nestrukturirani (npr. pdf dokumenti), ali popolnoma strukturirani (OpenEHR strukture ali HL7). Seveda so podprte tudi vse možne vmesne različice dokumentov.

Centralni register podatkov o pacientih sestavljata:

- povzetek podatkov o pacientu (PPoP)

- zdravstvena dokumentacija pacienta (nekoč $\mathrm{IH})$

Povzetek podatkov o pacientih (PPoP) sestavljajo:

- pacientovi identifikacijski in statusni podatki

- pacientovi zdravstveni podatki brez časovne omejitve

○ krvna skupina,

○ alergije in preobčutljivosti,

○ cepljenja,

○ kronične bolezni,

- medicinski pripomočki, ki so vsajeni v telo,

○ večji medicinski posegi,

- podatki o invalidnosti,

- pacientovi zdravstveni podatki s časovno omejitvijo:

○ nosečnost in pričakovan datum poroda,

○ zdravstvena stanja za zadnjih šest mesecev,

- medicinski posegi za zadnjih šest mesecev,

- zdravila, živila za posebne zdravstvene in prehranske namene, predpisana, prejeta ali izdana $\mathrm{v}$ zadnjih šestih mesecih,

○ medicinski pripomočki, izdani v zadnjih šestih mesecih.

Več o tem glej ZZPPZ, 14. člen.

Zdravstvena dokumentacija

V CRPP je registriranih 31 tipov dokumentov, od katerih podatki obstajajo za 14 tipov, ki so navedeni $\mathrm{v}$ tabeli 2.

\subsubsection{Pravice obdelave podatkov}

Pravico obdelave podatkov v CRPP določa Zakon o spremembah in dopolnitvah Zakona o zbirkah podatkov s področja zdravstvenega varstva (ZZPPZ). Obdelava podatkov iz CRPP pri izvajalcih v Republiki Sloveniji je dopustna brez privolitve pacienta, pri izvajalcih v tujini pa na podlagi privolitve pacienta. Pri tem ima pacient ima pravico $\mathrm{s}$ pisno izjavo prepovedati vpogled v povzetek podatkov o pacientu. Prepoved lahko poda 
36 ${ }^{\mathrm{TH}}$ International Conference on Organizational Science Development: RESPONSIBLE ORGANIZATION (MARCH $22^{\mathrm{ND}}-24^{\mathrm{TH}}$, PORTOROŽ SLOVENIA)

Ž. Rant, D. Stanimirović, V. Matetić, S. Indihar, J. Zidarn, M. Beštek \& A. Žlender: eZdravje Today for Tomorrow

za izvajalca ali državo izvajalca, vendar so nekateri podatki izvzeti iz prepovedi vpogleda - glej člen 14.c ZZPPZ. Dodatne možnosti prepovedi za določena zdravstvena stanja in medicinske posege lahko določi minister, pristojen za zdravje, na pobudo Komisije za medicinsko etiko.

\subsubsection{Proces CRPP - primer uporabe}

Osebni zdravnik izda napotnico. Mnenje z anamnezo kot dokument objavi v CRPP. Pri specialistični obravnavi pacienta specialist v svoji aplikaciji lahko dostopa do mnenja osebnega zdravnika. Po pregledu specialist izda izvid in ga objavi v CRPP. Osebni zdravnik pacienta lahko preko svoje aplikacije dostopa do izvida.

\subsection{Portal zVEM (na portal grem da nekaj zvem)}

V okviru projekta eZdravje je bila vzpostavljena rešitev spletni portal zVEM - zdravje vse na enem mestu, ki uporabnikom (tako pacientom kot zdravstvenim delavcem) omogoča varen dostop do storitev eZdravja. Rešitev Portal zVem (zdravje Vse na Enem Mestu) je bila tehnično vzpostavljena z zaključkom projekta eZdravje, novembra 2015. Za polno uporabo portala zVEM z možnostjo registracije uporabnikov se je rešitev zagotovila oktobra 2016. Časovni zamik med tehnično vzpostavljenim portalom in možnostjo polne uporabe portala je nastal zaradi urejanja dogovora in pridobivanja odločitev o uporabi, povezavi evidence o zavarovanih osebah obveznega zdravstvenega zavarovanja, katere upravljalec je Zavod za zdravstveno zavarovanje Slovenije in Centralnega registra prebivalcev, katere upravljalec je Ministrstvo za notranje zadeve. Razvoj portala še ni zaključen. Trenutno objavljena je t. i. beta različica.

Portal zVEM uporabnikom omogoča dostop do podatkov Centralnega registra o pacientih, eNaročanja, eRecepta in informacij javnega zdravja. Portal zVEM poleg omenjenih dostopov omogoča tudi zajem podatkov, kontrolo podatkov pri sprejemu, ki je namenjen sprejemanju podatkov pri oddaji različnih poročil, ki jih morajo izvajalci oddajati različnim pravnim subjektom v zdravstvenem sistemu. Možna je izvedba anket z možnostjo obdelave oddanih odgovorov. Omogočena je tudi uporaba e-učilnic z namenom izobraževanja na daljavo ali možnostjo osvežitev znanja po opravljenem izobraževanju.

Možen je vpogled v novice, oglasno desko in ankete. Poleg tega pa še v čakalne dobe in proste termine pri izvajalcih zdravstvene dejavnosti.

Pacient ob prijavi z digitalnim certificiranim potrdilom lahko dostopa do svojih podatkov o eNaročanju, dokumentih v CRPP, predpisanih in izdanih zdravilih in do povezave na podatke ZZZS.

$\mathrm{Na}$ portalu zVEM je zagotovljena tudi uporaba ter podpora za ljudi s posebnimi potrebami. 
Ž. Rant, D. Stanimirović, V. Matetić, S. Indihar, J. Zidarn, M. Beštek \& A. Žlender: eZdravje danes za jutri

Portal je še v fazi uvajanja.

\section{$3 \quad$ Razprava}

Predstavili bomo trenutno stanje pri rešitvah eZdravja.

\section{1 $\quad$ eRecept}

Uporaba eRecepta na primarni ravni v celotni Sloveniji se je začela 2. novembra 2015. Od 1. februarja 2016 je njegova uporaba obvezna tudi na sekundarni in terciarni ravni. Tako danes lahko govorimo o utečenem sistemu, ki je v uporabi že eno leto. V zadnjih mesecih je več kot 85 odstotkov predpisov elektronskih.

Za ilustracijo, v letu 2016 je bilo s pomočjo eRecepta predpisanih in izdanih več kot 12 milijonov receptov (glej tabelo 2 in sliki 1 in 2). eRecept uporablja okvirno 1450 izvajalcev zdravstvene dejavnosti (torej različnih organizacij).

\begin{tabular}{|c|c|c|c|c|}
\hline leto-mesec & $\begin{array}{c}\text { število predpisov } \\
\text { e-receptov }\end{array}$ & št. IZD & $\begin{array}{c}\text { število papirnatih } \\
\text { receptov }\end{array}$ & $\begin{array}{c}\text { delež } \\
\text { e-receptov }\end{array}$ \\
\hline $2015-12$ & 772.217 & 1275 & & \\
\hline $2016-01$ & 989.534 & 1395 & & \\
\hline $2016-02$ & 1.225 .642 & 1460 & & \\
\hline $2016-03$ & 936.635 & 1424 & & $86 \%$ \\
\hline $2016-04$ & 966.221 & 1435 & 151.181 & $87 \%$ \\
\hline $2016-05$ & 1.240 .842 & 1489 & 179.669 & $88 \%$ \\
\hline $2016-06$ & 954.024 & 1466 & 132.961 & $88 \%$ \\
\hline $2016-07$ & 838.069 & 1438 & 113.563 & $90 \%$ \\
\hline $2016-08$ & 1.013 .728 & 1437 & 116.429 & $91 \%$ \\
\hline $2016-09$ & 985.671 & 1462 & 97.379 & $86 \%$ \\
\hline $2016-10$ & 1.161 .421 & 1476 & 211.997 & $85 \%$ \\
\hline $2016-11$ & 1.041 .367 & 1468 & 175.545 & \\
\hline $2016-12$ & 973.691 & 1449 & 177.547 & \\
\hline
\end{tabular}

Tabela 1: Število elektronskih predpisov receptov in vključenih izvajalcev zdravstvene dejavnosti (IZD) 
36 ${ }^{\mathrm{TH}}$ International Conference on Organizational Science Development: RESPONSIBLE ORGANIZATION (MARCH $22^{\mathrm{ND}}-24^{\mathrm{TH}}$, PORTOROŽ SLOVENIA)

Ž. Rant, D. Stanimirović, V. Matetić, S. Indihar, J. Zidarn, M. Beštek \& A. Žlender: eZdravje Today for Tomorrow

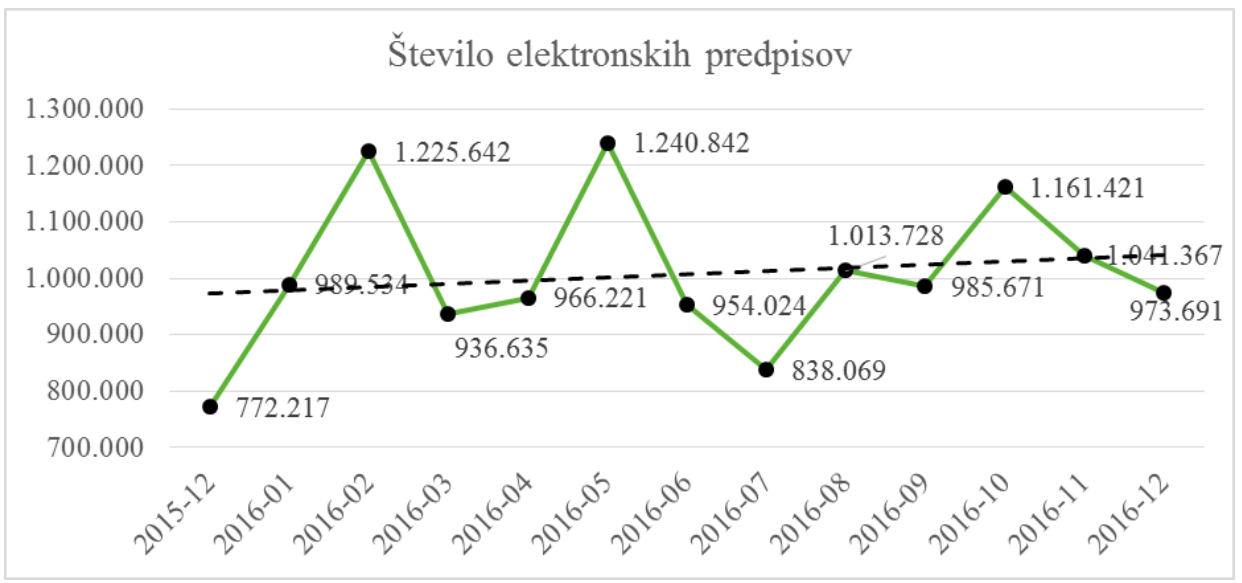

Slika 1: Število elektronskih predpisov receptov

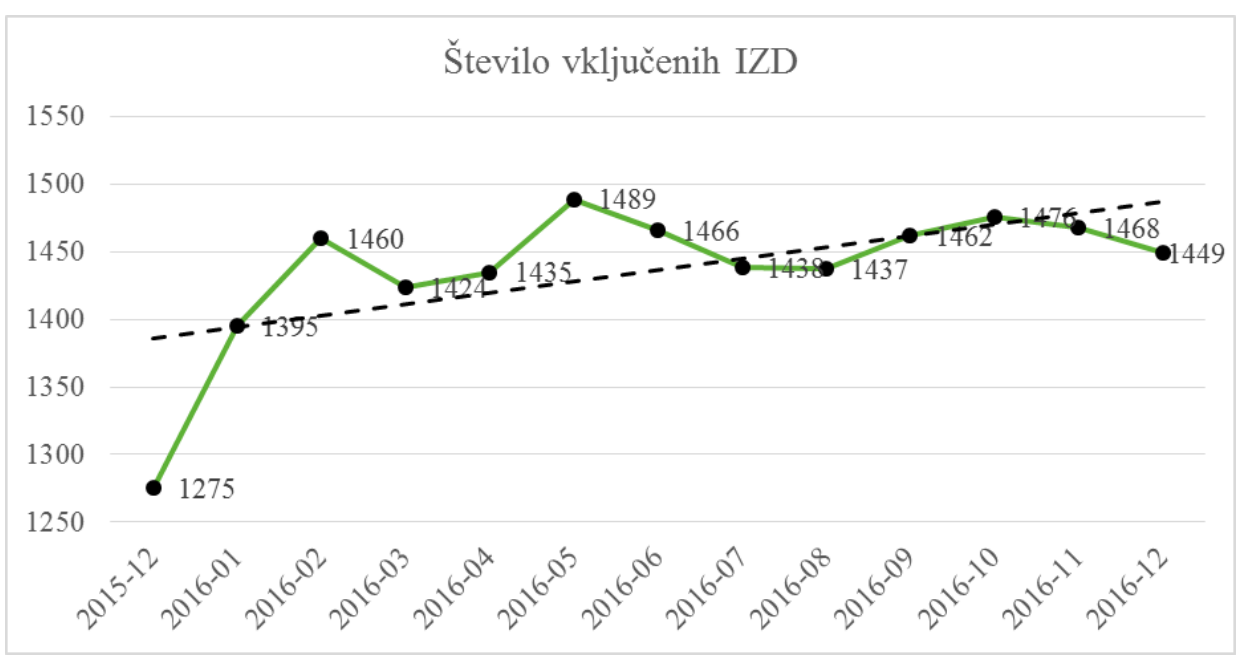

Slika 2: Število vključenih izvajalcev zdravstvene dejavnosti

$\mathrm{V}$ času uvedbe so se pokazale tudi pomanjkljivosti in priložnosti za izboljšave. Za stabilizacijo sistema in boljšo izvedbo so bili nadgrajeni strežniki, na katerih teče centralni del eRecepta. Omogočeno je bilo povezovanje spletnih zdravstvenih aplikacij z eReceptom (v uporabi npr. na Pediatrični kliniki v Ljubljani) ter uvedene dodatne kontrole, ki preprečujejo morebitne napake pri predpisovanju in izdajanju zdravil. Razvoj se $\mathrm{s}$ prehodom $\mathrm{v}$ nacionalno uporabo ni ustavil, ampak se celoten sistem vseskozi dopolnjuje. Odzivamo se na pobude končnih uporabnikov in deležnikov eZdravja in 
Ž. Rant, D. Stanimirović, V. Matetić, S. Indihar, J. Zidarn, M. Beštek \& A. Žlender: eZdravje danes za jutri

spodbujamo programske hiše, katerih rešitve se povezujejo $\mathrm{z}$ eReceptom, da implementirajo izboljšave tudi v lokalnih zdravstvenih informacijskih sistemih.

Pri vseh izboljšavah je nujno sodelovanje deležnikov eZdravja, saj eRecept kot sistem ne more delovati brez povezanih rešitev. Za delovanje so nujni urejeni podatki o zdravilih v Centralni bazi zdravil, za ustrezna pooblastila pa je potrebno zagotoviti tudi ažurnost in urejenost podatkov v Bazi podatkov o izvajalcih zdravstvene dejavnosti, za dostop s pooblastili je nujno ustrezno delovanje profesionalnih kartic in kvalificiranih digitalnih potrdil. Za predpisovanje in izdajanje receptov so odgovorni lokalni informacijski sistemi pri izvajalcih zdravstvenih dejavnosti, ki končnim uporabnikom omogočajo uporabo eRecepta. Zato v sklopu strokovne skupine za eRecept spodbujamo sodelovanje in izmenjavo izkušenj, mnenj in predlogov, ki vplivajo na nadaljnji razvoj in usmerjajo prihodnost eRecepta.

\section{2 eNaročanje}

Čeprav je bila rešitev razvita na način, da čim manj posega $\mathrm{v}$ informacijske sisteme izvajalcev zdravstvene dejavnosti, se je v obdobju od postopne uvedbe konec leta 2015 vse do danes rešitev eNaročanje soočala $\mathrm{z}$ različnimi ovirami in težavami. Zaradi tega uvajanje rešitve eNaročanje poteka počasneje, kot je bilo predvideno. Glavne težave tičijo $\mathrm{v}$ tem, da vsi izvajalci zdravstvene dejavnosti tako tehnično kot organizacijsko še niso povsem pripravljeni na vključitev in izvajanje eNaročanja. V skladu se tem se intenzivno izvaja preverjanje podatkov o storitvah, ki jih opravljajo izvajalci zdravstvene dejavnosti, hkrati pa se rešujejo tudi vse ugotovljene tehnične težave in pomanjkljivosti. Istočasno se izvaja tudi preverjanje kakovosti podatkov, ki jih izvajalci zdravstvenih storitev posredujejo $\mathrm{v}$ nacionalni čakalni seznam.

Resne ovire predstavljajo tudi dolgotrajna in težavna usklajevanja med izvajalci zdravstvene dejavnosti glede storitev $\mathrm{v}$ šifrantu Vrst zdravstvenih storitev (VZS), ki trenutno vsebuje preko 1000 vrst zdravstvenih storitev. Zaradi poenotenja označevanja zdravstvenih storitev na nacionalnem nivoju je bil vzpostavljen nov šifrant VZS, ki povezuje storitve, ki jih napotni zdravniki izvajajo, napotovalci pa nanje naročajo. Šifrant VZS je temeljni šifrant, ki se uporablja za razvrščanje storitev v zdravstvu in se bo uporabljal za opredelitev storitev na napotnicah znotraj eNaročanja in za spremljanje čakalnih dob v okviru sistema eNaročanje. Za rešitev kompleksnih težav na področju usklajevanja in upravljanja šifranta VZS iščemo rešitve, kako oblikovati čim bolj vsebinsko uravnotežen in strokovno uporaben šifrant in s tem zagotoviti izvajanje eNaročanja na čim bolj optimalen način - tako za izvajalce zdravstvene dejavnosti, kot tudi za vse paciente.

Kakovost podatkov se postopno popravlja, prav tako narašča uporaba eNapotnic in eNaročil. Kazalniki delovanja aplikacije eNaročanje (število eNapotnic in eNaročil po mesecih) v zadnjih 14 mesecih so prikazani na slikah 3 in 4 . Kazalniki so se sicer iz meseca $\mathrm{v}$ mesec izboljševali, opazen pa je padec nekaterih kazalnikov v dopustniških mesecih. 
$36^{\mathrm{TH}}$ INTERNATIONAL CONFERENCE ON ORganizational SCIENCE DeVElopment: Responsible Organization (MARCH $22^{\mathrm{ND}}-24^{\mathrm{TH}}$, PORTOROŽ SLOVENIA)

Ž. Rant, D. Stanimirović, V. Matetić, S. Indihar, J. Zidarn, M. Beštek \& A. Žlender: eZdravje Today for Tomorrow

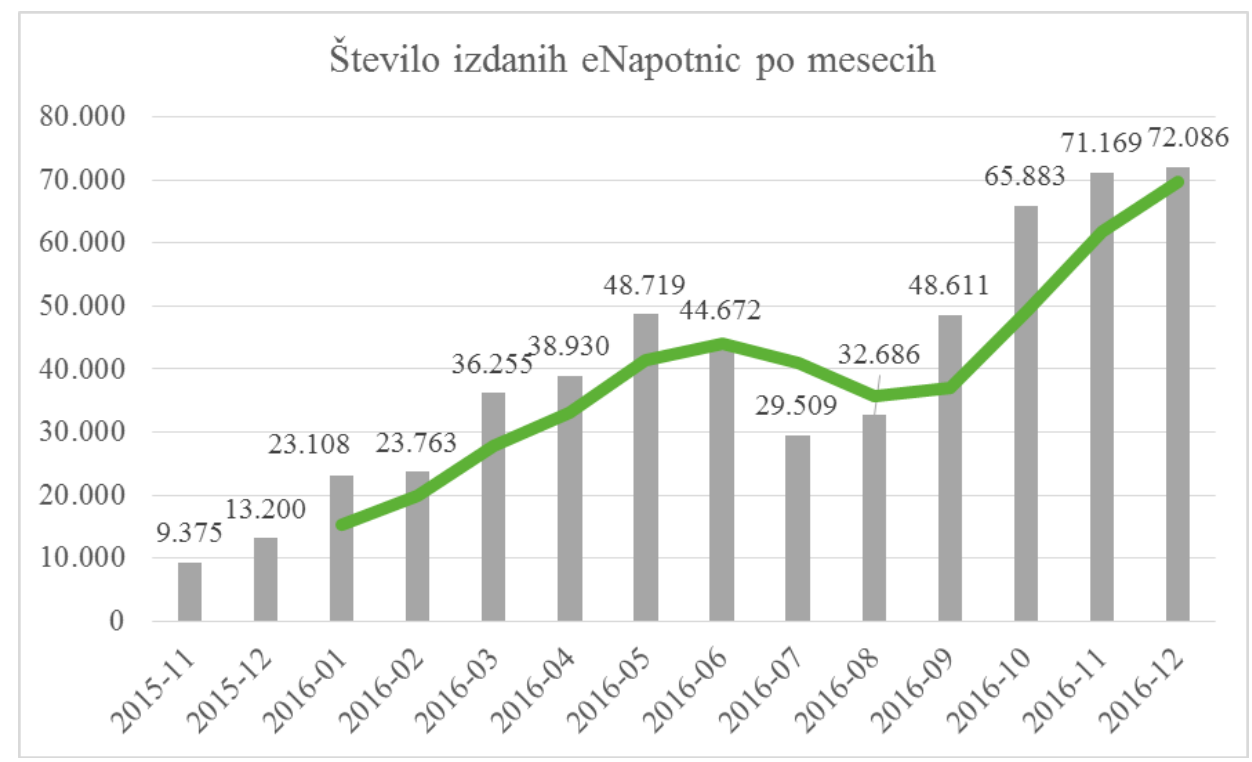

Slika 3: Število izdanih eNapotnic po mesecih.

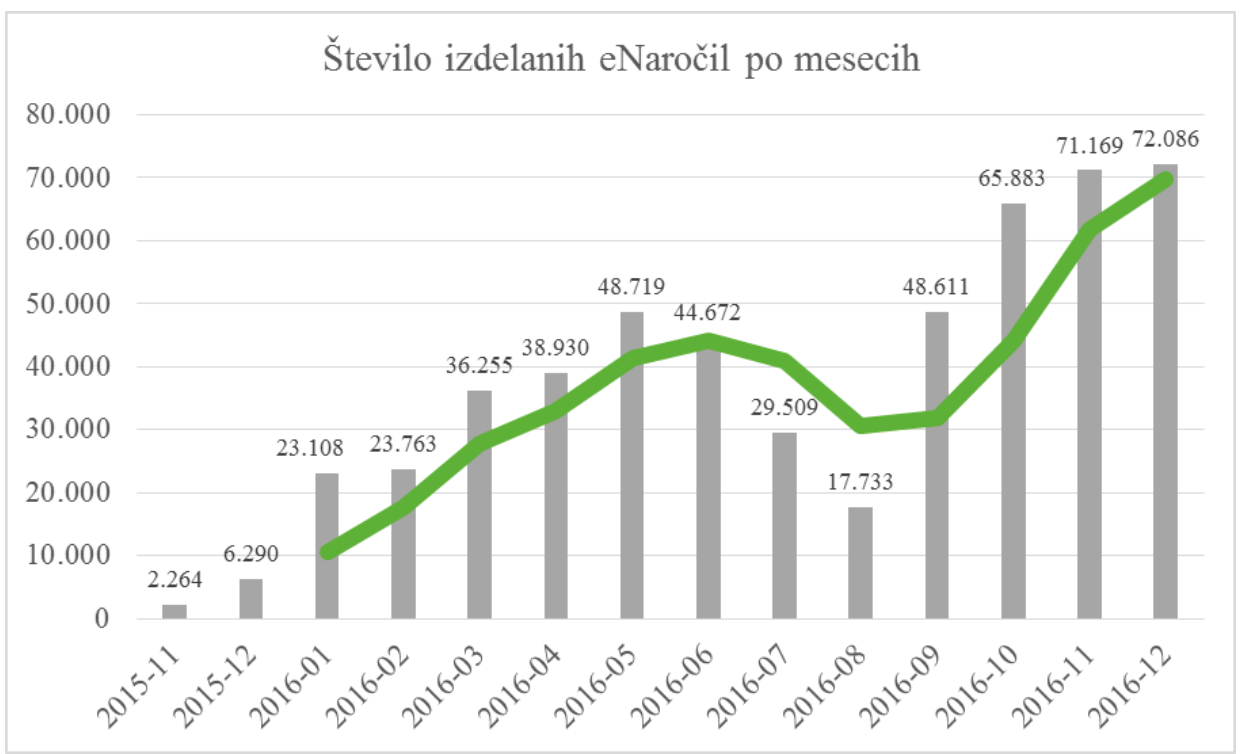

Slika 4: Število izdelanih eNaročil po mesecih. 
Ž. Rant, D. Stanimirović, V. Matetić, S. Indihar, J. Zidarn, M. Beštek \& A. Žlender: eZdravje danes za jutri

Dinamika naraščanja števila izvajalcev, ki so že poslali eNapotnico je prikazana na sliki 5 , prav tako pa se iz meseca v mesec veča tudi število vključenih izvajalcev zdravstvene dejavnosti, ki izvajajo storitve na sekundarni in terciarni ravni zdravstvenega sistema.

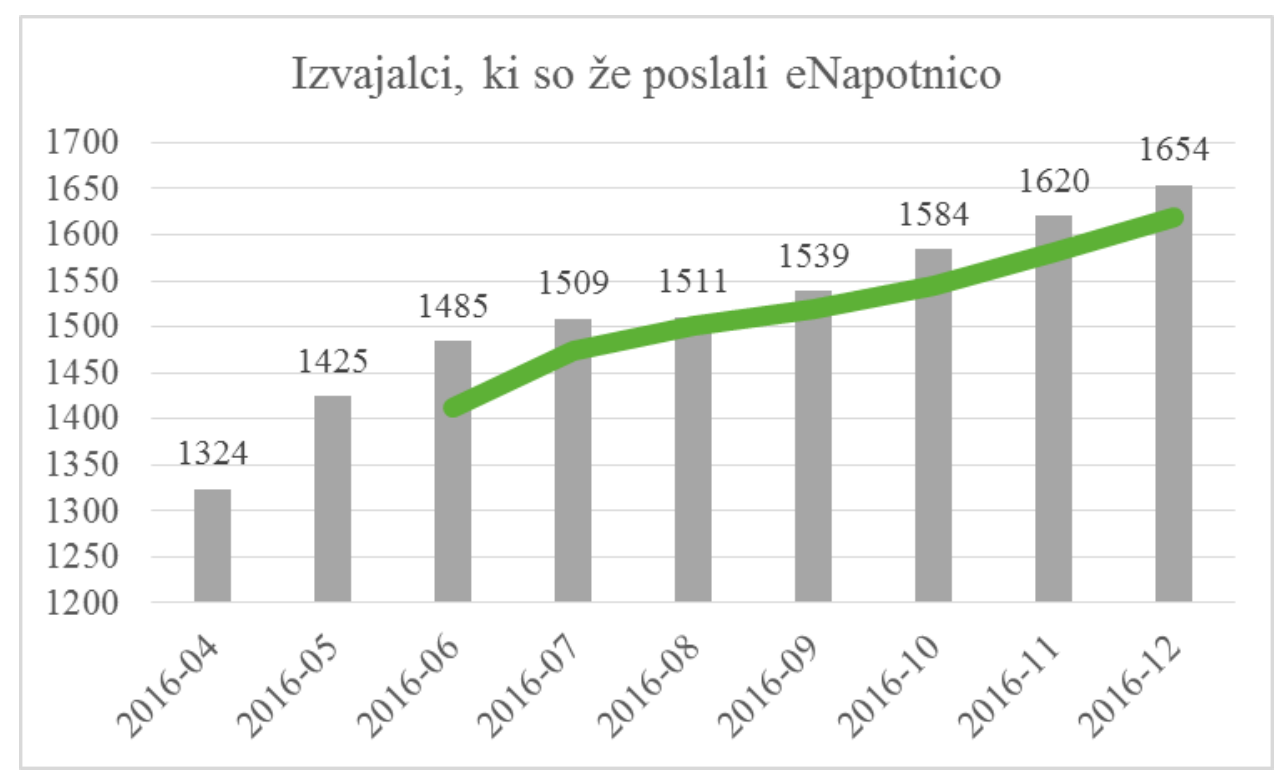

Slika 5: Izvajalci, ki so že poslali eNapotnico.

\subsection{Centralni register podatkov o pacientih (CRPP)}

V CRPP je zbranih okvirno 3 milijone dokumentov. V tabeli 2 je prikazan tudi delež dokumentov po posameznih tipih dokumentov. Poleg deleža vidimo tudi dejansko število dokumentov, ki so bili zbrani do decembra 2016. 
36 ${ }^{\mathrm{TH}}$ International Conference on Organizational Science Development: RESPONSIBLE ORGANIZATION (MARCH $22^{\mathrm{ND}}-24^{\mathrm{TH}}$, PORTOROŽ SLOVENIA)

Ž. Rant, D. Stanimirović, V. Matetić, S. Indihar, J. Zidarn, M. Beštek \& A. Žlender: eZdravje Today for Tomorrow

\begin{tabular}{|l|r|r|}
\hline Tip dokumenta & \multicolumn{1}{|c|}{ Delež } & \multicolumn{1}{|c|}{ Stevilo } \\
\hline \hline Ambulantni izvid & $58 \%$ & 1.830 .488 \\
\hline Napotnica & $21 \%$ & 655.079 \\
\hline Zapis podatkov o boleznih & $11 \%$ & 350.767 \\
\hline Odpustno pismo & $10 \%$ & 325.022 \\
\hline Zapis podatkov o posegih & $0 \%$ & 11.653 \\
\hline Zapis podatkov o nosečnosti & $0 \%$ & 3.828 \\
\hline Zapis o cepljenju & $0 \%$ & 3.026 \\
\hline Zapis podatkov o alergijah in neželenih učinkih & $0 \%$ & 511 \\
\hline Zapis podatkov o izdanih zdravilih & $0 \%$ & 207 \\
\hline Zapis podatkov o invalidnosti / avtonomnosti & $0 \%$ & 84 \\
\hline Zapis podatkov o socialni zgodovini & $0 \%$ & 15 \\
\hline Zapis podatkov o fizičnih ugotovitah (kliničnem \\
statusu)
\end{tabular}

Tabela 2: Tipi dokumentov v CRPP za katere obstajajo podatki in delež vseh dokumentov $v$ CRPP glede na tip dokumenta

Dinamika nastajanja dokumentov v CRPP je skozi obdobje od leta 2013 naprej zelo različna in je podrobneje prikazana na sliki 6 . Podana je primerjava po letih in mesecih od 1.4.2013 do vključno 31.12.2016. Podatki jasno kažejo velik porast v številu dokumentov od vključno decembra leta 2015, ko je NIJZ prevzel v upravljanje vse rešitve eZdravja. 
Ž. Rant, D. Stanimirović, V. Matetić, S. Indihar, J. Zidarn, M. Beštek \& A. Žlender:

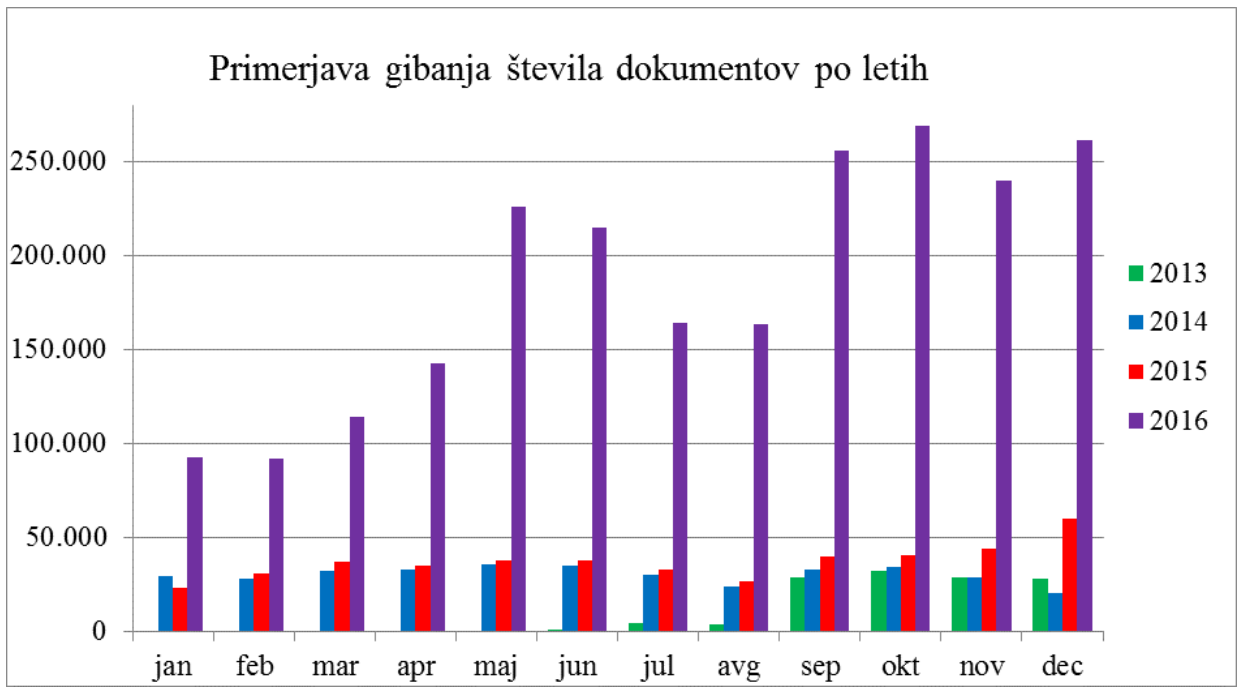

Slika 6: Primerjava gibanja števila dokumentov v CRPP po letih.

Dinamika gibanja števila pacientov, za katere so se zbirali podatki v CRPP, je dodatno prikazana na sliki 7 , kjer vidimo primerjave po letih in mesecih.

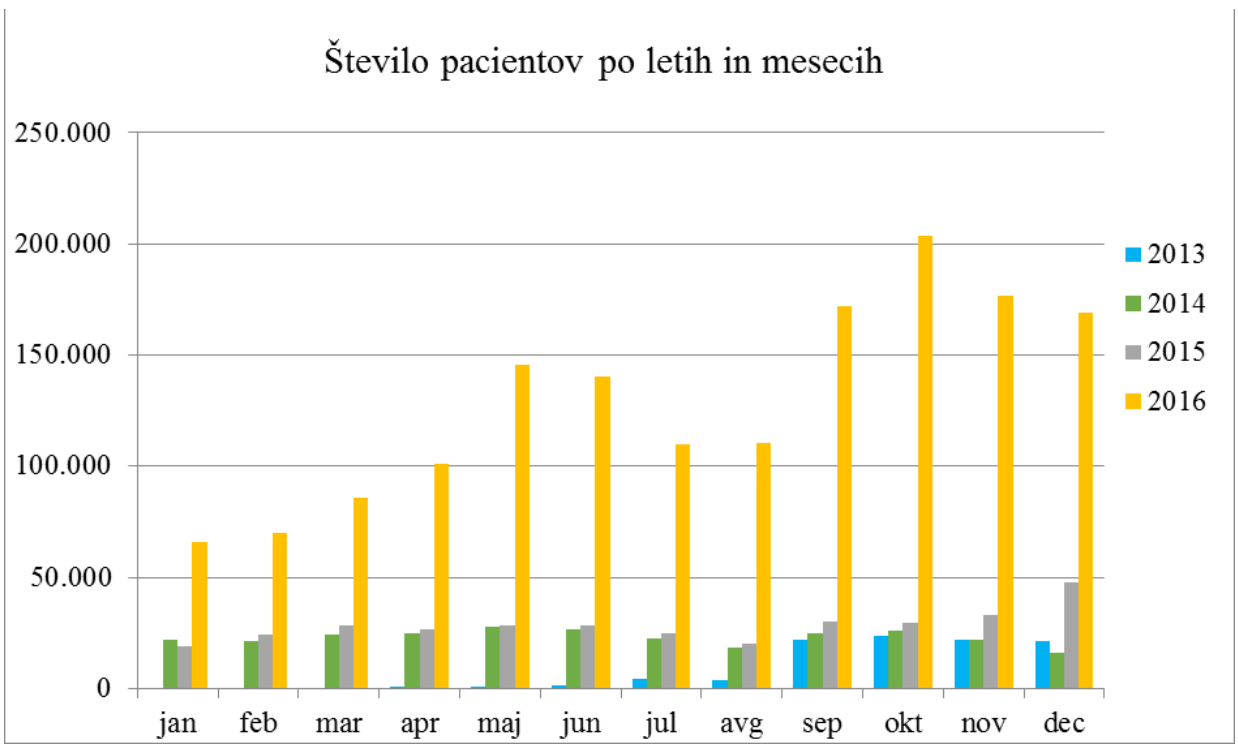

Slika 7: Dinamika gibanja števila pacientov po letih in mesecih, za katere so zbrani podatki $v$ CRPP 
$36^{\text {TH }}$ International Conference ON ORganizational SCIENCE Development: RESPONSIBLE ORGANIZATION (MARCH $22^{\mathrm{ND}}-24^{\mathrm{TH}}$, PORTOROŽ SLOVENIA)

Ž. Rant, D. Stanimirović, V. Matetić, S. Indihar, J. Zidarn, M. Beštek \& A. Žlender: eZdravje Today for Tomorrow

Iz podatkov lahko sklepamo, da se od decembra 2015 v CRPP pošilja neprimerljivo več podatkov kot $\mathrm{v}$ obdobju prej. Rešitve se torej pospešeno uvajajo, kar posledično generira potrebe po dodatnih virih, ki so za tovrstno širitev potrebni. Vsekakor je potrebno v bodoče upoštevati kompleksnost uvajanja CRPP, kot tudi ostalih rešitev eZdravja, predvsem pri načrtovanju potrebnih virov, tako kadrovskih kot drugih. Neustrezno načrtovanje virov lahko namreč povzroči različne težave, ki lahko pomenijo tudi prekinitev uvedbe katere od rešitev in dolgoročno ogrozijo celoten program eZdravja.

\section{$4 \quad$ Zaključek}

V slovenskem zdravstvenem sistemu se trenutno uporablja veliko število informacijskih rešitev, ki partikularno gledano s svojimi aplikacijami relativno dobro podpirajo posamezne segmente poslovanja zdravstvenih subjektov. Končni izkoristek oziroma sinergijski učinki tovrstnih informacijskih rešitev pa so zaradi njihove pretežne razdrobljenosti relativno nizki, tako na ravni zdravstvene oskrbe posameznega pacienta kot tudi na ravni upravljanja zdravstvenih zavodov in celotnega zdravstvenega sistema. Če želimo izkoristiti zmožnosti, ki jih ponujajo rešitve eZdravja, mora biti celoten proces razvoja, implementacije in uporabe rešitev podprt s sistemskimi ukrepi na različnih (politična, zakonska, tehnično-tehnološka, kadrovska, organizacijska ipd.) ravneh ter usklajen $\mathrm{z}$ interesi in potrebami vseh deležnikov. Uspešna mobilizacija deležnikov ter uskladitev njihovih različnih interesov predstavlja $\mathrm{v}$ trenutnih razmerah, ki vladajo $\mathrm{v}$ slovenskem zdravstvu, izredno zahtevno nalogo. Odraz vsesplošnih sistemskih težav se močno pozna tudi na področjih povezanih $\mathrm{s}$ spremenjeno paradigmo poslovanja $\mathrm{v}$ zdravstvu, ki jo prinaša informatizacija zdravstvenega sistema.

Kljub pomanjkanju enotnih strateških dokumentov in smernic, je $\mathrm{v}$ zadnjem letu prišlo do znatnega napredka pri razvoju in implementaciji določenih rešitev eZdravja. Glede na dinamiko dogodkov od objave prvega strateškega dokumenta na področju informatizacije zdravstva iz leta 2005, predstavlja implementacija slednjih rešitev pomemben mejnik. Ob tem upamo, da zadnji dogodki na področju eZdravja potrjujejo vse večje zavedanje odločevalcev, da ima informatika $\mathrm{v}$ zdravstvu velik razvojni potencial ter zagotavlja nujno podporo pri vseh procesih odločanja, načrtovanja in upravljanja $\mathrm{v}$ zdravstvenem sistemu.

\section{Literatura in viri}

Stanimirović D. et al. (2016). Projekt eZdravje na Nacionalnem inštitutu za javno zdravje tveganja, izzivi in nedavni napredek. V Leskošek B., Juvan P. (Ur.), Moč sodelovanja za zdravje (str. 1-7) Kongres MI' 2016. Slovensko društvo za medicinsko informatiko, Zreče, 10.11. november 2016.

Ministrstvo za zdravje (2015). Storitve eZdravja - zvočni in tekstovni zapisi. Dostopno 16.2.2017 na http://www.mz.gov.si/si/pogoste_vsebine_za_javnost/projekt_e_zdravje/

Nacionalni inštitut za javno zdravje (2016). eZdravje. Dostopno 16.2.2017 na http://www.nijz.si/sl/ezdravje 
Ž. Rant, D. Stanimirović, V. Matetić, S. Indihar, J. Zidarn, M. Beštek \& A. Žlender: eZdravje danes za jutri

Nacionalni inštitut za javno zdravje. Vse o projektu eZdravje. Dostopno 16.2.2017 na http://www.ezdrav.si/

Eržen, I. (2016). Je eNaročanje nov pripomoček za upravljanje v zdravstvu? Novis, Vol. 43, No. 10, str. 1. Dostopno 16.2.2017 na https://zdrzz.si/f/docs/Aktualno/Novis_10_oktober_2016.pdf Stanimirović, D., Indihar, S. (2016). eNaročanje - trenutno stanje in nadaljnji koraki. Novis, Vol. 43, No. 11, str. $4 \quad-\quad 6 \quad$. $\quad$ Dostopno 16.2 .2017 na https://zdrzz.si/f/docs/Aktualno/Novis_11_november_2016_1.pdf

Matetić, V. (2016). eRecept. Recept, Vol. 13, No. 2, str. 14 -15. Dostopno 16.2.2017 na http://www.zZzs.si/ZZZS/info/egradiva.nsf/0/e1c2f98ba88439c6c1258067002d0662/\$FILE/b ilten\%20Recept_\%C5\%A1t\%202_23.11.2016.pdf

Kralj, K. (2015). eNaročanje. Novis, Vol. 42, No. 04, str. 1 - 2. Dostopno 16.2.2017 na https://issuu.com/zdrzz_novis/docs/novis_04_april_2015

ZZPPZ. Zakon o zbirkah podatkov s področja zdravstvenega varstva, Uradni list RS, št. 47/15 in Uradni list RS, št. 65/00.

Zakon o varstvu osebnih podatkov (ZVOP-1-UPB1), Uradni list RS, št. 94/2007. 
868 36 $36^{\text {Th }}$ InTERnational CONFEREnCE ON ORganizational Science Development: Responsible Organization (MARCh $22^{\mathrm{ND}}-24^{\mathrm{TH}}$, PORTOROŽ SlOVENIA) 


\title{
Pogostost in višina prejete napitnine: faktorska analiza dejavnikov
}

\begin{abstract}
ANDREJ RASPOR
Povzetek Namen: Cilj študije je ugotoviti dejavnike, ki vplivajo na napitnino in jih združiti v posamezne skupine. Dejavniki s področij gostinstva in igralništva so med seboj primerljivi, hkrati pa so uporabni tudi za druge storitvene dejavnosti.

Metode: Za osvetlitev stanja v Sloveniji je bila izvedena lastna raziskava, kjer se je s pomočjo triangulacije združilo ugotovitve anketiranja, fokusnih skupin in opazovanja. Statistična analiza zbranih anketnih podatkov je bila opravljena $s$ programskim paketom SPSS, s katerim se je izvedlo univariatne, bivariatne in multivariatne analize (primerjava povprečij in deležev, Pearsonov koeficient korelacije, faktorska analiza). Zaključki in povzetki so se oblikovali s pomočjo metode analize, sinteze, kompilacije in komparacije.

Rezultati: Na osnovi vseh predstavljenih raziskav so se izoblikovale naslednje skupine dejavnikov, ki vplivajo na napitnino: (1) zunanji, nekontrolirani dejavniki, (2) zunanji, kontrolirani dejavniki, (3) kvantiteta obiska in storitve ter način plačila le-te, (4) medsebojni odnosi in urejenost delitve napitnine, (5) značilnosti ponudbe, (6) vedenje, izkušenost in ostale značilnosti osebja in (7) presenečenje gosta.

Zaključki: Gre za prvi znani prispevek na svetu, ki je združil dejavnike v enotno tabelo, ter jih obenem s pomočjo faktorske analize družil v skupine dejavnikov. Glede preveritve raziskovalnega vprašanja, »Ali se dejavniki, ki vplivajo na napitnino med gostinstvom in igralništvom razlikujejo?«, lahko zaljučimo, da obstajajo določene specifike. V osnovi pa je delitev skupin dejavnikov sorodna za obe dejavnosti.
\end{abstract}

KLJUČNE BESEDE: napitnina $・$ dejavniki $・$ zaposleni $・$ igralništvo $\bullet$ gostinstvo

NASLOV AVTORJA: dr. Andrej Raspor, docent, DOBA Fakulteta za uporabne poslovne in družbene študije Maribor, Prešernova ulica 1, 2000 Maribor, Slovenija, e-pošta: andrej.raspor@ceatm.org

DOI https://doi.org/10.18690/978-961-286-020-2.69

ISBN 978-961-286-020-2

(C) 2017 Univerzitetna založba Univerze v Mariboru

Dostopno na: http://press.um.si 


\title{
Influence Frequency and the Amount of Received Tips: Factor Analysis of Factors
}

\begin{abstract}
ANDREJ RASPOR
Abstract Purpose: The main objective of the research was to put factors that affect tipping fees into groups. These factors are comparable in the fields of hospitality and gaming industry, and are useful also in other service activities.

Methods: With the aim of illuminating the situation in Slovenia, we carried out our own survey using triangulation method which is combined with findings of the survey, focus groups and observation. Statistical analysis of survey data was performed with SPSS software, which helped us to conduct univariate, bivariate and multivariate analysis (comparison of averages and proportions, Pearson's correlation coefficient, factor analysis). Conclusions and summaries were formed by using methods of analysis, synthesis, compilation and comparison.

Results: Studies helped us form the following groups of factors that affects tipping fees: (1) external uncontrollable factors, (2) external controllable factors (3) the quantity of the visit and the service and method of payment (4) mutual relations and arrangement of tips division (5) characteristics of offer (6) behavior, experience and other characteristics of a staff, and (7) surprise effect.

Conclusions: This is the first article that presents factors in a single table and at the same time, through factor analysis, combines them in groups. To make a conclusion on our guiding premise: "Can we differnetiate between the factors that affect tipping fees in the field of hospitality industry from those in gambling industry?", we can conclude that there are certain specifics, but divisions into factor groups are similar in both fields.
\end{abstract}

KEYWORDS: tips $\bullet$ factors $\bullet$ employees $\bullet$ gaming industry $\bullet$ hospitality industry

CORRESPONDENCE AdDRESS: Andrej Raspor, Ph.D., Assistant Professor, DOBA Faculty of Applied Business and Social studies Maribor, Prešernova ulica 1, 2000 Maribor, Slovenia, e-mail: andrej.raspor@ceatm.org

DOI https://doi.org/10.18690/978-961-286-020-2.69 
A. Raspor: Pogostost in višina prejete napitnine: faktorska analiza dejavnikov

\section{$1 \quad$ Uvod}

V storitveni dejavnosti je običaj, da stranke občasno zaposlenim dajo majhne denarne zneske (Lynn 2004c; Raspor 2010d). Dejavnikov, ki vplivajo na samo napitnino je več. $\mathrm{V}$ eni od predhodnih raziskav sem s pomočjo deskriptivne in eksplikativne metode opisal ključne pojme povezane znapitnino. Poleg tega sem uporabil tudi primerjalno oz. komparativno metodo, saj ta metoda pomeni nadgradnjo prejšnje metode. Služila mi je za proučevanje na nivoju primerjanja dejstev, odnosov, procesov, z namenom odkrivanja podobnosti in razlik.

Dejansko pa vsi ti dejavniki nikoli niso bili zbrani v enoten okvir in razporejeni v skupine dejavnikov. Zato sem se sam lotil tega izziva in na ta način obogatil teoretičen diskurz o napitnini.

Osnovno izhodišče tega prispevka je bilo združiti dejavnike v skupne. Nadgradnja raziskave pa je potekala v smeri preveritve raziskovalnega vprašanja: Ali se dejavniki, ki vplivajo na napitnino med gostinstvom in igralništvom razlikujejo?

Za osvetlitev stanja v Sloveniji je bila izvedena lastna raziskava, kjer se je s pomočjo triangulacije združilo ugotovitve anketiranja, fokusnih skupin in opazovanja. Statistična analiza zbranih anketnih podatkov je bila opravljena s programskim paketom SPSS, s katerim se je izvedlo univariatne, bivariatne in multivariatne analize (primerjava povprečij in deležev, Pearsonov koeficient korelacije, faktorska analiza). Zaključki in povzetki so se oblikovali s pomočjo metode analize, sinteze, kompilacije in komparacije.

\section{Dejavniki, ki vplivajo na napitnino - raziskava}

Da bi realizirali zastavljene cilje sem izvedl več raziskav, ki jih navajam v nadaljevanju. 
$36^{\text {TH }}$ International Conference on Organizational Science Development: RESPONSIBLE ORGANIZATION (MARCH $22^{\mathrm{ND}}-24^{\mathrm{TH}}$, PORTOROŽ SLOVENIA)

A. Raspor: Influence Frequency and the Amount of Received Tips: Factor Analysis of Factors

\section{Raziskava: Zaposleni v gostinstvu in napitnina 2007}

Ciljna populacija so bili zaposleni iz strežbe (natakarski pomočnik, natakar, glavni natakar), kuhinje (kuharski pomočnik, kuhar in glavni kuhar) in recepcije (receptor in vodja recepcije), zaposleni $\mathrm{v}$ različnih organizacijah, ki se ukvarjajo $\mathrm{z}$ gostinsko dejavnostjo (tabela 1).

Tabela 3: Splošni podatki o raziskavi Zaposleni v gostinstvu in napitnina 2007

\begin{tabular}{|c|c|c|c|c|c|}
\hline Čas izvedbe raziskave & \multicolumn{5}{|c|}{2007} \\
\hline Metoda zbiranja podatkov & \multicolumn{5}{|c|}{ Anketiranje po pošti } \\
\hline Vprašalnik & \multicolumn{5}{|c|}{ Vprašalnik je razvil avtor } \\
\hline Kraj anketiranja & \multicolumn{5}{|c|}{ Slovenija } \\
\hline \multicolumn{2}{|c|}{$\begin{array}{l}\text { Skupina I GOSTINSTVO: I 55.1 Dejavnost hotelov in } \\
\text { podobnih nastanitvenih obratov, I } 56.1 \text { Dejavnost } \\
\text { restavracij in druga strežba jedi in I } 56.3 \text { Strežba pijač + } \\
\text { HIT, d. d., iz R KULTURNE, RAZVEDRILNE IN } \\
\text { REKREACIJSKE DEJAVNOSTI: 92.001 Dejavnost } \\
\text { igralnic }\end{array}$} & $\begin{array}{l}\text { Število vseh } \\
\text { velikih podjetij (z } \\
\text { več kot } 30 \\
\text { zaposlenimi)- } \\
\text { populacija }\end{array}$ & $\begin{array}{c}\text { Realiziran } \\
\text { vzorec }\end{array}$ & $\begin{array}{c}\text { Stopnja } \\
\text { odgovorov } \\
\text { glede na } \\
\text { populacijo }\end{array}$ & $\begin{array}{c}\text { Stopnja } \\
\text { odgovorov } \\
\text { glede na } \\
\text { dejavnost }\end{array}$ \\
\hline $\begin{array}{l}\text { Število podjetij (Vir: } \\
\text { AJPES) }\end{array}$ & 1.644 & 80 & 20 & $25 \%$ & $1,2 \%$ \\
\hline \multicolumn{6}{|l|}{ Zaposleni (Vir: SURS) } \\
\hline Strežba & 4.537 & 2.700 & 197 & $7,3 \%$ & $4,3 \%$ \\
\hline Kuhinja & 2.835 & 1.687 & 71 & $4,2 \%$ & $2,5 \%$ \\
\hline Recepcija & 963 & 573 & 26 & $4,5 \%$ & $2,7 \%$ \\
\hline Skupaj & 8.335 & 4.960 & 294 & $5,9 \%$ & $3,5 \%$ \\
\hline
\end{tabular}

\section{Raziskava: Zaposleni v igralništvu in napitnina 2007}

Ciljna populacija so bili zaposleni v igralništvu (krupjeji, vodje miz, inšpektorji na igralnih mizah, kontrolorji in inšpektorji na igralnih avtomatih ter blagajniki), ki so zaposleni v gospodarskih družbah, ki se ukvarjajo z igralniško dejavnostjo (tabela 2).

Tabela 4: Splošni podatki o raziskavi Zaposleni v igralništvu in napitnina 2007

\begin{tabular}{|c|c|c|c|}
\hline Čas izvedbe raziskave & \multicolumn{3}{|c|}{2007} \\
\hline Metoda zbiranja podatkov & \multicolumn{3}{|c|}{ Anketiranje po pošti } \\
\hline Vprašalnik & \multicolumn{3}{|c|}{ Vprašalnik je razvil avtor } \\
\hline Kraj anketiranja & \multicolumn{3}{|c|}{ Slovenija } \\
\hline \multicolumn{2}{|c|}{$\begin{array}{l}\text { Število vseh aktivnih gospodarskih družb v dejavnosti } \mathrm{R} \\
92.001 \text { Dejavnost igralnic - populacija }\end{array}$} & Odgovori & $\begin{array}{l}\text { Stopnja odgovorov } \\
\text { glede na dejavnost } \\
\text { igralnic }\end{array}$ \\
\hline Stevilo podjetij (Vir: AJPES) & 28 & 12 & $43 \%$ \\
\hline \multicolumn{4}{|l|}{ Zaposleni (Vir: SURS) } \\
\hline Igralne mize & 963 & 279 & $29 \%$ \\
\hline Igralni avtomati & 147 & 72 & $49 \%$ \\
\hline Blagajna & 271 & 122 & $45 \%$ \\
\hline Skupaj & 1.381 & 473 & $34 \%$ \\
\hline
\end{tabular}


Zadnja izmed anketnih raziskav je vključevala raziskavo med gostinskimi in igralniškimi gosti igralniško-zabaviščnega centra. Pridobljene (tabela 3 ) podatke se je zbiralo s pomočjo terenske ankete.

Tabela 5: Splošni podatki o raziskavi Gosti igralniško zabaviščnega centra in napitnina 2007

\begin{tabular}{|l|c|}
\hline Metoda zbiranja podatkov & Terensko anketiranje z anketarji \\
\hline Obdobje zbiranja & december 2007 - maj 2008 \\
\hline Trajanje anketiranja & 28 večerov med 20.00 in 23.00 \\
\hline Vprašalnik & Vprašalnik je razvil avtor \\
\hline Lokacija & Igralniško zabaviščna centra Park in Perla \\
\hline Skupno število gostov v dneh, ko je bilo izvedeno anketiranje & 48.979 \\
\hline $\begin{array}{l}\text { Realiziran vzorec (obiskovalci igralniško-zabaviščnega centra, ki so } \\
\text { bili anketirani) }\end{array}$ & 728 \\
\hline $\begin{array}{l}\text { \% odgovorov glede na skupno število gostov v dneh, ko je bilo } \\
\text { izvedeno anketiranje }\end{array}$ & $1,50 \%$ \\
\hline
\end{tabular}

\section{Fokusne skupine z zaposlenimi}

Izvedeno je bilo 15 fokusnih skupin z namenom izluščiti odprte dileme, ki sem jih zaznal pri anketiranju. Potekale so takoj po zaključenem anketiranju zaposlenih.

\section{Opazovanje zaposlenih in gostov $\mathrm{v}$ procesu nastanka napitnine}

Zadnja faza raziskovanja je bilo opazovanje zaposlenih in gostov. Opazovalo se je zaposlene pri njihovem delu ter goste, in sicer s ciljem ugotoviti, kako se gost in zaposleni odzivata na napitnino. $Z$ opazovanjem gostov in zaposlenih sem želel ugotoviti predvsem kakšno je obnašanje gosta, ko da napitnino in zaposlenega, ko prejme napitnino.

Izhajajoč iz zgornjih teoretičnih ugotovitev sem si zastavil cilj, da dejavnike ki vplivajo na napitnino združim v skupine dejavnikov, ki bodo kar se da med gostinstvom in igralništvom primerljivi, ter bodo uporabni tudi za druge storitvene dejavnosti.

Postavljeno je bilo tudi raziskovalno vprašanje: »Ali se dejavniki, ki vplivajo na napitnino med gostinstvom in igralništvom razlikujejo?«

\section{Ugotovitve}

\subsection{Kaj po mnenju zaposlenih in gostov vpliva napitnino}

\section{Rezultati ankete gosti igralniško-zabaviščnega centra in napitnina}

Najpomembnejša elementa, da se gost odloči dati napitnino, sta prijaznost (navedlo jo je $71 \%$ anketiranih gostov) in profesionalnost zaposlenih (69\%). Sledijo kvaliteta storitve $(63 \%)$, hitrost servisa $(36 \%)$ in osebna urejenost $(25 \%)$. Ostali elementi so se zdeli vprašanim manj pomembni, saj jih je izpostavilo manj kot $20 \%$ vprašanih. 
874 36 $6^{\mathrm{TH}}$ InTERnAtional CONFERENCE ON ORganizational SCIENCE Development: RESPONSIBLE ORGANIZATION (MARCH $22^{\mathrm{ND}}-24^{\mathrm{TH}}$, PORTOROŽ SlOVENIA)

A. Raspor: Influence Frequency and the Amount of Received Tips: Factor Analysis of Factors

\section{Rezultati ankete zaposlenih $\mathrm{v}$ gostinstvu}

Zaposleni v gostinstvu so najbolj izpostavili (tabela 4) tiste dejavnike, ki so povezani z njimi samimi in njihovim delom: prijaznost ( $\mathrm{v}$ povprečju so strinjanje s trditvijo pod zaporedno št. 19 ocenili s 4,50), profesionalnost (povprečje 4,46), kakovost storitve (povprečje 4,42), ustreznost servisa (povprečje 4,25) itd. Gre za tiste elemente, na katere lahko zaposleni sami najbolj vplivajo.

Tabela 6: Odločitev gostinskega gosta za napitnino z vidika zaposlenih

\begin{tabular}{|c|c|c|}
\hline \begin{tabular}{|l|} 
V nadaljevanju so navedene določene trditve, s katerimi bi želeli preveriti, \\
kaj po mnenju Vas, ki ste v neposrednem stiku z gosti, najbolj vpliva na \\
napitnino. Prosimo Vas, da s pomočjo navedene lestvice (od l - wsploh se ne \\
strinjam« do 5 »popolnoma se strinjam«) izrazite svoje strinjanje oziroma \\
nestrinjanje s posameznimi trditvami. Pri tem imejte v mislih izključno, kaj \\
po Vašem mnenju vpliva na odločitev gosta za dajanje napitnine. (n=250)
\end{tabular} & $\begin{array}{c}\text { Aritmetična } \\
\text { sredina }\end{array}$ & $\begin{array}{c}\text { Standardn } \\
\text { odklon }\end{array}$ \\
\hline (19)Prijaznost/dobra volja zaposlenih vpliva na višino napitnine. & 4,50 & 0,69 \\
\hline (18)Profesionalnost osebja vpliva na višino napitnine. & 4,47 & 0,70 \\
\hline (17)Napitnina je odvisna od kvalitete storitve. & 4,42 & 0,74 \\
\hline (27)Ustreznost servisa vpliva na višino napitnine. & 4,24 & 0,83 \\
\hline (29)Drobne pozornosti, ki jih poklonimo gostu, vplivajo na višino napitnine. & 4,23 & 0,88 \\
\hline (20)Osebna urejenost osebja vpliva na napitnino. & 4,22 & 0,85 \\
\hline (21)Hitrost servisa vpliva na višino napitnine. & 4,20 & 0,89 \\
\hline (23)Poznavanje jezika gosta vpliva na višino napitnine. & 4,05 & 0,92 \\
\hline (13)Kvaliteta vzdušja v lokalu (restavraciji) vpliva na višino napitnine. & 3,99 & 1,00 \\
\hline (24)To, da v danem trenutku razumeš občutke gosta, vpliva na višino napitnine. & 3,98 & 0,89 \\
\hline (26)Zadovoljstvo $\mathrm{z}$ reševanjem reklamacije vpliva na višino napitnine. & 3,94 & 0,96 \\
\hline (25)Natakarjevo poznavanje menijev vpliva na višino napitnine. & 3,86 & 0,94 \\
\hline (14)Notranjost lokala vpliva na višino napitnine. & 3,81 & 0,99 \\
\hline (16)Napitnina je odvisna od razmerja cena - kvaliteta. & 3,78 & 1,05 \\
\hline $\begin{array}{l}\text { (28)Na višino napitnine vpliva, če gost dobi za isto ceno nekaj več kot pri } \\
\text { konkurenci. }\end{array}$ & 3,74 & 1,10 \\
\hline (9)Napitnina je odvisna od vrste restavracije. & 3,72 & 1,12 \\
\hline (10)Dobri medseboini odnosi (v skupini) vplivajo na višino napitnine. & 3,48 & 1,09 \\
\hline (15)Napitnina je odvisna od raznolikosti ponudbe hrane. & 3,32 & 1,02 \\
\hline (11)Sistem nagrajevanja $\mathrm{z}$ napitnino vpliva na njeno višino. & 2,80 & 1,16 \\
\hline (2)Napitnina se veča s pogostostio obiska. & 2,79 & 1,10 \\
\hline (6)Spol osebja vpliva na višino napitnine. & 2,73 & 1,17 \\
\hline $\begin{array}{l}\text { (12)Pravila delodajalca, da dovoljuje sprejemanje napitnine, vplivajo na njeno } \\
\text { višino. }\end{array}$ & 2,69 & 1,33 \\
\hline (1)Gostje dajejo napitnino iz navade. & 2,68 & 1,10 \\
\hline (7)Narodnost osebja vpliva na višino napitnine. & 2,65 & 1,34 \\
\hline (4)Večje kot je število gostov, višja je napitnina. & 2,64 & 1,19 \\
\hline (22)Dodatki k oblačilom vplivajo na višino napitnine. & 2,48 & 1,13 \\
\hline (8)Vreme vpliva na višino napitnine. & 2,38 & 1,14 \\
\hline (3)Večje kot je naročilo (transakcija), višja je napitnina. & 2,34 & 1,05 \\
\hline (5)Pri plačilu s kreditno kartico je napitnina višja. & 1,55 & 0,82 \\
\hline
\end{tabular}

Od skupaj 29 ocenjevanih dejavnikov jih je 17 prejelo višje povprečje od 3,35 ${ }^{1}$, zato jih lahko vzamem kot dejavnike, ki po mnenju zaposlenih vplivajo na odločitev gosta, da se odloči dati napitnino. Zelo nizko strinjanje (povprečje nižje od 2,5) pa je značilno za 
dejavnike, kot so dodatki $\mathrm{k}$ oblačilom, vreme, velikost naročila in plačilo s kreditno kartico, torej dejavnike, na katere zaposleni večinoma ne morejo vplivati. Zaposleni torej visoko vrednotijo kot pomembne za napitnino podobne dejavnike kot gostinski gosti (Raspor, 2007b str. 103).

\section{Rezultati ankete zaposlenih v igralništvu}

Zaposleni v igralništvu menijo, da najbolj (tabela 5) vpliva na napitnino: prijaznost (v povprečju so strinjanje s trditvijo pod zaporedno št. 19 ocenili z 4,59), profesionalnost (povprečje 4,56), kvaliteta storitve (povprečje 4,44), višina dobitka (povprečje 4,21) itd.

Tabela 7: Odločitev igralniškega gosta za napitnino z vidika zaposlenih

\begin{tabular}{|c|c|c|}
\hline $\begin{array}{l}\text { V nadaljevanju so navedene določene trditve, s katerimi bi želeli preveriti, } \\
\text { kaj po mnenju Vas, ki ste v neposrednem stiku z gosti, najbolj vpliva na } \\
\text { napitnino. Prosimo Vas, da s pomočjo navedene lestvice (od l - «sploh se ne } \\
\text { strinjam« do } 5 \text { »popolnoma se strinjam«) izrazite svoje strinjanje oziroma } \\
\text { nestrinjanje s posameznimi trditvami. Pri tem imejte v mislih izključno, kaj } \\
\text { po Vašem mnenju vpliva na odločitev gosta za dajanje napitnine. }(n=389) \\
\end{array}$ & $\begin{array}{c}\text { Aritmetična } \\
\text { sredina }\end{array}$ & $\begin{array}{c}\begin{array}{c}\text { Standardni } \\
\text { odklon }\end{array} \\
\end{array}$ \\
\hline (19)Prijaznost/dobra volja zaposlenih vpliva na višino napitnine. & 4,59 & 0,63 \\
\hline (18)Profesionalnost osebja vpliva na višino napitnine. & 4,56 & 0,61 \\
\hline (17)Napitnina je odvisna od kvalitete storitve. & 4,44 & 0,73 \\
\hline (28)Višina dobitka vpliva na višino napitnine. & 4,21 & 0,91 \\
\hline (29)Drobne pozornosti, ki jih poklonimo gostu, vplivajo na višino napitnine. & 4,11 & 0,87 \\
\hline (10)Napitnina je odvisna od vrste igre. & 4,06 & 1,07 \\
\hline (20)Osebna urejenost osebja vpliva na napitnino. & 4,05 & 0,81 \\
\hline (24)To, da v danem trenutku razumeš občutke gosta, vpliva na višino napitnine. & 4,04 & 0,88 \\
\hline (14)Kvaliteta vzdušja v igralnici vpliva na višino napitnine. & 4,01 & 0,95 \\
\hline (21)Hitrost servisa vpliva na višino napitnine. & 3,96 & 0,92 \\
\hline (26)Zadovoljstvo $\mathrm{z}$ reševanjem reklamacije vpliva na višino napitnine. & 3,96 & 0,88 \\
\hline (27)Ustreznost servisa vpliva na višino napitnine. & 3,92 & 0,92 \\
\hline (23)Poznavanje jezika gosta vpliva na višino napitnine. & 3,88 & 0,96 \\
\hline (4)Višja kot je stava, višja je napitnina. & 3,68 & 1,10 \\
\hline (12)Sistem nagrajevanja $z$ napitnino vpliva na njeno višino. & 3,68 & 1,20 \\
\hline (15)Notranjost igralnice vpliva na višino napitnine. & 3,67 & 0,97 \\
\hline (11)Dobri medsebojni odnosi vplivajo na višino napitnine. & 3,66 & 1,02 \\
\hline (25)Krupjejevo poznavanje pravil igre vpliva na višino napitnine. & 3,62 & 1,01 \\
\hline $\begin{array}{l}\text { (13)Pravila delodajalca, da dovoljuje sprejemanje napitnine, vplivajo na njeno } \\
\text { višino. }\end{array}$ & 3,60 & 1,27 \\
\hline (2)Gostje dajejo napitnino misleč, da jim krupje prinaša srečo pri igri. & 3,34 & 0,94 \\
\hline (16)Napitnina je odvisna od raznolikosti ponudbe. & 3,33 & 0,93 \\
\hline (6)V primeru da dobitek razdrobiš, je večja možnost napitnine. & 3,18 & 1,06 \\
\hline (1)Gostje dajejo napitnino iz navade. & 3,15 & 0,97 \\
\hline (5)Večje kot je število gostov, višja je napitnina. & 3,11 & 1,20 \\
\hline (7)Spol osebja vpliva na višino napitnine. & 3,05 & 1,07 \\
\hline (3)Napitnina se veča s pogostostjo obiska. & 2,74 & 1,07 \\
\hline (22)Dodatki k oblačílom vplivajo na višino napitnine. & 2,42 & 1,03 \\
\hline (8)Narodnost osebja vpliva na višino napitnine. & 2,30 & 1,20 \\
\hline (9)Vreme vpliva na višino napitnine. & 2,13 & 1,06 \\
\hline
\end{tabular}

Poleg tega se je v zgornji sklop uvrstilo tudi to, da je napitnina odvisna od vrste iger (povprečje 4,06). V praksi je dejansko tako (kar sem ugotovili z opazovanjem in analizo 
$36^{\text {TH }}$ International Conference on Organizational Science Development: RESPONSIBLE ORGANIZATION (MARCH $22^{\mathrm{ND}}-24^{\mathrm{TH}}$, PortoroŽ SLOVENIA)

A. Raspor: Influence Frequency and the Amount of Received Tips: Factor Analysis of Factors

podatkov), da je za igro ameriško ruleta značilna večja napitnina kot za igro black jack, saj obstaja nepisano pravilo, da naj bi gost obdaril zaposlenega pri ameriški ruleti ob dobitku na polno z enim žetonom, medtem ko je napitnina na black jacku bolj izjema kot pravilo. Od skupaj 29 trditev jih je 20 prejelo višjo povprečno oceno od 3,35. Zato jih lahko vzamem kot elemente, ki po mnenju zaposlenih vplivajo na napitnino v igralništvu. Zelo nizko strinjanje pa je značilno za dodatke k oblačilom (povprečje 2,42), narodnost (povprečje 2,3) in vreme (povprečje 2,13).

\section{Dodatni dejavniki}

Zaposlenim je bilo postavljeno tudi odprto anketno vprašanje »Katere načine za dvigovanje napitnine poznate? «, in sicer z namenom, da bi sami poimenovali te prakse. To vprašanje je bilo postavljeno na začetku vprašalnika zato, da bi ob izpolnjevanju vprašalnika čim manj vplivali na anketirance z ostalimi vprašanji. Na ta način se je zbralo še dodatne primere dobre prakse za dvigovanje napitnine, ki mi iz literature in izkušenj niso bili poznani. Dejansko gre za prepoznavanje splošnih vzorcev in povezav (Ragin, 2007 str. 47), ki so prisotni med zaposlenimi in se prenašajo bolj ali manj nenadzorovano.

V gostinstvu je le slaba tretjina (29 \%) anketirancev (med natakarji 40 \%), v igralništvu pa dve petini (42\% oz. med krupjeji $52 \%$ ) v odgovoru navedlo vsaj en način za dvigovanje napitnine. Vzrokov za tako nizek odstotek navedb je več. Poleg tega, da je bilo vprašanje odprto, kar je iz anketne teorije poznano kot težko vprašanje z značilno večjo stopnjo neodgovorov (Groves in drugi, 2004), je to dejansko lahko posledica tega, da zaposleni pač ne poznajo načinov povečevanja napitnine ali pa se svojega obnašanja ne zavedajo oz. načine uporabljajo podzavestno. To je morda posledica tudi tega, da zaposleni niso deležni izobraževanja za dvigovanje napitnine.

Med načini, ki so bili omenjeni, imajo največji pomen prijaznost, ustrežljivost, nasmeh ipd., skratka dejavniki, ki jih štejemo med notranje dejavnike, odvisne od zaposlenih samih. Vendar so bili dejansko med odgovori omenjeni vsi dejavniki, ki sem jih prej (Tabele 4 in 5) že omenjal, navedenih pa je bilo tudi nekaj dejavnikov, ki jih do sedaj nisem obravnaval: timsko delo v kuhinji, domačnost $v$ restavraciji in sproščeno vzdušje v lokalu za gostinstvo ter motiviranost zaposlenih, sočutje, spodbudne besede, veselje zaposlenega ob gostovem dobitku, empatija, učenje bontona (kulture) napitnine za igralništvo. Vsem je skupno to, da so $\mathrm{v}$ neposredni povezavi z delom ali kakovostno storitvijo.

\subsection{Oblikovanje skupine dejavnikov}

\section{Rezultati ankete zaposlenih v gostinstvu}

S faktorsko analizo sem na osnovi 29 trditev (merjenih spremenljivk, ki so bile predstavljene v prejšnem poglavju) določil 7 dejavnikov, ki pojasnjujejo $50 \%$ celotne variabilnosti merjenih spremenljivk (tabela 6). 
A. Raspor: Pogostost in višina prejete napitnine: faktorska analiza dejavnikov

Faktorske uteži teh sedmih dejavnikov, dobljene po poševni rotaciji z metodo Oblimin, so predstavljene $\mathrm{v}$ tabeli 8 . Prvi dejavnik močno pozitivno korelira $\mathrm{z}$ naslednjimi šestimi trditvami: 19,18, 20,17, 13, in 29 (prijaznost, profesionalnost, osebna urejenost, kvaliteta storitve ter vzdušja in drobne pozornosti). Ta dejavnik torej meri neko »osebno noto « ali pridih, ki je odvisen večinoma zgolj od zaposlenega samega in sem ga zato poimenoval »tipične značilnosti osebja«. Drugi dejavnik močno pozitivno korelira s štirimi trditvami: $3,4,1$ in 2 (velikost naročila, številčnost gostov, dajanje napitnine iz navade ter večanje napitnine s pogostostjo obiska), torej meri nekakšne »neodvisne gostinske dejavnike«. Tretji dejavnik negativno korelira s trditvami 25, 24, 23, 26, 21, 27 in 22 (poznavanje menijev, razumevanja potreb gosta, poznavanja jezika, reševanje reklamacij, hitrost in ustreznost servisa ter dodatki k oblačilom), torej meri »kompetence zaposlenih«. Četrti dejavnik pozitivno korelira s trditvami 15, 16, 14, 28, katerih skupni imenovalec je storitev sama v povezavi s ceno (raznolikost ponudbe, razmerje cena/kvaliteta, urejena notranjost lokala in cenovna konkurenčnost). Poimenoval sem ga »posebnost ponudbe restavracije «. Trditve 6,7 in 8 (narodnost in spol osebja ter vreme) pozitivno korelirajo s petim dejavnikom in gre za dejavnike, na katere ne moramo vplivati, zato sem ta dejavnik poimenoval »neodvisni dejavniki«. Šesti dejavnik je pozitivno koreliran z eno samo trditvijo (5) in sem ga poimenoval »način plačila«. Zadnji, sedmi dejavnik negativno korelira s trditvami 12,11,10, 9 (pravila delodajalca, sistem nagrajevanja, medsebojni odnosi in vrsta restavracije). Dejavnik torej meri predvsem neka zunanja, vnaprej določena pravila in sem ga zato poimenoval »stopnja formalizacije dela $v$ restavraciji $\ll$. 
36 ${ }^{\mathrm{TH}}$ International Conference on Organizational Science Development: RESPONSIBLE ORGANIZATION (MARCH $22^{\mathrm{ND}}-24^{\mathrm{TH}}$, PORTOROŽ SlOVENIA)

A. Raspor: Influence Frequency and the Amount of Received Tips: Factor Analysis of Factors

Tabela 8: Total Variance Explained - gostinstvo

\begin{tabular}{|c|c|c|c|c|c|c|c|}
\hline \multirow[b]{2}{*}{ Factor } & \multicolumn{3}{|c|}{ Initial Eigenvalues } & \multicolumn{3}{|c|}{ Extraction Sums of Squared Loadings } & \multirow{2}{*}{$\begin{array}{c}\text { Rotation } \\
\text { Total } \\
\end{array}$} \\
\hline & Total & $\%$ of Variance & Cumulative $\%$ & Total & $\%$ of Variance & Cumulative $\%$ & \\
\hline 1 & 7,955 & 27.430 & 27,430 & 7,508 & 25,889 & 25,889 & $\overline{5,102}$ \\
\hline 2 & 3,093 & 10,864 & 38,094 & 2,578 & 8,889 & 34,778 & 2,233 \\
\hline 3 & 1,805 & 6,226 & 44,320 & 1,351 & 4,659 & 39,437 & 4,562 \\
\hline 4 & 1,599 & 5,513 & 49,833 & 1,085 & 3,741 & 43,179 & 3,982 \\
\hline 5 & 1,272 & 4,386 & 54,219 & .789 & 2,720 & 45,899 & 2,060 \\
\hline 6 & 1,110 & 3.829 & 58,048 & .611 & 2,105 & 48,004 & 1.130 \\
\hline 7 & 1,025 & 3,535 & 61,583 & .506 & 1,745 & 49,749 & 3,228 \\
\hline 8 & .988 & 3.408 & 64,991 & & & & \\
\hline 9 & .872 & 3,007 & 67,999 & & & & \\
\hline 10 & .806 & 2,781 & 70,780 & & & & \\
\hline 11 & .793 & 2,734 & 73,513 & & & & \\
\hline 12 & .703 & 2,424 & 75,937 & & & & \\
\hline 13 & .680 & 2,344 & 78.281 & & & & \\
\hline 14 & .644 & 2,222 & 80,503 & & & & \\
\hline 15 & .611 & 2,107 & 82,609 & & & & \\
\hline 16 & .545 & 1,880 & 84,489 & & & & \\
\hline 17 & .523 & 1,804 & 86,293 & & & & \\
\hline 18 & .495 & 1,707 & 88,000 & & & & \\
\hline 19 & .440 & 1,517 & 89,517 & & & & \\
\hline 20 & .422 & 1,458 & 90,974 & & & & \\
\hline 21 & .373 & 1,285 & 92,258 & & & & \\
\hline 22 & .350 & 1,208 & 93,464 & & & & \\
\hline 23 & 348 & 1,201 & 94,685 & & & & \\
\hline 24 & .334 & 1.151 & 95,815 & & & & \\
\hline 25 & .308 & 1,063 & 96,878 & & & & \\
\hline 26 & .283 & .906 & 97,785 & & & & \\
\hline 27 & .234 & .805 & 98,590 & & & & \\
\hline 28 & .213 & .734 & 99,324 & & & & \\
\hline 29 & .198 & .678 & 100,000 & & & & \\
\hline
\end{tabular}

Povprečje faktorskih indeksov je razvidno iz tabele 7. Dejavniki (1)»Tipične značilnosti osebja«, (3) »Kompetence zaposlenih« in (4)»Posebnost ponudbe restavracije« so dobili višje povprečje od 3,35. Dejavnik (6) »Način plačila« pa je dobil nižjo oceno od 2,5 $(1,974)$, kar kaže, da mu zaposleni ne dajejo nobene teže.

Tabela 9: Povprečje faktorskih indeksov za gostinstvo

\begin{tabular}{|c|c|c|c|c|c|c|c|c|c|c|}
\hline & $\mathrm{N}$ & Min. & Max. & Mean & \multicolumn{2}{|c|}{ Std. Deviation } & Skewness & & Kurtosis & \\
\hline & Statistic & Statistic & Statistic & Statistic & $\begin{array}{c}\text { Std. } \\
\text { Error }\end{array}$ & Statistic & Statistic & \begin{tabular}{|c|} 
Std. \\
Error \\
\end{tabular} & Statistic & $\begin{array}{c}\text { Std. } \\
\text { Error }\end{array}$ \\
\hline $\begin{array}{l}\text { (1)Tipične } \\
\text { značilnosti osebja }\end{array}$ & 245 & 2,3 & 5 & 4,327 & 0,037 & 0,585 & $-1,058$ & 0,156 & 0,644 & 0,310 \\
\hline $\begin{array}{l}\text { (3)Kompetence } \\
\text { zaposlenih }\end{array}$ & 245 & 1 & 5 & 3,826 & 0,043 & 0,675 & $-0,567$ & 0,156 & 0,726 & 0,310 \\
\hline $\begin{array}{l}\text { (4)Posebnost } \\
\text { ponudbe } \\
\text { restavracije }\end{array}$ & 253 & 1 & 5 & 3,664 & 0,050 & 0,789 & $-0,516$ & 0,153 & 0,235 & 0,305 \\
\hline $\begin{array}{l}\text { (7)Stopnjo } \\
\text { formalizacije } \\
\text { dela v restavraciji }\end{array}$ & 241 & 1 & 5 & 3,187 & 0,055 & 0,853 & $-0,375$ & 0,157 & 0,089 & 0,312 \\
\hline $\begin{array}{l}\text { (5)Neodvisni } \\
\text { dejavniki }\end{array}$ & 250 & 1 & 5 & 2,684 & 0,067 & 1,053 & $-0,049$ & 0,154 & $-0,765$ & 0,307 \\
\hline $\begin{array}{l}\text { (2)Neodvisni } \\
\text { gostinski } \\
\text { dejavniki }\end{array}$ & 249 & 1 & 4,5 & 2,616 & 0,049 & 0,768 & $-0,092$ & 0,154 & $-0,374$ & 0,307 \\
\hline (6)Način plačila & 247 & 1 & 5 & 1,974 & 0,051 & 0,794 & 0,848 & \begin{tabular}{|l|}
0,155 \\
\end{tabular} & 0,716 & 0,309 \\
\hline $\begin{array}{l}\text { Valid N } \\
\text { (listwise) }\end{array}$ & 215 & & & & & & & & & \\
\hline
\end{tabular}


Tabela 10: Faktorska analiza - gostinstvo

\begin{tabular}{|c|c|c|c|c|c|c|c|}
\hline & Pattern & Matrix & & & & & \\
\hline & $\begin{array}{ll}1 . \\
\text { faktor }\end{array}$ & \begin{tabular}{|l|}
2. \\
faktor
\end{tabular} & $\begin{array}{l}3 . \\
\text { faktor }\end{array}$ & \begin{tabular}{|l|}
4. \\
faktor
\end{tabular} & \begin{tabular}{|l|l}
5. \\
faktor
\end{tabular} & \begin{tabular}{|l|l|}
6. \\
faktor
\end{tabular} & $\begin{array}{l}7 . \\
\text { faktor }\end{array}$ \\
\hline $\begin{array}{l}\text { (19)Prijaznost/dobra volja zaposlenih vpliva na višino } \\
\text { napitnine. }\end{array}$ & 0,789 & & & & & & \\
\hline (18)Profesionalnost osebja vpliva na višino napitnine. & 0,771 & & & & & & \\
\hline (20)Osebna urejenost osebja vpliva na napitnino. & 0,601 & & & & & & \\
\hline (17)Napitnina je odvisna od kvalitete storitve. & 0,511 & & & & & & \\
\hline $\begin{array}{l}\text { (13)Kvaliteta vzdušja v lokalu (restavraciji) vpliva na } \\
\text { višino napitnine. }\end{array}$ & 0,448 & & & & & & \\
\hline $\begin{array}{l}\text { (29)Drobne pozornosti, ki jih poklonimo gostu, vplivajo } \\
\text { na višino napitnine. }\end{array}$ & 0,425 & & & & & & \\
\hline (3)Večje kot je naročilo (transakcija), višja je napitnina. & & 0,764 & & & & & \\
\hline (4)Večje kot je število gostov, višja je napitnina. & & 0,482 & & & & & \\
\hline (1)Gostje dajejo napitnino iz navade. & & 0,405 & & & & & \\
\hline (2)Napitnina se veča s pogostostio obiska. & & 0,388 & & & & & \\
\hline $\begin{array}{l}\text { (25)Natakarjevo poznavanje menijev vpliva na višino } \\
\text { napitnine. }\end{array}$ & & & $-0,787$ & & & & \\
\hline $\begin{array}{l}\text { (24)To, da v danem trenutku razumeš občutke gosta, } \\
\text { vpliva na višino napitnine. }\end{array}$ & & & $-0,621$ & & & & \\
\hline (23)Poznavanje jezika gosta vpliva na višino napitnine. & & & $-0,546$ & & & & \\
\hline $\begin{array}{l}\text { (26)Zadovoljstvo } z \text { reševanjem reklamacije vpliva na } \\
\text { višino napitnine. }\end{array}$ & & & $-0,542$ & & & & \\
\hline (21)Hitrost servisa vpliva na višino napitnine. & & & $-0,485$ & & & & \\
\hline (27)Ustreznost servisa vpliva na višino napitnine. & & & $-0,447$ & & & & \\
\hline (22)Dodatki k oblačilom vplivajo na višino napitnine. & & & $-0,428$ & & & & \\
\hline (15)Napitnina je odvisna od raznolikosti ponudbe hrane. & & & & 0,693 & & & \\
\hline (16)Napitnina je odvisna od razmerja cena - kvaliteta. & & & & 0,660 & & & \\
\hline (14)Notranjost lokala vpliva na višino napitnine. & & & & 0,502 & & & \\
\hline $\begin{array}{l}\text { (28)Na višino napitnine vpliva, če gost dobi za isto ceno } \\
\text { nekaj več kot pri konkurenci. }\end{array}$ & & & & 0,322 & & & \\
\hline (7)Narodnost osebja vpliva na višino napitnine. & & & & & 0,710 & & \\
\hline (6) Spol osebja vpliva na višino napitnine. & & & & & 0,575 & & \\
\hline (8)Vreme vpliva na višino napitnine. & & & & & 0,435 & & \\
\hline (5)Pri plačilu s kreditno kartico je napitnina višja. & & & & & & 0,257 & \\
\hline $\begin{array}{l}\text { (12)Pravila delodajalca, da dovoljuje sprejemanje } \\
\text { napitnine, vplivajo na njeno višino. }\end{array}$ & & & & & & & $-0,811$ \\
\hline $\begin{array}{l}\text { (11)Sistem nagrajevanja } \mathrm{z} \text { napitnino vpliva na njeno } \\
\text { višino. }\end{array}$ & & & & & & & $-0,651$ \\
\hline $\begin{array}{l}\text { (10)Dobri medsebojni odnosi ( } \mathrm{v} \text { skupini) vplivajo na } \\
\text { višino napitnine. }\end{array}$ & & & & & & & $\mid-0,416$ \\
\hline (9)Napitnina je odvisna od vrste restavracije. & & & & & & & $-0,246$ \\
\hline
\end{tabular}

\section{Rezultati ankete zaposlenih v igralništvu}

S faktorsko (tabela 10) analizo, izvedeno po poševni rotaciji z metodo Oblimin, pridobim 8 različnih dejavnikov, ki razložijo $42 \%$ celotne (tabela 9) variabilnosti.

Trije so pozitivni, pet pa negativnih. Prvi dejavnik močno pozitivno korelira z naslednjimi šestimi trditvami, ki so enake kot pri zaposlenih v gostinstvu: 19, 18, 20, 21, 17 in 11 (prijaznost, profesionalnost, osebna urejenost, hitrost servisa, kvaliteta storitve 
A. Raspor: Influence Frequency and the Amount of Received Tips: Factor Analysis of Factors

in dobri medsebojni odnosi). Te trditve prikazujejo neko »osebno noto« ali pridih, ki je odvisen večinoma zgolj od zaposlenih. Poimenoval sem ga »tipične značilnosti osebja«. Drugi dejavnik močno pozitivno korelira s štirimi trditvami: 5, 3, 4 in 6 (število gostov, pogostost obiska, višina stave in razdrobljen dobitek), torej meri nekakšne »neodvisne igralniške dejavnike«.

Tabela 11: Total Variance Explained - igralništvo

\begin{tabular}{|c|c|c|c|c|c|c|c|}
\hline \multirow[b]{2}{*}{ Factor } & \multicolumn{3}{|c|}{ Initial Eigenvalues } & \multicolumn{3}{|c|}{ Extraction Sums of Squared Loadings } & \multirow{2}{*}{$\begin{array}{c}\text { Rotation } \\
\text { Total } \\
\end{array}$} \\
\hline & Total & $\%$ of Variance & Cumulative \% & Total & $\%$ of Variance & Cumulative \% & \\
\hline 1 & 6,635 & 22,880 & 22,880 & 6,121 & 21,106 & 21,106 & 4,200 \\
\hline 2 & 2,236 & 7,712 & 30,592 & 1,646 & 5,675 & 26,781 & 1,904 \\
\hline 3 & 1,736 & 5,985 & 36,578 & 1,122 & 3,870 & 30,651 & 1,489 \\
\hline 4 & 1,514 & 5,220 & 41,797 & ,962 & 3,316 & 33,968 & 2,332 \\
\hline 5 & 1,343 & 4,633 & 46,430 &, 831 & 2,866 & 36,834 & 3,070 \\
\hline 6 & 1,250 & 4,312 & 50,741 & ,608 & 2,097 & 38,930 & 1,319 \\
\hline 7 & 1,140 & 3,931 & 54,673 &, 576 & 1,985 & 40,916 & 2,102 \\
\hline 8 & 1,030 & 3,551 & 58,224 & ,472 & 1,627 & 42,542 & 2,965 \\
\hline 9 & ,904 & 3,118 & 61,342 & & & & \\
\hline 10 & 857 & 2,953 & 64,295 & & & & \\
\hline 11 & ,805 & 2,777 & 67,072 & & & & \\
\hline 12 &, 787 & 2,713 & 69,786 & & & & \\
\hline 13 & ,769 & 2,653 & 72,439 & & & & \\
\hline 14 & ,750 & 2,587 & 75,026 & & & & \\
\hline 15 & ,699 & 2,410 & 77,436 & & & & \\
\hline 16 & ,656 & 2,263 & 79,699 & & & & \\
\hline 17 & ,612 & 2,112 & 81,810 & & & & \\
\hline 18 & ,587 & 2,025 & 83,836 & & & & \\
\hline 19 & ,546 & 1,884 & 85,720 & & & & \\
\hline 20 & ,539 & 1,860 & 87,580 & & & & \\
\hline 21 & ,508 & 1,753 & 89,333 & & & & \\
\hline 22 & ,470 & 1,620 & 90,953 & & & & \\
\hline 23 & ,440 & 1,518 & 92,471 & & & & \\
\hline 24 & ,417 & 1,438 & 93,909 & & & & \\
\hline 25 & ,399 & 1,374 & 95,283 & & & & \\
\hline 26 & ,382 & 1,317 & 96,600 & & & & \\
\hline 27 & ,351 & 1,211 & 97,811 & & & & \\
\hline 28 & ,336 & 1,159 & 98,970 & & & & \\
\hline 29 &, 299 & 1,030 & 100,000 & & & & \\
\hline
\end{tabular}

Tretji dejavnik pozitivno korelira s tremi trditvami: 9, 8, 7 in 22 (vreme, narodnost gostov, dodatki k oblačilom in spol osebja), torej meri »neodvisne dejavnike«, na katere nimamo vpliva. Četrti dejavnik močno negativno korelira s tremi trditvami: 12, 13 in 14 (sistem nagrajevanja, pravila delodajalca in kvaliteta vzdušja v igralnici). Dejavnik torej meri predvsem vnaprej določena pravila delodajalca in odnosov med zaposlenimi, zato sem ga poimenoval »stopnja formalizacije dela $\mathrm{v}$ igralnici«. Peti dejavnik ponovno močno negativno korelira s štirimi trditvami: $28,26,29$ in 27 (višina dobitka, reševanje reklamacij, drobne pozornosti in ustreznost servisa), ki jih lahko poimenujem kot 
»zadovoljstvo gostov«. Šesti dejavnik negativno korelira s tremi trditvami: 2,1 in 10 (vraževernost in navada gostov ter vrsta igre). Poimenoval sem ga »igralniški dejavniki«. S predzadnjim, sedmim dejavnikom negativno korelirajo trditve: 25,24 in 23 (poznavanje pravil igre, empatija in poznavanje jezika gosta), torej meri »kompetence zaposlenih «. Z zadnjim dejavnikom negativno korelirajo trditve: 15 in 16 katerih skupni imenovalec je notranjost igralnice in ponudba iger. Poimenoval sem ga $»$ posebnost ponudbe igralnice«.

Tabela 12: Faktorska analiza - igralništvo

\begin{tabular}{|c|c|c|c|c|c|c|c|c|}
\hline & \multicolumn{8}{|c|}{ Pattern Matrix(a) } \\
\hline & $\begin{array}{c}1 . \\
\text { faktor }\end{array}$ & $\begin{array}{c}2 . \\
\text { fakto } \\
\mathrm{r}\end{array}$ & $\begin{array}{c}3 . \\
\text { faktor }\end{array}$ & $\begin{array}{c}4 . \\
\text { faktor }\end{array}$ & $\begin{array}{c}5 . \\
\text { faktor }\end{array}$ & $\begin{array}{c}6 . \\
\text { faktor }\end{array}$ & 7. faktor & 8. faktor \\
\hline $\begin{array}{l}\text { (19)Prijaznost/dobra volja zaposlenih vpliva na } \\
\text { višino napitnine. }\end{array}$ & 0,823 & & & & & & & \\
\hline $\begin{array}{l}\text { (18)Profesionalnost osebja vpliva na višino } \\
\text { napitnine. }\end{array}$ & 0,687 & & & & & & & \\
\hline $\begin{array}{l}\text { (20)Osebna urejenost osebja vpliva na } \\
\text { napitnino. }\end{array}$ & 0,520 & & & & & & & \\
\hline (21)Hitrost servisa vpliva na višino napitnine. & 0,433 & & & & & & & \\
\hline (17)Napitnina je odvisna od kvalitete storitve. & 0,416 & & & & & & & \\
\hline $\begin{array}{l}\text { (11)Dobri medsebojni odnosi vplivajo na } \\
\text { višino napitnine. }\end{array}$ & 0,277 & & & & & & & \\
\hline $\begin{array}{l}\text { (5)Večje kot je število gostov, višja je } \\
\text { napitnina. }\end{array}$ & & 0,645 & & & & & & \\
\hline (3)Napitnina se veča s pogostostjo obiska. & & 0,508 & & & & & & \\
\hline (4)Višja kot je stava, višja je napitnina. & & 0,432 & & & & & & \\
\hline $\begin{array}{l}\text { (6)V primeru da dobitek razdrobiš, je večja } \\
\text { možnost napitnine. }\end{array}$ & & 0,367 & & & & & & \\
\hline (9) Vreme vpliva na višino napitnine. & & & 0,539 & & & & & \\
\hline (8)Narodnost osebja vpliva na višino napitnine. & & & 0,523 & & & & & \\
\hline $\begin{array}{l}\text { (22)Dodatki k oblačilom vplivajo na višino } \\
\text { napitnine. }\end{array}$ & & & 0,440 & & & & & \\
\hline (7)Spol osebja vpliva na višino napitnine. & & & 0,354 & & & & & \\
\hline $\begin{array}{l}\text { (12) Sistem nagrajevanja } z \text { napitnino vpliva na } \\
\text { njeno višino. }\end{array}$ & & & & $-0,762$ & & & & \\
\hline $\begin{array}{l}\text { (13)Pravila delodajalca, da dovoljuje } \\
\text { sprejemanje napitnine, vplivajo na njeno } \\
\text { višino. }\end{array}$ & & & & $-0,648$ & & & & \\
\hline $\begin{array}{l}\text { (14)Kvaliteta vzdušja v igralnici vpliva na } \\
\text { višino napitnine. }\end{array}$ & & & & $-0,312$ & & & & \\
\hline (28)Višina dobitka vpliva na višino napitnine. & & & & & $-0,756$ & & & \\
\hline $\begin{array}{l}\text { (26)Zadovoljstvo } z \text { reševanjem reklamacije } \\
\text { vpliva na višino napitnine. }\end{array}$ & & & & & $-0,509$ & & & \\
\hline $\begin{array}{l}\text { (29)Drobne pozornosti, ki jih poklonimo gostu, } \\
\text { vplivajo na višino napitnine. }\end{array}$ & & & & & $-0,460$ & & & \\
\hline $\begin{array}{l}\text { (27)Ustreznost servisa vpliva na višino } \\
\text { napitnine. }\end{array}$ & & & & & $-0,448$ & & & \\
\hline $\begin{array}{l}\text { (2)Gostje dajejo napitnino misleč, da jim } \\
\text { krupje prinaša srečo pri igri. }\end{array}$ & & & & & & $-0,526$ & & \\
\hline (1)Gostje dajejo napitnino iz navade. & & & & & & $-0,432$ & & \\
\hline (10)Napitnina je odvisna od vrste igre. & & & & & & $-0,383$ & & \\
\hline $\begin{array}{l}(25) \text { Krupjejevo poznavanje pravil igre vpliva } \\
\text { na višino napitnine. }\end{array}$ & & & & & & & $-0,514$ & \\
\hline $\begin{array}{l}\text { (24)To, da v danem trenutku razumeš občutke } \\
\text { gosta, vpliva na višino napitnine. }\end{array}$ & & & & & & & $-0,444$ & \\
\hline $\begin{array}{l}\text { (23)Poznavanje jezika gosta vpliva na višino } \\
\text { napitnine. }\end{array}$ & & & & & & & $-0,251$ & \\
\hline $\begin{array}{l}\text { (15)Notranjost igralnice vpliva na višino } \\
\text { napitnine. }\end{array}$ & & & & & & & & $-0,681$ \\
\hline $\begin{array}{l}\text { (16)Napitnina je odvisna od raznolikosti } \\
\text { ponudbe. }\end{array}$ & & & & & & & & $-0,481$ \\
\hline
\end{tabular}


$36^{\text {TH }}$ International Conference on Organizational Science Development: Responsible ORGANizATION (MARCH $22^{\mathrm{ND}}-24^{\mathrm{TH}}$, PoRTOROŽ Slovenia)

A. Raspor: Influence Frequency and the Amount of Received Tips: Factor Analysis of Factors

Povprečje faktorskih indeksov (tabela 11) kaže na to, da so dobili dejavniki (1) »Tipične značilnosti osebja«, (5) »Zadovoljstvo gostov«, (7) »Kompetence zaposlenih«, (4) »Stopnja formalizacije dela v igralnici«, (6) »Igralniški dejavniki« in (8) »Posebnost ponudbe igralnice« najvišjo oceno. Dejavnik (3) »Neodvisni dejavniki« pa je dobil oceno 2,478, kar kaže na to, da mu zaposleni dajejo minimalno težo.

Tabela 13: Povprečje faktorskih indeksov za igralništvo

\begin{tabular}{|c|c|c|c|c|c|c|c|c|c|c|}
\hline & $\mathrm{N}$ & Minimum & Maximum & Mean & & \begin{tabular}{|c|} 
Std. \\
Deviation \\
\end{tabular} & Skewness & & Kurtosis & \\
\hline & Statistic & Statistic & Statistic & Statistic & $\begin{array}{c}\text { Std. } \\
\text { Error }\end{array}$ & Statistic & Statistic & \begin{tabular}{c|} 
Std. \\
Error
\end{tabular} & Statistic & $\begin{array}{l}\text { Std. } \\
\text { Error }\end{array}$ \\
\hline $\begin{array}{l}\text { (1)Tipične } \\
\text { značilnosti osebja }\end{array}$ & 391 & 1,67 & 5,00 & 4,206 & 0,028 & 0,560 & $-0,827$ & 0,123 & 0,850 & 0,246 \\
\hline $\begin{array}{l}\text { (5)Zadovoljstvo } \\
\text { gostov }\end{array}$ & 388 & 1,00 & 5,00 & 4,055 & 0,034 & 0,672 & $-0,819$ & 0,124 & 1,240 & 0,247 \\
\hline $\begin{array}{l}\text { (7)Kompetence } \\
\text { zaposlenih }\end{array}$ & 390 & 1,00 & 5,00 & 3,845 & 0,038 & 0,749 & $-0,642$ & 0,124 & 0,598 & 0,247 \\
\hline $\begin{array}{l}\text { (4)Stopnja } \\
\text { formalizacija dela } \\
\text { v igralnici }\end{array}$ & 392 & 1,00 & 5,00 & 3,762 & 0,045 & 0,886 & $-0,586$ & 0,123 & 0,292 & 0,246 \\
\hline $\begin{array}{l}\text { (6)Igralniški } \\
\text { dejavniki }\end{array}$ & 387 & 1,00 & 5,00 & 3,523 & 0,034 & 0,678 & $-0,761$ & 0,124 & 1,028 & 0,247 \\
\hline $\begin{array}{l}\text { (8)Posebnost } \\
\text { ponudbe igralnice }\end{array}$ & 394 & 1,00 & 5,00 & 3,501 & 0,041 & 0,812 & $-0,201$ & 0,123 & 0,262 & 0,245 \\
\hline $\begin{array}{l}\text { (2)Neodvisni } \\
\text { igralniški dejavniki }\end{array}$ & 389 & 1,00 & 5,00 & 3,188 & 0,037 & 0,739 & $-0,349$ & 0,124 & 0,224 & 0,247 \\
\hline $\begin{array}{l}\text { (3)Neodvisni } \\
\text { dejavniki }\end{array}$ & 389 & 1,00 & 5,00 & 2,478 & 0,035 & 0,692 & 0,213 & 0,124 & 0,003 & 0,247 \\
\hline Valid N (listwise) & 363 & & & & & & & & & \\
\hline
\end{tabular}

\subsection{Primerjava dejavnikov med gostinstvom in igralništvom}

$\mathrm{Na}$ podlagi anketiranja zaposlenih, gostov, fokusnih skupin, opazovanja in drugih raziskav, ki so bile opravljene na slovenskem ozemlju (Raspor, 2007a; Raspor, 2010d), lahko zaključim, da tudi za Slovenijo veljajo podobne zakonitosti, kot jih ugotavlja Lynn (2004d), da si lahko dober natakar zasluži plačo tudi s pravim pristopom do gostov, saj njegovo kakovostno delo prinaša - preko pridobivanja napitnine - večjo možnost za dodatno izboljšanje zaslužka, kar povečuje pripravljenost za dodatno in kvalitetnejše delo.

Na grafu 1 so v razsevnem grafikonu v dvodimenzionalnem prostoru umeščeni dejavniki glede na to, kako jih ocenjujejo zaposleni v gostinstvu in igralništvu ${ }^{2}$.

Vidimo lahko (tabela 12), da v mnenju zaposlenih v igralništvu in gostinstvu ni bistvenih razlik: nakazuje se velika pozitivna povezanost med temi ocenami (Pearsonov koeficient korelacije je $0,777^{* *}$ ) in nakazuje na to, da so tisti dejavniki, ki so po mnenju zaposlenih $\mathrm{v}$ gostinstvu pomembni za to, da dajejo gosti napitnino, pomembni tudi po mnenju zaposlenih v igralništvu. 
$\mathrm{V}$ obeh dejavnostih so manj pomembni zunanji dejavniki (zunanji, nekontrolirani dejavniki ter kvantiteta obiska in storitve ter način plačila le-te), bolj pomembni pa notranji dejavniki, in sicer značilnosti ponudbe (dejavniki, ki so odvisni od organizacije) in vedenje, izkušenost in ostale značilnosti osebja (dejavniki, ki so odvisni od zaposlenih). Najpomembnejša sta prav prijaznost in profesionalnost osebja. Med značilnostmi osebja sta izjema »dodatki k oblačilom« in »spol zaposlenega«, ki po mnenju zaposlenih $\mathrm{v}$ obeh dejavnostih nimata večjega vpliva na napitnino. Edini dejavnik, ki ga zaposleni v igralništvu in gostinstvu bistveno drugače vrednotijo, je "pogostost obiska«, ki bolj vpliva na napitnino po mnenju zaposlenih v igralništvu, ne pa tudi v gostinstvu. To pa se je potrdilo tudi $\mathrm{z}$ anketiranjem gostov.

Graf 1: Ocena dejavnikov, ki vplivajo na dajanje napitnine, po mnenju zaposlenih v gostinstvu in igralništvu ${ }^{3}$

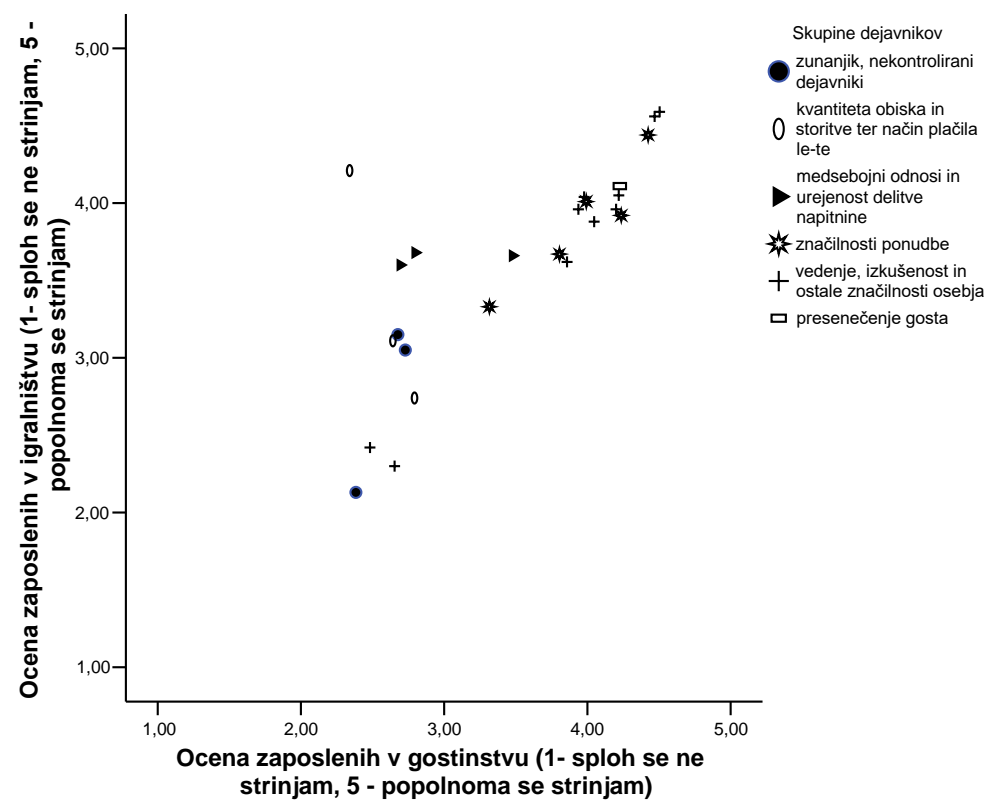

Tabela 14: Pearsonov koeficient korelacije rangov med mnenjem zaposlenih, kaj vpliva na napitnino $\mathrm{v}$ igralništvu in gostinstvu ${ }^{4}$

\begin{tabular}{|c|l|r|}
\hline \multicolumn{2}{|c|}{ Kaj vpliva na napitnino - igralništvo } \\
\hline \multirow{2}{*}{$\begin{array}{c}\text { Kaj vpliva na } \\
\text { napitnino - } \\
\text { gostinstvo }\end{array}$} & Koeficient korelacije rangov & $\mathbf{0 , 7 7 7 ^ { * * }}$ \\
\cline { 2 - 3 } & Stat. značilnost (2-stranski test) & 0,000 \\
\cline { 2 - 3 } & Stevilo anketirancev & 25 \\
\hline
\end{tabular}

**Statistično značilno pri p $<0.01(\square)$.

*Statistično značilno pri $p<0.05(a)$. 
36 ${ }^{\text {TH }}$ International Conference on Organizational Science Development: RESPONSIBLE ORGANIZATION (MARCH $22^{\mathrm{ND}}-24^{\mathrm{TH}}$, PortoroŽ SLOVENIA)

A. Raspor: Influence Frequency and the Amount of Received Tips: Factor Analysis of Factors

\section{Razprava}

V prispevku sem predstavil različne empirične raziskave, ki so ugotavljale, kaj vse vpliva na napitnino.

Da bi zaposlenim in menedžmentu pomagali pri spoznavanju ključnih dejavnikov, ki vplivajo na napitnino, sem na podlagi predhodnih in lastnih raziskav zbral te dejavnike v enotno tabelo (tabela 13). Na ta način sem olajšal pregled nad vsemi dejavniki, ki vplivajo nanjo. S tem pa sem tudi realiziral zastavljeni cilj, da dejavnike ki vplivajo na napitnino združim v skupine dejavnikov, ki bodo kar se da med gostinstvom in igralništvom primerljivi, ter bodo uporabni tudi za druge storitvene dejavnosti.

$\mathrm{Na}$ osnovi vseh predstavljenih raziskav sem oblikoval naslednje skupine dejavnikov teoretičnih indeksov (motivov in vedenj gostov ter zaposlenih), ki vplivajo na napitnino: (1) zunanji, nekontrolirani dejavniki, (2) zunanji, kontrolirani dejavniki, (3) kvantiteta obiska in storitve ter način plačila le-te, (4) medsebojni odnosi in urejenost delitve napitnine, (5) značilnosti ponudbe, (6) vedenje, izkušenost in ostale značilnosti osebja in (7) presenečenje gosta.

Nadalje jih delim še na (A) zunanje dejavnike ( 1, 2 in 3), (B) notranje dejavnike, ki so (I.) odvisni od organizacije (higieniki) (4 in 5) ali (II.) od zaposlenih (motivatorji) (6) in (C) dejavnike sreče/zadovoljstva gosta (7).

Glede na preveritve raziskovalnega vprašanja: ali se dejavniki, ki vplivajo na napitnino med gostinstvom in igralništvom razlikujejo?, lahko zaključim, da obstajajo določene specifike. V osnovi pa je delitev skupin dejavnikov sorodna.

Prispevek pa je prvi znani prispevek na svetu, ki je združil dejavnike v enotno tabelo, ter jih s pomočjo faktorske analize družil v skupine dejavnikov.Napitnino sem obravnavali iz različnih zornih kotov. Osnovno sporočilo je, da napitnina še ni bila celovito raziskana in se odpirajo nova in nova področja, ki bi jih kazalo vpeti v našo raziskavo. Ključno je sodelovanje menedžerjev, saj ti lahko zaposlene spodbudijo in jih naučijo, kako naj napitnino povečajo. 
Tabela 15: Zbir vseh zaznanih dejavnikov, ki vplivajo na napitnino

\begin{tabular}{|c|c|c|}
\hline & Gostinstvo & Igralništvo \\
\hline & \multicolumn{2}{|c|}{ A - Zunanji dejavniki: } \\
\hline \multirow{12}{*}{$\begin{array}{l}\text { (1)Zunanji, } \\
\text { nekontrolirani } \\
\text { dejavniki }\end{array}$} & $\begin{array}{l}\text { Vzgojenost gostov (kultura dajanja } \\
\text { napitnine) }\end{array}$ & $\begin{array}{l}\text { Vzgojenost gostov (kultura dajanja } \\
\text { napitnine) }\end{array}$ \\
\hline & Osebni stik & Osebni stik \\
\hline & & Vraževernost \\
\hline & Empatičnost & Empatičnost \\
\hline & $\begin{array}{l}\text { Čas koriščenja storitve (npr. malica, } \\
\text { večerja) }\end{array}$ & $\begin{array}{l}\text { Čas koriščenja storitve (npr. zvečer, pozno } \\
\text { ponoči) }\end{array}$ \\
\hline & Vreme (npr. sončno, deževno) & Vreme (npr. sončno, deževno) \\
\hline & Rasa/narodnost zaposlenega & Rasa/narodnost zaposlenega \\
\hline & Spol zaposlenega & Spol zaposlenega \\
\hline & $\begin{array}{l}\text { Zunanji fizični izgled zaposlnega } \\
\text { (atraktivnost) }\end{array}$ & $\begin{array}{l}\text { Zunanji fizični izgled zaposlnega } \\
\text { (atraktivnost) }\end{array}$ \\
\hline & Dodatki k oblačilom & Dodatki k oblačilom \\
\hline & Rasa/narodnost gosta & Rasa/narodnost gosta \\
\hline & Spol gosta & Spol gosta \\
\hline \multirow{4}{*}{$\begin{array}{l}\text { (2)Zunanji, } \\
\text { kontrolirani } \\
\text { dejavniki }\end{array}$} & Urejen sistem poročanja davčnemu organu & Urejen sistem poročanja davčnemu organu \\
\hline & $\begin{array}{l}\text { Splošne norme, ki spodbujajo } \mathrm{k} \text { dajanju } \\
\text { napitnine }\end{array}$ & $\begin{array}{l}\text { Splošne norme, ki spodbujajo } \mathrm{k} \text { dajanju } \\
\text { napitnine }\end{array}$ \\
\hline & Urejenost v gostinskem zakonu & Urejenost $\mathrm{v}$ igralniškem zakonu \\
\hline & Urejenost v branžni kolektivni pogodbi & Urejenost $\mathrm{v}$ branžni kolektivni pogodbi \\
\hline \multirow{7}{*}{$\begin{array}{c}\text { (3)Kvantiteta } \\
\text { obiska in storitve } \\
\text { ter način plačila } \\
\text { le-te }\end{array}$} & Velikost naročila (cena storitve) & Višina stave \\
\hline & $\begin{array}{l}\text { Način plačila (npr. gotovina, plačilna } \\
\text { kartica) }\end{array}$ & \\
\hline & & Zagotovitev denarja za igro igralcem \\
\hline & Način vračanja ostanka denarja od plačila & Način izplačila dobitka \\
\hline & Pogostost obiska (stalne stranke) & Pogostost obiska (stalne stranke) \\
\hline & Število gostov (npr. na večer) & Število igralcev (npr. na večer) \\
\hline & Število gostov (npr. omizje) & $\begin{array}{l}\text { Število igralcev (npr. igralcev na igralni } \\
\text { mizi) }\end{array}$ \\
\hline
\end{tabular}



RESPONSIBLE ORGANIZATION (MARCH $22^{\mathrm{ND}}-24^{\mathrm{TH}}$, PORTOROŽ SLOVENIA)

A. Raspor: Influence Frequency and the Amount of Received Tips: Factor Analysis of Factors

\begin{tabular}{|c|c|c|}
\hline & Gostinstvo & Igralništvo \\
\hline & \multicolumn{2}{|c|}{ B - Notranji dejavniki: } \\
\hline & \multicolumn{2}{|c|}{ I. ODVISNI OD ORGANIZACIJE (HIGIENIKI) } \\
\hline \multirow{9}{*}{$\begin{array}{l}\text { (4)Medsebojni } \\
\text { odnosi in } \\
\text { urejenost delitve } \\
\text { napitnine }\end{array}$} & Medsebojni odnosi & Medsebojni odnosi \\
\hline & \begin{tabular}{|l|} 
Višina plače \\
\end{tabular} & Višina plače \\
\hline & \begin{tabular}{|l|} 
Motiviranost zaposlenih \\
\end{tabular} & Motiviranost zaposlenih \\
\hline & Usklajenost in sodelovanje zaposlenih & Usklajenost in sodelovanje zaposlenih \\
\hline & $\begin{array}{l}\text { Delitev dela med kontaktnim in podpornim } \\
\text { osebjem }\end{array}$ & $\begin{array}{l}\text { Delitev dela med kontaktnim in podpornim } \\
\text { osebjem }\end{array}$ \\
\hline & \begin{tabular}{|l|} 
Sistem nagrajevanja $\mathrm{z}$ napitnino \\
\end{tabular} & Sistem nagrajevanja $\mathrm{z}$ napitnino \\
\hline & $\begin{array}{l}\begin{array}{l}\text { Stopnja formaliziranosti sprejemanja in } \\
\text { delitve }\end{array} \\
\end{array}$ & $\begin{array}{l}\text { Stopnja formaliziranosti sprejemanja in } \\
\text { delitve }\end{array}$ \\
\hline & Učenje bontona (kulture) dajanja napitnine & Učenje bontona (kulture) dajanja napitnine \\
\hline & $\begin{array}{l}\text { Število zaposlenih, ki participirajo } \mathrm{v} \\
\text { napitnini }\end{array}$ & $\begin{array}{l}\text { Število zaposlenih, ki participirajo } \mathrm{v} \\
\text { napitnini }\end{array}$ \\
\hline \multirow{9}{*}{$\begin{array}{l}\text { (5)Značilnosti } \\
\text { ponudbe }\end{array}$} & Vrsta storitve (npr. tip restavracije) & Igralna naprava \\
\hline & Zadovoljstvo $\mathrm{z}$ lokalom & Zadovoljstvo $\mathrm{z}$ lokalom \\
\hline & ØVzdušje v lokalu & ØVzdušje v igralnici \\
\hline & ØAmbient (čistost, zgled) v lokalu & ØAmbient (čistost, zgled) v lokalu \\
\hline & Zadovoljstvo s hrano/servisom & Zadovoljstvo izvajanjem igre/servisom \\
\hline & $\begin{array}{l}\text { ØRaznolikost ponudbe (npr. ponudba hrane } \\
\text { in pijače) }\end{array}$ & ØRaznolikost ponudbe (igralnih naprav) \\
\hline & ØKakovost servisa (videz, okus..) & $\begin{array}{l}\text { ØKakovost servisa (delovanje igralnih } \\
\text { naprav) }\end{array}$ \\
\hline & ØRazmerje med ceno in kakovostjo & \\
\hline & & ØRazmerje med ceno in kakovostjo \\
\hline & \multicolumn{2}{|c|}{ II. ODVISNI OD ZAPOSLENIH (MOTIVATORJI) } \\
\hline \multirow{17}{*}{$\begin{array}{c}\text { (6)Vedenje, } \\
\text { izkušenost in } \\
\text { ostale značilnosti } \\
\text { osebja }\end{array}$} & Zadovoljstvo $\mathrm{z}$ osebjem & ØZadovoljstwo $\mathrm{z}$ osebjem \\
\hline & ØKakovost servisa (postrežba) & ØKakovost servisa (izvajanje igre) \\
\hline & ØProfesionalen odnos & Ørofesionalen odnos \\
\hline & ØPrijaznost & $\emptyset_{\text {prijaznost }}$ \\
\hline & ØUrejenost & Øurejenost \\
\hline & ØHitrost postrežbe & $Ø$ Hitrost postrežbe \\
\hline & ØNasmejanost (izžarevanje zadovoljstva) & ØNasmejanost (izžarevanje zadovoljstva) \\
\hline & ØZabavanje gostov & ØZabavanje gostov \\
\hline & $\begin{array}{l}\text { Splošna razgledanost (npr. poznavanje } \\
\text { jezika) }\end{array}$ & $\begin{array}{l}\text { Splošna razgledanost (npr. poznavanje } \\
\text { jezika) }\end{array}$ \\
\hline & Neverbalna komunikacija & Neverbalna komunikacija \\
\hline & \begin{tabular}{|l|} 
Svetovanje storitve \\
\end{tabular} & Svetovanje storitve \\
\hline & Poznavanje menijev & Poznavanje pravil igre \\
\hline & \begin{tabular}{|l|} 
Reševanje reklamacij \\
\end{tabular} & Reševanje reklamacij \\
\hline & \begin{tabular}{|l|} 
Predstavitev zaposlenega po imenu \\
\end{tabular} & Predstavitev zaposlenega po imenu \\
\hline & Ponovitev naročila za gostom & Ponovitev napovedi za gostom \\
\hline & Očesni in fizični stik osebja s stranko & Očesni in fizični stik osebja s stranko \\
\hline & \multicolumn{2}{|c|}{ C - Dejavniki (sreče)/zadovoljstva gosta: } \\
\hline \multirow{5}{*}{$\begin{array}{l}\text { (7)Presenečenje } \\
\text { gosta }\end{array}$} & $\begin{array}{l}\text { Dobiti za isto ceno nekaj več, kot pri } \\
\text { konkurenci }\end{array}$ & \\
\hline & & Pozitivni finančni rezultat \\
\hline & & Veselje zaposlenega ob gostovem dobitku \\
\hline & $\begin{array}{l}\text { Nadstandardne storitve (npr. razkoščevanje } \\
\text { rib) }\end{array}$ & $\begin{array}{l}\text { Nadstandardne storitve (npr. postavitev } \\
\text { napovedi) }\end{array}$ \\
\hline & Drobne pozornosti (npr. bombon) & Drobne pozornost (npr. brezplačna pijača) \\
\hline
\end{tabular}


A. Raspor: Pogostost in višina prejete napitnine: faktorska analiza dejavnikov

\section{Opombe}

${ }^{1}$ Vrednost 3,35 predstavlja več kot $66 \%$ ali $2 / 3$ glede na lestvico od 1 »sploh se ne strinjam « do 5 "popolnoma se strinjam«, kar sem si postavili kot mejo za potrditev.

${ }_{2}^{2}$ Predstavljeni so seveda samo tisti dejavniki, za katere je bilo v obeh vprašalnikih postavljeno enako oz. primerljivo anketno vprašanje.

${ }^{3} \mathrm{Na}$ sliki so dejavniki označeni z zaporednimi številkami, ki se ujemajo s trditvami v tabeli 4 za gostinstvo in tabeli 5 za igralništvo.

${ }^{4}$ Pojasnilo k tabeli glede anketnih vprašanj in možnih odgovorov: Na podlagi mnenja zaposlenih koliko posamezen element vpliva na napitnino je bil izračunan Pearsonov koeficient korelacije med gostinstvom in igralništvom med tistimi elementi ki so bili enotni tako za gostinstvo, kot za igralništvo.

\section{Literatura}

Groves, R. M. in drugi. (2004). Survey Methodology. Wiley.

Lynn, M. (2004c). Increasing Servers' Tips: What Managers Can Do and Why They Should Do It. Journal of Foodservice Business Research 8(4): 89-98.

Lynn, M. (2004d). Mega tips Scientifically Tested Techniques to Increase your Tips. Pridobljeno dne 25.3.2007 s spletne strani http://people.cornell.edu/pages/wml3/pdf/megatips.pdf

Ragin, C. C. (2007). Družboslovno raziskovanje: enotnost in raznolikost metode. Ljubljana: Fakulteta za družbene vede.

Raspor, A. (2007a). Napitnina v gostinstvu. Organizacija 40(3): A27-A37.

Raspor, A. (2007b). Vpliv celovite kakovosti storitve v gostinstvu na napitnino natakarjev. V Vpliv produktivnosti in ustvarjalnosti na plače zaposlenih, ur. Mlakar Peter in Ivan Kejžar. 85111. XXII posvetovanje društva za vrednotenje dela.

Raspor. A. (2010d). Vpliv razdeljevanja napitnin na motivacijo zaposlenih: primerjava med gostinstvom in igralništvom. Doktorska disertacija. Ljubljana: Fakulteta za družbene vede. 
888 36 $36^{\text {Th }}$ International CONFEREnCE ON ORganizational Science Development: Responsible Organization (March $22^{\mathrm{ND}}-24^{\mathrm{TH}}$, PORTOROŽ SlOVENIA) 
36. MEDNARODNA KONFERENCA O RAZVOJU ORGANIZACIJSKIH ZNANOSTI: OdgOVORNA ORGANIZACIJA (22. - 24. MAREC 2017, PORTOROŽ, SLOVENIJA)

O. Arsenijević, M. Ferjan, I. Podbregar, P. Šprajc, D. Trivan \& Y. Ziegler

\title{
Dvojna kariera športnikov in družbena odgovornost $v$ Sloveniji
}

\author{
PETRA ROBNIK \& EDVARD KOKLAR
}

Povzetek Prispevek obravnava področje Managementa $v$ športu in je posebej namenjeno področju dvojne kariere športnikov. V uvodnem delu so predstavljena teoretična izhodišča in osnovni pojmi v povezavi dvojne kariere športnikov in družbene odgovornosti. V prispevku se ukvarjamo z vključenostjo deležnikov na področje dvojne kariere na nacionalni ravni, na primeru Slovenije. Glavni cilj je, z vidika družbene odgovornosti, poiskati pomanjkljivosti in priložnosti predlaganega slovenskega nacionalnega modela dvojne kariere. Razvoj nacionalnega modela bo predstavljal smernice za vse zainteresirane deležnike na tem področju in vzpostavil pogoje za vseživljenjsko učenje vrhunskih športnikov. Na osnovi usmeritve Evropske komisije glede minimalnih zahtev kakovosti za posameznega deležnika na področju zagotavljanja pogojev dvojne kariere športnikov (Evropska komisija, 2016), smo kritično analizirali družbeno odgovornost. Ugotovili smo, kateri pogoji na nacionalni ravni omogočajo podporo in razvoj dvojne kariere vrhunskih športnikov in katere deležnike je pomembno nasloviti za zagotovitev posameznih pogojev na več ravneh in sicer: na sistemski ravni in na ravni programske podpore, kako zagotoviti primeren kakovostni okvir in katere so minimalne zahteve za vzpostavitev pogojev dvojne kariere športnikov.

KLJUČNE BESEDE: Management $\mathrm{v}$ športu • dvojna kariera športnika • minimalne zahteve kakovosti $\bullet$ kakovostni okvir $\bullet$ deležniki na področju dvojne kariere $\cdot$ družbena odgovornost

\footnotetext{
Naslov AVtorJev: Petra Robnik, zunanja sodelavka, Univerza v Mariboru, Fakulteta za organizacijske vede, Kidričeva 55a, 4000 Kranj, Slovenija, e-pošta: petra.robnik@ fov.uni-mb.si; dr. Edvard Kolar, Olimpijski komite Slovenije - Združenje športnih zvez, Šmartinska 140, 1000 Ljubljana, Slovenija, e-pošta: edvard.kolar@olympic.si
} 
$36^{\text {TH }}$ International Conference on Organizational Science DEVElopMENT: Responsible ORganization (MARCH $22^{\mathrm{ND}}-24^{\mathrm{TH}}$, PORTOROŽ SLOVENIA)

O. Arsenijević, M. Ferjan, I. Podbregar, P. Šprajc, D. Trivan \& Y.

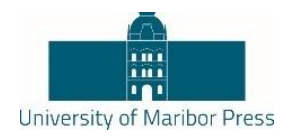

Ziegler

\title{
Dual Career of Athletes and Corporate Social Responsibility in Slovenia
}

\author{
PETRA ROBNIK \& EDVARD KOKLAR
}

\begin{abstract}
This article deals with the area of Management in sport and is specially oriented in the field of the Dual Career of Athletes. In the introductory part we represent the theoretical origin and elements in the context of the Dual career of Athletes and corporate social responsibility. The involvement of stakeholders at the national level is presented in the case of Slovenia. The main objective is to find where Slovenian national dual career model has options to improve and which Stakeholders should we address and include more. The development of national model will constitute the guidelines for all stakeholders in this area and establish the terms and conditions for lifelong learning of the athletes. Further on, we critically analyzed corporate social responsibility in the terms of the Dual career of athletes, based on the orientations of the European Commission on the minimum quality requirements for dual career services (European Commission, 2016). We found out which support enables the establishment of the conditions for the dual career of athletes at the national level and which stakeholders is important to address in order to ensure the conditions for the dual career, namely: on the system level and at the level of program support, how to ensure adequate quality frame, and what are the minimum quality requirements for the establishment of conditions of dual career athletes.
\end{abstract}

KEYWORDS: Management in sport - Dual Career of Athletes - the minimum Quality requirements • Quality framework • stakeholders in the field of dual careers $\bullet$ social responsibility

CORRESPONDENCE ADDRESS: Petra Robnik, an external coworker, University of Maribor, Faculty of Organizational Sciences, Kidričeva cesta 55a, 4000 Kranj, Slovenia, e-mail: petra.robnik@fov.uni-mb.si; Edvard Kolar, Ph.D., Olympic Committee of Slovenia - Association of Sports Federations, Šmartinska 140, 1000 Ljubljana, Slovenia, e-mail: edvard.kolar@ olympic.si 


\section{Teoretična izhodišča}

Športniki se pri združevanju svoje športne kariere z izobraževanjem ali delom pogosto srečujejo s težavami. Doseganje visoke ravni športne uspešnosti od športnika zahteva intenziven trening in sodelovanje na tekmovanjih doma in v tujini, kar je težko uskladiti $\mathrm{z}$ izzivi in omejitvami izobraževalnega sistema in trga dela. $\mathrm{V}$ izogib položaju, $\mathrm{v}$ katerem so se športniki prisiljeni odločati med izobraževanjem in športom ali delom in športom, so poleg njihove visoke motiviranosti, predanosti, vzdržljivosti in odgovornosti potrebne tudi posebne ureditve za dvojno kariero športnikov. Te bi morale podpirati športno kariero športnikov, varovati njihov položaj in omogočati njihovo izobraževanje ali delo oziroma lažji prehod na novo poklicno pot po končani športni karieri.

Dvojna kariera športnikov predstavlja večdimenzionalni proces, ki je odvisen od vplivov posameznika, medosebnih odnosov in politike (Capranica idr. 2015). Področje dvojne kariere zahteva na nacionalnem nivoju usklajeno delovanje in povezovanje več deležnikov hkrati, ki spremljajo športnika skozi njegovo celotno kariero. Življenjska doba nadarjenih in vrhunskih športnikov in vpogled v perspektivo za visoko intenzivne športe (Wylleman, Reints, 2010) ponazarjata, "celotno kariero/celotno osebo" in konceptualizacijo kariernega prehoda vrhunskih športnikov, razdeljenih $\mathrm{v}$ štiri specifične karierne prehode, $v$ razvoju perspektivnega mladega športnika in vrhunskega športnika. Za ta namen je potrebno pripraviti usklajen model celostnega razvoja dvojne kariere športnikov, s sistemskim pristopom na nacionalni ravni. Pomembno je med-nivojsko in medinstitucionalno sodelovanje, ter spodbujanje posameznih dobrih praks. Evropska unija, Mednarodni olimpijski komite (MOK), številne nacionalne vlade in športni organi so $\mathrm{v}$ zadnjem obdobju pokazali velik interes za reševanje problematike športnikovega razvoja v smislu urejanja združljivosti izobraževanja in športnega udejstvovanja (Henry, 2015). Smernice EU za dvojno kariero športnikov (EU Guidelines on Dual Careers of Athletes, 2012) naj bi prispevale $\mathrm{k}$ izmenjavi in širjenju dobrih praks ter učnih izkušenj na tem področju. Poleg tega podajajo okvir možnih ureditev na mednarodni ravni in spodbujajo Evropsko unijo, naj uvede dodatne ukrepe za lažje oblikovanje ureditev dvojne kariere $\mathrm{v}$ tujini zaradi visoke mobilnosti športnikov, posebnih potreb v nekaterih športih in manjših državah članicah. Spodbujanje dvojne kariere športnikov je v skladu z več cilji strategije Evropa 2020 (preprečevanje prezgodnjega opuščanje šolanja, več diplomantov, večja zaposljivost), $\mathrm{z}$ ohranjanjem perspektivnih in uspešnih športnikov v sistemu športa pa omogoča tudi učinkovitejše športne politike.

\section{Opredelitev osnovnih pojmov}

Najprej je potrebna utemeljitev in opredelitev osnovnih pojmov, ki se nanašajo na raziskavo, vezano na dvojno kariero športnikov in družbeno odgovornost.

Management $\mathbf{v}$ športu lahko v osnovnem pomenu opredelimo kot »koordinacijo« različnih virov, tehnologij, procesov, osebja in situacijskih slučajnosti, za dosego učinkovite proizvodnje in izmenjave športnih storitev. V skladu $\mathrm{z}$ definicijo tako management zajema proizvodnjo in trženje športnih storitev. Prav tako pojem koordinacije implicira pravilno izvajanje tradicionalnih funkcij managementa 
$36^{\mathrm{TH}}$ International Conference on Organizational Science Development: RESPONSIBLE ORGANIZATION (MARCH $22^{\mathrm{ND}}-24^{\mathrm{TH}}$, PortoroŽ SLOVENIA)

P. Robnik \& E. Kolar: Dual Career of Athletes and Corporate Social Responsibility in Slovenia

(planiranje, organiziranje, vodenje in vrednotenje), posedovanje posebnih managerskih spretnosti in managersko vlogo. (Chelladurai, 1994). Po navedbi definicije v Nacionalnem programu športa $\mathrm{v}$ Republiki Sloveniji (Nacionalni program športa $\mathrm{V}$ Republiki Sloveniji, 2014), je ravnanje ali ravnateljevanje (ang. management) proces odločanja, načrtovanja, osmišljanja, usmerjanja, razporejanja organizacijskih virov, vodenja ter nadzora in vrednotenja izvajanja različnih dejavnosti.

Dvojna kariera športnikov je z vidika športnika razvoj vseživljenjske odličnosti posameznega športnika, skozi njegove cilje na športnem področju, pri izobraževanju in kasnejši vključitvi na trg delovne sile. Področje dvojne kariere zajema strokovno načrtovanje in organizacijo optimalnih osnovnih pogojev za dvojno kariero vrhunskih športnikov. Dvojna kariera je, z vidika organizacij, posredovanje med vsemi pomembnimi deležniki na področju dvojne kariere, predvsem pa na področjih: vrhunskega športa, izobraževanja in ekonomije in vzpostavitev komunikacije, informiranje in podajanje informacij športnikom, pri čemer je potrebno posebno pozornost nameniti posebnim ciljnim skupinam (prejemniki olimpijskih medalj, medalj svetovnih in evropskih prvenstev), vendar hkrati vzpostaviti enakovredne pogoje in možnosti za vse vrhunske športnike. Dvojna kariera je, skladno z usmeritvami Evropske komisije glede minimalnih zahtev kakovosti za posameznega deležnika na področju zagotavljanja pogojev dvojne kariere športnikov, tudi zapleteno politično področje, ki povezuje več zainteresiranih strani političnih področij, kot so izobraževanje, mladina, zdravje in trg dela, s skupnim naporom, da se športnika usmeri k ustreznemu poklicnemu razvoju.

\section{Minimalne zahteve kakovosti in kakovostni okvir}

Standardi vodenja kakovosti so krovni standardi v vsaki organizaciji, področju in dejavnosti, kar pomeni, da morajo imeti dobro pokritost svoje dejavnosti tudi z drugimi standardi, kateri se nanašajo na njihovo dejavnost. Minimalne zahteve glede kakovosti so v smislu dvojne kariere športnikov, osnovne zahteve, ki so potrebne za zagotavljanje pogojev dvojne kariere športnikov. Usmeritve Evropske komisije glede minimalnih zahtev kakovosti za posameznega deležnika na področju zagotavljanja pogojev dvojne kariere športnikov predvidevajo pet stebrov in sicer: nastanitev, izobraževanje, osebje, objekti, storitve.

Skladno s smernicami, glede zagotavljanja minimalnih pogojev na področju dvojne kariere je bil razvit tudi kakovostni okvir, kot referenčni model za pregled vlog in odgovornosti posameznega deležnika dvojne kariere na nacionalni ravni. Kakovostni okvir ponuja večji pregled aktivnosti dvojne kariere in kvaliteto izvajanja storitev, ter varnost in jamstvo za športnike.

Deležnik je slovenska različica angleškega termina »stakeholder«. Freeman je deležnika opredelil kot »katerokoli skupino ali posameznika, ki lahko vpliva ali pa je vplivan $\mathrm{s}$ strani podjetja, ko ta skuša doseči svoje cilje.«(Freeman, 1984). Iz tega osnovnega pojma, ki ima za izhodišče proučevanja podjetje, nato izhajajo kasnejše različice in opisi pojma 
deležnik. V smislu dvojne kariere športnikov, pa so skladno z usmeritvami Evropske komisije glede minimalnih zahtev kakovosti za posameznega deležnika na področju zagotavljanja pogojev dvojne kariere športnikov, to osebe, skupine ali organizacije, oziroma zainteresirane strani, ki delujejo na sistemski in/ali organizacijski ravni, na področjih športa, izobraževanja in trga dela in zagotavljajo pogoje za dvojno kariero športnikov. V idealnem primeru, nosijo odgovornost za izvajanje obstoječe nacionalne zakonodaje ali pravil in odgovornost za posredovanje možnosti športnikom in njihovemu socialnem okolju. To zahteva komunikacijo med različnimi deležniki na različnih organizacijskih ravneh.

Družbena odgovornost je lahko definirana kot odgovornost organizacije za vplive njenih odločitev in dejavnosti na družbo in okolje, ki skozi pregledno in etično ravnanje prispeva $\mathrm{k}$ trajnostnemu razvoju, vključujoč zdravje in blaginjo družbe, upošteva pričakovanja deležnikov, je $\mathrm{v}$ skladu $\mathrm{z}$ veljavno zakonodajo in mednarodnimi normami ravnanja, ter je integrirana $v$ celotno organizacijo in se izvaja $v$ vseh njenih odnosih. Družbena odgovornost posameznega podjetja presega meje in pričakovanja pravnih okvirov ter zakonodaje, saj podjetje več pozornosti namenja človeškim virom, odnosom $\mathrm{z}$ deležniki in samemu okolju.

\section{Vključenost deležnikov na nacionalni ravni, primer Slovenije}

Politika Evropske unije o dvojni karieri predvideva pripravo in implementacijo smernic za dvojno kariero na nacionalni ravni. Strateški akti v Sloveniji, ki urejajo normativno podlago za dvojno kariero v Republiki Sloveniji so poleg Zakona o športu (ZŠpo, 1998): Nacionalni program športa v RS 2014-2023 (Nacionalni program športa v Republiki Sloveniji, 2014), Izvedbeni načrt nacionalnega programa športa v RS 2014-2023 (Izvedbeni načrt Nacionalnega programa športa v Republiki Sloveniji, 2014), Strategija OKS-ZŠZ (Strategija Olimpijskega komiteja Slovenije Združenja športnih zvez za obdobje 2014-2023, 2013), Akcijski načrt Strategije OKS-ZŠZ za obdobje 2014-2023 (Akcijski načrt 2014-2023, 2016). Kot izhaja iz Nacionalnega programa športa $\mathrm{v}$ Republiki Sloveniji, je eden izmed strateških ciljev na področju vrhunskega športa na državni ravni vsestranski razvoj vrhunskih športnikov v času njihove športne kariere in po njej. Ta strateški cilj sledi smernicam EU na področju dvojne kariere vrhunskih športnikov, podprte s strani Evropske komisije.

Dosedanji Zakon o športu (Zakon o športu, 1998) predvideva ukrepe na področju izobraževanja in zaposlovanja, ki bi jih lahko uvrstili na področje dvojne kariere, vendar ciljev ne izpolnjuje povsem, kar je razvidno iz ocene stanja in razlogov za sprejem predloga Zakona, v Uvodu (Predlog ZŠpo, Številka: 0070-13/2015, EVA 2013-33300161, z dne 15. 12. 2016), kjer je navedeno, da: »Nekateri podporni mehanizmi slovenskemu športu pa $v$ preteklem obdobju niso bili udejanjeni. Soočamo se s težavami pri uveljavljanju zdravstvenega varstva športnikov, skrbi za celostni osebnostni razvoj vrhunskih športnikov in vzpostavljanju statusnih pravic trenerjev, pri razvoju in uveljavljanju športne dejavnosti otrok in mladine s posebnimi potrebami in športnega udejstvovanja invalidov, pri racionalizaciji uporabe javnih športnih površin in objektov ter pomanjkanju ustrezne vadbene infrastrukture za nekatere športne panoge.« 
36 ${ }^{\mathrm{TH}}$ International Conference on Organizational Science Development: RESPONSIBLE ORGANIZATION (MARCH $22^{\mathrm{ND}}-24^{\mathrm{TH}}$, PortoroŽ SLOVENIA)

P. Robnik \& E. Kolar: Dual Career of Athletes and Corporate Social Responsibility in Slovenia

Izvedbeni načrt Nacionalnega programa športa v RS 2014-2023 je dokument, ki omogoča operacionalizacijo strateških zamisli in uresničevanje ciljev razvoja športa. Dvojno kariero športnikov izvedbeni načrt predvideva na dveh področjih in sicer izobraževanje in zaposlovanje. Ravnanje $\mathrm{z}$ nacionalnim programom športa 2014-2023 temelji na povezovanju vseh upravnih, strokovnih in organizacijskih nalog vseh vpletenih nosilcev posameznih dejavnosti nacionalnega programa. Za izpeljavo nacionalnega programa športa 2014-2023 so soodgovorni vsi:

1. nosilci dejavnosti nacionalnega programa: OKS-ZŠZ, lokalne skupnosti, resorna ministrstva, Fundacija za šport, Strokovni svet vlade RS za šport, idr. in

2. izvajalci nacionalnega programa: Nacionalne in občinske zveze in društva, javni zavodi, šole, gospodarske družbe, idr.

Medresorsko in med-organizacijsko sodelovanje na področju dvojne kariere športnikov, je posebej pomembno pri implementaciji rešitev v praksi, ker so zaradi svoje specifičnosti le te večplastne in kompleksne.

\subsection{Model dvojne kariere športnikov v Sloveniji}

Problematiko vrhunskih športnikov po končani športni karieri predstavlja predvsem prehod iz športne $\mathrm{v}$ zaposlitveno kariero, ki je za vrhunske športnike težaven zaradi neustrezne izobrazbe, pridobljene med športno kariero, in s tem povezanimi težavami z ustrezno ekonomsko vključitvijo vrhunskega športnika v poklicno kariero. Zato bi moralo biti to področje sistemsko usmerjeno in vodeno že pri športu mladih, obenem pa bi bilo potrebno zagotoviti pogoje za graditev kariere vrhunskega športnika. Zaradi specifičnosti vrhunskega športa in potreb po doseganju vrhunskih rezultatov, ki predstavljajo državo navzven, ter zaradi pozitivnega vpliva na družbo, je bilo v zvezi s tem podanih že precej predlogov in posameznih rešitev (Robnik, 2011).

Doseganje vrhunskih športnih dosežkov je rezultat načrtnega, tehnološko dovršenega, individualiziranega procesa, ne samo treniranja, v katerega je vključenih več ljudi, pogosto tudi več športnih organizacij. Glavni nosilci vrhunskega športa so športniki in njihovi trenerji ter športna društva in nacionalne panožne športne zveze, v katerih delujejo. Pomembna pa so tudi podporna okolja: družina (zasebno življenje športnika), šola (usklajevanje šolskih in športnih obveznosti), panožni tim (spremljanje zdravstvenega stanja in pripravljenosti športnika) in poklicno okolje (usklajevanje delovnih in športnih obveznosti). (Jurak, 2010).

Najpomembnejša je podpora vrhunskega športnika skozi celotno fazo njegovega procesa, tako na izobraževalnem področju, kot tudi $\mathrm{v}$ športnikovi karieri. Različni podporni programi in dodatna znanja, ki jih športnik lahko pridobi skozi proces dvojne kariere, omogočajo športniku konkretne rešitve, ki rešujejo to problematiko in pomagajo športniku k lažji vključitvi na trg dela. Obenem, pa športnik ni postavljen pred odločitev o nadaljevanju in obsegu njegove športne kariere. Predlagan nacionalni model dvojne 
kariere športnikov je grafično prikazan kot shema programov in časovnica aktivnosti, po posameznih fazah športnikove kariere, ki vrhunskega športnika pripelje do vstopa na trg dela. Slika torej grafično prikazuje model dvojne kariere in deležnike na tem področju.

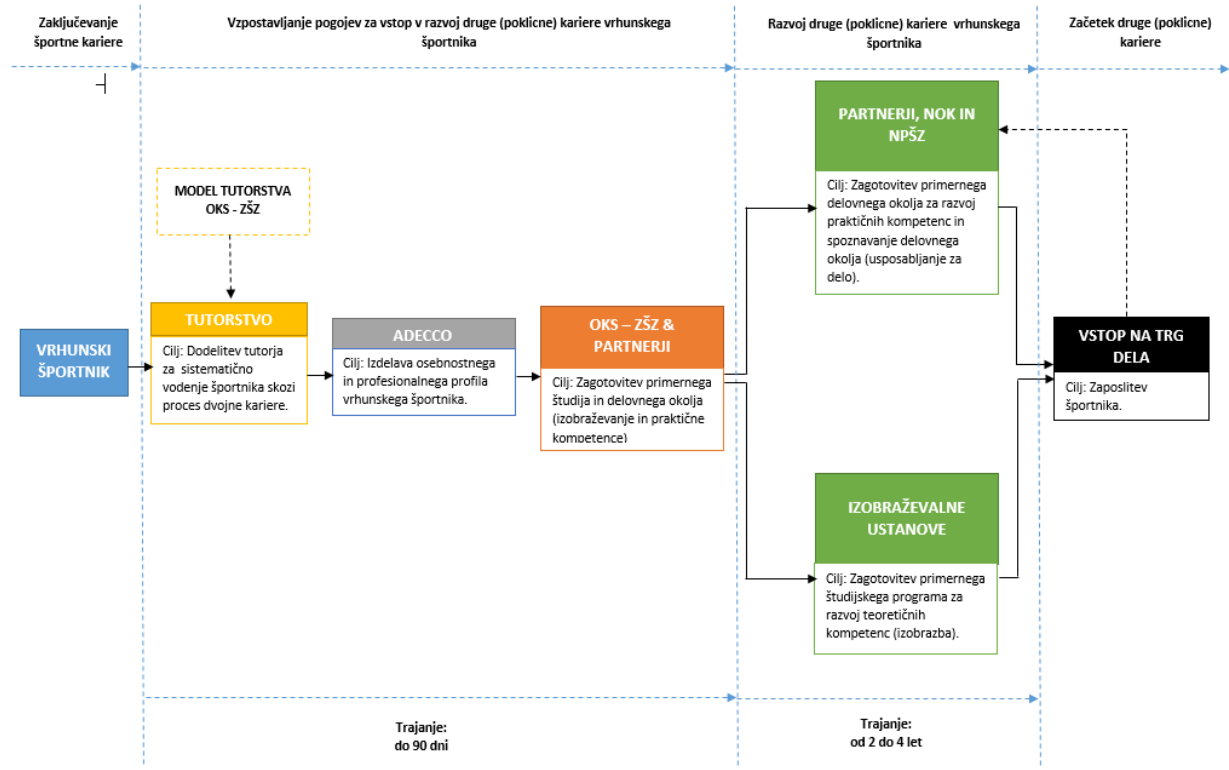

Slika 2: Shematski prikaz modela dvojne kariere vrhunskih športnikov. (Kolar, Pavletič Samardžija, Robnik, 2015)

\subsection{Izhodišča za nadaljnji razvoj področja dvojne kariere v Sloveniji}

Posvet dvojne kariere športnikov je bil organiziran dne 14.9.2016, s strani MIZŠ Direktorata za šport in OKS-ZŠZ. Namen posveta dvojne kariere športnikov je bil obveščanje in informiranje deležnikov, ki so aktivni na področju dvojne kariere športnikov na nacionalni ravni, ter povzetek stanja v RS. Število udeležencev na posvetu dvojne kariere športnikov je bilo 96, čeprav je elektronska baza prijavljenih udeležencev širša in je zato pregled strukture posveta narejen širše, za več kot 110 udeležencev. Strukturo udeležencev smo sistematično popisali in pripravili pregled, glede na strukturo po organizacijah in strukturo po posameznih funkcijah udeležencev posveta na področju dvojne kariere. Ugotovili smo, da sta bili obe kategoriji reprezentativni, na osnovi česar lahko ocenimo, da je interes različnih deležnikov na področju dvojne kariere primeren in kot tak dobro izhodišče za nadaljnje aktivnosti na področju dvojne kariere. Pestrost udeležencev je pomembna predvsem z vidika pomembnosti in teže, ki jo deležniki dajejo področju dvojne kariere športnikov in pomeni tudi interdisciplinarno in med-nivojsko sodelovanje vseh deležnikov na nacionalnem nivoju. Pomembna je tudi povratna informacija, katere strukture so bolj naklonjene področju dvojne kariere in preko katerih funkcij bo možno izvajati posamezne ukrepe. Kaže se tudi zastopanost (bivših) vrhunskih športnikov in olimpijcev v različnih funkcijah. Usmeritve nacionalnega posveta na temo 
$36^{\text {TH }}$ International Conference on Organizational Science Development: Responsible ORGANiZATION (MARCH $22^{\mathrm{ND}}-24^{\mathrm{TH}}$, Portorož Slovenia)

P. Robnik \& E. Kolar: Dual Career of Athletes and Corporate Social Responsibility in Slovenia

dvojne kariere športnikov, so poleg normativnih in sistemskih pogojev za zagotavljanje usklajenega področja športa, izobraževanja in zaposlovanja športnikov, tudi sistematično urejena shema financiranja. Pomembno je, da se za področje dvojne kariere pridobi sredstva iz različnih virov, kot tudi, da je shema financiranja sistematično urejena. S sistemsko in celovito podporo področju dvojne kariere športnikov se vzpostavi preventivni pristop $\mathrm{k}$ urejanju prehoda iz športne $\mathrm{v}$ zaposlitveno kariero vrhunskega športnika. Uvedba preventivnih ukrepov je $\mathrm{z}$ vidika države cenejša in bolj učinkovita metoda, za športnika pa zagotavlja varnost in celostni razvoj športnika. Pripomore tudi k reševanju vprašanja statusnih pravic športnikov po končani karieri. Športnik, kot vzornik, pa še naprej lahko doprinese $\mathrm{k}$ trajnostni promociji športnih in drugih pozitivnih vrednot v družbi. (Robnik, 2016)

Za potrebe razvoja nadaljnjih ukrepov in politike, ki zastavlja ter izvaja programe dvojne kariere, bi bilo potrebno ovrednotiti primernost že obstoječih programov ter preveriti potrebo po drugačnih ali dodatnih ukrepih, ki bi jih bilo smiselno uvesti (Lajh Rauter, 2016). Na osnovi izvedene analize potreb slovenskih športnikov avtorica navaja tudi predloge glede potrebne izboljšave obstoječih ukrepov in programov ter priprave novih programov na področju dvojne kariere v Sloveniji. Lajh Rauter navaja da bi država morala imeti glavno povezovalno vlogo in podpreti pobude športnih organizacij, izobraževalnih institucij ter OKS-ZŠZ na področju zagotavljanja podpornih storitev dvojne kariere in okrepiti sodelovanja s podjetji, ki posredujejo zaposlitve, ter večjimi sponzorji. Potrebne so tudi sistemske ureditve na področju zaposlovanja in trga dela. Goltnik Urnaut s sodelavci (Goltnik Urnaut, 2015) v svoji raziskavi, ki je vezana predvsem na področje izobraževanja ugotavlja, da se na področju osnovnega in srednješolskega sistema omogoča učinkovito usklajevanje šolskih ter športnih obveznosti. Za razliko od osnovnošolskega in srednješolskega sistema bi bilo treba $\mathrm{v}$ Sloveniji sistemsko urediti tudi pravila prilagajanja izobraževanja športnikov v višjem ter visokem šolstvu. Ugotovitve Golnik Urnautove in Lajh Rauterjeve so, da ni enotne zakonodajne ureditve na tem področju, kar postavlja študente - športnike glede na institucijo, v kateri se izobražujejo, v neenakopraven položaj. Za zagotavljanje enakih možnosti za prilagojeno izobraževanje vseh športnikov - študentov bi bilo treba tudi nivo višješolskega in visokošolskega izobraževanja sistemsko pravno urediti.

\section{Družbena odgovornost in kritična analiza na osnovi usmeritev Evropske komisije}

\subsection{Minimalne zahteve kakovosti za posameznega deležnika na področju zagotavljanja pogojev dvojne kariere športnikov}

Minimalne zahteve kakovosti so predstavljene na podlagi študije Evropske komisije (Evropska komisija, 2016). 


\section{Sistemska raven}

Usmeritve Evropske komisije na sistemski ravni so pripravljene na osnovi celovitega pregleda zakonodaje in programov na področju dvojne kariere v 28 državah članicah. Nekatere države članice imajo ob tem obsežno in dobro organizirane sisteme (v manjšini), drugi sistemi so bolj nepopolni, s posameznimi rešitvami. Na sistemski ravni so torej povzeli naslednje ugotovitve:

1. Politike in programi na področju dvojne kariere športnikov so v Evropi zelo raznoliki - Dejstvo, da morajo športniki združevati športno kariero in vzporedno graditi svojo izobraževalno kariero oziroma delo, ni nič novega. Vendar pa je šele pred kratkim večje število držav članic prepoznalo dvojno kariero športnikov, kot temo za ukrepe in politike.

2. Pomanjkanje usposobljenosti športnikov proti izobraževalni vrzeli - Države članice se razlikujejo v obsegu svojih pobud in politik. Razlikujejo so tudi glavni akterji na sceni: včasih so to športne organizacije, včasih izobraževalni centri, in včasih vlada. Iz raziskave je razvidno, da so primarne organizacije, ki zagotavljajo pogoje za dvojno kariero športnikov v največji meri izobraževalni sektor in šport. Deležniki, ki so odgovorni za uspešen prehod na trg dela pa očitno primanjkujejo. Zaposlovanje športnikov bi sicer morala biti skupna odgovornost vseh deležnikov.

3. Ni dosledne opredelitve: prostor za vseevropski okvir - Tak sistem bi vzpostavil smernice in pomoč športnikom in študentom pri svojih kariernih odločitvah. Potrebna je uporaba enotne terminologije področja dvojne kariere športnikov na Evropski ravni.

4. Programi vladnih in nevladnih politik - Na Evropski ravni so pripoznali visoko vrednost nevladnih programov, ki so lahko zelo velika podpora področja dvojna kariera športnikov.

\section{Raven programske podpore}

Storitvene organizacije, vključene v raziskavo imajo skupno lastnost: so neodvisni organi, ki se usmerjajo na različne vidike dvojne kariere športnikov. Usmeritve na ravni storitev so naslednje:

1. Za področje dvojne kariere športnikov naj bi bila odgovorna neodvisna organizacija - Ta organizacija zagotavlja dostopnost storitev kariernega svetovanja za izboljšanje prihodnjih zaposlitvenih možnosti za vse športnike, vključene v program dvojne kariere.

2. Za podporo dvojne kariere športnikov na ravni izobraževalnih inštitucij morajo biti zagotovljeni formalni sporazumi

3. Vsa podpora je prilagojena potrebam posameznega športnika - Dvojna kariera je del celotnega življenjskega razvojnega načrta.

4. Športni objekti naj se nahajajo v bližini izobraževalnih ustanov, za olajšanje mobilnosti športnikov

5. Spodbuja se oblikovanje mrež dvojne kariere športnikov - za prenos znanja, dobrih praks in razvoj skupnih sistemov. 
$36^{\mathrm{TH}}$ INTERNATIONAL CONFERENCE ON ORganizational SCIENCE DeVElopment: RESPONSIBLE ORGANIZATION (MARCH $22^{\mathrm{ND}}-24^{\mathrm{TH}}$, PortoroŽ SLOVENIA)

P. Robnik \& E. Kolar: Dual Career of Athletes and Corporate Social Responsibility in Slovenia

V splošnem so storitve dvojne kariere najučinkovitejše, ko zagotavljajo individualno podporo, spodbujajo mobilnost športnikov, so zapisane $\mathrm{v}$ formalnih sporazumih, združujejo objekte (npr. izobraževanje in trening na istem mestu), in spodbujanje strokovnosti, zavesti, interakcije in načrtnega spremljanja.

\section{Kakovostni okvir}

Glavni cilj kakovostnega modela je izboljšanje sistemov dvojne kariere, ob upoštevanju različnih vlog in odgovornosti. Opis kakovostnega okvira:

1. Športnik - V center tega modela je umeščen športnik. Športniki so si med seboj različni, zato potrebujejo različne podpore, v različnih obdobjih njihove kariere. Hkrati pa je ključno, da je interes športnika nesporen.

2. Športnikovo socialno okolje (trener, manager, učitelj, zaposlovalec, starši, sovrstniki) - Vpliv in uspeh programov je odvisna od njihovega izvajanja na osebni in strokovni ravni neposredno blizu športnika.

3. Deležniki (športne, izobraževalne organizacije, trg dela) - V idealnem primeru nosijo odgovornost za izvajanje obstoječe nacionalne zakonodaje ali pravil, ki jih nato posredujejo športniku in njegovemu socialnemu okolju. To zahteva komunikacijo med deležniki in med različnimi organizacijskimi ravnmi (od politike do prakse).

4. Nacionalne vlade (zakonodajni okvir in politike) - Zakonodaja in politični okvir, ki so potrebni za spodbujanje prevzema odgovornosti posameznih deležnikov za dvojno kariero - varen profesionalni razvoj študentov športnikov. Kakovostni okvir je primeren tako za pregled spodbud posameznih deležnikov, kakor tudi orodje za spremljanje in izboljšave.

5. Evropska unija (mobilnost športnikov, online izobraževanja) - Študenti športniki v Evropi postajajo vse bolj mobilni, izobrazba pa, zaradi elektronskih možnosti študija, manj vezana na fizične ustanove, zaradi česar naraščajo potrebe za spremljanje študentov športnikov. Pomembna je tudi povezava s trendi in razvojem v izobraževalnem sektorju in na trgu dela.

Kakovostni okvir predvideva tudi akreditacije za objekte in storitve dvojne kariere na nacionalni in evropski ravni. Prav tako so v okvir vključena priporočila za prihodnji razvoj politik in raziskav na področju dvojne kariere. Ta model pa omogoča tudi podporo in razvoj obstoječih možnosti in orodje za dolgoročno spremljanje dvojne kariere. Vsak deležnik je ocenjen na podlagi lestvice: šibko - zahteva izboljšanje - dobro - izjemno.

\section{Minimalne zahteve za vzpostavitev pogojev dvojne kariere športnikov}

Pet stebrov, ki jih predvidevajo smernice Evropske komisije, je pripravljenih na osnovi minimalnih pogojev za vzpostavitev visokozmogljivih centrov za usposabljanje (»High Performance Training Centres«), ki športniku omogočajo sočasno izobraževalne pogoje in pogoje za udejstvovanje v športu na najvišji ravni: 
P. Robnik \& E. Kolar: Dvojna kariera športnikov in družbena odgovornost v Sloveniji

1. Nastanitev - prilagojena športnikom.

2. Izobraževanje - ki naj bi bilo mednarodno izmenljivo in ponuja različne izobraževalne module, prilagojene potrebam športnikov. Le ti morajo biti uradno priznani s strani ministrstev.

3. Osebje - Uradno priznani strokovnjaki: fizioterapevt, trener, strokovnjak za prehrano, športni psiholog, zdravstvena podpora, ki so športniku ves čas na voljo.

4. Objekti - Vezani na nastanitev in izobraževanje, ki so locirani skupaj in omogočajo športniku sočasno izobraževanje in trenažne procese.

5. Storitve - podpora življenjskemu slogu, karierna podpora, zdravstvena podpora,..ipd.

\subsection{Primerjava in kritična analiza}

Kritična analiza predstavlja izhodišča za nadaljnje delo na področju dvojne kariere športnikov na nacionalnem nivoju. Glavno vodilo je sledenje smernicam minimalnih zahtev kakovosti za posameznega deležnika na področju zagotavljanja pogojev dvojne kariere športnikov. Doprinos teh smernic je predlog enotnega Evropskega delovnega okvirja za podporne in infrastrukturne rešitve za programe dvojne kariere športnikov, ki so lahko enakomerno razporejeni med državami članicami. Iz samih smernic izhajajo določene omejitve, ki se lahko pojavijo pri implementaciji delovnega okvira oziroma modela na nacionalni ravni in sicer sta uspeh pri implementaciji in seznam minimalnih zahtev močno odvisna od načina izvedbe v praksi.

\begin{tabular}{|c|c|}
\hline $\begin{array}{l}\text { SMERNICE EU GLEDE } \\
\text { MINIMALNIH ZAHTEV } \\
\text { DVOJNE KARIERE }\end{array}$ & PRIMER SLOVENIJE \\
\hline \multicolumn{2}{|l|}{ Sistemska raven } \\
\hline \multirow{2}{*}{$\begin{array}{l}\text { Pomanjkanje } \\
\text { usposobljenosti športnikov } \\
\text { proti izobraževalni vrzeli }\end{array}$} & $\begin{array}{l}\text { Deležniki, ki so odgovorni za uspešen prehod na trg dela } \\
\text { primanjkujejo. }\end{array}$ \\
\hline & $\begin{array}{l}\text { Potrebni so ukrepi: Usposabljanja športnikov za poklice, } \\
\text { povezane s športom. Predstavitev možnosti zaposlitve } \\
\text { športnikov po koncu športne kariere. Opravljanje prakse v } \\
\text { podjetjih in pri sponzorjih. Zaposlitev v državni upravi tudi v } \\
\text { času do dveh let po koncu športne kariere. Priprava kariernih } \\
\text { načrtov s pomočjo kariernih svetovalcev, specializiranih za } \\
\text { športnike. Praktična usposabljanja športnikov. }\end{array}$ \\
\hline $\begin{array}{l}\mathrm{Ni} \text { dosledne opredelitve: } \\
\text { prostor za vseevropski okvir }\end{array}$ & $\begin{array}{l}\text { Uporaba enotne terminologije področja dvojne kariere } \\
\text { športnikov - nacionalne smernice dvojne kariere }\end{array}$ \\
\hline \multicolumn{2}{|l|}{$\begin{array}{l}\text { Raven } \\
\text { podpore }\end{array} \quad$ programske } \\
\hline \multirow{3}{*}{$\begin{array}{lcr}\text { Za področje dvojne kariere } \\
\text { športnikov naj bi bila } \\
\text { odgovorna } & \text { neodvisna } \\
\text { organizacija } & \\
\end{array}$} & Ni samostojne organizacije za dvojno kariero športnikov. \\
\hline & Razvit predlog modela dvojne kariere. \\
\hline & Sistematično urejena shema financiranja. \\
\hline $\begin{array}{l}\text { Za podporo dvojne kariere } \\
\text { športnikov na ravni } \\
\text { izobraževalnih inštitucij }\end{array}$ & Dobro urejeno na osnovnošolski in srednješolski ravni. \\
\hline
\end{tabular}


P. Robnik \& E. Kolar: Dual Career of Athletes and Corporate Social Responsibility in Slovenia

\begin{tabular}{|c|c|}
\hline $\begin{array}{l}\text { morajo biti zagotovljeni } \\
\text { formalni sporazumi }\end{array}$ & \\
\hline & $\begin{array}{l}\text { Sistemsko urediti tudi pravila prilagajanja izobraževanja } \\
\text { športnikov v višjem ter visokem šolstvu. }\end{array}$ \\
\hline & Poenotenje pravilnikov na vseh treh ravneh. \\
\hline & Potrebno je urediti dodatke za kader za delo na daljavo. \\
\hline & Opravljanje mature in zaključnih izpitov pod posebnimi pogoji. \\
\hline & $\begin{array}{l}\text { Mentorji/tutorji za pomoč pri usklajevanju šolskih obveznosti s } \\
\text { športom. }\end{array}$ \\
\hline \multirow[t]{2}{*}{ 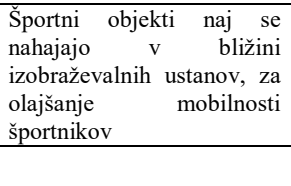 } & Studentski kampusi \\
\hline & Športni oddelki na več srednjih in poklicnih šolah. \\
\hline $\begin{array}{l}\text { Spodbuja se oblikovanje } \\
\text { mrež dvojne kariere } \\
\text { športnikov }\end{array}$ & Certifikat Športniku prijazno izobraževanje (podjetja) \\
\hline \multicolumn{2}{|l|}{ Kakovostni okvir } \\
\hline Športnik & Ključna je motivacija športnika za dvojno kariero. \\
\hline Športnikovo socialno okolje & $\begin{array}{l}\text { Izobraževanja, delavnice, predstavitve za športnikovo bližnje } \\
\text { okolje in ljudi, ki z njim delajo. Informiranje } \\
\text { učiteljev/profesorjev glede potreb športnikov. }\end{array}$ \\
\hline Deležniki & $\begin{array}{l}\text { Ustrezna komunikacija med deležniki na nacionalnem nivoju. } \\
\text { Ustrezne rešitve za nekdanje vrhunske športnike (na področju } \\
\text { zdravja ter socialnega varstva). }\end{array}$ \\
\hline Nacionalne vlade & Novi Zakon o športu. \\
\hline Evropska unija & $\begin{array}{l}\text { Povezovanje z Evropskimi mrežami. Priprava skupnih } \\
\text { izobraževalnih modulov. Možnost izobraževanja športnikov v } \\
\text { tujini/na tujih izobraževalnih institucijah. }\end{array}$ \\
\hline \multirow[t]{2}{*}{$\begin{array}{lr}\text { Minimalne } & \text { zahteve za } \\
\text { vzpostavitev } & \text { pogojev } \\
\text { dvojne kariere športnikov } \\
-\quad \text { \#igh Performance } \\
\text { Training Centres« } \\
\end{array}$} & \\
\hline & $\begin{array}{l}\text { Primer dobre prakse - Državni panožni nordijski center DPNC } \\
\text { Kranj }\end{array}$ \\
\hline
\end{tabular}

\section{Zaključek}

Vrhunski šport predstavlja eno najvišjih oblik človekove ustvarjalnosti na področju športa. Pogosto je to tudi športna dejavnost, s katero se dokazujejo zgornje meje človeških psihofizičnih sposobnosti. Ta pojavna oblika športa ima pomembno vlogo za druge vidike športa, zlasti za vključevanje mladih v šport. Vrhunski športniki so vzorniki mladim, z njihovimi dosežki pa se pogosto poistovetijo vsi pripadniki neke nacionalne skupnosti. Vrhunski šport je tudi področje, na katerem se lahko prek dosežkov na mednarodni ravni uresničujejo nekatere koristi države (npr. prepoznavnost). Vrhunski športni dosežki posredno odražajo razvitost športne panoge, kažejo na njeno organiziranost, vplivajo na športno industrijo, trgovino, turizem, medije, posredno pa usmerjajo načine (aktivnega in pasivnega) preživljanja prostega časa ljudi. (Jurak, 2010) 
Glavni cilj raziskave je bil z vidika družbene odgovornosti, poiskati pomanjkljivosti in priložnosti predlaganega slovenskega nacionalnega modela dvojne kariere. V kritični analizi smo na primeru Slovenije ugotovili, kateri pogoji na nacionalni ravni omogočajo podporo in razvoj dvojne kariere vrhunskih športnikov in katere deležnike je pomembno nasloviti za zagotovitev posameznih pogojev na več ravneh in sicer: na sistemski ravni je potrebno napore usmeriti predvsem na področje usposobljenosti športnikov in njihov prehod na trg dela. Te naloge bi kot deležnik na nacionalni ravni lahko opravljala samostojna organizacija za dvojno kariero, ali pa agencija, ki se ukvarja s področjem kadrovskega managementa in storitev zaposlovanja (npr. Adecco) v sodelovanju z ostalimi deležniki. Predvsem se potrebuje bolj praktične in konkretne rešitve. V smislu programske podpore, so v Sloveniji potrebne nekatere dopolnitve podpore dvojne kariere na ravni izobraževalnih inštitucij, predvsem na višje in visokošolski ravni in pri poenotenju. Naklonjenost podpori dvojne kariere športnikov s strani izobraževalnih institucij je dobra. Mentorji/tutorji za pomoč pri usklajevanju šolskih obveznosti s športom in usmerjanju mladih športnikov predstavljajo velik potencial, glede na usmeritve tudi v drugih državah članicah. Pri zagotavljanju primernega kakovostnega okvira smo ugotovili, da je ključna predvsem primerna in zadostna komunikacija obstoječih programov in sistemske podpore dvojne kariere med posameznimi deležniki in še posebej s športniki in njihovim ožjim socialnim okoljem. Evropska komisija (Evropska komisija, 2016) pa v smeri minimalnih zahtev za vzpostavitev pogojev dvojne kariere športnikov, izpostavlja »High Performance Training Centres«, torej visoko profesionalne centre, ki omogočajo hkratno izobraževanje in trenažni proces, ki je lokacijsko blizu. V Sloveniji imamo primer dobre prakse - Državni panožni nordijski center DPNC Kranj, ki bi mu bilo vredno slediti.

Več ovir pa je lahko pričakovati v realizaciji modela dvojne kariere športnikov, predvsem $\mathrm{z}$ vidika financiranja področja dvojne kariere, ki je temelj za kasnejšo uspešno izvedbo in operativno delovanje področja dvojne kariere na nacionalni ravni in uspešnosti operativne izvedbe posameznega subjekta, ki bo sodeloval pri posameznem procesu.

Iz navedenih opredelitev lahko povzamemo skupne temeljne značilnosti na področju dvojne kariere, tako na Evropski ravni, kot na primeru Slovenije. Družbena odgovornost je širši pojem, ki ne prinaša koristi samo posameznim organizacijam, ter celostnemu razvoju športnikov temveč tudi, na osnovi pozitivnih vrednot športa in sočasnega izobraževanja oziroma zaposlovanja, $\mathrm{k}$ razvoju družbe in njene odličnosti.

\section{Literatura}

Capranica, L., J. Foerster, O. Keldorf, V. Leseur, P. Vandewalle, M. Doupona Topič, I. Abelkalns, R. Keskitalo, T. Kozsla, A. Figueiredo in F. Guidotti. 2015. The European Athlete as Student Network (»EAS «): prioritising dual career of European studentathletes. Kinesiologia slovenica 21 (2): 5-10.

Chelladurai, P. (1994). Sport Management: Defining the field. European Journal for Sport Managament, 1994, 1, 7-21. 
36 ${ }^{\mathrm{TH}}$ International Conference on Organizational Science Development: RESPONSIBLE ORGANIZATION (MARCH $22^{\mathrm{ND}}-24^{\mathrm{TH}}$, PortoroŽ SLOVENIA)

P. Robnik \& E. Kolar: Dual Career of Athletes and Corporate Social Responsibility in Slovenia

Corrado, L., Tessitore, A., Capranica, L., Rauter, S., \& Topic, M. D. (2012). Abstract Motivation for a Dual-Career: Italian and Slovenian Student- Athletes Motivacija Za Dvojno Kariero : Italijanski in Slovenski Študenti. Kinesiologia Slovenica, 56, 47-56.

EU cooperation in education and training (ET 2020). Council conclusions on a strategic framework for European cooperation in education and training (2016). http://epp.eurostat.ec.europa.eu/portal/page/portal/employment_social_policy_e quality/education_training

EU Guidelines on Dual Careers of Athletes (2012). Recommended Policy Actions in Support of Dual Careers in High-Performance Sport. Brussels: Sport Unit of the Directorate-General for Education and Culture of the European Commission.

European Union; European Commission. (2016). Study on sport qualifications acquired through sport organisations and (sport) educational institutes.

European Commission, Sport (2016). Study on the Minimum Quality Requirements for Dual Career services: Executive summary. Luxembourg: Publications Office of the European Union, 2016. ISBN 978-92-79-54600-6, doi: 10.2766/801544.

European Parliament, Directorate-General for Internal Policies, Policy Department B: Structural and Cohesion Policies, Culture and Education: RESEARCH FOR CULT COMMITTEE QUALIFICATIONS/DUAL CAREERS IN SPORTS, Study. European Union, 2016. IP/B/CULT/IC/2015-144.

http://www.europarl.europa.eu/RegData/etudes/STUD/2016/573416/IPOL_STU(2016)57341 6_EN.pdf

Freeman, R. Edward. (1984). Strategic Management: A Stakeholder Approach. Boston: Pitman.

Goltnik Urnaut, A. (2015). PRIPRAVA NA DRUGO KARIERO V ČASU UKVARJANJA Z VRHUNSKIM ŠPORTOM. Fakulteta za komercialne in poslovne vede Celje.

Guidelines of Europe 2020. Europe 2020 in a nutshell. Targets. European Commission publishing (2016). http://ec.europa.eu/europe2020/index_en.htm

Henry, Ian Paul. 2015. Elite Athletes and Higher Education: Lifestyle, 'Balance' and the Management of Sporting and Educational Performance.(17.8.2016). ttp://www.researchgate.net/profile/Ian_Henry/publication/274070410_IOC_position_paper_ Henry/links/551411e10cf283ee0834a346.pdf

International Olympic Committee. (2014). Olympic Agenda 2020. 127th IOC Session. Retrieved from: http://www.olympic.org/documents/olympic_agenda_2020/olympic_agenda_2020-2020_recommendations-eng.pdf

International Olympic Committee. (2014). Mobility Agenda 2020.

International Olympic Committee. (2016). Athlete Career Programme ( ACP ) Table of contents. Retrieved from https://www.olympic.org/athlete-career-programme

JURAK, Gregor (ur.) (2010). Nacionalni program športa v Republiki Sloveniji 2011 - 2020. Predlog 21.4.2010, gradivo za razpravo na OKS-ZŚZ. Univerza v Ljubljani, Fakulteta za šport. Ljubljana.

KOLAR, Edvard, JURAK, Gregor, KOVAČ, Marjeta (2010). Analiza Nacionalnega programa športa v Republiki Sloveniji 2000 - 2010 (delovna neprečiščena različica). Univerza V Ljubljani, Fakulteta za šport, Ljubljana. (Ur. 1. RS, št. 24-1065/2000)

Kolar, E.; Pavletič Samardžija, P.; Robnik, P. (2015). Odličnost v dvojni karieri vrhunskih športnikov, interno gradivo. Olimpijski komite Slovenije - Združenje športnih zvez, Ljubljana.)

Ministrstvo za izobraževanje znanost in šport ter Zavod za šport RS Planica. (2014). IZVEDBENI NACRT NACIONALNEGA PROGRAMA ŠPORTA V REPUBLIKI SLOVENIJI: 2014-2023 (Vol. 5).

Ministrstvo za izobraževanje znanost in šport ter Zavod za šport RS Planica. (2014). NACIONALNI program športa v Republiki Sloveniji : 2014-2023. 
P. Robnik \& E. Kolar: Dvojna kariera športnikov in družbena odgovornost v Sloveniji

Olimpijski komite Slovenije. (2016). AKCIJSKI NAČRT 2014-2023/[uredila Edvard Kolar in Poljanka Pavletič Samardžija - 1.izd., 1. Natis. Ljubljana.

Olimpijski komite Slovenije. (2013). STRATEGIJA OLIMPIJSKEGA KOMITEJA SLOVENIJE ZDRUŽENJA ŠPORTNIH ZVEZ ZA OBDOBJE 2014 -2023.

Rauter Lajh, L. (2016). Programi dvojne kariere in prilagajanje športnikov na življenje po koncu športne kariere. Magistrska naloga, Univerza na Primorskem, Fakulteta za management.

Robnik, P. (2011). Management športnih organizacij. Ljubljana: UNIVERZA V LJUBLJANI, FAKULTETA ZA UPRAVO. Retrieved from http://www2.fu.unilj.si/diplome/pdfs/diplomska/robnikpetra.pdf

Robnik, P. (2016). Dvojna kariera vrhunskih športnikov, predstavitev dobre prakse in usmeritve na področju dvojne kariere na nacionalnem nivoju. Olimpijski komite Slovenije - Združenje športnih zvez, interno gradivo.

Robnik, P. (2016). Detajlno poročilo Posveta Ministrstva za izobraževanje, znanost in šport, o razvojnih dejavnostih $v$ športu (izobraževanje nadarjenih in vrhunskih športnikov, zaposlovanje vrhunskih športnikov in trenerjev, v javni upravi in podjetjih -dvojna športnikova kariera). Olimpijski komite Slovenije - Združenje športnih zvez, gradivo za udeležence posveta.

Zakon o športu (ZSpo), Uradni list RS, št. 22/1998, z dne 20. 3. 1998 (2016). http://www.uradnilist.si/1/objava.jsp?urlid=199822\&stevilka=929 
904 36 $36^{\mathrm{TH}}$ INTERnational CONFERENCE ON ORganizational SCIENCE DeVelopment: RESPONSIBLE ORGANIZATION (MARCH $22^{\mathrm{ND}}-24^{\mathrm{TH}}$, Portorož SLOVENIA) 
$36^{\text {Th }}$ International Conference on Organizational Science DEVElopMENT: Responsible ORganization (MARCH $22^{\mathrm{ND}}-24^{\mathrm{TH}}$, PORTOROŽ SLOVENIA)

O. Arsenijević, M. Ferjan, I. Podbregar, P. Šprajc, D. Trivan \& Y.

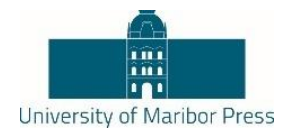

Ziegler

\title{
Perception of Sales Organizations for Luxury Speed Boats' Sales in Recession in Croatia
}

\author{
SINIŠA RUDELJ \& MILAN RUDELJ
}

\begin{abstract}
Luxury is derived from the psychological needs of individuals and has a link with prestige, symbolism and differentiating. Luxury boats are typical luxury goods which sales organizations (producers, agents, dealers, etc.) have a task to place on a particular market. On the other hand, the recession is in the foundations of the cycle of development of modern national economies and the world economy as a whole. Recession significantly affects sales of luxury goods. Sales organizations, as responsible organizations in terms of sustainable business, pay attention to the future sales and generation of demand and their supply through investment in marketing depend on their expectations. Executed empirical research, which covered a period of eleven years, has focused on the compliance of variation of Gross Domestic Product and perception (expectations) of selling a luxury speed boats. The aim is to analyze the perception of the sales of luxury goods in times of recession in Croatia by using a practical example of luxury speed boats. The conclusion is that there is a positive corelation between the expectations of sales of luxury speed boats and recession. However, the perception of sales in recession is late in relation to the sales of luxury goods in recession.
\end{abstract}

KEYWORDS: sales organization $\bullet$ luxury goods $\bullet$ recession $\bullet$ luxury speed boats $\cdot$ Croatia

CORRESPONDENCE AdDRESS: Siniša Rudelj, Ph.D., Bravo-Makarska d.o.o., Vukovarska 27, 21300

Makarska, Croatia, e-mail: sinisa.rudelj@ st.t-com.hr; Milan Rudelj, Femar Vukovarska 27, 21300

Makarska, Croatia, e-mail: milan.rudelj@gmail.com

DOI https://doi.org/10.18690/978-961-286-020-2.71

ISBN 978-961-286-020-2

(C) 2017 University of Maribor Press

Available at: http://press.um.si 
36 ${ }^{\text {TH }}$ International Conference on Organizational Science Development: RESPONSIBLE ORGANIZATION (MARCH $22^{\mathrm{ND}}-24^{\mathrm{TH}}$, PORTOROŽ SLOVENIA)

S. Rudelj \& M. Rudelj: Perception of Sales Organizations for Luxury Speed Boats'

Sales in Recession in Croatia

\section{$1 \quad$ Introduction}

Recessions are a reality of the modern world. Our globalized world requires only enough significant spark to extend the recession. From the central point, recession spreads outwards (Buturac, 2013). One of the examples is the big recession of 2008, which began in the US by explosion of the real estate bubble (Economic Policy Institute, 2015) and which lasted six years in Croatia. This recession has shown the level of interdepence between economies (Buturac, Rajh and Teodorović, 2009).

There is a variety of goods which serve to satisfy human needs. In times of recession motives for their fulfillment significantly change. For human needs, motivation can simultaneously exist for all three levels: Existence, Connection, Growth and development (Alderfer, 1969). Luxury goods have a strong link with higher levels of needs, because they satisfy certain psychological needs of the individual. Luxury is generally associated with symbolism, prestige and perception of difference (Rudelj, 2016). Typical luxury goods are expensive luxury speed boats which do not serve only for transportation and leisure but also, unlike small, inexpensive boats, satisfy needs of a higher level (Rudelj, 2016). In recession the rules of the business game are changing, especially when it comes to luxury goods

Business subjects, as responsible organizations that care not only for their environment and their community, but also for their mission, must respect the principles of strategic management. This means analyzing and forecasting market dynamics. The prediction of economic turning point is necessary (Dovern and Huber, 2015) because the business itself depends on the generating of future demand. Sales organizations' perception (in terms of observation and scanning, receiving stimulation and knowledge, understanding and acceptance) of the market dynamics and sale becomes a source of competitive advantage. Business organizations have a competitive advantage when they are better at something or when they can and/or have something useful that other competitors don't have or can't do (Coulter, 2010, pp. 41).

The concept of business competitiveness, although created at the end of the last century, is still relevant today. Harvard Business School, Boston Consulting Group and McKinsey \& Company (Ghemawat, 2002, pp. 37) have all given contribution to its development. One of the main tasks of management in business organizations is gaining and preserving a competitive advantage (Rudelj, 2011, pp. 2) whiletaking into account the external environment and resources. Causality between the internal and external environment has become a critical factor for organizational development of a responsible business organization. In doing so, the perception (in terms of skills and superiority of perception and cognition), along with intellectual capital, assets unavailable to senses and organizational culture, could also fall within specific soft variables of business organizations.

This poses a question of the perception of sales organizations, as responsible organizations, of the sale of certain goods in complex market conditions: a time of 
recession, luxury goods, a limited market. The main hypothesis of this paper is the following: There is a positive correlation between the expectations of sales of luxury speedboats by the sales organizations and recession as a phase of the business cycle.

\section{Sales of luxury goods in recession}

Human needs are complex and diverse. The man is a biological, but also a psychological being. According to Maslow, human needs are external, internal and needs of growth (Goble, 2004). All goods have the task to satisfy the needs. While luxury goods are not necessary for human survival, they satisfy specific human needs. Luxury is derived from the psychological needs of individuals.

Luxury goods above all have a link with symbolism. It represents their main quality by which they differ from the other goods. Nueno and Quelch (1998) reported six distinctive elements: price, quality, aesthetics, rarity, excellence and symbolism. They pointed out that the ratio of intangible / situational usefulness and prices for luxury goods is high, while the ratio between functionality and price is relatively low. Users of luxury goods are aware of their symbolism and thus send a message to their environment with the purpose of their own achievement.

Luxury goods may represent an element of socio-economic identification (Thomas, 2009). They are important to everyone, not just the individuals who have satisfied the lower level needs (this shows that the Alderfer rightly complemented Maslow). Luxury goods, dressed in a luxury brand mark, are characterized by the following: uniqueness, rarity, high price and quality, special messages and providing customer satisfaction, special availability to senses, excellence, symbolic value, style, fashion and aesthetics. Luxury products have Eccentric selling proposition - ESP (Sinčić Ćorić and Roglić, 2015), which is achieved by specific properties. Luxury goods can be categorized in several ways. Three selected categorizations: Statistic Portal (2016), Research and Markets (2013, as specified in Čorić Sinčić and Roglić, 2015) and Genier (2014) are shown in table 1. 
36 ${ }^{\mathrm{TH}}$ International Conference on Organizational Science Development: RESPONSIBLE ORGANIZATION (MARCH $22^{\mathrm{ND}}-24^{\mathrm{TH}}$, PORTOROŽ SLOVENIA)

S. Rudelj \& M. Rudelj: Perception of Sales Organizations for Luxury Speed Boats'

Sales in Recession in Croatia

\begin{tabular}{|l|l|l|}
\hline \multicolumn{1}{|c|}{ Statistic Portal } & Research and Markets & Genier \\
\hline \multicolumn{1}{|c|}{ II } & \multicolumn{1}{|c|}{ III } \\
\hline $\begin{array}{l}\text { luxury cars } \\
\text { personal luxury }\end{array}$ & fesigner clothes wines, champagnes and spirits & watches and jewelery \\
\hline $\begin{array}{l}\text { luxury services } \\
\text { luxury jewelry, watches and } \\
\text { accessories }\end{array}$ & cosmetics and perfumes \\
\hline $\begin{array}{l}\text { luxury wines and } \\
\text { fine spirits }\end{array}$ & luxury cigarettes & gifts and wine \\
\hline $\begin{array}{l}\text { luxury food } \\
\text { luxury in art }\end{array}$ & luxury office and stationery & other selective products \\
\hline designer furniture & luxury color cosmetics & fashion sector \\
\hline luxury aircraft & passenger cars & Hotels and tourism \\
\hline luxury yachts & yachts and private luxury aircraft & Luxury speed boats \\
\hline $\begin{array}{l}\text { cruise on luxury } \\
\text { vessels }\end{array}$ & other luxury goods & yacht \\
\hline
\end{tabular}

Table 1: Categorization of luxury goods

Luxury goods represent a variety of products and services. They have a wide range; from designer clothes to luxury cosmetics. Luxury yachts and luxury speed boats are a category which also belongs to luxury goods. In the luxury domain various other categorizations of consumption also exist. In contrast to the aforementioned functional classification, Vigneron and Johnson (1999) categorize luxury goods by their consumers. They believe that hedonists and perfectionist consumers are affected by personal values, and with the effects of Veblen, snob and bandwagon they explain luxury consumption of individuals who are under the influence of social values.

According According to The Statistics Portal (2016), the global market of luxury goods has exceeded 1,000 billion euros. The share of luxury cars, planes and boats is over 40 percent. Luxury services are at about 17 percent while luxury alcoholic beverages and food are at ten percent. The representation of global sales of luxury goods is very interesting. Consumers from countries of economic rise and transition countries are buying luxury material goods above all to show off, while in developed countries consumers demand more intangible goods and luxury services. The reasons for this should be sought in the level of development, but also in cultural determination of perceptions, desires and needs of an individual, which results in different understandings of luxury in general, and not just the ways of satisfying needs for luxury goods (Rudelj, 2016). Croatian newly born capitalism is characterized by evident passion for luxury status symbols. 
Recessions are built into the foundations of the development cycle of modern national economies and the world economy as a whole. It is a downward phase of the business cycle with the fall of the basic indicators of economy. In contrast to the upward phase of the business cycle, the recession is a period in which GDP is declining at least two quarters in a row (Filardo, 1999, pp. 35). Recessions bring major changes in the economic and social flows. Under these conditions, the demand for luxury goods declines, because lower level needs are satisfied first, and the use of the symbolic becomes less popular. The continuity of recession leads to changes in the attitude of the consumers. They now have a somewhat different perception of their money and consumer potential (which is usually reduced). In such conditions, luxury goods become even more attractive, but the environment does not take their emphasis so lightly anymore. This issue is very complex because it concerns people and variables which do not belong only to the economic domain but also to psychology and sociology.

Recession significantly affects sales of luxury goods but there is very little actual research on this connection. Ziccardi (2001) states that the emotional connection between consumers and luxury brands still manages to withstand recession. Some researchers put the focus not on sales, but instead they focused on fashion and luxury brands (Horvat, 2015, Sinčić Ćorić and Roglić, 2015; Genier, 2014; Kapferer and Laurent, 2016). In Croatia, research (Rudelj 2016) shows that the sales of certain typical luxury goods is affected by the recession. Sales have decreased significantly in times of recession while over the period of expansion they have significantly increased. The link between the observed phenomena is positive, strong and very strong.

Sales of luxury goods in times of recession represent a difficult task for the sales organizations. Guided by the principles of a responsible organization, sales organizations are, in general, responsible towards their environment. It is an imperative for the sale of goods. Their responsibility towards the fulfillment of their goals is almost equal. Sales organizations must devote their attention to market dynamics and expected sales. Their business activities are also generated based on their perception of future sales. Supply and generation of demand through concentration of effort, investment in marketing and other business activities all depend on their expectations of sales. An empirical research was conducted on the perception of certain sales organizations on the example of anticipated sales of luxury speed boats during the recession in Croatia.

\section{Empirical research on sales organizations' perceptions of the sale of luxury speed boats in recession in Croatia}

Luxury speed boats are typical example of luxury goods which sales organizations (producers, agents, dealers, etc.) have a task of placing on a particular market. The definition of luxury speedboat was also tested in this empirical research. The working definition was: Luxury speed boats are vessels of 7-10 meters of length which include: a high cost, a well-known brand and a high quality. The basic set consists of sales organizations that sell luxury speed boats in Croatia. 
There are two variables in the study. The independent variable $(\mathrm{X})$ is the Gross Domestic Product in Croatia while the dependent variable (Y) is related to the sale of luxury speed boats expected in Croatia. Empirical research was conducted in the spring of 2016 and it covered the whole base set. For operational research the technique of interviewing and/or developing research instruments using some of the measurement scales was imposed. Acceptable target threshold was set at $30 \%$ of filled instruments. Acceptable target is often 20\% (Pološki Vokić, 2004), but is often achieved about $30 \%$ or more: $25,81 \%$ (Vrdoljak Raguž, 2010), 28,30\% (Ekert and Ekert, 2009), 28,41\% (Aman, 2003), 32,0\% (Šošić et al., 2007), 40,52\% (Rudelj, 2011), 53,30\% (Češnovar, 2006). The research refers to respondents who have distributed luxury speed boats in Croatia in the period from 2005 to 2015. They are the manufacturers of luxury speed boats or their authorized sellers who had a head office in Croatia, Germany, Austria, Hungary and Italy (the basic set). The research has concentrated on the sale of luxury speed boats expectation for the period from 2005 to 2015 .

The survey instrument contains 10 elements of which eight use grading from 1-5 which was modeled after the Likert scale while two elements are designed in such a way that participants need to write down certain values associated with the sale of luxury speed boats during the observation period and the expectations of sales of luxury speed boats. The survey instrument was distributed by e-mail, but in some cases it was used for interviewing as well (the examiner filled out a questionnaire based on responses which were given by subjects). Languages used were Croatian and English and 38\% of the questionnaire was completed.

The data for Gross Domestic Product (GDP) in the Republic of Croatia from 2005 to 2015 were taken from databases of the Croatian Chamber of Commerce and compared with the data from the Central Bureau of Statistics and Eurostat data. They represent the index of real growth rate in the observed period. Table 2 shows the quantitative values of the observed variables. Indexes of perception of luxury speed boats' sales are listed; they were made on the basis of the research results. The data were analyzed, and for the base 100 the year 2005 was taken. 
S. Rudelj \& M. Rudelj: Perception of Sales Organizations for Luxury Speed Boats'

Sales in Recession in Croatia

\begin{tabular}{|c|c|c|c|c|}
\hline \multirow[b]{3}{*}{ Year } & \multicolumn{2}{|c|}{$\begin{array}{l}\text { Gross Domestic } \\
\text { Product } \\
\text { (GDP) in Croatia } \\
\text { (variable X) }\end{array}$} & \multicolumn{2}{|c|}{$\begin{array}{c}\text { Sales of luxury speed boats, } \\
\text { expected in Croatia } \\
\text { (variable Y) }\end{array}$} \\
\hline & \multicolumn{2}{|c|}{$\begin{array}{c}\text { Index of real growth } \\
\text { rate } \\
(2005-2015) \\
2005=100\end{array}$} & \multicolumn{2}{|c|}{$\begin{array}{c}\text { Perceptions index } \\
(2005-2015), 2005=100\end{array}$} \\
\hline & Index & $\begin{array}{l}\text { Chain } \\
\text { index }\end{array}$ & Index & Chain index \\
\hline I & II & III & IV & V \\
\hline 2005. & 100 & 100 & 100 & 100 \\
\hline 2006. & 104,8 & 104,8 & 108,6 & 108,6 \\
\hline 2007. & 110,25 & 105,2 & 121,3 & 111,9 \\
\hline 2008. & 112,56 & 102,1 & 126,7 & 104,5 \\
\hline 2009. & 104,24 & 92,5 & 127,8 & 100,9 \\
\hline 2010. & 102,46 & 98,4 & 118,5 & 92,7 \\
\hline 2011. & 102,16 & 99,7 & 111,2 & 93,8 \\
\hline 2012. & 99,91 & 97,7 & 108,3 & 97,4 \\
\hline 2013. & 98,81 & 98,8 & 107,2 & 99 \\
\hline 14. & 98,41 & 99,6 & 106,2 & 99,1 \\
\hline 2015 & 99,99 & 101,6 & 105,1 & 99 \\
\hline
\end{tabular}

Table 2: GDP and sales of luxury speed boats, expected in Croatia 2005-2015

Table 3 contains the data of descriptive statistics for the observed phenomena. The arithmetic mean (Mean) of the variable (X) is 103.06. The variable (Y) has a Mean of 112.81. The values of the variance of the basic set for observed variables are the mean squared deviations of individual numerical values from their arithmetic mean. It is obvious that the variable $\mathrm{Y}$ has a much higher deviation from the Mean. 
912 36 $6^{\mathrm{TH}}$ InTERnAtional CONFERENCE ON ORganizational SCIENCE Development: RESPONSIBLE ORGANIZATION (MARCH $22^{\mathrm{ND}}-24^{\mathrm{TH}}$, PortoroŽ SLOVENIA)

S. Rudelj \& M. Rudelj: Perception of Sales Organizations for Luxury Speed Boats'

Sales in Recession in Croatia

\begin{tabular}{|l|l|l|l|}
\hline \multicolumn{2}{|c|}{$\begin{array}{c}\text { Sales of luxury speed boats, } \\
\text { expected in Croatia } \\
\text { (variable Y) }\end{array}$} & \multicolumn{2}{c|}{$\begin{array}{c}\text { Gross domestic product (GDP) } \\
\text { in Croatia } \\
\text { (variable X) }\end{array}$} \\
\hline \multicolumn{2}{|c|}{$\begin{array}{c}\text { perceptions index } \\
\text { 2005-2015 }\end{array}$} & \multicolumn{2}{c|}{$\begin{array}{c}\text { index of real growth rate } \\
\text { 2005-2015 }\end{array}$} \\
\hline II & \multicolumn{1}{c|}{ III } & 103,06 \\
\hline Standard Error & 112,81 & Mean & 1,41 \\
\hline Median & 2,80 & Standard Error & 102,20 \\
\hline Standard Deviation & 9,28 & Median & 4,66 \\
\hline Sample Variance & 86,14 & Standard Deviation & 21,74 \\
\hline Minimum & 100 & Sample Variance & 98,40 \\
\hline Maximum & 127,80 & Minimum & 112,60 \\
\hline Sum & 1240,90 & Maximum & 1133,7 \\
\hline Count & 11 & Sum & 11 \\
\hline
\end{tabular}

Table 3: Descriptive statistics

The coefficient of variation (V) is a relative measure of dispersion, and can be used for the comparasion of the dispersion of two specified distributions (ratio of standard deviation and the mean - for each distribution). The coefficient of variation (V) for the dependent variable Sales of luxury speed boats expected in Croatia (in the period 2005 2015 ) is $8.23 \%$ while for the variable the Gross Domestic Product (GDP) in Croatia (per year from 2005 - 2015) is $4.52 \%$.

The paired data (Figure 1) shows how to calculate the regression equation. The coefficient of determination $\left(\mathrm{R}^{2}\right)$ is 0.5946 . This means that nearly $60 \%$ of the square deviations is interpreted with this regression. The corresponding Pearson correlation coefficient $(r)$ is 0.7711 and was obtained as the square root of the coefficient of determination. It shows the direction and strength of the connection between the phenomena.

According to Kukić and Rudelj (2015), in this case, the interval significance of Pearson's correlation coefficient from 0.67 to 0.82 testifies to the existence of a statistically significant connection between the phenomena. $\mathrm{H} 1: \mathrm{r} \neq 0$ is sustained. The direction of the connection is positive, i.e. when GDP grows, variable Y grows as well and vice versa. There is significant compliance in the variation of the two observed phenomena. 
S. Rudelj \& M. Rudelj: Perception of Sales Organizations for Luxury Speed Boats'

Sales in Recession in Croatia

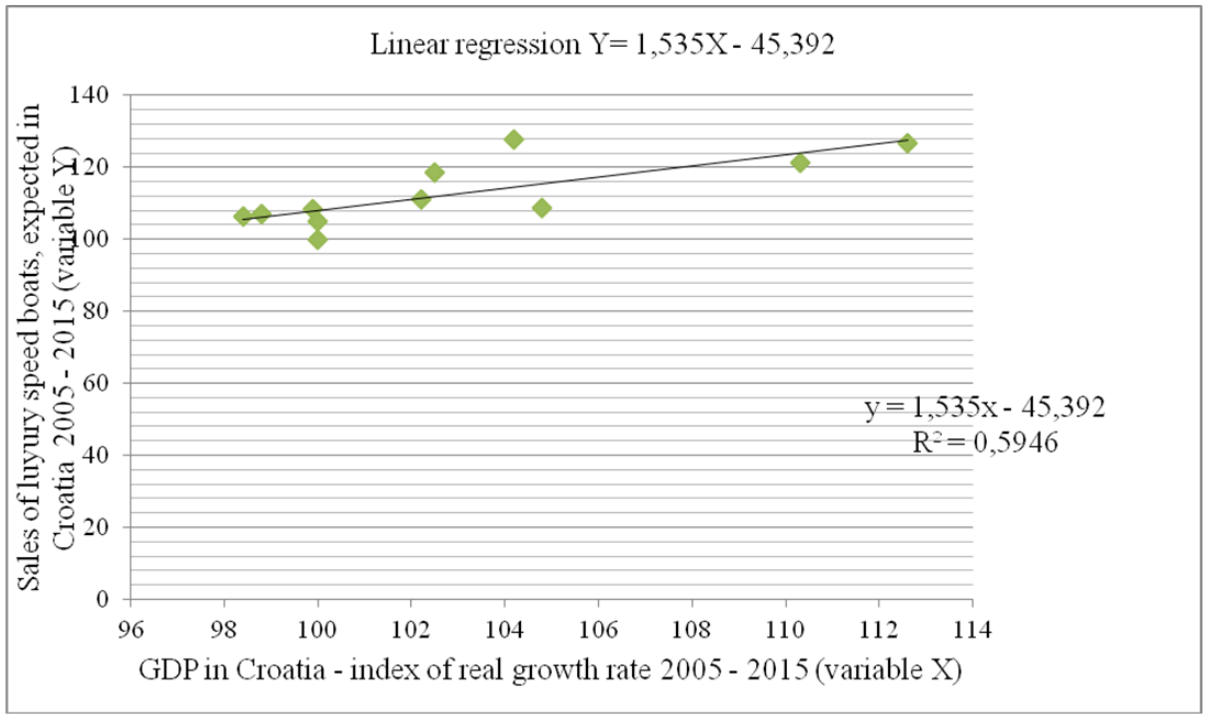

Figure 1: Linear regression

If we consider only the period of recession in Croatia (from 2009 to 2014), the results are very accurate (figure 2). With Regression has interpreted $83.73 \%$ of the squared deviations. Pearson's correlation coefficient (r) is 0.915. According to this source, the calculated $r$ is the evidence of the existence of very strong links between phenomena. $\mathrm{H} 1$ : $r \neq 0$ is sustained. The direction of the connection is positive, i.e. when GDP grows, variable $\mathrm{Y}$ grows, and vice versa. There is significant compliance in the variation of the two observed phenomena. 
$36^{\mathrm{TH}}$ InTERnational Conference on Organizational Science Development: RESPONSIBLE ORGANIZATION (MARCH $22^{\mathrm{ND}}-24^{\mathrm{TH}}$, PORTOROŽ SLOVENIA)

S. Rudelj \& M. Rudelj: Perception of Sales Organizations for Luxury Speed Boats'

Sales in Recession in Croatia

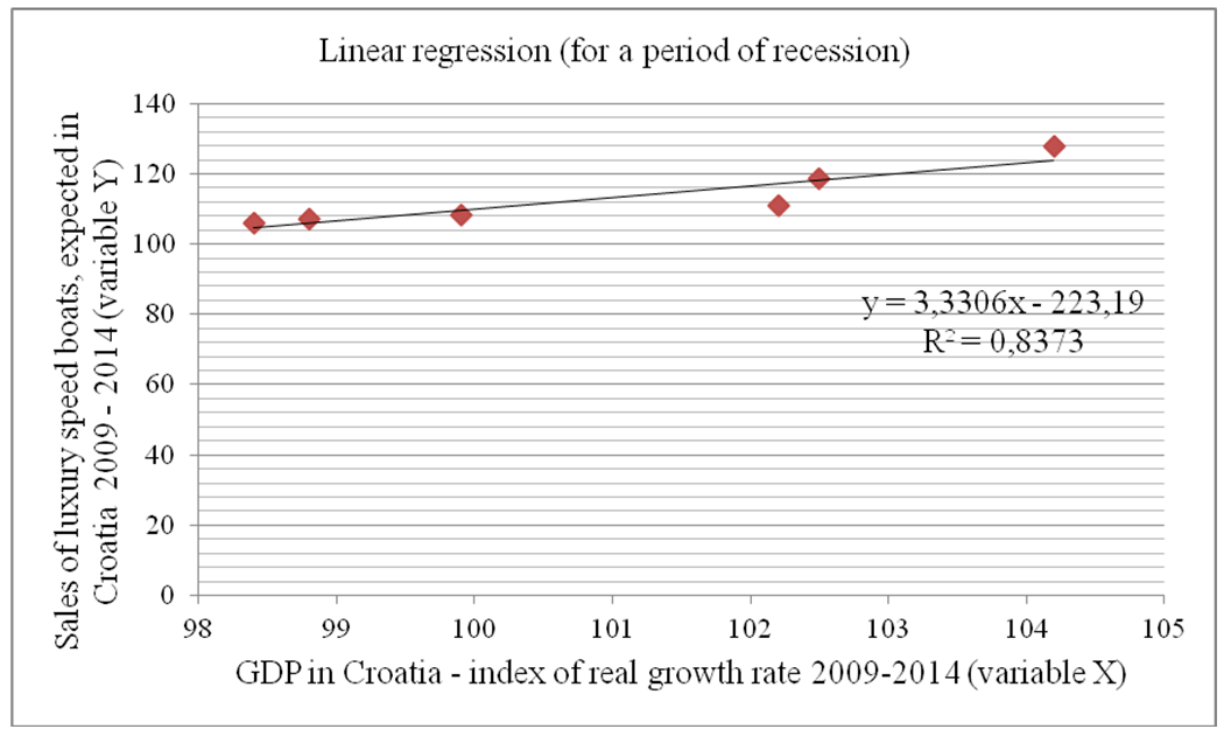

Figure 2: Linear regression for a period of recession in Croatia

The other results of the study are also interesting. Respondents have confirmed the working definition (score 4.9). They are aware of the impact of the recession. For the statement Sales of luxury speedboats over the past 10 years have been the worst in the period of the recession the average score is above 4.9. For the claim The next three years (2016-2018) will be a good opportunity for the sale of luxury speedboats the average rating was only 3.5 and this supports the fact that their optimism is hard returns - with a delay.

Limitations of this study are associated with the territory and the scope of the research. Future research could consider other luxury goods or entire categories with the scope of developed countries and economies on the rise.

\section{$5 \quad$ Conclusion}

Recessions are normal phenomena in economies. They represent a downward phase of the business cycle. Luxury goods satisfy psychological needs of humans as well. Expensive speed boats are a typical example of luxury goods. The empirical research on the relation between the expected sales of luxury speed boats for a certain period in Croatia and GDP included a basic set. This basic set consists of the sales organization in all forms (manufacturer, agent, representative, dealer, etc.). The basic objective was to analyze the perception of sales of luxury goods in times of recession in Croatia, on a practical example of luxury speed boats. 
The results showed that there is a significant correlation between the dependent variable Sales of luxury speed boats expected in Croatia (in the period 2005-2015) and independent variable Gross Domestic Product (GDP) in Croatia (from 2005 to 2015). The coefficient of determination $\left(\mathrm{R}^{2}\right)$ is approximately 0.6 . Almost $60 \%$ of the square deviation is explained by this regression. The corresponding Pearson correlation coefficient (r) was 0.77 indicating a statistically significant relation. Considering only the period of recession in Croatia, $\left(\mathrm{R}^{2}\right)$ is 0.84 . Pearson's correlation coefficient $(\mathrm{r})$ was 0.915 . This is a very strong connection between the observed phenomena. The direction of the connection is positive, i.e., when GDP grows, variable Y grows, and vice versa. There is a significant compliance in the variation of the two observed phenomena and thus the hypothesis set in this paper is confirmed. There is a positive correlation between the expectations of sales of luxury speed boats by the sales organization and recession as the phase of the business cycle. We conclude that there is a positive relation between the expectations of sales of luxury speed boats and recession (connection is very strong).

However, it is interesting to notice that the perception of the sale, or the expected sales in the recessionary period, is late in relation to GDP. This can be seen in Table 2 (chain indexes). Expectations were first optimistic and then they quickly reduced so that even the year of 2015 was not recognized as the year of recovery. From this it can be concluded that sales organizations inadequatly follow the market dynamics. Their expectations are in the zone of optimism, however, the recession surprises them, so then they become too careful. Perhaps they do not invest enough in market research or they do not respect the knowledge from the field of strategic management. This is certainly reflects in their business success and the status of the responsible organizations.

\section{Literature}

Alderfer, C. P. (1969). An empirical test of a new theory of human needs. Organizational Behavior and Human Performance, Vol. 4, No. 2, pp. 142-175.

Aman, W. (2003). The impact of internationalization on organizational culture a comparative study of international US and German companies. Dissertation Nr. 2791. Bamberg: Difo-Druck

Gmbh und St. Gallen: Der Universität St.Gallen, Hochschule für Wirtschafts-Rechts- und Sozialwissenschaften (HSG) zur Erlangung der Würde eines Doktors der Wirtschaftswissenschaften.

Buturac, G. (2013). Nakon globalne recesije: uzajamna trgovina i ekonomska konvergencija, Ekonomski pregled, Vol. 64, No 4, pp. 303-326.

Buturac, G., Rajh, E., \& Teodorović, I. (2009). Hrvatsko gospodarstvo u svijetlu globalne recesije, Ekonomski pregled, Vol. 60, No. 12, pp. 663-698.

Coulter, M. (2010). Strategijski menadžment. 4. izdanje. Beograd: Datastatus.

Češnovar, T. (2006). The impact of strategic management on business outcomes - Empirical

research. Journal for East European Management Studies, Vol. 11, No. 3, pp. 227 243.

Dovern, J., \& Huber, F. (2015) Global Prediction of Recessions, University of HeidelbergDiscussion Paper Series, No. 585, pp. 2.

DZS - Croatian Bureau of Statistics. (2016). First Release, Vol. LIII, No.14.1.4, pp. 1.

DZS - Croatian Bureau of Statistics. (2013). Statistical Yearbook 2013. Zagreb: DZS. 
36 ${ }^{\text {TH }}$ International Conference on Organizational Science Development: RESPONSIBLE ORGANIZATION (MARCH $22^{\mathrm{ND}}-24^{\mathrm{TH}}$, PORTOROŽ SLOVENIA)

S. Rudelj \& M. Rudelj: Perception of Sales Organizations for Luxury Speed Boats'

Sales in Recession in Croatia

DZS - Croatian Bureau of Statistics. (2015). Statistical Yearbook 2015. Zagreb: DZS.

Ekert, S., \& Ekert, M. (2009). An Empirical Analysis of the Association between the

Organizational Culture and Performance Measurement Systems in the Turkish

Manufacturing Sector. Journal of Economic and Social Research, Vol. 11, No. 2, pp. 43-76.

EPI - Economic Policy Institute. (2015). The Great Recession. Retrieved from

http://stateofwork ingamerica.org/great-recession/.

Eurostat. (2016). National accounts and GDP. Retrieved from: http://ec.europa.eu/eurostat/ statistics-explained/index.php/National_accounts_and_GDP.

Filardo, A. J. (1999). How Reliable Are Recession Prediction Models? Federal Reserve Bank

of Kansas City Economic Review, second quarter 1999, No. 84, pp. 35-55.

Genier, R. (2014). What Type Of Luxury Products Are You Offering. Retrieved from http://agenceluxury.com/type-luxury-products-offering/.

Ghemawat, P. (2002). Competition and Business Strategy in Historical Perspective. Business History Review, 76 (1), str. 37-74.

Goble, F. G. (2004). The Third Force: The Psychology of Abraham Maslow (Appendix: A

Theory of Human Motivation). Richmond: Maurice Bassett Publishing.

HGK - Croatian Chamber of Commerce. (2016). Gospodarska kretanja, Zagreb: HGK.

HGK - Croatian Chamber of Commerce. (2013). Gospodarska kretanja, Zagreb: HGK.

Horvat, M. (2015). Premium proizvodi - trendovi: Na dobro se lako naviknuti. Ja trgovac,

No. 49, pp. 31-37.

Kapferer, J. N., \& Laurent, G. (2016). Where do consumers think luxury begins? A study of perceived minimum price for 21 luxury goods in 7 countries. Journal of Business

Research, Vol. 69, No 1, pp. 332-340.

Kukić, S., \& Rudelj, S. (2015). MULTIGRAM as an instrument of collecting empirical data for scientific reasoning with scaling technique. U: Plenković, M., Toplak, L. i Galičić, V., ur.

Zbornik radova međunarodne konferencije xxii. International scientific conference SOCIETY \& TECHNOLOGY 2015, 28.-30. lipnja 2015, Opatija Hrvatska. Opatija: Hrvatsko komunikološko društvo / Croatian Communication Association, Alma Mater Europaea - ECM - the University for Leadership, Međunarodna federacija komunikoloških društava / International Federation of Communication Associations (IFCA), pp. 179-187.

Nueno, J. L., \& Quelch, J. A. (1998). The Mass Market of Luxury. U: Quelch, J. A (ed.)

Reading in modern marketing. Hong Kong: The Chinese University Press, pp. 97-113.

Pološki Vokić, N. (2004). Menadžment ljudskih potencijala u velikim hrvatskim poduzećima. Ekonomski pregled, Vol. 55 No. 5-6, pp. 455-478.

Rudelj, M. (2016). Utjecaj recesije na prodaju luksuznih glisera u Republici Hrvatskoj.

Zagreb: Ekomonski fakultet.

Rudelj, S. (2011). Utjecaj organizacijske kulture na razvoj strateškog menadžmenta u srednjim i velikim poduzećima. Split: Sveučilište u Splitu.

Sinčić Ćorić, D., \& Roglić, M. (2015). Osobnost luksuzne modne marke. Ekonomski pregled, Vol. 66, No. 2, pp. 138-155.

Šošić, I., Bahovec, V., \& Čižmešija, M. (2007). Pregled metodologije konjukturnih istraživanja zemalja Europske unije i hrvatsko iskustvo. Ekonomski pregled, Vol 58, No. 9-10, pp. 545-566.

The Statistics Portal. (2016). Statistics and facts on the global luxury goods industry. Retrieved from http://www.statista.com/topics/1110/global-luxury-goods-industry/. Thomas, D. (2009). Deluxe: Kako je luksuz izgubio sjaj. Zagreb: Algoritam.

Vigneron, F., \& Johnson, L. (1999). A review and a conceptual framework of prestigeseeking consumer behavior. Academy of Marketing Science Review, Vol. 1, No. 1, pp. 1-15. Vrdoljak Raguž, I. (2010). Utvrđivanje povezanosti demografskih obilježja vrhovnih 

ORGANIZACIJA (22. - 24. MAREC 2017, PORTOROŽ, SLOVENIJA)

S. Rudelj \& M. Rudelj: Perception of Sales Organizations for Luxury Speed Boats' Sales in Recession in Croatia

menadžera, stilova vođenja i uspješnosti poslovanja velikih hrvatskih poduzeća- empirijsko istraživanje. Ekonomski pregled, Vol. 61, No. 7-8, pp. 455-475.

Ziccardi, D. (2001). Recession-Proofing Your Luxury Brand. Brandweek, Vol. 42, No. 26, pp. 35. 
918 36 $6^{\text {Th }}$ InTERnational CONFERENCE ON ORganizational SCIENCE Development: Responsible Organization (MARCh $22^{\mathrm{ND}}-24^{\mathrm{TH}}$, PORTOROŽ SlOVENIA) 
$36^{\text {TH }}$ International Conference on Organizational Science DEVElopMENT: Responsible ORganization (MARCH $22^{\mathrm{ND}}-24^{\mathrm{TH}}$, PORTOROŽ SLOVENIA)

O. Arsenijević, M. Ferjan, I. Podbregar, P. Šprajc, D. Trivan \& Y. Ziegler

\title{
The Role of Brand Ambassador in Online Campaigns
}

\author{
SONJA SAVOVić, Slavica Cicvarić Kostić \& TAMARA Vlastelica
}

\begin{abstract}
Technological era led consumers into a state of content overload, but still, companies are seeking new ways to attract consumers' attention in online environment. One of them refers to online marketing campaigns, which are planned communication activities via online media, designed to increase awareness, inform, or change a behavior of target audience. In order to create an online brand presence, companies usually engage brand ambassadors. According to McCracken, brand ambassadors are individuals who not only use a brand but also enjoy public recognition. Hence, they are engaged in marketing campaigns for the purpose of amplifying the impact of a campaign. In order to be influential, brand ambassadors need to have following traits: credibility, attractiveness, and supremacy. Credibility is represented by knowledge, skills and expertise concerning the products, attractiveness includes likeability, familiarity and similarity, and supremacy is for effect on other consumer. This study examines the role and the characteristics of brand ambassadors in online campaigns by employing case study as a research method. It analyses four examples of brand ambassadors in online campaigns, channels used and results that campaigns generated. Examples include brand ambassadors who are influential in fashion, entertainment, music, and sports industry. The results indicate that engagement of brand ambassadors in online campaigns is a good tactic for attracting consumers' attention.
\end{abstract}

KEYWORDS: brand ambassador • online campaign

CORRESPONDENCE ADDRESS: Sonja Savović, Serbia. e-mail: sonja.savovic@outlook.com; Slavica Cicvarić Kostić, Ph.D., University of Belgrade, Faculty of Organizational Sciences, 154 Jove Ilića Street, 11000 Beograd, Serbia, e-mail: cicvaric.slavica@fon.bg.ac.rs; Tamara Vlastelica, Ph.D., University of Belgrade, Faculty of Organizational Sciences, 154 Jove Ilića Street, 11000 Beograd, Serbia, e-mail: vlastelica.tamara@fon.bg.ac.rs

DOI https://doi.org/10.18690/978-961-286-020-2.72

ISBN 978-961-286-020-2

(C) 2017 University of Maribor Press

Available at: http://press.um.si 
36 ${ }^{\text {TH }}$ International Conference on Organizational Science Development: RESPONSIBLE ORGANIZATION (MARCH $22^{\mathrm{ND}}-24^{\mathrm{TH}}$, Portorož SlOVENIA)

S. Savović, S. Cicvarić Kostić \& T. Vlastelica: The Role of Brand Ambassador in Online Campaigns

\section{Introduction}

The trend of brand ambassadors' engagement in online marketing campaigns has been growing recently. Technological era led consumers into a state of content overload. According to Arons (2011), the average consumer is exposed to several thousand brand messages a day, and companies found a brand ambassadors' engagement as one way to differ from competitors and show consumers what they have to offer.

Internet technologies and social media led to the changes in the way companies communicate with consumers (Maresh-Fuehrer \& Smith, 2016), as they spend a lot of time online, and they gather information about products, communicate with other consumers, even they establish relationships with companies and brands (Hall-Phillips et al., 2016; Hudson et al., 2016). Digital media have brought a paradigm shift in marketing communication where digital communication became its integral part (Veselinović et al., 2016). The digitalization has brought new communication tools and tactics for connecting brands and consumers (Mulhern, 2009).

This study examines the role and the characteristics of brand ambassadors in online campaigns by employing case study as a research method. As this field is not sufficiently explored in the academic literature, the paper analyzes the examples of good practice with the purpose of identifying if the engagement of brand ambassadors in online campaigns is a good tactic for attracting consumers' attention.

The first part of this paper describes basic characteristics of online campaigns. In second part the authors examine the concept of brand ambassadors, main characteristics they should have, as well as models for making choice of influential people to be engaged in campaigns. The third part presents the results of case studies analysis on brand ambassadors' engagement in several online campaigns. Examples include brand ambassadors who are influential in fashion, entertainment, music, and sports industry. The final part presents concluding remarks and identifies the direction for further analysis.

\section{Campaigns in online environment}

Campaigns are various, planned media activities, designed to awake interest, convey information, or to encourage the certain behavior of target groups (Vlastelica, 2007). Internet technologies, followed by intensive development of social media and mobile technologies have had a large impact in a way that we communicate (Maresh-Fuehrer \& Smith, 2016), as communication can be initiated through various digital channels from any location at any time (Yadav, Joshib \& Rahmanc, 2015). This is especially important for the generation of Millennials, whose main characteristic is that they are tech-savvy and that can be seen in many aspects of their lives (Todorović \& Pavićević, 2016).These trends have made a significant impact in the way of communication with consumers (Kannan \& Li, 2016) and has introduced digital channels in marketing communication and media campaigns. 
Digital technologies have created suitable online platforms for marketing campaigns, such as social networking sites, microblogging sites, corporate and personal blogs, sites with photo and video sharing, forums and platforms for discussion and others (Lau, 2017). Tiago and Verissimo (2014) found that the main shift in the communication strategy happened with the emergence of social media as they enabled companies to interact and develop relations with consumers. In order to create a digital influence in online campaigns, Solis (2012) identified basic criteria that should be met. They include reach, the number of people that have seen message from the campaign, relevance, the extant to what message is valuable to users, and resonance, the number of users who have shared the message. Online platforms offer a plethora of possibilities for companies (Bauer, 2013; Georgescu and Popescul, 2015), and consequently online campaigns are performed with the purpose of presentation of a new product, increasing brand awareness, or creating a positive brand image, as well as driving web traffic and visitors' loyalty (Ganguly, 2015).

On the other side, according to research conducted by Tap Influence Magazine, more than $60 \%$ of consumers claimed that they are overbooked with an online information (TapInfluence, 2016). With the fact that consumers have a large number of sources of information, companies find it difficult to attract their attention. In this context, the authors of the paper focused on the engagement of brand ambassadors in online campaigns as a tactic for attracting consumers' attention.

\section{Engagement of brand ambassadors in campaigns}

One of the tactics used in promotional campaigns is the engagement of people in the ads who guarantee the quality of the product/service (Belch \& Belch, 2003). They are identified as brand ambassadors, endorsers, or spokespersons. One of the most commonly cited definitions of brand ambassadors is the one provided by Friedman and Friedman (Jain \& Bagla, 2012), according to which they are individuals who public is familiar with due to their achievements in the fields not related to the presented products. McCracken defines the brand ambassador as every individual who enjoys recognition by the public and who is using this credit for the purpose of advertising and appearing in a campaign (McCracken, 1989). Brand ambassadors are people who have gained credibility in a particular area. They are trying to capitalize on its acquired credibility by promoting a particular company or a particular product or service (Bloggers network, 2016). In online context, brand ambassador is the person who is hired to represent the company and/or its brand in order to attract the attention of consumers, increase brand awareness, sales and traffic on the internet, by online retelling, sharing recommendation, advice and information on social networks (TapInfluence, 2016; Burks, 2010).

Mistry (in Dos) found that in the $19^{\text {th }}$-century celebrities had begun to represent brands as brand ambassadors. Such an example was the actress Lillie Langtry who advertised soap that was called Pears Soup. In contemporary marketing practice, the approach of using brand ambassadors in communication campaigns has been widely used in some markets. For instance, in the US in 1997, almost one out of four campaigns engaged a 
$36^{\text {TH }}$ International Conference on Organizational Science Development: RESPONSIBLE ORGANIZATION (MARCH $22^{\mathrm{ND}}-24^{\mathrm{TH}}$, PORTOROŽ SLOVENIA)

S. Savović, S. Cicvarić Kostić \& T. Vlastelica: The Role of Brand Ambassador in Online Campaigns

brand ambassador, and this number decreased in 2007 and amounted to 14\%, while in India to $24 \%$, and in Taiwan it ammounted to about $45 \%$ (Creswell in Elberse \& Verleun, 2012).

Brand ambassadors can be engaged in campaigns to be spokespersons for the product, to give their expert opinion or just to be associated with the product. In this regard, the types of campaigns are, explicit ("I use this product"), implicit ("You need to use this product") and co-presentation in which a person only appears with the product (Seno \& Lukas, 2007). One of the basis premises for successful engagement is that brand ambassador has to understand the concept of the brand and be a person whose personality, attitude and behavior are in line with the brand (Zabunov, 2014).

The representative of the brand is not necessarily a celebrity. In online environment companies and brands usually, engage people from real life such as bloggers who create interesting content. One of the important criteria is that brand ambassador has an online community of followers, which is measurable and visible, as well as the interactions between them that take place on a daily basis.

One of the important elements in campaigns is the choice of brand ambassador. Speck et al. (1988) stated that brand ambassador does not have to be directly associated with the product or to be an expert for the product. Consumers need to believe that the person has used and enjoyed the product. By analyzing existing literature, Temperli \& Tangen (2006) identified several models that explain how to make a choice of brand ambassador. Model FRED analyzes factors of familiarity, relevance, esteem and differentiation, while model of source credibility is focused on the credibility, that combines attractiveness, reliability and expertise of the brand ambassador. Furthermore, the authors suggested model of product-brand ambassador compatibility, as well as model of meaning transfer, that emphasizes the relevance of brand ambassadors characteristics as they are transferring to the brand.

According to McCracken (1989), in order to be influential, brand ambassadors need to have following traits: credibility, attractiveness, and supremacy. Credibility is represented by knowledge, skills, and expertise concerning the products, attractiveness includes likeability, familiarity, and similarity, and supremacy is for effect on other consumer.

Engagement of brand ambassador as a tactic used in campaigns also implies different risks that have to be taken into account, such as (Erdogan, 1999): brand ambassador can overshadow the brand, some controversy related to brand ambassador, change in brand image that is not followed by change in brand ambassadors image, high costs of engagement. 


\section{$4 \quad$ Analysis of online campaigns with brand ambassadors}

In order to examine if engagement of brand ambassadors in online campaigns is a good tactic for attracting consumers' attention, this study employed a case study analysis. The case study is a research method which tries to understand the dynamics present within single settings (Eisenhardt, 1989). As a particular case is unique that it represents one-off context (Woodside, 2010), and consequently the knowledge from one case is not suitable for generalization, this paper analyzed four cases for the purpose of illustrating the benefits of brand ambassadors' engagement in online campaigns. Cases were selected on the basis of the availability of campaigns data that can be compared. Data was collected through personal channels of brand ambassadors engaged in the cases, the official websites of companies/brands presented as cases, as well as available statistics on visits to channels used in campaigns.

Table 1 presents basic characteristics of online campaigns that engaged brand ambassadors, where a large number of followers and the duration of the campaigns show that engagement was effective. 
$36^{\text {Th }}$ International Conference on Organizational Science Development: RESPONSIBLE ORGANIZATION (MARCH $22^{\mathrm{ND}}-24^{\mathrm{TH}}$, PORTOROŽ SlOVENIA)

S. Savović, S. Cicvarić Kostić \& T. Vlastelica: The Role of Brand Ambassador in Online Campaigns

\begin{tabular}{|c|c|c|c|c|c|c|c|}
\hline $\begin{array}{c}\text { Field of } \\
\text { influence }\end{array}$ & $\begin{array}{c}\text { Brand } \\
\text { ambassa } \\
\text { dor }\end{array}$ & $\begin{array}{c}\text { Brand } \\
\text { ambassadors } \\
\text { characteristics }\end{array}$ & Brand & $\begin{array}{c}\text { Channels } \\
\text { used in } \\
\text { campaign }\end{array}$ & $\begin{array}{l}\text { Activities used in } \\
\text { campaign }\end{array}$ & $\begin{array}{c}\text { Foll } \\
\text { owe } \\
\text { rs }\end{array}$ & $\begin{array}{c}\text { Duration of } \\
\text { campaign }\end{array}$ \\
\hline Sports & $\begin{array}{c}\text { Jasmina } \\
\text { Aleksand } \\
\text { rov }\end{array}$ & $\begin{array}{c}\text { Former basketball } \\
\text { player, now a } \\
\text { fitness trainer in } \\
\text { Serbia. Jasmina } \\
\text { Aleksandrov is the } \\
\text { brand ambassador } \\
\text { for Reebok. Her } \\
\text { characteristics such } \\
\text { as speed, strength, } \\
\text { perseverance also } \\
\text { characterized } \\
\text { Reebok as a brand }\end{array}$ & $\begin{array}{c}\text { Reebo } \\
\text { k }\end{array}$ & $\begin{array}{l}\text { Instagram, } \\
\text { You Tube }\end{array}$ & $\begin{array}{l}\text { Jasmina Aleksnadrov } \\
\text { promoted Reebok by } \\
\text { posting the photos on } \\
\text { Instagram platform } \\
\text { on which she was } \\
\text { persistently } \\
\text { practicing in } \\
\text { equipment of this } \\
\text { brand and uploading } \\
\text { video clips on You } \\
\text { Tube platform, which } \\
\text { showed the correct } \\
\text { ways of training }\end{array}$ & $\begin{array}{c}20.8 \\
\mathrm{~K}\end{array}$ & 2 years \\
\hline Fashion & $\begin{array}{c}\text { Jelena } \\
\text { Karakaš }\end{array}$ & $\begin{array}{c}\text { Journalist at Elle } \\
\text { magazine. She is a } \\
\text { fashion lover and } \\
\text { Adidas brand } \\
\text { ambassador. She } \\
\text { has her blog with a } \\
\text { name "Who doesn't } \\
\text { love shoes, he } \\
\text { doesn't love } \\
\text { people." }\end{array}$ & Adidas & $\begin{array}{l}\text { Instagram, } \\
\text { Blog }\end{array}$ & $\begin{array}{l}\text { Jelena Karakaš } \\
\text { promoted Adidas } \\
\text { from a fashion } \\
\text { perspective. She } \\
\text { posted pictures on } \\
\text { her Instagram profile } \\
\text { and her Blog in } \\
\text { Adidas clothes. Also, } \\
\text { she posted pictures of } \\
\text { products she received } \\
\text { from this brand with } \\
\text { a hashtag \#nmd. She } \\
\text { took advantage of } \\
\text { Instagram stories and } \\
\text { sometimes went live } \\
\text { from Adidas event }\end{array}$ & $\begin{array}{c}15.6 \\
\mathrm{~K}\end{array}$ & 2 years \\
\hline Music & $\begin{array}{l}\text { VIP } \\
\text { Group }\end{array}$ & $\begin{array}{l}\text { Rap music } \\
\text { performers }\end{array}$ & $\begin{array}{c}\text { Samsu } \\
\text { ng }\end{array}$ & $\begin{array}{l}\text { Instagram, } \\
\text { Facebook, } \\
\text { You Tube }\end{array}$ & $\begin{array}{l}\text { They participated in } \\
\text { the campaign } \\
\text { consisted of slogans } \\
\text { STRONGER, } \\
\text { FASTER, BETTER } \\
\text { and conducted a } \\
\text { series of short } \\
\text { motivational videos } \\
\text { on YouTube } \\
\text { platform, which are } \\
\text { associated with } \\
\text { sports, music and } \\
\text { technology. Also, } \\
\text { promotion is } \\
\text { conducted on the } \\
\text { Samsung official } \\
\text { Instagram profile in } \\
\text { Serbia where is } \\
\text { organized giveaway } \\
\text { with a chance to win } \\
\text { tickets for the festival } \\
\text { in Vrnjacka Banja, on } \\
\text { their concert. Rules } \\
\text { of the game for } \\
\text { participation were } \\
\text { tags and labels such } \\
\text { as \#Mojlovefestbend } \\
\text { and @ samsungsrbija }\end{array}$ & $\begin{array}{l}10.2 \\
\mathrm{~K}+7 \\
254\end{array}$ & 6 months \\
\hline $\begin{array}{c}\text { Entertai } \\
\text { nment }\end{array}$ & $\begin{array}{c}\text { Iva } \\
\text { Čuljak }\end{array}$ & $\begin{array}{c}\text { Iva is online } \\
\text { influencer known } \\
\text { because of her } \\
\text { charisma and } \\
\text { beauty }\end{array}$ & $\begin{array}{c}\text { Schwe } \\
\text { ppes }\end{array}$ & $\begin{array}{l}\text { Instagram, } \\
\text { Facebook }\end{array}$ & $\begin{array}{c}\text { In her fairy tale } \\
\text { where she drives a } \\
\text { bicycle in high heels, } \\
\text { Iva is some kind of } \\
\text { storyteller. } \\
\text { Promotion was } \\
\text { composed of photos } \\
\text { that were usually } \\
\text { followed by } \\
\text { humorous content }\end{array}$ & $\begin{array}{c}36.8 \\
\mathrm{~K}\end{array}$ & 9 months \\
\hline
\end{tabular}


The analysis showed that engagement of brand ambassadors in online campaigns could be implemented in various industries. The cases presented in the paper employed the tactic of engaging people who are influential in sports, fashion, music and entertainment, and not directly connected to the industry and brand they promote. The most often used channel is Instagram, and it is followed by You Tube, Facebook and Blog. Presented campaigns generated a large number of followers, and had a long period of duration, which could be considered as the effects of implemented tactic. In this context, it can be concluded that engagement of brand ambassadors in an online campaign, who are properly selected and connected with brand can be effective way of attracting consumers' attention.

\section{$5 \quad$ Conclusion}

This paper presents the role and characteristics of engaging brand ambassadors in online campaigns. Digital era has brought important changes in the way companies communicate with consumers. One of the trends in this context is the emergence of influential people, with a lot of followers in online environment. This trend led to the engagement of these people as brand ambassadors in online campaigns. The analysis of four cases showed that this tactic could be successfully applied in different industries, and by using social networking sites can generate a large number of followers in a campaign. On the other side, influential people need to learn how to take advantage of their popularity in the right way as they can attract the attention of a large number of consumers.

As these results reflect four cases, further research can include larger number of industries and cases in analysis. Furthermore, analysis can include the cases of campaigns that faced some risks and were less successful, and identify reasons for ineffectiveness. That would be beneficial for better understanding of this tactic.

\section{Literature}

Arons, M.D. S. (2011). How Brands Were Born: A Brief History of Modern Marketing, The Atlantic, Retrieved from: http://www.theatlantic.com/business/archive/2011/10/how-brandswere-born-a-brief-history-ofmodern-marketing/246012/\#slide7

Bauer, I. (2013). Digitalni marketing, Beograd: Zavod za udžbenike

Belch, G. E., \& Belch, M. A. (2003). Advertising and Promotion, Sixth Edition, The McGraw-Hill Companies

Bildi, I. (2013) Why online marketing? Retrieved from: http://www.ivanbildi.com/zasto-onlajn marketing

Bloggers network (2016) What is influencer marketing? Retrieved from: http://www.bloggersnetwork.org.rs/funkcionisanje-bloggers-network/sta-je-influencermarketing/,

Burks, A. (2010) What Is the Job Description for a Brand Ambassador? Retrieved from: http://work.chron.com/job-description-brand-ambassador-17805.html 
$36^{\text {TH }}$ International Conference on Organizational Science Development: RESPONSIBLE ORGANIZATION (MARCH $22^{\mathrm{ND}}-24^{\mathrm{TH}}$, PORTOROŽ SLOVENIA)

S. Savović, S. Cicvarić Kostić \& T. Vlastelica: The Role of Brand Ambassador in Online Campaigns

Creswell, J. Nothing Sells Like Celebrity. New York Times, June 22, 2008 in Elberse, A., \& Verleun, J. (2012). The economic value of celebrity endorsements. Journal of Advertising Research, Vol. 52, No. 2, pp. 149-165.

Doss, S. The transference of brand attitude: the effect on the celebrity endorser, Journal of Management and Marketing Research. Retrieved from: http://www.aabri.com/manuscripts/10636.pdf

Eisenhardt, K. M. (1989). Building Theories from Case Study Research. The Academy of Management Review, Vol. 14, No. 4, pp. 532-50.

Erdogan, B. Z. (1999). Celebrity Endorsement: A Literature Review, Journal of Marketing Management, Vol. 15, pp. 291-314.

Ganguly, S. (2015.) 4 Components of theBest Media Social Media Campaigns, Retrieved from: http://marketingland.com/4-components-best-social-media-campaigns-140715

Georgescu, M., \& Popescul, D. (2015). Social media - the new paradigm of collaboration and communication for business environment, Procedia Economics and Finance, Vol. 20, pp. 277 -282 .

Hall-Phillips, A., Park, J., Chung, T. L., Anaza, N. A., \& Rathod, S. R. (2016). I (heart) social ventures: Identification and social media engagement, Journal of Business Research, Vol. 69, No. 2, pp. 484-491.

Hudson, S., Huang, L., Roth, M. S. \& Madden, T. J. (2016). The influence of social media interactions on consumer-brand relationships: A three-country study of brand perceptions and marketing behaviors, International Journal of Research in Marketing, Vol. 33, No. 1, pp. 2741.

International Journal of Research in Marketing, In Press, Corrected Proof. Retrieved from: http://ac.els-cdn.com.proxy.kobson.nb.rs:2048/S0167811616301550/1-s2.0S0167811616301550-main.pdf?_tid=e9518d26-e27d-11e6-90b400000aab0f6c\&acdnat=1485294289_0f10ec156d464330c6ac61a8ca5b980c

Jain V., \& Bagla A. (2012). Impact of Celebrity Endorsement, International Journal of Research in IT and Management, Vol. 2, No. 10, pp. 40-51.

Kannan, P.K., \& Li, A. (2016). Digital marketing: A framework, review and research agenda

Lau, W.W.F. (2017). Effects of social media usage and social media multitasking on the academic performance of university students, Computers in Human Behavior, Vol. 68, pp. 286-291.

Maresh-Fuehrer, M. M., \& Smith, R. (2016). Social media mapping innovations for crisis prevention, response, and evaluation, Computers in Human Behavior, Vol. 54, pp. 620-629.

McCracken ,G. (1989). Who is the Celebrity Endorser? Cultural Foundations of the Endorsement Process, Journal of consumer research, Vol. 16, pp. 310-314.

McCracken, G. (1989). Who is the Celebrity Endorser? Cultural Foundations of the Endorsement Process, Journal of consumer research, Vol. 16, pp. 310-314.

Mulhern, F. (2009). Integrated marketing communications: From media channels to digital connectivity. Journal of Marketing Communications, Vol. 15, No. 2/3, pp. 85-101.

Seno D., \& Lukas B. A. (2007). The equity effect of products endorsement by celebrities. European Journal of Marketing, Vol. 41, No. 1-2, pp. 121-134.

Solis, B. (2012). Report: The Rise Of Digital Influence And How To Measure It, Retrieved from: http://www.briansolis.com/2012/03/report-the-rise-of-digital-influence/

Speck, P.S., Schumann, D.V., \& Thompson, C. (1988). Celebrity Endorsements: Scripts, Schema and Roles: Theoretical Framework and Preliminary Tests, Advances in Consumer Research, Vol. 15, pp. 69-76.

Tap Influence (2016) What is Influencer Marketing? Retrieved from: https://www.tapinfluence.com/blog-what-is-influencer-marketing/,

Temperley J., \& Tangen D. (2006) The Pinocchio Factor in Consumer Attitudes Towards Celebrity Endorsement: Celebrity Endorsement, The Reebok brand and an examination of recent 
campaign, Special Edition on Consumer Satisfaction - Global Perspective. Retrieved from http://businessperspectives.org/journals_free/im/2006/im_en_2006_03_Temperley.pdf

Tiago, M.T.P.M.B. \& Verissimo, J.M.C. (2014). Digital marketing and social media: Why bother? Business Horizons, Vol. 57, No. 6, pp. 703-708.

Todorović, M. \& Pavićević, M. (2016). Bridge the gaps, retain the talented Millennials, Serbian Project Management Journal, Vol. 6, No. 1, pp. 81-90.

Veselinović, T., Vlastelica, T., \& Cicvarić Kostić, S. (2016). Is there a correlation between organizational features and digital communication usage? Industrija, Vol. 44, No. 3, pp. 41-60.

Vlastelica, T (2007). Media campaign - publicity and advertising. Beograd: Zadužbina Andrejević

Woodside, A. (2010). Case Study Research: Theory, Methods and Practice. Bingley: Emerald Group Publishing Limited

Yadav, M., Joshib, Y., \& Rahmanc, Z. (2015). Mobile social media: The new hybrid element of digital marketing communications, Procedia - Social and Behavioral Sciences, Vol. 189, pp. 335-343.

Zabunov U. (2014) Brand ambassadors: What they promote, they need to also feel! Retrieved from: http://kulturaposlovanja.rs/brend-ambasadori-ono-sto-promovisu-moraju-i-da-osecaju/ 
928 36 $6^{\text {Th }}$ InTERnational CONFERENCE ON ORganizational SCIENCE Development: Responsible Organization (MARCh $22^{\mathrm{ND}}-24^{\mathrm{TH}}$, PORTOROŽ SlOVENIA) 
$36^{\text {Th }}$ International Conference on Organizational Science DEVElopMENT: Responsible ORganization (MARCH $22^{\mathrm{ND}}-24^{\mathrm{TH}}$, PORTOROŽ SLOVENIA)

O. Arsenijević, M. Ferjan, I. Podbregar, P. Šprajc, D. Trivan \& Y.

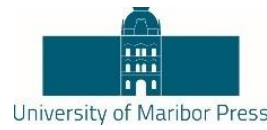

Ziegler

\title{
Black Carbon and Its Impact on Air Quality and on Development of Cardio-vascular Diseases
}

\author{
MARJAN SENEGAČNIK, DRAGo VuK \& NATAŠA PETROVIĆ
}

\begin{abstract}
Black carbon consists of carbon particles (mainly soot) with an aerodynamic diameter less than $2,5 \mu \mathrm{m}$ and therefore belongs to the PM 2,5 class. Black carbon can be present in the air from natural origin, however, a considerable problem present elevated levels of black carbon in the air from anthropogenic sources. Black carbon contributes to the greenhouse effect and exhibits noxious impact on human health. There are relatively well known adverse effects of black carbon on the respiratory tract and potential carcinogenic activity. On the other hand, minor attention is devoted to the atherogenic effects of black carbon and its impact on the development of atheroschlerotic processes and formation of cardiovascular diseases. The present paper is concerned with air pollution with the black carbon and includes a brief review of black carbon's influence on the formation of atheroschlerotic processes.
\end{abstract}

KEYWORDS: Black carbon - Particulate matter with diameter less than 2,5 $\mu \mathrm{m}(\mathrm{PM} 2,5) \cdot$ Air pollution $・$ Atheroschlerosis $\bullet$ Cardio-vascular diseas

CoRRESPONDENCE AdDRESS: Marjan Senegačnik, Ph.D., Assistant Professor, University of Maribor, Faculty of Organizational Sciences, Kidričeva cesta 55a, $4000 \mathrm{Kranj}$, Slovenia, e-mail: marjan.senegacnik@fov.uni-mb.si; Drago Vuk, Ph.D., Full Professor, University of Maribor, Faculty of Organizational Sciences, Kidričeva cesta 55a, 4000 Kranj, Slovenia, e-mail: drago.vuk@fov.uni-mb.si; Nataša Petrović, Ph.D., Associate Professor, University of Belgrade, Faculty of Organizational Sciences, 154 Jove Ilića Street, 11000 Beograd, Serbia, e-mail: petrovicn@fon.rs 


\section{$1 \quad$ Introduction}

Black carbon belongs mainly to the fine particulate matter group (PM 2,5, particles with the aerodynamic diameter less than $2,5 \mu \mathrm{m}$ ). Chemically it is composed of pure carbon in various forms. Air pollution due to black carbon results in various negative consequences as are climate changes and noxious health impact. Black carbon and particulates affect primary the respiratory tract. However the respiratory hazard and potential carcinogenity of black carbon are relatively well known and there is considerable attention devoted to this problem. Contrary to this it is less emphasized that black carbon is also involved in the process of atherogenesis and therefore can contribute to the development of cardiovascular diseases. The present paper is concerned particularly with the impact of black carbon on the development of atheroschlerosis.

\section{Air pollution and greenhouse effect}

Conventionally are characterized as air pollutants those substances which are present in the air and exhibit noxious impacts on human health or on other organisms. These substances can derive from natural sources as well as from human activities. However, aggravated air quality in urban areas is predominantly or almost exclusively caused by anthropogenic emissions of pollutants. The most important air pollutants are carbon monoxide, hydrocarbons, nitrogen oxide, sulphur dioxide, tropospheric ozone and particulate matter. When regarding air quality in Slovenia the last two pollutants are by far the most problematic - tropospheric ozone levels are elevated in summer meanwhile high concentrations of particles are common during the cold part of the year (ARSO, 2016).

As mentioned above particulates present considerably problematic sort of pollutant. Particulates are generally classified according to the size in two classes: PM $10-$ particulate matter with the aerodynamic diameter less than $10 \mu \mathrm{m}$ and PM 2,5 particulate matter with the aerodynamic diameter less than $2,5 \mu \mathrm{m}$. Somewhat more detailed classification can be obtained from Figure 1 (Brook et al., 2004). Composition of PM 2,5 class to which mainly belong black carbon particles is shown in Figure 2 (Cheng et al., 2015).

Air pollution may not be confused with greenhouse effect nevertheless certain substances can exhibit both effects - this is just the case by black carbon. The greenhouse effect is connected to the possibility of certain substance present in the air to detain heat in the atmosphere and therefore contribute to the global warming. 

ORGANIZACIJA (22. - 24. MAREC 2017, PORTOROŽ, SLOVENIJA)

M. Senegačnik, D. Vuk \& N. Petrović: Black Carbon and Its Impact on Air Quality and on Development of Cardio-vascular Diseases

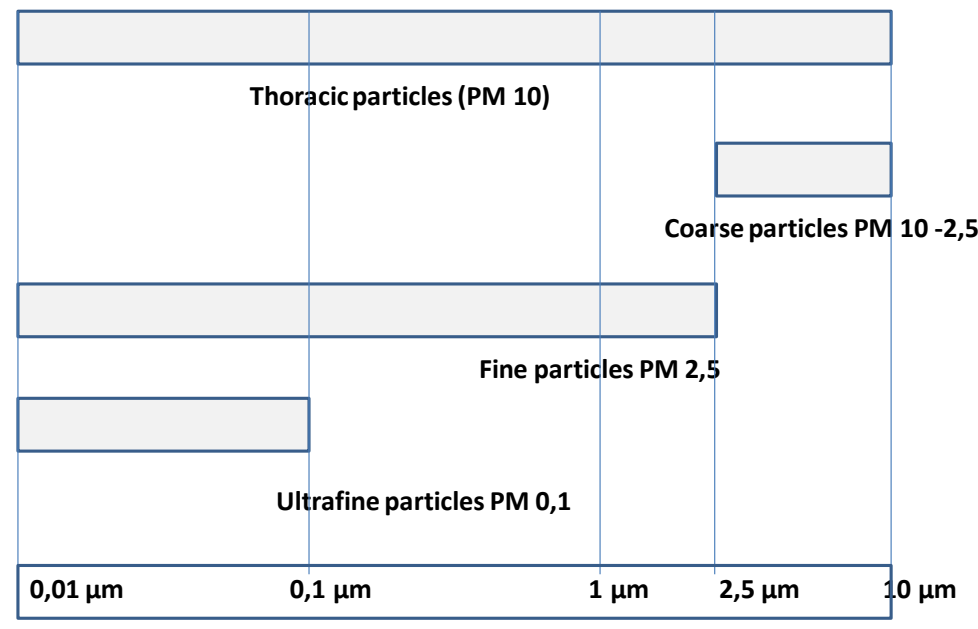

Figure 1: Classification of particulates according to their aerodynamic diameter - the logarithmic scale is used (Brook et al., 2004).

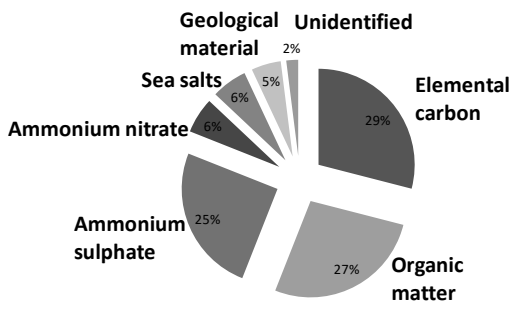

Figure 2: Composition of PM 2,5 particles (Cheng et al., 2015). 
36 ${ }^{\mathrm{TH}}$ International Conference on Organizational Science Development: RESPONSIBLE ORGANIZATION (MARCH $22^{\mathrm{ND}}-24^{\mathrm{TH}}$, Portorož SlOVENIA)

M. Senegačnik, D. Vuk \& N. Petrović: Black Carbon and Its Impact on Air Quality and on Development of Cardio-vascular Diseases

\section{Sources of black carbon pollution}

As mentioned above particulates (or particulate matter, PM) present probably the most problematic sort of pollutant. Particulate matter is usually divided in two categories

PM 10 (particles with the diameter bellow $10 \mu \mathrm{m}$ ) and

PM 2,5 (particles with diameter bellow 2,5 $\mu \mathrm{m}$ ).

The later particles are due to smaller dimensions more penetrating and therefore can present still more severe health hazard. Black carbon are soot particles mainly with the diameter bellow 2,5 $\mu \mathrm{m}$ and therefore belong the PM 2,5 group. Black carbon presents the most strongly light-absorbing fraction of particulate matter meanwhile other important kinds of particulates as are sulphates, nitrates and organic carbon mainly reflect light (Curry Brown, 2013).

The source of black carbon in the air is a result of combustion of fossil fuels, biofuels and biomass. In the developed countries road traffic presents one of the main sources of black carbon pollution. Until recently only compression ignition (diesel) engines were blamed because of particulate emissions meanwhile their emissions from spark ignition (Otto) engines were almost negligible. However in the last years situation has changed considerably due to the introduction of direct injection (DI) spark ignition engines. These engines excel because of their high efficiency and therefore low fuel consumption. However, the weak point of DI spark ignition engines is that their particulate (black carbon) emissions are comparable or even higher than in the case of compression ignition engines. Therefore also Euro standards series 5 and 6 introduced particulate emissions testing also for spark ignition engines with direct fuel injection. The level of permitted particulate (PM) emissions decreased considerably from Euro 1 to Euro 6 as can be seen from Figure 3 (DieselNet, 2016). 
M. Senegačnik, D. Vuk \& N. Petrović: Black Carbon and Its Impact on Air Quality and on Development of Cardio-vascular Diseases

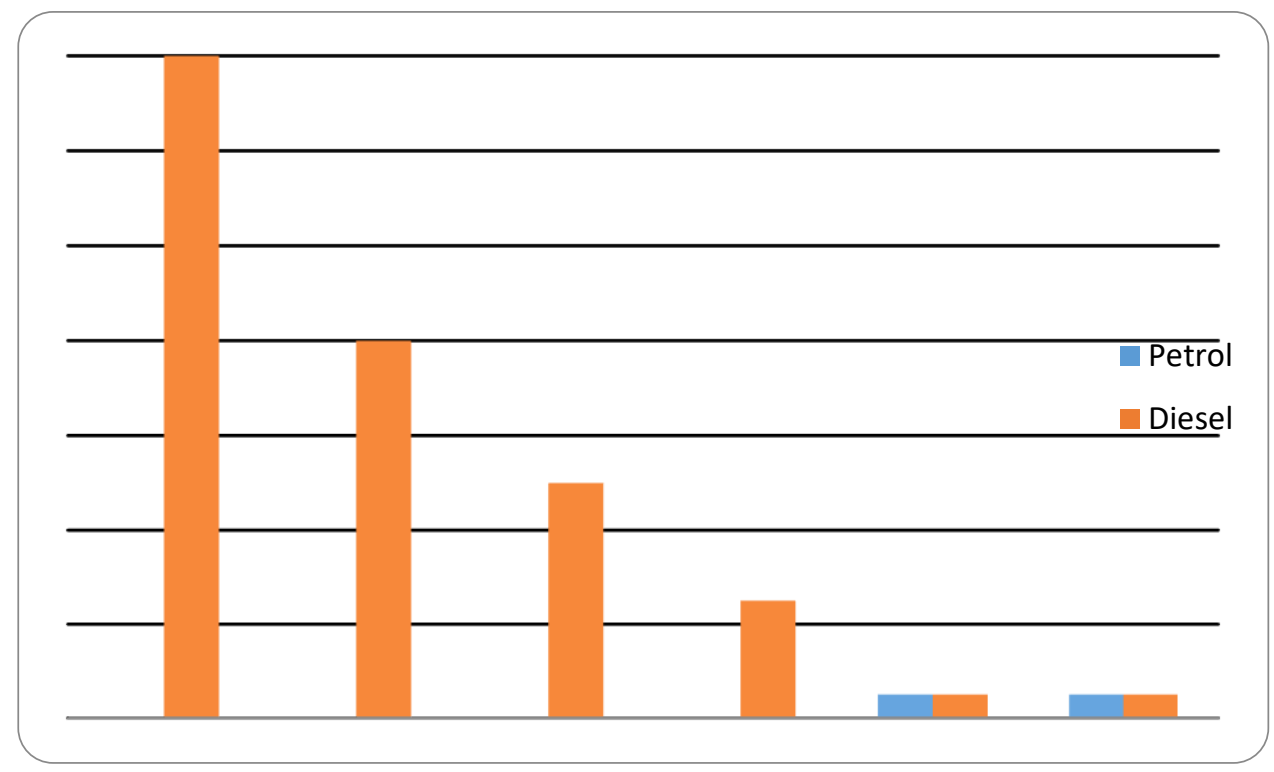

Figure 3: Permitted highest levels of particulates (PM) emissions (in $\mathrm{g} / \mathrm{km}$ ) from Euro 1 (1992) to Euro 6 (2014) standard series (DieselNet, 2016).

As mentioned above in the case of spark ignition (petrol powered) engines with indirect fuel injection systems particulates and black carbon emissions are considerably lower than in the case of compression ignition (diesel) engines. Therefore, Kirchstetter et al. found that emission of PM 2,5 from diesel powered heavy duty vehicles were 24 times higher than in the case of petrol powered light duty vehicles $(2,5+/-0,2 \mathrm{~g} / \mathrm{kg}$ fuel vs. 0,11 $+/-0,01 \mathrm{~g} / \mathrm{kg}$ fuel) meanwhile in the case of black carbon emissions the ratio was even higher - 37 (1,3 +/- 0,3 vs. 0,035 +/- 0,003) (Kirchstetter et al., 1999 in Fruin et al., 2001). Miguel et al. observed still higher ratio when comparing black carbon emissions from diesel and petrol engines - $48(1,4+/-0,16$ vs. 0,030 +/- 0,002) (Miguel et al. 1998 in Fruin et al. 2004). Fruin et al. (2004) emphasized the importance of exposure to black carbon during the time spent in vehicle.

\section{$4 \quad$ Black carbon health effects}

Air pollution with particulate matter and black carbon particularly causes considerable health problems which results in considerable number of premature deaths and decreased life-time expectancy. The adverse effects of particles are expressed not only in the diseases of respiratory tract and possible carcinogenic effects but affect also cardiovascular system and even neural tissue and brain (Curry Brown, 2013, Suglia, 2007). The results of 2010 Global Burden of Disease analysis have shown that PM 2,5 present one of the most important health risks causing over 3 million premature deaths every year worldwide (Curry Brown, 2013). 
36 ${ }^{\mathrm{TH}}$ International Conference on Organizational Science Development: RESPONSIBLE ORGANIZATION (MARCH $22^{\mathrm{ND}}-24^{\mathrm{TH}}$, Portorož SlOVENIA)

M. Senegačnik, D. Vuk \& N. Petrović: Black Carbon and Its Impact on Air Quality and on Development of Cardio-vascular Diseases

Brook et al. (2004) prepared comprehension overview of the scientific researches regarding the influence of polluted air on the cardio-vascular morbidity and mortality. They emphasize that both short-term as well as long-term exposure to actual ambient particulate concentrations of particulates increases risk of cardio-vascular complications (Brook, 2004).

When regarding long-term air pollution health effects there should be mentioned Harvard Six Cities study performed by Dockery et al. The results of study confirmed the link between cardiovascular mortality and air pollution as a group of over 8000 individuals was followed up for 14-16 years period. The overall mortality ratio for the most polluted city vs. the least polluted was 1.26 (95\% confidence interval, 1.08 to 1.47 ) (Dockery et al., 1993 in Brook et al., 2004). Pope et al. established in their study that long-term PM exposure is particularly connected with various forms of cardio-vascular mortality as are ischemic heart disease, dysrhythmias, hearth failure and cardiac arrest. An elevation of fine PM concentration of $10 \mu \mathrm{g} / \mathrm{m}^{3}$ resulted in $8-18 \%$ increase in mortality risk. On the other hand PM association with pulmonary diseases mortality was relatively weak (Pope et al., 2004).

As stated Brook et al. there is much greater number of studies concerned with short-time exposure to PM polluted air. Two of the most prominent studies from this group are NMMAPS in the United States and APHEA-2 in Europe (Brook, 2004).

APHEA-2 study (Air Pollution and Health - A European Approach 2) concerns with short-term exposure to PM effects on mortality. Data of daily measurements of PM 10 and/or black smoke for 29 European cities were collected and eventual impact of pollution on mortality was investigated. They established that a $10 \mu \mathrm{g} / \mathrm{m}^{3}$ increase of PM 10 or black smoke daily concentration resulted in $0,6 \%$ (confidence interval $95 \%, 0,4-$ 0,8 ) increased number of deaths per day generally, meanwhile in the group of elderly people the degree of increase was somewhat higher. There was observed certain synergy with PM 10/black smoke and nitrogen dioxide $\left(\mathrm{NO}_{2}\right)$ pollution as in cities with low $\mathrm{NO}_{2}$ levels the mortality rate increase for $10 \mu \mathrm{g} / \mathrm{m}^{3}$ elevation of PM was $0,19 \%$ (confidence interval 95\%,, 0,00-0,41) meanwhile in the cities with high $\mathrm{NO}_{2}$ levels it was $0,80 \%$ (confidence interval 95\%,, 0,67-0,93). There was also observed impact of climate as in the cities with relatively cold climate the increase was lower $(0,29 \%$, confidence interval $95 \%, 0,16-0,42)$ than in the cities with warm climate $(0,82 \%$ confidence interval $95 \%$, 0,69-0,96)(Katsouyanni et al., 2001).

In this study it was also estimated that when the survey of the exposure to pollution was prolonged from two to 40 days the rate of mortality increases from 0,69\% (confidence interval $95 \%, 0,31-1,08$ ) to $1,97 \%$ (confidence interval $95 \%, 1,38-2,55$ ) for cardivasscular deaths and even from $0,74 \%$ (confidence interval 95\%, -0,17-1,55) to 4,2\% (confidence interval 95\%,1,08-7,42) for respiratory deaths (Zanobetti et al., 2003). 

and on Development of Cardio-vascular Diseases

The NMMAPS (National Morbidity, Mortality and Air Pollution Study) research observed population of 50 million people in 20 largest cities in the United States. For every $10 \mu \mathrm{g} / \mathrm{m}^{3}$ elevation in PM 10 concentration there was observed an increase in daily mortality: 0,21\% (+/- 0,06 SE) for all cases and 0,31\% (+/- 0,09 SE) for cardiovascular mortality (Dominici et al., 2005; Brook et al., 2004).

In their study from 2010 Brook et al. oriented particularly on the impact of PM 2,5 (Brook et al., 2010).. They confirmed and partially supplemented their findings from 2004. Shortterm exposure to PM 2,5 can cause fatal or nonfatal cardiovascular events as are myocardial ischemia, myocardial infarction, heart failure, arrhythmias and strokes. Particularly susceptible groups are elderly people, patients with coronary artery disease, diabetes and obesity. Long-term exposure presents still greater increase of cardiovascular mortality risk and reduces the population life expectancy for several months to few years. Reductions in PM levels reduce cardio-vascular mortality. The results of surveys suggest that exposure to PM 2,5 particles support progress of atheroschlerosis. There is also supporting evidence that PM 2,5 promote the development of other cardio-vascular diseases as are hypertension, heart failure and diabetes. Brook et al. particularly emphasized that more recent studies indicate that PM 2,5 exposure present greater risk for cardio-vascular mortality than for pulmonary mortality (Brook et al., 2010).

Peters et al. observed in their study a positive association between incidence of defibrillator discharges and air pollution - positive correlation was observed for PM 2,5 and particularly for nitrogen dioxide and black carbon levels (Peters et al, 2000). Janssen et al. proposed that black carbon particles number (BCP) should be more relevant measure for air pollution derived health risk than particulate matter (PM) mass (Janssen et al., 2011).

When considering effects of long-term exposure to black carbon on the development of atheroschlerosis there should be mentioned research of Künzli et al. They presented a systematic review of studies about air pollution impact on atherogenesis. They emphasized the importance of the choice of an adequate method for evaluating the development of atheroschlerosis. The measurement of carotid intima-media thickness (CIMT) is the most frequent used technique in this kind of studies and Künzli et al. proposed it also as the most appropriate method (Künzli et al., 2011). Wilker et al. found positive correlation between black carbon particle concentration and intima-media thickness of the common carotid artery on the source from elderly men population from Boston, Massachusetts (Wilker et al., 2013). Moller et al. studied impacts of exposure to ambiental particulate matter, diesel exhaust and various nanomaterials on atheroschlerosis and vasomotor function in animals. Particles and nanomaterials show similar effects on atheroschlerosis development, increased vasoconstriction and less prominent vasorelaxation, meanwhile effects of diesel exhaust were somewhat lower (Moller et al., 2016).

Contrary to the above cited researches there are also certain number of studies which can not confirm the association between particulate air pollution and cardiovascular diseases 
36 ${ }^{\mathrm{TH}}$ International Conference on Organizational Science Development: RESPONSIBLE ORGANiZATION (MARCH $22^{\mathrm{ND}}-24^{\mathrm{TH}}$, PoRTOROŽ SLOVENIA)

M. Senegačnik, D. Vuk \& N. Petrović: Black Carbon and Its Impact on Air Quality and on Development of Cardio-vascular Diseases

morbidity. There should be mentioned study of Gan et al. who cannot confirm association between traffic-related air pollution and coronary atheroschlerosis (Gan et al., 2014).

Possible biological mechanisms of particulates link with cardio-vascular diseases progress as were proposed by Brook et al. are shown in Figure 4 (Brook et al., 2004).

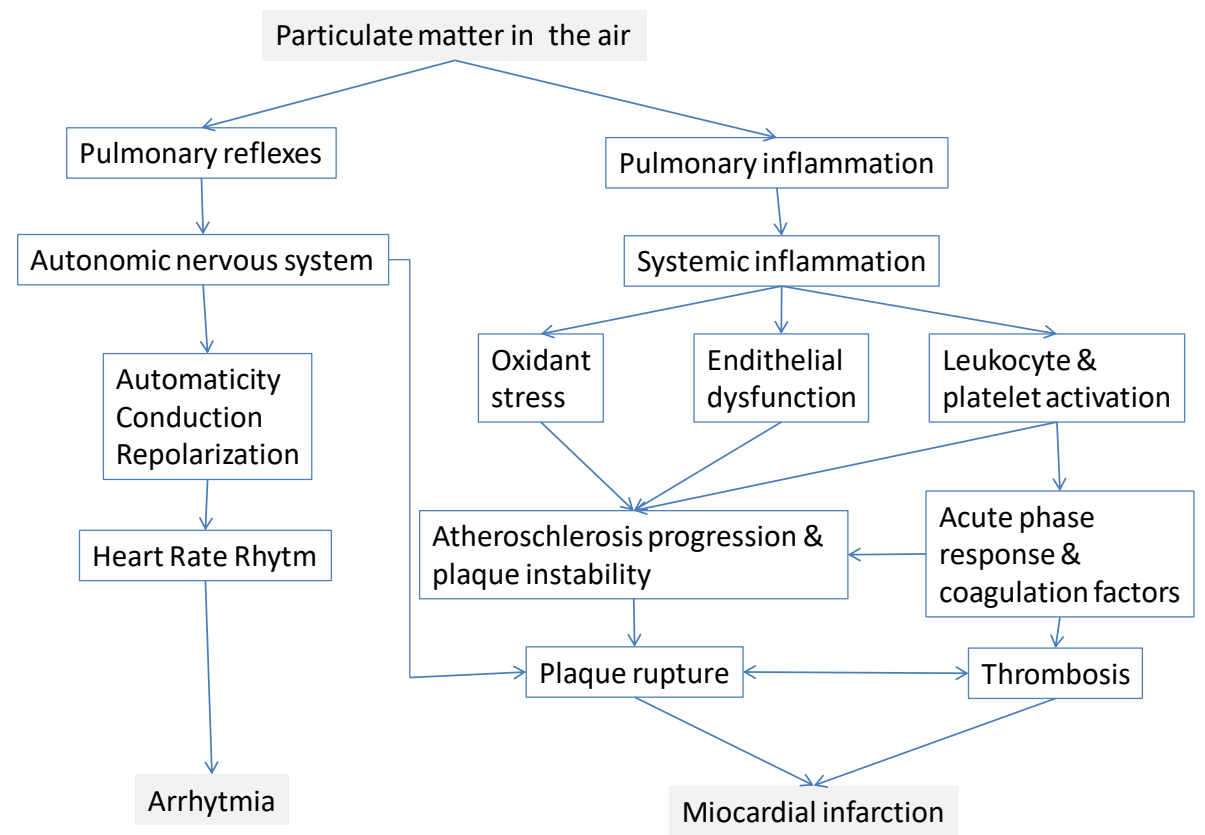

Figure 4: Possible biological mechanisms of particulate ection on the development of cardiovascular diseases (Brook et al., 2004).

A brief literature review presented in this paper shows that there exists evidence which can support certain link between particulate (black carbon) air pollution and cardiovascular diseases morbidity and mortality. Elevated particulate levels in ambient cause adverse health effects both on short-term as well as on long-term scale. Short-term effects reflect as arrhythmias, myocardial infarctions, myocardial ischemia and strokes and affect susceptible groups of population. Long-term effects are expressed in the progression of atheroschlerosis however these effects are more difficult to determine. Nevertheless many studies show positive correlation between air-pollution and cardiovascular morbidity and mortality there exist also many studies which cannot confirm the link between air pollution and cardiovascular diseases. Therefore experts 
M. Senegačnik, D. Vuk \& N. Petrović: Black Carbon and Its Impact on Air Quality and on Development of Cardio-vascular Diseases

from this field propose that further investigations are necessary for more clear estimation of ambient pollution impact on atherogenesis (Künzli et al., 2011). As black carbon and particulates are generally the most problematic kind of atmospheric pollutants this topic deserves to be devoted considerable attention in future.

\section{Literature}

ARSO (2016). Bullettin of the Environmental Agency of the Republic of Slovenia - monthly air quality reports for the year 2016 (published in Slovene: Bilten Agencije Republike Slovenije za okolje).

Brook, R.D., Franklin, B., Cascio, W., Hong, Y., Howard, G., Lipsett, M., Luepker, R., Mittleman, M., Samet, J., Smith, S.C.Jr. \& Tager, I. (2004). Air pollution and cardiovascular disease: A statement for healthcare professionals from the expert panel on population and prevention science of the American heart association. Circulation, Vol. 109, pp. 2655-2671.

Brook, R.D. et al. (2010). Particulate matter air pollution and cardiovascular disease - An update to the scientific statement of the American Heart Association. Circulation, Vol. 121, pp. 23312378 .

Cheng, Y, Lee, S., Gu, Z., Ho, K., Zhang, Y., Huang, Y., Chow, J.C., Watson, J.G., Cao, J. \& Zhang, R. (2015). $\mathrm{PM}_{2,5}$ and $\mathrm{PM}_{10-2,5}$ chemical composition and source apportionment near a Hong Kong roadway. Particuology, Vol. 18, pp. 96-104.

Curry Brown, A. (2013). Health Effects of particulates and black carbon. Transport and clean air seminar, U.S. EPA, December 2013. Accessed January 20, 2017 on https://www.epa.gov/sites/production/files/2014-05/documents/health-effects.pdf

DieselNet (2016). Emission Standards - Cars and Light Trucks. European Union. DieselNet. Accessed January 17, 2016 on https://www.dieselnet.com/standards/eu/ld.php

Dockery, D.W., Pope, C.A., Xu, X et al. (1993). An association between air pollution and mortality in six US cities. N Engl J Med, Vol. 329, pp. 1753-1759.

Dominici, F., McDermott, A., Daniels, M., Zeger, S.L. \& Samet, M.J. (2005). Revised Analysis of the National Morbidity, Mortality and Air Pollution Study: Mortality among residents of 90 cities. Journal of Toxicology and Environmental Health, Part A, Vol 68 (13-14), pp. 10711092.

Fruin, S.A., Winer, M.A. \& Rodes, C.A (2004). Black carbon concentration in California vehicles and estimation of in-vehicle diesel exhaust particulate matter exposures. Atmospheric Environment, Vol. 38, pp. 4123-4133.

Gan, W.Q. Allen, R.W, Brauer, M., Davies, H.W., Mancini, G.B.J. \& Lear, S.A. (2014). BMJ Open, Vol. 4, pp. 1-11.

Janssen, N.A.H. et al. (2011). Black carbon as an additional indicator of the adverse health effects of airborne particles compared with $\mathrm{PM}_{10}$ and $\mathrm{PM}_{2,5}$. Environ. Health Perspectives, Vol. 119, pp. 1691-1699.

Katsouyanni, K. et al. (2001). Counfonding and effect modification in the short-term effects of ambient particles on total mortality: results from 29 European cities in the APHEA-2 project. Epidemiology, Vol. 12(5), pp. 521-531.

Kirchstetter, T.W., Harley, R.A., Kreisberg, N.M., Stolzenburg, M.R. \& Hering, S.V. (1999). Onroad measurement of fine particle and nitrogen oxide emissions from light- and heavy-duty motor vehicles. Atmospheric Environment, Vol. 33, pp. 2955-2968.

Künzli, N. Et al. (2011). Investigating air pollution and atheroschlerosis in humans: Concepts and outlook. Progress in Cardiovascular Diseases, Vol. 53, pp. 334-343. 
$36^{\text {TH }}$ International Conference on Organizational Science Development: Responsible ORGANiZATION (MARCH $22^{\mathrm{ND}}-24^{\mathrm{TH}}$, PORTOROŽ SLOVENIA)

M. Senegačnik, D. Vuk \& N. Petrović: Black Carbon and Its Impact on Air Quality and on Development of Cardio-vascular Diseases

Miguel A.H, Kirchstetter, T.W., Harley, R.A. \& Hering, S.V. (1999). On-road emissions of particulate polycyclic aromatic hydrocarbons and black carbon from gasoline and diesel vehicles. Environmental Science and Technology, Vol. 32, pp.450-455.

Moller, P. et al. (2016). Atheroschlerosis and vasomotor dysfunction in arteries of animals after exposure to combustion-derived particulate matter or nanomaterials. Crit Rev Toxicol, Vol. 46(5), pp. 437-476.

Peters, A. et al. (2000). Air pollution and incidence of cardiac arrhythmia. Epidemiology, Vol. 11, pp. 11-17.

Pope, C.A. Burnett, R.T., Thurston, G.D, Thun, M.J., Calle, E.E., Krewski, D. \& Godleski, J.J. (2004). Cardiovascular mortality and long-term exposure to particulate air pollution Epidemiological avidence of general pathophysiological pathways of disease. Circulation, Vol. 109, pp. 71-77.

Suglia, S.F., Gryparis, A., Wright, R.O., Schwartz, J. \& Wright, R.J. (2007). Association of black carbon with cognition among children in prospective birth cohort study. American Journal of Epidemiology, Vol. 167 (3), pp. 280-286.

Wilker, E.H., Mittleman, M.A., Coull, B.A., Gryparis, A., Bots, M.L., Schwartz, J. \& Sparrow, D. (2013). Long term exposure to black carbon and carotid intima-media thickness : The normative aging study. Environ. Health Perspectives, Vol. 121 (9), pp.1061-1067.

Zanobetti, A. Et al. (2003). The temporal pattern of respiratory and hearth disease mortality in response to air pollution. Environ Health Perspectives, Vol. 111 (9), pp. 1188-1193. 
$36^{\text {Th }}$ International Conference on Organizational Science DEVElopMENT: Responsible ORganization (MARCH $22^{\mathrm{ND}}-24^{\mathrm{TH}}$, PORTOROŽ SLOVENIA)

O. Arsenijević, M. Ferjan, I. Podbregar, P. Šprajc, D. Trivan \& Y. Ziegler

\title{
Project Management in a VUCA World: Developing an Adaptive Leadership Style
}

\author{
STEFANO SETTI
}

\begin{abstract}
The modern project manager needs a synoptic vision of different approaches and methodologies to develop a multi-skill knowledge framework.

This presentation aims to help the attendant to reach a personal robust comprehension of the major skill management models, as well as the coaching and leadership styles, as it has become crucial creating a continuous learning approach when facing a VUCA context or an extreme environment.

The participants will be able to better know and understand the "extreme" cognitive context: what characterizes an Extreme Environment? what is typical of a VUCA world? how volatility, uncertainty, complexity and ambiguity affect project management style? and how do they impact leadership style? This will bring a higher level of capability to move around the huge amount of publications, articles, webinars and conferences referring to this third millennium global challenge. The emphasis is put on giving powerful meanings to words; the PM community is seen as an orchestra that need to harmonize languages and tune-up their cognitive instruments.
\end{abstract}

Keywords: project management $\bullet$ leadership $\bullet$ life-long learning $\bullet$ extreme $\mathrm{PM} \cdot \mathrm{VUCA}$

CoRrespondence AdDREss: Stefano Setti, Director at Large, BluPeak Consulting, Project Management Institute - Northern Italy Chapter, Piazza Santa Maria Beltrade, 2, 20123 Milano, Italy, e-mail: Stefano.Setti@pmi-nic.org 
36 ${ }^{\mathrm{TH}}$ International Conference on Organizational Science Development: RESPONSIBLE ORGANIZATION (MARCH $22^{\mathrm{ND}}-24^{\mathrm{TH}}$, PORTOROŽ SLOVENIA)

S. Setti: Project Management in a VUCA World: Developing an Adaptive Leadership Style

\section{$1 \quad$ Introduction}

The contents of this presentation are based on three major assumptions:

- the profession of Project Manager, during the last decades, has passed through a real revolution, starting from an engineering approach (focused on resources allocation and optimization), then discovering the central role of soft skills and the importance of people and the PM as a leader, finally facing the projects as complex systems, with emerging properties and behaviors,

- the environment in which our projects, programs and portfolios take place more and more often is a VUCA world (characterized by Volatility, Uncertainty, Complexity, Ambiguity). Today's projects - and not only the very large and complex ones - are very seldom suitable for traditional approaches, while extreme PM patterns seem to be more and more attractive,

- the profession of Project Manager is more and more recognized as a skill for life, as the art of leading change and delivering results.

In consideration of the long evolution of the project management culture and of the wide spectrum of human disciplines covered by the PM body of knowledge - also witnessed by the many important innovative experiences included in the PMI Educational Foundation's programs - Project Management is now focusing the person as a whole, not only from a professional perspective.

\subsection{What's the VUCA World?}

VUCA is an acronym used to describe the volatility, uncertainty, complexity and ambiguity of general conditions and situations. The VUCA idea began in the nineties, coming from military experience and lexicon, and subsequently has been used in emerging ideas in strategic leadership that apply in a wide range of organizations, including everything from for-profit corporations to education.

- Volatility. The nature and dynamics of change, the nature and speed of change forces and catalysts.

- Uncertainty. The lack of predictability, the prospects for surprise, and the sense of awareness and understanding of issues and events, naturally calling for a risk management cultural approach.

- Complexity. The multiplex of forces, the high numbers of connections between components.

- Ambiguity. The haziness of reality, the mixed meanings of conditions; causeand-effect misinterpretation, multiple semantic schemas overlapping, the potential for misreads.

The challenges of VUCA can be conveniently explored from the specific point of view of talents, skills and competences. What means for a Project Manager, as well as for a 
Program or Portfolio Manager, facing a VUCA context in terms of skills and learning? Are the classic categories of study, growth, competence assessment, gap analysis and roles delineation still valid? Which are the right mind-sets for the organizations to grow complete persons able to reach their goals in a fluctuant world?

\subsection{The person as a whole (a great convergence)}

In such a complex scenario we need to establish a new continuous learning framework for the person, not constrained only by technical concerns or performance goals. In order to answer to these questions it is possible to combine great lessons from different schools, far from each other in time and space, but strongly converging: the first one comes from the Howard Gardner's Multiple Intelligence paradigm (2008 - the minds useful to face the challenges of the future); the second one is from the philosopher Edgar Morin, one of the greatest thinker of the Sciences of Complexity movement, suggesting a new learning manifesto and a final one comes from one of the revolutionary school-for-kids manifesto, the so called "Reggio Emilia approach" - a new pedagogy oriented to a project-based development of a person as a whole.

It's a great convergence of different contributions, sharing the idea of the human centrality in organizational model, what we could define e new organizational humanism.

\section{Right mindset for the future}

This paradigm was envisioned by one of the major American psychologists, Howard Gardner; in 2008 he collected and integrated the results of many years of research on our mind and the way it approaches learning, distilling the key points of the mind-sets that we need to develop in order to face the future challenges of our society:

- The Disciplinary Mind: the mastery of major branches of knowledge, with one or a combination of some professional crafts;

- The Synthesizing Mind: the ability to integrate ideas from different disciplines or spheres into a coherent whole and to communicate that integration to others;

- The Creating Mind: the capacity to uncover and clarify new problems, questions and phenomena;

- The Respectful Mind: awareness of and appreciation for differences among human beings and human groups.

- The Ethical Mind: fulfilment of one's responsibilities as a worker and as a member of a social group.

In the following we want to explore into more details the correspondence between each of the 5 minds and a set of important attitudes that we recognize as part of the kernel of the PM profession. So what's the relevance of each of these "minds" in Project Management? 
36 ${ }^{\mathrm{TH}}$ International Conference on Organizational Science Development: RESPONSIBLE ORGANIZATION (MARCH $22^{\mathrm{ND}}-24^{\mathrm{TH}}$, PORTOROŽ SLOVENIA)

S. Setti: Project Management in a VUCA World: Developing an Adaptive Leadership Style

- Disciplinary: this mind can immediately point to the project specific Application Area, the deep technical competence; as well known, it is not mandatory for the $\mathrm{PM}$ to be a SME, even though it is important for the PM to be able to confront with SMEs on a peer-to-peer basis. Moreover, we can consider an application of a disciplinary mind also the exercise of a reached seniority in the Project Management discipline itself.

- Synthesizing: the ability to integrate is embodied in the PM toolkit since the beginning: $\mathrm{PMBOK} \circledast$ has always stressed the importance of keeping the coherence of the big picture of the project in its specific Integration knowledge area; the PM is by definition an integrator, responsible for keeping the project safe as a whole.

- Creating: assuming that the project is the human dimension that is referring to the creation of something new that doesn't exist yet, the creative mind must be a characteristic of the project manager/team; their performance is pro-jected in the future, in a land of complete uncertainty, and it creates something unique and new.

- Respectful: this mind seems to refer directly to stakeholders management; no profession like project management is called to face and respect diversity of cultures, languages, branches of knowledge, personal attitudes, psychological types, and so on, defining behavioural rules in the temporary time frame of the project.

- Ethical PMI has been developing since the beginning the importance of ethics; each project is a unique training ground for ethics.

\section{Re-liance for complexity}

"It's not about destroying, but connecting": that's the way the great French philosopher Edgar Morin draws a new path, as suggested by the neologism reliance (a French word, fusion of relationship and alliance). It's time to transform the idea itself that we have of knowledge: knowledge is not a readymade tool that can be used without considering its own nature. The supremacy of traditional knowledge models, in which fragmented disciplines are juxtaposed, must give way to a new kind of knowledge able to capture complexity. Uncertainty is the basis of all sciences; this believe offers us a straight connection with risk management - the art of dealing with uncertainty and change - that during the years has been embodied in the PM toolkit, transforming the project manager attitude from plan-addict to change-ready.

We may derive positive outcomes from errors, wherever a virtuous try \& learn culture is promoted and not opposed. "You look for India, you find America" as written by the poet Voznessenski. Errors cannot be detached from any knowledge. In the western culture an 
error is typically seen as a non-compliance and related to fault and punishment; while in other culture, like the Japanese one - where the total quality management has grown based on the continuous improvement cycle - it's not a shame to openly share a situation of deviation, as the beginning of a potential growth and innovation.

Moreover, we cannot be completely effective without considering the triple nature of humans:

- Biological (the way we function, the mechanisms that move us)

- Individual (the way we feel, the psychological dimension)

- Social (the way we interact, connect, communicate)

- These are the key ideas on which it is possible to establish the new knowledge building:

- The idea of system, in opposition to the reductionist conception; the great importance of connections, over components, beyond the WBS,

- The crucial role of dialectic, absorbing opposite poles and resolving the opposition in the name of the AND culture developed (global/local, cause/effect, analyse/synthetize, separate/connect), including the idea of circularity,

- The ologrammatic principle; the part is in the whole and the whole is in the part; the idea to develop a DNA, a manifesto of values, principles, beliefs, rules, that is shared by all the components of the system.

Morin emphasizes the importance of com-prehension as a true holistic approach, offering us a deep reasoning on the different kinds of comprehensions (intellectual, human, complex). We are called to respond to a multidimensional crisis with a multi-skill mindset. This implies the inversion of the master-disciples relationship, as well as the acceptance of the importance to learn how to learn, and design education for sustainability (in society, organizations, and - we could say - "in projects").

\section{$4 \quad$ Project/Learning virtuous loop}

Many experiences and researches have brought the Project Management culture into the schools at different levels, and the positive results have been synthetized by PMIEF in the guidelines Project Management Skills for Life ${ }^{\circledR}$. In the seventies an Italian pedagogist created an innovative manifesto, based on the "one hundreds languages" metaphor, which indicates the innate multi-skill talent that each individual has inside himself. Unless carefully developed and maintained free to express, this innate form of talent can be gradually killed by the specialized knowledge. Once recognized that the project must be faced as a complex system, where the "whole" is more than the sum of the components, the team is perceived as a source of emerging vital behaviours. From this comes the importance of being trained in every phase of life in continuous changing and re-learning. From this perspective "one hundred languages" can be easily taken DNA of stakeholders management; the negative meaning of the Babel's tower is reverted into a paradigm of continuous confrontation, a permanent training in respecting differences. 
$36^{\mathrm{TH}}$ INTERNATIONAL CONFERENCE ON ORganizational SCIENCE DeVElopment: Responsible ORganization (MARCh $22^{\mathrm{ND}}-24^{\mathrm{TH}}$, Portorož Slovenia)

S. Setti: Project Management in a VUCA World: Developing an Adaptive Leadership Style

The specialization can kill the "hundreds" that is there.

The manifesto was based on a few revolutionary ideas that anticipated what has been recently acquired by many schools of thought:

- The idea of the project itself as a learning experience,

- The value of collaboration and communication, between different categories of stakeholders,

- The pursuit of interdisciplinary, the value of contamination.

Leveraging these principles, the above pedagogists distilled among the others the following guiding strategies and hints:

- Revisiting and co-construction

- The next day

- The role of metaphor

- Reinforcement vs reflection

- Individuality within the collective
- Plans before production

- Thinking ve skills

- The value of misconception

- $\quad$ Emotion and knowledge

\section{Extreme PM}

According with the definition of Doug De Carlo "An extreme project is a complex, selfcorrecting venture in search of a desired result.". The emphasis is on the word "desired": the project stakeholders can admit to reach a different goal, without considering the project itself a failure.

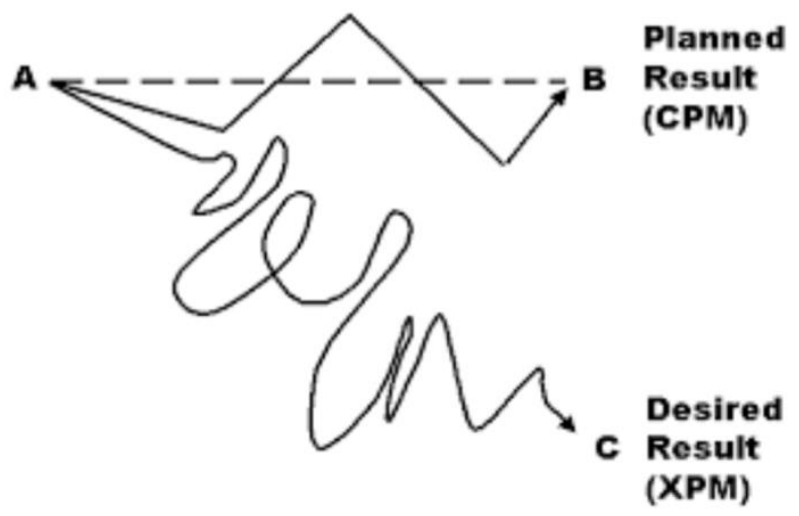

Image 1: Extreme Project representation

Extreme project management (XPM) refers to a method of managing very complex and very uncertain projects. Extreme project management differs from traditional project 
management mainly in its open, elastic and un-deterministic approach. The main focus of XPM is on the human side of project management (e.g. managing project stakeholders), rather than on intricate scheduling techniques and heavy formalism. But it is strong opinion of the author that this is becoming more and more true for any kind of projects.

An extreme project, led in an extreme environment, may be seen as a project with multiple and heavy constraints, that's why a reasoning about the "power of constraints" can produce many useful outcomes to help understanding and facing extreme

While the traditional PM has to passively respect constraints - sometimes negotiating them with stakeholders in a preliminary phase, but then acting with fixed goals and fixed constraints - the extreme PM is one who embraces constraints and embeds them in the holistic vision of the project, assuming constraints as the basis for creativity and success, if necessary changing goals. Exactly what happens when playing a game.

"The game appears in the meantime as a system of restrictions - that can be formulated as rules - and as an exercise of freedom. But such a freedom is a punctual act that is nothing but entering the game, through a voluntary assumption of restrictive rule A.J. Greimas, A propos du jeu, 1980

\begin{tabular}{|c|c|}
\hline Newtonian Mindset & Quantum Mindset \\
\hline $\begin{array}{ll}\text { - } & \text { Newtonian Mindset } \\
\text { - } & \text { Stability is the norm } \\
\text { - } & \text { The world is linear } \\
\text { - } & \text { and predictable } \\
\text { - } & \text { Minimize change } \\
\text { - } & \text { Increase the feeling of security by } \\
& \text { adding rigor the process controls }\end{array}$ & $\begin{array}{ll} & \text { Chaos is the norm } \\
\text { - } & \text { Uncertainty reigns } \\
\text { - } & \text { Murphy's law rules } \\
\text { - } & \text { Welcome change } \\
\text { - } & \text { Increase the feeling of security by } \\
& \text { relaxing the process controls }\end{array}$ \\
\hline Newtonian Hat & Quantum Mindset \\
\hline $\begin{array}{ll}\text { - } & \text { Deliver on the planned result } \\
\text { - } & \text { Use the plan to drive results } \\
\text { - } & \text { Aim, Aim, Fire, Fire. } \\
\text { - } & \text { Establish stronger } \\
\text { - } & \text { procedures and policies } \\
\text { - } & \text { Correct to the baseline } \\
\text { - } & \text { Be a task master } \\
\text { - } & \text { Get it right the first time }\end{array}$ & $\begin{array}{ll}\text { - } & \text { Discover the desired result } \\
\text { - } & \text { Use results to drive planning } \\
\text { - } & \text { Then, redirect the bullet } \\
\text { Agree on guidelines, } \\
\text { - } & \text { principles and values } \\
\text { - } & \text { Correct to what's possible } \\
\text { - } & \text { Be a relationship manager } \\
\text { - } & \text { Get it right the last time }\end{array}$ \\
\hline
\end{tabular}

Table 1: Newtonian vs Quantum approaches confrontation 
36 ${ }^{\mathrm{TH}}$ International Conference on Organizational Science Development: Responsible ORGANIZATION (MARCH $22^{\mathrm{ND}}-24^{\mathrm{TH}}$, Portorož SlOVENIA)

S. Setti: Project Management in a VUCA World: Developing an Adaptive Leadership Style

\section{Conclusions}

The XPM principles may be assumed as a manifesto for the VUCA projects:

- Requirements and activities being chaotic is normal

- Uncertainty is the most certain characteristic of an extreme project

- This type of projects are not fully controllable

- Change is the king and you need to welcome it every possible way

- The feeling of security is increased by relaxing the project controls

The summa of statements and ideas shown above can be integrated in a balanced and tailored organizational approach. This can be done at two different levels:

- at an organizational level, as a PMO responsibility: how to help grow complete and modern PMs, with an intimate sense of internal community

- at the project level, for the PM to engage and grow talented complete team members.

In order to put the basis for the next century cultural development, we have to establish a new paradigm, not through destroying but through including and refreshing all the knowledge from the past, adopting a combinatory invention approach.

So we can conclude, considering the profession of the modern project manager: no way, the hundred is there!

\section{Literature}

DeCarlo, D. (2001). A Different Drummer, Traditional Project Management vs. Extreme Project Management, An Apples and Cumquats Comparison. Retrieved March 1, 2017 from http://www.projectconnections.com/articles/070901-decarlo.html

Edwards, C., Gandini, L. and Forman, G. (2012). The Hundred Languages of Children - The Reggio Emilia Experience in Transformation - Third edition. Praeger, Oxford, England

Gardner, H. (1993). Multiple Intelligences: The Theory in Practice. Basic books.

Gardner, H. (2004). Changing Minds: The art and science of changing our own and other people's minds. Harvard Business School Press.

Gardner, H. (2010). GoodWork: Theory and Practice. Retrieved March 1, 2017 from http://www.thegoodproject.org/pdf/GoodWork-Theory_and_Practice-with_covers.pdf

Gardner, H. (2013). Frequently Asked Questions - Multiple Intelligences and Related Educational $\begin{array}{lllll}\text { Topics. } & \text { Retrieved } & \text { March } & \text { 1, } & \text { from }\end{array}$ https://howardgardner01.files.wordpress.com/2012/06/faq_march2013.pdf

Lugli, M. (2016). Leadership on thin air. PMI-NIC Leadership Event 2016, Milan.

Morin, E. (2010). I sette saperi necessari all'educazione del futuro. R. Cortina, Milano.

Morin, E. (2014). Enseigner à vivre. Actes Sud. 
S. Setti: Project Management in a VUCA World: Developing an Adaptive Leadership

Style

Project Management Institute. (2012). Project Management Skills for Life. Retrieved March 1, 2017 from http://Pmief.Org/Learning-Resources/Learning-Resources-Library/ProjectManagement-Skills-For-Life

Project Management Institute. (2013). A guide to the project management body of knowledge $\left(P M B O K^{\circledR}\right.$ guide $)$ - Fifth edition. Newtown Square, PA: Author.

Setti, S. (2010). Project and Process Integration: how to usefully combine two work management models. PMI EMEA Congress 2010, Milan.

Setti, S. (2013). Il linguaggio del progetto. FrancoAngeli editore, Milano.

Setti, S. (2016). Extreme Project Management: the strange idea we have about freedom. PMI-NIC TAAS Branch Event 2016, Bolzano.

Setti, S. (2016). Five minds and a hundred languages:the multi-skill challenge for the Project Manager in the VUCA world. PMI EMEA Congress 2016, Barcelona.

Setti, S. and Ruffa, M. (2011). Generating opportunities from constraints - ethics for project success. PMI EMEA Congress 2011, Dublin.

Setti, S. and Ruffa, M. (2012). Com-prehension - how to build a project ethical framework - MR rev1. PMI EMEA Congress 2012, Marseille.

Theory of multiple intelligences. (n.d.). Wikipedia. Retrieved March 1, 2017 from https://en.wikipedia.org/wiki/Theory_of_multiple_intelligences

Volatility, uncertainty, complexity and ambiguity. (n.d.). Wikipedia. Retrieved March 1, 2017 from https://en.wikipedia.org/wiki/Volatility,_uncertainty,_complexity_and

_ambiguity 
948 36 $36^{\text {Th }}$ International CONFerence on Organizational Science Development: Responsible Organization (MARCh $22^{\mathrm{ND}}-24^{\mathrm{TH}}$, PORTOROŽ SlOVENIA) 


\title{
Opredelitev kompetenčnega profila komercialista s pomočjo večkriterijske odločitvene metodologije
}

\author{
STANOJKA SOLAR, UROŠ RAJKOVIČ \& MOJCA BERNIK
}

Povzetek Poklic komercialista v nepremičninskem podjetju je zahteven, potrebne so ključne in delovno specifične kompetence, da lahko pridobi licenco nepremičninskega posrednika. V članku smo raziskovali kompetence komercialistov - nepremičninskih posrednikov v majhnem nepremičninskem podjetju in iskali ustrezno rešitev za sistematičen način izbire komercialista - nepremičninskega posrednika.

Rezultati raziskave so pokazali, da je povprečna ocena ključnih kompetenc komercialistov 4,04 in delovno specifičnih kompetenc 3,77, kar pomeni, da se anketirani $\mathrm{v}$ povprečju strinjajo $\mathrm{s}$ svojimi ključnimi in delovno specifičnimi kompetencami.

Rezultate raziskave smo nadgradili $\mathrm{z}$ večkriterijskim odločitvenim modelom. S pomočjo orodja DEXi smo izdelali drevo kriterijev za ocenjevanje kompetenc komercialista-nepremičninskega posrednika. Model bo $\mathrm{v}$ prihodnosti $\mathrm{v}$ pomoč podjetju pri izbiri ustreznega nepremičninskega posrednika za novo delovno mesto.

KLJUČNE BESEDE: kompetence • večkriterijski odločitveni model DEXI • delovno mesto komercialista

\footnotetext{
NASLOv AVtorJev: Stanojka Solar, Stan nepremičnine, Smrekarjeva 9, Ljubljana, Slovenija, epošta: tajnistvo@stan.si; dr. Uroš Rajkovič, izredni profesor, Univerza v Mariboru, Fakulteta za organizacijske vede, Kidričeva cesta 55a, 4000 Kranj, Slovenija, e-pošta: uros.rajkovic@fov.unimb.si; dr. Mojca Bernik, Univerza v Mariboru, Fakulteta za organizacijske vede, Slovenija, Kidričeva cesta 55a, 4000 Kranj, e-pošta:mojca.bernik@fov.uni-mb.si
} 
$36^{\text {Th }}$ International Conference on Organizational Science DeVElopment: Responsible ORGANIZATION (MARCH $22^{\mathrm{ND}}-24^{\mathrm{TH}}$, PORTOROŽ SLOVENIA)

O. Arsenijević, M. Ferjan, I. Podbregar, P. Šprajc, D. Trivan \& Y.

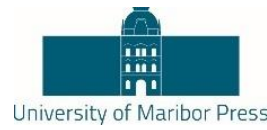

Ziegler

\title{
Definition of Sales Agent Competences Profile with Multi Attribute Decision Making Methodology
}

\author{
STANOJKA SOLAR, UROŠ RAJKOVIČ \& MOJCA BERNIK
}

\begin{abstract}
Profession of sales agent in real estate company is demanding, it requires key and job specific competences to get license for real estate agent. In article we researched competences of sales agents-real estate brokers in small real estate company and seeking a solution for systematical way of selecting real estate brokers for new job. The research results showed the average assessment of key competences 4,04 and the average assessment of job specific competences is 3,77. This means, that respondents agree on the average level with their key and job specific competences. The research results we upgraded with multi attribute decision model. With program for multi attribute decision making DEXi we defined tree of attributes for analysis competences of sales agent-real estate broker. In the future, the model can be used in company as important tool for selecting appropriate real estate broker for new job.
\end{abstract}

KEYWORDS: sales agent working place $\cdot$ competences $\cdot$ multi attribute decision model $\bullet$ DEXi

CoRRESPONDENCE AdDRESS: Stanojka Solar, Stan Real estate, Smrekarjeva 9, Ljubljana, Slovenia, e-mail: tajnistvo@stan.si; Uroš Rajkovič, Ph.D., Associate Professor, University of Maribor, Faculty of Organizational Sciences, Kidričeva cesta 55a, 4000 Kranj, Slovenia, e-mail: uros.rajkovic@fov.uni-mb.si; Mojca Bernik, Ph.D., Assistant Professor, University of Maribor, Faculty of Organizational Sciences, Kidričeva cesta 55a, 4000 Kranj, Slovenia, e-mail: mojca.bernik@fov.uni-mb.si 
S. Solar, U. Rajkovič \& M. Bernik: Opredelitev kompetenčnega profila komercialista s pomočjo večkriterijske odločitvene metodologije

\section{$1 \quad$ Uvod}

Razvoj tehnologije in vse večja konkurenca na trgu, sta dejavnika, ki zahtevata od podjetij nenehno prilagajanje in razvoj novih produktov oziroma storitev. Če želi podjetje temu slediti, mora imeti zaposlene z ustreznimi kompetencami, ki bodo realizirali zastavljene cilje. Pojem kompetenca posameznika v stroki pomeni sposobnost uporabe znanja in drugih zmožnosti, ki jih posameznik potrebuje, da lahko učinkovito in uspešno izvaja naloge $\mathrm{v}$ poslovnem procesu, na primer pri procesu trženja in prodaje nepremičnin. (Gavez in Karničnik, 2013, str. 3; Šrca Trunk et al., 2012, str. 2) Pojem kompetenca je sestavljen iz štirih sestavin (Gavez in Karničnik, 2013, str. 3):

- Otipljive sposobnosti in spretnosti, to so poslovne in osebne, ki so potrebne za izvajanje dela v skladu s standardi (Širca Trunk et al., 2012, str. 2).

- Znanja: splošna in specialna znanja, zahtevana za opravljanje dela.

- Vedenja: odnos in etični standardi vedenja.

- Strokovne usposobljenosti, kako uporabiti znanje, spretnosti in vedenja za doseganje uspešnosti dela.

Kompetenco posameznika lahko razumemo kot njegovo zmožnost, da lahko aktivira, uporabi in med seboj poveže pridobljeno znanje v nepredvidenih, raznolikih in zahtevnih situacijah (Perrenond,1997 v Svetlik, 2005, str. 7). Je več kot le znanje in spretnosti, gre za sposobnost posameznika za izpolnjevanje kompleksnih zahtev (OEC, 2005, str. 4). Kompetenca je kvaliteta posameznika, ki kaže njegovo moč, sposobnost ali z drugo besedo predstavlja njegovo znanje in spretnosti (Vincent, 2008, str. 1). Kot pravi Svetlik, so kompetence zmožnosti posameznika, da aktivira ter uporabi in poveže pridobljeno znanje v nepredvidljivih in kompleksnih situacijah (Turk, 2003).

Pri kompetencah posameznika bi lahko rekli, da gre predvsem za znanje o tem, kako in ne samo o tem kaj in zakaj (Lundvall in Johnson, 1994; Savage, 1999 povz. po Svetlik, 2005, str.13. O Kompetencah ). Ne zadošča samo poznavanje dejstev in zakonitosti posameznika o posameznem pojavu ali procesu, ampak ga mora tudi obvladovati, kar pomeni, da potrebuje tehnično znanje (Svetlik, 2005, str. 13).

\section{Razdelitev kompetenc in kompetentnost posameznika}

Posameznik potrebuje širok spekter kompetenc, da se lahko sooči s kompleksnimi izzivi današnjega trga, ki jih prinaša globalizacija in modernizacija ter z njimi povezane potrebe po razpoložljivosti informacij. Vsaka ključna kompetenca mora prispevati vrednost $\mathrm{k}$ doseganju ciljev in pomagati posamezniku, da lahko izpolni pričakovanja in zahteve strank (Organisation for Economic Co-operation and Development [OECD], 2005, str. 4). 
$36^{\mathrm{TH}}$ International Conference on Organizational Science Development: RESPONSIBLE ORGANIZATION (MARCH $22^{\mathrm{ND}}-24^{\mathrm{TH}}$, PORTOROŽ SLOVENIA)

S. Solar, U. Rajkovič \& M. Bernik: Opredelitev kompetenčnega profila komercialista s pomočjo večkriterijske odločitvene metodologije

\subsection{Ključne kompetence posameznika}

Ključne kompetence so po Evropskem referenčnem okvirju kompetence, ki jih človek mora imeti za osebno izpopolnjevanje, razvoj, socialno informiranost in zaposlitev. Med seboj se prekrivajo in povezujejo, razvrščene so v osem ključnih kompetenc (Uradni list Evropske unije, 2006):

1. Sporazumevanje v maternem jeziku: poslušanje, govor, branje in pisanje, ki kaže na sposobnost in znanje posameznika, da se lahko poveže $\mathrm{z}$ različnimi ljudmi v različnih okoljih, ob tem pa tudi spozna njihovo kulturo, vrednote in posebnosti.

2. Sporazumevanje $\mathbf{v}$ tujih jezikih: se praktično ne razlikuje od sporazumevanja $v$ maternem jeziku, poudarek je predvsem na razumevanju, komunikaciji, izražanju, miselnosti, poznavanju družbenih in kulturnih vrednot.

3. Matematična kompetenca in osnove kompetence $v$ znanosti in tehnologiji, ki je povezana z matematičnim znanjem računanja, poznavanja številk, simbolov, grafov, tabel, in predvsem z logičnim razmišljanjem in dojemanjem različnih pojmov v vsakdanjem življenju.

4. Digitalna pismenost je tesno povezana s poznavanjem in uporabo informacijske tehnologije (IKT), tako v vsakdanjem življenju kot pri delu, prostem času, sporazumevanju. Pomembno je obvladovanje računalniških aplikacij, sprejemanje novitet in spremljanje elektronskih medijev. Uporabna znanja pri digitalni pismenosti izkažejo posameznikovo sposobnost iskanja, zbiranja in obdelave informaciji ter njihovo uporabo.

5. Učenje učenja je sposobnost posameznika, da se nenehno uči in organizira učenje, ki je v njegovem lastnem interesu ter učinkovito izkorišča čas in informacije, prepoznava priložnosti in premaguje prepreke za doseganje uspešnosti z na novo pridobljenim znanjem. Učenje učenja je hkrati spretnost posameznika, ki zahteva, da je seznanjen in razume strategijo učenja, prednosti in pomanjkljivosti lastnega znanja in kvalifikacij ter da se znajde v pridobitvi novih izobraževanj, usposabljanj, sprejemanju nasvetov in pridobivanju novih izkušenj. Pozitiven pristop ob pridobivanju novih znanj pripelje posameznika do realizacije zastavljenega cilja.

6. Socialne in državljanske kompetence so kompetence osebne, medsebojne in medkulturne ravni, ki vključujejo vse značilnost vedenja in dajejo posamezniku učinkovito in konstruktivno obnašanje v različnih življenjskih situacijah.

7. Samoiniciativnost in podjetnost je sposobnost posameznika pri uresničevanju zastavljenih ciljev, da je ustvarjalen, inovativen, sposoben sprejemati tveganja, načrtovati in organizirati projekte za doseganje svojega uspeha. Za posameznika je pomembno, da za doseganje svojih ciljev pozna tudi etiko podjetja in na kakšen način je podjetju zgled.

8. Kultura zavesti in izražanja je kreativno izražanje in poznavanje znanja o lokalni, nacionalni in evropski kulturni dediščini, tako pri nas kot v svetu. Potrebno je razumeti kulturno in jezikovno razliko po svetu in v vsakdanjem življenju. Kulturo izražanja lahko prenesemo na različna področja. Bernik in 
drugi (2002, str. 473) navajajo, da je od kulture podjetja odvisno upravljanje z znanjem, zato je v prvi vrsti pomembno, da se vodstvo podjetja vključi v proces identifikacije in vrednotenja znanja zaposlenih $\mathrm{v}$ podjetju.

Po Širca Trunk in drugi (2012, str. 3) obstajajo naslednje ključne kompetence (znanja, veščine, stališča posameznika) za učinkovito delo, in sicer:

1. Komunikacija, ki je tesno povezana s sposobnostjo posameznika, da razume svet in se poveže z drugimi v skupnosti (pisno, govorno) na prepričljiv način, prilagojen vsakokratnim okoliščinam.

2. Matematično znanje za razmišljanje, razumevanje matematičnih dokazov (na primer analize pridobivanja potencialnih kupcev).

3. Digitalna pismenost kot je temeljno razumevanje in poznavanje narave, vloge in tehnologije informacijske družbe (na primer aplikacij za obvladovanje odnosov s strankami angl. customer relationship management). Če se posameznik zaveda pomembnosti informacijske tehnologije $\mathrm{z}$ vidika podpore poslu, lahko dosega boljše rezultate na trgu.

4. Učenje, ki je neposredno osredotočeno $\mathrm{k}$ določenemu cilju pri delu ali $\mathrm{v}$ zasebnem življenju (Širca Trunk et. al., 2012, str. 3). Po Bernik in Florjančič (2010, str. 12) so vzroki za neuspešnost podjetij, poleg nesposobnosti vodstva in slabe organiziranosti, tudi v nizki ravni znanja. Zato je v podjetju nujno potrebno skrbeti za ustrezen sistem spremljanja zaposlenih, da bodo nenehno razvijali svoje kompetence (Bernik in Florjančič, 2010, str. 12).

5. Inovativnost in podjetnost: pridobivanje potrebnega znanja za proaktivno delovanje posameznika na trgu (dajanje pobud, vpeljevanje novih postopkov in tehnologij za inovativno delo).

\section{Delovno specifične kompetence posameznika}

Delovno specifične kompetence so povezane $\mathrm{z}$ učinkovitim delovanjem posameznika. Sestavljajo jih atributi, ki so potrebni za uspešno izvajanje del in nalog (New, 1966 povz. po Kohont, 2005, str. 39.). Za specifične kompetence je značilno, da so zanje potrebna tehnična in postopkovna znanja za uspešno opravljanje dela. Se pa delovno specifične kompetence razlikujejo glede na različne panoge delovana okolja. Različni poklici zahtevajo različne kompetence (ZRSZ, 2016a). Te so po Tomažič in Svetlik (2003 v Turk) značilne za posamezno delovno mesto.

Če vzamemo na primer kompetenco komercialista, mu znanje o predpisih o nepremičninskih poslih, o kalkulacijah in analizi, o pridobivanju novih strank, omogoča, da uspešno realizira nepremičninski posel nakupa nepremičnine. Ta kompetenca je na primer za peka popolnoma nepomembna.

Za delovno specifične kompetence je značilno, da se ne prenašajo med podjetji in ne doprinašajo $\mathrm{k}$ uspehu pri opravljanju drugih nalog ali vlog $\mathrm{v}$ podjetju. Te kompetence so 
$36^{\text {TH }}$ International Conference on Organizational Science Development: RESPONSIBLE ORGANIZATION (MARCH $22^{\mathrm{ND}}-24^{\mathrm{TH}}$, PORTOROŽ SLOVENIA)

S. Solar, U. Rajkovič \& M. Bernik: Opredelitev kompetenčnega profila komercialista s pomočjo večkriterijske odločitvene metodologije

povezane z uspešnostjo posameznika na posameznem delovnem mestu (Kohont, 2005, str. 39), na primer na delovnem mestu komercialista $v$ nepremičninskem podjetju.

\section{Organizacijsko specifične kompetence posameznika}

Organizacijsko specifične kompetence predstavljajo sredstvo, s katerim posameznik prilagaja svoja ravnanja delovanju organizacijske kulture podjetja. (New,1996 povz. po Kohont, 2005, str. 39).

Organizacijsko specifične kompetence so povezane $\mathrm{z}$ uspešnostjo posameznika $\mathrm{V}$ podjetju kot celoti, to pomeni, da gre za ujemanje kulture in vrednot podjetja $s$ kompetencami posameznika (Kohont, 2005, str. 39).

\subsection{Kompetentnost posameznika}

Kompetentnost predstavlja lastnost posameznika ali podjetja, ki se nanaša na zmožnosti opravljanja nalog v podjetju (Majcen, 2009, str. 21). Kohont (2005, str. 34) navaja model kompetentnosti, katerega predstavljamo na sliki 1.

\begin{tabular}{|c|c|c|}
\hline Posameznik & \multirow[b]{3}{*}{ za uspešno } & Kontekst \\
\hline Hoteti, znati, moči & & Socialno okolje \\
\hline \multirow{4}{*}{$\begin{array}{l}\text { Znanje } \\
\text { Sposobnosti } \\
\text { Motivi } \\
\text { Samopodoba } \\
\text { Vrednote } \quad \text { uspešno }\end{array}$} & & Reševanje problemov \\
\hline & \multirow[t]{3}{*}{ delovanje } & $\begin{array}{l}\text { Opravljanje nalog in } \\
\text { izpolnjevanje vlog. }\end{array}$ \\
\hline & & $\begin{array}{c}\text { Doseganje standardov } \\
\text { pri delu. }\end{array}$ \\
\hline & & Fizično okolje \\
\hline
\end{tabular}

Slika 1: Kompetentnost (Kohont et al., 2005, str. 34)

Model kompetentnosti je sestavljen iz naslednjih elementov:

1. Znanja, ki predstavlja bogato izkušnjo posameznika. Temelji na spretnostih, informacijah, intuiciji in vrednotah posameznika (Kohont, 2005 str. 35). Je del zmožnosti posameznika za reševanje znanih problemov, takšnih, ki jih je že videl ali rešil, na primer postopek vpisa etažne lastnine in lastninske pravice $\mathrm{v}$ zemljiško knjigo. Ne glede na to, na kakšen način je posameznik prišel do znanja, mu pri reševanju problemov pomagajo izkušnje in znane rešitve problemov (Kohont, 2005, str. 35). Z uporabo znanja zaposlenih podjetje lahko prihrani pri stroških procesa, izboljša svetovanje strankam in poveča produktivnost (Bernik in drugi (2002, str. 473). 
S. Solar, U. Rajkovič \& M. Bernik: Opredelitev kompetenčnega profila komercialista s pomočjo večkriterijske odločitvene metodologije

2. Sposobnosti, s katero kombinira znanje pri reševanju neznanih problemov (Lipičnik, 1998, str. 27).Osebnostna lastnost je značilnost, na podlagi katere ugotavljamo osebnost posameznika kot je sposobnost, značaj, izgled in energičnost (Musek in Pečjak, 2001 povz. po Svetlik 2005, str. 35). Osebnostna lastnost predstavlja vrlino posameznika in njegove zmožnosti v splošnem pomenu. Zmožnosti posameznika v praksi predvsem povezujemo s pojmom sposobnosti (Lipičnik, 1998, str. 28). Osebne lastnosti so močno povezane med dimenzijami osebnosti in samopodobe na eni strani kot tudi psihičnega stanja posameznika in zadovoljstva na drugi strani, kot na primer čustvena stabilnost, samospoštovanje, zdravje, osamljenost, pozitivna naravnanost (Musek in Avsec, 2006, str. 51), zaupanje vase in moč (Musek, 1993a, str. 67, 71). Sposobnost je povezana $\mathrm{z}$ znanjem in motivacijo posameznika ter $\mathrm{z}$ razvojem pomembnih človekovih zmožnosti in kompetentnosti za doseganje zastavljenih ciljev in nalog (Musek in Pečjak, 2001 povz. po Kohont 2005, str. 35 Razvrščanje kompetenc ).).

3. Motivov in motivacije: motivi so tesno povezani z zadovoljitvijo individualnih potreb posameznika preko katerih dosežemo vnaprej zastavljen cilj (Kušar, 2014, str. 10). Motive posameznika delimo na primarne in sekundarne. Primarni motivi, ki usmerjajo posameznika k ciljem, da lahko preživi, so žeja, lahkota, spanje, počitek. Imenujemo jih tudi biološki motivi, saj so podedovani in $\mathrm{v}$ posamezniku že od samega rojstva. Ti primarni cilji so na splošno značilni za vse ljudi (Treven, 1998, str. 108).

4. Sekundarni motivi so povezani z učenjem, ki se nanaša na spodbujanje, ta pa na motivacijo posameznika. Spodbuda se v tem primeru uporabi za povečanje motivacije pri določenem vedenju, ki ga želimo doseči pri posamezniku. Tak primer je vodja $\mathbf{v}$ podjetju, ki uporabi pozitivno spodbudo tako, da dodeli en dan dodatnega dopusta tistim zaposlenim, ki so še posebej zaslužni za doseganje rezultatov in uspešnosti podjetja. Na ta način jih motivira, da so še bolj zavzeti za opravljanje svojega dela (Treven, 1998, str. 109).Za sekundarne motive je značilno, da se jih lahko naučimo, ker niso primarni, torej biološki, ki ji pridobimo z rojstvom. Med najpomembnejše sekundarne motive spadajo moč, uveljavljanje, pripadnost podjetju, varnost, status, motivi (Treven, 1998, str. 110).

5. Samopodoba: samopodobo razumemo kot konstrukt, ki se pojavlja že od Jamesove teorije sebstva dalje. Avtor je v knjigi Priciples of psychology že leta 1890 razvil pojav sebstva, s katerim pojmuje vse, kar lahko posameznik imenuje kot svoje, in ga na ta način razčlenil na sebstvo kot subjekt (čisti ego) in sebstvo kot objekt (Kobal Grum, 2004, str. 96).

6. Vrednote so motivacijski cilji, interesi in vedenje, ki odražajo trajno in časovno neopredeljeno naravnanost v strukturi osebnosti posameznika. Struktura vrednot je opredeljena na vedenje, stališča in prepričanja (Musek, 2000 povz. po Pogačnik, 2002, str. 33). Vrednote delimo na tri sklope, in sicer:

- Osebne vrednote so vrednote, ki veljajo samo za nivo posameznika, na primer razumevanje s sodelavci, s partnerjem, s starši. 
36 ${ }^{\mathrm{TH}}$ International Conference on Organizational Science Development: RESPONSIBLE ORGANIZATION (MARCH $22^{\mathrm{ND}}-24^{\mathrm{TH}}$, PORTOROŽ SLOVENIA)

S. Solar, U. Rajkovič \& M. Bernik: Opredelitev kompetenčnega profila komercialista s pomočjo večkriterijske odločitvene metodologije

○ Družbene vrednote so vrednote, ki veljajo za celotno družbo ali za posamezne dele družbe, kot je na primer vrednota v nepremičninskem podjetju, ko želimo določiti kompetenčen profil posameznika. Osebne in družbene vrednote se med seboj prepletajo.

- Splošne vrednote so zelo širok pojem in se pokrivajo z družbenimi vrednotami, kot na primer mir v okolju, v katerem živimo.

- Po znani Maslowovi klasifikaciji človekovih motivov in vrednot obstaja pet skupnih človekovih potreb, ki so razporejene hierarhično, in sicer: fiziološke potrebe, potrebe po varnosti, potrebe po pripadnosti, kognitivne potrebe in samouresničitev (Pogačnik, 2002, str. 35).Po Muskovi shemi vrednot pa delimo vrednote na (Musek, 2000 povz. po Pogačnik, 2002, str. 33):

- Dionizične: hedonske: čutne, zdravstvene, varnostne (zabava, udobje, spolnost, zdravje, varnost) in potenčne: statusne, patriotske, legalistične (ugled, denar, uspeh, domovina, zakoni).

- Apolonske; moralne: tradicionalne, družinske, societalne (poštenost, dobrota, ljubezen, partner, enakost) in izpolnitvene: kulturne, estetske, aktualizacijske, spoznavne, verske (ustvarjanje, lepota, samouresničitev, znanje, modrost).

Ne glede na to, katero klasifikacijo človekovih vrednot uporabimo (Muskovo lestvico vrednot- MLV ali Maslowovo klasifikacijo), moramo vedno imeti v mislih prioritetni vidik vrednot posameznika. (Pogačnik, 2002, str. 36).

Skozi proučevanje kompetenc in kompetentnosti smo pridobili znanja za pripravo raziskave in modela vrednotenja za delovno mesto, kot končnega rezultata raziskave, ki ga predstavljamo v naslednjem poglavju.

\section{$3 \quad$ Metodologija raziskovanja}

Za raziskavo smo uporabili metodo anketiranja komercialistov v mikro nepremičninskem podjetju. Anketni vprašalnik smo oblikovali na osnovi različnih virov (Gavez in Karničnik, 2013; Grubiša, 2001; Musek, 1993a, b; Uradni list Evropske unije L394/10, 2006; Zavod Republike Slovenije za zaposlovanje (ZRSZ), 2016; RealEstate, 2016; Jacobs, 2015), ki so nam bili v pomoč pri sestavljanju vprašalnika. Anketni vprašalnik je zato zajemal 3 bistvene dele za našo raziskavo:

1. Del: splošni demografski podatki o zaposlenih komercialistih nepremičninskih posrednikih.

2. Del: kompetentnosti in kompetence komercialista - nepremičninskega posrednika.

3. Del: ocenjevanje vrednosti ključnih in delovno specifičnih ključnih kompetenc komercialista

V raziskavi je sodelovalo vseh 7 zaposlenih komercialistov v majhnem nepremičninskem podjetju. Vprašalnik je bil razdeljen na sestanku v podjetju 9.8. 2016. Vseh 7 

ORGANIZACIJA (22. - 24. MAREC 2017, PORTOROŽ, SLOVENIJA)

S. Solar, U. Rajkovič \& M. Bernik: Opredelitev kompetenčnega profila komercialista s pomočjo večkriterijske odločitvene metodologije

komercialistov - nepremičninskih posrednikov je odgovorilo na vsa vprašanja anketnega vprašalnika.

\subsection{Rezultati raziskave}

\section{Rezultati raziskave I. splošnega dela ankete - demografskih podatkov o zaposlenih}

V raziskavi so sodelovali $3(50 \%)$ anketirani $\mathrm{z}$ več kot 10 let delovnih izkušenj; 2 anketirana (33\%) z delovno dobo do 5 let in $1(17 \%)$ anketirani z delovno dobo od 6 do 10 let. 3 anketirani (43\%) imajo do 5 let izkušenj pri nepremičninskem podjetju; 2 anketirana (29\%) imata od 6 do 10 let izkušenj na nepremičninskem področju; 2 anketirana ( $28 \%$ ) imata več kot 10 let izkušenj na nepremičninskem področju. Vseh 7 komercialistov - nepremičninskih posrednikov (100 \%) ima višjo ali visoko izobrazbo.

\section{Rezultati raziskave II. dela o kompetentnosti in kompetencah komercialistov}

Ocena znanja glede na potrebe delovnega mesta:

$\mathrm{V}$ povprečju se anketirani komercialisti zelo strinjajo, da imajo dovolj znanja za učinkovito komunikacijo s strankami $(\overline{\mathrm{x}}=4,57$; so $=0,49)$, da svoje znanje dopolnjujejo ob vsaki spremembi predpisov $(\overline{\mathrm{x}}=4,57$; so $=0,49)$ in da je v podjetju poskrbljeno za stalno izboljševanje znanj (na področju trženja, poslovnega bontona $(\overline{\mathrm{x}}=4,57$; so $=0,49)$. Anketirani komercialisti se strinjajo, da dobro poznajo nepremičninski $\operatorname{trg}(\overline{\mathrm{x}}=4,29$; so $=0,70)$ in dobro poznajo predpise za poslovanje nepremičninskih družb $(\overline{\mathrm{x}}=4,29$; so $=$ $0,70)$. Anketirani so znanje glede na potrebe delovnega mesta v povprečju ocenili kot dobro $(\overline{\mathrm{x}}=4,46)$.

Ocena sposobnosti glede na potrebe delovnega mesta:

Anketirani se v povprečju zelo strinjajo, da se prilagajajo potrebam $\operatorname{strank}(\overline{\mathrm{x}}=4,71$; so $=$ $0,45)$. V povprečju se strinjajo, da so odločni $(\bar{x}=4,43$; so $=0,73)$, imajo organizacijske sposobnosti in znajo organizirati svoje delo $(\overline{\mathrm{x}}=4,43$; so $=0,73)$, so prodorni in samostojni pri delu $(\overline{\mathrm{x}}=4,43$; so $=0,73)$. V povprečju se strinjajo, da so ciljno naravnani $(\overline{\mathrm{x}}=4,29$; so $=0,70)$, imajo pogajalske sposobnosti in so prepričljivi $\mathrm{v}$ komunikaciji s strankami $(\bar{x}=4,14$; so $=0,64)$. So dosledni pri delu $(\bar{x}=4,00$; so $=0,93)$, natančni in odgovorni $(\overline{\mathrm{x}}=4,00$; so $=0,93)$, pri reševanju nalog in problemov so uspešni pri svojem delu $(\overline{\mathrm{x}}=3,86$; so $=0,64)$ ter so nagnjeni $\mathrm{k}$ raziskovanju $\operatorname{trga}(\overline{\mathrm{x}}=3,43$; so $=0,49)$. Rezultati anketiranja kažejo, da imajo komercialisti - nepremičninski posredniki $\mathrm{v}$ proučevanem podjetju v povprečju dobre sposobnosti $(\overline{\mathrm{x}}=4,17)$.

\section{Ocena motiviranja v podjetju:}

Po mnenju anketiranih komercialistov - nepremičninskih posrednikov se v povprečju zelo strinjajo, da jih vodilni podpirajo pri delu $(\overline{\mathrm{x}}=4,57$; so $=0,73)$. Anketirani se strinjajo, da jih sistem nagrajevanja motivira za delo $(\overline{\mathrm{x}}=4,43$; so $=0,49)$, cilji podjetja 
36 ${ }^{\mathrm{TH}}$ International Conference on Organizational Science Development: RESPONSIBLE ORGANIZATION (MARCH $22^{\mathrm{ND}}-24^{\mathrm{TH}}$, PORTOROŽ SLOVENIA)

S. Solar, U. Rajkovič \& M. Bernik: Opredelitev kompetenčnega profila komercialista s pomočjo večkriterijske odločitvene metodologije

so skladni z njihovimi lastnimi cilji $(\overline{\mathrm{x}}=4,00$; so $=0,93)$. Povprečna ocena za urejenost sistema motiviranja v proučevanem nepremičninskem podjetju je 4,33, kar pomeni, da je sistem v povprečju dobro urejen.

Ocena samopodobe komercialistov - nepremičninskih posrednikov:

Anketirani se v povprečju zelo strinjajo, da so urejeni $(\overline{\mathrm{x}}=4,57$; so $=0,73)$. Strinjajo se, da so pozitivni in ustvarjajo pozitivno klimo v okolju $(\overline{\mathrm{x}}=4,43$; so $=0,73)$ ter zaupajo vase $(\overline{\mathrm{x}}=4,43$; so $=0,73)$. Delno se strinjajo, da uveljavljajo svojo moč $(\overline{\mathrm{x}}=3,29$; so $=$ $1,48)$ in so čustveno stabilni $(\overline{\mathrm{x}}=3,14$; so $=0,83)$. V povprečju je samopodoba zaposlenih ocenjena s povprečno oceno 3,98 - dobro.

\section{Ocena vrednot na delovnem mestu:}

Anketirani se v povprečju zelo strinjajo, da jim ugled podjetja na trgu zelo veliko pomeni $(\overline{\mathrm{x}}=5,00$; so $=0,00)$ in so za svoje delo pravično nagrajeni $(\overline{\mathrm{x}}=4,86$; so $=0,35)$, prav tako, da so pri njihovem delu pomembne moralne in statusne vrednote $(\overline{\mathrm{x}}=4,57$; so $=$ 0,49), da lahko svobodno načrtujejo delo (sestanke, delo na terenu, marketinške aktivnosti) $(\overline{\mathrm{x}}=4,57$; so $=0,49)$ ter da hitro pridobivajo potrebne informacije za delo $(\overline{\mathrm{x}}$ $=4,57$; so $=0,49)$.

V povprečju se anketirani strinjajo, da jim delovno mesto daje občutek varnosti $(\overline{\mathrm{x}}=4,29$; so $=0,70)$, pri delu so ustvarjalni $(\overline{\mathrm{x}}=4,14$; so $=0,64)$. Povprečna ocena za ocenjevanje vrednot na delovnem mestu je 4,57 kar pomeni, da se anketirani v povprečju strinjajo z vrednotami podjetja

\section{Rezultati raziskave III. dela o ocenjevanju vrednosti ključnih in delovno specifičnih ključnih kompetenc komercialista - nepremičninskega posrednika}

\section{Ocena ključnih kompetenc:}

Anketirani so svoje ključne kompetence v povprečju ocenili kot smo predstavili v tabeli 8. V povprečju se zelo strinjajo, da so podjetju pripadni $(\overline{\mathrm{x}} 4,71$; so $=0,79)$ in da so pozitivno naravnani do dela $(\overline{\mathrm{x}}=4,57$; so $=0,49)$.

Anketirani se v povprečju strinjajo, da imajo dober odnos do kupcev ( $\overline{\mathrm{x}}=4,43$; so $=0,49)$, pri delu so dosledni $(\overline{\mathrm{x}}=4,43$; so $=0,49)$, poznajo poslovne procese v podjetju $(\overline{\mathrm{x}}=4,43$; so $=0,73)$ ter razumejo predpise in navodila $(\overline{\mathrm{x}}=4,14$ so $=0,64)$.

V povprečju se anketirani delno strinjajo, da so samoiniciativni pri delu ( $\overline{\mathrm{x}}=3,43$; so $=$ $0,49)$ in se sporazumevajo $\mathrm{v}$ tujem jeziku $(\overline{\mathrm{x}}=2,86$; so $=1,25)$. Povprečna ocena za ocenjevanje ključnih kompetenc je 4,04, kar pomeni, da se anketirani v povprečju strinjajo s svojimi ključnimi kompetencami. 

ORGANIZACIJA (22. - 24. MAREC 2017, PORTOROŽ, SLOVENIJA)

S. Solar, U. Rajkovič \& M. Bernik: Opredelitev kompetenčnega profila komercialista s pomočjo večkriterijske odločitvene metodologije

\section{Ocena delovno specifičnih kompetenc:}

Anketirani se v povprečju zelo strinjajo, da so pošteni $(\overline{\mathrm{x}}=5,00$; so $=0,00)$ in vztrajni pri izpeljavi posla $(\overline{\mathrm{x}}=4,71$; so $=0,45)$. Strinjajo se, da so samostojni pri pridobivanju novih strank $(\overline{\mathrm{x}}=4,29$; so $=0,70)$, da so v nenehnem stiku/komunikaciji s stranko $(\overline{\mathrm{x}}=4,29$; so $=0,45)$, da poslušajo in motivirajo stranko za izpeljavo posla $(\overline{\mathrm{x}}=4,29$; so $=0,45)$ in da so uspešni pri prodaji $(\overline{\mathrm{x}}=4,00$; so $=1,2)$. Anketirani se v povprečju delno strinjajo, da imajo znanja za pravno izvajanje posla $\mathrm{z}$ nepremičninami $(\overline{\mathrm{x}}=3,29$; so $=0,45)$ in da iščejo nove priložnosti na trgu $(\overline{\mathrm{x}}=3,14$; so $=0,99)$. Se pa anketirani v povprečju sploh ne strinjajo, da samostojno pripravljajo kalkulacije in analize za izbiro ekonomsko upravičene investicije nepremičnin $(\overline{\mathrm{x}}=1,86$; so $=1,12)$. Povprečna ocena za ocenjevanje delovno specifičnih kompetenc je 3,77.

\section{Izdelava večkriterijskega modela za izbiro komercialista}

$\mathrm{Na}$ osnovi raziskave smo v nadaljevanju oblikovali večkriterijski odločitveni model. S pomočjo orodja DEXi smo izdelali drevo kriterijev za ocenjevanje kompetenc komercialista-nepremičninskega posrednika. Kot prikazuje slika 2, smo upoštevali naslednje kompetence: znanje, sposobnosti in motiviranost.Za kompetenco znanje smo upoštevali kriterije: izobrazba, tuji jezik in poznavanje trga. Za kompetenco sposobnost smo upoštevali kriterija: samopodoba (urejenost in samozaupanje) in komuniciranje (uspešnost, raziskovanje in odnos do strank. Za kompetenco motiviranost smo upoštevali kriterija: samoiniciativnost in nagrajevanje.

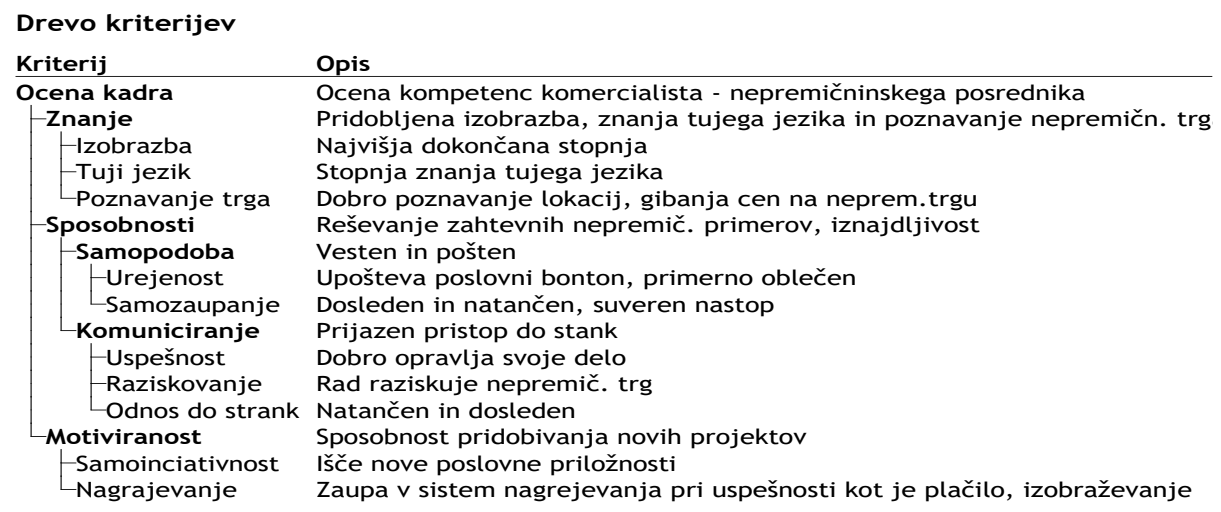

\section{Slika 2: Drevo kriterijev za izbiro komercialista-nepremičninskega posrednika}

Posameznim kriterijem smo določili zaloge vrednosti, ki smo jih utežili. Iz slike 3 je razvidno, da smo najbolj utežili znanje (69\%). Od končnih kriterijev je najpomembnejši poznavanje trga, ki h končni oceni prispeva $32 \%$ (globalna utež). Med najmanj pomembnimi končnimi kriteriji so raziskovanje (1 \%), samozaupanje (2\%) in nagrajevanje kot element motiviranja (3\%). 

RESPONSIBLE ORGANIZATION (MARCH $22^{\mathrm{ND}}-24^{\mathrm{TH}}$, PORTOROŽ SLOVENIA)

S. Solar, U. Rajkovič \& M. Bernik: Opredelitev kompetenčnega profila komercialista s pomočjo večkriterijske odločitvene metodologije

\begin{tabular}{|c|c|c|}
\hline \multicolumn{3}{|l|}{ Povprečne uteži } \\
\hline Kriterij & Lokalne & Globalne \\
\hline \multicolumn{3}{|l|}{ Ocena kadra } \\
\hline Znanje & 69 & 69 \\
\hline Izobrazba & 41 & 28 \\
\hline Tuji jezik & 12 & 8 \\
\hline Poznavanje trga & 47 & 32 \\
\hline Sposobnosti & 17 & 17 \\
\hline Samopodoba & 33 & 6 \\
\hline Urejenost & 60 & 3 \\
\hline Samozaupanje & 40 & 2 \\
\hline Komuniciranje & 67 & 11 \\
\hline Uspešnost & 50 & 6 \\
\hline Raziskovanje & 5 & 1 \\
\hline Odnos do strank & 45 & 5 \\
\hline Motiviranost & 14 & 14 \\
\hline Samoinciativnost & 80 & 11 \\
\hline Nagrajevanje & 20 & 3 \\
\hline
\end{tabular}

Slika 3: Povprečne uteži

V nadaljevanju smo s pomočjo programa DEXi vrednotili vseh 7 komercialistov (slika 4).

\begin{tabular}{|c|c|c|c|c|c|}
\hline Kriterij & KOMERCIALIST 1 & KOMERCIALIST 2 & KOMERCIALIST 3 & KOMERCIALIST 4 & KOME \\
\hline $\begin{array}{l}\text { Ocena kadra } \\
\text { Znanje } \\
\text { Izobrazba } \\
\text { Tuji jezik } \\
\text { Poznavanje trga } \\
\text { Sposobnosti } \\
\text { Samopodoba } \\
\text { Urejenost } \\
\text { Samozaupanje } \\
\text { Komuniciranje } \\
\text { Uspešnost } \\
\text { Raziskovanje } \\
\text { Odnos do strank } \\
\text { Motiviranost } \\
\text { Samoinciativnost } \\
\text { Nagrajevanje }\end{array}$ & $\begin{array}{l}\text { delno_p } \\
\text { prim. } \\
\text { višja } \\
\text { pas. } \\
\text { dobro } \\
\text { neprim. } \\
\text { neprim. } \\
\text { slabše } \\
\text { slabše } \\
\text { prim. } \\
\text { dobro } \\
\text { slabše } \\
\text { dobro } \\
\text { prim. } \\
\text { dobro } \\
\text { odl. }\end{array}$ & $\begin{array}{l}\text { delno_p } \\
\text { prim. } \\
\text { višja } \\
\text { pas. } \\
\text { dobro } \\
\text { prim. } \\
\text { prim. } \\
\text { dobro } \\
\text { dobro } \\
\text { prim. } \\
\text { dobro } \\
\text { slabše } \\
\text { dobro } \\
\text { neprim. } \\
\text { slabše } \\
\text { dobro }\end{array}$ & $\begin{array}{l}\text { delno_p } \\
\text { prim. } \\
\text { višja } \\
\text { pas. } \\
\text { odl. } \\
\text { odl. } \\
\text { odl. } \\
\text { odl. } \\
\text { odl. } \\
\text { odl. } \\
\text { odl. } \\
\text { odl. } \\
\text { dobro } \\
\text { odl. } \\
\text { odl. } \\
\text { odl. }\end{array}$ & $\begin{array}{l}\text { delno_p } \\
\text { prim. } \\
\text { višja } \\
\text { pas. } \\
\text { dobro } \\
\text { prim. } \\
\text { prim. } \\
\text { dobro } \\
\text { odl. } \\
\text { prim. } \\
\text { dobro } \\
\text { dobro } \\
\text { dobro } \\
\text { odl. } \\
\text { odl. } \\
\text { odl. }\end{array}$ & $\begin{array}{l}\text { delno. } \\
\text { prim. } \\
\text { višja } \\
\text { pas. } \\
\text { odl. } \\
\text { prim. } \\
\text { odl. } \\
\text { odl. } \\
\text { odl. } \\
\text { prim. } \\
\text { dobro } \\
\text { dobro } \\
\text { odl. } \\
\text { prim. } \\
\text { dobro } \\
\text { odl. }\end{array}$ \\
\hline
\end{tabular}



ORGANIZACIJA (22. - 24. MAREC 2017, PORTOROŽ, SLOVENIJA)

S. Solar, U. Rajkovič \& M. Bernik: Opredelitev kompetenčnega profila komercialista s pomočjo večkriterijske odločitvene metodologije

\begin{tabular}{|c|c|c|c|}
\hline DEXi & cena kadra $-28-8.2$ & 016 dexi 502 (1) (1).dxi 28.8.2016 & Stran 7 \\
\hline Kriterij & KOMERCIJALIST 6 & KOMERCIALIST 7 & \\
\hline Ocena kadra & prim. & prim. & \\
\hline -Znanje & odl. & odl. & \\
\hline Hzobrazba & višja & višja & \\
\hline -Tuji jezik & akt. & akt. & \\
\hline Loznavanje trga & odl. & odl. & \\
\hline -Sposobnosti & prim. & odl. & \\
\hline Samopodoba & odl. & odl. & \\
\hline -Urejenost & odl. & odl. & \\
\hline LSamozaupanje & odl. & odl. & \\
\hline Komuniciranje & prim. & odl. & \\
\hline -Uspešnost & dobro & odl. & \\
\hline -Raziskovanje & slabše & slabše & \\
\hline Lodnos do strank & odl. & odl. & \\
\hline $\begin{array}{l}\text { - Motiviranost } \\
\quad \text {-Samoinciativnost }\end{array}$ & $\begin{array}{l}\text { prim. } \\
\text { dobro }\end{array}$ & $\begin{array}{l}\text { neprim. } \\
\text { slabše }\end{array}$ & \\
\hline LNagrajevanje & odl. & odl. & \\
\hline
\end{tabular}

Slika 4: Zbir rezultatov vrednotenja komercialista - nepremičninskega posrednika

Kot lahko vidimo iz slike 4, ima komercialist 1 neprimerno samopodobo in posledično tudi nadrejen kriterij sposobnosti. Razloga, kot izhaja iz analize, sta urejenost in samozaupanje. $Z$ rezultati lahko pristopimo do kandidata in pričnemo skupaj reševati problem, kako dvigniti kakovost. Komercialist 2 je neprimerno motiviran zaradi samoiniciativnosti. V takem primeru se velja pogovoriti s kandidatom o tem, kje vidi možnosti izboljšav na omenjenem področju. Če bomo identificirali, da je npr. težava v nagrajevanju, lahko podjetje presodi glede spremembe sistema nagrajevanja. Komercialist 3 nima izrazitih slabosti, ki bi bile v modelu označene kot najslabše zaloge vrednosti. Vidimo, da ima precej kriterijev ocenjenih z najboljšimi zalogami vrednosti. Gre za komercialista, od katerega podjetje lahko pričakuje več kot od ostalih, kar mora vodstvo ustrezno podpreti in utemeljiti. Pri najboljših kandidatih obstaja bojazen menjave službe, zato je potrebno posvetiti dodatno pozornost temu, da kandidata podjetje zadrži. Komercialista 4 in 5 podobno kot komercialist 3 nimata izrazitih slabosti. V splošnem zanju veljajo podobne ugotovitve kot za komercialista 3, čeprav imata manj najboljših ocen. Boljše zaposlene bi lahko uporabili kot mentorje drugim, predvsem v bodoče novo zaposlenim. Komercialist 6 ima slabše sposobnosti raziskovanja trga. Ker ima sicer zelo veliko dobrih ocen, je pomembno, da kadrovska služba zanj načrtuje ustrezna izobraževanja, ki lahko vplivajo na izboljšanje raziskovalnih sposobnosti in zanimanja za trg. Komercialist 7 ima slabše sposobnosti raziskovanja trga in je neprimerno motiviran za delo. Za razliko od komercialista 6 je kandidat slabše ocenjen še pri enem kriteriju, in sicer samoiniciativnosti. Predlagamo, da se temu posveti več pozornosti pri naslednjem letnem razgovoru. To lahko vodi v nezadovoljstvo zaposlenega, kar se lahko kaže pri delu in vpliva na timsko delo ter rezultate podjetja

\section{$5 \quad$ Zaključek}

Z raziskavo smo ugotovili, da komercialisti - nepremičninski posredniki svoje znanje ocenjujejo v povprečju dobro. $43 \%$ jih zelo dobro pozna nepremičninski trg in $43 \%$ 
$36^{\text {TH }}$ International Conference on Organizational Science Development: RESPONSIBLE ORGANIZATION (MARCH $22^{\mathrm{ND}}-24^{\mathrm{TH}}$, PORTOROŽ SLOVENIA)

S. Solar, U. Rajkovič \& M. Bernik: Opredelitev kompetenčnega profila komercialista s pomočjo večkriterijske odločitvene metodologije

dobro. $57 \%$ anketiranih ima zelo veliko znanja za učinkovito komunikacijo s strankami, $43 \%$ jih zelo dobro pozna predpise za poslovanje nepremičninskih družb. $57 \%$ anketiranih svoje znanje zelo pogosto dopolnjuje, torej ob vsaki spremembi. $57 \%$ anketiranih se zelo strinja, da je v podjetju poskrbljeno za stalno izboljševanje znanj (na področju trženja, poslovnega bontona).

Prav tako smo ugotovili, da so komercialisti - nepremičninski posredniki pri reševanju nalog in problemov pri svojem delu uspešni. $57 \%$ jih meni, da so zelo odločni in $43 \%$, da so zelo ciljno naravnani. $43 \%$ anketiranih je doslednih pri delu, $43 \%$ delno natančnih in odgovornih, $57 \%$ jih je delno nagnjenih $\mathrm{k}$ raziskovanju trga, $57 \%$ anketiranih ima zelo dobre organizacijske sposobnosti in znajo organizirati svoje delo. $57 \%$ jih ima dobre pogajalske sposobnosti in so prepričljivi pri komunikaciji s strankami. $71 \%$ anketiranih se zelo prilagaja potrebam strank in so pri delu samostojni in prodorni.

Raziskava je pokazala, da v podjetju prevladuje višješolska ali visoka izobrazba. Takšno izobrazbo ima vseh 7 anketiranih komercialistov - nepremičninskih posrednikov. Povprečna ocena za ocenjevanje ključnih kompetenc je 4,04 in za ocenjevanje delovno specifičnih kompetenc 3,77 , kar pomeni, da se anketirani v povprečju strinjajo s svojimi ključnimi in delovno specifičnimi kompetencami.

Kot končni rezultat raziskave smo izdelali strukturo odločitvenega modela - drevo kriterijev, s pomočjo katerega smo vrednotili vseh 7 komercialistov v podjetju. Na osnovi rezultatov smo ugotovili prednosti in slabosti vseh komercialistov ter določili področja, ki jih morajo izboljšati posamezniki. V prihodnje vidimo model kot izjemno orodje pri odločitvi izbire kandidata za prosto delovno mesto komercialista - nepremičninakega posrednika, saj omogoča izbiro kandidata $\mathrm{z}$ najboljšimi kompetencami, ki jih podjetje potrebuje.

\section{Literatura}

Bernik, M. in Florjančič, J. (2010). Sistem spremljanja razvoja kadrov kot osnova za osebnostni razvoj posameznika v organizaciji. Dostopno na Zbornik-prispevkov-konferenca-final.pdf.

Bernik, M., Florjančič, J. in Rajkovič, V. (8. 10. 2002). Upravljanje z znanjem in uporaba informacijskih tehnologij. Organizacija, 35 (8) str. 473-477. Dostopno na http://lopes1.fov.unimb.si/is2002/bernik.pdf.

Gavez, S. in Karničnik, M. (2013). Model kompetenc za Kompetenčni center eko profili. Dostopno na https://stajerskagz.si/userfiles/file/Model\%20kompetenc\%20EKO\%20PROFILI_14_

Gorenak, M. (2013). Organizacijske vrednote in kompetence kot orodje za razvoj človeških virov str. 11-20.Celje.

Grubiša, N. (2001). Kako organizirati poslovanje in motivirati zaposlene. Ljubljana: Marbona.

Jacobs, C. (2015). Good real estate agents can be difficult to find if you don't know the qualities to look for. Dostopno na http://www.realestate.com.au/advice/8-qualities-good-agent/

Kobal Grum, D. (2004). Pomen samopodobe bibliotekarja v komunikacijskem procesu. Knjižnica, 48 (3), 95-105.

Kohont, A., Svetlik, I., Gorišek, K. Rozman, B. (2005). Kompetence v kadrovski praksi. Ljubljana: GV Založba. 

ORGANiZACIJA (22. - 24. MAREC 2017, PortOroŽ, SlOVENIJA)

S. Solar, U. Rajkovič \& M. Bernik: Opredelitev kompetenčnega profila komercialista s pomočjo večkriterijske odločitvene metodologije

Kušar, A. (2014). Kako motivirati zaposlene. Revija za univerzalno odličnost,3 (1), 10-21. Dostopno na http://www.fos.unm.si/media/pdf/RUO_2013_16_Kusar_Andreja.pdf

Lipičnik, B. (1998). Ravnanje z ljudmi pri delu. Ljubljana: Gospodarski vestnik.

Majcen, M. (2009). Management kompetenc. Ljubljana: GV Založba.

Musek, J. in Avsec, A. (2006). Osebnost, samopodoba in psihično zdravje. Anthropos, 1 -2 (201202), 51-75.

Musek, J. (1993a). Osebnost in vrednote. Ljubljana: Educy d.o.o.

Musek, J. (1993b). Znanstvena podoba osebnosti. Ljubljana: Educy d.o.o.

Organisation for Economic Co-operation and Development. (2005). The defintion and selection of key competencies. Pridobljeno 4. 8. 2016 na https://www.oecd.org/pisa/35070367.pdf

Pogačnik, V. (2002). Poimenovanje in struktura osebnih vrednot. Psihološka obzorja 11(1), 3150. Dostopno na http://psiholoska-obzorja.si/arhiv_clanki/2002_1/pogacnik.pdf

RealEstate (2016). 10 Characteristics of a Successful Real Estate Agent. Dostopno na 31. 7. 2016 na http://www.realestateinsidermag.com/business-tips/10-characteristics-of-a-successful-realestate-agent

Svetlik, I. (2005). O kompetencah. Vzgoja in izobraževanje: revija za teoretična in praktična vprašanja vzgojno izobraževalnega dela, 37(1), 4-12.

Širca Trunk, N., Kolenc, K. in Mohorko, J. (2012). Ključne kompetence na skupnem Evropskem trgu. Dostopno na www.eupika.mfdps.si/

Treven, S. (1998). Management človeških virov. Ljubljana: Gospodarski vestnik.

Turk, D. (2003). Na področju kompetenc vlada precejšnja zmeda; model kompetenc mora biti čimbolj enostaven, razumljiv, sicer je nemogoče doseči zastavljene cilje. Finance, 56/2003. Dostopno na http://www.finance.si/43637/Kompetence-je-najprej-treba-natancnodefinirati?metered=yes\&sid=391905653

Uradni list Evropske unije. 2006. L 394/10. Dostopno na http://www.zrss.si/pdf/240611121003_gla_kljucne_kompetence_eu.pdf

Vincent, L. (2008). Differentiating Competence, Capability and Capacity. Innovating Perspective, 16(3), 1-2. Dostopno na http://www.innovationsthatwork.com/images/pdf/June08newsltr.pdf Zavod Republike Slovenije za zaposlovanje (2016b). Opis poklica Nepremičninski posrednik. Dostopno na http://www.ess.gov.si/ncips/cips/opisi_poklicev/opis_poklica?Kljuc=3091\&Filter=N 
964 36 $36^{\mathrm{TH}}$ INTERnational CONFERENCE ON ORganizational SCIENCE DeVelopment: RESPONSIBLE ORGANIZATION (MARCH $22^{\mathrm{ND}}-24^{\mathrm{TH}}$, Portorož SLOVENIA) 
$36^{\text {Th }}$ International Conference on Organizational Science Development: Responsible ORganization (MARCH $22^{\mathrm{ND}}-24^{\mathrm{TH}}$, PORTOROŽ SLOVENIA)

O. Arsenijević, M. Ferjan, I. Podbregar, P. Šprajc, D. Trivan \& Y. Ziegler

\title{
Measuring Deaccessioning in American Museums: A Structural Equation Model / MIMIC Approach
}

\author{
Andrej Srakar, Marilena Vecco, Michele PiaZzai \& Miroslav Verbič
}

\begin{abstract}
The removal of objects from a museum's collection, i.e., deaccessioning, is one of the most debated topics in the professional and scholarly literature on museum management. Despite deaccessioning receiving a quite large coverage in the past years the issue of its measurement remains still a mystery. In our article, we use SEM (Structural Equation Modeling) technique of MIMIC (Multiple Indicators and Multiple Causes) to model the actual extent of »adverse« deaccessioning as a latent construct. We define »adverse« deaccessioning as deaccessioning not being focused on improving the collection (but, to other purposes, e.g. to the new facilities, solving financial issues of the museum, etc.), which closely follows the theoretical discussions. We model deaccessioning on micro level as being caused by and dependent upon several variables on museum and state level. The results enable us to estimate the relative extent of "adverse « deaccessioning and study its features. We demonstrate that smaller museums tend to deaccession more and, furthermore, the extent of deaccessioning does not depend significantly on the US state and year. Finally, we provide a reflection for future research work in this area. As MIMIC models have been used extremely seldom in cultural economics and management, and deaccessioning has even never been modelled empirically, our article represents a significant step ahead in gaining knowledge on this key phenomenon within the economics and management of museums.
\end{abstract}

KEYWORDS: economics of museums • museum collections • »adverse« deaccessioning $\bullet$ multiple indicators and multiple causes $\bullet$ structural equation models

CORRESPONDENCE AdDREsS: Andrej Srakar, Ph.D., Assistant, University of Ljubljana, Faculty of Economics, Karedeljeva ploščad 17, 1000 Ljubljana, Slovenia, e-mail: srakara@ier.si; Marilena Vecco, Ph.D., Erasmus University Rotterdam, Burgemeester Oudlaan 50, 3062 PA Rotterdam, Netherlands, e-mail: vecco@eshcc.eur.nl, Michele Piazzai, Junior Researcher, Delft University of Technology, Postbus 5, 2600 AA Delft, Netherlands, e-mail: m.piazzai@tudelft.nl; Miroslav Verbič, Ph.D., Associate Professor, University of Ljubljana, Faculty of Economics, Karedeljeva ploščad 17, 1000 Ljubljana, Slovenia, e-mail: miroslav.verbic@ef.uni-lj.si

DOI https://doi.org/10.18690/978-961-286-020-2.76

ISBN 978-961-286-020-2

(C) 2017 University of Maribor Press

Available at: http://press.um.si 
Museums are ubiquitous in the social and cultural landscape of Western societies. They are flexible and diverse institutions, varying greatly in ownership patterns, financial models, size and reputation. A cultural, historical, and geographical divide exists between museums based on the Anglo-Saxon model and those based on the Napoleonic model (Mossetto \& Vecco, 2001). Continuously accumulating objects, without being allowed to discard some of them, may create a clear problem of resource allocation (Weil, 1997; Chen, 2009; Dolák, 2010; Fayet, 2010; Mairesse, 2010a; Vilkuna, 2010). As a result of this "cumulative" approach, museums display only a fraction of their holdings at any given time, which is referred to as the »Prado effect « (Peacock, 1994). The removal of objects from a museum's collection, i.e. »deaccessioning «, is one of the most debated topics in the professional and scholarly literature on museum management. In some contexts, objects cannot be deaccessioned due to legal agreements, resistance by managers, and national laws on cultural heritage. Meanwhile, economic urges and ethical considerations cause deaccessioning to be viewed as inevitable (Fayet, 2010). Restrictions on object disposal and deaccessioning lead to »ossification « in the museum field (Johnson, 2003) by hindering the reallocation of collections over time. The legal standing of museums complicates the issue further: for institutions belonging to the private sphere, deaccessioning is more readily allowed while for public museums this practice - although some guidelines do exist - is still highly problematic. In contexts, where there is no strong tradition of donorship, and private institutions are viewed by the public as market-driven, deaccessioning represents a capitulation of culture before pragmatic demands (Acidini Luchinat, 1999; Settis, 2003; 2004; 2007). Indeed, museums are by nature opposed to market forces (Grampp, 1989); managers are generally riskaverse (Throsby, 2003); and the protection of elitist interests is also likely to play a role (O’Hagan, 1998).

Despite deaccessioning has received a quite large coverage in the past years (see e.g. O'Hagan, 1998; Srakar, 2014; Vecco and Piazzai, 2015; Di Gaetano and Mazza, 2016; Vecco, Srakar and Piazzai, 2016), the issue of its measurement remains a »mystery«. While O'Hagan (1998) and earlier works resort to theoretical reasonings, Srakar (2014) and Di Gaetano and Mazza (2016) present first mathematical models of this phenomenon, seeing it in light of contract theory and game theory respectively. Finally, Vecco, Srakar and Piazzai (2016) present probably the first empirical analysis of deaccessioning, but resort to observing visitor attitudes to deaccessioning and not the actual deaccessioning itself.

In our article, we use SEM (Structural Equation Modeling) technique of MIMIC (Multiple Indicators and Multiple Causes) to model the actual extent of »adverse « deaccessioning as a latent construct. We define »adverse " deaccessioning as deaccessioning not being focused on improving the collection (but, e.g., to the new facilities, solving financial issues of the museum, etc.). By nature of their construction, MIMIC models provide a quantitative measure of how well the conceptual domain is captured via the formative components (Posey et al., 2014) that a formatively modelled 
construct by itself cannot. Thus, this approach is a powerful technique to obtain a quantitative measure of a phenomenon that has traditionally been assessed only by qualitative means (i.e., content validity).

According to our conceptual framework, we model deaccessioning on micro level as being caused by and dependent upon several variables on museum and city and state level. To this end, we test the following set of three hypotheses focusing on the "estimated extent of »adverse« deaccessioning" (EEoAD):

H1: The EEoAD depends on the museum level as well as city and state level variables.

$\mathrm{H} 2$ : The EEoAD is higher for museums with lower revenues.

H3: The EEoAD is strongly influenced by the socio-demographic and socio-economic characteristics of the museum.

To our best knowledge, not only have MIMIC models been used extremely seldom so far in cultural economics and management, but also deaccessioning has never been modelled using them and, furthermore, not been modelled at all empirically. In this sense, our article represents a significant step ahead in gaining knowledge on this key phenomenon within the economics and management of museums, and cultural economics and management in general. Moreover, the database of US museums - accessible to the general public - allows replication of the findings as well as usage by other researchers interested in the topic.

The structure of our article is as follows. Section 1 provides the background to contextualize the study and our main research problem. Section 2 introduces the data and methodology while section 3 presents the main results and discussion. The final section provides some potential methodological extensions for future work and some policy and research relevance of the study.

\section{Data and Method}

In our analysis, we use the database, constructed on the basis of $990^{\prime}$ forms of US nonprofit art museums (source: NCCS Statistics). The database, which includes 283 American museums among 500 museums and information on over 40 variables best related to the deaccessioning in museums, covers the years 2002-2011. Within this frame, we rely on SEM and employ the MIMIC (Multiple Indicators and Multiple Causes) models (see e.g. Zellner, 1970; Goldberger, 1972; Jöreskog and Goldberger, 1975; Weck, 1983; Frey and Weck, 1983; Frey and Weck-Hannemann, 1984; Aigner et al., 1988; for some more recent applications see e.g. Lester, 2008; Proitsi et al., 2009; Rose and Spiegel, 2010), which have to our best knowledge so far been applied very rarely in cultural economics and management. MIMIC models are used similarly as done for modelling the underground economy (for discussion on this topic see e.g. Thomas, 1992; Lippert and Walker, 1997; Schneider, 1994; 1997; 2003; 2005; Johnson et al., 1998a, 1998b; 
$36^{\text {TH }}$ International Conference on Organizational Science Development: RESPONSIBLE ORGANiZATION (MARCH $22^{\mathrm{ND}}-24^{\mathrm{TH}}$, PoRTOROŽ SLOVENIA)

A. Srakar, M. Vecco, M. Piazzai \& M. Verbič: Measuring Deaccessioning in American Museums: A Structural Equation Model / MIMIC Approach

Tanzi, 1999; Giles, 1999; Mummert and Schneider, 2001; Giles and Tedds, 2002; Giles et al., 2002; Dell'Anno and Schneider, 2003; Buehn and Schneider, 2008; Barbosa et al., 2013; Nchor and Adamec, 2015; Breusch, 2016). To model deaccessioning, we use previous findings in the literature on the modelling of the effects of excess endowments in nonprofit firms (see e.g. Fisman and Hubbard, 2003; Core et al., 2006). As variables predicting the EEoAD we employ the state regulation; the stability of revenues; the loan status; extent of yearly revenues; and the level of public support. As variables being predicted by the EEoAD, we utilize the compensation of the managers; the level of yearly revenues; and the ratio of program to total expenses. To test the hypotheses several different models, estimators and variables are used to proxy for the extent of »adverse« deaccessioning.

The selected museums have data on their financial performance available on NCCS webpages. The main selection criterion used was the completeness of their information: they have missing data for at most one year in the period 2002-2011, and have no missing data due to filling out a shorter version of 990' form (the EZ or EO form).

In the analysed period, some museums have complete information while some had missing data on one or more variables for one year. The latter implied to have a so-called unbalanced panel (see e.g. Baltagi, 1995; Wooldridge, 2002). The information available have been clustered in several groups of variables:

- Cash, non-interest bearing (end of year); Savings and temporary cash investments; Investments - publicly traded securities; Investments - other securities; - Variables to proxy for the Endowment

- Total expenses; Total revenue

- Tax-exempt bond liabilities; Secured mortgages and notes payable to unrelated third parties; Unsecured notes and loans payable to unrelated third parties; Variables to proxy for the Loan Status of the Museum

- Salaries, other compensation, employee benefits; Total Compensation of Officers, Directors, Trustees, Key Employees, and Highest Compensated Employees - Variables to proxy for the Manager Perquisites

- Total Program Service Revenue; Total Program Service Expenses - Variables to proxy for the Museum Effectiveness

- Land, buildings, and equipment cost or other basis; Depreciation, depletion, etc. - Variables to proxy for the Investment

- Total public support - Variable to proxy for Outside fundraised sources

The basic descriptive statistics for the variables used are provided in the table below. All variables have been winsorized of $1 \%$ of the values above and below the distribution. 

ORGANIZACIJA (22. - 24. MAREC 2017, PORTOROŽ, SLOVENIJA) A. Srakar, M. Vecco, M. Piazzai \& M. Verbič: Measuring Deaccessioning in American Museums: A Structural Equation Model / MIMIC Approach

\begin{tabular}{cccccccccc} 
variable & $\mathrm{N}$ & $\mathrm{min}$ & $\mathrm{max}$ & mean & stand.dev & median & skewness & kurtosis & $\mathrm{cv}$ \\
\hline cash & 1409 & -141 & $1.10 \mathrm{E}+07$ & 528939.3 & 1556220 & 59038 & 4.994917 & 30.30195 & 2.942152 \\
savings & 1409 & 0 & $4.85 \mathrm{E}+07$ & 2601206 & 7259425 & 230699 & 4.521827 & 25.1894 & 2.790792 \\
investpublictra & 1409 & 0 & $5.72 \mathrm{E}+08$ & $2.74 \mathrm{E}+07$ & $8.28 \mathrm{E}+07$ & 1239015 & 4.744945 & 27.61694 & 3.02572 \\
investother & 1409 & 0 & $2.64 \mathrm{E}+08$ & $1.01 \mathrm{E}+07$ & $3.70 \mathrm{E}+07$ & 0 & 5.115479 & 31.16387 & 3.681162 \\
inventories & 1409 & 0 & $2.61 \mathrm{E}+06$ & 205881.4 & 411631.5 & 54007 & 3.693102 & 18.77672 & 1.999363 \\
totalexpenses & 1413 & 26249 & $1.57 \mathrm{E}+08$ & $9.14 \mathrm{E}+06$ & $2.18 \mathrm{E}+07$ & 2267049 & 4.755633 & 28.76976 & 2.381879 \\
totalrevenues & 1413 & $-1.39 \mathrm{E}+04$ & $2.06 \mathrm{E}+08$ & $1.18 \mathrm{E}+07$ & $2.93 \mathrm{E}+07$ & 2345092 & 4.709519 & 27.81066 & 2.495664 \\
taxexempt & 1409 & 0 & $1.85 \mathrm{E}+08$ & 5845889 & $2.69 \mathrm{E}+07$ & 0 & 5.692834 & 35.74364 & 4.602558 \\
securedmort & 1409 & 0 & $3.30 \mathrm{E}+07$ & 1152851 & 4331165 & 0 & 5.578143 & 36.93865 & 3.756918 \\
unsecuredmort & 1408 & 0 & $3.00 \mathrm{E}+06$ & 48326.91 & 348680.2 & 0 & 7.947345 & 65.87243 & 7.215031 \\
salaries & 1411 & 0 & $6.75 \mathrm{E}+07$ & 3458968 & 8535164 & 947773 & 5.387803 & 37.11842 & 2.467547 \\
compofficdir & 1411 & 0 & 4208954 & 321924.8 & 587122.5 & 126100 & 4.317602 & 25.74214 & 1.823788 \\
progrevenues & 1413 & 0 & $2.97 \mathrm{E}+07$ & 1217854 & 4013650 & 169177 & 5.836051 & 38.62637 & 3.295674 \\
progexpenses & 1413 & 0 & $1.17 \mathrm{E}+08$ & 6766626 & $1.70 \mathrm{E}+07$ & 1387148 & 4.628927 & 26.65196 & 2.508591 \\
landbuild & 1407 & 0 & $4.12 \mathrm{E}+08$ & $2.63 \mathrm{E}+07$ & $6.22 \mathrm{E}+07$ & 5195842 & 4.203629 & 22.61901 & 2.36552 \\
accumdeprec & 1407 & 0 & $1.37 \mathrm{E}+08$ & 7444769 & $1.84 \mathrm{E}+07$ & 1476181 & 4.996576 & 31.96403 & 2.476914 \\
publicsupport & 1412 & 0 & $1.31 \mathrm{E}+08$ & 7516925 & $1.87 \mathrm{E}+07$ & 1625347 & 4.674401 & 27.49474 & 2.494144
\end{tabular}

Table 1: Summary statistics for the variables in the model

\section{Results - MIMIC modelling}

In his article of 2014, based on his $\mathrm{PhD}$ thesis, Srakar provided a first mathematical model of management decisions in deaccessioning (Srakar, 2014). His model was extended in an empirical analysis (in his $\mathrm{PhD}$ thesis, see Srakar, 2015), using the same data for 283 US museums as we are using in the present article. In our specification of the model we will closely follow his model and findings which closely follow the previous literature on empirical modelling of excess endowments and its determinants in non-profit firms (Fisman and Hubbard, 2003; Core et al., 2006).

Srakar's mathematical model is specified below, where $d E$ is the extent of deaccessioning, $e$ the level of manager's effort, $R-w-F C$ is the net total budget $(R$ are the museum total revenues, $w$ the manager wages and $F C$ all the remaining costs of the museum - including both fixed and variable costs), $F$ is the cumulative distribution function, $u$ is the manager's utility function, $\psi$ is the manager's disutility from effort function and $\underline{u}$ is the minimal guaranteed level of manager's utility.

$$
\begin{aligned}
& \max _{\mathrm{R}, \mathrm{dE}, \mathrm{w}, \mathrm{e}}[R-w-F C][1-F(w+F C-d E-R)] \\
& \text { s.t. } u(w)[1-F(w+F C-d E-R)]-\psi(e) \geq \underline{u}
\end{aligned}
$$

Based on the solution of this model, Srakar proves the following three propositions (Srakar, 2014): 
Proposition 1:

In the equilibrium the marginal effect of deaccessioning to wage is greater than the marginal effect of additional net revenues to wage. Using deaccessioning funds is therefore more tempting for the manager than raising net revenues.

\section{Proposition 2:}

The marginal effect of deaccessioning to net revenues in the equilibrium is negative and greater than minus one. Allowing deaccessioning, leads, therefore, to the lower revenues of the museum.

\section{Proposition 3:}

If the principal is risk-neutral (or risk-averse) and we make deaccessioning depend upon effort, the provided effort by the agent / manager will be suboptimal.

In our empirical, MIMIC model, we therefore include the following variables:

- logtotexp: Logarithm of total expenses, expected to predict the total extent of »adverse« deaccessioning, the higher total expenses should lead to more »adverse « deaccessioning;

- logend: Logarithm of total endowment, expected to both predict and reflect the total extent of »adverse « deaccessioning - higher total endowment should lead to more possibilities for deaccessioning, while higher extent of »adverse« deaccessioning should lead to lower total endowment;

- loandummy: Dummy for the museum, having problems with loan, this variable is expected to be positively related to (influencing) the extent of »adverse « deaccessioning;

- regulation: Level of state regulation, expected to be negatively influencing the extent of »adverse« deaccessioning;

- logprogexp: Logarithm of program expenses, expected to be negatively related/affected by the extent of »adverse « deaccessioning;

- logcompceo: Logarithm of CEO compensation, expected to be positively affected by the extent of »adverse« deaccessioning, which was one of the main findings of Srakar's article (Srakar, 2014) - it is a consequence of »moral hazard « the deaccessioning causes in the museum management situations;

- logtotrev: Logarithm of total revenues, expected to be negatively related/affected by the extent of »adverse« deaccessioning - again a finding of Srakar's article (Srakar, 2014).

The full model is visualized in Image 1. 


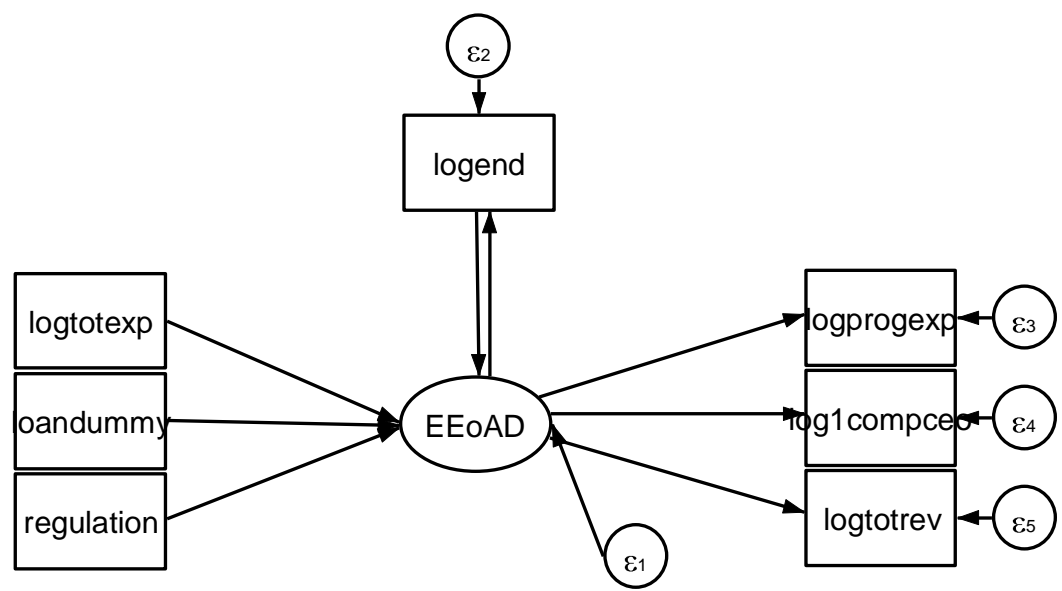

Image 1: The structure of the MIMIC model

Table 2 presents the results of the MIMIC modelling. At this stage of research, the MIMIC models are stationary ones, performed for each consecutive year. Interestingly, the models converged very well for all years with very good fit to the data (as shown in the goodness of fit statistics - Root Mean Squared Error of Approximation is always lower than 0.05, the CFI and TLI indexes are higher than 0.90; normed Chi Square statistic is lower than 2; and SRMR statistic is significantly lower than 0.08). Also, the coefficients among the models are very consistent, showing that:

- total endowment affects the extent of »adverse« deaccessioning in a positive and significant manner as expected ${ }^{1}$

- total expenses affect the extent of »adverse« deaccessioning in a positive and strongly significant manner as expected;

- loandummy and regulation variables are not statistically significant, but the coefficients are of the appropriate sign;

- »adverse « deaccessioning positively and statistically significantly affect the level of CEO compensation, as was expected;

- the coefficients on the effects of »adverse « deaccessioning on total revenues and program revenues are statistically significant but of the opposite, positive sign as would be expected - something still not entirely explained in our analysis.

Due to the very good fit of the models and most of the coefficients of the expected sign, we calculated the extent of »adverse « deaccessioning as a score from the linear regression from the structural part of the model (including only the predictors of and not also the variables influencing the extent of »adverse « deaccessioning). It has to be noted that we do not have any estimates to sensibly calibrate the resulting index (in line of e.g. Giles and Tedds, 2002; Giles et al., 2002; and other previously mentioned studies on shadow economy), therefore, our index has to be interpreted in relative (being useful only for 
$36^{\text {TH }}$ International Conference on Organizational Science Development: RESPONSIBLE ORGANIZATION (MARCH $22^{\mathrm{ND}}-24^{\mathrm{TH}}$, Portorož SlOVENIA)

A. Srakar, M. Vecco, M. Piazzai \& M. Verbič: Measuring Deaccessioning in American Museums: A Structural Equation Model / MIMIC Approach

comparison of its distribution and characteristics that influence it) and not absolute sense (in the sense of providing us "exact" amount of deaccessioning).

\begin{tabular}{|c|c|c|c|c|c|c|c|c|c|c|c|c|c|c|c|c|c|c|c|c|}
\hline & \multicolumn{2}{|c|}{2002} & \multicolumn{2}{|l|}{2003} & \multicolumn{2}{|c|}{2004} & \multicolumn{2}{|l|}{2005} & \multicolumn{2}{|l|}{2006} & \multicolumn{2}{|c|}{2007} & \multicolumn{2}{|c|}{2008} & \multicolumn{2}{|l|}{2009} & \multicolumn{2}{|c|}{2010} & \multicolumn{2}{|c|}{2011} \\
\hline & Coeff. & $\mathbf{P > \mathbf { z }}$ & Coeff. & $\mathbf{P > z}$ & Coeff. & $\overline{P>z}$ & Coeff. & $\begin{array}{l}\mathrm{P}>\mathrm{Z} \\
\end{array}$ & Coeff. & $\begin{array}{l}\mathbf{P}>\mathbf{z} \\
\end{array}$ & Coeff. & $\begin{array}{l}\mathbf{P}>\mathbf{z} \\
\end{array}$ & Coeff. & $P>z$ & Coeff. & $\overline{P>z}$ & Coeff. & $\overline{P>Z}$ & Coeff. & $\mathbf{P > \mathbf { z }}$ \\
\hline \multicolumn{21}{|l|}{ Structural } \\
\hline \multirow{2}{*}{\multicolumn{21}{|c|}{$\begin{array}{l}\text { logend <- } \\
\text { EEOAD }\end{array}$}} \\
\hline & & & & & & & & & 1 & & & & 1 & & 1 & & 1 & & 1 & \\
\hline Constant & -1.9031 & $* *$ & -1.7653 & $* *$ & -1.6534 & $* *$ & -1.9343 & $* *$ & -1.9444 & *** & -2.0002 & $* *$ & -1.4356 & $* *$ & -0.5678 & $* *$ & -1.5436 & $* *$ & -1.5436 & $* *$ \\
\hline \multicolumn{21}{|l|}{ EEOAD } \\
\hline logend & 0.0457 & $*$ & 0.0461 & & 0.0489 & & 0.0425 & $* *$ & 0.0484 & * & 0.0503 & $*$ & 0.0498 & *** & 0.0461 & & 0.0416 & $*$ & 0.0420 & $*$ \\
\hline logtotexp & 1.0845 & ***** & 1.0303 & *** & 1.1279 & ***** & 1.0303 & $* *$ & 1.0845 & **** & 0.9869 & ***** & 1.0845 & ***** & 1.0194 & $* *$ & 0.9761 & $* *$ & 1.0737 & $*$ \\
\hline loandummy & -0.0052 & & -0.0052 & & -0.0049 & & -0.0054 & & -0.0045 & & -0.0049 & & -0.0049 & & -0.0047 & & -0.0046 & & -0.0049 & \\
\hline regulation & 0.0075 & & 0.0073 & & 0.0069 & & 0.0073 & & 0.0073 & & 0.0064 & & 0.0061 & & 0.0065 & & 0.0073 & & 0.0068 & \\
\hline \multicolumn{21}{|l|}{ Measurement } \\
\hline \multicolumn{21}{|l|}{ logprogexp <- } \\
\hline EEOAD & 0.8475 & $* * *$ & 0.9238 & $* * *$ & 0.8899 & ***** & 0.8390 & $* * *$ & 0.8899 & **** & 0.9068 & $* * * *$ & 0.8729 & $* * *$ & 0.7882 & **** & 0.8306 & $* * *$ & 0.8645 & **** \\
\hline Constant & 0.0960 & & 0.0912 & & 0.0960 & & 0.1017 & & 0.0921 & & 0.0873 & & 0.0864 & & 0.0979 & & 0.1027 & & 0.1008 & \\
\hline \multicolumn{21}{|c|}{$\log 1$ compceo <- } \\
\hline EEoAD & 1.1976 & **** & 1.0778 & $* * *$ & 1.2335 & ***** & 1.1976 & $* * *$ & 1.2934 & **** & 1.0898 & *** & 1.0778 & $* * *$ & 1.1018 & $* *$ & 1.1138 & *** & 1.2814 & **** \\
\hline Constant & -10.5749 & $* * * *$ & -11.3152 & $* * *$ & -9.9404 & ***** & -10.6807 & **** & -11.1037 & ***** & -9.5174 & *** & -11.4209 & $* * * *$ & -10.3634 & $* *$ & -9.7289 & $* *$ & -10.2577 & ***** \\
\hline \multicolumn{21}{|l|}{ logtotrev <- } \\
\hline EEOAD & 0.8242 & **** & 0.8984 & **** & 0.8901 & ***** & 0.8654 & $* * *$ & 0.8407 & **** & 0.8242 & *** & 0.8654 & $* * *$ & 0.8654 & *** & 0.8736 & *** & 0.8819 & **** \\
\hline Constant & 1.0098 & ***** & 1.1007 & 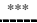 & 1.0704 & *米米 & 0.9290 & 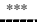 & 0.9997 & 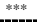 & 1.0603 & $* *$ & 1.0906 & ***** & 1.0906 & $* *$ & 0.9290 & *** & 1.0502 & 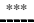 \\
\hline Normed chi 2 & 1.153 & & 1.187 & & 1.141 & & 1.176 & & 1.037 & & 1.153 & & 1.153 & & 1.164 & & 1.060 & & 1.050 & \\
\hline CFI & 0.999 & & 0.919 & & 0.938 & & 0.929 & & 0.919 & & 0.925 & & 0.979 & & 0.951 & & 0.989 & & 0.901 & \\
\hline TLI & 0.998 & & 0.978 & & 0.948 & & 0.943 & & 0.968 & & 0.931 & & 0.928 & & 0.948 & & 0.898 & & 0.817 & \\
\hline RSMEA & 0.025 & & 0.027 & & 0.023 & & 0.024 & & 0.026 & & 0.024 & & 0.026 & & 0.023 & & 0.023 & & 0.022 & \\
\hline SRMR & 0.016 & & 0.015 & & 0.015 & & 0.014 & & 0.017 & & 0.016 & & 0.017 & & 0.016 & & 0.015 & & 0.015 & \\
\hline
\end{tabular}

Table 2: Results of the MIMIC modelling, the asterisks denote statistical significance: $* * *-1 \%$; ** - 5\%; * $10 \%$.

Table 3 presents a short analysis of the properties of this empirically validated construct/index. We use panel data regression models (linear models, using random effects specification as strongly suggested by the Hausman's test), using two dependent variables: actual extent of »adverse « deaccessioning; and the extent of »adverse« deaccessioning scaled by the size of the museum ${ }^{2}$. Due to limited space we do not present all the econometric modellings, but relate to the verification of our set of three hypotheses they show:

Verification of H1: When included in the model, both museum and state level variables were statistically significant, but, interestingly, showed not much empirical regularities, in particular as related to the US states (although this would demand much more research and explanation which we plan to do in future work).

Verification of H3: Except for total revenues, EEoAD, in particular when scaled for the museum size, is not related to other socio-demographic and socio-economic characteristics of the museum.

Most interesting results are provided with verification of the hypothesis H2. As it turns out and is shown in Table 2, if we consider the extent of »adverse « deaccessioning in absolute terms, the museums with higher revenues (in the model we include dummies for five quintiles on the revenue distribution - RevBot (bottom quintile) until RevTop (top quintile)) indeed have significantly higher amount (level) of »adverse « deaccessioning. On the other hand, the situation is completely changed if we consider deaccessioning 
scaled for the size of the museum. In this case, basically, only one empirical observation is visible in our present models of this article - the museums with very bottom revenues (the excluded/comparison category) have a higher amount of scaled "adverse« deaccessioning. This observation is corroborated even when we include all controls (socioeconomic characteristics of the museums) and state and year dummies, it therefore appears robust. The hypothesis $\mathrm{H} 2$ therefore appears partly corroborated, although only in the very bottom part of the statistical distribution. It opens up an interesting question whether the size of the museum should be reflected in higher or lower need for deaccessioning. It is possible (and our results of Models 3 and 4 confirm this) that the relationship on this is even not linear, but should definitely be modelled more thoroughly in future.

\begin{tabular}{|c|c|c|c|c|c|c|c|c|c|c|c|c|}
\hline & \multicolumn{6}{|c|}{ Extent of adverse deaccessioning } & \multicolumn{6}{|c|}{ Adverse deaccessioning scaled } \\
\hline & \multicolumn{3}{|c|}{ Model 1} & \multicolumn{3}{|c|}{ Model 2} & \multicolumn{3}{|c|}{ Model 3} & \multicolumn{3}{|c|}{ Model 4} \\
\hline & Coeff. & $\mathrm{Z}$ & $\bar{P}>|\mathrm{z}|$ & Coeff. & $\mathrm{Z}$ & $\mathrm{P}>|\mathrm{z}|$ & Coeff. & $\mathrm{Z}$ & $\mathrm{P}>|\mathrm{z}|$ & Coeff. & $\mathrm{Z}$ & $\mathrm{P}>|\mathrm{z}|$ \\
\hline Constant & 10.1723 & 134.64 & **** & 9.4802 & 12.76 & *** & 0.0211 & 2.90 & **** & -0.0005 & -0.04 & \\
\hline RevBot & - & - & - & - & - & - & - & - & - & - & - & - \\
\hline RevSec & 1.4466 & 15.19 & $* * *$ & 0.4928 & 7.96 & $* * *$ & -0.0211 & -2.05 & $* *$ & -0.0039 & -1.61 & + \\
\hline RevThird & 2.3303 & 23.41 & $* * *$ & 0.9911 & 13.61 & $* * *$ & -0.0211 & -2.05 & $* *$ & -0.0053 & -2.10 & $* *$ \\
\hline RevFour & 3.1764 & 31.13 & $* * *$ & 1.5345 & 18.69 & $* * *$ & -0.0211 & -2.05 & $* *$ & -0.0044 & -1.70 & $*$ \\
\hline RevTop & 4.3117 & 40.44 & $* * *$ & 2.1034 & 22.90 & $* * *$ & -0.0211 & -2.05 & $* *$ & -0.0038 & -1.43 & + \\
\hline Controls & Yes & & & Yes & & & Yes & & & Yes & & \\
\hline State dummies & No & & & Yes & & & No & & & Yes & & \\
\hline Year dummies & No & & & Yes & & & No & & & Yes & & \\
\hline Nr. Obs & 2688 & & & 1377 & & & 2688 & & & 1377 & & \\
\hline Nr. Groups & 283 & & & 238 & & & 283 & & & 238 & & \\
\hline Wald chi 2 & 1775.30 & $* * *$ & & 833.43 & $* * *$ & & 10.73 & $* *$ & & 190.16 & $* * *$ & \\
\hline R sq overall & 0.6227 & & & 0.7094 & & & 0.0025 & & & 0.1977 & & \\
\hline
\end{tabular}

Table 3: Results of the panel data econometric models, the asterisks denote statistical significance: $* * *-1 \%$; ** $-5 \%$; $-10 \% ;+-15 \%$.

\section{Discussion and Conclusion}

In our article, we provide probably the first attempt to statistically measure the extent of so-called »adverse« deaccessioning, defined as deaccessioning not being focused on improving the collection but, e.g., to the new facilities, solving financial issues of the museum, etc. The problem was modelled as a latent construct problem, using MIMIC (Multiple Indicators, Multiple Causes) model, deriving from the structural equation modelling methodology. We followed the literature in the construction of our formative and reflective indicators of the model with goodness-of-fit criteria and interpretation of resulting coefficients confirming the fit of the model. On the basis of empirical modelling we were able to construct a first measure of empirical extent of »adverse « deaccessioning and observe some of its most basic characteristics. Mostly, we were able to prove that it has a strong relationship to the size of the museum, although this relationship is not uniform and is likely nonlinear. Our present evidence shows that smallest museums (in 
36 ${ }^{\mathrm{TH}}$ International Conference on Organizational Science Development: Responsible ORganization (MARCh $22^{\mathrm{ND}}-24^{\mathrm{TH}}$, Portorož SlOVENia)

A. Srakar, M. Vecco, M. Piazzai \& M. Verbič: Measuring Deaccessioning in American Museums: A Structural Equation Model / MIMIC Approach

the bottom quintile of the revenue distribution) tend to have more of »adverse« deaccessioning.

This finding and the discussion and methodological innovation of the article open up a lot of research avenues. Until recently, the literature on deaccessioning was dominated only by theoretical studies and the empirical knowledge on deaccessioning was inexistent. Questions such as: what is the relationship of »adverse « deaccessioning to size of the museum; to it financial situation in all different financial and performance measures: debt, endowment, revenues, total and program-based expenses, level of public support, etc.; to the museum demographic and geographic charateristics; to the institutional, economic, social, political and legal characteristics of its environment; to the country context. All those issues remain unanswered and are enabled to be explored with the methodoogy we propose.

On the other hand, we have to note also on the critiques of the method of MIMIC for estimating shadow economy and other concepts. As has been shown by e.g. Breusch (2016), MIMIC is not always a proper modelling technique to estimate the latent concepts under question. With this in mind, we hope that future work will be able to provide both robustness verifications of our findings as well as (mainly) important steps in the research directions which are at present almost blank.

\section{Notes}

${ }^{1}$ Furthermore, in the models with the coefficient of the effect of »adverse « deaccessioning on total endowment not having a default value of 1 , this coefficient was negative and statistically significant, again being in accordance with expectations.

${ }^{2}$ For the size of the museum we used two different variables - number of employees and level of total revenues with not much different results.

\section{Literature}

Acidini Luchinat, C. (1999). Il Museo d'Arte Americano: Dietro le Quinte di un Mito. Milan: Electa. Aigner, D., Schneider, F., \& Damayanti G. (1988). Me and my shadow: estimating the size of the US hidden economy from time series data, in W. A. Barnett; E. R. Berndt and H. White (eds.): Dynamic econometric modeling, Cambridge (Mass.): Cambridge University Press, pp. 224243.

Baltagi, B. H. (1995). Econometric Analysis of Panel Data. New York: Wiley.

Barbosa, E., Pereira, S., \& Brandão, E. (2013). The Shadow Economy in Portugal: An Analysis Using the MIMIC Model. FEP Working Paper, n. 514, December 2013.

Breusch, T. (2016). Estimating the Underground Economy using MIMIC Models. Journal of Tax Administration, 2(1), 41-72.

Buehn, A., \& Schneider, F. (2008). MIMIC Models, Cointegration and Error Correction: An Application to the French Shadow Economy. IZA Discussion Paper No. 3306, January 2008.

Chen, S. (2009). Art Deaccessions and the Limits of Fiduciary Duty. Art Antiquity and Law, 14, 103-142. 
Core, J.E., Guay, W.R., \& Verdi, R.S. (2006). Agency problems of excess endowment holdings in not for-profit firms. Journal of Accounting and Economics, 41, 307-333.

Dell'Anno, R., \& Schneider, F. (2003). The shadow economy of Italy and other OECD countries: What do we know? Journal of Public Finance and Public Choice, 21(2-3), 97-120.

Di Gaetano, L., \& Mazza, I. (2016). Better an egg today that a hen tomorrow. On the implications of deaccess policy on donations to museums. Journal of Cultural Economics, in press.

Dolák, J. (2010). On the Issues of Deaccessioning and Repatriation of Museum Collections. Deaccession and Return of Cultural Heritage: A New Global Ethics. Conference proceedings from Shanghai, 7-12 November 2010: International Council of Museums, pp. 43-50.

Fayet, R. (2010). Out of Neverland: Towards Consequentialist Ethics of Alienation. Deaccession and Return of Cultural Heritage: A New Global Ethics. Conference proceedings from Shanghai, 7-12 November 2010: International Conference of Museums, pp. 51-59.

Fisman, R., \& Hubbard, R.G. (2003). The Role of Nonprofit Endowments. In Glaeser, E.L. (ed.), The Governance of Not-for-Profit Organizations (pp. 217-234). Chicago: University of Chicago Press.

Frey, B.S., \& Weck, H. (1983). Estimating the Shadow Economy: A 'Naive' Approach. Oxford Economic Papers, 35, 23-44.

Frey, B.S., \& Weck-Hannemann, H. (1984). The hidden economy as an "unobserved" variable. European Economic Review, 26(1), 33-53.

Giles, D.E.A. (1999). Measuring the hidden economy: Implications for econometric modelling. The Economic Journal, 109(456), 370-380.

Giles, D.E.A., \& Tedds, L.M. (2002). Taxes and the Canadian Underground Economy. Canadian Tax Paper No. 106, Toronto: Canadian Tax Foundation.

Giles, D.E.A., Tedds, L.M., \& Werkneh, G. (2002). The Canadian underground and measured economies. Applied Economics, 34(4), 2347-2352.

Goldberger, A.S. (1972). Maximum Likelihood Estimation of Regressions Containing Unobservable Independent Variables. International Economic Review, Vol. XIII, 1-15.

Grampp, W.D. (1989). Pricing the Priceless: Art, Artists and Economics. New York: Basic Books.

Johnson, P.S. (2003). Museums. In R. Towse (ed.), A Handbook of Cultural Economics. Cheltenham: Edward Elgar, pp. 315-320.

Johnson, S., Kaufmann, D., \& Zoido-Lobatón, P. (1998a). Regulatory discretion and the unofficial economy. The American Economic Review, 88(2), 387-392.

Johnson, S., Kaufmann, D., \& Zoido-Lobatón, P. (1998b). Corruption, public finances and the unofficial economy. Discussion paper, The World Bank, Washington, D.C.

Joreskog, K., \& Goldberger, A.S. (1975). Estimation of a Model with a Multiple Indicators and Multiple Causes of a Single Latent Variable. Journal of American Statistical Association, Vol. 70, 631-639.

Lester, L.H. (2008). A Multiple Indicators and Multiple Causes (MIMIC) Model of Immigrant Settlement Success. National Institute of Labour Studies, Flinders University, Adelaide, Australia, Working Paper No. 160.

Lippert, O., \& Walker, M. (eds.) (1997). The Underground Economy: Global Evidences of its Size and Impact. Vancouver: The Frazer Institute.

Mairesse, F. (2010). The Issue of Deaccession: Five Lines of Thought for Reflection. Deaccession and Return of Cultural Heritage: A New Global Ethics. Conference proceedings from Shanghai, 7-12 November 2010: International Council of Museums, pp. 13-18.

Mossetto, G., \& Vecco, M. (2001). Modelli di Musei e la Loro Evoluzione. In G. Mossetto, \& P. A. Valentino (Eds.), Museo contro Museo: Le Strategie, gli Strumenti, i Risultati (pp. 3-14). Milan: Giunti.

Mummert, A., \& Schneider, F. (2002). The German shadow economy: Parted in a united Germany? Finanzarchiv, 58(3), 286-316. 
36 ${ }^{\mathrm{TH}}$ International Conference on Organizational Science Development: Responsible ORGANiZATION (MARCH $22^{\mathrm{ND}}-24^{\mathrm{TH}}$, PORTOROŽ SLOVENIA)

A. Srakar, M. Vecco, M. Piazzai \& M. Verbič: Measuring Deaccessioning in American Museums: A Structural Equation Model / MIMIC Approach

Nchor, D., \& Adamec, V. (2015). Unofficial Economy Estimation by the MIMIC Model: the Case of Kenya, Namibia, Ghana and Nigeria. Acta Universitatis Agriculturae et Silviculturae Mendelianae Brunensis, 63(6), 2043-2049.

O'Hagan, J. (1998). Art Museums: Collections, Deaccessioning and Donations. Journal of Cultural Economics, 22(2/3), 197-207.

Peacock, A. (1994). A Future for the Past: The Political Economy of Heritage. Proceedings of the British Academy, 87, 189-243.

Posey, C., Roberts, T.L., Lowry, P.B., \& Bennett, R.J. (2015). Multiple Indicators and Multiple Causes (MIMIC) Models as a Mixed-Modeling Technique: A Tutorial and an Annotated Example. Communications of the Association for Information Systems, 36, Article 11. http://aisel.aisnet.org/cais/vol36/iss1/11. Accessed 07 January 2017.

Proitsi, P., Hamilton, G., Tsolaki, M., Lupton, M., Daniilidou, M., Hollingworth, P., Archer, N., Foya, C., Stylios, F., McGuinness, B., Todde, S., Lawlor, B., Gill, M., Brayne, C., Rubinsztein, D.C., Owend, M., Williams, J., Craig, D., Passmore, P., Lovestone, S., \& Powell, J.F. (2009). A Multiple Indicators Multiple Causes (MIMIC) model of Behavioural and Psychological Symptoms in Dementia (BPSD). Neurobiol. Aging, doi:10.1016/j.neurobiolaging.2009.03.005.

Rose, A.K., \& Spiegel, M.M. (2010). Cross-Country Causes and Consequences of the 2008 Crisis: International Linkages and American Exposure. Pacific Economic Review, 15(3), August 2010, 340-363.

Schneider, F. (1994). Can the shadow economy be reduced through major tax reforms? An empirical investigation for Austria. Supplement to Public Financel Finances Publiques, 49, 137-152.

Schneider, F. (1997). The shadow economies of Western Europe. Economic Affairs, 17(3), 42-48.

Schneider, F. (2003). The shadow economy, in: Charles K. Rowley and Friedrich Schneider (eds.), Encyclopedia of Public Choice, Dordrecht: Kluwer Academic Publishers.

Schneider, F. (2005). Shadow economies around the world: what do we really know? European Journal of Political Economy, 21(3), September, 598-642.

Settis, S. (2003). Il Valore Culturale prima di Qualsiasi Interesse Economico. Il Giornale dell'Arte, 230,32 .

Settis, S. (2004, March 24). Patrimonio Culturale: La Svendita di Tremonti. http://eddyburg.it/article/articleview/270/1/92/. Accessed 20 May 2012.

Settis, S. (2007). Italia S.p.A.: L'Assalto al Patrimonio Culturale. Turin: Einaudi.

Srakar, A. (2014). Deaccessioning and agency costs of free cash flow in manager's hands: a formal model. Economic and Business Review, 16(3), 2015, pp. 225-246.

Srakar, A. (2015). Economic Analysis of Deaccessioning. Doctoral Dissertation. Ljubljana: Faculty of Economics, University of Ljubljana.

Tanzi, V. (1999). Uses and abuses of estimates of the underground economy. The Economic Journal, 109(456), pp. 338-340.

Thomas, J.J. (1992). Informal Economic Activity. LSE, Handbooks in Economics, London: Harvester Wheatsheaf.

Throsby, D. (2003). Cultural Sustainability. In R. Towse (Ed.), A Handbook of Cultural Economics (pp. 183-186). Cheltenham: Edward Elgar.

Vecco, M., \& Piazzai, M. (2015). Deaccessioning of museum collections: What do we know and where do we stand in Europe? Journal of Cultural Heritage, 15(2), pp. 221-227.

Vecco, M., Srakar, A., \& Piazzai, M. (2016). Visitor Attitudes to Deaccessioning in Italian Public Museums: An Econometric Analysis. Association for Cultural Economics, ACEI Working Paper Series, AWP-2-2016.

Vilkuna, J. (2010). The Deaccession of Cultural and Natural Heritage in the Traditional Museum and the 'Great Museum' - A Finnish View. Deaccession and Return of Cultural Heritage: A 
New Global Ethics. Conference proceedings from Shanghai, 7-12 November 2010: International Conference of Museums, pp. 73-78.

Weck, H. (1983). Schattenwirtschaft: Eine Möglichkeit zur Einschränkung der öffentlichen Verwaltung? Eine ökonomische Analyse. Frankfurt/Main: Lang.

Weil, S.E. (1997). A Deaccession Reader. Washington, DC: American Association of Museums. Wooldridge, J. M. (2002). Econometric Analysis of Cross Section and Panel Data, Boston: MIT Press.

Zellner, A. (1970). Estimation of Regression Relationship Containing Unobservable Independent Variables. International Economic Review, 11, pp. 441-54. 
978 36 $36^{\mathrm{TH}}$ INTERnational CONFERENCE ON ORganizational SCIENCE DeVelopment: Responsible Organization (MARCh $22^{\mathrm{ND}}-24^{\mathrm{TH}}$, PORTOROŽ SlOVENIA) 
$36^{\text {Th }}$ International Conference on Organizational Science Development: Responsible ORganization (MARCH $22^{\mathrm{ND}}-24^{\mathrm{TH}}$, PORTOROŽ SLOVENIA)

O. Arsenijević, M. Ferjan, I. Podbregar, P. Šprajc, D. Trivan \& Y. Ziegler

\title{
Multiple Chronic Conditions in Older People and Their Effects on Health Care Utilization: A Network Analysis Approach Using SHARE Data
}

\author{
ANDREJ SRAKAR \& VALENTINA PREVOLNIK RUPEL
}

\begin{abstract}
The presence of multiple coexisting chronic diseases in individuals and the expected rise in chronic diseases over the coming years are increasingly being recognized as major public health and health care challenges. At present, the common belief is that persons with multiple diseases have high rates of health care utilization. In our article we use Slovenian data of the Wave 5 of SHARE dataset (only population 65 years of age or older). We model the presence of multiple coexisting chronic diseases as a network analysis problem. This has special scientific relevance as, to our knowledge, network analysis has not been used so far to study this problem, and, also, very seldom before in the analysis using SHARE data. To verify the effects of multiple diseases on the rates of health care utilization we construct several different health care utilization variables and model the effects of different combinations of most commonly connected diseases on the health care utilization using econometric models. We find that a) the method of network analysis can be used for this purpose and provides a set of consistent main groupings/clusters of diseases with common prevalence among the elderly; b) the groupings have strongly statistically significant effects on the health care utilization. The analysis provides a new statistical method and model with extensive applications for the analysis of multiple coexisting diseases in health economics and medical sciences in general in future.
\end{abstract}

KEYWORDS: multiple chronic diseases $\bullet$ older people $\cdot$ health care utilization $\bullet$ SHARE $\bullet$ social network analysis $\bullet$ econometric models

CORRESPONDENCE AdDREsS: Andrej Srakar, Ph.D., Assistant, University of Ljubljana, Faculty of Economics, Karedeljeva ploščad 17, 1000 Ljubljana, Slovenia, e-mail: srakara@ier.si, Valentina Prevolnik Rupel, Ph.D., Associate Professor, DOBA Faculty of Applied Business and Social studies Maribor, Prešernova ulica 1, 2000 Maribor, Slovenia, e-mail: valentina.prevolnikrupel@net.doba.si 
36 ${ }^{\text {TH }}$ International Conference on Organizational Science Development: ResPonsible ORGaNizATION (MARCH $22^{\mathrm{ND}}-24^{\mathrm{TH}}$, PORTOROŽ SLOVENIA)

A. Srakar \& V. Prevolnik Rupel: Multiple Chronic Conditions in Older People and Their Effects on Health Care Utilization: A Network Analysis Approach Using SHARE Data

The presence of multiple coexisting chronic diseases in individuals and the expected rise in chronic diseases over the coming years are increasingly being recognized as major public health and health care challenges of modern societies (Marengoni et al., 2011; WHO, 2009; Vogeli et al., 2007; Glynn et al., 2011; Smith and O'Dowd, 2007; Barnett et al., 2012). Individuals with multiple conditions are presumed to have greater health needs, more risk of complications, and more difficulty to manage treatment regimens. At present, the main health care model is disease-focused rather than person-focused and, therefore, involvement of several different health care providers in managing multiple disorders is inevitable and often results in competing treatments, sub-optimal coordination and communication between care providers, and/or unnecessary replication of diagnostic tests or treatments (Vogeli et al., 2007; Clarfield et al., 2001; Greß et al., 2009). As a consequence, the common belief is that persons with multiple diseases have high rates of health care utilization and this is confirmed by some international studies (Glynn et al., 2011; Starfield, 2006; Fortin et al., 2007; Laux et al., 2008; Salisbury et al., 2011; van den Bussche et al., 2011; Lehnert et al., 2011).

In our article we use SHARE dataset of Wave $5^{1}$ (covering year 2013), including data on 14 European countries and Israel, but in this analysis we focus on Slovenian data. We model the presence of multiple coexisting chronic diseases as a network analysis problem (following e.g. Goyal and Joshi, 2003; Soramaki et al., 2007; Hiller, 2014). This has special scientific relevance as, to our knowledge, network analysis has not been used so far to study this problem, and, also, very seldom before in the analysis using SHARE data. In our case, therefore, the diseases are vertices/nodes and individuals having them the edges. Controlling for the frequency of network relationships, we calculate different network effects' parameters (e.g. centrality parameters) and use them in econometric modelling.

To verify the effects of multiple diseases on the rates of health care utilization we construct four different health care utilization variables: frequency of medical visits, number of taken medications, frequency of hospitalizations and probability of hospitalization. Main research questions of the analysis are: 1) What are the most frequent combinations of chronic diseases? 2) Which are the most common groupings of diseases which can be characterized from the data for the older people in Slovenia? 3) What are the effects of multiple coexisting chronic diseases on health care utilization of the older people when controlling for different groupings of diseases? 4) Are there different effects on health care utilization for different groupings of diseases? We model the effects of different combinations of most commonly connected diseases on the health care utilization using econometric regression models. Finally, in conclusions, we provide reflection of the findings for future work and policy relevance of the study.

The article has the following structure. In next, second section we provide information on the data and method used, including some descriptive statistics. In third section, we 
A. Srakar \& V. Prevolnik Rupel: Multiple Chronic Conditions in Older People and Their Effects on Health Care Utilization: A Network Analysis Approach Using

SHARE Data

provide analysis of results including both the results of social network analysis as well as econometric modelling. In the final, fourth section we provide a short discussion and, mainly, reflection of possible relevance of the study for future research and policy purposes.

\section{$2 \quad$ Data and Method}

The Survey of Health, Ageing and Retirement in Europe (SHARE) is a multidisciplinary and cross-national panel database of micro data on health, socio-economic status and social and family networks of approximately 123,000 individuals aged 50 or older (more than 293,000 interviews). SHARE now covers 27 European countries and Israel (for more details, see Börsch-Supan, 2015; Börsch-Supan et al., 2015; Malter and Börsch-Supan, 2015).

In our analysis, we limit ourselves to persons of age 65 or older. The main variables we include in our analysis are the diseases where we include the following variables:

ph006d1 - Has a doctor ever told you that you had/do you currently have any of the conditions on this card: A heart attack including myocardial infarction or coronary thrombosis or any other heart problem including congestive heart failure $(0-$ No, $1-$ Yes);

ph006d2 - Has a doctor ever told you that you had/do you currently have any of the conditions on this card: High blood pressure or hypertension $(0-$ No, $1-$ Yes);

ph006d3 - Has a doctor ever told you that you had/do you currently have any of the conditions on this card: High blood cholesterol $(0-\mathrm{No}, 1-\mathrm{Yes})$;

ph006d4 - Has a doctor ever told you that you had/do you currently have any of the conditions on this card: A stroke or cerebral vascular disease ( 0 - No, $1-$ Yes);

ph006d5 - Has a doctor ever told you that you had/do you currently have any of the conditions on this card: Diabetes or high blood sugar $(0-$ No, $1-$ Yes $)$;

ph006d6 - Has a doctor ever told you that you had/do you currently have any of the conditions on this card: Chronic lung disease such as chronic bronchitis or emphysema $(0-$ No, 1 - Yes);

ph006d10 - Has a doctor ever told you that you had/do you currently have any of the conditions on this card: Cancer or malignant tumour, including leukaemia or lymphoma, but excluding minor skin cancers $(0-$ No, $1-$ Yes $)$;

ph006d11 - Has a doctor ever told you that you had/do you currently have any of the conditions on this card: Stomach or duodenal ulcer, peptic ulcer (0 - No, $1-$ Yes); 
36 ${ }^{\mathrm{TH}}$ International Conference on Organizational Science Development: ResPonsible ORGaNizATION (MARCH $22^{\mathrm{ND}}-24^{\mathrm{TH}}$, PORTOROŽ SLOVENIA)

A. Srakar \& V. Prevolnik Rupel: Multiple Chronic Conditions in Older People and Their Effects on Health Care Utilization: A Network Analysis Approach Using SHARE Data

ph006d12 - Has a doctor ever told you that you had/do you currently have any of the conditions on this card: Parkinson disease (0-No, $1-$ Yes);

ph006d13 - Has a doctor ever told you that you had/do you currently have any of the conditions on this card: Cataracts $(0-$ No, $1-$ Yes $)$;

ph006d14 - Has a doctor ever told you that you had/do you currently have any of the conditions on this card: Hip fracture $(0-$ No, $1-$ Yes $)$;

ph006d15 - Has a doctor ever told you that you had/do you currently have any of the conditions on this card: Other fractures $(0-$ No, $1-$ Yes $)$;

ph006d16 - Has a doctor ever told you that you had/do you currently have any of the conditions on this card: Alzheimer's disease, dementia, organic brain syndrome, senility or any other serious memory impairment $(0-\mathrm{No}, 1-\mathrm{Yes})$;

ph006d18 - Has a doctor ever told you that you had/do you currently have any of the conditions on this card: Other affective or emotional disorders, including anxiety, nervous or psychiatric problems $(0-$ No, $1-$ Yes $)$;

ph006d19 - Has a doctor ever told you that you had/do you currently have any of the conditions on this card: Rheumatoid Arthritis ( $0-$ No, $1-$ Yes);

ph006d20 - Has a doctor ever told you that you had/do you currently have any of the conditions on this card: Osteoarthritis, or other rheumatism $(0-$ No, $1-$ Yes $)$;

ph006other - Has a doctor ever told you that you had/do you currently have any of the conditions on this card: Other conditions, not yet mentioned $(0-$ No, $1-$ Yes $)$.

Some of the basic descriptive statistics for most diseases over the SHARE countries are shown in Table 1.

\begin{tabular}{|c|c|c|c|c|c|c|c|c|c|c|c|c|c|c|}
\hline country & ph006d1 & ph006d2 & ph006d3 & ph006d4 & ph006d5 & ph006d6 & ph006d7 & ph006d8 & ph006d9 & ph006d10 & ph006d11 & ph006d12 & ph006d13 & ph006d14 \\
\hline AT & 11.17 & 35.3 & 19.75 & 4.58 & 10.64 & 4.96 & 3.28 & 13.75 & 7.08 & 4.99 & 5.02 & 0.69 & 8.2 & 2.83 \\
\hline $\mathrm{DE}$ & 11.09 & 37.89 & 18.19 & 3.81 & 12.18 & 5.93 & 2.83 & 13.13 & 5.28 & 5.68 & 3.98 & 0.57 & 7.08 & 1.53 \\
\hline SE & 16.05 & 32.64 & 16.83 & 4.33 & 9.11 & 3.46 & 5.47 & 10.83 & 2.61 & 6.09 & 3.43 & 0.47 & 10.25 & 2.82 \\
\hline NL & 10.35 & 26.75 & 16.16 & 3.67 & 9 & 6.4 & 4.37 & 9.85 & 7.54 & 4.94 & 2.99 & 0.42 & 6.11 & 1.22 \\
\hline ES & 11.49 & 35.91 & 26 & 2.6 & 15.88 & 6.24 & 2.22 & 30.79 & 5.13 & 3.52 & 4.59 & 0.92 & 9.94 & 2.35 \\
\hline IT & 10.36 & 39.06 & 21.67 & 3.11 & 12.11 & 7.21 & 3.1 & 33.86 & 7.3 & 3.8 & 5.03 & 0.73 & 6.14 & 1.69 \\
\hline$F R$ & 13 & 29.53 & 23.76 & 3.01 & 10.08 & 5.79 & 2.27 & 28.75 & 3.12 & 5.49 & 3.51 & 0.64 & 7.08 & 1.96 \\
\hline DK & 8.96 & 31.28 & 18.84 & 4.34 & 7.35 & 7.03 & 5.04 & 26.22 & 2.48 & 5.41 & 4.27 & 0.81 & 9.19 & 1.76 \\
\hline GR & 11 & 33.43 & 21.59 & 3 & 9.76 & 3.44 & 3.26 & 16.99 & 11.07 & 1.95 & 6.37 & 0.9 & 6.12 & 1.93 \\
\hline $\mathrm{CH}$ & 6.72 & 27.77 & 14.24 & 2.34 & 6.31 & 3.81 & 1.47 & 16.21 & 2.16 & 5.36 & 1.95 & 0.44 & 7.96 & 1.23 \\
\hline $\mathrm{BE}$ & 12.23 & 32.37 & 29.75 & 3.48 & 9.24 & 5.75 & 3.02 & 25.12 & 7.04 & 5.54 & 7.1 & 0.86 & 6.1 & 2.63 \\
\hline IL & 18.37 & 44.76 & 36.63 & 4.91 & 21.73 & 3.74 & 5.77 & 13.1 & 11.73 & 5.01 & 7.2 & 1.13 & 12.15 & 2.23 \\
\hline $\mathrm{CZ}$ & 14.91 & 45.88 & 21.25 & 4.89 & 15.96 & 5.96 & 1.77 & 18.07 & 3.1 & 4.84 & 6.67 & 0.73 & 8.47 & 2.22 \\
\hline PL & 18.99 & 43.31 & 20.41 & 5.03 & 12.24 & 5.51 & 4.36 & 33.46 & 4.36 & 2.95 & 7.4 & 0.72 & 6.9 & 2.04 \\
\hline IE & 7.38 & 29.42 & 26.84 & 3.73 & 8.27 & 3.11 & 7.82 & 21.69 & 5.6 & 4.53 & 7.11 & 0.53 & 5.69 & 3.11 \\
\hline $\mathrm{HU}$ & 20.98 & 53.12 & 20.95 & 7.34 & 16.57 & 7.41 & 0 & 39.58 & 0 & 4.89 & 9.07 & 0.85 & 5.45 & 3.75 \\
\hline PT & 10.68 & 42.09 & 37.18 & 5.05 & 18.45 & 5.49 & 0 & 28.93 & 0 & 5.44 & 7.82 & 0.58 & 8.4 & 2.82 \\
\hline SI & 14.35 & 40.8 & 21.04 & 3.51 & 11.25 & 5.73 & 0 & 10.01 & 0 & 5.48 & 7.52 & 0.44 & 7.71 & 2.81 \\
\hline $\mathrm{EE}$ & 23.54 & 48.28 & 19.65 & 7.31 & 11.78 & 8.72 & 0 & 28 & 0 & 6.68 & 12.09 & 0.91 & 11.29 & 2.62 \\
\hline Total & 13.06 & 36.24 & 22.12 & 4.01 & 11.55 & 5.71 & 2.95 & 21.88 & 4.93 & 4.93 & 5.52 & 0.71 & 7.92 & 2.17 \\
\hline
\end{tabular}

Table 1: Basic prevalences of diseases. 
A. Srakar \& V. Prevolnik Rupel: Multiple Chronic Conditions in Older People and Their Effects on Health Care Utilization: A Network Analysis Approach Using

SHARE Data

The method we use is social network analysis. We consider two persons as connected if they share a common disease among the above mentioned ones. In this manner, we get a 2-mode network where diseases serve as the second mode and persons (with diseases) as the first. In the analysis we group the diseases and persons having them on the basis of their modularity parameters. As stated by Newman (2006): "The idea, that true community structure in a network corresponds to a statistically surprising arrangement of edges, can be quantified by using the measure known as modularity." The modularity is, up to a multiplicative constant, the number of edges falling within groups minus the expected number in an equivalent network with edges placed at random. The modularity can be either positive or negative, with positive values indicating the possible presence of community structure. Thus, one can search for community structure precisely by looking for the divisions of a network that have positive, and preferably large, values of the modularity.

In the analysis, we also use models from econometric analysis. The regression methods we use are Poisson for the dependent variables of count nature (nr. of medical visits, nr. of taken medications, nr. of hospitalizations) and probit for the dependent variable of binary nature (probability of hospitalization). We test the models for goodness of fit (deviance and Pearson statistic for Poisson; Hosmer-Lemeshow test for probit) as well as classification and sensitivity (only for probit).

The dependent variables we use are listed below. In the selection of variables in econometric models and the methodology of regression we closely follow Srakar, Hren and Prevolnik Rupel (2016).

\begin{tabular}{|l|l|}
\hline Dependent variable & \multicolumn{1}{|c|}{ Description } \\
\hline Nr. of medical visits & $\begin{array}{l}\text { Number of visits to a medical doctor or qualified nurse about respondents health } \\
\text { (excluding dentist visits and hospital stays, but including emergency room or } \\
\text { outpatient clinic visits) }\end{array}$ \\
\hline $\begin{array}{l}\text { Nr. of taken } \\
\text { medications }\end{array}$ & $\begin{array}{l}\text { Number of taken medications as a sum of answers to the following question: } \text { yDo } \\
\text { you currently take drugs at least once a week for problems mentioned }{ }^{2} \text { « }\end{array}$ \\
\hline Nr. of hospitalisations & Number of hospitalisations in a hospital overnight during the last twelve months \\
\hline $\begin{array}{l}\text { Probability of } \\
\text { hospitalisation }\end{array}$ & $\begin{array}{l}\text { Response to the following question: } » \text { During the last twelve months, have you been } \\
\text { in a hospital overnight? Please consider stays in medical, surgical, psychiatric or in } \\
\text { any other specialised wards.« }\end{array}$ \\
\hline
\end{tabular}

Table 2: Dependent variables used in the study

We also use several independent variables which are mainly used as controls in our modelling. 
$36^{\mathrm{TH}}$ InTERnAtional CONFERENCE ON ORganizational SCIENCE DeVelopment: ResPonsible ORganization (MARCH $22^{\mathrm{ND}}-24^{\mathrm{TH}}$, Portorož SlOVENIA)

A. Srakar \& V. Prevolnik Rupel: Multiple Chronic Conditions in Older People and Their Effects on Health Care Utilization: A Network Analysis Approach Using SHARE Data

\begin{tabular}{|l|l|}
\hline $\begin{array}{l}\text { Independent } \\
\text { variable }\end{array}$ & \multicolumn{1}{|c|}{ Description } \\
\hline Gender & Male or female \\
\hline Age & Four groups - 65-69 years; 70-74 years; 75-79 years; 80 and more years \\
\hline EduYears & Years of education \\
\hline Income & $\begin{array}{l}\text { Total household income, classified into tertiles (low, middle, high) by individual } \\
\text { country }\end{array}$ \\
\hline Settlement & $\begin{array}{l}\text { Living in an urban (encompassing: 1. A big city; 2. The suburbs or outskirts of a big } \\
\text { city; 3. A large town; 4. A small town) or in a rural (A rural area or village) } \\
\text { environment }\end{array}$ \\
\hline LivingAlone & $\begin{array}{l}\text { Binary variable, having the value of 1 if the respondent lives alone in a household } \\
\text { and 0 otherwise }\end{array}$ \\
\hline ChildDist & $\begin{array}{l}\text { Binary variable, having the value of 1 if the respondent has a child living in the area } \\
\text { of 25 km and 0 otherwise }\end{array}$ \\
\hline Limited & $\begin{array}{l}\text { Binary variable, having the value of 1 if the respondent is severely limited because } \\
\text { of a health problem in activities people usually do and 0 otherwise }\end{array}$ \\
\hline
\end{tabular}

Table 3: Independent variables used in the study

\section{Results - social network analysis}

The visual representation of our network is depicted in Image 1. The analysis, which is still in exploratory phase, provided sensible results and pointed to 11 groups of diseases, based on the parameter of modularity class. The diseases which are definitely connected are: dmodul4 - A heart attack including myocardial infarction or coronary thrombosis or any other heart problem including congestive heart failure; and Diabetes or high blood sugar; dmodul9 - Parkinson disease; Hip fracture; and Other fractures; and dmodul11 Other affective or emotional disorders, including anxiety, nervous or psychiatric problems; Rheumatoid Arthritis; and Osteoarthritis, or other rheumatism.

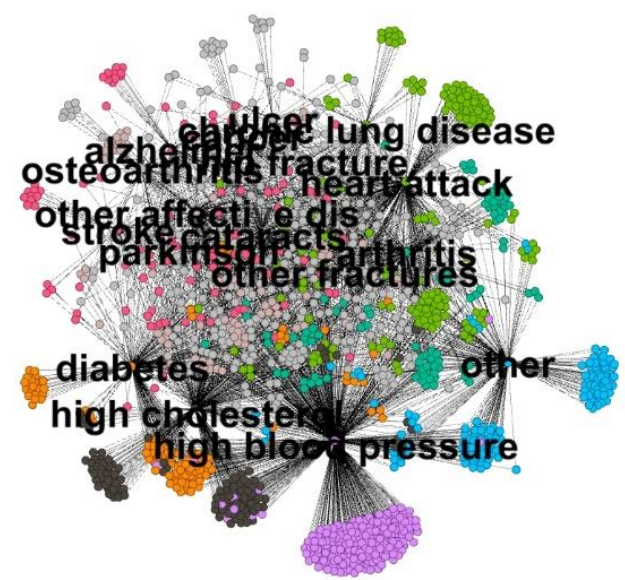

Image 1: Visualization of the network for Slovenian data. 

ORGANIZACIJA (22. - 24. MAREC 2017, PORTOROŽ, SlOVENIJA)

A. Srakar \& V. Prevolnik Rupel: Multiple Chronic Conditions in Older People and Their Effects on Health Care Utilization: A Network Analysis Approach Using

SHARE Data

\begin{tabular}{|c|c|c|c|}
\hline variable & disease 1 & disease 2 & disease 3 \\
\hline dmodul1 & $\begin{array}{l}\text { Other conditions, not yet } \\
\text { mentioned }\end{array}$ & $\begin{array}{l}\text { High blood } \\
\text { pressure or } \\
\text { hypertension }\end{array}$ & \\
\hline dmodul2 & High blood cholesterol & & \\
\hline dmodul3 & $\begin{array}{c}\text { A stroke or cerebral vascular } \\
\text { disease }\end{array}$ & & \\
\hline dmodul4 & $\begin{array}{l}\text { A heart attack including } \\
\text { myocardial infarction or } \\
\text { coronary thrombosis or any } \\
\text { other heart problem including } \\
\text { congestive heart failure }\end{array}$ & $\begin{array}{l}\text { Diabetes or high } \\
\text { blood sugar }\end{array}$ & \\
\hline dmodul5 & $\begin{array}{l}\text { Chronic lung disease such as } \\
\text { chronic bronchitis or } \\
\text { emphysema }\end{array}$ & & \\
\hline dmodul6 & $\begin{array}{c}\text { Cancer or malignant tumour, } \\
\text { including leukaemia or } \\
\text { lymphoma, but excluding } \\
\text { minor skin cancers } \\
\end{array}$ & & \\
\hline dmodul7 & $\begin{array}{c}\text { Stomach or duodenal ulcer, } \\
\text { peptic ulcer }\end{array}$ & & \\
\hline dmodul8 & Cataracts & & \\
\hline dmodul9 & Parkinson disease & Hip fracture & Other fractures \\
\hline dmodul10 & $\begin{array}{c}\text { Alzheimer's disease, dementia, } \\
\text { organic brain syndrome, } \\
\text { senility or any other serious } \\
\text { memory impairmen }\end{array}$ & & \\
\hline dmodul11 & $\begin{array}{c}\text { Other affective or emotional } \\
\text { disorders, including anxiety, } \\
\text { nervous or psychiatric } \\
\text { problems }\end{array}$ & $\begin{array}{l}\text { Rheumatoid } \\
\text { Arthritis }\end{array}$ & Osteoarthritis, or other rheumatism \\
\hline
\end{tabular}

Table 4: Classification of (multiple) diseases

Although we do not show the parameters of the network, the analysis performed well in terms of different centrality parameters, density of the graph and clustering coefficients.

Table 5 shows the final results of econometric verifications. As for the number of medical visits, belonging to group dmodul3 (broadly labelled as "A stroke or cerebral vascular disease" but can include other connected persons with similar diseases as well) caused significantly less visits to medical doctor than the comparison group dmodull (Other conditions, not yet mentioned; and High blood pressure or hypertension), while dmodul4 (A heart attack including myocardial infarction or coronary thrombosis or any other heart problem including congestive heart failure; and Diabetes or high blood sugar), dmodul5 (Chronic lung disease such as chronic bronchitis or emphysema), dmodul7 (Stomach or duodenal ulcer, peptic ulcer) and dmodul11 (Other affective or emotional disorders, including anxiety, nervous or psychiatric problem; Rheumatoid Arthritis; and Osteoarthritis, or other rheumatism) caused significantly more visits to the doctor. 
36 ${ }^{\mathrm{TH}}$ International Conference on Organizational Science Development: ResPonsible ORGaNizATION (MARCH $22^{\mathrm{ND}}-24^{\mathrm{TH}}$, PORTOROŽ SLOVENIA)

A. Srakar \& V. Prevolnik Rupel: Multiple Chronic Conditions in Older People and Their Effects on Health Care Utilization: A Network Analysis Approach Using SHARE Data

Similarly, for the number of taken medications, dmodul3 (A stroke or cerebral vascular disease), dmodul4 (A heart attack including myocardial infarction or coronary thrombosis or any other heart problem including congestive heart failure; and Diabetes or high blood sugar), and dmodul5 (Chronic lung disease such as chronic bronchitis or emphysema) caused more taken medications than the comparison group dmodul1 (Other conditions, not yet mentioned; and High blood pressure or hypertension), similar holds for dmodul7 (Stomach or duodenal ulcer, peptic ulcer), dmodul8 (Cataracts) and dmodul11 (Other affective or emotional disorders, including anxiety, nervous or psychiatric problem; Rheumatoid Arthritis; and Osteoarthritis, or other rheumatism).

Finally, for the number of hospitalizations, the comparison group was one among the lowest frequent. All modules/groups of diseases had higher frequency of hospitalizations than the comparison group dmodul1 (Other conditions, not yet mentioned; and High blood pressure or hypertension), with the exception of dmodul2 (High blood cholesterol) where the effect was not statistically significant.

The models were compared with two other specifications, where the first included only the general variables for number of chronic diseases (instead of the 11 dmodulae) and the second included dummies for each individual chronic disease. The models in Table 5 outperformed both in terms of goodness-of-fit (pseudo R squared), LR chi2 statistic and Log Likelihood criteria. This held in particular for the models with general variable for number of chronic diseases, but the improvement of fit was visible also for the second one. This confirms we gained improvement in the modelling using groups of diseases as predictors and serves as another argument for our choice of the method. 
36. MEDNARODNA KONFERENCA O RAZVOJU ORGANIZACIJSKIH ZNANOSTI: ODGOVORNA ORGANIZACIJA (22. - 24. MAREC 2017, PORTOROŽ, SLOVENIJA)

A. Srakar \& V. Prevolnik Rupel: Multiple Chronic Conditions in Older People and Their Effects on Health Care Utilization: A Network Analysis Approach Using

SHARE Data

\begin{tabular}{|c|c|c|c|c|c|c|c|c|c|c|c|c|}
\hline & \multicolumn{3}{|c|}{ Nr. medical visits } & \multicolumn{3}{|c|}{ Nr. taken medications } & \multicolumn{3}{|c|}{ Nr. hospitalizations } & \multicolumn{3}{|c|}{ Prob. of hospitalization } \\
\hline & Coeff & $\mathrm{z}$ & Sig & Coeff & $\mathrm{z}$ & Sig & Coeff & $\mathrm{z}$ & Sig & Coeff & $\mathrm{z}$ & Sig \\
\hline Constant & 1.5160 & $\begin{array}{c}11.2 \\
9\end{array}$ & $\begin{array}{l}* * \\
*\end{array}$ & 0.5190 & 2.15 & $* *$ & -0.9982 & -3.48 & $* * *$ & -0.7602 & -1.40 & \\
\hline Gender & -0.0288 & -0.54 & & 0.0732 & 0.80 & & 0.2531 & 3.04 & $* * *$ & 0.2526 & 1.16 & \\
\hline Age 70-74 & 0.0152 & 0.25 & & 0.3053 & 2.59 & $* *$ & -0.7095 & -6.06 & $* * *$ & 0.0673 & 0.25 & \\
\hline Age 75-79 & $\begin{array}{l}-0.3792 \\
\end{array}$ & -5.42 & $\begin{array}{l}* * \\
*\end{array}$ & 0.3515 & 3.02 & $* * *$ & -0.8181 & -8.59 & $* * *$ & 0.0409 & 0.15 & \\
\hline Age $80+$ & -0.4690 & -6.15 & $\begin{array}{l}* * \\
* \\
\end{array}$ & 0.0099 & 0.07 & & -0.9859 & -7.23 & $* * *$ & -0.2367 & -0.77 & \\
\hline Edu Years & 0.0010 & 0.17 & & $\begin{array}{c}- \\
0.0123\end{array}$ & -1.15 & & -0.0037 & -0.34 & & -0.0136 & -0.52 & \\
\hline IncomeMid & -0.0923 & -1.40 & & $\begin{array}{c}- \\
0.1116 \\
\end{array}$ & -1.00 & & 0.0771 & 0.64 & & -0.2271 & -0.85 & \\
\hline IncomeHigh & 0.3373 & 5.60 & $\begin{array}{l}* * * \\
*\end{array}$ & $\begin{array}{c}- \\
0.1642\end{array}$ & -1.49 & & 0.6819 & 6.79 & $* * *$ & 0.0568 & 0.22 & \\
\hline Settlement & 0.1643 & 3.26 & $\begin{array}{l}* * \\
*\end{array}$ & 0.0795 & 0.88 & & 0.4963 & 5.70 & **** & 0.1559 & 0.72 & \\
\hline $\begin{array}{l}\text { LivingAlon } \\
\mathrm{e}\end{array}$ & 0.2439 & 4.32 & $\begin{array}{l}* * \\
*\end{array}$ & 0.0175 & 0.18 & & 0.1458 & 1.42 & & -0.4985 & -2.05 & ** \\
\hline ChildDist & 0.1151 & 1.96 & $* *$ & 0.0521 & 0.51 & & -0.2211 & -2.19 & $* *$ & -0.1342 & -0.55 & \\
\hline $\begin{array}{l}\text { Limited- } \\
\text { GALI }\end{array}$ & 0.8349 & $\begin{array}{c}15.8 \\
2 \\
\end{array}$ & $\begin{array}{l}* * \\
* \\
\end{array}$ & 0.3256 & 3.21 & $* * *$ & 2.1137 & $\begin{array}{c}23.6 \\
0 \\
\end{array}$ & $* * *$ & 1.1244 & 4.51 & $\begin{array}{l}* * \\
* \\
\end{array}$ \\
\hline dmodul2 & -0.1015 & -0.73 & & 0.2356 & 1.02 & & 0.4055 & 1.00 & & -0.3574 & -0.60 & \\
\hline dmodul3 & -0.3292 & -1.79 & $*$ & 0.6768 & 2.84 & **** & 0.8693 & 2.66 & **** & -0.0882 & -0.14 & \\
\hline dmodul4 & 0.3276 & 3.81 & $\begin{array}{l}* * * \\
*\end{array}$ & 0.4627 & 2.85 & $* * *$ & 2.0548 & 9.71 & $* * *$ & 0.2472 & 0.69 & \\
\hline dmodul5 & 0.4290 & 4.14 & $\begin{array}{l}* * \\
*\end{array}$ & 0.4965 & 2.50 & $* *$ & 0.8652 & 3.28 & $* * *$ & 0.1131 & 0.24 & \\
\hline dmodul6 & 0.0153 & 0.13 & & 0.0818 & 0.35 & & 0.6892 & 2.75 & $* * *$ & 0.0236 & 0.05 & \\
\hline dmodul7 & 0.4558 & 4.91 & $\begin{array}{c}* * \\
*\end{array}$ & 0.3812 & 2.15 & *** & 0.9621 & 3.92 & **** & 0.5780 & 1.50 & \\
\hline dmodul8 & 0.1106 & 0.77 & & 0.4158 & 1.64 & $*$ & 2.7622 & $\begin{array}{c}11.9 \\
6 \\
\end{array}$ & $* * *$ & 0.1468 & 0.25 & \\
\hline dmodul9 & 0.0967 & 0.91 & & 0.0806 & 0.41 & & 1.8415 & 8.13 & $* * *$ & 0.2436 & 0.61 & \\
\hline dmodul10 & -0.1667 & -1.02 & & 0.0168 & 0.06 & & 1.6173 & 6.25 & ***** & $\begin{array}{c}-0.8978 \\
\end{array}$ & -1.28 & \\
\hline dmodul11 & 0.1752 & 2.06 & $* *$ & 0.3309 & 2.07 & *** & 0.4762 & 2.06 & $* *$ & -0.2269 & -0.62 & \\
\hline Nr. obs. & 219 & & & 223 & & & 222 & & & 223 & & \\
\hline LR chi2 & 466.55 & $* * *$ & & 62.44 & $* * *$ & & $\begin{array}{c}1857.8 \\
5 \\
\end{array}$ & $* * *$ & & 38.02 & $* *$ & \\
\hline $\begin{array}{l}\text { Log } \\
\text { Likelihood }\end{array}$ & $\begin{array}{c}- \\
1026.1 \\
8 \\
\end{array}$ & & & $\begin{array}{c}- \\
380.06\end{array}$ & & & -990.88 & & & -106.67 & & \\
\hline Pseudo R2 & 0.1852 & & & 0.0759 & & & 0.4839 & & & 0.1512 & & \\
\hline
\end{tabular}

Table 5: Results of econometric models, influence on health care utilization

\section{$4 \quad$ Discussion and Conclusion}

In our analysis, we tested a new method to model the presence of multiple co-existing chronic diseases in individuals: social network analysis, based on SHARE data. The method provided us an insight into the connections and groupings of disease for the case 
36 ${ }^{\mathrm{TH}}$ International Conference on Organizational Science Development: ResPonsible ORganization (MARCH $22^{\mathrm{ND}}-24^{\mathrm{TH}}$, Portorož SlOVENIA)

A. Srakar \& V. Prevolnik Rupel: Multiple Chronic Conditions in Older People and Their Effects on Health Care Utilization: A Network Analysis Approach Using SHARE Data

of $65+$ population in Slovenia and we were able to observe at least few groupings based on connectivity and structure of the network. We were also able to observe the effects of such a classification for the relationship to health care utilization and confirmed that by including the groupings of diseases the fit of the model is significantly improved than by including only general variables or separate variable for each disease.

Although the article is at this stage exploratory and we are still testing for the results of using a »new« (in terms of previous usage for modelling this problem) method, it is already clear that implications of such approach can be very rich, for both geronthology (if using SHARE data), heath economics and medicine sciences in general. Using improved clustering and classification methods (still under work), already existing for social network analysis can provide significant new insights into 1) the groups of diseases that are linked - if using SHARE data we are of course talking about the chronic diseases of the older people; and 2) their effects for different variables in the system, including the health policy variables - organization of the system and costs and their projections in future. At this point we are only able to say that we hope that work on the method in future will provide us with a more developed insights in terms of both methodology and results.

\section{Notes}

${ }^{1}$ This paper uses data from SHARE Wave 5 (DOI: 10.6103/SHARE.w5.100), see Börsch-Supan et al. (2013) for methodological details. The SHARE data collection has been primarily funded by the European Commission through FP5 (QLK6-CT-2001-00360), FP6 (SHARE-I3: RII-CT-2006062193, COMPARE: CIT5-CT-2005-028857, SHARELIFE: CIT4-CT-2006-028812) and FP7 (SHARE-PREP: N²11909, SHARE-LEAP: N²27822, SHARE M4: N²61982). Additional funding from the German Ministry of Education and Research, the U.S. National Institute on Aging (U01_AG09740-13S2, P01_AG005842, P01_AG08291, P30_AG12815, R21_AG025169, Y1AG-4553-01, IAG_BSR06-11, OGHA_04-064) and from various national funding sources is gratefully acknowledged (see www.share-project.org).

2 The drugs include the following: 1. Drugs for high blood cholesterol; 2. Drugs for high blood pressure; 3. Drugs for coronary or cerebrovascular diseases; 4. Drugs for other heart diseases; 6. Drugs for diabetes; 7. Drugs for joint pain or for joint inflammation; 8. Drugs for other pain (e.g. headache, back pain, etc.); 9. Drugs for sleep problems; 10. Drugs for anxiety or depression; 11. Drugs for osteoporosis; 13. Drugs for stomach burns; 14. Drugs for chronic bronchitis; 15. Drugs for suppressing inflammation (only glucocorticoids or steroids); 97. Other drugs, not yet mentioned

\section{Literature}

Barnett, K., Mercer, S.W., Norbury, M., Watt, G., Wyke, S., Guthrie, B. (2012). Epidemiology of multimorbidity and implications for health care, research, and medical education: a crosssectional study. Lancet, 2012, 380 (9836), pp. 37-43. 10.1016/S0140-6736(12)60240-2.

Börsch-Supan, A. (2015). Survey of Health, Ageing and Retirement in Europe (SHARE) Wave 5. Release version: 1.0.0. SHARE-ERIC. Data set. http://dx.doi.org/10.6103/SHARE.w5.100

Börsch-Supan, A., Brandt, M., Hunkler, C., Kneip, T., Korbmacher, J., Malter, F., Schaan, B., Stuck, S. \& Zuber, S. (2013). Data Resource Profile: The Survey of Health, Ageing and 
36. MEDNARODNA KONFERENCA O RAZVOJU ORGANIZACIJSKIH ZNANOSTI: ODGOVORNA 989 ORGANIZACIJA (22. - 24. MAREC 2017, PORTOROŽ, SLOVENIJA)

A. Srakar \& V. Prevolnik Rupel: Multiple Chronic Conditions in Older People and Their Effects on Health Care Utilization: A Network Analysis Approach Using SHARE Data

Retirement in Europe (SHARE). International Journal of Epidemiology, 42(4), 992-1001, http://dx.doi.org/10.1093/ije/dyt088

Börsch-Supan, A., Kneip, T., Litwin, H., Myck, M. \& Weber, G. (Eds.) (2015). Ageing in Europe - Supporting Policies for an Inclusive Society. Berlin: De Gruyter.

Clarfield, A.M., Bergman, H., Kane, R. (2001). Fragmentation of care for frail older people-an international problem. Experience from three countries: Israel, Canada, and the United States. J Am Geriatr Soc., 2001, 49 (12), pp. 1714-1721. 10.1046/j.1532-5415.2001.49285.x.

Fortin, M., Soubhi, H., Hudon, C., Bayliss, E.A., van den Akker, M. (2007). Multimorbidity's many challenges. BMJ, 2007, 334 (7602), pp. 1016-1017. 10.1136/bmj.39201.463819.2C.

Glynn, L.G., Valderas, J.M., Healy, P., Burke, E., Newell, J., Gillespie, P., Murphy, A.W. (2011). The prevalence of multimorbidity in primary care and its effect on health care utilization and cost. Fam Pract, 2011, 28 (5), pp. 516-523. 10.1093/fampra/cmr013.

Goyal, S., Joshi, S. (2003). Networks of Collaboration in Oligopoly. Games and Economic Behavior, 43(1), pp. 57-85.

Greß, S., Baan, C.A., Clanan, M., Dedeu, T., Groenewegen, P., Howson, H., Maroy, L., Nolte, E., Redaèlli, M., Saarelma, O., Schmacke, N., Schumacher, K., van Lente, E.J., Vrijhoef, B. (2009). Co-ordination and management of chronic conditions in Europe: the role of primary care - position paper of the European forum for primary care. Qual Prim Care, 2009, 17, pp. 75-86.

Hiller, T. (2015). Peer Effects in Endogenous Networks. (October 4, 2015). Retrieved from: http://ssrn.com/abstract=2478975.

Laux, G., Kuehlein, T., Rosemann, T., Szecsenyi, J. (2008). Co- and multimorbidity patterns in primary care based on episodes of care: results from the German CONTENT project. BMC Health Serv Res, 2008, 8, pp. 14-10.1186/1472-6963-8-14.

Lehnert, T., Heider, D., Leicht, H., Heinrich, S., Corrieri, S., Luppa, M., Riedel-Heller, S., Konig, H.H. (2011). Review: health care utilization and costs of elderly persons with multiple chronic conditions. Med Care Res Rev, 2011, 68 (4), pp. 387-420. 10.1177/1077558711399580.

Malter, F. \& Börsch-Supan, A. (Eds.) (2015). SHARE Wave 5: Innovations \& Methodology. Munich: MEA, Max Planck Institute for Social Law and Social Policy.

Marengoni, A., Angleman, S., Melis, R., Mangialasche, F., Karp, A., Garmen, A., Meinow, B., Fratiglioni, L. (2011). Aging with multimorbidity: a systematic review of the literature. Ageing Res Rev, 2011, 10 (4), pp. 430-439. 10.1016/j.arr.2011.03.003.

Newman, M.E.J. (2006). Modularity and community structure in networks. Proceedings of the National Academy of Sciences, 103(23), pp. 8577-8582.

Salisbury, C., Johnson, L., Purdy, S., Valderas, J.M., Montgomery, A.A. (2011). Epidemiology and impact of multimorbidity in primary care: a retrospective cohort study. Br J Gen Pract, 2011, 61 (582), pp. e12-21. 10.3399/bjgp11X548929.

Smith, S.M., O'Dowd, T. (2007). Chronic diseases: what happens when they come in multiples? Br J Gen Pract, 2007, 57 (537), pp. 268-270.

Soramaki, K. et al. (2007). The topology of interbank payment flows. Physica A, 379, pp. 317-333.

Srakar, A., Hren, R., Prevolnik Rupel, V. (2016). Health services utilization in older Europeans: an empirical study. Organizacija, May 2016, 49(2), pp. 127-137, doi: 10.1515/orga-2016-0009.

Starfield, A. (2006). Challenges to primary care from co- and multi-morbidity. Prima Health Care Res Dev, 2006, 12, pp. 1-2.

van den Bussche, H., Schon, G., Kolonko, T., Hansen, H., Wegscheider, K., Glaeske, G., Koller, D. (2011). Patterns of ambulatory medical care utilization in elderly patients with special reference to chronic diseases and multimorbidity-results from a claims data based observational study in Germany. BMC Geriatr, 2011, 11, pp. 54-10.1186/1471-2318-11-54. 
$36^{\text {TH }}$ International Conference on Organizational Science Development: RESPONSIBLE ORGANIZATION (MARCH $22^{\mathrm{ND}}-24^{\mathrm{TH}}$, PORTOROŽ SLOVENIA)

A. Srakar \& V. Prevolnik Rupel: Multiple Chronic Conditions in Older People and Their Effects on Health Care Utilization: A Network Analysis Approach Using SHARE Data

Vogeli, C., Shields, A.E., Lee, T.A., Gibson, T.B., Marder, W.D., Weiss, K.B., Blumenthal, D. (2007). Multiple chronic conditions: prevalence, health consequences, and implications for quality, care management, and costs. J Gen Intern Med, 2007, 22 (Suppl 3), pp. 391-395.

WHO (2009). The European health report 2009: health and health systems. Copenhagen: World Health Organisation. 
$36^{\text {Th }}$ International Conference on Organizational Science DeVElopment: Responsible ORGANIZATION (MARCH $22^{\mathrm{ND}}-24^{\mathrm{TH}}$, PORTOROŽ SLOVENIA)

O. Arsenijević, M. Ferjan, I. Podbregar, P. Šprajc, D. Trivan \& Y.

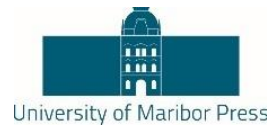

Ziegler

\title{
The Impact of the Value Added Tax on the Business Performance of Companies
}

\author{
BOJANA STARČEVIĆ \& FILIP ŽARKIĆ
}

\begin{abstract}
The essence of this paper is to highlight the importance of the value added tax has the liquidity crisis of companies. Value added tax is not neutral on the end result of the company, what is more on their negative impact on the business performance of the company is realized through the effects they have on cash flows. The large outflows of funds on the basis of value added tax in the event of a liquidity crisis, contributing even worse to business conditions and reducing overall business performance. The outflow of funds for the payment obligations on the basis of value added tax consequently acts on the additional debt the company has, reducing the possibility of investing and devaluing assets due to inflationary impact. In order to reduce the impact of the value added tax on the overall business performance,the company's management did a very important task of detailed planning and controling cash flows, because only the regular assembling plan cash flows can promptly react to disturbances in the flows of cash, but the negative effects can be surpassed or reduced.
\end{abstract}

Keywords: multiple chronic diseases $\bullet$ older people $\bullet$ health care utilization - SHARE • social network analysis • econometric models alue added tax • liquidity $\bullet$ company's buissiness performance $\bullet$ cash flow report

CORRESPONDENCE ADDRESS: Bojana Starčević, Master Student, University of Belgrade, Faculty of Organizational Sciences, 154 Jove Ilića Street, 11000 Beograd, Serbia, e mail:starcevic.bojana1 @ gmail.com; Filip Žarkić, Master Student, University of Belgrade, Faculty of Organizational Sciences, 154 Jove Ilića Street, 11000 Beograd, Serbia, e-mail: zarkic.f@gmail.com 
$36^{\mathrm{TH}}$ INTERNATIONAL CONFERENCE ON ORganizational SCIENCE DeVElopment: RESPONSIBLE ORGANIZATION (MARCH $22^{\mathrm{ND}}-24^{\mathrm{TH}}$, PORTOROŽ SLOVENIA)

B. Starčević \& F. Žarkić: The Impact of the Value Added Tax on the Business

Performance of Companies

\section{Efect of value added tax on business performance company}

Any company that operates in the public sector has a predefined goal depending on the area of operation. What is common for all companies of the public sector in the Republic of Serbia, is that their goals are not achieved in an efficient and effective manner. The functioning of the public sector directly affects the operations of the private sector, the standard of living and the general performance of the entire economy. The state is the largest employer in the economy, it is a consumer tax assets (Economics, 2011).

The introduction of value added tax is a very serious business, which includes certain preparations and measures for the successful functioning of this tax, which means providing the technical and economic conditions in the country. Key preparatory activities and tasks to do the adoption of bylaws arising from the Law on Value Added Tax, a decision regarding the selection of the organization of the tax administration, setting up a system of automatic data processing, conducting training on the functioning of the tax administration of taxes and implementation of information campaigns a new form of taxation. One of the essential conditions for the effective implementation of value added tax in the tax system of a country is the creation of stable socio-economic conditions. Experience has shown that the application of value added tax in all states at the time of economic instability with the presence of inflationary tendencies contributed to the further growth of inflation.

\subsection{The impact of the value added tax on the companies' liquidity, on additional borrowing company, on the investment company, on cash flows and on the movement of the general price level}

Liquidity is one of the major preoccupations of our management, because in most countries it is one of the main reasons the company going bankrupt. Same liquidity is the ability of companies to respond to the deadline due obligations. This means that the company after repayment of the debt is be able to operate normally. If a company does not have sufficient financial resources that should settle its outstanding liabilities, it is obliged to borrow. However, too much liquidity is not good, because in this case the company has a great value in positions of highly liquid assets such as cash and cash equivalents, reducing profitability.

In addition to the liquidity of the business of a company is essential and solvency as well as liquidity in the long term. Solvency is the ability of the company to continuously pay due obligations (Robajac, A., 2010).

The global economic crisis has affected the operation of small, medium and big companies in the Republic of Serbia through insolvency. Companies invest a lot of effort in order to be able to settle obligations to business partners. The companies that the crisis has hit the most are often unable to find a solution to exit the crisis, liquidity, and pass into a crisis of solvency, which leads to the liquidation of the company and dismissal of employees. 
The problem that creates billing system of value added tax arises during the time difference in the collection of receivables and payment of value added tax state on the basis of purchase invoices of suppliers, because usually these two actions do not run parallel, but it directly affects the liquidity of companies, which negatively affects the cash flows, and therefore the overall financial result of the company. Also, the state requires the company to regularly pay tax liability, while not performing duties of eventual return of the paid value added tax in a timely manner.

The company, by settling its tax liability to the state before executing collection of receivables or what is waiting for refund of value added tax, the state budget is financed from its working capital. Companies in Serbia generally have excess working capital, which would be able to settle their obligations, and this is another reason for interruption of operations of many companies in our market.

The business environment in the Republic of Serbia is characterized by high illiquidity of the company. The liquidity crisis is a situation in which company is not able to pay their due obligations in due time. The liquidity is most commonly affected by the company's business at a loss. The global economic crisis is reflected in the decline in economic activity in the whole country, a large number of companies have frozen accounts due to the inability to settle obligations and to survive in such a market. Also, the solvency crisis has affected the operations of many companies, whose ultimate outcome is bankruptcy and discontinued operations.

Very important influence on the phenomenon of insolvency in a company has a tax system. Tax policy measures in themselves are not the cause of the liquidity crisis, or in deficit conditions prevailing in the Republic of Serbia, certainly not contribute to its overcoming. The task of the state is to foster economic development and to help companies achieve optimal business performance; however, if they changed the system of payment of value added tax in favor of the companies would create an even bigger budget deficit, which would require additional government borrowing.

Business environment that exists in the market of the Republic of Serbia is characterized by frequent situation outstanding claims. This situation occurs when a buyer has declaredbankrupt because of insolvency, a large part of the assets claimed by the company itself will never be collected, because the amount of the bankruptcy estate is not sufficient to cover the entire debt. Value added tax has to be paid to the state, in this situation to, because the company has invoiced tax.

The liquidity crisis leading companies in a situation where they are unable to settle within financial liabilities. If the Company finds himself in this situation, companies are forced managers to obtain additional financial resources. Usually, the company identifies additional funding for taking loans from commercial banks for liquidity stimulus. Such borrowing to ensure a normal functioning of companies and settlement of liabilities due. However, these short-term loans significantly affect the business performance of the 
36 ${ }^{\text {TH }}$ International Conference on Organizational Science Development: RESPONSIBLE ORGANIZATION (MARCH $22^{\mathrm{ND}}-24^{\mathrm{TH}}$, PORTOROŽ SLOVENIA)

B. Starčević \& F. Žarkić: The Impact of the Value Added Tax on the Business Performance of Companies

organization, because of the obligations based on interest rates for amounts in our environment is high.

The company, prior to making the collection of receivables from customers or what is waiting for refund of value added tax sometimes even up to three months, the state budget is financed from its working capital. Not all companies are in a position to have excess working capital, payables and the countries settled by taking short-term loans to commercial banks and thus finance them.

The main goal of every company is to make profit. However, considering market conditions in the Republic of Serbia, characterized by illiquidity and high indebtedness, the survival of the company is called into question. Bearing in mind that the gain is the positive difference between total revenue and total expenditure, the influx of funds that acquire a company is not sufficient as a cover expenses. For this reason a large number of companies operating in our market went bankrupt.

Cash is the key to success, because it is the only company with a positive cash flow, able to meet its obligations towards both the country and towards business partners, employees and other stakeholders in the business.

Cash flow statement summarizes the changes in the movement of cash nastrale. Cash companies can change during the year due to the inability to collect receivables, failure to meet the obligations or generate income or expense.

The impact of the value added tax on the cash flows of the company is high. Value added tax itself is not classified as operating costs and has no negative impact on the end result of the company. However, value added tax cash flows and changes caused by cash outflows. Therefore, as the cause of the outflow wallet, value added tax should not be considered to be a factor that contributes to achieving the profits of the enterprise, furthermore added tax value is reflected negatively on the overall business performance of the company.

In a situation where the company has a shortage of money in the account, there is also a negative impact on the overall performance of the organization, because it directly affects the balance sheet and income statement, which entails the impossibility of settling the tax liability and the company creates serious difficulties in further operations.

Inflation is puffy money circulation over the real needs of commodity trading. It means a condition that occurs spontaneously or forced, as an increase in the total amount of money in circulation (Žarkić Joksimović, N., Benković, S., Milosavljević, M., 2013). This results in an increase in the price of available goods and services and increased costs and revenues. Inflation causes a negative effect on the entire course of social reproduction. Inflation is an increase in the price level, and the Republic of Serbia has expressed its effect significantly. The general price level can be seen as a general trend 
of rising prices, so that people have to pay more and more for goods and services they purchase.

The opposite phenomenon of inflation is deflation and is reflected as a general decline in the price level. Disinflation is a decrease in the inflation rate, and the last time was in the Republic of Serbia in 1994 during the hyperinflation.

Inflation is accompanied by rising prices of oil, electricity and food, growth in domestic demand and the rapid expansion of bank credit. By its nature, value-added tax is a neutral tax form, so it will not significantly affect the prices provided that the budget revenues do not change (Arnaut, E., 2015). The introduction of value added tax in the tax system of the Republic of Serbia undoubtedly had an impact on the level of inflation and the level of increase in the general price level. To avoid or reduce the inflationary effect when it is proposed appropriate measures. They imply that economic policy should be directed to the restrictive monetary policy, which are important measures through which the state influences the prices in order to preserve price stability and to control price freeze or price.

Value added tax in the Republic of Serbia affected the change in relative price relationships in favor of those products that are taxed at a lower rate of $10 \%$, and that the introduction of new tax forms were not taxed tax. This change has had a negative impact on the living standard of citizens, as it is a vital importance for products with inelastic demand and without adequate cheaper substitutes. The implication is that the government should look more carefully at the whole body of the result in the introduction of value added tax and does not allow the escalation of prices which are under its direct control. This circumstance has caused other goods and services that are taxed by the general rate of $20 \%$, to also record a significant increase in prices (Saković, D., 2012).

Inflation has a negative impact on the cash flows of the company. The funds that the company collected from the state through the refund of value added tax do not have the same real value as the moment when the tax liability is determined. Value added tax impact on reducing the inflow and outflow of the increase of a company and thus adversely affect its business performance.

How to reduce the negative impact of the value added tax on the business performance of companies in the Republic of Serbia?

The task of each manager is to enable the company to achieve optimal business performance. For managers, it is very important to analyze the external environment and to take advantage of all the opportunities and neutralize the negative opportunities facing the company, and that can roll back its operations. To be able to achieve good business performance, it is important to estimate the resources and capacity available to the company. On the result of a company affects greatly the knowledge of managers and their ability to make informed decisions that lead to achieving the objective of the company. 
$36^{\mathrm{TH}}$ INTERNATIONAL CONFERENCE ON ORganizational SCIENCE DeVElopment: RESPONSIBLE ORGANIZATION (MARCH $22^{\mathrm{ND}}-24^{\mathrm{TH}}$, PORTOROŽ SLOVENIA)

B. Starčević \& F. Žarkić: The Impact of the Value Added Tax on the Business Performance of Companies

The conditions prevailing in the market, such as high inflation, liquidity, indebtedness, are just some of the reasons that make it difficult for managers to achieve their task and allow the company to achieve good business performance. Value added tax is certainly a factor that negatively affects the company's operations. Value added tax indirectly affect the business performance of the company, especially as the cost of its operations. Company management has the task to reduce the negative impact caused by value added tax.

Periodically compiling the cash flow statement is one of the ways to reduce the insolvency of the company. Report on cash flow represents tabular inflows and outflows of a company and as such provides an insight into the possible gap between them.

Value added tax on the company's liquidity is affected by or through the payment of purchase invoices of suppliers or through calculating the tax liability. In order to reduce the impact of the value added tax on liquidity, companies should draw up a plan of inflows and outflows of money per month, in order to have access to the cash balance at the end of the period to which the tax return.

Management companies should harmonize procurement dynamics and the dynamics of sales, because in this way paid value added tax after the incoming invoices of suppliers fit outgoing invoices to customers and would create additional tax liability.

Also, if the collection of receivables from customers was carried out in a short period of time, the value added tax to maintain neutrality in relation to the business of the company, because the all paid input tax was transferred to the buyer. Also, the execution of payables should be postponed for longer period of time to affect the outflow that creates value added tax as low as possible.

In order for the management tobe able to reduce the impact of value added tax it should maintain a healthy cash flow and prepare periodical plans with emphasis on the extension of the period of payment of trade payables and amounts relating to a refund of value added tax by the state. It is necessary to constantly monitor and control cash flows and timely response and correcting the negative impact of the same.

The easiest way to neutralize the negative impact of the value added tax on the company's liquidity is to have stable sales volume and collection of receivables in the shortest possible period of time. This is very difficult to achieve, because companies need to take care of customers, to provide them with superior value compared to competitors and to provide them with benefits in the form of deferred payment, and on the other hand, and buyers are not always able to settle their obligations on time. It is very important to choose the customers to whom they sell their products. The credit rating of the customer is key when making a decision on whether the company should be trading with certain customers, or whether the buyer is able to settle its obligation. Due to the economic conditions prevailing in the Serbian market, companies have two choices, either to reduce the volume of sales, which will reduce the total income that they earn, or to enter into 
transactions with high-risk customers, even though they know that the obligations on the basis of value added tax waiting after each billing.

Companies that sell in the short and longer terms to buy with money in cash that positively affect the company's financial situation, and on the other companies that sell the longer and buying in the short term are in a very tense financial situation. Every company wants to defer payment settings from as long as possible, and to shorten payment terms, because it is in their interest.

The most important role and the greatest impact on the regulation of the problems that entails the payment of value added tax has precisely the state. The state and its authorities should take adequate measures to reduce the number of blocked companies and improve the liquidity situation of other companies operating in the territory of the Republic of Serbia. The reform of the law relating to value added tax and penalties in case of nonpayment of the same is very important for the survival of many companies and improving their business performance.

\section{Conclusion}

The operations of the company in the Republic of Serbia are largely influenced by internal and external environment. Great efforts have been directed precisely towards the settlement of obligations to business partners and appropriately reflect the business of domestic companies. One consequence of these market circumstances did illiquidity of domestic companies. The inability of settling due debts at maturity, together with the high indebtedness of companies, hinders economic activity participants in the domestic market.

Value added tax has a significant impact on the liquidity crisis of companies. He is not the only cause of this crisis, but it certainly contributes significantly to the prevailing recession conditions. Companies that have been most affected by the liquidity crisis, taking the solvency crisis that usually ends bankruptcy or liquidation and releasing employees.

Value added tax, their negative impact on the business performance of the company generates through the effects they have on cash flows. The large outflows of funds from liabilities for value added tax, in the event of a liquidity crisis, contribute to creating an even worse business conditions and reduce the performance of companies. It has a negative effect on cash flows, because the refund of tax paid waiting a long time because of the slow payment of claims. All this leads to the fact that value added tax represents a cost for the company until the prospect of recovery. Company's regular payment obligations on the basis of value added tax, to the detriment of its liquidity, funding the state budget.

Value added tax has a strong impact on the overall business performance of companies that have a problem with defaults regular duties due to illiquidity. The companies that are forced to take short-term loans to commercial banks to settle obligations on time, with 
additional interest expense on borrowed funds, with part of the amount of these loans are used to meet liabilities arising from value added tax. Outflows of funds related to the payment of value added tax consequently act on the additional debt the company, reducing the possibility of investing and devalue assets due to inflationary impact.

To management company was able to reduce the impact of the value added tax on the overall business performance, it is important detailed planning and control cash flows. Regular compilation of plan cash flows is monitored and reacts to disturbances within the cash flows.

From the aspect of value added tax it is very important to plan the payments to suppliers in the right way so that the company had an insight into the amount of value added tax to her later on the return of to be available in the form of tax credits. Also, it is necessary to monitor the deadlines for the collection of receivables from customers because of them depends largely on whether or not to switch the tax burden on customers. Time gap between payments by input suppliers' invoices that contain value added tax, with the time of collection of receivables from customers or the time of collection refund of value added tax from the tax authorities, has resulted in enormous difficulties of operating companies that are manifested through insolvency. In fact, the relationship between the amount which the company invoiced to customers, but did not collect the amounts invoiced suppliers, and the company has settled, creating a tax liability which the company management must be effectively managed.

In the end, the greatest impact on reducing the negative impact of the value added tax should have just state and its tax policy. Its influence is reflected in the improvement of the financial position of the institution, the payment of debts to businesses and amendments to parts of the Law on Value Added Tax.

\section{Literature}

Arnaut, E. (2015) Transition. University of Vitez, Tuzla, Bosnia and Hercegovina

Economics. (2011). Certain aspects of business performance measurement in organizations in the public sector. Faculty od Economics, University of Niš, Republic of Serbia

Robajac, A. (2010). The impact of the value added tax on the movement of the general price level in the Republic of Serbia. Accounting and Auditing, Niš, Republic of Serbia

Saković, D (2012). The impact of the value added tax on the management and performance of enterprises in Serbia. School of Business, Republic of Serbia

Žarkić Joksimović, N., Benković, S., Milosavljević, M. (2013). Financial Management. Faculty of Organizational Sciences, University of Belgrade, Republic of Serbia 


\title{
Dvig poklicnih kompetenc učiteljev $\mathrm{z}$ usposabljanjem $\mathrm{v}$ podjetju
}

\author{
GAŠPER STRNIŠA
}

Povzetek Strokovna usposobljenost in kompetentnost učiteljev sta ključni pri zagotavljanju kakovosti izobraževalnega procesa. Za izvajalce izobraževanj je torej izredno pomembno lastno vseživljenjsko učenje, ki zagotavlja nadgradnjo in osvežitev tako strokovnih kot tudi pedagoških znanj. Eden od teh načinov je tudi usposabljanje učiteljev v delovnem okolju. V prispevku je opisan primer dobre prakse učitelja strokovno tehniških predmetov iz področja računalništva, ki je opravil dvomesečno usposabljanje $\mathrm{v}$ podjetju, ki se ukvarja $\mathrm{z}$ računalniškim inženiringom. Takšna usposabljanja bi morala biti predvsem za učitelje strokovnih predmetov nujna, saj le na ta način lahko ohranijo stik z razvojem sodobnih tehnologij in spoznajo potrebe gospodarstva.

KLJUČNE BESEDE: učitelj • kompetence $\cdot$ podjetje $・$ program • izobraževanje

NASLOV AVTORJA: Gašper Strniša, učitelj strokovnih predmetov, Šolski center Kranj, Strokovna gimnazija, Kidričeva cesta 55, 4000 Kranj, Slovenija, e-pošta: gasper.strnisa@gmail.com 
$36^{\text {TH }}$ International Conference on Organizational Science DEVElopMENT: Responsible ORganization (MARCH $22^{\mathrm{ND}}-24^{\mathrm{TH}}$, PORTOROŽ SLOVENIA)

O. Arsenijević, M. Ferjan, I. Podbregar, P. Šprajc, D. Trivan \& Y. Ziegler

\title{
Improving the Vocational Competencies of Teachers with Training at the Enterprise
}

\section{GAŠPER STRNIŠA}

\begin{abstract}
Professional qualifications and teachers' competences are crucial in ensuring the quality of the educational process. Lifelong learning is extremely important also for education providers because it ensures the upgrade and refreshes the professional and pedagogical skills. One of options is the teacher training in the workplace. This paper describes an example of good practice from a teacher who is an expert in technical subjects in the field of computer science, and had conducted a two-month training at the enterprise, which is engaged in computer engineering. Such trainings should be mandatory primarily for teachers of technical subjects. This is the best way for them to maintain contact with the development of modern technologies and to meet the needs of economy.
\end{abstract}

KEYWORDS: teacher $\bullet$ competencies $\bullet$ enterprise $\bullet$ program $\bullet$ education

CORRESPONDENCE AdDRESS: Gašper Strniša, Teacher of Professional Subjects, School Centre Kranj, Professional Gymnasium, Kidričeva cesta 55, 4000 Kranj, Slovenia, e-mail: gasper.strnisa@gmail.com 


\section{$1 \quad$ Uvod}

Hitre tehnološke spremembe predstavljajo izzive ter potrebo po prilagajanju na vseh področjih človekovega udejstvovanja. Izjeme ne predstavlja niti šolstvo, ki mora zaradi težnje po zagotavljanju kakovostnih in sodobnih učnih vsebin, udeležencem učnega procesa omogočiti kar se da ažurna znanja.

Uspešen proces izobraževanja je odvisen predvsem od učiteljev, ki svoja znanja prenašajo na učence. Problem se pojavi, če učitelji ne sledijo načelu vseživljenjskega učenja in strokovnega izpopolnjevanja, saj le-ta predstavlja enega od temeljev profesionalnega razvoja učiteljev. Znanja, ki so jih pridobili $\mathrm{v}$ času svojega izobraževanja, na marsikaterem področju namreč postajajo zastarela.

Velik del profesionalnega razvoja učiteljev predstavlja njihovo formalno dodiplomsko izobraževanje ter formalna izobraževanja $\mathrm{v}$ sklopu stalnega strokovnega izpopolnjevanja, ne smemo pa spregledati tudi vloge neformalnih dejavnosti, ki nadgrajujejo profesionalni razvoj učitelja (Javornik Krečič, et al., 2015, 78).

Učenci zelo cenijo povezavo učnih vsebin z primeri iz realnega življenja, saj jih zaradi večje čustvene in miselne aktivacije bolje ponotranjijo in razumejo. Zaželeno je torej, da učitelj ni zgolj teoretični strokovnjak področja ki ga poučuje, pač pa da ima iz tega področja tudi kar se da veliko praktičnih izkušenj.

\section{Motivacija za dodatno strokovno izobraževanje}

Motivacija za dodatno strokovno izobraževanje je lahko notranja ali zunanja, včasih pa celo skupek obeh. Ko je govora o notranji motivaciji, posameznik ne potrebuje nagrade ali kazni za takšno izobraževanje, končni cilj pa nima takšnega pomena kot sam proces izobraževanja, v katerem posameznik uživa. Gre torej za željo po osebnem razvoju na določenem strokovnem področju ali pa na novih področjih, ki jih posameznik šele želi spoznati.

$\mathrm{V}$ primeru zunanje motivacije je cilj bistveno pomembnejši od procesa. Zaradi sistema napredovanja zaposlenih $\mathrm{v}$ vzgoji in izobraževanju, kjer zaposleni napredujejo $\mathrm{v}$ nazive z zbiranjem točk, ki jih lahko pridobijo tudi z določenimi izobraževanji, je takšnih primerov zelo veliko. Vendar obstaja nevarnost, ki jo izpostavi Razdevšek Pučkova $(2000,26)$, da učitelji pogosto ne iščejo programov za osebni razvoj ampak za ohranitev ali pridobitev službe. Posledično se udeležba na izobraževalnih programih pogosto sprevrže zgolj v zbiranje točk.

Razvoj učitelja je odvisen tudi od vodenja šole, šolske kulture in vzdušja. Šolsko vzdušje in kultura lahko omogočata ali omejujeta posameznikov razvoj, zato je treba oblikovati in ohranjati pozitivno šolsko klimo, ki bo podpirala posameznikovo spreminjanje, napredek in rast (Javornik Krečič in Ivanuš Grmek, 2008, 60). 
V raziskavi, kjer je Hribernikova $(2009,42)$ učitelje spraševala, ali sta izobraževanje in usposabljanje učiteljev potrebna, je od anketiranih dobila $100 \%$ pozitiven odziv, hkrati pa navedla še nekaj obrazložitev, zakaj sta potrebna:

- da sledijo stalnim novostim;

- zaradi nenehnih sprememb v učnem načrtu;

- da izmenjujejo izkušnje;

- s tem dvignejo kakovost dela;

- dobijo več idej za predstavljanje snovi;

- za osebnostno rast.

\section{Načini dodatnega strokovnega izobraževanja}

Učitelj se lahko dodatno strokovno izobražuje na več načinov. Najbolj atraktivna oblika so seminarji, objavljeni $\mathrm{v}$ Zavodovem katalogu nadaljnjega izobraževanja in usposabljanja, saj ta izobraževanja prinašajo točke za napredovanje v nazive. Vršnik in drugi $(2012,32)$ pravijo, da je pri nas je od leta 1998 področje stalnega strokovnega izpopolnjevanja urejeno s Pravilnikom o strokovnem spopolnjevanju, izobraževanju in usposabljanju strokovnih delavcev v vzgoji in izobraževanju in o postopku za izbiro programov (Uradni list 1998/80). Z njim smo dobili utečen sistem oblikovanja, zbiranja in objavljanja verificiranih programov (vsakoletni katalog), pestro ponudbo, povezave z drugimi (formalnimi) oblikami študija in povezanost $\mathrm{s}$ sistemom učiteljevega napredovanja v nazive.

Seveda se učitelji lahko dodatno strokovno izobražujejo tudi samoiniciativno, z željo po osebnem razvoju, ki ni pogojeno s pridobivanjem točk. Takšni načini so tudi bolj povezani z osebnim interesom, zaradi česar se jih lotevajo bolj zavzeto in od njih pridobijo bistveno večjo korist. Sem spadajo branje strokovne literature, obiskovanje tematskih konferenc, strokovna usposabljanja, strokovni seminarji, ipd.

V današnjem času, so vse bolj atraktivni tudi spletni tečaji in seminarji. Le-te za tečajnika predstavljajo udobno obliko udeležbe, saj jih lahko opravlja v svojem prostem času iz domačega naslonjača, ali iz katerekoli druge lokacije, ob uporabi računalnika ali pametne naprave, povezane $\mathrm{v}$ internet. Poleg novega znanja, nudijo tudi možnost pridobitve certifikatov, kar še poveča njihovo dodano vrednost. Seveda pa takšna izobraževanja predstavljajo tudi past, saj kljub pridobljenim teoretičnim znanjem in certifikatih, udeleženec takšnih seminarjev ni deležen praktičnih znanj iz realnega okolja. Takšna znanja lahko pridobi zgolj z delom v podjetju.

\section{$4 \quad$ Predstavitev programa DPKU}

Pilotni program »Dvig poklicnih kompetenc učiteljev« (v nadaljevanju DPKU) je nastal kot odziv na potrebe trga dela in delodajalcev, ki so s hitro napredujočo tehnologijo primorani slediti modernizaciji in novim načinom dela v podjetjih, ter izobraževalcev, ki 
se v danih okoliščinah na spremembe ne morejo vedno odzivati dovolj hitro. Pogosto ostajata trg dela in izobraževanje premalo povezana, dijaki so na trgu dela nekonkurenčni, podjetja pa morajo dijake dodatno usposobiti, da lahko začnejo delati.

Temeljni namen programa DPKU je bil spodbuditi in podpreti usposabljanje učiteljev strokovnih modulov (strokovne teorije in praktičnega pouka) ter drugih strokovnih delavcev (organizatorji praktičnega izobraževanja, organizatorji praktičnega usposabljanja $\mathrm{z}$ delom) srednjih poklicnih in strokovnih šol v podjetjih, jim omogočiti osvežitev njihovih obstoječih in pridobitev novih znanj, spretnosti in kompetenc ter s tem prispevati k dvigu kakovosti poklicnega izobraževanja in usposabljanja. Posledično pa tudi $\mathrm{k}$ povečanju zaposlitvenih možnosti in dolgoročne konkurenčnosti, spodbujanju inovativnosti in krepitvi povezovanja izobraževanja s trgom dela (Žnidaršič, et al., 2015, 18).

Program določa izvedbo krožnega zaposlovanja. To pomeni, da se za učitelja, ki se udeleži usposabljanja na šoli pridobi oz. zaposli nadomestnega učitelja. Nadomestni učitelj je $\mathrm{v}$ tem primeru lahko brezposelna oseba $\mathrm{z}$ ustrezno izobrazbo, lahko pa ga zagotovi kar podjetje, ki je učitelja vzelo na usposabljanje.

Operacijo sta delno financirala Evropska unija iz Evropskega socialnega sklada ter Ministrstvo za izobraževanje, znanost in šport. Slednje je določilo Center RS za poklicno izobraževanje za izvajalca programa, ki je bil zadolžen za pripravo in izvedbo javnega poziva šolam $\mathrm{k}$ sodelovanju $\mathrm{v}$ programu, koordinacijo izvedbe usposabljanj ter spremljanje in evalvacijo izvedbe programa. Imel je tudi vlogo spodbujevalca tesnejšega in učinkovitejšega sodelovanja in povezovanja izobraževanja in sfere dela, kar ustvarja pogoje za pretok strokovnega in pedagoškega znanja na način, da delodajalci učitelje seznanjajo z znanji, potrebnimi v modernih podjetjih, ti pa jih posredujejo dijakom, ki na trg dela vstopajo s potrebnimi znanji, ki jih delodajalci od njih pričakujejo (Žnidaršič, et al., 2015, 18).

\section{$5 \quad$ Primer dobre prakse}

Kot učitelj strokovno tehniških predmetov iz področja računalništva, sem po nekaj več kot sedmih letih dela $v$ šoli začutil pomanjkanje delovnega ritma $v$ podjetju in pridobitev novih in aktualnih strokovnih znanj. Sodobna tehnologija se hitro spreminja in napreduje, zato so znanja pridobljena $\mathrm{z}$ formalnim izobraževanjem, ki sem jih pridobil $\mathrm{v}$ okviru študija, postala zastarela.

Za dvig poklicnih kompetenc, oziroma za opravljanje praktičnega usposabljanja $\mathrm{v}$ podjetju sem izbral podjetje Elektronika Strniša d.o.o., ki se ukvarja z računalniškim inženiringom. Pri izbiri podjetja se mi je zdelo pomembno predvsem to, da bo zagotovilo mentorja, ki bo svoja znanja nesebično delil, mi strokovno svetoval in pomagal. Podjetje na prakso ( $v$ okviru poklicnega usposabljanja dijakov PUD) jemlje tudi naše dijake, ki so $\mathrm{z}$ opravljeno prakso zelo zadovoljni. Iz tega sem lahko sklepal, da imajo v podjetju tako strokovno, kot tudi pedagoško znanje za delo z tistimi, ki so željni novih znanj. 
$36^{\mathrm{TH}}$ International Conference on ORganizational Science Development: RESPONSIBLE ORGANIZATION (MARCH $22^{\mathrm{ND}}-24^{\mathrm{TH}}$, PORTOROŽ SlOVENIA)

G. Strniša: Improving the Vocational Competencies of Teachers with Training at the Enterprise

$\mathrm{Z}$ dvomesečnim delom $\mathrm{v}$ podjetju sem pridobil aktualna strokovna znanja povezana $\mathrm{Z}$ računalniškimi sistemi, sistemsko administracijo, omrežji, obdelavo podatkov, oblikovanjem spletnih vsebin, ipd. Delo je večinoma obsegalo diagnostiko in servis tako strojne kot tudi programske opreme, računalnikov in perifernih naprav. Izdelati, posodobiti in urejati je bilo potrebno spletne strani podjetja in strank. Konfigurirali smo tudi nekaj omrežnih naprav in vzpostavili delujoča omrežja.

Delo v podjetju mi je na dnevni osnovi predstavljalo nove izzive, za katere sem moral uporabiti stara znanja, vsekakor pa pridobiti tudi mnoga nova. Mentor mi je skozi celoten proces nudil strokovno pomoč in podporo, da so vsi problemi na koncu dobili tudi svoje rešitve. Pri takšnem načinu izobraževanja je udeleženec deležen neprecenljive izkušnje, ki bi jo moral na vsakih nekaj let ponoviti.

Pridobljene kompetence:

- Poznavanje sodobnih računalniških komponent;

- Poznavanje sodobnih računalniških sistemov;

- Poznavanje novosti na področju operacijskih sistemov;

- Poznavanje novosti na področju programskih jezikov;

- Poznavanje novosti na področju izdelave in oblikovanja spletnih strani;

- Reševanje težav na področju servisiranja računalnikov in računalniške opreme;

- Poznavanje in uporaba sodobnih tehnologij za računalniška omrežja;

- Ipd.

Od projekta pa zagotovo nima koristi le učitelj, pač pa tudi podjetje, ki učitelja vzame na opravljanje strokovnega izpopolnjevanja. S tem podjetje pridobi dodatnega delavca, ki lahko na začetku opravlja manj zahtevna dela, proti koncu projekta pa tudi že zahtevnejše naloge, ki jih tako ni potrebno narediti redno zaposlenim delavcem v podjetju.

Projekt bi priporočal vsem učiteljem ne glede na področje, ki ga poučujejo. Še posebej pa bi ga priporočal učiteljem, ki nikdar niso bili zaposleni v podjetju.

\section{Evalvacija programa}

Po zaključenih usposabljanjih učiteljev in strokovnih delavcev (v začetku aprila 2015) je bila opravljena obsežna evalvacija programa, $v$ okviru katere je bilo anketiranih skoraj 100 deležnikov programa, vodstva šol, učitelji/strokovni delavci, ki so se udeležili usposabljanja, gostiteljska podjetja, osebe, ki so nadomeščale odsotne učitelje na šolah, in vse šole, ki v programu niso sodelovale (Žnidaršič, et al., 2015, 23).

Uporabljena je bila deskriptivna raziskovalna metoda $\mathrm{z}$ vprašanji odprtega tipa. Opredeljena je bila naslednja temeljna hipoteza: 
1. Učitelji oziroma strokovni delavci srednjih poklicnih in strokovnih šol potrebujejo in si želijo strokovno usposabljanje.

Opredeljeni sta bili tudi naslednji raziskovalni hipotezi:

1. Učitelji oziroma strokovni delavci srednjih poklicnih in strokovnih šol so izkazali interes za vključitev v program »Dvig poklicnih kompetenc učiteljev«.

2. Učitelji oziroma strokovni delavci srednjih poklicnih in strokovnih šol želijo slediti novostim na trgu dela s področja, na katerem poučujejo.

V nadaljevanju so podani odgovori na vprašanja vprašalnika namenjenega učiteljem, ki sem ga izpolnil kot učitelj, ki se je udeležil programa DPKU. Predstavljena je tudi potrditev hipotez.

V: Ali je po vašem mnenju dvomesečna strnjena oblika krožnega zaposlovanja ustrezna?

O: Dvomesečna strnjena oblika krožnega zaposlovanja se mi zdi ustrezna, saj se je v tem času možno prilagoditi na novo delovno okolje in spoznati večino delovnih procesov tega delavnega mesta.

V: Ali je bil po vašem mnenju termin, v katerem ste se usposabljali, ustrezen?

O: Termin sem lahko izbral sam, tako da se mi od vseh razpoložljivih terminov zdi najbolj ustrezen.

V: Ali ste bili zadovoljni z izbiro podjetja?

O: Tudi podjetje sem lahko izbral sam, tako da sem z izbiro podjetja zelo zadovoljen.+

V: V kolikšni meri ste bili z mentorjem zadovoljni?

O: Mentor je moj sorodnik in mi je pri delu in učenju veliko pomagal. Že pred programom sem se pogosto obrnil nanj po nasvete in izkušnje iz prakse, a zaradi rednih pedagoških obveznosti bolj poredko in $\mathrm{v}$ skromnem časovnem obsegu. $\mathrm{Z}$ mentorjem sem izredno zadovoljen.

V: Ali ste bili v podjetju neposredno vključeni $\mathrm{v}$ delovni proces in imeli konkretne zadolžitve?

O: Seveda. Sprva sem bil v delovnem procesu res samo opazovalec, proti koncu, pa sem samostojno opravljal naloge in s tem razbremenil zaposlene.

V: Ali ste $\mathrm{v}$ času usposabljanja v podjetju sodelovali z osebo, ki vas je nadomeščala $\mathrm{v}$ šoli? 
$36^{\mathrm{TH}}$ International Conference on ORganizational Science Development: Responsible Organization (MARCh $22^{\mathrm{ND}}-24^{\mathrm{TH}}$, PORTOROŽ Slovenia)

G. Strniša: Improving the Vocational Competencies of Teachers with Training at the Enterprise

O: Takšnega sodelovanja v času usposabljanja ni bilo, saj sem osebi ki me je nadomeščala $\mathrm{v}$ šoli že pred pričetkom dela predal vse potrebne informacije in gradiva.

V: Ali ste poleg usposabljanja v podjetju opravljali tudi določene naloge v šoli?

O: $\mathrm{V}$ šoli sem se udeležil določenih konferenc in pomembnih sestankov povezanih s promocijo šole.

V: Ali je vodstvo šole spremljalo potek vašega usposabljanja?

O: Vodstvo šole je potek usposabljanja spremljalo z informativnim poizvedovanjem. Ravnateljica in koordinatorka projekta na šoli sta prišli tudi na delovni obisk v podjetje.

$\mathrm{V}$ : Ali boste lahko pridobljeno znanje/kompetence v podjetju uporabili pri svojem delu v šoli?

O: Nedvomno bom pridobljena znanja in kompetence lahko vključil v svoje delo, tako pri delu v razredu kot pri drugih obveznostih in zadolžitvah.

V: Ali je usposabljanje v podjetju v celoti izpolnilo vaša pričakovanja?

O: Več kot to. Pričakovanja so bila celo presežena.

V: Na kratko opišite, katere prednosti ima po vašem tovrstna oblika krožnega zaposlovanja?

O: Prednosti so seveda pridobitev izkušenj, poznanstev in novih znanj za učitelje. Od tega imajo korist tudi dijaki in šola.

$\mathrm{V}$ : Na kratko napišite, katere pomanjkljivosti ima po vašem mnenju tovrstna oblika krožnega zaposlovanja?

O: Velika pomanjkljivost je pomanjkanje didaktičnih in pedagoških znanj nadomestnih učiteljev. Prav tako je pri nekaterih izmed njih vprašljiva tudi motivacija za delo, ki traja zgolj dva meseca.

V: Ali je po vašem mnenju vaša odsotnost vplivala na organizacijo dela in uresničevanje zastavljenih ciljev izvedbenega kurikula v šoli?

O: Da. Za nekatera dela so potrebne izkušnje in dodatna znanja, ki jih nadomestni učitelj ni imel. Prav tako ni imel vseh potrebnih strokovnih znanj, zaradi česar so bile potrebne prilagoditve pri razporeditvi učnih vsebin.

V: Ali bi se ponovno udeležili usposabljanja? 
G. Strniša: Dvig poklicnih kompetenc učiteljev z usposabljanjem v podjetju

O: Seveda. Takšnega usposabljanja bi se rad udeležil vsako leto, ali pa vsaj na vsake dve leti.

V: Ali bi usposabljanje priporočili tudi drugim učiteljem/strokovnim delavcem?

O: Prav vsak učitelj, ne glede na področje ki ga poučuje bi moral opraviti takšno usposabljanje, še posebej tisti, ki nikoli niso bili zaposleni v podjetju.

\section{V: Ali bi nam želeli še kaj sporočiti?}

O: Usposabljanje DPKU bi moralo biti za učitelje obvezno in ne zgolj opcijsko. Na ta način bi bili učitelji bolj kompetentni pri podajanju učne snovi, prav tako pa bi dijakom lahko predstavili svoja doživetja iz realnega sektorja, kar bi predstavljalo dodano vrednost njihovim predavanjem.

Na podlagi podanih odgovorov deležnikov ki so sodelovali v programu DPKU, in vseh ostalih deležnikov, sta bili potrjeni tako raziskovalni kot tudi temeljna hipoteza. Odgovori $\mathrm{v}$ tem prispevku zgolj potrjujejo potrditve vseh treh hipotez.

\section{$7 \quad$ Zaključek}

Družba znanja pred učitelje postavlja nove zahteve in pričakovanja, zato je tudi vloga učitelja v sedanjosti drugačna, kot je bila v preteklosti (Peklaj, et al., 2008, 5). Danes zgolj formalna izobrazba in delovne izkušnje, ki so jih učitelji pridobili pred pričetkom dela v šoli še zdaleč niso dovolj. Slediti morajo konceptu vseživljenjskega učenja in izpopolnjevanja, tako na področju pedagogike kot tudi na svojem strokovnem področju. Le to jih namreč lahko naredi boljše učitelje.

Po besedah Javornik Krečič in dr., $(2015,89)$, le lastno aktivno vključevanje učiteljev v vodenje svojega profesionalnega razvoja lahko prinese napredek na področju kakovostnega izobraževanja, prav tako pa lahko učitelji le skozi lastno aktivno vodenje tega procesa ob njem doživljajo tudi zadovoljstvo in s tem vsaj delno zmanjšujejo svoj stres.

Dijakom je v izobraževalnem procesu potrebno zagotoviti kar se da zanimivo podajanje učnih vsebin. Učitelji to najlaže dosežejo s povezovanjem teoretičnih vsebin in praktičnih primerov iz svojih izkušenj, ki so jih bili deležni v gospodarstvu. To posebej velja za strokovna področja za katera se dijaki izobražujejo, saj jim na tak način še dodatno približamo njihovo poklicno pot. Program DPKU je tako skoraj nujen za vse učitelje, saj prinaša bogato zakladnico novih znanj in izkušenj.

\section{Literatura}

Hribernik, B. (2009). Management izobraževanja učiteljev osnovnih šol. Zaključna projektna naloga, Univerza na primorskem, Fakulteta za management, Koper. 
1008 36 $6^{\text {Th }}$ International Conference on Organizational Science Development: RESPONSIBLE ORGANIZATION (MARCH $22^{\mathrm{ND}}-24^{\mathrm{TH}}$, PORTOROŽ SLOVENIA)

G. Strniša: Improving the Vocational Competencies of Teachers with Training at the Enterprise

Javornik Krečič, M. \& Ivanuš Grmek, M. (2008). Cooperative Learning and Team Culture in Schools: Conditions for Teachers Professional Development. Teaching and Teacher Education, 24 (1), str. 59-68.

Javornik Krečič, M. et al. (2015). Pedagoški delavci v strokovnem in poklicnem izobraževanju kot aktivni oblikovalci in usmerjevalci lastnega poklicnega razvoja. Revija za elementarno izobraževanje, 8 (3), str. 77-89.

Peklaj, C. et al. (2008). Izobraževanje učiteljev za nove kompetence za družbo znanja ter vloga teh kompetenc pri uresničeva--nju vzgojno izobraževalnih ciljev v šoli. Zaključno poročilo, Filozofska fakulteta, Ljubljana.

Razdevšek Pučko, C. (2000). Primerjalne prednosti in slabosti izobraževanja učiteljev v Sloveniji - II. del. Vzgoja in izobraževanje, 35 (5), str. 21-29.

Vršnik, T. et al. (2012). Profesionalni razvoj strokovnih delavcev v poklicnem in strokovnem izobraževanju. Evalvacijska študija - poročilo, Ljubljana.

Žnidaršič, H. et al. (2015). Dvig poklicnih kompetenc učiteljev. Poročilo o izvedbi programa, Ljubljana. 


\title{
Pričakovanja zaposlenih z vidika opolnomočenja
}

\begin{abstract}
ALEŠA SVETIC
Povzetek Razlogi, ki vplivajo na odločitev posameznika, da se odloči za ustanovitev lastnega podjetja so različni, posamezniki imamo namreč različne poglede na svojo poklicno pot, kariero, prevzemanje tveganja in podjetništvo. Večina avtorjev pa se strinja, da so dejavniki, ki pripeljejo do te odločitve preplet dejavnikov osebnostne narave in okolja.

V sodobnem času, ko se vodstva podjetij soočajo z nenehnimi izzivi, ko se pojavlja nova tehnologija in se delovna mesta hitro preoblikujejo zaradi česar so tudi odpuščanja sodelavcev pogostejša, domnevamo, da so posamezniki, ki izgubijo zaposlitev, velikokrat prisiljeni v ustavljanje svojih podjetij in vstopanje v podjetništvo.

V prispevku analiziramo kateri motivi so tisti, ki prepričajo posameznike, da se podajo na samostojno podjetniško pot. S tem namenom smo opravili kvantitativno empirično raziskavo, s katero ugotavljamo motive posameznikov v Sloveniji, ki so ustanovili svoje podjetje v času največje krize, od leta 2008 do leta 2014. Namen raziskave je ugotoviti, kako pomemben motiv je izguba zaposlitve .
\end{abstract}

KLJUČNE BESEDE: podjetništvo • izguba zaposlitve • finančna neodvisnost - uresničitev dobre ideje

NASLOV AVTORICE: dr. Aleša Svetic, Gea College, Fakulteta za podjetništvo, Dunajska cesta 156, 1000 Ljubljana, Slovenija, e-pošta: alesa.svetic@gea-college.si 
$36^{\mathrm{TH}}$ International Conference on Organizational Science DeVelopment: Responsible ORganization (MARCH $22^{\mathrm{ND}}-24^{\mathrm{TH}}$, PORTOROŽ SLOVENIA)

O. Arsenijević, M. Ferjan, I. Podbregar, P. Šprajc, D. Trivan \& Y. Ziegler

\title{
Employee Expectations Towards Empowerment
}

\begin{abstract}
ALEŠA SVETIC
Abstract The reasons that influence an individual's decision to set up a business are different, people have different views on their career paths, risk-taking process and entrepreneurship. Most authors would agree that factors that lead to this decision are combination of personal characteristics and the environment conditions.

Nowadays, when managers are faced with ongoing business challenges, new technology and transformation of jobs which results in dismissals of employees more often than in the past, we assume that those who lose their jobs, are often forced to become entrepreneurs.

In the article we analyze the motives that convince individuals for independent entrepreneurial path. With this purpose, we conducted a quantitative empirical study to analyze motives of individuals in Slovenia who founded companies in the peak of the crisis, from 2008 to 2014 . The main goal of the study is to determine how important motive is the loss of employment.
\end{abstract}

KEYWORDS: business - loss of employment • financial independence • realization of good ideas.

Correspondence Address: Aleša Svetic, Ph.D., Gea College, Faculty of Entrepreneurship, Dunajska cesta 156, 1000 Ljubljana , Slovenia, e-pošta: alesa.svetic@gea-college.si

DOI https://doi.org/10.18690/978-961-286-020-2.80

ISBN 978-961-286-020-2

(C) 2017 University of Maribor Press

Available at: http://press.um.si 


\section{Uvod}

Za današnje poslovno okolje so značilne stalne spremembe, ki so posledica intenzivne globalne konkurenca, napredne tehnologije ter spreminjajočih zahtev kupcev in porabnikov, ki želijo izdelke in storitve prilagojene svojim individualnim željam. Vse te spremembe zahtevajo spremembe tudi v samih podjetjih, potrebne so spremembe pri delu in v razmišljanju, zato podjetja intenzivno iščejo rešitve od katerih pričakujejo preživetje, pa tudi rast in razvoj.

Managerske tehnike se tako od materialnih in finančnih virov vse bolj obračajo $\mathrm{k}$ ljudem, ki naj bi predstavljali tisto konkurenčno prednost, ki je lastna podjetju in jo je težko posnemati. Zavedati se moramo, da tisto, kar je učinkovalo pred 10 oziroma 20 leti, danes preprosto ne deluje in da tudi dejavniki uspešnosti danes niso enaki tistim iz preteklih obdobij. Prav tako, pa velja poudariti, da sodobna načela ravnanja s sodelavci postajajo dejavnik uspeha in konkurenčnosti podjetja le tedaj, če so ustrezno implementirana in sprejeta s strani sodelavcev. Če so bili sodelavci v preteklih obdobjih namenjeni zgolj izvrševanju nalog in spoštovanju navodil vodij, želijo danes v delovnem procesu aktivno sodelovati in prispevati $\mathrm{k}$ izboljšavam pri delu.

Ker se spreminja narava del in nalog, se klasična delovna mesta preoblikujejo, spreminjajo pa se tudi vzorci vedenja pri delu. Pomembne so spremembe v vrednotah, normah, odnosih, prepričanjih in vedenju. Poudarjena je večja potreba po mnogoterih znanjih, nenehnem učenju in iskanju izvirnih rešitev. Varnost zaposlitve se zmanjšuje, saj dinamično preoblikovanje delovnih mest ne zagotavlja dolgoročno varne zaposlitve. Tako posamezniki v zameno za delovne dosežke in pripadnost ne morejo več pričakovati stalnosti zaposlitve, in skladno z miselnim okvirom posameznika, se spreminja tudi njegov odnos do dela. Za tiste, ki so prožni, hitro odzivni, inovativni in zmožni spreminjanja je to priložnost, za druge, ki tega niso sposobni pa grožnja. Ključno managersko vprašanje sodobnih podjetij je torej, kako ravnati s sodelavci in katera motivacijska orodja uporabiti, da bodo le ti pri delu zavzeti in ustvarjalni, obenem pa tudi zvesti in predani delavci.

Spremenjena narava del, povezana s spremenjenimi vzorci vedenja pri delu pokaže, da danes sodelavci pričakujejo večjo samostojnost pri delu in možnosti za dajanje pobud, želijo pa tudi sodelovati pri sprejemanju odločitev, ki se nanašajo na njihovo delo. Prav tako pa želijo potrditev, da sta učenje in rast $\mathrm{v}$ organizaciji vrednoti. Podjetniško razmišljanje managerjev je naklonjeno iskanju inovativnih poslovnih rešitev, zato je ključno vprašanje, kako iz potencialov sodelavcev dobiti največ kar je mogoče.

Opolnomočenje je eden od možnih odgovorov, saj gre za mehanizem oziroma način vodenja $s$ katerim se prenaša moč na sodelavce. $S$ tem jim je omogočena večja samostojnost pri sprejemanju odločitev, sprosti se njihov potencial ter motivacija za boljše delo. Opolnomočeni posameznik sprejema tudi odgovornost za svoje delovanje, medtem, ko ga vodja le usmerja ter poučuje. Izkušnje kažejo, da tradicionalni pristop $\mathrm{k}$ vodenju ljudi - vodenje z nadzorovanjem in ukazovanjem v spremenjenem okolju ne daje 
zadovoljivih rezultatov, prav tako tudi ne spodbuja kreativnih posameznikov in $\mathrm{s}$ tem ne zagotavlja zadostnih možnosti za razvoj intelektualnega kapitala (Svetic, 2010).

$\mathrm{V}$ prispevku analiziramo pričakovanja zaposlenih do posameznih sestavin opolnomočenja in preverimo odnos sodelavcev do opolnomočenja.

\section{Pričakovanja zaposlenih in motivacijski dejavniki na delovnem mestu}

Poznano je, da posamezniki pri delu različno vrednotijo različne stvari in si tudi postavljajo različne cilje. Nekateri si za cilj postavijo zaslužek, drugim plača ni tako pomembna, pač pa je pomembneje, da delajo tisto, kar jih zares veseli in zanima in želijo ob tem napredovati, doseči priznanje in ugled, tretji delajo zato ker nimajo druge izbire in jim zaposlitev pomeni varnost.

Da bi lahko ustrezno motivirali sodelavce moramo poznati njihove potrebe in pričakovanja. Nezadovoljene potrebe silijo človeka k aktivnosti, delovanju. Res je tudi, da je ljudi z veliko potrebo po dosežkih lažje motivirati kot tiste pri katerih je ta potreba manj izražena. Uspeh pa je odvisen od več dejavnikov, katerih vpliv je težko natančno izmeriti. Znanje, veščine, sposobnosti in vloženi napor so pomembni dejavniki uspeha. Motivi, ki spodbujajo dejavnike uspeha so številni, med njimi je tudi strah pred neuspehom. Poleg večdimenzionalnih potreb po uspehu so še prirojene, pridobljene in družbene potrebe, ki so neizčrpni motivatorji uspeha.

$\mathrm{V}$ vsakem podjetju tako najdemo sodelavce, ki se trudijo, da bi dosegli dobre delovne učinke in začrtane cilje ali jih celo presegli in seveda tudi take, ki so naravnani le k opravljanju nalog brez večjih izzivov. Prvi so pripravljeni na prevzemanje odgovornosti, iščejo priložnosti za inovacije, si postavljajo realne delovne cilje, želijo povratne informacije in ocene o svoji delovni uspešnosti, plačo pojmujejo kot merilo za delovno uspešnost ter ob rešenem problemu doživljajo zadovoljstvo.

Tisti pa, ki želijo predvsem rutinske naloge, brez večjih izzivov, ne potrebujejo povratnih informacij o svojem delu, niti niso pripravljeni na prevzemanje odgovornosti, čakajo na navodila in si postavljajo nizke cilje. Stimulira jih višja plača, večje zadovoljstvo čutijo ob tem, ko problem rešujejo, kot pa ob rešitvi.

Izzivov pri delu si prvenstveno želijo sodelavci, ki so usmerjeni k ciljem. Gre za tiste, ki imajo znanje in izkušnje na svojem delovnem mestu in želijo z delom pokazati kaj zmorejo. Če so vključeni v proces izboljšav ali če so celo sami pobudniki izboljšav , novostim sledijo sami. Za te mora management poskrbeti tako, da jih nenehno zaposluje z novimi poslovnimi izzivi, da jih opolnomoči, da lahko pokažejo svoje kompetence ter dosegajo dobre rezultate ter osebnostno rastejo. 
Večina raziskav (Svetic, 2013) pokaže, da so pričakovanja sodelavcev pri delu povezana predvsem z naslednjimi sestavinami dela:

- Samostojnim odločanjem o svojem delu z vidika prispevka k organizacijskim ciljem.

Sodelovanje pri oblikovanju skupnih ciljev in reševanju delovnih nalog poveča zavzetost za delo še posebej, če je nanje prenesena odgovornost za delovne rezultate. Dober način vodenja je zlasti vodenje s cilji in pretok povratnih informacij o tem koliko delo posameznika prispeva $\mathrm{k}$ skupnim ciljem.

- Uporabo kompetenc in razvojem kompetenc

Če imajo posamezniki priložnost, da znanja, sposobnosti, zmožnosti in hotenja, preizkusijo $\mathrm{v}$ konkretni delovni situaciji potem jih uporabijo za reševanje delovnih nalog in se $\mathrm{z}$ delom želijo dokazati. Ta pričakovanja so povezana $\mathrm{z}$ razporeditvijo na ustrezno delovno mesto.

- Učinkovitim prenosom informacij

Sodelavci so lahko uspešni pri delu, se pravilno odločajo le, če informacije, ki jih potrebujejo za delo dobijo pravočasno in so točne. Poleg pisne komunikacije, vizije, strategije je nujna tudi dvosmerna neposredna komunikacija med vodstvom in zaposlenimi, saj vodstva le na tak način lahko preverjajo, da so sodelavci informacije pravilno razumeli. Prenos informacij, ki poteka do najnižjih ravni, naj bi bil čim bolj neposreden in transparenten.

- Sodelovanjem v teamu

Prednosti teamskega dela so številne od lažjega obvladovanja kompleksnih poslovnih procesov, večje produktivnosti, boljše kakovosti izdelkov ali storitev, izboljšanja konkurenčnih prednosti, možnosti uvedbe participativnega načina vodenja, večje avtonomije do večjega motivacijskega učinka pri sodelavcih. Opolnomočenje, kot sodobna managerska tehnika omogoča samostojno odločanje, hitro ukrepanje ter prilagajanje spremembam v okolju. Seveda so teami učinkoviti le, če jih sestavljajo člani, ki medsebojne vloge uravnotežijo in utrdijo medsebojne vezi.

- Dobrim plačilom za dobro opravljeno delo.

Plačilo po delovni uspešnosti je samo eden od elementov celotne motivacijske sheme v organizaciji. Sistem nagrajevanja ima velik motivacijski naboj, če temelji na delovni uspešnosti. Pri tem pa mora biti prispevek posameznika merljiv in jasno opredeljen, tako da tudi drugi vidijo, zakaj je dobil nekdo več, drugi manj. Pomembne so tako delovne zadolžitve, kriteriji ocenjevanja (standardi) kot roki, 
prav tako strinjanje posameznika z zastavljenim ciljem oziroma s pričakovanim rezultatom. Prispevek k delovnim oziroma organizacijskim ciljem je ključ k uspehu in merilo plačila.

- Osebnostno rastjo in kariernim razvojem

Zlasti najbolj perspektivni sodelavci, ki dosegajo visoko delovno uspešnost in imajo velik razvojni potencial pričakujejo nenehne izzive pri delu, delovne zadolžitve pri katerih so opolnomočeni, pa tudi možnosti za napredovanje in razvoj.

\section{Opredelitev pojma opolnomočenje}

Obstaja veliko različnih opredelitev pojma opolnomočenje, vsem pa je bolj ali manj skupno, da gre za prenos moči na sodelavce oziroma pooblaščanje sodelavcev.

Pojem opolnomočenje (ang. »empowerment «) in obravnavo pojma $\mathrm{v}$ znanstvenih razpravah iz področjih družboslovja zasledimo $\mathrm{v}$ večjem obsegu predvsem v zadnjem desetletju, čeprav se pojem uporablja tudi na drugih znanstvenih področjih (Hur 2006, 523). Pojem je sicer poznan že dalj časa in v glagolski obliki »opolnomočiti« ali »to empower « naj bi izviral iz 17. stoletja. Podeliti ali podariti moč z namenom usposabljanja, omogočanja, dovoljenja se je uporabljal predvsem v pravnih kontekstih (Denham [et al.]2002, 272). V slovenščini je bila beseda »opolnomočiti« največkrat uporabljana V pravniškem jeziku kot sinonim za besedo »pooblastiti«. Pojem opolnomočenje se je danes V slovenščini uveljavil kot prevod angleškega izraza »empowerment«, ki ga prevzemajo na različnih znanstvenih področjih (Kamin 2006, 81).

Conger in Kanungo (1988) sta med prvimi, ki sta začela raziskovati in preučevati koncept opolnomočenja. Avtorja pojasnjujeta opolnomočenje $\mathrm{z}$ dveh zornih kotov, in sicer opolnomočenje kot motivacijski dejavnik ter opolnomočenje kot dejavnik medsebojnih odnosov. Prednost dajeta opolnomočenju z vidika motivacije, ter ga opredelita kot proces, ki omogoča zaposlenim, da svoje znanje in veščine s pomočjo dostopa do informacij uporabijo za uspešno opravljanje svojega dela. Opolnomočenje lahko obravnavamo tudi kot mehanizem, skozi katerega ljudje pridobijo večji nadzor nad svojim življenjem, saj pojem vključuje tudi kritično zavedanje svojega sociopolitičnega okolja in demokratično participacijo znotraj skupnosti (Peterson [et al.]2005, 234).

Opolnomočenje pa lahko preučujemo kot proces ali kot izid. Kot proces je opolnomočenje nepredvidljivo in se v različnih časih ter krajih precej spreminja. Kot glagol »opolnomočiti« pa gre za proces, preko katerega ljudje dobivajo nadzor in moč skozi svoj lastni trud da postajajo opolnomočeni (Hur 2006).

Opolnomočenje lahko pomeni tudi pravico in sposobnost sodelavcev, da sprejemajo odločitve in da te odločitve uresničujejo (Bitenc, 2009, 23). V organizacijah s tradicionalno hierarhijo sodelavci le izpolnjujejo ukaze in naročila managerjev, opolnomočeni posamezniki pa se za to, da bi dosegli cilje organizacije, naslanjajo na svojo pobudo. Gre za več delegiranega dela in več delegiranih odločitev. 
Daft in Noe $(2001,216-217)$ definirata opolnomočenje kot delegiranje moči ali avtoritete na podrejene v organizaciji. Opolnomočenje pomeni, da le ti dobijo večjo moč, več svobode in informacij, ki jih potrebujejo pri sprejemanju odločitev in polni vključenosti v organizacijo. Opolnomočenje je bistvenega pomena za učeče se podjetje, saj sprošča ustvarjalne potenciale vseh sodelujočih, jim omogoča eksperimentiranje, učenje ter hkrati daje dovolj svobode, da ukrepajo glede na svoje znanje. Opolnomočenje organizacijam pomaga obdržati kakovostne sodelavce $\mathrm{z}$ znanjem, zvišuje motivacijo ter moč pri odločanju.

Opolnomočenje je večdimenzionalni pojem, ki se je uveljavil na različnih znanstvenih področjih in disciplinah. Večdimenzionalnost pojma pa ne pomeni zgolj vpetosti $\mathrm{v}$ različna področja, temveč tudi kontekstualno specifičnost. Razumevanje pojma je tako odvisno od konteksta in ljudi, $\mathrm{v}$ povezavi s katerimi ga obravnavamo. Zato je opolnomočenje vedno treba analizirati v skladu z družbenim poljem, v katerem se vzpostavlja.

Opolnomočenje se pojavlja na različnih družbenih ravneh in sicer na individualni, organizacijski in družbeni ravni.

Proces opolnomočenja v organizaciji lahko poteka le tedaj, kadar so zagotovljeni osnovni elementi, ti pa so naslednji:

1. Moč za samostojno odločanje.

2. Informacije kot dostop do informacij o okoliščinah dela, vključno z informacijami o uspešnosti podjetja ter plačah.

3. Znanje in veščine, ki jih sodelavci potrebujejo za svoj prispevek k ciljem organizacije.

4. Nagrade kot povračilo za uspešnost delovanja. Nagrada je lahko tudi udeležba v dobičku ali možnost nakupa delnic podjetja.

\section{$4 \quad$ Uvedba procesa opolnomočenja v podjetje}

Proces opolnomočenja običajno pojmujemo kot kontinuum, ki sega od stopnje, kjer sodelavci nimajo pooblastil za odločanje, do stopnje, kjer so maksimalno opolnomočeni ter pomagajo vodjam oblikovati organizacijsko strategijo. Na najvišji stopnji so sodelavci pristojni za odločanje ter vplivajo na organizacijske cilje, strukture in sisteme nagrajevanja in sami tudi nadzirajo svoje delo. Takšno stopnjo opolnomočenosti imajo samousmerjajoči se timi, ki so na vrhu kontinuuma (Daft in Noe, 2001, 218).

Uvedba opolnomočenja v podjetje ne poteka samodejno, pač pa ga management uvaja korakoma kot proces, ki je skrbno načrtovan in premišljen. Poteka postopoma in skozi različne stopnje, potreben je celovit pristop ker gre za dolgotrajni proces, ki zahteva podporo celotnega managementa. Uvedba procesa opolnomočenja poteka hitreje in uspešneje $\mathrm{v}$ okolju kjer obstaja timsko delovanje, saj je decentralizacija odgovornosti poglavitna za izboljšanje procesa sprejemanja odločitev (Parker 2003, 2). 
Proces opolnomočenja lahko izvedemo korakoma po naslednji shemi (Holpp 1994, 42):

- Opredelitev organizacijskih ciljev ter ključnih procesov.

- Planiranje, z natančnimi opisi, kaj se pričakuje od posameznih timov, skupin in posameznih sodelavcev.

- Opredelitev dolžnosti, ki se bodo tekom procesa opolnomočenja prenesle na nižje hierarhične ravni. Pri tem je potrebno poudariti, da ni smiselno vseh procesov, ki se odvijajo v podjetju, vključiti v proces opolnomočenja.

- Merjenje rezultatov, ki je prav tako ključni korak pri opolnomočenju, saj le tako lahko vpleteni v proces dobijo povratno informacijo o uspešnosti svojega dela.

- Priprava diagrama omejitev, iz katerega je razvidno, kateri procesi so vključeni v opolnomočenje in kateri niso, tako si sodelavci lažje predstavljajo svoj položaj v procesu opolnomočenja.

Poleg naštetih korakov v procesu, pa so pomembne tudi glavne dimenzije izkustva moči, ki so osnova procesa opolnomočenja in sicer:

1. Moč kot zaznan nadzor : občutek zaznanega nadzora je bistven za občutek moči. Ob tem se zaposleni počutijo samozavestne in imajo občutek, da nadzorujejo svoje okolje. Nanaša se na prepričanja o avtonomiji pri načrtovanju in delovanju, dostopnosti virov, avtoriteti in svobodi pri odločanju.

2. Moč kot zaznana sposobnost : ljudje se običajnoi izogibajo situacijam, ki bi presegale njihove sposobnosti in se udeležujejo aktivnosti, ki jih obvladajo. Ob tem je posameznik prepričan, da lahko uspešno opravlja rutinsko delo in tudi vse izzive, ki se lahko pojavijo pri delu.

3. Ponotranjenje ciljev :naloga vodij oziroma njihovega stila vodenja je, da sodelavci ponotranjijo organizacijske cilje. Vodje oblikujejo idealizirane cilje in opolnomočijo sodelavce do te mere, da cilje ponotranjijo, kajti posameznik, ki verjame $v$ cilje jih je pripravljen tudi uresničiti.

\section{$5 \quad$ Raziskava}

\subsection{Opis metode, vzorca in uporabljenega instrumentarija}

Da bi raziskali odnos sodelavcev do opolnomočenja $v$ izbranem podjetju, smo opravili kvantitativno empirično raziskavo, s katero smo ugotavljali kakšna so pričakovanja sodelavcev na delovnih mestih ter njihov odnos do nekaterih sestavin opolnomočenja.

$\mathrm{V}$ ta namen smo uporabili metodo zbiranja podatkov $\mathrm{z}$ lastno oblikovano anketo in izvedli elektronsko anketiranje. Postavke so izražale mnenje, s katerim se anketirani lahko v določeni meri strinjajo oziroma ne strinjajo. Uporabili smo format ponujenih odgovorov v obliki: 1 -sploh se ne strinjam; 2 - se ne strinjam; 3 - niti da, niti ne; 4-se strinjam;5se popolnoma strinjam. 


\subsubsection{Splošni podatki}

Raziskavo smo opravili elektronsko, potekala je na Fakulteti za podjetništvo. V raziskavo je vključenih 69 anketiranih.

Struktura anketiranih po spolu je naslednja: največ anketiranih 79,1 odstotka (55), je moškega in 20,9 odstotka (14) pa je ženskega spola.

Glede starosti pa je struktura naslednja: povprečna starost anketiranih je 38,2 let, pri čimer je najmlajši star 18 let, najstarejši pa 62 let.

Največji delež 42,1 odstotka (29) anektiranih je doseglo univerzitetno, magistrsko ali celo višjo izobrazbo. Sledi delež 21,7 odstotka (15) tistih, ki imajo poklicno strokovno izobrazbo, ter z dokončano srednjo tehnično izobrazbo 18,8 odstotka (13). Le manjši delež 13 odstotkov (9) pa ima dokončano osnovno šolo in manj. Najmanjši delež pa predstavljajo tisti z dokončano višjo in visoko strokovno izobrazbo in sicer 4,3 odstotka (3).

Od skupnega števila anketiranih je delež strokovnih sodelavcev 50,7 odstotkov (35), operativnih pa 49,3 odstotka (34). Strokovni sodelavci so tisti, ki opravljajo zahtevna strokovna dela in od katerih se pričakuje visoka stopnja sodelovanja in vpletenosti $\mathrm{v}$ strukturo in procese podjetja, operativni sodelavci pa opravljajo manj zahtevne, rutinske naloge.

\subsection{Analiza in interpretacija rezultatov}

\subsubsection{Pričakovanja anketiranih na delovnem mestu}

Da bi ugotovil kakšna pričakovanja na delovnem mestu imajo anketirani smo jim ponudili naslednji nabor pričakovanj na delovnem mestu:

1. Želim si, da bi imel možnost večino odločitev sprejeti sam,

2. Želim si možnosti podaje predlogov, novih idej in metod glede dela,

3. Želim si, da bi nadrejeni upoštevali moje ideje in predloge

4. Želim si, da bi nadrejeni moje predloge in ideje natančno preučijo

5. Želel bi, da bi se v primeru sprememb, ki se navezujejo na moj delovni proces, nadrejeni z menoj predhodno posvetovali

6. Želim da bi se nadrejeni posvetoval z menoj v primeru odločitev, ki so povezani z mojim delom

7. Želim si, da bi imel moč, da bi odločal o zadevah povezanih z mano

8. Želim si pomembne odgovornosti pri svojem delu

9. Želim doseči tisto, kar želi doseči organizacija

10. Želim si, da v delovnem okolju vlada sproščeno vzdušje

11. Želim si, da se moje delo spoštuje in ceni 
1018 36 $6^{\mathrm{TH}}$ INTERnational CONFERENCE ON ORganizational SCIENCE DeVElopment: Responsible Organization (MARCh $22^{\mathrm{ND}}-24^{\mathrm{TH}}$, PORTOROŽ Slovenia)

A. Svetic: Employee Expectations Towards Empowerment

Posamezne postavke iz nabora so anketirani ocenili glede na svoja pričakovanja na lestvici od 1-5 pri čimer pomeni 1 - sploh se ne strinjam; 2 - se ne strinjam; 3 - niti da, niti ne; 4 -se strinjam;5- se popolnoma strinjam.

Ocenjevali so jih strokovni sodelavci in operativni sodelavci.Rezultati odgovorov obeh skupin so naslednji: anketirani strokovni sodelavci želijo predvsem, da se njihovo delo ceni in spoštuje $(4,91)$, da pri delu vlada sproščeno vzdušje $(4,86)$, da bi imeli večjo moč pri posvetovanju glede odločitev o delu $(4,80)$, ter da bi dosegli tisto, kar želi doseči organizacija (4,77). Možnosti podajanja predlogov, novih idej in metod glede dela so ocenili s povprečno oceno 4,34, da bi nadrejeni upoštevali njihove ideje in predloge pa s 4,43. Iz rezultatov njihovih odgovorov sklepamo, da imajo pri delu dovolj možnosti podajanja idej in predlogov, ter da se jih tudi upošteva. Vsa druga pričakovanja so ocenjena na vrednostni lestvici med 3 in 4.

Operativni sodelavci pa želijo predvsem, da se njihovo delo spoštuje in ceni $(4,18)$ ter $d a$ bi vladalo sproščeno vzdušje pri delu $(4,15)$. Najmanj pa si želijo, da bi se nadrejeni $v$ primeru sprememb, ki se navezuje na njihovo delo, z njimi predhodno posvetovali $(3,44)$ ter da bi nadrejeni njihove predloge in ideje natančno preučili $(3,59)$. Moči odločanja $o$ zadevah povezanih $s$ svojim delom si bolj želijo strokovni sodelavci $(4,80)$ kot operativni sodelavci $(3,68)$, povprečje obeh skupin pa je 4,25 . Zanimivo pri operativnih sodelavcih je predvsem to, da si želijo, da so cenjeni in spoštovani, manj pa, da so opolnomočeni. Na podlagi tega bi lahko sklepali ali, da operativni sodelavci niso pripravljeni prevzemati večjih pooblastil za odločitve in da se tega morda celo bojijo, ali pa, da sprejemajo svoje delo le kot izpolnjevanje ukazov in naročil.

Iz rezultatov razberemo, da se pričakovanja med obema skupinama razlikujejo, ter, da opolnomočenju pripisujejo večji pomen strokovnjaki kot pa operativni sodelavci.

\subsubsection{Stališča anketiranih do nekaterih elementov opolnomočenja}

V kolikšni meri zaznavajo opolnomočenje anketirani iz obeh skupin smo ugotavljali v nadaljevanju. Anketiranim smo ponudili naslednji nabor trditev, ki opisujejo dejavnike opolnomočenja na delovnem mestu:

1. Imam možnost, da sam sprejemam odločitve Imam možnost podaje predlogov in idej glede dela

2. Imam možnost podajanje rešitev glede dela Imam možnost podajanja novih metod dela

3. Nadrejeni upoštevajo moje ideje in predloge

4. Dobim povratne informacije, zakaj moja ideja oz. predlog ni bil sprejet

5. V primeru sprememb, ki se navezujejo na moj delovni proces, se nadrejeni $z$ menoj predhodno posvetujejo

6. Svoje delo ocenjujem kot učinkovito

7. Pri svojem delu imam pomembno odgovornost

8. Navdihuje me tisto, kar želi doseči organizacija

9. Lahko se spopadam z izzivi, s katerimi se soočam pri delu 


\section{Sodelavcem pomagam pri reševanju njihovih problemov}

\section{V delovnem okolju vlada sproščeno vzdušje}

12. V organizaciji se moje delo spoštuje in ceni

Rezultati raziskave pokažejo, da se stališča do nekaterih elementov po katerih merimo opolnomočenje v podjetju razlikujejo glede na vrsto dela v podjetju. Tako anketirani strokovni sodelavci višje zaznavajo stopnjo opolnomočenja, kot anketirani operativni sodelavci. Anketirani strokovni sodelavci so najvišje ocenili trditve glede moči oz. možnosti sprejemanja odločitev $(4,77)$, da imajo pri svojem delu pomembno odgovornost $(4,71)$ ter da je svoje delo ocenjujejo kot učinkovito $(4,71)$. Nižje so ocenili, da v delovnem okolju vlada sproščeno vzdušje $(4,20)$ in da dobijo dovolj povratnih informacij, zakaj njihova ideja oziroma predlog ni bil sprejet $(4,09)$. Vse druge trditve so ocenili na vrednostni lestvici med 4 in 5.

Operativni sodelavci pa so najvišjo povprečno ocene dali trditvi, da je njihovo delo učinkovito $(3,98)$, da imajo pri svojem delu pomembno odgovornost $(3,85)$ ter da jih navdihuje tisto, kar želi doseči organizacija $(3,79)$. Najnižje pa so ocenili trditvi, da dobijo dovolj povratnih informacij, zakaj njihova ideja oziroma predlog ni bil sprejet $(3,12)$ in $d a v$ delovnem okolju vlada sproščeno vzdušje $(3,21)$. Vse ostale trditve so ocenili na vrednostni lestvici med 3 in 4, torej za eno oceno manj kot strokovni nivo. Tudi sicer so rezultati med obema skupinama. Nižji rezultati operativnih sodelavcev $\mathrm{v}$ povprečju navajajo na sklepanje, da se tej skupini sodelavcev morda daje manj možnosti za sodelovanje, odločanje, podajanje idej, vplivanje na delovni proces in podobno v primerjavi s strokovnimi sodelavci.

V skupnem povprečju so anketirani strokovni in operativni sodelavci najbolje ocenili trditve, da je njihovo delo učinkovito $(4,35)$ ter da imajo pri svojem delu pomembno odgovornost (4,29). Sledijo še vedno dobro ocenjene trditve, da imajo moč oziroma možnost odločanja $(4,12)$ da jih navdihuje tisto, kar želi doseči organizacija, podajanja predlogov $(4,07)$ ter da se vorganizaciji spoštuje in ceni njihovo delo $(4,04)$. Na skupnem povprečju vseh anketiranih, so najslabše ocenili trditvi, da dobijo dovolj informacij zakaj njihov predlog oziroma ideja ni bila sprejeta $(3,61)$ ter da v delovnem okolju vlada sproščeno vzdušje $(3,71)$. Ostale trditve pa so anketirani ocenili nižje.

Pri ugotavljanju nekaterih dejavnikov opolnomočenja smo nadalje preverjali ali obstajajo statistično značilne razlike med obema skupina anketiranih. Zato smo izvedli še enosmerno analizo variance (anova), s katero smo ugotavljali statistično pomembne razlike med obema skupinama anketiranih. Rezultati analize so pokazali, da pri vseh trditvah, z izjemo pri trditvi lahko se spopadam z izzivi, s katerimi se soočam pri delu, med anketiranimi strokovnimi in operativnimi delavci, prihaja do statistično pomembnih razlik, saj so rezultati povsod manjši od 0,005 . To pomeni, da dejansko obstaja tudi različno dojemanje stopnje opolnomočenja med anketiranimi v obravnavani organizaciji.

Sklepamo lahko, da se stališča anketiranih strokovnih sodelavcev do obravnavanih elementov opolnomočenja razlikujejo od stališč operativnih sodelavcev. Strokovni sodelavci očitno drugače dojemajo opolnomočenje kot operativni sodelavci. 
$1020 \quad 36^{\text {TH }}$ International Conference ON ORganizational SCIENCE Development: Responsible Organization (MARCh $22^{\mathrm{ND}}-24^{\mathrm{TH}}$, PORTOROŽ Slovenia)

A. Svetic: Employee Expectations Towards Empowerment

Domnevamo, da je različno dojemanje opolnomočenja povezano z različno naravo del ter $\mathrm{z}$ različnimi zadolžitvami in odgovornostmi na delovnih mestih.

\section{$6 \quad$ Zaključek}

Razlogi za uvedbo opolnomočenja v podjetje so različni, največkrat pa opolnomočenje povezujemo s strateško potrebo po izboljšanju proizvodov in storitev, pa tudi s podobnimi ravnanji drugih podjetij ter $\mathrm{z}$ uvedbo učeče se organizacije s superiornimi zmogljivostmi za doseganje uspešnosti (Daft ,2012).

Opolnomočenja je predvsem razvoj sodelavcev, ki na ta način postajajo učinkoviti samovodje, sposobni samoiniciativno delovati in sprejemati odločitve. Poleg tega pa jim moč in samostojnost, ki jo z opolnomočenjem pridobijo pomagata do večje motivirani za delo, večje samoiniciativnosti in pripravljenosti na prevzemanje tveganja.

S psihološkega vidika opolnomočenje izboljša samopodobo posameznika, poveča zavzetost za izboljšave ter pomaga do visoke vpletenosti v delovno mesto ter procese (Smith 1997, 121). Raziskave potrjujejo (Sigler in Pearson 2000, 45), da opolnomočeni zaposleni dosegajo večjo učinkovitost pri delu in so bolj predani, saj jim večja odgovornost pri delu in razpolaganje $\mathrm{z}$ informacijami dajejo občutek pomembnosti. Možnost sprejemanja odločitev pogosto tudi poveča pozitivno mnenje o managementu in podjetju, poveča pa se tudi zadovoljstvo z delom.

Seveda pa pri procesu opolnomočenja lahko naletimo tudi na različne ovire. Odpor lahko prihaja tako s strani managementa kot s strani sodelavcev. Pomisleki pri managementu običajno nastanejo pri prenosa določenih zadolžitev, pooblastil in odgovornosti na sodelavce zaradi nezaupanja. Lahko je prisoten tudi strah pred izgubo moči in vodilne pozicije ter bojazen pred izgubo nadzora. Nekateri managerji, ki so nagnjeni k popolnosti ne želijo prenašati svojih pooblastil na sodelavce tudi zato, ker zahtevajo, da se naloge izvajajo tako, kot želijo sami in ne pristajajo na drugačne načine dala. (Greasley [et al.]2005, 358).

Ena večjih ovir pri prenosu pooblastil pa je povezana z odrekanjem finančnih pooblastil. Ker je moč managementa neposredno povezana $\mathrm{z}$ razpolaganjem s finančnimi sredstvi, managerji pogosto razmišljajo, da bodo s prenosom pooblastil izgubili moč. Če pa sodelavci ustreznih pooblastil in virov nimajo, ne morejo uspešno opraviti svojega dela, torej proces opolnomočenja brez pooblastil ni mogoč (Bitenc 2009, 23). Seveda opolnomočenje ne pomeni, da menedžerji z njim izgubijo moč nagrajevanja ali kaznovanja.

Pogosto pa je ovira pri prenosu pooblastil povezana tudi z organizacijsko kulturo oziroma strahom pred spremembami ter odporom do prevzemanja obveznosti ter bojaznijo pred neuspehom. Če se podjetje iz napak lahko nauči česa novega, mora napake v nekem razumnem obsegu dovoliti. Ne sme pa dovoliti ponavljanja enakih napak $\mathrm{v}$ enakih okoliščinah. Premalo možnosti za izobraževanje je tako lahko resna ovira, ki tudi zavre proces opolnomočenja. 
$\mathrm{Na}$ stani sodelavcev pa ovire pogosto nastajajo zaradi zmotne želje le teh po večji odgovornosti, pooblastilih ter moči, ko pa jim management želi to predati, pa si tega ne želijo več in v tem ne vidijo dodatnega izziva, pač pa strah pred dodatnimi obremenitvami (Greasley [et al.]2005, 358-361).

Možne ovire na strani sodelavcev so še pomanjkanje znanja, nejasno opredeljene naloge in pristojnosti ter pomanjkanje timskega dela .

Da proces opolnomočenja lahko uspešno deluje, je polega naštetega potrebno zaupanje, poštenost in odkritost med vsemi vpletenimi, kajti le $\mathrm{v}$ takem ozračju se lahko uspešno izvede prenos delovnih nalog, pooblastil in odgovornosti za odločanje na nižje hierarhične ravni (Greasley [et al.]2005, 358-361).

Proces opolnomočenja, po teoretični in praktični strani, lahko vnese v podjetje veliko prednosti, ki še povečajo konkurenčne sposobnosti podjetja. Seveda pa mora biti proces izveden premišljeno in skrbno, sicer nastopijo ovire, ki proces zavrejo.

$\mathrm{Z}$ empirično raziskavo smo ugotovili, da imajo anketirani v preučevanem primeru pozitiven odnos do opolnomočenja, si ga želijo ter ga povezujejo s svojimi pričakovanji na delovnem mestu, pa tudi, da se pričakovanja glede opolnomočenja razlikujejo, glede na vrsto dela, ki ga posamezniki opravljajo v podjetju.

\section{Literatura}

Bitenc. Mateja. 2009. Osnove upravljanja in organizacija poslovanja. Ljubljana: Zavod IRC.

Conger, Jay. A., in Rabindra N. Kanungo. (1988). The Empowerment Process: Integrating Theory and Practice. The Academy of Management Review, 13(3), 471-482.

Daft, Richard, L in Dorothy Maricic. 2011. Understanding management (6th ed.). Australia.

Denham Lincoln, Nicola, Cheryl Travers, Peter Ackers in Adrian Wilkinson. 2002. The meaning of empowerment: The interdisciplinary etymology of a new management concept. International Journal of Management Reviews 4 (3): 271-90.

Greasley, Kay, Nicola King, Alan Bryman, Andrew Dainty Price in Robby Soetanto. 2005. Employee perceptions of empowerment. V Employee Relations, 27, 4, 354-368.

Hur, Mann Hyung. 2006. Empowerment in terms of theoretical perspectives: Exploring a typology of the process and components across disciplines. Journal of Community Psychology 34 (5): 523-40.

Kamin, Tanja. 2006. Zdravje na barikadah: Dileme promocije zdravja. Ljubljana: Fakulteta za družbene vede.

Parker, M. Glenn. 2003. Cross-Functional Teams: Working with Allies, Enemies, and Other Strangers. (2nd ed.) San Francisco: Jossey-Bass.

Peterson, N. Andre, John B Lowe in Mary L. Aquilino. 2005. Linking social cohesion and gender to intrapersonal and interactional empowerment: Support and new implications for theory. Journal of Community Psychology 33 (2): 233-244.

Smith, Bryan. 1997. Empowerment - the challenge is now. Journal: Empowerment in Organizations, 5 (3), 120-122.

Svetic, Aleša. Oblikovanje dela in kakovost delovnega življenja = Job design and quality of working life. V: BREZOVEC, Aleksandra (ur.), MEKINC, Janez (ur.). Management, 
1022 36 $6^{\text {TH }}$ International Conference on Organizational Science Development: Responsible Organization (MARCH $22^{\mathrm{ND}}-24^{\mathrm{TH}}$, PortoroŽ SlOVENIA)

A. Svetic: Employee Expectations Towards Empowerment

izobraževanje in turizem: družbena odgovornost za trajnostni razvoj: 2. znanstvena konferenca $z$ mednarodno udeležbo, 21.-22. oktober 2010, Portorož: zbornik referatov $=$ proceedings. Portorož: Turistica, Fakulteta za turistične študije, 2010, str. 1902-1910. 


\title{
Vpliv izgube zaposlitve na ustanovitev lastnega podjetja
}

\begin{abstract}
ALEŠA SVETIC
Povzetek Razlogi, ki vplivajo na odločitev posameznika, da se odloči za ustanovitev lastnega podjetja so različni, posamezniki imamo namreč različne poglede na svojo poklicno pot, kariero, prevzemanje tveganja in podjetništvo. Večina avtorjev pa se strinja, da so dejavniki, ki pripeljejo do te odločitve preplet dejavnikov osebnostne narave in okolja.

V sodobnem času, ko se vodstva podjetij soočajo z nenehnimi izzivi, ko se pojavlja nova tehnologija in se delovna mesta hitro preoblikujejo zaradi česar so tudi odpuščanja sodelavcev pogostejša, domnevamo, da so posamezniki, ki izgubijo zaposlitev, velikokrat prisiljeni $\mathrm{v}$ ustavljanje svojih podjetij in vstopanje v podjetništvo.

V prispevku analiziramo kateri motivi so tisti, ki prepričajo posameznike, da se podajo na samostojno podjetniško pot. S tem namenom smo opravili kvantitativno empirično raziskavo, s katero ugotavljamo motive posameznikov v Sloveniji, ki so ustanovili svoje podjetje v času največje krize, od leta 2008 do leta 2014. Namen raziskave je ugotoviti, kako pomemben motiv je izguba zaposlitve .
\end{abstract}

KLJUČNE BESEDE: podjetništvo • izguba zaposlitve • finančna neodvisnost - uresničitev dobre ideje

NASLOV AVTORICE: dr. Aleša Svetic, Gea College, Fakulteta za podjetništvo, Dunajska cesta 156, 1000 Ljubljana, Slovenija, e-pošta: alesa.svetic@gea-college.si 
$36^{\mathrm{TH}}$ International Conference on Organizational Science DEVElopMENT: Responsible ORganization (MARCH $22^{\mathrm{ND}}-24^{\mathrm{TH}}$, PORTOROŽ SLOVENIA)

O. Arsenijević, M. Ferjan, I. Podbregar, P. Šprajc, D. Trivan \& Y.

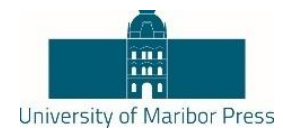

Ziegler

\title{
The Influence of Unemployment on Individual's Decision to Start up a Business
}

\begin{abstract}
ALEŠA SVETIC
Abstract The reasons that influence an individual's decision to set up a business are different, people have different views on their career paths, risk-taking process and entrepreneurship. Most authors would agree that factors that lead to this decision are combination of personal characteristics and the environment conditions.

Nowadays, when managers are faced with ongoing business challenges, new technology and transformation of jobs which results in dismissals of employees more often than in the past, we assume that those who lose their jobs, are often forced to become entrepreneurs.

In the article we analyze the motives that convince individuals for independent entrepreneurial path. With this purpose, we conducted a quantitative empirical study to analyze motives of individuals in Slovenia who founded companies in the peak of the crisis, from 2008 to 2014 . The main goal of the study is to determine how important motive is the loss of employment.
\end{abstract}

KEYWORDS: business - loss of employment - financial independence • realization of good ideas.

Correspondence Address: Aleša Svetic, Ph.D., Gea College, Faculty of Entrepreneurship, Dunajska cesta 156, 1000 Ljubljana , Slovenia, e-pošta: alesa.svetic@gea-college.si 


\section{$1 \quad$ Uvod}

Spremenjeno poslovno okolje in posledice krize, ki je prizadela svetovna gospodarstva zahtevajo spremembe tudi $\mathrm{v}$ delovanju podjetij. Potrebne so spremembe pri delu in razmišljanju, kajti le te so $\mathrm{v}$ nepredvidljivem in kompleksnem poslovnem okolju, predpogoj za napredek. V takih razmerah, metode evolucijskega, tekočega spreminjanja zamenjujejo metode revolucijskega spreminjanja, kjer je poudarek na spreminjanju procesov in struktur. Posledice so prodaje ali izločanje dejavnosti ter materialnih sredstev, izstopi iz kapitalskih in poslovnih zvez, prodaje blagovnih znamk, pa tudi preoblikovanje in ukinjanje delovnih mest, odpuščanje in brezposelnost.

Z vidika obravnavane teme, so zanimive predvsem spremembe, ki se nanašajo na delovna mesta oziroma tehnologijo dela, nove miselne vzorce pri oblikovanju delovnih rešitev in seveda iskanje novih inovativnih rešitev. Tako opazimo, da se spreminja narava del in nalog, klasična delovna mesta se preoblikujejo, s čimer se spreminjajo vzorci vedenja pri delu, spremembe pa se dogajajo tudi v vrednotah, normah, odnosih, prepričanjih in vedenju. Poudarjena je večja potreba po mnogoterih znanjih, nenehnem učenju in iskanju izvirnih rešitev.

Ker dinamično preoblikovanje delovnih mest ne zagotavlja dolgoročno varne zaposlitve, se tudi varnost zaposlitve zmanjšuje. Tako posamezniki v zameno za delovne dosežke in pripadnost ne morejo več pričakovati stalnosti zaposlitve in zato se skladno z miselnim okvirom posameznika, spreminja tudi njegov odnos do dela. Za tiste, ki so prožni, hitro odzivni, inovativni in zmožni spreminjanja je to priložnost, za druge, ki tega niso sposobni pa grožnja. Veliko jih v takih razmerah izgubi zaposlitev.

Zlasti so se velike spremembe dogodile po letu 2008, ko je svet zajela najprej finančna kriza, potem pa še gospodarska kriza (Dubrovski, 2010, 37-38).

Zaradi propada številnih podjetij je veliko ljudi izgubilo zaposlitev, stopnja brezposelnosti pa se je povečala. Nove okoliščine so pogojevale prelom z dotedanjo prakso - poslovnimi modeli, strukturami, procesi, sistemi, strategijami in kulturo - in začetek novega poslovnega življenjskega ciklusa podjetij. Spremenila so se načela uspešnosti, povečal pa zahtevnostni prag preživetja. Povečal pa se je tudi pritisk na zaposlene, prišlo je do stanj napetosti in konfliktov pa tudi skrbi, stresa in negotovosti, zlasti pa je veliko posameznikov ostalo brez zaposlitve.

Kako odreagira posameznik, ko izgubi zaposlitev, ni mogoče opisati enoznačno, saj posameznika na njegovi poklicni poti vodijo njegove zmožnosti in hotenja. Ljudje imamo namreč različne poglede na svojo poklicno pot, kariero, prevzemanje tveganja in podjetništvo.

V sodobnem času, ko je zaposlitev teže dosegljiva, domnevamo, da so posamezniki, ki izgubijo zaposlitev velikokrat prisiljeni $\mathrm{v}$ ustavljanje podjetij in $\mathrm{s}$ tem vstopanje $\mathrm{v}$ podjetništvo. 
36 ${ }^{\text {TH }}$ International Conference on ORganizational Science Development: RESPONSIBLE ORGANIZATION (MARCH $22^{\mathrm{ND}}-24^{\mathrm{TH}}$, PORTOROŽ SlOVENIA)

A. Svetic: The Influence of Unemployment on Individual's Decision to Start up a Business

Poznano je, da so razlogi, ki vplivajo na to, da se posameznik odloči za ustanovitev lastnega podjetja in samostojno podjetniško pot, različni. Večina avtorjev pa se strinja, da so dejavniki, ki pripeljejo do take odločitve osebnostne narave in dejavniki okolja. Praviloma pa gre vedno za preplet dejavnikov obeh skupin.

Za posameznika je odločitev za lastno podjetje, težka odločitev, povezana z neštetimi izzivi, sprva polnimi navdušenja in pričakovanja, pa tudi strahu, trdega dela, razočaranj in tveganj. Vzgibi, za odločitev so lahko različni, praviloma pa podjetnika povezujemo z uresničitvijo dobre poslovne zamisli, lahko pa se za tako pot odloči tudi posameznik, ki izgubi zaposlitev. V prispevku analiziramo, ali je ustanovitev zasebnega podjetja povezana $\mathrm{z}$ izgubo zaposlitve.

\section{Opredelitev pojma podjetništvo in njegov pomen}

Pojem podjetništvo pomeni iskanje, razvijanje zamisli ter delovanje s pravo ekipo in dobrim poslovnim načrtom. Podjetništvo je proces ustvarjanja nečesa novega, del katerega je prevzemanje nagrad in s tem tudi tveganja. Seveda pri tem ni dovolj, da imamo le dobro zamisel, ki jo želimo uresničiti, podjetništvo zahteva tudi veliko znanja.

Podjetniške dejavnosti ustvarjajo delovna mesta in postavljajo ekonomske temelje posamezne države, podjetništvo poteka kot dinamični proces ustvarjanja bogastva. Bogastvo pa lahko ustvarjajo samo posamezniki, ki prevzemajo veliko tveganja glede lastniškega kapitala, obveznosti, časa in kariere ter dajo vrednost izdelku oziroma storitvi (Antončič et al., 2002, 29-30). Podjetništvo povezujemo z ustanavljanjem podjetij, nastalih na pobudo podjetnikov.

Gospodarsko rast spodbujajo še zlasti inovacije, ki se razvijajo in komercializirajo s podjetniškimi dejavnostmi. S podjetništvom se uvajajo tudi spremembe v strukturo poslovanja in družbe. Podjetništvo zapolnjuje premostitveno vrzel med znanostjo in trgom ter je hkrati najuspešnejša metoda za ustanavljanje novih podjetij in uvajanje novih izdelkov in storitev na trg.

Pomen podjetništva najlažje ponazorimo s naslednjimi podatki; v Evropski uniji je okoli 23 milijonov malih in srednjih podjetij (MSP), kar je skoraj 99\% vseh obstoječih podjetij. Ta podjetja zagotavljajo več kot 100 milijonov delovnih mest ter so hkrati bistven vir inovacij in razvoja, zato imajo tudi ključno vlogo pri gospodarski rasti, socialni koheziji in konkurenčnosti evropskega gospodarstva (Putrih, 2016,12).

Podjetniški proces vključuje dejavnosti od prepoznavanja podjetniških priložnosti in razvoja podjetnikove vizije do vzpostavitve organizacije za njihovo uresničitev. Je splet treh temeljnih prvin podjetništva, in sicer: podjetnika ali tima, poslovne priložnosti in sredstev od inovacije do odločitve za podjetje in od implementacije do rasti. Sestavine podjetniškega procesa so: 
1. ustanovitelji - podjetnik in podjetniški oziroma menedžerski tim - kot osnovna gonilna sila modela, najpomembnejša in povezovalna pri prepoznavanju priložnosti ter tudi pri zbiranju in povezovanju potrebnih sredstev (tvorcev) za uresničitev ideje;

2. prepoznavanje priložnosti - vrednotenje podjetniških idej in izbor priložnosti kot proces, ključen za razvoj in uspeh posla. Tudi v tem primeru sta izjemno pomembna časovni okvir dogajanja in celoten družbeno-socialni okvir ideje;

3. potrebna sredstva vključujejo znanje, zaposlene in kapital v vseh oblikah (denar, prostori, oprema ipd.). Podjetniki sredstva najemajo (ne kupujejo) in jih obvladujejo s čim manjšim vložkom (mnoga uspešna podjetja so zrasla na čistih kooperantskih osnovah) oziroma zagotovijo minimalno potrebna finančna sredstva in število ljudi za uresničitev poslovne priložnosti.

\section{$3 \quad$ Podjetnik in njegove lastnosti}

\subsection{Kdo je podjetnik}

Izraz podjetnik izhaja iz francoske besede „entre-prende“, kar pomeni „nečesa se lotiti“, angleški izraz „entrepreneur“ pa pomeni „vmesnik“ ali „posrednik“ (Antončič et al., 2002, 26). Po zakonu o gospodarskih družbah je samostojni podjetnik fizična oseba, ki na trgu samostojno opravlja pridobitno dejavnost kot svojo izključno dejavnost. Podjetnik prevzema pripadajoča finančna, družbena in psihična tveganja za ustvarjanje nečesa novega, v kar verjame, da je vredno, in upa na nagrado v obliki denarja, neodvisnosti in osebnega zadovoljstva.

Podjetnik ima tudi več pomembnih vlog pri razvoju gospodarstva. Je tisti, ki spodbuja investicije, ustvarja zaposlitvene možnosti, spodbuja uravnoteženi regionalni razvoj, zmanjšuje koncentracijo ekonomske moči in izboljšuje življenjski standard.

Gre za osebo, ki ustvarja vrednost in $\mathrm{v}$ tem procesu prevzema tveganje izgube denarja, časa ali druge oblike vrednosti premoženja. $\mathrm{K}$ uspešnosti podjetja prispeva s svojim znanjem, izkušnjami, spretnostmi in motivacijo. Je pa tudi inovator (novi trgi in načini dela, nove organizacijske oblike itd.) in vizionar. Zna uresničiti cilje in prevzeti tveganja, ki so lahko: finančna tveganje (izguba prihrankov, vložkov, dohodka itd.); tveganja kariere (prekinitev izobraževanja, izguba položaja v organizaciji, možnosti poklicnega napredovanja $\mathrm{v}$ večji organizaciji itd.); tveganja $\mathrm{v}$ družini in okolju (ločitve, spori, nasledstvo, stres, osebnostna rast in razvoj itd.) in psihična tveganja (zdravje, izgorelost, druga obolenja.

\subsection{Lastnosti podjetnika}

Eno pogostih vprašanj je katere lastnosti naj bi imel podjetnik, da bi bil pri svoji dejavnosti uspešen, pa tudi ali so podjetniške lastnosti prirojene, ali jih je mogoče tudi pridobiti.

Že dolgo časa je poznano, da posameznik poleg prirojenega podjetniškega talenta, lahko pridobi potrebne lastnosti tudi z ustreznim usposabljanjem in izobraževanjem. Lastnosti 
$36^{\text {Th }}$ International Conference on Organizational Science Development: RESPONSIBLE ORGANIZATION (MARCH $22^{\mathrm{ND}}-24^{\mathrm{TH}}$, PORTOROŽ Slovenia)

A. Svetic: The Influence of Unemployment on Individual's Decision to Start up a Business

podjetnikov se tako deloma prenašajo iz generacije v generacijo, deloma pa se jih da tudi naučiti.

Strukturo posameznikove osebnosti tvorijo temperament, značaj, sposobnosti in zmožnosti ter motivacija. Našteti elementi povezujejo osebnost v celoto in se med drugim manifestirajo tudi v tistih lastnostih, ki so ključne za uspeh podjetnika (Putrih, 2016, 14). Te pa so:

1. Intelektualne lastnosti (kot so: izobrazba, domišljija,..)

2. Osebnostne lastnosti (kot so: starost, življenjske izkušnje,..)

3. Lastnosti voditeljev (kot so: vodstvene sposobnosti, planiranje,...) in

4. Značajske lastnosti (potrpežljivost, zanesljivost, pogum,..)

Med tipične značajske lastnosti, ki vplivajo na uspeh podjetnika, sodijo tudi vztrajnost, delavnost, moč volje, kritičnost, samostojnost, iskrenost, poštenost, družabnost, upornost, sodelovanje in samonadzor (Loehr in Schwartz, 2006, 125-126). Za podjetnika so pomembna tudi določena značajska nasprotja, kot so : radodarnost in varčnost, potrpežljivost, previdnost in drznost ter samozavest in ponižnost (Loehr in Schwartz, 2006, 125-126). Tem lastnostim dodamo še: inovativnost, kreativnost, samozavest, ambicioznost, odločnost, vztrajnost, usmerjenost h kupcem, pozitiven odnos do tveganja, organizacijske sposobnosti in izkušnje (Kostanjevec, 2005, 10).

Podjetniki na splošno veljajo za zelo ambiciozne, tekmovalne, samozavestne ljudi, ki vedno sami odpravljajo svoje težave, pogosto pa še težave drugih. Toda le redko se zavedajo, da niso imuni na stresna stanja, ki jih morajo premagovati, sicer lahko resno ogrozijo svoje delovanje.

\section{$4 \quad$ Razlogi posameznika za ustanovitev podjetja}

Na odločitev posameznika, da se odloči za ustanovitev podjetja vpliva več dejavnikov. Različni avtorji jih podobno opredelijo in sicer na dejavnike osebnostne narave in dejavnike okolja. Med osebnostnimi dejavniki so razlogi, ki posameznika vodijo k ustanovitvi podjetja in osebnostne lastnosti, ki ga k temu spodbujajo.

Razloge za ustanovitev podjetja avtorji (Kušče, Gomezelj Omerzel, 2011, 2) opredelijo takole : neodvisnost, osebna rast, večji zaslužek, želja po uspehu, želja po ugledu, zaznana dobra poslovna ideja, nadaljevanje družinske tradicije, uresničitev življenjskih ciljev, zagotovljeno delovno mesto, nezadovoljstvo s prejšnjim delom, ekonomska nujnost, naključje oziroma splet okoliščin, ugled v družbi, nadgrajevanje pridobljenega znanja in vpliv oziroma predlog sorodnikov, prijateljev ali znancev. Med osebnostne lastnosti podjetnika pa uvrščajo : željo po neodvisnosti, potrebo/željo po dosežkih, samoučinkovitost in samozaupanje, mesto obvladovanja, nagnjenost $\mathrm{k}$ tveganju, nagnjenost k notranjemu nadzoru,opodjetniško usposobljenost ter sposobnost zaznavanja in izrabe podjetniških priložnosti. 
Dejavniki okolja pa so predvsem naslednji: razpoložljivost kapitala, prisotnost izkušenega podjetnika, tehnične spretnosti delovne sile, dostop do dobaviteljev, dostop do potrošnikov ali novih trgov, vpliv vladne politike, bližina univerze, dostop do zemljišč in prostorov, dostop do transporta, stališče okoliškega prebivalstva, dostop do podpornih storitev, življenjske razmere, ovire za vstop na trg, tekmovalnost med obstoječimi konkurenti, pritisk substitutov, pogajalska moč kupcev in dobaviteljev, finančna podpora, vlada (vladna politika in vladni programi), izobraževanje in usposabljanje, poslovna in strokovna infrastruktura, odprtost in konkurenčnost na notranjem trgu, dostop do fizične infrastrukture ter kulturne in družbene norme

\section{$5 \quad$ Raziskava}

\subsection{Opis metode, vzorca in uporabljenega instrumentarija}

Eden od razlogov za ustanavljanje malega podjetja je lahko tudi izguba zaposlitve, zato v prispevku preučujemo povezavo med izgubo zaposlitve in ustanovitvijo podjetja. Cilj kvantitativne empirične raziskave je spoznati, kakšni so motivi slovenskih podjetnikov, ki so svoja podjetja ustanovili v obdobju 2008-2014

$\mathrm{V}$ ta namen smo uporabili metodo zbiranja podatkov $\mathrm{z}$ lastno oblikovano anketo in izvedli elektronsko anketiranje. Postavke so izražale mnenje, s katerim se anketirani lahko v določeni meri strinjajo oziroma ne strinjajo. Uporabili smo format ponujenih odgovorov v obliki: 1 -sploh se ne strinjam; 2 - se ne strinjam; 3 -niti da, niti ne; 4-se strinjam;5 - se popolnoma strinjam.

\subsubsection{Splošni podatki}

V raziskavo je vključenih 280 podjetnikov. Izbrani so po merilu, da so svoja podjetja ustanovili v letih od 2008 do 2014 in so še danes delujoča. Podjetja so bila izbrana naključno, pri tem smo si pomagali s poslovnimi registri GVIN, AJPES, IBON in BIZI. Raziskava je potekala na Fakulteti za podjetništvo v letu 2015/16. Uporabili smo metodo elektronskega anketiranja.

Struktura anketiranih po spolu je naslednja: dobro polovico (52,2 \%) anketiranih je moškega spola, preostali delež pa ženskega spola :47,8 \%).

Po starosti, so v največjem deležu zastopani podjetniki v skupini od 36-45 let $(39,8 \%)$, sledijo tisti v starostni skupini od 26-35 let; najmlajši in najstarejši so zastopani v manjšem deležu.

Največji delež podjetnikov ima zaključeno visoko strokovno ali univerzitetno izobrazbo $(43,2 \%)$.

\subsection{Analiza in interpretacija rezultatov}

\subsubsection{Podjetniške lastnosti}


$1030 \quad 36^{\mathrm{TH}}$ INTERNATIONAL CONFERENCE ON ORGANizATIONAL SCIENCE DEVElopment: RESPONSIBLE ORGANIZATION (MARCH $22^{\mathrm{ND}}-24^{\mathrm{TH}}$, PORTOROŽ SLOVENIA)

A. Svetic: The Influence of Unemployment on Individual's Decision to Start up a Business

Anketiranim smo ponudili nabor osebnostnih značilnosti, ki označujejo podjetnika in jih prosili, da se na lestvici od 1-5 ocenijo (slika 1).

Slika 1: Podjetniške lastnosti

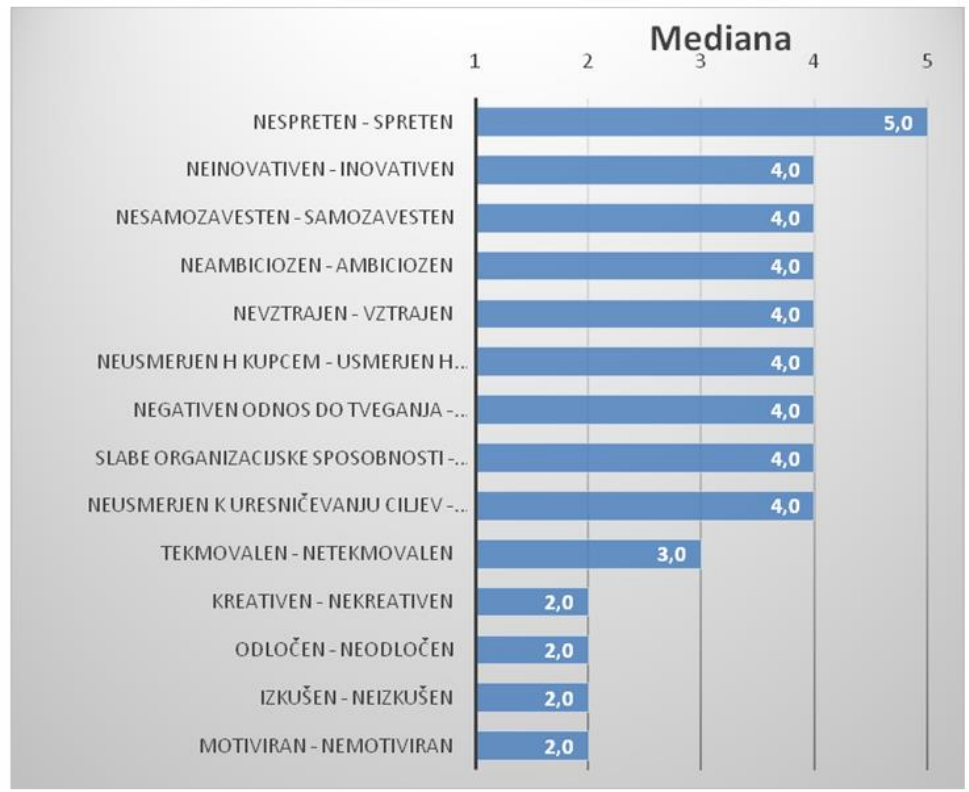

Podjetniki so v povprečju spretni $(\mathrm{Me}=5)$, pa tudi $(\mathrm{Me}=4)$ inovativni, samozavestni, ambiciozni, vztrajni, usmerjenih $k$ kupcem, imajo pozitivni odnos do tveganja, dobre organizacijske sposobnosti in so usmerjeni $k$ uresničevanju ciljev

Pri tekmovalnosti so v povprečju neodločeni $(\mathrm{Me}=3)$, manj pa so $(\mathrm{Me}=2)$ kreativni, odločni, izkušeni in motivirani. Najmanj podjetnikov je izbralo odgovor miren $(14,9 \%)$.

\subsection{2 Želja postati podjetnik}

Na vprašanje (graf 1) ali so imeli že od otroštva izraženo željo postati podjetnik so ogovorili takole: le dobra četrtina podjetnikov si je že v otroštvu želela postati podjetnik, večina pa ne $(72,8 \%)$. 
Graf 1: Želja postati podjetnik

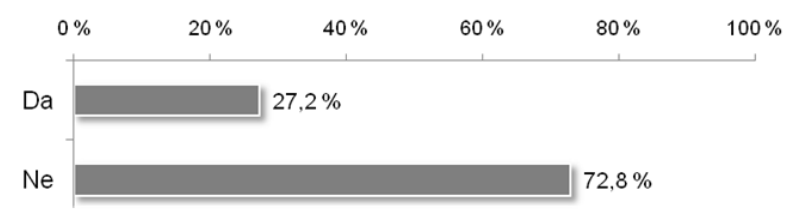

\subsection{3 Število ustanovljenih podjetij}

Da bi preverili njihovo podjetniško naravnanost smo postavili vprašanje o številu podjetij, ki so jih že ustanovili. Iz odgovorov respondentov spoznamo, da je večina podjetnikov ustanovila eno podjetje $(81,1 \%)$.

Graf 2: Število ustanovljenih podjetij

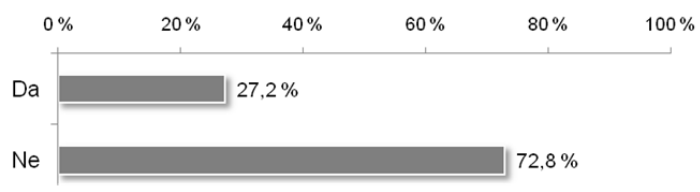

\subsubsection{Zadovoljstvo $\mathrm{z}$ odločitvijo da so ustanovili podjetje}

$\mathrm{Na}$ vprašanje ali so $\mathrm{z}$ odločitvijo da so ustanovili podjetje zadovoljni, je dobra polovica respondentov $(51,7 \%)$ odgovorila, da so, slaba tretjina pa je zadovoljnih $(32,7 \%)$.

Graf 3: Zadovoljstvo z odločitvijo da so ustanovili podjetje

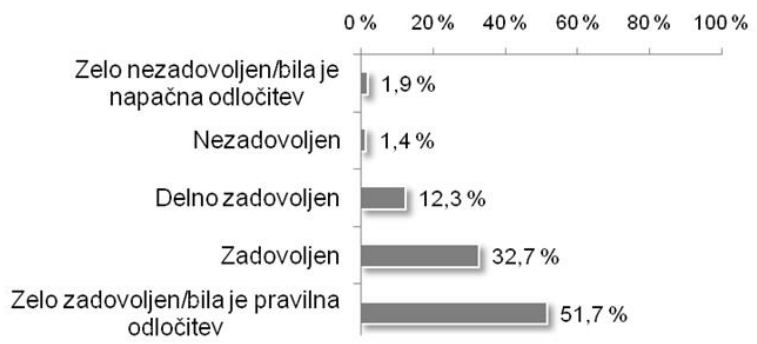

Večina podjetnikov je torej (zelo) zadovoljnih s svojo odločitvijo $(84,4$ \%), manjši delež pa je (zelo) nezadovoljnih $(3,3 \%)$.

Vpliv osebnostnih dejavnikov 
1032 36 $6^{\mathrm{TH}}$ INTERNATIONAL CONFERENCE ON ORGANizATIONAL SCIENCE DEVElopment: RESPONSIBLE ORGANIZATION (MARCH $22^{\mathrm{ND}}-24^{\mathrm{TH}}$, PORTOROŽ Slovenia)

A. Svetic: The Influence of Unemployment on Individual's Decision to Start up a Business

Kakšen je vpliv posameznih osebnostnih dejavnikov na njihovo podjetniško odločitev prikazujemo v grafu 4.

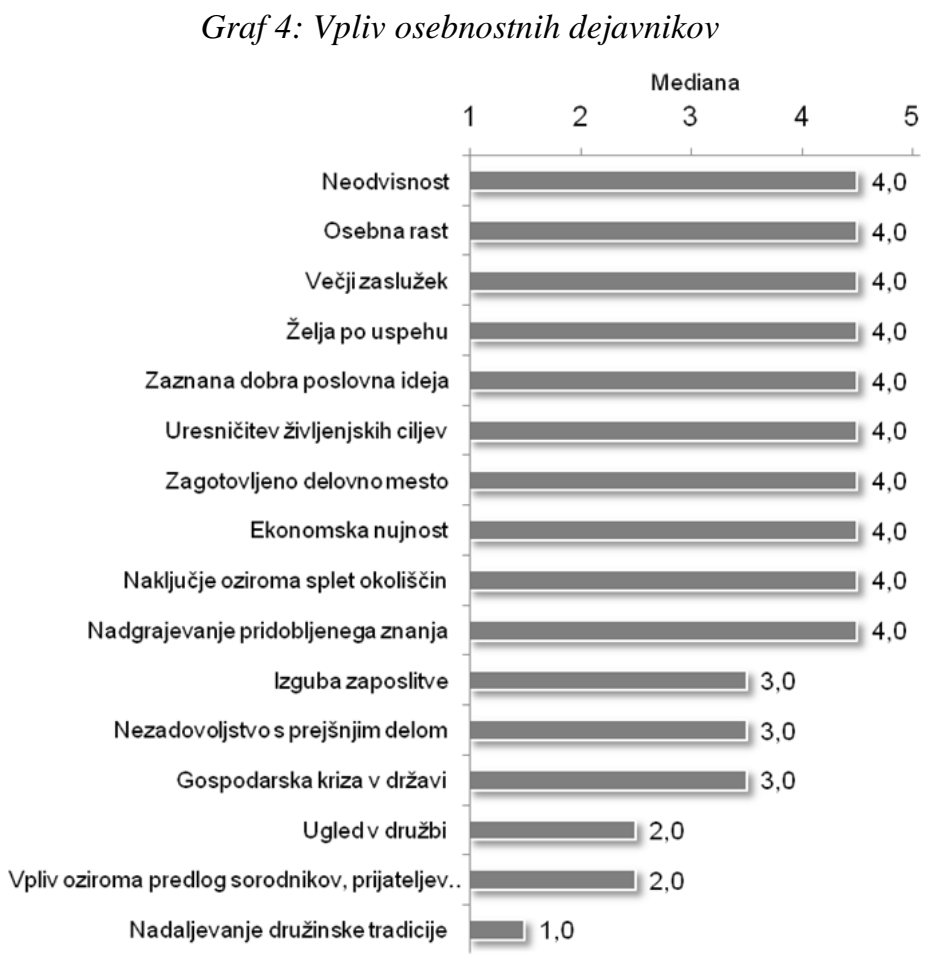

Lestvica odgovorov: 1 -nepomembno ... 5-zelo pomembno

Na lestvici odgovorov od 1 -nepomembno do 5 - zelo pomembno so respondenti odgovorili takole: nobeden od dejavnikov ni ocenjen kot najpomembnejši oz. v povprečju zelo pomemben dejavnik. Kar 10 dejavnikov pa je ocenjenih kot pomembnih $(\mathrm{Me}=4)$, medtem, ko je najmanj pomemben dejavnik (nepomemben) nadaljevanje družinske tradicije $(\mathrm{Me}=1)$.

Večji del analiziranih dejavnikov (deset) je tako v povprečju pomembnih $(\mathrm{Me}=4)$, in sicer: neodvisnost, osebna rast, večji zaslužek, želja po uspehu, zaznana dobra poslovna ideja, uresničitev življenjskih ciljev, zagotovljeno delovno mesto, ekonomska nujnost, naključje oziroma splet okoliščin, nadgrajevanje pridobljenega znanja. Izguba zaposlitve ni med pomembnimi motivi (Me=3), saj kar 121 podjetnikov označuje brezposelnost kot manj pomemben razlog v primerjavi z drugimi razlogi. 
V nadaljevanju smo še z Wilcoxonovim neparametričnim testom preverili ali obstajajo razlike $\mathrm{v}$ pomembnosti med razlogom brezposelnost in med drugimi razlogi. Ugotovili smo, da se pomembnost brezposelnosti statistično značilno razlikuje od pomembnosti drugih razlogov $(\mathrm{p}=0,000)$ zaradi česar sklepamo, da brezposelnost ni pomembnejša od drugih razlogov. Torej tudi izgube zaposlitve ne moremo povezati z odločitvijo za samostojno podjetniško pot.

\section{$6 \quad$ Zaključek}

Razlogi, ki spodbujajo podjetništvo so, kot že rečeno, zelo raznoliki, odločanje za ustanovitev podjetja pa odvisna od osebnostnih dejavnikov in dejavnikov okolja. V prispevku smo se posvetili predvsem preučevanju osebnostnih motivov za podjetništvo in skušali odgovoriti na vprašanje kako močan motiv za ustanovitev lastnega podjetja je izguba zaposlitve oziroma brezposelnost. Ugotovili smo, da se respondenti za ustanovitev lastnega podjetja niso odločili zato, ker so izgubili zaposlitev ter da brezposelnost ni pomembnejša od drugih razlogov zlasti neodvisnosti, osebne rasti, zaslužka, dobre poslovne zamisli, želje po uspehu in drugih razlogov.

Prav tako je zanimiva tudi ugotovitev, da večina ni imela želje postati podjetnik že od otroštva, s čimer pritrjujemo ugotovitvi, da podjetniške želje niso le prirojene, pač pa so tudi pridobljene tekom karierne poti posameznika. Neuresničeni karierni cilji so tako lahko dokaj velika spodbuda, da jih posameznik uresniči sam na podjetniški način.

Pri ugotavljanju koliko podjetij so respondenti že ustanovili smo ugotovili, da je za večino $(81,1 \%)$ to prvo podjetje. Sklepamo, da je bila odločitev skrbno pretehtana in dobro premišljena in prav zato je tudi večina $(84,4 \%)$ zadovoljnih s svojo odločitvijo .

Seveda, ko razpravljamo o podjetništvu moramo poleg osebnostnih razlogov omeniti tudi zunanje pogoje oziroma spodbude in ovire za podjetništvo (Lipičnik, 2003, 13). Med njimi so pomembni ekonomski pogoji, pa tudi sociološki in politični. Spodbudno podjetniško okolje je povezano s trgom in temeljnimi institucijami tržnega gospodarstva privatno lastnino, kapitalom, konkurenco in tržno strukturo. Podjetništvo povezuje ljudi, kapital, znanje in tudi tveganja.

Seveda pa ima nikakor ne smemo spregledati tudi drugih dimenzij podjetništva in sicer sociološkega in kulturnega pomena, pri katerem je čutiti vpliv najširših družbenih razmerij (politični in ideološki sistem) ter vrednostnih (etičnih) odnosov v družbi. S sociološkega vidika je za uspešnost predvsem pomembna mobilnost in izobrazbena raven ljudi, saj podjetništvo zahteva dinamično spreminjanje in prilagajanje družbe. Ekonomsko obnašanje ljudi na temelju privatne lastnine in tržne konkurence vpliva na socialno mobilnost ter slojevitost družbe. Povečanje socialne mobilnosti pa vpliva na razvoj podjetništva in oblikovanje srednjega sloja družbe.(Lipičnik, 2003, 13).

Na razvoj podjetništva pa pomembno vplivajo še temeljne politične in ekonomske vrednote, kot so demokracija, pluralizem, svoboda in tudi delovanje tržnih institucij je v veliki meri v kontekstu političnih razmerij in vrednostnih stališč. Vsekakor pa potrebne pogoje za uveljavitev podjetniškega okolja soustvarjajo volja in pripravljenost na 
1034 36 ${ }^{\mathrm{TH}}$ International Conference on Organizational Science Development: RESPONSIBLE ORGANIZATION (MARCH $22^{\mathrm{ND}}-24^{\mathrm{TH}}$, PORTOROŽ Slovenia)

A. Svetic: The Influence of Unemployment on Individual's Decision to Start up a Business

sodelovanje in ukrepi vseh akterjev političnega odločanja ter vseh sodelujočih posameznikov, kajti pomanjkljivo izpolnjevanje potrebnih pogojev predstavlja veliko oviro za razvoj podjetništva.

\section{Literatura}

Antončič, Boštjan, Robert D. Hisrich, Tea Petrin in Aleš Vahčič. 2002. Podjetništvo. Ljubljana: GV Založba. 485 str.

Deželak, Mojca. 2012. Izobraževanje za podjetništvo na visokošolskem bolonjskem študiju. Delo diplomskega seminarja bolonjskega visokošolskega programa, Ekonomsko-poslovna fakulteta, Univerza v Mariboru. 38 str.

Dubrovski, Drago. 2010. Pomembnost ugotavljanja pravilnih vzrokov za nastanek podjetniške krize. Univerza na Primorskem, Slovenija. 16 str.

Putrich Karin Kaja.2016.Analiza dejavnikov, ki vplivajo na odločitev za samostojno podjetniško pot od leta 2008 do leta 2014. Magistrsko delo, Fakulteta za podjetništvo, Ljubljana. 35 str.

Kostanjevec, Tatjana. 2005. Podjetniški profil Slovencev. Magistrsko delo, Ekonomska fakulteta, Univerza v Ljubljani. 91 str.

Kušče, Irena, Doris Gomezelj Omerzel. 2011. Analiza dejavnikov ustanavljanja podjetja. Management 6 (2): 147-164, 205-206.

Loehr, J.,Schwartz, T. 2006. Energija uspeha. Ljubljana: Mladinska knjiga Založba. 284 str.

Lipičnik, Marijan, 2003. Magistrsko delo: Primerjalna analiza modelov spodbujanja podjetništva z aplikacijo na slovenske razmere. 136 str. 


\title{
Alkohol in psihoaktivne substance - vzrok za cestno prometne nesreče in cestno prometne prekrške
}

\author{
NEVENKA ŠESTAN, ZVONE BALANTIČ \& METODA DODIČ FIKFAK
}

Povzetek V številnih razvitih državah po svetu se je v zadnjem desetletju stopnja smrtnosti zaradi prometnih nesreč nekoliko zmanjšala, kar pa ni primer v nerazvitih državah.

Kljub upadanju števila mrtvih in poškodovanih v cestnem prometu v zadnjih letih v Evropski uniji je število prometnih nesreč še vedno previsoko in zaskrbljujoče. Med povzročitelji je po statističnih podatkih velik odstotek voznikov pod vplivom alkohola, prepovedanih drog in drugih psihoaktivnih substanc (PAS), ki se v zadnjih letih še povečuje.

V Sloveniji je po statističnih podatkih okrog 33 odstotkov voznikov povzročiteljev prometnih nesreč s smrtnim izidom, ki vozijo pod vplivom alkohola.

Analiza podatkov Ministrstva za notranje zadeve Republike Slovenije (MNZ) in podatkov obravnavanih voznikov na Posebni zdravstveni komisiji (v nadaljevanju PZK), je pokazala, da so bili obravnavani na PZK pogostejši povzročitelji CPP in $\mathrm{PN}$, kot vozniki v običajni populaciji zajeti v podatkih MNZ.

Zaradi velikega števila smrti, poškodb in invalidnosti predstavljajo prometne nezgode veliko ekonomsko in socialno breme za posameznika in družbo kot celoto.

KLJUČNE BESEDE: alkohol • psihoaktivne substance • cestno prometne nesreče • cestno prometni prekrški

NASLOV AVTORJEV: dr. Nevenka Šestan, Univerzitetni klinični center Ljubljana, Klinični inštitut za medicino dela, prometa in športa, Zaloška cesta 2, 1000 Ljubljana, Slovenija, e-pošta: nevenka.sestan@kclj.si; dr. Zvone Balantič, redni profesor, Univerza v Mariboru, Fakulteta za organizacijske vede, Kidričeva cesta 55a, 4000 Kranj, Slovenija, e-pošta: zvone.balantic@ fov.unimb.si; dr. Metoda Dodič Fikfak, Univerzitetni klinični center Ljubljana, Klinični inštitut za medicino dela, prometa in športa, Zaloška cesta 2, 1000 Ljubljana, Slovenija, e-pošta: metoda.dodicfikfak@kclj.si 
$36^{\text {TH }}$ International Conference on Organizational Science Development: Responsible ORganization (MARCH $22^{\mathrm{ND}}-24^{\mathrm{TH}}$, PORTOROŽ SLOVENIA)

O. Arsenijević, M. Ferjan, I. Podbregar, P. Šprajc, D. Trivan \& Y.

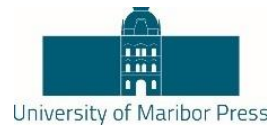

Ziegler

\title{
Alcohol and Psychoactive Substances: Causes of Traffic Accidents and Traffic Violations
}

\author{
NEVENKA ŠESTAN, ZvONE BALANTIČ \& METODA DODIČ FIKFAK
}

\begin{abstract}
In many developed countries around the globe, the traffic mortality rate has fallen slightly over the past decade. This, however, has not been the case in developing countries.

Despite the decreasing number of traffic fatalities and injuries recorded in the European Union in recent years, the number of traffic accidents is still too large and is very alarming. According to the statistical data, those causing these accidents include a high percentage of drunk drivers and drivers using illegal drugs and other psychoactive substances (PAS), and this percentage has been increasing in recent years.
\end{abstract}

In Slovenia, thirty-three percent of fatal traffic accidents are caused by drivers who drive under influence of alcohol.

The analysis of data on drivers causing traffic accidents and committing traffic violations provided by the Slovenian Ministry of the Interior and the Special Medical Committee (SMC) clearly showed that the drivers examined by the SMC pose a greater risk than drivers in the general population.

Because of the large number of fatalities, injuries, and disabilities, traffic accidents represent a great economic and social burden for the individual and for society as a whole.

KEYWORDS: alcohol $\bullet$ psychoactive substances $\bullet$ traffic accidents $\bullet$ traffic violations

CorReSPONDENCE AdDRESS: Nevenka Šestan, Ph.D., University Medical Centre Ljubljana, Clinical Institute of Occupational, Traffic and Sports, Zaloška cesta 2, 1000 Ljubljana, Slovenia, e-mail: nevenka.sestan@kclj.si; Zvone Balantič, Ph.D., Full Professor, University of Maribor, Faculty of Organizational Sciences, Kidričeva cesta 55a, 4000 Kranj, Slovenia, e-mail: zvone.balantic@fov.uni-mb.si; Metoda Dodič Fikfak, Ph.D., University Medical Centre Ljubljana, Clinical Institute of Occupational, Traffic and Sports, Zaloška cesta 2, 1000 Ljubljana, Slovenia, e-mail: metoda.dodicfikfak@kclj.si 
N. Šestan, Z. Balantič \& M. Dodič Fikfak: Alkohol in psihoaktivne substance - vzrok za cestno prometne nesreče in cestno prometne prekrške

\section{$1 \quad$ Uvod}

V zadnjem desetletju se je število smrtnih žrtev $\mathrm{v}$ prometnih nesrečah $\mathrm{v}$ številnih bogatejših državah nekoliko zmanjšalo ali stabiliziralo, $v$ revnejših državah in nekaterih regijah, kjer imajo zastarelo motorizacijo in $\mathrm{v}$ primerjavi $\mathrm{z}$ razvitim svetom nizek odstotek vseh vozil na svetu pa celo povečalo.

Po poročanju Svetovne Zdravstvene Organizacije (v nadaljevanju SZO) je leta 2000 umrlo v prometnih nesrečah 1,39 milijona ljudi. Napoved za leto 2020 pa je zaskrbljujoča, saj naj bi se to število zvišalo na 2,34 milijona.

Med povzročitelji prometnih nesreč in cestno prometnih prekrškov je po statističnih podatkih velik odstotek voznikov pod vplivom alkohola, prepovedanih drog in drugih psihoaktivnih substanc (v nadaljevanju PAS), ki pa se v zadnjih letih še povečuje. Veliko število umrlih in poškodovanih na cestah je tudi zelo velik socialno zdravstveni in ekonomski problem celotne družbe. Vlaganje finančnih sredstev, ki bi jih lahko prihranili na račun smrti in težjih poškodb v prometnih nezgodah, $\mathrm{v}$ ukrepe in aktivnosti, ki vodijo $\mathrm{k}$ boljšemu zdravju ljudi, pa bi pomembno vplivalo $\mathrm{k}$ napredku naše celotne družbe. (Šešok J., Sedlak S., 2006).

$\mathrm{Na}$ nastanek prometnih nesreč vpliva več dejavnikov, poglavitni pa so udeleženci $\mathrm{v}$ cestnem prometu, cestna infrastruktura, motorno vozilo in prometno okolje. Pri vseh teh dejavnikih ima človek najpomembnejšo vlogo.

\section{Alkohol in psihoaktivne substance}

Vožnja pod vplivom alkohola in PAS je eden najpomembnejših vzrokov za nastanek PN in CPP saj številne raziskave nakazujejo, da imajo izjemen vpliv na težo poškodbe v prometni nezgodi (Rok, 2004).

V Sloveniji je po statističnih podatkih okrog 33 odstotkov voznikov povzročiteljev prometnih nesreč s smrtnim izidom, ki vozijo pod vplivom alkohola.

V raziskavi izvedeni v letih od 2006 do 2009 v Španiji, so analizirali vzorce 8305 primerov kršiteljev prometnih nesreč. Bila je narejena statistična analiza o stopnji in pogostosti nesreč med vozniki, ki so bili udeleženi v prometnih nesrečah, in proučeni dejavniki tveganja zanje. Ugotovili so, da so prometne nesreče pogostejše med mladimi vozniki in ob koncu tedna, predvsem zaradi spremenjenega vedenja kot je pitje alkohola, zloraba drog, neprespanost in vožnja z določenimi kroničnimi boleznimi (Kanaan, 2009).

V ZDA se z neposrednimi ali posrednimi težavami z odvisnostmi (alkohol, druge PAS) ukvarja $63 \%$ prebivalcev. Tudi v Sloveniji je takšna ocena povsem realna in primerljiva glede na vse udeležence, ki se jih ta problematika dotika. Veliko ljudi, ki živijo z odvisniki (družine, v delovnih organizacijah ...), se navadi takšnega načina življenja in 
1038 36 $6^{\mathrm{TH}}$ INTERnational CONFERENCE ON ORganizational SCIENCE DeVElopment: Responsible Organization (MARCH $22^{\mathrm{ND}}-24^{\mathrm{TH}}$, Portorož SLOVENiA)

N. Šestan, Z. Balantič \& M. Dodič Fikfak: Alcohol and Psychoactive Substances:

Causes of Traffic Accidents and Traffic Violations

niti ne pomisli, da bi lahko kaj spremenili v korist odvisnika, temveč ga poskušajo celo zaščititi (Rus, 2014).

Vsekakor med vožnjo lahko pravočasno in pravilno ukrepa le trezen, spočit in zbran voznik. Alkohol, mamila ali PAS povzročijo podaljšanje reakcijskega časa in pogosto napačne odločitve. V Sloveniji velja popolna prepoved vožnje za voznike, ki bi pred ali med vožnjo uživali droge ali druge PAS. Med te sodijo tudi zdravila, označena z rdečim trikotnikom, ki imajo močno psihoaktivno delovanje in zmanjšujejo vozniške sposobnosti (Justinek in sodelavci, 2008).

Prometne nezgode predstavljajo znatno ekonomsko breme za družbo zaradi velikega števila smrti in poškodb med potniki v vozilih in pešcih. Poškodbe lastnine, stroški zdravljenja in nege, aktivnosti policije in drugih reševalnih enot, stroški zavarovalnic ter odsotnosti z dela to breme še povečujejo (Šešok J., Sedlak S., 2006).

\section{$3 \quad$ Namen in cilj raziskave}

Ugotoviti ali so vozniki z diagnozo kroničnega alkoholizma in/ali tveganega pitja, obravnavani na PZK pogostejši povzročitelji PN/CPP od voznikov, povzročiteljev PN/CPP v RS, ki nimajo diagnoze kroničnega alkoholizma in/ali tveganega pitja.

Ugotoviti ali so vozniki (uživalci PAS), obravnavani na PZK, pogostejši povzročitelji PN/CPP od voznikov, povzročiteljev PN/CPP v RS, ki ne uživajo PAS.

\section{$4 \quad$ Metode dela}

V prvem delu so obdelani podatki voznikov, 326.478 povzročiteljev prometnih nesreč in 5.056.956 povzročiteljev cestno prometnih prekrškov v RS od leta 2000 do 2010, ki jih vodi MNZ.

V drugem delu so obdelani podatki 1.556 pregledov, ki zajamejo vse voznike, ki so bili obravnavani na PZK od leta 2000 do 2010.

Pridobljene podatke smo opisali z deskriptivno statistiko (srednja vrednost, mediana, SD, asimetrični premik krivulje v desno, osamelci).

\section{$5 \quad$ Rezultati podatkov iz MNZ}

V opazovanem obdobju je v Sloveniji policija obravnavala 82,2 \% moških, ki so povzročili CPP in v 17,8 \% žensk povzročiteljic. Pri obeh spolih je bilo največ obravnavanih v letu 2001 in 2000. 
N. Šestan, Z. Balantič \& M. Dodič Fikfak: Alkohol in psihoaktivne substance - vzrok za cestno prometne nesreče in cestno prometne prekrške

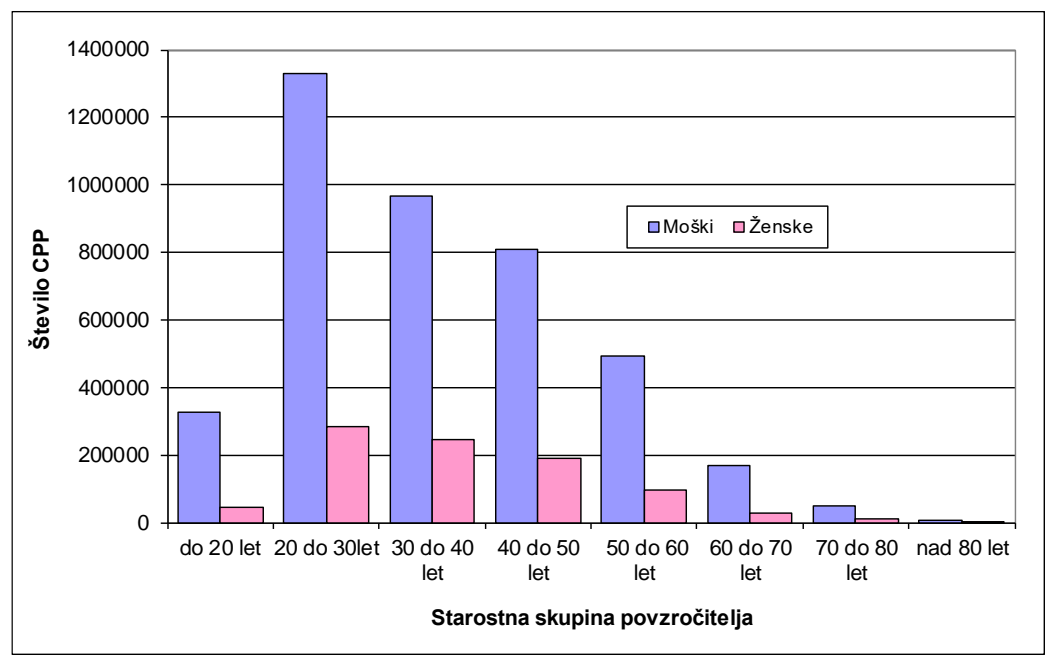

Slika 1: Število CPP po starostnih skupinah in spolu, od 2000 do 2010

Kot najpogostejši povzročitelji CPP so bili v starostni skupini od 20 do 30 let pri obeh spolih, saj je od 5.056.95,6 oseb , kar 1,615.48,0 zabeleženih prekrškarjev. V zelo velikem številu se pojavlja tudi starostna skupina od 30 do 40 let, kar 1.215.519,00 povzročiteljev CPP (slika1).

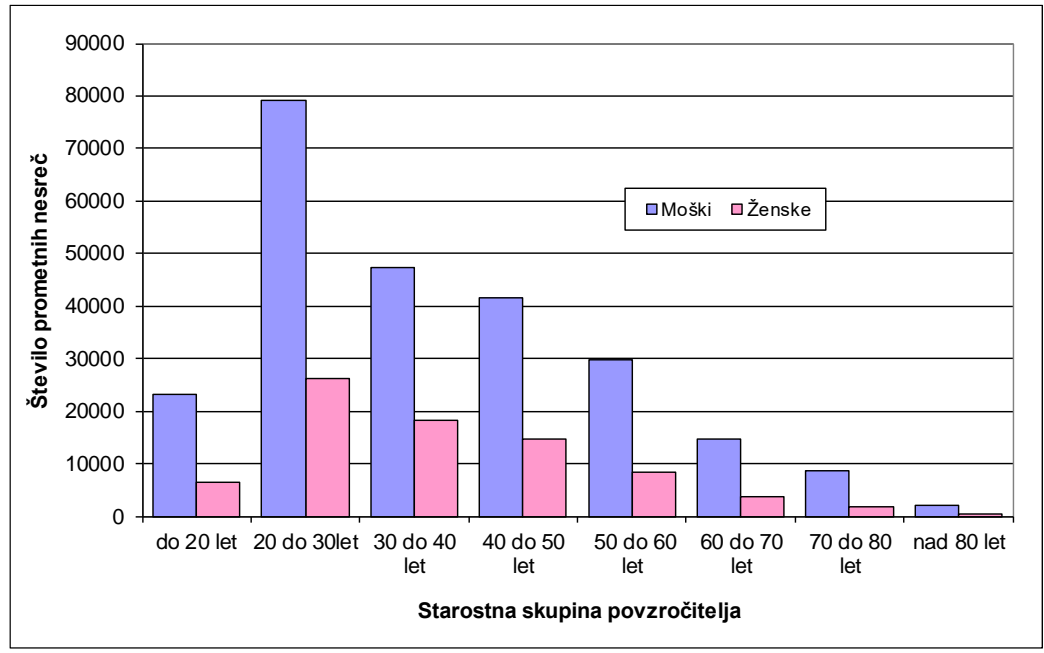

Slika 2: Število prometnih nesreč po starostnih skupinah in spolu, 2000 do 2010 
36 ${ }^{\mathrm{TH}}$ International Conference on Organizational Science Development: RESPONSIBLE ORGANIZATION (MARCH $22^{\mathrm{ND}}-24^{\mathrm{TH}}$, PORTOROŽ Slovenia)

N. Šestan, Z. Balantič \& M. Dodič Fikfak: Alcohol and Psychoactive Substances:

Causes of Traffic Accidents and Traffic Violations

V sliki 2 je prikazano da je 79026 (32,1\%) povzročiteljev PN v starostni skupini prav tako od 20 do 30 let, ki jo povzročijo moški, pri ženskah je ta številka nižja, ker je na splošno manj povzročiteljic ženskega spola, prevladuje pa tudi ta skupina z $26335(32,9$ $\%)$.

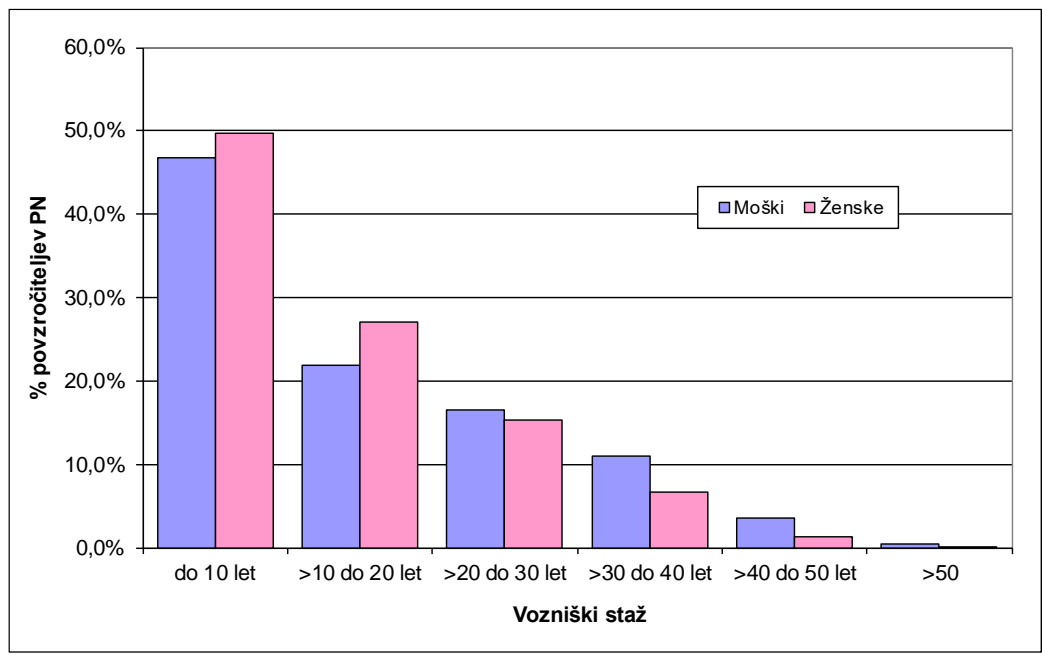

Slika 3: Povzročitelji prometnih nesreč glede na vozniški staž, 2000 do 2010

Najpogostejši povzročitelji PN imajo najnižji vozniški staž skupno pri obeh spolih, to je do 10 let z 41,7 \%, sledijo povzročitelji od 10 do 20 let s $27,3 \%$, pri moških je ta odstotek 46,8 pri ženskah pa 49,7 (slika3).

Povprečni vozniški staž pri povzročiteljih PN skupno pri obeh spolih je 14,3 leta. Pri moških je ta staž nekoliko višji in dosega 15 let, pri ženskah pa 12,7 let.

Iz slike 4 je razvidna, uporaba varnostnega pasu pri prometnih nesrečah in posledicah prometnih nesreč, kjer se ni uporabljal varnostni pas v obdobju enajstih let pri obeh spolih. V letih 2003 in 2004 je bilo $98 \%$ žensk, ki so uporabljale varnostni pas, pri moških pa je ta odstotek nižji 2003 je bil $95,1 \%$, v letu 2004 pa prav tako najvišji pri moških s $95,5 \%$, skozi vsa opazovana leta so moški z nižjim odstotkom uporabe varnostnega pasu. Od vseh povzročiteljev PN, ki niso uporabljali varnostnega pasu, jih je v prometnih nesrečah umrlo 48,6\%. Vendar je umrl skoraj enak odstotek tistih povzročiteljev, ki so uporabljali varnostni pas. Razlika se povečuje pri drugih posledicah, razen pri smrti. Tako je bistveno več tistih, ki so bili v PN huje, lažje poškodovani in so bili brez poškodb, pa so uporabljali varnostni pas (slika 4). 
N. Šestan, Z. Balantič \& M. Dodič Fikfak: Alkohol in psihoaktivne substance - vzrok za cestno prometne nesreče in cestno prometne prekrške

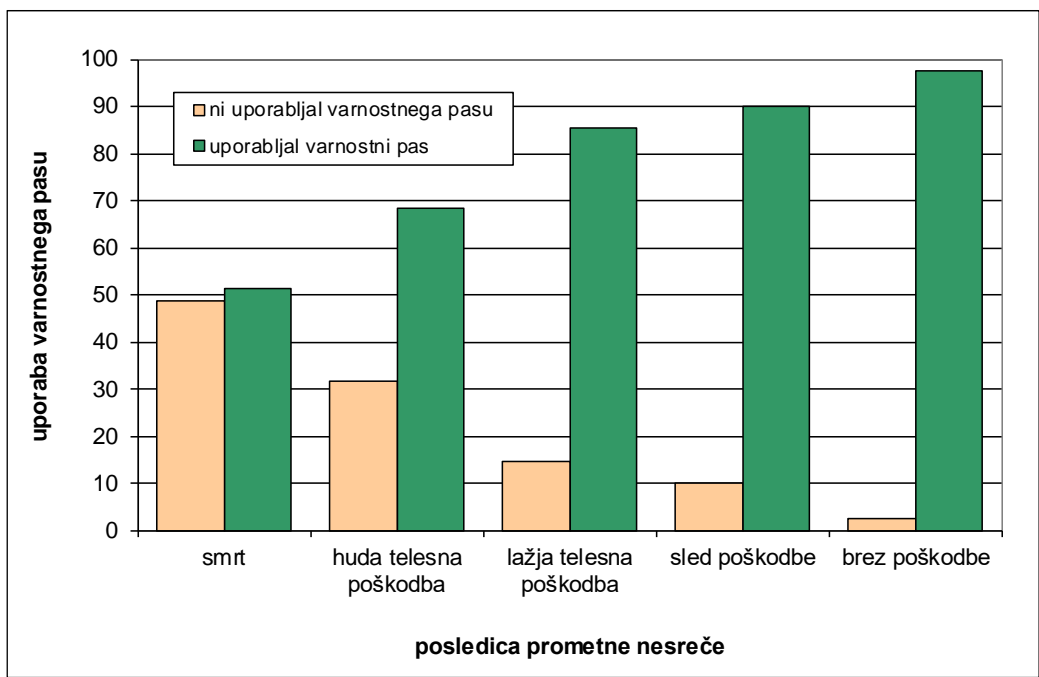

Slika 4: Uporaba varnostnega pasu glede na posledice prometnih nesreč, 2000 do 2010

$\mathrm{V}$ enajstletnem opazovanem obdobju je bil glavni vzrok PN prekoračitev hitrosti $(34,34$ $\%)$, sledi neuporaba varnostnega pasu $(19,33 \%)$ ter vožnja pod vplivom prepovedanih snovi $(7,95 \%)$ ter pod vplivom alkohola $(6,90 \%)$ (Slika 5).

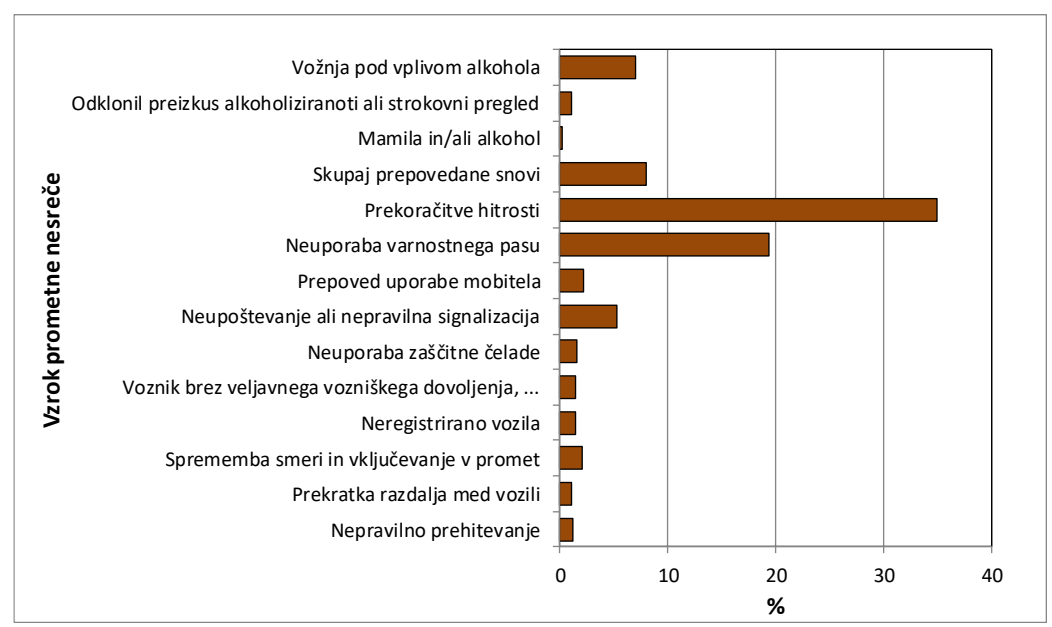

Slika 5: Odstotek PN po vzroku, od 2000 do 2010.

Preizkus alkoholiziranosti $\mathrm{z}$ alkotestom je bil odrejen $\mathrm{v} 41,88 \%$ primerov vseh povzročiteljev PN. Med njimi je bilo 14,05 \% pozitivnih rezultatov, meritev pa je odklonilo $1,72 \%$ povzročiteljev (Tabela 1 ). 
1042 36 $6^{\text {Th }}$ International Conference on Organizational Science Development: Responsible ORGaNiZATION (MARCH $22^{\mathrm{ND}}-24^{\mathrm{TH}}$, PorTOROŽ SlOVENIA)

N. Šestan, Z. Balantič \& M. Dodič Fikfak: Alcohol and Psychoactive Substances:

Causes of Traffic Accidents and Traffic Violations

\begin{tabular}{|c|c|c|c|c|c|c|c|c|}
\hline \multirow[b]{2}{*}{ Leto } & \multicolumn{2}{|c|}{ negativen } & \multicolumn{2}{|c|}{ pozitiven } & \multicolumn{2}{|c|}{ zavrnjen } & \multicolumn{2}{|c|}{ Skupaj odrejeni } \\
\hline & $\mathrm{n}$ & $\%$ & $\mathrm{n}$ & $\%$ & $\mathrm{n}$ & $\%$ & $\mathrm{n}$ & $\%$ \\
\hline \multirow{3}{*}{2000} & \multirow{3}{*}{12708} & 81,36 & \multirow{3}{*}{2910} & 18,63 & \multirow{3}{*}{1} & 0,01 & \multirow{3}{*}{15619} & 100,00 \\
\hline & & $\%$ & & $\%$ & & $\%$ & & $\%$ \\
\hline & & 82,58 & & 15,01 & & 2,40 & & 100,00 \\
\hline \multirow{2}{*}{2001} & \multirow{2}{*}{16758} & $\%$ & \multirow{2}{*}{3046} & $\%$ & \multirow{2}{*}{488} & $\%$ & \multirow{2}{*}{20292} & $\%$ \\
\hline & & 82,28 & & 15,18 & & 2,54 & & 100,00 \\
\hline \multirow[t]{2}{*}{2002} & \multirow[t]{2}{*}{16532} & $\%$ & \multirow[t]{2}{*}{3050} & $\%$ & \multirow[t]{2}{*}{510} & $\%$ & \multirow[t]{2}{*}{20092} & $\%$ \\
\hline & & 86,60 & & 11,60 & & 1,80 & & 100,00 \\
\hline \multirow[t]{2}{*}{2003} & \multirow[t]{2}{*}{25160} & $\%$ & \multirow[t]{2}{*}{3371} & $\%$ & \multirow[t]{2}{*}{523} & $\%$ & \multirow[t]{2}{*}{29054} & $\%$ \\
\hline & & 87,88 & & 10,50 & & 1,62 & & 100,00 \\
\hline \multirow[t]{2}{*}{2004} & \multirow[t]{2}{*}{27491} & $\%$ & \multirow[t]{2}{*}{3284} & $\%$ & \multirow[t]{2}{*}{508} & $\%$ & \multirow[t]{2}{*}{31283} & $\%$ \\
\hline & & 85,14 & & 13,08 & & 1,77 & & 100,00 \\
\hline \multirow[t]{2}{*}{2005} & \multirow[t]{2}{*}{17218} & $\%$ & 2646 & $\%$ & 358 & $\%$ & 20222 & $\%$ \\
\hline & & 83,67 & & 14,60 & & 1,73 & & 100,00 \\
\hline 2006 & 16769 & $\%$ & 2927 & $\%$ & 347 & $\%$ & 20043 & $\%$ \\
\hline & & 82,52 & & 15,39 & & 2,09 & & 100,00 \\
\hline 2007 & 15050 & $\%$ & 2806 & $\%$ & 382 & $\%$ & 18238 & $\%$ \\
\hline & & 81,23 & & 16,81 & & 1,96 & & 100,00 \\
\hline 2008 & 10426 & $\%$ & 2157 & $\%$ & 252 & $\%$ & 12835 & $\%$ \\
\hline & & 82,18 & & 16,69 & & 1,12 & & 100,00 \\
\hline 2009 & 9442 & $\%$ & 1918 & $\%$ & 129 & $\%$ & 11489 & $\%$ \\
\hline & & 85,96 & & 12,95 & & 1,09 & & 100,00 \\
\hline 2010 & 10845 & $\%$ & 1634 & $\%$ & 137 & $\%$ & 12616 & $\%$ \\
\hline & 178399 & $\begin{array}{r}84,24 \\
\% \\
\end{array}$ & 29749 & $\begin{array}{r}14,05 \\
\% \\
\end{array}$ & 3635 & $\begin{array}{r}1,72 \\
\% \\
\end{array}$ & 211783 & $\begin{array}{r}100,00 \\
\% \\
\end{array}$ \\
\hline
\end{tabular}

Tabela 1: Pozitivni, negativni in zavrnjeni preizkusi z alkotestom za PN, od 2000 do

\section{$6 \quad$ Rezultati PZK} 2010.

V opazovanem obdobju enajstih let je bilo narejenih 1556 pregledov, od tega je bilo 1353 moških in 203 ženske (slika 6). Najštevilčnejša starostna skupina je bila pri moških od 50 do 60 let, pri ženskah od 30 do 40 let. Na PZK je povprečna starost povzročiteljev $\mathrm{CPP}$ in PN višja kot struktura celotne baze podatkov vseh obravnavanih iz podatkov MNZ. 
N. Šestan, Z. Balantič \& M. Dodič Fikfak: Alkohol in psihoaktivne substance - vzrok za cestno prometne nesreče in cestno prometne prekrške

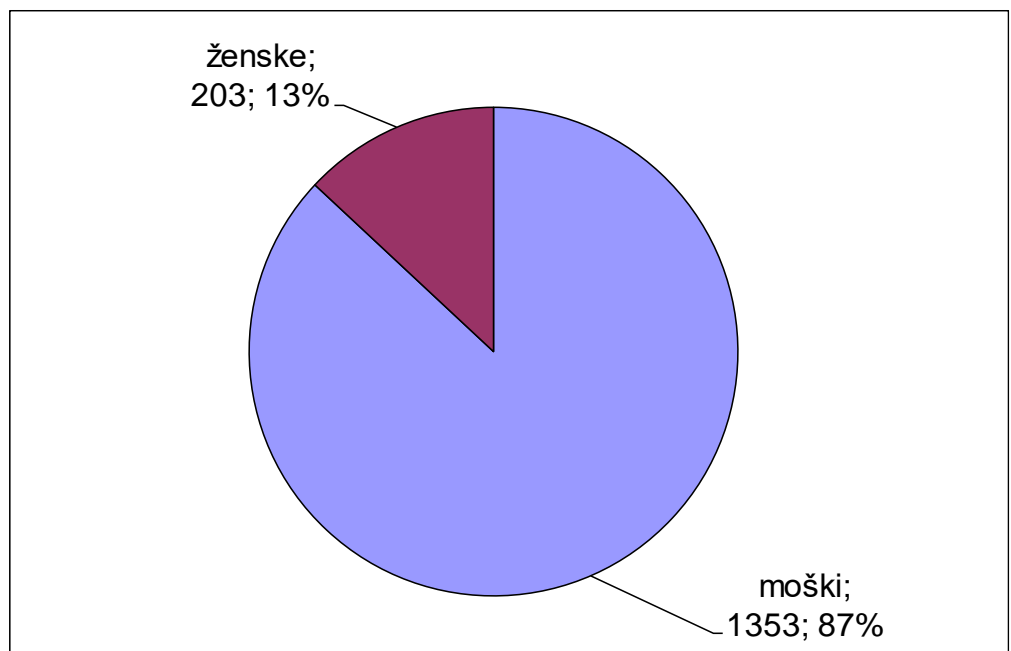

Slika 6: Število in odstotek obravnavanih po spolu na PZK od 2000 do 2010

Najpogostejši vzrok obravnave je bil zaradi epilepsije, obravnavanih je bilo 41,6\% voznikov, drugi najpomembnejši vzrok pa je bil zaradi odvisnosti od alkohola v 23,6\%. Iz celotne pregledovane populacije imamo 58\% abstinentov, kar $35 \%$ je zmernih pivcev, tistih voznikov, ki prekomerno uživajo alkohol pa se jih je izreklo v 7\% (slika 7). Po podatkih PZK imamo 98\% oseb, ki ne uživa psihoaktivnih snovi, 2\% pa se je izreklo, da jih uživa.

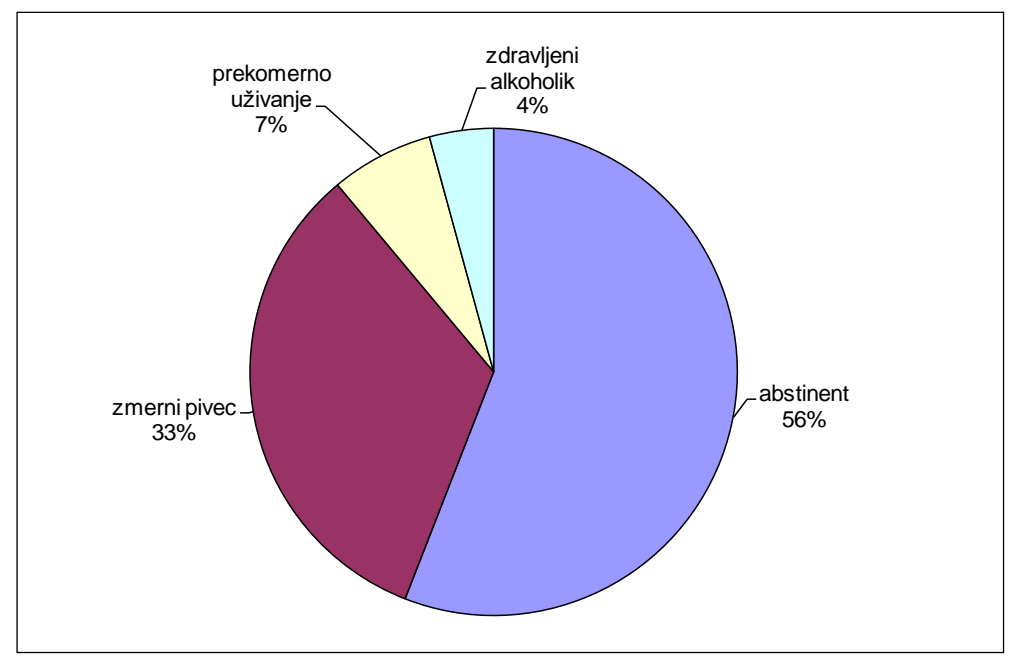

Slika 7: Odstotek primerov na PZK, ki so abstinenti, zmerni pivci in tisti, ki čezmerno uživajo alkohol, od 2000 do 2010 
$36^{\mathrm{TH}}$ International Conference on ORganizational Science Development: Responsible ORGANIZATION (MARCH $22^{\mathrm{ND}}-24^{\mathrm{TH}}$, PORTOROŽ SLOVENIA)

N. Šestan, Z. Balantič \& M. Dodič Fikfak: Alcohol and Psychoactive Substances:

Causes of Traffic Accidents and Traffic Violations

V 77 odstotkih so imeli pregledani vozniki na PZK normalne izvide jetrnih encimov in CDT $\%$, pri $23 \%$ so bili ti zvišani pri jetrnih encimih in v $22 \%$ pa v vrednostih CDT $\%, 2$ do $3 \%$ so bili ti mejni(slika 8 ).

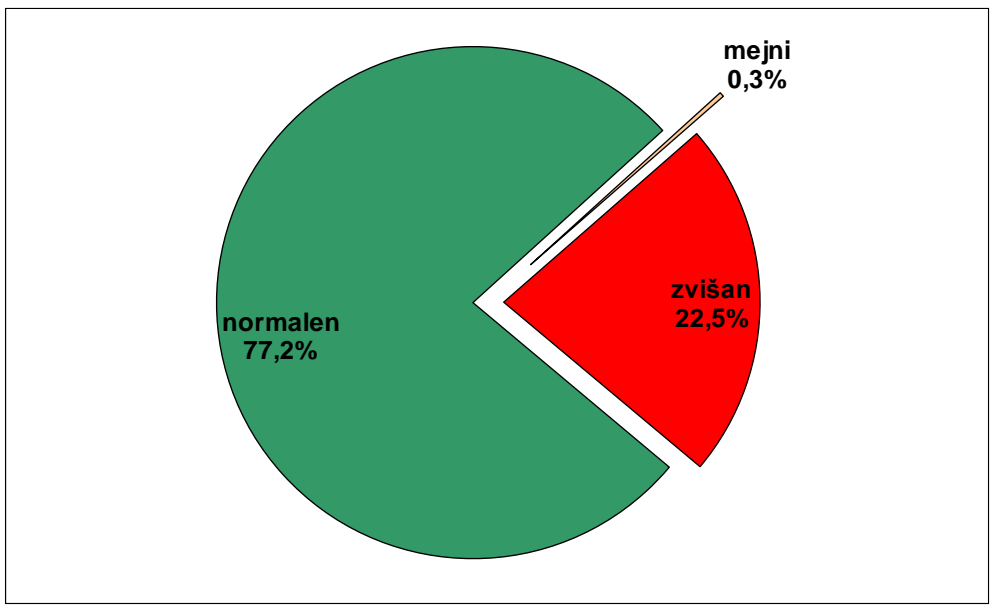

Slika 8: Vrednosti jetrnih encimov pri obravnavanih na PZK, od leta 2000 do 2010

Razprava in zaključek

Po podatkih MNZ so najpogostejši povzročitelji CPP in PN stari od 20 do 30 let. Ta starostna skupina predstavlja mlade voznike, ki zagotovo nimajo še dovolj izkušenj so tudi redkeje zasvojeni z alkoholom, večkrat pa tvegano ali škodljivo uživajo alkohol, ki $\mathrm{V}$ povezavi $\mathrm{z}$ večjo stopnjo impulzivnosti pomeni veliko tveganje za nesreče (Rus Makovec in Jakopič, 2010). Najštevilčnejša starostna skupina povzročiteljev obravnavanih na PZK je starih od 50 do 60 let, to so starejši vozniki, povzročitelji tako CPP kot PN, ki sicer imajo več izkušenj pri vožnji kot mladi vozniki so pa najverjetneje vplivale na izid prometnih nesreč v kombinaciji alkoholizma/tveganega pitja tudi različne druge kronične bolezni.

Alkoholizem predstavlja drugi najpogostejši vzrok obravnave na PZK, takoj za epilepsijo. Po podatkih PZK imamo skoraj 50 odstotkov voznikov, ki so se izrekli, da uživajo alkohol kot zmerni pivci, prekomerni uživalci in zdravljeni alkoholiki.

V naši raziskavi smo potrdili, da vozniki, ki so bili obravnavani na PZK, ki imajo diagnozo kroničnega alkoholizma in/ali tveganega pitja in vozniki uživalci PAS so pogostejši povzročitelji PN in CPP od voznikov povzročiteljev PN in CPP v RS.

V zadnjih letih je predvsem med mladimi v porastu tudi vse več uživalcev PAS, saj se na tržišču pojavljajo nove in nove substance, ki jih do dobra še ne poznamo in njihov vpliv na voznikovo sposobnost za vožnjo motornih vozil še ni bil podrobno raziskan. Vozniki, 
ki uživajo oziroma zlorabljajo alkohol in druge PAS predstavljajo resno grožnjo na področju prometne varnosti. Zato je potrebno raziskave o razširjenosti in vplivu PAS na varno vožnjo poglobiti in promocijske aktivnosti usmeriti predvsem v preprečevanje uporabe PAS.

\section{Literatura}

Rok M.S. Dejavniki, ki vplivajo na verjetnost smrti v prometu pri voznikih osebnih vozil v Sloveniji. Magisterska naloga UL MF-Biomedicina, Ljubljana 2004:2-9

Justinek, A., Leskovar, M., Markl, M., Pavlič, S., Sternad, G., Žlender, B. (2008). Zakon omejuje, da varuje: zakon o varnosti cestnega prometa: spoznajte spremembe 2008. Ljubljana: Ministrstvo za promet, Direkcija Republike Slovenije za ceste, 2008.

Kanaan, A., Huertas, P., Santiago, A., Sánchez, JA., Martínez, P. (2009). Incidence of different health factors and their influence on traffic accidents in the province of Madrid, Spain, Legal Medicine 11(1) S333-S336.

Rus, M.M. (2014). IV. paket znanja, Sodobna dognanja stroke, Ali je odvisnost res bolezen? Je, in to ozdravljiva bolezen možganov, Zgodbe upanja, Primeri celostnega zdravljenja odvisnosti, 228-241, 18-59, Furman, B.V., Gorše, G.A., Pišl, A., Purnat, Z., Otorepec, R.I., Radovanović, M., Rus M.M., Tabaković, K.V, eBesede, Ljubljana.

Rus, M.M., Jakopič, J. (2010). Vožnja pod vplivom alkohola in prometna varnost: kaznovati ali zdraviti z alkoholom nezasvojene in zasvojene voznike? Zdravniški vestnik, Ljubljana, 7—8, $582-592$.

Šestan N. (2016) Razvoj modela ocene tveganja voznikov s psihofizičnimi omejitvami pri nastanku prometnih incidentov, Doktorska disertacija, UM FOV Kranj

Šešok, J., Sedlak, S. (2006). Ekonomska ocena prezgodnjih smrti zaradi prometnih nezgod z udeležbo alkohola v Sloveniji za leto 2005, Inštitut za varovanje zdravja RS, Ljubljana.

Svetovna zdravstvena organizacija: Revni so pogosteje žrtve prometnih nesreč kot bogati. (15. junij 2009). Ljubljana: Dnevnik. (05. 02. 2011). http://www.dnevnik.si/novice /zdravje.

Zakon o duševnem zdravju (Uradni list RS, št. 77/2008).

Zakon o omejevanju porabe alkohola (ZOPA, Uradni list RS, št. 15/2003).

Zakon o proizvodnji in prometu s prepovedanimi drogami (Ur. 1. RS, št. 108/99, 44/00, 2/04 ZZdrl-A, 47/04 -ZPPPD).

Zakon o preprečevanju uporabe prepovedanih drog in o obravnavi uživalcev prepovedanih drog (Ur. 1. RS, št. 98/8 in 2/04-ZPUPD).

Zakon o pravilih cestnega prometa (ZPrCP, Uradni list RS, št. 109/2010). 
1046 36 ${ }^{\text {TH }}$ International Conference on Organizational Science Development: Responsible Organization (March $22^{\mathrm{ND}}-24^{\mathrm{TH}}$, Portorož Slovenia) 


\title{
Vpliv oblike reaktorja na dezintegracijo odpadnega blata iz čistilnih naprav
}

\begin{abstract}
MARKO ŠETINC
Povzetek Odpadno blato iz čistilnih naprav je danes predstavlja vse večji vpliv na okolje, zato ga je zakonsko potrebno sežgati ali obdelati tako, da nima nadaljnjih negativnih vplivov na okolje. To predstavlja visok strošek pri čiščenju vode. $\mathrm{Z}$ pomočjo dezintegracije odpadnega blata, je možno zmanjšati količino odpadnega blata tudi do $30 \%$ in s tem na nivoju Slovenije prihraniti tudi do milijon EUR letno. Učinkovitost dezintegracije blata je odvisna od samega procesa čiščenja, od tega, kje dezintegrator vključimo $\mathrm{v}$ proces in od same naprave za dezintegracijo blata. Ta je odvisna od tega, koliko energije se pretvori za učinek dezintegracije in oblike reaktorja. Namen prispevka je pokazati, kako oblika reaktorja vpliva na sam učinek dezintegracije blata. Pokazano je, da je učinkovitost dezintegracije večja v reaktorju s čepastim tokom v primerjavi z mešalnem reaktorju za do $30 \%$.

KLJUČNE BESEDE: dezintegracija odpadnega blata • čistilne naprave • ultrazvok
\end{abstract}

NASLOV AVTORJA: ddr. Marko Šetinc, Geopolis d.o.o., Teslova ulica 30, 1000 Ljubljana, Slovenija, e-pošta: marko.setinc@geopolis.si 
$36^{\text {Th }}$ International Conference on Organizational Science DeVElopment: Responsible ORGANIZATION (MARCH $22^{\mathrm{ND}}-24^{\mathrm{TH}}$, PORTOROŽ SLOVENIA)

O. Arsenijević, M. Ferjan, I. Podbregar, P. Šprajc, D. Trivan \& Y.

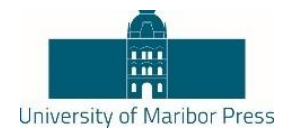

Ziegler

\title{
The Impact of Reactor Design on Disintegration of Waste Sludge from Wastewater Treatment Plants
}

\author{
MARKO ŠETINC
}

\begin{abstract}
Waste sludge from wastewater treatment plants causes an increasing impact on the environment. With that reason, the legal entities require that it has to be incinerated or processed, so there would be no further negative impact on the environment. The waste sludge removal represents a high cost for the water treatment plants. With the disintegration of sewage sludge, it is possible to reduce the amount of waste sludge up to $30 \%$. At the level of Slovenia, the cost reduction could be up to a million per year. The efficiency of sludge disintegrator depends on the wastewater treatment process, on where a disintegrator is incorporated in the process and on the type of the device for the disintegration of sludge. Different types of disintegrators have different energy input and different shape of the reactor. The purpose of this paper is to show how the shape of the reactor itself can affect the sludge disintegration. It is shown that the efficiency of plug flow reactor for disintegration has better results compared to stirred tank reactor by up to $30 \%$.
\end{abstract}

KEYWORDS: waste sludge disintegration • wastewater plants $\bullet$ ultrasound

CORRESPONDENCE AdDRESS: ddr. Marko Šetinc, Geopolis d.o.o., Teslova ulica 30, 1000 Ljubljana, Slovenia, e-mail: marko.setinc@geopolis.si 
M. Šetinc: Vpliv oblike reaktorja na dezintegracijo odpadnega blata iz čistilnih naprav

\section{$1 \quad$ Uvod}

Pri procesu čiščenja odpadne vode nastaja odpadno blato, ki se odstranjuje iz sistema. Ker večja količina oddanega odpadnega blata predstavlja večji strošek za čistilno napravo se to blato dehidrira na primer s pomočjo preše, centrifuge, sušilnice, anaerobne faze obdelave blata in podobno. V letu 2014 je po podatkih Ministrstva za okolje in prostor zabeleženo, da je v Sloveniji nastalo okoli 28.300 t (izraženo kot suha snov) blata iz komunalnih in skupnih čistilnih naprav (MOP, 2016). Če ta podatek primerjamo z količino odpadnega blata $v$ letu 2006 (20.160 t) ugotovimo, da je bila $v$ teh letih več kot $4 \%$ rast količine odpadnega blata.

V preteklosti se je večino odpadnega blata iz čistilnih naprav odlagalo na odlagališčih in kmetijskih površinah, kar je prestavljalo cenovno zelo ugodno rešitev, ki pa je bila okoljsko neustrezna. Zaradi pogoste onesnaženosti odpadnega blata s težkimi kovinami, danes tak način $\mathrm{v}$ večini primerov ni več dovoljen in je zato potrebno tovrstno blato sežgati ali ga vgraditi v netopne kompozite. Zaradi tega so cene odstranitve odpadnega blata vse višje in zato postajajo dodatni postopki, ki omogočajo zmanjšanje količine odpadnega blata vse bolj aktualni. To je razvidno tudi iz priporočil Nemškega združenja za vodo, odpadno vodo in odpadke (DWA-Regelwerk, 2015), ki obravnavajo različne postopke za dezintegracijo odpadnega blata. Postopki dezintegracije so lahko so lahko kemijski, termični in mehanski. Eden izmed vse bolj uveljajočih načinov je tudi dezintegracija blata ustvarjena s pomočjo kavitacije, ki je ustvarjena s pomočjo zvoka ali bolj natančno ultrazvoka. Takšno napravo je mogoče vgraditi v sistem na različne faze čiščenja odpadne vode, kot je prikazano na sliki 1.

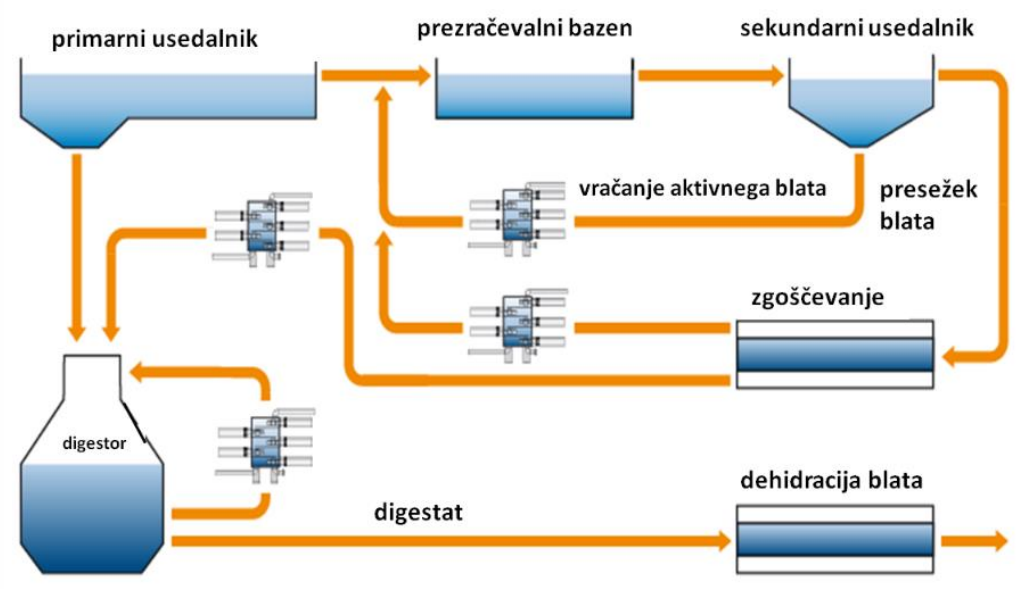

Slika 1: Možnosti postavitve dezintegratorja v proces čiščenja odpadne vode. (vir: http://www.ultrawaves.de/wastewater-treatment-plants)

Najbolj splošna uporaba ultrazvočnega dezintegratorja je pred anaerobnim digestorjem (Banduch, 2011), saj je dezintegrirano odpadno blato lažje razgradljivo oz. dostopno 
mikroorganizmom. Posledica tega je, da tako blato omogoča večjo proizvodnjo biplina oz. krajše zadrževalne čase v digestorju. Dezintegrirano blato je možno uporabiti tudi v fazi denitrifikacije kot vir ogljika ali ustvariti pogoje, ki preprečujejo nastajanje nitastih bakterij, ki povzročajo penjenje vode (Wünsh idr. 2002, Nickel in Neis, 2007, Neis idr., 2007, Blume idr 2003).

S pomočjo sistematične uvede dezintegratorja bi na nivoju Slovenije lahko prihranili okrog milijon evrov letno (Šetinc, 2017)

\section{$2 \quad$ Metode}

Na podlagi zbranih podatkov o delovanju ultrazvočnega dezintegratorja odpadnega blata in možnih načinov vgradnje $\mathrm{v}$ različne reaktorje bomo ocenili, kako vrsta oz. oblika reaktorja vpliva na učinkovitost dezintegracije.

\section{$3 \quad$ Raziskava}

V raziskavi smo povezali že objavljene raziskave s področja dezintegracije odpadnega blata s pomočjo ultrazvoka in vpliva vrste reaktorja na sam potek dezintegracije. Pri tem smo se osredotočili na dva tipa reaktorjev in sicer mešalni reaktor in reaktor s čepastim tokom.

\subsection{Ultrazvočni dezintegrator}

Pri izvedbi izračunov o učinkih dezintegracije odpadnega blata smo uporabili podatke o napravi podjetja Ultrawaves GMBH (Vergara idr. 2012). Podjetje je razvilo ultrazvočni sistem, ki omogoča zelo visok vnos energije $\mathrm{v}$ odpadno blato in s tem učinkovito dezintegracijo. Ker je na trgu več različnih dezintegratovrjev, ki se razlikujejo po velikem številu parametrov (volumen, zadrževalni čas, vnos energije, amplituda nihanja itd.), razlikovanje med njimi ni enostavna naloga. Vsi prej omenjeni parametri dezintegratorja so zelo pomembni, saj le pravilno izbran režim delovanja omogoča kvalitetno dezintegracijo odpadnega blata in visoko učinkovitost izrabe energije.

Dezintegrator deluje s pomočjo ultrazvoka, zvoka v frekvenčnem območju, ki je nad slišnim območjem človeka (to je nad $20 \mathrm{kHz}$ pa vse do reda velikosti MHz). V tekočini ultrazvočno valovanje povzroča ponavljajoče se stiskanje in raztezanje vodne faze. Pri tem nastajajo majhni mehurčki, ki se prav tako raztezajo in krčijo vse do trenutka, ko implodirajo. To je shematično prikazano na sliki 2. 

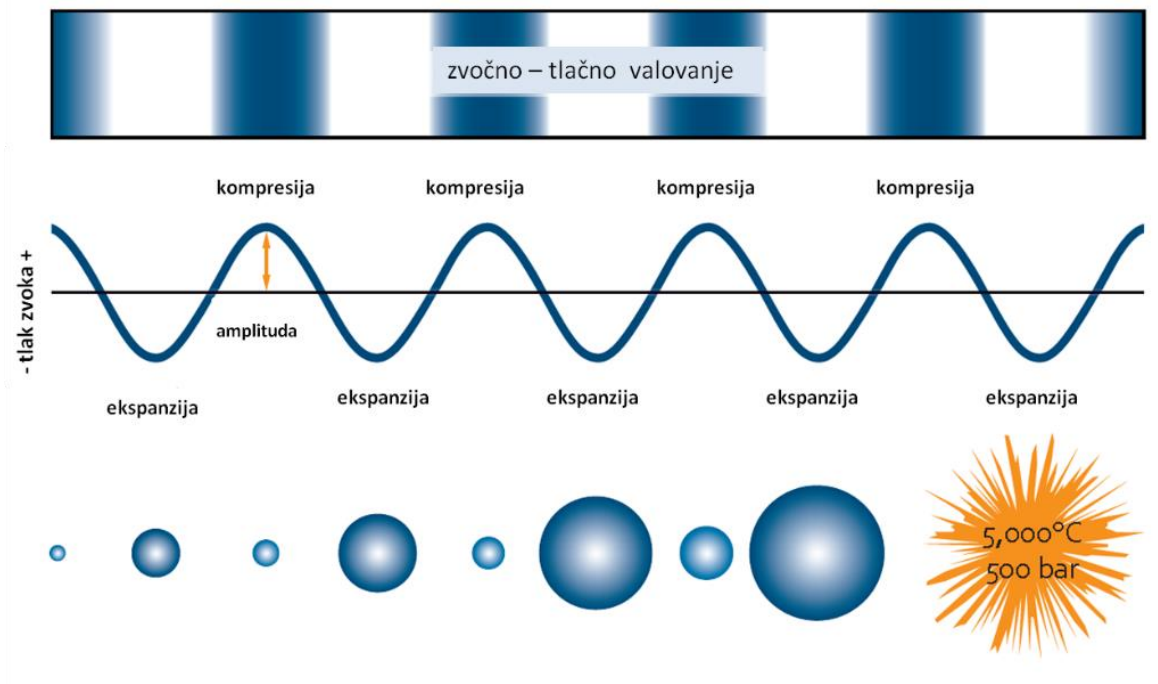

formacija mehurčka

rast mehurčka

Implozija mehurčka

Slika 2: Prikaz formiranja mehurčkov pri obdelavi vode z ultrazvokom in nastanek implozije (kavitacije) (vir: http://www.ultrawaves.de/technology/ultrasonicdisintegration)

Ta učinek se imenuje kavitacija. Pri kavitaciji se na mikro-nivoju ustvari zelo visok tlak in temperatura. Razmeroma veliki mehurčki nastajajo v frekvenčnem območju med 20 in $100 \mathrm{kHz}$. Pri imploziji mehurčkov le ti povzročijo zelo močne strižne sile, ki lahko razbijejo robustno površino in tudi celice $\mathrm{v}$ odpadnem blatu. Takšen postopek je priznan kot učinkovit in priporočljiv tudi po priporočilih Nemškega združenja za vodo, odpadno vodo in odpadke (DWA, 2015).

V prispevku smo se lotili teoretične raziskave, s katero bomo pokazali razliko med uporabo mešalnega reaktorja in reaktorja s čepastim tokom za tovrsten proces. Pri tem pa je potrebno opozoriti, da so med posameznimi vrstami naprav tudi ostale prej omenjene razlike, ki lahko bistveno vplivajo na učinkovitost delovanja. 


\subsection{Vrste reaktorjev}

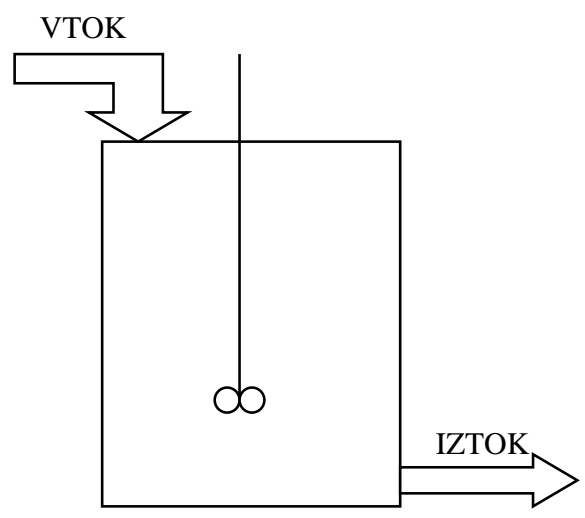

Slika 3: Prikaz modela mešalnega reaktorja

V pretočnem sistemu v osnovi poznamo dve vrsti reaktorjev. Prvi je mešalni reaktor, drugi pa reaktor s čepastim tokom. Mešalni reaktor je prikazan na sliki 3 in se ga $\mathrm{v}$ splošnem uporablja za modeliranje $\mathrm{v}$ kemijskem inženirstvu, saj se ga da matematično dobro popisati in z njim modelirati procese. Izračuni predpostavljajo idealno mešanje in to, da je koncentracija snovi na izhodu enaka koncentraciji snovi v reaktorju. Konverzija je odvisna od zadrževalnega časa in reda reakcije.

Reaktor s čepastim tokom, ki se imenuje tudi cevni reaktor, je pretočni reaktor, ki se ga prav tako uporablja za modeliranje v kemijskem inženirstvu. Pri tem tok snovi teče skozi cilindrično cev. Tudi reaktor s čepastim tokom je za namen modeliranja obravnavan kot idealni reaktor. Pri tem se predpostavlja, da je koncentracija snovi enaka v radialni smeri reaktorja oz. da ima čep prikazan na sliki 4 kot $\mathrm{dV} v$ radialni smeri popolno premešanje in enako koncentracijo. Vsak čep predstavlja svojo entiteto, zato lahko takšen reaktor modeliramo tudi kot zaporedje mešalnih reaktorjev.

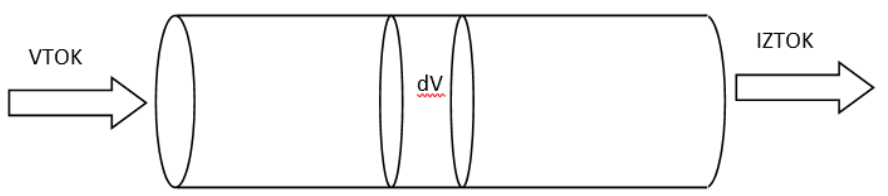

Slika 4: Prikaz modela reaktorja s čepastim tokom

Za obe vrsti reaktorjev obstaja vrsta zakonitosti in predpostavk, ki so v razširjeni obliki prikazane v knjigi Chemical Reaction Engineering (Levenspiel 1999) in presega obravnavo $\mathrm{v}$ tem prispevku. 
M. Šetinc: Vpliv oblike reaktorja na dezintegracijo odpadnega blata iz čistilnih naprav

Kot je znano iz raziskav, je ultrazvočna dezintegracija odpadnega blata reakcija prvega reda (Blume idr 2002, Nickel in Neis2007), kar je prikazano v enačbi 1

$\mathrm{n}=1(1)$

Hitrost reakcije je prikazana $v$ enačbi $2 . r_{A}$ je hitrost izginevanja snovi iz katere nastajane produkt, $\mathrm{k}$ pa je reakcijska konstanta, $\mathrm{C}_{\mathrm{A}}$ predstavlja koncentracijo razgradljive snovi (Levenspiel, 1999).

$-\mathrm{r}_{\mathrm{A}}=\mathrm{k} * \mathrm{C}_{\mathrm{A}}(2)$

Za mešalni reaktor, kjer poteka reakcija prvega reda velja naslednja enačba (3) (Levenspiel, 1999), pri čemer je $\tau$ zadrževalni čas, $C_{A 0}$ je začetna koncentracija nerazgradljive snovi, X pa konverzija. Označba Am pomeni snovi A v (m) mešalnem reaktorju.

$\mathrm{k}^{*} \tau=\left(\mathrm{C}_{\mathrm{A} 0}-\mathrm{C}_{\mathrm{Am}}\right) / \mathrm{C}_{\mathrm{Am}}=\mathrm{X}_{\mathrm{Am}} /\left(1-\mathrm{X}_{\mathrm{Am}}\right)(3)$

Za reaktor s čepastim tokom kjer poteka reakcija prvega reda velja naslednja enačba (4) (Levenspiel, 1999. Označba Ač pomeni snovi A v (č) reaktorju s čepastim tokom.

$\mathrm{k} * \tau=\ln \left(\mathrm{C}_{\mathrm{A} 0} / \mathrm{C}_{\mathrm{A} \check{c}}\right)=\ln \left(1 /\left(1-\mathrm{X}_{\mathrm{A} \check{c}}\right)\right)(4)$

Če sta oba reaktorja enake velikosti in imata enak pretok ter s tem zadrževalni čas, lahko obe enačbi izenačimo in dobimo enačbo (5).

$\ln \left(1 /\left(1-\mathrm{X}_{\mathrm{Ac}}\right)\right)=\mathrm{X}_{\mathrm{Am}} /\left(1-\mathrm{X}_{\mathrm{Am}}\right)(5)$

$\mathrm{S}$ pomočjo te enačbe smo primerjali konverzijo v mešalnem reaktorju $\left(\mathrm{X}_{\mathrm{Am}}\right) \mathrm{z}$ konverzijo, ki bi pri enakih pogojih nastala $\mathrm{v}$ reaktorju s čepastim tokom $\left(\mathrm{X}_{\mathrm{Ac}}\right)$.

\section{$4 \quad$ Rezultat}

Na podlagi enačbe (5) smo izdelali izračune za prvi red reakcije dezintegracije odpadnega blata s pomočjo ultrazvočne naprave. Pri tem smo dobili rezultate in jih prikazali kot odvisnost večje konverzije reaktorja s čepastim tokom izračunanega kot $\left(\mathrm{X}_{\mathrm{Acc}}-\mathrm{X}_{\mathrm{Am}}\right)$ od konverzijo v mešalnim reaktorju. Iz slike 4 je razvidno, koliko višja konverzija bi bila v reaktorju z čepastim tokom v primerjavi z mešalnim reaktorjem pri različnih konverzijah. Največja razlika v konverzijah je pri konverziji $0,71 \mathrm{v}$ mešalnem reaktorju in sicer za 0,2 . Po konverziji 0,71 se začne razlika zmanjševati. To je posledica tega, da je največja stopnja konverzije $\mathrm{v}$ reaktorju s čepastim tokom lahko največ 1 . V primerih, kjer je stopnja, konverzije $\mathrm{v}$ mešalnem reaktorju presegla maksimalno vrednost razlike konverzij (pri 0,71) je reaktor z čepastim tokom že dosegel konverzijo 1 in je v tem primeru reaktor predimenzioniran. 
36 ${ }^{\text {TH }}$ International Conference on Organizational Science Development: RESPONSIBLE ORGANIZATION (MARCH $22^{\mathrm{ND}}-24^{\mathrm{TH}}$, PortoroŽ SLOVENIA)

M. Šetinc: The Impact of Reactor Design on Disintegration of Waste Sludge from Wastewater Treatment Plants

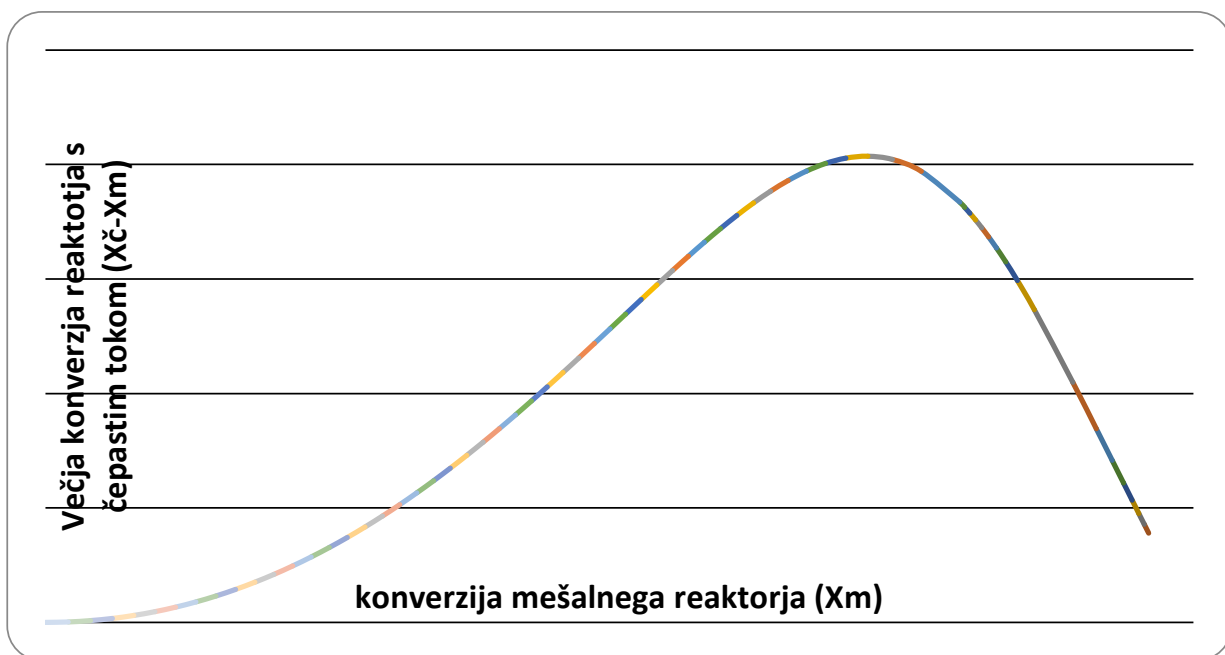

Slika 4: Večja konverzija v reaktorju s čepastim tokom v odvisnosti od konverzije v mešalnem reaktorju.

Iz slike 4 so razvidne absolutne vrednosti konverzije, ki dosegajo vrednost okrog 0,2. Za bolj nazorno predstavitev in soodvisnost smo uporabili še relativno skalo in sicer smo primerjali še, koliko se relativno poveča konverzija $\left(\left(\mathrm{X}_{\mathrm{Ač}}-\mathrm{X}_{\mathrm{Am}}\right) / \mathrm{X}_{\mathrm{Am}}\right)$ v odvisnosti od konverzije v mešalnem reaktorju. To je prikazali na sliki 5.

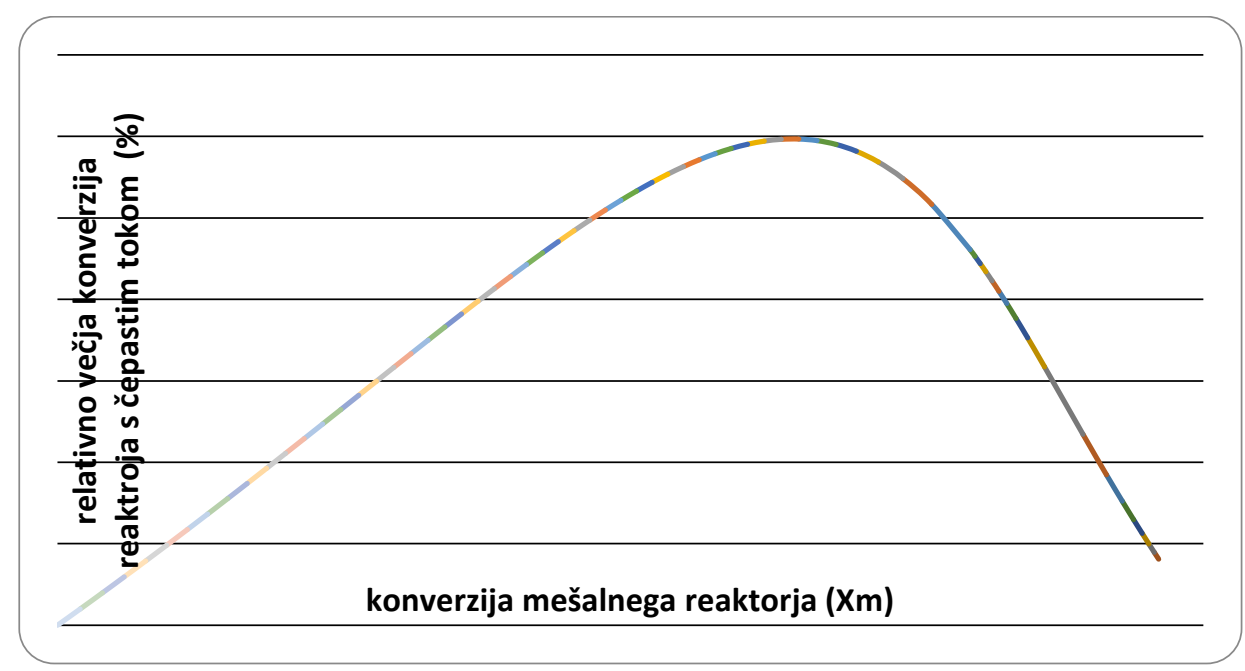


Slika 5: Relativno povečana konverzija v reaktorju s čepastim tokom v odvisnosti od konverzije v mešalnem reaktorju

Iz slike 5 je razvodno, da je povečanje konverzije $\mathrm{v}$ reaktorju $\mathrm{s}$ čepastim tokom razmeroma linearno, do vrednosti konverzije 0,6 . Pri konverziji 0,2 se poveča za okrog $10 \%$, pri konverziji 0,4 za $20 \%$ in konverziji 0,6 za okrog $30 \%$. Največjo relativno razliko konverzije doseže pri okrog 0,65 in sicer okrog $30 \%$. Po konverziji 0,65 se začne ta razlika zmanjševati, saj pri enakih velikostih reaktorjev reaktor s čepastim tokom doseže konverzijo 1.

Iz slik 4 in 5 tako lahko nazorno vidimo pomemben vpliv izbrane vrste reaktorja v samem procesu. Za primer dezintegracije odpadnega blata velja, da dobimo večjo konverzijo pri uporabi reaktorja $\mathrm{z}$ čepastim tokom ali njegov približek, kot pa pri klasičnem mešalnem reaktorju oz. njegovem približku.

\section{Zaključek}

Ker je dandanes vse večji problem $\mathrm{z}$ odpadnim blatom iz čistilnih naprav obstaja velika verjetnost, da se bo $\mathrm{v}$ večje čistilne naprave vgrajevalo vse več dezintegratorjev odpadnega blata. Pri nakupu le tega smo v veliki meri prepuščeni zaupanju do prodajalca, ki učinkovitosti oglašuje. Vnos energije, ki je namenjena dezintegracij odpadnega blata je bistven parameter, ki ga je potrebno preveriti, a je le ta žal odvisen od mnogih spremenljivk, kot so na primer amplituda nihanja, frekvenca nihanja, količina vnesene energije na površinsko enoto in sama oblika oz. vrsta reaktorja. V prispevku smo se v ta namen lotili parametra enega parametra in sicer vrste reaktorja. Pri tem smo pokazali, da je pri dezintegraciji odpadnega blata iz čistilnih naprav bolj primeren reaktor z čepastim tokom, kot mešalni reaktor, saj omogoča doseganje višjih konverzij, ki znašajo tudi do $30 \%$.

\section{Literatura}

Banduch, I. (2011). Die Wirkung von Ultraschall auf die mikrobiologische Diversität und Abbauleistung eines biologischen Reaktors zur Abwasserreinigung (Doktorsko delo). Technischen Universität Hamburg-Harburg.

Blume T., Martınez I., , Neis U.. (2002)astewater disinfection using ultrasound and UV light, in: Ultrasound in Environmental Engineering II, TU Hamburg-Harburg Reports on Sanitary Engineering, 35, str. 117-128.

Blume, T., Martin Perez I. in Neis U. (2003). A combined acustical-chemical method for wastewater disinfection. Applications for Power Ultrasound in Physical and Chemical Processing, Besancon, France, 22-23.5.2003.

DWA-Regelwerk (2015), Merkblatt DWA-M 301, Klärschlammdesintegration, Deutsche Vereinigung für Wasserwirtschaft, Abwasser und Abfalle e.V.

Levenspiel O. (1999). Chemical reaction engineering, John Wiley \& Sons, Ne York.

Neis, U., Nickel K., Lunden A., (2007). Improving anaerobic and aerobic degradation by ultasonic disintegrator of biomass. IVA-Conference Antalya/Turkey 28-30.3.2007. 
1056 36 $6^{\mathrm{TH}}$ InTERnAtional CONFERENCE ON ORganizational SCIENCE Development: ReSPONSIBLE ORGANIZATION (MARCH $22^{\mathrm{ND}}-24^{\mathrm{TH}}$, PORTOROŽ SLOVENIA)

M. Šetinc: The Impact of Reactor Design on Disintegration of Waste Sludge from Wastewater Treatment Plants

Neis U., Nickel K. in Lundén A. (2008). Improving anaerobic and aerobic degradation by ultrasonic disintegration of biomass Journal of Environmental Science and Health Part A

Nickel K. in Neis U. (2007). Ultrasonic disintegration of biosolids for improved biodegradation. Ultrasonic Sonochemisty Journal. 14 (2007) str. 450-455.

Vergara L., Nicke, K. in Neis. U. (2012): Desintegrating sludge as carbon source for denitrification, 17th European Biosolids Organic Resouces Cenference, Seminar \& Exhibition

Wünsch B., Heine W., Neis U., (2002). Combating bulking sludge with ultrasound, TU HamburgHarburg reports on Sanitary Engineering 35.

Wastewater Treatment Plants: http://www.ultrawaves.de/wastewater-treatment-plants

Ultrasonic Disintegration: http://www.ultrawaves.de/technology/ultrasonic-disintegration 


\section{Orodja kakovosti}

\section{BRANKO ŠKAFAR}

Povzetek Številne organizacije uporabljajo, zaradi učinkovitejšega in uspešnejšega delovanja svoje organizacije, različna orodja kakovosti. V nalogi predstavljamo, na osnovi raziskave $\mathrm{v}$ naključno izbranih organizacijah, kako orodja kakovosti, ki jih uporabljajo organizacije, delujejo in ali izpolnjujejo pričakovanja. Veliko je organizacij v katerih orodja kakovosti ne delujejo oz. ne izpolnjujejo njihovih pričakovanj. Vzroke za neizpolnjevanje pričakovanj in predloge za izboljšanje uporabe orodij kakovosti $\mathrm{v}$ organizacijah predstavljamo $\mathrm{v}$ tem referatu. Ustrezna uporaba orodij kakovosti pomeni, med drugim tudi to, da je organizacija odgovorna.

KLJUČNE BESEDE: orodja kakovosti • učinkovitost • uspešnost • odgovorna organizacija

NASLOV AVTORJA: dr. Branko Škafar, Ekonomska šola Murska Sobota, Višja strokovna šola, Noršinska ulica 139000 Murska Sobota, Slovenija, e-pošta: branko.skafar@siol.net 
$36^{\text {Th }}$ International Conference on Organizational Science DeVElopment: Responsible ORGANIZATION (MARCH $22^{\mathrm{ND}}-24^{\mathrm{TH}}$, PORTOROŽ SLOVENIA)

O. Arsenijević, M. Ferjan, I. Podbregar, P. Šprajc, D. Trivan \& Y.

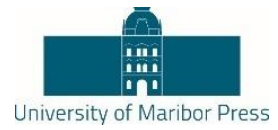

Ziegler

\title{
Quality Tools
}

\section{BRANKO ŠKAFAR}

\begin{abstract}
Due to a more efficient and effective operation a lot of organizations use various quality tools. Based on a survey of randomly selected organizations, this paper presents how quality tools used by organizations function and whether they meet their expectations. There are a lot of organizations where quality tools do not function or do not meet their expectations. The reasons for the failure of expectations as well as the proposals for improving the application of quality tools in organizations are presented in this paper. The appropriate use of quality tools means, among other things, that the organization is responsible.
\end{abstract}

KEYWORDS: tools of quality - efficiency $\cdot$ effectiveness $・$ responsible organization

CORRESPONDENCE AdDREsS: Branko Škafar, Ph.D., School of Economics Murska Sobota, Vocational College, Noršinska ulica 139000 Murska Sobota, Slovenia, e-mail: branko.skafar@siol.net

DOI https://doi.org/10.18690/978-961-286-020-2.84 ISBN 978-961-286-020-2

(C) 2017 University of Maribor Press

Available at: http://press.um.si 


\section{$1 \quad$ Uvod}

Živimo v času globalizacije svetovnega tržišča, hitrega razvoja tehnologij in njihove vse večje uporabe $\mathrm{v}$ poslovnih organizacijah. Globalizacija pomeni tudi vse močnejšo konkurenco in zaostritev pogojev plasmaja izdelkov in storitev (Skoko, 2000, str. 4).

V tem spletu zaostrenih pogojev poslovanja in realnih možnosti se vse bolj pojavljajo gospodarski subjekti, ki imajo za cilj stabilen in dolgoročen razvoj. Pri tem se ob pritisku konkurence srečujejo z vse močnejšim tekmovanjem v kakovosti. Kakovost je zaradi tega, v borbi za tržišče in potrošnika, zagotavljanje kakovosti in upravljanja z njo, postala pogoj za preživetje._Iz tega izhaja, da je pravi odgovor podjetij na svetovne izzive, koncept kakovosti, ki predpostavlja vključenost celotnega podjetja, vseh njenih poslovnih procesov in vseh zaposlenih ter menedžmenta.To je pomembno poudariti, saj se veliko menedžerjev še vedno angažira le v posameznih programih kakovosti (Malek, Škafar in Vorina, 2009).

$\mathrm{V}$ tem prispevku bomo predstavili pomen in skupne značilnosti nekaterih sistemov vodenja kakovosti ter na osnovi raziskav podali ugotovitve zakaj le ti v praksi delujejo oz. ne delujejo. Primerjali bomo sistem vodenja kakovosti ISO 9001, sistem vodenja kakovosti v višjih strokovnih šolah, sistem vodenja kakovosti v visokih šolah, sistem vodenja kakovosti Kakovost za prihodnost vzgoje in izobraževanja, sistem vodenja kakovosti v gasilstvu. Razen mednarodnega standarda ISO 9001 je avtor ali soavtor ostalih navedenih orodij, avtor tega članka.

\section{$2 \quad$ Pomen in opredelitev kakovosti}

Kakovost ni lahko opredeliti. Pojem kakovosti se uporablja v različne namene. Lahko povemo, da kakovosti ne moremo opredeliti, a vseeno vemo, kaj je kakovost. Kljub vsemu pa obstajajo različne opredelitve kakovosti (Malek idr., 2009).

Piskar in Dolinšek (2006) sta povzela različne opredelitve kakovosti nekaterih avtorjev (Crosby, Garvin, Gilles, Juran in drugi). Sinteza teh različnih opredelitev je:

- Kakovosten proizvod oziroma storitev je tista, ki ustreza zahtevam odjemalcem. Mogoče je, da odjemalec že prej določi tehnične specifikacije, katere je treba natančno upoštevati. Mogoče pa je, da so tehnične specifikacije že določene in jih pozneje prilagodimo odjemalcu.

- Ocena kakovosti proizvoda oziroma storitve je pogosto odvisna od cene stroškov, ki nastanejo med uporabo proizvoda oziroma opravljanjem storitve; vključujejo ljudi, orodja in čas.

- Kakovost proizvoda oziroma storitve se izmeri tako, da izmerimo dejavnike, ki vplivajo nanjo. Ti so odvisni drug od drugega. Marsikateri je izredno težko merljiv. Oceno kakovosti sestavimo iz ocen dejavnikov.

- Obstaja več plati kakovosti, ki si jih lahko predstavljamo, kot poglede iz različnih zornih kotov na eno in isto stvar. 
- Kakovostni proizvodi oziroma storitve nimajo škodljivega vpliva na naravno in družbeno okolje.

- Kakovostni proizvod je posledica kakovostnega razvojnega procesa tega proizvoda in kakovostnih materialov, iz katerih je izdelan ter kakovostnega procesa izdelave.

- Odlična storitev zvišuje lojalnost odjemalcev

- Kakovost je prihranek zaradi znižanja stroškov, nastalih kot posledica neustrezne kakovosti.

- Odlična storitev je najboljši način za pridobitev konkurenčne prednosti in uspešnosti.

Kakovost po standardu ISO 8402 opredelimo kot skupek vseh lastnosti in karakteristik proizvoda, procesa ali storitve, ki se nanašajo na sposobnost, da izpolnijo postavljene in neposredno izražene potrebe (Kovačič in Vukšić, 2005, str. 76).

Kakovost lahko opredelimo tudi kot izpolnjevanje pričakovanj, odličnost pa kot preseganje pričakovanj odjemalcev. Toda, katerih? Vseh, ki so kakor koli povezani z organizacijo. To so v predvsem kupci, sledijo pa zaposleni, lastniki, dobavitelji, ožja in širša družbena skupnost. Takšna opredelitev je $\mathrm{v}$ današnjem času nujna za poslovno uspešnost in učinkovitost, vse bolj pa postaja pogoj za preživetje (Malek idr., 2009, str. 21).

\section{$3 \quad$ Upravljanje kakovosti}

Upravljanje kakovosti je proces, ki prepozna in upravlja aktivnosti, ki so potrebne za doseganje ciljev kakovosti neke organizacije (Skoko, 2000, str. 10).

Upravljanje kakovosti je sklop dejavnosti splošne funkcije upravljanja, ki opredeljujejo politiko kakovosti, cilj in odgovornosti in jih v sistemu kakovosti uresničujejo s pomočjo planiranje kakovosti, spremljanja kakovosti, zagotavljanja in izboljševanja kakovosti. Ko se na področju upravljanja kakovosti eksplicitno izpostavi potreba za delovanje vseh članov organizacije pri uresničevanju ciljev kakovosti, pridemo do pojma celovitega upravljanja kakovosti (Total Quality Management, TQM). Lahko bi rekli, da je celovito upravljanje kakovosti način upravljanja organizacije, osredotočeno na kakovost, utemeljeno na sodelovanju vseh članov organizacije. Kot takšno zadovoljuje uporabnika (kupca), teži $\mathrm{k}$ zagotavljanju dolgoročnega uspeha in zadovoljevanju vseh članov organizacije in vseh, ki so z njo povezani (Malek idr., 2009, str. 21).

Sistem vodenja kakovosti in poslovna odličnost sta danes, kakor smo že ugotovili, konkurenčna prednost. Vse bolj pa postajata pogoj za preživetje. Prav zaradi tega si organizacije prizadevajo vzpostaviti sistem vodenja kakovosti in se podajajo na pot $\mathrm{k}$ poslovni odličnosti. Seveda mora biti vzpostavljen sistem kakovosti v organizaciji njen način življenja. Vse bolj se ugotavlja, da organizacije vzpostavijo sistem kakovosti, nato pa ne živijo po njem, zato jim bolj predstavlja breme kot korist. Vzrok je velikokrat tudi v nepoznavanju orodij, modelov in tehnik vodenja kakovosti. Poznamo veliko število 
orodij, modelov in tehnik vodenja kakovosti, ki pripomorejo organizacijam na poti $\mathrm{h}$ kakovosti in poslovni odličnosti. Poznavanje orodij, modelov in tehnik je danes nuja. Njihova uporaba pa postane odločitev organizacije. Uspešne organizacije v svetu uporabljajo več kot deset orodij istočasno in pri tem izgrajujejo lastni model, ki jim zagotavlja dolgoročno uspešnost in učinkovitost (Malek idr., 2009).

\section{Skupne značilnosti nekaterih sistemov vodenja kakovosti}

$\mathrm{V}$ prispevku bomo omejeni s primerjavo le nekaterih sistemov vodenja kakovosti. Primerjali bomo Sistem vodenja kakovosti ISO 9001, sistem vodenja kakovosti v višjih strokovnih šolah, sistem vodenja kakovosti $\mathrm{v}$ visokih šolah, sistem vodenja kakovosti Kakovost za prihodnost vzgoje in izobraževanja in sistem vodenja kakovosti v gasilstvu.

Skupne značilnosti omenjenih sistemov vodenja kakovosti so:

- vsi imajo osnovo v tako imenovanem PDCA (planiraj - izvedi - izmeri izboljšaj) krogu (spirali),

- voditeljstvo (ustrezni vodja - inovativni, timski, vizionarski, povezovalni, motivator) je osnova za dosego usmeritev organizacije (vizija, poslanstvo strategija, plani, merljivi cilji),

- ljudje in viri (ustrezni kadri (kompetentni), infrastruktura in tehnologija) so ključ za doseganje ciljev organizacije,

- procesni pristop (procese (organizacija mora imeti definirane proces) je potrebno stalno (vsaj vsako leto (op. avtor članka)) izboljševati). S tem se dosega izboljševanje kakovosti, zniževanje stroškov in skrajševanje časa samega procesa,

- meritve (organizacije morajo meriti ali so dosegle zastavljene merljive cilje),

- stalne izboljšave na vseh področjih (organizacije morajo za svoj obstoj izboljševati procese in poslovanje, saj se vse spreminja (izdelki, storitve, konkurenca, kupci, dobavitelji...)). Zato so nujen sistematičen pristop do izboljšav, inovacij (od zbiranja idej do uresničitve).

\section{5}

\section{Metodologija in rezultati analize uporabe orodij kakovosti}

Na osnovi uporabe sistemov vodenja kakovosti je bilo opravljenih več raziskav (opravil avtor tega članka). Uporabljena metodologija raziskave je kvantitativna metoda. $\mathrm{Na}$ osnovi raziskav se je ugotavljalo zakaj orodja za zagotavljanje kakovosti ne delujejo kot so si avtorji le teh zamislil oz. kako bi naj delovala na organizacije. Vsekakor bi se z njihovo pomočjo lahko organizacije izboljševale, zadovoljstvo deležnikov organizacije bilo vsako leto višje, poslovni rezultati nadpovprečni in še kaj.

Avtor članka je opravil 9 raziskav s pomočjo anketiranja (naključno vzorčenje vključenih nekaj več kot 100 organizacij $\mathrm{v}$ zasebnem in javnem sektorju, ki imajo vzpostavljen sistem vodenja kakovosti) in ugotovil sledeče: 
1062 36 $6^{\mathrm{TH}}$ INTERNATIONAL CONFERENCE ON ORGANizATIONAL SCIENCE DEVElopment: Responsible Organization (MARCH $22^{\mathrm{ND}}-24^{\mathrm{TH}}$, PORTOROŽ SLOVENia)

B. Škafar: Quality Tools

- problem voditeljstva (vodenje brez vizije, brez strategije, brez merljivih ciljev , vodja odloča vse sam...),

- problem poslovnih procesov (nedefinirani procesi, izboljšave redke),

- problem meritev (meritve v glavnem le iz poslovnega poročila - dobiček, prihodki, plače...),

- problem izboljšav (izboljšav je malo (5 do 20 na leto v organizacijah (analiza v več kot 100 organizacijah v velikosti do 100 zaposlenih), nesistematičen pristop izboljšav - naključno),

- preslabo poznavanje sistema vodenja kakovosti in modela odličnosti (običajno pozna skrbnik kakovosti in mogoče še direktor, ostali zaposleni premalo ali nič).

Seveda vse navedene ugotovitve ne veljajo za vse organizacije. V manj kot $20 \%$ organizacij (19) pa problemov povezanih s sistemov vodenja kakovosti niso zaznali.

Iz predstavljene kratke analize lahko povzamemo, da sistemi vodenja kakovosti in modeli odličnosti ne delujejo kot bi morali. Večina organizacij, ki imajo vzpostavljen sistem vodenja kakovosti in ali uporablja model odličnosti orodja ne izrablja kakor bi lahko zato lahko ima večje težave s poslovanjem kot organizacije, ki orodje v celoti uporabljajo. Tukaj predstavljene ugotovitve se ujemajo z ugotovitvami nekaterih avtorjev (Mulej, Likar, Karmen Kern Pipan, Kovačič, Vukšić in nenazadnje so na te elemente, kot slabo upoštevane ali delujoče v organizacijah, opozarjali guruji kakovosti Deming, Juran, Crosby, Ishikawa in drugi) ki poudarjajo slabše delovanje posameznih navedenih elementov kakovosti (voditeljstvo, ustvarjalnost in inovativnost, optimizacija poslovnih procesov...).

\section{$6 \quad$ Predlogi za izboljšanje}

Kakor smo omenili se orodja kakovosti še premalo v celoti uporabljajo, zato ne dosegajo želenih rezultatov. Vzroki so omenjeni v prejšnjem poglavju.

Predlogi, da bi se orodja za zagotavljanje kakovosti ustrezno uporabljali pa so:

- boljše voditeljstvo (vodenje z viziji in merljivimi cilji, vodja inovator, vodja ve fascinirati, je motivator, ima pravilen pristop do ravnanja z ljudmi...),

- optimizacija poslovnih procesov (določiti poslovne proces in skrbnike procesov, izboljševanje procesov vsako leto s timskim pristopom...),

- opravljanje meritev (razen poslovnih rezultatov še zadovoljstvo deležnikov organizacije, inovativnosti, bolniške, napak. Boljše morajo biti notranje presoje predlogi izboljšav, primeri dobrih praks),

- ustvarjalnost in inovativnost (sistematičen pristop od zbiranja idej do invencijsko - inovacijske dejavnosti),

- učeča se organizacija (vsi zaposleni se morajo v organizaciji učiti, to učenje mora biti sistematično in dolgoročno),

- družbena odgovornost (razen pomena dobičku in prihodkom biti tudi družbeno odgovorni), 
- seznanitev vseh zaposlenih s sistemom vodenja kakovosti in modelom odličnosti (če se uporablja)

- etično poslovanje (dolgoročna uspešnost se zagotavlja le z etičnim poslovanjem) in

- pomen upoštevanja stalnih sprememb (katerim se je treba prilagajat ali jih ustvarjati).

Navedeni predlogi za izboljšanje uporabe orodij za zagotavljanje kakovosti in modelov odličnosti veljajo za vse organizacije, ki omenjena orodja že uporabljajo in tudi za tiste, ki bodo na to pot stopile. Vsekakor pa so orodja odlična pomoč za učinkovitejše in uspešnejše delovanje organizacij, le uporabljati jih moramo znati.

\section{Zaključek}

Biti uspešna organizacija je cilj vsake organizacije.

Seveda lahko uspešnost podjetja presojamo $\mathrm{z}$ več vidikov. Razen finančnih kazalnikov, npr. dobička so za organizacije vedno bolj v ospredju tudi nefinančni kazalniki, kot so voditeljstvo, inovativnost, zadovoljstvo kupcev, zaposlenih, dobaviteljev in širše družbe (kraj, občina, država), kakovost življenja in dela, učinkovito izvajanje in krajšanje procesa dela, ki skupaj dolgoročno prispevajo $\mathrm{k}$ boljšemu poslovanju in kakovosti izdelkov ter storitev. Orodij, modelov in metod, ki zagotavljajo učinkovito presojanje uspešnosti, je veliko.

$\mathrm{V}$ tem članku smo predstavili primerjavo nekaj znanih in manj znanih sistemov vodenja kakovosti in na osnovi raziskav predstavili zakaj le ti ne delujejo $\mathrm{v}$ organizacijah kot bi morali.

Ključne ugotovitve so, da je $\mathrm{v}$ organizacijah premalo dobrega voditeljstva, poslovne procese se slabo izboljšuje, meritve niso povsod prisotne, $v$ organizacijah je premalo sistematičnega pristopa pri ustvarjalnosti in inovativnosti, stalno učenje ni povsod prisotno, zaposleni v organizacijah so premalo informirani o sistemih vodenja kakovosti in modelih odličnosti, družbena odgovornost in etično poslovanje je premalo prisotno $\mathrm{v}$ organizacijah ter stalne izboljšave niso stalnica.

Predlogi, ki so podani v tem prispevku vsekakor lahko organizacijam, ki imajo omenjena orodja kakovosti v uporabi, pomagajo, da bodo orodja boljše uporabili in s tem omogočili boljše poslovanje organizacije. Vsekakor pa lahko predloge upoštevajo tudi organizacije, ki bodo navedena orodja šele uporabila.

\section{Literatura}

Kovačič, A. \& Bosilj Vukšić, V. (2005). Management poslovnih procesov. Ljubljana: GV Založba. Malek, N. Škafar, B. \& Vorina, A. (2009). Ugotavljanje in zagotavljanje kakovosti. Učbenik za višje strokovne šole. Ministrstvo za šolstvo in šport Republike Slovenije. 
1064 36 $36^{\mathrm{TH}}$ INTERnational CONFERENCE ON ORganizational SCIENCE DeVElopment: RESPONSIBLE ORgANIZATION (MARCH $22^{\mathrm{ND}}-24^{\mathrm{TH}}$, PORTOROŽ SLOVENIA)

B. Škafar: Quality Tools

Piskar, F. \& Dolinšek, S. (2006) Učinki standarda kakovosti ISO. Koper: Fakulteta za management. RS MŠŠ. (2011). Projekt Impletum. Sistem vodenja kakovosti za višje strokovne šole. Dostopnona:http://www.impletum.zavodirc.si/docs/Skriti_dokumenti/Impletum_Sistem_vode nja_kakovosti_za_VSS_Zahteve_2_izdaja_2011_1.pdf

Skoko, H., (2010). Upravljanje kvalitetom. Zagreb: Sinergija, d.o.o.

Slovenski institut za kakovost in meroslovje. Kakovost za prihodnost vzgoje in izobraževanje. Dostopno na: http://www.siq.si/solstvo/ (22. 8. 2016)

Slovenski standard. 2008. SIST EN ISO 9001. Slovenski standard za standardizacijo. Ljubljana.

Sraka. M., Škafar, B. \& Žagar T. (2016). Diploma skupnosti višjih strokovnih šol za odličnost. Skupnost višjih strokovnih šol. Celje.

Škafar, B., 2009. Inovativnost kot pogoj za poslovno odličnost v komunalnem podjetju, Pomurski ekološki center. Murska Sobota.

Škafar, B. (2014). Orodje za ugotavljanje in zagotavljanje kakovosti v višjih strokovnih šolah. 33. mednarodna konferenca o razvoju organizacijskih znanosti. Portorož 19 - 21. marec 2014.

Škafar, B. (2015). Sistem vodenja kakovosti za gasilska društva. PDK. Murska Sobota.

Škafar, B. (2015). Sistem vodenja kakovosti v visokih šolah. PDK. Murska Sobota. 


\section{Xerte 3.3 - pet let izkušenj z uporabo portala}

\section{BRANISLAV ŠMITEK}

Povzetek V današnjem času je uporaba večpredstavnostnih učnih vsebin razvitih za splošno uporabo na spletu vse bolj pogosta. Izvajalci izobraževanja vse bolj pogosto iščejo preprosta in brezplačna orodja za njihov razvoj. Eno izmed takih orodij so Xerte orodja, ki so združena v portal in razvijalcem ter uporabnikom omogočajo pripravo prej navedenih vsebin brez dolgotrajnega izobraževanja in tako rekoč kadarkoli in kjerkoli. Velika prednost portala je predvsem $\mathrm{v}$ tem, da za delo $\mathrm{z}$ njim ne potrebujemo zelo zmogljivih računalnikov $\mathrm{s}$ specialno programsko opremo. Za delo $\mathrm{z}$ njim je dovolj računalnik ali pametna naprava $\mathrm{z}$ dostopom do interneta in brskalnikom.

KLJUČNE BESEDE: Xerte $\bullet$ portal $\bullet$ e-gradiva

NASLOV AVTORJA: dr. Branislav Šmitek, docent, Univerza v Mariboru, Fakulteta za organizacijske vede, Kidričeva cesta 55a, 4000 Kranj, Slovenija, e-pošta: brane.smitek@fov.uni-mb.si 
$36^{\text {Th }}$ International Conference on Organizational Science DEVElopMENT: Responsible ORganization (MARCH $22^{\mathrm{ND}}-24^{\mathrm{TH}}$, PORTOROŽ SLOVENIA)

O. Arsenijević, M. Ferjan, I. Podbregar, P. Šprajc, D. Trivan \& Y.

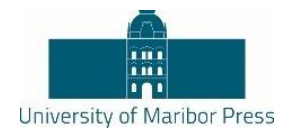

Ziegler

\title{
Xerte 3.3 - Five Years of Experience in the Use of the Portal
}

\author{
BRANISLAV ŠMITEK
}

\begin{abstract}
Nowadays, the use of multimedia educational content developed for general use on the Internet are becoming more common. Education providers are increasingly looking for simple and free tools for their development. One of these tools are Xerte tools, which are combined into the portal and developers don't need any special training for development and preparation of mentioned content. Developers and users can use portal from anywhere and anytime. The great advantage of the portal is in the fact that the work with it doesn't need high-performance computer with a special software. To work with it is enough smart phone, tablet or computer with Internet access and a browser.
\end{abstract}

KEYWORDS: Xerte $\bullet$ portal $\bullet$ e-learning materials

CORRESPONDENCE AdDRESS: Branislav Šmitek, Ph.D., Assistant Professor, University of Maribor, Faculty of Organizational Sciences, Kidričeva cesta 55a, 4000 Kranj, Slovenia, e-mail: brane.smitek@fov.uni-mb.si 


\section{$1 \quad$ Uvod}

Razvoj orodij se je začel leta 2004 z zagonom projekta na univerzi v Nottinghamu. Ideja razvojne ekipe je bila, da poskusijo razviti univerzalna orodja za razvoj učnih objektov kot so člani skupine poimenovali učne enote. Posamezna učna enota naj bi bila vsebinsko zaokrožena celota, ki se uporablja v spletnem okolju. Prva verzija orodij je bila narejena kot samostojna aplikacija za osebne računalnike. Njeni izdelki so se lahko uporabljali samostojno ali na spletnih straneh. V nadaljevanju so razvijalci orodja začeli združevati in nastal je odprtokodni spletni portal, ki v današnjem obsegu predstavlja zelo močno orodje za razvoj elektronskih učnih vsebin, ki omogoča tudi skupinsko delo. Vse učne enote so združene na enem samem spletnem portalu in vsaka njihova sprememba je takoj na razpolago uporabnikom. Več o idejni zasnovi portala in njegovem stanju leta 2013 sta avtor tega prispevka in vodja razvojne skupine napisala $\mathrm{v}$ prispevku, ki je bil objavljen na takratni konferenci (Šmitek, 2013). V treh letih je portal zelo napredoval in danes predstavlja zelo stabilno okolje za razvoj interaktivnih večpredstavnostnih učnih vsebin.

Morko piše o tem, da sistemi za upravljanje z učnimi vsebinami podpirajo veliko različnih oblik učnih vsebin. Običajno pa imajo uporabniku na razpolago funkcionalno dokaj omejena orodja z njihov razvoj. Na začetku so skoraj vse večpredstavnostne učne vsebine temeljile na Flash tehnologiji, ki je bila najbolj primerna za spletni prikaz večpredstavnosti. V letih uporabe se je pokazala slabost Flash-a in razvila se je alternativa v obliki HTML5 standarda. (Morko, 2015)

Morko navaja, da je Xerte portal eno izmed orodij, ki ponuja izobraževalnim institucijam in tudi podjetjem učinkovito razvojno okolje in tudi okolje za distribucijo pripravljenih interaktivnih učnih vsebin. Oblikovanje interaktivnih učnih vsebin predstavlja velik izziv razvijalcem $\mathrm{v}$ današnjem globalno usmerjen izobraževalnem in poslovnem okolju. Navedeno okolje pred razvijalce postavlja izziv razvoja večjezikovnih učnih vsebin in tudi vsebin, ki so neodvisne kar se tiče naprav za njihovo predvajanje. Za razvoj in uporabo učnih vsebin na Xerte portalu razvijalci in uporabniki potrebujejo samo pametno enoto in povezavo v svetovni splet. Za prikaz učnih vsebin se uporablja HTML5 in vsak brskalnik, ki prepozna standard bo tudi predvajal vsebino učne enote. (Morko, 2015)

\section{$2 \quad$ Novosti v verziji 3.3.}

Stabilna instalacija Xerte portala, verzija 3.3., je na razpolago na spletnih straneh razvijalca (http://www.xerte.org.uk). Namestitev portala zahteva računalniškega strokovnjaka. Uporabe orodij se vsak uporabnik z osnovnim znanjem dela s spletnimi tehnologijami lahko nauči $\mathrm{v}$ dveh dnevih. Večji izziv za razvijalce učnih vsebin predstavlja problem priprave strukture in vsebine gradiv kot pa njihov razvoj.

Razvijalci portala so v času med verzijo 2.0 in 3.3 posodobili preko 250 elementov, ki so povzročali težave. Dodali so tudi nabor novih orodij in posodobili stara orodja. 
36 ${ }^{\text {TH }}$ International Conference on ORganizational Science Development: Responsible Organization (MARCh $22^{\mathrm{ND}}-24^{\mathrm{TH}}$, PORTOROŽ Slovenia)

B. Šmitek: Xerte 3.3 - Five Years of Experience in the Use of the Portal

\subsection{Vstopna stran}

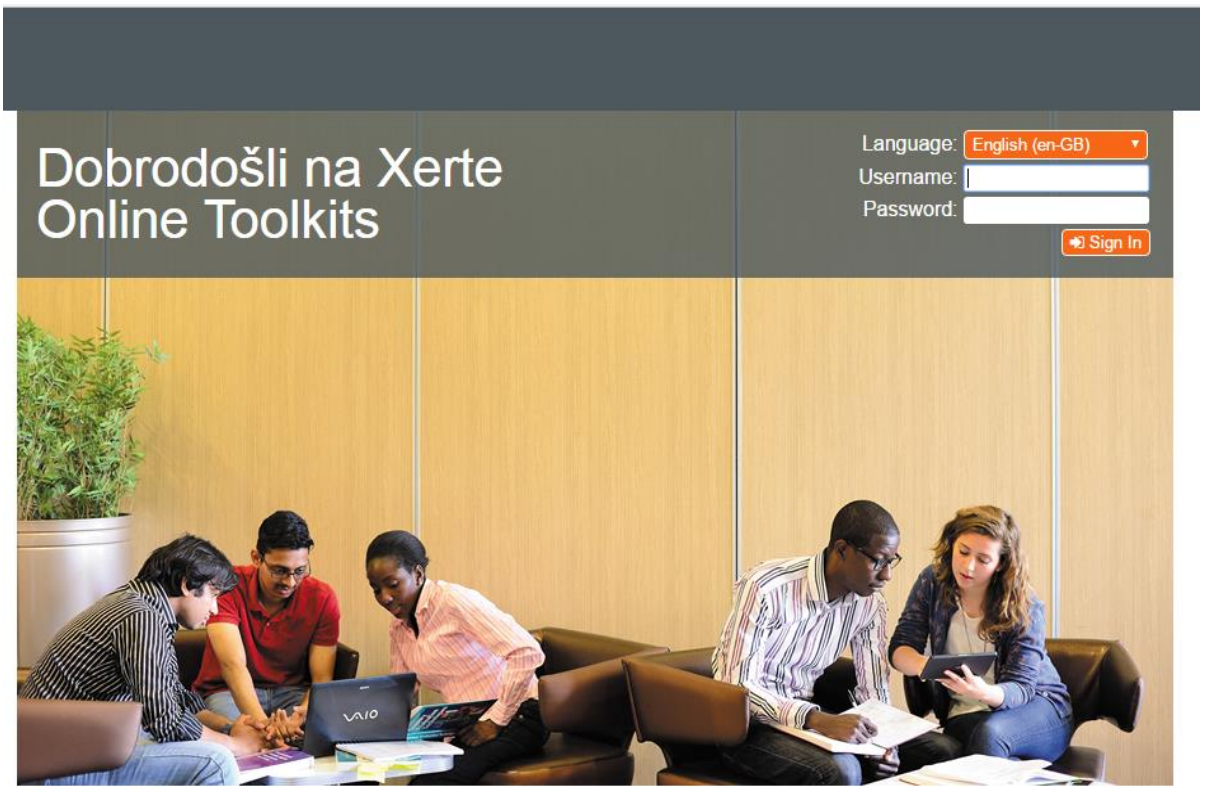

\section{Getting Started}

We've produced a short introduction to the Toolkits website

Copyright University of Nottingham $2008-2012$

\section{2. a Xerte}

Slika 1: Nov izgled vstopne strani portala

Slika 1 prikazuje novo vstopno stran portala. V primerjavi s prejšnjo verzijo nova vstopna ponuja povezavo na spletne strani razvijalca portala, kjer dobimo dodane informacije o orodjih. Vstopna stran je vizualno bolj privlačna kot prejšnja. Že na osnovni vstopni strani ima uporabnik tudi možnost izbire jezika s katerim bo delal.

\subsection{Knjižnica projektov}

Delo s portalom se začne v knjižnici projektov. Slika 2 prikazuje posodobljeno delovno ploščo za delo s projekti, kjer na enem mestu o projektih dobimo veliko več podatkov kot v prejšnji verziji. Dodana je možnost iskanja projektov. Prikaz razpoložljivih projektov je izboljšan in drevo projektov nam omogoča uporabo metode povleci-spusti. Dodana je tudi možnost kopiranja projektov in s tem se začetno delo $\mathrm{z}$ novim projektom občutno skrajša. 


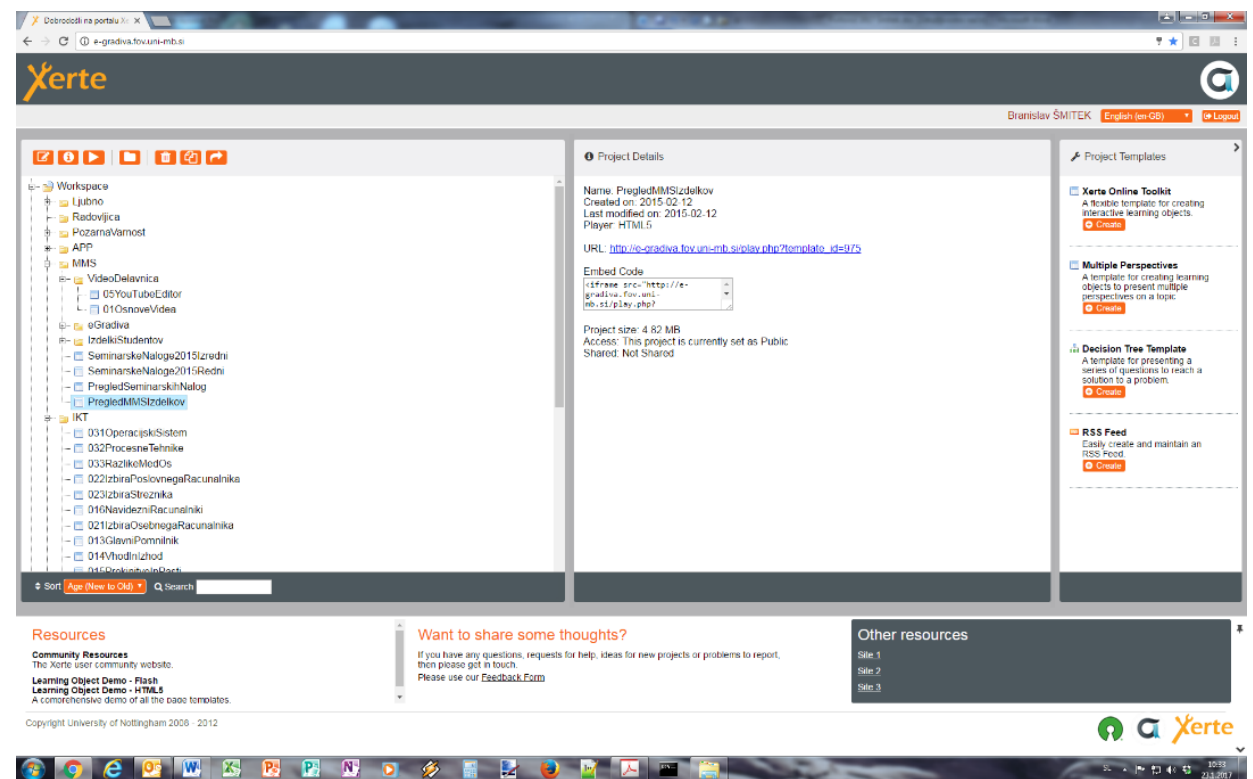

Slika 2: Delovna plošča za delo s projekti

\subsection{Nov HTML urejevalnik}

V primerjavi s prejšnjimi verzijami portala je nov urejevalnik HTML kode največja pridobitev. Slika 3 prikazuje izgled HTML urejevalnika, ki uporabniku omogoča urejanje besedila brez dodatnega znanja HTML standarda. Urejevalnik je narejen po principu WYSIWYG (What You See Is What You Get). Za uporabnike portala je še posebej dobrodošla tudi nova večpredstavnostna knjižnica. $Z$ njeno pomočjo urejamo večpredstavnostne datoteke in jih dodajamo $\mathrm{k}$ besedilu uporabljenih orodij posamezne učne enote. 
$36^{\text {TH }}$ International Conference on Organizational Science Development: Responsible Organization (MARCh $22^{\mathrm{ND}}-24^{\mathrm{TH}}$, PORTOROŽ Slovenia)

B. Šmitek: Xerte 3.3 - Five Years of Experience in the Use of the Portal

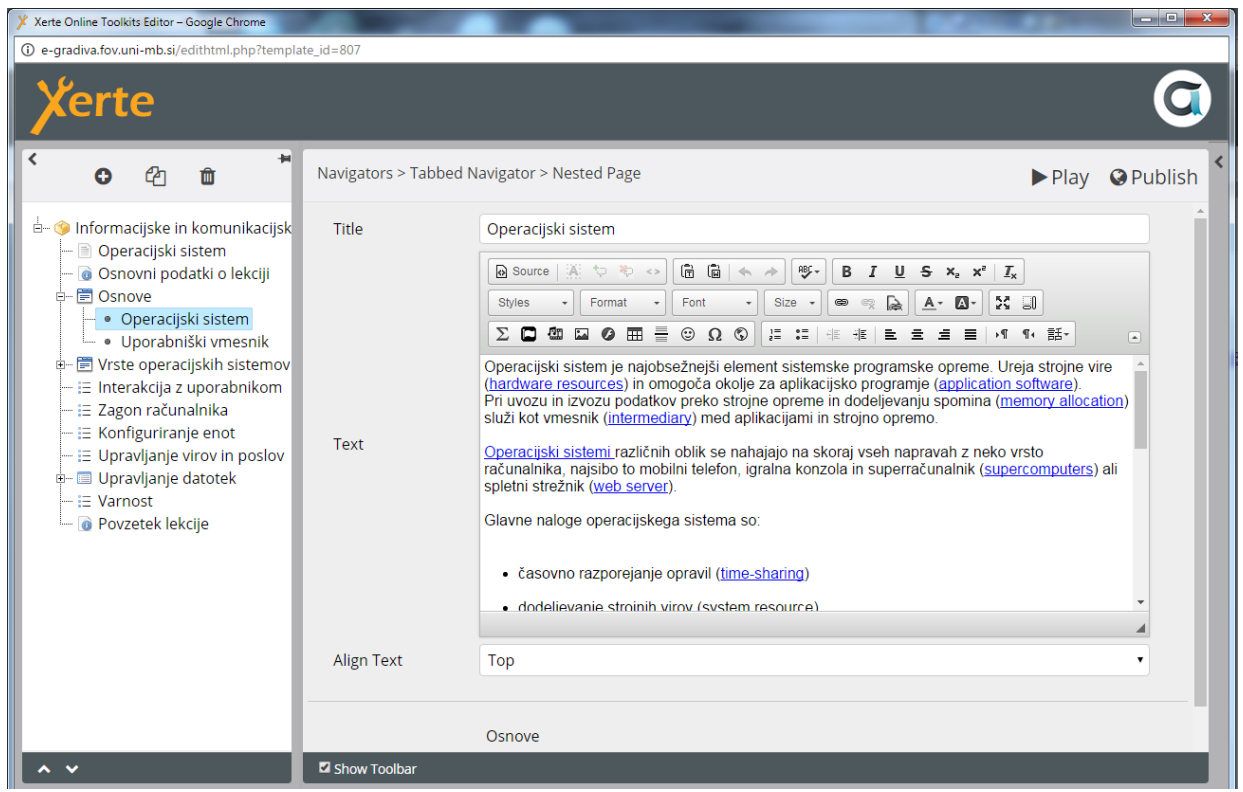

Slika 3: Izgled HTML urejevalnika

\subsection{Uporaba HTML5 standarda}

Razvijalci portala so že v prejšnji verziji naleteli na problem odvisnosti od uporabe Flash predvajalnika za uporabo učnih gradiv. V novi verziji so dodali možnost uporabe HTML5 standarda, ki je med tem postal zanesljivo nadomestilo Flash orodij, ki so na spletu začela izgubljati svoj primat in jih operacijski sistemi za pametne naprave niso podpirali. Z uporabo HTML5 standarda so uporabnikom ponudili možnost razvoja in uporabe egradiv tudi na pametnih telefonih in tablicah.

Uporabniki, ki so razvili učne objekte za Flash predvajalnik imajo na razpolago preprost način pretvorbe starih projektov v projekte, ki podpirajo HTML5. V oknu, prikazanem na sliki 4 , kjer so opisane lastnosti projekta enostavno izberejo nov standard in delo je zaključeno. 


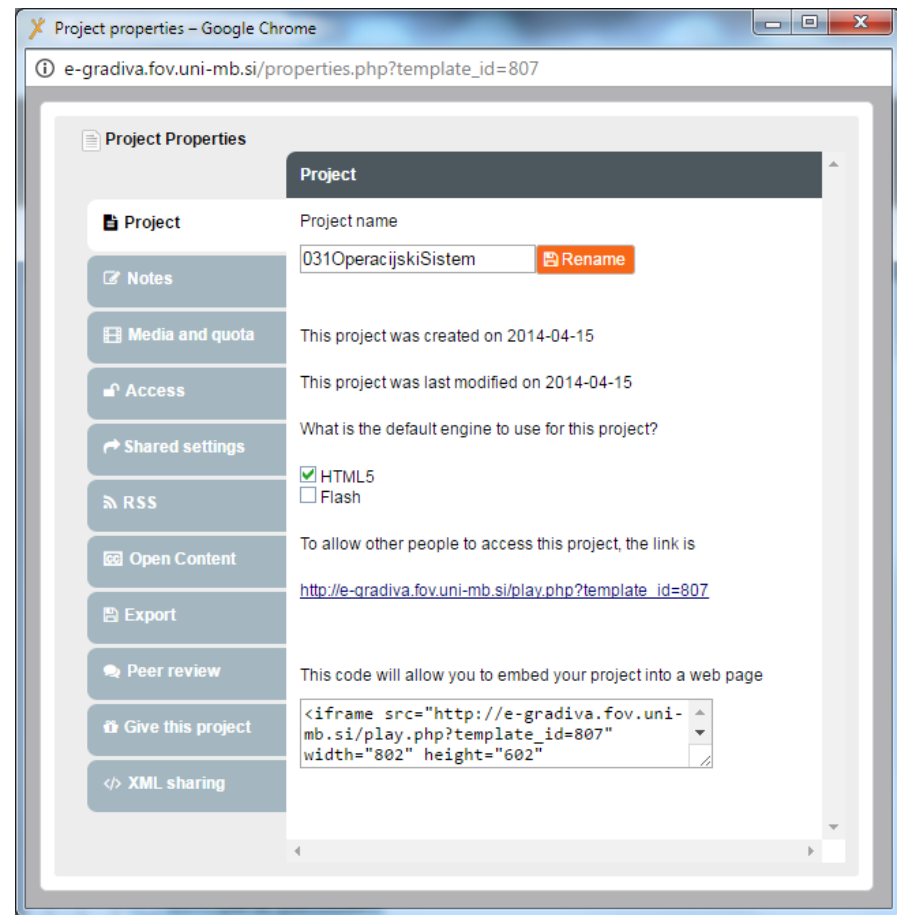

Slika 4: Pretvorba projekta iz Flash v HTML5 obliko

\subsection{Dodatne lastnosti za posamezna orodja}

Slika 5 prikazuje prenovljen način dodajanja lastnosti posameznega orodja. Razvijalci so dodali novo delovno površino (desni stolpec), ki prikazuje dodatne lastnosti posameznega orodja in uporabnik enostavno izbere želeno lastnost in nastavi parametre. Tak način dela je v primerjavi s prejšnjo varianto bolj pregleden in priročen. 
1072 36 $6^{\text {Th }}$ International Conference on Organizational Science Development: Responsible Organization (MARCh $22^{\mathrm{ND}}-24^{\mathrm{TH}}$, PORTOROŽ Slovenia)

B. Šmitek: Xerte 3.3 - Five Years of Experience in the Use of the Portal

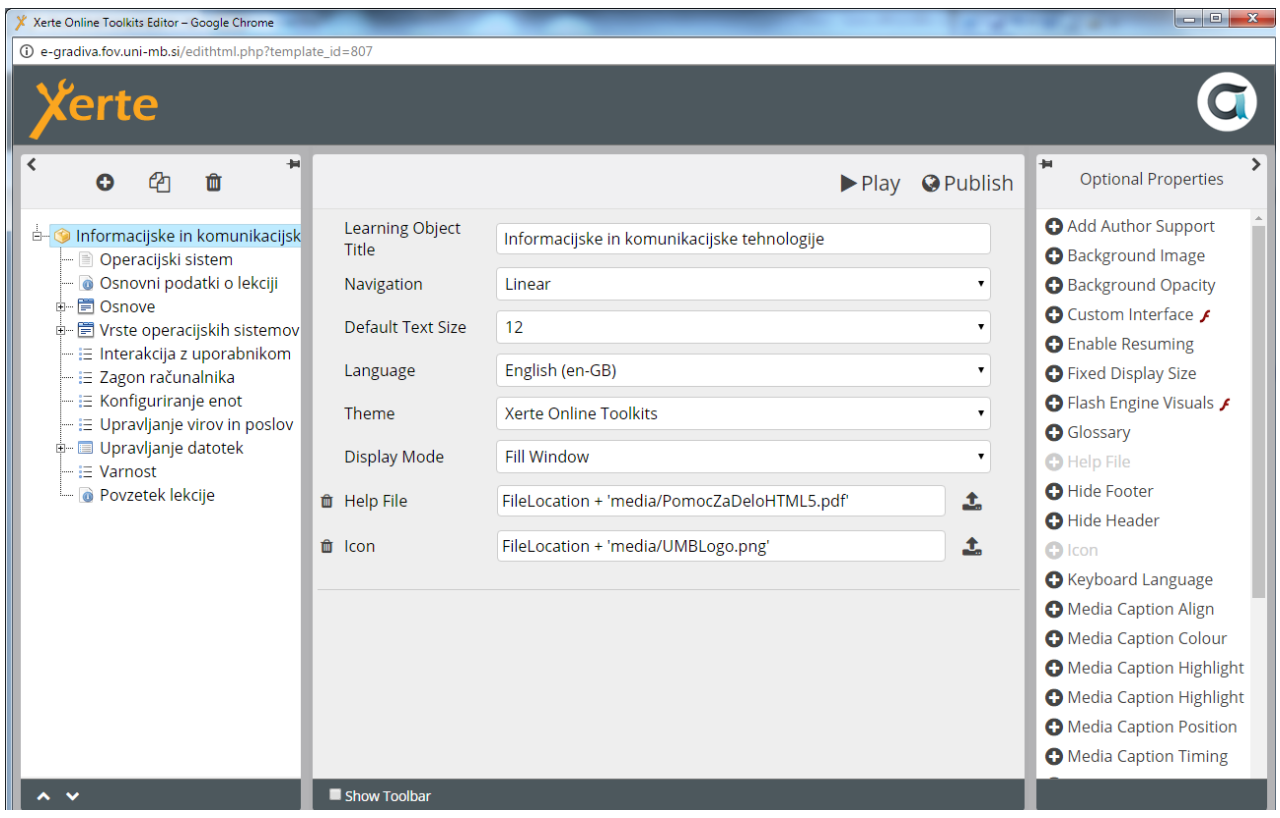

Slika 5: Izbira dodatnih lastnosti uporabljenega orodja

\subsection{Nov način dodajanja orodij}

Nova verzija portala ima izboljšan način dodajanja orodja v učno enoto. V novi verziji je vsako orodje, ki ga želimo dodati, bolj natančno opisano in prikazano. Proces dodajanja ponudi tudi možnost izbire lokacije (pred, za obstoječe orodje, ali na konec učne enote) kamor se bo orodje dodalo v učno enoto. 


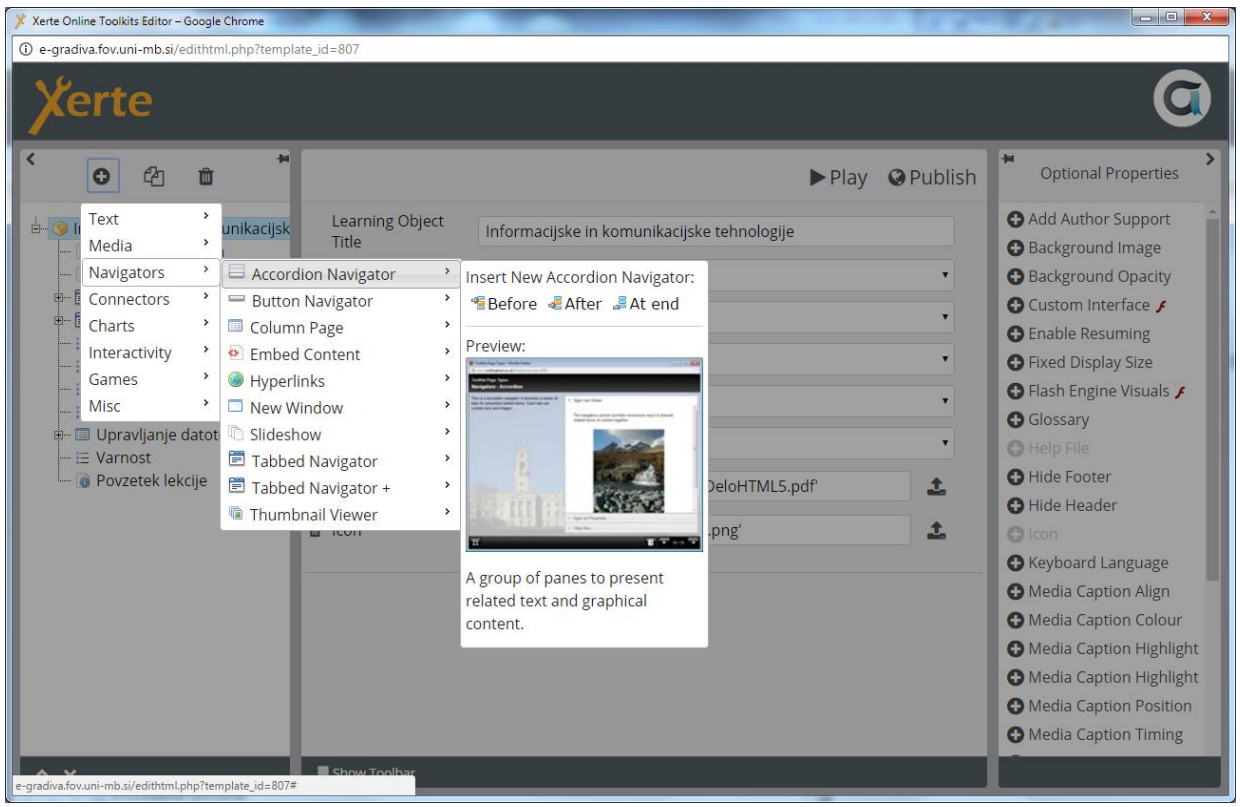

Slika 6: Primer dodajanja novega orodja

\subsection{Dodajanje besedila iz Word-a}

Izvajalci izobraževanja imajo $\mathrm{v}$ veliko primerih na razpolago že besedila napisana $\mathrm{z}$ Word-om. Prenos besedila iz Word-a v HTML urejevalnik velikokrat predstavlja težavo, ker Wordovo besedilo vsebuje znake za oblikovanje besedila, ki jih HTML urejevalnik ne razume. Zaradi tega so razvijalci portala v HTML urejevalnik dodali gumb, ki v veliko primerih ta problem reši in doda besedilo brez motečih znakov za oblikovanje. S tem delo $\mathrm{z}$ urejevalnikom in prenos besedila poenostavi in uporabo portala še bolj približa izvajalcem izobraževanja, ki niso vešči dela s HTML kodo. HTML urejevalnik ima tudi gumb, ki omogoča dodajanje besedila oblikovanega v Word-u kot golo besedilo in s tem omogoča kasnejše dodajanje HTML oznak za oblikovanje.

\subsection{Druge novosti}

Večpredstavnostna lekcija je popolnoma novo orodje, ki ga lahko uporabimo v učni enoti in uporabnikom vsebino še bolj atraktivno predstavi. Lekcija omogoča sinhroniziran prikaz večpredstavnostnih vsebin. Na tak način lahko sinhroniziramo zvočne ali video posnetke s spremljajočim besedilom. Tak način prikaza snovi omogoča novo, atraktivnejšo metodo dela $\mathrm{z}$ besedilom in večpredstavnostnimi elementi.

Razvijalci so portalu dodali nove predloge in teme, ki jih uporabniki lahko uporabljajo pri izdelavi elektronskih učnih vsebin. Ena izmed zanimivih novih predlog je odločitveno drevo. Predloga omogoča uporabo razvejane vsebine, ki uporabnika skozi sprejemanje 
odločitev pripelje do končnega cilja in tako s pomočjo poučne interaktivne zgodbe izobražuje. $Z$ novo verzijo so razvijalci dodali tudi predlogo za uporabo učnih vsebin na pametnih telefonih in tablicah.

\section{$3 \quad$ Zaključek}

V prispevku smo opisali novosti v razvoju portala Xerte online toolkits (Xerte, 2017). Skupek spletnih orodij, ki jih portal vsebuje omogočajo učinkovit razvoj večpredstavnih učnih vsebin. Prednost portala je predvsem v tem, da je orodje brezplačno, uporablja najnovejšo spletno tehnologijo, za razvoj in prikaz učnih vsebin uporabniki ne potrebujejo drugega kot spletni brskalnik in dostop do interneta. Razvite učne vsebine se zaradi uporabe HTML5 uporabljajo tako na računalnikih kot na pametnih napravah. Ena izmed prednosti, ki jih podobno zmogljiva odprtokodna orodja nimajo je tudi možnost skupinskega razvoja učnih vsebin. Portal je z novim WYSIWYG HTML urejevalnikom pridobil na enostavnosti oblikovanja besedila in zaradi tega se tudi uporabniki, ki ne poznajo podrobnosti navedenih tehnologij zelo hitro naučijo dela z njim.

Predstavljeno odprtokodno orodje predstavlja izziv vsem, ki želijo narediti večpredstavnostne spletne učne vsebine na čim bolj enostaven način in priporočamo njegovo uporabo. Na Fakulteti za organizacijske vede orodje uporabljamo že vrsto let za pripravo elektronskih učnih gradiv in tudi v izobraževalnem procesu kot orodje s katerim študentje izdelajo večpredstavnostno seminarsko nalogo. S tem dobijo osnovno znanje o orodju, ki bo mogoče v bodoče pomagalo pri njihovem vsakdanjem delu.

\section{Literatura}

Morko, M. (2015). Comparing Learning Management Systems for Corporate Environment, Bachelor's thesis, JAMK University of Applied Sciences

Šmitek, B. \& Tenney, J. (2013). Xerte online toolkits - browser based tools for the rapid development of interactive learning content; 32. mednarodna konferenca o razvoju organizacijskih znanosti,Moderna organizacija, str. 1059-1065, Kranj.

Xerte, http://xerte.org.uk/index.php?lang=en, Copyright (C) $2011 \quad$ - 2015 Xerte, an apereo community project, zadnji dostop - 20. januar 2017 
36. MEDNARODNA KONFERENCA O RAZVOJU ORGANIZACIJSKIH ZNANOSTI: OdgOVORNA ORGANIZACIJA (22. - 24. MAREC 2017, PORTOROŽ, SLOVENIJA)

O. Arsenijević, M. Ferjan, I. Podbregar, P. Šprajc, D. Trivan \& Y. Ziegler

\title{
Etika v kriznem menedžmentu
}

\author{
POLONA ŠPRAJC, DOMAGOJ CINGULA \& IZTOK PODBREGAR
}

\begin{abstract}
Povzetek Menedžment pomeni nabor procesov od odločanja, načrtovanja, usmerjanja, vodenja do nadzora in evalvacije. Organizacije se danes pogosteje soočajo s kriznimi situacijami. Težnje organizacij so, da se spodbuja ukrepe za odpravo ali omilitev situacij, vzpostavljanje nekriznih razmer ali včasih izkoristek učinkov krize za boljše poslovanje. Na krizo je potrebno odgovoriti s primernim menedžmentom. Ena izmed situacij, ki jih kriza generira je ogroženost temeljnih vrednot (npr. temeljnih človekovih pravic, varnosti, materialnih dobrin, celo človeških življenj). Zato je vprašanje etičnih principov, ki v svojem izhodišču predvideva željo po dobrem, moralno sprejemljivem in vsesplošni sprejetosti dobrega s strani posameznikov toliko bolj pomembno. Pogosto se zaradi omejenega časa, negotovosti, omejenosti informacij ipd. lahko srečamo s situacijo, ki postavlja utež na tehtnici moralne uravnoteženosti strokovnih odločitev in učinka na ljudi. Cilj prispevka je zato povezati trenutek, ko se človek odloča pod pritiskom zunanjih trendov (negativni vplivi, ki jih povzročijo ljudje, tehnologija in naravne sile), $\mathrm{v}$ različnih fazah kriznega menedžmenta (ocena stopnje ogroženosti, priprava na krizo, krizno odločanje in vodenje) do opredelitev objektivnih in etičnih načel, ki vodijo človeka pri odločanju. Poleg osnovne opredelitve kriznega menedžmenta, kriznih elementov, umeščenosti kriznega menedžmenta $\mathrm{v}$ koncept nacionalne varnosti, bodo glavno vodilo etičnih načel varnost, vrednote, interes, mir in stabilnost organizacij.
\end{abstract}

KLJUČNE BESEDE: krizni menedžment • etika $\bullet$ ogroženost • etična načela

NASLOV AVTORJEv: dr. Polona Šprajc, docentka, Univerza v Mariboru, Fakulteta za organizacijske vede, Kidričeva cesta 55a, 4000 Kranj, Slovenija, e-pošta: polona.sprajc@ fov.uni-mb.si; Domagoj Cingula, VADEA d.o.o., Mihanovićeva 4, 42000 Varaždin, Hrvaška, e-pošta: dcingula@esdconference.com; dr. Iztok Podbregar, redni profesor, Univerza v Mariboru, Fakulteta za organizacijske vede, Kidričeva cesta 55a, 4000 Kranj, Slovenija, e-pošta: iztok.podbregar@fov.uni-mb.si 
$36^{\mathrm{TH}}$ International Conference on Organizational Science Development: Responsible Organization (MARCh $22^{\mathrm{ND}}-24^{\mathrm{TH}}$, PORTOROŽ SLOVENIA)

O. Arsenijević, M. Ferjan, I. Podbregar, P. Šprajc, D. Trivan \& Y.

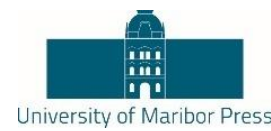

Ziegler

\title{
Ethics in Crisis Management
}

\author{
POLONA ŠPRAJC, DOMAGOJ CINGULA \& IZTOK PODBREGAR
}

\begin{abstract}
Management is a set of processes of decision-making, planning, directing, leading to the control and evaluation. Nowadays organizations are increasingly faced with different crisis situations. Therefore they promote measures to eliminate or mitigate the situation, the establishment of non-crisis situation, or sometimes yield effects of the crisis for better performance. The crisis must be answered with appropriate management. One of the important crisis situations is threat of fundamental values (eg. The fundamental human rights, security, material goods, even human lives). Therefore, the question of ethical principles, which at its core provide the desire for good, morally acceptable and widespread acceptance by individuals is more and more important. Due to the limited time, insecurity, scarcity of information, and such we may encounter a situation that puts weight on the scales of moral balance, professional decisions and the impact on people. The aim of this paper is therefore to link the moment of decision under the pressure of external trends (negative impacts caused by people, technology and natural forces), various stages of crisis management (assessment of the threat level, prepareness for a crisis, crisis decision-making and management) and definition of the objective and ethical principles that guide people in decision-making process. In addition to the basic definition of crisis management we will expose security, values, interests, peace and stability of the organization as most important factors.
\end{abstract}

KEYWORDS: crisis management $\bullet$ ethics $\bullet$ threats $\bullet$ ethical principles

Correspondence Address: Polona Šprajc, Ph.D., Assistant Professor, University of Maribor, Faculty of Organizational Sciences, Kidričeva cesta 55a, 4000 Kranj, Slovenia, e-mail: polona.sprajc@fov.uni-mb.si; Domagoj Cingula, VADEA d.o.o., Mihanovićeva 4, 42000 Varaždin, Croatia; e-mail: dcingula@esd-conference.com; Iztok Podbregar, Ph.D., Full Professor, University of Maribor, Faculty of Organizational Sciences, Kidričeva cesta 55a, 4000 Kranj, Slovenia, e-mail: iztok.podbregar@ fov.uni-mb.si

DOI https://doi.org/10.18690/978-961-286-020-2.86

ISBN 978-961-286-020-2

(C) 2017 University of Maribor Press

Available at: http://press.um.si 


\section{$1 \quad$ Uvod}

Krizni menedžment je področje, ki obsega osnovna vedenja o detekciji groženj, pomenu varnostne kulture, kompetencah ter ostalih elementih. Področje etike je pri kriznem menedžmentu neizogibno. Etičnost posameznika, ki deluje $\mathrm{v}$ konceptu kriznega menedžmenta, je povezana $\mathrm{z}$ osebno integriteto in osebno, profesionalno ter organizacijsko etiko. Osebna etika izhaja iz posameznika in njegovih osebnostnih lastnosti, profesionalna etika izhaja iz področja strokovnega področja posameznika, organizacijska etika pa zaokroži razumevanje integritete $\mathrm{v}$ celostnem prostoru organizacije. Integriteta je področje, ki izraža skladnost posameznika. Je polje, kjer so misli skladne $\mathrm{z}$ besedami in dejanji. Je ključ za uspešni krizni menedžment. Oseba z integriteto je zaupanja vredna in spoštovana. Zanjo je značilno suvereno odločanje, ki je podkrepljeno z občutkom za pravičnost, načelnost ter etiko.

V prispevku bomo predstavili krizni menedžment, etiko in etiko v kriznem menedžmentu. $\mathrm{V}$ kratkem bomo posredovali informacijo o splošnem determiniranju področja kriznega menedžmenta z vidika Evropske unije, Združenih držav Amerike in zveze NATO.

Dejstvo je, da družba v kateri živimo na raznolikih področjih kliče bodisi po zaznavanju ogroženosti bodisi po rešitvah, ki jih kot posamezniki in družba pričakujemo. Z ozirom na reševanje situacij, ki ogrožajo življenje ljudi ali vplivajo na negativne situacije $\mathrm{v}$ organizacijah in širše, se vzpostavlja pomen definicij moralnih prepričanj, ki pogosto še celo bolj spodbujajo ravnanja ljudi, ki se znajdejo v stiski.

Preteklost nas uči, da je soočanje s kakršnokoli težavo prilika, da se v bodoče takim težavam bodisi izognemo, bodisi jo znamo hitro in uspešno razrešiti. Problem, ki ga izpostavljamo v prispevku pa ne izpostavlja minornih težav družbe. Krizne situacije kličejo po ukrepih za odpravo ali omilitev situacij. H krizi pristopamo s kriznim menedžmentom. V primeru, da so na tnalu dejansko temeljne vrednote človeštva, je menedžment toliko bolj izpostavljeo očesu etičnega oziroma moralnega sodišča vseh prebivalcev. Prispevek bo v splošnem odprl področje etike v kriznem menedžmentu ter etična načela, ki so neizogiben del vsakršnega kriznega menedžmenta v katerikoli razsežnosti.

\section{$2 \quad$ Kriza in krizni menedžment}

Izhodišče besede krize se nanaša na odločitvene situacije, ki vodijo $\mathrm{k}$ ravnanju v nepričakovanih trenutkih in lahko rezultirajo $\mathrm{v}$ negativnih posledicah za posameznika ali družbo. Govorimo o stanju, ki glede na vzroke potrebuje določena ravnanja oz. ukrepanja. Izvor besede kriza ima grške korenine, in sicer v besedi »krinein«, kar pomeni »odločiti«. Nanaša se na odločilni trenutek $\mathrm{v}$ zaporedju dogodkov, $\mathrm{v}$ katerem se stvari bodisi izboljšajo bodisi poslabšajo (Prezelj, 2005, 16). Kriza je na splošno resno stanje, ki zahteva ukrepanje, oziroma situacija visokega ogrožanja, ki zahteva ukrepanje v končnem, običajno kratkem času (Russet in Starr, 1996, 226). 
Vsaka kriza ima specifične značilnosti, vse krize pa imajo tudi veliko skupnega. V krizi odločevalci na različnih vladnih ravneh zaznajo ogrožanje temeljnih vrednot in norm prebivalcev ali pa ogrožanje položaja vodilnih javnih uslužbencev. Kriza ponuja omejen čas za oblikovanje politike in sprejemanje odločitev. In nenazadnje, kriza postavlja odločevalce pod velik stres in jih prisili, da sprejemajo odločitve v negotovih razmerah, v katerih dogodki prehitevajo drug drugega (Malešič, 2004). Konkretneje lahko krizo definiramo kot situacijo, ki ogroža visoko prioritetne cilje odločanja, omejuje čas za odgovor, s pojavnimi oblikami preseneča člane skupine odločanja in vzbuja vtis katastrofalnih posledic v primeru neukrepanja. 't Hart (1993) opredeli krizo kot neprijazen dogodek, ki odločevalce izziva in preizkuša, da ukrepajo v razmerah ogrožanja, časovne stiske in negotovosti.

Po Holstijevem mnenju (1990) krizo označujeta resno ogrožanje pomembnih vrednot in omejen čas za ukrepanje. Značilno je tudi, da kriza povečuje stres med tistimi, ki se z njo ukvarjajo. Stern (1999) ponuja sintetično definicijo krize, ki pravi: kriza je situacija, ki izhaja iz spremembe zunanjega ali notranjega okolja določene kolektivitete in jo označujejo tri nujne in zadostne zaznave dela odgovornih odločevalcev: ogroženost temeljnih vrednot, nujnost in negotovost. Slednje povezujemo s stopnjo škodljivih pogojev. Značilnost krize namreč je, da gre za nepričakovano situacijo, pri kateri smo priča nizki stopnji psihološke pripravljenost in organizacijskega načrtovanja ter posledično visoki stopnji improvizacije pri kriznem odločanju. Značilni so časovni pritiski in negotove okoliščine. Malešič $(2004,12)$ skupne značilnosti krize opredeli kot:

- ogroženost temeljnih vrednot (npr. ozemeljske celovitosti, pravne države, temeljnih človekovih pravic, človeških življenj, materialnih dobrin, varnosti itd.),

- zelo omejen razpoložljiv čas za odločanje v razmerah, ki so presenetile ali celo šokirale organe upravljanja in vodenja,

- negotovost razmer (razmere se naglo spreminjajo),

- večpodročna in večsmerna posledičnost posamezne odločitve, pri čemer je dopustnost napačnih odločitev minimalna ali pa je sploh ni,

- omejena uporabnost preteklih informacij za odločanje in sredstev, na katere se je pri izbiri ukrepov mogoče nasloniti,

- omejena razpoložljivost primernih obstoječih informacijskih virov za odločanje,

- nenehno in nepričakovano pojavljanje novih znamenj in značilnosti krize,

- intenzivnejši notranji in zunanji nadzor nad odločitvami,

- možnost oviranja tistih, ki so za krizo odgovorni,

- neprestana psihična obremenitev odločevalcev z malo priložnostmi za popuščanje in sprostitev.

Krizni menedžment opredelimo kot prizadevanje za nadzor nad dogodki, pri čemer si prizadevamo za stopnjo kontrole, ki bo omogočila, da do krize sploh ne pride. Govorimo o organizirani dejavnosti, ki je usmerjena v reševanje in obvladovanje kakršnekoli krize. Cilj kriznega menedžmenta je vzpostavitev razmer, ki niso krizne s stališča prizadetih in vzpostavitev ponovnega nadzora nad dogodki kar pomeni predvsem odpravo vira 
ogrožanja varnosti. Zavedati se moramo, da potencialne krize ne moremo upravljati, obvladovati ali koristiti učinke glede na lastne interese in želje. Krizni menedžment razumemo kot dejavnost $\mathrm{v}$ smeri obvladovanja krize, pri čemer zajema tako identificiranje krize kot tudi načrtovanje odgovora na krizo, soočanje s krizo in samo odpravljanje krize.

Krizni menedžement in vodenje se običajno odvijata $\mathrm{v}$ organizacijskem kaosu, pod pritiskom množičnih občil, v stresnih razmerah in ob pomanjkanju natančnih informacij. Spremembe narave in konteksta sodobnih kriz pa krizni menedžment še otežujejo, saj so sodobne krize izjemno kompleksne, učinkujejo prek različnih »meja«, se povezujejo z drugimi pomembnimi problemi in so praviloma dolgotrajne (Malešič, 2004).

Krizni menedžement se nanaša na metode, ki nudijo takojšnjo kratkoročno pomoč vsem, ki so prizadeti v takšni ali drugačni katastrofi in potrebujejo pomoč (Joneis, 2006). Na bolj splošni ravni pa vsebuje strateško načrtovanje ukrepov v krizi, ki vsaj deloma odpravijo tveganje in negotovost ter omogoča večji nadzor nad trenutno situacijo in nadaljnjo usodo na vseh ravneh delovanja sistema kriznega menedžmenta (Thompson in Louie, 2006, 15-17).

\section{$3 \quad$ Etika in krizni menedžment}

»Pri zastavljanju neke vrste moralnih vprašanj, če smo dovolj vztrajni, odkrijemo, da nanje ne moremo odgovoriti, dokler ne zastavimo in odgovorimo na nekatera filozofska vprašanja. $Z$ zastavitvijo moralnih vprašanj pomen nekaterih ključnih besed, ki so bile pri tem uporabljene, ni več jasen in nedvoumen« (MacIntyre, 1993, str. 17).

Etiko razumljeno starogrško kot običaje in nravnost oziroma moralnost lahko jemljemo kot udejanjene etične prakse $\mathrm{v}$ vsakdanjem življenju. Vendar pa se moralni koncepti spreminjajo hkrati s spremembami družbenega življenja. Vpeti so v oblike družbenega življenja in jih deloma vzpostavljajo. Identifikacija razlik v moralnih konceptih je eden ključnih načinov identifikacije ene oblike družbenega življenja v razliko od druge (MacIntyre, 1993). Če hočemo torej razumeti konkretne oblike družbenega življenja in v njem vznikla etična dejanja ali sodbe, kamor spada tudi poslovno okolje in njegova specifična etika, moramo imeti vsaj v grobih obrisih opredeljene temeljne koncepte etike.

Filozofija je veda, ki išče odgovore na temeljna vprašanja človeka, družbe in sveta. Etika kot filozofska disciplina pa poskuša iskati rešitve na vprašanja, kako naj bi ljudje delovali, kako naj se obnašamo med seboj, da bo v svetu čim manj nesrečnih in kar največ srečnih situacij. S postavljanjem lastnih problemskih okvirov in moralnih načel nam etika torej lahko koristi tudi pri usmerjanju zaposlenih $\mathrm{v}$ pozitivna ravnanja. Koristnost etičnega mišljenja je nepogrešljiva takrat, ko se kot posamezniki znajdemo na razpotju različnih vrednot in se vprašamo: »Kaj bi bilo sedaj dobro (storiti)?«.

Etika se dandanes ukvarja z zelo različnimi temami, vendar njen pristop do določene teme po Miščeviću (v MacIntyre, 1993) lahko razdelimo na tri sklope, na normativno, aplikativno in meta-etiko. Prvič, obstajajo »vsebinska ali normativna vprašanja, ki so 
$1080 \quad 36^{\mathrm{TH}}$ International CONFERENCE ON ORganizational SCIENCE Development: Responsible ORganization (MARCh $22^{\mathrm{ND}}-24^{\mathrm{TH}}$, PORTOROŽ Slovenia) P. Šprajc, D. Cingula \& I. Podbregar: Ethics in Crisis Management

izražena v klasični obliki 'Kaj naj delam?',« da bi bila, denimo, družba nasploh pravična. Drugič, »normativna vprašanja variirajo glede na stopnjo občosti - ukvarjanje z zelo specifičnimi vprašanji, ki je usmerjeno v prakso, pogosto označujemo kot aplikativno (normativno) etiko, « tj. etično razreševanje konkretnih, dejanskih moralnih problemov. Poleg normativne in aplikativne etike, nadaljuje, »pa dobršen del filozofske etike ni vsebinsko-normativne narave, temveč analizira pojme in teorije vsebinsko-normativne etike. Ta del imenujemo 'meta-etika', v katero se uvrščajo vprašanja, kot so: Kaj razumemo kot 'dobro' ali 'pravično'?« (Miščević v MacIntyre, 1993, str. 269).

Krize, ki se dogajajo $\mathrm{v}$ okolju in organizacijah ter rezultirajo $\mathrm{v}$ obliki kriznega menedžmenta tudi $\mathrm{v}$ celoti predpisov in navodil absolutno ne pokrijejo celote obvladovanja odnosov. Generiranje vprašanja etike v kriznem menedžmentu usmerja vedenje in ravnanje na vseh tistih področjih, ki niso urejena s pravnim okvirom. Pravo je oblika privolitve ali prepovedi na določena ravnanja, ni pa nujno prisotno, ko se pogovarjamo o uveljavljanju etike. Pogosto se zato znajdemo v etičnih kolizijah, ko se presojanje po pravnem okviru izkaže za neetično.

Etiko $\mathrm{v}$ kriznem menedžmentu utemeljimo $\mathrm{z}$ etičnimi načeli, ki so prisotna $\mathrm{v}$ našem vsakdanjem življenju. Nadgradnja etičnih vidikov v krizne situacije pomeni doseganje dobrega $\mathrm{v}$ medsebojnih odnosih, spodbujanje etičnih norm med vsemi subjekti, ki rešujejo in, ki so reševani ter držanje vrednotnega sistema družbe ali organizacije, ki izhaja iz standardov, pravil in nasploh vrednot posameznika in celote.

Ko govorimo o kriznem menedžmentu, mislimo na načine obvladovanja in reševanja situacij, ki so pogosto rezultat človeškega dejanja. S pomočjo razumevanja fenomena etike v pogojih kriznega menedžmenta, se na eni strani dotikamo deskriptivne in po drugi strani normativne etike. Deskriptivni tip etike je omejen zgolj na pojasnjevanje trenutnih dogodkov krize ter odnosov in norm, ki so posledica krize, normativni tip pa predpostavlja prizadevanja, da se $\mathrm{v}$ kritičnih situacijah odločanje ter reševanje podredi moralnemu vrednotenju in racionalni presoji dogodkov.

Krizne situacije, kjer se v pogojih kriznega menedžmenta generirajo vzvodi etike (komunikacija, odnosi in navodila), vzpostavljajo določeno raven vrednot, ki so bistveno vodilo razreševanja situacij v prid posameznika in družbe. Problem nastopi, ki se pogovarjamo o pravi meri etičnosti odločanja in ravnanja.

$\mathrm{Na}$ videz najbolj prava bi bila t.i. absolutna etika, ki brezkompromisno vztraja pri uveljavljanju vrednot nekega kroga ljudi (političnega, ideološkega, verskega), vendar pri tem zapostavlja prav tako legitimne interese in vrednote drugih krogov ljudi. Prava tako nesprejemljiva je t.i. absolutna neetika, ki pravi, da cilj opraviči (vsa) sredstva (Možina et al., 2002).

Etično delovanje kriznega menedžmenta je absolutno pomembno. Etika in kakovost reševanja kriznih situacij ne moreta in ne smeta biti v konfliktu.

Dialektične in etične poglede na področje kriznega menedžmenta usmerjamo v tri vidike: 
Kriza se razvija pri posameznikih, $v$ organizacijah in družbi, kjer področje krize sproži področje učenja in zaznavanja sprememb v okolju.

Proučevanje načinov in razvijanje metod kriznega upravljanja, ki upoštevajo visoko stopnjo morale.

Danes zaznavamo modele teoretičnih temeljev kriznega menedžmenta, ki je središčno usmerjena $\mathrm{v}$ upoštevanje moralnih in etičnih vidikov posameznika, organizacije in družbe.

\section{$4 \quad$ Pogledi na krizni menedžment}

Evropska unija je izpostavljena paleti možnih kriz in katastrof, ki so povezane s podnebnimi spremembami, terorističnimi ali kibernetskimi napadi, napakami v kritični infrastrukturi. Države Evropske unije so odgovorne za upravljanje izrednih razmer na svojem ozemlju in za sprejem odločitev. Nesreče so pogosto čezmejne narave, zato zahtevajo večstransko in usklajeno ukrepanje (European Comission, 2017).

Evropska unija bi morala biti sposobna odziva na nesreče znotraj in zunaj svojih meja. Glavna spoznanja preteklih dogodkov kažejo, da obstajajo možnosti za nadaljnje izboljšave v smislu učinkovitosti in skladnosti, hitrosti uvajanja, operativno in politično usklajevanje ter notranjo in zunanjo prepoznavnost ukrepov Evropske unije (European Comission, 2017).

Državljani Evropske unije pričakujejo, da so sprejeti ukrepi za zaščito življenj in premoženja, kot tudi za zagotavljanje učinkovite pomoči državam, ki niso članice Evropske unije kot pomemben odraz evropske solidarnosti. Krepitev odpornosti Evrope na krize in nesreče, je eno ključnih ciljev strategije notranje varnosti, ki je bil sprejet novembra 2010. Strategija zahteva solidarnost $\mathrm{v}$ odgovor in odgovornost pri preprečevanju in v pripravljenosti, s poudarkom na boljši stopnji ocene tveganja in obvladovanja tveganja vseh potencialnih nevarnosti. Glede na raznolikost in pomen tveganj za notranjo varnost, strategija daje nevarnosti in oceni tveganja ključno vlogo pri podpiranju oblikovanja politik, razvoju in izvajanju (European Comission, 2017).

Po besedah ministrstva za domovinsko varnost v Združenih državah Amerike, je krizni menedžment naloga organov, ki skrbijo za red in varnost (policija, sile za zaščito in reševanje, agencije v ministrstvu za domovinsko varnost, zvezni preiskovalni urad in podobno) in vsebuje postopke prepoznavanja, pridobivanja in načrtovanja ter uporabe virov, ki so potrebni za preprečevanje ali rešitev groženj in terorističnih dejanj. Ukrepi v okviru kriznega menedžmenta lahko zajemajo tudi tradicionalne funkcije organov za red in varnost, kot so: obveščevalne naloge, nadzorovanje, taktične operacije, pogajanja, klasične in forenzične preiskave. Glavna naloga omenjenih organov je zagotavljanje dobrobiti in varnosti za celotno družbo, zato se razne agencije pri svojem delu med seboj povezujejo in oblikujejo enotne skupine za posebne naloge, kar jim omogoča večjo raven pristojnosti in s tem tudi večjo učinkovitost kriznega posredovanja (Crisis Management, 2006). 
1082 36 $6^{\text {Th }}$ International Conference on Organizational Science Development: Responsible Organization (MARCh $22^{\mathrm{ND}}-24^{\mathrm{TH}}$, PORTOROŽ Slovenia)

P. Šprajc, D. Cingula \& I. Podbregar: Ethics in Crisis Management

Zveza NATO pojem kriznega menedžmenta obravnava kot strateški koncept za preprečevanje sporov in zagotavljanja stabilnosti $\mathrm{v}$ evroatlantski regiji ter predvideva stalno pripravljenost za vsak primer krize posebej. Pri tem poudarja, da je ključna sposobnost uspešnega upravljanja s krizo, saj to omogoča vzdrževanje miru, varnosti in stabilnosti na območju zveze. Krizni menedžment mora biti prilagojen novim grožnjam varnosti in mora temeljiti na skupnem vzpostavljanju ključnih elementov, kot so dialog, sodelovanje $\mathrm{z}$ nečlanicami, vzdrževanje in nadgrajevanje kolektivne obrambne sposobnosti. Vsaka kriza zahteva posvetovanje s članicami, učinkovito posredovanje pa je odvisno od konsenza pri oblikovanju odločitev na vojaškem, političnem in civilnokriznem področju ter od takojšnje vzpostavitve komunikacije med vladami s pomočjo več koordinacijskih centrov (Crisis Management, 2001).

\section{5} Zaključek

Zaključek prispevka utemeljujemo z naborom štirih etičnih načel, ki jih je potrebno upoštevati pri izvajanju reševanja kriznih situacij in kriznega menedžmenta. Pri tem vsaka krizna situacija nedvomno svojstveno izkazuje in kliče po dodatnih opredelitvah načel kriznega menedžmenta.

Prvo etično načelo je nepristranskost. S tem načelom se pri kriznem menedžmentu zavežemo, da nepristransko obravnavamo vse subjekte, ki jih dotika krizna situacija. Poštena, pravična in enakopravna obravnava, pristop do subjektov ne glede na osebnostne karakteristike in demografske značilnosti, upoštevanje pravila - v krizi je vsak posameznik ranljiv in temu primerno podvržen stresu, ki je mnogokrat lahko zmanjšan v primeru pravilnega in moralno sprejemljivega pristopa.

Drugo etično načelo je vljudnost in odzivnost. Krizne situacije v katerih se znajdejo posamezniki in širša okolica so odraz stanj, ki pri vseh ranljivih subjektih učinkujejo najprej na osebnostni ravni in nato profesionalnim ozadjem. Vljudnost in volja do pripravljenosti reševanja kriznih situacij, ki iskreno ter odprto pristopata do ogroženih stanj, se zagotavljajo s kompetenčnim okvirom ljudi, ki vodijo ter upravljajo s tokom reševanja kriznih situacij. Odgovor na stisko ljudi, na vprašanja posameznikov, ki v danem trenutku morda sploh ne dojemajo resnosti situacij mora biti $\mathrm{v}$ čim večji meri pogojen $\mathrm{z}$ razumljivostjo in taktnostjo kriznega upravljalca.

Tretje etično načelo je varstvo osebnih podatkov. Zaradi negotovih, občutljivih in ranljivih situacij, v katere se združuje koncept družbe, je potrebno, da se moralna in etična kultura definira tudi skozi varstvo vseh zaupnih informacij, ki posameznika ali družbo v primeru neizvajanja lahko podvrže še težjim stiskam v krizi.

Četrto etično načelo je spoštovanje človeškega dostojanstva. V procesu kriznega menedžmenta, je potrebno varovati dostojanstvo, avtonomijo in individualnost posameznika, upoštevati njegovo kulturo in vrednote ter prizadevati si, da se uporablja razumljiv jezik in raven komuniciranja. 
Vsakodnevni dogodki v družbi in organizaciji so podvrženi presoji vrednot in varnosti pravičnosti ter enakopravnosti, ki $\mathrm{v}$ očeh javnosti predstavljajo najpomembnejši atribut zaupanja v nacionalne institucije varovanja. V kriznih situacijah se krizni menedžment sooča s kompleksnimi etičnimi presojami, ki so pogosto del negotovosti, časovnega pritiska in povečanega javnega nadzora. Pomanjkanje etičnih dimenzij v krizah pogosto rezultirajo v dogodkih, ki se ne zaključijo. Krize, ki se ne rešujejo $z$ etičnim okvirom spodbujajo pri ljudeh stopnjo cinizma predvsem pri politični oblasti in javnem aparatu. Krizni menedžment je presojan $\mathrm{z}$ upoštevanjem etičnih vprašanj kar še povečuje pomembnost obravnavne tematike $\mathrm{v}$ prispevku. Etične dileme, vloga etike $\mathrm{v}$ kriznih situacijah in odločanje $v$ krizi, so dejstva, ki so zaradi dogajanja v svetu na vseh področjih absolutno potrebna presoje in upoštevanja načel.

\section{Literatura}

Crisis Management. (2001). Nato Publications, Handbook Chapter 7, Policy and DecisionMaking. Dostopno na http://www.nato.int/docu/handbook/2001/hb0703.htm (26. julij 2006).

Crisis Management. (2006). US Environment Protection Agency Homeland Security. Dostopno na http://www.epa.gov/compliance/criminal/homelandsecurity/crisis.html (24. marec 2006).

European Comission. (2017). Crisis management. Dostopno na https://ec.europa.eu/homeaffairs/what-we-do/policies/crisis-and-terrorism/crisis-management_en (7. januar 2017).

't Hart, P. (1993). Symbols, Rituals and Power: The Lost Dimensions of Crisis Management. Journal of Contingencies and Crisis Management, 1(1), 36-48.

Holsti, O.R. (1990). Psychological Dimensions of War. Newbury Park: SAGE Publications.

Joneis, T. (2006). Crisis Intervention Encyclopedia of Mental Disorders. Dostopno na: http://www.minddisorders.com/Br-Del/Crisis-intervention.html (5. januar 2017).

MacIntyre, A. (1993). Kratka zgodovina etike. Ljubljana: ZPS.

Malešič, M. (ur.). (2004). Krizno upravljanje in vodenje v Sloveniji. Izziv in priložnost. Ljubljana: FDV.

Možina, S., Rozman, R., Tavčar, I., Pučko, D., Ivanko, Š., Lipičnik, B., Gričar, J. Glas, M., Kralj, J., Tekavčič, M., Dimovski, V in Kovač, B. (2002). Management: nova znanja za uspeh. Radovljica: Didakta.

NATO. (2001). Nato Handbook. Brussels: NATO of Information and Press.

Prezelj, I. (2005). Nacionalni sistemi kriznega menedžmenta. Ljubljana: Fakulteta za družbene vede.

Russet, B., \& Starr, H. (1996). World Politics: The Menu for Choice. New York: W.H. Freeman and Company.

Stern, E.K. (1999). Crisis and Learning: A Conceptual Balance Sheet. Journal of Contingencies and Crisis Management, 5(2), 69-86.

Thompson, D., \& Louie, R.P. (2006). Cooperative Crisis Management and Avian Influenza: A Risk Assessment Guide for International Contagious Disease Prevention and Risk Mitigation. Dostopno na http://www.dtic.mil/cgi-bin/GetTRDoc?AD=ADA450135 (5. januar 2017). 
1084 36 ${ }^{\text {TH }}$ International Conference on Organizational Science Development: Responsible Organization (March $22^{\mathrm{ND}}-24^{\mathrm{TH}}$, Portorož Slovenia) 


\title{
Kompetence ravnateljev, ki so pomembne za vodenje dijaških domov $v$ časih nenehnih sprememb
}

\author{
SAŠA ŠTERK
}

Povzetek Dobro vodenje je bistveno za uspeh podjetja ali organizacije. Spremembe okolja vplivajo na življenje in delo v dijaških domovih $\mathrm{v}$ Sloveniji. S tem vplivajo neposredno na vodenje domov, ki ga je potrebno prilagoditi novim zahtevam. Ravnatelj je tisti, ki se mora na te spremembe odzvati, kajti neustrezno vodenje prinese neuspeh organizacije. Vedno večji pomen zato $\mathrm{v}$ zadnjem času pridobivajo kompetence posameznika, ravnatelja. S prispevkom avtorica raziščem, katere kompetence $\mathrm{v}$ času nenehnih sprememb potrebuje ravnatelj, da postane uspešen vodja dijaškega doma.

KLJUČNE BESEDE: vodenje $・$ kompetence $\bullet$ ravnatelj $・$ dijaški domovi

NASLOV AVTORICE: Saša Šterk, predsednica sveta doma, Dijaški dom Tabor, Vidovdanska cesta 7, 1000 Ljubljana, Slovenija, e-pošta: sasa.sterk@guest.arnes.si 
$36^{\mathrm{TH}}$ InTERnational CONFERENCE ON ORganizational SCIENCE Development: Responsible Organization (MARCh $22^{\mathrm{ND}}-24^{\mathrm{TH}}$, PORTOROŽ SLOVENIA)

O. Arsenijević, M. Ferjan, I. Podbregar, P. Šprajc, D. Trivan \& Y. Ziegler

\title{
Competences of Headmasters Which Are Important for Management of Boarding Schools in Times of Constant Change
}

\author{
SA ̌̌A ŠTERK
}

\begin{abstract}
Good management is essential for the success of the company or organization. Change in the environment affect the life and work of boarding schools in Slovenia. The direct impact on the management of homes, which must be adapted to the new requirements. The headmaster is the one who must respond to these change, because improper management brings the failure of organization. There is more and more important to develop competencies of the individual, headmaster. With this article the author explores what competences at the time of constant change requires headmaster to become a successful leader of a boarding school.
\end{abstract}

KEYWORDS: management $\bullet$ competence $\bullet$ headmaster $\bullet$ boarding schools

CORRESPONDENCE ADDRESS: Saša Šterk, President of the Dorm Board, Youth Dorm Tabor, Vidovdanska cesta 7, 1000 Ljubljana, Slovenia, e-mail: sasa.sterk@guest.arnes.si 


\section{$1 \quad$ Uvod}

Vodenje je $\mathrm{v}$ središču pozornosti različnih strokovnjakov že dolgo časa. $\mathrm{V}$ teoriji prevladuje splošno stališče, da na pridobivanje položaja vodje vplivajo situacijski dejavniki, vendar pa kljub temu ne smemo zanemariti vpliva osebnosti in vedenja posameznika. Vodenje ljudi je posebna spretnost in veščina vodij in managerjev, ki je ne moremo enačiti z upravljanjem, saj zahteva od posameznika povsem drugačno znanje in spretnosti - spretnost ravnanja z ljudmi pri delu (Luckman Jagodič, 2007).

Organizacije so v zadnjih petdesetih letih priča velikim spremembam. Če je včasih veljalo, da so le-te delovale v stabilnem okolju, kjer konkurenca ni bila tako izrazita in delovna sila manj raznolika, je danes to povsem drugače. Turbulentni časi so s seboj prinesli vse več sprememb in negotovosti, kar pa zahteva od organizacij, da se razmeram v okolju čim hitreje prilagodijo. Prav tako se je spremenila tudi vloga vodij. Vodja je tisti, ki se mora na te spremembe odzvati, kajti neustrezno vodenje prinese neuspeh organizacije. Vse te spremembe vplivajo na vodje, njihovo delo in delo celotne organizacije. Vedno večji pomen zato v zadnjem času pridobivajo kompetence. Veliko organizacij je $\mathrm{v}$ zadnjih tridesetih letih spremenilo vodstvene strategije in se osredotočilo na kompetence. S pomočjo posameznikovih kompetenc želijo organizacije optimizirati svoje delovanje in povečati svojo učinkovitost.

Ključna oseba pri vodenju dijaškega doma je ravnatelj. Le ta mora biti sam profesionalen in izobražen, da lahko vodi organizacijo. Imeti mora ustrezne sposobnosti in občutek odgovornosti. Ravnateljevo vodenje je odvisno od več elementov: njegove osebnosti, vodenja in sprejemanja odločitev, od oblik komuniciranja, avtoritete in odgovornosti ter od zakonskih in normativnih določil. Ravnateljevo komuniciranje v dijaškem domu je usmerjeno v: komuniciranje z delavci, dijaki, starši in zunanjim okoljem. Vsekakor je ravnateljevo vodenje odvisno tudi od vrste in velikosti organizacije ter od okolja, v katerem organizacija deluje.

$\mathrm{Z}$ leti se $\mathrm{v}$ dijaških domovih zmanjšuje število vpisanih dijakov, kar je posledica spremembe okolja. Vzporedno z upadanjem števila dijakov se spreminja osnovni model dijaških domov. V novem okolju dijaški domovi ponujajo svoje storitve tudi osnovnošolcem, študentom ter otrokom s posebnimi potrebami, poleg tega ponujajo okolju tudi druge, profitne storitve. Dijaški domovi postajajo vse bolj različno organizirani, ker se prilagajajo okolju, v katerem delujejo in so od njega vse bolj odvisni. Skladno s temi spremembami se pojavljajo tudi nove zahteve pri vodenju domov. Domovi se prilagajajo okolju, uvajajo nove dejavnosti, skratka delujejo drugače. Vodenje domov se spreminja, saj se morajo ravnatelji ukvarjati z organizacijskimi nalogami in postopki, ki jih prej niso poznali.

\section{$2 \quad$ Vodenje organizacij}

Nikoli prej ni bil svet hkrati tako povezan in nepredvidljiv. Ni dvoma, da bo enaindvajseto stoletje še naprej označeno $s$ kaotičnimi, transformacijskimi in nenadnimi spremembami. 
$36^{\mathrm{TH}}$ INTERNATIONAL CONFERENCE ON ORganizational SCIENCE DeVElopment: ResPonsible ORGANIZATION (MARCH $22^{\mathrm{ND}}-24^{\mathrm{TH}}$, PorTOROŽ SLOVENIA)

S. Šterk: Competences of Headmasters Which Are Important for Management of Boarding Schools in Times of Constant Change

V resnici si noben razumen človek ne želi napovedati, kakšen bo svet čez petdeset, petindvajset ali petnajst let. Spremembe so preveč nenadne in povsod navzoče (Levart, 2012). Vse te spremembe vplivajo na vodje, njihovo delo in celotne organizacije. S spremembami je postala vloga vodij kritična. Uspešno vodenje se kaže tako zunaj kot znotraj organizacije. $Z$ neustreznim vodenjem se organizacije slabo odrežejo ali lahko celo propadejo. Vodje se zato vedno bolj soočajo s pritiski, da dosežejo tako kratkoročne kot tudi dolgoročne cilje organizacije (Levart, 2012).

Vodenje je ena večjih tem, ki jih najdemo v literaturi. $V$ zadnjih letih se je povečal interes za razvoj vodenja zaradi več razlogov. Prvič, zaradi že omenjenih hitrih sprememb, tehnologije, globalne komunikacije in človeških vrednot. Kadar se pojavijo v poslovanju spremembe, je potrebno vodenje. Prav tako je družba izgubila zaupanje v reševanje problemov s tehnologijo in $\mathrm{z}$ znanostjo, ki sta kvečjemu privedli do problemov, kot so odtujenost delavcev, brezposelnost in onesnaženje, zato se je vodenje izkazalo kot bolj perspektivno. Kot zadnje pa se je potreba po vodenju pokazala tudi v več študijah. Vse to je zahtevalo razvoj dobrih vodstvenih spretnosti oziroma kompetenc (Levart, 2012). Organizacije so torej začele $\mathrm{z}$ raziskovanjem kompetenc $\mathrm{z}$ namenom, da identificirajo, katere posameznikove spretnosti so zahtevane za opravljanje določene funkcije $\mathrm{v}$ organizaciji, da določijo prave ljudi na delovna mesta, da razvijajo posameznikove kompetence in s tem pripomorejo k optimiziranju delovanja organizacije. Konkurenčnost organizacije je torej odvisna od tega, kako bodo znale uporabiti kompetence in znanja posameznikov, se učiti in prilagajati.

Za vodje je pomembno da $\mathrm{v}$ spremembah poiščejo priložnosti in se na njih odzovejo. $\mathrm{V}$ vodenih morajo poiskati njihove talente, sposobnosti in znanja in skupaj z njimi poiskati rešitve za dosego ciljev organizacije.

\section{$3 \quad$ Kompetence}

Izraz kompetence je prvi uporabil Boyatzis leta 1982 (v Lorber, 2010). Kompetence je definiral kot notranjo značilnost posameznika, ki je vzročno povezana z nadpovprečno storilnostjo, njeni konstruktivni deli pa so: motivacija, sposobnosti, samopodoba, znanje, veščine in socialna vloga posameznika (Lorber, 2010).

Kompetence so vse sposobnosti uporabe znanja in druge zmožnosti, ki so potrebne, da nekdo uspešno in učinkovito ter v skladu s standardi izvrši določeno nalogo, opravi delo, uresniči cilje ali odigra vlogo v poslovnem procesu. Obsega tako znanja kot tudi veščine, spretnosti, osebnostne in vedenjske značilnosti, prepričanja, motive, vrednote, samopodobo ipd.; to pomeni vse tisto, kar je skupaj precej večje jamstvo za delovni uspeh, kot je znanje samo po sebi (Lorber, 2010).

Kompetentnost izraža dokazano oziroma prikazano sposobnost posameznika, da v obstoječih poklicnih situacijah ustrezno uporablja znanje, spretnosti ali usposobljenost oziroma kvalificiranost. Kompetentnost obsega vsa znanja, spretnosti in sposobnosti, potrebne za izvajanje nalog $\mathrm{v}$ določenem poklicu, oseba pa si jih je pridobila s formalnim in kontinuiranim izobraževanjem ali z drugimi izkušnjami (Može, 2005). 
Pri opredelitvi in definiranju pojma kompetenc naletimo na toliko različnih opredelitev, kolikor je avtorjev, ki so se začeli ukvarjati s tem pojmom. New (1996, v Levart, 2012) je mnenja, da ne glede na to kakšno definicijo kompetenc vzamemo, je vsem skupno to, da so kompetence nekaj, kar lahko opazujemo in kar vodi do določenega opravljenega dela, kako torej opravimo naše delo.

\section{Vrste kompetenc}

Kompetence lahko razvrščamo na več načinov:

\section{- ključne ali generične kompetence}

Ključne kompetence so kompetence, ki so pomembne na različnih področjih življenja in prispevajo $\mathrm{k}$ uspešnemu življenju in dobremu delovanju družbe. Predstavljajo torej splošno znanje, motive, lastnosti, samopodobo, sposobnosti, ki so nujne za opravljanje določenega dela, niso pa vzročno povezane z boljšim oziroma superiornim delovanjem na delovnem mestu. To so torej kompetence posameznika, ki pripomorejo k temu, da posameznik uspešno opravlja svoje delo; so načini kako posameznik deluje $\mathrm{z}$ ostalimi zaposlenimi v določeni organizaciji. Ključne kompetence lahko gledamo na ravni posameznika in ravni organizacije. $\mathrm{Na}$ ravni organizacije razlikujemo med generičnimi in ključnimi kompetencami. Prve predstavljajo osnovni pogoj za obstoj, druge pa pomenijo določeno prednost, ki jo ima organizacija pred drugimi (Levart, 2012).

\section{- delovno specifične kompetence}

Delovno specifične kompetence so tiste aktivnosti v določeni vlogi ali poziciji, ki so povezane z učinkovitim delom. To so atributi, ki so potrebni, da je določeno delo uspešno opravljeno (New 1996, v Levart 2012). Za razliko od generičnih kompetenc so te specifične za posamezna delovna mesta. S pomočjo specifičnih kompetenc lahko rešujemo specifične probleme, ki se pojavijo na delovnem mestu. Delovno specifične kompetence se navezujejo na uspešnost posameznika $\mathrm{v}$ določeni vlogi.

\section{- organizacijsko specifične kompetence}

Organizacijsko specifične kompetence so načini, s katerimi posameznik prilagaja svoj način delovanja, da lahko deluje znotraj kulture določene organizacije ne glede na funkcijo, ki jo opravlja (New 1996, v Levart 2012). Lahko jih opazujemo na ravni posameznika in na ravni organizacij. Za slednje pomenijo razlikovanje določene organizacije od ostalih. Vsaka organizacija ima svojo kulturo in svoje organizacijsko specifične kompetence, ki so lahko dobro uporabljene $\mathrm{v}$ eni organizaciji, $\mathrm{v}$ drugi pa ne, zato se te kompetence, če gledamo $\mathrm{z}$ vidika posameznika, navezujejo na njegovo uspešnost v organizaciji. 
$109036^{\text {Th }}$ International Conference on Organizational Science Development: Responsible ORganization (MARCH $22^{\mathrm{ND}}-24^{\mathrm{TH}}$, Portorož SLOVENiA)

S. Šterk: Competences of Headmasters Which Are Important for Management of Boarding Schools in Times of Constant Change

\section{- menedžerske kompetence}

Pri menedžerskih kompetencah gre za načine, kako posameznik sodeluje $\mathrm{z}$ ostalimi v organizaciji. Prištevamo jih med ključne kompetence, ker so ključni pogoji za opravljanje dela (New 1996, v Levart 2012). Za uspešnost menedžerjev je potrebno upoštevati njihov nabor kompetenc $v$ določeni vlogi. Določen posameznik bo uspešnejši od drugega, ker bodo njegove kompetence primernejše za določeno vlogo.

\section{$4 \quad$ Kompetence vodij}

Veliko avtorjev, ki so se ukvarjali z vodenjem, je želelo raziskati, kakšen stil vodenja je najboljši, katere so tiste sposobnosti, ki bi jih naj dobri vodje imeli. Katere so tiste kompetence, ki so pomembne za uspešno vodenje.

V Sloveniji se je z lastnostmi vodij ukvarjal Mayer (2004). Na podlagi dolgoletne študije, v kateri je sodelovalo 212 mladih strokovnjakov iz 12 večjih uspešnih slovenskih organizacij, kjer so bili izbrani za najobetavnejše ljudi, je identificiral naslednje lastnosti oziroma kompetence:

- motiviranje (navduševanje za delo, ustvarjanje dobrega vzdušja, nagrajevanje uspešnosti),

- poštenost (ravnanje po vesti, težnja po dobrem, pravičnost, spoštovanje dogovora, iskrenost),

- organiziranje (učinkovita izraba in koordinacija virov za optimalno doseganje delovnih ciljev),

- poslušanje (zagotavljanje svobode izražanja, upoštevanje problemov, stališč, zamisli sodelavcev),

- odgovornost (skrb za rezultate dela, lastno ravnanje, ravnanje sodelavcev in sankcioniranje),

- odločnost (pogumno, tvegano, hitro odločanje, samozavestno, jasno izražanje volje, mnenja),

- energija (aktivnost, samoiniciativnost, vztrajanje do izpolnitve nalog, dominantnost, karizma),

- razgledanost (preraščanje ozke strokovnosti, večdisciplinarno znanje, svetovljanstvo),

- samokritičnost (poznavanje sebe, priznavanje svojih pomanjkljivosti in napak, osebna merila),

- izrazna moč (lahkotnost izražanja, zanimivost, razumljivost, prepričljivost, vplivnost),

- moderiranje (spodbujanje dvoma in kritike v debati, obvladovanje časa in čustev, strpnost),

- ustvarjalnost (izvirnost, domišljija, duhovitost, nekonformnost, uresničitev novih zamisli), 
S. Šterk: Kompetence ravnateljev, ki so pomembne za vodenje dijaških domov v časih nenehnih sprememb

- sposobnost (hitrost in ustreznost razumevanja, sklepanja, uspešnost pri reševanju problemov),

- duhovitost (ustvarjalno izražanje, usmerjanje k pozitivnemu, $\mathrm{k}$ humorju, iz krize k priložnosti).

Najvišje so se uvrstile lastnosti oziroma kompetence motiviranja sodelavcev, poštenost in sposobnost organiziranja (Mayer 2004).

Karakteristike slovenskih menedžerjev oziroma vodij so predstavili tudi Cimerman in drugi $(2003,30)$. Opredelili so 15 najpomembnejših kompetenc menedžerjev, ki zajemajo tudi vodenje in jih razvrstili v 4 skupine:

- strateške kompetence (1. vizionarstvo, 2. ciljna usmerjenost, 3. strateška usmerjenost, 4. odločanje)

- organizacijske kompetence (5. organiziranost, 6. delegiranje, 7. upravljanje s kadri)

- operativne vodstvene kompetence (8. komunikacijske sposobnosti, 9. sposobnost motiviranja, 10. pogajanje, 11. vodenje tima)

- osebnostne kompetence (12. etičnost, 13. karizmatičnost, 14. odprtost nadzorov).

Kot 15. kompetenco so navedli obvladovanje sprememb, ki predstavlja sinergijo vseh navedenih kompetenc (Cimerman in drugi, 2003) .

Kot je razvidno iz raziskav, obstajajo določene lastnosti in kompetence, ki so pomembne za vodenje, da so vodje pri svojem delu uspešni.

\section{$5 \quad$ Dijaški dom kot organizacija}

Dijaški dom spada med nepridobitne organizacije. Cilj nepridobitnih organizacij je delovanje $\mathrm{v}$ javnem interesu in zagotavljanje storitev in dobrin, ki so pogoj za uspešno delovanje družbe kot celote. Namen delovanja nepridobitnih organizacij ni dobiček, če pa do njega pride, se z njim ne razpolaga po svobodni presoji, ampak se ta vlaga nazaj v dejavnost organizacije in služi ko sredstvo za razširitev te dejavnosti ali pa za dvig kvalitete storitev (Černetič 1999, 324).

Dijaški domovi v Sloveniji so javni zavodi in skoraj vse je ustanovila država, ki preko njih uresničuje svoje interese ter zaposluje ljudi, ki sledijo njenim ciljem. Največjo moč in oblast $\mathrm{v}$ dijaških domovih je država poverila ravnateljem kot izvrševalcem $\mathrm{z}$ zakonom predpisanih nalog in obveznosti. Vodenje $\mathrm{v}$ javnih organizacijah je $\mathrm{v}$ veliki meri odvisno od pripadnosti menedžerjev in drugih zaposlenih, saj mora zaradi narave dela pri ljudeh vladati popolno in enotno prepričanje o smotrih, viziji, vrednotah in ciljih. Tudi pri nas so vse pogostejši javni razpisi in javne organizacije tekmujejo s ponudbami za nove ali dodatne javne storitve in javne programe. Izvajanje storitev je na osnovi pogodbe lahko podeljeno katerikoli drugi organizaciji (Pečar,2001). 
V dijaških domovih vodijo, odločajo in organizirajo delo ravnatelji, seveda $\mathrm{v}$ mejah pristojnosti, ki jih država določa s svojimi zakoni. Ravnatelj predstavlja in zastopa dom. Delavci pa imajo pravico do soodločanja. To pravico uveljavljajo preko svojih predstavnikov v svetu zavoda. Pristojnosti sveta zavoda so določene v Zakonu o organizaciji in financiranju vzgoje in izobraževanja. Svet zavoda, ki opravlja tudi vlogo nadzornega organa dela ravnatelja, ima možnost izbirati ravnatelja. Za izbor ravnatelja $\mathrm{v}$ dijaških domovih in $v$ šolstvu nasploh, so z Zakonom o organizaciji in financiranju vzgoje in izobraževanja predpisana in določena merila in pogoji.

\section{$6 \quad$ Ravnatelj kot vodja}

Vlogo vodje in izvrševalca $\mathrm{z}$ zakonom predpisanih nalog in obveznosti $\mathrm{v}$ dijaških domovih je država zaupala ravnateljem in jim delegirala najpomembnejšo funkcijo upravljanja, odločanja in vodenja. Ravnatelj izbira in usmerja delavce na delovna mesta v dijaškem domu - pri tem mora delovati v skladu z zakonom in v soglasju z Ministrstvom za izobraževanje, znanost in šport. Ministrstvo ima kontrolno in oblastno funkcijo nad dijaškimi domovi, daje jim denar za izvajanje dejavnosti, plačuje kadre in materialne stroške, zato daje tudi soglasje $\mathrm{k}$ sistemizaciji delovnih mest.

Zakonodaja $\mathrm{v}$ Sloveniji se menja in prilagaja evropskim standardom, kar prinaša spremembe tudi $\mathrm{v}$ šolski sistem. V dijaških domovih so nekatere spremembe precej očitne, saj se menedžment dijaških domov vedno bolj ukvarja s konkurenco v okolju, išče nove načine ponudbe svojih dejavnosti in je vse bolj prodoren s svojo promocijo. Dijaški domovi se tržno usmerjajo, iščejo nove tržne niše, saj so dodatne dejavnosti, ki jih izvajajo dijaški domovi, poleg osnovne dejavnosti, v manjših dijaških domovih pogosto bistvenega pomena za njihov obstoj.

Ravnatelj je vodja dijaškega doma. Njegove naloge in delovne obveznosti so določene v Aktu o ustanovitvi doma. Določene so tudi z zakonskimi in podzakonskimi akti s področja izobraževanja. Ravnateljeva vloga je torej bolj ali manj določena. V razmerah, ko je bila osnovna dejavnost samo ena - vzgoja dijakov, in ko so bile dopolnilne dejavnosti postranska zadeva, je ta vloga zadostovala. V novem, spremenjenem okolju tako določen način vodenja žal ne zadostuje več.

Žunkovič (2007) nam prikaže, da novi model vodenja dijaškega doma zajema: vodenje, odnos, sodelovanje, strokovnost, timsko delo, gospodarnost. Krona vsega je vizija. Ena najpomembnejših nalog ravnatelja $\mathrm{v}$ novem modelu vodenja bo zato oblikovanje strategije dijaškega doma. Tako bo dobil celovito sliko podjetja in njegovega podjetniškega okolja. Na osnovi dobljenih podatkov bo ravnatelj, skupaj s sodelavci, oblikoval strategijo razvoja in sprejemal odločitve za potrebne spremembe. 


\section{Kompetence ravnateljev, ki so pomembne za vodenje dijaških domov v časih nenehnih sprememb}

Kot sem že omenila, se dijaški domovi srečujejo z različnimi izzivi, se prilagajajo okolju in so od njega vse bolj odvisni. Moja želja je bila raziskati, kakšno je trenutno stanje v dijaških domovih in katere kompetence $\mathrm{v}$ času nenehnih sprememb potrebujejo ravnatelji, da bodo dijaški domovi zopet dosegli pomembno mesto v vzgoji in izobraževanju.

Glede na Seznam dijaških domov, ki ga objavlja Ministrstvo za izobraževanje, znanost in šport (https://krka1.mss.edus.si/registriweb/Seznam2.aspx?Seznam=3020), naj bi trenutno v Sloveniji delovalo 39 dijaških domov. Vendar so nekateri od teh domov v zapiranju, tako da te številke ne moremo upoštevati kot dokončne. Glede na pridobljene podatke sem kontaktirala 37 ravnateljev dijaških domov, katerim sem posredovala spletno anketo. Le-to je izpolnilo 24 ravnateljev.

Tudi število zaposlenih vzgojiteljev nam ni točno znano. Giblje se med 170 in 180 vzgojiteljev. Za pomoč pri posredovanju ankete sem se obrnila na Društvo vzgojiteljev Slovenije, ki šteje 84 članov.

$\mathrm{Na}$ anketo se je odzvalo 65 vzgojiteljev, 46 pa jih je anketo tudi izpolnilo.

Glede na pridobljen vzorec lahko sklepamo naslednje:

1. V dijaških domovih prevladujejo ženske: od 24 sodelujočih je bilo kar 18 ravnateljic, pri vzgojiteljih pa od 46 sodelujočih 31 vzgojiteljic.

2. Povprečna starost zaposlenih $v$ domu je čez 50 let: od 46 vzgojiteljev jih je 33 starih več kot 50 let, 13 ravnateljev dijaških domov prav tako presega to starost.

3. Povprečna delovna doba zaposlenega $v$ dijaškem domu je 30 let: kar 31 anketiranih vzgojiteljev dela v dijaškem domu med 21 in 40 let. Pri ravnateljih pa jih je polovica zaposlenih v dijaškem domu manj kot 20 let.

4. Večina od zaposlenih ni najbolj zadovoljna $z$ delom svojih nadrejenih: kar $69 \%$ anketiranih vzgojiteljev je odgovorilo, da njihov ravnatelj svoje del opravlja pomanjkljivo oz. bi svoje delo lahko bolje opravljal.

5. Ravnatelji so mnenja da svoje delo opravljajo zelo dobro: saj je več kot $50 \%$ anketiranih odgovorilo, da svoje delo opravljajo popolnoma odgovorno in vestno (brez pomanjkljivosti).

6. Kompetence, ki naj bi jih imel ravnatelj v času nenehnih sprememb, so: odgovornost, strokovnost, poštenost, pozitivna usmerjenost. Te 4 kompetence se najdejo na vrhu seznama obojih anketiranih. Ravnatelji izpostavijo še sodelovalnost, čustveno stabilnost in vztrajnost, vzgojitelji pa dajo poudarek na spoštljivosti, komunikativnosti in samokritičnosti.

Iz zgoraj napisanega lahko razberemo, da poleg tega, da v dijaških domovih prevladuje starejši kolektiv, ta od svojih zaposlenih pričakuje boljše vodenje. Glede na izbor kompetenc vzgojiteljev, bi lahko sklepali, da si želijo več spoštovanja in komunikacije 
od svojih vodij. Pri izboru kompetenc ravnateljev, pa se mi poraja vprašanje ali se mogoče ravnatelji soočajo z nezainteresiranostjo za delo svojih zaposlenih, ko izpostavijo sodelovalnost in vztrajnost. Mogoče bi tu lahko iskali vzrok v visoki povprečni starosti in povprečni delovni dobi zaposlenih.

Na tem mestu bi rada izpostavila mnenje Žunkoviča (2007), ki pravi, da zaposleni v dijaških domovih, razen izjem, težko sledijo naglim in pomembnim spremembam, ki se dogajajo okrog njih. Sprememba mišljenja ljudi, tržno obnašanje in razmišljanje vstopata v negospodarske dejavnosti z zamudo. Gospodarstvo je nov način dela in razmišljanja vpeljalo in $\mathrm{z}$ večjimi in manjšimi pretresi prehodilo že pred leti. $V$ negospodarstvu se je uveljavljanje drugačnega načina razmišljanja komaj dobro začelo. V procesu uvajanja sprememb nastajajo ovire. Izpostavlja naslednje razloge, da spremembe ne uspejo: pomanjkljivo znanje, nerazumevanje, osebni interesi, omejeni viri.

Tudi Velikonja (1995) je mnenja da so ovire pri spreminjanju ustaljenih vzorcev in vzorcev razmišljanja zaposlenih včasih res velike in težko premostljive, pa tudi nepremostljive. »Pregovor, da starega konja težko naučiš jahati, v primeru vsebinskih sprememb v notranjem okolju neprofitne organizacije, zagotovo velja. Ena bistvenih sprememb, ki se mora zgoditi v notranjem okolju organizacije, ki zadeva spremembo vsebine (od vizije, do načina dela, načina obnašanja, ...), je prav sprememba načina razmišljanja« (Velikonja, 1995).

Uspešen ravnatelj ni samo tisti, ki predstavlja organizacijo v javnosti, ampak mora od svojih zaposlenih izvleči tiste lastnosti, ki organizaciji koristijo. Hkrati mora pokazati zaupanje in ravnati etično, saj mu bodo zaposleni le tako sledili. Če hoče voditi druge, mora najprej poznati samega sebe in svoje zmožnosti. Vsak od zaposlenih pa mora imeti tudi željo po permanentnem nadgrajevanju znanja, saj ta $\mathrm{v}$ inovativnem, nenehno spreminjajočem se okolju hitro zastara.

\section{8}

\section{Zaključek}

Vedno več organizacij uporablja modele kompetenc za to, da bi izboljšali individualno in organizacijsko produktivnost. Organizacije so začele z raziskovanjem kompetentnosti z namenom, da identificirajo spretnosti, katere so zahtevane za opravljanje določene funkcije $v$ organizaciji. S pomočjo kompetenc lahko organizacije optimizirajo delovanje organizacije na več načinov: izberejo prave ljudi za prave funkcije, vrednotijo posameznikove zmožnosti za nove funkcije in identificirajo potrebo posameznika po določenem usposabljanju. Strateški in konkurenčni uspeh zahtevata, da ima organizacija določen model kompetenc in da razporeja in izkorišča te kompetence učinkovito (Levart, 2012).

Kompetence so postale praksa, ki se vedno bolj pogosteje uporablja pri upravljanju človeških virov. Kot smo že povedali v teoretičnem delu, so kompetence karakteristike posameznikov, ki jih primerno in usklajeno uporabljajo, da dosežejo želeno učinkovitost. 
Te karakteristike vključujejo znanje, spretnosti, stališče samopodobe, motive, lastnosti, načine razmišljanja, občutenje in delovanje.

Dijaške domove prištevamo med organizacije posebnega družbenega pomena, ki dijakom, predvsem srednješolcem, nudijo možnost bivanja, prehranjevanja, učenja, preživljanja prostega časa in osebnostne rasti pod vodstvom pedagoških delavcev. Uvrščamo jih med nepridobitne organizacije, javne zavode, kar pomeni, da ustanoviteljem in lastnikom (državi) ne prinašajo dobička. Država dovoljuje tudi tržne, dodatne dejavnosti, ki pa so omejene. Dobiček od dodatnih dejavnosti se namenja nadaljnjemu razvoju in izboljšavam pogojev dela in razvoja. Plače zaposlenih v taki organizaciji so fiksne, državno določene $\mathrm{z}$ zakoni in niso odvisne od ustvarjenega dobička. Cilj nepridobitnih organizacij je zagotoviti storitve in dobrine, ki so potrebne za delovanje družbe kot celote. Značilno za storitve je, da so minljive in neotipljive. Iz tega izhaja, da je težko meriti učinkovitost dela zlasti v primerjavi z rezultati dela $v$ materialni proizvodnji v pridobitnih organizacijah. Po drugi strani pa nepridobitne organizacije $\mathrm{v}$ veliki meri zaposlujejo visoko usposobljene strokovnjake, ki v smislu plač ne dosegajo dohodkov primerljivih strokovnjakov $\mathrm{v}$ gospodarstvu. To je eden od razlogov, da je nepridobitni sektor manj privlačen za mnoge ambiciozne in sposobne strokovnjake (Černetič, 2004, 77).

\section{Literatura in viri}

Cimerman, M., Jerman, S., Klarič, R., Ložar, B. in Sušanj, Z. (2003).Manager, prvi med enakimi: knjiga o slovenskem managementu z mislimi 50 vodilnih direktorjev. Ljubljana: GV Založba.

Černetič, M. (1999): Ekonomika izobraževanja in raziskovanja, Založba Moderna organizacija, Kranj.

Černetič, M.(2004): Upravljanje in vodenje, Univerza v Mariboru, Pedagoška fakulteta, Maribor.

Levart, N. (2012): Kompetence vodij. Univerza v Ljubljani. Fakulteta za družbene vede. Ljubljana

Lorber, M. (2010): Vedenje, značilnosti in kompetence vodij v povezavi z zadovoljstvom in pripadnostjo zaposlenih $v$ zdravstveni negi. Univerza na primorskem, Fakulteta za management. Koper.

Luckman Jagodič, B. (2007). Vodenje - veščina, ki se je je moč naučiti. HRM: strokovna revija za ravnanje z ljudmi pri delu 5 (17): 52-53.

Mayer, J. (2004). Lastnosti uspešnih vodij. Organizacija 36 (6): 368-375.

Može, M. (2005). Pridobivanje nacionalnih poklicnih kvalifikacij na področju zdravstvene nege. Obzornik zdravstvene nege 39 (1): 39-45.

Pečar, Z. (2001): Management v javnem sektorju: Ljubljana: Visoka upravna šola.

Seznam dijaških domov. MIZŠ. https://krka1.mss.edus.si/registriweb/Seznam2.aspx?Seznam=3020

Velikonja, M. (1995): Menedžment v vzgoji in izobraževanju. Ljubljana: Zavod RS za šolstvo.

Žunkovič, F. (2007): Izzivi vodenja dijaških domov v evropskem okolju. Univerza v Mariboru. Fakulteta za organizacijske vede 
1096 36 ${ }^{\text {TH }}$ International Conference on Organizational Science Development: Responsible Organization (March $22^{\mathrm{ND}}-24^{\mathrm{TH}}$, Portorož Slovenia) 
36. MEDNARODNA KONFERENCA O RAZVOJU ORGANIZACIJSKIH ZNANOSTI: OdgOVORNA ORGANIZACIJA (22. - 24. MAREC 2017, PORTOROŽ, SLOVENIJA)

O. Arsenijević, M. Ferjan, I. Podbregar, P. Šprajc, D. Trivan \& Y. Ziegler

\section{Podjetništvo v višjem šolstvu}

\section{DARKO ŠTEVANČEC \& IRIS FINK GRUBAČEVIĆ}

Povzetek Moderna družba potrebuje več podjetnikov, zato je razvijanje podjetniških kompetenc, več inovativnosti in hitro rastočih podjetij nujno. Okolje izraža potrebo po razvijanju podjetniških kompetenc in spodbujanja podjetniškega načina razmišljanja. Tudi višješolske izobraževalne institucije imajo zato čedalje pomembnejšo vlogo $\mathrm{v}$ zagotavljanju podjetniškega izobraževanja in usposabljanja študentov za vstop v svet podjetništva, predvsem z uvajanjem različnih metod dela. Zanimala so nas stališča učiteljev ter študentov o možnostih ter kvaliteti razvijanja podjetniškega razmišljanja ter delovanja. V nadaljevanju bomo predstavili najpomembnejše izsledke raziskave o implementaciji podjetniškega delovanja v višješolskih organizacijah R Slovenije.

KLJUČNE BESEDE: podjetništvo $•$ višješolsko izobraževanje $\cdot$ metode poučevanja

NASLOV AVTORJEV: dr. Darko Števančec, Ekonomska šola Murska Sobota, Višja strokovna šola, Noršinska ulica 13, 9000 Murska Sobota, Slovenija, e-pošta: Da01111@ gmail.com; mag. Iris Fink Grubačević, višja predavateljica, Ekonomska šola Novo mesto, Ulica talcev 3a, 8000 Novo mesto, Slovenija, e-pošta: iris.fink@guest.arnes.si 
$36^{\mathrm{TH}}$ InTERnational CONFERENCE ON ORganizational SCIENCE Development: Responsible Organization (MARCh $22^{\mathrm{ND}}-24^{\mathrm{TH}}$, PORTOROŽ SLOVENIA)

O. Arsenijević, M. Ferjan, I. Podbregar, P. Šprajc, D. Trivan \& Y. Ziegler

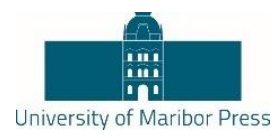

\title{
Entrepreneurship in Higher Vocational Education
}

\author{
DARKO ŠTEVANČEC \& IRIS FINK GRUBAČEVIĆ
}

\begin{abstract}
Modern society needs more entrepreneurs so developing entrepreneurial competences, more innovativity and fast growing businesses is imperative. Environment reflects the need to develop entrepreneurial competences and promote entrepreneurial mindsets. Higher educational institutions are having an increasingly important role in providing entrepreneurship education and training students to enter the world of entrepreneurship as well, especially with the introduction of different working methods. We were interested in the students and teachers views on opportunities and quality development of entrepreneurial thinking and action. In the article we present the most important findings of the study on the implementation of entrepreneurship in higher education organizations in Slovenia.
\end{abstract}

KEYWORDS: entrepreneurship • higher education • teaching methods

Correspondence AdDress: Darko Števančec, Ph.D., School of Economics Murska Sobota, Vocational College, Noršinska ulica 13, 9000 Murska Sobota, Slovenia, e-mail: Da01111@gmail.com; Iris Fink Grubačević, M.S., Senior Lecturer, School of Economics Novo mesto, Ulica talcev 3a, 8000 Novo mesto, Slovenia, e-mail: iris.fink@ guest.arnes.si

DOI https://doi.org/10.18690/978-961-286-020-2.88

ISBN 978-961-286-020-2

(C) 2017 University of Maribor Press

Available at: http://press.um.si 
Današnji čas je zaznamovan s spremembami v ekonomiji, z globalizacijo, inovativnostjo, ustanavljajo se mikro, mala in srednje velika podjetja, zato je potreben fleksibilen in hiter odziv na spremembe. Dinamična ekonomska situacija ustvarja številne priložnosti za bodoče podjetnike. Kultura podjetništva, ki temelji na znanju, praktičnih izkušnjah in inovativnosti, pomaga zaobiti težave, povzročene z globalno ekonomsko krizo. Lahko rečemo, da je podjetniško izobraževanje pomemben dejavnik pri ekonomskem razvoju posamezne države. Ta situacija je sedaj priložnost za izobraževalne institucije in posledično za študente, da postanejo podjetniki in se uspešno soočijo z nestabilnim ekonomskih trgom. V izobraževanju se zato osredotočamo na kombinacijo izobraževanja o podjetništvu in izobraževanja za podjetništvo/podjetnika.

\section{Umestitev višjih šol v terciarno izobraževanje}

Razvoj višjega strokovnega izobraževanja v Sloveniji se je začel leta 1995 s sodelovanjem šol v projektu Phare za prenovo poklicnega in strokovnega izobraževanja v Sloveniji. Leta 1996 je bilo na osnovi dveh temeljnih zakonov ustanovljenih prvih pet višjih šol s petimi različnimi programi. Po letu 2000 smo začeli dobivati nove šole in programe. V letu 2017 je v razvid vpisanih 61 višjih šol, ki izvajajo 33 programov (MIZŠ, 2017).

Bolonjska deklaracija je predvidela bolj prepoznavno umestitev višjega izobraževanja $v$ terciarno. Avgusta 2004 dobimo Zakon o višjem strokovnem izobraževanju, ki je višje šole umestil v terciarno stopnjo izobraževanja in uredil položaj višjih šol. Višje strokovno izobraževanje dopolnjuje oziroma zaokroža ponudbo v terciarnem izobraževanju in je postalo njegov nepogrešljivi del. V Evropi se imenuje tertiary short cycle education oziroma sub-degree level ali short cycle level (krajše terciarno izobraževanje oziroma kratki terciarni programi). Prepoznano je kot vitalni del visokošolskega in pomembno pripomore k razvoju vseživljenjskega izobraževanja (MIZŠ, 2017).

Višješolski študij je $\mathrm{v}$ svoji strukturi močno praktično naravnan in morda ravno zato primeren za vključevanje podjetniških vsebin, ki morajo temeljiti na izkustvenem učenju. Študenti aktivno sodelujejo $\mathrm{v}$ najrazličnejših delovnih procesih ter pri tem praktično preverjajo pridobljena znanja v okviru različnih študijskih predmetov ter kompetenc, ki jih zahteva poklicno specifično delovno področje.

\section{$3 \quad$ Definicije podjetništva}

Podjetništvo vidimo kot možnost uresničitve ideje in želje po uspehu. Predstavlja izziv, možnost razvoja in spoznavanja lastne osebnosti, svobodo, avtonomijo, spodbuja ustvarjalnost, sooča z odgovornostmi in izzivi ob neuspehu, nenazadnje nas spodbuja, da si postavljamo prioritete in ugotavljamo, koliko časa, denarja in energije smo $\mathrm{v}$ resnici pripravljeni žrtvovati za dosego ciljev oz. uspeh. Šubelj (2011) meni, da biti uspešen za nekoga lahko pomeni zaslužiti veliko denarja, za drugega imeti najboljši avto, veliko hišo, za tretjega pa to preprosto pomeni imeti veliko prostega časa in dostojno življenje. 
$1100 \quad 36^{\mathrm{TH}}$ International CONFERENCE ON ORganizational SCIENCE Development: Responsible ORganization (MARCh $22^{\mathrm{ND}}-24^{\mathrm{TH}}$, PORTOROŽ Slovenia)

D. Števančec \& I. Fink Grubačević: Entrepreneurship in Higher Vocational Education

Pšeničny in Vidic (2000) opredelita podjetništvo kot skupek aktivnosti posameznikov, ki jih ti izvajajo z namenom zadovoljevanja tržnih potreb in s katerimi želijo posamezniki ob prevzemanju osebnega tveganja doseči čim večji finančni uspeh.

Kos (2007) opredeli podjetništvo kot proces, v katerem podjetniki namenjajo svoj čas in prizadevanje, prevzamejo finančna, psihična in družbena tveganja za ustvarjanje nečesa novega in za to prejmejo pripadajoče nagrade $\mathrm{v}$ obliki denarja, osebnega zadovoljstva in neodvisnosti. Definicija poudarja štiri elemente: ustvarjalni proces, kjer se ustvarja nekaj novega, vrednega; poslu je potrebno nameniti čas in prizadevanje; prevzemanje tveganj ter nagrada podjetniku - neodvisnost.

Rebernik in ostali (2006) nadalje menijo, da širša definicija opredeljuje podjetništvo kot neko dejavnost posameznika, skupine posameznikov ali obstoječega podjetja, da bi ustvarili novo podjetje ali poslovno dejavnost, bodisi da gre za samozaposlitev, novo podjetje ali razširitev že obstoječega podjetja.

Motivi posameznikov, ki so se odločili za pot podjetnika, se razlikujejo. Nekateri to storijo zato, ker so lahko bolj svobodni in neodvisni pri delu, sami si določajo delovni čas, prioritete, drugi, ker želijo povečati svoje prihodke, tretji zaradi spleta dejavnikov kot npr. brezposelnost, preživetje. Na posameznikovo odločitev, da bi se uveljavil kot podjetnik, vplivajo številni dejavniki, kot sta npr. podjetniške zmogljivosti in nagnjenost k podjetništvu. Gre za sposobnost in pripravljenost prepoznavati poslovne priložnosti, dojemanje kulturne podpore za podjetništvo, podjetnikovo samozavedanje o potrebnem znanju in veščinah za podjetništvo in njegovem odnosu do rizika in neuspeha (Rebernik, Tominc, Pušnik, 2010).

\section{$4 \quad$ Podjetniško izobraževanje v višjem šolstvu}

Odnos do podjetništva kaže splošno naklonjenost populacije države do podjetniške kariere. Če je podjetništvo v družbi zaželeno in posameznik dobi pozitivno izkušnjo, da so uspešni podjetniki spoštovani in ugledni, bo verjetnost, da se bo tudi sam podal na podjetniško pot, večja. Tudi prepoznavanje podjetniških priložnosti bo delovalo pozitivno v smeri večjega podjetništva. Tisti, ki verjamejo, da imajo potrebne veščine in znanje, da bi ustanovili podjetje, bodo bolj verjetno ustanavljali podjetja kot tisti, ki menijo, da teh veščin nimajo. Odnos države do podjetništva je pomembna »infrastrukturna podlaga« za ustvarjanje splošne kulturne podpore, pomoči, podpornih mrež, zagotavljanja finančnih virov in ostalih elementov za delujoče podjetnike, kot tudi za tiste, ki o podjetniški karieri šele razmišljajo (Rebernik, Tominc, Pušnik, 2010).

Podjetniško izobraževanje spodbuja oz. ustvarja kulturo podjetništva. Izobraževalni sistem se je odzval na ekonomsko situacijo v državi in ustvaril formalne in neformalne oblike izobraževanja na vseh ravneh. Cilj izobraževanja je tako poslati na trg delovne sile čim več diplomantov, ki bi postali podjetniki in s tem pomagali državi ustvariti boljšo ekonomsko situacijo oz. gospodarsko rast. Visokošolski izobraževalni sistem mora med študenti promovirati podjetniško razmišljanje, da bodo ozaveščeni, kaj pomeni to za dvig ekonomske rasti v posamezni državi (Belwal, Al Balushi, Belwal, 2015). 
V podjetniškem izobraževanju je poudarek na oblikovanju vedenja, razmišljanja ter oblikovanju učinkovitih podjetniških lastnosti. Namen je povečati razvoj podjetniškega vedenja, da študenti začutijo in pridobijo željo po zaposlitvi kot samostojni podjetniki. Othman, Norashidah in Hariyaty (2012) menijo, da veščine, ki jih podjetnik potrebuje, temeljijo na spodbujanju ustvarjalnosti, inovativnosti in delu na lastni poslovni karieri. Višje šolstvo lahko pomaga pri kreiranju podjetniškega razmišljanja pri študentih in ustvarjanju spodbudnega, pristnega okolja za podjetništvo. Študenti morajo dobiti čimbolj realno sliko in realne izkušnje v času študija.

Othman in Nasrudin (2016) ugotavljata, da je potrebno študentom v času študija integrirati podjetništvo preko treh elementov: prvi je podjetniška zavest, ki se gradi na razumevanju pomembnosti podjetništva, njegovih vrednot; drugi je razvijanje podjetništva in krepitev lastnosti, ki študentom pomagajo najti strast in interes za podjetniško delovanje; tretji je utrjevanje podjetništva, kjer študente izpostavimo realnim situacijam, dogodkom ter jim pomagamo, da se znajdejo v različnih situacijah in dobijo pozitivne izkušnje. Nadalje McLarty, Highley in Aldersonova (2010) predlagajo pomembne vidike $\mathrm{v}$ podjetniškem izobraževanju: promocijo zavedanja podjetniških veščin, razvijanje podjetniških veščin, promocijo znanja o podjetništvu, razumevanje bistva podjetništva in ustreznega podjetniškega vedenja ter ustvarjanje priložnosti in ustreznega okolja, da lahko študent na koncu tudi odpre svoje podjetje. Pomembni faktorji uspeha v podjetniškem izobraževanju, da študenti izoblikujejo pozitiven odnos do podjetništva in podjetniško vedenje, so kvaliteta in kvantiteta metod poučevanja, motivacija, zrelost študentov ter učenje izven predavalnic (Lay, Khoo, 2012). Iacobucci in Micozzi (2012) dodajata še, da je pomemben cilj tudi promoviranje podjetništva kot uporabne in spoštovane poklicne kariere.

Othman in Nasrudin (2016) povzemata cilje podjetniškega izobraževanja: »know why« generiranje pravega odnosa do podjetništva in motivacije za podjetništvo, »know who« spodbujanje mreženja, »know when « - doseganje občutka za delovanje v pravem trenutku, »know what « - dobivanje znanja in informacij o poslovanju, »know how « dobivanje ustreznih veščin za odprtje podjetja. Gelderen (2010) pa meni, da je osrednji cilj podjetniškega izobraževanja avtonomnost, kar pomeni, da se posameznik zaveda, da vsaka akcija izhaja iz njega samega, iz njegove odločitve, da uresničuje cilje, interese, prepričanja, sanje. Če študent vloži v delo minimalen napor in študira samo zato, da bo zadovoljil pričakovanja predavateljev in na koncu dobil diplomo, potem mu manjka pomembna lastnost - avtonomnost. Glavni izvor zadovoljstva in motivacije podjetnika je v osnovi njegova avtonomija: raje vodi, kot da je voden, raje sam organizira, izvaja akcije, komunicira s strankami ipd. Če študentom v času izobraževanja to lastnost ojačamo, jih pripravimo na uspešno soočanje s kulturo podjetništva.

Višješolski študenti imajo velik potencial, da postanejo podjetniki, ker je način višješolskega izobraževanja prilagojen tako pridobivanju teoretičnega znanja kot konkretnih praktičnih izkušenj. Nenehno so izpostavljeni pridobivanju znanja iz različnih področij, veščin in izkušenj, učenju na praktičnih primerih, učenju z zgledom. Belwal, Al Balushi in Belwal (2015) ugotavljajo, da izobraževanje za podjetništvo zahteva angažiranje na večih ravneh ter povezanost med posameznikom, izobraževalnimi 
institucijami in lokalnim okoljem. Packham in ostali (2010) poudarjajo, da bodo tisti študenti, ki so bili deležni podjetniškega izobraževanja, bolj verjetno ustanovili svoje podjetje in začeli ustvarjati podjetniško kariero.

\subsection{Poučevanje za podjetništvo}

Učinkovito učenje podjetništva je v veliki meri odvisno od ustrezne vsebine in ustreznih metod poučevanja. To sta $\mathrm{v}$ izobraževanju glavna protagonista uspeha. Študente je potrebno kontinuirano vpeljevati $\mathrm{v}$ različne podjetniške aktivnosti, študije primera, druženja z uspešnimi podjetniki, ki so lahko njihovi vzorniki, jih učiti upoštevanja rokov ipd. Belwal, Al Balushi in Belwal (2015) predlagajo, da so študenti vključeni v organizacijo raznih dogodkov, tekmovanj $\mathrm{v}$ šoli ali izven nje, $\mathrm{v}$ razvijanje poslovnega načrta s supervizijo pravih podjetnikov. Kailer (2009) nadaljuje, da lahko razvijamo sinergijo s študenti različnih študijskih programov (npr. tehnika in ekonomija), kar lahko pomaga k povečanju podjetniških veščin, in sicer z izmenjavo idej, informacij in izkušenj.

Gibb (v Maritz, Jones, Shwetzer, 2015) je v svoji raziskavi ugotovil 44 specifičnih pedagoških pristopov za uresničevanje naslednjih področij: podjetniško vedenje, odnos in razvoj veščin; kreiranje empatije; ključne podjetniške vrednote; motiviranost za podjetniško kariero; razumevanje podjetniških procesov in nalog; splošne podjetniške kompetence; obvladovanje odnosov. Vsekakor je potreben premik od standardnih načinov poučevanja, kjer je študent pasiven in je vedno usmerjan s strani učitelja, $\mathrm{k}$ novejšemu pristopu, kjer je študentova aktivnost $\mathrm{v}$ središču učiteljevega dela, premik $\mathrm{k}$ mentoriranju in coachingu, da dosežemo razvoj podjetniških veščin in sprejemanja podjetniškega načina življenja. Mandel in Noyes (2016) menita, da gre trend poučevanja podjetništva ven iz predavalnic, s fokusom na akcijo v realnih situacijah. Gibb (2011) nadaljuje, da razvoj podjetniškega mišljenja zahteva učenje na primerih, učenje upravljanja odnosov in fleksibilnega odločanja, učenje na uspehih in napakah. Slednje je učinkovito v primeru, da se študent poglobi v izid in razume, kaj je naredil narobe, da ni dosegel želenega cilja in ozavesti, kaj bo naslednjič naredil bolje.

Tradicionalni pedagoški pristop podpira učenje o podjetništvu, dinamični pristop pa dovoli študentom, da se preizkušajo $\mathrm{v}$ vseh fazah učenja za podjetnika. Kombinacija obeh pristopov je idealna: $s$ tradicionalnim pristopom se študenta seznani s koncepti in orodji, $\mathrm{z}$ drugim pa spodbuja $\mathrm{k}$ učenju $\mathrm{z}$ izkušnjami $\mathrm{v}$ realnem podjetniškem okolju. Tako se razvijajo podjetniške veščine, kot so podjetniško vedenje, kreativno mišljenje, komunikacija, pogajalske veščine, vodenje, reševanje konfliktov, fleksibilnost, upravljanje s tveganji, avtonomija, načrtovanje, ciljna orientiranost, timsko delo itd. (Lourenço, Taylor, Taylor, 2013).

Učitelj, ki razvija avtonomijo pri študentih, bo najprej preveril njihove cilje, sposobnosti, znanje, vrednote, interese ter temu prilagodil učni proces in vsebino. Izhajamo iz njihove notranje motivacije in s tem dosežemo individualen pristop k študentu. Učitelj prevzema empatično vlogo, da lahko študenti razvijajo in uresničujejo osebne cilje. Potrebno je doseči pravo ravnovesje med vodenjem in svobodo, optimizirati avtonomijo posameznika, kadar je to mogoče, vendar ne izključiti vodenja. Včasih pa integracija 
učnih vsebin v študentove cilje, ambicije, potrebe ni mogoča, ker jih študent še ni razvil do prepoznavne mere in je raje voden s strani učitelja. Takrat je potreben drugačen motivacijski pristop ali pa se preveri njegova primernost za učenje podjetništva (Gelderen, 2010).

Povezovanje šole $\mathrm{z}$ gospodarstvom, podjetji in institucijami pomaga šolam, da vzpostavijo primerno poslovno podjetniško okolje, v katerem študenti dobijo želene podjetniške veščine in vedenje. Sledenje trendom družbe usmerja šolstvo v oblikovanje zanimivih formalnih in neformalnih načinov izobraževanja in usposabljanja za podjetništvo. Ni dovolj, da študenti dobijo samo ekonomsko znanje, ključne pri izobraževanju so aktivne metode poučevanja, $\mathrm{s}$ katerimi opremimo študente $\mathrm{z}$ veščinami, ki pomagajo pri prilagajanju na hitro se spreminjajoče poslovno okolje, dosežemo vživljanje študentov v inovativno podjetniško kulturo ter spodbudimo željo, da se odločijo za privlačno kariero podjetnika.

\section{$5 \quad$ Metodologija}

Zanimalo nas je, v kolikšni meri naše višje šolstvo skrbi za podjetniško orientiranost posameznika v okviru svojih učnih programov. Stališča do podjetništva in podjetniške kulture smo preverjali $\mathrm{s}$ pomočjo anketnega vprašalnika tako pri predavateljih kot študentih višjih šol. V raziskovalni vzorec smo vključili šest višješolskih organizacij iz cele Slovenije.

\subsection{Vzorec, metode in potek raziskave}

Za raziskavo smo uporabili neverjetnostni, namerni vzorec. Vključenih je bilo 122 oseb, od tega 29 višješolskih predavateljev in 93 študentov (Tabela 1), in sicer 55 oseb moškega spola $(45,1 \%)$ in 67 ženskega $(54,9 \%)$. Starost anketirancev je razporejena v asimetrično distribucijo, saj so študenti $(70,5 \%$ vzorca) stari od 18 do 28 let, večina predavateljev $(27,1 \%$ vzorca) pa od 51 do 61 let. V raziskavo je bilo vključenih šest višješolskih organizacij iz cele Slovenije. Večino vzorca $(74,6 \%)$ predstavljata višji strokovni šoli iz Murske Sobote in Novega mesta (Ekonomska šola Murska Sobota, Višja strokovna šola ter Ekonomska šola Novo mesto, Višja strokovna šola), preostalo pa druge (Ekonomska šola Celje, Višja strokovna šola; Ekonomska in trgovska šola Brežice, Višja strokovna šola; Šolski center Slovenj Gradec, Višja strokovna šola; Šolski center Postojna, Višja strokovna šola).

Tabela 1: Status
\begin{tabular}{|l|c|c|}
\hline Status & Frekvenca & Odstotek \\
\hline Predavatelj & 29 & 23,8 \\
Študent & 93 & 76,2 \\
\multicolumn{1}{|c|}{ Skupaj } & 122 & 100,0 \\
\hline
\end{tabular}

Vir: lastna raziskava 2017 
Podatke za raziskavo smo zbrali s pomočjo spletne ankete (1ka) meseca januarja 2017. Kot merski instrument smo uporabili anketni vprašalnik s sedemstopenjskimi lestvicami, kjer je pomenila ocena $1=$ čisto nič in ocena $7=$ povsem. Sklop šestih vprašanj je preverjal odnos do podjetništva (podjetništvo kot vrednota, podjetniška delovanja in filozofijo ter lastno podjetnost). Naslednji sklop šestih ocenjevalnih lestvic je ugotavljal stališča (predsodke in stereotipe) o podjetništvu. Podatke smo obdelali s statističnim programom IBM SPSS Statistics 19.

\section{Rezultati}

V rezultatih so prikazane najpomembnejše ugotovitve iz opisne statistike in testiranja razlik med skupinama predavateljev in študentov. Za testiranje razlik smo uporabili ttest s predhodnim testiranjem homogenosti varianc (Levenov test).

\subsection{Deskriptivna statistika}

Povprečne ocene odgovorov na vprašanja so podane $\mathrm{z}$ aritmetičnimi sredinami. Tabela 2 prikazuje povprečne ocene odgovorov respondentov na vprašanja, povezana s stališči do podjetništva (podjetništvo kot vrednota, podjetniško delovanje in filozofija ter lastna podjetnost).

Tabela 2: Povprečne ocene odgovorov

\begin{tabular}{|l|c|c|c|}
\hline Vprašanja & N & M & SD \\
\hline $\begin{array}{l}\text { V kolikšni meri je podjetništvo vrednota v } \\
\text { Sloveniji? }\end{array}$ & 122 & 4,61 & 1,351 \\
\hline $\begin{array}{l}\text { Ocenite, koliko je podjetniško delovanje } \\
\text { posameznika v Sloveniji cenjeno. }\end{array}$ & 122 & 3,91 & 1,199 \\
\hline $\begin{array}{l}\text { V kolikšni meri je podjetništvo vrednota } \\
\text { vaše višje strokovne šole? }\end{array}$ & 122 & 5,39 & 1,340 \\
\hline $\begin{array}{l}\text { Ocenite, koliko je podjetniško delovanje } \\
\text { posameznika na vaši višji strokovni šoli } \\
\text { cenjeno. }\end{array}$ & 122 & 5,07 & 1,489 \\
$\begin{array}{l}\text { V kolikšni meri višja strokovna šola } \\
\text { vzpodbuja podjetniško filozofijo v okviru } \\
\text { učnega programa? }\end{array}$ & 122 & 5,58 & 1,304 \\
\hline $\begin{array}{l}\text { Ocenite, v kolikšni meri se sami počutite } \\
\text { podjetnega. }\end{array}$ & 122 & 4,69 & 1,516 \\
\hline
\end{tabular}

Vir: lastna raziskava 2017

Rezultati so pokazali pozitivnejše vrednotenje podjetništva $\mathrm{v}$ okolju višjega šolstva kot na nivoju države. Tako respondenti ocenjujejo, da je podjetništvo v Sloveniji zelo šibka vrednota $(M=4,61)$, medtem ko podjetništvo predstavlja relativno trdno vrednoto šole 
$(\mathrm{M}=5,38)$. Podjetniško delovanje posameznika $\mathrm{v}$ državi niti je niti ni cenjeno, saj znaša povprečna ocena 3,91, za razliko od višje šole, kjer je podjetniško delovanje relativno cenjeno $(\mathrm{M}=5,07)$. Prav tako se $\mathrm{v}$ okviru šolskega učnega procesa dokaj vzpodbuja podjetniška filozofija $(M=5,58)$. Kljub temu se respondenti sami počutijo zgolj nekoliko bolj ja kot ne podjetne $(M=4,69)$. V naslednji tabeli (Tabela 3$)$ so predstavljene povprečne ocene strinjanja s trditvami o podjetništvu.

Tabela 3: Povprečne ocene strinjanja s trditvami o podjetništvu

\begin{tabular}{|c|c|c|c|c|c|c|}
\hline & $\begin{array}{c}\text { Podjetništvo } \\
\text { je } \\
\text { »tajkunstvo« }\end{array}$ & $\begin{array}{c}\text { Podjetništ } \\
\text { vo je } \\
\text { rešitev za } \\
\text { državo }\end{array}$ & $\begin{array}{c}\text { Podjetništ } \\
\text { vo je ideal }\end{array}$ & $\begin{array}{c}\text { Podjetništ } \\
\text { vo je } \\
\text { nepošteno }\end{array}$ & $\begin{array}{c}\text { Podjetništv } \\
\text { o je } \\
\text { primerno }\end{array}$ & $\begin{array}{c}\text { Podjetništv } \\
\text { o je } \\
\text { zastarelo }\end{array}$ \\
\hline $\mathbf{N}$ & 121 & 121 & 121 & 121 & 121 & 121 \\
$\mathbf{M}$ & 2,75 & 5,20 & 4,80 & 2,69 & 5,40 & 2,13 \\
$\mathbf{S D}$ & 1,645 & 1,621 & 1,481 & 1,383 & 1,313 & 1,494 \\
\hline
\end{tabular}

Vir: lastna raziskava 2017

Pri trditvah, povezanih s predsodki in stereotipi o podjetništvu, smo ugotovili, da predsodki skoraj niso prisotni. Tako dokaj ne drži, da bi bilo podjetništvo zastarelo $(M=2,13)$ in nepošteno $(M=2,69)$. Prav tako respondenti v veliki meri podjetništva ne povezujejo $\mathrm{z}$ neetičnimi poslovnimi praksami, poimenovanimi tajkunstvo $(\mathrm{M}=2,75)$. Stereotip, da je podjetništvo ideal, bolj ja kot ne drži $(M=4,80)$. Se pa respondenti relativno strinjajo s trditvama, da je podjetništvo primerno $(5,40)$ in rešitev za državo $(\mathrm{M}=5,20)$.

\subsection{Ugotavljanje razlik med skupinama}

Razlike $\mathrm{v}$ povprečnih ocenah odgovorov med skupinama predavateljev in študentov smo ugotavljali $\mathrm{s}$ t-testom, ob predhodnem testiranju homogenosti varianc z Levenovim testom. V vseh primerih smo ugotovili pričakovano enakost varianc med skupinama. V tabeli 4 predstavljamo povprečne ocene odgovorov na vprašanja obeh skupin in rezultate t-testa. 
$36^{\text {Th }}$ International Conference on Organizational Science Development: RESPONSIBLE ORGANIZATION (MARCH $22^{\mathrm{ND}}-24^{\mathrm{TH}}$, PORTOROŽ SlOVENIA)

D. Števančec \& I. Fink Grubačević: Entrepreneurship in Higher Vocational Education

Tabela 4: T- test ugotavljanja razlik v stališčih o podjetništvu med obema skupinama

\begin{tabular}{|c|c|c|c|c|c|c|}
\hline Vprašanja & $\mathbf{N}$ & M & SD & $\mathbf{t}$ & df & $\begin{array}{l}\text { Sig. } \\
(2- \\
\text { tailed })\end{array}$ \\
\hline $\begin{array}{l}\text { V kolikšni meri je podjetništvo vrednota Predavatelj } \\
\text { v Sloveniji? }\end{array}$ & $\begin{array}{l}29 \\
93\end{array}$ & $\begin{array}{l}4,24 \\
4,73\end{array}$ & $\begin{array}{l}1,455 \\
1,303\end{array}$ & $-1,718$ & 120 & 0,088 \\
\hline $\begin{array}{llrrr}\text { Ocenite, } & \text { koliko je } & \text { podjetniško } & \text { Predavatelj } \\
\text { delovanje } & \text { posameznika } & \text { v } & \text { Sloveniji } & \text { Student } \\
\text { cenjeno. } & & & & \end{array}$ & $\begin{array}{l}29 \\
93\end{array}$ & $\begin{array}{l}3,93 \\
3,90\end{array}$ & $\begin{array}{l}1,223 \\
1,198\end{array}$ & 0,109 & 120 & 0,914 \\
\hline $\begin{array}{lr}\text { V kolikšni meri je podjetništvo vrednota } & \text { Predavatelj } \\
\text { vaše višje strokovne šole? } & \text { Študent }\end{array}$ & \begin{tabular}{l|}
29 \\
93
\end{tabular} & \begin{tabular}{|l|}
5,24 \\
5,44
\end{tabular} & $\begin{array}{l}1,327 \\
1,347\end{array}$ & $-0,699$ & 120 & 0,486 \\
\hline $\begin{array}{l}\text { Ocenite, koliko je podjetniškor } \\
\text { delovanje posameznika na vaši višji } \\
\text { strokovni šoli cenjeno. }\end{array}$ & $\begin{array}{l}29 \\
93\end{array}$ & \begin{tabular}{|l|}
5,17 \\
5,04
\end{tabular} & $\begin{array}{l}1,490 \\
1,496\end{array}$ & 0,407 & 120 & 0,685 \\
\hline $\begin{array}{l}\text { V kolikšni meri višja strokovna šola } \\
\text { vzpodbuja podjetniško filozofijo v } \\
\text { okviru učnega programa? }\end{array}$ & $\begin{array}{l}29 \\
93\end{array}$ & \begin{tabular}{|l|}
5,79 \\
5,52
\end{tabular} & $\begin{array}{l}1,320 \\
1,299\end{array}$ & 0,999 & 120 & 0,320 \\
\hline $\begin{array}{l}\begin{array}{l}\text { Ocenite, v kolikšni meri se sami } \\
\text { počutite podjetnega. }\end{array} \\
\begin{array}{r}\text { Predavatelj } \\
\text { Študent }\end{array}\end{array}$ & $\begin{array}{l}29 \\
93\end{array}$ & $\begin{array}{l}5,14 \\
4,55\end{array}$ & $\begin{array}{l}1,274 \\
1,564\end{array}$ & 1,846 & 120 & 0,067 \\
\hline
\end{tabular}

$$
*(p<0,05) * *(p<0,01)
$$

Vir: lastna raziskava 2017

S t-testom med obema skupinama nismo ugotovili nobene statistično pomembne razlike. Med stališči predavateljev in študenti sicer obstajajo določene razlike. Tako podjetništvo študentom predstavlja večjo vrednoto kot predavateljem, tako v okviru šolskega okolja $(\mathrm{M}=4,73)$ kot tudi države $(\mathrm{M}=5,44)$. Obratno pa predavatelji smatrajo podjetniško delovanja posameznika kot bolj cenjeno, tako $v$ državi in na šoli ter se počutijo bolj podjetne $(M=5,14)$ od študentov $(M=4,55)$. Zanimiva je tudi statistično nepomembna razlika, kjer predavatelji $(M=5,79)$ nekoliko bolje ocenjujejo učne programe $\mathrm{v}$ smislu podjetniške iniciative kot študenti $(\mathrm{M}=5,52)$. V nadaljevanju predstavljamo razlike $\mathrm{v}$ ocenah trditev o podjetništvu med obema skupinama (Tabela 5). 

ORGANIZACIJA (22. - 24. MAREC 2017, PORTOROŽ, SLOVENIJA)

D. Števančec \& I. Fink Grubačević: Podjetništvo v višjem šolstvu

Tabela 5: T- test ugotavljanja razlik v ocenah trditev med obema skupinama

\begin{tabular}{|c|c|c|c|c|c|c|c|}
\hline \multirow{3}{*}{\begin{tabular}{|l|}
$\begin{array}{l}\text { Trditve } \\
\text { Podjetništvo je }\end{array}$ \\
»tajkunstvo«
\end{tabular}} & Status & $\mathbf{N}$ & $\mathbf{M}$ & SD & $\mathbf{t}$ & df & $\begin{array}{c}\text { Sig. (2- } \\
\text { tailed) }\end{array}$ \\
\hline & Predavatelj & 29 & 1,93 & 1,223 & $-3,200$ & 119 & $* * 0,002$ \\
\hline & Študent & 92 & 3,01 & 1,680 & & & \\
\hline \multirow{2}{*}{ rešitev za državo } & Predavatelj & 29 & 5,55 & 1,526 & 1,351 & 119 & 0,179 \\
\hline & Študent & 92 & 5,09 & 1,642 & & & \\
\hline \multirow[t]{2}{*}{ Ideal } & Predavatelj & 29 & 4,76 & 1,640 & $-0,179$ & 119 & 0,858 \\
\hline & Študent & 92 & 4,82 & 1,437 & & & \\
\hline \multirow[t]{2}{*}{ nepošteno } & Predavatelj & 29 & 2,31 & 1,285 & $-1,728$ & 119 & 0,087 \\
\hline & Študent & 92 & 2,82 & 1,398 & & & \\
\hline \multirow[t]{2}{*}{ primerno } & Predavatelj & 29 & 5,41 & 1,181 & 0,080 & 119 & 0,936 \\
\hline & Študent & 92 & 5,39 & 1,358 & & & \\
\hline \multirow[t]{2}{*}{ zastarelo } & Predavatelj & 29 & 1,76 & 1,244 & $-1,553$ & 119 & 0,123 \\
\hline & Študent & 92 & 2,25 & 1,552 & & & \\
\hline
\end{tabular}

$*(p<0,05) * *(p<0,01)$

Vir: lastna raziskava 2017

Ugotovili smo edino statistično pomembno razliko $* *(p=0,002)$ med predavatelji in študenti v oceni trditve, da podjetništvo predstavlja neetične poslovne prakse. In sicer se predavatelji veliko bolj ne strinjajo, da je podjetništvo tajkunstvo $(M=1,93)$ kot študenti $(\mathrm{M}=3,01)$. Nasploh skupina profesorjev nekoliko pozitivneje ocenjuje podjetništvo. Pri ocenah primernosti $(M=5,41)$ in podjetništva kot načina rešitve države $(M=5,55)$ je pri predavateljih večje strinjanje s trditvama. Prav tako je za njih podjetništvo manj nepošteno in zastarelo v primerjavi z ocenami študentov, vendar tudi te razlike statistično niso pomembne. Nepomembna razlika med skupinama obstaja tudi pri oceni stereotipa, kjer pa študentje malenkost bolj idealno pojmujejo podjetništvo $(M=4,82)$ kot predavatelji $(\mathrm{M}=4,76)$.

\section{$7 \quad$ Diskusija in zaključek}

Če je potrebno v višjem šolstvu razvijati podjetniško zavest, ki se gradi na razumevanju pomembnosti podjetništva ter njegovih vrednot, lahko povemo, da je obstoječe višje šolstvo v Sloveniji zelo dobro koncipirano. Podjetniško delovanje posameznika v višji šoli je relativno cenjeno in hkrati podjetništvo predstavlja vrednoto tako predavateljem kot študentom. Še več, percepcija podjetništva $\mathrm{v}$ višješolskem okolju je višja kot na nivoju celotne države, saj respondenti podjetniško delovanje v Sloveniji ocenjujejo kot niti ja niti ne cenjeno, hkrati pa podjetništvo predstavlja šibko vrednoto v državi. Verjetno se zaradi tega respondenti ne počutijo zadosti podjetne. In to kljub temu, da učni programi in metode dela v šoli podjetniško miselnost v veliki meri vzpodbujajo. Še en pokazatelj ustreznosti izobraževanja in razvijanja podjetniških kompetenc v višjem šolstvu so stališča o podjetništvu. Ugotavljamo, da predsodkov v zvezi s podjetništvom ni. Sicer je 
pri skupini predavateljev odnos do podjetništva malenkost bolj pozitiven kot pri študentih, vendar razlike niso pomembne. Edina razlika, ki ločuje skupino predavateljev od študentov, je, da se predavatelji veliko bolj ne strinjajo s trditvijo, da je podjetništvo povezano z neetičnimi praksami - »tajkunstvom « kot študenti. Podjetništvo je po oceni respondentov dokaj nezastarelo, primerno in pošteno ter predstavlja rešitev za državo. Velja tudi za stereotip, saj predstavlja šibek ideal.

Torej imamo na eni strani šolo, ki razvija podjetniško avtonomijo, sposobnosti, znanje, vrednote, interese in temu prilagaja učni proces ter vsebino, na drugi strani pa okolje, ki ga študenti in predavatelji ocenjujejo kot podjetniško manj vzpodbudno, to je celotna država. Iz rezultatov lahko razberemo, da je koncept višjega šolstva dovolj ustrezen in da so potrebne spremembe na področju podjetniške miselnosti in iniciative drugje.

\section{Literatura}

Belwal, R., Al Balushi, H., \& Belwal, S. (2015). Students' perception of entrepreneurship and enterprise education in Oman. Education + Training, Vol. 57, No. 8/9, str. 924 - 947.

Gelderen, M. (2010). Autonomy as the guiding aim of entrepreneurship education. Education + Training, Vol. 52, No. 8/9, str.710-721.

Gibb, A. (2002). In pursuit of a new 'enterprise' and 'entrepreneurship' paradigm for learning: creative destruction, new values, new ways of doing things and new combinations of knowledge. International Journal of Management Reviews, Vol. 4, No. 3, str. 233-69.

Gibb, A. (2011). Concepts into practice: meeting the challenge of development of entrepreneurship educators around an innovative paradigm. International Journal of Entrepreneurship Behavior \& Research, Vol. 17, No. 2, str. 146-165.

Iacobucci, A., \& Micozzi, A. (2012). Entrepreneurship education in Italian universities: trend, situation and opportunities. Education + Training, Vol. 54, No. 8/9, str. 673-696.

Kailer, N. (2009). Entrepreneurship education: empirical findings and proposals for the design of entrepreneurship education concepts at universities in German-speaking countries. Journal of Enterprising Culture, Vol. 17, No. 2, str. 201-231.

Kos, B. (2007). Podjetnik ali manager. Dostopno na http://www.blazkos.com/podjetnik-alimanager-kdo-je-bolj-kul.php

Lay, Y.F., \& Khoo, C.H. (2012). Relationships between actual and preferred science learning environment at tertiary level and attitudes towards science among pre-service science Teachers.

Pertanika Journal of Social Sciences \& Humanities, Vol. 20, No. 4, str. 1117-1142.

Lourenço, F., Taylor, T., \& Taylor, D. (2013), Integrating "education for entrepreneurship" in multiple faculties in "half-the-time" to enhance graduate entrepreneurship. Journal of Small Business and Enterprise Development, Vol. 20, No. 3, str. 503 - 525.

Mandel, R., \& Noyes, E. (2016). Survey of experiential entrepreneurship education offerings among top undergraduate entrepreneurship programs. Education + Training, Vol. 58, No. 2, str. $164-178$.

Maritz, A., Jones, C., \& Shwetzer, C. (2015). The status of entrepreneurship education in Australian universities. Education + Training, Vol. 57, No. 8/9, str.1020 - 1035.

McLarty, L., Highley, H., \& Alderson, S. (2010). Evaluation of enterprise education in England. Research Report No. DFE-RR015. UK government, Department of Education.

MIZŠ - Ministrstvo za izobraževanje, znanost in šport (2017). Višješolsko izobraževanje: programi.

Dostopno

na 
http://www.mizs.gov.si/si/delovna_podrocja/direktorat_za_srednje_in_visje_solstvo_ter_izob razevanje_odraslih/visjesolsko_izobrazevanje/

Othman, N., Norashidah, H., \& Hariyaty, A.W. (2012). Readiness towards entrepreneurship education. Education+Training, Vol. 54, No. 8/9, str. 697-708.

Othman, N., \& Nasrudin, N. (2016). Entrepreneurship education programs in Malysian polytechnics. Education + Training, Vol. 58, No. 7/8, str. 882-898.

Packham, G, Jones, G., Miller, P., Pickernell, D., \& Thomas, B. (2010). Attitudes towards entrepreneurship education: a comparative analysis. Education + Training, Vol. 52, No. 8/9, str. 568-586.

Pšeničny, V., \& Vidic, F. (2000). Podjetništvo. Portorož: Gea College, Visoka šola za podjetništvo.

Rebernik, M., Tominc, P. Pušnik, K. (2006). Podjetništvo med željami in stvarnostjo. GEM Slovenija 2005. Maribor: Univerza v Mariboru, Ekonomsko-poslovna fakulteta.

Rebernik, M., Tominc, P. Pušnik, K. (2010). Slovensko podjetništvo v času krize. GEM Slovenija 2009. Maribor: Univerza v Mariboru, Ekonomsko-poslovna fakulteta.

Šubelj, B. (2011). Podjetništvo in poslovanje podjetja. Bevke: Založba Smar-team. 
1110 36 ${ }^{\text {TH }}$ International Conference on Organizational Science Development: Responsible Organization (March $22^{\mathrm{ND}}-24^{\mathrm{TH}}$, Portorož Slovenia) 
36. MEDNARODNA KONFERENCA O RAZVOJU ORGANIZACIJSKIH ZNANOSTI: OdgOVORNA ORGANIZACIJA (22. - 24. MAREC 2017, PORTOROŽ, SLOVENIJA)

O. Arsenijević, M. Ferjan, I. Podbregar, P. Šprajc, D. Trivan \& Y. Ziegler

\title{
Vpliv standardov kakovosti na delo zaposlenih
}

\author{
Eva ŠTURM, EVA KRHAČ \& MARCEL POTRATA
}

Povzetek Cilj vpeljave določenega standarda kakovosti je vplivati na celotno podjetje, kar je možno z vplivom na en del podjetja, nek določen skupek ali pa celoto. Le to je odvisno od posameznega standarda, načina delovanja slednjega in seveda razkoraka med trenutnim in želenim stanjem, stanjem po vpeljavi standarda kakovosti. Nekatera podjetja le delno prilagodijo svoje postopke, dodajo dokument ali dva, druga podjetja pa posegajo po korenitejših spremembah. Količina sprememb v sistemu se odraža na delovanju slednjega ter na procesih, ki tam potekajo. Vendar pa se raziskovalno delo dotika tudi sprememb, ki nastanejo na posameznih delovnih mestih. Izvedena je bila anketa na delovnih mestih, ki so posredno ali neposredno povezana $\mathrm{z}$ uvajanjem ali uporabljanjem standardov kakovosti.

$\mathrm{V}$ raziskovalnem delu sta obravnavani podjetji Alpetour, Potovalna agencija d.d. in Hella Saturnus Slovenija d.o.o., ki uporabljata standarde kakovosti, vendar pa se bistveno razlikujeta - panoga delovanja podjetja, čas uvedbe standardov, število uvedenih standardov in pristop k uvajanju, obvladovanju ter upoštevanju standardov.

Raziskava zajema vse zgoraj opisane vidike, osredotoči pa se tudi na podobnosti, ki so vidne kljub razlikam v delovanju podjetij. Na podlagi rezultatov lahko sklepamo, da pri raziskanih podjetjih na nekaterih področjih prihaja do razlik v poslovanju in načinu dela.

KLJUČNE BESEDE: kakovost • management kakovosti • standardi kakovosti • ozaveščenost zaposlenih

NASLOV AVTORJEV: Eva Šturm, Univerza v Mariboru, Fakulteta za organizacijske vede, Kidričeva cesta 55a, 4000 Kranj, Slovenija, e-pošta: eva.sturm@student.um.si; Eva Krhač, asistentka, Univerza v Mariboru, Fakulteta za organizacijske vede, Kidričeva cesta 55a, 4000 Kranj, Slovenija, e-pošta: eva.krhac@fov.uni-mb.si; Marcel Potrata Univerza v Mariboru, Fakulteta za organizacijske vede, Kidričeva cesta 55a, 4000 Kranj, Slovenija, e-pošta: marcel.potrata@student.um.si

DOI https://doi.org/10.18690/978-961-286-020-2.89

ISBN 978-961-286-020-2

(C) 2017 Univerzitetna založba Univerze v Mariboru

Dostopno na: http://press.um.si 
$36^{\mathrm{TH}}$ InTERnational CONFERENCE ON ORganizational SCIENCE Development: Responsible Organization (MARCh $22^{\mathrm{ND}}-24^{\mathrm{TH}}$, PORTOROŽ SLOVENIA)

O. Arsenijević, M. Ferjan, I. Podbregar, P. Šprajc, D. Trivan \& Y. Ziegler

\title{
The Influence of Quality Standards on Employees Work
}

\author{
EVA ŠTURM, EVA KRHAČ \& MARCEL POTRATA
}

\begin{abstract}
The aim of introducing a certain quality standard is to influence on the entire company, which is possible with an impact on one part of the company, a particular set of departments or on the entire company. It depends on the individual standard, its way of working and the gap between the current and desired state (after introducing of the quality standard). Some companies partially adapt their own procedures (only added document or two), other companies reaching out for more radical changes. The quantity of changes in the system is displayed on way of system functioning and on their processes. However, the research also touches on the changes that arise in individual workplaces. It was conducted a survey on workplaces, which are directly or indirectly connected with the introduction or application of quality standards.
\end{abstract}

Alpetour, travel agency d.d. and Hella Saturnus Slovenia d.o.o. are discussed in the research work. Both use quality standards, but they are fundamentally different - the industry of the enterprise, time of standards introduction, the number of introduced standards and approach to the introduction, management and observance of standards.

The survey covers all the aspects as described above and also focuses on similarities that are visible despite differences in the functioning of companies. Based on the presented results, we can conclude that there are certain differences in operations and way of working.

KEYWORDS: Quality • quality management • quality standards • awareness of employees

CORRESPONDENCE AdDRESS: Eva Šturm, University of Maribor, Faculty of Organizational Sciences, Kidričeva cesta 55a, 4000 Kranj, Slovenia, e-mail:eva.sturm@ student.um.si; Eva Krhač, Assistant, University of Maribor, Faculty of Organizational Sciences, Kidričeva cesta 55a, 4000 Kranj, Slovenia, e-mail:eva.krhac@ fov.uni-mb.si; Marcel Potrata, University of Maribor, Faculty of Organizational Sciences, Kidričeva cesta 55a, 4000 Kranj, Slovenia, e-mail: marcel.potrata@student.um.si

DOI https://doi.org/10.18690/978-961-286-020-2.89 
Na podjetja gledamo kot na celoto oziroma sistem, ki proizvaja določen »output«, po katerem je sistem znan. Slednji je lahko izdelek ali storitev, ter v poslovnem svetu predstavlja podjetje in njegove zaposlene. Glede na to, da je na trgu vse bolj prisotna močna konkurenca, kakovost output-a postaja bistvenega pomena za kupce, dobavitelje in posledično tudi samo podjetje. Dejstvo je, da bodo preživela tista podjetja, ki bodo odjemalcem zagotavljala kakovostne produkte ali storitve. $Z$ izboljševanjem kakovosti na vseh področjih, podjetju lahko uspe zagotoviti potrebno kakovost (Udrih, 2008). S tem se ukvarja management celovite kakovosti, za katerega je kakovost tisti dejavnik, ki najbolj vpliva na uspešnost organizacije. Management kakovosti zajema vse dejavnosti kontrole, zagotavljanja in stalnega izboljševanja kakovosti (Marolt in Gomišček, 2005). Področje managementa kakovosti je po besedah Ingasona (2014) bogato tako na področju podatkov, kot tudi z različnimi raziskavami, vidiki in teorijami. Za relativno mlado disciplino so nekateri splošni vidiki dobro opredeljeni ter določeni s pomočjo razširjenih mednarodnih standardov, kot so ISO 9000, ISO 9001 in ISO 14001. Najbolj razširjen mednarodni standard je ISO 9000, ki organizacijam pomaga do finančnih prihrankov, bolj učinkovitega delovanja, izboljšanja zadovoljstva odjemalcev in večjega dobička. ISO 9000 predvsem strmi $\mathrm{k}$ inovacijam in razvoju novih standardiziranih izdelkov in storitev (Terziovski in Guerrero, 2014). Clougherty in Grajek (2014) sta v svojem prispevku opisala stanje izdanih certifikatov ISO 9000 po svetu, iz katerega razberemo, da je Slovenija (2114 izdanih certifikatov) na osmem mestu, glede na velikost države od skupno 91 držav. Priede (2012) je primerjal širjenje uporabe standarda ISO $9001 \mathrm{v}$ dveh obdobjih. Po celem svetu je bilo v obdobju med leti 1993 in 2010 izdanih 46.000 certifikatov v 60 različnih državah, do leta 2010 pa je številka narasla na 1.1 milijona izdanih certifikatov v 178 različnih državah.

Namen raziskave je bil preveriti:

- ali v managementu kakovosti v podjetjih obstajajo, glede na njihovo različnost, bistvene razlike,

- ali se mnenja zaposlenih o standardih kakovosti razlikujejo.

Raziskavo smo naredili v podjetjih Hella Satunus Slovenija d.o.o. in Alpetour, Potovalna agencija d.d. Podjetji se razlikujeta po dejavnosti, vendar jih povezuje nekaj lastnosti. Vpeljana je bila določena skupina standardov managementa kakovosti in pri tem so zaposleni občutili razlike. Obe podjetji sta standarde vpeljali zaradi izboljšanja kakovosti dela, izdelkov in storitev, doseganja primarnega cilja vsake pridobitne organizacije in usmerjanja $\mathrm{k}$ trajnostnemu razvoju. Al-Rawahi in Bashir (2011) sta v raziskavi analizirala 42 podjetij, ki so imela pridobljen certifikat ISO 9001:2000. Izbrana podjetja so bila del različnih sektorjev, različnih velikosti, skupna značilnost pa je bila predvsem poslovanje v sultanatu Oman. Zaključki raziskave nakazujejo, da pri motivih za implementacijo, samem procesu implementiranja ter stroških povezanih z implementacijo, ne prihaja do bistvenih razlik, kljub raznolikosti podjetij. 
1114 36 $6^{\text {Th }}$ International Conference on Organizational Science Development:

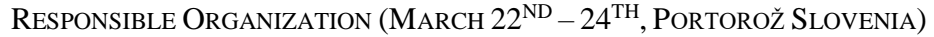

E. Šturm, E. Krhač, M. Potrata: Vpliv standardov kakovosti na delo zaposlenih

\section{$2 \quad$ Predstavitev podjetij}

V raziskavo sta bila vključena dva podjetja, in sicer Alpetour, Potovalna agencija d.d. in Hella Saturnus Slovenija d.o.o.

Alpetour, Potovalna agencija d.d. je največji avtobusni prevoznik na območju Gorenjske, ki ima storitveno dejavnost locirano v vseh večjih krajih. Leta 2015 je podjetje postalo del mednarodne skupine Arriva, Deutsche Bahn. Leta 2006 so pridobili certifikat standarda kakovosti ISO 9001 za področje servisiranja gospodarskih vozil. Tri leta kasneje pa so ga razširili tudi na ostala področja - prevoz potnikov, potovalna agencija in organizator potovanj ter servisiranje gospodarskih vozil. Kasneje so dobili tudi standard SIST EN SIO/IEC 17020 tip C, ki pa se nanaša na dejavnost laboratorija za kontrolo tahografov.

Hella Saturnus Slovenija d.o.o. je članica mednarodnega koncerna Hella in eden največjih slovenskih izvoznikov na področju avtomobilske industrije. Podjetje se ukvarja $\mathrm{z}$ izdelavo žarometov, meglenk in radarskih logotipnih pokrovov (RADOM), ter $\mathrm{v}$ treh obratih v Sloveniji zaposluje skupno 3000 oseb. Začetek vpeljave standardov na področju managementa kakovosti se je začel v letu 1994, in sicer z vpeljavo standarda kakovosti ISO 9001:1994. Leta 2002 so uvedli standard ISO 14001:1996 (standard za okolje), leta 2005 pa standard ISO TS 16949:2002 (glavni standard avtomobilske industrije). Saturnus avto oprema d.d. (prvotno ime podjetja) je bilo 39. slovensko podjetje, ki je s strani certifikatne hiše Boreas Veritas, prejelo certifikat za standarde kakovosti.

\section{$3 \quad$ Metodologija}

Z namenom proučevanja vpeljave standardov kakovosti in odnosa zaposlenih na spremembo dela, smo pripravili anketni vprašalnik in ga razdelili v obeh podjetjih. Prvo podjetje nam je vrnilo izpolnjenih 41 anketnih vprašalnikov, drugo podjetje pa 92 anketnih vprašalnikov.

S pomočjo analize rezultatov smo želeli preveriti ali obstajajo razlike med podjetjem, ki ima vpeljane standarde kakovosti na vseh področjih že od vsega začetka in podjetjem, ki je standarde kakovosti vpeljalo šele 10 let nazaj. V analizo podatkov so vključene naslednje statistične metode - opisna statistika, t-test za preučevanje razlik med aritmetičnima sredinama preučevanih spremenljivk ter korelacija za preverjanje povezave med spremenljivkami.

Omeniti moramo, da je v podjetju Hella Saturnus Slovenija d.o.o. bilo izpolnjenih enkrat več anketnih vprašalnikov, kot v podjetju Alpetour, Potovalna agencija d.d. Poleg tega so $\mathrm{v}$ podjetju Alpetour, Potovalna agencija d.d. na anketne vprašalnike odgovarjali zaposleni iz vseh oddelkov, čeprav posamezni nimajo stika s standardi kakovosti. S druge strani, v podjetju Hella Saturnus Slovenija d.o.o. so vsi zaposleni vključeni v sistem kakovosti ter so seznanjeni s pozitivnimi in negativnimi lastnostmi vpeljave standardov kakovosti. 
Za popisovanje vseh sprememb v podjetjih in dokumentiranje spremenjenega načina dela ter mišljenja posameznega zaposlenega, bi bilo potrebno izvesti bolj obširno anketo. Anketa bi morala biti delno prilagojena za posamezna področja znotraj podjetja in izvedena na vseh zaposlenih. Le to ni bilo mogoče, zato je anketa bila izvedena na delovnih mestih, ki so posredno ali neposredno povezana z uvajanjem ali uporabljanjem standardov kakovosti.

\section{$4 \quad$ Rezultati raziskave}

Kot je bilo omenjeno že v prejšnjem poglavju, $v$ analizo podatkov so vključene različne statistične metode. Prva med njimi je opisna statistika in je prikazana v prvem delu poglavja.

Najprej smo želeli ugotoviti kakšno je povprečje trajanja zaposlitve $\mathrm{v}$ obeh podjetjih, rezultate pa prikazuje tabela 1. Minimalno trajanje zaposlitve v podjetju Alpetour, Potovalna agencija d.d. je eno leto, v podjetju Hella Saturnus Slovenija d.o.o. pa pol leta. Zelo podobna sta si tudi podatka o maksimalni dobi zaposlitve. V podjetju Alpetour, Potovalna agencija d.d. je tako maksimalna doba 36 let, v podjetju Hella Saturnus Slovenija d.o.o. pa 38 let. Povprečno trajanje zaposlitve v prvem podjetju je 17,76 let, s standardnim odklonom 10,70 let. Povprečno trajanje zaposlitve v podjetju Hella Saturnus Slovenija d.o.o. je 6,36 let, s standardnim odklonom 8,13 let. Iz povprečij in standardnih odklonov je razvidno, da imajo zaposleni v prvem podjetju daljšo dobo zaposlitve.

\begin{tabular}{|ll|r|r|r|r|r|}
\hline ALPETOUR / HELLA SATURNUS & \multicolumn{1}{|c|}{$\mathrm{N}$} & Minimum & Maximum & \multicolumn{1}{c|}{ Mean } & Std. Deviation \\
\hline Alpetour & Leta zaposlitve & 41 & 1,0 & 36,0 & 17,756 & 10,6953 \\
& Valid N (listwise) & 41 & & & & \\
\hline \multirow{2}{*}{ Hella Saturnus } & Leta zaposlitve & 92 &, 5 & 38,0 & 6,359 & 8,1292 \\
& Valid N (listwise) & 92 & & & & \\
\hline
\end{tabular}

Tabela 1: Trajanje zaposlitve (SPSS, 2016)

Tabela v nadaljevanju prikazuje prisotnost zaposlenih pri uvajanju standardov kakovosti. Iz tabele lahko razberemo, da je povprečje prisotnosti pri uvajanju višje v podjetju Alpetour, Potovalna agencija d.d, kar pomeni, da je bilo pri uvedbi standardov prisotnih več oseb kot v podjetju Hella Saturnus Slovenija d.o.o. Slednje je posledica trajanja povprečne zaposlitve, ki je pri podjetju Alpetour, Potovalna agencija d.d. višja. Pri obeh skupinah je opazen velik standardni odklon, kar nakazuje na raznolikost odgovorov. 
$36^{\mathrm{TH}}$ International Conference on Organizational Science Development:

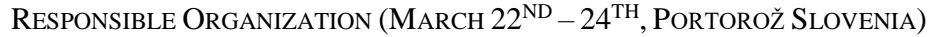

E. Šturm, E. Krhač, M. Potrata: Vpliv standardov kakovosti na delo zaposlenih

\begin{tabular}{|ll|r|r|r|r|r|}
\hline ALPETOUR/HELL SATURNUS & \multicolumn{1}{|c|}{ N } & Minimum & Maximum & \multicolumn{1}{c|}{ Mean } & Std. Deviation \\
\hline Alpetour & $\begin{array}{l}\text { Pri uvedbi sem bil } \\
\text { prisoten } \\
\text { Valid N (listwise) }\end{array}$ & 41 & 1 & 6 & 3,51 & 1,675 \\
\hline Hella Saturnus & $\begin{array}{l}\text { Pri uvedbi sem bil } \\
\text { prisoten } \\
\text { Valid N (listwise) }\end{array}$ & 91 & 1 & 6 & 2,85 & 1,505 \\
& 91 & & & & \\
\hline
\end{tabular}

Tabela 2: Prisotnost pri uvajanju (SPSS, 2016)

$\mathrm{Na}$ vprašanje »Ali je vaše delo zaradi vpeljave standardov manj stresno? « je z višjim povprečjem odgovorila skupina zaposlenih iz podjetja Hella Saturnus Slovenija d.o.o. Tudi pri tem vprašanju je opazen velik standardni odklon, kar ponovno nakazuje na raznolikost odgovorov.

\begin{tabular}{|ll|r|r|r|r|r|}
\hline ALPETOUR/HELLA SATURNUS & N & Minimum & Maximum & Mean & Std. Deviation \\
\hline Alpetour & $\begin{array}{l}\text { Moje delo je zaradi } \\
\text { vpeljave manj stresno } \\
\text { Valid N (listwise) }\end{array}$ & 41 & 1 & 5 & 2,88 & 1,418 \\
\hline Hella Saturnus & $\begin{array}{l}\text { Moje delo je zaradi } \\
\text { vpeljave manj stresno } \\
\text { Valid N (listwise) }\end{array}$ & 92 & 1 & 6 & 3,76 & 1,133 \\
\hline
\end{tabular}

Tabela 3: Delo je zaradi vpeljave standardov manj stresno (SPSS, 2016)

Naslednja tabela prikazuje vključenost zaposlenih v projekte. Iz nje lahko razberemo, da je v podjetju Hella Saturnus Slovenija d.o.o. udeležba na projektih večja (z vidika razlike povprečij). Iz tabele je prav tako razvidno, da je standardni odklon manjši, kar pomeni, da se odgovori zaposlenih manj razlikujejo.

\begin{tabular}{|ll|r|r|r|r|r|}
\hline ALPETOUR/HELLA SATURNUS & \multicolumn{1}{|c|}{ M } & Minimum & Maximum & Mean & Std. Deviation \\
\hline Alpetour & $\begin{array}{l}\text { Zaposleni so vključeni v } \\
\text { razne projekte } \\
\text { Valid N (listwise) }\end{array}$ & 41 & 1 & 6 & 3,93 & 1,034 \\
\hline Hella Saturnus & $\begin{array}{l}\text { Zaposleni so vključeni v } \\
\text { razne projekte } \\
\text { Valid N (listwise) }\end{array}$ & 91 & 3 & 6 & 4,99 &, 719 \\
\hline
\end{tabular}

Tabela 4: Zaposleni so vključeni v projekte (SPSS, 2016)

Tabela $\mathrm{v}$ nadaljevanju prikazuje koliko pozornosti $\mathrm{v}$ podjetjih posvečajo analiziranju izgubljenih poslov. Podjetje Alpetour, Potovalna agencija d.d. v večji meri analizira izgubljene posle kot podjetje Hella Saturnus Slovenija d.o.o. Vzrok temu je lahko večja razkropljenost zaposlenih v podjetju Alpetour, Potovalna agencija d.d. - zaposleni so dejavni na več področjih ter se zavedajo izvajanja analiz izgubljenih poslov. Na drugi strani je podjetje Hella Saturnus Slovenija d.o.o. v katerem imajo zaposleni naloge 
E. Šturm, E. Krhač, M. Potrata: Vpliv standardov kakovosti na delo zaposlenih

razdeljene po oddelkih - zaposleni, ki se s tovrstnimi analizami ne ukvarjajo, s problematiko niso seznanjeni.

\begin{tabular}{|ll|r|r|r|r|r|}
\hline ALPETOUR/ HELLA SATURNUS & N & Minimum & Maximum & Mean & Std. Deviation \\
\hline Alpetour & $\begin{array}{l}\text { Analiziranje izgubljenih } \\
\text { poslov } \\
\text { Valid N (listwise) }\end{array}$ & 37 & 1 & 6 & 3,62 & 1,622 \\
\hline Hella Saturnus & $\begin{array}{l}\text { Analiziranje izgubljenih } \\
\text { poslov }\end{array}$ & 92 & 1 & 6 & 2,62 & 1,525 \\
& Valid N (listwise) & 92 & & & & \\
\hline
\end{tabular}

Tabela 5: Analiziranje izgubljenih poslov (SPSS; 2016)

Glede na povprečne vrednosti lahko zaključimo, da se tudi analiziranje reklamacij v podjetjih razlikuje. Analiziranju reklamacij več pozornosti posveča Alpetour, Potovalna agencija d.d. Slednje je lahko posledica enakih vzrokov kot analiziranje izgubljenih poslov.

\begin{tabular}{|ll|r|r|r|r|r|}
\hline ALPETOUR/HELLA SATURNUS & N & Minimum & Maximum & Mean & Std. Deviation \\
\hline Alpetour & Analiziranje reklamacij & 39 & 1 & 6 & 4,67 & 1,493 \\
& Valid N (listwise) & 39 & & & & \\
\hline Hella Saturnus & Analiziranje reklamacij & 92 & 1 & 6 & 3,55 & 1,750 \\
& Valid N (listwise) & 92 & & & & \\
\hline
\end{tabular}

\section{Tabela 6: Analiziranje reklamacij (SPSS, 2016)}

Iz naslednje tabele lahko bolj podrobno razberemo kakšna je razporeditev odgovorov v podjetjih pri vprašanju »Kako pogosto analizirate izgubljene posle?«. Kumulativni procenti v primeru podjetja Alpetour, Potovalna agencija d.d. znašajo 27 \% vzorca za odgovora nikoli in redko, $\mathrm{v}$ primeru drugega podjetja pa kumulativni procenti znašajo $52,2 \%$ vzorca za ista odgovora. Slednje pomeni, da v podjetju Hella Saturnus Slovenija d.o.o. 52,2 \% anketirancev meni, da se analize izgubljenih poslov izvajajo redko, oziroma nikoli. 
$36^{\mathrm{TH}}$ International Conference on ORganizational Science Development: Responsible ORganization (MARCH $22^{\mathrm{ND}}-24^{\mathrm{TH}}$, PORTOROŽ SLOVENiA)

E. Šturm, E. Krhač, M. Potrata: Vpliv standardov kakovosti na delo zaposlenih

Analiziranje izgubljenih poslov

\begin{tabular}{|c|c|c|c|c|c|c|}
\hline \multicolumn{3}{|c|}{ ALPETOUR / HELLA SATURNUS } & Frequency & Percent & Valid Percent & $\begin{array}{l}\text { Cumulative } \\
\text { Percent }\end{array}$ \\
\hline \multirow[t]{9}{*}{ Alpetour } & Valid & Nikoli & $\overline{6}$ & $\overline{14,6}$ & 16,2 & $\overline{16,2}$ \\
\hline & & Redko & 4 & 9,8 & 10,8 & 27,0 \\
\hline & & Včasih & 5 & 12,2 & 13,5 & 40,5 \\
\hline & & Pogosto & 9 & 22,0 & 24,3 & 64,9 \\
\hline & & Redno & 9 & 22,0 & 24,3 & 89,2 \\
\hline & & Vedno & 4 & 9,8 & 10,8 & 100,0 \\
\hline & & Total & 37 & 90,2 & 100,0 & \\
\hline & Missing & System & 4 & 9,8 & & \\
\hline & Total & & 41 & 100,0 & & \\
\hline \multirow[t]{7}{*}{ Hella Saturnus } & Valid & Nikoli & 31 & 33,7 & 33,7 & 33,7 \\
\hline & & Redko & 17 & 18,5 & 18,5 & 52,2 \\
\hline & & Včasih & 17 & 18,5 & 18,5 & 70,7 \\
\hline & & Pogosto & 13 & 14,1 & 14,1 & 84,8 \\
\hline & & Redno & 11 & 12,0 & 12,0 & 96,7 \\
\hline & & Vedno & 3 & 3,3 & 3,3 & 100,0 \\
\hline & & Total & 92 & 100,0 & 100,0 & \\
\hline
\end{tabular}

Tabela 7: Analiziranje izgubljenih poslov (SPSS, 2016)

\subsection{Razlike med posameznimi delovnimi enotami}

Tabeli v nadaljevanju prikazujeta razlike med posameznimi delovnimi enotami. Pri tem sta izpostavljena vzorca vodstva v podjetju Alpetour, Potovalna agencija d.d. ter kakovosti v podjetju Hella Saturnus Slovenija d.o.o., saj obema oddelkoma obravnavanje standardov kakovosti ter delo z njimi predstavlja vsaj del aktivnosti.

Tabela $\mathrm{v}$ nadaljevanju prikazuje, da je na vprašanje »Ali se vam standardi zdijo uporabni? « z odgovorom »Popolnoma se strinjam« odgovorilo več oseb v podjetju Hella Saturnus Slovenija d.o.o. na oddelku kakovosti (35,3\%), kot pa v podjetju Alpetour, Potovalna agencija d.d. na oddelku vodstva (20\%). 

ORGANIZACIJA (22. - 24. MAREC 2017, PORTOROŽ, SLOVENIJA)

E. Šturm, E. Krhač, M. Potrata: Vpliv standardov kakovosti na delo zaposlenih

Standardi se mi zdijo uporabni

\begin{tabular}{|c|c|c|c|c|c|c|}
\hline Oddelek-stevilke & & & Frequency & Percent & Valid Percent & $\begin{array}{c}\text { Cumulative } \\
\text { Percent }\end{array}$ \\
\hline \multirow[t]{5}{*}{ A: Vodstvo } & Valid & Delno se ne strinjam & 1 & 10,0 & 10,0 & 10,0 \\
\hline & & Delno se strinjam & 3 & 30,0 & 30,0 & 40,0 \\
\hline & & Se strinjam & 4 & 40,0 & 40,0 & 80,0 \\
\hline & & Popolnoma se strinjam & 2 & 20,0 & 20,0 & 100,0 \\
\hline & & Total & 10 & 100,0 & 100,0 & \\
\hline \multirow[t]{5}{*}{ H: Kakovost } & Valid & Delno se ne strinjam & 1 & 2,0 & 2,0 & 2,0 \\
\hline & & Delno se strinjam & 12 & 23,5 & 23,5 & 25,5 \\
\hline & & Se strinjam & 20 & 39,2 & 39,2 & 64,7 \\
\hline & & Popolnoma se strinjam & 18 & 35,3 & 35,3 & 100,0 \\
\hline & & Total & 51 & 100,0 & 100,0 & \\
\hline
\end{tabular}

Tabela 8: Uporabnost standardov (SPSS, 2016)

V nadaljevanju nas je zanimalo ali se zaposleni strinjajo, da je pri njih sistem vodenja kakovosti na visokem nivoju. Kot je razvidno iz tabele, se s trditvijo popolnoma strinja več zaposlenih v podjetju Alpetour, Potovalna agencija d.d. (20\%). V podjetju Hella Saturnus Slovenija d.o.o. se s trditvijo, da je sistem vodenja kakovosti na visokem nivoju, popolnoma strinja samo 7,8 \% zaposlenih.

Sistem vodenja kakovosti je na visokem nivoju

\begin{tabular}{|c|c|c|c|c|c|c|}
\hline Oddelek-stevilke & & & Frequency & Percent & Valid Percent & $\begin{array}{c}\text { Cumulative } \\
\text { Percent }\end{array}$ \\
\hline \multirow[t]{4}{*}{ A: Vodstvo } & Valid & Delno se strinjam & 1 & 10,0 & 10,0 & 10,0 \\
\hline & & Se strinjam & 7 & 70,0 & 70,0 & 80,0 \\
\hline & & Se popolnoma strinjam & 2 & 20,0 & 20,0 & 100,0 \\
\hline & & Total & 10 & 100,0 & 100,0 & \\
\hline \multirow[t]{7}{*}{ H: Kakovost } & Valid & Sploh se ne strinjam & 2 & 3,9 & 3,9 & 3,9 \\
\hline & & Se ne strinjam & 2 & 3,9 & 3,9 & 7,8 \\
\hline & & Delno se ne strinjam & 6 & 11,8 & 11,8 & 19,6 \\
\hline & & Delno se strinjam & 18 & 35,3 & 35,3 & 54,9 \\
\hline & & Se strinjam & 19 & 37,3 & 37,3 & 92,2 \\
\hline & & Se popolnoma strinjam & 4 & 7,8 & 7,8 & 100,0 \\
\hline & & Total & 51 & 100,0 & 100,0 & \\
\hline
\end{tabular}

Tabela 9: Nivo sistema vodenja kakovosti (SPSS, 2016)

\subsection{Razlike med podjetjema}

Glede na rezultate opisne statistike, ki so prikazani v tabeli 10 ni bilo možno z gotovostjo potrditi obstoj razlik med podjetjema vključenima v raziskavo. Zato smo v nadaljevanju $\mathrm{z}$ namenom ugotavljanja ali obstajajo statistično pomembne razlike pri trditvah, glede na podjetje, oblikovali nekaj raziskovalnih vprašanj. 
$36^{\text {TH }}$ International Conference on Organizational Science Development: Responsible Organization (MARCh $22^{\mathrm{ND}}-24^{\mathrm{TH}}$, PORTOROŽ Slovenia)

E. Šturm, E. Krhač, M. Potrata: Vpliv standardov kakovosti na delo zaposlenih

\begin{tabular}{|c|c|c|c|c|c|}
\hline \multicolumn{6}{|c|}{ Opisne statistike } \\
\hline & Podjetje & $\mathrm{N}$ & Povprečje & Std. odklon & $\begin{array}{l}\text { Std. Napaka } \\
\text { povprečja }\end{array}$ \\
\hline \multirow{2}{*}{$\begin{array}{l}\text { Standarde kakovosti } \\
\text { dobro poznam }\end{array}$} & ALPETOUR & 41 & 4,83 & ,738 & ,115 \\
\hline & HELLA & 92 & 4,26 & 1,026 & ,107 \\
\hline \multirow{2}{*}{$\begin{array}{l}\text { Orodja in metode } \\
\text { dobro poznam }\end{array}$} & ALPETOUR & 41 & 4,63 &, 799 &, 125 \\
\hline & \begin{tabular}{|l} 
HELLA \\
\end{tabular} & 92 & 4,18 & ,948 & 099 \\
\hline \multirow{2}{*}{$\begin{array}{l}\text { Pri uvedbi sem bil } \\
\text { prisoten }\end{array}$} & ALPETOUR & 41 & 3,51 & 1,675 & 262 \\
\hline & HELLA & 91 & 2,85 & 1,505 & 158 \\
\hline \multirow{2}{*}{$\begin{array}{l}\text { Standardi se mi zdijo } \\
\text { uporabni }\end{array}$} & ALPETOUR & 41 & 4,32 & 1,011 &, 158 \\
\hline & HELLA & 92 & 4,79 & 1,115 &, 116 \\
\hline \multirow{2}{*}{$\begin{array}{l}\text { Po uvedbi dosegamo } \\
\text { boljše rezultate }\end{array}$} & \begin{tabular}{|l} 
ALPETOUR \\
\end{tabular} & 41 & 4,15 & 1,038 &, 162 \\
\hline & \begin{tabular}{|l} 
HELLA \\
\end{tabular} & 92 & 4,70 & ,923 &, 096 \\
\hline \multirow{2}{*}{ 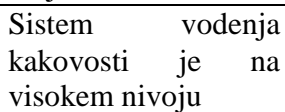 } & ALPETOUR & 41 & 4,63 & ,859 &, 134 \\
\hline & HELLA & 92 & 4,16 & 1,092 &, 114 \\
\hline \multirow{2}{*}{$\begin{array}{l}\text { Imeli smo uvajanje za } \\
\text { vse zaposlene }\end{array}$} & ALPETOUR & 41 & 3,71 & 1,346 &, 210 \\
\hline & HELLA & 92 & 3,63 & 1,450 & ,151 \\
\hline \multirow{2}{*}{ 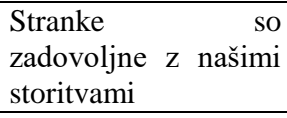 } & ALPETOUR & 41 & 4,66 &, 855 &, 133 \\
\hline & HELLA & 92 & 4,39 & ,925 & ,096 \\
\hline
\end{tabular}

Tabela 10: Opisne statistike (SPSS, 2016)

Trditve pri katerih, zaradi večjega standardnega odklona in standardne napake povprečja, nismo ugotovili statistično značilnih razlik, smo izključili iz nadaljnje analize (»Imeli smo uvajanje za vse zaposlene« in »Stranke so zadovoljne z našimi storitvami«).

Raziskovalna vprašanja:

- Ali v podjetju Alpetour, Potovalna agencija d.d. zaposleni bolje poznajo standarde kakovosti kot zaposleni v podjetju Hella Saturnus Slovenija d.o.o.?

- Ali v podjetju Alpetour, Potovalna agencija d.d. zaposleni bolje poznajo metode in orodja za zagotavljanje in izboljševanje kakovosti kot zaposleni v podjetju Hella Saturnus Slovenija d.o.o.?

- Ali so bili zaposleni v podjetju Alpetour, Potovalna agencija d.d. prisotni pri uvedbi standardov kakovosti pogosteje kot zaposleni v podjetju Hella Saturnus Slovenija d.o.o.?

- Ali se zaposlenim v podjetju Alpetour, Potovalna agencija d.d. zdijo standardi uporabnejši kot zaposlenim v podjetju Hella Saturnus Slovenija d.o.o.?

- Ali v podjetju Alpetour, Potovalna agencija d.d. po uvedbi standardov dosegajo boljše rezultate kot v podjetju Hella Saturnus Slovenija d.o.o.?

- Ali se zaposlenim v podjetju Alpetour, Potovalna agencija d.d. zdi, da je sistem kakovosti na višjem nivoju kot zaposlenim v podjetju Hella Saturnus Slovenija d.o.o.? 
E. Šturm, E. Krhač, M. Potrata: Vpliv standardov kakovosti na delo zaposlenih

Raziskovalno vprašanje 1: Ali v podjetju Alpetour, Potovalna agencija d.d. zaposleni bolje poznajo standarde kakovosti kot zaposleni v podjetju Hella Saturnus Slovenija d.o.o.?

Na podlagi Levenovega testa lahko zavrnemo ničelno domnevo o enakosti varianc pri 5 \% stopnji značilnosti, saj je p-vrednost enaka 0,031 < 0,05 (F=4,769). Glede na zgornji sklep, pri t-testu enakosti povprečij upoštevamo drugo vrstico. Ker smo uporabili neenačaj, moramo uporabiti enostranski test in dobimo $p=\frac{0.000}{2}=0.000$. Na podlagi rezultatov t-testa ničelno domnevo o enakosti povprečij zavrnemo pri $5 \%$ stopnji tveganja $(\mathrm{p}=0,000<0,05, \mathrm{tsp}=131=3,614)$. To pomeni, da zaposleni $\mathrm{v}$ podjetju Alpetour, Potovalna agencija d.d. bolje poznajo standarde kakovosti $(\bar{x}=4,92)$ kot zaposleni v podjetju Hella Saturnus Slovenija d.o.o. $(\bar{x}=4,70)$ - torej, raziskovalno vprašanje lahko potrdimo.

Raziskovalno vprašanje 2: Ali v podjetju Alpetour, Potovalna agencija d.d. zaposleni bolje poznajo metode in orodja za zagotavljanje in izboljševanje kakovosti kot zaposleni v podjetju Hella Saturnus Slovenija d.o.o.?

Na podlagi Levenovega testa lahko zavrnemo ničelno domnevo o enakosti varianc pri 5 $\%$ stopnji značilnosti, saj je p-vrednost enaka $0,370>0,05(\mathrm{~F}=0,810)$.

P-vrednost t-testa enakosti povprečij je enaka 0,009 <0,05 (tsp=131 = 2,643), kar pomeni, da ničelno domnevo o enakosti povprečij pri $5 \%$ stopnji značilnosti lahko zavrnemo. Torej, zaključimo lahko, da statistične razlike v poznavanju metod in orodij za zagotavljanje kakovosti obstajajo - raziskovalno vprašanje lahko potrdimo.

Raziskovalno vprašanje 3: Ali so bili zaposleni v podjetju Alpetour, Potovalna agencija d.d. prisotni pri uvedbi standardov kakovosti pogosteje kot zaposleni v podjetju Hella Saturnus Slovenija d.o.o.?

Na podlagi Levenovega testa lahko zavrnemo ničelno domnevo o enakosti varianc pri 5 \% stopnji značilnosti, saj je p-vrednost enaka 0,298 > 0,05 $(\mathrm{F}=1,091)$.

P-vrednost t-testa enakosti povprečij je enaka 0,025 < 0,05 (tsp=131 = 2,271), kar pomeni, da ničelno domnevo o enakosti povprečij pri $5 \%$ stopnji značilnosti lahko zavrnemo. Torej, zaključimo lahko, da statistične razlike o prisotnosti pri uvedbi standardov kakovosti obstajajo - raziskovalno vprašanje lahko potrdimo.

Raziskovalno vprašanje 4: Ali se zaposlenim v podjetju Alpetour, Potovalna agencija d.d. zdijo standardi uporabnejši kot zaposlenim v podjetju Hella Saturnus Slovenija d.o.o.?

Na podlagi Levenovega testa lahko zavrnemo ničelno domnevo o enakosti varianc pri $5 \%$ stopnji značilnosti, saj je p-vrednost enaka 0,859 > 0,05 $(\mathrm{F}=0,031)$. 
1122 36 $36^{\text {Th }}$ International Conference on Organizational Science Development:

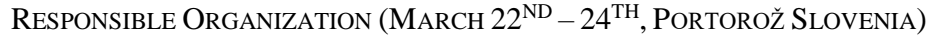

E. Šturm, E. Krhač, M. Potrata: Vpliv standardov kakovosti na delo zaposlenih

P-vrednost t-testa enakosti povprečij je enaka 0,021<0,05 (tsp=131 = -2,340), kar pomeni, da ničelno domnevo o enakosti povprečij pri $5 \%$ stopnji značilnosti lahko zavrnemo. Torej, zaključimo lahko, da statistične razlike $\mathrm{v}$ mnenju o uporabnosti standardov kakovosti obstajajo - raziskovalno vprašanje lahko potrdimo.

Raziskovalno vprašanje 5: Ali v podjetju Alpetour, Potovalna agencija d.d. po uvedbi standardov dosegajo boljše rezultate kot v podjetju Hella Saturnus Slovenija d.o.o.?

Na podlagi Levenovega testa lahko zavrnemo ničelno domnevo o enakosti varianc pri 5 \% stopnji značilnosti, saj je p-vrednost enaka 0,439 > 0,05 $(\mathrm{F}=0,603)$.

P-vrednost t-testa enakosti povprečij je enaka 0,003 < 0,05 (tsp=131 = -3,049), kar pomeni, da ničelno domnevo o enakosti povprečij pri $5 \%$ stopnji značilnosti lahko zavrnemo. Torej, zaključimo lahko, da statistične razlike v doseganju boljših rezultatov (po uvedbi standardov kakovosti) obstajajo - raziskovalno vprašanje lahko potrdimo.

Raziskovalno vprašanje 6: Ali se zaposlenim v podjetju Alpetour, Potovalna agencija d.d. zdi, da je sistem kakovosti na višjem nivoju kot zaposlenim v podjetju Hella Saturnus Slovenija d.o.o.?

Na podlagi Levenovega testa lahko zavrnemo ničelno domnevo o enakosti varianc pri $5 \%$ stopnji značilnosti, saj je p-vrednost enaka 0,278 > 0,05 $(\mathrm{F}=1,188)$.

P-vrednost t-testa enakosti povprečij je enaka 0,016 < 0,05 (tsp=131 = 2,444), kar pomeni, da ničelno domnevo o enakosti povprečij pri $5 \%$ stopnji značilnosti lahko zavrnemo. Torej, zaključimo lahko, da statistične razlike o nivoju samega sistema kakovosti v podjetju obstajajo - raziskovalno vprašanje lahko potrdimo.

Na podlagi Levenovega testa lahko pri vseh vprašanjih zavrnemo ničelno domnevo o enakosti varianc pri $5 \%$ stopnji značilnosti ter vsa raziskovalna vprašanja potrdimo. Odgovore na raziskovalna vprašanja smo analizirali s pomočjo t-testa, ki se uporablja za preverjanje domnev o povprečjih spremenljivk. V tabeli 11 so predstavljeni rezultati ttesta za neodvisne vzorce. 
ORGANIZACIJA (22. - 24. MAREC 2017, PORTOROŽ, SLOVENIJA)

E. Šturm, E. Krhač, M. Potrata: Vpliv standardov kakovosti na delo zaposlenih

\begin{tabular}{|c|c|c|c|c|c|c|c|c|c|c|}
\hline & & \multicolumn{2}{|c|}{$\begin{array}{c}\text { Levene's Test } \\
\text { for Equality } \\
\text { of Variances }\end{array}$} & \multicolumn{6}{|c|}{ t-test for Equality of Means } & \\
\hline & & \multirow[b]{2}{*}{$\mathrm{F}$} & \multirow[b]{2}{*}{ Sig. } & \multirow[b]{2}{*}{$\mathrm{t}$} & \multirow[b]{2}{*}{ df } & \multirow{2}{*}{$\begin{array}{l}\text { Sig. } \\
(2- \\
\text { tailed) }\end{array}$} & \multirow{2}{*}{$\begin{array}{l}\text { Mean } \\
\text { Differe } \\
\text { nce }\end{array}$} & \multirow{2}{*}{$\begin{array}{c}\text { Std. } \\
\text { Error } \\
\text { Differenc } \\
\mathrm{e}\end{array}$} & $\begin{array}{c}95 \% \\
\text { Confidence } \\
\text { Interval } \\
\end{array}$ & \\
\hline & & & & & & & & & Lower & Upper \\
\hline \multirow[t]{2}{*}{$\begin{array}{l}\text { Standarde } \\
\text { kakovosti } \\
\text { dobro poznam }\end{array}$} & $\begin{array}{l}\text { Equal } \\
\text { variances } \\
\text { assumed }\end{array}$ & $\begin{array}{r}4,76 \\
9\end{array}$ &, 031 & 3,196 & 131 &, 002 & ,568 &, 178 & ,217 & ,920 \\
\hline & $\begin{array}{l}\text { Equal } \\
\text { variances not } \\
\text { assumed }\end{array}$ & & & 3,614 & $\begin{array}{r}104,43 \\
8\end{array}$ &, 000 & ,568 &, 157 & ,257 &, 880 \\
\hline \multirow[t]{2}{*}{$\begin{array}{l}\text { Orodja in } \\
\text { metode dobro } \\
\text { poznam }\end{array}$} & $\begin{array}{l}\text { Equal } \\
\text { variances } \\
\text { assumed }\end{array}$ &, 810 & ,370 & 2,643 & 131 & ,009 & ,449 &, 170 &, 113 & ,786 \\
\hline & $\begin{array}{l}\text { Equal } \\
\text { variances not } \\
\text { assumed }\end{array}$ & & & 2,823 & 90,389 & ,006 & ,449 &, 159 &, 133 & ,766 \\
\hline \multirow[t]{2}{*}{$\begin{array}{lr}\text { Pri } & \text { uvedbi } \\
\text { sem } & \text { bil } \\
\text { prisoten } & \\
\end{array}$} & $\begin{array}{l}\text { Equal } \\
\text { variances } \\
\text { assumed }\end{array}$ & $\begin{array}{r}1,09 \\
1\end{array}$ & ,298 & 2,271 & 130 &, 025 & ,666 & ,293 & ,086 & 1,246 \\
\hline & $\begin{array}{l}\text { Equal } \\
\text { variances not } \\
\text { assumed }\end{array}$ & & & 2,180 & 70,254 &, 033 & ,666 & ,306 & ,057 & 1,275 \\
\hline \multirow[t]{2}{*}{$\begin{array}{l}\text { Standardi se } \\
\text { mi zdijo } \\
\text { uporabni }\end{array}$} & $\begin{array}{l}\text { Equal } \\
\text { variances } \\
\text { assumed } \\
\end{array}$ &, 031 &, 859 & $-2,340$ & 131 & ,021 &,- 476 & ,204 &,- 879 &,- 074 \\
\hline & $\begin{array}{l}\text { Equal } \\
\text { variances not } \\
\text { assumed }\end{array}$ & & & $-2,430$ & 84,224 &, 017 &,- 476 &, 196 &,- 866 &,- 087 \\
\hline \multirow{2}{*}{$\begin{array}{l}\text { Po uvedbi } \\
\text { dosegamo } \\
\text { boljše } \\
\text { rezultate }\end{array}$} & $\begin{array}{l}\text { Equal } \\
\text { variances } \\
\text { assumed } \\
\end{array}$ & ,603 & ,439 & $-3,049$ & 131 & ,003 &,- 549 & , 180 &,- 906 &,- 193 \\
\hline & $\begin{array}{l}\text { Equal } \\
\text { variances not } \\
\text { assumed }\end{array}$ & & & $-2,913$ & 69,337 & ,005 &,- 549 & , 189 &,- 925 &,- 173 \\
\hline \multirow{2}{*}{$\begin{array}{l}\text { Sistem } \\
\text { vodenja } \\
\text { kakovosti je } \\
\text { na visokem } \\
\text { nivoju }\end{array}$} & $\begin{array}{l}\text { Equal } \\
\text { variances } \\
\text { assumed }\end{array}$ & $\begin{array}{r}1,18 \\
8\end{array}$ & ,278 & 2,444 & 131 & ,016 & ,471 & , 193 & ,090 & ,852 \\
\hline & $\begin{array}{l}\text { Equal } \\
\text { variances not } \\
\text { assumed }\end{array}$ & & & 2,677 & 96,409 & ,009 & ,471 & , 176 & , 122 & ,820 \\
\hline
\end{tabular}

Tabela 11: T-test o enakosti varianc (SPSS, 2016)

\subsection{Korelacija}

Zadnji del poglavja prikazuje rezultate preverjanja $\mathrm{v}$ kakšni povezavi so posamezne trditve. Preverjali smo povezavo štirih trditev, in sicer »Standarde kakovosti dobro poznam «, »Orodja in metode dobro poznam «, »Po uvedbi dosegamo boljše rezultate« in »Imeli smo uvajanje za vse zaposlene«. 
1124 36 $6^{\mathrm{TH}}$ INTERnational CONFERENCE ON ORganizational SCIENCE DeVElopment: Responsible ORganization (MARCh $22^{\mathrm{ND}}-24^{\mathrm{TH}}$, PORTOROŽ Slovenia)

E. Šturm, E. Krhač, M. Potrata: Vpliv standardov kakovosti na delo zaposlenih

\section{Correlations}

\begin{tabular}{|c|c|c|c|c|c|}
\hline & & $\begin{array}{c}\text { Stand } \\
\text { arde } \\
\text { kakov } \\
\text { osti } \\
\text { dobro } \\
\text { pozna } \\
\text { m }\end{array}$ & $\begin{array}{l}\text { Orodja in } \\
\text { metode } \\
\text { dobro } \\
\text { poznam }\end{array}$ & $\begin{array}{l}\text { Po uvedbi } \\
\text { dosegamo } \\
\text { boljše } \\
\text { rezultate }\end{array}$ & $\begin{array}{l}\text { Imeli smo } \\
\text { uvajanje } \\
\text { za vse } \\
\text { zaposlene }\end{array}$ \\
\hline \multirow{3}{*}{$\begin{array}{ll}\text { Standarde } & \\
\text { kakovosti dobro } \\
\text { poznam }\end{array}$} & Pearson Correlation & 1 &, $821^{* *}$ &, $223^{*}$ &, $345^{* *}$ \\
\hline & Sig. (2-tailed) & &, 000 &, 010 & 000 \\
\hline & $\mathrm{N}$ & 133 & 133 & 133 & 133 \\
\hline \multirow{3}{*}{$\begin{array}{l}\text { Orodja in metode } \\
\text { dobro poznam }\end{array}$} & Pearson Correlation &, $821^{* * *}$ & 1 & $243^{* *}$ &, $323^{* *}$ \\
\hline & Sig. (2-tailed) &, 000 & &, 005 &, 000 \\
\hline & $\mathrm{N}$ & 133 & 133 & 133 & 133 \\
\hline \multirow{3}{*}{$\begin{array}{lr}\text { Po } & \text { uvedbi } \\
\text { dosegamo } & \text { boljše } \\
\text { rezultate } & \\
\end{array}$} & Pearson Correlation & $223^{*}$ &, $243^{* *}$ & 1 & $272^{* * *}$ \\
\hline & Sig. (2-tailed) & , 010 & 005 & & ,002 \\
\hline & $\mathrm{N}$ & 133 & 133 & 133 & 133 \\
\hline \multirow{3}{*}{$\begin{array}{l}\text { Imeli smo uvajanje } \\
\text { za vse zaposlene }\end{array}$} & Pearson Correlation & $345^{* *}$ & $323^{* *}$ & $272^{* *}$ & 1 \\
\hline & Sig. (2-tailed) &, 000 &, 000 & ,002 & \\
\hline & $\mathrm{N}$ & 133 & 133 & 133 & 133 \\
\hline
\end{tabular}

**. Correlation is significant at the 0.01 level (2-tailed).

*. Correlation is significant at the 0.05 level (2-tailed).

Tabela 12: Korelacija (SPSS, 2016)

Pri tem je bilo potrebno postaviti ustrezne hipoteze.

- $\mathrm{H}_{0}$ : Spremenljivki »Standarde kakovosti dobro poznam« in »Orodja in metode dobro poznam « nista v povezavi,

- $\mathrm{H}_{1}$ : Spremenljivki »Standarde kakovosti dobro poznam« in »Orodja in metode dobro poznam « sta v povezavi.

Iz tabele z izračunanimi korelacijskimi koeficienti dobimo p-vrednost $0,000<0,01$, kar pomeni, da sta spremenljivki »Standarde kakovosti dobro poznam« in »Orodja in metode dobro poznam « povezani pri $1 \%$ tveganja. Pearsonov koeficient korelacije je enak 0,821 , kar nakazuje, da je med spremenljivkami močna pozitivna linearna povezanost.

- $\mathrm{H}_{0}$ : Spremenljivki »Standarde kakovosti dobro poznam« in »Po uvedbi dosegamo boljše rezultate « nista v povezavi,

- $\mathrm{H}_{1}$ : Spremenljivki »Standarde kakovosti dobro poznam« in »Po uvedbi dosegamo boljše rezultate« sta v povezavi. 
E. Šturm, E. Krhač, M. Potrata: Vpliv standardov kakovosti na delo zaposlenih

Iz tabele $\mathrm{z}$ izračunanimi korelacijskimi koeficienti dobimo $\mathrm{p}$-vrednost $0,010 \leq 0,01$, kar pomeni, da sta spremenljivki »Standarde kakovosti dobro poznam《 in »Po uvedbi dosegamo boljše rezultate « povezani pri $1 \%$ tveganja. Pearsonov koeficient korelacije je enak 0,223 , kar nakazuje, da je med spremenljivkami šibka pozitivna linearna povezanost.

- $\mathrm{H}_{0}$ : Spremenljivki »Standarde kakovosti dobro poznam« in »Imeli smo uvajanje za vse zaposlene « nista v povezavi,

- $\mathrm{H}_{1}$ : Spremenljivki »Standarde kakovosti dobro poznam« in »Imeli smo uvajanje za vse zaposlene« sta v povezavi.

Iz tabele z izračunanimi korelacijskimi koeficienti dobimo p-vrednost $0,000<0,01$, kar pomeni, da sta spremenljivki »Standarde kakovosti dobro poznam» in »Imeli smo uvajanje za vse zaposlene « povezani pri $1 \%$ tveganja. Pearsonov koeficient korelacije je enak 0,345 , kar nakazuje, da je med spremenljivkami šibka pozitivna linearna povezanost.

- $\mathrm{H}_{0}$ : Spremenljivki »Orodja in metode dobro poznam« in »Imeli smo uvajanje za vse zaposlene« nista v povezavi,

- $\mathrm{H}_{1}$ : Spremenljivki »Orodja in metode dobro poznam« in »Imeli smo uvajanje za vse zaposlene« sta v povezavi.

Iz tabele z izračunanimi korelacijskimi koeficienti dobimo p-vrednost $0,000<0.01$, kar pomeni, da sta spremenljivki »Orodja in metode dobro poznam « in »Imeli smo uvajanje za vse zaposlene« povezani pri $1 \%$ tveganja. Pearsonov koeficient korelacije je enak 0,323 , kar nakazuje, da je med spremenljivkami šibka pozitivna linearna povezanost.

- $\mathrm{H}_{0}$ : Spremenljivki »Po uvedbi dosegamo boljše rezultate« in »Imeli smo uvajanje za vse zaposlene« nista v povezavi,

- $\mathrm{H}_{1}$ : Spremenljivki »Po uvedbi dosegamo boljše rezultate« in »Imeli smo uvajanje za vse zaposlene« sta v povezavi.

Iz tabele z izračunanimi korelacijskimi koeficienti dobimo p-vrednost $0,002<0,01$, kar pomeni, da sta spremenljivki »Po uvedbi dosegamo boljše rezultate « in »Imeli smo uvajanje za vse zaposlene « povezani pri $1 \%$ tveganja. Pearsonov koeficient korelacije je enak 0,272, kar nakazuje, da je med spremenljivkami šibka pozitivna linearna povezanost.

\section{$5 \quad$ Zaključek}

Namen raziskave je bil preveriti:

- ali v managementu kakovosti v podjetjih, glede na njihovo različnost, obstajajo bistvene razlike,

- ali se mnenja zaposlenih o standardih kakovosti razlikujejo. 
Glavno razliko med podjetjema predstavlja predvsem trajanje zaposlitve anketirancev, ki je v primeru podjetja Alpetour, Potovalna agencija d.d. precej višja. Le to je pripomoglo $\mathrm{k}$ kvalitetnejšim odgovorom na področju razlik pred in po vpeljavi standardov. Po besedah Nga in Feldmana (2013) je trajanje zaposlitve zmerno pozitivno povezano s splošnim pozitivnim vedenjem zaposlenih oseb, ter ocenjevanjem $\mathrm{s}$ strani nadrejenih. Slednje lahko vodi v boljše odnose med zaposlenimi ter zaposlenimi in nadrejenimi $\mathrm{v}$ primeru daljše zaposlitve. Prav tako je v podjetju Alpetour, Potovalna agencija d.d. odstotek zaposlenih, ki so sodelovali pri uvajanju na področju standardov, višji kot pa v podjetju Hella Saturnus Slovenija d.o.o. Z druge strani, več zaposlenih v podjetju Hella Saturnus Slovenija d.o.o. sodeluje v projektih in je mnenja, da je njihovo delo, po uvedbi standardov kakovosti, manj stresno. $\mathrm{V}$ posameznih odgovorih je standardni odklon zelo velik, zato trditve niso bile primerne za nadaljnje obravnave v programu SPSS. Ugotovili smo tudi to, da je večji odstotek anketirancev, ki se strinjajo z uporabnostjo standardov kakovosti, zaposlenih v podjetju Hella Saturnus Slovenija d.o.o. Zaposleni v podjetju Alpetour, Potovalna agencija d.d. pa v večji meri menijo, da je njihov sistem vodenja kakovosti, na visokem nivoju. V nadaljevanju smo želeli ugotoviti ali obstajajo statistično značilne razlike med posameznimi oddelki dveh podjetij. Ugotovili smo, da zaposleni iz podjetja Alpetour, Potovalna agencija d.d. bolje poznajo standarde kakovosti ter njihove metode in orodja za zagotavljanje in izboljševanje kakovosti. Prav tako pa obstajajo tudi statistično značilne razlike $\mathrm{v}$ mnenju o uporabnosti standardov, $\mathrm{v}$ doseganju boljših rezultatov in mnenju o nivoju sistema kakovosti.

Na podlagi analize lahko zaključimo, da $\mathrm{v}$ managementu kakovosti v podjetjih obstajajo razlike in da se mnenje zaposlenih o standardih kakovosti razlikuje. Pa vendar se je potrebno vprašati kakšni so razlogi za omenjene razlike. Skozi raziskavo smo lahko opazili, da sta ključna dejavnika trajanje zaposlitve (posledično, sodelovanje v podjetju pred in pol vpeljavi standardov kakovosti) in način razporeditve dela (v podjetju Hella Saturnus Slovenija d.o.o. je delo organizirano po oddelkih, v drugem podjetju je tega bistveno manj). Prav tako je razlog lahko tudi v tem, da je podjetje Hella Saturnus Slovenija d.o.o. avtomobilska industrija, kjer so standardi kakovosti zelo pomemben del vsakdanjega dela in jih poznati ter upoštevati morajo vsi zaposleni. $\mathrm{Z}$ druge strani, $\mathrm{v}$ podjetju Alpetour, Potovalna agencija d.d. je za kakovost in vpeljavo standardov kakovosti zadolžena le ena oseba. Zaradi tega, kot omejitev raziskave, moramo omeniti slabšo primernost vzorca, saj so v podjetju Alpetour, Potovalna agencija d.d. anketni vprašalnik izpolnjevali tudi v oddelkih, ki nimajo primernega znanja o sistemu kakovosti ali stika z njim. Vsi anketiranci iz podjetja Hella Saturnus Slovenija d.o.o. pa so vključeni $\mathrm{v}$ sistem kakovosti in za to so njihovi odgovori veliko bolj kritični, oziroma bolj realni.

\section{Literatura}

Al-Rawahi, A. M., \& Bashir, H. A. (2011). On the implementation of ISO 9001:2000: a comparative investigation. The TQM Journal, 23(6), 673-687.

Hella Slovenija (2017). Arhiv certifikatov (interno gradivo podjetja). 
E. Šturm, E. Krhač, M. Potrata: Vpliv standardov kakovosti na delo zaposlenih

Clougherty, J. A., \& Grajek, M. (2014). Internal standards and internal trade: Empirical evidence from ISO 9000 diffusion. Internal Juornal of Industrial Organization, 36, 70-82.

Ingason, H. T. (2014). Best Project Management Practices in the Implementation of an ISO 9001 Quality Management System. 28th IPMA World Congress, 194, 193-199.

Marolt, J., \& Gomišček, B. (2005). Management kakovosti. Kranj: Moderna organizacija.

Ng, W. H. T., \& Feldman, D C. (2013). Does longer job tenure help or hinder job performance? Journal of Vocational Behaviour, 83, 305-314.

Priede, J. (2012). Implementation of Quality Management System ISO 9001 in the World and Its Strategic Necessity. ProcediaSocial and Behavioral Sciences, 58, 1466-1475.

Alpetour (2017). Sistemi kakovosti - SIST ISO 9001. Dostopno na: https://www.alpetour.si/alpetour/sistemi-kakovosti/

Hella Slovenija (2017). Hella Saturnus Slovenija. Dostopno na: http://www.hella.com/hellasi/en/HELLA-Saturnus-Slovenija-61.html

Terziovski, M., \& Guerrero, J. (2014). ISO 9000 quality system certification and its impact on product and process innovation performance. Internal Journal of Production Economics, 158, 197-207.

Udrih, U. (2008). Uvajanje konceptov managementa kakovosti na primeru pivovarne (Diplomsko delo). Ekonomsko - poslovna fakulteta, Maribor.

Žnidaršič, A. (2013). Vodnik po SPSS-u: Delovna verzija (2). Ljubljana. 
1128 36 $6^{\text {Th }}$ International Conference on Organizational Science Development: Responsible Organization (March $22^{\mathrm{ND}}-24^{\mathrm{TH}}$, Portorož Slovenia) 
$36^{\mathrm{TH}}$ InTERnational CONFERENCE ON ORganizational SCIENCE Development: Responsible Organization (MARCh $22^{\mathrm{ND}}-24^{\mathrm{TH}}$, PORTOROŽ SLOVENIA)

O. Arsenijević, M. Ferjan, I. Podbregar, P. Šprajc, D. Trivan \& Y. Ziegler

\title{
Implementation of Benchmarks in Investment Strategies of Pension Funds in SEE Region
}

\author{
PETAR TALESKI \& VASKO BOGDANOVSKI
}

\begin{abstract}
The issue of setting up an adequate benchmark for pension funds is a subject to a continuous professional debate. Most common dilemmas include a benchmark set too low, which essentially leads to a situation where it can easily be overcome, or a benchmark set too high, making it difficult to achieve it, unless the fund managers are too much at risk. Another issue that can be discussed is whether the frequency of assessment of the benchmark (usually annually) is appropriate for investors in the long term. According to the theory and from the practice of asset management, valid benchmark should possess some properties in order to be useful and effective tool for investment management.
\end{abstract}

KEYWORDS: performance benchmarks • pension funds • index

CORRESPONDENCE AdDRESS: Petar Taleski, NLB Nov penziski fond a.d., Ul. Majka Tereza br. 1, 1000 Skopje, R. Macedonia, e-mail: p.taleski@npf.com.mk; Vasko Bogdanovski, NLB Nov penziski fond a.d., Ul. Majka Tereza br. 1, 1000 Skopje, R. Macedonia, e-mail: v.bogdanovski@npf.com.mk 
$1130 \quad 36^{\mathrm{TH}}$ INTERNATIONAL CONFERENCE ON ORganizational SCIENCE DEVElopment:

Responsible ORGaNiZATION (MARCH $22^{\mathrm{ND}}-24^{\mathrm{TH}}$, PortoroŽ SlOVENIA)

P. Taleski \& V. Bogdanovski: Implementation of Benchmarks in Investment

Strategies of Pension Funds in SEE Region

\section{Introduction}

Performance benchmarks have been applied in pension funds of European countries since the early 70 s of the last century. They are a significant part of every pension fund's investment strategy and assist in evaluating the performance of the steering pension funds by the client and other stakeholders with the intention to evaluate success in achieving the goal of the client (Grinblatt; Titman, 1989).

The benchmark is an effective tool for evaluating the performance of the funds managed by the Company. When out of context, absolute numbers of the rate of return have little meaning. For example, an annual $10 \%$ growth of a diversified portfolio's return should not be equally perceived in situation where the whole market of securities represented by the index has grown by $15 \%$ and in a situation where it has grown by $5 \%$ during the same period. If the pension company wants to a make significant evaluation of the pension funds' performance, it needs to develop an appropriate benchmark to compare with.

Basically the benchmark is a set of securities or risk factors, each with an adequate participation, representing the investment characteristics of the pension fund or the investment process of the manager of the fund. At the level of portfolio manager, the benchmark can be interpreted as passive representation of the investment style of the portfolio manager, incorporating prominent investment features that are included in the investment policy of the portfolio. The benchmark should cover the fields of expertise of the portfolio manager. The benchmark should adequately contain the set of opportunities of portfolio management which can be tightened or widened depending on the resources, regulation and investment process used by the portfolio manager regarding selection of the optimal portfolio, all in accordance with the defined strategy for achieving the goal of the fund (Fabozzi, 1997).

\section{Types of benchmarks}

The two main types of benchmarks applied by the pension funds in Europe and the US are a benchmark based on class of instruments (asset class benchmark) and a benchmark based on group of related funds (peer group benchmark).

These benchmarks are used by pension funds and other institutional investors. At the beginning of active performance measurement of the pension funds, in the 1970's, most pension funds set their own tailor made benchmarks (which included determining the participation of the classes of instruments invested according to the specific requirements of funds). Shortly thereafter, the trend was towards the introduction of a benchmark based on peer group concept. More recently, following the fact that the objectives of the various pension funds vary widely, the practitioners are returning to the principle of performance benchmarks based on the classes of instruments included in the portfolio (Brinson; Singer; \& Beebower, 1991). 


\section{Evaluate benchmarks based on index}

The first question that must be answered before the use of any external benchmarks based on indexes is how the benchmarks are built. Appropriate benchmarks based on the indexes must be created on the basis of the weighted value and based on the time frame. This essentially means that the components of the index are weighted according to their market capitalization and the timing of reinvested income does not allow disturbing the measured yield. Other types of indexes, such as price-weighted indexes (which simply summarize price index regardless of market capitalization) and geometric indices (which simply multiply together prices of the index regardless of market capitalization) would not be an appropriate benchmark for any fund. This is because it is impossible for any real portfolio to repeat the behaviour of either of these indices.

Even with defined benchmarks on money and time-weighted basis, there is a need for practical perception which must be considered before the start of assessing the performance.

First of all, benchmarks can be created without inclusion of types of costs which in reality exist for the fund managers such as brokerage commissions, taxes and so on.

Secondly, the content of the benchmarks changes quite often. While this does not incur costs for the benchmark, it still incurs costs for each fund manager who needs to implement changes in the portfolio. Securities which are excluded from the benchmark should be sold, while new instruments that have been added should be purchased as a cost and allocation and additional duties.

Also, the benchmark assumes that a payment of the gross income is reinvested at no cost to the benchmark on the day when the relevant shares ex-dividend. In practice, no fund manager could replicate this behaviour: dividends and coupon payments are not carried out at the same time dividend date, payment generally is carried out later and net income is in certain situations included by withholding tax. There are also other commissions and fees that occur when the income and payments of dividends or coupons are reinvested, and they are carried out at different time periods and will accrue differently to what they can say in advanced calculations. All these factors cause the error in the monitoring that occurs between the benchmark and the actual portfolios by seeking to achieve the benchmark. All this leads to the actual yield of the portfolio that tends to be lower than the performance of the benchmark (Blake; Timmermann, 2002).

Beside these practical considerations, there are other reasons why institutional investor can see that it will be difficult to overcome the external index set benchmarks.

First, there may be restrictions on fund managers that prevent them to even try to achieve or to overcome the benchmark. There are examples where there are imposed limits on the maximum percentage of the fund's investment in one instrument or other appropriate 
1132 36 $6^{\mathrm{TH}}$ INTERNATIONAL CONFERENCE ON ORganizational SCIENCE DEVElopment: Responsible ORGaNiZATION (MARCH $22^{\mathrm{ND}}-24^{\mathrm{TH}}$, PortoroŽ SlOVENIA) P. Taleski \& V. Bogdanovski: Implementation of Benchmarks in Investment Strategies of Pension Funds in SEE Region

investment limit. Frequent change of legislation in this context may indicate a disability to achieve that benchmark which was previously set accordingly to prior conditions.

Secondly, investors may not want to be represented in some of the markets covered by a broader global index. For example, an index of global markets will cover all continents, but investors may choose to avoid certain regions such as Africa, the Middle East and Korea, where it would be good to invest.

Thirdly, there may be a distortion due to the preferences of the domestic market. Also important factor can be the distortion which can be obtained related to currency risk due to the part of the portfolio that would be denominated in foreign currency and the index and also the return of the fund to have positive values, but a disruption of the currency exchange to reduce the value of the return. When forming this type of index, it is necessary to consider all possible negative factors that could impair its achievement and find ways to overcome them (Ferson; Warther, 1996).

\section{Evaluate benchmarks on related peer groups}

This question of peer group benchmark is relatively complex because we first need to define what would be included in the relevant group of similar funds. The answer largely depends on the organization of pension fund industry as well as the industry's practices for managing pension funds.

What is characteristic in Europe is that the industry pension fund management is often concentrated in a few funds (about 10 in number) and they manage more than $50 \%$ of the pension fund assets. On the other hand, the US top 5 largest pension funds manage less than $15 \%$ of the total assets at market fully funded pension funds. Also in Europe there is less fluctuation of members from one to another fund, which means greater loyalty that could help the smooth operation of pension funds during periods of weaker results, unlike the United States where fluctuation is high.

Furthermore, in Europe there is a dominant way of investing funds called balanced multi asset management, which contradicts the broader range of investment styles in the United States.

In Europe, the remuneration of the fund managers depends only on the total assets under management, not the fund manager's added value (return) contributing to the management of the pension fund, which would award or penalize the manager for outperforming in terms of a group of related funds or for failure of the benchmarks respectively. However, regardless of the manner of operation of financial institutions, it is necessary to note that the long-term success of a pension fund depends on its relative performance in terms of a related group of pension funds.

Basically fund managers of pension funds in Europe are based mostly on passive buyand-hold strategy. Only a small number of pension funds use active asset management of 
pension funds, such as proper selection of tools and appropriate timing in the purchase and sale. Proper selection means search of undervalued securities (corresponding reallocation of funds within certain classes of instruments) and timing means search of undervalued sectors that includes a reallocation of resources between sectors or categories of assets.

The most important task of a pension company is to establish maintenance of the strategic allocation of assets of the managed pension funds and the average return over the past decade by about $5-6 \%$ annually in $95 \%$ of European pension funds proves their passive policy. In terms of the active component or the timing, the generation of negative contribution to the total return indicates pension fund managers' lack of adequate judgement inclination towards the active approach to investing.

The reason why fund managers are not focused on the timing is probably the lack of appropriate remuneration which is not the case with fund managers of investment funds.

On the other hand, fund managers of pension funds in the United States are properly rewarded as an incentive to create results in the short term (so-called hot hands in the investment results). However these results are of short duration and usually last one to three years, but not longer (Antolín; Payet; Whitehouse; \& Yermo, 2011).

Therefore setting up a benchmark base on a group of related pension funds (peer group) should not focus on the positive and negative repercussions of having such a benchmark. In fact, this way of measuring the results can bring improved performance of pension funds. The question is whether the performances that are being compared to the relative benchmark and have aimed for a better result in the short race would give positive effects in the long term.

Basically, the fund managers of certain pension funds would usually set a target to achieve a return of the fund increased by $2 \%$ from the average return of the group. The question is whether it is sustainable in the long run, because it is likely that this result can be achieved effectively for a period of 1 to 3 years.

Also an important component that should be considered is the evaluation of the performance of fund manager's pension funds. Objectively the long-term nature of the activity indicates a need for measuring performances in the long term, which should be at least 10 years. However, it is a long period of time for evaluating the performance of a fund manager because of many circumstances involved within this long-term, such as fluctuations, changing circumstances and other relevant aspects. It is also necessary to find a compromise on a shorter period of assessing the performance of a fund manager of a pension fund. Practically its evaluation usually needs to be implemented in medium term, five to seven years of achieved performance of its operations (Bailey; Richards; \& Tierney, 2007). 
1134 36 $6^{\mathrm{TH}}$ INTERnational CONFERENCE ON ORganizational SCIENCE DeVElopment: Responsible ORGaNiZATION (MARCH $22^{\mathrm{ND}}-24^{\mathrm{TH}}$, PORTOROŽ SlOVENIA)

P. Taleski \& V. Bogdanovski: Implementation of Benchmarks in Investment

Strategies of Pension Funds in SEE Region

\section{Evaluating fixed income benchmarks}

Another option is to use fixed benchmarks of the pension funds. Fixed markers that can be used include:

- The rate of inflation;

- The average interest rate on the banking sector in the country;

- The average return of all securities in the economy;

- Wage growth in the country;

- GDP growth in the country;

- Increase of the consumption price index (CPI inflation);

The problem of these benchmarks is their arbitrary function. The benchmark that is based on the rate of GDP growth or the growth rate of inflation certainly should be overcome regarding the tendency of long-term trend of the return of dispersed financial instruments which is certainly higher than the rate of inflation and GDP growth. This fact is based on the reason that the economies can accumulate enough productive capital and thus further GDP growth would have less tendency of growth compared to the necessities of the population. In such a situation if capital does not find space to be directed to other productive purposes, the dynamic economy becomes ineffective. However, the market has the power and the capital is appropriately moved by the increasing consumption of the population, rather than the accumulation, and as a result the GDP tends to lower growth whereas stock prices provide enough good growth because of the possibility of moving the capital to productive industries for its further fully funding. Then the economy becomes dynamically effective again.

\section{Methods for creating and calculating the index-based benchmark}

The practice shows that it is far more appropriate to use benchmarks based on the indices. These benchmarks are commonly used in the practice of European pension funds. For these reasons we will discuss some ways of construction.

\section{Single index based benchmark}

Benchmarks based on single index can be confirmed by the CAPM which is one of the basic models in modern financial theory created by Nobel laureate Bill Sharpe.

CAPM makes decomposition of the expected return of the fund in two components. The first is the return of risk-free instrument like treasury bills. All professional investors would expect to generate higher yield than the yield on Treasury bills. Therefore there is a second component consisting of market risk. Accordingly, the second component consists of "market risk premium" (called "additional contribution from the market" or "market price risk") and the amount of market risk as measured by the coefficient $\beta$. 
Premium to the market risk is measured by the difference of the expected return on the market index and the risk free rate. Beta measures the fund's level of joint movement in the yield of the fund and returns of the market index. It is equal to the standard deviation of the returns of the fund and the correlation of the returns of the fund relative to the market. This corresponds to the formula of regression of time series where the additional contribution is represented by the slope of the regression line. If the standard deviation of the returns of the fund or the correlation between the returns of the fund and the market are high, then the beta will be high. If the beta of the fund is more volatile than the market, or for example beta is 1.1, it means that the fund will be $10 \%$ more volatile compared to the market, so if the market rises or falls by $20 \%$, it means that the fund will grow or will be reduced by $22 \%$.

CAPM can be represented by the formula:

Excess return on the fund $=\alpha+\beta$ x premium for market risk

where the additional return of the fund is the difference between the realized return and the risk-free rate of return. The model is shown in the image1 where if the additional return of the fund exceeds the market risk then the fund generated a performance above the benchmark. The difference between the extra yield and yield on the market is called "alpha" or sometimes called Jensen alpha. Successful fund in such a situation generates positive value for alpha. However, it should be noted that the yield of the fund which exceeds the market index does not always mean positive value for alpha. Funds could take greater market risk and generate a yield that is above the yield of the market and accordingly there will be a negative value for alpha, but in such a situation considering the risk, the risk-reward ratio of the fund was not paid off in full. It means that the risk was not in the proportional value relative to the yield which is provided. It is the situation in point $\mathrm{B}$ that shows that although the fund generated a yield that is above the market yield and the yield of the fund A, the long-term success of the fund A is more appropriate regarding the risks implemented in the portfolio and the management of the fund. 


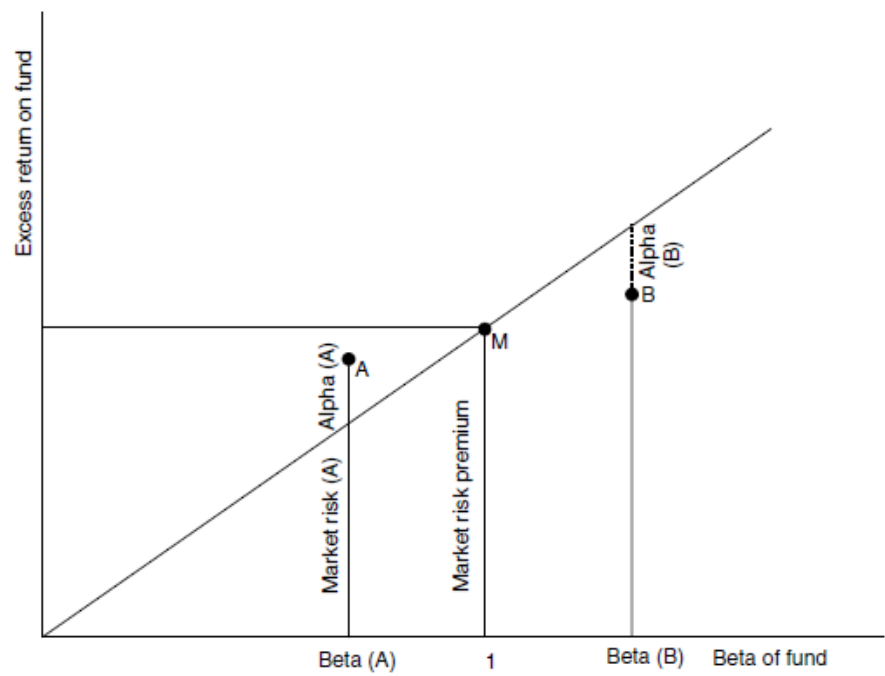

Image 1: $M$, excess return on the market index (which has a beta of unity), $A-$ Positive excess return $A, B$ - negative excess return of fund $B$

The previous example is a single benchmark index with constant coefficients for alpha and beta that operate in the context of CAPM model. Recent studies suggest that beta is variable over time and it is necessary to be adjusted in order to allow prediction of the time variable component in the beta coefficient based on the information that fund managers will receive about the investment opportunities that they have in the respective period. One way the beta to be adjusted is by creating a set of predetermined variables such as delay coefficient of short-term yield on treasury bills, long-term yields on government bonds and dividend yield of the stock index which need to be included in the calculations. These standard repressors in an adjusted ratio for proper prediction of returns on the market. Beta coefficient in this case is determined by the formula:

$\beta=\mathrm{B}(0)+\mathrm{B}(1) \times$ time lag of return on treasury bills $+\mathrm{B}(2) \times$ time lag of state bond yield $+\mathrm{B}(3) \times$ lagged of the dividend yield

\section{Multi index benchmark}

Recent observations include a recommendation for the use of multi index benchmarks. For example, the pension companies can use an index that is composed of several segments of the portfolio which would include comparable return that would be provided through shares with high capitalization, the comparable return that would be provided through shares at a lower capitalization, the difference in yield between the index of growth shares including dividend yield and index of price movement of shares without dividend yield on shares (growth factor reduced by dividend growth factor without dividend- equity growth index and equity income index) and the additional yield bond 
(return premium regarding risk of the bonds). Such a multi-factor index can be represented mathematically by the formula:

Excess return on the fund $=\alpha+\beta(1) \times$ Large cap shares $+\beta(2) \times$ Small cap shares $+\beta$ (3) $\times$ (index of growth shares including dividend yield - shares without dividend yield on shares) $+\beta(4) \times$ return premium regarding risk of the bonds

Another option is to split the benchmark by sector indices, regional structure indices or similar.

\section{Summary: Proposal for implementation of benchmarks in investment strategies of pension funds in SEE region}

The scope of activities, the evolution of the understanding of the theory and practice, and the anticipated developments with respect to changes in legislation (introduction of multifunds in some SEE countries) require the need to think about introducing a benchmark that would be integral part of the investment strategies of the pension funds in SEE.

According to the theory and from the practice of asset management, valid benchmark should possess some properties in order to be useful and effective tool for investment management. These attributes / properties formalize the intuitive aspects of what represents fair and relevant benchmark for comparing performance:

- Clear / unambiguous - Clearly defined identity and weights of individual securities or risk factors that make up the benchmark;

- Investable - Possibility of exposure to the benchmark by investing;

- Measurable - A benchmark's return that is clearly calculable on a reasonably frequent basis;

- Appropriate - A benchmark that is suitable to the investment style or the area in which the portfolio manager is an expert;

- The benchmark should reflect the current investment opportunities;

- Specified in advance - The benchmark is specified before the evaluation period and is known to all stakeholders;

- The benchmark should be owned - The portfolio manager should be aware of the components of the benchmark and should accept responsibility for the performance of the benchmark. It can be encouraging if the benchmark has to be included in operating procedures and be an integral part of the investment process.

From the analyzed possible scenarios for the introduction of a benchmark, we can conclude the following:

1. The introduction of benchmark for the investment portfolios of pension funds based on group of related funds (peer group) has specifics regarding the functioning of the system in the SEE fully-funded pension systems. In fact, it is 
1138 36 $6^{\text {Th }}$ International Conference on Organizational Science Development: Responsible ORGaNiZATION (MARCH $22^{\mathrm{ND}}-24^{\mathrm{TH}}$, PortoroŽ SlOVENIA)

P. Taleski \& V. Bogdanovski: Implementation of Benchmarks in Investment

Strategies of Pension Funds in SEE Region

known that on these markets usually there are few mandatory (Macedonia, Croatia) and few voluntary funds (all the countries in SEE) and it points to the fact that it cannot form a large group of related peer group funds. We could consider establishing a peer group of pension funds that exist in countries that have similar systems. However, in that situation we are faced with the fact of having different regulations regarding the investment activities of the pension companies that vary from country to country. For this reason it is necessary to make adjustments to the average that would be calculated for the peer group and to adjust the rate of each country. For this purpose it is needed to obtain additional information and create calculations that would have a relatively large dose of subjectivity. Therefore, the introduction of a benchmark based on peer group of funds could not be suitable to be the case for the operation of the pension funds in the SEE countries.

2. Many pension companies set benchmarks for the pension funds that they manage, which have to be achieved all the period of existence of the pension fund. That target is usually set in order to overcome the inflation rate. Usually, setting these targets has a great deal of relativity. The inflation rate does not correspond with the growth of the necessities of the population (with same electricity prices today and twenty years ago, the consumption of electricity increases in average household due to the increasing needs of the population - use of new types of electronical appliances). For these reasons, inflation in this context may not represent an adequate benchmark.

3. In this context, using the benchmark for pension funds in SEE countries would have to be index-based, based and created essentially on a methodology that would be most suitable for the conditions in which those pension funds now exist. For the operations of the pension funds it is suitable to create synthetic benchmark based on the principle of tailor made creation, which would involve a weighted average of the share of individual categories of investments within the portfolio. Benchmark, technically designed and based on the involvement of all the available securities is possible but not practical. Therefore, more appropriate is the benchmark based on the weighted average of the groups of instruments included in the portfolio in the appropriate weight according to the investment strategy of the funds. Benefits of using this kind of benchmark should be noted in the context of the existence of multi-funds and the principle of a benchmark based on a weighted average therefore would be most appropriate exactly where such systems of multi funds are introduced. The conclusion is that this type of benchmarks meets all the properties should have a benchmark.

Example of benchmark based on these characteristics is presented in formula:

Excess return on the fund $=\alpha+\beta(1) \times$ return from shares index from domestic market + $\beta(2) \times$ return from bonds index from domestic market $+\beta(3) \times$ return from share index from foreign markets $+\beta(4) \times$ return from bonds index from foreign markets $+\beta(5) \times$ average return of deposits 


\begin{tabular}{|l|c|c|c|}
\hline Type of benchmark & $\begin{array}{c}\text { Fixed } \\
\text { benchmark } \\
\text { (inflation }+ \text { X } \\
\text { pp) }\end{array}$ & $\begin{array}{c}\text { Peer group } \\
\text { benchmark }\end{array}$ & $\begin{array}{c}\text { Multi index } \\
\text { benchmark }\end{array}$ \\
\hline Clear / unambiguous & $\checkmark$ & $\checkmark$ & $\checkmark$ \\
\hline Investable & 区 & $\checkmark$ & $\checkmark$ \\
\hline Measurable & $\checkmark$ & $\checkmark$ & $\checkmark$ \\
\hline Appropriate & $\square$ & $\checkmark$ & $\checkmark$ \\
\hline $\begin{array}{l}\text { Reflection on current } \\
\text { investment } \\
\text { opportunities }\end{array}$ & $\checkmark$ & $\checkmark$ & $\checkmark$ \\
\hline Specified in advance & $\square$ & $\square$ & $\checkmark$ \\
\hline Owned & & $\square$ & $\checkmark$ \\
\hline
\end{tabular}

Table 1: Aspects of represents fair and relevant benchmark for comparing performance

\section{Literature}

Antolín, P., Payet, S., Whitehouse, E. R., \& Yermo, J. (2011). The role of guarantees in defined contribution pensions. OECD Working Papers on Finance, Insurance and Private Pensions, (11), 1 .

Bailey, J. V., Richards, T. M., \& Tierney, D. E. (2007). Evaluating portfolio performance. Managing Investment Portfolios: A Dynamic Process, 717-782.

Blake, D., \& Timmermann, A. (2002). Performance benchmarks for institutional investors: Measuring, monitoring and modifying investment behaviour. Performance Measurement in Finance: Firms, Funds and Managers, 108-141.

Brinson, G. P., Singer, B. D., \& Beebower, G. L. (1991). Determinants of portfolio performance II: An update. Financial Analysts Journal, 40-48.

Fabozzi, F. J. (Ed.). (1997). Pension fund investment management (Vol. 25). John Wiley \& Sons.

Ferson, W. E., \& Warther, V. A. (1996). Evaluating Fund Performance in a Dynamic Market (Digest Summary). Financial Analysts Journal, 52(6), 20-28.

Grinblatt, M., \& Titman, S. (1989). Portfolio performance evaluation: Old issues and new insights. Review of Financial Studies, 2(3), 393-421.

Rudolph, H., Hinz, R., Antolin, P., \& Yermo, J. (2010). Evaluating the financial performance of pension funds. Evaluating the Financial Performance of Pension Funds, 1.

Severinson, C., \& Stewart, F. (2012). Review of the swedish national pension funds. 
1140 36 ${ }^{\text {TH }}$ International Conference on Organizational Science Development: Responsible Organization (March $22^{\mathrm{ND}}-24^{\mathrm{TH}}$, Portorož Slovenia) 
$36^{\mathrm{TH}}$ InTERnational CONFERENCE ON ORganizational SCIENCE Development: Responsible Organization (MARCh $22^{\mathrm{ND}}-24^{\mathrm{TH}}$, PORTOROŽ SLOVENIA)

O. Arsenijević, M. Ferjan, I. Podbregar, P. Šprajc, D. Trivan \& Y. Ziegler

\title{
Predictive Maintenance Model for Automotive Production Line
}

\author{
JAKA TOMAN, VLADISLAV RAJKOVIČ \& MIRJANA KLJAJIĆ BORŠTNAR
}

\begin{abstract}
In this paper a predictive maintenance model for a real-life production line cell is introduced. Lean production trends and rising availability of data brings opportunities on the fields of maintenance. We have used machine learning methods to develop a model for predictive maintenance. Classification tree method was used as a training method. Model was developed in a machine learning and visual programming software Orange. Our model for predictive maintenance is able to successfully predict the outcome of a crimping production process in a production line. Predictions of fault pieces can be a trigger to maintenance department for initiation of maintenance process. Model provides a possibility to input new actual data for which predictions are made. At the end of this paper we have determined possible next steps in model implementation.
\end{abstract}

KEYWORDS: predictive maintenance $\bullet$ machine learning $\bullet$ manufacturing $\bullet$ smart factory

CORRESPONDENCE AdDRESS: Jaka Toman, University of Maribor, Faculty of Organizational Sciences, Kidričeva cesta 55a, 4000 Kranj, Slovenia, e-mail: jaka.toman@gmail.com; Vladislav Rajkovič, Ph.D., Professor Emeritus, University of Maribor, Faculty of Organizational Sciences, Kidričeva cesta 55a, 4000 Kranj, Slovenia, e-mail: vladislav.rajkovic@gmail.com; Mirjana Kljajić Borštnar, Ph.D., Assistant Professor, University of Maribor, Faculty of Organizational Sciences, Kidričeva cesta 55a, 4000 Kranj, Slovenia, e-mail: mirjana.kljajic@ fov.uni-mb.si 
1142 36 $6^{\text {Th }}$ International Conference on Organizational Science Development: Responsible Organization (MARCH $22^{\mathrm{ND}}-24^{\mathrm{TH}}$, Portorož SlOVENIA)

J. Toman, V. Rajkovič \& M. Kljajić Borštnar: Predictive Maintenance Model for

Automotive Production Line

\section{$1 \quad$ Introduction}

Production for automotive industry requires on one hand high quality products and on the other hand lean and low cost production. Such high demands can difficulty be met with traditional approaches. When addressing production cost reduction, maintenance costs should also be considered.

Literature recognizes different maintenance approaches (Chapin, 2000). Endrenyi (2001) defines four methods of maintenance in manufacturing: Manufacture's Specifications, Replacement, Scheduled Maintenance and Predictive Maintenance. Companies use different maintenance methods, two of the most important are corrective and preventive maintenance (Beebe, 2004). Corrective maintenance refers to the maintenance conducted after device fault. That is the main disadvantage of this method because the fault has occurred and loss has already been induced. In preventive maintenance, the maintenance is conducted based on the artificially prescribed maintenance cycle (Jamil et al., 2013). Machine breakdowns are understood as downtime needed for corrective and preventive maintenance activities. They occur randomly and are common to all classes of manufacturing systems (Charlot, Kenne, \& Nadeau, 2007). In order to lower maintenance cost companies are implementing methods of predictive maintenance (PM) into their processes. Recent studies have shown that high reliability and performance can be achieved when using PM approach (Mungani \& Visser, 2013).

PM anticipates the damage in the future. It can be periodic with fixed time intervals or predictive with forecasted failure times. We talk about intelligent PM when maintenance is predicted and optimised. Intelligent maintenance systems require data collection, data transfer, data storage, data processing and decision support system (Sirvio, 2015). The opportunities of PM are increasing with increasing availability of data and that is changing the way decisions are taken in companies (GE Intelligent Platroms, 2016).

Machine learning (ML) approaches have been shown to provide increasingly effective solutions in these areas, facilitated by the growing capabilities of hardware, cloud-based solutions, and newly introduced state-of-the-art algorithms (Susto, Schirru, Pampuri, McLoone, \& Beghi, 2015). ML is found most suitable for dealing with modelling of highdimensional problems (Lenz \& Barak, 2016). Such problems are arising in manufacturing companies where hundreds or thousands of physical variables (pressures, voltages, currents, length, etc.) influence the production process.

This paper introduces a real-life scenario in production company Iskra Mehanizmi, d.o.o (IM) which is a developer and producer of complex mechatronic solutions for automotive industry. We focused on the maintenance aspect of a production line with a goal to make a model for predictive maintenance with help of ML. 


\section{$2 \quad$ Methodology}

\subsection{Problem identification}

In the initial state, we had a meeting with director of production in IM. He suggested using ML for the purpose of PM. Then we had a meeting with chief of maintenance and the opportunity to make PM model with usage of tools for ML was presented to him. We then arranged a workshop with him and his co-workers. They proposed to make predictive maintenance model for a part of highly automated production line which produces adaptive cruise control actuators that are built in Tesla, Mercedes, Audi, BMW and Hyundai cars. This production line stores vast range of process and product parameters. Within this production line is a production cell where machine performs motor crimping. Crimping is done in two steps. First, machine crimps the motor. Then the motor is turned and crimped again. Two most important parameters with crimping are force and distance. Those two parameters are saved to the database before each crimping. At the end of this production cell a camera inspects the final product. If there is a fault on the product, machine eliminates that product. Data is saved accordingly. The aim of this research paper is to predict when the crimping machine has to be maintained in order to avoid producing fault products.

At the beginning we set the process of applying ML to real-world problem as Kotsiantis (2007) describes in Image 1. 
1144 36 $6^{\mathrm{TH}}$ INTERnational CONFERENCE ON ORganizational SCIENCE DeVElopment: Responsible Organization (MARCH $22^{\mathrm{ND}}-24^{\mathrm{TH}}$, PortoroŽ SlOVENIA)

J. Toman, V. Rajkovič \& M. Kljajić Borštnar: Predictive Maintenance Model for Automotive Production Line

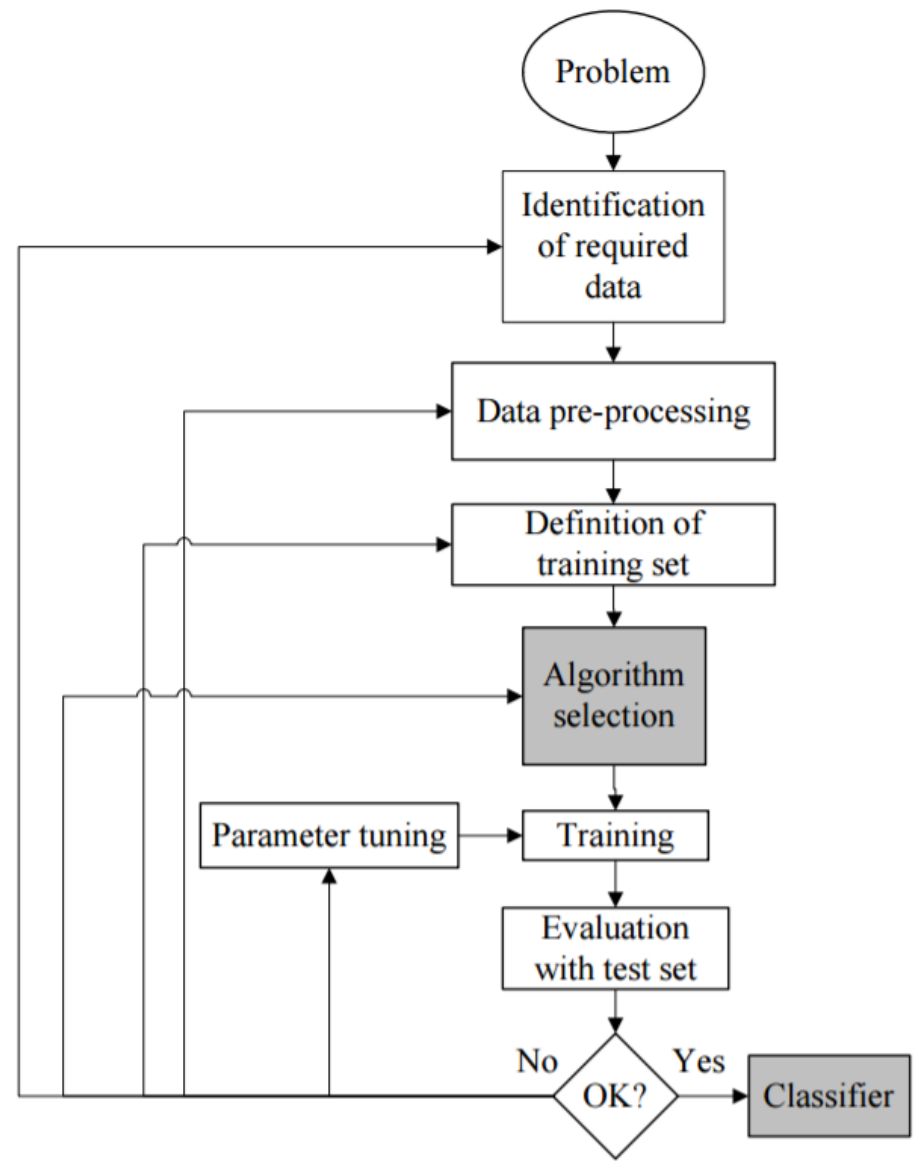

Image 1: Process of ML (Kotsiantis, 2007)

In the first step, we defined the problem. In second step, we retrieved data for the past four months. Data was retrieved from Mehadigger database. Mehadigger is a custommade system for IM. By its functionality, it covers the MES Historian function. It stores process and product parameters for each piece individually.

Therefore, we pre-processed the data so it only contained parameters that are relevant for our model. We found no missing data so no procedures to handle missing data was used. We imported the data into a software called Orange which is a ML and data mining suite for data analysis (Demšar et al., 2013).

In this software, we built a model based on supervised machine learning (Image 2). The goal of a supervised learning algorithm is to take some data with a known relationship and to create a model of those relationships. In our case the output is a category therefore 
we call this type of problem a classification problem. If the output was a numerical value, we would call it a regression problem. The algorithm then does the learning. The model contains the learned relationships (Jason Brownlee, 2015).

We chose the Classification Tree learning method since this works well for pattern recognition and process control (Chiang, Yung, \& Hsu, 2002). Since choosing learning algorithm is a crucial step in building a model we included evaluation of prediction's accuracy into the model.

\section{$3 \quad$ Results}

The result was the model for predictive maintenance built in Orange software (Image 2).

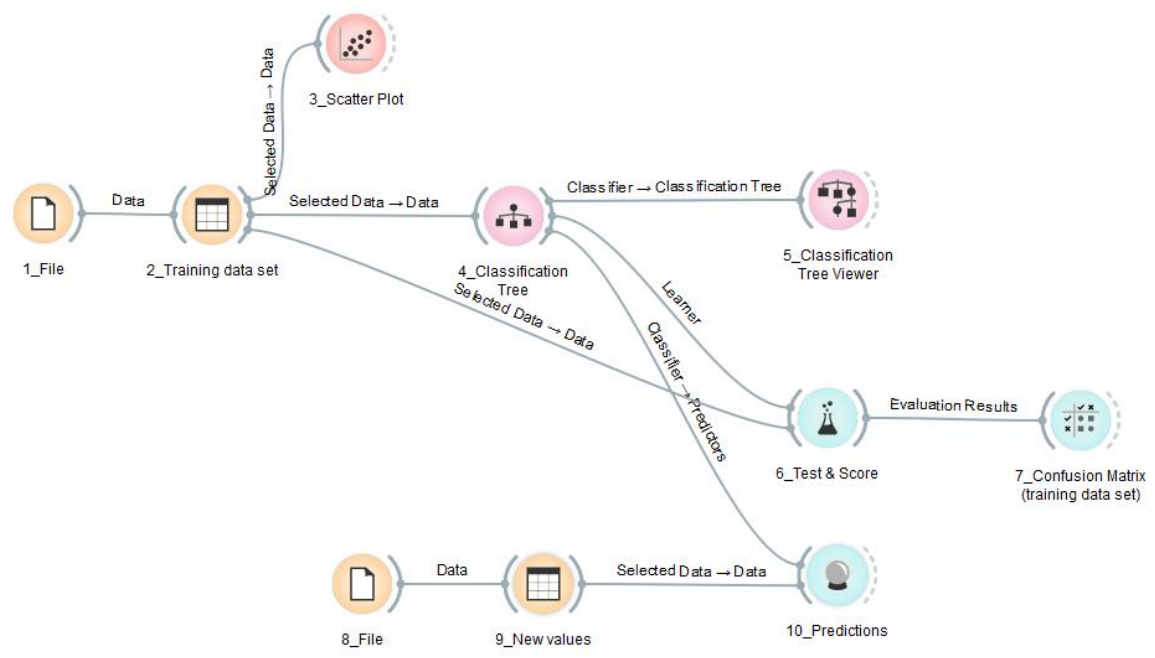

Image 2: Model for ML in Orange

First we retrieved data for the past four months, from 01.07.2016 to 01.12.2016. Data was retrieved from Mehadigger database. We retrieved 19.078 records. Each record represents individual piece (product) produced on the production line. For each record, there is 45 different parameters saved. For our model, we only need five parameters:

- Product status (PASS, FAIL)

- Crimping force 1

- Crimping distance 2

- Crimping force 2

- Crimping distance 2 
1146 36 $36^{\mathrm{TH}}$ International CONFERENCE ON ORganizational SCIENCE Development: RESPONSIBLE ORGANIZATION (MARCH $22^{\mathrm{ND}}-24^{\mathrm{TH}}$, PORTOROŽ Slovenia)

J. Toman, V. Rajkovič \& M. Kljajić Borštnar: Predictive Maintenance Model for

Automotive Production Line

Then we used widgets File and Data Table. Widgets are building blocks of data analysis workflows that are assembled in Orange's visual programming environment (Demšar et al., 2013). In File widged we uploaded .csv file. We used Data Table widget for tabular display of data. Because we use this data to train our classifier we name this traning data set. We also used Scatter Plot widget to visulize the training data set.

As a learning algorithm Classification tree widget was used. We set minimal instances in leaves to 2, stoped splitting nodes with less instances than 5 and limit the depth to 100 as shown in Image 3.

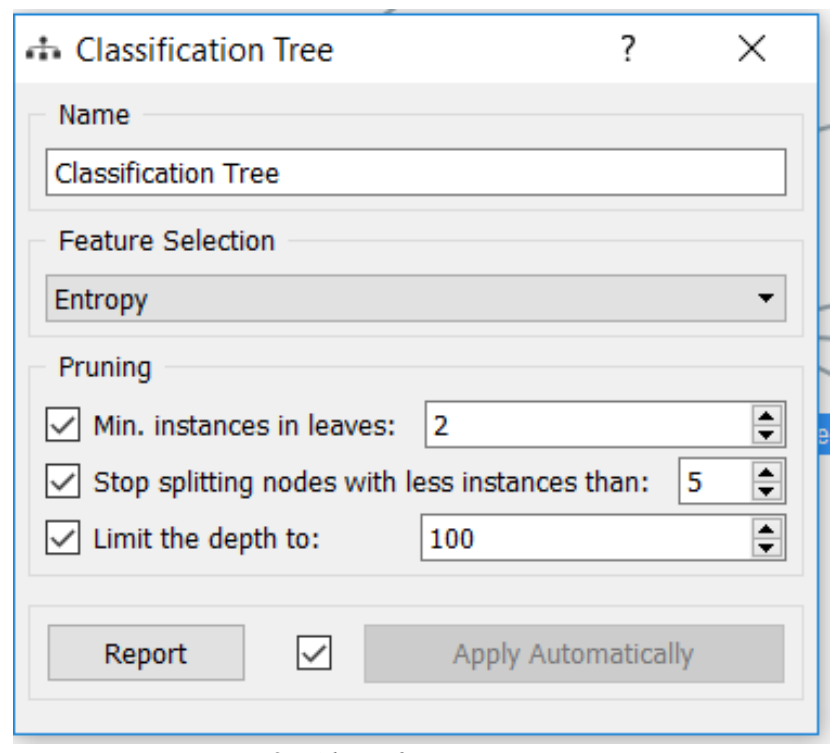

Image 3: Classification tree settings

We used Classification Tree Viewer to visualize the classification tree. We visualized which feature best splits the data to subsets where one of the classes prevails.

In the next step, we used widget Test \& Score to make cross validation and calculate average accuracy. Training data was split in ten subsets, using nine subsets for training the model and one for testing it. This procedure was repeated nine times, each time using different subset for testing.

The results obtained by this study are shown in Image 4. Classification accuracy (CA) was $98,5 \%$ which represents the proportion of correctly classified data instances. F1 represents weighted harmonic mean of precision and recall. Value of that result was $99,2 \%$. Precision valued at $98,6 \%$ and represents the proportion of true positives among instances classified as positive. Value in Recall column represents the proportion of true positives among all positive instances in the data and was $98,5 \%$. 
Evaluation Results

\begin{tabular}{|c|c|c|c|c|c|}
\hline Method & AUC & CA & F1 & Precision & Recall \\
\hline lassifica & 38 & 0.985 & 0.992 & 0.986 & 0.985 \\
\hline
\end{tabular}

Image 4: Validation results

To check $1,5 \%$ of data which was falsely classified we used widget Confusion Matrix. As shown in Image 5, model accurately classified 99,1\% instances to be good pieces. It was less successful at predicting fault pieces were $68,7 \%$ instances were accurately classified.

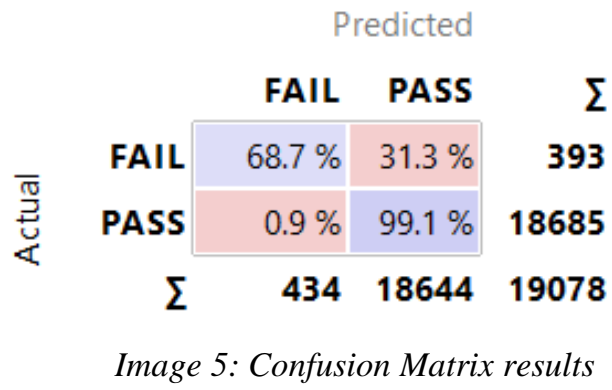

After conducting this steps, our model has successfully learned to classify good and fault pieces with a degree of accuracy on the basis of training data set.

In the next phase of our model we enabled an input for new data and prediction whether the piece will be good or fault. Again, we used File and Data Table widget. We created a .csv file with ten random instances from training data set. First eight data instances had Product status PASS, last two had Product status FAIL. We uploaded this file in widget File. Next used widget is Predictions. This widget is also connected to Classification tree from where it gets the acquired knowledge. As show in Image 6 the data set had no PASS/FAIL status. As seen on the left, the model predicted that first eight instances would have product status PASS, last two would have status FAIL. We have repeated this procedure 10 times with different data. Predictions of each repetition were respectively correct. 
1148 36 $6^{\mathrm{TH}}$ INTERNATIONAL CONFERENCE ON ORganizational SCIENCE DEVElopment: Responsible Organization (MARCH $22^{\mathrm{ND}}-24^{\mathrm{TH}}$, PortoroŽ SlOVENIA)

J. Toman, V. Rajkovič \& M. Kljajić Borštnar: Predictive Maintenance Model for

Automotive Production Line

\begin{tabular}{l|l||l|l|l|l|l|l|} 
& Classification Tree & S35Productstatus & S35Timestamp & \multicolumn{2}{c|}{ Data Forct } & ata Distal & Data Forct ta Disti \\
\hline 1 & PASS & $?$ & $2016-12-1406: 33: 20$ & 4536.000 & 4.118 & 4506.000 & 4.119 \\
\hline 2 & PASS & $?$ & $2016-12-1506: 33: 20$ & 4542.000 & 4.122 & 4559.000 & 4.124 \\
\hline 3 & PASS & $2016-12-1606: 33: 20$ & 4565.000 & 4.124 & 4500.000 & 4.121 \\
\hline 4 & PASS & $?$ & $2016-12-1706: 33: 20$ & 4545.000 & 4.117 & 4503.000 & 4.115 \\
\hline 5 & PASS & $?$ & $2016-12-1806: 33: 20$ & 4521.000 & 4.115 & 4542.000 & 4.116 \\
\hline 6 & PASS & $?$ & $2016-12-1906: 33: 20$ & 4509.000 & 4.131 & 4524.000 & 4.132 \\
\hline 7 & PASS & $?$ & $2016-12-2006: 33: 20$ & 4551.000 & 4.132 & 4539.000 & 4.132 \\
\hline 8 & PASS & $?$ & $2016-12-2106: 33: 20$ & 4515.000 & 4.133 & 4539.000 & 4.135 \\
\hline 9 & FAIL & $?$ & $2016-12-2206: 33: 20$ & 4544.000 & 4.165 & 4577.000 & 4.165 \\
\hline 10 & FAIL & $2016-12-2306: 33: 20$ & 4509.000 & 4.181 & 4562.000 & 4.183 \\
\hline
\end{tabular}

Image 6: Prediction results

\section{Discussion}

Our model for PM has successfully learned from training data set. Some implicit, previously unknown and useful information were found in the data. With its ability to predict whether the product will be good or fault, model can now be implemented and used in a predictive maintenance. In a situation when a model predicts a fault piece this can be a direct trigger to maintenance department. Maintenance department can perform appropriate procedures to return the machine back to its optimal state. That provides the possibility to avoid producing potentially fault pieces. Here we are only referring to fault pieces that would be made because of crimping machine problems.

Also, by replacing corrective and preventive maintenance with PM, we estimate that less time could be spent for maintenance. Mobley (2002) describes that cost associated with maintenance operation could be reduced by up to $50 \%$. With this model we have shown there are opportunities and tools available to make PM models and to harvest ML benefits. Since our model was only built on real-life data, implementation in actual production was not yet made. It is important to analyse the whole production line before implementation. PM model implemented only in one production cell would bring little benefit.

This model is a first of its kind for IM. Next step would be a presentation of this model to responsible maintenance employees. It is important to show what can be done and what cannot be done with tools for ML, with our model for PM. People who are daily involved in maintenance would be capable to determine where such model could also be used. In our experience, it is also very important to define a generic solution for implementation. This means a generic interface between data source and this prediction model. That could be one of the topics for further research.

The model only uses one machine learning algorithm. Research in the field of optimal algorithm selection would also be suggested for further work and possible improvements of this model. 
This model is expected to play an important role in IM project Smart factory 2020. For IM our model is an example that introduces PM and ML to the company and opens a wide range of possible implications.

\section{Literature}

Beebe, R. S. (2004). Predictive maintenance of pumps using condition monitoring. Elsevier Advanced Technology.

Chapin. (2000). Do we know what preventive maintenance is? In Proceedings International Conference on Software Maintenance ICSM-94 (pp. 15-17). IEEE Comput. Soc. Press. https://doi.org/10.1109/ICSM.2000.882970

Charlot, E., Kenne, J. P., \& Nadeau, S. (2007). Optimal production, maintenance and lockout/tagout control policies in manufacturing systems. Int. J. Production Economics, 107, 435-450. https://doi.org/10.1016/j.ijpe.2006.09.017

Chiang, I.-J., Yung, J., \& Hsu, -Jen. (2002). Fuzzy classiÿcation trees for data analysis. Fuzzy Sets and Systems, 130, 87-99. Retrieved from www.elsevier.com/locate/fss

Demšar, J., Curk, T., Erjavec, A., Hočevar, T., Milutinovič, M., Možina, M., ... Zupan, B. (2013). Orange: Data Mining Toolbox in Python. Journal of Machine Learning Research, 14, 23492353.

Endrenyi, J., Aboresheid, S., Allan, R. N., Anders, G. J., Asgarpoor, S., Billinton, R., ... Singh, C. (2001). The present status of maintenance strategies and the impact of maintenance on reliability. IEEE Transactions on Power Systems, 16(4), 638-646. https://doi.org/10.1109/59.962408

GE Intelligent Platroms. (2016). The Rise of Industrial Big Data. Retrieved December 11, 2016, from

http://leadwise.mediadroit.com/files/19174the_rise_of_industrial_big_data_wp_gft834.pdf

Jamil, I., Jamil, R., Jinquan, Z., Ming, L., Dong, W. Y., \& Jamil, R. (2013). Condition-Based Maintenance Decision-making Support System (DSS) of Hydropower Plant. International Journal of Innovation and Applied Studies, 4(3), 593-602.

Jason Brownlee. (2015). Gentle Introduction to Predictive Modeling. Retrieved December 13, 2016, from http://machinelearningmastery.com/gentle-introduction-to-predictive-modeling/

Kotsiantis, S. B. (2007). Supervised Machine Learning: A Review of Classification Techniques. Informatica, 31, 249-268.

Lenz, B., \& Barak, B. (2016). Data Mining and Support Vector Regression Machine Learning in Semiconductor Manufacturing to Improve Virtual Metrology. 2014 47th Hawaii International Conference on System Sciences, 0, 3447-3456. https://doi.org/10.1109/HICSS.2013.163

Mobley, R. K. (2002). 4 - Benefits of Predictive Maintenance. In An Introduction to Predictive Maintenance (pp. 60-73). https://doi.org/10.1016/B978-075067531-4/50004-X

Mungani, D. S., \& Visser, J. K. (2013). MAINTENANCE APPROACHES FOR DIFFERENT PRODUCTION METHODS. South African Journal of Industrial Engineering, 24(3), 1-13.

Sirvio, K. M. (2015). Intelligent Systems in Maintenance Planning and Management (pp. 221245). https://doi.org/10.1007/978-3-319-17906-3_10

Susto, G. A., Schirru, A., Pampuri, S., McLoone, S., \& Beghi, A. (2015). Machine learning for predictive maintenance: A multiple classifier approach. IEEE Transactions on Industrial Informatics, 11(3), 812-820. https://doi.org/10.1109/TII.2014.2349359 
1150 36 ${ }^{\text {Th }}$ International Conference on Organizational Science Development: Responsible Organization (March $22^{\mathrm{ND}}-24^{\mathrm{TH}}$, Portorož Slovenia) 
36. MEDNARODNA KONFERENCA O RAZVOJU ORGANIZACIJSKIH ZNANOSTI: ODGOVORNA ORGANIZACIJA (22. - 24. MAREC 2017, PORTOROŽ, SLOVENIJA)

O. Arsenijević, M. Ferjan, I. Podbregar, P. Šprajc, D. Trivan \& Y. Ziegler

\title{
Slovensko španski Poslovni klub ECE Club de Negocios ECE España Canarias Eslovenia
}

\author{
MLADEN TOMAŠIČ
}

Povzetek Slovensko španski poslovni klub v Španiji kot pomoč pri internacionalizaciji in servis gospodarstvu. Pravna oblika, glavne dejavnosti, cilji in namen. Dosedanji dosežki in aktivnosti. Izzivi v prihodnosti. Članstvo v poslovnem klubu je brezplačno, toda obvezno za obojestransko sodelovanje. Individualni razgovori preko mobilne pisarne. Posebnosti Kraljevine Španije in kako se soočiti z njimi. Poslovni običaji. Razpoznavnost Slovenije v Španiji. Kako poslovati v Španiji. Kjuč za uspeh je kakovostna mreža poslovnih stikov in natančna usmeritev. Dragocena izmenjava izkušenj $\mathrm{z}$ ostalimi slovenskimi in španskimi poslovnimi klubi po svetu. Pri prodoru na španski trg najem domačega manegerja ni strošek. Priporočljiva predhodna raziskava trga in izdelava poslovnega načrta. Katero obliko podjetja uporabiti, da bodo koristi večje od bremena, predstavništvo, hčerinsko podjetje ali podružnico. Plačilna disciplina na španskem trgu. Vspostavitev prvih stikov na tem trgu in pomembnost osebnih stikov. Priložnost za mlade raziskovalce in podjetnike, predvsem za start - up podjetja z izdelanim poslovnim modelom. Poslovni klub start - up podjetjem svetuje in sodeluje pri pridobitvi subvencij, najemu pisarn, laboratorijev, zemljišč in vseh potrebnih dokumentov in dovoljenj. Priporočljivo znanje španskega jezika, v nasprotnem zadostuje angleščina. Španske multinacionalke so zahtevne, a priložnost je velika. Slovenski izdelki in storitve so zanimivi za španski trg. S pomočjo španskih podjetij hitreje na trge Južne in Srednje Amerike in Zahodne Afrike. Sodelovanje poslovnega kluba z Veleposlaništvom Republike Slovenije v Madridu, konzularnimi predstavništvi, ostalimi številnimi institucijami in uradi v obeh državah in $\mathrm{z}$ Medobčinsko pobudo: Čezmejno e-sodelovanje v e-regiji.

KLJUČNE BESEDE: poslovni klub • španski trg • podjetništvo • mladi raziskovalci $\bullet$ start - up podjetja $\bullet$ e-sodelovanje.

\footnotetext{
NAslov AVtoRJA: mag. Mladen Tomašič, predsednik, Fañabé Mar Canarian Investments S.L., Club de Negocios ECE, ES-38650 Los Cristianos, S/C Tenerife, Španija, e-pošta: clubdenegocios.ece@gmail.com
} 


\title{
Slovenian Spanish Business Club ECE España Canarias Eslovenia
}

\author{
MLADEN TOMAŠIČ
}

\begin{abstract}
The Slovenian-Spanish business club in Spain as a means of helping internationalisation and servicing the economy. Legal form, main activities, goals, and purpose. Achievements and activities to date. Future challenges. Membership of the business club is free, but essential for bilateral cooperation. Individual discussions via a mobile office. The particularities of the Kingdom of Spain and how to tackle them. Business customs. Visibility of Slovenia in Spain. How to conduct business in Spain. The key to success is a wide network of business contacts and accurate targeting. Invaluable exchange of experience with other Slovenian and Spanish business clubs around the world. When penetrating the Spanish market, hiring a local manager should not be considered an expense. Prior market research and preparation a business plan are recommended. What form of company should be used in order to have a good benefit to cost ratio: representative office, subsidiary or branch. Payment discipline on the Spanish market. Establishing first contacts in this market and the importance of personal contacts. An opportunity for young researchers and entrepreneurs, especially for start-ups with a business model. The business club advises start-ups and helps with obtaining subsidies, renting office space, laboratories, and land as well as with obtaining all the necessary documents and permits. Knowledge of Spanish is recommended, but English will suffice. Spanish multinationals are demanding, but represent a very good opportunity. The Spanish market is interested in Slovenian services and products. Spanish companies can help with faster placement on South and Central American, as well as West African, markets. The business club collaborates with the Embassy of the Republic of Slovenia in Madrid, with consular offices, and other institutions and offices in both countries and Inter Municipality Intiative: Cross border eCollaboration in the eRegion.
\end{abstract}

KEYWORDS: business club • Spanish market • entrepreneurship • young researchers $\bullet$ start-ups $\bullet$ eCollaboration

CORRESPONDENCE ADDRESS: Mladen Tomašič, M.S., President, Fañabé Mar Canarian Investments S.L., Club de Negocios ECE, ES-38650 Los Cristianos, S/C Tenerife, Espania, e-mail: clubdenegocios.ece@gmail.com

DOI https://doi.org/10.18690/978-961-286-020-2.92

ISBN 978-961-286-020-2

(C) 2017 University of Maribor Press

Available at: http://press.um.si 


\section{$1 \quad$ Slovensko španski poslovni klub v Španiji}

Slovenski poslovni klubi v tujini so pomoč pri internacionalizaciji, so glas in servis slovenskega gospodarstva in podjetništva. Slovensko španski poslovni club ECE (Club de Negocios ECE - España Canarias Eslovenia; špansko), ustanovljen leta 2011 je profitna organizacija, ki ni podprta s strani SPIRIT Slovenija, Ministrstva za gospodarski razvoj in tehnologijo, Gospodarske Zbornice Slovenije ali katerekoli druge državne institucije. Poslovni klub deluje znotraj španskega podjetja Fañabé Mar Canarian Investments S.L., kratko FMCI S.L., ki je bilo ustanovljeno leta 2007 in je v stoodstotni slovenski lasti (Registro de Bienes Muebles, 2016). Namen pobude za ustanovitev prvega slovensko španskega poslovnega kluba v Španiji v letu 2011 in do sedaj še edinega tovrstnega slovenskega poslovnega kluba v Kraljevini Španiji, je bila povezava skupnih interesov slovenskih in španskih gospodarstvenikov in podjetnikov, ki so želeli poglobiti in razširiti bilateralno gospodarsko sodelovanje med obema državama (Cámara de Comercio de España, 2016; Cámara de Comercio de Santa Cruz de Tenerife, 2016; Cámara de Comercio de Las Palmas de Gran Canaria, 2016). Poslovni klub ECE uspešno sodeluje z Veleposlaništvom Republike Slovenije $\mathrm{v}$ Madridu in konzularnimi predstavništvi Republike Slovenije v Španiji. Z ustanovitvijo poslovnega kluba se tako gospodarstvenikom, podjetnikom, obrtnikom in fizičnim osebam ponuja možnost za osvajanje gospodarskega poslovnega prostora in nastopa na španskih trgih ter prav tako na trgih Južne in Srednje Amerike ter Zahodne Afrike. Poslovni klub opravlja svoje redne naloge in operativne aktivnosti skozi vse tekoče leto. Delo teče kontinuirano. Obseg dela se iz leta v leto povečuje. Redno delovanje poslovnega kluba je odvisno od pridobljenih lastnih finančnih sredstev. Poslovni klub ima pozitiven odnos do povezovanja z matično domovino, je popolnoma in v celoti nepolitičnega značaja. Članstvo v poslovnem klubu je brezplačno, toda obvezno za obojestransko sodelovanje. Medsebojne aktivnosti se dogovorijo s pogodbo o poslovnem sodelovanju.

\subsection{Glavne dejavnosti in namen poslovanja}

Navezovanje neformalnih in formalnih kontaktov med slovenskimi in španskimi vladnimi institucijami in ostalimi ustanovami obeh držav. Nudenje pomoči pri navezavi stikov s potencialnimi poslovnimi partnerji, povezovanje gospodarstvenikov in podjetnikov ter pospeševanje podjetništva. Promoviranje slovenskega gospodarstva. Raziskovalno podjetništvo, podjetniško svetovanje, marketinške in tržne storitve. Storitve razvoja, raziskav in znanosti $\left({ }^{1}\right)$ na organizacijskih, ekonomskih in tehničnih področjih. Sodelovanje pri realizaciji skupnih projektov. Seznanjanje španske poslovne javnosti o slovenskem poslovnem okolju, slovenskih ustreznih institucijah in podjetij o poslovnih dogodkih in njihovih spremembah v poslovnem okolju, v katerem poslovni klub deluje. Organizacija srečanj, izobraževalnih in informacijskih sestankov. Informiranje članov o medsebojnih recipročnih gospodarskih in davčnih zadevah. Ponudba storitev je osnovana tudi na tako imenovani "plug in office«, posebni pisarni v prostorih poslovnega kluba, katero lahko slovenska podjetja uporabljajo po dogovoru za določen čas. (Interno gradivo Club de Negocios ECE, 2016). 
36 ${ }^{\mathrm{TH}}$ InTernational Conference on ORganizational SCIENCE Development: Responsible Organization (MARCh $22^{\mathrm{ND}}-24^{\mathrm{TH}}$, Portorož Slovenia)

M. Tomašič: Slovenian Spanish Business Club ECE España Canarias Eslovenia

\subsection{Prednosti}

Poslovni klub predstavlja medresorsko podjetniško organizacijo, ki pokriva področja gospodarskega poslovanja in nudi s svojimi storitvami celovito paleto storitev za podjetnike, ki želijo aktivno sodelovati na španskem tržišču. Poznavanje poslovnega okolja na celini Španije, na Kanarskem in Balearskem otočju ter dveh španskih enklavah v Afriki, Melilla in Ceuta. Dostop do najvišjih vladnih in gospodarskih nosilcev odločanja v Sloveniji in Španiji. Dobro poznavanje španskega makro in mikro okolja. Reference s področja gospodarstva, podjetništva in financ. Izobražen, izkušen in strokoven kader. Pomoč slovenskim podjetjem pri oceni tržnega potenciala ter pri izdelavi strategije vstopa na trg. Posredovanje in interpretacija informacij novo uvedenih regulacijskih norm v Španiji, iskanje sodelovanja z regulacijskimi organi. Pridobivanje informacij za slovenska podjetja pri sodelovanju $\mathrm{v}$ španskih poslovnih združenjih $\mathrm{z}$ namenom mreženja in lobiranja za lastne interese. Transparenten pregled odprtih razpisov za nepovratna sredstva EU. Sodelovanje z referenčnimi španskimi univerzami, Madrid, Barcelona, Universidad de La Laguna Santa Cruz de Tenerife $\left({ }^{2}\right)$. Izmenjava izkušenj z drugimi slovenskimi in španskimi poslovnimi klubi po različnih državah sveta. (Interno gradivo Club de Negocios ECE, 2016).

\subsection{Cilji}

Poslovno sodelovanje med slovenskimi in španskimi podjetji, $\mathrm{v}$ obliki krepitve medsebojne gospodarske dejavnosti, $\mathrm{z}$ možnostjo sodelovanja mladih slovenskih strokovnjakov in znanstvenikov na različnih znanstvenih in strokovnih področjih. Medsebojno povezovanje Slovencev živečih v Španiji ter s tem ohranjanje in utrjevanje narodne, kulturne, duhovne, socialne, športne in jezikovne identitete. Poslanstvo poslovnega kluba je pomagati soustvariti konkurenčno prednost $\mathrm{z}$ dodano vrednostjo za slovenska podjetja na španskem gospodarskem in podjetniškem področju ter na povezovanju, skrbi in spoštovanju slovenskega človeka kot posameznika ali $\mathrm{v}$ skupini, (Interno gradivo Club de Negocios ECE, 2016).

\section{$1.4 \quad$ Aktivnosti}

Tržne raziskave za slovenska podjetja ob vstopu na španski trg in individualno svetovanje. Posredovanje poslovnih kontaktov, skrb za redne stike in izmenjave informacij med slovenskimi in španskimi podjetji. Navezovanje neformalnih stikov med podjetji in vladnimi institucijami obeh držav. Organizacija posvetov s pomembnimi državnimi regulatorji. Zbiranje in posredovanje informacij o slovenskem in španskem poslovnem okolju. Pomoč pri navezavi stikov s potencialnimi poslovnimi partnerji in skrb za privabljanje investitorjev iz Slovenije $\mathrm{v}$ Španijo in obratno. Promoviranje slovenskega in španskega gospodarstva. Seznanjanje slovenske poslovne javnosti $\mathrm{z}$ novimi aktivnostmi, zakonodajo in ostalimi zanimivostmi iz španskega poslovnega okolja. Pomoč, podpora, posredovanje poslovnih priložnosti, poslovne storitve in svetovanje za člane poslovnega kluba. Sodelovanje pri izvajanju španskih in evropskih projektov na področju obnovljivih virov energije, $s$ poudarkom na izgradnji sončnih elektrarn malih, srednjih in velikih moči. Strokovna 
pomoč pri nakupu, prodaji in financiranju na področju nepremičnin. Strokovna pomoč pri pridobitvi in ureditvi vseh vrst zahtevanih dokumentov za slovenske fizične in pravne osebe. Pomoč pri vključevanju mladih Slovencev v španske študijske, raziskovalne, razvojne in podjetniške procese. Organizacija poslovnih sestankov. Pravnim in fizičnim osebam poslovni klub ponuja možnost prijave na individualne razgovore preko mobilne pisarne in predlaga več različnih lokacij na območju Kanarskega arhipelaga, Melilla in Ceuta. Na območju celine Španije pa predhodno sklene dogovor $\mathrm{z}$ uzstreznim konzularnim predstavnikom. Predstavitev poslovanja, interes za nastop na španskem trgu, neposreden stik za pridobivanje informacij in pomoč pri uresničevanju svojih mednarodnih poslovnih načrov je tako hitrejša, neposredna in kvalitetnejša. (Interno gradivo Club de Negocios ECE, 2016).

\section{$2 \quad$ Kako poslovati v Španiji}

Španska industrija je razvita in tehnološko napredna. Na območju evra je četrto največje gospodarstvo, po klasifikaciji IMF pa štirinajsta gospodarska sila sveta. V povezavi s trgi Latino Amerike, Severne in Zahodne Afrike in mediteranskih držav zunaj EU, gre za ogromen trg v svetovnem merilu, $v$ katerem Španija uspešno deluje in je igralec številka ena. Dobro pozna poslovna okolja in sisteme, je eden največjih tujih investitorjev. Pred vstopom slovenskih podjetij na španski trg je potrebna predhodna temeljita priprava in ustrezno načrtovanje. V zadnjem obdobju je ponovno zaznati gospodarsko rast v Španiji, Slovenija pa ima pri medsebojnih gospodarskih odnosih še veliko rezerve. Španski trg je gotovo referenčen, ko uspeš na tem trgu, imaš odprta vrata tudi na drugih. Trg je zahteven, vendar transparenten. Pred nastopom na španskem trgu je priporočljivo, da slovenski izvozniki pripravijo kvaliteten izvozni načrt. Podjetnikom, ki želijo neposredno samostojno nastopati, pa izdelavo poslovnega načrta. Prevod izvoznega in poslovnega načrta $\mathrm{v}$ španščino je pogoj, prevod $\mathrm{v}$ angleščino pa priporočljiv. Slovenska podjetja lahko pridobijo osnovne informacije o delovanju na gospodarskem področju in dvostranskih odnosih med državama na Veleposlaništvu Republike Slovenije v Madridu, na Generalnem konzulatu Republike Slovenije v Barceloni, ki pokriva konzularno območje province Barcelona, Lleida, Tarragona, Girona, Castellon in Zaragoza, na Konzulatu Republike Slovenije v Sevilli, ki pokriva konzularno območje avtonomne pokrajine Andaluzija, na Konzulatu Republike Slovenije v San Sebastianu, ki pokriva konzularno območje avtonomnih pokrajin Baskija, Kantabrija, La Rioja in Navara. Za podjetniške "networking" informacije v Španiji prav tako uspešno deluje slovensko španski poslovni klub - Club de Negocios ECE, ki pokriva območje arhipelaga Kanarskih otokov (Confederación Provincial de Empresarios de Santa Cruz de Tenerife, 2016) in dveh španskih enklav v severozahodni Afriki, Mellila in Ceuta. Poslovni klub vzorno sodeluje z veleposlaništvom RS v Madridu in konzularnimi predstavništvi v Barceloni, Sevilli in San Sebastianu. Druga možnost za slovenska podjetja je najem španskega menedžerja ali katere od podjetniških svetovalnih agencij.

Temelji za uspešno podjetniško ekonomijo v Španiji so geografska lega, ki ponekod ponuja posebne davčne olajšave. Zgodovinska zapuščina. Živahna kulturna dejavnost in odlična infrastruktura. Odprtost za tuji kapital in investicije. Stroškovna in cenovna 
konkurenčnost. Multikulturno okolje. Podjetniška tradicija. Državna in regionalna podpora podjetjem. Pozitivno podjetniško razmišljanje in profesionalni odnos. Razvoj inovativnosti in tehnologije. Izobraževanje za podjetniško rast in razvoj. Visoka stopnja podjetniške kulture. Dosledno izvajanje sodobnih podjetniških znanj in izkušenj ter upoštevanje zakonov in predpisov. Visoko usposobljeni in konkurenčni človeški viri. Če slovenski podjetnik sebe najde v tem okviru, ima možnosti za uspeh. Skupen nastop na razpisih Svetovne banke in Evropske banke za obnovo in razvoj. Sodelovanje slovenskih in španskih podjetij pri projektih na tretjih trgih. Španija sodi med najuspešnejše države pri pridobivanju tovrstnih projektov in koriščenju evropskih sredstev. Skupno koriščenje španskega razpoložljivega kapitala za inovativne projekte. Prav tako obstajajo ugodnosti, ki jih ponujajo mnogoštevila ekonomska območja - ekonomske cone in po avtonomnih pokrajinah različne stopnje obdavčitve davka od dobička pravnih oseb in davka na dodano vredost. Kanarski arhipelag pozna eno samo stopnjo DDV, ki znaša 7 odstotka. Najnižja stopnja je v španski enklavi Melilla, le 4 odstotke. Odmisliti je potrebno zakoreninjene slovenske vzorce in sprejeti dejstvo, da nas je socializem naučil "kako se ne sme delati”. Iz lokalnega razmišljanja preiti v globalno. V praksi pa upoštevati sinergijo obeh. Omenjeno je ključnega pomena.

\subsection{Raziskava trga osnovni pogoj za vstop na španski trg, pripravite kvaliteten izvozni, finančni in poslovni načrt}

Podjetja pogosto menijo, da zaradi visokih stroškov raziskave trga ni smiselno pripraviti izvoznega načrta; napaka, izvozni načrt je nujen. Večina slovenskih malih podjetij se na tuje trge odpravlja brez posebnega načrta, spontano, na podlagi naključnih povpraševanj tujih podjetij ali občutka, kje so možnosti za prodajo njihovih izdelkov. Zaradi slabih razmer na domačem trgu zdaj še toliko bolj hitijo. Največkrat sicer načrtujejo določene aktivnosti, kot je udeležba na sejmu, obisk tujega trga, vendar velikokrat brez podrobnejše raziskave trgov in natančno določenih ciljev, posledica pa je neizkoriščenost ponujenih priložnosti. Slovenska podjetja imajo običajno preslabo izdelane izvozne načrte ali jih celo sploh nimajo. Premalo podroben je tudi finančni načrt, ki ne zajema vseh stroškov vstopa na španski trg. Napačna je miselnost, da vstop tuji trg stane toliko kot vstop na domači trg. Še zdaleč ni tako, največkrat je vstop na tuji trg veliko dražji. Zaradi pomanjkanja strategije, ki je opredeljena $\mathrm{v}$ izvoznem načrtu, delajo podjetja napake, ki jih drago stanejo, saj vstopajo na napačni trg in izbirajo napačne prodajne poti. Večinoma podjetja podcenjujejo vstop na tuji trg z vidika stroškov, kar je zlasti pri mikro in malih podjetjih, ki so kadrovsko in finančno šibkejša, velika težava.

Glavne napake podjetij na področju izvoznega poslovanja so prepričanje, da bodo $\mathrm{z}$ izvozom rešila težave, s katerimi se spopadajo na domačem trgu, vnaprejšnja odločenost, da je določena izbira tujega trga prava, vstop na preveč trgov hkrati, hitra širitev brez načrta, sklepanje pogodb s predstavniki, ki jih ne poznajo in ne preverijo, izvažati želijo vse svoje proizvode in storitve in udeležba na sejmih brez vnaprejšnjih priprav in analize trga.

Velikokrat podjetja prepustijo izdelavo izvoznega načrta kakšni svetovalni organizaciji, ki lahko metodološko izdela resnično popoln načrt, vendar pa je ta $\mathrm{v}$ praksi povsem 
neuporaben, saj predpostavke, na katerih temelji, po navadi niso uresničljive, njegovi avtorji pa niso podjetja ali izdelka nikoli videli in ne poznajo tujih odjemalcev. Osnovni pogoj je, da pred tem poznajo mehke dejavnike posla, interese kupcev, dobaviteljev, vlagateljev, dolgoročnih kapitalskih ali strateških poslovnih partnerjev in šele nato je mogoče izdelati izvedljiv izvozni načrt. Načrti pogosto ne zajemajo analize konkurence, saj temeljijo na predpostavki, da bodo tekmeci mirno opazovali aktivnosti slovenskega podjetja, novih tekmecev pa sploh ne bo. Konkurenčna analiza namreč lahko pomembno spremeni projekcije izidov naložbenih odločitev. Načrti morajo temeljiti na predhodnih raziskavah tujih trgov, te raziskave pa niso nujno povezane $\mathrm{z}$ visokimi stroški, saj se informacije $\mathrm{v}$ podjetju leta in leta lahko zbirajo $\mathrm{z}$ opazovanjem in preprostim raziskovanjem (več je pridobljenih izkušenj in podatkov, manj bo potrebe po podrobnih raziskovalnih nalogah). Podjetja pogosto menijo, da nima smisla izdelovati izvoznih načrtov, saj so raziskave, na katerih naj bi temeljili, predrage. Za ugotavljanje obetavnega izvoznega programa je treba ugotoviti gibanja $\mathrm{v}$ značilnostih okolja, $\mathrm{s}$ katerim je ponudbeni program povezan, kar pa ne zajema le ugotavljanja zdajšnjih kazalnikov, temveč mora biti pozornost usmerjena $\mathrm{k}$ prihodnjim razvojnim vidikom, za kar pa spet ni dovolj zgolj uporaba (prejšnjih) statističnih kazalnikov, temveč je treba proučiti pričakovane smernice iz mehkih informacij (pogovorov s panožnimi strokovnjaki, odjemalci in dobavitelji, analize povezanosti gibanj) ter oceniti tržne in prodajne potenciale. Načrti večkrat predvidevajo pozitivne finančne učinke že kar naslednji mesec, čeprav je iz mednarodne poslovne prakse znano, da osvajanje tujega trga traja v povprečju tri ali štiri leta. Podjetje namreč šele po tem obdobju doseže takšne izvozne količine in vrednosti, ki omogočajo donosnost izvoznega posla. Izvozni načrt, ki je strateški dokument, naj pripravi vodja izvoza $\mathrm{v}$ sodelovanju $\mathrm{z}$ vodji preostalih oddelkov (produktni, finančni, prodajni, trženje) in vodstvom podjetja. Predvsem pa izvozni načrt ni zacementiran dokument, temveč ga mora podjetje nenehno prilagajati tržnim razmeram in razmeram v podjetju (Finance, 2016).

\subsection{Podjetnik je v Španiji spoštovan in cenjen}

Španija je velika država s tradicijo in zavidljivo ter prepoznavno zgodovino in sodi med najbolj odprte države $\mathrm{v}$ svetu. Tipična katoliška država, $\mathrm{v}$ kateri brez večjih težav živijo različni narodi, narodnosti, različnih kultur in ver. Ima privlačno ekonomijo za zasebni sektor. Podjetniški portfelj je zelo razvit, možnosti je izredno veliko. Država ima prijazen davčni sistem in pozitiven odnos do podjetništva $\left({ }^{3}\right)$. Davčna uprava in davčna zakonodaja (Agencia Tributaria, 2016) sta do podjetnika zelo prijazni. Mikro in malih podjetij je okrog 2,4 mio, ki s svojim številom tvorijo temelj španskega gospodarstva. Skupno zaposlujejo 13 mio ljudi, od tega mikro podjetja zaposlujejo dobrih 39 odstotka. Špancev je 48 mio, kar pomeni, da je vsak dvajseti Španec mikro $\left(^{5}\right)$ ali mali podjetnik $\left({ }^{4}\right)$, (Tomašič M., 2010).

Ni vprašanje kako se soočiti s posebnostmi te države. Vprašanje je, kaj se lahko od nje naučimo in pridobimo. V Sloveniji vsi pričakujejo, da jim bo kdo kaj dal, naredil, prinesel, skrbel za njih, vsi so polni pričakovanj. Śpanci razmišljajo za pol kroga drugače kot Slovenci. Razmišljajo objektivno, realno, odgovorno in pozitivno. Družinska 
$36^{\mathrm{TH}}$ InTernational Conference on ORganizational SCIENCE Development: Responsible Organization (MARCh $22^{\mathrm{ND}}-24^{\mathrm{TH}}$, Portorož Slovenia)

M. Tomašič: Slovenian Spanish Business Club ECE España Canarias Eslovenia

podjetija so številna (Tomašič M., 2008) in so po strukturi, organiziranosti in ciljih podobna slovenskim družinskim podjetjem $\left(^{6}\right)$. Družina pa je tista neprecenljiva vrednota, kar je za njih na prvem mestu.

\subsection{Pomembnost osebnih stikov}

Zelo pomembni. Španci so družabni ljudje, toda nekoliko nezaupljivi. Tako v zasebnem življenju, kot v poslu. V bistvu si tega ne želijo, ampak tipajo. Če te ocenijo pozitivno, te kaj hitro sprejmejo med sebe. So enostavni, korektni in nekomplicirani. Veliko jim pomenijo, zaupanje, prijateljstvo, resnost, odnos in poštenje. Dajo na besedo. Težko prenašajo storjene jim krivice ali prevare.

\subsection{Poslovni običaji se razlikujejo od germanskih}

Pri Nemcih velja natančnost, točnost in hitrost. Pri Špancih je hiba natančnost. Običajno nekoliko zamude in umirjena hitrost, katere stereotip se je vlekel dolga leta, imenovan počasnost. Nam dobro znana španska beseda "mañana", slovensko “jutri”, izgublja na pomenu. Vzrok tiči predvsem v sodobni tehnologiji, ki narekuje človeku svoj tempo. Tehnološki razvoj je naredil svoje tako tudi Špancih, ki so se hitro prilagodili novim razmeram in zahtevam na trgu. Zmoreš ali ne zmoreš. Znaš ali ne znaš. Si ali nisi.

Primer: Dogovor z Nemcem za 10 dopoldansko uro pomeni, da bo le ta prišel 5 minut pred deseto. Anglež, nam dobro poznani "akademska četrt", bo prišel vsaj do 10 ure in 15 minut. Španec pa bo zamujal nekako do pol ure. Španci se prilagajajo času in potrebam in "mañana" počasi odhaja na smetišče zgodovine.

\subsection{Prepoznavnost Slovenije v Španiji}

Slovenije ne poznajo prav dobro. Bolje poznajo Slovaško. To so stare zgodbe. Španci, kot vsak velik narod, se sučejo večinoma okrog samih sebe. V njihovih glavah so v "prvi ligi" Angleži, Nemci, Skandinavci, Francozi. Izven Evrope pa Latino Američani in Severni Američani. Špancu postaviti na zemljevid Slovenijo pa je zelo enostavno. Šport! Večina ve za nastope nogometnega kluba Maribor v Ligi prvakov, košarkarskega kluba Union Olimpija v Euroligi in rokometnega kluba Celje v Ligi prvakov. Zanimanja za vse ostale športne panoge med Španci je precej manj. Po podatkih španskega Nacionalnega instituta za statistiko (Instituto Nacional de Estadística, 2016), je leta 2016 v Španiji imelo prijavljeno prebivališče 1.332 Slovencev, od tega na Kanarskih otokih 442.

\subsection{Znanje španskega jezika je prednost}

Znanje španščine je vsekakor prednost, ni pa pogoj. V Španiji zadostuje tudi angleščina, ki je najbolj pogost uraden jezik na svetu. Stereotip o tem, da španci ne znajo jezikov oziroma angleščine, ne velja več. Morda niste vedeli, španci trdijo, da se je angleščina razvila prav iz njihovega jezika. In to preverjeno drži. Ne pozabimo, da je španščina četrta po vrsti najbolj uporabljen jezik, takoj za kitajskim, angleškim in hindustanskim. Španec pri pogovornem angleškem jeziku uporablja španski poudarek in ne angleški. 
Zanj je pomembno le medsebojno dobro funkcionalno razumevanje. V Sloveniji to pojmujemo kot "popačeno angleščino". Pa to ne drži.

\subsection{Plačilna disciplina, plačilni roki in zavarovanja plačil}

Plačilna disciplina je sprejemljiva. Plačilni roki so med 30 in 45 dnevi ali po dogovoru krajši. Zavarovanja plačil so priporočljiva in potrebna. V Španiji velja lastoročni podpis, kot Španci sami pojmujejo, "smrtno obsodbo". Pomeni, dobro premisli, preden boš karkoli podpisal. Tudi temu "strahu" gre pripisati pozitivno plačilno disciplino. Pred sklenitvijo posla se je dobro pozanimati o poslovnem partnerju oziroma o njegovi boniteti. Podjetniške izkušnje in znanja pridobljene v Sloveniji pa so prednost ob začetku poslovanja v Španiji. Pravni sistem v Španiji dobro funkcionira.

\subsection{Vzpostavitev prvih stikov na španskem trgu}

Za vzpostavitev stikov z lokalnimi oblastmi, podjetji in institucijami je zelo pomembno poiskati poslovnega predstavnika, ki dobro pozna posamezna mikro in makro okolja. Le ta s svojim znanjem in izkušnjami predstavlja vir informacij za neizkušena podjetja, predvsem tista, ki prvič nastopajo na španskem trgu. Povezati se s predstavnikom tako ni strošek, ampak investicija. Na elektronsko pošto se odzivajo kratko, formalno in v razumnem roku. Osebni stik je priporočljiv, v večini primerov pa poslovno neizogiben.

\subsection{Slovenski izdelki zanimivi za španski trg}

Obnovljivi viri energije. Kvalitetni fotovoltačni proizvodi podjetja Bisol d.o.o. za izgradnjo Sončnih elektrarn malih, srednjih in velikih moči (Bisol, 2016). Španija je za Nemčijo druga svetovna velesila na tem področju, nato šele sledijo Američani in Japonci. Govor je o znanosti, raziskavah in razvoju, know how-u, kvaliteti in proizvodnih alternativnih energetskih kapacitetah. Primer: Španski otok El Hierro, eden izmed sedmih otokov Kanarskega arhipelaga, je prvi otok na svetu, ki pridobiva 100 odstotno električno energijo izključno iz obnovljivih virov - sončni in veterni sistemi (Instituto Tecnológico y de Energías Renovables, 2016). Trend v prihodnosti je, da se ves arhipelag samostojno oskrbuje izključno z alternativnimi viri energije. Postavitev dveh ali treh referenčnih Sončnih elektran na različnih lokacijah Španije bi pomenil za Slovenijo dostop na trge Latino Amerike, Severne in Zahodne Afrike. Ob tem velja omeniti, da je celoten otok pokrit $\mathrm{z}$ internetom WI - FI in je prost plačila. Slovenska podjetja, že prisotna na španskem trgu, Gorenje España S.L., Iskra Autoelectrique Spain S.A., Elan d.o.o. Gregal Sport, Lpkf Laser \& Electronics Spain S.L., Trimo d.d. - Iberica de Paneles Industriales S.L., Unior España S.L. in druga, že leta tržijo svoje izdelke, kot so električni stroji in njihova oprema, orodja, kotli, stroji in mehanske naprave, železo in jeklo, aparati za snemanje ali reprodukcijo slike in zvoka, farmacevtski proizvodi, in drugo. Ostala zanimiva področja za slovenska podjetja so avtomobilska industrija, informacijskokomunikacijske tehnologije, okoljske tehnologije, biotehnologija, proizvodnja elektronskih komponent, tehnološke platforme, znanstveni in tehnološki parki (Instituto Tecnologico de Canarias, 2016), nanotehnologija, mehatronika, gradbeništvo, zdravstvo, 
$116036^{\text {Th }}$ International Conference on Organizational Science Development: Responsible Organization (MARCh $22^{\mathrm{ND}}-24^{\mathrm{TH}}$, Portorož Slovenia)

M. Tomašič: Slovenian Spanish Business Club ECE España Canarias Eslovenia

astrofizika (Instituto por Astrofisico de Canarias, 2016), turizem (Ministerio de Industria, Turismo y Comercio España, 2016). V zadnjih desetih letih je Slovenija uvozila iz Španije v povprečju dvakrat več blaga in storitev, kot jih izvozila. Medsebojna blagovna menjava je skromna in nenehno pada. V razmerju izvoz - uvoz Slovenija beleži vsa leta negativno bilanco. Od prvotnih 600 mio evrov uvoza in 300 mio evrov izvoza, so danes te vrednosti manjše za polovico. Pričujoča blagovna menjava tako Španije ne uvršča na mesto najpomembnejših trgovinskih partneric Slovenije, kar je zaskrbljujoče. Hkrati pa gre za izziv spoprijeti se s tako ogromnim trgom. Potreben je temeljit progresiven in samozavesten prodor. V nasprotnem si, kakor da ne obstajaš.

\subsection{Odločitev o izbiri oblike podjetja za prodor na španski trg}

Po uspešnem prodoru v tujino se podjetnik navadno vpraša, ali je v neki državi smiselno odpreti predstavništvo ali pa poslovanje nadgraditi s podružnico ali hčerinskim podjetjem. Enoznačen odgovor na to ni mogoč, saj je primerna oblika zastopanosti na trgu precej odvisna tudi od države, v kateri poslujemo, ne le od poslovnega modela, ki ga zasleduje podjetje, in načrtovanega obsega poslovanja na ciljnem trgu. Sam proces internacionalizacije je večplasten, začne se s posrednim ali neposrednim izvozom, različnimi pogodbenimi oblikami sodelovanja, franšizingom, skupnimi vlaganji, vse do odprtja podjetja oziroma podružnice na tujem (Capital Investment Canarias, 2016). V nekaterih avtonomnih pokrajinah je lokalna poslovna enota pogoj pri izvedbi pridobljenih večjih javnih naročil. Vendar pa ustanavljanje podružnice ali hčerinskega podjetja brez razmeroma utečenih ali realno obetavnih poslov ni smiselno, saj stroškovno in organizacijsko breme lahko izniči dohodke. Navzočnost z eno od oblik podjetja na španskem trgu omogoča lažje izvajanje in nadzor nad proizvodnimi, prodajnimi in trženjskimi dejavnostmi, celosten pregled nad dogajanjem na trgu, nedvomno pa tudi lažjo zaščito blagovnih znamk in patentov. Podjetju sta s tem omogočena tudi hiter odziv pri morebitnih spremembah na njihovem področju in prilagoditev poslovanja. Vsekakor ustanovitev podjetja v Španiji zahteva veliko angažiranost pri izbiri zaposlenih. Ti morajo dobro poznati lokalni trg, izdelke, storitve podjetja in biti vredni zaupanja. Domače podjetje pa mora biti $\mathrm{v}$ nenehni navezi $\mathrm{s}$ podružnico zaradi podpore in nadzora poslovanja.

Predstavništvo slovenskega podjetja v Španiji ima navadno pooblastilo, enako kot za špansko predstavništvo $\mathrm{v}$ Sloveniji, da nastopa $\mathrm{v}$ imenu matičnega podjetja in za njegov račun. Predvsem služi kot komunikacijsko orodje med matičnim podjetjem v Sloveniji in španskim trgom. Namen je zbiranje in posredovanje informacij o poslovnih priložnostih tako za matično podjetje kot za morebitne poslovne partnerje, pospeševanje uvoza in izvoza ter izvajanje tehnične in finančne podpore pri sodelovanju med matičnim podjetjem in podjetji $\mathrm{v}$ Španiji. Predstavništvo se ne ukvarja s komercialnimi posli in tako ne pridobiva prihodkov. Večina tujih pravnih redov njegovega statusa posebej ne ureja in opredeljuje, a ker nima statusa pravne osebe, ne more samostojno nastopati $\mathrm{v}$ lokalnem poslovnem prometu. Posle splošnega trgovinskega zastopanja, agenture ali posredovanja urejajo splošni predpisi, ki urejajo trgovsko zastopanje oziroma zastopniške pogodbe. 
Slovensko hčerinsko podjetje je samostojna pravna oseba, kar pomeni, da matično podjetje ni odgovorno za poslovne dogovore, ki jih sklene hčerinsko podjetje. To zagotavlja določeno stopnjo zaščite za ustanovitelja. Hčerinsko podjetje ima sedež v Španiji in se v tej državi večinoma šteje kot domače podjetje. Matično podjetje je lahko njen ustanovitelj ali pa večinski lastnik in nosilec upravljavskih pravic. Hčerinska družba je od matice odvisna le v ekonomskem in posledično strateškem smislu, sicer pa deluje povsem samostojno in v okviru korporacijskih, gospodarskih, davčnih in statusnih značilnosti pravnega okolja, $v$ katerem je bila ustanovljena. Tudi ustanovitev hčerinske družbe poteka v skladu s pravom države, v kateri ima to novoustanovljeno podjetje sedež.

Slovenska podružnica v Španiji s pravnega vidika ni samostojna entiteta, temveč je le lokacijsko in organizacijsko ločena poslovna enota matičnega podjetja, ki v pravnem prometu nastopa $\mathrm{v}$ imenu matičnega podjetja in za njegov račun. Slovenska podružnica pa ima vseeno višjo stopnjo samostojnosti, kot predstavništvo, ki pa ob prenehanju matične družbe ne more neodvisno nadaljevati svoje dejavnosti. Praviloma deluje le v okviru matičnega podjetja in po zakonih, ki veljajo v državi, iz katere izvira matica. V državi, $v$ kateri deluje, ima navadno pooblaščenega predstavnika, ki ima v tej državi tudi stalno prebivališče. Pri ustanovitvi podružnice ustanovitveni kapital navadno ni potreben, zadostuje že vpis v sodni register države, kjer se podružnica ustanavlja. Registrirana je le za dejavnosti, za katere je registrirana matična družba. Sodi med manj pogoste oblike nastopanja na tujih trgih, saj podjetje $\mathrm{z}$ ustanovitvijo hčerinske družbe precej zmanjša morebitno odgovornost. V primeru tožbe, v nasprotju s podružnico, hčerinska družba odgovarja zgolj s svojim lastnim premoženjem.

\section{$3 \quad$ Mladi raziskovalci in start - up podjetja}

V Španiji je prisotnih veliko število tujih podjetjij vseh velikosti. Zavidljiv pa je porast domačih in tujih start-up podjetij, predvsem mikro in malih. $\mathrm{V}$ zadnjih letih govorimo le o presežkih. Sistem za razvoj start-upov v Španiji obsega veliko število javnih ustanov, tako za nefinančno in finančno podporo. Po državi so številni podjetniški inkubatorji. Močna je zasebna podpora $\mathrm{z}$ ustanovami za mreženje in promocijo, podjetniškimi sodelavnicami, različnimi pospeševalniki, podjetji za vlaganje in svetovanje $\mathrm{z}$ individualnimi rešitvami.

\section{1 Številne ugodnosti start - up podjetjem v Španiji}

Startapom in drugim podjetjem Španija podeljuje ogromno sredstev v obliki subvencij, poslovnih prostorov in zemljišč. Španska vlada (Gobierno de Canarias, 2016), ponujajo storitve mladim raziskovalcem $\mathrm{v}$ več kot desetih jezikih. Polovica sodelavcev v različnih svetovalnih agencijah so tujci, ki so se priselili v Španijo. Med njimi so pa tudi Španci, ko so več let delali in živeli $\mathrm{v}$ tujini in tako vedo, kako delati za velika podjetja. Za slovenska podjetja je tako $\mathrm{v}$ veliko pomoč poslovni klub, kjer lahko na enem mestu pridobite vse potrebne podatke in informacije. Posebnost Španije je, da namenja za start - up podjetja veliko različnih subvencij, kot so občinske subvencije, subvencije avtonomnih pokrajin, subvencije gospodarske agencije in državne subvencije (ICEX - 
1162 36 $6^{\mathrm{TH}}$ International Conference on Organizational Science Development: Responsible Organization (MARCH $22^{\mathrm{ND}}-24^{\mathrm{TH}}$, Portorož SlOVENIA)

M. Tomašič: Slovenian Spanish Business Club ECE España Canarias Eslovenia

Invest in Spain, Rising-Startup - Spain, 2016) . Ob vsem tem pa si prizadevajo, da so čim manj birokratski, tako rekoč vas brez velikih zapletov vodijo skozi predpisane postopke. Subvencije le za inovativne. Vsem novim priseljencem morajo zagotoviti delovna mesta, to pa lahko dosežejo le z inovativnostjo. Gospodarska agencija zato namenja svoje subvencije le za inovativne ideje in projekte, tako pri start-upih kot $\mathrm{v}$ tradicionalni industriji. Startupovsko okolje na Španiji je zelo dinamično. Spremljajo jih ves čas in jim po potrebi ponujajo podporo. Ta znaša od tisoč evrov za zagonska podjetja do sto tisoč evrov za bolj uveljavljena. Ko doseže zagonsko podjetje določeno velikost, lahko pridobi druge oblike pomoči, ki jih zagotavlja več državnih skladov. Za zagonska podjetja so objavljene tudi informacije o brezplačnih delavnicah in tečajih na najrazličnejše teme: od izdelave poslovnega načrta, trženja do poslovne strategije. Prirejajo tudi razna mreženja, srečanja za podjetja iz iste panoge, na primer za podjetja s področja tehnologije, znanosti o življenju, mobilnosti in pametne proizvodnje. Ta platforma je za nova podjetja zelo pomembna, saj lahko tako učinkovito spoznajo svoje profesionalno okolje. V Barceloni je tudi več kot 400 predstavništev mednarodnih korporacij, veliko izmed njih pokriva večji del trgov v Evropski uniji. Na številnih Univerzah lahko podjetja izbirajo med več kot nekaj sto tisočimi študenti, ki s svojim poznavanjem jezika, kulture in miselnosti v svojih državah pomenijo dodano vrednost, saj lažje in dovolj učinkovito delujejo za korporacije na teh trgih. Na primer, prestolnica avtonomne pokrajine Katalonija, Barcelona, je postala eno pomembnejših središč za raziskovalna podjetja. Avstralska agencija za inovacije je v raziskavi Madrid uvrstila med prvih 30 najinovativnejših mest na svetu (Innovation Cities Global Index, 2016). Prva tri mesta zasedajo London, San Francisco in Dunaj. Ljubljana je na 154. mestu. Ena od domiselnih rešitev so na primer coworking »čisti prostori«, za izvajanje raziskav opremljeni laboratoriji, ki jih je mogoče najemati po urah in so najprivlačnejši za start-upe, ki si težko privoščijo svoje raziskovalne prostore. Raziskava Global Economic Power Index 2015 (Global Residence Index, 2016) je Španijo uvrstila med petnajst gospodarsko najmočnejših na svetu. Pri tem so ocenjevali bruto domači proizvod, finančno moč, globalno konkurenčnost pa tudi družbeno enakopravnost in kakovost življenja. Po raziskavi se Španija že leta zapored po kakovosti življenja uvršča med deset najbolj zaželenih držav na svetu. Poslovni klub pogosto opozarja slovenska start-up podjetja, da brez raziskave trga in identifikacije potreb kupcev ni dobrega posla. Start-upi so pogosto prepočasni pri razvoju izdelkov. Prototipe bi morali izdelati čim prej in jih preizkusiti na trgu. Hkrati morajo imeti načrt, kako bodo v posameznih fazah pridobivali finančna sredstva. Pogosta napaka je ta, da je ustanovitelj mladega podjetja predolgo tudi njegov glavni menedžer. Še posebej start-upi s področja informacijskih tehnologij preveč časa posvečajo organizacijski zgradbi podjetja in kako bi ta ustrezala španskim vlagateljem. To so drugotna vprašanja. Namesto tega naj več energije posvetijo inovaciji, ki je jedro poslovnega modela, razumevanju izdelka in potreb, ki jih zadovoljuje. Španski vlagatelji vedno dajejo prednost inovaciji pred organizacijo, tega naj se zavedajo tisti, ki si prizadevajo najti tvegani kapital.

\subsection{Evropska komisija podpira španska start - up podjetja}

Evropska komisija naznanja, da sta zagon in širitev start - upov med novimi cilji Evropske Unije. V ospredje postavlja naložbe tveganega kapitala, ugodno obdavčenje in novosti na področju insolvečnega prava. Že $\mathrm{v}$ zadnjih letih predlagala več politik $\mathrm{v}$ podporo 
evropskim start-upom. Mednje spada unija kapitalskih trgov, strategija enotnega trga in enotni digitalni trg. Pri tem je podprla številna evropska zagonska podjetja, ki so dandanes uspešna na svetovni ravni. Komisija je v svojih prizadevanjih opredelila ključne težave, s katerimi se soočijo mladi podjetniki. Največja težava je dostop do financiranja, poleg tega so mnoge zakonodajne in administrativne ovire, ki omejujejo enostavnost poslovanja. Po mnenju Komisije si je treba vseeno močno prizadevati za rast in razvoj start - up podjetij, saj lahko kvalitetno poslovanje na evropskem trgu, ki šteje polovico miljarde, ključno za svetlo prihodnost Evrope. $Z$ aktualno pobudo želi Evropska komisija spodbuditi podjetnike, da bi izkoristili prednosti trga EU s pol miljarde potencialnih strank, namesto iskanja poslovnih priložnosti $\mathrm{v}$ državah tretjega sveta le zato, ker so proizvodni stroški nižji. Številne inovativne ideje in močan podjetniški duh lahko prineseta nova delovna mesta, inovacije in večjo samostojnost državljanov EU, v seštevku pa večjo blaginjo.

Ukrepi Evropske Komisije obsegajo: Izboljšan dostop do financiranja v sodelovanju s številnimi evropskimi investicijskimi bankami. Vseevropski sklad tveganega kapitala, podprt s 400 milijonskim vložkom iz proračuna EU. Upravljalci skladov so tako primorani, da zberejo vsaj trikrat toliko sredstev kot jih podari EU. Tak način generira 1,6 milijarde evrov vreden sklad za investicije. Druga priložnost za podjetnike se nanaša na novo zakonodajo o insolvenčnih postopkih. Podjetja v finančnih težavah se tako lažje izognejo kaznim zaradi predhodnega poslovnega neuspeha, saj bo njihov dolg v najkasneje treh letih odpisan. Poenostavitev davčnih napovedi je olajšana s pomočjo konsolidirane osnove za davek od dohodkov pravnih oseb CCCTB. Poleg tega se poenostavi sistem DDV v EU, razširijo smernice za dobre prakse na področju davčnih režimov članic za tvegani kapital (Šutanovič L., 2016).

\section{$4 \quad$ Izzivi v prihodnosti}

\subsection{Priložnosti}

Priložnosti je potrebno iskati $\mathrm{v}$ posameznih španskih avtonomnih pokrajinah, dobaviteljskih verigah velikih korporacij, biti prilagodljiv in skrbno raziskati trg. Kakovostna mreža poslovnih stikov in natančna usmeritev je izrednega pomena za poslovni uspeh. Napake pri slovenskih podjetjih se pokažejo, ko zaznajo, da niso naredili osnovnih stvari potrebnih za vstop na španski trg. Kot so na primer, dobra presoja in poznavanje španskega trga oziroma posameznih avtonomnih pokrajin in krajevno dislociranih enklav, preverjanje poslovnega koncepta na trgu, uspešno zbiranje sredstev, zavedanje kakšne partnerje potrebujejo, preslabo prepoznavanje potreb potencialnih kupcev, konkurence in zakonskih omejitev, želja po prehitrem uspehu. Nemalokrat izberejo neposredno prodajo, čeprav bi bilo bolje sodelovati $z$ distributerji. Slovenskim podjetjem svetujemo, ko opravijo prvo analizo trga, da najamejo španskega menedžerja, ki jim bo s svojim znanjem pomagal pripraviti najboljšo strategijo glede na potrebe trga. Ta menedžer (Tomašič M., 2010) naj bo izkušen posameznik, ki bo znal določiti jasne cilje in načrte, kako jih doseči. Za preboj na trg brez podrobno izdelanega poslovnega načrta v Španiji ne gre. Strošek za izdelavo le tega praviloma ni klasični strošek ampak 
investicija, ki se kaj hitro povrne. Pred vstopom na španski trg si mora podjetje zagotoviti dovolj denarja za financiranje vstopa na trg in se tako vključiti v dobaviteljske verige španskih podjetij. Podjetniki, ki razmišljajo o tej možnosti, se morajo zavedati, da imajo multinacionalke posebna merila $\mathrm{v}$ zvezi s prilagodljivostjo poslovanja ter kakovostjo in časovnimi termini. To je za podjetje, vajeno počasnejšega lokalnega trga, lahko precejšen izziv. Vendar je to priložnost za podjetja, da začnejo z enim izdelkom ali polizdelkom in nato postopno dodajajo druge.

\subsection{Medobčinska pobuda: Čezmejno e-sodelovanje v e-regiji}

Poslovni klub je član Medobčinske pobude - Čezmejno e-sodelovanje v e-regiji (Inter Municipality Initiative, 2016), katere programski koordinator je zaslužni profesor dr. Jože Gričar iz Fakultete za organizacijske vede, Univerze v Mariboru. Poslovni klub je v dogovoru s profesorjem povabil $\mathrm{k}$ sodelovanju vse španske avtonomne pokrajine in večje občine, med drugim tudi občino Lleida, v kateri je zaposlen Slovenec rojen v španski avtonomni pokrajini Katalonija (Ayuntamiento de Lleida, (2016). Poslovni klub je o nameri obvestil Veleposlaništvo RS v Madridu, vsa tri konzularna predstavništva RS v Španiji in Veleposlaništvo Kraljevine Španije v Sloveniji. Projekt je v začetni fazi, rezultat obojestranskega sodelovanja pričakovan v prihodnosti.

\subsection{Zaključna misel}

Špansko gospodarstvo, podjetništvo, pristojne državne, avtonomne in lokalne institucije in uradi na različnih ravneh $\mathrm{v}$ medsebojnih oblikah sodelovanja potrjujejo, da je zasebni slovensko španski poslovni klub njihov partner. Nasprotno pa instutucije in uradi v Sloveniji nemalokrat vidijo $\mathrm{v}$ njem prej konkurenco, kot partnerja. Velik izziv v prihodnosti je, da se ta miselnost v slovenskem javnem prostoru spremeni. Poslovni klub je proaktivna oblika, ki se zna hitro prilagoditi razmeram na trgu. Strmi k prepoznavnosti in odličnosti, ki se kaže predvsem s potencijalom, ki ga imajo ljudje znotraj njega samega. Mladim ljudem, diplomantom različnih programov in smeri priporočamo, da si čimprej poiščejo zaposlitev v tujini, v gospodarsko razvitih in uspešnih državah. Tisti, ki se bodo po nekaj letih odločili za vrnitev v domovino, bodo s pridobljenim znanjem in izkušnjami opazna dodana vrednost $\mathrm{v}$ slovenskem gospodarskem prostoru.

\section{Opombe}

1 Znanost (latinsko scientia - znanje): se nanaša na sistematično pridobivanje novega znanja o naravi in spoznanj, pridobljenih na ta način z obstoječim znanjem. Znanstvena metoda temelji na skrbnem opazovanju in preskušanju teorij s preskusi. Znanost se deli na vede, vede pa na področja (discipline).

${ }^{2}$ Znanstveno raziskovanje v teoretičnem smislu: ugotavljanje stališč. Znanstvena teorija kot splet logičnih povezanih trditev, ki sistematično pojasnjujejo določen pojav ali skupino pojavov v okvire določena področja realnosti. Je srce znanosti, preko nje razlagamo in napovedujemo določeno področje pojavov in spoznavamo njegovo notranjo strukturo. Sestava znanstvene teorije: struktura teorije (pojmi, dejstva, znanstveni zakon in funkcija teorije).

${ }^{3}$ REF: Regime de Economico Fiscal. 
${ }^{4}$ Mikro podjetje: družba, ki zaposluje povprečno število delavcev v poslovnem letu do 10 , čisti prihodki od prodaje ne presegajo 2 mio evrov in vrednost aktive ne presega 1 mio evrov.

${ }^{5}$ Malo podjetje: družba, ki zaposluje povprečno število delavcev v poslovnem letu od 11 do 50 , čisti prihodki od prodaje ne presegajo 8,8 mio evrov in vrednost aktive ne presega 4,4 mio evrov.

${ }^{6}$ Družinsko podjetje (La Empresa Familiar, špan.): nimamo enotne definicije, kaj je družinsko podjetje. Predlogov in interpretacij je več: družinsko podjetje je tisto podjetje, ki je v večinski lasti družine; družinsko podjetje je tisto podjetje, katerega družinski člani kot lastniki tudi upravljajo in vodijo; družinsko podjetje je tisto podjetje, ki strmi k temu, da se podjetje ohrani v lasti in vodenju družine; družinsko podjetje je tisto podjetje, katerega lastništvo je v rokah posamezne družine najmanj dve generaciji in katerega upravljanje je prav tako pod vplivom družinskih interesov.

\section{Literatura}

Agencia Tributaria (2016). Empresas y Profesionales. Dostopno na http://www.agenciatributaria.es/

Ayuntamiento de Lleida (2016). Ayuntamento de Lleida, Inicio. Dostopno na http://www.paeria.es/cas/ajuntament/

Bisol d.o.o. (2016). Products. Dostopno na http://www.bisol.com/en/products.html/

Cámara de Comercio de España (2016). Cámara de España. Dostopno na http://www.camara.es/la-camara-de-espana/

Cámara de Comercio de Las Palmas de Gran Canaria (2016). Inicio. Dostopno na http://www.camaragrancanaria.org/

Cámara de Comercio de Santa Cruz de Tenerife (2016). Guía de Empresas. Dostopno na http://www.camaratenerife.com/

Capital Investment Canarias (2016). Dostopno na http://www.capitalinvestmentcanaries.com/company-formations-tenerife-spain-canaryislands/

Club de Negocios ECE (2016). Objectivos. Actividades. Miembros. Entrevistas individuales.Enlaces útiles. Interno gradivo. Dostopno na http://clubdenegocios-ece.com/es/inicio/?locale_directory=es/

Confederación Provincial de Empresarios de Santa Cruz de Tenerife (2016). Ley de Transparencia. Dostopno na http://ceoe-tenerife.com/ley-de-transparencia/

Finance (2016). Kako delati v Španiji. Prispevek Mladen Tomašič. Časnik Finance, 28.4.2016, št. 81, str. 14 - 15. Dostopno na http://www.finance.si/casopis_finance?dat=2016-04-28

Global Residence Index (2016). Global Economic Power Index 2015, dosegljivo na, http://globalresidenceindex.com/hnwi-index/economic-power-index/

Gobierno de Canarias (2016). Dostopno na http://www.gobiernodecanarias.org/hacienda/

ICEX - Invest in Spain (2016). Rising-Startup-Spain. Dostopno na http://www.investinspain.org/invest/es/canal-de-informacion/servicios-de-acceso-ainformacion/Rising-Startup-Spain/index.html/

Innovation Cities Global Index (2016). Innovation Cities Global Index 2015. Dostopno na http://www.innovation-cities.com/innovation-cities-index-2015-global/9609/

Instituto Nacional de Estadística (2016). Dostopno na http://www.ine.es/

Instituto por Astrofisico de Canarias (2016). Proyectos. Dostopno na http://www.iac.es/proyectos.php?op1=6/

Instituto Tecnologico de Canarias (2016). Teconologías. Dostopno na 
1166 36 $36^{\mathrm{TH}}$ International Conference on ORganizational Science Development: Responsible ORGaNiZATION (MARCH $22^{\mathrm{ND}}-24^{\mathrm{TH}}$, Portorož SlOVENIA)

M. Tomašič: Slovenian Spanish Business Club ECE España Canarias Eslovenia

http://www.itccanarias.org/web/tecnologias/mecanica/index.jsp?lang=es/

Instituto Tecnológico y de Energías Renovables (2016). Energías Renovables. Dostopno na http://www.iter.es/

Inter Municipality Initiative (2016). Cross border eCollaboration in the eRegion. Dostopno na http://eregion.eu/

Ministerio de Industria, Turismo y Comercio España (2016). Invest in Spain. Dostopno na http://www.oficinascomerciales.es/icex/cda/controller/pageOfecomes/0,5280449_531100_53 10307_0,00.html/

Registro de Bienes Muebles (2016). Registro de Bienes Muebles, SC Tenerife. Dostopno na http://www.registrodebienesmuebles.com/registro-de-bienes-muebles-de-tenerife/

Šutanovič, L. (2016). Evropska komisija podpira evropske start - upe, Zavod mladi podjetnik, 24.11.2016. Dostopno na http://mladipodjetnik.si/

Tomašič, M. (2008). Družinska mikro podjetja v Sloveniji. Organizacija, ISSN 1318 5454, Nov.dec. 2008, letn. 41, št. 6, str. A279-A284. COBISS.SI-ID 244531968

Tomašič, M. (2010). Razumevanje miselnosti in razlik med podjetnikom in managerjem = Understanding the Mentality and the Differencess between the Enterpreneur and Manager, Človek in organizacija : zbornik vabljenih predavanj in povzetkov referatov $=$ People and Organization : conference proceedings of invited lectures and abstracts. Kranj: Moderna organizacija, 2010, str. 250. COBISS.SI-ID 65536257 
$36^{\text {TH }}$ International Conference on Organizational Science DeVElopment: Responsible ORGANIZATION (MARCH $22^{\mathrm{ND}}-24^{\mathrm{TH}}$, PORTOROŽ SLOVENIA)

O. Arsenijević, M. Ferjan, I. Podbregar, P. Šprajc, D. Trivan \& Y.

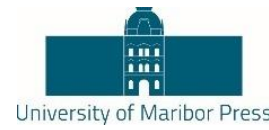

Ziegler

\title{
Cyclical Characteristics of the Industrial Production in Croatia
}

\section{DANIEL TOMIĆ \& SAŠA STJEPANOVIĆ}

\begin{abstract}
Industrial production is considered as one of the most important variable indicating the expansion or compression of economic activity in a country. It is not only recognized as the most important and widely analyzed high-frequency indicator, but it is also a crucial variable for forecasting the short-run evolution of national output. Indeed, it can provide ground for decision-making bodies with early signals of turning points and/or long-term trend fluctuations. Industrial production plays a very important role in Croatian economic growth perspective too as this indicator often reflects particular national output developments. Therefore, the objective of this study is to evaluate cyclical characteristics of industrial production and its main industrial groupings in Croatia as to detect their mutual dependency and extract reliable information about their comovements. By using the HP filter for extracting cyclical features and analyzing leads/lags disproportions inside a distinct time domain, this study also uses pairwise Granger causality test to emphasize the importance of their interconnection within a business cycle analysis. Quarterly data are collected from the Croatian National Bank database ranging from 1998 to 2016, short-term dynamics being the cornerstone of the analysis. Results reveal higher sensitivity of so-called cyclical industries suggesting their limited implications in short-run assessments and economic policy projections.
\end{abstract}

KEYWORDS: main industrial groupings $\bullet$ short-run analysis $\bullet$ business cycle $\bullet$ HP filter $\bullet$ Granger-causality $\bullet$ Croatia

CORRESPONDENCE ADDRESS: Daniel Tomić, Juraj Dobrila University of Pula, Faculty of Economics and Tourism »Dr. Mijo Mirković«, P. Preradovića 1, 52100 Pula, Croatia, e-mail: dtomic@unipu.hr; Saša Stjepanović, Juraj Dobrila University of Pula, Faculty of Economics and Tourism «Dr. Mijo Mirković». P. Preradovića 1, 52100 Pula, Croatia, e-mail: sstjepan@unipu.hr

DOI https://doi.org/10.18690/978-961-286-020-2.93

ISBN 978-961-286-020-2

(C) 2017 University of Maribor Press

Available at: http://press.um.si 
36 ${ }^{\text {TH }}$ International Conference on ORganizational Science Development: ResPonsible ORGaNiZATION (MARCH $22^{\mathrm{ND}}-24^{\mathrm{TH}}$, PORTOROŽ SLOVENIA)

D. Tomić \& S. Stjepanović: Cyclical Characteristics of the Industrial Production in Croatia

\section{Introduction}

Industrial production is considered as one of the most important variable indicating the expansion or compression of economic activity in a country. It is not only recognized as the most important and widely analyzed high-frequency indicator, but it is also a crucial variable, often used to forecast the short-run evolution of the gross domestic product (GDP) in most countries (Bulligan, Golinelli and Parigi, 2010). Indeed, it can provide ground for decision-making bodies with early signals of turning points and/or long-term trend fluctuations. Not only does the composition and/or fluctuation of the goods produced indicate the course of economic activity but it also reflects the changes in cyclical development of the economy (Tomić and Stjepanović, 2017). Most business cycle analyses in their fundament observe GDP movements, however variables such as employment or industrial production are also frequently used for identification of turning points. Although the industrial production covers a part of aggregate economic activity, its performance follows postulates very similar to those of the GDP, which makes it a good indicator of the business cycle (Sala, Torres and Farré, 2014). Namely, industrial production represents a significant portion of economic activity (despite growing importance of the service sector, industrial production is still an important factor of Croatian economic performance and competitiveness), hence the dynamics of industrial output is closely related to overall output dynamics. Fluctuations in industrial production index are often influenced by seasonal volatility, trend fluctuations and crisis appearances, as well as calendar and trading day effects, which cover relevant short and long-term movements of time series. It is therefore important to evaluate movements in the aggregate industrial production as well as in its disaggregated parts. In disaggregated terms, the literature is of course less extensive meaning that there is a large empirical gap left to be fulfilled.

In order to gain a better understanding of the business cycle characteristics in Croatia, this study is focused on assessing the cyclical characteristics of industrial production and its main industrial groupings (therefore, on both aggregated and disaggregated level) as to detect their mutual dependency and extract reliable information about their comovements. By using the Hodrick-Prescott filter for extracting cyclical features and analyzing leads/lags disproportions inside a distinct time domain, this study also uses (bivariate) pairwise Granger causality test to emphasize the importance of their interconnection within a business cycle analysis. Additional goal is to find specific cyclical behaviour as the nature of fluctuations should reveal cyclical or counter-cyclical characteristics of certain industrial sub-sector. Basic industrial production index in Croatia is composed of 5 basic sub-sectors i.e. main industrial groupings; energy, intermediate goods, capital goods, durable consumer goods and non-durable consumer goods which enables us also to tackle the industrial production assessments on a more disaggregated level. Quarterly data are collected from the Croatian National Bank database ranging from 1998:Q1 to 2016:Q2, short-term dynamics being the cornerstone of the analysis. Section 2 provides theoretical facts and empirical literature. Section 3 gives a full perspective to the analytical part by explaining used methodology, dataset 
and results whereas Section 4 evaluates the results through brief discussion, offering also some concluding remarks.

\section{Theoretical and empirical background}

This section provides a short introduction to the relevance of industrial production as an indicator as well as theoretical evaluation of its cyclical features. Furthermore, we will present some stylized facts about the nature of industrial production in Croatia which is to be complemented by empirical background related to the topic of the study.

\subsection{Relevance of the industrial production}

Industrial production measures the inflation-adjusted output produced by various industrial sectors (for example manufacturing, mining, electric and gas utilities industries and etc.) of the economy. The relevance of industrial production is confirmed both on theoretical ground as well as by practical 'philosophy'. Traditional theory states that the industry is still an important factor of economic growth in any country for it ensures accumulation of capital and knowledge, efficient allocation of workforce and capital towards sectors with higher resource utilization and higher rates of return which leads to a rise in demand; it provides diversification of economic structure and less exposure to changes in terms of trade; it offers better international position trough a rise in comparative and competitive advantages. For example, economist N. Kaldor, an unquestionable name in economic theory, through his famous Kaldor's growth laws proposed that economic growth and enhanced standard of living are positively correlated to national industrial activity (Kaldor, 1967). He suggested that growth in GDP is positively related to growth in manufacturing sector for productivity in the manufacturing industries is also positively related to growth in this sector. Additionally, he pointed that the productivity of the non-manufacturing sector should be positively related to the growth of the manufacturing sector.

The goal of generating, monitoring and publishing industrial production measurement (index) is to see the movements of production in time, to follow the changes between terms and the cyclical characteristics of the economy and to meet decision making bodies and scientists in this area (Kaynar, 2012). The industrial production index reacts quickly to fluctuations in the business cycle, therefore in any given situation we can answer the question whether the production of capital goods is growing more than the consumer goods or vice versa or do manufacturers still produce some types of materials. Hence it can serve as a leading indicator of economic health, as it gives a more current view of business activities and general picture of which sectors of the economy are growing and which are not. We can conclude that industrial production index has become an inevitable indicator for monitoring the production in industry as well as valuable standpoint for directing investment decisions.

This brings us to the next important feature i.e. cyclicality of the industrial production. Cyclical industry is consider as such type of industry that is sensitive to the business cycle 
36 ${ }^{\text {TH }}$ International Conference on ORganizational Science Development: ResPonsible ORGaNiZATION (MARCH $22^{\mathrm{ND}}-24^{\mathrm{TH}}$, PORTOROŽ SLOVENIA)

D. Tomić \& S. Stjepanović: Cyclical Characteristics of the Industrial Production in Croatia

so that the revenues are generally higher in periods of economic prosperity and expansion and lower in periods of economic downturn and contraction. The main drivers of cyclicality are business cycle, mismatch, and delay between different market dynamics including technology, investment, capacity, price and sales. Cyclical industries (provide cyclical stocks) include those that produce durable goods such as raw materials and heavy equipment (airline industry, shipping, steal industry, car manufactory, furniture industry, hotels and restaurants, clothing stores, travel and etc.). The stock price of the companies belonging to cyclical industry has a tendency of upward movement in times of economic growth and goes down during an economic recession (Chowdhury, 2014). On the other hand, counter-cyclical or sometimes called defensive or non-cyclical industries (provide non-cyclical stocks) are those that do well in economic downturns because demand for their products and services can continue regardless of the economy, i.e. their performance is negatively correlated to the overall state of the economy. These are namely pharmaceutical, educational service, insurance carriers, and public service industries. To conclude, cyclical industries offer greater potential for growth, as they tend to outperform the market during periods of economic strength. These markets could end up in trouble if during the up-swing, investors believe in further rise of prices and profits, adding a still further delay and exaggerating the boom. Investors usually opt for long-term growth with reduced volatility in order to balance their portfolios with a mix of cyclical stocks and non-cyclical stocks.

\subsection{Stylized facts about the industrial production in Croatia}

Industrial production does play a very important role in Croatian economic growth as this indicator is often used is some studies as an approximation for the national output measurement. Since mid 1990s the industry has been strongly influenced by an inappropriate exchange rate policy and continuous increase of tax and non-tax duties (Bezić, Cerović and Galović, 2011). Due to the inadequate exchange rate policy the manufacturing industry has lost half of its assets only on exchange rate differences since mid 1990s. At the same time, business costs have increased rapidly and without any control. Such over helmed results have decreased profits and competitiveness in the manufacturing industry. World financial crisis from 2008 brought some new problems. Registered average rate of change of industrial production between 2000 and 2007 was $4.50 \%$. Then, till 2009 , the index dropped by 15 percentage points to experience a relatively steady decline till 2012 with an average annual rate of more than $2.60 \%$. Croatia's average industrial production index for the first months of 2013 was comparable to the level in 2003 (Jaegers, 2013), however till then index grew steadily as the EU markets were in the process of healing ${ }^{1}$. Growth of the industrial production in Croatia took off during 2015 and increased by $2.7 \%$ with the rise in the labour productivity. Heavy burden of the crisis is' being paid', as the average annual growth in the period $1998-2015$ was only $1.17 \%$. 
D. Tomić \& S. Stjepanović: Cyclical Characteristics of the Industrial Production in Croatia

\subsection{Empirics; evidence from Croatia}

There are relatively heterogeneous research patterns concerning industrial production in Croatia. Bačić and Vizek $(2006,2008)$ evaluated composite leading indicator of the Croatian economy (CROLEI) whose purpose was to forecast classical business and growth cycles (in a form of its derivative CROLEI forecasting index). Authors conclude that the original CROLEI has by far the greatest forecasting power, but also that it predicts the turning points in economic cycle with highest probability. On the other hand, Cerovac (2005) developed some new composite indicators so as to identify and predict cyclical expansions and contractions. Čižmešija and Bahovec (2009) tested empirical relevance of two leading indicators, CROLEI and Industrial confidence indicator. Authors found a weakening of a correlation between the indicators and a reference series (industrial production) leading them to a conclusion that these indicators should undergo some moderations for improving their predictive features. Bezić, Cerović and Galović (2011) analyzed the position of competitive advantages of Croatia's manufacturing industry within foreign exchange trading. Research results have shown that Croatian manufacturing industry is facing accumulated issues whose consequences will have destructive proportions. Activities of the Croatian processing sector have been slowed down due to decreased foreign and domestic demand, and strengthened competitive forces of Asian countries. Lower productivity and innovation level has left a significant mark on Croatian export activity flow as well. The main conclusion is that there is a need for establishing new prerequisites and measures for structural changes in the Croatian manufacturing industry. Interesting research is provided by Tkalec and Vizek (2009) who analyzed the impact of macroeconomic policies on manufacturing industries in Croatia and came to conclusion that these industries in general react most to the changes in fiscal policy.

\section{$3 \quad$ Methodological issues and the results}

This section consists of three parts; first we will clarify some methodological issues, then evaluate the data and in the end interpret the results of the statistical analysis

\subsection{Methodology}

In order to evaluate cyclical characteristics of the industrial production and its subsectors, we have followed the works of Stock and Watson (1998), Agresti and Mojon (2001), and Napoletano, Roventini and Sapio (2005). Though their research framework was based on Baxter-King filter, we will use Hodrick-Prescott (HP) filter instead. The problem of the optimal method to decompose a data series into two components (long term trend and stationary cycle) is still much debated. In the context of business cycle analysis, this problem is much more important if the entire analysis that follows is based on the results of such filtering method. Taking into consideration fairly large literature that is criticizing HP filter, Ravn and Uhlig (2002) emphasised that this filtering method withstood the test of time and the intensity of discussion and criticism remarkably well, so it appear it will most likely remain the popular method for detrending in theoretically 
$117236^{\text {Th }}$ International Conference on Organizational Science Development: Responsible Organization (March $22^{\mathrm{ND}}-24^{\mathrm{TH}}$, Portorož Slovenia)

D. Tomić \& S. Stjepanović: Cyclical Characteristics of the Industrial Production in Croatia

oriented researches for a long time to come. The popularity of the HP filter in detrending time series certainly arises from the fact that it is easy to estimate and to comprehend. Hodrick and Prescott's (1997) analysis was based on the assumption that time series are consisted of cyclical and growth components, so if growth accounting can provide estimates of growth components with errors that are small relative to the cyclical component, computing the cyclical component is just a matter of calculating the difference between the observed value and the growth component. It resulted in creation of the filter that became the most popular method for removing long-run movements from the time series within the business cycle analyses. The HP filter focuses at removing a smooth trend $\tau_{t}$ from some given data $y_{t}$ by solving next equation:

$$
\min _{t} \sum_{t=1}\left(\left(y_{t}-\tau_{t}\right)^{2}+\lambda\left(\left(\tau_{t+1}-\tau_{t}\right)-\left(\tau_{t}-\tau_{t-1}\right)\right)^{2}\right)
$$

so the residual $y_{t}-\tau_{t}$ is then commonly referred to as the business cycle component. This is actually a linear filter that requires previous specification of a parameter known as lambda $(\lambda)$. Giving the form of the observation (annually, quarterly or monthly) this parameter tunes the smoothness of the trend i.e. penalizes the acceleration in the trend component relative to the cycle component. Many point that the parameter $\lambda$ does not have an intuitive interpretation for the user and that its choice is consider the main weakness of the HP filter. Non-the-less, HP filter has been applied in a number of studies; see Blackburn and Ravn (1992), De Arcangelis and Di Giorgio (1999), Benazić and Tomić (2014), Tomić and Pičuljan (2016), and etc.

According to Stock and Watson (1998) and Napoletano, Roventini and Sapio (2005), comovements between variables are revealed through the cross-correlation of the cyclical component of each series with the cyclical component of industrial production index as a benchmark variable, which is thought to represent the business cycle. This is the correlation between $x_{t}$ and $y_{t+k}$, where $x_{t}$ is the filtered series and $y_{t+k}$ is the $k$-quarter lead of the filtered industrial production. A large positive correlation at $k=0$ (i.e. around lag zero) indicates pro-cyclical behaviour of the series; a large negative correlation at $k=0$ indicates counter-cyclical behaviour; and no correlation indicates acyclical behaviour of the series. A maximum correlation at, for example, $k=-1$ indicates that the cyclical component of the variable tends to lag the aggregate business cycle by one quarter. In other words, if the absolute maximum (or minimum) is achieved at some industrial production lead, then the variable is denoted as leading, whereas it is called lagging in the opposite case. Finally, coincident variables are those displaying the bulk of their cross-correlation with industrial production index at lag zero.

To conclude, as to analyze behaviour/movements between the variables we will calculate cross-correlation coefficients (to estimate the degree to which two series are correlated with time lags/leads to evaluate time analogy between them) and autocorrelation coefficients (for finding repeating patterns) ${ }^{2}$ and in addition, we will derive bivariate 
D. Tomić \& S. Stjepanović: Cyclical Characteristics of the Industrial Production in Croatia

(pairwise) Granger causalities to emphasize mutual relationship between the industrial production index and its main components.

\subsection{Data}

Quarterly data on industrial production index covering the period 1998Q1 - 2016Q2 were taken from Croatian National Bank database 2010, being a base year. This database also provides time series for industrial production sub-sectors which enabled us to evaluate industry on a disaggregated level as well. Data were seasonally adjusted using the ARIMA X12 seasonal adjustment procedure but have not been transformed to logarithmic form. Namely, Croatian industrial production is strongly exposed to seasonality. Therefore, seasonal adjustment allows us to see the real movements and turning points in the variable (if we want to track long-term perspective) and to compare series from quarter to quarter (if we want to track short-run developments). Hence, fluctuations due to exceptional strong or weak seasonal influences (such as consequences of economic policy, strikes and etc.) will continue to be visible in the seasonally adjusted series (Tomić and Stjepanović, 2017). On the other part, we wanted to keep cyclical characteristics focusing on short-term diagnostic, therefore we eliminated the possibility of logarithmic transformation (similar to Van Ruth, Schouten and Wekker (2005)) ${ }^{3}$.

In order to extract the business cycle component that presents the stationary cycle of the variable we used smoothing parameter $\lambda$ of 1,600 which is the standard value for quarterly frequencies. To test the integration properties we analyzed graphical displays of the variables and applied three unit root tests; Augmented Dickey Fuller test, Phillips-Perron test and Kwiatkowski-Phillips-Schmidt-Shin test (see Table 1). Generally, figures and tests confirmed the absence of unit root in the observed variables which is important property of detrended variables.

Our analysis is therefore based on cyclically presented basic index i.e. variable industrial production ( $c \_I N D \_s a$ ) and variables that represent main industrial groupings: industrial production of capital goods ( $c \_I N D \_c a p i t a l$ goods_sa), energy ( $\left.c \_I N D \_e n e r g y \_s a\right)$, intermediate goods (c_IND_intermediate goods_sa), durable consumer goods (c_IND_durable consumer goods_sa) and non-durable consumer goods (c_IND_nondurable consumer goods_sa) where c_represents cyclical appellation and _sa stands for seasonally adjusted series. Next section is concerned with the results of the analysis. 
1174 36 ${ }^{\text {TH }}$ International Conference on Organizational Science Development: RESPONSIBLE ORGANIZATION (MARCH $22^{\mathrm{ND}}-24^{\mathrm{TH}}$, PORTOROŽ SLOVENIA)

D. Tomić \& S. Stjepanović: Cyclical Characteristics of the Industrial Production in Croatia

Table 1. Unit roots tests (variables in level)

\begin{tabular}{|c|c|c|}
\hline \multirow[t]{2}{*}{ Variables } & \multicolumn{2}{|c|}{ Augmented Dickey-Fuller test (ADF) } \\
\hline & constant & constant + trend \\
\hline c_IND_sa & $-3.705 * * *$ & $-3.670 * *$ \\
\hline c_IND_capital goods_sa & $-3.884 * * *$ & $-3.850 * *$ \\
\hline c_IND_durable consumergoods_sa & $-3.822 * * *$ & $-3.795 * *$ \\
\hline c_IND_energy_sa & $-4.749 * * *$ & $-4.725 * * *$ \\
\hline c_IND_intermediate goods_sa & $-4.191 * * *$ & $-4.155 * * *$ \\
\hline c_IND_non-durable $\quad$ consumer & $-5.149 * * *$ & $-5.115 * * *$ \\
\hline \multirow{2}{*}{ Variables } & \multicolumn{2}{|c|}{ Phillips-Perron test (PP) } \\
\hline & constant & constant + trend \\
\hline c_IND_sa & $-3.756^{* * *}$ & $-3.697 * *$ \\
\hline c_IND_capital goods_sa & $-4.052 * * *$ & $-4.009 * *$ \\
\hline c_IND_durable consumergoods_sa & $-3.910 * * *$ & $-3.884 * *$ \\
\hline c_IND_energy_sa & $-4.876 * * *$ & $-4.851 * * *$ \\
\hline c_IND_intermediate goods_sa & $-4.173 * * *$ & $-4.078 * *$ \\
\hline c_IND_non-durable & $-5.206 * * *$ & $-5.155 * * *$ \\
\hline \multirow{2}{*}{ Variables } & \multicolumn{2}{|c|}{$\begin{array}{c}\text { Kwiatkowski-Phillips-Schmidt-Shin test } \\
\text { (KPSS) }\end{array}$} \\
\hline & constant & constant + trend \\
\hline c_IND_sa & $0.074 * * *$ & 0.075 \\
\hline c_IND_capital goods_sa & 0.050 & 0.050 \\
\hline c_IND_durable consumergoods_sa & 0.057 & 0.057 \\
\hline c_IND_energy_sa & 0.034 & 0.034 \\
\hline c_IND_intermediate goods_sa & 0.092 & 0.092 \\
\hline c_IND_non-durable consumer & 0.049 & 0.049 \\
\hline
\end{tabular}

Source: Authors' calculation (in EViews 9). 


\subsection{The results}

First, we will evaluate basic properties and cyclical features of industrial production dynamics by analyzing (graphical) relation between the basic variable and its sub-sectors. Next, Table 2 presents extracted cyclical components on a disaggregated level, whereat we simply completed cross-correlations with lags/leads between the basic industrial production variable and the variables that represent main industrial sectors, In addition to current correlation coefficients $(t-0)$, lag/lead analysis was also introduced in order to determine if some variables lag, lead or coincide with fluctuations in basic industrial production. Table 3 displays autocorrelations (ACF), i.e. they are basis for the persistence analysis. And Table 4 presents results from the bivariate (pairwise) Granger causality tests.

Figure 1. Industrial production and its main industrial groupings (cyclical series)
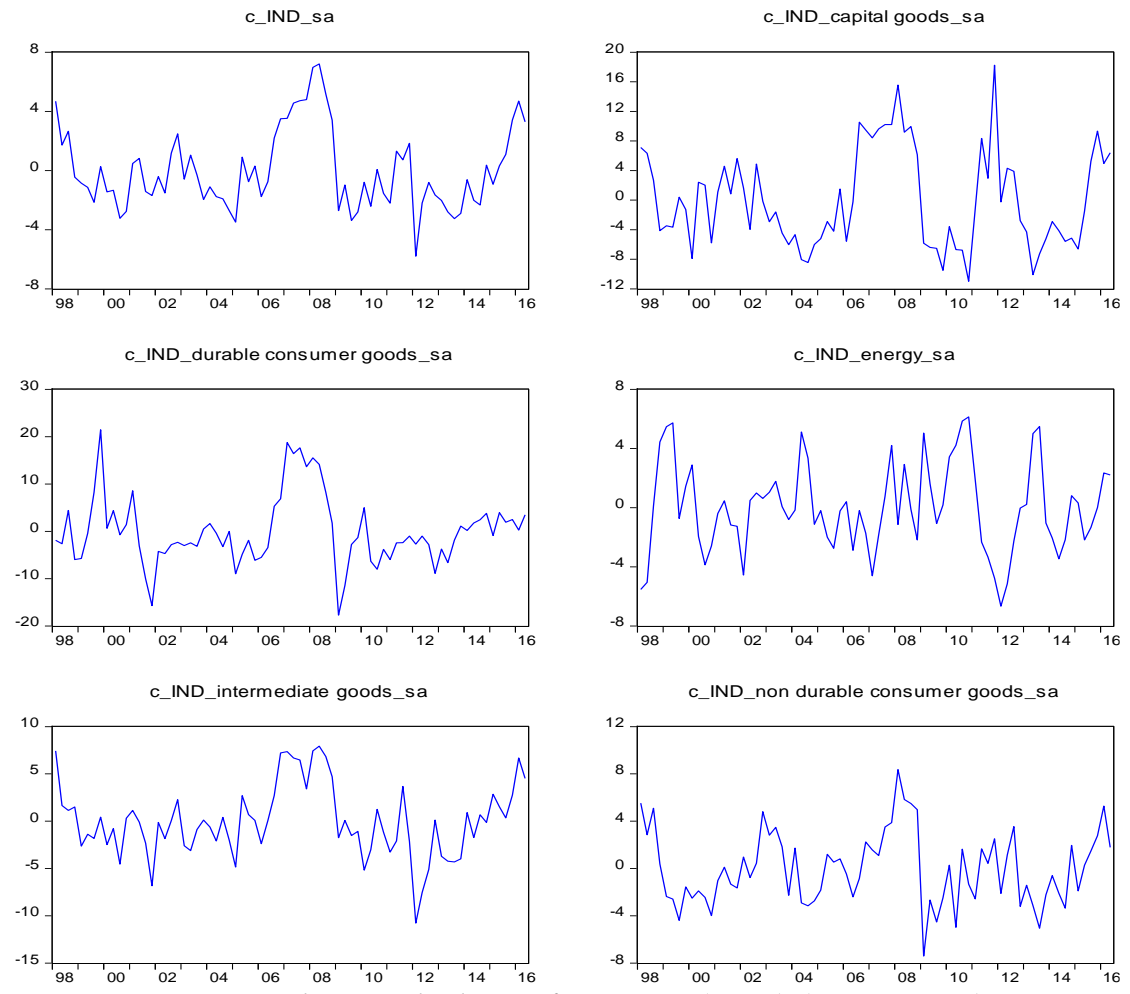

Source: Authors' calculation from CNB (2016) (in EViews 9).

Graphical display (Figure 1) of all variables indicates strong resemblance in their movements; following the relatively stable period in the first part of 2000s, the crisis of 2008 brought emphatic fluctuations (especially seen in 2008 and 2011) ${ }^{4}$ with persistent 
36 ${ }^{\text {TH }}$ International Conference on Organizational Science Development: ResPonsible ORGaNiZATION (MARCH $22^{\mathrm{ND}}-24^{\mathrm{TH}}$, PORTOROŽ SLOVENIA)

D. Tomić \& S. Stjepanović: Cyclical Characteristics of the Industrial Production in Croatia

dynamics throughout next few years. Interestingly, the intensity of those fluctuations was not evenly distributed through our variables, when observed on disaggregated level. Those industries typically called cyclical industries (such as industrial production of capital goods and durable consumer goods) were experiencing a larger fluctuation (fluctuated in between frequencies -20 to 20) which is to be expected for these sectors are de facto sensitive to a business cycle. In that way such industries are more volatile in comparison to the general movements of the industrial production index. Other subsectors portrayed relatively stable movements (average fluctuation in between frequencies -8 to 8 ) similar to that of the basic variable industrial production, but with much stronger volatility in the case of the energy sector (suggesting in that manner its exogenous character). These conclusions are in line with those depicted from the crosscorrelation analysis (Table 2).

Table 2: Cross-correlation to c_IND-sa with lags and leads up to 4 periods

\begin{tabular}{|c|c|c|c|c|c|c|c|c|c|}
\hline Variables & $t-4$ & $t-3$ & $t-2$ & $t-1$ & $t-0$ & $\begin{array}{c}t+ \\
1\end{array}$ & $\begin{array}{c}t+ \\
2\end{array}$ & $\begin{array}{c}t+ \\
3\end{array}$ & $\begin{array}{c}t+ \\
4\end{array}$ \\
\hline c_IND_capital goods_sa & $\begin{array}{c}0.1 \\
3\end{array}$ & $\begin{array}{c}0.3 \\
3\end{array}$ & $\begin{array}{c}0.4 \\
8\end{array}$ & $\begin{array}{c}0.5 \\
6\end{array}$ & $\begin{array}{c}0.7 \\
7\end{array}$ & $\begin{array}{c}0.5 \\
3\end{array}$ & $\begin{array}{c}0.4 \\
5\end{array}$ & $\begin{array}{c}0.2 \\
6\end{array}$ & $\begin{array}{c}0.1 \\
2\end{array}$ \\
\hline $\begin{array}{l}\text { c_IND_durable consumer } \\
\text { goods_sa }\end{array}$ & $\begin{array}{c}0.2 \\
4\end{array}$ & $\begin{array}{c}0.3 \\
4\end{array}$ & $\begin{array}{c}0.5 \\
1\end{array}$ & $\begin{array}{c}0.5 \\
2\end{array}$ & $\begin{array}{c}0.5 \\
8\end{array}$ & $\begin{array}{c}0.3 \\
4\end{array}$ & $\begin{array}{c}0.2 \\
4\end{array}$ & $\begin{array}{c}0.1 \\
5\end{array}$ & $\begin{array}{c}0.0 \\
8\end{array}$ \\
\hline c_IND_energy_sa & $\begin{array}{c}- \\
0.0 \\
5\end{array}$ & $\begin{array}{c}- \\
0.0 \\
9\end{array}$ & $\begin{array}{c}- \\
0.1 \\
3\end{array}$ & $\begin{array}{c}- \\
0.0 \\
8\end{array}$ & $\begin{array}{c}- \\
0.0 \\
5\end{array}$ & $\begin{array}{c}0.0 \\
3\end{array}$ & $\begin{array}{c}0.0 \\
6\end{array}$ & $\begin{array}{c}0.1 \\
4\end{array}$ & $\begin{array}{c}0.1 \\
6\end{array}$ \\
\hline c_IND_intermediate goods_sa & $\begin{array}{c}0.3 \\
3\end{array}$ & $\begin{array}{c}0.3 \\
9\end{array}$ & $\begin{array}{c}0.4 \\
6 \\
\end{array}$ & $\begin{array}{c}0.6 \\
2\end{array}$ & $\begin{array}{c}0.8 \\
4\end{array}$ & $\begin{array}{c}0.6 \\
1\end{array}$ & $\begin{array}{c}0.4 \\
0\end{array}$ & $\begin{array}{c}0.2 \\
3\end{array}$ & $\begin{array}{c}0.2 \\
7\end{array}$ \\
\hline $\begin{array}{l}\text { c_IND_non-durable } \\
\text { consumergoods_sa }\end{array}$ & $\begin{array}{c}0.0 \\
0\end{array}$ & $\begin{array}{c}0.1 \\
9\end{array}$ & $\begin{array}{c}0.3 \\
9\end{array}$ & $\begin{array}{c}0.4 \\
8\end{array}$ & $\begin{array}{c}0.8 \\
4\end{array}$ & $\begin{array}{c}0.5 \\
4\end{array}$ & $\begin{array}{c}0.4 \\
1\end{array}$ & $\begin{array}{c}0.2 \\
9\end{array}$ & $\begin{array}{c}0.0 \\
4 \\
\end{array}$ \\
\hline
\end{tabular}

- Bold number denotes $1 \%, 5 \%$ or $10 \%$ significance levels respectively.

Source: Authors' calculation (in EViews 9).

When observing cross-correlation coefficients we can notice relatively strong relationship between the movements in sub-sectors and the basic variable industrial production, energy being the only variable that has shown extremely weak and negative correlations. As expected we find medium to strong t-0 correlation of industrial production of capital goods and durable consumer goods to the basic variable, both which are showing to be pro-cyclical and lagging variables. Nothing strange, considering their cyclical sensitivity and their limited involvement in the aggregate production value. This cyclicality is persistent even in $\mathrm{t}-2$ and $\mathrm{t}+2$ periods which confirms the stronger volatility of those sub-sectors in comparison to the basic variable. On the other hand, fluctuations in the industrial production of intermediate goods and non-durable consumer goods seems to be very correlated to the movements of the aggregated variable in $\mathrm{t}-0$ time as well as in lags and leads. Both of these variables also tend to be pro-cyclical but with stronger leading indices, indicating their significant influence on the basic variable. As 
D. Tomić \& S. Stjepanović: Cyclical Characteristics of the Industrial Production in Croatia

mentioned, energy sub-sector is indicating negative (as well as statistically insignificant) cross-correlation coefficients, probably because production of energy is not related just to the industrial production but as to household consumption as well. Not being positively correlated to the basic industrial production we can mark this sector as a counter-cyclical industry. However, correlation coefficients are shown to be extremely low, meaning that we can evaluate this relation as economically insignificant in that manner.

Table 3. Autocorrelations (ACF)

\begin{tabular}{|l|c|c|c|c|c|}
\hline \multicolumn{1}{|c|}{ Variables } & $\mathbf{t}+\mathbf{1}$ & $\mathbf{t}+\mathbf{2}$ & $\mathbf{t}+\mathbf{3}$ & $\mathbf{t}+\mathbf{4}$ & $\mathbf{t}+\mathbf{5}$ \\
\hline $\begin{array}{l}\text { c_IND_sa } \\
\text { c_IND_capital goods_sa }\end{array}$ & 0.1992 & 0.0137 & 0.1606 & 0.1182 & 0.1182 \\
\hline $\begin{array}{l}\text { c_IND_durable } \\
\text { goods_sa }\end{array}$ & 0.2094 & 0.1953 & 0.0959 & $\mathbf{0 . 2 1 3 5}$ & $\mathbf{0 . 2 1 3 5}$ \\
\hline $\begin{array}{l}\text { c_IND_energy_sa } \\
\text { c_IND_intermediate goods_sa }\end{array}$ & 0.1595 & 0.0597 & 0.1541 & 0.0075 & 0.0075 \\
\hline $\begin{array}{l}\text { c_IND_non-durable consumer } \\
\text { goods_sa }\end{array}$ & - & & - & & \\
\hline
\end{tabular}

- Bold number denotes $1 \%$, 5\% or $10 \%$ significance levels respectively.

Source: Authors' calculation.

In addition, we have observed the persistence of the variables (Table 3). Persistence indicates the length in which one variable stays within a phase of a business cycle. Aggregated industrial production together with three sub-sectors (industrial production of capital goods, durable consumer goods and energy) is showing no persistence of a business cycle, which is very strange especially for the basic industrial production variable since its positive/negative movements should have some on-going effects on the national output at least through specific multiplicative impact. Both, industrial production of intermediate goods and non-durable consumer goods are persistent in a phase of a cycle for at least two periods, suggesting that variables fluctuate persistently and stabilize within specific economic periods. In that sense it reveals their low sensitivity for phases of business cycle. Finally, we will observe Granger causality test to provide additional evidence on the links between the movements in main industrial groupings and the movements in basic industrial production variable per se. 
36 ${ }^{\text {TH }}$ International Conference on ORganizational Science Development: ResPonsible ORGaNiZATION (MARCH $22^{\mathrm{ND}}-24^{\mathrm{TH}}$, PORTOROŽ SLOVENIA)

D. Tomić \& S. Stjepanović: Cyclical Characteristics of the Industrial Production in Croatia

Table 4. Bivariate Granger causality tests

\begin{tabular}{|l|c|c|c|c|}
\hline \multirow{2}{*}{ Variables } & \multicolumn{2}{c|}{ Cause c_IND_sa } & \multicolumn{2}{c|}{ C_IND_sa caused } \\
\cline { 2 - 5 } & $\boldsymbol{F}$ - & $\boldsymbol{p}$ - & $\boldsymbol{F}$ - & $\boldsymbol{p}$ - \\
\hline c_IND_capital goods_sa & 0.58279 & 0.45 & 0.79123 & 0.38 \\
\hline c_IND_durable consumergoods_sa & $\mathbf{3 . 4 7 8 0 4}$ & $\mathbf{0 . 0 7}$ & 0.05377 & 0.82 \\
\hline c_IND_energy_sa & 0.22658 & 0.64 & 0.49014 & 0.49 \\
\hline c_IND_intermediate goods_sa & 1.42649 & 0.24 & $\mathbf{4 . 2 8 8 0 2}$ & $\mathbf{0 . 0 4}$ \\
\hline c_IND_non-durable consumer & $\mathbf{3 . 5 8 1 4 1}$ & $\mathbf{0 . 0 6}$ & $\mathbf{7 . 2 7 6 8 0}$ & $\mathbf{0 . 0 1}$ \\
\hline
\end{tabular}

- Bivariate (pairwise) models with each variable and the c_IND_sa with one lag applied. Bold values are those for which the null (no causality) is rejected at 1\%, 5\% and $10 \%$ significance level.

Source: Authors' calculation (in EViews 9).

Bivariate (pairwise) Granger causality tests suggest no causal relationship between the industrial production of capital goods and energy to aggregated level of industrial production. Next, we find that industrial production of durable consumer goods Granger cause basic variable, but that the fluctuations of basic variable Granger caused the movements of industrial production of intermediate goods. We can also depict mutual Granger causality between the basic variable and the industrial production of non-durable consumer goods. Our research shows that there are no signs of discrepancies in the conclusion across different methods of analysis, hence some generalizations could be made about the cyclical characteristics of the industrial production in Croatia.

\section{$4 \quad$ Concluding remarks}

The level of industrial production is a narrower measure of the overall aggregate economic activity as the direction and timing tend to coincide with the reference cycle, namely gross national output. Furthermore, all industrial production indices are usually pro-cyclical and coincident (as our results suggest also), meaning they tend to rise when national output rises and fall when output growth declines. Sometimes the direction and/or timing do not have follow the reference cycle behaviour, especially if we take into account the industrial production indices on a disaggregated level. Hence, detailed analysis of individual series could help us in examining the common elements in the behaviour of all series (both, aggregated and disaggregated) as well as to pinpoint important differences in the series representing different sectors of the economy (Romer, 1991). In addition Romer (1991) states, that the use of disaggregate series has been largely abandoned by modern macroeconomists who typically use aggregate data such as gross national product or overall industrial production in the analysis of short-run fluctuations. Such confinement can have disastrous consequences within a short- and long run forecasting, especially if we know that industrial production is often used to forecast the evolution of gross national product itself. In that manner, we opted for an 
analysis which would include aggregated and disaggregated data. Through the paper that was focused on understanding the cyclical characteristics of industrial production and its main industrial groupings in Croatia, we wanted to evaluate fluctuations, changes, persistence and co-movement in the industrial production series over time. Disaggregated data are in fact used to analyze whether short-run fluctuations have become more or less extreme and erratic over time.

The analysis confirms that the basic industrial production indicator and its main subsectors are closely correlated, moreover four out of five sub-sectors indicated persistent - coincident - proc-cyclical behaviour with some leading characteristics, whereas only one suggested statistically and economically insignificant relation. Fluctuation of the level of industrial production of intermediate goods and non-durable consumer goods is particularly related to the cyclical component of the basic index, as they are considered as mostly coincident indicators of industrial production movements. They are also good up-to-two quarters leading indicators of the aggregate production level (with either oneway or two-way Granger causality), next they are persistent in a phase of a cycle for at least two periods, suggesting that these sub-sectors fluctuate persistently and stabilize within specific economic periods. All this reveals their low sensitivity for the phases of business cycle. We could conclude that fluctuations or actually a crisis did not result in deep cyclical recession in these industrial sectors, therefore it did not deteriorate their mid- to long-term growth prospects. Strong build-up in industrial production of these industrial groupings since 2013 certainly had some positive effects in the annulling of negative gross domestic output growth rates. Next, energy sub-sector is indicating insignificant counter-cyclical (negative) cross-correlation coefficients with no causal relation to the basic index, probably because the production of energy is not related just to the industrial production but as to household consumption as well. On the other hand, industrial production of capital goods and durable consumer goods are revealing their pro-cyclical but lagging nature with cyclicality that is persistent even in $t$ - and $t+$ periods which confirms the stronger volatility of those sub-sectors in comparison to the basic index. In this part, in general, we also found no causality, however we depicted that industrial production of durable consumer goods Granger cause basic variable. Such results are not unexpected if know that these types of industries are typical cyclical industries i.e. industries that are sensitive to a business cycle. All in all, cyclical analysis suggests that the basic index is dependant and closely correlated to the movements in its sub-sectors (even if we see that in the case of industrial production of energy, or in some aspects in the case of industrial production of capital goods and durable consumer goods, is not capable of correctly tracking aggregate industrial activity across the business cycle). Yet industrial production of intermediate goods and non-durable consumer goods are shown to be less cyclically sensitive, therefore a good choice for both short- and longrun (predictive) assessments of the aggregate industrial production level.

By using autocorrelations, cross-correlations and causality tests, de facto simple summary statistics, we gave an insight into a possible source of short-run fluctuations of industrial production indices. Structural adjustments in the Croatian industrial sector were mostly of a passive form and latent with no prospect related to new production technology 
36 ${ }^{\text {TH }}$ International Conference on Organizational Science Development: ResPonsible ORGaNiZATION (MARCH $22^{\mathrm{ND}}-24^{\mathrm{TH}}$, PORTOROŽ SLOVENIA)

D. Tomić \& S. Stjepanović: Cyclical Characteristics of the Industrial Production in Croatia

that would raise production knowledge and productivity, therefore economy passed through dramatic downscaling both in total output and export. Though this could be expected, a significant downturn of output of industrial sub-sectors of higher value has been registered, as their cyclical sensitivity is one of the reasons for it. By exposing these (in)stabilities, in a form of cyclical sensitivity among the main industrial groupings, we are raising many questions. If the productions of various goods move together, what would happen if the aggregate shocks were dominant sources of fluctuations or would sectoral shocks have large and rapid spill-overs? Are industry-specific shocks more important and does their relative importance varies over time? Could we witness the abrupt change in their sensitivity due to large shocks? These are questions for future research patterns that should be thoroughly tested with appropriate econometric techniques, hence would serve as a base for serious macroeconomic policy contemplations, reflections and speculations.

\section{Notes}

${ }^{1}$ Bezić, Cerović and Galović (2011) state that Croatian anti-recession measures have not brought any concrete (positive) results for the purpose of liquidity increase. Moreover, due to restrictive tax policy (VAT increase), the liquidity of the manufacturing industry in Croatia has been additionally undermined.

${ }^{2}$ In order to understand the presented tables it is first necessary to understand correlation as a measure of the linear relationship between two variables, the cross-correlation function (Table 2) as just the correlation of one time series versus lag/led version of the other i.e. industrial production, and the auto-correlation (Table 3 ) as the cross-correlation of a function and itself. Thus these tables display the time structure and the strength of the linear relationship, both internally (autocorrelation) and from one to another (cross-correlation)

${ }^{3}$ We also evaluated logarithmically transformed variables, however there was no significant difference in the results.

${ }^{4}$ From 2008Q2 which we can mark as the end of growth period for Croatian economy and which is followed by the crisis; from 2011:Q1 in which economy experienced a small peak as a result of modest growth in the EU (see Tomić and Stjepanović (2017).

\section{Literature}

Agresti, A. M. and Mojon, B. (2001). Some Stylized Facts on the Euro Area Business Cycle. ECB Working Paper, No. 95, pp.1-43.

Bačić, K. and Vizek, M. (2008). Forecasting business and growth cycles in Croatia. Economic Review, Vol. 59, No. 11, pp. 646-668.

Bačić, K. and Vizek, M. (2006). A brand new CROLEI - do we need a new forecasting index? Financial Theory and Practice, Vol. 30, No. 4, pp. 311-346.

Benazić, M. and Tomić, D. (2014). The evaluation of fiscal and monetary policy in Croatia over a business cycle. Proceedings of Rijeka Faculty of Economics: Journal of Economics and Business, Vol. 32, No. 1, pp. 75-99.

Bezić, H., Cerović, Lj. and Galović, T. (2011). Changes in the competitive advantages of Croatia's manufacturing industry. Proceedings of Rijeka Faculty of Economics: Journal of Economics and Business, Vol. 29, No. 2, pp. 465-487. 
Blackburn, K. and Ravn, M. O. (1992). Growth, Human Capital Spillovers and International Policy Coordination. Scandinavian Journal of Economics, Vol. 95, No. 4, pp. 495-515.

Bulligan, G., Golinelli, R. and Parigi, G. (2010). Forecasting monthly industrial production in real time: from single equations to factor based-models. Empirical Economics, Vol. 39, No. 2, pp. 303-336.

Cerovac, S. (2005). Novi kompozitni indikatori za hrvatsko gospodarstvo: prilog razvoju domaćeg sustava cikličkih indikatora. Istraživanja 1-16, travanj 2005, Hrvatska narodna banka.

Chowdhury, A. (2014). An investor's guide to cyclical and counter-cyclical industries. Available at: $\quad$ http://finance.yahoo.com/news/investor-guide-cyclical-counter-cyclical225307747.html > [Accessed November 16, 2016].

Croatian National Bank (2016). Available at: 〈http://hnb.hr $>$ [Accessed November 10, 2016].

De Arcangelis, G. and Di Giorgio, G. (1999). Monetary policy shocks and transmission in Italy: A VAR analysis. Economics Working Papers, No. 446, pp.1-47.

Dickey, D. A. and Fuller, A. W. (1981). Likelihood ratio statistics for autoregressive time series with a unit root. Econometrica, Vol. 49, No. 4, pp. 1057-1072.

Čižmešija, M. and Bahovec, V. (2009). Forecasting the direction of changes in Croatia's industrial production with ICI and CROLEI. Revista Investigacion Operacional, Vol. 30, No. 2, pp. 140148.

Hodrick, R. J. and Prescott, E. C. (1997). Postwar U.S. Business Cycles: An Empirical Investigation. Journal of Money, Credit and Banking, Vol. 29, No. 1, pp. 1-16.

Kwiatkowski, D., Philips, P., Schmidt, P. and Shin, Y. (1992). Testing the null hypothesis of stationarity against the alternative of a unit root: How sure are we that economic time series have a unit root? Journal of Econometrics, Vol. 54, No. 1-3, pp. 159-178.

Jaegers, T. (2013). Short-term business statistics for Croatia and the European Union. Production and turnover trends in Croatia and in the European Union. Statistics in Focus 23/2013, Eurostat.

Kaldor, N. (1967). Strategic Factors in Economic Development. New York: Ithaca.

Kaynar, O. (2012). Forecasting industrial production index with soft computing techniques. Economic computation and economic cybernetics studies and research, Vol. 3, No. 3, pp. 113138.

Sala, M., Torres, T. and Farré, M. (2014). Characterization of cyclical phases in the manufacturing industry in Spain. Journal of Industrial Engineering and Management, Vol. 7, No. 4, pp. 961 994.

Napoletano, M., Roventini, A. and Sapio, S. (2005). Are Business Cycles All Alike? A Bandpass Filter Analysis of Italian and US Cycles. LEM Working Paper Series, No. 2004/25, pp. 1-36. Available at: 〈http://www.lem.sssup.it/WPLem/files/2004-25.pdf $>$ [Accessed November 14, 2016].

Phillips, P. and Perron, P. (1988). Testing for a Unit Root in Time Series Regression. Biometrika, Vol. 75, No. 2, pp. 335-346.

Ravn, M. O. and Uhlig, H. (2002). On Adjusting the Hodrick-Prescott Filter for the Frequency of Observation. The Review of Economics and Statistics, Vol. 84, No. 2, pp. 371-376.

Romer, C.D. (1991). The cyclical behaviour of individual production series, 1889-1984. The Quarterly Journal of Economics, Vol. 106, No. 1, pp. 1-31.

Stock, J. H. and Watson, M. W. (1998). Business Cycle Fluctuations in U.S. Macroeconomic Time Series. NBER Working Paper Series, No. 6528, pp. 1-83.

Tkalec, M. and Vizek, M. (2009). The impact of Macroeconomic Policies on Manufacturing Production in Croatia. Privredna kretanja i ekonomska politika, Vol. 19, No. 121, pp. 61-92.

Tomić, D. and Pičuljan, M. (2016). Segmenting terms of trade; the case of Croatia. Proceedings of $35^{\text {th }}$ International Conference on Organizational Science Development: Sustainable Organization. Portorož, Slovenia, March 16-18, pp. 1207-1220. 
1182 36 $6^{\text {Th }}$ International Conference on Organizational Science Development: RESPONSIBLE ORGANIZATION (MARCH $22^{\mathrm{ND}}-24^{\mathrm{TH}}$, PORTOROŽ SlOVENIA)

D. Tomić \& S. Stjepanović: Cyclical Characteristics of the Industrial Production in Croatia

Tomić, D. and Stjepanović, S. (2017). Forecasting capacity of ARIMA models; a study on Croatian industrial production and its sub-sectors (in the process of publishing).

Van Ruth, F., Schouten, B. and Wekker, R. (2005). The Statistics Netherlands' Business Cycle Tracer. Methodological aspects; concept, cycle computation and indicator selection. Internal report, Statistics Netherlands. 


\section{Model zaposlovanja po opravljenem pripravništvu v zdravstveni negi}

\section{NINA TRIFONI \& VESNA NOVAK}

Povzetek Gospodarska kriza v Sloveniji in nezaposlovanje močno vplivata na delovanje ustanove oziroma organizacije v zdravstvu, saj so prav kadri tisti, ki omogočajo organizacijam razvoj in uspeh. V prispevku obravnavamo postopek pridobivanja in zaposlovanja kadrov v zdravstveni negi v Splošni bolnišnici, da bi lahko oblikovali dobre in prepoznavne kriterije za zaposlitev novega sodelavca po opravljenem pripravništvu. Proces iskanja in izbiranja kandidata je dolgotrajen proces in mora biti dobro zasnovan in premišljen. Glede na število brezposelnih v zdravstveni negi ni težko dobiti formalno izobraženih kadrov, problem je, ali se bo izbrani kandidat dobro ujel v delovnem timu. Napačna izbira kandidata povzroča organizaciji velik strošek, ker to pomeni, da bo potrebno iskati in uvajati novega zaposlenega. Na podlagi rezultatov raziskave smo oblikovali model zaposlovanja po opravljenem pripravništvu zdravstvene nege, ki je lahko zdravstvenim ustanovam v pomoč pri pridobivanju in izbiranju kadrov.

KLJUČNE BESEDE: zaposlovanje • pripravništvo • zdravstvena nega

NAslov AVtorJeV: Nina Trifoni, Splošna bolnišnica Jesenice, Cesta maršala Tita 112, 4270 Jesenice, Slovenija, e-pošta: nina.trifoni@gmail.com; dr. Vesna Novak, docentka, Univerza v Mariboru, Fakulteta za organizacijske vede, Kidričeva cesta 55a, 4000 Kranj, Slovenija, e-pošta: vesna.novak@fov.uni-mb.si 
$36^{\mathrm{TH}}$ InTERnational CONFERENCE ON ORganizational SCIENCE Development: Responsible Organization (MARCh $22^{\mathrm{ND}}-24^{\mathrm{TH}}$, PORTOROŽ SLOVENIA)

O. Arsenijević, M. Ferjan, I. Podbregar, P. Šprajc, D. Trivan \& Y.

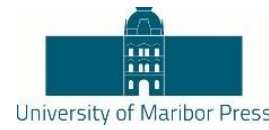

Ziegler

\title{
Employment Model after Their Internship in Nursing
}

\author{
NINA TRIFONI \& VESNA NOVAK
}

\begin{abstract}
The economic crisis in Slovenia and low employment rates have a strong impact on organisations in health sector. Human resources with their abilities, skills, knowledge and creativity significantly contribute to success of the organisations and allows them to develop and prosper. The paper deals with employment of personnel in nursing care at the General Hospital, in order to establish good and identifiable criteria for the employment of a new employee after the internship of nursing. Recruitment proces is lenghty and must be well designed and thought out. Because of high unemployment rate in health care, it is not difficult to find formally educated people. The problem is, if the coosen candidate will be good to fit into working existing team. Incorrect choice of candidate can causes costs to organisations, because they will need to undergo same recruitment and onboarding process again. Based on the survey results, we designed a model of employment after the internship nursing, which can contribute to better results in the recruitment of staff.
\end{abstract}

KEYWORDS: employment $\bullet$ traineeships $\bullet$ nursing care

CORRESPONDENCE ADDRESS: Nina Trifoni, General Hospital Jesenice, Cesta maršala Tita 112, 4270 Jesenice, Slovenia, e-mail: nina.trifoni@gmail.com; Vesna Novak, Ph.D., Assistant Professor, University of Maribor, Faculty of Organizational Sciences, Kidričeva cesta 55a, 4000 Kranj, Slovenia, e-mail: e-pošta: vesna.novak@fov.uni-mb.si

DOI https://doi.org/10.18690/978-961-286-020-2.94

ISBN 978-961-286-020-2

(C) 2017 University of Maribor Press

Available at: http://press.um.si 


\section{$1 \quad$ Uvod}

$\mathrm{V}$ današnjem času se dobro zavedamo, da so bogastvo $\mathrm{v}$ organizaciji zaposleni, zato je zelo pomembno, kakšne kadre organizacija zaposluje. Kadri namreč omogočajo razvoj in uspeh organizacije, saj s svojim znanjem, sposobnostjo, ustvarjalnostjo in delavnostjo bistveno prispevajo $\mathrm{k}$ uspešnemu delovanju organizacije. V Sloveniji imajo bolnišnice $\mathrm{v}$ zadnjih letih velike probleme pri zaposlovanju kadrov. Glede na raziskavo (Bregar, 2012) se v Sloveniji soočamo s povprečno več kot 20 odstotnim pomanjkanjem kadra $\mathrm{v}$ zdravstveni negi. Ministrstvo za zdravje je leta 2012 zmanjšalo oz. ustavilo zaposlovanje (Zakon za uravnoteženje javnih financ, 2012). Zaposluje se samo v primeru nadomeščanja porodniškega dopusta, daljše bolniške odsotnosti in nadomestitev delavca, če ta odhaja v pokoj (Zakon o zdravstveni dejavnosti, 2012). Izjemoma se zaposluje pripravnike za tehnika zdravstvene nege, ki se financira iz drugega proračuna. Za organizacijo pa je pomembno, da izbere ustreznega kandidata, ki bo pripomogel $\mathrm{k}$ boljšemu poslovanju, hkrati pa bo delo opravljal vestno, odločno in pripomogel $\mathrm{k}$ doseganju ciljev organizacije. Velik strošek organizaciji povzroča napačna izbira kandidata, kar pomeni, da bo potrebno iskati novega. Glede na število brezposelnih v zdravstveni negi ni težko dobiti formalno izobraženih, problem je, da se bo izbrani kandidat dobro ujel $\mathrm{v}$ delovnem timu.

$\mathrm{V}$ času pripravništva imajo organizacije še možnost opazovanja in spremljanja pripravnika. Opazujejo lahko njegove veščine in znanje, vključenost $\mathrm{v}$ delo na oddelku in $\mathrm{v}$ delovni tim. Po koncu pripravništva mentor napiše poročilo o poteku pripravništva in oceni pripravnikovo delo. Dodatno mnenje lahko dajo sodelavci, ki s kandidatom tesno sodelujejo oziroma delajo. Zato se pri končni izbiri novo zaposlenega upoštevajo različni kriteriji, kot so pripravnikov odnos do dela in do sodelavcev, njegova motivacija, kritičnost, spoštovanje, odnos do pacientov in sodelavcev.

Na razpis za prosto delovno mesto tehnik zdravstvene nege - pripravnik se prijavi veliko število kandidatov. Za Splošno bolnišnico Jesenice je pomembno, da izbere ustrezne kandidate za opravljanje pripravništva, ker bomo z njimi delali in sodelovali. Problem nastane, ko je potrebno izbirati novega sodelavca med vsemi pripravniki po končanem pripravništvu in uspešno opravljenem strokovnem izpitu. Zato smo oblikovali model, ki zajame proces zaposlovanja od začetka, kjer ugotovimo potrebo po pripravniku, do objave razpisa za prosto delovno mesto, izbiranje pripravnika, opravljanje pripravništva in izbiro novega sodelavca.

\section{Teoretično izhodišče zaposlovanja kadrov}

\subsection{Proces zaposlovanja}

Hellriegel in Slocum (1992: 391) v širšem smislu proces zaposlovanja opišeta kot planiranje kadrov, vabljenje, selekcijo, uvajanje $v$ delo, nadaljnji razvoj kadrov in prenehanje delovnega razmerja. Ko delavec svoje delovno mesto zapusti, se njegovo 
$36^{\text {Th }}$ International Conference on Organizational Science Development: Responsible ORganization (MARCh $22^{\mathrm{ND}}-24^{\mathrm{TH}}$, PORTOROŽ Slovenia)

N. Trifoni \& V. Novak: Model zaposlovanja po opravljenem pripravništvu v zdravstveni negi

delovno mesto sprosti in proces kadrovanja se začne znova, kar opisujemo v nadaljevanju. Novakova (2008: 86) podaja natančnejšo razložitev posameznih aktivnosti.

Florjančič, Ferjan in Bernik (1999: 14) definirajo planiranje kadrov kot sistematičen in kontinuiran proces spoznavanja potreb organizacije po kadrih, ob upoštevanju spreminjajočih se pogojev poslovanja organizacije in individualnih potreb posameznikov. Glede na omenjeno definicijo je potrebno najprej ugotoviti, kakšne delavce potrebujemo, kar ugotavljamo na osnovi sistemizacije dela, izdelave psihofizičnih profilov za posamezne skupine delovnih nalog oziroma za posamezne poklice. Ugotoviti je potrebno tudi koliko delavcev potrebujemo, za kar se poslužujemo analize potrebne delovne sile, analize strukture kadrov, planiranja potreb po kadrih za določeno dobo ali obdobje. S planiranjem kadrov predvidimo tudi roke, v katerih bomo potrebovali določeno število posameznih profilov delavcev.

Kot pravi Wilton (2016:151) sta pridobivanje in selekcija kadrov procesa, ki se nanašata na vse aktivnosti, da zapolnimo potrebe po kadrih. Sledi torej ugotavljanje, kje in kako bomo priskrbeli potrebne kadre; na osnovi analize virov kadrovanja, analize evidentiranih rezultatov spremljanja in ocenjevanja zaposlenih in planiranja pridobivanja kadrov. Skladno s planom pridobivanja kadrov moramo organizaciji pravočasno priskrbeti planirano število kadrov. To lahko opravimo z izobraževanjem lastnih kadrov, s sistemom namestništva, štipendiranja ali $\mathrm{z}$ raznimi marketinškimi akcijami za pridobivanje kandidatov. Pri tem se lahko poslužujemo različnih načinov (Svetlik, 2009): pridobivanje kandidatov s posredovanjem ZZRS ali zasebnih agencij, s pomočjo objav v javnih medijih, preko mreženja, kariernih sejmov, ipd.

Sledi selekcija kadrov, ki ga (Mondy, 2007: 160) definira kot proces izbire kandidata, ki se najbolje ujema z zahtevami delovnega mesta in organizacijo, v kateri bo opravljal svoje delo. Izbor kadrov je potrebno skrbno pripraviti in upoštevati načelo poštenosti in strokovnosti. Pogosto se dogaja, da kriteriji izbora niso enotni za vse kandidate, temveč vplivajo pri izbiri kadrov drugi faktorji, npr. osebne zveze. V takem primeru je selekcija nesmiselna, njen uspeh pa popačen. Smiselno glede na zahtevnost delovnega mesta in število prijavljenih kandidatov uporabimo različne selekcijske metode (Wilton, 2016: 161): prijave in življenjepise, kadrovske obrazce, intervjuje, psihometrična testiranja, ocenjevalne centre, delovne preizkuse, priporočila in grafologijo.

Po izbiri delavca in formalni potrditvi s podpisom pogodbe o delu je interes organizacije, da novega sodelavca čim prej in čim bolje vpelje v delo, da prevzame strokovne naloge, ki jih ima na svojem novem delovnem mestu. Zato ga je potrebno v delo uvesti, kar pomeni, da novo zaposlenega seznanimo z organizacijo, socialnim in fizičnim delovnim okoljem ter z delovnimi nalogami in opravili, To dosežemo npr. z organizacijo uvajalnih seminarjev, individualnim uvajanjem, pripravništvom, stažiranjem in kroženjem kandidatov. Uspešne, učinkovite in zanesljive delavce v organizaciji je potrebno znati zadržati. Zato organizacija skrbi za zadovoljstvo in razvoj zaposlenih s stalnim izobraževanjem, premeščanjem, napredovanjem in drugimi ugodnostmi, ki preprečujejo odhod delavcev iz organizacije (Novak, 2008). 
Proces zaposlovanja pa lahko v ožjem smislu omejimo na pridobivanje, selekcijo in uvajanje kadrov, kar predstavljamo v nadaljevanju na primeru zaposlovanja pripravnikov v Splošni bolnišnici Jesenice.

\subsection{Proces zaposlovanja pripravnikov v Splošni bolnišnici Jesenice}

Pripravniki v zdravstveni negi se zaposlujejo skozi celo leto, ker so financirani s strani Zavoda za zdravstveno zavarovanje Slovenije. Zaposlovanje ostalega kadra v bolnišnici je v okviru finančnega načrta, ki ga mora odobriti Ministrstvo za zdravje.

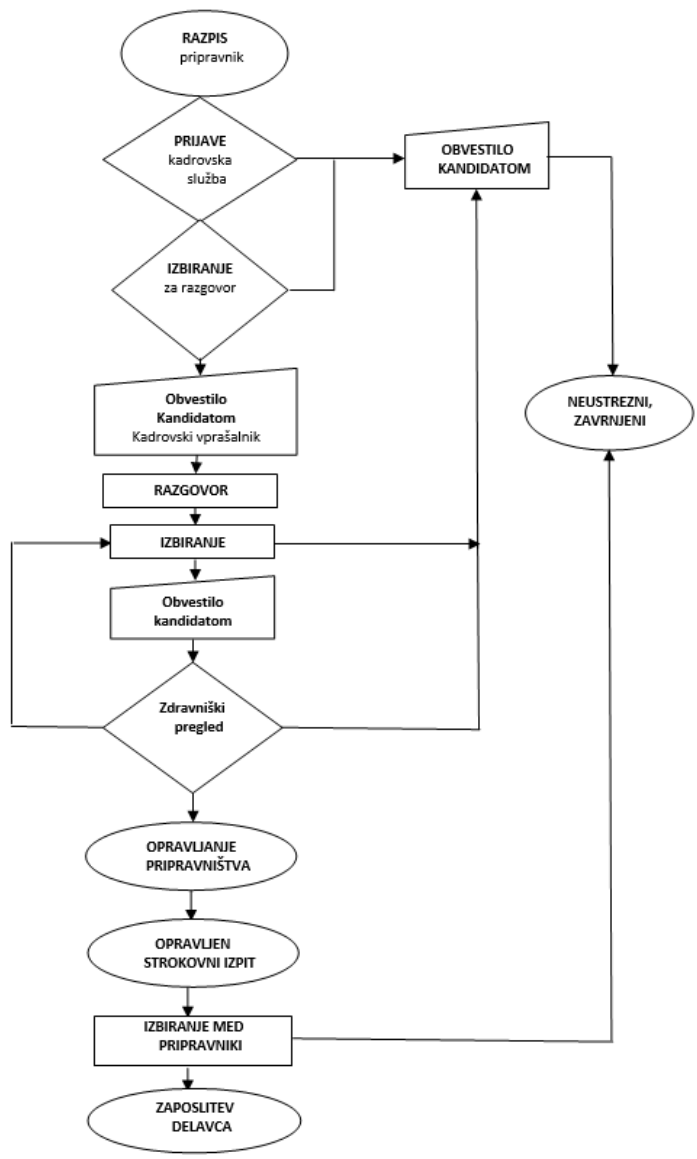

Slika 1: Proces zaposlovanja pripravnikov - tehnik zdravstvene nege v Splošni bolnišnici Jesenice

Skela-Savič (2001) pravi, da se pripravnike za tehnika zdravstvene nege največkrat zaposluje v primeru nadomeščanja daljše bolniške odsotnosti (več kot 30 dni) ali 
1188 36 $6^{\mathrm{TH}}$ INTERNATIONAL CONFERENCE ON ORganizational SCIENCE DeVElopment: Responsible Organization (MARCh $22^{\mathrm{ND}}-24^{\mathrm{TH}}$, PORTOROŽ Slovenia)

N. Trifoni \& V. Novak: Model zaposlovanja po opravljenem pripravništvu v zdravstveni negi

porodniškega dopusta, čeprav pripravnik ni ustrezno nadomestilo za odsotne strokovno usposobljene kadre. Zato je pomembno pravilno načrtovanje zaposlovanja pripravnikov, ki so nadomestilo za porodniški dopust ali daljše bolniške odsotnosti. Slika 1 prikazuje proces zaposlovanja pripravnika za tehnika zdravstvene nege v Splošni bolnišnici Jesenice. Prikazuje različne faze selekcije kadrov do izbire pripravnika za novega sodelavca.

Pomočnica direktorja za področje zdravstvene nege skupaj s kadrovnikom odloča, kdaj bodo objavili razpis za opravljanje pripravništva. Pripravnike se zaposluje zaradi daljše bolniške odsotnosti (več kot 30 delovnih dni) in porodniškega dopusta. Takrat Splošna bolnišnica Jesenice objavi razpis za prosto delovno mesto pripravnik - tehnik zdravstvene nege na internetni strani bolnišnice, zaposlitvenem portalu in na Zavodu RS za zaposlovanje. Po Zakonu o delovnih razmerjih (ZDR-1, 2013) so bolnišnice oziroma drugi javni zavodi dolžni objaviti prosto delovno mesto na Zavodu RS za zaposlovanje.

Kadrovska služba zbira prijave, izloči nepopolne vloge, o primernih kandidatih obvesti pomočnico direktorja za področje zdravstvene nege in nato izbranim kandidatom pošlje vabila na razgovor in vprašalnik pred zaposlitvijo. Pri razgovoru sodeluje pomočnica direktorja za področje zdravstvene nege ali njena namestnica, kadrovski referent in glavna medicinska sestra oddelka, kjer bo pripravnik opravljal pripravništvo. Vukovič in Miglič (2006) sta mnenja, da mora kandidat pri kadrovskih razgovorih govoriti več časa, kot vodje razgovorov. Vodje razgovorov morajo imeti znanje in izkušnje iz vodenja razgovora. Organizacija mora članom komisije, ki sodelujejo pri razgovorih zagotoviti osnovno izobraževanje s področja upravljanja kadrov, s posebnim poudarkom na vodenju in ocenjevanju razgovorov. Organizacija bi morala upoštevati željo kandidata, na katerem oddelku bi rad delal, če je to možno. Dobro je, da si komisija zabeleži enega ali dva rezervna kandidata za opravljanje pripravništva, če mogoče izbrani kandidat ne bo začel s pripravništvom.

Po končanem razgovoru, pregledu vprašalnika in življenjepisa se odločijo, kateri kandidati ustrezajo zahtevam bolnišnice. Kadrovska služba kandidate obvesti o izboru in izbranim kandidatom pošlje napotnico za zdravniški pregled in pogodbo o zaposlitvi. Kandidati po opravljenem zdravniškem pregledu v kadrovsko službo vrnejo podpisano pogodbo o zaposlitvi za določen čas (6 mesecev) in zdravniško potrdilo. Zasledili smo, da $\mathrm{v}$ tujini pri zdravniškem pregledu medicinske sestre testirajo na nedovoljene droge (Maloney, b. 1.), kar slovenska zakonodaja ne dovoljuje.

Prvi delovni dan pripravnik prične $\mathrm{z}$ delom na matičnem oddelku. Pripravnik pride v organizacijo neusposobljen za samostojno delo in ga je potrebno vključiti v proces dela na oddelku, v proces izobraževanja in usposabljanja. Že v fazi pripravništva moramo dati pripravniku možnost za njegov razvoj, da se izkaže pri delu, ga spodbujamo in dajemo pohvale za dosežke in za napredovanje pri delu. Pripravnik mora spoznati, kaj so njegove delovne naloge in kaj se od njega pričakuje. Pomembno je, da ima ob sebi neposrednega mentorja s katerim skupaj delata in nadzornega mentorja. Mentor ga vodi, usmerja, motivira, ga sproti ocenjuje in opazuje napredek. Da to lahko omogočimo, mora imeti 
pripravnik na vsakem oddelku svojega mentorja. Mentor mora imeti znanje in biti strokovno usposobljen, imeti mora dovolj delovnih izkušenj, da lahko uči in izobražuje pripravnike, predvsem pa mora delo mentorja opravljati z veseljem. Na vsakem oddelku, kjer pripravnik dela morata na koncu neposredni (tehnik zdravstvene nege) in nadzorni mentor (diplomirana medicinska sestra) skupaj oceniti pripravnikovo delo na oddelku. $\mathrm{Na}$ koncu pripravništva na matičnem oddelku oba mentorja skupaj izpolnita poročilo o poteku pripravništva. Na koncu se podpiše tudi pripravnik, da je seznanjen s svojo oceno. Vso pripravnikovo evidenco vodi glavna medicinska sestra oddelka. Če se pripravnik z oceno ne strinja, je nadzorni mentor dolžan, da oceno razloži pripravniku in se z njim pogovori. Na koncu obrazca ima mentor možnost dodati mnenje o pripravniku. Ko pripravnik konča s kroženjem na vseh oddelkih mora v Splošni bolnišnici Jesenice opraviti preverjanje praktičnega in teoretičnega znanja. Pri tem sodelujeta nadzorni in neposredni mentor iz matičnega oddelka in oseba, ki je odgovorna za pripravnike v Splošni bolnišnici Jesenice. Po uspešno opravljenem izpitu bolnišnica prijavi pripravnika na strokovni izpit pri zdravstvenih zavodih, ki jih je za opravljanje strokovnih izpitov pooblastil Ministrstvo za zdravje.

Po končanem pripravništvu in izteku pogodbe se pripravnika zaposli oziroma se delovno razmerje med bolnišnico in pripravnikom konča. Če bolnišnica potrebuje tehnika zdravstvene nege se pripravniku podaljša pogodba za določen čas. $Z$ novo pogodbo dobi ugodnosti, kot vsi redno zaposleni in $100 \%$ plačo. Med pripravniki, ki so zaključili strokovni izpit, izberemo novega sodelavca.

\section{$3 \quad$ Raziskava in ugotovitve stanja}

\subsection{Cilj in potek raziskave}

Glavni cilj je bil oblikovati model za zaposlitev novega sodelavca po opravljenem pripravništvu. Za izdelavo modela nas je zanimalo kakšna so stališča zaposlenih do opravljanja pripravništva $\mathrm{v}$ zdravstveni negi in kateri kriteriji oziroma kompetence so pomembne pri izbiri kandidata ter katere so lastnosti tehnika zdravstvene nege, da uspešno opravlja svoje delo.

Raziskava je bila opravljena s pomočjo anketnega vprašalnika $\mathrm{v}$ Splošni bolnišnice Jesenice na vseh splošnih oddelkih. Anketni vprašalnik so izpolnjevali tehniki zdravstvene nege in glavne medicinske sestre oddelkov in vodje enot. Razdelili smo 130 vprašalnikov, $\mathrm{v}$ celoti izpolnjenih je bilo 115 vprašalnikov. Anketo smo izvajali v mesecu januarju 2016. Vprašalnik je bil sestavljen iz več sklopov vprašanj zaprtega tipa $\mathrm{z}$ ocenjevanjem trditev na lestvici Likertovega tipa od 1 do 5. Zaradi omejenosti dolžine prispevka $\mathrm{v}$ tem poglavju predstavljamo samo najpomembnejše rezultate raziskave, podrobneje pa so rezultati anketiranja predstavljeni $\mathrm{v}$ specialističnem delu (Trifoni, 2016). 
$1190 \quad 36^{\mathrm{TH}}$ INTERnational CONFERENCE ON ORganizational SCIENCE DeVElopment: Responsible Organization (MARCh $22^{\mathrm{ND}}-24^{\mathrm{TH}}$, PORTOROŽ Slovenia)

N. Trifoni \& V. Novak: Model zaposlovanja po opravljenem pripravništvu v zdravstveni negi

\subsection{Rezultati raziskave}

Trditve glede šolanja in pripravništva so anketiranci ocenjevali na lestvici Likertovega tipa, kjer je ocena 1 pomenila, da se s trditvijo sploh ne strinjajo, ocena 5 pa, da se s trditvijo popolnoma strinjajo. Ugotovili smo, da se večina anketirancev strinja s trditvijo, da je pripravništvo potrebno, preden začneš samostojno delati, to povprečje znaša 4,45. To trditev potrjujejo tudi rezultati, ki jih omenjamo v nadaljevanju in kažejo, da dijaki iz srednjih šol nimajo zadostnega teoretičnega znanja in praktičnih izkušenj za samostojno delo. S trditvijo, da imajo po končanem šolanju dovolj praktičnih izkušenj za samostojno delo se anketiranci namreč ne strinjajo, saj povprečje znaša 2,39. Podobno mnenje imajo o pridobljenem teoretičnem znanju po končanem šolanju, povprečna ocena je 2,96. Visoke povprečne ocene pa so anketiranci namenili strinjanju s trditvami, da so v času pripravništva pridobili dovolj znanja in izkušenj za opravljanje strokovnega izpita $(3,80)$, da so se po opravljenem pripravništvu čutili dovolj usposobljeni za samostojno delo $(3,57)$ in da je pripravništvo dobro organizirano $(3,58)$.

Zbornica zdravstvene nege in babiške nege je leta 2008 izdala dokument »Poklicne aktivnosti in kompetence $\mathrm{v}$ zdravstveni in babiški negi«, kjer opredeljujejo aktivnosti v zdravstveni negi za poklic tehnik zdravstvene nege. Anketiranci so na Likertovi lestvici (ocena 1 je pomenila zelo nepomembno in 5 zelo pomembno) ocenjevali v kolikšni meri se jim zdijo pomembne naštete kompetence in dejavniki za delo tehnika zdravstvene nege. Kompetence, za katere anketiranci smatrajo, da so zelo pomembne za delo tehnika zdravstvene nege so: veselje za delo z ljudmi $(4,81)$, natančnost $(4,81)$, poštenost $(4,83)$, zanesljivost $(4,89)$, odgovornost $(4,90)$ in sposobnost opazovanja $(4,84)$. Najnižje so anketiranci ocenili pomembnost odličnega uspeha v šoli oz. odlično opravljenega strokovnega izpita in sicer s povprečno vrednostjo 3,01, kar kaže na srednjo pomembnost. Pod oceno 4 (pomembno) sta ocenjena samo še osnovno računalniško znanje in znanje tujega jezika s povprečno vrednostjo 3,78 ter razvitost ročnih spretnosti s povprečno vrednostjo 3,90.

\section{$4 \quad$ Predlog modela zaposlovanja po opravljenem pripravništvu v zdravstveni negi}

Želja po izboru najboljšega novega sodelavca med pripravniki z zaključenim strokovnim izpitom, ki se bo ujel $\mathrm{v}$ delovnem timu nas je vodila $\mathrm{v}$ izdelavo modela zaposlovanja po opravljenem pripravništvu $\mathrm{v}$ zdravstveni negi. Model je predstavljen na sliki 2 in prikazuje faze izbiranja novega sodelavca med pripravniki z opravljenim strokovnim izpitom. 


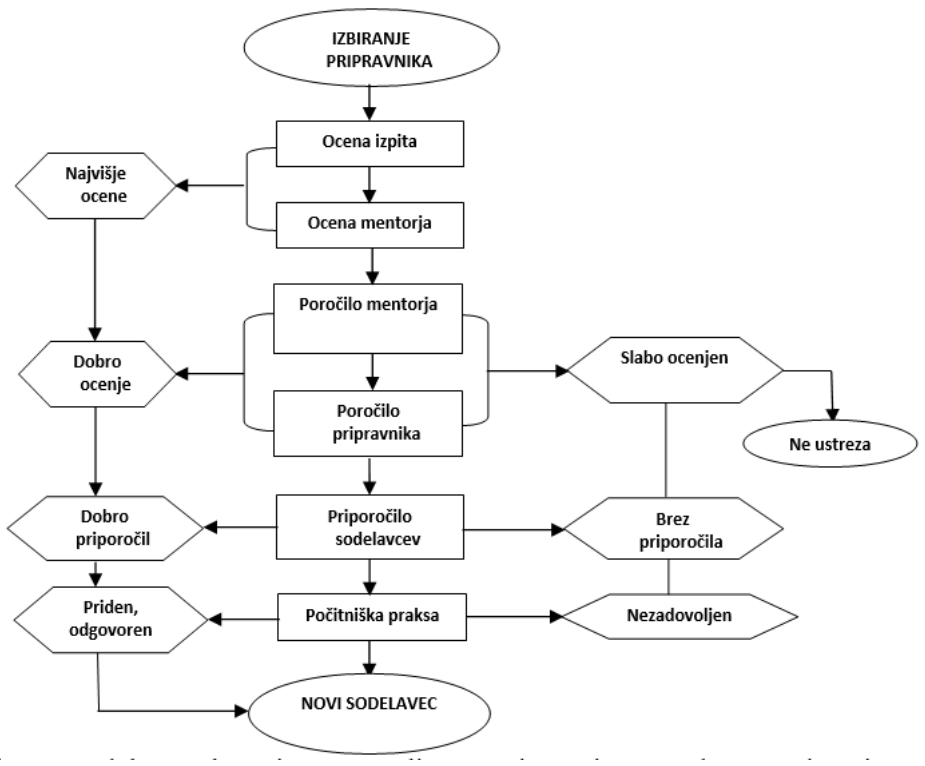

Slika 2: Model zaposlovanja po opravljenem pripravništvu v zdravstveni negi

Tuje raziskave so pokazale, da se uporabljajo različne metode ocenjevanja na novo kvalificiranih medicinskih sester. Uporabljajo različne teste in skupinske aktivnosti, ocenjuje se znanje, spretnosti (Newton, Chandler, Morris-Thomson, Sayer in Burke, 2014). V tuji literaturi smo zasledili različne metode in orodja ocenjevanja, postopkov izbire, kadrovskih vprašalnikov, ter lastnosti oziroma značilnosti za uspešno delo tehnika zdravstvene nege. Po raziskavi (Cleary, Horsfall, Jackson, Muthulakshmi in Hunt, 2013) so dobre lastnosti medicinske sestre skrb za druge, spoštljiva medosebna interakcija, sposobnost odločanja, znajo soočiti s kruto realnostjo na delovnem mestu in osebnostne lastnosti.

Splošna bolnišnica Jesenice pri izbiranju novega sodelavca med pripravniki upošteva mnenje mentorja in oceno izpita $\mathrm{v}$ bolnišnici. Pri končni izbiri novo zaposlenega se upoštevajo različni kriteriji, kot so pripravnikov odnos do dela in do sodelavcev, njegova motivacija, kritičnost, spoštovanje, odnos do pacientov in sodelavcev. Kakšnega novega sodelavca bodo dobili je odvisno od zaposlenih na oddelku, ki so skupaj delali s pripravnikom, od mentorja in glavne medicinske sestre oddelka. Na koncu vsi vpleteni odločajo, katerega pripravnika bodo zaposlili.

$\mathrm{Na}$ oddelku, kjer so potrebe po novem delavcu se glavna medicinska sestra oddelka in oba mentorja skupaj odločajo katerega kandidata izbrati med pripravniki. Upošteva se pripravnikova ocena pri opravljanju teoretičnega in praktičnega izpita v bolnišnici. Pri izbiri se upošteva poročila mentorjev o poteku pripravništva na oddelku in končna ocena. Če ima kandidat različne ocene iz oddelkov, se izračuna povprečje in upošteva ocena 
$36^{\mathrm{TH}}$ InTernational Conference on ORganizational SCIEnCE Development: Responsible Organization (MARCh $22^{\mathrm{ND}}-24^{\mathrm{TH}}$, PORTOROŽ Slovenia)

N. Trifoni \& V. Novak: Model zaposlovanja po opravljenem pripravništvu v zdravstveni negi

mentorja iz matičnega oddelka. Upošteva se poročilo pripravnika o poteku pripravništva, njegovo mnenje o delu na oddelku, kjer se išče novi delavec. Tehnike zdravstvene nege, ki so največ delali s pripravnikom se tudi vpraša za mnenje. Na matičnem oddelku je pripravnik začel, končal in opravljal pripravništvo največ časa. $\mathrm{Na}$ tem oddelku mentor spremlja, opazuje delo, sproti vrednoti in vidi napredek pripravnika. Upošteva se napisano dodatno mnenje mentorja. Če poznajo kandidata iz počitniške prakse ali kliničnih vaj in imajo z njim dobre izkušnje, se lahko tudi to upošteva pri izbiri. Če upoštevajo vse napisane kriterije bodo izbrali najbolj ustreznega kandidata, ki se bo vključil v delo na oddelku in delo opravljal z veseljem.

\section{5}

\section{Zaključek}

V prispevku smo se osredotočili na proces zaposlovanja pripravnikov v zdravstveni negi. $\mathrm{S}$ pregledom domače in tuje literature, $\mathrm{s}$ pomočjo rezultatov anketnega vprašalnika smo izdelali model procesa zaposlovanja v Splošni bolnišnici Jesenice po opravljenem pripravništvu. Pomembno je, da med kandidati za opravljanje pripravništva v zdravstveni negi izberemo najboljše kandidate in nato po pripravništvu izberemo najbolj ustreznega novo zaposlenega tehnika zdravstvene nege.

Današnja slika trga delovne sile kaže na povečano povpraševanje po delu in zmanjšano ponudbo delovnih mest, zato se na razpise za delovno mesto prijavi veliko število kandidatov. Za organizacijo je zelo pomembno, da izbere ustreznega kandidata, ki bo pripomogel $\mathrm{k}$ boljšemu poslovanju, hkrati pa bo delo opravljal vestno, odločno in pripomogel k doseganju ciljev organizacije. Proces iskanja in izbiranja kandidata je dolgotrajen proces, ki mora biti dobro zasnovan in premišljen. Glede na število brezposelnih v zdravstveni negi ni težko dobiti formalno izobraženih, problem je, da se bo izbrani kandidat dobro ujel v delovnem timu.

V zdravstveni negi mora tehnik zdravstvene nege opraviti in zaključiti pripravništvo z uspešnim preizkusom znanja preden lahko samostojno opravlja svoj poklic. Pripravništvo se izvaja po določenemu programu in pod vodstvom mentorja. V zdravstvenem zavodu lahko opravlja pripravništvo več pripravnikov hkrati. Po opravljenem strokovnem izpitu mogoče dobi zaposlitev en pripravnik. V času pripravništva imamo možnost opazovati pripravnikovo delo. Pokažejo se še druge lastnosti, ki so pomembne za opravljanje poklica tehnik zdravstvene nege. V dejavnosti zdravstvene nege je treba vzdrževati dobre medsebojne odnose, ustvarjati prijetno vzdušje, biti vztrajen, solidaren, čutiti pripadnost. Kakšnega novega sodelavca bomo dobili je odvisno od zaposlenih na oddelku, ki delajo skupaj s pripravnikom, od mentorja in glavne medicinske sestre oddelka, kjer pripravnik opravlja pripravništvo. Na koncu vsi vpleteni odločamo katerega pripravnika bomo redno zaposlili.

Z vzpostavitvijo modela smo zajeli proces zaposlovanja od začetka, kjer ugotovimo potrebo po novem delavcu oziroma pripravniku, do objave razpisa in do zaključka pripravništva. Prihranimo čas in denar, če v tem delu zaposlovanja izberemo ustrezne 
kandidate za opravljanje pripravništva in kasneje lažje izberemo enega pripravnika za novega sodelavca.

\section{Literatura}

Bregar, B. (2012). Kadrovske stiske zaposlenih v bolnišnični zdravstveni negi - vidik kakovosti in varnosti. V Skela-Savič, B., Hvalič-Touzery, S., Skinder-Savić B. in Zurc, J. (Ur.), Kakovostna zdravstvena nega skozi izobraževanje, raziskovanje in multiprofesionalno povezovanje - prispevek $k$ zdravju posameznika in družbe (str. 223-228) 5. mednarodna znanstvena konferenca. Jesenice: Fakulteta za zdravstvo.

Cleary, M., Horsfall, J., Jackson, D., Muthulakshmi, P. \& Hunt, G.E. (2013). Recent graduate nurse views of nursing, work and leadership. Journal of clinical nursing, Vol. 22, No. 19-20, str. 2904-11.

Florjančič, J., Ferjan, M. \& Bernik, M. (1999). Planiranje in razvoj kadrov. Kranj: Založba Moderna organizacija.

Hellriegel, D. \& Slocum, J.W. (1992). Management. New York: Addison-Wesley Publishing Company.

Maloney, T. Employee recruitment and selection: how to hire the right people. Ithaca. Dostopno na https://www.uvm.edu/extension/agriculture/.../employee_recruit.pdf

Mondy, R.W. (2007). Human Resource Management. Upper Saddle River: Pearson Prentice Hall.

Newton, P., Chandler, V., Morris - Thomson, T., Sayer, J. \& Burke, L. (2014). Exploring selection and recruitment processes for newly qualified nurses: a sequential-explanatory mixed-method study. Journal of advanced nursing, Vol. 71, No. 1, str. 54 - 64.

Novak, V. (2008). Kadrovanje. Kranj: Založba Moderna organizacija.

Skela-Savič, B. (2001). Uvajanje izboljšav v proces pripravništva v zdravstveni negi. Obzor Zdr N, 125-34.

Svetlik, I. (2009). Pridobivanje, izbiraje in uvajanje delavcev. V Zupan, N. in Svetlik, I. (Ur.), Menedžment človeških virov. (str. 283-336). Ljubljana: Fakulteta za družbene vede.

Trifoni, N. (2016). Model zaposlovanja po opravljenem pripravništvu $v$ zdravstveni negi. (Specialistično delo). Kranj: Fakulteta za organizacijske vede

Vukovič, G. \& Miglič, G. (2006). Zagotavljanje kadrovskih virov. Kranj: Moderna organizacija.

Wilton, N. (2016). An Introduction to Human Resource Management. Los Angeles: Sage.

Zakon o zdravstveni dejavnosti. (2012). Uradni list RS, št. 10/2012. Dostopno 12. 6. 2015 na https://www.uradni-list.si/1/content?id=107416.

Zakon za uravnoteženje javnih financ. (2012). Uradni list RS, št. 40/12. Dostopno 9. 5. 2015 na http://www.uradni-list.si/1/objava.jsp?urlid=201240\&stevilka=1700.

ZDR-1 (2013). Dostopno 5. 1. 2017 na https://www.uradni-list.si/1/content?id=112301. 
1194 36 ${ }^{\text {TH }}$ International Conference on ORganizational Science Development: Responsible Organization (March $22^{\mathrm{ND}}-24^{\mathrm{TH}}$, Portorož Slovenia) 
$36^{\mathrm{TH}}$ InTERnational CONFERENCE ON ORganizational SCIENCE Development: Responsible Organization (MARCh $22^{\mathrm{ND}}-24^{\mathrm{TH}}$, PORTOROŽ SLOVENIA)

O. Arsenijević, M. Ferjan, I. Podbregar, P. Šprajc, D. Trivan \& Y.

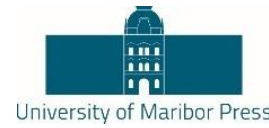

Ziegler

\title{
Diversification Effect of Investing in Gold
}

\author{
DEAN UČKAR \& IVAN BUDIĆ
}

\begin{abstract}
With the start of the financial and economic crisis that hit the whole world, including Croatia, there is an increasing number of investors who increased their interest in gold. Investing in gold has always been considered a safe haven in times of crisis, when it is supposed to ensure the protection of investors' wealth. The aim of this study is to test the diversification effect of investing in gold on the example of the Republic of Croatia for the period from 2010 to 2015. However, unlike similar international studies that have this problem approached from the point of view of the big investors who have at their disposal various forms of investment in gold and gold-covered securities, the emphasis in this study will be on the aspect of the small investors. Small investors are those who invest smaller amounts of money in securities and do not make it at the professional level. Experience in the Republic of Croatia has shown that with the appearance of the financial crisis, a large number of such small investors simply „,disappeared“ from the financial market. In this regard, a conducted study proved that the involvement of investment gold in a portfolio of a small investor exposed to money, bonds and equity markets, and through the application of modern portfolio theory, achieved the desired diversification effect. However, the strength of this effect is not equally distributed across all levels of risk exposure. The diversification effect will mostly affect those investors who are exposed to higher levels of risk which is a new finding in terms of its application at the level of personal finance.
\end{abstract}

KEYWORDS: investment gold • personal finance $\bullet$ diversification $\bullet$ small investors

CorRespondence AdDress: Dean Učkar, Ph.D., Juraj Dobrila University of Pula, Faculty of Economics and Tourism "Dr. Mijo Mirković", Preradovićeva 1/1, 52100 Pula, Croatia, e-mail: duckar@unipu.hr; Ivan Budić, Ph.D., Juraj Dobrila University of Pula, Faculty of Economics and Tourism “Dr. Mijo Mirković, Preradovićeva 1/1, 52100 Pula, Croatia, e-mail: ivbudic@efpu.hr

DOI https://doi.org/10.18690/978-961-286-020-2.95

ISBN 978-961-286-020-2

(C) 2017 University of Maribor Press

Available at: http://press.um.si 
In the last few years, especially in the period of global economic crisis, interest in investment gold is on rise. As a consequence of the sharp rise in the price of gold, in particular from 2009 till 2012, more and more investors decided to invest in gold. Even today, investments in gold are presented as a form of safe investments, designed especially for small investors. The questions raised are what kind of effect had the inclusion of investment gold in portfolios of these investors, and whether the inclusion of investment gold more contributed to the realization of returns or to the reduction of risk exposure through the diversification of investments. Therefore, the object and the purpose of this paper is to elaborate forms of gold investments and its impact on investment portfolio through the application of modern portfolio theory. The hypothesis that we hope to prove is that the inclusion of investment gold in a portfolio of small investor exposed to money, bond and equity market, reduces the risk of its investment.

Having that in mind, the article is organized as follows. After this introduction, where the object and the purpose of research are defined, there is a chapter in which the results of other research are presented and that is important as the theoretical basis for hypothesis formulation. The third chapter provides a brief overview of the investment opportunities in investment gold available to investors with a focus on the specifics of small investors. The fourth chapter presents the empirical testing of diversification effect of investment in gold with the methodological remarks and the presentation of research results. The article ends with the concluding consideration and with a list of references.

\section{Investment opportunities of investing in gold}

Gold has a characteristic of generally accepted form of investment with the relatively good liquidity. Additional characteristic of gold is in its intrinsic (internal) value and in the fact that it does not bear the risks carried by stocks or bonds (bankruptcy of the issuer). In other words, unlike other financial assets, gold does not have a counterparty risk (Michis, 2014). For investors, gold usually comes in focus at times of financial crisis or in times of financial market turbulence, considering that it is perceived as a refuge in times like these (Apak et al., 2012). In addition, it comes in focus at times of geopolitical instability, wars and expectations of high inflation (Kapoor et al., 2007).

Previously conducted researches tries to answer the question whether the gold is a safe haven for investors during the period of financial instability, whether can be used for hedging during the normal market conditions, or whether should be included in the portfolio only as a diversifier. Baur and Lucey (2009) conducted the research on the capital markets of the United States, the United Kingdom and Germany from 1995 until 2005. Assets used for safe haven is defined as a uncorrelated asset or negatively correlated asset to changes of stocks and bonds prices in times of stock market crash, the assets that is used for hedging is defined as one that is uncorrelated or negatively correlated with changes of stocks and bonds prices in normal market conditions, while the assets that serves as diversifier is positively correlated (but not perfectly) with other forms of investment in normal market conditions. The results showed that for the entire 
period, gold could serve as an asset for the protection against the risks in relation to the stock markets of the United States and the United Kingdom, but not in Germany. On the bond markets, gold could not serve as a protection against risk in the markets of the United States and the United Kingdom, but may in the German market. At specific periods, gold can better serve to protect against risks in the stock market, so in periods of long-term bear market it had better perform the function of hedging than in periods of long-term bull market.

Baur and McDermott (2009) investigated the role of gold in the global financial system with the hypothesis that gold is a safe haven in comparison to the stocks in leading developed countries and major developing countries. In addition, they explored the possibility of gold as a hedge against risks at G7 countries, the BRIC countries, Australia and Switzerland. The period taken into account includes 30 years, from 1979 until 2009. As a conclusion of research, they stated that for the entire period, gold represent a strong protection against the risks at the stock markets of the United States and European countries taken into research (Germany, France, Italy, Switzerland, United Kingdom). Gold is also a strong safe haven for those countries in times of crisis. Gold does not have a hedging effect in the BRIC countries, Australia, Japan and Canada, and in Brazil, India and Canada it has a poor safe haven effect at best. A poor safe haven function of gold in developing countries authors explain through the hypothesis that investors in these countries, in conditions of sharp drop in stocks values, replace equity investments in their own countries to those in developed countries, while investors in developed countries replace such investments by gold. In addition, authors state that gold is not a safe haven during the periods of extreme global uncertainty because then the gold moves in the same direction as stocks.

Ibrahim and Baharom (2011) analyzed the role of investment gold on the Malaysia market as a representative of the emerging markets for the period from August 2001 to March 2010. Gold investment roles are taken from the work of Baur and Lucey (2009) and accordingly the role of gold is defined as "gold as a safe haven", "gold as a hedge" or "gold as a diversifier". During the entire period, gold can at best serve as a diversifier, given that the returns on gold are positively correlated with the movements of returns on stocks (but not perfectly correlated). In cases of extreme movements on the Malaysian market, gold could not serve as a safe haven for investors. Also, in case of extreme market movements, the role of gold as a diversifier is diminished since the correlation between the return on gold and return on stocks in those circumstances strengthens. In the analysis of specific periods from August 2001 to November 2005, the gold takes on the characteristics of assets for hedging and safe haven on the stock market. This conclusion states that the role of gold on the Malaysian market is reduced from hedging instrument or as an instrument of safe haven to the role of asset that is used for diversification.

Miyazaki and Hamori (2013) test the relationship between the return on gold and return on stock indices (in this case the S\&P 500) in the period from 2000 to 2011, with an additional period from January 2000 till August 2007 and from August 2007 till April 2011 (representing pre-crisis and crisis/post-crisis period). For the entire period, the results suggest that the risks in one market does not spill over to other markets in the long 
1198 36 $6^{\mathrm{TH}}$ INTERnational CONFERENCE ON ORganizational SCIENCE DeVElopment: RESPONSIBLE ORGANIZATION (MARCH $22^{\mathrm{ND}}-24^{\mathrm{TH}}$, PORTOROŽ SLOVENIA)

D. Učkar \& I. Budić: Diversification Effect of Investing in Gold

term, but there is a correlation in price movements. The correlation between the S\&P 500 index and gold price have been strongly influenced by the continuous growth of the gold price, regardless of the movement of the stock market index. Lack of risk transmission, ie. causality between the variances of gold and the stock market index S\&P 500, shows that gold is not effective as a leading indicator of uncertainty in the stock market. The authors conclude from this that the gold is not used for hedging or as a safe haven for investment in the long term. Considering sub-periods, authors determined that there is a correlation between the gold price and the S\&P 500 index during the financial crisis of $2007 / 08$, and that there is a correlation between the variances in this period. The authors explain this through the hypothesis that investors in times of uncertainty invest in more secure assets, but that does not necessarily mean that investing in gold can reduce the risks associated with investments in the financial market.

Pullen, Benson and Faff (2014) conducted a study on investment opportunities of gold bullion, stocks of gold mining companies, gold mutual funds and gold exchange trade funds, and their ability to serve as a safe haven, risk hedge or as a diversifier in relation to the stock indexes on the capital market of the United States. Time range of data used in the study was more than 20 years, from July 1987 until June 2010, with an additional period from February 2005 until June 2010 for the inclusion of gold exchange trade funds. The research results indicate that the gold bullion can be used for hedging in the financial market. Stocks of gold mining companies, gold mutual funds and gold exchange trade funds can serve more as a diversifier. In addition, investors can use gold bullion and gold exchange trade funds as a safe haven as well.

Ratner and Klein (2008) explore the implications of investing in gold to portfolio through the measurement of the effect of adding 5\% of gold to the globally diversified portfolio consisting of securities from equity market of the United States and the stock indices of totally 50 different developed and developing countries. Period under consideration runs from 1975 until 2005, with the distribution of research results to the last five, 10 and 20 years and for the entire period (31 years). Due to the low correlation of the US stock market and the movement of gold, the authors assumed that the portfolio containing gold should have better results. For the calculation of optimal portfolios, Markowitz meanvariance model was used on three hypothetical portfolios. The first portfolio is formed exclusively from the US stock market, the second portfolio consists from stocks derived in $80 \%$ from the US market and $20 \%$ from the markets of other countries, while the third portfolio consists of $75 \%$ US market stocks, $20 \%$ other countries stocks and $5 \%$ of gold. The results suggest that the benefits of investing in gold depend on the proper investment moment (which is almost impossible to achieve), while keeping the gold for the entire period produces no benefits ("buy and hold" strategy). The investment period when the inclusion of gold is desirable varies from one to five years, but even then, the inclusion of gold resulted only in a portfolio minimum performance enhancement. For example, for the period of investment from 2001 to 2005 , gold has reduced the standard deviation of the portfolio, but only at lower levels of return (by 10\% at the lowest rates), while at higher levels has no effect. Authors also point out that the performance of the portfolio consisting exclusively from US stocks could improve by adding stocks from the global 
markets, and to a greater extent than would be the case with the additional inclusion of gold in the portfolio.

Emmrich and McGroarty (2013) analyze the performance of a global portfolio in which is allocated a certain percentage of gold bullion (also analyze other types of investment in gold) and whether such portfolios would be desirable to institutional investors. The period reviewed in the study covers 30 years, from 1981 to 2011. Results suggests that gold is a good investment at some period, but on other periods, the results will not be satisfactory. Unable to choose the correct moment for investment and selling of gold, investors could expect through the whole period a combination of low returns (even lower than the rate of inflation) and extremely high returns. As a general conclusion, authors says that institutional investors can benefit from investing in gold if the percentage of gold in their portfolio does not exceed $10 \%$. As an investment, they recommend investing in gold bullion since it increases the portfolio return while reducing the volatility of the portfolio at the same time.

Michis (2014) in his study about the impact of gold on the portfolio riskiness concludes that gold reduces the risk considering the medium to long-term investment. The period taken into account is from September 1991 until December 2012. Portfolio is formed of gold, stocks, ten-year government bonds and treasury bills in equal proportions on the example of the United States, the United Kingdom and Germany. In the short-term, volatility of gold is high and actually increases the risk of the portfolio.

Kapoor et al. (2007), in the pyramid of suggested investments for small investors, put the gold in the area of speculation as a risky investment, with the recommendation for small percentage of the portfolio allocated to gold (less than 5\%).

\section{Investments in gold available to small investors}

Investments in gold for small investors are available in several forms, and are generally divided into investment in physical gold or gold coins and gold bullion, gold mining stocks, gold mutual funds and gold exchange trade funds. Gold futures and derivative instruments covered in gold are aimed at professional and big investors and will not be discussed in this paper. Owning gold jewelry or gold coins of numismatic value in this case is not considered as an investment in gold.

It should be noted that in the Republic of Croatia, according to the Law on Value Added Tax (Official Gazette 73/13, 99/13, 148/13, 153/13, 143/14), investment gold is considered to be in the form of a bullion or plate, with the weight generally accepted on the market of precious metals, and purity equal or greater than 995 thousandths, whether or not it is represented by securities. According to the same Law, gold coins are also considered as investment gold if they meet the following requirements: purity equal or greater than 900 thousandths, minted after 1800, which currently are or have been legal tender in the country of origin. Furthermore, they should be usually sold at a price which does not exceeds more than $80 \%$ of the value of gold on the open market and are not sold in numismatic purposes. 
Croatian accession to the European Union (EU) could be largely credited for the availability of investment gold in Croatia. Before joining the EU, investment gold was charged with the value added tax of $25 \%$ and, on import, with the additional customs rate of at least $5 \%$. Extra burden was a special tax in the amount of $30 \%$ on luxury goods. Considering all, in the period just before the Croatian accession to the EU, investment gold were taxed at a rate of almost $60 \%$, making it unprofitable to buy. Thus, the purchase of investment gold was more cost effective in, for example, neighboring Slovenia, which did not have such a tax burden. With the abolition of the special tax on luxury goods at the end of 2012 and then with joining the EU at 2013, the tax burden on gold were abolished resulting in an increase of investment gold offering in Croatia while facilitating purchase within the EU. Gold trade in Croatia is possible through jewelry and specialized stores (usually through Internet), even though the development of gold bullion market is at its beginning.

Other forms of investment in gold in Croatia are generally not available or their availability is limited. This mainly refers to the fact that Croatia has no gold mines, making direct investment in the stocks of mining companies not possible. The form of indirect investment in gold is an investment in a gold mutual fund that holds part of the assets in gold and in stocks of gold mining companies and which has been for some time available to investors in Croatia. Other forms of investment in gold, as allocated/unallocated gold accounts and gold exchange trade funds, are not directly accessible to investors in Croatia, but it is possible to invest in them.

\section{Empirical testing of diversification effect of gold investments}

For the purpose of optimal portfolio calculation we will use a computer program Microsoft Excel and its Solver supplement. The idea is, through finding efficient portfolios with and without investment gold, to assess the impact that gold had on tested portfolios. On other words, we will try to conclude whether the inclusion of investment gold reduced the risk for small investors at the analyzed period from 2010 until 2015.

\subsection{Portfolio components}

The portfolio components seeks to cover the average market trends on investment funds, ie. on money, bond and equity funds, with the addition of domestic stock market conditions. In this way, we will assess the usefulness of the inclusion of gold in portfolio compared to the average market movements. Investment funds are selected as they provide small investors a wide investment options (especially participation on money and bond market) and allow participation in a number of different markets due to the geographical distribution of investments (stocks from various European and other countries). The following is a description of the portfolio components. 


\section{Investment gold}

For the calculation on monthly return on the investment gold, it has been chosen the gold bullion weighing $10 \mathrm{~g}$ that offers Jewelry Celje d.d. This particular seller of investment gold was chosen for convenience to small investors, a broad sales network, as well as the existence of long series of data on gold prices. Any dependent costs associated with gold (storage of gold, for example), as well as other possible difficulties arising from owning the physical gold (problems when selling), which would eventually reduce the returns of gold, are not taken into account. Table 1 shows the monthly returns on investment gold.

Table 1: The monthly returns on investment gold from 2010 to 2015

\begin{tabular}{|l|c|c|c|c|c|c|}
\hline $\begin{array}{l}\text { Months } \\
\text { Years }\end{array}$ & $\mathbf{2 0 1 0}$ & $\mathbf{2 0 1 1}$ & $\mathbf{2 0 1 2}$ & $\mathbf{2 0 1 3}$ & $\mathbf{2 0 1 4}$ & $\mathbf{2 0 1 5}$ \\
\hline January & $0,33 \%$ & $-10,36 \%$ & $9,00 \%$ & $-1,49 \%$ & $4,96 \%$ & $13,23 \%$ \\
\hline February & $5,26 \%$ & $6,44 \%$ & $0,48 \%$ & $-1,00 \%$ & $6,07 \%$ & $-3,33 \%$ \\
\hline March & $-1,69 \%$ & $-0,40 \%$ & $-6,11 \%$ & $1,53 \%$ & $-3,80 \%$ & $1,71 \%$ \\
\hline April & $9,74 \%$ & $1,90 \%$ & $0,51 \%$ & $-10,00 \%$ & $-0,34 \%$ & $0,00 \%$ \\
\hline May & $10,87 \%$ & $4,12 \%$ & $-1,01 \%$ & $-3,34 \%$ & $-1,02 \%$ & $-0,84 \%$ \\
\hline June & $3,33 \%$ & $-2,73 \%$ & $1,51 \%$ & $-13,78 \%$ & $4,38 \%$ & $-2,28 \%$ \\
\hline July & $-10,77 \%$ & $8,41 \%$ & $4,95 \%$ & $6,67 \%$ & $0,33 \%$ & $-6,44 \%$ \\
\hline August & $7,60 \%$ & $11,21 \%$ & $0,48 \%$ & $6,25 \%$ & $0,62 \%$ & $0,64 \%$ \\
\hline September & $-1,13 \%$ & $-6,41 \%$ & $3,28 \%$ & $-6,48 \%$ & $-1,27 \%$ & $0,60 \%$ \\
\hline October & $1,20 \%$ & $3,68 \%$ & $-3,64 \%$ & $-0,61 \%$ & $0,00 \%$ & $3,09 \%$ \\
\hline November & $7,15 \%$ & $4,58 \%$ & $0,48 \%$ & $-6,33 \%$ & $-1,28 \%$ & $-3,30 \%$ \\
\hline December & $2,63 \%$ & $-5,60 \%$ & $-5,17 \%$ & $-4,72 \%$ & $3,60 \%$ & $-2,15 \%$ \\
\hline
\end{tabular}

Source: Author's calculation according to the Jewelers Celje d.d. data available at: http://www.nalozbenozlato.com/?page $=$ statistika \&idC $=11$

\section{Investment funds}

Following tables (2, 3 and 4$)$ show the average returns on money, bond and equity funds (from 2014 called UCITS funds). These returns are calculated as weighted average by using data from Croatian financial services supervisory agency (HANFA) on the net asset size of the individual fund and data on funds return from the web portal hrportfolio.hr. Due to unavailability of data on funds that stopped working in the period from 2010 to 2015 , calculated weighted average returns will not have a complete set of data. On average, completeness of data for money funds (calculated as the average monthly share of fund's net assets value used in calculation of the return to total net assets value of all funds) is $98 \%$, while the completeness of data for bond and equity funds is $83 \%$. Considering the number of funds used in the analysis, it is covered on average $88 \%$ of all money funds, $82 \%$ of bond funds and $70 \%$ of equity funds. 
$36^{\mathrm{TH}}$ InTERnAtional CONFERENCE ON ORganizational SCIENCE Development: RESPONSIBLE ORGANIZATION (MARCH $22^{\mathrm{ND}}-24^{\mathrm{TH}}$, PORTOROŽ SLOVENIA)

D. Učkar \& I. Budić: Diversification Effect of Investing in Gold

Table 2: The monthly returns on money investment funds

\begin{tabular}{|l|c|c|c|c|c|c|}
\hline $\begin{array}{l}\text { Months } \\
\text { Years }\end{array}$ & $\mathbf{2 0 1 0}$ & $\mathbf{2 0 1 1}$ & $\mathbf{2 0 1 2}$ & $\mathbf{2 0 1 3}$ & $\mathbf{2 0 1 4}$ & $\mathbf{2 0 1 5}$ \\
\hline January & $0,36 \%$ & $0,21 \%$ & $0,17 \%$ & $0,16 \%$ & $0,13 \%$ & $0,06 \%$ \\
\hline February & $0,31 \%$ & $0,18 \%$ & $0,32 \%$ & $0,13 \%$ & $0,16 \%$ & $0,06 \%$ \\
\hline March & $0,43 \%$ & $0,27 \%$ & $0,28 \%$ & $0,13 \%$ & $0,14 \%$ & $0,09 \%$ \\
\hline April & $0,26 \%$ & $0,21 \%$ & $0,27 \%$ & $0,12 \%$ & $0,11 \%$ & $0,08 \%$ \\
\hline May & $0,25 \%$ & $0,22 \%$ & $0,28 \%$ & $0,11 \%$ & $0,10 \%$ & $0,05 \%$ \\
\hline June & $0,21 \%$ & $0,17 \%$ & $0,26 \%$ & $0,10 \%$ & $0,11 \%$ & $0,04 \%$ \\
\hline July & $0,29 \%$ & $0,09 \%$ & $0,26 \%$ & $0,13 \%$ & $0,09 \%$ & $0,06 \%$ \\
\hline August & $0,26 \%$ & $0,18 \%$ & $0,24 \%$ & $0,10 \%$ & $0,09 \%$ & $0,05 \%$ \\
\hline September & $0,23 \%$ & $0,18 \%$ & $0,22 \%$ & $0,10 \%$ & $0,08 \%$ & $0,06 \%$ \\
\hline October & $0,23 \%$ & $0,20 \%$ & $0,23 \%$ & $0,11 \%$ & $0,09 \%$ & $0,05 \%$ \\
\hline November & $0,24 \%$ & $0,20 \%$ & $0,18 \%$ & $0,11 \%$ & $0,08 \%$ & $0,05 \%$ \\
\hline December & $0,18 \%$ & $0,22 \%$ & $0,14 \%$ & $0,11 \%$ & $0,08 \%$ & $0,06 \%$ \\
\hline
\end{tabular}

Source: Author's calculation according to the data from HANFA (available at: http://www.hanfa.hr/getfile/40016/B-08_neto_imovina_OIF.xls) and from web portal hrportfolio.hr (available at: http://www.hrportfolio.hr/usporedba-fondova)

Table 3: The monthly returns on bond investments funds

\begin{tabular}{|l|c|c|c|c|c|c|}
\hline $\begin{array}{l}\text { Months } \\
\text { Years }\end{array}$ & $\mathbf{2 0 1 0}$ & $\mathbf{2 0 1 1}$ & $\mathbf{2 0 1 2}$ & $\mathbf{2 0 1 3}$ & $\mathbf{2 0 1 4}$ & $\mathbf{2 0 1 5}$ \\
\hline January & $0,84 \%$ & $0,26 \%$ & $0,88 \%$ & $0,50 \%$ & $0,50 \%$ & $1,85 \%$ \\
\hline February & $0,59 \%$ & $0,54 \%$ & $0,90 \%$ & $-1,43 \%$ & $1,80 \%$ & $0,51 \%$ \\
\hline March & $1,92 \%$ & $0,75 \%$ & $0,58 \%$ & $-0,29 \%$ & $0,27 \%$ & $1,05 \%$ \\
\hline April & $0,48 \%$ & $0,81 \%$ & $0,63 \%$ & $0,94 \%$ & $0,61 \%$ & $0,32 \%$ \\
\hline May & $0,16 \%$ & $0,09 \%$ & $0,00 \%$ & $-1,76 \%$ & $1,30 \%$ & $-0,29 \%$ \\
\hline June & $-0,04 \%$ & $-0,02 \%$ & $0,91 \%$ & $-1,07 \%$ & $0,81 \%$ & $-1,35 \%$ \\
\hline July & $1,07 \%$ & $-0,09 \%$ & $1,09 \%$ & $1,08 \%$ & $0,21 \%$ & $0,95 \%$ \\
\hline August & $0,95 \%$ & $-0,85 \%$ & $-0,34 \%$ & $0,26 \%$ & $0,59 \%$ & $-0,30 \%$ \\
\hline September & $0,22 \%$ & $-1,21 \%$ & $1,02 \%$ & $0,58 \%$ & $0,74 \%$ & $-0,41 \%$ \\
\hline October & $0,01 \%$ & $1,25 \%$ & $0,30 \%$ & $0,62 \%$ & $0,57 \%$ & $0,68 \%$ \\
\hline November & $0,07 \%$ & $-1,56 \%$ & $-1,04 \%$ & $0,12 \%$ & $0,51 \%$ & $0,51 \%$ \\
\hline December & $0,12 \%$ & $1,04 \%$ & $-3,45 \%$ & $0,06 \%$ & $0,19 \%$ & $-0,16 \%$ \\
\hline
\end{tabular}

Source: Author's calculation according to the data from HANFA (available at: http://www.hanfa.hr/getfile/40016/B-08_neto_imovina_OIF.xls) and from web portal hrportfolio.hr (available at: http://www.hrportfolio.hr/usporedba-fondova) 
Table 4: The monthly returns on equity investment funds

\begin{tabular}{|l|c|c|c|c|c|c|}
\hline $\begin{array}{l}\text { Months } \\
\text { Years }\end{array}$ & $\mathbf{2 0 1 0}$ & $\mathbf{2 0 1 1}$ & $\mathbf{2 0 1 2}$ & $\mathbf{2 0 1 3}$ & $\mathbf{2 0 1 4}$ & $\mathbf{2 0 1 5}$ \\
\hline January & $1,04 \%$ & $2,26 \%$ & $2,49 \%$ & $3,83 \%$ & $-0,87 \%$ & $1,80 \%$ \\
\hline February & $-0,17 \%$ & $1,45 \%$ & $2,38 \%$ & $0,76 \%$ & $1,42 \%$ & $2,69 \%$ \\
\hline March & $2,05 \%$ & $-1,22 \%$ & $0,77 \%$ & $1,30 \%$ & $-0,81 \%$ & $0,86 \%$ \\
\hline April & $2,18 \%$ & $-1,35 \%$ & $-1,96 \%$ & $-0,43 \%$ & $0,46 \%$ & $3,00 \%$ \\
\hline May & $-6,37 \%$ & $1,54 \%$ & $-5,42 \%$ & $-1,83 \%$ & $2,20 \%$ & $0,07 \%$ \\
\hline June & $-2,82 \%$ & $-2,95 \%$ & $1,84 \%$ & $-3,09 \%$ & $1,89 \%$ & $-2,39 \%$ \\
\hline July & $0,59 \%$ & $-1,43 \%$ & $1,90 \%$ & $2,82 \%$ & $0,42 \%$ & $2,32 \%$ \\
\hline August & $0,05 \%$ & $-6,46 \%$ & $-0,23 \%$ & $-0,84 \%$ & $2,47 \%$ & $-5,55 \%$ \\
\hline September & $1,88 \%$ & $-6,97 \%$ & $1,12 \%$ & $1,12 \%$ & $2,02 \%$ & $-2,82 \%$ \\
\hline October & $0,81 \%$ & $2,52 \%$ & $-0,23 \%$ & $0,67 \%$ & $-0,71 \%$ & $5,35 \%$ \\
\hline November & $-1,06 \%$ & $-4,08 \%$ & $3,14 \%$ & $0,64 \%$ & $-0,35 \%$ & $0,22 \%$ \\
\hline December & $6,04 \%$ & $-0,47 \%$ & $0,88 \%$ & $0,47 \%$ & $-2,75 \%$ & $-1,65 \%$ \\
\hline
\end{tabular}

Source: Author's calculation according to the data from HANFA (available at: http://www.hanfa.hr/getfile/40016/B-08_neto_imovina_OIF.xls) and from web portal hrportfolio.hr (available at: http://www.hrportfolio.hr/usporedba-fondova)

\section{Stocks}

As an indicator of the average return on the domestic equity market, OTP Index fund has been chosen. The fund replicates the composition and changes of the stock index CROBEX from the Zagreb Stock Exchange, but it differs from CROBEX index since its returns includes received dividends as well, considering that such income fund reinvest (OTP Invest, 2015). Although there is an index CROBEXtr containing dividends received, it was not used in the analysis due to the incompleteness of data. 
$36^{\text {Th }}$ International Conference on Organizational Science Development: Responsible Organization (MARCh $22^{\mathrm{ND}}-24^{\mathrm{TH}}$, PORTOROŽ Slovenia)

D. Učkar \& I. Budić: Diversification Effect of Investing in Gold

Table 5: The monthly returns on OTP Index fund

\begin{tabular}{|l|c|c|c|c|c|c|}
\hline $\begin{array}{l}\text { Months } \\
\text { Years }\end{array}$ & $\mathbf{2 0 1 0}$ & $\mathbf{2 0 1 1}$ & $\mathbf{2 0 1 2}$ & $\mathbf{2 0 1 3}$ & $\mathbf{2 0 1 4}$ & $\mathbf{2 0 1 5}$ \\
\hline January & $9,72 \%$ & $8,46 \%$ & $-1,03 \%$ & $7,96 \%$ & $0,47 \%$ & $2,01 \%$ \\
\hline February & $-3,06 \%$ & $-2,28 \%$ & $3,62 \%$ & $3,10 \%$ & $-1,24 \%$ & $-1,15 \%$ \\
\hline March & $0,31 \%$ & $2,32 \%$ & $2,54 \%$ & $2,83 \%$ & $-1,75 \%$ & $-1,19 \%$ \\
\hline April & $2,42 \%$ & $-2,47 \%$ & $-0,77 \%$ & $-2,79 \%$ & $-1,99 \%$ & $2,63 \%$ \\
\hline May & $-7,55 \%$ & $3,22 \%$ & $-7,33 \%$ & $-4,26 \%$ & $-0,80 \%$ & $-1,15 \%$ \\
\hline June & $-6,51 \%$ & $-0,89 \%$ & $3,00 \%$ & $-1,25 \%$ & $7,17 \%$ & $1,02 \%$ \\
\hline July & $0,58 \%$ & $-2,55 \%$ & $0,38 \%$ & $2,60 \%$ & $1,21 \%$ & $3,63 \%$ \\
\hline August & $-0,53 \%$ & $-6,90 \%$ & $-0,98 \%$ & $-0,33 \%$ & $2,76 \%$ & $-3,19 \%$ \\
\hline September & $3,28 \%$ & $-7,88 \%$ & $2,26 \%$ & $-1,67 \%$ & $5,19 \%$ & $-1,63 \%$ \\
\hline October & $-2,09 \%$ & $-0,70 \%$ & $2,29 \%$ & $-2,05 \%$ & $-4,26 \%$ & $3,51 \%$ \\
\hline November & $-4,42 \%$ & $-5,42 \%$ & $0,12 \%$ & $0,59 \%$ & $-2,47 \%$ & $-2,49 \%$ \\
\hline December & $17,37 \%$ & $-2,06 \%$ & $-0,92 \%$ & $1,13 \%$ & $-2,21 \%$ & $0,49 \%$ \\
\hline
\end{tabular}

Source: Author's calculation according to the data available at:

http://www.otpinvest.hr/main.aspx?id=20

\subsection{Descriptive statistics on portfolio components}

This chapter will present the additional statistical data obtained from the analysis of portfolio components. Such data are necessary at a later analysis and interpretation of the results on portfolio optimization with and without inclusion of investment gold.

Table 6 shows the matrix of variance and covariance between portfolio components. Variances are shown on matrix diagonal, while the covariance between portfolio components are shown in other parts of the matrix. According to the variance, the lowest risk is at money and bond investment fund, while the investment gold has the highest risk. Analyzing the covariance, investment gold has a negative covariance with the equity portfolio components.

Table 6: The matrix of variance and covariance of the portfolio components

\begin{tabular}{|l|c|c|c|c|c|}
\hline & $\begin{array}{c}\text { Investment } \\
\text { gold }\end{array}$ & $\begin{array}{c}\text { Money } \\
\text { funds }\end{array}$ & $\begin{array}{c}\text { Bond } \\
\text { funds }\end{array}$ & $\begin{array}{c}\text { Equity } \\
\text { funds }\end{array}$ & $\begin{array}{c}\text { OTP Index } \\
\text { fund }\end{array}$ \\
\hline $\begin{array}{l}\text { Investment } \\
\text { gold }\end{array}$ & 0,0028094 & 0,0000056 & 0,0001145 & $-0,0000046$ & $-0,0002082$ \\
\hline Money funds & 0,0000056 & 0,0000007 & 0,0000015 & $-0,0000006$ & 0,0000022 \\
\hline Bond funds & 0,0001145 & 0,0000015 & 0,0000820 & 0,0000900 & 0,0000871 \\
\hline Equity funds & $-0,0000046$ & $-0,0000006$ & 0,0000900 & 0,0006592 & 0,0007612 \\
\hline $\begin{array}{l}\text { OTP Index } \\
\text { fund }\end{array}$ & $-0,0002082$ & 0,0000022 & 0,0000871 & 0,0007612 & 0,0016704 \\
\hline
\end{tabular}

Source: Author's calculation 
The following table shows the average returns and standard deviations of portfolio components on a monthly and annual basis to facilitate comparison of risk among them. The annual standard deviation is calculated as the product of the monthly standard deviation and the root number of 12 (months in a year).

Table 7: Average return and risk of portfolio components on a monthly and annual basis

\begin{tabular}{|l|c|c|c|c|}
\hline $\begin{array}{c}\text { Portfolio } \\
\text { component }\end{array}$ & $\begin{array}{c}\text { Average } \\
\text { monthly } \\
\text { return }\end{array}$ & $\begin{array}{c}\text { Average } \\
\text { annual } \\
\text { return }\end{array}$ & $\begin{array}{c}\text { Monthly } \\
\text { standard } \\
\text { deviation }\end{array}$ & $\begin{array}{c}\text { Annual } \\
\text { standard } \\
\text { deviation }\end{array}$ \\
\hline Money funds & $0,15 \%$ & $1,86 \%$ & $0,08 \%$ & $0,29 \%$ \\
\hline Bond funds & $0,22 \%$ & $2,61 \%$ & $0,91 \%$ & $3,14 \%$ \\
\hline Equity funds & $0,08 \%$ & $1,01 \%$ & $2,57 \%$ & $8,89 \%$ \\
\hline OTP Index fund & $0,002 \%$ & $0,02 \%$ & $4,09 \%$ & $14,16 \%$ \\
\hline Investment gold & $0,33 \%$ & $3,98 \%$ & $5,30 \%$ & $18,36 \%$ \\
\hline
\end{tabular}

Source: Author's calculation

Finally, table 8 shows the correlation coefficient among portfolio components demonstrating so the interconnectivity among their returns. Investment gold has a negative correlation of weak character with equity components of the portfolio, expressed through equity funds and through OTP Index fund that simulate the stock exchange index CROBEX. With money and bond funds investment gold has a correlation of minor importance $(0,12$ for money funds and 0,24 for bond funds). Due to the relation which investment gold has over other components, it could reduce the portfolio risk. However, investment gold carries the largest single risk as well, possibly diminishing the diversification effect.

Table 8: Correlation matrix of the portfolio components

\begin{tabular}{|c|c|c|c|c|c|}
\hline & $\begin{array}{l}\text { Investment } \\
\text { gold }\end{array}$ & $\begin{array}{l}\text { Money } \\
\text { funds }\end{array}$ & $\begin{array}{l}\text { Bond } \\
\text { funds }\end{array}$ & $\begin{array}{l}\text { Equity } \\
\text { funds }\end{array}$ & $\begin{array}{c}\text { OTP } \\
\text { Index } \\
\text { fund }\end{array}$ \\
\hline $\begin{array}{l}\text { Investment } \\
\text { gold }\end{array}$ & 1 & & & & \\
\hline Money funds & 0,12 & 1 & & & \\
\hline Bond funds & 0,24 & 0,19 & 1 & & \\
\hline Equity funds & $-0,003$ & $-0,03$ & 0,39 & 1 & \\
\hline $\begin{array}{l}\text { OTP Index } \\
\text { fund }\end{array}$ & $-0,10$ & 0,06 & 0,24 & 0,73 & 1 \\
\hline
\end{tabular}

Source: Author's calculation 
36 ${ }^{\text {TH }}$ International Conference on Organizational Science Development: Responsible Organization (MARCh $22^{\mathrm{ND}}-24^{\mathrm{TH}}$, PORTOROŽ Slovenia)

D. Učkar \& I. Budić: Diversification Effect of Investing in Gold

\subsection{Portfolio optimization and diversification effect of investing in gold}

To prove the hypothesis and for the assessment of the impact of the inclusion of investment gold on the portfolio performance, we will compare the return and risk of portfolios with and without investment gold through the calculation of efficient frontiers. Calculation of the efficient frontier will be made through Excel supplement Solver that will, through the optimization procedure, reduce the portfolio standard deviation for a given level of return by changing the share of individual component in portfolio. In doing so, a limit was set so that the minimum share of individual components must be at least $3 \%$ in order to ensure the representation of each component. In addition, the negative values of the component shares are not allowed. The following graph shows the results of efficient frontier calculation for the portfolios with and without investment gold for comparative rates of return.

\section{Graph 1: Portfolios efficient frontiers}

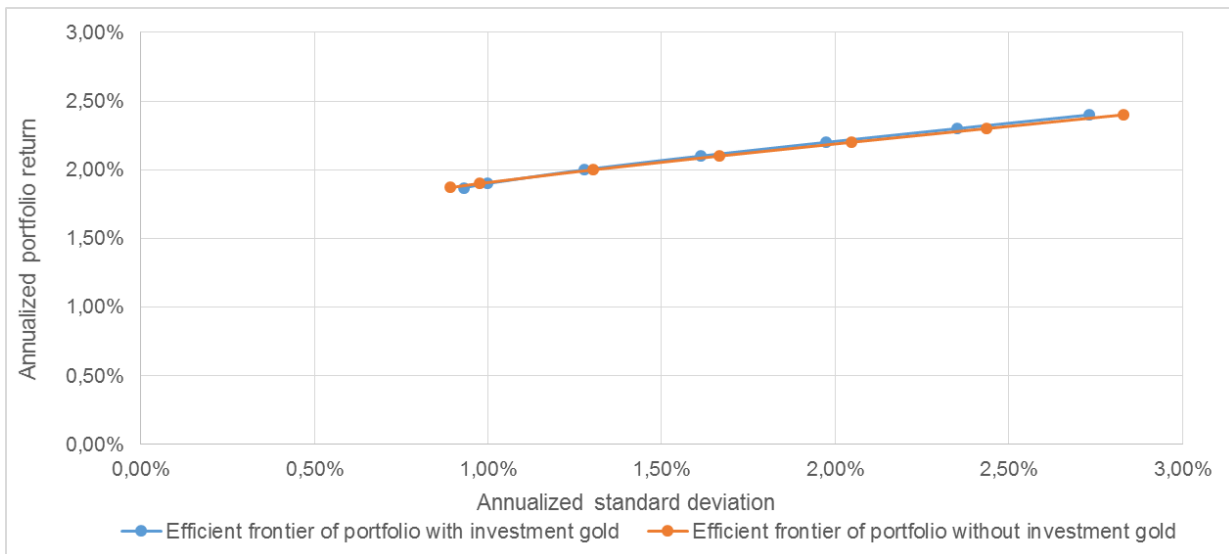

Source: Author's calculation

Investments in gold in the analyzed period had more impact on return (although not shown in the graph) than on the risk of the portfolio containing the money, bond and equity investment funds and fund investing on domestic share market. According to the calculations, the range of portfolio return was $50 \%$ higher with the included investment gold. Portfolio return ranges from $1,81 \%$ to $2,40 \%$ for the portfolio without investment gold, and from 1,87 to $3,67 \%$ for the portfolio with investment gold. Considering riskiness, investment gold generally reduces the risk at all levels of comparative returns, unless on the lowest levels of returns (up to the return level of $2 \%$ ). This reduction of risk is on average $1,27 \%$, although at the levels of return above the $2 \%$ average reduction of risk is $3,11 \%$. The greatest reduction of risk is present on a rate of return of $2,20 \%$, when the inclusion of investment gold reduces the risk of the portfolio by 0,07 percentage points, or $3,47 \%$. 
The following tables show the shares of portfolio components in selected efficient portfolios with and without the inclusion of investment gold, together with achieved returns and standard deviation of selected portfolios.

Table 9: Shares of components in selected efficient portfolios without investment gold

\begin{tabular}{|c|c|c|c|c|c|}
\hline \multirow{2}{*}{$\begin{array}{c}\text { Annual } \\
\text { portfolio } \\
\text { return }\end{array}$} & \multirow{2}{*}{$\begin{array}{c}\text { Annual } \\
\text { standard } \\
\text { deviation }\end{array}$} & \multicolumn{4}{|c|}{ Shares of components in portfolio } \\
\hline & & $\begin{array}{l}\text { Money } \\
\text { funds }\end{array}$ & Bond funds & $\begin{array}{l}\text { Equity } \\
\text { funds }\end{array}$ & $\begin{array}{c}\text { OTP Index } \\
\text { fund }\end{array}$ \\
\hline $1,90 \%$ & $\mathbf{0 , 9 8 \%}$ & $78,55 \%$ & $15,45 \%$ & $3,00 \%$ & $3,00 \%$ \\
\hline $2,00 \%$ & $\mathbf{1 , 3 0 \%}$ & $65,37 \%$ & $28,63 \%$ & $3,00 \%$ & $3,00 \%$ \\
\hline $2,20 \%$ & $\mathbf{2 , 0 5 \%}$ & $39,00 \%$ & $55,00 \%$ & $3,00 \%$ & $3,00 \%$ \\
\hline $2,40 \%$ & $2,83 \%$ & $12,64 \%$ & $81,36 \%$ & $3,00 \%$ & $3,00 \%$ \\
\hline
\end{tabular}

Source: Author's calculation

Investments in money and bond funds dominates in portfolios without investment gold. With the growth of return rate, investments in bond funds growth as well. Equity components, because on average lower return compared to other components, are not represented in efficient portfolios in percentage higher than $3 \%$, which is set as a minimum share for every component.

Adding investment gold in portfolios (table 10) reduces investment in the bond funds and increase investment in money funds. Shares of gold in portfolios are almost at the minimum level of $3 \%$, considering that gold has the highest risk and that there are better alternatives at lower rates of return. In addition, with the increase of the stock portion (for example at 20\%), results in an increase in the presence of gold in a portfolio, and there is a greater impact on risk reduction.

Table 10: Shares of components in selected efficient portfolios with investment gold

\begin{tabular}{|c|c|c|c|c|c|c|}
\hline \multirow{2}{*}{$\begin{array}{c}\text { Annual } \\
\text { portfolio } \\
\text { return }\end{array}$} & $\begin{array}{c}\text { Annual } \\
\text { standard } \\
\text { deviation }\end{array}$ & $\begin{array}{c}\text { Investment } \\
\text { gold }\end{array}$ & $\begin{array}{c}\text { Money } \\
\text { funds }\end{array}$ & $\begin{array}{c}\text { Bond } \\
\text { funds }\end{array}$ & $\begin{array}{c}\text { Equity } \\
\text { funds }\end{array}$ & $\begin{array}{c}\text { OTP } \\
\text { Index } \\
\text { fund }\end{array}$ \\
\hline $\mathbf{1 , 9 0 \%}$ & $\mathbf{1 , 0 0 \%}$ & $3,00 \%$ & $83,95 \%$ & $7,05 \%$ & $3,00 \%$ & $3,00 \%$ \\
\hline $\mathbf{2 , 0 0 \%}$ & $\mathbf{1 , 2 8 \%}$ & $3,00 \%$ & $70,77 \%$ & $20,23 \%$ & $3,00 \%$ & $3,00 \%$ \\
\hline $\mathbf{2 , 2 0 \%}$ & $\mathbf{1 , 9 8 \%}$ & $3,00 \%$ & $44,40 \%$ & $46,60 \%$ & $3,00 \%$ & $3,00 \%$ \\
\hline $\mathbf{2 , 4 0 \%}$ & $\mathbf{2 , 7 3 \%}$ & $3,98 \%$ & $19,81 \%$ & $70,21 \%$ & $3,00 \%$ & $3,00 \%$ \\
\hline
\end{tabular}

Source: Author's calculation

\section{Conclusion}

Gold in general has one characteristic, which is not usual for other widespread forms of investing in stocks and bonds, and that is that gold does not bear the counterparty risk and the risk of bankruptcy of the issuer. The value of gold is derived from its internal 
value, considering that it is worth in itself. It also has historical role as a mean of payment. To investors, gold usually comes in focus in times of high rate of inflation and fall in the value of money, since it is considered as the guardian of the values at such times, and during the financial crisis, economic and political instability. In periods when such dangers are not present, the value of gold tends to decline because investors then divert to other types of investment. Conducted researches on investment opportunities of gold are trying to conclude about the benefits that gold can achieve by including it in the investor's portfolios. The results of these studies suggest that gold generally can serve as a safe haven at the times of the global instability in the stock markets of developed countries. When used as hedging instrument, the results suggest that gold generally improves the performance of the portfolio, but the effect is relatively small.

The goal of this study was to implement a similar study on the financial market of the Republic of Croatia and determination of effect that will result from the inclusion of investment gold on the selected portfolio. The analysis was conducted for the period from 2010 until 2015, using data on a monthly basis and using the theoretical assumptions of modern portfolio theory. When selecting the components of the portfolio, the primacy was on investment products easily accessible to small investors, primarily investment funds, which invest in securities listed on the Zagreb Stock Exchange.

On average, the inclusion of gold on the comparative rates of portfolio return, reduced the risk of portfolio by $1,27 \%$. This proves the hypothesis that the inclusion of investment gold in the investor's portfolio will reduce their exposure to risk. However, investment in gold will contribute more to investors who are more exposed to the equity market, as the impact on reduction of the risk is in this case somewhat more significant. Investors who generally avoids risk, and are exposed to less risky securities, will have little benefit from investments in gold.

\section{Literature}

Apak, S. et al. (2012) The case for gold revisited: a safe haven or a hedge? Emerging markets journal. [Online] 2 (2), p. 1-8. Available at: http://emaj.pitt.edu/ojs/index.php/emaj/issue/view/5/showToc [Accessed: February 1, 2016]

Baur, D.G. and Lucey, B.M. (2009) Is gold a hedge or a safe haven? An analysis of stocks, bond and gold. [Online] Available at: http:// papers.ssrn.com/sol3/papers.cfm?abstract_id=952289 [Accessed: February 1, 2016]

Baur, D.G. and McDermott, T.K. (2009) Is gold a safe haven? International evidence. [Online] Available at: http://papers.ssrn.com/sol3/papers.cfm?abstract_id=1516838 [Accessed: February 1, 2016]

Croatian financial services supervisory agency at http://www.hanfa.hr

Emmrich, O. and McGroarty, F.J. (2013) Should gold be included in institutional investment portfolios? Applied financial economics, 23 (19), p. 1553-1565

Ibrahim, M.H. and Baharom, A.H. (2011) The role of gold in financial investment: a malaysian perspective. [Online] Available at: http://www.ecocyb.ase.ro/nr4\%20eng/Mansor\%20Ibrahim.pdf [Accessed: February 1, 2016]

Jewelers Celje d.d., Available at: http://www.nalozbenozlato.com/?page=statistika\&idC=11 [Accessed: February 1, 2016] 
Kapoor, J.R. et. al. (2007) Business and personal finance - interactive student edition. Woodland Hills: Glencoe/ McGraw-Hill

Law on Value Added Tax (Official Gazette 73/13, 99/13, 148/13, 153/13, 143/14)

Michis, A. (2014) Investing in gold: individual asset risk in the long run. Working paper series Central Bank of Cyprus [Online] Available at: http://www.centralbank.gov.cy/media/pdf/Investing_in_Gold.pdf [Accessed: February 1, 2016]

Miyazaki, T. and Hamori, S. (2013) Testing for causality between the gold return and stock market performance: evidence for „gold investment in case of emergency“ Applied financial economics, 23 (1), p. 27-40

OTP Invest (2015) Ključni podaci za ulagatelje. Available at: http://www.otpinvest.hr/UserDocsImages/KIID\%200TP\%20INDEKSNI\%20FOND31.12.15.pdf [Accessed: February 1, 2016]

OTP Invest fond at http://www.otpinvest.hr

Pullen, T., Benson, K. and Faff, R. (2014) A comparative analysis of the investment characteristics of alternative gold assets. ABACUS 50 (1), p. 76-92

Ratner, M. and Klein, S. (2008) The portfolio implications of gold investment. The Journal of investing 17 (1), p. 77-87

Web portal Hrportfolio.hr at http://www.hrportfolio.hr 
1210 36 ${ }^{\text {TH }}$ International Conference on Organizational Science Development: Responsible Organization (March $22^{\mathrm{ND}}-24^{\mathrm{TH}}$, Portorož Slovenia) 
36. MEDNARODNA KONFERENCA O RAZVOJU ORGANIZACIJSKIH ZNANOSTI: ODGOVORNA ORGANIZACIJA (22. - 24. MAREC 2017, PORTOROŽ, SLOVENIJA)

O. Arsenijević, M. Ferjan, I. Podbregar, P. Šprajc, D. Trivan \& Y. Ziegler

\title{
Kako postati ravnatelj osnovne šole
}

\author{
GREGOR UDOVČ
}

Povzetek Preden se nekdo odloči, da kandidira na mesto ravnatelja osnovne šole, je dobro, da pozna postopke izbora za delovno mesto ravnatelja, na kakšne težave lahko naleti in seveda kaj je tisto, kar ga loči od drugih kandidatov in mu daje prednost. Iz analize pravnih aktov lahko sklepamo, da novega ravnatelja izbirajo laiki, člani Sveta šole in ne strokovno usposobljeni kadrovski strokovnjaki. Pri svojih odločitvah se lahko opirajo na mnenja o kandidatih, ki jih podajo učiteljski zbor, Svet staršev in ustanovitelj zavoda. Mnenja podajajo laiki na podlagi dokumentacije o kandidatih in njihove kratke predstavitve pred zbrano množico. Glede na odgovornost in zahtevane kompetence, bi bilo več kot primerno, da pri izbiri novega ravnatelja sodelujejo izkušeni in kvalificirani kadrovski strokovnjaki, ki opravijo temeljito analizo kandidatov. Zakon in pravilniki določajo formalne pogoje za zasedbo funkcije ravnatelja, kakor tudi postopek načina izbire. Analiza izbirnega postopka novega ravnatelja na 8 šolah pokaže pomanjkljivosti in težave sistema izbora, ki ga je predvidel zakonodajalec. Pregled praktičnih primerov je pokazal, da v veliki večini nov mandat dobijo dosedanji ravnatelji ali pa kandidati, ki prihajajo iz zavoda, ki izbira novega ravnatelja. Za zunanje kandidate je prostora zelo malo.

KLJUČNE BESEDE: ravnatelj • izbor ravnatelja

NASLOV AVtoRJa: mag. Gregor Udovč, ravnatelj, Osnovna šola Veliki Gaber, Veliki Gaber 41, 8213 Veliki Gaber, Slovenija, e-pošta: gregor.udovc1@guest.arnes.si 
$36^{\text {TH }}$ International Conference on Organizational Science DEVElopMENT: Responsible ORganization (MARCH $22^{\mathrm{ND}}-24^{\mathrm{TH}}$, PORTOROŽ SLOVENIA)

O. Arsenijević, M. Ferjan, I. Podbregar, P. Šprajc, D. Trivan \& Y.

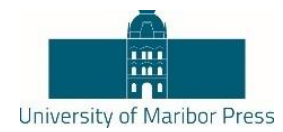

Ziegler

\title{
How to Become a Headmaster in Primary School
}

\author{
GREGOR UDOVČ
}

\begin{abstract}
Before anyone decides to run for headmaster position in primary school, they would be well-advised to know what procedures await them, what issues could arise and by all means what will distinguish them from other candidates, and therefore count in their favour. An analysis of legal acts makes us conclude that a new headmaster is selected by laymen, members of the Board of Governors and not by human resources experts. Their decisions can be based on opinions about the candidates, given by the teachers, the Board of parent Governors and the founder. Opinions are given by laymen, based on candidates' documentation and on their short presentations in front of the audience. Taking into account the responsibilities and the competence demanded, it would be more than appropriate, that the process of selecting a new headmaster would involve experienced and qualified human resources experts. The latter should perform a thorough analysis of candidates. The law and acts regulate the formal conditions to be met and the selection procedure before anyone can take the position of headmaster. The analysis of the selection procedure at eight schools shows deficiences and issues during the selection procedure as foreseen by the lawmaker. The overview of practical cases has shown that a new mandate is mostly won by headmasters finishing their term or by candidates already employed by the schools selecting a new head. Outer candidates are left with very little chance to succeed.
\end{abstract}

KEYWORDS: headmaster • selection of headmaster

CoRRESPONDENCE AdDRESS: Gregor Udovč, M.S., Headmaster, Primary School Veliki Gaber, Veliki Gaber 41, 8213 Veliki Gaber ,Slovenia, e-mail: gregor.udovc1@guest.arnes.si

DOI https://doi.org/10.18690/978-961-286-020-2.96

ISBN 978-961-286-020-2

(C) 2017 University of Maribor Press

Available at: http://press.um.si 
Ravnatelj osnovne šole je že od nekdaj zelo pomembna funkcija. Vodi ustanovo, ki je v družbi trdno zasidrana, dobro pa jo pozna tudi vsak državljan. Pomembnost funkcije se je z leti ohranila, zahtevnost pa se je povečala. Danes se na razpise za prosto delovno mesto ravnatelja javlja več kandidatov. Delovno mesto zahteva širok spekter kompetenc in osebno integriteto. $\mathrm{V}$ nadaljevanju bom predstavil, kako je formalo urejen izbor kandidatov in kako to poteka $\mathrm{v}$ praksi.

Javna osnovna šola je javni zavod, zato zanjo velja Zakon o zavodih (Ur. 1. RS, št. 12/1991). Omenjeni zakon v svojem 31. členu določa: "Poslovodni organ zavoda je direktor ali drug individualni organ ( $v$ nadaljnjem besedilu: direktor). Direktor organizira in vodi delo in poslovanje zavoda, predstavlja in zastopa zavod in je odgovoren za zakonitost dela zavoda. Direktor vodi strokovno delo zavoda in je odgovoren za strokovnost dela zavodu, če ni z zakonom ali aktom o ustanovitvi glede na naravo dejavnosti in obseg dela na poslovodni funkciji določeno, da sta poslovodna funkcija in funkcija vodenja strokovnega dela zavoda ločeni.«

V osnovni šoli se poslovodni organ zavoda imenuje ravnatelj. Po tem zakonu mora skrbeti tako za organizacijo, poslovanje, kot tudi za strokovno vodenje. Natančnejše pristojnosti ravnatelja $\mathrm{v}$ osnovnih šolah določa Zakon o organizaciji in financiranju vzgoje in izobraževanja (Ur. l. RS, št. 16/2007) (v nadaljevanju: ZOFVI) v 49. členu, ki med drugim pravi, da je ravnatelj pedagoški vodja in poslovodni organ.

Človek, ki zaseda to funkcijo mora imeti širok spekter kompetenc in znanj, da svoje delo opravi kvalitetno. Vendar se na tem mestu postavljajo naslednja vprašanja: kakšne formalne pogoje mora imeti kandidat, kdo izbira novega ravnatelja in kdo preverja vse potrebne kompetence pri prijavljenih kandidatih.

\subsection{Formalni pogoji}

Pogoje za zasedbo mesta ravnatelja v osnovni šoli določa ZOFVI v 53. členu (Ur. 1. RS, št. 16/2007): "Za ravnatelja javne šole je lahko imenovan, kdor ima najmanj izobrazbo, pridobljeno po študijskih programih za pridobitev izobrazbe druge stopnje, oziroma raven izobrazbe, pridobljeno po študijskih programih, ki v skladu z zakonom ustreza izobrazbi druge stopnje ter izpolnjuje druge pogoje za učitelja ali za svetovalnega delavca na šoli, na kateri bo opravljal funkcijo ravnatelja, ima najmanj pet let delovnih izkušenj $v$ vzgoji in izobraževanju, ima naziv svetnik ali svetovalec oziroma najmanj pet let naziv mentor in opravljen ravnateljski izpit.«

Omenjeni člen tudi določa, da lahko ravnatelj postane kandidat brez opravljenega ravnateljskega izpita, vendar mora tega opraviti v roku enega leta od pričetka mandata. Formalni pogoji za delovno mesto ravnatelj so jasno določeni. Izpolnjeni morajo biti vsi pogoji za učitelja oziroma strokovnega delavca $\mathrm{v}$ šoli, pridobljen ustrezen naziv, kandidat pa mora imeti tudi ustrezno število let delovnih izkušenj v vzgoji in izobraževanju. Običajno imajo ravnatelji, ki so prvič imenovani, veliko več kot 5 let delovnih izkušenj 
v vzgoji in izobraževanju, kar je z zakonom določen za minimum. Na funkcijo so lahko imenovani z nazivom mentor, svetovalec ali svetnik.

Naziv mentor lahko strokovni delavec $\mathrm{v}$ šoli pridobi $\mathrm{z}$ najmanj štirimi leti delovnih izkušenj v vzgoji in izobraževanju ter s Pravilnikom o napredovanju zaposlenih v vzgoji in izobraževanju $v$ nazive (Ur. 1. RS, št. 54/2002) določenimi pogoji o pridobljenih funkcionalnih znanjih ter dodatnemu opravljenemu delu. Če pridamo še 5 let, kolikor časa mora imeti ta naziv, ima ob nastopu funkcije ravnatelja najmanj 9 let delovne dobe.

Lahko pa posameznik kandidira tudi z nazivom svetovalec. Tega lahko sicer dobi že po štirih letih delovne dobe, vendar mora izkazovati visoko nadpovprečne rezultate. Takih kandidatov je izredno malo. Po taki izjemni poti bi lahko imel kandidat vsega skupaj 5 let delovnih izkušenj v vzgoji in izobraževanju ob nastopu funkcije, kar je najnižji pogoj.

Bolj običajno je, da do naziva svetovalec pride učitelj po redni poti, torej naprej pridobi naziv mentor za kar potrebuje najmanj 4 leta, nato pa lahko po štirih letih naziva mentor pridobi naziv svetovalec, $\mathrm{v}$ kolikor izkazuje s Pravilnikom o napredovanju zaposlenih $v$ vzgoji in izobraževanju $v$ nazive (Ur. 1. RS, št. 54/2002) določene rezultate. Tako ima lahko ob imenovanju na mesto ravnatelja osnovne šole 8 let delovnih izkušenj v vzgoji in izobraževanju.

Torej, če povzamem, lahko delovno mesto ravnatelja na osnovni šoli zasede učitelj ali svetovalni delavec z ustreznim nazivom in dovolj delovnimi izkušnjami v vzgoji in izobraževanju. Če sledimo zgornji razlagi je to možno z zgolj petimi leti dela v vzgoji in izobraževanju. Iz formalnih pogojev lahko sklepamo, da lahko mesto ravnatelja šole zasede strokovni delavec brez kakršnih koli praktičnih ali teoretičnih znanj s področja vodenja organizacij, brez ustreznih vodstvenih kompetenc itd.

\subsection{Postopek imenovanja ravnatelja}

Tudi postopek imenovanja ravnatelj je določen z istim zakonom, kot so določeni formalni pogoji za imenovanje na mesto ravnatelja. Zakonodajalec v ZOFVI v 53.a členu (Ur. 1. RS, št. 16/2007) opiše postopek. Ravnatelja imenuje Svet javne šole. V skladu s tem zakonom Svet šole sestavlja 11 članov, od tega pet zaposlenih v šoli, tri predstavniki staršev in tri predstavniki ustanovitelja, v primeru javne šole je to občina. Svet si mora pred odločitvijo o izbiri kandidata za ravnatelja pridobiti mnenje učiteljskega zbora, mnenje lokalne skupnosti (občinskega sveta oziroma občinskih delovnih teles) in mnenje sveta staršev. Lokalna skupnost in svet staršev obrazložijo mnenje o kandidatih. Učiteljski zbor o mnenju oziroma o kandidatih glasujejo tajno in mnenj ne potrebuje obrazložiti. Če lokalna skupnost, svet staršev ali učiteljski zbor ne dajo mnenja v 20 dneh od dneva, ko so bili zanj zaprošeni, lahko Svet o izbiri odloči brez tega mnenja. Ko Svet izbere kandidata za ravnatelja, posreduje obrazložen predlog za imenovanje ministru. Če minister ne poda mnenja v 30 dneh od dneva, ko je bil zanj zaprošen, lahko Svet šole imenuje ravnatelja s sklepom tudi brez tega mnenja. 
Celoten postopek je lahko dokaj transparenten. Edino kar pri postopku moti je, da člani niso $\mathrm{z}$ zakonom obvezani glasovati $\mathrm{v}$ skladu s pridobljenimi mnenji, tudi če jih pravočasno pridobijo. Še najmanj v tem delu moti mnenje ministra, saj se Svet že prej odloči, kateri kandidat je zanje najbolj primeren. Torej lahko glasujejo po svoji vesti in svojem občutku. Torej čemu so potem mnenja sploh potrebna?

\section{$2 \quad$ Izbira ravnatelja v praksi}

V začetku leta 2016 sem šel skozi celoten postopek tudi sam, saj sem se odločil kandidirati na delovno mesto ravnatelja. $\mathrm{Z}$ osmimi leti delovne dobe $\mathrm{v}$ vzgoji in izobraževanju sem izpolnil vse pogoje in tako zelo mlad prišel v postopek izbire za delovno mesto ravnatelja. Kandidiral sem na vseh šolah, ki so takrat razpisovale to delovno mesto in so bile na primerni oddaljenosti od bivališča. Tako sem skupno kandidiral na osmih šolah, preden sem bil imenovan. Šole bom v nadaljevanju poimenoval A, B, C, D, E, F, G in H. V tem delu bi želel prikazati, kako se vsi pravni akti, ki določajo kdo in kako zasede mesto ravnatelja, obnesejo $\mathrm{v}$ praksi.

\subsection{Prijava na razpis in predstavitev}

Običajno je delovno mesto ravnatelja razpisano $\mathrm{v}$ uradnem listu, na zavodu za zaposlovanje, občasno tudi v lokalnih medijih. Ob prijavi je potrebno, kot za vsako razpisano delovno mesto, priložiti, poleg vseh $\mathrm{z}$ zakonom določenimi dokazili, tudi življenjepis ter program vodenja zavoda za mandatno obdobje, ki traja 5 let. Seveda sem se prijave lotil resno. Še posebno življenjepisa in programa. Program je bil, kar sem kasneje opazil, zelo sodoben in drugačen od drugih kandidatov, kar se je kasneje izkazalo za ključno, poleg seveda kompetenc in izkušenj. Po zaključenem prijavnem roku, sem v vseh primerih od Sveta zavoda pisno prejel termin za predstavitev zaposlenim na šoli (običajno so prisotni le učitelji), staršem in lokalni skupnosti. Na predstavitev sem odšel na šole A, B, C, D in E. Na šolah F, G in H na predstavitvah nisem sodeloval, saj so se termini prekrivali, prestaviti pa jih ni bilo mogoče. Kronološko predstavitve niso potekale po šolah po vrstnem redu kot sem zapisal zgodaj. Takoj sem se zavedal, da brez predstavitve nimam veliko možnosti, da sem izbran na mesto ravnatelja. Tako sem imel realno možnost biti izbran le na šolah $\mathrm{A}, \mathrm{B}, \mathrm{C}, \mathrm{D}$ in $\mathrm{E}$.

Navadno imajo kandidati za predstavitev en termin, v prostoru so zbrani vsi deležniki, ki jih lahko nagovorimo. Le v primeru šole $\mathrm{C}$ smo imeli predstavitev za učitelje ločeno. Razlog je tičal $v$ tem, da je bila za učitelje predstavitev takoj, ko so zaključili z delom. Za ostale pa v poznih popoldanskih urah, ko so se lahko starši in predstavniki lokalne skupnosti zbrali. V tem primeru se kandidati med seboj tudi nismo srečali, saj so nas ločili po učilnicah, preden smo lahko stopili pred publiko.

Takoj drugi dan po predstavitvah sem $\mathrm{v}$ skoraj vseh primerih prejel prve klice ali elektronska sporočila s strani staršev. Izkazali so mi priznanje za pogum, pohvalili moj program ter izrazili podporo moji kandidaturi. To se je zgodilo v primerih šol A, B, C in D. Želeli so, da postanem ravnatelj šole, ki jo obiskujejo njihovi otroci. Tako sem imel na štirih šolah realne možnosti. Vendar so mi sporočili, da bo to zelo težko, če ne 
prepričam tudi lokalne skupnosti ali učiteljev. Na treh šolah (A, B in C) od omenjenih štirih je kandidiral tudi dosedanji ravnatelj oziroma ravnateljica. Vsi so imeli za seboj že tretji mandat ali več. Starši so si želeli svežine in zamenjave vodilne osebe na šoli. Vendar imajo sami le tri glasove $v$ svetu šole. Za izbiro in imenovanje pa je potrebnih 6 od 11 glasov, kolikor je članov v Svetu zavoda. Tako sem kaj hitro spoznal, da se je skoraj nemogoče boriti proti dosedanjim ravnateljem, saj si učitelji ne želijo sprememb pri vodenju, prav tako ne lokalna skupnost, če dosedanji ravnatelji opravljajo svoje delo brez večjih napak, kar pa ne pomeni, da ga opravljajo kvalitetno. Sam menim, da lahko starši povedo največ o kvaliteti dela prejšnjih ravnateljev.

$\mathrm{Na}$ četrti šoli $\mathrm{D}$, pa je dosedanja ravnateljica odhajala $\mathrm{v}$ pokoj. Tako so izbirali med novimi kandidati. Možnosti sem imel precej večje. Podporo staršev tudi. Izkazalo pa se je, da je eden izmed kandidatov dosedanji učitelj, ki so ga kolegialno podprli sodelavci. Prav tako tudi lokalna skupnost, ki si ne želi sprememb.

Po vseh neuspelih poskusih sem ugotovil, da imam realne možnosti, da sem izbran le na šoli na kateri sem zaposlen, $v$ kolikor moj dosedanji ravnatelj ne bi nadaljeval svojega dela ali pa na šoli, kjer bi bili vsi kandidati zunanji, kar pomeni, da ne prihajajo iz vrst strokovnih delavcev šole, ki izbira ravnatelja.

In ravno to se je zgodilo na peti šoli E. Med petimi kandidati sem bil daleč najmlajši. Dosedanja ravnateljica ni ponovno kandidirala, nihče izmed zaposlenih na tej šoli ni kandidiral, tako da smo bili vsi kandidati zunanji. Tako smo imeli vsi enake možnosti.

\subsection{Postopek izbire in imenovanja}

Po predstavitvah za delovno mesto ravnatelja Svet šole zaprosi za mnenja tudi deležnike. Strokovni delavci so v primerih šol A, B, C in D tajno glasovali in največ glasov je učiteljski zbor namenil bodisi dosedanjemu ravnatelju ali pa kolegu iz lastne zbornice. Lokalna skupnost je za vse kandidate ravno tako podala mnenje. V večini so za vse kandidate podali pozitivna mnenja, $\mathrm{v}$ enem primeru pa so podali samo priporočilo kandidatu. Svet staršev je v vseh štirih primerih podal mnenja o kandidatih ter priporočilo, da se jim zdim najbolj primeren kandidat.

Na Svetu šole so morali člani sveta na podlagi mnenj in lastnih občutkov izbrati med kandidati. Seveda za člane sveta pridobljena mnenja niso obvezujoča. V vseh primerih je bilo glasovanje tajno. Opazil sem, da je na tem področju ogromno pritiska na člane sveta šle, kar se je dogajalo tudi v mojih primerih. V primerih šol $\mathrm{A}, \mathrm{B}$ in $\mathrm{C}$ je bil izbran dosedanji ravnatelj, v primeru $D$ pa učiteljica iz obravnavane šole. $V$ primeru šole $E$ pa jaz.

Ko Svet šole izbere med kandidati, svoj predlog o izbiri pošlje ministru, ki poda pozitivno ali negativno mnenje $\mathrm{k}$ imenovanju. Zatem pa Svet šole s sklepom imenuje novega ravnatelja. Tako postopek od objave do imenovanja traja okoli 3 mesece.

Moja opažanja so, da odločevalci med kandidati izbirajo nestrokovno in subjektivno. Poudariti je potrebno, da so v Svetu šole zaposleni, ki morajo izbrati svojega nadrejenega 
in se lahko odločajo zgolj subjektivno. Prav tako tudi ostali deležniki nimajo ustreznih kompetenc za izbiro kandidatov za tako pomembno funkcijo.

\section{$3 \quad$ Predlogi za izboljšavo sistema izbire}

Vsekakor je celoten postopek izbire pomanjkljiv. Najprej mora Svet šole pridobiti vsa zgoraj omenjena mnenja, ki pa nato niso zavezujoča. Če ohranimo sistem, kjer Svet šole izbira med kandidati, bi bilo hitrejše in bolj učinkovito, da se kandidati predstavijo le članom Sveta šole, ki nato izberejo. Saj imajo vsi trije deležniki svoje predstavnike v Svetu šole.

Vsekakor pa je neprimerno, da svet zavoda sploh izbira med kandidati. V prvi vrsti se ravnatelja izbira zgolj na podlagi formalnih pogojev in osebnega 10 minutnega nastopa. Izbira je subjektivna in nestrokovna. Seveda članom sveta ne gre zameriti, saj niso strokovnjaki s področja kadrovanja.

Da vodjo izbirajo zaposleni, se je pokazalo kot neustrezno, saj mora dosedanji ravnatelj delati tako, kot ustreza zaposlenim, če želi biti ponovno izvoljen.

Iz primerov petih šol, kjer sem kandidiral za ravnatelja, so lokalne skupnosti najpogosteje podelile glasove dosedanjim ravnateljem. Zgodi pa se lahko sprememba, v kolikor se politično prepričanje $\mathrm{v}$ občinskem svetu zamenja in želijo dosedanjega ravnatelja zamenjati z njimi politično bližjemu kandidatu. Tudi ta političen vpliv, ki meji na korupcijo, sem pri svoji kandidacijskih postopkih izkusil. Najbolj na udaru v tem sistemu so starši. Kot zunanji deležniki, lahko jih imenujem tudi stranke šole, so lahko najbolj objektivni, saj želijo za svoje otroke najboljše. Mnogi prihajajo tudi iz gospodarstva, nekateri obvladajo tudi področje kadrovanja in zato imajo drugačne poglede, kakšnega ravnatelja in posledično šolo si želijo. Pa vendar tudi oni odločajo nestrokovno in subjektivno.

Sam vidim rešitev v kadrovski agenciji v sestavi obstoječe službe za kadre na ministrstvu pristojnem za šolstvo ali pa zasebne agencije, ki bi jo svet šole pooblastil za izbor. Tako bi šli vsi kandidati skozi poglobljene intervjuje, opravili psihološka in druga testiranja, kot to počnejo pri izbiri vodilnih kadrov v podjetjih. Agencija bi svetu šole posredovala rezultate in predlagala, koga naj imenujejo na mesto ravnatelja. Svet šole pa bi opravil le imenovanje.

Po preteku mandata se izbirni postopek ponovi, pri dosedanjem ravnatelju pa se lahko analizira in upošteva tudi dosedanje delo. Tako bi Svet šole razbremenili velike odgovornosti ter zmanjšali prostor za subjektivne in politične odločitve, hkrati pa omejili prostor za koruptivna dejanja.

\section{Literatura}

Zakon o zavodih. Ur. l. RS, št. 12/1991 in dopolnitve (21. marec 1991). 
1218 36 $6^{\text {TH }}$ International Conference on ORganizational Science Development:

Responsible ORGaNiZATION (MARCH $22^{\mathrm{ND}}-24^{\mathrm{TH}}$, PortoroŽ SLOVENIA)

G. Udovč: How to Become a Headmaster in Primary School

Zakon o organizaciji in financiranju vzgoje in izobraževanja. Ur. l. RS, št. 16/2007 in dopolnitve (6. februar 1996).

Pravilnik o napredovanju zaposlenih v vzgoji in izobraževanju v nazive. Ur. l. RS, št. 54/2002 in dopolnitve (21. junij 2002). 
36. MEDNARODNA KONFERENCA O RAZVOJU ORGANIZACIJSKIH ZNANOSTI: ODGOVORNA ORGANIZACIJA (22. - 24. MAREC 2017, PORTOROŽ, SLOVENIJA)

O. Arsenijević, M. Ferjan, I. Podbregar, P. Šprajc, D. Trivan \& Y. Ziegler

\title{
Ocena učinkovitosti prenove procesa na podlagi strukture procesa
}

\author{
BENJAMin URH, Eva KRHAČ, MATJAŽ ROBLEK \& TOMAŽ KERN
}

Povzetek V prispevku obravnavamo možnost ocene učinkovitosti izvajanja poslovnih procesov $\mathrm{s}$ pomočjo kazalnikov strukturne učinkovitosti kot alternativo ocenjevanju učinkovitosti izvajanja poslovnih procesov po kazalnikih operativne učinkovitosti. $Z$ vidika porabe časa in/ali vidika nastalih stroškov lahko učinkovitost procesa ocenimo, ko je proces že vzpostavljen oz. implementiran $\mathrm{v}$ podjetje. $\mathrm{V}$ tem primeru pa lahko učinkovitost izvajanja poslovnega procesa preverimo že $\mathrm{v}$ fazi oblikovanja novega ali prenovljenega procesa saj za oceno učinkovitosti s pomočjo kazalnikov strukturne učinkovitosti potrebujmo le ustrezen model prenovljenega poslovnega procesa. Uporabnost metode smo prikazali na primeru prenove procesa $\mathrm{v}$ enem izmed slovenskih podjetij.

KLJUČNE BESEDE: prenova procesov • kazalniki strukturne učinkovitosti • kazalniki operativne učinkovitosti $\bullet$ učinkovitost prenove procesov

\footnotetext{
NAslov AVtorJev: dr. Benjamin Urh, višji predavatelj, Univerza v Mariboru, Fakulteta za organizacijske vede, Kidričeva cesta 55a, 4000 Kranj, Slovenija, e-pošta: benjamin.urh @ fov.unimb.si; Eva Krhač, asistentka, Univerza v Mariboru, Fakulteta za organizacijske vede, Kidričeva cesta 55a, 4000 Kranj, Slovenija, e-pošta: eva.krhac@um.si; dr. Matjaž Roblek, docent, Univerza v Mariboru, Fakulteta za organizacijske vede, Kidričeva cesta 55a, 4000 Kranj, Slovenija, e-pošta: matjaz.roblek@um.si; dr. Tomaž Kern, redni profesor, Univerza v Mariboru, Fakulteta za organizacijske vede, Kidričeva cesta 55a, 4000 Kranj, Slovenija, e-pošta: tomaz.kern@um.si
} 
$36^{\text {TH }}$ International Conference on Organizational Science DeVElopMent: Responsible ORGANIZATION (MARCH $22^{\mathrm{ND}}-24^{\mathrm{TH}}$, PORTOROŽ SLOVENIA)

O. Arsenijević, M. Ferjan, I. Podbregar, P. Šprajc, D. Trivan \& Y.

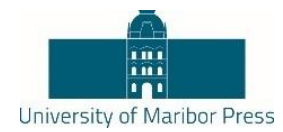

Ziegler

\title{
Assessment of Business Process Re-engineering Efficiency Based on Process Structure
}

\author{
BENJAMIN URH, EVA KRHAČ, MATJAŽ ROBLEK \& TOMAŽ KERN
}

\begin{abstract}
In this paper, we discuss above the business process performance efficiency assessment based on process structural efficiency indicators as an alternative to process performance efficiency assessment based on operational efficiency indicators. Business process efficiency we can assess from time and/or incurred costs point of view only when the process has already been established or implemented in the company. In the presented case, we can check process performance efficiency already at the renewed process designing stage, because we need only appropriate model of a renewed business process for assessment of its efficiency with structural efficiency indicators. We have demonstrated the method applicability on the case of process renovation in one of Slovenian companies.
\end{abstract}

KEYWORDS: process re-engineering - structural efficiency indicators • operational efficiency indicators $\bullet$ process re-engineering efficiency

Correspondence Address: Benjamin Urh, Ph.D., Seniore Lecturer, University of Maribor, Faculty of Organizational Sciences, Kidričeva cesta 55a, 4000 Kranj, Slovenia, e-mail: benjamin.urh@fov.uni-mb.si; Eva Krhač, Assistent, University of Maribor, Faculty of Organizational Sciences, Kidričeva cesta 55a, 4000 Kranj, Slovenia, e-mail: eva.krhac@um.si; Matjaž Roblek, Assistant Professor, University of Maribor, Faculty of Organizational Sciences, Kidričeva cesta 55a, 4000 Kranj, Slovenia, e-mail: matjaz.roblek@um.si; Tomaž Kern, Ph.D., Full Professor, University of Maribor, Faculty of Organizational Sciences, Kidričeva cesta 55a, 4000 Kranj, Slovenia, e-mail: tomaz.kern@um.si 


\section{$1 \quad$ Uvod}

Poslovni procesi so povezava aktivnosti posameznika, informacijske tehnologije, poslovnih pravil in organizacijskih aktivnosti. Razvoj in hitra razširitev uporabe informacijske tehnologije, $v$ zadnjem času predvsem internetnih in mobilnih aplikacij, vodi $\mathrm{k}$ vse hitrejšemu in pogostejšemu prilagajanju in posodabljanju izvajanja poslovnih procesov. Nove tehnologije lahko na eni strani znatno izboljšajo učinkovitost in uspešnost izvajanja poslovnega procesa, vendar na drugi strani lahko povzročijo povečanje kompleksnosti strukture procesa, zmanjšajo uporabnost procesa (podpora izvajanju samo določene variante procesa), in povzročijo večje težave pri medsebojnem povezovanju procesov. S povečevanjem kompleksnosti procesa se znatno povečuje tudi težavnost odkrivanja in razreševanja morebitnih težav v izvajanju procesa (Cheng, 2008).

V zadnjih desetletjih se vodilni v podjetjih, $v$ želji po znižanju stroškov in prihranku časa, zelo pogosto odločijo, da hkrati s prenovo poslovnih procesov izvedejo tudi posodobitev ali implementacijo in integracijo informacijske podpore poslovnega procesa oziroma podjetja. $\mathrm{Z}$ namenom opravičila dodatnih vlaganj $\mathrm{v}$ informacijsko tehnologijo in integracijo različnih komponent je potrebno poznati odgovor na pomembno vprašanje. Kakšno je tveganje $\mathrm{v}$ smislu povečanja kompleksnosti strukture procesov $\mathrm{v}$ želji po izboljšanju učinkovitosti z implementiranjem novih informacijskih rešitev in ostalih sprememb? V resnici je veliko implementacij informacijskih rešitev neuspešnih zaradi pomanjkanja poudarka oziroma pozornosti na strukturi poslovnih procesov in managementa sprememb (Bose, 2002; Jarrar, Al-Mudimigh, in Zairi, 2000). Glede na poročila Gartner Group do $70 \%$ implementacij programskih rešitev ni v skladu s temeljnimi cilji podjetja (Davis, 2002).

Prenove poslovnih procesov ( $\mathrm{z}$ ali brez implementacije ustrezne informacijske rešitve) se $\mathrm{v}$ podjetjih lotijo $\mathrm{v}$ bistvu $\mathrm{z}$ bolj ali manj enakim ciljem: doseči učinkovitejše poslovanje podjetja. Prenovo poslovnih procesov lahko izvedejo po različnih pristopih, $\mathrm{v}$ zadnjih desetletjih se je namreč izoblikovalo preko 50 različnih pristopov (Vila, 2006). Razlike med posameznimi pristopi prenove se pojavljajo predvsem v predlaganem načinu, kako v podjetju to doseči, od hitrih in korenitih (revolucionarnih) sprememb na eni strani, do bolj počasnih in postopnih (evolutivnih) sprememb na drugi strani. Vsi pristopi pa poudarjajo potrebo po obvladovanju procesov kot ključu do uspeha. Učinkovitost izvajanja poslovnih procesov je namreč pomembno povezana $\mathrm{z}$ uspešnostjo poslovanja.

Po uspešno opravljeni prilagoditvi izvajanja procesov oziroma prenovi poslovanja si vodilni $\mathrm{v}$ podjetjih $\mathrm{v}$ takem trenutku pogosto postavljajo pomembna vprašanja "Smo dosegli cilj?", "Je to tisto, kar smo potrebovali?", "Kam in kako naprej?" (Urh, Kern, Roblek, 2008). Tu vodilni naletijo na zelo zahtevna in pomembna vprašanja za vsako podjetje, kot so:

- kakšna je stopnja učinkovitosti izvajanja poslovnih procesov

- ali je izvajanje procesa glede na zahteve še sprejemljivo za podjetje

- ali je potrebno in ali je smotrno prilagoditi oziroma spremeniti proces 
1222 36 $6^{\mathrm{TH}}$ INTERnational CONFERENCE ON ORganizational SCIENCE DeVElopment: Responsible Organization (MARCH $22^{\mathrm{ND}}-24^{\mathrm{TH}}$, PORTOROŽ Slovenia)

B. Urh, E. Krhač, M. Roblek, T. Kern: Assessment of Business Process Re-engineering Efficiency Based on Process Structure

- kakšne spremembe ali prilagoditve je potrebno narediti v izvajanju procesa

- kako bodo predvidene spremembe vplivale na učinkovitost izvajanja procesa.

Ob pregledovanju relevantne literature o raziskavah na tem področju najdemo številne predloge za ovrednotenje učinkovitosti izvajanja poslovnih procesov (Aguilar, et al. 2006; Dibrell, et al. 2008; Frederiksen, \& Mathiassen, 2008; Cheng, 2008; Sharma, 2009). Večina predlogov se nanaša na ovrednotenje s pomočjo kazalnikov "operativne" učinkovitosti, le malo pa na kazalnike "strukturne" učinkovitosti. Kazalniki operativne učinkovitosti vključujejo vidik porabe časa in/ali vidik nastalih stroškov (Valiris, Glykas, 2004), do čim so kazalniki strukturne učinkovitosti povezani z ovrednotenjem strukturne kompleksnosti poslovnih procesov.

Oceno trenutnega stanja učinkovitosti izvajanja poslovnih procesov po kazalnikih operativne učinkovitosti si je v praksi mogoče predstavljati kot "on-line" zbiranje podatkov (KPI - ključnih indikatorjev izvajanja ${ }^{1}$ ) o izvajanju procesa. To pomeni da se mora proces $\mathrm{v}$ podjetju izvajati in da je njegovo izvajanje podprto $\mathrm{z}$ ustreznim programskim paketom, ki to omogoča. Ocena učinkovitosti izvajanja procesov po kazalnikih strukturne učinkovitosti pa si lahko na eni strani predstavljamo, kot oceno zahtevnosti izvedbe podpore izvajanja procesa $\mathrm{z}$ informacijsko tehnologijo ali na drugi strani kot oceno kompleksnosti poteka (modela) procesa (Cardoso, Mendling, Neumann, \& Reijers, 2006a). Prva možnost od podjetja zahteva, da imajo za ustrezno oceno predvideno informacijsko podporo procesa dokaj podrobno razdelano. $\mathrm{V}$ drugem primeru pa za oceno strukturne učinkovitosti potrebujemo zgolj ustrezen model poslovnega procesa.

$\mathrm{V}$ primerjavi s kazalniki operativne učinkovitosti poslovnih procesov so ocene učinkovitosti izvajanja procesov podane s kazalniki strukturne učinkovitosti sicer bolj grobe vendar je $\mathrm{v}$ tem primeru vložek za pridobitev take ocene bistveno nižji (Cheng, 2008). Po drugi strani pa je strukturna kompleksnost procesov eden glavnih vzrokov za pojavljanje napak in hitro naraščanje stroškov izvajanja procesov (Cardoso, Mendling, Neumann, \& Reijers, 2006b; Mendling, 2007).

Ker je implementacija prenovljenega poteka procesa oz. procesov povezana $\mathrm{z}$ visokimi stroški si vodilni v podjetjih želijo, da bi oceno predvidenega učinka prenove dobili še preden se odločijo za investicijo v le-to. $\mathrm{V}$ tem primeru torej odpade ocena učinkovitosti izvajanja procesa $\mathrm{s}$ kazalniki operativne učinkovitosti, lahko pa uporabimo oceno strukturne učinkovitosti izvajanja poslovnega procesa. Saj le-to lahko izvedemo že na podlagi ustrezno pripravljenega modela prenovljenega stanja poslovnega procesa.

$\mathrm{V}$ tem prispevku smo tako predstavili uporabo kazalnikov strukturne učinkovitosti pri oceni učinka predloga prenove procesa na izbranem procesu $\mathrm{v}$ enem izmed slovenskih podjetij. 


\section{$2 \quad$ Metode}

\subsection{Modeliranje poslovnih procesov}

Ocena strukturne učinkovitosti izvajanja poslovnega procesa je pogojena s predhodno opravljenim posnetkom poslovnega procesa (ang. process mapping) in njegovem zapisom v ustreznem repozitoriju.

Pri izvedbi posnetka obstoječega stanja poslovnega procesa (modeliranje obstoječega stanja in oblikovanju predloga prenovljenega procesa) lahko uporabimo različne metodologije kot so: REAL, BPMN, ARIS, ARMA in druge (po analizah Gartner Group je že vrsto let med najbolj izpopolnjenimi in ustreznimi programsko podprta metodologija ARIS podjetja Software AG). Zato smo za naše potrebe izbrali metodologijo ARIS in procesno - kontrolni pogled, konkretneje EPC (Event-driven Process Chain) tip modela, ker je proces na ta način prikazan tako kot si ga izvajalci najlaže predstavljajo (Pavlović, Kern, Miklavčič, 2009). Model temelji na logiki, da dogodek sproži aktivnost (opravilo) ali več aktivnosti, posledično se aktivnost konča $\mathrm{z}$ novim dogodkom ali več dogodki. $\mathrm{V}$ nadaljevanju bomo, $v$ primeru kadar bomo želeli poudariti tip modela, uporabili kratico EPC.

Pri ponazoritvi obstoječega stanja procesa in pripravi predloga prenovljenega stanja smo $\mathrm{v}$ modelu uporabili simbole, ki so prikazani v spodnji tabeli (Tabela 1). V tabeli so prikazana tudi pravila uporabe logičnih operatorjev. 
$36^{\text {Th }}$ International Conference on Organizational Science Development: Responsible Organization (MARCH $22^{\mathrm{ND}}-24^{\mathrm{TH}}$, Portorož SlOVENIA)

B. Urh, E. Krhač, M. Roblek, T. Kern: Assessment of Business Process Re-engineering Efficiency Based on Process Structure

Tabela 1: Simboli uporabljeni pri modeliranju EPC modelov procesov

\begin{tabular}{|c|c|c|}
\hline Naziv & $\begin{array}{l}\begin{array}{l}\text { Grafični } \\
\text { zapis }\end{array} \\
\end{array}$ & Namen uporabe simbola \\
\hline dogodek & & $\begin{array}{l}\text { Določeno stanje ali pojav, ki je vzrok ali posledica } \\
\text { nečesa. Vedno obstaja vzrok za izvajanje aktivnosti } \\
\text { in aktivnost ima vedno za posledico dogodek ali več } \\
\text { njih. }\end{array}$ \\
\hline $\begin{array}{l}\text { aktivnost } \\
\text { (funkcija) }\end{array}$ & & Naloga, opravilo, procesni korak \\
\hline $\begin{array}{l}\text { logični } \\
\text { operatorji }\end{array}$ & & $\begin{array}{l}\text { Razcepijo ali združijo procesno verigo: } \\
\text { IN - nadaljujemo obvezno po vseh mogočih poteh, } \\
\text { X-ALI - nadaljujemo izključno po eni mogoči poti, } \\
\text { ALI - nadaljujemo po kateri koli mogoči poti ali } \\
\text { kombinaciji mogočih poti. }\end{array}$ \\
\hline $\begin{array}{l}\text { proces } \\
\text { konektor }\end{array}$ & & $\begin{array}{l}\text { Uporabljen za prekinitev (prelom) procesa, če je ta } \\
\text { preobsežen (presega format A4). }\end{array}$ \\
\hline $\begin{array}{l}\text { organizacijska } \\
\text { enota }\end{array}$ & & Skupina ljudi, oddelek, služba \\
\hline delovno mesto & & $\begin{array}{l}\text { Delovno mesto izvajalca aktivnosti v organizacijski } \\
\text { strukturi (profil zaposlenega, ne konkretna oseba) }\end{array}$ \\
\hline aplikacija & $\underline{a t}$ & $\begin{array}{l}\text { Računalniška aplikacija (naziv aplikacije + ime ali } \\
\text { številka ali označba ekranske slike), ki se uporablja } \\
\text { pri posamezni aktivnosti }\end{array}$ \\
\hline dokument & & $\begin{array}{l}\text { Papirnati nosilec sporočil (obrazec, faks), ki je } \\
\text { potreben za izvedbo aktivnosti ali se v aktivnosti } \\
\text { ustvari }\end{array}$ \\
\hline
\end{tabular}

Model obstoječega stanja

Na spodnji sliki (Slika 1) je prikazan model obstoječega AS-IS stanja izbranega temeljnega procesa v podjetju. 

ORGANIZACIJA (22. - 24. MAREC 2017, PORTOROŽ, SLOVENIJA)

B. Urh, E. Krhač, M. Roblek \& T. Kern: Ocena učinkovitosti prenove procesa na podlagi strukture procesa

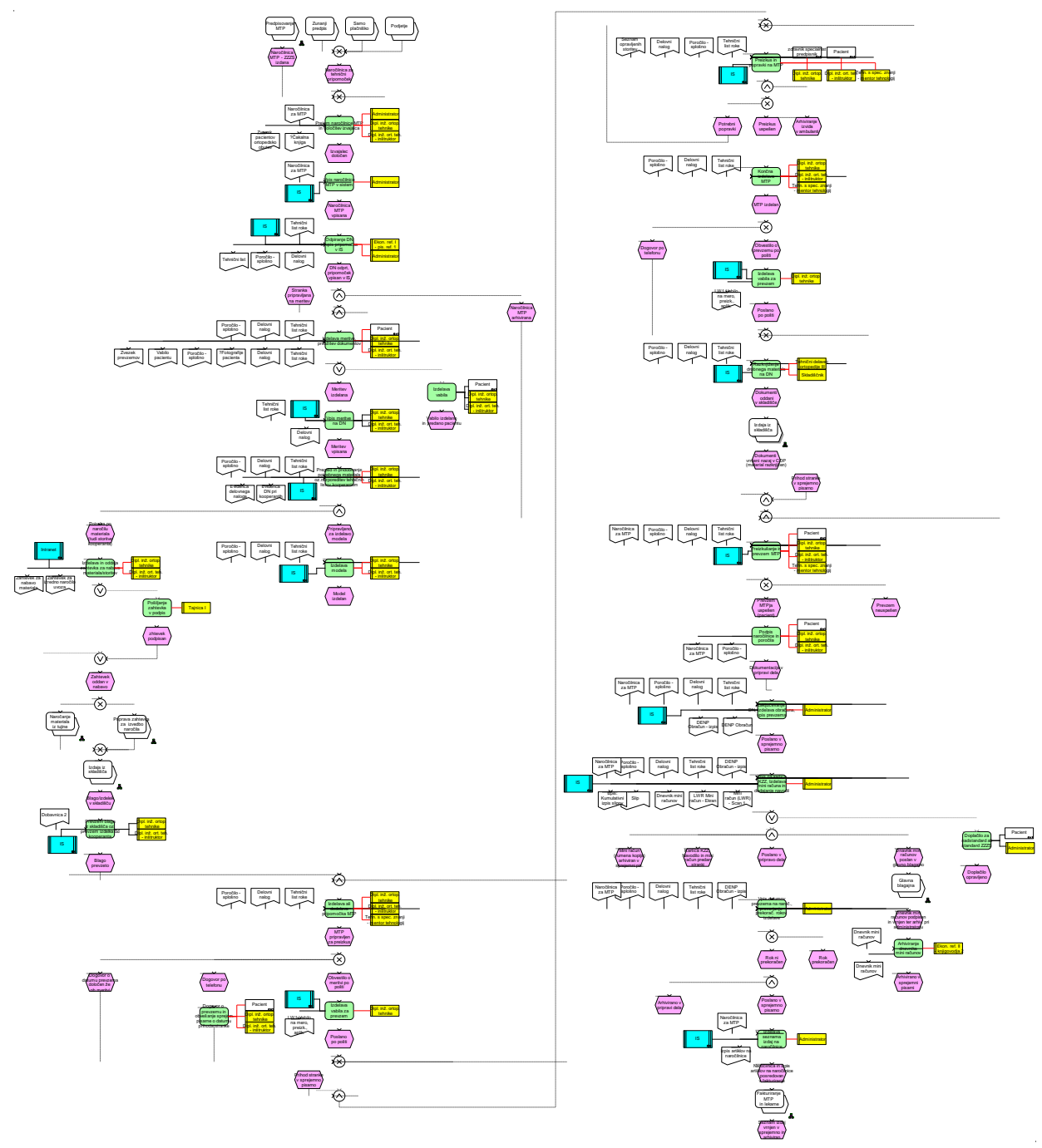

Slika 1: Model obstoječega stanja izbranega poslovnega procesa

\section{Model predlaganega prenovljenega stanja}

Na sliki 2 pa je prikazan model predlaganega TO-BE stanja izvajanja istega procesa $\mathrm{V}$ podjetju po prenovi. 
1226 36 $36^{\text {Th }}$ International Conference on Organizational Science Development: Responsible Organization (MARCH $22^{\mathrm{ND}}-24^{\mathrm{TH}}$, Portorož SlOVENIA)

B. Urh, E. Krhač, M. Roblek, T. Kern: Assessment of Business Process Re-engineering Efficiency Based on Process Structure
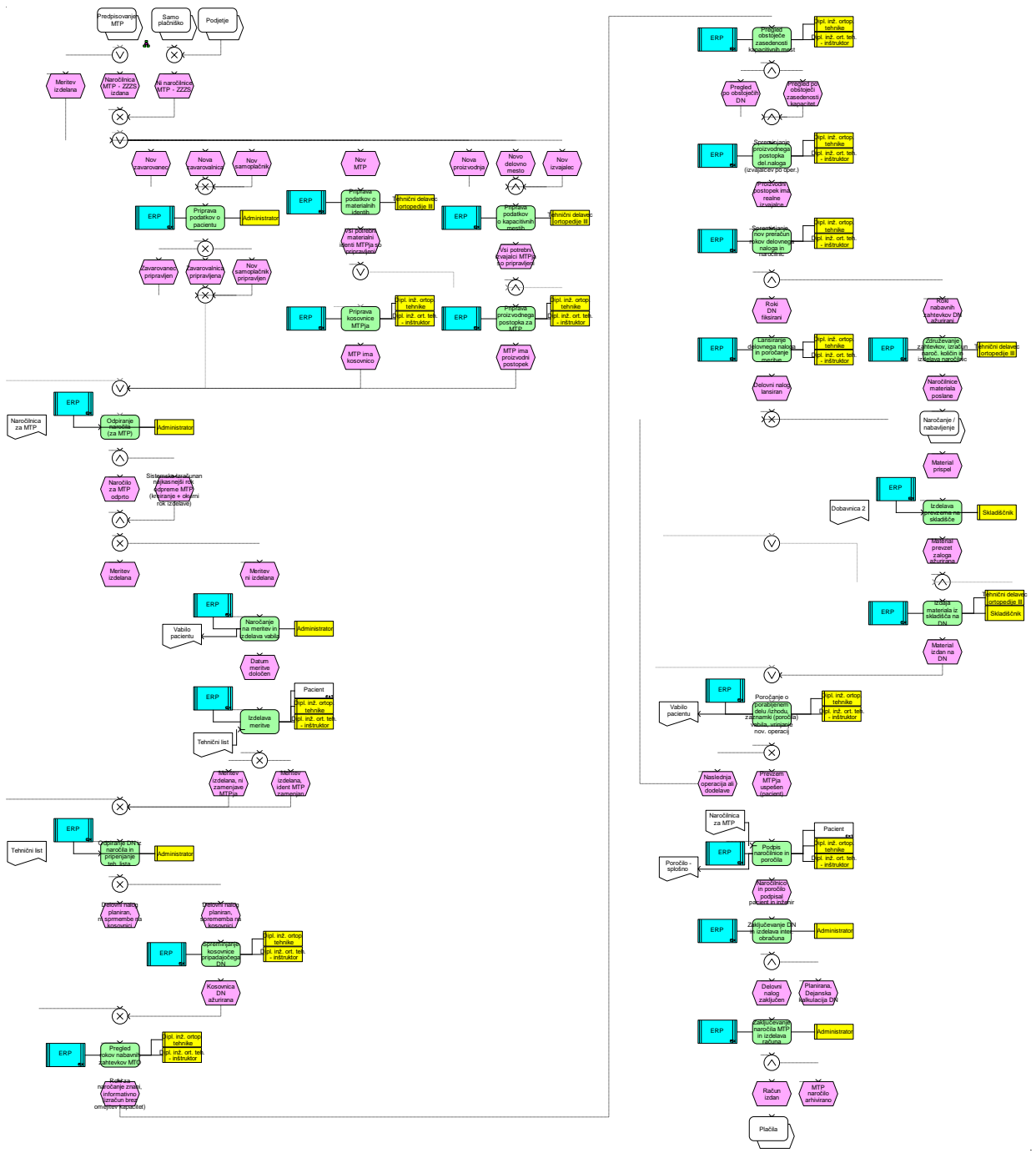

Slika 2: Model predloga izvajanja izbranega poslovnega procesa po prenovi

\subsection{Ocena strukturne učinkovitosti procesa}

\section{Analiza procesnega modela}

Oceno strukturne učinkovitosti izvajanja procesa izvedemo v več korakih. V prvem koraku $\mathrm{z}$ analizo modela procesa zberemo osnovne podatke (ključne indikatorje 
izvajanja) za ocenitev učinkovitosti izvajanja procesa po posameznih strukturnih kazalnikih. Pri analiziranju iz modelov procesov zberemo naslednje podatke (KPI-je) in sicer:

- število dogodkov v procesu ( $\left.\mathrm{n}_{\mathrm{E}}\right)$,

- število začetnih dogodkov procesa $\left(\mathrm{n}_{\mathrm{SE}}\right)$,

- število zaključnih in/ali ponornih dogodkov procesa $\left(\mathrm{n}_{\mathrm{FE}}\right)$,

- število aktivnosti v procesu (funkcije in procesni vmesniki) ( $\left.\mathrm{n}_{\mathrm{PA}}\right)$,

- število aktivnosti s povezavami na druge procese (procesni vmesniki) (n $\left.\mathrm{n}_{\mathrm{PI}}\right)$,

- število odločitev med izvajanjem procesa $\left(\mathrm{n}_{\mathrm{PD}}\right)$,

- število mogočih prehodov med aktivnostmi v procesu $\left(\mathrm{n}_{\mathrm{AT}}\right)$,

- število povratnih zank v procesu $\left(\mathrm{n}_{\mathrm{LB}}\right)$,

- število aktivnosti v procesu, $v$ katerih se ustvarja dodana vrednost (naA),

- število povezar med delovnimi mesti in aktivnostmi procesa ( $\mathrm{n}_{\mathrm{CPA}}$ ),

- število izvajalcev (delovnih mest), ki sodelujejo v procesu $\left(n_{P P}\right)$,

- število hierarhičnih ravni izvajalcev, ki sodelujejo v procesu ( $\left.\mathrm{n}_{\mathrm{HLP}}\right)$,

- število delovnih mest, ki sodeluje pri izvajanju vseh poslovnih procesov v poslovnem sistemu (n $\mathrm{n}_{\mathrm{PAP}}$ ),

- število izvajalcev (delovnih mest) v poslovnem sistemu ( $\left.\mathrm{n}_{\mathrm{PBS}}\right)$,

- število dokumentov, ki se uporabljajo v procesu $\left(\mathrm{n}_{\mathrm{DP}}\right)$,

- število dokumentov, ki jih je treba v procesu ustvariti (nPOD),

- število dokumentov, ki v proces vstopajo ( $\left.\mathrm{n}_{\mathrm{PID}}\right)$,

- število programskih rešitev, ki se uporabljajo v procesu (nswP),

- število aktivnosti procesa, katerih izvajanje je podprto s programskimi rešitvami (n $\mathrm{n}_{\mathrm{SWA}}$ ).

\section{Izračun kazalnikov strukturne učinkovitosti}

V naslednjem koraku na podlagi tako zbranih podatkov izračunamo kazalnike strukturne učinkovitosti (Poniatowski, \& Wichser, 2006; Bassi, \& McMurrer, 2007; Fitz-enz, 2009), ki jih glede na objekte oziroma simbole, ki tvorijo EPC modele poslovnih procesov lahko razvrstimo v štiri osnovne skupine (Aguilar et al, 2006) in sicer kazalnike ki so izraženi na osnovi:

- ključnih indikatorjev poteka procesa (vitki EPC model)

- ključnih indikatorjev povezav

- ključnih indikatorjev izvajalcev procesa oz. organizacijske strukture

- ključnih indikatorjev izdelkov oz. podpornih objektov (dokumenti, programske rešitve, ...)

$\mathrm{Na}$ podlagi zgoraj naštetih ključnih indikatorjev izvajanja poslovnih procesov tako dobimo 18 kazalnikov (različnih ocen) strukturne učinkovitosti izvajanja poslovnega procesa (Urh, Kokalj in Zajec, 2011). 
$36^{\mathrm{TH}}$ INTERNATIONAL CONFERENCE ON ORganizational SCIENCE DeVElopment: Responsible Organization (MARCh $22^{\mathrm{ND}}-24^{\mathrm{TH}}$, Portorož Slovenia)

B. Urh, E. Krhač, M. Roblek, T. Kern: Assessment of Business Process Re-engineering

Efficiency Based on Process Structure

\section{Končna ocena strukturne učinkovitosti procesa}

Pri izračunu končne ocene strukturne učinkovitosti izvajanja poslovnih procesov naletimo na problem kako veliko število izhodiščnih kazalnikov strukturne učinkovitosti združiti v enotno oceno saj ne vemo kateri kazalniki strukturne učinkovitosti poslovnih procesov so medsebojno povezani in kateri niso povezani, ter kateri kazalniki strukturne učinkovitosti najbolj relevantno izkazujejo stanje oz. imajo največji vpliv na učinkovitost izvajanja posameznega poslovnega procesa.

V raziskavi (Urh, Kokalj in Zajec, 2011) je bilo ugotovljeno, da lahko veliko število izhodiščnih kazalnikov strukturne učinkovitosti izvajanja poslovnih procesov nadomestimo s sedmimi nepovezanimi kazalniki strukturne učinkovitosti in pri tem ohranimo 77,068 \% variabilnosti osnovnih spremenljivk oz. izhodiščnih kazalnikov strukturne učinkovitosti. Končno oceno strukturne učinkovitosti izvajanja poslovnih procesov tako lahko izračunamo na podlagi vrednosti posameznega nepovezanega kazalnika strukturne učinkovitosti in njegovega deleža pojasnjene variance.

\section{$3 \quad$ Rezultati}

V nadaljevanju so prikazani rezultati ocenjevanja strukturne učinkovitosti na primeru izbranega temeljnega procesa $\mathrm{v}$ enem izmed slovenskih podjetij. Podjetje je prepoznano kot eno izmed bolj uspešnih na svojem področju. Podjetje je pred leti opravilo prenovo poslovnih procesov $\mathrm{z}$ izjemo temeljnih (proizvodnih) procesov. Z opravljenimi statističnimi analizami in izračuni kazalnikov operativne učinkovitosti so ugotovili, da imajo velike rezerve v prehodnih časih izdelave (Slika 3). Znižanje deleža časov čakanja so poskusili doseči s povečanjem kapacitet v ozkih grlih, ampak niso dosegli pričakovanih rezultatov, tako da smo se lotili korenitejše prenove procesa.

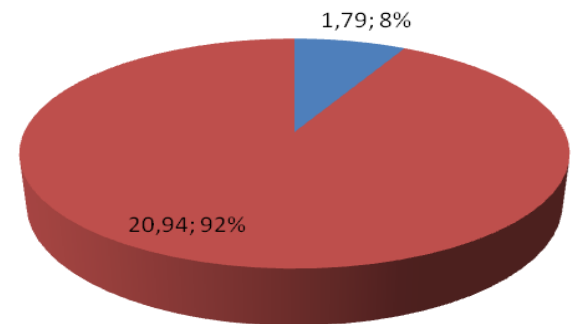

Slika 3: Distribucija čakalnih (rdeče), in izdelovalnih (modro), časov v izbranem temeljnem procesu

Ločeno smo izvedli ocenjevanje učinkovitosti izvajanja procesa po strukturnih kazalnikih za obstoječi način dela (AS-IS stanje) in predlagan način dela po prenovi procesa (TOBE stanje). 


\subsection{Analiza obstoječega in predloga prenovljenega modela procesa}

Na podlagi modela izbranega temeljnega procesa za obstoječi način dela (Slika 1) in predlagan način dela po prenovi procesa (Slika 2) smo zbrali podatke za izračun izhodiščnih oziroma nepovezanih kazalnikov strukturne učinkovitosti (Tabela 2).

\section{Tabela 2: Ključni podatki o izvajanju izbranega procesa}

\begin{tabular}{|c|c|c|c|}
\hline KPI & Oznaka & $\begin{array}{l}\text { AS-IS } \\
\text { stanje }\end{array}$ & $\begin{array}{l}\text { TO-BE } \\
\text { stanje }\end{array}$ \\
\hline število dogodkov v procesu & 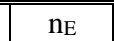 & 50 & 45 \\
\hline število začetnih dogodkov procesa & $\mathrm{n}_{\mathrm{SE}}$ & 8 & 3 \\
\hline število zaključnih in/ali ponornih dogodkov procesa & $n_{F E}$ & 8 & 3 \\
\hline število aktivnosti v procesu (funkcije in procesni vmesniki) & nPA & 36 & 27 \\
\hline $\begin{array}{l}\text { število aktivnosti s povezavami na druge procese (procesni } \\
\text { vmesniki) }\end{array}$ & $\mathrm{n}_{\mathrm{PI}}$ & 10 & 5 \\
\hline število odločitev med izvajanjem procesa & $\mathrm{n}_{\mathrm{PD}}$ & 0 & 0 \\
\hline število mogočih prehodov med aktivnostmi v procesu & $\mathrm{n}_{\mathrm{AT}}$ & 31 & 27 \\
\hline število povratnih zank v procesu & $\mathrm{n}_{\mathrm{LB}}$ & 0 & 0 \\
\hline $\begin{array}{l}\text { Število aktivnosti v procesu, v katerih se ustvarja dodana } \\
\text { vrednost }\end{array}$ & n & 6 & 8 \\
\hline število povezav med delovnimi mesti in aktivnostmi procesa & $\mathrm{n}_{\mathrm{CPA}}$ & 47 & 34 \\
\hline število izvajalcev (delovnih mest), ki sodelujejo v procesu & $\mathrm{n}_{\mathrm{PP}}$ & 11 & 6 \\
\hline število hierarhičnih ravni izvajalcev, ki sodelujejo v procesu & nHLP & 3 & 2 \\
\hline $\begin{array}{l}\text { število delovnih mest, ki sodeluje pri izvajanju vseh } \\
\text { poslovnih procesov v poslovnem sistemu }\end{array}$ & $\mathrm{n}_{\mathrm{PAP}}$ & 88 & 88 \\
\hline število izvajalcev (delovnih mest) v poslovnem sistemu & $\mathrm{n}_{\mathrm{PBS}}$ & 141 & 141 \\
\hline število dokumentov, ki se uporabljajo v procesu & $\mathrm{nDP}$ & 25 & 6 \\
\hline število dokumentov, ki jih je treba v procesu ustvariti & nPOD & 23 & 2 \\
\hline število dokumentov, ki v proces vstopajo & nPID & 8 & 3 \\
\hline število programskih rešitev, ki se uporabljajo v procesu & nswP & 2 & 1 \\
\hline $\begin{array}{l}\text { število aktivnosti procesa, katerih izvajanje je podprto s } \\
\text { programskimi rešitvami }\end{array}$ & nswa & 14 & 22 \\
\hline
\end{tabular}

\subsection{Nepovezani kazalniki strukturne učinkovitosti}

Na podlagi zbranih podatkov o strukturi izbranega temeljnega procesa in enačb za izračun nepovezanih kazalnikov strukturne učinkovitosti (Urh, 2011) smo za obstoječi način dela in predlagan način dela po prenovi procesa izračunali ocene nepovezanih kazalnikov strukturne učinkovitosti. Zaradi razlik $\mathrm{v}$ možnih intervalih vrednosti posameznega nepovezanega kazalnika strukturne učinkovitosti smo dobljene vrednosti pretvorili na enoten ocenjevalni interval. Rezultati, predstavljeni $v$ tabeli 3 so tako preračunani na interval vrednosti od 0 do 5 kjer vrednost 0 predstavlja slabo strukturno učinkovitost, vrednost 5 pa zelo dobro strukturno učinkovitost izbranega poslovnega procesa glede na posamezen nepovezan kazalnik strukturne učinkovitosti. 
36 ${ }^{\text {TH }}$ International Conference on ORganizational Science Development: Responsible Organization (MARCH $22^{\mathrm{ND}}-24^{\mathrm{TH}}$, Portorož SlOVENIA)

B. Urh, E. Krhač, M. Roblek, T. Kern: Assessment of Business Process Re-engineering Efficiency Based on Process Structure

Tabela 3: Ocene strukturne učinkovitosti izvajanj izbranega procesa

\begin{tabular}{|l|c||c|c||}
\hline Nepovezani kazalniki strukturne učinkovitosti & Oznaka & $\begin{array}{c}\text { AS-IS } \\
\text { stanje }\end{array}$ & $\begin{array}{c}\text { TO-BE } \\
\text { stanje }\end{array}$ \\
\hline Organiziranost poslovnega sistema & NSK01 & 3,12 & 3,53 \\
\hline Kompleksnost poslovnih procesov & NSK02 & 2,94 & 4,51 \\
\hline Dokumentiranost opravljenega dela & NSK03 & 0,51 & 3,86 \\
\hline Obsežnost poslovnih procesov & NSK04 & 3,44 & 3,35 \\
\hline Medsebojna povezanost procesov & NSK05 & 3,96 & 4,41 \\
\hline Podprtost z informacijsko tehnologijo & NSK06 & 2,61 & 5,00 \\
\hline Ustvarjanje dodane vrednosti & NSK07 & 1,15 & 1,80 \\
\hline
\end{tabular}

\subsection{Končna ocena strukturne učinkovitosti procesa}

$\mathrm{Na}$ podlagi ocene strukturne učinkovitosti po posameznem nepovezanem kazalniku strukturne učinkovitosti in razmerja deleža pojasnjene variance posameznega nepovezanega kazalnika strukturne učinkovitosti smo izračunali končno oceno strukturne učinkovitosti izbranega procesa. V spodnji tabeli (Tabela 4) so podani rezultati tako za model obstoječega izvajanja procesa kakor tudi za predlagani model izvajanja procesa po prenovi.

Tabela 4: Izračun končne ocene strukturne učinkovitosti izbranega procesa

\begin{tabular}{|l|c|c||c|c||}
\hline $\begin{array}{l}\text { Nepovezani kazalniki strukturne } \\
\text { učinkovitosti }\end{array}$ & Oznaka & $\begin{array}{c}\% \\
\text { variance }\end{array}$ & $\begin{array}{c}\text { AS-IS } \\
\text { stanje }\end{array}$ & $\begin{array}{c}\text { TO-BE } \\
\text { stanje }\end{array}$ \\
\hline Organiziranost poslovnega sistema & NSK01 & 24,237 & 3,12 & 3,53 \\
\hline Kompleksnost poslovnih procesov & NSK02 & 12,565 & 2,94 & 4,51 \\
\hline Dokumentiranost opravljenega dela & NSK03 & 10,328 & 0,51 & 3,86 \\
\hline Obsežnost poslovnih procesov & NSK04 & 9,303 & 3,44 & 3,35 \\
\hline Medsebojna povezanost procesov & NSK05 & 8,643 & 3,96 & 4,41 \\
\hline Podprtost z informacijsko tehnologijo & NSK06 & 6,286 & 2,61 & 5,00 \\
\hline Ustvarjanje dodane vrednosti & NSK07 & 5,706 & 1,15 & 1,80 \\
\hline Končna ocena strukturne učinkovitosti & & 2,69 & 3,80 \\
\hline
\end{tabular}

\section{$4 \quad$ Razprava rezultatov}

Smernice za ovrednotenje učinkovitosti izvajanja poslovnih procesov na podlagi strukturne kompleksnosti poslovnih procesov s tako imenovanimi kazalniki strukturne učinkovitosti, ki smo jo predstavili v prispevku smo zasledili le v prispevkih Aguilar et al. (2006) in Cheng (2008). Aguilar s svojimi sodelavci v raziskavi ugotavlja, katere ključne indikatorje izvajanja je treba nadzirati, če želimo spremljati spreminjanje strukturne učinkovitosti poslovnih procesov, Cheng pa v svojem delu obravnava načine za ugotavljanje strukturne kompleksnosti poslovnih procesov. 
B. Urh, E. Krhač, M. Roblek \& T. Kern: Ocena učinkovitosti prenove procesa na podlagi strukture procesa

$\mathrm{Na}$ izbranem primeru temeljnega procesa smo pokazali možnost praktične uporabe kazalnikov strukturne učinkovitosti. Rezultati ocenjevanja izbranega procesa (Tabela 3 in Tabela 4), kažejo, da bodo predlagane spremembe ob prenovi procesa pozitivno vplivale na učinkovitost izvajanja le-tega. Iz rezultatov ocenjevanja vidimo, da s predlaganimi spremembami ob prenovi procesa - oblikovanje TO-BE stanja dosežemo izboljšanje končne ocene strukturne učinkovitosti s 2,69 na oceno 3,80, kar je posledica:

- nekoliko izboljšano "organiziranost poslovnega sistema" (z ocene 3,12 na oceno $3,53)$; kar je posledica manjšega števila različnih izvajalcev vključenih v izvajanje procesa in manjšega števila različnih hierarhičnih nivojev na katerih so le-ti zaposleni

- znatno izboljšano "kompleksnost poslovnega procesa" (z ocene 2,94 na oceno 4,51); je posledica zmanjšanja števila odločitev vključenih v izvajanje procesa

- znatno izboljšano "dokumentiranost opravljenega dela" ( $\mathrm{z}$ ocene 0,51 na oceno 3,86 ); je posledica temeljitega znašanja števila "papirnih" - natisnjenih dokumentov, ki jih je potrebno tekom izvajanja procesa izdelati

- rahlo slabšo "obsežnost poslovnega procesa" (z ocene 3,44 na oceno 3,35); je posledica nekoliko zapletenejšim povezavam med različnimi možnostmi pri izvajanju procesa

- nekoliko izboljšano "medsebojna povezanost procesov" (z ocene 3,96 na oceno 4,41 ); je posledica bolj jasnim povezavam in prehodom v "povezane" procese (predhodne in posledične), ki jih je potrebno v podjetju izvesti

- znatno izboljšano "podprtost $\mathrm{z}$ informacijsko tehnologijo" ( $\mathrm{z}$ ocene 2,61 na oceno $5,00)$; je posledica uvedbe podpore izvajanja $\mathrm{z}$ celovito programsko rešitvijo (ERP sistem), in

- nekoliko izboljšano "ustvarjanje dodane vrednosti" (z ocene 1,15 na oceno 1,80 ); ki je posledica zmanjšanja števila aktivnosti v procesu v katerih se ne ustvarja dodana vrednost bodi si za stranko ali podjetje.

\section{$5 \quad$ Zaključek}

V pričujočem prispevku smo predstavili kako lahko učinkovitost izvajanja izbranega poslovnega procesa preverimo na podlagi ustrezno pripravljenega modela le-tega (EPC model procesa). S pomočjo kazalnikov strukturne učinkovitosti in modela procesa lahko ocenimo učinkovitost izvajanja procesa, ki se v podjetju že izvaja ali pa je model procesa pripravljen bodisi z namenom razvoja in vzpostavitve novega procesa oz. z namenom implementacije prenovljenega stanja procesa.

Na podlagi izračunanih nepovezanih strukturnih kazalnikov smo s preračunom na enotni merilni interval dobili ocene strukturne učinkovitosti izvajanja izbranega temeljnega procesa. $\mathrm{Na}$ podlagi izračunanega deleža pojasnjene variance posameznega nepovezanega kazalnika strukturne učinkovitosti smo nato izračunali končno oceno strukturne učinkovitosti izbranega procesa. 
36 ${ }^{\text {TH }}$ International Conference on Organizational Science Development: Responsible Organization (MARCh $22^{\mathrm{ND}}-24^{\mathrm{TH}}$, Portorož Slovenia)

B. Urh, E. Krhač, M. Roblek, T. Kern: Assessment of Business Process Re-engineering

Efficiency Based on Process Structure

V primeru želje oziroma potrebe po izboljšanju stanja učinkovitosti izvajanja poslovnih procesov se vodilni v podjetjih na podlagi predstavljenega postopka analize strukturne učinkovitosti lažje odločijo kaj bi bilo smiselno storiti (spremeniti organiziranost podjetja, prenesti pooblastila in odgovornosti na nižje nivoje, urediti povezanost poslovnih procesov, izpopolniti informacijsko podporo izvajanja procesov, zmanjšati število aktivnosti, ki ne ustvarjajo dodane vrednosti ali uvesti brez papirno poslovanje), da bi se učinkovitost izvajanja poslovnega procesa oz. procesov kar najbolj izboljšala.

\section{Opombe}

${ }^{1}$ Ključni indikatorji izvajanja (angleško: Key Performance Indicators) so merljive metrike s katerimi je izražena uspešnost doseganja zastavljenih nalog in ciljev v poslovnem sistemu (Bauer, 2004). Z njimi so lahko izraženi za podjetje strateško pomembni kazalniki ali pa je z njimi izražena učinkovitost izvajanja nepomembnih procesov ali aktivnosti.

\section{Literatura}

Aguilar, E. R.; Ruiz, F.; García, F., Piattini, M. (2006): Applying Software Metrics to evaluate Business Process Models, CLEI Electronic Journal, Vol. 9, No. 1, Paper 5.

Bassi, L., McMurrer, D. (2007): Maximizing Your Return on People, Harvard Business Review, Vol. 85, Iss. 3, pp. $115-123$.

Bauer, K. (2004): KPIs: Not All Metrics Are Created Equal, DM Review, 14(12), 42. Retrieved February 19, 2009, from ProQuest Computing database. (Document ID: 750265451).

Bose, R. (2002). Customer relationship management: key components for IT success. Industrial Management and Data Systems, 102(2), 89-97.

Cardoso, J., Mendling, J., Neumann, G., \& Reijers, H. A. (2006a). A Discourse on Complexity of Process Models. In Business Process Management Workshops (Vol. 4103). Heidelberg: Springer Berlin.

Cardoso, J., Mendling, J., Neumann, G., \& Reijers, H. A. (2006b). A Discourse on Complexity of Process Models. In Business Process Management Workshops (Vol. 4103, pp. 117-128). Heidelberg: Springer Berlin.

Cheng, C. (2008). Complexity and usability models for business process analysis. Available from ProQuest Dissertations \& Theses Global. Retrieved from http://search.proquest.com/docview/ 848640112 ?accountid $=28931$

Davis, R. (2002). The wizard of oz in CRMLAND: CRM's need for business process management. Information Systems Management.

Dibrell, C., Davis, P., Craig, J. (2008): Fueling Innovation through Information Technology in SMEs*, Journal of Small Business Management, Vol. 46, Iss. 2, pp. 203 - 218.

Fitz-enz, J. (2009): Predicting People: From Metrics to Analytics, Employment Relations Today, Vol. 36, Iss. 3, pg. 1.

Frederiksen, H., \& Mathiassen, L. (2008): A Contextual Approach to Improving Software Metrics Practices, IEEE Transactions on Engineering Management, Vol. 55, Iss. 4, pp. $602-616$.

Jarrar, Y. F., Al-Mudimigh, A., \& Zairi, M. (2000). ERP implementation critical success factorsthe role and impact of business process management. Paper presented at the Management of Innovation and Technology, 2000. ICMIT 2000. Proceedings of the 2000 IEEE International Conference on. 
Mendling, J. (2007). Detection and Prediction of Errors in EPC Business Process Models. Unpublished PhD, Vienna University of Economics and Business Administration (WU Wien), Austria.

Pavlović, I., Kern, T., Miklavčič, D. (2009): Comparison of paper-based and electronic data collection process in clinical trials: Costs simulation study, Contemporary Clinical Trials, Vol. 30, No. 4, pp. $300-316$.

Poniatowski, S., Wichser, J. D. (2006): A Better Metric For IT Efficiency, Optimize, Vol. 5, Iss. 5, pp. $43-46$.

Scanlon, R., Watts, J. (2009): A NEW ROUTE TO Performance Management, Baseline, Iss. 92, pp. $38-40$.

Sharma, A. (2009): Implementing Balance Scorecard for Performance Measurement, Institute of Chartered Financial Analysts of India (Hyderabad), The ICFAI Journal of Business Strategy, Vol. 6, Iss. 1, pp. 7 - 16.

Urh, B., Kern, T., Roblek, M. (2008): Business process modification management, In G. Putnik (Ed.), Encyclopedia of networked and virtual organizations, Hershey, Information Science Reference, pp. $112-120$.

Urh B. (2011): Predvidevanje uspešnosti poslovnega sistema z vidika obvladovanja učinkovitosti poslovnih procesov, Doktorska disertacija, Kranj.

Urh, B., Kokalj, Š., Zajec, M.(2011): The importance of structural indicators in assessing the efficiency of business process performance. V: KERN, Tomaž (ur.), RAJKOVIČ, Vladislav (ur.). People and sustainable organization. Frankfurt am Main [etc.]: Peter Lang, str. 248-270.

Valiris, G., Glykas, M. (2004): Business analysis metrics for business process redesign, Business Process Management Journal, Vol. 10, Iss. 4, pp. 445 - 480.

Vila, A. (2006): Sintetizirana organizacija, Management sprememb: zbornik 25. mednarodne konference o razvoju organizacijskih znanosti, pp. 1 - 12, Moderna organizacija v okviru FOV, Slovenija, Portorož 
1234 36 ${ }^{\text {TH }}$ International Conference on Organizational Science Development: Responsible Organization (March $22^{\mathrm{ND}}-24^{\mathrm{TH}}$, Portorož Slovenia) 
36. MEDNARODNA KONFERENCA O RAZVOJU ORGANIZACIJSKIH ZNANOSTI: OdgOVORNA ORGANIZACIJA (22. - 24. MAREC 2017, PORTOROŽ, SLOVENIJA)

O. Arsenijević, M. Ferjan, I. Podbregar, P. Šprajc, D. Trivan \& Y. Ziegler

\title{
Analiza spletnih strani za zaposlovanje s kadrovskega vidika
}

\author{
MARKO URH, LEA ZUPAN, DAVORIN KOFJAČ \& EVA JEREB
}

Povzetek Članek analizira najpomembnejše spletne strani za zaposlovanje $\mathrm{s}$ kadrovskega vidika. Analiza je bila narejena za najpomembnejše spletne strani v Sloveniji. V članku so predstavljene nekatere težave iskalcev in ponudnikov zaposlitev. Spletno kadrovanje ima svoje prednosti in slabosti. Pomembnost spletnih strani za zaposlovanje lahko prikažemo s kazalniki kot so število pregledanih podstrani, indeks zapustitve spletne strani, čas preživet na strani, priljubljenost in drugi. Spletne strani se razlikujejo glede števila elementov, ki so namenjeni iskalcem zaposlitve in ponudnikom zaposlitve. V članku so predstavljeni napotki za upravljanje spletnih strani za zaposlovanje.

KLJUČNE BESEDE: zaposlovanje - spletne strani za zaposlovanje • delodajalci $\bullet$ iskalci zaposlitve

\footnotetext{
NASLOV AVTORJEv: dr. Marko Urh, višji predavatelj, Univerza v Mariboru, Fakulteta za organizacijske vede, Kidričeva cesta 55a, 4000 Kranj, Slovenija, e-pošta: marko.urh@fov.unimb.si; Lea Zupan, Fitpro d.o.o., Stražiška ulica 17, 4000 Kranj, Slovenija, e-pošta: lea.zupan@fitpro.si; dr. Davorin Kofjač, docent, Univerza v Mariboru, Fakulteta za organizacijske vede, Kidričeva cesta 55a, 4000 Kranj, Slovenija, e-pošta: davorin.kofjac@fov.uni-mb.si; dr. Eva Jereb, redna profesorica, Univerza v Mariboru, Fakulteta za organizacijske vede, Kidričeva cesta 55a, 4000 Kranj, Slovenija, e-pošta: eva.jereb@fov.uni-mb.si
} 
$36^{\mathrm{TH}}$ InTERnational CONFERENCE ON ORganizational SCIENCE Development: Responsible Organization (MARCh $22^{\mathrm{ND}}-24^{\mathrm{TH}}$, PORTOROŽ SLOVENIA)

O. Arsenijević, M. Ferjan, I. Podbregar, P. Šprajc, D. Trivan \& Y.

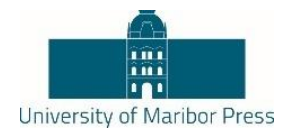

Ziegler

\title{
Analysis of Web Sites for Employment from HR Perspective
}

\author{
MARKO URH, LEA ZUPAN, DAVORIN KOFJAČ \& EVA JEREB
}

\begin{abstract}
This article analyzes the most important web sites for employment from HR perspective. The analysis was made for the most important web sites in Slovenia. The article presents some problems of job seekers and job providers. Online recruitment has its advantages and disadvantages. The importance of websites for employment can be shown by indicators such as daily pageviews per visitor, bounce rate, daily time on site, PageRank and others. Web sites vary according to the number of items that are designed for job seekers and job providers. The article presents the guidelines for the management of websites for employment.
\end{abstract}

KEYWORDS: employment • websites for employment $\bullet$ employers $\bullet$ job seekers

CORRESPONDENCE AdDRESS: Marko Urh, Ph.D., Senior Lecturer, University of Maribor, Faculty of Organizational Sciences, Kidričeva cesta 55a, 4000 Kranj, Slovenia, e-mail: marko.urh@ fov.unimb.si; Lea Zupan, Fitpro d.o.o., Stražiška ulica 17, 4000 Kranj, Slovenia, e-mail: lea.zupan@fitpro.si; Davorin Kofjač, Ph.D., Assistant Professor, University of Maribor, Faculty of Organizational Sciences, Kidričeva cesta 55a, 4000 Kranj, Slovenia, e-mail: davorin.kofjac@fov.uni-mb.si; Eva Jereb, Ph.D., Full Professor, University of Maribor, Faculty of Organizational Sciences, Kidričeva cesta 55a, 4000 Kranj, Slovenia, e-mail: eva.jereb@fov.unimb.si 


\section{$1 \quad$ Uvod}

Uporaba sodobnih tehnologij ima močan vpliv na praktično vsa življenjska področja. Ena izmed teh tehnologij je zagotovo informacijska tehnologija. Zaradi vpliva informacijskih tehnologij se je spremenil tudi način iskanja in nudenja zaposlitev. Pri iskanju zaposlitve se srečujemo $\mathrm{z}$ več težavami, ki se najpogosteje kažejo $\mathrm{v}$ dveh oblikah: vidik iskalca zaposlitve ter vidik podjetja, ki ǐšce ustrezen kader. Spletne strani za zaposlovanje morajo nuditi odgovor na dva osnovna vprašanja, ki s pojavljata na strani iskalcev zaposlitve in podjetij, ki nudijo zaposlitev in sicer: delodajalce zanima kje najti najbolj ustreznega kandidata, medtem, ko iskalce zaposlitve zanima kje najti najboljšo primerno zaposlitev. Za zagotavljanje rešitev, tako delodajalcev kot iskalcem zaposlitve, se na spletnih straneh pojavljajo različne tržne strategije, ki se kažejo v obliki različnih elementov na sami spletni strani. Spletne strani tako ponujajo različne informacije in podporne storitve za iskalce zaposlitve ter podjetja, ki iščejo kader, ko so: blogi, brezplačni nasveti, različni tečaji za brezposelne osebe, članki, kako iskati novo delovno mesto in drugo. Določene informacije in storitve so brezplačne, saj s tem pritegnejo pozornost. Glavni cilj večine spletnih strani je dobiček in dolgoročna vzdržnost poslovanja, saj se večina spletnih strani (z izjemo ess.gov.si) financira zgolj preko tržne dejavnosti. V prispevku so analizirane najpomembnejše slovenske spletne strani za zaposlovanje, kot so: adecco.si, zaposlitev.net, mojdedelo.com, mojazaposlitev.si, ess.gov.si, mservis.si in atama.si. Omenjene spletne strani so bile analizirane predvsem s kadrovskega vidika iskalca zaposlitve in podjetja, ki nudi zaposlitev. Analizirani in prikazni so elementi, ki se pojavljajo na spletnih straneh $\mathrm{z}$ vidika iskanja in nudenja zaposlitve. Prav tako so predstavljene in povzete so spletne karakteristike kot so: skupno število povezav, ki kažejo na našo stran (angl. Total Sites Linking In), PageRank, Global Rank, TrustRank, sklicne domene, ki pokažejo točno določanje povratnih povezav (angl. Reffering Domain), dnevni čas na spletni strani (angl. Daily Time on Site), Bounce Rate in dnevni ogled strani na obiskovalca (angl. Daily Pageviews per Visitor). Omenjene karakteristike prestavljajo realno sliko uporabe in dogajanja na posamezni spletni strani. So posledica uporabnosti in dogajanja na spletne strani in so v prispevku so nazorno predstavljene $\mathrm{v}$ tabelah.

\section{$2 \quad$ Kadrovanje}

Kadrovski proces obsega proces sprejemanja, usposabljanja, planiranja in razvoja kadrov. Omenjen proces sestavljajo številne dejavnosti, kot so (Florjančič, Bernik in Novak, 2004): razpis natečaja, intervju, testiranje, odločitev o zaposlitvi, izobraževanje ob delu, premeščanje, napredovanje, sprejem na novo delovno mesto, usposabljanje itd. Merkač Skok (2005) navaja, da je kadrovska služba organizacijska enota znotraj podjetja oziroma druge oblike organizacije, ki izvaja naloge in funkcije kadrovskega managementa. Vukovič in Miglič (2006) menita, da je podpora pridobivanju kadrov pomembna dejavnost kadrovske službe, ki večinoma vsebuje dela kot so: določanje in kategoriziranje dolgoročnih ter kratkoročnih potreb po kadrih v organizaciji; spremljanje sprememb na trgu dela; razvijanje gradiv o kadrovskih potrebah; evidentiranje primernih interesentov; spremljanje uporabnikov kadrov $\mathrm{v}$ organizaciji in evalvacija pridobivanja 
36 ${ }^{\mathrm{TH}}$ InTERnAtional CONFERENCE ON ORganizational SCIENCE Development: Responsible Organization (MARCH $22^{\mathrm{ND}}-24^{\mathrm{TH}}$, PortoroŽ SlOVENIA)

M. Urh, L. Zupan, D. Kofjač \& E. Jereb: Analysis of Web Sites for Employment from HR Perspective

kadrov. Kot navaja Merkač Skok (2005), potencialne kandidate za prosto delovno mesto privabljamo s pomočjo oglaševanja razpisanega delovnega mesta. Pri oglaševanju moramo biti pozorni na več dejavnikov in sicer: komu je sporočilo namenjeno, kaj želimo sporočiti, kako sporočilo definiramo in kakšne rezultate smo z določenim načinom oglaševanja dosegli in drugo. Namen oglaševanja je pridobiti ustrezne kandidate in zagotoviti nabor kandidatov, iz katerega lahko kasneje izberemo najbolj ustreznega kandidata za določeno delovno mesto. Potrebno je definirati ciljno skupino oglasa, določiti medije, oblikovati sporočilo in spremljati dobljene rezultate. Zaradi prednosti, ki jih ima spletno kadrovanje je postalo pridobivanje in iskanje kadrov na omenjen način vse bolj priljubljeno in razširjeno. Podobno lahko zasledimo tudi pri iskalcih zaposlitve. Do informacij na internetu lahko dostopamo praktično iz kjerkoli in kadarkoli, kar predstavlja pri iskanju zaposlitve veliko prednost. $\mathrm{V}$ nadaljevanju so predstavljene nekatere značilnosti spletnega kadrovanja.

\section{$3 \quad$ Spletno kadrovanje}

V praksi lahko zasledimo številne načine iskanja in pridobivanja kadrov. Kot navaja SAOP (2016), poteka v razvitih državah preko $50 \%$ kadrovanja preko interneta. Prednosti interneta za potrebe kadrovanja so predvsem $v$ hitrosti prenosa informacij med iskalci in ponudniki in cenovno ugodno obliko obveščanja. Specializirane aplikacije omogočajo hitro selekcijo prijav na delovno mesto in olajšajo potrebno korespondenco med iskalcem in ponudnikom zaposlitve. Centralne baze podatkov iskalcev zaposlitve s primerljivimi podatki in možnostjo uporabe iskalnikov so veliko bolj uporabne za potrebe kadrovanja kot registratorji zastarelih življenjepisov v papirni obliki. Hitra distribucija informacije o kadrovski potrebi in možnost hitre obdelave informacij o iskalcih zaposlitve sta glavna razloga za hiter razvoj spletnega kadrovanja v zadnjih petih letih.

Kot navaja mojazaposlitev.si (2016), nam iskanje preko interneta ponuja veliko prednosti, kot so: informacije o prostih delovnih mestih so nam dostopne kadarkoli (24 ur na dan); z nekaj kliki se nam odpre virtualni svet trga dela; zaposlitev lahko iščemo od tam, kjer želimo. Vse, kar moramo storiti, je, da sedemo za računalnik in pobrskamo po spletnih straneh. Prijavo na oglas lahko opravimo samo z nekaj kliki; informacijo o novi objavi zaposlitvenega oglasa, ki ustreza našim kriterijem, dobimo zelo hitro; ponuja nam informacije o prostih delovnih mestih $\mathrm{v}$ različnih državah; internet nam omogoča enostavno pridobivanje informacij o podjetju, za katerega se zanimamo; morda na internetu najdemo zaposlitvene priložnosti, o katerih doslej še nikoli nismo razmišljali; prihranimo čas in denar, saj ni več zamudnega tiskanja, kopiranja in poštnih stroškov; preden se lotimo iskanja zaposlitve prek spleta, si je priporočljivo odgovoriti na vprašanja, kot so: Kaj si želim delati? Katere so moje delovne izkušnje, veščine, ostala znanja in sposobnosti? Kateri so moji karierni cilji? Če povzamemo po spletni strani mojedelo.com (2016) in mojazaposlitev.si (2016), ima spletno kadrovanje nekaj bistvenih prednosti v primerjavi z ostalimi načini kadrovanja. nekatere izmed njih so: nižji stroški kadrovanja; prihranek časa; hitrejše iskanje; večja odzivnost bolj usposobljenih kandidatov in drugo. Spletno kadrovanje ima, tako kot vsaka druga zadeva tudi svoje pomanjkljivosti. Podjetje, ki išče kadre preko spleta mora razumeti proces 
iskanja kadrov preko interneta, ki se razlikuje od klasičnega načina iskanja kadra. Za potrebe takšnega iskanja mora imeti ustrezno tehnologijo in usposobljene ljudi, ki razumejo proces iskanja. Podjetje moramo imeti zagotovljene ustrezne tehnične zmogljivosti, ki so pri iskanju kadra na spletu nujno potrebni. Dobro je, če ima podjetje zagotovljene določene mehanizme avtomatizacije opravil selekcije kadrov (urejanje evidenc prijavljenih potencialnih kadrov, zbiranje in sortiranje življenjepisov, kontaktiranja kandidatov in drugo), ki pridejo v poštev pri velikem številu prijavljenih kandidatov. Pomanjkljivost spletnega kadrovanja se v določenih primerih lahko pokaže tudi takrat, ko mora podjetje izobraziti svoj kader za proces kadrovanja preko spleta. Kljub temu, da živimo v času in okolju, kjer je informacijska tehnologija prisotna, obstajajo ljudje, ki jim takšen način kadrovanja ni ravno domač oz. priljubljen. Podjetja, ki nimajo usposobljenega kadra za kadrovanje preko spleta se poslužujejo klasičnih načinov kadrovanja, kot so tiskani mediji in agencije. Pomanjkljivost spletnega kadrovanja lahko zasledimo tudi na strani iskalcev zaposlitve. Iskalci zaposlitve morajo biti računalniško pismeni. To predstavlja problem predvsem pri starejših in manj izobraženih iskalcih. Prav tako je ena izmed pomanjkljivosti dostop do interneta oz. infrastruktura, ki je v nekaterih krajih še vedno pereč problem. Pri iskanju zaposlitve preko spleta se velika večina komunikacije odvija elektronsko, zato je potrebno nenehno spreminjati stanje določenega oglasa in odgovore delodajalca. To pa zahteva neoviran in neprestan dostop do internega.

Spletna zaposlitvena stran podjetja bi morala vsebovati naslednje elemente (Schweyer, 2004): hiter (en klik) dostop do kadrovske spletne strani z vseh strani spletne predstavitve podjetja; spletni zaposlitveni oglasi podjetja na kadrovskih portalih vključujejo povezavo do spletne zaposlitvene strani podjetja; povezava do teh strani je oglaševana $v$ vseh korporativnih tiskovinah podjetja; spletna zaposlitvena stran vsebuje informacije o korporativni kulturi, delovnem okolju, kariernih priložnostih in prednostih zaposlitve $\mathrm{v}$ podjetju; vsebuje podstrani namenjene študentom in iskalcem prve zaposlitve; podrobne informacije o aktualnih delovnih mestih; možnost oddaje življenjepisa na spletnih strani podjetja, možnost spletnega iskanja po življenjepisih. Oddane življenjepise lahko kandidat $\mathrm{v}$ prihodnosti popravlja ali izbriše iz baze; možnost spletne prijave na zaposlitveni oglas. Arthur (2012) ugotavlja, da morajo podjetja, ki želijo imeti učinkovite kadrovske spletne strani, zagotoviti uporabnikom prijazne strani, preprosto in hitro iskanje aktualnih delovnih ponudb podjetja. Spletna stran mora biti ustrezno organizirana, vsebina strani pa ustrezno uravnotežena z grafičnimi elementi. Podjetje mora izkoristiti svoje kadrovske spletne strani za zbiranje informacij o svojih spletnih obiskovalcih, od njihovih e-naslovov do njihovih življenjepisov. Prav tako morajo zagotoviti hiter odziv na prijave kandidatov. Mojedelo.com (2016) navaja, da imajo delodajalci največ uspeha pri iskanju primernih kandidatov za tista delovna mesta, za katere je zahtevana peta do sedma stopnja izobrazbe, saj imajo ti kandidati več znanja s področja računalništva. Iskanje manj izobraženih kadrov so pogosto neuspešna, ker slednji ne uporabljajo interneta, za iskanja vodstvenega kadra pa se navadno uporabljajo druge, bolj osebne oblike kadrovanja. 
$36^{\text {Th }}$ International Conference on Organizational Science Development: Responsible Organization (MARCh $22^{\mathrm{ND}}-24^{\mathrm{TH}}$, PORTOROŽ Slovenia)

M. Urh, L. Zupan, D. Kofjač \& E. Jereb: Analysis of Web Sites for Employment from HR Perspective

\section{$4 \quad$ Značilnosti spletnih strani za zasposlovanje}

Analizirane so bile najpomembnejše slovenske spletne strani za zaposlovanje (adecco.si, zaposlitev.net, mojdedelo.com, mojazaposlitev.si, ess.gov.si, mservis.si in atama.si). V svetu so za prikaz pomembnosti posameznih elementov in značilnosti spletne strani uporabljajo določeni kazalniki (prikazani v nadaljevanju), ki veljajo za standard in so svetovno priznani. Podatki so prikazani v Tabeli 1, pomen uporabljenih oznak in razlaga nekaterih pojmov pa je opisana v nadaljevanju (povzeto po Pintar in drugi 2015):

- PR - PageRank: algoritem za analizo spletnih povezav, ki jih Google uporablja za pomoč pri ugotavljanju relativne pomembnosti spletne strani (Chelsea, 2013).

- GR - Global Rank: Groba ocena priljubljenosti spletne strani v primerjavi z drugimi spletnimi stranmi, glede več dejavnikov, kot so število obiskovalcev na dan, čas, ki ga obiskovalci preživijo na strani, itd (Rodriguez, 2013).

- TR - TrustRank: je tehnika analize povezav raziskovalcev Univerze Stanford in Yahoo!-ja za polavtomatsko ločevanje uporabnih spletnih strani pred neželeno pošto (Gyöngyi, Hecto in Pedersen, 2007).

- TSLI - Skupno število povezav, ki kažejo na našo stran (angl. Total Sites Linking In): število spletnih strani, ki imajo povezave na vašo spletno stran (Rodriguez, 2013).

- Reffering domain - sklicna domena, ki pokaže točno določanje povratnih povezav. Znana tudi kot 'ref' domena. Domena iz katere prihajajo povratne domene (Johnson, 2014).

- DToS - Dnevni čas na spletni strani (angl. Daily Time on Site): Povprečno število minut, preživetih na naši spletni strani za vsakega obiskovalca na dan. Več časa kot ga uporabniki preživijo na strani, bolj je vaša spletna stran pomembna (Rodriguez, 2013).

- BR - Bounce Rate: Odstotek obiskovalcev, ki zapustijo vašo spletno stran potem, ko so videli samo eno stran. Na splošno velja, da nižja kot je stopnja bolje je (Rodriguez, 2013).

- DPVpV - Dnevni ogled strani na obiskovalca (angl. Daily Pageviews per Visitor): povprečno število ogledalnih strani vsakega obiskovalca spletne strani na dan. Višja kot je številka boljša je stran, kar pomeni, da so informacije na strani privlačne (Rodriguez, 2013). 


\section{Tabela 1: Analiza spletnih strani po izbranih svetovnih spletnih kazalnikih}

\begin{tabular}{|c|c|c|c|c|c|c|c|}
\hline & 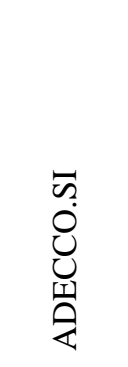 & 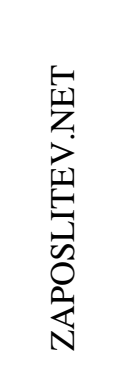 & 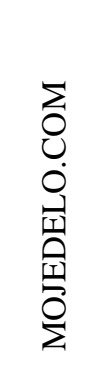 & 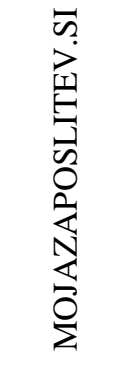 & $\begin{array}{l}\vec{n} \\
\partial \\
0 \\
0 \\
\dot{y} \\
\tilde{n}\end{array}$ & 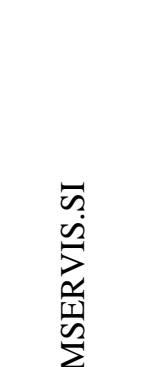 & 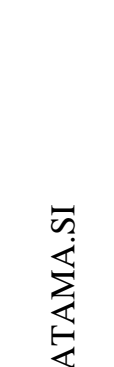 \\
\hline $\begin{array}{l}\text { PR } \\
\text { (maks } \\
10 \text { ) } \\
\end{array}$ & 7 & 6 & 7 & 5 & 7 & 5 & 5 \\
\hline GR & $\begin{array}{r}484.37 \\
2 \\
\end{array}$ & $\begin{array}{r}427.69 \\
9 \\
\end{array}$ & $\begin{array}{r}45.13 \\
9 \\
\end{array}$ & $\begin{array}{r}104.41 \\
8 \\
\end{array}$ & $\begin{array}{r}14.82 \\
5 \\
\end{array}$ & $\begin{array}{r}1.128 .21 \\
5 \\
\end{array}$ & $\begin{array}{r}975.16 \\
4 \\
\end{array}$ \\
\hline TR & 2 & 4 & 6 & 2 & 0 & 2 & 0 \\
\hline TSLI & 310 & 89 & 190 & 79 & 1 & 32 & 22 \\
\hline $\begin{array}{l}\text { Referrin } \\
\text { g } \\
\text { Domain }\end{array}$ & 556 & 298 & 652 & 241 & 1.875 & 166 & 97 \\
\hline $\begin{array}{l}\text { DToS } \\
\text { (min: } \\
\text { sek) }\end{array}$ & $1: 33$ & $1: 45$ & $13: 43$ & $4: 35$ & 1 & $2: 36$ & $0: 41$ \\
\hline BR & $37,5 \%$ & $38,6 \%$ & $\begin{array}{r}21,8 \\
\% \\
\end{array}$ & $28,6 \%$ & I & $33,3 \%$ & $55,9 \%$ \\
\hline$\overline{D P V p V}$ & 2,6 & 3,1 & 7,8 & 6,2 & & 3,1 & 2,2 \\
\hline
\end{tabular}

Kazalniki spletne strani mojedelo.com, kot so PageRank (7 od 10), Global Rank (45.139 spletna stran na svetu) in TrustRank (6) kažejo, da je omenjena spletna stran daleč najbolj rangirana. Iz Tabele 1 je razvidno, da po večini kazalnikov prav tako pozitivno izstopa spletna stran mojedelo.com. Na omenjeni spletni strani uporabniki ostanejo najdlje časa in sicer 13 minut in 43 sekund. Veliko časa, ki ga uporabniki preživijo na spletni strani, $\mathrm{v}$ primerjavi z drugimi spletnimi stranmi, pomeni, da je spletna stran $\mathrm{v}$ redu zasnovana in uporabna. Prav tako lahko sklepamo, da so informacije uporabne in relevantne. Na omenjeni spletni strani uporabniki pregledajo v povprečju 7,8 strani, kar je veliko. Sklepamo lahko, da omenjena spletna stran ponuja največ oglasov in ostalih informacij, ki so za ponudnike in iskalce zaposlitve pomembni. Največ spletnih strani, ki so povezani $\mathrm{z}$ omenjenimi spletnimi stranmi kaže na spletno stran adecco.si. Omenjena lastnost je pomembna zaradi širjenja in razvejanosti povezav z drugimi spletnimi stranmi (več je bolje). Odstotek obiskovalcev, ki zapustijo spletno stran potem, ko so videli samo eno stran je najmanjši pri spletni strani mojdedelo.si in sicer 21,8 \% (manj je bolje). 
1242 36 $6^{\mathrm{TH}}$ INTERnational CONFERENCE ON ORganizational SCIENCE DeVElopment: Responsible Organization (MARCH $22^{\mathrm{ND}}-24^{\mathrm{TH}}$, PortoroŽ SlOVENIA)

M. Urh, L. Zupan, D. Kofjač \& E. Jereb: Analysis of Web Sites for Employment from HR Perspective

Na področju iskanja zaposlitve preko spleta je potrebni upoštevati dva vidika in sicer vidik iskalca zaposlitve in vidik podjetja, ki nudi zaposlitev. V nadaljevanju so prikazane značilnosti spletnih strani za zaposlovanje s kadrovskega vidika, kot jih vidijo iskalci zaposlitve (Tabela 2) in kot jih lahko vidijo delodajalci oz. podjetja, ki nudijo zaposlitev (Tabela 3).

Tabela 2: Pregled razpoložljivih informacij za iskalce del

\begin{tabular}{|c|c|c|c|c|c|c|c|}
\hline & 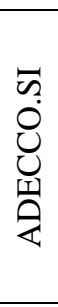 & 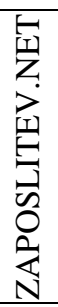 & 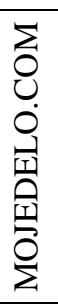 & 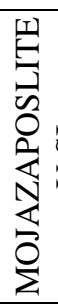 & 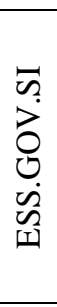 & 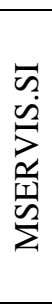 & 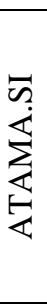 \\
\hline Brezplačen dostop do baze iskalcev & & $\bullet$ & & & $\bullet$ & & \\
\hline Brezplačni oglas & & $\bullet$ & & $\bullet$ & $\bullet$ & & \\
\hline Dostop do baze iskalcev & & $\bullet$ & $\bullet$ & $\bullet$ & $\bullet$ & & \\
\hline E-poslovalnice & & & & & $\bullet$ & $\bullet$ & $\bullet$ \\
\hline FAQ & & & & $\bullet$ & $\bullet$ & & $\bullet$ \\
\hline Iskanje kandidata po času vpisa v bazo & & & & $\bullet$ & & & \\
\hline Iskanje kandidata po delovnem času & & $\bullet$ & & & & & \\
\hline Iskanje kandidata po delovnih izkušnjah & & $\bullet$ & & & & & \\
\hline Iskanje kandidata po delovnih izkušnjah & & $\bullet$ & & $\bullet$ & & & \\
\hline Iskanje kandidata po ključnih besedah & & $\bullet$ & $\bullet$ & $\bullet$ & & & \\
\hline Iskanje kandidata po nazivu izobrazbe & & & & & $\bullet$ & & \\
\hline Iskanje kandidata po obliki dela & & $\bullet$ & & & & & \\
\hline Iskanje kandidata po področju dela & & $\bullet$ & $\bullet$ & $\bullet$ & & & \\
\hline Iskanje kandidata po poklicu & & & & & $\bullet$ & & \\
\hline Iskanje kandidata po regiji & & $\bullet$ & $\bullet$ & $\bullet$ & $\bullet$ & & \\
\hline Iskanje kandidata po starosti & & $\bullet$ & & & & & \\
\hline Iskanje kandidata po stopnji izobrazbe & & $\bullet$ & $\bullet$ & $\bullet$ & $\bullet$ & & \\
\hline Iskanje kandidatov v tujini & & & $\bullet$ & & & & \\
\hline Iskanje tujcev po tuji bazi podatkov & & & & & $\bullet$ & & \\
\hline Koraki za zaposlitev delavca & & & & $\bullet$ & & & \\
\hline Naročilo napotnice in obračun & & & & & & $\bullet$ & \\
\hline Naročilo študenta & & & & & & $\bullet$ & \\
\hline Nastavi 'head hunterja' & & & $\bullet$ & & & & \\
\hline Nasveti kako napisati oglas & & & & $\bullet$ & $\bullet$ & & \\
\hline Nasveti o zaposlitveni pogodbi & & & & $\bullet$ & & & \\
\hline Nasveti o zdravju na delovnem mestu & & & & $\bullet$ & & & \\
\hline
\end{tabular}


M. Urh, L. Zupan, D. Kofjač \& E. Jereb: Analiza spletnih strani za zaposlovanje s kadrovskega vidika

\begin{tabular}{|l|c|c|c|c|c|c|c|}
\hline Nasveti za odpuščanje & & & & $\bullet$ & $\bullet$ & & \\
\hline Nasveti za zaposlovanje & & & & $\bullet$ & & & \\
\hline Nasveti za zaposlovanje in delo tujcev & & & & & $\bullet$ & & \\
\hline Objava oglasa & & $\bullet$ & $\bullet$ & $\bullet$ & $\bullet$ & & \\
\hline Objavljen cenik & & $\bullet$ & $\bullet$ & $\bullet$ & $\bullet$ & & $\bullet$ \\
\hline Obvestilo ustrezne kandidate & & & $\bullet$ & $\bullet$ & & & \\
\hline Obveznosti delodajalca & & & & $\bullet$ & & & \\
\hline Ponudba kadrovskega svetovanja & & & & $\bullet$ & & $\bullet$ & $\bullet$ \\
\hline Ponudba osebnih storitev za delodajalce & $\bullet$ & $\bullet$ & $\bullet$ & $\bullet$ & $\bullet$ & $\bullet$ & $\bullet$ \\
\hline Posredovanje oglasa ustreznim kandidatom & & & $\bullet$ & $\bullet$ & & & \\
\hline Registracija & & $\bullet$ & $\bullet$ & $\bullet$ & $\bullet$ & $\bullet$ & \\
\hline Statistika oglasov & & $\bullet$ & & & $\bullet$ & & \\
\hline Število iskalcev zaposlitve & & & & & $\bullet$ & & \\
\hline Ugled delodajalca & & & $\bullet$ & & & & \\
\hline Video predstavitev & & $\bullet$ & & & & & \\
\hline SKUPAJ DA & $\mathbf{1}$ & $\mathbf{1 8}$ & $\mathbf{1 4}$ & $\mathbf{2 3}$ & $\mathbf{1 9}$ & $\mathbf{6}$ & $\mathbf{5}$ \\
\hline
\end{tabular}

Tabela 3: Analiza spletnih strani z vidika delodajalcev

\begin{tabular}{|c|c|c|c|c|c|c|c|}
\hline & \begin{tabular}{l}
$\bar{n}$ \\
0 \\
0 \\
0 \\
II \\
\multirow{2}{*}{}
\end{tabular} & 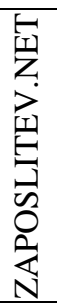 & 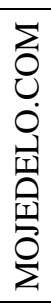 & 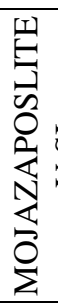 & $\begin{array}{l}\vec{n} \\
0 \\
0 \\
0 \\
\dot{n} \\
\tilde{n} \\
\text { In }\end{array}$ & 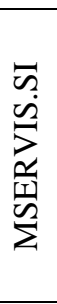 & 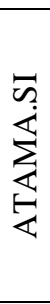 \\
\hline Registracija & - & - & - & - & - & - & - \\
\hline Vpis v bazo & - & - & $\bullet$ & - & - & - & - \\
\hline E-obveščevalec & $\bullet$ & $\bullet$ & $\bullet$ & $\bullet$ & $\bullet$ & $\bullet$ & $\bullet$ \\
\hline Top podjetja & & & $\bullet$ & & & & \\
\hline Delodajalci z negativnimi ocenami & & & & & $\bullet$ & & \\
\hline Izbrana podjetja & & & • & & & & \\
\hline Števec števila podjetij & & & $\bullet$ & & & & \\
\hline Najbolj iskana delovna mesta & & & $\bullet$ & $\bullet$ & & & \\
\hline Opis poklicev & & $\bullet$ & & & $\bullet$ & & \\
\hline Števec za št. prostih delovnih mest & $\bullet$ & $\bullet$ & $\bullet$ & & $\bullet$ & $\bullet$ & $\bullet$ \\
\hline Št. iskalcev zaposlitve & & & & & $\bullet$ & & \\
\hline Skupno št. oglasov glede na izobrazbo & & $\bullet$ & $\bullet$ & $\bullet$ & $\bullet$ & & \\
\hline Skupno št. oglasov glede na izobrazbo & & & & & $\bullet$ & & \\
\hline Skupno št. oglasov glede na poklic & & & & & $\bullet$ & & \\
\hline Iskanje rednega dela & $\bullet$ & $\bullet$ & $\bullet$ & - & $\bullet$ & $\bullet$ & $\bullet$ \\
\hline
\end{tabular}


36 ${ }^{\text {TH }}$ International Conference on ORganizational Science Development: Responsible Organization (MARCH $22^{\mathrm{ND}}-24^{\mathrm{TH}}$, PORTOROŽ SlOVENIA)

M. Urh, L. Zupan, D. Kofjač \& E. Jereb: Analysis of Web Sites for Employment from HR Perspective

\begin{tabular}{|c|c|c|c|c|c|c|c|}
\hline Iskanje študentskega dela & $\bullet$ & $\bullet$ & $\bullet$ & $\bullet$ & & $\bullet$ & $\bullet$ \\
\hline Iskanje dela v tujini & & $\bullet$ & $\bullet$ & $\bullet$ & $\bullet$ & $\bullet$ & \\
\hline Iskanje po nazivu izobrazbe & & & & & $\bullet$ & & \\
\hline Iskanje po stopnji izobrazbe & & $\bullet$ & $\bullet$ & $\bullet$ & $\bullet$ & & \\
\hline Iskanje po regijah & $\bullet$ & $\bullet$ & $\bullet$ & $\bullet$ & $\bullet$ & $\bullet$ & \\
\hline Iskanje po področjih & $\bullet$ & $\bullet$ & $\bullet$ & $\bullet$ & $\bullet$ & $\bullet$ & \\
\hline Števec objav po področjih & $\bullet$ & & $\bullet$ & $\bullet$ & & & \\
\hline Dodajanje CV & $\bullet$ & $\bullet$ & $\bullet$ & $\bullet$ & $\bullet$ & $\bullet$ & $\bullet$ \\
\hline Nasveti za izdelavo CV & & $\bullet$ & $\bullet$ & $\bullet$ & $\bullet$ & $\bullet$ & \\
\hline Voden način kreiranja CV & & & & $\bullet$ & & & \\
\hline Brezplačna osebna pomoč pri izdelavi CV & & & & & $\bullet$ & $\bullet$ & \\
\hline Plačljiva os. pomoč pri izdelavi CV & & & $\bullet$ & & & & \\
\hline Priročnik za izdelavo CV & & & $\bullet$ & & & & \\
\hline Karierni profil & & & $\bullet$ & & & & \\
\hline Zaposlitveni koraki & & $\bullet$ & $\bullet$ & $\bullet$ & $\bullet$ & $\bullet$ & \\
\hline Interaktivna svetovalka & & & & & $\bullet$ & & \\
\hline FAQ & & & & & $\bullet$ & & $\bullet$ \\
\hline $\mathrm{B} \log$ & $\bullet$ & & $\bullet$ & $\bullet$ & & & \\
\hline Psihometrični testi & & & $\bullet$ & & & & \\
\hline Nasveti za zaposlitveni razgovor & & $\bullet$ & $\bullet$ & $\bullet$ & $\bullet$ & & \\
\hline Forum & & $\bullet$ & & & & & \\
\hline Seznam plačljivih izobraževanj & & $\bullet$ & $\bullet$ & & $\bullet$ & & $\bullet$ \\
\hline Pomoč invalidnim iskalcem & & $\bullet$ & $\bullet$ & & $\bullet$ & & \\
\hline Zaposlovanje športnikov & $\bullet$ & & & & & & \\
\hline Mobilna aplikacija & $\bullet$ & & & & & $\bullet$ & $\bullet$ \\
\hline Facebook & $\bullet$ & $\bullet$ & $\bullet$ & $\bullet$ & $\bullet$ & $\bullet$ & $\bullet$ \\
\hline Video predstavitve podjetij & & $\bullet$ & & & & & \\
\hline E-zloženke in gradiva za iskanje zaposlitve & & $\bullet$ & & & & & \\
\hline SKUPAJ & 14 & 22 & 26 & 19 & 26 & 15 & 11 \\
\hline
\end{tabular}

Če primerjamo ugotovitve na osnovi podatkov spletnih strani po izbranih svetovnih spletnih kazalnikih (Tabela 1), ugotovitve na osnovi podatkov pridobljenih $\mathrm{z}$ analizo razpoložljivih informacij za iskalce del na spletnih straneh (Tabela 2) in ugotovitve analize spletnih strani $\mathrm{z}$ vidika delodajalcev (Tabela 3) lahko pridemo do nekaterih zanimivih ugotovitev. Pri analizi podatkov spletnih strani po izbranih svetovnih spletnih kazalnikih je bilo ugotovljeno, da ima spletna stran mojdedelo.com daleč najboljše kazalnike $\mathrm{v}$ več kategorijah. To pomeni, da je spletna stran uporabna, zanimiva in ponuja največ v proučevani kategoriji spletnih strani. Največ elementov ponujenih za iskalce zaposlitve lahko najdemo na spletni strani mojazapolsitev.si, ki se pa pri analizi svetovnih spletnih kazalnikov ne izkaže kot najboljša. 
Če primerjamo omenjene ugotovitve in ugotovitve na osnovi seštevka vseh elementov na spletni strani z vidika iskalcev zaposlitve (Tabela 2) vidimo, da le ta ni največji, kar pomeni, da količina ponujenih informacij za iskalca zaposlitve ni ključna za atraktivnost in uporabnost določene spletne strani. Nekako je to razumljivo, saj je z vidika iskalca zaposlitve najpomembnejše število in kakovost ponujenih zaposlitvenih oglasov na spletni strani, ki jih nudijo podjetja. Analiza elementov spletnih strani z vidika delodajalcev pokaže, da imata spletna stran mojedelo.com in ess.gov.si največ točk (26). Vse omenjene spletne strani (razen ess.gov.si) se financirajo same (trg). Pri spletnih straneh, kjer dejavnosti ne financira država, je zelo opazna tržna naravnanost. Zato je pomembno, da podjetjem, ki za objavo zaposlitvenega oglasa plačajo določeno ceno omogočijo čim večji nabor storitev.

\section{5}

\section{Zaključek}

Posledica razširjenosti in uporabe informacijske tehnologije se posledično odraža $v$ tem, da se veliko klasične komunikacije spreminja $\mathrm{v}$ elektronsko. $\mathrm{V}$ preteklosti so se prosta delovna mesta večinoma objavljala $\mathrm{v}$ klasični papirni obliki na oglasnih tablah in časopisih. Informacijska tehnologija in internet imata številne pozitivne lastnosti. Zaradi teh lastnosti (hitro, poceni, dostopno, ...) se je ogromno objav in iskanj po prostih delovnih mestih preselilo na internet. Kadrovanje preko interneta ima številne prednosti v primerjav s klasičnem kadrovanjem kot so: nižji stroški komuniciranja, prihranjen čas, hitrejše ažuriranje podatkov, informacije so na voljo 24 ur na dan, algoritmi za iskanje ustreznega kadra in drugo. Zato smo lahko prepričani, da bom internetno kadrovanje vse bolj razširjeno.

Pri analizi spletnih straneh za kadrovanje je bilo ugotovljeno, da uporabljajo različne elemente za iskalce del zaposlitve in za delodajalce. Primerjava in različna popularnost omenjenih spletnih strani glede na svetovne kazalnike pokaže, da spletne strani uporabljajo različne taktike za privabljanje iskalce del in za podjetja, ki objavljajo prosta delovan mesta. Skupno za ponudnike delovnih mest je to, da je večina spletnih strani (razen Zavod za zaposlovanje Republike Slovenije) plačljive. Za iskalce prostih delovnih mest pa so informacije večinoma brezplačne. $Z$ vidika poslovnih modelov in strategij bi bilo zanimivo če poslovni model obrnil, kar pomeni, da bi imela podjetja, ki objavljajo prosta delovna mest možnost brezplačnega objavljanja. Več objavljenih prostih delovnih mest bi pritegnilo več iskalcev zaposlitve. Iskalci zaposlitve bi lahko plačevali določen del za konkretne ponudbe delovnih mest. Ker je iskalcev zaposlitve bistveno več kot pa ponudnikov delovnih mest bi bilo zanimivo razmisliti o drugačnem poslovnem modelu, kot je se sedaj prisoten v svetu in Sloveniji.

$\mathrm{V}$ prihodnosti lahko na področju spletnega kadrovanja pričakujemo hud poj pri ponudnikih spletnih strani za kadrovanje. Vedno več bo ponudbe tako za iskalce zaposlitve kot za ponudnike delovnih mest. Napovedati je mogoče večjo prisotnost algoritmov, ki bodo opravili del selekcije prijavljenih kadrov za neko delovno mesto. Prav tako bo več iskalcev imelo svoje video predstavitve, ki so bolj organske kot pa samo opisni življenjepis. Pri izboru posameznega kadra podjetja uporabljajo specialistične teste 
36 ${ }^{\text {TH }}$ International Conference on Organizational Science Development: Responsible Organization (MARCh $22^{\mathrm{ND}}-24^{\mathrm{TH}}$, PORTOROŽ Slovenia)

M. Urh, L. Zupan, D. Kofjač \& E. Jereb: Analysis of Web Sites for Employment from HR Perspective

oz. strokovnjake predvsem s področja psihologije. Spletno kadrovanje bo omogočilo, da se določeni testi, ki jih izvajajo prej omenjeni strokovnjaki, preselijo na splet, kar posledično pomeni manj stroškov za podjetje. Na večino objavljenih prostih delovnih mest se prijavi veliko število potencialih kandidatov, zato bo takšen način selekcioniranja kadrov vedno bolj v uporabi.

Ob pregledu in analizi spletnih strani za kadrovanje je bilo opaziti, da so določena prosta delovna mesta neaktualna. Prav tako so nekateri potenciali iskalci zaposlitve nemotivirani in se prijavljajo na določena delovna mesta zgolj zaradi ohranitve mesečne podpore, ki je vezana na število oddanih prošenj.

\section{Literaura}

Arthur, D. (2012). Recruiting, Interviewing, Selecting \& Orienting New Employees (5th ed.). b.k.: Amacom.

Chelsea, A. (2013). What Is Google PageRank and How Is It Earned and Transferred? Dostopno na http://www.bruceclay.com/blog/what-is-pagerank/

Florjančič, J., Bernik, M., Novak, V. (2004). Kadrovski management. Kranj: Moderna organizacija.

Gyöngyi, Z., Hector, G. M., \& Pedersen, J. (2004). Combating Web Spam with TrustRank. Proceedings of the International Conference on Very Large Data Bases, 30(576).

Johnson, L. (2014). What is the difference between a referring domain and a backlink? Dostopno na http://www.fosterwebmarketing.com/faqs/what-is-the-difference-between-a-referringdomain-and-a-backlink-.cfm

Merkač Skok, M. (2005). Osnove managementa zaposlenih. Koper: Fakulteta za management.

Moja zaposlitev spletno oglaševanje, d. o. o. Mojazaposlitev. Pridobljeno april, maj 2016 na http://www.mojazaposlitev.si.

Najem kadrov (12. 3. 2012). MojeDelo.com. Pridobljeno 27. 4. 2016 na https://delodajalci.mojedelo.com/novica/outsourcing-najem-kadrov/d-2598.

Pintar, R., Jereb, E., Vukovič, G. \& Urh, M. (2015) Analysis of Web Sites for e-Learning in the Field of Foreign Exchange Trading, Procedia - Social and Behavioral Sciences, 197, 245-254.

Rodriguez, A., (2013). How to measure your tourism website's effectiveness with Alexa. Dostopno na http://www.freemads.com/blog/?p=1060\#sthash.O6sTQTol.dpbs

SAOP (4. 12. 2013) Sodobne metode kadrovanja preko spleta, Pridobljeno 13. 4. 2016 na http://www.saop.si/poslovne-informacije/kariera-755/kadrovskiproces- 771/sodobne-metodekadrovanja-preko-spleta.

Schweyer, A. (2004). Talent Management Systems: Best Practices in Technology Solutions for Recruitment, Retention and Workforce Planning. New York: Willey computer publishing John Willey \& Sons.

Vukovič, G., Miglič, G. (2006). Zagotavljanje kadrovnih virov. Kranj: Moderna organizacija. 
$36^{\mathrm{TH}}$ International CONFERENCE ON ORganizational SCIENCE Development: Responsible Organization (MARCh $22^{\mathrm{ND}}-24^{\mathrm{TH}}$, PORTOROŽ SLOVENIA)

O. Arsenijević, M. Ferjan, I. Podbregar, P. Šprajc, D. Trivan \& Y. Ziegler

\title{
Mexican SMEs in Organic Sector in the Asia Pacific Market: Internationalization Strategies
}

\author{
José G. VARGAS-HERnÁNDEZ, RiCARdo ARECHAVAla VARGAS \& LUZ ALICIA PULIDO \\ GARCÍA
}

\begin{abstract}
The aim of this work is to propose the internationalization strategies that will have the greatest impact on Mexican SMEs in the organic food industry that want to reach the Asia Pacific market. The study method is based on theoretical review of the internationalization theories: neoclassical and modern, tripod strategy that analyzes the vision based on industry, resources and institutions, as well as the types of foreign participation the companies can have. The results of the analysis shows that the tripod of the strategy, can be the best way for Mexican SMEs in the organic market, to start analyzing the entry to foreign markets, and do it the best way possible.
\end{abstract}

KEYWORDS: Organic food • internationalization strategies • SMEs internationalization $\bullet$ tripod of strategy

Correspondence AdDress: José G. Vargas-Hernández, Ph.D., University of Guadalajara, niversity Center for Economic and Managerial Sciences, Av. Juárez No. 976, Colonia Centro, C.P. 44100, Guadalajara, Jalisco, México, e-mail: jvargas2006@gmail.com, Ricardo Arechavala Vargas, Ph.D., University of Guadalajara, niversity Center for Economic and Managerial Sciences, Av. Juárez No. 976, Colonia Centro, C.P. 44100, Guadalajara, Jalisco, México, e-mail: josevargas@cucea.udg.mx, Luz Alicia Pulido García, Ph.D., Núcleo Universitario Los Belenes, U, Periférico Norte 799 Edif. G.201-7, Zapopan, Jalisco, 45100 México, e-mail: jgvh0811@yahoo.com

DOI https://doi.org/10.18690/978-961-286-020-2.99 
36 ${ }^{\text {TH }}$ International Conference on ORganizational Science Development: Responsible ORGANIZATION (MARCH $22^{\mathrm{ND}}-24^{\mathrm{TH}}$, PortoroŽ SLOVENIA)

J. G. Vargas-Hernández, R. Arechavala Vargas \& L. A. Pulido García: Mexican SMEs in Organic Sector in the Asia Pacific Market: Internationalization Strategies

\section{$1 \quad$ Introduction}

Mexican products have surprised the countries, categorizing Mexico as one of the richest cuisines in the world. There are geographic conditions that positively affect the production of inputs that cannot be produced anywhere else in the world (Gómez Cruz, Schwentesius Rindermann, Ortigoza Rufino, \& Gómez Tovar, 2010). These conditions benefit producers and marketers of Mexican food. With the growing worldwide demand for organic products, it is seen that there is an important opportunity for SMEs focused on the marketing of organic food. In Mexico only 5,000 small and medium companies maintain foreign trade operations, less than 1 percent of total 3 million 960 thousand SMEs registered by INEGI (Mexicoxport, 2012, s. P.).

Due to the low percentage of SMEs that send their products abroad, opportunities for organic food that can be offered, it is intended to analyze the strategies they can use to reach the Asia Pacific region.

Below it will found records that show the beginning of the organic market and the trend of this consumption worldwide. The delimitation of the problem with the research question, and the justification show the concerns for growth of the sector and opportunities in the Mexican countryside in food innovation products. The aim of this literature review and study is to obtain some opportunities. A review of literature will give a good base for analysis of these businesses and provide recommendations and conclusions.

\section{$2 \quad$ Background of the problem}

Since the 80 's the trend towards buying organic products has been growing. Arriving by concerns on issues such as health care, new eating habits and environmental care, a demand was created in developed countries. This demand could not be supplied by the same countries; therefore developing countries started producing under guidelines that would achieve quality by the required market (Gómez Cruz, et al. 2010).

Organic production in Mexico dates back to the 60, where a group of foreign investors seeking land that had not been used with chemical assets found in rural areas of Chiapas and Oaxaca (Schwentesius Rindermann, Nelson Gomez Cruz, 2010). Since then these states are the head of organic agriculture in Mexico, taking Mexico to be within the top 5 countries producing organic coffee in the world.

The World of Organic Agriculture Summary 2012, written showing the productive performance of countries worldwide, claims that Mexico has an area of 501.364 hectares are destined for organic agriculture, placing it at number 17. This section is headed by Australia, Argentina and the United States, with 17.2, 3.1 and 2.2 million hectares respectively (Willer, Yussefi-Menzler, \& Sorensen, 2011). 
Agriculture is one of the main economic activities in Mexico, contributing to be the 3rd country with more producers in the world. It is believed that this density producer is because agricultural production in Mexico is based on partnerships between small producers. Partnerships between small producers are known as agricultural cooperatives, which is in charge of collecting, promoting and selling inputs of small farmers. For $2007 / 08$, the participation of small producers corresponded to $99.9 \%$ and concentrating 93.9\% of the surface with an average of 2.9 ha per farmer (Gómez Cruz, et al. 2010, 28).

\section{Delimitation of the problem}

The marketing of organic food has an impact abroad 3 economic levels. Sales of organic food and beverages in Asia Pacific reached the amount of 4.403 billion dollars (USD) in 2014 (MarketLine, 2014). Therefore, this research is aimed to improve and ensure the internationalization of companies engaged in the sector. The low participation of SMEs in the overseas market and demand for organic consumption has defined the following question:

What kind of strategies can implement the SMEs to be able to reach Asia Pacific market?

The importance of research focus on identifying factors utilization, which will be proposed based on the causes identified by several authors in the literature.

\section{$4 \quad$ Assumptions}

Mexico is privileged by the geographical area in which it is located. It has access to trade and oceans bordering the leader of the world economy: United States of America. The new treaties of international economic cooperation show that Asia Pacific countries are a prominent target for Mexican companies, which must have solid internationalization processes to achieve established or doing business overseas bases. The target market was defined by a growth of over $13.8 \%$ annually in selling organic products, the highest compared to other regions of the world (Datamonitor, 2011). Asia Pacific includes areas of Australia, China, India, Indonesia, Japan, New Zealand, Singapore, South Korea, Taiwan, and Thailand. The growth of exports to Asia-Pacific has grown amounting to 17,262.9 million (INEGI, 2015).

The tripod of the strategy is the most influential strategy framework for SMEs to achieve positioning organic products in the Asia Pacific region.

The organic food market worldwide achieved sales of 84, 281 million in 2014 (MarketLine, 2014), featuring a 9.4\% growth between 2010 and 2014. 
$36^{\mathrm{TH}}$ INTERNATIONAL CONFERENCE ON ORganizational SCIENCE DeVElopment: Responsible ORGaNiZATION (MARCH $22^{\mathrm{ND}}-24^{\mathrm{TH}}$, PortoroŽ SLOVENIA)

J. G. Vargas-Hernández, R. Arechavala Vargas \& L. A. Pulido García: Mexican SMEs in Organic Sector in the Asia Pacific Market: Internationalization Strategies

\section{$5 \quad$ Conceptual framework}

\section{A. Organic market}

Since the 90's it has spread concern for the environment, followed by health care and preferences for natural products. The creation of organic products arises from the demand for products produced without the use of fertilizers, without genetic modification and without chemical use (Schwentesius Rindermann, et al. 2010). This demand has created that the entire world's countries start producing under organic guidelines, and generate a commitment of countries to impose regulatory agencies.

Europe is the geographical area that reported more sales in organic food, being the first continent to adopt this trend. The European market is considered a mature market, where consumer preferences are very rigid, and innovation of organic products are not surprise. It is anticipated that global growth tends to decline, however the Asia-Pacific reported an increase of more than $10 \%$ annually (DataMonitor, 2011).

In a study published reported in 2013 predicted that by 2014 sales of organic food in the Asia Pacific area would be worth 4417.6 million (KenResearch, 2013). Although the shape and parameters that were used to determine the estimated sales is unknown, it can be made a comparison with actual data. The Asia-Pacific market reported 8338.9 billion by 2014, an increase of $13.8 \%$ (DataMonitor, 2011). The growth of exports to AsiaPacific has grown by more than $149 \%$ since 2006, reaching 17,262.9 million (INEGI, 2015).

The organic consumer's preferences are flexible; there is an audience that is accustomed to organic products. A report says that consumers by the lack of differentiation in products choose the similar products by their price (MarketLine, 2014).

The Transpacific Partnership Treaty aims to streamline marketing processes and reduce costs and terms of negotiations. The government of Mexico mentions that the Treaty of Transpacific Partnership, for short TPP, has 4 main features: the elimination or reduction of tariff barriers in 6 new countries and improvements in 5 with which already had treated. Promotes innovation and productivity, it supports small economies to benefit and integration of economies in productivity. The marketing of organic food has an impact abroad 3 economic levels: 
J. G. Vargas-Hernández, R. Arechavala Vargas, L. A. Pulido García: Mexican SMEs in Organic Sector in the Asia Pacific Market: Internationalization Strategies

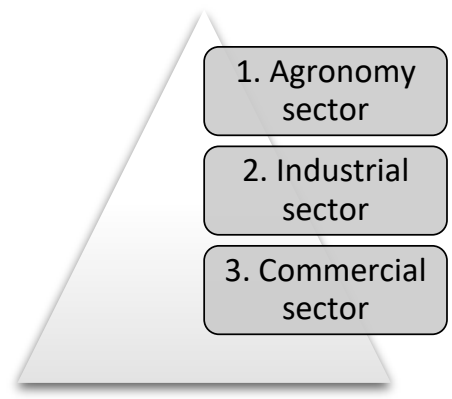

Figure 1: Economic Levels Source: INEGI (2014).

The agronomy sector it belongs to the first economic level, the primary sector. This sector involves producers in the field, which incurred on purchase of machinery, seeds and plants, water, natural fertilizers and inputs and technical assistance and certified organic plantations. The industrial sector belongs to the second economic level, the secondary sector. The industrial sector is responsible for transforming the proceeds of the primary sector in a product ready for sale. This sector impacts the entire packaging industry and packaging machinery purchase by specialized people responsible for production and quality. This sector may also involve certification costs if the company does not perform the agronomic sector.

Table 1:Internationalization theories

\begin{tabular}{lll} 
Theory & Concept & Most important authors \\
\hline $\begin{array}{l}\text { Classic } \\
\text { theory }\end{array}$ & $\begin{array}{l}\text { Absolute advantage } \\
\text { Comparative } \\
\text { advantage }\end{array}$ & Adam Smith (1776) \\
\hline $\begin{array}{l}\text { Neoclassic } \\
\text { theory }\end{array}$ & $\begin{array}{l}\text { Uppsala Model } \\
\text { Nordic School }\end{array}$ & $\begin{array}{l}\text { Johanson and } \\
\text { (1975), Johanson and Vahlne (1977) }\end{array}$ \\
\hline $\begin{array}{l}\text { Modern } \\
\text { theory }\end{array}$ & $\begin{array}{l}\text { Porter's paradigm } \\
\text { Networking theory }\end{array}$ & Porter (1990) \\
\hline
\end{tabular}

Source: Prepared based on Cardozo, P., Chavarro, A. Ramirez, C. (2007) and Aranda, Y., Montoya, I., (2006) 
36 ${ }^{\text {TH }}$ International Conference on Organizational Science Development: Responsible ORGaNiZATION (MARCH $22^{\mathrm{ND}}-24^{\mathrm{TH}}$, PortoroŽ SLOVENIA)

J. G. Vargas-Hernández, R. Arechavala Vargas \& L. A. Pulido García: Mexican SMEs in Organic Sector in the Asia Pacific Market: Internationalization Strategies

\section{1) Uppsala}

The Nordic model school, better known as Uppsala model, was developed by Johanson and Wiedersheim-Paul (1975) and talks about internationalization in stages. These stages are gradual and move as the company gains experience abroad. These stages or as they call chain, are based on 4 links. The first link puts it in no regular or sporadic exports. The second stage in exports is through representatives. The third is the establishment of a branch in the target country. The fourth and last link is the establishment of production units in the foreign country (Cardozo et al. 2007).

\section{2) Network theory}

The entry to foreign markets is defined by network theory. It discusses the approach that the company will be successful abroad because contacts and network individuals. These interactions achieve an accepted internationalization as networks to be found in the target countries that will have a profound knowledge of the market (Cardozo et al. 2007). Johanson and Mattson quoted by Cardozo, et al. (2007) analyzed internal networks also, saying that relationships that the company has with its suppliers, customers and competitors positively affect the company way.

\section{Tripod strategy}

The tripod strategy, talks about the 3 most used and successful prospects of the strategy: Vision industry-based, resource-based view-based institutions (Peng, 2012) vision.

1. Vision-based industry

This vision was proposed by Porter, and has been used and improved in many strategic internationalization areas and the breadth of what is proposed. Porter speaks of 5 forces affecting competitiveness and how they can manage in the industry. Each force explains important determinants so the company can continue weak or strong in that industry (Peng, 2012: 35).

5 forces are listed below (Peng, 2012):

\section{a) The rivalry of competitors}

It analyzes the number of competitors that are on the market, the similarity between the products, which have capacity and the allocation of costs to the company. It is said that there are high degrees of rivalry can come into existence with price wars (Peng, 2012).

b) The threat of potential inputs

Meanwhile, it analyzes the barriers to entry to the industry that generate low product diversification, affecting the market by lowering product prices.

Consumers are confused about which brand to choose and not generate brand 
J. G. Vargas-Hernández, R. Arechavala Vargas, L. A. Pulido García: Mexican SMEs in Organic Sector in the Asia Pacific Market: Internationalization Strategies

loyalty. This threat affects the industry as a time exceeding the supply of products or services (Peng, 2012) arrives.

c) The bargaining power with suppliers

It focuses on the internal processes of enterprises, and is understood as the relationship they have with suppliers. If providers are unique and what is the reason that it can be changed and the impact that have suppliers with differentiated products in the company (Peng, 2012) products.

\section{d) The bargaining power of buyers}

Meanwhile it is assessed the importance of the product or service the companies are giving to consumers, if consumers want products differentiated or not, and whether or not they trust the brand (Peng, 2012).

\section{e) The threat of substitute entry}

It focuses on the products which can be exchanged and have on the market. These products are characterized by meeting the same needs of products (Peng, 2012).

Porter's 5 forces will give the answers to the first column to the tripod strategy. Analyzing that Mexican SMEs in the organic sector wishing to export their products to Asia Pacific, it must be analyzed the entry and competition of SMEs in the organic sector:

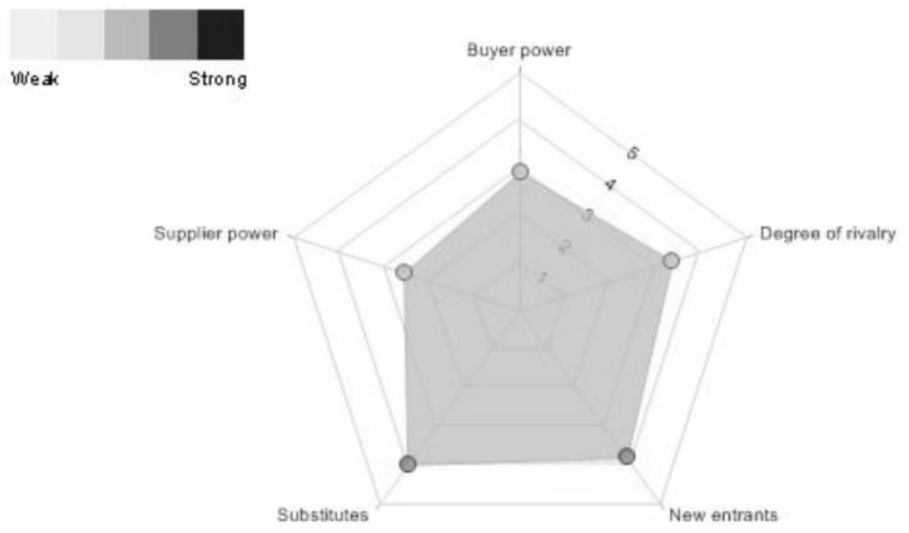

Figure 2: Diagram of the 5 forces of Porter on competition for the organic market in Asia-Pacific. Source: MarketLine (2014)

The following table contains the data that were analyzed on 5 forces of Porter in the organic market in Asia-Pacific. 
36 ${ }^{\text {TH }}$ International Conference on ORganizational Science Development: Responsible ORGANIZATION (MARCH $22^{\mathrm{ND}}-24^{\mathrm{TH}}$, PortoroŽ SLOVENIA)

J. G. Vargas-Hernández, R. Arechavala Vargas \& L. A. Pulido García: Mexican SMEs in Organic Sector in the Asia Pacific Market: Internationalization Strategies

\section{Table 2: Porter's 5 Forces Organic Market in Asia-Pacific.}

\begin{tabular}{|ll|}
\hline $\begin{array}{l}\text { Competitors } \\
\text { rivalry }\end{array}$ & $\begin{array}{l}\text { The rivalry score for the competitors is between } 3 \text { and 4, giving us } \\
\text { an approach that is difficult to compete in Asia Pacific. It is } \\
\text { believed that this rivalry is caused by Australia, the world's No. 1 } \\
\text { producer of organic. }\end{array}$ \\
\hline $\begin{array}{l}\text { Threat of } \\
\text { potential entries }\end{array}$ & $\begin{array}{l}\text { The threat of potential entries is high, at } 4 \text { points. This means that } \\
\text { there is no product differentiation, most of the products sold are } \\
\text { fruits and vegetables, and therefore we cannot say the same of the } \\
\text { products with organic innovation. }\end{array}$ \\
\hline $\begin{array}{l}\text { Bargaining } \\
\text { power } \\
\text { suppliers }\end{array}$ & $\begin{array}{l}\text { Bargaining power of suppliers in low, it is assumed that those who } \\
\text { are in the market are small farms that support organic consumption. }\end{array}$ \\
\hline $\begin{array}{l}\text { Bargaining } \\
\text { power of buyers }\end{array}$ & $\begin{array}{l}\text { Buyers can only find products in retail stores and specialized } \\
\text { organic markets, thus buying becomes somewhat difficult. }\end{array}$ \\
\hline $\begin{array}{l}\text { Threat } \\
\text { substitutes }\end{array}$ & $\begin{array}{l}\text { In this case the threat of substitutes is high because there are many } \\
\text { non-organic products, in turn can be replaced and cover the same } \\
\text { needs as other products. }\end{array}$ \\
\hline
\end{tabular}

Source: DataMonitor (2010).

\section{2) Resource-based view}

The resource-based view analyzes four important aspects that companies need to contemplate. VRIO frame shows the competitive advantage of the company (Peng, 2014.71):

a) Value. The first point of the frame VRIO analyzes that it must be kept in the company, only the resources that create value. There are capabilities within companies that do not create value, which may take it not be competitive (Peng, 2014).

b) Rareness. Rarity value is different, because we can have a company with valuable skills, but if these are similar to those of the competition, we will have an advantage if not a competitive comparison (Peng, 2014).

c) Imitation. Imitation is important when competitors cannot imitate. Find something that cannot be easily imitated within the organization, ensure some sort of advantage. Although it is the most difficult issues of VRIO frame, it must be considered and evaluated to have it in the company (Peng, 2014).

d) Organization. Business organization must be well done. Although have value, rarity and imitation, organization must be part of the company so that the frame works and generate a real competitive advantage (Peng, 2014).

Table 3. VRIO framework 
J. G. Vargas-Hernández, R. Arechavala Vargas, L. A. Pulido García: Mexican SMEs in Organic Sector in the Asia Pacific Market: Internationalization Strategies

\begin{tabular}{|c|c|c|c|c|c|}
\hline ¿Valuable? & ¿Rare? & $\begin{array}{l}\text { ¿Can I } \\
\text { imitate it } \\
(\$) ?\end{array}$ & $\begin{array}{l}\text { ¿It is made by an } \\
\text { organization? }\end{array}$ & Competition & Performance \\
\hline No & -- & -- & No & $\begin{array}{l}\text { Competitive } \\
\text { disadvantages }\end{array}$ & Below the average \\
\hline Yes & No & -- & Yes & Competitive parity & Average \\
\hline Yes & Yes & No & Yes & $\begin{array}{l}\text { Temporal } \\
\text { competitive } \\
\text { advantage }\end{array}$ & $\begin{array}{l}\text { Superior to the } \\
\text { average }\end{array}$ \\
\hline Yes & Yes & Yes & Yes & $\begin{array}{l}\text { Constant } \\
\text { competitive } \\
\text { advantage }\end{array}$ & $\begin{array}{l}\text { Consistency } \\
\text { superior to the } \\
\text { average }\end{array}$ \\
\hline
\end{tabular}

Source: Peng (2010:72).

Mexican SMEs are found with valuable products because the organic market has not been $100 \%$ satisfied with rare products they may make product innovations making unique products. Although these products are not costly to imitate, they can be difficult to imitate for the products used to perform. Leaving Mexican SMEs engaged in making food products with innovation and meet the organic requirements into a competitive advantage temporary or constant competitive advantage. Mexican SMEs who offer organic food products innovation would be at a competitive parity.

\section{3) Vision-based on institutions}

To start and understand the vision-based on the institutions, it is known that the institutional framework is based on formal and informal institutions (Peng, 2010). Formal institutions are represented by laws, regulations and rules (Vargas-Hernandez, GuerraGarcía, Bojórquez-Gutiérrez, Bojórquez-Gutierrez, 2014: 133)

Asia Pacific is an area with a very large cultural and institutional distance difference with Mexico. These distances indicate the difference between cultures and the degree of similarity between the rules of the countries (Peng, 2010: 113). This distance can affect the way of doing business, generating high transaction costs and high entry barriers for Mexican

SMEs. Two proposals as business strategies within the vision based theory of the institutions are (Peng 2010: 100):

Proposal 1: Companies rationally pursue their interests and make decisions within the constraints of institutional framework. 
$36^{\mathrm{TH}}$ INTERNATIONAL CONFERENCE ON ORganizational SCIENCE DEVElopment: Responsible ORGaNiZATION (MARCH $22^{\mathrm{ND}}-24^{\mathrm{TH}}$, PortoroŽ SLOVENIA)

J. G. Vargas-Hernández, R. Arechavala Vargas \& L. A. Pulido García: Mexican SMEs in Organic Sector in the Asia Pacific Market: Internationalization Strategies

Proposal 2: Formal and informal institutions combine to control the behavior of businesses when formal institutions fail. Informal institutions become more important, reducing uncertainty for businesses.

\section{Types of international participation}

Eight ways to internationalize the companies, which are divided into two and differ in moving the tangible and intangible assets of the company to another country, or just send their products to foreign markets, are recommended for Mexican SMEs to venture into foreign markets (Peng 2010).

Mexican SMEs have internationalized high costs of entering foreign markets. To remain $100 \%$ Mexican and to have some kind of internationalization, should consider the four internationalization strategies in the country of origin.

\section{Table 4. Internationalization strategies for companies}

\begin{tabular}{|ll|}
\hline $\begin{array}{l}\text { Internationalize entering to foreign } \\
\text { markets }\end{array}$ & $\begin{array}{l}\text { Internationalize keeping assets in the country of } \\
\text { origin }\end{array}$ \\
\hline Direct exports & Direct exports \\
Franchises / Licenses & Supplier of foreign firms \\
Direct foreign investment (IDE) & Franchises / Licenses of foreign origin \\
& Alliances with foreign shareholders \\
& Harvest and exit. \\
\hline
\end{tabular}

Source: Peng (2010:138)

Indirect export relates to send products through an intermediary. Being supplier of foreign firms can be very beneficial. This case goes hand in hand with franchises and licenses, and differs in the sense that the company does not obtain the foreign franchise, but it can provide such a franchise of the country of origin entering in a foreign market.

The internationalization by licensing and franchising, benefits the company to have a world class business, learn from it and replicate it in the future, but involves issues of ethics and morality. This action is very common in the globalized world. Partnerships with foreign shareholders may be an option although not recommended, as they can use and exploit the resources of small businesses and not benefit them at all. Harvest and exit talk about entering foreign markets to be successful and sell. Actually this point is to win market and exit.

\section{$6 \quad$ Analysis of results}

The literature review gives an overview on the situation of the SMEs to the Asia Pacific region. The picture shows although strategies or where to put care for successful internationalization. The process of the SMEs to any country must be escalated as 
proposed by the Uppsala model, for the company to constantly go reaching the desired market without high transaction costs.

Networks can benefit the company as long as they are internationally. If the company meets a recognized importer in Europe, it will not do anything for the Asia Pacific region. However, the importer can meet one goal in the region and help expand the network of the company. Tripod strategy gives us the best scenario for a SME may be involved abroad, for their ability to internal and external analysis: Porter's 5 forces give an overview of difficult environment to enter the organic market in Asia Pacific. Although this study shows mostly for agricultural products, it is considered that the companies that have organic food innovation will not have much competition or sales problems, but must be attentive to their suppliers.

The VRIO framework is interesting because it shows that the SMEs can have a constant competitive advantage, depending on the cost to imitate their products. It is noteworthy that the organization is a key to this frame work, having put much effort into the organization of the company factor.

The vision based on institutions although touches on issues of cultural and institutional distance which can seriously affect company costs, the country is carrying out actions that could reduce these costs. With the signing of the Trans-Pacific Partnership, tariffs will be reduced and will support SMEs in the process of internationalization.

Internationalization strategies for SMEs must be through the country of origin. There is not some sort of strategy that is best for all businesses, but all depends on its scope and economic stability in order to determine the level of internationalization that suits the company.

\section{$7 \quad$ Conclusion and recommendations}

SMEs certainly have an opportunity to enter the Asia Pacific market. It is known that being small businesses, often its actions do not go hand in hand with clear strategies. They act according to the motion. To achieve a successful export and not only make sporadic exports, if not entering the foreign market and maintained, it is important to have clear strategies, which the company knows that it can hold and attend day by day.

Broadly speaking, it is easy to say that this can be easily achieved, but it is the responsibility of the company analyzed internally and sincerely to choose the strategy it wants. Leverage its networks and maximize its capabilities, of course, without leaving aside the market that is already on. The following recommendations may be helpful and should be the first thing that must be evaluated after performing internal analysis:

1. Approaching the governing bodies of each state to support export, where they can attend fairs and business that may help us to begin this process. 
36 ${ }^{\text {TH }}$ International Conference on Organizational Science Development: ResPonsible ORGANIZATION (MARCH $22^{\mathrm{ND}}-24^{\mathrm{TH}}$, PortoroŽ SLOVENIA)

J. G. Vargas-Hernández, R. Arechavala Vargas \& L. A. Pulido García: Mexican SMEs in Organic Sector in the Asia Pacific Market: Internationalization Strategies

2. Analyze the costs of the company; be clear on where the higher costs as well as costs incurred by being exporting company.

3. Be familiar with all government permits for the production of organic products, as well as very important organic certifications that may affect entry to these countries.

It can be concluded that these 4 mentioned schemes may give an overview Mexican SMEs to achieve successful position abroad. Yet, there will be much work to do, and as stated previously discussed with sincerity can be one of the biggest battles before going to see strategies for internationalization.

\section{References}

Aranda, Y., \& Montoya, I. (2006). Principales enfoques conceptuales explicativos del proceso de internacionalización de empresas. Agronomía Colombiana 24(1), 170-181.

Cardozo, P. P., Chavarro, A., \& Ramírez, C. (2007). Teorías de internacionalización. Panorama, $3(3), 4-23$.

Data Monitor. (2011). Organic Food in Asia Pacific. Recuperado de http://wdg.biblio.cucea.mx en EBSCO

Gómez Cruz, M. Á., Schwentesius Rindermann, R., Ortigoza Rufino, J., \& Gómez Tovar, L. (2010). Agricultura, apicultura y ganadería orgánicas de México 2009: estado actual-retostendencia. Conacyt. Recuperado de http://bibliotecasibe.ecosur.mx/

INEGI (2015). Exportación de mercancías por zona geográfica y países. Recuperado de http://www.inegi.org.mx/

INEGI. (2014). Sectores económicos Recuperado de www.inegi.org.mx

KenResearch. (2013). Global Organic Food and Beverages Industry-Outlook to 2016. Recuperado de http://wdg.biblio.cucea.mx en EBSCO

Market Line. (2015). Global Organic Food. Londres, Gran Bretaña. Recuperado de http://wdg.biblio.cucea.mx en EBSCO

MarketLine. (2014). Organic Food in Asia Pacific. Londres, Gran Bretaña. Recuperado de http://wdg.biblio.cucea.mx en EBSCO

Mexicoxport (2012). Exporta solo una de cada cien PyMes Mexicanas. Recuperado de http://mexicoxport.com/

Peng, M. (2010). Estrategia Global, 2da. Ed., México, Cengage Learing.

Schwentesius Rindermann, R., Nelson, E., Gómez Cruz, M.A. (2010). Producción orgánica y mercados locales en México. Revista Vinculando. Recuperado de http://vinculando.org

Vargas-Hernández, J. G., Bojórquez-Gutiérrez, F., Bojórquez-Gutierrez, A., Guerra Garcia, E. (2014). Gestión estratégica de organizaciones. Ciudad Autónoma de Buenos Aires: Elaleph.

Willer, H., Yussefi-Menzler, M., \& Sorensen, N. (2011). The World of Organic Agriculture 2012: Summary. The World of Organic Agriculture. Recuperado de http://www.systemscomparison.fibl.org/ 
$36^{\mathrm{TH}}$ InTERnational CONFERENCE ON ORganizational SCIENCE Development: Responsible Organization (MARCh $22^{\mathrm{ND}}-24^{\mathrm{TH}}$, PORTOROŽ SLOVENIA)

O. Arsenijević, M. Ferjan, I. Podbregar, P. Šprajc, D. Trivan \& Y. Ziegler

\title{
Determining of Managerial Competencies: A Review of the Literature
}

\section{LIRIDON VELIU \& MIMOZA MANXHARI}

\begin{abstract}
A competence in general can be understood as the ability of an individual to activate, use and connect the acquired knowledge in the complex, diverse and unpredictable situations. Managerial competency is more than just knowledge and skills. It involves the ability to meet complex demands, by drawing on and mobilizing psychosocial resources in a particular context. Managerial competencies are becoming one of the key building blocks of success of the company. The purpose of this literature review is to analyze the issues of defining managerial competencies. The literature review comprises peer-reviewed journal articles, white papers, conference proceedings and the topic of managerial competencies.
\end{abstract}

KEYWORDS: manager - competencies - managerial competencies • organizations

Correspondence AdDress: Liridon Veliu, Msc., University of Prishtina "Hasan Prishtina", Faculty of Economics, Rr. "George Bush", p.n, 10000 Prishtinë, Kosovo, e-mail: liridon.veliu@uni-pr.edu; Mimoza Manxhari, University of Tirana, Faculty of Economics, Rr. Elbasanit, 1506 Tirana, Albania, e-mail: mmanxhari@yahoo.com

DOI https://doi.org/10.18690/978-961-286-020-2.100 ISBN 978-961-286-020-2

(C) 2017 University of Maribor Press

Available at: http://press.um.si 
36 ${ }^{\text {TH }}$ International Conference on ORganizational Science Development: Responsible Organization (MARCh $22^{\mathrm{ND}}-24^{\mathrm{TH}}$, PORTOROŽ Slovenia)

L. Veliu \& M. Manxhari: Determining of Managerial Competencies: A Review of the Literature

\section{$1 \quad$ Introduction}

Today, managerial competencies have an important role in all of organizations. Managers are required to ensure that organizations achieve their objectives. Management is a subject that all people have a vested interest in because all, both people, organizations and societies, want to be well managed. A lot of effort has been put in ways of achieving world-class status. Management is one of the main criteria in productivity of the management system in a large or small organization, and plays an important strategic and crucial role.

Managerial competencies are critical for business success and are used in the daily business practice as driven forces for performance on the market and to reach the company's goals in the nowadays turbulent business environment. The literature draws some strong correlations between a business's success in achieving results and the skills and abilities of its manager (Boyatzis, 1982; Quinn, 1988; Hogan, Hogan, \& Kaiser, 2011). Competencies vary depending on the type of business and manager competencies, similar to company core competencies, which can change with variables such as time, location of business or size of business. One of the most important criteria for having effective managers is competency. Thus, this study explores the competencies required for a manager to be effective. Managerial competencies are activities, knowledge, skills or attitudes and also personal characteristics necessary to improve management performance.

Managerial competencies identification and development has a number of advantages for organizations it broadens the labor potential of managers and thus also the possibilities for dynamic development of work teams and subsequently of the organization as a whole. In order to achieve this effect, the development program of an organization has to have a clear and systematic conception that would take into account expected future changes.

The literature on management competencies is a wide area and it has been more actualized in recent years. This can especially be attributed to globalization, which has put strong pressure on management skills. Therefore, management competences have been put firmly on the research agenda. Some managers use the advantages that globalization offers with great success and others are not able to handle this situation. The interesting question is what makes some managers successful while others fail.

According to Miller et al. (2001) the two prime reasons for organizations to use competencies are: a) that the application of competencies to appraisal, training and other personnel processes will help to increase the performance of employees b) that competencies provide a means of articulating corporate values and objectives, so that their requirements can be embodied in HR practices, and be readily understood by individuals and teams within the organization. Competency is an important concept in organization management since it is closely related to excellent work performance (Levenson, Van der Stede \& Cohen 2006). 


\section{Literature Review}

In the late 1970s, in the U.S. the first person who used the term "competency" in the managerial context was Boyatzis (1982) to identify the characteristics, which distinguish superior from average managerial performance.

According to McClelland (1973), competencies could be best described as an iceberg with a person's knowledge and skills representing the visible tip of iceberg, while underlying and enduring personal characteristic or self-concepts, traits and motives (for example, self-confidence, initiative, empathy, achievement orientation, etc.) which represent the larger portion of the iceberg, hidden below the waterline.

Katz (1974) has provided a legacy conceptual framework. Katz's (1974) three skill approach stated that the use of each of the skills varies with the level of management responsibility. At lower levels technical skill is indispensable to efficient operation. As the manager moves further from actual operations the need for technical skill decreases. On the other hand, at the top level conceptual skill becomes increasingly critical for successful administration. Human relation skills are the area that is essential at all levels of management according to Katz (1974). According to Boyatzis (1982), managerial competencies are characteristics that are causally related to effective and/or superior job performance and an individual's performance is assessed in terms of specific action or behavioural indicators.

British researchers (Constable and McCornick, 1987; Handy, 1987) introduced standards for managers in specific industries reflecting the expectations of their workplace performance. In this view, managers are assessed on set tasks with clearly standards termed as "competences" different from the individuals' competencies.

According to Spencer and Spencer (1993), managerial competencies are a specialized subset of the competencies, expressing the intention to have certain specific effects. These specific intentions are particularly important for managers. Hogg (1993) adds that managerial competencies lead to the demonstration of skills and abilities, which result in effective performance within an occupational area. Scott (1996) has provided a more holistic and detailed description of a competency, combining various facets (knowledge, skills, behaviour and attitude). Smart (1998) listed 50 critical competencies of top managers which primarily include intelligence, analytical skills, strategic skills, judgment and decision making, risk taking, excellence, team player, communications, assertiveness, ambition, adaptability, creativity, vision, and balance in life.

The concept of competency is describing essential human knowledge, attitudes, and skills at work; it is focused on the relation between person and work (Sandberg, 2000).

Henderson (2000) defines competency as a combination of knowledge and skills required to successfully perform an assignment. Its attainment is evidenced by the ability of an individual to gather data, process it into useful information, access it and arrive at an 
$36^{\mathrm{TH}}$ INTERNATIONAL CONFERENCE ON ORganizational SCIENCE DeVElopment: ResPonsible ORGaNiZATION (MARCH $22^{\mathrm{ND}}-24^{\mathrm{TH}}$, PORTOROŽ SLOVENIA)

L. Veliu \& M. Manxhari: Determining of Managerial Competencies: A Review of the Literature

appropriate and useful decision in order to initiate the actions necessary to accomplish the assignment in an acceptable manner. Specifically for managers, in the organizational literature competencies are used as a term to define the organizations as a whole, as well as the individuals working there and their core, personal, and managerial competencies (Abraham et al., 2001).

When competencies possessed by successful managers are discussed, the term "managerial competencies" is frequently used (Abraham et al. 2001; Moore et al. 2002; Childs, Gibson 2010; Xuejun Qiao, Wang 2009; Koenigsfeld et al. 2012). The structure of managerial competencies is widely discussed in the literature. (Antonacopoulou, Fitzgerald 1996; Clardy 2008; Oleksyn 2010; Alkahtani et al. 2011).

Bird (1995) defined competencies as primary characteristics such as basic and specific knowledge, motives, traits, self-image, roles and skills. Dubois et al. (2004) suggest that the term "competencies" refers to the characteristics such as "knowledge, skills, aspects of selfimage, social motives, feeling and acting" which is demonstrated by an individual to achieve the desired performance goal within an organization.

Competency management is referring to the use of the competency concept and of the results of competencies analysis, in order to document and improve the employees' recruitment, selection, development and rewarding processes (Armstrong, 2003). Depending on the context and perspective, in literature, multiple meanings are found for the term "competency" (Garavan \& McGuire, 2001; Viitala, 2005; Wickramasinghe \& Zoyza, 2008).

One reason for these multiple meanings is that the term competency usually includes potentiality, trait, value, abilities, knowledge, skills, preference, opinion, and aptitude. Goleman (2000); Palmer, Walls, Burgess \& Stough (2001) Abraham, Karns, Shaw and Mena (2001) report that effective managers possess skills that include communication, team building, problem-solving and decisionmaking. Cheng, Dainty and Moore (2005) propose that in addition to competencies and competences, managerial performance also requires the assuming of a role which emerges through social interaction with others at work. In the vast human resources literature, managerial competencies are associated with the organizational roles played by managers. Delamare Le Deist and Winterton (2005) differentiate four dimensions of competences in connection with their categorisation about competences associated with occupation and with individual effectiveness. Competencies, when properly designed, leverage experience and insight of leaders in an organization (Hollenbeck et al. 2006). Shirazi and Mortazavi (2009) found that responsiveness, pro-activeness, effective communication, team building, negotiation and decisiveness are the main characteristics of an effective manager. Chase (2010) used a previously developed and validated survey, based on the framework of Katz (1955), which exposed the interconnectedness of three levels of competencies: technical, human, and conceptual. Campion et al. (2011) pointed out that competencies are more than a simply list of knowledge, skills, abilities and other characteristics. Some competencies include also pro-social behaviours, such as organisational citizenship behaviours 
contributing to organisational performance. Chong (2013) found that managerial competencies associated with organizing, planning, motivating others are significant in the career-advancement and they are broadly similar in importance across cultural environments.

Managerial competency has been studied from many perspectives in academic research, including: the impact of competency-based methodologies on HRD (Rothwell, Lindholm 1999); the role which competencies play in education and training field (Camuffo, Gerli 2004; Hansson 2001; Kersh Evans 2005; Tovey 2006); individual and contextual factors influence competency levels (Wickramasinghe, De Zoyza 2008; Agut et al. 2003); the competency approach to study entrepreneurial and leadership characteristics (Wickramaratne et al. 2014; Jena, Sahoo 2014; Quintana et al. 2014; Jantti, Greenhalgh 2012; Man et al. 2002; Schmitt-Rodermund 2004); the specific character of managerial competencies depending on the type of company, industry or market which the company operates in. (Cappellen, Janssens 2008; Suh et al. 2012; Trivellas, Drimoussis 2013; Chong 2013; Kożuch, Szczepańska-Woszczyna 2014; Vila et al. 2014), evaluation of behavior, skills and commitment of managers (Moradi et al. 2011).

Managerial competencies has been used and is recommended regularly by several authors constructed initially on the basis of (Boyatzis and Goleman 2007; Boyatzis 1982) work. It is as follows.

\begin{tabular}{|l|l|l|}
\hline No. & $\begin{array}{c}\text { Blocks of } \\
\text { Managerial } \\
\text { Competencies }\end{array}$ & \multicolumn{1}{c|}{ Managerial Competencies } \\
\hline & $\begin{array}{l}\text { Professional } \\
\text { competencies }\end{array}$ & $\begin{array}{l}\text { Planning, problem solving, information gathering, analytical thinking, abstract } \\
\text { thinking, strategic thinking, learning from one's own and others' experience, } \\
\text { striving for results, initiative, business-like orientation, generation of ideas, } \\
\text { diligence, resolution, global perspective, organizational skills, team-work, } \\
\text { negotiation skills, leadership, conflict handling, communication, organizational } \\
\text { awareness, systemic logics, written communication, creativeness and ability to } \\
\text { implement innovations, modern knowledge, time management, risk } \\
\text { assessment, risk-taking, defining the circle of personal interests. }\end{array}$ \\
\hline 2. & $\begin{array}{l}\text { Communication and influencing others, verbal communication, convincing } \\
\text { communication, effective relations, orientation to customer, goal-setting, } \\
\text { delegation of authorities, change management, performance management, } \\
\text { fairness, responsibility, flexibility, cultural awareness, qualification, group- } \\
\text { building and development skills. }\end{array}$ \\
\hline 3. & $\begin{array}{l}\text { Self-confidence, stress management, personal reliability, loyalty, self-control, } \\
\text { self-confidence, self-management, listening skills, system of personal values, } \\
\text { personal goals, continuous personal self-development, personal responsibility } \\
\text { for taken decisions, awareness of ethics relevance in business. }\end{array}$ \\
\hline
\end{tabular}

Table 1: Contents of managerial competencies. Source: D. Goleman and R. E. Boyatzis (2008); M. Woodcock and D. Francis (1982); A. Baležentis (2006)

Based on the literature studies, Kearney et al. (2013) distinguish the following managerial competencies: 
$36^{\mathrm{TH}}$ INTERNATIONAL CONFERENCE ON ORganizational SCIENCE DeVElopment: RESPONSIBLE ORGANIZATION (MARCH $22^{\mathrm{ND}}-24^{\mathrm{TH}}$, PORTOROŽ Slovenia)

L. Veliu \& M. Manxhari: Determining of Managerial Competencies: A Review of the Literature

\begin{tabular}{|c|c|}
\hline Capability & Nature \\
\hline Leadership & $\begin{array}{l}\text { Shaping the culture of the firm (Kruse cited in Devins et al., 2005) } \\
\text { Paternalistic leadership (Kelliher and Reinl, 2009) } \\
\text { Personal resilience (Phillipson et al., 2006) } \\
\text { Delegation (Kelliher and Reinl, 2009) and the potential for distributed } \\
\text { leadership (Cope et al., 2011) } \\
\text { Dangers of owner/manager dominance stifling resource/employee } \\
\text { development (Chell, 1985) }\end{array}$ \\
\hline $\begin{array}{l}\text { Strategic } \\
\text { thinking }\end{array}$ & $\begin{array}{l}\text { Imaginative thinking (Beaver, 2007) } \\
\text { Owner/manager as businessman as opposed to manager-convergence } \\
\text { of ownership and control (O'Dwyer and Ryan, 2000) } \\
\text { Convergence of strategy and operational work in micro firm context } \\
\text { (Barnes et al., 2012; Cyr et al., 2011) } \\
\text { Emergence of strategy in shaped by competitor relationships } \\
\text { (Phillipson et al., 2004) }\end{array}$ \\
\hline $\begin{array}{l}\text { Problem } \\
\text { solving }\end{array}$ & $\begin{array}{l}\text { Day to day interaction with customers (O’Dwyer and Ryan, 2000) } \\
\text { Interaction with employees facilitating learning (Fillis et al., 2004) } \\
\text { Interaction with micro firm market (Greenbank, 2000) } \\
\text { Evolution of difficult to imitate and context effective heuristics (Cyr et } \\
\text { al., 2011; Liberman-Yaconi et al., 2010; Greenbank, 2000) } \\
\text { Merging of operations and strategic (Greenbank, 2000) } \\
\text { Market sensing capability (Foley and Fahy, 2004) }\end{array}$ \\
\hline $\begin{array}{l}\text { People } \\
\text { relationships }\end{array}$ & $\begin{array}{l}\text { Creation of effective dialogue with business advisors (Williams, 2007; } \\
\text { Devins et al., 2005) } \\
\text { Smoothing potential employee/management conflict (Matlay, 1999) } \\
\text { Communication with family members (Wheelock and Baines, 1998) }\end{array}$ \\
\hline
\end{tabular}

Table 2: Managerial competencies criteria, Source: (Kearney et al. 2013)

Managerial competencies are an interconnected set of unique knowledge, skills and abilities of managers aimed at achieving long-term and short-term goals of an organization. Managerial competencies become apparent through the process of making strategic and operational decisions. In a low-competitive environment managerial competencies are implemented through the passive adaptation of the organization to the market changes. 
In an extremely competitive market the promotion of goods is rather a tough process, that is why managerial competencies tend to become a strategic resource that affects the position of business on the market. The components of managerial competencies are closely linked.

Having summarized the attitudes of such authors as (Burgoyne, 1990; Spencer et al. 1993; Doyle, 1995; Siriwaiprapan, 1996; Lindsay et al. 1997; Nyhan, 1998; Clarke, 1998; McCarthy et al. 1999; Seige, 1999;Woodruffe, 2000; Cheetham et al. 2005; Ruth, 2006; Rappe et al. 2007; Brinckmann, 2008; Qiao et al. 2009; Heilmann et al. 2011) towards the models of managerial competence it is possible to maintain that the structure of managerial competence depends on a concrete situation, however, anyways it must include the following items: Common managerial and technical knowledge; Communicative skills; Psychological, behavioral abilities and Cognitive skills.

\section{Conclusion}

The quality of the activities of professional managers is determined by many factors, especially by competencies, which play a major role. Managerial competencies are strategically driven by organizational core competence. Studying managerial competencies on the basis of studies of literature and in the context of implementing in the company, the following categories of competencies were distinguished: conceptual and analytical skills, interpersonal skills, personal skills, managerial skills, qualities, attitudes and behaviors. Having analyzed in research publications various approaches to the concept of managerial competencies, it can be concluded that managerial competence as a research category reflects the following personal traits: knowledge, aptitude, ability, skills, attitudes, effective performance, activities, behavior, implications of behaviors and the form of personal activity.

Managerial competencies are a combination of the manager's professional knowledge, acquired skills, experience, traits and the proper attitude and motivation to act. The following elements play a very important role in managerial competencies: professional knowledge, the ability to make the right decisions at the right time, interaction, experience, ethical conduct and culture. Only a combination of these elements ensures the authority that allows competent management in an increasingly diverse structure of the organization.

Most authors point out similar elements that build competencies: knowledge, skills, personality predispositions, attitudes and patterns of behavior. In the relevant literature, the authors mention dozens of competencies; it should be noted, however, that it is extremely difficult to isolate a competency and treat it individually, as independent and detached from others, competencies are interdependent. When competencies possessed by successful managers are discussed, the term "managerial competencies" is frequently used (Abraham et al. 2001; Moore et al. 2002; Childs, Gibson 2010; Xuejun Qiao, Wang 2009; Koenigsfeld et al. 2012). With reference to the results of the study the definition of managerial competence is offered to formulate as follows: managerial competence is 
36 ${ }^{\text {TH }}$ International Conference on Organizational Science Development: Responsible ORgANiZATION (MARCh $22^{\mathrm{ND}}-24^{\mathrm{TH}}$, PORTOROŽ Slovenia)

L. Veliu \& M. Manxhari: Determining of Managerial Competencies: A Review of the Literature

multidimensional characteristic of an employee, which unites the employee's especial behavioral and intellectual features as well as capability to select appropriate methods to perform and integrate available professional knowledge.

\section{Literature}

Abraham, St. E., Karns, L. A., Shaw, K. et al. (2001). Managerial Competencies and the Managerial Performance Appraisal Process //Journal of Management Development. Vol. 20, No. 10, 842852.

Agut, S.; Grau, R.; Peiro, J. M. 2003. Competency needs among managers from Spanish hotels and restaurants and their trainings demands, Hospitality Management 22: 281-295. http://dx.doi.org/10.1016/S0278-4319(03)00045-8

Akanauskiene, I. Bartnikaite, E. (2006), Managerial competence, The attitude of Lithuanian managers, Problems and perspectives in management, Vol. 4 (2).

Al-Madhoun, M. I., \& Analoui, F. (2002). Developing managerial skills in Palestine. Education and Training, 44(8/9), 431-442.

Armstrong, M. (2003). A Handbook of Human Resource Management Practice (9th edition). Kogan Page, London.

Baladi, P. (1999). Knowledge and competence management: Ericsson Business Consulting, Business Strategy Review, Vol. 10 No. 4, pp. 1-9.

Berio G. (2005). Knowledge Management for Competence Management, Proceedings of I- KNOW 05 .

Birdir, K. \& Pearson, T. (2000). Research Chefs' Competencies: A Delphi Approach. International Journal of Contemporary Hospitality Management, 12(3), 205-209.

Boyatzis, R. E. (2008). Competencies in the 21st Century. Journal of Management Development, 27(1), 5-12.

Boyatzis, R. E., Goleman, D., \& Rhee, K. S. (2000). Clustering competence in emotional intelligence, Insights from the emotional competence inventory.

Boyatzis, R.E. (1982). The competent manager. John Wiley \& Sons, Inc., New York.

Brinckmann, J. (2008). Competence of top management teams and the success of new technology based firms: a theoretical and empirical analysis concerning competencies of entrepreneurial teams and the development of their ventures. Wiesbaden: Gabler Publishing.

Burgoyne, D.G. (1990). An introduction to business decision-making. Toronto: Methuen

Campion M.A., A.A. Fink, B.J. Ruggeberg, L. Carr, G.M. Phillips and R.B. Odman (2011) "Doing Competencies Well: Best Practices in Competency Modeling," Personnel Psychology, vol. 64(1), p. 225-262.

Camuffo, A.; Gerli, F. 2004. An integrated competency based approach to management education: an Italian MBA case study, International Journal of Training and Development 8(4): 240-257. http://dx.doi.org/10.1111/j.1360-3736.2004.00212.x

Cappellen, T.; Janssens, M. 2008. Global managers' career competencies, Career Development International 13(6): 514-537. http://dx.doi.org/10.1108/13620430810901679

Cheetham, G., Chivers, G. (2005). Professions, competence and informal learning. Cheltenham: Edward Elgar Publishing.

Cheng M, Dainty ARJ, Moore DR., 2005. Towards a multidimensional competency-based managerial performance framework: a hybrid approach. J Manag Psychol

Cheng, M., Dainty, A.R, and Moore, D.R. (2003), "The differing faces of managerial competency in Britain and America", Journal of Management Development, Vol. 22, No. 6, pp. 527-37. 
Chong E. (2011). Managerial Competencies and Career Advancement: A Comparative Study of Managers in Two Countries. Journal of Business Research. In Press.

Chong, E. 2013. Managerial competencies and career advancement: a comparative study of managers in two countries, Journal of Business Research 66(3): 345-353. http://dx.doi.org/10.1016/j.jbusres.2011.08.015

Clarke, J., Newman, J. (1997). The managerial state. London: Stage.

Constable CJ, McCormick R. (1987): The making of British managers. London: British Institute of Management \& Confederation of British Industry

Daft, R. L. (2003). Management. 6th Edition, Thomson, South-Western West.

Delamare le Deist, F., Winterton, J. (2005). What Is Competence? // Human Resource Development International. Vol. 8, No. 1.

Doyle, M. (1995). Organizational transformation and renewal: a case for reframing management development. Personnel Review, 24(6), 36-45.

Echanis, E. S. (2010). Holding companies: A structure for managing diversification. Philippine Management Review.

Edwin D. Davison (2008), Management competencies, EBSCO research starters.

Garavan, T. N., \& McGuire, D. (2001). Competencies and workplace learning: Some reflections on the rhetoric and the reality. Journal of Workplace Learning, 13(3/4), 144-163.

Goleman, D. (2000). Leadership that Gets Results. Harvard Business Review, March-April, 78-91.

Goleman, D., Boyatzis, R. E., \& McKee, A. (2002). Primal leadership: Realizing the power of emotional intelligence. Boston, MA: Harvard Business School Press.

Hansson, B. 2001. Competency models: are self-perceptions accurate enough?, Journal of European Industrial Training 25(9): 428-441. http://dx.doi.org/10.1108/03090590110410205

Heilmann, P., Heilmann, J. (2011). Competence management in maintenance: case - Finnish forest company. Management Research Review, 35(1), 4-13.

Henderson, R. (2000). Compensation Management in Knowledge - Based World, Prentice - Hall Englewood Cliff, NJ.

Hogg, B. (1993). European Managerial Competencies. European Business Review, 93 (2), 21-26. http://dx.doi.org/10.1108/EUM0000000001914

Hollenbeck, G., Mccalljr, M., \& Silzer, R. (2006) Leadership competency models. The Leadership Quarterly, 17(4), 398-413.

Holtzman, D.M. and E.M. Kraft (2010) "Skills Required of Business Graduates: Evidence from Undergraduate Alumni and Employers," Business Education \& Accreditation, vol. 2(1), p. 4976.

Jantti, M.; Greenhalgh, N. 2012. Leadership competencies: a reference point for development and $\begin{array}{llll}\text { evaluation, } & \text { Library } & \text { Management } & \text { 33(6/7): }\end{array}$ http://dx.doi.org/10.1108/01435121211266249

Jena, S.; Sahoo, Ch. K. 2014. Improving managerial performance: a study on entrepreneurial and leadership competencies, Industrial and Commercial Training 46(3): 143-149. http://dx.doi.org/10.1108/ICT-10-2013-0066

Katz, R. L. (1974). Skills of an effective administrator. Harvard Business Review, 52, 90-102.

Kersh, N.; Evans, K. 2005. Self-evaluation of tacit skills and competences of adult learners facilitating learning success and work re-entry, European Education 37(2): 87-98.

Kożuch, B.; Sienkiewicz-Małyjurek, K. 2014. New requirements for managers of public safety systems, Procedia - Social and Behavioral Sciences 149: 472-478.

Lindsay, Ph. R., Stuart, R. (1997). Reconstruing competence. Journal of European Industrial Training, 21(8-9), 32-38

Man, T. W. Y.; Lau, T.; Chan, K. F. 2002. The competitiveness of small and medium enterprises: a conceptualization with focus on entrepreneurial competencies, Journal of Business Venturing 17(2): 123-142. http://dx.doi.org/10.1016/S0883-9026(00)00058-6 
$36^{\text {Th }}$ International Conference on Organizational Science Development: Responsible ORganization (MARCh $22^{\mathrm{ND}}-24^{\mathrm{TH}}$, PORTOROŽ Slovenia)

L. Veliu \& M. Manxhari: Determining of Managerial Competencies: A Review of the Literature

McCarthy, M.A., Thomas, N.G. (1999). Developing self-awareness in the managerial career development process: the value of 360-degree feedback and the MBTI. Journal of European Industrial Training, 23(9), 437-445.

McClelland, D. C. (1975). Power: the inner experience. New York, NY: Irvington Publishers.

Miller, L., Ranking, N., and Neathey, F. (2001). Competency Frameworks in UK Organizations, CIPD, London.

Moradi, F.; Jajarmizadeh, M.; Nikkar, M.; Abbasi, N. 2011. Evaluation of behavior, skills and commitment, management, Advances in Management \& Applied Economics 1(2): 169-183.

Nyhan, B. (1998). Competence Development as a Key Organizational Strategy - Experiences of European Companies. Industrial \& Commercial Training, 30(7), 59-68.

Palmer, B., Walls, M., Burgess, Z., \& Stough, C. (2001). Emotional intelligence and effective leadership. Leadership \& Organization Development Journal, 22, 1- 7.

Qiao, J.X, Wang, W. (2009). Managerial competencies for middle managers: some empirical findings from China. Journal of European Industrial Training, 33(1), 69-81.

Quintana, C. D. D.; Ruiz, J.-G. M.; Vila, L. E. 2014. Competencies which shape leadership, International Journal of Manpower 35(4): 514-535. http://dx.doi.org/10.1108/IJM-05-20130107

Rappe, Ch., Zwick, T. (2007). Developing leadership competence of production unit managers. Journal of Management Development, 26(4), 312-330.

Rothwell, W. J. \& Lindholm, J. E. (1999). Competency Identification Modelling and Assessment in the USA. International Journal of Training and Development, 3 (2), 90-105.

Ruth, D. (2006). Frameworks of managerial competence: limits, problems and suggestions. Journal of European Industrial Training, 30(3), 206-226.

Sandberg, J. (2000) Understanding human kompetence at work: an interpretative approach. The Academy of Management Journal, 73, 9-25.

Schmitt-Rodermund, E. 2004. Pathways to successful entrepreneurship: parenting, personality, early entrepreneurial competence, and interests, Journal of Vocational Behavior 65(3): 498518. http://dx.doi.org/10.1016/j.jvb.2003.10.007

Schroder, H. M. (1989). Managerial Competence: The Key to Excellence: A New Strateg y for Management Development in the Information Age. London: Kendall \& Kent Publications.

Scott J., McInnes R., Tappin D. \& Guthrie E. (2003) Breastfeeding opinions, knowledge, management practices and training of Scottish midwives. Report for the Scottish Executive Health Department Chief Scientist Office, Edinburgh.

Scott, B.P. (1996). Competency-based HRD. Princeton: Training House

Scott, D., \& Willits, F. K. (1994). Enviromental attitudes and behaviour: A Pennsylvania survey. Environment and Behaviour, 26(2), 239-260.

Seige, G. (1999). Clarifying The Use of Competence and Competency Models in Recruitment, Assessment and Staff Development. Industrial \& Commercial Training, 27(11), 5-12.

Shirazi Ali and Mortazvi Saeed (2009), "Effective management performance a competency based perspective", International Review of Business Research Papers, Vol. 5, No. 1, pp. 1-10.

Shuayto, N. (2013) "Management Skills Desired by Business School Deans and Employers: an Empirical Investigation," Business Education \& Accreditation, vol. 5(2), p. 93-105.

Siriwaiprapan, S. (1996). The concept, practice, and future of human resources development as perceived by Thai human resources practitioners, Doctoral Dissertation. Washington: The George Washington University.

Smart, Bradfort D. (1999), Top grading: how leading companies win by hiring, coaching and keeping the best people, Englewood Cliffs: Prentice Hall, New York.

Spencer, L. M., Spencer, S. M. (1993). Competence at Work: Models for Superior Performance. New York: John Wiley \& Sons, Inc. 
L. Veliu \& M. Manxhari: Determining of Managerial Competencies: A Review of the

Literature

Spencer, L.M., Spencer, S.M. (1993). Competence at work: model for superior performance. New York: Wiley and Sons.

Tahir., I. M., \& Abu Bakar, N. M. (2010). Managerial competencies in the Malaysian financial services sector. Interdisciplinary Journal of Contemporary Research in Business, 1(12), 114124.

Talukder, D., \& Hawkins, B. (2014). Managerial skills and competencies in New Zealand organisations: a cause for concern. International Journal of Economics and Business Research, $8(2), 125-142$.

Tate W (1995), Developing Managerial Competence: A Critical Guide to Methods and Materials, Gower, UK.

Tovey, L. 2006. Meeting business and management training and development needs through competency assessment, Strategic Change 3(2): 71-86. http://dx.doi.org/10.1002/jsc.4240030204

Trivellas, P.; Drimoussis, Ch. 2013. Investigating leadership styles, behavioural and managerial competency profiles of successful project managers in Greece, Procedia - Social and Behavioral Sciences 73: 692-700.

Viitala, R. (2005). Perceived development needs of managers compared to an integrated management competency model. Journal of Workplace Learning, 17(7), 436-451.

Wickramaratne, A.; Kiminami, A.; Yagi, H. 2014. Entrepreneurial competencies and entrepreneurial orientation of tea manufacturing firms in Sri Lanka, Asian Social Science 10(18): 50-62. http://dx.doi.org/10.5539/ass.v10n18p50

Wickramasinghe, V.; De Zoyza, N. 2008. Gender, age and marital status as predictors of managerial competency needs, Gender in Management: An International Journal 23(5): 337-354. http://dx.doi.org/10.1108/17542410810887365

Woodruffe, Ch. (2000). Development and assessment centres: identifying and assessing competence, 3rd ed. London: Institute of Personnel and Development. 
1270 36 $6^{\text {Th }}$ International Conference on Organizational Science Development: Responsible Organization (March $22^{\mathrm{ND}}-24^{\mathrm{TH}}$, Portorož Slovenia) 
$36^{\mathrm{TH}}$ InTERnational CONFERENCE ON ORganizational SCIENCE Development: Responsible Organization (MARCh $22^{\mathrm{ND}}-24^{\mathrm{TH}}$, PORTOROŽ SLOVENIA)

O. Arsenijević, M. Ferjan, I. Podbregar, P. Šprajc, D. Trivan \& Y. Ziegler

\title{
Determinants of Domestic Value Added in EU Exports: the Difference Between »new» and »core« Member Countries
}

\author{
NATAŠA VRH
}

\begin{abstract}
A large part of today's export is not fully or originally produced in the exporting country but includes certain share of imported intermediates. Research emphasises the fact that trading countries can face an important concern regarding the part of exports created in the country and their position in global value chains. Beside participation in GVCs, the significant importance lies in the amount of the value which is created in export-related industries, since it actually affects domestic employment and growth (Banga, 2014).
\end{abstract}

Focusing on EU, share of domestic value added in exports (DVA) is in almost all industries in EU countries from Central and Eastern Europe (NMS-10) lower compared to core EU countries (EU-15). The paper looks at main drivers of the differences in DVA between this two groups of countries and it focuses on determinants of DVA. To decompose each country's exports into domestic and foreign content I use the methodology provided by Koopman et al. (2010) and industry-level data from the World Input-Output Database (WIOD). I show that there are many cases where the determinants have different effects on domestic content of export. Among the most evident are intangible capital investments in high knowledge intensive sectors, especially investments in economic competencies, suggesting that specific level of investments in intangible capital is required in order to even integrate in GVCs.

KEYWORDS: Global value chains • Value-added in exports • International trade

CORRESPONDENCE ADDRESS: Nataša Vrh, Assistant, University of Ljubljana, Faculty of Economics, Kardeljeva ploščad 17, 1000 Ljubljana, Slovenia, e-mail: natasa.vrh@ef.uni-lj.si

DOI https://doi.org/10.18690/978-961-286-020-2.101 ISBN 978-961-286-020-2

(C) 2017 University of Maribor Press

Available at: http://press.um.si 
36 ${ }^{\text {TH }}$ International Conference on Organizational Science Development: Responsible Organization (MARCh $22^{\mathrm{ND}}-24^{\mathrm{TH}}$, PORTOROŽ Slovenia)

N. Vrh: Determinants of Domestic Value Added in EU Exports: the Difference Between »new« and »core« Member Countries

\section{Introduction}

With the emergence of global value chains (henceforth GVCs) different countries in the production chain add value before final consumption. Consequently most of today's export is not fully or originally produced in the exporting country since it incorporates certain share of imported intermediates (Cheng \& Fukumoto, 2010). Therefore around one fifth of country's export represents other countries' value added in imported intermediates.

Research emphasises the fact that trading countries can face an important concern regarding the part of exports created in the country and their position in GVCs. The integration into GVCs is related with favourable employment situation, improved working conditions and workers' income gains which depend on the firm's position in value chain (Shingal, 2015). However, beside participation in GVCs, the significant importance lies in the amount of the value which is created in export-related industries, since it actually affects domestic employment (job creation) and growth (Banga, 2014). Thus, countries are increasingly focusing on improving value added earned per exports and are not solely concentrating on increasing their export market share (OECD, 2013).

Domestic value added in country's exports indeed represents an important measure of income from trade and thus an important development policy's guideline (Caraballo \& Jiang, 2016). Namely, the high country's volume of exports is not necessarily reflected in its economic growth as it was in the past, since only domestic part of country's total exports contributes to its GDP.

When DVA in exports is closely observed, some features of DVA in exports dynamics can be identified (Figure 1). First, in the period 1995-2011, DVA in exports declined in all sectors which is observable using different types of DVA in exports measures (Koopman et al, 2010, Koopman, Wang \& Wei, 2014; Hummels, Ishii, \& Yi, 2001; Dean, Fung, \& Wang, 2007; Daudin, Rifflart \& Schweisguth, 2011; Johnson \& Noguera, 2012).

Second, manufacturing sector has the lowest DVA in exports shares compared to services and natural resources, what could indicate higher degree of cross-border production fragmentation (Johnson \& Noguera, 2012). Third, DVA in exports increased in crisis year 2009. Regarding this increase, Stehrer and Stöllinger (2013) argue that crisis could have caused firms to start re-shoring before offshored activities, which lead to higher DVA in exports, especially if re-shoring activities were present in sectors with relatively high foreign VA in exports.

The last observed feature on which my research is focused on represents the fact that EU countries from Central and Eastern Europe (henceforth NMS-10) have lower shares of DVA in exports than core EU countries (henceforth EU-15). The paper's main research question is what are the main drivers of the differences in DVA share between EU-15 and NMS-10, by exploring the role of FDI, intangible investments and financial development on DVA share in total exports. To decompose each country's exports into 
N. Vrh: Determinants of Domestic Value Added in EU Exports: the Difference Between »new « and »core« Member Countries

domestic and foreign content I use the methodology provided by Koopman et al. (2010) and data from the World Input-Output Database (WIOD) (Timmer et al., 2015).
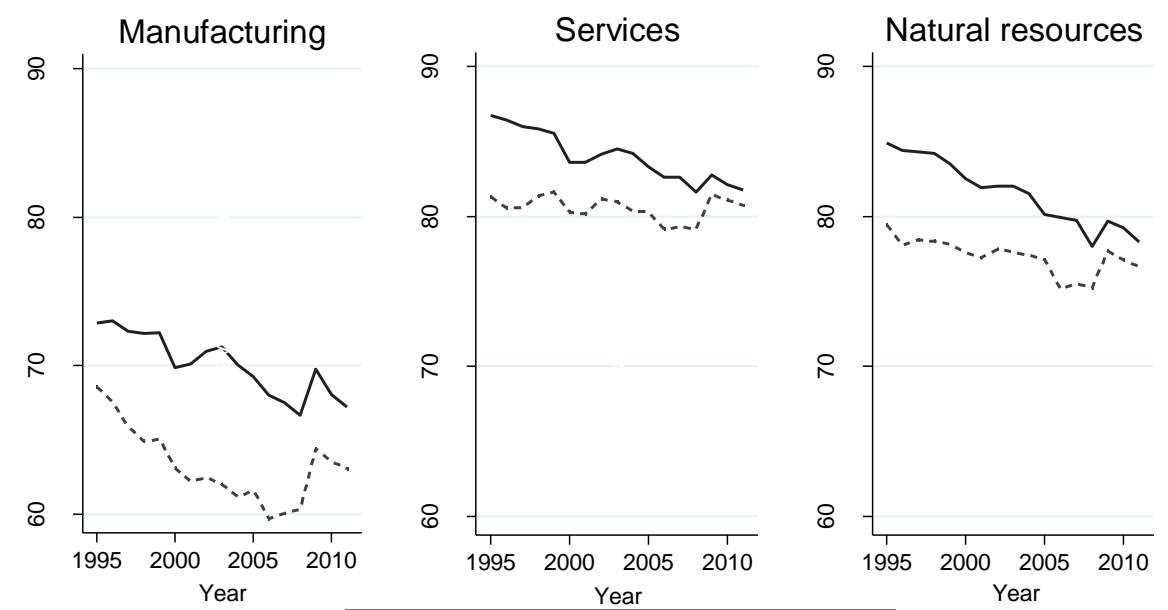

EU-15

NMS-10

Figure 1: Share (\%) of the domestic value added in exports for core EU countries (EU15) and EU countries from Central and Eastern Europe (NMS-10), period 1995-2011, by sector groups (Source: WIOD tables, own calculations).

The paper goes beyond the analysis of Koopman et al. (2010), since it explores the determinants that influence DVA in exports in EU countries and explains the heterogeneity among two groups of EU countries in terms of DVA in exports using industry-level data. Furthermore, the existing empirical studies mainly focus on evaluating the determinants that could facilitate the establishment of supply links i.e. the determinants that influence foreign value added in exports (Stehrer \& Stöllinger, 2015; Rahman \& Zhao, 2013), determinants of participation in GVCs (Van der Marel, 2015; Stehrer \& Stöllinger, 2015; Kowalski et al., 2015) and determinants of trade in value added (Baldwin \& Taglioni, 2011; Brooks \& Ferrarini, 2012; Cheng \& Fukumoto, 2010; Noguera, 2012; Choi, 2013).

The rest of the paper is structured as follows. Section 2 presents the evidence of the existing empirical research findings regarding the determinants of DVA (FVA) in exports. Section 3 describes regression specification and presents results and section 4 concludes.

\section{Potential factors of the value added in exports}

Although there is certain GVC related theoretical literature emerging (Milberg, 2004; Heintz, 2005; Li \& Liu, 2014), GVC literature is mainly empirical. 
$36^{\mathrm{TH}}$ INTERNATIONAL CONFERENCE ON ORganizational SCIENCE DeVElopment: Responsible Organization (MARCh $22^{\mathrm{ND}}-24^{\mathrm{TH}}$, PORTOROŽ Slovenia)

N. Vrh: Determinants of Domestic Value Added in EU Exports: the Difference Between »new « and »core« Member Countries

Stehrer and Stöllinger (2015) research potential factors that foster and factors that hinder further economic integration for manufacturing sector. With Germany assumed to be, as described, an "anchor" of the Central European supply chain, this enables them to use the classical gravity model (country-level version) and thus to introduce the "distance to Germany" and "relative GDP to Germany" as controlled variables. They find that greater inward FDI is associated with higher foreign content in gross exports and that larger countries tend to have, ceteris paribus, a lower FVA. Similarly Kowalski et al. (2015) find, using TiVA data for 57 countries, positive and significant correlation between FVA and revealed openness to FDI (measured as a share of inward FDI stock as percent of GDP). As they explain in their analysis, in the observed countries inward FDI is likely to be more related with imports of foreign intermediates for exports processing.

Regarding the skill structure of the workforce Stehrer and Stöllinger (2015) find a negative coefficient for the medium-skilled labour which suggests that more mediumskilled labour (including an important group of skilled production workers), reduces FVA. They also find a negative correlation for the export sophistication since, as they explain, the more sophisticated a country's export base is the greater are country's skills and capacities. Thus the country uses less imported inputs and consequently decreases the share of FVA in exports.

OECD (2013) studies the role of knowledge based capital in GVC upgrading. Using data from Intan-invest database for 14 European countries (in which only two countries in the sample belong to NMS-10 group), they find that larger stock of knowledge based capital stimulates larger value-added in exports (measured in $\mathrm{VAX}^{66}$ terms). They find noticeable differences in size and significance when they observe estimated coefficients among three subgroups of intangible capital (computerized information, innovative property and economic competencies). By all of subgroups, the coefficient on economic competencies appears to be the largest and most significant, while for computerized information it is considerably smaller and not significant.

Caraballo and Jiang (2016) focus on the determinants which could explain the "valueadded erosion" and find that increase of foreign high-skilled labour share embodied in country's imports has a negative impact on the share of value-added generated by exports. Additionally, they find a positive correlation between the tariffs imposed on manufactured products and DVA share, suggesting that countries which practice limited protectionism or lack strong industrial policies are likely to face decrease in DVA share.

Kee and Tang (2016) perform a more detailed analysis, using customs transaction-level data and firm-survey data for Chinese firms in the period 2000-2007. Since China has, in contrast to majority of other countries, increasing trend in DVA share, they research what led to China's resistance to falling DVA in exports to gross exports despite that China is strongly involved in GVCs. They find that rising DVA share can be related with firms'

\footnotetext{
${ }^{66}$ Sum of (A), (B) and (C) in Figure 2 divided by gross exports represent the VAX ratio defined by Johnson and Noguera (2012).
} 
substitution of domestic for imported materials, both in terms of volume and varieties. Additionally, they find that trade and FDI liberalization since 2000 promotes country's DVA through input-output linkages and spillover effects.

However, for firms that pursue the path of upgrading in GVCs based on formation of knowledge-based capital, the access to finance is crucial in this process. As noted by Manova and $\mathrm{Yu}$ (2016) strengthening capital markets represents an important precondition since, as presented in their study, the credit-constrained exporting firms from China are likely to conduct pure assembly with low value added (earn low profits) compared to less financially constrained firms which conduct import and assembly or even normal trade. However, as explained by OECD (2013) financial development might have a more significant contribution to DVA (in VAX terms) in emerging economies. Namely, their study sample includes European economies that have relatively developed (advanced) financial institutions which could explain the insignificant coefficient on the measure of financial development when DVA is regressed on financial development indicator.

The following section analyses the possible determinants of DVA in exports and their impact on DVA in each group of EU countries.

\subsection{Regression specification}

Motivated by the differences in DVA shares between EU-15 and NMS-10 countries, the paper attempts to explain these differences. For this purpose a dummy variable $(N M S)$ is introduced in order to compare the partial elasticities of two groups of EU countries (NMS-10 and EU-15). The indicator variable is interacted with each of selected variables and thus the following empirical specification is estimated:

$$
D V A_{i j t}=\alpha+\alpha N M S+\left(\mathrm{X}_{i j t-1}\right) \beta+\left(\mathrm{X}_{i j t-1} \mathrm{NMS}\right) \gamma+\mu_{i}+\mu_{j}+\mu_{t}+\varepsilon_{i j t}
$$

where DVA represents estimated measure of DVA in exports as a share of total exports relating to country $i$, industry ${ }^{1} j j$ and time $t$. $\varepsilon_{i j t}$ is random error term, the $\mu$ 's are country, industry- and time-fixed effects. Methodology of measuring value added in exports used in this paper represents conceptual framework developed by Koopman, Powers, Wang, $\&$ Wei (2010, p. 5-21). Complete decomposition of gross exports into its value added exports is illustrated in Figure 2. 
$36^{\text {Th }}$ International Conference on Organizational Science Development: Responsible Organization (MARCh $22^{\mathrm{ND}}-24^{\mathrm{TH}}$, Portorož Slovenia)

N. Vrh: Determinants of Domestic Value Added in EU Exports: the Difference Between »new « and »core« Member Countries

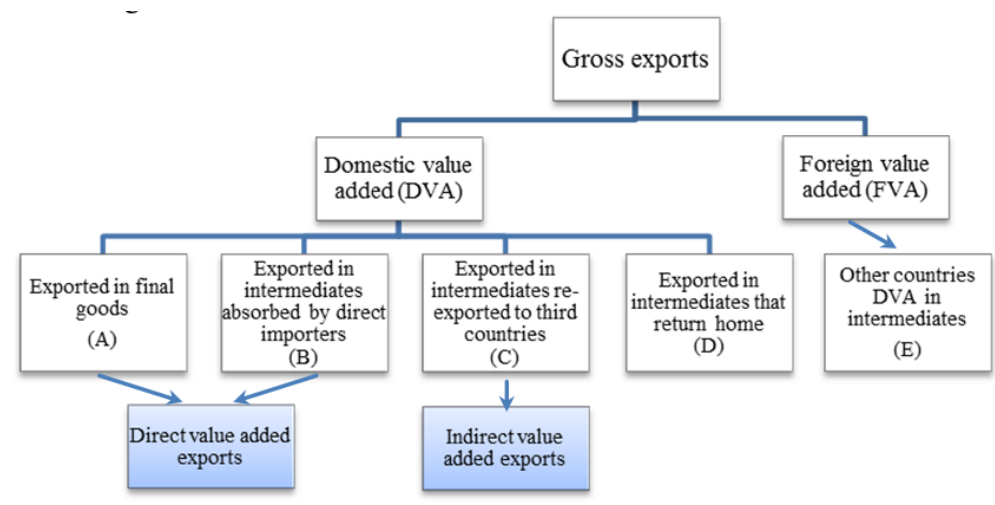

Figure 2: Decomposition of gross exports into value added exports (Source: Koopman et al. (2010))

$X_{i j t-1}$ represent vector of explanatory variables, $X_{i j t-1} N M S$ represent interaction terms between the explanatory variable and NMS dummy variable, where $N M S=1$ if the observation belongs to NMS-10 and $N M S=0$ for EU-15. Based on the empirical evidences from the literature and theoretical predictions of the upgrading within GVCs, the main explanatory variables $(X)$ included in equation (1) are hourly wage (WAGE), openness to FDI as a share of inward FDI stock in GDP (IFDI), physical capital endowment measured as capital stock per hours worked (CAPend), import of intermediates from China as a share of total intermediates consumption (IMintCHN), financial development $(F D)$ and investments in intangible capital per hour worked $(I N T A N)$. All variables are transformed using natural logarithm. To reduce potential concerns of endogeneity ${ }^{2}$ and to allow for a deferred reaction of DVA, all explanatory variables are 1-year lagged.

Since data for intangible capital and financial development are not available at industry level, I rely on the methodology of OECD (2013) and Klasinc (2016). In this form (first used by Rajan and Zingales, 1998) the dependent variable is explained by interactions of a country characteristic with an industry characteristic (Nunn, 2007; OECD, 2013).

Thus, following OECD (2013) and Klasinc (2016), industry level estimates of intangible capital are proxied by the industry knowledge intensity:

$I N T A N=k * I K$,

where $k$ represent the industry knowledge intensity in each country (high skill labour compensation as a share of total labour compensation) and $I K$ is the investment in intangible capital of country $j$ in time $t$. $I K$ separately stands for all intangible investments, and three subsets (computerized information, innovative property, economic competencies $)^{3}$ as well as $\mathrm{R} \& \mathrm{D}$ investments. As they point out, the use of proxies is 
reasonable since sophisticated knowledge, in order to be created and managed, requires advanced educational attainment. Following the explanation by Nunn (2007), a positive coefficient indicates that countries with higher intangible capital investment $(I K)$ have relatively higher DVA in industries for which knowledge intensity $(k)$ is more relevant. Positive coefficient thus suggests that correlation between DVA and investments in intangible capital is higher for knowledge intensive industries. Data for intangible capital investments ${ }^{4}$ are obtained from Intan-invest database ${ }^{5}$.

In a similar way, following OECD (2013) and Klasinc (2016), financial development at the industry level is proxied by an interaction with industry financial dependency:

$F D=f * C R E D I T$

where $f$ presents financial dependency at the industry level measured as input share of financial intermediation in each industry, provided from WIOD database. CREDIT represents country level measure of private credit by banks and other financial institutions as a share of GDP, provided by World's Bank Global Financial Development Database. A positive coefficient indicates that countries with better financial development (CREDIT) have relatively higher DVA in industries with higher financial dependency $(f)$.

All regression specifications are estimated with fixed effects model, which allows correlation between the vectors of industry and country-specific time-invariant effects $\left(\mu_{\mathrm{ij}}\right)$ and the independent variable. Sargan-Hansen test statistic confirms the fixed effects as more appropriate than random effects model, which means that unobservable factors (i.e. shocks in business cycles, difference between industries, culture and history, participation in GVCs) are important in determining DVA in exports. In all regressions, standard errors are calculated using White's heteroscedasticity robust standard errors.

\subsection{Results}

Results for manufacturing sector ${ }^{6}$ are presented in Table 1. All columns include time, industry and country fixed effects. In columns (2)-(5) the intangible capital investments are replaced by the subgroups.

Estimated results show that hourly wage is positively correlated with DVA in exports in EU-15 countries while there are no statistically different results for NMS-10. These results hence confirm that lower wages are correlated with higher FVA share, which is in line with the theory of offshoring that assumes that firms offshore tasks to countries with lower wages.

IFDI has a negative sign in all specifications, as expected. Inward FDI can be associated (particularly at the beginning) with higher volume of destination country's imports from country of FDI's origin, due to increased imports of intermediates and capital goods related with production offshoring (Aminian, Fung, \& Iizaka, 2007) and is in 
36 ${ }^{\text {TH }}$ International Conference on ORganizational Science Development: Responsible ORganization (MARCh $22^{\mathrm{ND}}-24^{\mathrm{TH}}$, PORTOROŽ Slovenia)

N. Vrh: Determinants of Domestic Value Added in EU Exports: the Difference Between »new « and »core« Member Countries

manufacturing, as already found by Stehrer \& Stöllinger (2015), positively correlated with FVA. However, the difference for NMS-10 is not statistically different from zero.

Capital endowment has a negative correlation with DVA in EU-15 and the difference for NMS-10 is not significant. However, when controlled with F-test the coefficients for NMS-10 are significant. Anyhow, the results are not in line with my expectations, since OECD (2013) finds a positive correlation with physical capital stock per hour worked and VAX ratio.

Results show that higher imported intermediate shares from China are negatively correlated with DVA for NMS-10 (significant F-test). As Amador, Cappariello, and Stehrer (2013, p. 19) show, using WIOD tables for period 2000-2011, China represents an increasingly important source of imported value added for euro area member economies. These are also strongly integrated with Eastern European countries that have become their significant trade partners, especially for Germany.

Other estimates confirm that investments in intangible capital are positively correlated with DVA. The largest and most significant coefficient between different subgroups of intangible investments is observed for investments in economic competencies. Correlation coefficient between DVA and investment in economic competencies in sectors which are high knowledge intensive is positive for EU-15 while the coefficient for NMS-10 becomes slightly negative (-0.02) and F-test confirms that it is statistically different from 0 . Other coefficients of intangible capital are positive but not significant for EU-15, while the difference for NMS-10 is significant and negative.

The results suggest that the difference in DVA between NMS-10 and EU-15 countries varies with respect to intangible capital investments in sectors which are high knowledge intensive, especially investments in economic competencies. Similarly OECD (2013) finds that economic competencies stock has the largest correlation between all intangible capital stock subgroups with VAX ratio. However the correlation between DVA and intangible assets is slightly negative for NMS-10. A possible explanation could be that higher investments in intangible capital decreases the need for imported inputs in EU-15 but however in NMS-10 a specific level of investments ${ }^{7}$ in intangible capital is required in order to integrate in $\mathrm{GVC}^{8}$. 

ORGANIZACIJA (22. - 24. MAREC 2017, PORTOROŽ, SLOVENIJA)

N. Vrh: Determinants of Domestic Value Added in EU Exports: the Difference Between »new « and »core« Member Countries

Dependent variable: DVA in exports

\begin{tabular}{|c|c|c|c|c|c|}
\hline VARIABLES & $(1)$ & (2) & (3) & (4) & (5) \\
\hline \multirow[t]{2}{*}{$N M S$} & $0.279 *$ & 0.380 & $0.278^{*}$ & $0.351 * *$ & 0.154 \\
\hline & $(0.151)$ & $(0.262)$ & $(0.146)$ & $(0.144)$ & $(0.138)$ \\
\hline \multirow[t]{2}{*}{$W A G E$} & $0.0597 * *$ & $0.0577 * *$ & $0.0603 * *$ & $0.0571 * *$ & $0.0554 *$ \\
\hline & $(0.0252)$ & $(0.0248)$ & $(0.0263)$ & $(0.0252)$ & $(0.0250)$ \\
\hline \multirow[t]{2}{*}{$W A G E \times N M S$} & -0.0124 & 0.00330 & -0.00935 & -0.00296 & 0.00342 \\
\hline & $(0.0551)$ & $(0.0504)$ & $(0.0541)$ & $(0.0515)$ & $(0.0500)$ \\
\hline \multirow[t]{2}{*}{ IFDI } & $-0.0126 * *$ & $-0.0129 * *$ & $-0.0128 * *$ & $-0.0130 * *$ & $-0.0131 * *$ \\
\hline & $(0.00510)$ & $(0.00512)$ & $(0.00511)$ & $(0.00507)$ & $(0.00508)$ \\
\hline \multirow[t]{2}{*}{$I F D I \times N M S$} & 0.0151 & 0.0157 & 0.0154 & 0.0158 & 0.0159 \\
\hline & $(0.0159)$ & $(0.0158)$ & $(0.0159)$ & $(0.0158)$ & $(0.0158)$ \\
\hline \multirow{2}{*}{ CAPend } & $-0.0329 * *$ & $-0.0322^{* *}$ & $-0.0327 * *$ & $-0.0322 * *$ & $-0.0317 * *$ \\
\hline & $(0.0117)$ & $(0.0118)$ & $(0.0118)$ & $(0.0117)$ & $(0.0117)$ \\
\hline \multirow{2}{*}{ CAPend x NMS } & -0.0508 & -0.0546 & -0.0518 & -0.0527 & -0.0540 \\
\hline & $(0.0375)$ & $(0.0369)$ & $(0.0374)$ & $(0.0369)$ & $(0.0367)$ \\
\hline \multirow[t]{2}{*}{$F D$} & 0.00014 & 0.00031 & 0.00013 & 0.00024 & 0.000315 \\
\hline & $(0.00127)$ & $(0.00129)$ & $(0.00130)$ & $(0.00126)$ & $(0.00126)$ \\
\hline \multirow[t]{2}{*}{$F D \times N M S$} & 0.00256 & 0.00227 & 0.00246 & 0.00240 & 0.00224 \\
\hline & $(0.00193)$ & $(0.00204)$ & $(0.00197)$ & $(0.00199)$ & $(0.00202)$ \\
\hline \multirow{2}{*}{ IMintCHN } & 0.0180 & 0.0173 & 0.0180 & 0.0171 & 0.0169 \\
\hline & $(0.0169)$ & $(0.0170)$ & $(0.0170)$ & $(0.0170)$ & $(0.0170)$ \\
\hline \multirow[t]{2}{*}{ IMintCHN x $N M S$} & $-0.066 * * *$ & $-0.064 * * *$ & $-0.065 * * *$ & $-0.065 * * *$ & $-0.0639 * * *$ \\
\hline & $(0.0178)$ & $(0.0183)$ & $(0.0180)$ & $(0.0182)$ & $(0.0184)$ \\
\hline ALLintan $\mathrm{x} k$ & 0.0228 & & & & \\
\hline \multirow[t]{2}{*}{ ALLintan $\times k \times N M S$} & $-0.0547 * *$ & & & & \\
\hline & $(0.0182)$ & & & & \\
\hline \multirow{2}{*}{ COMPinf $\mathrm{x} k$} & & 0.0165 & & & \\
\hline & & $(0.0114)$ & & & \\
\hline \multirow[t]{2}{*}{ COMPinf $\mathrm{x} k \mathrm{x} N M S$} & & $-0.0325^{* *}$ & & & \\
\hline & & $(0.0132)$ & & & \\
\hline \multirow[t]{2}{*}{ ECONcomp $\mathrm{x} k$} & & & $0.0307 *$ & & \\
\hline & & & $(0.0155)$ & & \\
\hline \multirow{2}{*}{ ECONcomp $\mathrm{x} k \times \mathrm{x} M S$} & & & $-0.0531 * *$ & & \\
\hline & & & $(0.0179)$ & & \\
\hline \multirow[t]{2}{*}{ INNOVprop $\mathrm{x} k$} & & & & 0.0212 & \\
\hline & & & & $(0.0131)$ & \\
\hline \multirow[t]{2}{*}{ INNOVprop x $k \times$ x NMS } & & & & $-0.0431 * *$ & \\
\hline & & & & $(0.0156)$ & \\
\hline \multirow[t]{2}{*}{$R \& D \times k$} & & & & & 0.0134 \\
\hline & & & & & $(0.0105)$ \\
\hline \multirow[t]{2}{*}{$R \& D \times k \times N M S$} & & & & & $-0.0306 * *$ \\
\hline & & & & & $(0.0130)$ \\
\hline Observations & 1,478 & 1,478 & 1,478 & 1,478 & 1,478 \\
\hline R-squared & 0.743 & 0.741 & 0.742 & 0.742 & 0.742 \\
\hline Number of industry & 11 & 11 & 11 & 11 & 11 \\
\hline Time FE & $\mathrm{Y}$ & $\mathrm{Y}$ & $\mathrm{Y}$ & $\mathrm{Y}$ & $\mathrm{Y}$ \\
\hline Industry FE & $\mathrm{Y}$ & $\mathrm{Y}$ & $\mathrm{Y}$ & $\mathrm{Y}$ & $\mathrm{Y}$ \\
\hline Country FE & $\mathrm{Y}$ & $\mathrm{Y}$ & $\mathrm{Y}$ & $\mathrm{Y}$ & $Y$ \\
\hline
\end{tabular}

Table 1: Determinants of domestic value added in exports in manufacturing sectorcomparison between NMS-10 and EU-15 countries ${ }^{9}$ 
$128036^{\text {Th }}$ International Conference on Organizational Science Development: Responsible Organization (MARCh $22^{\mathrm{ND}}-24^{\mathrm{TH}}$, PORTOROŽ Slovenia)

N. Vrh: Determinants of Domestic Value Added in EU Exports: the Difference Between »new « and »core« Member Countries

To check the robustness of the results I reestimate the basic specification. In first robustness check the industry-level data of business enterprise research and developments expenditure per hour worked (BERD) are used. These are the only available data of intangible capital investments on industry level. Coefficients remain robust in terms of sign (

Table 2), although they lose its significance. However negative correlation between IFDI and DVA for EU-15 remains highly significant. Coefficient of intangible capital investments $(B E R D)$ remains positive for EU-15 and is slightly negative for NMS-10, as in basic specification. However it has to be noted that there are many missing data for $B E R D$ and consequently number of observations is reduced for almost one third.

\begin{tabular}{lc}
\hline \hline VARIABLES & $(1)$ \\
\hline WAGE & $0.0526^{*}$ \\
WAGE x NMS & $(0.0265)$ \\
& 0.0359 \\
IFDI & $(0.0503)$ \\
& $-0.0198^{* *}$ \\
IFDI x NMS & $(0.00627)$ \\
& 0.0156 \\
CAPend & $(0.0173)$ \\
& $-0.0382^{* *}$ \\
CAPend $\mathrm{x} N M S$ & $(0.0156)$ \\
& -0.0278 \\
FD & $(0.0335)$ \\
& 0.0011 \\
FD x NMS & $(0.0013)$ \\
& -0.0029 \\
IMintCHN & $(0.0017)$ \\
& 0.0208 \\
IMintCHN x NMS & $(0.0197)$ \\
& $-0.0413^{*}$ \\
BERD & $(0.0192)$ \\
& $0.0173^{* *}$ \\
BERD x NMS & $(0.00733)$ \\
& $-0.0182^{* * *}$ \\
Observations & $(0.00458)$ \\
R-squared & 1,057 \\
Number of industry & 0.683 \\
Time FE & 11 \\
Industry FE & $\mathrm{Y}$ \\
Country FE & $\mathrm{Y}$ \\
\hline \hline & $\mathrm{Y}$ \\
\hline
\end{tabular}

Table 2: Determinants of domestic value added in exports in manufacturing sector comparison between NMS-10 and EU-15 countries (Robustness check I) ${ }^{10}$

\section{Conclusion}

In this paper I rely on a recent methodology for the decomposition of gross export into value added export provided by Koopman et. al (2010) and recent research findings 
regarding the potential factors of value added in exports (Stehrer \& Stöllinger, 2015; Kowalski et al., 2015; Caraballo \& Jiang, 2016; OECD, 2013). I am focused particularly on (1) DVA in exports, which represents an important measure of income from trade and thus it can be recognized as a crucial guideline of development policy (Caraballo \& Jiang, 2016) and (2) on EU countries. The main contribution of my research compared to previous work is the distinction between NMS-10 and EU-15 countries in order to explain what are the main drivers of the differences in DVA in exports share between EU-15 and NMS-10 countries.

The results suggest that the size of DVA between NMS-10 and EU-15 countries varies with respect to intangible capital investments in sectors which are high knowledge intensive, especially investments in economic competencies. Elasticities between DVA and investments in intangible capital are positive for EU-15, but not for NMS-10 when controlled for country specific unobservable factors. A possible explanation for this could be that higher investment in intangible capital decreases the need for imported inputs in EU-15 but however in NMS-10 a specific level of investments in intangible capital is required in order to even integrate in GVC. By observing the elasticities of these determinants in two groups of countries, it can be concluded that they have differentiated effects on DVA in exports for core EU countries and NMS-10 countries.

Considering some limitations (construction of I-O tables, quality of data), the results presented in the paper offer an insight into possible determinants of EU countries' domestic content of exports from value added perspective. Most of all, one could improve methodology of export decomposition to value added terms and use different source of input-output tables to compare the estimated results. Moreover, instead of using industrylevel data one could extend this research and use firm-level data.

\section{Notes}

${ }^{1}$ Two industries are excluded from the analysis: Coke, Refined Petroleum and Nuclear Fuel (since EU countries (except UK) do not have their own production) and Private Households with Employed Persons (since the estimated DVA in the majority of countries has extreme values 0 or 1).

${ }^{2}$ However, when considering the effect of selected determinants on a DVA in exports, the fact that the causality can also operate in the other direction has to be taken into account. Thus, it is difficult to determine the existence of a direct causal relationship between selected determinants and DVA, but nonetheless correlations are informative in many aspects.

${ }^{3}$ Computerized information includes investments in software and databases. Innovative property includes expenses for R\&D, design, new products and financial services, mineral exploration. Economic competencies include investments in brand equity (advertising and market research) and firm-specific resources (training, firm-specific skills, organizational structure) (Corrado et al, 2012).

${ }^{4}$ OECD (2013) and Klasinc (2016) use data for intangible capital stock which is available only for 14 (especially EU-15) countries. Data for intangible capital investments are available for all EU countries.

${ }^{5}$ For the methods and data sources for estimates see Corrado et al. (2012). 
$36^{\mathrm{TH}}$ InTERnAtional CONFERENCE ON ORganizational SCIENCE DeVElopment: Responsible Organization (MARCH $22^{\mathrm{ND}}-24^{\mathrm{TH}}$, PortoroŽ SlOVENIA)

N. Vrh: Determinants of Domestic Value Added in EU Exports: the Difference Between »new « and »core« Member Countries

${ }^{6}$ Estimation results of the baseline specification using services data show negative and significant elasticities with DVA for IFDI and imports of intermediates from China for EU-15 countries, while these results are not significantly different in NMS-10. In the group of intangible investments the investments in economic competencies, investments in innovative property and investments in computerized information are positively correlated with DVA in exports, but coefficients are significant only for EU-15 (F-tests are not significantly different from 0 ).

${ }^{7}$ Similar to relationship-specific investments. These represent the investments realized by suppliers in the value chain in order to obtain a certain required level of compatibility of their components with components of other suppliers (Alfaro, Antràs, Chor, \& Conconi, 2015).

${ }^{8}$ Explanation is based on findings of Stehrer \& Stöllinger (2015) for export sophistication.

${ }^{9}$ Note: Robust standard errors in parentheses: $* * * \mathrm{p}<0.001 * * \mathrm{p}<0.05 * \mathrm{p}<0.1$. All variables are in natural logarithm. Explanatory variables are lagged for 1 year. $N M S=1$ if the observation belongs to NMS-10. NMS $=0$ if the observation belongs to EU-15. Data included in regression cover period 2000-2010. All regressions include a constant term.

${ }^{10}$ Note: Robust standard errors in parentheses: $* * * \mathrm{p}<0.001 * * \mathrm{p}<0.05 * \mathrm{p}<0.1$. All variables are in natural logarithm. Explanatory variables are lagged for 1 year. $N M S=1$ if the observation belongs to NMS-10, NMS $=0$ if the observation belongs to EU-15. Data included in regression cover period 2000-2010. All regressions include a constant term.

\section{Literature}

Alfaro, L., Antràs, P., Chor, D., \& Conconi, P. (2015). Internalizing Global Value Chains: A FirmLevel Analysis (No. w21582). National Bureau of Economic Research.

Amador, J., Cappariello, R., \& Stehrer, R. (2014). Global Value Chains: A View From the Euro Area (Working Papers 2014). Banco de Portugal, Economics and Research Department.

Aminian, N., Fung, K. C., \& Iizaka, H. (2007). Foreign direct investment, intra-regional trade and production sharing in East Asia (RIETI Discussion Paper Series 07-E-064). Tokyo: The Research Institute of Economy, Trade and Industry.

Baldwin, R., \& Taglioni, D. (2011). Gravity chains: Estimating bilateral trade flows when parts and components trade is important (ECB working paper series No- 1401). ECB.

Banga, R. (2014). Linking into Global Value Chains Is Not Sufficient: Do You Export Domestic Value Added Contents? Journal of Economic Integration, 29(2), 267-297.

Brooks, D. H., \& Ferrarini, B. (2012). Vertical Gravity. ADB Economics Working Paper Series No.303. Metro Manila: Asian Development Bank.

Caraballo, J. G., \& Jiang, X. (2016). Value-Added Erosion in Global Value Chains: An Empirical Assessment. Journal of Economic Issues, 50(1), 288-296.

Cheng, L., \& Fukumoto, M. (2010). Vertical Specialization and its Implications for the Gravity Model of International Trade. Hong Kong University of Science and Technology.

Choi, N. (2013). Measurement and Determinants of Trade in Value Added. KIEP Working Paper 13-01. Seoul: Korea Institute for International Economic Policy.

Corrado, C., Haskel, J., Jona-lasinio, C., \& Iommi, M. (2012). Intangible Capital and Growth in Advanced Economies: Measurement Methods and Comparative Results. Available at www.INTAN-Invest.net.

Daudin, G., Rifflart, C., \& Schweisguth, D. (2011). Who produces for whom in the world economy? Canadian Journal of Economics, 44(4), 1403-1437.

Dean, J. M., Fung, K. C., \& Wang, Z. (2007). Measuring the Vertical Specialization in Chinese Trade (Working Papers No. 07-01). U.S International Trade Commission.

Heintz, J. (2005). Low-wage manufacturing and global commodity chains: a model in the unequal exchange tradition. Cambridge Journal of Economics, 30(4), 507-520. 
Hummels, D., Ishii, J., \& Yi, K. M. (2001). The nature and growth of vertical specialization in world trade. Journal of International Economics, 54(1), 75-96.

Johnson, R. C., \& Noguera, G. (2012). Accounting for intermediates: Production sharing and trade in value added. Journal of International Economics, 86(2), 224-236.

Kee, H. L., \& Tang, H. (2016). Domestic Value Added in Exports : Theory and Firm Evidence from China. American Economic Review, 106(6), 1402-1436.

Klasinc, J. (2016). Investment in green economy as a potential source of value added. International Journal of Business and Economic Sciences Applied Research, 8(3), 109-118.

Koopman, R., Powers, W., Wang, Z., \& Wei, S. J. (2010). Give Credit where Credit is Due: Tracing Value Added in Global Production Chains (Working Paper No. 16426). National Bureau of Economic Research.

Koopman, R., Wang, Z., \& Wei, S. J. (2014). Tracing Value-Added and Double Counting. American Economic Review, 104(2), 459-494.

Kowalski, P., Lopez Gonzalez, J., Ragoussis, A., \& Ugarte, C. (2015). Participation of Developing Countries in Global Value Chains. OECD Trade Policy Papers, No. 179. Paris: OECD Publishing.

Li, B., \& Liu, Y. (2014). Moving Up the Value Chain. Boston College Working Paper.

Manova, K., \& Yu, Z. (2016). How firms export: Processing vs. ordinary trade with financial frictions. Journal of International Economics, 100, 120-137.

Milberg, W. (2004). The changing structure of trade linked to global production systems: What are the policy implications? International Labour Review, 143(1-2), 45-90.

Noguera, G. (2012). Trade Costs and Gravity for Gross and Value Added Trade. Unpublished Manuscript, University of Warwick.

Nunn, N. (2007). Relationship-specificity, incomplete contracts, and the pattern of trade. Quarterly Journal of Economics, 122(2), 569-600.

OECD. (2013). Knowledge-based capital and upgrading in global value chains. In Supporting Investment in Knowledge Capital, Growth and Innovation (pp. 215-252). Paris: OECD Publishing.

Rahman, J., \& Zhao, T. (2013). Export Performance in Europe: What Do We Know from Supply Links?. IMF Working Paper No. 13/62.

Rajan, R.G. \& L. Zingales (1998). Financial Dependence and Growth. American Economic Review, $88(3), 559-586$.

Shingal, A. (2015). Labour market effects of integration into GVCs: Review of literature. Swiss Programme for Research on Global Issues for Development. R4D Working Paper 2015/10.

Stehrer, R., \& Stöllinger, R. (2013). Positioning Austria in the global economy: Value added trade, international production sharing and global linkages. FIW Research Reports series V-002, FIW.

Stehrer, R., \& Stöllinger, R. (2015). The Central European Manufacturing Core: What is Driving Regional Production Sharing? (FIW Research Reports 2014/15 N02). FIW.

Timmer, M. P., Dietzenbacher, E., Los, B., Stehrer, R., \& Vries, G. J. (2015). An illustrated user guide to the world input-output database: the case of global automotive production. Review of International Economics, 23(3), 575-605.

Van der Marel, E. (2015). Positioning on the Global Value Chain Map: Where do You Want to Be? Journal of World Trade, 49(6), 915-949. 
1284 36 ${ }^{\text {TH }}$ International Conference on Organizational Science Development: Responsible Organization (March $22^{\mathrm{ND}}-24^{\mathrm{TH}}$, Portorož Slovenia) 
36. MEDNARODNA KONFERENCA O RAZVOJU ORGANIZACIJSKIH ZNANOSTI: OdgOVORNA ORGANIZACIJA (22. - 24. MAREC 2017, PORTOROŽ, SLOVENIJA)

O. Arsenijević, M. Ferjan, I. Podbregar, P. Šprajc, D. Trivan \& Y. Ziegler

\title{
Krožno gospodarstvo v slovenskih podjetjih
}

\author{
Petra VujKovič, Polona ŠPraJC \& AlenKa Baggia
}

\begin{abstract}
Povzetek Ko govorimo o krožnem gospodarstvu opisujemo nov model gospodarstva, ki poskuša čim dlje časa zadržati izdelke v uporabi in s tem zmanjšati prekomerno porabo surovin in množično količino odpadkov. V Sloveniji vsako leto pridelamo ogromno odpadkov tako kot tudi mnoge druge države sveta. Pa vendar, če želimo izstopiti iz tega povprečja, postati soustvarjalci in ne le ostati opazovalci moramo še danes poprijeti za nov model gospodarstva in to je krožno gospodarstvo. $\mathrm{V}$ teoriji je bilo $\mathrm{v}$ Sloveniji o krožnem gospodarstvu že nekaj razprav, predstavljeni so bili tudi predlogi pa vendar, nas zanima, kakšen je torej odnos posameznikovzaposlenih v slovenskih podjetjih na krožno gospodarstvo. Dejstvo je, da se prilagajanje in sprejemanje takšnega modela izvaja na različnih ravneh in ena izmed njih so ravno zaposleni, ki so v okviru podjetja pomemben dejavnik. Cilj predstavljene raziskave o poznavanju krožnega gospodarstva je bil pridobiti informacije v zvezi z ozaveščenostjo zaposlenih o modelu krožnega gospodarstva $\mathrm{v}$ smislu ali pojem krožno gospodarstvo sploh poznajo, vedo kaj pomeni, kaj bi jih spodbudilo, da bi se v podjetju odločili da bi model krožnega gospodarstva uvedli kot poslovni model, kaj jih ovira oziroma jim preprečuje, da ga še niso uvedli. Po rezultatih anketnega vprašalnika lahko za Slovenijo rečemo, da potrebovala še nekaj časa, da bo lahko dosegla tako veliko spremembo kot je prehod model krožnega gospodarstva.
\end{abstract}

KLJUČNE BESEDE: krožno gospodarstvo • mala in srednje velika podjetja - Slovenija

\footnotetext{
NASLOV AVTORJEv: Petra Vujkovič, Univerza v Mariboru, Fakulteta za organizacijske vede; Kidričeva cesta 55a, 4000 Kranj, Slovenija, e-pošta: petra.vujkovic@student.um.si; dr. Polona Šprajc, docentka, Univerza v Mariboru, Fakulteta za organizacijske vede; Kidričeva cesta 55a, 4000 Kranj, Slovenija, e-pošta: polona.sprajc@fov.uni-mb.si; dr. Alenka Baggia, docentka, Univerza v Mariboru, Fakulteta za organizacijske vede; Kidričeva cesta 55a, 4000 Kranj, Slovenija, e-pošta: alenka.baggia@fov.uni-mb.si
} 
$36^{\mathrm{TH}}$ InTERnational CONFERENCE ON ORganizational SCIENCE Development: Responsible Organization (MARCh $22^{\mathrm{ND}}-24^{\mathrm{TH}}$, PORTOROŽ SLOVENIA)

O. Arsenijević, M. Ferjan, I. Podbregar, P. Šprajc, D. Trivan \& Y.

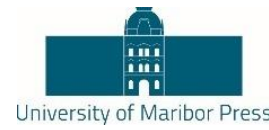

Ziegler

\title{
Circular Economy in Slovenian Companies
}

\author{
Petra Vujkovič, Polona ŠprajC \& Alenka BAGgia
}

\begin{abstract}
Circular economy describes a new model of the economy, which is trying to keep the products in use as long as possible and thereby reduce the excessive consumption of raw materials and the massive amount of waste. Similar to other countries, Slovenia produces large amounts of waste each year. If we would like to withdraw from this average, and become cocreators and not only observers of change, we have to incorporate a new model of economy - circular economy. In theory, circular economy has been presented and discussed in Slovenia. Nevertheless, we are interested to research individual's/employee's attitude to the new model. Adoption and acceptance of new economical models is performed on different levels, among which emplyees are an important factor each company. The aim of the presented research is to gain information about individual's awareness about circular economy, to establish wheter the concept of circular economy is even known, what would encourage companies or employees to make a decision to shift to circular economy and which obstacles preventing introduction have been identified. According to the results of a questionnaire we can say that in Slovenia, several more steps will be needed to achieve such a major change as the transition model of circular economy.
\end{abstract}

KEYWORDS: circular economy $\bullet$ small and medium enterprises $\bullet$ Slovenia

CoRRESPONDENCE AdDRess: Petra Vujkovič, University of Maribor, Faculty of Organizational Sciences, Kidričeva cesta 55a, 4000 Kranj, Slovenia, e-mail: petra.vujkovic@ student.um.si; Polona Šprajc, Ph.D., Assistant Professor, University of Maribor, Faculty of Organizational Sciences, Kidričeva cesta 55a, 4000 Kranj, Slovenia, e-mail: polona.sprajc@fov.uni-mb.si; dr. Alenka Baggia, Ph.D., Assistant Professor, University of Maribor, Faculty of Organizational Sciences, Kidričeva cesta 55a, 4000 Kranj, Slovenia, e-mail: alenka.baggia@ fov.uni-mb.si

DOI https://doi.org/10.18690/978-961-286-020-2.102 ISBN 978-961-286-020-2

(C) 2017 University of Maribor Press

Available at: http://press.um.si 


\section{$1 \quad$ Uvod}

Onesnaženost okolja in klimatske spremembe so privedle človeštvo do vedno večjega zavedanja o pomenu ohranjanja okolja. Čeprav se veliko držav lahko pohvali z velikim napredkom na področju varovanja okolja $\mathrm{v}$ zadnjih dveh desetletjih, vzorci klasične proizvodnje, potrošnje in trgovine ostajajo $\mathrm{v}$ nasprotju $\mathrm{s}$ trajnostnimi usmeritvami (Preston, 2012). Da bi prispevala svoj delež $\mathrm{k}$ ohranjanju okolja ter povečala konkurenčno prednost, se podjetja poslužujejo različnih pristopov, na področju okoljskega managementa in trajnostnega razvoja (Ying \& Zhou, 2012).

Najpogosteje uporabljeni model gospodarstva $\mathrm{v}$ današnjem poslovnem okolju je linearno gospodarstvo, ki deluje po načelu vzemi-proizvedi-zavrzi (Ellen MacArthur Foundation, 2013). Za linearno gospodarstvo je značilno množično izčrpavanje in koriščenje surovin za proizvodnjo izdelkov oziroma produktov, ki na koncu svojega življenjskega cikla postanejo odpadki. Čeprav je na področju učinkovite rabe virov narejen velik napredek, pa se celotna prednost tega pristopa izgubi zaradi sistema, ki namesto na ponovni uporabi temelji izključno na potrošnji (The Ellen MacArthur Foundation, 2012). Kot navaja (Yuan, Bi, Moriguichi, \& Yuan, 2006), lahko krožno gospodarstvo pripomore $\mathrm{k}$ boljši produktivnosti, ekološki učinkovitosti, prenovi sistema ravnanja z okoljem ter pri doseganju ciljev trajnostnega razvoja. Krožno gospodarstvo nekateri avtorji imenujejo tudi gospodarstvo življenjskega cikla ali gospodarstvo zapiranja materialnega toka (Romero \& Molina, 2012). Kljub temu, da se podjetja vedno bolj zavedajo pomena trajnostnega razvoja in varovanja okolja, pa so k razvoju krožnega gospodarstva prispevali tudi nekateri drugi dejavniki oziroma spremembe (Planing, 2014):

- Cene materiala in polizdelkov rastejo

- Informacijska tehnologija omogoča razvoj novih poslovnih modelov

- Smo na pragu večjih sprememb v obnašanju potrošnika

V literaturi najdemo več primerov predlogov implementacije oziroma prehoda podjetja (Romero \& Molina, 2012; Schetters et al., 2015; Smol, Kulczycka, Henclik, Gorazda, \& Wzorek, 2015) ali države (Bastein, 2014; Geng \& Doberstein, 2008; Mathews \& Tan, 2011; Yuan et al., 2006) v sistem krožnega gospodarstva. Kot je razvidno iz literature, je tema krožnega gospodarstva v preteklih letih na azijskem trgu veliko bolj raziskana kot na ostalih področjih.

Cilj raziskave, ki jo predstavljamo v članku, je bil ugotoviti, v kolikšni meri so slovenska podjetja in njihovi zaposleni seznanjeni s pojmom krožno gospodarstvo, ali model krožnega gospodarstva že poznajo, kateri so glavni motivatorji, ki bi jih spodbudili, da bi ga v podjetje vključili in kateri so tisti zaviralci, ki jim to vključitev onemogočajo. 


\section{$1.1 \quad$ Krožno gospodarstvo}

Ko govorimo o krožnem gospodarstvu opisujemo nov model gospodarstva, ki poskuša čim dlje časa zadržati izdelke $\mathrm{v}$ uporabi in $\mathrm{s}$ tem zmanjšati prekomerno porabo surovin in množično količino odpadkov. Delovanje krožnega gospodarstva najlažje opišemo s pomočjo načel (Slika 1), na katerih sloni model (The Ellen MacArthur Foundation, 2012):

1. načelo: Potrebno je ohranjati in krepiti naravni kapital preko nadzora omejenih virov in preko ohranjanja uravnoteženosti toka obnovljivih virov. Povedano drugače, ko se pojavi potreba po virih jih krožno gospodarstvo "pametno izbere" skupaj z ustreznimi procesi in tehnologijo. Ob tem pride do krepitve naravnega kapitala poleg tega pa se prav tako spodbudi tok hranil v sistemu, ki ustvari pogoje za obnovo virov.

2. načelo: Optimizacija donosnosti virov preko kroženja izdelkov, komponent in materialov, ki so v uporabi z največjo možno koristnostjo v vsaki točki biološkega in tehnološkega kroga. Povedano drugače, izdelke, ki bodo obnovljivi, ponovno uporabljeni v proizvodnji ali pa reciklirani lahko oblikujemo le, če vzpostavimo sistem kroženja tehnoloških sestavnih delov in materialov. Krožni sistemi na eni strani maksimirajo število zaporednih krožnih ciklov in čas, ki je potreben za vsak cikel, s podaljšanjem življenjskega cikla izdelka in ponovno uporabo ter po drugi strani omogočajo, da biološka (razkrojena) hranila ponovno vstopijo v biosfero kot koristne surovine za nov cikel.

3. načelo: Spodbujati učinkovitost sistema $z$ odprtostjo in oblikovanjem tako, da se izognemo negativnim zunanjim stroškom. Povedano drugače, govorimo o želji po zmanjšanju škode znotraj sistema in vpliva na področje prehrane, bivališča, družabnega življenja, mobilnosti, izobrazbe, zdravstva ter nadzora nad onesnaževanjem zemlje, vode, izpustov škodljivih snovi, uporabo površin in zmanjšanjem hrupa. 


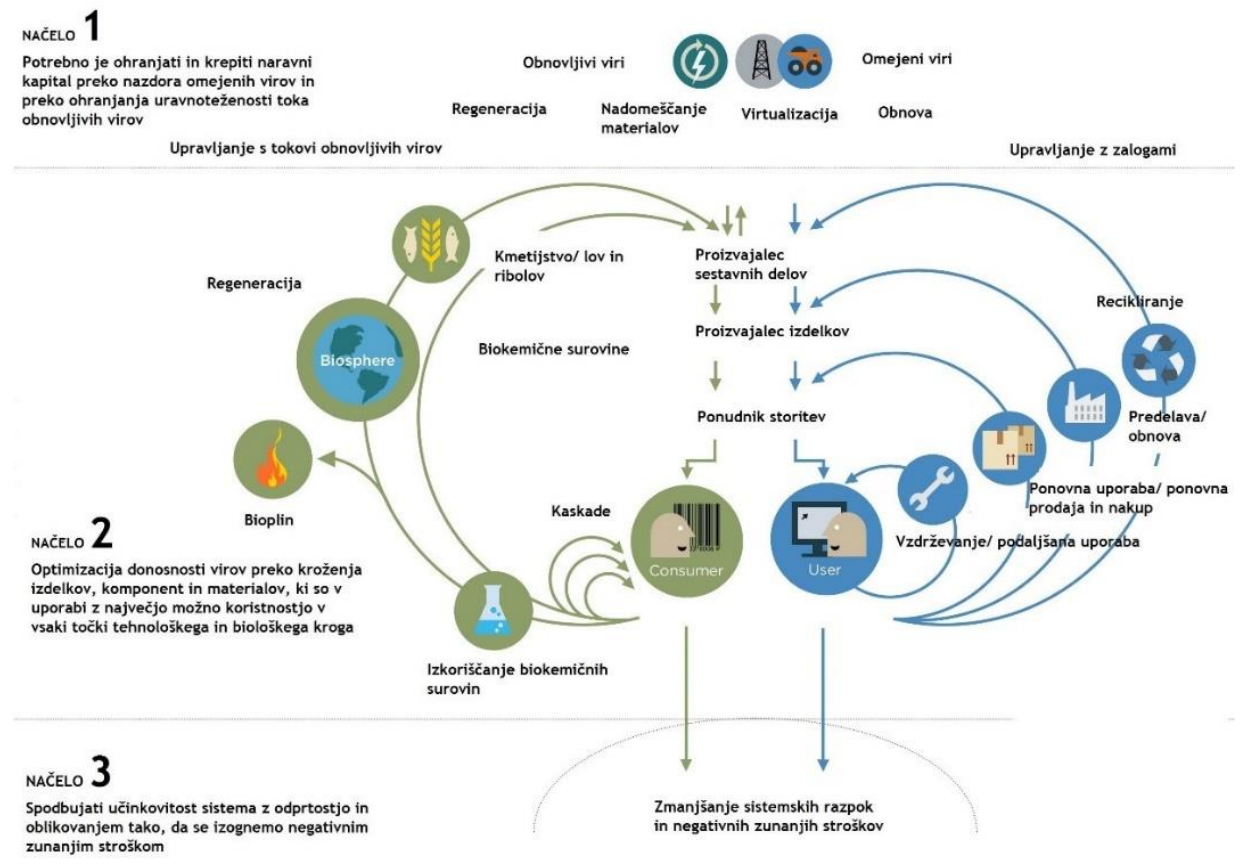

Slika 1: Tri ključna načela na katerih sloni model krožnega gospodarstva (vir: (The Ellen MacArthur Foundation, 2012).

Če povzamemo opis modela krožnega gospodarstva, lahko zaključimo z mislijo, da krožno gospodarstvo dejansko ponuja na novo zasnovane izdelke, ki so bolj prijazni za spremenljiv trg proizvodnje.

\section{$2 \quad$ Metodologija}

Podatki uporabljeni v članku so bili pridobljeni preko spletnega anketiranja, pri čemer so bili anketiranci izbrani naključno glede na demografsko ustreznost vzorca malih in srednje velikih podjetij. Vabilo $\mathrm{k}$ izpolnjevanju ankete je bilo posredovano na 2000 elektronskih naslovov slovenskih podjetij vključenih v vzorec, v mesecu maju 2016. Prejeli smo odgovore 25 zaposlenih v podjetjih. V anketi je tako sodelovalo $32 \%$ žensk in $68 \%$ moških. Največ, 64 \% anketirancev spada v starostno skupino 41-60 let. $24 \%$ anketirancev spada v starostno skupino 21-40 let. Najmanj, $12 \%$ pa v starostno skupino 61 let ali več. Na Sliki 2 je predstavljena struktura vzorca anketirancev glede na spol in starost. 

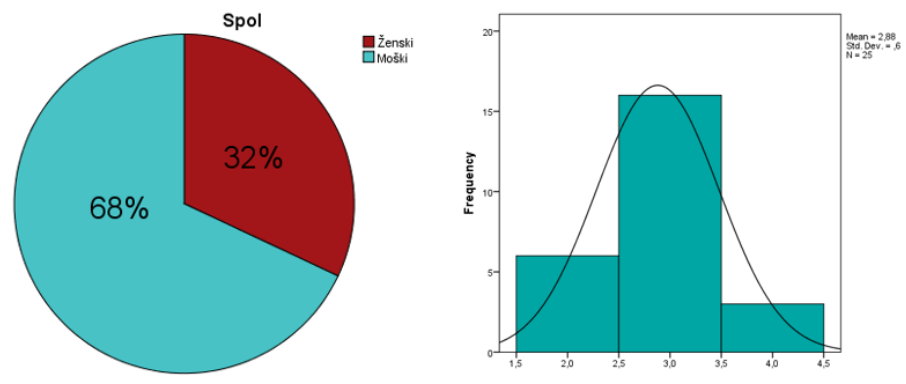

Slika 2: Spol in starostna sestava anketirancev

Največ, kar $36 \%$ anketiranih podjetij spada v področje E - oskrba z vodo; ravnanje z odplakami in odpadki; saniranje okolja. $20 \%$ anketiranih podjetij spada v področje $\mathrm{G}$ trgovina. $12 \% \mathrm{v}$ področje D - oskrba z električno energijo, plinom in paro ter področje $\mathrm{F}$ - gradbeništvo. $8 \%$ v področje $\mathrm{A}$ - kmetijstvo in lov, gozdarstvo in ribištvo. Najmanj, $4 \%$ anketiranih podjetij pa spada v področje B - rudarstvo, v področje $\mathrm{C}$ - predelovalne dejavnosti in v področje $\mathrm{S}$ - druge dejavnosti. Strukturo podjetij glede na dejavnost predstavljamo na Sliki 3.

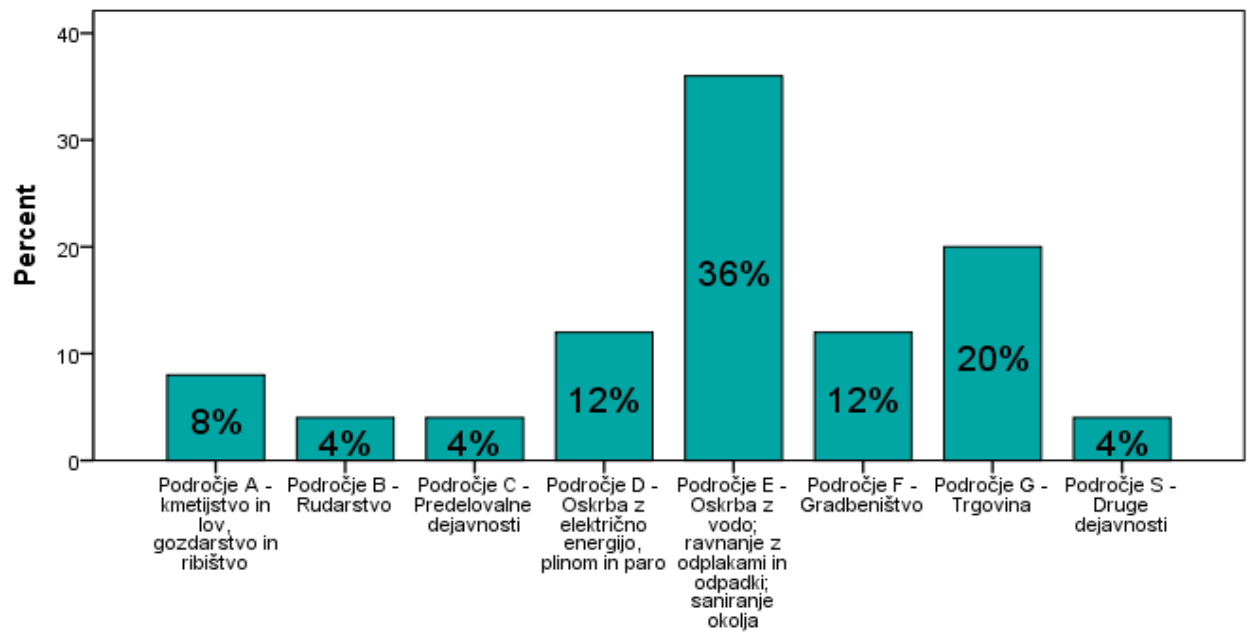

Slika 3: Klasifikacijska dejavnost podjetja.

Največ, $40 \%$ podjetij, ki so sodelovala v anketi, spada med mikro podjetja (imajo do 9 zaposlenih). $28 \%$ podjetij, ki so sodelovala $\mathrm{v}$ anketi, spada med majhna podjetja (imajo 10-49 zaposlenih) ali srednje velika podjetja (imajo 50-249 zaposlenih). Najmanj, $4 \%$ podjetij, ki so sodelovala $\mathrm{v}$ anketi pa spada med velika podjetja (imajo 250 ali več zaposlenih). 
P. Vujkovič, P. Šprajc \& A. Baggia: Krožno gospodarstvo v slovenskih podjetjih

Poleg osnovnih demografskih vprašanj, je raziskava vključevala tudi vprašanja povezana s poznavanjem pojma krožno gospodarstvo. Vprašanja so bila izbirna, nekatera tudi z možnostjo več izbir.

\section{$3 \quad$ Rezultati raziskave}

Osnovni namen raziskave je bil pridobiti vpogled v stanje na področju krožnega gospodarstva v Sloveniji. V skladu s tem so bila med drugim postavljena 3 ključna raziskovalna vprašanja:

- RV1: Ali je več kot polovica slovenskih podjetij seznanjena s pojmom krožno gospodarstvo?

- RV2: Kateri motivatorji za vzpostavitev krožnega gospodarstva so ključnega pomena za več kot polovico anketirancev?

- RV3: Katere ovire ki podjetjem preprečujejo, da bi se vključila v projekte krožnega gospodarstva so pomembne več kot polovici anketirancev?

Največ, 68 \% anketirancev je za pojem krožno gospodarstvo že slišalo vendar niso vedeli kaj pomeni. $20 \%$ anketirancev je za krožno gospodarstvo že slišalo in pojem dobro poznajo. $8 \%$ anketirancev se strinja s trditvijo, da je krožno gospodarstvo odlična rešitev za ohranjanje naravnih virov surovin, zato v podjetju že izvajajo poslovni model. Najmanj, 4 \% anketirancev pa razume pojem in način delovanja krožnega gospodarstva in zato razmišlja v smeri sodelovanja v projektu zapiranja snovnih tokov. Porazdelitev odgovorov glede poznavanja pojma krožno gospodarstvo je prikazana na Sliki 4.

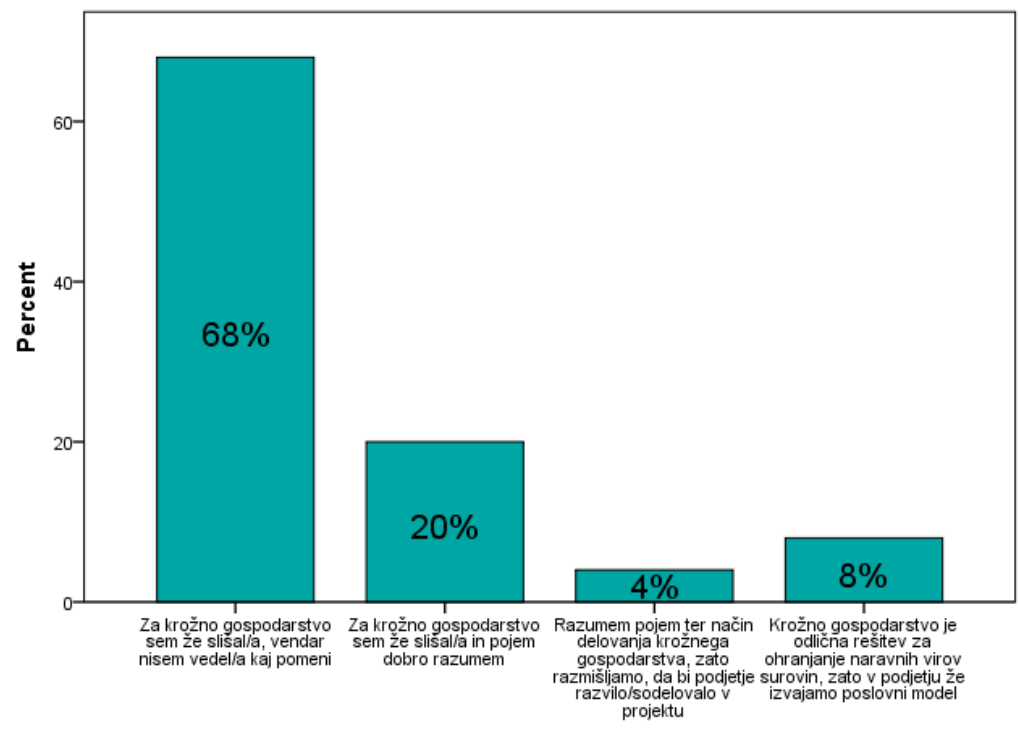

Slika 4: Poznavanje pojma krožno gospodarstvo. 
Prvi odgovor so izbrali anketiranci, ki so sicer že slišali za pojem krožno gospodarstvo, vendar ne vedo, kaj pomeni. Ostale 3 odgovore so izbrali anketiranci, ki so s pojmom krožno gospodarstvo bolj ali manj dobro seznanjeni. Na osnovi tega smo za analizo odgovore združili v 2 skupini: poznavalce in nepoznavalce. S testom deležev za en vzorec smo preverili, ali je več kot polovica anketirancev seznanjenih s pojmom krožno gospodarstvo. Rezultati so potrdili predvidevanja: trdimo lahko, da več kot polovica anketirancev ni seznanjenih s pojmom krožno gospodarstvo.

Glede na študij literature smo oblikovali seznam ključnih motivatorjev, ki bi lahko spodbujali podjetja k vključevanju v projekte krožnega gospodarstva. Na Sliki 5 so prikazane pogostosti odgovorov, ki so jih podali anketiranci. Vidimo lahko, da so najpogostejši motivatorji vezani na ekonomske priložnosti. Temu sledijo okoljske priložnosti, ter spremembe zakonodaje in povečan obseg recikliranja.

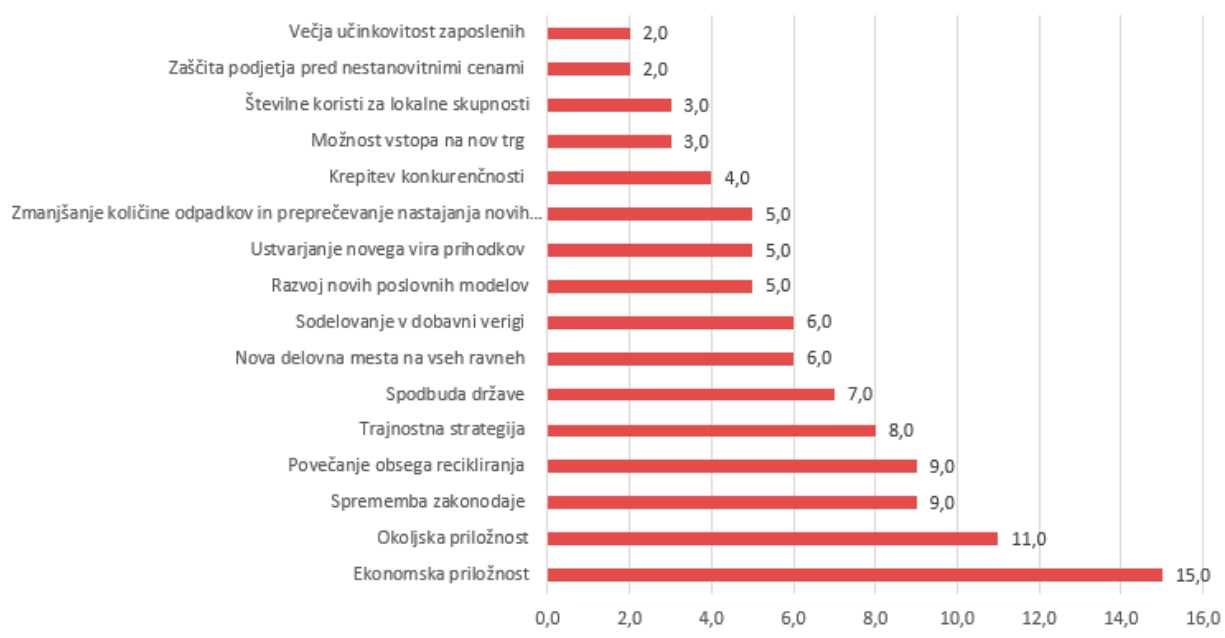

Slika 5: Ključni motivatorji za vključevanje v projekte krožnega gospodarstva.

S pomočjo testa deležev smo želeli ugotoviti, kateri motivatorji so pomembni za več kot $50 \%$ anketirancev. Več kot polovica anketirancev se strinja, da so pomembni motivatorji ekonomska priložnost, sprememba zakonodaje, okoljska priložnost, spodbuda države, povečanje obsega recikliranja ter trajnostna strategija.

Podjetja smo povprašali tudi o ovirah, ki jim preprečujejo, da bi izkoristili prednosti krožnega gospodarstva. Na Sliki 6 je prikazana pogostost pojavljanja posamezne ovire. 


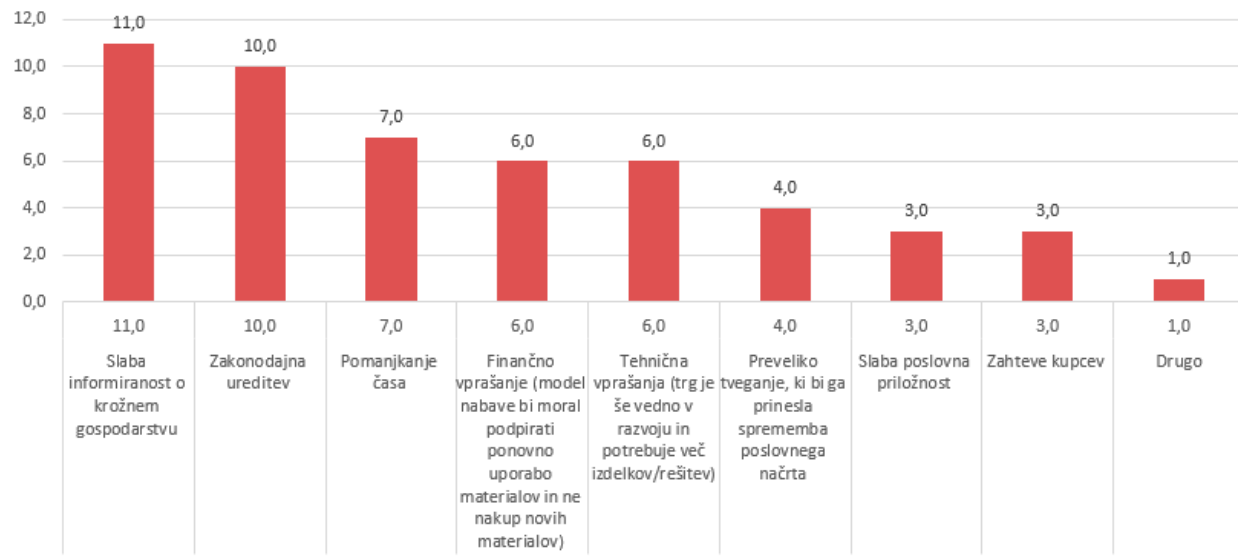

Slika 6: Ovire, ki podjetjem preprečujejo izkoriščanje prednosti krožnega gospodarstva.

Med ovirami, ki podjetjem preprečujejo, da bi primerno izkoristila prednosti krožnega gospodarstva, več kot polovico podjetij izbere slabo informiranost o krožnem gospodarstvu, zakonodajno ureditev ter pomanjkanje časa.

$34,8 \%$ anketirancev meni, da v njihovem podjetju zaposleni ne poznajo pojma krožnega gospodarstva. Pri tem ženske $(\bar{x}=2,75)$ v povprečju raven ozaveščenosti sodelavcev ocenjujejo statistično značilno višje $\left(\mathrm{p}=0,009<0,05, \mathrm{t}_{\mathrm{sp}=21}=-2,788\right)$ kot moški $(\bar{x}=$ $1,60)$. V $76 \%$ pa anketiranci menijo, da bi se moralo z uvajanjem in uresničevanjem modela krožnega gospodarstva v njihovem podjetju ukvarjati vodstvo. Spodbuden je podatek, da je 58,3 \% anketirancev pripravljenih prispevati $\mathrm{k}$ temu, da bi se krožno gospodarstvo bolj uveljavilo. Le 33,3\% anketirancev meni, da bi lahko uvedba modela krožnega gospodarstva podjetju prineslo dobiček (v obdobju od 2 do 10 let).

\section{$4 \quad$ Zaključek}

Če začnemo razmišljati trajnostno že danes, bomo lahko prihajajočim generacijam omogočili, da bodo lahko uživali vsaj v delčku narave, kakršne poznamo danes in ne v svetu polnem odpadkov. Model krožnega gospodarstva lahko bistveno prispeva k ohranjanju narave, virov ter omogoča določene ekonomske prednosti. Države po svetu se lotevajo uvajanja modela krožnega gospodarstva $\mathrm{v}$ podjetja na različne načine (Ghisellini, Cialani, \& Ulgiati, 2016). Kljub temu, da smo za področje Evropske unije našli bistveno manj relevantne literature na temo krožnega gospodarstva, kot pa na primer za področje Kitajske, se stvari premikajo tudi v Evropski uniji (Kobza \& Schuster, 2016). Slovenija kot del Evropske unije prav gotovo ne sme zaostajati pri uvajanju modela krožnega gospodarstva. Da bi ugotovili trenutno stanje in postavili izhodišča za promocijo modela krožnega gospodarstva v Sloveniji, smo izvedli pričujočo raziskavo. 
Že pri analizi vzorca lahko ugotovimo, da največji delež podjetij (36\%), ki so si vzeli čas in odgovarjali na vprašanja, predstavljajo podjetja, ki se ukvarjajo z oskrbo z vodo, ravnanjem $\mathrm{z}$ odplakami in odpadki. Rezultati so pokazali, da se slovenska podjetja premalo zavedajo pomena modela krožnega gospodarstva in na splošno model slabo poznajo. Med motivatorji so podjetja izpostavila ekonomske priložnosti, sledijo pa okoljske priložnosti. Slednje kaže, da se podjetja vedno bolj zavedajo okoljskih problemov. Dokaj velik pomen pa podjetja pripisujejo tudi zakonodaji in pobudam države, kar kaže na dejstvo, da bi bilo določene ukrepe smiselno sprejeti na državni ravni. Kot navajata Lieder \& Rashid (2016), za uspešno uvajanja modela krožnega gospodarstva ni dovolj samo pripravljenost posameznega podjetja, pač pa podpora vseh deležnikov, vključno z državo. Država bi navsezadnje lahko poskrbela tudi za boljšo informiranost podjetij glede modela krožnega gospodarstva, kar se je pokazalo kot najpogostejša ovira pri uvajanju modela v prakso. Predvidevamo, da bi v skladu z večjo informiranostjo pomen zakonodajnih ovir izgubil del pomena, ki mu ga podjetja trenutno pripisujejo.

Največja omejitev predstavljene raziskave je vsekakor velikost vzorca. Zaradi slabega odziva podjetij, predvsem pa velikega deleža podjetij, ki se z okoljem ukvarjajo že v svoji osnovni dejavnosti, bi morda lahko domnevamo, da so rezultati raziskave pristranski in bi večji vzorec pokazal na dejansko še manjše zavedanje podjetij in zaposlenih o modelu krožnega gospodarstva. V prihodnosti bi bilo smiselno raziskavo ponoviti ter poskušati primerjati rezultate raziskave s katero od ostalih evropskih držav.

\section{Literatura}

Bastein, T. (2014). Opportunities for a Circular Economy in The Netherlands An inspiring vision : the circular economy according to the Ellen MacArthur Foundation, 1-13.

Ellen MacArthur Foundation. (2013). Towards the Circular Economy: Opportunities for the consumer goods sector. Ellen MacArthur Foundation, 1-112. http://doi.org/10.1162/108819806775545321

Geng, Y., \& Doberstein, B. (2008). Developing the circular economy in China: Challenges and opportunities for achieving'leapfrog development'. International Journal of Sustainable Development \& World Ecology, 15(April 2016), 231-239. http://doi.org/10.3843/SusDev.15.3

Ghisellini, P., Cialani, C., \& Ulgiati, S. (2016). A review on circular economy: the expected transition to a balanced interplay of environmental and economic systems. Journal of Cleaner Production, 114, 11-32. http://doi.org/10.1016/j.jclepro.2015.09.007

Kobza, N., \& Schuster, A. (2016). Building a responsible Europe - the value of circular economy. IFAC-PapersOnLine, 49(29), 111-116. http://doi.org/10.1016/j.ifacol.2016.11.067

Lieder, M., \& Rashid, A. (2016). Towards circular economy implementation: a comprehensive review in context of manufacturing industry. Journal of Cleaner Production, 115, 36-51. http://doi.org/10.1016/j.jclepro.2015.12.042

Mathews, J. A., \& Tan, H. (2011). Progress toward a circular economy in China: The drivers (and inhibitors) of eco-industrial initiative. Journal of Industrial Ecology, 15(3), 435-457. http://doi.org/10.1111/j.1530-9290.2011.00332.x

Planing, P. (2014). Business Model Innovation in a Circular Economy Reasons for NonAcceptance of Circular Business Models. Open Journal of Business Model Innovation, (April 2015), 1-11. 
Preston, F. (2012). A Global Redesign? Shaping the Circular Economy. Energy, Environment and Resource Governance, (March), 1-20. http://doi.org/10.1080/0034676042000253936

Romero, D., \& Molina, A. (2012). Green virtual enterprise breeding environments: A sustainable industrial development model for a circular economy. IFIP Advances in Information and Communication Technology, 380 AICT, 427-436. http://doi.org/10.1007/978-3-642-327759_43

Schetters, M. J. A., Van Der Hoek, J. P., Kramer, O. J. I., Kors, L. J., Palmen, L. J., Hofs, B., \& Koppers, H. (2015). Circular economy in drinking water treatment: Reuse of ground pellets as seeding material in the pellet softening process. Water Science and Technology, 71(4), 479486. http://doi.org/10.2166/wst.2014.494

Smol, M., Kulczycka, J., Henclik, A., Gorazda, K., \& Wzorek, Z. (2015). The possible use of sewage sludge ash (SSA) in the construction industry as a way towards a circular economy. Journal of Cleaner Production, 95, 45-54. http://doi.org/10.1016/j.jclepro.2015.02.051

The Ellen MacArthur Foundation. (2012). Towards a Circular Economy - Economic and Business Rationale for an Accelerated Transition. Greener Management International, 97. http://doi.org/2012-04-03

Ying, J., \& Zhou, L.-J. (2012). Study on Green Supply Chain Management Based on Circular Economy. Physics Procedia, 25, 1682-1688. http://doi.org/10.1016/j.phpro.2012.03.295

Yuan, Z., Bi, J., Moriguichi, Y., \& Yuan. (2006). The Circular Economy: A New Development Strategy in China. Journal of Industrial Ecology, 10(1,2), 4-8. http://doi.org/10.1162/108819806775545321 
1296 36 ${ }^{\text {TH }}$ International Conference on Organizational Science Development: Responsible Organization (March $22^{\mathrm{ND}}-24^{\mathrm{TH}}$, Portorož Slovenia) 
$36^{\mathrm{TH}}$ InTERnational CONFERENCE ON ORganizational SCIENCE Development: Responsible Organization (MARCh $22^{\mathrm{ND}}-24^{\mathrm{TH}}$, PORTOROŽ SLOVENIA)

O. Arsenijević, M. Ferjan, I. Podbregar, P. Šprajc, D. Trivan \& Y.

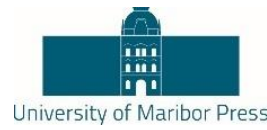

Ziegler?

\title{
Why are Virtual Teams Perfect for Marketing?
}

\author{
GORAN VUKOVIČ, MIHA MARIČ \& GAŠPER JORDAN
}

\begin{abstract}
In order to keep in step with the fast changing business world, organizations have to use all possibilities available to get advantage against competition. The use of technology is inevitable nowadays and it definitely gives the edge to organizations. When we talk about working teams, we generally have in mind a traditional face-to-face team. The use of technology gives organizations a possibility for team creation, of which members are dislocated, they do not interact in person between each other and they collaborate only by use of technology - they can create virtual teams. By that, we can get together different professional from all around the world who can generate knowledge, skills together with abilities to accomplish a given task. Virtual teams are increasing within different industries, because with them the organizations can get positive effects due to lower wages, cut of office space costs, decreased travel expenses, improved productivity, timing effectiveness, higher response speed and enhancing quality aspects of work. Furthermore, we believe they are perfect for marketing and we give recommendations for practical implications.
\end{abstract}

KEYWORDS: HRM・ marketing • virtual teams

CORRESPONDENCE AdDRESs: Goran Vukovič, Ph.D., Full Professor, University of Maribor, Faculty of Organizational Sciences, Kidričeva cesta 55a, 4000 Kranj, Slovenia, e-mail: goran.vukovic@fov.uni-mb.si; Miha Maričm, Ph.D., Assistant Professor, University of Maribor, Faculty of Organizational Sciences, Kidričeva cesta 55a, 4000 Kranj, Slovenia, e-mail: miha.maric@fov.uni-mb.si, Gašper Jordan, University of Maribor, Faculty of Organizational Sciences, Kidričeva cesta 55a, 4000 Kranj, Slovenia, e-mail: gasper.jordan77@gmail.com 


\section{$1 \quad$ Introduction}

Collaborative work environments and team-based structures are commonly used across different types of organizations (Webber \& Webber, 2015). Virtual team (VT) functions independently of organizational boundaries, geographical locations, and time zones while striving effectively to reach the team-specific goals (Haines, 2014; Snellman, 2014). VTs are more widespread than ever, because advances in technology have made it easier to organize and manager dispersed groups of people (DeRosa \& Lepsinger, 2010).

The competitive pressures in the business world and the need of today's global market workforce have made virtual teams a necessity for many organizations, so for that reason many companies are using VTs to reach business objectives (DeRosa \& Lepsinger, 2010; Mukherjee, Lahiri, Mukherjee \& Billing, 2012). Information and communication technologies (ICT) helped at the VT creation, a new type of working team (Duran \& Popescu, 2014). The ICT can consist of e-mail, telephony, instant messaging, and, in more sophisticated forms, videoconferencing, shared workspaces, and group decision support systems (Haines, 2014).

VTs are used by different organizations for increasing efficiency in vast activities domains, such as research and development, knowledge management, learning and training, manufacturing, marketing and others (Duran \& Popescu, 2014). There are some obvious VTs' advantages: people no longer have to work in the same place, participants can be involved in task attendance from any location around the globe, in any moment of day or night (Duran \& Popescu, 2014). Because VTs break the time and space barriers, can also utilizes at maximum the members experience from the organization (Duran \& Popescu, 2014). Taking into consideration such characteristics, VTs have a huge potential for improving the organizational efficiency (Duran \& Popescu, 2014), because of that, VTs are becoming more and more important and continuing to grow in popularity (Olariu \& Aldea, 2014).

Consequently, VTs can more easily respond to the changing requirements of the environment by making use of the latest knowledge, and adaptable working arrangements, and by taking advantage of increased application of information and communication technologies (Snellman, 2014). The new technologically mediated working arrangements require new leadership approaches that may explain how leadership is best practiced in virtual environment and what kind of leaders make VTs succeed (Snellman, 2014).

\section{$2 \quad$ Virtual teams}

As a result of the ever evolving concept of VTs, there is not even one common definition for it (Chen \& Messner, 2010; Schweitzer \& Duxbury, 2010). Positive facts of implementing the VTs are in overcoming geographical and time boundaries (Fuller, Marett \& Twitchell, 2012); profits due to lower wages (Hunsaker \& Hunsaker, 2008); the cut of office space costs, and decreased travel expenses (Schweitzer \& Duxbury, 2010); improved productivity (Chen \& Messner, 2010); timing effectiveness and higher 
response speed (Gressgård, 2011), and enhancing quality aspects of the work (Gignac, 2005). In addition, they get structures that are more flexible and agile in the organizational processes (Algesheimer, Dholakia \& Gurău, 2011).

With the VTs, organizations have an access to a comprehensive pool of dislocated skilled personnel with a variety of qualifications (Kirkman, Rosen, Gibson, Tesluk \& McPherson, 2002) resulting in better creativity and more innovations (Gibson \& Vermeulen, 2003). Some studies opined that implementing VTs for an organization could mean shifting from failure to success (Duarte \& Snyder, 2006).

On the contrary, any negligence in recognizing, addressing and taking appropriate measures to resolve the inherent challenges of any VT will jeopardize the efforts and investments by any organization to adopt them (Ebrahim, Ahmed \& Taha, 2009). The challenges in implementing the VTs could be regarded as the main disadvantages of utilizing them, which might end up with the project manager in having teams with less effectiveness and facing much more unknown risks than their conventional counterparts (Chen \& Messner, 2010; DeRosa \& Lepsinger, 2010).

Organizations that proactively take steps to support virtual team as well as periodically assess their effectiveness will see a much better return on investment. Therefore, they have to be focused on the crucial categories for assembling VT, due to their direct impact on VT's effectiveness (DeRosa \& Lepsinger, 2010):

- team composition;

- communication;

- training and,

- team leadership.

\section{$3 \quad$ How to build VTs in marketing}

\section{Team composition}

VTs should have a core group of members whose membership did not fluctuate frequently, because it can lead to a confusion "who is on the team" together with role ambiguity. If changes occur less frequently, the VTs will have a greater stability and more time for members to build productive work relationships (DeRosa \& Lepsinger, 2010).

We recommend the same number of team members for VTs, which is commonly used for "normal" teams, and that is between five and nine. VTs can still be bigger if so, but then members often create subgroups, which can paralyse VT's functioning. Therefore, it is much easier if we create smaller teams, which can collaborate.

Another matter, which we have to be aware of is, that team members should not be cross functional. That means that in marketing VT, we have to combine different specialist from marketing (e. g., sale persons, specialists for digital marketing, specialist for 
telephone marketing) to get best results possible. Because specialist or "best ones in the game" are not often in one location, we believe VTs are perfect solution to solve this issue.

\section{Team roles}

Belbin's $(1981,2012)$ model of team roles has been used extensively in organizations and research as a typology of teamwork behaviour and work group effectiveness. The Belbin Team Role Self-Perception Inventory (1981, 1993), has become widely known and utilized for selection of individuals into teams (Anderson \& Sleap, 2004). Belbin (2012) defined nine team roles: plant, resource investigator, co-ordinator, shaper, monitor evaluator, teamworker, implementer, complete finisher, and specialist.

\section{Communication}

Communication in organization and its structures is situated in time and space (Ocasio, Loewenstein \& Nigam, 2015). One of the main and hardest to achieve factors, which is a result of good relationships between team members and can enhance the effectiveness of the VTs, is trust (DeRosa \& Lepsinger, 2010).

Research shows that VTs with high degrees of trust are more proactive, more taskfocused, more optimistic, more frequently initiate interactions, and provide more productive feedback (Clark, Clark, \& Crossley, 2010). Team members have to trust their leaders, each other, and the organization to be effective, especially in the case of VTs (Chae, 2016; Gilson, Maynard, Young, Vartiainen, \& Hakonen, 2015).

Studies have shown that workers' trust in others is impacted by their ability to observe directly what others are doing (Aubert \& Kelsey, 2003; Clark, Clark \& Crossley, 2010; Robert, Denis, \& Hung, 2009), but some people are predisposed to trust because of their personalities or they can rely on the use of stereotypes to make initial judgments of trustworthiness (Ford, Piccolo \& Ford, 2017). Due to this fact, virtual environments make it difficult, if not impossible, for team members to observe each other as the fine distinction of daily informal interactions and nonverbal communications are lost in webbased communications (Kasper-Fuehrer \& Ashkanasy, 2001). Therefore, the organization, the leader, and team members must invent ways to be transparent with each other to build and sustain trust (Ford, Piccolo \& Ford, 2017).

The ability to collaborate in virtual environment relies heavily on extant trust among virtual members as knowledge sharing cannot occur freely without it (Tsai, Ma, Lin, Chiu $\&$ Chen, 2014). While the technology is the hardware of creating virtual trust, the actions of the involved in VTs are the software that builds and sustains the needed trust (Ford, Piccolo \& Ford, 2017). 
36. MEDNARODNA KONFERENCA O RAZVOJU ORGANIZACIJSKIH ZNANOSTI: ODGOVORNA 1301 ORgANIZACIJA (22. - 24. MAREC 2017, PORTOROŽ, SLOVENIJA)

G. Vukovič, M. Marič \& G. Jordan: Why are Virtual Teams Perfect for Marketing?

\section{Training}

Members have to develop skills, such as communication, interpersonal skills, collaboration skills, action planning, problem solving, and decision making. Firstly, you have to assess and choose those people, who have appropriate set of skills to work in VTs. Then it is better to choose targeted training over overall training. We have to provide necessary training before we launch VT, and then we can expect VT to perform well. We have to engage people, virtual training sessions are recommended. Members can work

\section{Team leadership}

There are evidences showing that around 50\% of unsuccessful projects with VTs are the results of the manager's incompetency at working with VTs (Schweitzer \& Duxbury, 2010). The main reason is that leaders use the same principals in VTs as they are used to do in "classic" teams (Ahuja, 2010).

\section{$4 \quad$ Discussion and implications}

VTs have grown in use in organizations to solve two key problems: (1) how to assemble an optimal array of human resources to solve problems that cross traditional teams, and (2) how to assemble teams that can address location-specific needs (Ford, Piccolo \& Ford, 2017). It is of great importance to be in step with the technological development, because it can give organizations to get ahead against competition.

In the first instance, organizations find that while they may have the human capabilities to address problems or take on tasks, these people are not co-located in one place, one building, or even in one organizational unit; they can be located in a variety of organizational or/as physical locations (Kirkman, Gibson, \& Kim, 2012).

Consequently, the only way to benefit from collective capabilities is to form a VT that can integrate and coordinate knowledge, skills, and abilities to accomplish a task (Ford, Piccolo \& Ford, 2017). Complicating the management and effectiveness of these teams is the common situation that some or even all of the team members are not assigned fulltime to a particular project team, but instead have multiple projects reporting to several different managers (Cummings \& Haas, 2012).

VTs depend on having appropriate communication technology to connect and support the members in ways that develop trust and organizations show that they support the team and its mission by providing this technology (Ford, Piccolo \& Ford, 2017). They can also consistently provide cues to the VTs, proving the organization is trustworthy (Ford, Piccolo \& Ford, 2017).

Specifically, the organization makes sure it assembles and sustains the best array of team members for the task, ensures that the team's leader is competent and capable of managing VTs, provides training and technology to support the team, and carefully monitors the professional and emotional needs of its remotely located employees. In 
36 ${ }^{\text {TH }}$ International Conference on Organizational Science Development: Responsible Organization (MARCH $22^{\mathrm{ND}}-24^{\mathrm{TH}}$, Portorož SlOVENIA)

G. Vukovič, M. Marič \& G. Jordan: Why are Virtual Teams Perfect for Marketing?

viewing these cues, VT members make determinations (as individuals and as a group) about whether the organization can be trusted (Ford, Piccolo \& Ford, 2017).

If trust is the glue that holds virtual teams together and ties them and their members to the organization's mission, then developing strategies that focus on these trust-building cues is a crucial component of managing VTs (Ford, Piccolo \& Ford, 2017). Therefore, fostering good teamwork, reducing uncertainty, and building successful relationships are particularly essential for successful collaboration in VTs (Chae, 2016). VTs with efficient communication can avoid the lack of team planning and eventually achieve team effectiveness (Berry, 2011).

\section{Literature}

Ahuja, J. (2010). A study of virtuality impact on team performance. IUP Journal of Management Research, 9(5), 27-56.

Algesheimer, R., Dholakia, U. M., \& Gurău, C. (2011). Virtual team performance in a highly competitive environment. Group \& Organization Management,36(2), 161-190. DOI: $10.1177 / 1059601110391251$

Anderson, N., \& Sleap, S. (2004). An evaluation of gender differences on the Belbin Team Role Self-Perception Inventory. Journal of Occupational and Organizational Psychology, 77(3), 429-437, DOI: 10.1348/0963179041752637

Aubert, B. A., \& Kelsey, B. L. (2003). Further understanding of trust and performance in virtual teams. Small group research, 34(5), 575-618. DOI: 10.1177/1046496403256011

Belbin, R. M. (1981). Managing teams: Why they succeed or fail. London: Heinemann.

Belbin, R. M. (1993). A reply to the Belbin team-role self-perception inventory by Furnham, Steele and Pendleton. Journal of Occupational and Organizational Psychology, 66, 249-260, DOI: 10.1111/j.2044-8325.1993.tb00536.x

Belbin, R. M. (2012). Team roles at work. Routledge.

Berry, G. R. (2011). Enhancing effectiveness on virtual teams: Understanding why traditional team skills are insufficient. The Journal of Business Communication (1973), 48(2), 186-206, doi: $10.1177 / 0021943610397270$

Camarinha-Matos, L., Afsarmanesh, H., \& Ollus, M., (2005). Virtual Organizations: Systems and Practices. Springer Verlag.

Chae, S. W. (2016). Perceived Proximity and Trust Network on Creative Performance in Virtual $\begin{array}{llll}\text { Collaboration } \quad \text { Environment. Procedia Computer } & \text { Science, 91, }\end{array}$ http://dx.doi.org/10.1016/j.procs.2016.07.084

Chen, C., \& Messner, J. I. (2010). A recommended practices system for a global virtual engineering team. Architectural Engineering and Design Management, 6(3), 207-221.

Clark, W. R., Clark, L. A., \& Crossley, K. (2010). Developing multidimensional trust without touch in virtual teams. Marketing Management Journal, 20(1), 177-193. Retrieved on 5.1.2017 from http://www.mmaglobal.org/publications/MMJ/MMJ-Issues/2010-Spring/MMJ-2010-SpringVol20-Issue1-Clark-Clark-Crossley-pp177-193.pdf

Clark, W. R., Clark, L. A., \& Crossley, K. (2010). Developing multidimensional trust without touch in virtual teams. Marketing Management Journal, 20(1), 177-193. Retrieved on 6.1.2017 from http://www.mmaglobal.org/publications/MMJ/MMJ-Issues/2010-Spring/MMJ-2010-SpringVol20-Issue1-Clark-Clark-Crossley-pp177-193.pdf 
36. MEDNARODNA KONFERENCA O RAZVOJU ORGANIZACIJSKIH ZNANOSTI: ODGOVORNA 1303 ORGANIZACIJA (22. - 24. MAREC 2017, PORTOROŽ, SLOVENIJA)

G. Vukovič, M. Marič \& G. Jordan: Why are Virtual Teams Perfect for Marketing?

Cummings, J. N., \& Haas, M. R. (2012). So many teams, so little time: Time allocation matters in geographically dispersed teams. Journal of Organizational Behavior, 33(3), 316-341. DOI: 10.1002/job.777

DeRosa, D. M., \& Lepsinger, R. (2010). Virtual Team Success. San Francisco: Jossey-Bass.

Duarte, D. L., \& Snyder, N. T. (2006). Mastering virtual teams: Strategies, tools, and techniques that succeed. John Wiley \& Sons.

Duran, V., \& Popescu, A. D. (2014). The challenge of multicultural communication in virtual teams. Procedia-Social and Behavioral Sciences, 109, 365-369. DOI: 10.1016/j.sbspro.2013.12.473

Ebrahim, N. A., Ahmed, S., \& Taha, Z. (2009). Virtual teams: a literature review. Australian Journal of Basic and Applied Sciences, 3(3), 2653-2669.

Ford, R. C., Piccolo, R. F., \& Ford, L. R. (2017). Strategies for building effective virtual teams: Trust is key. Business Horizons 60(1), 25-34. http://dx.doi.org/10.1016/j.bushor.2016.08.009

Fuller, C. M., Marett, K., \& Twitchell, D. P. (2012). An examination of deception in virtual teams: Effects of deception on task performance, mutuality, and trust. IEEE Transactions on Professional Communication, 55(1), 20-35. DOI: 10.1109/TPC.2011.2172731

Gibson, C., \& Vermeulen, F. (2003). A healthy divide: Subgroups as a stimulus for team learning behavior. Administrative Science Quarterly, 48(2), 202-239. DOI: 10.2307/3556657

Gignac, F., (2005). Building Successful Virtual Teams. Artech House: Boston.

Gilson, L. L., Maynard, M. T., Young, N. C. J., Vartiainen, M., \& Hakonen, M. (2015). Virtual teams research 10 years, 10 themes, and 10 opportunities. Journal of Management, 41(5), 1313-1337. DOI: $10.1177 / 0149206314559946$

Gressgård, L. J. (2011). Virtual team collaboration and innovation in organizations. Team Performance Management: An International Journal, 17(1/2), 102-119. http://dx.doi.org/10.1108/13527591111114738

Haines, R. (2014). Group development in virtual teams: An experimental $\begin{array}{llr}\text { reexamination. Computers in Human 213-222. } & \text { Behavior, 39, }\end{array}$ http://dx.doi.org/10.1016/j.chb.2014.07.019

Hunsaker, P. L., \& Hunsaker, J. S. (2008). Virtual teams: a leader's guide. Team Performance Management: An International Journal, 14(1/2), 86-101. http://dx.doi.org/10.1108/13527590810860221

Kasper-Fuehrera, E. C., \& Ashkanasy, N. M. (2001). Communicating trustworthiness and building trust in interorganizational virtual organizations. Journal of Management, 27(3), 235-254. DOI: $10.1177 / 014920630102700302$

Kirkman, B. L., Gibson, C. B., \& Kim, K. (2012). Across borders and technologies: Advancements in virtual teams research. In Kozlowski, S. W. J. (Ed.), The Oxford Handbook of Organizational Psychology, Volume 2. DOI: 10.1093/oxfordhb/9780199928286.013.0025

Kirkman, B. L., Rosen, B., Gibson, C. B., Tesluk, P. E., \& McPherson, S. O. (2002). Five challenges to virtual team success: Lessons from Sabre, Inc. The Academy of Management Executive, 16(3), 67-79. DOI: 10.5465/AME.2002.8540322

Mukherjee, D., Lahiri, S., Mukherjee, D., \& Billing, T. K. (2012). Leading virtual teams: how do social, cognitive, and behavioral capabilities matter?. Management Decision, 50(2), 273-290. http://dx.doi.org/10.1108/00251741211203560

Ocasio, W., Loewenstein, J., \& Nigam, A. (2015). How streams of communication reproduce and change institutional logics: The role of categories. Academy of Management Review, 40(1), 28-48, doi: 10.5465/amr.2013.0274

Olariu, C., \& Aldea, C. C. (2014). Managing processes for Virtual Teams-a BPM approach. Procedia-Social and Behavioral Sciences, 109, 380-384. DOI: 10.1016/j.sbspro.2013.12.476 
1304 36 $6^{\text {TH }}$ International Conference on Organizational Science Development: Responsible Organization (MARCH $22^{\mathrm{ND}}-24^{\mathrm{TH}}$, Portorož SlOVENIA)

G. Vukovič, M. Marič \& G. Jordan: Why are Virtual Teams Perfect for Marketing?

Robert, L. P., Denis, A. R., \& Hung, Y. T. C. (2009). Individual swift trust and knowledge-based trust in face-to-face and virtual team members. Journal of Management Information Systems, 26(2), 241-279.

Schweitzer, L., \& Duxbury, L. (2010). Conceptualizing and measuring the virtuality of teams. Information Systems Journal, 20(3), 267-295. DOI: 10.1111/j.1365-2575.2009.00326.x

Snellman, C. L. (2014). Virtual teams: opportunities and challenges for e-leaders. Procedia-Social and Behavioral Sciences, 110, 1251-1261. DOI: 10.1016/j.sbspro.2013.12.972

Tsai, Y. H., Ma, H. C., Lin, C. P., Chiu, C. K., \& Chen, S. C. (2014). Group social capital in virtual teaming contexts: A moderating role of positive affective tone in knowledge sharing. Technological Forecasting and Social Change, 86, 13-20. http://dx.doi.org/10.1016/j.techfore.2013.08.015

Webber, S. S., \& Webber, D. S. (2015). Launching and leading intense teams. Business Horizons, 58(4), 449-457. http://dx.doi.org/10.1016/j.bushor.2015.03.009 


\section{Strategija in kakovost visokega šolstva}

\section{BORUT WERBER}

Povzetek V prispevku so predstavljeni rezultati preliminarne študije glede stanja zapisanih strategij v visokošolskih zavodih in univerzah. Podatki so bili pridobljeni iz javno dostopnih spletnih strani univerz in visokošolskih zavodov. Ugotavlja se, da ni možno predvideti, kateri visokošolski zavod bo imel zapisano strategijo, glede na področje, kjer deluje. Ugotavlja se, da imajo samostojni zavodi v večini primerov bolje zapisano strategijo kot visokošolski zavodi, ki so člani univerz. Zapisani so nekateri razlogi za takšno stanje in predlogi za izboljšanje stanja v prihodnosti.

KLJUČNE BESEDE: strategija • visoko šolstvo • kakovost

\footnotetext{
NASLOV AVTORJEV: dr. Borut Werber, docent, Univerza v Mariboru, Fakulteta za organizacijske vede, Kidričeva cesta 55a, 4000 Kranj Slovenija, e-pošta: borut.werber@fov.uni-mb.si

DOI https://doi.org/10.18690/978-961-286-020-2.104 ISBN 978-961-286-020-2

(C) 2017 Univerzitetna založba Univerze v Mariboru

Dostopno na: http://press.um.si
} 
$36^{\text {Th }}$ International Conference on Organizational Science DEVElopMENT: Responsible ORganization (MARCH $22^{\mathrm{ND}}-24^{\mathrm{TH}}$, PORTOROŽ SLOVENIA)

O. Arsenijević, M. Ferjan, I. Podbregar, P. Šprajc, D. Trivan \& Y.

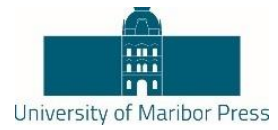

Ziegler

\title{
Strategy and Quality of Higher Education
}

\section{BORUT WERBER}

\begin{abstract}
This paper presents the results of a preliminary study dealing with implementation of strategies in written form on higher education institutions and universities. The data were obtained from public accessible websites of universities and higher education institutions. We found out that it's not possible to predict if strategy in written form will exist on higher education institution depending on the area where it operates. It is also noted that in most cases independent higher education institutions have a better-written strategy than the higher education institutions that are members of universities. Reasons for present situation are explained and suggestions for future improvement actions are given.
\end{abstract}

KEYWORDS: Strategy • High education • Quality

CorRespondence Address: Borut Werber, Ph.D., Assistant Professor, University of Maribor, Faculty of Organizational Sciences, Kidričeva cesta 55a, 4000 Kranj, Slovenia, e-mail: borut.werber@fov.uni-mb.si

DOI https://doi.org/10.18690/978-961-286-020-2.104 ISBN 978-961-286-020-2

(C) 2017 University of Maribor Press

Available at: http://press.um.si 


\section{$1 \quad$ Uvod}

V zadnjem desetletju so se razmere na področju slovenskega visokega šolstva zelo spremenile. Najprej se je pojavilo veliko število javnih in privatnih samostojnih visokošolskih zavodov, nato so se ustanovile še nove univerze, leta 2003 Univerza na Primorskem, leta 2006 Univerza v Novi Gorici in leta 2008 Evro-sredozemska univerza (EMUNI univerza), ki ima status zavoda. Po seznamu Ministrstva za izobraževanje znanost in šport je bilo na dan, 27.12.2016 v Sloveniji vpisanih v Razvid visokošolskih zavodov 105 visokošolski zavodov (MIZŠ, 2016). Na isti dan je bilo vpisanih 1635 študijskih programov prve, druge in tretje stopnje, vendar se nekateri ne izvajajo (MIZŠ (a), 2016). Za primerjavo $v$ študijskem letu 2002/2003 je študijsko dejavnost izvajalo 48 visokošolskih zavodov (Komljenovič \& Marjetič, 2010). Iz istega vira razberemo, da je bilo na dan, 30.6.2010 v Sloveniji vpisanih v Razvid visokošolskih zavodov 610 študijskih programov vseh treh stopenj. Ob vsej konkurenci se je pokazal vpliv gospodarske krize na število vpisanih izrednih študentov. Med tem, ko je v najboljših časih leta 2005 študiralo 42114 izrednih študentov (Komljenovič \& Marjetič, 2010), jih je v letih 2015/2016 le še 15529 (SURS, 2016).

Slovenija je kot članica EU upoštevala priporočila s področja kakovosti visokega šolstva in leta 2010 ustanovila Nacionalno agencijo Republike Slovenije za kakovost v visokem šolstvu (NAKVIS), ki skrbi za zunanje zagotavljanje kakovosti v skladu s Standardi in smernicami za zagotavljanje kakovosti v evropskem visokošolskem prostoru (Standards and Guidelines for Quality Assurance in the European Higher Education Area (European Association for Quality Assurance in Higher Education - ENQA)) (Debevec, Horvat, \& Šumig, 2013). NAKVIS skrbi za akreditacije in zunanje evalvacije visokošolskih in višješolskih zavodov in študijskih programov. Postopek se izvaja na osnovi Meril za akreditacijo in evalvacijo visokošolskih zavodov in študijskih programov (NAKVIS, 2014).

Agencija odloča o:

- akreditacijah visokošolskih zavodov;

- akreditacijah študijskih programov: prve stopnje, druge stopnje, tretje stopnje, skupnih študijskih programov in študijskih programov za izpopolnjevanje;

- preoblikovanju visokošolskih zavodov;

- spremembah obveznih sestavin študijskih programov samostojnih visokošolskih zavodov.

Visokošolski zavodi se presojajo po področjih:

1. vpetost $\mathrm{v}$ okolje,

2. delovanje visokošolskega zavoda,

3. kadri,

4. študenti,

5. materialni pogoji, 
1308 36 $6^{\text {Th }}$ International Conference on Organizational Science Development: Responsible Organization (MARCh $22^{\mathrm{ND}}-24^{\mathrm{TH}}$, PORTOROŽ Slovenia)

B. Werber: Strategy and Quality of Higher Education

6. zagotavljanje kakovosti, inovativnosti in razvojne naravnanosti.

Študijski programi se presojajo predvsem po:

7. sestavi in vsebini (NAKVIS, 2014).

Delovanje visokošolskega zavoda se ocenjuje po devetih točkah, pri čemer se v tem prispevku osredotočamo samo na drugo točko, ki se glasi:

2. Strategija visokošolskega zavoda vsebuje načrt in načine za uresničevanje postavljenih ciljev.

Cilj tega prispevka je prikazati pomen strategije v modelih kakovosti in dejansko stanje zapisanih strategij visokošolskih zavodov na osnovi javno objavljenih strategij visokošolskih zavodov in akreditacijskih poročil objavljenih na straneh NAKVISA.

\subsection{Teoretične osnove}

Strategija je sestavni del vsakega procesa kakovosti. Strategija vključuje vse organizacijske dejavnosti ter uporabo in dodeljevanje omejenih sredstev $\mathrm{v}$ organizacijskem okolju, tako da izpolnjujejo sedanje cilje (Lopez, 2016). Izdelava uspešnega strateškega plana ni enostavna naloga. V strokovni literaturi (Chaffee, 1985) se opisujejo trije osnovni modeli strategije in sicer, linearni, prilagodljivi - adaptivni in interpretativni. Organizacije največkrat uporabljajo linearni model strategije, ki temelji na planiranju in reševanju problemov za doseganje planiranih ciljev. Model prilagajanja ali adaptivni model temelji na spremljanju zunanjih in notranjih pogojev $\mathrm{s}$ ciljem prilagoditi dejavnost organizacije glede na priložnosti in nevarnosti $\mathrm{v}$ okolju. Interpretativni model temelji na usmerjenih metaforah izdelanih za namene konceptualizacije in vodenja posameznih stališč ali udeležencev v organizaciji (Chaffee, 1985).

Univerze $\mathrm{z}$ visokošolskimi zavodi in samostojni visokošolski zavodi morajo delovati tako, da zagotovijo skladnost delovanja zavoda $\mathrm{z}$ Merili za akreditacijo in evalvacijo visokošolskih zavodov in študijskih programov. Lahko pa uporabijo tudi kakšen drug model kakovosti, kot je evropski model poslovne odličnosti po European Foundation for Quality Management (EFQM) (Arjomandi, Kestell, \& Grimshaw, 2009; Becket, 2008), skupni ocenjevalni okvir v javnem sektorju (Common Assessment Framework - CAF) ali ISO 9001 (Becket, 2008). V vseh modelih je vsaj v nekaj členih zapisano, kako naj ima podjetje, organizacija ali zavod zapisano strategijo. V Merilih za akreditacijo in evalvacijo visokošolskih zavodov in študijskih programov je pod 24. členom za podaljšanje akreditacije zapisano;

Visokošolski zavod ima javno objavljeno poslanstvo in strategijo svojega delovanja, oziroma razvoja, iz katerih so jasno razvidni izobraževalni, znanstveni, raziskovalni, oziroma umetniški in strokovnimi cilji. Strategijo posodablja na podlagi samoevalvacijskih izsledkov. 
V modelu EFQM je pod strategijo zapisano:

- Odlična organizacija uresničuje svoje poslanstvo in vizijo z razvijanjem strategije, ki je ciljno usmerjena na deležnike. Za udejanjenje strategije razvijajo in širijo ustrezne politike, načrte, cilje in procese.

- Strategija temelji na razumevanju potreb in pričakovanj deležnikov ter zunanjega okolja.

- Strategija temelji na razumevanju lastnega delovanja in sposobnosti.

- Strategija in podporne politike se razvijajo, pregledujejo in posodabljajo.

- Strategija in podporne politike se posredujejo, izvajajo in spremljajo.

Skupni ocenjevalni okvir za organizacije v javnem sektorju - CAF, je kot izpeljanka EFQM modela za javni sektor in pod strategijo in načrtovanje določa:

- Zbiranje podatkov o trenutnih in prihodnjih potrebah udeleženih strani in relevantnih upravljavskih informacij

- Razvijanje strategije in načrtovanja ob upoštevanju zbranih informacij

- Sporočanje in izvajanje strategije in načrtovanja v celotni organizaciji ter redno pregledovanje

- Načrtovanje, izvajanje in pregledovanje inoviranja in sprememb

V ISO standardu ISO 9001:2015 (Kasperaviciute, 2013; Lopez, 2016), posebno poglavje namenjeno strateškemu planiranju. Razdeljeno je na naslednje korake:

- Analiza / Ocena - razumevanje in razvoj sistema notranjega in zunanjega okolja.

- Oblikovanje strategije - Razviti in dokumentirati strategijo na visoki ravni in osnovno strategijo na organizacijski ravni.

- Izvedba strategije - Prevedi načrte v ukrepe, kjer so opredeljeni bolj operativni cilji in so prepoznani in določeni specifični potrebni ukrepi.

- Vrednotenje / ohranjanje uspešnosti / upravljanje - Opravite stalno izpopolnjevanje in vrednotenje uspešnosti delovanja, kulture, komunikacij, sporočanja podatkov, in drugih vprašanja strateškega upravljanja.

Predstavljen je proces strateškega planiranja, ki ga sestavljajo naslednji koraki:

- Zbiranje vhodnih podatkov (vseh deležnikov, analiza strank, konkurence, okolja, delovnega področja, delovanja organizacije in strategije organizacije)

- Izvedba SWOT analize (zunanja- priložnosti in nevarnosti, notranja-prednosti in slabosti, strateška vprašanja, strateški cilji)

- Pregled podatkov (vseh deležnikov, vhodnih podatkov, SWOT analize, določitev 3-4 ključnih strateških stališč)

- Strateška matrika (vseh deležnikov, določi strategije za rezultate SWOT analize za kombinacije - priložnosti nasproti prednostim, priložnosti nasproti slabostim, grožnjam nasproti prednostim, grožnjam nasproti slabostim) 
$1310 \quad 36^{\mathrm{TH}}$ INTERnational CONFERENCE ON ORganizational SCIENCE DeVElopment: Responsible ORganization (MARCh $22^{\mathrm{ND}}-24^{\mathrm{TH}}$, PORTOROŽ Slovenia)

B. Werber: Strategy and Quality of Higher Education

- Opredeli strategije (strateške cilje, ključne strategije, dolgoročne in kratkoročne cilje, operativne načrte)

- Končni pregled in prilagoditve (vseh deležnikov, pregled strategij, ciljev, planov in po potrebi njihova prilagoditev)

Predlaga se tudi identifikacija ključnih dejavnikov uspeha. Identifikacija naj bi bila na osnovi pogleda s strani trga in uporabnikov naših uslug in produktov (Lopez, 2016).

\section{$2 \quad$ Strategija v visokošolskih zavodih}

V Sloveniji imamo različne načine organiziranosti univerz. V nekaterih primerih so visokošolski zavodi pravni subjekti $\mathrm{z}$ avtonomijo znotraj univerze, $\mathrm{v}$ drugih bolj centraliziranih univerzah se vse odvija preko univerze in so fakultete odvisne od njenega delovanja. $\mathrm{V}$ določenih primerih imajo skupne finančne in druge podporne službe, $\mathrm{v}$ drugih imajo lastne službe ločene od univerze. Sodelovali smo v postopkih akreditacij nekaterih visokošolskih zavodov in njihovih študijskih programov. Med analizo vlog smo opazili, da je področje strategije v nekaterih visokošolskih zavodih večkrat zapostavljeno saj imajo namesto zapisane strategije bodisi samo strateške cilje, akcijske načrte, nekateri pa se sklicujejo na strategijo univerze in nimajo lastne strategije. Zanimalo nas je ali je opazna razlika pri pisanju strategij visokošolskih zavodov glede na področje delovanja. Zanimalo nas je tudi, ali imajo samostojni visokošolski zavodi drugače definirane strategije kot visokošolski zavodi, ki so člani univerz.

\subsection{Metodologija}

Glavni namen našega raziskovanja je bilo potrditi ali zavrniti domneve iz prakse o neustrezno zapisanih strategijah na nekaterih visokošolskih zavodih in univerzah ter pripraviti okvirje za izvedbo kvantitativne raziskave s statistično obdelavo podatkov. Kot osnovno metodo raziskovanja smo izbrali preliminarno študijo. Za opis teoretičnih osnov smo uporabili metodo študija literature z metodo komparacije in sinteze.

Zapisane strategije ali njihove približke smo pridobili na spletnih straneh univerz in visokošolskih zavodih. Kadar nismo našli podatkov o strategiji med vizijo in poslanstvom, smo preverili, če je strategija omenjena kje na področju kakovosti.

\subsection{Rezultati preliminarne študije}

Najprej smo pregledali kako imajo strategije zapisane na visokošolskih zavodih univerz. Najstarejša univerza v Sloveniji, Univerza v Ljubljani (UL, 2017) ima 26 fakultet in akademij. Strategija na članicah je bodisi v obliki enega ali več strateških ciljev ali pa neposredno nadomeščena s strategijo univerze. Zanimivo je, da na fakultetah, kjer bi naj poučevali tudi s področja strateškega planiranja in strategij, strategij sploh nimajo zapisanih, medtem ko na nekaterih tehničnih fakultetah (npr. FRI UL) najdemo dobro zapisane strategije $\mathrm{z}$ realnimi cilji razdeljeno po vseh področjih ocenjevanja. Nekatere fakultete imajo namesto strategije zapisane strategije kakovosti, kar pa ni isto. Če 
povzamemo, ni pravila, po katerem bi lahko v naprej napovedali, katera fakulteta ali akademija bo imela zapisano lastno strategijo in ostalo za potrebe akreditacije zapisano v Merilih za akreditacijo in evalvacijo visokošolskih zavodov in študijskih programov.

Univerza v Mariboru (UM, 2017) je po organizacijski strukturi drugačna od Univerze v Ljubljani. Univerza v Mariboru ima 17 visokošolskih zavodov. Tudi tukaj ni možno v naprej napovedati, katera fakulteta bo imela strategijo v obliki strateških usmeritev, strateških ciljev, strategije delovanja in strateških načrtov, je pa verjetnost, da boste našli nekaj v zvezi s strategijo vseeno večja kot na Univerzi v Ljubljani.

Univerza na Primorskem (UP, 2017) ima šest visokošolskih zavodov in eno pridruženo članico. Na spletnih straneh nismo našli informacij o strategiji univerze ali dokumentov s podobnim naslovom. Iskanje s pomočjo Googl-a pa je prikazalo Srednjeročno razvojno strategijo za obdobje 2014-2020. Tudi na članicah je malo informacij o strategijah, nekatere fakultete imajo strateške cilje ali poslovnik kakovosti.

Univerza v Novi gorici (UNG, 2017) vključuje pet fakultet, eno visoko šolo in eno akademijo. Na spletnih straneh univerze najdemo zapis vizije ni pa podatkov o strategiji, podobno je na straneh članic. Večina ima zapisano vizijo.

Samostojni visokošolski zavodi so razporejeni po celi Sloveniji. Seznam vodi Ministrstvo za visoko šolstvo, znanost in tehnologijo (MZVŠZT, 2017). Za test smo si izbrali naslednje samostojne visokošolske zavode:

- Evropska pravna fakulteta v Novi Gorici (Poslanstvo, vizija in strategija) http://www.evro-pf.si/fakulteta/o-fakulteti/poslanstvo-vizija-in-strategija/

- Fakulteta za državne in evropske študije (STRATEGIJA RAZVOJA IN INTERNACIONALIZACIJE DO LETOA 2020) http://www.fds.si/attachments/article/1444/STRATEGIJA\%20RAZVOJA\%20I N\%20INTERNACIONALIZACIJE\%20FDS\%20DO\%202020.pdf

- Fakulteta za informacijske študije v Novem mestu (STRATEŠKI NAČRT FAKULTETE ZA INFORMACIJSKE ŠTUDIJE V NOVEM MESTU 20152020) http://www.fis.unm.si/si/o-fakulteti/katalog-dokumentov/

- Fakulteta za organizacijske študije v Novem mestu (STRATEŠKI NAČRT FAKULTETE ZA ORGANIZACIJSKE ŠTUDIJE V NOVEM MESTU 20152020) http://www.fos.unm.si/media/pdf/Programski\%20in\%20strateki\%20dokumenti/ STRATEsKI_NAcRT_FOs_2015_2020_sprejet 2014_12_22_za_spletno_stran .pdf

- Fakultete za komercialne in poslovne vede iz Celja (STRATEGIJA FKPV 2014-2020) http://www.fkpv.si/wp-content/uploads/2016/09/strategija_20142020_zadnja.pdf

- Fakulteta za uporabne družbene študije v Novi Gorici_(STRATEŠKI NAČRT FUDS 2015-2010) 
1312 36 $6^{\mathrm{TH}}$ INTERnational CONFERENCE ON ORganizational SCIENCE DeVElopment: ResPonsible Organization (MARCH $22^{\mathrm{ND}}-24^{\mathrm{TH}}$, PortoroŽ SLOVENIA)

B. Werber: Strategy and Quality of Higher Education

http://www.fuds.si/sites/default/files/strateski_nacrt_fuds_2015-20_20-

kot_sprejet_na_senatu.pdf

- Visoka šola za računovodstvo, Ljubljana (STRATEŠKI NAČRT VISOKE ŠOLE ZA RAČUNOVODSTVO ZA OBDOBJE 2014 - 2018)

http://www.vsr.si/Datoteke/STRATESKINACRTVSR20142018.pdf

- IBS Mednarodna poslovna šola Ljubljana (STRATEGIJA MEDNARODNE POSLOVNE ŠOLE LJUBLJANA 2015 - 2020)

http://www.ibs.si/docs/STRATEGIJA_IBS.pdf

Izbira samostojnih visokošolskih zavodov je bila narejena tako, da smo poskusili zajeti raznolike zavode tako po področju delovanja kot po regiji. Ker se samostojni visokošolski zavodi ne morejo izgovarjati na strateške akte univerze, imajo svoje strategije zapisane na zavidljivi ravni. Zanimivo je, da ni pomembno ali visokošolski zavod izvaja redni ali izredni študij, niti s katerega področja prihaja.

\subsection{Povzetek ugotovitev}

Če povzamemo ugotovitve pregleda javno dostopnih informacij na spletnih straneh univerz in visokošolskih zavodov, lahko zaključimo, da obstaja večja verjetnost, da bo imel samostojni visokošolski zavod bolje opredeljeno vizijo, poslanstvo in strategijo, kot članice univerz. Skoraj ni dvoma, da je eden od razlogov takega stanja možnost, da se visokošolski zavod sklicuje na skupno strategijo univerze in s tem zagovarja zakaj visokošolski zavod nima svoje strategije. Sedaj se postavi vprašanje ali je lahko strategija univerze enaka strategiji visokošolskega zavoda. Če gledamo iz organizacijskega vidika, bi to pomenilo, da je strategija korporacije enaka strategijam podjetij v njej in verjetno se vsi strinjamo, da to ni izvedljivo. Lahko imajo skupne strateške cilje, nikakor pa ne more strategija korporacije zajemati različne strateške cilje podjetij iz različnih področij. Na primer področje izrednega študija. Nekatere fakultete ne čutijo potrebe, da bi izvajale izredni študij, medtem, ko je za druge to spet pomemben vir financiranja. Če taka fakulteta nima opredeljene strategije izrednega študija, ne bo postavila potrebnih ciljev, marketinških pristopov (Ackerman \& Schibrowsky, 2007), definirala postopkov in akcij ter rezervirala sredstva s katerimi bo lahko te akcije izvedla in tako zagotovila ustrezne pogoje za izvedbo izrednega študija. Podobno je s področjem študij na daljavo (Allen \& Seaman, 2013). Ena izmed univerz je sprejela sklep, da morajo fakultete $50 \%$ gradiv predmetov prilagoditi študiju na daljavo. Ker strategija uvedbe študija na daljavo ni bila dodelana, ni bilo ustreznih mehanizmov za podporo in je vse ostalo na nivoju osnovnih funkcionalnosti v odvisnosti od samoiniciative visokošolskih zavodov. Po nekaj izvedbah predavanj so ugotovili, da e-predavanja niso enako primerna $\mathrm{z}$ vse predmete in so pri nekaterih začeli z nižanjem razmerij med klasičnimi in e-predavanji. Še vedno ni mehanizmov, ki bi omogočili pripravo dobrih elektronskih gradiv ali alternativnih metod dela, ki jih omogoča e-študij. Tudi področje strategije kadrov (Obeng, 2016) je drugačno s stališča univerze in visokošolskih zavodov. Ker ni zapisanih strategij kadrovske politike, ciljev, planiranih sredstev se kadruje na hitro, po potrebi, in še to po možnosti med sorodniki in znanci. Še en efekt centralizacije (López, 2006) univerze lahko vpliva na delovanje visokošolskih zavodov. Ker se finančna sredstva iz države nakažejo 
neposredno na univerzo ima ta možnost upravljati s finančnimi viri. Visokošolski zavodi so odvisni od modelov delitev sredstev, ki v tistem obdobju veljajo tudi, če niso osnovani na strateških ciljih in načrtih univerz in visokošolskih zavodov. Zanimivo je dejstvo, da je strategija vezana na izgradnjo stavb in predavalnic in dokler tak projekt traja, je vsakemu visokošolskemu zavodu kristalno jasno, kaj je njihov glavni strateški cilj za naslednje obdobje. Ko pa se materialni pogoji ustalijo in večino stroškov pokrijejo viri iz javnih sredstev, pa vodstvom visokošolskih zavodov beseda strategija spremeni pomen in jo raje zavijejo v strateške cilje, analize, samoevalvacije in mednarodne akreditacije. Zakaj prihaja do takih razlik? Najprej lahko ugotovimo, da so dekani fakultet voljeni iz vrst visokošolskih učiteljev, ki pa $\mathrm{v}$ večini primerov ne delujejo znanstveno niti pedagoško na področju managementa in torej nimajo ustreznih znanj, ki bi jih potrebovali za izdelavo strategij. Drugi razlog je ta, da ni enostavno napisati dobro strategijo (Lopez, 2016). Tretji razlog je dejstvo, da strategijo ne uporabljajo niti na nivoju nekaterih univerz, zato je posledično tudi manj strateških načrtov na članicah takih univerz. Vse skupaj kaže, da je to področje potrebno dodatne analize in bi s pomočjo uporabe strateških mehanizmov (Ahmed, Ahmed, Shimul, \& Zuñiga, 2015) izboljšali delovanje in kakovost marsikaterega visokošolskega zavoda.

\subsection{Omejitve raziskovanja}

Kot je bilo povedano že prej, ta prispevek predstavlja rezultate preliminarne študije, ki je imela namen ugotoviti ali so zaznani indici iz prakse med postopki evalvacij, o slabo zapisanih strategijah na nekaterih visokošolskih zavodih, resnični. Ker nismo preverili zapisanih strategij vseh visokošolskih zavodov v Slovenji bi morali naše zaključke preveriti s kvantitativno analizo in statistično obdelavo podatkov. Rezultati temeljijo na osnovi opazovanj januarja, 2017. To pomeni, da ni nujno, da je stanje na današnji dan, ko je ta prispevek objavljen, enako, saj so lahko visokošolski zavodi v tem času kakšen zapis strategije spremenili. Mnenje avtorja je osebno mnenje in ni njuno, da je skladno s stališči NAKVIS-a.

\section{Zaključek}

Pregled javno dostopnih informacij o zapisih strategij na univerzah in visokošolskih zavodih je pokazal, da stanje po našem mnenju ni zadovoljivo. Večina visokošolskih zavodov ima sicer zapisano vizijo in poslanstvo, nekateri imajo nekaj strateških ciljev, zelo malo pa ima dejansko zapisano strategijo bodisi omejeno na področje poučevanja in raziskovanja ali pa celotno strategijo za vsa področja ocenjevanja kakovosti visokošolskih zavodov. Ugotavlja se, da imajo samostojni visokošolski zavodi v večini primerov bolje zapisano strategijo kot članice univerz. Razlog je $\mathrm{v}$ dejstvu, da se samostojni visokošolski zavodi ne morejo sklicevati na strategijo univerze. Ugotavlja se, da strategija univerze ne more biti nadomestilo za strategijo članice, saj je strategija univerze na višjem nivoju in ne more zajemati vseh specifičnih potreb visokošolskih zavodov. Ugotavlja se, da je oblika strategije odvisna od kompetenc vodstev visokošolskih zavodov, ki prihajajo iz vrst visokošolskih učiteljev in v večini primerov nimajo formalne izobrazbe s področja managementa, zato se predlaga univerzam naj omogočijo dodatno usposabljanje za novo izvoljene dekane in prodekane. Ni odveč niti 
1314 36 $6^{\text {TH }}$ International Conference on ORganizational Science Development: Responsible Organization (MARCh $22^{\mathrm{ND}}-24^{\mathrm{TH}}$, PORTOROŽ Slovenia)

B. Werber: Strategy and Quality of Higher Education

primerjava s srednješolskim in osnovnošolskim sistemom, kjer je za funkcijo ravnatelja potrebno opraviti strokovni izpit za ravnatelja. Svet NAKVIS-a oziroma NAKVIS kot izvajalec zagotavljanja kakovosti $\mathrm{v}$ slovenskem prostoru, bi moral zahtevati, da se to področje bolj upošteva pri akreditacijah tudi tako, da bi v Merilih za akreditacijo in evalvacijo visokošolskih zavodov in študijskih programov bolj natančno opredelil pomen zapisanih strategij podobno kot je v modelih odličnosti EFQM, CAF, ISO in drugih, ki se nanašajo na kakovost.

\section{Literatura}

Ackerman, R., \& Schibrowsky, J. (2007). A Business Marketing Strategy Applied to Student Retention: A Higher Education Initiative. Journal of College Student Retention: Research, Theory and Practice, 9(3), 307-336. https://doi.org/10.2190/CS.9.3.d

Ahmed, J. U., Ahmed, K. U., Shimul, M. A. S., \& Zuñiga, R. (2015). Managing strategies for higher education institutions in the UK: An overview. Higher Education for the Future, 2(1), 32-48. https://doi.org/10.1177/2347631114558189

Allen, I. E., \& Seaman, J. (2013). Changing course: ten years of tracking online education in the United States. Nursing Standard (Royal College of Nursing (Great Britain) : 1987), 26, 47. https://doi.org/10.1177/0165551508095781

Arjomandi, M., Kestell, C., \& Grimshaw, P. (2009). An EFQM Excellence Model for higher education quality assessment. Engineering Education, (2004), 1015-1020. Retrieved from http://aaee.com.au/conferences/AAEE2009/PDF/AUTHOR/AE090149.PDF

Becket, N. (2008). Quality Management Practice in Higher Education - What Quality Are We Actually Enhancing? The Journal of Hospitality, Leisure, Sport and Tourism, 7(1), 40-54. https://doi.org/10.3794/johlste.71.174

Chaffee, E. E. (1985). Three Models of Strategy. Academy of Management Review, 10(1), 89-98. https://doi.org/10.5465/AMR.1985.4277354

Debevec, T., Horvat, T., \& Šumig, D. (2013). Predstavitvena brošura Nacionalne agencije Republike Slovenije za kakovost v visokem šolstvu. Nacionalna agencija Republike Slovenije za kakovost v visokem šolstvu. Retrieved from http://www.nakvis.si/sl-SI/Content/GetFile/235

Kasperaviciute, R. (2013). Application of ISO 9001 and EFQM Excellence Model within Higher Education Institutions: Practical Experiences Analysis. En Línea, 2013(1), 81-92. Retrieved from http://stics.mruni.eu/wp-content/uploads/2013/06/STICS_2013_1.pdf\#page=81

Komljenovič, J., \& Marjetič, E. (2010). DRZNA SLOVENIJA: na poti v družbo znanja. DRZNA SLOVENIJA: na poti v družbo znanja.

Lopez, C. (2016). The New ISO 9001_2015 - Strategic Planning is Key to Implementation Missouri Enterprise. Retrieved January 29, 2017, from http://www.missourienterprise.org/blog/24-business-growth/119-the-new-iso-9001-2015strategic-planning-is-key-to-implementation

López, M. J. G. (2006). Towards decentralized and goal-oriented models of institutional resource allocation: The Spanish case. Higher Education, 51(4), 589-617. https://doi.org/10.1007/s10734-004-1905-y

MIZŠ. (2016). EVŠ EVIDENCA VISOKOŠOLSKIH ZAVODOV IN ŠTUDIJSKI PROGRAMOV - zavodi. Ministrstvo za izobraževanje, znanost in šport. Retrieved from http://www.mizs.gov.si/fileadmin/mizs.gov.si/pageuploads/Visoko_solstvo/razvid/eVS_VSZ _27122016.xlsx

MIŽ́ (a). (2016). EVŠ EVIDENCA VISOKOŠOLSKIH ZAVODOV IN ŠTUDIJSKI PROGRAMOV - programi. Ministrstvo za izobraževanje, znanost in šport. Retrieved from 
http://www.mizs.gov.si/fileadmin/mizs.gov.si/pageuploads/Visoko_solstvo/razvid/eVS_progr ami_27122016.xlsx

MZVŠZT. (2017). Ministrstvo za visoko šolstvo, znanost in tehnologijo. Retrieved January 23, 2017 , from http://www.arhiv.mvzt.gov.si/si/delovna_podrocja/visoko_solstvo/dejavnost_visokega_solstv a/seznam_visokosolskih_zavodov/index.html\#c16323

NAKVIS. M E R I L A za akreditacijo in zunanjo evalvacijo visokošolskih zavodov in študijskih programov, Pub. L. No. 0072-6/2010/39 (2014). Slovenija: NAKVIS. Retrieved from http://www.nakvis.si/sl-SI/Content/GetFile/633

Obeng, E. (2016). Human Resource Management: Gaining a Competitive Advantage, 1-4.

SURS. (2016). Število študentov v Sloveniji še naprej pada, a še vedno študira skoraj polovica mladih (19-24 let). Retrieved from http://www.stat.si/StatWeb/prikazinovico id $=5929 \&$ idp $=9$ \&headerbar $=7$

UL. (2017). Univerza v Ljubljani. Retrieved January 23, 2017, from https://www.uni-lj.si/slo/\#

UM. (2017). Univerza v Mariboru. Retrieved January 23, 2017, from https://www.um.si/univerza/clanice/Strani/default.aspx

UNG. (2017). Univerza v Novi Gorici. Retrieved January 23, 2017, from http://www.ung.si/sl/studij/

UP. (2017). Univerza na Primorskem. Retrieved January 23, 2017, from https://www.upr.si/s1 
1316 36 $36^{\text {Th }}$ International Conference on ORganizational Science DeVelopment: RESPonsible ORGANIZATION (MARCH $22^{\mathrm{ND}}-24^{\mathrm{TH}}$, PORTOROŽ SLOVENIA) 
$36^{\mathrm{TH}}$ InTERnational CONFERENCE ON ORganizational SCIENCE Development: Responsible Organization (MARCh $22^{\mathrm{ND}}-24^{\mathrm{TH}}$, PORTOROŽ SLOVENIA)

O. Arsenijević, M. Ferjan, I. Podbregar, P. Šprajc, D. Trivan \& Y. Ziegler

\title{
The Role of Marketing Communications in Responsible Organizations
}

\author{
LePosava ZEČEVIĆ, OlgiCA ZEČEVIĆ STANOJEVIĆ \& ANA MilenKOVić
}

\begin{abstract}
In the contemporary business environment, the number of responsible organizations is constantly increasing. Responsibility is reflected onto various fields such as micro environment of an organization, and macro environment, as well. Being responsible means being precise, consistent, correct, taking control, making strategy, motivating, making achievements for the overall business system. If we discuss the ethical, moral, social or financial workforce responsibility, we have to bear in mind that good communication within an organization and communication between the organization and public audience create an excellent predisposition to responsible business. Since marketing communications nowadays provide us with $100 \%$ transparency, organizations invest additional effort to position its responsibility and spread it to new segments. Therefore, this paper will focus on the role and the importance of marketing communications in responsible organizations. Through the current examples of leading companies from the field of social responsibility, we demonstrate how marketing communications affect awareness of customers and their complementary activities.
\end{abstract}

KEYWORDS: organization - responsible - social - communication • marketing $\bullet$ traditional $\bullet$ digital $\bullet$ target $\bullet$ companies $\bullet$ audience $\bullet$ media $\bullet$ business

CORRESPONDENCE AdDRESS: Leposava Zečević, Ph.D., European University, Faculty of European Business and Marketing, Duke Dobrnjca 15, 11000 Belgrade, Serbia, e-mail: febmeu@gmail.com; Olgica Zečević Stanojević, Ph.D., European University, Faculty of European Business and Marketing, Duke Dobrnjca 15, 11000 Belgrade, Serbia, e-mail: febmeu@gmail.com; Ana Milenković, Ph.D., European University, Faculty of European Business and Marketing, Duke Dobrnjca 15, 11000 Belgrade, Serbia, e-mail: febmeu@gmail.com 
1318 36 $6^{\mathrm{TH}}$ INTERNATIONAL CONFERENCE ON ORGANizATIONAL SCIENCE DEVElopment: RESPONSIBLE ORGANIZATION (MARCH $22^{\mathrm{ND}}-24^{\mathrm{TH}}$, PORTOROŽ SLOVENIA)

L. Zečević, O. Zečević Stanojević \& A. Milenković The Role of Marketing Communications in Responsible Organizations

\section{The Role of Marketing Communications}

The challenge of marketing communications is to convey the correct and clear message in a right way to a selected target audience, at the right place at the right time.

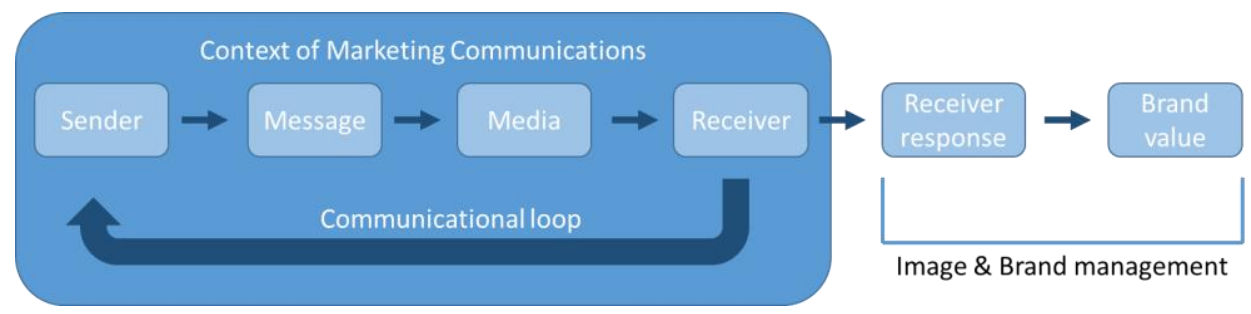

Image 1: [ Macromodel of marketing communications ]

The model points out the key factors in the effective communication. The senders must know the audience they want to reach as well as the answers they want to get. The senders codify their messages that the audience can decipher. The messages are sent via media that reach the target audience and build the channels for receiving feedback so that the answer could be followed. The more experiences of the sender overlap with the experiences of the receiver, the higher the possibility of message effectiveness.

\subsection{Using traditional media vs. digital communication}

Traditional media such as print, TV and radio are push media - one-way streets where information is mainly unidirectional, from company to customer unless direct response elements are built in. In contrast, many digital marketing activities like content, search and social media marketing are pull media and inbound marketing. Amongst marketing professionals this new approach to marketing is now commonly known as inbound marketing (Shah and Halligan 2009). Inbound marketing is powerful since advertising wastage is reduced. Content and search marketing can be used to target prospects with a defined need - they are proactive and self-selecting. But this is a weakness since marketers may have less control than in traditional communications where the message is pushed out to a defined audience and can help generate awareness and demand. Advocates of inbound marketing argue that content, social media and search marketing do have a role to play in generating demand. The implications are that stimuli to encourage online interactions are still important though online or traditional ads, direct mail, physical reminders or encouraging word-of-mouth. "Push" from e-mail marketing remains important and is part of the inbound marketing approach:, it should be a priority objective of website design to capture customers' e-mail addresses in order that opt-in e-mail can be used to push relevant and timely messages to customers.

Creating a dialogue through interactivity is the next important feature of the web digital media such as mobile and interactive TV which provide the opportunity for two way 
interaction with the customer. This is a key distinguishing feature of the medium according to Peters (1998), and Deighton (1996) which proclaimed the interactive benefits of the internet as a means of developing long-term relationships. Walmsley (2007) believes that the main impact of digital media has not been to find new ways to connect brands to consumers as originally anticipated, but in connecting those consumers to each other. Walmsley believes this trialogue will influence every aspect of marketing, from product design through to product recommendation.

Traditional push communications are one-to-many, from one company to many customers often the same message to different segments and often poorly targeted. With digital media "one-to-some" - reaching a niche or micro-segment becomes more practical - e-marketers can afford to tailor and target their message to different segments through providing different site content or e-mail for different audiences through mass customization and personalization.

Image 1. illustrates the opportunities for mass customization as interaction occurs between an organization $(0)$ communicating a message $(\mathrm{M})$ to customers $(\mathrm{C})$ for a singlestep flow of communication. It is apparent that for traditional mass marketing in (a) a single message (M1) is communicated to all customers (C1 to C5).

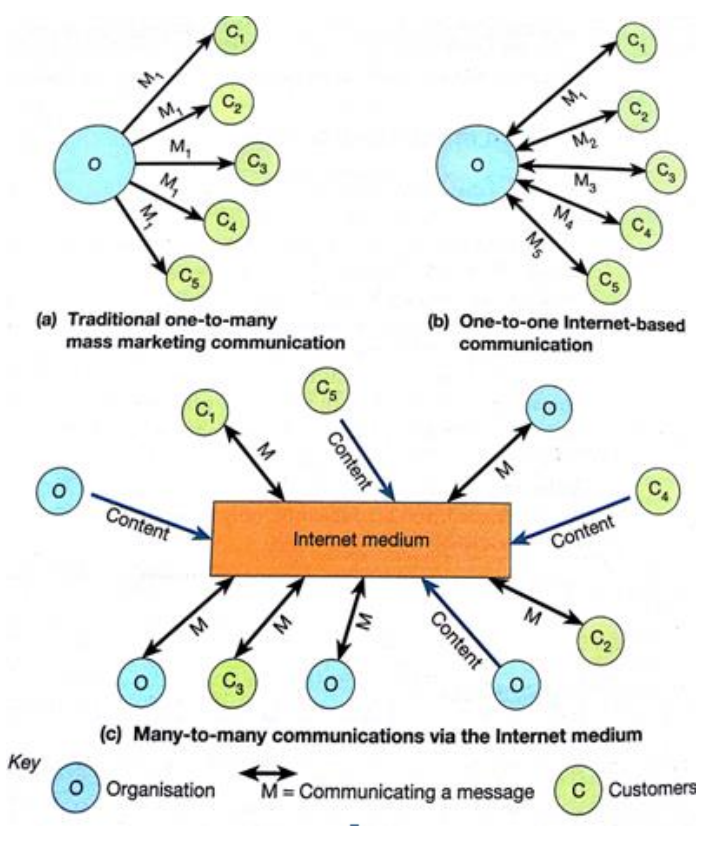

Image 2: The differences between one to many and one to one communication using Internet 
$36^{\mathrm{TH}}$ INTERNATIONAL CONFERENCE ON ORganizational SCIENCE DeVElopment: RESPONSIBLE ORGANIZATION (MARCH $22^{\mathrm{ND}}-24^{\mathrm{TH}}$, PORTOROŽ Slovenia)

L. Zečević, O. Zečević Stanojević \& A. Milenković The Role of Marketing Communications in Responsible Organizations

Holfrnan and Novak (1997) believed that this change was significant enough to represent a new model for marketing. They suggest the facilities of the Internet, including the web, represent a computer-in-mediated environment in which the interactions are not between the sender and receiver of information, but with the medium itself. Their vision of the future is now apparent in the popularity of social networks, blogs and specialist communities.

Consumers can interact with the medium, organizations can provide content to the medium and in the most radical departure from traditional marketing environments, consumers can provide commercially-oriented content to the media.

Digital media also enable many-to-many communications. Here customers can interact with other customers via a website, in independent communities or on their personal websites and blogs. Many-to-many communications require monitoring of information sources, but it opens more opportunities to reach out to influencers to expand reach.

Digital media are also intense media - they are interactive, lean-forward media where the customer wants to be in control and wants to experience flow of responsiveness to their needs. First impressions and devices to encourage the visitor to interact are important. If the visitor to site does not find what they are looking for immediately, whether through poor design or slow speed, they will move on, probably never to return.

In addition to offering the opportunity for one-to-one marketing, the Internet can be, and widely still is, used for one-to-many advertising. The website or social media site can be considered as similar in function to an advertisement (since it can inform, persuade and remind customers about the offering, although it is not paid for in the same way as a traditional advertisement). Berthon et al. (1996) consider a website as a mix between advertising and direct selling since it can also be used to engage the visitor in a dialogue. Constraints on advertising in traditional mass media, such as paying for time or space, become less important. The wastage in traditional advertising where ads are either ignored or are not relevant for an audience is reduced in online marketing and search marketing in particular. In pay-per-click (PPC) advertising, display of ads can be controlled according to user need based on what searchers are looking for and cost is only incurred where interest is indicated by a click.

Peters (1998) suggests that communication via the new medium is differentiated from communication using traditional media in four different ways. First, communication style is changed with immediate, or synchronous, transfer of information through online customer service being possible. Second, social presence or the feeling that communications exchange is sociable, warm, personal and active may be lower if standard web page is delivered, but can be enhanced, perhaps by personalization. Third, consumer has more control of contact; and fourth the user has control of content, for example through personalization facilities or posting their own user-generated content. 


\section{US TV* vs. Digital** Ad Spending, 2015-2020 billions}

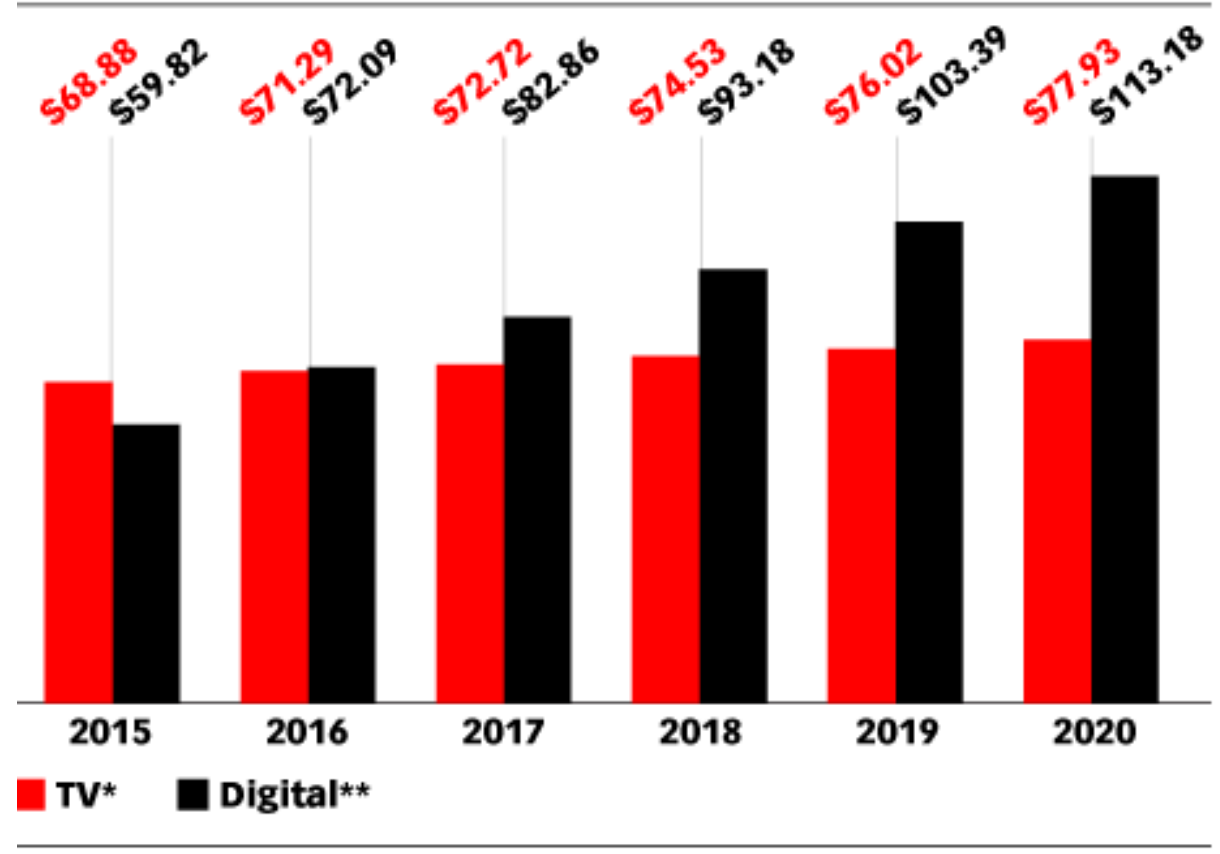

Graph 1: [*Includes broadcast TV and cable TV; ** includes advertising that appears on desktop and laptop computers, mobile phones, tablets]; Source:eMarketer.com, Sep 2016

According to research conducted by eMarketer company, the investment in mobile marketing in the USA will reach 73 billion dollars by the end of the year, and it is expected that it will continue growing.

\section{Use of marketing communication for raising social responsibility of the organization}

Many companies believe they have a responsibility to give back to society. This focus includes contributions of time and money, a duty to provide environmentally friendly products and services, and a desire to improve the lives of individuals here and around the globe. Such socially responsible companies see to it that this consciousness permeates everything they do. (Bob Liodice 2010).

The research conducted by companies Burson Marsteller i Roper Starch Worldwide has shown that the oral compliments of a distinguished person influences the attitude toward purchase of the other two persons. The number is bigger, that is eight, if we talk about 
$36^{\mathrm{TH}}$ International Conference on Organizational Science Development: Responsible Organization (MARCH $22^{\mathrm{ND}}-24^{\mathrm{TH}}$, PORTOROŽ Slovenia)

L. Zečević, O. Zečević Stanojević \& A. Milenković The Role of Marketing Communications in Responsible Organizations

online compliments. Many types of communications take place on the internet, between customers, on various topics. Not only do internet users produce information about a product, but they also create it.

Social media marketing can often be assisted through viral marketing that harnesses the network effect of the Internet and can be effective in reaching a large number of people rapidly as a marketing message is rapidly transmitted in the same way as a natural virus or a computer virus. It is effectively an online form of word-of-mouth communications which is sometimes also known as 'buzz marketing'. The two main forms of online viral marketing are through passalong-e-mails or discussions within social networks. When planning integrated campaigns, it is important to note that the online viral effect can be amplified through offline media mentions or advertising either on TV and radio or in print. Word-of-mouth (WOM) marketing is an established concept closely related to viral marketing, but broader in context. Companies can work hard to make people happier, they can listen to consumers, they can make it easier for them to tell their friends, and they can make certain that influential individuals know about the good qualities of a product or service. Word-of-mouth marketing techniques which are based on the concepts elements are: of customer satisfaction, two-way dialogue and transparent communications. The basic elements are: educating people about your products and services, identifying people most likely to share their opinions, providing tools that make it easier to share information, studying how, where and when opinions are being shared, listening and responding to supporters, detractors and neutrals. Positive WOM is believed to increase purchase intent.

WOM marketing identifies different approaches for facilitating WOM. The ones that are most relevant to online marketing are:

- Buzz marketing. Using high-profile entertainment or news to get people to talk about your brand.

- Viral marketing. Creating entertaining or informative messages that are designed to be passed along in an exponential fashion, often electronically or by e-mail.

- Community marketing. Forming or supporting niche communities that are likely to share interests about the brand (such as user groups, fan clubs and discussion forums); providing tools, content and information to support those communities.

- Influencer marketing. Identifying key communities and opinion leaders who are likely to talk about products and have the ability to influence the opinions of others.

- Conversation creation. Interesting or fun advertising, e-mails, catch phrases, entertainment or promotions designed to start word-of-mouth activity.

- Brand blogging. Creating Blogs and participating in the blogosphere, in the spirit of open, transparent communications; sharing information of value that the blog community may talk about. 
The following companies stand out as prime examples of how social responsibility can be productively coupled with sound strategies to advance goodwill, while building sustainable and impressive businesses. They provide the leadership to demonstrate how marketers can pursue both objectives simultaneously. As such, socially conscious companies have stepped up their efforts with increasing effectiveness and productivity. It is an impressive movement and one that invites society at large to do even more.

\subsection{The Body Shop}

The Body Shop is regarded as a pioneer of modern corporate social responsibility as one of the first companies to publish a full report on its efforts and initiatives. Founder Anita Roddick led her company to stand up for its beliefs and champion causes such as selfesteem, environmental protection, animal rights, community trade and human rights. From sponsoring posters in 1985 for Greenpeace to presenting a petition against animal testing to the European Union with 4,000,000 signatures, The Body Shop has contributed significantly to the causes it supports, and exemplifies how other companies can do the same.

Much like The Body Shop's campaigns of the past, it will focus less on putting marketing pounds behind TV and instead plans to create a lot of video, in-store, and social media content. With 65 per cent of its shoppers under 35 years old, the brand has been increasingly testing emerging channels like Snapchat, Instagram and Pinterest.

With a global staff of over 22,000 some of the most important communications around 'Enrich Not Exploit' have happened behind closed doors. To keep employees around the world - from the top to the bottom of the company- in the loop it created a campaign, starting with a teaser video and culminating in a full-length film outlining its ambitions and how each person could help.

Next up came a redesign of its stores. In the longer term The Body Shop is investing heavily in making every retail outlet eco-friendly by using locally-sourced SSC-certified wood, sustainable materials in its flooring, LED lighting and non-toxic paints. However, to make consumers aware of 'Enrich not Exploit' in the shorter term it's made some more cosmetic changes including the introduction of a vibrant yellow color-scheme and eyecatching front window featuring a specially designed symbol.

To show shoppers the impact that every pound spent with The Body Shop has on the wider world, it's put one square meter of faux-grass on at the checkout point which the customer stands on as they pay to see what they're helping to build.

This idea of being able to physically see where spending with The Body Shop's goes will be taken further with web-cams which show things like where ingredients are being grown. 
L. Zečević, O. Zečević Stanojević \& A. Milenković The Role of Marketing Communications in Responsible Organizations

\section{THE BODY SHOP.}

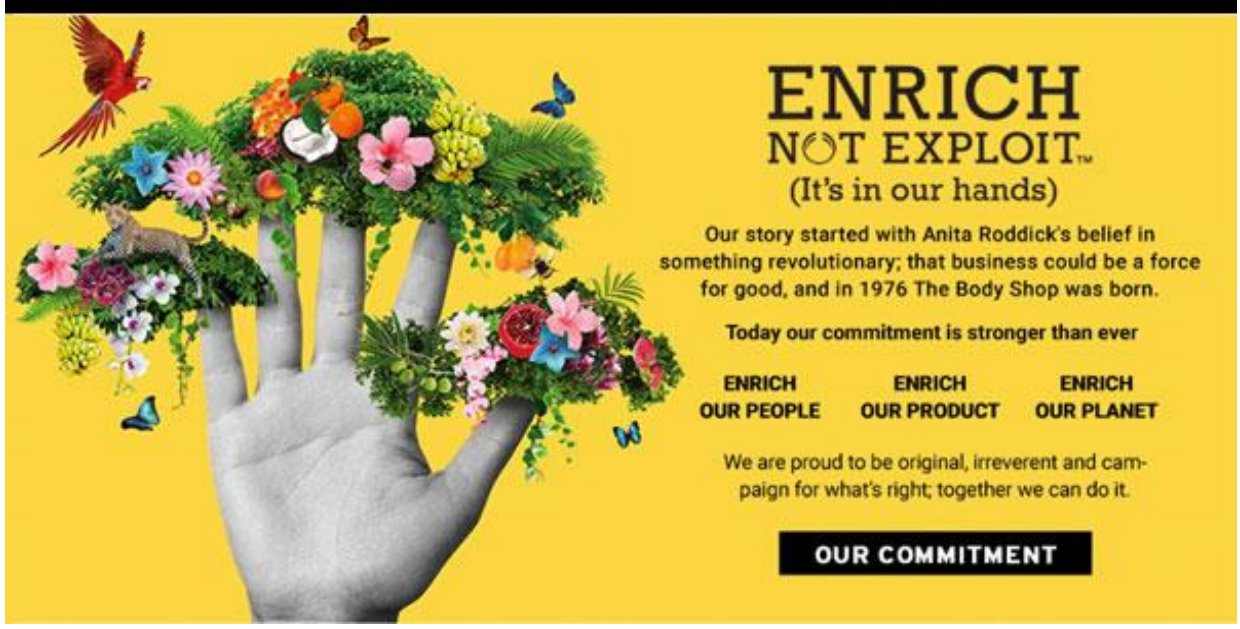

Image 3: [Strong marketing communication presented by responsible organization]

\subsection{Starbucks Coffee}

Since Starbucks Coffee started in 1971, the company has focused on acting responsibly and ethically. One of Starbucks' main focuses is the sustainable production of green coffee. With this in mind, it created C.A.F.E. Practices, a set of guidelines to achieve product quality, economic accountability, social responsibility and environmental leadership. The company supports products such as Ethos Water, which brings clean water to more than 1 billion people who do not have access.

In 2012, Starbucks, Seattle Theatre Group and KEXP 90.3 FM, joined forces to create Little Big Show, a concert series designed to support arts organizations for young people. Several times a year, Starbucks find a great band or two, give them a stage at the Neptune Theatre in Seattle, WA, and donate $100 \%$ of the ticket sales to a different nonprofit beneficiary. Not only does the series provide critical funding for youth organizations, but also provides a unique platform for fans and artists to engage with the local community.

The company Starbucks has recognized the importance of their customers, and therefore it has given a phenomenal opportunity to the customers to be included in the making of their products and services. Via mystarbucksidea.com the customers create and give their suggestions so that the company could improve their business and take the customers' wishes into account. For the five years of their existence the company has received over 150,000 ideas and 277 have been turned into reality. The customers send their ideas about new flavors of drinks or cookies, and they also send valuable ideas about the 
functionality: the way they can pay, organization of space, events, the more efficient service.

On daily basis, the site receives couple of ideas. The site is completely transparent and simple to use. Organization can see the descriptions of the ideas and vote for them. In this way the company builds strong relationships with their customers, builds its credibility, and improves itself in accordance with the environment.

\section{Environmental Stewardship \\ - Reduction of Energy and Water consumption. \\ - Purchase renewable energy. \\ - Recycling \& Reusable Cups.}

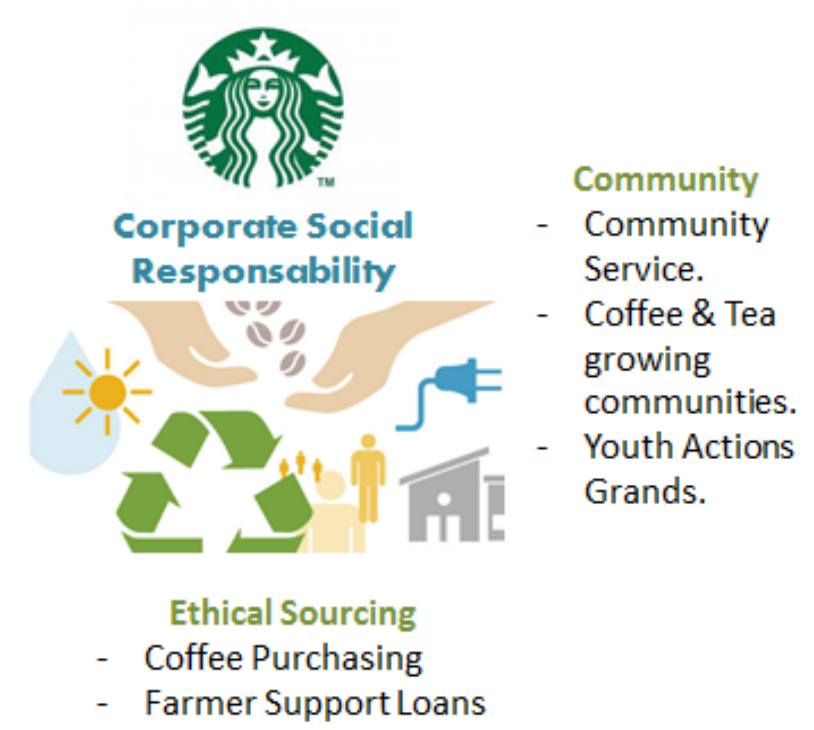

Image 4: Starbucks, Corporate Social Responsibility

\section{Corporative Blog on Social Responsibility}

Blogs enable marketers to create content in form of announcement, by which, in some ideal cases, trust and the sense of authenticity among consumers is built. After the content has been published, the audience can offer the feedback in form of a comment. Since a blog gives a chance to consumers to open dialogues and give their own opinions, the comments section on the blog represents one of the most vital methods for communication between brands and consumers.

Blogs can be divided into two categories: first category comprises of corporative and professional blogs, and second of non-corporative, personal blogs.

Corporative blogs are endorsed by the companies, or by some of its brands and the blogs are managed by one or more employees in the company. Those blogs serve as a channel 
$36^{\mathrm{TH}}$ InTERNATIONAL CONFERENCE ON ORganizational SCIENCE DeVElopment: Responsible Organization (MARCH $22^{\mathrm{ND}}-24^{\mathrm{TH}}$, PORTOROŽ Slovenia)

L. Zečević, O. Zečević Stanojević \& A. Milenković The Role of Marketing Communications in Responsible Organizations

for distribution of marketing information, and represent an effective platform that enables the organization to become a leading authority in its field, to build better relationships with shareholders, to create optimal conditions for consumers, to attract new buyers, to create predilection for the organization via anecdotes and stories about brands, and to make an active forum for testing new ideas.

Socially responsible companies, such as Toms Shoes, Whole Foods and GE inform their customers about new trends via their blogs.

\subsection{Toms Shoes, Whole Foods and GE}

Blake Mycoskie started Toms Shoes on the premise that for every pair of shoes sold, one pair would be donated to a child in need. This innovative idea resulted from a trip to Argentina where Mycoskie saw an overwhelming number of children without shoes. Toms Shoes recognized that consumers want to feel good about what they buy, and thus directly tied the purchase with the donation. In just four years, Toms Shoes has donated more than 400,000 shoes.

On the other hand Whole Foods supports sustainable agriculture, promotes the reduction of waste and consumption of nonrenewable resources and encourages environmentally sound cleaning and store-maintenance programs. The company created the Local Producer Loan program, which provides up to $\$ 10$ million in low-interest loans to small local producers to help grow their businesses. Whole Foods has also created Whole Planet Foundation, which fights poverty through microlending in rural communities around the world.

To stay true to GE's mission, Ecomagination offerings include products that significantly and measurably improve customers' operating performance or value proposition and environmental performance. Ecomagination helped GE build its business by increasing awareness of how the company is using renewable energy and reducing carbon emissions. 

ORGANIZACIJA (22. - 24. MAREC 2017, PORTOROŽ, SLOVENIJA)

L. Zečević, O. Zečević Stanojević, A. Milenković The Role of Marketing Communications in Responsible Organizations

\section{Conclusion}

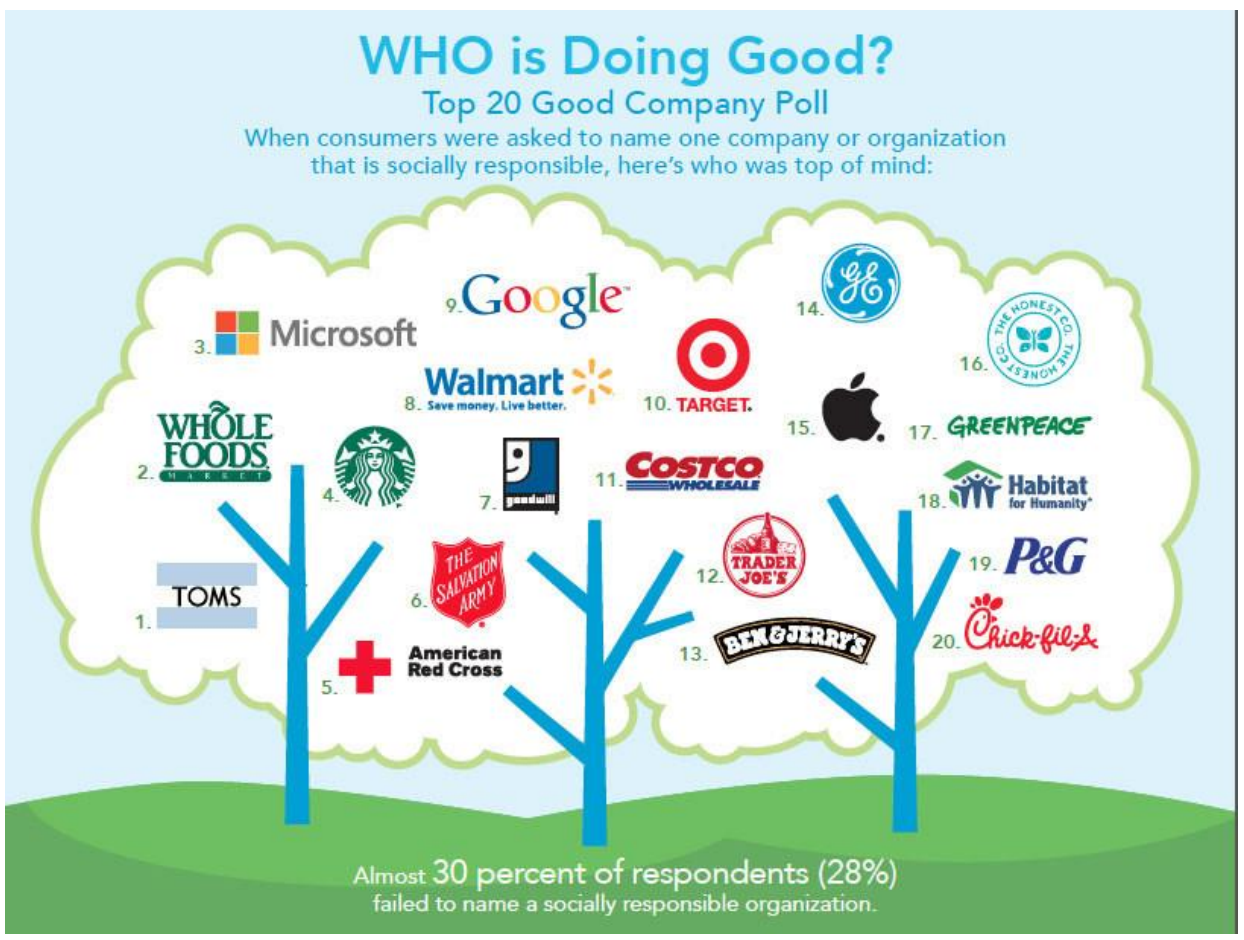

Image 5: Top 20 responsible companies

Companies consciously work on improving environment and life standard. That's a winwin situation because companies depend on natural resources. By taking care of natural resources companies make good base for their further development. Also, by taking care of people, as stated in the example, companies make good atmosphere towards the existing and prospective customers. Thanks to adequate marketing communication the audience is informed about the companies' projects. Therefore, the solution would be to create such a win-win project and then to communicate in appropriate way with the audience in order to convey the precise and unique message.

We can be satisfied with the fact that companies have become aware of the responsibility towards their employees and customers. The image above illustrates brands that customers labeled as socially responsible thus shows that the awareness does exist. This trend continues to grow, because by setting their own examples, companies motivate their environment, competitors, consumers and potential consumers to follow their ethics and come up with some innovative solutions. 
1328 36 $6^{\mathrm{TH}}$ INTERnational CONFERENCE ON ORganizational SCIENCE DeVElopment: RESPONSIBLE ORGANIZATION (MARCH $22^{\mathrm{ND}}-24^{\mathrm{TH}}$, PORTOROŽ SLOVENIA)

L. Zečević, O. Zečević Stanojević \& A. Milenković The Role of Marketing Communications in Responsible Organizations

\section{Literature}

Chaffey, Dave, and Fiona Ellis-Chadwick. Digital Marketing. Harlow, United Kingdom: Pearson, 2016.

Fill, Chris. Marketing Communications: Contexts, Strategies and Practice. Harlow: FT Prentice Hall, 2006.

Lamb Charles W., Joseph F. Hair, and Carl McDaniel. MKTG: Marketing, Mexico, D.F.: Cengage Learning, 2014

Pickton, David, and Amanda Broderick. Integrated Marketing Communications, Harlow, Prentice Hall, 2013.

Halligan, Brian, and Dharmesh Shah. Inbound Marketing: Get Found Using Google, social media and blogs. Hoboken: John Wiley \& Sons, 2014.

"Advice on creating effective marketing campaign include custom insight and attribution modeling." Smart Insights Accessed February 2017. http:// http://www.smartinsights.com/digital-marketing-strategy/.

„Socially Responsible Companies.“ The Huffington Post. Accessed February 2017. http://www.huffingtonpost.com/news /Socially Responsible Companies/.

„World most ethical and sustainable brands.“ The Drum. Accessed February 2017. http://www.thedrum.com 


\title{
Urejanje managerskih plač v javnem sektorju
}

\author{
JANEZ ZENI
}

\begin{abstract}
Povzetek Plače so bile in bodo vedno aktualna socialna tema, pogosto izrabljena tudi za politične namene. Vedno, posebno pa še $\mathrm{v}$ sedanjih zaostrenih razmerah gospodarjenja in varčevanja in »rahljanja « teh varčevalnih ukrepov ter pritiska sindikatov za povečanje plač $\mathrm{v}$ našem javnem sektorju, pa bi morali biti posebej aktualne plače managerjev $\mathrm{v}$ javnem sektorju, pa ne le po višini, ampak predvsem po vsebini, od česa so odvisne. Predvsem gre za povezavo njihovih plač s cilji organizacijskih enot, ki jih vodijo in za motivacijo vseh vpletenih.

V referatu so analizirane pomanjkljivosti managerskih pogodb o zaposlitvi $\mathrm{v}$ našem javnem sektorju, zakonske in druge osnove za njihovo urejanje, strokovna izhodišča ter nekaj namigov, kako naj bi se to zahtevno področje urejalo v Sloveniji.
\end{abstract}

KLJUČNE BESEDE: managerske plače in managerske pogodbe o zaposlitvi

- motivacija zakoni in stroka

NASLOV AVTORJA: mag. Janez Zeni, gospodarski svetovalec, Spodnja Besnica, Trata 9, 4201 Zgornja Besnica, Slovenija, e-pošta: zeni.janez@amis.net

DOI https://doi.org/10.18690/978-961-286-020-2.106

ISBN 978-961-286-020-2

(C) 2017 Univerzitetna založba Univerze v Mariboru

Dostopno na: http://press.um.si 
$36^{\mathrm{TH}}$ InTERnational CONFERENCE ON ORganizational SCIENCE Development: Responsible Organization (MARCh $22^{\mathrm{ND}}-24^{\mathrm{TH}}$, PORTOROŽ SLOVENIA)

O. Arsenijević, M. Ferjan, I. Podbregar, P. Šprajc, D. Trivan \& Y. Ziegler

\title{
The Managers Salary in the Public Sector
}

JANEZ ZENI

\begin{abstract}
Wages have been and will remain valid social issue, often utilized for political purposes.

Manager wages in public sector should always depend on the organisational unit goals. This is particularly important in the period of slump conditions, economizing and pressure of trade unions to pay increase.

This paper analyses the shortcomings of manager employment contracts in our public sector, the legal and other basis for their development, professional positions, and some tips, how this demanding issue should be arranged in Slovenia.
\end{abstract}

KEYWORDS: manager wages - manager employment contracts • motivation $\bullet$ laws and profession

Correspondence Address: Janez Zeni, M.S., Economic Consultant, Spodnja Besnica, Trata 9, 4201 Zgornja Besnica, Slovenia, e-mail: zeni.janez@ amis.net

DOI https://doi.org/10.18690/978-961-286-020-2.106 ISBN 978-961-286-020-2

(C) 2017 University of Maribor Press

Available at: http://press.um.si 


\section{$1 \quad$ Uvod}

Plače v našem javnem sektorju že od septembra leta 2008 ureja Zakon o sistemu plač v javnem sektorju. S tem krovnim zakonom se urejajo plače vseh v državi Sloveniji, kjer se njihove dejavnosti $\mathrm{v}$ celoti ali pretežno financirajo $\mathrm{z}$ državnimi sredstvi, to je iz državnega ali proračunov lokalnih skupnosti. $V$ tem smislu $\mathrm{v}$ to skupino sodijo: državna uprava, šolstvo, od osnovnih šol do fakultet, višjih in visokih šol, predšolska vzgoja in varstvo, kultura, zdravstvo, policija in podobno. Naslednji zakon, ki so mu podvrženi tudi $\mathrm{v}$ javnem sektorju in velja za vse zaposlene $\mathrm{v}$ gospodarstvu, je Zakon o delovnih razmerjih. Slednji ureja vse v zvezi z urejanjem delovnih razmerij in načelno tudi v zvezi s plačami vseh zaposlenih. Medtem ko prvi ureja le plače za zaposlene v našem javnem sektorju in to brez izjeme, razen za tiste privilegirane (Banka Slovenije), ki so si ta status izborili že pri nastajanju omenjenega Zakona. Posebnosti posameznih dejavnosti iz našega javnega sektorja pa se urejajo s tako imenovanimi panožnimi kolektivnimi pogodbami (šolstvo, zdravstvo, policija itd), pravilniki, na primer: Pravilnik o umestitvi delovnih mest direktorjev s področja javne uprave v plačne razrede, uredbami, na primer: Uredba o plačah direktorjev v javnem sektorju, in morda še kaj.

V panožnih kolektivnih pogodbah se urejajo posebnosti v posameznih dejavnostih, kot so normativi dela za zdravnike in še zlasti posebnosti za ugotavljanje delovne (redne) uspešnosti in s tem določanja gibljivega (stimulativnega) dela plač. Pomemben del teh kolektivnih pogodb pa so določbe o napredovanjih zaposlenih $\mathrm{v}$ okviru delovnih mest (horizontalno napredovanje) in izven njih (vertikalno napredovanje). $\mathrm{K}$ temu je potrebno dodati še nekaj določb o urejanju sistemizacije delovnih mest, brez nujno potrebnih podrobnosti in navodil za organiziranje in sistemiziranje delovnih mest in morda še nekatere posebnosti.

\section{$2 \quad$ Nekaj značilnosti pogodb o zaposlitvi}

V skladu z določbami Zakona o delovnih razmerjih se z vsemi zaposlenimi v Sloveniji sklepajo pogodbe o zaposlitvi, kjer se določajo vse podrobnosti o delovnem mestu, delovnih nalogah, delovnih razmerah, pristojnostih in odgovornostih, obveznostih, dolžnostih in seveda tudi delavčevih pravicah. Še posebej je občutljivo poglavje o plačah teh delavcev, kjer se določajo osnovne plače, stimulacije, dodatki in nadomestila za nezmožnostih za delo in podobno in tudi splošni pogoji glede sklepanja delovnega razmerja.

V omenjenem Zakonu je posebna določba, s katero za poslovodne osebe »drugače uredijo pravice, obveznosti in odgovornosti iz delovnega razmerja za: določen čas, delovni čas, odmori in počitki, plačilo za delo, disciplinsko odgovornost, prenehanje pogodbe o zaposlitvi«.

\section{$3 \quad$ Managerske pogodbe o zaposlitvi}

Na osnovi omenjenega krovnega Zakona o delovnih razmerjih se lahko za vse zaposlene v Sloveniji na enoten način sklepajo pogodbe o zaposlitvi za vse zaposlene, vključno $s$ poslovodnimi osebami, oziroma managerji, kot jih večinoma imenuje stroka, politika in 
tudi strokovna in druga javnost. Takoj po osamosvojitvi leta 1991 se je začelo tudi vsebinsko ločeno obravnavanje pogodb o zaposlitvi za poslovodne osebe, to so managerji in managerske pogodbe o zaposlitvi, ki smo jih po vzoru gospodarsko razvitega sveta začeli pri nas poimenovati. Poseben in skoraj edini omembe vreden tehten razlog za to je prav gotovo v posebnosti (ekskluzivnosti) in veliki odgovornosti za doseganje strateških, dolgoročnih, srednjeročnih in iz tega izvedenih kratkoročnih operativnih ciljev na vseh ravneh posamezne družbe ter v prestižnosti, ki posameznikom daje poseben status, kot priznanje za potrebno izjemno strokovnost ali posebne dosežke, odgovornosti za delovanje in poslovanje organizacijske enote ali pravnega subjekta za njegov nemoten in skladen razvoj in obstoj ki ga vodijo. To pa najbolj zanima lastnike in seveda tudi zaposlene, kajti v mnogočem je od teh managerjev odvisna njihova usoda.

$\mathrm{S}$ tem v zvezi so se $\mathrm{v}$ teoriji in praksi za opredeljevanje teh pogodb o zaposlitvi razvile zelo zanimive in strokovno poglobljene metode $\mathrm{z}$ bolj ali manj življenjskimi in uporabnimi rešitvami. Na trgu, bi lahko rekli, so se in se še pojavljajo zelo različni bolj ali manj uporabni primeri in vzorci. Stvar se je izjemno skomercializirala, čeprav vedno rešitve in predlogi niso strokovno primerni, včasih tudi zakonsko in strokovno sporni: na primer, obračunavanje neizkoriščenega dopusta za vršne (top) managerje. Posebno vlogo pri urejanju managerskih pogodb o zaposlitvi ima v pozitivnem smislu nedvomno Združenje manager, ki te stvari za svoje člane in tudi druge poskuša urejati na povsem profesionalen način. V ta namen so razvili nekaj metodologij in poenotenj, še zlasti za določanje osnovnih plač managerejv glede na velikost družb, ki jih vodijo, vrste in oblike stimulacij, bonitet in podobno. Kljub temu pa se v praksi kažejo nekatere pomanjkljivosti, ki jih velja izpostaviti in nam bodo pri opredeljevanju teh pogodb za managerje $\mathrm{v}$ javnem sektorju lahko koristile. Mednje lahko štejemo: (1) ne dovolj natančno načrtovani in opredeljeni podjetniški cilji ter ne dovolj konkretizirane pristojnosti in odgovornosti za njihovo doseganje; (2) pomanjkljiva merila za določanje osnovnih plač in še zlasti nagrad, bonusov in drugih oblik plačil na osnovi doseženih rezultatov; (3) prevelik delež osnovnih plač v škodo ti. gibljivega dela; (4) nedosledno spoštovanje določb managerskih pogodb, ki je posledica ugotovitev iz prvih treh točk in neodgovornega ravnanja nadzornikov.

Posebno velja izpostaviti nepovezanost plač managerjev z rezultati in s plačami drugih zaposlenih v družbah, ki jih vodijo. Dejanska izplačila, kot je razvidno iz statističnih poročil in medijev ter mnogi protesti delavcev, to trditev $\mathrm{v}$ celoti potrjujejo. Ta nepovezanost se izkazuje $\mathrm{z}$ neodvisnostjo njihovih plač in drugih prejemkov $\mathrm{z}$ doseganjem načrtovanih rezultatov družb in $\mathrm{z}$ veliko vrzeljo - razkorakom s plačami drugih zaposlenih $v$ teh družbah. Poleg tega pa so sporne same višine plač in drugih prejemkov, ki so za naš prostor in razmere pogosto nevzdržne.

Pri tem ne gre le za vršni management prve in druge vodstvene ali organizacijske ravni. $\mathrm{V}$ družbah, ki managerske pogodbe sklepajo tudi z nižje nivojskimi managerji, kot so vodje sektorjev, služb ali celo oddelkov, pa je problem (ne) povezanosti plač z drugimi zaposlenimi po kolektivnih pogodbah še bolj pereč in zelo moteč socialni dejavnik. Pogosto je razkorak med najvišjo plačo (osnovno) po kolektivni pogodbi in najnižjo po managerski pogodbi nerazumljivo velik, kar odnose in povezanost usode vseh zaposlenih 
v družbi še bolj oddaljuje. Te razlike v praksi presegajo razumno mejo, ki naj bi znašala največ $20 \%$, kar je stroka že večkrat dokazala, praksa pa potrdila.

Posledice takšnega ravnanja managementa, lastnikov in nadzornikov $\mathrm{v}$ mnogih gospodarskih družbah v privatni in državni lasti ne povzročajo le ekonomskih motenj poslovanja, ampak generirajo tudi težke socialne pretrese na lokalni in državni ravni ter majejo tako potrebno medsebojno zaupanje med vsemi zaposlenimi, vključno $\mathrm{z}$ managementom na vseh ravneh.

Opisani odkloni od pričakovanega in družbeno še sprejemljivega niso le konstrukcijske napake managerskih plačnih sistemov, ki jih zakonodaja in oblast očitno tolerirata, ampak so tudi hudo moralno vprašanje in odgovornost vse vpletenih.

\section{$4 \quad$ Primerjanje s tujino}

Nobena skrivnost ni, da so managerske pogodbe o zaposlitvi in s tem povezani tudi sistemi plač in drugih prejemkov naših managerjev vsebinsko povzeti po pozitivnih tujih praksah. Manj povezave pa je zaznati glede povezav med odgovornostmi za rezultate in plačami, nagradami in drugimi prejemki. Še druga pomembna zaznamba pa je v deležih osnovnih plač in stimulacij glede na dosežene rezultate, ki so v tujini bolj v korist slednjih, v Sloveniji po obratno. V Sloveniji je po znanih podatkih Združenja manager v povprečju delež stimulacij v celotni plači manj kot $15 \%$, kar je odločno premalo in ne dovolj stimulativno. Sicer pa je dobro znano, da so plače zaposlenih v javnih sektorjih v tujini od 10 do $20 \%$ nižje od primerljivih v gospodarstvu, pri nas pa se teh primerjav ciljno sploh ne dela, kar je $\mathrm{v}$ bistvu povsem nerazumljivo in $\mathrm{s}$ tem slabi pogajalska izhodišča Vlade pri pogajanjih s sindikati našega javnega sektorja.

\section{$5 \quad$ Nekaj izhodišč za urejanje managerskih plač}

$\mathrm{Z}$ uveljavitvijo novega Zakona o delovnih razmerjih se delovna razmerja $\mathrm{z}$ vsakim zaposlenim v gospodarstvu in javnem sektorju urejajo s pogodbami o zaposlitvi. Kljub temu pa so managerji, ki jih Zakon v 72. členu poimenuje »poslovodne osebe«, glede na potrebe posamezne družbe lahko deležni posebne obravnave. Za poslovodne osebe iz javnega sektorja pogodbe o zaposlitvi sklepajo pristojna resorna ministrstva.

Načelno skrb za plače managerjev in pripravo managerskih pogodb o zaposlitvi in njihovih plačah na ravni priporočil urejajo v okviru Združenja Manager. Pri tem gre zlasti za merila za določanje osnovnih plač ter nekaj osnov za določanje »variabile«, to je nagrad, bonusov in podobno. $\mathrm{V}$ teh okvirih je vse prepuščeno nadzornim svetom, kot predstavnikom lastnikov kapitala.

Žal, pa za javni sektor na omenjenem Združenju nimajo nobenih oprijemljivih podatkov ali kakšnih drugih strokovnih priporočil za urejanje plač in s tem tudi ne za sklepanje pogodb o zaposlitvi s poslovodnimi osebami iz javnega sektorja. Temu primeren je bil tudi odgovor na naše tozadevno vprašanje na eni od naših večjih občin. Zato se sedaj te pogodbe o zaposlitvi in s tem tudi plače ureja na poseben način, ne pretirano strokoven 
način, kot to določa že omenjeni Zakon o sistemu plač v javnem sektorju. Ko smo raziskovali še malo naprej, smo ugotovili, da kakšnih strokovnih podlag za urejanje tega zelo pomembnega področja ni, sta pa: Uredba o plačah direktorjev $\mathrm{v}$ javnem sektorju in Pravilnik o uvrstitvi delovnih mest direktorjev s področja javne uprave v plačne razrede znotraj razponov plačnih razredov. Kakšnih drugih strokovnih izhodišč ali morda strokovnih podlag, da bi se vse to delalo na osnovi potrebnih sistemizacij delovnih mest, kot je to ustaljena navada v naših gospodarskih družbah, nismo našli ali zasledili. Morda obstajajo v okviru kakšnih kolektivnih pogodb dejavnosti, vendar bi iskanje teh virov že presegalo okvire te naloge.

V obeh omenjenih dokumentih so brez kakšnih strokovnih podlag nanizane organizacijske enote, šifre in nazivi delovnih mest ter končno tudi plačni razred, na osnovi katerega se zaposlenemu, ki takšno delovno mesto zaseda, določi osnovna plača. Kot rečeno, o kakšni sistemizaciji delovnih mest ni nobene omembe. Žal, to velja tudi za druge zaposlene, ki se jih po enakem načelu uvršča v določene plačne razrede $\mathrm{v}$ okviru določenih plačnih skupin. V skladu z določbami omenjenega krovnega Zakona, s katerim se določajo plače $v$ našem javnem sektorju, so določbe za tako imenovani variabilni stimulativni del, ki bi lahko enako veljal za vse zaposlene v javnem sektorju, pa ne, ker ga je Vlada $v$ okviru varčevalnih ukrepov zamrznila. Zato so večinoma zaposleni $v$ javnem sektorju le na osnovnih plačah, brez možnosti napredovanj in drugih stimulacij na osnovi dosežene delovne uspešnosti. Glede na to, tudi za managerje v tem sektorju ni nobenih otipljivih možnosti za kakšne spodbude in stimulacije, tudi brez napredovanj v okviru delovnega mesta, ki ga zasedajo, tudi za managerje, to je direktorje in ravnatelje, kot jih poimenujeta preje omenjena dokumenta. Poleg tega pa je v našem javnem sektorju po zaslugi njihovih sindikatov vsakršno odpuščanje povsem nemogoče. KJE JE POTEM MOTIVACIJA ZA DELO? Prepuščena je zavedanju posameznikov, da po svoji vesti in karakterju delajo in izpolnjujejo vsakodnevne obveznosti in dolžnosti.

\section{Podjetniška managerska pogodba o zaposlitvi v javnem sektorju?}

Zakaj pa ne tudi v javnem sektorju s poudarkom na »podjetniška«, podjetništvo? Pa ne zato, da bi morale biti natanko tako urejene kot $\mathrm{v}$ gospodarstvu. Seveda to ni mogoče zaradi več razlogov, predvsem zaradi tega, ker $\mathrm{v}$ javnem sektorju nikakor ni mogoče $\mathrm{v}$ prvi plan postavljati materializiranih ciljev in še posebno ne dobička, ki je, žal, v mnogih gospodarskih družbah številka ena (1). Potrebno pa je plače urejati na podjetniški način, kjer so v prvi plan postavljeni cilji pravnega subjekta, kakovost storitev in počutje zaposlenih, za katere mora prvo odgovornost nositi prav njihov manager. Pri tem predvsem mislim na del javnega sektorja, ki s trgom nima prav nobene povezave, kot je državna uprava, izobraževanje, kultura in morda še kaj.

Podjetništvo izhaja iz besede podjeten, kar pomeni, zavzemati se za čim boljše gospodarske in druge rezultate, prizadevati se in biti odgovoren zanje. Iz tega izhajajoč bi lahko to podjetniško paradigmo ali vzorec podjetniškega obnašanja prenesli tudi na sklepanja managerskih pogodb, kjer se pričakuje odgovorno opredeljevanje medsebojnih obveznosti in dosledno njihovo spoštovanje v obojestransko korist. 
Praksa kaže na veliko raznolikost vsebin podjetniških managerskih pogodb, kjer so pravice dokaj natančno določene, manj, pa obveznosti in odgovornosti, za katere bi jih kasneje lahko »držali«. Upoštevaje vse zakonske določbe in priporočila, so se v praksi izoblikovala vsebinska strokovna stališča managerskih pogodb, ki jih lahko opredelimo v naslednjih točkah:

- natančno opredeljene strateške, dolgoročne, srednjeročne in kratkoročne naloge določene družbe ter iz tega opredeljeni konkretni cilji,

- pristojnosti in odgovornosti za obstoj in dolgoročni razvoj družbe v krajevnem in globalnem okolju ter za doseganje ciljev družbe,

- natančna in objektivizirana merila za doseganje teh ciljev, ki jih je mogoče objektivno in v časovnih obdobjih (današnja informacijska tehnologija omogoča dnevno ali vsaj mesečno spremljanje) spremljati ter na teh osnovah pravočasno in kakovostno tudi ukrepati.

Naloge in cilji managerjev pa niso le materialni, ekonomski, tehnični, ampak so vse bolj pomembni tudi ti. mehki, ki se tičejo zlasti zaposlenih, njihove motiviranosti, počutja, vpetosti v procese in zainteresiranost za obstoj in razvoj družbe.

Kakšne vzporednice lahko vlečemo iz teh načelnih opredelitev za sklepanje managerskih pogodb, ki veljajo predvsem za gospodarske družbe, na mangerske pogodbe v javnem sektorju? V tem primeru se bomo omejili predvsem na del teh pogodb, ki se tičejo managerskih plač. S tem v zvezi lahko opredelimo nekaj možnih načinov za določanje njihovih plač:

Prvi je verjetno ta, ki je sedaj, v času varčevalnih ukrepov in ZUJF-a (Zakon o urejanju javnih financ) $v$ veljavi. Zanj je značilno, da ne vsebuje nikakršnih motivacijskih vzvodov, da je povsem uravnilovski, brez možnosti razlikovanja glede na dosežene rezultate. Močno upamo, da je to le res trenutni in, da bo kmalu šel v pozabo in ga bodo zamenjali drugi, v svetu in tudi doma bolj spodbudni, preizkušeni in uveljavljeni. Omeniti velja vsaj dva, ki bi bila uporabna tudi v našem javnem sektorju, seveda prilagojena posebnostim posameznih dejavnosti, še posebej za državno upravo, šolstvo, zdravstvo itd. V vsakem primeru se je potrebno zavzemati za čim večji delež variabilnega dela na osnovi ciljev določene dejavnosti oziroma pravnega subjekta, ki je lahko odvisen predvsem od vpliva posameznega managerja na: (1) načrtovanje kar seda merljivih rezultatov in ciljev. Pri tem gre lahko tudi za nematerialne cilje, kot so zadovoljstvo zaposlenih, njihova motiviranost in pripadnost za skupne in jasno opredeljene cilje določenega pravnega subjekta. .(2) Za ugotavljane doseganja teh rezultatov in ciljev ter neposredna vezava le teh na dela plače managerjev in morda $v$ določenih primerih tudi drugih zaposlenih.

S tem v zvezi bi lahko izpostavili najmanj dve možnosti, dva načina - tipa - urejanja managerskih plač: 
36 ${ }^{\text {TH }}$ International Conference on Organizational Science Development: ResPonsible ORGANIZATION (MARCH $22^{\mathrm{ND}}-24^{\mathrm{TH}}$, PORTOROŽ SLOVENIA)

J. Zeni: The Managers Salary in the Public Sector

\section{Osnovna plača in variabilni, oziroma gibljivi del na osnovi doseganja rezultatov in ciljev.}

V zvezi s tem tipom urejanja managerskih plač je potrebno v prvi vrsti na ravni države opredeliti in sprejeti potrebne zakonske akte, ki bodo takšne možnosti omogočali in jim dajali potrebne strokovne podlage in usmeritve za to. $\mathrm{Na}$ teh skupnih osnovah bi se posebnosti morale urejati s podzakonskimi akti (kolektivnimi pogodbami posameznih dejavnosti). Poleg tega bi kazalo, kot tudi sicer velja, urediti potreben nadzor nad poslovanjem posameznih pravnih subjektov. Pri tem bo zelo pomembna odločitev deleža med osnovno plačo in variabilnim delom. Pri tem velja omeniti splošno veljavno načelo, da je v največji meri odvisno od zanesljivosti meril za merjenje doseganja rezultatov in ciljev; čim večja je zanesljivost, tem večja je lahko razlika. V našem javnem sektorju bo to moralo biti zelo različno: tam, kjer se lahko določeni deleži prihodkov dosegajo na trgu, bo delež variabilnega dela lahko večji in obratno. V javnem sektorju, kjer so cilji opredeljeni bolj vsebinsko kot kvantitativno, bi bil že uspeh, če bi bil variabilni del vsaj v začetku vsaj kakšnih 10\%, ki bi s povečevanjem zanesljivosti in objektivnosti poslovnih ciljev lahko naraščal. V vsakem primeru pa bo morala biti trdna zaveza in povezava med načrtovanimi cilji in deležem denarja za stroške dela vseh tam zaposlenih in ne le managerjev. $\mathrm{S}$ tem v zvezi kaže poudariti tudi to, kdo bo postavljal in potrjeval cilje in kdo jih bo spremljal ter odločal o deležih za variabilni del plač managerjev. Morda pa ne bilo napak, če bi se po tem načelu ravnali tudi pri odločanju dela plač na osnovi delovne uspešnosti tudi za vse druge zaposlene.

\section{Fiksna plača po določenih kriterijih po znanem in $v$ tujini uveljavljenem sistemu »up or out«, napreduj ali ven, po slovensko.}

To je sicer zelo enostavna metoda za določanje plač managerjev in pri doslednem spremljanju in izvajanju pa lahko tudi zelo kruta. V praksi ni vedno tako. Pogosto se lahko malo »skozi preste pogleda«, čeprav s tem izgubi na svoji motivacijski moči. S tem v zvezi kaže poudariti tudi to, da načelno pri vodilnih delavcih - managerjih, popuščanja pri doseganju postavljenih ciljev ne bi smelo biti. Kakšen drugi zaposleni lahko občasno ne dosega postavljenih ciljev, ali morda celo norm. Pri vodilnih pa tak odpustek ni mogoč, torej up or out. Kruto, glede na to, da se to v naprej ve, je stvar mogoče malo bolj sprejemljiva.

$\mathrm{V}$ obeh navedenih načinih, ki jih bomo podrobneje opredelili, je nekaj pomembnih pogojev, ki so tudi sicer in že sedaj neobhodni za uspešno delo in poslovanje. To so:

- učinkovito in racionalno organiziranje delovnih procesov in dela,

- učinkovito načrtovanje in spremljanje učinkovitosti delovnih procesov in dela,

- zakonsko in sistemsko urediti trdno povezanost doseganja ciljev in rezultatov $z$ »maso«, to je $z$ deležem denarja za stroške dela, 
- primeren in učinkovit informacijski sistem, ki bo zagotavljal pravočasne in kakovostne informacije za odločanje.

Odločitev in podrobnejša razdelava enega od predlaganih sistemov bo najmanjši problem za uspešno uveljavitev motivacijskega sistema plač za managerje. Večji problem in izziv pa bodo potrebni pogoji za njihovo delovanje, ki so na kratko opredeljeni v zgornjih štirih točkah.

\section{$7 \quad$ Dodatki in nadomestila plač}

Dodatki $\mathrm{k}$ plačam so sicer $\mathrm{v}$ skladu $\mathrm{z}$ našo zakonodajo lahko pomemben del plač zaposlenih, tudi $\mathrm{v}$ javnem sektorju. Za njihove managerje, še posebej vrhunske, pa je stvar malo drugačna. Vsekakor jim pripada, če $\mathrm{v}$ pogodbi o zaposlitvi tako določijo, dodatek za delovno dobo, morda tudi stalnost, v izjemnih primerih, morda gasilci, policisti, tudi za neugodne vplive okolja in podobno. Vse drugo pa mora biti vračunano v osnovni plači in še posebej v različnih vrstah stimulacij. Predvsem gre za to, da so obravnavani managerji prvi $\mathrm{v} »$ svojem podjetju «, da tam delo na osnovi predpisov, ciljev in drugih dokumentov organizirajo, kontrolirajo, usklajujejo (vodijo) in morajo njihove plače biti odvisne predvsem od tega, kako se tam ti cilji dosegajo, ne pa od podrobnosti, ki so pomembne za njihove podrejene sodelavce. Nikakor pa, to je zaradi določenih praks potrebno posebej poudariti, nimajo pravice do obračunavanja nadomestila za neizkoriščen dopust ali morda celo za že zloglasno stalno pripravljenost. Vse to in še kaj $\mathrm{v}$ določenih primerih pripada njihovim podrejenim sodelavcem.

Nadomestila plač pa se managerjem lahko obravnavajo, kot to veleva naša zakonodaja za vse zaposlene.

\section{$8 \quad$ Sklep}

S primerno ureditvijo managerskih pogodb o zaposlitvi, kjer bodo določene medsebojne obveznosti, plavice in dolžnosti, bodo odpadle mnoge večinoma upravičene kritike o nepravilnostih, ki se $\mathrm{v}$ nekaterih okoljih javnega sektorja pogosto pojavljajo. Vsi zaposleni in posledično tudi drugi državljani pa bomo imeli od tega pomembne koristi in zadovoljstvo. 
1338 36 ${ }^{\mathrm{TH}}$ International Conference on Organizational Science Development:

RESPONSIBLE ORGANIZATION (MARCH $22^{\mathrm{ND}}-24^{\mathrm{TH}}$, PorTOROŽ SLOVENIA)

J. Zeni: The Managers Salary in the Public Sector

\section{Literatura}

Zakon o delovnih razmerjih, Pravna praksa, 2002 in dopolnila, Ljubljana.

Zakon o sistemu plač v javnem sektorju, Uradni list RS Št. 36/208.

Pravilnik o uvrstitvi delovnih mest direktorjev s področja javne uprave v plačne razrede znotraj razponov plačnih razredov, $03.01,2017$.

Uredba o plačah direktorjev v javnem sektorju, 03.01.2017.

Janez Zeni, avtorjevi svetovalni projekti od 2000 do 2015.

How to develop a job description program, Aleksander Hamilton institute, Moderen business reports, NY, USA, 2005. 


\title{
Trajnostna družba prihodnosti, skozi kritični pregled trenutnega stanja
}

\author{
DAVORIN ŽNIDARIČ
}

Povzetek Nahajamo se v času, družbenih, socialnih in okoljskih pritiskov. Izraba fosilnih goriv in mineralov, izkoriščanje preostalih naravnih virov čez njihove samo obnovitvene sposobnosti, zmanjševanje kvalitete in kvantitete pitne vode, nas kot odgovorne prebivalce planeta, vodijo v drugačno razmišljanje in odnos do narave, okolja in soljudi. Neustrezno ravnanje $\mathrm{z}$ naravo in prostorom, povečevanje števila prebivalcev in rabe naravnih virov, obremenjevanje okolja in negativne posledice $\mathrm{v}$ prostoru, tako na lokalnem kot globalnem nivoju, večanje socialnih razlik in konfliktov, izgubljanje osnovnih človeških načel, kot so solidarnost, empatija, sočutje, nas silijo v drugačen, spremenjen odnos do okolja in družbe. Še posebej ob dejstvu, da so antropogeni vplivi na naravo in prostor že dosegli kritične razsežnosti in le manjši del svetovne populacije skupaj z velikimi multinacionalkami kreira usodo večine na planetu. Trajnostna družba, sloni na popolnoma drugačnih temeljih, kot sedanja neoliberalno usmerjena, je družba prihodnosti, ki se zavzema za vse družbene sloje in predstavlja sinergijo med družbo, ekonomijo in okoljem. Je družba enakopravnih, sodelujočih in soodgovornih ljudi, ki znajo in zmorejo sprejeti odgovornost in posledice za svoja ravnanja, je družba usmerjena $\mathrm{v}$ in za okolje in naravo, ter družba vrednot, ki so usmerjene v skupno dobro in ne samo posameznikom. Da jo bomo dosegli (družbo prihodnosti), so potrebne korenite spremembe v nas samih, našem odnosu do soljudi in še posebej do narave in okolja, saj nam drugače sledi ekološki in civilizacijski propad.

KLJUČNE BESEDE: narava • družba • spremembe • trajnostni način • neoliberalizem

\footnotetext{
NASLOV AVTORJA: Davorin Žnidarič, Slovenija, e-pošta: davorinznidaric@gmail.com
}

DOI https://doi.org/10.18690/978-961-286-020-2.107 ISBN 978-961-286-020-2

(C) 2017 Univerzitetna založba Univerze v Mariboru

Dostopno na: http://press.um.si 
$36^{\mathrm{TH}}$ InTERnational CONFERENCE ON ORganizational SCIENCE Development: Responsible Organization (MARCh $22^{\mathrm{ND}}-24^{\mathrm{TH}}$, PORTOROŽ SLOVENIA)

O. Arsenijević, M. Ferjan, I. Podbregar, P. Šprajc, D. Trivan \& Y. Ziegler

\title{
A Sustainable Society of the Future, through of a Critical Review of the Current Situation
}

\author{
DAVORIN ŽNIDARIČ
}

\begin{abstract}
We are in time of social and environmental pressures. The utilization of fosil fuels and minerals and exploitation of other natural resources, accros to their restorative capabilities, reducing the quality and quantity of drinking water, forced us like responsible inhabitants on planet, to the different thinking and relation to the nature, environment and people. The mismanagement of nature and space, increasing number of inhabitants and the use of natural resources, environmental pollution and negative consequences in the area, both on local and global levels, increasing social disparities and conflicts, and the loss of basic human principles of solidarity, empathy, compassion, are forcing us to different, changed attitudes towards the environment and society.
\end{abstract}

Especially given at the fact that the human impact on nature and space has reached critical mass and only a small part of the world population, together with the large multinationals creates the fate of most of the planet. A sustainable society is based on a totally different basis, like the current neoliberal. And is in of the future orientated society, which represent a synergy between the company, economy and the environment. Is the society of equal, cooperative and the joint responsible people, who know and are able to accept the responsibility and consequences for their actions. Is the company focused on and for the environment and nature, and society of values, which are aimed at the common good and not just for individuals. If we want to achieved it (the future society), we must needed a radical change in ourselves, our relationship to others and especially to nature and the environment, because otherwise we followed the ecological and civilizational collapse.

KEYWORDS: nature $\bullet$ society $\bullet$ changes $\bullet$ sistanable way $\bullet$ neoliberalism

CORRESPONDENCE ADDRESS: Davorin Žnidarič, Slovenia, e-mail: davorinznidaric@ gmail.com

DOI https://doi.org/10.18690/978-961-286-020-2.107 ISBN 978-961-286-020-2

(C) 2017 University of Maribor Press

Available at: http://press.um.si 


\section{Problemi sodobne družbe}

Smo v dobi neoliberalnega družbenega sistema, ki temelji na zakonitostih prostega trga in principih ponudbe in povpraševanja. Trajna rast in v potrošnjo orientirana družba, ki ga takšno razmišljanje producira, povzročata v prostoru povečane pritiske, tako okoljske, kot družbeno socialne. Zaradi rabe virov žive in nežive narave, ki se zaradi rasti prebivalstva ter njihove lastne omejenosti nenehno zmanjšujejo, se v okolju pojavljajo spremembe, ki se kažejo v okoljski in družbeni degradiranosti, tako na lokalnem kot globalnem področju (Kirn 2016, Plut 2014). Vplivi toplogrednih plinov zaradi industrijskega obremenjevanja in uporabe fosilnih goriv, zmanjševanje kvalitetnih kmetijskih površin zaradi pozidave ter obremenjevanj $\mathrm{v}$ prostoru, izguba biotske raznovrstnosti, naraščajoči promet in izpusti obremenil v okolje, pomanjkanje vode, so samo najizrazitejše stalnice, ki nas vsakodnevno obkrožajo in kažejo na neustrezen odnos, človeka do okolja (Žnidarič, 2016,). Okoljska degradiranost, ki jo s takšnim ravnanjem povzročamo, pa posredno vpliva na družbeno-socialno stanje, saj v prostoru onemogoča kvalitetno življenje, tako s prehranskega kot zdravstvenega vidika.

Dolgoletne posledice obremenjevanja, so nekatera industrijska področja v svetu in pri nas izrazito negativno zaznamovala. Težke kovine $\mathrm{v}$ zemljinah, uničeni gozdovi in posledično povečane zdravstvene težave, so vidne posledice, $s$ katerimi se bodo ta območja še dolgo soočala, če ne bo prišlo do konkretnih ukrepov in sanacij v prostoru. Posredne posledice, zaradi izseljevanja in spreminjanje demografske slike, pa so nemerljive in lahko trajno onemogočajo razvoj degradiranih okolij. V Sloveniji so področja (Zasavje, Mežiška dolina, Celjska kotlina), ki bi jih bilo potrebno nemudoma okoljsko sanirati, vendar se vse konča pri sredstvih, saj so sanacije povezane z velikimi stroški (Žnidarič, 2012). Namesto, da bi te stroške pokrili obremenjevalci, se največkrat porazdelijo med davkoplačevalce, ki tako plačujejo večkratno ceno (zdravstveno, ekonomsko in okoljsko). Ironično dejstvo ostaja, da se velikokrat isti obremenjevalci, čez noč prelevijo $\mathrm{v}$ rešitelje okolja, ki so ga sami degradirali, tako, da so na koncu za obremenjevanje okolja še nagrajeni (Kirn, 2012). Sreča v nesreči je, da se vse več ljudi kritično odraža do negativnih družbenih in okoljskih sprememb, ki so jih takšna ravnanja v prostoru pustila. Okoljsko področje postaja $\mathrm{v}$ zadnjih nekaj desetletjih eno najbolj eksistencialno občutljivih področij (Lukšič, 2005). Vse več ljudi spoznava, da jim denar in nove tehnologije ne bodo prinesle zdravega in čistega okolja ali nadomestile pitne vode, oziroma podaljšale življenja (Dryzek, 2005).

Če smo še pred slabimi tridesetimi leti živeli $\mathrm{v}$ obdobju nekega drugačnega (socialističnega) družbenega sistema, ki naj bi bil za ljudi in družbo prijaznejši in danes živimo v ekonomsko in politično popolnoma spremenjenem (kapitalističnem), lahko trdimo, da sta se oba, glede okolja in skrbi zanj obnašala popolnoma enako (Kirn, 2016), izkoriščevalsko, neekološko, neetično, kot, da se lahko takšna ravnanja in antropogeni vplivi brez posledic nadaljujejo. Kljub raziskavam in dejstvom, da so degradacije $\mathrm{v}$ prostoru realnost, njihove posledice pa za družbo in prostor moteče in obremenjujoče, se tudi na državni ravni dogaja, da se zakonodaja glede okoljskih problemov ne izboljšuje v smeri bolj restriktivnega ukrepanja, ampak ravno nasprotno, v Spremembe zakona o 
$36^{\mathrm{TH}}$ InTERnAtional CONFERENCE ON ORganizational SCIENCE DeVElopment: Responsible Organization (MARCh $22^{\mathrm{ND}}-24^{\mathrm{TH}}$, PORTOROŽ Slovenia)

D. Žnidarič: A Sustainable Society of the Future, through of a Critical Review of the Current Situation

varstvu okolja, so se vnesla dopolnila, ki obremenjevalcem okolja omogočajo nižje okoljske standarde in večja obremenjevanja (Žnidarič, 2016).

\section{Okoljska degradacija in vplivi v prostoru}

Okoljska degradacija, ki je osnova za vse nadaljnje (krize), se kaže na različnih področjih. Izseljevanje mladih (Zasavje, Slovenija), zdravstvene težave (Zasavje, Celjska kotlina, Mežiška dolina), mortaliteta nad nataliteto, prehranska in energetska odvisnost, večanje socialnih razlik, če $\mathrm{k}$ temu dodamo še ne prilagajanje gospodarstva $\mathrm{v}$ času in prostoru, vse skupaj vodi v degradiranost $\mathrm{v}$ prostoru (kot je to primer v Zasavju) (Žnidarič, 2016). Če k temu dodamo še divje lastninjenje, ki je povzročilo, da so nekdaj uspešna podjetja, ki so zaposlovala na stotine ljudi prešla $\mathrm{v}$ roke novodobnim kapitalistom $\mathrm{z}$ dvomljivim kapitalom in so jih ti večinoma izrabili za lastno bogatenje, je korak do socialne in družbene krize zelo majhen.

Poglabljanje socialnih in družbenih razlik, razslojevanje in revščina, ter bogatenje in vpliv kapitala na drugi strani, so povzročili stanje, ko se večina ljudi sooča s stiskami v vsakdanjem življenju in išče odgovore in rešitve za nastalo krizo.

Gledano v celoti, so potrebne spremembe, najprej v nas samih, zatem do soljudi in okolja. Nadaljevanje in poglabljanje razlik in pritiskov $\mathrm{v}$ prostoru, nedvomno pelje $\mathrm{v}$ družbeno krizo in konflikt. Tako med generacijami, kot narodi, torej med tistimi, ki trenutno še imajo pogoje za preživetje in tistimi, ki so zaradi različnih razlogov (okoljski vplivi, politični razlogi) te pogoje izgubili.

\section{$3 \quad$ Okolje in trajnostni razvoj}

Trajnostni razvoj, ki zajema kompleksno področje gospodarstva, družbe in okolja, se v zadnjem obdobju pojavlja kot vmesna faza do družbe prihodnosti, ki naj ne bi slonela (trajnostni razvoj) na rasti, tako kot to velja za trenutni neoliberalni koncept.

Upoštevati je potrebno prostorske in naravne danosti ter samo obnovitvene sposobnosti narave, drugače se bo trend obremenjevanja in s tem degradacije samo še nadaljeval. Za to, da se začnemo obnašati trajnostno, pa so potrebne spremembe v naši miselnosti, ki mora iti v smeri zmanjševanja potreb, večkratni rabi materialov in produktov, ki imajo več življenj (Vuk, 2009), rabi alternativnih, obnovljivih virov energije, prehranski samooskrbi, ter sprememb v družbi, ki bodo šle v smeri zmanjševanja obremenitev delavcev.

Pomen zaščite naravnih virov ima za prebivalce držav velik in večplasten pomen. Velik zaradi zmanjševanja njihove odvisnosti od tujih virov, ter večplasten, ker vpliva na vse segmente družbe, ekonomijo, politiko, okolje. Zdi se, da nacionalni interesi, danes v času globalizacije izgubljajo svoj pomen, vendar temu ni tako. Že prej omenjene energetske in prehranske odvisnosti, vplivajo na družbene in politične tokove. Če trajnostni razvoj temelji na uravnovešenosti gospodarskih, družbenih in okoljskih področij, je prav zaščita 
virov tista, ki lahko na vseh segmentih izboljša stanje $\mathrm{v}$ prostoru (Plut, 2014). Temeljni izziv nove-bodoče ekonomije, je po Brownu (2008) dejstvo, da mora trg poleg osnovnih zakonitosti, prepoznati in upoštevati tudi okoljsko problematiko. Reševanje te pa osnova za rešitev vseh preostalih težav vezanih na prostor, naravo in družbo.

Okoljski vidik: Podjetja so ne glede na lastniško in upravljalsko strukturo usmerjena v ustvarjanje prihodka-dobička. V preteklosti jim je bilo zaradi neustrezne okoljske zakonodaje, premajhne okoljske skrbi in nepoznavanje in minimizacije posledic obremenjevanj, malo mar za okolje. Maksima je bila le ustvarjanje čim večjega dobička. Danes, ko so na vsakem koraku vidne posledice takšnega neekološkega ravnanja, v obliki degradiranih področij, posledic toplogrednih plinov, prašnih delcev, ter ekstremnih vremenskih pojavov, je nerazumljivo, da se neekološka in družbeno ter za naravo sporna ravnanja, še vedno nadaljujejo. Primeri (nekaterih tujih) podjetij pri nas, ki so zaradi neetičnega, neekološkega delovanja $\mathrm{v}$ prišle $\mathrm{v}$ konflikt $\mathrm{z}$ okoljem in civilno družbo, kažejo prakso delovanja po proncipu ne na mojem dvorišču, ko se v okolja prinašajo tehnologije ali uporaba dokazano okoljsko spornih in škodljivih energentov. Primer petrolkoksa in Lafargea, ter teženj po sežiganju alternativnih goriv, med katerimi jih je bilo večina označenih kot nevarnih odpadkov, kažejo na ravnanja, ki so za okolje sporna, predstavljajo pa dodatna tveganja za zdravje prebivalcev (izpusti dioxinov, furanov v okolje). Še večjo skrb pa povzročajo težnje kapitala, da si skozi pravne in lobistične prijeme, pri politiki zagotovijo podporo za delovanje. Izkoriščanje dejstev o brezposelnosti in nerazvitosti področij, kamor takšna podjetja poskušajo skriti svoje delovanje, se kaže v izsiljevanju (podjetij), v primeru prevelike kritične javnosti, (glede njihovega neekološkega delovanja), da se bodo umaknili v druga področja in države, (ki nimajo tako stroge okoljske politike) brezposelnost pa se bo povečala. Za takšnim kapitalom ostajajo degradirana področja in problemi povezani z okoljem. Stroški in posledice pa ostanejo prebivalcem obremenjenih področij. Kljub povečani skrbi za izboljšanje stanj v prostoru, država nemalokrat zamiži na obe oči, ko tehta med delovnimi mesti in (zdravstvenim, ter okoljskim) stanjem v prostoru. Ne zaveda pa se, da takšno ravnanje $\mathrm{v}$ prid kapitala, povzroča dolgoročne probleme $\mathrm{v}$ družbi. Primer zdravstvenih problemov v Zasavju in stroškov zdravljenja (Onkološki inštitut, 2008, 2014), ter zmanjševanja življenjske dobe prebivalcev v regiji, kažejo, da so prav okoljske težave tiste, ki bistveno vplivajo na kvaliteto življenja.

Gospodarstvo: varovanje okolja in iskanje alternativnih možnosti na področju preskrbe $\mathrm{z}$ energijo, gradbeništvom, prehransko preskrbo, .. nudi različne razvojne možnosti. Zelena delovna mesta, uvajanje remediacijskih metod za sanacijo degradiranih področij, zadružništvo in mikro podjetja, ki niso vezana na logistiko, predstavljajo potencial v regijah, ki so zaradi opustelih in okoljsko spornih dejavnosti (energetika, rudarstvo) utrpela največje pritiske.

Usklajena strategija na ravni države in regij, bi morala temeljiti na zaščiti obdelovalnih površin, ki jih je v Sloveniji vse manj. V petindvajsetih letih smo izgubili kar štiri in osemdeset tisoč ha, kvalitetnih kmetijskih površin, s katerih bi lahko pridelovali hrano in zmanjšali prehransko odvisnost. Prehranska samopreskrba lahko predstavlja velik potencial, če bomo znali zaščititi kvalitetne obdelovalne površine. Nedavni primeri 
$36^{\text {Th }}$ International Conference on Organizational Science Development: Responsible ORGaNiZATION (MARCH $22^{\mathrm{ND}}-24^{\mathrm{TH}}$, PortoroŽ SLOVENIA)

D. Žnidarič: A Sustainable Society of the Future, through of a Critical Review of the Current Situation

(Hoče-Magna Steyr) pa še vedno kažejo na neusklajenost med ministrstvi, saj kmetijsko namreč predlogu za lokacijo tovarne nasprotuje zaradi izgube kvalitetnih kmetijskih površin, gospodarsko pa ga zagovarja zaradi kriz (brezposelnost in socialna kriza) $\mathrm{v}$ severovzhodni Sloveniji. Najbolj zaskrbljujoče pa je dejstvo, da lahko država s svojimi instrumenti, kot so intervencijski zakoni, kmetom nasilno odvzame površine, v smislu višjih nacionalnih interesov. Pričakovali bi, da se ti interesi uveljavijo tudi na področju varovanja vodnih virov, saj že več kot sedem deset odstotkov komercialnih virov upravljajo tujci, ki ustvarjajo dobičke, ki bi lahko ostali državi za zadovoljevanje lastnih potreb, ne pa da odtekajo v tujino.

\section{Družba:}

Družba se bo morala iz potrošniške in $\mathrm{v}$ trajno rast orientirane, spremeniti v ekološko, če želimo ob vseh problemih v prostoru preživeti na omejenem planetu. Po Hanžku (2011) mora cilj družbenega razvoja postati kakovost človekovega življenja, ne pa maksimiranje materialnega bogastva, kar pa nujno vodi $\mathrm{v}$ spremembo obstoječega neoliberalnega sistema. Za te spremembe, bo potrebna najprej sprememba miselnosti in zadostna kritična masa, ter seveda čas. Potreben prehod iz neoliberalizma v eko-socialistično družbo prihodnosti, ki bo slonela na drugačnih temeljih kot obstoječa, pa ne bo možna brez prehodnega obdobja, ki ga predstavlja eko-kapitalizem. Ta (eko kapitalizem) še vedno temelji na rasti, vendar ob upoštevanju okoljskih omejitev. Postopna sprememba, je potrebna zaradi ne prilagajanja industrije in dela družbe, ki si še vedno zatiska oči pred družbenimi in okoljskimi problemi. Uvajanje principov obremenjevalec plača, ter uvajanje najnovejših tehnologij $\mathrm{BAT}^{1}$ za vsak nov obrat, uporaba $\mathrm{OVE}^{2}$ in principov $\mathrm{URE}^{3}$ vodijo v pravo smer, če bomo spremenili odnos do soljudi in okolja in se soočili s okoljskimi posledicami ter zmanjševanjem naravnih virov.

\section{Družba, lastnina in odločanje}

Družbena lastnina, kjer ljudje odločajo vsi o vsem, je zaradi lastniške strukture trenutno še en, za nekatere utopičen projekt, ki pa skozi delavsko soupravljanje in deleže v podjetjih, tudi na zahodu pridobiva vse večjo veljavo. Nekatere države, (Finska, Francija,..) se zavzemajo za zmanjševanje števila delovnih ur, uvajanjem univerzalnega temeljnega dohodka in večji skrbi za socialno ogrožene skupine in starostnike, saj so razlike med bogato manjšino in čedalje revnejšo manjšino vsak dan izrazitejše in na dolgi rok predstavljajo potencialne vzroke za konfliktno situacijo.

Tudi same organizacijsko odločevalske funkcije v podjetjih se bodo morale spremeniti $\mathrm{v}$ smeri večje participacije zaposlenih. Predvsem pa vključevanje mladih v so-odločanje ob predpogoju, da se jim delo omogoči. Izmenjava izkušenj s starejšimi, ki naj bi prevzeli svetovalno vlogo, sta samo dva izmed bistvenih segmentov, ki vodijo v sodobne družbe in podjetja prihodnosti. Uvajanje delavskih svetov, kooperativ, zadrug, soupravljanja podjetij v svetu kaže, da takšne oblike soodločanja (v podjetjih) dajejo sinergijske učinke in so uspešnejše od podjetij, kjer so v veljavi hierarhični odnosi. Če smo v preteklosti govorili o socialističnih projektih, samoupravljanju v Jugoslaviji, ki je (kljub vsiljenemu 
konceptu delavcem, ob njegovem striktnem uveljavljanju v praksi), na začetku dalo spodbudne rezultate, (rast gospodarstva je bila med največjimi v svetu in je v povprečju znašala okrog $9 \%$ letno), se je kasneje, ko se je oblast vpletala v politiko vodstva podjetij, klavrno propadla (Mitrović, 2016). Danes se podobne oblike odločanja v podjetjih uveljavljajo večinoma v zahodnih državah. Zadruge v Španiji, Japonskem, Franciji, dajejo zgled, da se lahko takšno delavsko socialistični koncepti uspešno uveljavljajo tudi v kapitalizmu. Tudi lastniški deleži delavcev v podjetjih, kažejo na uspešnost takšnih projektov. V letu 2013 so znašali 266 milijard evrov, medtem, ko ima kar 84,6\% vseh evropskih podjetij uveljavljene delavske lastniške sheme (Delo si., 2016). Odločanje vseh vpletenih o vseh pomembnih zadevah tako ne predstavlja le še ene utopične ideje nostalgikov socializma ampak tudi realnost družbe prihodnosti.

\section{$4 \quad$ Zaključek}

Stanje v družbi in okolju, je že desetletja podrejeno neoliberalistični miselnosti, trajni rasti in principom trga. Nezmanjšano izčrpavanje naravnih in človeških virov ter poglabljanje razlik med prebivalci, kaže na dejstvo, da so potrebne spremembe na vseh ravneh družbe. Na miselni, sistemski, politični. Potrebujemo družbeni sistem, ki bo vpeljal vrednote, ki ne temeljijo na egu in dobičku, ampak na družbi solidarnosti, empatiji do soljudi in skrbi za okolje. Degradacije v času in prostoru, ki smo jim priča danes zaradi vpliva neoliberalizma in politike trajne rasti, kažejo na nujne sistemske spremembo, saj nam $\mathrm{v}$ nasprotnem primeru sledi propad.

\section{Opombe}

${ }^{1}$ BAT Best available technology

${ }^{2}$ OVE Obnovljivi viri energije

${ }^{3}$ URE Učinkovita raba energije

\section{Literatura}

Brown, L. (2008). Plan B 3.0 Mobilizing to save Civilisation. Earth Policy Institute, New York.

Delo.si, (2016). Ekonomska demokracija 3: Evropsko lastništvo zaposlenih se krepi. Dostopno na: (http://www.delo.si/gospodarstvo/finance/ekonomska-demokracija-3-evropsko-lastnistvozaposlenih-se-krepi.html).

Dryzek, J.S.(2005). The Politics of the Earth .Oxford:Oxford University press.

Hanžek, M. (2011). Kam po krizi? Prispevek k oblikovanju trajnostne vizije prihodnosti Slovenije, kabinet predsednika vlade.

Lukšič, A. (2005). Modificiranje in odpiranje okoljskih političnih aren. Časopis za kritiko znanosti letnik 33, številka 219, str. 91-107.

Kirn, A. (2012). Družbenoekološki obrat ali propad, FDV, Ljubljana

Kirn, A. (2016). Ekosocializem kot povezava družbenosti in sonaravnosti: Realna alternativa ali utopija. Varstvo narave, 29 (49-72).

Dostopno na: (http://www.zrsvn.si/dokumenti/63/2/2016/Kirn_4527.pdf).

Mitrovič, M. (2016). Samoupravljanje:Budučnost jedne utopije; Dostopno na; (http://pescanik.net/samoupravljanje-buducnosti-jedne-utopije/). 
$36^{\text {Th }}$ International Conference on Organizational Science Development: ResPonsible ORGaNiZATION (MARCH $22^{\mathrm{ND}}-24^{\mathrm{TH}}$, PortoroŽ SLOVENIA)

D. Žnidarič: A Sustainable Society of the Future, through of a Critical Review of the Current Situation

Onkološki inštitut Ljubljana, (2008). Razširjenost rakavih obolenj v Sloveniji in Zasavju, dostopno na; (http://www.slora.si/c/document_library/get_file?uuid=e2d50781-52fb-4a33-9e366e8adc5c81f8\&groupId=11561)

Onkološki inštitut Ljubljana, (2014) Incidenca raka v Sloveniji, dostopno na: (http://www.onkoi.si/fileadmin/onko/datoteke/dokumenti/RRS/LP_2014.pdf)

Plut, D. (2004). Zeleni Planet?; prebivalstvo, energija in okolje v 21. stoletju, Radovljica, Didakta.

Plut, D. (2014); Ekosocializem ali barbarstvo, Ljubljana, TRS, Ljubljana.

Vuk, D. (2011). Zapiski predavanj, FOV Kranj.

Žnidarič, D. (2016). Vpliv družbeno okoljskih dejavnikov na trajnostno-prostorsko politiko v svetu in pri nas; 35. Mednarodna konferenca o razvoju organizacijskih znanosti; Trajnostna organizacija, Marec 2016, Portorož. Zbornik izdan: Kranj, Fakulteta za organizacijske vede, Kranj, 2016, stran 1485 - 1492.

Žnidarič, D. (2009). Reševanje problematike težkih kovin v zemlji s postopki remediacije, Mednarodna konferenca, Marec 2009, Portorož. Zbornik izdan: Kranj, Fakulteta za organizacijske vede Kranj, 2009, stran 287.

Žnidarič, D. (2012). Zdravo okolje kot prioriteta za uravnotežen trajnostni razvoj v Sloveniji in svetu, Mednarodna konferenca, Marec 2012, Portorož. Zbornik izdan: Kranj, Fakulteta za organizacijske vede, Kranj, 2012.

Žnidarič, D.(2016). Vpliv družbeno okoljskih dejavnikov na trajnostno-prostorsko politiko v svetu in pri nas; Mednarodna konferenca; Trajnostna organizacija, Marec 2016, Portorož. Zbornik izdan: Kranj, Fakulteta za organizacijske vede, Kranj, 2016, stran 1485 - 1492.

Žnidarič,D., (2016), Naraščanje socialne krize v Zasavju zaradi upada gospodarstva v regiji, Diplomsko delo visokošolskega strokovnega študija-organizacija in management kadrovskih in izobraževalnih procesov. Fakulteta za Organizacijske vede, Kranj, 2016. 
36. MEDNARODNA KONFERENCA O RAZVOJU ORGANIZACIJSKIH ZNANOSTI: OdgOVORNA ORGANIZACIJA (22. - 24. MAREC 2017, PORTOROŽ, SLOVENIJA)

O. Arsenijević, M. Ferjan, I. Podbregar, P. Šprajc, D. Trivan \& Y. Ziegler

\title{
Percepcija zelenih informacijskih sistemov med slovenskimi managerji
}

\author{
ANJA ŽnIDARŠIČ, ALENKA BREZAVŠČEK, MATJAŽ MALETIČ \& AlENKA BAGGIA
}

Povzetek Trajnostni razvoj, okoljevarstveni problemi in zakonodaja silijo organizacije k stalnem izboljševanju poslovnih procesov, ki morajo biti skladni z danimi direktivami. Kljub temu, da poslovne procese v že več let neprestano spreminjamo $\mathrm{z}$ namenom zmanjševanja emisij, pa smo pozornost informacijski tehnologiji in še posebej informacijskim sistemom začeli namenjati šele nedavno. Informacijske sisteme (IS), ki omogočajo trajnostni razvoj in gospodarstvo, imenujemo zeleni IS. Predhodne raziskave kažejo, da kultura managerjev in osebno dojemanje problematike trajnostnega razvoja, igrajo pomembno vlogo pri sprejemanju zelenih IS. $\mathrm{V}$ prispevku predstavljamo semantično analizo omrežja asociacij na besedno zvezo zeleni IS, ki so jih podali managerji v nedavni raziskavi. Asociacije smo združili v skupine, na osnovi semantične analize omrežja pa smo podali razpravo o konceptu zelenih IS.

KLJUČNE BESEDE: zeleni informacijski sistemi • okolje, managerji • zavedanje $\bullet$ besedne zveze $\bullet$ analiza omrežij

NASLOV AVTORJEV: dr. Anja Žnidaršič, docentka, Univerza v Mariboru, Fakulteta za organizacijske vede, Kidričeva cesta 55a, 4000 Kranj, Slovenija, e-pošta: anja.znidarsic@fov.uni-mb.si, dr. Alenka Brezavšček, docentka, Univerza v Mariboru, Fakulteta za organizacijske vede, Kidričeva cesta 55a, 4000 Kranj, Slovenija, e-pošta: alenka.brezavscek@fov.uni-mb.si, dr. Matjaž Maletič, docent, Univerza v Mariboru, Fakulteta za organizacijske vede, Kidričeva cesta 55a, 4000 Kranj, Slovenija, e-pošta: matjaz.maletic@fov.uni-mb.si, dr. Alenka Baggia, docentka, Univerza v Mariboru, Fakulteta za organizacijske vede, Kidričeva cesta 55a, 4000 Kranj, Slovenija, e-pošta: alenka.baggia@fov.uni-mb.si

DOI https://doi.org/10.18690/978-961-286-020-2.108 ISBN 978-961-286-020-2

(C) 2017 Univerzitetna založba Univerze v Mariboru

Dostopno na: http://press.um.si 
$36^{\mathrm{TH}}$ InTERnational CONFERENCE ON ORganizational SCIENCE Development: Responsible Organization (MARCh $22^{\mathrm{ND}}-24^{\mathrm{TH}}$, PORTOROŽ SLOVENIA)

O. Arsenijević, M. Ferjan, I. Podbregar, P. Šprajc, D. Trivan \& Y. Ziegler

\title{
Perception of Green Information System Concept among Slovenian Managers
}

\author{
ANJA ŽNiDARŠIČ, AlenKa BREZAVŠČEK, MATJAŽ MaletiČ \& AlENKA BAGGIA
}

\begin{abstract}
Sustainability, environmental issues and legislation force organizations to improve their businesses in line with given directions. Even though business processes are facing a constant change for years to ensure a lower level of emissions, the information technology and especially information systems have gained this attention only recently. Information systems enabling the sustainable development and economy have been addressed as Green Information systems (Green IS). According to the previous research, the culture or individual perception of managers play an important role in Green IS adoption. In this paper, we present the semantic network analysis of the associations to the Green IS concept, given by managers in a recent research. The associations are grouped and the perception of the Green IS concept is discussed based on the results of the semantic network.
\end{abstract}

KEYWORDS: green information systems • environment $\bullet$ manager • awareness $\bullet$ word associations $\bullet$ network analysis

CoRrespondence AdDress: Anja Žnidaršič, Ph.D., Assistant Professor, University of Maribor, Faculty of Organizational Sciences, Kidričeva cesta 55a, 4000 Kranj, Slovenia, e-mail: anja.znidarsic@fov.uni-mb.si, Alenka Brezavšček, Ph.D., Assistant Professor, University of Maribor, Faculty of Organizational Sciences, Kidričeva cesta 55a, $4000 \mathrm{Kranj}$, Slovenia, e-mail: alenka.brezavscek@fov.uni-mb.si, Matjaž Maletič, Ph.D., Assistant Professor, University of Maribor, Faculty of Organizational Sciences, Kidričeva cesta 55a, $4000 \mathrm{Kranj}$, Slovenia, e-mail: matjaz.maletic@fov.uni-mb.si, Alenka Baggia, Ph.D., Assistant Professor, University of Maribor, Faculty of Organizational Sciences, Kidričeva cesta 55a, 4000 Kranj, Slovenia, e-mail: alenka.baggia@fov.uni-mb.si

DOI https://doi.org/10.18690/978-961-286-020-2.108 ISBN 978-961-286-020-2

(C) 2017 University of Maribor Press

Available at: http://press.um.si 


\section{$1 \quad$ Uvod}

$\mathrm{Z}$ naraščanjem problemov, povezanih s spreminjanjem okolja in ostalih problemov $\mathrm{s}$ področja trajnostnega razvoja, so postali informacijski sistemi (IS) pomemben dejavnik, ki omogoča trajnostni razvoj. Kot taki, skupaj z okolju prijazno zeleno informacijsko tehnologijo, tako imenovani zeleni IS igrajo pomembno vlogo pri ohranjanju okolja in trajnostnemu razvoju. Čeprav je okoljska informatika in ostale pobude, ki povezujejo IS in trajnostne vidike, tema razprav že več kot desetletje prej, pa so zeleni IS postali aktualna tema raziskav od leta 2008 dalje, ko je bilo objavljenih nekaj prispevkov, ki so koncept podrobneje opredelili (npr. Boudreau, Chen, \& Huber, 2008; Chen, Boudreau, \& Watson, 2008; Pernici, Ardagna, \& Cappiello, 2008). Kasneje je več avtorjev prepoznalo zelene IS kot vzhajajoče področje raziskav v IS skupnosti (Cardoso \& Carvalho, 2010; Dedrick, 2010; Melville, 2010). Glede na veliko število objav in dejstvo, da okoljski problem in splošno problem trajnostnega razvoja še vedno niso rešeni, je tema ostala aktualna.

Kot navaja (Boudreau et al., 2008), pod pojmom zeleni IS razumemo oblikovanje in implementacijo IS, ki omogočajo trajnostno naravnane poslovne procese (Seidel, Recker, \& Pimmer, 2010). Eno pomembnejših podskupin zelenih IS predstavlja tudi področje energetske informatike, ki se osredotoča na energetsko učinkovitost (Watson, Boudreau, \& Chen, 2010). Obširen pregled literature in konceptov, ki jih vključujemo v zelene IS, je predstavljen v Baggia \& Brezavšček (2015).

Ker je koncept zelenih IS dokaj nov in kot kažejo rezultati raziskave (Baggia et al., 2016), se managerji na splošno premalo zavedajo pomena uvajanja zelenih IS, smo želeli v okviru pričujoče raziskave ugotoviti, kakšne so asociacije, ki se slovenskim managerjem, vodilnim delavcem na področju informatike, porajajo ob besedni zvezi zeleni IS. V prispevku prikazujemo analizo asociacij, ki smo jo izvedli s pomočjo metod iz analize omrežij s programom Pajek (Batagelj \& Mrvar, 1998), na osnovi katere lahko dobimo bolj natančen vpogled $\mathrm{v}$ miselnost in koncepte, ki jih slovenski managerji povezujejo $\mathrm{z}$ zelenimi IS.

Proučevanja asociacij se raziskovalci lotevajo na različne načine. Navadno izhajajo iz večje začetne množice besed, na katere udeleženci podajajo svoje asociacije (npr. Gravino, Servedio, Barrat, \& Loreto, 2012; Nelson, McEvoy, \& Schreiber, 2004; Zortea, Menegola, Villavicencio, \& Salles, 2014), ali pa omrežje asociacij zgradijo na podlagi objavljenih tvitov (Adib Imtiyazi, Alamsyah, Junaedi, \& Pradana, 2016). V našem primeru smo se osredotočili na eno začetno ključno besedo in sicer »zeleni IS«.

Metodologija

\subsection{Zasnova raziskave in vzorčenje}

Raziskava o asociacijah, ki se slovenskim managerjem porajajo ob besedni zvezi zeleni IS, je del obsežnejše raziskave o zavedanju in odnosu do zelenih IS (Baggia et al., 2016). 
$36^{\mathrm{TH}}$ INTERNATIONAL CONFERENCE ON ORganizational SCIENCE DeVElopment: Responsible Organization (MARCh $22^{\mathrm{ND}}-24^{\mathrm{TH}}$, Portorož Slovenia)

A. Žnidaršič, A. Brezavšček, M. Maletič, A. Baggia: Perception of Green Information System Concept among Slovenian Managers

Na koncu vprašalnika smo anketirance prosili, naj navedejo štiri asociacije, torej štiri besede (ali besedne zveze), na katere pomislijo ob omembi zelenih IS.

Povabilo za sodelovanje v raziskavi, naslovljeno na direktorja podjetja oz. na direktorja oddelka informatike, smo po elektronski pošti poslali 3623 izbranim podjetjem v Sloveniji. Kot vzorčni okvir smo uporabili Poslovni imenik Slovenije (PIRS), kjer smo izločili podjetja z manj kot dvema zaposlenima. Uporabili smo stratificirano kvotno vzorčenje glede na regijo in glavno dejavnost podjetja, znotraj stratumov smo vzorčili slučajno. Tako izbran vzorec je odražal demografsko strukturo podjetij v Sloveniji. Raziskava je potekala med majem in avgustom 2015. Skupno smo prejeli 222 odgovorov, polovica anketirancev pa je na koncu vprašalnika podala tudi asociacije.

\subsection{Analiza omrežij kot orodje za analizo zbranih asociacij}

Omrežje sestavljajo končna množica ali množice enot z eno ali več relacijami med njimi (Wasserman \& Faust, 1994). V našem primeru smo na začetku iz podatkov ankete sestavili t. i. dvovrstno omrežje $\mathrm{z}$ dvema množicama enot. Prvo množico enot predstavljajo anketiranci, drugo pa vse navedene (različne) besede. Relacija, ki povezuje enote obeh množic, je 'imenovanje besede'. Omrežje lahko predstavimo na dva načina: v matrični obliki in grafično. Dvovrstno omrežje v matrični obliki predstavlja pravokotna matrika, kjer vrstice predstavljajo anketirance, stolpci pa vse različne besede, ki so jih navedli vsi anketiranci. Če je določen anketiranec izbral besedo, zapišemo v matriko 1 , drugod so ničle.

Slika 8 (levo) predstavlja del dvovrstnega omrežja, kjer so na abscisni osi navedene besede, na ordinati pa anketiranci. Povezava med anketirancem in besedo je označena $\mathbf{S}$ črnim kvadratkom. Dvovrstno omrežje lahko pretvorimo $\mathrm{v}$ enovrstno omrežje $\mathrm{z}$ vrednostmi na povezavah. Ker nas zanimajo asociacije, omrežje pretvorimo v enovrstno glede na stolpce tako, da v novem omrežju enote predstavljajo besede. Dobljeno omrežje je simetrično, kjer vrednosti na povezavah povedo, kolikokrat so anketiranci besedi navedli skupaj. Diagonalni elementi matrike pa povedo, kolikokrat je bila posamezna beseda omenjena. Del omrežja besed (brez diagonalnih vrednosti) je predstavljen na desni strani

Slika 8 , kjer različne sivine predstavljajo različne vrednosti na povezavah. 

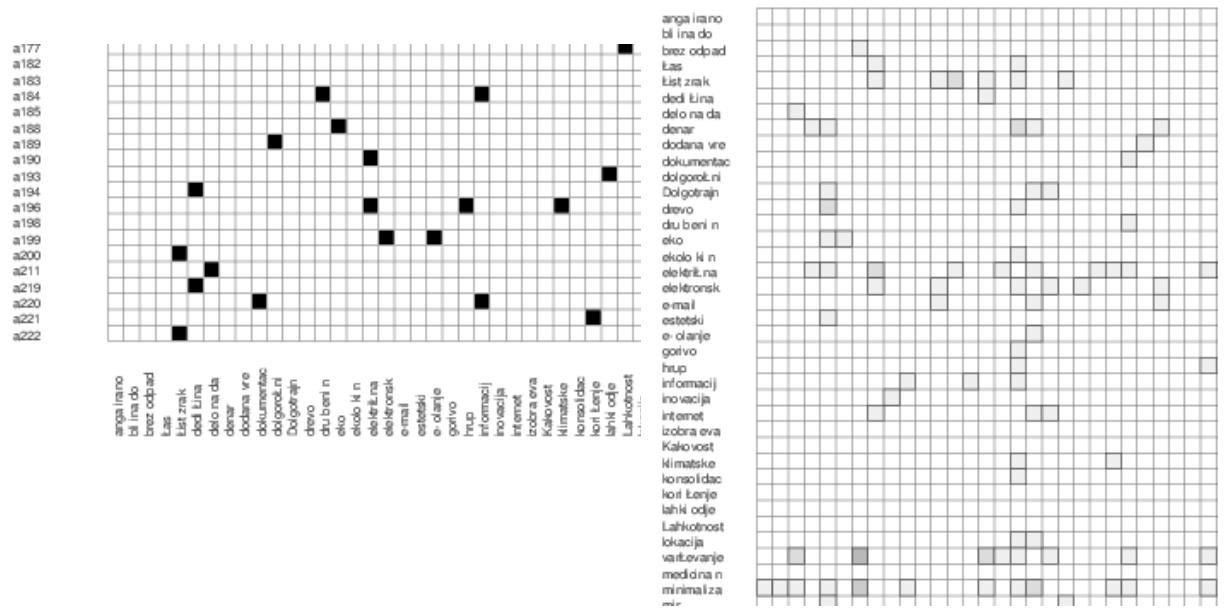

Slika 8: Del dvovrstnega omrežja »anketiranec x besede« (levo) in del preoblikovanega enovrstnega omrežja besed (desno)

Predstavljeni omrežji sta precej nepregledni, zato bomo z različnimi metodami analize omrežij v nadaljevanju prikazali najzanimivejše dele omrežja. Raziskali bomo stopnje točk ter poiskali razvrstitve točk oz. besed v skupine s pomočjo posrednega bločnega modeliranja (Doreian, Batagelj, \& Ferligoj, 2005).

\section{$3 \quad$ Rezultati}

\subsection{Osnovne karakteristike omrežja asociacij}

Omrežje asociacij ima 101 točk, kar pomeni, da je 111 anketirancev navedlo 101 različnih besed (oz. besednih zvez). Pri tem smo združili sopomenke (npr. prihodnost in bodočnost) in preoblikovali oz. združili glagole ter pridevnike v ustrezno samostalniško obliko (npr. ohranjanje v ohranitev; ekološko in eko v ekologija, ipd.). Omrežje ima 313 povezav $\mathrm{z}$ vrednostjo 1 ter 88 povezav $\mathrm{z}$ vrednostjo večjo od 1, kar pomeni, da imamo 88 parov besed, ki sta jih skupaj navedla vsaj dva anketiranca.

Pobliže smo želeli pogledati najpogosteje navedene besede oz. pare besed, zato smo iz omrežja odstranili vse povezave $\mathrm{z}$ vrednostjo 1 in pripadajoče točke. Torej, odstranili smo vse besede, ki jih je navedel le en anketiranec. Dobljeno omrežje ima tako 39 besed in je predstavljeno na

Slika 9. Velikost točke je premosorazmerna s številom omemb posamezne besede, debelina povezave pa nakazuje, kolikokrat so anketiranci omenili obe besedi hkrati.

Največkrat omenjena je bila beseda okolje (30), sledi varčevanje/manjša poraba energije (23), prihodnost (21), minimalizacija tiska (19), narava (18), varčevanje (17), električna energija (16), čist zrak (13), zdravje (12), recikliranje (11) in odpadki (8). 
$36^{\mathrm{TH}}$ InTERnAtional CONFERENCE ON ORganizational SCIENCE DeVElopment: Responsible Organization (MARCH $22^{\mathrm{ND}}-24^{\mathrm{TH}}$, PortoroŽ SlOVENIA)

A. Žnidaršič, A. Brezavšček, M. Maletič, A. Baggia: Perception of Green Information System Concept among Slovenian Managers

Če pogledamo vrednosti na povezavah, so anketiranci največkrat skupaj navedli naslednje pare besed: prihodnost - okolje (12), prihodnost - narava (7), minimizacija tiska - varčevanje/manjša poraba energije (7), okolje - električna energija (6) in okolje varčevanje (6).

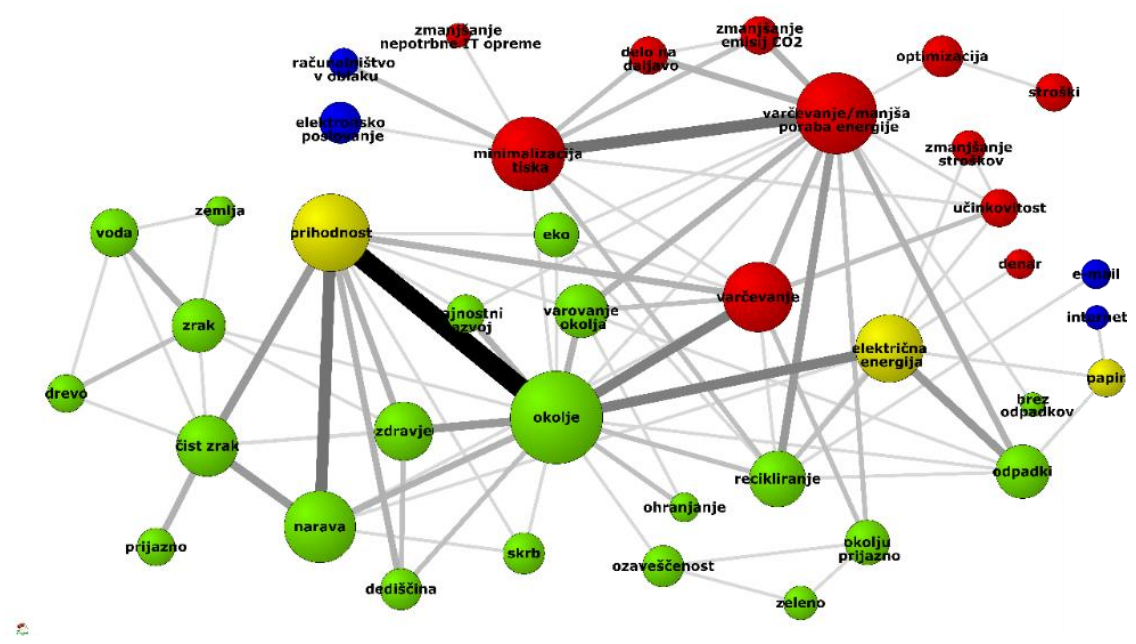

Slika 9: Omrě̌je asociacij, ki sta jih navedla vsaj dva anketiranca

Točke smo označili s štirimi barvami. Prevladujejo besede obarvane z zeleno, ki se nanašajo na okolje in naravo ter na našo ozaveščenost pri ravnanju $z$ odpadki. $Z$ rumeno smo obarvali besede, ki jih lahko interpretiramo na različne načine. Glede na to, da je prihodnost močno povezana $\mathrm{z}$ naravo in okoljem, lahko sklepamo, da anketiranci menijo, da bodo zeleni IS vplivali na varovanje okolja, hkrati pa se prihodnost povezuje z varčevanjem. S tega vidika lahko argumentiramo, da so anketiranci mnenja, da bomo v prihodnosti z uvedbo zelenih IS varčevali oz. zmanjšali stroške.

Papir lahko tako na eni strani predstavlja odpadek, ali pa z uporabo interneta zmanjšamo njegovo uporabo. Modre točke predstavljajo najbolj prepoznane/uporabljane informacijsko-komunikacijske storitve: elektronsko pošto, internet, računalništvo $\mathrm{v}$ oblaku in elektronsko poslovanje. Rdeče točke predstavljajo prednosti, ki jih prinaša uvedba zelenih IS. S tehničnega vidika je to npr. zmanjšanje nepotrebne IT opreme, hkrati pa uvedba zelenih IS zmanjša emisije $\mathrm{CO}_{2}$, porabo električne energije ter stroške z zelo različnih zornih kotov (delo na daljavo, minimalizacija tiska, optimizacija procesov).

Slika 10 prikazuje 62 besed, ki se niso pojavile skupaj pri dveh anketirancih ali več. Kljub temu pa te besede prikazujejo zanimiv, edinstven pogled posameznika na zelene IS. Z različnimi barvami so prikazane t.i. komponente tega omrežja, torej točke, ki so povezane med sabo. S svetlo modro barvo je obarvanih 23 besed, ki niso povezane $\mathrm{z}$ ostalimi $\mathrm{v}$ tem podomrežju. To pomeni, da jih je anketiranec navedel skupaj s katero od besed iz s 
Slika 9 oz. je navedel le eno besedno zvezo, kot je npr. 'ne more biti zelen'. Kot rečeno, lahko s pregledom komponent, ki jih sestavljajo besede, ki jih v paru ni izreklo več anketirancev, temveč jih je med svojimi asociacijami navedel posameznik, razberemo mnenja anketirancev, ki odstopajo od večine. Tako nekdo meni, da so zeleni IS modna muha, ki prinaša novo "papirologijo«. Zeleni IS nekoga spominjajo na zavedanje, ki ga pridobimo v procesu izobraževanja skozi teorijo in prakso. Zeleni IS so jasno povezani z IT, ki prinaša družbeni napredek. Nekdo v zelenih IS vidi priložnost, tudi v medicini na daljavo. So preventiva pred onesnaženjem. Predstavljajo inovacijo ter dodano vrednost.

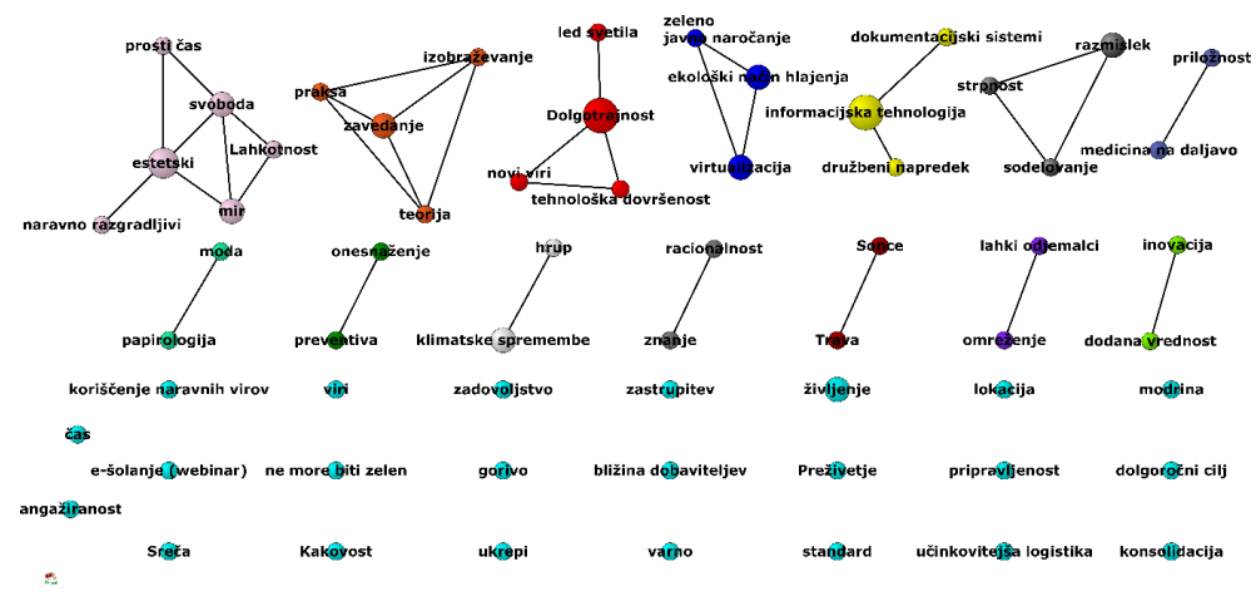

Slika 10: Besede, ki niso bile navedene skupaj pri več kot enem anketirancu

\subsection{Posredno bločno modeliranje omrežja asociacij}

Pogosto uporabljena metoda $\mathrm{v}$ analizi omrežji je bločno modeliranje (Doreian et al., 2005), s pomočjo katerega želimo odkriti osnovno strukturo navadno velikega nepreglednega omrežja. Cilj bločnega modeliranja je raziskati strukturo povezav med enotami. Natančneje, $v$ omrežju želimo poiskati skupine enot, ki imajo enak (ali podoben) vzorec povezav z drugimi skupinami enot ter hkrati opisati povezave med skupinami enot. Poznamo neposredni in posredni pristop $\mathrm{k}$ bločnemu modeliranju (Batagelj et al., 1992). V tem prispevku bomo prikazali rezultate posrednega bločnega modeliranja, ki zajema dva koraka. Najprej izračunamo mero različnosti med vsemi enotami omrežja glede na izbrano enakovrednost. V drugem koraku pa uporabimo klasičen pristop razvrščanja. V našem primeru smo se odločili za uporabo strukturne enakovrednosti, kar pomeni, da so strukturno enakovredne enote na enak način povezane $\mathrm{z}$ istimi enotami. Uporabljena mera različnosti, ki je skladna $\mathrm{s}$ strukturno enakovrednostjo, je (popravljena) kvadrirana evklidska razdalja, kot metodo razvrščanja pa smo izbrali hierarhično razvrščanje z Wardovo metodo. 
36 ${ }^{\text {TH }}$ International Conference on Organizational Science Development: Responsible ORGaNiZATION (MARCH $22^{\mathrm{ND}}-24^{\mathrm{TH}}$, PORTOROŽ SLOVENIA)

A. Žnidaršič, A. Brezavšček, M. Maletič, A. Baggia: Perception of Green Information System Concept among Slovenian Managers

Slika 11 prikazuje omrežje vseh 101 besed. Velikost točke ponovno prikazuje število omemb posamezne besede, medtem ko sedaj barve razkrivajo 8 skupin točk glede na posredno bločno modeliranje. Besede iz posamezne skupine imajo enake vzorce povezav med seboj, hkrati pa so na enak način povezane s istimi enotami iz drugih skupin.

Prvo skupino sestavljata prihodnost in okolje (vijolični točki), torej dve besedi, ki so ju anketiranci največkrat navedli skupaj. Navedeni besedi sta precej močno povezani s štirimi točkami iz rumene skupine (čist zrak, zdravje, narava in prijazno) ter s štirimi točkami iz bele skupine (varčevanje, odpadki, električna energija in recikliranje). Vsebinsko podoben pomen, (torej varčevalni vidik) kot besede iz bele skupine imata tudi minimizacija tiska in varčevanje / manjša poraba energije (oranžni točki). Skupino treh točk, ki je močneje povezana z okoljem, sestavljajo voda, drevo in zrak (rumene točke). Nekoliko več točk imata šesta oz. rdeča (13) in sedma oz. modra skupina (12). Rdečo skupino točk sestavljajo naslednje besede: dediščina, skrb, ozaveščenost, ohranjanje, zeleno, okolju prijazno, učinkovitost, informacijska tehnologija, delo na daljavo, zmanjšanje emisij $\mathrm{CO}_{2}$, trajnostni razvoj, varovanje okolja in eko. Skupni imenovalec vseh teh besed je učinkovita skrb za okolje. Modro skupino sestavljajo besede: dolgotrajnost, virtualizacija, elektronsko poslovanje, računalništvo v oblaku, zmanjšanje nepotrebne IT opreme, optimizacija, stroški, led svetila, denar, e-pošta, internet in papir. To so torej besede, ki se nanašajo na IKT v povezavi z zmanjšanjem stroškom. Ostale besede, obarvane z zeleno, sestavljajo t.i. periferijo. Le-te nimajo značilnega vzorca povezav med sabo in tudi ne $\mathrm{z}$ drugimi skupinami točk.

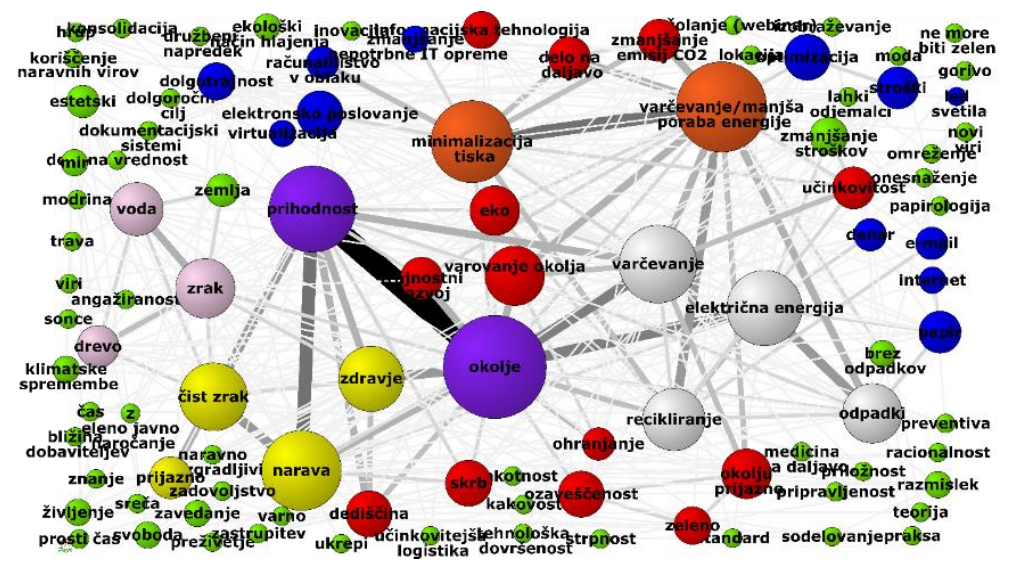

Slika 11: Omrežje asociacij z osmimi skupinami glede na posredno bločno modeliranje

\section{Zaključek}

V prispevku obravnavamo koncept zelenih IS in asociacije, ki se posameznikom pojavijo, ko slišijo besedno zvezo zeleni IS. Predstavili smo analizo omrežij kot orodje ter posredno bločno modeliranje omrežja asociacij. Analizo asociacij smo izvedli s pomočjo 
metod analize omrežij s programom Pajek (Batagelj \& Mrvar, 1998) ter tako dobili pregleden prikaz miselnosti in konceptov, ki jih s pojmom zeleni IS povezujejo slovenski managerji.

Pri analizi lahko izpostavimo nekaj zanimivosti. Najpogosteje managerji povezujejo pojem zeleni IS z okoljem, naravo in prihodnostjo. Velik pomen pa imajo tudi različni načini varčevanja naravnih virov (električna energija, papir). Zanimiva je tudi ugotovitev, da se negativen odnos do pojma zeleni IS pojavi zelo redko, v manj kot $1 \%$ asociacij (načeloma samo v enem primeru: »ne more biti zelen«). Anketiranci torej v zelenih IS vidijo prednosti, boljšo prihodnost. Kot so ugotovili že (Gholami, Sulaiman, Ramayah, \& Molla, 2013), je sprejetje zelenih IS v določeni meri odvisno tudi od managerjevega osebnega odnosa do okolja. V obravnavanem primeru smo tako pokazali, da ima večina managerjev pozitiven odnos do pojma zeleni IS, zato lahko pričakujemo, da bo podrobnejša raziskava faktorjev, ki vplivajo na odnos managerjev do pojma zeleni IS, pokazala pozitiven vpliv osebnega odnosa do okolja na sprejetje zelenih IS.

\section{Literatura}

Adib Imtiyazi, M., Alamsyah, A., Junaedi, D., \& Pradana, J. A. (2016). Word association network approach for summarizing Twitter conversation about public election. 2016 4th International Conference on Information and Communication Technology, ICoICT 2016, 4(c). http://doi.org/10.1109/ICoICT.2016.7571909

Baggia, A., \& Brezavšček, A. (2015). Green Information Systems. In P. Doucek, A. Novak, \& B. Paape (Eds.), Internationalization and cooperation: proceedings of the 34th International Conference on Organizational Science Development. Kranj: Moderna Organizacija.

Baggia, A., Brezavšček, A., Maletič, M., Šparl, P., Raharjo, H., \& Žnidaršič, A. (2016). Awareness and Attitude Towards Green IS in Slovenian Enterprises. Organizacija, 49(1), 15-27.

Batagelj, V., \& Mrvar, A. (1998). Pajek - program for large network analysis. Connections, 21(2), 47-57. http://doi.org/10.1.1.27.9156

Boudreau, M.-C., Chen, A. J., \& Huber, M. (2008). Green IS : Building Sustainable Business Practices. Information Systems Journal, 76, 1-15. http://doi.org/10.1108/13287260810916907

Cardoso, A. ., \& Carvalho, J. Á. (2010). Green Information Systems: the Use of Information Systems To Enhance Sustainable Development. MIS Quarterly, 34(1), 23-38. Retrieved from http://www3.dsi.uminho.pt/seeum2010/CD/abstracts/anacristinacardoso - abstract.pdf

Chen, A. J. W., Boudreau, M.-C., \& Watson, R. T. (2008). Information systems and ecological sustainability. Journal of Systems and Information Technology, 10(3), 186-201. http://doi.org/10.1108/13287260810916907

Dedrick, J. (2010). Green IS: Concepts and issues for information systems research. Communications of the Association for Information Systems, 27(1), 173-184.

Doreian, P., Batagelj, V., \& Ferligoj, A. (2005). Generalized Blockmodeling. Cambridge: Cambridge University Press.

Gholami, R., Sulaiman, A. B., Ramayah, T., \& Molla, A. (2013). Senior managers' perception on green information systems (IS) adoption and environmental performance: Results from a field survey. Information \& Management, 50(7), 431-438. http://doi.org/10.1016/j.im.2013.01.004

Gravino, P., Servedio, V. D. P., Barrat, A., \& Loreto, V. (2012). Complex Structures and Semantics in Free Word Association. Advances in Complex Systems, 15(03n04), 1250054. http://doi.org/10.1142/S0219525912500543 
1356 36 $36^{\mathrm{TH}}$ International CONFERENCE ON ORganizational SCIENCE DeVElopment: Responsible Organization (March $22^{\mathrm{ND}}-24^{\mathrm{TH}}$, Portorož Slovenia)

A. Žnidaršič, A. Brezavšček, M. Maletič, A. Baggia: Perception of Green Information System Concept among Slovenian Managers

Melville, N. P. (2010). Information Systems Innovation for Environmental Sustainability. MIS Quarterly, 34(1), 1-21. http://doi.org/Article

Nelson, D. L., McEvoy, C. L., \& Schreiber, T. A. (2004). The University of South Florida free association, rhyme, and word fragment norms. Behavior Research Methods, Instruments, \& Computers, 36(3), 402-407. http://doi.org/10.3758/BF03195588

Pernici, B., Ardagna, D., \& Cappiello, C. (2008). Business Process Design: Towards ServiceBased Green Information Systems. Information Systems Journal, 280, 195-203. http://doi.org/10.1007/978-0-387-09712-1_22

Seidel, S., Recker, J., \& Pimmer, C. (2010). Enablers and barriers to the organizational adoption of sustainable business practices. AMCIS 2010 Proceedings, (August), 12-15. Retrieved from http://eprints.qut.edu.au/32286/

Wasserman, S., \& Faust, K. (1994). Social network analysis: Methods and applications (Vol. 8). Cambridge university press.

Watson, R. T., Boudreau, M.-C., \& Chen, A. J. (2010). Information systems and environmentally sustainable development: energy informatics and new directions for the is community. MIS Quarterly, 34(1), 23-38. http://doi.org/Article

Zortea, M., Menegola, B., Villavicencio, A., \& Salles, J. F. de. (2014). Graph analysis of semantic word association among children, adults, and the elderly. Psicologia: Reflexão E Crítica, 9099. http://doi.org/10.1590/S0102-79722014000100011 


\title{
Ali imajo vodje in sledilci različen odnos do sprememb? Primer Gorenja, d.d.
}

\begin{abstract}
MIHA ŽOVE
Povzetek Mnoge raziskave ugotavljajo, da ima posameznikov odnos do organizacijskih sprememb pomembno vlogo pri uvajanju teh sprememb in da je ključni dejavnik njihovega uspeha.

Nekateri raziskovalci ugotavljajo, da lahko odnos do sprememb opredelimo z dvema komponentama: situacijskim odnosom do sprememb (odnos do konkretne spremembe) ter dispozicijskim odnosom do sprememb (odnos do sprememb na splošno). Obe komponenti sta lahko izraženi pozitivno (sprejemanje sprememb) ali negativno (odpor do sprememb).
\end{abstract}

Kot velja za vsakršen odnos, gre za individualno značilnost. John Kotter, eno izmed najbolj znanih imen v upravljanju sprememb, trdi da je sposobnost spoprijemanja s spremembami pomembna na vseh ravneh organizacije. Toda, ali je odnos do sprememb enak za vse v organizaciji? Natančneje, ali je odnos vodij do sprememb različen od odnosa sledilcev do sprememb?

Naša raziskava, ki smo jo leta 2016 izvedli na primeru Gorenja, d.d., kaže, da v splošnem ni statistično značilnih razlik v odnosu do sprememb, kot ga izkazujejo vodje in sledilci. V praksi sta si situacijski in dispozicijski odnos do sprememb tako vodij kot sledilcev podobna in pozitivno izražena.

Glede na izsledke naše raziskave je situacijski odnos do sprememb v splošnem statistično značilen napovedovalec skupne ocene vodenja posamezne spremembe. Končno in najpomembneje, ugotovili smo, da je situacijski odnos vodij in sledilcev do sprememb najbolj pomemben dejavnik v zaznani uspešnosti sprememb.

KLJUČNE BESEDE: organizacijske spremembe • vodenje sprememb • upravljanje sprememb • odnos do sprememb • odpor do sprememb • organizacijski razvoj

NASlov AVTORJA: Miha Žove, Gorenje, d.d., Partizanska 12, 3320 Velenje, Slovenija, e-pošta: miha.zove@gorenje.com

DOI https://doi.org/10.18690/978-961-286-020-2.109 ISBN 978-961-286-020-2

(C) 2017 Univerzitetna založba Univerze v Mariboru

Dostopno na: http://press.um.si 
$36^{\mathrm{TH}}$ InTERnational CONFEREnCE ON ORganizational SCIENCE DeVElopment: Responsible ORGANIZATION (MARCH $22^{\mathrm{ND}}-24^{\mathrm{TH}}$, PORTOROŽ SLOVENIA)

O. Arsenijević, M. Ferjan, I. Podbregar, P. Šprajc, D. Trivan \& Y. Ziegler

\title{
Do Leaders and Followers Have Different Attitudes towards Change? The Case of Gorenje, d. d.
}

\author{
MIHA ŽOVE
}

\begin{abstract}
Extensive body of research shows that individual attitude towards organizational change plays a significant role in change management initiatives and is a key factor for their success.

Some researchers show that we can deconstruct change attitude into two basic components: the situational change attitude (attitude towards specific change) and the dispositional change attitude (attitude towards changes in general). Both can be positive (accepting the change) or negative (resisting the change).

As applies to all attitudes, this is an inherently individual characteristic. John Kotter, one of the most prominent names in change management, claims that the ability to cope with changes is important on all levels of the organization. However, is the change attitude the same across the organization? Specifically, is the change attitude of leaders in the organization different from followers?
\end{abstract}

Our research, conducted in 2016 on the case of Gorenje, d.d., a home appliances company, shows that in general, no statistically significant differences in change attitudes exist between leaders and followers. For all practical purposes, situational and dispositional change attitudes of both leaders and followers are similar and positively expressed.

Per our research, the situational change attitude in general is a statistically significant predictor of the overall assessment of leadership of a specific change initiative. Finally, and most importantly, we find that the situational change attitude of both leaders and followers is the most important factor in the perceived success of change initiatives.

KEYWORDS: organizational change - change leadership, - hange management $\cdot$ change attitude $\cdot$ resistance to change, organizational development

CORRESPONDENCE ADDRESS: Miha Žove, Gorenje, d.d., Partizanska 12, 3320 Velenje, Slovenia, email: miha.zove@gorenje.com

DOI https://doi.org/10.18690/978-961-286-020-2.109 ISBN 978-961-286-020-2

(C) 2017 University of Maribor Press

Available at: http://press.um.si 
M. Žove: Ali imajo vodje in sledilci različen odnos do sprememb? Primer Gorenja, d.d.

\section{The nature and importance of organizational changes}

Change is a complex process (Higgs \& Rowland, 2005) and is inherent to all living systems, especially social systems (Chia, 1999). Change may come under many flags (Kotter, 2007), including total quality management, business process reengineering, restructuring, turnaround, etc. Regardless of the name, the goal is usually the same: change the business operations to enable the company to cope with the challenging business environment (Kotter, 2007).

Organizational changes are frequent and the rate of change is exponential (Kotter, 2011). Some might say that organizational changes are inevitable, whether organizations are ready or not (cf. By, 2007).

Changes are closely interrelated with strategy implementation (Franken, Edwards, \& Lambert, 2009). The main challenges therein are to determine what to change in the current situation, how to implement changes and ensure change acceptance and how to establish sustainable change (Bruch, Gerber, \& Maier, 2005).

Most of the organizations, however, struggle with the implementation of changes. Some researchers show that only about a third of change initiatives are implemented successfully (Jarret, 2003; Hart, 2014). Among the factors that contribute to change failure, Keenan et al. (2012) list the following: the lack of clear objectives, the lack of commitment by the top management, resistance by the employees and inadequate communication.

Summarizing the research on success of change initiatives (cf. Cummings \& Worley, 2005; Dyer, Freeland, Gunby, \& DeTar, 2011; Gill, 2002; Green, 2007; Kotter, 2015; Oakland \& Tanner, 2007), we found that the key success factors might be constructed as follows:

- change management process, including the communication of change;

- the roles of stakeholders in the process;

- change attitude;

- leadership.

In our research, we focused on the latter two, but we have taken into account some of the most important implications from the change management process.

\section{Change management methodologies}

Lewin first defined planned approach to organizational change in 1946 (By, 2005) as a three-stage process of unfreezing, changing and freezing. 
36 ${ }^{\text {TH }}$ International Conference on ORganizational Science Development: Responsible Organization (MARCH $22^{\mathrm{ND}}-24^{\mathrm{TH}}$, PortoroŽ SlOVENIA)

M. Žove: Do Leaders and Followers Have Different Attitudes towards Change? The Case of Gorenje, d.d.

Change management notorious and most cited approach (per Lundy \& Morin, 2013) is the Kotter's eight-step approach (Kotter, 1996). Kotter developed it based on his research and experience, and prescribed eight steps to handle change: from establishing a sense of urgency, a guiding coalition, developing a clear vision and communicating it, to removing obstacles, getting quick wins, consolidating changes and embedding them into organizational culture.

There are many more approaches to change management, but presenting them would exceed the scope of this paper. Some researchers and practitioners argue that such prescribed methods of change management are not effective in complex environments of organizations. Charles and Dawson (2011) even claim that improvisation and adaptation are of key importance in change management. Woodward and Hendry (2004) propose that change management is actually a dynamic and holistic process whereby the organizational change is achieved by changing relations, competencies and abilities that define the organization. Doing so, the relationship between the change leaders and the change followers is of key importance (ibid.).

\section{Leaders and Followers in Change}

Participants in change are those that implement, accept or adapt to it (Ford, Ford, \& Amelio, 2008). Those that implement change are usually called change agents or change champions (Caldwell, 2003; Kotter, 2007).

Even though Nikolaou, Gouras, Vakola, and Bourantas (2007) argue that all employees that are included in a particular change are its change agents, the traditional conceptualization is that change agents manage or lead the change, and all others are change followers. However, no change can happen without willing and committed followers (Bennis, 2000).

Change leaders are often analyzed and/or defined through the lens of leadership and leadership traits. Dulewicz and Higgs (2005) claim that successful leadership is a combination of personal traits, skills, behaviors, and leadership styles. Leadership styles may range from authoritative to participative (Levasseur, 2005), whereby authoritative signifies a top-down, dominant, directional, individualistic approach whereas participative leadership signifies bottom-up, collaborative, team approach.

Dulewicz and Higgs (2005) clustered the leadership traits into three leadership styles: goal-oriented, involving and engaging. Based on research of management competencies in Slovenia, Verle, Markič and Kodrič (2012) defined the following two factors of competencies: social-leadership competencies and action-based competencies.

In regards to change, leaders are especially important. As Barker (2001) puts it, if there is no need for change, there is no need for leaders. Leadership is the motor of change (Kotter, 1996) and leadership is the most critical part of every change (Karp, 2006). However, even leaders are not immune to their own reactions to change (Hart, 2014). 
M. Žove: Ali imajo vodje in sledilci različen odnos do sprememb? Primer Gorenja, d.d.

\section{$4 \quad$ Change Attitude}

Successful organizational change can only happen as a result of personal change (Gravells, 2006). The attitude to change is inherent to every person and is influenced by experience with past changes (Hart, 2014). Changes might be frightening and may cause restlessness, fear and anxiety (Frost \& Robinson, 1999). Reaction to change usually corresponds to stages of grief: denial, resistance, exploration and commitment (Calarco \& Gurvis, 2006). Change attitude depends on individual cognitive schemes, personal traits and characteristics, personal values, emotions and experience - therefore, change attitude is individual and differs among different people (Vakola, Tsaousis, \& Nikolaou, 2004).

In the context of a particular change, the change attitude may differ from passive avoidance to active resistance or sincere acceptance (Kotter \& Schlesinger, 2008). Resistance may be a consequence of cognitive or emotional factors that a person experiences before and during the change (Gill, 2002). In general, emotional resilience will likely induce positive change attitude (Shin, Taylor, \& Seo, 2012). Individuals with higher emotional intelligence will also better handle emotions during the change (Vakola et al., 2004).

Research shows that change attitude is linked to success of organizational change (Shin et al., 2012) and that change leadership may influence behavior of the change participants (Lawson \& Price, 2003). In contrast, change resistance as an element of change attitude is often found guilty of change failure (Fuchs \& Prouska, 2014).

The other important factor in change attitude is the difference between general change attitude and attitude towards specific change, as shown by Dunham, Grube, Gardner, Cummings, and Pierce (1989). Change attitude could be separately defined as cognitiveemotional-behavioral reactions to changes in general and specific, concrete changes (ibid.). Bareil, Savoie and Meunier (2007) found that the individual's predispositions (e.g. optimism, self-confidence, anxiety, cynicism) may impact his or her attitude to change regardless of the nature or type of the change. Furthermore, we can distinguish change discomfort as situational and dispositional (Bareil et al., 2007). The first is related to change in general and the second to a specific change.

\section{Research - the case of Gorenje, d.d.}

\subsection{Overview of the company and its recent organizational changes}

Gorenje, d.d., is a publicly traded stock company, established in Slovenia. It is a parent company of Gorenje Group (both entities hereinafter also referred to as Gorenje or company), one of the leading European producers of home appliances. Throughout its history, starting in 1950, the company faced some significant changes. The growth from a small manufacture shop to an international player; the loss of the entire home market with dissolution of Yugoslavia and adaptation to the European market; the transformation 
$36^{\mathrm{TH}}$ InTERnAtional CONFERENCE ON ORganizational SCIENCE DeVElopment: RESPONSIBLE ORGANIZATION (MARCH $22^{\mathrm{ND}}-24^{\mathrm{TH}}$, PORTOROŽ Slovenia)

M. Žove: Do Leaders and Followers Have Different Attitudes towards Change? The Case of Gorenje, d.d.

from socialistic to a capitalistic company; acquisitions, greenfield investments and international expansions; business diversification, consolidation, etc.

In 2016, Gorenje Group had 1.257 billion EUR of revenues and 38.7 million EUR of operating profit (net profit of 7.6 million), as per publicly stated estimate of 2016 results (http://www.gorenjegroup.com/en/media/news/2017/01/7556-Following-the-successfulpursuit-of-our-strategic-plan-in-its-first-year-our-profit-planned-for-2016-will-be-

exceeded [15.1.2017]). The core business of the company is the development, production and sales of major and small domestic appliances. In total, Gorenje Group employs about 11 thousand employees globally.

The company's vision, mission statement and corporate values are shown in Figure 1. There is a clear emphasis on innovation, entrepreneurship, open-mindedness and engagement, which could be an indication of positive attitude and openness towards changes.

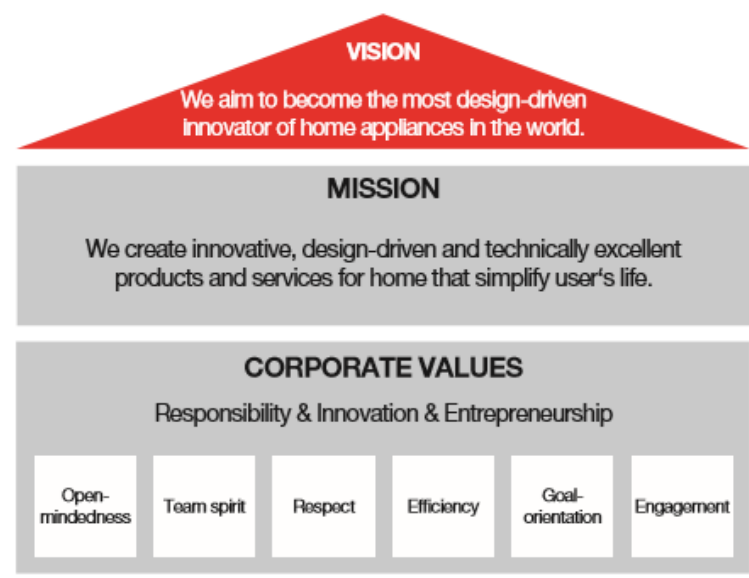

Figure 7: Vision, Mission and Values of Gorenje Group (source: Gorenje Group

Strategic Plan 2016-2020 Summary, available at:

http://static14.gorenje.com/files/default/corporate/investorrelations/Strategic\%20Plan\%20Summary\%202020.pdf [15.1.2017])

For the purpose of this research, we assumed that only the recent major organizational changes in the company would have a measurable effect on the employees. Those changes were implemented between 2012 and 2015 and included:

- the establishment of functional-based organization on the corporate level;

- the establishment of corporate functions;

- the implementation of regional sales organization; 
M. Žove: Ali imajo vodje in sledilci različen odnos do sprememb? Primer Gorenja,

- the integration of acquired companies of ATAG and ASKO in the Gorenje Group;

- the establishment of $R \& D$ competence centers;

- the establishment of Financial-Accounting shared service center;

- the redefinition of the product development process;

- the redefinition of supply chain planning process;

- the establishment of corporate marketing function;

- the internationalization of management team.

\subsection{Research methodology}

We hypothesized that:

- change attitude is different between leaders and followers (H1),

- change attitude may be deconstructed into situational and dispositional attitude (H2),

- leadership of specific change initiative is linked to situational change attitude (H3),

- assessment of change success is linked to situational change attitude (H4).

The research was based on the population of 1484 employees in Gorenje, d.d., employed in the organizational units outside of production. Within this population, we identified 61 leaders (based on the company's management positions) and 1423 followers. The population of leaders was included in the research in full $(\mathrm{N}=61)$ whereas the sample included 33 leaders that responded to our survey. For the population of followers $(\mathrm{N}=1423)$, we formed a simple random sample of 152 followers, thus ensuring $95 \%$ confidence level and confidence interval (error margin) of 10\%, with assumed $60 \%$ respond rate (actual response rate was 70\%).

The research was performed using an online questionnaire that included statements ${ }^{1}$ on change attitudes, leadership and change success, and the answers were formed as a 5point Likert scale ranging from 1 ("Not true at all") to 5 ("Completely true").

Survey statements were designed in line with literature review and were mostly based on the examples and recommendations of Dunham et al. (1989); Herscovitch and Meyer (2002); Woodward and Hendry (2004); Vakola et al. (2004); Calarco and Gurvis (2006); Bareil et al. (2007); Meyer et al. (2007); Oreg and Berson (2009); Mehta, Maheshwari and Sharma (2014); Fuchs and Prouska (2014).

Statements that were related to change attitude were formed in two parts, the general attitude and the attitude towards specific change, both contained 10 statements $^{2}$. For the attitude towards specific change, we asked the participants to recall one of recent organizational change in which they were involved. 
$36^{\mathrm{TH}}$ INTERNATIONAL CONFERENCE ON ORganizational SCIENCE DeVElopment: Responsible Organization (March $22^{\mathrm{ND}}-24^{\mathrm{TH}}$, Portorož Slovenia)

M. Žove: Do Leaders and Followers Have Different Attitudes towards Change? The Case of Gorenje, d.d.

The questionnaire also included 9 statements $^{3}$ on perceived change leadership and 2 statements on perceived change success. Based on response within the five-day timeframe, we had 33 useful responses for the leader sample and 106 useful responses for the follower sample; only valid responses were used for analysis with SPSS software.

\subsection{Key findings}

Based on descriptive statistics (average response value), both leaders and followers exhibit positive attitude towards change in general (dispositional change attitude; Figure 2) and towards particular change (situational change attitude; Figure 3).

Based on statistical testing (using t-test and Mann-Whitney U-test), we found that there are practically no significant differences between leaders and followers in their response to the statements. The only statistically significant difference ( $\mathrm{p}=0.016$ for t-test and $\mathrm{p}$ $=0.022$ for Mann-Whitney U-test) was found for the statement "I did everything in my power to implement the change", where leaders exhibited a higher rate of agreement. This could be interpreted as a lower engagement level of followers, but also as selfattribution (self-credit) by the leaders.

Comparing the aggregated data using composite variables for change attitude, we found no statistically significant differences between the two groups (leaders and followers), therefore we cannot confirm hypothesis H1.

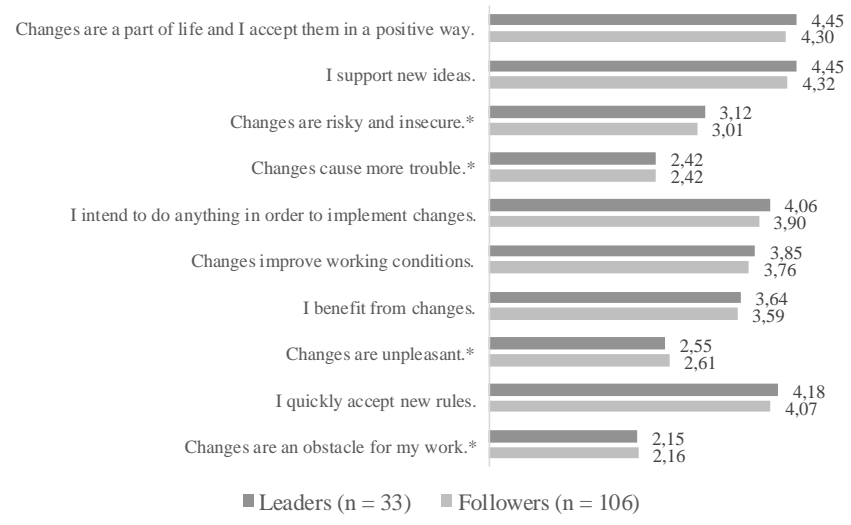

Note: Possible answers are ranked from 1 (Not true at all) to 5 (Completely true). * marks the statements that are reversely coded $(1=5,2=4,4=2,5=1)$; original answers are shown; reverse-coded answers were used in statistical analysis.

Figure 8: Average response values for dispositional change attitude 
M. Žove: Ali imajo vodje in sledilci različen odnos do sprememb? Primer Gorenja,

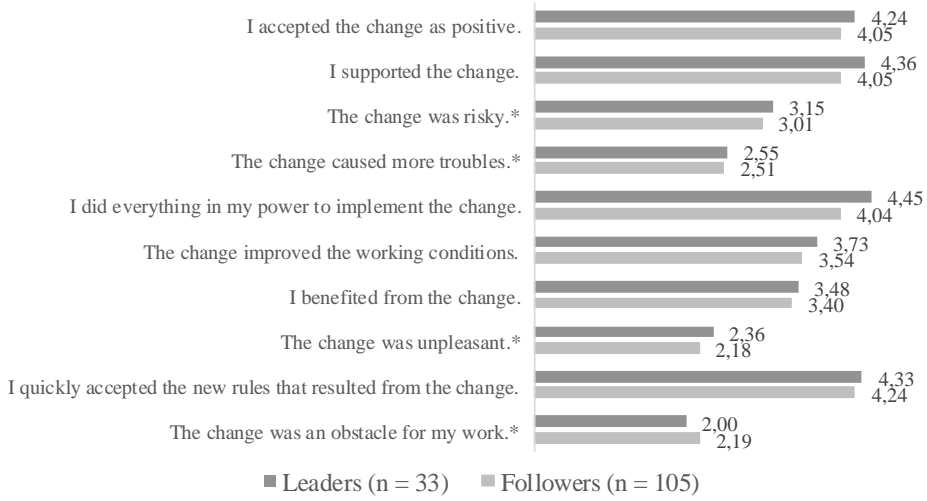

Note: Possible answers are ranked from 1 (Not true at all) to 5 (Completely true). * marks the statements that are reversely coded $(1=5,2=4,4=2,5=1)$; original answers are shown; reverse-coded answers were used in statistical analysis.

Figure 9: Average response values for situational change attitude

With factor analysis of all change attitude responses, we initially identified five factors, which were later (by subsequent limiting of factors) found to converge into two distinct factors: the situational and dispositional attitude towards change. Contrary to our expectations, two of the general statements ("Changes are risky and insecure"; "Changes are unpleasant") loaded onto situational attitude factor instead of a dispositional attitude factor.

We can conclude that difference between the two attitudes (situational and dispositional) is only valid for positively expressed statements, whereas negatively expressed statements could be interpreted as change resistance and attributed to situational attitude (towards a specific change). Even when isolating the statements that loaded on a third factor and could be interpreted as change resistance, we found no statistically significant differences between the leader and follower groups. However, as we cannot ignore or omit change resistance factor, we cannot confirm our hypothesis $\mathrm{H} 2$.

Apart from change attitude, we were interested in change leadership. We used two sets of statements to represent adequately the position of respondents (leader/follower); average response values are shown in Figure 4. We can immediately find that the differences in assessment and self-assessment of change leadership are relatively large. 
$36^{\text {Th }}$ International Conference on Organizational Science Development: Responsible Organization (MARCH $22^{\mathrm{ND}}-24^{\mathrm{TH}}$, PortoroŽ SlOVENIA)

M. Žove: Do Leaders and Followers Have Different Attitudes towards Change? The Case of Gorenje, d.d.

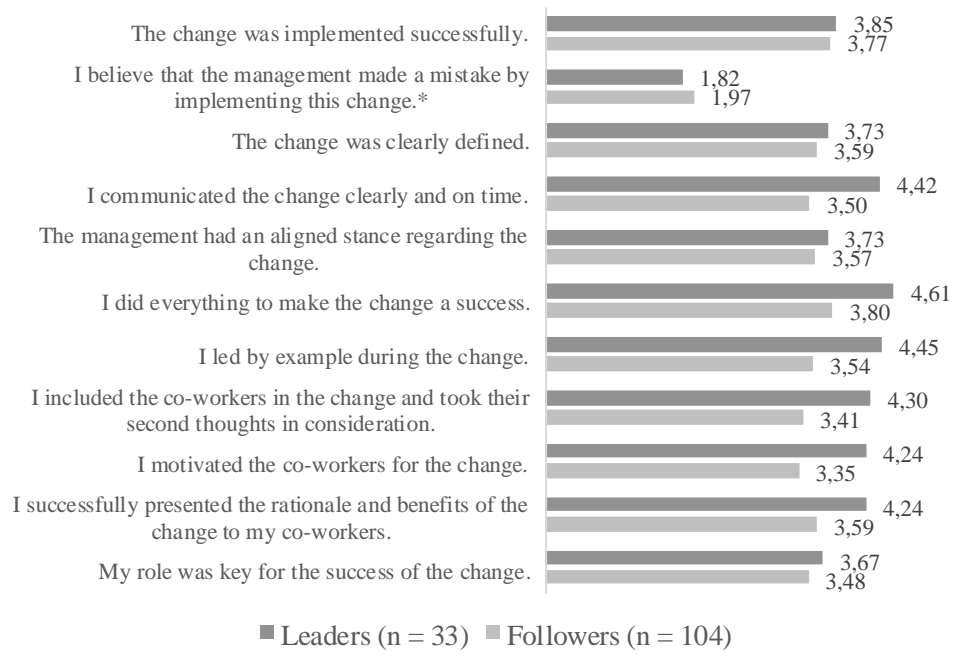

Note: Possible answers are ranked from 1 (Not true at all) to 5 (Completely true). * marks the statements that are reversely coded $(1=5,2=4,4=2,5=1)$. Statements are shown for the leader set; equivalent statements were used also in the follower form.

Figure 10: Average response values for change leadership statements

Almost all statements show statistically significant differences (at $\alpha=0.05$ ), except for the statements on the role of leaders (Figure 4, statement no. 11) and on aligned management stance (statement no. 5). These mostly differing views could signalize that the followers undervalue the role of leaders and/or that the leaders overvalue it.

Correlation analysis ${ }^{4}$ shows the highest correlation coefficient $($ Pearson Correlation $=$ $0.603, p=0.000)$ between assessment of change leadership and situational change attitude. The latter is also statistically significant $(\mathrm{p}=0.000)$ predictor of the former. Positive attitude towards particular change correlates positively with the assessment of change leadership, both for followers and leaders, thus confirming our $\mathrm{H} 3$ hypothesis.

We measured change success with two statements (Figure 4, statements no. 1 and 2), the latter reversely coded. In general, change success was positively evaluated, with more than 70 percent of respondents evaluating the change as successful ${ }^{5}$. Regression analysis ${ }^{6}$ shows that situational change attitude affects the perceived change success the most (regression coefficient of $0.429, \mathrm{p}=0.000$ ), as hypothesized with $\mathrm{H} 4$. 


\section{Conclusion}

Our research showed that for the selected company, attitudes towards change are expressed positively for both leaders and followers. In addition, no significant differences exist in the change attitude between the two groups.

Change leadership, however, is assessed differently between the two groups; the followers express a significantly lower assessment of change leadership categories in comparison with leaders. For both groups, situational change attitude (towards specific change) has the highest impact on perceived change leadership which follows the findings of Hart (2014) and Klaussner (2012). Additionally, we found that situational change attitude is the most important factor in perceived change success.

Our findings would suggest that the attitude towards change in general (including change resistance) is not as important when managing change efforts and that more focus is due on managing the attitude towards specific change at hand. Change leaders should tackle this, as some researchers and practitioners suggest, with better communication, as well as more involvement and engagement of employees.

\section{Opombe}

${ }^{1}$ Statements were formed in Slovenian language; the statements shown in this paper are author's translation.

${ }^{2}$ For the general attitude statements, Cronbach $\alpha=0.697$. For specific attitude statements, Cronbach $\alpha=0.815$ for sample of followers and $\alpha=0.795$ for sample of leaders.

${ }^{3}$ Cronbach $\alpha=0.856$ for sample of leaders and $\alpha=0.887$ for sample of followers.

${ }^{4}$ Analysis included the variables of change attitude and change resistance as well as leadership characteristics and context of change. Due to limited scope, we only focus on change attitude in this paper. The complete set of variables was used in linear regression analysis that explained change leadership with four variables (adjusted R2 $=0.694 ; \mathrm{p}=0.000$ ).

${ }^{5}$ Positive statement evaluated with "mostly true" or "completely true" and the reverse-coded statement evaluated with "mostly not true" or "not true at all".

${ }^{6}$ Analysis included the variables of change attitude, change leadership, the importance of change and its scope. Due to limitations of this paper, we only focus on change attitude herein. Change success was explained with a linear regression model of four variables (adjusted $R^{2}=0.538 ; \mathrm{p}=$ $0.000)$.

\section{Literature}

Bareil, C., Savoie, A., \& Meunier, S. (2007). Patterns of Discomfort with Organizational Change. Journal of Change Management Vol. 7, No. 1, p. 13-24.

Barker, R. A. (2001). The nature of leadership. Human relations Vol. 54, No. 4, p. 469-494.

Bennis, W. (2000). Leadership of change. In: Breaking the code of change, ed. Michael Beer and Nitin Nohria, p. 113-121. Boston, Massachusetts: Harvard Business School Press.

Bruch, H., Gerber, P., \& Maier, V. (2005). Strategic Change Decisions: Doing the Right Change Right. Journal of Change Management Vol. 5, No. 1, p. 97-107. 
$36^{\mathrm{TH}}$ InTERnAtional CONFERENCE ON ORganizational SCIENCE DeVElopment: RESPONSIBLE ORGANIZATION (MARCH $22^{\mathrm{ND}}-24^{\mathrm{TH}}$, PORTOROŽ Slovenia)

M. Žove: Do Leaders and Followers Have Different Attitudes towards Change? The Case of Gorenje, d.d.

By, R. T. (2005). Organisational change management: A critical review. Journal of Change Management Vol. 5, No. 4, p. 369-380.

By, R. T. (2007). Ready or Not... Journal Of Change Management Vol. 7, No. 1, p. 3-11.

Calarco, A., \& Gurvis, J. (2006). Adaptability: Responding Effectively to Change. Greensboro: Center for Creative Leadership.

Caldwell, R. (2003). Models of Change Agency: a Fourfold Classification. British Journal of Management Vol. 14, No. 2, p. 131-142.

Charles, K.. \& Dawson, P. (2011). Dispersed Change Agency and the Improvisation of Strategies During Processes of Change. Journal of Change Management Vol. 11, No. 3, p. 329-351.

Chia, R. (1999). A 'rhizomic' model of organizational change and transformation: perspectives from a metaphysics of change. British Journal of Management Vol. 10, No. 3, p. 209-227.

Cummings, T. G., \& Worley, C. G. (2005). Organization Development and Change. 8th ed. Cincinnati, Ohio: Thomson South-Western.

Dulewicz, V., \& Higgs, M. (2005). Assessing leadership styles and organisational context. Journal of Managerial Psychology Vol. 20, No. 2, p. 105-123.

Dunham, R. B., Grube, J. A., Gardner, D. B., Cummings, L. L., \& Pierce, J. L. (1989). The Development of an Attitude Toward Change Instrument [discussion paper]. Strategic Management Research Center, University of Minnesota. Https://www.researchgate.net/publication/265267565_The_development_of_an_attitude_tow ard change instrument.

Dyer, A., Freeland, G., Gunby, S., \& DeTar, C. (2011). Leading Transformation: Conversations with Leaders on Driving Change. BCG Perspectives 10/2011, p. 1-44.

Ford, J. D., Ford, L. W., \& D'Amelio, A. (2008). Resistance to change: The rest of the story. Academy of management Review Vol. 33, No. 2, p. 362-377.

Franken, A., Edwards, C., \& Lambert, R. (2009). Executing Strategic Change: Understanding the Critical Management Elements that Lead to Success. California Management Review Vol. 51, No. 3, p. 49-73.

Frost, P., \& Robinson, S. (1999). The Toxic Handler: Organizational Hero - And Casualty. Harvard Business Review Vol. 77, No. 4, p. 96-107.

Fuchs, S., \& Prouska, R. (2014). Creating Positive Employee Change Evaluation: The Role of Different Levels of Organizational Support and Change Participation. Journal Of Change Management Vol. 14, No. 3, p. 361-383.

Gill, R. (2002). Change management - or change leadership? Journal Of Change Management Vol. 3, No. 4, p. 307-318.

Gravells, J. (2006). The myth of change management: A reflection on personal change and its lessons for leadership development. Human Resource Development International Vol. 9, No. 2, p. 283-289.

Green, M. (2007). Change management masterclass: a step by step guide to successful change management. London in Philadelphia: Kogan Page.

Hart, G. (2014). Stop trying to sell change and build a movement. New Zealand Management Vol. 61, No. 4, p. 16-17.

Herscovitch, L., \& Meyer, J. P. (2002). Commitment to organizational change: extension of a threecomponent model. Journal of Applied Psychology Vol. 87, No. 3, p. 474-487.

Higgs, M., \& Rowland, D. (2005). All changes great and small: Exploring approaches to change and its leadership. Journal of Change Management Vol. 5, No. 2, p. 121-151.

Jarrett, M. (2003). The seven myths of change management. Business Strategy Review Vol. 14, No. 4, p. 22-29.

Karp, T. (2006). Transforming organisations for organic growth: The DNA of change leadership. Journal Of Change Management Vol. 6, No. 1, p. 3-20. 
M. Žove: Ali imajo vodje in sledilci različen odnos do sprememb? Primer Gorenja,

Keenan, P., Powell, K., Kurstjens, H., Shanahan, M., Lewis, M., \& Busetti, M. (2012). Changing Change Management: A Blueprint that takes hold. BCG Perspectives 12/2012, p. 1-29.

Klaussner, S. (2012). Trust and Leadership: Toward an Interactive Perspective. Journal of Change Management Vol. 12, No. 4, p. 417-439.

Kotter, J. P. (1996). Leading Change. Boston, Massachusetts: Harvard Business Press.

Kotter, J. P. (2007). Leading Change: Why Transformation Efforts Fail. Harvard Business Review Vol. 85, No. 1, p. 96-103.

Kotter, J. P. (2011). Can You Handle an Exponential Rate of Change? Http://www.forbes.com/sites/johnkotter/2011/07/19/can-you-handle-an-exponential-rate-ofchange/\#116775e71f6f.

Kotter, J. P. (2015). 8 Steps to Accelerate Change in 2015. Http://www.kotterinternational.com/ebook/eBook-Final-Copyright-2015.pdf.

Kotter, J. P., \& Schlesinger, L. A. (2008). Choosing Strategies for Change. Harvard Business Review Vol. 86, No. 7/8, p. 130-139.

Lawson, E., \& Price, C. (2003). The psychology of change management. Mckinsey Quarterly Vol. 4, p. 30-41.

Levasseur, R. E. (2005). People Skills: Change Management Tools - Leading Teams. Interfaces Vol. 35, No. 2, p. 179-180.

Lundy, V., \& Morin, P. (2013). Project Leadership Influences Resistance to Change: The Case of the Canadian Public Service. Project Management Journal Vol. 44, No. 4, p. 45-64.

Mehta, S., Maheshwari, G. C., \& Sharma, S. K. 2014. Role of Leadership in Leading Successful Change: An Empirical Study. Journal Of Contemporary Management Research Vol. 8, No. 2, p. 1-22.

Meyer, J. P., Srinivas, E. S., Lal, J. B., \& Topolnytsky, L. (2007). Employee commitment and support for an organizational change: Test of the three-component model in two cultures. Journal of Occupational and Organizational Psychology Vol. 80, No. 2, p. 185-211.

Nikolaou, I., Gouras, A., Vakola, M., \& Bourantas, D. (2007). Selecting change agents: Exploring traits and skills in a simulated environment. Journal of Change Management Vol. 7, No. 3-4, p. 291-313.

Oakland, J. S., \& Tanner, S. (2007). Successful Change Management. Total Quality Management \& Business Excellence Vol. 18, No. 1/2, p. 1-19.

Oreg, S., \& Berson, Y. (2009). Leaders' Characteristics and Behaviors And Employees' Resistance To Organizational Change. Academy Of Management Annual Meeting Proceedings, p. 1-6.

Shin, J., Taylor, M. S., \& Seo M.-G. (2012). Resources for Change: the Relationships of Organizational Inducements and Psychological Resilience to Employees' Attitudes and Behaviors toward Organizational Change. Academy of Management Journal Vol. 55, No. 3, p. 727-748.

Vakola, M., Tsaousis, I., \& Nikolaou, I. (2004). The role of emotional intelligence and personality variables on attitudes toward organisational change. Journal of managerial psychology Vol. 19, No. 2, p. 88-110.

Verle, K., Markič M., \& Kodrič B. (2012). Kompetence slovenskih managerjev in organizacijska struktura. Organizacija Vol. 45, No. 1, p. A2-A13.

Woodward, S., \& Hendry, S. (2004). Leading and coping with change. Journal of Change Management Vol. 4, No. 2, p. 155-183. 
1370 36 ${ }^{\text {Th }}$ International Conference on Organizational Science Development: Responsible Organization (March $22^{\mathrm{ND}}-24^{\mathrm{TH}}$, Portorož Slovenia) 


\section{Zahvaljujemo se / \\ Thanks to}

\section{O POŠTA SLOVENIJE}

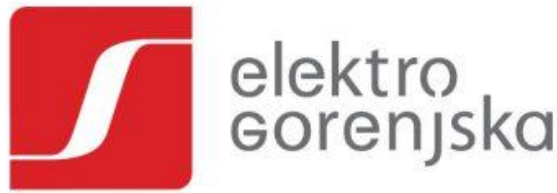

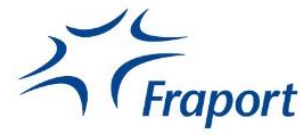
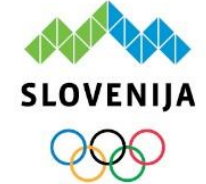

OLIMPIJSKI KOMITE SLOVENIJE

\section{COOD Y YYAR}

MADE TO FEEL GOOD.

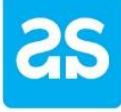

REPUBLIKA SLOVENIJA
MINISTRSTVO ZA GOSPODARSKI RAZVOJ IN TEHNOLOGIJO

URAD RS ZA MEROSLOVJE

ii REPUBLIKA SLOVENIJA

MINISTRSTVO ZA IZOBRAŽEVANJE,

ZNANOST IN ŠPORT

(ii) REPUBLIKA SLOVENIJA

MINISTRSTVO ZA JAVNO UPRAVO

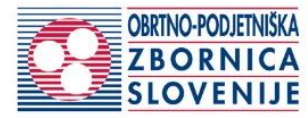

Gospodarska

zbornica

Slovenije 